DEPARTMENT OF THE INTERIOR

Franklin K. LANE, Secretary

United States Geological SURVeY

George Otis Smith, Director

Professional Paper 111

\title{
THE ORE DEPOSITS OF UTAH
}

BY

B. S. BUTLER, G. F. LOUGHLIN, V. C. HEIKES

AND OTHERS

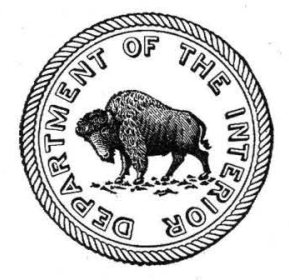

WASHINGTON

GOVERNMENT PRINTING OFFICE

1920 


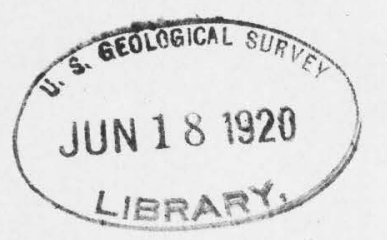




\section{CONTENTS.}

Page.

Outline of report. . .

Part I. General features, by B. S. Butler . . . . . . . . . . . . . .

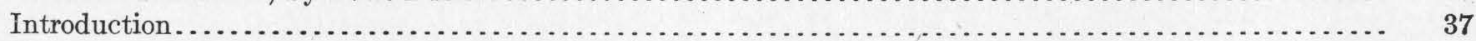

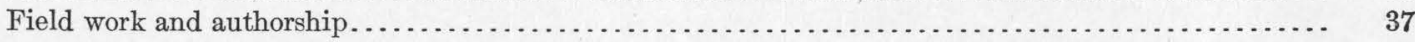

Scope of the report. . . . . . . . . . . . . . . . .

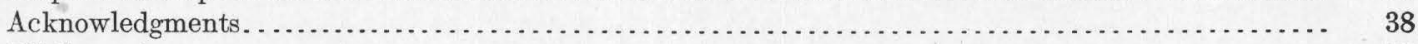

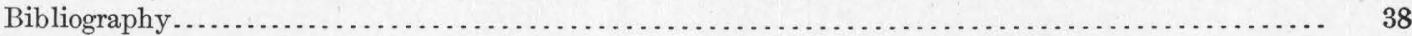

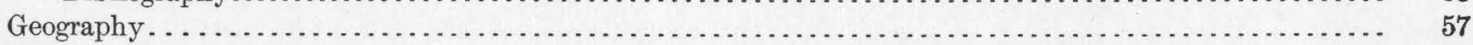

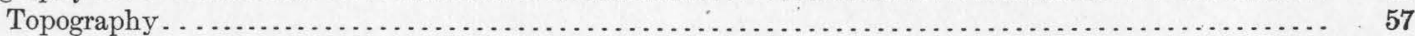

Relief. . . . . . . . . . . . .

Drainage . . . . . . . . . . . . .

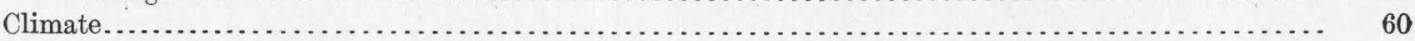

Vegetation . . . . . . . . . . . . . .

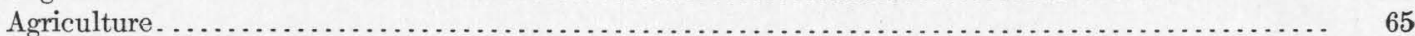

Transportation. . . . . . . . . . . .

Water power, by Herman Stabler................................................ 65

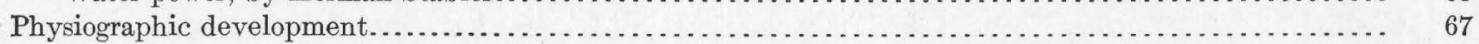

General outline . . . . . . . . . . . .

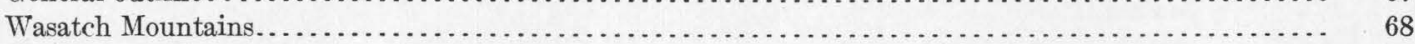

Uinta Mountains. . . . . . . . . . .

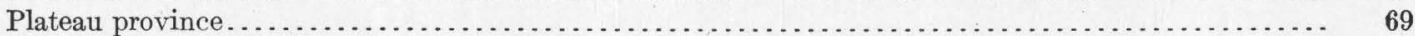

Topographic features. . . . . . . . . .

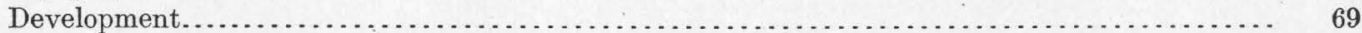

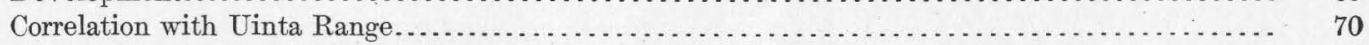

Correlation with Wyoming and Colorado . . . . . . . . . . . . . . . . . . .

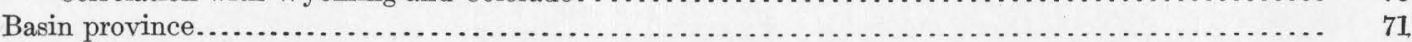

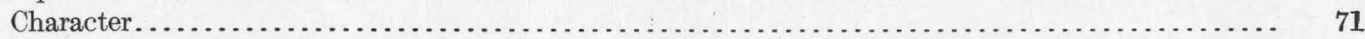

Origin of the Basin ranges. . . . . . . . . . . . . .

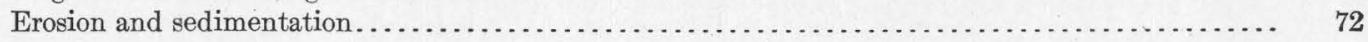

Development........................................................... 73

Correlation of the Great Basin with the other provinces . . . . . . . . .

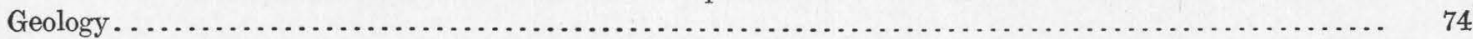

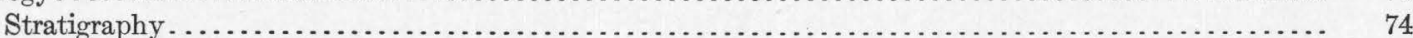

Geologic map.............................................................. 74

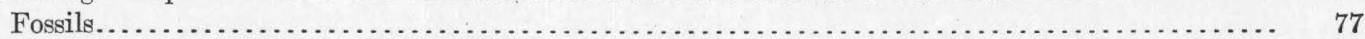

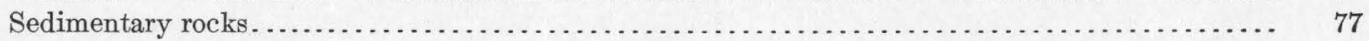

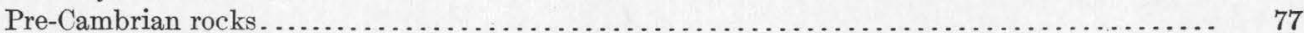

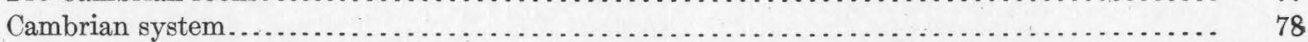

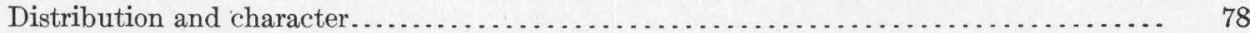

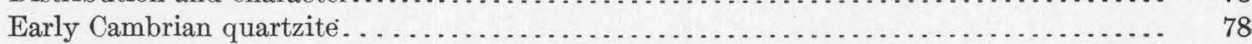

Ophir formation. . . . . . . . .

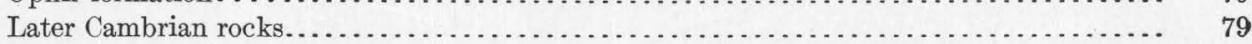

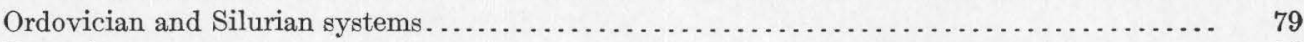

Devonian system........................................................ 80

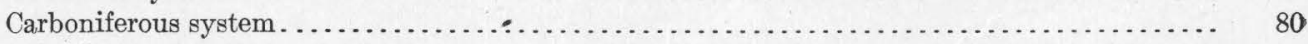

Triassic system ....................................................... 81

Jurassic system . . . . . . . . . . . .

Correlation of Jurassic and Triassic formations.............................. 84

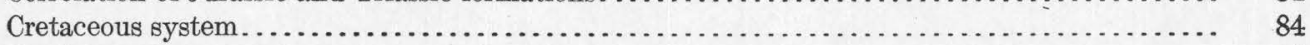

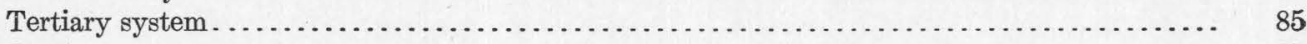

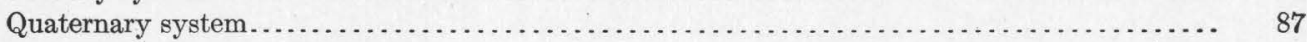

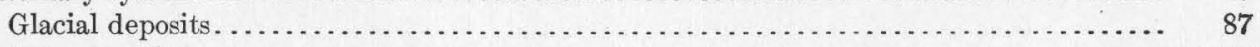

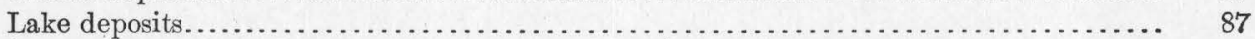

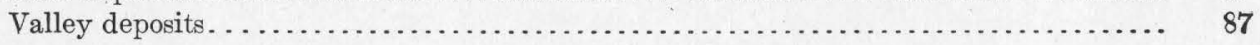




\section{THE ORE DEPOSITS OF UTAH.}

By B. S. Butler.

PART I.-GENERAL FEATURES.

INTRODUCTION. FIELD WORK AND AUTHORSHIP.

The senior author, B. S. Butler, began field work on the ore deposits of Utah in the summer of 1908 by making a detailed study of the ore deposits of the San Francisco and adjacent districts. The results of this work were published as Professional Paper 80 of the United States Geological Survey. Later he made a reconnaissance of the other districts in southern Utah, and eventually of the districts farther north, including the Deep Creek, Fish Springs, Dugway, Silver Islet, Grouse Creek, Raft River, Promontory, and Oquirrh ranges and, together with G. F. Loughlin, of the Cottonwood-American Fork area. In order to gain a personal knowledge of the geology and to make observations on later developments, visits were made to districts that had previously been studied in detail by other writers. In 1913 the senior author, in company with F. L. Hess, examined deposits in the Uinta Mountains and in the vicinity of the La Sal and Henry mountains. In 1914, in company with W. L. Whitehead, he spent two months in a further study of the geology and ore deposits in the Plateau region.

The junior author, G. F. Loughlin, began work in the Tintic district in 1911 in collaboration with Waldemar Lindgren. The results of this work are presented in Professional Paper 107. Reconnaissance studies were afterward made by him of the districts between the Tintic and Thomas ranges, of the Leamington district, and of districts in the Wasatch Range.

Several of the mining districts of the State have been studied in detail by other writers, and their reports have been published. The general results of these studies have been embodied in this report. The more important reports are those on the Mercur district, by J. E. Spurr and S. F. Emmons; the Bingham district, by J. M. Boutwell, Arthur Keith, and S. F. Emmons; the Park City district, by J. M. Boutwell and L. H. Woolsey; the Iron Springs district, by C. K. Leith and E. C. Harder; and the Tintic district, described first by G. W. Tower and G. O. Smith and later by Waldemar Lindgren and G. F. Loughlin.

In 1916 and 1917 detailed work was carried on in the Cottonwood-American Fork region. This work was interrupted by the war, but some of the results are incorporated in this paper.

The general section of this report was prepared by B. S. Butler, and the reports on the several districts by the writers indicated in the body of the report. The historical and statistical data, both for the general section and for the individual districts, were collected by V. C. Heikes, of the Salt Lake City office of the Geological Survey.

SCOPE OF THE REPORT.

There are several well-defined mineral belts within the State, and particular attention has been given to the relation of the ore deposits within these belts. Individual districts have been described in as much detail as the conditions of study have warranted. In some districts there was little or no activity at the times of visit and very meager opportunity for studies below the surface, whereas in other districts there were abundant opportunities for such studies. No attempt has been made to describe individual mines except as illustrations of a particular type of deposit. The mines in several of the larger districts have already been described in reports published by the Geological Survey, and those in other districts 
Part I. General features-Continued.

Geology-Continued.

Stratigraphy-Continued.

General distribution

Extrusive rocks . . . . . . . . . . .

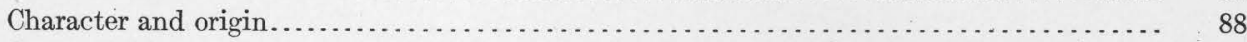

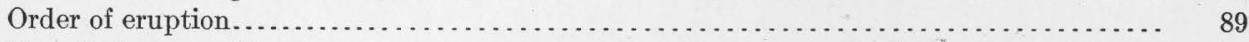

Chemical composition. . . . . . . . . . . . .

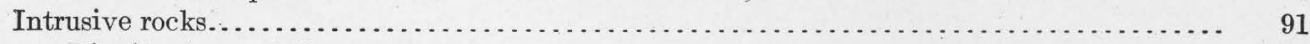

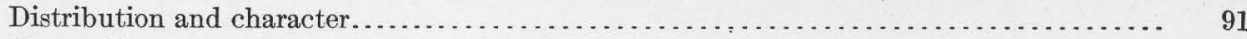

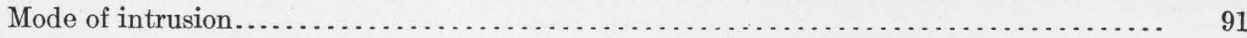

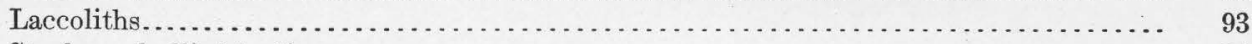

Stocks and allied bodies............................................... 94

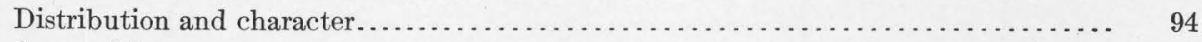

Composition....................................................... 95

General features.................................................... 95

Analyses. . . . . . . . . . . . . . . . .

Causes of differences in composition. . . . . . . . . . . . . . . . . .

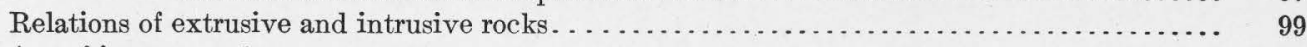

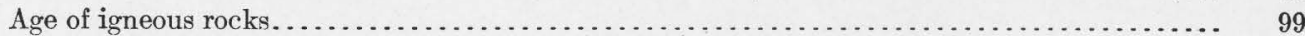

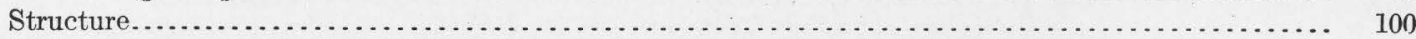

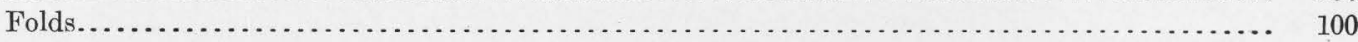

Domical uplifts. . . . . . . . . . . .

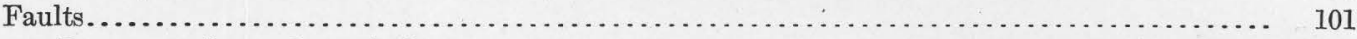

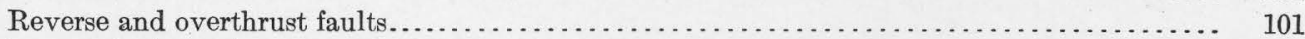

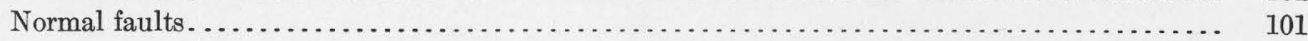

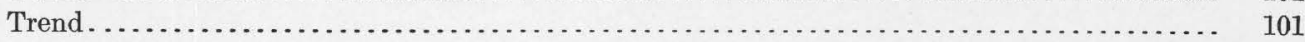

Relations of the different structural types.................................... 102

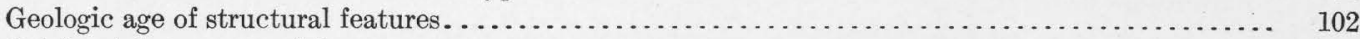

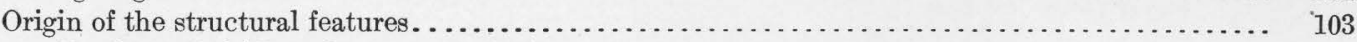

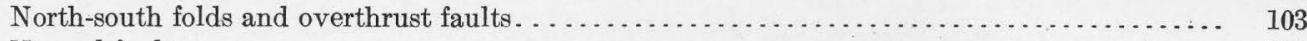

Normal faults. . . . . . . . . . . . .

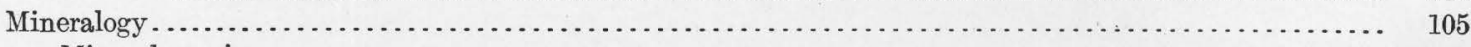

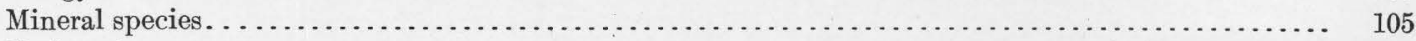

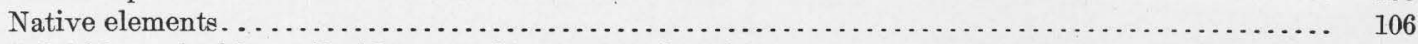

Sulphides, selenides, tellurides, arsenides, and antimonides........................... 106

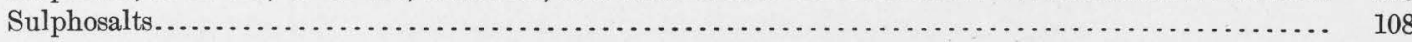

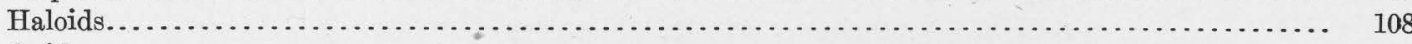

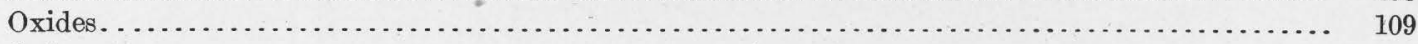

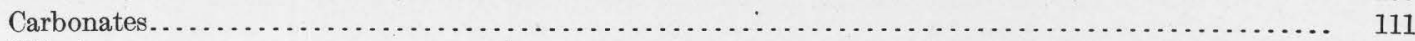

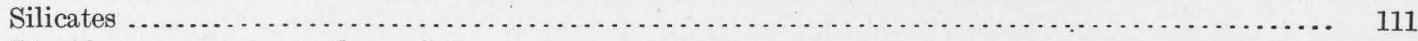

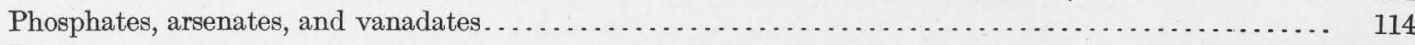

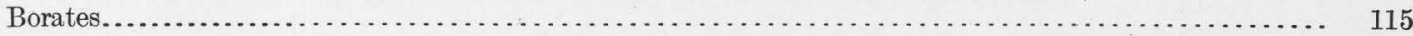

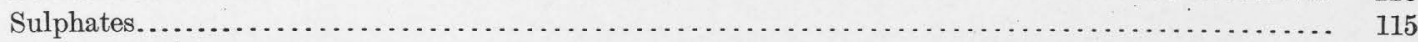

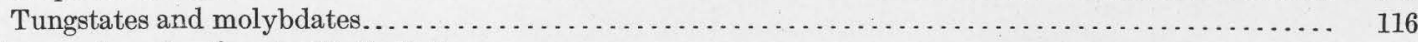

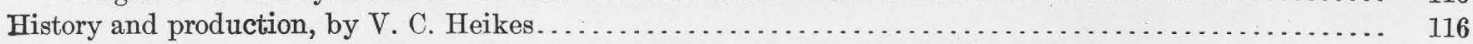

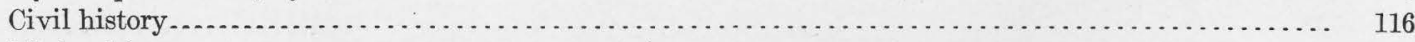

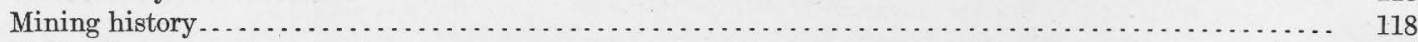

Railroad construction..................................................... 118

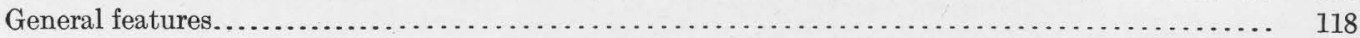

Union Pacific system ....................................................... 119

Denver \& Rio Grande system............................................. 119

Los Angeles \& Salt Lake Railroad......................................... 120

Metallurgic development................................................... 120

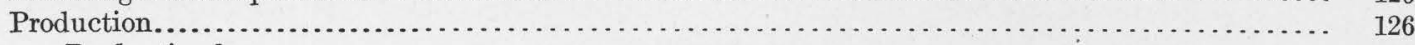

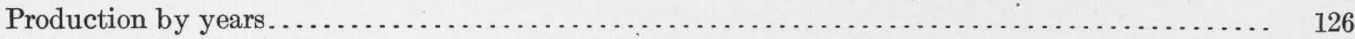

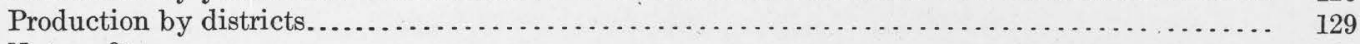

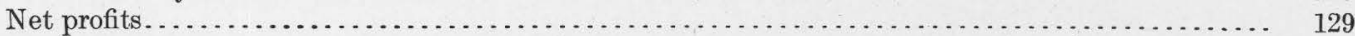

Production of the principal metals....................................... 131

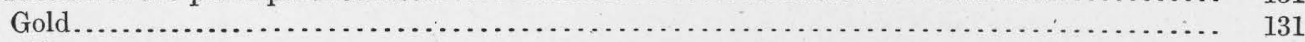

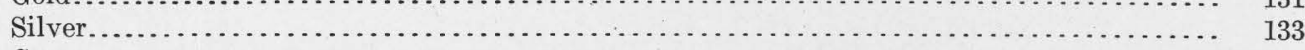

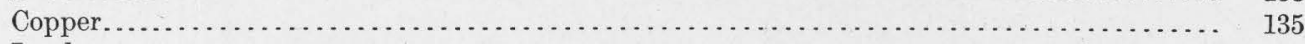

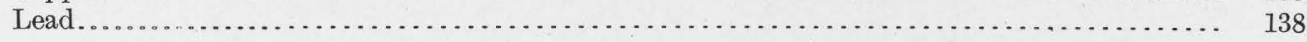


Part I. General features-Continued.

History and production-Continued.

Production-Continued.

Production of the principal metals-Continued.

Zinc.

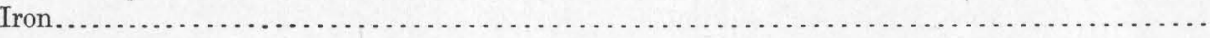

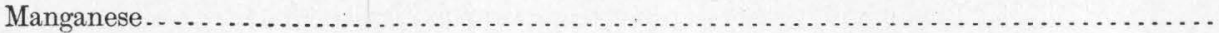

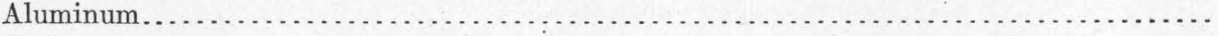

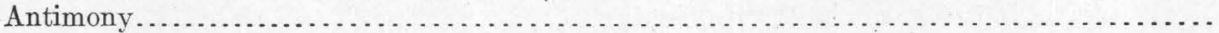

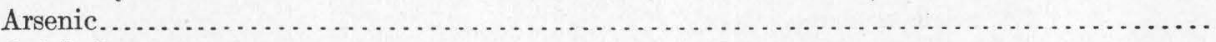

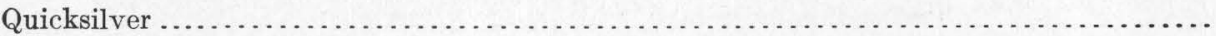

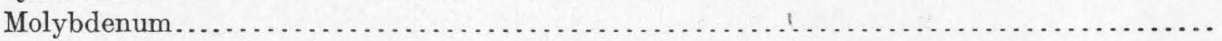

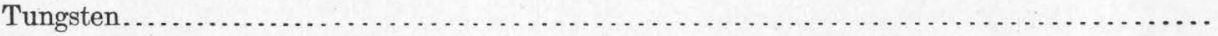

Bismuth.

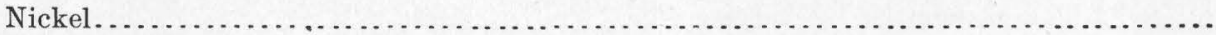

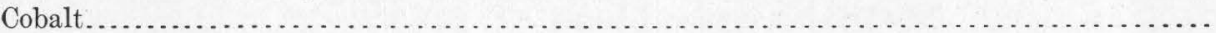

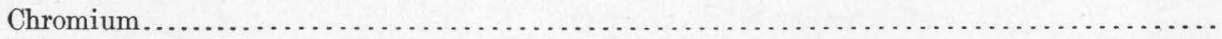

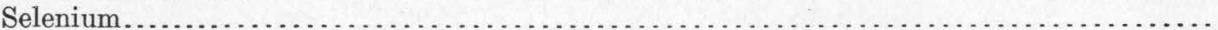

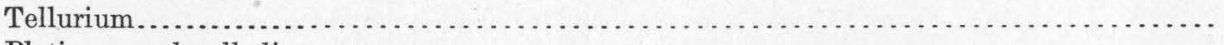

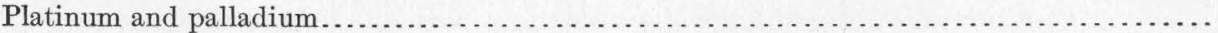

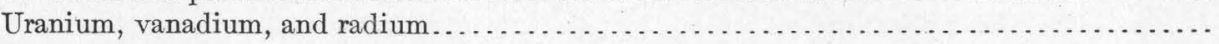

Mining districts

Ore deposits.

Origin .

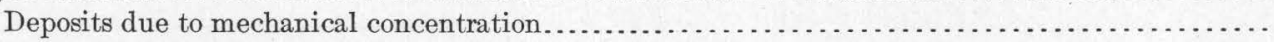

Gold placers

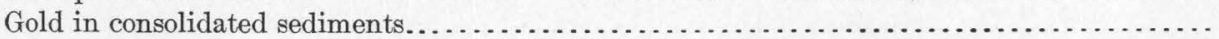

Deposits due to chemical concentration of material originally disseminated in the rock...........

Distribution of the deposits.

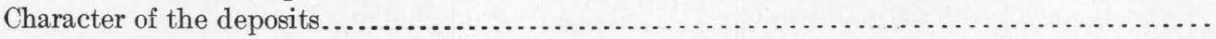

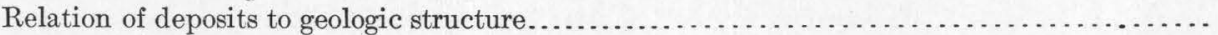

Genesis of the ores.

Conflicting theories

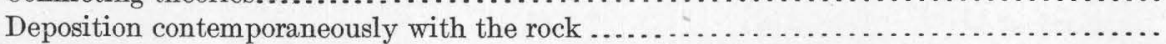

Concentration by solutions due to igneous activity.

Concentration by atmospheric waters.

Mode of concentration

Age of the deposits. Summary.

Deposits due to concentration effected by the introduction (possibly independently of igneous

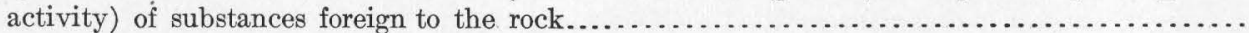

Deposits due to concentration of substances introduced by igneous activity....................

Distribution.

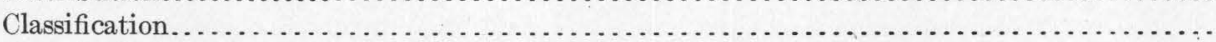

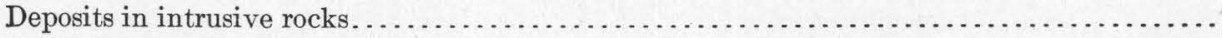

Veins closely allied to pegmatite.

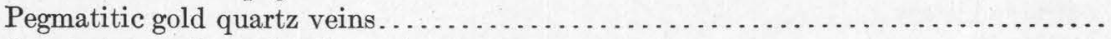

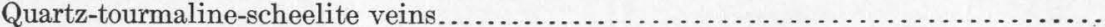

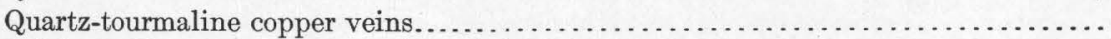

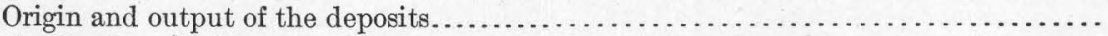

Similar deposits in other regions.

Quartz copper veins.

Quartz silver-lead veins.

Gold quartz veins.

Magnetite-hematite veins.

Relations of different ve

Mineralizing solutions.

Physical conditions of deposition

Deposits in sedimentary rocks.

Contact deposits

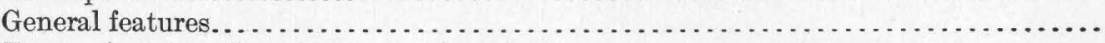

Types of contact deposits

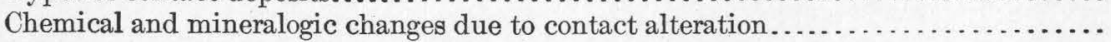

Volumetric changes due to contact metamorphism ..........................

Page.

142

143

143

143

143

143

14

144

144

144

144

144

144

144

145

145

145

145

150

150
150

150

150

151

152

152

153

154

155

155

155

156

156

156

157

158

158

158

159

159

159

159

159

159

160

160

161

161

161

162

162

162

163

163

167

168

168

168

168

169

172 
Part I. General features-Continued. Ore deposits-Continued.

Origin-Continued.

Deposits due to concentration of substances introduced by igneous activity-Continued.

Deposits in sedimentary rocks-Continued.

Contact deposits-Continued. Page.

Relation of contact deposits to deposits in intrusive rocks...................... 173

Genesis of the contact deposits........................................ 174

Deposits associated with fissures........................................ 174

Selective deposition................................................... 174

Classification by metals............................................ 175

Genesis of the deposits. . . . . . . . . . . 177

Deposits in extrusive rocks. . . . . . .

Distribution and character............................................... 179

Classification by metals.............................................. 179

Silver-lead-zinc-copper deposits. . . . . . . . . . . . . . . . . . . . . . . . . 179

Gold-silver deposits. . .................................................... 179

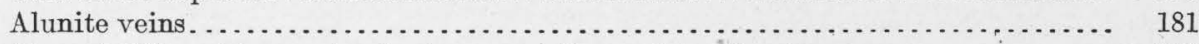

Relations of different types of veins to one another and to other types . . . . . . . . . . 181

Comparison of different types of deposits associated with igneous rocks . . . . . . . . . . . .

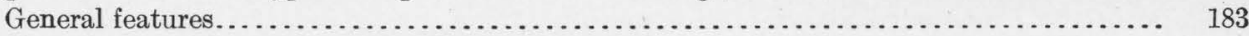

Significance of primary sulphate minerals in the genesis of ore deposits. . . . . . . . . $\quad 184$

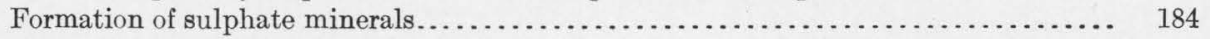

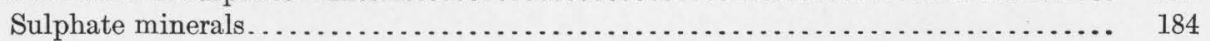

Haüynite and noselite......................................... 184

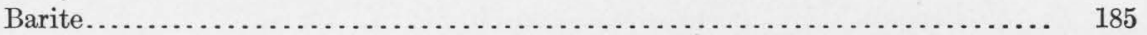

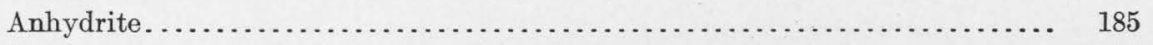

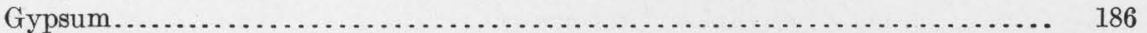

Celestite..................................................... 186

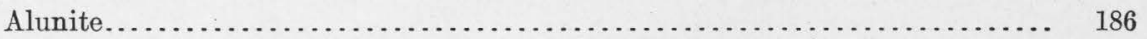

Hinsdalite....................................................... 187

Creedite.................................................... 187

Thaumasite....................................................... 187

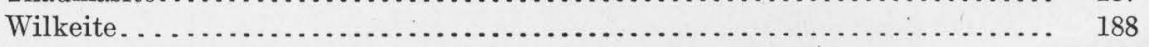

Scapolite..................................................... 188

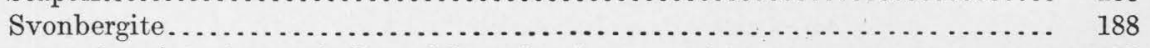

Character of ore solutions as indicated by volcanic emanations . . . . . . . . . . . . 188

Conditions of formation of sulphur trioxide.......................... 189

Formation of sulphuric acid in nature . . . . . . . . . . . . . . 190

Formation of primary sulphate minerals. . . . . . . . 190

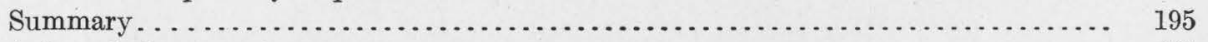

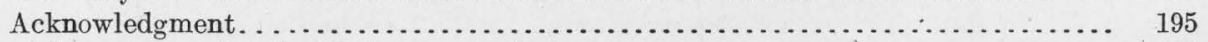

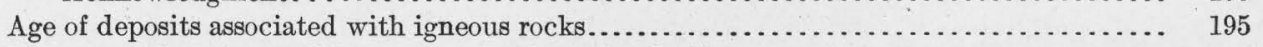

Relation of ore deposits to different types of intrusive bodies....................... 196

Nomenclature..................................................... 196

Mineralization associated with different types of intrusive bodies . . . . . . . . . . . . . 196

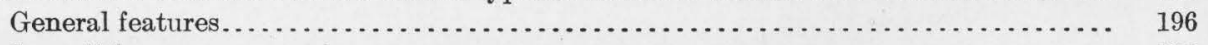

Laccoliths....................................................... 196

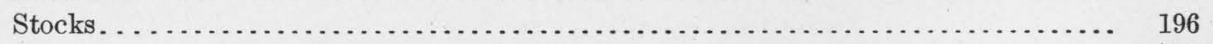

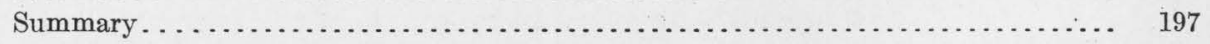

Causes of differences in mineralization. . . . . . . . . . . 197

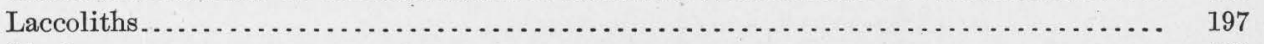

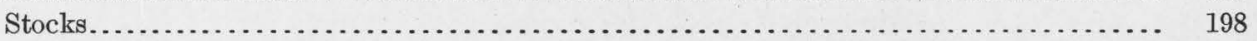

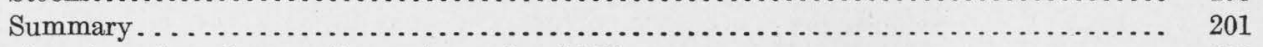

Relation of ore deposits to sedimentary rocks of different ages. . . . . . . . . . . . . . . . . 202

Alteration of the ore deposits by surface agencies................................... 202

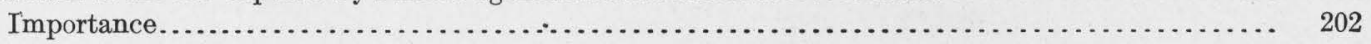

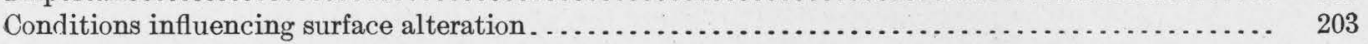

Ground-water level . . . . . . . . . . 203

Erosion . . . . . . . . . . . . . . . . 204

Character and geologic relations of the deposits................................ 204

Alteration of the principal primary metallic minerals. . . . . . . . . . . . . .

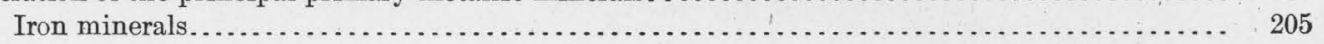

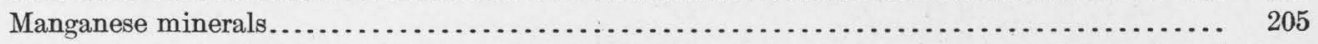


Part I. General features-Continued.

Ore deposits-Continued.

Alteration of the ore deposits by surface agencies-Continued.

Alteration of the principal primary metallic minerals-Continued. Page,

Copper minerals...................................................... 206

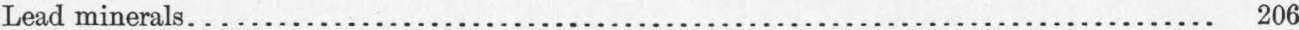

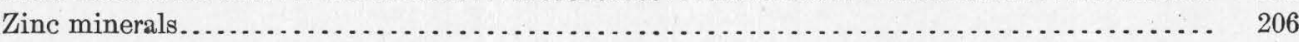

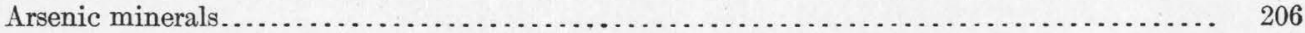

Antimony minerals. . . . . . . . .

Silver minerals..................................................... 207

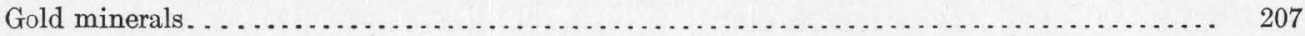

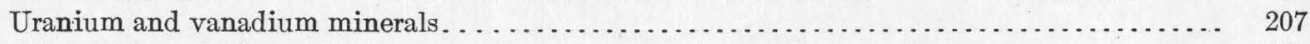

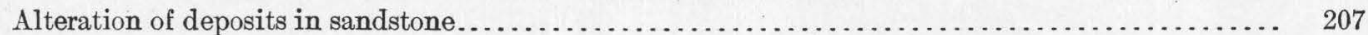

Silver deposits. . . . . . . . . . . . . 207

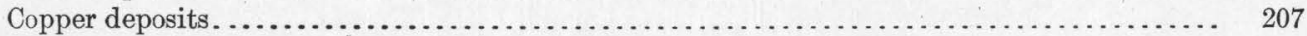

Uranium and vanadium deposits............................................ 207

Deposits in intrusive rocks................................................. 208

Pegmatitic gold quartz veins. ............................................... 208

Copper deposits in intrusive rocks . ..................................... 208

Quartz-tourmaline copper deposits................................. 208

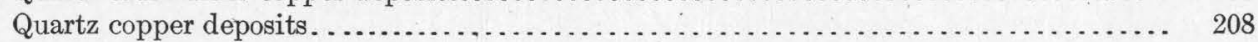

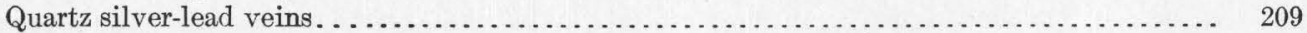

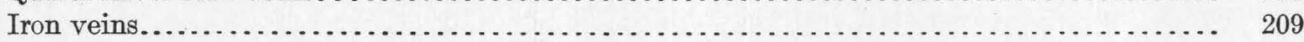

Contact deposits . . . . . . . . . . . . . .

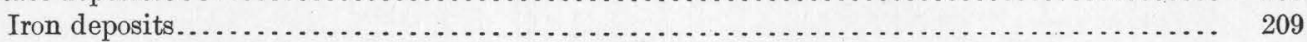

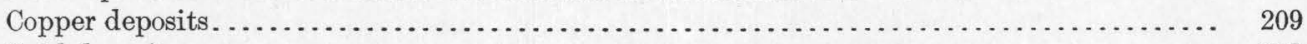

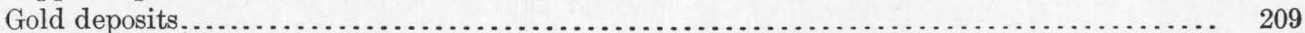

Replacement deposits in and adjacent to fissures in sedimentary rock . . . . . . . . . . . . 210

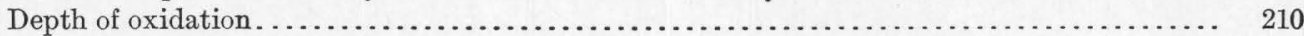

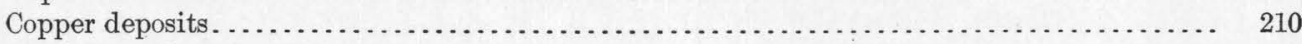

Lead-silver deposits................................................... 210

Silver deposits. . . . . . . . . . . . . . .

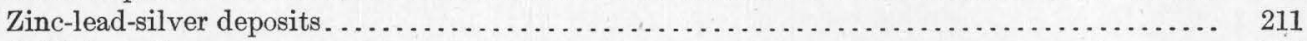

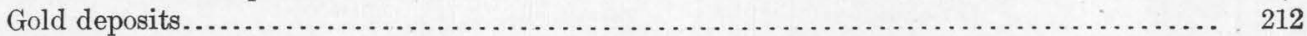

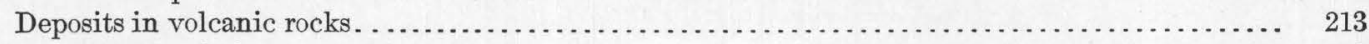

Silver-lead-zinc-copper deposits......................................... 213

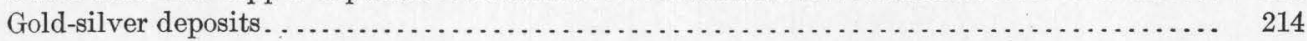

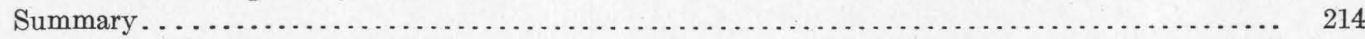

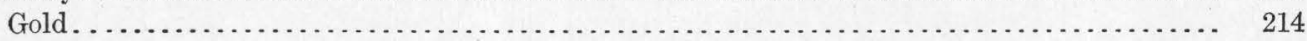

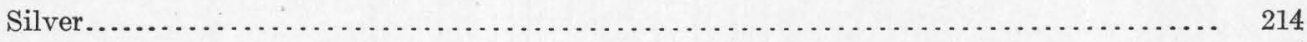

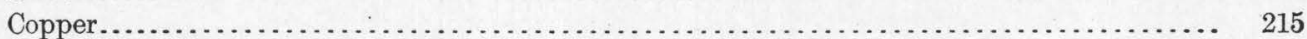

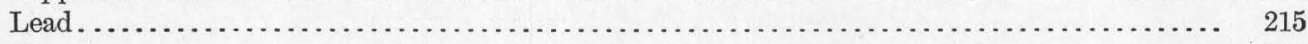

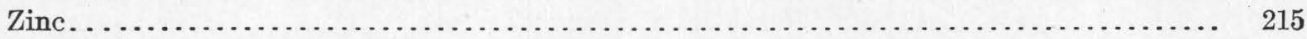

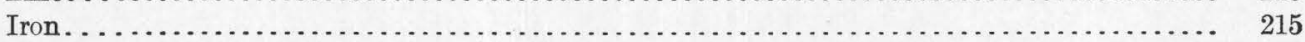

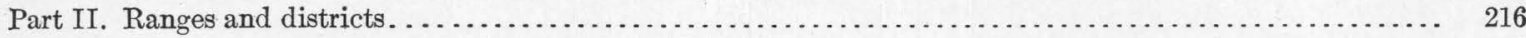

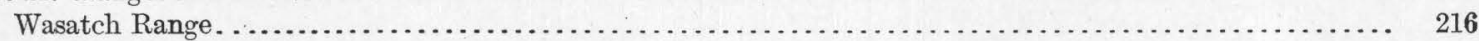

Region north of Ogden, by G. F. Loughlin....................................... 216

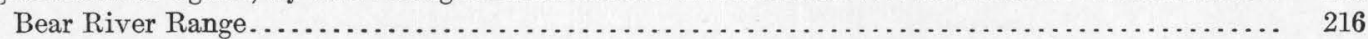

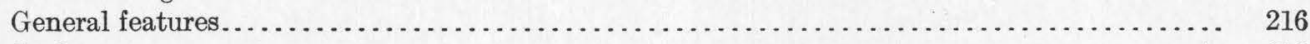

Geology . . . . . . . . . . . . . .

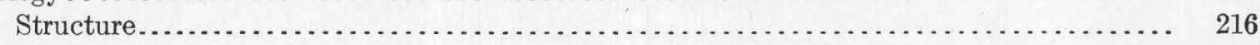

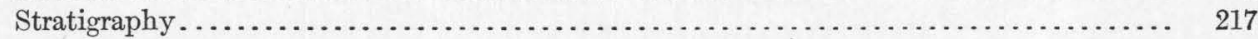

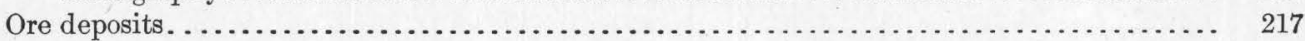

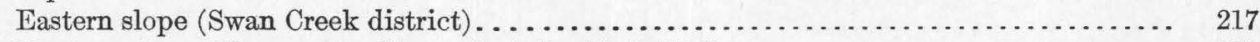

Western slope (Hyrum-Paradise region), by V. C. Heikes . . . . . . . . . . . . . . . 217

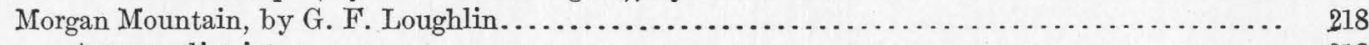

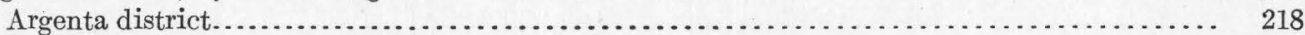

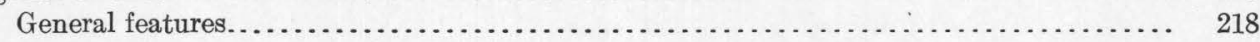

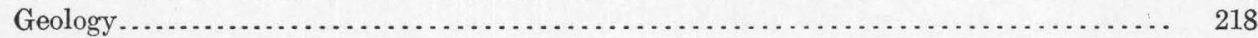

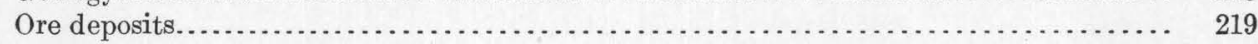

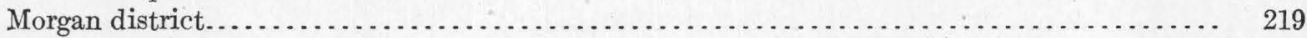

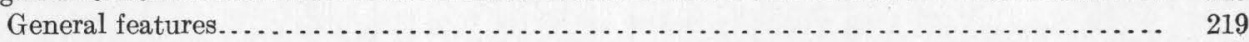

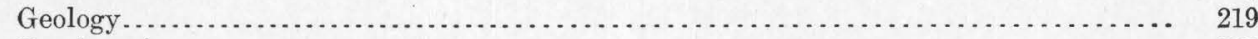

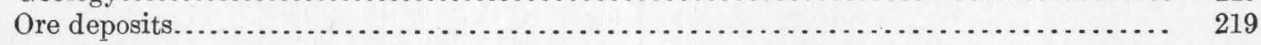


Part II. Ranges and districts-Continued.

Wasatch Range-Continued.

Region north of Ogden-Continued. Page.

Box Elder, Willard, and Weber districts................................... 221

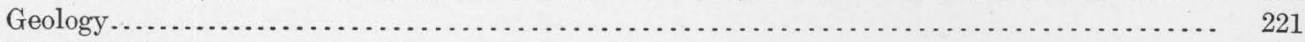

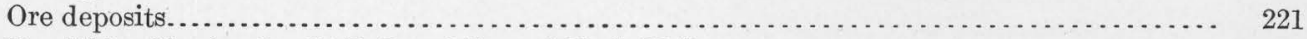

Box Elder district, by G. F. Loughlin and V. C. Heikes.......................... 222

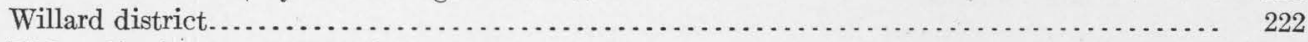

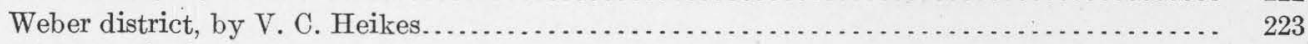

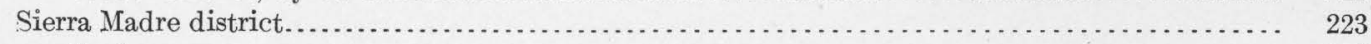

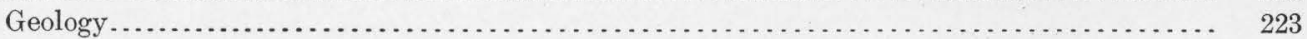

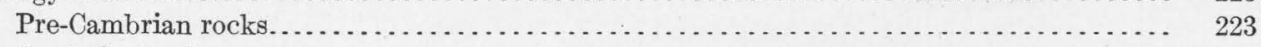

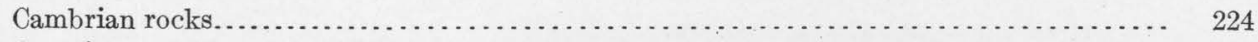

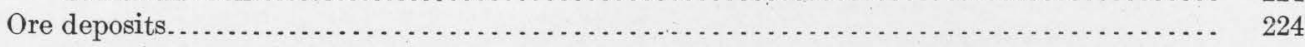

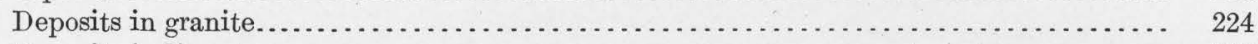

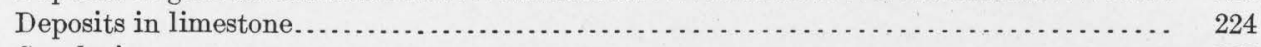

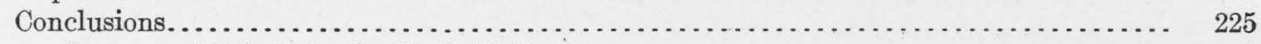

Region between Ogden and Salt Lake, by V. C. Heikes. . . . . . . . . . . . . . . . . . . . . 226

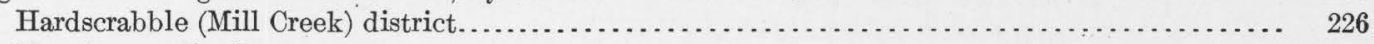

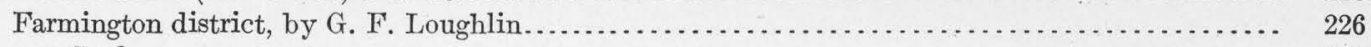

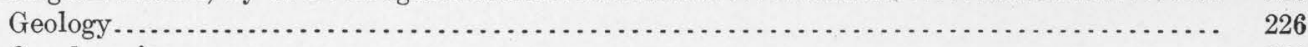

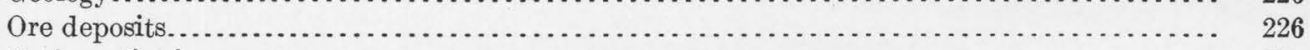

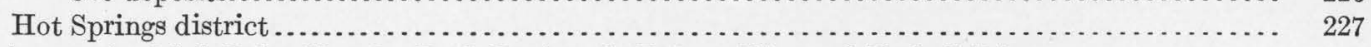

Region south of Salt Lake City, by B. S. Butler, G. F. Loughlin, and F. C. Calkins................ 227

Cottonwood-Park City region ............................................... 227

General features, by F. C. Calkins.................................... 227

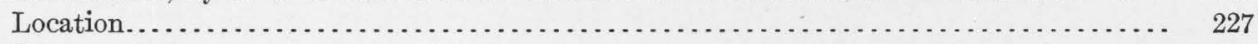

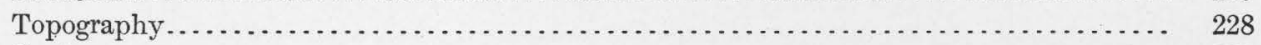

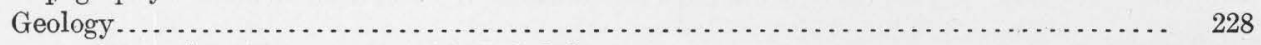

Cottonwood-American Fork area, by F. C. Calkins.......................... 229

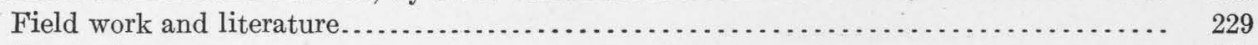

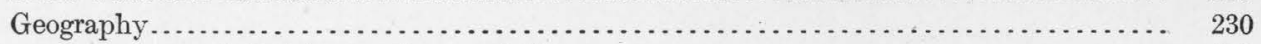

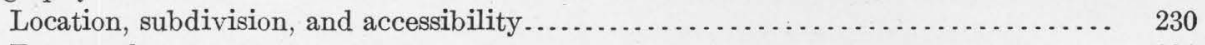

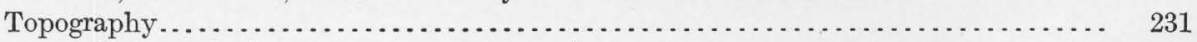

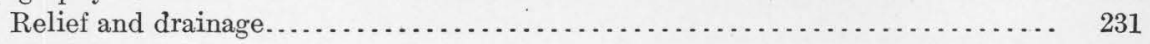

Glacial features............................................. 232

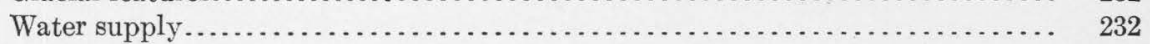

Climate and vegetation............................................ 232

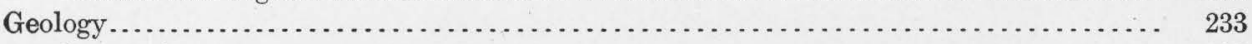

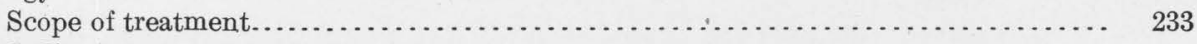

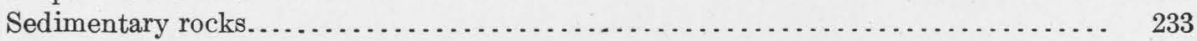

Treatment and subdivision...................................... 233

Pre-Cambrian rocks......................................... 234

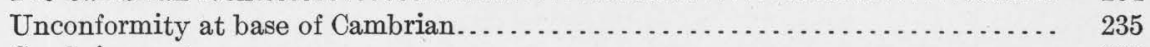

Cambrian system.............................................. 235

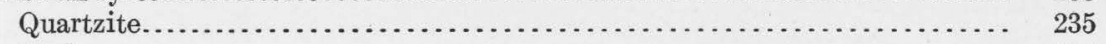

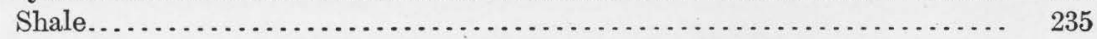

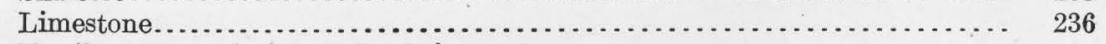

Fossils and correlation of Cambrian rocks........................ 237

Unconformity at base of Devonian or Carboniferous limestone................ 237

Devonian (?) and Carboniferous limestone.......................... 238

Distribution and character.................................. 238

Age and correlation.......................................... 239

Igneous rocks...................................................... 239

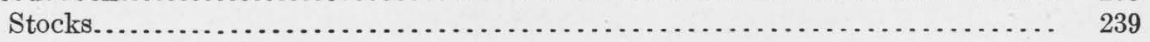

General relations............................................. 239

Little Cottonwood stock..................................... 239

Alta-Clayton Peak stock....................................... 240

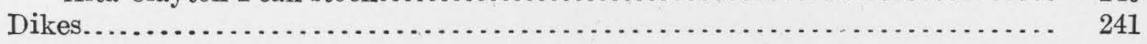

Classification............................................. 241

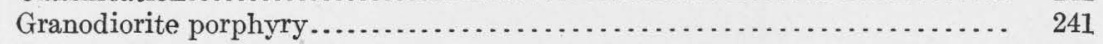

Soda granite porphyry.......................................... 241

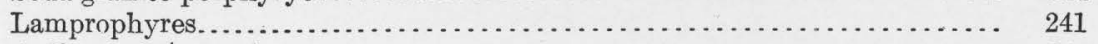

Aplite and pegmatite....................................... 241

Contact metamorphism....................................... 242 
Part II. Ranges and districts-Continued.

Wasatch Range-Continued.

Region south of Salt Lake City-Continued.

Cottonwood-Park City region-Continued.

Cottonwood-American Fork area-Continued.

Geology-Continued.

Page.

Structure.................................................... 243

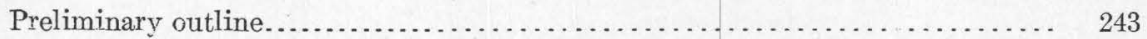

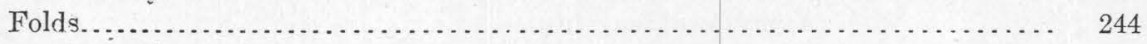

Park City anticline..................................... 244

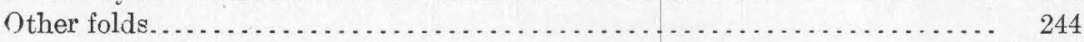

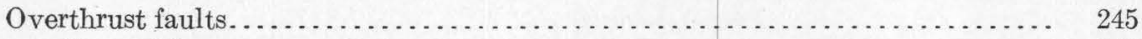

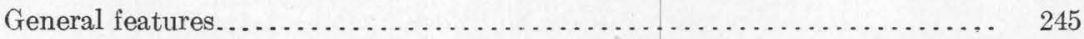

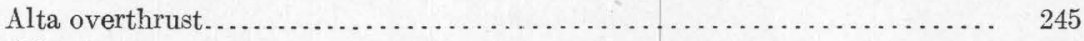

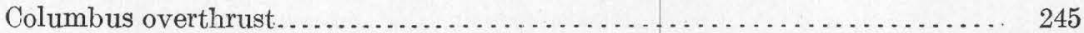

Reade and Benson thrust zone............................... 246

Grizzly thrust zone........................................ 246

Normal faults and steep reversed faults............................. 247

General features........................................ 247

Big Cottonwood fault........................................ 247

Silver Fork fault ..................................... 247

Superior faults ................................................... 248

Minor faults near Mill D South Fork ............................. 248

General character................................... 248

Carbonate fault......................................... 249

Evarena fault............................................. 249

Sampson and other east-west faults............................ 249

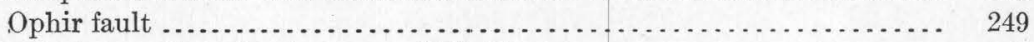

Minor faults crossing the Cottonwood Divide.......................... 249

General character...................................... 249

Snow fault.............................................. 249

Montezuma fault........................................... 249

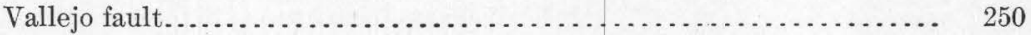

Flagstaff fault............................................ 250

Minor faults near City Rock Gulch......................... 250

Minor faults near Honeycomb Fork.......................... 250

Minor faults south of Little Cottonwood Creek..................... 250

Devils Castle group....................................... 251

Faults northwest of Mountain Lake........................ 251

Faults at head of American Fork........................... 251

Faults near Peruvian Gulch............................. 251

Mineralized fissures............................................... 251

Some genetic relations of the structural features.......................... 251

Wasatch and Uinta elements................................. 251

Relation of intrusion to deformation............................ 252

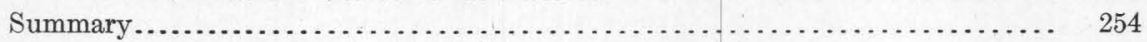

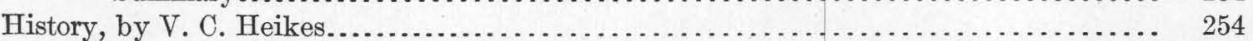

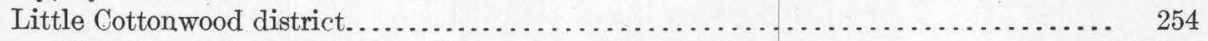

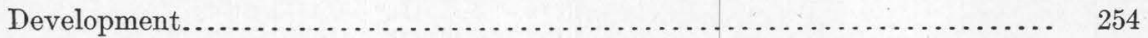

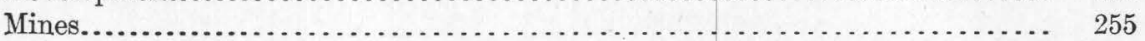

Tunnel sites...................................................... 256

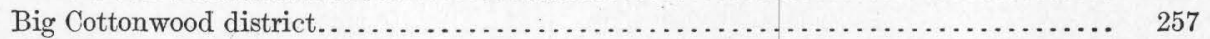

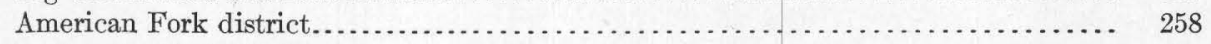

Production, by V. C. Heikes................................................ 259

Little and Big Cottonwood districts................................... 259

Total production.............................................. 259

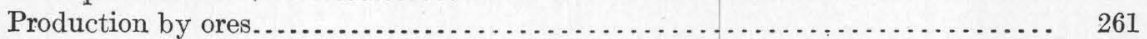

Dry or siliceous ores.................................... 261

Copper ore and concentrates.................................... 261

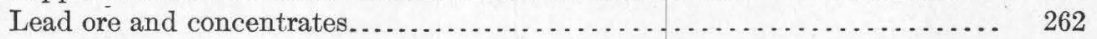

Copper-lead ore and concentrates............................... 262

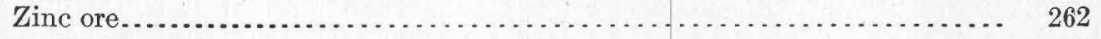

Lead-zinc ore.............................................. 262

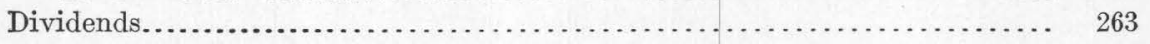

American Fork district............................................... 263 
Part II. Ranges and districts-Continued.

Wasatch Range-Continued.

Region south of Salt Lake City-Continued.

Cottonwood-Park City region-Continued.

Cottonwood-American Fork area-Continued. Page.

Ore deposits, by B. S. Butler............................................ 265

Development.................................................... $\quad 265$

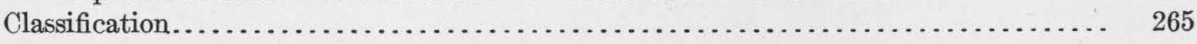

Veins in intrusive rocks............................................. 265

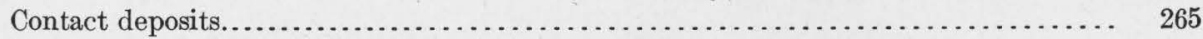

Fissure deposits................................................. ${ }_{26} 66$

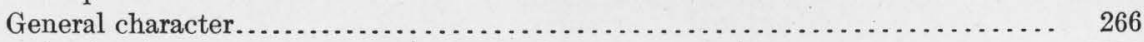

Veins in Big and Little Cottonwood districts........................... 266

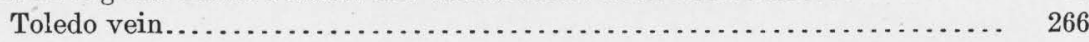

Grizzly and City Rock fissures................................ 266

Honeycomb Fork....................................... 267

Savage and Montezuma claims................................. 267

Cardiff vein............................................... 268

Veins on American Consolidated Copper Co.'s property................ 268

Howell mine.............................................. 268

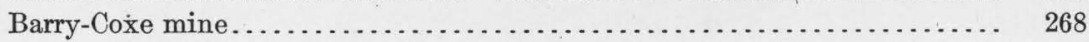

Veins in American Fork district................................. 269

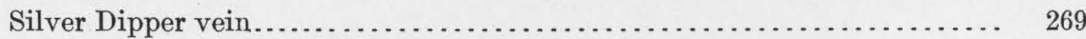

Waterfall vein............................................ 269

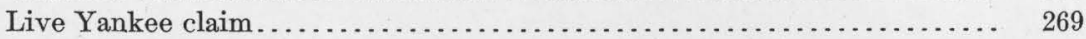

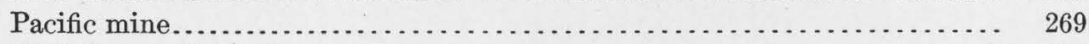

Utah Centennial claims...................................... 269

Wild Dutchman mine......................................... 270

Dutchman mine........................................ 270

Bay State mine............................................... 270

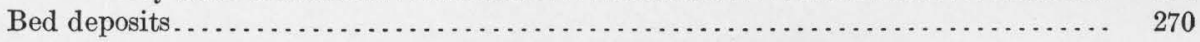

Little Cottonwood district........................................ 270

Occurrence and character of deposits ........................... 270

Horizon of the bed deposits................................... 272

Physical condition of replaced rock........................... 272

Emma mine............................................ 273

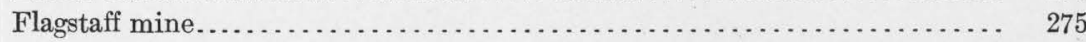

Vallejo and North Star claims.............................. 275

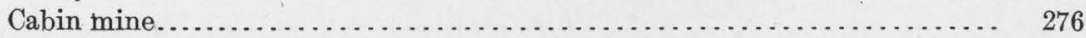

South Hecla mine...................................... 276

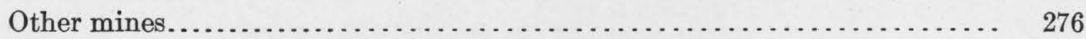

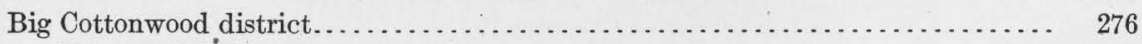

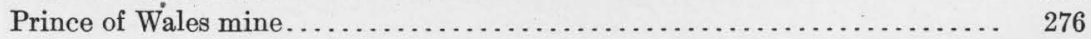

Kennebec group...................................... 277

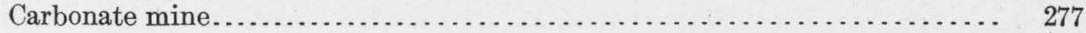

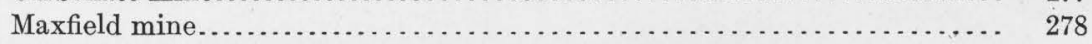

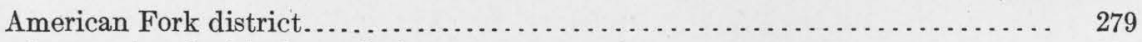

Deposits associated with thrust faults................................... 280

General features......................................... 280

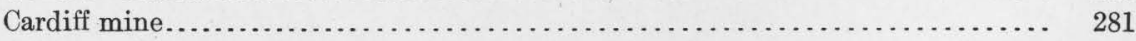

Columbus-Rexall mine...................................... 281

Wasatch mines............................................ 282

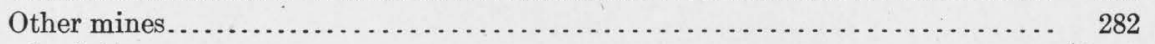

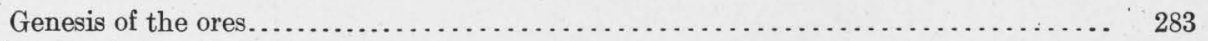

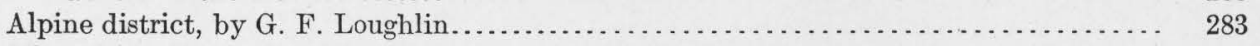

Silver Lake district, by V. C. Heikes.......................................... 284

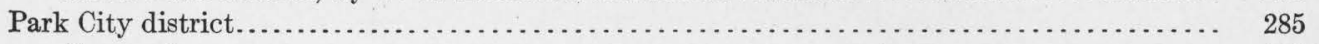

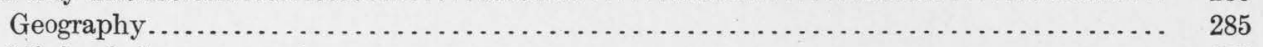

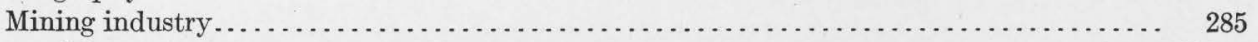

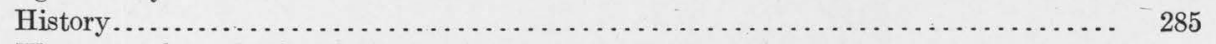

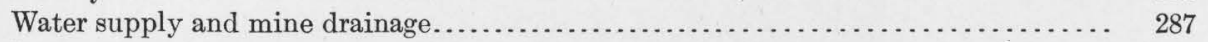

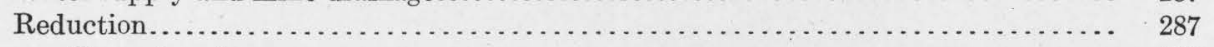

Character of ores........................................... 287

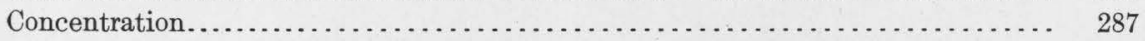


Part II. Ranges and districts-Continued.

Wasatch Range-Continued.

Region south of Salt Lake City-Continued.

Cottonwood-Park City region-Continued.

Park City district-Continued.

Mining industry-Continued.

Reduction-Continued.

Treatment of zinc ores.

Page.

.

Metal content of ores, by V. C. Heikes...................................... 289

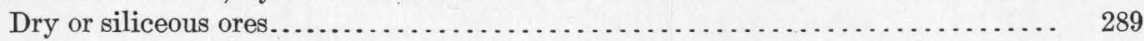

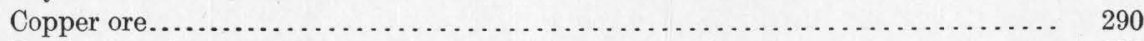

Lead ore and concentrates...................................... $\quad 290$

Copper-lead ores......................................... 291

Zinc concentrates............................................. 291

Lead-zinc concentrates........................................... 291

Production, by V. C. Heikes........................................... 292

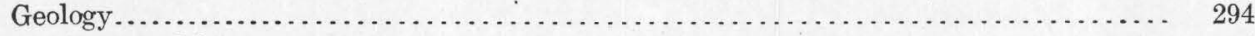

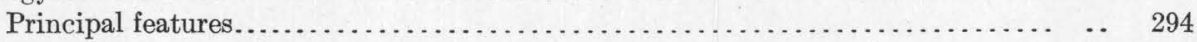

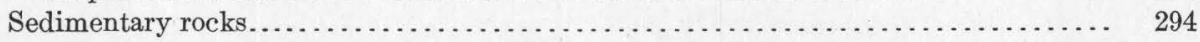

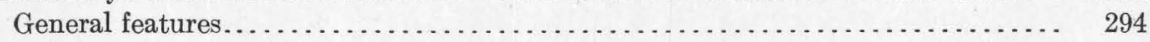

Carboniferous system ......................................... 294

Undifferentiated limestones ................................... 294

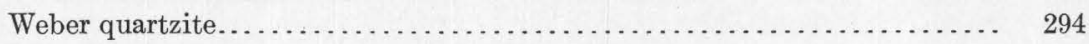

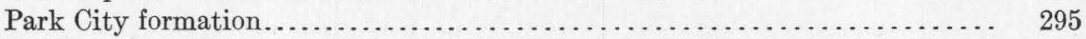

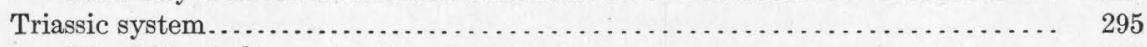

Woodside shale.............................................. 295

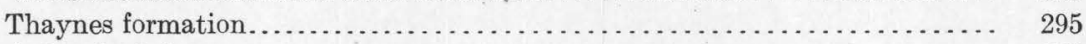

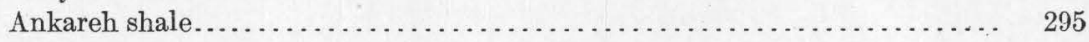

Nugget sandstone......................................... 295

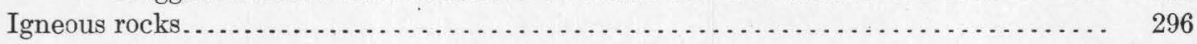

Topographic occurrence....................................... 296

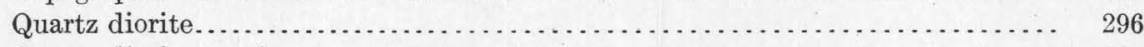

Quartz diorite porphyry..................................... 297

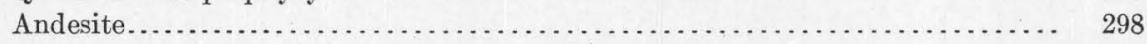

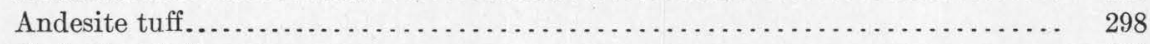

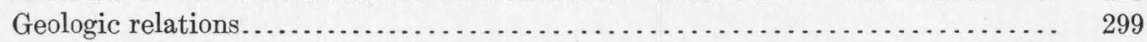

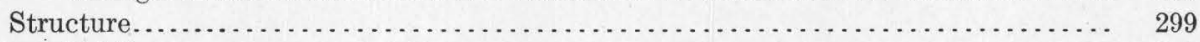

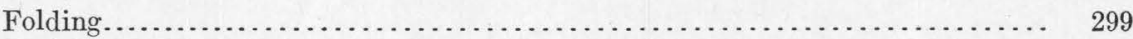

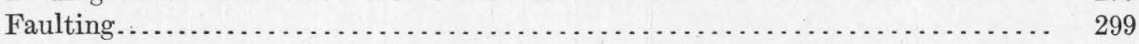

Deformation by intrusion.................................... 301

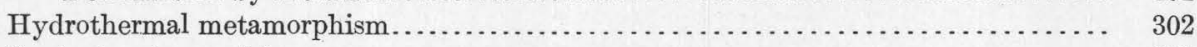

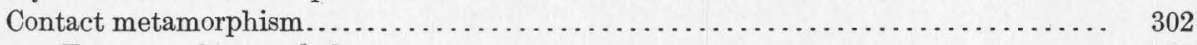

Extent and general character.................................. 302

Alteration of limestone.................................... $\quad 302$

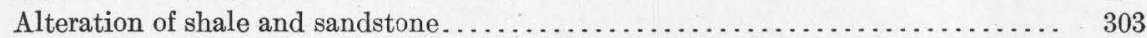

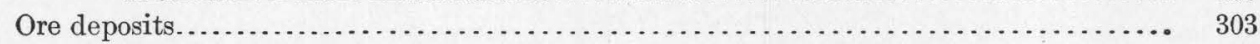

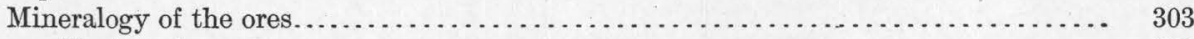

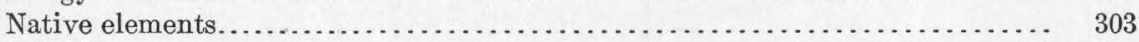

Sulphides................................................. 303

Sulpharsenites and sulphantimonites................................. 303

Chlorides and fluorides..................................... 304

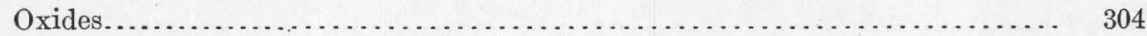

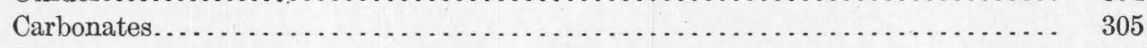

Silicates.................................................. 305

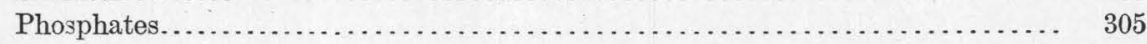

Arsenates................................................... 306

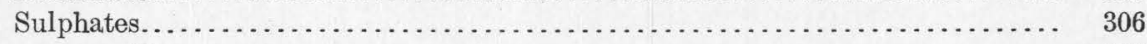

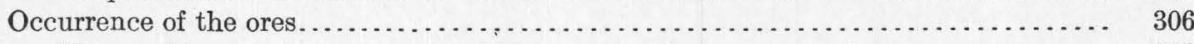

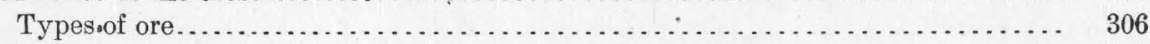

Lode deposits.............................................. 306

Bed deposits............................................... $\quad 310$ 
Part II. Ranges and districts-Continued.

Wasatch Range-Continued.

Region south of Salt Lake City - Continued.

Cottonwood-Park City region-Continued.

Park City district-Continued.

Ore deposits-Continued.

uperficial alteration of ores...................................... 315

Ground-water level......................................... $\quad 315$

Extent and character of alteration................................. 315

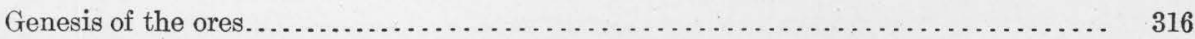

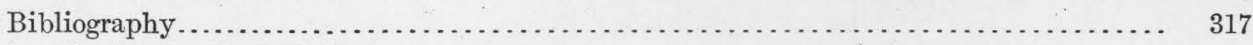

Blue Ledge district, by V. C. Heikes....................................... 318

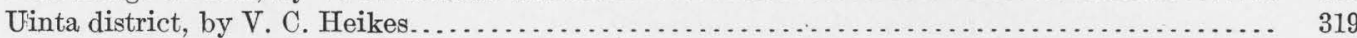

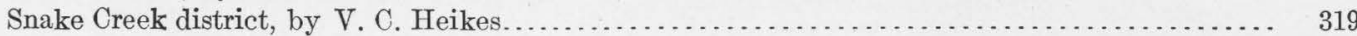

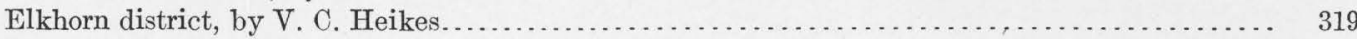

Provo district, by G. F. Loughlin ....................................... 320

General features..................................................... 320

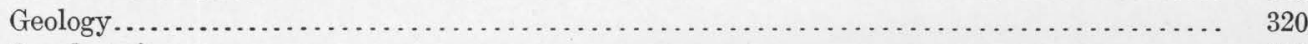

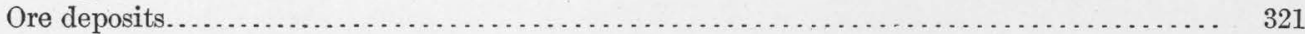

Payson district, by V. C. Heikes............................................ 322

Spanish Fork district, by V. C. Heikes........................................... 322

Santaquin and Mount Nebo region, by G. F. Loughlin................................... 322

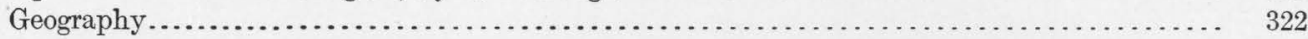

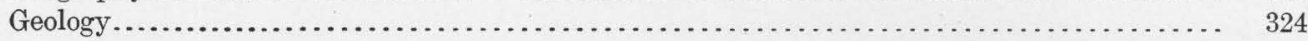

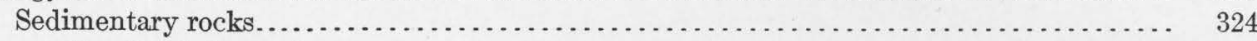

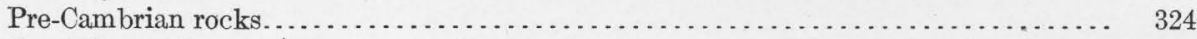

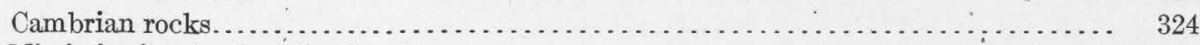

Mississippian (and earlier?) rocks.................................... 325

Mesozoic rocks.................................................. 326

Tertiary rocks............................................... 326

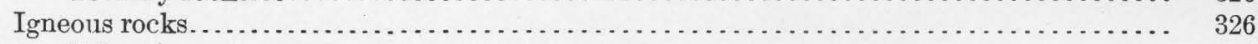

Volcanic rocks............................................ 326

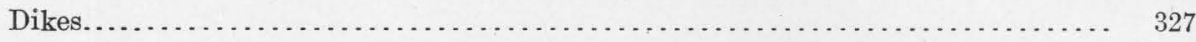

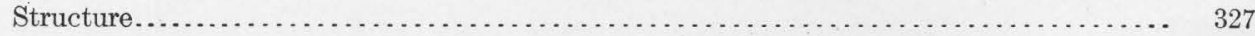

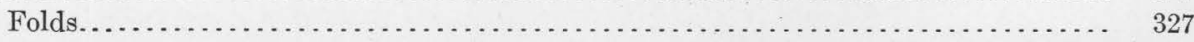

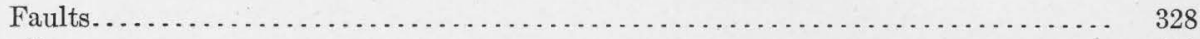

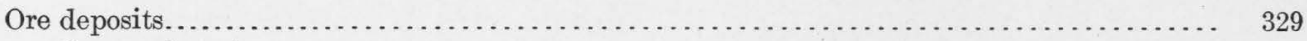

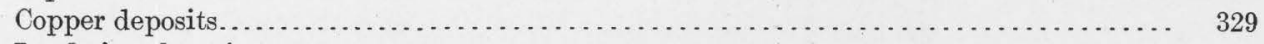

Lead-zinc deposits................................................... 330

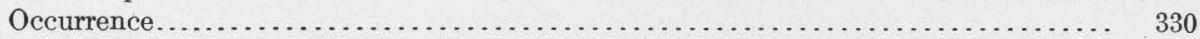

Santaquin Ridge............................................. 330

Union Chief mine............................................ 330

Blue Eagle and White Dragon prospects........................... 331

Mount Nebo Ridge............................................... 332

Big Nebo mine............................................... 332

Santaquin Chief mine............................................. 332

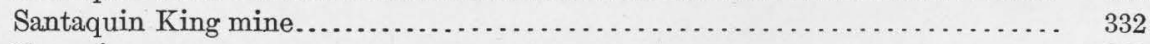

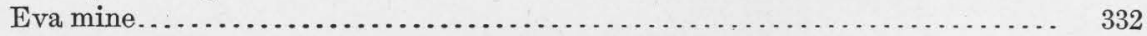

Eureka Leasing \& Mining Co.'s claims.............................. 333

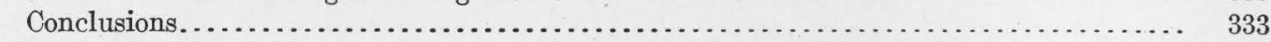

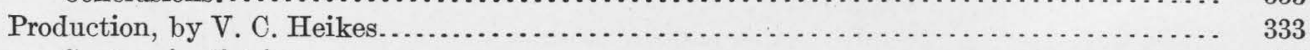

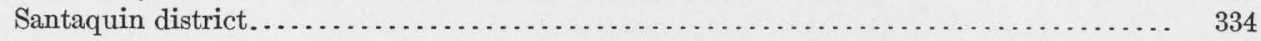

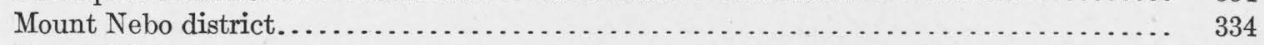

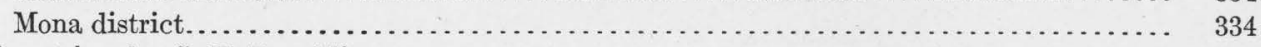

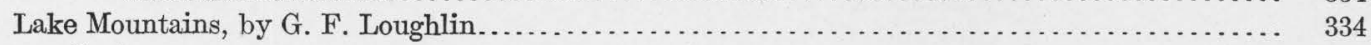

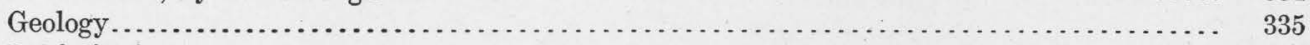

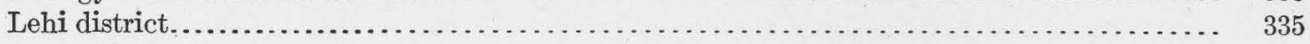

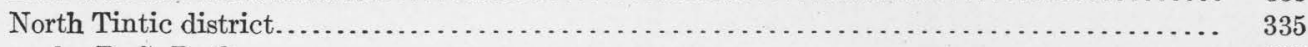

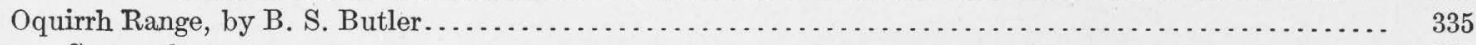

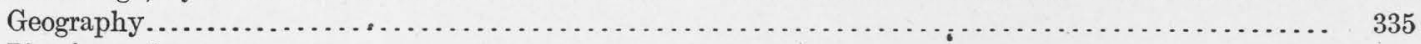

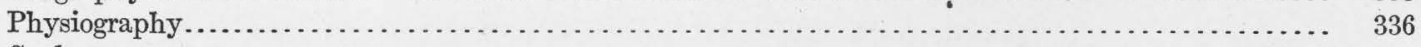

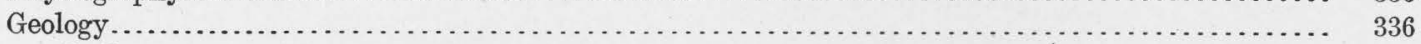

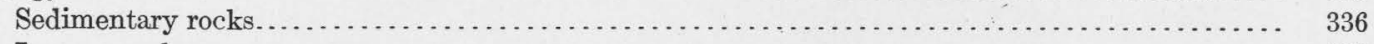

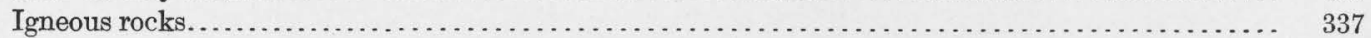


Part II. Ranges and districts-Continued.

Oquirrh Range-Continued.

Geology-Continued.

Structure.

Folding..

Faulting.

Ore deposits.

Character and distribution

Geologic relations

Mineralogy.

(1) 340

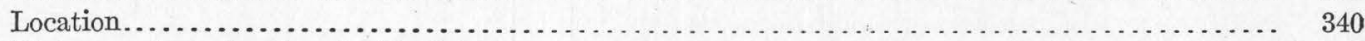

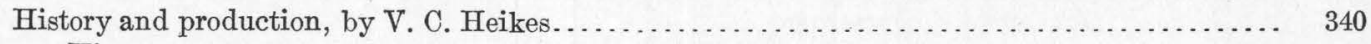

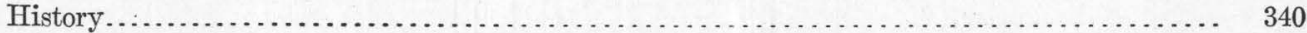

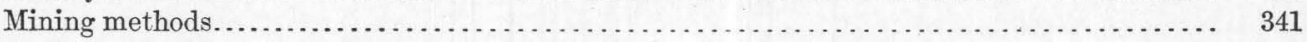

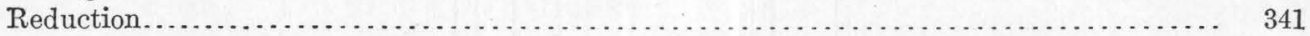

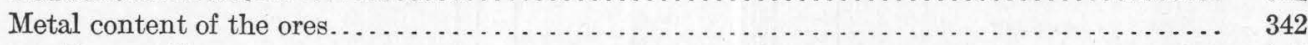

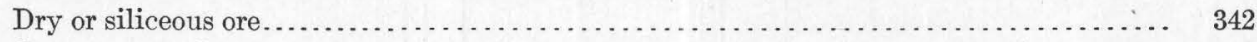

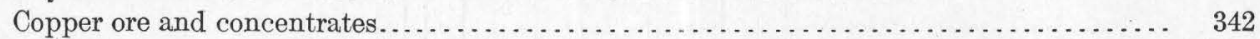

Lead ore and concentrates............................................. 343

Copper-lead ore ..................................................... 344

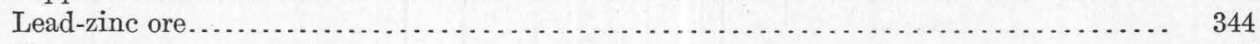

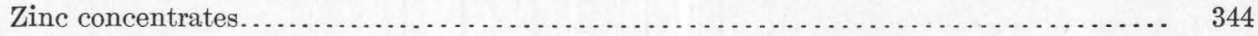

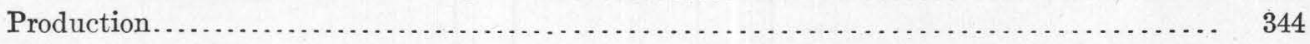

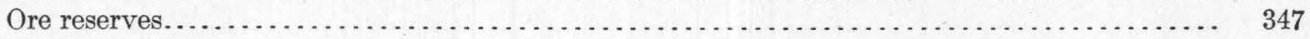

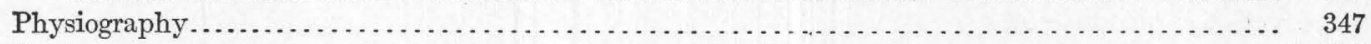

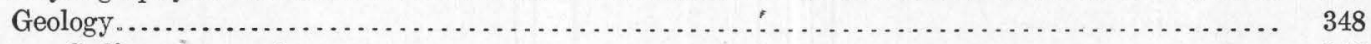

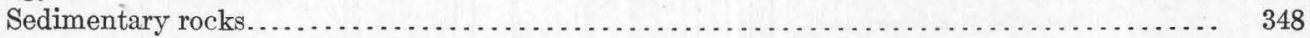

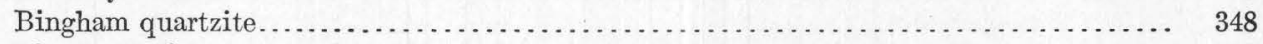

Limestones interbedded in Bingham quartzite............................ 348

Recent deposits..................................................... 349

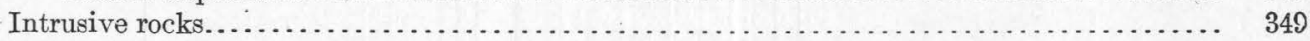

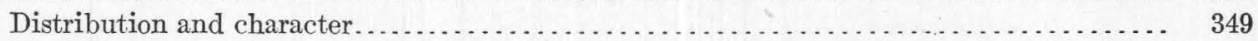

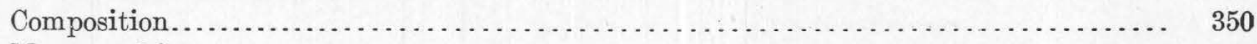

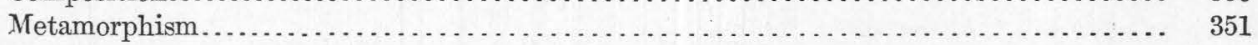

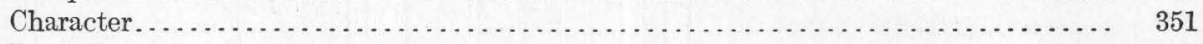

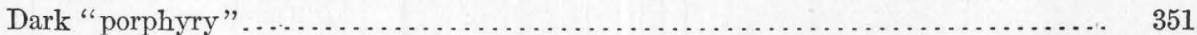

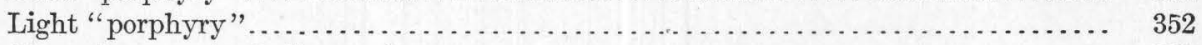

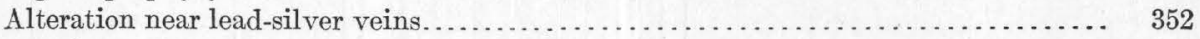

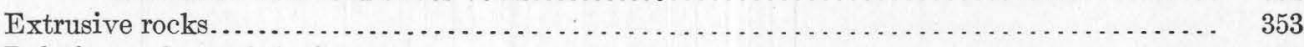

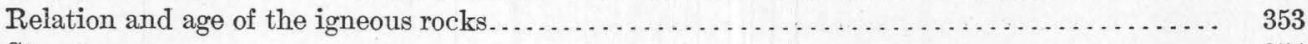

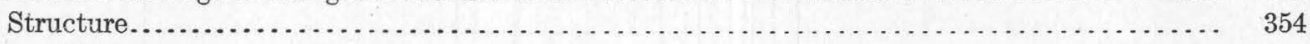

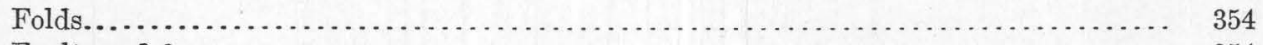

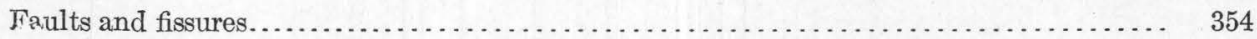

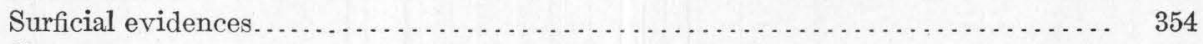

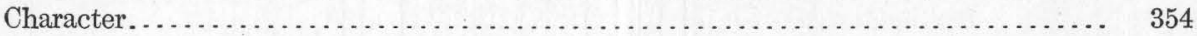

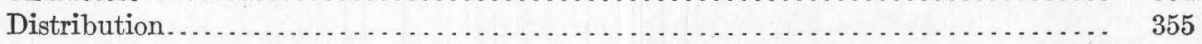

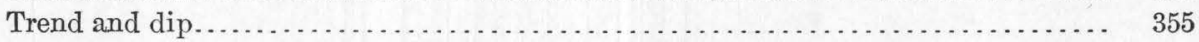

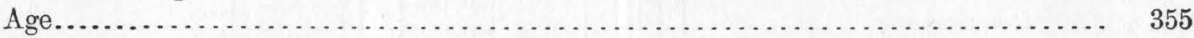

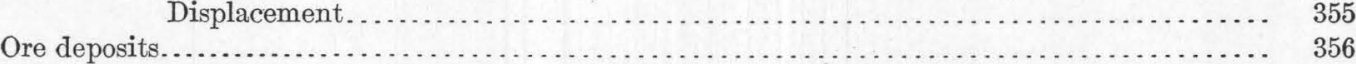

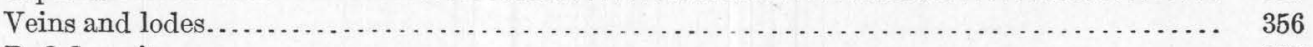

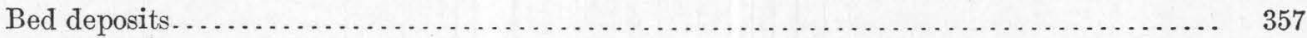

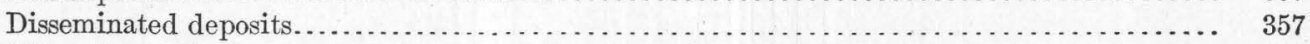

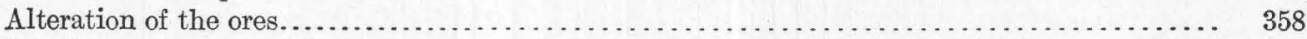

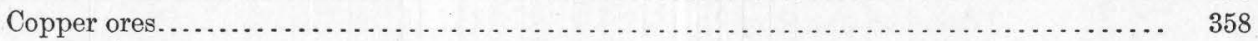

Replacement deposits.......................................... 358

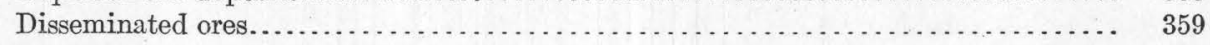

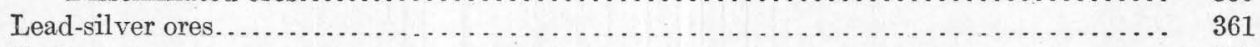

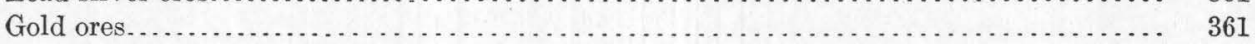

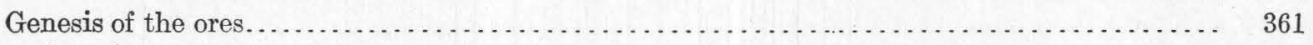

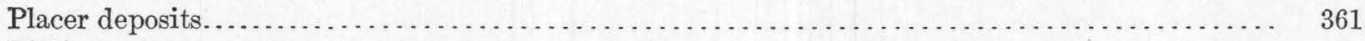

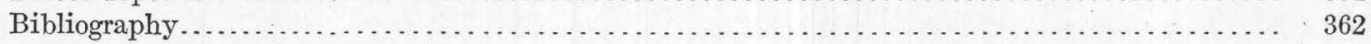


Part II. Ranges and districts-Continued.

Oquirrh Range-Continued.

ining history and production, by V. C. Heikes................................... 362

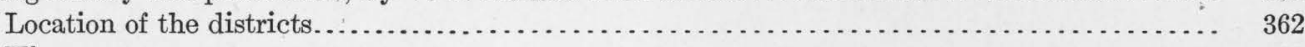

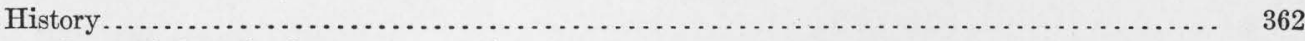

Rush Valley district.................................................. 362

Ophir district..................................................... 366

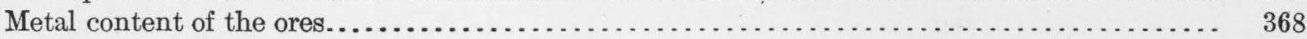

Dry or siliceous ores.................................................. 368

Copper ore........................................................ 368

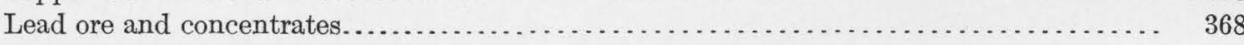

Copper-lead ore and concentrates....................................... 368

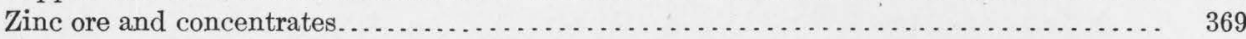

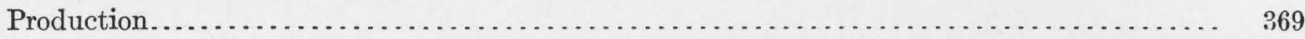

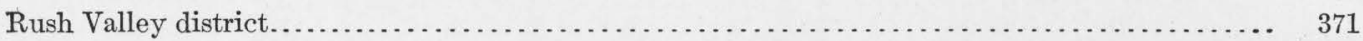

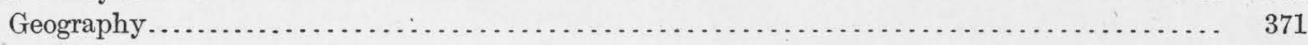

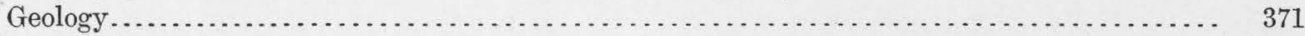

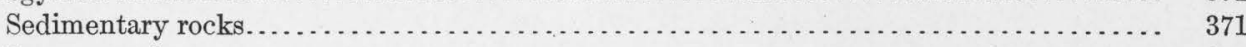

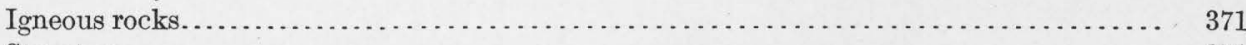

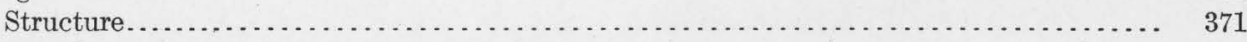

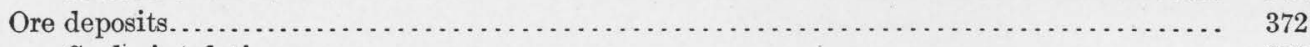

Geologic relations.................................................. 372

Metamorphism................................................ 372

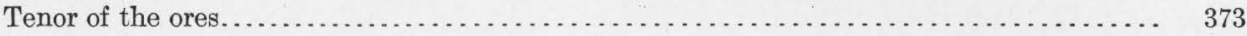

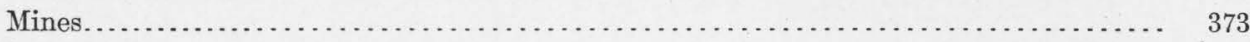

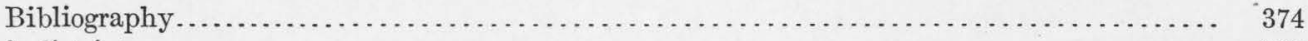

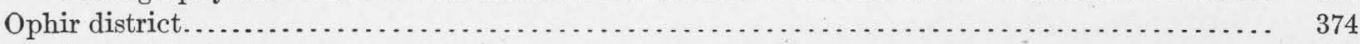

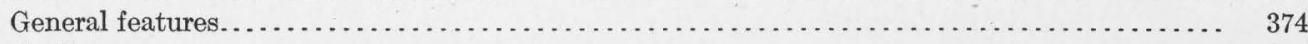

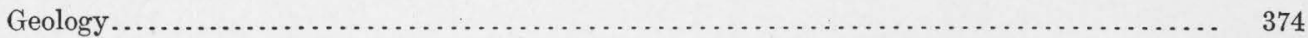

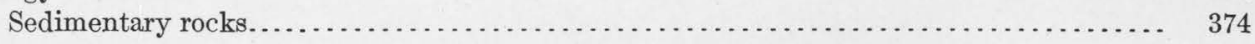

Igneous rocks....................................................... 375

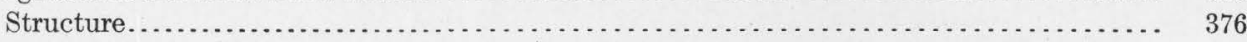

Ore deposits......................................................... 376

Replacement deposits................................................... 376

Alteration of the limestone.......................................... 376

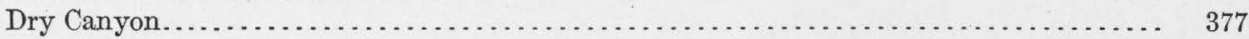

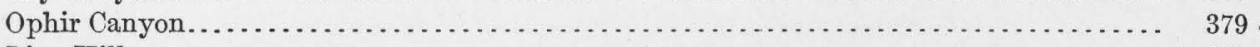

Lion Hill.................................................... $\quad 381$

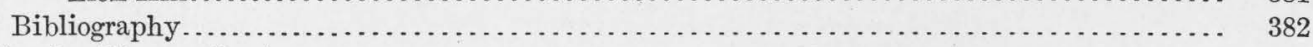

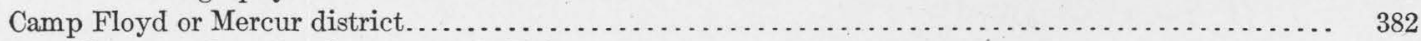

History and production, by V. C. Heikes.................................. 382

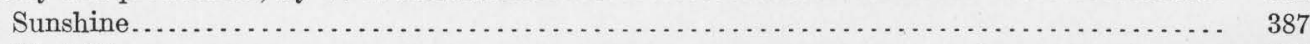

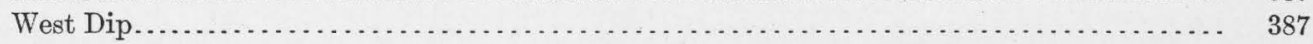

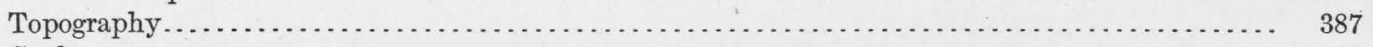

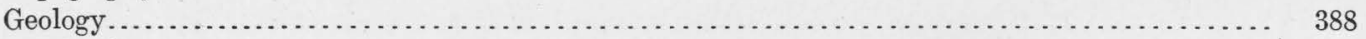

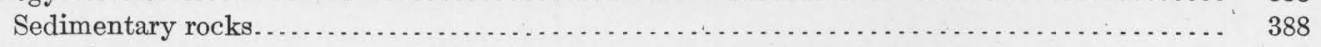

Eruptive rocks................................................ $\quad 389$

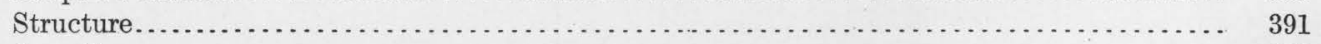

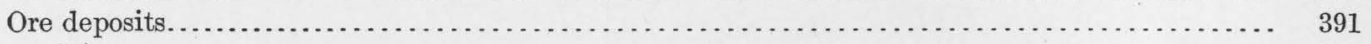

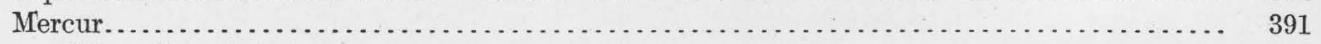

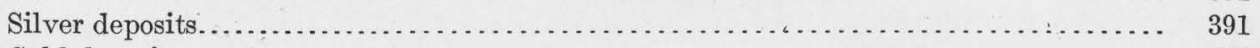

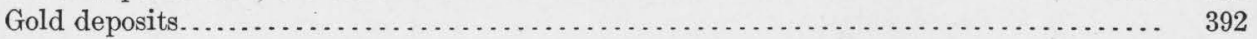

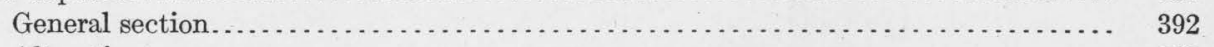

Alteration......................................................... 393

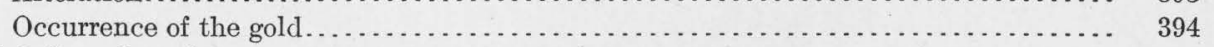

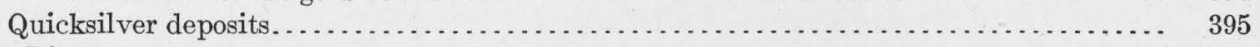

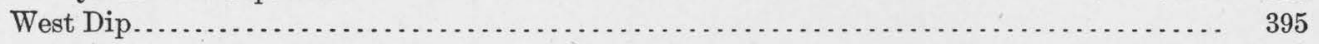

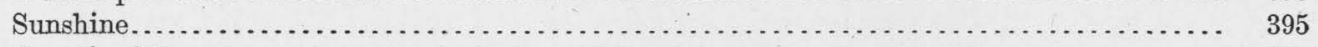

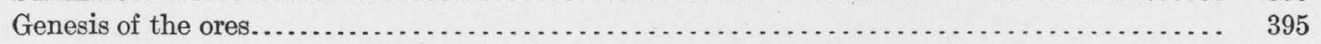

Bibliography . . . .

East Tintic Mountains, by Waldemar Lindgren and G. F. Loughlin . . . . . . . . . . . . . . . . . . 396

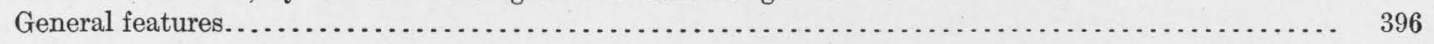


Part II. Ranges and districts-Continued.

East Tintic Mountains-Continued.

Topography.

Tintic district

Geology

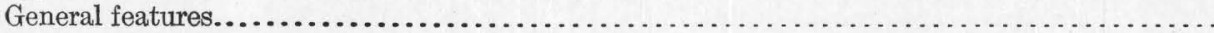

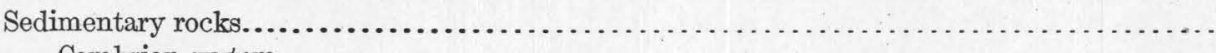

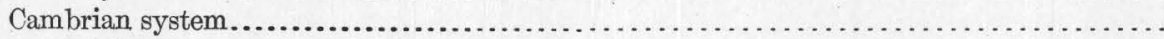

Ordovician system.

Upper Devonian system $\ldots$

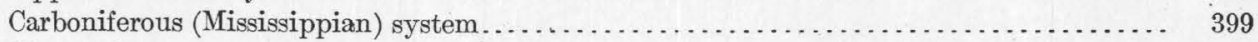

Nomenclature .................................................. 400

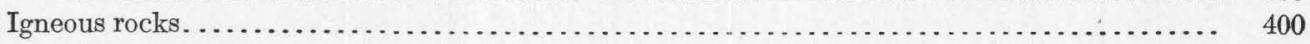

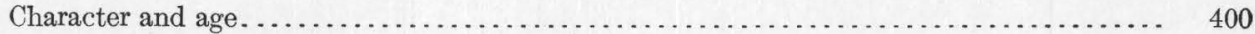

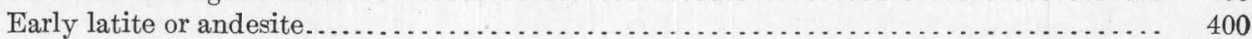

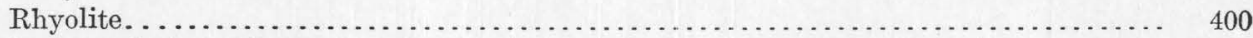

Latite-andesite series. .............................................. 401

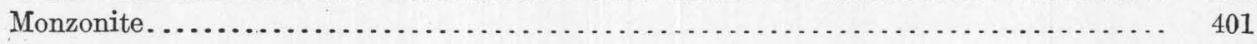

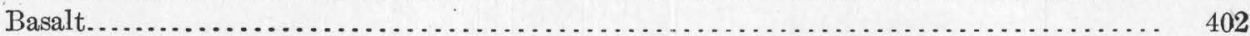

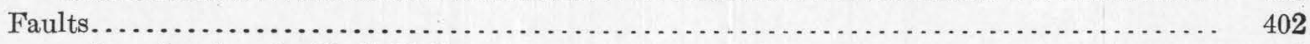

History and production, by V. C. Heikes. . . . . . . . . . . . . . . . . . . . . . . 403

Metallurgic developments............................................... 403

General features................................................. 403

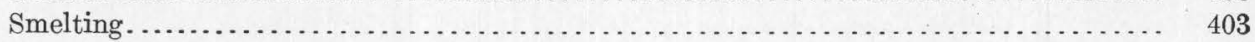

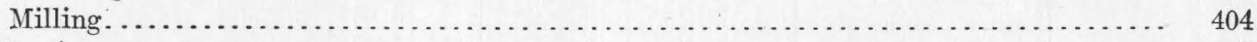

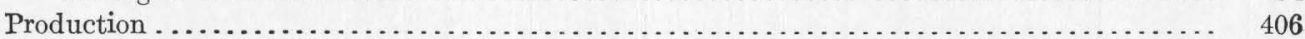

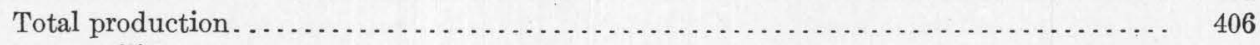

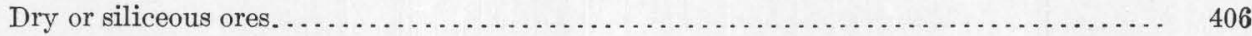

Copper ores. . . . . .

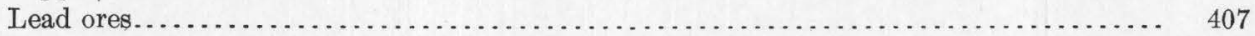

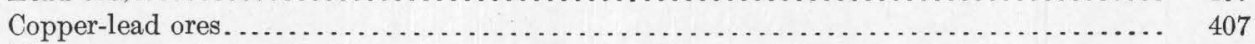

Zinc ores. . . . . . . . . . . . . .

Lead-zinc ores. . . . . . . . . . . . .

Ore deposits. . . . . . . . . . .

Distribution. . . . . . . . . . . . .

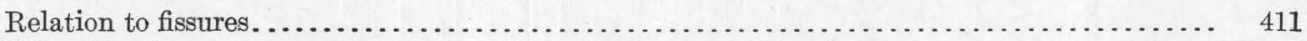

Mineralization....................................................... 412

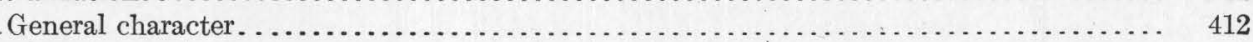

Deposits in igneous rocks.......................................... 412

Veins...................................................... 412

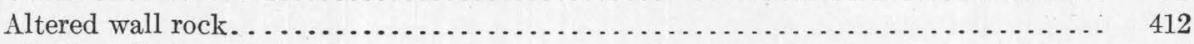

Deposits in sedimentary rocks. . . . . . . . . . . . . . . . . . . . . . . . .

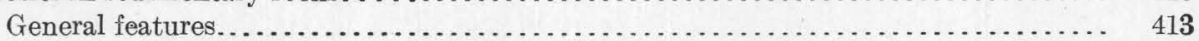

Oxidation .................................................. 413

Relation of ore bodies to country rock. . . . . . . . . . . . . . .

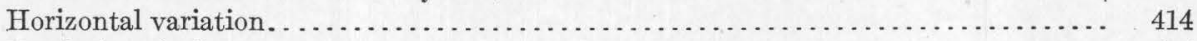

Vertical variation . . . . . . . . . . . . . . . . . . . . . . . . . . . .

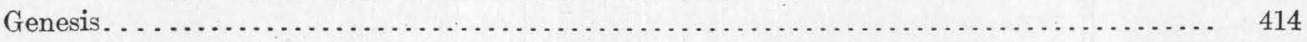

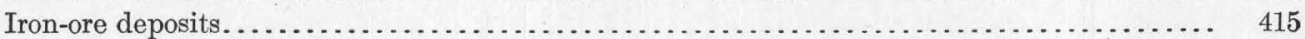

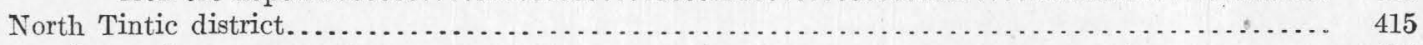

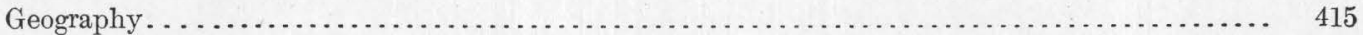

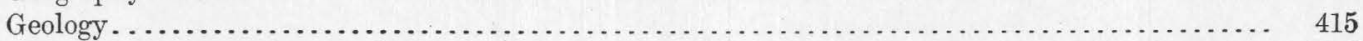

History and production, by V. C. Heikes...................................... 416

Ore deposits. . . . . . . . . . . . . . . . .

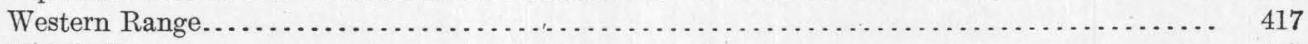

Middle Range......................................................... 417

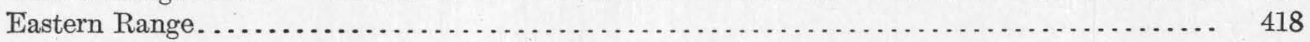

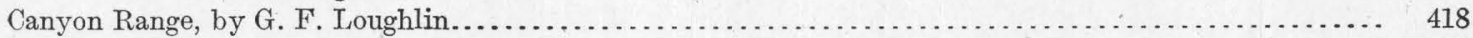

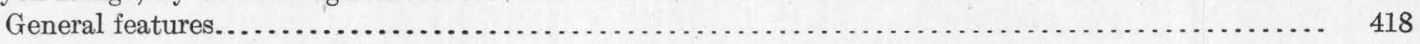

Geology . . . . . . . . . . . . . . . . .

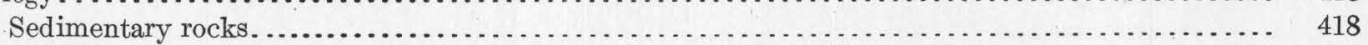

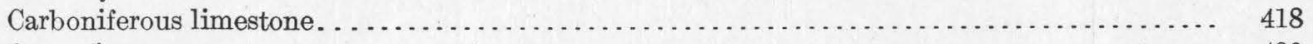

Quartzite.......................................................... 420 
Part II. Ranges and districts-Continued.

Canyon Range-Continued.

Geology-Continued.

Sedimentary rocks-Continued. Page.

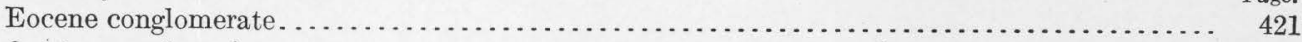

Quaternary deposits. . . . . . . . . . . . .

Volcanic rocks......................................................... 421

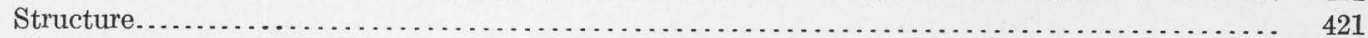

Leamington $(\mathrm{Oak}$ Creek) district. . . . . . . . . . . . . . . . . . . . . . .

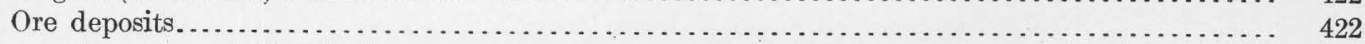

Character and distribution. . . . . . . . . .

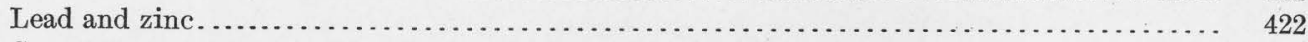

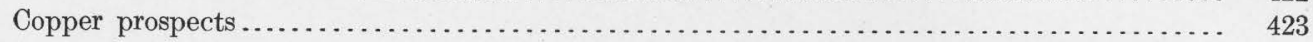

Comparison with ores of other districts ....................................... 423

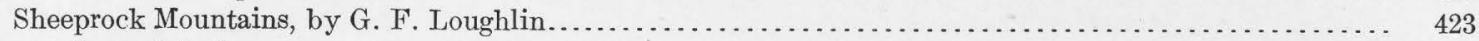

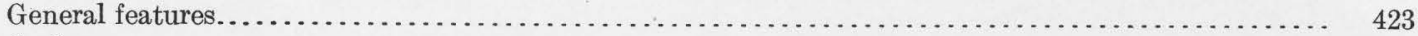

Geology . . . . . . . . . . . . . . . . . . .

Columbia and Erickson districts. . . . . . . . . . . . . . . . . . . .

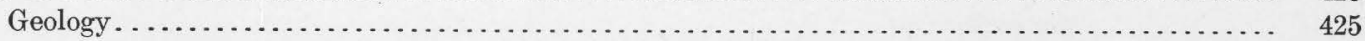

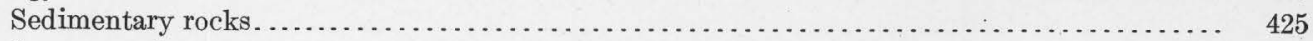

Igneous rocks. . . . . . . . . . . . . . . . . . . . . . . . . . .

Fissures. . . . . . . . . . . . . .

History and production, by V. C. Heikes . . . . . . . . . . . . . . . . . . . . . . . . . 426

Ore deposits. . . . . . . . . . . . . . . .

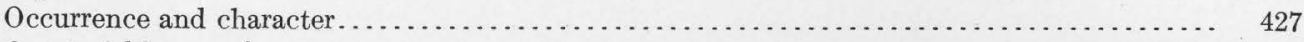

Quartz-feldspar veins................................................. 427

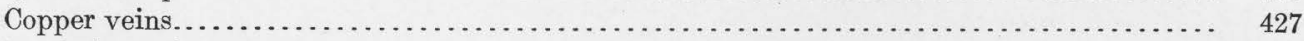

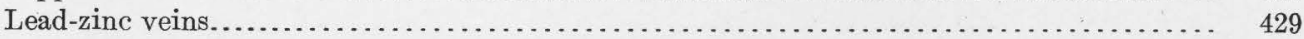

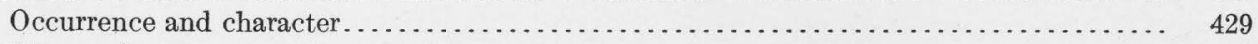

Sharp mine..................................................... 429

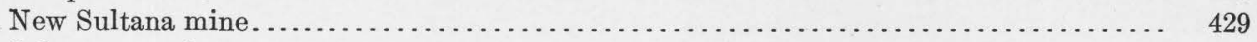

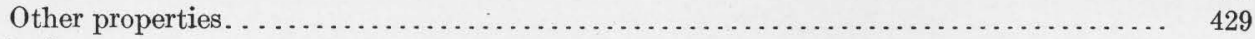

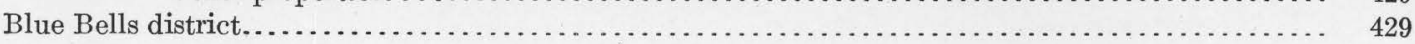

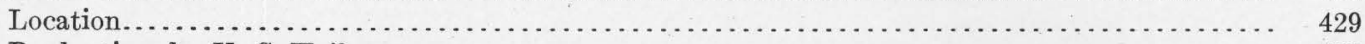

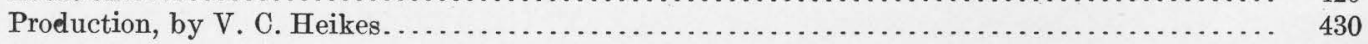

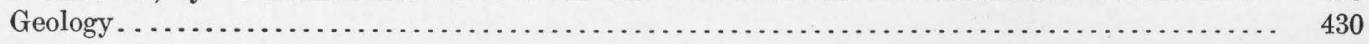

Ore deposits. . . . . . . . . . . . . . .

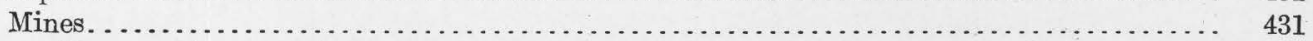

Morgan mine.................................................... 431

Black Hawk mine. . . . . . . . . . . . . .

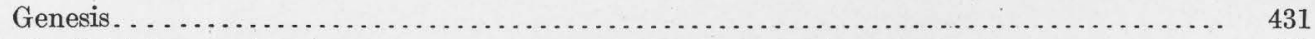

West Tintic district. . . . . . . . . . . . . . . .

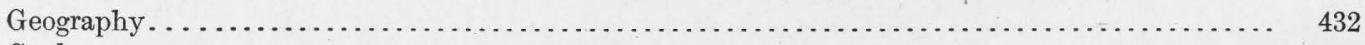

Geology ........................................................... 432

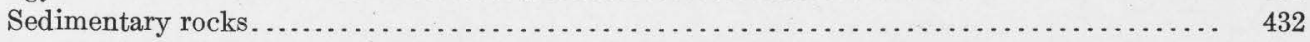

Pre-Cambrian (?) quartzite . . . . . . . . . . . . . . . . . . . . . . . . . . . . . . . . 432

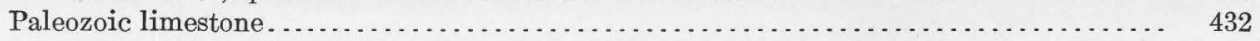

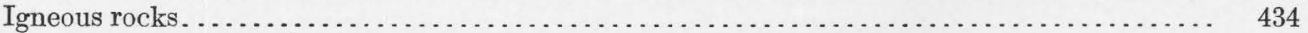

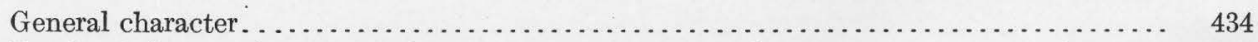

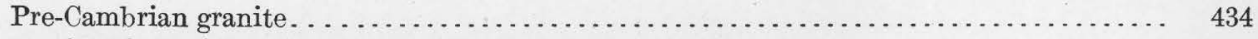

Tertiary intrusive rocks............................................. 434

Character and distribution..................................... 434

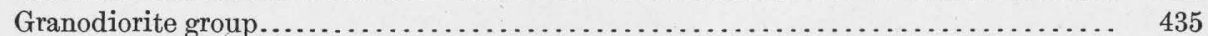

Monzonite.................................................... 436

Alteration. . . . . . . . . . . . . .

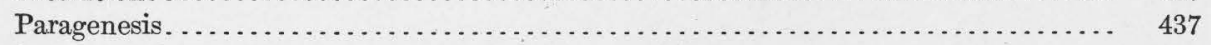

Tertiary extrusive rocks. . . . . . . . . . . . . . . . . . . . .

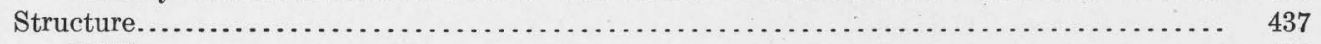

Folding . . . . . . . . . . . . . 437

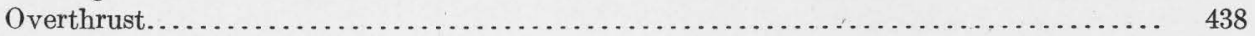

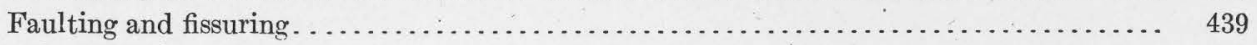

History and production . . . . . . . . . . . . . . . . . . . . . . . . . . . . . . . . . . . 439

Ore deposits. . . . . . . . . . . . . 439

General character. . . . . . . . . . . . . . . . . . . . . . . . . . . . 439 
Part II. Ranges and districts-Continued.

Sheeprock Mountains-Continued.

West Tintic district-Continued.

Ore deposits-Continued.

Mines.

Iron King mine.

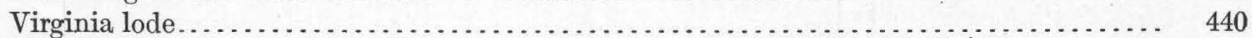

War Eagle claims.................................................. 440

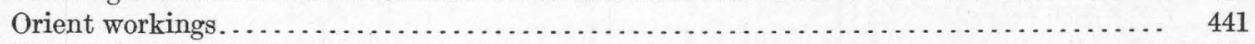

" 1903 " or " 1888 " mine............................................ 441

Allah prospect.................................................. 442

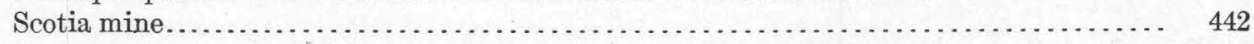

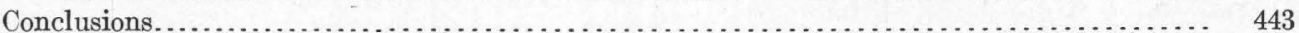

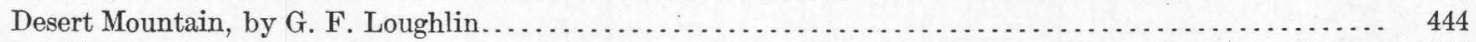

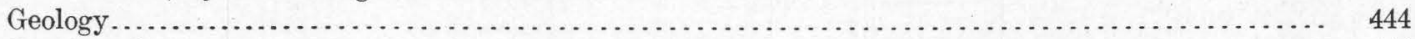

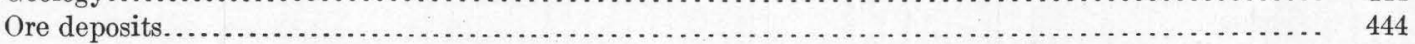

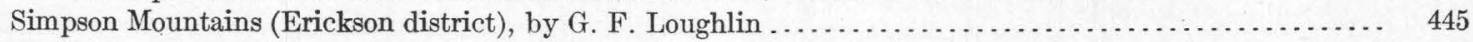

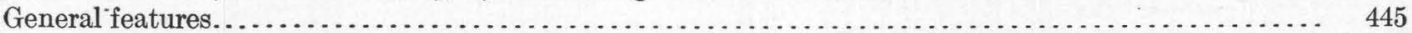

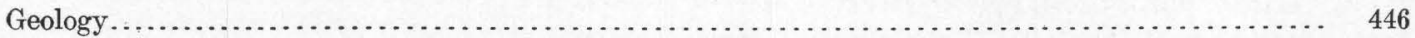

Sedimentary rocks...................................................... 446

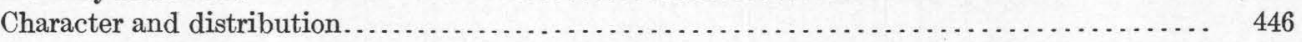

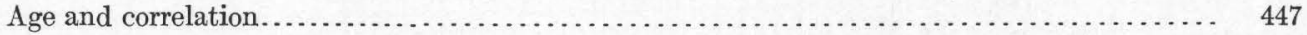

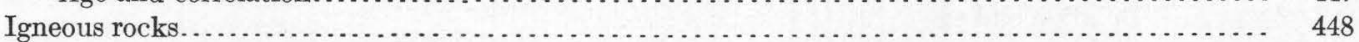

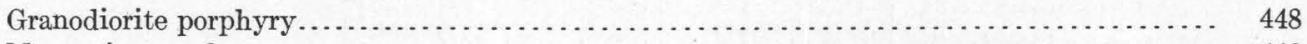

Monzonite porphyry................................................. 448

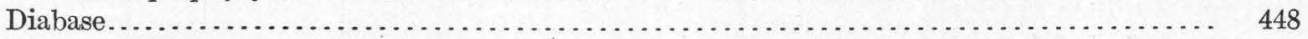

Extrusive rocks........................................................ 449

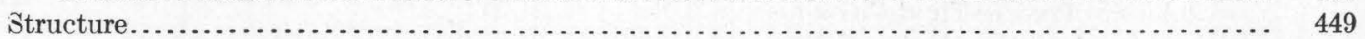

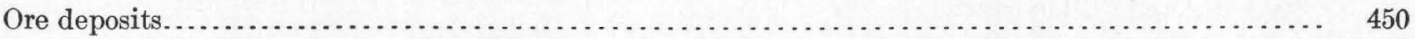

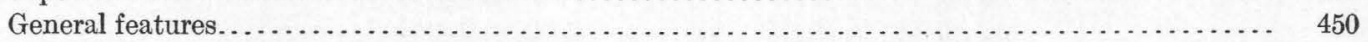

Occurrence and character.............................................. 450

Bed deposits........................................................... 451

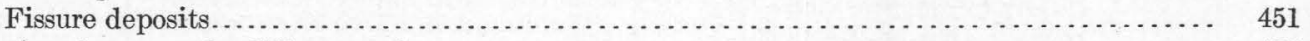

Relations between the different veins......................................... 452

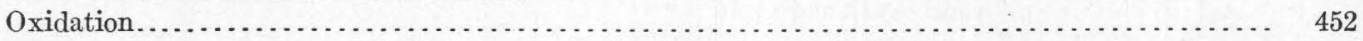

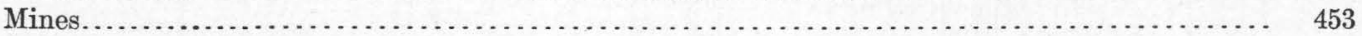

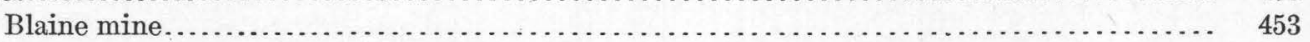

Happy Jack prospect................................................... 454

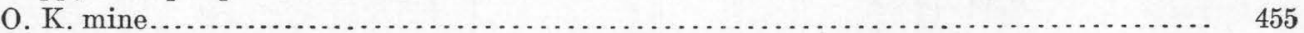

Silver Reef mine................................................ 455

Indian Chief prospect................................................ 455

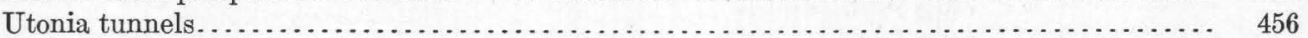

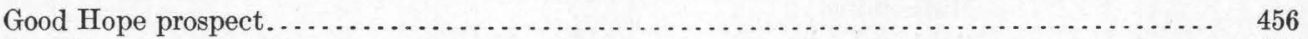

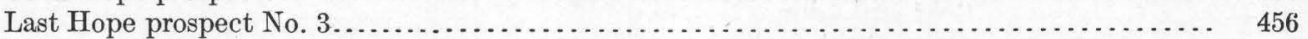

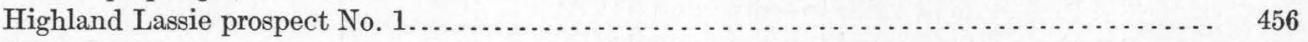

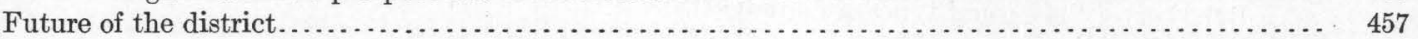

Fumarole Butte and Lava Plateau, by G. F. Loughlin ................................... 457

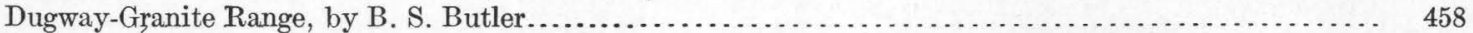

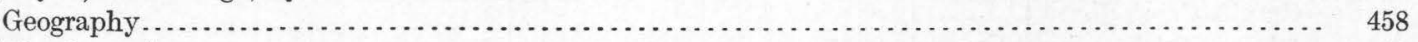

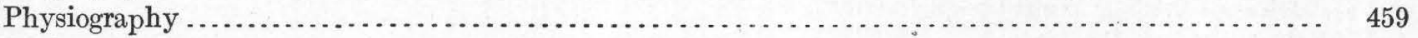

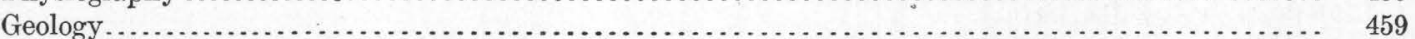

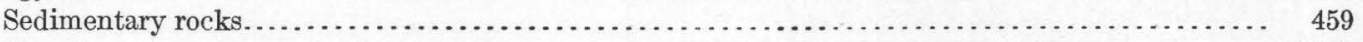

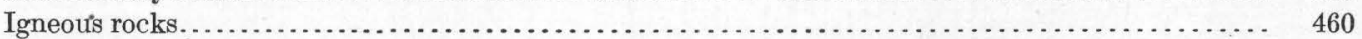

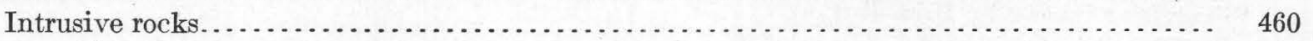

Extrusive rocks...................................................... 461

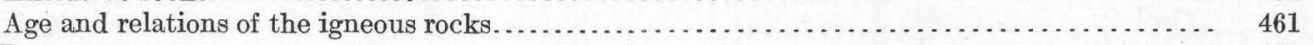

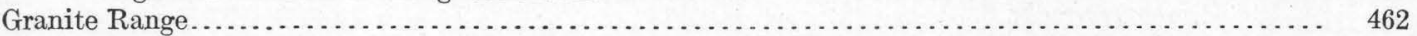

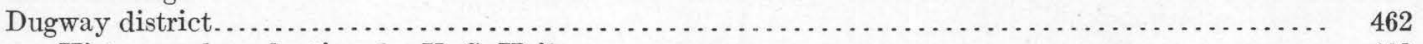

History and production, by V. C. Heikes.................................... 462

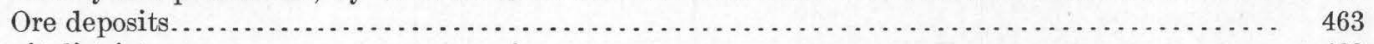

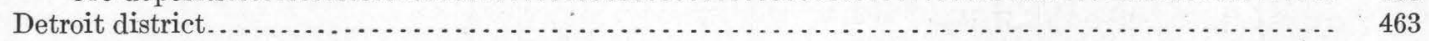

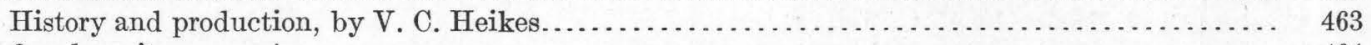

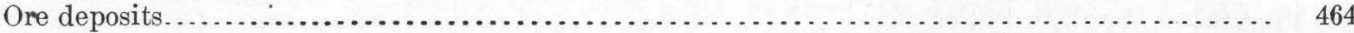

$35416^{\circ}-19-2$ 
Part II. Ranges and districts-Continued.

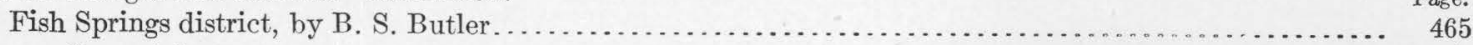

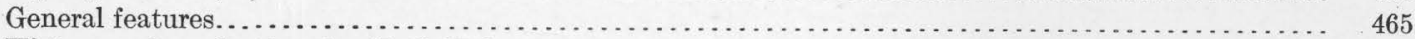

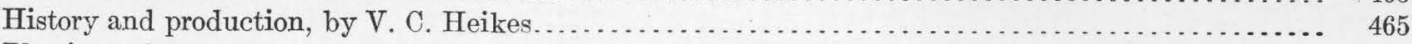

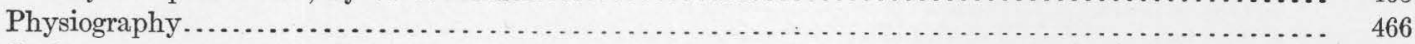

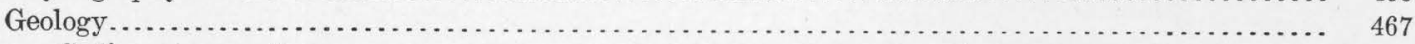

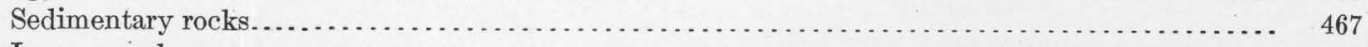

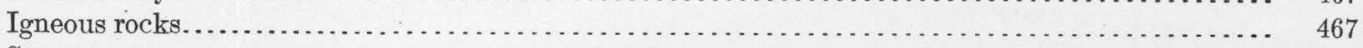

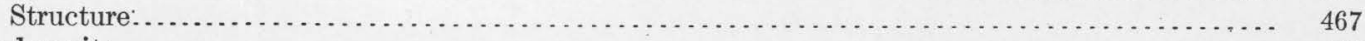

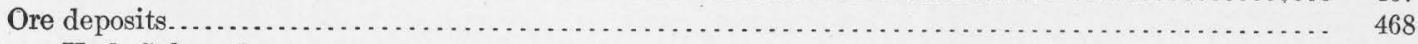

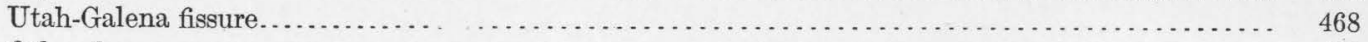

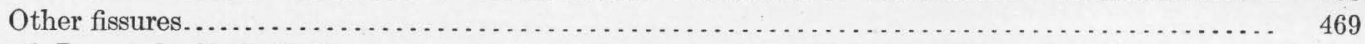

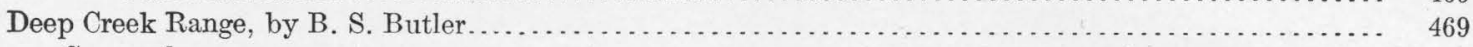

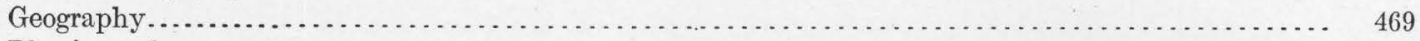

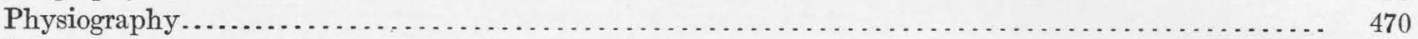

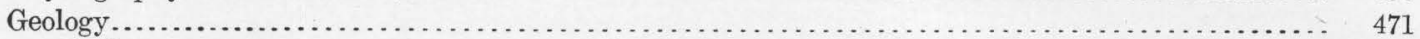

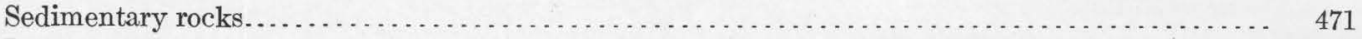

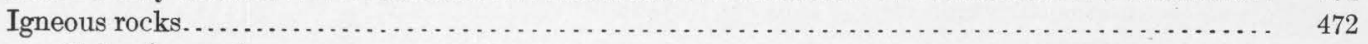

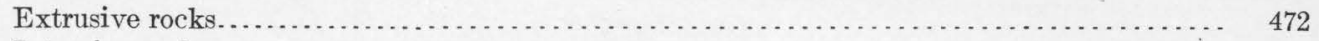

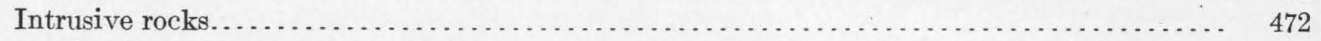

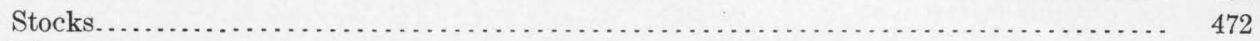

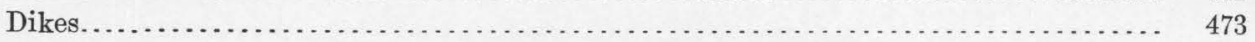

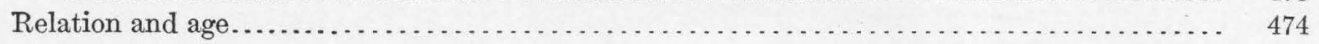

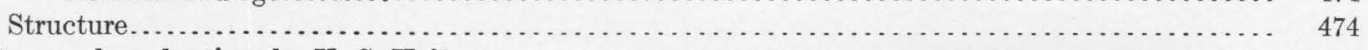

History and production, by V. C. Heikes ... . . . . . . . . . . . . . . . . . . . . . . . 475

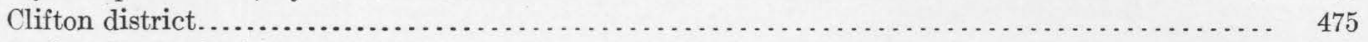

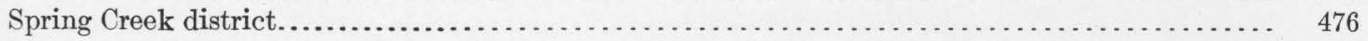

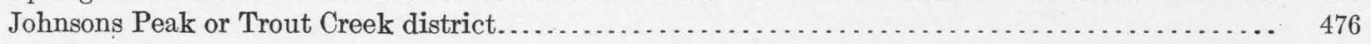

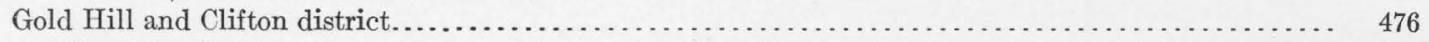

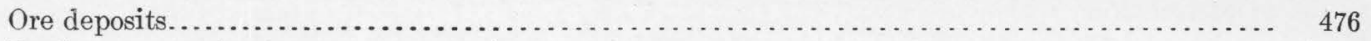

Replacement veins in quartz monzonite.................................... 476

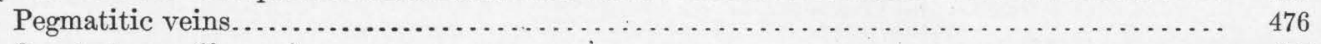

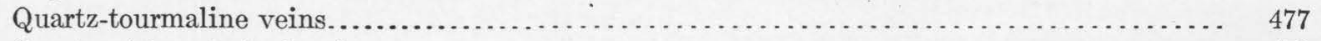

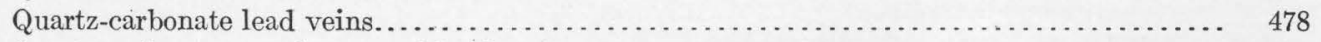

Quartz and quartz-carbonate gold veins.............................. 478

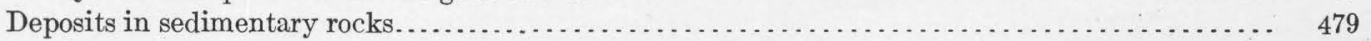

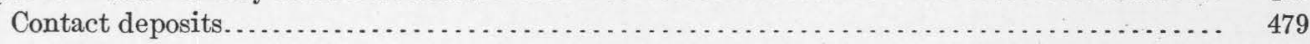

Copper deposits....................................................... 479

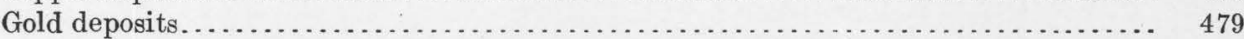

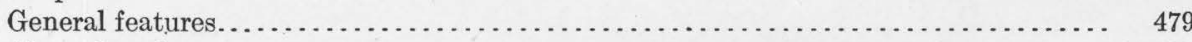

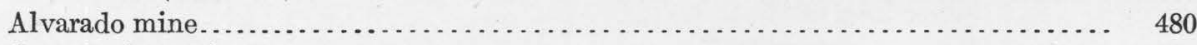

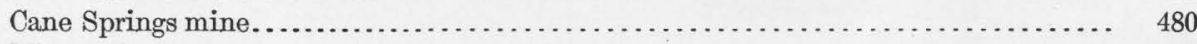

Midas mine....................................................... 480

Gold Hill mine.................................................... 481

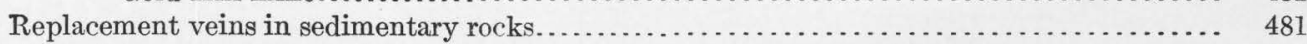

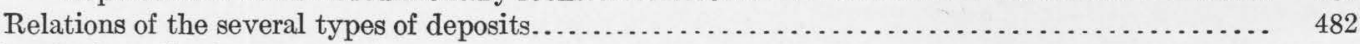

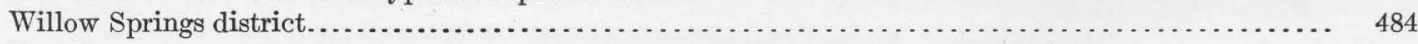

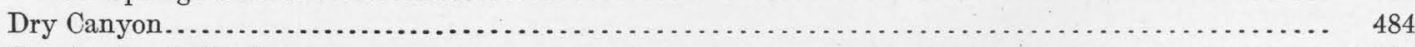

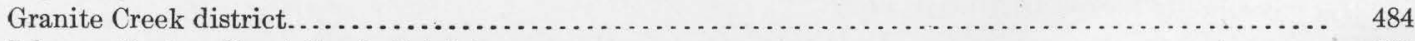

Johnson Peak or Trout Creek district.................... 485

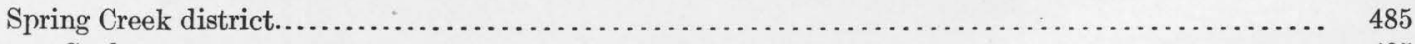

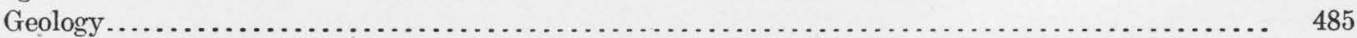

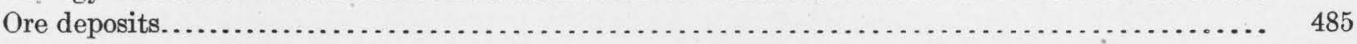

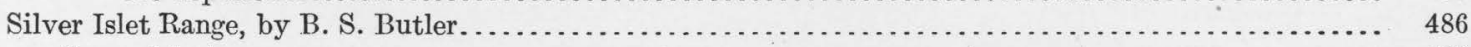

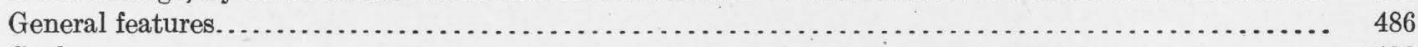

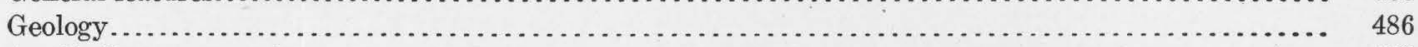

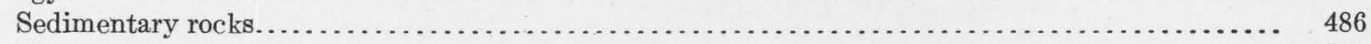

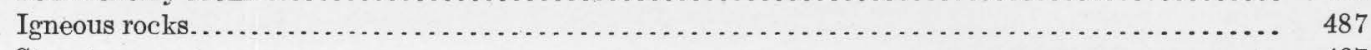

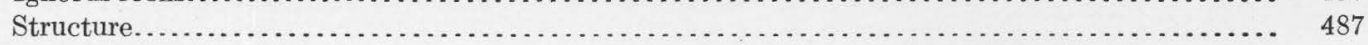

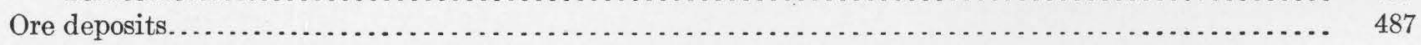

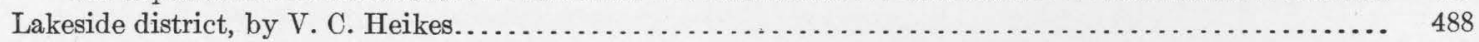

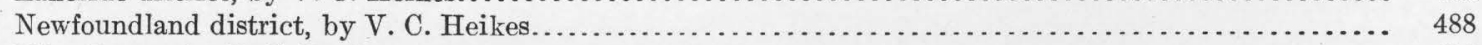

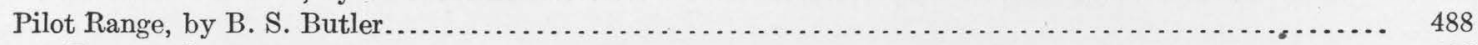

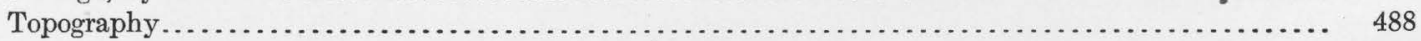


Part II. Ranges and districts-Continued.

Pilot Range-Continued.

Lucin district:

Location

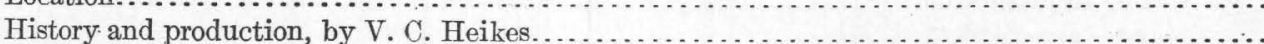

Geology.

Sedimentary rocks.

Igneous rocks.

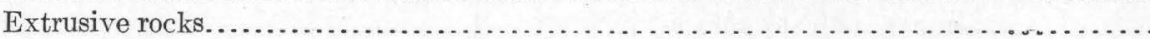

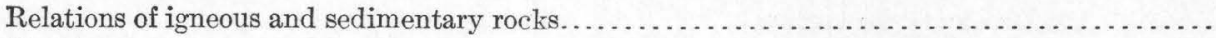
Structure.

Ore deposits

Contact deposits.

Fissure deposits.

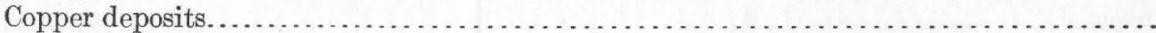

Lead-silver deposits.

Genesis.

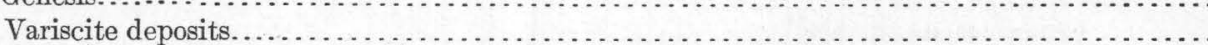

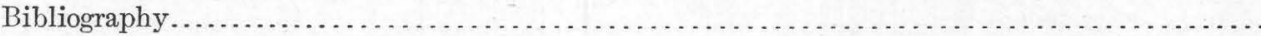

Grouse Creek Range, by B. S. Butler.

Location

Geology

Intrusive rocks.

Production

Ore deposits.

Development.

Tungsten deposits

Rosebud Creek district.

Occurrence.

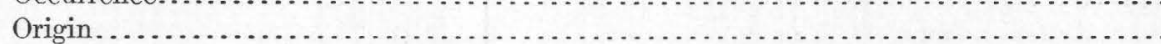

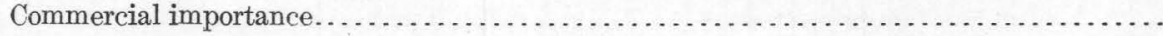

Other deposits.

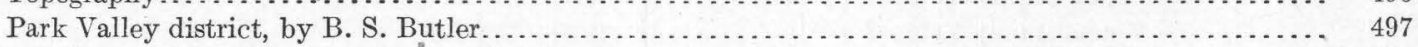

General features.......................................................... 497

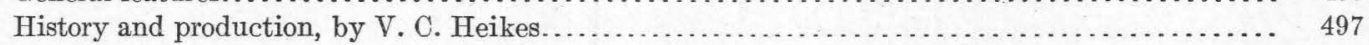

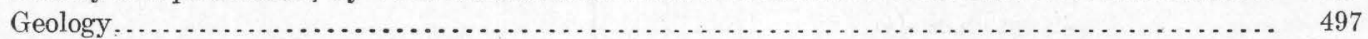

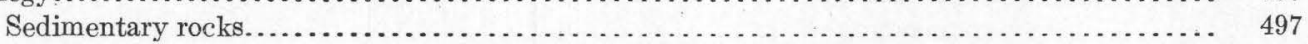

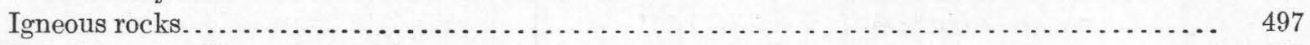

Relations of sedimentary and igneous rocks............................... 498

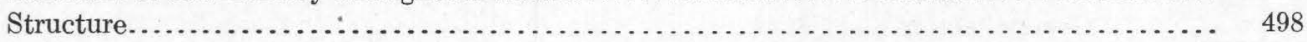

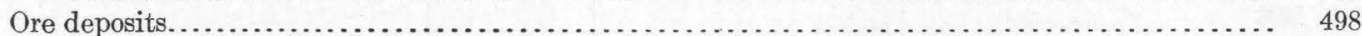

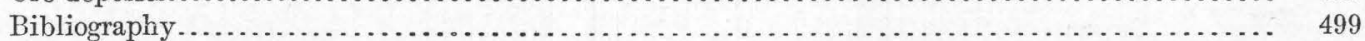

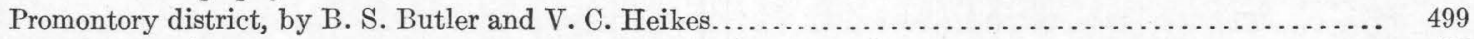

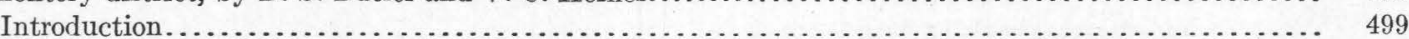

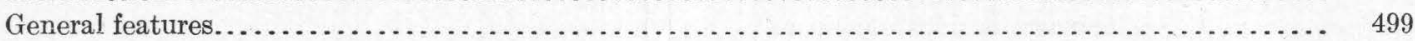

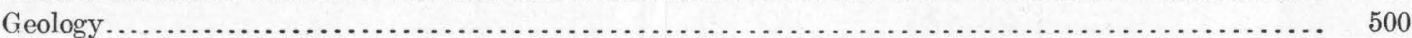

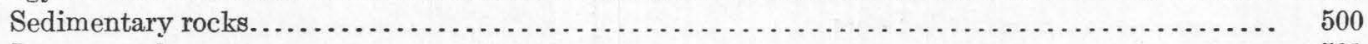

Igneous rocks............................................................. 501

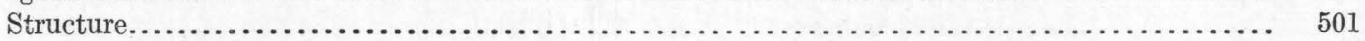

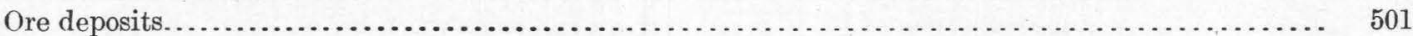

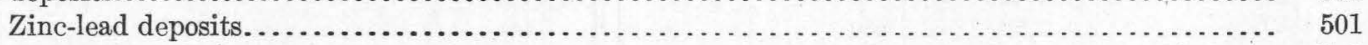

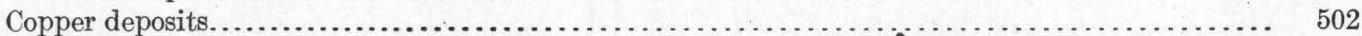

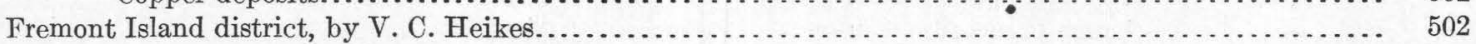

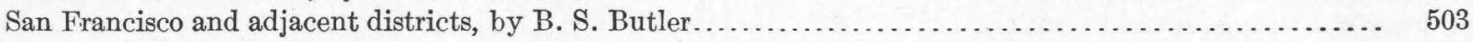

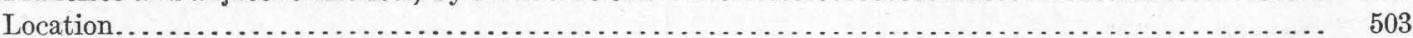

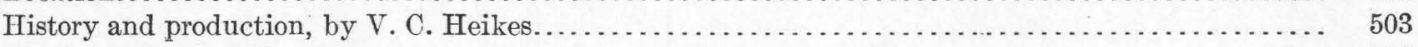

San Francisco district...................................................... 503

Preuss district. . . . . . . . . . . .

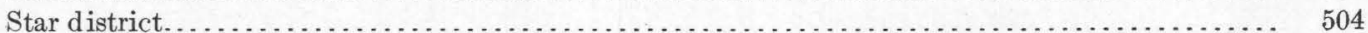


Part II. Ranges and districts-Continued.

San Francisco and adjacent districts-Continued.

History and production-Continued.

North Star district.

505

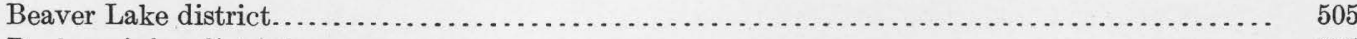

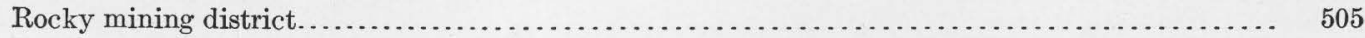

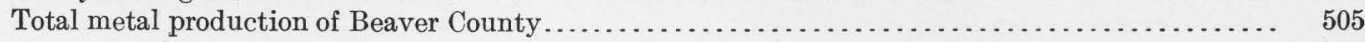

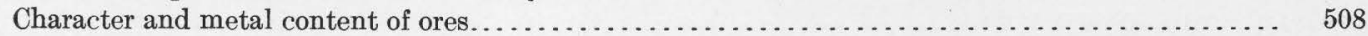

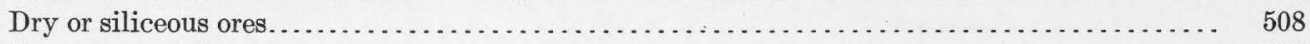

Copper ores and concentrates.............................................. 508

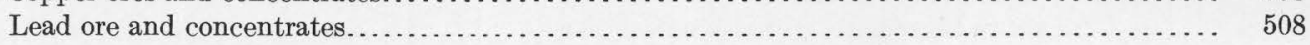

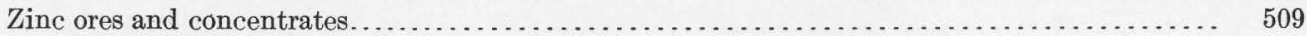

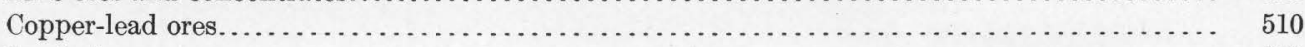

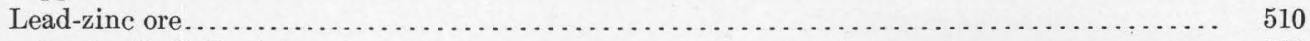

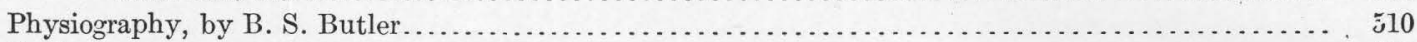

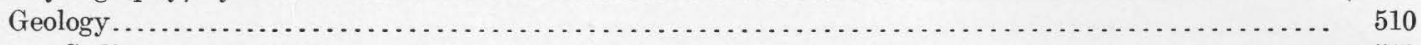

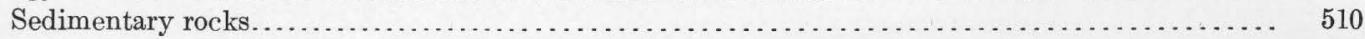

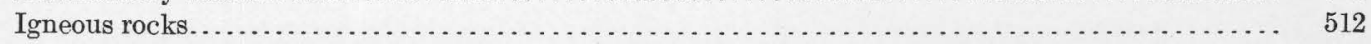

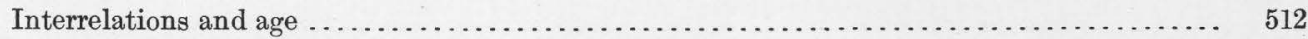

Extrusive rocks. . . . . . . . . . .

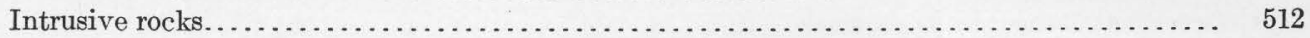

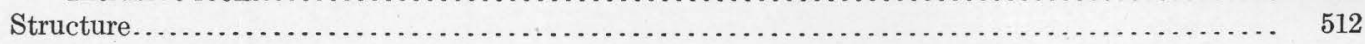

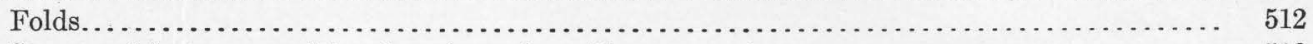

Structural features resulting from intrusion of igneous rocks....................... 512

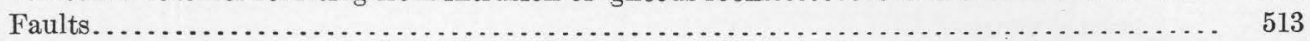

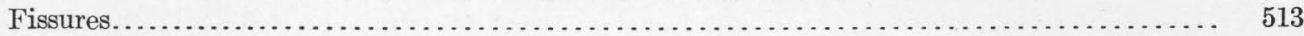

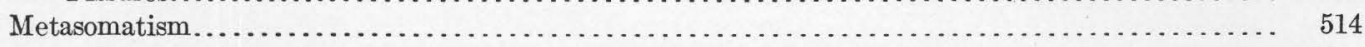

Alteration of quartz monzonite......................................... 514

Alteration of lavas..................................................... 514

Alteration of sedimentary rocks...................................... 515

Comparison of alteration of different kinds of rock.............................. 516

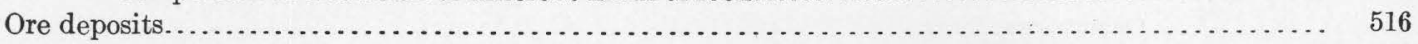

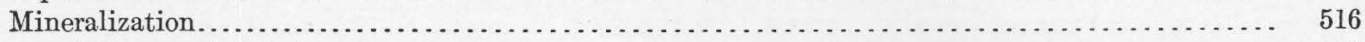

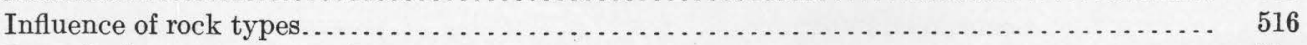

Deposits in quartz monzonite.......................................... 516

Deposits in sedimentary rocks. . . . . . . . . . . . . . . . . . . . . . . . . . . . . . 518

Contact deposits.............................................. 518

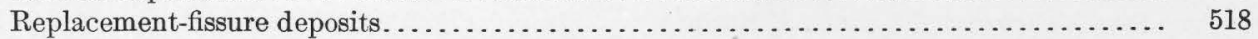

Transition deposits. . . . . . . . . . . . . . . . . 519

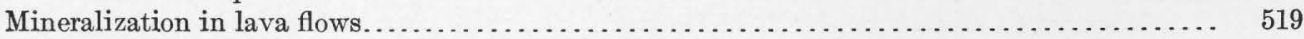

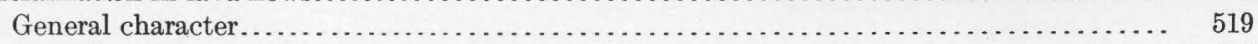

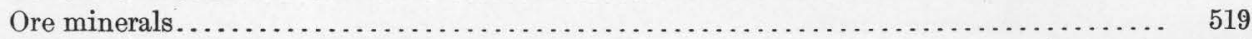

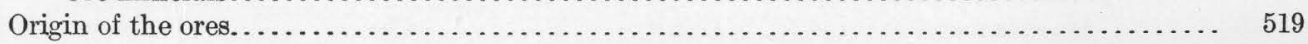

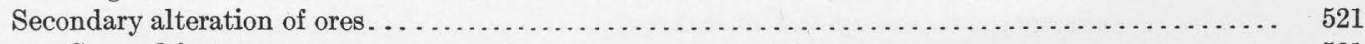

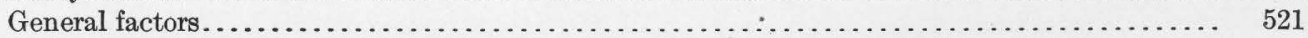

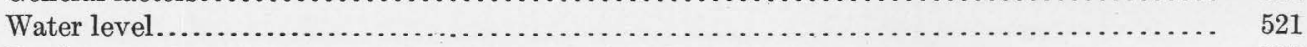

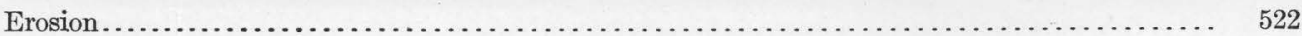

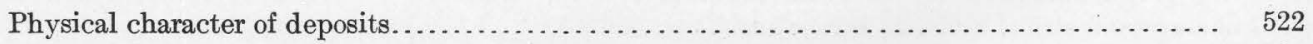

Mineralogic character of deposits. . . . . . . . . . . . . . . . 522

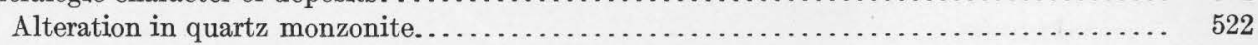

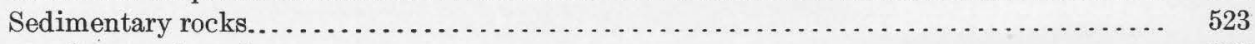

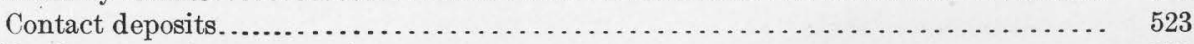

Replacement-fissure deposits. . . . . . . . . . . . . . . . . . . . . . . . . . 523

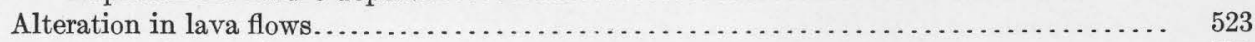

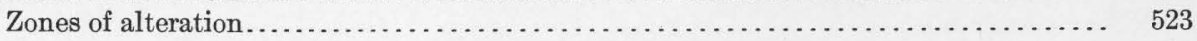

Oxidized zone.................................................. 524

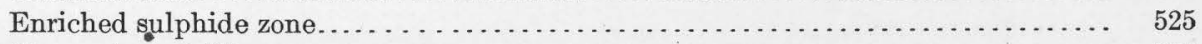

Change in metallic content. . . . . . . . . . . . . . . . . . . . 525

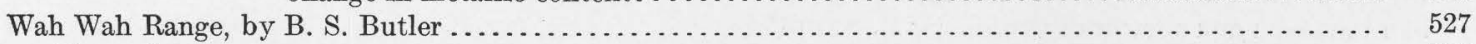

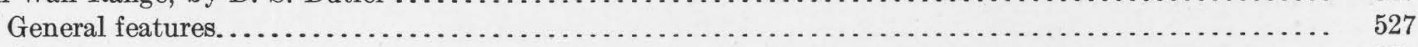

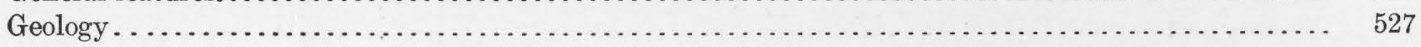

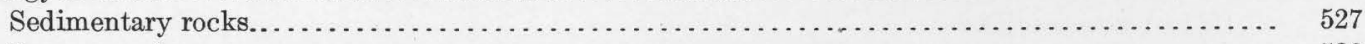

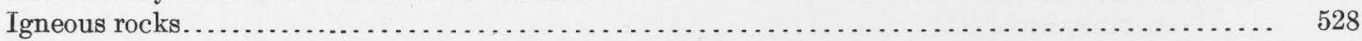

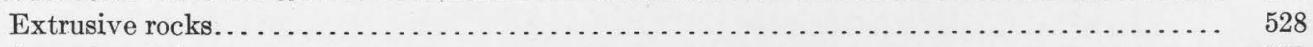

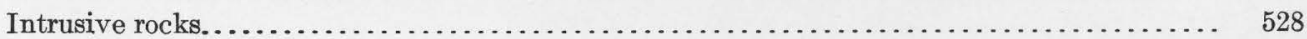


Part II. Ranges and districts-Continued.

Wah Wah Range-Continued.

Geology-Continued.

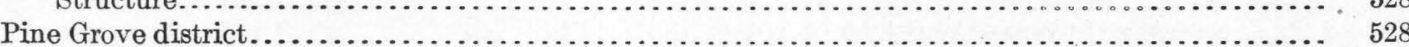

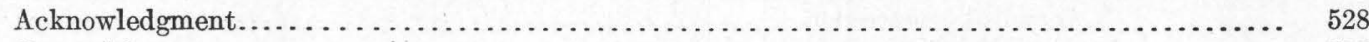

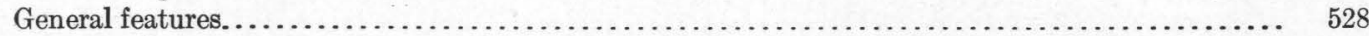

Ore deposits. . . . . . . . . . . . . 529

Wah Wah Pass region........................................................... 529

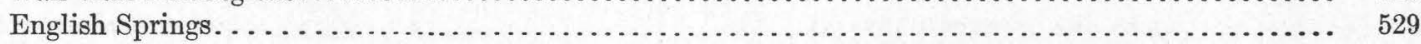

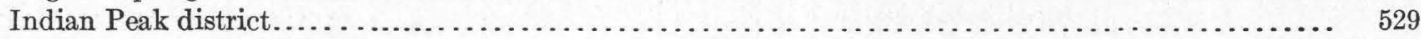

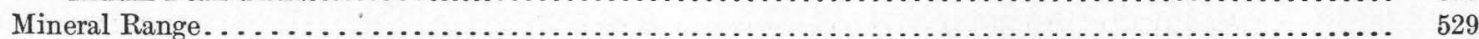

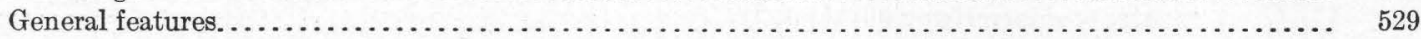

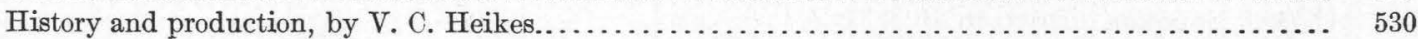

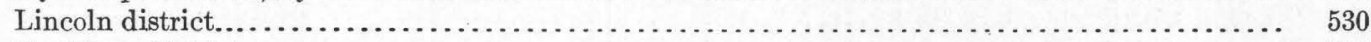

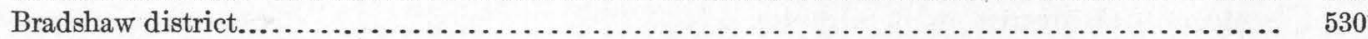

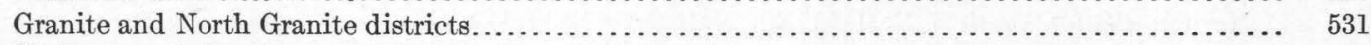

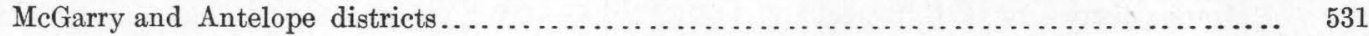

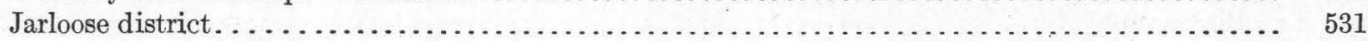

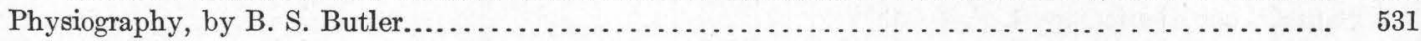

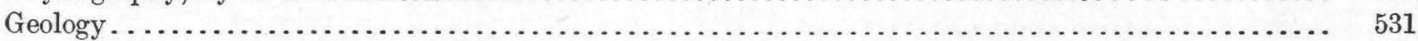

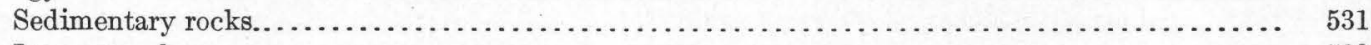

Igneous rocks. . . . . . . . . . . . . .

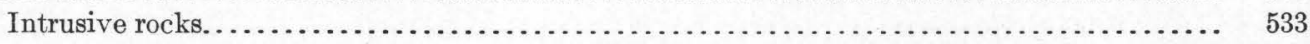

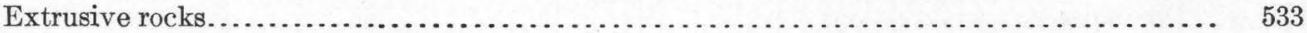

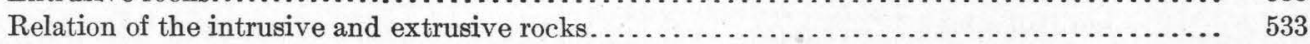

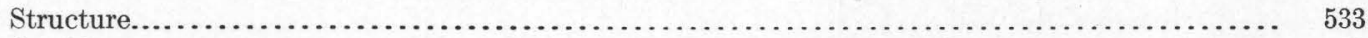

Ore deposits. . . . . . . . . . . .

Replacement deposits in sedimentary rocks................................... 533

Contact deposits..................................................... 534

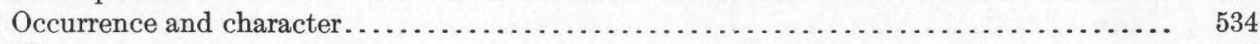

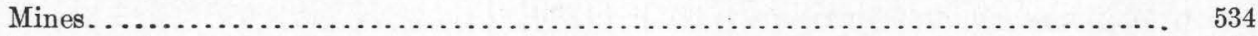

Replacement-fissure deposits. . . . . . . . . . . . .

Bradshaw district. . . . . . . . . .

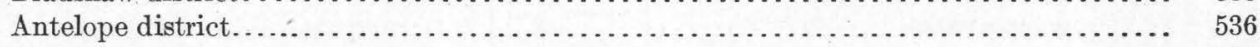

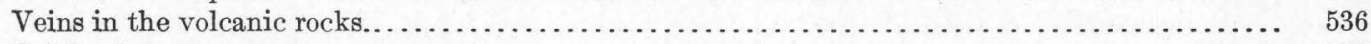

Origin of the ores. . . . . . . . . . .

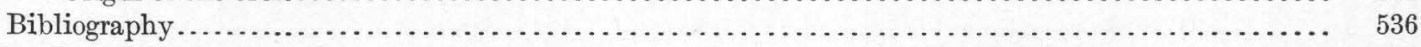

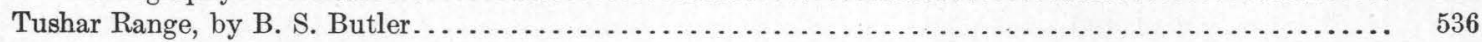

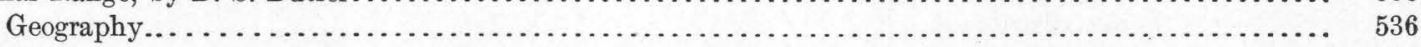

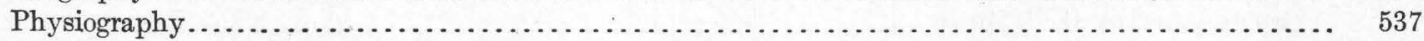

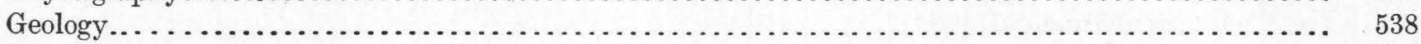

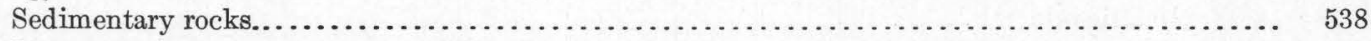

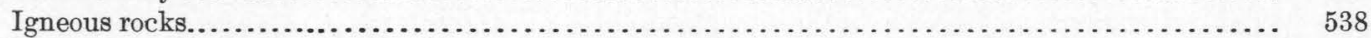

Extrusive rocks. . . . . . . . . . . .

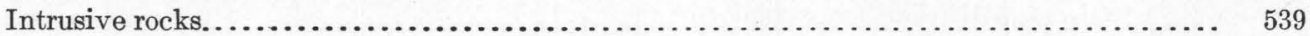

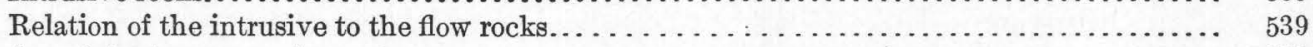

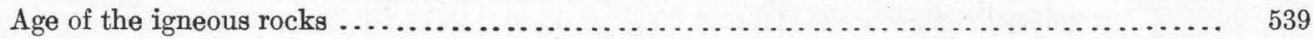

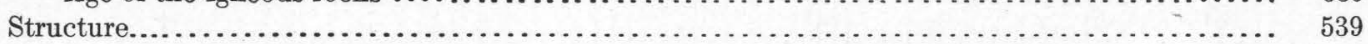

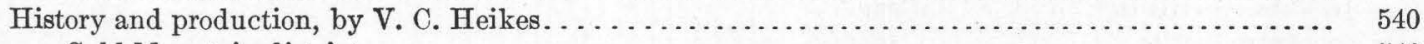

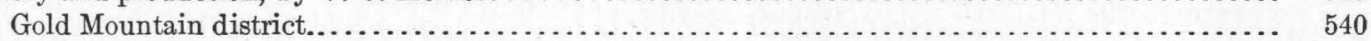

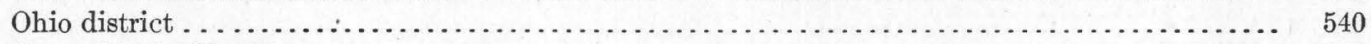

Mount Baldy district. . . . . . . . . . . . .

Newton district. . . . . . . . . . . . .

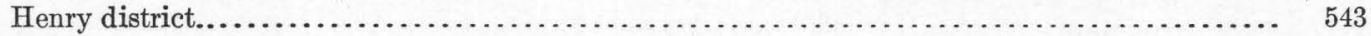

Ore deposits. . . .

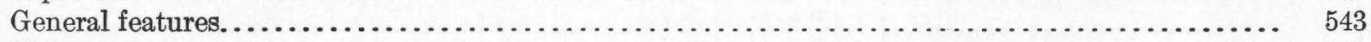

Veins. . . . . .

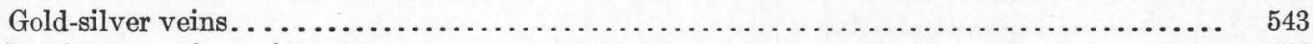

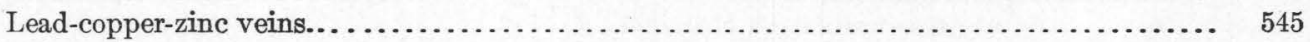

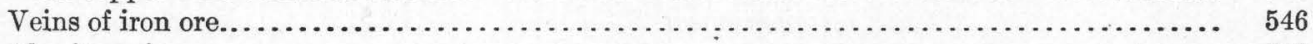

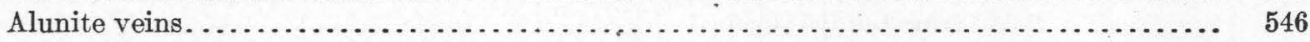

Alteration of the country rock. . . . . . . . . . . . .

Occurrence and character................................................ 547 
Part II. Ranges and districts-Continued.

Tushar Range-Continued.

Ore deposits-Continued.

Veins-Continued.

Alunite veins-Continued.

Chemical composition.

Sheep Rock deposit.

Replacement deposits.

Lucky Boy prospect

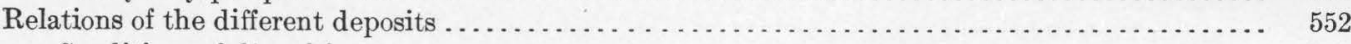

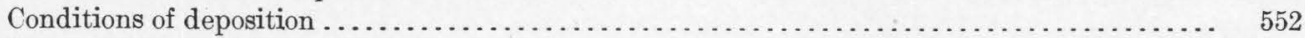

Source of mineralizing solutions. . . . . . . . . . . . . . .

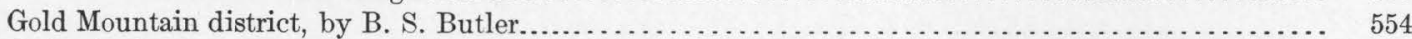

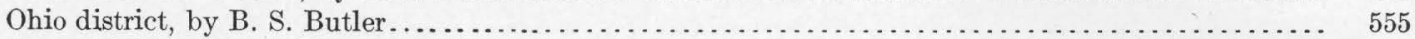

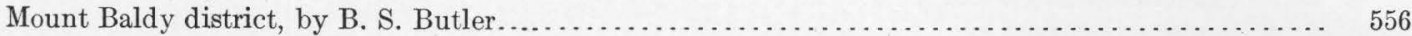

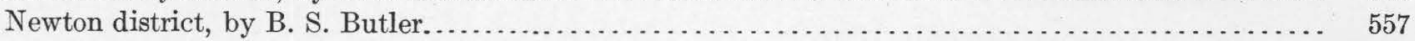

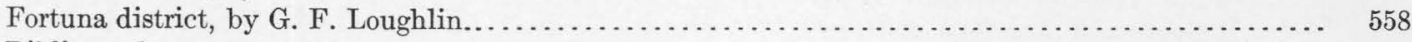

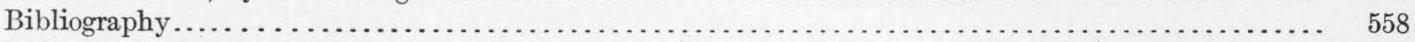

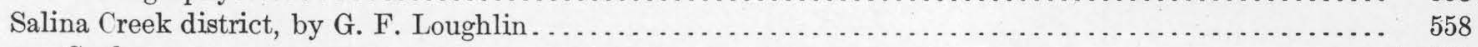

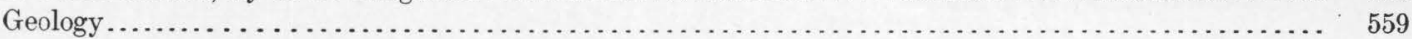

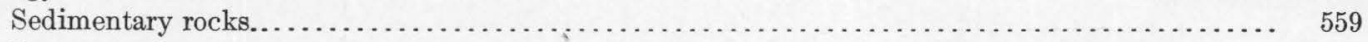

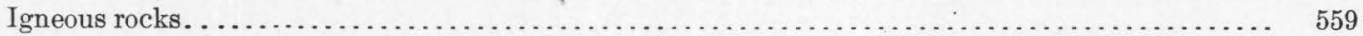

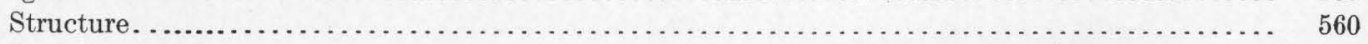

Ore deposits . . . . . . . . .

Lead Hill mine. . . . . . . . . . . .

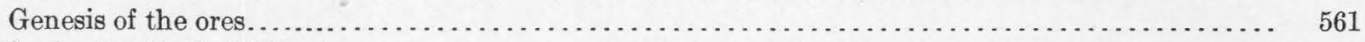

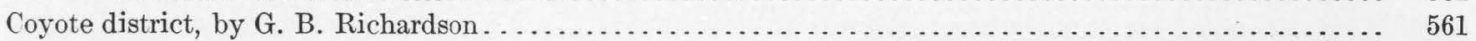

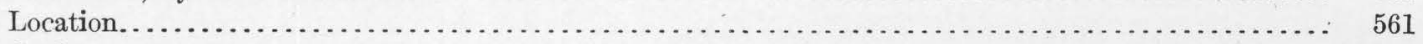

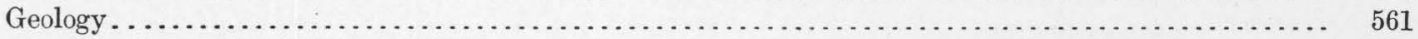

Ore deposits. . . . . . . . . . . .

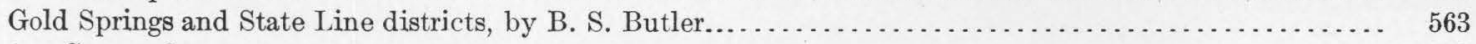

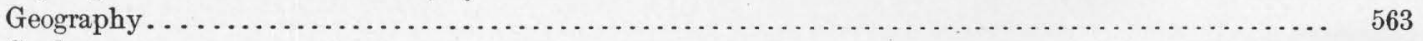

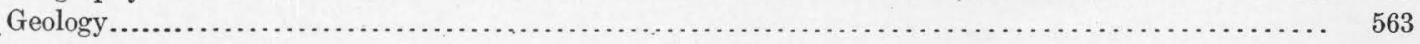

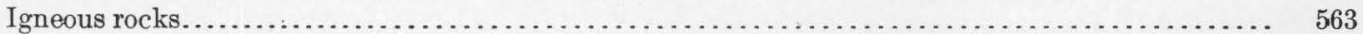

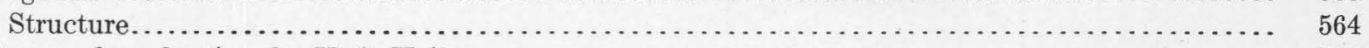

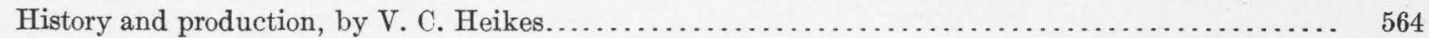

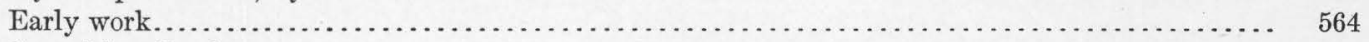

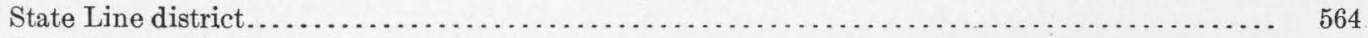

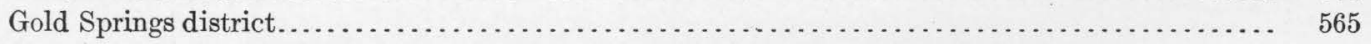

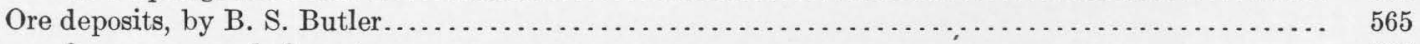

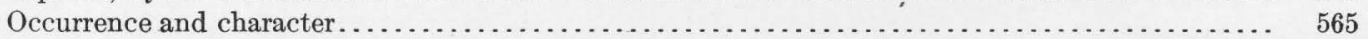

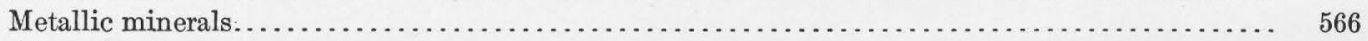

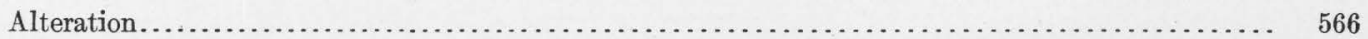

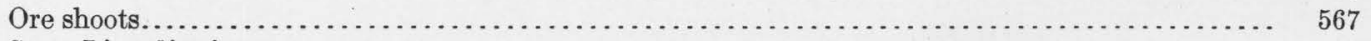

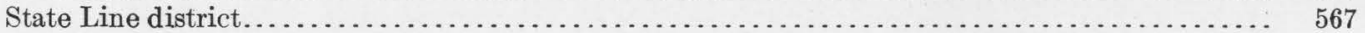

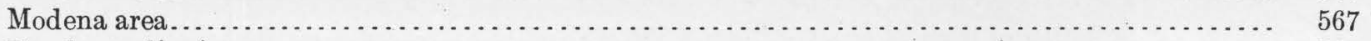

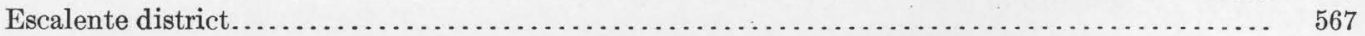

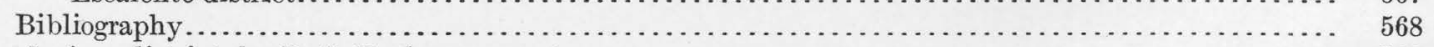

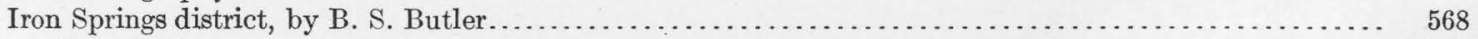

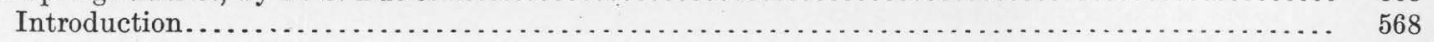

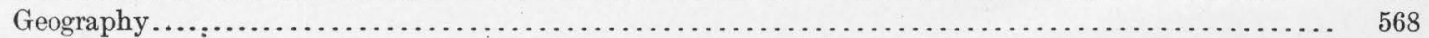

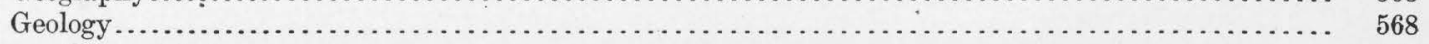

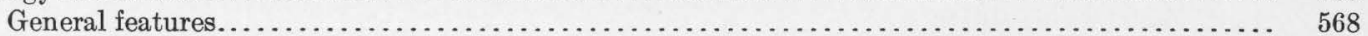

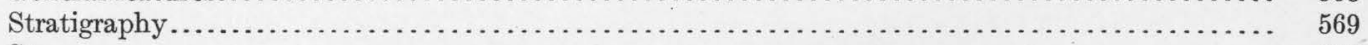

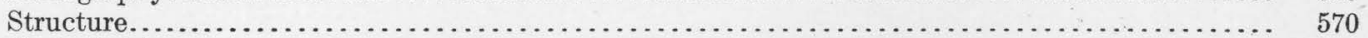

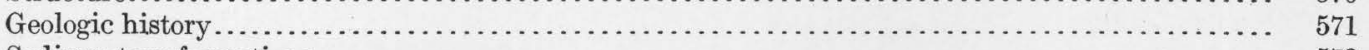

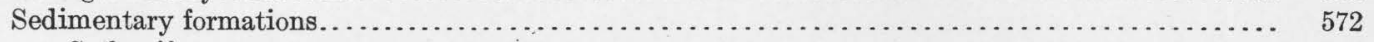

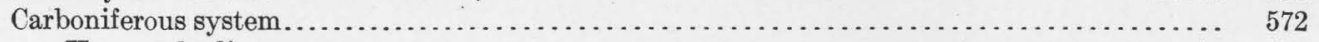

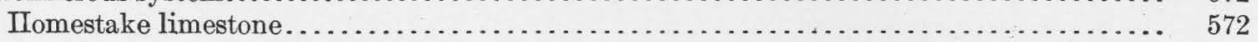

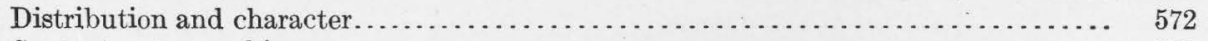

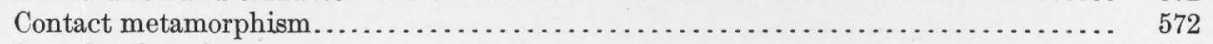

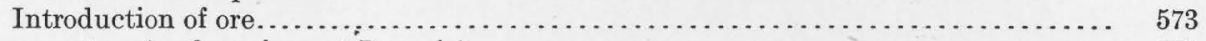

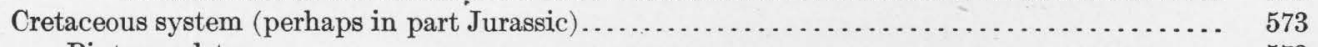

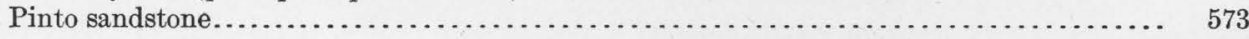


Part II. Ranges and districts-Continued.

Iron Springs district-Continued.

Geology-Continued.

Sedimentary formations-Continued. Page.

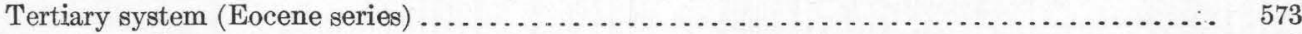

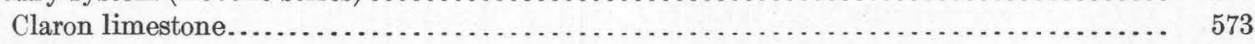

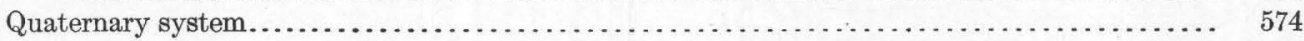

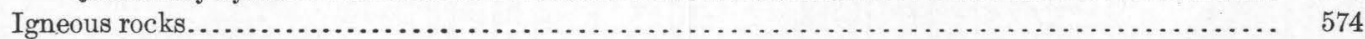

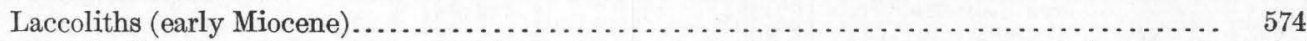

Distribution and structure............................................ 574

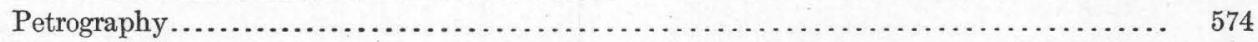

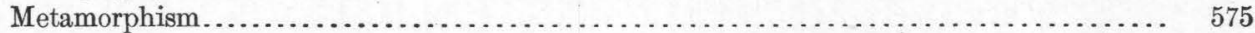

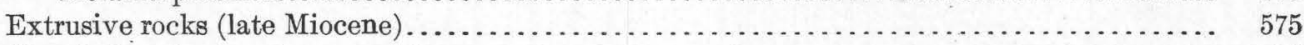

Chemical and mineral composition......................................... 576

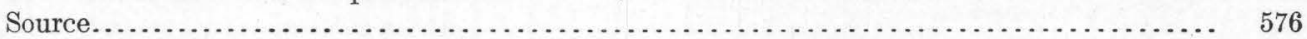

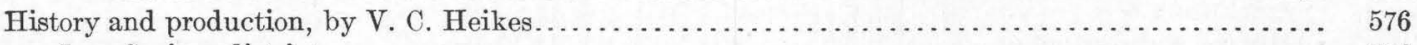

Iron Springs district. . . . . . . . .

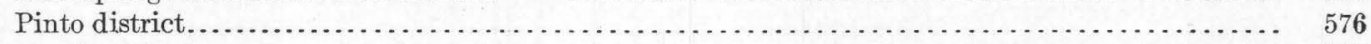

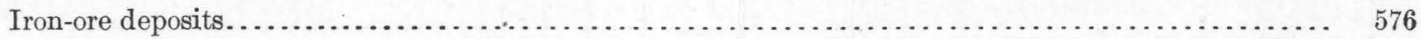

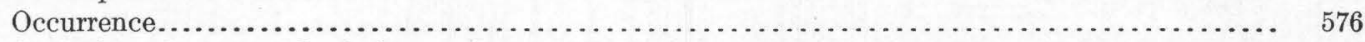

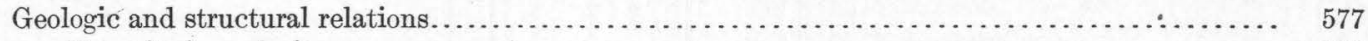

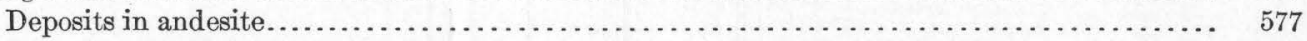

Deposits at andesite-limestone contact................................... 577

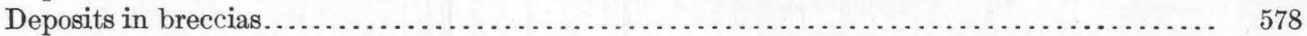

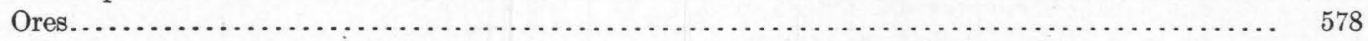

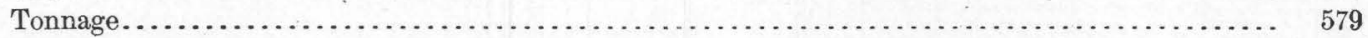

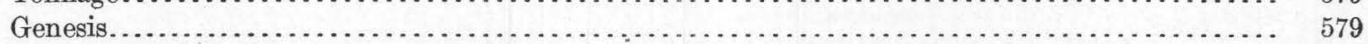

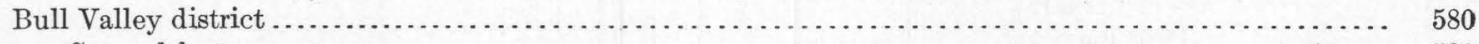

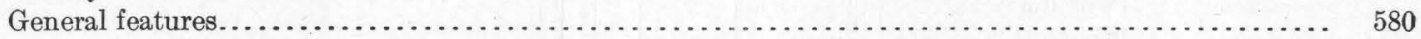

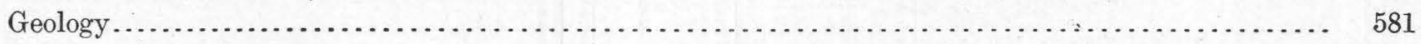

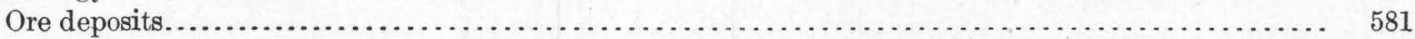

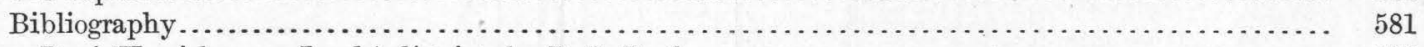

Silver Reef (Harrisburg or Leeds) district, by B. S. Butler . . . . . . . . . . . . . . . . . . . . . . 582

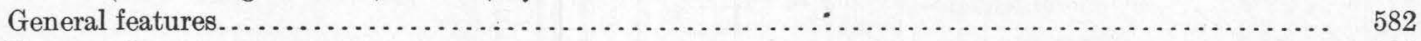

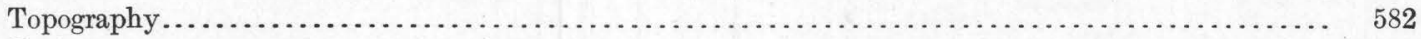

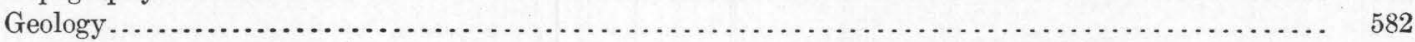

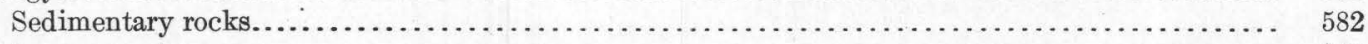

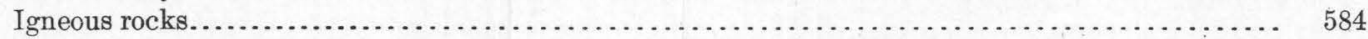

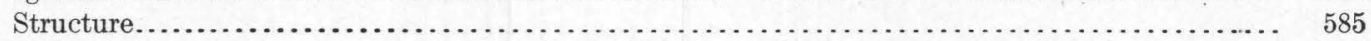

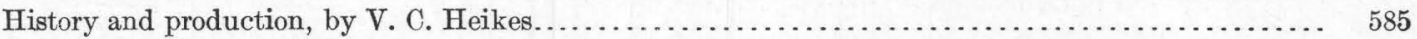

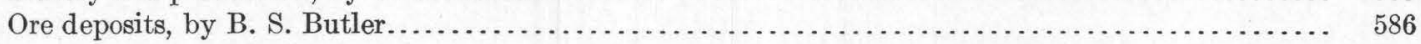

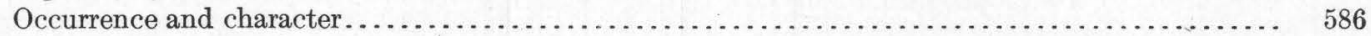

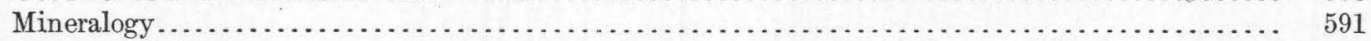

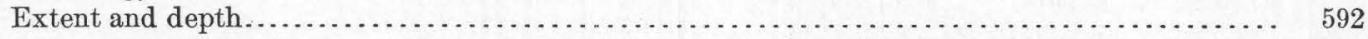

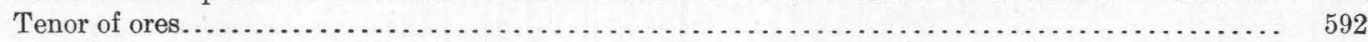

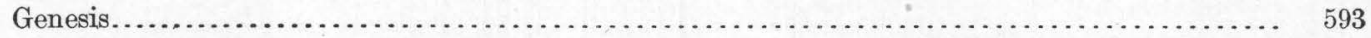

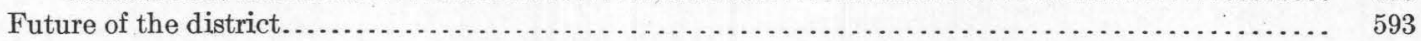

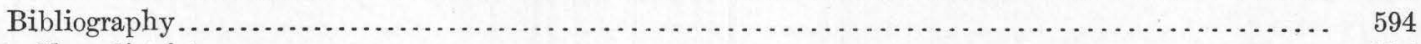

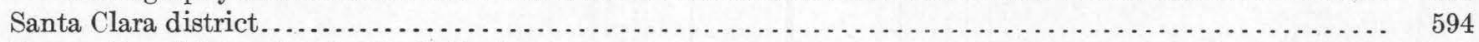

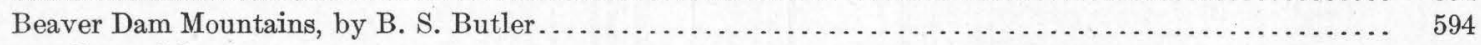

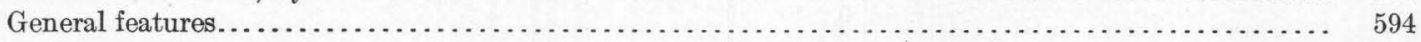

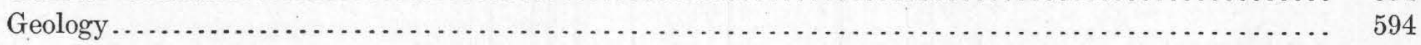

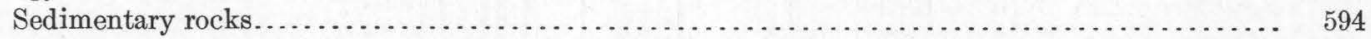

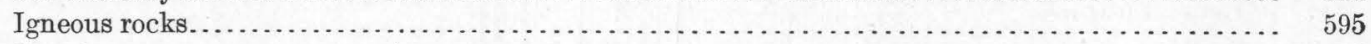

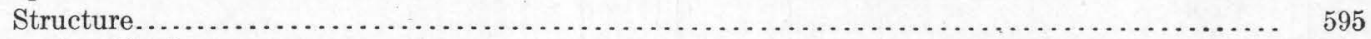

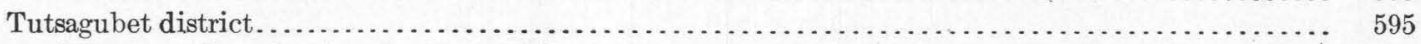

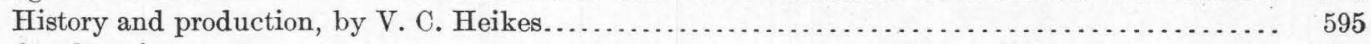

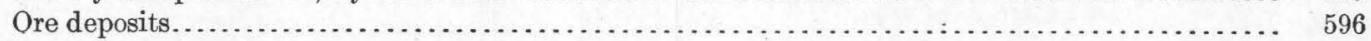

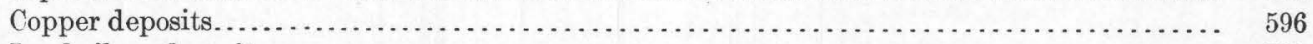

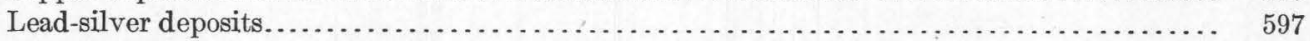

Bull Valley (Goldstrike) district. . . . . . . . . . . . . . . . .

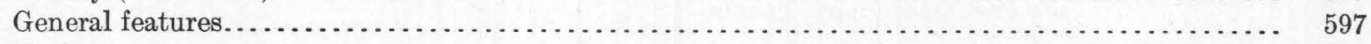

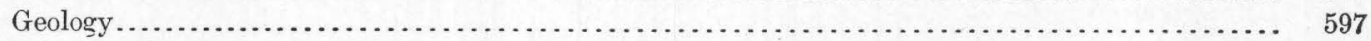


Part II. Ranges and districts-Continued.

Beaver Dam Mountains-Continued.

Bull Valley (Goldstrike) district-Continued. Page

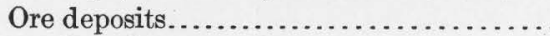

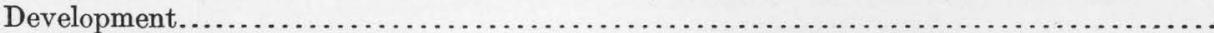

Gold deposits. .

Arsenic deposits.

Antimony deposits

Iron deposits.

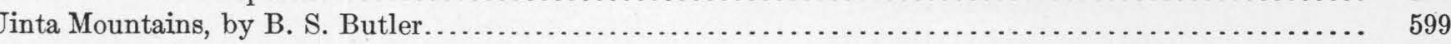

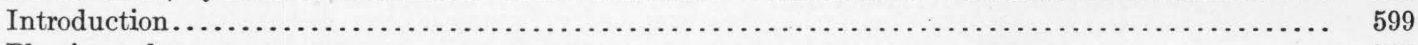

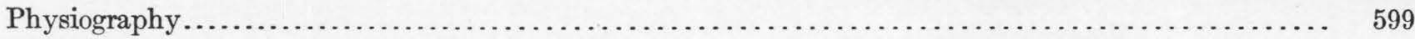

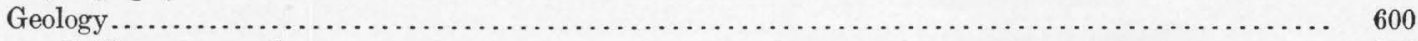

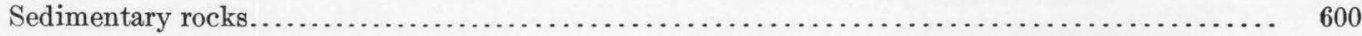

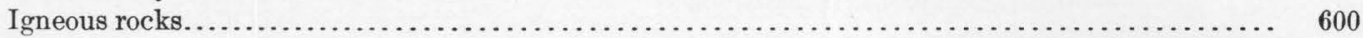

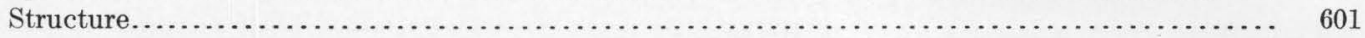

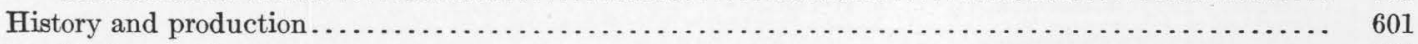

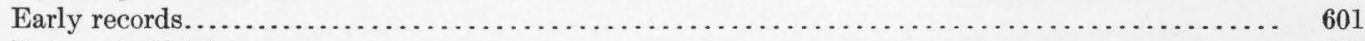

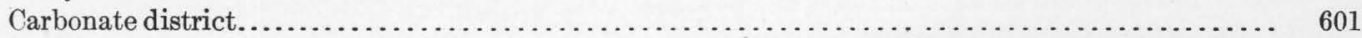

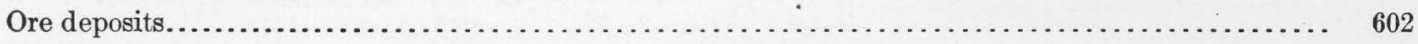

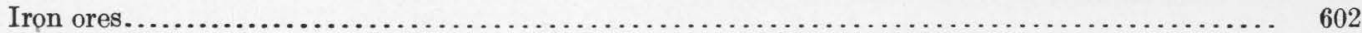

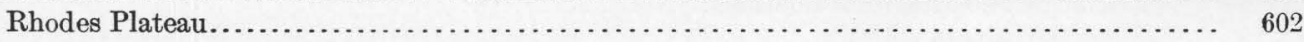

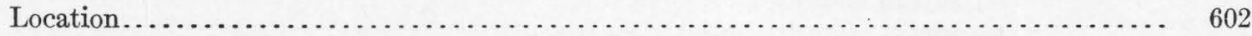

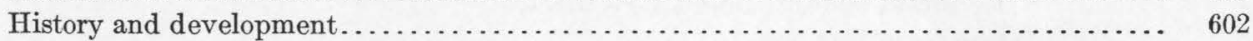

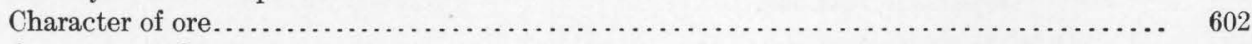

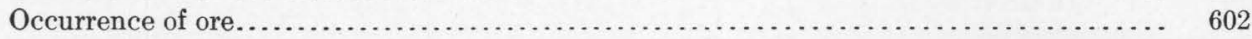

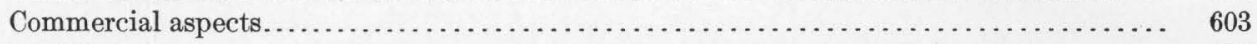

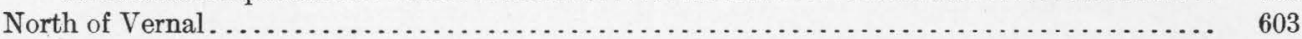

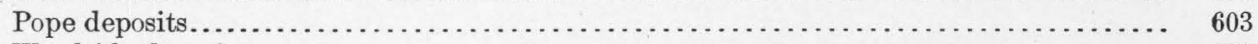

Woodside deposits. . . . . . . . . . . . . . . . . . . . . . . . . . . . . . . . . . . . 603

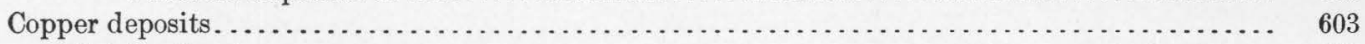

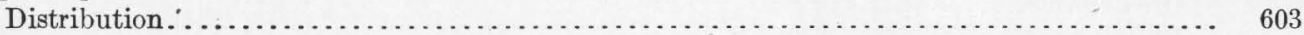

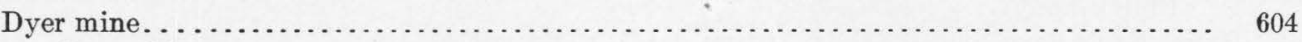

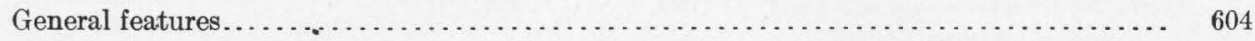

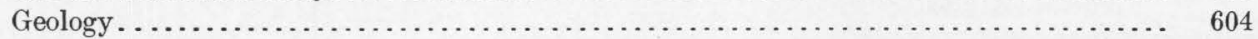

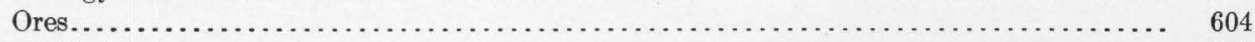

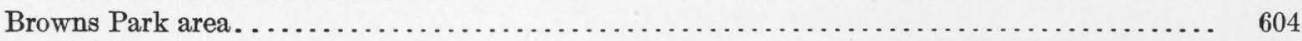

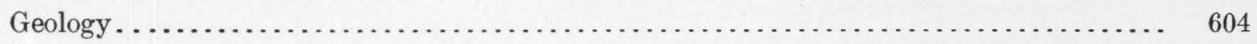

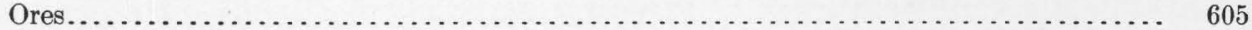

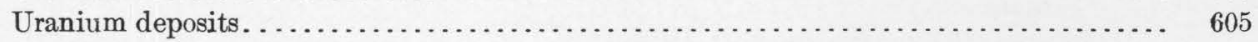

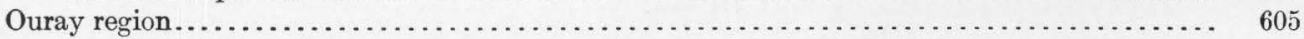

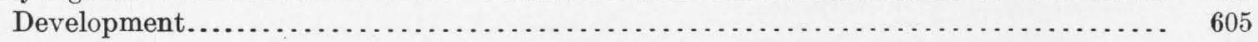

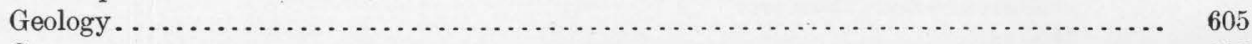

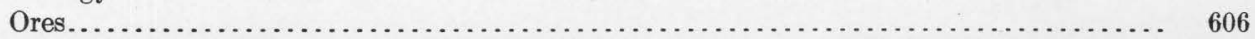

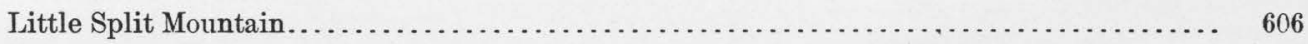

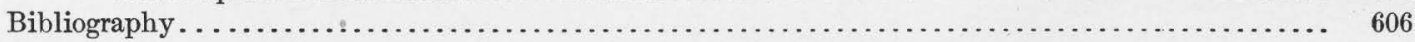

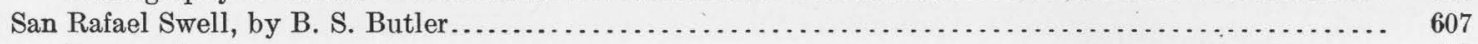

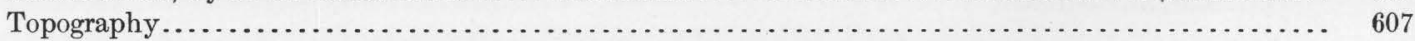

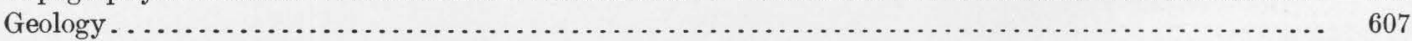

Ore deposits. . . . . . . . . . . . . . .

Uranium-vanadium-radium deposits......................................... 608

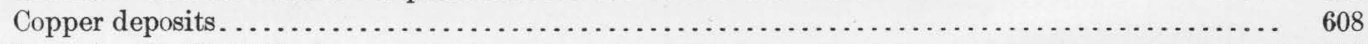

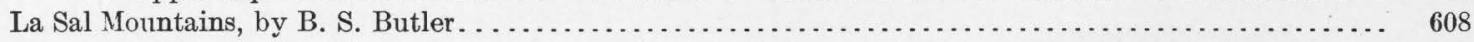

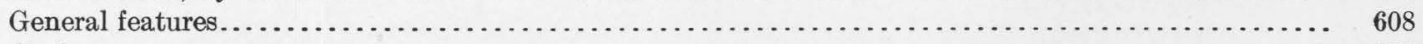

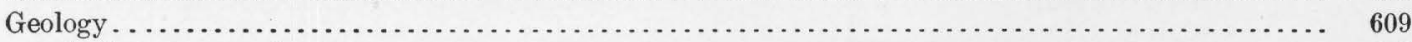

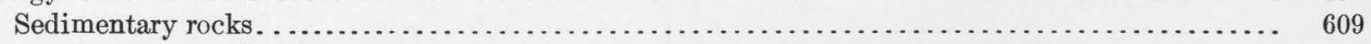

Sequence and correlation ........................................... 609

Carboniferous system . . . . . . . . 609

Triassic system...................................................... 610

Jurassic system . . . . . .

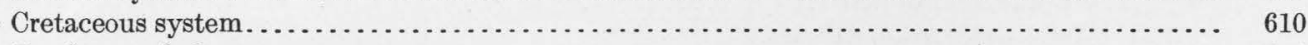

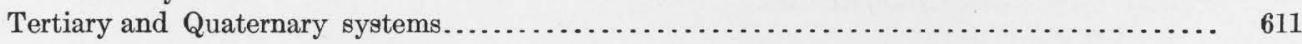

Igneous rocks. . . . . . . . . . . . . 611 
Part II. Ranges and districts-Continued.

La Sal Mountains-Continued.

Geology-Continued.

Structure...

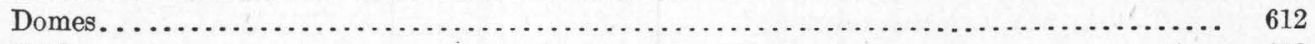

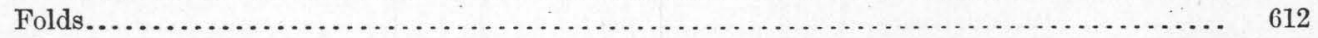

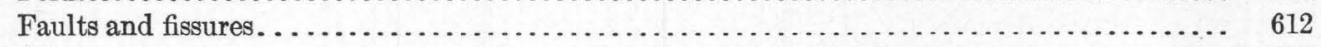

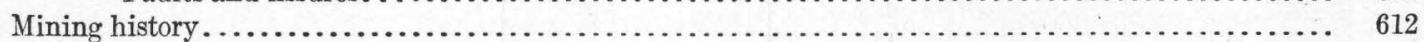

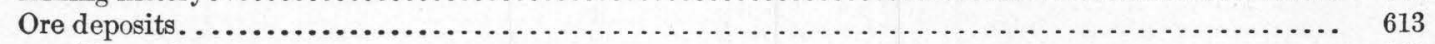

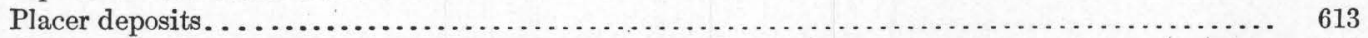

Gold-copper veins in intrusive rocks . . . . . . . . . . . . . . . . .

Copper deposits in sedimentary rocks........................................ 614

Distribution. . . . . . . . . .

Big Indian Valley. . . . . . . . . . .

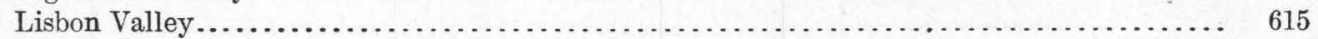

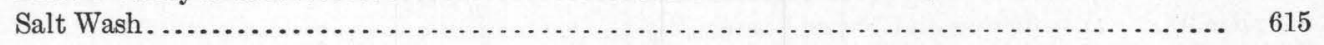

Uranium-vanadium deposits. . . . . . . . . . . . . . . . . . . . . . . . 616

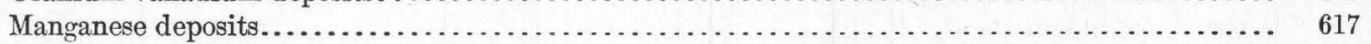

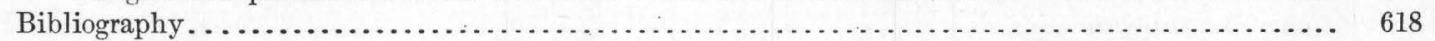

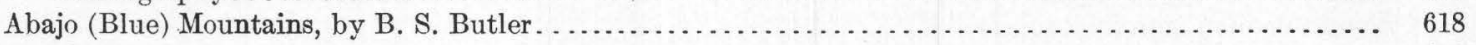

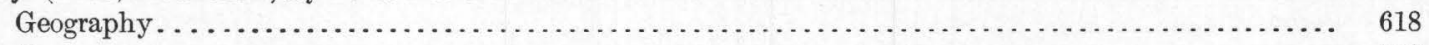

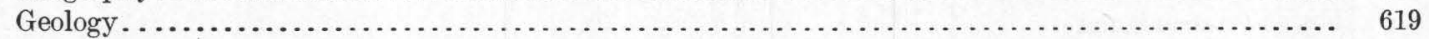

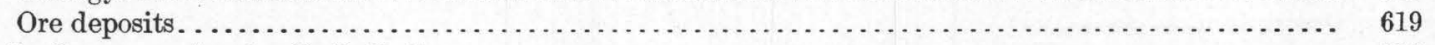

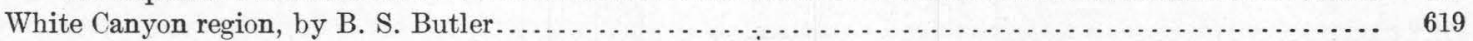

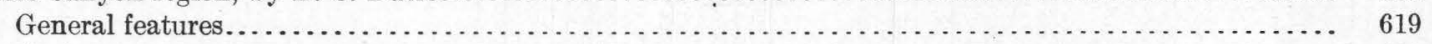

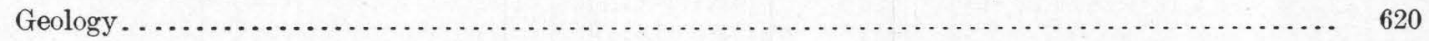

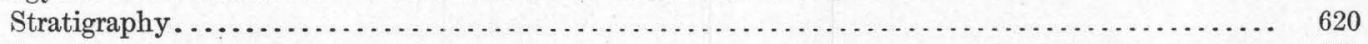

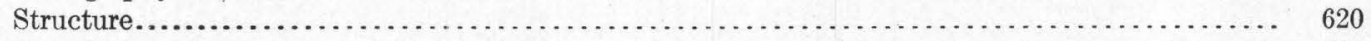

Ore deposits. . . .

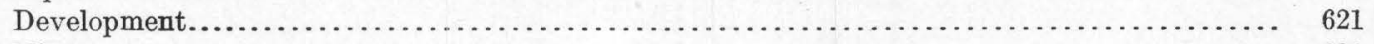

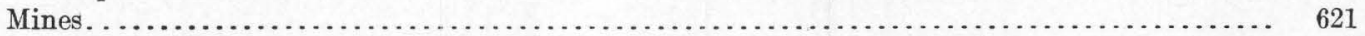

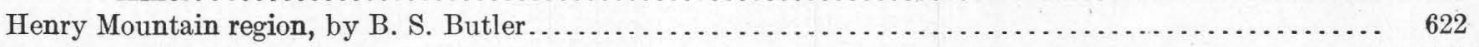

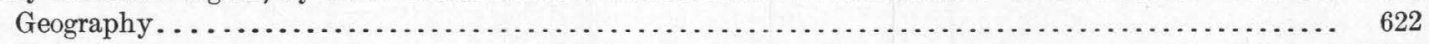

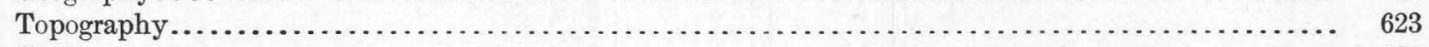

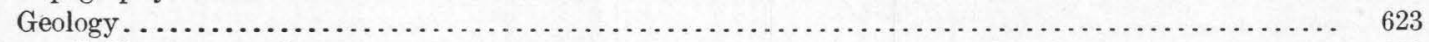

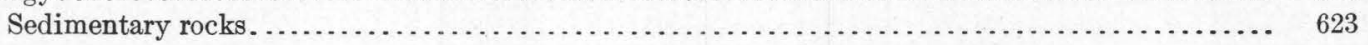

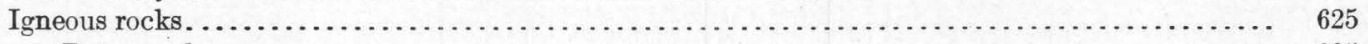

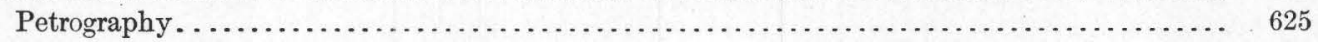

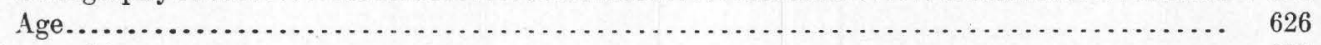

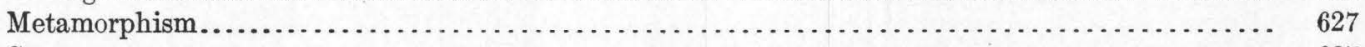

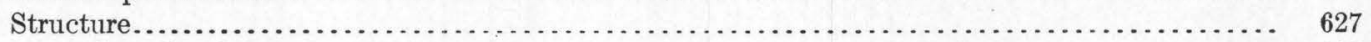

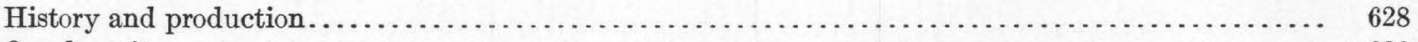

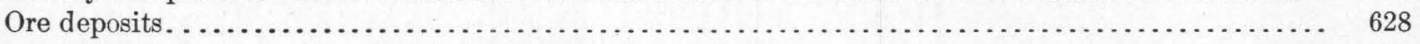

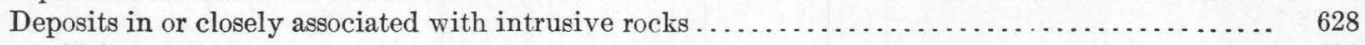

Veins. . . . . . . . . . . .

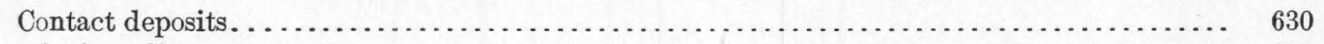

Deposits in sedimentary rocks. . . .

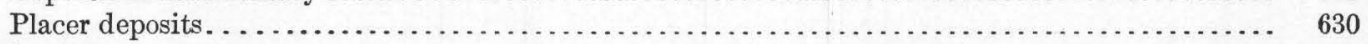

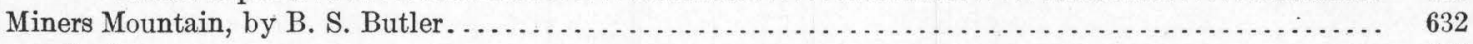

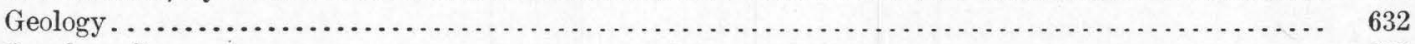

Ore deposits. . . . . . . . . . . .

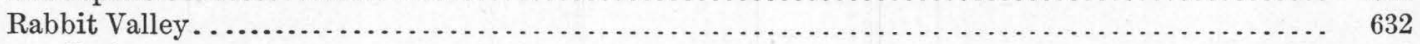

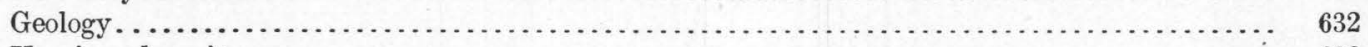

Uranium deposits. . . . . . . . . . .

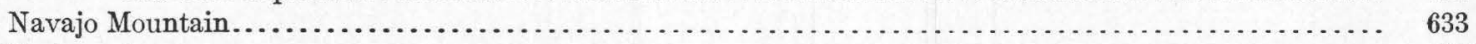

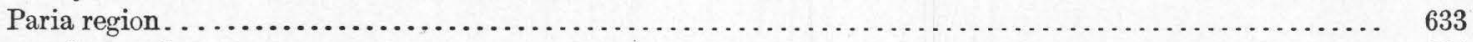

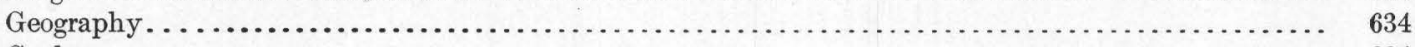

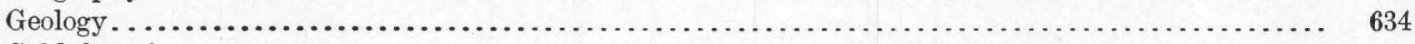

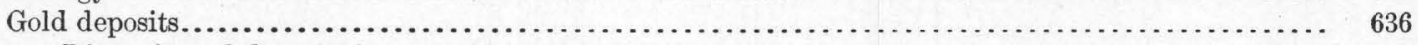

Disseminated deposits in consolidated sedimentary rocks......................... 636

Character of the sediments. . . . . . . . . . . .

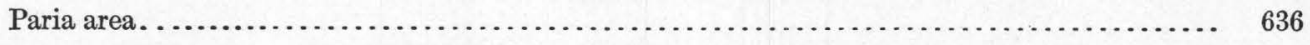


Part II. Ranges and districts-Continued.

Paria region-Continued.

Gold deposits-Continued.

Disseminated deposits in consolidated sedimentary rocks-Continued.

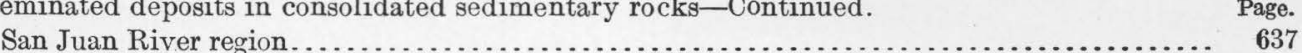

Other deposits. . . . . . . . . .

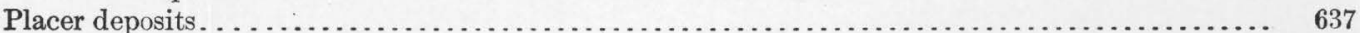

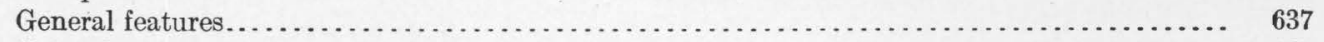

Colorado River. . . . . . . . . . . . . . . . . . . .

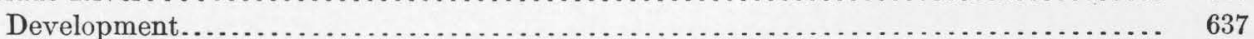

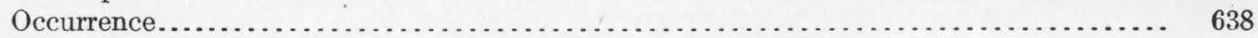

San Juan River......................................................... 639

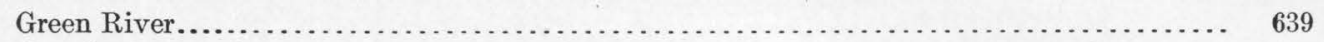

Grand River........................................................ 640

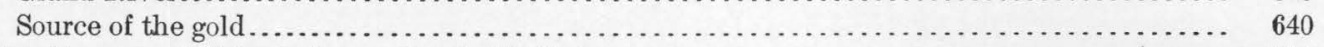

Appendix. Carboniferous and Triassic faunas, by G. H. Girty ..................................... 641

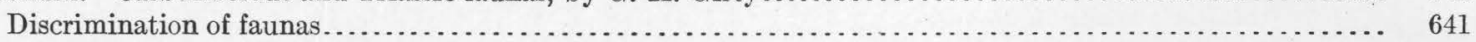

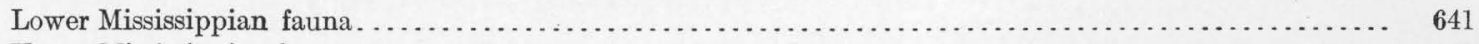

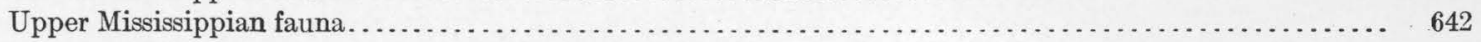

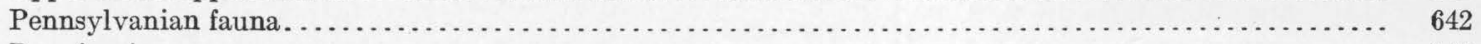

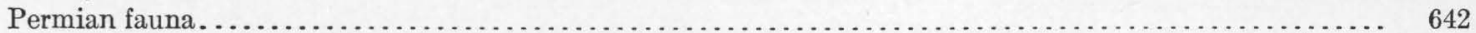

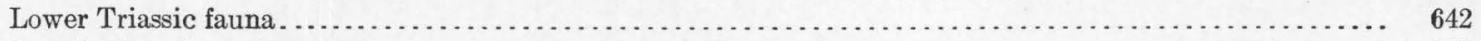

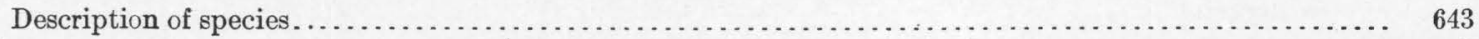

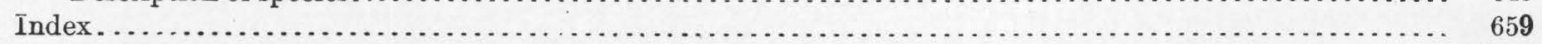




\section{ILLUSTRATIONS.}

Page.

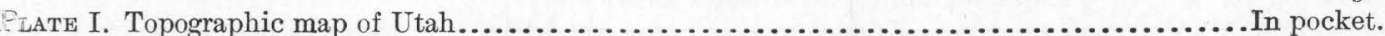

II. Relief map showing parts of Rocky Mountain, Colorado Plateau, and Great Basin areas..... 68

III. $A$, Rocky Range; $B$, Beaver Lake Mountains; $C$, Front of Wasatch Range, near Little Cot-

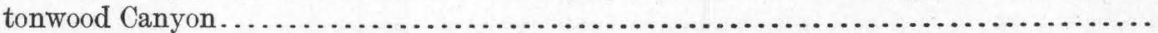

IV. Reconnaissance geologic map of Utah.........................................

V. Correlated geologic columnar sections of northern Utah........................... In pocket.

VI. Correlated geologic columnar sections of southern Utah and adjacent parts of Colorado,

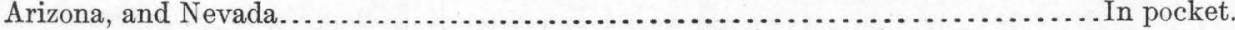

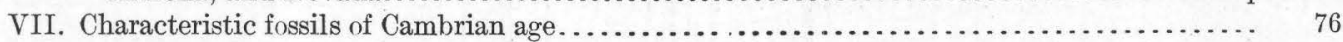

VIII. Characteristic fossils of Cambrian and Ordovician age............................ 77

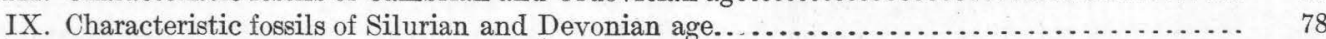

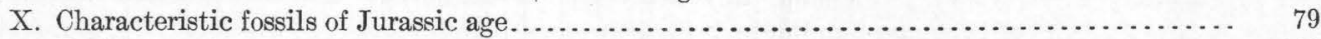

XI. Position and relation of major structural features of Utah........................ 100

XII. $A$, Recent fault along Wasatch Mountain front near Provo; $B$, Hanging valley in Sheep

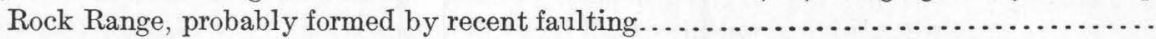

XIII. Curves showing by yearly averages the value of the metallic output of the mines of Utah, the tons of ore produced, and the average value per ton.............................

XIV. Replacement of vegetable matter by ores: $A$, Photomicrograph of carbonized vegetable material from the Dolly Varden mine, showing cellular structure; $B$, Photomicrograph of vegetable material replaced by sulphide from the Blue Dike mine, showing cellular structure; $C$, Replacement of vegetable matter by iron sulphide (pyrites and marcasite?) largely altered to limonite, which still retain cellular structure, from Circle Cliffs; $D$, Enlargement of $C$, showing remnants of iron sulphide; $E$, Photomicrograph showing longitudinal section of cellular structure; $F$; Photomicrograph showing cross section of cellular structure.

XV. $A$, Photomicrógraph of quartz monzonite of Cactus area, San Francisco district; $B$, Photomicrograph of altered quartz monzonite, Cactus area.

XVI. $A$, Photomicrograph of quartz monzonite porphyry, Bingham district; $B$, Photomicrograph of quartz monzonite porphyry, Bingham district; $C$, Photomicrograph of quartz monzonite porphyry enriched with biotite, Bingham district; $D$, Photomicrograph of quartz monzonite porphyry enriched with orthoclase, Bingham district.

XVII. Breccia ores: $A$, Mineralized limestone breccia. Old Emma mine; $B$, Mineralized latite breccia, Horn Silver mine; $C$, Mineralized quartz monzonite breccia, Cactus mine.........

XVIII. A, Photomicrograph of specimen of ore from Gold Springs district, showing replacement of calcite by quartz and adularia; $B$, Photomicrograph of specimen of ore from Marysvale district, showing replacement of barite by quartz and adularia; $C$, Photomicrograph of specimen of vein material, from Gold Springs district, showing.quartz and adularia.......

XIX. A, Photomicrograph of specimen showing alteration of wall rock adjacent to gold veins in Gold Springs district; $B$, Photomicrograph of specimen of highly altered wall rock adjacent to veins from Gold Springs district.

XX. A, Photomicrograph of specimen of alunite from Tushar Range, showing plumose character of crystals; $B$, Specimen of alunite from Tushar Range, showing banded structure of veins

XXI. A, Photomicrograph of specimen of rock from Sheep Rock, on the west side of Tushar Range, showing banding of alunite and quartz; $B$, Photomicrograph of specimen showing wall rock of alunite vein altered to alunite, Marysvale district.

XXII. Chart showing variation in level of Great Salt Lake and the monthly and annual precipitation in Great Salt Lake Basin

XXIII. $A$, Oxidized copper ore from the Copper Mountain mine, Lucin district; $B$, Smithsonite pseudomorphs after calcite, from the seventh level of the Horn Silver mine; $C$, Covellite replacing zinc sulphide.

XXIV. $A$, Photomicrograph of specimen of zinc sulphides from the Horn Silver mine; $B$, Photomicrograph of specimen shown in $A$, with crossed nicols; $C$, Photomicrograph of crystal of zinc sulphide in ordinary light; $D$, Photomicrograph of crystal shown in $C$, with crossed nicols. 
Plate XXV. A, West front of Wasatch Range in Sierra Madre district, showing geologic formations; $B$, Unconformity showing pre-Cambrian granite and pegmatite dikes cut off by basal Cambrian conglomerate, Sierra Madre district.

XXVI. $A$, Undulatory vertical fissures (tight) and horizontal fissures with quartz and chlorite in pre-Cambrian granite, Sierra Madre district; $B$, Santa Maria mineralized fissure in pre-

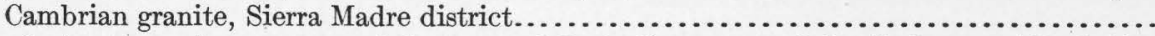

XXVII. Geologic reconnaissance map of Cottonwood-Park City area and detailed map of Park City

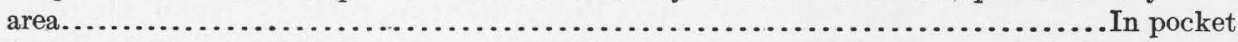

XXVIII. Columnar section showing formations present in Big Cottonwood Canyon................. 280

XXIX. $A$, View in Mill D (South) Fork, Big Cottonwood Canyon, showing Cardiff and other mines; $B$, View on north side of Little Cottonwood Canyon, near Alta.....................

XXX. $A$, Park City monocline; $B$, Clayton Peak diorite stock..........................

XXXI. Wasatch front at Provo, showing shore line of Lake Bonneville........................

XXXII. Longitudinal or strike valley separating main Wasatch Ridge at Provo Peaks from the front hills

XXXIII. Geologic map and sections of the Bingham mining district.

XXXIV. A, View of Bingham Canyon in 1900, showing location of disseminated deposits; $B$, View

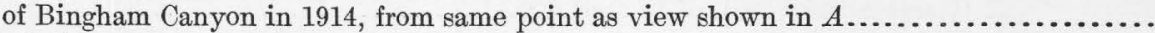

XXXV. Geologic map and section of Utah Copper Co.'s mining property at Bingham............

XXXVI. Outcrop of porphyry ore deposits of Utah Copper Co. in Bingham Canyon; A, View in 1908, when original outline of hill was still apparent; $B$, View in 1915, after stripping is nearly

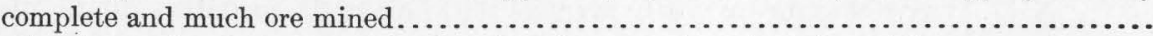

XXXVII. $A$, Specimen of rock from the Ophir Hill mine, showing alteration of limestone that contains ore deposits; $B$, Photomicrograph showing gradation from epidote layer to quartzorthoclase layer.

XXXVIII. $A$, View of West Tintic district in the vicinity of Scotia mine, showing characteristic exposures of geologic formations; $B$, Lion Hill, showing Ophir anticline on south side of Ophir Canyon, Ophir.

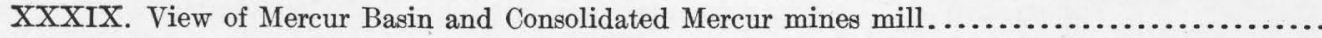

XL. Geologic map and sections of the mining districts of the San Francisco region.............

$X L I$. $A$, Horn Silver mine and village of Frisco; $B$, View looking west from a point near Comet mine, showing outcrop of Cactus ore body.

XLII. Sections of the Horn Silver ore body.

XIIII $A$, Photomicrograph of specimen of zinc sulphides from the Horn Silver mine; $B$, Photomicrograph of same specimen as that shown in $A$, taken with crossed nicols.....

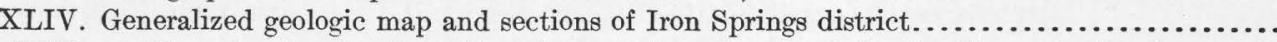

XLV. A, View showing Southern Cross iron-ore deposit, east of Granite Mountain, looking north; $B$, View showing Chesapeake iron-ore fissure vein, Iron Mountain..................

XLVI. Geologic map and sections of the Silver Reef district......................... In pocket.

XLVII. $A$, View looking north along White and Buckeye reefs in the Silver Reef district; $B$, View

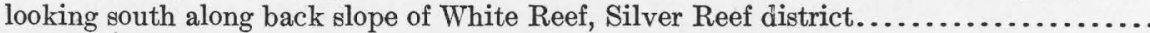

XLVIII. $A$, Specimen of clay "conglomerate" ore, Silver Reef district; $B$, Specimen shown in $A$ viewed across bedding, showing lenticular form of clay "pebbles"; $C$, Specimen of silver ore from White Reef, Silver Reef district, showing fossil plant remains..............

XLIX. $A$, Specimen of native gold in carbonate gangue from the Bull Valley district; $B$, Polished surface of specimen shown in $A$, enlarged 4 diameters; $C$, Photomicrograph showing rosette of quartz in specimen of arsenic ores from Bull Valley district; $D$, Specimen shown in $C$, with crossed nicols

L. Photomicrographs of ore from the Big Indian mine, La Sal Mountains: A, Photomicrograph of sandstone copper ore; B, Photomicrograph of sandstone copper ore, showing copper sulphide matrix; $C$, Concentric bands of pyrite and covellite; $D$, Nodules of

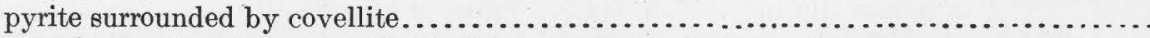

LI. Photomicrographs of placer gold; $A$, Colorado River; $B$, Green River..................

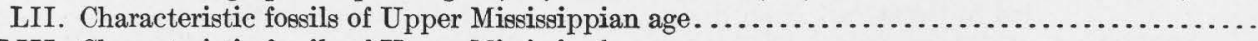

LIII. Characteristic fossils of Upper Mississippian age . . . . . . . . . . . . . . . . . . . . . . . . .

LIV. Characteristic fossils of Lower Mississippian and Pennsylvanian age.................

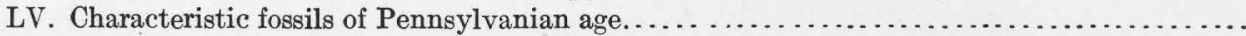

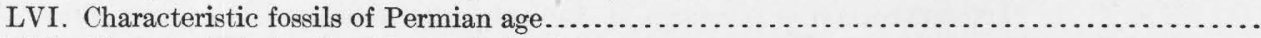

LVII. Characteristic fossils of Lower Triassic age. 


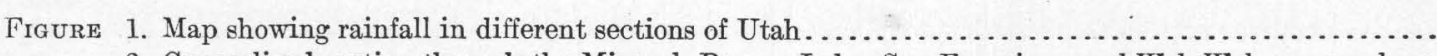

2. Generalized section through the Mineral, Beaver Lake, San Francisco; and Wah Wah ranges, show-

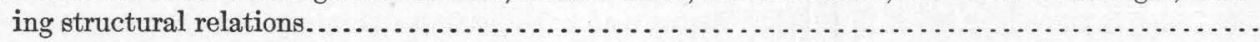

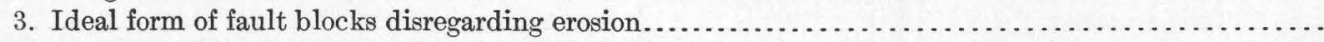

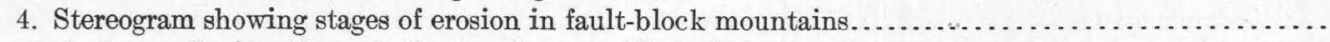

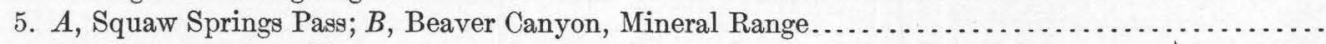

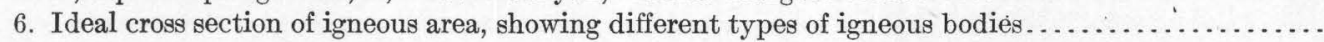

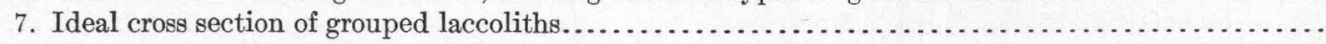

8. Diagram showing relation of silica to other principal oxides of the intrusive rocks of the belt com-

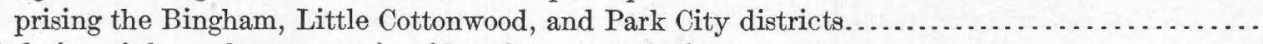

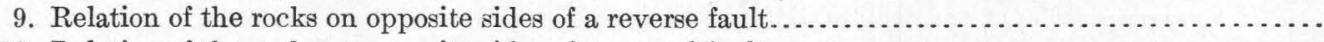

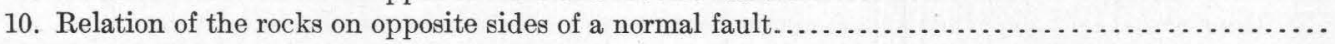

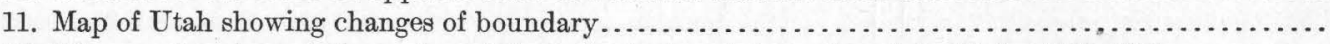

12. Diagram showing relative value of the principal metals produced in Utah, $1865-1916 \ldots \ldots \ldots \ldots$.

13. Diagram showing relative value of the metal output of the principal mining districts of Utah, 18651916 .

14. Diagram showing the relative amounts paid in dividends by companies in the larger mining districts of Utah, 1865-1916.

15. Diagram showing relative importance of mining districts of Utah in production of gold, $1865-1916 \ldots$

16. Curve showing yearly variation in the production of gold in Utah, $1865-1916 \ldots \ldots \ldots \ldots . . . . . . . . .$.

17. Diagram showing relative importance of the principal districts of Utah in the production of silver, 1865-1916.

18. Curves showing the annual variation in the production, value, and average price of silver in Utah, 1865-1916.

19. Curves showing yearly production, value of production, and average yearly price of copper, 1870-

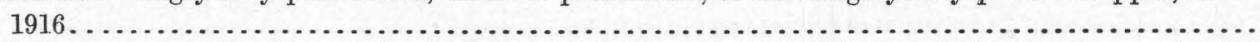

20. Diagram representing the relative importance of the total output of the principal copper-producing

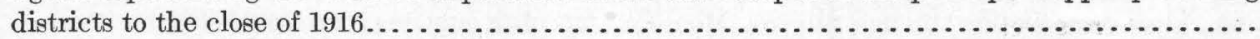

21. Diagram showing annual variation in the production, value, and average price of lead in Utah, 1870-1916.

22. Diagram showing the relative production of lead from the principal districts of Utah, 1870-1916...

23. Diagram showing the yearly production, value, and average price of zinc in Utah, 1904-1916.....

24. Diagram showing the relative production of zinc from the principal districts of Utah, 1904-1916....

25. Diagram showing gain or loss in grams of each constituent in alteration of 100 cubic centimeters of quartz monzonite wall rock of tourmaline-quartz copper vein at Cactus mine, San Francisco district, Beaver County.

26. Diagram showing gain or loss in grams of each constituent in sericitization of 100 cubic centimeter of quartz monzonite wall rock of quartz copper veins at $\mathrm{O}$. K. mine, Beaver Lake district, Beaver County

27. Diagram showing gain or loss in grams of each constituent in alteration of 100 cubic centimeters of quartz monzonite wall rock of quartz copper veins of Bingham district by addition of biotite and orthoclase.

28. Diagram showing gain or loss in grams of each constituent in the metamorphism of 100 cubic centimeters of limestone in the San Francisco district.

29. Diagram showing gain or loss in grams of each important constituent in the contact alteration of 100

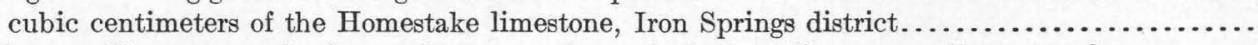

30. Diagram illustrating selective replacement of certain beds of limestone adjacent to fissures......

31. Ideal section through the top portion of an intrusive zone, showing the portions where differentiation became more important and the places where metals were precipitated.

32. Generalized vertical section along a fissure outcropping at different elevations, showing the distribution and flow of the waters in the fissure.

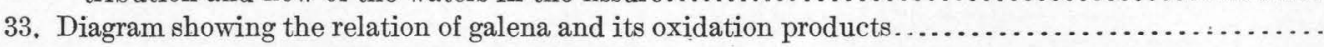

34. Diagram showing a condition favorable to the formation of oxidized zinc deposits.................

35. Diagram showing a condition unfavorable to the formation of oxidized zinc deposits...............

36. Diagram showing the sequence of the different zones in the Horn Silver mine..................

37. Map showing relation of mining prospects to Bear River Range and overthrust....................

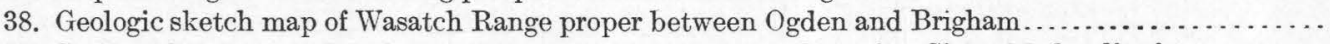

39. Section showing relations between deposits in dolomite and granite, Sierra Madre district..........

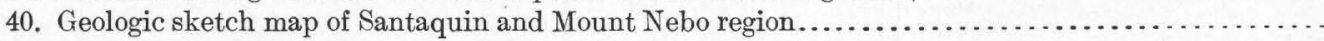

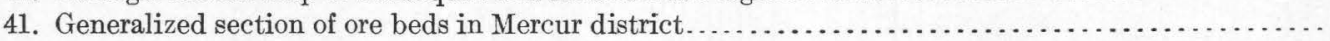

42. Map showing the relation of mines to the geologic formations in the Tintic district.................

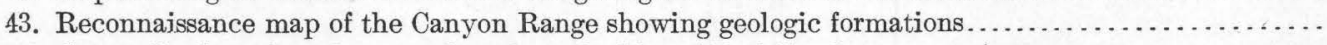

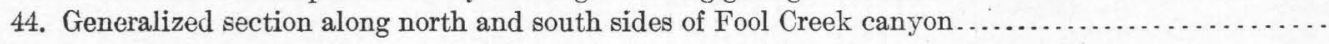

Page.

64

71

72

72

75

92

93

97

97
101

101

117

126

131

132

132

133

134

136

137

139

140

141

142

164

164

164

171

173

175

200

203

210

212

212

214

216

221

225

323

392

397

418

420 


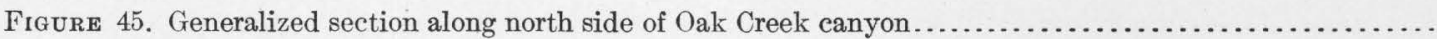

46. Reconnaissance geologic map of Sheeprock Mountains and part of the West Tintic Mountains....

47. Sketch map showing main geologic features and the locations of mines and prospects in the West Tintic district.

48. Contour map showing positions of Simpson and McDowell mountains, Fumarole Butte, and Desert Mountain.

49. Fault of steep westward dip cut off by a bedding fault at a small prospect on the southern peak east of Camp Blaine, Simpson Mountains.

50. Reverse fault exposed in Blaine lower tunnel, Camp Blaine, Simpson Mountains...............

51. Diagram showing relations of different fissures to one another; also relation of ore shoots to fissuring and composition of wall rock in southern part of Simpson Mountains.

52. Generalized section of the sedimentary series in the San Francisco and adjacent districts.........

53. Generalized stereogram representing the relations of the formations in part of the San Francisco Range north of Squaw Springs Pass.

54. Generalized stereogram showing the relation of pegmatitic quartz and altered and mineralized quartz monzonite in the $\mathrm{O}$. K. mine.

55. Diagram showing the relative period of formation of the principal ore and gangue minerals of the Cactus ore zone.

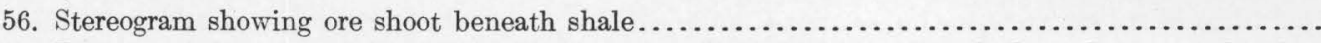

57. Diagram showing the relation of secondary alteration to outcrop of ore body and to water level in San Francisco and adjacent districts.

58. Reconnaissance geologic map of Mineral Range

59. Map showing location of prospects in the principal group of alunite deposits near Marysvale.......

60. Geologic sketch map showing relation of Sheep Rock quartz-alunite deposits to country rock and metalliferous veins.

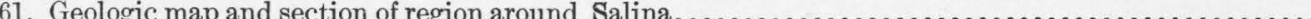

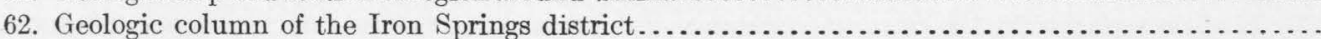

63. Ideal cross section through the Iron Mountain laccolith showing structural relations of ore.........

64. Sketch map of Bull Valley iron district.

65. Section of rocks exposed along Le Verkin canyon between Toquerville and Colob.............

66. Generalized diagram showing relations of the formations near Silver Reef . . . . . . . . . . . . . .

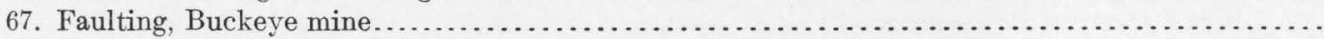

68. Faulting, Last Chance mine.

69. Structure of Buckeye Reef, Kinner mine.

70. Vertical cross section of Last Chance mine...

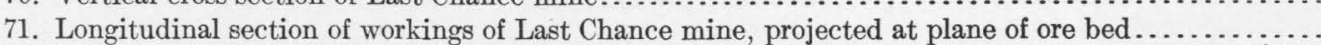

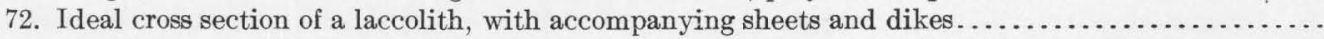

73. Diagram showing the vertical distribution of the laccoliths of the Henry Mountains............

74. Sketch map showing the distribution of the uranium-vanadium bearing sandstone in the vicinity of the Henry Mountains.

\section{INSERT.}

Comparison of some sections of volcanic rocks in Utah with generalized sections proposed by Dutton and Spurr 


\section{PREFACE.}

By F. L. Ransome.

Twelve years ago, when Mr. Waldemar Lindgren was in charge of the Survey's work on the geology of metalliferous deposits, he planned the preparation of a series of volumes to be published as professional papers, in each of which should be described the geology and ore deposits of a single State. His idea was to summarize and bring up to date such detailed monographic work as had already been done on individual districts, to make reconnaissance examinations of districts that had not been geologically studied, and to extend, by reconnaissance where necessary, our knowledge of the general geology of the State sufficiently to provide an adequate setting for the descriptions of the mining districts. It was realized that at least three general purposes might be fulfilled by these volumes. Each would constitute a convenient reference book of the geology and ore deposits of the State described, wherein one might ascertain what is known of each district and find references, where appropriate, to other publications; each would contain accounts of districts not elsewhere geologically described; finally, the broad survey of all the ore deposits of the State with reference to their geologic history and surroundings would, it might reasonably be expected, result in the discovery of important truths not evident to the geologist whose attention is focused for the time being on a single district. Inasmuch as New Mexico appeared to offer the fewest complications and difficulties, the ore deposits of that State were selected as the subject of the first volume, which appeared in $1910 . .^{1}$

This report not only proved widely useful but fulfilled the expectation above referred to in that the work upon which it was based resulted in the recognition of a number of distinct epochs of metallization, and in the de-

1 Lindgren, Waldemar, Graton, L. C., and Gordon, C. H., The ore deposits of New Mexico: U. S. Geol. Survey Prof. Paper 68, 1910. termination of the relation of these epochs to one another and of the mineral character and structural features pertaining to each.

The plan so successfully begun has been. continued. No member of the Survey has been able to devote all of his time to one of these State reports, but where the work of a geologist has lain more or less continuously in a single State, he has gradually, in connection with his other duties, accumulated material for such a publication.

The present report on Utah by Mr. Butler and others is the second of the series to appear. Another on Idaho is well advanced, and one on Arizona will probably follow, although its actual compilation can scarcely be said to have begun. In the development and output of its mines and in the mineralogic variety of its ores, Utah far surpasses New Mexico. The State also contains a large number of less-developed districts concerning which little geologic information has hitherto been available. Both of these facts, in spite of persistent efforts at condensation on the part of the authors, have favored the growth of the present volume to a size which may, by some, be considered unwieldy. It is felt, however, that one function of the report, that of a reference work to which a reader might turn for information about a particular district, would be impaired if the more famous and productive districts were less fully described or if the accounts of the littleknown districts were lacking in those details which, perhaps, Mr. Butler and his associates are best able to supply.

An interesting result which has come from the general survey of all the known ore deposits of the State is the generalization by Mr. Butler that the occurrence of ore bodies around an intrusive stock, within depths accessible to mining, depends upon the vertical distance between the present erosion surface and the original top or apex of the igneous mass. 



\section{OUTLINE OF REPORT.}

The main physiographic divisions of Utah are (1) the Great Basin, occupying most of the western part of the State; (2) the Wasatch Mountains, flanking the Great Basin on the east for 200 miles southward from the Idaho boundary; (3) the Uinta Mountains, extending eastward from the Wasatch into Colorado; (4) the southwest margin of the Wyoming Basin, lying north of the Uinta and east of the Wasatch; and (5) the Plateau province, lying south and southwest of the Uinta.

Throughout the Mesozoic era a large part of the Basin Range province in Utah was above sea level and was undergoing erosion, the débris from which was largely deposited in the area now occupied by the Plateau and Uinta provinces. In post-Cretaceous time there was a general elevation of the entire region. The elevation was greatest along certain east-west belts forming the Uinta and Raft River ranges. Other uplifts that are less prominent physiographically though equally important structurally are the Tintic-Deep Creek and Beaver County uplifts. Contemporaneous with or soon after the general uplift there was a great outpouring of lavas over much of the Great Basin and part of the Plateau province. This volcanic action was followed by subsidence by which the Basin region was depressed below the Plateau region and was broken into blocks of general north-south trend, which were tilted at different angles and which formed the Basin ranges. The main effect of the movement in the Plateau region, where it was less pronounced, was to throw the more pliable Mesozoic sediments into folds with accompanying faults.

The sedimentary rocks of Utah range in age from pre-Cambrian to Recent. Pre-Cambrian rocks, mainly schist, shale, and quartzite, are exposed along the great east-west upliftsthe Uinta Mountains, Raft River Mountains, the Tintic-Deep Creek uplift-and adjacent to the great fault scarp which forms the west face of the Wasatch.

$$
35416^{\circ}-19-3
$$

Resting unconformably on the pre-Cambrian rocks is a great series of Paleozoic quartzites, shales, and limestones ranging in age from Lower Cambrian to Permian. These beds show no marked angular unconformity, but they contain abundant evidence of periods of nondeposition and of erosion. These Paleozoic rocks form most of the Basin ranges, but they pass eastward beneath Mesozoic formations. Near the Colorado boundary, north of the Denver \& Rio Grande Railroad, where the pre-Cambrian rocks are exposed, the Paleozoic formations are absent, having apparently wedged out toward the east.

Upon the Paleozoic formations lies a thick series of Mesozoic rocks, consisting principally of shales and sandstones but including some beds of limestone. These strata are exposed principally in the eastern part of the State, but they are found also at a few places in the Great Basin. They rest with little or no angular unconformity on the Paleozoic rocks; and within the Mesozoic strata there are no pronounced angular unconformities, though in the Mesozoic era, as in the Paleozoic, there were periods of nondeposition and of erosion.

Overlying the Mesozoic rocks in large areas south of the Uinta Mountains and in the Plateau region are Tertiary formations, which consist largely of sandstone and shale but include some limestone. At a few places in the Great Basin Tertiary sediments lying unconformably on the older rocks are exposed. Quaternary sediments occupy large areas in the Great Basin between the ranges.

Igneous rocks are of interest and importance in Utah, the extrusive rocks because of their great extent and the intrusive rocks, which are not relatively very abundant, because of their intimate relation to the ore deposits.

Extrusive rocks are most important in southern Utah, where they form a broad belt extending from the Nevada line eastward to the High Plateau and occupy large areas farther north in the Great Basin. A large part 
of the lava is of intermediate composition, near latite, though rhyolites occur, and the latest flows are of basalt.

The intrusive rocks are largely confined to rather definite belts, the more important being the Park City, Little Cottonwood, and Bingham belt, the Tintic-Deep Creek belt, the Tushar, Mineral, Star, Beaver Lake, and San Francisco ranges belt, and the Iron Springs belt. In addition to these there are intrusions in the Grouse Creek, Raft River, and Pilot ranges and three centers of intrusion, the Henry, Abajo, and La Sal mountains, in the eastern part of the State.

In the western part of the State the large intrusive bodies are characteristically stocks; in the Plateau region they are laccoliths.

The composition of the intrusive rocks, like that of the extrusives, is prevailingly intermediatè, near quartz monzonite and quartz diorite. In the stocks in the western part of the State the deeper exposed portions are the more siliceous, probably because of differentiation produced by the sinking of the ferromagnesian minerals, which were the earliest to form. In the laccoliths of the Plateau region there has been little such differentiation.

The age of many of the igneous bodies is not known from direct evidence. Those that have been determined are of post-Cretaceous age, probably most if not all of them are of Tertiary age.

The oldest large structural feature in the Paleozoic and later rocks is a general northsouth folding, which is accompanied by overthrust faulting.

After the folding there were east-west uplifts, some of which were accompanied by intrusions. The Uinta and Raft River ranges represent such uplifts, and such structural features are associated with the intrusive belts farther south. The domes or swells and the broad uplifts that characterize the Plateau region may have been formed at the same time.

The youngest important structural features are the north-south faults that outline the Basin ranges and that also occur in the Plateau area.

The presence of metallic deposits in the mountains of Utah was known in the fifties, and a little lead ore was reduced to metal in a crude way by the Mormon settlers. Active prospecting began with the arrival of Gen.
Connor's California volunteers, in 1862, and the first claim was located in Bingham Canyon in 1863. The production of placer gold began in 1865. Since 1870 there has been a steady and increasing output from lode mines, which to the close of 1917 had yielded a total of $\$ 816,827,182$ and had paid dividends of $\$ 152,774,801$.

The ore deposits of the State may be separated into two general classes - those that were deposited at the same time as their inclosing rock and those that were introduced after the formation of the rocks in which they are found. Those deposited with the inclosing rocks comprise no deposits of any importance except gold placers, and from these the yield has been relatively small. Those introduced later than the inclosing rocks may in turn be subdivided into two principal groups-those that show no close relation with igneous rocks and those that are believed to be genetically associated with igneous intrusion. Of those not associated with igneous rocks the most a bundant representatives are the "red bed" or sandstone deposits of silver, copper, and uraniumvanadium, all of which are most commonly found in association with fossilized vegetable matter. The relations of certain of these deposits has led to the belief that they were formed later than most of the folds and faults and that these features were important factors in controlling the movement of the solutions that deposited the ores.

By far the greater number of deposits are so closely associated with igneous rocks that there can be little doubt that their origin is directly dependent on the igneous activity. They are most numerous and most extensive in the zones of greatest igneous activity in the western part of the State. They occur in the intrusive bodies, in the extrusive rocks, and in the sedimentary rocks adjacent to the intrusive bodies.

Deposits in the intrusive bodies are pegmatitic gold quartz veins, quartz-tourmalinescheelite veins, copper quartz-tourmaline veins, quartz-pyrite-molybdenite veins, quartz copper veins, silver-lead quartz veins, gold quartz veins, silver-lead-copper quartz-barite veins, and magnetite-hematite veins. The close similarity of some of these veins to pegmatites and the gradation from one type to another has led to the belief that all the deposits in the 
intrusive rocks were derived from material that separated from the crystallizing magma.

Deposits in the sedimentary rocks are subdivided into contact deposits and replacement deposits associated with fissures. The contact deposits include iron deposits, copper deposits, and gold deposits. Comparison of the changes that took place in the sediments while the contact deposits were being formed with the changes that took place in the intrusive rocks adjacent to the deposits leads to the conclusion that the solutions effecting the two sets of changes were so similar that it is reasonable to conclude that they had a common origin. The replacement deposits in sedimentary rocks associated with fissures include copper deposits, lead-silver deposits, zinc-leadsilver deposits, silver deposits, gold deposits, and quicksilver deposits. The transition and gradation from contact deposits to certain of the replacement deposits associated with fissures and among the different types of the replacement fissure deposits leave no doubt that all have a common origin.

Deposits in extrusive rocks are subdivided into silver-lead-zinc-copper deposits, gold-silver deposits, and alunite deposits. The relation of these deposits to those in the intrusive rocks and in the sediments indicate that all have a common origin.

The larger intrusive bodies of Utah are of two types, laccoliths and stocks. The laccoliths occur in the sandy and shaly sedimentary rocks in the southeastern part of the State and the stocks in the quartzites and limestones in the western part of the State. The stocks may be subdivided into those truncated by erosion near the apex and those truncated at a greater depth. Those truncated near the apex (apically truncated stocks) are monzo. nitic to dioritic in composition and those more deeply truncated are uniformly more siliceous, having the composition of granodiorite to granite.

Ore deposits associated with the laccoliths and the more deeply truncated stocks have proved to be of comparatively slight commercial importance, and those associated with the apically truncated stocks have proved to be of great value. It is believed that after intrusion the laccoliths were sealed off from their deepseated source and that the amount of material already in them was too small and the differ- entiation on solidifying too incomplete to furnish large deposits. It is also believed that in the stocks the differentiation was greater at depth, and that the mobile constituents of the magma (water and gases carrying minerals in solution) rose toward the surface, whereas the heavier minerals that crystallized early sank to greater depths. When the mobile constituents reached a point where the magma was sufficiently solidified to fracture they were guided by the fractures or fissures and on reaching favorable physical and chemical environment began to deposit their metals. The more deeply truncated stocks are regarded as remnants from which the portion in which the metals were concentrated has been eroded.

It is regarded as possible that the connection of a magmatic body with the surface or zone of fracture at the time of intrusion may have been favorable to the rapid separation of the materials that formed the ore deposits.

Consideration of the relation of primary sulphates (barite, anhydrite, or alunite) in the ore deposits has led to the belief that they were formed directly from magmatic emanations. That they occur only in veins that were formed at relatively low temperature is believed to be due to the fact that the sulphate radicle $\left(\mathrm{SO}_{3}\right)$ is unstable at high temperature and that it forms rapidly and is stable only at relatively low temperature. The oxygen to form the sulphate is probably derived from oxygen compounds of iron and other elements. These compounds may be reduced to the lower state of oxidation or to sulphides.

The alteration of the ore deposits by surface agencies has had an important though variable effect on their composition. It has enhanced the value of nearly all the deposits by concentrating a certain metal, as copper, or by removing a part of one of the metals from a complex deposit, as zinc from lead-silver-zinc ore; or by changing the character of the ore during its oxidation so as to render it more amenable to metallurgic treatment, as in some of the gold and silver deposits. In general, lead, silver, and gold migrated but little during the process of oxidation, and their ores were improved by the removal of other constituents. Copper and zinc, on the other hand, migrated readily and under favorable conditions were reprecipitated in a concentrated form, producing valuable deposits. 
will doubtless be described as opportunity affords.

\section{ACKNOWLEDGMENTS.}

For a large proportion of the data contained in the report the writers are indebted to other workers. From its earliest exploration the region has been one of unusual interest to geologists, and studies made within it have resulted in reports that have become classic. Perhaps no area of equal size in the West has been so productive of geologic literature; even to enumerate the papers requires many pages. (See Bibliography, pp. 38-57.) It is hardly necessary to say that the accumulation of such data was a condition precedent to the preparation of the present report, a considerable part of which consists of an attempt to correlate systematically the data relative to ore deposits contained in the papers previously published.

The authors are deeply indebted to the mining men of the State, who have freely furnished information and presented and discussed relations and ideas which have not appeared in print and for which it is difficult to give proper credit, though an attempt to do so has been made. The authors feel that they will be pardoned if in this general acknowledgment they do not mention by name those who have extended courtesies during the long period that field work was in progress. To those who are familiar with the mining districts of the State it is unnecessary to say that the traveler in them is everywhere most cordially received. The pleasant recollections of trips to remote and in many respects uninviting places are due in no small part to the hospitality generously extended by the residents, which remains fresh in memory after the discomforts have long been forgotten.

The authors also wish to express their indebtedness to other members of the Survey for the determination of fossils, for chemical and mineralogic determinations, and for suggestions and criticism bearing on the geologic problems involved. It is a pleasure especially to acknowledge the helpful suggestions and criticisms of Mr. Waldemar Lindgren, under whose direction this work was begun, and of Mr. F, L. Ransome, under whose supervision it was completed.

\section{BIBLIOGRAPHY.}

In the following bibliography are included the papers relative to the geology of Utah listed in the bibliographies of North American geology, 1732 to 1917, published by the United States Geological Survey. The author has added papers that have come to his attention that were not included in the publications mentioned, but he has found so many interesting references to the geology of the State in such unexpected places that he feels certain that numerous observations have been overlooked. No attempt has been made to include references to the geology of the State included in textbooks and other general works.

Allen, R. H., Mines and mills of the Consolidated Mercur Co.: Eng. and Min. Jour., vol. 89, pp. 1273-1277, 3 figs., 1910.

Includes a brief account of the geology and of the occurrence and character of the gold ores of the Mercur district, Utah.

Anderson, G. E., Stream piracy of the Provo and Weber rivers, Utah: Am. Jour. Sci., 4th ser., vol. 40, pp. 314-316, 2 figs., 1915.

Aтwood, W. W., The glaciation of the Uinta Mountains: Jour. Geology, vol. 15, No. 8, pp. 790-804, 4 figs., 1907. - Lakes of the Uinta Mountains: Am. Geog. Soc. Bull., vol. 40, pp. 12-17, 6 figs., 1908.

Glaciation of the Uinta and Wasatch mountains: U. S. Geol. Survey Prof. Paper 61, 96 pp., 15 pls., 24 figs., 1909.

- The physiographic conditions at Butte, Mont., and Bingham Canyon, Utah, when the copper ores in these districts were enriched: Econ. Geology, vol. 11, no. 8, pp. 697-740, 14 pls., 7 figs., December, 1916.

Becker, G. F., Reconnaissance of the San Francisco, Eureka, and Bodie districts: U. S. Geol. Survey First Ann. Rept., pp. 37-47, 1880. Geological sketch of the Pacific division: Tenth Census U. S., vol. 13, Statistics and technology of the precious metals, pp. 5-59, 1885 .

Beeson, J. J., The disseminated copper ores of Bingham Canyon, Utah: Am. Inst. Min. Eng. Bull. 107, pp. 2191-2236, 18 pls., 1 fig., 1915; Am. Inst. Min. Eng. Trans., vol. 54, pp. 356-401, 18 pls., 1 fig., 1917.

BeLL, R. N., Geology of Park City, Utah, district: Lead and Zinc News, vol. 8, pp. 57, 60, 1904.

Describes the general geology and the occurrence of lead-ore deposits.

Berkey, C. P., Mineral resources of the Uinta Mountains, Utah: Eng. and Min. Jour., vol. 77, p. 841, 1904.

Discusses the stratigraphy and geologic structure of the Uinta Mountains and their mineral resources.

- A geological reconnaissance of the Uinta Reservation, southeastern Utah: Abstract in Science, new ser., vol. 19, p. 618, 1904.

Describes stratigraphic succession in this region. 
Berkey, C. P., Stratigraphy of the Uinta Mountains: Geol. Soc. America Bull., vol. 16, pp. 517-530, 2 pls., 3 figs., 1905.

Discusses the occurrence, character, and relations of the formations of the Uinta Mountains of Utah and the correlation of the Wasateh and Uinta sections.

Blackwelder, Eliot, Phosphate deposits east of Ogden, Utah: U. S. Geol. Survey Bull. 430, pp. 536-551, 4 figs., 1910.

Describes the general geology, Carboniferous formations, geologic structure, and the distribution, characteristics, and relations of phosphate deposits.

New light on the geology of the Wasatch Mountains: Abstract in Science, new ser., vol. 32, p. 188, 1910 .

- New light on the geology of the Wasatch Mountains, Utah: Geol. Soc. America Bull., vol. 21, No. 4, pp. 517-542, 5 pls., 9 figs., 1910; discussion, p. 767.

Discusses the occurrence and relations of pre-Cambrian and various Paleozoic formations and the geologic structure, describing overthrust faults and folding.

BLAKE, W. P., On the orography of the western portion of the United States: Am. Assoc. Adv. Sci. Proc., vol. 10 , pt. 2 , pp. 119-134, 1857.

Upon the gradual desiccation of the surface of the western portion of North America: Am. Naturalist, vol. 2, p. 444, 1869 .

- Notes on some points in the mineralogy and geology of Utah: Am. Jour. Sci., 3d ser., vol. 2, p. 216, 1871. - Iron ore deposits of southern Utah: Am. Inst. Min. Eng. Trans., vol. 14, pp. 809-811, 1886.

- Age of the limestone strata of Deep Creek, Utah, and the occurrence of gold in the crystalline portions of the formation: Am. Geologist, vol. 9, pp. 47-48, 1892 .

The limestone forms the ranges of hills and mountains and has been metamorphosed by the intrusion of granitic dikes. Its Carboniferous age is indicated by the contained fossils.

Association of apatite with beds of magnetite: Am.

Inst. Min. Eng. Trans., vol. 21, pp. 159-160, 1893.

Mentions examples of such association in New York,

Missouri, Utah, and New Jersey.

See also Hitchcock and Blake.

Boutwelt, J. M., Ore deposits of Bingham, Utah: U. S. Geol. Survey Bull. 213, pp. 105-122, 1903.

Describes the history of mining developments at this locality, the character and occurrence of sedimentary and igneous rocks, the geologic structure, and the occurrence and character of the ore deposits.

Progress report on the Park City mining district,

Utah: U. S. Geol. Survey Bull. 213, pp. 31-40, 1903. Contains a general account of the geology and ore deposits of the region.

- Iron ores in the Uinta Mountains, Utah: U. S. Geol. Survey Bull. 225, pp. 221-228, 1904.

Describes the general geologic structure and stratigraphy of the region and the occurrence and character of the iron-ore deposits.

-Gypsum deposits in Utah: U. S. Geol. Survey Bull.

223, pp. 102-110, 1 pl., 1904.

Describes character, occurrence, economic development, and geologic relations of gypsum deposits in Utah.
Boutwell, J. M., Rock gypsum at Nephi, Utah: U. S. Geol. Survey Bull. 225, pp. 483-487, 1904.

Describes the character, occurrence, and development of rock gypsum near Nephi, Utah.

Progress report on the Park City mining district, Utah: U. S. Geol. Survey Bull. 225, pp. 141-150, 1904.

Describes the character and occurrence of the sedimentary, igneous, and metamorphic rocks, the geologic structure, and the occurrence and mining of silver-lead ores.

Economic geology of the Bingham mining district, Utah: U. S. Geol. Survey Prof. Paper 38, pp. 71-385, 34 pls., 10 figs., 1905.

Describes the history and development of the district, the character, occurrence, and genesis of the ores, chiefly gold, silver, and copper, and in detail the mines and mining operations.

Genesis of the ore deposits at Bingham, Utah: Am. Inst. Min. Eng. Bi-Monthly Bull. 6, pp. 1153-1192, 13 figs., 1905. Abstract in Science, new ser., vol. 21, p. $662,1905$.

Describes the general geology and the character and occurrence of the copper and lead ores and discusses their origin.

- Vanadium and uranium in southeastern Utah: U. S. Geol. Survey Bull. 260, pp. 200-210, 1 fig., 1905.

Describes the occurrence, geologic relations, and character of ore deposits yielding vanadium and uranium.

- Progress report on Park City mining district, Utah: U. S. Geol. Survey Bull. 260, pp. 150-153, 1905.

Describes the progress of the mining operations in this district and the occurrence of the ore bodies, which yield chiefly gold and silver.

- Ore deposits of Bingham, Utah: Eng. and Min. Jour., vol. 79, pp. 1176-1178, 3 figs., 1905.

- Ore deposits of Bingham, Utah: U. S. Geol. Survey Bull. 260, pp. 236-241, 1905.

Describes the character, occurrence, and origin of the ores, which yield principally copper, and the recent mining developments.

Oil and asphalt prospects in Salt Lake basin, Utah: U. S. Geol. Survey Bull. 260, pp. 468-479, 1 fig., 1905.

Describes the general geography and geology, the prospecting for oil, and the occurrence and character of asphalt.

- Stratigraphy and structure of the Park City mining district, Utah: Jour. Geology, vol. 15, No. 5, pp. 434-458, 1907.

Describes the general geology, the character, occurrence, and relations of Carboniferous, Triassic, and Jurassic strata, and the geologic structure.

Geology and ore deposits of the Park City district, Utah: U. S. Geol. Survey Prof. Paper 77, 231 pp., 44 pls., 18 figs., 1912.

Bowman, H. L., Note on the refractive indices of pyromorphite, mimetite, and vanadinite: Mineralog. Mag., vol. 13, pp. 324-329, December, 1903.

Bradford, R. H., Some Utah mineral deposits and their metallurgical treatment: Am. Min. Cong., 11th ann. sess., Papers and addresses, pp. 101-118, 1909.

Bradley, F. H., Explorations of 1872, United States geological survey of the Territories, under Dr. F. V. Hayden, Snake River division: Am. Jour. Sci., 3d ser., vol. 6, pp. 194-207, 1873. 
Bradley, F. H., Report as geologist of the Snake River division: U. S. Geol. Survey Terr. Sixth Ann. Rept., pp. 191-271, 1873.

Bradley, W. M, See Ford and Bradley.

Brewer, W. H., Warren's New physical geography, 144 pages, Philadelphia, 1890.

Brinsmade, R. B., Mining at Bingham, Utah: History and geology of the region: Mines and Minerals, vol. 28, No. 3, pp. 90-93; No. 4, pp. 105-108, 7 figs., 1907.

The Utah copper mill near Garfield, Utah: Min. World, vol. 28, pp. 553-556, 6 figs., 1908.

Describes the occurrence of the ore bodies.

Mines of Tintic district, Utah: Mines and Minerals, vol. 28, No. 6, pp. 291-295, 5 figs., 1908.

Includes an account of the local geology and the occurrence, character, relations, and origin of the lead and copper ores.

- Mining and milling at Stockton, Utah: Eng. and Min. Jour., vol. 85, pp. 611-612, 1 fig., 1908.

Includes a brief account of the local geology and the occurrence and origin of the lead-silver ores.

- Daly-West mine and mill (Park City, Utah): Mines and Minerals, vol. 28, No. 8, pp. 353-356, 4 figs., 1908.

Includes a brief account of the geology in the vicinity of Park City, Utah, and of the occurrence and character of the ore bodies.

Burling, L. D., A key to Basin Range structure in the Cricket Range, Utah: Science, new ser., vol. 36, p. 240, 1912 .

Early Cambrian stratigraphy in the North American Cordillera, with discussion of Albertella and related faunas: Canada Geol. Survey Mus. Bull. 2, pp. 93-129, 1914.

Butler, B. S., Notes on the San Francisco region, Utah: U. S. Geol. Survey Bull. 529, pp. 197-199, 1913. Gives notes on the character and occurrence of the ores.

- Occurrence of complex and little-known sulphates and sulpharsenates as ore minerals in Utah: Econ. Geology, vol. 8, No. 4, pp. 311-322, 1 fig., 1913.

Geology and ore deposits of the San Francisco and adjacent districts, Utah: U. S. Geol. Survey Prof. Paper 80, 212 pp., 41 pls., 16 figs., 1913.

Geology and ore deposits of the San Francisco and adjacent districts, Utah: Econ. Geology, vol. 9, No. 5, pp. 413-434, 1 pl. (map), 2 figs.; No. 6, pp. 529-558, 8 figs., 1914.

- Relation of ore deposits to different types of intrusion bodies in Utah: Econ. Geology, vol. 10, No. 2, pp. 101-122, 1915; 4 figs. Abstract and discussion in Washington Acad. Sci. Jour., vol. 5, No. 11, pp. 407408, 1915.

Butler, B. S., and Gale, H. S., Alunite; a newly discovered deposit near Marysvale, Utah: U. S. Geol. Survey Bull. 511, 64 pp., 3 pls., 1912. Abstract in Washington Acad. Sci. Jour., vol. 2, No. 7, p. 193, 1912.

Describes the occurrence, extent, and geologic relations of the alunite vein, the geology and mineralization of the Tushar Range in which the vein is found, other known occurrences of alunite in the United States and some foreign deposits, and discusses the origin of the Marysvale alunite deposit.
Butler, B. S., and Heikes, V. C., Notes on the Promontory district, Utah: U. S. Geol. Survey Bull. 640, pp. 1-10, 2 figs., Mar. 16, 1916.

Butler, B. S., and Loughuin, G. F., A reconnaissance of the Cottonwood-American Fork mining region, Utah: U. S. Geol. Survey Bull. 620, pp. 165-226, 1 pl. (map), 1915.

Butler, B. S., and Schaller, W. T., Some minerals from Beaver County, Utah: Am. Jour. Sci., 4th ser., vol. 32, pp. 418-424, 1 fig., 1911.

Describes beaverite (new), wurtzite, plumbojarosite, and corkite.

- Thaumasite from Beaver County, Utah: Am. Jour. Sci., 4th ser., vol. 31, pp. 131-134, 1911. Zeitschr. Kryst. Min., Band 49, Heft 3, pp. 236-238, 1911. Abstract in Washington Acad. Sci. Jour., vol. 1, p. 37, July, 1911.

Describes the occurrence and composition.

- Beaverite, a new mineral: Washington Acad. Sci. Jour., vol. 1, pp. 26-27, 1911.

- Magnesioludwigite, a new mineral: Washington Acad. Sci. Jour., vol. 7, no. 2, pp. 29-31, Jan. 19, 1917.

Butler, B. S., Loughuin, G. F., and Heikes, V. C., A reconnaissance of the Cottonwood-American Fork mining region, Utah: U. S. Geol. Survey Bull. 620 , pp. 165-226, 1915.

Describes the geology and ore deposits of the region. See also Wells and Butler.

C. T., The Eureka-Beck decision: Eng. and Min. Jour., vol. 41, pp. 206-208, 1886.

CALL, R. E., On the Quaternary and Recent mollusca of the Great Basin, with descriptions of new forms: U. S. Geol. Survey Bull. 11, 66 pp., 6 pls., 1884 .

Carpenter, Everett, Ground water in Boxelder and Tooele counties, Utah: U. S. Geol. Survey WaterSupply Paper 333, 90 pp., 2 pls. (maps), 9 figs., 1913.

Clark, F. R., Coal near Thompson, Grand County, Utah: U. S. Geol. Survey Bull. 541, pp. 453-477, 1 fig., map, 1914.

Coal near Wales, Sanpete County, Utah: U. S. Geol. Survey Bull. 541, pp. 478-489, map, 1914.

Clark, R. W., A new occurrence of crystallized willemite (Star district, Beaver County, Utah): Am. Mineralogist, vol. 1, no. 6, pp. 89-91, 1 fig., December, 1916. Abstract in Science, new ser., vol. 43, p. 399, Mar. $17,1916$.

Clarke, F. W., An aluminum arsenate from Utah: Washington Acad. Sci. Jour., vol, 2, No. 21, pp. 516518, 1912.

Cockerell, T. D., A fossil gar pike from Utah: Science, new ser., vol. 29 , p. $796,1909$.

Conrad, T. A., On the Eocene beds of Utah: Am. Jour. Sci., 3d ser., vol. 1, pp. 381-383, 1871.

Cope, E. D., Report on the vertebrate paleontology of Colorado: U. S. Geol. and Geog. Survey Terr. Seventh Ann. Rept., pt. 2, pp. 427-533, pls. 1-8, 1874.

The Vertebrata of the Cretaceous formations of the West: U. S. Geol. Survey Terr. Final Rept., vol. 2, pp. 15-41, 1875.

The Manti beds of Utah: Am. Naturalist, vol. 14, pp. 303-304, 1880.

The Tertiary formation of the central region of the United States: Am. Naturalist, vol. 16, pp. 177-195, pl., 1882. 
Cope, E. D., The vertebrata of the Tertiary formations of the West, book 1: U. S. Geol. Survey Terr. Final Rept., vol. 3, xxxrv, 1009 pp., 75 pls., 1884. Reviewed in Science, vol. 5, pp. 467-469, 1885.

Crane, Guy W., Geology of Tintic ore deposits, Utah: Eng. and Min. Jour., vol. 100, No. 19, pp. 753-757, 1915.

- Geology of the ore deposits of the Tintic mining district, Utah: Am. Inst. Min. Eng. Bull. 106, pp. 2147-2160, 1915; Am. Inst. Min. Eng. Trans., vol. 54, pp. 342-355, 1917.

Cross, Whitman, Petrography: Geology and mining industry of Leadville, Colo.: U. S. Geol. Survey Mon. 12, pp. 319-362, 2 pls., 1886. Abstract in Am. Naturalist, vol. 22 , p. $62,1887$.

Describes some rocks collected by G. K. Gilbert from the Henry Mountains.

The laccolitic mountain groups of Colorado, Utah, and Arizona: U. S. Geol. Survey Fourteenth Ann. Rept., pt. 2, pp. 165-241, pls. 7-16, figs. 25-43, 1894.

Reviews the literature of the laccolithic theory. Describes the laccoliths of the Henry, West Elk, San Miguel, La Plata, Carriso, El Late, Abajo, and La Sal mountains, Mosquito Range, and the intrusive rocks of the Tenmile district, Colo. Discusses the chemical and mineralogic characters of laccolithic rocks, the conditions under which they were formed, and the forms and origin of laccoliths.

- Stratigraphic results of a reconnaissance in western Colorado and eastern Utah: Jour. Geology, vol. 15, No. 7, pp. 634-679, 11 figs., 1907.

Discusses the correlation of Cretaceous, Jurassic, Triassic, and Carboniferous formations.

- Wind erosion in the plateau country: Geol. Soc. America Bull., vol. 19, pp. 53-62, 2 pls., 1908.

Describes a red soil in Colorado and Utah believed to have been formed from material transported by wind. Describes also evidences of eolian erosion in Utah.

Crowthek, H. M., The copper deposits of the Beaver River Range, Utah: Eng. and Min. Jour., vol, 75, p. 965, 1903.

Describes the geologic structure and the occurrence of the ores.

See also Iddings and Cross.

Cummings, Brron, The great natural bridges of Utah: Nat. Geog. Mag., vol. 21, No. 2, pp. 157-167, 7 figs., 1910.

Curran, T. F. V., Carnotite: Eng. and Min. Jour., vol. 96, pp. 1165-1167, 1223-1225, 1913.

Custer, A. E., Deep Creek, Clifton mining district, Utah: Eng. and Min. Jour., vol. 103, no. 21, pp. 915-920, 5 figs., May 26, 1917.

Dale, T. N., Slate deposits of the United States: U. S. Geol. Survey Bull. 275, pp. 51-125, 18 pls., 12 figs., 1906 .

Describes the character and occurrence of slates in the several States including Utah.

Dana, J. D., Rocky Mountain protaxis and the postCretaceous mountain making along its course: Am. Jour. Sci., 3d ser., vol. 40, pp. 181-196, 1890.
Davis, C. A., On the fossil algae of the petroleum-yielding shales of the Green River formation of Colorado and Utah: Acad. Nat. Sci. Proc., vol. 2, no. 3, pp. 114-119, March, 1916.

- Some fossil algae from the oil-yielding shales of the Green River formation of Colorado and Utah. Abstract in Geol. Soc. America Bull., vol. 27, no. 1, pp. 159-160, Mar. 31, 1916.

Davis, W. M., Notes on geological observations in Colorado and Utah; in Macfarlane, James, An American geological railway guide, p. 165, 1879 .

On the classification of lake basins: Boston Soc. Nat. Hist. Proc., vol. 21, pp. 315-381, 1883. Abstracts in Am. Naturalist, vol. 16, pp. 1028-1029, 1882; Am. Jour. Sci., 3d ser., vol. 24, p. 230, 1882.

- Utah; in Macfarlane, James, An American geological railway guide, $2 \mathrm{~d}$ ed., pp. 114, 115, 1890.

- Notes on the Colorado Canyon district: Am. Jour. Sci., 4th ser., vol. 10, pp. 251-259, 1 fig., 1900.

Discusses the physiographic and dynamic history of the region.

- An excursion to the Plateau province of Utah and Arizona: Harvard Coll. Mus. Comp. Zool. Bull., vol. 42, pp. 1-50, 7 pls., 14 figs., 1903.

Describes physiographic features of this region.

The mountain ranges of the Great Basin: Harvard Coll. Mus. Comp. Zool. Bull., vol. 42, pp. 129-177, 7 pls., 18 figs., 1903.

Discusses the explanations offered for the formation of the mountain ranges of the Great Basin, describes his observations, and reaches the conclusion that the Basin ranges are examples of dissected faultblock mountains.

The Wasatch, Canyon, and House ranges, Utah: Harvard Coll. Mus. Comp. Zool. Bull., vol. 49, Geol. ser., vol. 8, No. 2, pp. 17-56, 3 pls., 28 figs., 1905.

Discusses the structure, physiographic features, and mode of formation of these mountains.

- Submerged valleys and barrier reefs: Nature, vol. 91, pp. 423-424, 1913.

Day, D. T. See Woodruff and Day.

De Kalb, Courtenay, Boston Consolidated Mine, Bingham, Utah: Min. and Sci. Press, vol. 98, pp. 553-556, 6 figs. 1909.

Includes notes on the occurrence of copper ores in Bingham Canyon, Utah.

The Utah copper mine: Min. and Sci. Press, vol. 98, pp. 516-521, 7 figs., 1909.

Includes notes on the occurrence of the copper ores in Bingham Canyon, Utah.

DERN, G. H., The geology of Mercur, Utah: Mines and Minerals, vol. 24, pp. 543-545, 3 figs., 1904.

Describes the general geology and the occurrence and character of the gold and silver ledges and discusses the origin of the ores.

DERN, JoHN, The mining and mineral resources of Utah, Am. Min. Cong. Proc., 9th ann. sess., pp. 166-177, 1907; Mines and Minerals, vol. 27, No. 6, pp. 250-252, 1907.

DienL, C. C., Gypsum: Michigan Miner, vol. 6, No. 6, pp. 21-24, 1904.

Describes the occurrence of gypsum in Michigan and Utah. 
Douglass, Earl, Preliminary descriptions of some new Titanotheres from the Uinta deposits: Carnegie Mus. Annals, vol. 6, pp. 304-313, 8 figs., 1910.

- Geology of the Uinta formation: Geol. Soc. America Bull., vol. 25, No. 3, pp. 417-420, 1914.

DufField, M. S., Western phosphate mines: Mines and Methods, vol. 2, No. 1, pp. 9-13, 6 figs., Sept., 1910. Includes notes on the geology of the phosphate area in Utah, Idaho, and Wyoming.

Dutton, C. E., Report on work on lava fields of southern Utah: U. S. Geog. and Geol. Survey Rocky Mtn. region Final Rept., pp. 6-7, 1877. Also in Am. Jour. Sci., 3d ser., vol. 15, pp. 353-358, 1878.

On the Permian formation of North America: Philos. Soc. Washington Bull., vol. 3, pp. 67-68, 1880.

- Report on the geology of the high plateaus of Utah, xxxii, 307 pp., atlas, U. S. Geog. and Geol. Survey Rocky Mtn. Region, 1880. Abstract in Am. Jour. Sci., 3 d ser., vol. 20 , pp. $63-69,1880$.

- Report on the lithologic characters of the Henry Mountain intrusives; in Gilbert, G. K., Report on the geology of the Henry Mountains, pp. 61-65, U. S. Geog. and Geol. Survey Rocky Mtn. Region, 1877; 2d ed., pp. 147-151, 1880.

- Report on work in High Plateau region: U. S. Geol. Survey Second Ann. Rept., 1880-81, pp. 5-10, 1882 .

- The physical geology of the Grand Canyon district: U. S. Geol. Survey Second Ann. Rept., 1880-81, pp. 47-166, 1882.

Tertiary history of the Grand Canyon district: U. S. Geol. Survey Mon. 2, xiv, 264 pp., 42 pls., and 24 sheets accompanying folio atlas, 1882. Abstracts in Science, vol. 3, pp. 327-331, 1884; Am. Jour. Sci., 3 d ser., vol. 24, pp. 81-89, pl. 4, 1882; Am. Naturalist, vol. 18, pp. 511-513, pls., 1884; Soc. géol. France Bull., 3d ser., vol. 11, pp. 529-539, 1883; Liverpool Geol. Assoc. Jour., vol. 9, pp. 49-55, 1890; Scottish Geog. Mag., vol. 3, pp. 441-460, 2 pls., map, 1887.

Dyar, W. W., The colossal bridges of Utah; A recent discovery of natural wonders: Century Mag., vol. 68, pp. 505-511, 1904.

EAkזns, L. G., Analyses of adobe soils: U. S. Geol. Survey Bull. 64, p. 51, 1890.

Eckel, E. C., The slate deposits of California and Utah: U. S. Geol. Survey Bull. 225, pp. 417-422, 1904.

Describes the occurrence and character of slate deposits in Eldorado County, Cal., and near Provo, Utah.

The salt industry in Utah and California: U. S. Geol. Survey Bull. 225, pp. 488-495, 1904.

Describes the character and sources of the materials used and the methods of manufacture employed.

Cement materials and industry of the United States: U. S. Geol. Survey Bull. 243, 395 pp., 15 pls., 1 fig., 1905.

Describes the character and general occurrence of cement materials and their preparation, and in detail the occurrence, geologic relations, and character of limestones, shales, and marls in the various States.
Eldridge, G. H., The uintaite (gilsonite) deposits of Utah: U. S. Geol. Survey Seventeenth Ann. Rept., pt. 1, pp. 909-949, pls. 59-60, figs. 26-33, 1896.

Describes the classification and chemical relations of hydrocarbons, the geology of the region, and the occurrence and character of the veins. Presents a geologic map of the country.

Occurrence of uintaite in Utah: Science, new ser., vol. 3, pp. 830-832, 1896.

Describes the veins of uintaite cutting Tertiary strata in Utah. Gives chemical analysis of uintaite.

Emmens, N. W., The Bingham mining camp, Utah: Min. Mag., vol. 12, pp. 457-464, 5 figs., 1905.

Includes brief notes on the geology and the occurrence and character of the copper ores.

Emmons, S. F., Structural relations of ore deposits: Am. Inst. Min. Eng. Trans., vol. 16, pp. 804-839, 1888.

- Orographic movements in the Rocky Mountains: Geol. Soc. America Bull., vol. 1, pp. 245-286, 1890. Abstract in Am. Naturalist, vol. 24, pp. 211-212, 1890.

The Wasatch Mountains and the geological panorama of the Wasatch Range: Cong. géol. internat. 5th sess., Compt. rend., pp. 381-391, 1893.

Describes the geologic history of this range, the outcrops of the strata, and the structure of the mountain range.

- Itinerary, Spanish Fork Canyon, Utah, to Grand Junction, Colo.: Cong. géol.internat., 5 th sess., Compt. rend., pp. 397-402, 1893.

Describes the geology along the railroad between the points named.

- Geological distribution of the useful metals in the United States: Am. Inst. Min. Eng. Trans., vol. 22, pp. 53-95, 737-738, 1894.

Describes the geologic occurrence in different parts of the United States of iron, manganese, nickel, tin, copper, lead, zinc, quicksilver, gold, and silver, and gives a summary of conclusions concernings the genesis of their minerals.

Economic geology of the Mercur mining district, Utah: U. S. Geol. Survey Sixteenth Ann. Rept., pt. 2, pp. 349-369, 1895.

Describes the topography and gives an account of the discovery, development, and production of the mining district. Describes the structure of the range, the occurrence of the sedimentary and igneous rocks, and the general economic geology of the district.

Origin of Green River: Science, new ser., vol. 6, pp. 19-21, 1897.

Discusses the evidence as to the origin and development of the river.

Tintic district, Utah: U. S. Geol. Survey Geol. Atlas, Tintic special folio (No. 65), pp. 7-8, 1900.

Gives general conclusions with regard to the economic geology of the region.

Notes on two desert mines in southern Nevada and Utah: Abstract in Science, new ser., vol. 13, pp. 426427, 1901.

Contains abstract of paper read before the Geological Society of Washington. 
Emmons, S. F., The Delamar and the Horn-Silver mines; two types of ore deposits in the deserts of Nevada and Utah: Am. Inst. Min. Eng. Trans., vol. 31, pp. 658683, 10 figs., 1902.

Describes topography and geologic structure of the region, characters of the ore, and history and development of these mines.

- In discussion of paper by W. P. Jenney, The mineral crest, or the hydrostatic level attained by the oredepositing solutions in certain mining districts of the Great Salt Lake Basin: Am. Inst. Min. Eng. Trans., vol. 33, pp. 1062-1063, 1903.

The Little Cottonwood granite body of the Wasatch Mountains: Am. Jour. Sci., 4th ser., vol. 16, pp. 139-147, 1 fig., 1903.

Discusses the geologic relations and age of this granitic mass.

Economic geology of the Bingham mining district, Utah: U. S. Geol. Survey Prof. Paper 38, pp. 17-25, 1905.

Describes the general geology of the region, and the occurrence and character of Carboniferous sedimentary strata and of igneous rocks.

- The Cactus copper mine, Utah: U. S. Geol. Survey Bull. 260, pp. 242-248, 1 fig., 1905.

Describes the location and history of the mine, the general geology, and the character and occurrence of the copper ores.

- Geological structure of the Uinta Mountains: Abstract in Science, new ser., vol. 25, pp. 767-768, 1907.

- Uinta Mountains: Geol. Soc. America Bull., vol. 18, pp. 287-302, 1 pl., 2 figs., 1907.

Reviews previous geologic work in the region, describes the general structure and stratigraphic succession of the Uinta Mountains, and discusses the origin of Green River.

See also Hague and Emmons.

Engelmann, H., Preliminary report on the geology of the country between Fort Bridger and Camp Floyd, Utah Territory, and southwest of the latter place, along J. H. Simpson's routes; 1858: 35th Cong., 2 d sess., S. Ex. Doc. 40, pp. 45-75, 1859.

The brown coals of Utah and adjoining territories: Am. Inst. Min. Eng. Trans., vol. 4, pp. 298-308, 1876. - Report on the geology of the country between Fort Leavenworth, Kans., and the Sierra Nevada near Carson Valley: in Simpson, J. H., Report of explorations across the Great Basin of the Territory of Utah in 1859, pp. 247-336, 1876.

See also Meek and Engelmann.

FAUR, FABER DU, The sulphur deposits of southern Utah: Am. Inst. Min. Eng. Trans., vol. 16, pp. 33-35, 1887.

Fenner, Clarence, The Old Telegraph mine, Bingham Canyon, Utah: School of Mines Quart., vol. 14, pp. 354-358, 1893.

Describes the character and structure of the ore bodies.

Ferrier, W. F. See Weeks and Ferrier.

Field, V. W., Clayton Peak, Utah; one of nature's storehouses of minerals: Am. Mineralogist, vol. 2, No. 7, pp. 92-93, July, 1917.

Foote, H. W. See Penfield and Foote.
Ford, W. E., and Bradley, W. M., On the identity of footeite with connelite, together with the description of two new occurrences of the mineral: Am. Jour. Sci., 4th ser., vol. 39 , pp. $670-676,1915$.

Forrester, J. B., Geology of the Black Hawk coal mine, Emery County, Utah: Colliery Eng., vol. 36, No. 1, pp. 17-18, August, 1915.

Forrester, Roвert, Coal fields of Utah: U. S. Geol. Survey Mineral Resources, 1892, pp. 511-520, 1893.

States that the coal measures of the Laramie are best developed on the eastern slopes of the Wasatch, the beds attaining a maximum thickness of 28 feet, and the coal also occurs in the Montana and Colorado Cretaceous. Gives analyses of coal from different localities.

Foster, Whliam, Colorado, California, Montana, Utah, etc. [building stones]; in Report on the building stones of the United States and statistics of the quarry industry for 1880: Tenth Census U. S., vol. 10 (separate pagination), pp. 277-279, 1884.

GABB, W. M., Reply to Jules Marcou's criticism on Jurassic fossils: Acad. Nat. Sci. Philadelphia Proc., vol. 12, pp. 548-549, 1860.

GALE, H. S., Coal fields of northwestern Colorado and northeastern Utah: U. S. Geol. Survey Bull. 341, pp. 283-315, 5 pls. (maps), 1 fig., 1909.

Describes the general stratigraphy and structure of the region, the occurrence, character, and relations of the coal-bearing formations, and the distribution and character of the coals.

Coal fields of northwestern Colorado and northeastern Utah: U. S. Geol. Survey Bull. 415, 265 pp., 22 pls., 8 figs., 1910.

- Supposed graphite deposits near Brigham, Utah: U. S. Geol. Survey Bull. 430, pp. 639-640, 1910.

Nitrate deposits: U. S. Geol. Survey Bull. 523, 36 pp., 2 pls., 2 figs., 1912.

A general review of the occurrence and origin of nitrate deposits.

Potash in Salduro salt deposit (Utah): Eng. and Min. Jour., vol. 102, No. 18, pp. 780-782, Oct. 28, 1916.

See also Butler and Gale.

Gale, H. S., and Richards, R. W., Preliminary report on the phosphate deposits in southeastern Idaho and adjacent parts of Wyoming and Utah: U. S. Geol. Survey Bull. 430, pp. 457-535, 10 pls., 3 figs., 1910.

Describes the nature, origin, and composition of the phosphate rock, the general geology of the region, the character, occurrence, and relations of Carboniferous, Triassic, Jurassic, Cretaceous, and Tertiary formations, and the geologic structure. Gives a detailed account of the local geology, distribution, area, tonnage, etc., of phosphate deposits.

Gannett, Henry, A gazetteer of Utah: U. S. Geol. Survey Bull. 166, 43 pp., 1 pl., 1900.

Gansl, G. C., and Keep, G. A., The Ophir mining district of Utah: Salt Lake Min. Rev., vol. 12, no. 8, pp. 17-20, 5 figs., July 30, 1910.

Includes notes on the geologic structure and stratigraphy, and on the character and occurrence of the silver-lead ores in the southern part of the Oquirrh Mountains. 
Geikie, Archibald, Archean rocks of the Wasatch Mountains: Am. Jour. Sci., 3d ser., vol. 19, pp. 363$367,1880$.

The ancient glaciers of the Rocky Mountains: Am. Naturalist, vol. 15, pp. 1-7, 1881.

Gemmell, R. C., The Camp Floyd mining district and the Mercur mine, Utah: Eng. and Min. Jour., vol. 63, pp. 403-404, 1897.

Describes the topographic and geologic features of the district.

Gilbert, G. K., On the glacial epoch in Utah and Nevada: Philos. Soc. Washington Bull., vol. 1, pp. 84-85, 1873. Notes on West Mountain, Camp Floyd, Ophir, Clifton, North Star, Star, Rocky, Lincoln, and Granite districts, Utah: U. S. Geog. Surveys W. 100th Mer. Progress Rept. for 1874, pp. 18-22, 1874.

- Preliminary geological report: U. S. Geog. Surveys W. 100th Mer. Progress Rept. for 1874, pp. 48-52, Washington, 1874. Abstract in Am. Jour. Sci., 3d ser., vol. 9 , p. 328,1875 .

The recency of certain volcanoes of the western United States: Am. Assoc. Proc., vol. 23, pt. 2, pp. 29-32, 1875.

- Report on the geology of portions of Nevada, Utah, California, and Arizona in 1871 and 1872: U. S. Geog. and Geol. Surveys W. 100th Mer. Rept., vol. 3, pp. 17-187, 196, 1875. Abstract in Am. Naturalist, vol. 10, pp. 498-499, 1876.

On the outlet of the Great Salt Lake: Am. Jour. Sci., 3d ser., vol. 11, pp. 228-229, 1876.

The Colorado plateau province as a field for geological study: Am. Jour. Sci., 3d ser., vol. 12, pp. 16-24, 85-103, 1876. Abstract in Am. Assoc. Proc., vol. 23 , pp. 32-35, pt. 2, 1875.

-_ Lake Bonneville: Abstracts in Philos. Soc. Washington Bull., vol. 2, p. 103, 1877; Am. Naturalist, vol. 11, p. $445,1877$.

- Report on the geology of the Henry Mountains, x, 160 pp., U. S. Geog. and Geol. Survey Rocky Mtn. Region, 1877.

- Geological investigations in the Henry Mountains of Utah: Abstract in Am. Naturalist, vol. 11, p. $447,1877$.

[Report on work in Henry Mountains and on history of Lake Bonneville]: U. S. Geol. and Geog. Survey Rocky Mtn. Region Rept., pp. 5-6, 17, 1877. Abstract in Am. Jour. Sci., 3d ser., vol. 15, pp. 351-353, 1878.

The ancient outlet of Great Salt Lake: Am. Jour. Sci., 3d ser., vol. 15, pp. 256-259, 1878. Reviewed by A. C. Peale, pp. 439-444.

The outlet of Lake Bonneville: Am. Jour. Sci., 3d ser., vol. 19, pp. 341-349, 1880.

Relations of Permian beds to Aubrey limestone: Philos. Soc. Washington Bull., vol. 3, pp. 105-106, 1880.

- Report of division of the Great Basin: U. S. Geol. Survey First Ann. Rept., pp. 23-28, 1880.

The Wasatch, a growing mountain: Philos. Soc. Washington Bull., vol. 2, p. 195, 1880. Remarks by Antisell, p. 196.
Gilbert, G. K., On the origin of jointed structure: Am. Jour. Sci., 3d ser., vol. 24, pp. 50-53, 1882. Abstract in Am. Naturalist; vol. 16, p. 834, 1882.

Contributions to the history of Lake Bonneville: U. S. Geol. Survey Second Ann. Rept., pp. 167-200, 1882. Abstracts in Am. Naturalist, vol. 18, pp. 401-402, pls.; Science, vol. 1, p. 570, 1883; Am. Jour. Sci., 3d ser., vol. 26, pp. 150-151, 1883; Sci. Am. Supp., vol. 18, no. 450, p. 7187, 1884.

Postglacial joints: Am. Jour. Sci., 3d ser., vol. 23, pp. 25-27, 1882

Report on work in Great Basin: U. S. Geol. Survey Second Ann. Rept., pp. 167-200, 1882. Abstracts in Am. Naturalist, vol. 18, pp. 401-402, pls.; Science, vol. 1, p. 570, 1883; Am. Jour. Sci., 3d ser., vol. 26, pp. 150-151, 1883; Sci. Am. Suppl., vol. 18, no. 450, p. $7187,1884$.

Pre-Bonneville climate: Science, vol. 2, p. 170, 1883.

- Report on work in Great Basin: U. S. Geol. Survey Third Ann. Rept., pp. 14-16, pl., 1883.

Faults and earthquakes in Great Basin region: Science, vol. 2, pp. 580-581, 1883. Salt Lake Weekly Tribune, Sept. 20, 1883. Abstract in Am. Naturalist, vol. 17, p. 1158,1883 .

Ripple marks: Science, vol. 3, pp. 375-376, 1884. A theory of the earthquakes of the Great Basin, with a practical application: Am. Jour. Sci., 3d ser., vol. 27, pp. 49-53, 1884.

Report of operations in Great Basin: U. S. Geol. Survey Fifth Ann. Rept., pp. 30-34, 1885.

The topographic features of lake shores: U. S. Geol. Survey Fifth Ann. Rept., pp. 69-123, 1885. Abstracts in Am. Jour. Sci., 3d ser., vol. 31, p. 402, 1886; Am. Naturalist, vol. 20, pp. 626-628, pls., 1886.

- Introductory sketch of the Quaternary lakes of the Great Basin, in Call, R. E., On the Quaternary [Pleistocene] and Recent Mollusca of the Great Basin: U. S. Geol. Survey Bull. 11, pp. 363-366, map, 1885.

The strength of the earth's crust: Geol. Soc. America Bull., vol. 1, pp. 23-24, 26, 27, 1890. Discussed by A, Winchell, Robert Hay, J. J. Stevenson, and J. C. Branner, pp. 25-27. Abstracts in Am. Naturalist, vol. 24, pp. 109, 467-470, 1890.

Lake Bonneville: U. S. Geol. Survey Mon. 1, xx, 438 pp., 51 pls., map, 1890. Abstracts in Am. Geologist, vol. 7, pp. 132-134, 1891; Am. Jour. Sci., 3d ser., vol. 41, pp. 327-329, 1891.

Includes Appendix A, on altitudes and their determination, by A. L. Webster; B, on the deformation of the geoid by the removal, through evaporation, of the water of Lake Bonneville, by R. S. Woodward; and $\mathrm{C}$, on the elevation of the surface of the Bonneville Basin by expansion due to change of climate, by R. S. Woodward.

Utah: Macfarlane, James, An American geological railway guide, 2 d ed., pp. $313-315,1890$.

Great Salt Lake Valley, and itinerary, Salt Lake City to Spanish Fork Canyon, Utah: Cong. géol. internat., 5th sess., Compt. rend., pp. 391-397, 1893.

Describes the geologic history of Great Salt Lake Valley and the local geology along the railroad to Spanish Fork Canyon. 
Grubert, G. K., Great Salt Lake and Lake Bonneville; fault scarps; itinerary, Pocatello, Idaho, to Salt Lake City, Utah: Cong. géol. internat., 5th sess., Compt. rend., pp. 374-380, 1893.

Describes the geologic history of Lake Bonneville, the fault scarps of the mountains of the Great Basin, and the geology along the railroad from Pocatello to Salt Lake City.

- On some joint veins: Abstract in Science, new ser., vol. 15 , pp. 84-85, 1902.

- A highly viscous eruption of rhyolite: Abstract in Science, new ser., vol. 17, p. 221, 1903.

- Joint veins: Abstract in Geol. Soc. America Bull., vol. 13, pp. 521-522, 1903.

Contains brief note on joint structures in the House Range, Utah.

Gilbert, G. K., and Howell, E. E., Restored outline of Lake Bonneville: U. S. Geog. Surveys W. 100th Mer., Geol. Atlas, 1876.

Gilbert, G. K., Marvine, A. R., and Howell, E. E., Parts of eastern California, southeastern Nevada, northwestern Arizona, and southwestern Utah (No. 66 ); southern and southwestern Utah (No. 59); central and western Utah (No. 50); parts of northern and northwestern Arizona and southern Utah (No. 67); parts of eastern Arizona and western New Mexico (No. 76); parts of Colorado and New Mexico (parts of Nos. 69, 77, 78); U. S. Geog. Surveys W. 100th Mer., Geol. Atlas, 1876.

Gilmore, C. W., Description of a new species of tortoise from the Jurassic of Utah (Glyptops utahensis): Carnegie Mus. Annals, vol. 10, Nos. 1-2, pp. 7-12, 2 pls., 2 figs., January, 1916.

The fossil turtles of the Uinta formation: Carnegie Mus. Mem., vol..7, No. 2, pp. 101-161, 10 pls. 22 figs., November, 1916.

Grrty, G. H., Paleontology of the Bingham mining district, Utah: U. S. Geol. Survey Prof. Paper 38, pp. 387-393, 1905.

Gives notes upon the occurrence and lists of fossils identified in collections there made.

- New species of fossils from the Thaynes limestone of Utah: New York Acad. Sci. Annals, vol. 20, pt. 2, pp. 239-242, 1910.

The fauna of the phosphate beds of the Park City formation in Idaho, Wyoming, and Utah: U. S. Geol. Survey Bull. 436, 82 pp., 7 pls., 1910.

Goldthwait, J. W., See Huntington and Goldthwait.

Gow, P. A., and others, Report on the property of the Daly-Judge Mining Company, Park City, Utah: Colorado School of Mines Bull., vol. 4, no. 1, pp. 31-70, 15 figs., 1907.

Includes an account of the local geology and the occurrence, character, and relations of the lead-silver ores.

The Daly-Judge mine and mill, Park City, Utah: Mines and Minerals, vol. 28, pp. 32-35, 79-82, 11 figs., 1907.

Describes the local geology and the character and occurrence of the lead-silver ores.

Gregory, H. E., Some features of the geology of the Navajo Reservation (Arizona-Utah): Abstract in Science, new ser., vol. 32, p. 62, July 8, 1910.
Gregory, H. E., The Shinarump conglomerate: Am. Jour. Sci., 4th ser., vol. 35, pp. 424-428, 1913.

The igneous origin of the "glacial deposits" on the Navajo Reservation, Arizona and Utah: Am. Jour. Sci., 4th ser., vol. 40, pp. 97-115, 8 figs. (incl. map), 1915

The San Juan oil field, San Juan County, Utah: U. S. Geol. Survey Bull. 431, pp. 11-25, 1 fig., 1911.

The Navajo country; a geographic and hydrographic reconnaissance of parts of Arizona, New Mexico, and Utah: U. S. Geol. Survey Water-Supply Paper 380, 219 pp., 29 pls. (incl. maps), 29 figs., 1916.

- Garnet deposits on the Navajo Reservation, Ariz. and Utah: Econ. Geology, vol. 11, No. 3, pp. 223-230, 1 fig., April-May, 1916.

- Geology of the Navajo country; a reconnaissance of parts of Arizona, New Mexico, and Utah: U. S. Geol. Survey Prof. Paper 93, 161 pp., 34 pls. (incl. maps), 3 figs, 1917.

Gregory, W. K., Notes on the upper Eocene titanotheroid Telmatherium? incisivum Douglass from the Uinta basin: Science, new ser., vol. 35, p. 546, 1912.

Proposes for this species the new generic name Sthenodectes.

HAGue, ARnold, Wyoming, Utah, Nevada, and Idaho, in Macfarlane, James, An American geological railway guide, 2 d ed., pp. 309-315, 1890.

Hague, Arnold, and Emmons, S. F., Descriptive geology: U. S. Geol. Expl. 40th Par., vol. 2, 890 pp., 25 pls., 1877. Abstract in Am. Jour. Sci., 3d ser., vol. 16, pp. 234-236, 1877.

HALL, JAMES, Geology and paleontology: Exploration and survey of the valley of the. Great Salt Lake of Utah, by Howard Stansbury, special sess., Mar., 1851, S. Ex. Doc. 3, pp. 401-406, Philadelphia, 1852. Abstract in Am. Jour. Sci., $2 d$ ser., vol. 15, pp. 126-128, 1852.

Paleontology (of New York), vol. 3, containing descriptions and figures of the organic remains of the lower Helderberg group and the Oriskany sandstone, 1855-1859 (with volume of 120 pls., 1861), xii, 523 pp., 1859.

Description or new species of fossils from the Carboniferous limestone of Indiana and Illinois: Albany Inst. Trans., vol. 4, pp. 1-36, 1864.

Hall, James, and Whitfield, R. P., U. S. Geol. Expl. 40th Par., vol. 4, pp. 199-204, 1877.

Hannibal, Harolid, A synopsis of the recent and Tertiary fresh-water Mollusca of the Californian province, based upon an ontogenetic classification: Malacological Soc. Proc., vol. 10, pp. 112-166, 167-211, 1912.

HARDER, E. C. See Leith and Harder.

Harrington, Daniel, Coal mining at Sunnyside, Utah: Colorado School of Mines Bull., vol. 1, pp. 227-235, 1901.

Describes the general geology, the occurrence of the coal in the Laramie formation, and the mining operations.

HAYDEN, F. V., Explanations of a second edition of a geological map of Nebraska and Kansas: Acad. Nat. Sci. Philadelphia Proc., vol. 10, pp. 139-158, map, 1859. Abstract in Am. Jour. Sci., 2d ser., vol. 26, pp. 276-278, 1858; map in black in Petermanns Mitt., vol. 6, p. 53,1860 . 
HAYDEN, F. V., Notes on the geology of Nebraska and Utah Territory: Am. Jour. Sci., 2d ser., vol. 29, pp. 433-434, 1860.

The primordial sandstone of the Rocky Mountains in the Northwestern Territories of the United States: Am. Jour. Sci., 2d ser., vol. 33, pp. 68-79, 1862 . Canadian Jour., new ser., vol. 7, pp. 149-151, 1862.

—_ Sun pictures of Rocky Mountain scenery, with a description of the geographical and geological features and some accounts of the resources of the great West, pp. 1-135, 30 pls., 1870. Abstracts in Am. Jour. Sci., 2d ser., vol. 50, pp. 125-127, 1870.

- On the geography of the Missouri Valley: U. S. Geol. Survey Terr. Second Ann. Rept., pp. 83-188, 1872. Abstract in Am. Naturalist, vol. 5, pp. 637-640, 1871.

[General report]: U. S. Geol. Survey Terr. Fifth Ann. Rept., pp. 11-164, pls., 1872.

- Profiles, sections, and other illustrations designed to accompany the final report of the chief geologist of the survey, and sketched under his direction by H. W. Elliot: U. S. Geol. Survey Terr. Fifth Ann. Prelim. Rept., 65 pls., 1872.

- Prefatory note [on age of lignitic group]: U. S. Geol. and Geog. Survey Terr. Bull., vol. 1 [1st ser.], No. 2, pp. 1-2, 1874.

Preliminary report of the field work: U. S. Geol. and Geog. Survey Terr. Tenth Ann. Rept., pp. 16-21, 1878.

- — Letter [to the Secretary on general results]: U. S. Geol. and Geog. Survey Terr. Tenth Ann. Rept., pp. xiii-xxix, 1878.

- The Great West; its attractions and resources, containing a popular description of the marvelous scenery, physical geography, fossils, and glaciers of this wonderful region, and the recent explorations in the Yellowstone Park, the wonderland of America, $87 \mathrm{pp}$., Bloomington, Ill., and Philadelphia, Pa., 1880.

- Geological and geographical atlas of Colorado and portions of adjacent territory: U. S. Geol. and Geog. Survey Terr., 1881. Detailed geologic sheets, by Endlich, W. H. Holmes, Peale, Marvine, and C. A. White.

Headden, W. P., Mineralogical notes, No. 2: Colorado Sci. Soc. Proc., vol. 8, pp. 53-70, 1905.

Describes the characters and composition of minerals from various localities.

- Mineralogical notes, No. 3: Colorado Sci. Soc.

Proc., vol. 8, pp. 167-182, 1906.

Describes phosphorescent zinc blendes from Utah.

HeIKes, V. C., Relative production in Utah in 1908 and 1909, by classes of ore deposits: U. S. Geol. Survey Mineral Resources, 1909, pt. 1, p. 458, 1911.

Gold, silver, copper, lead, and zinc in Utah, 1902 to 1917: U. S. Geol. Survey, Mineral Resources.

Hess, F. L., Some molybdenum deposits of Maine, Utah, and California: U. S. Geol. Survey Bull. 340, pp. 231240, 1908.

- Carnotite near Green River, Utah: U. S. Geol. Survey Bull. 530, pp. 161-164, 1913.

- A sulphur deposit in the San Rafael Canyon, Utah: U. S. Geol. Survey Bull. 530, pp. 347-349, 1913.
Hess, F. L., A hypothesis for the origin of the carnotites of Colorado and Utah: Econ. Geology, vol. 9, no. 7, pp. 675-688, October, 1914. Abstract in Washington Acad. Sci. Jour., vol. 4, No. 9, p. 236, 1914.

Hess, F. L., and Schaller, W. T., Pintadoite and uvanite, two new vanadium minerals from Utah: Washington Acad. Sci. Jour., vol. 4, No. 20, pp. 576-579, 1914.

Higarns, W. C., The Century and the Susannah mines, Golden, Utah: Salt Lake Min. Rev., vol. 11, No. 15, pp. 19-22, 4 figs., 1909.

Includes notes on the local geology and the occurrence of the gold ore.

- Napoleon-Maghera mines in Sierra Madre Mountains, Box Elder County, Utah: Salt Lake Min. Rev., vol. 11, No. 14, pp. 19-23, 7 figs., 1909.

Includes notes on the local geology and the ore deposits producing copper, gold, and silver.

The Sevier Consolidated mine of Gold Mountain, Piute County, Utah: Salt Lake Min. Rev., vol. 11, No. 3, pp. 15-18, 5 figs., 1909.

Includes a short account of the local geology and the character and occurrence of the gold ores.

The Union Chief and Santaquin mines, Utah: Salt Lake Min. Rev., vol. 14, No. 10, pp. 11-16, 9 figs., 1912.

Includes notes on the local geology and the occurrence and character of the iron-lead-silver ores.

- The American Ozokerite Co.: Utah State Inspector of Mines Eighth Bien. Rept., 1911-1912, pp. 130-141, 5 pls., 1913.

Includes notes on the occurrence of ozokerite near Colton, Utah.

HıLL, J. M., The zinc-lead deposits of the Yellow Pine district, Nev.: Abstract in Washington Acad. Sci. Jour., vol. 3, No. 8, pp. 238-239, 1913.

Notes on the northern La Sal Mountains, Grand County, Utah: U. S. Geol. Survey Bull. 530, pp. 99118, 1913.

Hrul, R. T., The Permian rocks of Texas: Science, vol. 13, p. 92, 1889.

HILlebrand, W. F., Red beryl from Utah: Am. Jour. Sci., 4th ser., vol. 19, pp. 330-331, 1905.

Hullebrand, W. F., and Merwin, H. E., Two varieties of calciovolborthite (?) from eastern Utah: Am. Jour. Sci., 4th ser., vol. 35, pp. 441-445, April, 1913. Washington Acad. Sci. Jour., vol. 3, No. 5, p. 138, Mar. 4, 1913; abstract, vol. 3, No. 20, p. 503, 1913. Zeitschr. Kryst. Min., Band 53, Heft 1, pp. 4-9, 1913.

Hillebrand, W. F., and Wright, F. E., A new occurrence of plumbojarosite: Am. Jour. Sci., 4th ser., vol. 30, pp. 191-192, 1910.

Describes the composition and crystallographic and optical properties of plumbojarosite from Utah.

Hillebrand, W. F., Wright, F. E., and Merwin, H. E., Calcium vanadates from Peru, Colorado, and Utah: Washington Acad. Sci. Jour., vol. 3, No. 6, pp. 157158, 1913.

- Hewettite, metahewettite, and pascoite, hydrous calcium vanadates: Am. Philos. Soc. Proc., vol. 53, pp. 21-54, 2 figs., 1914.

Hills, R. C., Orographic and structural features of Rocky Mountain geology: Colorado Sci. Soc. Proc., vol. 3, pp. 362-458, pl., 1891. 
Hills, R. C., Types of past eruptions in the Rocky Mountains: Colorado Sci. Soc. Proc., vol. 4, pp. 14-32, 1891. Includes brief remarks on the pre-Tertiary and Cenozoic eruptions in this region. Ascribes the Sangre de Cristo, Henry, and La Plata mountains and the Spanish Peaks to intrusive bodies, and the San Juan Mountains, the White River Plateau, Raton and Uinkaret mountains, and Mount Taylor to extrusive bodies. Gives a table of the intrusive, extrusive, and tufaceous rocks, and describes briefly their distribution.

- Ore deposits of Camp Floyd district, Tooele County, Utah: Colorado Sci. Soc. Proc., vol. 5, pp. 54-65, 2 figs., 1898.

Describes the geologic features of the region and the mode of occurrence and character of the gold ores and discusses their origin.

Hintze, F. F., Jr., A contribution to the geology of the Wasatch Mountains, Utah: New York Acad. Sci. Annals, vol. 23, pp. 85-143, 6 pls., 5 figs., 1913.

Нттснсоск, С. H., Geological map of the United States and part of Canada: Am. Inst. Min. Eng. Trans., map 17 by 27 inches and explanation, vol. 15, pp. 465$488,1887$.

Compiled to illustrate the scheme of coloration and nomenclature recommended by the International Geological Congress.

Нттснсоск, C. H., and Blake, W. P., Geological map of the United States, in Raymond, R. W., Statistics of mines and mining in the States and Territories west of the Rocky Mountains for 1872, pp. 480-484, 1873; Walker, F. A., Statistical atlas of the United States, based on results of the Ninth Census, 1870, pls. 13, 14, 1874. Petermann's Mitt., vol. 21, pl. 16, 1875. Special rep. Smithsonian Inst. for Centennial, 1876. Gray, -, Atlas of the United States and the world, Philadelphia, 1877. Reproduced (probably) by F. Ratzel, "Die Vereinigten Staaten von Nord-Amerika," vol. 1, München, 1878.

Hodge, J. T., On the Tertiary coals of the West: U. S. Geol. Survey Terr. [Fourth Ann.] Prelim. Rept., pt. 4, No. 2, pp. 318-329, 1872.

Holland, W.J., A new species of A patosaurus (near Jensen, Utah): Carnegie Mus. Annals, vol. 10, Nos. 1-2, pp. 143-145, January, 1916.

Hollister, O. J., Gold and silver mining in Utah: Am. Inst. Min. Eng. Trans., vol. 16, pp. 3-18, 1887.

Howard, L. O., The development of our radium-bearing ores: Assoc. Eng. Soc. Jour., vol. 52, No. 4, pp. 185216, map, 8 figs., 1914.

Geology of the Cottonwood districts (Utah): Min. and Sci. Press, vol. 112, pp. 557-562, 2 figs., Apr. 15, 1916.

HoweLL, E. E., Report on the geology of portions of Utah, Nevada, Arizona, and New Mexico, examined in 1872 and 1873: U. S. Geog. and Geol. Surveys W. 100th Mer. Final Rept., vol. 3, pp. 227-301, 1875 .

See also Gilbert and Howell.

HunT, T. S., Mineral physiology and physiography, a second series of chemical and gevlogical essays, xvii, 710 pp., Boston, 1886 . Review in Am. Geologist, vol. 8, pp. 110-114, 1886.
Hunt, W. F. See Van Horn and Hunt.

Huntington, Elisworth, Some characteristics of the glacial period in nonglaciated regions: Geol. Soc. America Bull., vol. 18, pp. 351-388, 9 pls., 16 figs., 1917.

Includes a discussion of the mode of formation of the Moencopie formation of Utah.

Huntington, Elis'torth, and Goldthwait, J. W., The Hurricane fault in southwestern Utah: Jour. Geology, vol. 11, pp. 46-63, 10 figs., 1903.

Gives a table showing the succession of formations in the region, describes physiographic features, and outlines geologis history.

The Hurricsne fault in the Toquerville district, Utah: Harvard Coll. Mus. Comp. Zool. Bull., vol. 42 (Geol. Ser., vol. 6), pp. 199-259, 7 pls., 13 figs., 1904.

Describes geographic and physiographic features of the region, the character and occurrence of the geologic formations, the geologic history (deposition, uplift, folding, aulting, erosion, and volcanism), and the occurrence and effects of lava flows.

Huntley, D. B., The mining industries of Utah: Tenth Census U. S., vol. 13, statistics and technology of the precious metals, pp. 405-489, 1885.

Iddings, J. P., and Cross, Whitman, On the widespread occurrence of allanite as an accessory constituent of mariy rocks: Am. Jour. Sci., 3d ser., vol. 30, pp. 108-111, 1885. Abstract in Am. Naturalist, vol. 19, p. 1098, 1885.

Ingalls, W. R., Mining the porphyry ore of Bingham, Utah: Eng. and Min. Jour., vol. 84, pp. 431-440, 1 pl., 17 figs., 1907.

Includes a brief account of the geology and the occurrence and character of the copper ores.

Inving, J. D., The stratigraphical relations of the Browns Park beds of Utah: New York Acad. Sci. Trans., vol. 15, pp. 252-259, pl. 18, 1896.

Gives a brief summary of previous work in the Tertiary strata of Utah, reviews certain descriptions of the Browns Park formation, and discusses the evidences as to its geologic age.

IrviNG, R. D., and VAN Hise, G. R., On secondary enlargements of mineral fragments in certain rocks: U. S. Geol. Survey Bull. 8, 56 pp., 1885.

James, G. D., The San Juan oil field of Utah: Eng. and Min. Jour., vol. 42, pp. 1082-1084, 3 figs., 1911.

Jefferson, M. S. W., The antecedent Colorado: Science, new ser., vol. 6, pp. 293-295, 1897.

Discusses the origin of Colorado River.

Jenney, W. P., The mineral crest, or the hydrostatic level attained by the ore-depositing solutions, in certain mining districts of the Great Salt Lake Basin: Min. and Sci. Press, vol. 85, p. 297, 1902. Am. Inst. Min. Eng. Trans., vol. 33, pp. 46-50, 1903.

The ore deposits of the Ontario mineral belt, Utah: Min. and Sci. Press, vol. 92, pp. 108-109, 2 figs., 1906.

Discusses the occurrence and origin of ore deposits. The fissure system of the Ontario mineral belt Utah: Min. and Sci. Press, vol. 92, pp. 24-25, 3 figs. 1906. 
JENNEY, W. P., Structural features of the Otario mineral belt, Park City, Utah: Min. and Sci. Press, vol. 92, pp. 6-7, 1 fig., 1906.

Describes the stratigraphy and the relations of the ore-bearing veins.

Jennings, E. P., Origin of the magnetic iron ores of Iron County, Utah: Am. Inst. Min. Eng. Trans., vol. 35, pp. 338-342, 2 figs., 1905.

Describes the occurrence and character of the magnetic iron-ore deposits and discusses their origin.

Jensen, Joseph, and others, Some salient features of the geology of Newhouse, Utah, and vicinity, $35 \mathrm{pp}$., 1908.

Describes the stratigraphy and structural features of the region, the petrographic characters of the igneous and metamorphic rocks, and the occurrence and relations of silver-lead, copper, and iron ores.

Jessur, D. W., The Lakeview mine (Box Elder County), Utah: Eng. and Min. Jour., vol. 102, No. 14, pp. 573-576, 3 figs., Sept. 30, 1916.

Johnson, D. W., Report on the geological excursion through New Mexico, Arizona, and Utah, summer of 1906: Tech. Quart., vol. 19, no. 4, pp. 408-415, 1906.

Includes notes on physiographic features of the region examined.

Jones, A. J., Topaz crystals of Thomas Mountain, Utah: Iowa Acad. Sci. Proc., vol. 2, pp. 175-177, 1895.

Describes the occurrence of the crystals and discusses briefly their origin.

Jones, C. C., Phosphate rock in Utah, Idaho, and Wyoming: Eng. and Min. Jour., vol. 83, pp. 953-955, 6 figs., May 18, 1907.

- The discovery and opening of a new phosphate field in the United States: Am. Inst. Min. Eng. Bull. 82, pp. 2411-2435, 13 figs., October, 1913.

Describes phosphate deposits in northeastern Utah, southeastern Idaho, and western Wyoming.

Jones, T. R., On some fossil Ostracoda from southwest Wyoming and from Utah: Geol. Mag., decade 3, vol. 10, pp. 385-391, 1893.

Describes some species from the Cretaceous of Wyoming and Utah.

Jones, W. A., Report of a survey and exploration in the Uinta Mountains, Utah: U. S. Army Chief of Engineers Report for 1872, pp. 1108-1118, Appendix AA, 1873.

Keck, Rudolf, The genesis of ore deposits: Eng. and Min. Jour., vol. 35, pp. 3-4, 1883.

Keep, G. A. See Gansl and Keep.

Keith, Arthur, Economic geology of the Bingham mining district, Utah: U. S. Geol. Survey Prof. Paper 38, pp. 27-70, 15 pls., 1905.

Describes the geography, topography, the character, occurrence, and relations of Carboniferous strata and of igneous rocks, and the geologic structure of the region.

KEMP, J. F., Review of The iron ores of the Iron Springs district in southern Utah, by C. K. Leith and E. C. Harder (U. S. Geol. Survey Bull. 338): Jour. Geology, vol. 4, No. 8, pp. 782-791, 1909.

Keyes, C. R., Climatic index of Bonneville lake beds: Science, new ser., vol. 46, pp. 139-140, Aug. 10, 1917.
Keyes, C. R., Orographic origin of ancient Lake Bonneville: Geol. Soc. America Bull., vol. 28, No. 2, pp. 351-374, June 11, 1917. Abstract in vol.28, no. 1, p. 164, Mar. 31, 1917.

Kindle, E. M., Occurrence of the Silurian fauna in western America: Am. Jour. Sci., 4th ser., vol. 25, pp. 125-129, 1908. Abstract in Science, new ser., vol. 27, p. $348,1908$.

The fauna and stratigraphy of the Jefferson limestone in the northern Rocky Mountain region: Bull. Am. Paleontology, vol. 4, no. 20, 39 pp., 4 pls., 1908.

Paleozoic and associated rocks of the upper Yukon, Alaska.

King, Clarence, The Green River coal basin: U. S. Geol. Expl. 40th Par., vol. 3, pp. 11-96, maps in atlas, 1870.

Note on the Uinta and Wasatch ranges; a correction: Am. Jour. Sci., 3d ser., vol. 11, p. 494, 1876.

- Paleozoic subdivisions on the fortieth parallel: Am. Jour. Sci., 3d ser., vol. 11, pp. 475-482, 1876.

Systematic geology: U. S. Geol. Expl. 40th Par. vol. 1, 803 pp., 40 pls., atlas, 1878. Review in Am. Jour. Sci., 3d ser., vol. 17, pp. 296-302, 1879. Abstracts in Pop. Sci. Monthly, vol. 15, pp. 302-317, 1879. Am. Jour. Sci., 3d ser., vol. 17, pp. 170-175, 1879.

KiтнiL, K. L. See Moore and Kithil.

Kneeland, Samuel, Notes on the geology along the Union Pacific Railroad: Boston Soc. Nat. Hist. Proc., vol. 16, pp. 375-376, 1874.

Knight, W. C., The Green River, Utah, oil field: Salt Lake Min. Rev., vol. 13, No. 22, pp. 11-14, 5 figs., 1912.

Includes notes on the geology of the field.

Knowtton, F. H., Flora of the Montana formation: U. S. Geol. Survey Bull. 163, pp. 1-77, pls. 1-19, 1900.

Discusses the flora of this formation from Utah, Wyoming, and Montana, and describes many genera and species. Includes notes by T. W. Stanton on certain plant-bearing strata along Missouri River. See also Stanton and Knowlton.

KuHRE, K. D., Tungstenite, a new mineral, in the Cottonwoods (Utah): Salt Lake Min. Rev., vol. 19, No. 18, pp. 23-24, 1 fig., Dec. 30, 1917.

Kunz, G. F., Precious stones: U. S. Geol. Survey Sixteenth Ann. Rept., pt. 4, pp. 595-605, 1895.

Describes occurrence of utahlite, opal, and hyalite in Utah,

LaForge, Laurence. See Palache and LaForge.

Lakes, Arthur, The Oquirrh Mountains or the Mercur mining district, Utah: Colliery Eng., vol, 16, pp. 243-245, 1896.

Describes the geologic features of the region and the occurrence of the gold and silver ores.

- Great Salt Lake basin: Mines and Minerals, vol. 23, pp. 112-113, 2 figs., 1902.

Describes the terraces which mark the shores of the ancient lake when it was much larger than it is now.

The Utah coal fields of the Wasatch, near Grass Creek and Weber Canyon: Mines and Minerals, vol. 27, no. 12, pp. 61-62, 2 figs., 1906.

Describes thick veins of lignitic coal with numerous faults. 
LAKEs, Arthur, The natural bridges of Utah: Min. World, vol. 26, p. 595,5 figs., 1907.

Cause of fine gold in San Juan River, Utah: Min. Reporter, vol. 56, pp. 308-309, 1907.

Geology and economics of Rio San Juan, Utah: Min. World, vol. 28, pp. 761-762, 1 fig., 1908.

Describes the geology of the region and the occurrence of placer gold.

The San Juan oil field, Utah: Min. Sci., vol. 61, pp. 412-413, 2 figs., 1910.

Lavagnino, G., The Old Telegraph mine, Utah: Am. Inst. Min. Eng. Trans., vol. 16, pp. 25-33, 1887.

- The Old Telegraph mine, Utah: Min. and Sci. Press, vol. 78, p. 589, 1899.

Describes the occurrence of gold and silver.

Lawson, A. C., Section of the Shinarump: Abstract in Geol. Soc. America Bull., vol. 23, No. 1, p. 74, 1912. The gold of the Shinarump at Paria, Utah: Econ. Geology, vol. 8, No. 5, pp. 434-448, 5 figs., 1913.

Describes stratigraphic and physiographic features in the vicinity of Paria and discusses the gold content of the Shinarump clay.

LE CONTE, Joseph, On the structure and origin of mountains, with special reference to recent objections to the contractional theory: Am. Jour. Sci., 3d ser., vol. 18, pp. 35-44, 1879.

Ledoux, A., Aurichalcite from Big Cottonwood Canyon, Salt Lake County, Utah: Washington Acad. Sci. Jour., vol. 7, No. 12, pp. 361-365, 1 fig., June 19, 1917.

LeE, L. A., A peculiar cave in Utah: Am. Naturalist, vol. 13, pp. 460-462, 1879.

LeE, W. T., The Iron County coal field, Utah: U. S. Geol. Survey Bull. 316, pp. 359-375, 1 pl., 1 fig., 1907.

The Cove Creek sulphur beds, Utah: U. S. Geol. Survey Bull. 315, pp. 485-489, 1907.

- Water resources of Beaver Valley, Utah: U. S. Geol. Survey Water-Supply Paper 217, 57 pp., 1 pl., 3 figs., 1908.

Includes an account of the geology of the region.

İeItH, C. K., Iron ores in southern Utah: U. S. Geol. Survey Bull. 225, pp. 229-237, 1904.

Describes the distribution, geologic relations, and character of the iron ores and discusses their origin.

- Iron ores of the western United States and British Columbia: U. S. Geol. Survey Bull. 285, pp. 194-200, 1906.

Gives a summarized account of the iron-ore deposits of Wyoming, Washington, British Columbia, Colorado, California, and Utah.

Discussion of review by J. F. Kemp of paper on iron ores of Iron Springs, Utah: Econ. Geology, vol. 2, pp. 188-192, 1910.

Leith, C. K., and Harder, E. C., The iron ores of the Iron Springs district, southern Utah: U. S. Geol. Survey Bull. 338, 102 pp., 21 pls., 11 figs., 1908.

Describes the geography and general geology of the district, the distribution and relations of Carboniferous, Cretaceous, Tertiary, and Quaternary strata, and of igneous rocks, and the occurrence, character, and origin of the iron ores.

$$
35416^{\circ}-19-4
$$

Lesquereux, Leo, Contributions to the fossil flora of the Western Territories, part 2, the Tertiary flora: U. S. Geol. and Geog. Survey Terr. Final Rept., vol. 7, pp. 3-31, 1878. Review in Am. Naturalist, vol. 12, pp. 243-246, 1878.

Lewis, R. S., The Book Cliffs coal field, Utah: Am. Inst. Min. Eng. Bull. 91, pp. 1729-1749, 9 figs., 1914.

Lindgren, Waldemar, The geological features of the gold production of North America: Am. Inst. Min. Eng. Trans., vol. 33, pp. 790-845, 1903.

Discusses the occurrence and geologic relations of gold-bearing veins and deposits and the production of gold in general and in the several gold-producing States, Alaska, Canada, and Mexico.

The Annie Laurie mine, Piute County, Utah: U. S. Geol. Survey Bull. 285, pp. 87-90, 1906.

Describes the geology and the occurrence and character of the ore deposits yielding gold and silver.

Will the production of gold in the world keep pace with the increasing demands of commerce and trade?: Am. Min. Cong. Proc., 10th ann. sess., pp. 265-271, 1908.

Anhydrite as a gangue mineral: Econ. Geology, vol. 5, No. 6, pp. 522-527, 1910.

- Processes of mineralization and enrichment in the Tintic mining district, Utah: Econ. Geology, vol. 10, No. 3, pp. 225-240, 2 pls., April-May, 1915.

Lindgren, Waldemar, and Loughuin, G. F., Geology and ore deposits of the Tintic mining district, Utah: U. S. Geol. Survey Prof. Paper 107, 282 pp., 39 pls., 49 figs., 1919.

LoughuIn, G. F., Reconnaissance in the southern Wasatch Mountains, Utah: Jour. Geology, vol. 21, No. 5, pp. 436-452, 4 figs., 1913. Abstract in Washington Acad. Sci. Jour., vol. 3, No. 2, pp. 50-51, 1913.

- A reconnaissance in the Canyon Range, west-central Utah: U. S. Geol. Survey Prof. Paper 90, pp. 51-60, 1 pl., 5 figs. (incl. map), 1914.

The oxidized ores of the Tintic district, Utah: Econ. Geology, vol. 9, No. 1, pp. 1-19, 2 pls., 8 figs., 1914.

- Recent alunite developments near Marysvale and Beaver, Utah: U. S. Geol. Survey Bull. 620, pp. 237-270, 3 figs., 1915.

- Stratigraphy of the Tintic mining district, Utah: Abstract in Washington Acad. Sci. Jour., vol. 5, No. 4, p. 143, 1915.

Faulting in the Tintic mining district, Utah: Abstract in Washington Acad.Sci. Jour., vol. 6, No. 7, p. 190, Apr. 4, 1916.

- Ores, magmatic emanations, and modes of igneous intrusion: Discussion in Econ. Geology, vol.11, No. 3, pp. 284-288, April-May, 1916.

Zinc carbonate and related copper carbonate ores at Ophir, Utah: U. S. Geol. Survey Bull. 690, pp. 1-14, 4 figs., Dec. 24, 1917.

Two lamprophyre dikes near Santaquin and Mount Nebo, Utah: U. S. Geol. Survey Prof. Paper 120, 1918 (Prof. Paper 120-E).

See also Butler and Loughlin; Butler, Loughlin, and Heikes. 
Loughuin, G. F., and Schaller, W. T., Crandallite, a new mineral (Tintic mining district, Utah): Am. Jour. Sci., 4th ser., vol. 43, pp. 69-74, 2 figs., January, 1917.

Lucas, F. A., Contributions to paleontology: Am. Jour. Sci., 4th ser., vol. 6, pp. 399-400, 1898.

Describes a new genus and species of crocodile and a new species of Dinictis.

Lupton, C. T., Notes on the geology of the San Rafael Swell, Utah: Washington Acad. Sci. Jour., vol. 2, No. 7, pp. 185-188, 1912.

- The Deep Creek district of the Vernal coal field, Uinta County, Utah: U. S. Geol. Survey Bull. 471, pp. 579-594, 1 pl., 1 fig. (maps), 1912.

The Blacktail (Tabby) Mountain coai fiold, Wasatch County, Utah: U. S. Geol. Survey Bull. 471, pp. 595-628, 2 pls. (map and sections), 1912.

Gypsum along the west flank of the San Rafael Swell, Utah: U. S. Geol. Survey Bull. 530, pp. 221-231 1 pl. (map), 1913.

Oil and gas near Green River, Grand County, Utah: U. S. Geol. Survey Bull. 541, pp. 115-133, 1 fig., map, 1914.

Coal resources of Castle Valley in Carbon, Emery, and Sevier counties, Utah: U. S. Geol. Survey Bull. $628,1916$.

Discusses stratigraphy, structure, and coal resources.

McDonatd, W. T., The San Juan oil field, Utah: Western Eng., vol. 1, No. 1, pp. 37-46, 9 figs., 1912.

MacFarlane, James, The Ohio Copper Co., Bingham, Utah: Min. World, vol. 30, pp. 345-348, 4 figs., 1909.

Includes notes on the local geology and the occurrence of the copper ores.

MacFarren, H. W., Ozokerite in Utah: Min. and Sci. Press, vol. 99, pp. 789-790, 1 fig., 1909.

The story of Bingham Canyon, Utah: Min. and Sci. Press, vol. 99, pp. 129-130, 1 fig., 1909.

Includes notes on the geology and occurrence of the ores.

Maguire, Don, Gold mines of Mercur, Utah: Mines and Minerals, vol. 19, pp. 81-83, 2 figs., 130-131, 1898.

Describes the occurrence of the ore bodies of the region.

- The hydrocarbons of eastern Utah, with special reference to deposits of ozokerite, gilsonite, and elaterite: Mines and Minerals, vol. 20, pp. 398-400, 4 figs., 1900.

- Silver-beáring sandstones of southern Utah: Mines and Minerals, vol. 20, pp. 323-324, 1900.

Mansfield, G. R. See Richards and Mansfield.

Marcou, Jules, Geological map of the United States and British provinces of North America (with explanatory text and geological sections), 92 pp., 8 pls., Boston, 1853. Soc. géol. France Bull., 2d ser., vol. 12, pp. 813-936, map, pl., under title "Résumé explicatif d'une carte géologique des États-Unis et des provinces anglaises de l'Amérique du Nord, avec un profil géologique allant de la vallée du Mississippi aux côtes du Pacifique, et une planche de fossiles." Map in atlas to "Voyage dans l'Amérique du Nord," by G. Lambert, Bruxelles, 1855; Annales des mines, vol. 7, p. 320, pl. 9; Geology of North America, Zurich, 1858; "La vie souterraine, ou les mines et les mineurs," by L. Simonin, pls. 10, 11, 14, Paris, 1867; "Physicalische Karten Geologie," Vienna, 1872. Review in Am. Jour. Sci., 2d ser., vol. 22, pp. 383-388; Anon., idem, vol. 17, pp. 199-206.
Marcou, Jules, Ueber die Geologie der Vereinigten Staaten und der englischen Provinzen von Nord-Amerika: Petermann's Mitt., vol. 1, pp. 149-159, map, 1855.

- Geology of North America, with two reports on the prairies of Arkansas and Texas, the Rocky Mountains of New Mexico, and the Sierra Nevada of California, 144 pp., 7 pls., 3 maps, Zurich, 1858. Reviews in Am. Jour. Sci., 2d ser., vol. 26, pp. 323-334, 1858; vol. 27, pp. 137-140; vol. 27, pp. 134-137, 1859.

Marsh, O. C., The Reptilia of the Baptanodon beds: Am. Jour. Sci., 3d ser., vol. 1, pp. 405-406, 1895.

Describes the occurrence of species of Baptanodon in Utah, Oregon, and Wyoming.

Marvine, A. R., Report on the geology of the route from St. George, Utah, to Gila River, Ariz., examined in 1871: U. S. Geol. and Geog. Surveys W. 100th Mer. Final Rept., vol. 3, pt. 2, pp. 189-225, 1875.

See also Gilbert, Marvine, and Howell.

Maury, M. F., On the geologic agency of the winds: Am. Assoc. Adv. Sci. Proc., vol. 6, pp. 277-296, 1852.

McGeE, W J, Map of the United States exhibiting the present status of knowledge relating to the areal distribution of geologic groups, $17 \frac{1}{4}$ by 28 inches: U. S. Geol. Survey Fifth Ann. Rept., for 1883-84; map in pocket explanation on pp. 34-38, 1885.

Means, A. H., Some new mineral occurrences from the Tintic district, Utah: Am. Jour. Sci., 4th ser., vol. 41, pp. 125-130, January, 1916.

Mекк, F. B., Lists of fossils from Utah, with some notes: U. S. Geol. Expl. 40th Par. Final Rept., vol. 3, pp. 459-466, 1870.

- Preliminary paleontological report consisting of lists of fossils, with descriptions of some new types, etc.: U.S. Geol. Survey Terr. Fourth Ann. Rept., pp. 287-318, 1871. Abstract in Am. Jour. Sci., 3d ser., vol. 5, p. 310, 1873 .

- Preliminary paleontological report consisting of lists and descriptions of fossils, with remarks on the ages of the rocks in which they were found: U. S. Geol. Survey Terr. Sixth Ann. Rept., pp. 429-518, 1873. On the age of the lignitic formation of the Rocky Mountain region: Abstract in Am. Jour. Sci., 3d ser., vol. 8, pp. $459-463,1873$.

- Note on some fossils from near the eastern base of the Rocky Mountains; west of Greeley and Evans, Colo., and others from about 200 miles farther eastward, with descriptions of a few new species: U. S. Geol. and Geog. Survey Terr. Bull., vol. 1, 2d ser., No. 1, pp. 39-47, 1875.

- Report on the paleontological collections of the expedition, in Simpson, J.H., Report of explorations across the great basin of the Territory of Utah in 1859 , pp. 339-375, pls. 1-4, 1876.

- Introductory remarks on [Mesozoic and Cenozoic]: U. S. Geol. Expl. 40th Par. Final Rept., vol. 4, pp. $3-15,1877$.

Meek, F. B., and Engelmann, H., Notice of geological discoveries made by $\mathrm{J}$. H. Simpson in the recent exploration across the continent: Acad. Nat. Sci. Philadelphia Proc., vol. 12, pp. 126-131, 1861.

Meinzer, O. E., Ground water in Juab, Millard, and Iron counties, Utah: U. S. Geol. Survey Water-Supply Paper 277, 162 pp., 5 pls., 13 figs., 1911. Abstract in Washington Acad. Sci. Jour., vol. 2, no. 9, p. 226, 1912. 
Merriam, J. C., New anchitheriine horses from the Ter tiary of the Great Basin area: California Univ. Dept. Geology Bull., vol. 7, no. 22, pp. 419-434, 5 figs., 1913.

Merrill, G. P., Stones for building and decoration, 453 pp., New York, 1891.

The onyx marbles; their origin, composition, and uses, both ancient and modern: U. S. Nat. Mus. Rept. for 1893, pp. 539-585, pls. 1-18.

Discusses origin, mode of occurrence, and chemical and physical properties, and describes occurrences in Arizona, California, eastern Appalachian region, Colorado, Utah, New Mexico, and foreign countries.

MerriLl, N. F., Concerning the lithological collection of the exploration of the fortieth parallel: Boston Soc. Nat. Hist. Proc., vol. 21, pp. 234-243, 452-470, 1883 reviewed on pp. 243-274.

Merwin, H. E. See Hillebrand and Merwin; Hillebrand, Wright, and Merwin.

Mrller, S. A., North American Mesozoic and Cenozoic geology and paleontology: Cincinnati Soc. Nat. Hist. Jour., vol. 2, pp. 140-161, 223-244, 1879; vol. 3, pp. 9-32, 79-118, 165-202, 245-288, 1880; vol. 4, pp. 3-46, 93-144, 183-234, 1881. Also issued 338 pages, Cincinnati, 1881.

Mock, Charles Craig, A study of the Morrison formation: New York Acad. Sci. Annals, vol. 27, pp. 39-191, 1 pl. (map), 94 figs., June 12, 1916.

Moeller, W. H., The Mercur gold deposits in the Camp Floyd district, Utah: Eng. and Min. Jour., vol. 57, p. 51 (correspondence), 1894.

Describes the character and structure of the gold deposits.

Montgomery, Henry, Volcanic dust in Utah and Colorado: Science, new ser., vol, 1, pp. 656-657, 1895.

Describes deposits of volcanic dust occurring in the Oquirrh and Wasatch mountains, Utah, and in the Green River region of northwestern Colorado.

Moore, R. B., and Kiтнil, K. L., A preliminary report on uranium, radium, and vanadium: U. S. Bur. Mines Bull. 70, 101 pp., 4 pls., 2 figs., 1913.

Morgan, H. J., Illustrations of polished rock surfaces: Tenth Census U. S., vol. 10, pls. 27-58, 1884 .

Moses, A. J., One of the gypsum crystals from the cave at South Wash, Wayne County, Utah: Science, vol. 21, pp. 230-231, 1893.

Gives the crystallographic measurements of the crystal.

NeIul, J. W., Camp Floyd district, Utah: Eng. and Min. Jour., vol. 61, pp. 85-86, 1896.

Describes the geologic features of the region and the occurrence of the gold ores.

Newberry, J. S., The ancient lakes of western America; their deposits and drainage: U. S. Geol. Survey Terr. Fourth Ann. Rept., pp. 329-339, 1872. Am. Naturalist, vol.4, pp. 640-660, 1872. Hayden, F. V., Sun pictures of the Rocky Mountains, pp. 135-150, 1872. Abstracts in Canadian Naturalist, vol. 6, new ser., pp. 112-118; Am. Jour. Sci., 2d ser., vol. 50, pp. 129-130, 1870.

On the lignites and plant beds of western America: Am. Jour. Sci., 3d ser., vol. 7, pp. 399-404, 1874.

On the discovery of mineral wax, ozokerite, in Utah: Am. Jour. Sci., 3d ser., vol. 17, pp. 340-341, 1879 .
New BERRy, J. S., The geological survey of the fortieth parallel: Pop. Sci. Monthly, vol. 15, pp. 302-317, 1879. The genesis of iron ores: School of Mines Quart., vol. 2, pp. 1-17, 1880. Abstracts in Am. Jour. Sci., 3d ser., vol. 21, p. 80, 1881; Am. Naturalist, vol. 15, pp. 410-412, 1881.

- Geological facts recently observed in Montana, Idaho, Utah, and Colorado: New York Acad. Sci. Trans., vol. 1, pp. 4-8, 1882. Science, vol. 2, pp. 523-524, 1882.

- Marble deposits of the western United States: School of Mines Quart., vol. 10, pp. 69-72, 1888.

- The deposition of ores: School of Mines Quart., vol. 5, pp. 329-344, 1884.

Newell, F. H., The public lands and their water supply: U. S. Geol. Survey Sixteenth Ann. Rept., pt. 2, pp. $457-533$, pls. $35-39$, figs. $48-57,1895$.

Describes the character of the public lands of the Western States and their water supply.

Ochsenius, Carl, Geologisches und Montanistisches aus Utah: Deutsche Geol. Gesell. Zeitschr., vol. 34, pp. $288-372,1882$.

Oнцy, J., Ozokerite: Min. and Sci. Press, vol. 81, pp. 8-9, 1900.

Describes occurrence in Utah and Colorado.

Osborn, H. F., Fossil mammals of the Uinta Basin; expedition of 1894: Am. Mus. Nat. Hist. Bull., vol. 7, pp. 71-106, figs. 1-17, 1895.

Gives a description of the occurrence of the fossils and the character of the formations in the Uinta Basin, in northeastern Utah, by O. A. Peterson. Shows the succession of species in the three faunal levels and describes the fossils collected, including several new species.

PACKARD, A. S., Jr., On the supposed ancient outlet of Great Salt Lake: U. S. Geol. and Geog. Survey Terr. Bull., vol. 1, 2d ser., No. 5,pp. 413-414, 1876. Abstract in Am. Jour. Sci., 3d ser., vol. 11, pp. 149-150, 1876.

PACKARD, R. L., Natural sodium salts: U. S. Geol. Survey Mineral Resources, 1893, pp. 728-738, 1894.

Describes the lakes of Utah, Nevada, and California in which sodium salts have become concentrated, and gives in tabular form the composition of the salts and discusses their origin.

Variscite from Utah: Am. Jour. Sci., 3d ser., vol. 47, pp. 297-298, 1894. Abstract in Am. Naturalist, vol. 28, p. 873, 1894.

Describes the characteristics of this material and gives its chemical analysis.

Palache, C., and LaForge, Laurence, Notes on the crystallography of leadhillite: Am. Acad. Arts and Sci. Proc., vol. 44, No. 17, pp. 435-463, 3 pls., 1909.

- Notizen über die Krystallographie des Leadhillits: Zeitschr. Kryst. und Min., Band 48, Heft 2, pp. 129 133, 1910.

Describes the optical characters of leadhillite from Utah.

Palmer, Chase, The geochemical interpretation of water analyses: U. S. Geol. Survey Bull. 479, 31 pp., 1 fig., 1911.

Palmer, L. A., Modern mining at Alta, Utah: Mines and Minerals, vol. 26, No. 10, pp. 438-440, 3 figs., 1906.

Includes an account of the local geology and the occurrence of the ore bodies. 
Palmer, L. A., Mining copper ore with steam shovels: Min. Mag., vol. 4, No. 4, pp. 293-296, 4 figs., 1911. Includes notes on the geology and the occurrence of ore bodies at Bingham, Utah.

Parker, E. W., Abrasive materials: U. S. Geol. Survey Nineteenth Ann. Rept., pt. 6 cont., pp. 515-533, 1898.

Includes statistics of production and notes on the occurrence of corundum in Ontario, by Courtenay De Kalb, and on the occurrence of pumice stone in Nebraska, South Dakota, and Utah.

Parsons, C. L., Our radium resources: Am. Min. Cong. Rept., 16th ann. sess., 1913, pp. 223-234, 1914.

PARsons, T. S., Some unknown American natural bridges: Mineral Collector, vol. 14, No. 7, pp. 103-104, 1907. Describes natural bridges in southeastern Utah.

Patton, H. B., Topaz-bearing rhyolite of the Thomas Range, Utah: Geol. Soc. America Bull., vol. 19, pp. 177-192, 2 pls., 1908 Abstract in Science, new ser., vol. 27, p. 410, 1908.

Describes the location and character of the rhyolite and the topaz and other minerals occurring in its cavities.

Peale, A. C., Report on minerals, rocks, thermal springs, etc.: U. S. Geol. Survey Terr. Fifth Ann. Rept., pp. 165-204, 1872.

- Report: U. S. Geol. Survey Terr. Sixth Ann. Rept., pp. 99-187, 1873.

Report of the geology of the Green River district: U. S. Geol. and Geog. Survey Terr. Eleventh Ann. Rept. for 1877, pp. 509-646, 1879. Abstracts in Am. Naturalist, vol. 12, pp. 98-99, 1878; Am. Jour. Sci., 3d ser., vol. 15, p. 57, 1878.

Peet, C. A., Green River oil fields in Wayne County, Utah: Salt Lake Min. Rev., vol. 11, No. 18, pp. 19-21, 6 figs., 1909.

Penfield, S. L., On chemical composition of aurichalcite: Am. Jour. Sci., 3d ser., vol. 41, pp. 106-108, 1891.

Penfield, S. L., and Foote, H. W., On bixbyite, a new mineral, and notes on the associated topaz: Am. Jour. Sci., 4th ser., vol. 4, pp. 105-108, 1897.

Describes its crystallographic and chemical characters.

Pepperberg, L. J., Variscite near Lucin, Utah: Min. and Sci. Press, vol. 103, pp. 233-234, 1911.

Peterson, O. A., Some undescribed remains of the Uinta titanothere Dolichorhinus: Carnegie Mus. Annals, vol. 9, Nos. 1-2, pp. 129-138, 7 figs., 1914.

A new titanothere from the Uinta Eocene: Carnegie Mus. Annals, vol. 9, Nos. 1-2, pp. 29-52, 5 pls., 14 figs., 1914.

- A small titanothere from the lower Uinta beds: Carnegie Mus. Annals, vol. 9, Nos. 1-2, pp. 53-57, 1 pl., 2 figs., 1914.

Peterson, William, Phosphate deposits in the Mississippian rocks of northern Utah: Science, new ser., vol. 40 , pp. 755-756, 1914.

Phillips, A. H., Radium in an American ore: Am. Philos. Soc. Proc., vol. 43, pp. 157-160, 1904.

Describes the occurrence and composition of carnotite from Utah and Colorado and the extraction of radium therefrom.

Pogue, J. E., Nonnezoshe, the great natural bridge of southern Utah: Abstract in Science, new ser., vol. 33, p. $355,1911$.
Pogue, J. E., The great Rainbow natural bridge of southern Utah: Nat. Geog. Mag., vol. 22, No. 11, pp. 10481056, 6 figs., 1911.

Poole, Henry, The great American desert: Nova Scotian Inst. Trans., vol. 3, pp. 208-220, 1874.

Posepny, F., The genesis of ore deposits: Am. Inst. Min. Eng. Trans., vol. 23, pp. 197-369, figs. 1-100, 1894.

Reviews the general facts and theories concerning the origin of ore deposits. Describes the constitution and effects of underground circulating waters, the character of ore deposits occurring in fissures and in soluble rocks, those occurring in distinctly stratified rocks and in crystalline schists and eruptive rocks, and those formed by chemical and mechanical influences of the surface region. Advocates the ascension theory of the formation of ore deposits.

Powell, J. W., Some remarks on the geological structure of a district of country lying to the north of the Grand Canyon of the Colorado: Am. Jour. Sci., 3d ser., vol. 5, pp. 456-465, 1873.

Report of explorations in 1873 of the Colorado of the West and its tributaries, under the direction of the Smithsonian Institution, 36 pp., 1874.

Remarks on the structural geology of the valley of the Colorado of the West: Washington Philos. Soc. Bull., vol. 1, pp. 48-51, 1874.

- Report on the geology of the eastern portion of the Uinta Mountains and a region of country adjacent thereto, vii, 218 pp., atlas folio, U. S. Geol. and Geog. Survey Terr., 2d div., 1876. Types of orographic structure: Abstract in Am. Jour. Sci., 3d ser., vol. 12, pp. 414-428, 1877.

Exploration of the Colorado River of the West and its tributaries, xi, $291 \mathrm{pp}$., pls., map, and profiles in pocket, 1875. Abstracts in Sci. Am. Suppl., vol. 5, No. 118 , pp. 1869-1871; No. 121, pp. 1917-1919; No. 124, pp. 1965-1967; vol. 6, No. 131, pp. 20752077; No. 135, pp..2139-2141; Pop. Sci. Monthly, vol. 7, pp. 385-399, 531-542, 670-680; Am. Jour. Sci., 3d ser., vol. 10, pp. 303-304; Am. Naturalist, vol. 10, pp. 736-739 (all, 1876).

The lands of Utah: Report on the lands of the arid region of the United States, with a more detailed account of the lands of Utah, pp. 93-112, maps (2d ed.), 1879.

Report of the Director: U. S. Geol. Survey Second Ann. Rept., pp. i-lv, Washington, 1882.

Putnam, B. T., Notes on the samples of iron ore collected west of the one hundredth meridian: Tenth Census U. S., vol. 15, pp. 469-505, maps, 1886.

Rath, G. vom, Geologisches aus Utah: Neues Jahrb., 1884, vol. 1, pp. 158-168, 1885.

Einige Bemerkungen über das Territorium Utah: Niederrhein. Gesell. Natur- und Heilkunde Bonn Sitzungsber. (Separat-Abdruck), pp. 29-66, 1887.

Raymond, R. W., Note on a specimen of gilsonite from Uinta County, Utah: Am. Inst. Min. Eng. Trans., vol. 17, pp. 113-115, 1889.

READE, T. M., Origin of normal faults: Am. Jour. Sci., 3d ser., vol. 39, pp. 51-52, 1890.

ReaGan, A. B., Geology of the Deep Creek region, Utah: Salt Lake Min. Rev., vol. 19, No. 6, pp. 25-28, 2 figs., June 30, 1917. 
Reagan, A. B., The Deep Creek Reservation and its Indians (Utah): The Red Man, vol. 9, No. 7, pp. 219236, May-June, 1917.

Richards, R. W., Notes on lead and copper deposits in the Bear River Range, Idaho and Utah: U. S. Geol. Survey Bull. 470, pp. 177-187, 3 figs., 1911.

Describes the general geologic structure and stratigraphy of the region and gives local descriptions of the mineral deposits.

See also Gale and Richards.

Richards, R. W., and Mansfield, G. R., The Bannock overthrust, a major fault in southeastern Idaho and northeastern Utah: Jour. Geology, vol. 20, No. 8, pp. 681-709, 5 figs., 1912.

Richardson, G. B., Natural gas near Salt Lake City, Utah: U. S. Geol. Survey Bull. 260, pp. 480-483, 1905.

Describes the occurrence and character of natural gas near Salt Lake City, Utah.

- Occurrence of underground waters in Sanpete and Sevier valleys, Utah: Abstract in Science, new ser., vol. 23, p. 817, 1906.

- Underground water in the valleys of Utah Lake and Jordan River, Utah: U. S. Geol. Survey WaterSupply Paper, 157, 81 pp., 9 pls., 5 figs., 1906.

Describes the topography and drainage, the general geology, and the occurrence and character of underground water.

- Coal in Sanpete County, Utah: U. S. Geol. Survey Bull. 285, pp. 280-284, 1 pl. (map), 1906.

Describes the general geology, the occurrence and character of the coal beds, and the composition and character of the coals.

- Underground waters in Sanpete and central Sevier valleys, Utah: U. S. Geol. Survey WaterSupply Paper 199, 63 pp., 6 pls., 5 figs., 1907. Includes an account of the geology.

The Book Cliffs coal field, between Grand River, Colo., and Sunnyside, Utah: U. S. Geol. Survey Bull. 316, pp. 302-320, 1 pl., 1907.

- Antimony in southern Utah: U. S. Geol. Survey Bull. 340, pp. 253-256, 1908.

Describes the general geology of the region, the occurrence of the ore, and the mining developments.

- Petroleum in southern Utah: U. S. Geol. Survey Bull. 340, pp. 343-347, 1908.

Gives an outline of the geology in the vicinity of Virgin City, Utah, and describes the occurrence of petroleum and the character of the oil.

- The Harmony, Colob, and Kanab coal fields, southern Utah: U. S. Geol. Survey Bull. 341, pp. 379-400, 1 pl. (map), 1909. Reprinted in Utah State Mine Inspector Eighth Bien. Rept., 1911-12, pp. 141-170, 1 pl. (map), 1913.

Describes the location and topography, the stratigraphy and structure of the field, the occurrence and character of the coal beds, and the quality and composition of the coals.

- Reconnaissance of the Book Cliffs coal field between Grand River, Colo., and Sunnyside, Utah: U. S. Geol. Survey Bull. 371, 54 pp., 10 pls., 1 fig., 1909.

Describes the topography, stratigraphy, including Cretaceous and Tertiary formations, and structure of the field, and the occurrence, character, and development of the coal beds and quality of the coal.
Rrchardson, G. B., The Paleozoic section in northern Utah: Am. Jour. Sci., 4th ser.,vol. 36, pp. 406-416, 1913.

RigGs, E. S., New or little-known titanotheres from the lower Uinta formations, with notes on the stratigraphy and distribution of fossils: Field Mus. Nat. Hist. Pub. 159, geol. ser., vol. 4, no. 2, pp. 17-41, 9 pls., 2 figs., 1912.

RIGGS, R. B., Eruptive rock from Henry Mountains, Utah: U. S. Geol. Survey Bull, 60, p. 154, 1890.

Riter, G. W., Asphalt and rare hydrocarbons: Utah State Mine Inspector Eighth Bien. Rept., 1911-12, pp. 126-129, 1913.

Gives notes on the occurrence of hydrocarbons in Utah.

Robinson, H. M., Ozokerite in central Utah: U. S. Geol. Survey Bull, 641, pp. 1-16, 1 pl. (map), 1916.

Rogers, A. F., Pyrite crystals from Bingham, Utah: Am. Jour. Sci., 4th ser., vol. 27, pp. 467-468, 1 fig., 1909.

Rogers, A. P., The new oil field in Utah: Eng. and Min. Jour., vol. 87, p. 989, 1 fig., 1909.

Rogers, H. D., Sketch of the geology of the United States: Geology of Pennsylvania, vol. 2, pp. 741-775, Philadelphia, 1858.

Rohlfing, D. P., The great Horn Silver vein in Beaver County (Utah): Salt Lake Min. Rev., vol. 19, No. 12, pp. 23-24, Sept. 30, 1917.

Rolker, C. M., The silver sandstone district of Utah: Am. Inst. Min. Eng. Trans., vol. 9, pp. 21-33, 1881; discussed on p. 33.

Rose, - Vorkommen und Gewinnung der an Durchbruchgesteine gebundenen Kupfererze in den Wüstengebieten des südwestlichen Nordamerikas: Glückauf, Jahrg. 47, nos. 1-5, pp. 1-14, 69-81, 101110, 141-155, 181-194, 49 figs., 1911.

Describes the copper-ore deposits and the copper industry of the desert regions of southwestern United States.

Rothpletz, A., On the formation of oolite: Am. Geologist, vol. 10, pp. 279-282, 1892. Abstract in Am. Naturalist, vol. 27, p. 34, 1893.

Describes Glaeocapsa and Glaeothece cells found on the shores of Great Salt Lake. Describes the calcareous oolites and concludes that a majority of the marine Cretaceous oolites, with regular zonal and radial structure, are of plant origin.

Russell, I. C., Sulphur deposits in Utah and Nevada: New York Acad. Sci. Trans., vol. 1, pp. 168-175, 1882. Eng. and Min. Jour., vol. 35, pp. 31-32, 40, 1883. Abstract in Am. Jour. Sci., 3d ser., vol. 25, 1883.

Playas and playa lakes: Pop. Sci. Monthly, vol. 22 , pp. $380-385,1883$. Abstract in Science, vol. 1, pp. 77-78, 1883.

Ryan, G. H., Geology and ore deposits of Miller Hill, American Fork mining district, Utah: Salt Lake Min. Rev., vol. 19, No. 9, pp. 21-25, 6 figs., Aug. 15, 1917.

Schaller, W. T., Crystallized variscite from Utah: Abstract in Washington Acad. Sci. Jour., vol. 1, no. 5, pp. 150-151, 1911.

The crystallography of variscite: Washington Acad. Sci. Jour., vol. 2, no. 6, p. 143, 1912. 
Schaller, W. T., Crystallized variscite from Utah: U. S. Nat. Mus. Proc., vol. 41, pp. 413-430, 1 pl., 2 figs., 1912. Zeitschr. Kryst., Band 50, Heft 4-5, pp. 321342, 2 figs., 1912

Describes the characters and occurrence, the optical properties, the structure, the crystallography, and the chemical composition.

- Mineralogical notes, series 2: U. S: Geol. Survey Bull. 509, 115 pp., 1 pl., 5 figs., 1912. Abstract in Washington Acad. Sci. Jour., vol. 2, no. 14, p. 349, 1912.

- Ilsemannite, hydrous sulphate of molybdenum: Washington Acad. Sci. Jour., vol. 7, No. 13, pp. 417420, July 19, 1917.

See also Butler and Schaller; Hess and Schaller.

Schiel, James; Geological report of the country explored under the thirty-eighth and forty-first parallels of north latitude in 1853-54: in Beckwith, E. G., Report of explorations for the Pacific Railroad on the line of the forty-first parallel of north latitude, pp. 120-133, 1854. Also in Beckwith, E. G., Explorations and Surveys for a railroad route from the Mississippi to the Pacific Ocean, 33d Cong., 2d sess., S. Ex. Doc. 78 vol. 2, pp. 96-112, 1855.

Sсотт, W. B., Geological and faunal relations of the Uinta formation: Am. Philos. Soc. Trans., vol. 16, new ser., pp. 461-470, 1890. Abstract in Am. Naturalist, vol. 24, p. $470,1890$.

Stlliman, Benjamin, Jr., Geological and mineralogical notes on some of the mining districts of Utah Territory, and especially those of the Wasatch and Oquirrh ranges of mountains: Am. Jour. Sci., 3d ser., vol. 3, pp. 195301, 1872.

Sмiтн, C. D. See Taff and Smith.

Sмгтн, G. H., Stateline mining district, Iron County, Utah: Min. and Sci. Press, vol. 84, p. 101, 1902.

Describes the general geology of the region and the mining developments.

Sмгтн, G. O., Igneous phenomena in the Tintic Mountains, Utah: Science, new ser., vol. 7, p. 502, 1898.

Contains summary of paper read before the Geological Society of Washington.

- Physiography and general geology: U. S. Geol. Survey Geol. Atlas, Tintic special folio (No. 65), pp. 1-4, 1900.

Describes the topographic features and drainage, the occurrence and character of the Cambrian, Carboniferous, and igneous rocks, and the geologic structure and history. Includes geologic maps and structure sections.

- Discussion of paper by Jenney, W. P., The mineral crest, or the hydrostatic level attained by the ore-depositing solutions in certain mining districts of the Great Salt Lake Basin: Am. Inst. Min. Eng. Trans., vol. 33, pp. 1060-1062, 1903.

Gives geologic observations bearing upon the subject of the paper discussed.

See also Tower and Smith.

Sмrтн, W. S., Mineral resources of Uinta Reservation, Utah: Min. World, vol. 23, No. 18, pp. 491-492, 1 fig., 1905.
Spurr, J. E., Economic geology of the Mercur mining district, Utah: U. S. Geol. Survey Sixteenth Ann. Rept., pt. 2, pp. 343-455, pls. 25-34, figs. 42-47, 1895.

Describes the general geology of the mining district, the geology of the Silver Ledge and the nature and origin of the silver ores, and the occurrence, character, and origin of the gold ores.

Stanton, T. W., and Knowlton, F. H., Stratigraphy and paleontology of the Laramie and related formations in Wyoming: Geol. Soc. America Bull., vol. 8, pp. 127-156, 1897. Reviewed in Torrey Bot. Club Bull., vol. 24, p. 26, 1897.

Describes the stratigraphic and paleontologic features of the various beds.

Stevenson, J. J., On the geological relations of the lignitic groups of the far West: Am. Philos. Soc. Proc., vol. 14, pp. $447-475,1876$.

Sт. Jонn, O. H., Report on the geology of the Wind River district: U. S. Geol. and Geog. Survey Terr. Twelfth Ann. Rept., pt. 1, sec. 1, pp. 173-269, pls., maps, 1883.

Stone, G. H., Notes on the asphaltum of Utah and Colorado: Am. Jour. Sci., 3d ser., vol. 42, pp. 148-159, 1891. Abstract in Am. Naturalist, vol. 25, p. 1127, 1891.

Storm, L. W., The Valdez gold-mining district, Alaska: Min. and Eng. World, vol. 36, pp. 653-655, 3 figs., 1912.

Storrs, L. S., The Rocky Mountain coal fields: U. S. Geol. Survey Twenty-second Ann. Rept., pt. 3, pp. 415-471, 2 pls., 1 fig., 1902.

Describes location, extent, geologic relations, and development of coal areas in the Rocky Mountains region, the occurrence, thickness, and extent of coal beds, and the character, composition, and utilization of the coal and lignite.

TAFF, J. A., Natural coke in the Wasatch Plateau. Abstract in Science, new ser., vol. 23, p. 696, May 4, 1906. Notes on the Weber River coal field, Utah: U. S. Geol. Survey Bull. 285, pp. 285-288, 1906.

Describes the stratigraphy and structure of the field, and the occurrence, character, and composition of the coals.

- Book Cliffs coal field, Utah, west of Green River: U. S. Geol. Survey Bull. 285, pp. 289-302, 1 pl. (map), 1906.

Describes the stratigraphy and structure of the field, and the occurrence, character, and composition of the coals.

The Pleasant Valley coal district, Carbon and Emery counties, Utah: U. S. Geol. Survey Bull. 316, pp. 338-358, 1 pl., 1907.

TAFF, J. A., and SмITH, C. D., Ozokerite deposits in Utah: U. S. Geol. Survey Bull. 285, pp. 369-372, 1906.

Describes the geologic relations of the deposits, the character of the mineral, and the economic developments.

Talmage, J. E., A remarkable occurrence of selenite: Science, vol. 21, pp. 85-86, 1893 . Abstract in Am. Naturalist, vol. 27, p. 1091, 1893.

Describes an occurrence of gypsum in a cave in southern Utah, and contains illustrations of crystals in place. 
Talmage, J. E., The geology of Utah: Internat. Min. Cong. Proc., 4th sess., pp. 42-48, 1901.

Describes some of the gèologic features of the State.

Seismographs in Utah: Science, new ser., vol. 26, pp. 556-558, 1907.

Includes notes on the geology in the vicinity of Salt Lake City.

The Deseret Museum: Deseret Mus. Bull., new ser., No. 1, 32 pp., 22 figs., 1911.

Includes an account, with figures, of mammoth selenite crystals from southern Utah.

Tenney, Sanborn, On Devonian fossils in the Wasatch Mountains: Am. Jour. Sci., 3d ser., vol. 5, pp. 139140, 1873.

Tomlinson, C. W., The middle Paleozoic stratigraphy of the central Rocky Mountain region: Jour. Geology, vol. 25, Nos. 2-4, pp. 112-134, 244-257, 373-394, 13 figs., 1917.

Toula, F., Geologische Forschungsergebnisse aus dem Flussgebiet des Colorado. Ein Vortrag gehalten im Vereine zur Verbreitung naturwissenschaftlicher Kenntnisse in Wien am 5 Januar 1887, 51 pp., Wien, 1887.

Tower, G. W., Jr., U. S. Geol. Survey Geol. Atlas, Tintic special folio (No. 65), pp. 4-7, 1900.

Describes the fracture systems in the sedimentary and igneous rocks, the character of the ore deposition, and the geological relations of the ore deposits. Includes geologic and structure-section maps.

Tower, G. W., Jr., and SмIтн, G. O., Geology and mining industry of the Tintic district, Utah: U. S. Geol. Survey Nineteenth Ann. Rept., pt. 3, pp. 601-767, pls. 73-99, figs. 81-92, 1899

Describes the occurrence and character of the Cambrian and Carboniferous strata and igneous rocks, the volcanic and metamorphic phenomena, and the occurrence and origin of the ore bodies.

UPHAM, WARREN, A classification of mountain ranges according to their structure, origin, and age: Appalachia, vol. 6, pp. 191-207, 1891.

Van Hise, G. R. See Irving and Van Hise.

VAN Horn, F. B., The phosphate deposits of the United States: U. S. Geol. Survey Bull. 394, pp. 157-171, 1909. Rept. Nat. Conservation Comm., 60th Cong., 2 d sess., S. Doc. 676, vol. 3, pp. 558-570, 1909. Abstracts in Min. and Sci. Press, vol. 99, pp. 88-90, 2 figs., 1909; Mineral resources of the United States, pp. 629-642, 1908.

VAN Horn, F. R., The occurrence of bournonite, jamesonite, and calamine at Park City, Utah: Am Inst. Min. Eng. Bull. 92, pp. 2223-2230, 1 fig., 1914.

Minerals from the ore deposits at Park City, Utah: Abstract, with discussion, in Geol. Soc. America Bull., vol. 25 , No. 1, pp. 47-48, 1914.

VAn Horn, F. R., and Hunt, W. F., Bournonite crystals of unusual size from Park City, Utah: Am. Jour. Sci., 4th ser., vol. 40, pp. 145-150, 4 figs., 1915.

Vivian, A. P., Wanderings in the western land, London, 1879.

Contains geological map from Colorado to the $\mathrm{Pa}$ cific; scale, 45 miles to the inch. (Not seen.)
WADSworth, M. E., Some points relating to the geological exploration of the fortieth parallel: Boston Soc. Nat. Hist. Proc., vol. 21, pp. 243-274, 1883.

The fortieth parallel rocks: Boston Soc. Nat. Hist. Proc., vol. 22, pp. 412-432, 1884. See also Whitney and Wadsworth.

WAGGAMAN, W. H., A review of the phosphate fields of Idaho, Utah, and Wyoming, with special reference to the thickness and quality of the deposits: U. S. Dept. Agr. Bur. Soils Bull. 69, 48 pp., 1 map, 1910.

Waggaman, W. H., and Cullen, J. A., The recovery of potash from alunite: U. S. Dept. Agr. Bull. 415, 14 pp., 1 fig., Oct. 10, 1916.

WaLcotT, C. D., Report on observations in Nevada and the canyon of the Colorado: U. S. Geol. Survey Fourth Ann. Rept., pp. 44-48, 1884.

Classification of the Cambrian system of North America: Am. Jour. Sci., 3d ser., vol. 32, pp. 138-157, 1886.

- Second contribution to the studies of the Cambrian faunas of North America: U. S. Geol. Survey Bull. 30, 369 pp., 33 pls.,1 886. Abstract in Science, vol. 9, pp. 545-546, 1887.

Stratigraphic position of the Olenellus fauna of North America and Europe: Am. Jour. Sci., 3d ser., vol. 37 , pp. 374-392; vol. 38 , pp. 29-42, 1889 . Abstracts in Nature, vol. 40, pp. 68,310-311; New York Acad. Sci. Trans., vol. 8, p. 176, 1889.

The fauna of the Lower Cambrian or Olenellus zone: U. S. Geol. Survey Tenth Ann. Rept., pt. 1, pp. 509760 , pls. 43-98, 1890. Abstracts in Am. Jour. Sci., 3d ser., vol. 42, pp. 345-346; Am. Geologist, vol. 8, pp. 82-86 (by J. F. James), 1891.

Correlation papers; the Cambrian group of rocks in North America: U. S. Geol. Survey Bull. 81, 447 pp., 3 pls., 1891.

- Cambrian geology and paleontology, No. 5; Cambrian sections of the Cordilleran area: Smithsonian Misc. Coll., vol. 53, pp. 167-230, 10 pls., 3 figs., 1908. - Cambrian geology and paleontology, No. 1; Nomenclature of some Cambrian Cordilleran formations: Smithsonian Misc. Coll., vol. 53, pp. 1-12, 1908.

Walther, Johannes, A comparison of the deserts of North America with those of North Africa and northern India (abstract of paper read before Geographical Society of Berlin): Science, vol. 19, p. 158, 1892.

- The North American deserts: Nat. Geog. Mag., vol. 4 , pp. 163-176, 1892.

Describes the badlands of Dakota, the region about Great Salt Lake, and the Mohave Desert and compares them with the deserts of northern Africa. Discusses the causes of erosion in the canyon of the Colorado.

Warren, G. K., An essay concerning important physical features exhibited in the valley of the Minnesota River, and upon their signification: Report of the result of the examination and survey of the Minnesota River, 43d Cong., 2d sess., H. Ex. Doc. 76, pp. 6-23, pls., 1875. Abstract in Am. Jour. Sci., 3d ser., vol. 9, p. 313,1875 .

WArwick, A. W., The iron ores of the Uinta Mountains: Min. Rept., vol. 50, pp. 166-167, 1904.

Describes the geology and the character and occurrence of iron-ore deposits. 
Watts, A. C., Coal-mining methods in Utah: Colorado School Mines Mag., vol. 6, No. 9, pp. 197-201, 2 figs. September, 1916.

Coal-mining methods in Utah: Coal Age, vol. 10, No. 6, pp. 214-219, 6 figs., Aug. 5, 1916.

WEED, W. H., The copper mines of the United States in 1905: U. S. Geol. Survey Bull. 285, pp. 93-124, 2 figs., 1906.

Describes the general condition of the copper industry in the United States, and the geology, character, occurrence, and other features of the copper ores of the several States.

WeEкs, F. B., Stratigraphy and structure of the Uinta Range: Geol. Soc. America Bull., vol. 18, pp. 427448, 6 pls., 3 figs., 1907.

Describes the occurrence and relations of preCambrian, Paleozoic, Mesozoic, and Tertiary formations, and the geologic structure of the region.

- Phosphate deposits in the western United States: U. S. Geol. Survey Bull. 340, 441-447, 1908.

Weers, F. B., and Ferrier, W. F., Phosphate deposits in western United States: U. S. Geol. Survey Bull. 315, pp. 449-462, 1 pl., 3 figs., 1907. Abstract in Science, new ser., vol. 25, pp. 620-621, 1907.

WegemanN, C. H., The Coalville coal field, Utah: U. S. Geol. Survey Bull. 581, pp. 161-184, 6 pls. (incl. map), 1915.

Wells, R. C., and Butuer, B. S., Tungstenite, a new mineral: Washington Acad. Sci. Jour., vol. 7, No. 20, pp. 596-599, Dec. 4, 1917.

Whiте, C. A., Remarks on the paleontological characteristics of the Cenozoic and Mesozoic groups as developed in the Green River district: U. S. Geol. and Geog. Survey Terr. Bull., vol. 3, pp. 625-629, 1877 . Abstract in Am. Jour. Sci., 3d ser., vol. 14, p. 155, 1877. - Remarks upon the Laramie group: U. S. Geol. and Geog. Survey Terr. Bull., vol. 4, pp. 865-876, 1878.

- Report on the geology of a portion of northwestern Colorado: U. S. Geol. and Geog. Survey Terr. Tenth Ann. Rept. for 1876, pp. 1-60, 1878. Abstracts in Am. Naturalist, vol. 11, pp. 84-86, 1877; Am. Jour: Sci., 3d ser., vol. 13, pp. 72-74, 1877.

- Report on the paleontological field work for the season of 1877: U. S. Geol. and Geog. Survey Terr., Eleventh Ann. Rept., pp. 161-272, 1879. Abstracts in Am. Naturalist, vol. 12, pp. 103-106, 1878; Am. Jour. Sci., 3d ser., vol. 15, p. 59, 1878.

- Remarks upon certain Carboniferous fossils from Colorado, Arizona, Idaho, Utah, and Wyoming, and certain Cretaceous corals from Colorado, together with descriptions of new forms: U. S. Geol. and Geog. Survey Terr. Bull., vol. 5, pp. 209-221, 1879 . Abstract in Am. Jour. Sci., 3d ser., vol. 18, p. 409, 1879.

- Remarks on the Jura-Trias of western North America: Am. Jour. Sci., 3d ser., vol. 17, pp. 214-218, 1879. - Invertebrate paleontology of the Plateau province, together with notice of a few species from localities beyond its limits in Colorado: Report on the geology of the eastern portion of the Uinta Mountains, pp. vii, 74-135, U. S. Geol. and Geog. Survey Terr., 2d div., 1876. Abstract in Am. Jour. Sci., 3d ser., vol. 11, p. $161,1876$.
White, C. A., Fossils of the Laramie group: U. S. Geol. and Geog. Survey Terr. Twelfth Ann. Rept., for 1878 , pt. 1 , pp. $49-103$, pls. $20-30,1883$.

A review of the nonmarine fossil Mollusca of North America: U. S. Geol. Survey Third Ann. Rept., pp. 403-555, pls. 1-32, 1883. Abstracts in Am. Jour. Sci., 3d ser., vol. 27, pp. 68-69, 1884; Am. Naturalist, vol. 17, pp. 765-767, 1883.

- Certain Tertiary Mollusca from Colorado, Utah, and Wyoming: U. S. Geol. and Geog. Survey Terr. Twelfth Ann. Rept., pt. 1, pp. 41-48, pls., 1883.

Notes on the Jurassic strata of North America: Am. Jour. Sci., 3d ser., vol. 29, pp. 277-280, 1885.

On the relation of the Laramie molluscan fauna to that of the succeeding fresh-water Eocene and other groups: U. S. Geol. Survey Bull. 34, 54 pp., 5 pls., 1886. Abstracts in Science, vol. 10, pp. 126-127, 1888; Pop. Sci. Monthly, vol. 33, p. 420, 1888.

Mountain upthrusts: Am. Naturalist, vol. 22, pp. 399-408, 1888.

Report: Mesozoic division of invertebrate paleontology: U. S. Geol. Survey Seventh Ann. Rept., pp. 117-120, 1888.

- On the geology and physiography of a portion of northwestern Colorado and adjacent points of Utah and Wyoming: U. S. Geol. Survey Ninth Ann. Rept., pp. 677-712, pl. 88, 1889. Abstract in Am. Geologist, vol. 7, pp. 57-58, 1891.

Correlation papers, Cretaceous; a review of the Cretaceous formations of North America: U. S. Geol. Survey Bull. 82, 273 pp., 3 pls., 1891.

Whitfield, R. P. See Hall and Whitfield.

Whitney, J. D., On the climatic changes of later geological times: Harvard Coll. Mus. Comp. Zool. Memoirs, vol. 7,pt. 2, pp.i-xiv, 1-394, pls., 1884 . Reviewed in Science, vol. 1, pp. 141-142, 169-173, 192-195, 1883. Abstract in Am. Jour. Sci., 3d ser., vol. 21, pp. 149-150, 1881.

Whitney, J. D., and Wadsworth, M. E., The Azoic system and its proposed subdivisions: Harvard Coll. Mus. Comp. Zool. Bull., vol. 7, pp. 331-565, 1884. Reviewed in Am. Jour. Sci., 3d ser., vol. 28, pp. 313-314, 1884.

Wrulrams, H. S., Correlation papers, Devonian and Carboniferous: U. S. Geol. Survey Bull. 80, 279 pp., 1891.

Wruson, G. B., Geology of the Honerine mine, Stockton, Utah: Eng. and Min. Jour., vol. 85, pp. 869-870, 1908.

Winchell, N. H., The colossal bridges of Utah: Am. Geologist, vol. 34, pp. 189-192, 1 fig., 1904.

Describes briefly these arches produced by erosion, situated in San Juan County, Utah.

Winchester, D. E., Oil shale in northwestern Colorado and adjacent areas: U. S. Geol. Survey Bull. 641, pp. 139-198, 10 pls. (incl. maps), 2 figs., Dec. 18, 1916.

- Oil shale in the United States: Econ. Geology, vol. 12 , No. 6, pp. 505-518, 2 pls., 2 figs., September, 1917. 
Winslow, Arthur, A natural bridge in Utah: Science, new ser., vol. 7, pp. 557-558, 2 figs., 1898.

Describes its character and origin.

Woodruff, E. G., Marsh gas along Grand River near Moab, Utah: U. S. Geol. Survey Bull. 471, pp. 76-104, 2 pls. (maps), 1 fig., 1912.

- Geology of the San Juan oil field, Utah: U. S. Geol. Survey Bull. 471, pp. 76-104, 2 pls. (maps), 1 fig., 1912.

Woodruff, E. G., and DAY, D. T., Oil shale of northwestern Colorado and northeastern Utah: U. S. Geol. Survey Bull. 581, pp. 1-21, 1 pl. (map), 1914.

- Bituminous shale in northwestern Colorado and northeastern Utah: Abstract in Washington Acad. Sci. Jour., vol. 4, No. 7, pp. 170-171, 1914.

WoODWARD, R. S., On deformation of the geoid by removal through evaporation of the water of Lake Bonneville: U. S. Geol. Survey Mon. 1, pp. 421-424, 1890.

Wright, F. E. See Hillebrand and Wright; Hillebrand, Wright, and Merwin.

ZALINski, E. R., Ore occurrence at Fortuna mine, Bingham: Eng. and Min. Jour., vol. 86, pp. 1191-1195, 5 figs., 1908.

Describes the local geology, and the character, occurrence, and genesis of the copper ores near Bingham, Utah.

Amatrice, a new gem stone of Utah: Eng. and Min. Jour., vol. 87, pp. 1038-1039, 2 figs., 1909.

Describes the gem material and its geologic occurrence in Tooele County, Utah.

-Discussion of oxidized zinc ores at Tintic, giving analyses: Eng. and Min. Jour., p. 1305, 1914.

- Occurrence of oxidized zinc ores at Tintic: Eng. and Min. Jour., p. 1228, 1913.

- Ore occurrence at Little Bell mine, Park City, Utah: Eng. and Min. Jour., vol. 91, pp. 1101-1103, 4 figs., 1911.

Describes the local geology and the character, occurrence, and relations of the silver-lead ores.

- Occurrence of oxidized zinc ores at Tintic, Utah:

Eng. and Min. Jour., vol. 95, No. 25, pp. 1227-1228, 2 figs., 1913.

Zirkel, Ferdinand, Microscopical petrography: U. S. Geol. Expl. 40th Par., vol. 6, 297 pp., 12 pls., 1876. Reviewed in Am. Jour. Sci., 3d ser., vol. 13, pp. 309-313, 1877.

- Some remarks upon the petrographical collection of the geological explobation of the fortieth parallel: Boston Soc. Nat. Hist. Proc., vol. 22, pp. 109-116, 1884.

Anonymous. The geology of Stateline district, Utah: Salt Lake Min. Rev., vol. 9, No. 23, pp.15-17, 2 figs., 1908.

- Genesis of the porphyry ores: Mines and Methods, vol. 1, No. 12, pp. 391-394, 1 fig., 1910.

Discusses the genesis of copper orest at Bingham. Utah.

- Development of the Green River oil fields, Utah: Salt Lake Min. Rev., vol. 14, No. 4, pp. 11-14, 3 figs., 1912.

Includes notes on the geology of the field.

\section{GEOGRAPHY.}

As Utah lies in both the Plateau and the Great Basin provinces of the Cordilleran region it possesses a great variety of geographic and climatic features. The differences in the latitude and the altitude of the different sections result in temperature differences, ranging from semitropical to semifrigid and in equally marked differences in precipitation. The topographic and climatic conditions have exerted a marked influence on the development of the industries of the State

TOPOGRAPHY.

RELIEF.

The most important physiographic frontier in Utah sweeps as a curve of gentle westward concavity from about the middle of the northern boundary to the southwest corner of the State. The part of Utah lying west of this line is almost entirely within the Great Basin; the larger part of the State which lies to the east belongs to the Plateau province as defined by Powell, but as some parts of it have not the plateau character it may be best designated, as a whole, the eastern section.

The typical features of the Great Basin, a vast region having no outlet to the sea and characterized topographically by the alternation of relatively broad, coalescing desert valleys with relatively narrow mountain ranges of general north-south trend, are well epitomized in western Utah. The Raft River Mountains, in the northwest corner of the State, are exceptional in their east-west elongation and irregular plan, but these lie on the very border of the province, the drainage of their northern flank being tributary to Snake River. The other ranges of western Utah are typical in trend and form. They rise like islands and peninsulas above a desert floor, large parts of which appear almost as level as a sea. The broadest open portion of this surface, the Great Salt Lake Desert, is one of the most extensive arid plains in the whole Great Basin, as Great Salt Lake is by far the largest of the saline lakes in which the rivers of that province generally terminate.

Despite the apparent flatness of the desert floor, its elevation ranges from about 4,300 
feet at the shore of Great Salt Lake to nearly 6,000 feet at the head of Escalante Desert. It rises gradually southward as a whole, and the border of each desert valley slopes gently upward toward the bordering mountains. The broad valley floors are but slightly intrenched by the few streams that reach them; their borders are somewhat diversified, however, by the erosive work of mountain streams, and in places by the abandoned shore features of Lake Bonneville, of which Great Salt Lake is a shrunken remnant. Some of the isolated mountain ridges rise 4,000 to 5,000 feet above the general surface of the desert, and some of their highest peaks are more than 12,000 feet above sea level. Their topography is necessarily rugged because of their relatively high and narrow form.

The eastern section of Utah has far less unity of character than the western or Great Basin section. Powell, ${ }^{1}$ indeed, assigned the eastern section as a whole to the Plateau province, and this assignment may in a measure be justified. Viewed in a very broad way, the region is a rolling upland surface; it is high above sea level, and, although a large part of its surface is Iower than the Escalante Desert, all of its western margin stands above the desert floor of the Great Basin.

The physiographic unity of the region is, however, interrupted in the northeastern part of the State by two great mountain ranges, the Wasatch and the Uinta, which can not be neglected in any but the broadest classification. The Wasatch Mountains, which rise directly from the eastern limit of the Great Basin, extend from southern Idaho to the town of Nephi, near the center of Utah. The Uinta Range nearly meets the Wasatch about southeast of Salt Lake City and extends eastward into Wyoming and Colorado, the axes of the two ranges running nearly at right angles to each other. The classification adopted recently by the physiographic committee includes both the Wasatch and Uinta ranges in the northern Rocky Mountain province, assigns the tract in the angle northeast of them to the Wyoming Basin - a subprovince of the Rocky Mountains - and leaves to the PIateau province only that part of the eastern section of Utah that lies south of the Uinta Range. According to this scheme the PIateau province

1 Powell, J. W., Report on the geology of the eastern portion of the Uinta Mountains: U. S. Geol. and Geog. Survey Terr., 2d div., 1876. described by Powell is divided by a physiographic boundary of the first rank - the common limit of the northern Rockies and of the Plateau region in the narrower sense.

A mental picture of the eastern section of Utah is most easily formed by bearing in mind these four main subdivisions - the Plateau region at the south, the Wasatch Range along the northwest border, the Uinta Range extending eastward from the Wasatch, and the Wyoming Basin, overlapping slightly the northeastern reentrant of the State boundary. The relief of each of these subdivisions may now be briefly characterized.

The Plateau region is, broadly speaking, a gently rolling surface deeply intrenched by streams, being, unlike the desert floor of the Great Basin, diversified chiefly by depressions rather than by prominences; but a few clusters of knoblike mountains-the Henry, Abajo, and La Sal groups and Navajo Mountain-are superposed upon the plateau surface. The elevation of this surface ranges from more than 9,000 to about 3,000 feet; it decreases on the whole, though by no means uniformly, southward and southwestward from the base of the Uinta Mountains. The deepest intrenchment has been effected near the southern boundary of the State by Colorado River, the bottom of whose canyon is there about 4,000 feet below the top of the neighboring Kaiparowits Plateau. The walls of this canyon and of others in the nearly horizontal strata that underlie most of the region tend to simulate the well-known style of the Grand Canyon of Arizona, with its characteristic alternation of talus, cliff, and terrace, and much of the upland surface is diversified by "badland" topography and other picturesque details. The superposed mountains, which differ from the plateaus in structure and in sculpture, attain elevations of about 11,000 feet above sea level, or 5,000 feet above the surrounding plateau surfaces.

The Uinta Mountains are simpler than most ranges in form and structure, having been produced principally by uplift along an east and west axis in such manner that their typical cross section is essentially a flat-topped but rather steep-sided arch. The Uinta was regarded by Powell as a plateau, and structurally it is one, but its great height and deep dissection justify its usual designation as a mountain range. In its axial part broad glaciated amphi- 
theaters and canyons alternate with flat or acute ridges and summits, many of which are more than 10,000 feet and the highest more than 13,000 feet above sea level. The range has a well-defined western terminus at Kamas Prairie but is not very sharply delimited on the north and south from the Wyoming Basin and the Plateau region.

The Wyoming Basin, of which Utah contains but a very small part and with which this report is little concerned, may be dismissed with the sta tement that it bears some general resemblance to the Plateau region.

The Wasatch Mountains are far more heterogeneous and complex than the Uinta Mountains and are divisible into three sections of markedly differing character.

The southern Wasatch extends from the southern terminus of the range, at Nephi, to the canyon of the American Fork. It consists of a curving row of lofty peaks and ridges which rise abruptly both from the desert floor on the west and from the plateau surface on the east, and which are separated from each other by canyons that head far eastward. The highest mountain of the southern Wasatch is Mount Timpanogos, which stands 11,957 feet above sea level and more than 7,000 feet above the town of Pleasant Grove, which lies at its base.

The middle Wasatch extends from the American Fork to Weber River. Unlike the southern section, but like most other mountain ranges, it has a persistent main divide, namely, the watershed that parts the tributaries of Weber and Provo rivers from the short streams that reach the Great Basin more directly. The loftiest part of this section-that lying south of Salt Lake City-resembles the southern Wasatch in that its highest peaks lie west of the main divide and rise abruptly from the desert; but these peaks do not form a prominent row and are connected with the divide by nearly level spurs. The highest summits are about 11,000 feet high. The east side of this broad, massive, rugged portion of the range descends about 3,000 feet or more to the prairie zone that separates it from the Uinta. North of Salt Lake City the divide lies farther west, is considerably lower than to the south, and is really nothing more than the western edge of the deeply dissected Wyoming Basin.
The northern Wasatch, which extends from Weber River into southern Idaho, has two branches that are separated by the broad Logan Valley. The western branch, which may be called the northern Wasatch proper, is a narrow ridge that is about 10,000 feet in maximum height but becomes lower and less continuous northward. The eastern branch, generally called the Bear River Range or Plateau, maintains more uniformly this level of about 10,000 feet; it merges rather gradually on the east with the dissected upland margin of the Wyoming Basin.

DRAINAGE.

The extreme northwestern part of Utah drains by way of Raft River to Snake River. The drainage of the remainder of the State is divided almost equally, in the areal sense, between the Great Basin and Colorado River, for much of the larger eastern section of the State drains into the western or Great Basin section, whose drainage, by definition, is self-contained. The course of the divide between these two main drainage areas is extremely tortuous.

The distribution of the streams in the eastern section shows remarkable disregard of physiographic boundaries. Most of the section is drained by Colorado River, of which Green River is the main branch and, in all but name, the upper headwater portion. Green River crosses the eastern Uinta Mountains in Colorado by way of a profound canyon, through which it drains a large part of the Wyoming Basin. Its tributaries also drain the greater part of both flanks of the Uinta Range. Most of the Plateau region is drained by the Colorado through Green River and other tributaries, the largest of which are Grand, Frémont, San Juan, and Virgin rivers. The longest stream that flows from the eastern section of Utah to the Great Basin is Bear River, which rises in the southwestern corner of the Wyoming Basin, flows northward through Bear Lake into Idaho, turns abruptly southward into Utah, and finally empties into Great Salt Lake. Other streams that flow from, the Wasatch Mountains or the plateaus to the Great Basin are the Ogden, Weber, Provo, Spanish Fork, and Sevier. All these rivers but the last cut across the Wasatch Range, whose east flank is drained by them, its run-off thus being wholly tributary to the Great Basin. 
Only two streams not already mentioned flow | degree on the latitude. In the Great Basin far on the floor of the Great Basin-the Jordan region there are no great extremes of either runs from Utah Lake to Great Salt Lake; the heat or cold. In the lower valleys the summer Sevier sinks in the Sevier Desert and Lake. A temperature is sometimes disagreeably warm few other small streams flow into Great Salt but in the mountains it is usually moderate. Lake. Few of those that rise in the basin The cold in winter is rarely extreme. In the ranges persist far into the desert. Many of higher portions of the State, as the Uinta and the lower ranges give rise to no perennial Wasatch mountains and portions of the Plateau streams, their only permanent water supply region, the summers are short and cool and being derived from springs.

\section{CLIMATE.}

The variation in climate of different parts of (Dixie) the Utah depends chiefly on the altitude and in less are mild, snow rarely accumulating.

Mean temperature $\left({ }^{\circ} \mathrm{F}\right.$.) at stations in Utah to end of 1918.

Western Utah.

\begin{tabular}{|c|c|c|c|c|c|c|c|c|c|c|c|c|c|c|}
\hline Station. & $\begin{array}{l}\text { Length } \\
\text { of } \\
\text { record. }\end{array}$ & $\begin{array}{l}\text { Janu- } \\
\text { ary. }\end{array}$ & $\begin{array}{c}\text { Febru- } \\
\text { ary. }\end{array}$ & March. & April. & May. & June. & July. & August. & $\begin{array}{l}\text { Septem } \\
\text { ber. }\end{array}$ & $\begin{array}{l}\text { Octo- } \\
\text { ber. }\end{array}$ & $\begin{array}{c}\text { Novem- } \\
\text { ber. }\end{array}$ & $\begin{array}{l}\text { Decem- } \\
\text { ber. }\end{array}$ & Anno \\
\hline Beaver. & $\begin{array}{c}\text { Years. } \\
10\end{array}$ & 29.1 & 30.1 & 39.2 & 45.3 & 60.8 & 60.8 & 67.8 & 67.1 & 57.6 & 47.6 & 38.7 & 27.3 & 47. \\
\hline Black R & 14 & 26.1 & 31.8 & 40.6 & 48.1 & 55.2 & 62.8 & 70.6 & 68.9 & 59.2 & 48.0 & 38.5 & 26. 4 & 47.6 \\
\hline Blue Creel & 13 & 25.4 & 28.8 & 37.9 & 50.8 & 60.9 & 70.3 & 78. 9 & 77.3 & 63.5 & 50.0 & & 27.5 & 50.9 \\
\hline Cedar City & 12 & 32.2 & 35.1 & 41.8 & 48.4 & 55.4 & 65.9 & 72.9 & 70.4 & 61.8 & 50.6 & 41.4 & 31.1 & 50. \\
\hline Corinne. & 28 & 24.4 & 29.8 & 39.8 & 50.1 & 59.4 & 69.7 & 78.0 & 74.0 & 64.6 & 50.8 & 37.4 & 28.3 & 50.5 \\
\hline Deseret. & 23 & 26. 6 & 31. 2 & 40.6 & 48.2 & 55.8 & 65.0 & 72.5 & 71.4 & 60.6 & 49.2 & 37.6 & 25.9 & 48.7 \\
\hline Elberta. & 15 & 27.9 & 31.4 & 40.7 & 50.1 & 56.8 & 67.0 & 74. 4 & 73.6 & 62.7 & 50.5 & 39.0 & 28.1 & 50.2 \\
\hline Farmingt & 17 & 29.1 & 33.0 & 40. & 48.8 & 56.2 & 64.7 & 72.8 & 70.8 & 59.9 & 49.5 & 39.9 & 30.5 & 49.7 \\
\hline Fillmore. & 26 & 30.5 & 34.1 & 41.7 & 50.0 & 57.8 & 67.6 & 75.2 & 74.4 & 64.8 & 52.6 & 41.8 & 29.8 & 51.7 \\
\hline & 16 & 31.9 & 33.1 & 38.8 & 46.5 & 54.9 & 67.7 & 73.5 & 67.0 & 62.6 & 49.3 & 39.8 & 31.0 & 49.7 \\
\hline Gar & 12 & 27.8 & 32.6 & 40.3 & 48.4 & 55.2 & 64.2 & 72.0 & 70.5 & 61.6 & 48.2 & 39.7 & 29.1 & 49.1 \\
\hline t & 17 & 27.0 & 30.4 & 38.3 & 46.6 & 53.1 & 63.0 & 72.8 & 71.9 & 61.0 & 49.0 & 38.3 & 27.6 & 48.2 \\
\hline $\mathrm{He}$ & 25 & 20.9 & 23.9 & 33.9 & 44.2 & 51.5 & 59.1 & 65.7 & 64.5 & 55.2 & 45. 3 & 35.2 & 22.4 & 43.5 \\
\hline$\overline{\mathrm{H}}$ & 18 & 22.1 & 25.8 & 35.2 & $44 . \overline{1}$ & 50.8 & 58.2 & 65.1 & 63.9 & 54.7 & 4 & 35.0 & 23.6 & \\
\hline & 12 & 24.7 & 27.9 & 35.6 & .7 & 48.5 & 56. 7 & 65.8 & 9 & 56 & 4 & 3 & 24.4 & 44.2 \\
\hline & 26 & 22.0 & 27.2 & 38. & 47.3 & 56. 2 & 66.4 & 74.9 & 71.9 & 59. & 47. 4 & 34.9 & 25.5 & 47.6 \\
\hline & 17 & 21.8 & 21.7 & 29 . & 41.1 & 48. 9 & 56.7 & 64.6 & 63.2 & 53.7 & 43.5 & 33.3 & 24.4 & 41.8 \\
\hline Lev & 27 & 24.5 & 28.6 & 37.1 & 46.4 & 52.5 & 63.6 & 71.4 & 69.8 & 60.0 & 47.5 & 36.9 & 25.5 & 47.0 \\
\hline & 26 & 24.1 & 26.7 & 36.0 & 47.6 & 54.4 & 63.2 & 71.7 & 70.8 & 61.2 & & & 25.6 & \\
\hline Luc & 11 & 22.5 & 29.1 & 39.9 & 47.2 & 53. 3 & 62.1 & 71. 3 & 70.5 & 59.8 & 46. 0 & 35.3 & 24.3 & 46.8 \\
\hline & 22 & 24.8 & 28.3 & 37.8 & 46.1 & 54.5 & 63.3 & 69.4 & 67.8 & 59.0 & 47 & 37.4 & 25.3 & 46.8 \\
\hline $\bar{M}$ & 16 & 28.2 & 31.0 & 37.7 & 45.0 & 51.0 & 59.7 & 66.0 & 65.0 & 58.0 & 47.2 & 37.0 & 25.0 & 45.9 \\
\hline & 17 & 27. 3 & 30.9 & 38.5 & 45.9 & 52.8 & 63.0 & & 69.2 & 59. & 48. 3 & 37.6 & 27.5 & 47.9 \\
\hline & 12 & 22.9 & 26.7 & 35.9 & 45.6 & 51.6 & 59.3 & 66 & 65.7 & 56.3 & 46.0 & 36.3 & 23.2 & 44.8 \\
\hline Plea & 15 & 27.7 & 31.0 & 38.1 & 47.5 & 54.9 & 63.9 & 7. & 71.4 & 61 & 4 & 38.6 & 26.9 & 48 \\
\hline & 27 & 29.3 & 32.1 & 40.6 & 51.4 & 59.1 & 68.8 & 76.5 & 75.4 & 63.0 & 51. 1 & 40.1 & 30.6 & \\
\hline $\mathrm{P}$ & 15 & 23.0 & 25.8 & 30.3 & 39.8 & 48.8 & 56.9 & 63.7 & 62.0 & 55.2 & 4 & 34.4 & 24.6 & 42.5 \\
\hline & 27 & 29.0 & 31. 9 & 39 & 47.1 & 54.6 & 64.1 & & 66.6 & & & & 28.8 & 48.5 \\
\hline $\mathrm{Pj}$ & 19 & 26.6 & 30.1 & 35.5 & 43.0 & 48.9 & 58.5 & 66.0 & 64.3 & 53.2 & 44.3 & 36.4 & 26.0 & 44.4 \\
\hline & 24 & 26.9 & 31.4 & 39.2 & 48.4 & 56. 6 & 64.2 & & 70.3 & a & & & 28.5 & 48.9 \\
\hline $\mathrm{R}$ & 23 & 26. 8 & 32.0 & 40.1 & 47.8 & 54.9 & 63.4 & 70.3 & 68.1 & 58.9 & 48.2 & 37.7 & 27.6 & 48. 0 \\
\hline & 14 & 28.0 & 32.7 & 40.9 & 50.1 & 57.0 & 66.4 & 74. 9 & 73. 7 & 63.3 & 50.6 & 39.7 & 29.9 & 50.6 \\
\hline & 44 & 29.2 & 33.4 & 41.6 & 50.0 & 57.4 & 67.0 & 76.0 & 74. 6 & 64.4 & 52.4 & 40.9 & 31.9 & 51.6 \\
\hline & 23 & 27.3 & 31.3 & 38.6 & 46 & 53. 2 & 62.7 & 69.7 & 68.4 & 59.2 & 47.7 & 37.8 & 26.6 & 47.4 \\
\hline & 24 & 22.7 & 27.3 & 35.8 & 45.5 & & 60.2 & 68.4 & 67.2 & 57.6 & 46.9 & 36.2 & 25.3 & 45. 5 \\
\hline Summit & 13 & 17.7 & 21.8 & 28.4 & 39. & 46. 6 & 53.5 & 60.5 & 60.8 & 51.1 & 41.2 & 29.0 & 17.5 & 39.0 \\
\hline & 21 & 24.2 & 29.4 & 36.9 & 47.0 & & 61.6 & 69.4 & 68.4 & 57.9 & 47.8 & 36.5 & 75.6 & \\
\hline & 22 & 29.2 & 32.6 & 39.8 & 48.7 & 55.4 & 65.2 & 73.0 & 72.5 & 62.8 & 50.3 & 39.7 & 30.6 & 50.0 \\
\hline Woodruff.. & 14 & 15.3 & 16.7 & 27.8 & 40.3 & 46.9 & 55.0 & 60.7 & 59.6 & 51.0 & 40.6 & 30.2 & 19.1 & 38.6 \\
\hline
\end{tabular}


GEOGRAPHY.

Mean temperature $\left({ }^{\circ} \mathrm{F}.\right)$ at stations in Utah to end of 1918 -Continued.

Eastern Utah.

\begin{tabular}{|c|c|c|c|c|c|c|c|c|c|c|c|c|c|c|}
\hline Station. & $\begin{array}{l}\text { Length } \\
\text { of } \\
\text { record. }\end{array}$ & $\begin{array}{l}\text { Janu- } \\
\text { ary. }\end{array}$ & $\begin{array}{c}\text { Febru- } \\
\text { ary. }\end{array}$ & March. & April. & May. & June. & July. & $\begin{array}{l}\text { Au- } \\
\text { gust. }\end{array}$ & $\begin{array}{c}\text { Sep- } \\
\text { tember. }\end{array}$ & $\begin{array}{l}\text { Octo- } \\
\text { ber. }\end{array}$ & $\begin{array}{c}\text { Novem- } \\
\text { ber. }\end{array}$ & $\begin{array}{c}\text { Decem- } \\
\text { ber. }\end{array}$ & Annual. \\
\hline Altor & 15 & 24.6 & 27.4 & 32.5 & 41.9 & 48.0 & 56.1 & 62.0 & 61.8 & 54.8 & 45.8 & 36.5 & 26.5 & 43.1 \\
\hline Aneth... & 10 & 30.4 & 37.8 & 46.2 & 54.7 & 63.1 & 72.2 & 78.1 & 77.3 & 67.5 & 50.5 & 42.6 & 31.1 & 54.3 \\
\hline Blanding. & 11 & 27.1 & 32.9 & 40.5 & 48.1 & 53.9 & 65.0 & 71. 0 & 70.2 & 61.2 & 51.2 & 40.2 & 28.2 & 49. 1 \\
\hline Castle Dale. . . . . . & 18 & 18.9 & 25. 7 & 37.4 & 46.1 & 53. 9 & 63.2 & 69.1 & 68.1 & 58.8 & 47.1 & 36.9 & 23.3 & 45. 6 \\
\hline Cisco ................. & 12 & 23.2 & 29.7 & 42.0 & 53.1 & 62.0 & 72.0 & 79.3 & 77.3 & 67.2 & 52.2 & 39.3 & 25.6 & 51. 9 \\
\hline Duchesne.......... & 12 & 16.1 & 21. 6 & 35.4 & 46.1 & 52.1 & 60.5 & 68.0 & 66.8 & 57.9 & 46.1 & 33.1 & 18.9 & 43.8 \\
\hline Emery..... & 16 & 24.3 & 29.1 & 37.4 & 44.9 & 51.8 & 59.9 & 65.0 & 64.9 & 56.9 & 46.9 & 37.9 & 27.7 & 45.3 \\
\hline Escalante. & 12 & 26.4 & 32.7 & 40.9 & 48.2 & 55.0 & 64.2 & 69.2 & 67.8 & 59.9 & 49.9 & 39.4 & 28.5 & 48.8 \\
\hline Fort Duchesne....... & 26 & 13.5 & 18.4 & 34.3 & $45 . \overline{5}$ & 53.5 & 62.0 & 68.2 & 67.1 & 58.0 & 44. 8 & 32.6 & 16.3 & 43.0 \\
\hline Giles................ . & 12 & 25.1 & 31.2 & 42.5 & 52.2 & 61.8 & 69.7 & 77.2 & 74.6 & 64. 6 & 50.9 & 38.0 & 24.9 & 51.1 \\
\hline Green River. & 17 & 23.2 & 33.3 & 45.2 & 54.0 & 62.1 & 73.5 & 79.0 & 76.7 & 65.6 & 52.0 & 39.1 & 24. 4 & 52.1 \\
\hline Hite....... & 14 & 35.7 & 42.4 & 51.1 & 59.2 & 68.2 & 77.7 & 84.2 & 82.8 & 72.5 & 59.7 & 47.5 & 35.2 & 59.7 \\
\hline La Sal.. & 14 & 25.2 & 28.4 & 35.4 & 44.5 & 51. 4 & 61. 0 & 67.1 & 66.0 & 57.2 & 46.2 & 37.4 & 24.8 & 45. 4 \\
\hline Loa. . & 19 & 24.6 & 24.1 & 32.2 & 40.5 & 48.7 & 58.6 & 65.9 & 62.9 & 53.0 & 41.3 & 31.1 & 20.9 & 42. 0 \\
\hline Moab.................... & 28 & 28.8 & 36.2 & 43.1 & 55.5 & 63.8 & 72.0 & 77.9 & 75.5 & 66.2 & 55.3 & 41.5 & 30.3 & 53. 9 \\
\hline St. George.......... & 27 & 37.5 & 42.0 & 49.4 & 57.4 & 66.4 & 75.9 & 82.1 & 80.6 & 71.1 & 59.1 & 45.8 & 37.6 & 58.7 \\
\hline Springdale........... & 12 & 38.2 & 44. 9 & 50.2 & 55.5 & 63.4 & 75.4 & 80.5 & 78. 2 & 71.1 & 61.9 & 49.5 & 40.9 & 59.1 \\
\hline Tropic...... & 20 & 27.4 & 30.4 & 38.2 & 44.8 & 52.1 & 61.3 & 67.1 & 64.9 & 57.9 & 48.1 & 38.2 & 28.3 & 46. 4 \\
\hline Vernal............. & 19 & 18.8 & 23.5 & 36.3 & 48.9 & 55.6 & 65.8 & 71.0 & 69.1 & 59.4 & 47.1 & 36.0 & 20.2 & 46.1 \\
\hline
\end{tabular}

Highest and lowest temperatures ( ${ }^{\circ} F$.) at stations in Utah to end of 1918.

Western Utah.

\begin{tabular}{|c|c|c|c|c|c|c|c|c|c|c|c|c|c|c|c|c|c|c|c|c|c|c|c|c|c|c|c|}
\hline \multirow[b]{2}{*}{ Station. } & \multirow{2}{*}{ 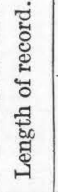 } & \multicolumn{2}{|c|}{$\begin{array}{l}\text { Janu- } \\
\text { ary. }\end{array}$} & \multicolumn{2}{|c|}{$\begin{array}{c}\text { Febru- } \\
\text { ary. }\end{array}$} & \multicolumn{2}{|c|}{ March. } & \multicolumn{2}{|c|}{ April. } & \multicolumn{2}{|c|}{ May. } & \multicolumn{2}{|c|}{ June. } & \multicolumn{2}{|c|}{ July. } & \multicolumn{2}{|c|}{$\begin{array}{l}\text { Au- } \\
\text { gust. }\end{array}$} & \multicolumn{2}{|c|}{$\begin{array}{l}\text { Sep- } \\
\text { tember. }\end{array}$} & $\begin{array}{l}\text { Oct } \\
\text { be }\end{array}$ & $\begin{array}{l}\text { to- } \\
\text { er. }\end{array}$ & $\begin{array}{c}\text { Nor } \\
\text { be }\end{array}$ & $\begin{array}{l}\text { vem- } \\
\text { er. }\end{array}$ & $\begin{array}{c}\text { Dec } \\
\text { be }\end{array}$ & $\begin{array}{l}\text { cem- } \\
\text { er. }\end{array}$ & A & da \\
\hline & & 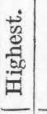 & $\begin{array}{l}\dot{\vec{u}} \\
\stackrel{0}{0} \\
\stackrel{0}{0} \\
\stackrel{H}{H}\end{array}$ & 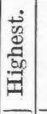 & 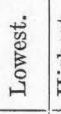 & $\begin{array}{l}\overrightarrow{0} \\
\frac{0}{50} \\
\frac{50}{10}\end{array}$ & 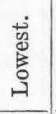 & 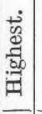 & 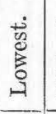 & 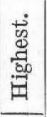 & 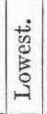 & 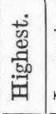 & 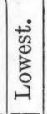 & . & 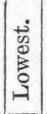 & , & 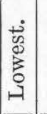 & , & $\mid$ & 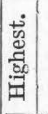 & 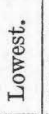 & 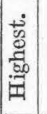 & 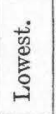 & 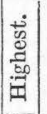 & 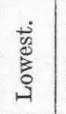 & 苟 & 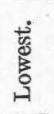 \\
\hline & Yrs. & & -22 & & & & & 79 & & & & & & & & & & & & & & & & & & & \\
\hline & & 60 & $\begin{array}{l}-22 \\
-33\end{array}$ & 80 & $\begin{array}{l}-21 \\
-26\end{array}$ & 78 & $\begin{array}{l}-0 \\
-1\end{array}$ & 90 & 10 & 99 & 18 & $\begin{array}{l}102 \\
106\end{array}$ & 25 & $\begin{array}{r}97 \\
105\end{array}$ & 30 & $\begin{array}{l}101 \\
102\end{array}$ & \begin{tabular}{l|}
32 \\
29 \\
\end{tabular} & $\begin{array}{l}89 \\
96\end{array}$ & \begin{tabular}{|l|}
14 \\
17
\end{tabular} & $\begin{array}{l}84 \\
90\end{array}$ & $\begin{array}{l}0 \\
5\end{array}$ & $\begin{array}{l}80 \\
79\end{array}$ & $\begin{array}{l}-10 \\
-7\end{array}$ & 64 & $\begin{array}{l}-17 \\
-32\end{array}$ & $\begin{array}{l}102 \\
106\end{array}$ & $\begin{array}{l}-24 \\
-33\end{array}$ \\
\hline & 13 & 64 & -18 & 63 & -17 & 74 & & 80 & 14 & 95 & 19 & 98 & 33 & 97 & 43 & 98 & 37 & 91 & 26 & 85 & 14 & 74 & & 67 & -5 & 98 & -18 \\
\hline & 28 & 60 & -22 & 67 & -16 & 76 & & 89 & 9 & 99 & 20 & 105 & 27 & 109 & 38 & 110 & 31 & 102 & 23 & 95 & 13 & 76 & & 9 & -13 & 110 & -22 \\
\hline & 24 & 60 & -28 & 71 & -28 & 80 & -9 & 87 & 7 & 91 & 21 & 106 & 22 & 104 & 32 & 104 & 26 & 98 & 21 & 89 & 10 & 79 & -4 & 67 & -17 & 106 & -28 \\
\hline & & 60 & -12 & 64 & -15 & 76 & & 86 & 12 & 90 & 23 & 104 & 32 & 100 & 34 & 102 & 34 & 95 & 27 & 86 & 18 & 76 & & 62 & -10 & 104 & -15 \\
\hline & 18 & 58 & -10 & 62 & -9 & 76 & & 84 & 18 & 92 & 26 & 101 & 30 & 100 & 37 & 99 & 36 & 90 & 27 & 85 & 19 & 70 & & 59 & 5 & 101 & -18 \\
\hline$F$ & 27 & 74 & -23 & 74 & -17 & 80 & -2 & 92 & 7 & 103 & 19 & 106 & 22 & 115 & 32 & 109 & 32 & 104 & 9 & 95 & 13 & 86 & -11 & $67 \mid$ & -14 & 115 & -2 \\
\hline & 16 & 68 & -7 & 63 & -17 & 72 & & 84 & 11 & 97 & 16 & 100 & 29 & 103 & 33 & 100 & 37 & 93 & 27 & 84 & 10 & \begin{tabular}{|l|}
69 \\
\end{tabular} & -4 & i. & & 103 & -17 \\
\hline & 11 & 62 & -17 & 68 & -22 & 75 & & 86 & 10 & 94 & 22 & 97 & 27 & 100 & 33 & 98 & 32 & 92 & 17 & 91 & 2 & 78 & -5 & 67 & -19 & 100 & -22 \\
\hline & 18 & 59 & -17 & 63 & -22 & 75 & -2 & 84 & 9 & 95 & 21 & 99 & 28 & 101 & 34 & 102 & 37. & .95 & 23 & 85 & 14 & 71 & & 60 & - & 102 & -2 \\
\hline & 26 & 60 & -30 & 58 & -38 & 70 & -14 & 83 & 0 & 91 & 15 & 100 & 25 & 100 & 28 & 96 & 24 & 92 & 18 & 8 & 6 & 70 & & 60 & -28 & 100 & -3 \\
\hline & 19 & 57 & -28 & 60 & -39 & 73 & 18 & 83 & 1 & 92 & 15 & 101 & 25 & 98 & 29 & 95 & $23 \mid$ & 92 & $\mid$\begin{tabular}{l|}
17 \\
$\mid$
\end{tabular} & 85 & 4 & 72 & -19 & 63 & -27 & 101 & -3 \\
\hline & 13 & 67 & -29 & 64 & -32 & 74 & -8 & 81 & $\overline{0}$ & 88 & 12 & 98 & 22 & 98 & 28 & 97 & 26 & 93 & 14 & 84 & 4 & 73 & -9 & 67 & -25 & 98 & -32 \\
\hline & 27 & 60 & -25 & 56 & -27 & 72 & -5 & 80 & 13. & 92 & 13 & 106 & 28 & 114 & 37 & 107 & 30 & 94 & 12 & & 6 & 74 & & 61 & -22 & 114 & -2 \\
\hline & & 50 & -20 & 55 & -36 & 66 & -22 & 78 & 2 & 84 & 19 & 94 & 27 & 106 & 31 & 93 & 25 & $\begin{array}{l}89 \\
\end{array}$ & 22 & 83 & 9 & 67 & & 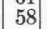 & -11 & 103 & - \\
\hline & & 58 & -23 & 58 & -12 & 76 & -4 & 85 & 13 & 96 & 24 & 102 & 31 & 100 & 38 & 100 & 35 & 91 & 26 & 87 & 12 & 75 & & 54 & -17 & 102 & -2 \\
\hline & & 63 & -20 & 78 & -5 & 76 & 10 & 83 & 10 & 95 & 27 & 105 & 30 & 110 & 46 & 107 & 40 & \begin{tabular}{|l|}
97 \\
\end{tabular} & 28 & 84 & 10 & 68 & 4 & 58 & -12 & 110 & -2 \\
\hline & 26 & 57 & -26 & 59 & -23 & 74 & & 86 & 12 & 91 & 20 & 98 & 29 & 101 & 34 & 98 & 33 & 91 & 21 & 85 & 14 & 74 & -10 & 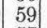 & 7 & 101 & - \\
\hline & & 54 & -19 & 58 & -19 & 73 & -6 & 90 & 13 & 92 & 16 & 98 & 28 & 101 & 37 & 99 & 35 & 93 & 26 & & 16 & & 1 & & & 101 & \\
\hline & 11 & 59 & -23 & 79 & -10 & 72 & & & 8 & 95 & 18 & 102 & 16 & 105 & 29 & 100 & 26 & 95 & 17 & 89 & 7 & 72 & -1 & 62 & -13 & 105 & -2 \\
\hline & 23 & 60 & -22 & 70 & -25 & 82 & -4 & 88 & 8 & 98 & 18 & 106 & 27 & 108 & 32 & 110 & 27 & 100 & 20 & 90 & 11 & 74 & $-\overline{8}$ & 62 & -18 & 110 & -2 \\
\hline & 15 & 62 & -22 & 67 & -33 & & -5 & 84 & 11 & 96 & 17 & 96 & 26 & 99 & 29 & & 31 & 91 & 20 & & 7 & 75 & -11 & & -21 & 99 & -3 \\
\hline & & 49 & & 48 & 10 & 63 & & & 26 & & 32 & 91 & 35 & 92 & 55 & 90 & 55 & 82 & 42 & 73 & 25 & 63 & 17 & & 13 & & \\
\hline & 11 & 60 & -25 & 65 & -15 & 80 & -4 & 8 & 11 & 98 & 20 & 102 & 20 & 102 & 37 & 99 & 30 & 96 & 22 & 86 & 9 & 75 & & 8 & -25 & 102 & -2 \\
\hline & 18 & 64 & -19 & 66 & -17 & 72 & -1 & 80 & 14 & 92 & 21 & 99 & 30 & 98 & 31 & 97 & 41 & 92 & 24 & 84 & 13 & 74 & -7 & 5 & -24 & 99 & -2 \\
\hline & 12 & 59 & -20 & 61 & -31 & & -10 & 81 & 1 & 89 & 19 & 98 & 28 & 98 & 32 & 96 & 28 & \begin{tabular}{|l|}
92 \\
\end{tabular} & 21 & & 4 & 73 & -14 & ) & & & -3 \\
\hline & & 54 & -17 & & -18 & 73 & & 79 & 0 & 85 & 21 & 100 & 28 & 97 & 42 & 96 & 39 & 89 & 28 & 86 & 11 & 73 & -9 & 61 & & 100 & -1 \\
\hline & 15 & 68 & & 64 & & 75 & & 95 & 12 & 99 & 19 & 100 & 30 & 110 & 33 & 111 & & 99 & 20 & & 14 & 73 & & & 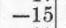 & 1 & 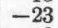 \\
\hline & 10 & 62 & -12 & 64 & -5 & 80 & & 87 & 18 & 100 & 27 & 102 & 29 & 103 & 42 & 104 & 3 & 98 & 29 & & 12 & 72 & & & & 104 & -1 \\
\hline & & 57 & -13 & 64 & -16 & 76 & -10 & & 16 & 92 & & 101 & 30 & 104 & 36 & 101 & 36 & 96 & 26 & & & 74 & - & ) & & 104 & -1 \\
\hline & 16 & 64 & -28 & 64 & & 71 & -23 & & -4 & 91 & 12 & 101 & 11 & 99 & 21 & 92 & 26 & 91 & 8 & 82 & -5 & 77 & -11 & 56 & & 101 & \\
\hline & & 63 & & 66 & & 82 & & 9 & & 92 & 20 & 102 & 27 & 102 & 29 & 102 & & 95 & 23 & & 15 & 76 & & 7 & - & 12 & -1 \\
\hline & 20 & 65 & -27 & 63 & -20 & 72 & -13 & 79 & -3 & 93 & 11 & 95 & 24 & 100 & 26 & 95 & 30 & 91 & 20 & 95 & 7 & 72 & -13 & 70 & -27 & 100 & -2 \\
\hline & 20 & 66 . & & & & & & & & & & 110. & & 105. & & 105. & & 96 . & & 93. & & & & 63. & & 110. & \\
\hline & 23 & 62 & - & 70 & - & 81 & 5 & 90 & 5 & 103 & 19 & 100 & & 102 & 30 & 99 & 2 & 98 & 12 & & i0 & 79 & $\because$ & & $\ddot{z}$ & 103 & - \\
\hline & & 62 & & 00 & & 71 & 11 & & 18 & 84 & 30 & 94 & 36 & 96 & 48 & 94 & 45 & 91 & 32 & & 21 & 0 & & & & & \\
\hline & 45 & 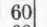 & -20 & 68 & -13 & 77 & & 8 & 18 & 93 & 25 & 101 & 32 & 102 & \begin{tabular}{|l|}
43 \\
\end{tabular} & 101 & 44 & 93 & 29 & 88 & 22 & 74 & -2 & 61 & -10 & 102 & - \\
\hline & 24 & 69 & -33 & 70 & -39 & 78 & -4 & & 7 & 94 & 13 & 102 & 24 & 106 & 30 & 101 & 26 & 95 & 19 & & 6 & 77 & -23 & 67 & & 106 & - \\
\hline & & 57 & -26 & 64 & -30 & 70 & -12 & 81 & 2 & 90 & 16 & 102 & 21 & 102 & 30 & 100 & 27 & 93 & 11 & & f & 70 & -12 & 58 & -18 & 102 & - \\
\hline & & 49 & & $6 ?$ & & 66 & & & $?$ & 91 & 12 & 97 & 20 & 100 & 23 & 100 & 22 & 88 & 15 & & 2 & 64 & 0 & 60 & & is & \\
\hline & & 74 & -16 & 64 & -5 & 76 & & 85 & 18 & 92 & 20 & 98 & 31 & 101 & 42 & 101 & 41 & 96 & 31 & 86 & 11 & 87 & 0 & 64 & -5 & 101 & - \\
\hline & 11 & 58 & -16 & 56 & -10 & 69 & -2 & 80 & 12 & 84 & 15 & 93 & 27 & 92 & 35 & 92 & 33 & 87 & 22 & 78 & 12 & 68 & & 59 & -5 & 93 & -1 \\
\hline & 22 & 63 & -35 & 70 & & 78 & -18 & 8 & 8 & 96 & $\mid 19$ & 108 & 23 & 112 & 26 & 105 & 25 & 100 & 17 & 98 & 2 & 90 & -11 & 65 & -25 & 112 & 2 \\
\hline & 23 & 60 & & 64 & & 76 & & & 16 & 90 & 22 & 98 & 31 & 100 & 35 & & & 96 & 28 & & 21 & 80 & & 60 & & 20 & \\
\hline w & 14 & 55 & -38 & 65 & -50 & 67 & -32 & 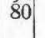 & 0 & 66 & 6 & 93 & 21 & 102 & 21 & 115 & 20 & 111 & & 83 & & 67 & -20 & 67 & -30 & 115 & -5 \\
\hline
\end{tabular}


Highest and lowest temperatures $\left(^{\circ} \mathrm{F}\right.$.) at stations in Utah to end of 1918 -Continued.

Eastern Utah.

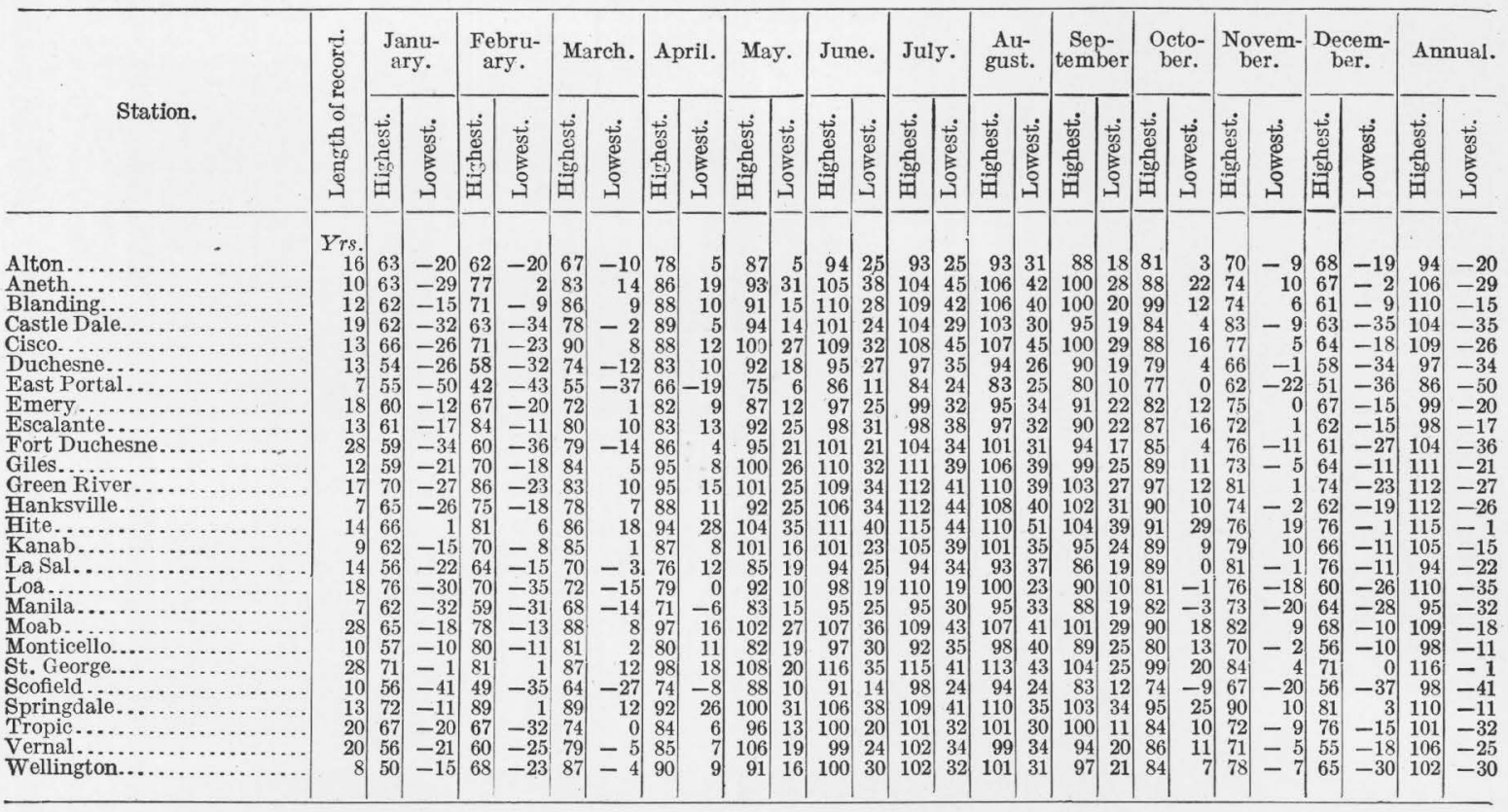

The precipitation, like the temperature, is much less. In the higher areas much of the prevery different in different sections of the State, cipitation comes as snow, which does not comand, like the temperature, is largely dependent pletely melt till late in spring or in summer and on altitude, being greatest in the higher por- thus tends to equalize the flow of the streams. tions. Thus the Uinta and Wasatch ranges The following table and diagram (fig. 1, p. 64), and portions of the High Plateau have rather taken from the reports of the United States abundant rain and snowfall, whereas the lower Weather Bureau, show the precipitation in lands of the western part of the State have different sections of the State:

Average monthly and annual precipitation (in inches) at Weather Bureau stations in Utah.

\begin{tabular}{|c|c|c|c|c|c|c|c|c|c|c|c|c|c|c|c|c|}
\hline Station. & County. & $\begin{array}{l}\text { Eleva- } \\
\text { tion } \\
\text { (feet). }\end{array}$ & Years. & $\begin{array}{l}\text { Jan- } \\
\text { uary. }\end{array}$ & $\begin{array}{l}\text { Feb- } \\
\text { ruary. }\end{array}$ & March & A pril. & May. & June. & July. & \begin{tabular}{|} 
Aus- \\
gust.
\end{tabular} & $\begin{array}{l}\text { Sep- } \\
\text { tem- } \\
\text { ber. }\end{array}$ & $\begin{array}{l}\text { Octo- } \\
\text { ber- }\end{array}$ & $\begin{array}{l}\text { No- } \\
\text { vem- } \\
\text { ber. }\end{array}$ & $\begin{array}{c}\text { De- } \\
\text { cem- } \\
\text { ber. }\end{array}$ & $\begin{array}{l}\text { An- } \\
\text { nual. }\end{array}$ \\
\hline 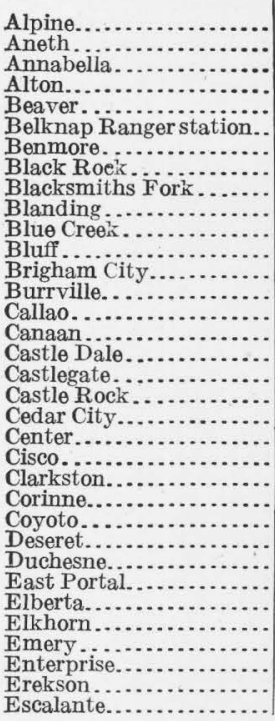 & $\begin{array}{l}\text { Washington } \\
\text { Tooele..... } \\
\text { Garfield.... }\end{array}$ & 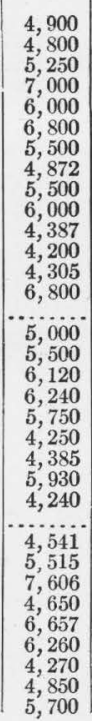 & $\begin{array}{l}1896-1918 \\
1900-1913 \\
1908-1910 \\
1902-1918 \\
1889-1918 \\
1914-1916 \\
1912-1918 \\
1901-1918 \\
1904-1910 \\
1905-1918 \\
1878-1904 \\
1911-1918 \\
1895-1918 \\
1911-1918 \\
1902-1905 \\
1912-1917 \\
1899-1918 \\
1893-1897 \\
1904-1918 \\
1899-1918 \\
1911-1916 \\
1892-1914 \\
1911-1918 \\
1870-1918 \\
1902-1908 \\
1892-1918 \\
1906-1918 \\
1912-1918 \\
1902-1918 \\
1910-1918 \\
1901-1918 \\
1905-1918 \\
1911-1918 \\
1901-1918\end{array}$ & $\begin{array}{r}1.70 \\
.49 \\
.71 \\
3.34 \\
.99 \\
1.04 \\
1.63 \\
.73 \\
2.05 \\
2.03 \\
1.01 \\
.72 \\
2.13 \\
1.18 \\
.51 \\
2.16 \\
.97 \\
1.07 \\
1.82 \\
.94 \\
1.67 \\
.67 \\
1.74 \\
1.41 \\
.58 \\
.69 \\
.76 \\
3.05 \\
1.99 \\
.77 \\
.56 \\
1.88 \\
1.34\end{array}$ & $\begin{array}{r}1.80 \\
.67 \\
.75 \\
2.62 \\
1.03 \\
.98 \\
1.43 \\
.97 \\
1.20 \\
1.55 \\
.77 \\
1.49 \\
1.64 \\
.98 \\
.83 \\
1.52 \\
.78 \\
.78 \\
1.80 \\
.94 \\
1.08 \\
.94 \\
1.84 \\
1.22 \\
.30 \\
.85 \\
.60 \\
2.10 \\
1.21 \\
.56 \\
.65 \\
1.85 \\
1.61 \\
1.01\end{array}$ & $\begin{array}{r}2.12 \\
.83 \\
.63 \\
4.18 \\
1.21 \\
.36 \\
1.67 \\
.92 \\
1.84 \\
1.42 \\
.81 \\
.60 \\
2.11 \\
.70 \\
1.16 \\
.56 \\
1.65 \\
1.76 \\
1.18 \\
1.16 \\
.48 \\
1.70 \\
1.31 \\
.76 \\
.89 \\
2.63 \\
1.30 \\
.84 \\
2.05 \\
1.44 \\
1.14\end{array}$ & $\begin{array}{r}1.90 \\
.41 \\
.58 \\
1.30 \\
.91 \\
1.60 \\
1.54 \\
1.98 \\
1.80 \\
1.06 \\
.44 \\
1.49 \\
1.16 \\
1.74 \\
1.74 \\
. .27 \\
1.28 \\
1.20 \\
1.06 \\
.39 \\
1.61 \\
1.11 \\
.84 \\
.95 \\
1.66 \\
. .22 \\
.52 \\
.46 \\
1.18 \\
1.41 \\
.50\end{array}$ & $\begin{array}{r}2.26 \\
.29 \\
.66 \\
. .97 \\
1.04 \\
1.62 \\
.93 \\
3.28 \\
.67 \\
.90 \\
2.50 \\
.62 \\
1.66 \\
.52 \\
.42 \\
1.34 \\
1.72 \\
.95 \\
.62 \\
1.88 \\
1.48 \\
.72 \\
1.03 \\
.64 \\
1.32 \\
1.19 \\
.79 \\
.52 \\
1.83 \\
.32 \\
.45\end{array}$ & $\begin{array}{r}0.81 \\
.26 \\
.20 \\
.47 \\
1.42 \\
1.18 \\
.36 \\
.97 \\
.41 \\
.48 \\
.10 \\
.08 \\
.83 \\
1.52 \\
.38 \\
.63 \\
.53 \\
1.24 \\
.37 \\
1.02 \\
.10 \\
1.53 \\
.67 \\
.42 \\
.39 \\
.75 \\
1.07 \\
.50 \\
.78 \\
.44 \\
.44 \\
.97 \\
.50\end{array}$ & \begin{tabular}{|r|}
0.69 \\
.74 \\
.92 \\
2.08 \\
1.54 \\
1.94 \\
1.09 \\
.76 \\
.72 \\
1.43 \\
1.19 \\
.81 \\
1.45 \\
.02 \\
2.43 \\
.88 \\
1.09 \\
1.50 \\
1.05 \\
.28 \\
.97 \\
.49 \\
.78 \\
.42 \\
1.99 \\
.63 \\
1.27 \\
.89 \\
1.31 \\
1.11 \\
1.66
\end{tabular} & $\begin{array}{r}0.96 \\
.76 \\
2.04 \\
1.99 \\
1.56 \\
.42 \\
.69 \\
2.58 \\
2.15 \\
1.47 \\
.36 \\
.63 \\
.40 \\
.51 \\
1.17 \\
1.11 \\
.64 \\
1.15 \\
1.21 \\
.60 \\
.52 \\
.50 \\
1.04 \\
.46 \\
.93 \\
.90 \\
.57 \\
.84 \\
1.21 \\
1.39 \\
.34 \\
1.71\end{array}$ & $\begin{array}{r}1.22 \\
1.08 \\
.82 \\
1.83 \\
1.40 \\
.92 \\
1.12 \\
.96 \\
1.07 \\
1.19 \\
.44 \\
1.48 \\
.87 \\
. .33 \\
1.35 \\
1.94 \\
1.39 \\
1.20 \\
.62 \\
.90 \\
1.19 \\
.73 \\
.88 \\
1.32 \\
1.80 \\
.96 \\
1.58 \\
1.14 \\
1.30 \\
.89 \\
1.07\end{array}$ & \begin{tabular}{|r|}
1.60 \\
.55 \\
.80 \\
1.52 \\
.98 \\
1.75 \\
1.06 \\
1.04 \\
1.81 \\
.87 \\
1.64 \\
.89 \\
.47 \\
1.42 \\
.87 \\
1.49 \\
1.29 \\
1.28 \\
1.67 \\
1.79 \\
.67 \\
.71 \\
1.08 \\
2.43 \\
1.01 \\
1.12 \\
1.75 \\
1.10 \\
1.12 \\
1.12
\end{tabular} & $\begin{array}{r}1.27 \\
.60 \\
1.69 \\
1.80 \\
.66 \\
.96 \\
.66 \\
1.50 \\
1.53 \\
.59 \\
1.47 \\
.74 \\
.20 \\
.83 \\
.74 \\
.60 \\
1.09 \\
.86 \\
.37 \\
1.69 \\
.99 \\
.83 \\
.57 \\
1.58 \\
.70 \\
.30 \\
.36 \\
1.97 \\
.06\end{array}$ & $\begin{array}{r}1.41 \\
.42 \\
1.13 \\
1.65 \\
1.20 \\
.34 \\
.86 \\
.40 \\
1.32 \\
2.18 \\
.87 \\
.73 \\
1.19 \\
.56 \\
.13 \\
.63 \\
1.27 \\
.96 \\
.83 \\
.52 \\
.54 \\
1.42 \\
.39 \\
.50 \\
1.55 \\
1.72 \\
.51 \\
.49 \\
.94 \\
.82 \\
.72\end{array}$ & \begin{tabular}{|r}
18.45 \\
7.10 \\
9.93 \\
23.62 \\
13.08 \\
11.32 \\
15.01 \\
9.38 \\
17.97 \\
16.70 \\
8.19 \\
6.31 \\
17.34 \\
10.45 \\
7.24 \\
14.71 \\
9.28 \\
9.43 \\
16.63 \\
12.70 \\
11.44 \\
6.50 \\
17.36 \\
12.46 \\
8.21 \\
8.28 \\
9.48 \\
21.06 \\
10.80 \\
9.89 \\
7.93 \\
16.24 \\
13.62 \\
11.69
\end{tabular} \\
\hline
\end{tabular}


Average monthly and annual precipitation (in inches) at Weather Bureau stations in Utah-Continued.

\begin{tabular}{|c|c|}
\hline Station. & County. \\
\hline armingt & Dav \\
\hline Fillmore. & Millard. \\
\hline Fort Due & Uinta.. \\
\hline risco.. & Beaver. \\
\hline no & Duch \\
\hline Garland. & Boxelder \\
\hline Garrison. & Millard. \\
\hline le & Wayne. \\
\hline overnm & Tooele. \\
\hline Granger. & Salt Lak \\
\hline G & Tooele. \\
\hline Gre & Emery. \\
\hline Grou & Boxelder \\
\hline Hanksvil & Wayne. \\
\hline Heber... & Wasatch \\
\hline Hen & Summit \\
\hline Hite... & Garfield \\
\hline Huntsvil & Weber. \\
\hline an $>>$ & Washing \\
\hline Tbapa & Tooele. \\
\hline Internati & ..... do. \\
\hline & ....do. do. \\
\hline Kan & Kane \\
\hline Kan & Millard. \\
\hline Kelt & Boxelder \\
\hline & Rich.. \\
\hline La $\mathrm{S}$ & San Jua \\
\hline Leeds (n & Washing \\
\hline Lehi. & Utah... \\
\hline Le & Boxeld \\
\hline Levan. & Juab \\
\hline Loa.... & Waynes \\
\hline Lo & Cache. \\
\hline & Tooele. \\
\hline Lower Ai & Utal \\
\hline Lon & Salt Lak \\
\hline $\bar{L}$ & Boxelder \\
\hline Lu & Iron. \\
\hline Mar & Uint \\
\hline $\mathrm{Ma}$ & San \\
\hline M & Sun \\
\hline & $\mathrm{Pi}$ \\
\hline Mid & Boxelder \\
\hline Mid & Salt Lake \\
\hline M & Beaver. \\
\hline Mills & Juab.. \\
\hline Milly & Cache. \\
\hline $\mathrm{M}$ & Beay \\
\hline M $>$ & G \\
\hline Mod & Iron \\
\hline Mon & San \\
\hline Mo & Mor \\
\hline & $\mathrm{Sa}$ \\
\hline Mo & Utah \\
\hline M & San \\
\hline M & $\mathrm{D}$ \\
\hline $\mathrm{Nad}$ & $\mathrm{Ber}$ \\
\hline $\mathrm{Ne}$ & Jua \\
\hline $\mathrm{N}$ & $\mathrm{Ir}$ \\
\hline $\bar{N}$ & y \\
\hline Oak & Millard. \\
\hline O & Web \\
\hline 0 & $\ldots .$. \\
\hline 0 & $\mathrm{Ka}$ \\
\hline $\mathrm{Pa}$ & \\
\hline $\mathrm{P}$ & Garfield. \\
\hline $\mathrm{P}$ & Sur \\
\hline $\mathrm{P}$ & $\mathrm{Bo}$ \\
\hline $\mathrm{P}$ & Iro \\
\hline & \\
\hline$P$ & W \\
\hline $\mathrm{Pi}$ & Si \\
\hline Pin & Washingt \\
\hline $\mathrm{P}$ & Sevi \\
\hline & \\
\hline & $C$ \\
\hline & $\mathrm{U}$ \\
\hline olph. & $\mathrm{R}$ \\
\hline & \\
\hline & Salt Lake \\
\hline $\mathrm{Ri}$ & \\
\hline & \\
\hline & \\
\hline & Washingt \\
\hline & Salt Lake \\
\hline Sa & \\
\hline & Uta \\
\hline & Millarc \\
\hline & Cart \\
\hline & \\
\hline & \\
\hline & W \\
\hline & $\mathrm{B} \cap \mathrm{x}$ \\
\hline $\mathrm{Sp}$ & $\mathrm{U}$ \\
\hline & Washin \\
\hline Standrod. & Boxelder. \\
\hline
\end{tabular}


Average monthly and annual precipitation (in inches) at Weather Bureau stations in Utah-Continued.

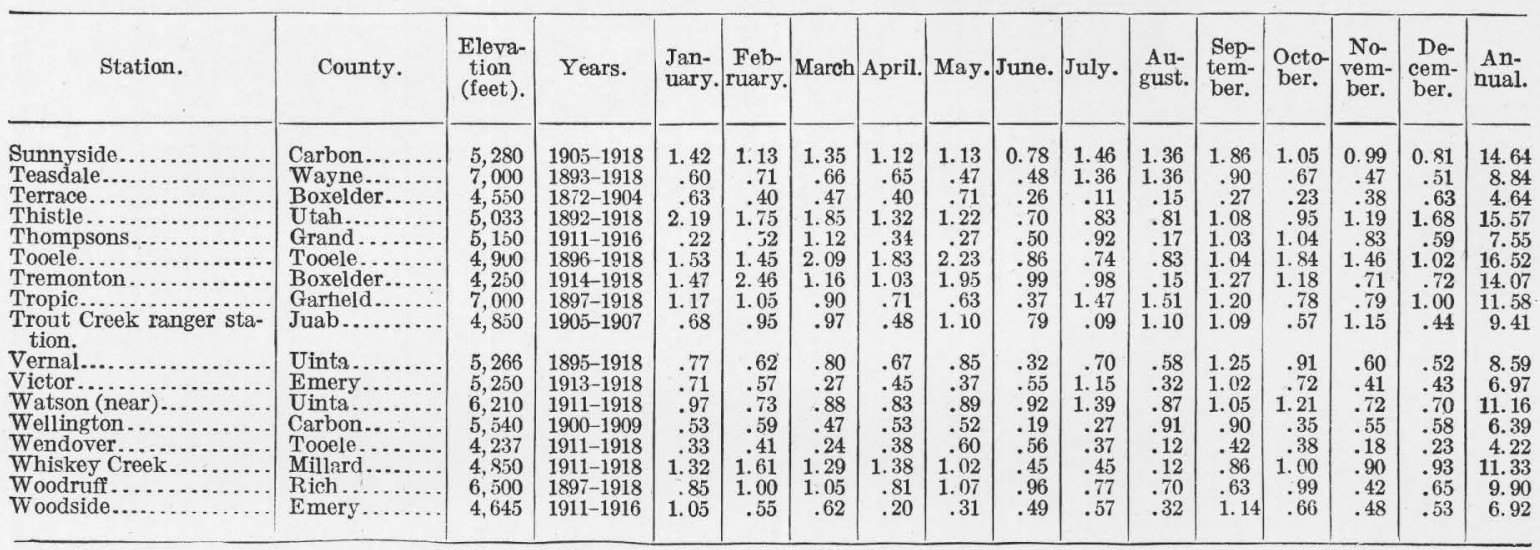
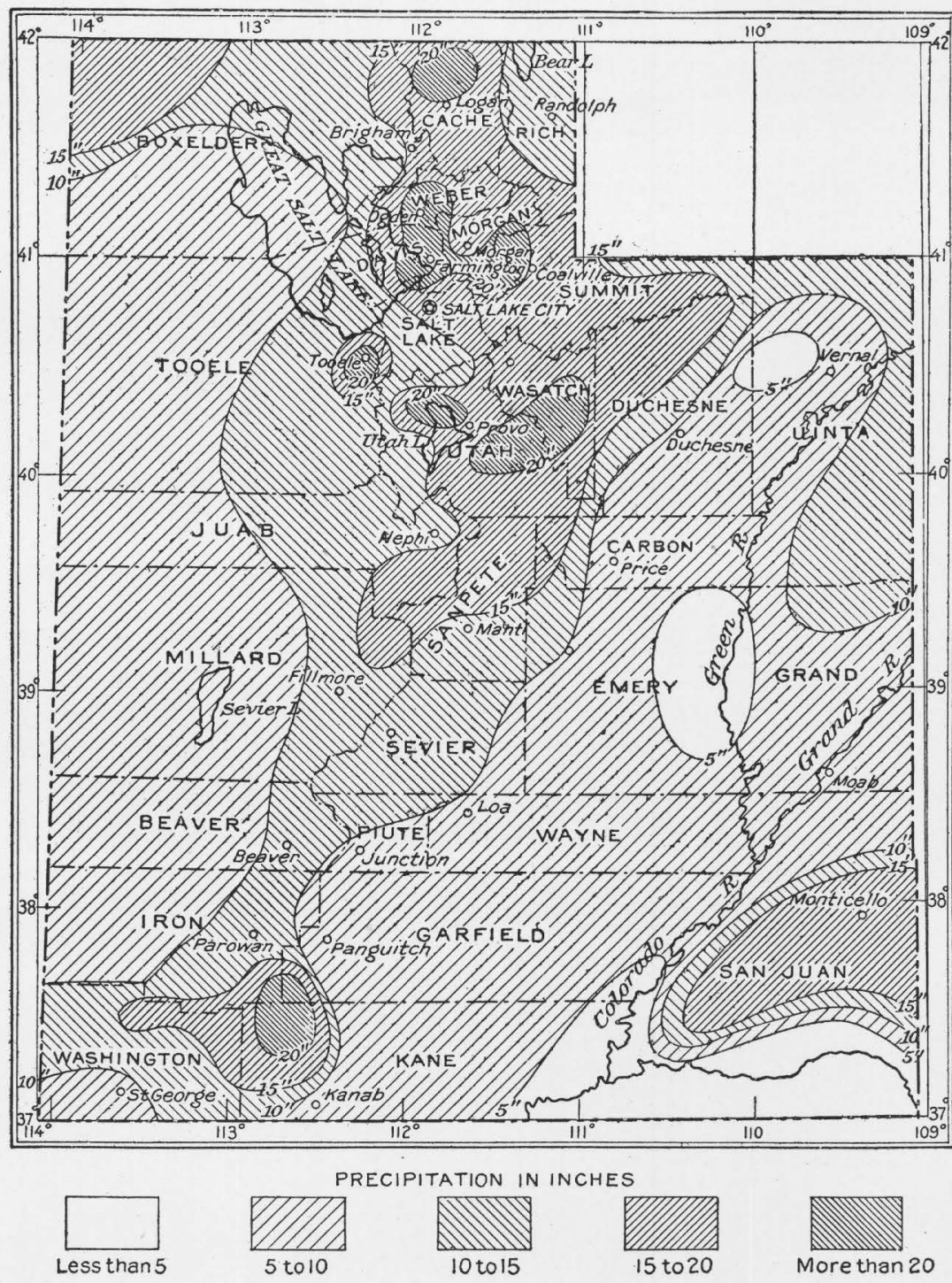

FIGURE 1.--Map showing rainfall in different sections of Utah. From United States Weather Bureau Reports. 
VEGETATION.

Except in some alkali areas the soil of Utah is generally fertile, and the native vegetation is largely dependent on the temperature and the precipitation. In the higher areas, notably the Uinta Mountains; the Wasatch Range, and the High Plateau, timber is abundant. At lower levels this gives place to scrub pine, juniper (cedar), and oak, and these in turn to sagebrush and other desert plants. In the lowest and driest areas the vegetation is scanty and confined to desert plants that require little moisture. Bunch and other grass grows rather plentifully over most of the State but has been greatly reduced over large areas by overgrazing.

\section{AGRICULTURE.}

Until recent years agriculture has been confined to the areas where irrigation was possible, and the more important agricultural interests have grown up around the points where the streams emerged from the mountains onto the flat area, notably along the west front of the Wasatch Range and its southern extension. Farther west in the Great Basin cultivated lands are limited to a few ranches irrigated from small streams coming from the higher ranges and from a few wells.

Some of the flat-bottomed valleys east of the Wasatch Range have proved exceedingly fertile, especially the Sevier and Sanpete valleys. South of the Uinta Mountains is an area containing large tracts that can be irrigated and that has in some degree been brought under cultivation. In southern and southeastern Utah only small areas are cultivated, and though these can be considerably enlarged most of the land never can be irrigated.

In recent years cultivation without irrigation has been attempted in several sections of the State and in the higher areas, where there is considerable precipitation, has been successful. Large tracts of this character have not yet been brought under cultivation, many of them because of lack of transportation or of water suitable for domestic use and for stock. Probably a large acreage of this type of land will eventually be utilized.

Since the earliest settlement of the State stock raising has been an important industry. Cattle, sheep, and horses range over practically all of the State that has not been given over to more intensive agriculture. In many sections the range has been overstocked and seriously damaged, but in recent years the regulation governing the forest reserves has brought about great improvement and will doubtless eventually lead to the regulation of the range in general.

Practically all the important mining districts are within easy reach of farming sections, where all the essential agricultural products may be had at reasonable prices.

TRANSPORTATION.

In the Great Basin region railroads can be constructed along the flat valleys between the ranges at moderate cost, and such extensions have been made wherever traffic has seemed to warrant. The principal mining camps and larger agricultural communities are now provided with railroad transportation. Large areas, however, are without railroads and have consequently been greatly retarded in their development. The transcontinental lines have greatly benefited large areas that of themselves would not have attracted a railroad.

In eastern Utah the topography is usually not favorable to cheap railroad construction, and transportation facilities are meager. The Denver \& Rio Grande Railroad traverses the central part and has branches to some of the more important coal deposits. The history of railroad development in the State is discussed on page 118 .

In the thickly settled parts of Utah the highways are good, but in the large, sparsely settled parts they are generally poor, though a system of improved roads that will greatly aid development is being gradually extended over the State.

\section{WATER POWER.}

By Herman Stabler.

The streams of. Utah warrant the development of about three-quarters of a million horsepower under conditions of low-water flow, and this amount may be nearly doubled by the use of storage reservoirs. About 40 per cent of the power possibilities of the State can be developed only in large units on Colorado River and its main tributaries, the Green, Grand, and San Juan. The remainder is distributed chiefly among the smaller mountain streams and can be developed in relatively small units in accord- 
ance with local needs. Generally speaking, the mountain areas, particularly those included in forest reserves, abound in opportunities for the development of small power plants. Such small units are of importance to mines that are beyond the limits of transmission from existing power systems of public-utility corporations. That they have proved advantageous in the past is clearly indicated by the fact that of the 60 developed water-power plants in the State only 3 are of more than 10,000 horsepower capacity, whereas 20 are of 1,000 to 6,000 horsepower, 9 of 500 to 1,000 , and 28 of less than 500 .

The Utah Power \& Light Co., a relatively recent combination of 20 to 30 plants, many of which were originally developed for local mining use, is by far the most important public-utility corporation that provides electric service in the State. Its chief source of water power is Bear River and its tributaries in Idaho and Utah, and Provo, Ogden, and Weber rivers in Utah, though several smaller streams are utilized. This company serves the eastern part of the drainage basin of Great Salt Lake from the Utah-Idaho line south to Silver City, and has recently con- structed a line from Springville to Helper, Blackhawk, and Huntington, in the basin of Price River. An extension of this line along the general route of the Denver \& Rio Grande Railroad into Colorado to connect with the system of its subsidiary, the Western Colorado Power Co., is contemplated. The two companies together operate hydroelectric plants with a generator capacity of over 130,000 kilowatts and have an annual output of electric energy in excess of 500,000,000 kilowatt-hours, over half of which is used by the mining industry: Among the large mining interests served are the Utah Copper Co. and the American Smelting \& Refining Co.

The topographic map (PI. I, in pocket) shows the location of the several water-power plants and transmission systems and of the principal undeveloped water-power possibilities; and the following table sets forth the principal facts with reference to the water-power plants whose electric output is available for use in the State. Plants numbered 1 to 45 , inclusive, are operated as public-utility properties, and the remainder are operated solely for the municipalities or mining companies specified.

Water-power plants of power systems operating in Utah.

\begin{tabular}{|c|c|c|c|c|c|c|}
\hline \multirow{2}{*}{ No. } & \multirow{2}{*}{ Name of power system. } & \multirow{2}{*}{ Name of plant and stream utilized. } & \multicolumn{3}{|c|}{ Location of plant. } & \multirow{2}{*}{$\begin{array}{l}\text { Horse- } \\
\text { power of } \\
\text { water } \\
\text { wheels. }\end{array}$} \\
\hline & & & T. & R. & Sec. & \\
\hline \multirow{3}{*}{\begin{tabular}{l|}
1 \\
2 \\
3 \\
4 \\
5 \\
6
\end{tabular}} & \multirow{3}{*}{ 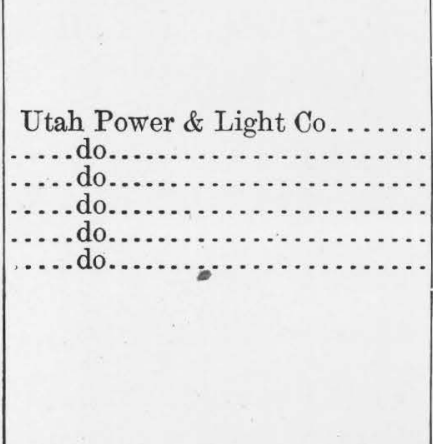 } & \multirow{3}{*}{ 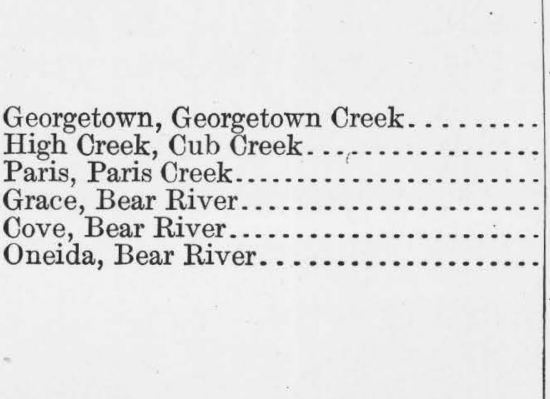 } & \multicolumn{3}{|c|}{ Idaho; Boise meridian. } & \multirow{4}{*}{$\begin{array}{r}300 \\
1,000 \\
1,180 \\
50,000 \\
10,000 \\
27,000\end{array}$} \\
\hline & & & $\begin{array}{l}11 \mathrm{~S} . \\
15 \mathrm{~S} . \\
14 \mathrm{~S} . \\
10 \mathrm{~S} . \\
10 \mathrm{~S} . \\
13 \mathrm{~S} .\end{array}$ & $\begin{array}{l}44 \mathrm{E} . \\
40 \mathrm{E} . \\
43 \mathrm{E} . \\
40 \mathrm{E} . \\
40 \mathrm{E} . \\
40 \mathrm{E} .\end{array}$ & $\begin{array}{r}4 \\
34 \\
9 \\
21 \\
33 \\
23\end{array}$ & \\
\hline & & & \multicolumn{3}{|c|}{$\begin{array}{l}\text { Utah; Salt Lake } \\
\text { meridian. }\end{array}$} & \\
\hline $\begin{array}{r}7 \\
8 \\
9 \\
10 \\
11 \\
12 \\
13 \\
14 \\
15 \\
16 \\
17 \\
18\end{array}$ & $\begin{array}{l}\ldots \ldots \text { do } \ldots \\
\ldots \ldots \text { do } \ldots \\
\ldots \ldots \text { do } \ldots \\
\ldots \ldots \text { do } \ldots \\
\ldots \ldots \text { do } \ldots \\
\ldots \ldots \text { do } \ldots \\
\ldots \ldots \text { do } \ldots \\
\ldots \ldots \text { do } \ldots \\
\ldots . \text { do } \ldots \\
\end{array}$ & 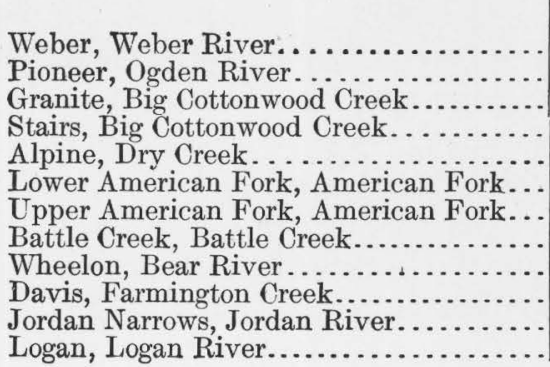 & $\begin{array}{r}\text { Weber } \\
\text { Ogden. } \\
2 \text { S. } \\
2 \text { S. } \\
44 \mathrm{~S} . \\
44 \mathrm{~S} . \\
4 \\
5 \\
5 \\
13 \mathrm{~S} . \\
3 \mathrm{~N} . \\
4 \mathrm{~S} . \\
12 \mathrm{~N} .\end{array}$ & 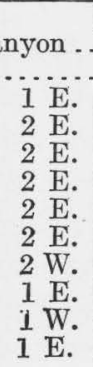 & $\begin{array}{r}25 \\
30 \\
8 \\
32 \\
28 \\
22 \\
23 \\
17 \\
15 \\
36\end{array}$ & \\
\hline
\end{tabular}


Water-power plants of power systems operating in Utah-Continued.

\begin{tabular}{|c|c|c|c|c|c|c|}
\hline \multirow{2}{*}{ No. } & \multirow{2}{*}{ Name of power system. } & \multirow{2}{*}{ Name of plant and stream utilized. } & \multicolumn{3}{|c|}{ Location of plant. } & \multirow{2}{*}{$\begin{array}{l}\text { Horse- } \\
\text { power of } \\
\text { water } \\
\text { wheels. }\end{array}$} \\
\hline & & & T. & R. & Sec. & \\
\hline & n & & \multicolumn{3}{|c|}{$\begin{array}{l}\text { Utah; Salt Lake } \\
\text { meridian. }\end{array}$} & \\
\hline 19 & Utah Power \& Light Co & Murdock, Provo River & $2 \mathrm{~S}$. & 5 E. & 32 & 3,300 \\
\hline 20 & ....do....................... & Upper Mill Creek, Mill Cree & $1 \mathrm{~s}$. & $2 \mathrm{E}$. & 27 & 650 \\
\hline 21 & .....do. do. & Lower Mill Creek, Mill Creel & $1 \mathrm{~S}$. & $1 \mathrm{E}$. & 36 & 2,600 \\
\hline 22 & .....do. & Olmstead, Provo River... & $6 \mathrm{~S}$. & $3 \mathrm{E}$. & 7 & 10,800 \\
\hline 23 & ..... do. & Park City, Ontario Tunnel. & $2 \mathrm{~S}$. & $4 \mathrm{E}$. & 24 & 300 \\
\hline 24 & .....do... & Riverdale, Weber River... & $5 \mathrm{~N}$. & $1 \mathrm{~W}$. & 19 & 5,750 \\
\hline 25 & ..... do. & Santaquin, Santaquin Creek & $10 \mathrm{~s}$. & $1 \mathrm{E}$. & 13 & 1,700 \\
\hline 26 & ......do. & Snake Creek, Snake Creek. & $3 \mathrm{~s}$. & $4 \mathrm{E}$. & 21 & 2,000 \\
\hline 27 & .....do. & Hyrum, Blacksmith Fork. & $10 \mathrm{~N}$. & $1 \mathrm{E}$. & 11 & 4,300 \\
\hline 28 & ...do.. & Williard, Williard Creek. & $8 \mathrm{~N}$. & $2 \mathrm{~W}$. & 23 & 700 \\
\hline 29 & Beaver River Pov & Beaver River, Beaver Riv & $29 \mathrm{~S}$. & $6 \mathrm{~W}$. & 24 & 2,500 \\
\hline 30 & Bennion, Hyrur & Bennion's, Jordan River. & Taylorv & ille.. & & 100 \\
\hline 31 & Big Springs Electric Co.. & Big Springs, Big Springs Creek & $13 \mathrm{~s}$. & $2 \mathrm{E}$. & 36 & 260 \\
\hline 32 & Clark Electric Power Co. & Tooele, Settlement Creek..... & $3 \mathrm{~S}$. & $4 \mathrm{~W}$. & 33 & 250 \\
\hline 33 & Como Light \& Power Co. & 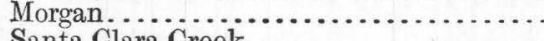 & & & & 500 \\
\hline 34 & Dixie Power Co & Santa Clara Creek... & $43 \mathrm{~S}$. & $18 \mathrm{~W}$. & 11 & 1,100 \\
\hline $\begin{array}{l}35 \\
36\end{array}$ & $\begin{array}{l}\text { Electric Power \& Milling Co. } \\
\text { Nunn, L. L ..................... }\end{array}$ & $\begin{array}{l}\text { Orangeville ....................... } \\
\text { Gunnison, Sixmile Creek }\end{array}$ & $19 \mathrm{~s}$ & & & 125 \\
\hline $\begin{array}{l}36 \\
37\end{array}$ & Nunn, L. L................ & $\begin{array}{l}\text { Gunnison, Sixmile Creek .......... } \\
\text { Kunsden, Big Cottonwood Creek. }\end{array}$ & $\begin{aligned} 19 \mathrm{~S} . \\
2 \mathrm{~S}\end{aligned}$ & $2 \underset{\mathrm{E}}{\mathrm{E}}$ & $\begin{array}{r}3 \\
23\end{array}$ & $\begin{array}{l}550 \\
200\end{array}$ \\
\hline $\begin{array}{l}37 \\
38\end{array}$ & 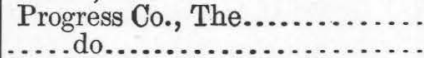 & State Street, Big Cottonwood Creek. & $2 \mathrm{~S}$. & $1 \mathrm{E}$. & $\begin{array}{r}23 \\
8\end{array}$ & $\begin{array}{l}200 \\
200\end{array}$ \\
\hline 39 & Spring Gity Ligh & Spring City, Oak Creek.............. & $16 \mathrm{~s}$. & $4 \mathrm{E}$. & 2 & 22 \\
\hline 40 & Swan Creek Electric $\mathrm{Co}$. & Swan Creek, Swan Creek. & $14 \mathrm{~N}$. & $5 \mathrm{E}$. & 6 & 125 \\
\hline 41 & U.S. R & h Fork, Spa & $8 \mathrm{~S}$. & $3 \mathrm{E}$. & 35 & 1,200 \\
\hline 42 & Vernal Milling \& Light $\mathrm{Cc}$ & Vernal, Äshley Creek. . & $3 \mathrm{~s}$. & $21 \mathrm{E}$. & 7 & 350 \\
\hline 43 & Wasatch Mines Co... & Alta, Little Cottonwood Creek & $3 \mathrm{~s}$. & $2 \mathrm{E}$. & 10 & 800 \\
\hline 44 & Municipal. & er River.. & $29 \mathrm{~S}$. & $7 \mathrm{~W}$. & 14 & 200 \\
\hline 45 & ......do...... & Brigham, Box Elder Creek & $9 \mathrm{~N}$. & $1 \mathrm{~W}$. & 20 & 1,200 \\
\hline 46 & ......do & , Cottonwood Creek. & $17 \mathrm{~S}$. & 3 E. & 13 & 300 \\
\hline 47 & .....do. & Fairview, Cottonwood Creek. & $13 \mathrm{~s}$. & $5 \mathrm{E}$. & 32 & 126 \\
\hline 48 & do & Heber, Provo River.... & $3 \mathrm{~s}$. & $5 \mathrm{E}$. & 7 & 1,280 \\
\hline 49 & .....do. & Helper, Price River..... & $12 \mathrm{~s}$. & $9 \mathrm{E}$. & & 250 \\
\hline 50 & $\mathrm{do}$ & Hyrum, Blacksmith Fork... & $10 \mathrm{~N}$. & $1 \mathrm{E}$. & 2 & 174 \\
\hline 51 & .... do & Logan, Logan River.. & $12 \mathrm{~N}$. & $2 \mathrm{E}$. & 29 & 800 \\
\hline 52 & .....do.. & Manti, Manti Creek... & $18 \mathrm{~s}$. & $2 \mathrm{E}$ & 8 & 100 \\
\hline 53 & do & , Monroe Creek...... & $25 \mathrm{~S}$. & $3 \mathrm{~W}$. & 22 & 100 \\
\hline 54 & .....do.. & Mount Pleasant, Pleasant Creek & $15 \mathrm{~S}$. & $5 \mathrm{E}$. & & 275 \\
\hline 55 & & Murray, Little Cottonwood Creek & & & & 1,200 \\
\hline 56 & ..... do. & Nephi, Salt Creek.. & $13 \mathrm{~s}$. & $1 \mathrm{E}$. & 2 & 250 \\
\hline 57 & ......do.. & Parowan, Center Creek...... & $34 \mathrm{~S}$. & $9 \mathrm{~W}$. & 24 & 86 \\
\hline 58 & ......do.. & Springville, Hobble Creek. & $8 \mathrm{~S}$. & $4 \mathrm{E}$. & & 150 \\
\hline 59 & ..... do & Cottonwood Creek... & $41 \mathrm{~s}$. & $15 \mathrm{~W}$. & 30 & 60 \\
\hline 60 & $\ldots . \mathrm{d}$ & , Logan River.. & $12 \mathrm{~N}$. & $1 \mathrm{E}$. & 36 & 600 \\
\hline 61 & Michigan-Utah Mining Co. & Alta, Little Cottonwood Creek... & $3 \mathrm{~s}$ & $2 \mathrm{E}$. & 11 & 60 \\
\hline 62 & Ophir Hill Consolidated Mining & & & & & \\
\hline 63 & $\begin{array}{c}\text { Co. } \\
\ldots \text { do } \ldots \ldots \ldots \ldots \ldots \ldots\end{array}$ & 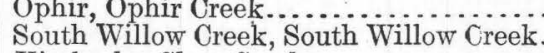 & $\begin{array}{ll}5 \mathrm{~S} \\
3 \mathrm{~S} .\end{array}$ & $\begin{array}{l}4 \mathrm{~W} . \\
6 \mathrm{~W} .\end{array}$ & $\begin{array}{l}28 \\
27\end{array}$ & 300 \\
\hline 64 & $\begin{array}{l}\text { Sevier-Miller Coalition Mining } \\
\text { Co. }\end{array}$ & Kimberly, Clear Creek... & $25 \mathrm{~S}$. & $4 \frac{1}{2} \mathrm{~W}$. & 34 & 300 \\
\hline
\end{tabular}

PHYSIOGRAPHIC DEVELOPMENT. GENERAL OUTLINE.

In Mesozoic time a large part of what is now the Basin province was probably above sea level and was being actively eroded, and a part at least of its waste was being deposited to the east, where it formed a great thickness of Triassic, Jurassic, and Cretaceous shales and sandstones. The boundary between the area of erosion and that of deposition is generally regarded as approxi- mately the eastern limit of the Great Basin, though in the latitude of the Mineral and Star ranges Triassic sediments at least were deposited well within the Basin province.

At the end of the Mesozoic or early in the Cenozoic era there occurred a general uplift accompanied by folding, by overthrust and other faulting, by igneous intrusion, and by doming which was at least in part the result of intrusion. (SeePl.XI,p. 100.) Erosion of the 
more greatly uplifted surfaces began at once, the resulting waste being laid down on lower ground near by or carried oceanward. The period of upheaval and intrusion was overlapped or followed by one of volcanism, during which immense quantities of lava and tuff were erupted, especially in southern Utah.

The transfer of this great volume of magma from the earth's interior to its surface was perhaps the cause of a widespread fracturing and differential settling of the crust which followed. The greatest relative subsidence took place in what is now the Great Basin, whose eastern margin was marked out by a persistent zone of normal faults on which the downthrow was to the west. The Basin Ranges were outlined by other great north-south faults; smaller faults and some persistent flexures affected the Plateau region; and the Wasatch Range was relatively upheaved and tilted eastward. The masses blocked out by these movements have since been continuously modified by erosion and deposition. Erosion has been most active in the elevated eastern area, and its products have largely been deposited in the Great Basin or carried oceanward, the main theaters of erosion and of deposition having exchanged places since Mesozoic time.

\section{WASATCH MOUNTAINS.}

The Wasatch Mountains were the scene of vigorous action in both periods of deformation. The range is characterized as a whole by strong folding and thrust faulting and in part by other faults and by intrusion. The structure indicates that in the period during which these movements occurred the range was upheaved as a whole with reference to the tract on the east, though it may not have been raised higher than the region to the west was at that period. After being greatly reduced by erosion it was again relatively upheaved by faulting. The thesis that its western face is a fault scarp of westward dip was first advanced by Emmons ${ }^{1}$ and was confirmed by some of the latest field work of G. K. Gilbert. ${ }^{2}$

It is possible, though less certain, that the east side of the range, where it is sharply defined, is also determined by faults with downthrow to the east. At any rate, the decline in the height of the summits from west to east indi-

1 U. S. Geol. Expl. 40th Par., vol. 2, p. 345, 1 S77.

2 Gilbert, G. K., unpublished manuscript. cates that the fault block was tilted eastward. The range is allied by its physiographic history, as well as by its drainage, to the Basin Ranyes, though it is part of an upland whose topography, as shown on pages 57 and 58 , stands in strong contrast to that of the Great Basin.

The range has been thoroughly dissected, though the westward-flowing streams, being of steeper grade in their lower than in their upper courses, show incomplete adjustment to the upheaval by faulting. The higher parts of the range have been strongly glaciated. Some moraines extend to the western base; these have been broken by recent faulting along the old scarp.

\section{UINTA MOUNTAINS.}

The Uinta Mountains were formed primarily as the result of an arching up along an eastwest axis, which took place later than most of the early deformation of the Wasatch belt. (See p. 252.) The present form of the Uinta, however, has been determined by many other factors than this primary uplift. Early in the Tertiary the crest of the arch became maturely dissected by stream erosion. Certain of the more powerful streams cut headward nearly or quite through the range, as they are now cutting in some of the Basin Ranges, notably at Squaw Springs Pass, in the San Francisco Range, and in Sevier.Canyon, in the Canyon Mountains. Much of the material eroded from the arch was laid down on the adjacent parts of the Wyoming Basin at the north and of the Plateau region at the south. The original surface of these deposits is thought to be approximately represented by the flat summits of Diamond Mountain, Split Mountain, and Yampa Plateau on the south side of the range, and similar headlike remnants on the north side of the range have been described by Rich. ${ }^{3}$

The remarkable course of Green River athwart the axis of the range is thought to have been established at the time when the range was thus worn down and flanked by gravel plains which probably coalesced in some of the lower passes. This explanation of Green River as superimposed is regarded as more probable than the once popular view that the stream maintained upon the slowly

3 Rich, J. L., The physiography of the Dishop conglomerate, southern Wyoming: Jour. Geology, vol. 18, p. 601, 1910. 


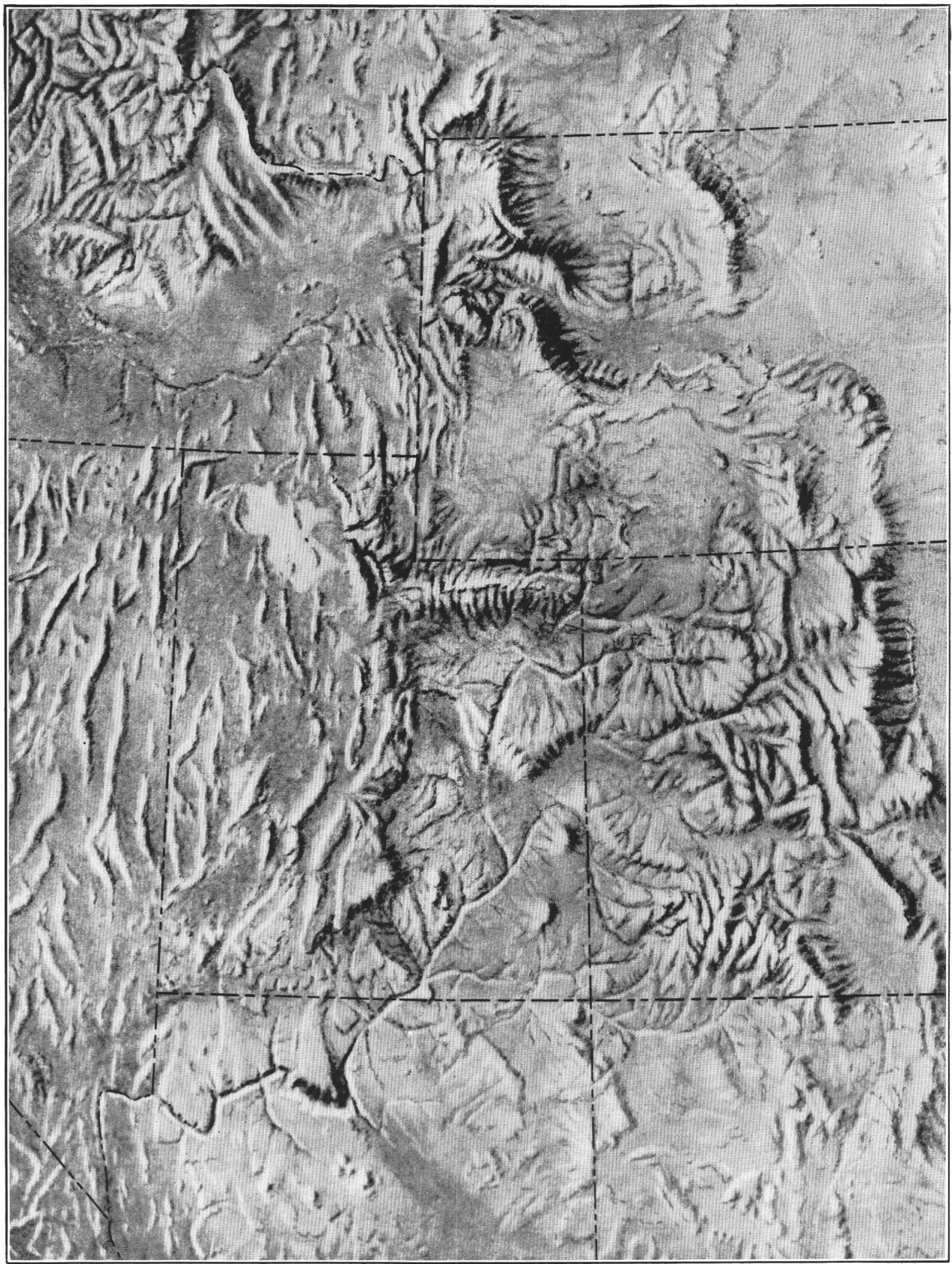

RELIEF MAP SHOWING PARTS OF ROCKY MOUNTAIN, COLORADO PLATEAU, AND GREAT BASIN AREAS. 
U. S. GEOLOGICAL SURVEY

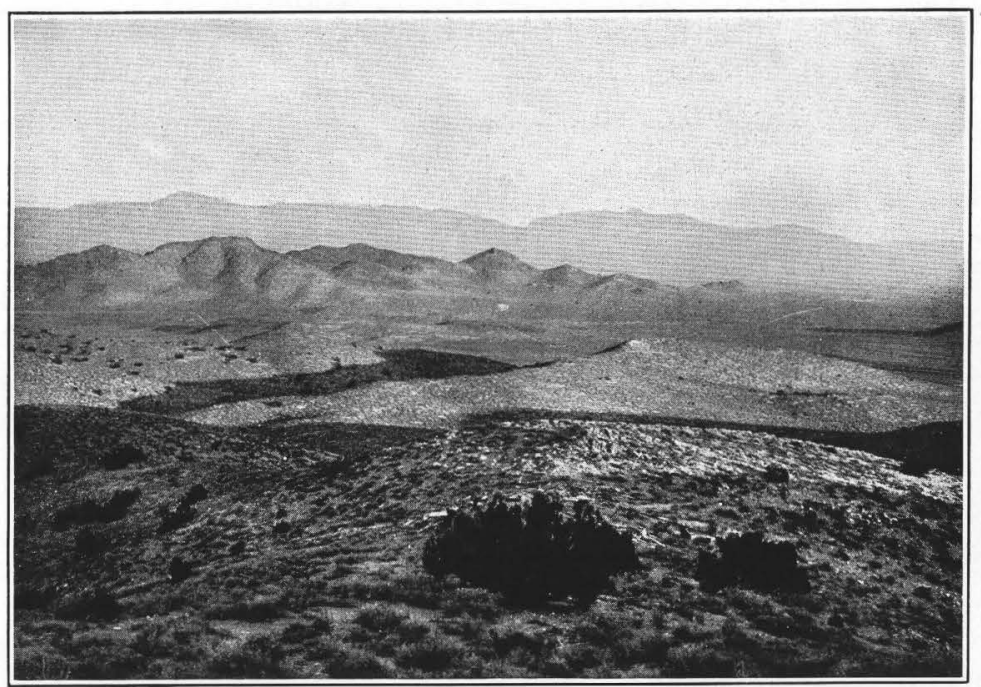

A. ROCKY RANGE; PHYSIOGRAPHICALLY OLD MOUNTAINS.
PROFESSIONAL PAPER 111 PLATE III

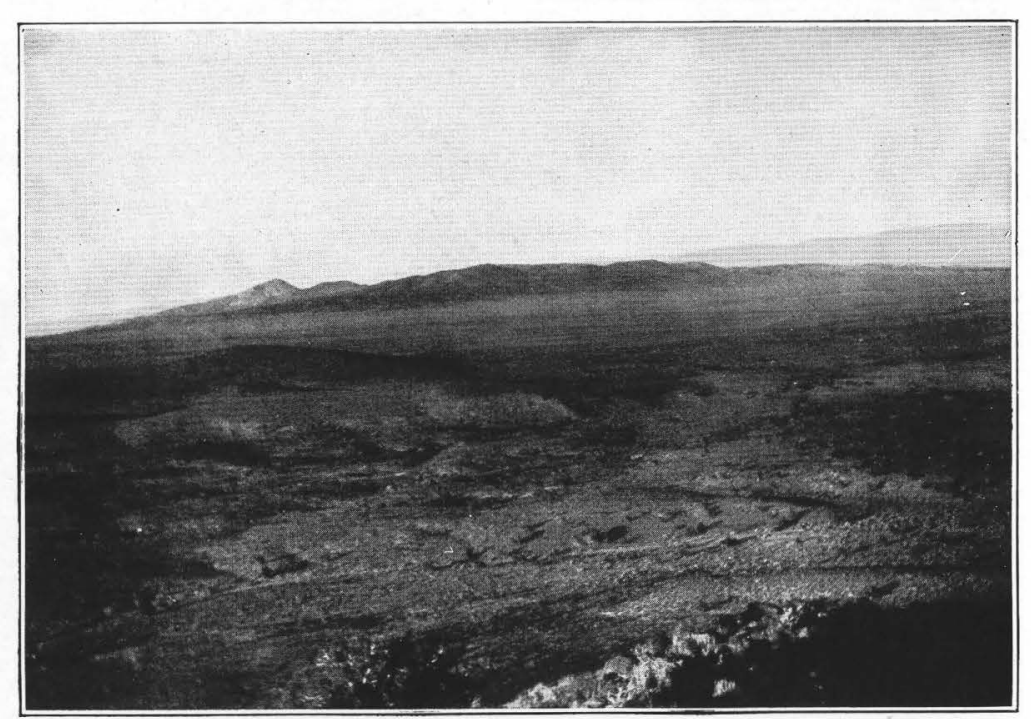

B. BEAVER LAKE MOUNTAINS; PHYSIOGRAPHICALLY OLD MOUNTAINS DEEPLY BURIED IN DÉBRIS.

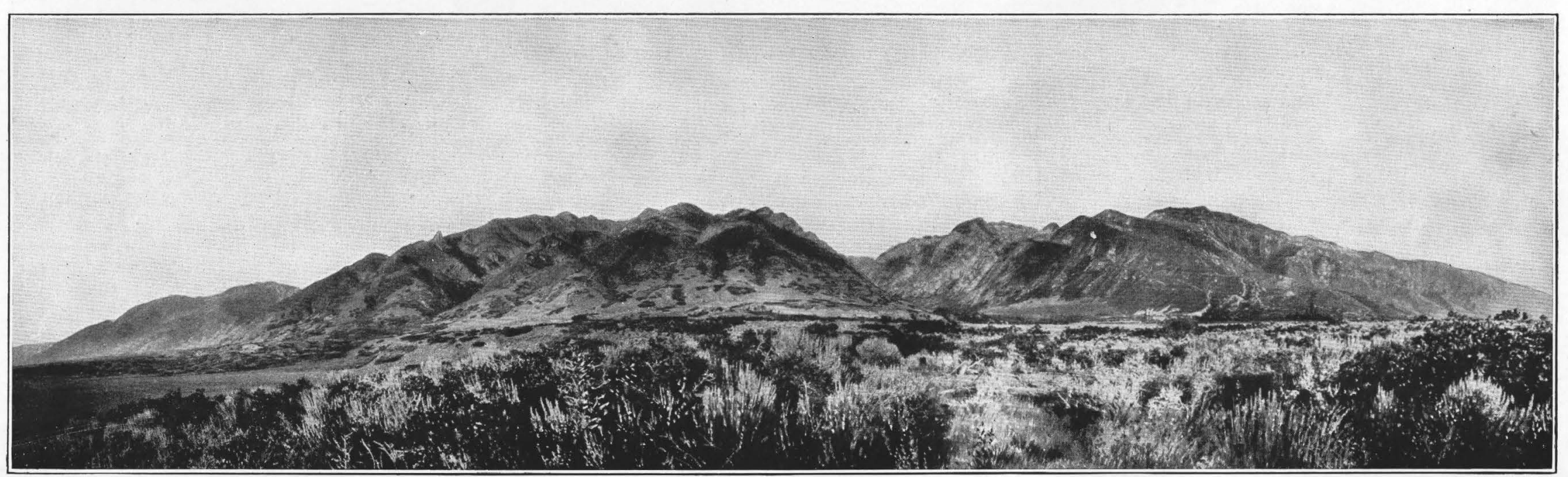

c. FRONT OF WASATCH RANGE, NEAR LITTLE COTTONWOOD GANYON; PHYSIOGRAPHICALLY YOUNG MOUNTAIN RANGE. 
arching strata a course determined while these strata still lay flat. ${ }^{1}$

Intermittent uplift of the range as a whole is indicated, however, by the terracing of the stream valleys in the gravel deposits. The terraces presumably were formed in periods of relative quiescence during which the streams widened their valleys in the softer flanking formations but were able only to deepen their canyons in the hard rocks that form the core of the range; in periods of uplift the channels were deepened in the soft formations also.

The large canyons of the range have been strongly glaciated, and heavy moraines extend beyond the mouths of many of these canyons. The glacial features have been described by Atwood. ${ }^{2}$

\section{PLATEAU PROVINCE.}

TOPOGRAPHIC FEATURES."

The rocks exposed in the Plateau regions of Utah are chiefly sedimentary strata that range in age from pre-Cambrian to Tertiary. These rocks are capped on the High Plateau by a thick layer of volcanic rocks and are locally injected with intrusive rocks, the more important bodies of which are laccolithic. The strata lie for the most part nearly flat, but they have been deformed by some faults and flexures and domed up by the laccoliths. The general horizontality of the bedding and the rather simple dislocations by which it is affected determine the topographic character of the region.

The usual horizontal stratification is expressed by the prevalence of terraces of differential erosion. The rise from Colorado River in the region of the Grand Canyon to the High Plateau is a series of steps, the abrupt rises being separated by broad, nearly flat benches surfaced with relatively hard and resistant rock and underlain by softer material. In northern Arizona and southern Utah this bench topography is developed on a magnificent scale; farther north it is less marked, and along Green River, south of the Uinta Mountains, where the valley is in Tertiary rocks, it is on a greatly reduced scale, though still conspicuous.

The rathersharp, generally north-south monoclinal folds that traverse the region have been carved by erosion into strong topographic

1 This problem is fully discussed by E. T. Hancock, The history of a portion of Yampa River, Colo., and its possible bearing on that of Green River: U. S. Geol. Survey Prof. Paper 90, pp. 185-189, 1915.

2 Atwood, W. W., Glaciation of the Uinta and Wasatch mountains: U. S. Geol. Survey Prof. Paper 61, 1909. features. Massive formations, as the White Cliff sandstone, form prominent ridges or hogbacks well above the level of the area, on the downwarp side of the folds. Such ridges, seen in Comb Wash, the Water Pocket flexure, the east border of the San Rafael Swell, the Paria flexure, and others (see Pl. II), are very striking though minor features of the Plateau region.

Where the rocks have been elevated and domed by intrusive masses, as in the Henry, Abajo, and La Sal mountains, the soft strata have been etched out by erosion, leaving the harder formations as encircling ridges through which the main streams have cut passes.

Long lines of north-south cliffs that follow lines of faulting may be due either to the actual raising or lowering of the surface on one side of the fault line relative to that on the other side, or perhaps more commonly to bringing a soft formation against a hard resistant one, the subsequent denudation quickly lowering the soft rock and leaving the hard rock standing as a cliff.

\section{DEVELOPMENT.}

At the close of Mesozoic or early in Cenozoic time the Plateau region was elevated, somewhat folded, and probably broadly domed and faulted. Erosion of its higher areas began forthwith, and the sediment derived from them was deposited in the lower areas.

Gradually a general northwest-southeast drainage system, corresponding in general to that of the present Colorado River, was developed across it. Erosion was naturally at first most rapid in the lower portion of this drainage system, and doubtless deep main valleys and a well-developed system of tributaries drained the area to the south, while sedimentation, at least in local areas, was still progressing to the north. The drainage system, however, gradually extended its headwaters into areas of previous deposition and began the removal of the sediments.

Since the beginning of Tertiary time there have been several periods of uplift, followed by periods of relative stability or possibly of partial subsidence. Following a period of uplift the streams cut narrow, steep-walled canyons. During a long period of stability these canyons are gradually broadened into flat, gravel-floored valleys, in which, on the renewal of uplift, narrow canyons are cut.

Most of the valleys of the Plateau province can be attributed with much certainty to weathering and to stream erosion. Some of 
those in the transition zone between the Plateau and Basin provinces have, however, been generally regarded as due primarily to structural rather than erosional causes. Such, for example, is the Sevier Valley, which in its middle course at least, has been considered as resulting from the settling of a block between two great faults, forming a fault valley or "graben."

\section{CORRELATION WITH UINTA RANGE.}

Systematic correlation of the physiographic forms in the Uinta and Plateau regions has never been undertaken but presents a problem of great interest. It can best be accomplished by carefully following the typical forms from one region to the other. As has already been noted, there are gravel-covered benches at different elevations in the Uinta Range, and these seem to find their counterparts in similar benches around the higher mountain groups of the Plateau province, notably in the La Sal and Abajo and less prominently in the Henry mountains. These benches, which evenly truncate upturned strata of different powers of resistance, were undoubtedly formed during a period of stability, and are doubtless to be correlated with certain benches that have been developed in areas of essentially horizontal rocks. In the areas of horizontal rocks, however, it is frequently difficult to determine whether a given bench represents a definite stage of degradation, whether it has resulted from the differential erosion of hard and soft strata, or whether it is due to both causes. Correlation of the forms developed at different localities, unless actually traced one into the other, is therefore open to doubt.

\section{CORRELATION WITH WYOMING AND COLORADO.}

Westgate and Branson, ${ }^{1}$ Blackwelder, and others have worked out in considerable detail the physiographic history of areas in Wyoming that probably find corresponding features in the Uinta and the Plateau regions. Blackwelder ${ }^{2}$ summarizes the physiographic history of central western Wyoming as follows:

1 Westgate, L. G., and Branson, E. B., The Cenozoic history of the Wind River Mountains, Wyo.: Geol. Soc. America Bull., vol. 23, p. $739,1912$.

2 Blackwelder, Eliot, Post-Cretaceous history of the mountains of central western Wyoming: Jour. Geology, vol. 23, No. 4, pp. 339-340, 1915.
Divested of details and qualifications, the history of the district may now be reviewed in general terms. About the close of the Cretaceous period, the entire region was probably a monotonous plain underlain by unconsolidated sediments. Soon thereafter tangential forces within the earth's crust produced a series of moderate folds, trending northwest and southeast. The process of folding tended to produce a series of mountain ranges and basins corresponding to the anticlines and synclines; but the uplifts were certainly being eroded even while they were growing, and after the disturbance ceased they continued to be worn down until the surface became a well-dissected mountainous or hilly region interspersed with wide, relatively flat basins.

In the Wasatch or Lower Eocene epoch, terrestrial sediments began to accumulate in the lowlands, probably in response to mild warping movements and perhaps climatic changes, which disturbed the activities of the previously graded streams. * * * Somewhat later, probably near the middle of the Miocene epoch, the district was notably warped and locally faulted in part along the structural lines established at the close of the Cretaceous, but in part at variance with them. It is probable that this midTertiary disturbance involved also a general elevation which left the region above base-level, and therefore subject chiefly to erosion rather than to sedimentation.

From the mid-Tertiary revolution down to the present time the history of western Wyoming is a chronicle of denudation. * * * The progress of general stream erosion was evidently not steady but was interrupted by successive elevatory movements or other changes which compelled the readjustment of stream activities.

Atwood ${ }^{3}$ has summarized the post-Mesozoic history of the San Juan Mountain region, Colo., whose movements are doubtless to be correlated with those of eastern Utah, as follows:

At the close of the Mesozoic era and the opening of the Cenozoic era there were mountain-making movements which affected the entire Rocky Mountain province of North America, and the great dome which was then formed in the San Juan area was at once subjected to vigorous erosion.

* * * The western portion of the San Juan Mountain area was reduced to a surface of slight relief which may be thought of as a peneplain. ${ }^{4}$ This peneplain bordered on the west a higher area of mountainous character, which supplied the material for the Telluride conglomerate. The deposition of gravels upon this peneplain surface was probably due to some uplift and rejuvenation of the streams in the eastern portion of the range. After the deposition of the Telluride conglomerate there was further erosion in the range, and then came the three great epochs of volcanism, the San Juan, the Silverton, and the Potosi. During these epochs of volcanism a great volcanic plateau was developed. By this time the Miocene epoch had been reached and possibly passed, and with the quieting down of volcanic activity began the erosion and dissection of the volcanic plateau. During this period of dissection an-

${ }^{3}$ Atwood, W. W., Eocene glacial deposits in southern Colorado: U. S. Geol. Survey Prof. Paper 95, pp. 22-24, 1915.

'Cross, Whitman, U. S. Geol. Survey Geol. Atlas, Silverton folio (No. 120), 1905. 
other generation of San Juan Mountains were carved, this time out of volcanic débris and great lava flows.

With the redoming of the area, which involved the warping or doming of the summit peneplain, another cycle of erosion was begun.

\section{BASIN PROVINCE.}

CHARACTER.

The Basin province, as already indicated, is characterized by a series of nearly northsouth ranges rising above a plateau of broad, flat desert valleys 4,000 to 5,000 feet above sea level.

The ranges show great diversity in composition and structure. Many are complexes of sedimentary, intrusive, and extrusive rocks, the complexity being especially prominent in the Tushar-San Francisco intrusive zone. Some of them exhibit little folding, while in others, as in elevation and finally merge with the valley bottoms and cease to be recognizable. Many of these cones extend far back into the ranges and in some, like the Beaver Lake Range, nearly bury the mountain.

The deposits of the valleys consist of gravels, sands, and clays. Their depth is unknown, but at several places they have been penetrated by wells to depths of several hundred feet, and there is little doubt that their thickness is to be measured in thousands of feet.

\section{ORIGIN OF THE BASIN RANGES.}

The processes by which the physiographic features of the Basin Ranges were formed have been discussed by many investigators, including Gilbert, King, Powell, Dutton, Russell, and more recently by Spurr, Davis, Louderback,

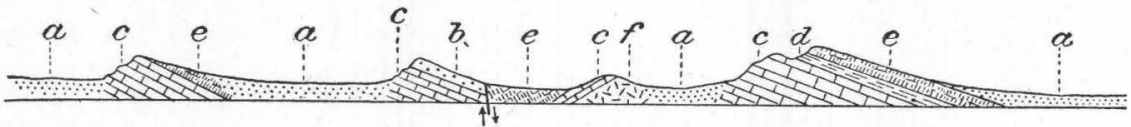

Figure 2.-Generalized section through the Mineral, Beaver Lake, San Francisco, and Wah Wah ranges, showing structural relations. $a$, Recent sediments; $b$, quartzite; $c$, limestone; $d$, shale; $e$, lava; $f$, granitic rock.

the Tintic and Oquirrh, folding is an important structural feature.

A characteristic of the ranges that has been recorded by several observers is that their fronts, which truncate rocks of very different degrees of resistance to denudation, form essentially straight lines, though the variation in the amount of erosion that has taken place in the different rocks within the range may be pronounced. The trend of the ranges bears no close relation to the internal structure. Where folding is important, as in the Oquirrh Range, the general trend of the range is at an angle to the trend of the folds, so that along the margins of the ranges the folds are truncated. This is true also of the Wasatch Range.

In several ranges, especially the southern ones, the sedimentary rocks dip in one general direction throughout. In some of these the uppermost formation oonsists of flows of lava having the same attitude as the underlying sedimentary rocks. (See fig. 2.)

Extending outward from the principal valleys in the ranges are the great débris cones or fans characteristic of the region. The cones from adjacent valleys may coalesce laterally, forming a débris apron along the range. Outward from the range they gradually decrease
Ransome, Lawson, and others, in whose writings the prevailing ideas of the origin of the Basin Ranges and the evidence therefor can be found.

One of the earliest views formulated was that of Clarence King, ${ }^{1}$ who wrote:

These low mountain chains which lie traced across the desert with a north and south trend are ordinarily the tops of folds whose deep synclinal valleys are filled with Tertiary and Quaternary detritus.

Later. King ${ }^{2}$ greatly modified his earlier views and came more nearly to agree with Gilbert (see below) as to their manner of origin. J. E. Spurr, ${ }^{3}$ however, more recently advanced the belief that the present form of the ranges is due primarily to erosion, a belief in general accordance with the earlier views of King.

Soon after King published his earlier explanation of the origin of the Basin Ranges, Gilbert ${ }^{4}$ suggested that the region had been broken, mainly along north-south lines, into blocks that had been tilted at various angles. (See fig. 3.) Gilbert's theory of the origin of the

1 U. S. Geol. Expl. 40th Par., Final Rept., rol. 3, p. 451, 1870.

2 King, Clarence, Systematic geology: U. S. Geol. Expl. 40th Par. Final Rept., vol, 1, p. 735, 1878.

3 Geol. Soc. America Bull., vol. 12, p. 217, 1901.

- Gilbert, G. K., Preliminary geological report: U. S. Geog. Surveys

W. 100th Mer. Prog. Rept., for 1872, Appendix D, p. 50, 1874. 
Basin Ranges has been pretty generally accepted by subsequent observers, with some modifications. In a paper prepared by Dr. Gilbert shortly before his death in 1918 he reached essentially the same conclusion regarding the origin of the Basin Ranges as he did in his earlier paper. Le Conte ${ }^{1}$ has suggested that the region was broken into blocks by a subsidence following an uplift, or more probably by

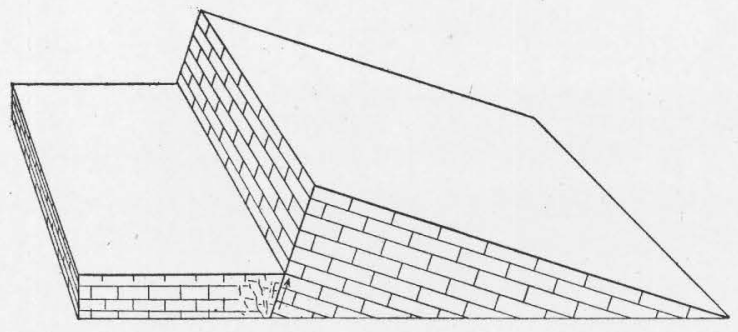

FIGURE 3.-Ideal form of fault blocks disregarding erosion.

a succession of uplifts and subsidences caused by intumescent lava. The writer has offered a similar explanation for the Basin Ranges in southern Utah, ${ }^{2}$ where faulting followed the extrusion of a large amount of lava. Louderback $^{3}$ has given convincing evidence of faultblock structure in the Humboldt Range in Nevada, the faulting having occurred subsequent to the latest volcanic activity of that region. W. M. Davis ${ }^{4}$ has called attention especially to the character of the region previous to the faulting and to the changes in the ranges that may be expected to result from erosion (see fig. 4), and has been able to show ${ }^{5}$ that the ranges are in different stages of dissection. (See Pl.III.) Lawson ${ }^{6}$ has very clearly described the cycle of erosion in a desert region and the gradual progress of the débris cones up the valleys until in advanced stages they may almost bury the range. To judge from the criteria developed by Davis and by Lawson the least mature and presumably the youngest ranges of Utah, as the Wasatch and Tushar ranges, lie along the eastern boundary of the

${ }^{1}$ Le Conte, Joseph, On the origin of normal faults and the structure of the Basin Ranges: Am. Jour. Sci., 3d ser., vol. 38, pp. 257-263, 1889.

2 Butler, B. S., Geology and ore deposits of the San Francisco and adjacent districts, Utah: U. S. Geol. Survey Prof. Paper 80, p. 27, 1913.

${ }^{3}$ Louderback, G. D., Basin Range structure of the Humboldt region: Geol. Soc. America Bull., vol. 15, pp. 289-346, 1904.

4 Davis, W. M., Harvard Coll. Mus. Comp. Zool. Bull., vol. 42, pp. 129-177, 1903.

5 Idem, vol. 49, pp. 15-56; 1905

'Lawson, A. C., The epigene profiles of the desert: California Univ. Dept. Geology Bull., vol. 9, no. 3, pp. 23-48, 1915.
Basin province, and the more matured forms lie well within it. The younger ranges are distinguished not alone by their physiographic form but by the presence of fault scarps in the Pleistocene sediments along their fronts. Recent earthquake shocks in the region are probably due to movement on some of these faults. A somewhat similar condition seems to obtain on the western side of the Great Basin, and one is led to wonder if the Basin province is and has been expanding at the expense of the more elevated regions on both sides. It should be noted, however, that there are ranges of apparently rather recent origin well within the borders of the Basin province, notably the Humboldt Range described by Louderback. ${ }^{7}$

EROSION AND SEDIMENTATION.

Subsequent to the formation of the Basin Ranges the principal physiographic features developed have been those due to erosion and
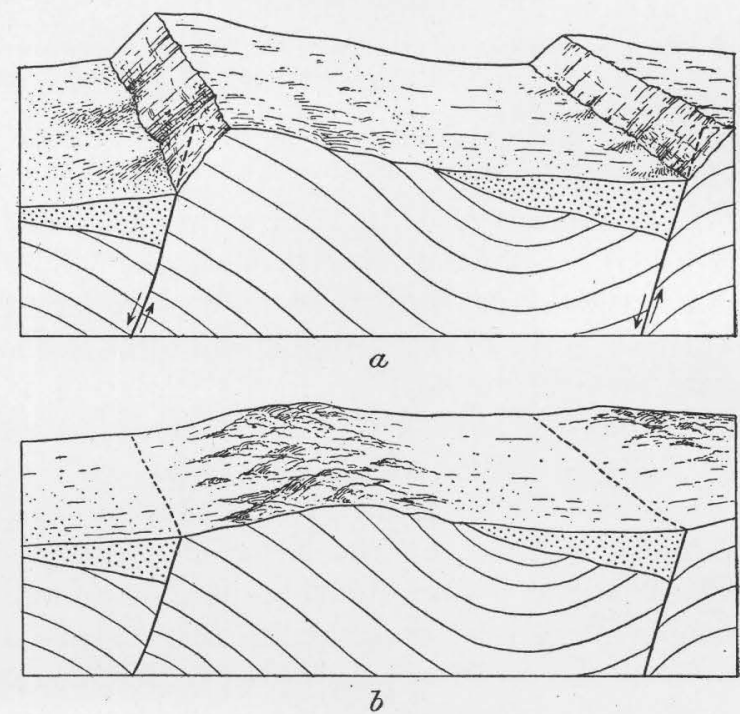

FIGURE 4.-Stereogram showing stages of erosion in fault-block mountains. $a$, Young stage; $b$, mature stage. After W. M. Davis.

sedimentation. The valleys in younger ranges like the Wasatch are characteristically of the canyon type, and in older ranges like the Beaver Lake are broad and open. Where the streams pass from the mountain ranges to the flat intermountain areas, alluvial cones have been built.

During the period when a large part of the Great Basin region of the State was occupied by Lake Bonneville, of which Great Salt Lake and

' Louderback, G. D., op. cit., pp. 289-346. 
other smaller lakes may be regarded as remnants, deltas and various types of shore deposits and wave-cut cliffs were formed. 1 The highest or Bonneville beach is about 1,000 feet above the present level of Great Salt Lake. The Provo beach is about 375 feet lower. Other beaches can be recognized at many localities.

The work of wind as an agent of erosion and transportation is less understood than that of water, and there is considerable difference of opinion concerning its importance. No one familiar with arid regions can doubt its ability to transport sediments, and locally, as Cross ${ }^{2}$ has shown, it is an erosive agent of some importance. But the writer's observations have led him to believe that the major features, both of the Basin and Plateau provinces, are the result of water erosion, transportation, and deposition. All the larger physiographic features resulting from denudation are related to features that are clearly the result of the work of waters. Ransome ${ }^{3}$ has pointed out the inconsistency and absurdity of considering the wind to have been the dominant cause of the Basin Ranges, and there seems to be little basis for considering it to have been dominant in the Plateau province.

\section{DEVELOPMENT.}

Throughout the Mesozoic era, and perhaps into the Cenozoic, most of the Basin province in Utah was undergoing erosion, the sediments being deposited to the eastward in what is now the Plateau province. In post-Cretaceous or early Tertiary time there was a general uplifting of the region, including both the present Basin and Plateau provinces. Accompanying, or closely following, this uplift there was extensive volcanic activity, and following, and possibly accompanying, the volcanic activity there was a partial subsidence, during which the Basin region broke into a series of blocks, which settled unevenly, producing the ridges. This uplift and subsidence need not be supposed to have been two clearly defined events; the relations are far more readily understood if attributed to intermittent uplift, volcanic activity, and subsidence extending over a long period. The relative uplift of the Plateau province was greater than that of the Basin

1 Gilbert, G. K., Lake Bonneville: U. S. Geol. Survey Mon. 1 1890.

2 Cross, Whitman, Wind erosion in the Plateau country: Geol. Soc. America Bull., vol. 19, pp. 53-62, 1908.

3 Problems in American geology, p. 341, Yale University Press, 191j. province, or more probably the subsidence in the Basin province was greater than that in the Plateau province. Eventually this relative difference in elevation and subsidence caused the Plateau province to stand at a higher elevation than the Basin province; and differential elevation and subsidence in the Basin province caused the formation of a basin whose lowest portion was considerably below the rim. Whether this differential settling has been in progress over the present area of the Basin province throughout its period of formation, or whether it began within the present boundary and has been gradually progressing outward, is not yet known. As noted (p. 72), the relative immaturity along its borders suggests progression.

As soon as the irregular settling of the blocks had caused some areas to be lower than others agencies of denudation attacked the higher portions, and the resulting detritus was deposited in the lower areas and produced the broad flat intermountain valleys.

The lowering of the Basin province below the Plateau province caused a reversal of the drainage, which had previously been from the Basin region to the Plateau province. The streams began to work gradually back by headwater erosion into the Plateau region. This process has, however, been relatively slow, and the Great Basin drainage has been able to encroach only a few miles on the Plateau region. The slightness of this encroachment, as compared with that of the Colorado drainage (see Pl. I), may be due to two principal causes. First, the Great Basin drainage was probably not initiated till some time after the elevation of the region, whereas that of the Colorado probably had its beginning simultaneously with the initial uplift; and, second, each additional uplift of the region raised it higher above the base-level of the Colorado system (the sea), giving renewed power to that system, whereas the uplift of the Great Basin raised its baselevel (the lower portion of the Basin) along with the rest of the region, and gave no additional power to the streams. The only change in base-level for the streams entering the (Yreat Basin has resulted from the relatively greater sinking of the Basin province as compared with the Plateau, and this has been in part balanced by the filling of the basin with sediment, which has tended to raise the base-level. 
It is considered by some that the streams that pass from the Plateau region to the Basin region are antecedent-that is, that they have maintained their courses while the mountain ranges were rising across their path. If the development of the region has been correctly interpreted in the preceding paragraphs, this seems extremely unlikely. If, at the beginning of the uplift, the drainage was from the Basin Range province to the Plateau, there was, at the time of the reversal, no drainage westward from the Plateau province to maintain itself. It also seems significant that the Canyon Range, the most notable example of a mountain cut directly across by a river, was probably completely buried by early Tertiary sediments ${ }^{1}$ and was gradually uncovered as the stream cut its valley. The Beaver River canyon through the Mineral Range has been developed along a line of faulting and is evidently controlled by the weakness of the rock at that locality and has no connection with preuplift drainage. The Squaw Springs Pass through the San Francisco Range has also developed along a line of faulting. The western drainage has pushed through the range and has captured a small drainage area on the east side of the range. Other canyons of the western slope of the San Francisco Range have pushed far inward toward its eastern margin but have not yet cut completely through. Here the western drainage has a much shorter distance to the same base-level (Sevier Lake) than the eastern and has therefore been able to accomplish much more, and the development of a valley across the range plainly can not be attributed to antecedent drainage. (See fig.5.) Most of the streams crossing a range that have been noted by the writer may be logically accounted for by normal headward erosion.

An unpublished manuscript on the Basin Ranges by Dr. G. K. Gilbert cites evidence to support the idea that a relative uplift of the area east of the Wasatch Range resulted in a reversal of the drainage before the present Wasatch Mountains were formed, and that that drainage was maintained across this range as it was uplifted.

1 Loughlin, G. F., Reconnaissance in the Canyon Range of westcentral Utah: U. s. Geol. Survey Prof. Paper 90, p. 58, 1914.
CORRELATION OF THE GREAT BASIN WITH THE OTHER PROVINCES.

With the data at present available it is not possible closely to correlate the later physiographic development of the Basin province of Utah with that of the provinces to the east. The several striking stages of erosional development that have been recognized to the east are either absent in the Basin province or if present are so modified that they have not been recognized. A careful determination and correlation of the late physiographic developments within and without the Basin drainage promises most interesting and important results. The rather meager observations of the writer suggest that development has been very different within and without the Basin. Outside the Basin every elevation or depression of the region has changed the elevation relative to the base-level, and the consequent renewal or retardation of the work of the streams has found expression in the physiography. Inside the Basin such elevations and depressions have not changed the elevation relative to the baselevel; the streams have therefore not been rejuvenated, and the physiographic development has been more uniform. The results due to climatic changes both within and without the Basin are probably nearly uniform in the more elevated portions. The results in the lower portions, however, are markedly different; outside the Basin a change in precipitation simply affected the size of the streams, which flowed freely to the sea; whereas within the Basin it affected the areas of the lakes.

\section{GEOLOGY.}

STRATIGRAPHY.

The stratigraphy of Utah is so complex that its complete discussion would require space far in excess of that available. The attempt here is merely to outline the major features and prepare a general setting for the more detailed discussions devoted to the several districts.

\section{GEOLOGIC MAP.}

The topographic base map (Pl. I), on which the geology has been platted, was compiled for the most part from the older topographic 

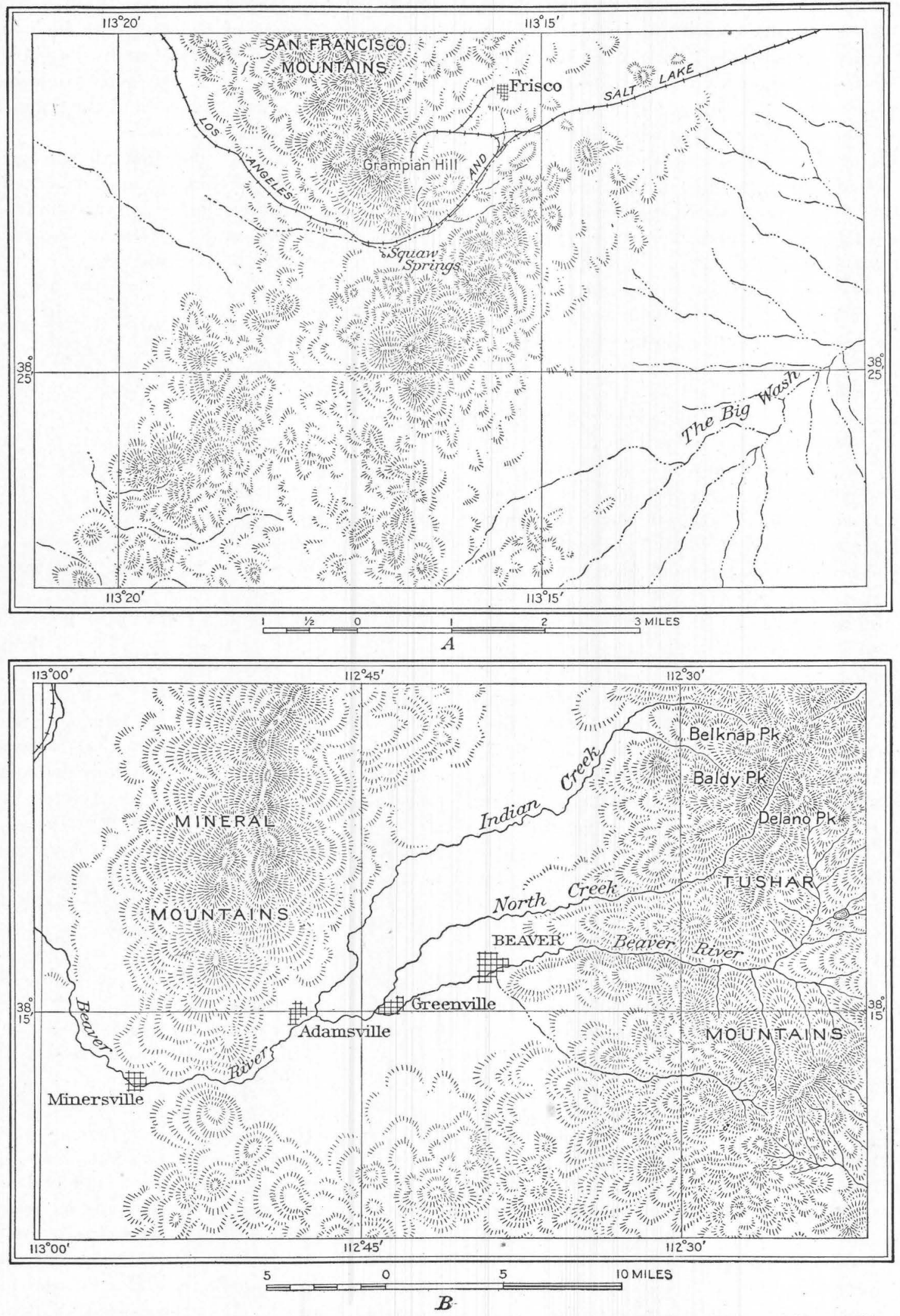

Figure 5. $-A$, Squaw Springs Pass. Headwater erosion has developed a valley through the range. (From Frisco special topographic map.) $B$, Beaver Canyon, Mineral Range. The stream has developed a valley through the range and has acquired a large drainage area beyond. (From Beaver topographic map.) 
maps of the United States Geological Survey, on the 1:250,000 seale, now issued as reconnaissance maps. These maps leave much to be desired in the way of detail and accuracy, but they give a fair idea of the topography of the region and are of great value in the absence of better maps. The small-scale map compiled from them naturally inherits their imperfections but nevertheless gives a better idea of the relations of geology to topography than a map without contours.

The geologic map (Pl. IV) has been compiled from many sources and includes considerable unpublished material kindly furnished by members of the Geological Survey. The material used differed widely in accuracy, ranging from large-scale maps of mining districts on which the formations have been outlined with great care to reconnaissance sketches based in part on long-range observations. It is hoped that the users of the map will keep this in mind. The material used includes the maps made by the Wheeler, Hayden, and Fortieth Parallel surveys; those of Gilbert, Dutton, Powell, White, Eldridge, and Gregory; mining maps of several districts in the State, including those by Spurr, Boutwell, Leith and Harder, Tower and Smith, and Lindgren and Loughlin; maps of coal and oil regions by Richardson, Gale, Wegemann, Woodruff, Lupton, and Clarke; and maps of the phosphatic deposits by Richards, Mansfield, Blackwelder, and Schultz. Messrs. Schultz and Lupton have furnished data from unpublished reports, the former for the region around the Uinta Mountains, and the latter for that around the San Rafael Swell. Most of the mining districts of the State have been visited by the writer or by Mr. Loughlin, and such stratigraphic information as was collected has been incorporated in the map. Additional data concerning local areas have been obtained from many other sources.

The units of representation chosen have been geologic systems rather than formations, for two reasons: First, it is desired to keep the map as simple as possible in order that the general features may not be hidden in a mass of detail; and second, the information necessary for a consistent mapping by formations throughout the State does not yet exist.

Under the pre-Cambrian are included areas of schists and quartzites that are unquestion- ably older than the known Cambrian. It is probable that some of the quartzite included under the Cambrian will eventually be shown to be pre-Cambrian, but the separation has been made in only a few places and the regional separation requires further study.

Under Cambrian are included all the sediments known to be of that age and, as already noted, some quartzites that are probably older.

Under Ordovician and Silurian are included the strata known to be of those ages.

Under Carboniferous are included all the known Carboniferous rocks, but not the "Permo-Carboniferous" of earlier surveys.

Under the Triassic are included the Triassic of the recent maps and the "Permo-Carboniferous" of some of the older maps. Study of the fossils in the phosphate fields of Idaho, Wyoming, and Utah in recent years has led to the assignment to the Triassic of the strata previously designated "Permo-Carboniferous"; and as the "Permo-Carboniferous" beds of southern Utah contain the same fossil forms they are also assigned to the Triassic.

The upper boundary of the Triassic in southern Utah is placed at the bottom of the White Cliff sandstone of Powell and Dutton, which is considered (though not proved) to be equivalent in whole or part to the La Plata sandstone of western Colorado. In Utah no convincing evidence that this is the boundary between Triassic and Jurassic has been discovered, but in Colorado an unconformity found by Cross at the base of the La Plata seems to warrant making this dividing line. Around the Uinta Range there has been little detailed mapping separating the Jurassic and Triassic, and their distribution as shown on the map is largely an arbitrary division of the area covered by the rocks of those systems.

The Jurassic includes the rocks from the base of the White Cliff sandstone to the base of the Dakota sandstone. The upper portion includes the McElmo formation, equivalent to the "Lower Dakota" of the Hayden survey in Utah and approximately equivalent to the Flaming Gorge of Powell, Gilbert, and Dutton. There is no general agreement among geologists as to the separation of the Jurassic and Cretaceous. On the map all the red and variegated beds above the White Cliff sandstone are shown as Jurassic. It is recognized by many geologists and strongly contended by some that 

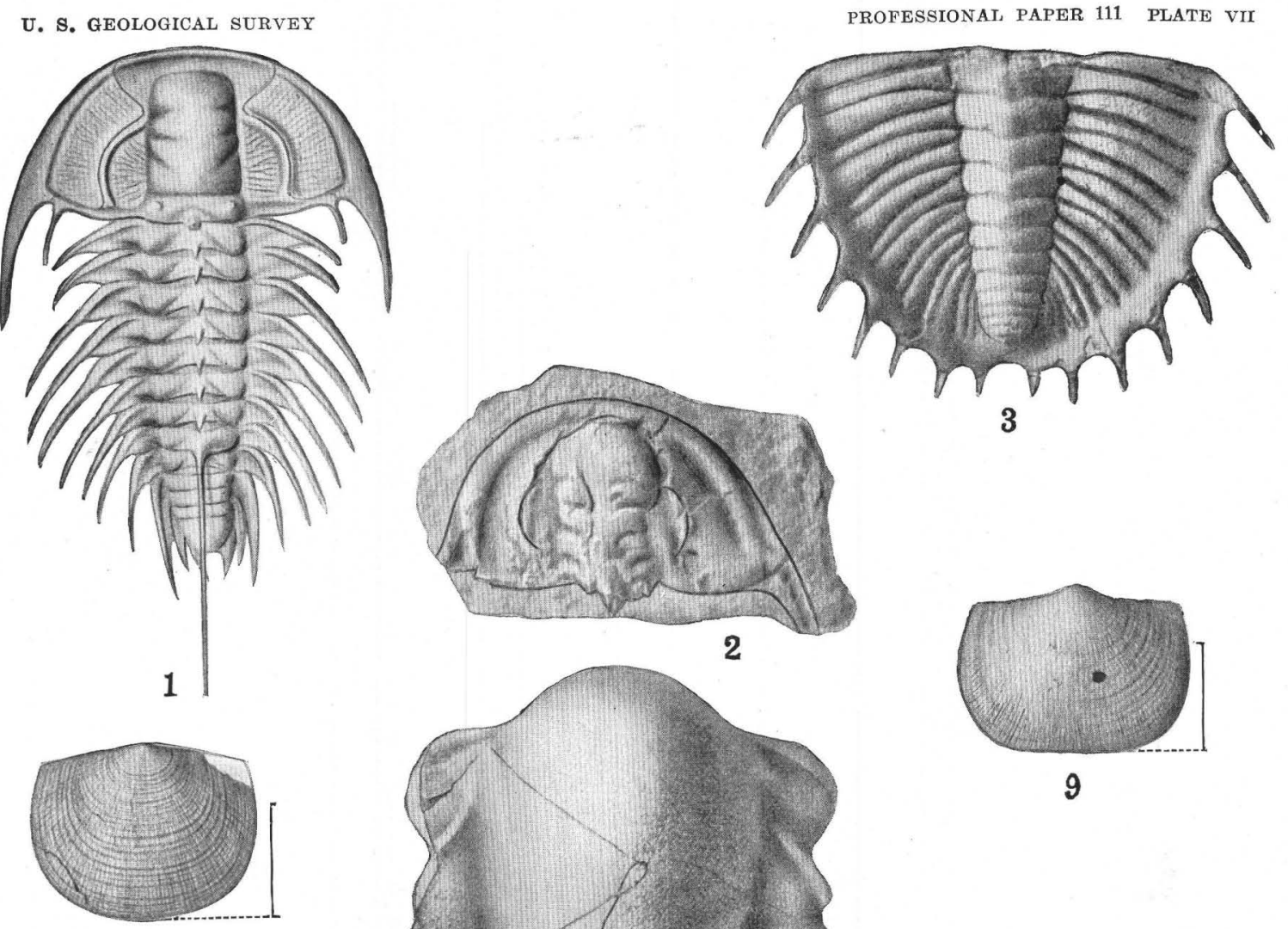

8
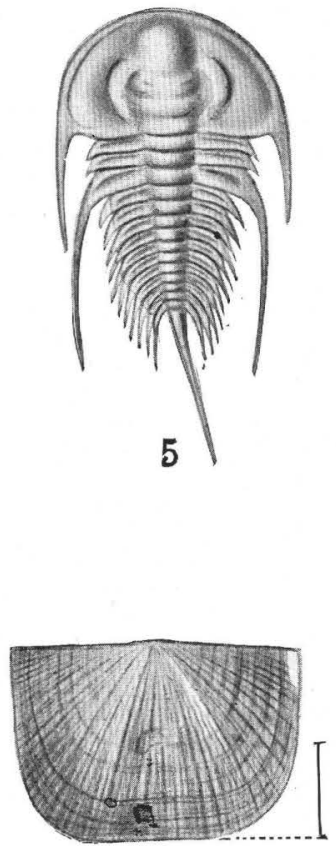

10
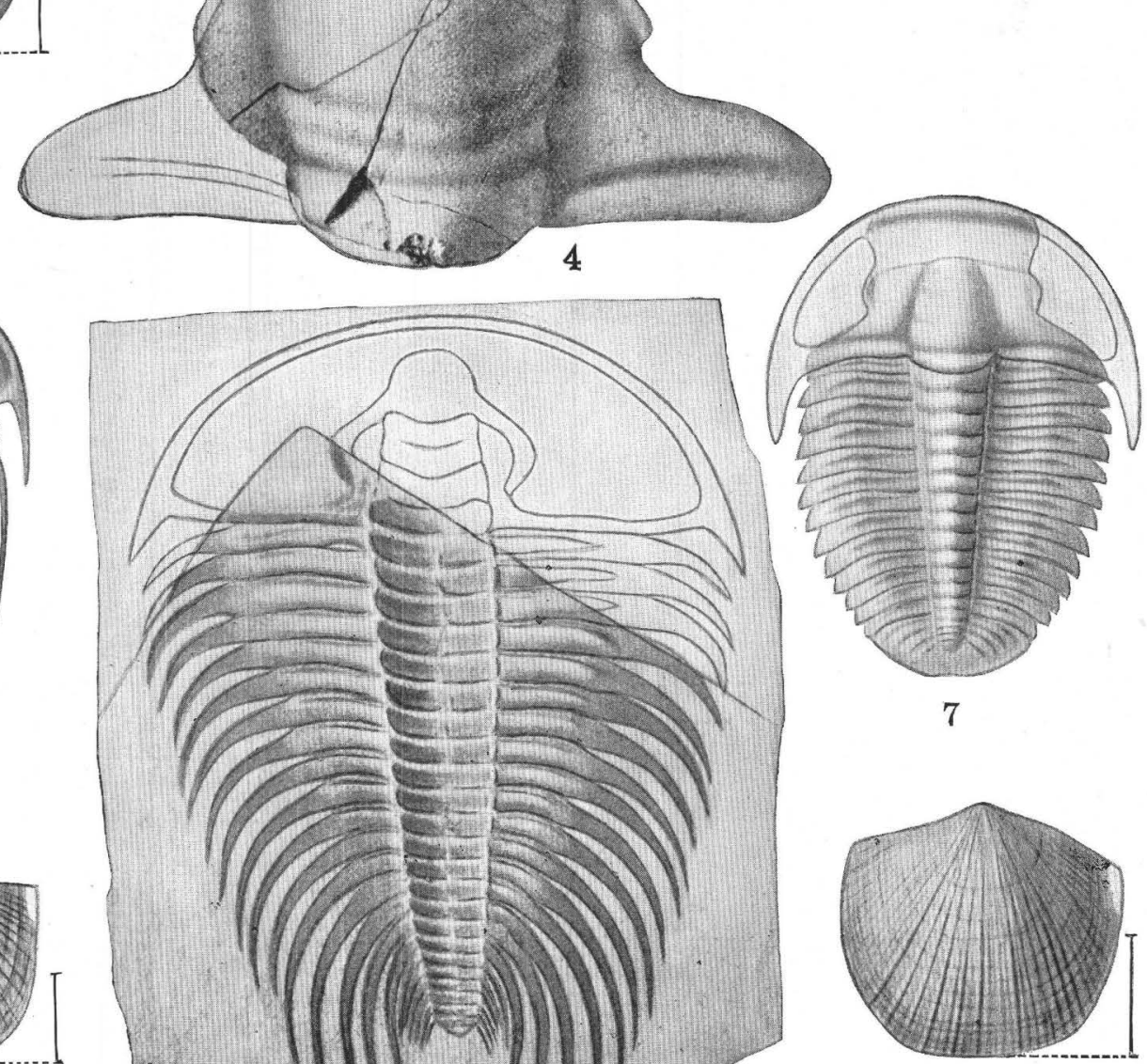

11

6

CHARACTERISTIC FOSSILS OF CAMBRIAN AGE.

1, Zacanthoides typicalis Walcott; 2, Holmia rowei Walcott; 3, 4, Neolenus inflatus Walcott; 5, Mesonacis gilberti Meek; 6, Nevadia weeksi Walcott; 7, Ptychoparia kingi Meek; 8, 9, Eoorthis newberryi Walcott; 10, 11, Billingsella coloradoensis (Shumard). 
U. S. GEOLOGICAL SURVEY

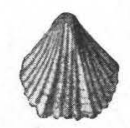

12

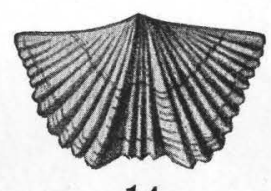

14

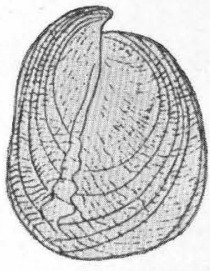

10

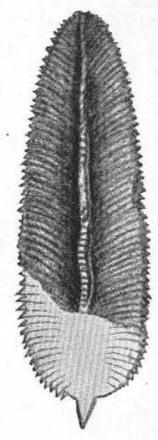

5

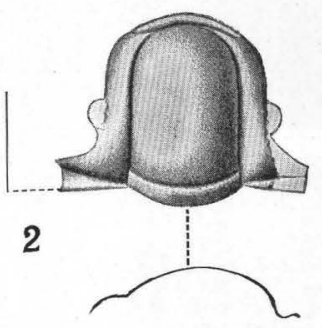

$8 a$

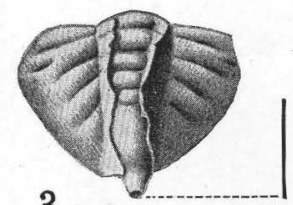

PROFESSIONAL PAPER 111 PLATE VIII

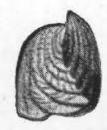

13

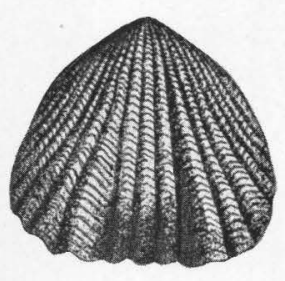

11

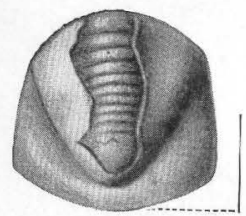

7

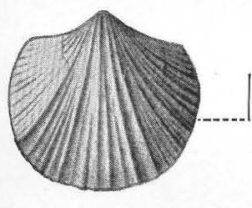

6

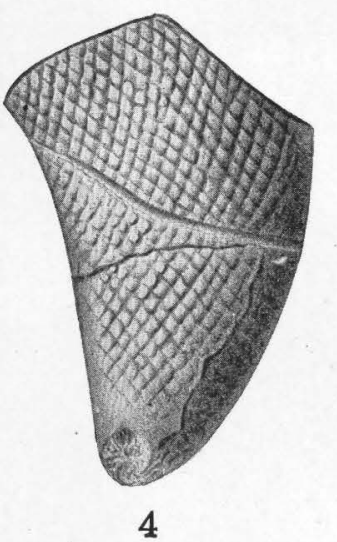

CHARACTERISTIC FOSSILS OF CAMBRIAN AND ORDOVICIAN AGE.

1, Cambrian; 2-14, Ordovician. 1, Crepicephalus texanus (Shumard); 2, 3, Holasaphus congeneris (Walcott); 4, Receptaculites ellipticus Walcott; 5, Phyllograptus loringi White; 6, Orthis hamburgensis Walcott; 7, Asaphus? curiosus Billings; 8, 9 , Maclurea subannulata Walcott and sections of outer whorl of same; 10, 11, Rhynchotrema capax (Conrad); 12, 13, Rhynchotrema argenturbica (White); 14, Platystrophia sp. 
the Cretaceous may include the McElmo formation, in which case it extends down to the marine Jurassic shales, which in Utah extend for only a few hundred feet above the White Cliff sandstone. In recent years, however, the United States Geological Survey has called these rocks questionable Jurassic, and this usage is followed in this report. The reader should clearly recognize, however, the uncertainty as to the age of these rocks.

Under Cretaceous are included the formations from the base of the Dakota sandstone to the Tertiary.

Under Tertiary are included all sedimentary formations so mapped in reports on the State.

Under Quaternary are included the valley fillings between the basin ranges, the unconsolidated deposits along some of the larger streams, and other areas of recent débris, where it buries the earlier rocks.

Under extrusive rocks are included all flows, tuffs, breccias, and other igneous rocks of whatever age or composition that reached the surface before solidifying. For the most part they are Tertiary.

Under intrusive rocks are included all postPaleozoic rocks that solidified below the surface and were later exposed by erosion. Small areas of pre-Cambrian intrusives have not been differentiated from other pre-Cambrian rocks.

Geologic sections in the several districts of the State are assembled and correlated on Plates V and VI, in pocket.

\section{FOSSILS.}

Plates showing some of the fossils respectively characteristic of Paleozoic eras and of the Triassic and Jurassic periods have been prepared by the paleontologists of the Survey and will, it is hoped, assist the mining men of the State to determine the age of the rocks in which they are working. (See Pls. VII to X and LII to LVII.)

It is perhaps needless to say that persons not trained in the determination of fossils will find difficulty in recognizing the different forms, and certainly caution should be observed in basing age determination on a single specimen. But it is believed that the layman will generally be able readily to determine from which of the major divisions a collection of fossils has been derived.

\section{SEDIMENTARY ROCKS.}

PRE-CAMBRIAN ROCKS.

The pre-Cambrian rocks include some granite but consist mainly of schists, quartzites, and slates, all more or less metamorphosed. Locally, at least, as in Big and Little Cottonwood canyons, tillite is an important and interesting member of the series. In general, the lower members are the most highly altered. The schists, as those of Browns Park in the Uinta Range, have been generally regarded as Archean; and the members immediately underlying the Cambrian in the Big Cottonwood region are pretty certainly Algonkian.

The boundary between the Cambrian and Algonkian rocks has been determined in but few places in the State. Blackwelder, Hintze, and others have located it from American Fork and the Cottonwoods northward to Brigham, and it seems highly probable that future studies may differentiate the great quartziteslate-shale series at other localities.

Little is known regarding the thickness of the series. (See Pls. V, VI.) In the Big Cottonwood Canyon 10,000 to 11,000 feet of Algonkian strata are exposed. To the north the upper members have been removed by erosion and in places the Cambrian rests directly on the Archean. In other parts of the Cordilleran region the Algonkian rocks show great thickness and more varied character than in Utah. Walcott ${ }^{1}$ says:

In Arizona the Algonkian period of sedimentation is represented by nearly 12,000 feet in thickness of sandstone, shale, and limestone of the Grand Canyon group. In Utah and Nevada sediments forming only sandstone and siliceous shale appear to have gathered, while in Montana there is a development of limestone 4,800 feet in thickness in addition to nearly 20,000 feet of siliceous and arenaceous beds.

The most extensive area of pre-Cambrian in the State is along the front of the Wasatch Range, where it is present from a point near Willard to Centerville and again near the Cottonwood canyons. It also forms Fremont and Antelope islands in Great Salt Lake and probably the western portion of Promontory Point. The pre-Cambrian makes up a large part of the ranges between the Tintic and

1 Walcott, C. D., The Cambrian and its problems in the Cordilleran region: Problems in American geology, p. 165, Yale University Press, 1915. 
Thomas ranges, and farther to the west small areas of schist are exposed in the Granite and Deep Creek ranges. In the northwestern part of the State the pre-Cambrian is present in the Raft River and Grouse Creek mountains. In the eastern Uinta Mountains the pre-Cambrian is exposed north of Browns Peak in the vicinity of Red, Creek and for several miles to the east and west, and a part of the great quartzite series of the range is probably preCambrian. It is also exposed in some of the valleys near the Colorado State line north of the Denver \& Rio Grande Railroad. A small exposure of pre-Cambrian in the extreme southwestern corner of the State in the Beaver Dam Mountains is a portion of a larger area in Arizona and Nevada.

CAMBRIAN SYSTEM.

DISTRIBUTION AND CHARACTER.

Cambrian rocks are widely distributed in western Utah. They lie at the western base of the Beaver Dam Mountains in the extreme southwestern corner of the State. Farther north they form the Wah Wah Range, part of the San Francisco-Beaver Creek Range, a large part of the House Range and of the southern part of the Thomas Range. Still farther north they are present in the southern portion of the Deep Creek Range and in the Simpson, Tintic, Stansbury, and Oquirrh ranges. They are exposed in the Wasatch Range at several places from Mount Nebo northward. In the extreme northwestern part of the State Cambrian rocks are present in the Raft River Range. In the northeastern part of the State the central plateau of the Uinta Range is probably principally Cambrian, though older rocks may be exposed in the canyons. (See Pl. V, in pocket.) Certain fossils that are characteristic of Cambrian rocks and by which they may be identified are shown in Plate VII.

The character of the Cambrian varies somewhat from place to place, but everywhere the early Cambrian is composed mainly of quartzite and sandy shale and the later Cambrian mainly of limestone. The thickness of the Cambrian differs greatly in different parts of the State. Along the eastern border of the State, north of the La Sal Mountains and in adjacent parts of Colorado, the Cambrian is entirely lacking and along the southern border and in adjacent portions of Arizona it is represented by only a few hundred feet of quartzite and shale. In western and northern Utah, on the other hand, its thickness is thousands of feet-in the House Range more than 9,000 feet are exposed. Although close correlation is not possible where the formations can not be traced from one range to another, nevertheless certain formations are so characteristic that they are readily recognized over wide areas, and, though they may not everywhere represent precisely the same horizon, their recognition aids greatly in understanding the geology. (See Pls. V, VI, in pocket.)

\section{EARLY CAMBRIAN QUARTZITE.}

The lowest formation of the Cambrian is a massive quartzite that is probably several thousand feet in thickness in many localities. Its exact thickness, however, is known in but few places, for in but few has it been separated from the Algonkian. In Big Cottonwood Canyon, where the boundary has been determined, the thickness of the Cambrian quartzite is given by Hintze as about 700 or 800 feet. In the Tintic Mountains, however, over 6,000 feet of quartzite is exposed, in which no Algonkian has been recognized, though Mr. Loughlin states (p. 398) that the lower portion may prove to be pre-Cambrian. The quartzite has been given different names in the different ranges, as Tintic quartzite, in the Tintic Range; Brigham quartzite, in the northern Wasatch Range; "Weber" quartzite, in the Uinta Mountains; and Prospect Mountain quartzite in the House Range, where it is correlated with the Lower Cambrian quartzite of the Eureka district, Nevada. The quartzite is present over so wide an area in Utah, has so strong a lithologic similarity at different localities, and everywhere lies so nearly, though probably not exactly, at the same horizon, that it seems desirable for the purposes of the present paper to call it by a single name. The Tintic Mountains, where it is well exposed and where its relations to the overlying formations have been carefully worked out, is rather central for the State and is well known to those interested in mining, and therefore readily comparable with less well known districts. It is therefore suggested that if a single name is desired Tintic quartzite may well be chosen. The quartzite is present in the Tintic Range; at 


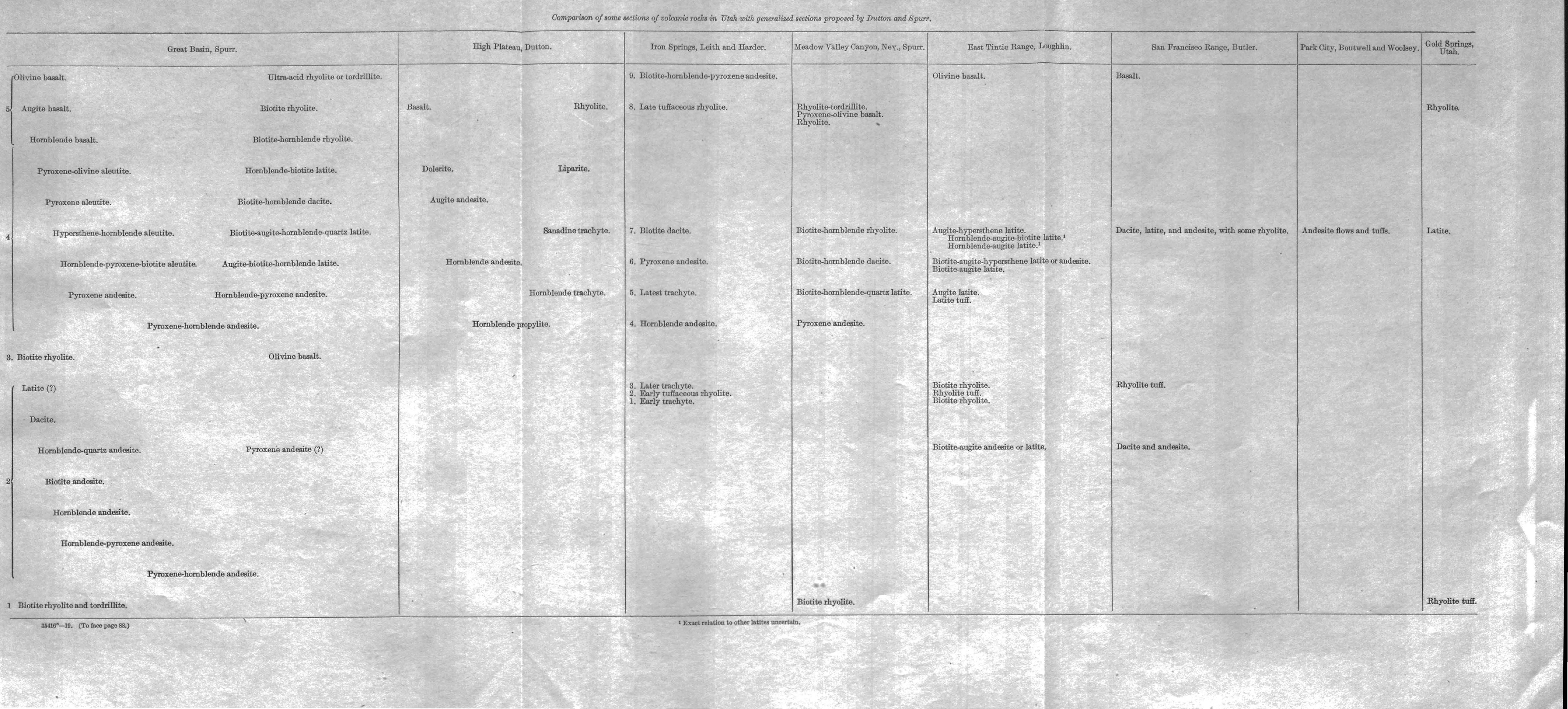




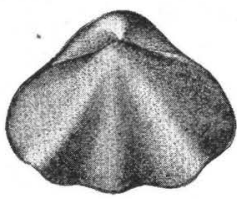

1

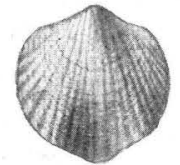

8

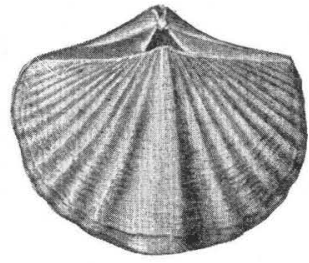

9

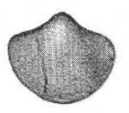

3

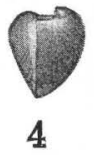

4

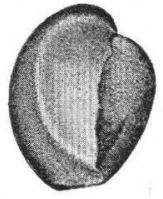

2

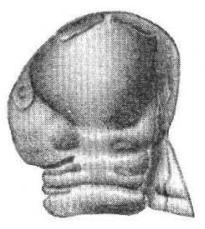

6

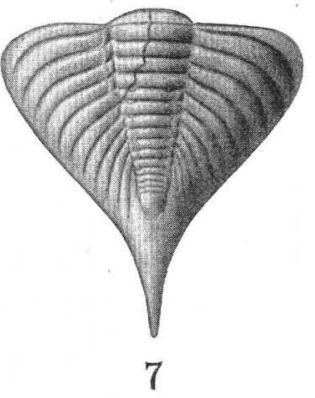

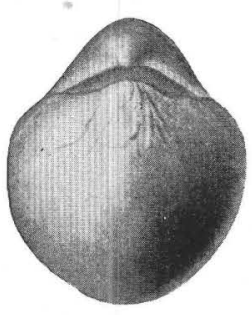

5

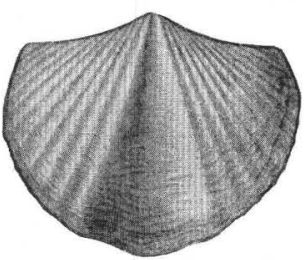

10

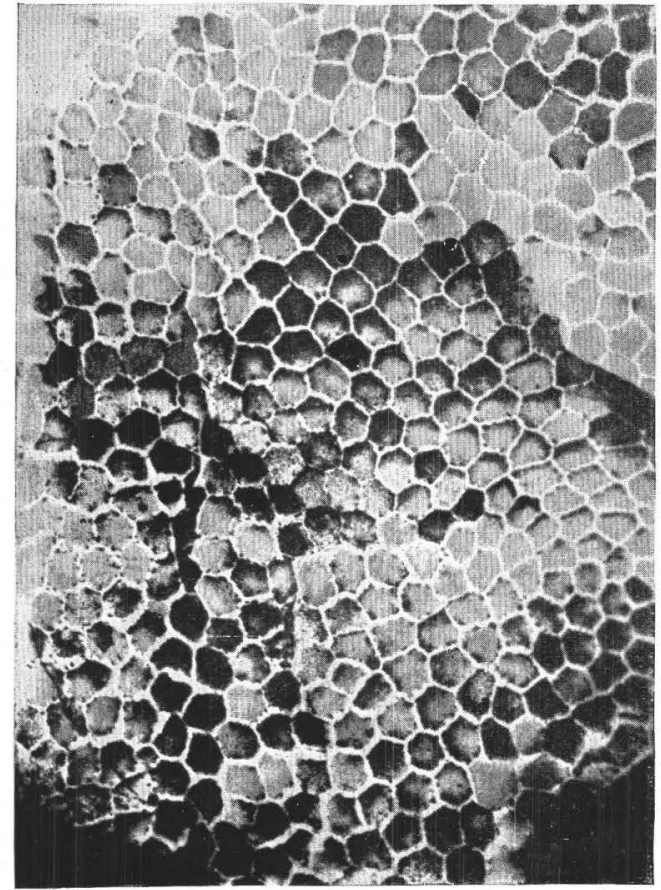

11

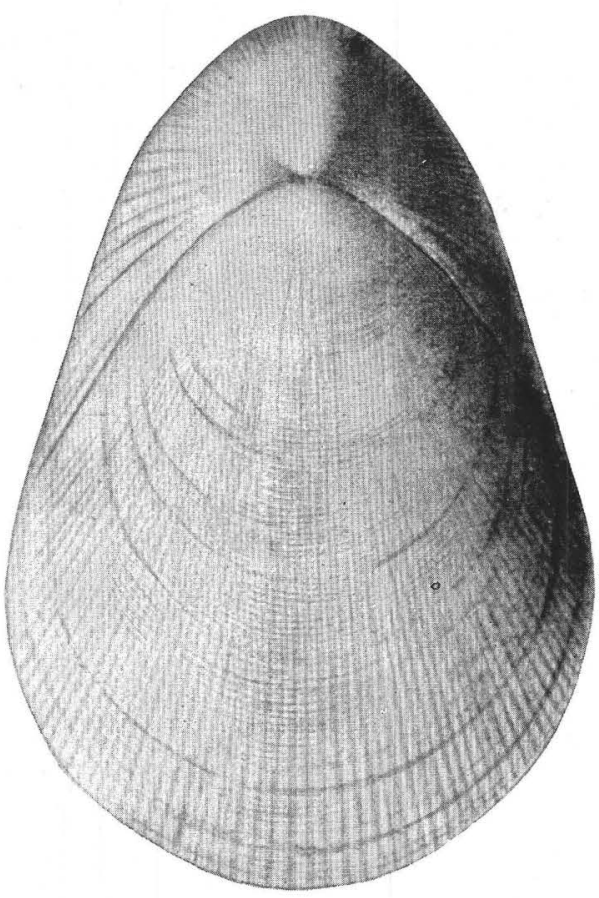

12

CHARACTERISTIC FOSSILS OF SILURIAN AND DEVONIAN AGE. 1-10, Devonian; 11, 12, Silurian. 1,2, Pentamerus lotis Walcott; 3, 4, 5, Martinia maia (Billings); 6, 7, Dalmanites meeki
Walcott; 8, Atrypa reticularis (Linnaeus); 9, 10, Spirifer pinonensis Meek; 11, Favosites favosus Goldfuss; 12, Conchidium decussatum Whiteaves. Figures 3 and 4 represent young shells. 


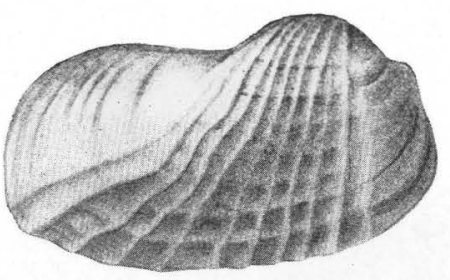

1
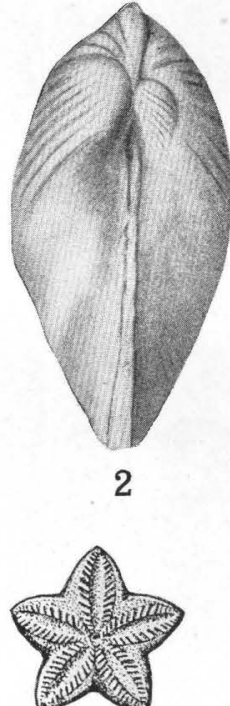

11

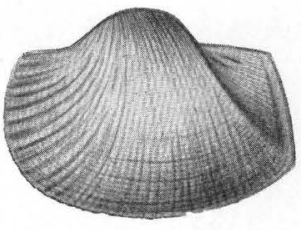

12

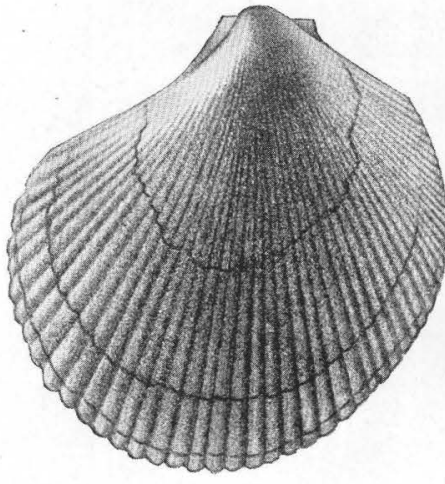

16

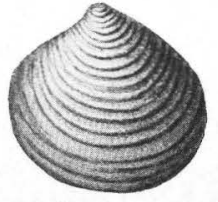

4

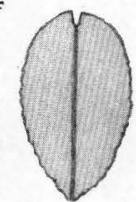

5

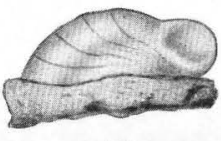

8

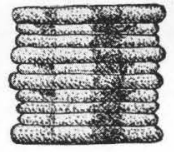

10

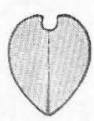

13

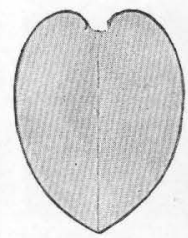

14

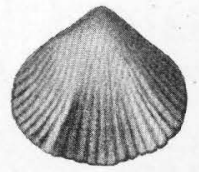

17

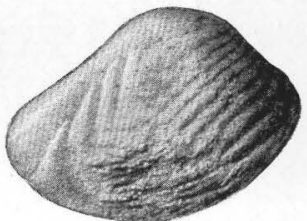

18

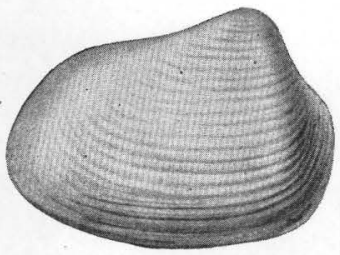

15
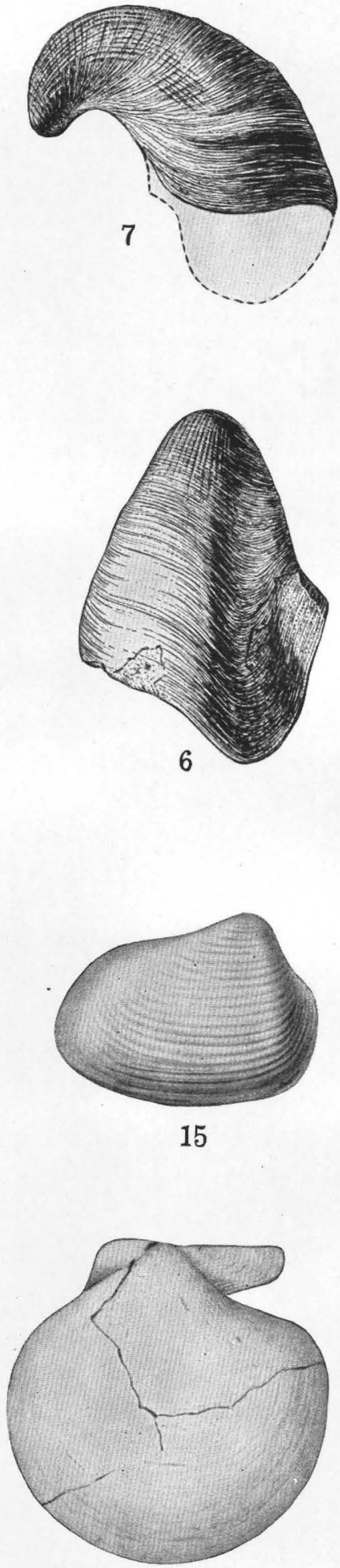

19

CHARACTERISTIC FOSSILS OF JURASSIC AGE.

1, 2, Pholadomya kingii Meek; 3, Pseudomonotis (Eumicrotis) curta (Hall); 4, 5, Astarte packardi White; 6, 7, Cryphaea calceola var. nebrascensis Meek and Hayden; 8, 9, Ostrea strigilecula White; 10, 11, Pentacrinus whitei Clark; 12, 13, Cucullaea haguei Meek; 14, 15, Pleuromya subcompressa Meek; 16; Lima occidentalis Hall and Whitfield; 17, Rhyn-
chonella myrina Hall and Whitfield; 18, Trigonia quadrangularis Hall and Whitfield; 19, Camptonectes stygius White. 
Ophir in the Oquirrh Range; in the Mount. Nebo Range; in the central and northern Wasatch Range; probably in the Raft River Range; in the Promontory Range; the Stansbury Range; the Simpson Mountains; the southern part of the Thomas Range; the House Range; the Deep Creek Mountains; and the Wah Wah Range.

It is possible that the lower quartzite and shales (Tonto group) exposed in the Beaver Dam Mountains and in northern Arjzona are to be correlated with this quartzite, though the data at present available do not warrant such a correlation, for the Tonto group appears to be the younger. No fossils have been found in this quartzite, but at several localities it is overlain, apparently conformably, by fossiliferous shale of Lower (?) and Middle Cambrian age, indicating that for the most part it is Lower (?) Cambrian, though in some localities its upper part may be Middle Cambrian.

OPHIR FORMATION.

Overlying the early Cambrian quartzite is a series of shaly sediments, commonly including some calcareous beds and in places some welldefined strata of limestone, the whole overlain by the more massive Cambrian limestones. These shaly beds overlying the quartzites ${ }^{1}$ are present nearly everywhere. They range in thickness from not more than 100 feet to several hundred feet. They contain Middle Cambrian fossils practically everywhere and, in the House Range, at Ophir, and in Big Cottonwood Canyon, supposed Lower Cambrian forms also. In most of the localities examined by the writer where only Middle Cambrian fossils have been found, lower shales are present that may represent the Lower Cambrian. In the northeastern part of the State, however, Middle Cambrian shales apparently rest directly on the quartzite, and it seems possible that they lie at a slightly higher horizon than in the western part of the State.

In certain localities and ranges, such as the Bear Lake region and the House Range, these shales and limestones have been divided into several formations, which, however, can probably not be recognized throughout the region. The series as a whole, however, is characteristic, easily recognized, and widely distributed.

1 Howell, E. E., Geology of portions of Utah, Nevada, Arizona, and New Mexico: U.S. Geog. and Geol. Surveys W. 100th Mer. Rept., vol. 3, p. $244,1875$.
Where it is not divided the name Ophir formation is adopted for it, as it is well exposed in the Ophir district, where it contains large deposits of ore. The name Alta shale has been proposed by F. F. Hintze for this series in the Cottonwood region, but as that name had previously been adopted for another formation it is not available, though otherwise appropriate and desirable.

The Ophir formation is represented in practically all the ranges in which the early Cambrian quartzite occurs.

\section{LATER CAMBRIAN ROCKS.}

The Cambrian sediments lying above the shaly series in the different ranges are somewhat varied in character, and sufficient data are not available for their definite correlation. Prevailingly they are limestones and dolomites. The sections (Pls. V, VI) show marked variations in the thickness of the Cambrian rocks above the Ophir formation. How far the differences in thickness are due to erosion, which is known to have taken place before the Mississippian period, and how far to nondeposition can not now be positively stated.

Readers who are interested in geologic conditions in the Cordilleran region during Cambrian time, so far as they have been ascertained, are referred to Walcott's paper on the subject. $^{2}$

ORDOVICIAN AND SILURIAN SYSTEMS.

The Ordovician and Silurian deposits are grouped together (see Pl. IV, in pocket) because in many of the ranges sufficient detailed work has not been done to determine the boundary between the two. In many places, too, the boundaries between the Cambrian and Ordovician and between the Silurian and Devonian have been only approximately determined.

In western Utah the Ordovician and Silurian rocks are widely distributed and seem to be present in most places where the systems above and below are exposed. They have been recognized in the San Francisco, House, Deep Creek, Fish Springs, Tintic, Lake Side, Silver Islet, northern Wasatch, and Bear River ranges, and are probably present in the Promontory Range. In eastern Utah, however, where erosion has exposed the pre-Paleozoic rocks, and in the

2 Walcott, C. D., The Cambrian and its problems in the Cordilleran region: Problems of American geology, Yale University Press, 1915. 
extreme southwestern part of the State, they have not been recognized, though more detailed work may reveal them in the Beaver Dam Mountains. They are absent from the Cottonwood district, where they were removed by pre-Mississippian erosion. (See Pls. V, VI.)

The Ordovician and Silurian sediments are in large part calcareous and dolomitic, the dolomitic deposits being especially important. They include, however, an important quartzite member in both the northern and the southwestern parts of the State, though this appears to be lacking in the Tintic Range.

In northern Utah the Ordovician and Silurian beds reach a thickness of 3,000 feet according to Richardson; and in southwestern Utah they probably attain as great or greater thickness. In both sections of the State the lower beds are limestone and dolomites overlain by quartzite, which in turn is overlain by more limestone and dolomites. Certain fossil forms that are characteristic of the Ordovician and Silurian and by which they may be identified are shown in Plates VIII and IX.

\section{DEVONIAN SYSTEM.}

Devonian sediments have been recognized in northern Utah, in the Wasatch and Bear River ranges, in the Bear Lake region, in the central Wasatch Range, in the Tintic Range, and in the Star Range in Beaver County, and they are probably present in other ranges in western Utah. (See Pl. IV, in pocket.)

The Devonian sediments are prevailingly calcareous and dolomitic, the dolomitic deposits predominating. (See Pls. V, VI.) In the Bear Lake region Richardson has described 1,400 feet of prevailingly dolomitic Middle to Upper Devonian. In the northern Wasatch E. M. Kindle found 2,250 feet of Devonian, and in the central Wasatch F. F. Hintze found Devonian fossils in rocks overlying Cambrian. In the Tintic Range the Devonian is unconformably overlain by the Carboniferous rocks, and only a few hundred feet of it has been preserved. In the Star Range the known Devonian consists of about 50 feet of fossiliferous calcareous shale conformably overlying massive limestone and dolomite and underlying similar rocks in which no fossils have been found. As the fossiliferous beds are Upper Devonian, it is highly probable that some of the underlying beds and possible that some of the overlying are Devonian. (For fossil forms characteristic of the Devonian, see Pl. IX.)

\section{CARBONIFEROUS SYSTEM.}

Sediments of Carboniferous age are the most widely distributed and are probably the most extensive and the most important economically of any within the State. (See Pl. IV.)

In western Utah Carboniferous rocks are present in all the ranges where erosion has not removed them together with all later rocks. In eastern Utah Carboniferous rocks are exposed in all localities where erosion has cut through the later formations except in some small areas near the Utah-Colorado boundary south of the Denver \& Rio Grande Railroad, where the Mesozoic rocks rest directly on the pre-Cambrian.

Carboniferous sediments were deposited over nearly all and probably all of the State, and their present absence from certain areas is due to erosion. Over much of eastern Utah they are buried beneath many hundreds of feet of later sedimentary and volcanic rocks, but there is little doubt of their presence beneath these rocks.

The thickness of the Carboniferous deposits differs at different localities. (See Pls. V, VI.) In the Star Range in Beaver County abvut 3,000 feet of Carboniferous sediments are present and in the extreme southern part of the State and adjacent parts of Arizona similar thicknesses occur. In the extreme northern part of the State Richardson found about the same thickness. In the Uinta Range Powell and Weeks each found a somewhat greater thickness. In the central Wasatch Range the thickness of the Carboniferous series probably attains 4,000 feet. In the Tintic mining district only the lower Carboniferous or Mississippian, amounting to about 2,000 feet, is present. In the northern part of the Tintic Range, however, the system attains a great though unmeasured thickness. Its greatest thickness is attained in the Oquirrh Range, where it appears to be several times as great as in any other locality in the State. The whole range has never been studied in detail, and it is possible that future work may show considerable duplication by faults, though there can be little doubt that tho Carboniferous is unusually thick and that the Devonian, 
Silurian, and Ordovician, if present at all, are very thin. In eastern and southeastern Utah the formations underlying the Carboniferous have not been exposed except along the Utah-Colorado boundary south of the Denver \& Rio Grande Railroad, where the Mesozoic sediments rest upon the pre-Cambrian. It seems probable that the Carboniferous thins in this part of the State, though no definite data are available.

The lower Carboniferous (Mississippian) sediments in all parts of the State are prevailingly limestones. The later Carboniferous rocks contain much sandstone and quartzite and are prevailingly sandy in many localities, as in the Wasatch and Oquirrh ranges, where the Weber quartzite (Pennsylvanian) is strongly developed, and farther south and east, where the Pennsylvanian rocks form an important part of the Carboniferous. One persistent horizon approximately at the transition from lower to upper Mississippian is characterized by two or three beds of coarse-grained bluish-gray limestone that carry important ores in districts south of the Cottonwoods in the Wasatch and Oquirrh ranges. In southeastern Utah the Carboniferous sediments are not very deeply exposed, but so far as known they contain much sandy material. Phosphate beds occur persistently in the Park City formation, which is of Pennsylvanian and Permian age.

Fossil forms characteristic of the Carboniferous are shown on Plates LII to LVI (pp. 650$655)$.

TRIASSIC SYSTEM.

Rocks regarded as Triassic (see Pl. IV) are confined to the eastern, central, and southern parts of the State. The only typical basin ranges in which Triassic recks have been recognized are the Mineral and Star ranges in Beaver County. Triassic rocks are doubtless present in all parts of eastern Utah where erosion has not cut the surface to lower formations, though over a large part of the area they are buried beneath later formations. Along the southern border of the State and in northern Arizona the removal of later rocks has exposed large areas of Triassic. In southeastern Utah the Colorado River has everywhere cut down to and in places through the Triassic. (See Pls. V, VI.)

Several of the "uplifts" in southeastern Utah have so elevated the Triassic rocks that the erosion surface has reached and in places passed below them. In the Circle Cliffs (Burr Flats) and Miners Mountain (Rabbit Valley) domes along the Water Pocket flexure, in the broad anticline west of the Comb Wash flexure, in the San Rafael Swell, around the Uinta anticline, and along the Wasatch Range the Triassic is exposed.

Triassic rocks appear to have their greatest development in the western part of the exposed areas. In the San Francisco Range 5,000 feet is exposed. At Le Verkin Canyon, according to Huntington and Goldthwaite, 3,800 feet is present. In the Henry Mountains region, according to Gilbert, a thickness of 1,230 feet is present. In the San Rafael region probably not more than 1,500 feet occurs. In the eastern Uinta region Powell ascribes a thickness of 1,600 feet to beds that are probably Triassic. In the Wasatch Range Boutwell finds a thickness of 3,500 feet.

The rocks of the southeastern part of the State supposedly Triassic are readily separated into two divisions, the lower division being designated "Shinarump group" by Powell, Dutton, and others, and the upper division called Vermilion Cliff sandstone by the early workers in the region.

The lower division consists mainly of red and chocolate-colored shales and shaly sandstone, beds of gypsum, and near the base some limestone. Within it is the Shinarump conglomerate, a stratum of conglomerate and sandstone that is present over large areas and that reaches a maximum thickness of perhaps 200 feet. It is particularly conspicuous as a bench and cliff forming rock. Lenticular beds of fine conglomerate and sandstone are present at different horizons in the upper part of the shales, and at any given locality it is sometimes difficult or impossible to tell whether one or any of them is the true Shinarump conglomerate. The sandstone members are commonly light gray and distinctly lighter colored than the shales. They are of particular interest economically, for it is in them that the silver, copper, and uranium deposits in the Triassic beds are found.

In many places the sandstone layers contain rather abundant plant remains, which range in character from reeds to large trees, and some of which have been almost entirely silicified. At other places carbonized material is rather plentiful. In the Circle Cliffs (Burr Flats)

$$
35416^{\circ}-19-6
$$


region many stumps in which carbonization is very pronounced and silicification relatively slight were observed in a red shale underlying a lens of sandstone in which almost wholly silicified iree trunks are numerous and within restricted areas are abundant. Similar though perhaps less pronounced differences in the alteration of fossil plants were noted farther north along the Water Pocket fold southward from Fruita.

As already noted, the early workers in the region regarded this lower division as a single group-the "Shinarump." Later C. D. Walcott found "Permo-Carboniferous" fossils in the limestone near the base of this group. He also recognized an unconformity at the base of the Shinarump conglomerate which he interpreted as marking the boundary between the Triassic and older formations. Since then the Shinarump conglomerate has generally been regarded as the basal division of the Triassic, and the portion below has been classed as "Permo-Carboniferous."' In recent years, however, extended paleontologic study of the supposed "Permo-Carboniferous" rocks of northern Utah and adjacent regions has led to the conclusion that they are of Lower Triassic age. Similar rocks in southern and southeastern Utah are essentially the same paleontologically and are also now assigned to the Triassic. (For fossil forms characteristic of the Lower Triassic, see Pl. LVII, p. 656.)

The upper formation of the Triassic, as determined by Dutton for the Plateau region, is the Vermilion Cliff sandstone. Dutton says:

The contact with the shales below is usually conformable, but in the vicinity of the Hurricane fault, where the whole Triassic series is displayed, the junction is often unconformable. The separation, however, of the Trias into an upper and lower series, so far as southern Utah is concerned, is based upon lithological grounds chiefly. It is also a matter of great convenience to effect this separation, since each division has its own topography, and their distributions differ notably. There is, also, a decided contrast in their respective aspects, and the geologist who studies them in the field is constantly reminded of the distinctions. The Upper Trias consists of many beds of sandstone with shaly partings. Usually the component members do not attain great thickness, but a few of them occasionally have a thickness exceeding 200 feet. Very

1 Cross, Whitman, The Triassic portion of the Shinarump group of Powell: Jour. Geology, vol. 16, pp. 97-123, 1908. Gregory, H. E., The Shinarump conglomerate: Am. Jour. Sci., 4th ser., vol. 35, pp. 424-438, 1913.

2 Dutton, C. E., Geology of the High Plateaus of Utah, p. 148, U.S. Geog. and Geol. Survey Rocky Mtn. Region, 1880. many of them are cross-bedded in a beautiful manner, and although this feature is not so strongly marked as in the Jurassic sandstone, it is almost always conspicuous enough to attract attention. The whole formation is brilliantly colored. * * * The predominant red, approximating to vermilion, induced Prof. Powell to give the local name of Vermilion Cliffs to their grandest and most typical exposure.

Farther east the distinguishing characteristics of the Vermilion Cliff and the overlying White Cliff sandstone become less conspicuous. Dutton ${ }^{3}$ says:

* * * It has been a long-standing and difficult question whether the Jurassic sandstone is not, after all, a mere upward continuation of the Vermilion Cliff beneath. Much color was given to this supposition by the fact that no unconformity between them has bern detected in this vicinity and still more by the fact that as we travel eastward and southeastward from the High Plateaus the distinction between them gradually fades and the two seem to mergeinto one. Neither of them have yielded any determinable fossils. Nevertheless, I am convinced that the probable plane between the Jura and the Trias lies between these two sandstones. * * *

Gilbert $^{4}$ describes the Vermilion Cliff and the "Gray Cliff" (White Cliff) sandstones in the vicinity of the Henry Mountains as follows:

The Gray Cliff and Vermi:ion Clifr sandstones are often difficult to distinguish, but the latter is usually the firmer, standing in bold relief in the topography, with level top, and at its edge a precipitous face. The former is apt to weather into a wilderness of domelike pinnacles, so steep sided that they can not often be scaled by the experienced mountaineer, and separated by narrow clefts which are equally impassable.

The colors of the two sandstones are not invariable. The lower, which although not reddened throughout its mass is usually stained upon its surface with a uniform deep color, appears in Mount Ellsworth and at other points of elevation with as pale a tint as that of the Gray Cliff. The latter sandstone, on the other hand, where it lies low, is often as deep in color as the Vermilion. * * * The bleaching of the redder sandstone in Mount Ellsworth is probably a result of metamorphism; the reddening of the gray sandstone may depend on the hydration of the iron which it contains.

This similarity of the two great sandstone formations toward the east has sometimes caused them to be classed as a single formation. Wherever the writer has observed them in eastern Utah, however, he found them to be separated by a weaker shaly member about 100 feet in thickness that usually shows in the topography. The Vermilion Cliff sandstone

8 Idem, p. 150.

Gilbert, G. K., Geology of the Henry Mountains, p. 7, U. S. Geog. and Geol. Survey Rocky Mtn. Region, 1877. 
is distinctly the more highly colored, though locally the difference may not be marked.

Powell ${ }^{1}$ describes the Vermilion Cliff and White Cliff sandstone in the Uinta region as follows:

In this region the Vermilion Cliff and White Cliff groups are massive sandstones and hence stand in monoclinal ridges. Sometimes the base of the White Cliff group is a series of softer beds, and two ridges are formed. Elsewhere the White Cliff group rises high over the Vermilion Cliff beds in a wall which faces the axis of the Uinta upheaval on either side. Throughout this entire region the White Cliff sandstone is lighter colored than the Vermilion Cliff group and everywhere exhibits that oblique structure known as false bedding.

The age of the Vermilion Cliff sandstone has not been determined by paleontologic evidence, and whether it is really Triassic or Jurassic is open to question. Dutton has, however, classed it with the Triassic and it may well be left there till it is definitely shown to belong elsewhere.

\section{JURASSIC SYSTEM.}

The distribution of the Jurassic rocks is much the same as that of the Triassic. They are probably everywhere present in eastern Utah unless removed by erosion. They are most extensively exposed in southeastern Utah, where they outcrop over much of the surface south of latitude $40^{\circ} 30^{\prime}$ and east of longitude $111^{\circ} 30^{\prime}$. A broad belt extends through the southern part of the State to the Nevada line, and another encircles the Uinta uplift and borders the Plateau Province on the west. (See Pl. IV.)

The Jurassic, like the Triassic of eastern Utah, can readily be separated into two main divisions, called by Powell the White Cliff group and the Flaming Gorge group. (See Pls. V, VI, in pocket.)

The White Cliff consists almost entirely of a gray cross-bedded sandstone of remarkable similarity over a wide area. Dutton ${ }^{2}$ describes this formation for the area of the High Plateau as follows:

The lithological characters of the Jurassic white sandstone render it a very conspicuous formation. Through a thickness of more than 1,000 feet, sometimes of nearly

\footnotetext{
1 Powell, J. W., Report on the geology of the eastern portion of the Uinta Mountains, p. 151, U. S. Geol. and Geog. Survey Terr., 2d div., 1876.

2 Dutton, C. E., Report on the geology of the High Plateaus of Utah, p. 152, U. S. Geog. and Geol. Survey Rocky Mtn. Region, 1880.
}

2,000 feet, it is one solid stratum, without a single heterogeneous layer or shaly parting. * * * The color of the rock is almost always gray, verging toward white. Occasionally it is a very pale cream color, and again pale red. The red becomes more common as we recede from the old shore line towards the east. But of all the features of this rock the most striking is the cross-bedding. It is hard to find a single rock face which is not lined off with rich tracery produced by the action of weathering upon the cross-lamination. *** The Jurassic sandstone was deposited over an area which can not fall much short of 35,000 square miles, and the average thickness exceeds 1,000 feet.

The formation thins from west to east. Dutton assigns it a thickness of 1,400 feet in the Kanab section, Gilbert 500 feet in the Henry Mountains region, and Lupton 800 feet in the San Rafael Swell region. Farther east, near the La Sal Mountains, Cross ${ }^{3}$ assigns a thickness of 550 feet to the La Plata, which he correlates with the White Cliff, and which in western Colorado is reduced to 100 feet. 'In the Uinta region Powell gives a thickness of 1,025 feet for the White Cliff.

The origin of the White Cliff sandstone and similar formations has been much discussed and is still not generally agreed upon, though the evidence presented in recent years favors a continental origin in which wind was an important factor. ${ }^{4}$

The age of the White Cliff sandstone has not been definitely determined from paleontologic evidence. The formation is overlain, apparently conformably, by marine Jurassic and has been generally considered to be Jurassic. Fossiliferous Jurassic limestones lie a short distance above it over large areas of Utah as far east as Colorado River, beyond which they have not been reported. (For fossil forms characteristic of the Jurassic see Pl. X, p. 79.)

The upper formation of the Jurassic, named Flaming Gorge by Powell, is much more varied in character. Though sections made at many widely separated localities exhibit a general similarity, great differences of detail are shown by sections that are very close together. Dutton says: ${ }^{5}$

That constancy of lithological character which is so conspicuous in older Mesozoic members does not prevail in

3 Jour. Geology, vol. 15, pp. 644-645, 1907.

4 Gregory, H. E., Geology of the Navajo Indian reservation: U. S. Geol. Survey Prof. Paper 93, p. 59, 1917.

5 Dutton, C. E., op. cit., pp. 153-154. 
this one, for it is highly variable not only in the mass, but also in the constitution of the beds. In some exposures it is more than a thousand feet thick; in others, it is less than 200. Where its volume is greatest it is more arenaceous, and where the volume is less the beds are shaly, marly, and calcareous. Usually several seams of limestone occur, and in these the fossils are found, often abundantly. One notable feature is the small amount of cement in the arenaceous layers, which are therefore very poorly consolidated, and the rock weathers and wastes away with extreme facility. Gypsum and selenite occur abundantly in these beds, and especially noticeable is the latter mineral, which is seen sparkling and glittering in the sunlight in the bad lands to which the decay of the strata gives rise.

In the Green River field Lupton ${ }^{1}$ separates the formation, which he calls the McElmo, correlating it with the McElmo of Colorado, into three members-the lower "red sandstone," thin bedded above, massive below, thickness about 700 feet; the middle Salt Wash sandstone member (a "gray conglomeratic sandstone which outcrops in cliffs," and is in places "lenticular, soft, and friable"), thickness 150 to 175 feet; and the upper member (a "gray conglomerate, variegated sandy shale, and clay, and a few feet of limestone about 175 feet from the top"), thickness 325 to 350 feet.

The Salt Wash sandstone member in places consists of shale, sandstone, and conglomeratic sandstone, the sandstone usually showing pronounced cross-bedding. In other places, as south of the Henry Mountains and in the vicinity of Bluff, beds that appear to represent the Salt Wash sandstone consist of massive sandstone, of rather uniform texture and strongly cross-bedded, that locally so closely resembles the White Cliff sandstone that it is difficult or impossible to recognize it except by its stratigraphic position. The positions of the beds correlated with the Salt Wash member also show notable differences at different localities. South and east of the La Sal Mountains what is regarded as the Salt Wash sandstone is scarcely more than 200 feet above the White Cliff sandstone, and in the vicinity of Bluff what seems to represent the Salt Wash is separated from the White Cliff by only about 100 feet of red shaly and sandy beds.

The age of the Flaming Gorge formation is somewhat uncertain. The base is unquestionably marine Jurassic, but the assignment of the higher portions of the formation, which were apparently accumulated under subaerial

1 Lupton, C. T., Oil and gas near Green River, Utah: U. S. Geol. Survey Bull. 541, p. 124, 1914. and possibly in part lacustrine conditions, is in doubt, some writers regarding them as Jurassic and others as Cretaceous. ${ }^{2}$ On the geologic map (Pl. IV, in pocket), the entire formation is represented as Jurassic.

\section{CORRELATION OF JURASSIC AND TRIASSIC} FORMATIONS.

The correlation of the Jurassic and Triassic rocks of Utah with those of Colorado is as yet somewhat uncertain. (See Pls.V,VI, in pocket.)

Cross ${ }^{3}$ considers the La Plata sandstone of Colorado as equivalent to the White Cliff sandstone of Utah and the McElmo as the equivalent of the Flaming Gorge.

In following the formations from the Green River region to the Water Pockets flexure and Henry Mountains and thence southeastward to Bluff (see Pl. VI), the writer reached the conclusion that the rocks at Bluff that Woodruff ${ }^{4}$ designated upper La Plata are the equivalent of the Salt Wash member of the McElmo of the Green River region, and that the rocks that Woodruff classed as lower La Plata include the White Cliff and Vermilion Cliff formations of the sections farther west. This, however, does not seem to agree with Cross's determination of the upper La Plata south of the La Sal Mountains. Assuming the correctness of Cross's determination of the upper La Plata in the La Sal region, there seems little doubt that the La Plata occupies the stratigraphic position of the White Cliff of Dutton, while the Flaming Gorge is the equivalent of the McElmo.

\section{CRETACEOUS SYSTEM.}

Rocks of Cretaceous age, like those of the earlier Mesozoic formations, are largely confined to eastern Utah and extend into the western part of the State near the southern border only. Like the earlier Mesozoic formations they were doubtless deposited over all of eastern Utah but have been removed from large areas by erosion and in other large areas buried beneath later formations. (See Pl. IV.)

In the northern part of the State the Cretaceous is exposed around the Uinta Moun-

2 Those interested in a discussion of this subject are referred to Geol. Soc. America Bull., vol. 26, pp. 295-348, 1915.

3 Cross, Whitman, Jour. Geology, vol. 15, pp. 634-675, 1907.

4 Woodruff, E. G., Geology of the San Juan cil field, Utah: U. S. Geol. Survey Bull. 471 , p. $89,1912$. 
tains, its largest outcrop being east of Vernal. It is also exposed in a number of places along the western front of the Plateau province from the Wasatch Range southward by the partial removal of the Tertiary rocks. A broad belt of Cretaceous extends from the Colorado boundary westward, south of the Book Cliffs and in general parallel to the Denver \& Rio Grande Railroad, to the vicinity of the San Rafael Swell, thence northwest around the northern end of the swell and southwest nearly to Fremont River. An area of Cretaceous is exposed along the western side of the Henry Mountains, which extends northward nearly to the San Rafael Swell. A large area of Cretaceous is exposed between Escalante and Paria rivers, and from it a belt extends westward as far as Cedar. A narrow belt is exposed around the Pine Mountains. In the southeastern part of the State, north of San Juan River, a large area of Cretaceous extends from the Abajo Mountains eastward into Colorado and there is a small area around the La Sal Mountains.

The Cretaceous sediments are not known to contain metalliferous deposits of commercial importance, and have been studied only incidentally by the writer. They do, however, contain important deposits of coal, which have been carefully studied in many fields and which form the subject of several detailed reports.

The Cretaceous sediments are prevailingly sandstones and shales with some limestones, and were evidently deposited in shallow water. (See Pls. V, VI, in pocket.)

In the Book Cliffs region, Richardson ${ }^{1}$ gives the general section of the Cretaceous from the base up as follows:

General section of Cretaceous rocks in the Book Cliffs region.

Dakota sandstone; buff sandstone in many places conglomeratic...................

Mancos shale; fissile black to drab clay shales and local lenses of limestone; thin beds of buff sandstone at top mark transition to the overlying formation....................

Mesaverde formation; alternating beds of buff sandstone and drab shale; workable beds of coal in lower part.............. 1,200-2,200

Lupton ${ }^{2}$ describes a section of over 5,000 feet of Cretaceous beds in the vicinity of the San Rafael Swell, as follows:

1 Richardson, G, B, Reconnaissance of the Book Cliffs coal fields: U. S. Geol. Survey Bull. 371, pl. 3, 1909.

2 Lupton, C. T., Notes on the geology of the San Rafael Swell, Utah: Washington Acad. Sci. Jour., vol. 2, No. 7, p. 188, 1912. Also, Geology and coal resources of Castle Valley, in Carbon, Emery, and Sevier counties, Utah: U.S. Geol. Survey Bull. 628, pp. 33-34, 1916.
Section of Cretaceous beds in vicinity of San Rafael Swell.

Mesaverde formation; mainly sandstone, with in- Feet. tercalated beds of shale and coal............. 1, 100 Mancos shale:

Shale............................ 3, $000 \pm$

Sandstone, shale, and coal (Ferron sandstome

member $\left.^{3}\right) \ldots \ldots \ldots \ldots \ldots \ldots \ldots \ldots \ldots \ldots \ldots \ldots \ldots \ldots \ldots \ldots$

Shale.............................. $600+$

Dakota sandstone......................... 20-60

For the eastern Uinta Mountains Powell ${ }^{4}$ gives a section of 5,000 to 6,000 feet of Cretaceous sediments. For the Henry Mountains region Gilbert ${ }^{5}$ gives sections of about 3,000 feet of sandstone and shales that he correlated with the Cretaceous to the north. For southern Utah Richardson ${ }^{6}$ describes 3,000 feet of Cretaceous beds. The Cretaceous of the southern Rocky Mountain region has been discussed by Lee, to whose paper those especially interested are referred. ${ }^{7}$

\section{TERTIARY SYSTEM.}

Rocks of Tertiary age are exposed over large areas in eastern and central Utah. (See Pl. II.) The largest outcrop is in the Uinta Basin south of the Uinta Mountains, and other large outcrops lie north of the Uinta and east of the Wasatch Range. A broad belt of Tertiary sediments trends southward along the western poriion of the Plateau province, locally extending into the Basin Range province, as in the Canyon and adjacent ranges, and finally swinging westward toward the Nevada State line. Over considerable areas in southern Utah the Tertiary sediments are buried beneath volcanic rocks.

The Tertiary rocks contain few metalliferous deposits and, like the Cretaceous, have only incidentally come under the writer's observation. Their chief commercial importance lies in their carbohydrates, especially in the productive gilsonite deposits of the Uinta Basin and the potentially important oil shales.

The Tertiary sediments of Utah were collected in basins or in low areas after the uplift that began at the close of the Mesozoic or early in the Cenozoic. (See Pls. V, VI, in pocket.)

- Lupton, C. T., Oil and gas near Green River, Grand County, Utah: U. S. Geol. Survey Bull. 541, pp. 124, 128, $129,1914$.

' Powell, J. W., Report on the geology of the eastern portion of the Uinta Mountains, p. 40, U. S. Geol. and Geog. Survey Terr., 2d div. 1876 .

${ }^{5}$ Gilbert, G. K., Report on the geology of the Henry Mountains, p. 4 U. S. Geog. Surveys Rocky Mtn. Region, 1877.

${ }^{6}$ Richardson, G. B., The Harmony, Colob, and Kanab coal fields, southern Utah: U. S. Geol. Survey Bull. 341, p. 379, 1909.

${ }^{7}$ Lee, W. T., Relation of the Cretaceous formations to the Rocky Mountains in Colorado and New Mexico: U. S. Geol. Survey Prof. Paper 95, pp. 27-58, 1915. 
The character of the sediments in the Uinta Basin is given by Eldridge ${ }^{1}$ as follows:

Formations of the Uinta Baisin.

\begin{tabular}{|c|c|c|c|}
\hline Series. & $\begin{array}{c}\text { Formation } \\
\text { name. }\end{array}$ & $\begin{array}{l}\text { Maxi- } \\
\text { mum } \\
\text { thickness, } \\
\text { in feet. } a\end{array}$ & Description. \\
\hline & Uinta. & $500-1,000$ & $\begin{array}{l}\text { Conglomerate, sand- } \\
\text { stone, and shale, } \\
\text { the first two pre- } \\
\text { dominating, es - } \\
\text { peciallytowardthe } \\
\text { top. Material de- } \\
\text { rived chiefly from } \\
\text { Paleozoic quartz- } \\
\text { ites of U i } \mathbf{n} \text { a } \\
\text { Range and Yampa } \\
\text { Plateau. Prevail- } \\
\text { ingly red to pink, } \\
\text { though many of } \\
\text { the sandstones are } \\
\text { rusty yellow to } \\
\text { brown.b }\end{array}$ \\
\hline & Washakie. & 200 & $\begin{array}{l}\text { Sandstone and shale. } \\
\text { Difficultly recog- } \\
\text { nizable.c }\end{array}$ \\
\hline \multirow[t]{3}{*}{ Eocene. } & Bridger. & $600-1,000$ & $\begin{array}{l}\text { Conglomerate, sand- } \\
\text { stone, shale, and } \\
\text { some } 1 \text { to } 2 \text { foot } \\
\text { layers of white } \\
\text { limestone. Sand- } \\
\text { stones prevail; } \\
\text { they are heavy } \\
\text { bedded, somewhat } \\
\text { ferruginous, and } \\
\text { gray to rusty yel- } \\
\text { low and chocolate- } \\
\text { brown. Conglom- } \\
\text { erate fine. For- } \\
\text { mation said to be } \\
\text { identified by ver- } \\
\text { tebrate remains. }\end{array}$ \\
\hline & Green River. & 2,000 & $\begin{array}{l}\text { Calcareousshalesand } \\
\text { thin limestones. } \\
\text { Shales and lime- } \\
\text { stones bituminous, } \\
\text { locally, in a degree } \\
\text { to be of economic } \\
\text { value. Prevailing } \\
\text { color gray, weath- } \\
\text { ering light. Some } \\
\text { thin sand stone } \\
\text { layers, becoming } \\
\text { more prominent } \\
\text { toward top. Coun- } \\
\text { try deeply eroded. }\end{array}$ \\
\hline & Wasatch. & $1,000-1,500$ & $\begin{array}{l}\text { Conglomerates and } \\
\text { sandstones in } \\
\text { heavy beds; red. }\end{array}$ \\
\hline
\end{tabular}

$a$ Largely estimated.

$b$ According to J. B. Hatcher the Uinta of this region is the equivalent of Osborn's Diplacodon elatus beds.

$c$ Equivalent to the top of the Bridger, according to some authorities. [The United States Geological Survey now includes these beds in the Bridger.

1 Eldridge, G. H., The uintaite (gilsonite) deposits of Utah: U. S. Geol. Survey Serenteenth Ann. Rept., pt. 1, p. 922, 1896.
The general character of the Tertiary beds in the vicinity of the High Plateau is described by Dutton ${ }^{2}$ as follows:

The Tertiary system of the Plateau Country is lacustrine throughout, with the exception of a few layers near the base of the series, which have yielded estuarine fossils. The widely varying strata were accumulated upon the bottom of a lake of vast dimensions, and were derived from the waste of mainlands and mountain platiorms, some of which are still discernible. The region of maximum deposit was in the vicinity of the Wasatch and Uintas, where in the course of Eocene time more than 8,000 feet of beds were laid down. As we proceed southward, these heavy deposits attenuate, partly by a diminution in the thickness of the individual members and partly because the period of deposition ceased earlier the farther southward we go, until in the southern part of the province only the lower Eocene is found, or, indeed, was ever deposited. The High Plateaus occupy the belt through which this diminishing bulk and successive elimination of upper members is well seen. In the Wasatch Plateau, at the extreme northern part of the district, we find the two lower divisions of the Eocene present in great volume; and in the valley of the Sevier and San Pete we find what is undoubtedly a still higher division. At the southern portion of the district only the lower division can be clearly made out, though some of the upper beds may prove to belong to a later period. The present weight of evidence, however, seems to me to place them in one division, the "Bitter Creek" 3 of Powell.

In the southern plateaus, the Markagunt and Paunsagunt, we find the following members of the Bitter Creek, which are much the same in all exposures:

\section{Southern Bitter Creek.}

1. Upper white limestone and calcareous marl Feet. (summit of series).................... $\quad 300$

2. Pink calcareous sandstone.................. 800

3. Pink conglomerate (base of the series) ........ 550

1,650

In the northern part of the district we have a larger development of the Bitter Creek series, and resting upon it some heavy masses of the Lower Green River shales, and probably a considerable portion of the Upper Green River Group.

The Pink Cliffs, which form such a striking feature in the scenery of the southern terraces, are exposures of the fine-grained calcareous sandstone forming the middle member of the Bitter Creek. The same exposures are exhibited in the southern and southwestern flanks of the Markagunt around the entire promontory of the Paunsagunt and in the circuit of the Table Cliff. In the Aquarius Plateau the Lower Eocene is found, but in smaller volume than elsewhere, and it is decidedly diminished in mass upon the summit of Thousand Lake Mountain. But it resumes its normal thickness farther north, and then grows more and more massive throughout the extent of the Wasatch Plateau.

2 Dutton, C. E.,' Geology of the High Plateaus of Utah, pp. 158-159, U. S. Geog. and Geol. Survey Rocky Mtn. Region, 1880.

3 The name Bitter Creek group is no longer in use. In its typical area the group included all the rocks between the top of the Lewis shale and the top of the Bridger formation. 
In their general characteristics these Tertiary strata are similar to the Laramie beds upon which they generally rest, being shaly and marly and sometimes lignitic.

In northwestern Utah tuffaceous beds around the northern end of the Pilot Range and in the Grouse Creek valley are supposed to be of Tertiary age, and more detailed study may reveal other Tertiary sediments in western Utah.

Those especially interested in a discussion of the Tertiary stratigraphy are referred to W. D. Mathews's paper ${ }^{1}$ on the subject.

\section{QUATERNARY SYSTEM.}

The Quaternary deposits of the State may be roughly separated into three principal typesglacial deposits, lake deposits, and valley deposits.

GLACIAI DEPOSITS.

Glacial deposits are confined principally to high altitudes and their surrounding areas. The largest deposits are present around the Uinta Range. Others are present around the higher portions of the Wasatch Range, notably in the vicinity of the Cottonwood and American Fork canyons. The deposits in both these ranges have been mapped and described by Atwood, ${ }^{2}$ by whom deposits of two periods are definitely recognized.

In other parts of the State small areas have been glaciated. The higher portions of the Tushar Range ${ }^{3}$ and, according to Dutton, the higher portions of the High Plateau ${ }^{4}$ contained glaciers, and Hill reports glacial deposits in the La Sal Mountains. ${ }^{5}$

It is probable that such deposits oocur in the Abajo (Blue) Mountains, but they have not been recognized in the Henry Mountains. Woodruff ${ }^{6}$ and Sterrett ${ }^{7}$ have described a deposit of till-like material in San Juan County, near the Arizona boundary, which was regarded of possible glacial origin. Gregory, ${ }^{8}$

1 The Tertiary sedimentary record and its problems: Problems of American geology, Yale University Press, 1915.

${ }^{2}$ Atwood, W. W., Glaciation of the Uinta and Wasatch mountains:

U. S. Geol. Survey Prof. Paper 61, 1909.

${ }^{3}$ Lindgren, Waldemar, The Annie Laurie mine, Piute County, Utah

U. S. Geol. Survey Bull. 285, p. 89, 1906.

${ }^{4}$ Dutton, C. E., The Tertiary history of the Grand Canyon district:

U. S. Geol. Survey Mon. 2, p. 202, 1882.

${ }^{5}$ Hill, J. N., Notes on the northern La Sal Mountains, Utah: U. S. Geol. Survey Bull. 530, p. 105, 1913.

${ }^{6}$ Woodruff, E. G., Geology of the San Juan oil field, Utah: U. S. Geol. Survey Bull. 471, p. 89, 1912.

${ }^{7}$ Sterrett, D. B., U. S. Geol. Survey Mineral Resources, 1908, pp. 823$827,1909$.

${ }^{8}$ Gregory, H. E., The igneous origin of the "glacial deposits" on the Navajo Reservation, Arizona and Utah: Am. Jour. Sci., 4th ser., vol. 40, pp. 97-115, 1915. however, has shown that it is probably an intrusive breccia.

On the geologic map (Pl. IV) no attempt has been made to show the glacial deposits, as they are of relatively slight importance.

\section{LAKE DEPOSITS.}

While glaciers were accumulating on the higher elevations water collected in the lower areas, and a lake, from which the tops of the Basin Ranges projected as islands, spread over a large area in western Utah. This lake, which may be regarded as a vast expansion of the present Great Salt Lake, has been called Lake Bonneville. The streams flowing from the mountains brought to it large amounts of sediment, which were distributed by the waves. Terraces represent the beach and near-shore deposits of the lake, and rock-cut benches on the exposed headlands exhibit the work of the waves.

Two shore lines, distinct in many localities, mark levels at which the waters of the lake were stationary for considerable periods, and other less distinct lines mark levels at which the waters were comparatively stationary for shorter periods. The extent of the lake and its shore features have been fully described and discussed by Gilbert. ${ }^{9}$ While the shore features were being formed deposits were of course being laid down in the deeper portions of the basin, but these have for the most part been buried beneath later deposits and are largely inaccessible to observation.

The deposits of the Great Salt Lake desert are doubtless, in general, similar to those forming in the present lake. They consist of saline muds and locally of beds of salt of considerable extent that accumulated in places where the desert was flooded only at intervals. In Great Salt Lake there have formed and still are forming deposits consisting very largely of oolitic grains composed of calcium carbonate. On the geologic map (Pl. IV) no attempt has been made to separate the lake deposits from the other Quaternary deposits.

\section{VALLEY DEPOSITS.}

In the low areas, especially in the valleys between the desert ranges, large quantities of rock material from the higher elevations have accumulated. Many of the streams are intermittent, flowing on the surface only during

${ }^{9}$ Gilbert, G. K., Lake Bonneville: U. S. Geol. Survey Mon. 1, 1890. 
torrential rains and even then sinking into the soil close to the points where they emerge from the ranges. The relatively few streams that maintain a perennial flow likewise sink into the soil in whole or in part after they reach the relatively flat desert valleys. Conditions are therefore favorable for transporting large amounts of rock material to the mouths of the mountain canyons and dropping them to build up the immense débris fans or cones that characterize the desert regions. These fans spread out laterally from the mouths of the valleys and in places coalesce into a continuous débris apron. Outwardly from the mountain front they decrease in slope and become progressively finer grained till they finally flatten out and can be no longer recognized. In many desert valleys, however, débris fans from ranges on opposite sides reach the center and coalesce; and everywhere the fine material is gradually carried to the lower areas, so that the surface is being gradually built up.

Little is known concerning the thickness of the valley deposits, and in areas that were covered by the Quaternary lakes it is not always easy to separate deposits formed in the lake from those deposited in the dry valleys both before and after the lake period. Wells have penetrated these deposits for several hundred feet, and there can be little doubt that in some places they are thousands of feet in thickness. So far as ascertained, they consist of a very variable succession of clay, sand, and gravel.

Stream deposits are a form of valley deposits. They are comparatively insignificant in amount but are economically important, for they are the only recent deposits that have yielded metals. Important amounts of gold have been obtained from them in Bingham Canyon, less amounts from Green, Colorado, and San Juan rivers, and very small amounts from some other localities.

\section{IGNEOUS ROCKS.}

\section{GENERAL DISTRIBUTION.}

Igneous rocks are widely distributed in Utah and over large areas are the prevailing surface formation. They are closely associated with many of the metalliferous deposits of the State and are consequently of great interest to those engaged in metal mining. The igneous rocks may be separated into extrusive rocks, or those that have flowed out on the surface and solidified, and intrusive rocks, or those that have solidified beneath the surface.

The great bulk of the igneous rocks is confined to two zones, each of which contains both intrusive and extrusive rocks. The largest of these zones lies in the southern part of the State, where it extends from the High Plateau through the Basin Range province to eastern Nevada (Pl. IV, in pocket). Farther east it may be regarded as represented by the detached laccolithic masses of the Henry, Abajo, and La Sal mountains. This great belt can be subdivided, as will be indicated later.

The second zone extends from the western end of the Uinta Mountains westward and southwestward across the State, including the igneous masses in the Wasatch, Oquirrh, Tintic, Sheeprock, Dugway, Granite, Deep Creek, and other ranges. It may be subdivided into a northern division extending from the Uinta Mountains westward to Bingham, and a southern division extending from the latitude of Mount Nebo westward through the Tintic, Dugway, Deep Creek, and other ranges.

Smaller areas of igneous rocks outcrop in the Raft River Mountains in the northwestern part of the State, in the Pilot Range near the Nevada State line, and in many other localities. The extrusive rocks (see Pl. IV) cover a much larger area than the intrusive, especially in the southern belt, where great areas have been buried by lavas in some localities to a depth of hundreds of feet. It is not improbable that lavas were once much more extensive in the northern belt and have been largely removed by erosion. Such erosion may not only have actually decreased the amount of extrusive rock but, by revealing the intrusive bodies, may also have increased the apparent relative proportion of the intrusive rocks in the northern area.

\section{EXTRUSIVE ROCKS.}

CHARACTER AND ORIGIN,

The extrusive rocks include some lava, but they are in greater part fragmental. In the southern part of the State, especially, large bodies consist of clastic or fragmental material. According to Dutton, the great bulk of this material in the High Plateau region 
is not true tuff resulting from explosive volcanism but is the result mainly of the breaking down of earlier lavas and the deposition of the resulting material as volcanic sediments. The same is probably true of large bodies of fragmental material in the southwestern part of the State and in adjacent parts of Nevada. ${ }^{1}$ The most extensive fragmental beds are near the base of the extrusive series. Higher in the series at several localities is some fragmental material that is probably true tuff.

The nature of the eruptions which resulted in the great accumulation of extrusive material is not everywhere clear, and much more work will be required before it can be definitely outlined for the entire series. That the later eruptions were what are commonly termed central rather than fissure eruptions, though the centers may be closely associated with fissures, is indicated by numerous cones that are scattered over the southern Utah field. In the case of the older deposits where erosion has largely or entirely removed the ancient volcanic cones, the arrangement and attitude of the flows frequently indicate that they originated from centers. Several centers from which the great body of extrusive rocks of the High Plateau region emanated have been identified by Dutton; and to the north in the Tintic Mountains three centers of eruption have been located. (See p. 398.) However, some at least of the southern flows, especially the earlier ones, were not improbably allied to fissure eruptions, though they may have been confined to numerous centers along the fissures.

In composition the rocks range from rhyolite to basalt, but the great bulk of the series is of intermediate composition, including rather basic rhyolites, quartz latites, dacites, and andesites. Basalt is very subordinate in amount when compared with the series as a whole, though present in many localities and usually conspicuous as representing the latest volcanic outflows. The alkaline types of rock, such as the leucite and nepheline-bearing lavas, are very scarce, having been noted only in

\footnotetext{
1 Spurr, J. E., Descriptive geology of Nevada south of the fortieth parallel: U. S. Ceol. Survey Bull. 208, p. 140, 1903.
}

East Fork Canyon, where Dutton ${ }^{2}$ has described an isolated occurrence of phonolite. It is not improbable that detailed work will disclose other areas of alkaline lava, but it seems certain that they are rare and are nowhere of large extent.

\section{ORDER OF ERUPTION.}

The relation of the different types of volcanic rocks to one another and the relative time of their expulsion is a matter of much interest, but sufficient data are not available to warrant definite generalizations.

From his studies in the High Plateau region Dutton ${ }^{3}$ suggested a generalized order of eruption, based partly on the earlier order suggested by Richthofen, that seemed to agree with the observed order at different localities in that area. Later Spurr ${ }^{4}$ proposed a more complicated system to which he referred the lavas over a wide area in the Great Basin region.

The accompanying table compares several sections of the Utah volcanic rocks with the generalized sections of Dutton and Spurr.

Though most of the observed sections can be made to fit into the generalized sections so far as regards general chemical composition, it is apparent that they show much greater variation in mineral composition. Ransome ${ }^{5}$ has suggested that the apparent agreement with the generalized series of Spurr in the Goldfield district, Nevada, is due to the fact that almost any limited series can be made to fit the system, and the writer inclines to the same view for the Utah districts. So far as he has been able to determine in his study of the effusive rocks in Utah the succession of different lavas is not sufficiently regular to permit confident predictions as to the kind of lava that underlies any particular kind that is exposed on the surface. Comparison of the different sections, however, does show that in Utah the great bulk of the lavas is of intermediate composition and that the latest eruptions are basaltic.

2 Dutton, C. E., Geology of the High Plateaus of Utah, p. 248 , U. S. Gcog. Survey Rocky Mtn. Region, 1880.

${ }^{3}$ Idem, p. 68.

${ }^{4}$ Spurr., J. E., Lavas in the Great Dasin region: Jour. Geology, vol. 8, p. $643,1900$.

${ }^{5}$ Ransome, F. L., Geology and ore deposits of Goldfield, Nev.: U. S. Geol. Survey Prof. Paper 66, p. 106, 1909. 
CHEMICAI COMPOSITION.

In the following tables the published chemical analyses of the effusive rocks of the State are brought together for comparison:

Analyses of extrusive rocks from Iron Springs district. ${ }^{a}$

Chemical composition.

\begin{tabular}{|c|c|c|c|c|c|c|}
\hline & 1 & 2 & 3 & $3 a$ & 4 & 5 \\
\hline $\mathrm{SiO}_{2}$ & 64.83 & 58.04 & 66.38 & 70.03 & 73. 17 & 61.05 \\
\hline $\mathrm{Al}_{2} \mathrm{O}_{3} \ldots \ldots$ & 16. 68 & 18. 96 & 13. 72 & 14. 47 & 13. 34 & 16. 03 \\
\hline $\mathrm{Fe}_{2} \mathrm{O}_{3} \ldots \ldots$ & 3. 74 & 5. 88 & 2. 23 & 2. 35 & 1. 35 & 5. 42 \\
\hline $\mathrm{FeO} \ldots . .$. & 1. 22 & 1. 33 & .80 & .84 & .76 & .98 \\
\hline $\mathrm{MgO} . . . .$. & .79 & 1. 11 & .54 & .57 & .81 & 3. 03 \\
\hline $\mathrm{CaO} \ldots . . .$. & 2. 85 & 6.12 & 5. 49 & 2. 42 & 1. 32 & 5. 40 \\
\hline $\mathrm{Na}_{2} \mathrm{O} \ldots \ldots$ & .86 & 2. 26 & 2. 50 & 2. 64 & 1. 80 & 1. 43 \\
\hline $\mathrm{K}_{2} \mathrm{O} \ldots \ldots$ & 7. 56 & 4. 08 & 5. 20 & 5. 48 & 7. 10 & 5. 58 \\
\hline $\mathrm{H}_{2} \mathrm{O} \ldots$. & .92 & 2.05 & .92 & .97 & .54 & .81 \\
\hline $\mathrm{P}_{2} \mathrm{O}_{5} \ldots \ldots$ & .35 & .34 & .08 & .08 & .07 & .30 \\
\hline $\mathrm{BaO}$.. & . & 04 & $\begin{array}{r}2.52 \\
.11\end{array}$ & ii & . 10 & 08 \\
\hline & 99.91 & 100. 21 & 100. 49 & 99.96 & 100. 36 & 100.11 \\
\hline
\end{tabular}

$a$ Leith, C. K., and Harder, E. C., The iron ores of the Iron Spring district, southern Utah: U. S. Geol. Survey Bull. 338, p. 58, 1908.

Mineral composition calculated from chemical composition.

\begin{tabular}{|c|c|c|c|c|c|}
\hline & 1 & 2 & 3 & 4 & 5 \\
\hline Quartz. & 22. 02 & 15. 06 & 27.60 & 33.12 & 19. 38 \\
\hline Orthoclase........ & 43. 37 & 22.79 & 28. 35 & 39.47 & 28. 35 \\
\hline Albite........... & 7. 34 & 18. 86 & 20.96 & 15. 19 & 12.05 \\
\hline Anorthite......... & 11. 12 & 25. 85 & 10. 56 & 5. 56 & 15. 84 \\
\hline Biotite $a \ldots \ldots$. & 3. 81 & 3. 71 & 3. 70 & 2. 70 & 2. 70 \\
\hline Phlogopite $a \ldots$. . & $\ldots \ldots$ & …... & - & 1. 62 & 4. 16 \\
\hline Diopside......... & .86 & 2. 16 & $\ldots \ldots$ & $\ldots \ldots$ & 7. 12 \\
\hline Magnetite........ & 1. 85 & 2. 78 & 1. 62 & .92 & 1. 85 \\
\hline Apatite........... & .62 & .62 & .31 & .31 & .62 \\
\hline Limonite.......... & .75 & 4. 11 & .56 & .75 & .75 \\
\hline Hematite......... & 1. 28 & $\ldots$ & & - & 3.52 \\
\hline Calcite............ & $\ldots$ & & 5. 70 & & \\
\hline Kaolin..... . . & 5. 16 & 3. 09 & $\ldots \ldots$ & & 3. 61 \\
\hline Water............. & $\ldots \ldots$ & .97 & .76 & 34 & $\ldots$. \\
\hline \multirow[t]{2}{*}{ Sillimanite....... } & 1. 45 & $\ldots$. & $\ldots \ldots$ & & \\
\hline & 99.63 & 100.00 & 100. 12 & 99.98 & 99.95 \\
\hline
\end{tabular}

$a$ Composition based on average of analyses in Dana's Manual of mineralogy.

1. Specimen 46533. Fresh early trachyte from Antelope Range (No. 1 of flows). Analysis by R. D. Hall, University of Wisconsin.

2. Specimen 46584. Andesite from same formation as specimen $\mathrm{C}$ north of Stoddard Mountain. Analysis by $\mathrm{R}$. D. Hall, University of Wisconsin.

3. Specimen 46521. Early rhyolite from Eightmile Hills (No. 2 of flows). Analysis by R. D. Hall, University of Wisconsin.

3a. Specimen 46521. Early rhyolite. Recalculated on the basis of 100 per cent after removing $\mathrm{CaO}$ and $\mathrm{CO}_{2}$ of the infiltrated calcite.

4. Specimen 46557. Latest trachyte from Antelope Hills

(No. 5 of flows). Analysis by R. D. Hall, University of

Wisconsin.
5. Specimen 46586A. Dacite from Swett Hills (No. 7 of flows). Analysis by R. D. Hall, University of Wisconsin. Chemical analyses of lavas from the San Francisco and adjacent districts.

Chemical composition.

\begin{tabular}{|c|c|c|c|c|c|}
\hline & 1 & 2 & 3 & 4 & 5 \\
\hline & 68.04 & 67.93 & 64.48 & 63.04 & 57.72 \\
\hline & 19.02 & 19.46 & $\ldots \ldots$ & 21.98 & ...... \\
\hline - & .84 & .28 & None. & 1. 49 & .90 \\
\hline $\mathrm{CaO}$ & 2. 76 & 1. 42 & 1.95 & 4. 13 & 6. 40 \\
\hline $\mathrm{Na}_{2} \mathrm{O} \ldots \ldots \ldots \ldots$ & 4. 06 & 3. 54 & 4. 81 & 3. 43 & 4. 94 \\
\hline $\mathrm{K}_{2} \mathrm{O} \ldots \ldots \ldots \ldots$ & 4. 27 & 3. 91 & 3. 39 & 3.26 & 4. 36 \\
\hline
\end{tabular}

Probable mineral composition of crystalline rock

\begin{tabular}{|c|c|c|c|c|c|}
\hline Quartz. & 21 & 31 & 20 & 21 & \\
\hline $\begin{array}{l}\text { Orthoclase mole- } \\
\text { cule........... }\end{array}$ & 25 & 22 & 20 & 18 & 26 \\
\hline Albite molecule... & $34 \zeta_{44}$ & $30 \bigcup_{37}$ & $40\}_{50}$ & $28\}_{44}$ & $42\} 62$ \\
\hline Anorthite molecule & $10\}^{11}$ & $7 \int^{\pi}$ & $10 \int^{\circ}$ & $16 \int^{T x}$ & $20 \int^{02}$ \\
\hline $\begin{array}{r}\text { Hornblende,augite, } \\
\text { and biotite.... }\end{array}$ & 7 & 3 & & 9 & 6 \\
\hline
\end{tabular}

1. Heavy-bedded lava southeast of Squaw Springs specimen 49).

2. Thin-bedded lava northeast of Frisco (specimen 20). 3. Lava from prospect $1 \frac{1}{4}$ miles north of O.K. mine (specimen 187).

4. Lava northeast of Carbonate mine (specimen 22).

5. Lava from northwestern part of Star district (specimen 148)

Chemical analyses of effusive rocks from Tintic, Park City, and Marysvale districts and from Thomas Range.

Chemical composition.

\begin{tabular}{|c|c|c|c|c|}
\hline & 1 & 2 & 4 & 5 \\
\hline $\mathrm{SiO}_{2}$ & 74. 49 & 70. 17 & 69. 18 & 60.17 \\
\hline $\mathrm{Al}_{2} \mathrm{O}_{3} \ldots \ldots \ldots \ldots$ & 14. 51 & 11. 83 & 14. 37 & 15. 78 \\
\hline $\mathrm{Fe}_{2} \mathrm{O}_{3} \ldots \ldots \ldots \ldots$ & .57 & .93 & 2. 52 & 3. 42 \\
\hline $\mathrm{FeO} \ldots \ldots \ldots \ldots \ldots$ & .32 & ........ & .57 & 2.95 \\
\hline $\mathrm{MgO}$. & Trace. & .06 & .70 & 2. 52 \\
\hline$\ldots \ldots$ & 1. 03 & .76 & 1.88 & 4. 69 \\
\hline $\mathrm{Na}_{2} \mathrm{O} \ldots \ldots$ & 3. 79 & 3.85 & 3.58 & 2. 96 \\
\hline $\mathrm{K}_{2} \mathrm{O} \ldots \ldots$ & 4. 64 & 3. 74 & 5.00 & 4. 16 \\
\hline $\mathrm{H}_{2} \mathrm{O} \ldots \ldots$ & .64 & 8. 72 & ........ & 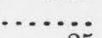 \\
\hline $\mathrm{H}_{2} \mathrm{O}-\ldots \ldots \ldots \ldots$ & $\ldots \ldots$ & ........ & .35 & \\
\hline $\mathrm{H}_{2} \mathrm{O}+\ldots \ldots \ldots \ldots$ & $\ldots \ldots$ & $\ldots \ldots$ & .25 & 1. $2:$ \\
\hline $\mathrm{P}_{2} \mathrm{O}_{5} \ldots \ldots \ldots \ldots \ldots \ldots$ & $\cdots$ & $\ldots \ldots$ & .26 & .40 \\
\hline $\mathrm{CO}_{2} \cdots \cdots$ & - & $\cdots$ & $\cdots \cdots$ & e \\
\hline$\underset{\mathrm{TiO}_{2} \ldots}{\mathrm{BaO}}$ & & $\cdots$ & $\begin{array}{l}.09 \\
.69\end{array}$ & - \\
\hline $\mathrm{MnO}$. & Trace. & $\ldots$. & .10 & 1 \\
\hline $\mathrm{Li}_{2} \mathrm{O} \ldots \ldots \ldots \ldots \ldots$ & Trace. & $\cdots$ & Trace. & Trace \\
\hline $\mathrm{Z}_{\mathrm{Cl}} \mathrm{rO}_{2}$ & $\ldots \ldots \ldots$ & $\cdots$ & Trace.... & $\cdots \cdots$ \\
\hline $\mathrm{FeS}_{2}$ & & & & \\
\hline $\mathrm{SrO}$ & & & Trace: & .09 \\
\hline $\mathrm{Cr}_{2} \mathrm{O}_{3} \ldots \ldots \ldots \ldots \ldots \ldots$ & & . & Trace. & \\
\hline $\mathrm{V}$ as $\mathrm{V}_{2} \mathrm{O}_{5} \ldots \ldots$ & $\cdots$ & $\cdots$ & .01 & .01 \\
\hline 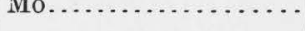 & & - & Trace. & \\
\hline
\end{tabular}


Chemical analysis of effusive rocks from Tintic, Park City, and Marysvale districts and from Thomas Range-Con.

Norm or theoretic mineral composition. $a$

\begin{tabular}{|c|c|c|c|c|}
\hline & 1 & 2 & 4 & 5 \\
\hline Quartz. & 32.4 & 31.8 & 24.0 & 13. \\
\hline Orthoclase........... & 27.8 & 22.2 & 30.0 & 25.0 \\
\hline Albite.............. & 32.0 & 32.5 & 30.4 & 25.2 \\
\hline Anorthite.......... & 5. 0 & 3. 6 & 8. 1 & 17. 0 \\
\hline Hypersthene........ & $\ldots \ldots$ & .2 & 1. 3 & 5. 0 \\
\hline Hematite........... & ....... & 9 & 2. 5 & \\
\hline Diopside........... & ........ & $\ldots \ldots \ldots$ & 1. 1 & 5. \\
\hline Ilmenite............. & $\ldots \ldots$ & $\ldots \ldots$ & 1. 2 & 1. \\
\hline Magnetite............ & . $\quad 9$ & $\ldots \ldots$ & $\ldots$ & 4. \\
\hline Corundum........... & 1. 3 & $\ldots$ & & $\cdots$ \\
\hline
\end{tabular}

$a$ Washington, H. S., Chemical analyses of igneous rocks: U. S. Geol. Survey Prof. Paper 99, pp. 125, 183, 1917.

1. Rhyolite, Thomas Range. Analysis made by L. G. Eakins in the Denver Laboratory.

2. Rhyolitic glass or pitchstone, edge of Gold Mountain mining district, 8 miles north of west from Marysvale. Analysis by W. F. Hillebrand, record No. 1833 .

4. Packard rhyolite, Tintic district. Analysis by Dr. Stokes.

5. "Tintic" andesite, or latite. Analysis by Dr. Stokes.

\section{INTRUSIVE ROCKS.}

DISTRIBUTION AND CHARACTER.

Intrusive rocks are widely distributed over the western part of the State and are present at several localities in the southeastern part.

In the western part the principal large bodies from north to south are in the Raft River Range in the northwestern corner of the State; the Pilot Range on the Nevada border; the eastwest belt extending from the Park City region westward through the Little Cottonwood and the Bingham regions; the belt extending from the Tintic Range westward in the Sheeprock, Granite, and Deep Creek ranges; the igneous belt extending from the San Francisco Range eastward through the Beaver Lake, Rocky, Star, Mineral, and Tushar ranges to the Antelope district northeast of Marysvale; and the belt which extends southwestward through the Iron Springs district and the Bull Valley region and is reported to continue into Nevada. In the southeastern part of the State are the laccolithic bodies of the Henry, Abajo, and La Sal mountains. Small intrusive bodies like dikes and sills are present at numerous other localities in the State.

Intrusive bodies have been given names depending on their shape, size, relation to surrounding rocks, and supposed mode of origin.
For the purpose of the present discussion it will be sufficient to state what is meant by a few of the terms when used in this report. (See fig. 6, p. 92.)

A dike is an injected body, has nearly parallel walls, is narrow in proportion to its outcropping edge, cuts across the bedding when the injected formation is stratified, and has any angle of dip.

A sheet or sill is a tabular injected body lying parallel to the bedding planes of the country rock.

A laccolith is closely related to a sheet or sill but typically has a more lenticular form, the overlying rocks or roof being raised as a dome over the thicker portion, or the underlying rocks or floor perhaps depressed into a basin. The distinguishing and important feature of the laccolith is that it has a floor separating it from lower bodies of similar material and that the opening through which its material entered is relatively small.

A stock extends indefinitely downward and in many instances increases in area with increasing depth. It has no floor and consequently is not separated from the source of its material. A stock of large dimensions is frequently termed a batholith.

The laccoliths and stocks of the State are rather definitely separated geographically, the intrusive bodies of the southeastern part of the State being typically laccoliths and those of the western part typically stocks. There may be some true laccoliths in the western area but there are probably no true stocks in the southeastern.

\section{MODE OF INTRUSION.}

The space occupied by an intrusive body may be considered as having been formed in either one of two ways or by a combination of the two. It may have been formed by the pushing upward or aside bodily of the material previously occupying the space, or it may have been formed by the assimilation of that material in the intruding body. Assimilation may take place in several ways. The molten material may have simply dissolved the rock and thus advanced into the solid rock mass, or it may have wedged off blocks from the top or sides or even from the bottom of the chamber. If these blocks are heavier than the 
molten material, they will sink until dissolved. the associated rocks that is well developed in If they are lighter, they will rise. By this the Central Wasatch, in the Raft River Range, method, which is called by Daly magmatic and less clearly in many other places. The stoping, a body of molten rock could advance stocks, however, are distinctly crosscutting into a solid formation without disturbing the bodies, and the doming can not account for all position of the invaded rocks other than those the rock displaced. In some localities these immediately affected.

crosscutting bodies have formed the space, in

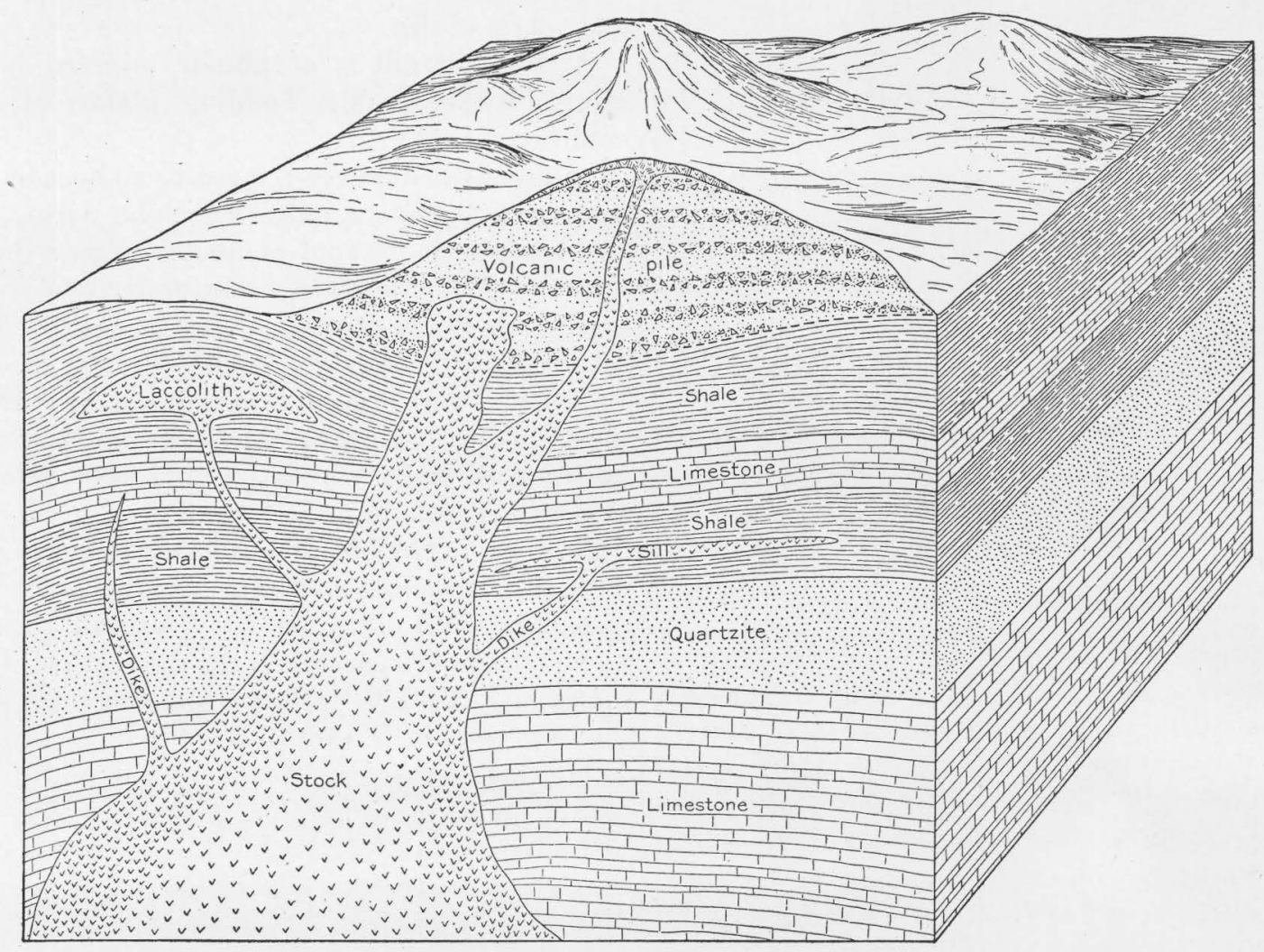

FIGURE 6.-Ideal cross section of igneous area, showing different types of igneous bodies.

There is ample evidence from different parts of the world that space for intrusive bodies has been formed by each of these methods.

A typical product of intrusion by simple displacement is the Iaccolith, ${ }^{1}$ and it was in southeastern Utah that this type of intrusive body was first recognized. The laccoliths of this region clearly were formed by the doming up of the sedimentary strata, to which the intrusive contacts are for the most part parallel. There is no evidence of material assimilation of the sedimentary rocks by the intruded magma.

The stocks in the western part of the State also show evidence of displacement of the earlier rocks, especially in the dome structure of

1 Gilbert, G. K., Report on the geology of the Henry Mountains, 160 pp., U. S. Geog. and Geol. Survey Rocky Mtn. Region, 1877. part at least, by forcing blocks of earlier rocks bodily before the entering mass, as in the Park City district, ${ }^{2}$ in the Tintic district, ${ }^{3}$ and apparently in the Star district. ${ }^{4}$

Evidence of stoping is perhaps less easily detected and for this reason perhaps is not known to have been of prime importance in Utah. In the Tintic district there is abundant evidence of stoping, but all of it is later than the faulting due to the igneous intrusions.

Numerous blocks of sediment are included in the stocks of the San Francisco Range, the Raft River Range, the Park City district, and the

${ }^{2}$ Boutwell, J. M., and Woolsey, L. H., Geology and ore deposits of the Park City district, Utah: U. S. Geol. Survey Prof. Paper 77, p. 97, 1912. ${ }^{3}$ Lindgren, Waldemar, and Loughlin, G. F., Geology and ore deposits of the Tintic mining district, Utah: U. S. Geol. Survey Prof. Paper 107, 282 pp., 1919.

4 Butler, B. S., Geology and ore deposits of the San Francisco and adjacent districts, Utah: U. S. Geol. Survey Prof. Paper 80, p. 71, 1913. 
Tintic district. In the Park City district ${ }^{1}$ bodies of Pennsylvanian and Mississippian limestone have been raised many feet above their normal position, and the same is true of a body of quartzite in the Tintic district; but in neither locality has it been shown that there has been important assimilation of the included blocks.

Leith and Harder consider that there has been a notable shrinkage of the limestone adjacent to the intrusives in the Iron Springs district. This, however, could provide only a small fraction of the space occupied by the intrusive bodies.

The available evidence indicates that mosi of the space occupied by the visible parts of the

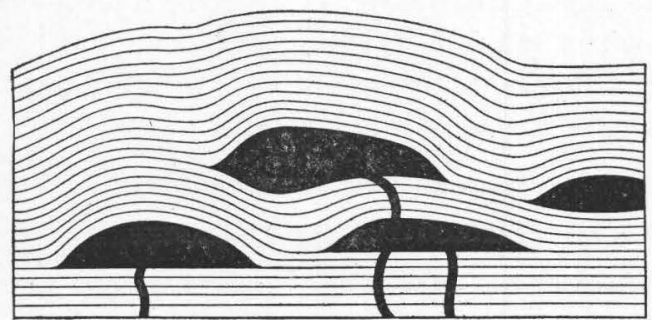

FIGURE 7.-Ideal cross section of grouped laccoliths. After Gilbert.

intrusive bodies was formed by a displacement of the earlier rocks and little of it by assimilation.

LACCOLITHS.

Laccolithic bodies have been exposed by erosion in the Henry, Abajo, and La Sal mountains. In other areas, for example, in Navajo Mountain and the San Rafael Swell, the structure suggests the presence of similar bodies that have not yet been revealed by erosion.

The three groups are of a single type. Each is composed of numerous laccoliths, sheets, and dikes intruded into the sedimentary rocks from the Triassic to the Cretaceous. They range from bodies only a few feet thick, whose lateral dimensions are measured in rods, to bodies hundreds of feet thick which cover severaI square miles. In form they show every gradation from the true sheet with essentially parallel floor and roof to lenticular laccoliths with high-domed roofs. (See fig. 7.)

Rocks from different bodies differ greatly in general appearance, principally owing to the different conditions under which they were solidified. All are porphyritic, but in some the

${ }_{1}^{1}$ Boutwell, J. M., and Woolsey, L. H., p. 97, 1912. groundmass is very fine and the rocks resemble surface flows, for which indeed they have sometimes been mistaken where erosion has removed the overlying sediments. In the larger bodies much of the groundmass is rather coarsely crystalline and even granitic in texture.

As a group the rocks are characteristically of intermediate composition, not only in Utah but also in Colorado and Arizona. ${ }^{2}$ The difference in the composition of different bodies would be considered great enough to justify different petrographic names were it not that equally great differences occur in single rock masses. All the rocks have the general composition of quartz monzonites or granodiorites.

The following tables contain chemical analyses of rocks from the La Sal and the Henry mountains:

Analyses of rocks from the La Sal Mountains.

\begin{tabular}{|c|c|c|c|c|c|c|}
\hline & 1 & 2 & 3 & 4 & 5 & 6 \\
\hline $\begin{array}{l}\mathrm{CO}_{2} \\
\mathrm{rO}_{2} \\
\mathrm{O}_{2} \\
\mathrm{O}_{2} \\
\mathrm{O}_{5}\end{array}$ & $\begin{array}{r}61.21 \\
17.10 \\
2.72 \\
1.88 \\
1.47 \\
4.83 \\
5.66 \\
3.00 \\
.34 \\
.68 \\
.51 \\
.02 \\
\text { None. } \\
.24 \\
\text { None. } \\
.04 \\
.15 \\
.13 \\
.07 \\
\text { Trace? }\end{array}$ & \begin{tabular}{|r}
73.27 \\
13.29 \\
1.16 \\
.13 \\
.07 \\
.21 \\
3.44 \\
7.53 \\
.23 \\
.43 \\
.10 \\
.02 \\
.02 \\
Trace. \\
.07 \\
.01 \\
.03 \\
.10 \\
None? \\
Trace?
\end{tabular} & $\begin{array}{r}70.02 \\
14.38 \\
1.17 \\
.13 \\
.61 \\
.66 \\
5.48 \\
5.87 \\
.27 \\
.44 \\
.10 \\
.01 \\
.38 \\
\text { Trace. } \\
.19 \\
.03 \\
.02 \\
.13 \\
.06 \\
\text { Trace. }\end{array}$ & $\begin{array}{r}68.96 \\
15.42 \\
1.99 \\
.16 \\
.22 \\
.25 \\
6.59 \\
5.48 \\
.22 \\
.30 \\
.12 \\
.04 \\
.13 \\
\text { Trace. } \\
\text { None. } \\
.01 \\
.07 \\
\text { Trace. } \\
\text { None. } \\
\text { Trace. }\end{array}$ & $\begin{array}{r}62.64 \\
17.36 \\
2.79 \\
.63 \\
.53 \\
1.70 \\
7.00 \\
4.97 \\
.43 \\
.53 \\
.43 \\
.02 \\
.54 \\
.12 \\
.06 \\
.03 \\
.04 \\
.10 \\
.07 \\
\text { None. }\end{array}$ & $\begin{array}{r}58.99 \\
19.01 \\
1.74 \\
.59 \\
.27 \\
2.02 \\
9.11 \\
5.07 \\
.38 \\
1.24 \\
.21 \\
.07 \\
\text { None. } \\
.04 \\
.96 \\
.15 \\
.08 \\
.02 \\
.02 \\
\text { Trace. }\end{array}$ \\
\hline & 00 & 100.11 & 99.95 & 99.96 & 99 & .97 \\
\hline
\end{tabular}

1. Monzonite porphyry, 2 miles west of Mount Peale. Analysis by W. F. Hillebrand.

2. Aegirite granite porphyry, about 1.5 miles south of Mount Waas. Analysis by W. F. Hillebrand.

3. Syenite aplite porphyry resembling grorudite. About 2 miles south of Mount Waas. Analysis by W. F. Hillebrand.

4. Syenite porphyry resembling sölvsbergite. About 1 mile northwest of Mount Waas. Analysis by W. F. Hillebrand.

5. Pulaskite, 1 mile west of Mount Waas. Analysis by W. F. Hillebrand.

6. Noselite syenite porphyry, dike on northwest shoulder of Mount Waas. Analysis by W. F. Hillebrand.

2 Cross, Whitman, The laccolithic mountain groups of Colorado, Utah, and Arizona: U. S. Geol. Survey Fourteenth Ann. Rept., pt. 2, p. 227, 1893. 
Chemical analyses of rocks from Henry Mountains.

Chemical composition.

\begin{tabular}{|c|c|c|c|}
\hline & 1 & 2 & 3 \\
\hline 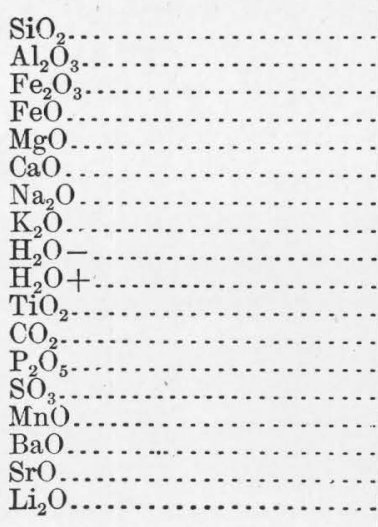 & $\begin{array}{r}63.16 \\
17.21 \\
2.43 \\
2.30 \\
1.27 \\
6.27 \\
4.70 \\
1.84 \\
\ldots . .69 \\
.69 \\
.21 \\
. .12 \\
\text { Trace. } \\
\text { Trace. } \\
.09 \\
\text { Trace? } \\
\text { Trace. }\end{array}$ & $\begin{array}{r}62.88 \\
17.13 \\
1.86 \\
2.58 \\
1.48 \\
5.39 \\
4.50 \\
2.25 \\
.16 \\
.42 \\
.51 \\
.26 \\
.16 \\
.16 \\
.12 \\
\text { Trace. }\end{array}$ & $\begin{array}{r}60.98 \\
19.09 \\
1.76 \\
1.15 \\
.65 \\
3.67 \\
6.70 \\
3.53 \\
.48 \\
.44 \\
.36 \\
.52 \\
.10 \\
\ldots . .15 \\
.15 \\
.43 \\
.28 \\
\text { Trace. }\end{array}$ \\
\hline & 100. 29 & 100.29 & 99.86 \\
\hline
\end{tabular}

Approximate mineral composition.

\begin{tabular}{l|r|r|r}
\hline Quartz................... & 14.8 & 14.9 & 1.3 \\
Orthoclase molecule......... & 11.1 & 13.3 & 20.6 \\
Albite molecule............ & 39.8 & 37. & 56.6 \\
Anorthite molecule......... & 20.3 & 20.0 & 11.7 \\
Hornblende and augite...... & 9.6 & 8.9 & 4.8 \\
Magnetite..................... & 3.5 & 2.8 & 2.6 \\
Ilmenite................. & .5 & .9 & .8 \\
\hline
\end{tabular}

1. Porphyry. Analysis by W. F. Hillebrand.

2. Hornblende porphyrite. Sheet, revet-crag, Mount Hellers. Analysis by W. F. Hillebrand.

3. Augite porphyrite. Dike on north spur of Mount Pennell. Analysis by W. F. Hillebrand.

In the smaller laccolithic bodies no later dikes are present, and in the larger laccoliths they are few and small. Such rocks have been carefully studied in the La Sal Mountains by Prindle, who finds them high in alkalies, especially sodium, and low in calcium and magnesium. Detailed study of the other groups will doubtless reveal dikes associated with the larger laccoliths; some, indeed, are known to be present in the Henry Mountains.

The similarity in the composition of the several laccolithic bodies in a group and the absence of dikes from all but the larger are characteristic. These conditions may be explained as follows: The material forming the laccolith entered the space it occupies through a relatively narrow opening, which, it is reasonable to suppose, was quickly choked once the active flow of material ceased, and the laccolithic body was thereby effectually sealed off from the deep-seated sources. In small and relatively thin bodies the molten material solidified quickly and the part remaining longest fluid had little opportunity to form dikes of a composition differing from that of the main body of the laccolith. In the larger laccoliths, however, the inner portions may have solidified slowly and have remained partly fluid after the outer crust was sufficiently solid to permit fissuring. This fluid portion might readily have been squeezed into the fissures in the solid crust and, solidifying there, have formed dikes differing in composition from the body of the laccolith. A similar origin of mineralizing solutions is discussed on page 197.

If this explanation is correct it is evident that the amount of differentiation and therefore the abundance of dikes is roughly dependent on the size of the laccolith.

\section{STOCKS AND ALLIED BODIES.}

DISTRIBUTION AND CHARACTER.

Stocks are found only in the western part of the State, where they are present in many of the ranges crossed by the igneous belts. (See $\mathrm{Pl}$. IV, in pocket.)

They cut rocks from pre-Cambrian to Tertiary in age, some single stocks or series of stocks intruding nearly all of the formations lying between rocks of these two ages. For example, the stocks of the middle Wasatch extend from pre-Cambrian to Triassic, those of the San Francisco and adjacent regions from Cambrian to Triassic, and those of the Tintic Range from Cambrian sediments to Tertiary lavas. They show no apparent tendency to be more abundant in the rocks of one period than in those of another, though it may be noted that several of the largest bodies are associated with the older rocks, as, for example, the Little Cottonwood and Granite Mountain stocks in the preCambrian rocks and the Ibapah stock of the Deep Creek Range in the pre-Cambrian though extending into the Carboniferous. The large stock of the Mineral Range, however, cuts sediments of Carboniferous and later ages. It is worthy of note that the area in which the stocks occur was probably never covered by the great thickness of Cretaceous shales that covered eastern Utah.

The rocks of the stocks range in texture from typically granitic to typically porphyritic, 
not only in different stocks, but in many individuals. It is not confined to the smaller bodies, for the large Ibapah, Little Cottonwood, and Granite Range stocks are characterized by large phenocrysts of feldspar. In some localities, however, the smaller bodies and those intruded nearest the surface apparently tend to porphyritic and the larger and deeper seated bodies to granitic texture. In individual stocks also (in the stock of the San Francisco Range, for instance) the higher or marginal portions may be pronouncedly porphyritic, and the main body of the stock granitic.

\section{COMPOSITION.}

General features.-The stocks of theState, like the laccolithic bodies, are as a whole of intermediate composition. They show much greater variation, however, ranging from granite through granodiorite and quartz monzonite to quartz diorite. There is apparently a rather marked relation between the size of a stock and possibly also the depth at which it solidified, and its chemical composition. The larger stocks are generally richer in silica, alumina, pqtassium, and sodium, and poorer in calcium, magnesia, and iron. This holds true for the Little Cottonwood, Sheeprock Mountain, Desert Mountain, Granite Mountain, Ibapah Mountain, and Mineral Mountain bodies. In general, also, the more siliceous rocks are in- truded into the older sediments. This is true of the Little Cottonwood, Sheeprock Mountain, Desert Mountain, Raft River Mountain, Granite Mountain, and Ibapah Mountain stocks, all of which are intruded into Cambrian and pre-Cambrian rocks, though the Ibapah stock probably extended nearly or quite to the Carboniferous.

In the southern belt the most siliceous rocks, those of the Mineral Mountains, are associated with the Carboniferous and Triassic sediments, and the less siliceous rocks (those of the San Francisco Mountains, for instance) are associated with older rocks, intruding Ordovician and possibly older sediments. The San Francisco stock, however, intrudes also Tertiary eruptives, indicating that although associated with older sedimentary rocks it is not a deepseated body.

The possible significance of the two facts that the more siliceous rocks form the larger intrusive bodies and that they are intruded into the older strata are discussed on page 98.

Analyses.-In the following tables are given the available chemical analyses of rocks from stocks or allied bodies of intrusive rock in the State. Those that seem to illustrate significant variations in composition are assembled in the tables, and a few analyses of extrusive rocks are included for the sake of ready comparison with the associated intrusive rocks.

Analyses of rocks from the Little Cottonwood, Bingham, and Park City stocks and of the extrusive rock of Park City area.

\begin{tabular}{|c|c|c|c|c|c|c|c|c|}
\hline & 1 & 2 & 3 & 4 & 5 & 6 & 7 & 8 \\
\hline $\mathrm{SiO}_{2} \ldots$ & 67.02 & 63. 46 & 61.64 & 59.68 & 59.35 & 58. 64 & 57.16 & 54.23 \\
\hline $\mathrm{Al}_{2} \mathrm{O}_{3} \ldots \ldots \ldots$ & 15. 78 & 15.93 & 14. 66 & 15. 61 & 16.36 & 15. 35 & 16. 69 & 17. 37 \\
\hline $\mathrm{Fe}_{2} \mathrm{O}_{3}$ & 1. 56 & 2. 61 & 1.95 & 2.49 & 2. 90 & 3.25 & 3. 47 & 4. 00 \\
\hline $\mathrm{FeO} \ldots \ldots \ldots \ldots$ & 2.8 & 2. 31 & 1. 68 & 2.38 & 3.36 & 2.54 & 2. 76 & 1. 95 \\
\hline $\mathrm{MgO} \ldots \ldots \ldots \ldots \ldots \ldots$ & 1. 09 & 2. 27 & 2.55 & 2.52 & 3.08 & 2.84 & 2. 47 & 3. 00 \\
\hline $\mathrm{CaO} \ldots \ldots \ldots$ & 3.31 & 4. 33 & 4. 65 & 4. 63 & 5.03 & 5. 37 & 5. 86 & 6.67 \\
\hline $\mathrm{Na}_{2} \mathrm{O} \ldots \ldots \ldots$ & 3.85 & 3. 66 & 2.71 & 3.96 & 3. 73 & 3.60 & 3.82 & 2.96 \\
\hline $\mathrm{K}_{2} \mathrm{O}$ & 3.67 & 3. 49 & 3.07 & 2.92 & 3.85 & 4. 23 & 4. 49 & 2. 80 \\
\hline $\mathrm{H}_{2} \mathrm{O}-\ldots \ldots$ & .29 & .27 & 3.60 & 2.51 & .28 & .86 & .83 & 1. 60 \\
\hline $\mathrm{H}_{2} \mathrm{O}+\ldots \ldots \ldots \ldots \ldots$ & .63 & .74 & 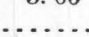 & ...... & .64 & 1. 50 & 1.06 & 3. 71 \\
\hline $\mathrm{TiO}_{2} \ldots \ldots$ & .37 & 62 & 48 & 62 & .87 & .83 & .87 & .75 \\
\hline $\mathrm{Z} \mathrm{rO}_{2} \ldots \ldots$ & .04 & .03 & 01 & .01 & .03 & & & .02 \\
\hline $\mathrm{CO}_{2}$ & $\ldots . .$. & Trace. & 2.15 & 2.29 & Trace. & None. & None. & .33 \\
\hline $\mathrm{P}_{2} \mathrm{O}_{5} \ldots \ldots$ & .26 & .16 & .24 & .29 & .44 & .02 & .41 & .34 \\
\hline $\mathrm{MnO}$ & .03 & $\cdots$ & $\cdots$ & $\cdots$ & 7 & .05 & $\mathrm{~T}$ & io \\
\hline $\mathrm{BaO}$ & .02 & .16 & $\begin{array}{l}.00 \\
.18\end{array}$ & .08 & .01 & .18 & .30 & $\therefore 15$ \\
\hline
\end{tabular}

1. Granodiorite, Little Cottonwood stock. R. C. Wells, analyst.

2. Quartz diorite, east side of Brighton Gap. W. F. Hillebrand, analyst.

3. Quartz diorite porphyry, Valeo mine, Cottonwood Canyon. W. F. Hillebrand, analyst.

4. Quartz diorite porphyry, dike northwest of Daly-West shaft, Park City district. W. F. Hillebrand, analyst.

5. Quartz diorite, three-fourths of a mile northeast of Clayton Peak. W. F. Hillebrand, analyst.

6. Monzonite, British tunnel, Last Chance mine, Bingham district. E. T. Allen, analyst.

7. Monzonite, Tribune tunnel, Telegraph mine, Bingham district. E. T. Allen, analyst.

8. Andesite, Ontario drain tunnel, Park City district. W. F. Hillebrand, analyst. 
Chemical analyses of rocks from the Ibapah stock and from a locality near Gold Hill, Deep Creek Range. [R. C. Wells, analyst.]

\begin{tabular}{|c|c|c|}
\hline & 1 & 2 \\
\hline $\mathrm{SiO}_{2} .$. & 70.67 & 62.84 \\
\hline $\mathrm{Al}_{2} \mathrm{O}_{3}$ & 16.24 & 14.21 \\
\hline $\mathrm{Fe}_{2} \mathrm{O}_{3} \ldots \ldots \ldots \ldots \ldots \ldots \ldots \ldots$ & .37 & .91 \\
\hline $\mathrm{FeO}$ & 1. 15 & 3.75 \\
\hline $\mathrm{MgO} \ldots \ldots \ldots \ldots \ldots \ldots \ldots \ldots$ & .26 & 3.04 \\
\hline$\ldots \ldots \ldots \ldots \ldots \ldots \ldots$ & 1. 71 & 4. 72 \\
\hline $\mathrm{Na}_{2} \mathrm{O} \ldots$ & 3.95 & 2.85 \\
\hline $\mathrm{K}_{2} \mathrm{O} \ldots$ & 4.85 & 4. 60 \\
\hline$\ldots \ldots \ldots \ldots \ldots \ldots$ & .29 & .26 \\
\hline $\mathrm{H}_{2} \mathrm{O}+\ldots \ldots \ldots \ldots \ldots \ldots \ldots$ & .64 & 1.23 \\
\hline $\mathrm{TiO}_{2} \ldots \ldots \ldots \ldots \ldots \ldots \ldots \ldots \ldots \ldots$ & .23 & .42 \\
\hline $\mathrm{ZrO} \ldots \ldots$ & $\ldots \ldots$ & Trace. \\
\hline $\mathrm{CO}_{2} \ldots \ldots \ldots \ldots \ldots \ldots \ldots \ldots$ & Trace. & .38 \\
\hline $\mathrm{P}_{2} \mathrm{O}_{5} \ldots \ldots \ldots \ldots \ldots \ldots \ldots \ldots \ldots \ldots$ & .11 & .41 \\
\hline 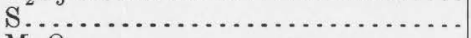 & .01 & .01 \\
\hline 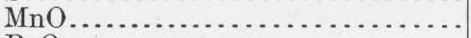 & .03 & .06 \\
\hline 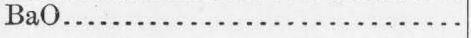 & .05 & .03 \\
\hline
\end{tabular}

1. Granodiorite, Ibapah stock.

2. Quartz monzonite, Clifton district.

Chemical analyses of quartz monzonite from the San Francisco and adjacent districts.

\begin{tabular}{|c|c|c|c|c|}
\hline & 1 & 2 & 3 & 4 \\
\hline $\mathrm{SiO}_{2}$ & 62.10 & 66.00 & 64.00 & 64.41 \\
\hline $\mathrm{Al}_{2} \mathrm{O}_{3}$. & 15.47 & & & 15.85 \\
\hline $\mathrm{Fe}_{2} \mathrm{O}_{3} \ldots \ldots \ldots$ & 2.64 & & & 1.95 \\
\hline $\begin{array}{l}\mathrm{FeO} . . \\
\mathrm{MgO} .\end{array}$ & 3.15 & 1.13 & 171 & 2.52 \\
\hline $\mathrm{CaO}$. & 5.31 & $\begin{array}{l}1.10 \\
3.93\end{array}$ & 2.95 & $\begin{array}{l}1.00 \\
3.71\end{array}$ \\
\hline $\mathrm{Na}_{2} \mathrm{O}$. & 3.56 & 3.60 & 3.55 & 3.60 \\
\hline $\mathrm{K}_{2} \mathrm{O}$.. & 3.15 & 4.04 & 5.45 & 3.46 \\
\hline $\mathrm{H}_{2}^{2} \mathrm{O}-\ldots \ldots$. & .14 & 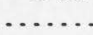 & ... & .12 \\
\hline $\mathrm{H}_{2} \mathrm{O}+\ldots \ldots$ & .72 & & & 1.09 \\
\hline $\mathrm{TiO}_{2} \ldots \ldots \ldots$ & .81 & & & .46 \\
\hline $\mathrm{CO}_{2}$. & Trace. & & & .72 \\
\hline $\mathrm{MnO}$ & & & & .07 \\
\hline
\end{tabular}

1. Quartz monzonite, Cactus area, San Francisco district.

2. Quartz monzonite, Beaver Lake district.

3. Quartz monzonite, Star district.

4. Quartz monzonite, O. K. vertical shaft, Beaver Lake district.

Chemical analyses of quartz monzonite and andesite from the Tintic and Iron Springs districts.

\begin{tabular}{|c|c|c|c|}
\hline & 1 & 2 & 3 \\
\hline $\mathrm{SiO}_{2}$ & 59.76 & 65.29 & 63.63 \\
\hline $\mathrm{Al}_{2} \mathrm{O}_{3}$. & 15. 79 & 11.57 & 15.64 \\
\hline $\mathrm{Fe}_{2} \mathrm{O}_{3}$. & 3.77 & 2.10 & 3.59 \\
\hline $\mathrm{FeO}$.. & 3.30 & 2.67 & .93 \\
\hline $\mathrm{MgO}$. & 2.16 & 2.87 & 2.32 \\
\hline $\mathrm{CaO} .$. & 3.88 & 4.85 & 4.46 \\
\hline $\mathrm{Na}_{2} \mathrm{O}$. & 3.01 & 2.10 & 1.70 \\
\hline $\mathrm{K}_{2} \mathrm{O}$.. & 4.40 & 5.18 & 5.22 \\
\hline $\mathrm{H}_{2} \mathrm{O}-$ & .31 & & \\
\hline $\overrightarrow{\mathrm{H}}_{2} \mathrm{O}+\ldots \ldots$ & 1.11 & 2.32 & 2.10 \\
\hline $\mathrm{TiO}_{2} \ldots \ldots \ldots \ldots \ldots \ldots$ & .87 & .... & …. \\
\hline $\begin{array}{l}\mathrm{CO}_{2} \ldots \ldots \ldots \ldots \ldots \ldots \\
\mathrm{P}_{0} \mathrm{O}_{5} \ldots \ldots \ldots \ldots \ldots\end{array}$ & $\begin{array}{r}78 \\
42\end{array}$ & 22 & 15 \\
\hline $\mathrm{MnO} \ldots \ldots \ldots \ldots$ & .42 & & \\
\hline $\mathrm{BaO} \ldots \ldots \ldots$ & .09 & .17 & .05 \\
\hline $\mathrm{SrO} \ldots \ldots \ldots \ldots \ldots$ & Trace. & & \\
\hline
\end{tabular}

1. Monzonite, Iron Duke mine, Tintic district. 2. Andesite, east of Granite Mountains, Iron Springs district.

3. Weathered andesite, Desert Mound, Iron Springs district.

An examination of the analyses from the Little Cottonwood, Park City, and Bingham districts shows that the largest body which is associated with the oldest rocks is the most siliceous and is relatively low in calcium, magnesium, and aluminum. Farther to the east, smaller bodies that intrude higher formations are lower in silica and markedly richer in aluminum, calcium, and magnesium. Sodium, potàssium, and iron show no very marked differences. The Bingham stock, which intrudes upper Carboniferous rocks, does not differ greatly from the Park City stocks at ahout the same horizon.

In the accompanying diagram (fig. 8) an analysis of the Bingham rock and the three available analyses from the Cottonwood and Park City districts that are free from carbon dioxide and that evidently represent nearly fresh rocks are plotted to show the relation of the principal oxides to the silica content. The silica in each analysis is plotted as an abscissa and the remaining oxides in each analysis on a single vertical ordinate located by the silica abscissa. ${ }^{1}$ The form of the line that connects the points representing an oxide on the several ordinates expresses the variations in the ratio of their oxide to silica.

The analyses thus arranged according to decreasing silica are likewise arranged in order of the age of the rocks in which the stocks are intruded, the more siliceou's being in the older rocks. An analysis of the andesite of the Park City area is also plotted, and it falls in fairly well with the series, being higher in alumina and calcium, essentially the same in magnesium, and slightly lower in alkalies and iron.

The analyses representing the stocks in the Deep Creek Range show that the stocks are similar as to age of the intruded rocks and the composition of the intrusive rock, but that they differ through a decrease of alumina in the less siliceous rock and a more pronounced increase in iron.

The Granite Range contains but one large stock, which is distinctly granitic and, with the abundant pegmatite (pegmatite dikes are estimated to occupy 20 per cent of the exposure

${ }^{1}$ Iddings, J. P., Igneous rocks, vol. 1, p. 10, 1909. 
over large areas), is probably the most siliceous late rocks and are relatively small. In comand most highly alkaline large intrusive body in the State. The Raft River Range stock is similar in composition to the stock of the Granite Range. The main intrusive stock of the Tintic Range is similar in composition to those of the Bingham and Park City districts. Comparison of these widely separated stocks would probposition they are similar to the smaller stocks in the younger rocks in other parts of the State.

Causes of differences in composition. ${ }^{1}-$ The composition of a molten rock mass or magma can be changed by the solution of rocks of different composition, and by the separation of

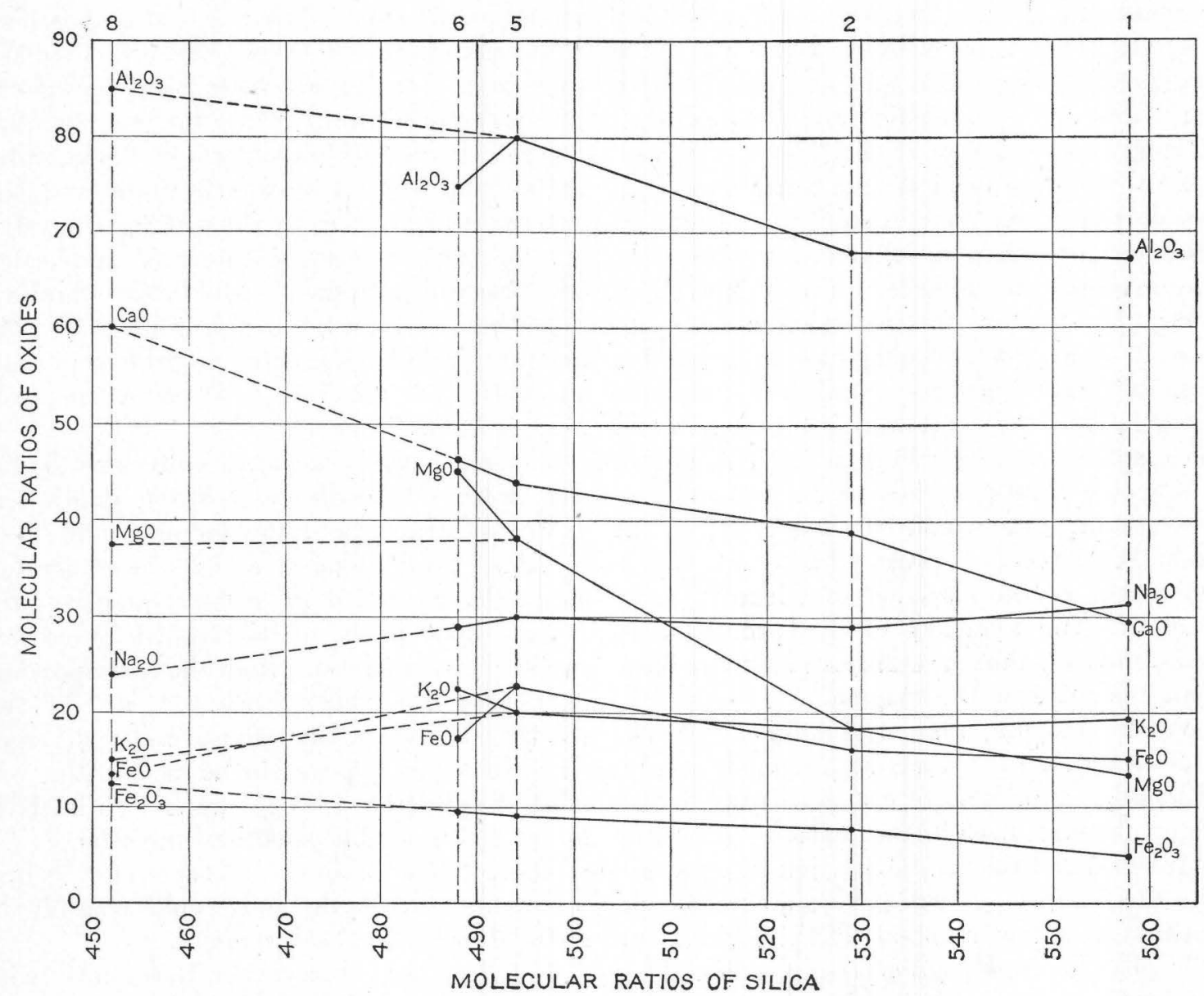

FIGURE 8.-Diagram showing relation of silica to other principal oxides of the intrusive rocks of the belt comprising the Bingham, Little Cottonwood, and Park City districts. 1, Granodiorite, Little Cottonwood stock; 2, quartz diorite, east side of Brighton Gap; 5, quartz diorite, three-fourths of a mile northeast of Clayton Peak; 6, quartz monzonite, British Tunnel, Last Chance Mine, Bingham district; 8, andesite, Ontario drain tunnel, Park City district.

ably fail to show the fairly regular relationships that obtain between closely associated bodies.

Chemical analyses are not available of the larger stock of the Mineral Range in the southern belt, but it is certainly distinctly more siliceous and lower in calcium and magnesium than those either to the east or west. So far as indicated by present knowledge the change in this belt is similar to that in the central Wasatch and the Deep Creek ranges.

All the stocks in the belt extending through the Iron Springs district were intruded into the Iron Springs district
\[ 35416^{\circ}-19-7 \] tion. The first process is called assimilation, the second differentiation.

It is apparent that if a quantity of basaltic rock were dissolved in a magma having the composition of granite the resultant mixture would be more basic, or if quartzite were dis-

1 Those desiring a general discussion of this subject are referred to the textbooks, especially to the following: Igneous rocks, by J. P. Iddings; Igneous rocks and their origin, by R. A. Daly; The natural history of igneous rocks, by A. Harker. An especially suggestive discussion based on experimental data has been presented by N. L. Bowen (The later stages of the evolution of the igneous rocks: Jour. Geology, vol. 23, No. 8, suppl., 1915). 
solved in a basaltic magma the resultant material would be more siliceous than basalt.

The separation of a magma into portions differing in composition may be thought of as occurring in several ways.

In a fluid magma the heavier portions may settle in a manner similar to the separation of matte and slag in a smelting mixture. On crystallization, basic minerals commonly form earliest. They are heavier than the fluid magma and may settle and at greater depth may dissolve or remain undissolved, thus tending to decrease the basicity of the portion where they were formed and to increase it in the portion where they dissolve or collect. If siliceous minerals form that are lighter than the magma the reverse takes place. If a portion of the magma, as that near the inclosing walls, cools faster than the rest, the basic minerals begin to crystallize first and the composition of the remaining liquid becomes more siliceous. According to the well-known law that a solution tends to become uniform throughout, there would be a movement of the basic constituents toward this area, and a movement of the siliceous constituents away from it. The tendency of this process is to make the rock that crystallizes first more basic than the mass of the magma.

When a magma is largely solidified and consists of a mass of crystals with a small portion of liquid, comparable to gravel saturated with water, the mass itself or the inclosing rocks may be fissured and this liquid portion be squeezed into the fissures. It will have a different composition from the main body of the magma, and it is possible that pegmatite and aplite dikes are frequently formed in this way.

The basic dikes that commonly occur in the intrusive masses may have been forced into the fissured rock from deeper-seated sources where the basic constituents have collected and have not solidified as quickly as the portions nearer the surface.

The intrusive bodies of Utah are believed to have been affected both by assimilation and by differentiation, but the relative importance of these two processes is somewhat doubtful.

Assimilation might explain the relatively siliceous character of the stocks that reach only the older strata as compared with those that penetrate the Carboniferous and later beds; for the older sediments are dominantly siliceous, whereas the younger consist in great part of shale and limestone, whose assimilation would enrich the magma in calcium, magnesium, and aluminum. But similar results may have been produced by differentiation, especially by the settling of heavy crystals. The composition of the original magma in a single intrusive body should be most nearly represented by the material that crystallized earliest. Solidification would take place first in dikes, then in the apices, the peripheral parts, and the minor projections of the magma chamber. In the central and lower parts of the chamber the magma would long remain liquid and subject to differentiation by the sinking of crystals of the ferromagnesium minerais and calcic feldspar, which begin to solidify early and are much heavier than the inclosing magma. The magma would thus become progressively more siliceous and alkaline and poorer in iron, magnesia, and lime.

Of two entirely separate intrusive bodies that were similar in composition, depth, and extent of truncation, the larger would have remained liquid longest and its basic crystals would have settled in greater quantity; the portion of it likely to be exposed by erosion would be more siliceous than the corresponding portion of the smaller stock. Again, of two wholly similar bodies whose walls diverged downward, as appears to be usual, the one most deeply eroded would appear to be both larger and more siliceous than the other.

The settling basic crystals should of course accumulate in depth, and would possibly be re-fused to form a basic magma.

The facts of observation harmonize with this hypothesis. The rocks of the dikes and small bodies are generally more basic than the main bodies with which they are connected, and of separate bodies belonging to a single group the larger are in general the more siliceous. No large bodies of basic rock have been found, but this may be because erosion has not reached them; the hypothetical deeplying magma may be represented by the basic dikes that are associated with many of the stocks.

The differences of composition observed in the stocks are believed to be due in greater measure to differentiation, probably by the settling of basic crystals, than to assimilation, because comparatively little direct evidence of 
assimilation has been observed and because the differentiation hypothesis explains the facts more fully.

The bearing of differentiation in igneous bodies, on the deposition of ores is discussed on page 198.

\section{RELATIONS OF EXTRUSIVE AND INTRUSIVE ROCKS.}

The relation of the intrusive and extrusive rocks is not everywhere clear. In some areas extrusion was followed by intrusion, in others intrusion appears to have come first, and in still others the two appear to have been essentially contemporaneous.

Boutwell and Woolsey consider that the extrusion of the large body of andesite occupying the depression between the Wasatch and Uinta ranges was later than the intrusions of the Wasatch Range. The evidence, however, is not entirely conclusive, and that these authors consider that the two were essentially contemporaneous is indicated by their description of the Clayton Peak intrusive body, as follows: ${ }^{1}$

In like manner the attitude of the Clayton Peak intrusive mass and of the porphyrites in the sediments suggests entrance from the west and progressive movement eastward until the climax was attained in the extensive extrusions of andesite between the Wasatch and Uinta ranges.

The chemical relation of the andesite to the intrusive bodies, as shown in figure 8 , seems to support this idea.

In the Bingham district the extrusive rocks are probably the later, ${ }^{2}$ but the opportunities for observing the relations are very meager. In the Tintic district ${ }^{3}$ the main intrusive bodies are later than the rhyolite and the earlier andesite and are contemporaneous with the latest latites and andesites. In the Tushar Range the intrusive rocks are later than a part of the extrusives. Basalts, however, are latest of all, and some of the rhyolite may be later than the intrusive rock. In the Mineral Range the relations have not been determined, but

1 Boutwell, J. M., and Woolsey, L. H., Geology and ore deposits of the Park City district, Utah: U. S. Geol. Survey Prof. Paper 77, p. 67, 1912.

${ }^{2}$ Boutwell, J. M., Economic geology of the Bingham mining district;

Utah: U. S. Geol. Survey Prof. Paper 38, p. 56, 1905.

3 Tower, G. W., and Smith, G. O., Geology and mining industry of the Tintic district, Utah: U. S. Geol. Survey Ninteenth Ann. Rept.,

pt. 3, p. 657, 1899. Also Lindgren, Waldemar, and Loughlin, G. F., Geology and ore deposits of the Tintic mining district: U. S. Geol. Survey Prof. Paper 107, p. 75, 1919 farther west in the Rocky, Beaver Lake, and San Francisco ranges the main intrusive bodies are believed to be later than most of the extrusives. In the Iron Springs district Leith and Harder consider that the intrusive rocks are earlier than the extrusive ones, but (see p. 571) it seems possible to interpret the relations to mean the opposite. Farther west in Utah the intrusive and extrusive rocks have but rarely been observed in contact and their relation has nowhere been definitely determined.

It thus seems very probable that most of the igneous rocks represent one long general epoch of igneous activity, during which both intrusion and extrusion occurred. Whether this applies to the igneous rocks near the western border of the State is not known.

AGE OF IGNEOUS ROCKS.

The principal volcanic areas of Utah lie almost midway between the Pacific coast region, in which the intrusive rocks are of late Jurassic or early Cretaceous age, and the Rocky Mountain area, in which the monzonitic and allied intrusives are of Tertiary age.

Workers in Nevada have generally considered the large intrusive bodies to be of the same age as those of the Sierra Nevada region, namely, late Jurassic or early Cretaceous. The intrusive bodies of the Plateau region and several of those of the eastern part of the Great Basin region in Utah are with considerable assurance assigned to the Tertiary, and may be correlated with the intrusives of the Rocky Mountain region rather than with those of the coast region. In western Utah, where sedimentary formations later than Carboniferous are absent, there are usually no definite data for determining whether the intrusive rocks should be correlated in age with the rocks on the east or with those on the west.

The time of volcanic activity in the State is perhaps most definitely determined for the High Plateau region. Of this Dutton says: ${ }^{4}$

The oldest eruptions go back to middle Eocene; the latest can not be as old as the Christian era. It is hard to believe that they are as old as the conquest of Mexico by Cortez. Between the opening and cessation of that activity (if, indeed, it has even yet ceased forever) the eruptions have been intermittent.

1 Dutton, C. E., Report on the geology of the high plateaus of Utah, p. 55, U. S. Geog. and Geol. Survey Rocky Mtn. Region, 1830 . 
There is little doubt that the extensive fields of lava extending westward from the High Plateau into Nevada are essentially contemporaneous with those of the plateaus, and the flows in other parts of the State are probably also of essentially the same age, though the evidence is less conclusive. Several of the intrusive bodies of the State are contemporaneous with the flows (see p. 99), and it is believed that this is true for all those lying along the eastern margin of the Great Basin. Whether it is true of the intrusive bodies near the western border of the State is not known.

Volcanic activity, therefore, apparently broke out in early Tertiary time, and both extrusion and intrusion continued through middle and late Tertiary into recent time, the latest basaltic eruptions having taken place only a few hundred years ago.

\section{STRUCTURE.}

Archean rocks are exposed in only relatively small areas, and data are not available for the discussion of their complex structural history. The following description of the structure is, therefore, confined to rocks younger than $\mathrm{Ar}$ chean. The positions and relations of the major structural features are shown in Plate XI.

FOLDS.

Folding, though less conspicuous than faulting in most parts of Utah, is yet of importance. It appears to be greatest in a north-south zone that extends across the State, along the boundary of the Basin and Plateau provinces. In this zone the pre-Tertiary rocks have been thrown into a series of folds, most of which strike north-south but some of which strike from nearly northwest-southeast to considerably east of north.

In southeastern Idaho ${ }^{1}$ and southwestern Wyoming, ${ }^{2}$ in the northern continuation of this belt, the folds are close, in many places overturned, and are associated with extensive thrust faulting. To the south the folds are more open and the thrust faulting is less important, and south of the southern Wasatch both folds and faults have largely died out, though open folding is recognized much

1 Richards, R. W., and Mansfield, G. R., The Bannock overthrust; a major fault in southeastern Idaho and northeastern Utah: Jour. Geology, vol. 20, p. 704, 1912.

2 Veatch, A. C., Geography and geology of a portion o southwestern Wyoming: U. S. Geol. Survey Prof. Paper 56, p. 108, 1907. farther to the south. It is probable that the folds that antedate the Tertiary rocks of the High Plateau ${ }^{3}$ were produced at the same time as these folds. In the southern part of the State, over a width of several miles, from St. George nearly to Cedar City, a series of north-south open anticlines and synclines, with local overturning of the folds, ${ }^{4}$ is conspicuous.

\section{DOMICAL UPLIFTS.}

Broad uplifts consisting of an anticlinal folding or doming of the rocks are of prime importance in Utah. These uplifts may be separated into those that show a distinct trend and those that show no marked trend. Among those with a distinct trend are the great eastwest Uinta uplift and its westward extension through the Wasatch and Oquirrh ranges, the similar but lesser uplift of the Raft River Range in the northwestern part of the State, and the less clearly defined east-west uplift in the latitude of the Tintic and Deep Creek ranges, in which pre-Cambrian rocks have been raised above the present erosion surface in numerous localities, though not exposed in the adjacent regions either to the north or south. (See Pl. XI.) This structure apparently flattens out before reaching the Tintic Range. Farther south a similar structural feature extends across the Tushar, Mineral, Star, San Francisco, and Wah Wah ranges, and still farther south a series of domical uplifts, associated with intrusions, extends northeast and southwest through the Iron SpringsBull Valley region.

In the southeastern part of the State the San Rafael Swell, Henry Mountains, Abajo Mountains, and Navajo Mountain show less definite trends. The La Sal Mountains, however, form the central portion of a series of northwest-southeast folds several miles long. The Water Pocket flexure consists of an unsymmetrical uplift, of which the eastern limb dips steeply and the western limb gently, and along which the Circle Cliff (Burr Flats) and Miners Mountain swells are subsidiary domes. The great Monument Valley uplift east of Colorado River trends distinctly west of south from the region of the Abajo Mountains into Arizona,

${ }^{3}$ Dutton, C. E., Geology of the high plateaus of Utah, p. 44, U. S. Geog. and Geol. Survey Rocky Mtn. Region, 1880.

4 The Hurricane fault in the Toquerville district, Utah: Harvard Coll. Mus. Comp. Zool. Bull., vol. 42, p. 233, 1914. 


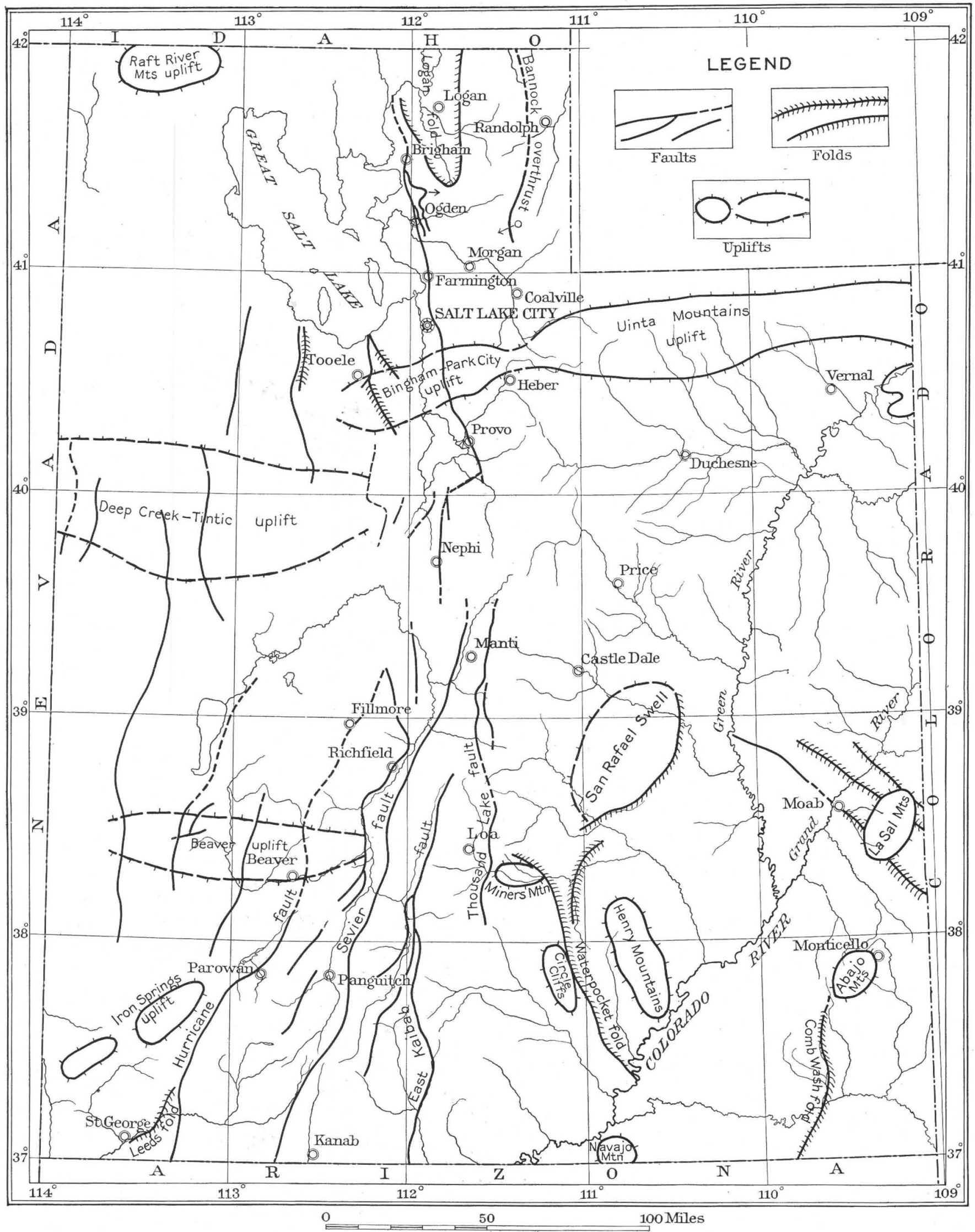

POSITION AND RELATION OF MAJOR STRUCTURAL FEATURES OF UTAH. 


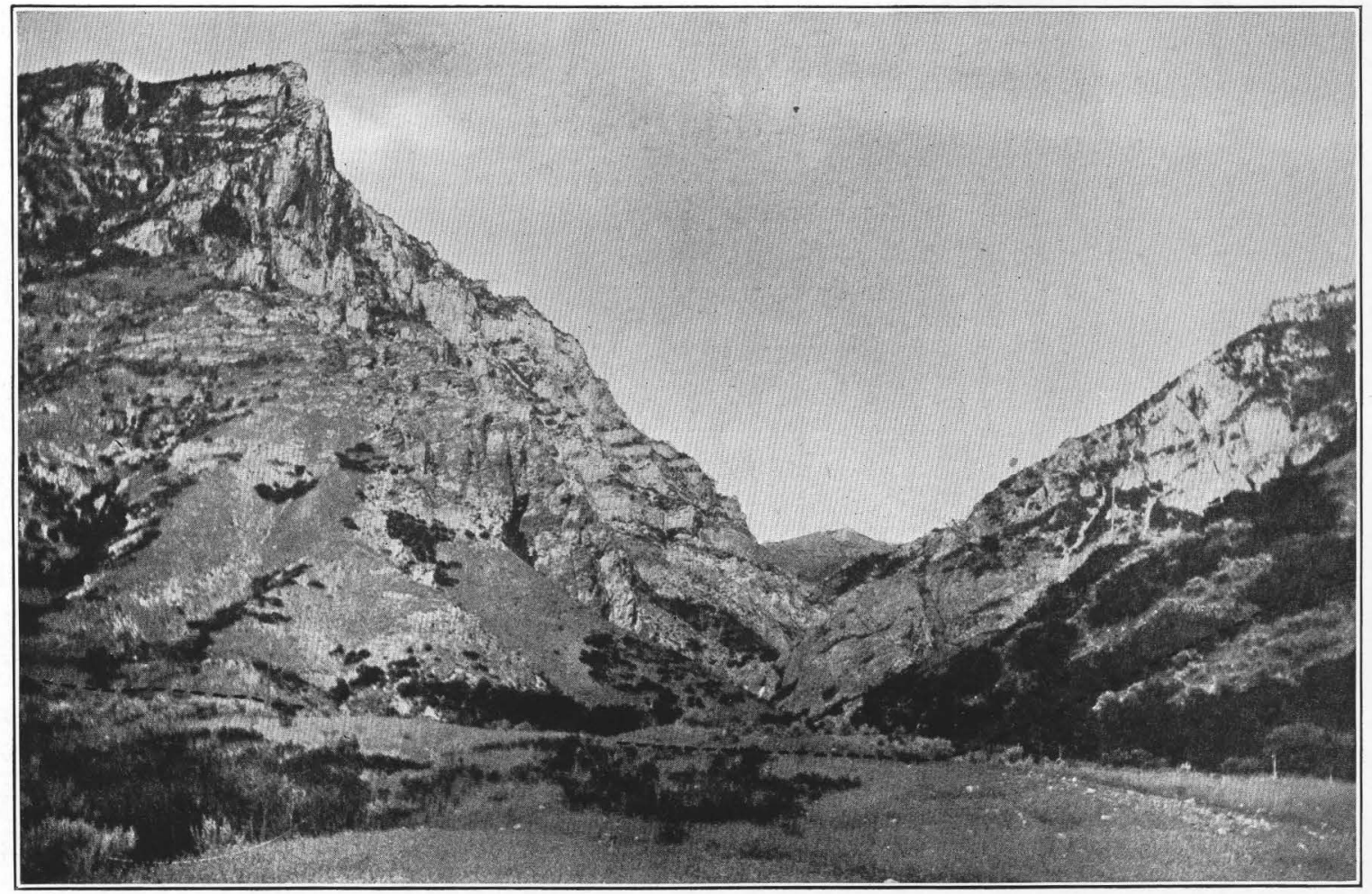

A. RECENT FAULT ALONG WASATCH MOUNTAIN FRONT NEAR PROVO.

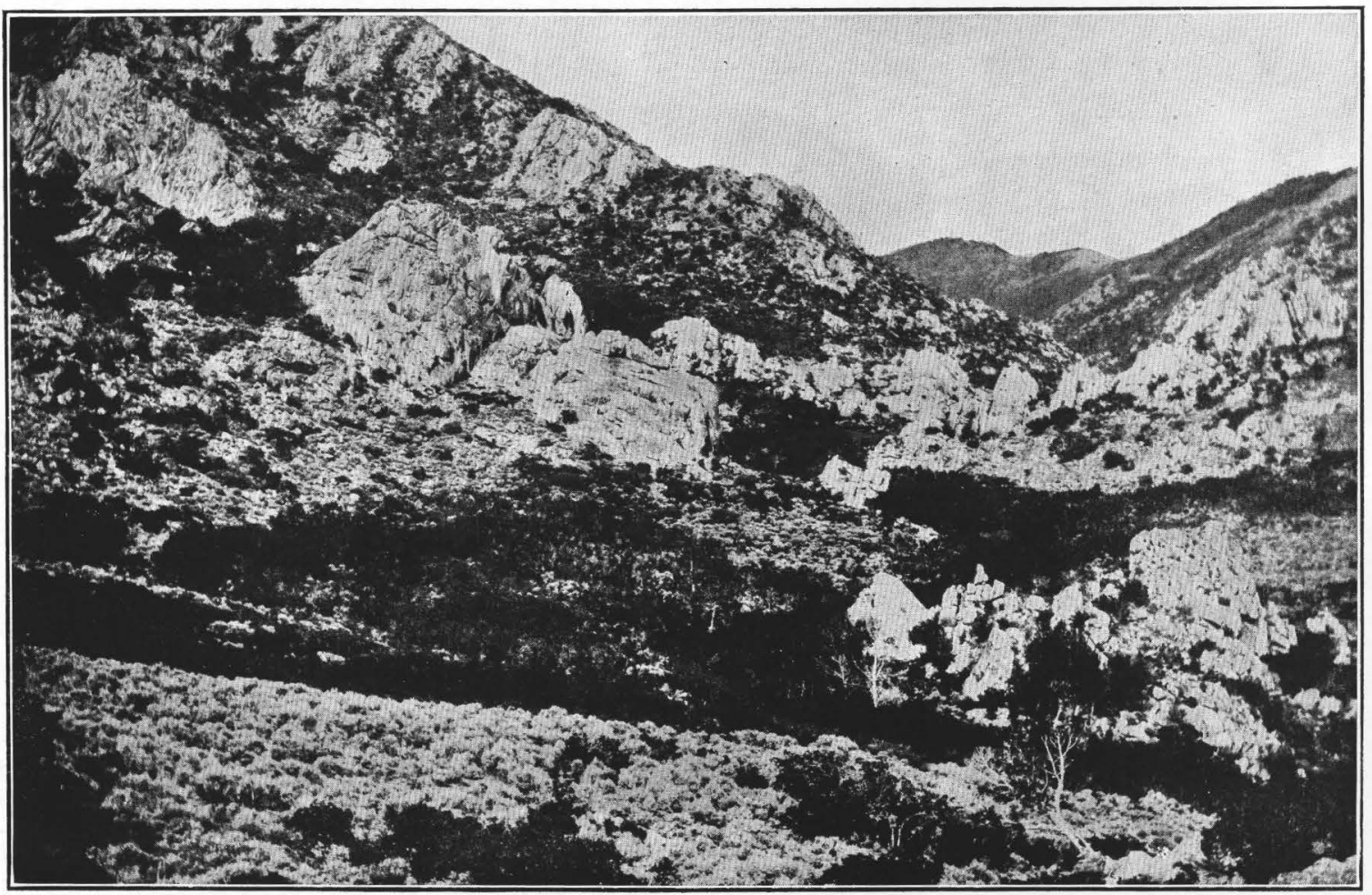

B. HANGING VALLEY IN SHEEP ROCK RANGE, PROBABLY FORMED BY RECENT FAULTING. 
and the Henry Mountains group trends distinctly southeast. The San Rafael Swell is less definite, though the sharp eastern flexure, its most conspicuous structural feature, trends northeasterly, as does also the general elongation of the swell.

In the western part of the State faulted domes that are in many respects similar to

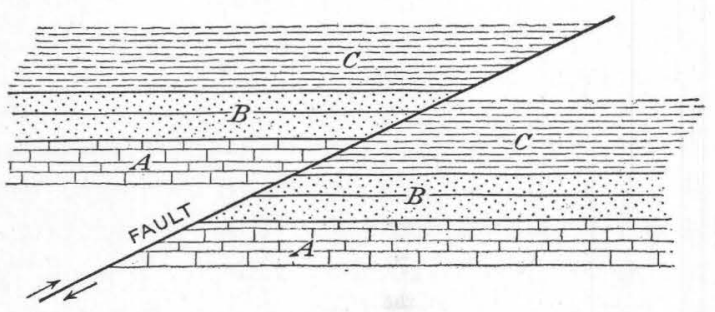

FIGURE 9.-Relation of the rocks on opposite sides of a reverse fault.

the smaller domes of eastern Utah are present at Ophir, in the Oquirrh Range, and near the American Fork Canyon, in the Wasatch Range.

\section{FAULTS.}

Faults are important, both in their relation to large topographic features and to metalliferous and other mineral deposits.

For convenience in description they may be separated into reverse or overthrust faults, which resulted from compression that broke the rocks and pushed one portion over the other (fig. 9), and normal faults, which resulted from areal extension that broke the rocks and allowed one portion to slip down past the other (fig. 10). Reverse and normal faults are commonly if not invariably of different ages.

REVERSE AND OVERTHRUST FAULTS.

The reverse and overthrust faults are largely confined to the areas of rather close folding and to areas adjacent to igneous intrusions. Like the close folds they are most abundant north of Utah in Idaho and Wyoming but extend southward into Utah. One has been traced for many miles nearly due south from Bear Lake, and others have been recognized in the Wasatch Range, notably between Willard and Ogden, in the Cottonwood-Park City region, in the West Butte mining district, and as far south as Mount Nebo. Little detailed geologic work has been done in the Wasatch Range and there is little doubt that overthrust faults are more abundant there than is at present known.
Locally reverse or overthrust faulting has resulted from the pushing aside of earlier rocks to make room for the stocks. Such faulting has been recognized in the Park City and Little Cottonwood districts and is probablypresent in other localities.

\section{NORMAL FAULTS.}

Normal faults are very abundant in Utah and many of them are remarkable for the scores and'even hundreds of miles that they can be traced and for their great vertical displacement. (See Pl. XI.) Many if not all of the ranges of western Utah are believed to be outlined by them, and farther east they are strongly marked by such physiographic features as the great Hurricane scarp.

In general, displacement has apparently been less in the eastern than in the western part of the State. In the faults associated with the Basin Ranges it is commonly large; in the Plateau region it is far less noticeable, some folds passing into monoclinal flexures, the displacement not having been sufficient to cause actual rupture. In some places this failure to break may have been due to the character of the rock, for shales are far more prevalent in the Plateau region, but there can be little

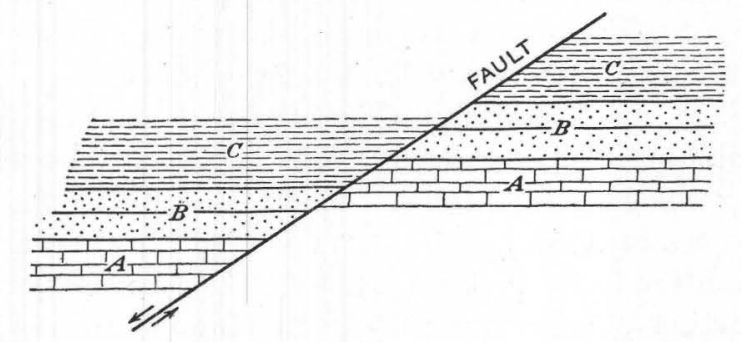

Figure 10.-Relation of the rocks on opposite sides of a normal fault.

doubt that the displacement in general decreases toward the east.

TREND.

Most of the faults trend generally south (see Pl. XI) but finally swing westward, paralleling the boundary between the Plateau and Basin provinces, which, indeed, is mainly determined by faults.

In the western part of the Plateau province the faults converge toward the north and diverge toward the south. Dutton ${ }^{1}$ has called attention to this convergence, stating that "several of the grander faults at length become 
merged into one vast monoclinal flexure, forming the western flank of the Wasatch Plateau." It seems not improbable that the great displacement represented by the Wasatch fault to the north is distributed among several faults farther to the south.

East-west normal faulting is far less conspicuous than north-south faulting but is important, especially in the Basin province. Where these east-west faults cross the ranges they show large displacements, as in the San Francisco Range, where a thick series of lavas are thrown against early Paleozoic sediments, the relatively depressed block being to the south. A similar relation exists in the Mineral Range. Detailed work in the Basin Ranges of Utah will doubtless show the east-west faults to be rather abundant.

RELATIONS OF THE DIFFERENT STRUCTURAL TYPES.

The relations of the different structural types are not everywhere clear, but viewed as a whole the sequence of events appears to be rather definite.

The north-south folds are with little doubt the earlier and are contemporaneous with the overthrust faulting, both having resulted from the forces tending to compress the area in an east-west direction. East-west uplifts like the Uinta uplift are younger than the north-south folding and overthrust faulting, as is shown by the fact that these structures are affected where crossed by the extension of the Uinta uplift in the Wasatch Range. East-west uplifts farther south than the Uinta Range are less conspicuously connected with the north-south folds, but in the San Francisco Range at least the evidence shows that they are the younger.

The relation of the domical uplifts in southeastern Utah to the east-west uplifts farther west has not been established. Both, however, were connected with igneous activity, which gives some reason for supposing that they were essentially contemporaneous.

That the normal faults are the latest important structuralfeature of the region is repeatedly shown by their cutting across the other structures. Thus many faults outlining the Basin Ranges cut across the folds in those ranges. The great Wasatch fault crosses the westward extension of the Uinta uplift, and other faults, notably those of the Mineral and San Francisco ranges, cross the Tushar-San Francisco uplift.

All normal faults are not of the same age, and not a few of them have been the locus of repeated movements. Normal faulting began some time after the folding and east-west uplifts and is probably still in progress along some of the faults.

GeOlogic AGE OF STRUCtural FEATURES.

The geologic age of many of the structural features is difficult to ascertain, owing to the absence over a large part of the region of the later sedimentary rocks. This is especially true in the Great Basin region in Utah where, for the most part, there are no well-exposed sedimentary formations between Paleozoic and Recent,

That changes in the level of the land were frequent throughout Paleozoic time is indicated by different thicknesses of the formations, showing deposition, nondeposition, and erosion. The slightness of the angular unconformities in the sedimentary rocks throughout the Paleozoic and Mesozoic in Utah suggests that the changes that occurred through these eras, especially in the central part of the State, were in the nature of low domings and did not involve important folding or faulting. The north-south folds and overthrust faults involved Cretaceous and probably early Tertiary rocks and are believed to have been formed in post-Cretaceous or early Tertiary time. In Utah the early Tertiary rocks are apparently less intensely folded than the Cretaceous. In most of the Basin Ranges the Mesozoic sediments are absent, and it is therefore impossible by direct evidence to determine the age of the folding closer than post-Carboniferous. It is possible, therefore, that some of the folding occurred at the time of the uplift at the close of the Carboniferous or that the great post-Jurassic upheaval along the Pacific coast affected the rock as far east as Utah and that some of the folding is to be ascribed to that period. However this may be, all the folds whose age can be rather definitely determined were formed during the post-Cretaceous uplift, and there is no recognized evidence that the folds whose age has not been determined were not 
of the same period. Ransome ${ }^{1}$ has reviewed the evidence of this folding, and concerning the much discussed question of its age he says:

Toward the close of Cretaceous time, the oscillations recorded in the character of the Laramie sediments indicate the approach of diastrophic conditions. In the northern section of the Rocky Mountain region, the principal deformation appears to have taken place at the close of the Fort Union; along the eastern side of the Front Range in Colorado the decisive movement has been interpreted as having taken place at the close of the Laramie and before the deposition of the Arapahoe beds. At the south end of the Rocky Mountains strong unconformities have been described both above and below the Nacimiento group, which means that notable deformation and erosion occurred at the close of the Cretaceous and again just before the deposition of the Wasatch Eocene. In the northwestern part of the Park Range Province, there was uplift and vigorous erosion at the close of the Cretaceous and renewed uplift after the deposition of the Wasatch and Green River beds.

Apparently the movements of the Laramide revolution were not of the same intensity in all parts of the Laramide system at the same time, and the accurate correlation of these movements is still a work for the future requiring much more detailed and comprehensive study than has yet been given to this problem. It is clearly not safe to assume that an unconformity observed in any one locality in this vast province is indicative of movement provincial in its extent.

The boundary between the Basin and Plateau provinces in general also marks the boundary between the Cretaceous areas of erosion and sedimentation, and it is perhaps significant that the most folding and thrust faulting occurred in this zone.

The age of domical uplifts later than the folds is not very closely ascertained, and indeed they may not all have occurred at the same time. They were evidently closely associated with the igneous activity of the region, which has probably been in progress from early Tertiary to Recent time.

The intrusions of the Park City and Little Cottonwood districts are believed by Boutwell to have occurred in early Tertiary, and the Uinta uplift is probably contemporaneous with these. Some of the intrusions farther south with which the uplifts are associated are notably younger, for they cut lavas believed to be at least as late as middle Tertiary.

The age of the domical uplifts in the southeastern part of the State is not easy to determine closely. They are post-Cretaceous, and

\footnotetext{
1 Ransome, F. L., The Tertiary orogeny of the North American Cordillera and its problems: Problems of American geology, pp. 360-361, 1915.
}

most investigators have regarded them as probably early to middle Tertiary, though the evidence for fixing the date closer than postCretaceous is very meager.

Normal faulting has continued over a long period and the time of its beginning is uncertain. It has been important, in very recent time, as is shown by Gilbert ${ }^{2}$ for the Wasatch Range, and is suggested by hanging valleys in the Sheeprock Range. (See Pl. XII.) It is also indicated for some of the ranges of southern Utah by recent earthquakes, notably by that of November, 1901, which affected the area along the border of the Plateau and Basin Range provinces in southern Utah. The Weather Bureau says of this earthquake: "On the night of November 13 (1901), Utah experienced the most severe earthquake that has occurred since its settlement. The area affected by this disturbance can be inclosed by a triangle of which the southern boundary of the State is the base and Salt Lake City the apex. The shock was quite severe over an area comprising Sevier, Wayne, Garfield, and the eastern portion of Juab, Millard, and Beaver counties." The evidence is convincing that normal faulting took place in Recent and late Tertiary time, though at what time in the Tertiary it began is unknown.

ORIGIN OF THE STRUCTURAL FEATURES.

\section{NORTH-SOUTH FOLDS AND OVERTHRUST FAULTS.}

That the north-south folds and overthrust faults were produced by pressure from the west that tended to compress the region is indicated by the attitude of the folds and the direction of most of the overthrusts. Ransome,${ }^{3}$ who has recently discussed the hypotheses offered in explanation of Cordilleran Mountain structure, says:

It has been a rather widely held tenet among geologists that most of the great mountain ranges of the globe have been formed by thrust from the nearest ocean basin, the classic example being the Appalachians. It has also been believed by many that the Laramide system is essentially Pacific in origin and that the deformation which gave it birth was the consequence of interaction between the Pacific Basin and the continental margin. Daly, as previously noted, maintains this view, which was also that of G. M. Dawson. * * * Keeping fully in mind the speculative and tentative nature of the suggestion, we may suppose that in Cretaceous time the Cordilleran

2 Gilbert, G. K., Lake Bonneville: U. S. Geol. Survey Mon. 1, 1890.

3 Op. cit., p. 364 . 
land mass was rising and was being eroded. In accordance with the general principles enunciated by Suess and Chamberlin, the rising mass probably had a tendency to spread laterally, particularly to the east where sediments had previously accumulated to enormous thickness in the Laramide trough, derived doubtless from older land masses which occupied in part the position of the Cretaceous land. For a time, as Chamberlin ${ }^{1}$ has pointed out, the effect of this creep of the protuberant mass would be to favor sedimentation by pushing the sea shelf outward and slightly downward. As uplift of the land mass and sedimentation of the adjoining area continued resistance to lateral spread would diminish. Erosion, by cutting down the land, would tend to delay the final diastrophic event; but deposition, the complement of erosion, would tend to hasten it. Finally, if the forces causing the uplift of the land area were relaxed, by just so much as the underlying support of the protuberant arch was lessened would thrusting stresses accumulate along the borders of the land mass. Relief of these presumably would be accomplished by a thrusting forward of the land mass against the sediments to the east, the crumpling of these into folds, and their further deformation by thrust faulting. This diastrophic revolution it is to be expected would be followed by collapse and down-sinking of the imperfectly supported Cretaceous continent and by normal faulting behind the overthrusts.

Many of the domical structures, as already indicated, are visibly closely associated with bodies of intrusive rocks, and such an association is probable in others where the intrusive bodies are not exposed. It is not everywhere entirely clear, however, whether the domes were the result of the forcible injection of material with a consequent raising of the overlying rocks or to some other cause which relieved the pressure and permitted the igneous material to enter. The Henry Mountains seem to offer no escape from the conolusion that their injected material was under sufficient pressure to lift the overlying sediments, as has been pointed out by Gilbert. The La Sal Mountains, however, though in most respects similar to the Henry Mountains, are near the center of a series of northwestsoutheast folds (see Pl. XI, p. 100), which suggest lateral compression and may have been a factor in the intrusion, though there can be little doubt that the intrusive force was very great. Likewise in the east-west zones of uplift and intrusion it is possible that the uplift may have been primarily due to pressure at right angles to the trend, and that the starting of the uplift may have determined the location of the intrusive bodies. The Uinta uplift (except in the western extension) shows no surface evidence

1 Chamberlin, T. C., Diastrophism and deformative processes: Jour. Geology, vol. 21, p. 585, 1913. of igneous forces. Its general character, however, is rather strikingly similar to that of the Raft River Range, where the uplift was very evidently associated with igneous activity.

The stocks, like the laccolithic bodies, offer abundant evidence that the material forming them was under pressure sufficient to cause local doming and overthrust or reverse faulting. The discussion of the ultimate cause of this injection force would lead far into the field of speculation, but it is at least reasonably certain that at the time of the domical uplifts and intrusion certain forces were tending to raise the region.

\section{NORMAL FAULTS.}

Two explanations for the normal faults have been offered. One, advanced first by Gilbert $^{2}$ and adopted by numerous other writers, supposes that the region was broken into a series of blocks by vertical pressure from below. Gilbert considers that this might be brought about by a deep-seated force that would fold the deeply buried rocks and fault those near the surface.

The other explanation, advanced first by Le Conte ${ }^{3}$ and also adopted by others, supposes that the faulting has resulted from a settling and collapse of the region, which caused it to break into blocks that settled irregularly. Le Conte supposes that the region was raised by volcanic forces and that when this upward pressure was relieved by the extrusion of vast amounts of lava, the weight of which was added to the overlying portion, subsidence of the whole region occurred. Ransome, ${ }^{4}$ who has recently reviewed the evidence on this subject, agrees with Le Conte that the structures were produced by a collapse of the region rather than an elevation, but sees no reason for supposing that any elevation by voleanic forces preceded the collapse. The writer, in accounting for the structure in the San Francisco region, ${ }^{5}$ bases an explanation similar to that of Le Conte on the effect of intrusions and extrusions which apparently accompanied the east-west uplift

${ }^{2}$ Report on the geology of portions of Nevada, Utah, California, and Arizona: U. S. Geog. and Geol. Surveys W. 100th Mer. Rept., vol. 3, pt. 1, p. $60,1875$.

${ }^{3}$ Le Conte, Joseph, On the origin of normal faults and of the structure of the Basin region: Am. Jour. Sci., 3d ser., vol. 38, pp. 257-263, 1889.

4 Ransome, F. L., op. cit., p. 343.

5 Butler, B. S., Geology and ore deposits of the San Francisco and adjacent districts, Utah: U. S. Geol. Survey Prof. Paper 80, p. 27, 1913. 
shortly before the faulting. The smaller uplifts (domes) may well have been formed after the forces that had raised the general region had reached a maximum, and the breaking through of the igneous material into the upper strata and out to the surface had inaugurated a collapse.

That the normal faulting was a result of the settling of the region seems the most rational explanation. Similar structural relations may be observed on a pond where the water has drained from beneath a sheet of ice. In settling, the ice sheet forms monoclinal folds which pass into faults, faults of small displacement come together in faults of greater displacement, and where settling is pronounced a structure comparable to that of the Basin Ranges may develop.

It has been generally recognized by workers in the Basin Range and Plateau provinces that the structures of the two areas grade into one another and have a common origin. It is reasonable to suppose that the Basin Ranges represent the more intense action of the same character of forces that have produced the Plateau structure. If this be supposed to be a settling of an uplifted area, the settling in the Basin province has been much more pronounced than that in the Plateau province, a conclusion which is in accord with the stratigraphic evidence.

\section{MINERALOGY. MINERAL SPECIES}

The large number of metals and the variety in the character of the ore deposits of Utah have resulted in the presence of many mineral species. Most of the metals occur both in minerals like the sulphides and arsenides, in which they were originally deposited, and in minerals like the sulphates and carbonates, formed by the oxidation of the primary minerals.

In the discussion of the minerals the arrangement in Dana's "System of mineralogy" is followed, but an alphabetic list is given below for convenient reference.

Minerals associated with the metal deposits of Utah.

\begin{tabular}{|c|c|c|c|}
\hline $\begin{array}{l}\text { Actinolite (amphibole } \\
\text { Adamite. } \\
\text { Alunite. } \\
\text { Amphibole. } \\
\text { Andalusite. } \\
\text { Andradite (garnet). } \\
\text { Anglesite. } \\
\text { Anhydrite. } \\
\text { Ankerite. } \\
\text { Annabergite. } \\
\text { Apatite. } \\
\text { Aragonite. } \\
\text { Argentite. } \\
\text { Arsenobismite. } \\
\text { Arsenopyrite. } \\
\text { Aurichalcite. } \\
\text { Autunite. } \\
\text { Axinite. } \\
\text { Azurite. } \\
\text { Barite. } \\
\text { Beaverite. } \\
\text { Beryl. } \\
\text { Beudendite. } \\
\text { Bindheimite. } \\
\text { Biotite. } \\
\text { Bismite. } \\
\text { Bismuth. } \\
\text { Bismuthinite. } \\
\text { Bismutite } \\
\text { Bixbyite. } \\
\text { Borickite. } \\
\text { Bornite. } \\
\text { Bournonite. }\end{array}$ & $\begin{array}{l}\text { Brochantite. } \\
\text { Brucite. } \\
\text { Calamine. } \\
\text { Calcite. } \\
\text { Carnotite. } \\
\text { Celestite. } \\
\text { Cerargyrite. } \\
\text { Cerusite. } \\
\text { Chabazite. } \\
\text { Chalcanthite. } \\
\text { Chalcedony. } \\
\text { Chalcocite. } \\
\text { Chalcophyllite. } \\
\text { Chalcopyrite. } \\
\text { Chenevixite. } \\
\text { Chlorite. } \\
\text { Chrome garnet (uvarovite). } \\
\text { Chromite. } \\
\text { Chrysocolla. } \\
\text { Cinnabar. } \\
\text { Clinoclasite. } \\
\text { Conichalcite. } \\
\text { Connellite. } \\
\text { Copper. } \\
\text { "Copper pitch ore." } \\
\text { Corkite. } \\
\text { Cosalite. } \\
\text { Cotunnite. } \\
\text { Covellite. } \\
\text { Crandallite. } \\
\text { Cuprite. } \\
\text { Cuprosheelite. } \\
\text { Danburite. }\end{array}$ & $\begin{array}{l}\text { Daubreeite. } \\
\text { Descloizite. } \\
\text { Diaspore. } \\
\text { Diopside (pyroxene). } \\
\text { Dolomite. } \\
\text { Dufrenoysite. } \\
\text { Embolite. } \\
\text { Enargite. } \\
\text { Enstatite (pyroxene). } \\
\text { Epidote. } \\
\text { Erinite. } \\
\text { Famatinite. } \\
\text { Fluorite. } \\
\text { Galena. } \\
\text { Garnet. } \\
\text { Geocronite. } \\
\text { Goethite. } \\
\text { Gold. } \\
\text { Goslarite. } \\
\text { Greenockite. } \\
\text { Gypsum. } \\
\text { Hematite. } \\
\text { Heulandite. } \\
\text { Hornblende (amphibole). } \\
\text { Hydrozincite. } \\
\text { Ilmenite. } \\
\text { Jamesonite. } \\
\text { Jarosite. } \\
\text { Kaolinite. } \\
\text { Kermesite. } \\
\text { Lead oxychloride(unnamed). } \\
\text { Laumontite. } \\
\text { Leadhillite. }\end{array}$ & $\begin{array}{l}\text { Lettsomite. } \\
\text { Leverrierite (racewinite) } \\
\text { Limonite. } \\
\text { Linarite. } \\
\text { Ludwigite. } \\
\text { Magnesite. } \\
\text { Magnesolugwigite. } \\
\text { Magnetite. } \\
\text { Malachite. } \\
\text { Malanterite. } \\
\text { Manganite. } \\
\text { Marcasite. } \\
\text { Massicot. } \\
\text { Melaconite. } \\
\text { Mercury. } \\
\text { Mica. } \\
\text { Mimetite. } \\
\text { Minium. } \\
\text { Mixite. } \\
\text { Molybdenite. } \\
\text { Molybdite. } \\
\text { Monticellite. } \\
\text { Muscovite (white mica). } \\
\text { Octahedrite. } \\
\text { Olivenite. } \\
\text { Onofrite. } \\
\text { Opal. } \\
\text { Orpiment. } \\
\text { Orthoclase. } \\
\text { Pearceite. } \\
\text { Periclase. } \\
\text { Pharmacosiderite. }\end{array}$ \\
\hline
\end{tabular}


Minerals associated with the metal deposits of Utah-Continued.

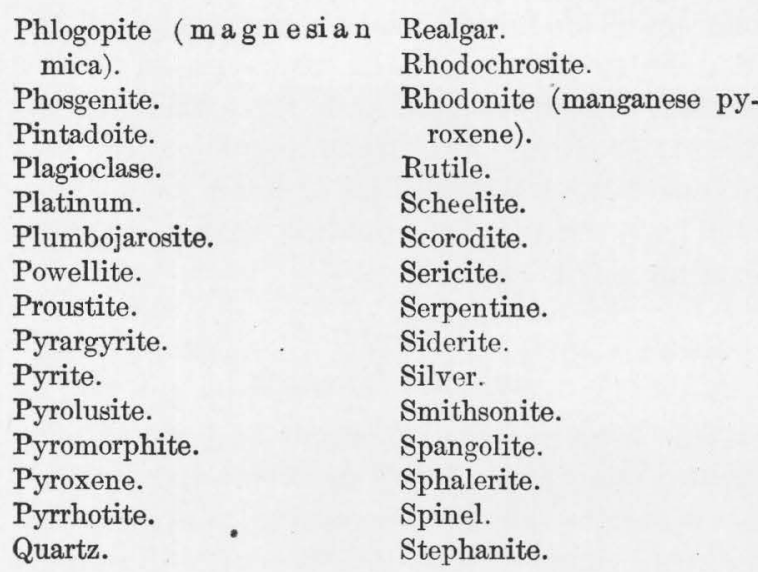

NATIVE ELEMENTS .

Sulphur.-Sulphur has been recognized in the oxidized ores in the San Francisco and Star districts and in small amounts in the ores of the Tintic and Santaquin districts. It also occurs at several localities where it is not associated with metal deposits, notably in eastern Beaver County, ${ }^{1}$ in San Rafael Canyon, on the east side of San Rafael Swell, ${ }^{2}$ near Virgin River south of Toquerville, and at other localities.

Bismuth.-Native bismuth occurs in the Clifton and Tintic districts and is reported from the Detroit district. It probably occurs in other districts where bismuth minerals are present.

Gold.-Gold has been recovered from placers in Bingham Canyon on Green, Colorado, and San Juan rivers, around the La Sal and Henry mountains, and to a slight extent at other localities. It occurs more or less in most of the lode deposits of the State and is the most important constituent in those of the Mercur, Park Valley, and Spring Creek districts, and in some of the deposits of the Tushar Range, Gold Springs, State Line, and Clifton districts.

Silver.-Native silver is probably present in small amounts in the oxidized ores at numerous localities but is rarely of much commercial importance. It is reported in considerable amount in some of the ores of the Silver Reef district, and it has been recognized in ores from the Star and Tintic districts.

Copper.-Native copper, like silver, is probably present in small amounts at numerous

1 Lee, W. T., The Cove Creek sulphur beds, Utah: U. S. Geol. Survey Bull.315, pp. 485-489, 1907.

2 Hess, F. L., A sulphur deposit in San Rafael Canyon, Utah: U. S. Geol. Survey Bull. 530, pp. 347-349, 1913.
Stibnite. Tyuyamunite.

Stolzite. Uranospinite.

Sulphur. Utahite.

Sylvanite. Uvanite.

Talc. Uvarovite (chrome garnet).

Tennantite. Vanadinite.

Tenorite. Variscite.

Tetrahedrite. Vesuvianite.

Thaumasite. Volborthite.

Tiemannite. Willemite.

Titanite. Wollastonite (pyroxene)

Topaz.

Tourmaline. Wurtzite.

Tremolite (amphibole). Zeunerite.

Tungstenite. Zircon.

Tyrolite. Zoisite.

localities, but nowhere has it been of large commercial importance. It has been noted from the San Francisco, Star, Beaver Lake, Tintic, Morgan, and Lucin districts.

Mercury.-Native mercury is reported from several mines in the Gold Springs district.

Platinum.- Native platinum has been noted in the Colorado and Green river placers. Platinum is present in the copper ores of the Bingham and probably of other districts, but whether it occurs native or in combination is not known.

SULPHIDES, SELENIDES, TELLURIDES, ARSENIDES, AND ANTIMONIDES.

Realgar.-Realgar, arsenic monosulphide, AsS (sulphur, 29.9 per cent; arsenic, 70.1 per cent), has been observed in the Mercur and Bull Valley districts and is probably present at other localities.

Orpiment.-Orpiment, , arsenic trisulphide, $\mathrm{As}_{2} \mathrm{~S}_{3}$ (sulphur, 39 per cent; arsenic, 61 per cent), occurs in the same localities as realgar.

Stibnite.-The largest deposits of stibnite, antimony trisulphide, $\mathrm{Sb}_{2} \mathrm{~S}_{3}$. (sulphur, 28.6 per cent; antimony, 71.4 per cent), that have been developed are those at Antimony, Coyote Creek, Garfield County. Small deposits have been found in the Bull Valley district and small amounts of the mineral noted in the ores of the Mercur and other districts.

Bismuthinite.-Bismuthinite, bismuth trisulphide, $\mathrm{Bi}_{2} \mathrm{~S}_{3}$ (sulphur, 18.8 per cent; bismuth, 81.2 per cent), occurs in contact deposits in the Mineral Range and in replacement veins in limestone in the Clifton and Star districts.

Molybdenite.-Molybdenite, molybdenum disulphide, $\mathrm{MoS}_{2}$ (sulphur, 40 per cent; molybde- 
num, 60 per cent), occurs in small amount in replacement veins in quartz monzonite, notably in the O. K. mine, Beaver Lake district; in contact gold deposits in the Clifton district; in disseminated copper deposits in the Bingham district; in contact deposits in the Mineral Range; and in veins cutting granodiorite in the Little Cottonwood district. Molybdenum minerals present in several other districts have probably resulted from the oxidation of molybdenite.

Tungstenite.-Tungstenite, $\mathrm{WS}_{2}$ (tungsten, 75 per cent; sulphur, 25 per cent). The only known occurrence of this mineral is in the ores of the Old Emma mine of Little Cottonwood district, where it is found in small amount in lead-silver ores. It is one of the latest sulphides to be deposited and apparently in part replaces earlier minerals.

Galena.-Galena, lead sulphide, PbS (sulphur, 13.4 per cent; lead, 86.6 per cent), is the most important primary lead mineral in all of the lead deposits of the State.

Argentite (silver glance).-Argentite, silver sulphide, $\mathrm{Ag}_{2} \mathrm{~S}$ (sulphur, 12.9 per cent; silver, 87.1 per cent), is important in the unoxidized ores of the Silver Reef district. It has been recognized in the gold-silver veins of the Tushar Range, in the Horn Silver mine of the San Francisco district, and in the Tintic district. Possibly the silver in much of the argentiferous galena is present as microscopic argentite.

Chalcocite-Chalcocite, cuprous sulphide, $\mathrm{Cu}_{2} \mathrm{~S}$ (sulphur, 20.2 per cent; copper, 79.8 per cent), is present in most of the copper deposits of the State. It was the principal copper mineral in the Dyer mine in the Uinta Range, is important in the disseminated copper deposits of the Bingham district, and is present in different amounts in other deposits of the State. It usually occurs as a replacement of other sulphides.

Sphaterite (zinc blende, blende, blackjack).Sphalerite, zinc sulphide, $\mathrm{ZnS}$ (sulphur, 33 per cent; zinc, 67 per cent), is the most important primary zinc mineral in the ores of the State. It occurs in important amounts in the Park City, Little Cottonwood, Bingham, Stockton, Ophir, San Francisco, and Star districts, and is present in most of the others.
Tiemannite.-Tiemannite, mercuric selenide, $\mathrm{HgSe}$, occurs in the Lucky Boy mine near Marysvale, Utah.

Onofrite.-Onofrite, $\mathrm{Hg}(\mathrm{S}, \mathrm{Se})$, occurs with tiemannite in the Lucky Boy mine.

Cinnabar.-Cinnabar, mercuric sulphide, HgS (sulphur, 13.8 per cent; mercury, 86.2 per cent), occurs in the gold deposits of the Mercur district.

Covellite.-Covellite, cupric sulphide, CuS (sulphur, 33.6 per cent; copper, 66.4 per cent), is abundant in the copper ores of the Horn Silver mine, San Francisco district. It also occurs in the O. K. mine, Beaver Lake district, in the disseminated deposits of the Bingham district, in the Tintic district, and has been recognized from other districts everywhere as a replacement of other sulphides.

Greenockite.-Greenockite, cadmium sulphide, CdS (sulphur, 22.3 per cent; cadmium, 77.7 per cent), occurs as films on sphalerite from the Moscow mine, Star district.

Wurtzite.-Wurtzite, zinc sulphide, ZnS (sulphur, 33 per cent; zinc, 67 per cent), is abundant in the zinc ores of the Horn Silver mine and has been recognized from the Clyde mine in the Tushar Range. In the Horn Silver ores it is regarded as secondary, but in the Clyde ores it appears to be primary.

Pyrrhotite.-Pyrrhotite, sulphide of iron, $\mathrm{Fe}_{5} \mathrm{~S}_{6}$ to $\mathrm{Fe}_{18} \mathrm{~S}_{17}$ (sulphur, about 40 per cent; iron, 60 per cent), is reported from the bedded deposits in the Bingham district and is probably present in other districts but is nowhere known to be abundant.

Bornite--Bornite, sulphide of copper ard iron, $\mathrm{Cu}_{5} \mathrm{FeS}_{4}$ (sulphur, 28.1 per cent; copper, 55.5 per cent; iron, 16.4 per cent), is nowhere abundant but has been recognized in the contact gold ores of the Clifton district; in the Bingham and Ophir districts; in the Imperial mine, San Francisco district; in the Dolly Varden mine, White Canyon; and in the Mountain View, Steamboat, and other mines of the Cottonwood district.

Chalcopyrite (copper pyrites).-Chalcopyrite, sulphide of copper and iron, $\mathrm{CuFeS}_{2}$ (sulphur, 35 per cent; copper, 34.5 per cent; iron, 30.5 per cent), is the most abundant primary copper mineral in the State, and is present in most districts. Particularly fine specimens of chalco- 
pyrite crystals occur in the Cactus mine, San Francisco district.

Pyrite.-Pyrite, iron disulphide, $\mathrm{FeS}_{2}$ (sulphur, 53.4; iron, 46.6 per cent), is an important primary mineral in practically all of the western districts of the State.

Marcasite.-Marcasite, iron disulphide, $\mathrm{FeS}_{2}$ (sulphur, 53.4 per cent; iron, 46.6 per cent), occurs as a replacement of carbonaceous material in the "red beds" of the Plateau region and is associated with oxidized copper ore in limestone in the Morgan district.

Arsenopyrite (mispickel.) -Arsenopyrite, sulpharsenide of iron, FeAsS (arsenic, 46 per cent; sulphur, 19.7 per cent; iron, 34.3 per cent), though nowhere present in great abundance has been recognized in the ores of the Clifton, West Tintic, Park Valley, Bingham, and Stockton districts.

Sylvanite.-An undetermined telluride of gold and silver that occurs in the ores of the Tushar Range and in the State Line district is possibly sylvanite, telluride of gold and silver $(\mathrm{Au}, \mathrm{Ag}) \mathrm{Te}_{2}$, though material suitable for positive determination is not available. Selenium is usually present in the specimens, as well as tellurium, but whether in the same mineral has not been determined.

\section{SULPHOSALTS.}

Jamesonite.-Jamesonite, $\mathrm{Pb}_{2} \mathrm{Sb}_{2} \mathrm{~S}_{5}$ (sulphur, 19.7 per cent; antimony, 29.5 per cent; lead, 50.8 per cent), has been recognized in the ores of the Park City and West Tintic districts, and in the Horn Silver mine, San Francisco district.

Dufrenoysite.-Dufrenoysite, $2 \mathrm{PbS} . \mathrm{As}_{2} \mathrm{~S}_{3}$, is reported by Maryland Bixby from the San Francisco district.

Cosalite.-Cosalite, $2 \mathrm{PbS} . \mathrm{Bi}_{2} \mathrm{~S}_{3}$, occurs in small amount in the ores of the Cactus mine, San Francisco district.

Bournonite.-Bournonite, $\left(\mathrm{PbCu}_{2}\right)_{3} \cdot \mathrm{Sb}_{2} \mathrm{~S}_{6}$ (sulphur, 19.8 per cent; antimony, 24.7 per cent; lead, 42.5 per cent; copper, 13 per cent), is reported from the Silver King and Daly-West mines, Park City district, and from the Little Cottonwood district.

Pyrargyrite.-Pyrargyrite, $\mathrm{Ag}_{3} . \mathrm{SbS}_{3}$ (sulphur, 17.8 per cent; antimony, 22.3 per cent; silver, 59.9 per cent), occurs in the ores of the Horn Silver mine, San Francisco district, and probably at other localities.
Proustite.-Proustite, $\mathrm{Ag}_{3} \mathrm{AsS}_{3}$ (sulphur, 19.4 per cent; arsenic, 15.2 per cent; silver, 65.4 per cent), is reported by Maryland Bixby from the San Francisco district and by Lindgren from the Tintic district.

Tetrahedrite.-Tetrahedrite, of variable composition but essentially $\mathrm{Cu}_{8} \mathrm{Sb}_{2} \mathrm{~S}_{\text {7 }}$ (sulphur, 23.1 per cent; antimony, 24.8 per cent; copper, 52.1 per cent), is abundant in the ores of the Park City, Cottonwood, and American Fork districts, and rather abundant in the lead ores of the Bingham district. It is present in the ores of the Stockton and East Tintic districts, in the Cactus mine, of the San Francisco district, and in some of the gold-silver veins of the Tushar Range. Specimens of tetrahedrite from the Park City district contain notable amounts of zinc; and some specimens from the Little Cottonwood district contain lead.

Tennantite.- Tennantite, essentially $\mathrm{Cu}_{8} \mathrm{As}_{2} \mathrm{~S}_{7}$ (sulphur, 25.5 per cent; arsenic, 17 per cent; copper, 57.5 per cent), occurs in the Tintic district.

Stephanite.-Stephanite, $\mathrm{Ag}_{5} \mathrm{SbS}_{4}$ (sulphur, 16.3 per cent; antimony, 15.2 per cent; silver, 68.5 per cent), occurs in the ores of the Tintic district.

Geocronite.-Geocronite, $5 \mathrm{PbS} . \mathrm{Sb}_{2} \mathrm{~S}_{3}$, occurs as fine veinlets in galena from the 300 -foot level of the Colorado mine, Tintic district.

Enargite.-Enargite, $\mathrm{Cu}_{3} \mathrm{AsS}_{4}$ (sulphur, 32.6 per cent; arsenic, 19.1 per cent; copper, 48.3 per cent), is abundant in the primary ores of the Tintic, is present in the Little Cottonwood district, and is probably present in the primary ores of other districts, notably the Clifton, that contain abundant arsenic and copper in their oxidized ores.

Famatinite.-Famatinite, $\mathrm{Cu}_{3} \mathrm{SbS}_{4}$, is intimately associated with enargite in the apex ore body of the Mammoth mine, Tintic district.

Pearceite.-Pearceite, $9 \mathrm{Ag}_{2} \mathrm{~S} . \mathrm{As}_{2} \mathrm{~S}_{3}$, occurs microscopically intergrown with galena in the "Gem Channel," levels 14 to 19, of the Gemini mine, Tintic district.

\section{HALOIDS.}

Cerargyrite (horn silver, silver chloride).Cerargyrite, $\mathrm{AgCl}$ (chlorine, 24.7 per cent; silver, 75.3 per cent), is one of the important silver minerals and is present in many and probably most of the oxidized silver deposits of 
the State. It is especially abundant in the ores of the Tintic, Ophir, San Francisco, and Silver Reef districts.

Embolite.-Silver chlorobromide, $\mathrm{Ag}(\mathrm{BrCl})$, and other bromides of silver are frequently reported from the mines of Utah, but most of them have proved to be some other mineral. It is possible and perhaps probable that embolite or bromyrite $(\mathrm{AgBr})$ are present in the ores of the State in small amount.

Cotunnite.-Cotunnite, $\mathrm{PbCl}_{2}$, may be present in the complex oxidized ores of the Tintic district.

Fluorite.-Fluorite, $\mathrm{CaF}_{2}$ (fluorine, 48.9 per cent; calcium, 51.1 per cent), occurs as a contact mineral in the Mineral Range and the Star district; as a gangue mineral in gold veins in the Tushar Range and Gold Springs district; as a gangue mineral with sphalerite in zinc ores in the Trout Creek district, Deep Creek Range; with chalcopyrite and pyrite in the Erickson district; and in the Wasatch Range east of Ogden.

Daubreeite.-Daubreeite, $2 \mathrm{Bi}_{2} \mathrm{O}_{3} \cdot \mathrm{BiCl}_{3} \cdot 3 \mathrm{H}_{2} \mathrm{O}$, has been determined from the 1,200-foot level of the Eagle and Blue Bell mines, Tintic district.

Lead oxychlorite (unnamed).-An unnamed lead oxychlorite that has been determined in ore from the 1,000-foot level of the Eureka Hill mine, Tintic district, occurs as minute yellow orthorhombic (?) prisms and rounded aggregates.

\section{OXIDES.}

Quartz.-Quartz, $\mathrm{SiO}_{2}$ (oxygen, 53.3 per cent; silicon, 46.7 per cent), occurs in many forms, being an important constituent of both the igneous and sedimentary rocks of the State and being perhaps the most universal and abundant gangue mineral of the ore deposits. It varies from the coarsely crystalline variety of many of the ore deposits, as those of the Park City district, and especially of the O. K. mine in the Beaver Lake district, and the Cactus mine in the San Francisco district, to the fine cherty variety common in the gold veins in the volcanic rocks of the Tushar Range and the Gold Springs-State Line districts and in the lead-silver deposits of the San Francisco district, and the cherty replacement of limestone that occurs in the Tintic, Ophir, and other districts.
Chalcedony.-Chalcedony, cryptocrystalline silica, essentially identical with the cherty material described under quartz, also forms veinlets and spherulites in the Tintic district.

Opal.-Opal, an amorphous silica with variable amount of water, though not recognized in the ore deposits, is associated with lavas at numerous localities.

Bismite.-Bismite, $\mathrm{Bi}_{2} \mathrm{O}_{3}$, occurs in the Eagle and Blue Bell mines, Tintic district, where it forms yellow earthy crusts on ore.

Arsenobismite.-Arsenobismite, $2 \mathrm{Bi}_{2} \mathrm{O}_{3} \cdot \mathrm{As}_{2} \mathrm{O}_{3}$ $2 \mathrm{H}_{2} \mathrm{O}$ or $4 \mathrm{Bi}_{2} \mathrm{O}_{3} \cdot 3 \mathrm{As}_{2} \mathrm{O}_{5} .5 \mathrm{H}_{2} \mathrm{O}$, is described from the 600-foot level of the Mammoth mine, Tintic district.

Kermesite.-Kermesite, $2 \mathrm{Sb}_{2} \mathrm{~S}_{3} . \mathrm{Sb}_{2} \mathrm{O}_{3}$, is associated with stibnite in the Bay State workings, American Fork district. It forms minute tufts of red prismatic crystals and probably accounts for the red staining along the stibnite seams.

Molybdite.-Molybdite, $\mathrm{MoO}_{3}$, was noted from a prospect near the Jumbo vein, Gold Springs district, where it is evidently a secondary mineral.

Cuprite-Cuprite, cuprous oxide, $\mathrm{Cu}_{2} \mathrm{O}$ (oxygen, 11.2 per cent; copper, 88.8 per cent), is especially abundant in the oxidized copper ores of the Copper Mountain mine, Lucin district, of the Dixie mine, Tutsagubet district, and of the Imperial mine, San Francisco district, and is present elsewhere.

Tenorite or melaconite.-Tenorite, cupric oxide, $\mathrm{CuO}$, is associated in the Brooklyn mine of the Tintic district with the new mineral crandallite. The cuprite of the Copper Mountain mine is surrounded by a thin layer of a black mineral, probably tenorite or melaconite, that has apparently resulted from the alteration of the cuprite.

Melaconite.-Melaconite, $\mathrm{CuO}$, a black earthy mineral containing copper as its only metallic constituent, occurs as an alteration product of cuprite in the Copper Mountain mine, Lucin district, and in the Imperial mine, San Francisco district. This is melaconite or some allied mineral.

Periclase.-Periclase, $\mathrm{MgO}$, occurs in contactmetamorphosed limestone in the Little Cottonwood district. It commonly forms the center of spherical bodies of brucite which have resulted from its alteration. 
Massicot.-Massicot, lead monoxide, $\mathrm{PbO}$, occurs as an alteration product of galena in the Park City district.

Hematite.-Hematite, iron sesquioxide, $\mathrm{Fe}_{2} \mathrm{O}_{3}$ (oxygen, 30 per cent; iron, 70 per cent), is an important constituent of the iron deposits of Iron County and is the principal mineral in the iron deposits of the Uinta Range. It is present in contact zones in several districts, being especially abundant in the Clifton, San Francisco, and Beaver Lake districts, as well as in Iron County. The well-crystallized variety, specularite, is abundant in the Cactus mine, San Francisco district, where it occurs in replacement deposits in quartz monzonite; and it is associated with pyrite and chalcopyrite in quartz veins of the Farmington district. Micaceous hematite with quartz forms a few prominent beds in the Algonkian rocks north of Ogden.

Ilmenite.-Ilmenite, titanic iron ore, $\mathrm{FeTiO}_{3}$ (oxygen, 31.6 per cent; titanium, 31.6 per cent; iron, 36.8 per cent), occurs in the Colorado and Green river placers and in most of the igneous rocks of the State.

Spinel.-Spinel, $\mathrm{MgAl}_{2} \mathrm{O}_{4}$ (aluminum, 71.8 per cent; magnesia, 28.2 per cent), occurs in the Tintic, Park City, and Cottonwood districts as a contact mineral.

Brucite.-Brucite, $\mathrm{MgO} \cdot \mathrm{H}_{2} \mathrm{O}$, occurs in magnesian limestone near the contact with the granodiorite east of Alta; it appears to have been formed by the alteration of periclase.

Magnetite.-Magnetite, $\mathrm{Fe}_{3} \mathrm{O}_{4}$ (oxygen, 27.6 per cent; iron, 72.4 per cent), is an important constituent in the iron deposits of Iron County, where it occurs as a contact mineral and in veins in intrusive rock. It is also especially abundant in the Rocky, Little Cottonwood, and Clifton districts, and forms bodies of considerable size remote from exposed igneous contacts in the Willard district. It is present in small amount in practically all of the igneous rocks of the State and is abundant in the placer deposits of the Colorado and Green rivers.

Chromite.-Chromite, $\mathrm{FeCr}_{2} \mathrm{O}_{4}$, occurs in the Colorado and Green river placers.

Minium.-Minium, lead oxide, $\mathrm{Pb}_{3} \mathrm{O}_{4}$, has been recognized in the oxidized ores of the Park City and Tintic districts as a bright-red earthy coating.

Bixbyite.-Bixbyite, $\mathrm{FeO} \cdot \mathrm{MnO}_{2}$, occurs with topaz in altered lava in the Thomas Range.
Rutile.-Rutile, $\mathrm{TiO}_{2}$ (oxygen, 40 per cent; titanium, 60 per cent), occurs in the tourmaline veins of the Clifton district and of the Cactus mine of the San Francisco district, in the disseminated copper deposits of the Bingham district, and doubtless in small amounts in many other localities.

Octahedrite.-Octahedrite, $\mathrm{TiO}_{2}$ (oxygen, 40 per cent; titanium, 60 per cent), occurs in the sericitic ore of the Deertrail mine, near Marysvale.

Diaspore.-Diaspore, $\mathrm{AlO}(\mathrm{OH})$ (alumina, 85 per cent; water, 15 per cent), occurs in the altered lavas of the Beaver Lake Mountains.

Pyrolusite.-Pyrolusite, $\mathrm{MnO}_{2}$, has been mined in the Little Grande district, where it occurs in sandstone, and similar occurrences are present in numerous localities through the Plateau region. It is present in considerable abundance in some of the deposits in the Little Cottonwood district, in prospects near Modena, in the Escalante mine and near-by prospects, in deposits in Bullion Canyon of the Tushar Range, in the iron deposits of the Antelope Range in Piute County, and at numerous other localities.

Manganite.-Manganite, $\mathrm{MnO}(\mathrm{OH})$, occurs in the Horn Silver mine, San Francisco district, and probably in small amount in numerous localities.

Psilomelane.-Psilomelane, a hydrous manganese manganate, $\mathrm{H}_{4} \mathrm{MnO}_{5}$ ? (usually very impure), is common as black earthy masses or stains in oxidized ore bodies throughout the State.

'Wad.-Wad, an impure black hydrous manganese oxide similar to psilomelane but usually soft and loosely aggregated, and psilomelane are present at some places, as in the Tintic district, in minable amounts.

Limonite.-Limonite, $2 \mathrm{Fe}_{2} \mathrm{O}_{3} \cdot 3 \mathrm{H}_{2} \mathrm{O}$ (oxygen, 25.7 per cent; iron, 59.8 per cent; water, 14.5 per eent), is present in practically all the ore deposits of the State and in many is very abundant. It has been mined as a flux from the Tintic and Lucin districts and from the Antelope Range, Piute County, and to a small extent from other localities.

Göthite.-Göthite, $\mathrm{FeO}(\mathrm{OH})$, has been recognized in the gossan of the Cactus mine, San Francisco district.

"Copper pitch ore."-Hydrous oxides of copper, iron, and manganese, of variable com- 
position, commonly termed "copper pitch," occur as oxidation products of copper ores, especially in the Imperial mine, San Francisco district, and in the Tintic district.

\section{CARBONATES.}

Calcite.-Calcite, calcium carbonate, $\mathrm{CaCO}_{3}$, occurs in many forms. As limestone it makes up a large part of many of the mountain ranges of the State. As a gangue mineral it is present in many ore deposits, especially in replacement deposits in limestone and in the gold-silver veins in the volcanic rocks.

Dolomite.-Dolomite, carbonate of calcium and magnesium, $(\mathrm{CaMg}) \mathrm{CO}_{3}$, like calcite, is an important part of the sedimentary rocks in the mountains of the State, and is a common gangue mineral, especially in lead-silver and zinc ores.

Siderite.-Siderite, $\mathrm{FeCO}_{3}$, an impure iron carbonate, is especially abundant in the Cactus mine, San Francisco district, but is also present in deposits of the Clifton district, the Tushar Range, and elsewhere.

Ankerite.-Ankerite, $(\mathrm{CaMgFe}) \mathrm{CO}_{3}$, resembles dolomite in appearance and mode of occurrence. It has been recognized in the Tintic district and is doubtless present elsewhere.

Rhodochrosite.-Rhodochrosite, $\mathrm{MgCO}_{3}$, is not abundant, though much of the vein carbonate contains manganese in notable amount. Rhodochrosite occurs in the Dillon mine in the Tushar Range, is present in small amount in the Park City and Star districts, and doubtless occurs in small amounts at other localities.

Smithsonite.-Smithsonite, $\mathrm{ZnCO}_{3}$ (zinc, 51.96 per cent), is present in many oxidized ore deposits of western Utah. It is everywhere secondary and very commonly replaces limestone or dolomite. It has been found in greatest abundance in the North Tintic, Tintic, Promontory, Ophir (Dry Canyon), and Star districts.

Hydrozincite.-Hydrozincite, basic zine carbonate $\left(\mathrm{ZnCO}_{3} \cdot 2 \mathrm{ZnO}_{2} \mathrm{H}_{2}\right.$ ? $)$, occurs in the Tintic, Ophir, and Mount Nebo districts and probably elsewhere as chalk-white dense earthy masses and incrustations closely associated with smithsonite.

Aragonite.-Aragonite, calcium carbonate, $\mathrm{CaCO}_{3}$, crystallizing in the orthorhombic system, has been noted in oxidized ore of the " 1903 " mine, West Tintic district, and in caves near ore bodies in the Tintic district. Aragonite containing a little zine is associated with the oxidized zinc ores of the Gemini mine, Tintic district.

Cerusite.-Cerusite, lead carbonate, $\mathrm{PbCO}_{3}$ (lead, 77.5 per cent), is the most important lead mineral in the oxidized ores of the State and is present in practically all deposits in which lead occurs, everywhere as an alteration product of galena or other lead minerals. Ordinarily the sulphide alters first to the lead sulphate, anglesite, and the sulphate to the carbonate.

Malachite.-Malachite, $\mathrm{CuCO}_{2} \cdot \mathrm{Cu}(\mathrm{OH})_{2}$ (copper, 57.4 per cent), is present in the oxidized portion of practically all the copper deposits of the State.

Azurite.-Azurite, $2 \mathrm{CuCO}_{3} \cdot \mathrm{Cu}(\mathrm{OH})_{2}$ (copper, 55 per cent), like malachite, is present in the oxidized portion of practically all the copper deposits.

Aurichalcite.-Aurichalcite, $\quad 2(\mathrm{ZnCu}) \mathrm{CO}_{3} .3$ $(\mathrm{ZnCu})(\mathrm{OH})_{2}$, has been noted in oxidized zinc ore from the Hidden Treasure mine in the Ophir district (Dry Canyon), in the Tintic district, from the Cave mine in the Mineral Range, and from the Carbonate mine, Big Cottonwood district.

Bismuthite.-Bismuthite, $\mathrm{Bi}_{2} \mathrm{O}_{3} \cdot \mathrm{CO}_{2} \cdot \mathrm{H}_{2} \mathrm{O}$, occurs in the Boss Tweed mine and in the Victoria mine, Tintic district.

Leadhillite.-Leadhillite, $\mathrm{H}_{2} \mathrm{~Pb}_{4} \mathrm{C}_{2} \mathrm{SO}_{12}$, hydrous sulphate-carbonate of lead, appears in the only specimen found (from the Eureka Hill mine, Tintic district) as white crystals associated with anglesite.

Phosgenite.-Phosgenite, $\mathrm{PbCl} . \mathrm{CO}_{3}$, has been found in the State only as gray crusts replacing the lead carbonate, cerusite.

\section{SIIICATES}

Orthoclase.-Orthoclase, $\mathrm{KAlSi}_{3} \mathrm{O}_{8}$, is an important constituent of most of the igneous rocks of the State. As a gangue mineral of ore deposits it occurs in the pegmatitic veins of the Park Valley district, in those of the Queen of Sheba mine, in the Deep Creek Range, and in the pegmatitic deposits of the Clifton district. It is present as adularia in the geld-silver veins in lavas of the Tushar and Gold Spring-State Line districts; it is an important alteration mineral of the quartz monzonite in the disseminated deposits of the Bingham district; 
and it occurs as a replacement mineral in limestone in the Ophir district.

Plagioclase group.-The plagioclase group is an important constituent of most of the igneous rocks of the State. (End members of group: Albite, $\mathrm{NaAlSi}_{3} \mathrm{O}_{8}$, and anorthite, $\mathrm{CaAl}_{2} \mathrm{Si}_{2} \mathrm{O}_{8}$; intermediate members are mixtures of these in different proportions.) Albite replaces limestone in the contact zones in the Iron Springs district.

Pyroxene group. - Of the members of the pyroxene group, augite and hypersthene are constituents of many of the igneous rocks of the State. Enstatite, associated with spinel, is an abundant microscopic mineral in altered dolomite in the contact zone of the Tintic district. Diopside is present in the altered limestone of most of the contact zones. Wollastonite is the principal gangue mineral in some of the contact gold deposits of the Clifton district, and has been found in the Tintic district. Rhodonite is present in the Park City district as a gangue mineral but is nowhere abundant.

Amphibole group.-Members of the amphibole group, especially hornblende, are, like those of the pyroxene group, important constituents of many of the igneous rocks of the State. Tremolite is especially common in the metamorphic limestone in contact zones. Actinolite has the same general distribution and mode of occurrence as tremolite. Hornblende in small amount has been noted in metamorphic limestone of the West Tintic district. Amphibole is a constituent of some of the veins in the quartz monzonite of the Clifton district.

Beryl.-Beryl, $\mathrm{Gl}_{3} \mathrm{Al}_{2}\left(\mathrm{SiO}_{3}\right)_{6}$, is reported from quartz veins in the Ibapah stock, Deep Creek Range.

Willemite.-Willemite, anhydrous zinc silicate, $\mathrm{Zn}_{2} \mathrm{SiO}_{4}$ (zinc, 58.5 per cent), occurs in specimens of oxidized zinc ore from the Cedar Talisman mine, Star district, Beaver County, presented to the Survey by Mr. W. H. Parker. The willemite appears as abundant short, stout, hexagonal crystals associated with smithsonite, calamine, pyromorphite, and hydrous oxide of iron. It is in part at least later than calamine and is unquestionably secondary.

Garnet group.-Garnet of different compositions has been formed by a replacement of calcareous rocks in most of the contact zones of the State. Most of it is a mixture of andradite (iron-calcium garnet), grossularite (calcium-alumina garnet), and pyrope (magnesium-aluminum garnet), the andradite portion predominating. In the Little Cottonwood district a green chrome garnet (uvarovite) occurs in the contact zone. Garnet occurs in tourmaline veins in the quartz monzonite of the Clifton district and in the pegmatitic gold veins of the Queen of Sheba mine in the Deep Creek Range. It is present, commonly as the iron-aluminum variety, almandite, in many schists and gneisses. Garnet is a rather abundant constituent of the Colorado and Green river placers.

Vesuvianite.-Vesuvianite, basic calciumaluminum silicate, has been recognized as a replacement mineral in the contact zones of the Park City, Little Cottonwood, and San Francisco districts and in the Mineral Range. It occurs in the tourmaline veins in quartz monzonite in the Clifton district.

Zircon.-Zircon, $\mathrm{ZrSiO}_{4}$, is present in small amount in many of the igneous rocks of the State. It is rather abundant in the sericitic ores of the Deertrail mine and is present in the placers of Colorado and Green rivers.

Danburite.-Danburite, $\mathrm{CaB}_{2}\left(\mathrm{SiO}_{4}\right)_{2}$, occurs in the tourmaline veins of the Clifton district. Topaz.-Topaz, $(\mathrm{AlF})_{2} \mathrm{SiO}_{4}$, occurs in altered volcanic rocks in the Thomas Range.

Andalusite.-Andalusite, $\mathrm{Al}_{2} \mathrm{SiO}_{5}$, occurs in hydrothermally altered volcanic rocks of the Beaver Lake Mountains.

Monticellite.-Monticellite, $\mathrm{CaMgSiO}_{4}$, forms microscopic crystals in the contact-metamorphosed limestone of the Cottonwood-American Fork region.

Zoisite.-Zoisite, $\mathrm{Ca}_{2}(\mathrm{AlOH}) \mathrm{Al}_{2}\left(\mathrm{SiO}_{4}\right)_{3}$, has been recognized as an alteration product of limestone in the contact zone in the Little Cottonwood district and in inclusions in monzonite of the Tintic district, and it is probably present at other localities.

Epidote.-Epidote, $\mathrm{HCa}_{2}(\mathrm{Al}, \mathrm{Fe})_{3} \mathrm{Si}_{3} \mathrm{O}_{13}$, is a common alteration product of limestone in the contact zones, as in the Iron King mine, West Tintic district. It is also produced by the hydrothermal alteration of limestones that are not closely associated with igneous rocks, notably in the deposits of the Ophir district. It occurs in the tourmaline veins of the Clifton district. 
Axinite-Axinite, boro-silicate of aluminum and calcium with varying amounts of iron and manganese, occurs as a replacement of limestone in the contact deposits of the Clifton district.

Calamine.-Calamine, $\mathrm{H}_{2} \mathrm{ZnSiO}_{5}$ (zinc, 54.2 per cent), is present in small or considerable amounts in the oxidized zinc ores of the State, but nowhere predominates in oxidized zinc ores. It has been noted in the Star, San Francisco, North Tintic, Tintic, and- Mount Nebo districts and is present in small amounts at several other localities.

Tourmaline.-Tourmaline, complex silicate of boron and aluminum with magnesium, iron, or alkali metals, occurs in the Clifton district in pegmatite dikes, in veins in quartz monzonite, and in contact deposits. It is abundant in the Cactus mine, San Francisco district, in replacement veins in quartz monzonite.

Laumontite.-Laumontite, $\mathrm{H}_{4} \mathrm{CaAl}_{2} \mathrm{Si}_{4} \mathrm{O}_{14}$, occurs in a gold-copper vein in quartz monzonite in the Bromide mine in the Henry Mountains.

Heulandite. - Heulandite, $\mathrm{H}_{4} \mathrm{CaAl}_{2}\left(\mathrm{SiO}_{3}\right)_{5}+$ $3 \mathrm{H}_{2} \mathrm{O}$, occurs in small gray to yellowish crystal aggregates lining cavities in rhyolite in a north continuation of the Gemini ore zone, Tintic district.

Chabazite.-Chabazite, $\left(\mathrm{CaNa}_{2}\right) \mathrm{Al}_{2} \mathrm{Si}_{4} \mathrm{O}_{12}$, occurs in small amount in the contact zone of the Park City and Cottonwood districts.

Muscovite (white mica).-Muscovite, $\mathrm{H}_{2} \mathrm{KAl}_{3}$ $\left(\mathrm{SiO}_{4}\right)_{3}$, occurs as an original constituent of igneous rocks and as a replacement of limestone near the contact of igneous rocks. As a contact mineral it has been noted especially in the San Francisco, Clifton, and Little Cottonwood districts and in the Mineral Range but is present at other localities. The finely crystallized variety commonly known as sericite is abundant as a product of the alteration of igneous rocks by vein-forming solutions. Such alteration is important in the Bingham, Tintic, San Francisco, Beaver Lake, Clifton, and other districts. Sericite has also formed abundantly in replacement veins in limestone, most strikingly in the Deertrail mine near Marysvale, where it is the most important gangue mineral. It is also plentiful in places in the Park City, Little Cottonwood, Bingham, Stockton, Ophir, and Fish Springs districts.

$$
35416^{\circ}-19-8
$$

Sericite. See Muscovite.

Biotite (black mica).-Biotite, $(\mathrm{H}, \mathrm{K})_{2}(\mathrm{MgFe})_{2}$ $(\mathrm{AlFe})_{2}\left(\mathrm{SiO}_{4}\right)_{3}$, is a constituent of much of the igneous rock of the region. It is a product of the alteration of monzonitic rocks by ore solutions in the Bingham and Clifton districts. It occurs as a contact mineral in the Rocky district.

Phlogopite (magnesian mica).-Phlogopite, $(\mathrm{H}, \mathrm{K}, \mathrm{MgF})_{3} \cdot \mathrm{Mg}_{3} \cdot \mathrm{Al}\left(\mathrm{SiO}_{4}\right)_{3}$, has been noted as a contact mineral in limestone in the Cottonwood districts and in the Rocky district.

Chlorite.-Chlorite, a variable compound of iron, magnesium, and aluminum silicate, is a common alteration product of the dark silicates of the igneous rocks. It occurs in the Park City, West Tintic, and Mineral Range contact zones, in the tourmaline veins of the Clifton district, in the altered latite adjacent to the Beaver-Carbonate vein in the San Francisco district, and in veins cutting shale in the western part of the Erickson district, Simpson Mountains.

Serpentine.-Serpentine, $\mathrm{H}_{4} \mathrm{Mg}_{3} \mathrm{Si}_{2} \mathrm{O}_{9}$, is a common alteration product of the magnesian silicates both of the igneous rocks and of the contact zones.

Talc.-Talc, $\mathrm{H}_{2} \mathrm{Mg}_{3}\left(\mathrm{SiO}_{3}\right)_{4}$, probably occurs at numerous localities in the State, as in the contact zone of the Tintic district, but is not nearly so abundant as it is generally supposed to be. Most of the white materials commonly designated talc prove, on examination, to be some other substance, as sericite, alunite, kaolin, or some other hydrous aluminum silicate.

Kaotinite (kaotin).-Kaolin, $\mathrm{H}_{4} \mathrm{Al}_{2} \mathrm{Si}_{2} \mathrm{O}_{9}$, hydrous aluminum silicates, are of common occurrence. Most of them are of variable composition and probably few correspond to kaolinite. They are particularly abundant in the Copper Mountain mine in the Lucin district and in the Dragon iron mine in the Tintic district.

Leverrierite (racewinite).-A hydrous ironaluminum silicate corresponding in general to leverrierite has been described by A. N. WincheII from the Highland Boy mine, Bingham district, and called racewinite.

Thaumasite.-Thaumasite, $\mathrm{CaSiO}_{3} \cdot \mathrm{CaCO}_{3}$.- $^{-}$ $\mathrm{CaSO}_{4} \cdot 15 \mathrm{H}_{2} \mathrm{O}$, occurs in veinlets cutting the zone of contact minerals in the Old Hickory mine, Rocky district. 
Chrysocolla. - Chrysocolla, $\mathrm{CuSiO}_{3}+2 \mathrm{H}_{2} \mathrm{O}$ (silica, 34.3 per cent; copper oxide, 45.2 per cent (copper, 36 per cent); water, 20.5 per cent), is commonly present in oxidized copper ores. It is especially abundant in the Copper Mountain mine, Lucin district, and is present in considerable amount in the San Francisco, Tintic, West Tintic, and other districts.

Titanite.-Titanite, $\mathrm{CaTiSiO}_{5}$, is a common minor constituent of the intrusive rocks of the State and occurs as microscopic crystals in the tourmaline veins of the Clifton district and in the contact zones of the West Tintic district.

PHOSPHATES, ARSENATES, AND VANADATES.

Apatite.-Apatite, $(\mathrm{CaF}, \mathrm{O}) \mathrm{Ca}_{4}\left(\mathrm{PO}_{4}\right)_{3}$, is a common minor constituent of the igneous rocks of the State and is rather abundant in the tourmaline veins of the Clifton district.

Pyromorphite. - Pyromorphite, $(\mathrm{PbO}) \mathrm{Pb}_{4}-$ $\left(\mathrm{PO}_{4}\right)_{3}$, is of rather rare occurrence in the State but has been found in the Park City district; in the Escalante mine, of Iron County; in the Cedar Talisman mine, of the Star district; and in the Eureka Hill mine, of the Tintic district.

Crandallite.-Crandallite, hydrous phosphate of calcium and aluminum, has been found as light gray to yellowish or brownish, fibrous to dense crusts, lining cavities in quartz-baritesulphide vein matter at the Brooklyn mine, Tintic district.

Borickite.-Borickite, hydrous basic phosphate of iron and calcium, has been reported to occur in the Ajax mine in reddish-brown massive form.

Mimetite.-Mimetite, $(\mathrm{PbCl}) \mathrm{Pb}_{4}\left(\mathrm{AsO}_{4}\right)_{3}$, occurs in the oxidized ores of the Park City district and occurs rarely in the Tintic district.

Vanadinite.-Vanadinite, $(\mathrm{PbO}) \mathrm{Pb}_{4}\left(\mathrm{VO}_{4}\right)_{3}$, occurs in the oxidized lead ores of the Harrington-Hickory mine, Star district.

Adamite.-Adamite, $\mathrm{Zn}_{3} \mathrm{As}_{2} \mathrm{O}_{8} \cdot \mathrm{Zn}(\mathrm{OH})_{2}$, has been found with limonite in the Iron Blossom mine (No. 3 shaft), Tintic district.

Chenevixite. - Chenevixite, $\mathrm{Cu}_{2}(\mathrm{FeO})_{2} \mathrm{As}_{2} \mathrm{O}_{8}+$ $3 \mathrm{H}_{2} \mathrm{O}$ (?), was obtained from the American Eagle mine, Tintic district, as a massive greenish-yellow mineral, not easily distinguished from massive varieties of olivenite.

Conichalcite. Conichalcite, (Cu, Ca $)_{3} \mathrm{As}_{2} \mathrm{O}_{8}$.$\mathrm{CuCa}(\mathrm{OH})_{2}+\frac{1}{2} \mathrm{H}_{2} \mathrm{O}$ (?), probably the most widely distributed copper arsenate in the Tintic district, occurs as small, bright, yellowish-green fibrous spheres or more rarely as mammillary crusts; also present in the Gold Hill mine, Clifton district.

Erinite.-Erinite, $\mathrm{Cu}_{3} \mathrm{As}_{2} \mathrm{O}_{8} \cdot 2 \mathrm{Cu}(\mathrm{OH})_{2}$, is a rather common arsenate in the Tintic district, forming small dark-green or dirty grayish-green mammillary crusts and fibrous spheres.

Chalcophyllite and tyrolite. - Chalcophyllite, $\left(\mathrm{Cu}_{3} \mathrm{As}_{2} \mathrm{O}_{8} \cdot 2 \mathrm{Cu}(\mathrm{OH})_{2}+14 \mathrm{H}_{2} \mathrm{O}(?)\right)$ and tyrolite $\left(\mathrm{Cu}_{3} \mathrm{As}_{2} \mathrm{O}_{8} \cdot 2 \mathrm{Cu}(\mathrm{OH})_{2}+7 \mathrm{H}_{2} \mathrm{O}\right.$ (?)) are found rather commonly in the oxidized copper ores of the Tintic district, particularly in the Ajax and Mammoth mines. They form foliated and fan-shaped aggregates and are not readily distinguished except by optical means (chalcophyllite is uniaxial).

Olivenite.-Olivenite, $\mathrm{Cu}_{2}(\mathrm{OH}) \mathrm{AsO}_{4}$, occurs in the Tintic district as an oxidation product of enargite; also in the Clifton district.

Descloizite.-Descloizite, $(\mathrm{PbZn})_{2}(\mathrm{OH}) \mathrm{VO}_{4}$, occurs as a coating of cavities in the ores of the Escalante mine.

Clinoclasite.-Clinoclasite, $\quad \mathrm{Cu}_{3} \mathrm{As}_{2} \mathrm{O}_{8} \cdot 3 \mathrm{Cu}-$ $(\mathrm{OH})_{2}$, occurs in the Tintic district as an alteration product of enargite.

Annabergite.-Annabergite, $\mathrm{Ni}_{3} \mathrm{As}_{2} \mathrm{O}_{8}+8 \mathrm{H}_{2} \mathrm{O}$, occurs in the ores of the Escalante mine.

Scorodite.-Scorodite, $\mathrm{FeAsO}_{4}+2 \mathrm{H}_{2} \mathrm{O}$, occurs as an oxidation product of arsenic minerals in several districts, including the Tintic, West Tintic, Star, Mercur, and Clifton. It is especially abundant in the Gold Hill mine of the Clifton district.

Variscite.-Variscite, $\mathrm{AlPO}_{4}+2 \mathrm{H}_{2} \mathrm{O}$, occurs about 5 miles northwest of Lucin, where it has been mined to some extent as a gem material.

Volborthite.-Volborthite, hydrous vanadate of copper barium and calcium, occurs in the ores of the Silver Reef and other sandstone deposits of the Plateau region.

Pharmacosiderite.-Pharma cosiderite, $6 \mathrm{FeAsO}_{4} \cdot 2 \mathrm{Fe}(\mathrm{OH})_{3}+12 \mathrm{H}_{2} \mathrm{O}$, occurs in the Tintic and West Tintic districts.

Pintadoite.-Pintadoite, hydrous calcium vanadate, $2 \mathrm{CaO} . \mathrm{V}_{2} \mathrm{O}_{5}+9 \mathrm{H}_{2} \mathrm{O}$, occurs as an efflorescence on the surface of vanadiumbearing sandstones of the Plateau region from Pintado Canyon, near the La Sal Mountains. Uvanite.-Uvanite, hydrous uranium vanadate, $2 \mathrm{UO}_{3} .3 \mathrm{~V}_{2} \mathrm{O}_{5}+15 \mathrm{H}_{2} \mathrm{O}$, occurs at Temple Rock on the east side of San Rafael Swell. 
Carnotite. - Carnotite, $\mathrm{K}_{2} \mathrm{O} .2 \mathrm{VO}_{3} \cdot \mathrm{V}_{2} \mathrm{O}_{5}+$ $3 \mathrm{H}_{2} \mathrm{O}$, occurs at numerous localities in the Plateau region, and is especially abundant around the La Sal and Henry mountains and the San Rafael Swell.

Tyuyamunite.-Tyuyamunite, $\quad \mathrm{CaO} .2 \mathrm{VO}_{3}$. $\mathrm{V}_{2} \mathrm{O}_{5}+\mathrm{H}_{2} \mathrm{O}$, occurs in Browns Park, Uinta Mountains.

Auinnite-Autunite, $\mathrm{Ca}\left(\mathrm{UO}_{2}\right)_{2} \mathrm{P}_{2} \mathrm{O}_{8}+8 \mathrm{H}_{2} \mathrm{O}$, is reported from the ores of the Silver Reef, from "sandstone" deposits 9 miles south of Pahreah, and is probably present in other uranium deposits of the Plateau region.

Uranospinite.-Uranospinite, $\mathrm{Ca}\left(\mathrm{UO}_{2}\right)_{2} \cdot \mathrm{As}_{2}$. $\mathrm{O}_{8}+8 \mathrm{H}_{2} \mathrm{O}$, is reported from 9 miles south of Pahreah, Kane County.

Zeunerite. - Zeunerite, $\mathrm{Cu}\left(\mathrm{UO}_{2}\right)_{2} \cdot \mathrm{As}_{2} \cdot \mathrm{O}_{8}+$ $\mathrm{H}_{2} \mathrm{O}$, has been found occasionally as small, yellowish-green tabular crystals on barite in the ore of the Centennial Eureka mine, Tintic district.

Mixite.-Mixite, hydrous basic arsenate of copper and bismuth, occurs in the ores of the Tintic district.

Bindheimite.-Bindheimite, hydrous antimonate of lead, occurs in the ores of the Park City and West Tintic districts and in the Horn Silver mine, San Francisco district.

Beudantite.-Beudantite, arsenate with sulphate of ferric iron and lead, occurs as an oxidation product in lead ores in the Clifton district.

Corkite.-Corkite, phosphate with sulphate of ferric iron and lead, occurs as an oxidation mineral in the Harrington-Hickory and Wild Bill mines, Star district.

\section{BORATES.}

Ludwigite.- $\mathrm{L}$ u d w i g i t e, $3 \mathrm{MgO} . \mathrm{B}_{2} \mathrm{O}_{3}+$ $\mathrm{FeO} \cdot \mathrm{Fe}_{2} \mathrm{O}_{3}$, occurs as a replacement of calcareous rocks in the Little Cottonwood district.

Magnesoludwigite.-Magnesoludwigite, $3 \mathrm{MgO} . \mathrm{B}_{2} \mathrm{O}_{3}+\mathrm{MgO} \cdot \mathrm{Fe}_{2} \mathrm{O}_{3}$, described from the Mountain View mine, at the head of Big Cottonwood Canyon. Replaces limestone the same as ludwigite.

\section{SULPHATES.}

Barite.-Barite, barium sulphate, $\mathrm{BaSO}_{4}$, as a gangue mineral is especially abundant in the Tintic district and in the Horn Silver mine of the San Francisco district and is present in the Mineral Range, Tushar Range, Mercur, Ophir, Park City, American Fork, and other districts.
Anglesite.-Anglesite, lead sulphate, $\mathrm{PbSO}_{4}$ (lead, 68.3 per cent) is the usual alteration product of galena, though it in turn is commonly altered to the carbonate, cerusite, which is more abundant in the oxidized ores than the sulphate. Anglesite is very abundant in the oxidized ores of the Horn Silver mine and is present in most, if not all, of the lead deposits of the State.

Anhydrite.-Anhydrite, anhydrous calcium sulphate, $\mathrm{CaSO}_{4}$, occurs as a gangue mineral in the deposits of the Cactus mine, San Francisco district, and in some of the gypsum beds in the "red beds" of the Plateau region.

Celestite.-Celestite, strontium sulphate, $\mathrm{SrSO}_{4}$, is associated with galena and zinc blende in Eocene sandstone, Salina Creek district.

Brochantite.-Brochantite, basic sulphate of copper, $\mathrm{CuSO}_{4} \cdot 3 \mathrm{Cu}(\mathrm{OH})_{2}$, is rather abundant in the oxidized copper ores of the Horn Silver mine and is present in ores of the Tintic district and probably other districts.

Connellite and spangolite.-Connellite, basic hydrous chlorosulphite of copper, and spangolite, basic hydrous chlorosulphite of copper and aluminum, have recently been described from the Grand Central mine, Tintic district. Connellite forms bright Prussian-blue fibrous radiating crystals of almost metallic luster; spangolite forms hexagonal thick prisms, pale green to bluish green, with perfect basal cleavage. Linarite.-Linarite, basic sulphate of lead and copper, $(\mathrm{Pb}, \mathrm{Cu}) \mathrm{SO}_{4}(\mathrm{~Pb}, \mathrm{Cu})(\mathrm{OH})_{2}$, occurs in the oxidized ores of the Horn Silver mine, San Francisco district, and has been reported from the Bullion Beck or the Gemini mine and from the Mammoth mine, Tintic district.

Gypsum.-Gypsum, hydrous calcium sulphate, $\mathrm{CaSO}_{4}+2 \mathrm{H}_{2} \mathrm{O}$, is present in most of the districts and is rather abundant in the San Francisco district. It occurs in large amounts in the "red beds" of the Plateau region.

Gostarite.-Goslarite, hydrous zinc sulphate, $\mathrm{ZnSO}_{4}+7 \mathrm{H}_{2} \mathrm{O}$, is abundant as an efflorescence on the walls of old workings in the Horn Silver mine, San Francisco district, and is present in small amounts in other districts.

Melanterite.-Melanterite, hydrous ferrous sulphate, $\mathrm{FeSO}_{4}+7 \mathrm{H}_{2} \mathrm{O}$, has been recognized in the oxidized ores of the Mercur and Tintic districts and is doubtless present in other deposits. 
Chalcanthite.-Chalcanthite, hydrous copper sulphate, $\mathrm{CuSO}_{4} \cdot 5 \mathrm{H}_{2} \mathrm{O}$, is a common efflorescence on the walls of old copper workings. It is especially abundant in the Horn Silver mine, San Francisco district, and the O K mine, Beaver Lake district, but it is present in many other mines.

Lettsomite (cyanotrichite). - Lettsomite, $4 \mathrm{CuO} \cdot \mathrm{Al}_{2} \mathrm{O}_{3} \cdot \mathrm{SO}_{3} \cdot 8 \mathrm{H}_{2} \mathrm{O}$, occurs in the Ajax, formerly the Copperopolis or American Eagle mine, Tintic district.

Utahite. - Utahite, $3 \mathrm{Fe}_{2} \mathrm{O}_{3} \cdot 2 \mathrm{SO}_{3} \cdot 7 \mathrm{H}_{2} \mathrm{O}$, has been described from the oxidized ores of the Tintic district It may be identical with jarosite, which is abundant in the Tintic ores. Alunite.-Alunite, hydrous sulphate of aluminum and potassium, $\mathrm{K}_{2} \mathrm{O} \cdot 3 \mathrm{Al}_{2} \mathrm{O}_{3} \cdot 4 \mathrm{SO}_{3} \cdot 6 \mathrm{H}_{2} \mathrm{O}$, occurs in veins in the Tushar Range and is a rare microscopic vein mineral in the Tintic and Erickson districts. It is an alteration product of igneous rocks in mineralized areas of the Tushar Range and Tintic district. In the Horn Silver mine, San Francisco district, and in the Tintic district it has formed during the oxidation of the ores.

Jarosite. 一 Jarosite, $\mathrm{K}_{2} \mathrm{O} .3 \mathrm{Fe}_{2} \mathrm{O}_{3} \cdot 4 \mathrm{SO}_{3} \cdot 6 \mathrm{H}_{2} \mathrm{O}$, has been recognized in the Mercur, Tintic, Detroit, Star, San Francisco, Tutsagubet, and Argenta districts, in the Deertrail mine, near Marysvale, and at several localities in the Plateau region, and is probably present in other localities. It invariably occurs as a product of oxidation of sulphides.

Plumbojarosite.-Plumbojarosite, PbO.$3 \mathrm{Fe}_{2} \mathrm{O}_{3} \cdot 4 \mathrm{SO}_{3} \cdot 6 \mathrm{H}_{2} \mathrm{O}$, is rather common as an oxidation product in the oxidized lead ores of Utah. It has been recognized in the Star, San Francisco, Tutsagubet, Tintic, Ophir, Stockton, Lucin, Fish Springs, Clifton, Big Cottonwood, Little Cottonwood, and American Fork districts. In several mines it is a valuable ore mineral.

Beaverite.-Beaverite, $\mathrm{CuO} . \mathrm{PbO} . \mathrm{Fe}_{2} \mathrm{O}_{3} \cdot 2 \mathrm{SO}_{3}$.$4 \mathrm{H}_{2} \mathrm{O}$, like the other basic ferric sulphates, is a product of the oxidation of sulphide ores. It was first described from the Horn Silver mine, San Francisco district. Material containing the same constituents and possibly identical with beaverite occurs in the Little Cottonwood and Ophir districts.

TUNGSTATES AND MOLYBDATES.

Scheelite.-Scheelite, calcium tungstate, $\mathrm{CaWO}_{4}$ (tungsten trioxide, 80.6 per cent; calcium oxide 19.4 per cent), occurs in veins in quartz monzonite in the Clifton district; it also occurs 15 miles northeast of Lucin, as a contact deposit in limestone associated with the Grouse Creek stock.

Cuproscheelite.-Cuproscheelite is reported by F. L. Hess from the Clifton district.

Powellite.-Powellite, calcium molybdate, $\mathrm{CaMoO}_{4}$, occurs as an oxidation product of molybdate in the Clifton and Beaver Lake districts.

Stolzite.-Stolzite, lead tungstate, $\mathrm{PbWO}_{4}$, occurs in replacement veins in limestone in the Clifton district.

Wulfenite.-Wulfenite, lead molybdate, $\mathrm{Pb}$ $\mathrm{MoO}_{4}$, occurs as an oxidation product in the Lucin district, especially in the Tecoma mine, in several mines in the Little Cottonwood and American Fork districts, in the HarringtonHickory mine, Star district, and in the Horn Silver mine, San Francisco district.

\section{HISTORY AND PRODUCTION.}

By V. C. Herkes.

CIVIL HISTORY.

The early history of the mining industry of Utah is closely bound up in that of the exploration and settlement of the region, an outline of which, prepared by Henry Gannett, ${ }^{1}$ is in large part quoted below:

The Territory of Utah was organized September 9, 1850, its area being a part of that acquired from Mexico by the United States in 1848. As originally organized, it extended from the summit of the Rocky Mountains in central Colorado westward to the east boundary of California, including all the territory between the parallels of $37^{\circ}$ and $42^{\circ}$ north latitude.

The organization of Colorado Territory in 1861 reduced it on the east to its present eastern boundary, and the formation of the Territory of Nevada in the same year reduced it on the west to the meridian of $39^{\circ}$ west of Washington. The enabling act of the State of Nevada, passed in 1864 . moved the west boundary of Utah a degree farther east, placing it upon the meridian of $38^{\circ}$, and upon the admission of Nevada as a State in 1866 Utah was still further diminished and Nevada increased, the eastern boundary of the latter being placed upon the meridian of $37^{\circ}$ west of Washington. Meantime, in 1863, the northeast corner of the State was cut off and added to the Territory of Idaho, and in 1866 a square degree in the northeast was added to the Territory of Wyoming, thus reducing Utah to its present dimensions. [See fig. 11.] On January 4, 1896, it was admitted as a State.

The area of the State is 84,970 square miles, of which it is estimated that 2,780 square miles are water surface, including Great Salt, Utah, and other lakes, and 82,190 square miles are land surface.

1 Gannett, Henry, A gazetteer of Utah: U. S. Geol. Survey Bull. 166, $1 \mathrm{SCO}$. 
From a very early time this region was traversed by Spanish caravans, traveling from Santa Fe, N. Mex., to Los Angeles, Cal. The old Spanish trail, which these caravans followed, entered Utah on the east near Dolores River, crossed the Grand near the Sierra La Sal, and the Green at the present crossing of the Rio Grande Western Railway. It reached the valley of Sevier River near its bend, and turning south followed its valley to the head and down the Virgin to a point near its southwest corner. This traffic, which at one time was great, left, however, no trace behind in the form of a settlement, and it was not until the hegira of the Mormons from the Mississippi Valley in 1847 that the present State of Utah received any permanent inhabitants.

The earliest recorded exploration of any part of Utah was a journey by two Franciscan fathers, Escalante and Dominguez, from Santa Fe, N. Mex., to the shores of Great Salt Lake, in 1776-77. So far as can be learned, their route followed in the main that of the old Spanish trail, and it is not at all improbable that they were the pioneers in laying out the western part of this route to southern California. So far as known, they were the first white men to visit the eastern part of the Great Basin of Utah. This

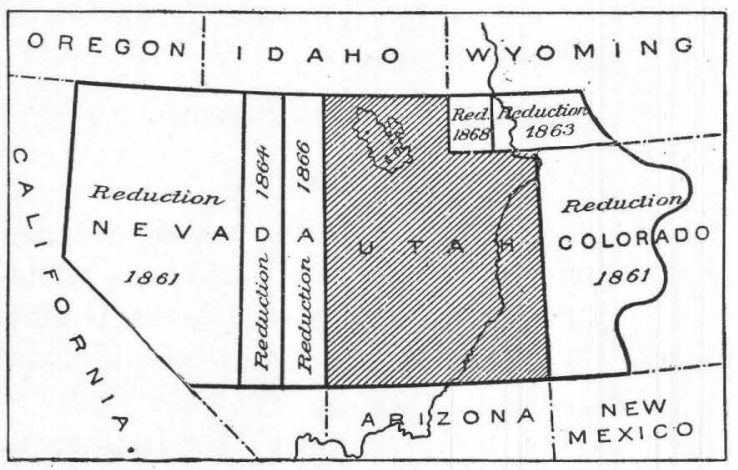

FIGURE 11.-Map of Utah showing changes of boundary.

journey was not, however, fruitful in geographical discovery, excepting the fact that it may have determined the route of travel between the Spanish settlements of New Mexico and those of California.

Between 1832 and 1836 Capt. B. L. E. Bonneville, of the United States Army, while on leave of absence, engaged in the fur trade in the West and coupled with it a certain amount of exploration. He traveled extensively over the northeastern part of Utah, including the area drained by Bear River and its tributaries, and sent a branch expedition, under Capt. Walker, to Great Salt Lake, down Humboldt River, and across the Sierra Nevada to California, returning by the route of the Spanish trail. No maps were prepared, and the only information derived from these explorations is contained in Washington Irving's narrative, which is very scanty and often erroneous.

The real exploration of Utah began in 1842, when Capt. J. C. Frémont, with an army expedition, entering the region via Bear River, explored Great Salt Lake and the adjacent region. Upon his return from California in the following year he entered the Territory again, on the south, via Virgin River and the Sevier, reaching Utah Lake, and thence proceeded northeastward down Uinta River.
Subsequent expeditions under army auspices, notably those of the Pacific Railroad explorations, Capt. Stansbury's survey of Great Salt Lake, and Capt. Simpson's explorations, made the main features of the Territory well known.

Green and Colorado rivers, which flow mainly within this State, were explored by a daring boat journey undertaken and carried through by J. W. Powell in 1869, and in the course of this exploration the greater features of the plateau region traversed by the rivers were delineated and their structure was explained.

The explorations of the geoıgists of the Fortieth Parallel Survey, Messrs. King, Hague, and Emmons, of the Wheeler and Hayden surveys, and later of the United States Geological Survey, carried on mainly by Messrs. Powell, Gilbert, Walcott, Marvine, Howell, Holmes, Peale, and Dutton, early gave a general knowledge of the geography and geology of the State, which has later been studied in greater detail in many areas by members of the United States Geological Survey and others.

Although the early explorations of the area date back to the time of the Declaration of Independence, 1776, no permanent settlement of white people was made till 1847. On July 24 of that year a company of Mormons, under the leadership of Brigham Young, arrived in the valley of Great Salt Lake and formed a settlement on the site of Salt Lake City. The first pioneers were quickly followed by many of their fellows who had been driven from their homes in the Mississippi Valley, so that by 1850 the Territory had a population of 11,380 people. Under the direction of the Mormon Church colonization was rapid, and 25 years after the arrival of the first immigrants at Salt Lake settlements had been established on nearly all the important streams where irrigation was practicable or where conditions were especially favorable to stock raising.

The rapid increase of population of the State is shown in the following table:

Population of Utah at the census years since 1850.

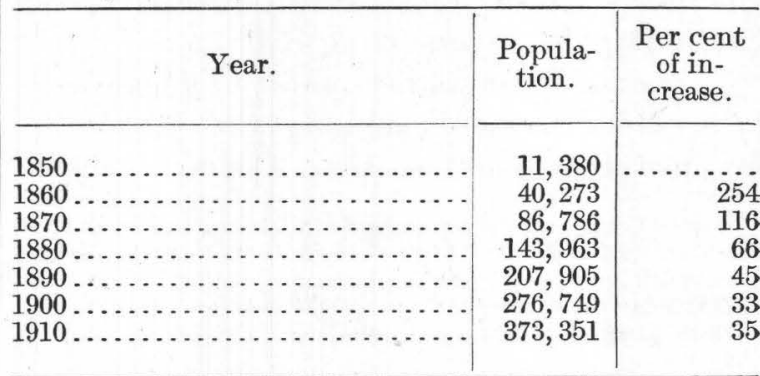


MINING HISTORY.

In contrast with many of the Cordilleran States the rancher preceded the prospector, and many agricultural communities were well established before mining became of any importance. Several factors doubtless contributed to this order of development. The leaders of the Mormon Church for several years discouraged prospecting; the rich and extensive placer deposits that were the first incentive to mining in many western camps were lacking; and the lode deposits, though many of them were very rich, required extensive machinery for profitable exploitation.

That the settlers were aware of the presence of metalliferous deposits in the mountains is shown by the fact that in the fifties some lead ore was crudely reduced to bullion for use as bullets. In 1859 a Government report ${ }^{1}$ mentions the existence of a rich mine of lead ore in Washington County, near the Vagas (now Las Vegas, Nev.) According to the records ${ }^{2}$ of the Las Vegas Mormon Mission four members who were taken to this mine by a Piute Indian guide on April 21, 1856, returned two days later with 180 pounds of the ore and reported that they had procured it 35 miles southwest of Las Vegas. In December, 1856, some of this ore was reduced to metal.

Isaac Grundy, who is credited with ${ }^{3}$ building a lead furnace (the first west of the Rocky Mountains) in the Lincoln district, was, according to the records of the Mormon Church, a Virginian who came to Salt Lake City in 1847 , and years later was called upon by Brigham Young to develop the lead mines near the place later called Minersville. The first metal produced in the State is said to have been from the Rollins or Lincoln mine in this district.

An event of great importance in the mining industry of Utah was the arrival in October, 1862, of Gen. E. P. Conner, with his California volunteers, who established themselves at Camp Douglas, overlooking Salt Lake City.

Parties of these soldiers, most of whom were prospectors, began searching the mountains for metals. Whether Gen. Conner deliber-

1 Explorations across the Great Basin of Utah; contains letter dated March 26, 1859, concerning the resources of Utah, from Dr. Garland Hurt, of Salt Lake City, to Capt. J. H. Simpson, at Camp Floyd.

2 Historian's Office, Mormon Church, Salt Lake City.

3 Eissler, Manuel, Metallurgy of argentiferous lead, preface, 1891. ately encouraged prospecting with the hope of causing an influx of gentile population, as the Mormon leaders are reported to have discouraged it to prevent such an influx, may be doubted. Hismen, many of whom had seen the gold excitement of California, doubtless needed little encouragement.

The year following the coming of the California soldiers metalliferous deposits were located in the ranges in the vicinity of Salt Lake; on September 17, 1863, the first mineral location in Utah (the West Jordan claim) was made in Bingham Canyon; and in December the first mining district (the West Jordan) was formed. After this, discoveries and locations were made rapidly. In 1865 the production of gold from the placers in Bingham Canyon began, but it was not till 1870 that production from the lead-silver deposits of the State became important. Since that time, except for a few depressions, increase in the metal output has been steady.

\section{RAILROAD CONSTRUCTION.}

GENERAL FEATURES.

In 1849-50 Capt. Stansbury was detailed by the Government to find a route for a transcontinental railroad; and in 1853 Lieut. Gunnison was detailed to survey a route south of the Uinta Mountains through central Utah to California but was killed by the Indians in Utah. The Union Pacific was completed to Ogden in 1869 and the Utah Central to Salt Lake in 1870.

On the advent of these railroads metal production became important, and as each branch line was completed a notable increase in output was observed. Several smelting towns, Sandy, Midvale (Bingham Junction), Murray (Germania), and Morgan, were built along the new lines south of Salt Lake, and several smelters along the branch line to Bingham. The road from Sandy to Alta was also beneficial, and as the railroad extended southward other mining regions were benefited, notably Tintic and several districts in Beaver County.

The principal railroad systems operating in Utah to-day are the Union Pacific (Oregon Short Line and Southern Pacific), the Denver \& Rio Grande, the Western Pacific, and the Los Angeles \& Salt Lake. 
UNION PACIFIC SYSTEM.

The first line built was the Union Pacific Railroad, which reached Ogden on March 3, 1869 , and Promontory on May 10, 1869, completing the first transcontinental railway by connecting there with the Central Pacific Railroad. In 1904 the Southern Pacific OgdenLucin cut-off, with an easier grade and less mileage, was built farther south across the, Great Salt Lake, and now handles most of the traffic, though trains are still operated over the old line and serve the Park Valley district in Box Elder County and the northern end of Promontory district.

The Utah Central Railroad Co. started construction from Ogden May 17, 1869, a week after the completion of the transcontinental route, and completed the 37 miles to Salt Lake City on January 10, 1870. In 1881 it was consolidated with the Utah Southern. In 1890 the Utah \& Nevada, Utah \& Northern, Salt Lake \& Western, Oregon Short Line, and Echo \& Park City railroads were united under the management of the Union Pacific as the Oregon Short Line and the Utah \& Northern railroads. Later, the line north of Salt Lake was taken over by the Oregon Short Line, and all the lines south of Salt Lake (including the Utah Central) not owned by the Denver \& Rio Grande by the Los Angeles \& Salt Lake Railroad.

The Echo \& Park City Railroad was completed from Echo to Park City in December, 1880, as a broadgage branch of the Union Pacific. It soon replaced two other roads, the Summit County Railroad from Echo to Coalville and the Utah Eastern Railroad from Coalville to Park City.

The Utah \& Northern Railroad was organized August 23, 1871, and was completed from Brigham to Logan in Cache County January 1, 1873, and to Franklin, Idaho, in May, 1874. It connected with the Central Pacific at Brigham and also at Corinne, 4 miles farther west. On February 8, 1874, the road was extended to Ogden and operated independently till February, 1877, when it was purchased by the Union Pacific Railroad, made broadgage, and, in 1890, absorbed by the Oregon Short Line system.
DENVER \& RIO GRANDE SYSTEM.

The Denver \& Rio Grande Railroad began construction in Colorado. Its line in Utah was the Rio Grande Western, a narrow-gage road begun in 1881, completed in May, 1883, and widened to standard gage in May, 1890. In June, 1890, the company began the construction from Thistle Junction southward through San Pete and Sevier valleys of a branch line which it completed to Marysvale, its southern terminus, in 1900. In 1891 it built a branch line from Springrille to Eureka and Mammoth in the Tintic district.

Other branches of the Rio Grande Western are the Alta branch (Wasatch \& Jordan Valley Railroad), between Sandy and Wasatch; Bingham branch (Bingham Canyon \& Camp Floyd Railroad), between Midvale and Bingham; Pleasant Valley branch, between Colton on the main line and Clear Creek; Park City branch, between Roper on the main line and Park City. The oldest of these branches is the Bingham Canyon \& Camp Floyd, which was completed from Sandy to Bingham by December 1, 1874, was bought in 1883 by the Rio Grande Western, and was made standard gage in 1890. It now connects with the main line at Midvale (Bingham Junction).

The Wasatch \& Jordan Valley Railroad was completed to Granite on May 3, 1873, to Fairfield Flat on September 28, 1873, and later to Alta. The road, about 8 miles of which was covered by snowsheds, was abandoned from Granite (now called Wasatch) to Alta in the eighties, but its lower part to Wasatch was later repaired and used to haul granite to Salt Lake City and ore from Wasatch. Tracks were laid on the old roadbed from Midvale to Wasatch in 1913-14. The line is now known as the Salt Lake \& Alta Railroad. A narrowgage line was completed from Wasatch to Alta in 1918.

The Utah \& Pleasant Valley Railroad was commenced in 1876, and in 1883 became part of the main line of the Rio Grande Western.

The San Pete Valley Railroad, which extends from Nephi through Salt Creek Canyon to Morrison is now operated by the Denver \& Rio Grande Railroad. 
The Salt Lake \& Eastern Railroad, now the Park City branch of the Denver \& Rio Grande, was finished in 1890 .

The Western Pacific Railroad, part of the Rio Grande system, was started in 1905 to connect Salt Lake City with San Francisco.

In 1917 a branch line of the Western Pacific was established from Wendover to Gold Hill in the Clifton district.

LOS ANGELES \& SALT LAKE RAILROAD.

Early in 1905 the Los Angeles \& Salt Lake Railroad was completed from Salt Lake to Los Angeles and San Pedro. The Ophir district is connected with the line at St. John by the St. John \& Ophir branch.

The Utah Southern Railroad was begun at Salt Lake May 1, 1871, and had reached Provo by December, 1873, and Juab by June, 1879. From Juab the road was continued by the Utah Southern Railroad Extension Co. to Milford in May, 1880. The Horn Silver mine in the town of Frisco was reached June 23, 1880. Continuation of this branch to Newhouse, the present terminus, was completed in 1905 . The line from Milford was continued to Modena and thence to the Pacific coast by the Los Angeles \& Salt Lake Railroad.

In 1872 the Salt Lake, Sevier Valley \& Pioche Railroad, afterward called the Utah Western and also the Utah \& Nevada, a narrow-gage road designed to serve the mines and smelters at Stockton and Ophir, was begun and after some years was finished to Terminus, near Stockton. The road was subsequently purchased by the Union Pacific system and in 1905 made part of the broadgage line of the Los Angeles \& Salt Lake Railroad.

The Salt Lake \& Western Railroad was built as a branch of the Union Pacific, which subsequently turned it over to the San Pedro, Los Angeles \& Salt Lake Railway Co. It starts from Lehi, in Utah Valley, serving Fairfield, the junction of the abandoned line to Mercur. Short spurs were built to Mammoth and Silver City, and the line was completed to Eureka in 1883.

The Salt Lake \& Mercur Railroad, a broadgage line, was completed in 1895 and dismantled in 1914, a year after most operations at Mercur had ceased.
The American Fork Railroad, from the old Utah Central station on American Fork, to Deer Creek in American Fork Canyon, was completed in 1872 but was soon abandoned.

In 1907 the Eureka Hill Railway Co. built a narrow-gage railroad to connect various mines with the smelter and ore sampler at Silver City in the Tintic district.

The Bingham \& Garfield Railroad, owned by the Utah Copper Co., was completed in 1911 to haul ore to the Garfield mill.

\section{METALLURGIC DEVELOPMENT.}

Utah has been the scene of many important advances in metallurgy, and an adequate treatment of the development of processes in use within her borders would require much study and a volume for its presentation. No serious attempt is therefore made in this paper to treat this phase of the mining industry systematically, though its commercial importance is commensurate with that of the development of the mines. Only the general changes in treatment are outlined and, in the history of the several districts, the general treatment of the ores at different stages is stated.

In the early days of the industry most of the metallurgic plants were at the mines or as near them as suitable supplies could be had. The plants consisted mainly of mills for the treatment of the silver ores and of crude smelters, which often failed, for the reduction of the oxidized lead ores. Later there was a marked tendency to concentrate the smelters in Salt Lake Valley and to bring the ores and fuel to them. This change was probably largely due to the greater efficiency of the larger plants, the advantages to be gained by mixing the ores of different districts, and the exhaustion of the fuel supply in many districts.

Still later, when the rich oxidized ores were exhausted, it became necessary to erect mills at or near the mines to concentrate the metallic constituents and in some ores to separate the different metallic minerals, which were then sent to the smelters for reduction. Such mills have been erected in the ParkCity,Bingham, and other districts. In recent years the development of the large bodies of low-grade copper ores of the Bingham district has resulted in the erection 
of the great mills at Garfield, where more than the State for final treatment, though electro30,000 tons of ore can be daily concentrated, lytic plants for producing zinc are in operation. and the smaller mill at Lark. A mill was also Several mills for the treatment of gold ores are constructed at Newhouse to treat the ore from the Cactus mine.

In the treatment of gold ores Utah was a pioneer in developing the cyanide process, which transformed the operations of the Mercur camp from a forlorn hope to an important commercial enterprise.

At present most of the ores and concentrates produced from the mines in Utah are treated at the four valley smelters, but the zinc ores, which in recent years have become of increasoperated, and in the last few years processes have been developed for the treatment of ores that are chiefly valuable for their silver. It is expected that these processes will make it possible to rework much of the waste of earlier operations.

The relative importance of the different types of treatment are indicated in the following tables, which show the output of the mills by amalgamation and by cyanidation and of the ing importance, are still mostly shipped out of $/$ for the period 1903-1916.

Tonnage of and recovery from ores handled by gold and silver mills by amalgamation and cyanidation, 1903-1917.

\begin{tabular}{|c|c|c|c|c|c|c|c|c|c|}
\hline \multirow{2}{*}{ Year. } & \multirow{2}{*}{$\begin{array}{c}\text { Quantity } \\
\text { (short } \\
\text { tons). }\end{array}$} & \multicolumn{3}{|c|}{ Gold. } & \multicolumn{3}{|c|}{ Silver. } & \multirow{2}{*}{ Total value. } & \multirow{2}{*}{$\begin{array}{c}\text { Average } \\
\text { recovery } \\
\text { value } \\
\text { per ton. }\end{array}$} \\
\hline & & $\begin{array}{c}\text { Fine } \\
\text { ounces. }\end{array}$ & Value. & $\begin{array}{c}\text { Value } \\
\text { perton. }\end{array}$ & $\begin{array}{c}\text { Fine } \\
\text { ounces. }\end{array}$ & Value. & $\begin{array}{l}\text { Ounces } \\
\text { per ton. }\end{array}$ & & \\
\hline ......... & 445,114 & $84,651.00$ & $\$ 1,749,891$ & $\$ 3.93$ & 124,046 & $\$ 66,985$ & 0.28 & $\$ 1,816,876$ & $\$ 4.08$ \\
\hline $1904 \ldots$ & 363,883 & $57,773.00$ & $1,194,274$ & 3. 28 & 72,493 & 42,046 & .20 & $1,236,320$ & 3.40 \\
\hline $1905 \ldots$ & 416,530 & $64,117.00$ & $1,325,416$ & 3.18 & 80,713 & 49,235 & .19 & $1,365,651$ & 3.28 \\
\hline $1906 \ldots$ & 408,712 & $61,365.60$ & $1,268,540$ & 3. 10 & 52,994 & 36,036 & .13 & $1,304,576$ & 3.19 \\
\hline $1907 \ldots$ & 263,020 & $41,507.06$ & 858,027 & 3.26 & 42,049 & 27,752 & .16 & 885,779 & 3.37 \\
\hline $1908 \ldots$ & 313,845 & $45,968.09$ & 950,245 & 3.03 & 18,662 & 9,891 & .06 & a 960,136 & 3.06 \\
\hline ........ & 287,659 & $39,861.43$ & 824,009 & 2.86 & 5,153 & 2,680 & .02 & 826,689 & 2.87 \\
\hline ........ & 263,041 & $36,480.92$ & 754,127 & 2.87 & 4,612 & 2,490 & .02 & b 756,617 & 2.88 \\
\hline ........ & 267,111 & $30,312.22$ & 626,609 & 2.35 & 112,493 & 59,621 & .42 & c 686,230 & 2.57 \\
\hline ......... & 171,117 & $21,288.69$ & 440,076 & 2.57 & 64,468 & 39,648 & .38 & $d 479,724$ & 2.80 \\
\hline $1913 \ldots$ & 75,972 & $13,117.41$ & 271,161 & 3. 57 & 61,032 & 36,863 & .80 & e 308,024 & 4. 05 \\
\hline $1914 \ldots$ & 2,166 & 739.33 & 15,282 & 7.06 & 11,536 & 6,379 & 5. 33 & $f 21,706$ & 10.02 \\
\hline $1915 \ldots$ & 2,167 & $1,388.88$ & 28,708 & 13.25 & 6,494 & 3,292 & 3.00 & $g 32,003$ & 14.77 \\
\hline 1916. & 1,423 & 309. 09 & 6,389 & 4. 49 & 340 & 224 & .24 & 6,613 & 4. 65 \\
\hline $1917 \ldots$ & 190 & 140.66 & 2,908 & 15. 31 & 26 & 21 & .11 & 2,929 & 15.42 \\
\hline
\end{tabular}

$a$ Includes bullion from 32,773 tons of old tailings re-treated by cyanidation.

$b$ Includes bullion from 34,754 tons of old tailings re-treated by cyanidation.

c Includes bullion from 4,600 tons of old tailings re-treated by cyanidation.

$e$ Includes bullion from 7,125 tons of old tailings re-treated by cyanidation.

$f$ Includes bullion from 1,125 tons of old tailings re-treated by cyanidation.

$g$ Includes bullion from 46 tons of old tailings re-treated by amalgamation; and bullion from 11,250 tons of old tailings re-treated by cyanidation. 
Crude ores produced in Utah and shipped to smelters, by kinds, 1903-191\%.

\begin{tabular}{|c|c|c|c|c|c|c|c|c|c|c|c|c|c|}
\hline \multirow{2}{*}{ Kinds of crude ore. } & \multirow{2}{*}{$\begin{array}{l}\text { Quantity } \\
\text { (short } \\
\text { tons). }\end{array}$} & \multicolumn{2}{|c|}{ Gold. } & \multicolumn{2}{|c|}{ Silver. } & \multicolumn{2}{|c|}{ Copper. } & \multicolumn{2}{|c|}{ Lead. } & \multicolumn{2}{|c|}{ Recoverable zinc. } & \multirow{2}{*}{$\begin{array}{l}\text { Total } \\
\text { value. }\end{array}$} & \multirow{2}{*}{$\begin{array}{l}\text { Average } \\
\text { gross } \\
\text { value } \\
\text { perton. }\end{array}$} \\
\hline & & $\begin{array}{l}\text { Fine } \\
\text { ounces. }\end{array}$ & $\begin{array}{c}\text { Value } \\
\text { perton. }\end{array}$ & $\begin{array}{c}\text { Fine } \\
\text { ounces. }\end{array}$ & $\begin{array}{l}\text { Ounces } \\
\text { per ton. }\end{array}$ & Pounds. & $\begin{array}{l}\text { Per } \\
\text { cent. }\end{array}$ & Pounds. & $\begin{array}{l}\text { Per } \\
\text { cent. }\end{array}$ & Pounds. & $\begin{array}{l}\text { Per } \\
\text { cent. }\end{array}$ & & \\
\hline \multicolumn{14}{|l|}{ Dry or siliceous: } \\
\hline 1903. & 67,463 & $35,784.75$ & $\$ 10.96$ & 932,743 & 13.82 & 847,239 & 0.63 & 379,970 & 0.28 & & & $\$ 1,375,448$ & $\$ 20.39$ \\
\hline 1904. & 53,036 & $25,129.00$ & 9.79 & 770,900 & 14.53 & 221,648 & .21 & 662,047 & .62 & & & $1,023,423$ & 19. 30 \\
\hline 1905. & 57,573 & $11,302.00$ & 4. 06 & 756,512 & 13. 14 & 454,799 & .39 & $1,445,004$ & 1. 25 & & & 833,968 & 14.48 \\
\hline 1906. & 86,912 & $25,225.89$ & 6.00 & 863,863 & $\begin{array}{r}1.14 \\
9.94\end{array}$ & 714,763 & .41 & $1,169,687$ & .67 & & & $1,313,514$ & 15. 11 \\
\hline 1907. & 37,002 & $25,865.93$ & 14.45 & 337,376 & 9.12 & 120,527 & .16 & 51,126 & .07 & & & 784,179 & 21. 19 \\
\hline $1908 .$. & 7,646 & $2,211.41$ & 5.98 & 195,411 & 25.56 & 9,911 & .06 & 69,580 & .45 & & & 153,512 & 20.08 \\
\hline 1909. & 21,101 & $9,110.84$ & $\begin{array}{l}8.90 \\
8.92\end{array}$ & 397,922 & 18.86 & 299,031 & .71 & 357,285 & .85 & & & 449,494 & 21.30 \\
\hline 1910. & 93,772 & $10,735.91$ & 2.37 & 543,886 & 5.70 & $1,029,927$ & .55 & 522,889 & .28 & & & 669,438 & 7. 14 \\
\hline 1911. & 189,424 & $48,567.32$ & 5. 30 & $2,451,673$ & 12.94 & $3,256,340$ & .86 & $2,552,128$ & .67 & & & $2,825,253$ & 14. 91 \\
\hline 19 & 196,846 & $49,822.50$ & 5. 23 & $3,410,636$ & 17.33 & $3,326,787$ & .84 & $1,763,257$ & .45 & & & $3,755,731$ & 19.08 \\
\hline 1913. & 127,253 & $19,559.62$ & 3. 17 & $1,769,019$ & 13. 90 & $1,447,177$ & .57 & $1,019,255$ & .40 & & & $1,741,98 \mathbf{i}$ & 13. 69 \\
\hline 1914. & 89,246 & $17,274.07$ & 4.00 & $1,005,761$ & 11. 27 & $1,972,888$ & 1.11 & 686,949 & .38 & & & $1,202,458$ & 13.47 \\
\hline 19 & $\begin{array}{l}05,240 \\
47,513\end{array}$ & $7,817.78$ & $\begin{array}{l}4.00 \\
3.40\end{array}$ & $1,018,088$ & $\begin{array}{l}11.42 \\
21.42\end{array}$ & 686,681 & $\begin{array}{r}1.11 \\
.72\end{array}$ & $1,010,054$ & $\begin{array}{l}.00 \\
1.06\end{array}$ & & & 845,419 & 17. 79 \\
\hline 191 & 58,514 & $7,940.63$ & 2.80 & 946,333 & 16.17 & 977,497 & .84 & 246,028 & .21 & & & $1,044,274$ & 17.84 \\
\hline \multirow{2}{*}{\multicolumn{14}{|c|}{\begin{tabular}{l|l|}
18.76 & $1,760,377$
\end{tabular}}} \\
\hline & & & & & & & & & & & & & \\
\hline 1903. & 517,882 & $70,020.91$ & 2. 79 & $2,291,016$ & 4.42 & $26,622,504$ & 2. 57 & 750 & & & & $6,331,924$ & 12. 23 \\
\hline & 587 & $98,150.00$ & 2.99 & $2,824,597$ & 4. 17 & $35,718.670$ & 2.64 & 8,169 & & & & $8,239,547$ & 12. 16 \\
\hline 19 & 821,154 & $144,427.00$ & 3. 64 & $3,554,064$ & 4. 33 & $40,763,987$ & 2.48 & 87,815 & & & & $11,516,860$ & 14.02 \\
\hline 1906 & 767,068 & $132,260.84$ & 3.56 & $2,750,206$ & 3. 58 & $38,663,339$ & 2.52 & 256,410 & 02 & & & $12,080,853$ & 15. 75 \\
\hline 19 & 908,319 & $137,211.81$ & 3. 12 & $3,110,686$ & 3. 42 & $41,317,808$ & 2.27 & 62,744 & & & & $13,156,360$ & 14.49 \\
\hline & 644,488 & $93,245.58$ & 2.99 & $2,282,903$ & 3. 54 & $29,987,867$ & 2.33 & $1,195,285$ & 09 & & & $7,146,097$ & 11. 09 \\
\hline 1909 & 753,278 & $93,454.82$ & 2.56 & $2,257,839$ & 3. 00 & $35,315,285$ & 2. 34 & $1,547,324$ & .10 & & & $7,763,480$ & 10. 31 \\
\hline 1910 & 568,845 & $72,713.33$ & 2.64 & $1,654,963$ & $\begin{array}{l}0.91 \\
2.91\end{array}$ & $30,116,632$ & 2.65 & 221,127 & .02 & & & $6,231,385$ & 10. 95 \\
\hline 19 & 640,729 & $73,160.10$ & 2. 36 & $1,926,406$ & 3. 01 & $32,637,950$ & 2.55 & 338,688 & .03 & & & $6,628,332$ & 10. 34 \\
\hline 1912 & 572,354 & $68,251.32$ & 2.46 & $2,187,869$ & 3. 82 & $25,000,452$ & 2.18 & $2,194,024$ & .19 & & & $6,980,226$ & 12. 19 \\
\hline 1913 & 662,892 & $70,385.88$ & 3. 19 & $1,988,922$ & $\begin{array}{l}3.00 \\
3.00\end{array}$ & $25,719,652$ & $\begin{array}{l}1.94 \\
1.9\end{array}$ & 147,344 & .01 & & & $6,649,343$ & 10. 03 \\
\hline 10 & 471,626 & $62,091.43$ & 2.72 & $1,367,744$ & 2. 90 & $17,209,706$ & $\begin{array}{l}1.81 \\
1.82\end{array}$ & $\begin{array}{r}2,179 \\
\end{array}$ & & & & $4,328,883$ & 9.18 \\
\hline 1915 & 509,762 & $63,583.24$ & 2.58 & $1,667,586$ & 3. 27 & $21,478,606$ & 2.10 & 20,401 & 02 & & & $5,919,566$ & 11.61 \\
\hline 1916 & 732,680 & $66,367.81$ & 1. 87 & $2,144,660$ & $\begin{array}{l}2.92 \\
\end{array}$ & $29,962,228$ & 2.04 & 6. 540 & Trace. & & & $10,154,290$ & 13. 86 \\
\hline 191 & 617,156 & $44,546.28$ & 1. 49 & $1,698,521$ & 2.75 & $28,262,873$ & 2.29 & 12,772 & ...do... & & & $10,042,757$ & 16,27 \\
\hline \\
\hline 199 & 150,862 & $15,502.48$ & 2. 12 & $6,965,581$ & 46.17 & $3,233,847$ & 1.07 & $73,420,251$ & 24. 33 & & & $7,608,566$ & 50.43 \\
\hline & 7,620 & $15,210.00$ & 1. 68 & $6,317,459$ & 33.67 & $3,000,313$ & .80 & $86,263,622$ & 22.99 & & & $8,071,921$ & 43. 02 \\
\hline 1905 & 179,679 & $20,014.00$ & 2.30 & $4,594,862$ & 25.57 & $2,215,582$ & .62 & $77,411,488$ & 21. 54 & & & $7,200,563$ & 40.07 \\
\hline 1906 & 266,450 & $23,119.96$ & 1. 79 & $5,999,799$ & 22.52 & $2,631,334$ & .49 & $87,927,835$ & 16.50 & & & $10,077,530$ & 37. 82 \\
\hline 190 & 222,685 & $27,620.67$ & 2.56 & $5,429,476$ & 24.38 & $1,987,936$ & .45 & $81,052,354$ & 18. 20 & & & $8,847,786$ & 39. 73 \\
\hline 190 & 130,931 & $15,783.91$ & 2.49 & $4,606,656$ & 35. 18 & $1,685,373$ & .64 & $62,423,595$ & 23. 84 & & & $5,612,070$ & 42. 86 \\
\hline 1909 & 220,616 & $30,260.82$ & 2.83 & $7,194,261$ & 32.60 & $2,356,409$ & .04 & $101,915,747$ & $\begin{array}{l}20.04 \\
23.10\end{array}$ & & & $9,055,273$ & 41. 04 \\
\hline 191 & 221,648 & $26,565.39$ & 2.48 & $5,926,111$ & 26.74 & $2,408,908$ & .54 & $69,645,351$ & 15. 71 & & & $7,119,581$ & 32.12 \\
\hline 191 & 261,333 & $22,989.65$ & 1. 82 & $5,400,455$ & 20.66 & $2,587,717$ & .50 & $84,244,320$ & 16.12 & & & $7,451,938$ & 28.51 \\
\hline 101 & 252,888 & $20,647.98$ & 1.68 & $5,073,891$ & 20.06 & $3,058,179$ & .60 & $83,074,776$ & 16.42 & & & $7,790,239$ & 30.80 \\
\hline $1913 .$. & 357,196 & $30,343.39$ & 1.76 & $6,241,585$ & 17.47 & $4,582,358$ & .64 & $107,078,919$ & 14. 99 & & & $9,818,909$ & 27.49 \\
\hline
\end{tabular}




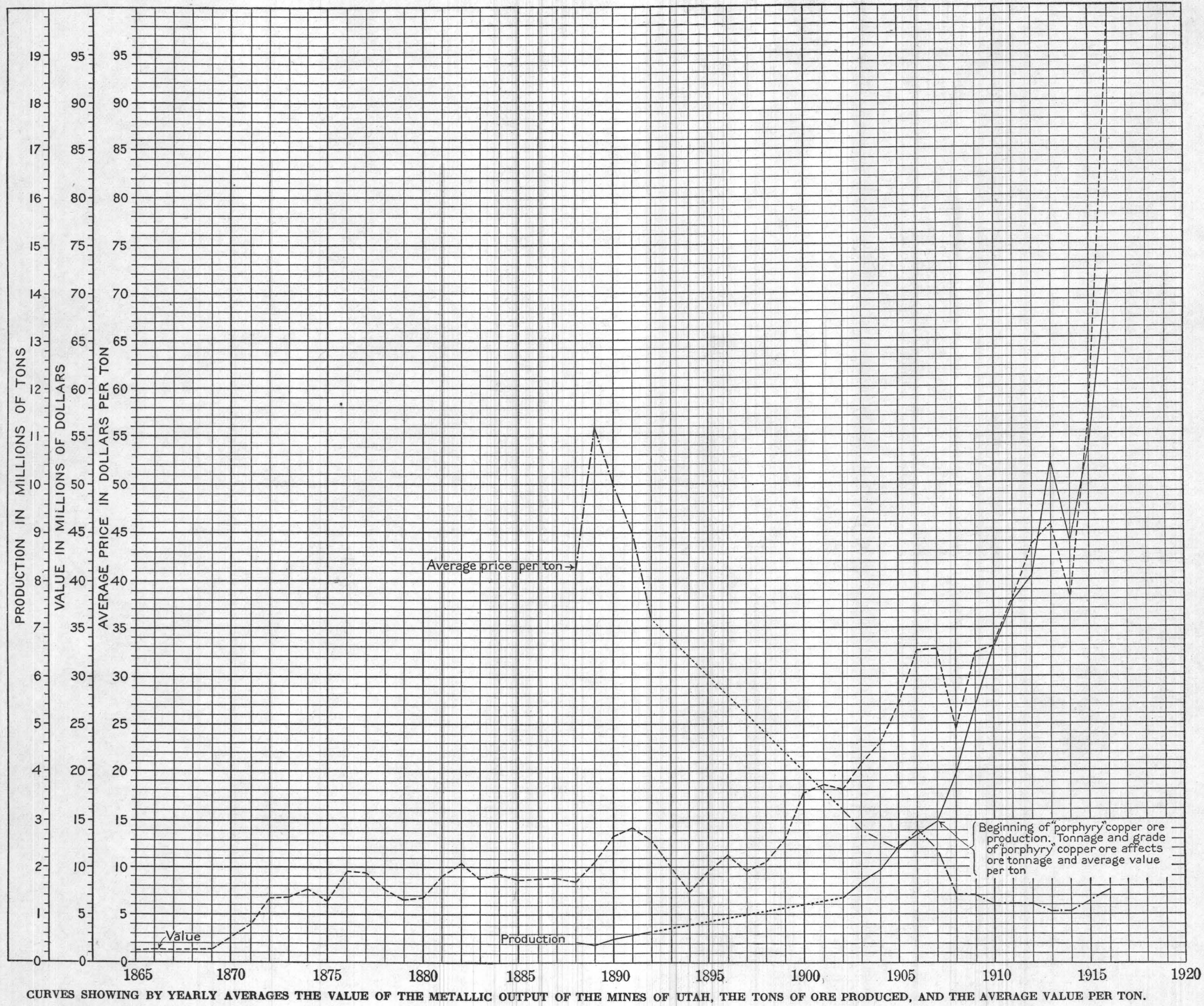





\begin{tabular}{|c|c|c|c|c|c|c|c|c|c|c|c|c|c|}
\hline \multicolumn{14}{|l|}{ Zinc: } \\
\hline 1905. & 90 & 3. 00 & .69 & 3,270 & 36. 33 & 3,750 & 2. 08 & 6,000 & 3. 33 & 60,750 & 33.75 & 6,508 & 72.31 \\
\hline $1906 \ldots$ & 8,921 & 219.98 & .51 & 73,334 & 8.22 & & & & & $3,349,389$ & 18. 77 & 258,726 & 29.00 \\
\hline 1908. & 3,153 & 3. 39 & .02 & 2,568 & .81 & & & 4,415 & 07 & $1,405,652$ & 22.29 & 67,682 & 21. 46 \\
\hline 1909. & 18,969 & 363. 43 & .40 & 92,458 & 4.87 & 2,808 & & 730,609 & 1. 93 & $6,967,237$ & 18. 36 & 463,603 & 24. 44 \\
\hline $1910 .$. & 12,710 & 5. 09 & & 140,279 & 11. 04 & & & 890,545 & 3. 50 & $8,742,135$ & 34. 39 & 587,115 & 46. 19 \\
\hline 1911. & 13,858 & 75. 64 & .11 & 39,300 & 2. 83 & 9,944 & .04 & 390,062 & 1. 41 & $9,065,043$ & 32.71 & 557,898 & 40. 26 \\
\hline 1912. & 14,992 & 253. 92 & .35 & 175,229 & 11. 69 & 85,376 & .28 & 938,813 & 3. 13 & $10,716,314$ & 35.74 & 908,775 & 60.62 \\
\hline 1913.. & 13,802 & 193. 66 & .29 & 134,762 & 9.76 & 68,216 & .25 & 791,513 & 2. 87 & $9,134,638$ & 33.09 & 642,339 & 46. 54 \\
\hline $1914 .$. & 11,869 & 74. 39 & .13 & 59,079 & 4. 97 & 3,344 & .01 & 261,569 & 1. 10 & $8,885,621$ & 37.43 & 498,021 & 41. 12 \\
\hline 1915. & 19,587 & 197. 06 & .21 & 164,515 & 8.40 & 12,787 & .33 & 859,580 & 2. 19 & $14,835,304$ & 37.87 & $1,969,699$ & 100.56 \\
\hline $1916 .$. & 18,433 & 126.88 & .13 & 84,955 & 4. 61 & 25,440 & .07 & 390,460 & 1. 05 & $14,020,354$ & 38.03 & $1,970,450$ & 106.89 \\
\hline $1917 .$. & 14,094 & 294. 14 & .43 & 131,615 & 9.34 & 168, 483 & .60 & 655,534 & 2.33 & $9,210,334$ & 32.67 & $1,156,357$ & 82.04 \\
\hline Copper-lead: & & & & & & & & & & & & & \\
\hline 1903. & 14,210 & 162.18 & .24 & 225,268 & 15.85 & 908,208 & 3. 20 & $2,591,636$ & 9.12 & & & 358,270 & 25. 21 \\
\hline 1904. & 16,982 & 173. 00 & .21 & 231,178 & 13.61 & $1,001,543$ & 2. 95 & $2,450,856$ & 7. 22 & & & 371,244 & 21.86 \\
\hline 1905. & 22,018 & 377. 00 & .35 & 330,855 & 15. 03 & $1,320,555$ & 3. 00 & $3,501,732$ & 7. 95 & & & 580,202 & 26.35 \\
\hline $1906 \ldots$ & 3,249 & 114. 75 & .73 & 37,600 & 11.57 & 253,546 & 3.90 & 806,175 & 12. 40 & & & 122,827 & 37.80 \\
\hline 1907. & 3,224 & 151. 98 & .97 & 80,976 & 25.12 & 272,819 & 4. 23 & 807,832 & 12.53 & & & 153,965 & 47.75 \\
\hline 1908. & 1,090 & 36.40 & .69 & 22,838 & 20.95 & 88,064 & 4. 04 & 223,921 & 10. 27 & & & 33,886 & 31.09 \\
\hline $1909 \ldots$ & 438 & 11.95 & .56 & 7,941 & 18. 13 & 65,668 & 7.50 & 81,603 & 9. 32 & & & 16,423 & 37. 49 \\
\hline 1910 & 2,152 & 35. 24 & .34 & 62,154 & 28. 88 & 154,924 & 3. 60 & 570,955 & 13. 27 & & & 79,089 & 36.75 \\
\hline 1911. & 291 & 3.76 & .26 & 9,021 & 31.00 & 29,354 & 5. 04 & 45,872 & 7.88 & & & 10,591 & 36. 39 \\
\hline 1912. & 426 & 1. 07 & .05 & 15,008 & 35. 23 & 60,167 & 7.06 & 86,777 & 10. 18 & & & 23,083 & 54. 18 \\
\hline 1915. & 21 & .52 & .51 & 499 & 23.76 & 2,060 & 4.90 & 2,994 & 7. 13 & & & 765 & 36.43 \\
\hline Lead-zinc: $a$ & & & & & & & & & & & & & \\
\hline $1905 \ldots$ & 3,794 & 86.00 & .47 & 34,370 & 9. 06 & & & 361,413 & 4. 76 & $1,911,577$ & 25. 19 & 152,514 & 40. 20 \\
\hline $1906 \ldots$ & 375 & 11. 25 & .62 & 6,563 & 17.50 & & & 37,500 & 5. 00 & 168,750 & 22.50 & 17,127 & 45. 67 \\
\hline 1907. & 574 & 6. 03 & .22 & 9,415 & 16. 40 & & & 46,361 & 4. 04 & 258,784 & 22.54 & 24,064 & 41.92 \\
\hline 1909. & 1,084 & 23. 68 & .45 & 13,179 & 12. 16 & 1,593 & .07 & 132,669 & 6.12 & 419,542 & 19. 35 & 35,909 & 33. 12 \\
\hline $1910 .$. & 12,714 & 278.90 & .45 & 104,095 & 8.18 & 11,018 & .04 & $1,069,848$ & 4. 21 & $4,217,287$ & 16.59 & 294,132 & 23. 14 \\
\hline & 7,054 & 10. 70 & 03 & 98,549 & 13. 97 & 3,009 & .02 & 817,481 & 5. 79 & $4,091,639$ & 29. 00 & 322,838 & 145.76 \\
\hline 1916. & 6,042 & 337.73 & 1. 16 & 106,244 & 17.58 & 105,367 & .87 & 917,528 & 7.59 & $3,719,160$ & 30.78 & 664,487 & 09.98 \\
\hline 1917. & 12,924 & 571.00 & .91 & 133,976 & 10.37 & 219,167 & .84 & $1,944,380$ & 7.52 & $7,657,236$ & 29.62 & $1,130,287$ & 87.46 \\
\hline
\end{tabular}

$a$ Lead-zinc ore concentrated in 1912-15 produced lead concentrate and zinc concentrate but no lead-zine concentrate. In 1916-17 lead-zinc ore produced lead concentrate, zinc concentrate, and lead-zinc 


\section{PRODUCTION.}

The production of mineral substances has long been among the important industries of Utah. In addition to the metals, which alone are treated in this report, the State contains large deposits of coal and phosphate rock, important deposits of hydrocarbons and oil shale, and deposits of salines, building materials, and sulphur. In 1916, the nonmetallic mineral products were valued at $\$ 8,690,172$ and the metallic products at $\$ 44,916,348$, making a total of $\$ 53,606,520$.

\section{PRODUCTION BY YEARS,}

Production of metals on a commercial scale began in 1865. (See p. 118.) The quantity and value of the principal metals, by years, from 1865 to 1917, inclusive, is given in the table 'on pages 127-128, and the growth of the metal-mining industry is graphically shown in Plate XIII.

The increase in the metal output of the State since 1870, when railroad transportation reached Salt Lake City, has been rather uniform. There have, however, been several depressions of short duration, perhaps the most conspicuous being that in the middle nineties, when the rapid fall in the price of silver caused a considerable decrease in the output of both silver and lead, and that in 1907 to 1909 when the general commercial depression caused a considerable decrease in the value of the metal output. In 1915, 1916, and 1917 there was rapid increase due to war conditions. The discovery of a new deposit or the exhaustion of an old one has from time to time caused minor variations in the production curve, though usually these are not of large importance as regards the State production, as the falling off in one district is likely to be in part balanced by an increase in another. In the individual districts the production of a single mine is of course of far greater relative importance.

The relatively rapid rise in total metallic value (see Pl. XIII) since the late nineties is due in large part to the increase in the production of copper, principally from the Bingham district, though other districts have contributed important amounts.

The yearly tonnage of ore treated and the average value per ton are also shown in Plate XIII. Statistics regarding these items are complete only since 1902, but reliable estimates are available from 1888 to 1892 . There has been a very rapid increase in the amount of ore produced and a very rapid decrease in the average value per ton, which dropped from more than $\$ 15$ in 1892 to $\$ 4.39$ in 1913.

The decrease in the value per ton may be attributed principally to the great advances made in mining and metallurgic processes, which have made it profitable to mine and treat material that but a few years ago was not regarded as ore, and to the exhaustion of the bonanza portions of many of the old mines. The rapid decrease in the last few years is due, in large part, to increase in the amount of low-grade copper ore treated. In the future it is likely to be much less marked, though it will doubtless continue and will be welcomed

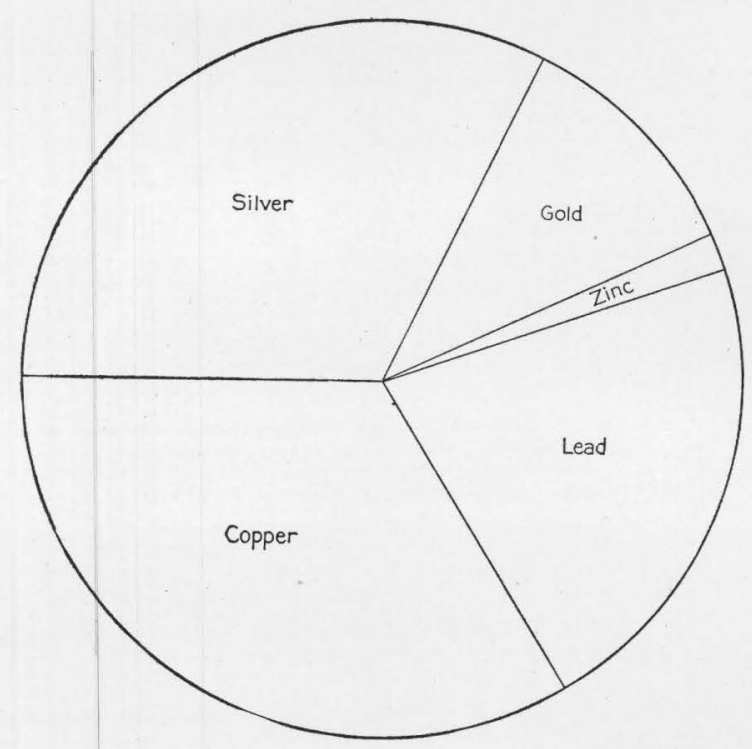

FrgURE 12.-Diagram showing relative value of the principal metals produced in Utah, 1865-1916.

so far as it means an improvement in mining and metallurgic practices, for even a slight decrease in the value of material that can be commercially treated adds materially to the amount of the ore available.

The total value of the principal metals produced to the close of 1917, amounting to $\$ 916,155,337$, is distributed as follows: Silver, $\$ 271,788,824$; copper, $\$ 346,681,440$; lead, $\$ 188,715,846$; gold, $\$ 93,119,333$; and zinc, $\$ 15,849,894$. To obtain the total value of all metals produced it would be necessary to add to these figures the output of less important metals, accurate statistics of which are for the most part not available. The relative value of the different metals is shown graphically in figure 12 . 
Quantity of ore sold or treated in Utah, 1865-191\%, and total metals recovered.

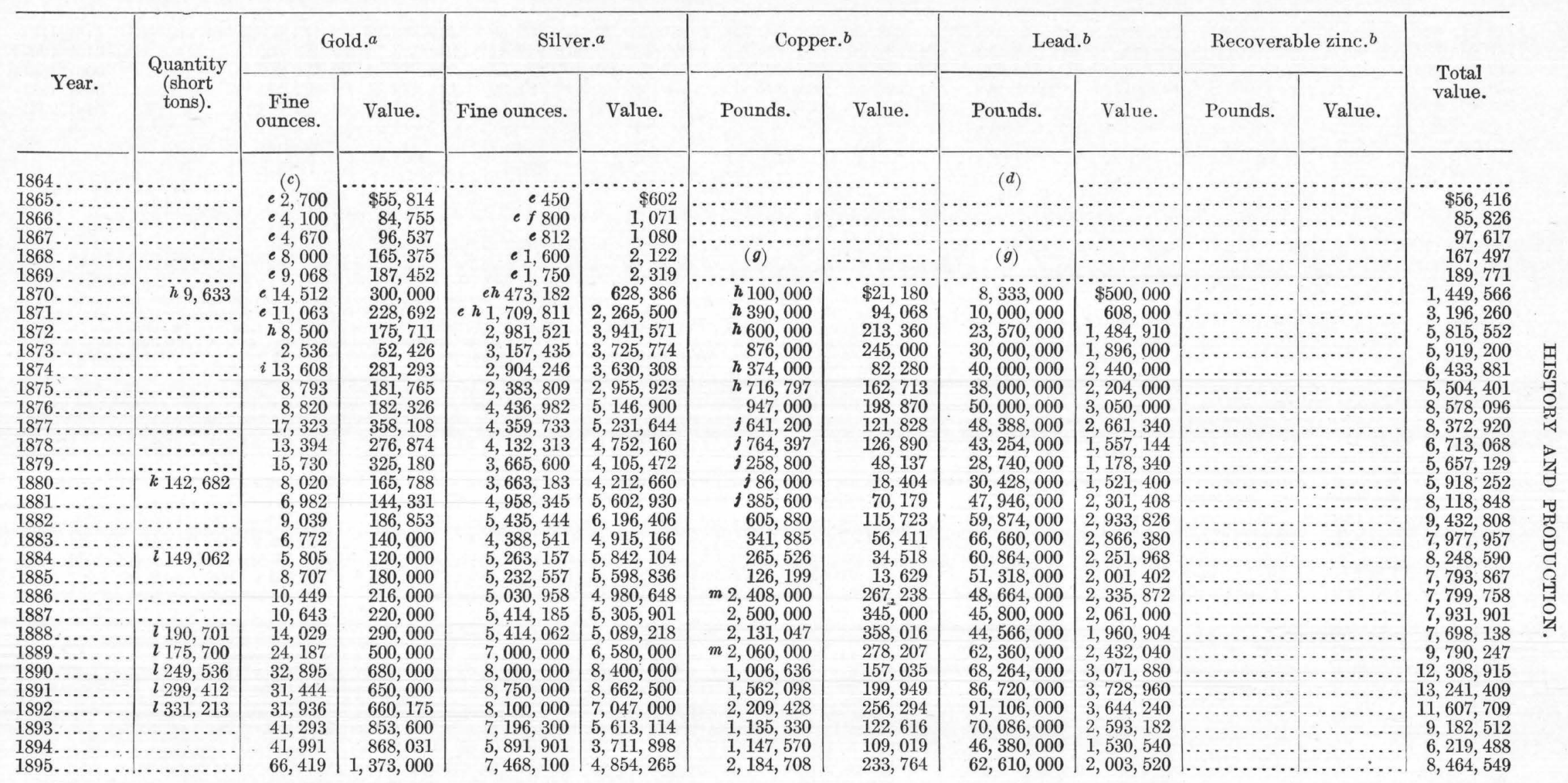

a Director of Mint estimates unless otherwise indicated.

c Californians find placer gold at Bingham, and in spring of 1865 smelters and refiners unless otherwise indicated.

$d$ Lead was first produced from ore reduced in a furnace built near the Rollins or Lincoln mine, Beaver County, in the fifties, by a Mormon named Isaac Grundy. See Eissler, M., The metallurgy of argentiferous

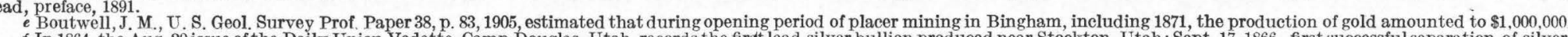

$f$ In 1864, the Aug. 29 issue of the Daily Union Vedette, Camp Douglas, Utah, records the first lead-silver bullion produced near Stockton, Utah; Sept. 17, 1866, first successful separation of silver from lead bullion

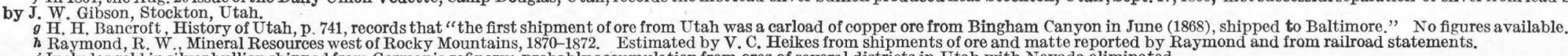
$i$ Includes gold in silver bullion shipped from Germania refinery; probably accumulation from ores of several districts
$j \mathrm{Utah}$ Central Railioad statement, $1872-1880 ;$ metal production for years $1876-1881$; estimates by V. C. Heikes.

Tenth Census United States, vol. 13, pp. 313-316, 1885

$m$ Wells Fargo \& Co., estimates confirmed by smelter totals. Refiners' figures f( $\mathrm{r} 1886$ are 500,000 pounds; for $1889,65,467$ pounds. 
Quantity of ore sold or treated in Utah, 1865-191\%, and total metals recovered-Continued.

\begin{tabular}{|c|c|c|c|c|c|c|c|c|c|c|c|c|}
\hline \multirow{2}{*}{ Year. } & \multirow{2}{*}{$\begin{array}{l}\text { Quantity } \\
\text { (short } \\
\text { tons). }\end{array}$} & \multicolumn{2}{|c|}{ Gold. } & \multicolumn{2}{|c|}{ Silver. } & \multicolumn{2}{|c|}{ Copper. } & \multicolumn{2}{|c|}{ Lead. } & \multicolumn{2}{|c|}{ Recoverable zinc. } & \multirow{2}{*}{$\begin{array}{l}\text { Total } \\
\text { value. }\end{array}$} \\
\hline & & $\begin{array}{c}\text { Fine } \\
\text { ounces. }\end{array}$ & Value. & Fine ounces. & Value. & Pounds. & Value. & Pounds. & Value. & Pounds. & Value. & \\
\hline $\begin{array}{l}1896 \ldots \\
1897 \ldots \\
1898 \ldots \\
1899 \ldots \\
1900 \ldots \\
1901 \ldots \\
1902 \ldots \\
1903 \ldots \\
1904 \ldots \\
1905 \ldots \\
1906 \ldots \\
1907 \ldots \\
1908 \ldots \\
1909 \ldots \\
1910 \ldots \\
1911 \ldots \\
1912 \ldots \\
1913 \ldots \\
1914 \ldots \\
1915 \ldots \\
1916 \ldots \\
1917 \ldots\end{array}$ & $\begin{array}{r}1,114,785 \\
1,412,379 \\
1,716,947 \\
2,181,061 \\
2,348,819 \\
2,669,696 \\
3,658,957 \\
5,122,589 \\
6,389,398 \\
7,268,530 \\
7,770,270 \\
10,202,566 \\
8,544,014 \\
10,451,445 \\
13,920,643 \\
15,358,481\end{array}$ & 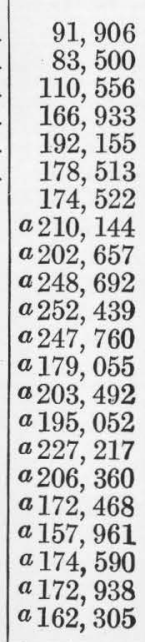 & $\begin{array}{r}\$ 1,899,900 \\
1,726,100 \\
2,285,400 \\
3,450,800 \\
3,972,200 \\
3,690,191 \\
3,607,686 \\
4,344,069 \\
4,189,292 \\
5,140,920 \\
5,218,386 \\
5,121,646 \\
3,701,387 \\
4,206,548 \\
4,032,085 \\
4,696,998 \\
4,265,851 \\
3,565,229 \\
3,265,347 \\
3,609,109 \\
3,574,947 \\
3,355,156\end{array}$ & $\begin{array}{r}8,827,600 \\
6,265,600 \\
6,485,900 \\
7,093,300 \\
9,267,600 \\
10,760,800 \\
11,842,015 \\
a 12,204,011 \\
a 12,049,446 \\
a 11,036,471 \\
a 11,550,634 \\
a 10,990,076 \\
a \quad 8,451,338 \\
a 11,717,172 \\
a 10,466,971 \\
a 12,473,787 \\
a 13,835,903 \\
a 13,084,835 \\
a 11,154,916 \\
a 12,313,205 \\
a 13,253,037 \\
a 13,479,133\end{array}$ & $\begin{array}{r}\$ 6,002,768 \\
3,759,360 \\
3,826,681 \\
4,255,980 \\
5,745,912 \\
6,456,480 \\
6,176,795 \\
6,518,162 \\
6,898,308 \\
6,666,028 \\
7,738,925 \\
7,253,450 \\
4,479,209 \\
6,092,929 \\
5,652,164 \\
6,611,107 \\
8,509,080 \\
7,903,240 \\
6,168,669 \\
6,242,795 \\
8,720,498 \\
11,106,806\end{array}$ & 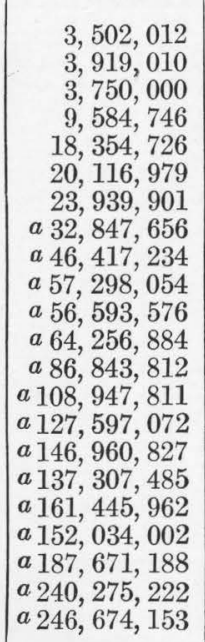 & $\begin{array}{r}\$ 378,217 \\
470,281 \\
465,000 \\
1,638,991 \\
3,046,885 \\
3,359,535 \\
2,920,668 \\
4,542,831 \\
5,802,154 \\
8,938,496 \\
10,922,560 \\
12,851,377 \\
11,463,383 \\
14,163,215 \\
16,204,828 \\
18,370,103 \\
22,655,735 \\
25,024,124 \\
20,220,522 \\
32,842,458 \\
59,107,705 \\
67,342,044\end{array}$ & $\begin{array}{r}71,156,000 \\
81,074,000 \\
78,598,000 \\
59,974,000 \\
96,088,000 \\
99,740,000 \\
107,828,000 \\
a 100,742,633 \\
a 116,479,764 \\
a \quad 103,882,009 \\
a 125,342,836 \\
a 115,938,037 \\
a \quad 88,777,498 \\
a 148,486,463 \\
a 123,324,635 \\
a 136,496,750 \\
a 140,311,135 \\
a 166,126,790 \\
a 171,323,137 \\
a 199,967,437 \\
a \quad 201,490,075 \\
a_{1} 178,521,958\end{array}$ & $\begin{array}{r}\$ 2,134,680 \\
2,918,664 \\
2,986,724 \\
2,698,830 \\
4,227,872 \\
4,288,820 \\
4,420,948 \\
4,311,785 \\
5,095,989 \\
4,882,454 \\
7,144,542 \\
6,144,716 \\
3,728,655 \\
6,384,918 \\
5,426,284 \\
6,142,354 \\
6,314,001 \\
7,309,579 \\
6,681,602 \\
9,398,470 \\
13,902,815 \\
15,352,888\end{array}$ & $\begin{array}{r}b 332,924 \\
b 7,102,547 \\
6,474,615 \\
5,452,916 \\
1,460,554 \\
9,860,778 \\
16,367,104 \\
17,840,261 \\
17,067,177 \\
18,857,827 \\
15,989,267 \\
24,292,240 \\
29,572,528 \\
21,286,871\end{array}$ & $\begin{array}{r}\$ 16,979 \\
419,050 \\
394,952 \\
321,722 \\
68,646 \\
532,482 \\
883,824 \\
1,016,895 \\
1,177,635 \\
1,056,038 \\
815,453 \\
3,012,238 \\
3,962,719 \\
2,171,261\end{array}$ & $\begin{array}{r}\$ 10,415,565 \\
8,874,405 \\
9,563,805 \\
12,044,601 \\
16,992,869 \\
17,795,026 \\
17,126,097 \\
19,716,847 \\
b 22,002,722 \\
b 26,046,948 \\
31,419,365 \\
31,692,911 \\
23,441,280 \\
31,380,092 \\
32,199,185 \\
36,837,457 \\
42,922,302 \\
44,858,210 \\
37,151,593 \\
55,105,070 \\
89,268,684 \\
99,328,155\end{array}$ \\
\hline Total & & $4,504,646$ & $93,119,333$ & $366,020,527$ & $271,788,824$ & $1,962,162,413$ & $346,681,440$ & $3,975,600,157$ & $188,715,846$ & $191,957,609$ & $15,849,894$ & $916,155,337$ \\
\hline
\end{tabular}

$b$ Previous figures of the U. S. Geol. Survey are corrected.
$c$ For a complete table of copper statistics, according to refiners' figures, of the United States, by States, from 1845 to 1910 reference is made to U. S. Geol. Survey Mineral Resources, 1910, pp. 170-173, 1911, and for lead in Utah from $1877-1912$ see same publication for 1912, pp. $339-340,1913$

$d$ These totals are largely smelter and refiners' totals, which are less than mine output shown in district totals on account of smelter losses.

Metals produced in Utah, 1864-191\%, by periods.

\begin{tabular}{|c|c|c|c|c|c|c|c|c|c|c|c|c|}
\hline \multirow{2}{*}{ Period. } & \multirow{2}{*}{$\begin{array}{l}\text { Quantity } \\
\text { (short } \\
\text { tons). }\end{array}$} & \multicolumn{2}{|c|}{ Gold. } & \multicolumn{2}{|c|}{ Silver. } & \multicolumn{2}{|c|}{ Copper. } & \multicolumn{2}{|c|}{ Lead. } & \multicolumn{2}{|c|}{$\begin{array}{c}\text { Zinc } \\
\text { (recoverable). }\end{array}$} & \multirow{2}{*}{$\begin{array}{l}\text { Total } \\
\text { value. }\end{array}$} \\
\hline & & $\begin{array}{l}\text { Fine } \\
\text { ounces. }\end{array}$ & Value. & $\begin{array}{c}\text { Fine } \\
\text { ounces. }\end{array}$ & Value. & Pounds. & Value. & Pounds. & Value. & Pounds. & Value. & \\
\hline $\begin{array}{l}1865-1880 . \\
1881-1890 . \\
1891-1900 . \\
1901-1910 . \\
1911-1917 .\end{array}$ & $73,515,949$ & $\begin{array}{r}150,837.00 \\
129,508.00 \\
858,135.00 \\
2,092,325.52 \\
1,273,841.32 \\
\end{array}$ & $\begin{array}{r}\$ 3,118,096 \\
2,677,184 \\
17,739,206 \\
43,252,210 \\
26,332,637 \\
\end{array}$ & $\begin{array}{r}33,873,227 \\
56,137,249 \\
75,346,301 \\
111,068,934 \\
89,594,816 \\
\end{array}$ & $\begin{array}{r}\$ 40,603,492 \\
58,511,209 \\
53,479,478 \\
63,932,450 \\
55,262,195 \\
\end{array}$ & $\begin{array}{r}3,754,194 \\
11,830,773 \\
47,349,628 \\
624,858,979 \\
1,272,368,839 \\
\end{array}$ & $\begin{array}{r}\$ 1,332,730 \\
1,695,956 \\
6,921,016 \\
91,169,047 \\
245,562,691 \\
\end{array}$ & $\begin{array}{r}350,713,000 \\
556,316,000 \\
743,792,000 \\
1,130,541,875 \\
1,194,237,282 \\
\end{array}$ & $\begin{array}{r}\$ 19,101,134 \\
24,216,680 \\
28,467,212 \\
51,829,111 \\
65,101,709\end{array}$ & $\begin{array}{r} \\
47,051,438 \\
144,906,171\end{array}$ & $\begin{array}{r}2,637,655 \\
13,212,239\end{array}$ & $\begin{array}{r}\$ 64,155,452 \\
87,101,029 \\
106,606,912 \\
252,820,473 \\
405,471,471 \\
\end{array}$ \\
\hline
\end{tabular}


In the early days of mining silver was the most important metaI. In recent years, however, the precious metals have been of much less relative importance. In 1917 copper alone yielded considerably more than 67 per cent of the total value.

\section{PRODUCTION · BY DISTRICTS.}

The table on page 130 gives the production of each important district. The total value given is somewhat larger than that given in the table by years (pp. 127-128) and is doubtless less

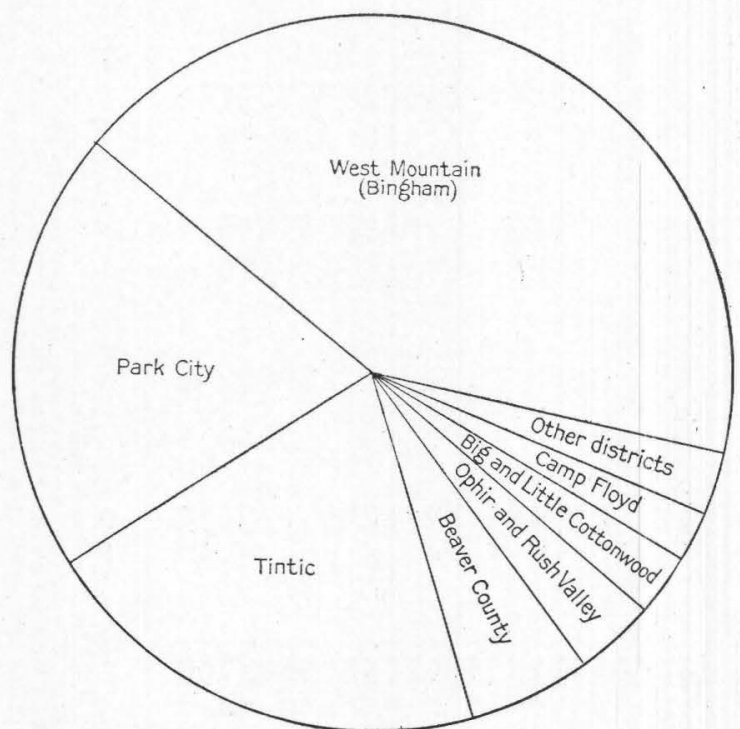

FIGURE 13,-Diagram showing relative value of the metal output of the principal mining districts of Utah, 1865-1916.

accurate, the present table having been compiled from many sources. The difference, however, is but a small fraction of 1 per cent, and the figures for the individual districts may be regarded as essentially accurate. Figure 13 shows the relative rank of the largest districts.

\section{NET PROFITS.}

It is impossible to get data for even an approximate comparison of the amount of money expended in mining operations and the value of the metal produced. There is no doubt that the value of the metals is in excess of the expenditures, but if all expenditures of time and money are considered the excess will not be as great as many believe. The profits of a relatively few companies have been very large, but, as in most mining regions, the great majority of operations have resulted in losses. These losses are due to many causes, ranging

$$
35416^{\circ}-19-9
$$

from those incident to thoroughly legitimate prospecting under capable management to operation of individuals and companies that lack both technical skill and honesty. The table on page 130 shows the known dividends of several of the more important mining districts, and the following list gives the names by districts of companies that have paid dividends.

Ajax.

Beck Tunnel.

Bullion Beck.

Carisa.

Centennial-Eureka.

Chief Consolidated.

Colorado.

Dragoon.

Eagle and Blue Bell.

Eureka Hill.

Gemini-Keystone.

Godiva.

Gold Chain.

Grand Central.

Hamburg.

Annie Laưrie.

$$
\text { Camp Floyd (Mercur district). }
$$

Boston-Sunshine. Geyser-Marion.

Consolidated Mercur. Sacramento.

Bingham district (West Mountain).

Bingham New Haven. U. S. Mining Co.

Brooklyn Lead.

Dalton \& Lark.

Utah Apex.

Old Telegraph and Galena. Utah Copper.

Petro.

Utah Metal and Tunnel.

\section{Park City region.}

Crescent.

Daly.

Daly-Judge.

Daly West.

\section{Little Bell.}

Ontario.

Silver King Coalition.

Silver King Consolidated.

Washington County (Silver Reef district).

Barbee \& Walker. Leeds.

Christy. Stormont.

Gethin Leroy.

Silver Islet district.

Ophir and Rush Valley districts.

Chicago. Honorine.

Cliff. Mono.

Hidden Treasure. Northern Light.

Little Cottonwood and Big Cottonwood districts.

Cardiff. Joab Lawrence.

Columbus Consolidated. Maxfield.

Emma. Prince of Wales.

Flagstaff. South Hecla. 
Production in Utah mining districts.

\begin{tabular}{|c|c|c|c|c|c|c|c|c|c|c|c|c|c|c|c|}
\hline \multirow[b]{2}{*}{ District. } & \multirow[b]{2}{*}{ Period. } & \multirow{2}{*}{$\begin{array}{l}\text { Ore } \\
\text { (short } \\
\text { tons). }\end{array}$} & \multicolumn{2}{|c|}{ Gold. } & \multicolumn{2}{|c|}{ Silver. } & \multicolumn{2}{|c|}{ Copper. } & \multicolumn{2}{|c|}{ Lead. } & \multicolumn{2}{|c|}{ Zine (recoverable). } & \multirow{2}{*}{$\begin{array}{l}\text { Total } \\
\text { value. } a\end{array}$} & \multirow[b]{2}{*}{ Dividends. } & \multirow{2}{*}{$\begin{array}{c}\text { Num } \\
\text { ber } \\
\text { mines } \\
\text { that } \\
\text { have } \\
\text { paid } \\
\text { divi- } \\
\text { dends }\end{array}$} \\
\hline & & & $\begin{array}{l}\text { Fine } \\
\text { ounces. }\end{array}$ & Value. & $\begin{array}{c}\text { Fine } \\
\text { ounces. }\end{array}$ & Value. & Pounds. & Value. & Pounds. & Value. & Pounds. & Value. & & & \\
\hline Bingham (West Mountain) & $1865-1917$ & & $1,515,018.90$ & $\$ 31,318,190$ & $48,415,824$ & $\$ 35,665,120$ & $1,658,636,866$ & $\$ 296,608,196$ & $1,058,092,538$ & 29,453 & $40,052,718$ & $\$ 3,678,727$ & $\$ 419,699,686$ & $\$ 88,501,870$ & 9 \\
\hline y......... & $\begin{array}{l}1870-1917 \\
1860-1917\end{array}$ & & $211,263.81$ & $\begin{array}{l}4,367,178 \\
32,556936\end{array}$ & $135,299,810$ & $99,202,886$ & $31,028,556$ & $4,917,960$ & 1,252, & & $66,191,185$ & $4,951,107$ & $169,814,024$ & $43,586,698$ & \\
\hline aver county. & $1869-1917$ & & $\begin{array}{l}1,574,942.11 \\
37139.51\end{array}$ & 32, 756,936 & $125,271,682$ & $83,343,232$ & $\begin{array}{l}171,493,635 \\
49\end{array}$ & $\begin{array}{r}27,552,435 \\
8\end{array}$ & 752, & 411 & $16,803,653$ & $1,590,790$ & 1,804 & $31,959,096$ & 29 \\
\hline Ophir and Rush Valley.... & 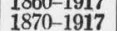 & & $\begin{array}{l}31,139.01 \\
28,394.15\end{array}$ & $\begin{array}{l}486,978 \\
48\end{array}$ & $\begin{array}{l}21,100,900 \\
14,259,680\end{array}$ & $\begin{array}{l}19,088,392 \\
11,818,698\end{array}$ & $\begin{array}{l}49,038,383 \\
23,026,554\end{array}$ & $\begin{array}{l}8,478,593 \\
4,044,373\end{array}$ & $\begin{array}{l}411,403,954 \\
275 \\
860,038\end{array}$ & $\begin{array}{l}17,980,774 \\
14643,698\end{array}$ & $\left|\begin{array}{r}33,507,519 \\
4,823,331\end{array}\right|$ & $\begin{array}{r}2,577,029 \\
442\end{array} 691$ & $\begin{array}{l}49,392,527 \\
31,536,438\end{array}$ & $\begin{array}{l}7,747,704 \\
7,235000\end{array}$ & $\begin{array}{l}4 \\
6\end{array}$ \\
\hline Big and Little Cottonwood . & $\begin{array}{l}186-1917 \\
1867-1907\end{array}$ & 429,495 & $\begin{array}{l}24,213.05 \\
020\end{array}$ & $\begin{array}{r}500,529 \\
\\
-10\end{array}$ & $13,140,345$ & $\mid \begin{array}{l}13,215,139 \\
1312\end{array}$ & $9,855,917$ & $\begin{array}{l}4,044,373 \\
1,741,962\end{array}$ & $\begin{array}{l}280,616,785 \\
180,610\end{array}$ & $\begin{array}{l}10,225,648 \\
10,2240\end{array}$ & $\mid \begin{array}{r}4,820,351 \\
320,934\end{array}$ & $\begin{array}{r}442,001 \\
39,283\end{array}$ & $\begin{array}{l}31,030,458 \\
25,722,553\end{array}$ & $2,474,060$ & \\
\hline $\begin{array}{l}\text { Camp Floyd } \\
\text { Washington County. }\end{array}$ & $\begin{array}{l}187-1917 \\
1875-1917\end{array}$ & & $\begin{array}{l}920,842.87 \\
634.14\end{array}$ & $\begin{array}{r}19,035,112 \\
13,110\end{array}$ & $\begin{array}{r}048,760 \\
7,356,657\end{array}$ & $\begin{array}{r}57,512 \\
8,079,416\end{array}$ & $10,609,492$ & $1,536,775$ & c 43,669 & 2,315 & & & $\begin{array}{r}19,093,024 \\
9,631,616\end{array}$ & $\begin{array}{l}3,881,323 \\
d, 900,000\end{array}$ & 4 \\
\hline American Fork. & 1870-1917 & 64,217 & $13,127.80$ & $\begin{array}{l}271,373 \\
0\end{array}$ & $1,887,596$ & $\begin{array}{l}8,014,647 \\
2,047\end{array}$ & $\begin{array}{ll}10,009,492 \\
159,091\end{array}$ & $\begin{array}{l}1,030,160 \\
30,077\end{array}$ & $28,586,796$ & $1,574,129$ & 46,911 & $\dddot{4}, 224$ & 年, & $\begin{array}{l}4900,000 \\
8,000\end{array}$ & 1 \\
\hline Piute County.. & 1868-1917 & 485,740 & $150,595.75$ & $3,113,089$ & 704,748 & 490,999 & e 73,616 & 14,049 & e 847,883 & $\begin{array}{l}1,01,060 \\
61,006\end{array}$ & & & $\begin{array}{l}3,69,143 \\
3,3,69\end{array}$ & 439, 561 & \\
\hline $\begin{array}{l}\text { Lucin............ } \\
\text { Fish Springs.. }\end{array}$ & $\begin{array}{l}1870-1917 \\
1891-1917\end{array}$ & $\begin{array}{r}152,495 \\
18,459\end{array}$ & $\begin{array}{l}104.43 \\
449.60\end{array}$ & $\begin{array}{l}2,158 \\
9,296\end{array}$ & $\begin{array}{r}225,136 \\
2,499,603\end{array}$ & $\begin{array}{r}265,484 \\
1,627,832\end{array}$ & $\begin{array}{r}16,577,321 \\
4,315\end{array}$ & $2,702,258$ & $\begin{array}{r}4,749,122 \\
16.069 .128\end{array}$ & $\begin{array}{l}294,756 \\
678,655\end{array}$ & 34,680 & 3,537 & $\begin{array}{l}3,256,193 \\
2,316,464\end{array}$ & 363.720 & 2 \\
\hline North Tinti & 1902-1917 & 56,483 & $\begin{array}{r}44.00 \\
7.67\end{array}$ & 158 & $\begin{array}{r}2,496,050 \\
36,539\end{array}$ & r, & $\begin{array}{r}40 \\
182 \\
182\end{array}$ & $\begin{array}{r}681 \\
23\end{array}$ & $11,406,680$ & $\begin{array}{l}678,655 \\
577,742\end{array}$ & $18,792,296$ & $1,246,697$ & $\begin{array}{l}1,847,744 \\
1,814\end{array}$ & & \\
\hline Carbonate... & $1891-1917$ & 4,377 & 912.21 & 18,857 & 102,747 & 63,496 & $2,589,245$ & 395,655 & 1,328 & 114 & & & 478, 122 & & \\
\hline Mount Nebo. & 1870-1917 & 4,065 & 15. 29 & 317 & 37,226 & 24,295 & 1,526 & 274 & $1,932,683$ & 90,780 & 788,679 & 75,096 & 190,762 & & \\
\hline $\begin{array}{l}\text { Argenta...... } \\
\text { Ashbrook... }\end{array}$ & $\begin{array}{l}1905-1917 \\
1899-1917\end{array}$ & $\begin{array}{r}1,662 \\
712\end{array}$ & $\begin{array}{r}8.46 \\
70.88\end{array}$ & $\begin{array}{r}175 \\
1,464\end{array}$ & $\begin{array}{r}9,559 \\
31,099\end{array}$ & $\begin{array}{r}6,037 \\
18,689\end{array}$ & & & 803,005 & 43,525 & & & $\begin{array}{l}49,812 \\
20,153\end{array}$ & & \\
\hline Blue 1 & 1891-1917 & 249 & $\begin{array}{l}5.14 \\
5\end{array}$ & 105 & $\begin{array}{r}4,945 \\
4,45\end{array}$ & 3,179 & & & 284,557 & 12,731 & & & $\begin{array}{l}16,015 \\
10,150\end{array}$ & & \\
\hline & 1908-1917 & 151 & $\begin{array}{l}5.25 \\
200\end{array}$ & 108 & 189 & 105 & 23,080 & 3,073 & 7,097 & 496 & & & 3,782 & & \\
\hline $\begin{array}{l}\text { Calt } \\
\text { Clift }\end{array}$ & $\begin{array}{l}1916-1917 \\
1892-1917\end{array}$ & $\begin{array}{l}71,576 \\
876\end{array}$ & $12,199.06$ & 252,177 & 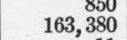 & $\begin{array}{r}641 \\
134,213\end{array}$ & $1,911,840$ & 520,791 & $\begin{array}{l}290,780 \\
520,721\end{array}$ & $\begin{array}{l}22,720 \\
44,222\end{array}$ & & & $\begin{array}{r}23,423 \\
951,803\end{array}$ & & \\
\hline River..................... & $1911-1916$ & 100 & 47.51 & & 11 & 6000 & & & ‥ & & & & 988 & & \\
\hline $\begin{array}{l}\text { Columbia } \\
\text { Detroit (Juab and Miliard }\end{array}$ & 1908-1917 & 3,262 & 18.76 & & 9,552 & 6,030 & 4,907 & 782 & $1,265,974$ & 71,670 & 41,500 & 4,262 & 83,132 & & \\
\hline Cou & 1904-1917 & 1,511 & 538.98 & 11,142 & 5,127 & 2,991 & 169,250 & 31,676 & & & & & 45,809 & & \\
\hline $\begin{array}{l}\text { Dugw: } \\
\text { Frivto }\end{array}$ & 1916-1917 & 167 & $\begin{array}{r}1.36 \\
27\end{array}$ & & 906 & 630 & 9,067 & 2,428 & 114,733 & 8,49 & & & 11,565 & & \\
\hline $\begin{array}{l}\text { Ericks } \\
\text { Freee C }\end{array}$ & 1916-1917 & $\begin{array}{c}264 \\
54\end{array}$ & 37.82 & $\begin{array}{r}782 \\
3\end{array}$ & 50,344 & 33,634 & 364 & 92 & & & & & $\begin{array}{l}37,057 \\
?, 77\end{array}$ & & \\
\hline $\begin{array}{l}\text { Freeco } \\
\text { Gold Sp }\end{array}$ & 1907-1917 & 12,939 & $2,482.26$ & $51,314^{3}$ & $\begin{array}{r}36,962 \\
8,2\end{array}$ & $\begin{array}{r}298 \\
5,048\end{array}$ & & & 28,765 & 2,474 & & & $\begin{array}{r}2,775 \\
56,362\end{array}$ & & \\
\hline Goriold Countro & 1902-1916 & 1,607 & 416.96 & 8,619 & 28,332 & 16,104 & 3,056 & 752 & $\dddot{90}$ & $\dddot{7}$ & & & 25,482 & & \\
\hline $\begin{array}{l}\text { rial (Garfield County). } \\
\text { Side }\end{array}$ & 1914-1917 & $\begin{array}{r}54 \\
333\end{array}$ & 87.09 & 1,800 & $\begin{array}{r}46 \\
998\end{array}$ & & $\begin{array}{r}2,749 \\
817\end{array}$ & 751 & & 6050 & & & 2,587 & & \\
\hline g Indian.......... & $\begin{array}{l}\begin{array}{l}1903-1917 \\
1907-1917\end{array} \\
\end{array}$ & $\begin{array}{l}335 \\
166\end{array}$ & 21.04 & 435 & 7,569 & $\begin{array}{r}638 \\
5,393\end{array}$ & 22,963 & $\begin{array}{r}201 \\
5,355\end{array}$ & $\begin{array}{r}78,616 \\
236\end{array}$ & $\begin{array}{r}6,050 \\
11\end{array}$ & & & $\begin{array}{r}6,908 \\
11,194\end{array}$ & & \\
\hline Leam & 1903-1917 & 387 & 2.20 & 45 & 1,682 & 1,052 & 36 & 6 & 126,963 & 6,198 & & & 7,301 & & \\
\hline $\begin{array}{l}\text { Lost \& } \\
\text { Miner }\end{array}$ & \begin{tabular}{|l|}
$1906-1917$ \\
$1903-193$
\end{tabular} & $\begin{array}{r}42 \\
385\end{array}$ & $\begin{aligned} 6.33 \\
1,172.71\end{aligned}$ & 24,243 & $\begin{array}{r}{ }_{6.143}^{233} \\
-\end{array}$ & $\begin{array}{l}159 \\
3.322\end{array}$ & 6,744 & 1,788 & 218 & 12 & & & $\begin{array}{r}2,090 \\
27,565\end{array}$ & & \\
\hline ounty).. & $\begin{array}{l}\text { - } \\
1914-1917\end{array}$ & 182 & $1,17.11$ & 24,240 & 6,188 & $\begin{array}{ll}3,329 \\
129\end{array}$ & 10,762 & $\dddot{2} \dddot{2}, \mathbf{7 i i}$ & 15,277 & 776 & 17,883 & 2,227 & $\begin{array}{r}2,565 \\
5,873\end{array}$ & & \\
\hline $\mathrm{Pa}$ & $1902-1917$ & 67,755 & $17,945.33$ & 370,962 & 8,968 & 5,141 & 49,075 & 6,44 & 21,867 & 1,115 & & & 383,660 & 49,000 & 1 \\
\hline $\begin{array}{l}\mathrm{Pr} \\
\mathrm{Sa}\end{array}$ & 1907-1917 & $\begin{array}{r}13,714 \\
470\end{array}$ & & & & 248 & 1,078 & 5 & $1,256,021$ & 91,220 & $5,725,336$ & 723,990 & $\begin{array}{r}815,673 \\
11,639\end{array}$ & 109,000 & \\
\hline Silve & 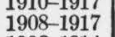 & 954 & 46.93 & 971 & $\begin{array}{l}322,836 \\
122\end{array}$ & 70,124 & 70,082 & 10,143 & $\begin{array}{l}200,522 \\
479,835\end{array}$ & $\begin{array}{r}9,566 \\
20,969\end{array}$ & & & $\begin{array}{r}1,039 \\
102,207\end{array}$ & $7,500^{\circ}$ & 1 \\
\hline ……... & 1902-1914 & 50 & $\begin{array}{r}8.10 \\
810\end{array}$ & 167 & 2,429 & 1,428 & 12 & 1 & 37,810 & 1,831 & & & 3,427 & & \\
\hline eek & & $\begin{array}{r}80,623 \\
6.992\end{array}$ & $\begin{array}{r}812.40 \\
2.048 .05\end{array}$ & 16,793 & $\begin{array}{r}110,515 \\
5,587\end{array}$ & $\begin{array}{r}80,042 \\
2,951\end{array}$ & $\begin{array}{l}753,925 \\
1,227\end{array}$ & 131,445 & $2,218,632$ & 166,368 & $4,751,909$ & 502,309 & $\begin{array}{r}896,957 \\
45783\end{array}$ & & \\
\hline …............ & $\begin{array}{l}1902-1915 \\
1901-1917\end{array}$ & $\begin{array}{r}0,994 \\
13,102\end{array}$ & $\begin{array}{l}2,048.09 \\
3,032\end{array}$ & 62,726 & $\begin{array}{l}5,587 \\
95,676\end{array}$ & 51,638 & & & $\begin{array}{r}5,609 \\
75,000\end{array}$ & $\begin{array}{r}263 \\
3,075\end{array}$ & & & $\begin{array}{r}417,783 \\
117,451\end{array}$ & & \\
\hline Su & 1902-1915 & 169 & & & & 381 & 166 & 29 & 8,262 & 340 & 59,075 & 7,325 & 8,075 & & \\
\hline tic & $\begin{array}{l}1916-1917 \\
1902-1917\end{array}$ & $\begin{array}{r}317 \\
4,180\end{array}$ & $1,197.65$ & 24,757 & $\begin{array}{l}1,366 \\
35,085\end{array}$ & $\begin{array}{r}1,0066 \\
21,959\end{array}$ & $\begin{array}{r}2,623 \\
10,456\end{array}$ & $\begin{array}{r}661 \\
\mathbf{1 , 9 0 7}\end{array}$ & $\begin{array}{r}77,451 \\
1,437,322\end{array}$ & $\begin{array}{l}6,618 \\
90,395\end{array}$ & & & $\begin{array}{r}8,369 \\
139,018\end{array}$ & & \\
\hline $\begin{array}{l}\text { White Canyon (San Juan).. } \\
\text { Wild Cat Range... }\end{array}$ & 1915-1917 & $\begin{array}{r}96 \\
182\end{array}$ & $\begin{array}{l}6.06 \\
.85\end{array}$ & $\begin{array}{l}126 \\
17\end{array}$ & $\begin{array}{r}384 \\
2,340\end{array}$ & 1.271 & $\begin{array}{r}49,889 \\
4,382\end{array}$ & $\begin{array}{l}12,676 \\
648\end{array}$ & …רii. & $\because 5 i^{3}$ & & & $\begin{array}{l}13,073 \\
2,466\end{array}$ & & \\
\hline & & & & & & & & & & & & & & & \\
\hline
\end{tabular}

$a$ Commercial values used for metals produced in each calendar year.
$b$ The yearly production of silver, between 1871 and 1881 , was estimated to be 46,000 ounces. (See U. S. Geol. Survey Sixteenth Ann. Rept., pt. 2, p. 355, 1895.) Since that period the gold ores mined carried very little silver, and only 2,760 ounces were reported by producers whose ores yielded a total of $920,741.10$ ounces of gold from 1890 to 1913 , inclusive.
$c$ No records were preserved by producers of occasional lots of lead ore shipped from the Black Warrior and Dixie mines in the Tutsagubet district.

$\boldsymbol{a}$ Dividends paid by operators in the Silver Reef section are known to be incomplete. A fair estimate is given by competent authorities.
$e$ Between 1904 and 1911 the production was 44,24 pounds of copper and 134,361 pounds of lead as reported by producers. Prior to this period no record of production was found. 
Century.

Park Valley district.

Lakeview.

Promontory district.

Beaver County.

Utah Leasing (Cactus tailing).

Moscow.

Newhouse.

Fish Springs district.

Galena.

Utah.

Pacific Gold.

American Fork district.

The relative importance of the several regions as dividend payers is shown graphically in figure 14 . The Bingham district has yielded the most in dividends, though this leadership has only recently been taken from the Park City district. In the ratio of dividends paid to the value of the metals produced the Park City district has the best record of the important camps of the State.

The total of $\$ 182,245,816$ in dividends to the end of 1917 from mining operations is large, but if from this should be subtracted all the losses in labor and material over a period of 50 years the net results would be less impressive.

That there are large losses should not discourage either mining operations or mining investments, but it should cause investors to look carefully to the character of their investments and to remember that there is a great difference in mines and that relatively few ever reach a dividend basis. The layman investor should also realize that there is no necessary relation between the value of metal produced and the amount paid to the stockholders. Mines can be cited where the value of the metals produced ran into millions of dollars, but where, nevertheless, the operations resulted in a total loss of the investment. A certain class of promoters are wont to cite the metal production of a district or property as recommending it, but the point of interest to the investor should be the dividends that may be expected to result from the operation of the mine.

\section{PRODUCTION OF THE PRINCIPAL METALS.} GOLD.

In Utah, as in many of the Western States, the earliest important metal production was of placer gold. Placer mining was begun at Bingham Canyon in 1865 and for some years yielded an important production, totaling about $\$ 1,000,000$. No other district has obtained important amounts from placers, though placer gold has been produced on Colorado, Green, and San Juan rivers; from the La Sal and Henry mountains; and from the vicinity of Marysvale; and placer ground is reported from the west base of the Tushar Range and in other localities.

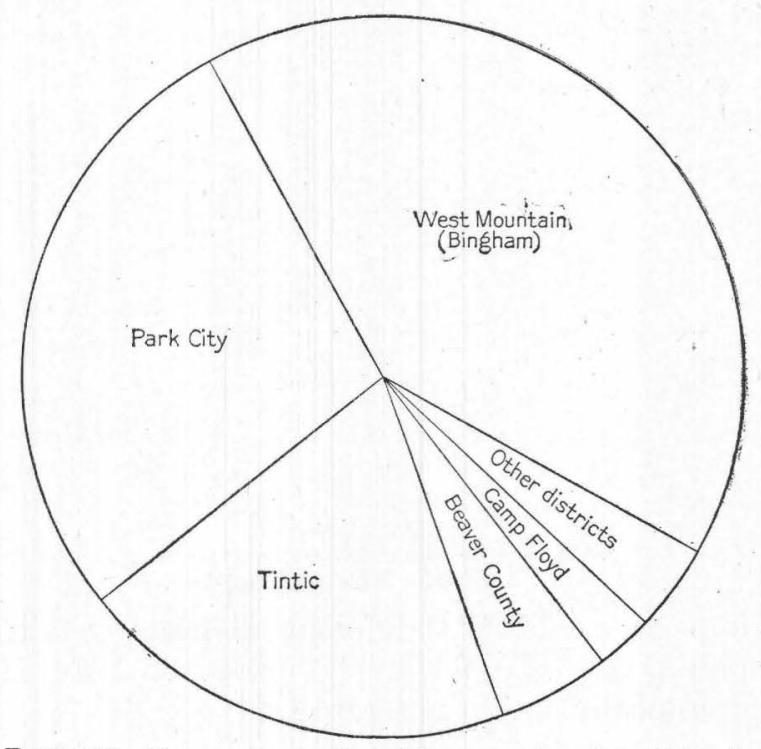

FIGURE 14.-Diagram showing the relative amounts paid in dividends by companies in the larger mining districts of Utah, 1865-1916.

Gold produced in Utah to end of 1917, by districts.

\begin{tabular}{|c|c|c|}
\hline District. & Fine ounces. & Value. \\
\hline 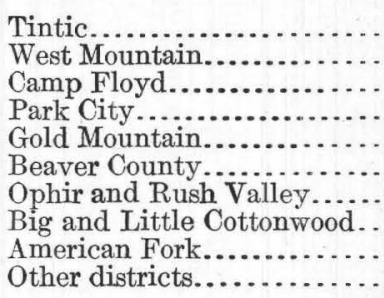 & $\begin{array}{r}1,574,941.78 \\
1,515,018.90 \\
920,842.87 \\
211,263.77 \\
143,561.26 \\
37,139.51 \\
28,395.07 \\
24,213.05 \\
13,127.80 \\
36,146.96\end{array}$ & $\begin{array}{r}\$ 32,556,936 \\
31,318,190 \\
19,035,512 \\
4,367,178 \\
2,967,674 \\
767,739 \\
586,978 \\
500,529 \\
271,373 \\
747,224\end{array}$ \\
\hline & $4,504,650.97$ & $93,119,333$ \\
\hline
\end{tabular}

Gold is present in practically all the metal deposits of the State except the iron ores and the "sandstone" deposits of the Plateau region. In but few districts, however, is the most important metal production in gold, and only one of these, Camp Floyd (Mercur), ranks among the important gold-producing districts of the country; others are the districts in the Tushar Range and the Gold Springs-State Line section. Gold, however, is produced in several districts where other metals constitute the more valuable part of the total output, notably in the Tintic and 
West Mountain (Bingham) districts, in both of which the yield of gold has been greater than in the Mercur district. The relative

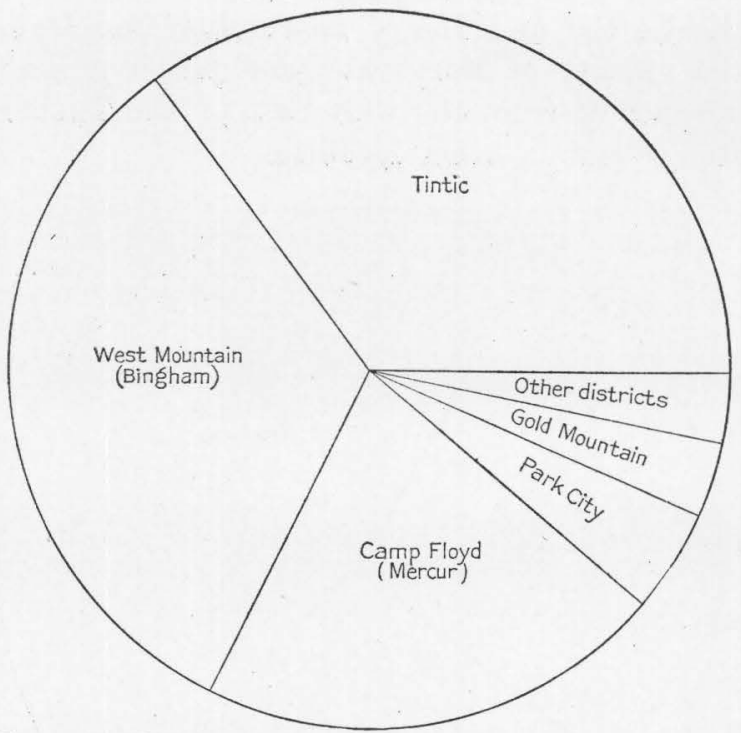

FIGURE 15.-Diagram showing relative importance of mining district of Utah in production of gold, 1855-1916.

importance of the different districts in the production of gold to the close of 1916 is graphically shown in figure 15.
Although gold was the first metal to be produced in important amounts in the State its output was not large till the late eighties, when the Tintic district became important, and did not pass the million-dollar mark till the early nineties, when the cyanide process was successfully applied to the ores of the Mercur district.

The yearly variation in the production of gold is shown in figure 16 . After 1890 the increase in production was rapid and, with the exception of a few years, continuous till 1906. Since 1906 there has been a general decline, which was very considerable during the depression of 1907-8 and which, though in part retrieved in the next few years, has not yet been wholly recovered from.

The decrease due to the exhaustion of the most important mine in the Mercur district has been partly offset by an increase from other districts and from other ores, notably copper ores.

The accompanying table shows the character of the different ores from which gold has been recovered and the amount recovered from each for the period 1904-1917.

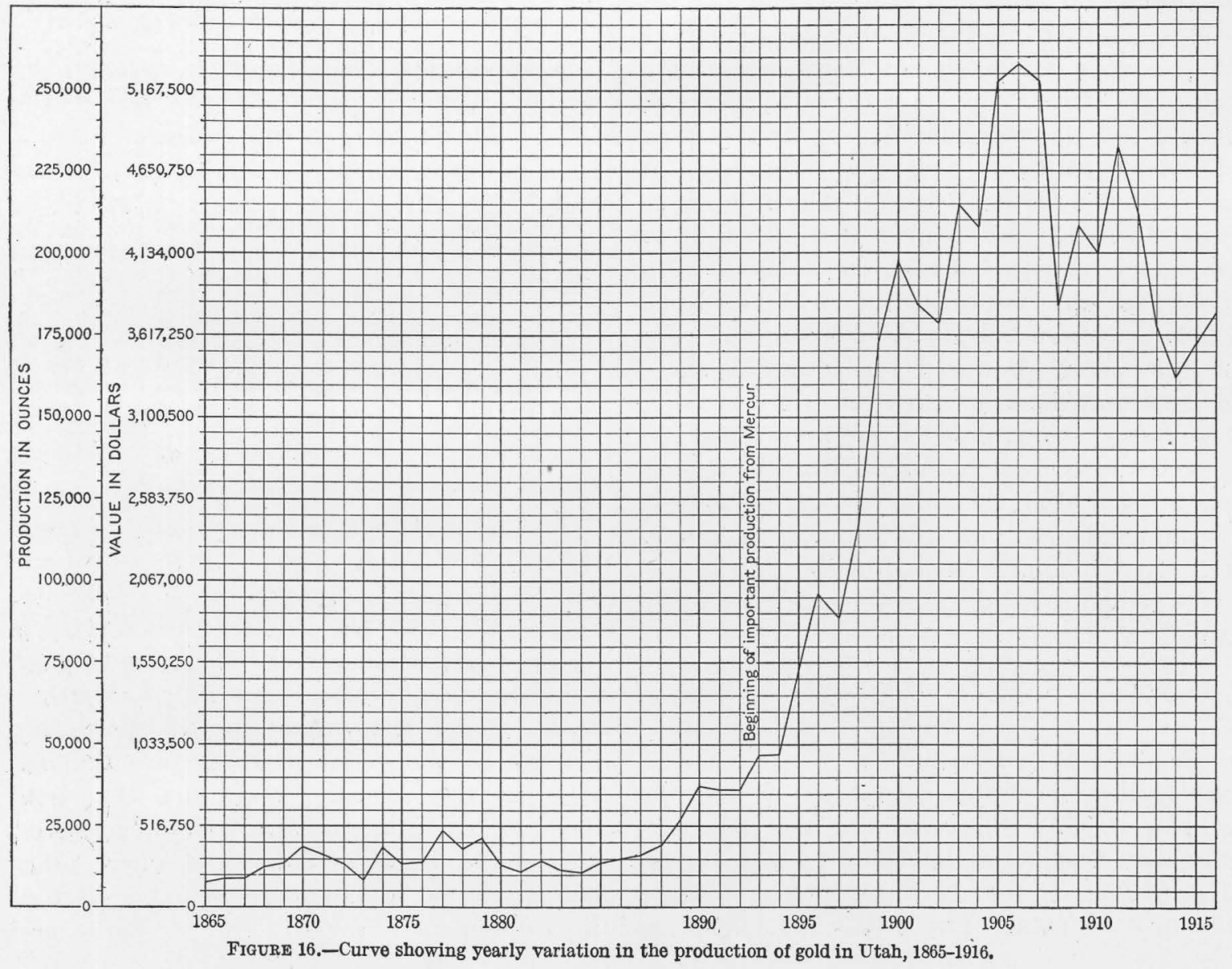


HISTORY AND PRODUCTION.

Gold produced in Utah, 1904-1917, by kinds of ore, in fine ounces.

\begin{tabular}{|c|c|c|c|c|c|c|c|c|c|}
\hline Year. & Placers. & $\begin{array}{l}\text { Dry or sili- } \\
\text { ceous ore. }\end{array}$ & Copper ore. & Lead ore. & $\begin{array}{l}\text { Zinc } \\
\text { ore. }\end{array}$ & $\begin{array}{l}\text { Copper- } \\
\text { lead-zinc } \\
\text { ore. }\end{array}$ & $\begin{array}{l}\text { Copper- } \\
\text { lead ore. }\end{array}$ & $\begin{array}{c}\text { Lead-zinc } \\
\text { ore. }\end{array}$ & Total. \\
\hline 1904. & 65.00 & $58,803.00$ & $92,271.00$ & $3,468.00$ & 6.00 & $2,552.00$ & $45,428.00$ & 82.00 & $202,675.00$ \\
\hline 1905. & 322.00 & $64,383.00$ & $125,897.00$ & $17,805.00$ & 95.00 & $1,682.00$ & $36,818.00$ & $1,690.00$ & $248,692.00$ \\
\hline $1906 \ldots$ & 416.63 & $62,866.25$ & $120,766.53$ & $12,785.54$ & 50.00 & $4,783.07$ & $50,215.63$ & 555.77 & $252,439.42$ \\
\hline $1907 \ldots$ & 438.35 & $42,853.89$ & $158,154.83$ & $46,170.73$ & $\ldots$. & $\ldots \ldots$ & 123.77 & 18.06 & $247,759.63$ \\
\hline 1908 . & 440.69 & $47,439.15$ & $111,086.12$ & $19,986.36$ & 1. 35 & - - - encos & 90.17 & 10. 76 & $179,054.60$ \\
\hline 1909. & 122.15 & $48,931.33$ & $117,265.85$ & $35,858.36$ & & & 102.89 & $1,211.18$ & $203,491.76$ \\
\hline 1910 . & 192.53 & $47,216.85$ & $113,978.49$ & $28,327.58$ & 17.72 & & 154. 63 & $5,164.31$ & $195,052.11$ \\
\hline 1911. & 272.54 & $a 78,912.69$ & $117,247.94$ & $25,709.04$ & 1. 60 & & 114.16 & $4,959.31$ & $227,217.28$ \\
\hline 1912 & 274.77 & b $71,243.22$ & $105,720.03$ & $24,310.76$ & 102.17 & & 171.58 & $4,538.01$ & $206,360.54$ \\
\hline 1913. & 92.88 & c $32,830.03$ & $100,093.39$ & $34,213.80$ & $\ldots$ & 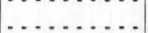 & 70.58 & $5,167.27$ & 172.467 .95 \\
\hline 1914. & 59.55 & $d 18,274.43$ & $97,955.32$ & $33,094.69$ & & & 78.17 & $8,499.00$ & $157,961.16$ \\
\hline 1915 & 46. 34 & e9, 248.67 & $101,247.86$ & $45,541.34$ & 32.85 & & 65.89 & $18,407.70$ & $174,590.65$ \\
\hline 19 & 60.47 & $f 9,122,41$ & $113,396.52$ & $33,535.63$ & s. & & 421. 68 & $16,401.35$ & $172,938.06$ \\
\hline $1917 \ldots$ & 5.42 & $g 720,394.61$ & $94,844.85$ & $27,115.49$ & & & 92.25 & $19,853.05$ & $162,305.67$ \\
\hline
\end{tabular}

$a$ Siliceous gold and silver ores contained 58,204.33 ounces; silver ores, 19,£41.87 ounces; oxidized gold and silver bearing iron-manganese ores,

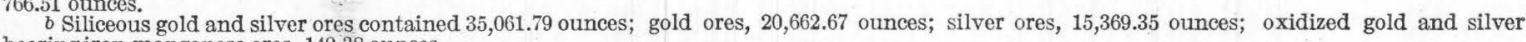
bearing iron-manganese ores, 149.38 ounces.
$c$ Siliceous gold and silver ores contained $16,425.10$ ounces; gold ores, $11,974.24$ ounces; silver ores, $4,172.90$ ounces; oxidized gold and silver bearing iron-manganese ores, 257.84 ounces.

$d$ Gold ore contained 856.32 ounces; gold and silver ore, $11,901.80$ ounces; silver ore, $5,508.11$ ounces; iron ore, 8.20 ounces.

e Gold ore contained 3,226.24 ounces; gold and silver ore, $1,534.16$ ounces; silver ore, $4,488.27$ ounces.

$f$ Includes 663.82 oumces from gold ore, $1,130.40$ ounces from gold and silver ore, and $7,328.18$ ounces from silver ore.

$g$ Includes 4,678.60 ounces from gold ore, $4,864.68$ ounces from gold and silver ore, and 10,851.33 ounces from silver ore.

SILVER.

In value of total output silver ranks second among the metals produced in the State. In recent years the relative importance of silver has been much less and that of copper much greater than in the total period. Nearly all the metal deposits of the State, except the iron deposits, contain silver, and in many it has been the most important constituent.

The following table gives the output and value of silver from the more important districts to the close of 1917:

Silver produced in Utah to end of $191 \%$, by districts.

\begin{tabular}{|c|c|c|}
\hline District. & Fine ounces. & Value. \\
\hline 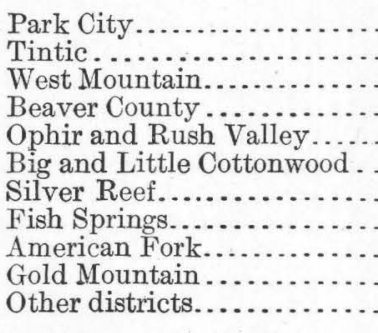 & $\begin{array}{r}135,299,810 \\
125,271,682 \\
48,415,824 \\
21,160,906 \\
14,259,680 \\
13,140,345 \\
7,211,463 \\
2,499,603 \\
1,887,596 \\
460,228 \\
1,578,803\end{array}$ & $\begin{array}{r}99,202,886 \\
83,343,232 \\
35,665,120 \\
19,588,392 \\
11,818,698 \\
13,215,039 \\
7,987,142 \\
1,627,832 \\
2,014,647 \\
273,909 \\
1,095,717\end{array}$ \\
\hline & $a 370,985,940$ & $276,832,614$ \\
\hline
\end{tabular}

$a$ The total production of silver by districts is more than the total by years for the State, as shown in the table on pages 127-128, because the production for early years was largely estimated.
The relative importance of the several districts in the production of silver is shown graphically in figure 17.

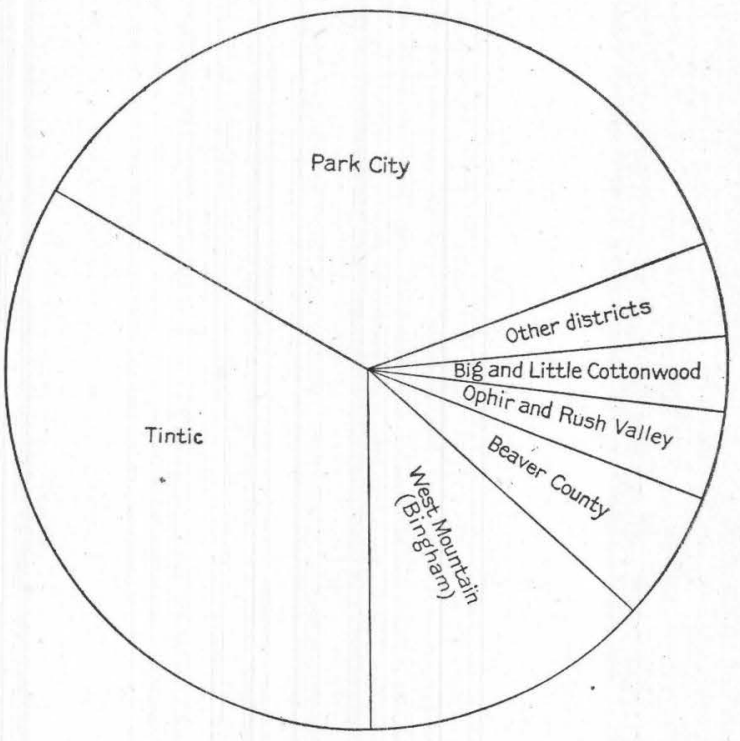

FIGURE 17.-Diagram showing relative importance of the principal districts of Utah in the production of silver, 1865-1916.

Silver production was not large till about 1870 , when the discovery of the bonanzas in the Cottonwood districts caused a rapid increase. Before the exhaustion of these deposits caused serious depression the output from the Horn Silver mine in the San Francisco dis- 


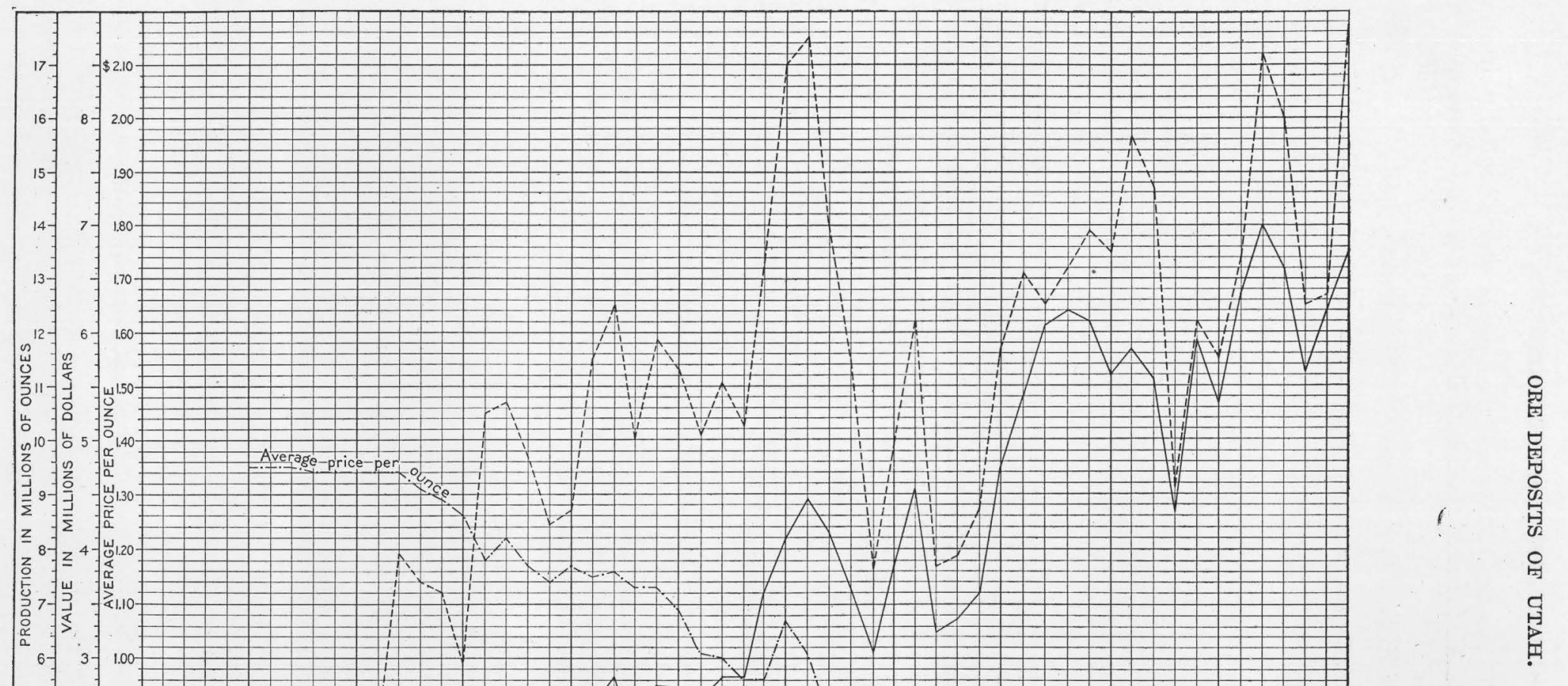


trict, from the mines of the Silver Reef dis- $\mid$ when the price of silver fell rapidly from more trict, and from lesser districts caused a further than a dollar to about 65 cents per ounce rise; and before the output from these had and a notable decrease in production folgreatly decreased the mines of the Park City, lowed. From that time to 1917 the price did Tintic, and Bingham districts caused a still not rise much above 65 cents and most of the further increase.

The yearly variation in production, value, and average price of silver is shown in figure 18. The production shows a general increase with decreases over short periods. From 1870 to about 1900 the average price decreased, but the loss was more than balanced by the increase in production, and the general upward trend in total value continued. The most notable depression was in the early nineties, 10 years:

Silver produced in Utah, 1904-1917, by kinds of ore, in fine ounces.

\begin{tabular}{|c|c|c|c|c|c|c|c|c|c|}
\hline Year. & Placers. & $\begin{array}{l}\text { Dry or } \\
\text { siliceous } \\
\text { ore. }\end{array}$ & $\begin{array}{c}\text { Copper } \\
\text { ore. }\end{array}$ & $\begin{array}{l}\text { Lead } \\
\text { ore. }\end{array}$ & $\begin{array}{l}\text { Zine } \\
\text { ore. }\end{array}$ & $\begin{array}{l}\text { Copper- } \\
\text { lead-zinc } \\
\text { ore. }\end{array}$ & $\begin{array}{l}\text { Copper- } \\
\text { lead } \\
\text { ore. }\end{array}$ & $\begin{array}{l}\text { Lead- } \\
\text { zinc } \\
\text { ore. }\end{array}$ & Total. \\
\hline 1904. & & 161,209 & $2,386,794$ & $1,147,565$ & 1,176 & $3,296,960$ & $5,019,274$ & 36,468 & $12,049,446$ \\
\hline 1905. & 61 & 94,497 & $2,301,349$ & $3,104,375$ & 18,108 & $2,080,294$ & $3,200,828$ & 227,959 & $11,036,471$ \\
\hline $1906 \ldots$ & 57 & 111,614 & $2,032,205$ & $2,688,624$ & 10,416 & $2,290,437$ & $4,254,953$ & 162,328 & $11,550,634$ \\
\hline $1907 \ldots$ & 97 & 131,596 & $3,448,172$ & $7,300,010$ & 33,059 & & 55,804 & 21,338 & $10,990,076$ \\
\hline $1908 \ldots$. & 63 & 163,285 & $2,620,680$ & $5,570,548$ & 1,044 & & 86,132 & 9,586 & $8,451,338$ \\
\hline $1909 \ldots \ldots$ & 22 & 402,313 & $2,500,717$ & $8,314,766$ & & & 99,958 & 399,396 & $11,717,172$ \\
\hline 1910. & 25 & 548,498 & $2,036,909$ & $6,423,523$ & 6,510 & & 223,108 & $1,228,398$ & $10,466,971$ \\
\hline 1911. & 33 & $a_{2}, 569,157$ & $2,377,946$ & $6,083,877$ & 491 & & 83,972 & $1,358,311$ & $12,473,787$ \\
\hline $1912 \ldots$. & 46 & $b 3,486,562$ & $2,542,381$ & $6,212,219$ & 14,941 & & 154,091 & $1,425,663$ & $13,835,903$ \\
\hline 1913. & 13 & $c 2,027,542$ & $2,314,348$ & $7,537,361$ & 14,476 & & 105,286 & $\overrightarrow{1}, 085,809$ & $13,084,835$ \\
\hline 1914. & 9 & $d 1,317,364$ & $1,726,230$ & $7,350,213$ & & & 37,216 & 723,884 & $11,154,916$ \\
\hline 19 & 4 & $e 1,035,712$ & $2,065,661$ & $7,759,842$ & 17,633 & & 71,497 & $1,362,856$ & $12,313,205$ \\
\hline 1916. & 2 & $f 1,153,993$ & $2,633,402$ & $8,118,264$ & 2,914 & & 145,439 & $1,199,023$ & $13,253,037$ \\
\hline 1917. & & $g 2,340,437$ & $2,225,119$ & $7,490,650$ & & & 93,296 & $1,329,531$ & $13,479,133$ \\
\hline
\end{tabular}

$a$ Siliceous gold and silver ores contained 581,878 ounces; silver ores, 1,962,527 ounces; gold and silver bearing oxidized iron-manganese ores, 24,752 ounces.

$b$ Siliceous gold and silver ores contained 1,283,317 ounces; gold ores, 2,420 ounces; silver ores, 2,198,559 ounces; gold and silver bearing oxidized iron-manganese ores, 2,266 ounces.

c Siliceous gold and silver ores contained 837,086 ounces; gold ores, 9,041 ounces; silver ores, 1,177,418 ounces; gold and silver bearing oxidized ron-manganese ores, 3,997 ounces.

Gold ores contained 6,671 ounces; gold and silver ores, 503,487 ounces; silver ores, 795,646 ounces; iron ores, 11,560 ounces

$e$ Gold ores, contained 10.613 ounces; gold and silver ores, 114,580 ounces; silver ores, 910,519 ounces.

g Includes 56,383 ounces from gold ore, 152,231 ounces from gold and silver ore, and 1,114.284 ounces from silver ore.

COPPER.

Copper has been produced in a small way in Utah since 1870 , but for many years it did not form an important part of the metal output of the State. In the early years of mining it (like zinc) was regarded as undesirable in gold and silver ores, and at some mines-at the Horn Silver mine for instance-high-grade copper ore was thrown on the waste dumps.

The copper industry assumed real importance in the State in the late nineties with the beginning of extensive output from the limestone deposits of the Bingham district, notably from that of the Highland Boy mine. The Tintic year, district was already producing a few million pounds a year and there was some production from other districts. Since 1897 the yearly increase has been rapid and, with two exceptions, uninterrupted. Production from the great disseminated deposit of the Bingham district began about 1905 and has steadily and rapidly increased. A slight decrease in 1906 was mainly due to metallurgic difficulties met in starting the newly constructed Garfield smelter, and another slight decrease in 1912 was due to labor troubles in the Bingham district which closed the mines for part of the 


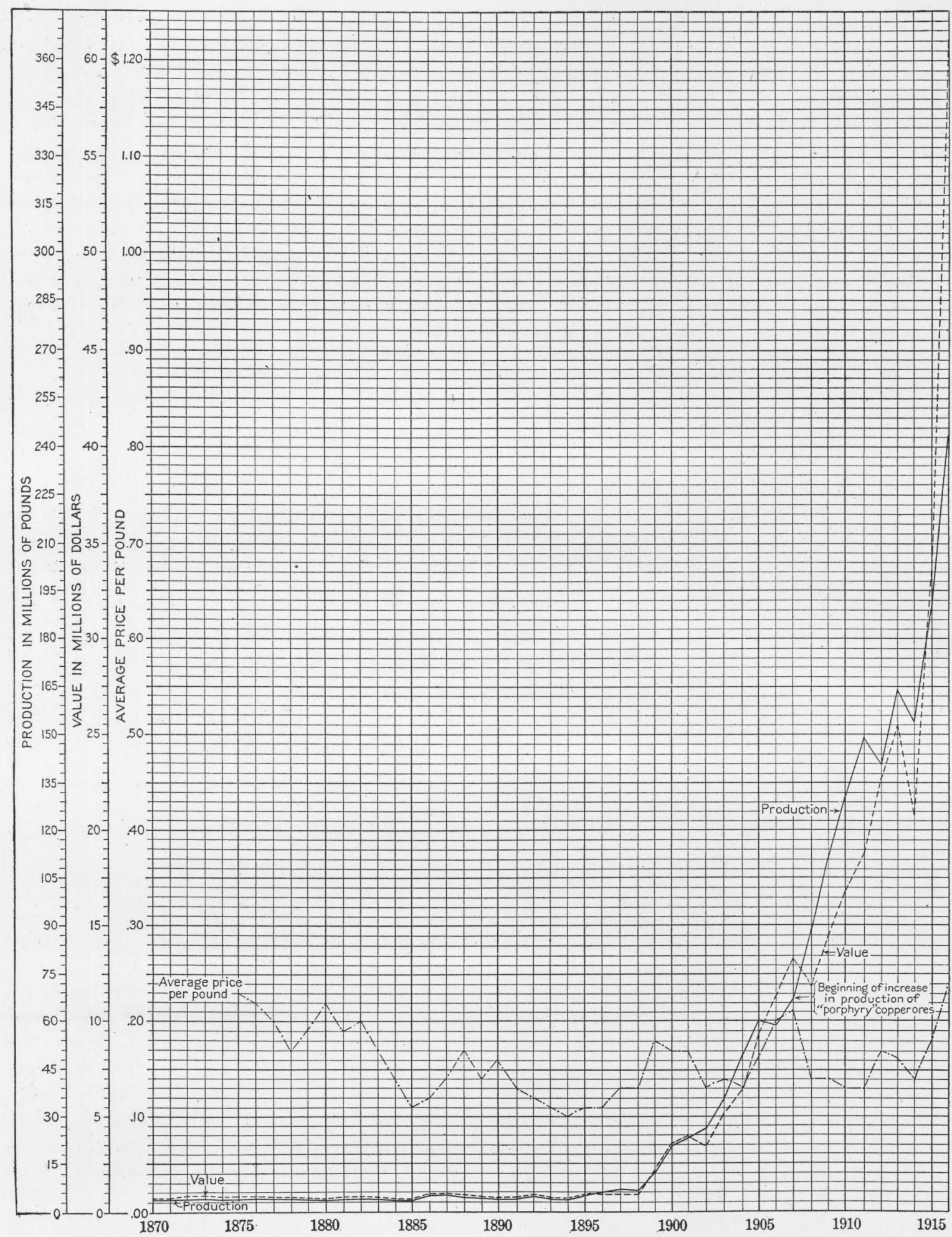

FIGURE 19.-Curves showing yearly production, value of production, and average yearly price of copper, 1870-1916. 
The yearly production, the value, and the average yearly price for the period 1870-1916 are shown in figure 19.

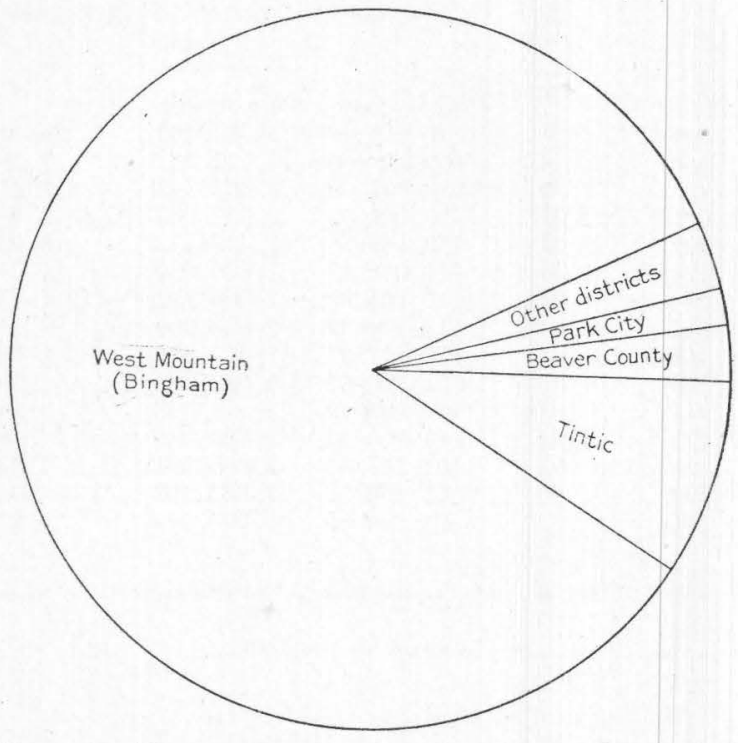

FIGURE 20.-Diagram representing the relative importance of the total output of the principal copper-producing districts to the close of 1916.

Copper is widely distributed through the State and is mined in many districts. Most of the production, however, comes from a com- paratively few and the great bulk of it from one - the Bingham. The following table shows the production of the more important districts to the close of 1917 :

Copper produced in Utah to end of 1917, by districts.

\begin{tabular}{|c|c|c|}
\hline District. & Pounds. & Value. \\
\hline 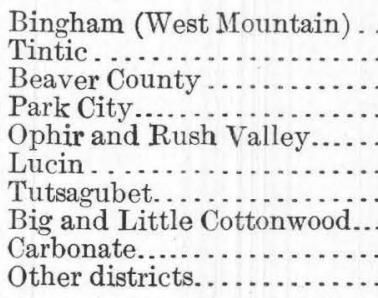 & $\begin{array}{r}1,658,636,866 \\
171,493,635 \\
49,638,383 \\
31,028,556 \\
23,026,554 \\
16,576,321 \\
10,595,066 \\
9,855,917 \\
2,564,245 \\
3,395,468\end{array}$ & $\begin{array}{r}\$ 296,608,196 \\
27,552,435 \\
8,478,593 \\
4,917,960 \\
4,044,373 \\
2,702,258 \\
1,533,116 \\
1,741,962 \\
392,530 \\
790,449\end{array}$ \\
\hline & $1,976,811,011$ & $348,761,872$ \\
\hline
\end{tabular}

$a$ The total production of copper by districts is more than the total by years for the state because of estimates in early years.

The rank of the principal districts in total production is shown graphically in figure 20.

Most of the copper has been derived from copper ores, though ores chiefly valuable for other metals have yielded large amounts. The accompanying table shows its derivation by classes of ores for the period 1910-1917:

Copper produced in Utah, 1910-1917, by kinds of ore, in dry pounds.

\begin{tabular}{|c|c|c|c|c|c|c|c|}
\hline Year. & $\begin{array}{l}\text { Dry or } \\
\text { siliceous } \\
\text { ore. }\end{array}$ & Copper ore. & Lead ore. & $\begin{array}{l}\text { Zinc } \\
\text { ore. }\end{array}$ & $\begin{array}{l}\text { Copper- } \\
\text { lead ore. }\end{array}$ & $\begin{array}{l}\text { Lead- } \\
\text { zinc ore. }\end{array}$ & Total. \\
\hline 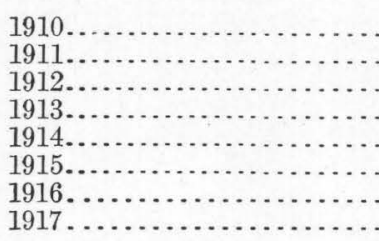 & $\begin{array}{r}1,029,927 \\
d 3,259,690 \\
b 3,373,103 \\
c 1,466,398 \\
d 2,020,504 \\
e \quad 687,998 \\
f 1,426,917 \\
g 2,579,070\end{array}$ & $\begin{array}{l}122,306,847 \\
139,382,161 \\
127,712,169 \\
152,137,467 \\
142,988,221 \\
177,784,460 \\
229,960,014 \\
235,899,850\end{array}$ & $\begin{array}{l}2,818,234 \\
2,885,369 \\
4,482,998 \\
6,627,953 \\
6,147,939 \\
7,135,528 \\
7,212,843 \\
6,256,268\end{array}$ & $\begin{array}{r}1,628 \\
478 \\
660 \\
\ldots \ldots \\
\cdots \\
1,250 \\
\cdots \ldots\end{array}$ & $\begin{array}{l}578,250 \\
317,359 \\
355,779 \\
254,773 \\
101,794 \\
354,162 \\
559,954 \\
393,079\end{array}$ & $\begin{array}{r}862,186 \\
1,115,770 \\
1,382,776 \\
959,371 \\
775,544 \\
1,707,790 \\
1,115,494 \\
1,545,886\end{array}$ & $\begin{array}{l}127,597,072 \\
146,960,827 \\
137,307,485 \\
161,445,962 \\
152,034,002 \\
187,671,188 \\
240,275,222 \\
246,674,153\end{array}$ \\
\hline
\end{tabular}

$a$ Siliceous gold and silver ores contained 2,260,868 pounds; silver ores, 983,235 pounds; gold and silver bearing oxidized iron-manganese ores, 15,587 pounds.

Siliceous gold and silver ores contained 3,162,441 pounds; silver ores, 210,662 pounds

$c$ Siliceous gold and silver ores contained 1,332,520 pounds; gold ores, 1,306 pounds; silver ores, 129,720 pounds; gold and silver bearing oxiized iron-manganese ores, 12,852 pounds.

$d$ Gold ores contained 12,440 pounds; gold and silver ores, 1,777,510 pounds; silver ores, 222,885 pounds, and iron ores, 7,669 pounds.

$e$ Gold ores contained 2,648 pounds; gold and silver ores, 254,211 pounds; silver ores, 431,139 pounds.

$f$ Includes 2,529 pounds from gold ore, 13,820 pounds from gold and silver ore, and 1,410,568 pounds from silver ore.

Before 1907 the main production was from ores which were treated directly in smelters near Salt Lake and in Bingham Canyon. Since 1907 , however, the proportion of copper derived from low-grade disseminated copper ores (which require concentration) has greatly increased.
The tables on page 138 show the total quantity of copper ore treated in Utah and the copper, gold, and silver recovered from it, and also the copper ore concentrated and smelted, and the copper recovered by each process for the period 1903-1917. 
Total copper, gold, and silver recovered from ores in which copper constitutes the principal value, 1903-191\%.

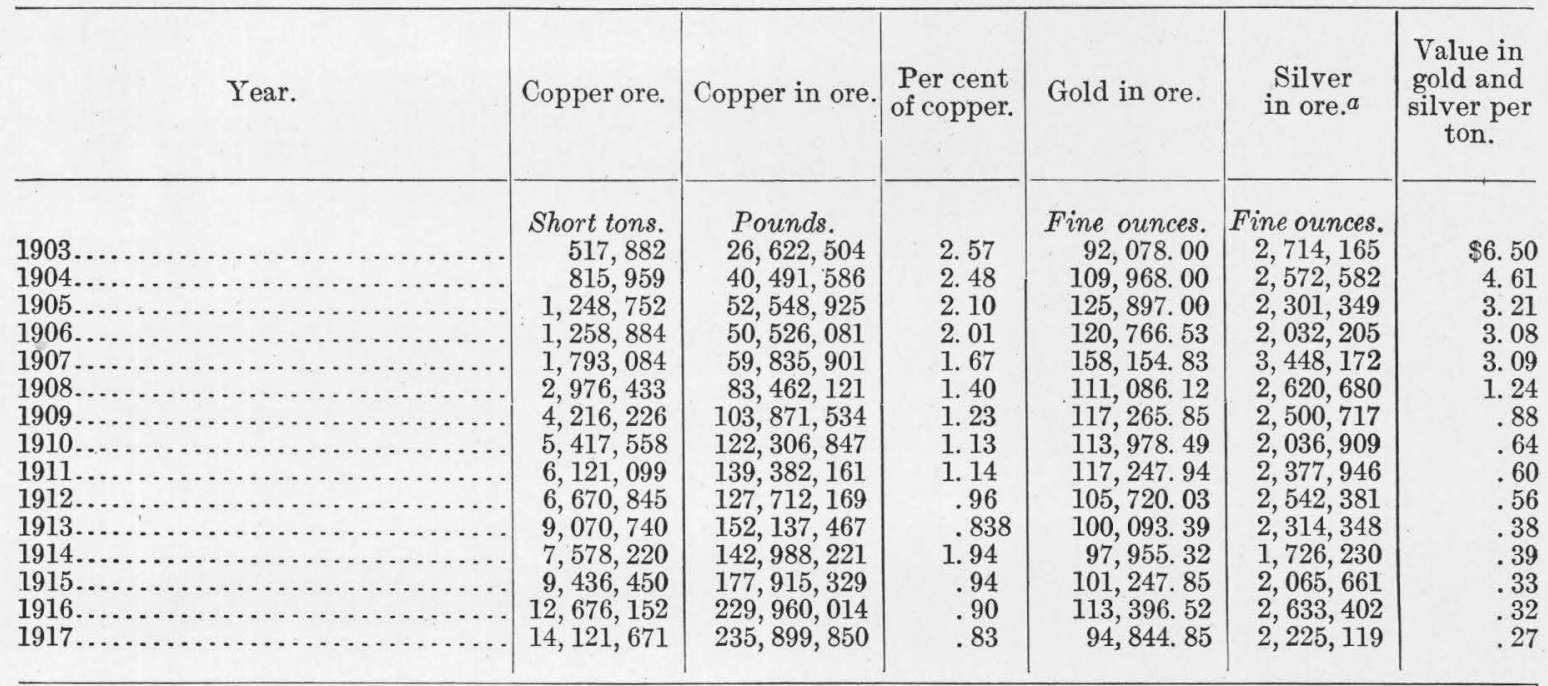
years.

These figures are arranged according to the first method of classification, 1903 to 1910, as printed in the Mineral Resources reports for those

Copper ores concentrated and smelted and percentage of copper recovered by each process, 1903-1917.

\begin{tabular}{|c|c|c|c|c|c|c|c|}
\hline \multirow{2}{*}{ Year. } & \multicolumn{4}{|c|}{ Ores concentrated. } & \multicolumn{3}{|c|}{ Ores smelted. } \\
\hline & Ores. & $\begin{array}{c}\text { Concentrates } \\
\text { produced. }\end{array}$ & $\begin{array}{l}\text { Copper } \\
\text { produced. }\end{array}$ & $\begin{array}{c}\text { Per cent } \\
\text { of copper. }\end{array}$ & Ores. & $\begin{array}{l}\text { Copper } \\
\text { produced. }\end{array}$ & $\begin{array}{l}\text { Per cent } \\
\text { of copper. }\end{array}$ \\
\hline 1903 & Short tons. & Short tons. & Pounds. & & Short tons. & Pounds. & 2.57 \\
\hline 1904. & 138,372 & 9,215 & $4,772,916$ & i. 72 & 677,587 & $35,718,670$ & 2. 64 \\
\hline 1905. & 427,598 & 32,266 & 11,784 & 1.3 & 821,154 & $40,763,987$ & 2.45 \\
\hline 1906. & 491,816 & 35,322 & $11,862,742$ & 1. 21 & 767,068 & $38,663,339$ & 2. 52 \\
\hline 1907. & 863,606 & 51,224 & $18,518,093$ & 1. 0 & 908,319 & $41,317,808$ & 2. 27 \\
\hline 1908 & $2,331,514$ & 121,046 & $53,411,303$ & 1.15 & 644,488 & $29,987,867$ & 2. 33 \\
\hline $1909 \ldots$ & $3,462,481$ & 147,976 & $68,173,413$ & .98 & 753,278 & $35,315,285$ & 2. 34 \\
\hline 10 & $4,846,429$ & 181,201 & $91,975,100$ & .9 & 568,951 & $30,152,343$ & 2.65 \\
\hline 1911.. & $5,476,916$ & 228,591 & $105,951,888$ & .97 & 640,729 & $32,637,950$ & 2. 55 \\
\hline - & $6,095,728$ & 261,941 & $102,539,091$ & .8 & 572,354 & $25,000,452$ & 2. 18 \\
\hline 12 & $8,406,816$ & 382,663 & $126,364,491$ & .7 & 662,892 & $25,719,652$ & 1. 94 \\
\hline & $7,106,594$ & 360,569 & $125,778,515$ & .8 & 471,626 & $17,209,706$ & 1. 82 \\
\hline & $8,926,688$ & 427,495 & $156,436,723$ & .8 & 509,762 & $21,478,606$ & 2. 11 \\
\hline & $\alpha 11,943,472$ & 559,840 & $199,997,786$ & .8 & 732,680 & $29,962,228$ & 2. 04 \\
\hline & b13,504, 435 & 655,259 & $207,603,875$ & .76 & 617,156 & $28,282,873$ & 2. 29 \\
\hline
\end{tabular}

$a$ Includes 175,923 tons of old tailings concentrated.

The copper industry is now the most important mining industry in the State, and as very large reserves of ore have been developed, especially in the Bingham district, it is certain to be of prime importance for many years to come.

LEAD.

Lead mining in Utah is very closely allied to silver mining, much of the lead ore containing an equal or greater value of silver, and consequently influences that have affected silver production have had an effect in lead production. The production of lead began at essentially the same time as that of silver, and the early producing districts were the same with the exception of the Silver Reef, which was entirely silver, the Lion Hill section of the Ophir district, and the early production from the Ontario vein of the Park City district.

The yearly production and value, and the average yearly price for the period 1870-1916 are shown in figure 21 . Lead mining has experienced many and rather important vicissitudes, but the general trend in both quantity and value has been upward from the beginning of production to the close of 1917 . 


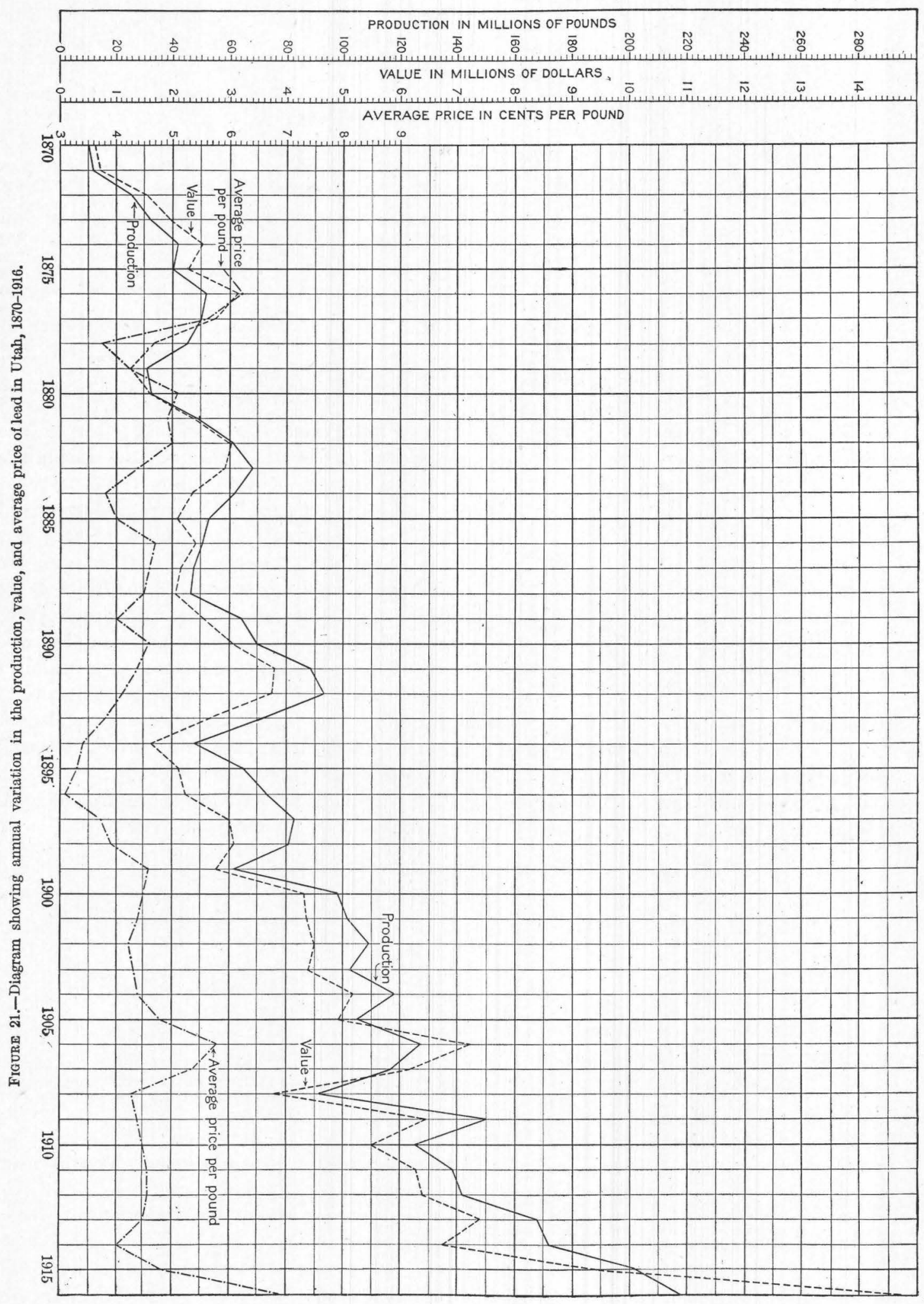


The two marked depressions (those of the middle nineties and of 1907-1909) in silver production are also notable in the lead curve, which, however, shows also some earlier rises and depressions, due to the opening or exhaustion of bonanzas, during which the silver production was kept more uniform by the output

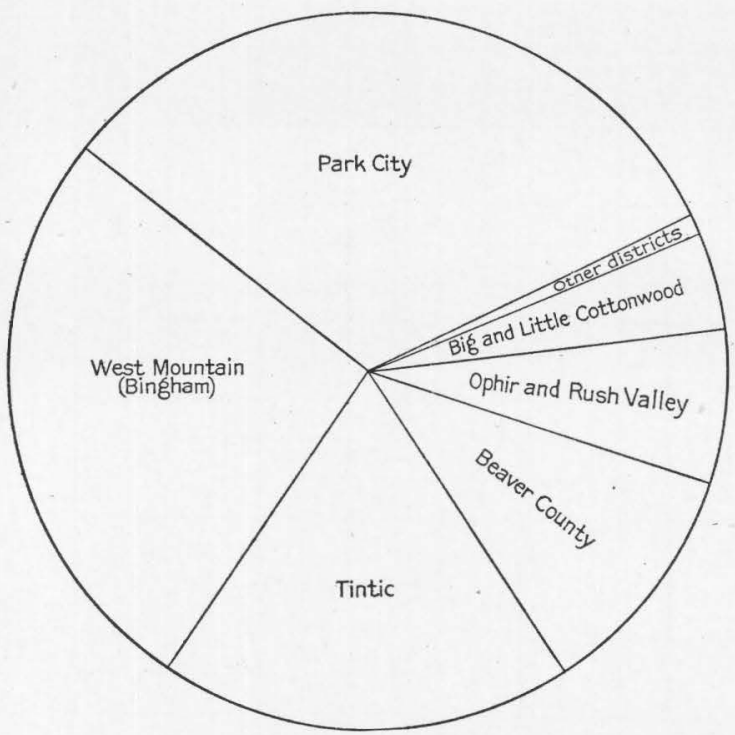

Figure 22.-Diagram showing the relative production of lead from the principal districts of Utah, 1870-1916.

from mines that yielded silver as their main product. The lead production of the more important districts of the State is given in the table in the next column, and is shown graphically in figure 22 .
Production of lead in Utah to close of 191\%, by districts.

\begin{tabular}{|c|c|c|}
\hline District. & Pounds. & Value. \\
\hline 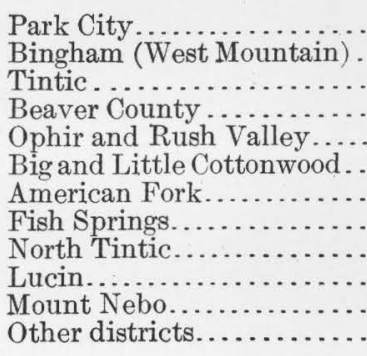 & $\begin{array}{r}1,252,444,864 \\
1,058,092,538 \\
752,049,426 \\
411,403,954 \\
275,860,038 \\
180,616,785 \\
28,586,796 \\
16,069,128 \\
11,526,680 \\
4,749,125 \\
1,932,683 \\
10,470,807\end{array}$ & $\begin{array}{r}\$ 56,374,893 \\
52,429,453 \\
35,358,411 \\
17,980,774 \\
14,643,698 \\
10,225,640 \\
1,574,129 \\
678,655 \\
583,142 \\
294,756 \\
90,780 \\
686,991\end{array}$ \\
\hline & $a 4,003,802,824$ & $190,921,322$ \\
\hline
\end{tabular}

$a$ This total is $28,202,667$ pounds more than the total by years for the State, and is accounted for in the table on p.128. The excess in value is State, and is accounted for in the table on $p$.
$\$ 2,205,476$. See same excess at close of 1913 .

The production of lead at the close of the period was greater than at any time during the period, and it is possible that it has not yet reached its maximum. The richer portions of many of the deposits have been mined, but there is reasonable assurance that enough ore remains in many districts to insure a large future yield. Moreover, as in other ores, improvements in mining and metallurgic methods have steadily decreased the grade of material that can be profitably mined, and it is probable that such improvements will continue and will make available much material that is not now of commercial value.

The following table shows the source of lead, by kinds of ore, for the period 1910-1917:

Lead produced in Utah, 1910-1917, by kinds of ore, in dry pounds.

\begin{tabular}{|c|c|c|c|c|c|c|c|}
\hline Yes & $\begin{array}{l}\text { Dry or sili- } \\
\text { ceous ore. }\end{array}$ & $\begin{array}{l}\text { Copper } \\
\text { ore. }\end{array}$ & Lead ore. & Zinc ore. & $\begin{array}{l}\text { Copper- } \\
\text { lead ore. }\end{array}$ & $\begin{array}{l}\text { Lead-zinc } \\
\text { ore. }\end{array}$ & Total. \\
\hline $\begin{array}{l}1910 . \\
1916 . \\
1917 .\end{array}$ & $\begin{array}{r}522,046 \\
a 2,757,084 \\
b 1,809,989 \\
c 1,083,039 \\
d 814,047 \\
e 1,015,806 \\
f 246,028 \\
g 976,227\end{array}$ & $\begin{array}{r}222,127 \\
338,688 \\
2,194,024 \\
167,227 \\
2,179 \\
20,401 \\
6,540 \\
14,872\end{array}$ & $\begin{array}{r}85,396,907 \\
97,494,377 \\
106,978,033 \\
138,075,527 \\
146,373,700 \\
151,803,997 \\
159,260,831 \\
137,245,961\end{array}$ & \begin{tabular}{r}
221,292 \\
9,601 \\
626,503 \\
871,435 \\
\hdashline$\ldots \ldots .7$ \\
307,737 \\
230,877 \\
60,078
\end{tabular} & $\begin{array}{r}4,451,792 \\
796,237 \\
941,532 \\
926,422 \\
272,376 \\
911,594 \\
1,696,276 \\
1,436,782\end{array}$ & $\begin{array}{l}32,510,471 \\
35,100,763 \\
27,761,054 \\
25,003,140 \\
23,860,835 \\
45,907,902 \\
40,049,523 \\
38,788,038\end{array}$ & $\begin{array}{l}123,324,635 \\
136,496,750 \\
140,311,135 \\
166,126,790 \\
171,323,137 \\
199,967,437 \\
201,490,075 \\
178,521,958\end{array}$ \\
\hline
\end{tabular}

$a$ Siliceous gold and silver ores contained 1,662,819 pounds; silver ores, 1,079,435 pounds; gold and silver bearing oxidized iron-manganese ores, 14,830 pounds.

Siliceous gold and silver ores contained 262,817 pounds; silver ores, $1,547,172$ pounds.

$c$ Siliceous gold and silver ores contained 486,692 pounds; gold ores, 17,575 pounds; silver ores, 578,772 pounds.

$d$ Gold ores contained 1,696 pounds; gold and silver ores, 35,476 pounds; silver ores, 763,993 pounds; and iron ore, 12,882 pounds.

$e$ Gold ores contained 953 pounds; gold and silver ores, 2,305 pounds; silver ore, 1,012,548 pounds.

$f$ Includes 94,635 pounds from gold and silver ore and 151,393 pounds from silver ore.

$g$ All from silver ore. 


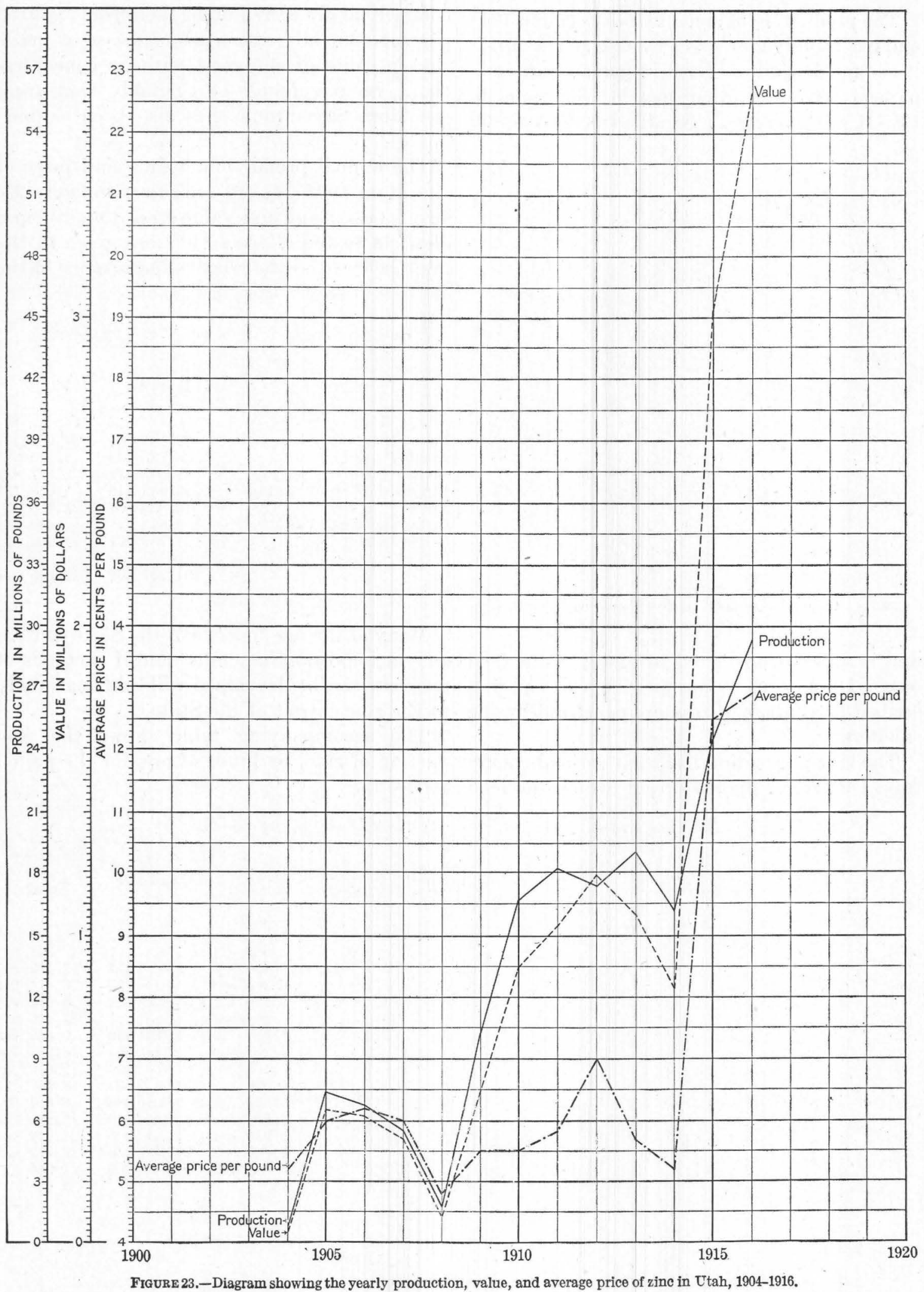


zINC.

The production of zine in Utah began in 1904 and has rapidly increased, though as yet (1917) it has not become of great importance in comparison with the other metals. Previous to 1904 it was universally regarded as detrimental

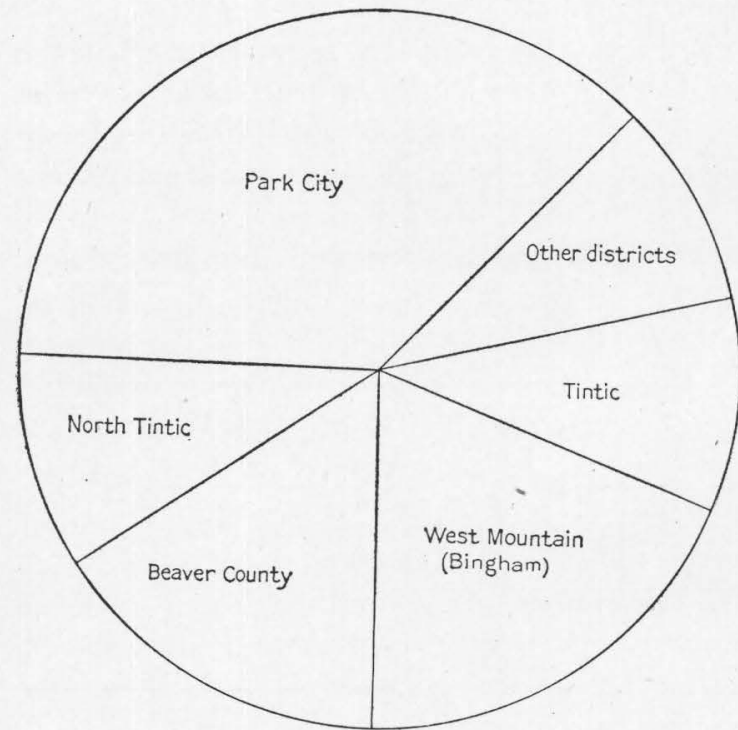

FIGURE 24.-Diagram showing the relative production of zinc from the principal districts of Utah, 1904-1916.

and is still so considered in many of the lead ores. Lead ores containing above a prescribed percentage of zinc are penalized by the smelters.

The zinc production has been derived chiefly from lead-zinc sulphide ore, in which the lead and zinc are partly separated and raised to commercial grade by milling, and from oxidized zinc ore (mainly zine carbonate) of a grade that permits of shipment without concentration. Some sulphide ore, notably that from the Horn Silver mine, has also been shipped direct.

The annual production, value, and price of zinc from 1904 to 1916 are shown in figure 23. The total output and value from the principal districts to the close of 1917 are given in the table below, and the relative importance of the districts is shown in figure 24 .

Zinc produced in Utah to end of 1917, by districts.

\begin{tabular}{|c|c|c|}
\hline District. & Pounds. & Value. \\
\hline 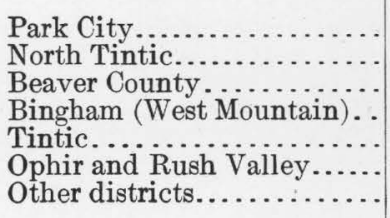 & $\begin{array}{r}66,191,185 \\
18,792,296 \\
33,507,519 \\
40,052,718 \\
16,803,653 \\
4,823,331 \\
11,786,907\end{array}$ & $\begin{array}{r}\$ 4,951,107 \\
1,246,697 \\
2,577,029 \\
3,678,727 \\
1,590,790 \\
442,691 \\
1,362,853\end{array}$ \\
\hline & $191,957,609$ & $15,849,894$ \\
\hline
\end{tabular}

Many of the ore deposits of the State contain zinc in important amounts, and if methods of recovery can be developed will add materially to the zinc output of the State.

The accompanying table shows the production of zinc, by kinds of ore, for the period 1904-1917:

Zinc produced in Utah, 1904-1917, by kinds of ore, in dry pounds.

\begin{tabular}{|c|c|c|c|c|c|}
\hline Year. & $\begin{array}{l}\text { Copper } \\
\text { ore. }\end{array}$ & Lead ore. & Zinc ore. & $\begin{array}{l}\text { Lead-zinc } \\
\text { ore. }\end{array}$ & Total. \\
\hline 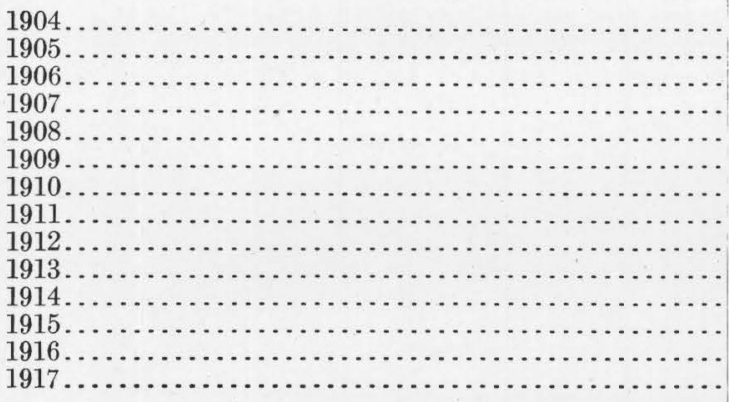 & 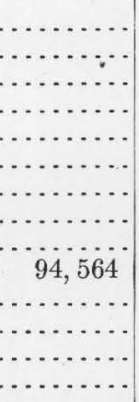 & 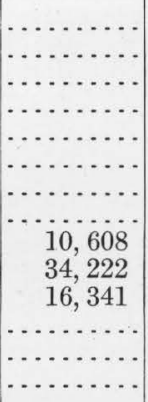 & $\begin{array}{r}332,924 \\
5,190,970 \\
6,305,865 \\
5,194,132 \\
1,460,554 \\
8,784,779 \\
11,271,700 \\
1,165,064 \\
5,599,262 \\
9,539,053 \\
2,984,486 \\
9,915,334 \\
8,865,582 \\
3,664,962\end{array}$ & $\begin{array}{r}1,911,577 \\
168,750 \\
258,784 \\
\ldots \ldots .7 . \\
1,075,999 \\
5,095,404 \\
16,675,197 \\
11,457,307 \\
9,189,988 \\
12,988,440 \\
14,376,906 \\
20,706,946 \\
17,621,909\end{array}$ & $\begin{array}{r}332,924 \\
7,102,547 \\
6,474,615 \\
5,452,916 \\
1,460,554 \\
9,860,778 \\
16,367,104 \\
17,840,261 \\
17,067,177 \\
18,857,827 \\
15,989,267 \\
24,292,240 \\
29,572,528 \\
21,286,871\end{array}$ \\
\hline
\end{tabular}


IRON.

Metallic iron has not been produced in commercial quantities in Utah, though some attempts at smelting it were made in Iron County in early days.

Some ore chiefly valuable for its iron content has been mined and shipped to the smelters to be used as a flux for siliceous ores; and many ores chiefly valuable for other metals have brcught materially higher prices from the smeliers because of their iron content. The iron content of the ores has therefore been a source of considerable revenue, but as it has yielded no metallic output it has not been included in the total metal production of the State.

The following table gives the quantity and value of the iron ore mined in Utah for the years for which statistics are available. Iron was mined in other years, but no figures are to be had.

Iron ore mined in Utah.

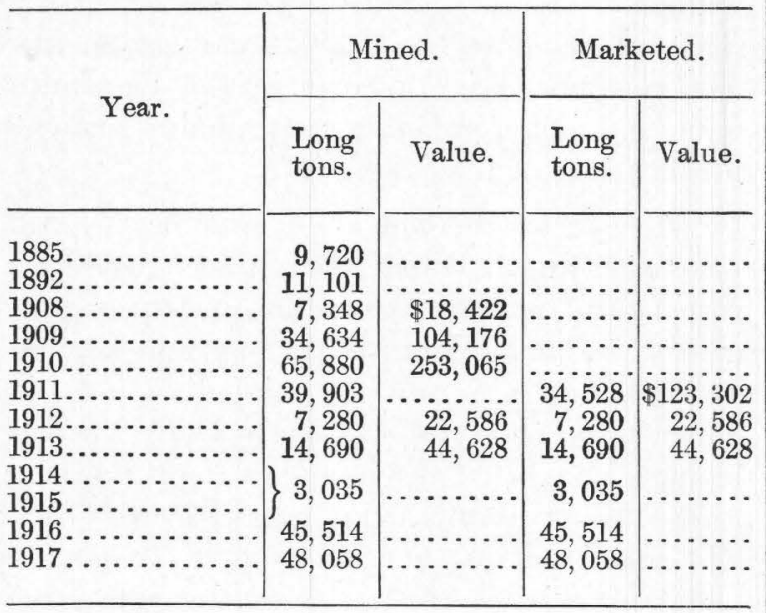

There are large deposits of iron ore in Iron County (see p. 568), to which railway transportation can be readily extended, and at some time iron production will doubtless become important.

\section{MANGANESE.}

Some manganese ore has been mined in Utah, mainly in the Little Grande district. The known production, by years, is given in the following table:
Manganese ore produced in Utah.

Long tons.

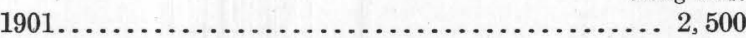

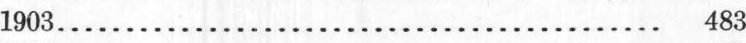

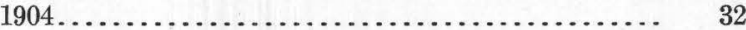

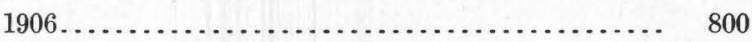

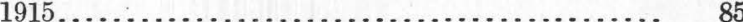

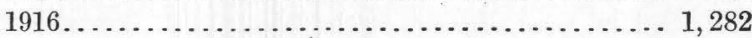

1917 (preliminary estimate) ................. 3, 580

Numerous deposits of manganese exist in the Plateau region of southeastern Utah, but most of them are remote from transportation facilities and of too low grade or of too small extent to be profitably worked at present. Some of the ores of the State contain manganese, which, like iron, serves as a flux and adds to the value of the ores. The demand for manganese ores in 1916 and 1917 resulted in a vigorous search, and ore was shipped from the Tintic, West Tintic, Little Grande, Marysvale, Ophir, Little Cottonwood, and other districts.

\section{ALUMINUM.}

No production of aluminum ores from Utah has been recorded. The alunite deposits in the Tushar Range are, however, a possible source of this metal.

Antimony ores have been shipped at intervals since 1880 , principally from the deposits on Coyote Creek, Garfield County, to an estimated total value of $\$ 100,000$.

Small amounts of antimony ore were shipped from prospects near Brighton City in 1916 and 1917.

Most of the lead-silver-copper ores contain antimony and have yielded amounts far more important than that derived from antimony ores. No statistics, however, are available.

There seems little probability that the mining of antimony ores will become important, but the production of antimony from lead ores is certain to continue to yield a revenue.

Arsenic, like antimony, is present in many ores, notably those of the Tintic district, and in recent years some of it has been recovered as a by-product. No statistics are available. No promising deposits of arsenic are known, but the amount recovered as a by-product is likely to increase. 
QUTCKSILVER.

The following table shows the output of quicksilver by years:

Quicksilver produced in Utah, 1881-190\%.

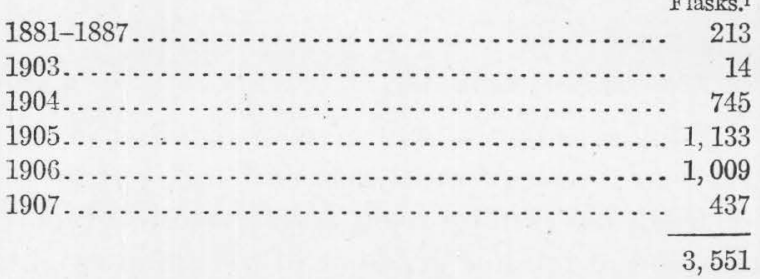

The quicksilver industry of the State is summarized by H. D. McCaskey ${ }^{2}$ as follows:

There has been no production of quicksilver in Utah since 1907, when output of this metal as a by-product ceased at the properties of the Sacramento Gold Mining Co., in the Mercur or Camp Floyd districts in Tooele County. This company had been producing quicksilver during the period from 1903 to 1907, inclusive, prior to which there had been no reported output of metal since the Richmond Quicksilver Co. ceased operations at the Lucky Boy mine in Marysvale, Piute County, after a short run during the period 1881-1887. These two operators are the only producers in Utah of which records are at hand.

The total output of quicksilver in Utah during its productive periods from 1881 to 1887 and from 1903 to 1907 , inclusive, was 3,551 flasks, valued at $\$ 139,600$. Of this production 3,338 flasks, valued at $\$ 131,292$, is to be credited to the Mercur district and 213 flasks, valued at $\$ 8,308$, is estimated to have been the output of the Marysvale district. The entire output of the State has been from retorts.

It does not seem probable that the production of quicksilver from the State will be important.

MOLYBDENUM.

Molybdenum minerals are present in small amounts in several districts, among which are Little Cottonwood, Bingham, Lucin, Beaver Lake, Star, and Clifton. A few tons of ore has been shipped from the Little Cottonwood district.

\section{TUNGSTEN.}

Tungsten is known to occur in the Clifton district, Tooele County, the Grouse Creek Range, BoxElderCounty, and in the Little Cottonwood district, Salt Lake County. A few tons of scheelite ore have been shipped from the first two of these districts.

\section{BISMUTH.}

No large production of bismuth in Utah is recorded, though small shipments of bismuth ores from the Clifton and Detroit districts are

\footnotetext{
1 During 1902, 1903, and five months of 1904 the flask contained $76 \frac{1}{2}$ pounds net; since June 1, 1904, it has contained 75 pounds.

2 McCaskey, H. D., Quicksilver: U. S. Geol. Survey Mineral Resources, 1911, pt. 1, p. 913, 1912.
}

reported. Bismuth is present in several districts in small amounts, however, and is collected in the bullion produced. It is relatively high in the ores of the Tintic district, from. which a considerable quantity is reported to have been recovered in recent years. Each 100 tons of the blister copper produced at the Garfield smelter contains, according to Eilers, ${ }^{3}$ an average of 6.1 pounds of bismuth.

\section{NICKEL.}

So far as known no nickel ore has been produced in the State, though small amounts of nickel are present in ores and are collected in the bullion. Thus, according to Eilers, ${ }^{4}$ each 100 tons of blister copper produced at the Garfield smelter (largely derived from Bingham ores) contains an average of 40 pounds of nickel. Nickel is doubtless present in small amount in other districts, and if it averages as high in all the copper ores of the State as it does in those treated at Garfield its output for the year 1913 from copper ores alone would be about 30.000 pounds.

Nickel arsenate, probably annabergite, has been recognized in the ores of the Escalante mine, and nickel minerals are probably present in other ores of the State.

\section{COBALT.}

So far as known cobalt has not been produced from Utah, though, like nickel, it is probably present in small amount in the ores and may be recovered in the refining of bullion. It is known to occur in the ores of the Dolly Varden prospect in White Canyon and in the Blue Dike prospect in the same region, and it seems probable that it is present in some of the other "sandstone" deposits in the southeastern section of the State.

\section{CHROMIUM.}

So far as known chromium has not been produced from Utah. Chromium in small amount is rather widely distributed in southeastern Utah, being associated with many uranium-vanadium deposits, and is also present in garnet in the Little Cottonwood district.

\section{SELENIUM.}

Selenium occurs in small amount in many of the ore deposits of the State. It collects in the bullion and some of it is probably recovered in

\footnotetext{
3 Eilers, A., Notes on the occurrence of some of the rarer metals in blister copper: Am. Inst. Min. Eng. Bull. 78, pp. 999-1000, 1913.
} 4 Op. cit., pp. 999-1000 
the refining. According to Eilers ${ }^{1}$ each 100 tons of blister copper produced at the Garfield smelter contains an average of 56 pounds of selenium.

Selenium is present in the gold-silver ores of the Gold Springs-State Line region, in the Tushar Range, in the mercury ore of the Lucky Boy mine near Marysvale, and is widely distributed in the "sandstone" deposits in the southeastern part of the State, but is nowhere sufficiently abundant to be profitably extracted, except, possibly, as a by-product in the recovery of other metals.

TELLURIUM.

Tellurium, like selenium, is present in small amount in the ores of the State. Eilers ${ }^{2}$ states that each 100 tons of blister copper produced at the Garfield smelter contains an average of 5.54 pounds of it. Tellurium is present in the gold ores of the Gold Springs-State Line region, in deposits of the Tushar Range, and probably in the gold ores of the Mercur district. So far as known no tellurium has been recovered in the ores of the State.

\section{PLATINUM AND PALLADIUM.}

Platinum and palladium are present in the copper ores of the Bingham district and probably in the ores of other districts. They are collected in the bullion and can be recovered, with other metals, from the "muds" resulting from the electrolytic refining of the copper. According to Eilers, ${ }^{3}$ each 100 tons of blister copper from the Garfield plant contains an average of 0.342 ounce of platinum and 1.183 ounces of palladium. Platinum in small amount is present in the placers of Colorado and Green rivers.

URANIUM, VANADIUM, AND RADIUM.

Deposits containing uranium and vanadium are rather widely distributed in southeastern Utah and have been exploited chiefly for radium, which is always associated with the uranium, though the uranium and vanadium are also recovered. The principal production of these metals has been from the region around

1 Eilers, A., op. cit., pp. 999-1000. $35416^{\circ}-19-10$ the La Sal Mountains, the San Rafael Swell, the Henry Mountains, and near Fruita in Rabbit Valley. Uranium minerals are known to occur in the Silver Reef deposits, Washington County, near Pahriah, along the west side of Colorado River between the mouths of Green and Fremont rivers, at Circle Cliffs (Burr Flats), in White Canyon, and near Browns Park in the Uinta Mountains, and are reported from other localities.

Vanadium is present in nearly all the uranium localities and also in small amount in many of the ores of the western part of the State. It has been recognized from the Escalante mine, from the Star and Little Cottonwood districts, and from the Dyer copper mine in the Uinta Mountains, and is doubtless present in other deposits.

The first shipment of uranium-vanadium ores was made about 1904. There has been an important production of uranium-radium ores from Utah in recent years.

\section{MINING DISTRICTS.}

Most of the mining districts of Utah are organized and are described in papers filed in the office of the United States surveyor general at Salt Lake City. The districts were generally organized by the miners in order to keep accurate record of the claims located and of the assessment work done on each. One hundred dollars a year is required to be expended in development work on each unpatented claim, in default of which the claim may be relocated by other miners. In early days each district had a recorder to keep such records, but in later years the recorder was abolished and all records were transferred to the county seats.

Some districts have maintained a rather steady output for many years; others have had a large but short-lived production; and still others have never had any noteworthy production and are almost unknown to the industry.

In 1917 there were 167 organized and unorganized mining districts in Utah. The following is a nearly complete list, with the date of organization, location, and the predominating metals and minerals: 
Mining districts in Utah.

\begin{tabular}{|c|c|c|c|c|c|c|}
\hline $\begin{array}{l}\text { No. on } \\
\text { Pl. I. }\end{array}$ & District. & County. & $\begin{array}{c}\text { Date of } \\
\text { organization. }\end{array}$ & Approximate location. $a$ & $\begin{array}{l}\text { Patents } \\
\text { issued } a \\
\text { (showing } \\
\text { impor- } \\
\text { tance of } \\
\text { district). }\end{array}$ & $\begin{array}{l}\text { Predominating } \\
\text { metals and } \\
\text { minerals, in } \\
\text { order of } \\
\text { importance. }\end{array}$ \\
\hline & ORGANIZED DISTRICTS. & & & & & \\
\hline 43 & $\begin{array}{l}\text { Adams (see also Hot } \\
\text { Springs). }\end{array}$ & Salt Lak & July $\quad 3,1873$ & T. 1 N., R. 1 E.... & 3 & Silver, lead. \\
\hline 1 & & Utah & & T. 4 S., R. 1 E. & 1 & Do. \\
\hline $\begin{array}{l}2 \\
3\end{array}$ & $\begin{array}{l}\text { American } \\
\text { Antelope.. }\end{array}$ & Beaver. & $\begin{array}{c}\text { July } \\
1877\end{array}$ & $\begin{array}{l}\text { T. } 3 \mathrm{~S} ., \mathrm{R} .3 \mathrm{E} \\
\text { West slope of Granite } \\
\text { Range to north of }\end{array}$ & 86 & $\begin{array}{l}\text { Do. } \\
\text { Iron, silver. }\end{array}$ \\
\hline 4 & Argenta & Morgan & Feb. 11, 1893 & $\begin{array}{l}\text { Bradshaw. } \\
\text { T. } 5 \text { N., Rs. } 2 \text { and } 3 \text { E. . }\end{array}$ & 3 & Lead, silver, \\
\hline 5 & Ashbrook. & Box Elde & July $\quad 1,1874$ & T. 14 N., R. $18 \mathrm{~W}$...... & 11 & Silver, gold. \\
\hline & Be & B & Aug., 1871 & $\mathrm{~T}$ & 19 & $\begin{array}{l}\text { Copper, silver, } \\
\text { lead. }\end{array}$ \\
\hline 7 & Big Cottonwood. & Salt La & July 11,1870 & T. 2 S., R. 2 E.... & 186 & $\begin{array}{l}\text { Silver, lead, } \\
\text { copper. }\end{array}$ \\
\hline 8 & Big Indian. & San Ju & June 19,1892 & .., R. 24 E. & 4 & Copper. \\
\hline 9 & $\begin{array}{l}\text { Black Crook, or } \\
\text { Erickson. }\end{array}$ & 1 & Jan. 30,1894 & $\mathrm{~T}$ & 6 & $\begin{array}{l}\text { Silver, gold, } \\
\text { lead, zinc. }\end{array}$ \\
\hline 10 & Blue Bel & .....do. & Feb. 12,1896 & T. 10 S., R. 5 W.. & 1 & $\begin{array}{l}\text { Lead, silver, } \\
\text { gold. }\end{array}$ \\
\hline 11 & Blue Ledge. & Vasatcl & May 10,1870 & T. 2 S., R. 4 E..... & 167 & Lead, silver, \\
\hline 12 & $\begin{array}{l}\text { Blue Mountain } \\
\text { (Monticello). }\end{array}$ & San J & Dec. $\quad 9,1892$ & T. 34 S., R. 22 E. & & Copper, gold. \\
\hline 13 & Bolter or Boulder... & Tooele & 2 1889 & T. $9 \mathrm{~S}_{.,}$R. $3 . \mathrm{W}$ & 1 & \\
\hline & & & Oct. $\quad 2,1889$ & $\mathrm{~T}$. & & $\begin{array}{l}\text { Gold, silver, } \\
\text { lead, copper. }\end{array}$ \\
\hline 15 & Bradshav & Beav & May 1,1875 & T. 29 S., Rs. 9 and $10 \mathrm{~W}$. & 9 & $\begin{array}{l}\text { Gold, silver, } \\
\text { lead, iron. }\end{array}$ \\
\hline 16 & Bull Valley & Washin & & 28 miles south of Modena & & Gold, iron. \\
\hline 17 & Floyd (Mer- & Tooele. & $\left\{\begin{array}{l}\text { Apr. } 16,1870 \\
\text { June } 24,1894\end{array}\right.$ & T. 6 S., Rs. 3 and 4 W.. & 291 & $\left\{\begin{array}{c}\text { Gold, mercury, } \\
\text { silver. }\end{array}\right.$ \\
\hline 18 & Car & Uinta & (1)................. & T. 1 & 12 & $\mathrm{Col}$ \\
\hline 19 & Cas & $\mathrm{W}$ & & $\mathrm{T}$. & 12 & $\begin{array}{l}\text { Asphalt and bi- } \\
\text { tuminousrock } \\
\text { deposits. }\end{array}$ \\
\hline 20 & Clifton (Gold Hill) & Tooele & Oct. 18,1869 & $\begin{array}{l}\text { Tps. } 7 \text { and } 8 \text { S., Rs. } 17 \\
\text { and } 18 \mathrm{~W} \text {. }\end{array}$ & 111 & $\begin{array}{l}\text { Copper, g o } 1 \mathrm{~d} \text {, } \\
\text { lead. }\end{array}$ \\
\hline 21 & Colorado $\mathrm{I}$ & Garfie & & & & \\
\hline $\begin{array}{l}22 \\
23\end{array}$ & $\begin{array}{l}\text { Col } \\
\text { Coy }\end{array}$ & & $\operatorname{Mav}^{1871} 3,1$ & $\mathrm{~T}$. & $\begin{array}{r}13 \\
9\end{array}$ & Silver, lead. \\
\hline 24 & $\begin{array}{l}\text { Deseret (D e s e r t } \\
\text { Mountain). }\end{array}$ & Jual & May 0,18 . & T. & & $\begin{array}{l}\text { Antmony. } \\
\text { Copper, silver. }\end{array}$ \\
\hline 25 & $\begin{array}{l}\text { Detroit (Joy) (Drum } \\
\text { 1872). }\end{array}$ & $\begin{array}{l}\text { Juab and Mil- } \\
\text { lard. }\end{array}$ & Aug. 27,1879 & $\begin{array}{l}\text { Tps. } 14 \text { and } 15 \text { S., R. } \\
10 \text { W. }\end{array}$ & 35 & $\begin{array}{l}\text { Copper, silver, } \\
\text { gold, manga- } \\
\text { nese. }\end{array}$ \\
\hline 26 & Dug & & Feb. 21, & , R. $12 \mathrm{~W}$. & 59 & Lead, silver. \\
\hline 28 & $\begin{array}{l}\text { Elkhorn .................... } \\
\text { Emery (Lost Springs) }\end{array}$ & & $\begin{array}{l}\text { May 21, } \\
\text { Dec. 6, }\end{array}$ & E........... & 2 & Silver. \\
\hline & & & Dec. 6, & $\begin{array}{l}10 \text { miles west of Wood- } \\
\text { side. }\end{array}$ & & $\begin{array}{l}\text { Copper, lead, } \\
\text { gold, silver. }\end{array}$ \\
\hline 9 & $\begin{array}{l}\text { Erickson (see Black } \\
\text { Crook). }\end{array}$ & Tooe & & & & $\begin{array}{l}\text { Silver, g o l d , } \\
\text { lead, z i n c,, } \\
\text { copper. }\end{array}$ \\
\hline 29 & Farmington & Davis. & & East and southeast of & & Copper. \\
\hline 30 & Fish Springs & Juab & Mar. 20,1891 & T. $11 \mathrm{~S}, \mathrm{P}$ & 26 & Silver, lead. \\
\hline 31 & & & May 29 , & T. 2 S., Rs. 6 and $7 \mathrm{~W}$. & 3 & Clay and lime. \\
\hline 32 & Fr & $\mathrm{n}$ & Aug. 3, & $\begin{array}{l}\text { Island in Great Salt } \\
\text { Lake. }\end{array}$ & & $\begin{array}{c}\text { Copper, gold, } \\
\text { silver, lead, }\end{array}$ \\
\hline 33 & $\begin{array}{l}\text { G o l d Mountain } \\
\text { (Kimberly). }\end{array}$ & Piut & Apr. 24,1889 & T. 27 S., R. 5 V & 42 & Gold, silver. \\
\hline $\begin{array}{l}34 \\
35\end{array}$ & $\begin{array}{l}\text { Gold Springs... } \\
\text { Gordon......... }\end{array}$ & $\begin{array}{l}\text { Iron.............. } \\
\text { Millard a n d } \\
\text { Beaver. }\end{array}$ & June 15,1872 & T. 25 S., Rs. 6 and 7 W & 21 & $\begin{array}{l}\text { Gold, silver. } \\
\text { Sulphur. }\end{array}$ \\
\hline
\end{tabular}
of 1912 . 
Mining districts in Utah-Continued.

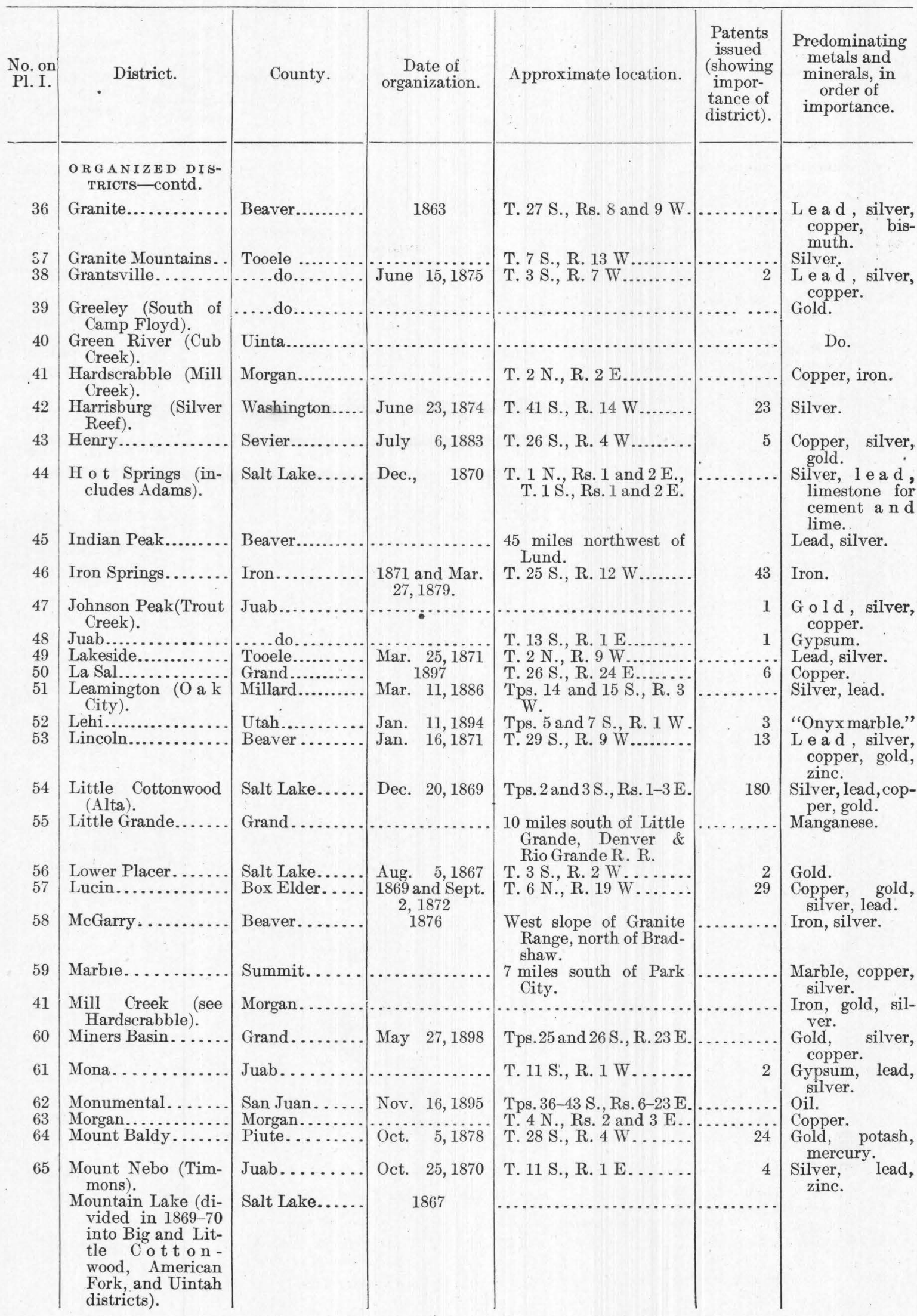


Mining districts in Utah-Continued.

\begin{tabular}{|c|c|c|c|c|c|c|}
\hline $\begin{array}{l}\text { No. on } \\
\text { Pl.I. }\end{array}$ & District. & County. & $\begin{array}{c}\text { Date of } \\
\text { organization. }\end{array}$ & Approximate location. & $\begin{array}{l}\text { Patents } \\
\text { issued } \\
\text { (showing } \\
\text { impor- } \\
\text { tance of } \\
\text { district). }\end{array}$ & $\begin{array}{l}\text { Predominating } \\
\text { metals and } \\
\text { minerals, in } \\
\text { order of } \\
\text { importance. }\end{array}$ \\
\hline & $\begin{array}{l}\text { O R G A N I ZE D DI S- } \\
\text { TRICTS-contd. }\end{array}$ & & & & & \\
\hline 66 & Newfoundland. . & Box Elder. & 1872 & T. 5 N., R. 13 W. & 2 & Copper, silver, \\
\hline 67 & Newton. & Beaver. & Nov. 26,1892 & Tps. 27 and $28 \mathrm{~S} .$, R. $6 \mathrm{~W}$. & 6 & Gold, silver. \\
\hline 36 & $\begin{array}{l}\text { North Granite (see } \\
\text { also Granite). }\end{array}$ & ..... do.. & 1865 & North of Granite district. & & $\begin{array}{l}\text { Lead, low-grade } \\
\text { ore. }\end{array}$ \\
\hline 98 & $\begin{array}{l}\text { North Star (see also } \\
\text { Star). }\end{array}$ & ....do. do. & Nov. 11,1871 & T. 28 S., R. 11 W... & 26 & $\begin{array}{l}\text { Silver, gold, } \\
\text { copper, lead, }\end{array}$ \\
\hline 68 & $\begin{array}{l}\text { North Tintic (Oasis } \\
\text { in } 1873 \text { and Cale- } \\
\text { donia in 1875). }\end{array}$ & $\begin{array}{l}\text { Tooele and } \\
\text { Utah............ }\end{array}$ & $\begin{array}{c}1879 \text { and May } \\
4,1891\end{array}$ & T. 9 S., R. 2 W. & 38 & $\begin{array}{l}\text { Zinc, lead, sil- } \\
\text { ver. }\end{array}$ \\
\hline 68 & Oasis (Caledonia). . . & Tooele. & 1875-1879 & & & \\
\hline 69 & Ohio (Marysvale)... & Piute. . & $\begin{array}{ll}\text { Feb., } & 1868 \\
\text { Aug., } & 1872\end{array}$ & Tps. 27 and 28 S., R. $4 \mathrm{~W}$. & 46 & $\begin{array}{l}\text { Gold, silver, } \\
\text { lead. }\end{array}$ \\
\hline 70 & Ophir.... & Tooele. & Aug. $\quad 6,1870$ & T. 5 S., R. 4 W. & 154 & Silver, lead, \\
\hline 71 & $\begin{array}{l}\text { Osceola (south of } \\
\text { Camp Floyd). }\end{array}$ & $\ldots d$ & & & & \\
\hline $\begin{array}{l}72 \\
73\end{array}$ & $\begin{array}{l}\text { Paradise (La Plata). } \\
\text { Park Vallev }\end{array}$ & Cache..... & May 26,1881 & T. 9 N., R. 2 E.... & 6 & Lead, silver. \\
\hline & & & & Kelton. & 16 & copper, lead. \\
\hline 74 & Payson.. & Utah. & $1871-72$ & $\begin{array}{l}\text { Western foothills of Wa- } \\
\text { satch Range. }\end{array}$ & & $\begin{array}{l}\text { Silver } \\
\text { grade). }\end{array}$ \\
\hline 75 & Pine Grove.......... & Beaver. & 1873 & Tps. 28 and 29 S., R. 16 W. & 4 & Gold, silver. \\
\hline 76 & $\begin{array}{l}\text { Pinto Iron (silver } \\
\text { belt). }\end{array}$ & Iron... & May 26,1868 & .T. 36 S., R. 14 W..... & 57 & $\begin{array}{l}\text { Iron, lead, sil- } \\
\text { ver. }\end{array}$ \\
\hline 77 & Promontory...... & Box Elder & & $\begin{array}{l}\text { Lakeside, Saline, South- } \\
\text { ern Pacific R. R. }\end{array}$ & & $\begin{array}{l}\text { Zinc, lead, cop- } \\
\text { per, silver. }\end{array}$ \\
\hline 78 & Provo .............. & Utah... & Mar. 11, 1871 & T. 6 S., R. 3 E....... & 3 & Lead, silver. \\
\hline 79 & Pruess (Newhouse).. & Beaver & Sept. 4,1880 & T. 26 S., R. 13 W. & 8 & $\begin{array}{l}\text { Copper, gold, } \\
\text { silver. }\end{array}$ \\
\hline 80 & Richardson. & Grand. & & $\begin{array}{l}27 \text { miles south of Cisco, } \\
\text { Denver \& Rio Grande } \\
\text { R. R. }\end{array}$ & & $\begin{array}{l}\text { Uranium, vana- } \\
\text { dium. }\end{array}$ \\
\hline 81 & Richmond.......... & Cache & & T. 13 N., R. 2 E..... & 1 & Copper. \\
\hline 82 & $\begin{array}{l}\text { Rhodes Pla teau } \\
\text { (Woodland). }\end{array}$ & & & & & $\begin{array}{l}\text { Iron and man- } \\
\text { ganese. }\end{array}$ \\
\hline 83 & Rocky......... & Beaver. & Mar. 27,1872 & T. 27 S., R. 11 W. & 6 & $\begin{array}{l}\text { Copper, gold, } \\
\text { silver, iron. }\end{array}$ \\
\hline 84 & Rosebud.. & Box Elder. & 1873 & 10 miles northwest of & & $\begin{array}{l}\text { Lead, silver, } \\
\text { gold. }\end{array}$ \\
\hline 85 & $\begin{array}{l}\text { Rush Valley (Stock- } \\
\text { ton). }\end{array}$ & Tooele. & June 12,1864 & T. 4 S., R. $4 \mathrm{~W}$... & 137 & Silver. \\
\hline 86 & Salina Creek. & Sevier & & 4 miles east of Salin & & Lead, zinc. \\
\hline 87 & $\begin{array}{l}\text { San Francisco (Fris- } \\
\text { co). }\end{array}$ & Beaver. & Aug. 12,1871 & T. 27 S., R. 13 W.. & 74 & $\begin{array}{l}\text { Lead, copper, } \\
\text { silver, gold, }\end{array}$ \\
\hline 88 & San Rafael.. & Emery.. & & 18 miles southwest of & & $\begin{array}{l}\text { Uranium, vana- } \\
\text { dium, copper. }\end{array}$ \\
\hline 89 & Santa Clara. & Washington. & 1880 & 10 miles west of St. & & Silver. \\
\hline $\begin{array}{l}90 \\
91\end{array}$ & $\begin{array}{l}\text { Santaquin..... } \\
\text { Saw Back..... }\end{array}$ & $\begin{array}{l}\text { Utah.... } \\
\text { Millard. }\end{array}$ & $\begin{array}{l}1871 \\
1872\end{array}$ & $\begin{array}{l}\text { T. } 10 \text { S., R. } 2 \text { E....... } \\
\text { West of Sevier Lake... }\end{array}$ & 3 & Silver, lead. \\
\hline 92 & Sierra Madre... & Weber. & Feb. 12,1902 & $\left\{\begin{array}{l}\text { Tps. } 7-8 \mathrm{~N} ., \\
\text { Tps. } 1 \mathrm{~W} .\end{array}\right.$ & 2 & Copper, silver. \\
\hline 93 & Silver Islet.. & Tooele.. & 1872 & & & Lead, silver, \\
\hline 94 & Silver Lake........... & Utah...... & Jan. $\quad 28,1871$ & T. $4 \mathrm{~S} .$, R. $2 \mathrm{~W} \ldots \ldots \ldots$ & 5 & Lead, silver. \\
\hline 95 & $\begin{array}{l}\text { Snake Creek (for- } \\
\text { merly White Pine, } \\
\text { Howland). }\end{array}$ & Wasatch.. & May 10,1870 & $\begin{array}{l}\text { Tps. } 2 \text { and } 3 \text { S., Rs. } 3 \\
\text { and } 4 \mathrm{E} \text {. }\end{array}$ & 191 & Silver, lead. \\
\hline $96 \mathrm{a}$ & Spanish Fork (Cook) & Utah.. & $1870-71$ & $\begin{array}{l}\text { Western flank Wasatch } \\
\text { Range south of Provo } \\
\text { district. }\end{array}$ & & Lead, silver. \\
\hline
\end{tabular}


Mining districts in Utah-Continued.

\begin{tabular}{|c|c|c|c|c|c|c|}
\hline $\begin{array}{l}\text { No. on } \\
\text { Pl. I. }\end{array}$ & District. & County. & $\begin{array}{c}\text { Date of } \\
\text { organization. }\end{array}$ & Approximate location. & $\begin{array}{l}\text { Patents } \\
\text { issued } \\
\text { (showing } \\
\text { impor- } \\
\text { tance of } \\
\text { district). }\end{array}$ & $\begin{array}{l}\text { Predominating } \\
\text { metals and } \\
\text { minerals, in } \\
\text { order of } \\
\text { importance. }\end{array}$ \\
\hline & $\begin{array}{l} \\
\text { ORG A N I Z E D D IS - } \\
\text { TRICTS-contd. }\end{array}$ & & & & & \\
\hline 97 & Spring Creek.......... & Juab.. & June $\quad 4,1891$ & Tps. 11 and $12 \mathrm{~S} .$, R.19 W & 22 & Gold, silver. \\
\hline 98 & $\begin{array}{l}\text { Star (known as } \\
\text { South Star). }\end{array}$ & Beaver & July $\quad 8,1870$ & T. 28 S., R. 12 W $\ldots .$. & 35 & $\begin{array}{l}\text { Lead, silver, } \\
\text { copper, gold, } \\
\text { zinc. }\end{array}$ \\
\hline 99 & Smelter............. & Salt Lake.... . . & & South of Salt Lake City. & & \\
\hline 100 & Stateline.............. & Iron..... & 1896 & Tps. $32-34$ S., Rs. 19 & 21 & Gold, silver. \\
\hline 101 & Sterling.... & Beaver. & Feb., .1880 & $\begin{array}{l}\text { Wahwah Range west of } \\
\text { Frisco. }\end{array}$ & $\ldots$ & Iron. \\
\hline 102 & Sulphur. . & & & T. 29 S., R. 14 W & 1 & Sulphur. \\
\hline 38 & $\begin{array}{l}\text { Third Term (see } \\
\text { also Grantsville). }\end{array}$ & Tooele. & & & 1 & $\begin{array}{l}\text { Lead, silver, } \\
\text { copper. }\end{array}$ \\
\hline 103 & Tidewell \& Rideout. & Carbon & Feb. 21,1890 & T. 13 S., R. 13 E. & 1 & Asphalt. \\
\hline 65 & $\begin{array}{l}\text { Timmons (see also } \\
\text { Mount Nebo). }\end{array}$ & & 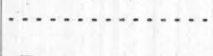 & & & \\
\hline 104 & Tintic............. & Juab and Utah.. & Dec. 13,1869 & Tps. 9-11 S., Rs. 2 and & 873 & Gold, silver, \\
\hline 105 & Tooele... & Tooele......... & 1870 & T. 3 S., R. 3 W........... & 26 & Gold, silver, \\
\hline 106 & Tutsagubet... & Washington..... & June 2,1883 & T. 43 S., R. 17 V & 3 & Copper, lead. \\
\hline 107 & Uintah (Park City)... & Summit........ & July 8,1871 & $\begin{array}{l}\text { Tps. } 1 \text { and } 2 \text { S., Rs. } 3 \text { and } \\
4 \text { E. }\end{array}$ & 845 & $\begin{array}{l}\text { Silver, lead, } \\
\text { zinc, copper. }\end{array}$ \\
\hline 108 & $\begin{array}{l}\text { Utah (eastern part } \\
\text { of Tintic district). } \\
\text { Wasateh (see also } \\
\text { Mountain Lake). }\end{array}$ & $\begin{array}{l}\text { Utah........... } \\
\text { Salt Lake...... }\end{array}$ & July 20,1864 & T. 10 S., R. 2 W.......... & 3 & $\begin{array}{l}\text { Silver, copper, } \\
\text { lead. } \\
\text { Granite, }\end{array}$ \\
\hline 109 & Washington.......... & Beaver. & 1879 & T. 29 S., R. 19 W........ & 8 & $\begin{array}{l}\text { Silver, copper } \\
\text { lead, gold. }\end{array}$ \\
\hline 110 & $\begin{array}{l}\text { Weber (f ormerly } \\
\text { Junction 1860). }\end{array}$ & \} Weber......... & Feb., $\quad 1878$ & $\left\{\begin{array}{l}\text { T. } 6 \text { N., R. } 1 \text { E.......... } \\
\text { T. } 6 \text { N., R. } 1 \text { W. . . . . }\end{array}\right.$ & 4 & $\left\{\begin{array}{l}\text { Silver, lead, } \\
\text { gold. }\end{array}\right.$ \\
\hline 111 & $\begin{array}{l}\text { West Mountain } \\
\text { (Bingham). }\end{array}$ & Salt Lake. . . . . . & Dec. 17,1863 & T. 3 S., R. 3 W........... & 837 & $\begin{array}{l}\text { Copper, lead, sil- } \\
\text { ver, gold, zinc. }\end{array}$ \\
\hline 112 & West Tintic......... & Juab.......... & $\begin{array}{l}\text { 1870, reorgan- } \\
\text { ized Nov. } \\
29,1892\end{array}$ & T. 11 S., R. 5 W....... & 5 & Silver, lead. \\
\hline 113 & Wheeler Desert.. ... & Grand. & June 24, 1901 & T. 23 S., R. 17 E. & 5 & \\
\hline 114 & White Canyon (Hite) & Garfield..... & 1892 & $\left\{\begin{array}{l}\text { T. } 31 \text { S., R. } 10 \text { E...... } \\
\text { T. } 36 \text { S., R. } 13 \text { E..... }\end{array}\right.$ & 9 & $\left\{\begin{array}{c}\text { Gold, copper, } \\
\text { uranium. }\end{array}\right.$ \\
\hline & White River......... & $\begin{array}{l}\text { Wasatch and } \\
\text { Utah. }\end{array}$ & Sept., $\quad 1879$ & $\begin{array}{l}\text { Northeast of Clear Creek } \\
\text { station, Denver \& Rio } \\
\text { Grande R R }\end{array}$ & & Hydrocarbons. \\
\hline 115 & Willard... . & Box Elder.. & July 30,1870 & T. $8 \mathrm{~N}, \mathrm{R}, 2 \mathrm{~W} \ldots \ldots \ldots$ & 6 & Iron, antimony. \\
\hline 116 & Willow Springs. .... & Tooele..... & May 21,1891 & $\left\{\begin{array}{l}\text { T. } 10 \mathrm{~S} ., \mathrm{R} .18 \mathrm{~W} . . \\
\text { T. } 9 \text { S., R. } 18 \mathrm{~W} . .\end{array}\right.$ & 1 & Silver, lead. \\
\hline 50 & $\begin{array}{l}\text { Wilson Mesa (see } \\
\text { also La Sal). } \\
\text { UNORGANIZED DIS- } \\
\text { TRICTS. }\end{array}$ & 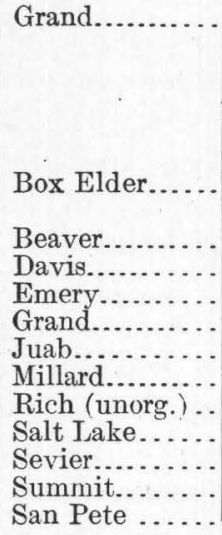 & 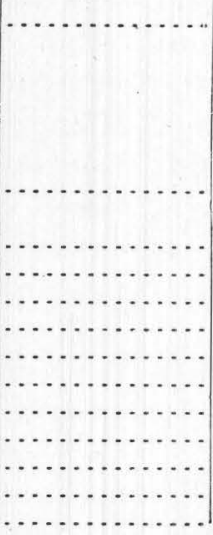 & 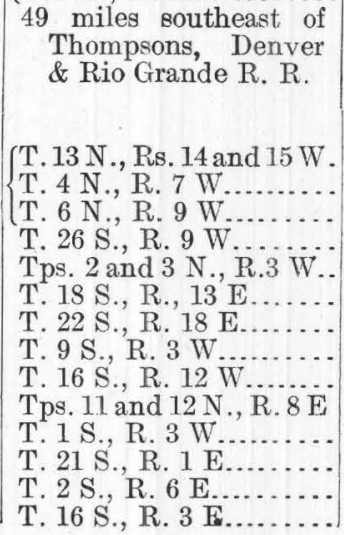 & $\begin{array}{l}2 \\
1 \\
1 \\
4 \\
1 \\
2 \\
1 \\
1 \\
1 \\
1\end{array}$ & $\begin{array}{l}\text { Lead. } \\
\text { Stone. }\end{array}$ \\
\hline
\end{tabular}


Mining districts in Utah-Continued.

\begin{tabular}{|c|c|c|c|c|c|c|}
\hline $\begin{array}{l}\text { No. on } \\
\text { Pl. I. }\end{array}$ & District. & County. & $\begin{array}{c}\text { Date of } \\
\text { organization. }\end{array}$ & Approximate location. & $\begin{array}{l}\text { Patents } \\
\text { issued } \\
\text { (showing } \\
\text { impor- } \\
\text { tance of } \\
\text { district). }\end{array}$ & $\begin{array}{l}\text { Predominating } \\
\text { metals and } \\
\text { minerals, in } \\
\text { order of } \\
\text { importance. }\end{array}$ \\
\hline$\therefore$ & $\begin{array}{l}\text { UNORGANIZED DIS- } \\
\text { TRICTS - contd. } \\
\left(\begin{array}{l}\text { Wild Cat Moun- } \\
\text { tains.) }\end{array}\right.\end{array}$ & $\begin{array}{l}\text { Tonele..... } \\
\text {.....do.... } \\
\text { Uinta...... } \\
\\
\text { Utah....... } \\
\text { Wasatch... } \\
\text { Washington }\end{array}$ & - & 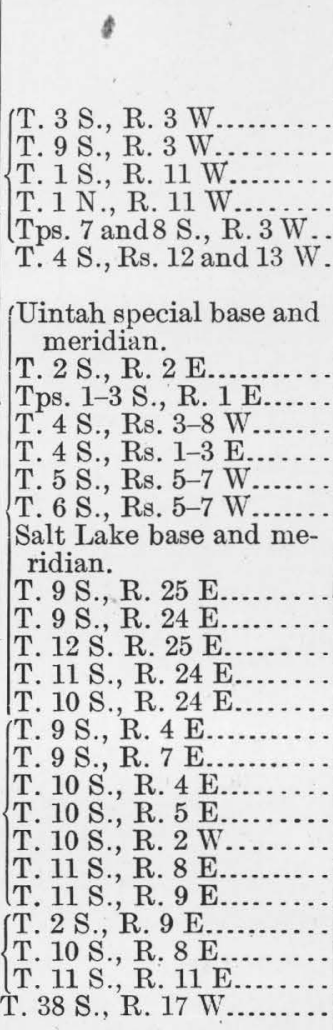 & $\begin{array}{r}21 \\
2\end{array}$ & $\begin{array}{l}\text { Copper, gold, } \\
\text { silver. } \\
\text { Silver, copper, } \\
\text { and fluorite. } \\
\\
\text { Hydrocarbons, } \\
\text { copper, gold, } \\
\text { silver, build- } \\
\text { ing stone. } \\
\\
\text { Hydrocarbons, } \\
\text { li mest } \begin{array}{l}\text { He, } \\
\text { lith ograph } \\
\text { rock. }\end{array} \\
\text { Building stone. } \\
\text { Copper. }\end{array}$ \\
\hline
\end{tabular}

ORE DEPOSITS.

CLASSIFICATION.

The ore deposits of the State may be classified according to age, form, or genesis. For the purpose of comparison of the various deposits, which is one of the main objects of the general discussion, a genetic classification has numerous advantages and is used in this paper as the basis for the main divisions, further subdivision being made on the basis of the metal content. In the discussion of individual districts use is made of such other characteristic features as seem best to bring out the relations in the particular area.

The classification adopted is based on that proposed by Lindgren. ${ }^{1}$

1 Lindgren, Waldemar, Mineral depostts, p. 188, New York, MeGrawHill Book Co., 1913
ORIGIN.

DEPOSITS DUE TO MECHANICAL CONCENTRATION. GOLD PLACERS.

Gold placers within the State are neither numerous nor of great importance. The only ones that have contributed largely to the gold output are those of the Bingham district, though others have been worked in the La Sal Mountains, the Henry Mountains, near Marysvale, and on Colorado River and its tributaries, Green, Grand, and San Juan rivers. The total output probably has not exceeded $\$ 1,800,000$ in value.

The deposits in the Bingham district are in the bench gravels of Bingham Canyon and its tributaries and in stream gravels that have been largely derived from the reworking of the bench deposits. 
The occurrence of the gold is typical. In general, the richest deposits are near bedrock though some are in pay streaks higher in the gravels. The gold is rather coarse, especially near the heads of the canyons, and finer farther downstream. The canyons drain a mineralized area and there can be little doubt that the gold was freed and concentrated through the weathering and erosion of the neighboring rocks. (See also p. 361.)

The deposits in the La Sal Mountains occur on a high bench or mesa that marks the level at which the mountain streams flowed out on a plain surrounding the mountains at an earlier period in the physiographic development of the region. Later an uplift of the region caused the streams to cut canyons in the mesas surrounding the mountains. The weathering of the material in these deposits has not been very complete and the short distance that the gold has been transported has not entirely freed it from gangue minerals, so that its recovery is difficult. The associated rocks and minerals indicate that the gold has been derived from the goldcopper veins of the La Sal Mountains.

The deposits of the Henry Mountains are apparently in general similar to those of the La Sal Mountains, though gold has been recovered from stream beds as well as from gravels on benches and mesas. As in the La Sal Mountains the gold has been derived from the neighboring gold-copper veins.

The deposits near Marysvale are at the base of the range on a bench that marks the level at which the streams once flowed. The principal deposits are near the mouth of Bullion Canyon, and there is little doubt that the gold was derived from gold-bearing veins cut by the stream flowing therein.

A little gold has been recovered from placers below the outcrop of the Annie Laurie vein in the Mount Baldy district. Gold is also reported in the gravels on the west side of the Tushar Range, but none has been produced.

Some of the gold-bearing districts, notably the Mercur and the Tintic, contain no placer deposits. In the Mercur, and possibly in the Tintic, this is attributable to the finely divided condition of the gold, which does not favor its concentration in placers. In the Tintic district the small amount of the deposits that have been removed by erosion may also be a factor.
Numerous river placers, both bench and stream, occur along Colorado River and its principal tributaries. The gold is very finely divided and shows little tendency to form rich pay streaks. A little platinum has been found with the gold. The deposits have been worked to some extent at numerous localities, but recovery of the fine gold has everywhere been difficult and the operations have not been very successful. Dredging has been tried on Green and Colorado rivers but has not proved successful.

The gold has possibly been derived from the sedimentary rocks of the region, which are known to contain the metal in small amounts, or from gold-bearing deposits near the headwaters of the streams. The bench placers were formed in the river channels during earlier stages in the physiographic development of the region, and modern stream placers are now being formed by a concentration of the gold brought into the rivers by the weathering and erosion of the rocks of the adjacent areas and of the earlier deposits. (See also p. 640.)

The black sands that accompany the gold might be of commercial value under favorable conditions. These black sands are composed mainly of magnetite withlesser amounts of ilmenite and chromite and of heary silicates, such as garnet and zircon. In some placers they aresaid to constitute 7 to 8 per cent of the gold-bearing material, and to contain, after amalgamation treatment, as much as $\$ 3$ to $\$ 4$ in gold to the ton, but they doubtless average much less. If such material could be shipped cheaply to the smelters, the value of its iron for fluxing might pay a large part of the cost, leaving the gold as a profit. Under present transportation conditions, however, the black sands probably have no value.

\section{GOLD IN CONSOLIDATED SEDIMENTS.}

The Triassic and Jurassic sandstones and shales of the plateau region contain small amounts of gold over large areas. Lawson estimates that at Paria, where they have been carefully and rather extensively sampled, each cubic yard of rock contains about 5 cents worth of gold. Similar quantities are probably present in the rocks over many hundreds of square miles. The gold is very finely divided and, it is said, can not be collected by 
panning. Unsuccessful attempts to exploit deposits of this character have been made at Paria and on lower San Juan River.

The gold content of the rocks was doubtless derived from the same source as the other materials making up the sediments, possibly from the area to the north and east, where the Triassic and Jurassic formations overlap the pre-Cambrian rocks. Many and perhaps most sedimentary rocks contain traces of gold, but the content of these rocks is above the normal. The wide distribution of the auriferous sediments indicates that the rocks from which they were derived must have contained rather abundant metal deposits. (See also p. 636.)

DEPOSITS DUE TO CHEMICAL CONCENTRATION OF MATERIAL ORIGINALLY DISSEMINATED IN THE ROCK.

The deposits in the sandstones of the Plateau region show great differences in their metal content and some differences in their geologic occurrence, but they possess so many features in common that practically all geologists and engineers who have examined them consider them to be of one type. There is, however, no such agreement as to the source of their metals, which are believed by some to have been introduced from outside sources and by others to have been deposited with the rocks in essentially their present concentration. The author believes that they were produced by the concentration of metals originally deposited with the sediments.

\section{DISTRIBUTION OF THE DEPOSITS.}

Geologically the deposits of this type range in age from upper Carboniferous to Tertiary. Geographically they are widely distributed, but those of commercial importance that have been thus far developed lie in a few rather well-defined regions, namely, the areas around the La Sal Mountains, the San Rafael Swell, the Henry Mountains, and the vicinity of Leeds.

On the basis of metal content the deposits may be separated into four principal groupssilver deposits, copper deposits, uraniumvanadium deposits, and manganese deposits, a deposit rich in one of these metals or group of metals being usually deficient in the others. For example, the deposits of the Silver Reef district are rich in silver, but contain relatively little copper, and, so far as known, relatively little uranium and vanadium. Most commercial deposits of copper contain little or no uranium and vanadium and little silver, though a few of them are rather rich in silver. Most deposits that are particularly rich in uranium and vanadium contain little copper and commonly little silver, though many of them contain chromium and some contain it in abundance. Manganese in small amount is rather generally present, but where it is sufficiently concentrated to form an ore the other metals are commonly absent. Of the minor metals selenium is rather widely distributed in deposits of this type, but thus far has not been found in commercial quantities. Cobalt is present in the Dolly Varden mine in White Canyon and perhaps in other deposits, lead occurs at Miners Mountain, and iron is associated with all the deposits.

The copper deposits are most widely distributed geographically. They are scattered over the Plateau region from the southern border of the State north to the line of the Denver \& Rio Grande Railroad and are found still farther north in the Uinta Basin, most extensively in the vicinity of Ouray. Similar deposits are present over a wide area in Arizona, New Mexico, Colorado, Texas, and Oklahoma.

Important silver deposits are far more restricted in distribution, the Silver Reef district being the only large producer of silver ores of this type in Utah, though similar ores occur in Colorado and copper ores containing important amounts of silver have been extracted from deposits north of the La Sal Mountains, and especially from the Cashin mine in western Colorado, a few miles east of the Utah-Colorado State line.

The uranium-vanadium deposits are also far more restricted geographically than the copper deposits, the more important deposits being apparently confined to the Plateau area of eastern Utah and western Colorado. In Utah the larger known deposits of this type lie south of the Denver \& Rio Grande Railroad and extend from the San Rafael Swell eastward to Colorado and southward to the Henry Mountains. Uranium and vanadium minerals have been found outside of this area, at Silver Reef and near Paria at Burr Flats, in Rabbit Valley, 


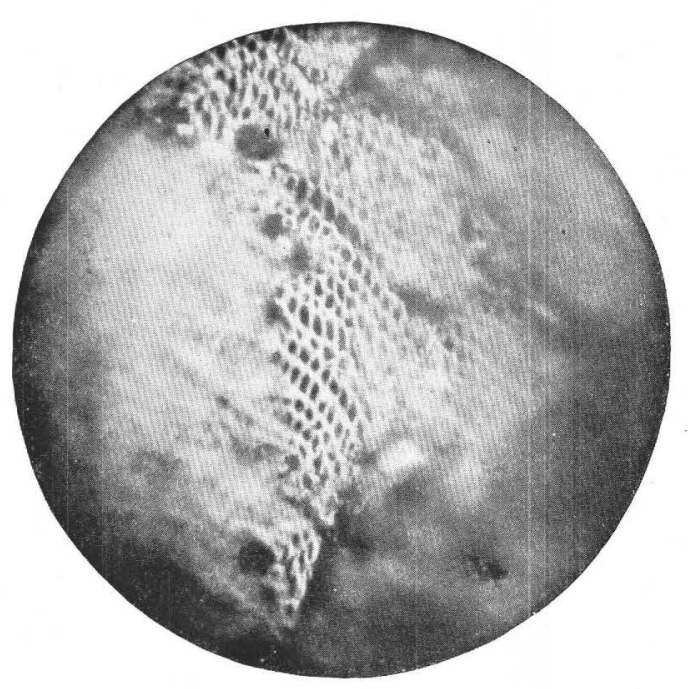

A. PHOTOMICROGRAPH OF CARBONIZED VEGETABLE MATERIAI FROM THE DOLCY VARDEN MINE, SHOWING CELLULAR STRUCTURE.

Enlarged 150 diameters.

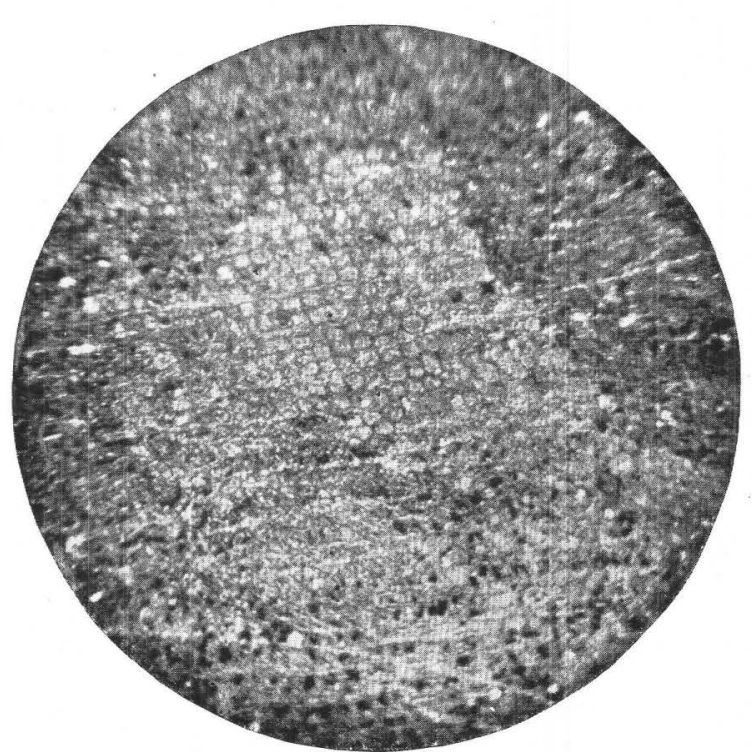

C. REPLACEMENT OF VEGETABLE MATTER BY IRON SULPHIDE (PYRITES AND MARCASITE?) LARGELY ALTERED TO LIMONITE, WHICH STILL RETAINS CELLULAR STRUCTURE, FROM CIRCLE CLIFFS.

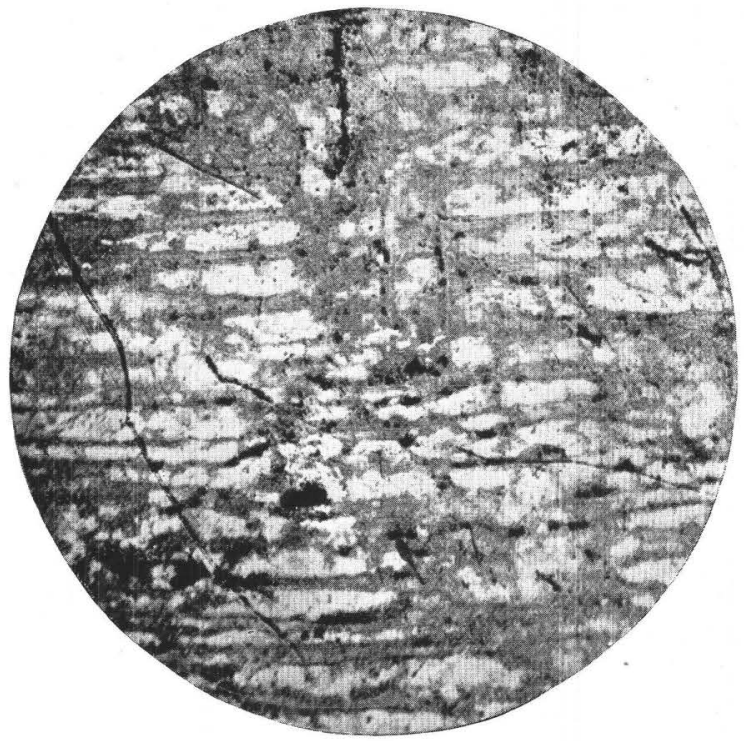

E. PHOTOMICROGRAPH SHOWING LONGITUDINAL SECTION OF CELLULAR STRUCTURE.

Light areas, chalcopyrite; dark areas, chalcocite.

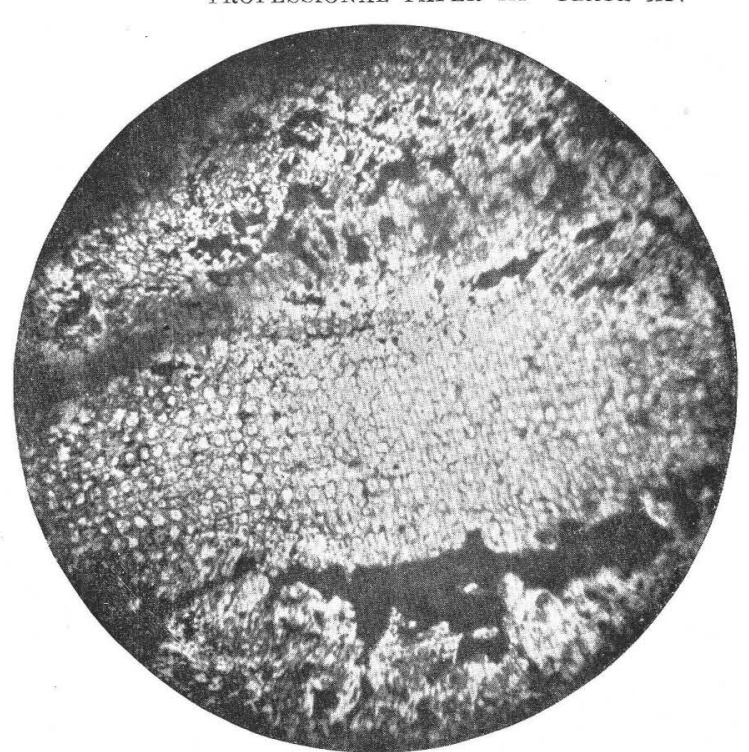

E. PHOTOMICROGRAPH OF VEGETABLE MATERIAL REPLACED BY SULPHIDE FHOM THE BLUE DIKE MINE, SHOWING CELLULAR STRUCTURE.

Light areas, chalcopyrite; dark interstitial areas, chalcocito. Enlarged 50 diameters.

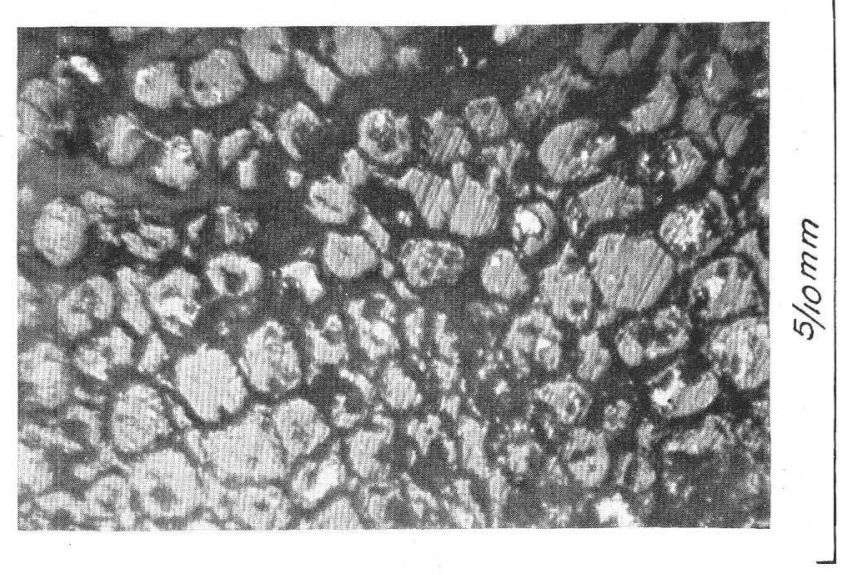

D. ENLARGEMENT OF $C$, SHOWING REMNANTS OF IRON SULPHIDE.

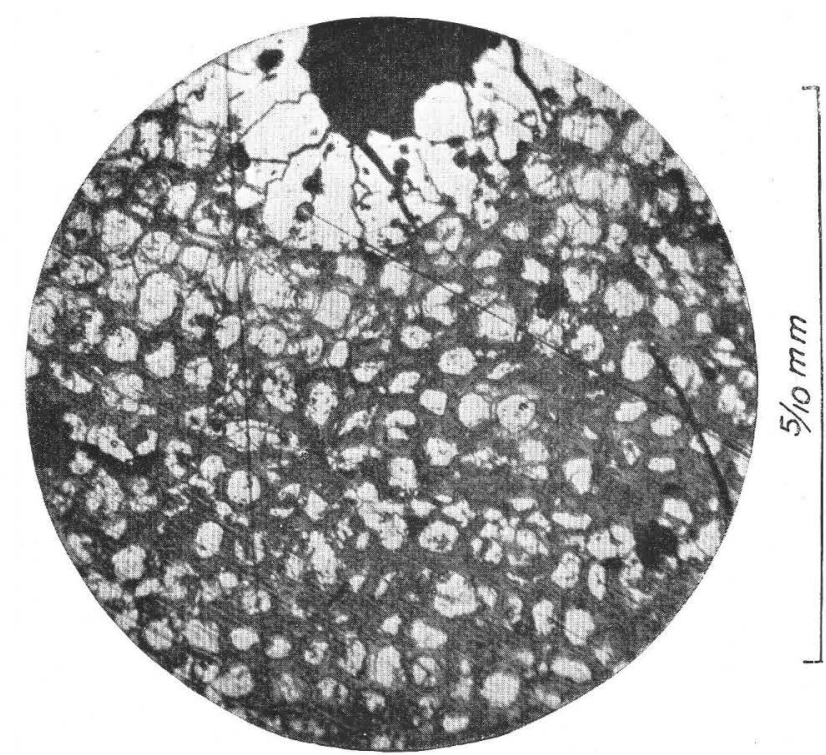

F. PHOTOMICROGRAPH SHOWING CROSS SECTION OF CELLULAR STRUCTURE.

Light areas, chalcopyrite; dark areas, chalcocite.

REPLACEMENT OF VEGETABLE MATTER BY ORES. 

and in other localities, but so far have not been commercially exploited.

Manganese has been extracted on a commercial scale at only a few localities, mainly in the Little Grande district, about 25 miles southeast of Green River, and at several localities east of this district.

Geologically as well as geographically copper is the most widely distributed of the metals, occurring in rock from upper Carboniferous to Tertiary in age. The deposits in the Uinta Basin are, so far as known to the writer, the only occurrences in the West of deposits of this type in rocks as late as Tertiary.

The only large deposits in which silver is the important metallic constituent are those in the Triassic rocks of the Silver Reef district. Somewhat similar deposits at Eagle, Colo., are probably in Jurassic sandstones. In the Cashin mine in western Colorado rich copper-silver ores occur in a fissure in Jurassic and Triassic rocks and the ores are probably in both.

The uranium and vanadium deposits thus far developed are in the Upper Jurassic (?) (McElmo formation) and the Triassic, as at Temple Rock on the San Rafael Swell, near Fruita, at Richardson, north of the La Sal Mountains, and in White Canyon.

The only manganese deposits from which ore has been shipped are in Jurassic (?) rocks of the McElmo formation. Manganese is present, however, in many deposits and at several horizons.

\section{CHARACTER OF THE DEPOSITS.}

Deposits of this type are characteristically lenticular bodies in sandstone, frequently associated with vegetable matter. They may vary in extent from those confined to a single tree trunk to the impregnation of the strata with mineral over a large area.

The deposits of this type within the State have several characteristics in common, regardless of their geographical distribution, the age of their inclosing rock, and their metal content. Nearly all of them occur in sandstones, most of which are rather coarse and many of which contain lenses of conglomerate. The sandstones are almost invariably light gray in color, though the series of rocks of which they form a part is prevailingly red. Some of the deposits, as those of the Silver Reef district, occur in small lenses of shale in the sandstone that have been converted into ore through the deposition of minerals along planes of movement.

Plant remains are characteristically associated with the deposits, and in many places are abundant. They are commonly in part silicified and in part carbonized. The ore minerals are associated with the carbonized material and have replaced the calcareous or clayey cementing material of the rock and also some of the quartz grains. Silicified fossil plants contain little, if any, metal, but carbonized plants may contain much.

Sulphide minerals have been found by the writer in few of the Utah deposits, and the material collected by him is not suitable for an adequate study of the original mineralization. Sulphides replace both the vegetable material, as in the Blue Dike mine, White Canyon, and the cement of the rock. In the Blue Dike material the earliest sulphides represented are pyrite and chalcopyrite, which have been partly altered to chalcocite and covellite.

The cellular structure of the vegetable material is well preserved (see Pl. XIV) in these specimens as well as in those from other localities. Fath ${ }^{1}$ has described the preservation of the cellular structure of wood during its replacement by iron sulphide in the "Red Beds" in Oklahoma and the subsequent replacement of the iron sulphide by chalcocite.

Hess $^{2}$ has pointed out that the cellular structure of the wood is preserved in specimens of copper ore replacing vegetable matter examined by him, and has concluded that the replacement occurred before the wood was carbonized.

Carbonized material in which the cellular structure is preserved, and which is known to be similar to that replaced by sulphides, was not obtained. Carbonized material from the Dolly Varden mine, near the Blue Dike prospect, has the cellular structure preserved with no indication of flattening of the cells. The cells, however, are much smaller than those replaced by copper in the Blue Dike material. (See Pl. XIV.) David White believes that the cells in the carbonized material have

1 Fath, A. E., Copper deposits of the red beds of southwestern Oklahoma: Econ. Geology, vol. 10, pp. 140-150, 1915.

2 Hess, F. L., A hypothesis for the origin of the carnotites of Colorado and Utah: Econ. Geology, vol. 9, p. 681, 1914. 
shrunk materially during carbonization. If this represents the same type of material as that replaced by the sulphide, the replacement evidently occurred before the carbonized material reached its present condition.

The alteration of the wood in shale beds differs markedly from that in the sandstone. In several localities in the Circle Cliffs (Burr Flats) region, and also in Rabbit Valley, the shale beds beneath the "tree-bearing" sandstones contain what appear to be upright stumps, though it was not shown that they have roots in place. These stumps, instead of being converted into cherty material as are those in the overlying sandstones, consist of a friable mass of silica, gypsum, carbonized wood, and iron sulphide with its oxidation products, basic sulphate, and limonite. The iron sulphide has replaced the wood and preserved the cellular structure, which is brought out prominently on the alteration to limonite. (See Pl. XIV.) So far as the writer is aware, no metallic minerals other than iron have been found in petrified wood in the shale, though the yellow basic iron sulphate jarosite, which in many places is rather abundant, has frequently been mistaken for carnotite.

Nodular masses of iron sulphide partly replaced by copper sulphide were observed in the ore from the Big Indian mine. (See Pl. L, $B$, p. 614.)

In the Silver Reef district the primary silver mineral was probably the sulphide argentite, though it has been suggested (p. 593) that this may be secondary. In the oxidized zone the silver is present as the chloride cerargyrite and as native silver.

The form in which the uranium and vanadium minerals were originally present is as yet uncertain. At present much of the uranium is in the form of carnotite, though in some deposits other uranium minerals are more important. Hewettite and carnotite are the common vanadium compounds, but others are present.

RELATION OF DEPOSITS TO GEOLOGIC STRUCTURE

The relation of the more important deposits to the geologic structure is very apparent, and careful study of the lesser deposits will probably reveal similar though less obvious relations.
The Silver Reef deposits, ${ }^{1}$ which commercially are by far the most important of this type yet found in this country, are near the crest of a prominent anticline. Where the ore-bearing strata have been removed for several hundred feet below the crest of the anticline the remaining portion does not contain ore. (See Pls. XLVI, in pocket, and XLVII, p. 586.)

The copper deposits in Salt Wash, northwest of the La Sal Mountains, show a similar relation to the Salt Wash anticline; and the deposits of Big Indian Valley are associated with fissures and are in the south limb of an anticline. The Cashin deposit in western Colorado is distinctly associated with a fissure. In other copper deposits the relation to structure is not superficially apparent; for example, the deposits in the Tertiary sandstones near Ouray.

Reports on the uranium and vanadium deposits of Utah and Colorado do not call attention to any close relation between them and the geologic structure, though Gale ${ }^{2}$ states that the deposits in Routt County, Colo., are "very evidently mere crusts or coatings or superficial impregnations in sheared, brecciated, and jointed zones in the rock mass. The zones of brecciation evidently mark the path of the mineralizing solutions." Gale further notes that the deposits are "on the southern flank of a domal flexure or uplift." Ransome ${ }^{3}$ has called attention to their association with minor structures believed to be of recent origin.

It may be pointed out that all the districts in which important deposits have thus far been discovered are associated with important structural features. Thus, the largest field in Colorado and adjacent parts of Utah is within the great series of northwest-southeast folds that center in the La Sal Mountains. From the relations of the Silver Reef and Salt Wash deposits one might expect a relation between the Paradox anticline and the deposits of that region, between the Gypsum Valley anticline and the deposits of that region, between the Salt Wash anticline (or the associated faults) and the Richardson deposits, and between the Dome Plateau anticline and the deposits near Thomp-

1 The writer places the Silver Reef deposits in this class, though he realizes (see p. 593) that they may have had a different origin.

2 Gale, H. S., Carnotite and associated minerals in western Routt County, Colo.: U. S. Geol. Survey Bull. 340, p. 262, 1907.

3 Hillebrand, W. F., and Ransome, F. L., On carnotite and associated vanadiferous minerals in western Colorado: U. S. Geol. Survey Bull. 262, pp. 14-15, 1905. 
son. Likewise the deposits along the San Rafael Swell are apparently associated with the sharp monoclinal fold along the eastern side of that great dome; and the deposits of the Henry Mountains region are apparently associated. with the domical uplift of those mountains.

\section{GENESIS OF THE ORES.}

CONFLICTING THEORIES.

The genesis of the deposits in sandstone is a subject on which geologists have long differed, perhaps because the deposits at different localities have had different modes of originalthough they have differed quite as much regarding the origin of individual deposits as regarding that of the class as a whole.

The first deposit of commercial importance developed in the sandstones in Utah was that of Silver Reef district, and very soon a rather heated discussion arose concerning its genesis. Two fundamentally different ideas were advanced-first, that the silver and accompanying copper, vanadium, uranium, and selenium minerals were contemporaneous in origin with the sedimentary rocks in which they are now found, having been deposited from a body of mineral-bearing waters, in which the sediments accumulated, by the reducing action of decaying vegetation; second, that the metallic minerals were later than the sandstones and were deposited by mineralizing solutions whose circulation was connected with the igneous activity of the region. The first explanation was advanced by Newberry, and the second by Rolker, Maynard, Rothwell, and Cozin. More recently a third mode of origin has been suggested by Lindgren, ${ }^{1}$ who sought to explain similar copper deposits by the "concentration of minute traces of copper in certain strata or in fissures, by circulating atmospheric waters charged with chloride and sulphate." Lindgren thought that the copper had been deposited in the original strata from the erosion of earlier deposits in the areas from which the sediments were derived.

DEPOSITION CONTEMPORANEOUSLY WITH THE ROCK

The explanation advanced by Newberry was interpreted by the miners to indicate that the deposits would extend to great depth and that

\footnotetext{
1 Lindgren, Waldemar, Graton, L. C., and Gordon, C. H., The ore deposits of New Mexico: U. S. Geol. Survey Prof. Paper 68, p. 87, 1910.
}

others were to be expected where the same strata were present. The decrease in value of the ores at Silver Reef with increase of depth on the dip of the ore strata and the failure to find other commercial deposits at the same horizon, have apparently led to the pretty general abandonment of Newberry's explanation for the Silver Reef deposits.

If the relation of the deposits to the Leeds anticline (see p. 154) was a factor in their formation and was not purely accidental, the theory of deposition of the ores contemporaneously with the deposition of the sediments is eliminated, for the anticline was not formed till long after the sediments. Similar relation between several of the larger copper deposits and structural features that are of much later formation than the inclosing rocks also indicates that the ores were formed later than the sediments. Certain copper deposits whose structural relations are not readily apparent may be explainable by Newberry's hypothesis, but in the absence of detailed studies to determine the less obvious structure the writer prefers to refer them to the same cause as other closely similar deposits.

Hess ${ }^{2}$ has proposed the following explana tion of the origin of the carnotite deposits of Utah and Colorado:

It is thought possible that the sandstone deposits have been deposited in a very shallow inland sea with many islands and spits on which lodged vegetable débris which had been washed from surrounding shores. Also that sulphidic veins carrying uranium, vanadium, iron, and chromium minerals were eroded; that sulphuric acid set free by the oxidation of pyrite formed soluble sulphates of the other metals; that these were carried into the sea and on coming into contact with the vegetation were, in part at least, reduced to sulphide, though the uranium was possibly reduced to an oxide, or to some combination with vanadium. Upon the raising, draining, and oxidation of the rocks the minerals now found were formed.

This is essentially the explanation offered by Newberry for the Silver Reef deposits and may be subjected to the same tests. The close association of these deposits with the largestructural features of the Plateau region suggests a genetic relation similar to that of the silver and copper deposits. These structures are much younger than the rocks, and if the association is more than accidental it eliminates the possibility of formation of the ores contemporaneously with the inclosing sediments. Some

${ }^{2}$ Hess, F. L., A hypothesis for the origin of the carnotite deposits of Utah and Colorado: Washington Acad. Sci. Jour., vol. 4, p. 236, 1914. 
extensive deposits of fossil wood at essentially the same stratigraphic horizon as the mineral deposits are barren, especially those in the sandstones southwest of the Henry Mountains (probably Salt Wash sandstone), in the Triassic in the western part of Rabbit Valley, at Circle Cliffs, and at Orange Cliffs (under the ledge).

The probability, indicated by the size of the replaced cells (see p. 153), that sulphides replaced the vegetable matter before it was carbonized may be interpreted as favoring the view that the ore deposits were formed before the wood was carbonized. A careful study of suitable material promises important results on this point. Material from these sandstones shows that the cellular structure may be preserved during carbonization quite as clearly as by replacement by silica or sulphide, though in the material examined the size of the cells indicate a shrinkage. The problem, however, is more complex than the simple determination of the time of original replacement, for it has been shown that the original sulphide can be replaced by other minerals without destroying the cellular structure. ${ }^{1}$ It may be significant that though the replacement of wood in the shale beds of the region by iron sulphide is common, the replacement of iron sulphide by copper or other metals is not known in shale, though it is known in sandstone, where circulation is relatively free. This suggests that the original replacement may have occurred relatively early in the decomposition of the vegetable matter and that the replacement by copper may have occurred much later. The early replacement by iron is favored by the great abundance of that element in the "red beds."

\section{CONCENTRATION BY SOLUTIONS DUE TO IGNEOUS} ACTIVITY.

Evidence connecting the deposits of this type with igneous activity is not conclusive. No deposit in Utah has been positively shown to have close genetic association with igneous rocks, and several deposits are so remote from areas of such rocks as almost certainly to disprove any connection. Most of the deposits, however, are rather closely associated with laccolithic mountains or other domical uplifts that are believed to be of similar origin; and the Silver Reef deposits are in a region of igneous

1 Fath, A. E., Econ. Geology, vol. 10, pp. 140-150, 1915. Also, Rogers, A. F., Econ. Geology, vol. 11, pp. 366-380, 1916. activity. This association naturally suggests a genetic relation with the intrusive rocks. The intrusive bodies themselves, however, so far as known, contain only small deposits of copper and none of vanadium or uranium. The existence of similar deposits in areas where igneous rocks have pretty certainly not been factors in their formation, together with the lack of a definite connection between the laccolithic bodies and the deposits, leads one seriously to doubt the existence of a direct genetic relation involving the derivation of the metallic constituents from the igneous material.

\section{CONCENTRATION BY ATMOSPHERIC WATERS.}

The idea of concentration from material disseminated in the sediments is stated by Lindgren ${ }^{2}$ as follows:

In considering the class as a whole it appears that igneous agencies had no part in the genesis. The ores are assuredly epigenetic and their universal appearance in land or shallow-water beds is significant. In all probability these ores have been concentrated by atmospheric waters which leached the small quantities of metals disseminated in the strata. The sediments were rapidly accumulated under arid conditions from adjacent land areas and the metals were probably carried down as fine detritus and in solutions from older ore deposits in these continental areas.

The waters which concentrated the ores are believed to have been mainly sodium chloride and calcium sulphate solutions containing sulphates and perhaps chlorides of copper and lead. The mineral association and geological features indicate deposition at low temperature, probably well below $100^{\circ} \mathrm{C}$., and at shallow depths but below the zone of direct oxidation. Very likely these ores have been forming continuously since the establishment of active water circulation in the beds; in favorable places below the surface concentration may now be in progress. SOURCE OF THE METALS.

The manner in which the sediments were deposited is of importance in determining the origin of the ore bodies, but this, like the origin of the ores, is a matter concerning which there is as yet no general agreement. The sediments have been variously regarded as deposits formed in shallow seas, as continental deposits along the base of a mountainous region similar to the great plains east of the Rocky Mountains, as river and delta deposits, as wind-blown deposits, and as combinations of these. There is apparently a growing tendency to regard the sandstones, in large part at least, as of land

2 Lindgren, Waldemar, Mineral deposits, pp. 368-369, 1913. Includes a summary of the literature. 
rather than of marine or lacustrine origin, and it is generally believed that they were accumulated under arid conditions.

The derivation of the metals from the same areas as the sediments seems reasonable for the Utah deposits. Hess ${ }^{1}$ has shown that uranium minerals are present in deposits of probable pre-Cambrian age in the Uinta Mountains, and copper deposits of the same age are present in the same region. (See p. 604.) The Triassic and Jurassic sediments were certainly not derived from the pre-Cambrian rocks of the Uinta region, for these were deeply buried beneath Paleozoic strata in Triassic and Jurassic time, but they may have come from the pre-Cambrian of areas farther to the east, where the later sedimentary formations overlap on the pre-Cambrian rocks. The presence of gold in the sediments over large areas (see p. 151) to an amount considerably in excess of that present in most sedimentary rocks further indicates derivation from a mineralized area and makes it reasonable to suppose that metals other than gold were present.

\section{MODE OF CONCENTRATION.}

Concentration of small amounts of metals disseminated through the sediments may be ascribed to circulating waters which collected the disseminated metals and redeposited them under favorable conditions. If the sediments were truly continental, circulation of waters may have been in progress when they were deposited and may have continued till they were submerged. Any circulation that took place after the elevation, folding, and faulting of the region must have been affected by the structural features. At present, at the Blue Dike prospect in White Canyon, waters that are seeping out of certain strata carry uranium, copper, and other metals, mainly as sulphates, indicating the readiness with which the metals are taken into solution. The salts are deposited as an efflorescence on the rock when the waters evaporate on reaching the surface.

Emmons ${ }^{2}$ has attributed the movement of the solutions in the Cashin mine to an artesian circulation that found an outlet along a strong fissure in the rocks. The importance of artesian

\footnotetext{
1 Hess, F. L., op. cit., p. 258.

2 Emmons, W. H., The Cashin mine, Montrose County, Colo.: U. S. Geol. Survey Bull. 285, p. 127, 1906.
}

circulation in the formation of ore deposits has been emphasized by Siebenthal, ${ }^{3}$ who has also emphasized the importance of structural relations that are apparent only on careful study. In the Silver Reef and Salt Wash deposits, for example, artesian conditions may have existed after the uplift and folding of the region. It is a well-established physiographic principle, beautifully illustrated in this region, that in the erosion of anticlines and synclines valleys develop in the anticlines, which become lines of surface drainage. It follows that if artesian conditions prevailed in a region the strata in which the waters were confined would first be tapped by the erosion of the anticlinal valleys at or near the crests of the anticlines. This would be equally true if they were tapped by the master streams (which are not controlled by the structure), for these would naturally cut the beds in the anticlines before they cut the same beds in the synclines. This might start an artesian flow along the anticline toward the outlet and from the synclines toward the anticlines, and might concentrate the flow from large areas along rather restricted zones. If, in particular areas along these zones of flowage, conditions were especially favorable to the precipitation of metallic constituents (if, for instance, there were lenses of rock rich in plant remains or in sulphide), metals in considerable amount might well be deposited. If fissures were present along the anticlines, as they are most likely to be, they would furnish an outlet to waters rising under artesian pressure. The association of some deposits with fissures is evident, as in the Cashin mine in Colorado and the Big Indian mine in Utah, and with more detailed work may be found more prevalent than is at present known.

It is believed that some such movement of the ground waters has concentrated the more soluble metallic constituents of the rocks, and has left the gold and other relatively insoluble constituents rather uniformly distributed. Such an explanation would seem to account for the association of the deposits with the folds and fissures of the region.

No satisfactory explanation of the predominance of one or more of the metals in the individual deposits and the relative paucity of others is as yet possible. So far as the ura-

3 Siebenthal, C. E., Origin of the zinc and lead deposits of the Joplin district: U. S. Geol. Survey Bull. 606, 1915. 
nium-vanadium deposits are concerned, Hess ${ }^{1}$ has suggested that the original area of uranium and vanadium bearing rocks was small and that sediments from it were not widely scattered. A similar explanation may of course apply to the silver deposits. However, as the areas from which the sediments were derived and the character of their mineralization are both uncertain, any explanation must be tentative.

Alteration by surface solutions has been important. It is discussed on page 207 .

The commercial deposits of manganese are believed by Harder and Pardee to have resulted from the concentration from earlier deposits during the erosion of the region.

AGE OF THE DEPOSITS.

The age of the deposits depends upon their mode of origin. If they were deposited with the sediments they are of course of the same age as the inclosing rocks. If they are due to the igneous activity of the region they are doubtless of Tertiary age. If, as the writer believes to be true, they were formed after the uplifting, folding, and faulting of the region their formation began in Tertiary time and in places may be still in progress.

\section{SUMMARY.}

All the deposits in the sandstones of the Plateau province, whether mined for silver, for copper, or for uranium and vanadium, are believed to be of one type. Deposits in which certain metals or groups of metals predominate range widely both geographically and geologically, Copper has the widest distribution; uranium and vanadium and silver are more restricted in area and in the age of the rocks in which they occur. The genetic relation between the structural features of the region and the ore deposits is believed to be intimate. The deposits are regarded as having been formed by circulating waters that collected the metals disseminated through the sedimentary rocks and deposited them on contact with carbonaceous matter, earlier sulphides, or other precipitating agents. The circulation in some places is believed to have been of artesian character and to have been controlled to a large extent by structural

1 U. S. Geol. Survey Bull. 625, p. 334, 1917. features. Most of the minerals at present exposed are the products of alteration of the original minerals by surface solutions. The formation of the deposits probably began in Tertiary time, and in places is possibly still in progress.

DEPOSITS DUE TO CONCENTRATION EFFECTED BY THE INTRODUCTION (POSSIBLY INDEPENDENTLY OF IGNEOUS ACTIVITY) OF SUBSTANCES FOREIGN TO THE ROCK.

Certain replacement deposits that have formed along fissures or faults in sedimentary rocks, mainly limestones, are not closely associated with igneous rocks, and the origin of their metallic constituents is not known. They may or may not have been introduced from igneous sources.

In this class are the hematite deposits of the Uinta Mountains, the copper deposits of the Dyer mine north of Vernal in the same range, and the copper and lead deposits in the BeaverDam Mountains in the southeastern part of the State. In the northern and southern parts of the Wasatch Range and in the North Tintic ,district are lead-zine deposits low in silver and copper that are remote from important igneous intrusions but that are similar in general character to deposits whose derivation from igneous sources can be directly traced.

In the Uinta Range there are no exposures of igneous rocks that are younger than the sediments in which the deposits occur, except in the pre-Cambrian rocks, though (see p. 252) the structure of the range may be interpreted as the result of an extensive intrusion.

Sources of the metals other than igneous are easily possible. Iron may have been derived from the quartzite and shale, in which it is abundantly present; and a similar origin for the copper and for the other deposits is entirely possible. At least some of these deposits may have been derived from material leached from underlying strata and deposited at places where the solutions rose along fissures in the limestones, but their similarity in composition and in structural relations to deposits directly associated with igneous intrusions leaves the matter in doubt. The geology of this type of deposit has nowhere in the State been studied in detail and for the present its genesis must be regarded as undetermined. 
DEPOSITS DUE TO CONCENTRATION OF SUBSTANCES INTRODUCED BY IGNEOUS ACTIVITY.

DISTRIBUTION.

By far the greater number of deposits within the State are so closely associated with intrusive rocks that there can be no reasonable doubt that their formation was directly due to igneous activity. Ore deposits are most numerous and most extensive in the zones of greatest igneous activity (see p. 91) and are associated with igneous rocks in other localities, as in the Raft River and Pilot ranges and in the southeastern part of the State.

\section{CLASSIFICATION.}

Ore deposits associated with the igneous rocks may be conveniently separated into three groups - those in intrusive rocks, those in extrusive rocks, and those in sedimentary rocks. A few individual deposits occur partly in one type of rock and partly in another, but most deposits occur in one type only. Each group may be further subdivided according to mineralogic associations, geologic relations, or metal content.

\section{DEPOSITS IN INTRUSIVE ROCKS.}

The deposits in the intrusive rocks differ greatly in mineral association and in the metals for which they are chiefly valuable, but for the most part they agree in containing minerals formed only at relatively high temperature and pressure. Gradation between the different types indicates that all represent stages in a single process rather than deposits formed during separate periods.

VEINS CLOSELY ALLIED TO PEGMATITE.

PEGMATITIC GOLD QUARTZ VEINS.

Pegmatitic gold quartz veins are present in the Park Valley district of the Raft River Range and in the Spring Creek district of the Deep Creek Range. In both districts the veins extend from the intrusive into the adjacent sedimentary rocks. In the Queen of Sheba mine in the Deep Creek Range most of the ore has been taken from the portions inclosed in the quartzite, and in the Park Valley district practically all of it has been taken from the portions in the granite. The typical gangue mineral of the ore shoots is a rather fine grained vuggy quartz containing sulphides and arsenides, commonly in small amounts, in the primary ore and the oxidation products of these in the oxidized portion of the veins. This finer vuggy quartz of the ore shoot gives place along the dip or strike (as in the Queen of Sheba vein) or from the middle toward the wall (as in parts of the Century vein) to coarser pegmatitic quartz which in turn grades into a mixture of quartz and feldspar. With the increase of the coarse pegmatitic quartz or the feldspar the metallic minerals greatly decrease, and the vein filling ceases to be ore.

The gradation from pegmatitic material to metal-bearing vein quartz indicates that the ore shoots have resulted from a differentiation of the magmatic material that filled the fissures. Opportunity for a study of this type of deposit has been rather slight, but the segregation of the feldspathic constituents along the walls, as in the Century vein, suggests that the vein was first filled with siliceous magmatic material derived from the earlier crystallization of the main granitic rock and that the earliest minerals to crystallize were collected along the walls, and that the latest, including the quartz and sulphides, were segregated toward the center. In the Queen of Sheba vein there are some indications that the feldspathic material decreased and the metallic constituents increased with increasing distance from the granitic rock, but developments within the granitic rock at the time of study were altogether too slight to permit of a definite conclusion on this point. Both the Century and Queen of Sheba deposits are associated with intrusive bodies in Cambrian or pre-Cambrian rocks, indicating deep-seated conditions, with high temperature and pressure. No similar deposits have been found far from the intrusive rocks. This suggests that the contacts of these deep-seated intrusives with the sedimentary rocks were favorable to the formation of this type of deposit. The production from such deposits in Utah has been relatively small.

Spurr ${ }^{1}$ has described similar but more productive deposits from the Silver Peak district, Nev., where more extensive developments afford better opportunity for study. Spurr considers that the Nevada deposits have resulted from a differentiation of alaskite (pegmatite), which, in turn, he believes was a differentiation product of a granitic magma.

1 Spurr, J. E., Ore deposits of the Silver Peak quadrangle, Nev.: U.S. Geol. Survey Paper 55, 1906. 
QUARTZ-TOURMALINE-SCHEELITE VEINS.

Quartz-tourmaline-scheelite veins are known only from the Clifton district near the northern end of the Deep Creek Range and have been but slightly developed there. The deposits are in quartz monzonite, probably a part of the same intrusion as the larger Ibapah stock in the southern part of the range, with which the pegmatitic gold veins of the Queen of Sheba mine are associated. (See p. 485.) So far as determined, the primary minerals are coarsely crystalline quartz, orthoclase, amphibole, tourmaline, a little epidote and iron bearing carbonate, a little apatite, and the metallic minerals magnetite, molybdenite, and scheelite. At the surface the minerals have been partly oxidized, especially the molybdenite, which has been largely altered to powellite; and a little copper carbonate is present, which has doubtless resulted from oxidation of copper-bearing sulphides. Gold is also said to be present in small amount. The minerals, notably the scheelite, appear to be segregated in the vein; some lenses consist largely of scheelite, but in much of the vein this mineral is in small amount or is lacking.

Alteration of the quartz monzonite has extended but a short distance from the veins. The resultant rock is composed essentially of quartz, muscovite (sericite), chlorite, and some iron oxide. The chlorite may have resulted from the surface alteration of an earlier magnesian mineral, though no remnant of such was detected.

A pegmatite dike associated with the veins consists of coarsely crystalline pink feldspar, quartz, and amphibole, with no metallic constituents. The feldspar and amphibole are similar to those in the metal-bearing veins, and this, together with the close association, suggests that both dike and veins were differentiation products of the same magmatic material, which itself was probably a differentiate from the magma that formed the main mass of the quartz monzonite. .

So far as known; the only output from this type of deposit has been a few tons of scheelite ore.

Scheelite-bearing pegmatites are known in Maine and Idaho, and pegmatites containing other tungsten minerals are relatively common. No important production of tungsten from scheelite-bearing pegmatites is known.
QUARTZ-TOURMALINE COPPER VEINS.

Quartz-tourmaline copper veins are present in the Clifton district (p. 517) in the Deep Creek Range and in the San Francisco district of the San Francisco Range (p.517). In both districts the veins are in quartz monzonite of similar character. The differences in both the gangue minerals and the metallic minerals in the two districts are rather marked, but the similarities are far more striking.

In the Clifton district the usual gangue minerals are quartz, tourmaline, carbonate (probably iron-magnesium-manganese carbonate), amphibole, diopside, vesuvianite, garnet, and in some veins epidote; apatite and titanite occur in most veins, danburite in several, and fluorite and orthoclase in a few. The metallic minerals pyrite, chalcopyrite, magnetite, and hematite are universally present, and in some veins the iron oxides are abundant. Scheelite was noted in several veins and possibly is present in most of them in small amount. The veins contain some gold and silver. Galena is present in some veins but is probably abundant in none.

The Cactus vein in the San Francisco district is composed of quartz, tourmaline, magnesiummanganese-iron carbonate, and lesser amounts of anhydrite and barite as the principal gangue minerals, and of pyrite, chalcopyrite, and hematite as the important metallic minerals. The vein contains also small amounts of tetrahedrite and galena.

The deposits are similar in containing abundant quartz, tourmaline, carbonate, and oxides of iron. Those of each district contain several minerals not present in the other, but the chemical differences are not so marked, for though the Cactus deposit contains no magnesium silicates it contains notable amounts of magnesium-bearing carbonate, and though the Clifton deposits are not known to contain anhydrite they contain calcium in the form of carbonate.

The quartz monzonite adjacent to the veins alters characteristically to a rock composed essentially of quartz and mica, muscovite (sericite) being associated with the Cactus vein and biotite as well as muscovite with the Clifton veins. A green mica and chlorite are present among the alteration products in the Clifton district but have probably resulted from the alteration of the biotite. The alteration of the wall rock of these veins is compared with that of other types on page 164 . 
ORIGIN AND OUTPUT OF THE DEPOSITS.

The similarity seen in the Clifton district between the quartz-tourmaline copper veins and the quartz-tourmaline-scheelite deposits leaves no doubt that they had a common origin, both being probably differentiates from igneous material which in part crystallized as barren pegmatite, in part as metalliferous pegmatite, and in part as true veins.

The output from this type of deposit has not been large and is practically all derived from the Cactus mine, though there has been considerable development on veins of this type in the Clifton district.

SIMILAR DEPOSTTS IN OTHER REGION3.

Quartz-tourmaline copper deposits occur ${ }^{1}$ in many localities outside of Utah, particularly at Meadow Lake, Nevada County, Cal.," where the veins are in granitic and dioritic rocks, and in the Blue Mountains, Oreg., ${ }^{3}$ where they are in diabase and diorite. Tourmaline veins are numerous in the Helena region, Mont., ${ }^{4}$ where Knopf has distinguished tourmaline silver-lead, tourmaline silver-copper, and tourmaline gold veins.

QUARTZ COPPER VEINS.

Quartz copper veins have been developed on a commercial scale in two districts, and closely allied deposits are present in other districts. They show by far their greatest extent and importance in the Bingham district where their yield of copper has been very large for several years and probably will continue to be so for many years to come, but they have yielded considerable metal in the Beaver Lake district and are possibly present in other districts. Closely allied goldcopper deposits have been developed to a slight extent in the La Sal and Henry mountains. The quartz copper veins are characterized by the dominance of quartz as gangue (though a little orthoclase is sometimes present) and by the occurrence of the metals chiefly in sulphides. They are typically replacement veins, filling fissures and replacing the adjacent rock, which is quartz monzonite or quartz monzonite porphyry. The deposits are in

1 Lindgren, Waldemar, Metasomatic processes in fissure veins: Am. Inst. Min. Eng. Trans., vol. 30, pp. 626-643, 1901.

${ }^{2}$ Lindgren, Waldemar, The auriferous veins of Meadow Lake, Calif.: Am. Jour. Sci., 3d ser., vol. 46, p. 201, 1893.

${ }^{3}$ Lindgren, Waldemar, The gold belt of the Blue Mountains of Oregon: U. S. Geol. Survey Twenty-second Ann. Rept., pt. 2, p. 629, 1901.

1 Knopf, Adolph, Ore deposits of the Helena mining region, Mont.: U. S. Geol. Survey Bull. 527, 1913. $35416^{\circ}-19-11$ places confined to a definite vein or to a few veins, and in places consist of a stockwork of small veins permeating a large body of minutely fissured rock. The former type occur in the Beaver Lake district, and the stockwork is represented by the great disseminated deposits of the Bingham district. In both the characteristic gangue is quartz and the original metallic minerals are mainly pyrite and chalcopyrite but include small amounts of molybdenite.

The alteration of the quartz monzonite adjacent to the fissures shows considerable variation. In the O. K. mine in the Beaver Lake district, what appears to have been the main mineralizing channel, is a roughly cylindrical "pipe" of coarse pegmatitic quartz, from which small branching veins of quartz and of quartz and sulphide extend into the surrounding rock. (See fig. 54.) The quartz monzonite adjacent to the veins has been altered to a rock consisting essentially of quartz and muscovite (sericite), accessory minerals, and sulphides of iron and copper.

In the Bingham district the earlier stages of alteration resulted in the transformation of the hornblende and augite into biotite, in the partial sericitization of the feldspars, and in the transformation of much of the groundmass of the rock into a fine-grained aggregate of quartz and orthoclase known as "dark porphyry." Pyrite and chalcopyrite are scattered through the rock. Where the alteration has been more intense the rock has been largely converted into a fine-grained aggregate of quartz and orthoclase, some sericite, and small disseminated grains of pyrite and chalcopyrite. This is known as "light porphyry." The chemical and mineralogic changes in the wall rock are compared with those of other localities on pages 153-157.

The deposits in the La Sal and Henry mountains are, in general, similar in character to those of the Beaver Lake district, though most of the veins are small and the action of the mineralizing solutions on the rocks adjacent to the fissures has been feeble. The preciousmetal content of the veins in the La Sal and Henry Mountains is higher than in the other districts.

Much of the ore of these deposits has resulted from the alteration and concentration of original metallic minerals by surface solutions. (See p. 208.) The general similarity of these 
deposits to the quartz-tourmaline copper veins leaves no doubt of their close relation and indicates that both were deposited from solutions that had resulted from the differentiation of the quartz monzonite magma.

The main production from deposits of this type has been in copper from the Bingham districts. In recent years it has been large and will continue so for many years to come.

In other western States deposits of this type are numerous and many of them are large and of great commercial importance. Those at Ely, Nev., ${ }^{1}$ correspond most nearly to those at Bingham. Similar deposits occur at Santa Rita, ${ }^{2}$ N. Mex., at Morenci, ${ }^{3}$ Globe, ${ }^{4}$ Ray, ${ }^{5}$ Bisbee, ${ }^{6}$ and in the Ajo district, ${ }^{7}$ Ariz., and in many other less developed districts. The deposits at Butte, ${ }^{8}$ Mont., show many similarities to this type.

\section{QUARTZ SILVER-LEAD. VEINS.}

The gangue of the quartz silver-lead veins, though chiefly quartz, locally contains a good deal of barite. Pyrite and galena are the most abundant metallic minerals, though sphalerite is commonly present, and copper as chalcopyrite or as the antimony or arsenic minerals, tetrahedrite or enargite, is locally present in small amounts. Silver in some combination is present in the galena and probably in the other metallic minerals. The deposits commonly occupy a rather definite fissure or a series of fissures forming a lode.

The wall rock has been conspicuously altered for only a short distance from the fissures. In the Bingham district, in the Last Chance mine, it has been changed, immediately adjacent to the fissures, to a rock composed essentially of quartz, muscovite (sericite), and secondary orthoclase. In the Tintic district sericitization appears to have been the common alteration. The change in the wall rock is similar to that in the quartz copper veins but has

\footnotetext{
1 Spencer, A. C., The geology and ore deposits of Ely, Nev.: U. S. Geol. Survey Prof.Paper 96, 1917.

${ }^{2}$ Lindgren, Waldemar, Graton, L. C., and Gordon, C. H., The ore deposits of New Mexico: U. S. Geol. Survey Prof. Paper 68, p. 305, 1910. ${ }^{3}$ Lindgren, Waldemar, The copper deposits of Clifton-Morenci district. Ariz.: U. S. Geol. Survey Prof. Paper 43, 1905.

4 Ransome, F. L., The Globe and Miami districts: U. S. Geol. Survey Bull. 529, pp. 183-186, 1913.

5 Ransome, F. I., Ray, Ariz.: U. S. Geol. Survey Bull. 529, p. 186, 1913,

6 Jenney, J. B., Bisbee porphyry deposits: Eng. and Min. Jour., vol. 97, p. 467, 1914.

7 Jorelemon, I. B., The Ajo copper mining district: Am. Inst. Min. Eng. Bull. 92, pp. 2011-2028, 1914.

${ }^{8}$ Weed, W. H., Geology and ore deposits of the Butte district, Mont., U. S. Geol. Survey Prof. Paper 74, 1912. Sales, R. H., Am. Inst. Min. Eng. Trans., vol. 46, pp. 3-106, 1914.
}

apparently been less extensive. The mineralogic changes in the two are compared on piges $163-167$.

The most important deposits occur in the Bingham and Tintic districts. Small veins are known in the San Francisco and other districts but so far have not been commercially important.

A type of deposit differing somewhat from the quartz silver-lead reins is present in the Clifton district. The veins are composed essentially of quartz and calcite (probably containing iron), whose relative amounts differ in different veins and in different parts of a single vein. The important original metallic mineral is "argentiferous" galena. The characteristic alteration of the wall rock is pronounced sericitization. These deposits differ from those of the Bingham and Tintic districts, chiefly by containing abundant carbonates. The quartz silver-lead veins from the Bingham and Tintic districts have yielded important amounts of metal, though much less than other types of silver-lead deposits.

\section{GOLD QUARTZ VEINS.}

Some veins in the Clifton district appear to be chiefly valuable for their gold. The wall rock is quartz monzonite, and the principal gangue mineral is quartz with some carbonates. In many places specular hematite is abundantly scattered through the quartz in fine flakes, giving it a dark appearance. Pyrite and chalcopyrite are commonly present in small amount, and galena and sphalerite have been noted. The gold is said to occur free. The wall rock has undergone sericitization of the feldspar and chloritization of the magnesian minerals.

The output from this type of vein has been small, being thus far confined to the yield of a few rich "pockets."

\section{MAGNETITE-HEMATITE VEINS.}

In the Iron Springs district some veins in the intrusive bodies of quartz monzonite porphyry consist essentially of magnetite and hematite with a little quartz gangue and oxidized copper and lead minerals in small amount. The most notable change in the wall rock has apparently been the addition of soda, probably in the form of albite.

A small vein very similar to those in the Iron Springs district is inclosed in quartz monzonite porphyry in the Henry Mountains on the 
Cuprum claim. The principal vein mineral is magnetite with a little quartz gangue and commonly some copper carbonates, probably derived from the oxidation of sulphides.

Deposits of this character have made no production, though those of the Iron Springs district contain important amounts of iron ore.

In the Antelope Range, northeast of Marysvale, Piute County, deposits of hydrous oxides of iron and manganese are associated with rather indistinct fissures. The inclosing rock is quartz monzonite porphyry which has been intensely altered, essentially to cherty quartz containing small specks of iron oxide. The iron minerals are yellow and red hydrous oxides in vuggy porous masses, many of which show beautiful stalactitic structure. The minerals, as they now exist, appear to have resulted from the alteration of some earlier mineral or minerals and in many respects resemble the gossan resulting from the oxidation of a sulphide body. No remnants of sulphide were, however, observed in the ore at the shallow depth to which developments have been carried. Iron has been removed from a large body of the adjacent altered quartz monzonite, and may have been redeposited in the fissures, but no very definite statement as to the origin of the deposit is warranted.

The deposit in the Tintic or Dragon iron mine in the Tintic district is somewhat similar to the deposits of the Antelope Range, though it is on the contact of quartz monzonite and limestone. Both the quartz monzonite and the adjacent volcanic rocks at the Tintic mine have been sericitized and pyritized. They formerly covered the present surface to a depth of 1,000 feet or more, and the iron-ore deposit is attributed (p.415) todownward concentration of the iron from the now eroded and superficial portions and to replacement of limestone by it along the contact.

The Tintic iron deposits have yielded a considerable tonnage of ore, which has been mainly used for flux, and those of the Antelope Range have furnished some shipments. Both deposits are said to contain small amounts of precious metals.

RELATIONS OF DIFFERENT VEIN TYPES IN THE IGNEOUS ROCKS.

Most of the types of veins in igneous rocks are closely related, and some types grade into others. Such transitions in one district give good ground for the interpretation of deposits in districts where the full series is not represented. Broadly speaking, all the types seem to be due to deposition by rather similar solutions, and their differences appear to be largely due to the physical conditions under which the deposition took place. MINERALIZING SOLUTIONS.

The character of the mineralizing solutions may be deduced from the mineral composition of the veins and from a comparison of the altered with the unaltered wall rock.

Mineral composition of the veins. - The following table shows the important mineral constituents in the different veins:

Principal vein minerals present in different types of deposits in intrusive rocks.

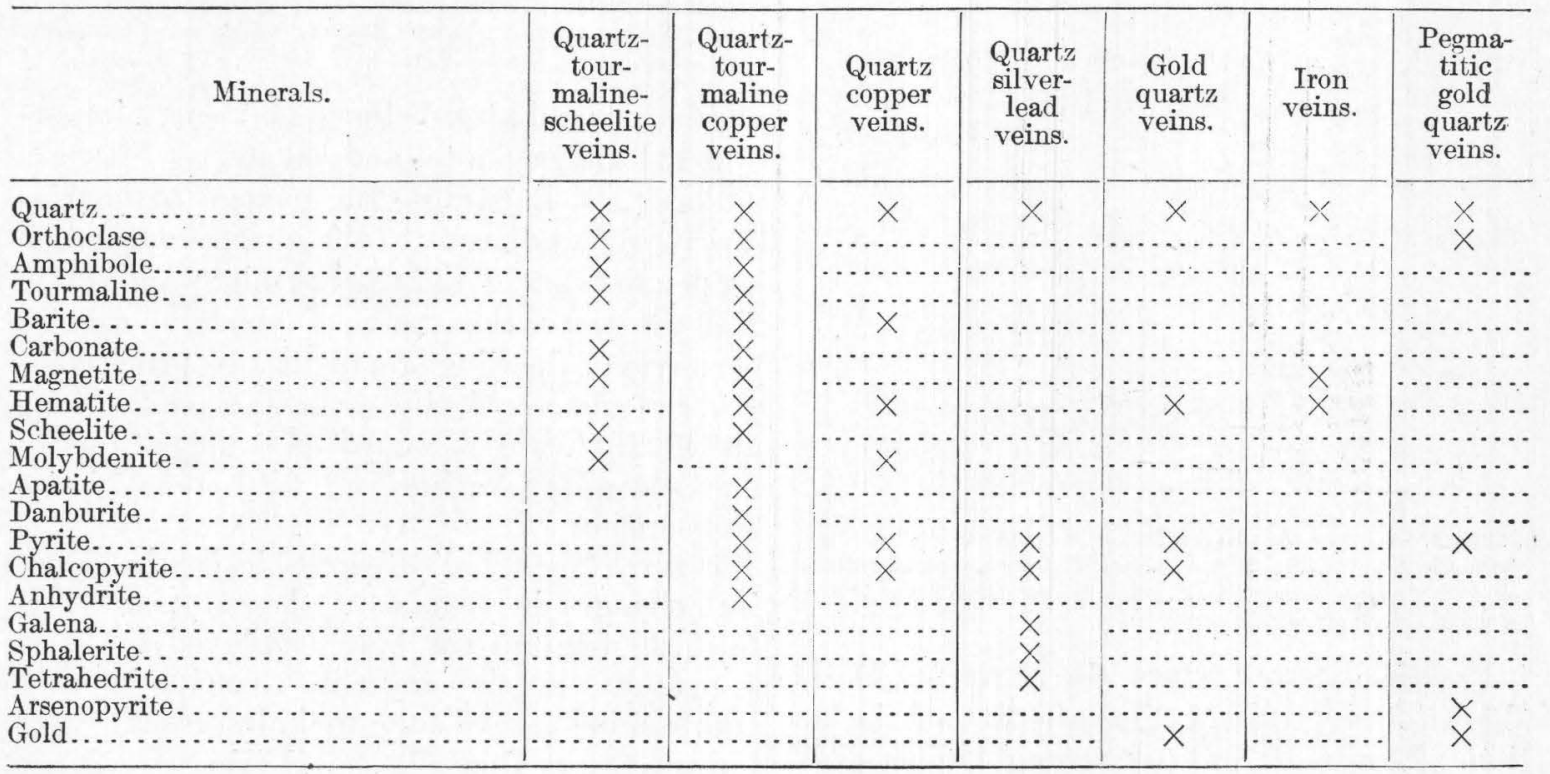


Alterations in the wall rock.-The alteration of the wall rock adjacent to the veins is an importantindication of the nature of the solutions

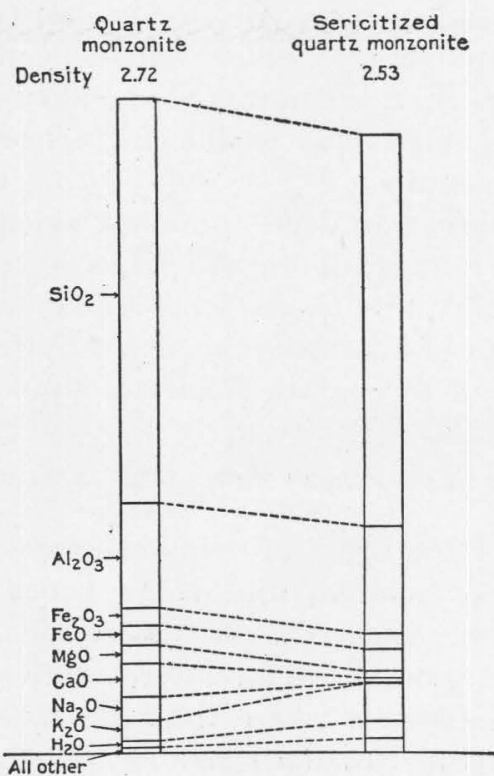

Figure 25.-Diagram showing gain or loss in grams of each constituent in alteration of 100 cubic centimeters of quartz monzonite wall rock of tourmaline-quartz copper vein at Cactus mine, San Francisco district, Beaver County. Scale, 1 inch $=50$ grams.

that carried constituents of the ores and of the conditions under which the ores were deposited.

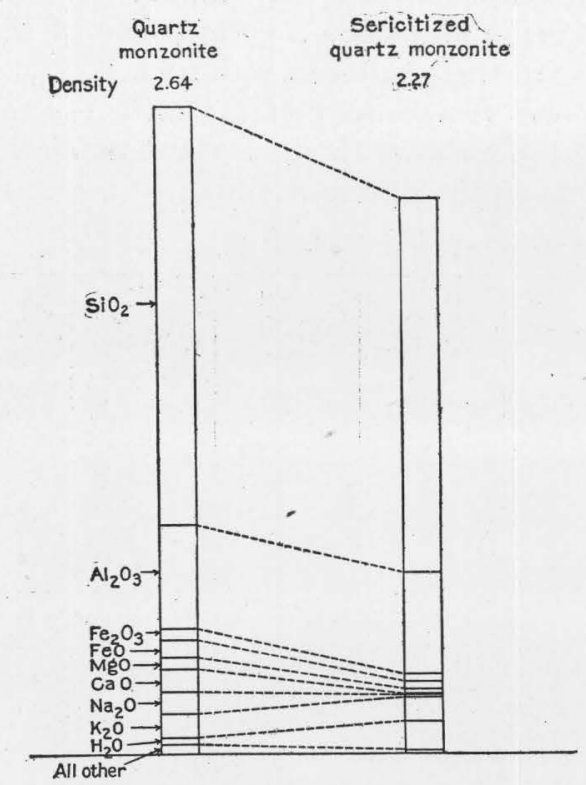

Figure 26.-Diagram showing gain or loss in grams of each constituen in sericitization of 100 cubic centimeters of quartz monzonite wall roc of quartz copper veins at $\mathrm{O} . \mathrm{K}$. mine, Beaver Lake district, Beaver County. Scale, 1 inch $=50$ grams.

Practically everywhere the character of the alteration depends on the intensity of the action. Thus, adjacent to a strongly mineralized fissure the rock is changed to an aggregate of quartz and mica (sericite), which at a greater distance grades into rock composed of quartz, mica, chlorite, epidote, calcite, and the like; and the latter group of minerals characterize the alteration adjacent to a feebly mineralized fissure.

The veins in the intrusive rocks of the Tintic district are lead-copper veins with quartz and barite as the principal gangue minerals. The alteration adjacent to the veins has been characteristically to a quartzsericite rock carrying pyrite, though close to the veins it may be composed largely of quartz

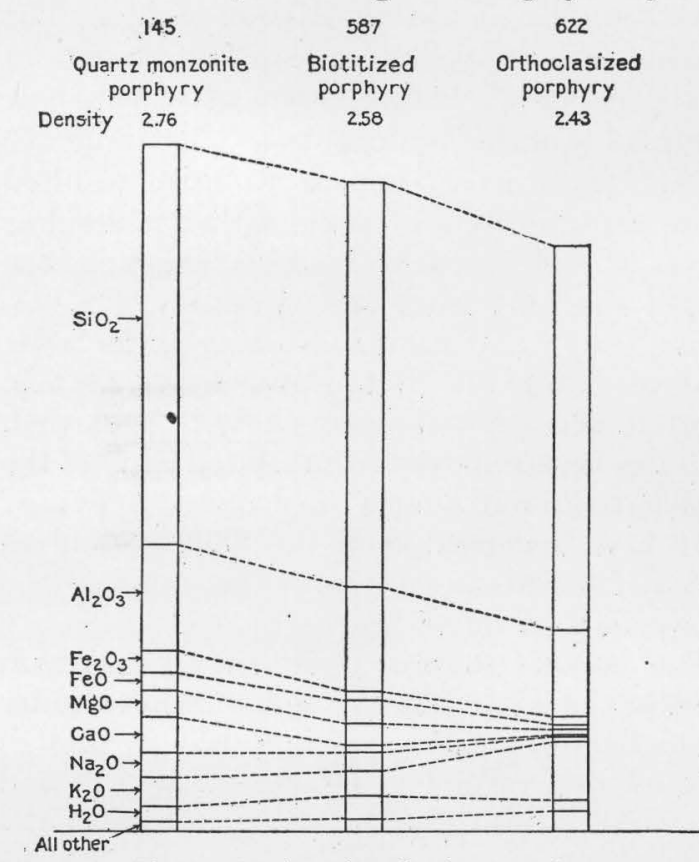

FIGURE 27.-Diagram showing gain or loss in grams of each constituent in alteration of 100 cubic centimeters of quartz monzonite wall rock of quartz copper veins of Bingham district by addition of biotite and orthoclase. Scale, 1 inch $=50$ grams.

and barite and at a distance may carry important chlorite, epidote, and calcite.

Plate XV illustrates the change to quartzsericite rock adjacent to the quartz-tourmaline copper deposit of the Cactus mine; and Plate XVI illustrates the change of quartz monzonite porphyry of the Bingham district to a rock composed of quartz, biotite, orthoclase, and sericite and finally to a rock composed largely of quartz and secondary orthoclase, with some biotite and sericite.

Figures 25-27 indicate graphically the chemical changes in certain of these types. This form of diagram has been employed by J. B. Umpleby ${ }^{1}$ in showing the changes in rock composition in hydrothermal alteration.

1 The genesis of the Mackay copper deposits, Idaho: Econ. Geology, vol. 10, pp. 307-358, 1915 . 


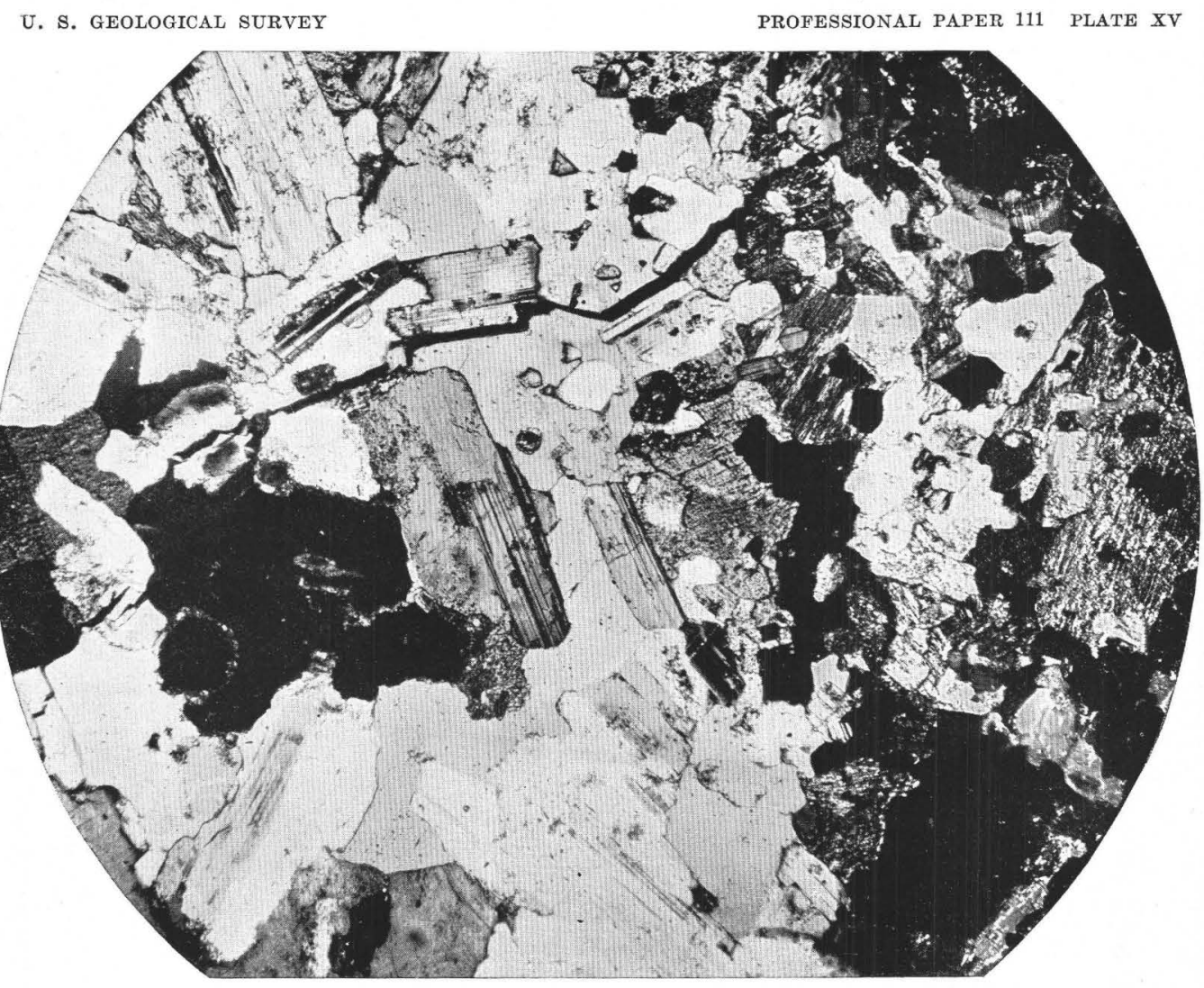

A. PHOTOMICROGRAPH OF QUARTZ MONZONITE OF CACTUS AREA, SAN FRANCISCO DISTRICT.

Crossed nicols. Enlarged 30 diameters.

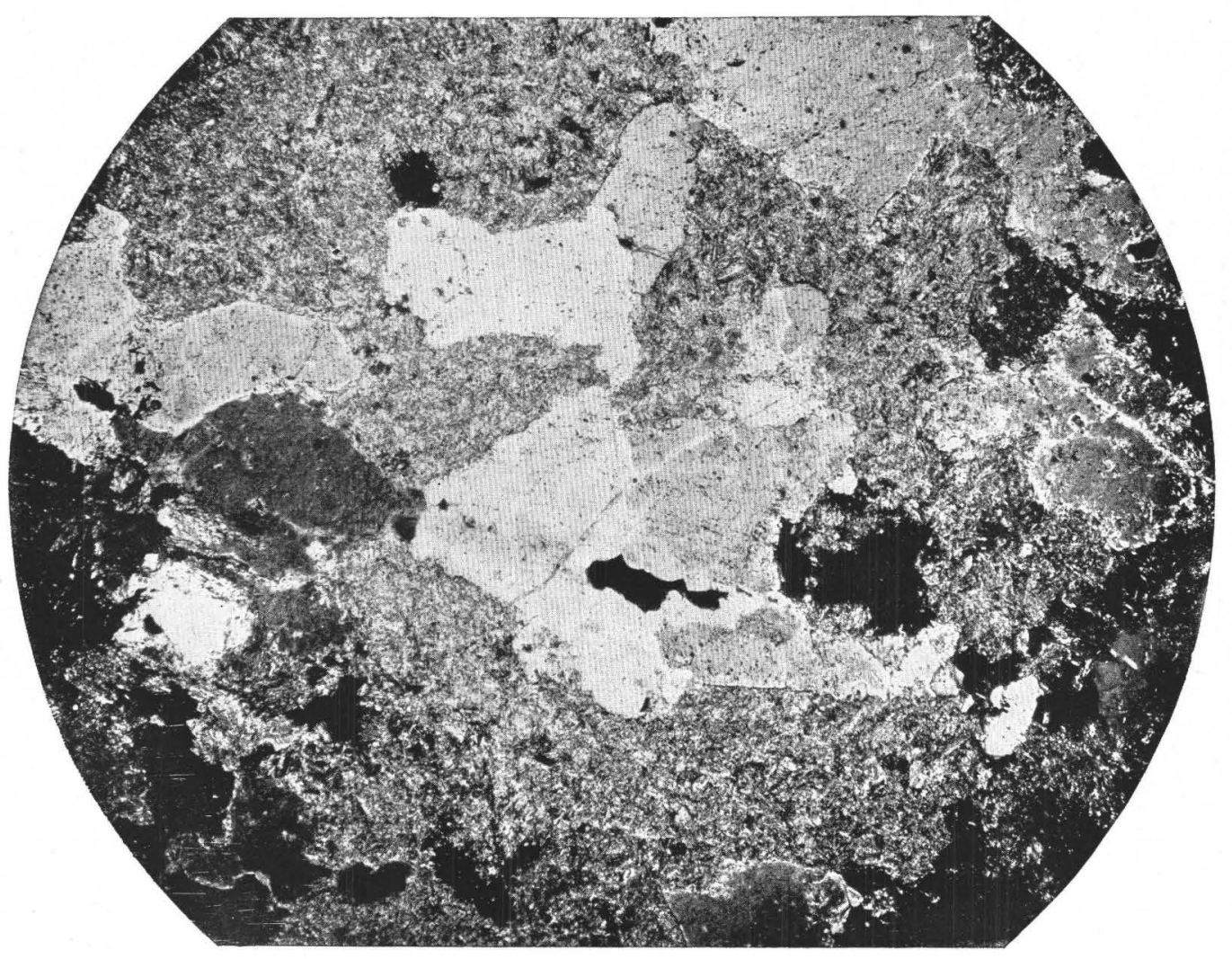

B. PHOTOMICROGRAPH OF ALTERED QUARTZ MONZONITE, CACTUS AREA.

Folted area, sericite; clear areas, quartz. Enlarged 30 diameters. 
U. S. GEOLOGICAL SURVEY

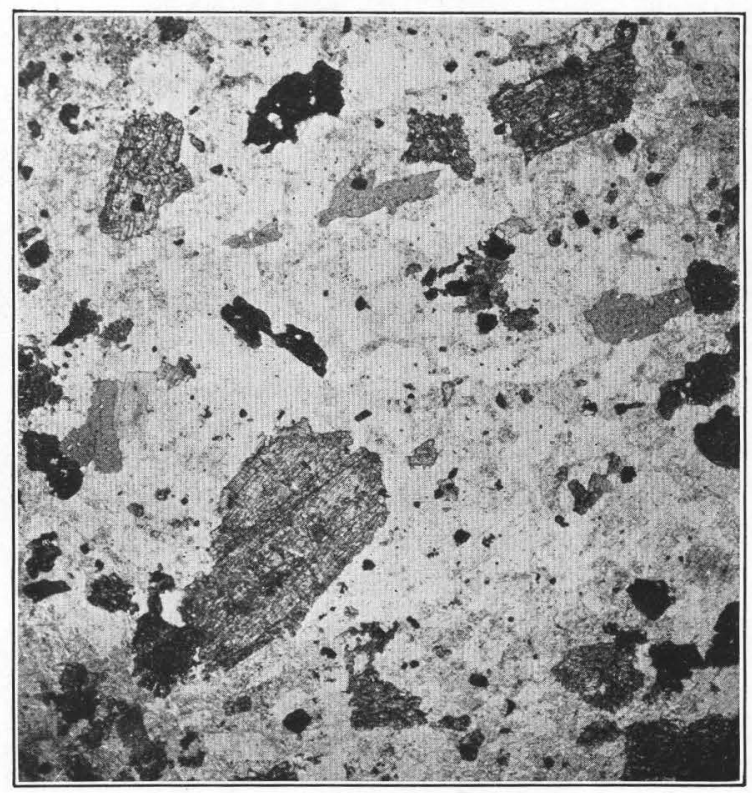

A. PHOTOMICROGRAPH OF QUARTZ MONZONITE PORPHYRY, BINGHAM DISTRICT.

Ordinary light. Enlarged 30 diameters.

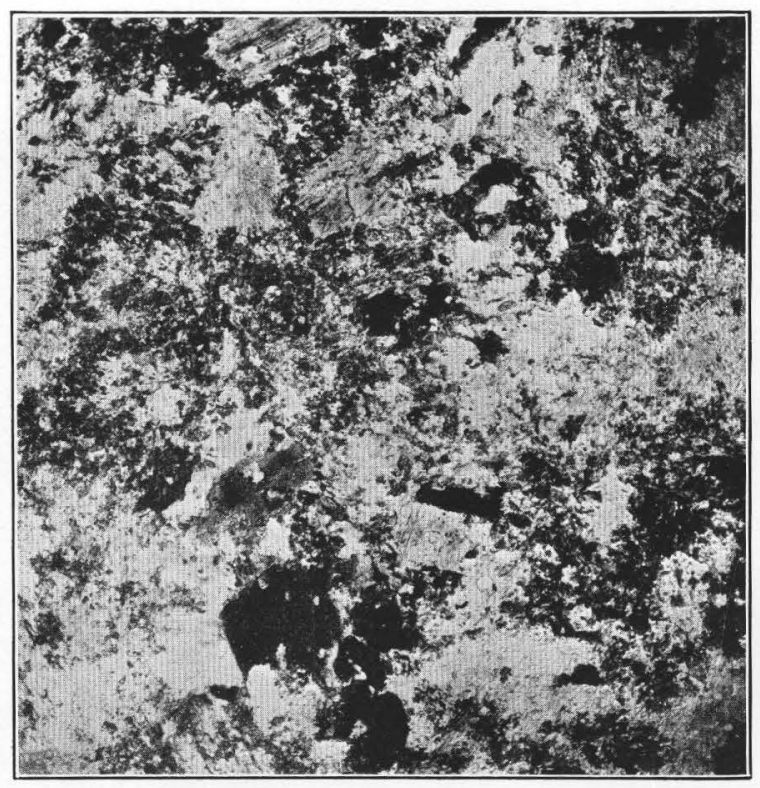

C. PHOTOMICROGRAPH OF QUARTZ MONZONITE PORPHYRY ENRICHED WITH BIOTITE, BINGHAM DISTRICT.

Small dark areas, secondary biotite; light areas, muscovite, quartz, and orthoclase. Enlarged 30 diameters.
PROFESSIONAL PAPER 111 PLATE XVI

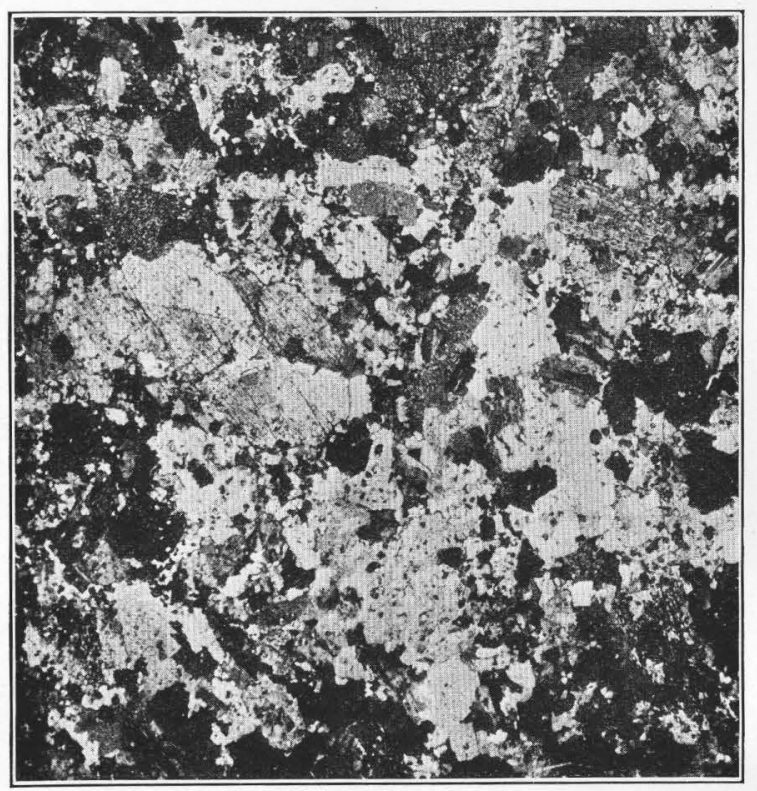

B. PHOTOMICROGRAPH OF QUARTZ MONZONITE PORPHYRY, BINGHAM DISTRICT.

Crossed nicols. Enlarged 30 diameters.

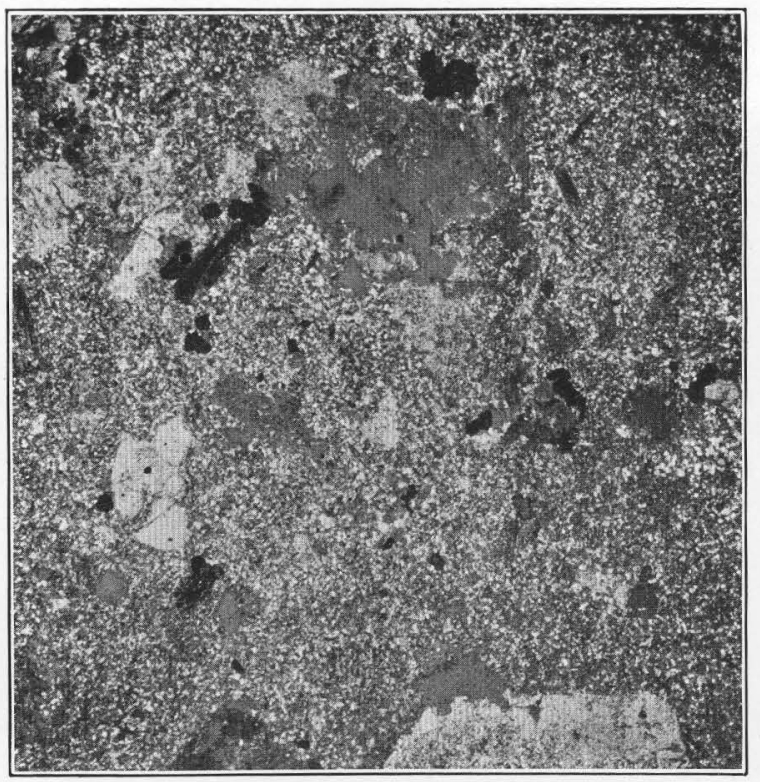

D. PHOTOMICROGRAPH OF QUARTZ MONZONITE PORPHYRY ENRICHED WITH ORTHOCLASE, BINGHAM DISTRICT.

Small, light areas, orthoclase. Enlarged 30 diameters. 
The following tables show the chemical and Alteration of wall rock of quartz copper veins (sericitization mineralogic changes that have taken place in the alteration of the wall rocks of the different types of veins:

Alteration of wall rock of tourmaline-quartz veins.

\begin{tabular}{|c|c|c|}
\hline \multicolumn{3}{|l|}{ Analyses. } \\
\hline & 1 & la \\
\hline 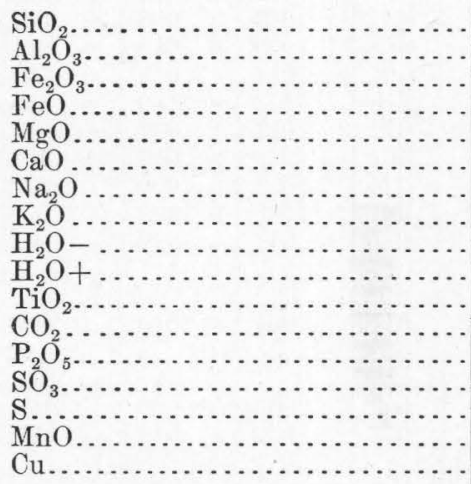 & 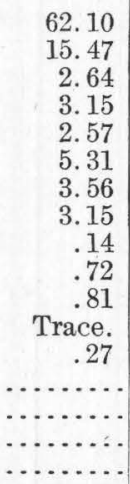 & $\begin{array}{r}62.56 \\
17.21 \\
2.29 \\
3.64 \\
1.13 \\
.29 \\
.07 \\
6.02 \\
.14 \\
2.70 \\
.70 \\
1.93 \\
.24 \\
.02 \\
.13 \\
.45 \\
.09\end{array}$ \\
\hline 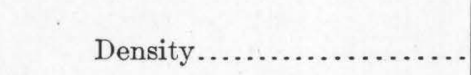 & $\begin{array}{r}99.89 \\
2.72\end{array}$ & $\begin{array}{r}99.61 \\
2.53\end{array}$ \\
\hline
\end{tabular}

Weight of the principal oxides (grams in 1 cubic centimeter).

\begin{tabular}{|c|c|c|c|}
\hline & 1 & la & $\begin{array}{c}\text { Increase } \\
(+) \text { or } \\
\text { decrease } \\
(-)\end{array}$ \\
\hline 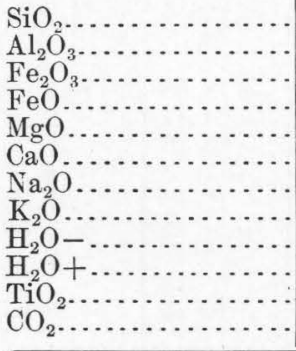 & $\begin{array}{r}1.689 \\
.420 \\
.071 \\
.085 \\
.069 \\
.144 \\
.096 \\
.085 \\
.003 \\
.019 \\
.022 \\
.000\end{array}$ & $\begin{array}{r}1.582 \\
.435 \\
.057 \\
.092 \\
.028 \\
.007 \\
.001 \\
.152 \\
.003 \\
.068 \\
.017 \\
.048\end{array}$ & $\begin{array}{l}-0.107 \\
+.015 \\
-.014 \\
+.007 \\
-.041 \\
-.0137 \\
\overline{1} .095 \\
+.067 \\
+.000 \\
+.049 \\
+.0048\end{array}$ \\
\hline
\end{tabular}

Mineral composition calculated from chemical analyses.

\begin{tabular}{|c|c|c|c|}
\hline Quartz. & 16.20 & 38.16 & +21.96 \\
\hline Orthoclase molecule. & 16. 68 & 6.12 & -10.56 \\
\hline Albite molecule.... & 28.82 & $\cdots$ & -28.82 \\
\hline Anorthite molecule. . & 15.57 & & -15.57 \\
\hline Hornblende......... & 13. 48 & & -13.48 \\
\hline Biotite........ & 5.24 & & -5.24 \\
\hline Magnetite..... & 2.09 & 3.25 & +1.16 \\
\hline Titanite........ & 1.57 & .20 & -1.37 \\
\hline Apatite.... & .67 & .34 & -.33 \\
\hline Muscovite (sericite) &. & 42.98 & +42.98 \\
\hline Pyrite........... & $\cdots$ & .12 & +12 \\
\hline Rutile. & $\cdots$ & .64 & +64 \\
\hline Iron carbonate & . & 3.95 & +3.95 \\
\hline Magnesium carbonate & $\cdots$ & $.34\} 4.98$ & +.3434 .98 \\
\hline Manganese carbonate. & & $.69]$ & $+.69]$ \\
\hline Serpentine... & & 2.23 & +2.2 \\
\hline
\end{tabular}

1. Fresh quartz monzonite, Copper Gulch, Beaver County; George Steiger, analyst.

la. Altered quartz monzonite, Copper Gulch, Beaver County; R. C. Wells, analyst.

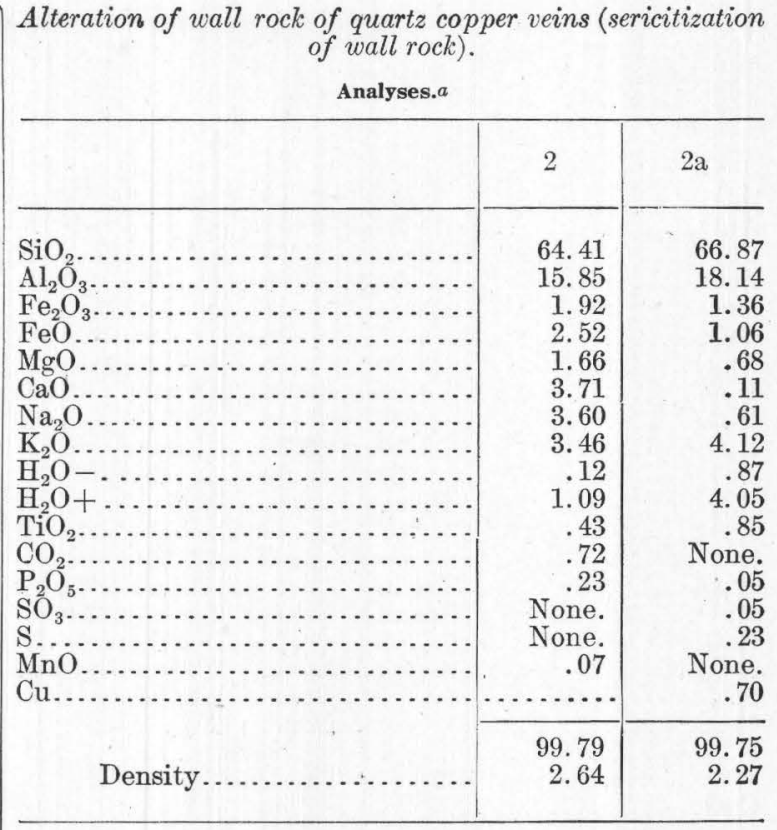

$a$ R. C. Wells, analyst.

Weight of the principal oxides (grams in 1 cubic centimeter).

\begin{tabular}{|c|c|c|c|}
\hline & 2 & $2 a$ & $\begin{array}{c}\text { Increase } \\
(+) \text { or } \\
\text { decrease } \\
(-) \text {. }\end{array}$ \\
\hline 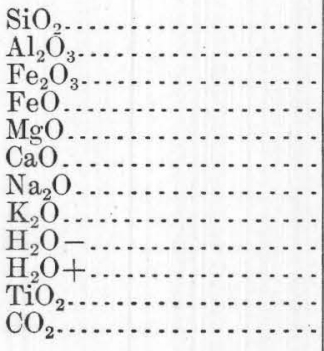 & $\begin{array}{r}1.700 \\
.418 \\
.050 \\
.066 \\
.043 \\
.097 \\
.095 \\
.091 \\
.003 \\
.028 \\
.011 \\
.019\end{array}$ & $\begin{array}{r}1.518 \\
.411 \\
.030 \\
.024 \\
.015 \\
.002 \\
.013 \\
.093 \\
.019 \\
.092 \\
.000 \\
.001\end{array}$ & $\begin{array}{l}+0.182 \\
-.007 \\
-.020 \\
-.042 \\
-.028 \\
-.095 \\
-.082 \\
+.002 \\
+.016 \\
+.064 \\
-.011 \\
-.018\end{array}$ \\
\hline \multicolumn{4}{|c|}{ Mineral composition calculated from chemical analyses. } \\
\hline 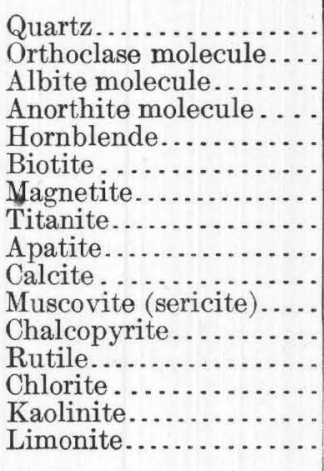 & 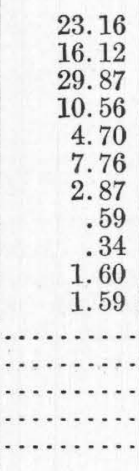 & 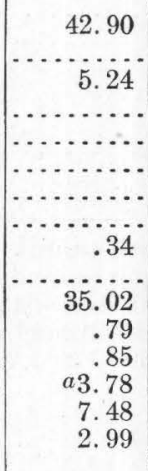 & $\begin{array}{l}+19.74 \\
-16.12 \\
24.63 \\
-10.56 \\
-4.70 \\
-7.76 \\
-2.87 \\
-\quad .59 \\
+\quad 1.60 \\
+33.43 \\
+\quad .79 \\
+\quad .85 \\
+3.78 \\
+7.48 \\
+2.99\end{array}$ \\
\hline
\end{tabular}

$a$ Clinochlore, $\mathrm{MgO}: \mathrm{FeO}: 17: 14$.

2. Fresh quartz monzonite, vertical shaft, O. K. mine, Beaver County.

2a. Altered quartz monzonite, stope shaft, O. K. mine, Beaver County. 
Alteration of monzonite wall rock adjacent to fissure, Bingham district.

\begin{tabular}{|c|c|c|c|c|c|c|c|c|c|c|}
\hline \multicolumn{5}{|c|}{ Analyses. } & \multicolumn{6}{|c|}{ Weight (grams in 1 cubic centimeter of rock). } \\
\hline & 1 & 2 & 3 & 4 & & \multirow{3}{*}{1} & \multirow{3}{*}{2} & \multirow{3}{*}{3} & \multirow{2}{*}{\multicolumn{2}{|c|}{$\begin{array}{l}\text { Increase }(+) \text { or } \\
\text { decrease }(-) \text {. }\end{array}$}} \\
\hline $\mathrm{SiO}_{2} \ldots \ldots \ldots \ldots \ldots \ldots$ & \multirow{2}{*}{$\begin{array}{r}58.64 \\
15.35 \\
3.25 \\
2.54 \\
3.84\end{array}$} & $\begin{array}{l}63.09 \\
16.33\end{array}$ & $\begin{array}{l}66.27 \\
15.01\end{array}$ & \multirow{2}{*}{$\begin{array}{r}56.78 \\
16.90 \\
6.87 \\
2.34\end{array}$} & & & & & & \\
\hline $\begin{array}{l}\mathrm{Fe}_{2} \mathrm{O}_{3} \ldots \ldots \ldots \ldots \ldots \ldots \\
\mathrm{FeO} \ldots \ldots \ldots \ldots \ldots \ldots\end{array}$ & & $\begin{array}{r}16.33 \\
1.37 \\
3.29 \\
3.53\end{array}$ & $\begin{array}{r}15.01 \\
1.84 \\
.39 \\
.71\end{array}$ & & & & & & 2 & 3 \\
\hline $\mathrm{aO}$. & 5.37 & .70 & .18 & 1.18 & & & & & & \\
\hline$a_{2} \mathrm{O}$. & 3.60 & 2.79 & .72 & .37 & & $\begin{array}{r}1.618 \\
424\end{array}$ & $\begin{array}{r}1.627 \\
421\end{array}$ & 1. 551 & $\begin{array}{r}+0.009 \\
-\quad 003\end{array}$ & $\begin{array}{l}-0.067 \\
-\quad 073\end{array}$ \\
\hline $\mathrm{K}_{2} \mathrm{O}$. & $\begin{array}{l}4.23 \\
86\end{array}$ & 3.91 & 9.62 & $\begin{array}{l}7.02 \\
7.29\end{array}$ & $\begin{array}{l}\mathrm{Al}_{2} \mathrm{O}_{3} \text {. } \\
\mathrm{Fe}_{2} \mathrm{O}_{3}\end{array}$ & $\begin{array}{l}.424 \\
.090\end{array}$ & $\begin{array}{l}.421 \\
.035\end{array}$ & $\begin{array}{l}.301 \\
.043\end{array}$ & -.005 & $\begin{array}{l}-.073 \\
-.047\end{array}$ \\
\hline${ }_{2}^{2} \mathrm{O}+$ & $\begin{array}{r}.86 \\
1.50\end{array}$ & $\begin{array}{r}.90 \\
2.35\end{array}$ & $\begin{array}{r}.34 \\
1.50\end{array}$ & $\begin{array}{l}1.32 \\
2.23\end{array}$ & $\mathrm{FeC}$ & .070 & .085 & .009 & +.015 & -.061 \\
\hline $\mathrm{iO}_{2}$... & $\begin{array}{r}1.00 \\
.83\end{array}$ & $\begin{array}{r}2.50 \\
.43\end{array}$ & $\begin{array}{r}1.00 \\
.47\end{array}$ & $\begin{array}{r}.20 \\
.81\end{array}$ & $\mathrm{MgO}$ & .106 & .091 & .017 & -.015 & -.089 \\
\hline $\mathrm{CO}_{2} \ldots$ & None. & None. & None. & .26 & & $\begin{array}{r}.148 \\
099\end{array}$ & .018 & .004 & -.130 & - .144 \\
\hline $\mathrm{P}_{2} \mathrm{O}_{5}$.. & $\begin{array}{r}.02 \\
.05\end{array}$ & .42 & .16 & .04 & $\begin{array}{l}\mathrm{Na}_{2} \mathrm{O} \\
\mathrm{K}_{2} \mathrm{O} \text {. }\end{array}$ & .099 & .101 & $\begin{array}{l}.018 \\
.225\end{array}$ & -.016 & $\begin{array}{r}-.082 \\
+.108\end{array}$ \\
\hline$\cdots$ & Trace. & .07 & 1.66 & $\begin{array}{r}5.93 \\
\text { Trace. }\end{array}$ & $\mathrm{H}_{2} \mathrm{O}-$ & .024 & .024 & .008 & .000 & -.016 \\
\hline InO. & Trace. & None. & None. & Trace. & $\mathrm{H}_{2}^{2} \mathrm{O}+$ & .041 & .061 & .035 & +.020 & -.006 \\
\hline $\mathrm{BaO}$. & .18 & .09 & .17 & .14 & $\mathrm{TiO}_{2}$. & .023 & .011 & .011 & -.012 & -.012 \\
\hline $\mathrm{ZrO}_{2}$. & 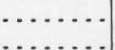 & None. & None. & ... & $\begin{array}{l}\mathrm{ZrC} \\
\mathrm{CO}\end{array}$ & & & & $\cdots$ & $\cdots$ \\
\hline & & $\begin{array}{l}\text { None. } \\
\text { None. }\end{array}$ & $\begin{array}{l}\text { None. } \\
\text { None. }\end{array}$ & & $\mathrm{P}_{2} \mathrm{O}_{5}$ & .001 & .011 & .004 & +.010 & +.003 \\
\hline & & .08 & .15 & & & 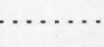 & 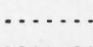 & 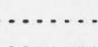 & ........ & $\ldots \ldots$ \\
\hline U & & Trace. & Trace. & & & & 002 & 004 & t. & +.004 \\
\hline & & & 1.02 & & & .001 & .017 & .039 & +.016 & +.038 \\
\hline \multirow{3}{*}{$\mathrm{O}$ equivalent to $\mathrm{S} \ldots}$. & 100.26 & 100.55 & 100.81 & 102.22 & & & & & & \\
\hline & & & & 2.22 & $\mathrm{BaO}$. & .005 & .002 & .004 & -.003 & -.001 \\
\hline & $\begin{array}{r}100.24 \\
2.76\end{array}$ & $\begin{array}{r}100.18 \\
2.58\end{array}$ & $\begin{array}{r}99.91 \\
2.43\end{array}$ & 100.00 & & & .014 & .038 & +.014 & +.038 \\
\hline
\end{tabular}

Mineral composition calculated from chemical analyses.

\begin{tabular}{|c|c|c|c|c|c|c|c|}
\hline & \multirow{2}{*}{1} & \multirow{2}{*}{2} & \multirow{2}{*}{3} & \multirow{2}{*}{4} & \multicolumn{3}{|c|}{ Increase $(+)$ or decrease $(-)$} \\
\hline & & & & & 2 & 3 & 4 \\
\hline Quartz...... & 13. 20 & 30.54 & 25.26 & 26. 28 & +17.34 & +12.06 & +13.08 \\
\hline Orthoclase molecule............... & 23.35 & 9. 45 & 47.82 & 21. 13 & -13.90 & +24.47 & -2.22 \\
\hline Albite molecule. . . . . . . . . . . . & 30.39 & 9.96 & 4. 19 & 3. 14 & -20.43 & -23.20 & -27.25 \\
\hline Anorthite molecule................ & 8. 06 & 2. 78 & .83 & 3. 89 & -5.28 & -7.23 & -4.17 \\
\hline Augite...................... & 12. 70 & & & $\ldots$ & -12.70 & -12.70 & -12.70 \\
\hline 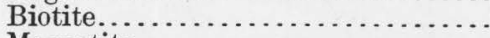 & 5. 50 & 29. 19 & 5.05 & . & +23.69 & -.45 & -5.50 \\
\hline 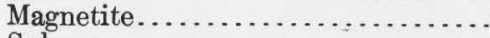 & 4. 41 & & 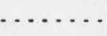 & 2.00 & -4.41 & -4.41 & -2.41 \\
\hline 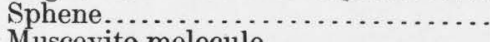 & .78 & & & ......... & -.78 & -78 & -.78 \\
\hline $\begin{array}{l}\text { Muscovite molecule } . . . \ldots \ldots \ldots \ldots \ldots \\
\text { Paragonite molecule. }\end{array}$ & $\cdots$. & $\left.\begin{array}{l}6.37 \\
6.87\end{array}\right\} 13.24$ & 10. 35 & 28.65 & +13.24 & $\{+10.35$ & +28.65 \\
\hline 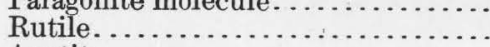 & & 6.87) .43 & .47 & - & +.43 & +.47 & $\cdots+8$ \\
\hline 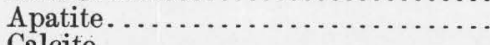 & & 1. 01 & .34 & $\ldots \ldots \ldots$ & $\ldots \ldots \ldots$ & $\ldots \ldots$ & $\ldots \ldots \ldots$ \\
\hline 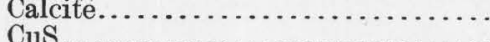 & & 25 & . & .60 & $\cdots \ldots \ldots$ & &.$+ \dot{0}$ \\
\hline 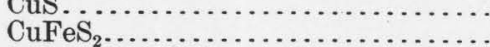 & $\cdots$ & $\begin{array}{l}.35 \\
.47\end{array}$ & .45 & $\cdots$ & + & +.45 & $\cdots \cdots \cdots$ \\
\hline 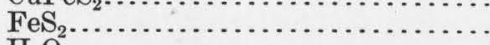 & ... & .83 & $\begin{array}{r}2.04 \\
.95\end{array}$ & ii. 11 & +.83 & $\begin{array}{l}+2.84 \\
+\quad .95\end{array}$ & +11.11 \\
\hline $\mathrm{H}_{2} \mathrm{O} \ldots \ldots \ldots \ldots \ldots \ldots \ldots \ldots \ldots \ldots \ldots \ldots \ldots$ & 1. 50 & 2.09 & 1. 26 & & +.59 & -.24 & $\cdots$ \\
\hline
\end{tabular}

1. British tunnel, Last Chance mine, Bingham district; fresh rock.

2. Boston Consolidated mine, Sub. 8, No. 31, crosscut north of drift No. 6; altered rock, "dark porphyry."

3. North end of Pit-Utah copper mine; altered rock, "light porphyry."

4. British tunnel, Last Chance mine, Bingham district; wall of lode.

Analysts: 1 and 2, E. T. Allen (U. S. Geol. Survey Prof. Paper 38, p. 178, 1905); 3 and 4, George Steiger. 
It is readily apparent that in all types of wall rock, regardless of the mineralogic changes that resulted, sodium, calcium, and magnesium have notably decreased, silica and alumina have remained nearly constant, and ferrous and ferric iron have remained nearly constant or shown relatively slight decreases. Potassium in every instance shows a notable increase. The total decreases in every comparison are considerably in excess of the total increases, showing that during the alteration there has been a notable loss of mass.

It should be remembered also that the extent of the alteration adjacent to the different types of veins varies notably. In the tourmaline copper veins and the quartz copper veins the alteration is commonly intense for several feet from the wall of the fissure and in many places is pronounced for much greater distances; and in the quartz lead-silver veins, especially in those of the Bingham district, the intensive alteration has extended only to a distance usually measured in inches rather than in feet.

Composition of the solution.-Both the vein minerals and the alteration of the rock adjacent to the veins give an idea of the character of the mineralizing solutions. These solutions, especially those forming tourmaline-quartz veins must have contained iron and carbon dioxide, abundant silica and potassium, and doubtless abundant alumina (though the evidence, as to alumina from the tourmalinequartz veins alone is not conclusive), and abundant boron, as well as sulphur and most of the common metals. That is to say, they were probably alkali-carbonate solutions containing silica, sulphur, and most of the common metals and under certain conditions abundant boron and other constituents.

PHYSICAL CONDITIONS OF DEPOSITION.

The relation of the types is shown in the different districts. In the Clifton district there can be no doubt of the common origin of the quartz-orthoclase-tourmaline-scheelite veins and of the quartz-tourmaline copper veins, and the latter give place to those in which there is little tourmaline and these in turn to veins in which lead is abundant.

In the San Francisco region the close general similarity of the quartz-tourmaline copper and the quartz copper veins gives good reason for attributing a common origin to them. In the Bingham district many points of similarity between the quartz copper veins and the quartz lead veins indicate a common origin. The magnetite-hematite veins do not show' so close a similarity or relation to the other types, though many of the copper veins in the Clifton district contain magnetite and specularite in abundance; in fact, if favorably located some could probably be mined for iron flux. The iron-ore veins may be regarded as an extreme type in which iron is especially abundant and copper especially deficient.

The origin of all these veins has already been indicated. The close similarity of the feldspathic tourmaline deposits to true pegmatites seems sufficient evidence for regarding them as having been derived from the differentiation of the same igneous material, and their resemblance to and gradation into other types justifies the belief that all are produced by the same process, the difference in types being due in part, probably in large part, to the physical conditions under which they were deposited. Thus under conditions of high temperature and pressure tourmaline, iron oxides, quartz, and scheelite were deposited, but most of 1 he other metallic constituents remained in solution. With decreasing temperature and pressure copper and finally lead and zine were successively deposited. As conditions favoring the deposition of a certain mineral were reached the solutions would eventually become deficient in the constituents of that mineral and subsequently would deposit it in decreasing amounts. Thus in the original deposition the metals were roughly separated, iron oxides apparently being deposited under conditions of high temperature and pressure, copper under lower conditions, and lead and zinc under still lower conditions.

If this explanation of the change in types is correct, it would be expected that a space relation would exist indicating the different physical conditions, and this appears to be the case. In the Clifton district this relation has been pointed out. (See p. 482.) In the Bingham district the Bingham Canyon stock, which contains the copper deposits, seems to have been the center of much more intense hydrothermal action than the Last Chance stock, which contains lead deposits. In the Tintic district all the mineralization seems to have been accomplished under moderate conditions. The dif- 
ference in the distances from the fissures to which alteration of the wall rock of the different types has extended also points to conditions of decreasing temperature and pressure. It would also be expected that as the igneous activities died out there would be a gradual overlapping of the less intense on the more intense conditions. What appears to be such overlap is seen in the Bingham district, where small lead-zinc veins occupy fissures in copper deposits. The mineralization, however, seems to have been largely accomplished at essentially one time, the deposits formed during the dying stages being small and of relatively slight importance. For further discussion of change in types due to change in temperature see page 184.

\section{DEPOSITS IN SEDIMENTARY ROCKS.}

Deposits in sedimentary rocks may be separated into contact deposits and deposits associated with fissures.

CONTACT DEPOSITS.

GENERAL FEATURES

Contact deposits lie at or near the contact of sedimentary and intrusive rocks and are characterized by the presence of the silicates and other minerals commonly known as "contact minerals," such as garnet, diopside, tremolite, and wollastonite. The contact deposits of commercial importance within the State consist of replacements of limestone and are present in practically every district where limestones are intruded by igneous rock, but they differ greatly in development and have thus far proved of economic importance in but few districts.

The principal metals that have been produced from contact deposits are copper, gold, and silver. There are important contact iron deposits in the State, but these as yet have not been worked extensively for the production of iron, though the iron in some of the copper ores has been utilized as flux and has thus increased the value of the ore.

TYPES OF CONTACT DEPOSITS.

Iron deposits.-Large contact iron deposits occur in the Iron Springs and Bull Valley districts. Deposits containing important amounts of iron, usually accompanied by some copper, exist in the Rocky, Clifton, Little Cottonwood, West Tintic, and other districts, but at present they do not promise to be of importance for the production of iron, though the iron content adds to the value of the ores.

The Iron Springs contact deposits are described in the discussion of the Iron Springs district (see p. 568) and it suffices to state here that they occur as replacements of limestone near quartz monzonite porphyry intrusions. The limestone adjacent to the intrusive has been replaced by albite, kaolin, actinolite, diopside, quartz, orthoclase, serpentine, phlogopite, andradite, iron oxides, andalusite, wollastonite, and other minerals in small amounts. The iron oxides have for the most part been deposited later than the contact silicates. The chemical changes are compared with those of similar deposits on page 173 .

Copper deposits.-Contact copper deposits are present in many districts, of which the more important are the Rocky, Beaver Lake, San Francisco, Star, Lincoln, Little Cottonwood, and Clifton. They have been most extensively mined in the Rocky and San Francisco districts. Very closely allied deposits associated with fissures are present in other districts and have been much more important commercially.

The deposits which have the common characteristic of being replacements of limestone and containing the contact minerals garnet, diopside, tremolite, magnetite, and hematite occur irregularly along the limestone intrusive contacts. Long stretches of the contact show only recrystallization of the limestone with very slight replacement, but other stretches show almost complete replacement by silicates and other minerals.

The various deposits differ greatly in their content of the replacing minerals. In some the silicates constitute a large percentage of the material and in others magnetite or hematite is more important. Sulphides are present in greater or less amounts and are apparently about as abundant in some deposits composed largely of silicates as in those in which iron oxides predominate. There are large areas replaced by silicates, however, that contain very little sulphide.

The different minerals were in part formed at the same time, though both sulphides and iron oxides were also deposited after the main replacement of the limestone by silicates, as is 
shown by small veins of these minerals cutting the contact silicates. Where sulphides are most abundant they were apparently deposited in large part later than the silicates. The principal original sulphides are pyrite, chalcopyrite, and bornite, and smaller amounts of sphalerite and galena.

In the Clifton and Grouse Creek districts scheelite occurs in contact deposits.

Most of thedeposits outcrop prominently, and they have been prospected in many places. The original deposits commonly contain only relatively small amounts of copper, and few of those in which the gangue is principally silicates have proved to be of commercial grade. The heavy gangue minerals have prevented successful concentration by methods dependent on differences in specific gravity. The deposits that contain large proportions of the iron oxides have been successfully mined where transportation costs were moderate, the value of the iron as a flux adding materially to the value of the ore. Such ores have been most extensively mined in the Rocky district.

The alteration of the ores has resulted in local enrichments that have produced "pockets" of relatively high grade material. These have been successfully mined on a small scale but have not been of great importance.

Altogether, the developments on the contact copper deposits have probably been the most unsatisfactory of those on any important type of deposit in the State. Very closely allied deposits associated with fissures have, however, been large producers of copper.

Gold deposits.-Gold and silver are present in small amount in all of the contact copper deposits of the State, but only in the Clifton district in the north end of the Deep Creek Range have contact deposits been developed in which gold is the most important constituent.

The characteristic occurrence is as a replacement of certain beds of Carboniferous limestone near but not necessarily at the contact with intrusive rock. The limestone is replaced by silicates, principally wollastonite with small amounts of diopside, vesurianite, and garnet, and by sulphides, including chalcopyrite, bornite, and molybdenite, and in at least one place some arsenopyrite.

The sulphides were among the latest minerals to form, being in part at least later than the silicates. The gold is in part free and probably in part associated with the sulphides. In what appears to be unaltered material it occurs between the silicate grains. In some of the richest ore the action of oxidizing solutions is evident and the gold is in part contained in small fissures. Most of the ore treated contained only small quantities of sulphides. Commonly the gold is not uniformly distributed through the replaced limestone but occurs in irregular shoots.

Other contact deposits. - A few deposits have been prospected or mined formetals other than iron, copper, or gold. In the Lincoln district in the Mineral Range there has been a small production of lead from deposits very closely allied to the contact type; and in the Clifton and Grouse Creek districts some prospecting has been done on contact deposits containing scheelite, from which some tungsten has been produced.

CHEMICAL AND MINERALOGIC CHANGES DUE TO CONTACT ALTERATION

The chemical and mineralogic changes that take place in the contact alteration of the limestone differ greatly in different deposits, though the more important ones show general similarity. Such deposits have been studied in detail in but relatively few districts in the State. There is no sharp distinction between the changes in typical contact alteration and in replacements associated with fissures, though there is usually a mineralogic difference that indicates different physical conditions of formation.

By far the most extensive change along the contacts is a recrystallization of the limestone, usually with relatively slight additions and subtractions, the former probably due to small amounts of material given off directly from the contact. The more intensive changes are far more localized and are apparently due to solutions that have followed the intrusion and at least partial solidification of the igneous material. Such solutions have been directed and concentrated along lines of relatively easy passage.

The following table shows the changes that took place in the marmarization of limestone in the Bingham district: ${ }^{1}$

1 Boutwell, J. M., Economic geology of the Bingham mining district: U. S. Geol. Survey Prof. Paper 38, p. 189, 1905. 
Analyses showing changes in metamorphism of limestone.

[Analyst, W. F. Hillebrand.]

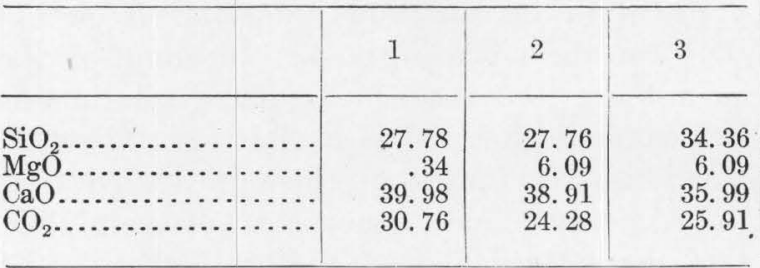

1. Blue limestone from south slope of West Mountain, on road to Tooele.

2. Slightly marmarized limestone from same locality

3. Marble from same locality.

The changes have been comparatively slight, the especially notable ones being a slight increase in silica and magnesium and a decrease in calcium and carbon dioxide.

The following tables show the chemical and mineralogic changes that have taken place in the contact alteration of limestone in the San Francisco district:

Analyses of slightly altered and highly altered limestone from the San Francisco district, Utah.

[George Steiger, analyst.]

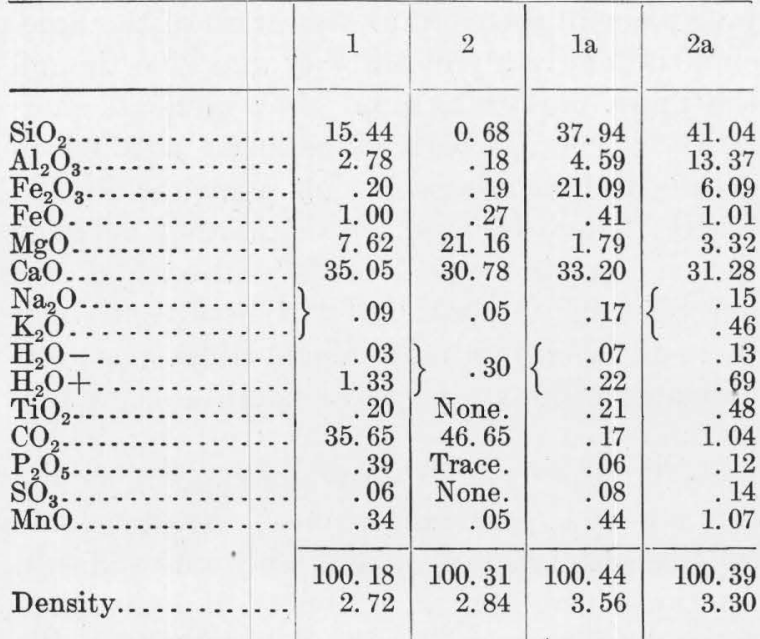

1. Banded crystalline limestone from near Reciprocity mine (specimen 123)

2. Gray dolomitic limestone from east of Reciprocity mine (specimen 121)

1a. Banded rock representing alteration of limestone from near Reciprocity mine (specimen 119).

2a. Massive garnet rock from northeast of Reciprocity mine (specimen 124).
Mineral composition of slightly altered and highly altered limestone from the San Francisco district, Utah.

\begin{tabular}{|c|c|c|c|c|}
\hline & 1 & 2 & la & $2 a$ \\
\hline Calcite molecule & 62.60 & 54.90 & & 2.40 \\
\hline Magn & 15.51 & 44.97 & & \\
\hline Quartz.............. & 14. 71 & & 1.02 & .96 \\
\hline $\begin{array}{l}\text { Chlorite ................ } \\
\text { Andradite molecule. }\end{array}$ & 3.74 & 2.28 & 0706 & 156 \\
\hline $\begin{array}{l}\text { Andradite molecule. } \\
\text { Grossularite mole- } \\
\text { cule............. }\end{array}$ & & & 67.06 & 15. \\
\hline Tremolite........ & & & 7.07 & 21.40 \\
\hline $\begin{array}{l}\text { Vesuvianite............. } \\
\text { Epidote............ }\end{array}$ & & $\ldots \ldots \ldots$ & 23.49 & \\
\hline \multirow{9}{*}{ 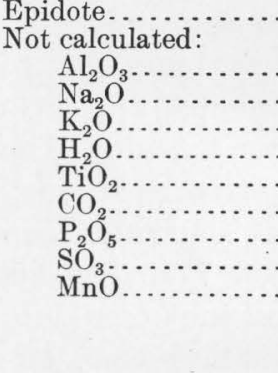 } & & & $\cdots$ & 10.40 \\
\hline & 1.43 & & & \\
\hline & .09 & .05 & .17 & .61 \\
\hline & .86 & $\ldots$ & .17 & .6 \\
\hline & .20 & & .21 & .4 \\
\hline & .39 & & .06 & .12 \\
\hline & .06 & & .08 & \\
\hline & & & 9950 & \\
\hline & & & & \\
\hline
\end{tabular}

The following table shows the increase and decrease of the principal constituents in a given volume of rock. It is assumed that there has been no change in volume during the metamorphism.

Weight of the principal oxides in cubic centimeters of slightly altered and highly altered limestone from the San Francisco district, Utah.

[Grams in 1 cubic centimeter of rock.]

\begin{tabular}{|c|c|c|c|c|c|c|}
\hline & & \multirow{2}{*}{2} & \multirow{2}{*}{ 1a } & \multirow{2}{*}{$2 a$} & \multicolumn{2}{|c|}{$\begin{array}{l}\text { Increase }(+) \text {, } \\
\text { decrease }(-) \text {. }\end{array}$} \\
\hline & & & & & $1,1 \mathrm{a}$ & $2,2 \mathrm{a}$ \\
\hline $\mathrm{iO}_{2}$ & 0.419 & 0.019 & 1. 350 & 1. 354 & +0.931 & +1.335 \\
\hline $\mathrm{Al}_{2} \mathrm{O}_{3} \ldots$ & .075 & .005 & .163 & .441 & +.088 & $\begin{array}{r}+ \\
+\quad .436\end{array}$ \\
\hline $\mathrm{Fe}_{2} \mathrm{O}_{3} \ldots$ & .005 & .005 & .751 & .201 & +.746 & .196 \\
\hline e & .027 & .007 & .014 & .033 & -.013 & 026 \\
\hline $\lg$ & 207 & .601 & .064 & .109 & -.143 & .492 \\
\hline $\mathrm{CaO}$. & .953 & .874 & 1. 182 & 1. 032 & +.229 & +.158 \\
\hline $\mathrm{CO}_{2}$. & .969 & 1. 325 & .006 & .034 & -.963 & -1.291 \\
\hline
\end{tabular}

Figure 28 shows diagrammatically the change in a unit volume in the different constituents on the assumption that there has been no change in volume during metamorphism. 
The important chemical changes are evidently additions of silica, alumina, and ferric iron and nearly complete elimination of carbon dioxide. In both analyses magnesia shows a decrease and calcium an increase. Combined calcium and magnesium show a slight increase in one analysis and a decrease in the other. The net

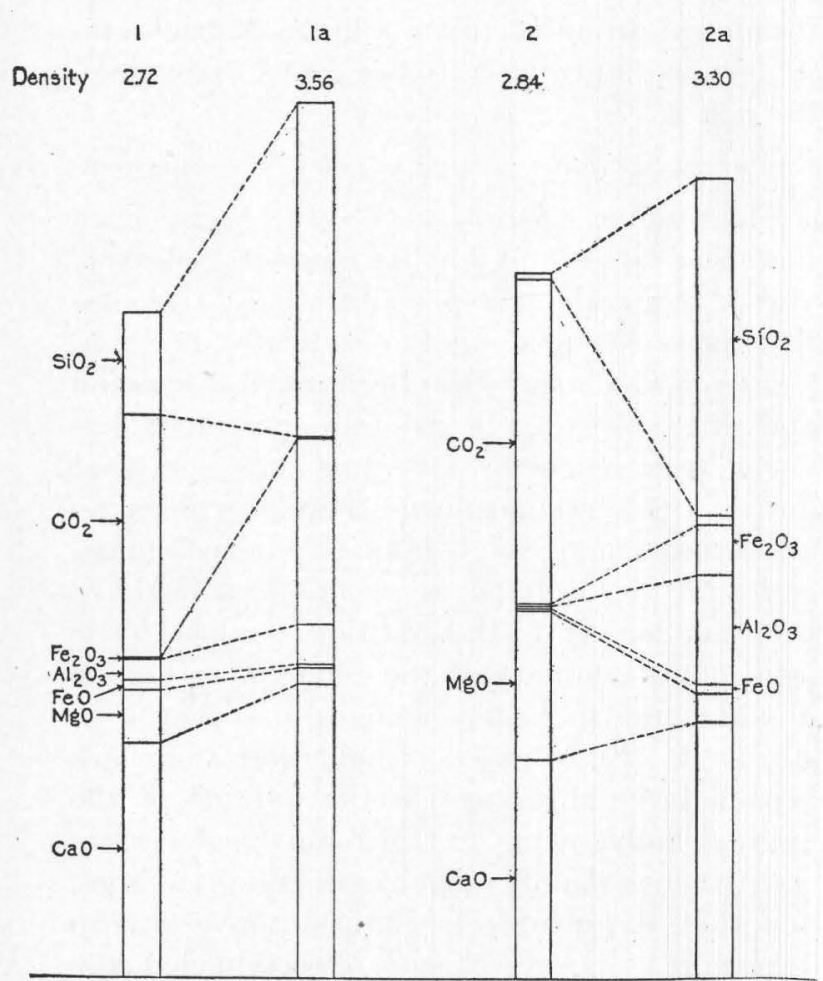

FIGURE 28.-Diagram showing gain or loss in grams of each constituen in the metamorphism of 100 cubic centimeters of limestones in the San Francisco district. Scale, 1 inch $=50$ grams.

result of the additions and subtractions shows a notable increase in the mass.

The mineral composition of the metamorphosed limestone is plainly in part dependent on the chemical composition of the original rock.

In the Iron Springs district the alteration of the limestone adjacent to quartz monzonite stocks has been studied by Leith and Harder. The following table of analyses ${ }^{1}$ shows the chemical composition of the unaltered and normal types of metamorphosed limestone:

1 The iron ores of the Iron Springs district: U. S. Geol. Survey Buli. 338, p. 26, 1908.

\begin{tabular}{|c|c|c|c|c|c|}
\hline & 1 & 2 & 3 & 4 & 5 \\
\hline $\begin{array}{l}\mathrm{SiO}_{2} \ldots \ldots \ldots \\
\mathrm{Al}_{2} \mathrm{O}_{3} \ldots \ldots \ldots \\
\mathrm{Fe}_{2} \mathrm{O}_{3} \ldots \ldots \ldots \\
\mathrm{FeO} \ldots \ldots \ldots \\
\mathrm{MgO} \ldots \ldots \ldots \\
\mathrm{CaO} \ldots \ldots \ldots \\
\mathrm{Na}_{2} \mathrm{O} \ldots \ldots \ldots \\
\mathrm{K}_{2} \mathrm{O} \ldots \ldots \ldots \\
\mathrm{H}_{2} \mathrm{O} \ldots \ldots \ldots \\
\mathrm{P}_{2} \mathrm{O}_{5} \ldots \ldots \ldots \\
\mathrm{CO}_{2} \ldots \ldots \ldots \ldots \\
\mathrm{BaO} \ldots \ldots \ldots\end{array}$ & $\begin{array}{r}8.08 \\
1.95 \\
.87 \\
.06 \\
2.86 \\
46.67 \\
.13 \\
.77 \\
1.01 \\
.05 \\
37.60 \\
\text { None. }\end{array}$ & $\begin{array}{r}6.90 \\
1.03 \\
1.04 \\
.75 \\
4.52 \\
47.15 \\
.13 \\
.93 \\
1.04 \\
.04 \\
36.42 \\
\text { None. }\end{array}$ & $\begin{array}{r}52.00 \\
9.32 \\
5.08 \\
2.41 \\
9.40 \\
14.47 \\
1.94 \\
1.41 \\
3.30 \\
.12 \\
.63 \\
\text { None. }\end{array}$ & $\begin{array}{r}57.05 \\
9.86 \\
3.10 \\
1.80 \\
8.16 \\
8.61 \\
4.30 \\
1.56 \\
3.89 \\
.13 \\
1.74 \\
\text { None. }\end{array}$ & $\begin{array}{r}50.73 \\
14.63 \\
11.51 \\
1.13 \\
6.36 \\
1.24 \\
2.02 \\
4.24 \\
7.03 \\
.32 \\
.21 \\
.01\end{array}$ \\
\hline Density... & $\begin{array}{c}100.05 \\
2.705\end{array}$ & $\begin{array}{c}99.95 \\
2.706\end{array}$ & $\begin{array}{r}100.08 \\
2.59\end{array}$ & $\begin{array}{r}100.20 \\
2.57\end{array}$ & $\begin{array}{r}99.43 \\
2.22\end{array}$ \\
\hline
\end{tabular}

1. Specimen No. 46319. Unaltered blue limestone from west of Three Peaks.

2. Specimen No. 46375 . Unaltered blue limestone from Desert Mound.

3. Specimen No. 46349. Altered limestone between ore and unaltered blue limestone at Desert Mound.

4. Specimen No. 46376. Altered limestone between ore and andesite at Desert Mound.

5. Specimen No. 46338. Altered limestone between ore and andesite on Lindsay Hill.

The following table shows the weight of the principal oxides in a given volume of the unaltered and metamorphosed limestone; and on the assumption that there has been no change in volume during metamorphism it shows the additions and subtractions as in the table for the San Francisco district (p. 170). Leith and Harder, however, do not consider that the volume has remained constant. (See p. 573.)

Weight of the principal oxides in unaltered and contactmetamorphosed Homestake limestone from Iron Springs district.

[Grams in 1 cubic centimeter of rock.]

\begin{tabular}{|c|c|c|c|c|c|}
\hline & 1 & 2 & 3 & 4 & 5 \\
\hline $\begin{array}{l}\mathrm{SiO}_{2} \ldots \ldots \ldots \\
\mathrm{Al}_{2} \mathrm{O}_{3} \ldots \ldots \ldots \\
\mathrm{Fe}_{2} \mathrm{O}_{3} \ldots \ldots \ldots \\
\mathrm{FeO} \ldots \ldots \\
\mathrm{MgO}{ }^{2} \ldots \ldots \ldots \\
\mathrm{CaO} \ldots \ldots \ldots \\
\mathrm{Na}_{2} \mathrm{O} \ldots \ldots \ldots \\
\mathrm{K}_{2} \mathrm{O} \ldots \ldots \ldots \\
\mathrm{H}_{2} \mathrm{O} \ldots \ldots \ldots \\
\mathrm{P}_{2} \mathrm{O}_{5} \ldots \ldots \ldots \\
\mathrm{CO}_{2} \ldots \ldots \ldots \ldots\end{array}$ & $\begin{array}{r}0.2185 \\
.0527 \\
.0235 \\
.0016 \\
.0773 \\
1.2624 \\
.0035 \\
.0208 \\
.0273 \\
.0013 \\
1.0170\end{array}$ & $\begin{array}{r}0.1867 \\
.0278 \\
.0281 \\
.0203 \\
.1223 \\
1.2758 \\
.0035 \\
.0251 \\
.0281 \\
.0010 \\
.9855\end{array}$ & $\begin{array}{r}1.3468 \\
.2413 \\
.1315 \\
.0624 \\
.2434 \\
.3747 \\
.0502 \\
.0365 \\
.0854 \\
.0031 \\
.0163\end{array}$ & $\begin{array}{r}1.4661 \\
.2534 \\
.0796 \\
.0462 \\
.2097 \\
.2212 \\
.1105 \\
.0401 \\
.0999 \\
.0033 \\
.0447\end{array}$ & $\begin{array}{r}1.1262 \\
.3247 \\
.2555 \\
.0250 \\
.1412 \\
.0275 \\
.0448 \\
.0941 \\
.1560 \\
.0071 \\
.0046\end{array}$ \\
\hline
\end{tabular}


Figure 29 brings out the change in the principal constituents based on the assumption of constant volume. The most important additions are of silica, alumina, ferric iron, magnesium, and sodium. The loss of calcium and of carbon dioxide has been large. The total subtractions are somewhat greater than the total additions resulting in a slight net decrease in the mass.

The following table shows the mineral composition of the unaltered and metamorphosed limestone:

Mineral composition of fresh and altered beds of Homestake limestone, calculated from chemicul composition.

\begin{tabular}{|c|c|c|c|c|c|}
\hline \multirow{2}{*}{ Mineral. } & \multicolumn{2}{|c|}{$\begin{array}{c}\text { Fresh } \\
\text { limestones. }\end{array}$} & \multicolumn{3}{|c|}{ Altered limestones. } \\
\hline & 1 & 2 & 3 & 4 & $5^{a}$ \\
\hline Calcite. & 78.30 & 72.40 & 1.40 & 3.90 & 0.50 \\
\hline Kaolin. & $\begin{array}{r}4.90 \\
\end{array}$ & 2.58 & 11.61 & 3. 09 & 24. 77 \\
\hline Chert. & 2.64 & & 1. 50 & 6. 30 & 18.78 \\
\hline Actinolite & & & 15.55 & 19.00 & \\
\hline Diopsid & & & 20.52 & 4.32 & 2.16 \\
\hline Phlogo & & & & & 15.57 \\
\hline Serpe & & & 4. 9 & 6. & 5. \\
\hline Andrad & & & 11.2 & 3.14 & $\cdots$ \\
\hline Magnes & 5. 96 & 8.65 & & & \\
\hline Wollastonite.. & 6.03 & 9.86 & 4. 76 & 3.13 & \\
\hline Albite. & 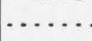 & ...... & 16. 24 & 36.15 & 16.77 \\
\hline Orthoc & & & 8.34 & & \\
\hline Limonite. & 1. 12 & .56 & 1. 31 & 2. 62 & 3. 74 \\
\hline Magn & & .69 & & & 3.48 \\
\hline Hema & & & & & 5. \\
\hline Enst & & 1.00 & & & \\
\hline Apatite. & & & .31 & .31 & .62 \\
\hline $\begin{array}{l}\text { Pyrite... } \\
\text { Water.. }\end{array}$ & .12 & $\begin{array}{r}.84 \\
59\end{array}$ & & & \\
\hline $\begin{array}{l}\text { Water... } \\
\text { Siderite. }\end{array}$ & & .59 & .81 & 2.21 & 1. 54 \\
\hline \multirow[t]{2}{*}{ Witherite.... } & & & & & 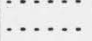 \\
\hline & 99.23 & 97.17 & 98.52 & 99.82 & 99.09 \\
\hline
\end{tabular}

$a$ Contains glass which has been calculated in terms of minerals.

The most notable difference in the alterations in the Iron Springs and San Francisco districts, as shown by the analyses, is the large decrease in calcium and the increase in 'sodium in the Iron Springs district, and the relative smallness of the change in those constituents in the San Francisco district; also, the slight decrease in the density of the resultant rock in the Iron Springs district, and the corresponding notable increase in the San Francisco district.

A type of contact alteration that is present in some districts consists of the addition of abundant silica and some iron, resulting in masses of cherty quartz, some of which contain enough iron to give them a jasperoidal character. Such bodies are present in the Clifton district and in places along the Tintic contact zone. Enstatite and spinel are the most abundant contact minerals in the Tintic district.

In other districts the contact metamorphism has added elements that are not common to all the deposits. Thus boron has been added in forming tourmaline in the Clifton district and in forming ludwigite in the Big Cottonwood district.

VOLUMETRIC CHANGES DUE TO CONTACT METAMORPHISM.

The volume relation that exists between an unaltered limestone and its contact metamorphosed equivalent, especially where the contact facies consists largely of silicates, is a subject over which there has been much discussion and one on which a general agreement has never been reached. By some it is held that during the metamorphism there has been no important change of volume in the rock mass, and that the differences in composition have been due largely to the addition of silica, ferric iron, and alumina and the removal of carbon dioxide and to lesser changes in other constituents. By others it is held that there has been a large shrinkage in the volume of the original body, owing to the removal of certain constituents, mainly carbon dioxide and calcium, and that the change in composition is due in large part to a concentration of certain elements of the original rock-a concentration that might be compared in result to the relatively small residuum of clay derived from the weathering of limestone. By this process the change is regarded as due chiefly to removal of certain constituents, although it is recognized that additions have played some part in the changeand in the case of metallic constituents an important part. The literature on the subject has been reviewed by $\mathrm{Uglow}^{1}$ and in textbooks, notably by Lindgren. ${ }^{2}$

Where deposits are adjacent to large intrusive masses it is usually difficult to ascertain positively whether or not there have been important changes in volume during metamorphism, though Umpleby ${ }^{3}$ has secured convincing evidence of essential constancy of vol-

1 Uglow, W. L., A review of the existing hypotheses on the origin of the secondary silicate zones at the contact of intrusives with limestones: Econ. Geology, vol. 8, pp. 19-50, 215-234, 1913.

2 Lindgren, Waldemar, Mineral deposits, p. 669, 1913.

3 Umpleby, J. B., The genesis of the Mackay copper deposits: Econ. Geology, vol. 9, pp. 307-358, 1914. 
ume in the Mackay deposits in Idaho. Where by the writer in which the evidence seemed replacement has occurred at some distance conclusive no change in volume was apparent, from intrusive bodies, especially in closely and in numerous occurrences in which the eviallied deposits associated with fissures, opportunities for determination are far more favorable.

In the contact gold deposits of the Clifton district certain beds of limestone for considerable distances along the strike and dip have been converted largely to wollastonite without any appreciable change in volume. In the Mineral Range at the "Bismuth mine," several hundred feet from any large body of intrusive rock, a bed of limestone for a considerable distance along the strike has been largely con-

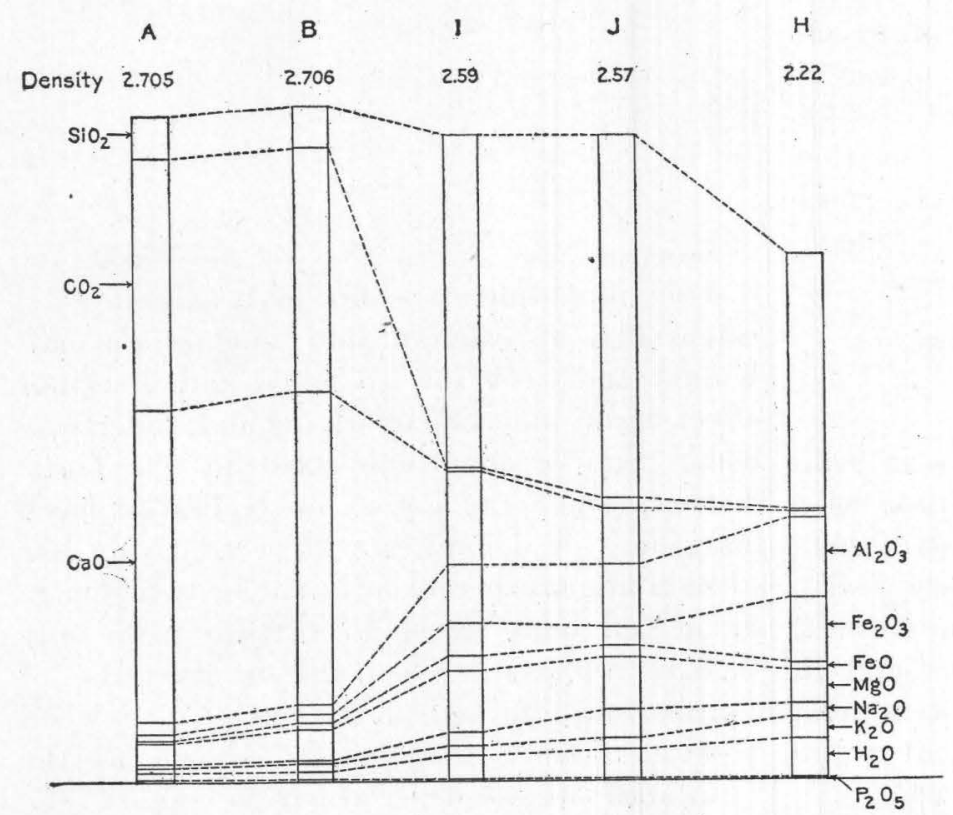

FIGURE 29.-Diagram showing gain or loss in grams of each important constituent in the contact alteration of 100 cubic centimeters of the Homestake limestone, Iron Springs district.

verted to garnet and other silicates without appreciable change in volume. In the Ophir Hill mine in Ophir district the limestone strata in the shale adjacent to fissures have been in places (see PI. XXXVII, $A$, p. 376) largely converted to silicates and to sulphides without destroying the details of the bedded structure of the limestone and without showing any indications of important change in volume. In the Deertrail mine near Marysvale a stratum of limestone over a considerable area has been largely replaced by muscovite (sericite) without apparent change of volume; the alteration is adjacent to a fissure and only small dikes of intrusive rock later than the alteration of the limestone are present. In every occurrence seen dence could not be regarded as conclusive the relations were most readily explained by the supposition of essential constancy in volume.

RELATION OF CONTACT DEPOSITS TO DEPOSITS IN INTRUSIVE ROCKS.

The solutions producing the deposits in the intrusive rocks contained abundant silica and iron and some alumina, as well as sulphur and most of the common metals; and the solutions effecting the contact metamorphism of the limestone contained essentially these same constituents. The similarity in these solutions is most strikingly shown where they contain some unusual constituent. Thus in the Clifton district the abundance of tourmaline in both types of deposits indicates that boron was an important constituent in both solutions, and the presence of scheelite in small amounts in both types indicates that tungsten also was present in both. In the Iron Springs district the deposition of albite in both types is a notable feature. These close similarities in the composition of the solutions naturally lead to the belief that the two had a common origin and that the differences in the character of the deposits are due largely to the differences in the character of the rocks on which they acted.

Too close likenesses can not be expected in the two types, but some interesting comparisons are possible. In the Iron Springs district the magnetitehematite veins within the intrusive rocks correspond to iron deposits in the contact zone, and in the Clifton district the tourmaline-quartz copper veins with abundant iron oxides find their counterpart in tourmaline iron-copper contact deposits. Even the wollastonite contact gold deposits of the Clifton district find their counterpart in the quartz gold deposits in the intrusive rocks, as do also the contact jasperoidal masses in the silicified zones in the intrusive rocks. Similar relations have been pointed out in the San Francisco and adjacent districts and less notable ones in other districts. 
It is believed, therefore, that the solutions producing the two types of deposits had a common origin.

GENESIS OF THE CONTACT DEPOSITS.

If the solutions forming the contact deposits and the deposits in the intrusive rocks had a common origin, they resulted from differentiation of the magmas that formed the main intrusive bodies, as has been pointed out in the discussion of deposits in intrusive rocks. The contacts of the intruded and intrusive rocks were favorable localities for the passage of solutions, and where conditions favored the concentration of solutions from deep-seated sources large masses of limestone were metamorphosed. In the Little Cottonwood district aplitic and pegmatitic dikes are very abundant in the intrusive body adjacent to large areas of contactaltered limestone, strongly suggesting that they now fill the channels through which the metamorphosing solutions passed from the igneous body into the adjacent sedimentary rocks.

DEPOSITS ASSOCIATED WITH FISSURES.

SELECTIVE DEPOSITION.

Deposits in or adjacent to fissures in sedimentary rocks have to the present time been the most productive in the State. Most of them occur as replacements of sedimentary rocks, commonly limestone, adjacent to the fissures, though some occur in breccia zones and in fissures in siliceous rocks. The most notable of the deposits in siliceous rocks is that in the Ontario fissure in the Park City district.

Influence of the chemical composition of rocks. - Selective replacement of especially soluble beds has been observed in many districts. In the Bingham district, where the great ore bodies in the sedimentary rocks occur in large part as a replacement of relatively small bodies of limestone interstratified with the great quartzite series, there can be no doubt of this selective action. In the Ophir district, deposits that are mainly replacements of limestone in a series composed predominantly of shale and underlain by massive quartzite show a similar selective action. In the Stockton district a remarkable regularity in the mineralization where certain limestone beds are intersected by mineralizing fissures is apparently due to the composition of the limestones. The following partial analysis shows the composition of the limestone of the Honorine mine, locally called "Honorine limestone," one of the most important ore-bearing beds of the district, in comparison with that of the overlying "dolomite." The highly siliceous beds are apparently much less susceptible to replacement than the rather pure limestone. The underlying bed is apparently similar in composition to the overlying.

Partial analysis of the limestone of Honorine mine and of the overlying "dolomite."

[By R. C. Wells.]

\begin{tabular}{|c|c|c|}
\hline & $\begin{array}{c}\text { Honor- } \\
\text { ine } \\
\text { limestone. }\end{array}$ & $\begin{array}{c}\text { White } \\
\text { dolomite. }\end{array}$ \\
\hline \begin{tabular}{|l}
$\mathrm{SiO}_{2} \ldots \ldots$ \\
$\mathrm{CaO} \ldots \ldots$ \\
$\mathrm{MgO} \ldots \ldots$
\end{tabular} & $\begin{array}{r}2.39 \\
53.85 \\
.53\end{array}$ & $\begin{array}{r}42.12 \\
29.20 \\
7.29\end{array}$ \\
\hline
\end{tabular}

Boutwell has shown that in the Park City district replacement occurs in beds composed essentially of calcium and magnesium carbonate and very low in silica and does not affect highly siliceous overlying and underlying beds. Similar conditions exist in the Tintic district, where the larger ore bodies replaced limestones or dolomites with a relatively low silica content, whereas adjacent beds higher in silica and more dense in texture were only slightly replaced. The same is also true of certain limestone beds in the Little Cottonwood district, notably that locally known as the "Flagstaff limestone," which is one of the main ore-bearing beds of the district. (See fig. 30.) Conditions in many other localities indicate that rocks composed essentially of carbonate are especially susceptible to replacement by metal-bearing solutions.

In some places minor constituents have probably helped to precipitate the metals, beds containing them having been more favorable to deposition than the carbonate beds. Thus, the gold deposits of the Mercur district occur mainly in shaly beds, although they are overlain by limestones and underlain by other limestones that have been extensively replaced by silica. Apparently the shales were especially favorable for the precipitation of the gold.

Influence of physical conditions of rocks.Physical conditions that are especially favor- 


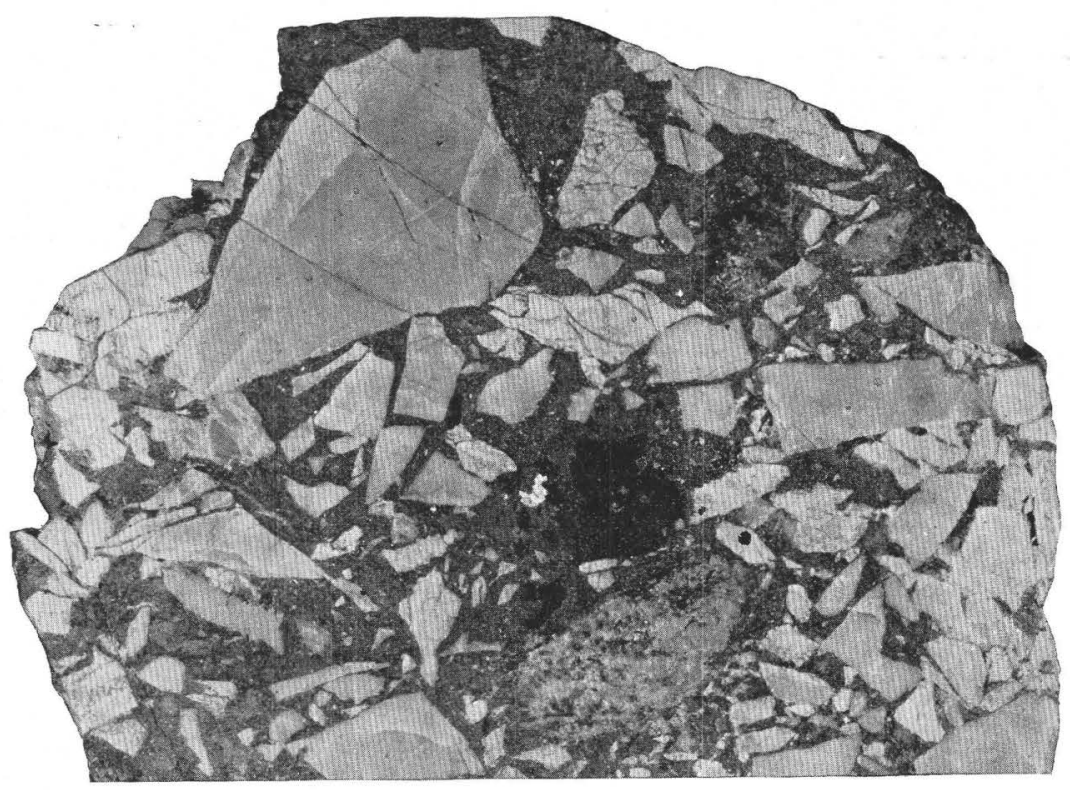

A. MINERALIZED LIMESTONE BRECCIA, OLD EMMA MINE.

Photograph by F. B. Laney.

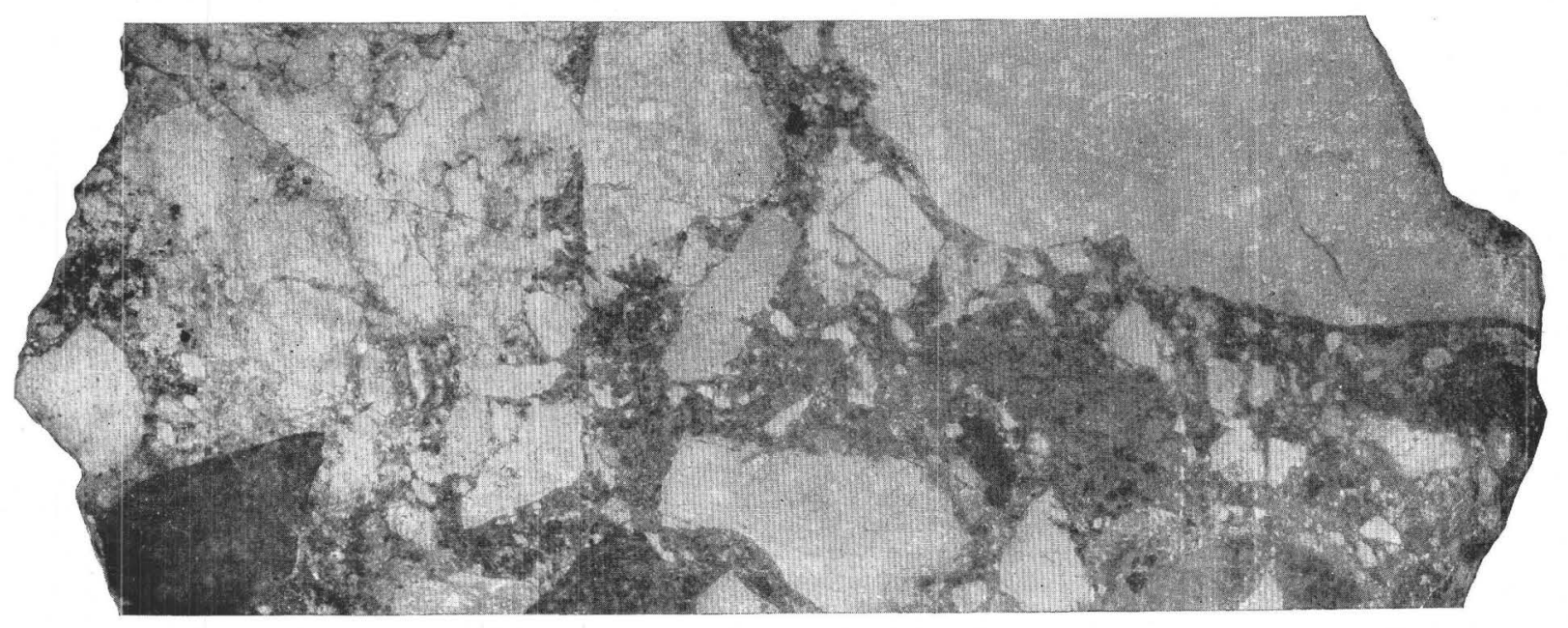

B. MINERALIZED LATITE BRECCIA, HORN SILVER MINE.

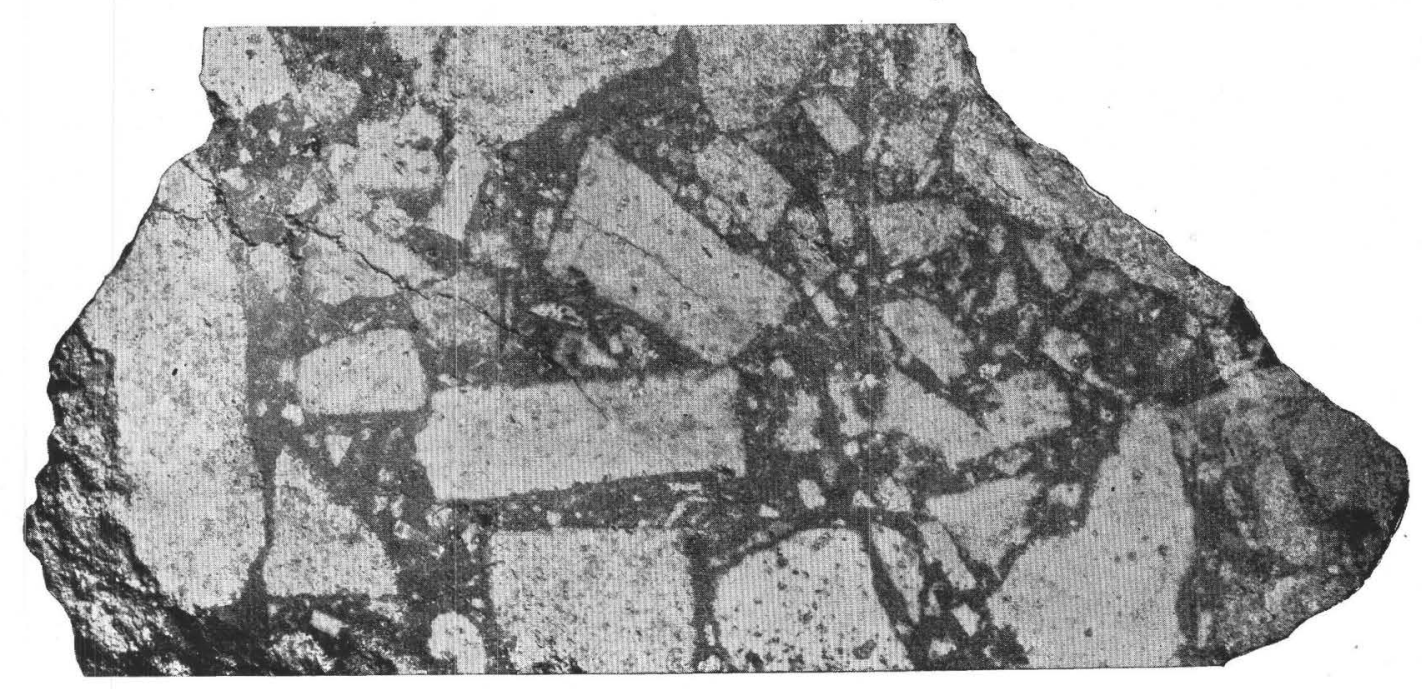

C. MINERALIZED QUARTZ MONZONITE BRECGIA, CACTUS MINE.

BRECCIA ORES. 
U. S. GEOLOGICAL SURVEY

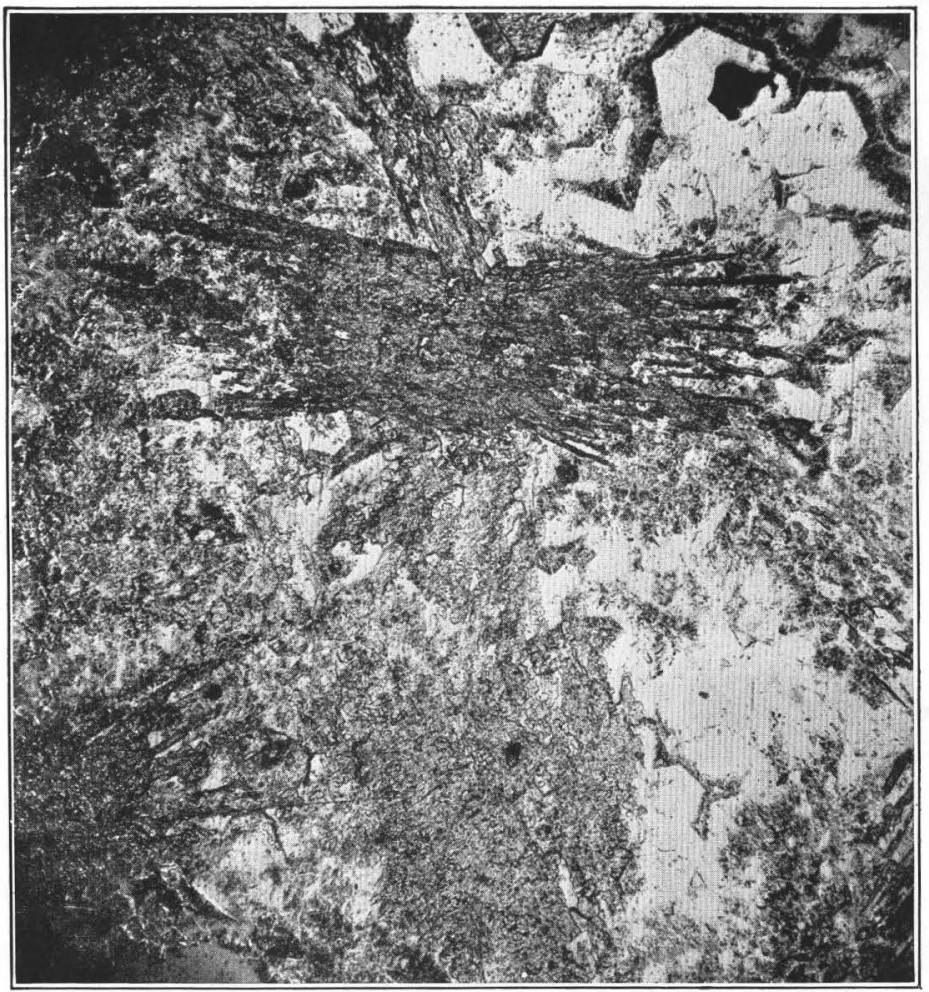

A. PHOTOMICROGRAPH OF SPECIMEN OF ORE FROM GOLD SPRINGS DISTRICT, SHOWING REPLACEMENT OF CALCITE BY QUARTZ AND ADULARIA; LATH-SHAPED BODIES PARTLY REPLACING CALGITE CRYSTALS.

Enlarged 30 diameters.
PROFESSIONAL PAPER 111 PLATE XVIT

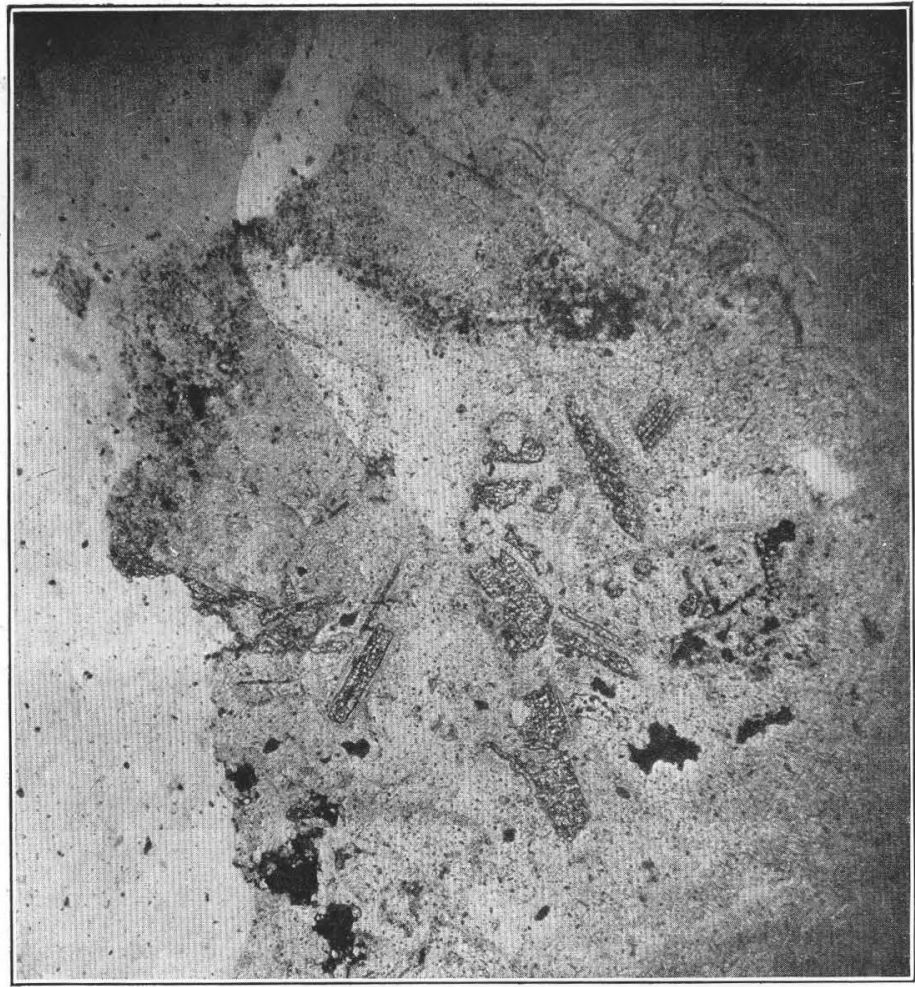

B. PHOTOMICROGRAPH OF SPECIMEN OF ORE FROM MARYSVALE DISTRICT, SHOWING REPLACEMENT OF BARITE BY QUARTZ AND ADULARIA.

Rough areas, barite. Enlarged 30 diameters.

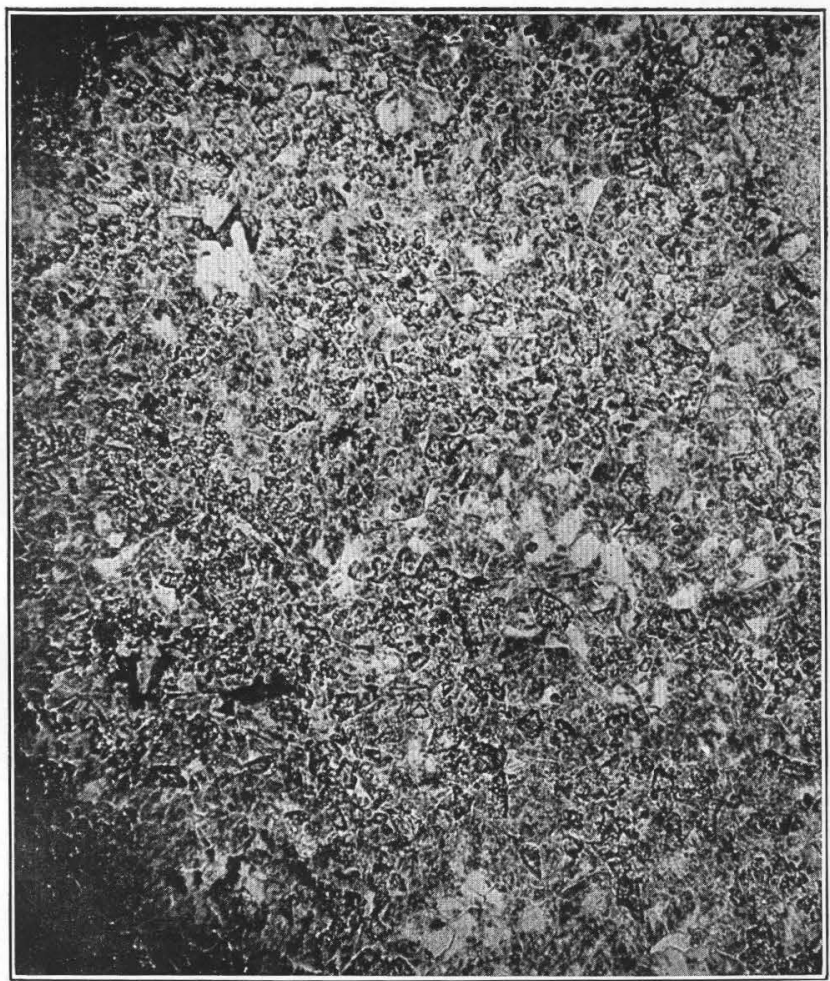

C. PHOTOMICROGRAPH OF SPECIMEN OF VEIN MATERIAL FROM GOLD SPRINGS DISTRICT, SHOWING QUARTZ AND ADULARIA.

Rough areas, adularia. Enlarged 30 diameters. 
able to the concentration of solutions along certain channels are of course favorable to the deposition of ores.

Brecciation along fissures and slight movements along bedding have produced conditions favorable to mineralization. (See Pl. XVII.) Very commonly certain beds in a series brecciate much more readily than the others, and where a fissure cuts such a series of beds a strong breccia zone follows the intersection of the fissure and the easily brecciated bed. This forms a favorable place for deposition of ore. Such conditions are well illustrated in the Little Cottonwood district. Overthrust faulting also forms breccia zones
The distribution of developed ore bodies in the Park City, Bingham, Tintic, and Ophir districts, all of which contain large quantities of quartzite, gives no support to the idea that ore is especially likely to occur at the contact of quartzite with another kind of sedimentary rock if the contact is the result of normal sedimentation. But the fact that normally superposed formations commonly intergrade establishes a slight presumption that the contact of two sharply contrasted rocks, like limestone and quartzite, is due to faulting. The limestone that is brecciated along such a fault is likely to be permeated and in part replaced by any mineralizing solutions that

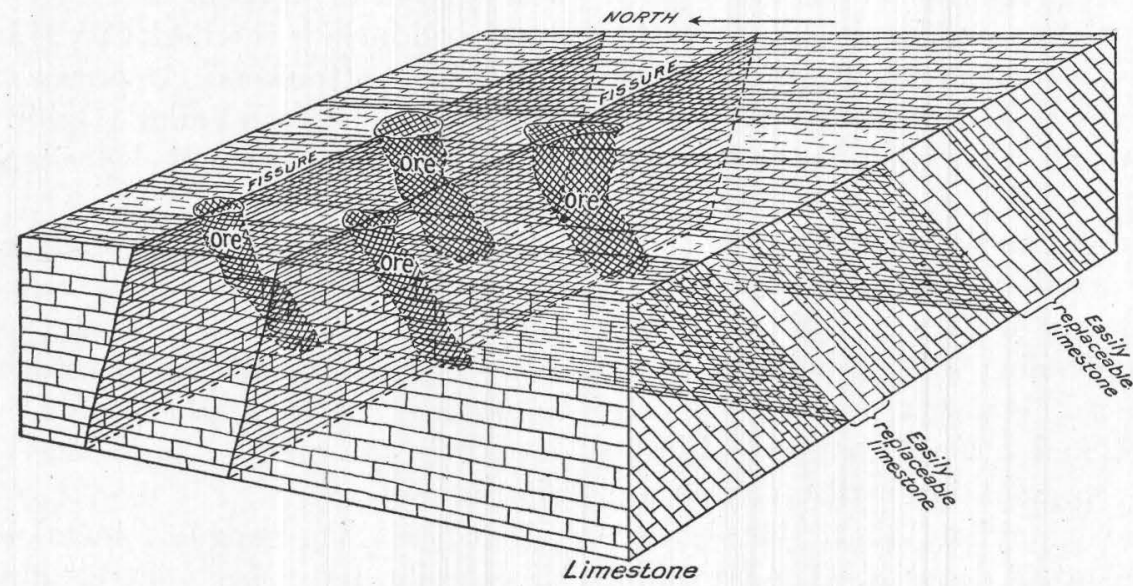

FIGURE 30.-Diagram illustrating selective replacement of certain beds of limestone adjacent to fissures.

that favor ore deposition, as is shown by several deposits in the Cottonwood area.

It has long been recognized that fissures passing through shales become "tight" and relatively impervious, and that in many places solutions rising along them spread out beneath the shales and deposit their metal content. Localization of deposits due to this cause have been noted in the Star district and elsewhere.

Dikes and sills of igneous rock have in some places apparently exerted a similar influence. Such appears to have been the case in the Fish Springs district, probably in the Lion Hill section of the Ophir district, and possibly to some extent in the Mercur district.

Many prospectors consider the contact of quartzite with limestone or some other rock to be especially favorable to ore deposition, and some of them have expended much effort and money in exploring such contacts, but the results have frequently been disappointing. may find access to it; and some important ore bodies, such as those along the thrust contacts of limestone and quartzite in the Little Cottonwood district, have been formed in this way. Quartzite contacts, then, should not be explored on the blind assumption that they are somehow favorable; but they may sometimes repay judicious exploration guided by knowledge of the physical and chemical factors that favor the deposition of ore.

CLASSIFICATION BY METALS.

Deposits in the sedimentary rocks associated with fissures, like deposits in the igneous rocks, can be grouped according to the metals for which they are chiefly valuable. As in the igneous rocks, these groups usually grade into each other, so that, though most deposits are valuable for one metal or group of metals, others are intermediate and contain important amounts of several. 
Copper deposits.-Copper deposits of this type have been most extensively developed in the Bingham district, though they are present in other districts, notably in the Lucin and less notably in the Star district, and may be considered to include some of the deposits of the Tintic district, which commonly have their greatest values in precious metals rather than in copper.

Most of the deposits have formed very largely as a replacement of limestone, though a few of them occupy fissures. An exception is found in the mines of the Ohio Copper Co., at Bingham, where the ores occur along fissures in quartzite. The great majority of the deposits in the sedimentary rock, however, are replacements of limestone, as, for instance, in the Highland Boy, Commercial, Boston Consolidated, and Yampa, and in certain sections of the Old Jordan and other mines in the Bingham district.

The mineralogy of the primary ores shows considerable variation in different districts and even in the same district. In the Bingham district the prevailing gangue mineral, aside from unreplaced country rock, is quartz, though garnet and other "contact" silicates are commonly present in small amounts and locally are so abundant that the deposits resemble true contact deposits. The prevailing primary metallic minerals are pyrite and chalcopyrite, though locally hematite is abundant, as in parts of the Highland Boy mine, and other sulphides are present in small amount. Oxidation processes have been an important factor in the enrichment of the upper parts of most of the Bingham deposits.

The copper deposits of the Star district, though similar in character to those of the Bingham district, are of relatively slight importance. Some of the deposits in the Beaver County region resemble and grade into contact deposits.

The principal deposits of the Lucin district are entirely oxidized so far as developed, and the primary mineralization can only be inferred. The abundance of limonite suggests that iron sulphide was an important primary mineral, and it is probable that the copper was mainly present as chalcopyrite.

The deposits of the Tintic district, in which copper is an important constituent, differ somewhat from those in the other districts in that the precious metals are more important and the primary copper mineral is enargite. Fine-grained quartz and barite are the common gangue minerals, but garnet and allied deep-vein silicates are absent.

Lead-silver deposits.-Lead-silver deposits in sedimentary rocks have so far been the most productive type in the State. They furnished most of the "bonanzas" of the early days of mining, and they have yielded steadily and largely ever since. They are altogether lacking in but few of the districts in the State where limestones have been intruded by granitic stocks, but they are most important in the zone extending from Park City to the Oquirrh Range and in the Tintic Range. Districts in which large deposits of this type have been developed include the Park City, Little Cottonwood, Big Cottonwood, American Fork, Bingham, Stockton (Rush Valley), Ophir, Tintic, and Star districts, and small deposits are present in many other districts.

The occurrence of the lead-silver deposits is in general similar to that of the copper deposits, into which they grade. Most typically they occur as replacements in limestones adjacent to fissures, but they also occupy fissure veins, notably in the great Ontario lode of the Park City district.

The prevailing gangue mineral is quartz in all deposits, but other minerals are important in certain districts, as barite in the Tintic district, muscovite (sericite) in the Park City, Little Cottonwood, Bingham, Marysville, and other districts, and orthoclase in some of the replacement deposits of the Ophir district. In the Star district and in the Mineral Range some of the deposits contain rather abundant garnet and diopside and show transition to the contact type. In the primary ores lead is commonly present as galena, usually argentiferous, and silver is present to some extent in other sulphides. Pyrite is rather abundant, and sphalerite ranges from very little to as much or more than galena. Copper is commonly present in small amounts-as tetrahedrite in the Park City and Cottonwood districts, as enargite in the Tintic district, or as chalcopyrite in the Star, Bingham, and other districts. Other metallic minerals are present in small amount. The ores usually contain relatively little copper or gold, but in the aggregate they yield a considerable quantity of both these metals. 
Most of the deposits are extensively oxidized, and in several districts the development of the primary ores is slight; in others, however, notably the Park City and Bingham districts, the production from these ores has been large.

Zinc-silver-lead deposits.-In several districts the original deposits contain, in addition to lead and silver, valuable amounts of zinc in the form of sphalerite; in other localities important bodies of zinc ore have been segregated during the process of oxidation. (See p. 211.)

Primary ores containing commercial amounts of zinc have been developed in the Park City and Bingham districts, and to a lesser extent in the Ophir, Stockton, and Star districts; and oxidized zinc ores have been mined in the Tintic, North Tintic, Ophir, and Star districts. The occurrence of the original ores is in every way similar to that of the leadsilver ores, and there is every gradation from ores containing little sphalerite to those from which zinc is commercially recoverable.

Sitver deposits.-In some deposits the silver content is so large that the ores are essentially silver ores, although all of them contain some lead, zinc, and copper and usually a little antimony and arsenic. Important deposits of this type occur in the Lion Hill section of the Ophir district and lesser deposits in the Marysvale region in the Star, Silver Islet, and other districts. Some of the rich silver ores from the Ontario mine of the Park City district may be assigned to this type. The general occurrence and character of these deposits differs in no wise from the lead-silver deposits except in the relative proportion of the different metals.

Gold deposits.-Although gold in small amount is present in practically all of the deposits in the sedimentary rocks associated with intrusive rocks, deposits in which gold is the principal valuable constituent are rare. The only deposits of this type that have yielded a large amount of gold are those of the Mercur and adjoining Sunshine and West Dip districts. Deposits in which gold is the most valuable constituent are present in the Deertrail mine in the Marysvale district. Some gold ores also occur in the Tintic district, where the gold forms microscopic and occasionally megascopic grains in chalcedonic quartz.

The gold deposits in the Mercur and adjacent districts have been described (see p. 392), $35416^{\circ}-19-12$ and it is here only necessary to state that the ore occurs in the sediments adjacent to fissures. Both limestone and shale have been converted to ore, though the shale appears to have been more favorable than the limestone to the deposition of the gold.

In the alteration of the rocks, and especially of the limestone, adjacent to gold veins there has been a notable addition of silica, and the abundance of potassium in some of the ores suggests that it also has been added in important amounts. Barium has been added to the form of barite. The principal metallic minerals are pyrite, realgar, and cinnabar in small though locally important amounts. In the Deertrail deposit there have been large additions of silica, alumina, and potassium. Certain strata of limestone have been replaced over considerable areas by muscovite and quartz. Pyrite and galena rich in silver are also present.

Quicksilver deposits.-Deposits of quicksilver in the sedimentary rocks have been developed in but two districts, in neither of which they have been of large commercial importance.

In the Mercur district a small amount of cinnabar occurs in the gold ores, and in certain shoots in the Sacramento mine it was sufficiently abundant to permit its commercial extraction. The general occurrence of the ore is similar to that of the other ores.

In the Marysvale district a small body of quicksilver ore, developed in the Lucky Boy mine near the Deertrail mine, occurs as a replacement of limestone adjacent to fissures. The chief gangue mineral aside from the limestone is barite, and the metallic minerals are tiemannite and onofrite. Quicksilver is also said to be present in small amount in the Deertrail mine.

GENESIS OF THE DEPOSITS.

The mineralogic similarity of deposits in sedimentary rocks associated with fissures to typical contact deposits and the gradations of the one into the other are especially striking in certain deposits in the San Francisco and Star districts and, in the Mineral Range but are present in the Bingham, Tintic, Clifton, Little Cottonwood, and other districts. Some of the mineralogic gradations between typical contact deposits and typical hydrothermal replace- 
ment deposits are so complete that there can be no doubt of the common origin of the two types, and it seems reasonable and natural to assign a similar origin to others where the gradation is less complete or absent, provided there is no evidence opposed to such an explanation.

The general composition of the mineralizing solutions, so far as can be judged from the minerals they have formed, leads to the same conclusion. In the contact alteration of the limestones there were large additions of silica, alumina, and iron, in addition to sulphur and metallic elements, and the same elements were added to the deposits associated with fissures.

In all the deposits of this type silica was added in large amount. In many of these deposits a considerable quantity of alumina was added as sericite, as is well shown in the ores of the Deertrail mine and in those of the Park City and Little Cottonwood and to a less extent in those of other districts. Abundant alumina must have been added in the formation of the Copper Mountain deposits of the Lucin district and in the replacement of the limestone by feldspar and epidote in some of the deposits of the Ophir district. That potassium was a constituent of the solution producing the mineralization is indicated by the presence of sericite in most deposits and of feldspar in some deposits, as those of Ophir Hill. In all the deposits iron, in the form of sulphide and more rarely as oxide, is abundant, indicating that the solutions were rich in iron and that other metallic constituents were present in various amounts.

It is evident, therefore, that the mineral composition, the character of solutions, and the geologic relations all offer the strongest evidence that the contact deposits and the replacement deposits in the sediments adjacent to fissures were of common origin.

Differences in deposits in a given district are believed to be due in large part to the different physical conditions under which they were formed. Differences in deposits in more widely separated areas may be due to differences in the original character of the solutions.

It is evident that when an area of sedimentary rocks is intruded by igneous material there is a progressive change in physical conditions from the contact outward, and it is to be expected that these differences will be recorded in the changes produced in the rocks. These changes are probably due in greater part to the agency of solutions that are expelled from the magma in the form of hot gases under high pressure. The gaseous solutions thoroughly permeate the rocks for only a short distance from the contact, but they penetrate much farther along fissures and other avenues of easy passage. Wherever they penetrate without losing their high temperature they react with the constituents of the sedimentary rocks to form characteristic contact minerals, such as garnet, diopside, tremolite, tourmaline, and other silicates, magnetite, hematite, copper, and iron sulphides, and other metallic minerals in lesser amount. Commonly, copper and iron are the metals most abundantly deposited.

At greater and greater distances from the intrusive mass the temperature and pressure decraase more and more, the solutions condense to the liquid form, and the alteration in the adjacent rocks changes accordingly. Silicification and in some places sericitization takes place instead of the formation of "contact" silicates; lead, zinc, silver, arsenic, and antimony minerals are more abundantly deposited, and the deposition of copper materially decreases.

In the Tintic district Lindgren ${ }^{1}$ finds that the limestone has been replaced by fine-grained quartz that he regards as having been originally deposited largely as gelatinous silica. The veins in the intrusize rocks also indicate formation at moderate to rather low temperatures. The similarity in composition of the veins in the monzonite and the deposits in the sediments and the actual tracing of one vein across the contact point to a common origin for the solutions. The deposits also show, with distance from the intrusive rocks, a progressive change from those containing considerable copper and gold to those having their chief value in lead and silver. At still greater distances the quartz-barite gangue gives place to carbonates and the silver content of primary ore tends to decrease.

It is apparent that as a solution moves outward, depositing some of its constituents and taking up others, it must constan tly change in composition, and this, as well as the changing physical conditions, must influence the charac-

1 Lindgren, Waldemar, Processes of mineralization and enrichment in the Tintic district: Econ. Geology, vol. 10, pp. 225-240, 1915. 
ter of the deposits at different distances. It is also evident that as a region gradually loses its heat the temperature at a given place will decrease, and deposits formed at lower temperature will be superimposed on those previously formed at higher temperature. For further discussion see page 184 .

\section{DEPOSITS IN EXTRUSIVE ROCKS.}

DISTRIBUTION AND CHARACTER.

Deposits in extrusive rocks are of less importance in Utah than in the neighboring States of Nevada and Colorado and are of much less importance than the deposits in the intrusive or sedimentary rocks of Utah itself. They occur in lavas of rhyolitic, latitic, or dacitic composition. They have been found much more frequently in rather massive flows than in tuffaceous rocks, a fact that may be due to the more ready fracturing of the flows. The most extensive deposits of the type are in the southern zone of mineralization, notably in the San Francisco, Gold Springs, and State Line districts, and in the districts of the Tushar Range. Such deposits are also present in the Tintic district but have not been shown to be of commercial importance there.

The deposits commonly have their greatest value in the precious metals, though they have yielded notable amounts of lead, copper, and zinc. The base metals are especially abundant in the deposits of the San Francisco district but are important in some of the deposits of the Tushar Range also.

CLASSIFICATION BY METALS.

On the basis of metal content deposits in extrusive rocks may be subdivided into silverlead-zinc-copper deposits, gold-silver deposits, and alunite deposits, though some of them, notably those in the Tushar Range, grade from those containing the base metals in abundance to those in which the precious metals are the more valuable.

SILVER-LEAD-ZINC-COPPER DEPOSITS.

Deposits in which lead, zinc, and copper are important have been most productive in the San Francisco district, where the Horn Silver mine has yielded them in large quantity, and the Beaver Carbonate mine has yielded lead, zinc, and copper. Silver is a very important constituent in both of these deposits but gold is very sparingly present. In the
Tushar Range numerous mines contain lead, zinc, and copper, though none has produced them in important amounts.

The ore and gangue minerals and altered wall rock adjacent to the veins show considerable differences in different deposits. In the Horn Silver deposit the principal primary metallic minerals are pyrite, galena, sphalerite, chalcopyrite, and possibly other copper minerals, jamesonite or some closely allied antimony mineral, and some undetermined arsenic mineral. The gangue minerals are mainly cherty quartz, barite, and the minerals composing the altered wall rock. In the Beaver Carbonate mine arsenic and antimony minerals and barite have not been recognized and calcite is a gangue mineral. In the Tushar Range tetrahedrite is commonly the principal copper mineral in deposits that contain important amounts of the base metals. Carbonate, commonly containing iron and manganese, is abundant, and barite is present in small amount.

In the Horn. Silver deposit the wall rock is intensely silicified. In the early stages of the alteration sericitization is the characteristic change, but there is a progressive removal of all the original constituents except silica and probably iron till the more intensely altered rock consists principally of cherty quartz containing crystals of pyrite. In the Beaver Carbonate deposit the alteration has been less intense, sericite, kaolin, chlorite, calcite, and probably some secondary orthoclase having been formed. The mineralogic changes have been more extensive than the chemical, for none of the original constituents, except possibly sodium, has been notably removed. In the Tushar Range the characteristic alterations are sericitization and silicification.

Important deposits of base metals are not abundant in the Tertiary lavas. ${ }^{1}$. Those of the San Juan region, Colo., are the most important in the United States and exhibit many similarities to the deposits in Utah.

\section{GOLD-SILVER DEPOSITS.}

Deposits in which gold and silver are the chief valuable metals have been most extensively developed in the Tushar Range and along the Utah-Nevada line, the State line, Gold Springs, and Fay districts.

1 Lindgren, Waldemar, Mineral deposits, p. 496, 1913. 
Typically the deposits are fissure fillings, | in places absent and in places as abundant as many of which have a distinct crustified the quartz. The quartz is fine grained and structure. Some show a well-defined wall and much of it is chalcedonic. The feldspar is presome have the vein matter "frozen" to the dominantly potassic but in places contains conwall. In neither does the wall rock adjacent siderable soda, as in the Jennie vein in the Gold to the veins contain more than small amounts of the precious metals and rarely, if ever, is it of commercial value.

Some veins, as those in the districts on the Utah-Nevada line, are very persistent along the strike, outcrops having been traced with considerable certainty for 2 or 3 miles. Other veins, as some of those in the Tushar Range, are very short. In vertical extent also they appear to show a similar variation. Some veins that have been explored to a depth of several hundred feet show no notable change in width, but others change in less than 100 feet below the outcrop into small stringers in a zone of altered rock. Within the State few developments on this type of deposit have been carried below 400 or 500 feet, so that general statements concerning their behavior in depth are not warranted.

The vein fillings of the different deposits resemble each other and also those of corresponding deposits in adjacent States. Typically they consist of fine-grained quartz, calcite, and orthoclase (adularia), with some barite, fluorite, and other minerals. In different veins or in different parts of the same vein any one of these minerals may predominate.

The earliest minerals to form were carbonates, and in some veins of the Tushar Range barite. The carbonates vary in composition from those that are essentially calcite to those containing abundant iron and manganese, these metals being especially notable in veins near Modena, at the Escalante mine, and at the Dalton vein in the Tushar Range. The carbonate has in many places been partly or wholly replaced by quartz or by quartz and adularia. (See Pl. XVIII.) The forms and structures of the earlier minerals were preserved in many places as pseudomorphs, giving the ore a peculiar and characteristic lamellar or hackly structure.

The minerals present in these replacements differ markedly. Much of the carbonate has been so completely replaced that its earlier presence can only be recognized by the forms preserved. Quartz is everywhere abundant where the carbonate is replaced; adularia is Springs district, where it contains about 20 per cent of the albite molecule. Fluorite has been noted from numerous localities but is important in few of them.

In metallic constituents the veins range from those in which the base metals are nearly absent to those in which they are relatively abundant. Pyrite is nearly everywhere present and is locally rather abundant. Lead and zinc are relatively abundant and arsenic and nickel are present in small amounts in the Escalante vein. Copper and antimony in the form of tetrahedrite are present in considerable quantity in some of the veins of the Tushar Range. Mercury has been recognized in the veins of the Gold Springs-State Line area and may be present at other localities.

The only primary gold-silver mineral noted by the writer is a silvery-white mineral carrying selenium and tellurium and containing fissures filled with pale gold that has probably resulted from its alteration. Sulphide of silver is reported from the Annie Laurie mine. The greater part of the gold occurs as free gold and much of the silver thus far extracted has been the chloride, cerargyrite. Possibly the gold as well as the cerargyrite is secondary in origin.

The veins differ greatly in their gold and silver content. Some are essentially gold veins, others essentially silver veins, and still others contain gold and silver in all proportions. Sharply contrasting veins occur in the same district. The causes of these differences are unknown.

The metallic constituents are segregated in the veins in irregular shoots, many of which constitute only a small part of the vein and are with difficulty found and followed. This has prevented the profitable exploitation of some veins that are known to be ore bearing.

The minerals formed in the wall rock differ greatly in different localities. In the Gold Springs and State Line districts the extensive alteration consists chiefly in the replacement of the country rock by a fine-grained mixture of quartz and orthoclase which constitutes a resistant rock that causes the veins to outcrop prominently. (See Pl. XIX.) To a lesser 


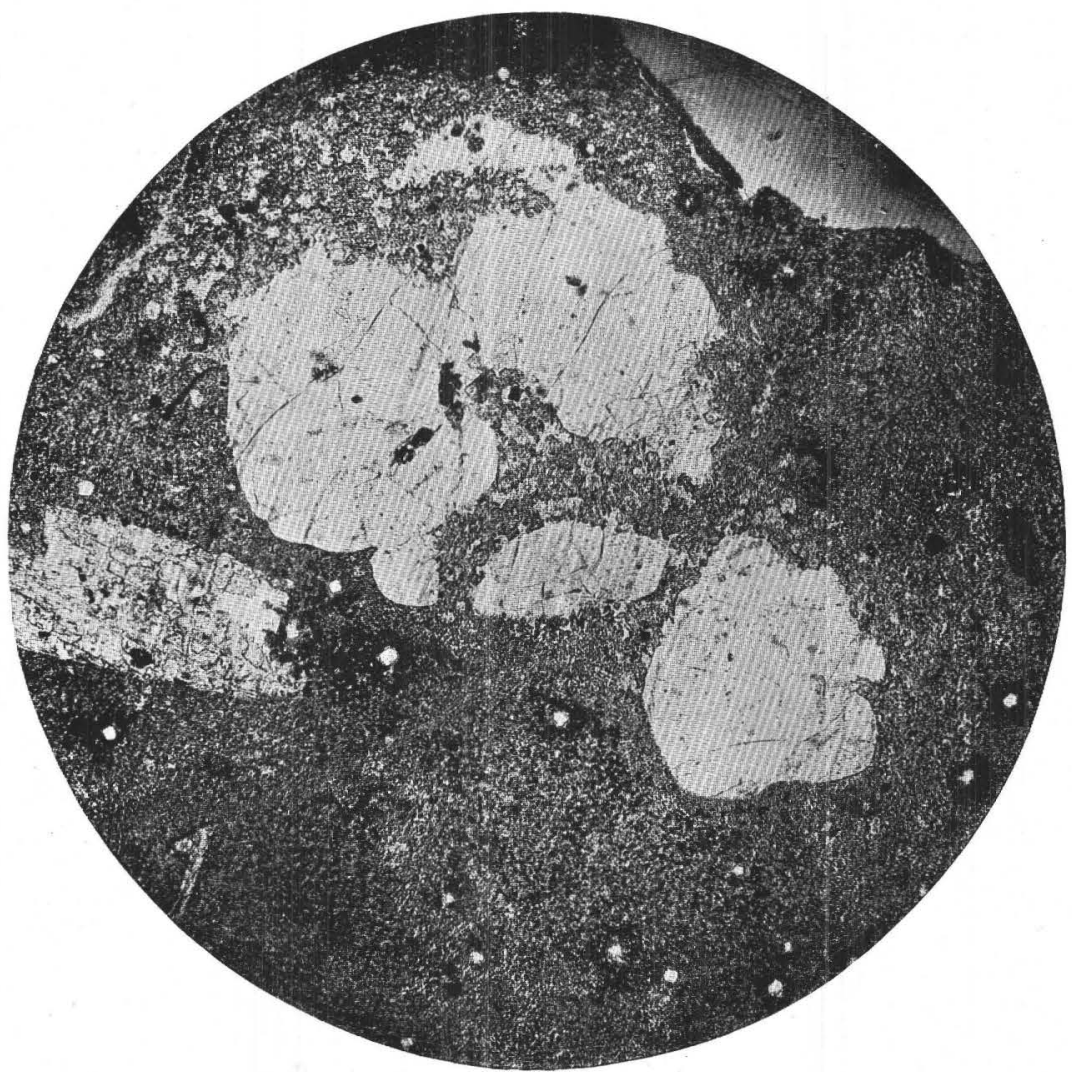

A. PHOTOMICROGRAPH OF SPECIMEN SHOWING ALTERATION OF WALL ROCK ADJACENT TO GOLD VEINS IN GOLD SPRINGS DISTRICT.

Quartz and feldspar crystals partly replaced by quartz and adularia. Enlarged 30 diameters.

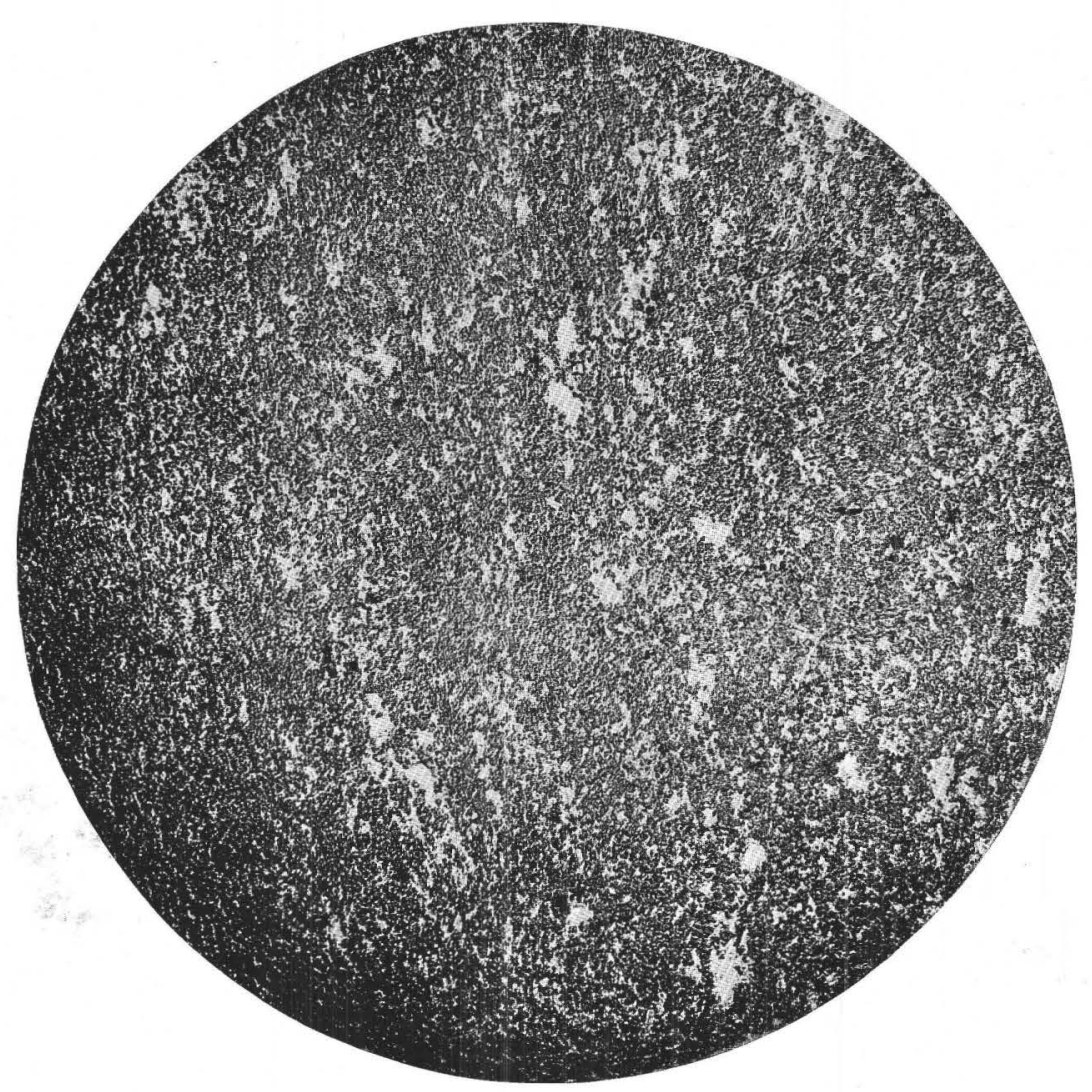

B. PHOTOMICROGRAPH OF SPECIMEN OF HIGHLY ALTERED WALL ROCK ADJACENT TO VEINS FROM GOLD SPRINGS DISTRICT.

Dark areas, adularia; light areas, quartz. Enlarged 30 diameters. 


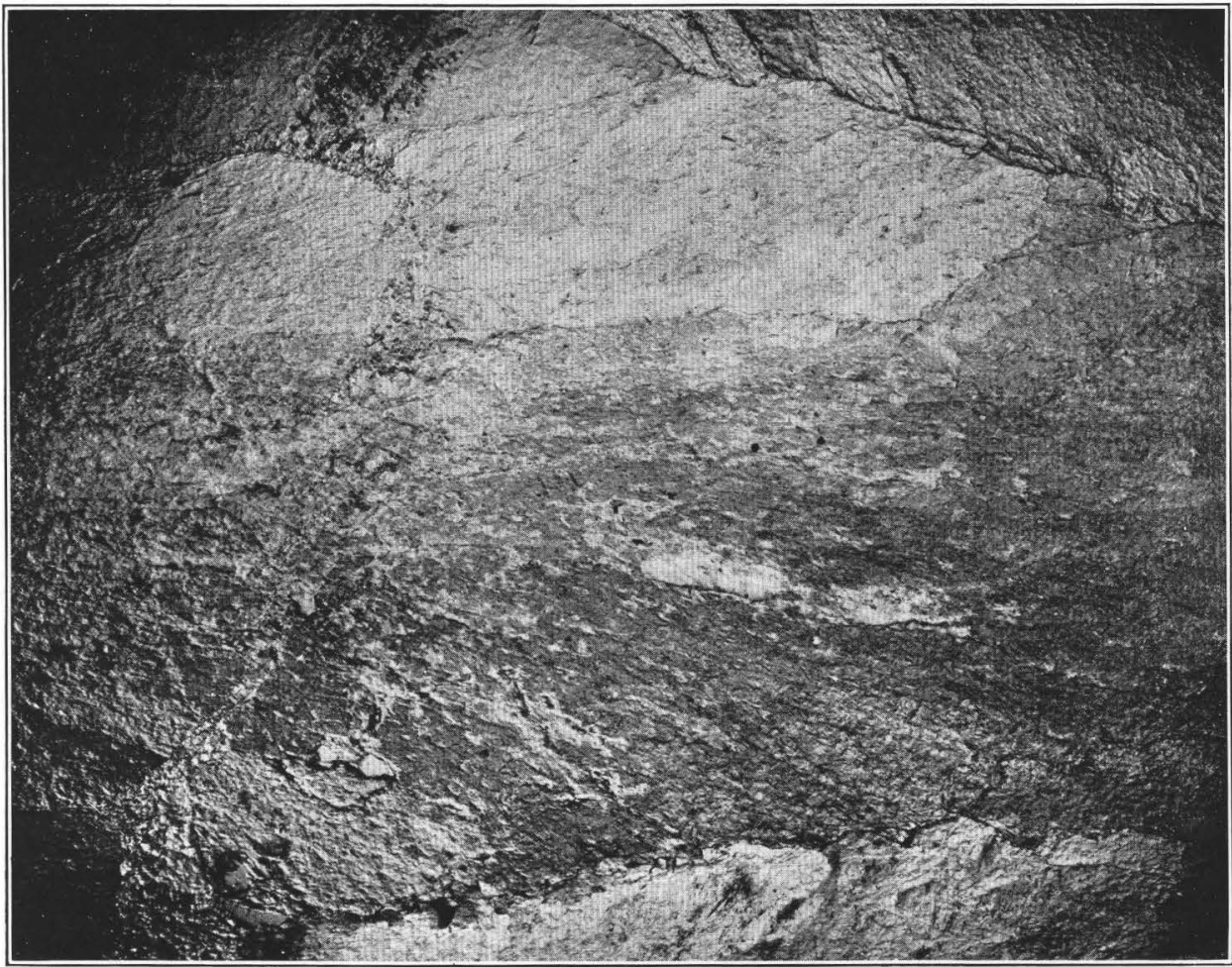

A. PHOTOMICROGRAPH OF SPECIMEN OF ALUNITE FROM TUSHAR RANGE, SHOWING PLUMOSE CHARACTER OF CRYSTALS.

Enlarged 25 diameters.

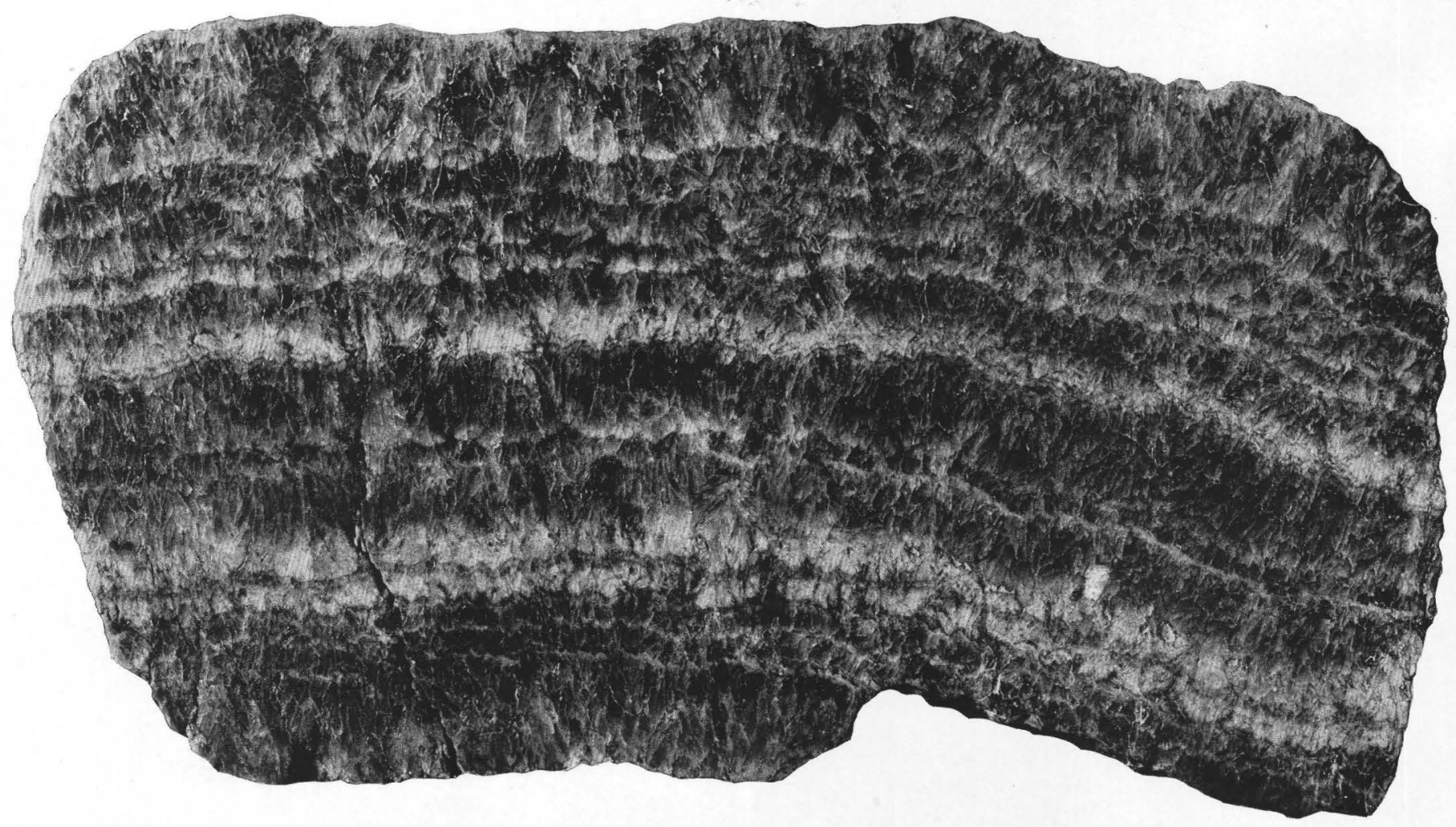

$B$. SPECIMEN OF ALUNITE FROM TUSHAR RANGE, SHOWING BANDED STRUCTURE OF VEINS. 
extent there has been sericitization and, where alteration is slight, chloritization of the dark silicates. In the Tushar Range the prevailing metasomatic alteration has been of the latter character.

No chemical analyses are available that show the quantitative changes that took place in the alteration, but there was evidently removal of soda, lime, and magnesia, and notable additions of potassium. The mineralogic alteration was much greater than the chemical.

Gold and silver deposits of this type in Utah have not yielded large returns. The Annie Laurie mine was an important producer for several years, and numerous other mines have produced a little ore, but developments so far do not give reason for expecting large production. However, the districts in which the deposits occur have not been extensively prospected and valuable deposits may yet be found. Probably also improvements in metallurgy will make it possible to treat some partly developed ores of too low grade to be profitably handled at present. Similar deposits are abundant in other Western States and have yielded large amounts of gold and silver. Like the Utah deposits they differ greatly in their relative content of gold and silver. They include the Comstock, Tonopah, Rawhide, and Bullfrog districts in Nevada ${ }^{1}$ and many others.

ALUNITE VEINS.

Veins composed essentially of the mineral alunite and having value for their potassium and possibly for their aluminum content have been worked in the Tushar Range.

The deposits are distinctly banded or crustified (see Pl. XX) and have apparently been formed for the most part as a filling of open fissures. The vein material, which is essentially pure alunite, varies in texture from rather coarsely crystalline to fine and porcelain-like, and in many places has a slightly schistose structure, probably due to movements along the vein.

Some of the wall rock has been highly altered for scores of feet from the main vein, usually to a rock composed essentially of quartz, alunite, and pyrite. (See Pl. XXI.) The alunite has replaced feldspar and other aluminous minerals, and the silica, freed by the breaking up of the silicates, has crystallized

${ }^{1}$ Lindgren. Waldemar, Mineral deposits, pp. 475-512, 1913. as fine-grained quartz. The iron of the dark silicates, in large part at least, has combined with sulphur to form pyrite.

No chemical analyses are available to show the quantitative changes, but mineralogic study discloses that essentially all the soda, calcium, and magnesium were removed and that large amounts of sulphur and water were added. The changes in silica, alumina, and potassium are not so readily determined. The potassium in the original rock seems sufficient to form the alunite in the altered rock and some of it may have been removed. In the absence of chemical analyses it is uncertain to what extent the alumina and the silica have been changed. (See also p. 184.)

RELATIONS OF DIFFERENT TYPES OF VEINS TO ONE ANOTHER AND TO OTHER TYPES.

The close genetic relation between the goldsilver veins and those containing important amounts of base metals (see p.179) is perhaps best shown in the Tushar Range, where there is practically every graduation from veins containing but small amounts of the base metals to those in which tetrahedrite is rather plentiful, and from these in turn to veins containing abundant tetrahedrite, sphalerite, and galena. The same conditions exist, in lesser degree, in the zone extending from the State Line district southward through Gold Springs and Modena to the Escalante mine. In the San Francisco district the gold-silver veins are not represented, but the lead-silver-zinc-copper veins show so many similarities to those in the Tushar Range that there can be little doubt that they belong in the same type. It seems reasonable to conclude then that the precious metal and base metal veins are members of a continuous series.

The alunite veins, so far as known, are present only in the Tushar Range, where their relationship to the other veins of the district is indicated by their presence in the main mineralized zone, by their general conformity in strike with the metal-bearing veins, and by their composition. The metal-bearing veins are notably rich in potash and aluminum and in this respect resemble the alunite veins. The notable difference of the two lies in the absence, so far as known, of the common metals of the district from the alunite veins and in the presence in them of abundant sulphate, which appears in the other veins in 
relatively small amount as barium sulphate (barite).

Alunite deposits have been found only in the Tushar Range, where erosion since the deposits were formed has been relatively slight, and are absent from districts like the San Francisco, where erosion has been relatively great, deeply exposing the intrusive bodies beneath the lavas. It seems not improbable that alunite formed only near the surface and has been preserved only where erosion has been exceptionally slight. This interpretation seems to agree with occurrences in the San Juan region of Colorado. ${ }^{1}$

In the Tushar Range the deposits in the volcanic rocks may be attributed to a common origin with deposits in the sedimentary rocks (p. 552), and those in the sedimentary rocks in turn show a genetic relation to those in the intrusive rocks. The same holds true in the San Francisco district. In the Gold SpringsState Line district no intrusive or sedimentary rocks have been recognized, but it seems reasonable to attribute the deposits in the volcanic rocks to a similar origin.

It has already been pointed out that the deposits in the intrusive and sedimentary rocks were derived (see p.177) from materials differentiated from crystallizing igneous material. In the volcanic rocks the differentiates have risen along well-defined fissures from deep-seated sources, probably from bodies of intrusive quartz monzonite, which in the Tushar and San Francisco ranges have been partly exposed by erosion.

It is evident that a notable change took place in the character of the solutions during the formation of the deposits in the volcanic rocks and during the passing of the solutions from their deep-seated source toward the surface.

The earliest solutions deposited abundant carbonates and some sulphate (barite). They were followed by solutions that deposited abundant quartiz and feldspar and some metallic minerals that replaced the earlier carbonates. The alunite veins were apparently deposited near the surface, and it is not certain whether they were formed later than the quartz-

1 Cross, Whitman, Geology of Silver Cliff and Rosita Hills, Colo. U. S. Geol. Survey Seventeenth Ann. Rept., pt. 2, pp. 263-403, 1906. Cross, Whitman, and Spencer, A. C., Geology of Rico Mountains, Colo.: U. S. Geol. Survey Twenty-first Ann. Rept., pt. 2, pp. 92-94, 1900 Larsen, E. S., Alunite in the San Cristobal quadrangle, Colo.: U. S. Geol. Survey Bull. 530, pp. 179-183, 1913. adularia veins, after the solutions had further changed in character, or were deposited from solutions which had become relatively rich in sulphates by the removal of the carbonates, silicates, and sulphides or from solutions containing abundant hydrogen sulphide that had been oxidized near the surface by admixture with descending solutions.

The origin of the potassium and aluminum of the alunite is also uncertain. The goldsilver veins are rich in both, and in some places, especially in the Gold Springs-State Line district, they have been added to the wall rock, which would suggest that these constituents were derived from deep-seated sources. On the other hand, some of the deeper-seated deposits in the lavas, as in the Horn Silver mine, and some of the deposits in the associated intrusive rocks, as in the Antelope Mountains northeast of Marysvale, show a pronounced leaching of aluminum and potassium from adjacent rock, together with most of the other elements with the exception of silica. This suggests that potassium and aluminum, together with other elements, may have been leached from the deeper zone and redeposited near the surface where conditions of solution were less favorable. The alteration of the wall rocks indicates that, with the exception of silica, aluminum and potassium were the last elements to be removed in the zone of leaching, and it seems reasonable to suppose that they would be among the earliest to be deposited (following quartz). It might be supposed then that much of the vein material was leached from the rocks adjacent to the veins at lower horizons and redeposited as it rose toward the surface, the quartz or the quartz and feldspar being deposited before the alunite and the more soluble materials deposited nearer the surface, where they have since been eroded, or carried out on the surface in thermal springs.

That sulphates become relatively abundant in the later stages of ore deposition is indicated at numerous localities, especially in the Cactus deposit, where anhydrite was abundantly deposited during the later stages of deposition. Barite is abundant in the Tintic deposits, which were formed under relatively shallow conditions and from which small amounts of alunite are reported. Barite is also an abundant gangue in the Horn Silver deposit, and occurs in deposits in the volcanic rocks in the 


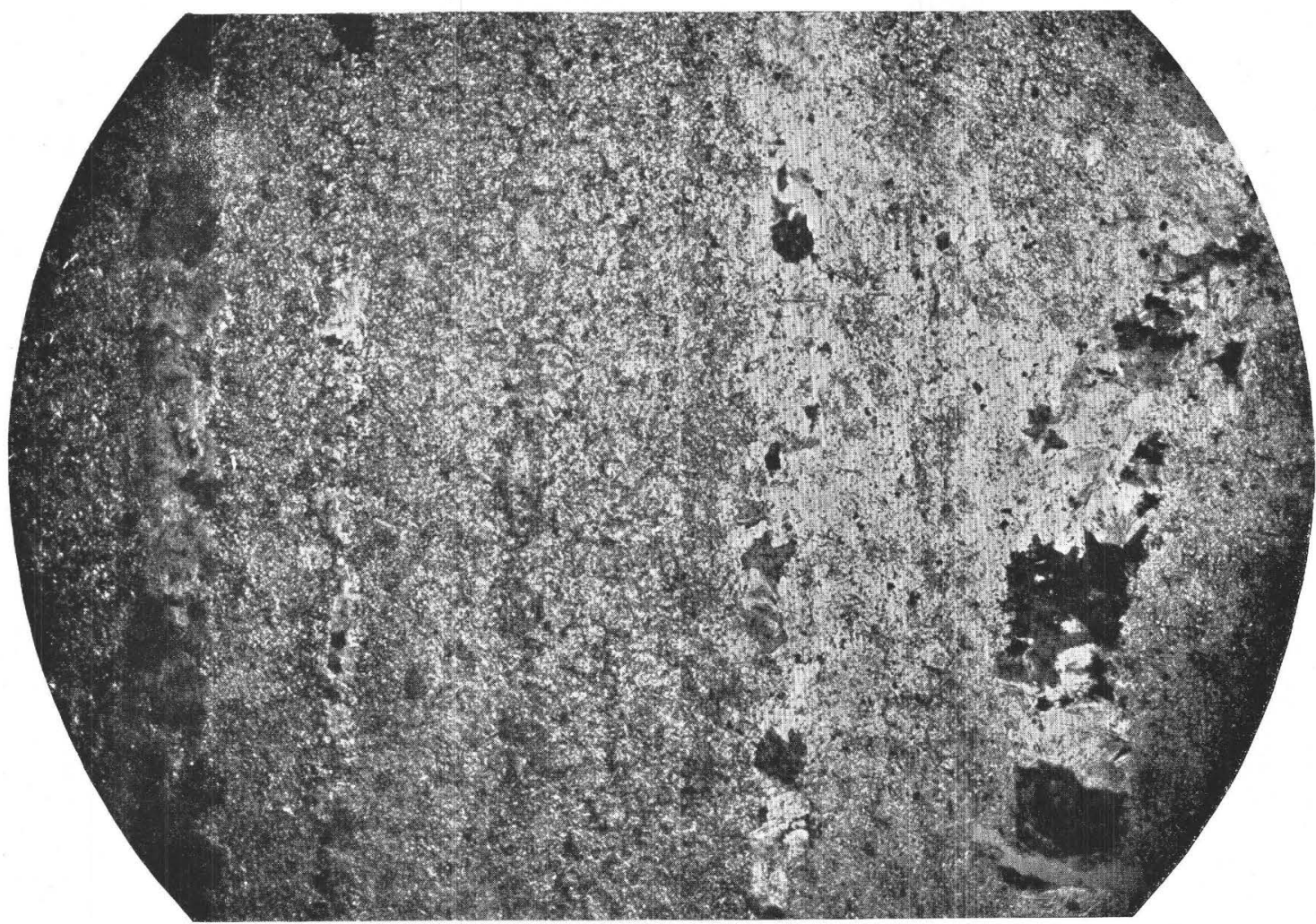

A. PHOTOMICROGRAPH OF A SPECIMEN OF ROCK FROM SHEEP ROCK, ON THE WEST SIDE OF TUSHAR RANGE, SHOWING BANDING OF ALUNITE AND QUARTZ.

Enlarged 30 diameters.

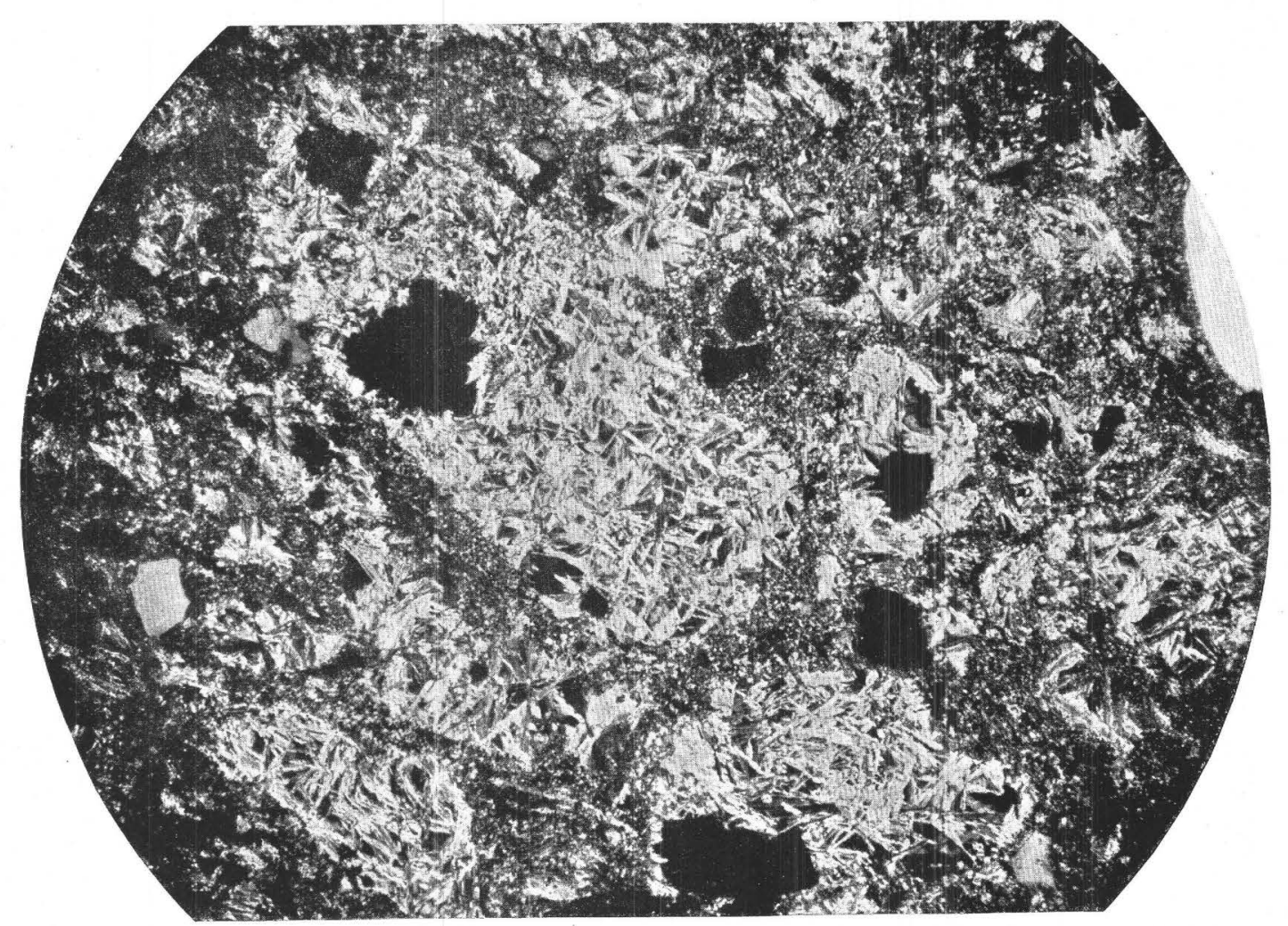

$B$. PHOTOMICROGRAPH OF SPECIMEN SHOWING WALL ROGK OF ALUNITE VEIN ALTERED TO ALUNITE, MARYSVALE DISTRICT.

Dark areas, pyrite; lath-shaped crystals, alunite; groundmass, intergrowth of alunite and quartz. Enlarged 30 diameters. 

Tushar Range, where, however, it has been locally replaced by quartz and adularia.

The solutions that formed the ore in the Horn Silver deposit removed potassium, aluminum, and other constituents from the wall rock (p. 519). As the solutions passed upward they doubtless contained the sulphate radicle together with potassium, aluminum, and waterall the constituents of alunite - and it seems entirely possible that at some higher horizon, now removed, alunite deposits similar to those of the Tushar Range may have been formed.

A mineral occurrence of especial interest in this connection is that of hinsdalite, similar in character to alunite $\left(2 \mathrm{PbO} \cdot 3 \mathrm{Al}_{2} \mathrm{O}_{3} \cdot 2 \mathrm{SO}_{3} \cdot \mathrm{P}_{2} \mathrm{O}_{5}\right.$. $6 \mathrm{H}_{2} \mathrm{O}$ ), which occurs in the Golden Fleece mine, ${ }^{1}$ near Lake City, Hinsdale County, Colo. It occurs as an original vein mineral with quartz, barite, pyrite, galena, tetrahedrite, and rhodochrosite in a vein cutting a series of volcanic rocks. Its general occurrence is in many respects similar to that of alunite in the deposits in the volcanic rocks of Utah. Larsen ${ }^{2}$ has suggested a possible relation between the hinsdalite in the Golden Fleece mine and the alunite of the neighboring deposits, and considers it as most readily explained as formed by "deep-seated hot sulphuric acid solutions without the aid of surface agents." For further discussion see page 84 .

COMPARISON OF DIFFERENT TYPES OF DEPOSITS ASSOCIATED WITH IGNEOUS ROCKS.

GENERAI FEATURES.

If, as seems probable, most of the ore deposits of western Utah associated with igneous rocks were deposited from solutions migrating upward and outward from differentiating magmatic material into zones of successively lower temperature and pressure, then even those in the different types of rock should show certain similarities corresponding to similar conditions of temperature and pressure.

Such similarities might be expected, for instance, between deposits in the sedimentary rocks and those in the extrusive rocks. The zone of highest temperature and pressure in the sedimentary rocks contains contact deposits

${ }_{1}^{1}$ Larsen, E. S., jr., and Schaller, W. T., Hinsdalite, a new mineral Am. Jour. Sci., vol. 32, pp. 251-255, 1911. Irving, J. D., and Bancroft, Howland, Geology and ore deposits near Lake City, Colo.: U. S. Geol. Survey Bull. 478, p. 54, 1911.

${ }^{2}$ Larsen, E. S., jr., Alunite in the San Cristobal quadrangle, Colo.: U. S. Geol. Survey Bull. 530, p. 182, 1913. which have copper and iron as their chief valuable metal constituents. Nowhere in the State, however, are corresponding deposits in the extrusive rocks found.

Failure to find such deposits may be attributed to one of two principal causes or a combination of the two. First, the contact deposits in the sedimentary rock were formed where the solutions passed into a chemical environment very different from the one they had been traversing and the deposits were due in large part to chemical reactions. In passing from an intrusive to an extrusive rock, on the other hand, the chemical conditions are not greatly changed and important reactions are not induced. Second, most intrusions into sedimentary rocks occurred at great depth and consequently under conditions of temperature and pressure favorable to the formation of contact deposits. Intrusions into extrusive rocks, on the other hand, occurred relatively near the surface under correspondingly unfavorable conditions for the formation of deep-seated deposits. Either individually or jointly these causes would tend to prevent the formation of deposits in extrusive rocks corresponding to the contact deposits in the sedimentary rocks.

Deposits formed in the sedimentary rocks under conditions of moderate and relatively low temperature and pressure (the replacement fissure deposits) have closely analogous types in the deposits in the extrusive rocks. The base-metal deposits in the extrusive rocks in the Horn Silver and Beaver Carbonate mines of the San Francisco district and in less important mines in the Tushar Range resemble the replacement veins in the sedimentary rocks of the Tintic, Park City, Bingham, and other districts. The similarity of the deposits of the Horn Silver mine to those of the Tintic district is especially striking, the rock in both places having been largely replaced by cherty quartz and the gangue minerals in both being finegrained quartz and barite. Again, the goldsilver veins in the extrusive rocks of the Tushar Range and Gold Springs-State Line area resemble certain deposits in the sedimentary rocks that have their greatest value in the precious metals but that contain also copper, lead, zinc, arsenic, antimony, and locally quicksilver. Such deposits are present in the Tintic district and in the Tushar Range (in the Deertrail mine) but have been most extensively 
mined in the Lion Hill section of the Ophir district and in the Mercur district. Both types of rock contain deposits in which gold predominates and other deposits in which silver predominates. In the extrusive rocks both gold deposits and silver deposits occur in the different veins of the Tushar Range and Gold SpringsState Line districts, and in the sedimentary rocks gold deposits occur in the Mercur district and silver deposits in the neighboring Lion Hill district.

In the Tushar Range (see p. 552) there appears to be a progressive change in the character of the deposits as the distance from their source increases or as more deep-seated give place to less deep-seated conditions; and in general the relative amounts of the precious metals increase as the distance from the source increases or as less deep-seated conditions are attained. A similar condition exists in the deposits in the sedimentary rock in the Oquirrh Range in passing outward from the main intrusive body in the Bingham district through the lead-zinccopper-silver-gold deposits of the Stockton and Ophir districts to the essentially silver deposits of the Lion Hill and the gold and quicksilver deposits of the Mercur and adjacent districts. It may be noted that arsenic and antimony are more abundant in deposits formed at relatively shallow depth.

In the Tintic district, however, Lindgren notes that gold is most abundant near the intrusive rocks. Silver increases with increased distance from the intrusive bodies to a maximum beyond which there is a decrease, the lead and zinc in the extreme outer zone being accompanied by relatively little silver.

No deposits that bear a close analogy to the alunite veins in the extrusive rocks have been recognized in the sedimentary rocks. However, some of the deposits in the sedimentary rocks that are believed to have formed at relatively shallow depth are, like the déposits in the extrusive rocks, rich in potassium and aluminum. This is notably true of the Deertrail deposit, of the Mercur deposits, and of some of the deposits in the Ophir district.

SIGNIFICANCE OF PRIMARY SULPHATE MINERALS IN THE GENESIS OF ORE DEPOSITS.

FORMATION OF SULPHATE MINERALS.

In studying ore deposits the writer has several times been confronted with the problem of accounting for the formation of sulphate minerals that are apparently primary. These minerals occur at places where no evidence can be found of their formation by surface oxidation. Either they were formed directly by igneous emanations or, if they were formed by surface agencies, those agencies must have affected the deposits of other associated minerals that would ordinarily be regarded as of hypogene origin. An attempt will be made to analyze this problem by starting with the belief, based on deductions from field observations, that the sulphates in certain deposits have been formed directly by igneous emanations. To avoid complications the occurrence of the minerals in deposits that are not generally regarded as associated with igneous rock is discussed only incidentally. It is recognized that nearly all the sulphates that occur as apparently primary minerals in ore deposits associated with igneous rocks have also been formed in places where they are not associated with igneous rocks. It is likewise recognized that in the formations of at least some of the primary sulphates in ore deposits that are associated with igneous rocks surface agencies may have played a part. The general conclusion reached is that some of the metals that at high temperature are combined with oxygen give up oxygen as the temperature is reduced, and both the metals and the oxygen tend to combine with sulphur, producing sulphides of the metals and oxides of sulphur. At suitable temperatures the sulphites and sulphates are doubtless formed and the less soluble sulphates are deposited. Moreover, it is believed that certain conditions lead to the formation of free sulphuric acid, which, on reaction with potassium-aluminum rocks, forms alunite.

SULPHATE MTNERALS.

Brief summaries of the occurrence of the principal primary sulphate minerals in igneous rocks or of the sulphate minerals that are apparently primary in veins which are believed to be associated with igneous rocks are given below. No attempt is made to include in this summary occurrence of these minerals in other relations, or to give a complete list of localities.

Haüynite and noselite.-Haüynite $\left[\left(\mathrm{Na}_{2} \mathrm{Ca}\right)_{2}\right.$ $\left.\left(\mathrm{NaSO}_{4} \mathrm{Al}\right) \mathrm{Al}_{2}\left(\mathrm{SO}_{4}\right)_{3}\right]$ and noselite $\left[\mathrm{Na}_{4}\left(\mathrm{NaSO}_{4} \mathrm{Al}\right)\right.$ $\left.\mathrm{Al}_{2}\left(\mathrm{SiO}_{4}\right)_{3}\right]$ are primary minerals in certain rather uncommon types of eruptive rocks such as those of the Cripple Creek volcano. It is 
noteworthy that these minerals are characteristic components of volcanic rocks, whereas the closely related chloride minerals are components of plutonic or deep-seated rocks. In Utah they are known in small dikes, as those in the La Sal mountain laccoliths.

Barite.-Barite $\left(\mathrm{BaSO}_{4}\right)$ is perhaps the most common primary sulphate vein mineral. It occurs usually if not invariably in deposits formed at moderate and low temperature ${ }^{1}$ or among later minerals formed in deposits that contain minerals deposited at high temperature. Barite also occurs where it is not known to be related to igneous rocks.

It is difficult to determine even approximately the temperature at which any mineral deposit was formed, but Lindgren ${ }^{2}$ has grouped the minerals in such deposits in three classesthose formed at low temperature $\left(200^{\circ} \mathrm{C}\right.$. or less, perhaps much less), at moderate temperatures $\left(175^{\circ}\right.$ to $300^{\circ} \mathrm{C}$.), and at high temperatures $\left(300^{\circ}\right.$ to $575^{\circ}$ C.). Contact deposits may have been formed at much higher temperatures, such as those of magmas, which range from $800^{\circ}$ to $1,400^{\circ} \mathrm{C}$.

Anhydrite.-Anhydrite $\left(\mathrm{CaSO}_{4}\right)$ has only recently been recognized as a primary vein mineral, and its associations indicate deposition at moderate temperature. Anhydrite has the unusual property of decreasing in solubility with increase of temperature, being but slightly soluble at $200^{\circ} \mathrm{C} .^{3}$

It might be supposed that anhydrite would form most abundantly in deposits that replace limestone, but the recorded occurrences do not justify this supposition. Probably the abundant carbon dioxide that must necessarily be present in solutions that are replacing limestone inhibits the precipitation of calcium sulphate.

Lindgren ${ }^{4}$ first observed anhydrite as a veinforming mineral in the Cactus mine, Utah, where it occurs in a vein in monzonite associated with tourmaline, hematite, pyrite, chalcopyrite, barite, and siderite. Anhydrite, barite, and siderite were among the latest minerals to form. Lindgren gave the following suggestion as to the origin of the anhydrite:

1 Emmons, W. H., A genetic classification of minerals: Econ. Geology, vol. 3, p. 618,1908 .

2 Lindgren, Waldemar, Mineral deposits: MeGraw-Hill Publishing

Co. New York, 1913.

${ }^{3}$ Melcher, A. C., Am. Chem. Soc. Jour., vol. 32, pp. 50-66, 1910

4 Lindgren, Waldemar, New occurrenoe of willemite and anhydrite:

Science, new ser., vol. 28, p. 933,2908
It is suggested as a possibility that during the later part of mineralization the anhydrite was precipitated by a reaction between ascending solutions of sodium sulphate and descending solutions containing calcium carbonate.

The writer ${ }^{5}$ accepted this interpretation, but with reservations and doubts that are among the motives which led to the preparation of this discussion.

Anhydrite occurs in the Bully Hill district, Calif., in lodes in alaskite porphyry and is associated with pyrite, chalcopyrite, sphalerite, and barite. Graton ${ }^{6}$ apparently regards it as having been deposited airectly from ascending solutions.

Boyle ${ }^{7}$ also regards the gypsum and anhydrite of the Bully Hill district as of deepseated origin, supposing that the calcium was derived from the limestone through which the solutions passed.

Anhydrite is reported from the Cobre district, Santiago, Cuba. The deposits are in andesite tuff cut by dikes of andesite. The associated minerals are pyrite, chalcopyrite, and quartz. ${ }^{8}$

Geÿer ${ }^{9}$ describes anhydrite in deposits in Sweden associated with tremolite, galena, chalcopyrite, and pyrite.

Hewett $^{10}$ and Miller and Singewald ${ }^{11}$ have described the remarkable deposits of the Minasragra vanadium mine of Peru. Hewett is quoted by Miller and Singewald as follows:

The central lens of patronite (a greenish-black mineral that is a sulphide of vanadium), coke (a dull-black vesicular hydrocarbon), and quisqueite (a black lustrous hydrocarbon) which attains a maximum thickness of nearly 30 feet, is entirely inclosed in a zone of material that is locally called veta madre, which is about 40 feet thick on both walls of the smaller lines and extends beyond its ends. Veta madre is a mixture of earthy material, disseminated sulphide of vanadium, and anhydrite, which is largely altered to gypsum on the level of tunnel No. 2, 120 feet below the surface. It represents shale that has been more or less saturated by sulphide of vanadium and replaced by anhydrite. *** It appears that after the intrusion of the dikes of igneous rocks, the "dike"-like lens

5 Butler, B. S., Geology and ore deposits of the San Francisco and adjacent districts, Utah: U. S. Geol. Survey Prof. Paper 80 p. 124, 1913. 6 Graton, L. C., The occurrence of copper in Shasta County, Calif U. S. Geol. Survey Bull. 430, p. 100, 1910.

7 Boyle, A. C., jr., Geology and ore deposits of the Bully Hill mining district, Calif.: Am. Inst. Min. Eng. Trans., vol. 48, p. 111, 1915.

8 Emerson, E. H., Geologia de las minas: Bol. de Minas, Cuba, No. 4, pp. 47-52, 1918.

${ }^{9}$ Geÿer, Per, Falutraktens berggrund ack malmfyndigheter: Geol Survey Sweden Arsbok, 1916, p. 156

.10 Hewett, D. F., Am. Inst. Min. Eng. Trans., vol. 40, pp. 274-299, 1909. in Miller, B. L., and Singewald, J. T., The mineral deposits of South America, pp. 487-491, New York, McGraw-Hill Book Co., 1919. 
of patronite, coke, and quisqueite entered a crushed zone in red shale. At the same time the shale walls were partially replaced by anhydrite and sulphide of vanadium.

Bastin ${ }^{1}$ has described primary anhydrite and gypsum in the Braden copper deposits of Chile. The rocks and ores of the district record a complicated series of igneous activities, including extrusions and intrusions and three distinct periods of mineralization. The minerals of the first period were tourmaline and relatively small amounts of pyrite and chalcopyrite. The minerals of the second period were mainly quartz, pyrite, and chalcopyrite and small amounts of black tourmaline and a little biotite. The metallic minerals of the third period include pyrite, chalcopyite, bornite, galena, sphalerite, molybdenite, tennantite, enargite, and hübnerite, and the gangue minerals siderite, rhodochrosite, calcite, anhydrite, gypsum, and barite. The mineralization of the third period is thought by Bastin to have taken place at a lower temperature than that of the earlier periods and was characterized by solution of tourmaline as contrasted with deposition of that mineral in the first two periods.

Anhydrite is also present in the copper deposits of Cuka-Dulkan at Bor, Serbia. ${ }^{2}$ It is regarded by Lazarevic, however, as secondary.

Anhydrite occurs most abundantly where it is not associated with either igneous rocks or veins.

Gypsum.-Gypsum is a common mineral in ore deposits but has doutless usually been formed by the alteration of anhydrite or by reaction between solutions of sulphuric acids (produced by the oxidation of sulphides) and calcium-bearing minerals. As already noted, Bastin considers gypsum in the Braden mine as primary.

Adolph Knopf has kindly furnished the following note on the occurrence of gypsum at the Utica mine, Calif.:

The ore on the 2,100-foot level of the Utica mine, on the Mother Lode at Angels, Calif.-a low-grade ore averaging $\$ 2$ in gold-consists of quartz and subordinate dolomite, gypsum, and, as shown under the microscope, albite. The only sulphide present is some extremely fine grained galena disseminated in small patches. The vein, which is vertical, is inclosed in amphibolite schist, and the

1 Bastin, E. S., private report based on detailed study.

2 Lazarevic, M., Enargit-covellin-lagerstätte von Cuka-Dulkan bei Bor in Ost-Serbien: Zeitschr. prakt. Geologie, vol. 20, p. 337, 1912. vein and country rock are so impervious and dry that the mine workings are dusty, although the mine above the 900 -foot level makes large quantities of water. The gypsum is intimately intergrown with the quartz, and this fact, togetber with its occurrence so far below the zone of oxidation and the obvious imperviousness of the vein to descending waters, suggests that the gypsum is a primary (hypogene) constituent of the ore. Under the microscope the gypsum is seen to be intergrown with quartz in patterns somewhat like micrographic intergrowths, and this feature possibly corroborates the evidence of its primary origin.

Celestite.-Celestite, like barite and anhydrite, occurs in deposits formed at intermediate to low temperature and also at many places where it is not associated with igneous rocks.

Alunite.-Alunite has the chemical formula $\mathrm{K}_{2} \mathrm{O} .3 \mathrm{Al}_{2} \mathrm{O}_{3} \cdot 4 \mathrm{SO}_{3} \cdot 6 \mathrm{H}_{2} \mathrm{O}$, in which $\mathrm{Na}$ may replace $\mathrm{K}$ in varying proportions. Alunite is perhaps the most abundant and widely distributed sulphate mineral that is associated with altered volcanic rocks. It occurs also as a secondary (supergene) mineral in the oxidized zone of ore deposits. Its genesis has been variously interpreted by different geologists, doubtless because it has been formed in various ways. The occurrences of the mineral have been summarized by Ransome ${ }^{3}$ and later by Butler and Gale.4

Perhaps the best-known deposit worked for alunite is that at Tolfa, Italy, where the alunite occurs in trachyte and is said to give place in depth to pyritic trachyte. Concerning the formation of the alunite De Launay says: ${ }^{5}$

Alunite is, in my opinion, a product of the decomposition of feldspar similar to kaolin, which is worked in the same region, and often from the same vein, and, like this kaolin, is bound to disappear in depth. The theory which was formerly held is somewhat different. It was thought that the sulphur vapors of solfataric kinds circulated in the fissures of trachyte and attacked directly in depth the feldspars of the latter, and a relation was supposed to exist between these different phenomena and the trachyte itself. I believe, on the contrary, that there are two entirely distinct phases in the phenomenon-first, a vein deposit, clearly delimited, of pyritic trachyte, corresponding perhaps to the veins of a trachyte particularly feldspathic and at the same time pyritic like the granulites of Berezowsk (Oural); second, penetration by superficial waters of the feldspathic rocks, producing, where pyrite fails, the ordi-

3 Ransome, F. L., The geology and ore deposits of Goldfield, Nev. U. S. Geol. Survey Prof. Paper 66, pp. 189-195, 1909.

4 Butler, B. S., and Gale, H. S., Alunite, a newly discovered deposit near Marysvale, Utah: U. S. Geol. Survey Bull. 511, 1912.

- Translation by Butler, B. S., and Gale, H. S., op. cit., p. 52, from De Launay, L., La métallogénie de l'Italie: Cong. géol. internat., 10th sess., Compt. rend., pt. 1, 1907. 
nary forms of altered feldspars - that is to say, kaolinbut where, on the other hand, pyrite furnishes sulphuric acid, crystalline alunite.

Lindgren ${ }^{5}$ and others have described the occurrence of alunite formed by the action of solutions that contained sulphuric acid, which were derived from oxidizing sulphides on potassium-aluminum silicates.

In the United States there are numerous deposits of alunite which are believed to have been formed and others that are perhaps now forming by the action of hot sulphurous waters on potassium-aluminum rocks. Large bodies of volcanic rock so altered are composed chiefly of quartz, alunite, and pyrite. The calcium, magnesium, and sodium were largely removed from the original rock, but iron appears to have been converted to pyrite at the same time that alunite was formed. In discussing the origin of the gold deposits at Goldfield, Ner., Ransome ${ }^{2}$ states

that the ore constituents were brought up in hot solutions charged with hydrogen sulphide, a little carbon dioxide, and probably also with some alkali sulphides; that the hydrogen sulphide was oxidized at and near the surface to sulphuric acid, which percolated down through the warm rocks to mingle with the uprising currents carrying sulphydric acid.

For the deposits near Marysvale, Utah, which occur as veins in effusive rocks and have been developed for the alunite, Butler and Gale say: ${ }^{3}$

The evidence in the Marysvale district, however, indicates that the materials constituting the veins were deposited by ascending solutions and that these solutions brought in the constituents of the alunite. At just what stage the sulphuric acid may have been formed can not now be positively stated, but it seems most natural to suppose that it was a part of the original solutions and that the potassium and aluminum were in part original in the solution and in part dissolved from the walls of the fissure at greater depth.

The veins in this district are nearly pure alunite, but the altered wall rock is mainly alunite, quartz, and pyrite. Concerning alunitized rocks at Rico Mountains, Colo., Cross ${ }^{4}$ writes:

The alteration of the porphyry of Calico Peak into a rock consisting largely of alunite, a hydrous sulphate of alumina and the alkalies, *** can be explained only as the result of the attack of sulphurous agents, and from the circumstances of occurrence there can be no doubt that

1 Lindgren, Waldemar, The copper deposits of the Clifton-Morenei district, Ariz.: U. S. Geol. Survey Prof. Paper 43, pp. 119, 120, 1905.

2 Ransome, F. L., op. cit., p. 193.

3 Butler, B. S., and Gale, H. S., op. cit., p. 36.

$\checkmark$ Cross, Whitman, and Spencer, A. C., Geology of the Rico Mountains,

Colo.: U. S. Geol. Survey Twenty-first Ann. Rept., pt. 2, pp. 92-94, 1900. the action is to be attributed to solfataric emanations of the Rico eruptive center in the period of waning igneous activity.

Larsen ${ }^{1}$ has described several areas of alunitized rock in Colorado. The altered rocks consist essentially of quartz, alunite, and pyrite, one analysis giving quartz, 69 per cent; alunite, 29 per cent; and pyrite, 2 per cent. Concerning the genesis of these deposits Larsen writes:

The evidence suggests hot ascending solutions as the cause of the alunitization. The field relations point strongly to deep-seated hot sulphuric acid solutions without the aid of surface agents. However, in view of the fact that geologists do not generally admit the presence of such solutions, the evidence in the present case is not sufficient to justify the assumption of such a source for the alunitization in the San Cristobal quadrangle. The alternative source is the mingling of hot ascending solutions or gases carrying $\mathrm{H}_{2} \mathrm{~S}$ and of surface oxidizing waters.

Clapp ${ }^{6}$ regards the deposit of Kynquot Sound, British Columbia, as formed by "hot ascending solutions of volcanic origin and that at least these solutions causing alunitization carried free sulphuric acid."

A. L. Day and E. T. Allen have studied the hot springs of Mount Lassen, Calif., where alunite and pyrite are being deposited in the acid waters of the springs. ${ }^{7}$

Descriptions of occurrences of alunite could be multiplied but the above seem sufficient to give the general modes of occurrence.

Hinsdalite.-Hinsdalite $\left(2 \mathrm{PbO} .3 \mathrm{Al}_{2} \mathrm{O}_{3} .2 \mathrm{SO}_{3}\right.$.$\mathrm{P}_{2} \mathrm{O}_{5} \cdot 6 \mathrm{H}_{2} \mathrm{O}$ ) from the Golden Fleece mine, near Lake City, Colo., has been described by Larsen ${ }^{8}$ and by Irving and Bancroft. ${ }^{9}$ It is a primary mineral in a vein in volcanic rocks associated with pyrite, tetrahedrite, galena, pyrargyrite, quartz, rhodochrosite, and barite. Barite is abundant also in neighboring deposits. The deposits are regarded by Irving and Bancroft as forming at shallow to moderate depth.

Creedite.-Larsen ${ }^{10}$ describes creedite $\left(\mathrm{CaSO}_{4}\right.$.$\left.2 \mathrm{CaF}_{2} \cdot 2 \mathrm{Al}(\mathrm{F}, \mathrm{OH})_{3} \cdot 2 \mathrm{H}_{2} \mathrm{O}\right)$ as occurring with barite and fluorite in a vein in Tertiary lavas near Wagon Wheel Gap, Colo. Larsen does

5 Larsen, E. S., Alunite in the San Cristobal quadrangle, Colo.: U. S. Geol. Survey Bull. 530, pp. 179-183, 1913.

6 Clapp, C. H., Alunite and pyrophyllite in Triassic and Jurassic volcanics at Kynquot Sound, British Columbia: Econ. Geology, vol. 10, pp. $70-88,1915$.

7 Allen, E. T., personal communication.

8 Larsen, E. S., and Schaller, W. T., Hinsdalite, a new mineral: Am. Jour. Sci., 4th ser., vol. 32, pp. 251-255, 1911.

9 Irving, J. D., and Bancroft, Howland, Geology and ore deposits near Lake City, Colo.: U. S. Geol. Survey Bull. 478, pp. 54-55, 1911.

10 Larsen, E. S., and Wells, R. C. Some minerals from the fluorite-barite vein near Wagon Wheel Gap, Colo.: Nat. Acad. Sci. Proc., vol. 2, pp. 362-364, 1916. 
not state whether he regards it as a primary or secondary mineral in the vein.

Thaumasite.-The unusual mineral thaumasite $\left(3 \mathrm{CaO} \cdot \mathrm{SiO}_{2} \cdot \mathrm{SO}_{3} \cdot \mathrm{CO}_{2} \cdot 15 \mathrm{H}_{2} \mathrm{O}\right)$ occurs in veins which cut contact-altered limestone in the Old Hickory mine, Beaver County, Utah. ${ }^{1}$ It is regarded as forming under conditions similiar to those favorable to the formation of zeolites. The best known localities of this mineral in the United States are at West Paterson and other places in New Jersey, where it occurs in trap associated with zeolites.

Witkeite.-Wilkeite ${ }^{2} \quad\left(3 \mathrm{Ca}_{3}\left(\mathrm{P}_{2} \mathrm{O}_{4}\right) \cdot 3 \mathrm{Ca}_{2} \mathrm{SiO}_{4}\right.$. $\left.3 \mathrm{CaSO}_{4} \cdot \mathrm{CaCO}_{3} \cdot \mathrm{CaO}\right)$ occurs in contact-altered limestone associated with wollastonite and garnet near Riverside, Calif.

Scapolite.-Scapolites occur as products of contact metamorphism and as alteration products of igneous rocks. Some of the scapolites contain the sulphate molecule. ${ }^{3}$

Svonbergite.-Svonbergite is apparently a rather rare primary mineral in ore deposits. ${ }^{4}$

CHARACTER OF ORE SOLUTIONS AS INDICATED BY VOLCANIC EMANATIONS.

The data concerning the composition of volcanic emanations have been summarized by many writers. A rather complete outline with bibliography has been prepared by Clarke ${ }^{5}$ who briefly summarizes the results as follows:

That the volcanic gases appear in a certain regular order has been shown by the various researches upon their composition, and especially by the labors of Deville and Leblanc. What, now, in the light of all the evidence, is that order, and what do the chemical changes mean?

First. The gases issue from an active crater at so high a temperature that they are practically dry. They contain superheated steam, hydrogen, carbon monoxide, methane, the vapor of metallic chlorides, and other substances of minor importance. Oxygen may be present in them, with some nitrogen, argon, sulphur vapor, and gaseous compounds of fluorine.

Second. The hydrogen burns to form more water vapor, and the carbon gases oxidize to carbon dioxide. From the sulphur, sulphur dioxide is produced. The steam reacts upon a part of the metallic chlorides, gener-

\footnotetext{
1 Butler, B. S., Geology and ore deposits of the San Francisco and adjacent districts, Utah: U. S. Geol. Survey Prof. Paper 80, p. 104, 1913. 2 Eakle, A. S., and Rogers, A.F., Wilkeite, a new mineral of the apatite group, and okenite, its alteration product from southern California: Am. Jour. Sci., 4th ser. vol. 37, p. 262, 1914.

s Borgström, L. H., Die Skapolithlagerstätte von Laurinkari: Com. geol. Finland, Bull. 41, p. 23, 1913.

Brauns, R., Skapolithführende Auswürflinge aus dem Laacher Seigebiet: Neues Jahrb., Beilage Band 39, p. 119, 1914.

4 Lacroix, A., Pyritiferous deposits at the contact of granite at Chezeuil, Saone-et-Loire, and its metamorphic rocks: Soc. franç. min. Bull. 41, pp. 14-21, 1918.

${ }^{5}$ Clarke, F. W. The data of geochemistry, 3d ed.: U. S. Geol. Survey Bull. 616 pp. 260-290, 1916.
}

ates hydrochloric acid, and so acid fumaroles make their appearance.

Third. The acid gases of the second phase force their way through crevices in the lava and the adjacent rocks, and their acid contents are consumed in effecting various pneumatolytic reactions. The rocks are corroded, and where sulphides occur hydrogen sulphide is set free. If carbonate rocks are encountered, carbon dioxide is also liberated.

Fourth. Only steam with some carbon dioxide remains, and even the latter compound soon disappears.

This seems to be the general course of events, although it is modified in details by local peculiarities. All of the substances enumerated in the lists of gases and sublimates given in the earlier portions of this chapter may take part in the reactions, and they do not seriously affect the larger processes which have just been described. The order is essentially laid down by Deville and Leblanc, except that the early evolution of hydrogen and carbonic oxide is taken into account. The current of events may be disturbed, so to speak, by ripples and eddies-that is, by subsidiary and reversed reactions-but its main course seems to be clearly indicated. ${ }^{6}$

\section{Harker ${ }^{7}$ states:}

Different types of solfataric action might be distinguished, and these are in some degree characteristic of different kinds of lavas. But it is also to be remarked that different volatile constituents may figure prominently at a given volcanic center at different stages in decline of activity. This is in part a matter of direct observation; for it has frequently been remarked that only the hottest fumaroles emit hydrochloric and hydrofluoric acids, while sulphurous and hydrosulphuric acids are connected with lower temperatures of emission, and water and carbonic acid with the lowest temperatures. Some indications of a like sequence have already been noted in pneumatolysis under plutonic conditions.

The volcanic emanations contain carbon, hydrogen, sulphur, oxygen, nitrogen, and minor constituents such as chlorine, fluorine, and metals in varying proportions and combinations depending probably both on the original character and the temperature of the gases. Day and Shepherd ${ }^{8}$ collected gases from Kilauea with great care to avoid contamination with air, and state that the absence of argon "affords a most desirable confirmation of our belief that the volcano gases were successfully collected before they had come in contact with atmospheric air at all and were

9 For a summary of our knowledge concerning the magmatic gases previous to the work of Brun and Chamberlin, see Lincoln, F. C., Econ. Geology, vol. 2, p. 258, 1907. Lincoln gives a good table of analyses and proposes a classification of the volcanic exhalations. For a theoretical discussion relative to "gas mineralizers" in magmas see Niggli, P., Zeitschr. anorg. Chemie, vol. 75, p. 161, 1912, and vol. 77, p. 321. 1912. Also Centralbl. Mineralogie, 1912, p. 321; and Geol. Rundschau, vol. 3, p. 472,1912 .

7 Harker. Alfred, The natural history of igneous rocks, p. 307, Methuen \& Co., London, 1909.

${ }^{8}$ Day, A. L., and Shepherd, E. S., Water and volcanic activity: Geol. Soc. America Bull., vol. 24, p. 588, 1913. 
therefore entirely uncontaminated either by reaction or admixture with it." These gases were analyzed with the following results:

Composition of gases from Halemaumau (Kilauea), Hawaï, May, 1912.

[Percentages by volume.]

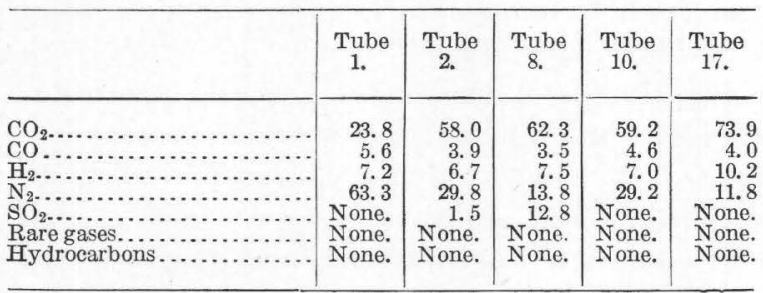

These gases contained abundant water and before cooling more sulphur dioxide than is shown in the analysis. The authors say:

The $\mathrm{SO}_{2}$, for example, has gone over in part or altogether to $\mathrm{SO}_{3}$ and gone into solution, and only two of the five tubes analyzed now show $\mathrm{SO}_{2}$ as such. Moreover, the resulting acid solutions may have reacted to a limited extent on the glass tube and accordingly be responsible for all or a part of the alkalies, lime, and alumina shown in the analyses of water.

The writer understands that the authors cited do not suppose that any sulphuric acid was formed from original constituents on the cooling of the gases.

The analyses of the materials contained in the water are given in the following table:

Analyses of material contained in the water collected in the tubes of gases from Halemaumau, Hawaii.

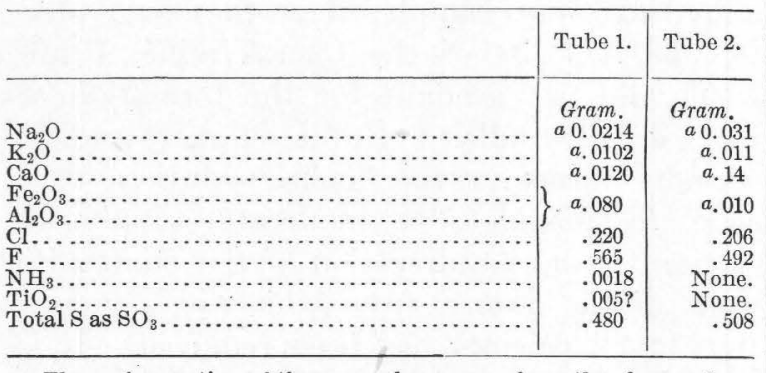

$a$ The major portion of these may have come from the glass or from Pele's hair.

The analyses recorded in the literature indicate that sulphur is present in different volcanic emanations as $\mathrm{H}_{2} \mathrm{~S}, \mathrm{SO}_{2}, \mathrm{SO}_{3}$, and as sulphur vapor, and many of the analyses show free oxygen.

CONDITIONS OF FORMATION OF SULPHUR TRIOXIDE.

It is obvious that the first step in the deposition of the sulphate minerais is the formation of the sulphate radicle. and the conditions under which this radicle forms are therefore of interest. The commercial importance of sulphuric acid has led to careful investigation of the modes of formation of sulphur trioxide. Much information on this subject has been brought together by Lunge. ${ }^{1}$

Sulphuric acid can be formed in many ways, but one way in which it may be formed in igneous emanations is that known as the contact process. This process consists essentially in bringing about the combination of sulphur dioxide and oxygen by the aid of a catalyzer. Knietsch, as stated by Lunge, ${ }^{2}$ has shown the reaction at different temperatures at atmospheric pressure. Lunge ${ }^{3}$ says:

The most important result of Knietsch's experiments was that a line of stable equilibria exists which divides the range of temperature into two parts [with the catalyzers used]. The range below $200^{\circ}$ and above $900^{\circ}$ or $1,000^{\circ}$ may be called devoid of reaction in a technical sense; between $200^{\circ}$ and $450^{\circ}$ the reaction of formation prevails; above $450^{\circ}$ the dissociation of $\mathrm{SO}_{3}$ comes into play very ,rapidly.

It is apparent that the range of temperature in which sulphur trioxide forms at all rapidly and is stable under atmospheric pressure and in a system containing only sulphur and oxygen is not large.

In the manufacture of sulphuric acid the catalyzer commonly employed is platinum, but ferric oxide and many other substances act as catalyzers, so that many catalyzers may be present in mineral veins.

Another method of producing sulphuric acid, which is employed at the plant of the New Cornelia Copper Co. at Ajo, Ariz., should be mentioned here. In the treatment of copper ores the copper is leached by sulphuric acid and electrolytically precipitated. For successful precipitation it is necessary to keep the ferric iron of the solutions low. When the solutions become polluted with ferric sulphate, that substance is reduced to ferrous sulphate by spraying the solution through a chamber containing sulphur dioxide. ${ }^{4}$

The gas is cooled from $600^{\circ}$ to $150^{\circ} \mathrm{F}$. in passing through the chamber. The ferric iron in the solution is practically all reduced, according to the following reaction:

$$
\mathrm{Fe}_{2}\left(\mathrm{SO}_{4}\right)_{3}+\mathrm{SO}_{2}+2 \mathrm{H}_{2} \mathrm{O}=2 \mathrm{FeSO}_{4}+2 \mathrm{H}_{2} \mathrm{SO}_{4}
$$

1 Lunge, George, The manufacture of sulphuric acid and alkali, 3 vols., New York, D. Van Nostrand Co., 1913.

2 Lunge, George, op. cit., p. 1307.

${ }^{3}$ Idem, p. 1311.

1 Tablemann, H. A., and Potter, J. A., First year of leaching by the New Cornelia Copper Co.: Am. Inst. Min. Eng. Bull. 146, p. 475, 1919. 5 Idem, p. 478. 
FORMATION OF SULPHURIC ACID IN NATURE.

The possible conditions under which sulphuric acid is formed in nature have been considered in detail by Ransome. ${ }^{1}$ In discussing the origin of the ore deposits of Goldfield, Nev., Ransome considers three hypotheses-first, "the direct volcanic hypothesis," which postulates that the solutions come from deep-seated sources charged with sulphuric acid, a hypothesis supported by the presence of the sulphate-bearing minerals haüynite and noselite as original constituents of volcanic rocks and the presence of barite and celestite in mineral deposits that are generally believed to have been formed independently of surface agencies; second, "the hypothesis of the derivation of sulphuric acidfrom the oxidation of pyrite," a process so well known as to require no discussion; third, "the hypothesis of simultaneous solfatarism and oxidation," which postulates the rising of solutions containing hydrogen sulphide to or nearly to the surface, their oxidation to sulphuric acid by atmospheric oxygen, and the descent of the acid solutions thus formed into the veins again, where they react with the ascending solutions and cause the precipitation of metals, sulphides, etc.

FORMATION OF PRIMARY SULPHATE MINERALS.

In considering the formation of the primary sulphate minerals, it must of course be recognized that sulphates, either as minerals or in solution, are prevalent at the surface and that, if waters from the surface have had a large part in the formation of a mineral deposit, the insoluble sulphates would most naturally be formed. On the other hand, sulphates are often found where there is good reason to believe that surface waters were not involved in their formation, and we may inquire whether sulphates can form without the aid of surface agencies. First let us see what consequences follow the assumption that free oxygen is present in a given magmatic emanation, even though many investigators regard the presence of free oxygen in a magma as improbable. With such an emanation the formation of sulphur trioxide would not only be possible but under certain conditions would be in-

IRansome, F. L., The geology and ore deposits of Goldfield, Nev. U. S. Geol. Survey Prof. Paper 66, pp. 189-195, 1909. evitable. For instance, a gas that contained only sulphur or sulphur dioxide and free oxygen at $1,000^{\circ}$ or higher temperatures would, on cooling, pass through the interval favorable to the formation of sulphur trioxide, and that compound would form. At the higher temperatures, at which sulphur trioxide is unstable, it would be in low concentration, and the formation and precipitation of abundant sulphates would not be expected, but when temperatures favorable to formation and stability were reached a high concentration might result and there would be a proportionate tendency to the formation of sulphates. It is natural to suppose that barium present in the form of the more soluble compounds would be the first substance to be precipitated as sulphate on account of the very slight solubility of barite in ore solutions, as indicated by its common occurrence. The same reasoning applies to some extent to the formation of anhydrite $\left(\mathrm{CaSO}_{4}\right)$ at high temperature and probably also to the formation of celestite. Barite is by far the most insoluble of the sulphates in pure water, and apparently also in mineralizing solutions, and, if it were not for this mineral, there would be little trace of sulphates as primary minerals except where near-surface conditions are reached. Such a development of sulphate would seem to be a more natural method for the formation of anhydrite, for example, than that suggested for the deposits of the Cactus mine, Utah, which did not account for the formation of the sulphate radicle. If the sulphate radicle actually forms in the cooling'solution, it is easy to postulate a moderate supply of calcium from the alteration of the monzonite walls of the fissure, from which it is known that much calcium has been removed. It is possible that under favorable conditions the sulphate radicle may form to an extent that would result in a solution containing sulphuric acid, which in rocks high in alkali and aluminum would at favorable temperature give the conditions for the formation of alunite. As Ransome has pointed out, it is notable that solutions which form alunite apparently are not good carriers of metal. The Goldfield deposits are a distinct exception in their association with metallic sulphides, although cinnabar is associated with 
alunite in deposits east of Beatty, Nev., which have been described by Knopf. ${ }^{1}$ The cinnabar occurs in silicified and alunitized rhyolite. In the great alunitized areas there does not appear to have been extensive removal of iron, much of which, whether originally present as oxide or in silicates, seems to have been altered to pyrite and remained. Morever, the alunite in the vein is remarkably free from other minerals. When sulphur trioxide had developed in the cooling solution to the extent of yielding sulphuric acid the solution probably ceased to be a carrier of most of the metals, ${ }^{2}$ and the formation of sulphur trioxide may possibly be a factor in the precipitation of the metals.

The behavior of smelter gases gives some indication of the temperature at which certain sulphates will form abundantly under given conditions. Fulton ${ }^{3}$ says:

The smoke stream also carries water vapor, the origin of which is the moisture in the ore charges fed to the furnaces. As long as the smoke stream has a temperature above $440^{\circ}$ C., no combination of sulphur trioxide with water vapor to form sulphuric acid is possible, but as the temperature falls in the flues as the stack is approached, sulphuric acid vapor forms by the combination of water vapor and sulphur trioxide vapor, until at about $350^{\circ} \mathrm{C}$. one-half of the sulphur trioxide present in the smokestream is in the form of sulphuric acid vapor. At ordinary atmospheric pressure (760 millimeters) sulphuric acid, or rather a mixture of 98.54 per cent of sulphuric acid and 1.46 per cent of water, has a boiling point of $338^{\circ} \mathrm{C}$. From this it follows that above $338^{\circ} \mathrm{C}$. all sulphuric acid present must be in a vapor form or dissociated, but that below this temperature it may be present in the smoke stream in the liquid form as a fine mist or small liquid particles. * * * When the ore charge smelted or roasted contains a considerable precentage of volatile metals, such as lead, zinc, and cadmium, these partly pass to the fume and, under oxidizing conditions, form oxides. The fine fume particles combine readily with the sulphuric acid formed, giving rise to sulphates and the consequent neutralization of the acid. The neutralization or the formation of sulphates probably does not readily take place until temperatures below $200^{\circ} \mathrm{C}$. are reached, meaning practically that before sulphates are formed the sulphuric acid must be below its condensation point.

There seems little doubt that some sulphates will form at temperatures above $200^{\circ}$.

Certain theoretical considerations and facts of observation support to some degree the method of formation of sulphates here sug-

\footnotetext{
$1 \mathrm{Knopf}$, Adolph, Some cinnabar deposits in western Nevada: U. S. Geol. Survey Bull. 620, p. 64, 1916.

¿Ransome (op. cit., p. 195) suggests sulphuric acid as a precipitant. `Fulton, C. H., Metallurgical smoke: Bur. Mines Bull. 84, pp. 25-26, 1915.
}

gested. Sulphates would not be expected in deep-seated rocks, and apparently they are absent. They might form in low-temperature magmas, but their abundant formation in such magmas would not be expected, and this seems to agree with observations. On the cooling of certain mixtures of gases, the formation of sulphur trioxide would be expected, and under certain conditions the formation of sulphates, and this seems to accord with the facts of observation.

The fact must not be overlooked, however, that the sulphates under discussion are associated with sulphides and were apparently deposited at the same time. The method would appear to make it necessary to suppose that sulphides were deposited in the presence of free oxygen.

We may next assume that free oxygen does not occur in the assumed magmatic emanation and see if there is an available supply of combined oxygen for oxidation of sulphur to form sulphuric compounds. There seems ample evidence to indicate that the oxygen present in the magma and in the surrounding mineralized zone is not sufficient to insure that all the elements will be in their highest state of oxidation. It is sufficient, however, to insure that much of the iron in igneous rocks may be present as ferric compounds, notably magnetite and hematite. In fact, ferric iron is an important constituent of most igneous rocks, and in the contact deposits and veins formed at high temperatures ferric iron is abundant in the minerals magnetite, hematite, garnet (andradite), and other ferric compounds.

In deposits formed at lower temperature ferric minerals are far less abundant and may be entirely absent, the iron present being in ferrous minerals or in sulphides and allied compounds. Of veins formed at intermediate temperature Lindgren ${ }^{4}$ says:

Scarcely ever do we find the oxides, such as magnetite, specularite, and ilmenite. The predominating gangue mineral is quartz, but carbonates are also common, such as calcite, dolomite, and ankerite, more rarely siderite; fluorite and barite are occasionally of importance.

In veins that contain abundant sulphates the ferric minerals seem to be at least unusual, though ferrous minerals - siderite or ankerite or manganous minerals - as rhodochrosite or rhodonite may be abundant. Thus in the 
Coeur d'Alene district, Idaho, Ransome ${ }^{1}$ found that magnetite with garnet is confined largely to the "contact" type of deposits. In most of the veins of the district ferric minerals are absent, though siderite is abundant. Barite is locally abundant.

Spencer ${ }^{2}$ recognizes a transition in the socalled "contact" deposits of the Santa Rita district, New Mexico, from a zone near the intrusive rock characterized by garnet (andradite) to one characterized by manganiferous siderite and hedenbergite - that is, an inner zone where ferric iron predominates and an outer zone where ferrous iron predominates. No sulphates are recognized in these zones. Primary ferrous and manganous minerals in abundance are associated with some of the large ore deposits that are believed to have formed at intermediate temperatures, such as those of Leadville, Gilpin County, Rico, Lake City, and Creede, Colo., Butte and Philipsburg, Mont., and many others. Barite is present in some of the deposits, but it has not been reported from others. It is abundant in some deposits, as those of the Tintic district, Utah, ${ }^{3}$ where ferrous and manganous minerals are not abundant, though iron sulphide is plentiful.

The Cactus mine, Utah, ${ }^{4}$ appears to offer a good example of the relation of ferric, ferrous, and sulphate minerals. In that deposit hematite was abundantly formed. After its deposition had ceased siderite, anhydrite, and barite were deposited. (See fig. 55.) Pyrite and and chalcopyrite were deposited throughout the period.

From a consideration of igneous rocks and different types of ore deposits, it would appear that ferric iron is common and ferric minerals form in nearly all magmas and their emanations. Sulphur, on the other hand, does not tend to form combinations that crystallize from magmas. Under some conditions sulphur combines with the metals as sulphides in magmas and may form large deposits or it may be oxidized to sulphate, which may then produce complex silicate-sulphate minerals.

\footnotetext{
1 Ransome, F. L., Geology and ore deposits of the Coeur d'Alene district, Idaho: U. S. Geol. Survey Prof. Paper 62, p. 94, 1908.

2 Spencer, A. C., personal communication.

${ }^{3}$ Lindgren, Waldemar, and Loughlin, G. F., Geology and ore deposits of the Tintic district, Utah: U. S. Geol. Survey Prof. Paper 107, p. 153, 1919.

$\$$ Butler, B. S., Geology and ore deposits of the San Francisco and adjacent districts, Utah: U. S. Geol. Survey Prof. Paper 80, p. 121, 1913.
}

In the contact zone and the deep-vein zone the higher oxide of iron continues to be stable, and ferric minerals as oxide and silicate are abundantly deposited. Sulphur combines with the metals to form sulphides, but the sulphides are in large part later than the ferric oxides and silicates. The sulphate radicle is rarely present and only in silicate minerals. As no insoluble sulphites are formed there is no record as to the presence or absence of the sulphite radicle in the solutions that formed the contact minerals. In veins formed at intermediate and low temperatures ferric minerals are very scarce or absent, whereas ferrous minerals in some deposits are abundant. Sulphides are abundant, and the presence of barite, which is by far the most insoluble of the sulphates, indicates that sulphates probably formed relatively abundantly, but for the most part were carried away in solution.

This change from ferric to ferrous minerals, together with the appearance of sulphate minerals associated with the ferrous minerals, may be interpreted as indicating that at the higher temperatures the conditions were favorable to the oxidation of iron and the reduction of sulphur, whereas at the lower temperatures the conditions were favorable to the reduction of ferric compounds and the oxidation of the sulphur. This interpretation agrees with the experimental data so far as the oxidation of sulphur dioxide and the reduction of ferric compounds are concerned. Possibly this reduction of the ferric compounds takes place to some extent even after the ferric minerals have been deposited from the ore-bearing solutions. The hematite in the Cactus mine, which has already been mentioned, is distinctly magnetic and may have become so by the partial reduction of ferric oxide when sulphur or its compounds were oxidized to sulphuric compounds. This record of the ores, then, reveals one possible source of oxygen to form sulphates apart from free oxygen in magmatic emanation. If a large part of the iron in the magma is in ferric and ferrous oxide, the combination of part of the iron with sulphur to form pyrite would greatly reduce the amount of sulphur and at the same time would furnish oxygen to oxidize the excess of sulphur. It has already been pointed out that the iron in the wall rock of many veins as ferrous and 
ferric oxide has combined, in part at least, with sulphur and thus freed the oxygen to go into some other combination.

The deposits of native copper at Corocoro, Bolivia, are worthy of note in this connection. The deposits are in a series of red sediments. The ore solutions have apparently reduced the ferric iron in the beds containing the ores, and sulphates have been deposited. Miller and Singewald ${ }^{1}$ say:

The mineral solutions that circulated through the ore beds have bleached them to a white or light green color, but the impervious shales between have not been affected by the solutions. Patches of red sandstone within the ore bodies that have been protected from the bleaching action of the mineralizers are barren of ore. **** Gypsum and, less abundantly, barite and celestite occur as gangue minerals.

Steinmann, according to Miller and Singewald ${ }^{2}$ believes that

The mineralizing solutions were analogous to those that formed the other copper deposits of the Andesthat is, characterized by the presence of sulphur and arsenic to the subordination of oxygen. On coming in contact with the ferric oxide of the red beds, they reduced it and bleached those strata, and the sulphur was oxidized to sulphuric acid. On account of the greater affinity of sulphuric acid for lime, magnesium, and iron, the sulphates of those metals were formed and copper was set free.

There is evidence that many of the elements in the magmas besides iron were combined with oxygen and that with decrease in temperature they tended to combine with sulphur. The remarkable deposits at Franklin Furnace, N. J., ${ }^{3}$ are instructive in this connection. There was probably a lack of sulphur in the emanations that formed the deposit, and under those conditions manganic minerals were deposited. Zinc was deposited abundantly as oxide and silicate. In deposits containing sulphides manganic minerals are certainly rare, though manganous minerals may be abundant and under some conditions manganese sulphide has been deposited. Likewise if sulphur is present in the emanations the zinc oxide and silicate apparently are never deposited, but zinc at the temperature at which it will be deposited combines with the sulphur.

1 Miller, B. L., and Singewald, J. T., The mineral deposits of South America, p. 92, New York, MeGraw-Hill Book Co., 1919.

2 Idem, p. 94

${ }^{3}$ Spenser, A. C., U. S. Geol. Survey Geol. Atlas, Franklin Furnace folio (No. 101), 1908.

$35416^{\circ}-19-13$
It may also be noted that tungsten is most commonly deposited as tungstate, but it may be deposited as sulphide. The only known occurrence of the sulphide, that in the Emma mine, Utah, ${ }^{4}$ is a deposit that is believed to have been formed at moderate temperature. Here the sulphide of tungsten was one of the latest minerals to form and apparently, in part at least, replaced earlier sulphides.

Tin is commonly deposited as the oxide, but in some of the Bolivian deposits which seem to have been formed at only moderate temperatures and in which sulphides are relatively abundant the sulphide of tin was deposited. Some of these deposits contain barite.

Lunge ${ }^{5}$ states that "on boiling sulphur with water, hydrogen sulphide is evolved and sulphuric acid is found in the residue." The formation of sulphuric acid by heating sulphur with water has been demonstrated by Allen, ${ }^{6}$ thus hydrogen under certain conditions gives up its oxygen, and the oxygen so released goes to oxidize sulphur. The production of sulphuric acid ${ }^{7}$ by the reaction of sulphur dioxide and water at about $150^{\circ} \mathrm{C}$. will also take place ${ }^{8}$ according to the equation $3 \mathrm{SO}_{2}+2 \mathrm{H}_{2} \mathrm{O}$ $=2 \mathrm{H}_{2} \mathrm{SO}_{4}+\mathrm{S}$. The resulting sulphur would of course be available for reaction with water under proper conditions for producing sulphuric acid $\left(\mathrm{H}_{2} \mathrm{SO}_{4}\right)$.

If it is granted that sulphates form in the zone of intermediate temperatures without the influence of surface agencies, the question then arises whether a similiar origin can be attributed to alunite deposits. There seems to be universal agreement among geologists that alunite deposits have been formed near the surface and also that some of them, at least, are formed by acid solutions that result from surface oxidation. It is manifestly difficult to prove the part that surface and deep-seated agencies have played under such conditions, but if barite, anhydrite, and celestite can and do originate from deep-

${ }^{4}$ Wells, R. C., and Butler, B. S., Washington Acad. Sci. Jour., vol.7, pp. 596-599, 1917.

5 Lunge, George, op. cit., vol. 1, pt. 1, p. 17.

6 Allen, E. T., personal communication.

7 Randall, M., and Bi howsky, R. V., Equilibrium in reaction between water and sulphur at high temperatures; The dissociation of hydrogen sulphide: Am. Chem. Soc. Jour., vol. 40, p. 368, 1918.

${ }^{8}$ Lewis, G. N., Randall, M., Bichowsky, R. V., A preliminary study of reversible reastions of sulphur compounds: Am. Chem. Soc. Jour., vol. 40, p. 356, 1918. 
seated solutions without surface oxidation there seems to be no good reason why alunite might not also and why this mode of origin may not be considered if it seems to accord best with the observed facts.

The occurrence of hinsdalite as a primary mineral in deposits that are believed by the geologists who have described them to be of deep-seated (hypergene) origin is of interest. This mineral is chemically closely allied to alunite - in fact is a member of the alunite group of minerals-and if it can form from the same solutions as sulphides, rhodochrosite, and barite there seems to be no inherent reason why alunite might not also form from ascending solutions under the proper physical conditions.

The evidence in the field indicates that alunite can form only at low temperatures, probably considerably below the initial temperature at which sulphuric acid and the sulphates of potassium and aluminum may appear in the solutions.

The mineralogically allied minerals of the jerosite groups and other allied basic ferric sulphates are apparently formed only by surface solution, and under near-surface conditions favorable for oxidizing iron, where they may form abundantly. It is obvious that they can form only under conditions favorable to the stability of the higher oxides of both iron and sulphur, and it appears that alunite forms under conditions that favor the reduction of the higher oxide of iron to ferrous compounds or sulphide, on the one hand, and that favor the formation of the higher oxide of sulphur, on the other hand.

The fact that ore solutions may change their character during the deposition of the ore has been long recognized.

Thus Lindgren, ${ }^{1}$ in describing the alteration of the rocks adjacent to the veins in the De Lamar mine, Idaho, states:

This confirms the view set forth that two different. processes have been active - first, an ordinary process of sericitization, accompanied by a vein filling of barite and calcite, effected by waters containing alkaline carbonates; second, pseudomorphic replacement of the filling by quartz and leaching of $\mathrm{Al}_{2} \mathrm{O}_{3}$ from the sericitized country rock by siliceous (probably acid) waters.

1 Lindgren, Waldemar, The gold and silver veins of Silver City, De Lamar, and other mining districts in Idaho: U. S. Geol. Survey Twentieth Ann. Rept.,pt. 3, p. 182, 1900.
Lindgren ${ }^{2}$ also states that "the loss of so much $\mathrm{Al}_{2} \mathrm{O}_{3}$ can be explained on the supposition that the waters contained sulphuric acid, as only such thermal waters are known to dissolve alumina in large quantities." In another work he says: ${ }^{3}$

Veins formed near the surface in volcanic regions are sometimes subject to peculiar changes, which are rarely observed in deposits of more deep-seated origin. An earlier gangue mineral, such as calcite or barite, may be wholly wiped out and replaced by a new gangue of quartz and adularia. This alteration has nothing to do with surface waters; it is plainly caused by a change in the composition of ascending current.

In the San Francisco district, Utah, there is a notable difference in the alteration of the wall rock and in gangue minerals in neighboring deposits in Tertiary lavas, which, it is believed, represent different stages in the process of ore deposition. Thus regarding the Horn Silver and Beaver Carbonate mines, it is stated. ${ }^{4}$

Although the principal ore minerals of the two deposits are the same there is a notable difference in the gangue minerals. Carbonates are important in the Beaver Carbonate mine and sulphates in the Horn Silver mine. This difference points to a difference in the character of the solutions that deposited the ores, and a similar difference is indicated in the alteration of the rock adjacent to the deposits. The extensive removal of alumina from the rock of the Horn Silver deposit and the presence of abundant sulphates is contrasted with the failure to remove alumina and the presence of calcite in the Beaver Carbonate deposit.

The presence of sulphuric acid in solutions that deposited sulphides is suggested by Spurr. Concerning the alterations of the wall rocks at Tonopah, Nev., ${ }^{5}$ he says:

However, they [the mineralizing solutions] attack the rock vigorously by virtue of the carbonic acid, probably also sulphuric acid, and perhaps to a less extent by acids of chlorine and fluorine.

The many known reversible reactions that go on with changing conditions make the problems of changes in ore solutions most complex. These problems really belong in the field of chemistry, but as the reactions that go on in ore solutions as a result of changes in temperature and in concentration

\footnotetext{
2 Idem, p. 181.

3 Lindgren, Waldemar, Mineral deposits, p. 436, New York, 1913.

4 Butler, B. S., Geology and ore deposits of the San Francisco and adjacent districts, Utah: U. S. Geol. Survey Prof. Paper 80, p. 133, 1913. ${ }_{5}$ Spurr, J. E., Geology of the Tonopah mining district, Nev.: U. S. Geol. Survey Prof. Paper 42, p.'234, 1905.
} 
may exert a large influence on the deposition of the ores, the geologist may properly point out some of the facts that need explanation and indicate the evidence of the changes that have taken place as it is preserved in the rocks and ores. There are undoubtedly changes of which no record remains; indeed, were it not for the presence in ore deposits of a few sulphates that are relatively insoluble, there would be little record of the existence of the sulphate radicle in ore solutions from deep sources. In this discussion attention has been directed to some possible relation of sulphur and oxygen to other constituents of ore solutions, but it is obvious that other elements should be considered, especially carbon.

The possibility of the formation of sulphuric acid and sulphates in magmatic emanations may have a bearing on many problems, but it is not the purpose to pursue their study here. It may, however, be pointed out that close observation of the relations of minerals is essential to a clear understanding. It seems certain that although barite, for instance, does not form at high temperature, it may be associated with minerals that were formed earlier at high temperature, or even later, as when once formed and perhaps covered with other minerals it might persist, even though the temperature might be raised.

A student of copper deposits who considers the possibility of a deep-seated source of sulphuric acid will read with added interest the paper by Zies, Allen, and Merwin ${ }^{1}$ on reactions between copper sulphate and sulphuric acid and various sulphides at moderately high temperature. It seems that there is an almost unlimited field for similar investigations which will contribute directly to the solution of some problems of ore deposition.

SUMMARY.

Sulphates in igneous rocks and in deposits formed at high temperature are confined to a few complex silicate minerals that contain the sulphate radicle. In deposits formed at intermediate temperature barite is common and anhydrite and celestite are not uncommon. Under favorable conditions, and probably at

1 Zies, E. S., Allen, E. T., and Merwin, H. E., Some reactions involved in secondary copper sulphide enrichment: Econ. Geology, vol. 11. pp. 407-503, 1916. comparatively low temperature, alunite forms abundantly. In some deposits at least the sulphate of the alunite was probably derived. from deep-seated solutions.

A study of volcanic emanations has shown that they exhibit changes in character and that in the later stage of fumarolic activity they may contain sulphurous and sulphuric compounds. Sulphuric acid can readily be formed by the reducing action of sulphur dioxide on ferric solutions. If igneous emanations contain free oxygen and sulphur or sulphur dioxide it would be expected that as they became cool sulphur trioxide would be formed and that at suitable temperature the sulphates would be formed. Sulphur trioxide is unstable at high temperatures, and the temperature range in which it forms rapidly and is stable is narrow. If emanations contain no free oxygen, that combined with the metals or with hydrogen at high temperatures may at lower temperatures combine with sulphur to form the oxides of sulphur and sulphuric compounds. This interchange of oxygen from certain elements at high temperature to sulphur at lower temperature is believed to be an important factor not only in the formation of sulphates in solutions of deep-seated origin but also in the precipitation of primary (hypergene) ore minerals.

\section{ACKNOWLEDGMENT,}

In closing the discussion of this subject the writer wishes to acknowledge gratefully the criticisms and helpful suggestions of coworkers on ore deposits, especially those of E. S. Bastin, Adolph Knopf, E. S. Larsen, G. F. Loughlin, Chase Palmer, F. L. Ransome, Max Roesler, A. C. Spencer, and R. C. Wells, of the United States Geological Survey; Drs. E. T. Allen, J. B. Ferguson, and R. B. Sosman, of the Carnegie Institution of Washington; and Prof. John Johnson, of Yale University, without implying, however, that all these students subscribe to all the ideas here put forward.

AGE OF DEPOSITS ASSOCIATED WITH IGNEOUS ROCKS.

The age of the deposits associated with the igneous rocks is essentially that of the igneous rocks to which they are related in origin. (See p. 99.) So far as has been definitely shown, the main igneous activity began in post-Cretaceous time and may have continued through much of Tertiary time. Possibly some of the igneous 
bodies and the associated ore deposits in the of eastern Utah are too small to have their western part of the State are Cretaceous or relative sizes even approximately shown on a older. A few deposits in the Wasatch and map of the scale used.

Uinta ranges appear to be of pre-Cambrian age.

RELATION OF ORE DEPOSITS TO DIFFERENT TYPES OF INTRUSIVE BODIES. ${ }^{1}$

The ore deposits associated with igneous rocks present especially favorable opportunities for observations on the relations of ore deposition to different types of intrusive rock bodies. This is due in no small part to block faulting since intrusion, which (along the Wasatch front and the west side of the Mineral Range, for instance) has brought into the field of observation bodies intruded at greatly differing depths. The small size of all of the intrusive bodies in comparison with those in California, Idaho, and Montana is also favorable to such a study.

NOMENCLATURE.

The intrusive bodies may be divided into laccoliths and stocks. (See p. 91.) The stocks differ according to the distance below their tops to which they have been eroded and may be designated apically truncated stocks, or those cut by the present erosion surface not far below the original top; medially trurtcated stocks, or those cut much farther below the original top; and deeply truncated stocks, or those cut to still greater depths. It is apparent that the erosion surface may have reached the zone of mineralization induced by a stock without having exposed the stock itself. Such conditions may be present in Utah in the Gold Springs-State Line area, at Ophir, and at other localities.

The medially truncated stocks probably comprise more than 75 per cent of the area of the exposed intrusive masses and are nearly equal in number to the other types. The apically truncated stocks and laccolithic bodies are each represented in several places, the apically truncated stocks being both areally and numerically most important.

The geologic map (Pl. IV, in pocket) shows the number and location of the different intrusive bodies in the State and in a general way the relative sizes of the different intrusive bodies in the western part of the State. The individual members of the laccolithic groups

1 The essential features of this discussion were published in Econ. Geology, vol. 10, pp. 101-122, 1915.

\section{MINERALIZATION ASSOCIATED WITH DIFFERENT TYPES OF INTRUSIVE BODIES. \\ GENERAL FEATURES.}

With the relative abundance of the types in mind it is somewhat surprising that not a single mine of first or even of second class importance is associated with either the medially truncated stocks or the laccolithic bodies. Of the total metal output of the State, valued at over $\$ 916,000,000$ to the end of 1917, less than one-half of 1 per cent has been derived from deposits associated with these two types; and it is certain that the commercial importance of both has been negative; that is, that more has been expended on them than has been realized from them.

The deposits in the western part of the Little Cottonwood district may possibly be associated with the Little Cottonwood stock instead of the Alta-Clayton Peak stock, in which case this statement would have to be somewhat modified; but in any case the mineralization either in the Little Cottonwood stock or in the associated pre-Cambrian rocks is trifling as compared with that in the early Paleozoic rocks of the Little Cottonwood district and in the late Paleozoic and early Mesozoic rocks of the Park City district. On the other hand, important ore bodies are associated with nearly every one of the apically truncated stocks, and it is from these bodies that the great bulk of the metal output of the State has been derived.

LACCOLITHS.

Mineralization associated with the laccoliths consists of small gold-copper veins in the larger laccoliths and a little contact mineralization in adjacent calcareous sediments. Practically no mineralization is associated with the smaller laccolithic bodies.

STOCKs.

Medially truncated stocks.-Mineralization is slight in the more deeply truncated stocks. Pegmatitic gold quartz veins extend from the Ibapah stock into the adjacent quartzites. Galena-fluorite veins are present in the Granite Range stock and quartz-fluorite pyrite veins 
in the Sheeprock Mountains stock. Small veins said to contain copper are reported from the Mineral Range stock, copper-molybdenite reins occur in the Little Cottonwood stock, and similar veins are present in some of the other deeply eroded stocks.

Contact deposits and replacement veins in the adjacent sedimentary rocks are associated with practically all the stocks, especially with that of the Mineral Range, but none of them are large.

Apically truncated stocks.-Extensive fissure and replacement fissure deposits are present in practically all the apically truncated stocks. Quartz-tourmaline copper replacement veins are present in the San Francisco and Clifton stocks; tourmaline-scheelite pegmatitic veins or dikes in the Clifton stock; biotite-orthoclasesericite copper deposits in the Bingham Canyon stock; lead-silver-zinc veins in the Bingham Canyon stock; and lead-silver and gold-copper veins in the Tintic stock. Few deposits have been extensively worked in the Park City stocks, though lead-silver veins have been followed from the sedimentary into the intrusive rock.

The adjacent sedimentary rocks have undergone intense contact metamorphism near the San Francisco, Clifton, Clayton Peak, and Iron Springs stocks, and less intense metamorphism near the Bingham, Tintic, and other stocks. Replacement veins, which are present in the rocks adjacent to all the stocks, have yielded large amounts of lead, copper, silver, and zinc, and to the present time have been the most productive type in the State. Associated with the stocks in the southern belt are deposits in the extrusive rocks that have yielded important amounts of lead, zinc, copper, and precious metals.

SUMMARY.

Mineralization associated with the laccoliths is not extensive and is largely confined to the intrusive bodies, though slight mineralization has occurred in the adjacent sedimentary rocks.

Mineralization associated with the medially truncated stocks is comparatively slight and is present both in the intrusive bodies and in the adjacent rocks. That in the intrusive bodies is prevailingly of the deep-seated type, approaching pegmatite in character, as is shown by the pegmatitic gold quartz veins of the Ibapah stock. Mineralization in the adjacent sedimentary rocks is most important in the Mineral Range, where limestone is present-a fact that has doubtless influenced the extent of mineralization. (Most of the deeper-truncated stocks are in contact with the siliceous early Cambrian and pre-Cambrian rocks.) That the character of the inclosing rock has not been the determining factor in the mineralization is indicated by the important deposits that occur in siliceous sediments and extrusive rocks associated with apically truncated stocks, as in the Bingham, Park City, San Francisco and other districts; and by the small importance of the deposits in the limestone of the Mineral Range as compared with those of the Star and Park City districts, which occur in sedimentary rocks of essentially the same age and character associated with apically truncated stocks.

Mineralization associated with the apically truncated stocks is extensive both in the intrusive rock and in the adjacent sedimentary and extrusive rocks. The mineralization in the stocks is prevailingly of the high-temperature type, though the lead-silver veins of the Tintic and Bingham districts indicate formation at only moderate temperature and pressure. In the sedimentary and effusive rocks the mineralization shows more or less complete gradation from the high-temperature contact type to fissure deposits formed at moderate and comparatively low temperatures.

\section{CAUSES OF DIFFERENCES IN MINERALIZATION.}

LACCOLITHS.

The material forming the laccolithic bodies entered the space occupied through a relatively narrow channel. As soon as the active flow through this passage into the laccolithic chamber ceased, the material in the passage quickly solidified, effectively sealing off the laccolith from the deeper source from which its material had been derived. If the body was small the solidification was rapid and there was little opportunity for differentiation. Some of the smaller laccolithic bodies have almost the texture of lava and evidently afforded little more opportunity for differentiation than a surface flow. If the mineralization associated with the igneous rocks was, as the writer holds, a late phase of their differentiation, it is not 
surprising to find that practically no mineralization, either in the igneous masses or in the adjacent sedimentary rocks, is associated with these small undifferentiated laccoliths.

In the larger laccoliths solidification proceeded more slowly. The resultant rocks are much more coarsely crystalline and in some of them a few dikes are present. The presence of these dikes may indicate that crystallization was slow enough to permit the crystallizing mass to separate into portions of different composition, and that before the entire mass had solidified portions had become sufficiently solid to fracture as a result of the stresses set up in the cooling and solidifying mass, and that the more fluid portions had been forced into these fractures and formed dikes therein. Mineralization in these larger laccoliths occurs along fissures in the intrusive rock and in the sedimentary rocks adjacent to the intrusives. It seems reasonable that the mineralizing solutions, like the dikes, should have separated from the crystallizing magma and have passed along fissures into the solidified portions, where they deposited the ore minerals, or have escaped into the adjacent sedimentary rocks, where they formed the contact deposits.

On the assumption that the ore solutions have resulted from a differentiation of the magma within the laccolithic reservoirs, certain deductions concerning the probable size and abundance of the ore deposits are possible. In the smaller outlying reservoirs, where solidification was so rapid that there was little opportunity for a differentiation of the magma, there was little possibility for the different materials to collect in bodies of any considerable size. In the larger bodies, where the solidification was slower, the opportunity for separation was more favorable, but even in the largest of the laccoliths in southeastern Utah solidification must have been so rapid that in a large part of the material there would be little opportunity for differentiation and in the remaining portion conditions would not be favorable to a high degree of differentiation. It may be presumed then that in the crystallization and solidification of these rock masses the proportion of the metals expelled was small when compared with what would have been expelled under conditions of slow crystallization that gave ample time for separation and segregation of the constituents.
It should be remembered also that laccolithic bodies are usually cut off from their deep-seated source and that in them there is no tendency to concentrate the more mobile substances resulting from deeper-seated differentiation.

Movements of the rocks might conceivably keep open the supply channels to some of the deeper igneous reservoirs, thus permitting the entrance of mobile constituents from below and the formation of large ore deposits, but no known evidence indicates that this has taken place in any of the laccoliths of Utah.

If the above suppositions and deductions are correct the extent of the ore deposits associated with laccolithic bodies, other things being equal, is dependent on the size of the laccolith. If it is small, there will likely be no mineralization; if very large, extensive deposits might be expected. In the laccolithic groups of southeastern Utah the total amount of igneous material is considerable, but that contained in any individual laccolithic body is relatively small. From theoretical considerations, then, it is to be expected that only small metal deposits are present in these laccoliths.

Gilbert ${ }^{1}$ many years ago arrived at essentially this conclusion, though he based it on the belief that conditions were not favorable to the formation of fissures rather than on the considerations presented above. Since then prospecting has been carried on intermittently for 40 years, and many thousands of dollars have been expended in the search for and development of metalliferous veins. Some have been found and have yielded a little gold, silver, and copper. Those developed to the present time, however, are relatively small and are associated with weak fissuring and give little promise of important production. Gilbert's prediction that "gold and silver will not be found in paying quantities in the laccolithic mountains, including the La Sal, Abajo, and Henry mountains," seems to hold good. The foregoing statements, of course, apply only to lode deposits and not to the sandstone and placer deposits in the vicinity of these mountain groups.

STOCKS.

The space occupied by the igneous material constituting the stocks was probably gained in large part by a pushing aside and doming of the

1 Gilbert, G. K., Report on the geology of the Henry Mountains: U. S. Geol. and Geog. Survey Rocky Mtn. Region Final Rept., pp. $82-83,151-152,1877$ 
earlier rocks. That there was some stoping and assimilation of the invaded rocks, especially in the deeper portions of the stocks, seems not improbable, though little evidence of it has been observed, and it is not thought to have been important. (Seep. 91.)

Daly ${ }^{1}$ has pointed out that the diagram (fig. 31, previously published by the writer ${ }^{2}$ ) may be interpreted as indicating that stoping has been important. This weakness in the diagram is due to the fact that it presents only two dimensions and therefore can not show the displacement of the rocks without great complication, which would obscure its main purpose of showing the position of the ore bodies with reference to the stocks. ${ }^{3}$

The formation of the stocks as they now occur may be thought of as taking place in the following general manner, though the actual process was doubtless more complex. (See also p. 98.)

After the intrusion had taken place crystallization of the fluid magma began, or continued if it had already begun. The higher portions of the intrusive bodies and the whole of the smaller masses lost their heat most rapidly and crystallized most quickly, so that the upper part of a body and the relatively small apophyses underwent comparatively slight differentiation and became sufficiently solid to fracture while the deeper-seated portions were still fluid. This presumes that the rocks now exposed in the apically truncated stocks have a composition nearer that of the original magma than those exposed in the more deeply truncated stocks, an assumption that seems to be borne out in a general way by the composition of the laccoliths, where differentiation was certainly slight. No laccolith has been found associated with a stock where a direct comparison would be warranted.

As crystallization proceeded slowly water and other light and very mobile constituents, with metals, sulphur, silica, and other materials in

\footnotetext{
${ }^{1}$ Daly, R. A., Ores, magmatic emanations, and modes of igneous intrusion: Econ. Geology, vol. 10, p. 471, 1915.

2 Butler, B. S., Relation of ore deposits to different types of intrusive bodies in Utah: Econ. Geology, vol. 10, p. 119, 1915.

${ }^{3}$ The manner of intrusion of the Little Cottonwood and Tintic stocks has been described by Loughlin (Econ. Geology, vol. 11, pp. 284-288, 1916) in reply to Daly's criticism above cited. The intrusion process of the Tintic stock has also been more thoroughly discussed by Loughlin (Geology and ore deposits of the Tintic mining district, Utah: U.S. Geol. Survey Prof. Paper 107, p. 87, 1919), who shows that the visible effects of intrusion are due mainly to the thrusting action of the magma, although stoping subsequent to the thrusting was of considerable importance.
}

solution, were expelled from the crystallizing magma and tended to move upward. This movement apparently took place through the fluid with no marked tendency to concentration other than a convergence as the size of the stock decreased upward, or to migration into the inclosing walls. When the material was sufficiently crystallized and solidified, fracture formed, in which these mobile constituents concentrated and passed on into cooler portions of the intrusive body or into the inclosing rocks. When the physical-chemical conditions were favorable to the precipitation of metals the formation of ore bodies began. In the intrusive bodies the tourmaline veins formed first and copper-gold and lead-silver veins later. As the solutions passed from the intrusive bodies into the inclosing sedimentary and extrusive rocks under differing chemical and physical environments, various types of deposits formed. (See fig. 31.)

If this interpretation is correct fractures in passing downward should disappear at a level where the material was too liquid to retain a fracture at the time they were formed. That such conditions are not more often seen is perhaps due chiefly to the fact that this level was not favorable to extensive mineralization and offers little inducement for economic development, but they seem to be exemplified in the fracture zone of the Cactus mine in the San Francisco stock. At the surface a broad breccia exceeding 100 feet in width is traceable along the strike for several thousand feet. As it passes downward the width contracts and the brecciation decreases until at a depth of 900 feet the width is only a few feet and the brecciation is very slight; at a few hundred feet deeper the fracture may disappear entirely. The early minerals of this deposit, as would be expected, are of the high-temperature type. Similar conditions probably obtain in other deposits in the State, as in the pegmatitic tourmaline veins of the Clifton district, but developments have been too meager to reveal them. Somewhat similar conditions occur where pegmatitic gold quartz veins of the Ibapah stock pass into true pegmatite carrying no metals.

The most important deposits of the State are associated with igneous masses that have been eroded to only a relatively short distance below their top, as those in the Park 
City, Bingham, Tintic, San Francisco, and Iron Springs districts, and the Tushar Range. That deposits, now eroded away, comparable in extent with these may have been associated with higher portions of the larger and more deeply eroded masses seems entirely probable, but that such deposits will be found associated with the deeply eroded remnants now remaining seems highly improbable.

This explanation supposes that there was a relatively greater expulsion of metallic constituents from the portions of the magmas that crystallized slowly than from those that cooled rapidly near the surface, and that there was a was everywhere the same, differing only in degree.

The general relations and processes here described have for the most part been recognized before, but they are especially well illustrated and their commercial importance is especially well shown in the ore deposits of Utah.

Spencer ${ }^{1}$ has pointed out that cross-cutting intrusive bodies are more favorable to ore deposition than sills because of the more direct connection with the deep-seated source. Ferguson and Bateman ${ }^{2}$ have shown that tin deposits commonly occur near the top of granite bodies.

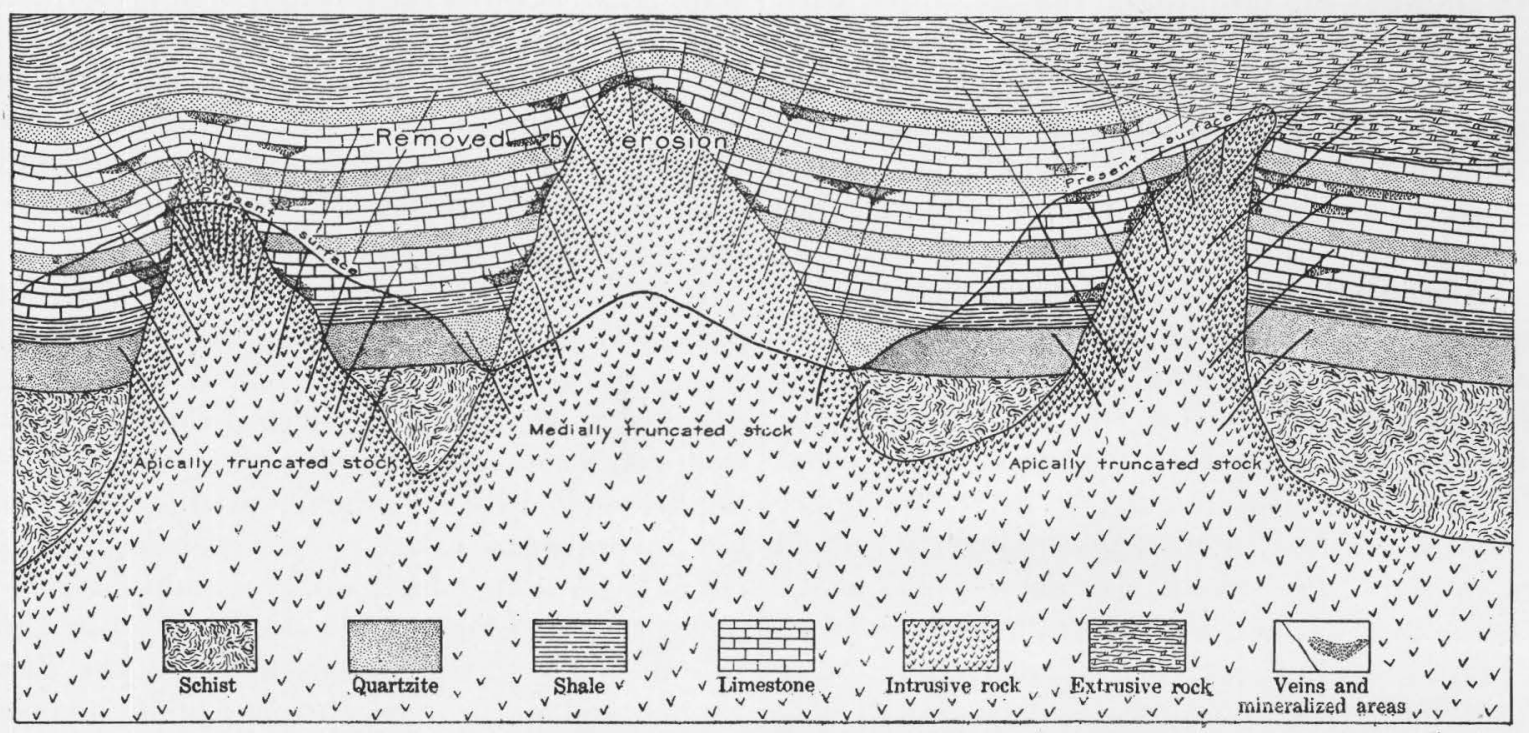

Figure 31.-Tdeal section through the top portion of an intrusive zone, showing the portions where differentiation kecame more important and the places where metals were precipitated. The lighter portions of the stock are more highly differentiated in this horizon, being most siliceous.

transfer of metallic constituents from the deeper zone to points nearer the surface - that is, if the different rock bodies were to be sampled it would be found that the disseminated metal content of the rock of the small laccoliths would be highest and would not differ materially from corresponding extrusive rocks; that of the large laccoliths would be less, for part of their metals are collected in veins; that of the apically truncated stocks would doubtless be less than that of the laccoliths, for the conditions under which they consolidated doubtless permitted greater differentiation; and that of the more deeply truncated stocks would be least of all, for in them opportunity was ample for extensive differentiation and for the migration of metallic constituents toward the surface. The process
The general process of differentiation here outlined does not differ materially from those previously suggested, notably by Spurr. ${ }^{3}$

Probably the relations of the intrusive bodies in Utah are unusually simple, owing perhaps to relatively stable conditions following the intrusions. After the magma had been partly solidified and the still fluid part consisted of a siliceous portion underlying the solid and perhaps of a basic portion underlying the siliceous portion, an impulse from below might drive the fluid portions into or through the solidified portions and might even

\footnotetext{
1 Spencer, A. C., Magnetite deposits of the Cornwall type in Pennsylvania: U. S. Geol. Survey Bull. 359, p. 16, 1908.

2 Ferguson, H. G., and Bateman, A. M., Geologic features of tin deposits: Econ. Geology, vol. 7, p. 223, 1912.

3 Spurr, J. E., Theory of ore deposition: Econ. Geology, vol. 7, p. 485,
} 1912. 
force them to the surface as flows. That bodies. Whether aplites and pegmatites are such conditions are undoubtedly present in significant or not, it may be noted that the Utah is shown by pegmatitic and basic dikes intrusive rocks of all the districts containing of the Granite Range, but for the most part they seem to have been of minor importance

It is possible that the concentration of metals near the apex of a stock is influenced by the relation of the magma at the time of intrusion to the surface or to the zone of fracture. If a magma containing gases held in solution under pressure is forced through the overlying rock until it connects with the surface or with the zone of fracture we may imagine a condition similar to that produced by removing the cork from a bottle of champagne, when the dissolved gases move toward the region of lower pressure. In this manner there might be relatively rapid movement of previously dissolved gases into a restricted area from a large volume of magma. The expansion of gases under decreased pressure and chemical reactions would effect temperature changes that may be factors in precipitating metallic and other substances. If the magma did not reach the surface the influence of difference in pressure would not be effective or would be less effective. This may account for the conditions in the Park Valley district and in the Grouse Creek Range, where the intrusive bodies (whether laccoliths or stocks is not apparent), whose tops are exposed by deep erosion, do not appear to contain large deposits of ore. It is not always possible to determine whether an intrusive body was connected with the surface before solidifying. There is, however, evidence that some of the stocks of Utah were so connected, notably those of the Tintic and Marysvale districts. Proof that an intrusive body now exposed had no connection with the surface before solidification is more difficult to discover. There are perhaps some criteria that would aid in such a determination, and their recognition will be valuable. The deep-seated intrusive body of the Park Valley district and the Granite Mountain intrusive mass contain abundant aplite and pegmatite dikes. Possibly the retention of these differentiation products indicates a lack of surface connection. Large ore deposits have not been found associated with these large ore deposits are similar in character to those that are believed to have had a surface connection before solidification.

SUMMARY.

The larger intrusive bodies of Utah are of two types, laccoliths and stocks. The laccoliths occur in the sandy and shaly sedimentary rocks in the southeastern part of the State, the stocks in the quartzites and limestones in the western part of the State.

The stocks may be subdivided into those truncated near the apex and those truncated at greater depth. The deeper truncated stocks are uniformly the more siliceous. The apically truncated stocks range in composition from monzonite to diorite and the deeper truncated stocks from granodiorite to granite.

Ore deposits associated with the laccoliths and deeper truncated stocks are of comparatively slight commercial importance and those associated with the apically truncated stocks are of great value.

The lack of large deposits associated with laccoliths is probably due to the fact that after intrusion the laccoliths were sealed off from their deep-seated source and that the amount of material in them was too small and the differentiation on solidifying too incomplete to furnish large deposits.

In the stocks the differentiation was probably greater at depth. The water and other lighter mobile constituents of the magma, with metals, sulphur, and other materials in solution, rose toward the surface; and the heavier minerals that crystallized early sank to greater depth. When the mobile constituents reached a portion of the solidified magma that was fractured they were guided by the fissures and on reaching favorable physical and chemical environments began to deposit their metals. The deeper truncated stocks are probably remnants from which the portion in which the metals were concentrated has been eroded. 
RELATION OF ORE DEPOSITS TO SEDIMENTARY ROCKS OF DIFFERENT AGES.

Ore deposits occur in sedimentary rocks ranging in age from pre-Cambrian to Tertiary. Deposits of large commercial importance thus far developed are, however, confined to those ranging from Middle Cambrian to Jurassic.

A few small deposits are present in pre-Cambrian rocks in the Simpson Mountains (Erickson district), Sheeprock Mountains (Blue Bells district), northern Wasatch area, in the Santaquin region, and in the Browns Park region (Uinta Mountains). Deposits in Tertiary rocks, so far as known, are confined to copper deposits in the Ouray region and lead-zinc-copper deposits in the Salina Creek district. No metallic deposits are known in rocks of Cretaceous age. Placer deposits occur in the Quaternary sediments.

Deposits in Cambrian rocks occur in the Little and Big Cottonwood, American Fork, Promontory, Ophir, and Tintic districts, in the Mount Nebo-Santaquin region, in some of the districts west of Tintic, in the Deep Creek Range, and in the Pine Grove district. The most important deposits are in the Tintic, Ophir, Cottonwood, American Fork, and Promontory districts. In the Ophir, Cottonwood, and Promontory districts important deposits occur in the Middle Cambrian shale-limestone series. In the Tintic district important mineralization is present in Upper (?) Cambrian dolomite, the Centennial-Eureka mine being in rocks of that age.

The most valuable deposits in the Ordovician to Devonian rocks are in the Tintic and Fish Springs districts; less valuable ones are in the Santaquin-Mount Nebo and San Francisco districts.

The most extensive deposits in the lower Carboniferous rocks are in the Tintic, Ophir, Mercur, Camp Floyd, and Cottonwood districts; less extensive ones are in the North Tintic, Provo, Santaquir-Mount Nebo, San Francisco, and Clifton districts. The most valuable deposits in the upper Carboniferous rock are in the Park City, Bingham, Lucin, and Star districts in the Mineral Range and the Iron Springs district; less valuable ones are in the Clifton district.

Deposits in the Triassic rocks occur in the Park City and Star districts and in some of the "Red Beds" deposits of the Plateau region, the most important deposit of this type being the Silver Reef.

Deposits in Jurassic beds occur in the Tushar Range and in the Plateau region, where they include many of the uranium and some of the copper and manganese deposits.

The deposits in the sedimentary rocks are mainly in limestone and dolomite. (See p. 174.) The age of the formation appears less significant economically than the composition and relations of the limestone and the character of the associated intrusive rocks. Age alone gives no definite measure of the depth to which a formation was buried at the time of the deposition of the ores; for previous to the great igneous activity of Tertiary time an old erosion surface cut all the earlier formations in the western part of the State, and Tertiary extrusive rocks lie unconformably on all formations from early Paleozoic to Tertiary.

\section{ALTERATION OF THE ORE DEPOSITS BY SURFACE} AGENCIES. ${ }^{1}$

IMPORTANCE.

All of the ore deposits have been changed to a greater or less extent by the action of surface agencies, mainly of meteoric water carrying materials in solution. The effects differ greatly both in amount and character in the different types of ore deposits. The magnetite-hematite iron deposits, for example, have been but slightly affected either in character or in value, but some of the copper and zinc deposits owe their commercial importance to the action of surface agencies.

Economically the alteration of the ores has been important, first, by effecting a partial segregation of the individual metals or groups of metals of the original deposits; and second, by greatly simplifying the necessary metallurgic treatment. The extensive development of the mining industry of the State would doubtless have been much delayed had it not been for the existence of large bodies of oxidized ores that readily yielded to the simple metallurgic treatment of the early days. Methods of treating the complex primary ores have been developed slowly and even now are only partly successful.

1 No complete discussion of this subject is intended. Those especially interested should consult Emmons, W. H., U. S. Geol. Survey Bull. 625,1917 , in which a general discussion and references to the extensive literature may be found. 
CONDITIONS INFLUENCING SURFACE ALTERATION.

GROUND-WATER LEVEL.

The ground-water level is perhaps the most important factor in the superficial alteration of the ores, for in many deposits it approximately marks the line to which alteration has progressed and beyond which it has usually not extended far. The position of ground-water level varies greatly with the precipitation, structure, and other conditions of the region.

The movement of ground waters has been discussed by numerous authors. ${ }^{1}$ Finch has separated the area affected by surface waters into the gathering zone, extending from the surface to the water table; the zone of discharge, the portion, of the saturated zone in which the movement of the water is well

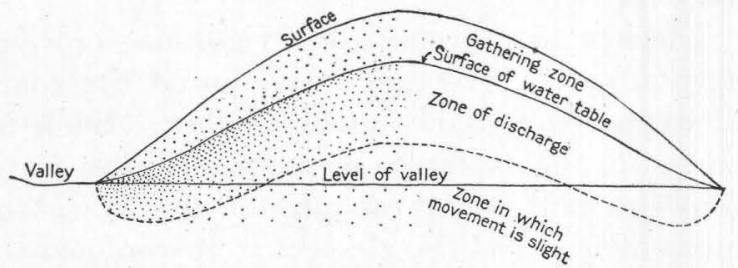

FIGURE 32.-Generalized vertical section along a fissure outcropping at different elevations, showing the distribution and flow of the waters in the fissure. The shading indicates the variation in amount of flow at different points.

marked, extending from the top of the water table to the lowest level from which horizontal discharge is ordinarily possible; and the static zone, in which the movement of the water is ordinarily infinitesimal.

The position of these zones in a vein that outcrops at different levels, for example, one extending from a valley through a ridge to a second valley, is shown in figure 32 . Conditions of circulation and consequently of oxidation at given distances below the surface are evidently materially different on the divide and in the valleys. The zone above the water table is materially thicker near the divide, and the active circulation of water probably extends much farther below the top of the water table on the divide. The actual thickness of the zones, especially those of the gathering zone

1 Slichter, C. S., Thecretical investigation of the motion of grcund waters: U. S. Geol. Survey Nineteenth Ann. Rept., pt. 2, pp. 297-384, 1899.

Van Hise, C. R., A treatise on metamorphism: U. S. Geol. Survey Mon. 47 , pp. 571-576, 1904

Finch, J. W., The circulation of underground aqueous solutions and the deposition of lode ores: Colorado Sci. Soc. Proc., vol. 7, pp. 193-252, 1904. and the zone or discharge, is dependent to a large extent on the amount of precipitation. For example, the heavy precipitation in the Wasatch Range causes the water table to stand only a few hundred feet below the surface, even near the divides and in readily permeable formations: whereas in some of the ranges in the central and southwestern part of the State, where precipitation is slight, the top of the water table lies very deep. In the Tintic district it is 1,600 to 1,800 feet below the valleys and 2,100 to over 2,300 feet below the higher ground.

Usually a single vein or fissure does not extend for a great distance, and the height of the water table in the vein is dependent in large part on the permeability of the rock in which it occurs. This difference is well illustrated in areas of igneous rocks adjacent to limestones and quartzites, the water table in the igneous areas commonly being much nearer the surface, as in the Tintic district, where permanent water is reached only 300 to 800 feet below the surface in the igneous rocks but is very much lower in the adjacent sedimentary rocks. Similar conditions occur in the San Francisco district; in the volcanic rocks about Frisco the water level is but a few feet below the surface, whereas in the Horn Silver mine on the contact of limestone and volcanic rocks it lies at a depth of more than 1,000 feet.

To various combinations of the conditions outlined above are due the great differences in the depths to which there is active circulation of oxidizing waters in the different deposits and consequently in the depths to which the ore deposits have been altered.

A further complication in the area within the Great Basin is that at earlier periods the water level has stood higher and probably also lower than at present. Shore lines on the sides of the basin show that the waters once rose approximately 1,000 feet above the present level of Great Salt Lake, and alluvial cones traceable nearly to the lowest points of the basin suggest that at some time the waters may have been lower than at present. ${ }^{2}$

These differences in the accumulation of waters in the inclosed basin indicate climatic variations, though such were probably slight.

${ }^{2}$ Gilbert, G. K., Lake Bonneville: U. S. Geol. Survey Mon. 1, pp 90, 220, 1890. 
A small increase in precipitation or decrease in evaporation would account for the change. The readiness with which the level of the Great Salt Lake responds to climatic changes is shown by fluctuations of more than $\mathbf{1 5}$ feet that have been recorded since 1850, the higher levels corresponding to periods of relatively high precipitation and the low to periods of low precipitation. ${ }^{1}$ (See Pl. XXII.) Evidently the balance between accumulation and evaporation in the basin is very close, and a very slight increase in precipitation or decrease in evaporation over a long period would cause an important rise in the lake level. That the climatic conditions at the time of the higher lake stages were not very different from the present is indicated by the fact that only basins fed by streams draining high mountain areas contained such lakes. ${ }^{2}$

The effects, therefore, during the higher lake stages on deposits at high elevations did not differ greatly from the present ones, for the deposits were too high above the lake to be much affected by its rise and fall and the precipitation was much the same. In the higher areas the chief changes were probably due to erosion by the glaciers that doubtless formed at that time in a few of the ranges. In the lower areas, however, the effect was pronounced. The rising of the water level of the lake 1,000 feet might cause as a maximum an equal rise in the water table in certain veins and an important change in many of the veins in the lower ranges.

In some of the deposits in the lower ranges the ores are oxidized considerably below the present water level and it seems not unlikely that the alteration occurred while the waters in the basins were lower than at present and probably before the sediments had accumulated in the basins to the present level. The water level in the veins in limestone in the Tintic district is only slightly above the level of Utah Lake, but oxidation has evidently extended considerably below this level, and a similar condition is true of the water level and oxidation in the Star district.

\footnotetext{
${ }^{1}$ Henshaw, F. F., Porter, E. A., and Stevens, G. C., Surface water supply of the Great Basin: U. S. Geol. Survey Water-Supply Paper 330, pl. $3,1914$.

2 Gale, H. S., Notes on the Quaternary lakes of the Great Basin, with special reference to the deposition of potash and other salines: U. S. Geol. Survey Bull. 540, p. 399, 1914.
}

The rapidity of erosion has an effect on the depth to which alteration extends. If erosion is rapid oxidation may be able to keep only a short distance in advance of it and will be shallow. On the other hand, if erosion is very slow oxidation may reach far below it.

Ordinarily the higher the elevation the more rapid the erosion, but in Utah precipitation is so great on the higher areas, as the Wasatch and Uinta ranges, that they support a dense vegetation which retards erosion and partly offsets the heavier precipitation and greater elevation. Moreover, the high areas are less subject to the torrential rains that from time to time accomplish such rapid erosion in the comparatively bare desert ranges. In small areas that extend above timber line erosion is very rapid.

Glaciers are especially vigorous erosive agents, and where they have flowed the zone of oxidation is likely to be shallow. Such is the case, for example, in parts of Little Cottonwood and other canyons of the Wasatch Mountains. But the glaciers were confined to the heads and axial portions of the canyons, and on the intervening unglaciated ridges the veins are deeply oxidized.

The extent of oxidation has doubtless varied with the length of the seasons. In higher altitudes, like those of the Wasatch Range, the long cold winters tend to restrict the amount of waters circulating for a large part of each year and undoubtedly did so even more during the period when parts of the region were covered with ice and snow throughout the year.

The character of the rock is also of prime importance. In all parts of the State areas of soft rock have been lowered far more than neighboring areas of harder rock. Naturally ore deposits inclosed in the different types of rock will be similarly affected.

\section{CHARACTER AND GEOLOGIC RELATIONS OF THE} DEPOSITS.

Besides being subjected to the general conditions affecting the ore bodies, each type of ore deposit differs in oxidation according to its mineralogic composition and to the character of the inclosing rocks. For this reason the the alteration of each type is best discussed separately. 


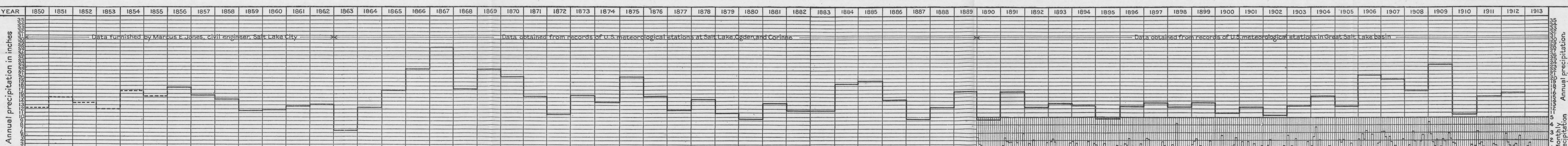

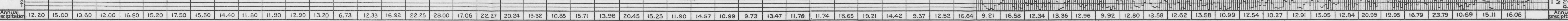

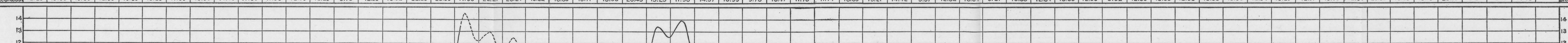
(n)

Ninativas

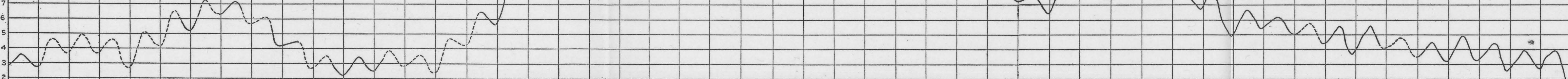

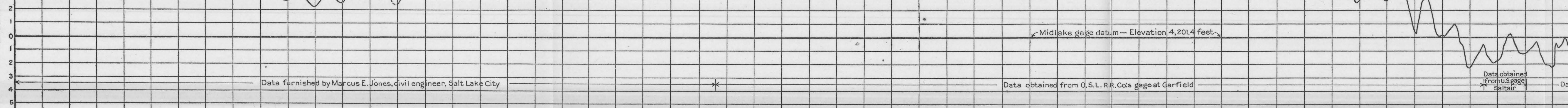

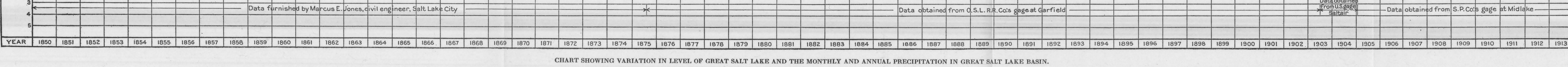


ALTERATION OF THE PRINCIPAL PRIMARY METALLIC MINERALS. ${ }^{1}$

Ores and minerals are commonly designated as primary or secondary. By primary ores or minerals are meant those that have not been affected by the action of surface solutions, and by secondary, those that have resulted from the action of superficial agencies. Hypogene and supergene have been suggested by Ransome to designate these types. The minerals in the upper part of most of the ore bodies, or the oxidized zone, are prevailingly secondary or supergene, and those at greater depth that have not been affected by surface solutions are primary or hypogene. Between the two zones is an area in which both classes are present.

\section{IRON MINERALS.}

The principal primary iron minerals in the ore deposits are magnetite, hematite, pyrite, iron-bearing garnets, and carbonates containing iron. Lessimportant aresmall amounts of pyrrhotite, several silicates containing iron, and sulphides like chalcopyrite and bornite that contain other metals combined with iron.

Magnetite is apparently very slightly acted on by surface waters. In many magnetitebearing outcrops the mineral is perfectly fresh, and in the float from such deposits the mineral, though finely divided, is apparently not hydrated and is strongly magnetic. Likewise, in some of the bench gravels along Colorado and Green rivers finely divided magnetite that has been exposed to surface solutions for a long period is strongly magnetic and apparently little, if any, changed. Under the conditions prevailing in Utah the main effect of surface agencies on magnetite seems to be a mechanical breaking down and removal. An exception to the rule is the occurrence of martite (magnetite oxidized to hematite) grains in the basal beds of Cambrian quartzite in the Sierra Madre district.

Hematite, so far as ascertained, behaves similarly to magnetite, but its more friable character causes it to break into much finer particles, which are less readily recognized in the float and waste of the deposits.

Pyrite readily breaks down chemically when acted on by oxygen-bearing waters; and the

1 For detailed discussion of the chemistry of the alteration see Emmons, W. H., The enrichment of ore deposits: U. S. Geol. Survey Bull. 625,1917 , also textbooks and special articles. resulting products, including ferrous and ferric sulphate and sulphuric acid, react with the other sulphides, so that the pyrite in an ore body is an important factor in its alteration. The final product of the alteration of pyrite is commonly hydrous ferric oxides (limonite), but before this product is reached the iron may have formed, not only the very soluble ferrous and ferric sulphate, but also, with other substances, the more stable basic sulphates jarosite, plumbojarosite, and beaverite, which, however, usually break down under surface conditions to less complex compounds, including hydrous iron oxides.

Iron migrates less readily, as a rule, in limestone than in siliceous rocks, probably because the ferric sulphate reacts with calcium carbonate and precipitates hydrous ferric oxide, according to the equation ${ }^{2}$

$\mathrm{Fe}_{2}\left(\mathrm{SO}_{4}\right)_{3}+3 \mathrm{CaCO}_{3}+3 \mathrm{H}_{2} \mathrm{O}=$

$$
2 \mathrm{Fe}(\mathrm{OH})_{3}+3 \mathrm{CaSO}_{4}+3 \mathrm{CO}_{2}
$$

Where limonite is found in limestones at a considerable distance from its source, it is because the limestones through which it has migrated are of dense texture and siliceous or argillaceous composition and therefore are not readily susceptible to replacement.

The iron-bearing silicates, of which garnet is perhaps the most abundant in the ore deposits, break down under surface conditions, yielding hydrous iron oxide, opaline silica, and other products.

Iron-bearing carbonates are apparently not very rapidly acted on directly by oxidizing waters, though they darken on exposure, suggesting oxidation of the iron. They readily break down under the action of oxidation products of pyrite, notably of sulphurio acid, and finally form hydrous iron oxides.

\section{MANGANESE MINERALS}

Primary manganese minerals in the ore deposits of the State are relatively few and are of relatively slight importance in individual deposits except in the "sandstone manganese deposits" of the Plateau region. Manganese occurs in much of the vein carbonate and is probably present in the sulphides, though it has not been recognized in them. In the West Tintic district the manganese ores have apparently resulted from the alteration of rhodonite.

${ }^{2} \mathrm{Knnopf}, \mathrm{Adolph}$, Mineral resources of the Inyo and White mountains, Cal.: U. S. Geol. Survey Bull. 540, p. 106, 1914. 
In the secondary ores small amounts of manganese oxide and hydrous oxide are present in nearly all the deposits and in a few are abundant. Manganese has recently been mined in the East Tintic district, just south of Homansville Canyon. In 1917 and 1918 shipments were made from the North Tintic and West Tintic districts. It has been shipped from the Little Cottonwood district and is present in the Marysvale district, near Modena, and at other localities.

COPPER MINERALS.

The more important primary copper minerals are chalcopyrite, enargite, and tetrahedrite, and numerous others have copper as a constituent. (See Pl. XXIII.)

Chalcopyrite, unaer the influence of oxidizing waters, especially when associated with pyrite, as it almost invariably is in the ore deposits, readily alters to iron and copper sulphates. The iron, like that in pyrite, is in part eventually converted into hydrous ferric oxide. If calcite is present, the copper sulphate resulting from the first alteration reacts with it to form copper carbonate or with silica to form copper silicates; the relatively stable basic sulphates may form under some conditions, though, so far as observed, brochantite commonly forms from the alteration of chalcocite or covellite. In the absence of calcite the copper-bearing solutions and other products of the alteration of chalcopyrite and pyrite pass out of the zone in which they formed. If they come in contact with sulphides below the zone in which oxygen is available, the copper is precipitated as the secondary sulphides chalcocite, covellite, or bornite, or, more rarely, as secondary chalcopyrite. The secondary sulphides in turn come into the zone of oxidation and on alteration produce native copper, the oxides cuprite and melaconite, the carbonates and silicates, and the basic sulphate brochantite; or they may again form soluble sulphate and be carried away in solution to be again precipitated by other sulphide.

The alteration of enargite results in a series of copper-arsenic compounds and the more common copper carbonates and silicates. Scorodite and pharmacosiderite are common alteration products of arsenic compounds and are doubtless formed in the oxidation of enargite associated with iron minerals as well as in the alteration of arsenopyrite.
The copper of tetrahedrite on oxidation usually forms the common carbonates and silicates, and the antimony, if lead is present, commonly unites with it to form bindheimite or closely allied compounds.

\section{LEAD MINERALS.}

Galena is by far the most important primary lead mineral in the ore deposits of the State, jamesonite or some closely allied mineral is present in some of the deposits, and other lead minerals occur in small amount.

The alteration of galena as a rule first forms the sulphate, anglesite, which in deposits in limestone usually alters to the carbonate, cerusite. Frequently, however, more complex sulphates, such as plumbojarosite (see fig. 33 , p. 210) and beaverite, are formed, which eventually break dowI and form simpler combinations, the final oxidation mineral of the lead most commonly being cerusite. Jamesonite commonly alters to antimony-lead compounds, probably most commonly to bindheimite.

ZINC MINERALS.

Sphalerite is the only primary zinc mineral of importance thus far recognized in the ore deposits of the State. When acted on by sulphuric acid or by certain sulphates it alters to the sulphate, which is very soluble and is readily carried in solution. On coming in contact with limestone the zinc of the sulphate is precipitated as smithsonite, hydrozincite, or under certain conditions in the presence of silica as the hydrous silicate, calamine, or, rarely, as the anhydrous silicate, willemite. Other minerals are formed to a slight extent, as aurichalcite and zinc-bearing clay. If the acid sulphate solutions pass below the zone of free oxygen into primary sulphides, the acidity is reduced and the zinc may be precipitated as sulphide; in some places as the hexagonal sulphide, wurtzite. Smithsonite, hydrozincite, calamine, and wurtzite are the principal secondary minerals, though others are present in small amounts. (See Pls. XXIII, XXIV, and fig. 33.)

\section{ARSENIC MINERAIS.}

Several primary arsenic minerals are present in the ore deposits. On oxidation these yield realgar, orpiment, scorodite, pharmacosiderite, 


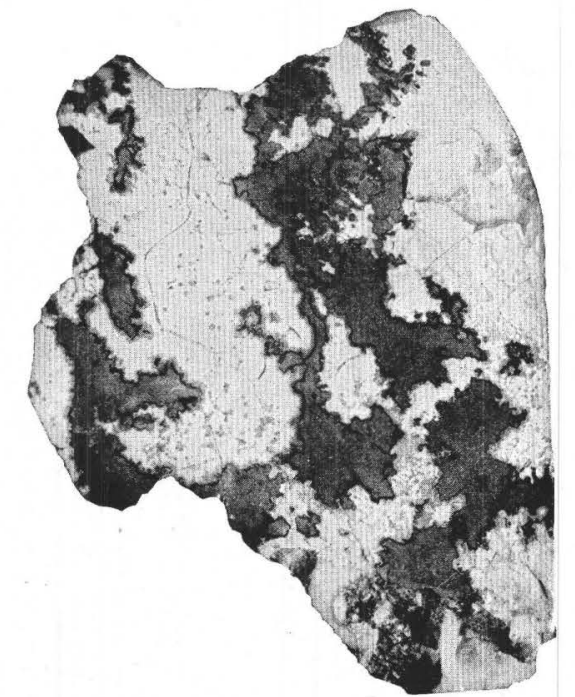

A. OXIDIZED COPPER ORE FROM THE COPPER MOUNTAIN MINE, LUCIN DISTRICT.

Large, dark areas, cuprite; dark bands surrounding cuprite, melaconite; light band outside of melaconite and small spots in the light areas, malachite; light areas, aluminum silicate containing variable amounts of copper.

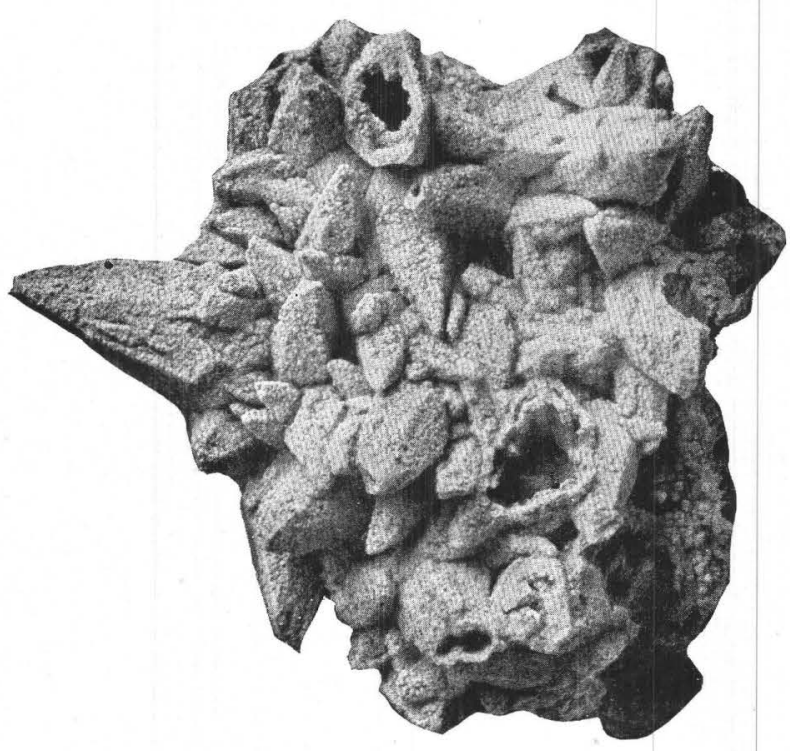

B. SMITHSONITE PSEUDOMORPHS AFTER CALCITE, FROMi THE SEVENTH LEVEL OF THE HORN SILVER MINE. Natural size.

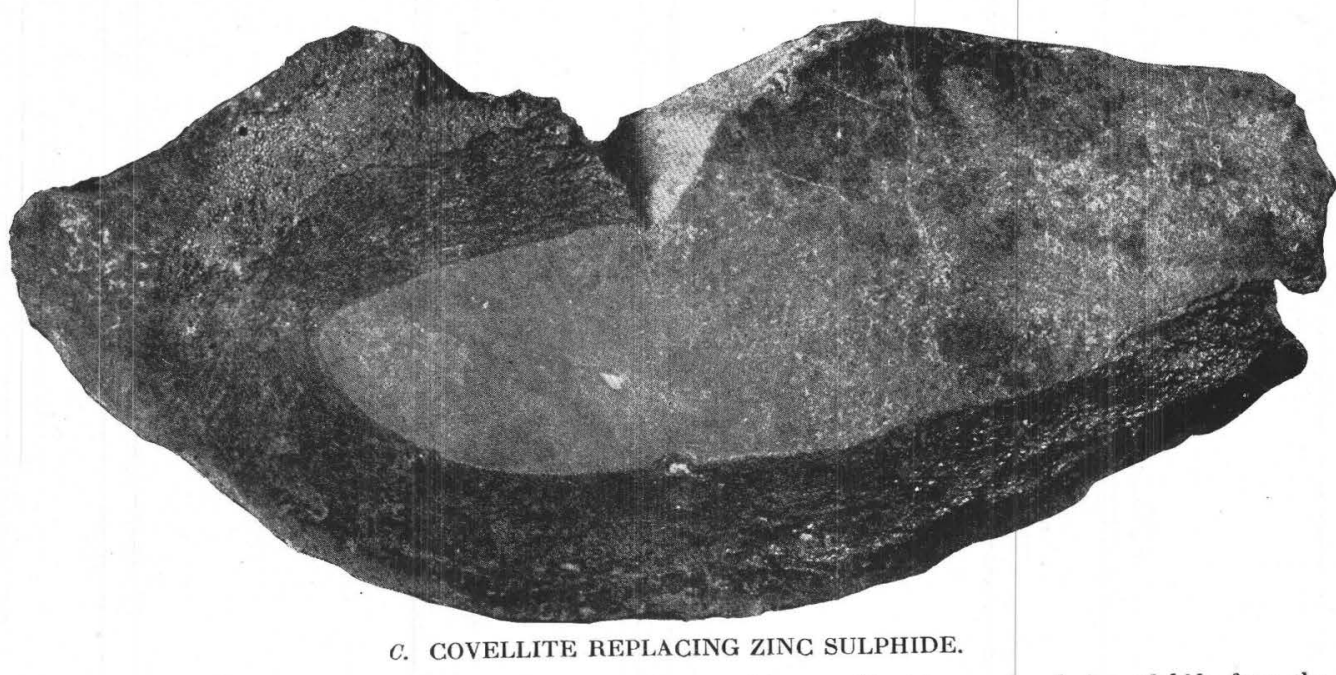

Zinc sulphide in the center surrounded by zones of covellite containing considerable unreplaced zinc sulphide, from the Horn Silver mine. Collected by D. P. Rolfing. 


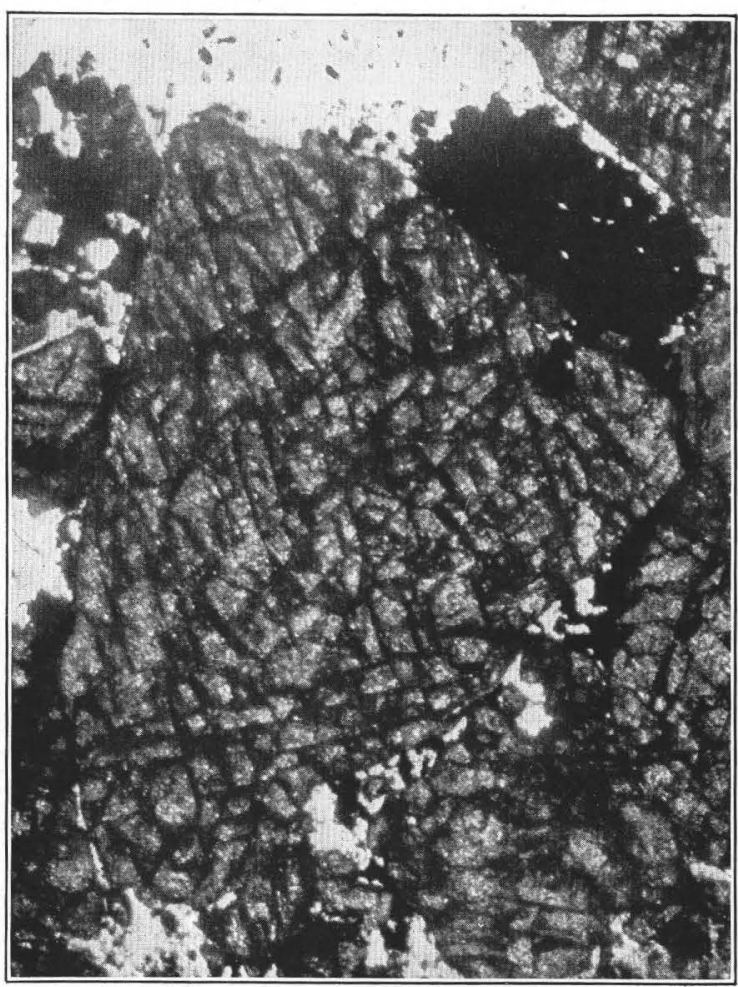

A. PHOTOMICROGRAPH OF SPECIMEN OF ZINC SULPHIDES FROM THE HORN SILVER MINE.

Dark-gray areas, zincsulphides, sphalerite, and wurtzite. Ordinary light. Enlarged 43 diameters.

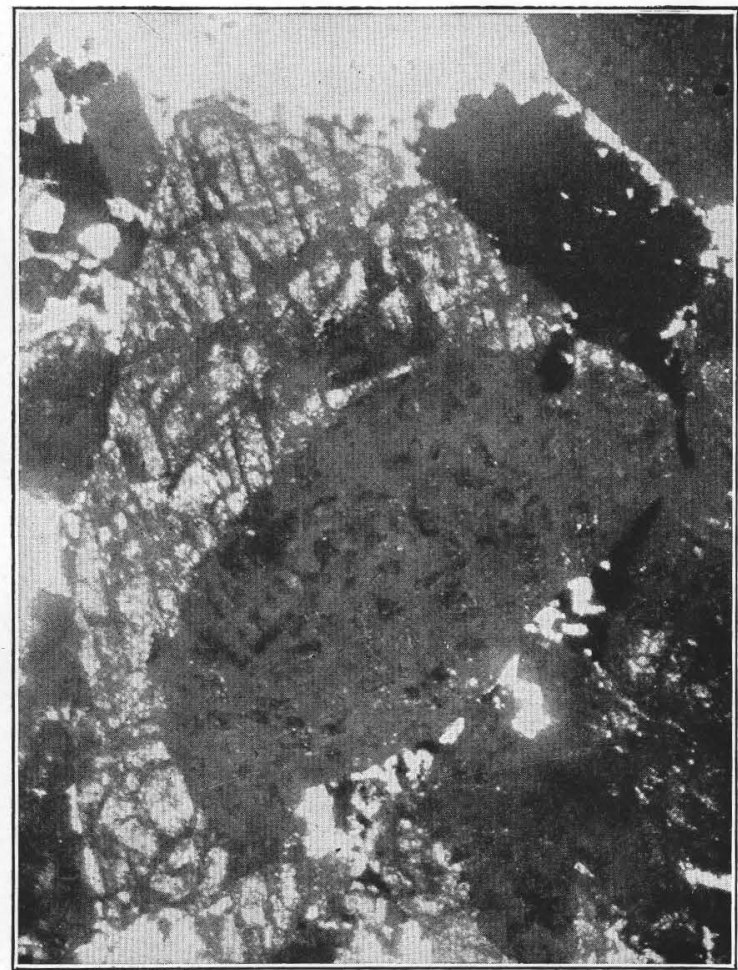

B. PHOTOMICROGRAPH OF SPECIMEN SHOWN IN $A$, WITH CROSSED NICOLS.

Dark areas, sphalerite; light-gray areas, wurtzite. Enlarged 43 diameters.

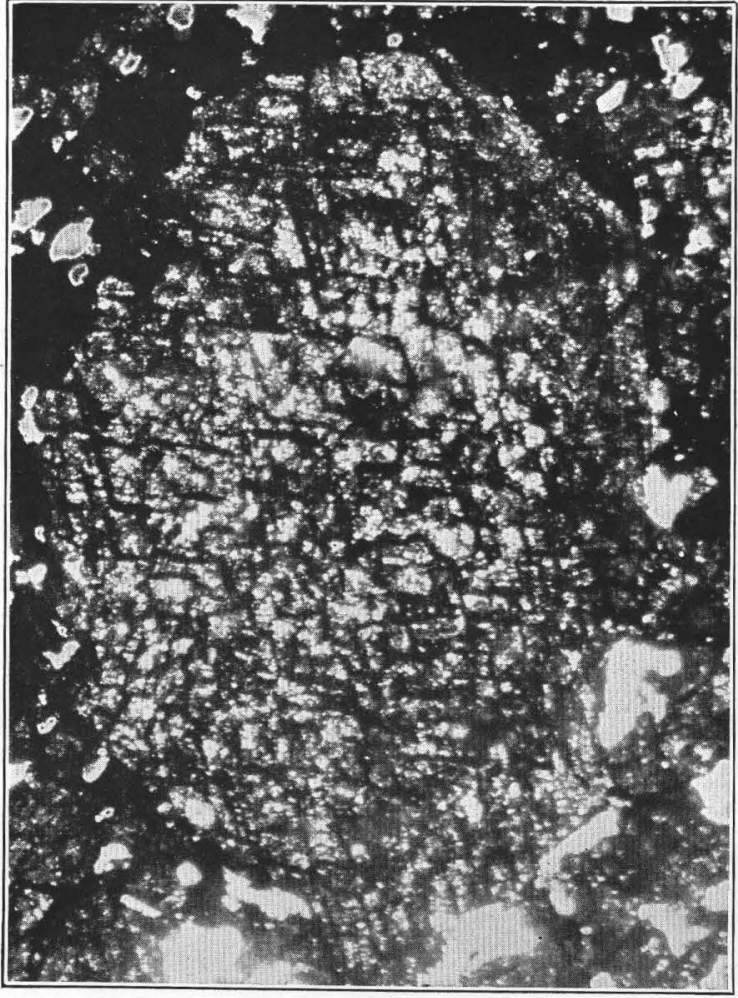

C. PHOTOMICROGRAPH OF CRYSTAL OF ZINC SULPHIDE IN ORDINARY LIGHT.

Enlarged 43 diameters.

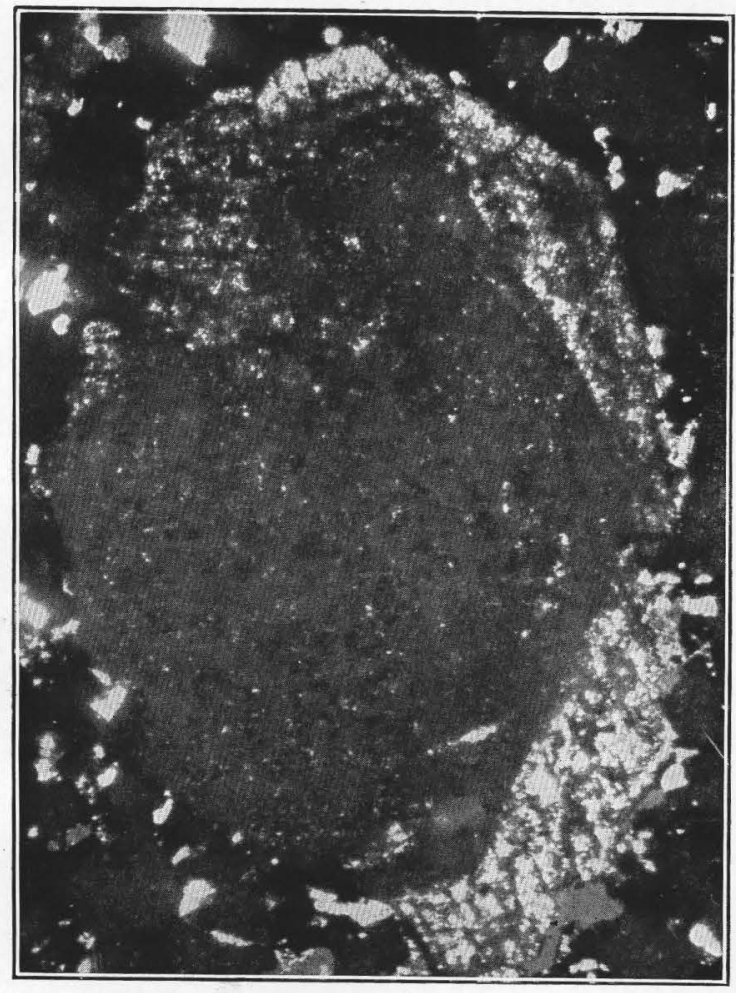

D. PHOTOMICROGRAPH OF CRYSTAL SHOWN IN $C$, WITH CROSSED NICOLS.

Light areas, wurtzite surrounding a center of sphalerite. 
and compounds of arsenic with other metals, notably copper.

\section{ANTIMONY MINERALS.}

Antimony is present in the primary ores as stibnite and in combination with other metals, notably as tetrahedrite and jamesonite. The alteration products of stibnite are valentinite, kermesite, or closely allied minerals. Bindheimite is a common alteration product of ores containing both lead and antimony.

\section{SILVER MINERALS.}

The silver of the primary ores occurs in argentite and in several arsenic and antimony compounds, and to a slight extent in selenides and tellurides. By far the most abundant secondary mineral is cerargyrite, though some native silver and some secondary sulphide and antimony and arsenic compounds are present.

\section{GOLD MINERALS.}

The gold of the primary ores occurs as native metal in selenium and tellurium compounds, and in sulphides in an undetermined form. The native metal is the only secondary product recognized.

URANIUM AND VANADIUM MINERALS.

Uranium and vanadium deposits in the Plateau region have not yet been sufficiently developed to determine positively which minerals are primary and which secondary. Some of the minerals that have formed as an efflorescence are certainly secondary, as pintadoite, uvanite, and certain undetermined uranium sulphates. Whether some of the more abundant minerals, as carnotite and hewettite, are primary or secondary is doubtful.

\section{ALTERATION OF DEPOSITS IN SANDSTONE.}

Most of the ore deposits in sandstone (see p. 152 ), as seen in natural exposures and in shallow development works, are thoroughly oxidized, though sulphides have been reached in a few such deposits.

\section{SILVER DEPOSITS.}

In the Silver Reef district cerargyrite and native silver lie near the surface, but at greater depth give place to argentite, which is believed to be the original silver mineral. Lindgren ${ }^{1}$ has suggested that the argentite is secondary and that it resulted from a concentration from

${ }^{1}$ Lindgren, Waldemar, Mineral deposits, p. 374, 1913. argentiferous chalcocite. Some secondary argentite may have been deposited, but the writer has failed to find evidence that it is important.

The copper minerals of the Silver Reef district are mainly azurite, malachite, and chalcocite. Whether or not the chalcocite is original has not been determined. Secondary iron minerals are rather abundant, and were probably derived in part at least from the alteration of iron or copper-iron sulphides. The chalcocite may have formed by replacement of such iron-bearing minerals as did chalcocite in some of the "sandstone" copper deposits.

So far as determined alteration has neither pronouncedly enriched or impoverished the silver deposits in the Silver Reef district. In the main the change has been to minerals that are relatively stable under surface conditions and migration has been slight.

COPPER DEPOSITS.

The few instances where sulphides have been observed in "sandstone" deposits in which copper is the principal valuable constituent affords abundant evidence of replacement of chalcopyrite and pyrite by covellite and chalcocite. Such replacements are especially well shown in the Big Indian deposits (Pl. XLIX) and in the Blue Dike deposits in White Canyon, where the structure of the wood is preserved through replacement by chalcopyrite and subsequent replacement of the chalcopyrite by chalcocite and covellite (Pl. XIV, p. 152). The rather abundant secondary iron minerals associated with the oxidized copper ores also suggest that iron-bearing sulphide occurred in the original ores of the deposits where it has not been found. Chalcocite and covellite have in turn been altered to the carbonates malachite and azurite, which are the prevailing copper minerals in most of the deposits to the depth to which they have been developed.

Most copper deposits of this character observed by the writer lack a marked zone of leaching, and it is not certain that the copper sulphides are due to the surface solutions.

URANIUM AND VANADIUM DEPOSITS.

Too little is known of the original character of the uranium and vanadium deposits to make discussion of their alteration at this time profitable. An undetermined uranium sulphate that 
is associated with chalcopyrite, chalcocite, and covellite in the Blue Dike prospect in White Canyon may have been derived from the oxidation of the sulphides, but in the material at hand it was not possible to free the sulphides from the uranium sulphate so as to test them for the presence of uranium.

DEPOSITS IN INTRUSIVE ROCKS.

PEGMATITIC GOLD QUARTZ VEINS.

The pegmatitic gold quartz veins (see p. 159) are open and readily accessible to the agents of surface alteration, and the presence of abundant hydrous oxide of iron indicates that iron minerals have been oxidized. Developments below the oxidized zone had been too meager to determine the change in metal content due to oxidation, but the gold content seems to be as large near the surface as at any point at greater depth, as if leaching of gold had not been important. However (see p. 486), the richest ore shoots in the Queen of Sheba mine occur in fractures younger than the veins and are most readily accounted for by concentration of the gold by surface agencies.

COPPER DEPOSITS IN INTRUSIVE ROCKS.

The oxidized products of the different types of copper deposits (see p. 160) in intrusive rocks show many similarities and some marked differences, due primarily to differences in the original mineral composition.

QUARTZ-TOURMALINE COPPER DEPOSITS.

The primary ores of the quartz-tourmaline copper deposits, in both the San Francisco and Clifton districts, contain important amounts of calcite and of calcium-magnesium-iron-manganese carbonate. This has resulted in the formation of abundant copper carbonate in the zone of oxidation and in very little sulphide enrichment. The Cactus mine, for instance, contains practically no enriched sulphide ore. Development in veins of this type in the Clifton district has not extended below the zone of carbonates, but the abundance of carbonates in the surface zone indicates that sulphide enrichment has not been great.

QUARTZ COPPER DEPOSITS.

The quartz copper veins and associated replacement deposits of the Bingham and Beaver Lake districts, in which carbonates are lacking in the primary ores or are present only in small amounts, afford alteration products of very different character. In the upper part the sulphides have been entirely oxidized and practically all of the copper and much of the iron removed. The iron not removed is present as limonite or similar hydrous ferric oxides. The gold content shows no decrease, and doubtless the gold has been eroded with the silicates and has contributed to the placers, as those of Bingham Canyon. At greater depth the copper content in the form of carbonates and possibly in part as basic sulphate increases, and a little iron is apparently present as basic sulphate, though in what mineral combination has not been determined. At still greater depth sulphides are mixed with carbonates, oxides, and sulphates, and these give place to the zone of secondary sulphide, which consists of pyrite, chalcopyrite, and some bornite, partly replaced by chalcocite and covellite.

In the Bingham district the amount of copper in the form of carbonates and other oxidized minerals in the material above the sulphide ores varies considerably. ${ }^{1}$ (See also p. 359.) In the portions of the deposits highest above the canyon bottom very little copper is present above the sulphides, but near the canyon bottom the oxidized ores immediately above the sulphides contain nearly or quite as much copper as the sulphide ores.

The relative amount of the secondary sulphide minerals in the enriched sulphide zone also varies. Beeson states that in the deposits highest above the canyon bottom covellite predominates over chalcocite and that near the canyon bottom the reverse is true. This difference he attributes to varying conditions of acidity and the content of ferrous sulphate.

At greater depth the amount of the secondary sulphides gradually decreases till the zone of primary sulphides is reached below the influence of oxidizing solutions. The transition from the zone of carbonates and sulphates to that of sulphides is rather abrupt, taking place within a few feet and in many places within a few inches. In general, however, the copper content shows no such notable change, and where the ores are high grade they are of about

1 Beeson, J. J., The disseminated copper ores of Bingham Canyon, Utah: Am. Inst. Min. Eng. Bull. 107, pp. 2191-2236, 1915. 
the same value above and below the transition. Where they are low grade, however, as in the Bingham deposits, the difficulties of treatment have caused the ores from above this line to be stored to await metallurgic development. The greatest concentration of copper apparently lies near the line separating secondary sulphides and the more highly oxidized carbonate oxide and sulphate. Above this line there is a decrease in copper due to downward leaching and below it there is a progressive change toward the leaner primary sulphides. The change from the secondary sulphides to primary ore is gradual, no sharp line separating ore from material too low in metals to be profitably treated.

In the Utah Copper Co.'s ore body (see Pl. XXXV, p. 358) the depth at which the sulphides have been changed to carbonates and oxides varies with the elevation above the canyon bottom. The thickness of the oxidized zone on the higher elevations is more than twice what it is under the bottom of the canyon.

QUARTZ SILVER-LEAD VEINS.

The oxidation of the silver-lead veins in the intrusive rocks (see p. 162) is in general similar to that of the silver-lead veins and replacement deposits in the sedimentary rocks and need not be described in detail. The zinc content of the deposits, however, has been markedly reduced. Whether the zinc has been in part precipitated in the sulphide zone, as in the Horn Silver mine (see p. 213), or has been dissipated by the circulating waters has not been determined.

IRON VEINS.

Alteration of the magnetite-hematite. iron deposits in the intrusive rocks is similar to that of the replacement deposits. (See p. 168.) Certain iron deposits in the Antelope Range near Marysvale and in the Dragon mine in the Tintic district consist of hydrous iron oxide and are attributed principally to the concentration of the oxidized products of disseminated pyrite in altered igneous rocks. (See p. 163.)

\section{CONTACT DEPOSITS.}

The physical and chemical character of the contact deposits is not favorable to rapid oxidation, and their alteration by surface solutions is usually relatively superficial. Physically the deposits are characteristically dense and relatively impervious to solutions. Mineralogically they are composed largely of relatively inert oxides and silicates and of sulphides in too small amount to cause the rock to break down rapidly.

IRON DEPOSITS.

Contact deposits chiefly valuable for their iron content are present in the Iron Springs and Bull Valley districts (p. 168) but show relatively slight surface alteration. Leith and Harder note that hematite appears to be more abundant below the surface and that silica is distinctly so. The sulphur content also appears to be less near the surface. The changes due to oxidation are favorable to the quality of the ore.

COPPER DEPOSITS.

The surface alteration of the contact copper deposits has been relatively shollow. Some concentration of the copper has occurred producing "bunches" of relatively high grade enriched sulphide and carbonate and oxide ores.

For a short distance below the surface the deposits have been impoverished in copper. At greater depth the copper content increases but is commonly concentrated along lines of easiest passage of solutions. At greater depth the primary ores are reached. In the oxidized zone some "bunches" of rather high-grade ore have been extracted, some of them probably at a profit. In the primary zone, where silicates are the prevailing gangue, most of the material is too low grade for profitable mining. In the deposits in which the gangue is largely iron oxides there has been a similar enrichment, though usually less localized and consequently producing ore with a lower copper content. With favorable mining and transportation facilities, however, even the primary ore with an iron oxide gangue can be profitably mined, owing to the value of the iron as a flux.

\section{GOLD DEPOSITS.}

The contact gold deposits of the Clifton district consist mainly of silicates and have undergone relatively slight surface alteration. Some of the richest specimens seen, however, were distinctly oxidized; the gold in them occurs along fissures and is associated in places with copper sulphide. This relation suggests that there has been some movement of the gold during oxidation. 
REPLACEMENT DEPOSITS IN AND ADJACENT TO FISSURES IN SEDIMENTARY ROCK.

\section{DEPTH OF OXIDATION.}

Replacement deposits associated with fissures in the sedimentary rocks have commonly been extensively oxidized, many of the fissures being sufficiently open to permit rather free circulation of waters. The minerals forming the deposits yield readily to oxidizing solutions. The relatively open character of the fissures, especially in limestones, as compared with those in the intrusive rocks, permits deep circulation of the oxidizing waters. These factors have produced a very deep zone of oxidation in many of the deposits.

The results of alteration vary greatly with the metal content of the deposits.

COPPER DEPOSITS.

The alteration of the copper deposits is in general similar to that of those in the intrusive rocks and, as in the intrusive rocks, varies considerably with the character and mineral composition of individual deposits. The primary ores of the larger deposits consist principally of pyrite but contain chalcopyrite and other metallic minerals. Gold and silver are present in variable but usually in small amount. Quartz is the prevailing gangue mineral and in many places has replaced the limestones surrounding the main sulphide bodies. Where these replacement bodies are oxidized the copper has migrated downward in notable amounts and has formed an important zone of sulphide enrichment, as in the Highland Boy and other deposits of the Bingham district. The gold, in part at least, has remained in the leached portion, and some of the gossans in the Bingham district have been treated to recover it. The secondary sulphides, however, are richer in gold and silver than the primary deposits, indicating a concentration.

In many smaller deposits, where the replacement of the limestone is less complete and calcium carbonate is an important gangue mineral, the sulphide enrichment is far less important. In these the copper sulphate formed by the oxidation of the original sulphides has reacted with the calcite of the gangue and has formed the relatively stable copper carbonates. Some secondary sulphide was usually formed but is of relatively slight importance.
The oxidation of a secondary sulphide zone that has been so enriched that it consists largely of copper sulphides results in the formation of native copper, cuprite, and melaconite or tenorite, and very commonly of silicates and carbonates. Such an alteration seems to have produced the rich oxidized ores of the Copper Mountain mine in the Lucin district (see $\mathrm{Pl}$. XXIII), though sulphides were not observed in the mine at the time of the writer's visit. The absorption of copper by amorphous siliceous and aluminous material has formed ore ranging from rather high grade to that containing but little copper.

In the deposits containing abundant arsenic, as the Tintic mines and the Gold Hill mine of the Clifton district, a series of copper-arsenic oxidation minerals form an important part of the ore.

\section{LEAD-SILVER DEPOSITS.}

The primary ore of deposits in which lead and silver are the most important metallic constituents is composed chiefly of pyrite and

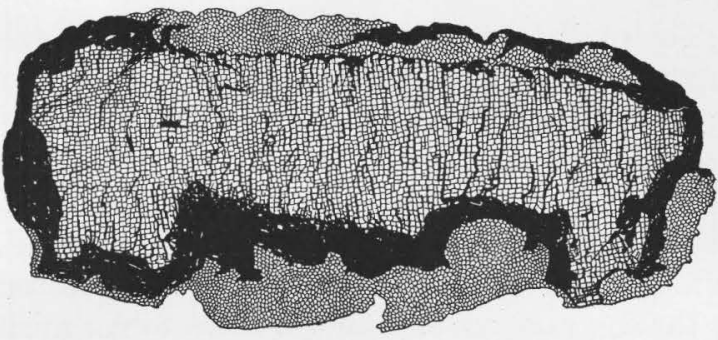

FIGURE 33.-Diagram showing the relation of galena and its oxidation products. Drawn from specimen from Alta Consolidated mine, Little Cottonwood district. Central area, galena; dark band surrounding galena and penetrating it along cleavages, anglesite with some cerusite; outer band, basic ferric sulphate, possibly beaverite.

galena with variable amounts of sphalerite, tetrahedrite, enargite, chalcopyrite, and other minerals. In most deposits the mineral combination in which the silver is present has not been determined. It is closely associated with the sulphides and allied minerals and probably occurs as silver sulphide and combined with arsenic and antimony, intergrown with lead, zinc, and copper minerals.

When acted on by oxidizing solutions, the galena first alters to the sulphate, anglesite. The anglesite in the presence of calcium and magnesium carbonates changes to the lead carbonate, cerusite, or combines with ferric sulphate to form plumbojarosite or other complex basic ferric sulphates. (See fig. 33.) If antimony is present, lead-antimony minerals may result. 
Other oxidized lead minerals are present in the deposits in small amounts. All the lead minerals resulting from oxidation are relatively insoluble, and lead migration is consequently small.

The mineral combinations of the silver in the oxidized ores are not all known. Many ores contain it in large part as the chloride, cerargyrite; but others (as some in the Lion Hill area) consist of earthy yellow or greenish material, commonly designated "chlorides" or "bromide," which is too finely divided for determination even under the microscope. It contains ferric iron and sulphate radicle and in appearance suggests some of the complex basic sulphates, but it has not been determined that the silver is present in such a combination. Some yellow "chlorides" consist essentially of the hydrous lead antimonate bindheimite; and some green ores rich in silver owe their color to copper minerals.

The oxidized ores are commonly quite as rich in silver as the unoxidized, indicating that there has been little migration of the silver. In some mines silver has been concentrated in oxidized ore. Salt is abundant in the desert valleys, and doubtless there is sufficient salt in the waters entering the deposits to precipitate all the silver from the sulphate solutions as chloride. Even in the Park City district, relatively remote from the desert valleys and with moderately high precipitation, the mine waters contain rather abundant chlorine. Probably there has been some migration of the silver, but it does not appear to have been important. Zinc, however, has been largely removed from deposits containing sphalerite; and iron has been removed from at least some ores and deposited as ferruginous zinc carbonate, as in the Tintic district, though in large part it has been changed to the stable hydrous ferric oxide. In general, therefore, removal of other constituents has caused some enrichment in lead and silver. Moreover, the treatment of the oxidized ore is commonly cheaper than that of the primary ore.

\section{SILVER DEPOSITS.}

Deposits whose content of lead, zinc, and copper is relatively low, and which may therefore be regarded as silver deposits, occur in the Lion Hill region, in parts of the Ontario vein system of the Park City district, and elsewhere.
The alteration of the ores does not differ in character from that of the lead-silver ores.

ZINC-LEAD-SILVER DEPOSITS.

Zinc is present in the primary ores of most of the replacement deposits, and in many of them is sufficiently abundant to be profitably recovered. Thus for several years zinc has been recovered from the sulphide ores of the Park City and Bingham districts.

The oxidation of this type of ore differs in no wise from that of the lead-silver ores, the only difference in the ores themselves being the relative amounts of the several mineral constituents. The oxidation of the sulphides (p. 206) produced sulphates of the different metals. The lead sulphide, which altered to sulphate and eventually to carbonate, both relatively insoluble, migrated little if any. The silver sulphate in large part probably reacted with chlorides in the waters, producing the slightly soluble silver chloride, and it, too, migrated little. Iron and zine sulphates, on the other hand, are easily soluble and migrate readily, though in the presence of abundant oxygen the iron sulphate may change to the hydrous iron oxide, which has little tendency to migrate. The sulphate solutions pass downward under the influence of gravity and eventually pass out of the original ore body, usually into the footwall along structural breaks or bedding planes. On coming in contact with limestone the zinc is precipitated as carbonate or basic carbonate, the ferrous iron is precipitated as carbonate, and any ferric iron present is probably precipitated as hydrous ferric oxide. ${ }^{1}$ The ferrous iron and zinc may be precipitated together, as in the Tintic district, as the ironzinc carbonate monheimite. The relative proportion of the metals in the mineral is probably dependent on their relative concentration in the solution. The carbonate thus formed may subsequently alter to limonite, calamine, hydrozincite, aurichalcite, and probably other minerals.

If the solutions in their downward journey do not encounter limestone but traverse quartzite or other siliceous materials the metals show little tendency to precipitate and are probably either carried away in solution or are so dispersed before precipitation that

1 Knopf, Adolph, Mineral resources of the Inyo and White mountains, Cal.: U. S. Geol. Survey Bull. 540, p. 106, 1914. 
they do not form deposits of economic importance. Under favorable conditions the solutions might travel for some distance through siliceous beds without being dispersed and on coming in contact with limestone might form commercial deposits.

The most favorable conditions, then, for the formation of oxidized zinc ores are where

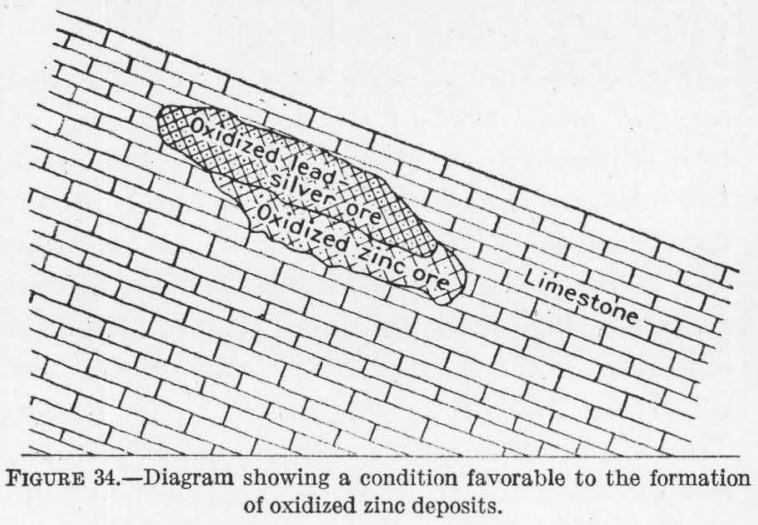

the primary ores are underlain by limestones or dolomites which are free from insoluble impurities, and into which the downwardmoving solutions from the oxidizing sulphides may pass. (See fig. 34.) The purity of the limestone probably has an important effect on the value of the deposits, both because any siliceous impurities would doubtless remain in the carbonate ore and thus reduce its value, and because the precipitating effect of impure limestones is probably much less than that of the relatively pure limestone, as it apparently is in primary deposits (p. 174).

Under the most favorable conditions important secondary zinc deposits may form from primary deposits containing only a small percentage of zinc. Thus Knopf ${ }^{1}$ has shown that in the Cerro Gordo mine large bodies of oxidized zinc ores have been formed by the alteration of sulphide bodies containing only 1 to 2 per cent of sphalerite.

In Utah considerable zinc is present in the primary deposits of many districts but important secondary zinc deposits have been developed in but few, the principal ones being the North Tintic, Tintic, Ophir (Dry Canyon), Promontory, Big Cottonwood, and Star districts. The Park City and Bingham districts contain primary deposits sufficiently rich in zinc to be mined, but so far as known the

${ }_{1}^{1}$ Knopf, Adolph, op. cit., p. 107. oxidation of these deposits has not formed extensive carbonate deposits. This apparent lack may be due to the fact that in the Park City districts some of the principal deposits lie but a short distance above the great Weber quartzite, and that in the Bingham district most of them occur in lenses of limestone in the Bingham quartzite. In both localities solutions passing downward from the deposits would enter the siliceous rocks and would probably be dispersed. (See fig. 35.) In the Tintic, Ophir, and Star districts, on the other hand, the developed zinc deposits are so situated that the solutions from the oxidizing sulphide bodies enter limestone and precipitate their zinc close to the primary ore bodies.

Some deposits in which oxidized zinc ores have not yet been found in large amount seem favorable for their formation, as, for instance, some of the deposits in the limestone in the Little Cottonwood district. Oxidized zinc minerals are known to occur in that district, but as yet no large deposits have been developed.

\section{GOLD DEPOSITS.}

Important gold deposits of the replacement fissure type in the sedimentary rocks occur in but few districts. In the Mercur district,

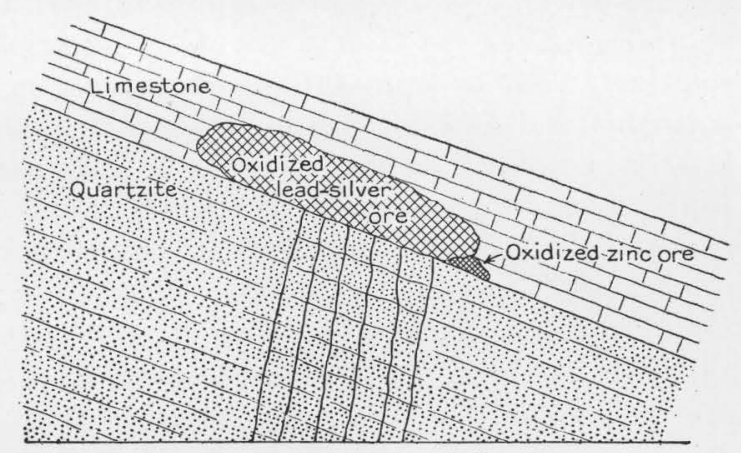

Figure 35.-Diagram showing a condition unfavorable to the formation of oxidized zinc deposits.

however, deposits of this type have yielded a large output, and in other districts, notably in the Deertrail mine in the Marysvale district, ores have been developed.

Whether or not surface alteration has caused important changes in the gold content of the ore is difficult of proof. In the Mercur district the gold is so finely divided that neither free gold nor gold minerals have ever been recognized, and consequently it has not been possible to determine the relation of the gold to other 
constituents of the ore. On the basis of the gold content the evidence seems conflicting. The ore contains quite as much gold at or very near the outcrop of the ore bodies as at any greater depth, indicating that there has been no important leaching from the surface zone with reprecipitation at greater depth. On the other hand, as the depth below the outcrop of the deposit increases there is in general a decrease in the gold content, though there is no notable change in the character of the material after the sulphide zone is reached. This decrease in gold content downward may be interpreted as meaning that there has been enrichment near the surface due to oxidation processes, or that more metal was originally deposited at higher horizons. From the evidence now available no definite conclusion seems justified.

\section{DEPOSITS IN VOLCANIC ROCKS.}

SILVER-LEAD-ZINC-COPPER DEPOSITS

Deposits in the volcanic rocks containing large amounts of silver, lead, zinc, and copper are confined to the San Francisco district and the Tushar Range, and important production is confined to the San Francisco district alone.

The Horn Silver mine, which presents an excellent example of the changes due to oxidation, is the only deposit of the type in the State that has been studied in detail. The deposit is a replacement of brecciated volcanic rock, which forms the hanging wall of a fault fissure whose footwall consists of limestone. Its geologic relations are such that the oxidizing solutions have passed to the ores through the volcanic rocks rather than through the limestone, and, except along fractures, have apparently penetrated but a short distance into the limestone. The unusual phenomenon is thus presented of an ore body that has formed in siliceous rock rather than in adjoining limestone.

The primary ore consists of sulphides of iron, lead, zinc, and copper and some antimony and arsenic minerals and silver in an undetermined mineral combination. The gangue is mainly quartz and barite and altered volcanic rock. In alteration the sulphides are first oxidized to sulphates. As there is little or no carbonate in the gangue and apparently little in the solutions, alteration from sulphates to carbonates has been slight. Most of the lead of the oxidized ores occurs as anglesite, and much of the copper occurs as the basic sulphate, brochantite; the more complex sulphates plumbojarosite, beaverite, and linarite are also present. Chlorine is abundant in the waters and has combined with the silver to form cerargyrite, the principal silver mineral in the oxidized ores. The lead sulphate and the silver chloride are both relatively insoluble and neither has migrated much. The soluble iron, zinc, and copper sulphates have, on the other hand, been carried downward in large part. Some of the copper, as already noted, forms the relatively insoluble basic sulphate, which, however, breaks down under nearsurface conditions. Some of the iron is oxidized to hydrous ferric oxides.

A large part of the iron sulphate and probably much of the zine sulphate has apparently been carried away in solution and dispersed. Part of the zinc, however, was reprecipitated in the sulphide zone as the hexagonal sulphide wurtzite, usually forming in zones of brecciated ore and frequently surrounding grains of sphalerite. (See Pl. XVII.) The cause of precipitation is believed to be essentially as follows: ${ }^{1}$ The solutions passing from the oxidizing zone contain, in addition to zinc sulphate, sulphuric acid and hydrogen sulphide. As the solutions pass to deeper levels their acidity is reduced by reaction with alkaline solutions from the adjacent rocks or with the alkaline silicates of the gangue minerals. This reduction of acidity causes the precipitation of a part of the zinc as wurtzite. The precipitation apparently takes place slowly and the zone of sulphide enrichment of zinc is deep.

When the solutions have passed below the zone of oxidizing conditions their copper content reacts with the zinc, iron, and lead sulphides, forming covellite and chalcocite, principally covellite. This reaction takes place much more rapidly than the reduction of the zinc, and consequently the zone of enriched copper sulphides is relatively shallow and the copper itself is probably much more completely precipitated.

Owing to this difference in precipitation and to the fact that the secondary copper sulphide

1 Butler, B. S., Geology and ore deposits of the San Francisco and adjacent districts, Utah: U. S. Geol. Survey Prof. Paper 80, p. 154, 1913. 
is largely formed by the replacement of the zinc sulphide, the secondary copper ores generally overlie the zinc ores, though of course with many irregularities. The general vertical arrangement of the ores (see fig. 36) begins with oxidized lead-silver ores at the top; followed in turn by oxidized lead-copper ores,

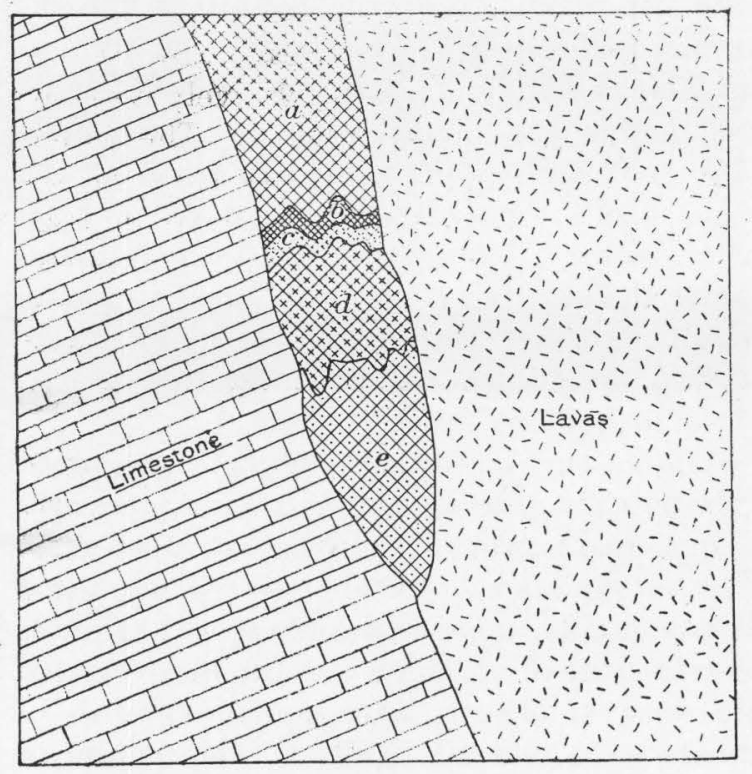

Figure 36.-Diagram showing the sequence of the different zones in the Horn Silver mine. $\quad a$, Oxidized lead-silver ore; $b$, oxidized copper ore; $c$, enriched sulphide copper ores; $d$, enriched sulphide zinc ores; $e$, primary mixed sulphides.

enriched sulphide copper ores, enriched sulphide zinc ores, and primary mixed sulphide ores.

GOLD-SILVER DEPOSITS.

Gold-silver deposits in the volcanic rocks have been productive in the State Line-Gold Springs districts and in the Tushar Range. At the time these districts were examined very few of the gold-silver veins were being mined or developed and there was little opportunity to study the changes at depth. The primary ore occurs as shoots in the veins, and it is difficult to tell whether the decrease in metal content with depth in individual deposits is due to surface alteration or to differences in the original ore. Nowhere in the State have operations in this type of ore been carried below 600 feet and much of them not below 300 feet. Most ore bodies contained as much metal at the outcrop or very near the surface as at any greater depth, and so far as can be learned the decrease in value with depth was general. This, however, did not cause the closing of all the mines; several were closed on account of inflows of water that were too large to be profitably pumped.

Part of the gold and silver occurred as selenide and telluride. Part of the gold was probably native and some of the silver occurred as sulphide. In alteration the silver, for the most part at least, formed chloride and the gold minerals metallic gold. A little native silver is reported from the deposits but is of slight importance. As there is no leached zoneat the outcrop, it is not probable that the migration of the gold and silver was extensive.

The absence of important placers associated with the deposits might be interpreted as indicating downward migration of the gold. More probably, however, the gold, which is finely disseminated in a quartz or silicate gangue with little sulphide, has not been freed from the gangue minerals on weathering and has been carried away in the silicate débris.

\section{SUMMARY.}

The processes of oxidation have had very different effects on the different metals but have ordinarily enriched each of the principal metals in some portion of the resulting deposits by the rearrangement and removal of the constituents.

GOLD.

So far as known gold has migrated but little during oxidation, though the relative richness of some of the secondary sulphides indicates some downward movement. There has been some concentration of gold in the upper portion of the zone of oxidation by the removal of other constituents, and probably there has been some mechanical concentration at and near the surface. Perhaps the most important effect of the oxidation, however, has been to make the gold much more readily recoverable by ordinary milling treatment.

\section{SILVER.}

The migration of silver has apparently been slight, probably owing to the fact that the surface waters of most of the districts contain abundant chlorine and that the insoluble silver chloride is readily formed. The enrichment has resulted chiefly from the removal of other constituents in the upper part of the zone of oxidation. Under favorable conditions there has doubtless been some downward movement 
of silver and some concentration in the zone of sulphide enrichment. The oxidation of the silver ores, however, rendered them much more amenable to milling.

COPPER.

Much of the copper ore of the State has resulted directly from oxidizing processes. The primary material in many of the deposits has proved to be of too low grade for profitable treatment. During oxidation the copper was carried downward and was precipitated at lower levels as either carbonate or secondary sulphide. The upper portion of the enriched sulphide zone was commonly altered to native metal, oxides, and carbonates. In the early days of copper mining in the United States the carbonate and oxide ores were much more cheaply treated than the sulphide ores. When the industry became important in Utah, however, the smelting of sulphide ores was well developed, and the low-grade sulphide ores are, at present, more readily treated than oxidized ores. IEAD.

The principal oxidation products of leadcerusite and anglesite-are very slightly soluble, and lead has moved little during oxidation. In many of the deposits, however, the lead content in the upper portion of the deposits has been increased by the removal of other constituents, and the character of the ore has been greatly improved by the removal of objectionable constituents. This alteration was especially important in simplifying metallurgic processes for the treatment of the lead-silver ores during early development.

zINC.

Zinc has migrated very extensively during oxidation and doubtless much of that contained in the original deposits has been dispersed and lost. Only under favorable conditions has zinc been concentrated during oxidation.

Oxidation of the primary sulphide formed the very soluble sulphate, which was carried downward. When it came into contact with limestone the metal was precipitated as the relatively insoluble carbonate or basic carbonate; and when it passed into the sulphide zone, as in the Horn Silver mine, it was deposited as secondary sulphide. Some valuable zine deposits have resulted from the alteration, and the ores of the other metals have been improved by the removal of the zinc.

IRON.

Deposits in which the primary iron minerals were mainly oxides have been little changed by oxidation processes, but deposits composed largely of pyrite have been greatly changed. In the deposits in limestone migration of the iron has apparently been relatively slight, most of it changing to the hydrous oxide, but there. has probably been some enrichment from the removal of other constituents. Some movement of the iron is indicated by its precipitation with zinc in secondary deposits. Migration of iron on a large scale is illustrated by the Tintic or Dragon iron mine, where iron derived from the oxidation of pyritized volcanic rock moved downward and formed a.large replacement body in the underlying limestone. In noncalcareous rocks migration has apparently been much greater. In some places it has apparently been largely dispersed, but in other places it may have been precipitated along fissures or other openings as hydrous oxide concentrated from disseminated sulphides. 


\section{PART II.-RANGES AND DISTRICTS.}

WASATCH RANGE.

\section{REGION NORTH OF OGDEN.}

By G. F. Loughuin.

BEAR RIVER RANGE.

GENERAL FEATURES.

North of Ogden, the Wasatch Mountains, as defined by the United States Geographic Board, consist of two distinct parallel ranges which are separated by depressions 4 to 10

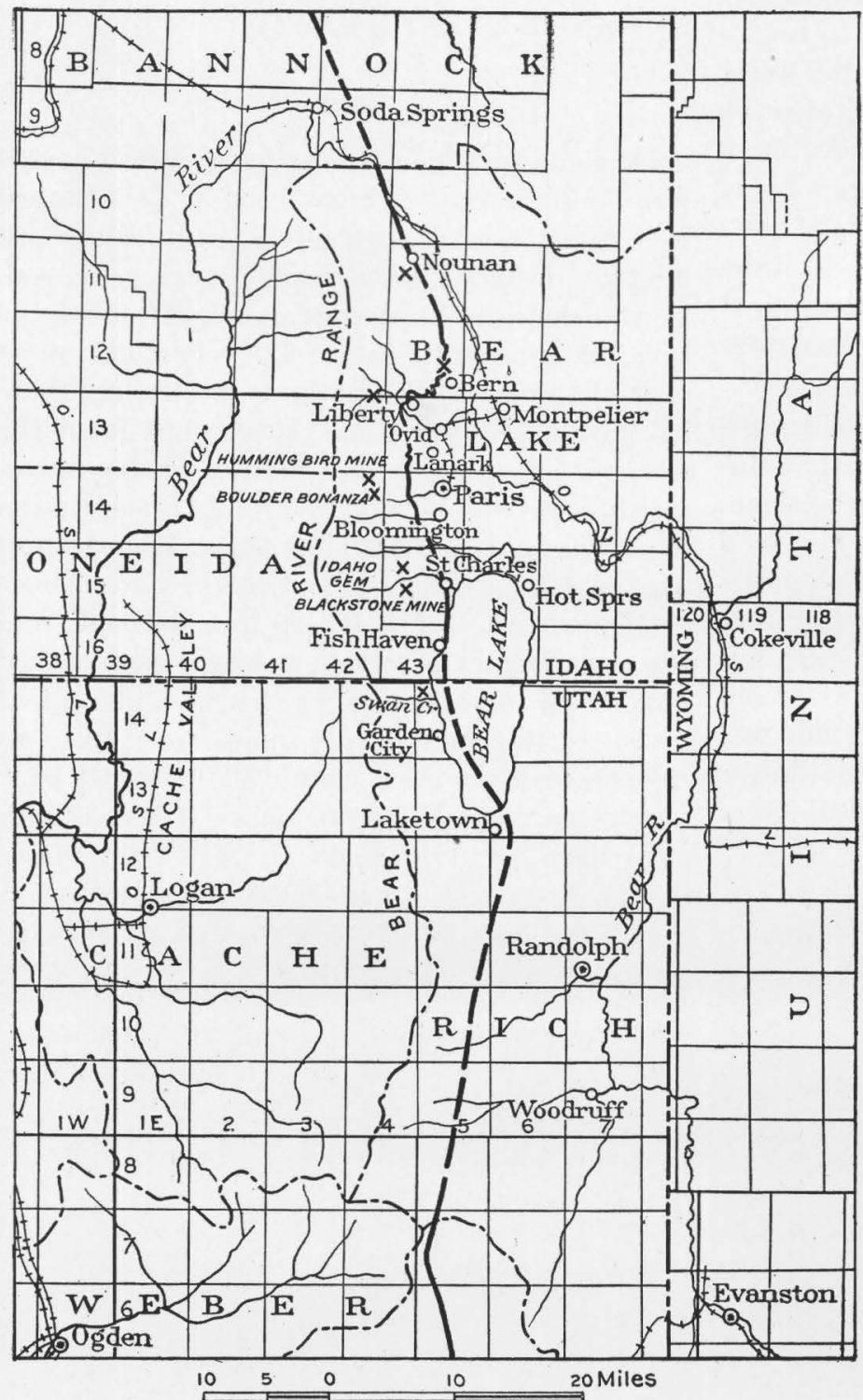

FiguRE 37.-Map showing relation of mining prospects to Bear River Range and overthrust. The margin of the overthrust block is indicated by the heavy, broken line. (After R. W. Richards.) miles wide. (See Pl. I, in pocket.) The eastern range is often called the Bear River Range or Plateau.

The Bear River Range or Plateau extends north from latitude $41^{\circ} 45^{\prime}$ to latitude $42^{\circ} 45^{\prime}$, between Cache Valley on the west and Bear Lake valley on the east. Its length is approximately 120 miles and its average width 10 to 15 miles.

The Bear River Range includes the Garden City or Swan Creek district in Rich County and the districts of the Hyrum-Paradise region in Cache County. (See fig. 37.) Production from these districts comprises small shipments of lead and zinc ore and a little copper ore, all low in silver and gold and typical of deposits formed remote from important igneous intrusions. The period of mineralization has not been determined from local evidence.

\section{GEOLOGY ${ }^{1}$}

\section{STRUCTURE.}

The geologic structure of therange as a whole has not been worked out, but data collected by the geologists of the Hayden Survey ${ }^{2}$ indicate that it is synclinal, the youngest rocks occupying the center of the trough. The eastern flank consists of a great overthrust block of folded and broken Middle Cambrian to Mississippian limestones and quartzites that rests on rocks in part of Triassic age. The magnitude of the thrust is indicated by the fact that it is traceable for about 100 miles, from near Woodruff, Utah, to north of Soda Springs, Idaho (see fig. 38), practically coextensive with the range itself. The direction of

1 The notes on the geology of the Bear River Range and on the ore deposits of the eastern slope are condensed from a report by R. W. Richards, U. S, Geol. Survey Bull. 470, pp. 177-187, 1911.

2 Peale, A. C., Geology of the Green River district: U. S. Geol. and Geog. Survey Terr. Eleventh Ann. Rept., pp. 587-589, 1879. 
movement is toward the east and the maximum apparent displacement is about 10 miles. The dip of the fault plane does not average over $10^{\circ}$, although locally it exceeds that amount. In general the fault is not expressed in the topography, but west of Lanark, Idaho, a retreating scarp bears evidence of erosion. In the vicinity of St. Charles and Paris, Idaho, the strata along the eastern margin of the thrust block form an anticline paralleled on the west by a syncline, and the mineral deposits in that neighborhood are on the intervening monocline, which dips $20^{\circ}$ to $30^{\circ} \mathrm{W}$.

\section{STRATIGRAPHY.}

The main mass of the Bear River Range is made up of Paleozoic sediments ranging in age from Middle Cambrian to Mississippian. Rocks of probable Triassic age underlie the overthrust block on the east, and patches of Tertiary lake beds lie on the summits and in a terrace-like fringe about the lower hills. No igneous rocks are known in the range proper, but its northern end is embayed by basaltic flows of post-Pliocene and possibly late Quaternary time. The mineral deposits are found particularly at the base of the Middle Cambrian Ute limestone.

\section{ORE DEPOSITS.}

\section{EASTERN SLOPE (SWAN CREEK DISTRICT).}

The mineral deposits of the eastern slope of the Bear River Range lie in the Garden City or Swan Creek district in Utah and to the north in Idaho. They have been known and prospected for 15 or 20 years and the prospect pits are scattered from the vicinity of Woodruff, Utah, to Soda Springs, Idaho. The lead ores, which consist of galena with small amounts of cerusite and wulfenite in a gangue of ironstained calcite and dolomite, are found at Swan Creek, Utah, and near St. Charles and Paris, Idaho. They appear to be tabular replacement deposits in limestone, more or less parallel to the bedding and cut and limited by fissures.

The copper ores consist mainly of the carbonates, azurite and malachite, in quartz veins and locally of the sulpharsenite and sulphantimonite, tennantite and tetrahedrite, in a brecciated quartz and jasper gangue. Both modes of occurrence are found in quartzites of probable Cambrian age. Igneous rocks are not associated with either the lead or the copper ores.

Shipments of ore have been made from two localities-the Boulder Bonanza-Humming Bird group, west of Paris, Idaho, and the Blackstone mine, west of St. Charles, Idaho. The shipments from the former group amount to less than 100 tons, partly lead and partly copper ore; and from the latter to about 800 tons of high-grade concentrates.

The Victoria No. 1 prospect on Swan Creek, a short distance south of the Utah-Idaho line, is said to be the center of a group of eight claims. The wall rock is massive limestone. The ore consists of malachite, azurite, accompanying barite, and calcite in a much brecciated zone approximately parallel to the stratification of the beds. Recrystallization or marbleizing of the limestone appears at the same horizon 100 yards or more to the south.

The amount of ore at this place has not yet been proved to be sufficient to be commercially valuable. Up to 1913 prospecting had been carried on for nearly 20 years. None of the deposits appear to be promising, but the locality is of interest, for it shows the continuation of the mineralized zone in association with the sedimentary rocks.

WESTERN SLOPE (HYRUM-PARADISE REGION).

$$
\text { By V. C. Heikes. }
$$

Hyrum is in Cache County, near the mouth of Blacksmith Fork Canyon, on a branch line of the Oregon Short Line Railroad. (See fig. 37.) Logan, the county seat, is 6 miles north, and Paradise, a small village, 4 miles south of it. All three villages are on the east side of Cache Valley, near the foothills of the Bear River Range, at altitudes of about 4,500 feet above sea level. The length of Cache Valley from Paradise to the Utah-Idaho line is nearly 50 miles, and its width ranges from 6 to 16 miles, average 12 miles. Muddy Creek, Blacksmith Fork, High Fork, Gros Bois Fork, and Logans Fork, all small streams, flow into the valley from the Bear River Mountains on the east, and Rush Creek enters it from the west.

Small amounts of ores containing gold, silver, copper, lead, and zinc have been shipped from Richmond, Smithfield, Logan, Hyrum, Paradise, and La Plata. Shipments in the early 
nineties were largely of lead ore from the La Plata region, where the Sundown, La Plata, Silver King, and Lead King properties are situated.

A sheep herder is reported ${ }^{1}$ to have found the first ore in the La Plata claim - a boulder weighing about 150 pounds, consisting principally of galena. A shaft sunk here to a depth of 165 feet and a tunnel driven for about 190 feet on the Sundown claim found no ore. At another place south of the tunnel, on the Sundown claim, some copper croppings were found and slightly developed without any particular result. It is reported that the Sunrise claim has been developed by an incline shaft 100 feet deep that shows some galena, and that the Yellow Jacket shows low-grade carbonate lead ore. According to J. F. Heald, ${ }^{2}$ the Utah \& Idaho Mining Co., predecessor of the Silver-Lead Mines Co., shipped over 8 tons of ore from the same property that averaged 76 per cent lead and 2 ounces of silver to the ton.

In 1908 the Silver-Lead Mines Co. produced from the Lead King property near Avon, a village 4 miles south of Paradise, 18 tons of ore containing 36.3 per cent of lead and 1 ounce of silver per ton. From the Lucky Star claim, at the head of the left fork of Blacksmith Fork Canyon, about 13 miles east from Hyrum, 10 tons of lead sulphide ore was shipped containing 46.3 per cent of lead, 3.9 ounces of silver per ton, and 1.5 per cent of copper and from the Tip Top claim about 17 tons of zinc carbonate averaging 29.92 per cent of zinc, 6.3 per cent of lead, and 0.6 ounce of silver per ton.

In August, 1915, a new zinc deposit was discovered about $3 \frac{1}{2}$ miles east of Hyrum, and about a mile south of Blacksmith Fork Canyon in an oxidized iron cropping on an old gold location known as the Moon claim. Some of the early samples assayed 42 per cent of zinc. A carload returned the owners 28 per cent of zinc and a second car about 22 per cent. With better sorting a better grade of ore might be shipped. The claim is 300 to 400 feet higher than Hyrum and is reached by steeply inclined roads. The ore is in blue limestone, with overlying quartzite (?) that dips $33^{\circ} \mathrm{E}$. The thickness of the ore-bearing

1 Sloan, R. W., Handbook of the mines of Utah, Salt Lake City, 1895 2 Personal communication. limestone could not be ascertained, no exposures being visible. Fossils show the age of the limestone to be Carboniferous.

From observations at a few shallow openings the ore appears to lie in a certain favorable bed of the limestone that dips toward a fissure filled with oxidized iron. This fissure, which was traceable for over a mile to the Moon iron outcrop, cuts the limestone beds vertically. The dark-colored iron samples carry 2.8 per cent of zinc, and others from lighter-colored portions, 1.2 per cent of zinc.

\section{MORGAN MOUNTAIN}

By G. F. Loughuin.

Morgan Mountain is a southward continuation cf the Bear River Range. It comprises the Argenta and Morgan districts.

\section{ARGENTA DISTRICT.}

GENERAI FEATURES.

The Argenta district is about 15 miles east of Ogden and 6 miles north of Peterson, a station on the Union Pacific Railroad. The principal workings are on the slopes south of Little Cottonwood Creek, a tributary of Weber River. Three properties, owned by the Carbonate Hill, Carbonate Gem, and MorganArgentine mining companies, have been the most active, but none of them has been worked continuously. The first shipment of ore from the Carbonate Hill mine was made in $1905,^{3}$ and small shipments have been made during every year since then. A few shipments have been made from the Carbonate Gem. Work on the Morgan-Argentine property up to 1913 consisted only of development.

GEOLOGY.

The formations in the vicinity of the mines include pre-Cambrian granite schist and gneiss, Cambrian quartzite, and Paleozoic limestone. The pre-Cambrian rocks lie west of the mines in the low foothills, and are bounded on the west by Tertiary and Quaternary strata. On the east they are overlain by Cambrian quartzite and conglomerate which dip from vertical to steeply eastward. The quartzite is overlain by shale, and the shale by a great thickness of limestone which also dips steeply eastward. The lower limestone beds have the lithologic

3 Heikes, V. C., U. S. Geol. Survey Mineral Resources, 1905, p. 320, 1906. 
characters common to the Middle Cambrian limestones of Utah. The upper (eastern) beds contain lower Mississippian fossils, the only fossils found in the district. Between the Mississippian and Cambrian other ages may be represented, but the strata are poorly exposed and largely concealed beneath brush and reddish disintegrated material that may be remnants of Tertiary (Wasatch) beds. The Mississippian limestone passes upward into a series of limestone, limy sandstone, and shale beds, many of them red, which probably represent the Morgan formation. These beds are overlain on the east and southeast by a bed of conglomerate with abundant well-rounded pebbles, which dips at a lower angle to the east and is overlain by the Weber quartzite. No igneous rocks, other than the pre-Cambrian granite, have been found.

\section{ORE DEPOSITS.}

The deposits thus far worked or prospected are in the limestone. Those of the Carbonate Hill and Carbonate Gem mines are in Cambrian limestone; those of the Morgan Argentine are in the Morgan (?) formation. The ore occurs in small bunches along the bedding and along fissures of northwest, northeast, and eastwest trends. The ore minerals are galena, cerusite, pyrite, and limonite: the principal gangue minerals are barite and more or less calcite. Fragments of smithsonite-limonite ore were found on the lower dump, and jarosite was found on the upper dumps of the Carbonate Hill mine. The sulphide ore, so far as seen, consists of fine-grained galena and pyrite in about equal volumes; the oxidized ore is a mixture of cerusite and limonite, the latter in such large amount that some shipments of the ore were smelted free of charge because of their fluxing qualities. The average contents of shipments from the Carbonate Hill mine are silver, 2.7 ounces to the ton; lead, 16.9 per cent; insoluble, 17.2 per cent; zinc, 2.7 per cent; sulphur, 0.5 per cent; iron 33.4 per cent. One mineralized outerop on the MorganArgentine property is said to have yielded on assay 4 per cent of copper, but assays of several samples show the ore from this property to be generally similar to that from the Carbonate Hill mine.

The mineral composition of the ore, its low silver content, and the general absence of quartz in the gangue are characteristic of ore bodies remote from intrusive igneous bodies. The small size of the ore shoots thus far found is evidently due to the unfavorable character of the inclosing rock. The Cambrian limestones and also the limestone beds of the reddish Morgan (?) formation are prevailingly impure and of dense texture, and therefore not very susceptible of replacement by this type of ore. More favorable limestone beds are present in the Mississippian beds below the Morgan (?) formation, but so far as known no mineralized fissures have been found in them.

\section{MORGAN DISTRICT.}

GENERAL FEATURES.

The Morgan district is north and east of Morgan on the Union Pacific Railroad. Active prospecting in 1913 was confined to the claims north and northwest of the town and within 4 miles northwest of Morgan station. One property, the Chicago-Utah, about 8 miles east of the town, was active a few years earlier. Small quantities of ore containing copper and silver were shipped from one or more of the properties in 1907 and 1908.

\section{GEOLOGY.}

The geologic formations in the district trend north and most of them dip east. They include in ascending order the lower Mississippian or Madison limestone, which includes a few red shaly and sandy beds, the Morgan formation, prevailingly red, the Weber quartzite, and the Park City formation, which includes the principal phosphate beds of the region. The workings of the Morgan-Crescent Mining Co. are in the Madison limestone; those of the Chicago-Utah are said to be east of the phosphate beds. No igneous rocks were seen by the writer, and the only ones reported are a few "quartz porphyry" dikes east of the Morgan Crescent mine.

$$
\text { OR. } د \text { EPOSITS. }
$$

All the deposits near Morgan station are of the same general type. On the Iron King claim, about 4 miles northwest of Morgan, the principal showing is a vein of coarse-grained calcite, whose outcrop strikes about N. $30^{\circ}$ W. obliquely across the northward-trending country rock. Its continuity is concealed beneath brush and talus, and no work has been 
done along it, other than a snallow pit at the outcrop. The limestone and shale along it are crisscrossed with calcite veinlets, which are accompanied by small streaks and spots of oxidized copper minerals. Close by the vein a shale bed, similarly mineralized and dipping $70^{\circ} \mathrm{W}$., has been prospected by an inclined shaft 80 feet deep, and has yielded specimens said to assay very high in gold. No continuous ore streaks have been found, however. The shale has also been prospected by a tunnel, at a level 300 feet lower than the shaft collar, and is found to contain local sprinklings of very fine pyrite crystals, perhaps accompanied by fine specks of gold, and by a few small lenses of quartz. One specimen is said to have assayed over $\$ 1,000$ in gold.

The Red Eagle and Morgan Consolidated claims, about a mile north of Morgan, are on what appears to be a single vein striking $\mathrm{N}$. $45^{\circ}$ W., which consists of crushed fragments of impure limestone and shale cemented by inconspicuous quartz and by calcite which contains small thickly scattered pyrite crystals. No replacement of the rock fragments by vein matter is evident. The width of the vein on the Red Eagle claim is about 4 feet, and on the Morgan Consolidated workings is said to reach a maximum of 12 feet. The vein near the surface is oxidized to a yellow ocherous material with a few green copper stains and is said to have assayed $\$ 50$ a ton, presumably in copper, silver, and gold. No assays of the sulphide ore are available. The character of the ore suggests that it may be concentrated successfully.

The Morgan-Crescent claim lies east of the Red Eagle, well up the slope of a high hill. The only deposit worked up to 1913 was a body of copper-silver-gold ore that had replaced a bed of relatively pure limestone in a series of limy shales and quartzite. It is said to have yielded about $\$ 45$ a ton, but assays of small samples reported by the American Smelting \& Refining Co. show only gold 0.6 ounce and silver 0.2 to 0.3 ounce to the ton; copper, 0.1 per cent; iron, 53.3 to 55.6 per cent; insoluble, 4.9 to 8 per cent. The deposit is marked at the surface by a strong outcrop of limonite accompanied by malachite, azurite, chrysocolla, tenorite, cuprite, and native copper. The stopes extend a short distance down the dip into the hill and end in short tongues and pipes. The only primary (hypogene) ore minerals recognized in the main ore body are fine-grained pyrite and a few doubtful traces of chalcopyrite. A small body of marcasite, possibly of secondary (supergene) origin, was found at the down-dip end of one stope, and small amounts of galena are found along two vertical fissures a short distance beyond the down-dip ends of the stopes. The gangue minerals include, besides altered limestone, small amounts of quartz, barite, and calcite in the main stopes, and calcite associated with galena along the vertical fissures.

The source of the main ore body is in dou't. No connections between it and the galenacalcite fissures have been found. It therefore can only be suggested that before the steep slope of the hill had been eroded back to its present position, solutions similar to that which formed the Red Eagle vein rose along a fissure and spread along a limestone bed; that subsequent erosion has worn away the connection between the bedded deposit and the fissure, concealing the fissure beneath talus; and that oxidation and downward concentration along the dip of the ore body accompanied the erosion and produced a small isolated deposit of high-grade copper-gold-silver ore. The mineralogy of the ores in the Morgan district differs from that of most others remote from intrusive igneous bodies in that copper, instead of lead or zinc, is the principal base metal present and that the gold-silver content is unusually high. The gold-silver content, however, and the copper content of the Morgan-Crescent mine represent secondary concentration and are not fair indications of the amount of these metals in unoxidized ore. The unoxidized ore of the Red Eagle vein indicates a low copper content, and it is probable that the precious-metal content is also low. The absence of marked replacement action by unoxidized ore indicates that the ore-forming solutions were weak, and this is in keeping with the small amount of quartz and the prominence of calcite in the gangue. The small amount of galena and calcite noted along the fissures in the Morgan-Crescent workings are a further indication of weak, relatively cool solutions. Marcasite is too exceptional in Utah ore deposits to be of much significance, but its modes of occurrence in general point to deposition at low tempera- 
tures. It is improbable that such solutions formed extensive ore bodies, except where excessive shattering, as in the Red Eagle fissure, or an easily permeable limestone bed, as at the Morgan-Crescent mine, provided exceptional conditions.

BOX ELDER, WILLARD, AND WEBER DISTRICTS.

\section{GEOLOGY.}

By G. F. LoughLin.

The geology of the Box Elder, Willard, and Weber districts is most conveniently considered as a unit. The formations represented include

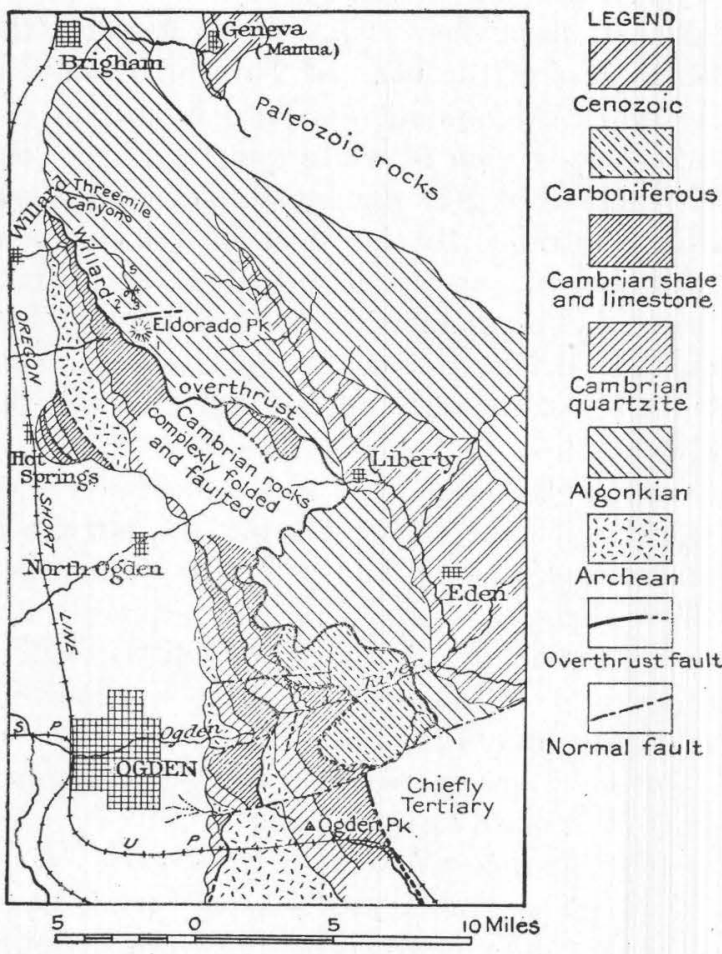

Figure 38,-Geologic sketch map of Wasatch Range proper between Ogden and Brigham. (After Blackwelder, with minor additions.)

Archean, Algonkian, Cambrian, Carboniferous, and Tertiary rocks, but their relations are complicated by extensive overthrusts and large east-west, or transverse, normal faults.

Archean granite extends southward along the range from Willard to a point east of Hot Springs and is exposed in smaller masses along the foothills east of Ogden. (See fig. 38.) A larger mass of it extends from a point near Ogden southward for several miles. East of Hot Springs it is overthrust upon Cambrian limestone.
The Algonkian outcrops in a broad belt that extends southeastward from Brigham beyond the latitude of Ogden. On the east it is overlain unconformably by Cambrian quartzite; on the west it is overthrust upon Cambrian and Carboniferous rocks. The Algonkian in the Willard (and also in the Sierra Madre district, pp. 223-224) comprises in ascending order: (1) A lower quartzite, exposed on Eldorado Peak, in the Sierra Madre district, and containing in its lower part two prominent beds of ferruginous schist; (2) a slate full of quartz lenses, well exposed on the divide at the head of Willard Canyon and separated from the lower quartzite by an east-west fault along the north side of Eldorado Peak; (3) a green schist specked with minute black crystals of an amphibole which extends southeastward across the cirque at the head of Willard Canyon; (4) a dark-gray finely "knotted" schist that forms the southwest slope of the canyon and passes just north of the cirques; and (5) an upper quartzite with interbeds and partings of mica schist that forms the floor of lower Willard Canyon, and the area to the north and east. (See fig. 38.)

The Cambrian includes two formations: The Brigham quartzite below and a series of shales and limestones above. It occurs in two belts, one extending southeastward from near Brigham, and one extending more southward from Willard to Ogden and beyond. Ordovician and later strata lie east of the Cambrian limestones near Geneva (Mantua) but arenot present in the mineralized part of the region.

The Carboniferous is limited to an area over a mile wide, which extends for about a mile both north and south of Ogden River. It is overridden on the east by Algonkian rocks and appears on the west to be overthrust upon Cambrian limestone. Tertiary conglomerate and sandstone cover an extensive area east of the range. (See fig. 38.)

\section{ORE DEPOSITS.}

The mineral deposits include veins in all the different kinds of rocks, and a few bedded replacements in Cambrian limestone. Very little ore, however, has been shipped from any of these deposits. The principal metals are copper, lead, and zinc, and small amounts of silver and gold. Magnetite deposits have been prospected in the Willard district. 
BOX ELDER DISTRICT.

By G. F. Loughirn and V. C. Heikes.

The Box Elder district, organized October 2, 1889, is in Box Elder County, near Bakers, a station on the Oregon Short Line Railroad. One property, known as the Mineral Ridge, worked for years under different names, has an aerial tramway, a mill, and other improvements, but has never reported any production to the United States Geological Survey. The property lies about 4 miles north of Brigham, on the front slope of the Wasatch Range. Its workings consist of three short tunnels and a few shallow pits along a crushed zone which strikes N. $60^{\circ} \mathrm{E}$. and dips about $50^{\circ} \mathrm{SE}$. The country rock is dark bluish-gray Cambrian limestone, part dolomitic and part shaly. The crushed zone is 25 to 30 feet wide and is stained yellowish brown. The only evidence of mineralization at the surface is a few veins of columnar and banded calcite, or travertine, which is common in the vicinity of lead-zinc ofes low in silver.

A small production of copper ore, carrying gold and silver, was reported from the Box Elder district in 1908 as having been sold to the Independent Smelting Co., which operated a furnace near Ogden.

\section{WILLARD DISTRICT.}

By G. F. Loughuin.

The Willard mining district includes a considerable area east of Willard and on both sides of Willard Canyon. (See fig. 38.) The prospected deposits include magnetite, hematite, copper, and lead ores.

Magnetite bodies have been prospected on the Twin Pine and Mormon Girl claims, which are on the south slope at the head of Threemile Canyon, the first canyon north of Willard Canyon. The ore bodies are local replacements of quartzite beds, which dip steeply eastward. That on the Mormon Girl claim contains films of malachite and azurite filling cracks and is said to assay about 5 per cent copper. It is opened by a shallow inclined shaft and a 70-foot tunnel, which show the ore to be a replacement of shattered quartzite. Quartz-muscovite veins trending in various directions are associated with the ore body.
Specular hematite was noted in two beds of ferruginous schist in the lower quartzite member of the Algonkian. Their horizon extends from the foothills west of Willard southward into the Sierra Madre district, where they are exposed high on the west slope of Eldorado Peak. Microscopic examination of a specimen from one of these beds showed that it consisted mainly of quartz and hematite and a little muscovite. The hematite averaged about 25 per cent, by volume, of the rock.

Copper and lead minerals have been found in the same vein, as on the Ogden Boilermakers prospect, and in separate veins, as on the Overland and Silver Queen claims. On the Ogden Boilermakers claim, which lies over the divide east of the head of Threemile Canyon, the upper Algonkian quartzite is cut on the surface by a vien of white quartz, which contains scattered granular bunches of galena and a little tetrahedrite and is stained with malachite, azurite, and a little yellow earthy material like bindheimite. A tunnel 1,200 feet long was driven to cut the ore at considerable depth below the outcrop but failed to find the downward continuation of the vein.

On the Overland claim at the head of Threemile Canyon the upper Algonkian quartzite is mineralized along a bed 3 feet or more thick which dips $30^{\circ} \mathrm{SE}$. The ore minerals are pyrite, malachite, and azurite, a little chalcopyrite and tetrahedrite, and, it is reported, small amounts of gold and silver.

On the Silver Queen, which lies on the south slope of Willard Canyon about a mile from its mouth, the upper Algonkian quartzite is cut by a vein, of probable north-south trend, composed of white quartz and fine-grained laminated galena. The vein in places is sheared and shattered, which probably accounts for the laminated appearance of the galena. The vein, when seen in 1913, was opened by two short tunnels, neither of which had penetrated beyond the broken superficial material.

These deposits in general are of promise, so far as mineral composition is concerned, but the lack of persistence of some and the small dimensions of others are not encouraging. Too little prospecting has been done to warrant a very positive opinion as to the extent of mineralization. 


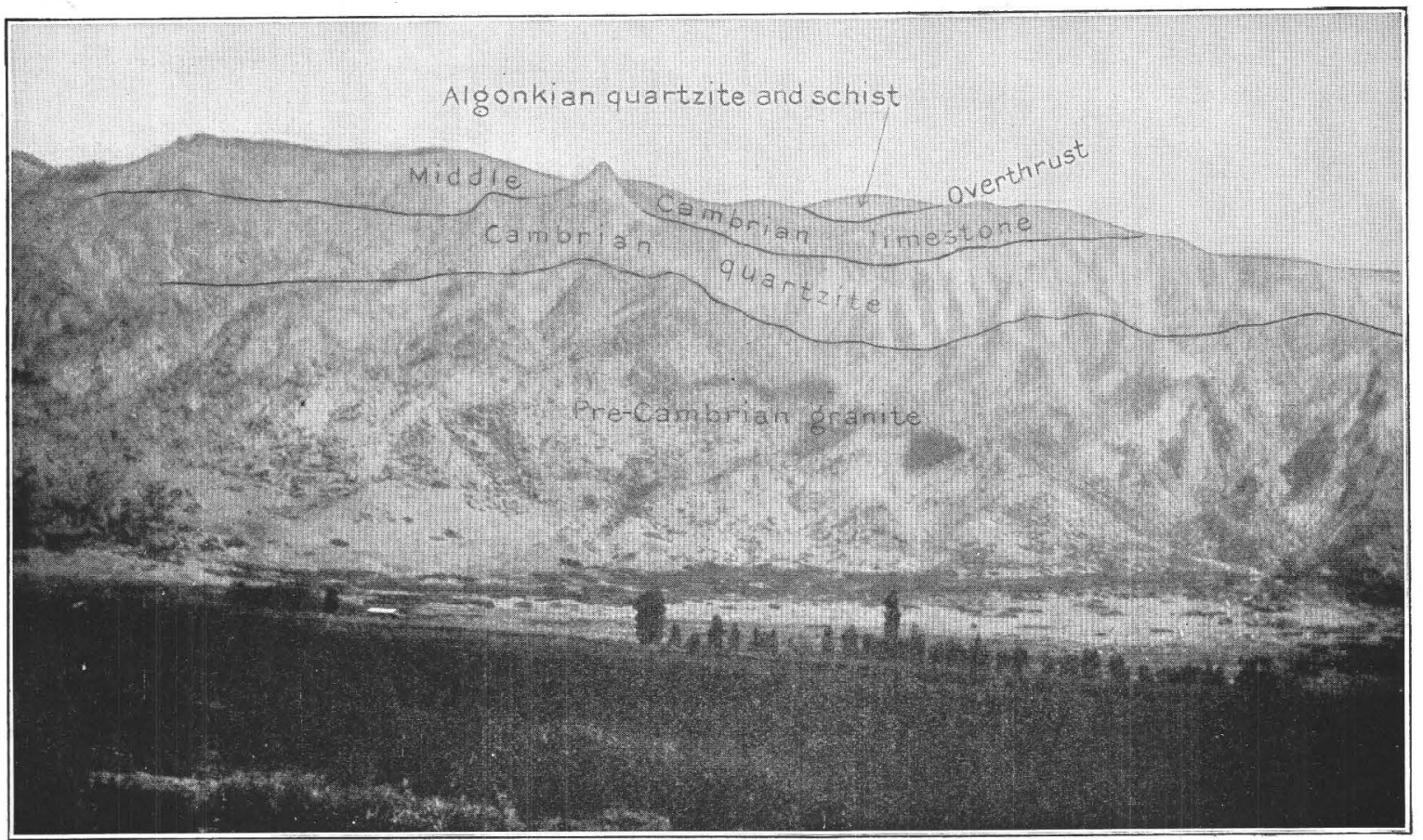

A. WEST FRONT OF WASATCH RANGE IN SIERRA MADRE DISTRICT, SHOWING GEOLOGIG FORMATIONS,

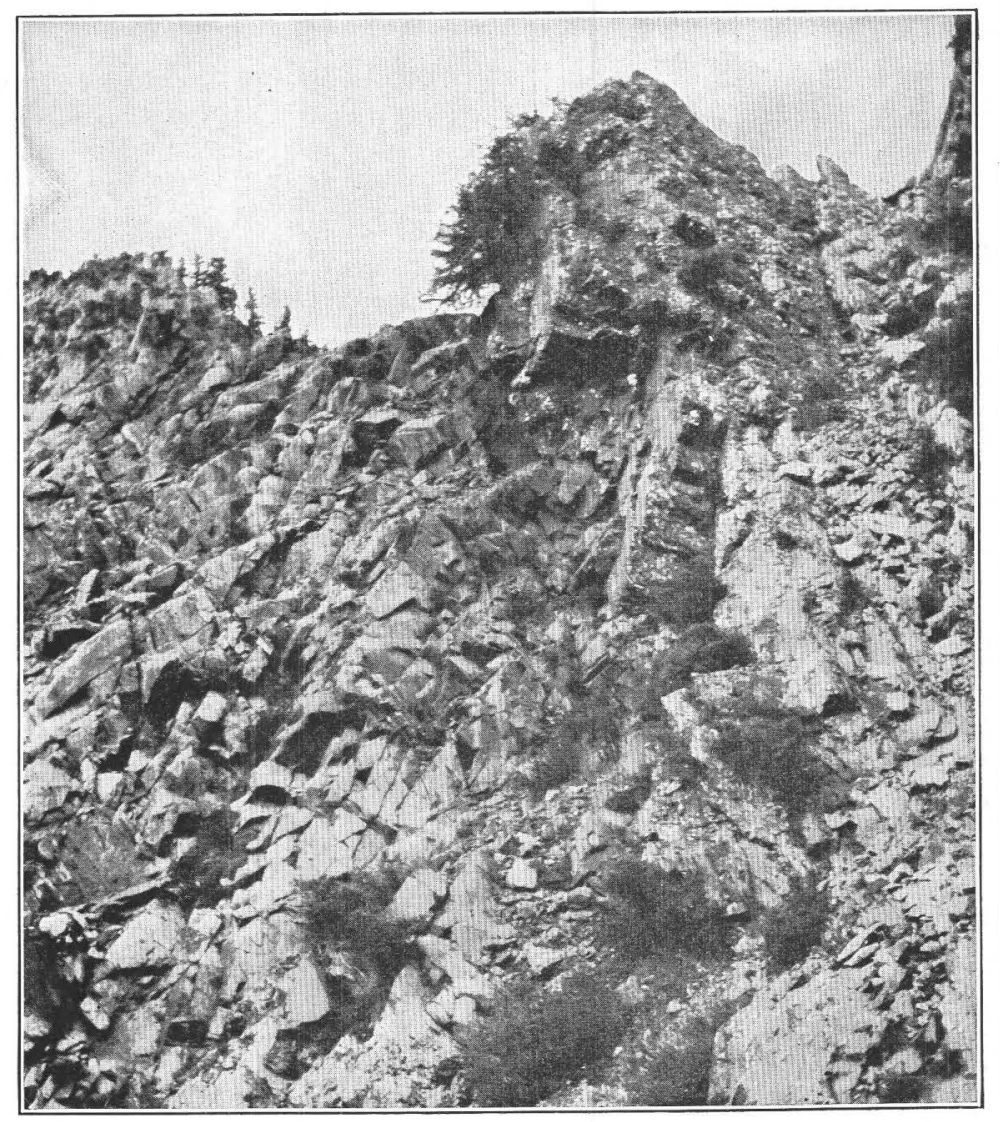

B. UNCONFORMITY SHOWING PRE-CAMBRIAN GRANITE AND PEGMATITE DIKES CUT OFF BY BASAL CAMBRIAN GONGLOMERATE, SIERRA MADRE DISTRICT. 


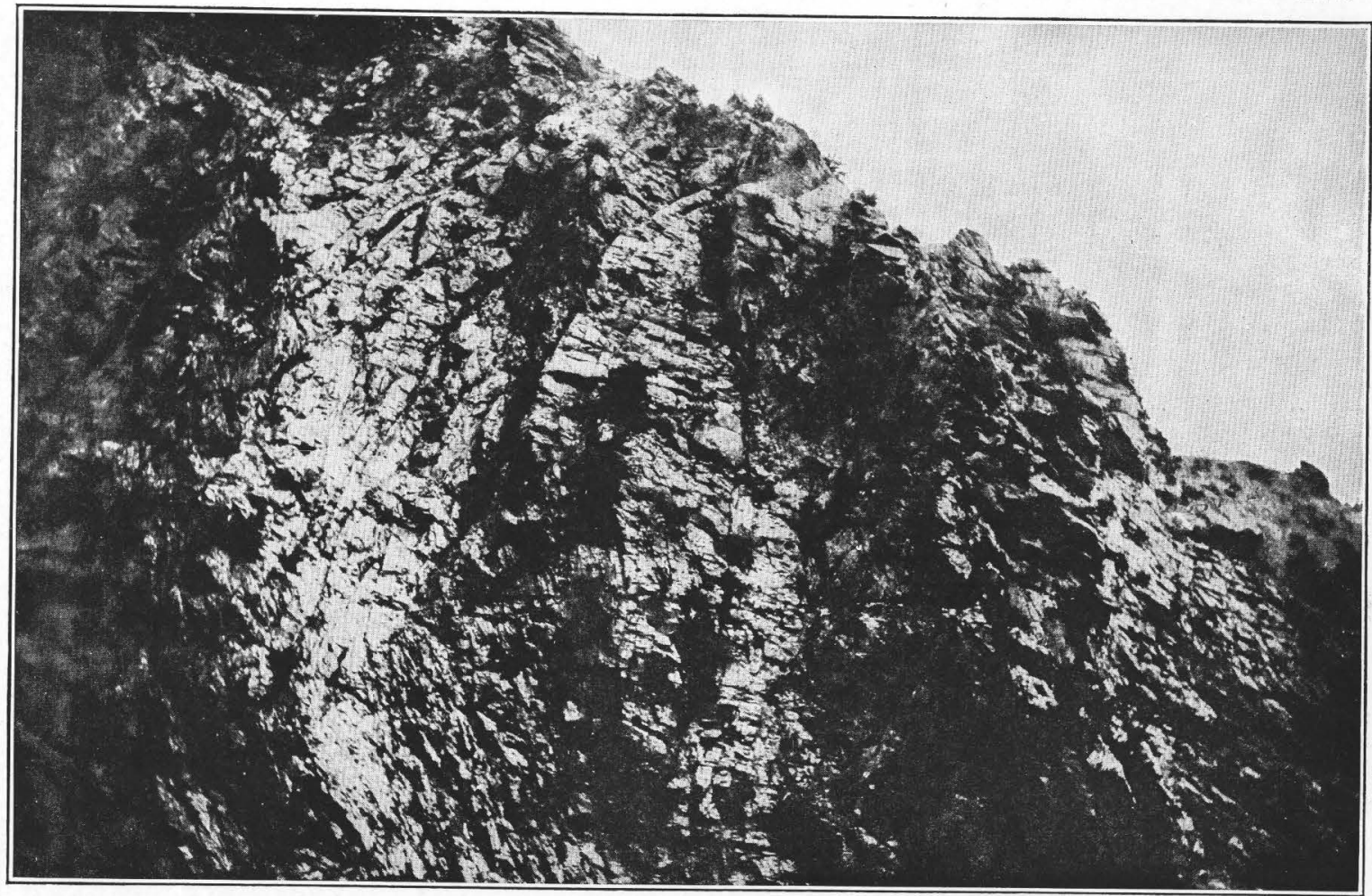

A. UNDULATORY VERTICAL FISSURES (TIGHT) AND HORIZONTAL FISSURES WITH QUARTZ AND CHLORITE IN PRE-CAMBRIAN GRANITE, SIERRA MADRE DISTRICT.

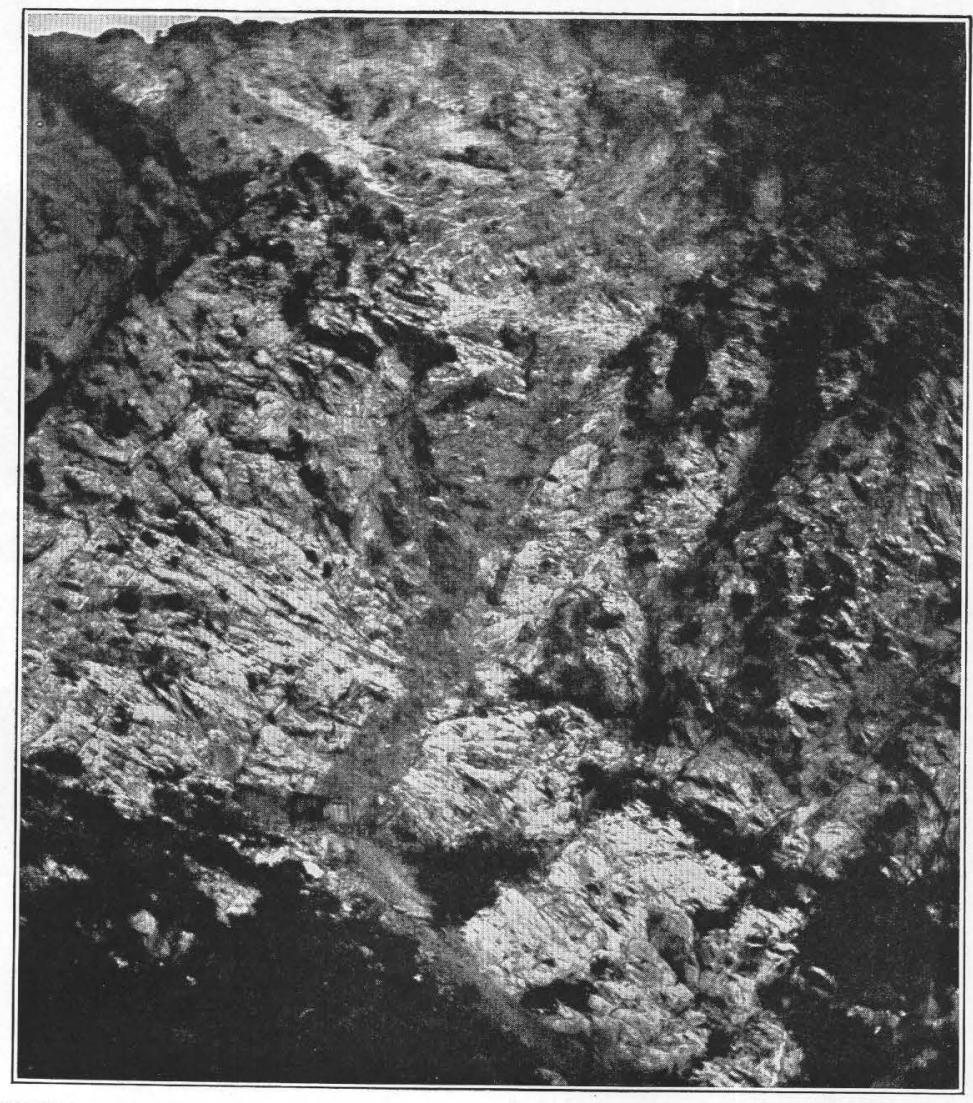

B. SANTA MARIA MINERALIZED FISSURE IN PRE-CAMBRIAN GRANITE, SIERRA MADRE DISTRICT. Fissure extends upward from cabin. 
WEBER DISTRICT.

$$
\text { By V. C. Heikes. }
$$

The Weber district, in Weber County, known in 1860 as the Junction district, is 2 miles northeast of Ogden. Huntley ${ }^{1}$ reports that it was organized in February, 1878, and in 1881 contained about 130 locations, all mere prospects. A company organized to work large deposits of hematite and magnetite ore said to exist from 3 to 8 miles north of Ogden, built a furnace and ran for a weat in 1876 .

Small outcrops of mineralized rock, containing barite, fluorite, quartz, and copper minerals, are said to occur east and northeast of Ogden, but only one serious attempt at prospecting has been undertaken in recent years. This was on the Ogden Buckhorn Mining Co.'s property in Cold Water Canyon, east of Ogden. The deposit is said to be a vein between quartzite and limestone and to contain copper ore with low gold and silver content, mostly of milling grade. ${ }^{2}$ No shipments have been reported.

\section{SIERRA MADRE DISTRICT.}

By G. F. Loughurn.

The Sierra Madre district lies on the west slope of the Wasatch Range northeast of Hot Springs and 10 miles north of Ogden. (See fig. 38 and Pl. XXV, A.) From 1901 to 1905, inclusive, the production as reported was 205 tons of ore, containing $\$ 100$ in gold, 152 ounces of silver, and 3,387 pounds of copper; total value $\$ 996$. No lead production was reported.

GEOLOGY.

The geology of the district is much the same as that of the Box Elder, Weber, and Willard districts. (See p. 221.) Archean granite forms the lower front slopes of the range, Cambrian quartzite a central band, and Cambrian shale and limestone an upper band, which is overridden almost at the summit, by Algonkian quartzite.

\section{PRE-CAMBRIAN ROCKS.}

The granite, or granodiorite, is gray to pink, medium grained, and massive to gneissoid in structure. It consists essentially of plagio-

1 Precious metals: Tenth Census U. S., vol. 13, p. 483, 1885.

${ }^{2}$ Salt Lake Min. Rev., vol. 9, June 15, 1907. clase (oligoclase to andesine), microcline, quartz, hornblende, and biotite. Plagioclase is commonly somewhat altered to sericite, and hornblende and biotite to chlorite, but alteration as a rule is not far advanced. In places feldspars and quartz and a little magnetite form small rounded or orbicular segregations, but practically no biotite or hornblende are present. The granite contains short dikelike bodies of dark-green, rather fine grained rock, which proves under the microseope to be a special variety of the granite, consisting of about 50 per cent quartz, 30 per cent altered feldspar (chiefly plagioclase), and 20 per cent altered biotite. The feldspar is altered to an aggregate of quartz, sericite, chlorite, and a little epidote; the biotite to chlorite, sericite, and titanite. Pegmatite veins are abundant in the granite, following foliation planes, shear zones, with micaceous borders, and strike and dip fissures, and cutting the dark-green dikelike bodies. The pegmatites contain the same essential minerals as the granite; in some of them small amounts of pyrite and perhaps chalcopyrite were noted. The pre-Cambrian age of the pegmatite is shown (see $\mathrm{Pl}$. XXV, $B$ ) by a pegmatite dike in the granite which is cut off by a basal conglomerate bed at the unconformable contact with the Cambrian.

Several short veins, 5 inches or less in thickness, composed of quartz and chlorite and a little pyrite and chalcopyrite, follow for the most part nearly horizontal fractures that dip $10^{\circ}$ to $20^{\circ} \mathrm{W}$. and are distinctly later than the pegmatite. The probable pre-Cambrian age of these veins is indicated by some chloritestained quartz pebbles in conglomerate beds of the Cambrian quartzite, though these may have been derived from chloritized pegmatite veins. The quartz-chlorite veins however are distinct from the persistent mineralized fissures that have been extensively prospected.

The granite is complexly fissured. Some of the fissures (see Pl. XXVI, $A$ ) are of undulating trend and "tight." Others are nearly horizontal and contain quartz-chlorite veins. Still others (see Pl. XXVI, $B$ ) are relatively straight, trend either approximately north or east, are nearly vertical, and are mineralized. They pass upward into the quartzite. One prominent north-south fissure (the "crosscountry" vein) in Eldorado Canyon, which appears to offset the east-west fissures is said 
to extend for a considerable distance. (See below.)

The Algonkian quartzite at the summit of the ridge, above the overthrust, is not closely associated with important mineralization. (See also p. 222.)

\section{CAMBRIAN ROCKS.}

The Cambrian quartzite varies in color and texture. The basal beds contain considerable conglomerate (see $\mathrm{Pl}$. XXV, $A$ ), which also appears less 'conspicuously at higher levels. The conglomerates are composed of white pebbles and a few red, jasper-like pebbles of rhyolite porphyry in a dark-green chloritic matrix, which turns brown on weathering. Some beds contain a conspicuous amount of dark-gray hematite (martite) grains, which were probably derived from the rather large magnetite grains in the pre-Cambrian pegmatite veins. The finergrained, or typical, quartzite beds range in color from light gray to greenish and to red or brown. Many of them are separated by greenish-gray, red, or brown shale partings. The thickness of the quartzite was not measured but is roughly estimated at 1,000 feet.

A narrow band of shale overlies the quartzite and is overlain by limestone with intercalated beds of shale. The limestone for the most part is of mottled blue and yellowish color and of argillaceous composition but includes near its base a narrow band of relatively pure dolomite, which is dark gray except where bleached by alteration. This bed is the wall rock of the ore body in the Eldorado mine. It is overlain and underlain by beds of shale.

\section{ORE DEPOSITS.}

The mineral deposits include veins or mineralized fissures in granite, and bedded replacements in limestone, both of which are attributed to the same period of mineralization.

\section{DEPOSITS IN GRANITE.}

The mineralized fissures in the granite lie in north and in east trending systems, which appear to be of contemporaneous mineralization. The north-trending " cross-country" vein which crosses the Napoleon-Maghera group of claims differs in mineral composition from the others and deflects intersecting east-west fissures. The amount of the deflection, however, is neither uniform nor proportional, and it is doubt- ful if the cross-country vein actually faults the east-west fissures.

The mineralized fissures, except the "crosscountry" vein, are marked by an impregnation of the granite with fine crystals of pyrite. The pyrite appears mostly to have replaced the hornblende and biotite, and the impregnated rock has a lighter color than ordinary. It also forms scattered grains or microscopic veinlets in feldspar and locally in quartz. Streaks or lenses of chalcopyrite, in part oxidized, accompany the pyrite in places. Oxidized copper minerals have been reported, but none were seen by the writer. The gangue minerals introduced with the pyrite are microscopic sericite and quartz. The sericite replaces biotite and in places plagioclase; the quartz is in part associated with sericite and pyrite and also forms barren veinlets. At one place in Eldorado Canyon, where a local enlargement of the King Solomon vein is intersected by the "crosscountry" vein, dolomite and calcite and a little galena and zinc blende accompany the pyrite, showing similarity in composition between the mineralized fissures in the granite and the bed replacements in the limestone.

Mineralization in the granite varies from a mere streak of pyritic or limonitic material along the fissure to zones several feet wide. The greatest width noted was 40 feet, at a coalescence of fissures on the King Solomon vein in Eldorado Canyon. The mineralized rock is said to be for the most part of milling grade, although small shoots of copper ore of shipping grade have been reported. Assays of samples from the Illinois tunnel on the Napoleon-Maghera group in 1913 show from nil to a trace in gold, nil to 0.32 ounce of silver to the ton, and nil to 2.51 per cent copper. The ore produced from 1901 to 1905, inclusive, averaged $\$ 0.50$ in gold and 7.5 ounces of silver to the ton, and 0.85 per cent copper.

The "cross-country" vein was seen only on the north wall of Eldorado Canyon, where it consists of barren calcite, which forms scalenohedral crystals around cavities and apparently represents the latest phase of mineralization after the ore minerals had been deposited.

DEPOSITS IN LIMESTONE.

Some of the east-west veins in the granite have been traced upward through the quartz into the shale and limestone. (See fig. 39.) The 
showings along them are not promising in the quartzite and shale but are so in the dolomite bed in the lower part of the limestone. The mineralized rock is in the upper part of the dolomite, and, as seen on the Eldorado property, is indicated by a bleaching of the rock from dark bluish to white. Their upper contacts end abruptly along the shale contact at the top of the dolomite; the lower contact is irregular and extends downward along zones of shattering into the underlying shale. It is said that mineralization has been noted at intervals along this horizon for 3 miles but no noteworthy prospecting has been reported except on the Eldorado property.

The ore consists of varying amounts of fine-grained galena, zinc blende, and pyrite, oxidized in places, in a gangue of quartz, a little sericite, and locally coarsegrained white dolomite. Calcite forms veinlets in the bleached dolomite rock and the coarse-grained dolomite. The quartz and sericite are inconspicuous, but microscopic examination shows that they may amount to 25 per cent by volume of the ore body. There is some evidence that mineralization took place in two stages-the first marked by replacement of the dolomite rock by fine-grained cherty quartz; the second by further replacement of the rock by ore minerals, quartz, and sericite. Microscopic fragments of quartz of the first stage have been found in some of the sulphide ore but not in all of it. Local deposition of the coarse-grained dolomite was probably contemporaneous with the second stage. A little fluorite is said to have been found in the ore horizon, but none was seen in the Eldorado workings.

The ore occurs in irregular bunches along the dolomite bed, and in the largest workings on the Eldorado property has been followed for about 100 feet north along the strike and an equal distance down the eastward dip. The assay records following show the variation in composition of the ore.

The first two of these represent bunches of ore with galena greatly predominating; the third a nearly pure mixture of pyrite and quartz; the fourth a segregation of zinc blende.
Assays of ore from the Eldorado mine, Sierra Madre district.

\begin{tabular}{|c|c|c|c|c|c|c|c|}
\hline Gold. & Silver. & Lead. & Copper. & $\begin{array}{l}\text { Insol- } \\
\text { uble. }\end{array}$ & Zinc. & $\begin{array}{c}\text { Sul- } \\
\text { phur. }\end{array}$ & Iron. \\
\hline $\begin{array}{l}\text { Trace. } \\
\text { None. } \\
\text { None. } \\
\text { None. }\end{array}$ & $\begin{array}{r}\text { Oz. } \\
4.0 \\
1.6 \\
\text { Trace. } \\
1.2\end{array}$ & $\begin{array}{r}\text { P. ct. } \\
56.0 \\
23.3 \\
\text { None. } \\
\text { None. }\end{array}$ & $\begin{array}{l}P . c t . \\
\text { Trace. } \\
\text { Trace. } \\
\text { Trace. } \\
(a)\end{array}$ & $\begin{array}{r}P . c t . \\
22.7 \\
53.1 \\
41.6 \\
2.7\end{array}$ & $\begin{array}{c}\text { P.ct. } \\
3.2 \\
4.9 \\
2.9 \\
46.47\end{array}$ & $\begin{array}{c}\text { P.ct. } \\
12.6 \\
10.1 \\
26.5 \\
(a)\end{array}$ & $\begin{array}{r}\text { P.ct. } \\
2.6 \\
4.8 \\
24.4 \\
3.0\end{array}$ \\
\hline
\end{tabular}

Samples of mineralized rock intervening between ore bunches range in content from a

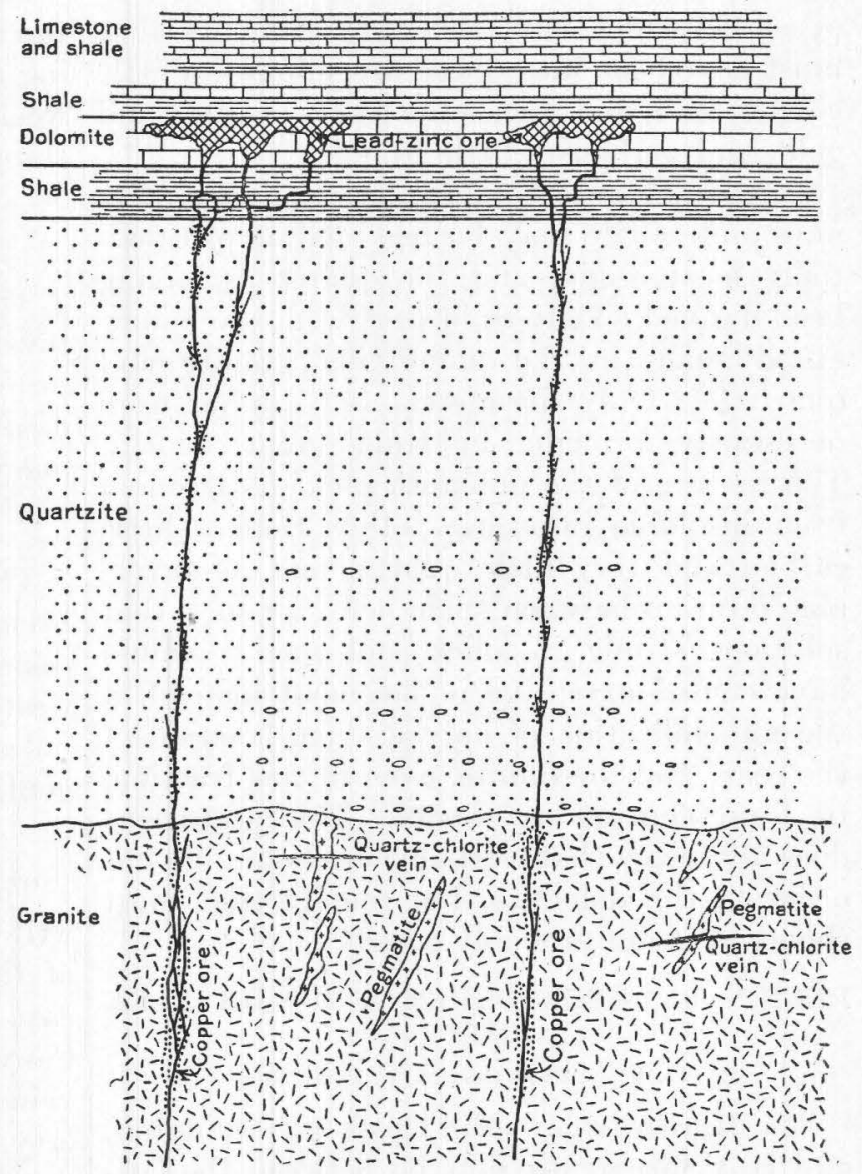

Figure 39.-Section showing relations between deposits in dolomite and granite, Sierra Madre district.

trace to an ounce of silver to the ton and from 4 to 5 per cent each of lead and zinc. The success of working this deposit depends largely on the careful separation of the lead and zinc ores and in the elimination of gangue matter from material shipped.

CONCLUSIONS.

The character of the mineralization, both in the granite and in the dolomite, point to the action of weak solutions remote from their 
source. The failure of ore and gangue minerals to replace the plagioclase of the granite more extensively and their practically complete inability to replace the microcline indicate lack of concentration and scarcity of strong mineralizing elements like fluorine and carbon dioxide. The small amounts of secondary sericite, quartz, dolomite, and calcite in the mineralized zones of the granite may be regarded as merely recrystallized and more or less transferred constituents of plagioclase and biotite that were replaced by the pyrite and other sulphides, and the only elements that must have been introduced are sulphur, a little copper, lead, and zinc, some traces of silver and gold, and perhaps a little iron.

In the dolomite horizon the secondary dolomite and calcite may be regarded as of essentially local origin, and the quartz as having been derived wholly or in part from the mineralized zones in the underlying granite and quartzite. Only the metals and sulphur were necessarily brought in from great depths. The texture of the dolomite rock, its treedom from insoluble impurities other than a little carbon and very little quartz, and its favorable position between shale beds are such that solutions strong in silica and metals would have caused extensive replacement instead of the mineralization of only a small fraction of the rock, and the failure, even in this fraction, to form continuous shoots. This statement does not imply that workable ore bodies do not occur in the dolomite, but merely that most shoots in it are probably small.

\section{REGION BETWEEN OGDEN AND SALT LAKE CITY.}

By G. F. Loughuin and V. C. Heikes.

The Hardscrabble (Mill Creek), Farmington, and Hot Springs districts lie between the latitudes of Ogden and Salt Lake, in Morgan, Davis, and Salt Lake counties. Some of them have made small shipments but none has been consistently productive, and each at present is represented by only a few small operations or is idle.

HARDSCRABBLE (MILL CREEK) DISTRICT. By V. C. Heikes.

Hardscrabble (Mill Creek) district, 10 miles southwest of Morgan on the Union Pacific Railroad, was organized February 11, 1893.
Long before this, however, the claims of the Norway Iron Mining \& Manufacturing Co. (incorporated Nov. 19, 1879) were operated, yielding some iron ore containing 56.12 to 65.08 per cent of iron. A sample of brown ore from the Norway group contained: ${ }^{1}$ Iron, 56 per cent; silica, 3 per cent; carbonate of lime, 4.5 per cent; alumina, 4.3 per cent; sulphur, trace. Some of this ore was tried in the experimental iron furnace during the eighties at Ogden. ${ }^{2}$

Previous to 1900 no records are available of the iron ore shipped out of the district for testing at the iron works (operated for only a few weeks) near Ogden and the several car lots shipped to different smelters as flux.

FARMINGTON DISTRICT.

By G. F. Loughuin.

The Farmington district lies east of the towns of Farmington and Centerville. Three properties have been prospected, but no shipments had been made up to 1913, and only one was then active.

\section{GEOLOGY.}

The country rock is a complex of pre-Cambrian schists and gneisses, cut by numerous dikes and sills of pegmatite. The foliation dips west at a low angle along the range front, but 2 miles to the east, opposite Centerville, it arches gently over to an eastward dip.

\section{ORE DEPOSITS.}

The most promising deposit seen by the writer was a vein of copper ore on the prospect of the Buckland Mining \& Development Co., east of Centerville, on the north side of Parish Canyon, about 3 miles from its mouth. Seven veins are said to have been found on the property, three of which have been prospected to a depth of 200 feet or more. The principal work has been done on a vein which enters along the north canyon slope and has been traced for about a mile within the company's property, and for about a mile more outside of it. Within the property the vein strikes about east and is remarkably straight, cutting squarely across the foliation of the inclosing gneiss. Its dip is $60^{\circ}-90^{\circ} \mathrm{N}$. Its maximum exposed thickness

1 Bishop, F. M., U. S. Geol. Survey Mineral Resources, 1883-84, p. $288,1885$.

2 Jones, M. E., Report on the international commerce of the United States, p. 883, Bur. Statisties, 1890. 
is 12 feet and at only a few places is less than 4 feet.

The vein has been prospected by an inclined shaft 50 feet deep and by two crosscut tunnels from which drifts have been run along the vein to the east and the west. The upper tunnel is short and level with the bottom of the shaft; the lower tunnel is about 500 feet long and cuts the vein 300 feet below its outcrop. The vein contents are encouraging in all the openings, but up to 1913 no assays had been made except from material near the surface, which was said to average about 10 per cent copper and a little silver.

The vein consists of chalcopyrite, pyrite, and specularite in a gangue of quartz and pyrite. No galena or blende have been found in the workings, although ore containing some galena with low silver content is said to have been found in line with the vein beyond the limits of the property. The chalcopyrite and pyrite are as a whole evenly distributed, the former in irregular grains and masses up to 4 inches and more in diameter, the latter in small scattered crystals. The specularite tends to form bunches around small cavities, which are lined with crystals of specularite and quartz. The quartz is milky and massive, containing scattered bunches of dark-green fine-grained chlorite. The vein grades laterally into quartz chlorite-pyrite rock in which the texture of the gneiss is more or less distinctly preserved.

Oxidized ore extends down to the level of the upper tunnel, which approximately marks the ground-water level. It is characterized by green copper stains and by limonite, the limonite occupying the spaces of original chalcopyrite. In the ore from the lower tunnel cracks in the chalcopyrite are filled with thin seams of chalcocite. Encouraging concentrating experiments were in progress in 1913.

The only other prospects seen by the writer were those on the Morning Star group of claims, in the front of the range due east of Farmington. Several openings have been made here on quartz-chalcopyrite veins which lie along the bedding or foliation of the schist and gneiss. One vein has been followed down on an incline (now caved) for 90 feet and is said to bave yielded, about 20 years ago, a 20 to 25 ton shipment of copper-gold ore, in which the value of the gold was $\$ 14$ a ton. Most of the exposed ore appears to be oxidized and consists prin- cipally of malachite and azurite, remnants of chalcopyrite and pyrite, and some cuprite.

The other prospects on the Morning Star property contain the same type of ore, but their showings are too low grade to be of much promise. A tunnel to strike some of these veins at considerable depth had been driven about 400 feet in 1913.

Several outcrops and prospects of copper ore ${ }^{1}$ containing a little gold have been reported from the Farmington district, but no shipments have been made.

\section{HOT SPRINGS DISTRICT}

By V. C. Heikes.

Hot Springs district extends 10 miles east and west and 5 miles north and south in the Wasatch Range, adjacent to and east of Salt Lake City. It was organized in December, 1870, and now includes the old Adams district, in Salt Lake County. According to Huntley, ${ }^{2}$ up to the end of 1880 about 230 locations had been made, but not more than 40 were being held and worked. The country rock is limestone. The ore, said to occur in small veins, was described as a low-grade ocher containing cerusite and galena, some of which assayed 15 to 25 ounces of silver per ton, but only a few tons of which had been shipped. The principal claims were the Henry Lawrence, the General Scott, and the Magnet Iron mine, from which several hundred tons of iron flux had been shipped. No large amount of development seems to have been performed.

REGION SOUTH OF SALT LAKE CITY.

By B. S. Butler, G. F. Loughuin, and F. C. Calkins.

The richest part of the Wasatch Range lies south of the parallel of Salt Lake City. It includes the Park City, Cottonwood, American Fork, Provo, Santaquin, and Mount Nebo districts, besides a few others that have never been productive.

COTTONWOOD-PARK CITY REGION.

GENERAL FEATURES.

By F. C. CaLkins.

LOCATION.

The Park City, Big and Little Cottonwood, and American Fork districts together form an irregular area whose center lies in the heart of

1 Salt Lake Min. Rev., vol. 7, March and May, 1906.

${ }^{2}$ Precious metals: Tenth Census U. S., vol. 13, p. 431, 1885. 
the Wasatch Range, about 20 miles southeast of Salt Lake City, in line with the east-west axis of the Uinta Mountains. The Park City district, which is east of the Wasatch divide, is shown on the Park City map published by the United States Geological Survey; the main part of the Cottonwood districts and the northern part of the American Fork district, which lie west of the divide, are represented on the Cottonwood special map. The two maps cover adjoining areas and constitute the topographic base of Plate XXVII (in pocket). The ParkCity district and the Cottonwood-American Fork area will be described in two separate sections, which may be prefaced by an outline of the topography and geology of the region as a whole.

TOPOGRAPHY.

The western front of the Wasatch Range in the latitude of the Cottonwood-Park City region rises abruptly from the border of Salt Lake Valley, 5,000 feet above sea level, to elevations of about 11,000 feet. The crests of the ridges between the westward-flowing streams maintain this general level for several miles to the east and bear some peaks that are nearly 11,500 feet high, but they begin gradually to decrease in height before they terminate against the main north-south divide of the range. The highest summit on this divide is Clayton Peak, which rises 10,728 feet above sea level and lies near the southwest corner of the Park City quadrangle. Eastward from the north-south crest the surface descends with moderate steepness to a zone of low hills, interspersed with parks and meadows that stand about 6,500 feet above sea level, beyond which fairly steep acclivities lead up to the western brow of the Uinta Mountains.

The principal drainage lines of this region radiate from the vicinity of Clayton Peak. The crest extending north from that summit separates the drainage basins of Jordan and Weber rivers and constitutes the main divide of a long segment of the Wasatch Range. The southward prolongation of this crest first parts the Cottonwood creeks and American Fork from Provo River, and then subsides between two branches of the Provo, a stream which rises far to the east, and south of whose canyon the range has no principal divide. The watershed between the Provo and the Weber, which extends eastward from a summit about a mile north of Clayton Peak, is the most prominent spur on the east slope of the central Wasatch and connects that range with the Uinta Mountains.

\section{GEOLOGY.}

The position of the Cottonwood-Park City region at the intersection of the Wasatch and Uinta axes is geologically as well as topographically significant. The dominant structural trend in the Wasatch Range is a little west of north. The dominant structure in the Uinta Range is an anticline whose axis runs a little north of east. The region, therefore, has been subjected to compression in two directions at right angles to each other; and the resultant effect of these forces has been the formation of a broad east-pitching anticline, which will be called, following Boutwell, ${ }^{1}$ the Park City anticline. This fold is shown very prominently on the generalized map of the Fortieth Parallel Survey, ${ }^{2}$ but it appears less conspicuous on Plate IV, where some details neglected by the pioneers are shown; and in the still more detailed view of a smaller area given in Plate XXVII it is further obscured by the representation of the complex faulting which appears as the most prominent structural feature. The faults are widely varied in direction, attitude, and amount of throw. The greatest of those in the Cottonwood quadrangle are two or three overthrusts dipping toward the east, and a normal fault with downthrow to the west; the greatest in the Park City quadrangle is an overthrust whose dip is westward.

This folding and faulting have deformed a series of stratified rocks which ranges in age from pre-Cambrian (Algonkian) to later Triassic or early Jurassic and whose total thickness as exposed in this part of the range is about 20,000 feet. About half this thickness belongs to the pre-Cambrian, which consists mainly of quartzites and other siliceous rocks and is probably for the most part of terrestrial origin. These ancient rocks are not very much more altered in general than the Paleozoic rocks, which lie upon them unconformably but with only a slight angular discordance. The Paleozoic rocks, which are about 6,000 feet thick, are chiefly of marine origin. Their medial and

Boutwell, J. M., op. cit., p. 94. 2 U. S. Geol. Expl. 40th Par. Atlas, map 3. 
greatest part consists of limestone, but they comprise a good deal of shale and two thick formations of quartzite, one at the base and another just above the greatest body of limestone. The continuity of Paleozoic sedimentation was several times interrupted; the most distinct of the resulting unconformities lies at the base of Devonian or Carboniferous limestone, which rests in most places on one stratum or another of Cambrian limestone; but not even this unconformity is marked by strong angular discordance. The Mesozoic strata, whose total thickness in the region studied is about 4,000 feet, consist mainly of shale but include large quantities both of limestone and of sandstone. They are in part marine but may be in part of fresh-water or terrestrial origin. The Mesozoic formations are not divided from the Paleozoic strata, nor from one another, by distinct unconformities. Not until after the Jurassic period was there any vigorous deformation of the strata.

The igneous rocks of the Cottonwood-Park City region are also post-Jurassic. They include the only large post-Cambrian intrusive masses that occur in the Wasatch Range. All these masses, whose rocks range from quartz monzonite to quartz diorite porphyry, are exposed along the axis of the Park City arch. Besides the larger bodies, the region contains dikes of varied composition. The intrusive rocks are younger than the sedimentary strata, which are profoundly metamorphosed by the larger intrusive masses. Extrusive igneous rocks, chiefly andesitic lava and breccia, lie in the trough between the Wasatch and Uinta ranges and occur in the eastern part of the Park City district.

The region was subjected in the Quaternary period to vigorous alpine glaciation, as is attested by characteristic glacial deposits and sculpture.

The ore deposits were formed mainly by replacement of the sedimentary rocks-especially of Paleozoic limestones-and are associated with fissures, many of which strike nearly parallel to the general trend of the row of intrusive masses and probably were formed at the time of their intrusion. The deposits are valuable chiefly for silver, lead, zinc, gold, and copper.
COTTONWOOD-AMERICAN FORK AREA.

By F. C. Calkins.

FIELD WORK AND LITERATURE.

The Cottonwood-American Fork area lies well within the zone explored by the Fortieth Parallel Survey, whose reports and maps, published between 1870 and 1880, are still of great interest and use to every student of the geology of Utah. The middle part of the range was examined in 1869, mainly by S. F. Emmons. The fine sections in Big and Little Cottonwood canyons were regarded by him as among the most instructive in the Wasatch Mountains and formed the chief basis of important deductions drawn by Clarence King regarding the general stratigraphy of the range. These deductions are now known to be in part erroneous, the most serious errors consisting in the assignment of the post-Jurassic intrusive rocks to the Archean and in the failure to recognize the presence of overthrust faults.

J. M. Boutwell, in 1902, examined parts of the Cottonwood quadrangle in connection with his survey of the Park City district, and in his report ${ }^{1}$ he briefly reviewed the geology of the middle Wasatch. He recognized the true nature of the intrusive rocks and mapped some overthrust faults in the Park City district, thus being the first to recognize this type of fracture in the Wasatch Mountains.

But the full importance of overthrust faulting in the structure of the range was first appreciated by Eliot Blackwelder as a result of his work near Ogden in $1909 .{ }^{2}$ The discovery of great overthrusts in the Ogden region entailed a radical revision of the Paleozoic stratigraphy. Blackwelder's paper deserves citation here, not only because it utilizes observations made on Cottonwood Creek, but even more because of the close parallelism of his results with those obtained in the Cottonwood quadrangle, three years later, by Butler, Loughlin, and Hintze. In 1912 a reconnaissance of several districts in the central Wasatch was made by Butler

1 Boutwell, J. M., Geology and ore deposits of the Park City district, Utah, with contributions by L. H. Woolsey: U. S. Geol. Survey Prof. Paper 77, p. 41, 1912.

2 Blackwelcer, Eliot, New light on the geology of the Wasatch Mountains, Utah: Geol. Soc. America Bull., vol. 21, pp. 517-542, 1910 
and Loughlin, ${ }^{1}$ who prepared a geologic sketch map of the Cottonwood quadrangle. In the same year F. F. Hintze, jr., made a study of part of the quadrangle, the results of which were presented as a thesis to the faculty of Columbia University. ${ }^{2}$ Hintze and the Survey party worked unknown to each other, but both found great overthrust faults and revised the stratigraphic scheme much as Blackwelder had revised that of the Ogden region. Their most striking results were derived from the section in Little Cottonwood Canyon, which was not studied by Blackwelder.

A firm basis had now been laid for detailed field work, which was carried on for the Geological Survey by Messrs. Butler and Hintze together in 1916 and was continued by Messrs. Butler and Calkins in 1917, but which has not yet been completed.

Collaterally with the more general geologic investigations, whose sequence has been outlined, much work has been devoted to certain special phases of the geology. The Cambrian and pre-Cambrian rocks of the Big Cottonwood section have been studied by Walcott. ${ }^{3}$ The glacial geology of the Wasatch and Uinta ranges has been described by Atwood. ${ }^{4}$ Descriptions of certain mines studied in 1880 were published in the report of the Tenth Census. The congressional report of the investigation of the Emma mine ${ }^{5}$ contains testimony regarding the mine by Clarence King, J. E. Clayton, W. P. Blake, and other geologists and engineers. Other articles ${ }^{6}$ concerning the

\footnotetext{
1 Loughlin, G. F., Reconnaissance in the Wasatch Mountains, Utah: Jour. Geology, vol. 21, pp. 436-452, 1913 . Butler, B. S., and Loughlin, G.F., A reconnaissance of the Cottonwood-American Fork miningregion, Utah: U. S. Geol. Survey Bull. 620, pp. 165-266, 1915.

2 Hintze, F. F., jr., A contribution to the geology of the Wasatch Mountains, Utah: New York Acad. Sci. Annals, vol. 23, pp. 85-143, pls. 1-6, 1913.

${ }^{3}$ Walcott, C. D., The Cambrian faunas of North America, second contribution: U. S. Geol. Survey Bull. 30, p. 38, 1886; Correlation papers-Cambrian: U. S. Geol. Survey Bull. 81, pp. 159, 319, 1891.

Atwood, W. W., Glaciation of the Uinta and Wasatch mountains: U. S. Geol. Survey Prof. Paper 61, 1909.

544 th Cong., 1st sess., H. Rep. 579.

6 Ryan, G. H., The strike in the Cardiff: Salt Lake Min. Rev., Nov. 30, 1914 , p. 15 (describes the relation of the newly found ore body to local geologic structure); Some Alta activities: Eng. and Min. Jour., Apr. 17, 1915 , pp. 689-690 (shows that the replacement ore bodies along the limestone-quartzite contact are connected with ore-bearing fissures and describes developments in the Cardiff, Columbus Extension, and South Hecla mines); Geology and ore deposits of Miller Hill, American Fork Mining district, Utah: Salt Lake Min. Rev., vol: 19, Aug. 15, 1917 (describes the stratigraphy, structure, and ore deposits of the Miller Hill area). Howard, L. O., Mining in Utah: Min. (and Sci.) Press, Sept. 18, 1915, pp. 445-446 (describes conditions in the Big and Little Cottonwood districts, especially as regards the intrinsic value of mining shares, and gives map showing claim boundaries of principal properties).
}

mines have appeared in mining journals and newspapers since the recent revival of mining activity.

The most thorough geologic work that has been done in this region by any mining geologist is that of J. J. Beeson. In the years 1916-1918 Mr. Beeson mapped in detail the surface and the more important underground workings on the north side of the canyon, in the vicinity of the Emma Consolidated Copper Co.'s claims, and his work resulted in the recovery of the long-lost Emma ore body. He has published brief articles in newspapers and trade journals but no general account of his results. His unpublished material was generously placed at the service of the writers.

GEOGRAPHY.

LOCATION, SUBDIVISION, AND ACCESSIBILITY.

The Cottonwood-American Fork area, which lies on the western slope of the Wasatch Range, about 20 miles southeast of Salt Lake City and immediately southwest of the Park City district, includes the Big Cottonwood, Little Cottonwood, and American Fork districts, which contain the mines that lie in the respective drainage basins of the three principal streams whose names they bear.

The northernmost district is the Big Cottonwood, which is connected with Salt Lake Valley by a wagon road that follows Big Cottonwood Canyon and crosses the Wasatch divide to Park City. In summer an automobile stage runs from Salt Lake City to Brighton (Silver Lake), a resort near the head of the canyon, and the ores mined in the district are hauled by wagon and by auto truck to smelters in Salt Lake Valley.

The mines of the Little Cottonwood district, which lies next south, are clustered about Alta, in Little Cottonwood Canyon. The camp is reached from the west by a wagon road and by a narrow-gage railway spur from Alta to $\mathrm{Wa}$ satch, near the mouth of the canyon, where it connects with a standard-gage spur that joins the Denver \& Rio Grande Railroad at Midvale. The portion of the spur above Wasatch was long in disuse but was relaid in 1917. It is now used, except for the period when it is blocked bysnow, for conveying stage passengers, who are carried in automobiles between Salt Lake and Wasatch, 
and for transporting part of the ore. The ore from some of the mines is conveyed by aerial tramway about 5 miles to Tanners Flat, and thence about 2 miles by wagon to Wasatch, where it is transferred to the railway, but the ore from other mines is still carried from Alta to Wasatch by wagon.

The American Fork district, the southernmost of the three, is connected by wagon road with the town of American Fork, on the Denver $\&$ Rio Grande and the Los Angeles \& Salt Lake railways. Its largest mines are grouped about Miller Hill, a prominence near the head of the canyon. A stage has been operated intermittently between the mines and the town of American Fork. About 16 miles of railroad was laid along the canyon in the early days but was demolished in 1878.

Most of the mines of the Cottonwood-American Fork area are contained in the Cottonwood special quadrangle, which is bounded by parallels $40^{\circ} 33^{\prime}$ and $40^{\circ} 39^{\prime}$ and meridians $111^{\circ} 34^{\prime}$ and $111^{\circ} 40^{\prime}$ and forms the western part of the area mapped in Plate XXVII. Nearly all the mines of the Big and Little Cottonwood districts lie within these limits, though the Maxwell mine, on Big Cottonwood Creek, and a few prospects on Little Cottonwood Creek, are a mile or two farther west. Some of the more productive properties on the upper part of American Fork lie less than 2 miles south of the quadrangle, and the lower part of the canyon contains some prospects and unimportant mines. The properties in the basin of Snake Creek, a tributary of the Provo rising in the southeastern part of the Cottonwood quadrangle, are described with those of the Cottonwood-American Fork area.

TOPOGRAPHY.

RELIEF AND DRAINAGE.

The principal topographic features of the Cottonwood-American Fork region are the canyons of the three main westward-flowing streams, the two ridges that lie between them, and the north-south divide of the central Wasatch, which parts their waters from those of Weber and Provo rivers. These crests and canyons are the chief lineaments of a boldly mountainous landscape. The principal summits are about 11,000 feet high and those at the very brink of the western face are even higher than those on the main divide; the main streams receive their first large branches at 8,000 to 8,500 feet above sea level and descend 3,000 feet or more in flowing 8 or 10 miles farther to the mouths of their canyons.

The Cottonwood quadrangle is so placed that the Wasatch crest divide winds in and out along its eastern border. From the north boundary of the quadrangle to Sunset Peak the crest line, which is here the eastern boundary of Salt Lake County, curves gently westward around the head of Cottonwood Creek; and at Sunset Peak, where it becomes the boundary between Wasatch and Utah counties, it turns more sharply eastward around the head of Snake Creek.

At Sunset Peak the bold ridge, locally known as the Bullion Divide, that forms the northern boundary of Utah County and of the basin of American Fork, branches westward from the main divide. The Bullion Divide leaves the Cottonwood quadrangle near the southwest corner, just beyond the Twin Peaks, whose higher summit, 11,491 feet above sea level, is the highest point within that area.

The ridge which parts the two Cottonwood creeks and may be called the Cottonwood Divide does not quite reach the Wasatch orest but joins the Bullion Divide near Sunset Peak. Thence it runs northward to what will be called hereafter Honeycomb Hill, where it turns abruptly westward. The highest point on this divide within the quadrangle is, like the Twin Peaks, close to the western boundary; it is a very steep red mountain, 11,030 feet high, which is the most impressive feature of the landscape around Alta. This peak marks the junotion of the Cottonwood Divide with the bold north spur whose brow is formed by Carbonate Peak. The next spur to the east is Reade and Benson Ridge, the strongest crest of secondary rank within the quadrangle.

More than the northern half of the quadrangle lies in the open upper valley of Cottonwood Creek. Rising in the broad lake-dotted basin, made up of coalescing amphitheaters, that is overlooked by Honeycomb Hill and by Sunset and Clayton peaks, this creek flows northwestward to the corner of the quadrangle, near which it takes the general westward course that it holds in its relatively narrow and rugged lower canyon. Its longer tributaries enter from the south, heading in amphitheaters on the north slope of the Cottonwood divide. 
Those to which most frequent reference will be made are Mill D South Fork and Silver Fork, whose main branch is Honeycomb Fork.

The main part of Little Cottonwood Canyon, with its headward prolongation, City Rock Gulch, forms a U-shaped trough which runs nearly straight westward from Honeycomb Hill to the front of the range. Its northern and southern tributaries are even more unequal than those of Cottonwood Canyon. From its south side, within the quadrangle, there open three hanging valleys, besides the great composite basin that is drained by the headwater branches of the main stream; its north side, on the contrary, is merely scarred by shallow gullies.

The valley of American Fork has a general southwesterly course, but its main headwater branch and Dry Fork, which rise within the quadrangle, flow eastward and southward. Mary Ellen Gulch, another branch on which there is a good deal of mining activity, heads southwest of the Silver Dipper mine, in an elbow of the eastern spur of the Twin Peaks.

GLacial Features.

The U-shaped sections, smooth walls, and basin-like heads of most of the canyons in this area, the hanging valleys, and the numerous lakes are the unmistakable work of alpine glaciers. ${ }^{1}$ Little Cottonwood Canyon, which illustrates every typical feature of a glacial valley, contained the longest of the Pleistocene glaciers of the central Wasatch. The ice was once 1,000 feet deep near Alta and extended downstream beyond the mouth of the canyon, where it left strong lateral moraines that are broken by recent faults. ${ }^{2}$ The glaciers of Cottonwood Creek and American Fork reached only about halfway to the mouths of their canyons.

The heaviest glacial deposits within the quadrangle are probably those about Giles Flat, on Cottonwood Creek. Strong moraine terraces rise to the 8,750-foot contour southwest of that place, and the long spur east of it is a

1 Atwood, W. W., Glaciation of the Uinta and Wasatch mountains: U. S. Geol. Survey Prof. Paper 61, 1909. Describes glacial phenomena in all these canyons rather fully. It may be remarked that the "Mill A" branch of Cottonwood Creek described on p. 87 of Atwood's report is evidently Mill D South Fork and should be shown on his Plate X as lying just east of Basin 42 (Mineral Fork).

2 Gilbert, G. K., Lake Bonneville: U.S. Geol. Survey Mon. 1, pp. 346347, 1890. Atwood, W. W., op. cit., p. 82, pl. 14. moraine. There is much morainic material about Alta. That on the slope north of the town has indirect economic interest because it obscures the geologic structure, the deciphering of which is likely to be of great help in exploiting the ore bodies.

\section{WATER SUPPLY.}

The region is well supplied, on the whole, with excellent water, though many of the stream beds are usually dry - a fact that is probably due in part to the prevalence of limestone, in which there may be underground channels that engulf the normal flow. The sunken streams emerge as copious cold springs on Mill D South Fork and on Silver Fork.

Each of the three main streams is made to generate electric power, which is used by several of the mines and might, if fully developed, supply all the needs not only of this mining region but of neighboring towns in Salt Lake and Utah valleys. Cottonwood Creek also furnishes part of Salt Lake City's water supply. Its flow is somewhat equalized by the utilization of several lakes as reservoirs, the largest one being formed by the damming of the Twin Lakes, which have been so raised as to form a single sheet of water.

CLIMATE AND VEGETATION.

The climate of the region is cool, and the precipitation considerable, the snowfall being so heavy that winter operations are greatly hampered and the roads are not clear until late in spring. Snow lingers on some high, shady slopes until late in summer, and in years of especially heavy snowfall a few banks may survive until they are covered by the fresh snows of autumn. Destructive snowslides are remarkably frequent. They are said to have destroyed 300 lives, besides much property, in the Little Cottonwood district alone. ${ }^{3}$

The frequency of slides is due largely to the improvident completeness with which the timber has been removed. Of the once heavy coniferous forest only straggling pines and firs remain in places difficult of access, and little reforestation is taking place. Aspen and scrub oak and other bushes are common in the Cottonwood basin, where the larger aspens are cut for poles and logs.

\footnotetext{
s Palmer, Leroy, Modern Milling at Alta, Utah: Salt Lake Min. Rev.
} vol. 8, p. 17, 1906. 
GEOLOGY.

SCOPE OF TREATMENT.

The geology of the Cottonwood-Park City region is described in the following pages with rather more detail than that of the other mining districts considered in this volume. It seems best to record here somewhat fully the information that is now in hand, much of which has been gathered since the last general account of the region was published.

This account concerns itself chiefly, though not exclusively, with the Cottonwood quadrangle, to which intensive geologic field work and mapping have been confined.

\section{SEDIMENTARY ROCKS.}

TREATMENT AND SUBDIVISION.

The shortest line that traverses all the sedimentary strata exposed in the area represented by Plate XXVII extends from the intersection of Little Cottonwood Creek with the 8,000-foot contour to the northeast corner of the Cottonwood quadrangle, which is also the northwest corner of the Park City quadrangle. All along this line the strata dip northeastward, and, although they are re- peated by faulting, the oldest of them are found at the southwest, in contact with the Little Cottonwood stock of granodiorite, and the youngest at the northeast, in the corner common to the two quadrangles.

The Cottonwood quadrangle thus contains a complete section of all the sedimentary formations that occur in the Park City district, and of a great thickness of older strata besides; the geologic description of this quadrangle might therefore logically include the complete stratigraphy of the Cottonwood-Park City region. But inasmuch as the ore deposits of the Cottonwood-American Fork area lie almost wholly in the formations below the Weber quartzite, which is the lowest formation that is fully developed near Park City, it is more convenient to reserve the description of the Weber and later formations for the pages devoted to the Park City district, and to describe in the present division of the report only the strata below the Weber quartzite.

The age of the Weber quartzite is Pennsylvanian, and that of the strata below it ranges downward from Mississippian to pre-Cambrian. For the purpose of preliminary mapping and description the pre-Pennsylvanian strata have been divided into five formations, as follows:

Divisions of pre-Pennsylvanian strata.

\begin{tabular}{|c|c|c|c|}
\hline & Age. & Dominant rock. & $\begin{array}{l}\text { Maximum } \\
\text { thickness } \\
\text { (feet). }\end{array}$ \\
\hline 5 & $\begin{array}{l}\text { Mississippian (and Devonian?)............................ } \\
\text { Unconformity, locally cutting down as low as } \\
\text { division } 2 \text {; no Silurian or Ordovician strata } \\
\text { present. }\end{array}$ & Limestone. & 2,400 \\
\hline $\begin{array}{l}4 \\
3\end{array}$ & $\begin{array}{r}\text { Cambrian. } \\
\text { Do } \ldots \ldots \ldots \ldots \ldots \ldots \\
\end{array}$ & \multirow{2}{*}{ 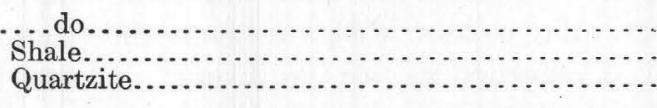 } & \multirow{2}{*}{$\begin{array}{l}600 \\
420 \\
800\end{array}$} \\
\hline 2 & Do & & \\
\hline \multirow{3}{*}{1} & $\begin{array}{l}\text { Unconformity. } \\
\text { Pre-Cambrian.... }\end{array}$ & \multirow{3}{*}{$\begin{array}{l}\text { Tillite and quartzite in Cottonwood quadrangle, } \\
\text { also shale and schist farther west (base not } \\
\text { exposed). }\end{array}$} & $10,000 \pm$ \\
\hline & & & \\
\hline & & & $14,220 \pm$ \\
\hline
\end{tabular}

On the geologic map (Pl. XXVII) the two limestones, 4 and 5, are shown as merged together south of Little Cottonwood Creek, and a few small areas of pre-Cambrian rocks are merged with the Cambrian quartzite.

The interpretation of the pre-Pennsylvanian stratigraphy that is outlined above differs radically in some respects from that which was offered by the geologists of the Fortieth Parallel
Survey. ${ }^{1}$ These pioneers believed that the granitic rocks were Archean, and they overlooked the sub-Cambrian and sub-Devonian unconformities. An oversight entailing more serious consequences was their failure to recognize the great overthrust faults that have pushed the Cambrian quartzite on top of Mississippian limestone in both the sections ${ }^{1}$ U. S. Geol. Expl. 40th Par. Rept., vol. 1, pp. 155-172, 1878. 
that they chose for special study, that in the canyon of Weber River ${ }^{1}$ and that in the Cottonwood region.
The former and present interpretations of the pre-Pennsylvanian section on Cottonwood and Little Cottonwood creeks are as follows:

Stratigraphy of Cottonwood region, according to earlier and later authors.

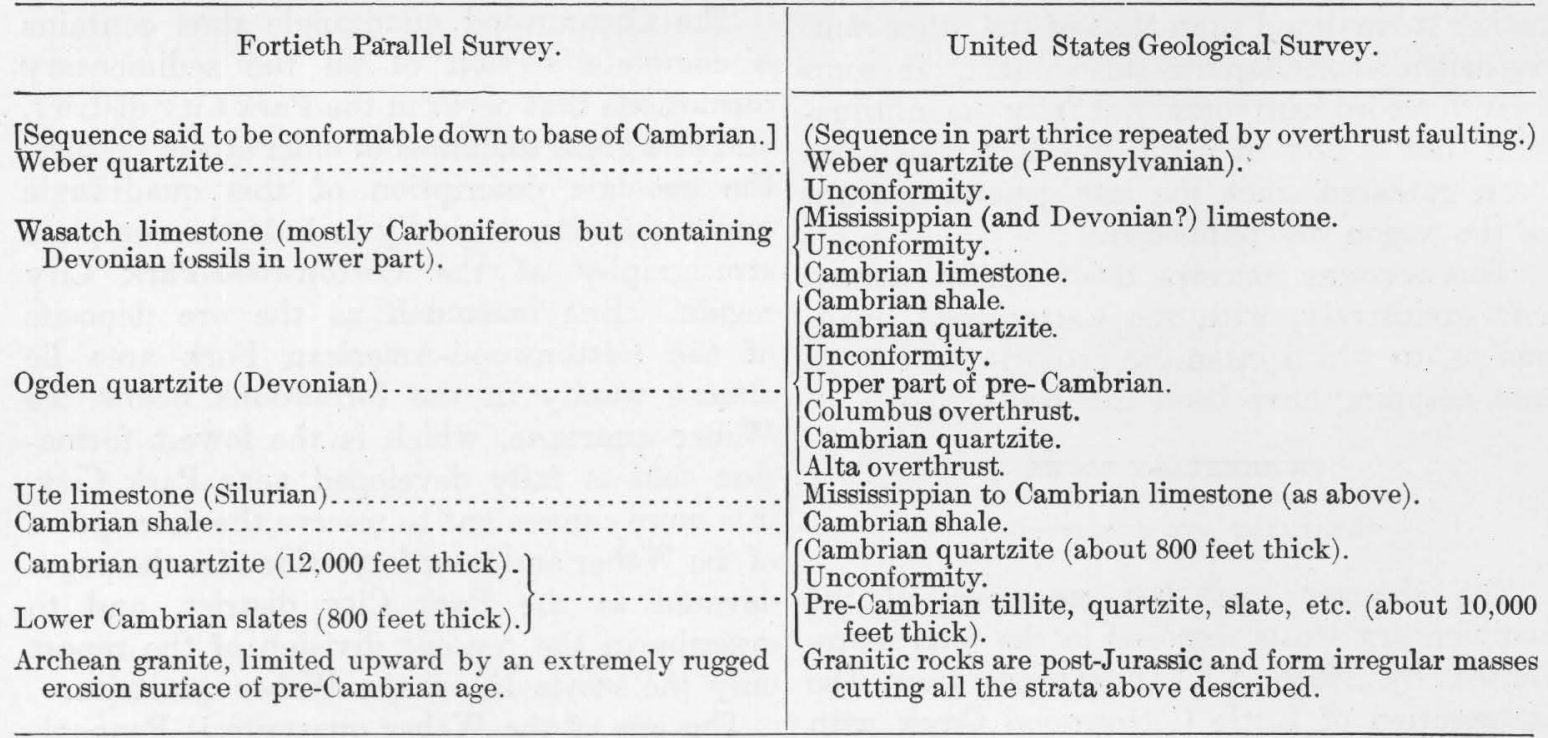

PRE-CAMBRIAN ROCKS.

One of the classic sections of late pre-Cambrian (Algonkian) strata is exposed along Cottonwood Creek, where their total thickness as measured by Walcott ${ }^{2}$ is about 11,000 feet. All the beds below the lowest limestone were classed as Cambrian by the geologists of the Fortieth Parallel Survey and also by Walcott in his earlier paper. In his later paper Walcott regarded as pre-Cambrian all or most of the strata below the fossiliferous Cambrian shale. It is now established that there is an unconformity about 1,000 feet below this shale; and the 10,000 feet, more or less, of strata below the unconformity is regarded as pre-Cambrian.

The general features of the pre-Cambrian are summarized by Blackwelder ${ }^{3}$ as follows:

It consists of alternating beds of quartzite, slate, and conglomerate, which are variable from place to place; cross-bedding, ripple marks, and mud cracks are prevalent. The materials are not well assorted, and in the sandy beds the prevailing colors are yellow, gray, and red, while purple, maroon, and green predominate in the

1 Blackwelder, Eliot, op. cit.

${ }^{2}$ Walcott, C. D., The Cambrian faumas of North America, second contribution: U. S. Geol. Survey Bull. 30, p. 38, 1886; Correlation papersCambrian: U.S. Geol. Survey Bull. 81, pp. 159, 319, 1891. This measurement can hardly be considered reliable in view of the thrust faults which have been discovered since Walcott's visit and which probably cross this section.

${ }^{8}$ Blackwelder, Eliot, op. cit., p. 524. shaly layers. There is apparently a general lack of limestone and of fossils.

The series is regarded by Blackwelder as probably of continental origin.

On Little Cottonwood Creek the pre-Cambrian strata are in great part engulfed or displaced by granodiorite. Schists and quartzites, altered by the intrusion, are exposed near the mouth of the canyon; they may belong to the lower part of the Algonkian or may be Archean. In the western part of the Cottonwood quadrangle about 2,000 feet of pre-Cambrian strata intervene between the base of the Cambrian and the granodiorite. The lower portion of these beds consists mainly of grayish rusty quartzite. The upper portion is regarded by Hintze $^{4}$ as tillite, an ancient glacial deposit. Both quartzite and tillite occur in the broad belt of pre-Cambrian rocks in the southwestern part of the quadrangle; the strip farther east, extending south from City Rock Gulch, consists of tillite.

The great outcrops of tillite at the head of Superior Gulch are conspicuously dark and rusty. The bedding of this rock appears distinct in distant views, but the beds are usually thick, the tillite being generally free from lamination and notably tough. Typical blocks consist in greater part of a uniformly dark 
bluish-green matrix, having the average texture of medium-grained sandstone, in which pebbles and boulders are embedded at wide intervals. Most of the pebbles and boulders are less than 6 inches in diameter; some are well rounded; others are more or less angular. Most of them consist of quartzite, limestone, and other sedimentary rocks, but a few are granitic. The matrix, examined microscopically, shows rounded to angular grains of quartz and feldspar embedded in abundant cloudy mud. The imperfect sorting thus shown by the structure of the matrix as well as by the sparse distribution of the boulders is characteristic of glacial deposits and indicative of glacial origin.

UNCONFORMITY AT BASE OF CAMBRIAN.

An unconformity in the upper part of the great quartzite series of Big Cottonwood Canyon was discovered by Blackwelder ${ }^{1}$ in 1909 and was regarded by him as dividing Cambrian from Algonkian strata. A conglomerate lying, at a rough estimate, about 1,500 feet below the top of the quartzites rests here with slight but visible angular discordance upon the beveled edges of lower beds of quartzite and shale. Hintze ${ }^{2}$ regards the same unconformity as dividing the tillite of the Cottonwood quadrangle from a persistent conglomerate which forms the base of the overlying quartzite. Although no angular discordance at this horizon has actually been seen within the quadrangle, evidence of unconformity is given by the presence of pebbles of tillite in the conglomerate and by the tapering out of the tillite between the Cottonwood Divide and Cottonwood Creek.

Additional evidence is afforded by comparison of sections in various parts of the Wasatch Mountains. Throughout the range the great body of limestone is underlain by shale, from which in places Cambrian fossils have been taken. Immediately beneath the shale in all known sections there lies a stratum of quartzite, which rests on beds that are mainly siliceous but not wholly quartzitic. The thickness of the series below the Cambrian shale is remarkably uneven. The 11,000-foot section on Cottonwood Creek is the thickest that has been measured in the Wasatch Mountains. At Wil-

1 Blackwelder, Eliot, op. cit., pp. 520-523.

${ }^{2}$ Hintze, F. F., jr., op. cit., pp. 96-99. lard, ${ }^{3}$ about 50 miles to the north, only 1,000 to 1,500 feet of quartzite intervene between the Cambrian shale and Archean gneiss; near Santaquin, ${ }^{4}$ about 40 miles south of the Cottonwood section, 800 feet of the quartzite rests on gneissoid pre-Cambrian granite containing large inclusions of schist. These variations in thickness may well be due in part to inequalities in the amount of deposition at different places, but considered in the light of the relations observed in the Cottonwood region, they appear to be due in greater part to prolonged and general erosion of gently folded pre-Cambrian strata, followed in early Cambrian time by the deposition of a thick and extensive layer of sand, which now forms the basal member of the Cambrian.

$$
\text { CAMBRIAN SYSTEM. }
$$

Quartzite.-Cambrian quartzite is abundant in the western and southern parts of the quadrangle but is nowhere better exposed than in the hill on the Cottonwood Divide due east of the Monte Cristo mine. Its total thickness at this place is about 800 feet. The basal conglomerate, which is here only 4 feet thick and whose thickness elsewhere in the quadrangle hardly exceeds 10 feet, contains pebbles of quartzite, gneiss, and tillite. The great body of the formation consists of thick-bedded quartzite, which contrasts with the tillite below and the shale above by its bold outcrops and its light though somewhat rusty color. The quartzite is white, pale gray, or pinkish on fresh fracture, hard, vitreous, and rather coarsegrained. Some layers besides the basal one are pebbly, and some are cross-bedded. Between the quartzite and the overlying shale is a transitional zone, about 20 feet thick, of interbedded shale and quartzite.

Shate.-The shaly division of the Cambrian system consists of three well-defined members; the upper and lower members are shales and the middle member is a limestone.

The lower shale is about 240 feet thick. It is fairly uniform in color, unweathered pieces usually being dark gray tinged with bluish green; its outcrops are stained with reddish iron oxide. The uppermost part of this shale is fine grained and fissile, but most of it is

\footnotetext{
${ }^{3}$ Blackwelder, Eliot, op. cit., p. 520, pl. 36, fig. 2.

4 Loughlin, G. F., Reconnaissance in the southern Wasatch Mountains, Utah: Jour. Geology, vol. 21, p. 447, 1913.
} 
sandy and rather tough, with wavy and lumpy bedding planes. It is not calcareous with the exception of a few layers which are slightly so. Fossils are numerous, though most of them are poorly preserved. Branching twiglike bodies that may represent some low organism are common in certain beds.

The limestone member, which is about 80 feet thick, is characterized by a peculiar type of lamination. Most of the limestone is fairly massive in appearance and consists in greatest part of blue-gray granular calcite, but it contains thin crinkly layers of a fine-grained siliceous substance which projects in relief on the weathered surface. The siliceous material is most abundant near the top of the limestone stratum, where the thicker layers of it inclose calcareous nodules.

The upper shale is about 100 feet thick. It is lighter and more greenish in original color than the lower, and its weathered outcrops, though even more deeply stained with iron oxide than those of the lower shale, are brownish rather than reddish. Its texture is fine, its bedding planes are smooth, and it is divided into blocks by clean-cut intersecting joints. The upper shale is slightly calcareous and therefore more sensitive to metamorphism than the lower. It contains very few fossils.

Limestone.-The Cambrian limestone of this area is limited at the top by an unconformity. In some places it was wholly removed by erosion before the deposition of the overlying beds; elsewhere as much as 600 feet of it remains. In the neighborhood of the Flagstaff tunnel and at certain places on the top and western slope of Reade and Benson Ridge it is exposed with maximum thickness and minimum alteration, and it is to such exposures that the following description applies.

The Cambrian limestones are in greater part magnesian; they are characterized by various kinds of mottling and lamination and by oolitic and "wormy" structures, and they are interbedded with a little shale and limestone conglomerate. The more peculiar rocks of the series have the following features, which are best observed on weathered surfaces:

"Gray-mottled" limestone: Irregular interpenetrating patches of lighter and darker gray appear on weathered surfaces, the darker patches more gritty than the lighter. Much of this rock is oolitic or "wormy."
Oolitic limestone: Dark-gray spherules, like fish eggs, a millimeter or less in diameter, are thickly crowded in a lighter matrix. These are commonly associated with distinctly larger ellipsoidal bodies about a centimeter in average diameter.

"Wormy" limestone: White bodies, about 2 to 3 millimeters thick and about ten times as long, either roughly cylindrical, branching, or irregular in shape, are embedded in a darker matrix.

Buff-mottled limestone and shale: The nature of the buff-mottled rock is similar to that of the limestone interbedded with the shale below. It is made up of two materials, bluegray nonmagnesian limestone and calcareous but also more or less siliceous material which has a buff color and stands in relief on weathered surfaces. Every gradation may be observed between blue limestone slightly mottled or banded with buff, buff rock containing thin lenses and flat nodules of blue limestone, shale containing rounder nodules, and fissile, buff-stained olive-green shale that is free from nodules.

Limestone conglomerate: Several thin beds of intraformational limestone conglomerate are associated with the buff-mottled limestone. The pebbles are flat, consist exclusively of limestone, and are embedded in a limestone matrix.

The following section is compiled from exposures between the Cardiff and Flagstaff mines. The thicknesses given are approximate.

Composite section of Cambrian limestones.

8. Magnesian limestone, gritty surfaced, dark to light Feet. gray, gray mottled, and oolitic................ 70

7. Shale and partly flaggy buff-mottled limestone, shale dominating near top and bottom ......... 150

6. Dark buff-mottled limestone, the buff material generally subordinate; some gray-mottled layers.... $\quad 75$

5. Magnesian limestone, mostly dark and gray mottled, with oolitic and "wormy" layers. (A thin bed of limestone conglomerate near the top of this division and several others in divisions 6 and 7). 75

4. Fine-grained limestone; lower half cream-white and finely fluted on weathered surface; upper half yellowish, in part sandy, and strongly fluted. 30

3. Magnesian limestone, nearly black, crowded with conspicuous white "worms," alternating with thinner light-gray bands; called "guinea-hen" limestone in the field...................... 
2. Magnesian limestone, rather thick bedded, sharply jointed, mostly dirty light gray and unmottled but containing some coarsely mottled layers and some "wormy" layers like division 3 .

1. Magnesian limestones, generally dark blue-gray and thin bedded; gray mottling with some tinges of buff is common; many layers are oolitic and some are "wormy"; sandy laminae in lowest 10 feet........................ 105 Cambrian shale.

The most useful horizon markers in the formation are the white stratum (division 4) and the shaly beds and associated buff-mottled limestone (division 7). The white stratum is conspicuous on the slope west of the Flagstaff tunnel, and on the west slope of Reade and Benson Ridge its occurrence in several parallel bands with nearly uniform easterly dip is the most clearly visible evidence of the repeated thrust faulting that has there taken place. The shale and buff-mottled limestone, though less prominent, are even more distinctive, and their contrast to the other beds is not diminished by metamorphism, which obscures or obliterates the peculiarities of most of the other sorts of Cambrian limestone. (Seep.242.)

Fossits and correlation of Cambrian rocks.Abundant fossils collected by Messrs. Butler and Loughlin from the lowest member of the Cambrian shale have been identified by Edwin Kirk as Middle Cambrian. Walcott ${ }^{1}$ reports the Lower Cambrian fossils Olenellus gitberti and Cruziana sp. from a narrow zone at the base of this shale on Big Cottonwood Canyon, as well as Middle Cambrian fossils about 100 feet higher; but Lower Cambrian fossils were not found in the recent examination of the region. The quartzite below the shale has yielded no fossils in this region, but its Cambrian age is fairly evident from its gradation to the overlying shale and its unconformity with the underlying strata.

A few fossils taken from the upper member of the shale formation and from the base of the limestone are regarded by Messrs. Walcott and Kirk as possibly Upper Cambrian. Some of the highest beds of shale associated with the buff-mottled limestone (division 7, p. 236) have yielded two brachiopods and a trilobite which, according to E. O. Ulrich, indicate a horizon rather low in the Upper Cambrian.

1 Walcott, C. D., Correlation papers-Cambrian: U. S. Geol. Surve Bull. 81, p. 319, 1891.
It has not been proved that the gray-mottled beds above this shale are Cambrian, but their resemblance to lower beds that are certainly Cambrian may justify a provisional assignment to that system.

The peculiar oolitic, "wormy," and mottled structures are perfectly duplicated in the Cambrian limestones of Montana and other regions. The general ascending sequencequartzite, shale, limestone-is characteristic of the Cambrian in the American Rockies, and there is a striking resemblance in many respects between the Cottonwood section and the section at Philipsburg, Mont. ${ }^{2}$

UNCONFORMITY AT BASE OF DEVONIAN OR CARBONIFEROUS LIMESTONE.

The base of the limestone series above the Cambrian is marked by an unconformity, the evidence of which is best observed on the west slope of Reade and Benson Ridge. At a point 1,100 feet northeast of the Kennebec tunnel, a pebbly sandstone lies with a discordance in dip of about $5^{\circ}$ upon ocherous limestone, limestone conglomerate, and shale belonging to the upper part of division 7 of the Cambrian limestone. (See p. 236.) The beds above and below the unconformity diverge toward the south, and in that direction the uppermost gray-mottled limestone of the Cambrian soon appears and gradually thickens.

These relations give the clue to the great differences in the thickness of the Cambrian limestone at different places. At a point 100 yards northwest of the locality described above, but separated from it by an overthrust, the unconformity lies on the gray-mottled stratum (division 4) below the main buffmottled beds. On Montreal Hill, across Mill D South Fork, it lies near the base of the Cambrian limestone, the thin remnant of which is not distinguished on the map. The juxtaposition of limestone with Cambrian quartzite at the mouth of Days Fork is probably due to this unconformity. In the vicinity of Mill D South Fork, therefore, the amount of erosion increased westward and northward; if, therefore, the old erosion surface was nearly plane, the Cambrian rocks in

${ }^{2}$ Emmons, W. H., and Calkins, F. C., Geology and ore deposits of the Philipsburg quadrangle, Mont.: U. S. Geol. Survey Frof. Taper 78, pp. 49-64, 1913; U. S. Geol. Survey, Geol. Atlas, Philipsburg folio (No. 196), 1915. 
this part of the quadrangle were tilted southeastward before the period of erosion.

Southeast of the Bodfish tunnel on Silver Fork the buff-mottled limestone and an unknown thickness of rock below it are cut away by the unconformity.

In passing along the south slope of the Cottonwood Divide, from Superior Gulch, one finds an abrupt change in the level of the unconformity on crossing each major fault. In the cliffs just east of Superior Gulch the unconformity lies below the buff-mottled limestone (division 6). North of Alta it lies on the uppermost gray-mottled Cambrian limestone. At the Alta Consolidated mine, on the contrary, the Cambrian limestone is entirely absent, the highest Cambrian bed belonging to the upper member of the shale. On Honeycomb Hill, again, the buff-mottled limestone and shale (division 7) and a little of the uppermost gray limestone are present.

As already indicated, the boundaries between the Cambrian and the later limestone have not been traced south of Little Cottonwood Creek, and the fact that the map fails to show a distinctive color for Cambrian limestone in the southern part of the area therefore does not mean that the unconformity here lies on the Cambrian shale.

DEVONIAN (?) AND CARBONIFEROUS LIMESTONE.

Distribution and character.-The strata that occupy the interval of nearly 2,400 feet between the post-Cambrian unconformity and the Weber quartzite occur chiefly in a broad zone extending from the northwest to the southeast corner of the quadrangle, and they form the country rock of some valuable ore bodies. They consist predominantly of limestone but comprise a little shale and sandstone near the base and a well-defined member, about 300 feet thick, consisting chiefly of the same rocks not far below the top. The limestones bear none of the peculiar markings that are characteristic of the Cambrian limestones. In greater part they are nonmagnesian, prevailingly dark bluegray, though varying almost from black to white, and more or less cherty and fossiliferous; but the lower strata contain little chert and few fossils, and some of them are magnesian. The chert forms lenses, pods, and irregular lumps, quite unlike the thin layers of siliceous material in some of the Cambrian limestones.
The stratigraphy of these post-Cambrian limestones has been less carefully worked out than that of the Cambrian limestones. Some of the measures of thickness given in the following section are averages from several rough measurements, whose differences, though probably due in part to errors and to undetected faulting, must in part represent actual variations in the thicknesses of the strata.

Generalized section of Mississippian (and Devonian?)
limestones.

Unconformity (?) at base of Weber quartzite. Feet. 11. Limestone, blue to white............... $350+$

10. Sandstone, calcareous, buff weathering, commonly brecciated, interbedded with limestone and overlain by about 35 feet of reddish shale. 285

9. Limestone, dark blue to white, containing little chert, interbedded with one or two layers of sandstone near the top.................. $400-$

8. Very cherty limestone, dark blue gray; conspicuous coral beds in upper part......... 250+

7. Whitish crinoided limestone containing large lumps of pale-tinted chert near the base... 10-120

6 . Very cherty limestone, dark blue; thin beds of black shale near base................. 300

5 . Limestone, less cherty, proportion of chert decreasing downward, blue-gray............ 450

4. Conspicuous bed of bluish-white, pure, brittle, fine-grained limestone................... 15

3. Limestone, dark blue-gray to light blue-gray or white, slightly magnesian in part, thickbedded above, thinner bedded below; basal part (20 feet \pm ) is flaggy and rusty and contains abundant vugs .....................

2. Massive, whitish, somewhat magnesian limestone, containing a few vugs............. 50

1. Thin-bedded impure vuggy limestone, mostly greenish gray, locally interbedded with dark gray shale and underlain by pebbly sandstone............................... $20 \pm$ Unconformity. Cambrian rocks.

The divisions most useful as horizon markers are probably $1,2,4$, and 7 .

The character of division 1 is very distinctive at the locality northeast of the Kennebec tunnel (see p. 237), where it includes a basal bed of pebbly sandstone and some layers of dark shale. The pebbly bed is present north of Cottonwood Creek but is absent in most of the other sections observed. Near Alta this division is best recognized by its thin bedding, by the presence of crystal-lined cavities or vugs, and by its relation to division 2 .

Division 2 is unique in its combination of light color and massive, homogeneous char- 
acter which form a contrast with the gray flaggy beds both below and above.

Division 4, a thin bed conspicuous for its light color, has sometimes been confused with division 4 of the Cambrian limestone (see p. 236) and is similarly useful in the working out of the structure of the northwestern part of the quadrangle. East and south of Alta its whitish color is less distinctive because the dark limestones are there so largely bleached by contact-metamorphic agency, the dark colors mentioned in the table being those of the unaltered limestones.

Division 7 is in most places the thickest light-colored bed that lies well up in the series, but it shows marked variation in thickness, being 120 feet thick on the north side of the Cottonwood Divide, and hardly 10 feet thick in some places on the south side.

Age and correlation.-Hintze ${ }^{1}$ draws from the study of numerous fossils collected by him the conclusion that more than 1,000 feet of the great post-Cambrian limestone is of Devonian age. On the other hand, G. H. Girty ${ }^{2}$ considers that the fossils collected by B. S. Butler from the limestone below the sandstone (mainly within 500 feet of the base) are of lower Mississippian (Madison) age. It may be assumed, provisionally, that both Devonian and Madison limestones are present, but further field study will be necessary to locate the boundary between them. The shaly beds that in some places immediately overlie division 2 (see p. 236) suggest a discontinuity of sedimentation and possibly mark the base of the Madison.

The fossils in the limestone (division 11) above the sandstone indicate an upper Mississippian (Brazer) age. The sandstone itself is barren of fossils but is thought to be of lower Brazer age. It probably is the equivalent of a shale formation found by Blackwelder ${ }^{3}$ in the Ogden region. According to Blackwelder, this formation is unconformable with the underlying limestone and grades into another limestone that overlies it.

${ }^{1}$ Hintze, F. F., jr., A contribution to the geology of the Wasatch Mountains, Utah: New York Acad. Sci. Annals, vol. 23, pp. 108-113, 1913. 2 Personal communication.

3 Blackwelder, Eliot, New light on the geology of the Wasatch Mountains: Geol. Soc. America Bull., vol. 21, p. 528, 1910.
IGNEOUS ROCKS.

STOCKS.

General relations.-The igneous rocks of the Cottonwood-American Fork area are all intrusive. Two of the intrusive masses that lie on the prolongation of the Uinta axis are exposed within the Cottonwood quadrangle. At the west is the Little Cottonwood stock of granodiorite, which extends to the front of the range, and at the east, extending from Alta into the Park City district, is the composite AltaClayton Peak stock of granodiorite and quartz diorite. Although there is no surface connection between these two stocks, they are probably connected beneath the surface and were certainly derived from a common magma. They are closely related in composition. The Little Cottonwood stock is the most siliceous, the granodiorite east of Alta is slightly less so, and the quartz diorite, which lies farthest east, is the least siliceous.

The intrusive relation of the Alta-Clayton Peak stock to the sedimentary formations is proved by the general truncation of the bedding along the contact, by the projection of narrow tongues or apophyses of igneous rock from the main body into the sediments, and by striking phenomena of contact metamorphism. The Little Cottonwood stock is less plainly intrusive, but close examination of its contact shows that this mass also sent out apophyses and produced metamorphic effects. Both stocks, however, were regarded by the geologists of the Fortieth Parallel Survey as Archean. Their intrusive nature was argued first by Geikie in $1880^{4}$ and some years later by Van Hise. ${ }^{5}$ It was subsequently verified by Boutwell and by Emmons, ${ }^{6}$ who revisited the district in 1902.

Little Cottonwood stock.-The Little Cottonwood stock consists of siliceous granodiorite. A specimen obtained on Little Cottonwood Creek a third of a mile below the power house is typical of a great part of the mass and has been chemically analyzed. (See p. 95.) It is

4 Geilie, Archibald, Archean rocks of the Wahsatch Mountains: Am Jour. Sci., 3d ser., vol. 19, pp. 363-367, 1880.

5 Van Hise, C. R., Correlation papers-Archean and Algonkian: U. S. Geol. Survey Bull. 86, pp. 294, 297-298, 1892.

6 Emmons, S. F., The Little Cottonwood granite body of the Wahsatch Mountains: Am. Jour. Sci., 4th ser., vol. 16, pp. 139-147, 1903. 
light gray and medium grained. Its predominant minerals are quartz, pure-white plagioclase, and more transparent, slightly pinkish orthoclase. Quartz and orthoclase are each about half as abundant as plagioclase. Biotite and hornblende in small, nearly equal quantities form black irregular particles; and small yellowish-brown crystals of titanite are numerous. The plagioclase, as determined microscopically, is a calcic oligoclase near $\mathrm{Ab}_{75} \mathrm{An}_{25}$. A slight porphyritic tendency is shown by the orthoclase, which forms crystals as much as a centimeter long, fairly idiomorphic though full of inclusions. In other parts of the mass, as in Gad Valley, near the southwest corner of the quadrangle, the rock is distinctly and coarsely porphyritic, some phenocrysts of potash feldspar being more than an inch in length.

Dark inclusions, commonly a few inches in diameter, composed of the same minerals as the dominant rock but containing a greater proportion of plagioclase, biotite, hornblende, and accessories, are abundant and conspicuous in the Little Cottonwood stock. They are regarded as representing material which crystallized against the walls of the stock at an early period and was subsequently broken up and scattered through the magma.

Alta-Clayton Peak stock.-The Alta-Clayton Peak stock is composed of two parts that differ considerably in appearance but only slightly in composition. The western part, near Alta, consists of a moderately coarse-grained lightcolored granodiorite; the eastern part, surrounding Clayton Peak, consists of quartz diorite that is distinctly darker and finer. ${ }^{1}$ The boundary between these rocks extends from a spur of Pioneer Peak, in the southeastern part of the Cottonwood quadrangle, to the head of Thaynes Canyon, near the western limit of the Park City quadrangle. A small isolated area of diorite lies north of Mount Evergreen, and there are two others near the head of Snake Creek.

The relation of the diorite to the granodiorite is not entirely clear. A suggestion that

1 These two rocks were discriminated and the general course of the boundary was traced by Boutwell (op. cit., p. 65), but the granoiorite was not delimited on his map nor specially described in his report, because of its insignificant extent and its gradation to diorite within the Park City quadrangle. the diorite is the older is given by the presence of inclusions resembling it in the granodiorite at some places, as near the pass between Alta and Brighton. Along the greater part of their contact the transition from the one rock to the other is rather abrupt, the distance between outcrops of normal diorite and of normal granodiorite being at most a few hundred feet and in places only a few yards. But where this contact approaches the northern boundary of the stock the transition is gradual, and no sharp line of demarcation is found, although the exposures are excellent.

These somewhat ambiguous facts appear to be reconciled by supposing that the two rocks were derived from a common magma; that the diorite is the material that solidified first, before much differentiation had taken place; and that when solidification was still far from complete the magma was disturbed by crustal movement, and liquid which had undergone some differentiation and which possessed the composition of granodiorite was generally brought into contact with the diorite that had already congealed. In the embayment at the north, where the transition is gradual, the magma was sheltered from the movement produced in the main body of the stock.

The granodiorite east of Alta is a light-gray rock, only a little darker than that of the Little Cottonwood stock. Its texture is granular and medium grained. In a fresh hand specimen the plagioclase, quartz, and orthoclase, which make up the bulk of the rock, are translucent grayish white and are not easily distinguished from one another. Blackish hornblende and biotite are noticeably more abundant and more perfect in crystal form than they are in the Little Cottonwood stock; the hornblende is especially prominent, forming many prisms as much as 5 millimeters in length, while the diameter of most of the biotite crystals is less than 2 millimeters. Small grains of titanite are common though inconspicuous. The microscope shows that the plagioclase has an average composition near that of oligoclase andesine $\left(\mathrm{Ab}_{70} \mathrm{An}_{30}\right)$ and that the orthoclase, which occurs interstitially, is less than half as abundant as plagioclase.

A description of the diorite, which occurs mainly in the Park City quadrangle, is given in the account of that district. (See p. 296.) 
DIKES.

Classification.-The dikes of the area, only the more important of which are shown on the map (Pl. XXVII), comprise (1) porphyry resembling granodiorite in composition, (2) a more siliceous soda granite porphyry, (3) dark lamprophyric rocks rich in hornblende or biotite, and (4) aplite and pegmatite. The dikes of the first class represent undifferentiated or slightly differentiated magma from the large irruptive masses, injected into fissures leading from the magma chamber; the others are doubtless derived from the same magma by differentiation. The most usual trend of all these dikes is easterly or northeasterly, though some of them strike nearly due north.

Granodiorite porphyry.-Gradation from normal granodiorite to fine-grained porphyry may be traced in a dike that branches from the main mass near the head of City Rock Gulch and extends northeastward toward the Black Bess shaft. The texture becomes finer and more distinctly porphyritic and the color becomes darker as the width of the dike and the distance from the main body diminish. This observed gradation makes it fairly certain that many other dikes of porphyry, varying from granodiorite toward monzonite on the one hand or diorite on the other, are offshoots from the large intrusive bodies, even though the connection is usually concealed. Such dikes occur in many places, especially in the vicinity of the granodiorite, one of the most remote being the Tar Baby dike, which crosses Reade and Benson Ridge a mile and a half from the Cottonwood Divide. They are also to be seen in the vicinity of the Maxwell mine, outside of the Cottonwood quadrangle.

The dikes of this class bear phenocrysts of plagioclase, hornblende, and biotite in a groundmass consisting of the same minerals together with orthoclase and quartz. In one or more of the dikes near the east end of the Cottonwood Divide there are remarkably abundant inclusions of sedimentary rock.

Soda granite porphyry.-A white porphyry of very uniform character is found at many places on the north side of Little Cottonwood Canyon, from the Frederick tunnel to the Honeycomb Cliffs. The rock consists mainly of a grayishwhite extremely fine grained groundmass, in which are embedded a few small phenocrysts of $35416^{\circ}-19-16$ white feldspar and of dark-looking quartz. The feldspar phenocrysts are albite; the groundmass consists of albite, quartz, and perhaps a little orthoclase. No ferromagnesian minerals are present. The freshest specimens obtainable are much decomposed.

A prominent dike of this rock occurs near the top of the knoll just north of the Columbus Consolidated plant and is penetrated by the Tom Moore tunnel of the Columbus workings. Another, or possibly a continuation of the same dike, crops out near the Grizzly tunnel at the head of City Rock Gulch. Several dikes of white porphyry are exposed in the Honeycomb Cliffs, where one of them cuts diagonally across a dike of diorite porphyry.

Lamprophyres.-Fine-grained nearly black dikes have been found in some places but are not common. A group of narrow parallel dikes injected in a fissure zone east of Superior Gulch consists of a rock that is rich in biotite and is probably minette or kersantite, the feldspar being so thoroughly decomposed that a closer identification is impossible. A rock resembling fine-grained basalt occurs northwest of the Prince of Wales shaft. The microscope shows that it once contained phenocrysts, probably of olivine, which are now completely replaced by carbonate and a micaceous mineral. The groundmass that makes up most of the rock is a feltlike mixture of hornblende and feldspar laths. The rock may be classed provisionally as a camptonite.

Aplite and pegmatite.-In the stocks of granodiorite, as in such bodies generally, aplitic dikes are numerous and a few of pegmatite were noted, but such dikes are not common in the sedimentary rocks at a distance from the large intrusive bodies, and none of them appear to require especial notice except one or two that are of unusual character.

One of these is an aplite that forms a prominent outcrop on the ridge west of Lake Solitude. This rock is pale greenish gray; its texture is aplitic, but it contains many little vugs. It has two essential constituents, the more abundant of which is white and the other applegreen and which prove, on microscopic examination, to be scapolite and monoclinic pyroxene, respectively. Quartz is wholly lacking, and no feldspar is present except a very little orthoclase. Titanite, apatite, and zircon are 
notably abundant accessories. The rock is similar to some that occur in the Philipsburg district, Mont., though the Montana rocks contain abundant feldspar. ${ }^{1}$ A pyroxene-scapolite dike rock without feldspar, occurring in California, is described by Harder. ${ }^{2}$ The scapolite in these and in the Cottonwood rock is regarded as primary.

Associated with an amphibole-bearing aplite that occurs in diorite northwest of the pass between Silver Lake and Snake Creek is a coarsely crystalline vein consisting of quartz and darkgreen pyroxene that is partly altered to fibrous amphibole. This vein, though small, is of interest as being presumably a product, within the intrusive mass, of solutions which were expelled from the magma in the later stages of its solidification and which reacted upon the adjoining limestones to form pyroxene and other silicates.

\section{CONTACT METAMORPHISM.}

The contact metamorphism produced by the Little Cottonwood stock has been exerted mainly on siliceous rocks, which do not show its effects very plainly. It extends, however, to the southern part of the westernmost band of limestone. The metamorphism apparent in the limestone cliff just east of Superior Gulch is due, at least in part, to this intrusion, though it may also be due partly to the Alta-Clayton Peak stock, for the contact zones of the two stocks apparently coalesce in Little Cottonwood Canyon. The metamorphic effects of the AltaClayton Peakstock, which is surrounded mainly by limestones, are far more striking than those of the Little Cottonwood stock. They extend northward on Silver Fork at least a mile from the visible contact, and have been traced about as far beyond the southern boundary of the stock at the head of Snake Creek.

The sedimentary rocks in the contact zone include all sorts from quartzite to pure limestone. Near the intrusive rocks the purer quartzites are more vitreous than elsewhere and the less pure quartzites and the siliceous shales glisten with mica and are in places dappled. Dappled hornstones derived from Cambrian shale in City Rock Gulch are found micro-

1 Emmons, W. H., and Calkins, F. C., Geology and ore deposits of the Philipsburg quadrangle, Mont.: U. S. Geol. Survey Prof. Paper 78, p. 120,1913

${ }^{2}$ Harder, E. C., Iron-ore deposits of the Eagle Mountains, Cal.: U. S. Geol. Survey Bull. 503, p. 53, 1912. scopically to consist of a mosaic of quartz, orthoclase, and biotite, inclosing aggregates of mica that probably represent altered andalusite or cordierite or both. The shales are garnetized in places close to the intrusive contact. The most striking effects of contact metamorphism are shown by the limestones and are best observed around the Alta-Clayton Peak stock. Some of them do not prove the combination of magmatic with sedimentary material, but others clearly do involve such combination.

The most widespread effects of metamorphism on the limestones are coarsening of texture and bleaching. The bleaching is most strikingly displayed on the cliff east of Superior Gulch and on the west slope of the Prince of Wales Hill. The limestones at both these places display a certain amount of original banding, but they are also blotched with great irregular patches and streaks of white whose boundaries cut across the stratification; and some white streaks of uneven width extend along fissures, which clearly afforded passage to the vapors or liquids that effected the bleaching.

An effect that extends almost as far as bleaching and that constitutes more definite proof of metamorphism is the development of the lime-magnesia silicate tremolite. This mineral, which is easily recognized by its splintery form, white or gray color, and silky luster, is common in the Carboniferous limestones and is found as much as a mile from any outcrop of granular intrusive rock. It forms most abundantly around nodules of chert and in beds of sandy limestone, an association which indicates that the silica contained by the tremolite is at least in part of local origin; and the magnesia, too, may have been derived from the limestone, though tremolite abounds in beds that are not visibly magnesian.

Tremolite occurs in the magnesian limestones of the Cambrian system, but forsterite, a lime-free silicate of magnesia, is more characteristic of these rocks, though it does not occur so far from intrusive contacts. It is best perceived on the weathered surface, where it has a yellow discoloration. The presence of forsterite in the Cambrian and its absence from the Carboniferous limestone gives much help in tracing the obscure Michigan-Utah overthrust along the west slope of Honeycomb Hill. The forsterite occurs so abundantly in beds that 
originally were nonsiliceous that it probably contains magmatic silica. Abundant pellets of brucite $\left(\mathrm{Mg}(\mathrm{OH})_{2}\right)$ occur in some of the limestone that contains forsterite. The forsterite, however, is altering to serpentine, while the mineral from which the brucite is derived is represented by residual grains, inclosed in many of these pellets, of an isotropic strongly refracting mineral which is probably periclase $(\mathrm{MgO}){ }^{1}$

In the alteration of the banded, buff-mottled limestone of the Cambrian (division 7, p. 236) for some rods from the contact on Honeycomb Hill, the dominant effect has been a combination of the lime with the silica and other matter in the buff layers, which are represented in the altered rock by a coarsely crystalline mixture of reddish garnet and greenish vesurianite with a little inconspicuous pyroxene. These resistant silicates project from the weathered surface in rough lumps and ridges.

Elsewhere hard masses of silicates and other minerals, mixed with residual calcite, are formed from nearly pure limestone. Near the head of City Rock Gulch the Carboniferous limestone is almost wholly converted to garnet, pyroxene, and other silicates for at least 15 feet from the contact, and the replacement extends much farther than this along certain beds, which are not siliceous. It is clear that large amounts of silica, iron, and probably magnesia and other substances carried outward from the magma in hot, perhaps gaseous solution have combined with the lime of the sedimentary rock. The alteration has affected the walls of certain fissures through which these emanations moved. It is even more evident that the thick sheets of garnet rock which border dikes a few feet or even a few inches thick on the slopes both north and south of City Rock Gulch could not have been formed by the action of the dikes themselves, for thicker dikes near by exerted no visible effect on their walls; these sheets were clearly produced by emanations that issued from the main intrusive body through the fissures into which the dikes were injected. Especially intense metamorphism is observed also along the contact south of Dog Lake, where the diorite is cut by unusually numerous dikes of aplite and pegmatite, and it is probable that the fissures occupied by these dikes served as channels for solutions expelled by the magma.

1 Cf. Rogers, A. F., American occurrence of periclase and its bearing on the origin and history of calcite-brucite rocks: Am. Jour. Sci., 4th ser., vol. 46, pp. 581-586, 1918.
The silicate minerals that are most abundant in these massive contact rocks are garnet, monoclinic pyroxene, vesuvianite, forsterite, epidote, and micas; scapolite is found but does not seem to be common. The oxides spinel and magnetite are abundant in places. Magnetite occurs in the South Hecla mine; it is conspicuous along the contact south of Dog Lake; it crops out on the Michigan-Utah property near the Brighton trail; and a large mass of it is penetrated by the workings of the Alta Consolidated and Michigan-Utah mines. The rare magnesium-iron borate ludwigite occurs near Dog Lake, where it is associated with magnetite and forsterite, and also near the head of City Rock Gulch and in the South Columbus tunnel. Sulphides of iron and copper are among the contact minerals in places, and the presence of copper is of ten betrayed by a green stain. Some contact rock rich in magnetite is even mined for copper. The presence of magnetite, of ludwigite, and of sulphides is especially strong evidence of accession of material from the magma, for the sediments clearly did not contain enough iron, boron, or sulphur to form these minerals.

STRUCTURE.

PRELIMINARY OUTLINE.

The main lineaments of the geologic map of the Cottonwood quadrangle, which appears almost chaotic at first glance, are determined by a comparatively small number of major structural features.

The fundamental structure, affecting the whole body of stratified rock, is the northeastward-pitching Park City anticline, whose axis passes through the center of the quadrangle. The expression of this fold, if it were unmodified and the surface were flat, would be an arrangement of the formations as concentric bands of northeastward convexity in sequence of decreasing age from southwest to northeast. A tendency to such arrangement is still visible but is greatly obscured by intrusion and faulting.

The most conspicuous interruption of the bands is caused by the Little Cottonwood and Alta-Clayton Peak intrusive stocks.

Other striking modifications are caused by a few great faults. The greatest of these is the Silver Fork fault, a north-south fracture of low west dip extending through the center of the quadrangle and causing a downthrow of at least 
2,000 feet on the west side. Two faults of similar direction but steeper and causing a downthrow to the east extend northward from Superior Gulch. Another fault of the first magnitude runs northwestward along Cottonwood Creek and has caused a downthrow of about 2,000 feet on the southwest side.

Dislocations even greater than those described have been effected by a series of overthrusts that lie for the most part nearly parallel to the planes of stratification and for this reason are less conspicuous than the other great faults which cut the beds at fairly large angles almost throughout their course. The chief effect of these overthrusts on the areal distribution of the rocks has been to duplicate or to broaden the outcrops of the Cambrian formations. By far the greatest is the westernmost, which enters the area mapped near the Carbonate mine and probably extends to Mineral Flat. Some higher overthrusts that cross the creek near Alta are thought to have been brought to the surface again on the east side of the Silver Fork fault.

The details of the pattern whose outlines have been sketched are formed in very small part by minor folds but mainly by a great number of faults whose throw is measurable in tens or hundreds rather than in thousands of feet. Most of these relatively minor faults are steep in dip, but only a part of them are normal, many of them being reversed. Many of the minor faults are still unmapped, the traces of many having been lost in large areas of homogeneous rock and others being neglected, for the present at least, because of their very small throw. Among these last are the mineralbearing fissures, which, though structurally unimportant, are preeminent in practical interest.

The many obscurities involving the character and relation of the minor faults form one of the chief obstacles to a thoroughly systematic grouping of the structural features. The groups that will be set up for the purposes of the following description include (1) the folds, (2) the overthrust faults, (3) the other mapped faults, including normal faults and steep reversed faults, and (4) the mineralized fissures. After the principal features of each group have been described, the genetic relations of the folds, faults, and fissures to one another, to the igneous intrusions, and to the broad structure of the Wasatch and Uinta ranges will be briefly considered.

\author{
Park City anticline.
}

FOLDS.

The structural feature that has the greatest effect on the distribution of the rocks throughout the Cottonwood-Park City region is the Park City anticline, a westward continuation of the Uinta anticline. The crest of this great arch runs nearly level along the main body of the Uinta Range, dips downward between that range and the Wasatch, pitches strongly eastward through its course across the Wasatch, and is cut off by the great normal fault whose footwall, degraded and dissected by erosion, forms the western face of the range.

Throughout the Wasatch Range the fold is much defaced by intrusion and by faulting. The reader who views the Cottonwood map (Pl. XXVII) with his attention abstracted from these features will see that the sedimentary formations tend to form concentric bands, whose curvature is sharpest along the line of Little Cottonwood Canyon and is convex northeastward. The strata are observed in the field to dip, in general, northward, northeastward, and eastward. The dip ranges in steepness from vertical to horizontal. Near Alta it is usually not far from $35^{\circ}$; gentler dips are common to the east and north; steeper dips prevail to the west and south.

Other folds.

The only other fold that is large enough to be clearly expressed on the map is an open eastward-pitching syncline that flanks. the Park City anticline on the south. This fold is outlined by the band of Cambrian shale west of the Devils Castle. It is not comparable in magnitude to the Park City anticline, being inconspicuous on the geologic map of the State. (See Pl. III, p. 69.)

Some crumpling is associated with and clearly incidental to the overthrust faulting. It is especially well developed in the Cambrian shale between the Alta and Columbus overthrusts and in the shale under the Alta overthrust on Carbonate Peak. Minor folding apparently unconnected with thrusting is conspicuous in the rusty pre-Cambrian rocks west of Superior Gulch. Its character is indicated in structure section $A-A^{\prime}$, Plate 
XXVII. Its principal elements are a syncline $\mid$ to them in dip (about $30^{\circ}$ E.) lies a second and an anticline leaning over toward the east; thick stratum of quartzite, which the geologists they indicate the agency of an overriding of the Fortieth Parallel Survey called the pressure from the west that would, if continued until the strata broke, result in an overthrust of westward dip. Similar folding, less well developed, is shown in the quartzite north of the Columbus mine.

Small folds that are still more strongly recumbent toward the northeast are well exposed on the hill that lies across Silver Fork from the Prince of Wales shaft. Several small folds of easterly strike are developed in the limestones of Honeycomb Hill and are clearly exposed in the Honeycomb Cliffs.

OVERTHRUST FAULTS.

General features.

The reversed faults here classed as overthrusts are only those that have the usual low dips, the discussion of steep reversed faults being reserved for another section. The overthrusts of low dip that have been found in the Cottonwood quadrangle strike about north and dip, on the average, about $30^{\circ} \mathrm{E}$., but their dip is not uniform and they appear to have been affected by later folding. In general they are rudely parallel to the tilted sedimentary strata, though they locally cut the beds at all angles up to $90^{\circ}$. They are older than the intrusive rocks and older than most of the other faults.

The overthrusts that have been traced are, in east-west order, the Alta overthrust, the Columbus overthrust, the Reade and Benson thrust zone, and the Grizzly thrust zone; the last two may be equivalent to each other. All these are cut by structure section $\mathrm{A}-\mathrm{A}^{\prime}$, Plate XXVII (in pocket).

\section{Alta overthrust.}

The westernmost and greatest of the thrust faults was discovered independently in 1912 by Loughlin ${ }^{1}$ and by Hintze ${ }^{2}$ and was named by Hintze the Alta overthrust. It is best exposed on the steep slope east of Superior Gulch. The lowest part of this slope is Cambrian quartzite, which is overlain by shales and by limestones whose upper beds contain Mississippian fossils. Upon the limestones and nearly conformable

${ }^{1}$ Loughlin, G. F., Reconnaissance in the Wasatch Mountains, Utah: Jour. Geology, vol. 21, pp. 439-443; 1913.

${ }^{2}$ Hintze, F. F., jr., op. cit., p. 133.
"Ogden quartzite" and regarded as of Devonian age. This quartzite, however, is Cambrian, and is thrust over the Mississippian limestone, from which it is separated through part of its extent by a crumpled wedge of Cambrian shale. The fissures that bound the wedge of shale are two branches of the Alta overthrust, the movement on which amounted certainly to thousands of feet and perhaps to several miles. The movement was confined for long distances to what is virtually a single fissure, but two main branches are present in the workings of the Cardiff and Columbus-Rexall mines and on the surface near the heads of Superior Gulch and Mill D South Fork. (See Pl. XXIV, p. 207.)

The Alta overthrust has been traced southward to Mineral Flat, where its identity is lost in a complex of block faults; probably, however, it extends much farther south. A short distance north of Little Cottonwood Creek it is cut off by the east branch of the Superior fault; the fault-bounded triangular area of Cambrian shale and quartzite northwest of the Cardiff mine may represent a piece of the overriding block, and the second fault south of the Carbonate mine is probably the continuation of the Alta overthrust. Where this fault reaches the crest near the Carbonate mine the contact of the flat-dipping quartzite with the overridden, steeply dipping crumpled shale is visible at a great distance. The overthrust has not been traced beyond this crest, but it probably extends much farther and may well cause an apparent thickening of the Algonkian strata on Cottonwood Creek.

\section{Columbus overthrust.}

The next overthrust east of the Alta crosses Cottonwood Creek near the mouth of the Columbus tunnel and therefore may be called the Columbus overthrust. This fault probably has far less throw than the Alta overthrust, but it virtually duplicates the Cambrian quartzite on the Cottonwood Divide. Its dip is $30^{\circ} \mathrm{NE}$. where it crosses the gulch northwest of the Columbus tunnel. The Cambrian shale beneath it on the slope is very strongly crumpled. At the head of Mill D South Fork its best exposure shows it steep- 
ening downward, with an average dip of $65^{\circ}$ $\mathrm{E}$; here it is parallel to the bedding and is attended with no local crumpling and little brecciation.

The Columbus overthrust is thrown down to the west by a small fault that crosses the Cottonwood Divide. West of this later fault the thrust plane has a low dip and for the most part is nearly parallel to the bedding above and below; but by a favorable light sharp folding may be seen in the overridden quartzite. The overthrust is probably cut off by the east Superior fault, beyond which it has not yet been picked up. It has not been traced far south of Little Cottonwood Creek.

Reade and Benson thrust zone.

All the overthrusts that have been mapped between the Columbus and Grizzly faults are confined to a rather narrow strip that will be called the Reade and Benson thrust zone. The portion of this zone that has been studied with any degree of thoroughness may be described roughly as the main belt of Cambrian shale and limestone between Alta and Montreal Spring. South of Little Cottonwood Creek, where the Cambrian limestone has not been separated, the thrust zone has not been followed, though it probably persists as far as the Silver Fork fault. At the north it certainly extends into the cliffs of Devonian and Carboniferous limestone northeast of Montreal Spring and is known to account in part for their intricate structure; but faults are traced less readily in this great mass of relatively homogeneous rock than in the strongly differentiated strata of the Cambrian system.

Favorable stratigraphic position and excellent exposures make the evidence of this overthrusting especially clear in the Cambrian rocks that extend along the west slope of Reade and Benson Ridge. Here the greater faults bring Cambrian shale over limestone, or Cambrian over post-Cambrian limestone; the lesser ones thicken the limestone or the shale, as is proved by the repetition of distinctive beds. The overthrusting has not been accompanied, as a rule, by much brecciation or crumpling; but the displacement must have amounted to many hundreds of feet on some of the overthrusts, and the easternmost is more than a mile in length.
At the south end of Reade and Benson Ridge the exposures are less good and the structure has minor complexities that are not represented on the map. No individual members of this thrust zone, therefore, hate been traced continuously across the Cottonwood Divide to Alta. North and northwest of Alta there are two overthrusts that converge northwestward. The more northerly is the more clearly proved by the areal relations; where it is shown as being within the limestone it has pushed the lowest part of the formation over the highest. The more southerly overthrust is clearly exposed in the Tom Moore tunnel.

The Grizzly overthrust emerges from the southwest slope of Honeycomb Hill at about the level of the Grizzly tunnel. Although its throw is comparable to that of the Alta and Columbus overthrusts, it is rather inconspicuous, for both its walls consist of eastwarddipping metamorphosed limestone to whose bedding it is nearly parallel, and its fissure is not marked by extensive brecciation or crumpling. The presence of the fault was first suggested by the occurrence of the buff-mottled Cambrian limestone (division 7, p. 236) high on the slope and of cherty Mississippian limestone (division 6) at the foot of the hill. The magnesian Cambrian limestone just above the overthrust is crowded with crystals of forsterite; the more purely calcitic Mississippian limestone below is more coarsely crystalline, is free from forsterite, and contains lumps of chert. The fault fissure crosses the Cleves tunnel about 1,200 feet from the portal, and it is well exposed in a prospect 600 feet east of the City Rock tunnel, where it dips $45^{\circ} \mathrm{E}$. and contains metamorphic minerals that show it to be older than the granodiorite.

North and west from the Grizzly tunnel the thrust plane flattens and in places even dips west. It runs under Davenport Hill and is cut off by the great Silver Fork fault. Apparently it branches under Davenport Hill, for in the basin to the northeast and on the west spur of the Prince of Wales Hill there are at least two overthrusts. The northernmost observed exposure of any fault belonging to this group is that of a thrust contact between Cambrian and Mississippian limestone in the gulch southeast of the Bodfish tunnel. 
The Grizzly overthrust is cut off by the AltaClayton Peak stock, south of which it has not been definitely identified. Overthrusting has occurred, however, in the great area of undifferentiated limestone that contains the Devils Castle and Sunset Peak. Two or three overthrusts, broken by later faults, cross the Bullion Divide between those two summits but have not been followed out sufficiently to be shown on the map. One or more of them, presumably, form the continuation of the Grizzly overthrust.

The possible identity of the Grizzly with the Reade and Benson thrust zone is discussed in connection with the Silver Fork fault. (See p. 248.)

NORMAL FAULTS AND STEEP REVERSED FAULTS.

General features.

Among the faults whose dip is known, the so-called normal faults, with dip toward the downthrown side, are apparently not more numerous than reversed faults that dip steeply in the direction of upthrow. One fault appears to be in part normal and in part reversed; and the direction of dip of many faults whose course on the surface shows them to be steep is unknown. It is therefore impracticable to classify all these faults as being either normal or reversed.

The commonness of steep reversed faultsa condition that is not peculiar to this regionis a fact which the mining geologist may find it practically useful to bear in mind. An ore body cut off by a steep fault is generally presumed to have moved downward on the side toward which the fault plane dips, as the wellknown ore body of the Emma mine actually did. It is best, however, to attack such a problem without assuming that the fault is of the type that is, perhaps unfortunately, called "normal," and to ascertain the direction of movement, if possible, by the usual methods of field geology, before undertaking exploratory development work.

In respect of strike the faults are not obviously systematic. It is found, however, on projecting their courses through a common center, that strikes approximating the cardinal directions north and east are much commoner than those very close to northeast or northwest. Sheaves of especial density extend about north-northwest and west-northwest. The widest segment that is free from known faults of appreciable throw is bisected by a line striking N. $60^{\circ} \mathrm{E}$., which, however, is not far from the average strike of the mineral-bearing fissures. Faults whose strike is nearly north are especially common north of Little Cottonwood Creek, south of which east-west faults are more numerous.

No clear evidence has yet been found that there were distinct periods of faulting, each of which resulted in the formation of approximately parallel faults. Apparently, however, the east-west faults are in general the oldest. At least two of them are jogged by other steep faults, and some of them terminate against overthrust faults. Yet the Mountain Lake fault, striking east-northeast, throws the Silver Fork fault, which strikes north. The other faults, so far as observed, are all later than the overthrusts. Instances of one fault clearly thrown by another fault beyond which it can be definitely identified are not common. Some faults, on the other hand, apparently terminate against others which they meet at a large or a small angle, the relations indicating relative movement between blocks or wedges rather than between parallel slices.

Big Cottonwood fault.

The alluvial and glacial deposits in the upper part of Big Cottonwood Canyon cover a great fault which apparently causes relative downthrow to the southwest. At the mouth of Mill D South Fork the beds to the south of the main stream belong considerably above the base of the Weber quartzite, while those to the north belong, stratigraphically, at least 2,000 feet lower. Farther east the relations are more obscure; the fault probably diminishes in this direction and is cut off by the Alta-Clayton Peak stock. The fault runs up the north side of the valley beyond the point, just north of the quadrangle, at which the creek turns southwestward; its course on the slope indicates a steep dip, whose direction, however, has not been ascertained.

Silver Fork fault.

The evidence of a great dislocation which, from its alinement with the general course of Silver Fork, may appropriately be called the Silver Fork fault is clearest in the gorge of 
Little Cottonwood Creek southeast of Alta. level makes their correlation difficult, though The west wall of this gorge consists mainly of not impossible; but there is even greater diffilimestone, and the east wall mainly of preCambrian tillite; both formations dip eastward. The fault plane dips about $45^{\circ} \mathrm{W}$., and the fault is most simply interpreted as a normal one, whose westward downthrow must have amounted to at least 2,000 feet. The fault is conspicuous for nearly 2 miles south of Alta and probably will be found, when the structure has been worked out in detail, to extend much farther.

This great fault must be bent or offset eastward under the drift-covered floor of Little Cottonwood Canyon and must cross the Cottonwood Divide a few yards east of the summit of Davenport Hill, for this divide is not crossed elsewhere by a fracture which resembles that in the gorge in dip, strike, and amount of displacement. The relations at this locality, so far as they are shown on the map, might be explained by an overthrusting movement of relatively slight extent from the west, resulting in the uplift and the removal by erosion of the Grizzly overthrust on this side; but this hypothesis is made untenable by facts which the map does not express. First, the youngest rock east of the fault is considerably older than the youngest rock west of it. Second, the unconformity between the Cambrian and postCambrian limestone immediately east of the fault and below the Grizzly overthrust is near the top of the Cambrian shale, whereas it is nearly at its highest observed level both on Honeycomb Hill and near the Montezuma tunnel.

The simplest explanation of these facts is that the block above the Grizzly overthrust is the same (aside from smaller fractures) as the block west of the Silver Fork fault, which would accordingly have caused a downthrow to the west whose least possible measure would be the difference of stratigraphic level between the rocks just east and just west of the summit of Davenport Hill. This stratigraphic throw would be, like that in the Little Cottonwood gorge, about 2,000 feet; the movement on the fault plane would be some hundreds of feet more, and the vertical displacement considerably less. To restrict the downthrow to this minimum value it is necessary to correlate the Grizzly thrust zone with the Reade and Benson thrust zone. Their difference in stratigraphic culty in correlating the Grizzly overthrust with the Columbus or the Alta overthrust.

The Silver Fork fault zone is reached by the westerly drifts of the Silver King tunnel of the Alta Consolidated mine, where it appears as a heavy breccia in which the principal fissures have a low west dip. The fault may be thrown by certain steeper faults on the southwest slope of Davenport Hill, but its exact course is difficult to follow here in the crushed, thickbedded limestones. The complication is even greater on the northerly slopes of the hill, which consist of one huge mass of limestone breccia produced by converging faults. The evidence of a great downthrow to the west persists to the mouth of Silver Fork, where the Silver Fork fault either is greatly offset by the Big Cottonwood fault or terminates against it.

Superior faults.

The east and west Superior faults are the two strong north-south faults that meet in Superior Gulch. At the head of Mill D South Fork they form the sides of a wedge of limestone which appears at first sight to be let down into the Cambrian quartzite. In reality, both faults effect a downthrow to the east, for the eastern mass of quartzite lies above and the western mass below the Alta overthrust. (See section A-A, Pl. XXVII.) The west fault is the greater, its estimated throw being about 1,000 feet; that of the east fault is perhaps half as great. The dip of the west fault in a prospect about northeast of the Monte Cristo mine is nearly vertical; that of the east fault, as exposed at many places in the Cardiff mine, is generally steep to the east but varies somewhat in different places.

\section{Minor faults near Mill D South Fork.}

General character.-The faults near Mill D South Fork, other than the overthrusts and the Superior faults, all depart widely from the northerly trend that generally prevails north of Little Cottonwood Creek; they strike about east, northeast, and southeast. Many of them are poorly exposed, the structure in the canyon bottom north of the Cardiff mine being especially obscure. The more interesting of the faults are those that may be called the Carbonate, the Evarena, the Sampson, and the Ophir. 
Carbonate fault. - The Carbonate fault strikes south-southeastward from the Carbonate mine and is conspicuous on the steep west slope of the South Fork canyon. This fault has perhaps a greater throw than any other in the quadrangle except the principal overthrusts and other major faults already described; the displacement by which it brings limestone against Cambrian quartzite is necessarily more than 500 feet. It terminates, however, against the West Superior fault, beyond which it has not been found. It cuts an overthrust supposed to be the Alta. Its dip is about vertical in the Carbonate mine, where it cuts off the ore.

Evarena fault.-The Evarena fault, which extends northeastward from the East Superior fault near the Cardiff mine, is named for a mining claim that parallels it on the northwest side. Its downthrow to the northwest of about 300 feet is proved by the offsetting of Cambrian strata and of the Reade and Benson thrust zone, as inferred from scattered outcrops on a gentle slope that is partly mantled with talus. The fault has formed a strong breccia in the Mississippian limestone to the east, and the main fissure in this breccia dips $75^{\circ} \mathrm{NW}$., indicating that the fault is a normal one.

Sampson and other east-west faults.-The Sampson fault, which passes a few rods south of the Sampson shaft, is chiefly remarkable for its ambiguous relation to two overthrusts; it offsets the upper of these and is cut off by the lower. Apparently it was formed within the period of overthrusting.

Another east-west fault of similar relations is postulated to explain the apparent abutting of older against younger limestones east of Montreal Spring, but this fault is hardly proved. On the other hand, a well-exposed but partly inaccessible vertical east fault south of the Sampson fault is thought to be younger than the overthrusting.

Ophir fautt.-The fault that strikes southeastward from the Cardiff mine may be called the Ophir, from one of the claims that it crosses. It is much obscured by talus, but its presence is proved by fairly numerous outcrops which indicate a downthrow of at least 200 feet to the northeast. At the Cottonwood Divide there are complications which are not fully under- stood, and the fault has not been traced any farther southeast.

$$
\text { Minor faults crossing the Cottonwood Divide. }
$$

General character.-The Cottonwood Divide is crossed by numerous faults of nearly north strike, many of which are readily traceable on the steep high slopes, where some are marked by prominent limestone breccias; but on the lower part of the slope toward Alta they become so much obscured by waste and glacial drift that their relations, which have considerable economic significance, remain in large part to be worked out by further underground study.

One of the fractures, locally called the Snow fault, has a low northwesterly dip and a downthrow to the northwest. The other faults are all fairly steep, and the downthrow of most of them is on the east side; several of them are known to be reversed faults, and none are known to have a "normal" dip throughout. The faults that seem to deserve separate notice, named in order from east to west, are the Snow, Montezuma, Vallejo, and Flagstaff.

Snow fault.-The Snow fault may best be observed on the Tom Moore tunnel level of the Wasatch Mines Co., where it forms a zone of strong fissuring and crushing in which the fissures dip $25^{\circ}-55^{\circ}$ WNW. It is not well exposed on the surface, and its relation to some of the north-northwest faults which the map shows as being cut off by it is in fact uncertain. There is better evidence that the Snow fault is offset southeastward by the Montezuma fault and is represented by a zone of strong brecciation that may be followed continuously across the Cottonwood Divide, just south of which the breccia forms two or three bold crags. If this interpretation is correct, the course of the Snow fault on the surface indicates a steepening of dip or a change of strike or both about 1,200 feet east of the Montezuma tunnel. North of the crest the Snow fault apparently converges with the Silver Fork fault, which it resembles in its low west dip, strong brecciation, and normal character and of which it may be a branch. Montezuma fault. - The slumping of the surface rock toward the old caved stopes of the Emma mine has left exposed, beside the portal of the Montezuma tunnel, an overhanging fissure wall that strikes $\mathrm{N} .42^{\circ} \mathrm{W}$. and dips $70^{\circ} \mathrm{NE}$. 
Halfway up the slope between this place and the Cottonwood Divide the Tiger cabin leans against the boldly cropping breccia of a fault that strikes $\mathrm{N} .15^{\circ} \mathrm{W}$. and dips $80^{\circ} \mathrm{W}$. It is believed that both exposures represent a continuous fracture, which may be called the Montezuma fault.

There are, however, certain difficulties in supposing the fault continuous. First, it is normal at the Montezuma tunnel and reversed at the Tiger tunnel, the downthrow at both places being to the east; second, its change of strike appears to take place at an angle rather than a curve. Continuity, on the other hand, is argued by two other facts; the dip of the fissure in a prospect near the bend is $85^{\circ} \mathrm{E}$., or intermediate between the opposing dips already mentioned, and the downthrow north of the bend, as measured by the crinoidal bed of the Mississippian (division 7, p. 238), is approximately equal to that southeast of the bend, which, as measured by the Emma ore body, amounts to about 300 feet. The caved stopes already mentioned were in the segment of this ore body lying southwest of the fault; the downthrown eastern segment was recovered in 1917, after some 40 years of desultory search, through exploration based on the geologic study of J. J. Beeson.

Vallejo fault.-The Vallejo fault, which is the first one east of the Eclipse shaft, derives its name from the fact that the portal of the Vallejo tunnel lies on its course. This fault causes a downthrow of about 150 feet to the east, best measured by the displacement of the white crinoidal limestone on cliffs north of the Cottonwood Divide. Its dip as noted at two or three places on the upper part of the slope is about $70^{\circ} \mathrm{W}$., or in the direction of upthrow; the Vallejo fault thus appears to be of the steep reversed type, but its dip at the Alta level is not known.

Flagstaff fault.-The Flagstaff fault is the first one west of the Flagstaff tunnel. It is a steep reversed fault, its dip being about $65^{\circ} \mathrm{W}$. and its downthrow to the east. The amount of downthrow is about 150 feet. The Flagstaff fault is met near the Cottonwood Divide by a vertical fault of north strike. It is marked near the Flagstaff tunnel by a strong breccia, but it becomes obscure on the lower part of the slope toward Little Cottonwood Creek, and it may be cut off by the Snow fault.
Minor faults near City Rock Gulch.-The Cambrian shale and quartzite along the bottom of City Rock Gulch are broken by several small faults that are not shown on the geologic map (Pl. XXVII), and at the west they are brought into contact. with limestone by a fault that dips about $50^{\circ} \mathrm{NW}$. and may be a part of the Silver Fork fault. The whitish limestones along the lower part of the gulch are clearly affected by numerous faults but are so much altered that their stratigraphic position can hardly be determined; and the throws of the faults therefore can not be measured. The gentle slopes north and south of the rocky stream channel are strewn with morainic material, which greatly obscures the structure and adds to the difficulty of mapping.

Just south of City Rock Gulch the Cambrian shale is limited on the east by a dike which apparently occupies the fissure of a fault with downthrow on the east, for the east wall of the fissure consists of cherty Carboniferous limestone.

Minor faults near Honeycomb Fork.-The thick series of limestone beds exposed in the Honeycomb Cliffs are deformed and folded and are cut by strong northeasterly fissures, most of which contain dikes. At many of these fissures there is so abrupt a discordance in the attitude of the strata on either side as to suggest faulting, but at only one fissure, which contains no dike, has a fault of appreciable throw been proved. This Honeycomb fault, to use the obvious name, is reversed and dips for the most part rather steeply to the northwest, but at the base of the cliff it is sharply contorted as a result of later movement.

Another fault, which strikes east and has caused apparent downthrow to the north, forms the north boundary of the Cambrian limestone in the bottom of the canyon. This fault may be called the Woodlawn, from the mine of that name which lies just south of it. The effect of the Woodlawn fault becomes rather obscure in both directions from Honeycomb Fork. It is thought to be, like the Sampson fault, older than or contemporaneous with the overthrusts of easterly dip.

Minor faults south of Little Cottonwood Creek.

The faults south of Little Cottonwood Creek have been studied less thoroughly than those farther north, and the direction of dip of none 
of them is known. Most of them fall naturally into four local groups.

Devits Castle group. - The faults on the east side of the main headwater basin of Little Cottonwood Creek possess in common an easterly strike, though they converge a little toward the west. Some cause a downthrow to the south, others a downthrow to the north. The southernmost and greatest, which may appropriately be called the Pittsburgh fault. The downthrow on this fracture can not be less than 500 feet to the north.

Faults northwest of Mountain Lake.-The Mountain Lake fault, which is nearly tangent to the north side of Mountain Lake, has, as mapped, an ambiguous effect on the distribution of the rocks; it offsets the great Silver Fork fault westward, which indicates a downthrow to the south, but the relations farther east suggest a downthrow to the north.

This fault forms one of a group of fractures which radiate from Mount Baldy (though having no significant relation to it) and which include some dike-filled fissures north of the Mountain Lake fault.

Faults at head of American Fork.-The mosaic of faulted blocks at the head of American Fork may be, in a sense, the southward continuation of the Silver Fork fault, for the general result of the faulting at this place is a downthrow to the west. No special effort has yet been made to trace the Silver Fork fault southward.

Faults near Peruvian Gulch.-Four east-west faults lie athwart Peruvian Gulch, forming a system that may perhaps be regarded as a westward continuation of the Devils Castle group, but the downthrow is on the north side in every case. A fault near the head of Collins Gulch has the same character, but anotherfault that crosses Collins Gulch lower down resembles the nearest of the Devils Castle group in having an easterly strike and causing downthrow to the south.

\section{MINERALIZED FISSURES.}

The movement that has occurred along the mineralized fissures has apparently been slight, and they are not marked by strong breccias such as those that follow some of the faults. They are comparatively inconspicuous at the surface, being recognized only as seams or narrow breccias, which are stained brown with oxides of iron and manganese. The breccia- tion is most marked in certain beds of limestone.

The fissures range in strike from north through northeast to east. Most of those noted near Mill D South Fork strike about N. $35^{\circ}-40^{\circ}$ E. and $\operatorname{dip} 60^{\circ}-65^{\circ}$ NW.; the Carbonate fissure, however, strikes about N. $75^{\circ}$ E. and dips $70^{\circ} \mathrm{N}$. The principal fissures near Alta strike N. $60^{\circ}-70^{\circ}$ E. and dip $60^{\circ}-65^{\circ} \mathrm{N}$. Those in the American Fork district appear to belong to two systems, one of northeasterly and one of easterly strike. The stopes of the famous Miller mine extend in both directions, the longest N. $85^{\circ} \mathrm{E}$. The Pacific vein and the Dutchman vein belong to the northeasterly system. Far to the northeast again two systems are found. In the Barry-Coxe mine, on the north slope of the pass between Silver Lake and Park City, the mineralized fissures strike about north and east; the northerly fissures are the more heavily mineralized.

SOME GENETIC RELATIONS OF THE STRUCTURAL FEATURES.

Wasatch and Vinta elements.-Perhaps the most broadly interesting problem upon which light is thrown by the geologic structure of the Cottonwood-Park City region is that of the relative age of the Uinta Range and of the primitive Wasatch uplift, without regard to the late rejurenescence of the Wasatch Range by faulting. Both ranges were formed primarily by uplift and deformation, and the structural features of this region, which lies at the intersection of their axes, are related in part to the Uinta uplift and in part to the Wasatch uplift. It is possible to separate, at least in part, the Wasatch elements from the Uinta elements and to determine the relative age of the groups thus formed.

The Wasatch Range as a whole is characterized by north-south folds, and the more fully its structure is understood the more these folds are found to be accompanied by overthrusts of nearly north-south strike. Both the overthrusting and the longitudinal folding are plainly the result of tangential pressure acting from the east and west, and the two kinds of deformation were probably almost contemporaneous.

The Uinta Range, on the other hand, was formed by a relatively simple uplift along an easterly axis. The line of this axis, west of the Uinta, is marked by a row of intrusive 
bodies. This fact can hardly be accidental; whether the intrusion caused the uplift or the uplift caused the intrusion, the two activities must have been causally connected and virtually contemporaneous.

In the complex structure of the CottonwoodPark City region, the Uinta elements are chiefly represented by the intrusive rocks and by the Park City anticline. The eastward plunge of the anticline, however, is regarded as a Wasatch element. It may conceivably be due to one or more of the following causes: (1) Tilting of the Wasatch Range as a whole at the time of the faulting along the west face; (2) a bodily eastward tilting of the anticline by later Wasatch folding; (3) differential upward pressure by intrusive bodies; (4) an eastward inclination of the beds before the Uinta uplift.

The first-named cause can not have been important, for the physiographic evidence indicates that the tilting correlative to the faulting was very much less than that evinced by the general eastward dip of about $30^{\circ}$ along the axis of the Park City anticline. This tilting merely increased an inclination that was already pronounced.

The assignment of the Wasatch deformation to a later date than the Uinta uplift is negatived by the relation of the overthrusting (a Wasatch feature) to the intrusion (a Uinta feature). The overthrusting is earlier than the intrusion: the Columbus overthrust is crossed by at least one dike of soda granite porphyry; the fissure of the Grizzly overthrust carries metamorphic minerals that must have been formed by the passage of emanations from the magma; and neither this overthrustnor any other, so far as known, has fractured the AltaClayton Peak stock. The second of the possibilities proposed above is thus eliminated; the Wasatch deformation is the earlier, on the assumption that the obvious grouping of the major structural features is accordant with the facts of genesis.

Evidence, independent of this last assumption, that not only the intrusion but the Uinta folding was later than the overthrusting would be supplied if the overthrusts were shown to have the same northeastward convexity as the sedimentary strata. Unfortunately, no endeavor has been made to trace the overthrusts to an end, and their curvature for the short distances that they have been traced is hardly decisive; but if the thrust contact south of the Carbonate mine is, as is believed, a part of the Alta overthrust, its westerly strike, in general accordance with that of the adjacent strata, confirms the hypothesis.

It may be asserted with much confidence, therefore, that the earliest deformation of the strata exposed in the Cottonwood-Park City region was effected by folding and overthrusting on north-south lines. These strata form a part of the western limb of the Great Logan syncline which has been deformed by the agencies that gave birth to the Uinta Range. Relation of intrusion to deformation.-The eastward pitch of the Park City anticline is thus explained without invoking differential uplift by the exposed intrusive bodies. Whether uplift all along the Uinta axis was caused primarily by injection of igneous material that remains wholly concealed in the Uinta Range itself is another question, upon which the writer feels unprepared to pronounce a final opinion. There are some structural features that suggest, at least, that the intruded magma deformed or dislocated the sedimentary rocks.

The most obvious suggestion of the bending of strata by intrusion is given by the general dip of the strata away from the Little Cottonwood stock; but the walls of this body cut across the strata in great part, and its western wall, if it were visible, might prove as radically discordant with the bedding as the western wall of the Alta-Clayton Peak stock is readily seen to be. The dip of the strata around the AltaClayton Peak stock is not quaquaversal; the fact that they dip outward from it farther east results necessarily from the position of the stock on the axis of an anticline; and the same is true of the Little Cottonwood stock. Although the evidence of doming is thus ambiguous, a suggestion of nearly horizontal pressure acting outward from a steep wall is conveyed by the minor folds in Honeycomb Hill and by those near Superior Gulch. (See p. 244.) Some instances of minor folding caused by intrusion in the Park City district are cited by Boutwell. ${ }^{1}$

The mineralized fissures and most of the faults other than overthrusts are later than the Wasatch folding and overthrust faulting. It

1 Boutwell, J. M., Geology and ore deposits of the Park City district, Utah: U. S. Geol. Survey Prof. Paper 77, p. 97, 1912 
is natural to seek for evidence of genetic relationship between these later fractures and intrusion, for intrusion, whatever its mechanism, must be attended by some fissuring of the surrounding rocks, and the readjustments attendant on contraction of the cooling magma must cause some dislocations. Unfortunately the relations between faults, fissures, and intrusive bodies are much obscured at critical localities by surficial deposits; some more or less tentative conclusions, however, may be deduced from the facts that are known.

There are several indications, quite independent of most of the arguments advanced by Mr. Butler (see p. 283) in support of a genetic relation between the ore deposits and intrusion, that the formation of the mineralized fissures was due to the intrusion of the stocks. ${ }^{1}$ The strike of the great majority of these fissures is about east-northeast, or parallel to the alinement of the intrusive stocks. Not only is it to be expected that intrusion would give rise to fissures of this trend, but this is actually the trend of most of the dikes, which must have been injected into fissures opened by the intrusion. Where, as at some places in the Big Cottonwood and American Forks distriets, the mineralized fissures depart from the usual east-northeast direction, they are either parallel or radial to the periphery of the nearest intrusive body, and in either case may well be related to it. In the Dutchman, Live Yankee, and Miller mines of the American Fork area the veins are bordered by dikes on one side for parts of their courses, though the dikes are somewhat earlier than the veins. The ore-bearing fissures, then, were pretty clearly formed as a result of the intrusion but were not mineralized at the very beginning of the igneous period.

Some of the faults are known to cut igneous rocks and ore bodies. The best known instance of postmineral faulting is the displacement of the Emma ore body by the Montezuma fault. The Live Yankee vein is broken by a fault that makes a rather small angle with the mineralbearing fissure. The east Superior fault cuts off the Cardiff ore body. All these postmineral faults are presumably later than the period of

1 The facts relating to the mineralized fissures are taken from Butler, B. S., and Loughlin, G. F., A reconnaissance of the CottonwoodAmerican Fork mining region, Utah: U. S. Geol. Survey Bull. 620, pp. 180-181, 1915. intrusion, and many other faults can be directly observed to cut intrusive rocks. The outcrops of soda granite porphyry found near a line which extends from the Wasatch drain tunnel to Honeycomb Fork probably belong to a single large dike, but if so this dike is thrown by several faults, though it crosses the Grizzly overthrust with only a slight jog which is probably due to a swerving of the dike-filled fissure at its intersection with the thrust plane. The great Silver Fork fault has affected the intrusive rocks; it jogs the boundary of the Alta-Clayton Peak stock in the gorge of Little Cottonwood Creek, and farther south it cuts off numerous dikes of granodiorite porphyry. It also cuts off the ore-bearing fissures whose course it intersects. Some east-west faults appear to be cut off by the Little Cottonwood granodiorite. The relation of many faults to intrusive bodies and to the ores is indeterminate.

Despite the doubt concerning the age of some of the faults, it is clear that faulting began before intrusion and ended after the intrusive rocks now visible had solidified. It can hardly be doubted that some of the faulting is due to unequal subsidence of the crust above a cooling mass of magma, which at a certain depth presumably underlay a large continuous tract that included all the area in which intrusive rocks are now exposed; and some faulting may have been caused by differential upward movement of the magma. The latter agency affords a possible explanation of the abundance of steep reversed faults, which are not easily accounted for by the simple lateral stretching of the crust that is generally supposed to be the cause of normal faulting. Steep reversed faults appear to presuppose the action of forces whose chief component is vertical. The movement on the Montezuma fissure, if this fissure is, as supposed, concave eastward in vertical section, involves a differential tilting of the blocks on either side, the west edge of the block to the east having swung downward. Such movement in the roof of an unsolidified magma is not difficult to imagine.

Even faults that dislocate the visible igneous rocks may be due to movements in deeplying parts of the magma chamber, where solidification occurred later than at the levels accessible to observation. An instance of a fissure in granite that dies out in depth is 
described by Mr. Butler on page 199, and some of the post-mineral faults of the Cottonwood district might similarly vanish at the depth of a few thousand feet. The extent to which this relationship exists is, however, a highly speculative question. It is probable that some of the faults are unrelated to intrusion; some of the later ones may have been formed at the same time as the great fault that defines the Wasatch front, and this fault is so recent and so extensive that it can hardly be related to the intrusions of the Bingham-Park City zone. The Silver Fork and Snow faults resemble the Wasatch fault in their low westerly dip, but since they have no direct expression in the topography and are thrown by other faults they may well be of earlier date.

SUMMARY.

The earliest deformation of the strata in this region was the Wasatch folding and overthrust faulting along north-south lines. The strata, having been thus tilted eastward and reduplicated by thrust faults of eastward dip, were bent upward and invaded by granodiorite magma along the east-west Uinta axis, simultaneously with the formation of the Uinta Range. The mineral-bearing fissures probably were formed at an early stage and mineralized at a later stage of the period within which the magmas were intruded and became solidified. Normal faults and reverse faults of steep dip began to be formed in the period of overthrusting. Probably a large proportion of the faults were formed in the period of intrusion and solidification, and many of these may have been due to movements of the magma. Some are more recent than the igneous rocks and the ores; these may be due in part to adjustments in the deep-seated, late-solidifying portions of the magmas, but they may be due in part or wholly to other causes.

HISTORY.

By V. C. Heikes.

\section{LITTLE COTTONWOOD DISTRICT}

DEVELOPMENT.

Ore was first discovered in the Little Cottonwood district by Gen. Conner's soldiers in 1864, and the Wasatch district was then organized, but it was soon abandoned owing to the great expense of working.
In 1867 most of the claims were "jumped" and the Mountain Lake district, which included a large area in the Wasatch Range, was organized. It was divided in 1869-70 into the Little and Big Cottonwood, American Fork, and Uinta districts. The mining claims recorded in the Little Cottonwood district covered an area about $2 \frac{1}{2}$ miles square. Alta, the principal camp, is 16 miles east of Sandy, a station on the Denver \& Rio Grande and Los Angeles \& Salt Lake railroads. A railroad was completed to the district in May, 1873, but was discontinued a few years later. In 1913 the grade was repaired and rails laid as far as Wasatch for the transportation of building stone to Salt Lake City. The mine operators in the district took advantage of this renewed method of transportation, thus saving a wagon haul of 9 miles to the smelters. In 1916 construction on a narrow-gage extension of the road to Alta was begun, and in 1917 it had been extended to a point a.short distance below Alta.

The most productive period was between 1871 and 1877. At the time of Huntley's visit $^{1}$ (October, 1880) only two mines-the Vallejo and the City Rock-were working regularly, the others having closed down, for several causes, including legal troubles, the exhaustion of working capital, the giving out of surface bodies, the finding of pyrite and water in the lower levels, and the low price of lead.

Very little metallurgic work was ever done in the district, as most of the ore was sold in the Salt Lake market. In 1866 the owner of the North Star mine built a Scotch hearth furnace and ran out about 3 tons of lead. In the following year he erected a reverberatory furnace, which succeeded, and a cupel furnace, which failed. The Jones smelter, about $4 \frac{1}{2}$ miles from the mouth of Little Cottonwood Canyon, was operated in 1871 and ran on custom ores for two years. In 1872 or 1873 the Davenport smelter was started at the same place. In addition to the ore from the mine it worked some custom ore but was shut down in 1875 . The Flagstaff Co. also erected three stacks in this vicinity. Several unsuccessful attempts were made to leach ores on a small scale. Concentration works were built for the Emma

1 Huntley, D. B., The mining industries of Utah: Tenth Census U. S., vol. 13, p. 422, 1885. 
mine and were financially successful, though the percentage obtained was low.

MINES.

The history of the Emma and other mines was given by Huntley ${ }^{1}$ in 1880 , as follows:

The Emma mine * * * was located in 1868 by Woodman, Chisholm, Woodhull \& Reich. Little work was done until the autumn of 1869, when the ore body was struck. Some ore was shipped and sold prior to the sale of the mine to the Emma Mining Co., of New York, in 1870. This company worked the mine quite vigorously and shipped a large amount of ore. The following year the property was sold to the Emma Silver Mining Co. of Utah (Ltd.) for $\$ 5,000,000$ cash; another authority placed the price at $\$ 3,500,000$. The mine was then worked by English managers, paid $\$ 300,000$ in dividends (one authority says $\$ 1,300,000)$ until September, 1874 , when it was attached by T. W. Park and others for an indebtedness of $\$ 300,000$. It was then idle until October, 1877 , when the American Emma Mining Co. was incorporated and work resumed. The second ore body failed in the autumn of 1873, up to which time most of the ore had been shipped to Swansea, Wales. During the years 1873, 1874, 1878, and 1879 much low-grade ore was concentrated by jigs.

When the American Emma Mining Co. began work it first prospected the old ore bodies and then leased the Bay City tunnel, which was 1,700 feet long and 90 feet below the lowest old workings of the Emma. This tunnel had been run by a St. Louis company at a cost of $\$ 75,000$ and had been abandoned in 1876. Since making the connection a small ocherstained seam, in an incline or winze 130 feet below the tunnel level, has been followed. * * * From Mr. Charles Smith, of Salt Lake City, whose accounts included all but the first few hundred tons sold, the writer learned that the sales of ore to June 1, 1880, amounted to 27,451 tons, for which $\$ 2,637,727.44$ was received. (See also p. 261.)

The Flagstaff mine * * * was located in 1869 by Groesbeck, Schneider, and others, who worked it under the name of the Salt Lake Mining Co. until February, 1872 , when it was bonded to one Davis for $\$ 300,000$, who sold it to English capitalists for $\$ 1,500,000$. They organized the Flagstaff Silver Mining Co. of Utah (Ltd.) and worked the mine in a very expensive manner until December, 1873, when the ore bodies in sight gave out. * * * Davis took the mine and worked it under agreement with the company until December 24, 1876, when he was dispossessed by the United States marshal under orders from the English directors. Heavy lawsuits with small results followed. Since 1876 the mine has been leased and subleased many times, but has been idle since the summer of 1880. At the time of examination it was owned by Seligman Bros., of New York, who took it for debt. * * * The English company erected the Flagstaff smelter (three stacks) at the mouth of Little Cottonwood Canyon and ran it until November, 1873, when they leased the Last Chance smelter near Sandy. Smelting was not as profitable as selling the ore, which after April,

1 Tenth Census U. S., 1880, vol. 13, p. 423, 1885 .
1876, was disposed of in the Salt Lake market. The dividends paid to the English company amounted to about $\$ 350,000$. The property consists of the Flagstaff, South Star and Titus, Virginia, and Nabob. The Flagstaff is 2,200 by 100 feet, but it extends across and not along the belt.

The total product was estimated by the superintendent to be 100,000 tons. Of this, 30,000 tons probably assayed $\$ 10$ gold, 60 ounces silver, and 40 per cent lead and sold for or was worth $\$ 80$ per ton. The remainder probably assayed $\$ 4$ gold, 30 ounces silver, and 20 per cent lead and was worth $\$ 30$ per ton. * * *

The South Star and Titus, an older location than the Flagstaff, has been constantly harassed by lawsuits. Several hundred thousand dollars' worth of ore has been extracted. * * * Active work ceased in 1878 .

The Nabob was located in 1876. A large body of ore, lying partly in the Virginia ground, was struck in the winter of 1876-77, which yielded about $\$ 100,000$. * * * An ore body, 30 by 25 by 4 feet, was found not 50 feet from the surface. The average assay of this ore was $\$ 74.76$, of which $\$ 26$ was gold. * * *

The Joab Lawrence Co., the principal actively working company on Emma Hill at the time of the writer's visit, was organized in the spring of 1879. Its property consists of the Vallejo and the North Star, adjacent claims, situated between the Emma and the Flagstaff. The North Star was one of the earliest claims of the district, having been located in 1865, and has yielded largely. * * * The Vallejo was worked in $1872,1873,1874,1875$, and 1877 by several companies, and much ore was extracted. * * * It [the ore] was fine and contained from 20 to 45 per cent lead and from 15 to 90 ounces silver, from 20 to 35 per cent iron and from 9 to 14 per cent of moisture. It was in great demand among the smelters owing to the lack of silica and the presence of so much iron. A low grade of ore containing from 40 to 50 per cent of iron, no lead, and a few ounces of silver was also shipped. * * *

The Toledo-Utah Silver Mining \& Smelting Co. bought the Toledo mine shortly after its discovery in 1872 and worked it quite extensively until April, 1880. The property consists of the Toledo and the Fuller claims. On the latter most of the ore has been found and most of the work done. * * *

The Emily mine is situated in a small ravine between the Toledo and Emma Hill. It was discovered in 1870 . It is owned by the Emily Mining Co., of Pittsburgh, Pa. They ceased regular work in 1874 , and the mine has been leased since at one-fifth royalty. It is a bedded vein of clay slate in quartzite, dipping about $60^{\circ} \mathrm{E}$. The ore is from 1 to 6 inches wide and consists of quartz containing pyrite, sphalerite, galena, and tetrahedrite. When sorted it assays from $\$ 80$ to $\$ 100$. * * *

The City Rock and Utah group is situated at the head of Little Cottonwood Canyon and comprises the Utah, 100 by 1,000 feet; City Rock, 100 by 1,000 feet; West Wind, 100 by 495 feet; King of the West, Utah No. 2, Utah No. 3, and Freeland. The first three are on the Utah vein, and the others are on the parallel King of the West vein, 200 feet distant, and have but little development. * * * 
The other mines of the Little Cottonwood district are:

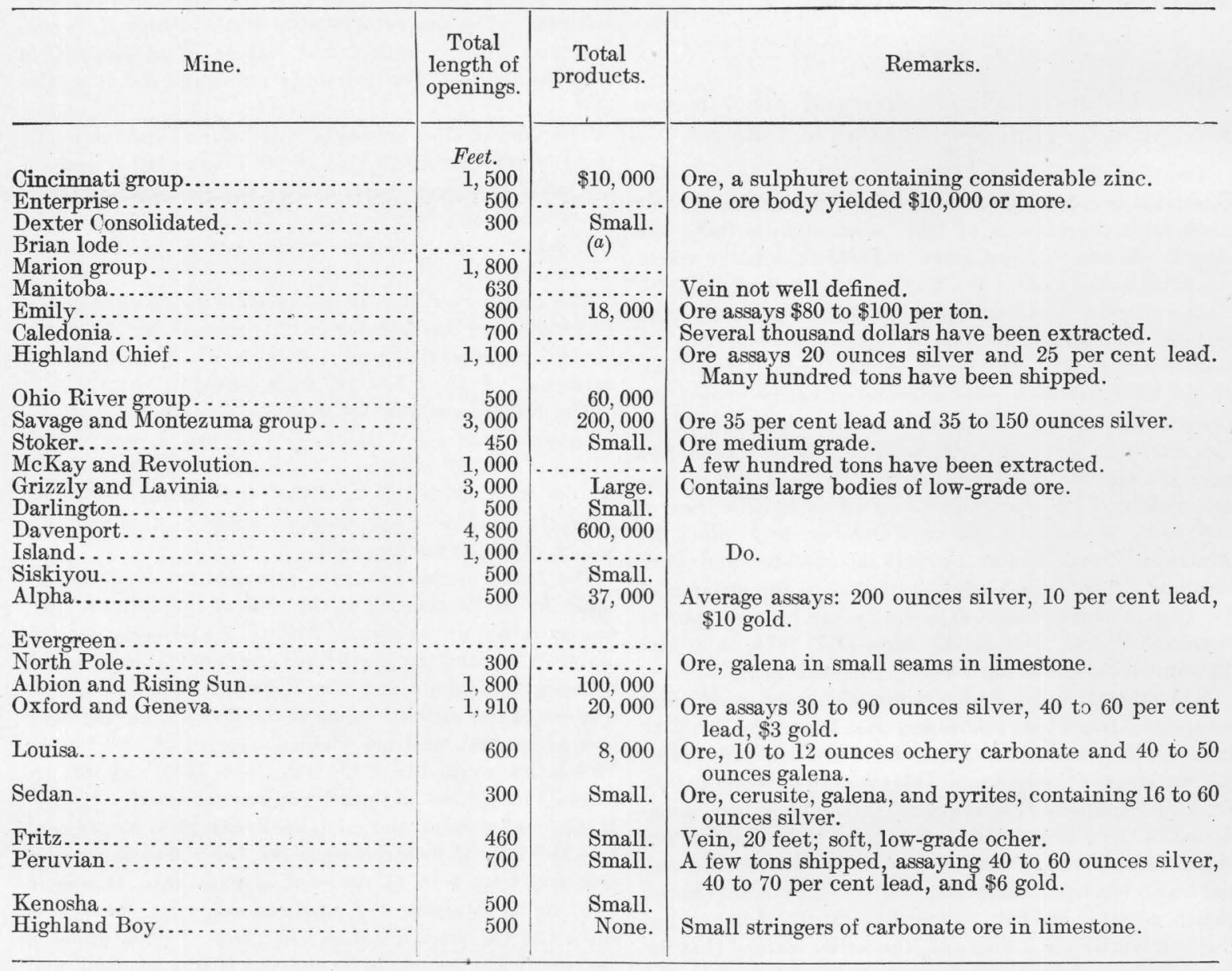

a A few thousand dollars.

TUNNEL SITES.

The topography of this district is very favorable for the location of tunnel sites. Accordingly, in early times work was begun upon a great many. They have cost fortunes but have rarely been successful in finding ore; and though all are still claimed, few are worked more than is sufficient for assessment work. These tunnel sites, in a legal way, are a great drawback to the district. They were located before many of the present claims; they ran in all directions, and, in case large and rich ore bodies should be found, some of them might be used to make serious legal difficulties. The following are the principal tunnel sites in the order of their situation, beginning at the west, on the north side of Little Cottonwood, and continuing in a semicircle around the head of the canyon:

Frederick tunnel.- This was driven to develop the Frederick and Crown Point claims. These are parallel veins, 70 feet apart, 3 and $4 \frac{1}{2}$ feet wide, dipping $54^{\circ} \mathrm{N}$. in limestone and between limestone and quartzite. The ore is a carbonate, 18 inches wide, and averages 60 ounces silver and 35 per cent lead. The claims were located in 1870 and were worked until 1873, when water and galena were encountered at a depth of 337 feet. The value of the ore sold was estimated at $\$ 35,000$. The mines were leased until May, 1876, when the tunnel was begun. * * *
Howland tunnel.-Work was begun on this several years ago. It has been relocated several times and was, at the period under review, known as the Solitary. Its length is 600 feet. * * *

Geneva tunnel.-Abandoned. Length unknown.

Lady Emma tunnel.-Length, 370 feet. Relocated and called the Prince of the Hills. * * *

Chicago tunnel.-Length, 600 feet. Relocated and called the Fitzgerald tunnel.

Vallejo tunnel.-Used in the early development of the Vallejo mine.

Utah tunnel.-Relocated as the Burgess and used to work the Vallejo mine.

Gladiator tunnel.-Length, about 1,000 feet. Used to work the North Star mine.

Great Salt Lake Tunnel \& Mining Co.-This is better known as the Buffalo tunnel. It was located in 1871, is 600 feet in length, and is regularly worked, 275 feet having been run the preceding year. This company has located two claims, the Buffalo and another, having 9 -inch veins, containing galena and pyrites. Three small bodies were found. The ore sold for about $\$ 80$ per ton and yielded a few thousand dollars. The Allegan mine, operated through this tunnel, has about 550 feet of cuttings and yielded a few thousand dollars some years ago. 
Bay City tunnel.-Length, 1,700 feet. * * * Illinois tunnel.-Length, 800 feet. ***

Equitable Tunnel \& Mining Co.-This company's tunnel is about 1,500 feet in length, with side drifts and winzes amounting to 900 feet, and is situated above the Bay City. * * *

Little Cottonwood tunnel.-Relocated and called the Buckland. It is 600 feet long and was run to tap the Savage and Montezuma group.

Reliance tunnel.-Abandoned. Little work done.

Manhattan tunnel.-Abandoned and relocated as the

McKay and Revolution. Length, 500 feet.

Ely tunnel.-Abandoned.

Phoenix tunnel.-Owned by the Equitable Tunnel \& Mining Co. Length, 700 feet.

Herman tunnel, known as the Tilden.-Length, 500 feet. Emma Hill tunnel.-Length, 900 feet.

Victoria tunnel.-Length, 900 feet. Used to work the Victoria, Imperial, Emma May, and Alice mines. These have a large amount of cuttings, have shipped considerable ore, and are being worked upon lease.

Christiana tunnel, known as the Oneida.-Length, 250 feet.

Brewer \& Lapham tunnel.-Length, 150 feet. Located to develop the Darlington mine.

Lady Esten tunnel.-Length, 300 feet. Owned by the Equitable Tunnel \& Mining Co.

Iris Tunnel Co.-This was a San Francisco company which began work in the spring of 1872 and failed in the autumn of 1877 , having spent about $\$ 100,000$. The tunnel was taken by one of the creditors for debt. The property consists of eight locations and two sites on Emerald Hill. * * *

The Etna, St. Joseph, Wasatch, Silver Belt, and Rothschild tunnel sites are of varying lengths and have all been abandoned.

Besides the tunnels above mentioned, there are many others having more or less development.

BIG COTTONWOOD DISTRICT.

The Big Cottonwood district, organized July 11, 1870, is in Big Cottonwood Canyon, in Salt Lake County, north and east of the Little Cottonwood district, and is bounded by the summits of the ranges on each side of the canyon. Most of the mines are on the southern ridge. Since the earliest days most of the ore has been hauled by wagon down the canyon to Sandy, at present a station of the Denver \& Rio Grande and Los Angeles \& Salt Lake railroads, or directly to the smelters and samplers in that vicinity.

The Maxfield mine is on the north side of Big Cottonwood Canyon, 14 miles east of Sandy and a quarter of a mile from Argenta, which in the seventies was the principal mining camp of the district. During 1880 , according to Huntley, ${ }^{1}$ it produced about 90 tons of lead ore, containing

1 Huntley, D. B., op. cit., p. 428.

$35416^{\circ}-19-17$
30 to 100 ounces of silver, which was sold for $\$ 4,518$. The value of the product prior to 1880 was roughly estimated at $\$ 20,000$. No records of the total quantity of silver and lead produced from the mine are available, but $\$ 1$,053,000 would cover ${ }^{2}$ the total yield to the end of 1906. Since 1906 lessees have produced some lead ore each year. The total dividends paid by the Maxfield Co. amounted to $\$ 118,000$. The mine was pumped out early in 1915. In 1916 ore was produced from the lower levels and prospecting was being done on the tunnel level.

On the south side of Cottonwood Canyon,

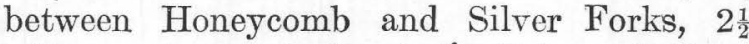
miles northeast of Alta, is the Prince of Wales group, consisting of the Antelope, Prince of Wales, Wandering Boy, Highland Chief, Wellington, and Warrior claims. All were discovered about 1870. The Prince of Wales group is credited with a production of 10,121 tons of ore $^{3}$ to the end of 1890 . Since that time a very little has been produced by lessees, who in 1909-1911 shipped ore containing 0.01 ounce of gold and 90 to 144 ounces of silver to the ton, 1.25 to 3.75 per cent of copper, and 12 to 21 per cent of lead. In 1915 lessees opened the ore body on the lower tunnel level, and in 1916 and 1917 ore was extracted above this level. Assays made on shipments in 1879 show the lead to have averaged between 25 and 48 per cent and the silver between 61 and 224 ounces to the ton.

The total value of the ore produced from the Prince of Wales group between 1870 and 1890, including a few shipments since, is variously estimated from $\$ 1,012,000$ to $\$ 2,000,000$.

The Richmond and Theresa claims, south of the Prince of Wales, produced lead-silver ore valued at $\$ 150,000$ to the end of 1880 . The Reade and Benson claims are often mentioned in early reviews as producers of rich ore. Subsequently these and other claims in the vicinity were incorporated into the Kennebec group, whose record as a producer was not important. The total product to 1880 is placed at $\$ 600,000$.

The Ophir, discovered in 1870, produced about $\$ 30,000$ worth of ore to 1880 .

The mines of the Kessler Mining Co., later purchased by the Carbonate Co., are estimated

2 Personal statement of A. L. Thomas, jr., Salt Lake City.

3 Compiled from reports of Director of Mint and commissioners, $1870-1890$ 
to have produced ore valued at about $\$ 380,000$

Other mines active in the district previous previous to 1880 . to 1880 are mentioned by Huntley as follows:

\begin{tabular}{|c|c|c|c|}
\hline Mine. & $\begin{array}{c}\text { Total } \\
\text { length of } \\
\text { openings. }\end{array}$ & $\begin{array}{l}\text { Total } \\
\text { product. }\end{array}$ & Remarks. \\
\hline Silver Mountain Mining Co.... & $\begin{array}{l}\text { Feet. } \\
500\end{array}$ & $\$ 10,000$ & Ore assays 50 ounces silver, 35 per cent lead, and $\$ 3$ \\
\hline Thor and Bright Point... & 500 & 2,000 & $\begin{array}{l}\text { Ore assays } 60 \text { to } 100 \text { ounces silver and } 40 \text { to } 60 \text { per cent } \\
\text { lead. }\end{array}$ \\
\hline Elgin Mining Co........ & 700 & Small. & Veins small. \\
\hline $\begin{array}{l}\text { Puterbaugh................................. } \\
\text { Imperial Mining, Milling \& Smelting Co. }\end{array}$ & $\begin{array}{c}300 \\
\ldots\end{array}$ & $\begin{array}{r}a 840 \\
\text { Small. }\end{array}$ & A few hundred feet of cuttings. Worked irregularly \\
\hline Dolly Varden. & 1,400 & 25,000 & $\begin{array}{l}\text { for two other years. } \\
\text { Property in litigation. }\end{array}$ \\
\hline
\end{tabular}

AMERICAN FORK DISTRICT.

The American Fork district, at the head of American Fork canyon, was organized July 21, 1870 , and has an area of 6 square miles. The mining town, called Forest City, was 18 miles from the town of American Fork. In later years, since the decline of the Miller mine, the district has yielded only a small production.

The following notes are abstracted from Huntley's ${ }^{1}$ review of the conditions in 1880:

The Miller mine, formerly the principal mine of the district, was discovered in September, 1870, and was sold the following year for $\$ 120,000$ or over. The Sultana smelter (three stacks) was erected in 1871-72 and ran irregularly until the spring of 1875. In 1871-72 a narrow-gage railroad was built up the canyon to within 4 miles of the smelter, and 25 stone charcoal kilns were constructed.

${ }^{1}$ Huntley, D. B., op. cit., p. 444.
The ore bodies gave out, and the company shut down the mine in 1876, since which time it has been worked only on lease. The charcoal kilns, which were of the beehive pattern and held about 25 cords each, ran almost continuously from 1872 to 1877 , making coal for the Salt Lake smelters. The track was taken up in 1878 and the iron sold. The bottoms of the old furnaces were torn up to get the large amount of lead contained in them, and the old slag dumps were profitably picked over four times to find scraps of lead, unreduced ore, and matte. Estimates of the total product and the average grade of the ore of the Miller mine range from 13,000 to 15,000 tons, assaying from 40 to 54 per cent lead, from 30 to 47 ounces of silver, and from $\$ 2$ to $\$ 10$ gold. (See also pp. 263-265.)

The Wild Dutchman mine is a quarter of a mile east of Forest City. It was discovered in 1872 and sold to the Omaha Smelting \& Refining Co. of Nebraska, who worked it until September, 1876, when it was leased. (See also p. 263.)

Other mines of the American For's district are:

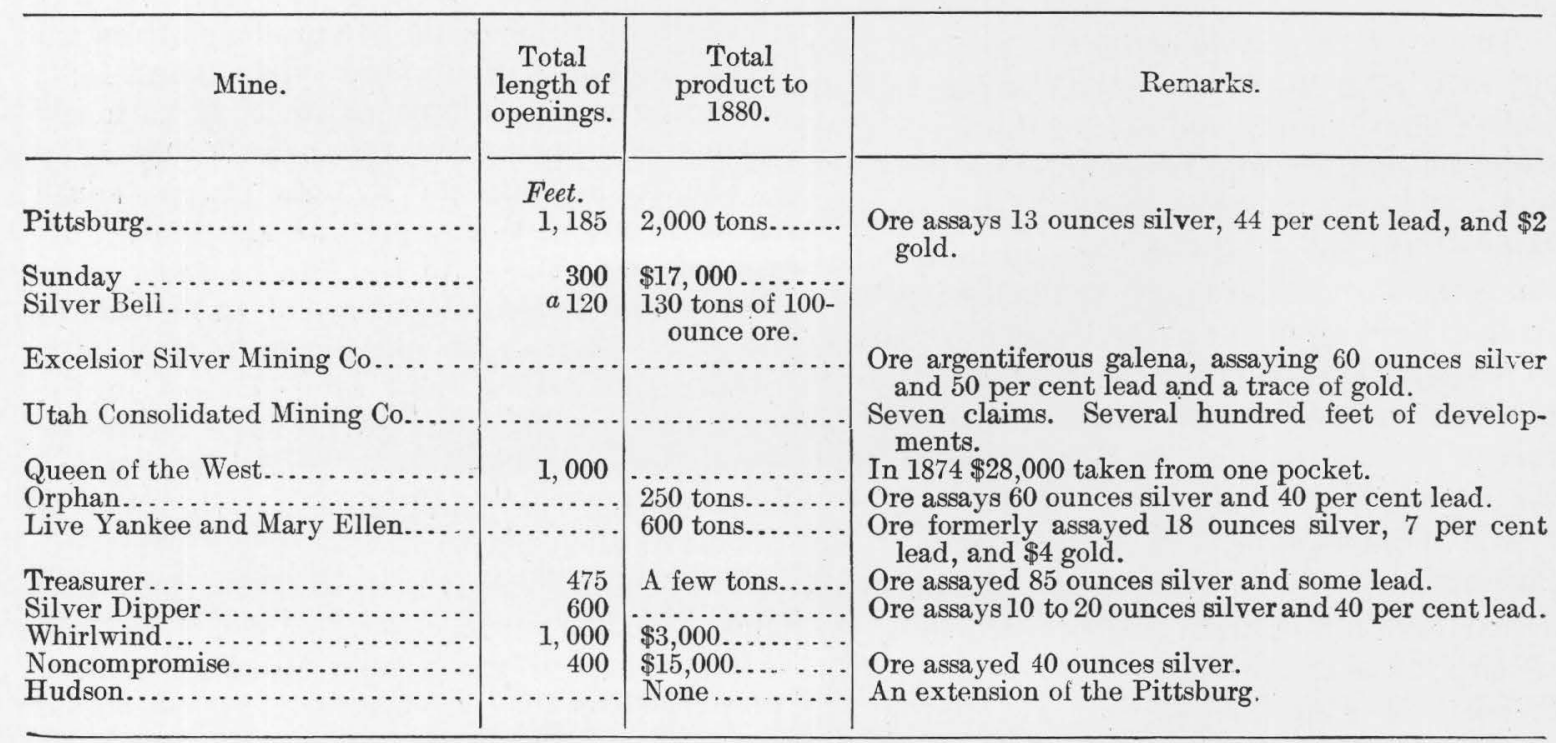


After the closing of the Miller mine in 1876 assessment work was performed yearly and some ore produced and shipped. In 1904 a body of ore was found in the Miller mine, which during the next few years yielded metals to the value of several hundred thousand dollars, but since 1907 the output has declined.

\section{PRODUCTION.}

By V. C. Heikes.

IITTLE AND BIG COTTONWOOD DISTRICTS.

TOTAL PRODUCTION.

The Little Cottonwood district has yielded production of metal annually since 1867 and may be expected to continue productive for many years to come. No complete records were kept of the annual production in the early days, but enough data to make very close estimates possible are found in the statistical reports on mines and mining in the States and Territories west of the Rocky Mountains for the years 1867 to 1876 . Between 1875 and 1880 statistics were not compiled by the Government, and for these years the figures in the mining journals and the Salt Lake Tribune are used. The operations and statistics of many of the most prominent producers from 1870 to 1880 were ably reviewed by D. B. Huntley. ${ }^{1}$ During the succeeding years the reports of the Director of the Mint give fragmentary figures until the year 1901, and the statistics from that year to the end of 1917 have been compiled by the United States Geological Survey.

In recent years (1901-1917) the most important producers in the Little Cottonwood district have been the Wasatch Mines group, which include the Columbus Consolidated group and the Flagstaff; the ContinentalAlta, reorganized as the Unity and later as the Michigan-Utah Mining Co. (includes the early producing claims known as the Darlington, Grizzly, Regulator, and Lavinia); the City Rocks, now part of the Michigan-Utah group (includes the Utah, an early producer); the South Hecla (includes the Alta Hecla, South Columbus, and Wedge); the Emma Consolidated; the Columbus-Rexall, and the Sells.

In the Big Cottonwood district very few properties have in recent years produced any ore. The more productive have been the Black

${ }_{1}$ Huntley, D. B., op. cit., pp. 422-430.

c
Bess group of the Michigan-Utah Mining Co., the Maxfield, and the Cardiff, which in the last few years has been the largest producer in the region.

It is impossible to segregate the production of the Big and Little Cottonwood districts, and all the available statistics have been combined in the tables below.

J.R. Browne ${ }^{2}$ refers to the operation (in 1867) of two small furnares in Cottonwood Canyon. These furnaces were under construction in 1866, according to the Daily Union Vedette of August 25,1866 , and in September they began producing lead, which evidently was lost in slag and cinders (Vedette, Ost. 26, 1867) and recovered in 1867 by a German metallurgist named Reese under the supervision of A. A. Hirst, who had reconstructed the works for treatment of North Star ores. According to R. W. Raymond ${ }^{3}$ the first efficient smelter (a cupola), erected by Woodhull Bros., 7 miles south of Salt Lake City, began to operate in June, 1870, producing 5,000 pounds of bullion in 36 hours. Most of the ore was from the Monitor and Magnet claims. Shipments of ore from the Emma mine (located August, 1868) began in June, 1870, and up to December 31, 1870, Walker Bros. had shipped 4,200 tons of ore (mostly from the Emma, with an average assay of 35 per cent of lead and $\$ 182$ in silver to the ton).

Lead bullion shipments, mostly from Cottonwood ores, were 2 tons to England and $6 \frac{1}{2}$ tons to San Francisco. ${ }^{4}$ In the fall of 1870 mining locations in the Big Cottonwood district (the Davenport, Theresa, Wandering Boy, Maxfield, and Prince of Wales) had each yielded. some ore for shipment. ${ }^{5}$ On the Little Cottonwood side the Emma mine had produced, up to August, $1871,10,000$ to 12,000 tons of ore, which assayed 100 to 216 ounces of silver to the ton and from 30 to 66 per cent of lead, averaging 160 ounces of silver and from 45 to 50 per cent of lead. The total value of the ore, at the cash price paid for it, a large part of it at Liverpool, was about $\$ 2,000,000 .^{\circ}$ The Flagstaff mine, up to April, 1871, had yrelded over 80 tons of shipping ore.

2 Mineral resources of the States and Territories west of the Rocky Mountains for 1867, p. 486, 1868.

${ }^{8}$ Idem for 1870, p. 223, 1872.

- Idem for 1872 , p. 319, 1873.

B Idem, p. 321.

6 Idem, p. 323 
Gold, silver, copper, lead, and zinc produced in Big and Little Cottonwood mining districts, 1867-191\%.

\begin{tabular}{|c|c|c|c|c|c|c|c|c|c|c|c|c|}
\hline \multirow{2}{*}{ Period. } & \multirow{2}{*}{$\begin{array}{c}\text { Ore } \\
\text { mined. }\end{array}$} & \multicolumn{2}{|c|}{ Gold. } & \multicolumn{2}{|c|}{ Silver. } & \multicolumn{2}{|c|}{ Copper. } & \multicolumn{2}{|c|}{ Lead. } & \multicolumn{2}{|c|}{ Recoverable zinc. } & \multirow{2}{*}{$\begin{array}{c}\text { Total } \\
\text { value. }\end{array}$} \\
\hline & & Quantity. & Value. & Quantity. & Value. & Quantity. & Value. & Quantity. & Value. & Quantity. & Value. & \\
\hline $\begin{array}{l}1867-1870 . . \\
1871-1880 . \\
1881-1890 . \\
1891-1900 . .\end{array}$ & $\begin{array}{r}\text { Short tons. } \\
5,573 \\
133,796 \\
22,515 \\
13,885\end{array}$ & $\begin{array}{r}\text { Fine ounces. } \\
59.99 \\
3,585.02 \\
5,426.90 \\
7,581.38\end{array}$ & $\begin{array}{r}\$ 1,240 \\
74,109 \\
112,184 \\
156,721\end{array}$ & $\begin{array}{r}\text { Fine ounces. } \\
703,138 \\
6,259,000 \\
883,034 \\
707,731\end{array}$ & $\begin{array}{r}\$ 933,667 \\
7,876,458 \\
927,886 \\
525,144\end{array}$ & $\begin{array}{c}\text { Pounds. } \\
\text {............... }\end{array}$ & & $\begin{array}{r}\text { Pounds. } \\
6,444,800 \\
95,201,998 \\
14,784,900 \\
8,457,869\end{array}$ & $\begin{array}{r}\$ 387,048 \\
5,450,541 \\
662,998 \\
323,954\end{array}$ & $\begin{array}{c}\text { Pounds. } \\
\ldots \ldots \ldots \\
\ldots \ldots\end{array}$ & & $\begin{array}{r}\$ 1,321,955 \\
13,401,108 \\
1,703,068 \\
1,005,819\end{array}$ \\
\hline $\begin{array}{l}1901 \ldots \\
1902 \ldots \\
1903 \ldots \\
1904 \ldots \\
1905 \ldots \\
1906 \ldots \\
1907 \ldots \\
1908 . . \\
1909 \ldots \\
1910 . .\end{array}$ & $\begin{array}{r}935 \\
850 \\
1,977 \\
4,878 \\
26,003 \\
20,801 \\
19,896 \\
5,866 \\
13,208 \\
14,203\end{array}$ & $\begin{array}{r}161.19 \\
146.53 \\
85.24 \\
306.36 \\
949.99 \\
762.05 \\
976.93 \\
321,36 \\
335.72 \\
381.87\end{array}$ & $\begin{array}{r}\$ 3,332 \\
3,029 \\
1,762 \\
6,333 \\
19,638 \\
15,753 \\
20,195 \\
6,643 \\
6,940 \\
7,894\end{array}$ & $\begin{array}{r}37,532 \\
34,120 \\
69,336 \\
106,249 \\
371,683 \\
345,102 \\
399,417 \\
63,246 \\
158,867 \\
202,010\end{array}$ & $\begin{array}{r}22,519 \\
18,084 \\
37,441 \\
60,828 \\
224,496 \\
231,218 \\
263,615 \\
33,520 \\
82,611 \\
109,085\end{array}$ & $\begin{array}{r}58,490 \\
102,260 \\
235,832 \\
811,639 \\
1,193,743 \\
1,074,238 \\
269,212 \\
1,842,711 \\
804,018\end{array}$ & $\begin{array}{r}\$ 7,136 \\
14,010 \\
29,479 \\
126,616 \\
230,392 \\
214,848 \\
35,536 \\
239,553 \\
102,110\end{array}$ & $\begin{array}{r}300,298 \\
272,999 \\
552,483 \\
1,190,005 \\
1,702,258 \\
1,922,276 \\
2,337,924 \\
603,840 \\
332,475 \\
1,102,907\end{array}$ & $\begin{array}{r}12,913 \\
11,193 \\
23,204 \\
52,063 \\
80,006 \\
109,570 \\
123,910 \\
25,362 \\
14,296 \\
48,528\end{array}$ & & & $\begin{array}{r}\$ 38,764 \\
39,442 \\
76,417 \\
148,703 \\
450,756 \\
586,933 \\
622,568 \\
101,061 \\
343,400 \\
267,617\end{array}$ \\
\hline $1901-1910^{a}$. & 108,617 & $4,427.24$ & 91,519 & $1,787,562$ & $1,083,417$ & $6,392,143$ & 999,680 & $10,317,465$ & 501,045 & & & $2,675,661$ \\
\hline $\begin{array}{l}1911 \ldots \ldots \\
1912 \ldots \ldots \\
1913 \ldots \ldots \\
1914 \ldots \ldots \\
1915 \ldots \ldots \\
1916 \ldots \ldots \\
1917 \ldots \ldots\end{array}$ & $\begin{array}{r}6,040 \\
6,566 \\
5,167 \\
12,583 \\
24,590 \\
41,960 \\
48,203\end{array}$ & $\begin{array}{r}139.17 \\
142,46 \\
112.08 \\
372.22 \\
430.37 \\
1,035.90 \\
900.33\end{array}$ & $\begin{array}{r}2,877 \\
2,945 \\
2,317 \\
7,695 \\
8,897 \\
21,414 \\
18,611\end{array}$ & $\begin{array}{r}158,448 \\
186,183 \\
93,821 \\
242,825 \\
445,111 \\
755,980 \\
917,512\end{array}$ & $\begin{array}{r}83,978 \\
114,503 \\
56,668 \\
134,282 \\
225,671 \\
497,435 \\
756,030\end{array}$ & $\begin{array}{r}407,719 \\
386,963 \\
136,901 \\
214,971 \\
334,944 \\
819,192 \\
1,163,084\end{array}$ & $\begin{array}{r}50,965 \\
63,849 \\
21,219 \\
28,591 \\
58,615 \\
201,521 \\
317,522\end{array}$ & $\begin{array}{r}1,043,608 \\
1,135,191 \\
1,091,617 \\
2,887,109 \\
12,263,403 \\
15,061,273 \\
11,927,552\end{array}$ & $\begin{array}{r}46,963 \\
51,084 \\
48,031 \\
112,597 \\
576,380 \\
1,039,228 \\
1,025,770\end{array}$ & $\begin{array}{r}8,804 \\
229,663 \\
60,746 \\
21,721\end{array}$ & $\begin{array}{r}449 \\
28,478 \\
8,140 \\
2,216\end{array}$ & $\begin{array}{r}184,783 \\
232,381 \\
128,235 \\
283,614 \\
898,041 \\
1,767,738 \\
2,120,149\end{array}$ \\
\hline 1911-1917. & 145,109 & $3,132.52$ & 64,756 & $2,799,880$ & $1,868,567$ & $3,463,774$ & 742,282 & $45,409,753$ & $2,900,054$ & 320,934 & 39,283 & $5,614,942$ \\
\hline $1867-1917 \ldots$ & 429,495 & $24,213.05$ & 500,529 & $13,140,345$ & $13,215,139$ & $9,855,917$ & $1,741,962$ & $180,616,785$ & $10,225,640$ & 320,934 & 39,283 & $25,722,553$ \\
\hline
\end{tabular}
$a$ Within the period covered by this total the Columbus Consolidated Co. operated its concentration mill from 1904 to 1912 , inclusive, producing 15,172 tons of copper-lead concentrates. In 1905 the Conti-
nental Alta produced lead concentrates, and in 1910 some copper-lead concentrates were recovered from Columbus Extension ores. 
Between 1871 and 1880 the largest producers were the Emma (largely depleted by 1873), Flagstaff, North Star, Vallejo, Joab Lawrence Co., City Rocks, Grizzly and Lavinia, Davenport, Savage and Montezuma, Reade \& Benson, and Prince of Wales. According to Huntley, ${ }_{1}^{1}$ the Emma mine had yielded, to June 1, 1880, ore aggregating 27,451 tons, for which $\$ 2,637$,727 was received. The rich ore bodies of the Flagstaff mine gave out in December, 1873, having produced about 31,000 tons, which probably assayed $\$ 10$ in gold and 60 ounces of silver to the ton and 40 per cent of lead and which sold for $\$ 80$ a ton. Between 1874 and 1879 about 69,000 tons of ore was produced from the Flagstaff, probably assaying $\$ 4$ in gold and 30 ounces of silver to the ton and 20 per cent of lead, and was sold for $\$ 30$ a ton, aggregating from the beginning about $\$ 4,550,000 .^{2}$ The Prince of Wales and Antelope groups of claims were discovered about 1870 and had a record of producing over $\$ 1,000,000$ to the end of $1884 .^{3}$ Subsequent records of the Prince of Wales in the reports of the Director of the Mint to 1890 show not over 10,121 tons of ore shipped, averaging probably 105 ounces of silver to the ton and 30 per cent of lead.

The Flagstaff produced between 1881 and 1890, the Joab Lawrence or Vallejo and City Rocks almost continuously to 1891, and the Maxfield was the heaviest shipper in the years 1884, 1887, 1888, and 1890. In 1891 and 1892 the Maxfield and Flagstaff were the principal producers. Between 1891 and 1900 very little or no mention of these districts was made in the reports of the Director of the Mint. The figures given in the table are differences between the known output of the other districts in Salt Lake County and the total for the county as given by the Director of the Mint in the reports for each year.

$$
\text { PRODUCTION, BY ORES. }
$$

The character of the ores produced and the average metal content and average value are shown in the following descriptions and tables.

Dry or siliceous ores. - The dry or siliceous ores shipped to smelters from the Big and Little Cottonwood districts comprise gold and silver ores carrying copper and lead sulphides too small in amount to be of value. The contributors of the dry or siliceous ores in 1903

\footnotetext{
1 Huntley, D. B., op. cit., pp. 423, 424.

${ }^{2}$ Idem, p. 428.

3 Rept. Director of the Mint upon production of precious metals, 1884, p. 421,1885 .
}

and 1909 were the Scottish Chief, Dipper, Big Mitt, Columbus Extension, Noah, Red Bell, Alta Michigan, Alta Utah, Old Emma, Alta Wasatch, and Morning Star.

Siliceous ore, with average metallic content, produced in Big and Little Cottonwood districts and shipped to smelters, 1903, 1909, 1914-1917.

\begin{tabular}{|c|c|c|c|c|c|c|}
\hline Year. & $\begin{array}{l}\text { Ore } \\
\text { (short } \\
\text { tons). }\end{array}$ & $\begin{array}{l}\text { Gold } \\
\text { (value } \\
\text { per } \\
\text { ton). }\end{array}$ & $\begin{array}{c}\text { Silver } \\
\text { (ounces } \\
\text { per } \\
\text { ton). }\end{array}$ & $\begin{array}{l}\text { Cop- } \\
\text { per } \\
\text { (per } \\
\text { cent). }\end{array}$ & $\begin{array}{l}\text { Lead } \\
\text { (per } \\
\text { cent). }\end{array}$ & $\begin{array}{l}\text { Aver- } \\
\text { age } \\
\text { gross } \\
\text { value } \\
\text { per } \\
\text { ton. }\end{array}$ \\
\hline 1903. & 104 & $\$ 0.79$ & 22.09 & & 1. 63 & $\$ 14.10$ \\
\hline 1909 . & 10 & 36.80 & .30 & i. 17 & & 40.20 \\
\hline 1914. & 67 & 3. 99 & 4. 84 & 1. 54 & 1.95 & 8. 94 \\
\hline 1915. & None. & Bi & 伍 & & & \\
\hline 1916. & 38 & .84 & 2.47 & 1. 34 & 1. 93 & 11. 71 \\
\hline 1917. & 9,120 & .17 & 41. 26 & .12 & 3.13 & 40.19 \\
\hline
\end{tabular}

Copper ore and concentrates.-The copper ores and concentrates include those carrying over 2.5 per cent of copper. Shipments were made most frequently by the City Rocks, Columbus, and Cardiff properties, and less frequently by the Wasatch-Utah, Alta Hecla, South Columbus, South Hecla, West Columbus, Blue Point, Copper Apex, Mountain Lake, Iowa, Consolidated Jefferson, Columbus Extension, White Captain, Alta Emerald, Carbonate, Morning Star, Big Cottonwood, Great Western, South Hecla Extension, Evergreen, Woodlawn, Columbus-Rexall, and Alta Consolidated.

Copper ore and concentrates, with average metallic content, produced in the Big and Little Cottonwood districts and shipped to smelters, 1903-191\%.

Crude ore.

\begin{tabular}{|c|c|c|c|c|c|c|}
\hline Year. & $\begin{array}{l}\text { Quan- } \\
\text { tity } \\
\text { (short } \\
\text { tons). }\end{array}$ & $\begin{array}{c}\text { Gold } \\
\text { (value } \\
\text { per } \\
\text { ton). }\end{array}$ & $\begin{array}{c}\text { Silver } \\
\text { (ounces } \\
\text { per } \\
\text { ton). }\end{array}$ & $\begin{array}{l}\text { Cop- } \\
\text { per } \\
\text { (per } \\
\text { cent). }\end{array}$ & $\begin{array}{l}\text { Lead } \\
\text { (per } \\
\text { cent). }\end{array}$ & $\begin{array}{c}\text { Aver- } \\
\text { age } \\
\text { gross } \\
\text { value } \\
\text { per } \\
\text { ton. }\end{array}$ \\
\hline 1903. & 30 & $\$ 2.40$ & 32.10 & 11.00 & 1.25 & $\$ 50.17$ \\
\hline 1904. & 30 & .70 & 23.60 & 14.15 & & 50.60 \\
\hline 1905. & 2,743 & 4. 22 & 67.29 & 6.41 & 1. 54 & 66.70 \\
\hline 1906. & 3,608 & 2.04 & 44.06 & 6.93 & 2.58 & 61.70 \\
\hline 1907. & 207 & 1. 14 & 18.61 & 8.03 & 3.16 & 48.88 \\
\hline 1908. & 214 & 20.83 & 11.05 & 4. 42 & 1. 46 & 39.59 \\
\hline 1909. & 9,907 & .54 & 12.24 & 8.22 & .03 & 28.30 \\
\hline 1910 . & 2,463 & 1. 49 & 24.79 & 9.05 & .08 & 37.94 \\
\hline 1911. & 1,356 & .65 & 26.72 & 7.85 & & 34.43 \\
\hline 1912 . & 813 & .68 & 20.89 & 5.27 & & 38.96 \\
\hline 1913. & 328 & .53 & 35.68 & 6.70 & & 42.84 \\
\hline 1914. & 165 & .61 & 58.54 & 7.75 & & 53.60 \\
\hline 1915 & 134 & 1. 19 & 20.58 & 9.14 & & 43.95 \\
\hline 191 & 170 & 1. 12 & 2.54 & 6.01 & & 32.37 \\
\hline 1917 & 3,374 & .87 & 9.64 & 7.23 & & 48.29 \\
\hline \multicolumn{7}{|c|}{ Concentrates. } \\
\hline 190 & 152 & 0.36 & 13.54 & 9.67 & & 32.55 \\
\hline 1911 & 8 & 10.62 & 1.87 & 7.90 & & 31.37 \\
\hline
\end{tabular}


Lead ore and concentrates.-In general the crude lead ores and concentrates are those containing over 4.5 per cent of lead. Shipments were made most frequently during the last decade by the Maxfield, Columbus, Emma, Albion, Golconda, Cardiff, and Flagstaff, and less frequently by the North Star, Caledonia, Cabin, Silver King, Alta Consolidated, Michigan-Utah, Carbonate, South Hecla, Sells, Continental Alta, City Rocks, Columbus Wedge, Black Bess, Columbus Extension, Reed Peak, West Toledo, Hayes, Scottish Chief, Phoenix, Copper Apex, Carbonate, Silver Mountain, South Columbus, Frederick, Progress, East Columbus, Baby McKee, Prince of Wales, Wasatch Mines, Alta Hecla, Howell, AltaTiger, Democrat, Woodlawn, Peruvian, and Highland Chief.

Lead ore and concentrates, with average metallic content, produced in Big and Little Cottonwood districts and shipped to smelters, 1903-191\%.

Crude ore.

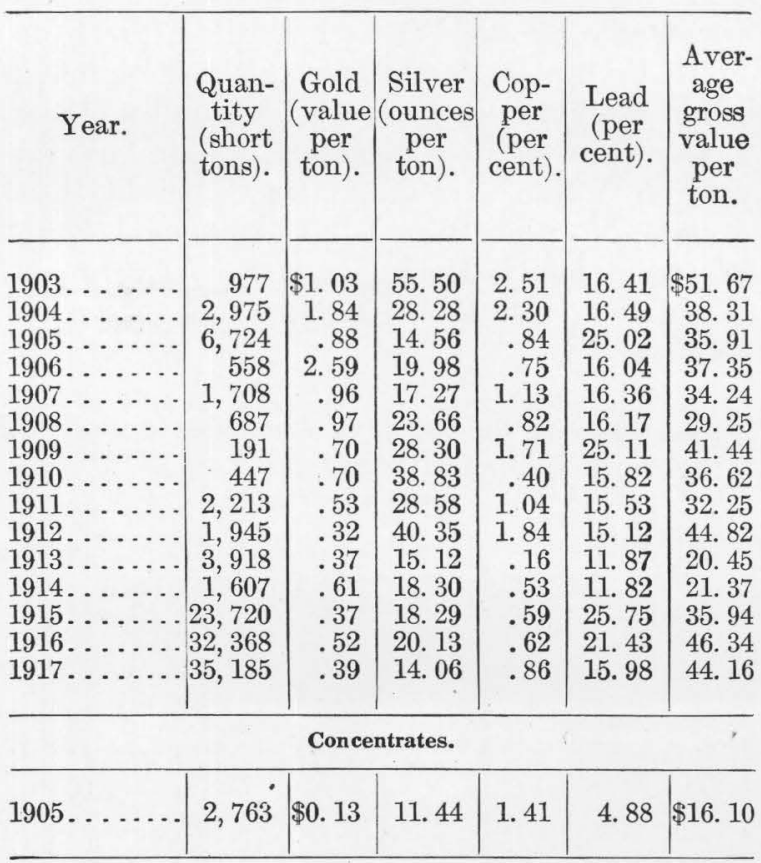

Copper-lead ore and concentrates.-Copperlead ore and concentrates are classified in the same way as copper and lead ores. Shipments were made most frequently during the last decade by the Columbus, Continental Alta, South Columbus, City Rocks, Alta Consolidated, Michigan-Utah, Prince of Wales, Copper Apex, Gypsy Blair, Caledonia, Columbus Extension, Wasatch Mines, Alta Utah, ColumbusRexall, and Henefer.
Copper-lead ore and concentrates, with average metallic content, produced in Big and Little Cottonwood districts and shipped to smelters, 1903-191\%.

\begin{tabular}{|c|c|c|c|c|c|c|}
\hline \multicolumn{7}{|c|}{ Crude ore. } \\
\hline Year. & $\begin{array}{l}\text { Quan- } \\
\text { tity } \\
\text { (short } \\
\text { tons). }\end{array}$ & $\begin{array}{c}\text { Gold } \\
\text { (value } \\
\text { per } \\
\text { ton). }\end{array}$ & $\begin{array}{c}\text { Silver } \\
\text { (ounces } \\
\text { per } \\
\text { ton). }\end{array}$ & $\begin{array}{l}\text { Cop- } \\
\text { per } \\
\text { (per } \\
\text { cent). }\end{array}$ & $\begin{array}{l}\text { Lead } \\
\text { (per } \\
\text { cent). }\end{array}$ & $\begin{array}{l}\text { Aver- } \\
\text { age } \\
\text { gross } \\
\text { value } \\
\text { per } \\
\text { ton. }\end{array}$ \\
\hline $\begin{array}{l}1903 \ldots \ldots \\
1904 \ldots \ldots \\
1905 \ldots \ldots \\
1906 \ldots \ldots \\
1907 \ldots \ldots \\
1908 \ldots \ldots \\
1909 \ldots \ldots \\
1910 \ldots \ldots \\
1911 \ldots \ldots \\
1912 \ldots \ldots \\
1913 \ldots \ldots \\
1914 \ldots \ldots \\
1915 \ldots \ldots \\
1916 \ldots \ldots \\
1917 \ldots \ldots\end{array}$ & $\begin{array}{r}866 \\
844 \\
112 \\
4,336 \\
7,413 \\
1,149 \\
857 \\
1,961 \\
1,120 \\
2,093 \\
890 \\
727 \\
204 \\
7,168 \\
486\end{array}$ & $\begin{array}{r}\$ 0.82 \\
.88 \\
.55 \\
1.06 \\
2.05 \\
.66 \\
.94 \\
.66 \\
.33 \\
.80 \\
.77 \\
.39 \\
.22 \\
.36 \\
.47\end{array}$ & $\begin{array}{l}16.60 \\
18.11 \\
16.37 \\
31.68 \\
38.49 \\
18.93 \\
25.75 \\
31.32 \\
44.56 \\
31.09 \\
25.65 \\
28.06 \\
38.04 \\
13.63 \\
27.74\end{array}$ & $\begin{array}{l}3.40 \\
4.23 \\
4.35 \\
4.98 \\
4.93 \\
6.56 \\
6.58 \\
5.09 \\
5.29 \\
4.05 \\
4.51 \\
4.40 \\
6.24 \\
2.65 \\
5.12\end{array}$ & $\begin{array}{r}15.40 \\
7.20 \\
10.73 \\
8.66 \\
6.48 \\
6.57 \\
8.65 \\
9.86 \\
13.86 \\
11.00 \\
8.93 \\
9.78 \\
9.50 \\
6.65 \\
10.75\end{array}$ & $\begin{array}{r}\$ 32.04 \\
28.40 \\
34.20 \\
51.68 \\
54.00 \\
33.54 \\
38.88 \\
39.18 \\
49.64 \\
43.19 \\
38.09 \\
35.34 \\
50.28 \\
31.56 \\
69.81\end{array}$ \\
\hline \multicolumn{7}{|c|}{ Concentrates. } \\
\hline $\begin{array}{l}1904 \ldots \ldots \\
1905 \ldots \ldots \\
1906 \ldots \ldots \\
1907 \ldots \ldots \\
1908 \ldots \ldots \\
1909 \ldots \ldots \\
1910 \ldots \ldots \\
1911 \ldots \ldots \\
1912 \ldots \ldots \\
1915 \ldots \ldots \\
\end{array}$ & $\begin{array}{r}275 \\
2,956 \\
3,249 \\
3,216 \\
1,090 \\
438 \\
2,152 \\
291 \\
426 \\
21\end{array}$ & $\begin{array}{r}\$ 0.37 \\
1.44 \\
.73 \\
.97 \\
.69 \\
.56 \\
.34 \\
.26 \\
.05 \\
.52\end{array}$ & $\begin{array}{l}22.28 \\
27.89 \\
11.57 \\
25.10 \\
20.95 \\
18.13 \\
28.88 \\
31.00 \\
35.23 \\
23.76\end{array}$ & $\begin{array}{l}3.45 \\
4.38 \\
3.90 \\
4.23 \\
4.04 \\
7.50 \\
3.60 \\
5.04 \\
7.06 \\
4.90\end{array}$ & $\begin{array}{r}15.93 \\
10.34 \\
12.41 \\
12.51 \\
10.27 \\
9.32 \\
13.27 \\
7.88 \\
10.19 \\
7.13\end{array}$ & $\begin{array}{r}\$ 35.82 \\
41.83 \\
37.80 \\
47.72 \\
31.08 \\
37.49 \\
36.75 \\
36.39 \\
54.19 \\
36.48\end{array}$ \\
\hline
\end{tabular}

Zinc ore.-There is zinc ore of shipping grade in the Carbonate mine in the Big Cottonwood district and in the Wasatch mines at Alta. Shipments were made from the former in 1916. Lessees on the Albion dump at Alta have shipped some zinc concentrates. The output shown below came largely from the Carbonate mine. The Columbus-Rexall and Wasatch mines each produced a carload in 1915.

Lead-zinc ore.-Lead-zinc ore was shipped in small quantity from the Albion in 1917 and from the Woodlawn in 1915 and 1916.

Zinc ore, with average metallic content produced in Big and Little Cottonwood districts and shipped to smelters, 1914$191 \%$.

\begin{tabular}{|c|c|c|c|c|c|}
\hline Year. & $\begin{array}{l}\text { Quan- } \\
\text { tity } \\
\text { (short } \\
\text { tons). }\end{array}$ & $\begin{array}{c}\text { Silver } \\
\text { (ounces } \\
\text { per } \\
\text { ton). }\end{array}$ & $\begin{array}{l}\text { Lead } \\
\text { (per } \\
\text { cent). }\end{array}$ & $\begin{array}{c}\text { Recov- } \\
\text { erable } \\
\text { zinc } \\
\text { (per } \\
\text { cent). }\end{array}$ & $\begin{array}{l}\text { Aver- } \\
\text { age } \\
\text { gross } \\
\text { value } \\
\text { per } \\
\text { ton. }\end{array}$ \\
\hline $1914 \ldots \ldots \ldots$ & 17 & & & 25.89 & $\$ 26.41$ \\
\hline $1915 \ldots$ & 437 & & & 25.70 & 63.74 \\
\hline $1916 \ldots$ & 94 & 6.91 & 2.08 & 23.59 & 70.65 \\
\hline $1917 \ldots \ldots$. & 9 & ....... & ........ & 26. 23 & 53.55 \\
\hline
\end{tabular}


DIVIDENDS.

Dividends aggregating several million dollars are reported to have been paid to stockholders by mining companies operating in the Little Cottonwood and Big Cottonwood districts. Some of the published statements follow, but many of them are discredited by old residents, who say that the early managements were very expensive. Raymond ${ }^{1}$ gives a statement furnished by N. M. Maxwell, superintendent of the Flagstaff mine, as follows:

The product of the Flagstaff furnaces during 1872 was 3,000 tons of metal, containing

$$
\begin{aligned}
& \text { Silver...... } \$ 390,000 ; \text { average per ton, } \$ 130 \\
& \text { Gold....... } 120,000 ; \text { average per ton, } 40 \\
& \text { Lead....... } \frac{240,000 ; \text { average per ton, } 80}{750,000}
\end{aligned}
$$

The capital of the company is $£ 300,000$, on which 30 per cent in dividends have been paid during the last three months and 24 per cent during those preceding, the total amount of dividends paid being $£ 76,000$.

In a later report ${ }^{2}$ Raymond says:

This splendid mine has produced during 1873, according to the directors' report, 15,000 tons of ore of an average value of $\$ 54$ per ton in the ore market. The same report says the expenses for mining ought to have been $\$ 5$, hauling $\$ 8$, establishment charges $\$ 4$, total $\$ 17$, leaving $\$ 37$ profit per ton. Yet there was not only no profit made, but in the fall the company was very heavily in debt and the value of shares depreciated rapidly in London.

According to Huntley, ${ }^{3}$ who reviews conditions in the district up to October, '1880, the Emma mine, worked by English managers, paid $\$ 300,000$ in dividends (one authority says $\$ 1,300,000)$ until September, 1874, when it was attached for an indebtedness of $\$ 300,000$. It was then idle until October, 1877. The Flagstaff mine, when owned by the English company, paid dividends that amounted to about $\$ 350,000$.

From all available data the dividends paid by the mining companies in the Little and Big Cottonwood districts to the end of 1917 are as follows: Emma, \$300,000; Flagstaff, $\$ 350,000$; Columbus Consolidated, $\$ 212,623$; Vallejo and Titus (Joab Lawrence), $\$ 180,000$; Maxfield, $\$ 118,000$; Cardiff, $\$ 625,000$; South Hecla, $\$ 39,450$. If $\$ 700,000$ is estimated to cover the dividends realized from other prop-

\footnotetext{
1 Raymond, R. W., Statistics of mines and mining in the States and Territories west of the Rocky Mountains for 1872, p. 247, 1873.

2 Idem for 1873 , p. 260, 1874

${ }^{8}$ Huntley, D. B., op. cit., p. 423.
}

erties, including the Prince of Wales, the total dividends exceed $\$ 2,500,000$.

\section{AMERICAN FORK DISTRICT.}

The American Fork district was organized July 21, 1870, but work was not commenced to any extent on the mining claims until the fall of that year. The Miller mine, discovered in September, 1870 , was the principal producer. In 1871-72 the Sultana smelter was built for the reduction of Miller ore and ran irregularly until the spring of 1875 . The Miller ore bodies gave out and the mine was closed in December, 1876. It was in the hands of lessees at different periods to the end of 1880 . D. B. Huntley ${ }^{4}$ estimates the production of ore from the Miller mine to the end of 1880 between 13,000 and 15,000 tons, assaying from 40 to 54 per cent of lead and 30 to 47 ounces of silver and $\$ 2$ to $\$ 10$ in gold to the ton. In 1872 the Wild Dutchman mine was discovered and worked by the company until September, 1876, when it was leased. Its total production to 1880 was estimated at 7,900 tons of ore, averaging 45 ounces of silver to the ton and 40 per cent of lead. The Pittsburgh, Sunday, Silver Bell, Orphan, Queen of the West, Live Yankee, Whirlwind, Noncompromise, and, in the Silver Lake section, the Milkmaid and Wasatch King, were producers prior to 1880 .

During the period 1881-1890 development work was done, but very little ore was shipped, probably not averaging over 100 tons a year. The aggregate shipments of the Bellerophon, Live Yankee, Milkmaid, Miller, Silver Bell, Sultana, Wild Dutchman, and E. H. Bailey \& Co. in 1886 amounted to $80 \frac{1}{2}$ tons. $^{5}$

In 1891 the Wild Dutchman, North Star, Kalamazoo, and Live Yankee properties yielded an aggregate of 100 tons of ore. ${ }^{8}$ Estimates were made for the remaining years of this decade, and it is presumed that the average ore yield was not greater than in 1891 .

For the period 1902 to 1917 , inclusive, the figures of production were collected by the Survey; those for the year 1901 are estimated from the best-records available.

The total ore mined between 1870 and 1880 is estimated at 39,950 tons; $1881-1890,990$ tons; $1891-1900,1,000$ tons; and 1901 to 1917 , 22,277 tons, making the total output of ore

4 Idem., p. 444.

- Director of the Mint Rept. upon production of precious metals, 1886, p. 224, 1887.

6Idem, 1891, p. 224, 1892 . 
Gold, silver, copper, lead, and zinc produced in American Fork district, 1870-1917.

\begin{tabular}{|c|c|c|c|c|c|c|c|c|c|c|c|c|}
\hline \multirow{2}{*}{ Period. } & \multirow{2}{*}{ Ore. } & \multicolumn{2}{|c|}{ Gold. } & \multicolumn{2}{|c|}{ Silver. } & \multicolumn{2}{|c|}{ Copper. } & \multicolumn{2}{|c|}{ Lead. } & \multicolumn{2}{|c|}{ Recoverable zinc. } & \multirow{2}{*}{ Total value. } \\
\hline & & Quantity. & Value. & Quantity. & Value. & Quantity. & Value. & Quantity. & Value. & Quantity. & Value. & \\
\hline $\begin{array}{l}1870-1880 \ldots \ldots \\
1881-1890 \ldots \ldots \\
1891-1900 \ldots \ldots\end{array}$ & $\begin{array}{l}\text { Tons. } \\
39,950 \\
990 \\
1,000\end{array}$ & $\begin{array}{r}\text { Fine ounces. } \\
3,116.10 \\
526.80 \\
200.00\end{array}$ & $\begin{array}{r}\$ 64,415 \\
10,890 \\
4,134\end{array}$ & $\begin{array}{r}\text { Fine ounces. } \\
1,377,600 \\
32,475 \\
22,000\end{array}$ & $\begin{array}{r}\$ 1,683,542 \\
34,071 \\
15,876\end{array}$ & Pounds. & & $\begin{array}{r}\text { Pounds. } \\
14,868,000 \\
693,000 \\
510,000\end{array}$ & $\begin{array}{r}\$ 882,744 \\
30,405 \\
17,655\end{array}$ & $\begin{array}{c}\text { Pounds. } \\
\text {.......... }\end{array}$ & & $\begin{array}{r}\$ 2,630,701 \\
75,366 \\
37,665\end{array}$ \\
\hline $\begin{array}{l}1901 \ldots \ldots \\
1902 \ldots \\
1903 \ldots \\
1904 \ldots \\
1905 \ldots \\
1906 \ldots \\
1907 \ldots \ldots \\
1908 \ldots \\
1909 \ldots \\
1910 \ldots \cdots\end{array}$ & $\begin{array}{r}128 \\
39 \\
64 \\
922 \\
2,479 \\
2,914 \\
4,706 \\
2,356 \\
1,025 \\
965\end{array}$ & $\begin{array}{r}35.40 \\
3.53 \\
21.28 \\
800.00 \\
1,301.00 \\
2,096.82 \\
3,483.80 \\
745.52 \\
125.13 \\
183.12\end{array}$ & $\begin{array}{r}732 \\
73 \\
440 \\
16,537 \\
26,894 \\
43,345 \\
72,017 \\
15,411 \\
2,587 \\
3,785\end{array}$ & $\begin{array}{r}3,508 \\
663 \\
1,872 \\
18,880 \\
27,740 \\
47,611 \\
93,551 \\
64,840 \\
39,821 \\
34,204\end{array}$ & $\begin{array}{r}2,111 \\
351 \\
1,011 \\
10,809 \\
16,755 \\
31,899 \\
61,744 \\
34,365 \\
20,707 \\
18,470\end{array}$ & $\begin{array}{r}88 \\
\ldots \ldots . \ldots \\
45,098 \\
26,073 \\
10,670 \\
12,227\end{array}$ & $\begin{array}{r}\$ 14 \\
\cdots, 020 \\
3,442 \\
1,387 \\
1,553\end{array}$ & $\begin{array}{r}76,800 \\
23,666 \\
11,214 \\
617,280 \\
1,374,660 \\
1,959,784 \\
3,612,785 \\
1,386,596 \\
628,148 \\
519,749\end{array}$ & $\begin{array}{r}3,302 \\
970 \\
471 \\
27,006 \\
64,609 \\
111,708 \\
191,478 \\
58,237 \\
27,011 \\
22,869\end{array}$ & & & $\begin{array}{r}6,145 \\
1,394 \\
1,922 \\
54,352 \\
108,272 \\
186,952 \\
334,259 \\
111,455 \\
51,692 \\
46,677\end{array}$ \\
\hline 1901-1910. & 15,598 & $8,795.60$ & 181,821 & 332,690 & 198,222 & 94,156 & 15,416 & $10,210,682$ & 507,661 & & & 903,120 \\
\hline 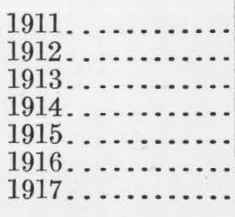 & $\begin{array}{r}494 \\
659 \\
411 \\
224 \\
413 \\
868 \\
3,610\end{array}$ & $\begin{array}{r}79.05 \\
121.44 \\
30.61 \\
68.93 \\
49.03 \\
43.25 \\
96,94\end{array}$ & $\begin{array}{r}1,634 \\
2,510 \\
632 \\
1,425 \\
1,013 \\
895 \\
2,004\end{array}$ & $\begin{array}{r}9,441 \\
11,172 \\
6,609 \\
4,189 \\
8,039 \\
48,360 \\
35,021\end{array}$ & $\begin{array}{r}5,004 \\
6,871 \\
3,991 \\
2,316 \\
4,076 \\
31,821 \\
28,857\end{array}$ & $\begin{array}{r}4,092 \\
3,466 \\
2,949 \\
3,591 \\
4,018 \\
31,189 \\
15,630\end{array}$ & $\begin{array}{r}511 \\
572 \\
457 \\
478 \\
703 \\
7,673 \\
4,267\end{array}$ & $\begin{array}{l}386,544 \\
380,630 \\
279,772 \\
106,219 \\
259,499 \\
250,460 \\
641,990\end{array}$ & $\begin{array}{r}17,394 \\
17,128 \\
12,310 \\
4,143 \\
12,196 \\
17,282 \\
55,211\end{array}$ & $\begin{array}{r}2,712 \\
14,830 \\
2,050 \\
27,319\end{array}$ & $\begin{array}{r}\$ 152 \\
757 \\
254 \\
3,661\end{array}$ & $\begin{array}{r}24,543 \\
27,081 \\
17,542 \\
9,119 \\
18,242 \\
61,332 \\
90,339\end{array}$ \\
\hline 1911-1917. & 6,679 & 489.30 & 10,113 & 122,831 & 82,936 & 64,935 & 14,661 & $2,305,114$ & 135,664 & 46,911 & 4,824 & 248,194 \\
\hline $1870-1917 .$. & 64,217 & $13,127.80$ & 271,373 & $1,887,596$ & $2,014,647$ & 159,091 & 30,077 & $28,586,796$ & $1,574,129$ & 46,911 & 4,824 & $3,895,050$ \\
\hline
\end{tabular}


64,217 tons. This figure, used in seeking the average of the ore produced, gave $\$ 4.40$ in gold and 29.43 ounces of silver to the ton and 23.05 per cent of lead, and, in value, including small quantities of copper and zinc, $\$ 60.73$ to the ton.

ORE DEPOSITS.

By B. S. Butler.

DEVELOPMENT.

As in most other mining districts, the earliest development work on the ore bodies consisted in following them down with shafts or inclines. The large flows of water frequently encountered at relatively shallow depth, the heavy cost of pumping, and the strong relief of the region, however, soon led to the driving of tunnels, which have been carried to increasing depths; and in recent years the tendency has been toward the consolidation of properties into large groups and their development by deep drainage tunnels.

The strong relief of the region makes it especially adapted to exploration by tunnel, and there can be no question that this is the most practical method of development. The great abundance of "fine tunnel sites" has apparently been a temptation that was hard to resist, as is shown by the scores of tunnels that have been started. That more than a "site" is necessary to success, however, is indicated by the many failures.

\section{CLASSIFICATION.}

All the deposits of proved commercial importance are in the sedimentary rocks, though some small veins in the intrusive rocks have been prospected and a little ore has been shipped from them. The deposits in the sedimentary rocks can be referred to three general classes, but the assignment of deposits to these classes is not always easy, as they show transitions. The main classes recognized are contact deposits and deposits associated with fissures in the sedimentary rocks. The deposits associated with fissures are all related but may readily be separated into fissure deposits and bed deposits. Deposits associated with thrust faults may be regarded as a particular type of bed deposit.

VEINS IN INTRUSIVE ROCKS.

The intrusive rocks of the Little Cottonwood and Alta-Clayton Peak stocks have been much jointed and in places sheared and crushed, and over considerable areas have been mineralized along the joints. The weathering of the sulphides stains the rocks with oxide of iron. Such staining is notable in the Little Cottonwood stock from White Pine Gulch eastward for a mile or more, and in many localities in the Alta-Clayton Peak stock. Pyrite is the most abundant mineral in the veins in the intrusive rocks, but chalcopyrite, galena, and molybdenite are present.

The Alta-Gladstone vein, about 2 miles southwest of Alta, in the Little Cottonwood stock, consists mainly of coarsely crystalline quartz, pyrite, molybdenite, and a little white carbonate, probably calcite. The coarsely crystalline quartz is strongly suggestive of pegmatite, though neither feldspar nor muscovite was recognized as a vein mineral. The wall rock is altered to an aggregate of quartz and muscovite, in which sulphides are disseminated. In the vein the sulphides show a tendency to segregate. In the portion accessible at the time of visit the vein material along one wall consisted largely of coarsely crystalline pyrite, and the remainder contained molybdenite with the gangue minerals and some pyrite.

Small veins containing molybdenite are reported from several places in the Little Cottonwood stock but have been only slightly prospected. In White Pine Gulch veins containing pyrite, galena, sphalerite, and chalcopyrite in a quartz gangue have been prospected. The largest vein seen was about a foot thick and could be traced for 300 to 400 feet.

On the South Fork of Little Cottonwood Creek the intrusive rock is cut by east to northeast joints and fissures, carrying quartz-sulphide veins. Pyrite is the most abundant sulphide, but some galena is present. Similar veins occur in the intrusive rocks around the head of Big Cottonwood Canyon, though copper appears to be more abundant in this section. Some of the rocks south of Silver Lake show a rather pronounced copper stain which has resulted from the oxidation of sulphide veins along the joints.

CONTACT DEPOSITS.

The bodies of limestone adjacent to the intrusive rocks that have been most prospected are those which contain abundant magnetite. These contain variable but usually small amounts of iron and copper sulphide and some gold and silver. The production from these 
deposits has so far been small, as most of the material is of too low grade to be profitably mined and shipped under ordinary conditions with the available transportation facilities.

Contact deposits containing a high percentage of iron have been developed in the Michigan-Utah, Alta Consolidated, and South Hecla mines, and some ore has been shipped from them. Such deposits have been prospected around the head of Little Cottonwood Canyon on both sides of the Alta-Clayton Peak stock and at the head of Big Cottonwood Canyon, especially around the head of Dog Lake canyon and across the divide in Snake Creek canyon. Some of the deposits in Dog Lake and Snake Creek canyons contain abundant ludwigite and forsterite. Near Dog Lake they contain abundant magnetite. Bornite appears to be the principal original sulphide, though chalcopyrite is present and in some places may be more plentiful than bornite.

The Steamboat mine, which is developed by a tunnel extending from Snake Creek toward the head of Big Cottonwood canyon, contains some copper ore in which forsterite is an important gangue mineral and chalcocite is the principal sulphide. In the hand specimen the relation of the forsterite and chalcocite strongly suggests that the sulphide is primary, but microscopic examination shows it to contain remnants of bornite which indicate that it has replaced that mineral. In some specimens collected from the dump and said to come from the same part of the mine as those containing the chalcocite, the bornite has been partly replaced by chalcopyrite. In this deposit, as in those near Dog Lake, bornite appears to have been the important primary sulphide.

As has been stated in the discussion of the contact alteration of the limestone the evidence seems to point to solutions given off by the igneous magma as the source of the metallic and some of the nonmetallic constituents of the deposits.

FISSURE DEPOSITS.

GENERAL CHARACTER.

In the fissure deposits the minerals occur mainly as a filling of fissures. In nearly all there is some replacement of the wall rock, and in some the replacement is so extensive at certain points that the deposit approaches the bed type. In others contact minerals are present in the replaced wall rocks, and the deposits approach the contact type. The fissure deposits arefound at different stratigraphic horizons, but where the adjacent rock is especially susceptible to replacement, either on account of its chemical composition or of its physical character, they give place to bed deposits. In several places the limestone adjacent to fissures has been strongly brecciated and the breccia has been partly replaced by ore minerals, forming a deposit intermediate between fissure and bed deposits. Most of the fissure deposits strike northeast and east-northeast and have steep northwesterly dips, but a few strike nearly due north. They occur in rocks of very different character and composition, including the Cambrian and pre-Cambrian quartzites and shales, in which the Toledo, American Consolidated Copper (Branborg), Cardiff (upper tunnel), $\mathrm{Pa}$ cific, and one of the Live Yankee veins occur; the Paleozoic limestone, which is the predominant wall rock in the Michigan-Utah and Prince of Wales mines; and even the Thaynes formation (lower Triassic), in which the veinlike body of the Barry-Coxe mine is located. The Dutchman, Bay State, and two of the Live Yankee veins are in early Paleozoic, probably Cambrian limestone.

VEINS IN BIG AND LITTLE COTTONWOOD DISTRICTS.

Toledo vein.-The Toledo vein was not being worked at the time of the writer's examination. The following description of the vein is given by Huntley: ${ }^{1}$

The ore occurs in a fissure vein, from 1 to 3 feet wide, cutting diagonally across a quartzite formation, dipping $80^{\circ} \mathrm{NNW}$, and is found in several chimneys 50 feet long on the strike and about 50 feet apart. They dip with the strike toward the east. The ore is a hard, porous brown siliceous oxide of iron of very high grade. It was said to have averaged from 80 to 109 ounces to the ton. Water was found 200 feet from the surface, but the character of the ore did not change. Where the vein passed from the quartzite into a belt of schist there was much pyrite. The mine is operated through a shaft 455 feet deep, vertical for part of its length. The horizontal development of the vein is 350 feet, and the total cuttings are estimated at 2,000 feet.

Grizzly and City Rocks fissures.-The deposits associated with the Grizzly and City Rocks fissures in the territory of the MichiganUtah Consolidated Mining Co. may be classed as fissure deposits, though in places they ap- 
proach the bed deposits in character. The sedimentary rocks consist mainly of Paleozoic limestones. Cambrian limestone has been thrust over Carboniferous rocks, as shown on the map (Pl. XXVII). The sedimentary rocks are cut by several northeast fissures that dip steeply northwest, of which the Grizzly and City Rocks fissures are the most prominent. Several dikes have the same general strike as the fissures; a dike of white granite porphyry follows the Grizzly fissure for a considerable distance and forms one wall of the ore bodies, and other dikes of monzonitic or dioritic composition are exposed at the surface and are cut in the workings.

Certain beds of the limestone, where crossed by the dikes and fissures, have been strongly brecciated, and the limestone has been brecciated along the thrust faults. Some mineralization occurs all along the fissures but is by far the most extensive in the brecciated limestone, where it forms the more valuable ore shoots. The larger shoots, therefore, roughly follow the intersections of certain beds of limestone and the fissures, or the intersections of the thrust-fault planes and the fissures. The fissures have been followed through the ridge between Little Cottonwood Canyon and Honeycomb Fork; and the City Rocks fissure is cut by the Lake Solitude tunnel near the head of Solitude Fork, about 300 feet below the Cleve tunnel, and has been developed by a winze sunk 200 feet below the Lake Solitude tunnel level. A raise connects the Lake Solitude and Cleve tunnels.

The ore is largely oxidized to the Lake Solitude level and is said to be oxidized to the bottom ' of the winze. There are, however, remnants of sulphide even near the surface. The metals present in commercial quantity are lead, silver, and copper, with a iittle gold. Limonite is abundant, manganese oxide locally plentiful, and wulfenite present in notable amounts. A little manganese ore has been shipped, principally from the Stewart vein. Huntley ${ }^{1}$ describes the upper portion of what is probably now known as the Grizzly fissure as follows:

The Utah is a fissure vein, from 1 foot to 20 feet wide, dipping $70^{\circ}$ or more $\mathrm{NW}$. through strata of blue and white siliceous limestone or dolomite, which dip about $30^{\circ} \mathrm{NE}$. It had outcrops in places and is known to extend 4,000

1 Huntley, D. B., op. cit., p. 425. feet in length and 700 feet in depth. The gangue of the vein is oxide of iron and a sand, apparently the result of the decomposition of the siliceous country rock. The ore is from 1 foot to 10 feet (averaging from 2 to 3 feet) wide, immediately in contact with the walls but not confined to either. Three chimneys have been found 200 feet long and about 300 feet apart. One came to the surface, and the others to within 100 feet of it. They dip with the strike about $65^{\circ} \mathrm{NE}$. The positions of these chimneys appear to be determined by the strata of white limestone. The ore makes where the vein crosses the white limestone but pinches where the harder blue limestone is encoun. tered. It is a soft red, sometimes rather sandy oxide of iron containing carbonate of lead and galena and in places stains of malachite. The first class assays 30 per cent lead, 30 ounces and upward of silver, and a trace of gold. There is also much low-grade jigging ore in the mine. On the south side a dike of porphyry appears, running nearly parallel with the vein. Near the porphyry the ore has not been so rich.

Honeycomb Fork.-Huntley ${ }^{2}$ describes the mines on Honeycomb Fork as follows:

The Butte mine, at the head of Honeycomb Fork, $2 \frac{1}{2}$ miles northeast of Alta, was discovered in 1869 and has been worked irregularly since. It is said to be a fissure vein in limestone, from 6 inches to 4 feet wide, dipping $55^{\circ} \mathrm{N}$, and is supposed to be an extension of the Utah and City Rocks of Little Cottonwood district. It outcropped for several hundred feet on the hillside in the form of a soft ocher-stained limestone. Ore occurs on the footwall in 8 or 10 lenticular bodies, from 1 inch to 3 feet wide, at considerable distance below the surface. It is a high-grade ocher and carbonate. Sometimes much black oxide of manganese is found. The mine is dry (excepting surface water) and is worked through a 200 -foot tunnel. * * * The total product to June 1,1880 , was estimated at $\$ 27,000$. The Oregon is an extension of the Butte. The property also includes four patented prospects on which very little work has been done-the Columbus, the Taylor, the Abbey, and the Black Bess. It is a fissure vein, from 1 to 15 feet (average, 3 feet) wide, dipping $60^{\circ} \mathrm{NNE}$. in limestone. Only one body of ore has been found. This came to the surface and was 120 feet long, from 3 inches to 3 feet wide, and extended to a depth of 300 feet. It assayed about 50 ounces silver and 30 per cent lead. * * * Water was found at 100 feet, but no change occurred in the oxidized character of the ore. *** The total product to 1880 was estimated at $\$ 10,000$.

Savage and Montezuma claims.-Raymond ${ }^{3}$ describes the mineralization in the Savage and Montezuma claims as follows:

Savage: The ore shows near the entrance of the incline as a rusty, gossan-like mass or vein, cutting the beds of limestone vertically. A few feet below the surface, within the incline, the thickness of the vein overhead is about 3 feet. It pinches up at a point lower down and toward the bottom of the incline opens out again to a vein from 2 to 3 feet wide of rich ore, yellowish and rusty in color

2 Idem, p. 428.

${ }^{3}$ Raymond, R. W., Statisties of mines and mining in the States and Territories west of the Rocky Mountains for 1871, p. 324, 1872. 
and in places streaked with green stains of copper. Quartz vein stone is found at the bottom of the mine, and it is hoped that this will prove to be a continuous, regular vein formation. The ore is soft and earthy, much like that from the Emma and other claims. It is rich in silver and lead. The mineral wulfenite is found disseminated in small, thin crystals throughout the vein.

The Montezuma is about 90 feet west of the dump of the Savage. The vein is vertical, or nearly so, like the Savage, and extends apparently from $3^{\circ}$ to $5^{\circ}$ west of north (magnetic). The croppings are rusty and rather hard, but below the ore is softer and richer in silver and lead. The country rock is a hard black limestone. *** The vein may be said to average, where opened, $2 \frac{1}{2}$ feet in thickness.

Cardiff vein.-The vein of the Cardiff mine, exposed in the upper tunnel, follows a fissure that strikes N. $35^{\circ} \mathrm{E}$. and dips $65^{\circ} \mathrm{NW}$. The wall rock is the "overthrust quartzite" above the Alta overthrust. The ore consisted of pyrite and tetrahedrite and a minor amount of galena in a quartz gangue. No zine blende was noted, but a qualitative test proved the presence of a little zinc in the tetrahedrite. No zinc blende was detected by microscopic study. Tetrahedrite containing a notable amount of zine has been reported from the Park City district. The ore minerals formed apparently pure bands or lenses 1 to 6 feet thick, separated by bands of white quartz and unreplaced quartzite. The ore mined was said to contain about 12 per cent of copper, a good proportion of silver, and $\$ 1$ to $\$ 2$ in gold to the ton. The galena was said to increase above the upper tunnel and, locally at least, to mark the upward termination of pay ore. The ore was practically free from oxidation at and below the level of the upper tunnel. At higher levels, in a vein on which the old Cardiff shaft was sunk, lead carbonate ore was found down to a depth of 150 feet below the shaft collar. The large ore body which furnishes the present output belongs to the thrust-fault type of deposits. (See p.281.)

Veins on American Consolidated Copper Co.'s property. - The American Consolidated Copper Co.'s (Branborg) property contains three fissures - the Garfield, Silver King, and Gustavus Adolphus-all striking N. $35^{\circ}-40^{\circ} \mathrm{E}$. and dipping about $60^{\circ} \mathrm{NW}$. Another fissure, probably a branch of the Garfield, strikes N. $10^{\circ} \mathrm{E}$. and dips about $60^{\circ} \mathrm{W}$. The Garfield fissure and its branch carry ore containing pyrite, blende, and galena in a quartz gangue. They have been cut by a long adit, and the Garfield fissure has been followed by drifts to the southwest and northeast. Northeastward it pinches at the quartzite and shale contact. No prospecting for a continuation of the fissure in the limestone above the shale has been undertaken. Shallow pits in the limestone, however, have struck small quantities of lead carbonate with a high silver content, which may be connected with northeasterly fissures.

The Silver King fissure was cut by the tunnel 1,200 feet from the portal. At the time of visit, in the summer of 1916, a short drift exposed vein quartz and a little sulphide.

The Gustavus Adolphus fissure has the same type of mineralization, but its ore contains less zine and more silver than that from the Garfield fissure. Small amounts of oxidized ore mined from shallow workings are said to have yielded 1,000 ounces of silver to the ton, but the oxidized ores are very superficial and almost negligible.

Howell mine.-The Howell mine is developed on a fissure in the Cambrian quartzite that strikes about N. $30^{\circ}$ E. and dips steeply northwest. This fissure has been followed along the strike for several hundred feet. The ore has apparently formed as shoots in the fissure. At several points ore has been stoped from shoots. The original minerals consisted of quartz and sulphides of iron, lead, zinc, and copper.

Barry Coxe mine.-The ore deposits in the Barry-Coxe mine, on the southwest slope of Scott Hill, are transitional between the contact and fissure types of deposits, also between the fissure and bed replacement types. The ore, so far as developed by shallow workings in 1912 , occurs as pockets in partly metamorphosed limestone along fissures trending N. $13^{\circ}$ W. north and east. The pay ore is found between layers of lean silicate rock and replaces the walls for a few feet from the fissure. The most pronounced replacement exposed at the time of examination extended 10 feet from the N. $13^{\circ} \mathrm{W}$. fissure. The ore seen was a mixture of pyrite, blende, and galena in a gangue consisting essentially of garnet, diopside, sericite, and quartz. One of the easterly fissures, along a fault plane against which the ore along a northerly fissure stopped, contained green copper stains. The garnet and diopside were formed before the ore and other gangue min- 
erals, but there is no evidence to determine whether the country rock was first partly replaced by contact-metamorphic minerals and at a distinctly later period replaced further by the ore, or whether all the minerals were deposited in definite sequence during one period. Absence of fracturing in the metamorphic minerals favors the latter view.

VEINS IN AMERICAN FORK DISTRICT.

Silver Dipper vein.-The Silver Dipper vein follows a fissure that strikes N. $65^{\circ} \mathrm{E}$. and dips $60^{\circ}-65^{\circ} \mathrm{NW}$. in Cambrian quartzite. The vein, which was worked in the seventies, is said to have consisted of pyrite and quartz with some good shoots of galena.

Waterfall vein.-The Waterfall vein lies along a fault trending nearly due north between shale and quartzite. It is marked by pinches and swells, and the swells are about 4 feet thick. The ore minerals are galena, pyrite, tetrahedrite, and a little zinc blende in a gangue of quartz. The vein has been opened by two tunnels that in 1912 extended northward 50 feet and southward 300 feet from the creek bed.

Live Yankee claim.-Three veins have been worked or prospected on the Live Yankee property, near the head of Mary Ellen Gulch, but only one was accessible in 1912. This vein lies between a footwall of quartzite and a hanging wall of pyritized porphyry and trends N. $85^{\circ} \mathrm{W}$. Its ore minerals are pyrite, chalcopyrite, zinc blende, and galena, and its gangue minerals quartz and barite. One of the other veins lies along an east-west fault zone and is said to have contained the "big stope," mined in early days, which is said to have lain between walls of shale at the base of the limestone. Its ore minerals, to judge from specimens on the dump, were chiefly pyrite and chalcopyrite in a gangue of quartz and barite. The gold content is said to have been unusually high, ranging from $\$ 20$ to $\$ 80$ or more to the ton. The third vein strikes N. $40^{\circ}$ E. in Cambrian limestone but is said to pinch on reaching and following a porphyry dike. Specimens of its ore consist of pyrite, a little chalcopyrite, zinc blende, galena, and jamesonite in a gangue of quartz, barite, and a little ferruginous dolomite. A fourth vein,

1 The descriptions of mines in the American Fork district are by G. F Loughlin. too small at its outcrop to be of much promise, strikes N. $45^{\circ} \mathrm{E}$. in Cambrian limestone and consists mostly of galena in a gangue of dolomite spar. This group of veins differs from those already described in the prominence of chalcopyrite and in a corresponding high gold content. Their mineral and chemical composition, however, show them to be closely related to the other ore bodies of the region, and there is every reason to believe that they were formed at the same time.

Another source of ore on the Live Yankee property has been the glacial drift in the gulch, from which boulders of galena ore have been washed. It is said that in some of the boulders quartzite was attached to the ore, and this may indicate a westward continuation of the N. $85^{\circ} \mathrm{W}$. vein, or possibly another vein concealed a short distance up the gulch.

Pacific mine.-A strong vein is being worked in the Pacific (Blue Rock) mine, just south of the southward bend in the American Fork canyon. The vein strikes N. $45^{\circ}$ E. in Cambrian quartzite and at one place has a horizontal offset of 18 feet along a N. $70^{\circ} \mathrm{W}$. fault. It is 4 to 8 feet in width and has been followed horizontally for about 450 feet, being worked through the lower tunnel of the mine. Below the tunnel its dip is $60^{\circ} \mathrm{NW}$. Above the tunnel the dip flattens and the vein narrows upward until it coincides with a bedding plane at or near the shale contact. In the southern part of the mine the ore is continuous from the shale contact, 130 feet up the dip from the tunnel, to and beyond the lowest workings, 70 feet down the dip from the tunnel. The pay ore pinches northward as well as upward. The ore consists of gảlena and pyrite in a gangue of quartz and barite. The galena diminishes upward, and near the shale contact granular pyrite is the only ore mineral. The barite tends to be localized in lenticular shoots. The ore is in part of milling and in part of shipping grade.

The old workings of the Pacific mine have found showings of ore but were inaccessible in 1912. Oxidized ore rich in silver from a small inclined shaft north of the main workings contains green stains, locally called "bromides," but proved by chemical tests to be the copper carbonate, malachite.

Utah Centennial claims.-The main vein of the Utah Centennial property, southeast of 
Pittsburg Lake, trends about east and shows some lead ore at the outcrop. In 1912 two tunnels were being driven to reach this vein. The eastern tunnel starts in quartzite at the upper road in a north-northeast direction and follows a narrow vein of white quartz with some pyrite and a few small pockets of galena. The tunnel had penetrated the shale, in which the quartz of the vein has largely disappeared and dolomite and barite have become conspicuous.

Wild Dutchman mine.-Huntley ${ }^{1}$ describes the Wild Dutchman mine as follows:

The ore-bearing formation is a bedded vein, from 3 to 40 feet (average, 20 feet) wide, in dolomite, dipping $40^{\circ}$ SE. * * * The gangue in general consists of from 2 to 3 feet of shale upon the footwall and a soft clay containing fragments of silica, and strongly stained by oxide of iron, locally known as "lime porphyry." The ore occurs in scattered egg-shaped bunches of from a few pounds to 600 tons. Five large [ore] bodies have been found, one 20 feet from the surface, one 300 feet from the surface, and the others between these. The ore is the usual ochery carbonate of lead found in a lime formation and contains small amounts of heavy spar. At the water line, in the 450-foot tunnel level, a large body of base ore was found. This consisted of iron and copper pyrites, galena, and a very large percentage of zinc blende. A porphyry dike is said to cut through the footwall into the vein near the large bodies of ore. * * * The total product of the mine is estimated at 7,900 tons, averaging 45 ounces silver and 40 per cent lead.

Dutchman mine.-The principal vein of the Dutchman mine, seen in 1912, is in Cambrian limestone. It strikes N. $40^{\circ}$ E. and dips vertically or steeply southeastward. Its width ranges from a mere streak up to 8 feet. Its greatest width is attained in a dark-blue limestone bed which overlies argillaceous beds in the lower part of the Cambrian limestone. The vein, for most of its course, lies along the contact of a narrow porphyry dike. It ends abruptly on the northeast against a dense, blocky argillaceous limestone, which probably marks a northwesterly fault but which could not be studied closely.

A minor vein parallels the main vein. Both have been followed up to the cemented talus that caps the bedrock, and several masses of ore are said to have been found in the talus. The ore mined from both veins is mostly a sandy mixed lead and zinc carbonate. That mined by lessees in recent years is said to average about 30 per cent of lead, 9 to 17 per

1 Huntley, D. B., op. cit., pp. 444-445. cent of zinc, and 50 ounces of silver to the ton. Remnants of primary ore are composed of galena and blende in a barite and carbonate gangue. Quartz is inconspicuous.

Bay State mine.-The best showings of ore recently reported in the Bay State mine, about midway between the Dutchman and Pacific mines, but on the east side of the canyon, had not been found in 1912. In that year a few small prospect tunnels showed small amounts of galena and barite impregnating a rather light gray limestone, and one showed an interesting occurrence of stibnite. The stibnite, accompanied by barite and a little dolomite, forms small seams or stringers cutting both the limestone and a porphyry dike. Both the limestone and the dike are altered and have a sericitized appearance. The stibnite is partly altered to kermesite, the oxysulphide of antimony $\left(2 \mathrm{Sb}_{2} \mathrm{~S}_{3} \cdot \mathrm{Sb}_{2} \mathrm{O}_{3}\right)$, which.occurs in tufts of minute red prismatic crystals and probably accounts for all the red staining along the stibnite seams.

BED DEPOSITS.

LITTLE COTTONWOOD DISTRICT.

Occurrence and character of deposits.-The bed deposits have been the most productive of all the types in the Little Cottonwood district, and most of the "bonanzas" that made the district famous in the early days were of this type. Typically these deposits have been formed by the replacement of certain sedimentary beds adjacent to crosscutting fissures. The deposits are thus more or less tabular in form, lie as a whole parallel to the bedding of the sedimentary rocks, and pitch with the intersection of the replaced bedding and the fissures-commonly to the northeast. Where the replacement has extended only a short distance from the fissures the deposits have more nearly the form of "chimneys" than of tabular deposits. The somewhat similar deposits associated with thrust faults are discussed in a later section.

Most of the deposits are oxidized as far down as they have been mined, and it is not possible to determine the original replaced minerals except by scattered remnants of unaltered material. Some deposits that consist largely of sulphide have been developed, notably in the old Emma mine and also in the allied deposits associated with thrust faults, such as the Columbus-Rexall. The original minerals 
recognized in the Columbus deposit are pyrite, galena, sphalerite, and tetrahedrite in a gangue of quartz and unreplaced carbonate. Sericitic muscovite also is a common gangue mineral in the bed as well as in the fissure deposits and is prominent both in limestone and shaly beds and in "porphyry."

A specimen of tetrahedrite from the Columbus Consolidated mine was examined by R. C. Wells in the chemical laboratory of the Geological Survey and found to contain 6.24 per cent of lead together with arsenic, as well as antimony. In the material examined no lead mineral other than the tetrahedrite was recognized, and it is believed that the lead is contained in that mineral. Whether or not the tetrahedrite of the district carries lead generally or only at certain localities has not been determined. Specimens of supposed tetrahedrite from the neighboring Park City district have been shown by F. R. Van Horn ${ }^{1}$ to contain notable amounts of lead. It has already been noted that tetrahedrite from the Cardiff mine and from the Park City district contains zinc in notable amounts. Probably other minerals will be recognized in the primary ores with more detailed study.

The sulphide ores of the old Emma and Columbus-Rexall mines have not at this writing been examined in detail by the writer. The former consist of pyrite, galena, tetrahedrite or a closely allied mineral, argentite and possibly other silver minerals, and tungstenite in a gangue consisting mainly of quartz and unreplaced and recrystallized limestone. The tungstenite is a new mineral - the first natural sulphide of tungsten ${ }^{2}$ whose occurrence has been reported. Pyrite was the earliest mineral to crystallize, and the tungstenite was in part at least later than the galena. The sulphide ore of the Columbus-Rexall consists mainly of pyrite and tetrahedrite with some enargite, galena, and chalcopyrite.

The deposit contains but little nonmetallic gangue. The pyrite was the earliest mineral to crystallize; the other minerals surround the pyrite crystals, giving much of the ore a distinctly porphyritic appearance.

Most of the deposits have been oxidized as far down as they have been developed. In many

\footnotetext{
1 Geol. Soc. America Bull., vol. 25, p. 47, 1914.

2 Wells, R. C., and Butler, B. S., Washington Acad. Sci. Jour., vol. 7, pp. 595-599, 1917
}

places oxidation has extended far below the level of ground water, though it has not been shown to penetrate below the surface drainage, which, because of the strong topographic relief, descends to great depth in the veins that crop out at high elevations. The typical oxidized ore consists of hydrous iron oxides, carbonate and sulphate of lead (cerusite and anglesite), carbonates of copper, and usually manganese oxide.

The ore of several of the mines, notably the Cardiff, Cabin, Alta Consolidated, and South Hecla, contains a large proportion of a basic sulphate of ferric iron, lead, and, in some specimens, copper. This is a yellow earthy mineral that can usually be crushed in the fingers, though some of it forms rather hard lumps, many of which have a core of galena. The mineral has not been quantitatively analyzed but is probably plumbojarosite, with some beaverite and possibly other allied minerals. A massive piece of this ore was sectioned and found to have a core of galena, surrounded and penetrated along cleavage planes by a narrow zone of anglesite, which gives place outward to the yellow mineral with specks of green, possibly malachite. It is evident that in this specimen the mineral has not resulted from the oxidation of a mixture of iron, lead, and copper sulphides, but that the galena has first altered to sulphate and that this has subsequently combined with iron and possibly with copper brought to it in solution. To what extent minerals of this character were present in the large oxidized bodies formerly mined in this district is not known, but published descriptions suggest that they were fairly abundant.

Wulfenite, the molybdate of lead, is rather abundant in the City Rocks vein and in some of the ores from the Alta Consolidated mine, and is present in many of the mines. It is also reported that the ores contain vanadium, but no vanadium-bearing mineral was recognized. Carbonate and silicate of zinc have been recognized in the oxidized ores throughout the district. Considerable zine from such ores has been produced from the Carbonate mine; and zinc ores have been shipped from the head of Honeycomb Fork and from the Albion mine, in Little Cottonwood Canyon. Sphalerite is rather plentiful in some of the sulphide ores; and it is to be expected that oxidized zinc ores 
will be found elsewhere, though perhaps not in commercial quantities.

Horizon of the bed deposits. - Several horizons in the sedimentary series have apparently been especially favorable to the deposition of ores, though it is a rather striking fact that a given bed does not seem to be uniformly favorable throughout the district. The lowest beds in which important bed deposits have formed is the limestone member of the Cambrian shale. This limestone has been especially productive in the Wasatch mines (Columbus Consolidated) and in the area south of Little Cottonwood Canyon, including the South Hecla, Peruvian, and Albion mines.

The next ore-bearing strata of importance are the dark, "wormy," and mottled limestones immediately above and below the prominent white stratum (division 4, p. 236) in the Cambrian limestone series. So far as observed, no ore bodies have been found in the white limestone, which, however, is useful as a marker.

Ore has been found in these dark beds at the old Reade \& Benson mine and at other places on both sides of Reade and Benson Ridge. The deposits of the Carbonate mine are in these strata, as are apparently the lower deposits in Michigan-Utah and Alta Consolidated properties. Some of the deposits in the American Fork district are apparently in these beds.

It is frequently said that the ore bodies of the Flagstaff, Old Emma, and certain other mines are in the same strata as the Reade \& Benson deposits, but this statement is an error, due to the confounding of the Cambrian white bed with a somewhat similar but higher bed.

The white Cambrian limestone, which may readily be traced from the Reade \& Benson mine, crops out conspicuously on the slope west of the Flagstaff tunnel with an eastward dip, which, if projected, would bring it close to the portal and very little below the strata that carry the Flagstaff ores. Just west of the tunnel, however, there is a fault with downthrow to the east in consequence of which this limestone crops out below the foot of the great dump. Outcrops of another whitish bed are found along the slope above, more nearly in line with the white band west of the mine. It is in or near this higher bed that the ores of the Flagstaff-Emma zone occur. The bed is the pale-gray fine-grained limestone that lies about
150 feet above the post-Cambrian unconformity (division 4, p. 233). "Chemically it seems to be nearly pure calcite; physically it is brittle, and near fissures it has broken or cracked into small pieces. It is probable that the combination of favorable chemical composition and physical properties has caused this limestone to be the most productive of the district. In addition to the deposits of the Flagstaff-Emma zone others occur at nearly the same horizon in the Michigan-Utah mine and in the Prince of Wales mine.

Ore deposits occur in higher limestones in the district, but no well-defined productive bed above that of the Flagstaff has been recognized. The stratigraphic. series in the underthrust block has not yet been definitely correlated with that of the overthrust. There is apparently a rather definite horizon in this lower block at which ore deposits of the South Hecla and Sells mines have formed. This may prove to be essentially the same as the Flagstaff-Old Emma zone. Other deposits in the lower block cut across the strata and are apparently controlled more by physical conditions than by the composition of the replaced limestone.

Physical condition of replaced rock.-The physical condition of the replaced rock has probably been an important if not a controlling factor in the formation of the deposits that occur in the limestones immediately beneath the thrust-fault planes. This is indicated by the facts that deposits have formed in beds that in their normal condition have apparently not been particularly favorable to ore deposition, and that only where limestone is overridden by a hard rock, as limestone, quartzite, or siliceous shale, and strongly brecciated, have such contacts been shown to be especially favorable. Where weak clay shale has been thrust upon limestone, ore has not yet been found in large bodies. Ore bodies connected with faults that have thrust quartzite and siliceous shale over limestone have been developed in the Cardiff, Columbus-Rexall, Wasatch (Columbus Consolidated), South Hecla, and Cottonwood-Atlantis properties. Extensive areas of such contacts have not yet been thoroughly prospected. Where limestones have been brought together by thrust faulting a brecciation has resulted that has apparently been favorable to ore deposition. Such con- 
ditions are present in the Michigan-Utah and possibly in the Old Emma mine.

The deposits of the Flagstaff-Emma zone are all very similar in occurrence. The zone is crossed by a series of northeast fissures, with some fissures striking north and west of north, at whose intersection with the orebearing limestone the ore deposits occur in forms varying from chimney-like to roughly tabular, according to the distance from the fissure to which mineralization has extended. Most of the openings in the ore bodies along this belt were inaccessible at the time of visit; the following statements are based on what could then be seen and on old mine maps and reports.

The limestone of the replaced beds near the fissures has been much shattered and in the Old Emma deposit forms a very distinct breccia that probably represents movement parallel with the beds as well as along the fissures. This breaking of the limestone into fragments gave a large surface for solutions to act upon and was doubtless a considerable factor in the production of the ore deposits in this bed of limestone. In some localities the limestone was largely replaced by ore and gangue minerals, in others much of the limestone was not replaced, the ore minerals forming around the fragments.

The deposits mined have been largely oxidized, but the original metallic minerals probably consisted largely of galena, pyrite, tetrahedrite, sphalerite, and some silver mineral or minerals, as argentite or pyrargyrite.

The Old Emma ore body was cut off about 475 feet below the surface by the Montezuma fault, a north-south fault with downthrow to the east. The continuation of the ore east of the fault and 250 feet lower was opened in 1917 , and in the summer of that year it had been followed down for about 300 feet. The ore below the fault shows little oxidation. The metallic minerals are pyrite, galena, tetrahedrite, argentite and possibly other silver minerals, tungstenite, and a little sphalerite. The chief gangue minerals are quartz and unreplaced and recrystallized limestone. For at least a part of the shoot there is a central core which consists mainly of quartz that has completely replaced the limestone and contains but relatively small amounts of the metallic minerals. The limestone breccia surrounding this core is less completely replaced and sulphides are more abundant. The ore shoots to the northwest of the Emma shoot on the Emma-Flagstaff belt have been cut by north-south faults and dislocated to distances ranging from a few feet to at least 40 feet and probably considerably more. In nearly all the shoots that have been mined the most of the ore was within a few hundred feet of the surface; at greater depth. on the dip of the ore bed the shoots decreased both in size and in content of lead and silver.

The character of the ore bodies mined in the early days can be gathered from the following quotation from Huntley: ${ }^{1}$

The ore-bearing formation [Old Emma] is a belt of siliceous limestone, between a limestone hanging and a dolomite foot wall, the belt being about 200 feet wide, dipping $45^{\circ} \mathrm{NE}$., parallel to the stratification of the country rock. The ore did not come to the surface but was found by following a small seam of ocher 50 feet in a tunnel. Two large bodies were found somewhat nearer to the hanging than to the foot wall, following the general dip and strike of the belt. One began near the surface and was 100 feet deep, 300 feet long, and from 1 to 30 feet wide; and the other, a few feet below the first, was 200 feet long, 150 feet deep, and from 1 to 20 feet wide. The ore was a soft brownish-red ocher, containing cerusite, anglesite, galena, and some manganese oxide.

Emma mine.-In 1872 Raymond ${ }^{2}$ described' the Emma mine as follows:

The Emma mine is one of the most remarkable deposits of argentiferous ore ever opened. Without any wellmarked outcroppings, there was nothing upon the surface to indicate the presence of such a mass of ore except a slight discoloration of the limestone and a few ferruginous streaks visible in the face of a cut made for starting the shaft. Some of the earliest locators in the canyon assert, however, that in the little ravines below this shaft large masses of galena, some weighing over 100 pounds, were found upon the surface and in the soil. After the discovery of the deposit by means of the shaft a tunnel was run in so as to intersect it in depth. This tunnel extends in a northwesterly direction and is 365 feet long. It intersects the ore mass where it was about 60 feet long and 40 feet wide, measured horizontally. From this level, called the first floor, ore has been mined above and below until an excavation or chamber has been formed varying from 20 to 50 feet in width and from 50 to 70 in length and 77 in height above the tunnel level and 50 in depth below.

In August last a portion of the ore below the tunnel level was still standing, but the mine had produced from 10,000 to 12,000 tons of ore, assaying from 100 to 216 ounces of silver per ton of 2,000 pounds and from 30 to 66 per cent of lead, averaging about 160 ounces of silver and from 45 to 50 per cent of lead. The total value of

\footnotetext{
1 Huntley, D. B., op. cit., p. 423.

2 Raymond, R. W., Statisties of mines and mining in the States and Territories west of the Rocky Mountains for 1871, p. 321, 1872
} 
this ore, at the cash price paid for a large part of it in Liverpool, $£ 36$, or $\$ 175$ in round numbers, was about $\$ 2,000,000$.

This ore was extracted at comparatively little cost. Most of it was stoped from below upward and was delivered by chutes into the cars upon the tramway laid in the tunnel. In general the ore was soft and easily excavated by picks and shovels, without the aid of gunpowder. It consisted chiefly of ferruginous and earthy-looking mixtures of carbonate and oxide of lead, oxide of iron, and of antimony, mixed with nodules of galena. It appears to have resulted from the decomposition of argentiferous galena and other sulphureted and antimonial minerals containing silver. The ore may be said to be without gangue and does not require hand sorting or separating by mechanical means from worthless vein stone. This ore was shoveled up and put into sacks for shipment without any other delay or expense. The larger part was shipped overland by railroad to New York, and thence by steamer to Liverpool.

The walls of the excavation are very irregular but consist of a hard, white, dolomitic limestone. The ore mass appears to conform to the stratification and to have a general northwesterly direction, dipping to the northeast. The extent of the ore mass in the direction of its length had not been fully ascertained at some of the levels when I visited the mine in July, though in most of the floors it had all been taken out, and the form of the excavation may be taken as marking in a general way the limits of the main body. A peculiar brecciated mass of dolomitic limestone accompanies the ore and may be regarded as vein matter, for nodules of galena are found isolated in its midst, as well as small patches of soft earthy ore disconnected with the main body. The limits of this ore-bearing breccia are not yet ascertained, and prospecting drifts to the northwest along its course may reach other bodies of rich ore.

Raymond ${ }^{1}$ quotes from a description of the ores by Silliman, as follows:

The ores of the mines thus far opened in the Wasatch Mountains are largely composed of species resulting from the oxidation of sulphides, especially galenite and antimonial galena, with some salts of zinc and copper, all containing silver and rarely a little gold. Iron and manganese ochers occur in considerable quantity in some of them, but the process of oxidation has prevailed very extensively, so that the ochraceous character of the ores is the striking feature of most of the mines in this range.

The great chamber of the Emma mine * * * was found to be filled almost exclusively with epigene species, the product of oxidation of sulphides, and capable of removal without the aid of gunpowder for the most part. The study of this mass reveals the interesting fact that it is very largely composed of metallic oxides, with but comparatively small proportions of carbonates and sulphates. Fortunately $\mathrm{I}$ am able to present an analysis of an average sample of 82 tons (183,080 pounds) of first-class ore from Emma mine, made by James P. Merry, of Swansea, April, 1871, which is as follows, viz:

\footnotetext{
${ }^{1}$ Raymond, R W., op. cit., p. 325 .
}

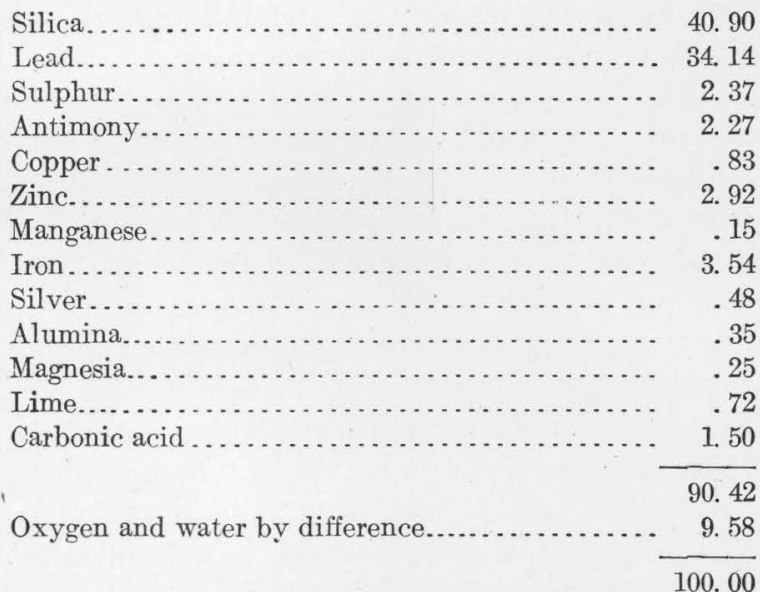

The quantity of silver obtained from this lot of ore was 156 troy ounces to the gross ton of 2,240 pounds.

This analysis sheds important light on the chemical history of this remarkable metallic deposit and will aid us in the study of the paragenesis of the derived species. It is pretty certain that all the heavy metals have existed originally as sulphides, and we may, therefore, state the analysis thus, allowing 8.52 sulphur to convert the heavy metals to this state:

Silica................................... 40.90 Metallic sulphides....................... 52.60 $\mathrm{Al}, .35 ; \dot{\mathrm{Mg}}, .25 ; \dot{\mathrm{Ca}}, 72 ; \dddot{\mathrm{Mn}}_{2} ; \dddot{\mathrm{M}} \mathrm{n}, .20 \ldots \ldots \ldots \ldots . \quad 1.52$ 95. 20 Water, carhonic acid, and loss............. $\begin{array}{r}95.20 \\ 4.95\end{array}$

This ealculation assumes that the sulphides are as follows, viz:

Galenite............................. 38.69

Stibnite . . . . . . . . . . . . . . . . . . . . . . . . 3.30

Bornite............................. 1.03

Sphalerite $(b ! c n c, e) \ldots \ldots \ldots \ldots \ldots \ldots \ldots \ldots \ldots$. 3. 62

Pyrite................................... 5.42

Argentite............................... .54

52. 60

This statement excludes the presence of any other gangue than silica, and considering that the ores exist in limestone, the almost total absence of lime in the composition of the average mass is certainly remarkable. The amount of silica found is noticeable, since quartz is not seen as such in this great ore chamber, nor, so far as I could find, in other parts of the mine. The silica can have existed in chemical combination only in the most inconsiderable quantity, since the bases with which it could have combined are present to the extent of less than $1 \frac{1}{2}$ per cent; nor do we find in the mine any noticeable quantity of kaolin or lithomarge, resulting from the decomposition of silicates, nor are there any feldspathic minerals. It is most probable that the silica existed in a state of minute subdivision diffused in the sulphides, as I have seen it in some of the unchanged silver ores of Lion Hill, in the Oquirrh Range.

The absence of chlorine and of phosphoric acid in the analysis corresponds well with absence of the species 
cerargyrite and pyromorphite, of which no trace could be found by the most careful search among the contents of the mine. The miners speak of the "chlorides," and the unscientific observers have repeated the statement that silver chloride is found in the Emma mine, but the ores indicated to me as such are chiefly antimonic ochers.

The general (perhaps total) absence of the phosphates of lead in the Wasatch and Oquirrh mountains, so far as explored, is a-striking peculiarity of the mineralogy of these ranges. On the other hand, the absence of chlorine in the mines of the two Cottonwoods and the American Fork is in striking contrast with the constant occurrence of cerargyrite (horn silver) in the Oquirrh and also in the southern extension of the Wasatch. I have sought in vain for a trace of this species in the districts of the Wasatch just named, and the occurrence of pyromorphite is extremely doubtful.

Molybdic acid, however, exists pretty uniformly disseminated in the mines of the Wasatch in the form of wulfenite. Although it occurs in minute quantity, it is rarely absent, and may be regarded as a mineralogical characteristic of the districts of the two Cottonwoods and of the American Fork. For this reason a few particulars will be in place here.

Wulfenite is found associated with calamine (smithsonite), cerusite, malachite, azurite, and more rarely alone in little cavities in the ochraceous ores. In the Emma mine vugs or geodes are occasionally found lined with botryoidal apple-green calamine, rarely crystallized, often brownish and sometimes colorless, but invariably associated with wulfenite. The calamine incloses and covers the crystals of wulfenite, which form a lining of considerable thickness. The wulfenite is in thin tabular crystals of a yellow color, resembling the Carinthian variety of this species. The crystals are very brilliant and perfect but quite minute, rarely 2 or 3 millimeters in width and not over millimeter in thickness, often less. They are quite abundant in this association, no piece of the calamine which I have seen being without them. They sometimes, but rarely, penetrate through the globules of the calamine so as to show themselves on the upper surface of that species. But the calamine has obviously formed botryoidal masses around the wulfenite, a crystal of this species being often seen forming the nucleus of the calamine globules.

These facts are of interest in the paragenesis of these epigene species. The order of production has obviously been, first, the cerusite resting on ochraceous iron, manganese, and other metallic oxides; next, the wulfenite crystals were deposited upon and among the crystals of cerusite; and lastly came the calamine, crystalline at first and as it accumulated becoming fibrous and amorphous, completely inclosing and capping the other species.

Wulfenite occurs also in this mine, as likewise in the Flagstaff, the Savage, and Robert Emmet, without the calamine, but never, as far as observed, without cerusite and other carbonates. In the Savage masses of cerusite, with various oxides, are interpenetrated by the tabular crystals of wulfenite.

Although wulfenite forms a very minute factor of the entire ore mass in these mines, by the law of mineral association it may be considered as the characteristic species of the ores of these districts, occurring in the magnesian limestones. * * *
The oxidizing and desulphurizing agency which has acted upon the great ore mass of the Emma mine, whatever it was, has performed its work with remarkable thoroughness. A careful study of its action discloses some other facts of interest in the paragenesis of species. From the appearance of numerous large blocks of ore, forming solid boulders in the general mass, a concentric arrangement is easily recognized. On breaking these masses across, the fresh fractures disclose a dark center which consists almost entirely of decomposed sulphides, composed chiefly of cerusite blackened by argentite and metallic silver in a pulverulent form. This dark center, chiefly of cerusite, is often pseudomorphic of galenite in its fracture. Next is usually a zone of yellowish and orange-yellow antimonial ocher, cervantite, often quite pulverulent, at times only staining the cerusite; then follows a narrow zone of green and blue copper salts, malachite, azurite, cupreous anglesite, with, rarely, wulfenite; then follows cerusite, sometimes stained with antimony ocher, and not unfrequently associated with wulfenite; outside all are the iron and manganese ochers. This concentric arrangement I have observed in a great number of cases; and the above order of species, while not invariable, is believed to reflect accurately the general arrangement. Well-crystallized species, as mineralogical specimens, are rare in this great mass; but the following may be recognized as its chief components: Galenite, sphalerite, pyrite, jamesonite (?), argentite, stephanite, boulangerite (?), antimonial galenite, cervantite, mimetite (?), limonite, wad, kaolin, lithomarge, cerusite, anglesite, linarite, wulfenite, azurite, malachite, smithsonite. Those most abundant or best crystallized are in italic. This list can no doubt be extended as opportunity occurs for the more careful study of the ores, the great mass of which, amounting to many thousand tons, have gone into commerce without passing under any mineralogical eye.

Flagstaff mine.-The Flagstaff mine was located and worked about the same time as the Emma and like the Emma was long idle. Huntley ${ }^{1}$ gives the following description of the deposit:

The formation is the same mineral belt as the Emma. Ore came to the surface in one spot, and following this indication a short distance the discoverers came to the first and largest body. It was 400 feet long and 500 feet deep, extreme dimensions, and 3 feet wide. Some 20 or 30 other large-sized bodies were found, in all shapes and positions, usually near the hanging wall and invariably connected with one another by a small seam of ore of ocher. One body upon the footwall was joined to another near the hanging wall by a pipe of galena the size of a lead pencil.

Vallejo and North Star claims.-Huntley ${ }^{2}$ gives the following description of the ore bodies of the Vallejo and North Star claims:

The ore is found in irregular shoots or pipes near the hanging wall. Three bodies began near the grass roots, and others were found as depth was attained. At the period under review there were 10 shoots having a tri-

1 IHuntly, D. B., op. cit., p. 423.

${ }^{2}$ Idem, p. 424. 
angular or lenticular cross section and a uniform dip SE. $80^{\circ}$. These were from 20 to 100 feet apart and lay almost at right angles to the strike of the belt. The largest was 150 feet long, extreme dimensions from 6 inches to 10 feet wide, and has been followed 300 feet deep.

Cabin mine.-The Cabin mine is just northeast of Alta. The limestone in which the ores occur appears to be lower than that of the Flagstaff, though there is yet some doubt, owing to the incomplete understanding of the complex faulting. The deposits occur in a bed of white limestone associated with a strong fissure, the ore forming irregular "chimneys" along fractures in the limestone. The ore consists of galena, pyrite, cerusite, anglesite, some copper carbonate, and a yellow earthy sulphate of lead and iron, probably plumbojarosite, that is said to contain considerable silver.

South Hecla mine.-Some of the largest deposits in the South Hecla mine may be classed as bed deposits, in that in general they follow the intersections of fissures and certain beds of limestone. A characteristic feature of these deposits is the highly brecciated condition of the mineralized limestone adjacent to the fissure, which has been partly replaced by the ore minerals. Most of the ore is screened to separate the unreplaced portion of limestone from the metallic minerals.

The No. 1 shoot on the Wedge fissure above and below the Dwyer tunnel is of this type, as is the ore shoot on the Kate Hayes fissure, worked from the fourth east crosscut of the Quincy tunnel. The No. 2 shoot on the Wedge fissure, on the other hand, crosses the bedding planes of the limestone, and the brecciation appears to have resulted from the intersection of the fissure and an earlier break in the limestone. A porphyry dike follows the shoot rather closely, and the intrusion of this dike may have had an important influence on the character of the limestone.

Other mines.-Deposits similar to those in the South Hecla, in that the ore shoots have formed in the brecciated portions of certain limestone beds adjacent to fissures, are present in the Sells, Peruvian, and Albion mines. Some of the largest deposits of the Alta Consolidated. mine extend into certain beds from fissures and may be regarded as bed deposits, though at some places the deposits are rather closely confined to the fissures.
BIG COTTONWOOD DISTRICT.

The Prince of Wales and other mines are just north of the Cottonwood Divide on Silver Fork, a branch of Cottonwood Creek. Like many of the other mines of the district they were worked extensively in the early days and were then idle for a long period. In the last few years considerable work has been done and some ore shipped by lessees. The structure of the Prince of Wales hill is very complex and has not been completely worked out. There are at least two overthrust faults which bring Cambrian limestone over Carboniferous limestone. The limestone in which the main ore shoots occur are probably at the same horizon as those of the Flagstaff-Emma zone and some of those of the Michigan-Utah mine.

Prince of Wales mine.-Huntley ${ }^{1}$ gires the following description of the Prince of Wales deposits:

The ore-bearing formation is said to be a bedded vein, dipping about $45^{\circ} \mathrm{NW}$. in blue and white limestone. Four distinct chimneys or shoots of ore, 130 feet, 200 feet, and 260 feet apart, have been found. They occur where the limestone is white, metamorphic, and soft, while the barren spaces between these shoots contain the vein only as a narrow seam in hard blue limestone. These shoots outcropped at the surface, or were covered by a few feet of drift, as low-grade, ocher-stained seams of limestone and clay. Good ore was found by sinking a few feet. The Antelope and Prince of Wales shoot is from 2 inches to 4 feet (average, 12 inches) wide, 120 feet long, and has been followed on the dip 1,200 feet. The Highland Chief shoot is from 2 inches to 3 feet (average, 8 inches) wide, 75 feet long, and 800 feet deep. The Wellington shoots are each about from $2 \frac{1}{2}$ to 7 feet (average, 3 feet) wide, from 10 to 30 feet long, and 700 feet deep. The ore from the first assays about 140 ounces silver and 45 per cent lead; that from the second, 100 ounces silver and 40 per cent lead; and that from the third and fourth, 60 ounces silver and 50 per cent lead. The ore is a soft brownishyellow ocher, containing argentiferous cerusite and galena and occasional stains of oxides of manganese and copper.

In 1916 and 1917 work was being carried on from the lowest tunnel level on the Honeycomb Fork side and drifting on the vein below the old tunnel level was in progress. The ore, which ranges in thickness from that of a knife blade to a little more than 6 inches, consists mainly of galena surrounded by oxidation products. The ore bodies, so far as developed on the lowest level, seem to be smaller than those at higher levels, but the content of silver

\footnotetext{
1 Huntley, D. B., op. cit., p. 428.
} 
and lead seems to be quite as high as in the upper workings.

Kennebec group.-The old Reade \& Benson mine, which was an important producer in the early days, is now a part of the Kennebec group. Two tunnels have been driven on the Kennebec property to explore the ground at greater depth than the old workings of the Reade \& Benson but as yet have developed no ore. The ore bodies have formed in a spotted and mottled Cambrian limestone lying below and above the band of thinly laminated white limestone (division 4, p. 236). The beds are below those in which the Flagstaff deposits occur. Huntley has described the early workings as follows:

The Reade \& Benson mine is situated on a spur of the Cottonwood Divide, between Day's and South forks, 11,000 feet above sea level and $2 \frac{1}{2}$ miles northwest of Alta. It was located in 1870 and was worked vigorously from September, 1871,-until April, 1878. Since then it has been idle or leased to a very limited extent. This mine is supposed to be upon the same mineral belt as the Flagstaff and the Emma. The belt at this point is about 200 feet wide. The ore occurs in a vein or chimney on the hangingwall side and in about 20 irregular lenticular bodies, which branch at all angles from the chimney, on its footwall side. These do not, as a rule, extend more than 75 feet from the main chimney and vary from 6 inches to several feet in width. One outcropped as a low-grade ocher. The largest is about 170 feet from the surface. The ore is of the kind usually found in this limestone formation, namely, a yellow and red oxide of iron carrying argentiferous cerusite and galena. It is claimed that the total shipments have averaged 120 ounces silver and 35 per cent lead per ton. The mine is developed by a 380 -foot tunnel, in which there is a whim on a 400 -foot incline, dipping $35^{\circ}$ NNE. Below this there are four windlasses, which carry the incline down 400 or 500 feet deeper. In general, the mine may be said to have been opened from the surface 1,100 feet on the dip $\left(35^{\circ}\right)$ by an irregular incline following the chimney. Near the surface the ore extended 100 feet and the workings 200 feet horizontally; but in the bottom. of the incline not over 40 feet of drifting have been done. The openings have a total length of 1,950 feet.

The Ophir is a few hundred feet southwest of the Reade \& Benson. * * * It was discovered in 1870 , purchased by Reade \& Goodspeed in 1871, leased until May, 1878, and worked steadily since by about 10 men. Ore is found in three bodies in a 30 -foot stratum of compact dark-blue limestone. A stratum of white limestone above carried no ore. The outcrop was a pipe $2 \frac{1}{2}$ feet in diameter of low-grade ocher. The shape of the bodies is that of a flattened or an elongated ball, the largest being 50 by 20 by 15 feet. They are 4 and 10 feet apart and not over 50 feet from the surface. At the period under review drifting was being carried on upon a seam of ocher in the expectation of finding another body. The total cuttings did not exceed 700 feet. During the census year 173 tons of ore similar to that of the Reade \& Benson, excepting that it was of lower grade, assaying only about 45 per cent lead, 42 ounces silver, with 3 per cent moisture, were sold for $\$ 8,581$. The previous product was estimated at $\$ 22,000$.

Carbonate mine.-The Carbonate mine, ${ }^{1}$ in common with many others of the region, made an important production in the early days and then little for a long period. In the last few years lessees have extracted considerable oxidized zinc ore and some lead-silver ore.

The ore bodies are in the spotted and mottled Cambrian limestones near the base of the great limestone series, apparently at the same horizon as the old Reade \& Benson deposits. Just south of the mine a strong east-west fault has thrown the limestone down against the Cambrian quartzite. The limestone is cut by fissures striking about N. $75^{\circ} \mathrm{W}$. and dipping steeply south. Fissures that strike in other directions seem to be less important with relation to the ore bodies, though one, striking about N. $40^{\circ}$ E. and dipping northwest (corresponding in general to the direction of most of the ore fissures of the district), may be more important than is apparent. The rocks have been broken since the primary mineralization by nearly vertical north-south joints, which have influenced the deposition of the secondary deposits, notably the oxidized zinc ores.

The ore deposits have replaced certain beds of limestone adjacent to the fissures. Two factors appear to have controlled the replacement, the composition of the limestones and the degree to which they are fractured. The deposits are largely oxidized, but the original minerals were probably sulphides of lead, iron, zinc, and copper, together with some manganiferous mineral. In the oxidation the lead remained essentially in its original position, but the zinc, iron, manganese, and copper were largely leached into the adjacent limestone, where they were in part precipitated. The oxidized zinc deposits occur mainly beneath and for some distance up along the sides of the old lead stopes and along the northsouth joints. Iron and manganese are rather abundant in the oxidized zinc ores. It is said that some of the lead ores consisted largely of galena, and it seems certain that galena must have persisted after the other sulphides had been largely oxidized. Copper was not an important constituent of the ore, though small

1 The writers are indebted to Mr. G. H. Ryan for much information relating to the Carbonate mine. 
bodies of good copper ore have been found. Beautiful specimens of the copper-zinc carbonate, aurichalcite, occur in the mine. The following description of the early operations of the mine is given by Huntley: ${ }^{1}$

The mine of the Kessler Mining Co. covers part of the ground of the old Provo claim. It was worked by a New York company in 1872, 1873, and 1874. Little ore was obtained, and it was abandoned. About 1875 a prospector discovered the carbonate ore body while overhauling the old dump, so says tradition. The mine was bought by the Carbonate Co., of Salt Lake City, which extracted large quantities of ore. In January, 1879, after the large discovery the mine was sold to the Kessler Mining Co., of New York City. This company took out considerable ore and did much prospecting but ceased work some months previous to the writer's visit, at which time the mine was worked by a few lessees. The property consists of the following overlapping unpatented claims: Carbonate $(1,500$ by 200 feet), Little Giant, Sailor Jack, Alturas, Baker, and Defiance. These are situated on the summit of the ridge of Silver Mountain, about 11,000 feet above sea level, 3 miles south of Argenta, and about 7 miles northwest of Alta. * * * The ore is found in several bodies near the surface on the hanging-wall side of a stratum or belt of limestone. The largest body was just below the surface and was lenticular in shape, its dimensions being 200 by 100 by 50 feet. It was timbered by 365 square sets but had caved in. The gangue, if such it may be called, which surrounds the bodies and also serves as a connecting link between them, consists of a valueless ocher or limonite. It is very abundant, sometimes fine and soft; at other points hard and siliceous. Occasionally heavy spar, oxide of manganese, and stains of malachite are found. The ore is an ocher, containing cerusite and galena, and assays from 30 to 50 per cent lead and from 30 to 100 ounces silver. A fissure vein, called the "Sailor Jack," connects with this body and has been the cause of much litigation. There is also a vertical fault of 500 feet. * * * The total product of the mine prior to October, 1877, is estimated at $\$ 120,000$. Between the above date and the beginning of [1880] the census year 4,549 gross tons, averaging about 8 per cent moisture, were sold for $\$ 261,044.41$.

Maxfield mine.-The Maxfield mine is about 7 miles from the mouth of Big Cottonwood Canyon. The ore body crops out in Maxfield Gulch, a few hundred feet north of its junction with the main canyon. The sedimentary rocks are the Cambrian quartzite, the Cambrian shale and limestone, and the great series of post-Cambrian limestones. All these rocks are cut by dikes of monzonitic porphyry. The largest dike, which crops out in Maxfield Gulch northeast of the mine workings; is several hundred feet wide and can be followed along the west fork of the gulch to an eleva-

1 Op. cit., p. 436. tion of 400 or 500 feet above the canyon. Dikes cut the limestone in the Baker mine, are exposed in road cuts along Big Cottonwood Canyon, and are cut at numerous points in the northeastern extension of the Maxwell workings, both on the main tunnel level and at higher levels. Small dikes and sills of the porphyry extend along fissures and along certain of the beds.

The limestone adjacent to the dikes has commonly been altered to a mixture of silicates and calcite. Epidote and mica are the most abundant, but garnet and probably other silicates are present. Magnetite, hematite, and sulphides are nearly or quite lacking. In many places the porphyry appears to have undergone an alteration similar to that of the limestone, indicating that it had solidified before the time of the alteration.

Numerous fissures in the limestono strike from a few degrees west of north to N. $20^{\circ} \mathrm{E}$. and dip irregularly. The Alligator fissure, which is believed though not proved to be the same as the Logger fissure, on the opposite side of Big Cottonwood Canyon, is perhaps the most regular, with steep westerly dip, but even this varies considerably at depth.

The larger ore deposits of the mine have formed in a bed of banded blue and white limestone near the base of the great limestone series. The ore has replaced the limestone adjacent to fissures, forming chimneys of varying size. The deposits so far developed appear to form a northwestward-pitching zone near the porphyry dikes. This belt has been followed from the outcrop in Maxfield Gulch to the bottom of the Alligator extension winze, a distance of more than 1,300 feet. In the older workings several of the pipes of ore have been followed to the porphyry dikes. Near the dikes the lead and silver content becomes unprofitable, although the limonite persists. The limestone adjacent to fissures near the dikes is partly replaced by silicates, including mica and epidote.

The ore is rarely if ever found where the limestone has been replaced by the silicates-a fact which suggests that the ore solutions came up along the dikes and passed into the fissures. The absence of ore and the presence of silicates near the dikes may be interpreted as indicating that the conditions of temperature, pressure, etc., near the dikes were not favorable to the deposition of the ore minerals. 
Operations are conducted through a tunnel from Big Cottonwood Canyon that intersects the ore zone about 1,000 feet from the portal. The ore zone has been followed for a distance of more than 1,000 feet northwest, and, in the Alligator extension winze and main shaft, to a depth of about 140 feet vertically below the tunnel. In the summer of 1916 ore was being extracted at this depth from the Alligator shoot and prospecting was being carried on from the tunnel level. Much of the ore above the tunnel level was oxidized, but below the tunnel the ore is mainly sulphides, pyrite, galena, and tetrahedrite. The large amount of water has handicapped prospecting and development. Huntley ${ }^{1}$ gives the following description of the old workings:

The Maxfield is a bedded vein, from 1 to 8 feetwide, dipping $45^{\circ} \mathrm{NE}$. between strata of a compact bluish-white ilmestone. The ore occurs usually upon the footwall, in one chimney 200 feet long and 2 feet wide. It is a soft brown ochery carbonate and galena, assaying from 30 to 100 ounces. On the hanging wall there was a band of quartz, from 3 to 8 inches wide, containing galena and pyrites. When carefully sorted this yields good ore.

\section{AMERICAN FORK DISTRICT. ${ }^{2}$}

The only bed deposits in the American Fork district are those of the famous old Miller mine, on Miller Hill, just east of the divide between the head of American Fork canyon and Mary Ellen Gulch. According to Huntley ${ }^{3}$ the mine "was discovered in 1870 and was sold the following year for $\$ 120,000$ or over." It was examined in 1872 by J. P. Kimball, from whose published report the following data are abstracted:

The earliest workings were inaccessible in 1872. The "vein" then worked lies near the base of the limestone series and follows the bedding, which dips $15^{\circ}-25^{\circ}$ SE. The ore cropped out on the southwest side of the hill and was followed along the footwall for about 120 feet, when it "rolled" downward for a short distance and again followed the bedding. Below the roll (at the car tunnel) the "vein" was 17 feet thick. The footwall was clearly defined, but the top of the ore body graded into the limestone. The footwall was a bed of "tight lime," with a streak of clay

1 Huntley, D. B., op cit., pp. 427-430.

${ }_{2}$ The descriptions of the deposits in the American Fork district are by G. F. Loughlin.

${ }^{3}$ Huntley, D. B., op. cit., pp. $444-445$. selvage marking the contact with the ore The hanging wall was shaly, much fractured, and partly altered to "ocherous matter." Fragments of the hanging-wall rock were found throughout the vein. The east side of the old incline showed either a steep pitch, a horse of loosened rock, or a fault causing the abrupt disappearance of the vein material on this side. Not enough work had been done at the time to determine the structure.

Quartz and calcite were generally absent, except as "a residue of country rock." The ore minerals were galena, cerusite, and "plumbic ocher," all carrying silver. Considerable hydrous ferric oxide was present, presumably an alteration product or pyrite, and the green and blue stains of copper carbonate were found in drusy cavities in the hanging wall. Black manganese stains were commonly present with the iron oxide.

Cerusite, both black and white, was the most abundant of the three lead minerals. The black variety probably owed its color, in Kimball's opinion, to finely divided silver sulphide, and was the rich ore of the mine, "containing 83 per cent lead, along with some 76 ounces of silver to the ton." This black variety must have been largely galena, for pure cerusite contains only 76 per cent of lead, whereas galena contains 86 per cent. It occurred in granular masses in the lower and middle parts of the "vein." Some of the masses were 1 to 6 feet in diameter and constituted from 10 to 16 per cent of the total ore shipped. The white variety, carrying about 60 ounces of silver to the ton, was the predominant ore and in a concentrated form occupied the lower half of the ore body. It was arranged in lenticular layers, separated by thin seams of clay and "plumbic ocher." "Perfectly pure lenses" of it, 3 to 5 feet thick, had the consistency of quicksand. The "plumbic ocher" occurred in irregularly distributed masses or lenses in the lower part of the vein and carried as much as 36 ounces of silver and 2.45 ounces of gold to the ton. Some gold was also present in the ferric oxide. The upper part of the "vein" consisted of brecciated limestone and ferric oxide, the former more or less impregnated with copper salts and partly oxidized galena. The ore body was said to be the largest deposit of lead carbonate known. 
The following table of assays, taken from Kimball's report, represents the western ore bodies of the mine, worked up to 1872 :

Assays of ore from Miller mine.

\begin{tabular}{|c|c|c|c|}
\hline Kind of ore. & Lead. & Silver. & Gold. \\
\hline 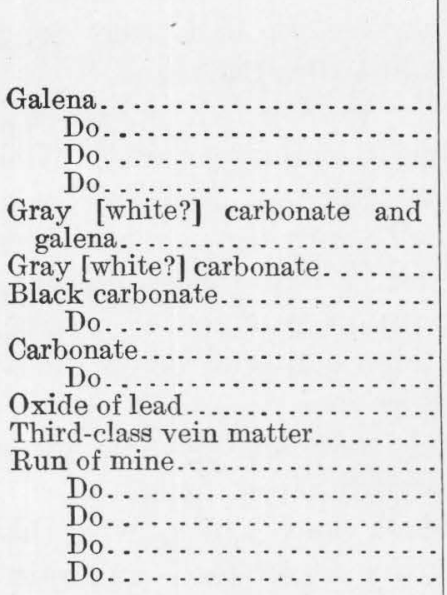 & $\begin{array}{c}\text { Per } \\
\text { cent. } \\
56 \\
70 \\
64 \\
62 \\
75 \\
60 \\
68 \\
72 \\
75 \\
83 \\
(a) \\
40 \\
58 \\
53 \\
60 \\
57 \\
55\end{array}$ & 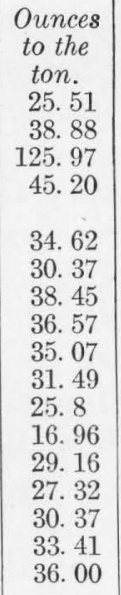 & $\begin{array}{l}\text { Ounces } \\
\text { to the } \\
\text { ton. } \\
0.30 \\
.60 \\
\text { None. } \\
.43 \\
\\
.75 \\
.60 \\
\text { Trace. } \\
\text { Trace. } \\
2.34 \\
2.77 \\
(b) \\
\text { None. } \\
.50 \\
.60 \\
.60 \\
.60 \\
(a)\end{array}$ \\
\hline
\end{tabular}

The average value per ton of base bullion produced from these ores at the old Sultan smelter in American Fork Canyon for 60 working days was as follows: Lead, $\$ 140.70$; silver (60.36 ounces), \$86.47; gold $(0.97$ ounce), $\$ 22.27$; total, $\$ 249.44$.

According to Huntley, ${ }^{1}$ ore was found in six or eight large bodies which began within 70 feet of the surface in a belt of dolomite. About 4,800 tons was extracted from the largest body. In addition to the minerals mentioned by Kimball, wulfenite was present in the oxidized ore, and a little zinc blende and pyrite were found below water level (500 feet). The total production of the old workings was estimated to have been between 13,000 and 15,000 tons, assaying 40 to 54 per cent of lead and 30 to 47 ounces of silver and $\$ 2$ to $\$ 10$ in gold to the ton. These figures do not range as high as some of those given by Kimball.

The old ore bodies gave out and the company ceased operations in December, 1876, and since that time the mine has been worked by lessees. No great amount of ore was produced until 1905, when the Tyng Bros., then leasing, opened another large body, which replaced the limestone along a nearly due east

${ }^{1}$ Huntley, D. B., op. eit., pp. 444-445. fissure for a total distance of over 400 feet and was 10 to 40 feet wide. The increased production from 1905 to 1908 was due to this deposit. The rock replaced was a gray dolomite (?), overlain and underlain by shaly limestone. Two other bodies, smaller and less regular, were found 100 feet north of the main body, one on each side of a porphyry dike, whose strike is about $\mathrm{N} .70^{\circ} \mathrm{E}$. The main ore body ended abruptly on the east, possibly against a fault, and a search has recently been made for its eastward continuation, but up to 1913 only relatively low-grade oxidized ore had been found. The ore was principally rusted "sand carbonate" containing residual boulders of galena and showing copper stains but assaying less than 2 per cent copper. The average content of the ore shipped from the Tyng lease was 0.98 ounce of gold and 21.72 ounces of silver to the ton, 39.29 per cent of lead, 4.90 per cent of zinc, 20.17 per cent of iron, 2.61 per cent of sulphur, and 3.56 per cent of insoluble matter. These figures show that the ore was mostly oxidized and contained very little quartz or barite gangue.

Shipments of low-grade ore along the fault(?) east of the main body, in 1913, averaged about $\$ 6$ in gold and 11 ounces of silver to the ton, 18 per cent of lead, 37 per cent of iron, 2.5 per cent of zinc, 2.3 per cent of sulphur, and 2.7 per cent of insoluble matter.

\section{DEPOSITS ASSOCIATED WITH THRUST FAULTS.}

General features.-Several deposits associated with thrust faults occur in the two Cottonwood districts. Among the more important of this type thus far developed are those of the Cardiff mine, the Wasatch mines (old Columbus Consolidated), and the Columbus-Rexall mine. Similar deposits occur in the South Hecla and Cottonwood-Atlantis. Some of the deposits of the Michigan-Utah mine are also probably associated with thrust faults.

The rocks adjacent to the thrust zones have been rather highly brecciated, especially where a hard rock like quartzite or siliceous shale has been thrust upon limestone. This brecciation of the limestone has proved favorable to mineralization. Where the softer clay shales have been thrust upon limestone particularly favorable conditions do not seem to have resulted. The ore deposits were formed where these zones are crossed by the mineralizing 


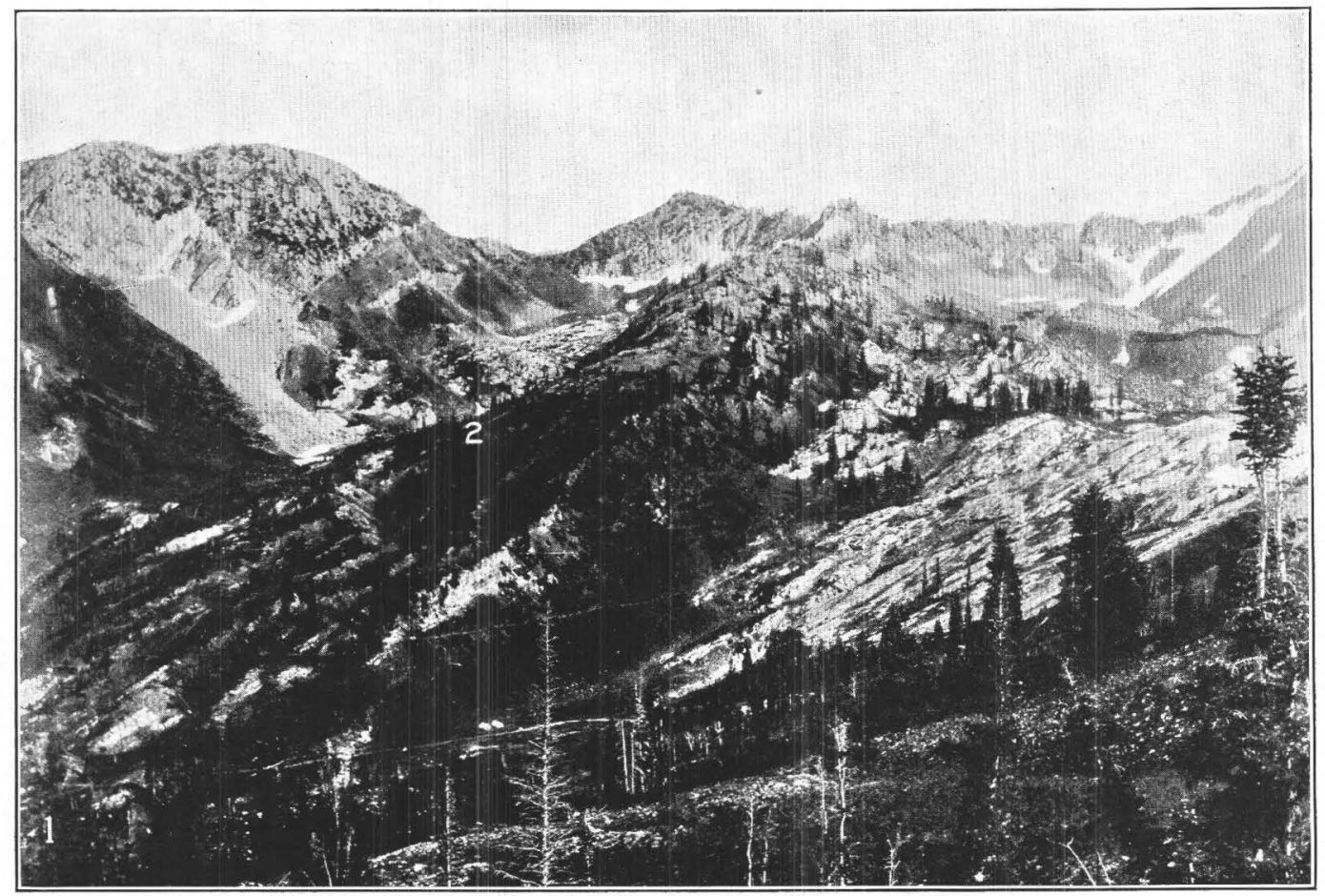

A. VIEW IN MILL D (SOUTH) FORK, BIG COTTONWOOD CANYON, SHOWING CARDIFF AND OTHER MINES. 1, Cardiff mine, lower tunnel; 2, Rexall mine.

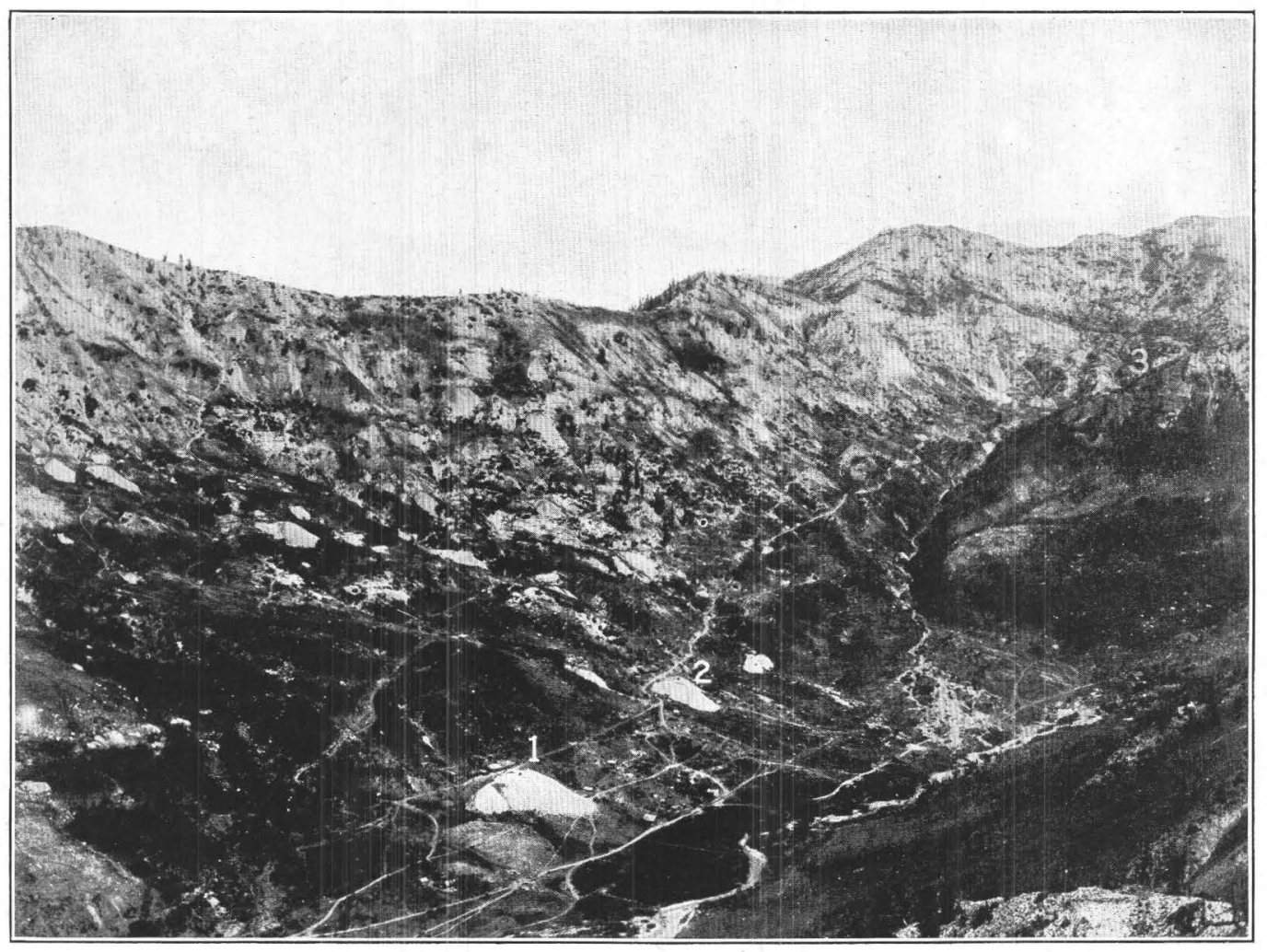

B. VIEW ON NORTH SIDE OF LITTLE COTTONWOOD CANYON NEAR ALTA.

1, Tom Moore tunnel; 2, Big City tunnel; 3, Michigan-Utah mine. 

fissures, and like the bed deposits, the ore shoots dip with the intersection of the fissures and the fault zones, commonly to the northeast.

Valuable ore deposits have been developed on the Alta overthrust, on the Columbus overthrust, and in the Grizzly thrust zone. Those on the Alta overthrust include the deposits of the Cardiff mine, the Columbus-Rexall mine, and the Howland shoot of the Columbus Consolidated (Wasatch) mine. As indicated in the description of this fault (p. 245), it consists in this portion of two branches. On the Howland tunnel the wedge of shale begins just north of the Howland ore body of the Columbus Consolidated mine and apparently extends beyond the Cardiff ore body, though it has not been proved all the way.

Cardiff mine.-The country rock adjacent to the Cardiff mine consists of the "lower limestone," the overthrust quartzite, and the Cambrian shale. The two north-south Superior faults in South Fork (see Pl. XXVII) have thrown the strata up to the west or down to the east. East of these two faults (part of the "east contact") the overthrust quartzite forms the surface; between the faults erosion has removed the quartzite from the surface, leaving the underthrust limestone exposed; beyond the west fault the limestone and the underlying shale has in turn been stripped away from the lower band of quartzite.

The large ore body of the Cardiff mine occurs on the thrust contact in the block east of the east Superior fault. The overthrust quartzite forms the hanging wall, and the underthrust limestone the footwall. The contact dips eastward at a low angle. The ore bodies are closely associated with a strong northeast fissure, from which they make out into the brecciated limestone along the contact. Vein deposits, described on page 268, have formed in this fissure both above and below the fault zone.

The main ore body on the thrust contact was first entered several hundred feet from the east fault. In following the fissure westward before the fault was encountered the crosscut entered a shaly formation that has not been positively identified, but that is possibly the Cambrian shale, which would indicate that the Cardiff ore body that has been developed is on the upper branch of the Alta thrust fault and that at this point the wedge between the two branches contained some limestone overlying the Cambrian shale. The shale formation was also encountered when the ore body was followed up the dip. The fault in that direction therefore appears to truncate the limestone beds till it brings the shale into contact with the overlying quartzite. The amount of mineralization varies considerably at different points along the dip of the ore body, apparently because some beds of limestone have been more favorable to mineralization than others. In the shaly beds, so far as observed, mineralization has been comparatively slight.

The ore thus far extracted is largely oxidized. Below the present tunnel level, however, it consists more and more of sulphides, and at 200 feet below it becomes mainly galena, pyrite, sphalerite, and tetrahedrite. Shipments for 1915 are reported by the company to average 38.2 per cent of lead, 13.4 ounces of silver per ton, and 3 per cent of copper. Second-class ore is stored for future treatment. In 1916 the mine was producing about 100 tons of ore daily. A view showing the lower tunnel is given in Plate XXVIII, $A$.

Columbus-Rexall mine.-The Columbus-Rexall mine is a consolidation of the old Columbus Extension and the Rexall. The claims of the former were mainly in Little Cottonwood Canyon; those of the latter were mainly on the Big Cottonwood side of the divide.

The rocks of the area consist of the preCambrian quartzite and tillite, the Cambrian quartzite, the Cambrian shales and limestone, and the post-Cambrian limestone. The Alta thrust-fault zone passes through the ColumbusRexall. The lower branch brings the middle and upper members of the Cambrian shale into contact with underlying Carboniferous limestone. The upper branch brings the overthrust quartzite into contact for part of the distance, as exposed in the tunnel, with the post-Cambrian limestone, for part of the distance with the Cambrian shale, and for short distances with limestone that is probably the Cambrian, just above the Cambrian shale. The wedge between the branches of the thrust is cut by minor thrusts and is highly complex in structure.

The ore deposits in the old Columbus Extension portion of the property were on 
the upper thrust contact, where it is crossed by northeast fissures and where limestone forms the footwall of the fault. As in other deposits of this type, the ore minerals have replaced the limestone.

The lower thrust has been little prospected, though a crosscut was driven from the upper to the lower contact. The deposits in the Rexall portion of the property are mainly on the contact where the lens of shale has pinched out and the quartzite lies directly on the Carboniferous limestone. The ore deposit discovered in the summer of 1917 had been but slightly developed when examined by the writer. It apparently occurs as a replacement of brecciated limestone along the thrust contact, which is rather flat. From analogy with other deposits of the district it is probable that the Rexall ore body is associated with a northeast fissure, though no such fissure was apparent in the workings at the time of visit.

The ore minerals were mainly pyrite, tetrahedrite, enargite, galena, and a little chalcopyrite. There is little gangue with the metallic minerals. The relative amount of the different minerals varies greatly. In places pyrite is present nearly to the exclusion of the other minerals, while some of the richest ore is largely tetrahedrite. Pyrite was the earliest mineral to form, and the other minerals have formed by replacement of the pyrite. Next to pyrite, tetrahedrite is most abundant. Enargite is plentiful in certain specimens but does not form an important part of the whole, so far as observed. Galena is present in small amount, but the ore contains but a relatively small percentage of lead. Chalcopyrite, so far as observed, is confined to veinlets in the pyrite grains. The sulphide along the minute fissures in the pyrite appears to have been replaced by chalcopyrite instead of by the more abundant tetrahedrite.

The ores mined during the later part of 1917 are reported to have averaged about 9 per cent of copper, 10 ounces of silver per ton, and a little lead and gold.

Wasatch mines.-The country rock of the deposits of the old Columbus Consolidated mine consists of Cambrian quartzite, Cambrian shales, and limestone. Both the Alta and the
Columbus thrust faults pass through the area. The Alta fault, where it is exposed in the underground workings of this mine, has thrust the Cambrian quartzite upon the lower portion of the great limestone series, though, as stated above, it is known that to the northwest there are lenses of the Cambrian shale and limestone faulted between the limestone and overlying quartzite. The Columbus fault has thrust the Cambrian quartzite upon the Cambrian limestone and shale. At the surface only small areas of the limestone are exposed along this fault, but underground much larger bodies indicate that the fault truncates the beds. Other minor thrusts are present. The rocks are cut by several northeast fissures, the strongest of which is apparently the Braine, at whose intersections with the thrust faults large ore bodies occur. These ore shoots have been followed below the tunnel level till the amount of water developed made the working costs prohibitive. In 1917 a drain tunnel was being driven from a point down the canyon to permit the deeper exploration of the ore shoots. The ore minerals were mainly pyrite, galena, and tetrahedrite. As in the Rexall, copper was more abundant than in most of the mines of the district.

Other mines. - In the South Hecla mine both the Alta and higher thrust faults are present. No large deposit has been developed on the Alta thrust, but on the higher thrusts deposits have been developed in the Ophir limestone from which considerable ore has been taken.

In the Cottonwood-Atlantis mine some work has been done on the Alta thrust contact. Ore is said to have been shipped from this deposit in the early days and has also been mined from the Defiance fissure, in the quartzite above the contact. Prospecting was in progress in 1917.

Ore deposits are known to occur in the Grizzly thrust zone, but the writer has not now sufficient data to determine to what extent the deposits of that section are connected with thrust faults. It is probable that further study and further development will show other deposits associated with thrust faults. There are large areas along the thrusts that have not been prospected. 
GENESIS OF THE ORES. 1

The main types of deposits-contact, fissure, and bed-show complete mineralogic gradation and are without doubt of common origin. At several places contact deposits pass into fissure deposits, and, as a rule, the classification into fissure and bed deposits is based on form rather than on any inherent difference in the character of the mineralization.

The deposits in the igneous rocks, so far as shown by present developments, are of little importance in this region, and their relation to the deposits in the adjacent sedimentary rocks is not as clearly shown as in some other districts of the State. The mineralization in the igneous rocks, however, is such as might have been effected by the same solutions that produced the deposits in the sedimentary rocks.

That the source of the metal-bearing solutions is the igneous material that forms the stocks in the region is indicated by the location and character of the deposits. The principal mineralized areas (see Pl. XXVII) of both the Cottonwood-American Fork and the Park City regions are grouped around the Alta-Clayton Peak stock, and are associated with fissures that were apparently formed at the time of its intrusion. This grouping in itself suggests that the ore-bearing solutions were derived from the intrusive material. Moreover, the aplitic and pegmatitic dikes or veins, which were evidently late phases of the igneous activity, contain sulphides in notable amount, suggesting that the solutions which escaped from the igneous bodies carried ore-forming materials. The association of diopside and pyrite both in aplitic veins and in contact deposits is especially suggestive. The deposits, notably the contact deposits, are similar in character to those of other districts where deposition of ores by solutions emanating from igneous sources is pretty definitely established. Of particular significance in this connection are magnetite and the boron mineral ludwigite, for the boron and iron were clearly transferred from the magma to the contact zone.

The deposits in this region are similar in many respects to those of the Park City

1 For a fuller discussion of the genesis see Part I. district, which Boutwell ${ }^{2}$ concludes are genetically related to the intrusive rocks. They differ from these, however, in ways that should not be overlooked. The ore deposits of the Park City district are all in the Weber quartzite and higher formations; the known deposits of the Cottonwood area are, with few exceptions, in formations below the Weber quartzite. Few if any deposits of commercial importance are closely associated with the Little Cottonwood stock of granodiorite, intruded into the pre-Cambrian and early Cambrian rocks, most of the important deposits of the region being associated with the AltaClayton Peak stock of quartz diorite, intruded into Paleozoic and Mesozoic rocks. Moreover, there is a general increase in mineralization from the lower to the higher formations, the ore bodies in the late Paleozoic and early Mesozoic rocks of the Park City district being more valuable than any known in the earlier rocks of the Cottonwood area.

It is needless to say that this statement does not imply that valuable deposits do not exist in the Cottonwood-American Fork region, for several such deposits have been developed; bout, so far as known, they are neither so large nor so continuous as those in the Park City district.

The greatest mineralization generally occurs toward the top of intrusive stocks or in the adjacent sedimentary formations at a corresponding horizon (see pp. 199-201), and therefore it is not probable that the mineralization in the Cottonwood-American Fork area was as extensive as that in the Park City district.

\section{ALPINE DISTRICT.}

By G. F. Loughlin.

The Alpine mining district is in the foothills of the Wasatch Range, north and east of Alpine, which is about 5 miles north of the town of American Fork. It includes the southwestern part of the Little Cottonwood granodiorite stock (see p. 239) and much of the great limestone series. Cambrian quartzite is also present but is not closely related to either of the two properties examined.

The only fissure deposit in igneous rock examined is that of the Lucky Chance mine,

${ }^{2}$ Boutwell, J. M., Geology and ore deposits of the Park City district, Utah: U. S. Geol. Survey Prof. Paper 77, p. 128, 1912. 
about 3 miles north of Alpine. The country rock is typical granodiorite. The ore occurs in shear zones along which the rock has developed a highly schistose structure. The shear zones strike N. $60^{\circ} \mathrm{E}$. and N. $80^{\circ} \mathrm{W}$. and $\operatorname{dip} 30^{\circ}-60^{\circ} \mathrm{N}$. They appear to be grouped in a belt of north-northeastward trend, 100 feet or more wide and of unknown length.

The mineralized rock consists principally of quartz that fills openings and more or less completely replaces the sheared rock, which is colored dark green by micaceous alteration minerals. The ore minerals are pyrite and galena. The deposits range from thin sprinklings along a fracture to well-defined lenticular veins as much as 1 foot wide and 20 feet long.

Thin sections of rock that is but moderately mineralized show greatly shattered feldspar and quartz as chief constituents. The feldspars are traversed by veinlets of sericite and calcite, and the large quartz grains by veinlets of minutely granular quartz. Chlorite in small drawn-out aggregates represents the original biotite of the rock. Pyrite in small grains is closely associated with the veinlets of sericite and quartz. The absence of magnetite suggests that its iron, with probably some from the biotite, has gone to form the pyrite. The sericite (if it is all of the potash variety) implies an introduction of potash to replace the soda and lime of plagioclase, but the principal materials introduced appear to have been water, carbon dioxide, and a little sulphur.

The more completely mineralized rock shows in thin section the same character, but the feldspar and chlorite are nearly all replaced, and the quartz is nearly all recrystallized. Secondary quartz is abundant and sericite subordinate. Galena accompanies the pyrite. Both ore minerals form aggregates, confined principally to the network of veinlets but also sending short branches into the inclosing minerals. The quantity of replacing minerals in this rock shows that silica, iron, and lead, as well as sulphur, water, and carbon dioxide, were introduced. Sericitization, characteristic of the less intense alteration, is here overshadowed by silicification.

A small shipment from this mine, made a few years ago, ran well in silver and comparatively well in gold.

The only deposit in the limestone of the Alpine district visited by the writer is on the
Alpine-Galena property, near the mouth of Boxelder Canyon, northeast of Alpine. The country rock is near the base of the great limestone series and is probably of Cambrian age. The only ore found up to 1912 was in small masses of silver-bearing galena and lead carbonate along a bedding plane. The bedding plane has been followed down about 50 feet to a small body of leached replacement quartz originally pyritic.

The mineralization in the Alpine district, so far as disclosed both in the Lucky Chance and in the Alpine-Galena ground, was of the same character as that in the productive mines of the Cottonwood-American Fork region, but the amount was decidedly small:

\section{SILVER LAKE DISTRICT.}

By V. C. Heikes.

The Silver Lake district is in Utah County, 15 miles east of American Fork, on the Denver \& Rio Grande and Los Angeles \& Salt Lake railroads. The district was organized January 28,1871 . No records of early production are available. The period previous to 1880 is reviewed by Huntley, ${ }^{1}$ who names the Milkmaid claim as the principal producer, with an output of $\$ 13,000$. He says that the records showed 260 locations, of which not over 10 were held. He names the mines of the district as follows:

Mines of Silver Lake district.

\begin{tabular}{|c|r|r|r}
\hline Mines. & $\begin{array}{c}\text { Total } \\
\text { length } \\
\text { of } \\
\text { open- } \\
\text { ings. }\end{array}$ & $\begin{array}{c}\text { Total } \\
\text { product. }\end{array}$ & \multicolumn{1}{c}{ Remarks. } \\
\hline Milkmaid.... & 535 & $\$ 13,000$ & $\begin{array}{c}\text { Ore assays } 36 \text { per cent } \\
\text { lead, } 58 \text { ounces silver, } \\
\text { and a trace of gold; } \\
\text { sells for } \$ 55 . \\
\text { Ore assays } 11 \text { ounces sil- } \\
\text { ver and } 27 \text { per cent } \\
\text { lead. } \\
\text { From 200 to } 300 \text { tons of } \\
\text { ore and waste on the } \\
\text { dump. } \\
\text { Ore assays } 30 \text { ounces sil- } \\
\text { ver and } 35 \text { per cent } \\
\text { lead. }\end{array}$ \\
\hline Nebraska..... & 250 & 10 tons. & None. \\
\hline
\end{tabular}

The total output of this district is included in the figures given for the American Fork district. (See p. 264.) 
PARK CITY DISTRICT. ${ }^{1}$

GEOGRAPHY.

Park City is on the eastern slope of the Wasatch Range, in the north-central part of Utah, about 25 miles southeast of and 3,000 feet above Salt Lake City and 7,000 feet above sea level. A branch line of the Denver \& Rio Grande Railroad unites it by way of Parleys Park with Salt Lake City (35 miles), and a branch line of the Union Pacific Railroad extends from the main line at Echo (28 miles). It thus forms a most convenient outlet point for the producing mines on the slopes of the three canyons that lead southward from Parleys Park.

The Park City district lies between the precipitous cliffs and ledges that mark the main crest of the range and the verdant mountain meadows of Heber, Kamas, and Parleys that lie along its' eastern foothills. The Park City quadrangle (see Pl. XXVII) contains, near the middle of its western border, the junction of the Wasatch crest with the Weber-Provo divide, which is the most prominent spur on the east slope of the central Wasatch and which forms a part of the boundary between Summit and Wasatch counties, and a connecting link between the Wasatch and Uinta ranges. This divide juts boldly forth from the main crest a mile north of Clayton Peak, and thence runs eastward for $3 \frac{1}{2}$ miles to the knob south of Bald Mountain, where it turns abruptly northward. The north-south part of the divide, together with a spur extending southward from the elbow, form a linear ridge that extends entirely across the quadrangle.

These main crests form the boundaries of three principal slopes, which drain to the east, south, and north, respectively. The long and gradual eastern slope, deeply incised by canyons, descends from the Bald Mountain ridge toward the intermontane lowland. The southern slope is occupied in great part by Bonanza Flat, the floor of an extensive glaciated basin, from which there is a steep acclivity to the crest of the Weber-Provo divide. The north slope, which lies in the elbow of this divide, is deeply cut by four narrow steep-

1 The description of the Park City district is largely abstracted from Boutwell, J. M., Geology and ore deposits of the Park City district, Utah: U. S. Geol. Survey Prof. Paper 77, 1912. Those desiring descriptions of the mines or more details concerning the geology are referred to - that report. sided gulches-Thaynes, Woodside, Empire, and Ontario-which drain to East Canyon Creek and the main branch of Weber River. On this slope lie Park City and the principal mines of the Park City district.

The climate is remarkably bracing, with short, cool summers, short autumns, and long, rigorous winters marked by heavy snowfalls and low temperature. Springs and watercourses cut by underground workings flow the year round, and natural rock basins at the foot of the pinnacle of Clayton Peak are utilized as reservoirs. Water for domestic purposes is obtained from the Alliance tunnel, and power for the Park City Electric Light plant from the Ontario drain tunnel. Water from the Snake Creek tunnel is also utilized for hydroelectric power. The slopes originally supported pine 3 to 5 feet in diameter, but to-day little heavy timber remains. Young aspen is common on canyon slopes, and the higher divides support patches of scrubby evergreens. Fuel is supplied from extensive veins of good coal at Coalville, 28 miles north, and from the forest growth on distant parts of the Wasatch and Uinta ranges.

\section{MINING INDUSTRY.}

HISTORY.

In the fall of 1869 locations in Little Cottonwood Canyon became so numerous that the Little Cottonwood mining district, with very nearly its present boundaries, was cut off from the somewhat extensive Mountain Lake district. Prospectors continued to spread into Big Cottonwood and American Fork, and some crossed the divide to the narrow gulches leading to Parleys Park.

When the first find was made is not certain, but the discovery of the Walker \& Webster claim in 1869 by Rufus Walker and a subsequent find of ore the same summer by Ephraim Hanks are the earliest notices on record. The first location was the Easterly Extension of the Young America lode, made on December 23, 1868 , and the next four were the Westerly Extension of the Young America lode, the Young America lode, the Yellow Jacket lode, and the Green Monster lode, all made in the following month. The first shipment of ore from this region, called in the records Parleys Park, is said to have been 40 tons for the month 
of July, 1870.1 Later records credit it to the Flagstaff mine. The Piñon mine in 1871 had a large body of galena and carbonate ores, said to assay 30 to 250 ounces to the ton, ${ }^{2}$ and is said to have contracted to deliver 20 tons a day to a smelter to be erected at Ogden. In the same year the Flagstaff, Walker \& Webster, Wild Bill, Rocky Bar, and other prospects were located. All are said to have been lead mines, principally carbonate, in limestone.

The increasing number of locations outgrew the supervision of the Mountain Lake district, which up to that time had included this area, and the Uinta (organized November 18, 1869), and the Snake Creek and Blue Ledge districts (established April or May, 1870) were set off from it. Parts of these three districts form what is now commonly known as the Park City district. The Uinta district lies in the southern part of Summit County and embraces all the present large mines in the Park City area; the Blue Ledge and Snake Creek districts are in Wasatch County and bound the Uinta district on the east and south, respectively.

In 1872 , about two years after the first locations were made, the famous Ontario ledge was discovered. Rector Steen describes this discovery in these words: ${ }^{3}$

I camped in a brush shanty for six months at the branch just below the Ontario, waiting for the snow to melt off. I went then to what is called the Badger mine, and about the 15th of June, 1872, we discovered the Ontario mine. There stood right near this mine a pine tree, and near by was a fine spring. We camped under this tree and got water from the spring. When we discovered this mine we found a little knob sticking out of the ground about 2 inches. * * We had the rock assayed and it went from 100 to 400 ounces to the ton. We sold the mine to Hearst and Stanley on the 21st day of August, 1872, for $\$ 27,000$. My partners were John Kain and Gus McDowell:

With the inception of the Ontario began an effort to mine lode ores. The Piñon, Walker \& Webster, Flagstaff, McHenry, Buckeye, and other mines, some of which were discovered before the Ontario, had opened small ore bodies and had shipped small amounts of marketable ore from time to time, but in comparison with the Ontario none of them were conspicuous.

1 Raymond, R. W., Statisties of mines and mining in the States and Territories west of the Rocky Mountains for 1870, p. 223, 1872, quoted from a Salt Lake City correspondent.

2 Idem, 1871, p. 329, 1873.

${ }^{3}$ Letter from Rector Steen to J. M. Boutwell dated Dec. 10, 1902. Steen was living in Missouri in 1902 in the enjoyment of good health, having left for his old home the day after the Ontario sale.
Machinery and some other articles had to be hauled 35 miles from Salt Lake City or 24 miles from Echo City, but fuel and timber were abundant.

The Marsac Co., which had bought the Flagstaff mine, and the McHenry Co. each built a stamp mill during the summer of 1874 , but from lack of ore neither was largely used that year. The Ontario people then rented the McHenry mill and treated ore there in 1875 . It also leased the Marsac mill but abandoned it on the completion of the Ontario 40-stamp mill. In the same year the first concentrator of the camp was erected to work over the Ontario tailings. In February, 1876, the Ontario mine alone was producing $\$ 14,000$ a week, and the whole camp was producing $\$ 20,000$.

The Daly Co. began work on the western extension of the Ontario vein; the tramway from the Crescent mine to the town was finished, and three or four small producers swelled the shipments of the camp. This renewed activity was enhanced by an advance in the metal market which aroused many old and abandoned mines carrying low-grade ore. As a result the producing area outside of the Ontario-Daly properties, which had hitherto been restricted to Crescent Ridge, became centered on Treasure Hill, which thenceforth rivaled the Ontario-Daly vein. For some years longer lode mining continued, but the activity on Treasure Hill was the beginning of mining bed ores, which continues still. In 1888 lode mining was given new life by the owners of the Ontario mine when they began its 3-mile drain tunnel. Their example was followed by the owners of the Anchor and Alliance mines. The passage by Congress of a law providing for the purchase of $4,500,000$ ounces of silver a month greatly improved the silver market, increased the output of the Utah mines, and caused general prosperity.

In 1892, however, silver dropped to 83 cents an ounce - the greatest decline then on record. The effect on the annual output of Summit County was scarcely noticed, owing to the advent of two new producers, the Silver King and Mayflower; but it was seen in the passing of the Ontario dividend and the closing of the Crescent, Woodside, and Daly West mines. The production of silver in Utah steadily decreased after 1891, but that of Park City 
curiously increased till 1893, when it suddenly fell off. The mines of Park City worked only intermittently during that year; even the Ontario-Daly, which in 1892 was producing nearly three-fourths of the Park City product, fell off one-third. The year 1893 marked the beginning of cheaper methods, more effective saving, relief from water, and realizing from other metals besides silver, all of which aided greatly in raising the output of the camp.

In 1897 the price of silver dropped to 54 cents. In consequence the Daly West and Ontario mines closed down, but the silver-lead producers, of which the Silver King was the leader, were able to withstand the low metal market. Lower prices caused new economies in mining and reduction. Large concentration mills gave an increased capacity for lowgrade ores. Rich smelting ore was discovered in Quincy ground in 1901 which quickly placed that property at the head of the list of producers, and the camp again assumed the lead in the production of silver in Utah.

In general the recent period has been one of continued mining of rich ores and an increase in the milling ores produced, which have been made profitable through improved methods of mining and metallurgy.

\section{WATER SUPPLY AND MINE DRAINAGE.}

Mountain lakes, springs, and mine openings afford sufficient and excellent water; and the large flows of water from the deep drainage tunnels furnish hydraulic power. Many of the mines have been very wet, and the handling of the water has been a great problem. In the early days pumping was used, but ultimately drainage tunnels were extended to progressively greater depth, culminating in the Ontario and Snake Creek tunnels. ${ }^{1}$

REDUCTION.

CHARACTER OF ORES.

The ores of the Park City mines are of both smelting and milling grades. Many large bodies of first-class ore have brought the camp its reputation for bonanzas. Recently, however, extensive bodies of low-grade ore have been opened, and more and more attention has been given to concentration.

1 The history of the drainage problem is detailed in Boutwell, J. M. op. cit., pp. 24-26.
The Park City ores carry high contents of lead and silver with accessory gold and copper. The first-class ore is essentially sulphides of lead (galena), copper, and iron (tetrahedrite) with high accessory silver values. This combination together with carbonates and oxides constitutes the normal smelting ore.

The milling ores are made up of galena, pyrite, and zinc blende scattered through a quartz gangue. The silver lies in the pyrite and in the galena. Hence the problem in concentration is to save the galena and pyrite, together with any chalcopyrite and tetrahedrite which may be present, and to throw out silica and all the zinc blende in excess of the allowance. In practice difficulty is found in saving the silver, which tends to escape with the fines. Unusually high savings are now effected.

CONCENTRATION.

In a broad sense the milling of Park City ores falls into three periods characterized by different methods - the early experimental stage, relying chiefly on mechanical means; the intermediate stage, in which both chemical and physical methods were employed; and the third stage marked by the purely physical processes of modern wet concentration.

During 1874 and 1875 three 20-stamp mills were built and put into operation. All used simple devices for separation. The intermediate stage was marked by enlargement of the leading mills and by refinement and development of processes, dry crushing, chloridizingroasting, and pan amalgamation being used. In 1880-1882 the Marsac mill was remodeled and fitted with dry kilns and water, and a process which was largely chemical was developed. Its inventor, Russell, in addition to extracting the silver by normal lixiviation methods after chloridizing-roasting, sought by new methods to produce bullion free from lead and to minimize or abandon the chloridizingroasting. His process ${ }^{2}$ consisted in general of (1) matting the sulphides in an iron pot; (2) roasting the pulverized matte in a muffle

2 Stetefeldt, C. A., Russell's improved process for the lixiviation of silverores: Trans. Am. Inst.Min. Eng., vol.13, pp. 47-118,1885. Daggett, Ellsworth, The Russell process in its practical applications: Trans, A.m. Inst. Min. Eng., vol. 16, pp. 362-495, 1888; Amalgamation at the Ontario mill compared with the Russell process at the Marsac mill: Eng. and Min. Jour., Mar., 1821. Stetefeldt, C. A., The Marsac refinery, Park City, Utah: Trans. Am. Inst. Min. Eng., vol. 21, pp. 286-298, 1892-\$3, 
furnace; (3) dissolving the roasted matte in modeled without having run long on ore. It dilute sulphuric acid; (4) crystallizing from the has a capacity of 500 tons a day and is the solution bluestone which is used in the mill for largest in camp. It does not differ in general preparing Russell's extra solution; (5) washing plan and process from the Daly West mill the silver residue, pressing it into cakes, and melting the dry cakes to bars.

While these two processes, lixiviation and amalgamation, were being thoroughly tried out the initial steps in the direction of modern wet concentration were being taken. "In a building near the Marsac mill and owned by that company four McKim concentrating machines were used successfully to concentrate both the tailings of the Ontario and the second tailings of the same mine after they had passed through the Marsac mill." ${ }^{1}$ These pioneer machines originated at Park City and were patented February $15,1876$.

The Crescent Co., after endeavoring to smelt its ores without success, remodeled the old Crescent mill in 1886 and refitted it with additional machinery, including seven Frue vanners, two Huntington rolls, two Cornish rolls, and two rock crushers and screens, which raised its capacity to 100 tons a day.

In 1889 the Union concentrator was erected in Empire Gulch and equipped to handle 100 tons a day by the general method of modern wet concentration. It started in July and first $\operatorname{ran}$ on 10,000 tons of Woodside ore averaging $\$ 15$ a ton. The Mayflower mill was built soon after in Woodside Canyon, and the Union mill, which had been running on custom ores, was gradually restricted to the Anchor ores.

The wet concentration process was so successful that it gradually supplanted the others, and during the nineties each of the great companies erected a large mill on its own property for the treatment of its own ores by this method. Each of these mills has been enlarged and remodeled more than once, and other mills have been built.

The Daly West mill was built in the middle nineties at a moderate cost and had a capacity of 50 tons a day. In 1900 it was remodeled and since then has been enlarged and rendered more and more efficient, until late in 1904 it treated 400 tons daily.

The Daly-Judge mill was built and then greatly enlarged in 1902 and subsequently re-

${ }^{1}$ Huntley, D. B., Tenth Census U. S., vol. 13, p. 441, 1885. described above.

The Silver King plant is the most complete and the most expensive in the district, and in equipment and efficiency is excelled at very few camps.

The mill erected at the Kearns-Keith property in 1903 is an exact duplicate of a single unit of the Silver King mill. The ore, however, differs considerably from that of the Silver King, being largely of milling grade and high in zinc blende and iron. A fairly satisfactory concentrate was obtained.

In 1904, both the walls and the interior of the old Ontario amalgamation mill were remodeled and a modern plant for wet concentration was installed. The remodeled mill was started in February, 1904, with a small initial equipment, which was increased after some experimenting. In 1912 the capacity of the mill was 150 to 200 tons a day.

Smaller mills at other mines are run intermittently. The Comstock mill is reported to have a capacity of 120 tons. The equipment comprises a wet crusher, 3 cylindrical screens, 3 jigs, and 1 Huntington and 6 Wilfley tables. A smail mill at the California mine comprises the equipment of the old Sampson mill with some additions and adaptations, and is understood to have given fair satisfaction in the treatment of the highly zinciferous ores. In Woodside Canyon just below the Silver King plant the old Mayflower mill has been run for a part of each year on old dumps and tailings. In Empire Canyon several small temporary plants from time to time rework the tailings from the Daly West and Daly-Judge mills.

TREATMENT OF ZINC ORES.

Numerous efforts to separate and to save the zinc have been made. Considerable zinc blende occurs in the sulphide ores, more particularly in those from the deeper parts of the veins and from the western section of the district. Among the large producers the only mines that yield rich zine ore are the Daly West and Daly Judge. The average percentages of the main constituents in the concentrated ores of these mines, which consist almost 
entirely of sulphides, are as follows: Daly Judge mine, lead 8 to 10 per cent, zinc 8 to 10 per cent, iron 6 to 10 per cent; Daly West mine, lead 4 to 6 per cent, zine 6 to 8 per cent, iron 4 to 6 per cent. In 1904 the Ontario milling ore averaged 6 per cent zinc. The California and Comstock ores also carried much zinc.

The zinc blende (specific gravity, 3.9 to 4.1 ) usually occurs in a quartz gangue associated with pyrite (specific gravity, 4.95 to 5.1 ), galena (specific gravity, 7.4 to 7.6 ), and a small amount of chalcopyrite (specific gravity, 4.1 to 4.3). Gravity methods of wet concentration separate zinc blende from galena but will not separate it from chalcopyrite and pyrite, which too nearly equal it in specific gravity.

The particular characters of the respective ores also present special problems.

In August, 1902, a plant to save the zinc from the Park City ores was built by the Park City Metals Co. According to Mr. Glazebrook, its former superintendent, it embraced the old Peck concentrator building, roaster, and separator, and important new machinery. The equipment comprised one cylindrical furnace, a Howell and Hoyt roaster, a Hooe conveyor and magnetic separator, and six Wilfley tables. Over 1,000 tons were successfully treated by this process. It is stated that one lot of 35 tons ran 55 per cent zinc, that the average was about 52 per cent, that the product rarely fell to 48 per cent, and that in the ultimate rejection the tailings loss was not over 5 per cent of zinc. The plant burned to the ground in May, 1903, and the company being unable to obtain a renewal of its contract for middlings did not rebuild.

SAMPLING AND SMELTING.

The concentrates and crude ores from all the properties in the district are shipped for reduction to a custom smelter at Murray, 8 miles south of Salt Lake City. The ores from the Silver King mine are sampled at the mine and thence go directly to the smelter. The ores from all the other properties in the camp are sampled at the Park City sampler, on the northern boundary of Park City, and are then shipped to the smelter.

Since Boutwell's review of milling in the district (outlined above) was written the progress in milling has perhaps been most marked in the development of methods for the separation of a marketable zinc product and in the development of a chemical method of treatment of second-class ores of the Ontario mine that could not be profitably treated in the older mills.

The oil flotation process is now extensively used in the milling of the ores, and metallic zinc is being produced in the district by the electrolytic treatment of the ores.

\section{METAL CONTENT OF ORES.}

By V. C. Herkes.

The following synopsis of the character and metal content of the ores produced in the Park City district in recent years is compiled from the records of the United States Geological Survey.

$$
\text { DRY OR SILICEOUS ORES. }
$$

The dry or siliceous ores shipped to smelters from the Park City region are gold and silver ores carrying, on an average, very little copper and too little lead to be of value. The largest producer of this kind of ore has been the Ontario mine, which, for the greater part of the last decade, has been worked by lessees, who shipped considerable of the stope fillings. During 1913 and 1914 important quantities of silver bullion have been extracted in the mill by the Holt-Dern leaching process of chloridizing-roasting. The average of the ore treated is not included. The New York and American Flag properties were also important shippers of this class of ore. The quantity and average metallic contents of the dry ore shipped from the Park City region for each year during the last decade are as follows:

Quantity and average metallic contents of dry or siliceous ores produced in the Park City region and shipped to smelters, 1905-1917.

\begin{tabular}{|c|c|c|c|c|c|c|}
\hline Year. & $\begin{array}{l}\text { Quan- } \\
\text { tity } \\
\text { (short } \\
\text { tons). }\end{array}$ & $\begin{array}{c}\text { Gold } \\
\text { (value } \\
\text { per } \\
\text { ton). }\end{array}$ & $\begin{array}{c}\text { Silver } \\
\text { (ounces } \\
\text { per } \\
\text { ton). }\end{array}$ & $\begin{array}{c}\text { Cop- } \\
\text { per } \\
\text { (per } \\
\text { cent). }\end{array}$ & $\begin{array}{c}\text { Lead } \\
\text { (per } \\
\text { cent). }\end{array}$ & $\begin{array}{l}\text { Aver- } \\
\text { age } \\
\text { gross } \\
\text { value } \\
\text { per } \\
\text { ton. }\end{array}$ \\
\hline 1905 & $a 16,204$ & $\$ 0.30$ & 5.13 & & 1.53 & $\$ 4.88$ \\
\hline 1907 & 2,477 & 5.46 & 39.01 & & 04 & 31.25 \\
\hline 1908 & 1,990 & 7. 69 & 24.62 & 0.24 & 1.00 & 22.22 \\
\hline 1909 & 1,132 & 7.95 & 21.44 & .17 & .80 & 20.24 \\
\hline 191 & 2,713 & 7.26 & 25.50 & .42 & .64 & 22.67 \\
\hline 18 & 4,231 & 1.44 & 21. & .02 & .03 & 12.89 \\
\hline & 1,032 & 1. 18 & 24.81 & .12 & 4.01 & 20.45 \\
\hline 191 & 1,635 & .63 & 37. & & & \\
\hline & 2,750 & 49 & 27 & .04 & 1.52 & 15. 90 \\
\hline 191 & 8,018 & .56 & 25. 38 & .07 & .60 & 18. 45 \\
\hline & 12,277 & .64 & 29.74 & .06 & 1. 61 & 28. 28 \\
\hline
\end{tabular}
$35416^{\circ}-19-19$ 
COPPER ORE.

The copper ores include those carrying over $2 \frac{1}{2}$ per cent of copper. The Valeo and Odin properties have shipped most frequently. The average of these ores is as follows:

Quantity and average metallic contents of copper ore produced in the Park City region and shipped to smelters, 1906-1909, 1914-1917.

\begin{tabular}{|c|c|c|c|c|c|}
\hline Year. & $\begin{array}{c}\text { Quan- } \\
\text { tity } \\
\text { (short } \\
\text { tons). }\end{array}$ & $\begin{array}{c}\text { Gold } \\
\text { (value } \\
\text { per ton) }\end{array}$ & $\begin{array}{c}\text { Silver } \\
\text { (ounces } \\
\text { per ton). }\end{array}$ & $\begin{array}{l}\text { Copper } \\
\text { (per } \\
\text { cent). }\end{array}$ & $\begin{array}{c}\text { Average } \\
\text { gross } \\
\text { value } \\
\text { per } \\
\text { ton. }\end{array}$ \\
\hline 1906. & 166 & $\$ 0.81$ & 0.81 & 3.33 & $\$ 14.23$ \\
\hline 1907. & 1,295 & .87 & .85 & 3. 01 & 13. 49 \\
\hline 1909 & 57 & .63 & 1.23 & 6.61 & 18.44 \\
\hline $1914 \ldots$ & 16 & & 1. 87 & 1. 55 & 5. 19 \\
\hline $1915 \ldots \ldots \ldots$ & 25 & .66 & 1. 08 & 3. 78 & 14. 36 \\
\hline $1917 \ldots \ldots$ & 44 & & 5. 18 & 7. 06 & 42.82 \\
\hline
\end{tabular}

LEAD ORE AND CONCENTRATES.

In general the crude lead ores and concentrates are those that contain over $4 \frac{1}{2}$ per cent of lead. The regular shippers of this class of crude ore have been the Silver King Coalition, Daly-Judge, Daly West, Daly, and Silver King Consolidated and, in less degree, the Little Bell, Ontario, New York, Naildriver, Creole, Kearns-Keith, American Flag, Jupiter, Old Curtis, Revelator, J. I. C., Comstock, Wabash, Woodside, California, Kennedy Group, and Kennelly. Lead concentrates have come in recent years from the Silver King Coalition, Daly West, and Daly-Judge, and in earlier years from the California, Comstock, Ontario, Kearns-Keith, Little Bell, Kennelly, Daly, and Charles Moore. The quantity and average grade of the crude lead ore and concentrates is as follows:

Quantity and average metallic contents of lead ore produced in the Park City region and shipped to smelters, 1903-1917.

Crude ore.

\begin{tabular}{|c|c|c|c|c|c|c|}
\hline Year. & $\begin{array}{l}\text { Quantity } \\
\text { (short } \\
\text { tons). }\end{array}$ & $\begin{array}{c}\text { Gold } \\
\text { (value } \\
\text { per ton). }\end{array}$ & $\begin{array}{c}\text { Silver } \\
\text { (ounces } \\
\text { per ton). }\end{array}$ & $\begin{array}{l}\text { Copper } \\
\text { (per } \\
\text { cent). }\end{array}$ & $\begin{array}{l}\text { Lead } \\
\text { (per } \\
\text { cent). }\end{array}$ & $\begin{array}{c}\text { Average } \\
\text { gross } \\
\text { value } \\
\text { per ton. }\end{array}$ \\
\hline $1903 \ldots$ & 100,980 & $\$ 2.37$ & 54. 76 & 1. 40 & 27.85 & $\$ 59.16$ \\
\hline $1904 \ldots \ldots \ldots \ldots$ & 91,871 & 2. 27 & 45.88 & .85 & 23. 06 & 50.87 \\
\hline $1905 . \ldots \ldots \ldots$ & 51,338 & 4. 42 & 47. 17 & .69 & 27.05 & 60.79 \\
\hline $1906 \ldots \ldots \ldots \ldots \ldots$ & 59,743 & 2.56 & 41.36 & .66 & 21.03 & 57. 19 \\
\hline 1907 & 46,854 & 1. 98 & 35.53 & .59 & 20.70 & 49. 71 \\
\hline 1908 & 32,105 & 1. 59 & 52.82 & .56 & 29.78 & 56.09 \\
\hline 1909 & 41,521 & 1. 15 & 43. 16 & 1. 51 & 30.49 & 52.25 \\
\hline 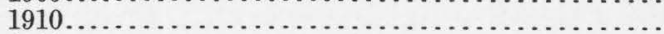 & 27,427 & 1. 12 & 43. 78 & 1. 38 & 24. 29 & 45. 17 \\
\hline $1911 \ldots \ldots \ldots$ & 38,358 & 1. 19 & 43. 65 & .70 & 23. 40 & 47. 12 \\
\hline $1912 \ldots \ldots \ldots \ldots$ & 30,987 & 1. 06 & 55. 30 & 1. 59 & 25.32 & 63.11 \\
\hline 1913 & 33,952 & 1. 47 & 58. 60 & 1. 68 & 30.00 & 68. 47 \\
\hline $1914 \ldots \ldots \ldots \ldots$ & 37,326 & 1. 62 & 49. 74 & 1. 57 & 24. 98 & 52. 79 \\
\hline $1915 \ldots \ldots \ldots \ldots$ & 56,355 & 1. 04 & 47. 19 & 1. 57 & 26. 96 & 55.83 \\
\hline $1916 \ldots \ldots$ & 43,238 & 1. 76 & 46. 51 & 1. 29 & 23. 36 & 70.96 \\
\hline 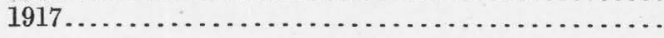 & 48,436 & 1. 36 & 36. 17 & .77 & 20.53 & 70.63 \\
\hline
\end{tabular}

Concentrates.

\begin{tabular}{|c|c|c|c|c|c|c|}
\hline 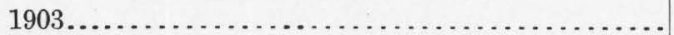 & 35,405 & $\$ 2.10$ & 44. 60 & 0.95 & 31. 08 & $\$ 54.90$ \\
\hline 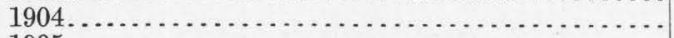 & 34,173 & 2.15 & 46. 79 & .82 & 32. 11 & 59.01 \\
\hline 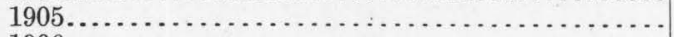 & 31,897 & 2. 26 & 45. 60 & .84 & 26. 08 & 57. 22 \\
\hline $1906 \ldots \ldots$ & 36,600 & 2. 40 & 32.85 & .54 & 29.15 & 60.05 \\
\hline 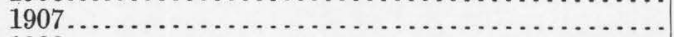 & 34,105 & 1. 95 & 29.98 & .47 & 24. 61 & 49.69 \\
\hline 1908 & 25,061 & 1. 54 & 28.58 & 34 & 29. 70 & 42.52 \\
\hline $1909 \ldots \ldots$ & 30,941 & 1. 12 & 29. 19 & 62 & 37.56 & 45. 92 \\
\hline 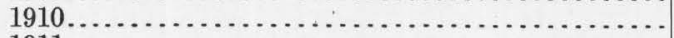 & 34,473 & 1. 04 & 30.67 & .92 & 33. 08 & 49.05 \\
\hline 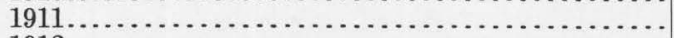 & 47,906 & 1. 01 & 31. 85 & .76 & 29. 72 & 46.55 \\
\hline 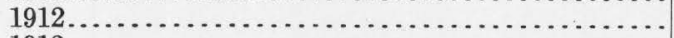 & 39,768 & .97 & 43. 58 & 1. 18 & 32.10 & 60.56 \\
\hline 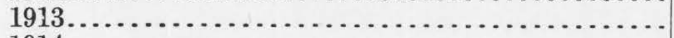 & 34,356 & .98 & 39.23 & .88 & 30.09 & 53. 89 \\
\hline 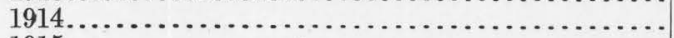 & 25,071 & 1. 42 & 29.83 & .67 & 26. 70 & 40.54 \\
\hline 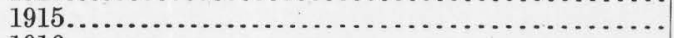 & 27,264 & .84 & 31. 20 & .90 & 33. 14 & 50.97 \\
\hline 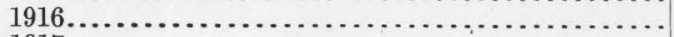 & 23,618 & 1. 24 & 27. 11 & .78 & 26. 96 & 60.16 \\
\hline 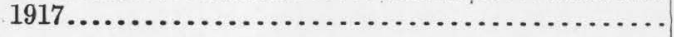 & 27,278 & 1. 31 & 25.90 & .77 & 23. 94 & 68.08 \\
\hline
\end{tabular}


COPPER-LEAD ORES.

Copper-lead ores are classified according to the same method as the copper and the lead ores. The producers were the Columbus and Marie properties, in 1905 and 1906. The quantity and average grade of the ore shipped was as follows:

Quantity and average metallic contents of copper-lead ore produced in the Park City region and shipped to smelters, 1905-6.

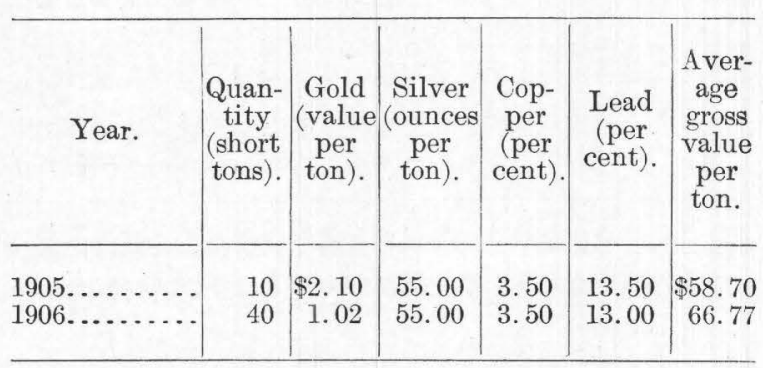

ZINC CONCENTRATES.

The zinc concentrates shipped are those usually containing over 25 per cent of zinc, but in the Park City region it had been the practice until 1912 to make a middling, which was re-treated at separator plants. The Daly-Judge mill has most frequently produced this kind of product, which, at first, was treated at a plant in north Salt Lake City, later at the Grasselli mill near Park City and at Midvale. Better concentration methods at the mills connected with the mines have allowed the shipment direct to zine smelters. The loss of considerable zinc and some lead at the Park City mills caused the erection of many small plants during different years to re-treat the tailings lodged along Silver Creek. The producers of straight zine concentrates with little lead were the Daly-Judge, Daly West, and Daly mines. The quantity and average grade of the zine concentrates shipped is as follows:
Quantity and average metallic contents of zinc concentrates produced in the Park City region and shipped to smelters, $1905-191 \%$.

\begin{tabular}{|c|c|c|c|c|c|c|c|}
\hline Year. & $\begin{array}{l}\text { Quan- } \\
\text { tity } \\
\text { (short } \\
\text { tons). }\end{array}$ & $\begin{array}{c}\text { Gold } \\
\text { (value } \\
\text { per } \\
\text { ton). }\end{array}$ & $\begin{array}{c}\text { Silver } \\
\text { (ounces } \\
\text { per } \\
\text { ton). }\end{array}$ & $\begin{array}{c}\text { Cop- } \\
\text { per } \\
\text { (per } \\
\text { cent). }\end{array}$ & $\begin{array}{c}\text { Lead } \\
\text { (per } \\
\text { cent). }\end{array}$ & $\begin{array}{c}\operatorname{Zinc}^{a} \\
\text { (per } \\
\text { cent). }\end{array}$ & \begin{tabular}{|l} 
Aver- \\
age \\
gross \\
value \\
per \\
ton.
\end{tabular} \\
\hline 1905 & 90 & $\$ 0.69$ & 36.33 & 2.08 & 3. 33 & 33. 75 & $\$ 72.31$ \\
\hline 1906 & 8,921 & .50 & 8. 22 & $\ldots .$. & ..... & 18. 77 & 29.00 \\
\hline 1908. & 3,153 & .02 & 81 & & 07 & 22. 29 & 21. 46 \\
\hline 1909. & 17,969 & .42 & 5. 14 & & 2. 03 & 17. 58 & 23.85 \\
\hline 1910 . & 8,162 & .01 & 17. 18 & & 5. 46 & 31. 98 & 48. 63 \\
\hline 19 & 8,189 & 19 & 4. 80 & .06 & 2. 38 & 27.50 & 36. 38 \\
\hline 19 & 11,948 & 25 & 13. 72 & .16 & 3.38 & 33.48 & 58.47 \\
\hline 19 & 6,794 & 23 & 18. 19 & .09 & 4. 45 & 35. 75 & 55. 46 \\
\hline 191 & 4,413 & .35 & 13. 39 & .04 & 2.96 & 35.95 & 46.84 \\
\hline 19 & 11,162 & 36 & 14. 19 & 06 & 3. 57 & 34.81 & 97.46 \\
\hline 19 & 7,308 & 36 & 11. 62 & .02 & 2. 67 & 33. 91 & 103.45 \\
\hline 191 & 8,083 & .24 & 14. 21 & .57 & 2. 19 & 31.68 & 83.47 \\
\hline
\end{tabular}

The lead-zine concentrates shipped were usually brought to a higher degree at separation mills. The Daly-Judge and Daly West were the largest shippers. The quantity and average grade of the lead-zinc concentrates is as follows:

Quantity and average metallic contents of lead-zinc concentrates produced in the Park City region and shipped to smelters, 1905-1917.

\begin{tabular}{|c|c|c|c|c|c|c|c|}
\hline Year. & $\begin{array}{l}\text { Quan- } \\
\text { tity } \\
\text { (short } \\
\text { tons). }\end{array}$ & $\begin{array}{c}\text { Gold } \\
\text { (value } \\
\text { per } \\
\text { ton). }\end{array}$ & $\begin{array}{l}\text { Silver } \\
\text { (ounces } \\
\text { per } \\
\text { ton). }\end{array}$ & $\begin{array}{c}\text { Cop- } \\
\text { per } \\
\text { (per } \\
\text { cent). }\end{array}$ & $\begin{array}{c}\text { Lead } \\
\text { (per } \\
\text { cent). }\end{array}$ & $\begin{array}{c}\text { Re- } \\
\text { cov- } \\
\text { erable } \\
\text { zinc } \\
\text { (per } \\
\text { cent). }\end{array}$ & $\begin{array}{l}\text { Aver- } \\
\text { age } \\
\text { gross } \\
\text { value } \\
\text { per } \\
\text { ton. }\end{array}$ \\
\hline 1905 & 3,794 & $\$ 0.47$ & 9.06 & & 76 & 25. 19 & $\$ 40.20$ \\
\hline 06 . & 375 & .62 & 17. 50 & & 5. 00 & 22.50 & 45. 67 \\
\hline 1907 & 574 & 22 & 16. 37 & & 4. 04 & 22.54 & 41.92 \\
\hline 1909 & 1,084 & .45 & 12. 15 & 0.07 & 6. 12 & 19.35 & 33. 12 \\
\hline 191 & 12,714 & .45 & 8. 19 & .05 & 4. 21 & 16. 59 & 26. 60 \\
\hline & 7,054 & .03 & 13. 97 & .02 & 5. 79 & 29.00 & 45. 76 \\
\hline 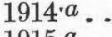 & & & & & & & \\
\hline & 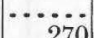 & & 2 & & & & \\
\hline & 128 & $\begin{array}{r}.40 \\
.32\end{array}$ & $\begin{array}{r}11.03 \\
7.50\end{array}$ & 18 & & $\begin{array}{l}30.76 \\
31.26\end{array}$ & $\begin{array}{l}99.38 \\
79.82\end{array}$ \\
\hline
\end{tabular}


PRODUCTION.

The following tables give the production of gold, silver, copper, lead, and zinc in the Park City district from the beginning of operations in 1870 to 1917 :

Quantity of ore sold or treated in Park City mining region, 18\%0-1917, and metals recovered.

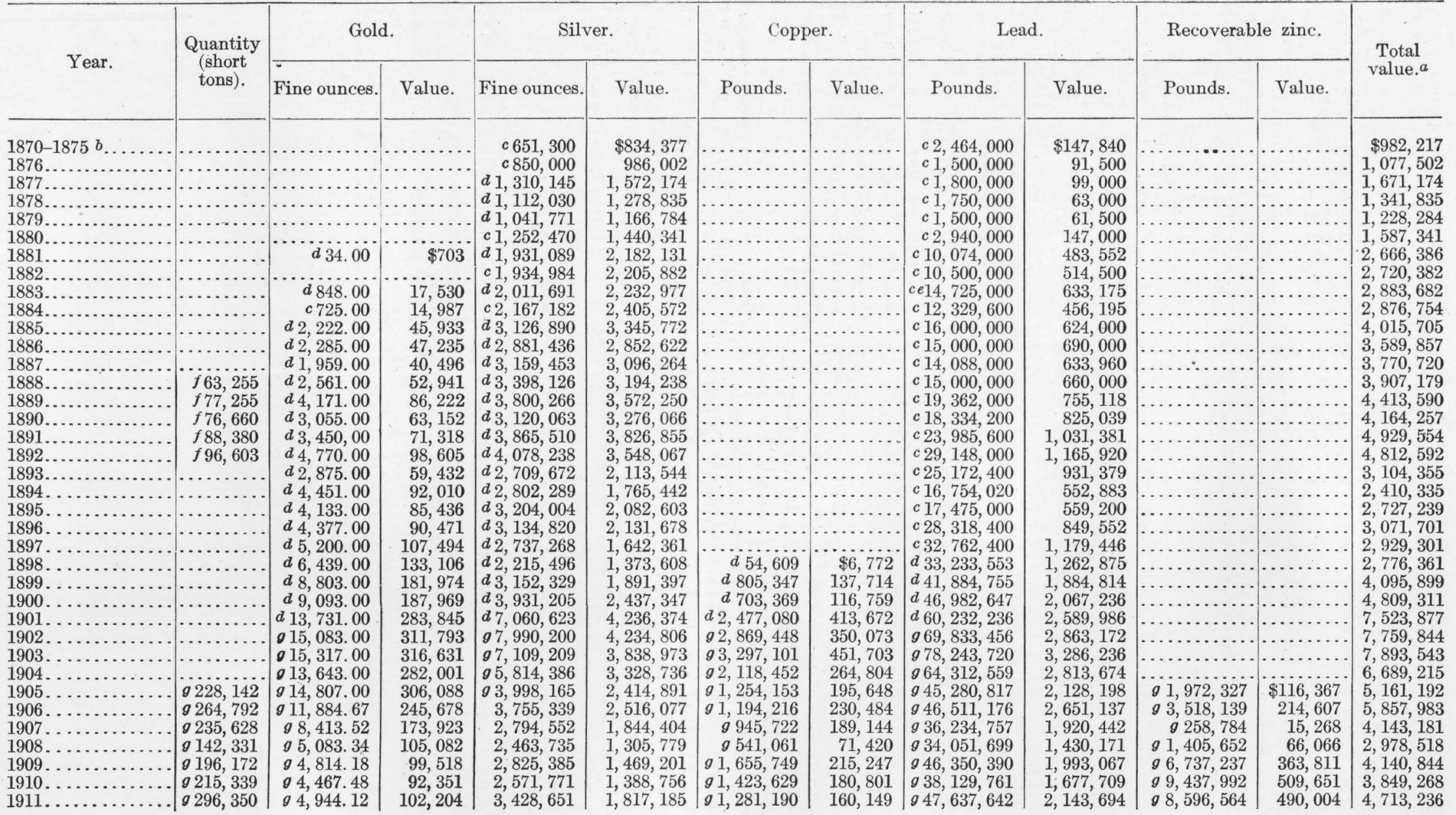




\begin{tabular}{|c|c|c|c|c|c|c|c|c|c|c|c|c|}
\hline 1912. & $g 280,671$ & $g 3,664.30$ & 75,748 & $3,642,749$ & $2,240,290$ & $g 1,968,249$ & 324,761 & $g 42,111,561$ & $1,895,021$ & $g 8,001,512$ & 552,104 & $5,087,924$ \\
\hline 1913. & $g 270,527$ & g $4,221.00$ & 87,256 & $3,717,556$ & $2,245,404$ & g $1,794,170$ & 278,096 & g $41,808,713$ & $1,839,584$ & $g 4,980,206$ & 278,892 & $4,729,232$ \\
\hline 1914 & g 236, 952 & $g 4,797.99$ & 99,183 & $2,955,008$ & $1,634,119$ & $g 1,559,953$ & 207,474 & $g 32,323,066$ & $1,260,600$ & $g 3,173,313$ & 161,839 & $3,363,215$ \\
\hline 1915 & g 263,342 & อ $4,207.66$ & 86,980 & $3,754,598$ & $1,903,581$ & $g 2,287,172$ & 400,256 & $g 49,350,377$ & $2,319,467$ & $7,771,350$ & 963,647 & $5,673,931$ \\
\hline 196 & $g 300,598$ & $g 5,381.04$ & 111,236 & $2,900,718$ & $1,908,672$ & $g 1,512,578$ & 372,094 & $g 33,233,794$ & $2,293,131$ & $5,136,353$ & 688,272 & $5,373,405$ \\
\hline & $g 240,610$ & $g 5,352.51$ & 110,647 & $2,937,438$ & $2,420,449$ & o 1,285, 308 & 350,889 & $g 33,715,565$ & $2,899,539$ & $5,201,756$ & 530,579 & $6,312,103$ \\
\hline Tot & & $211,263.81$ & $4,367,178$ & $135,299,810$ & $99,202,886$ & $31,028,556$ & $4,917,960$ & $1,252,444,864$ & $56,374,893$ & $66,191,185$ & $4,951,107$ & $169,814,024$ \\
\hline
\end{tabular}

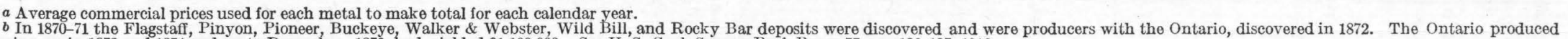
shipping ore in 1873 and 1874 and up to December, 1876 , had yielded \$1,100,000. See U.'S. Geol. Survey Prof. Paper 77, pp. 136-137, 1912.

$1882-1897$. Part of the records of some early producers were used in the estimates.
$d$ U. S. Geol. Survey Prof. Paper 77, p. 36, 1912 .

$e$ Crescent and Sampson were the heaviest shippers of lead ores.

Hanauer, A. jr., Mineral industry, vol. 1, p. 185, 1892; see also reports of Director of Mint, 1888-1892.

$h$ These totals are for mine output and aggregate more than if smelters' and refiners' figures were used.

Metals produced in the Park City mining region, 1870-1917, by periods.

\begin{tabular}{|c|c|c|c|c|c|c|c|c|c|c|c|c|}
\hline \multirow{2}{*}{ Period. } & \multirow{2}{*}{$\begin{array}{l}\text { Quantity } \\
\text { (short } \\
\text { tons). }\end{array}$} & \multicolumn{2}{|c|}{ Gold. } & \multicolumn{2}{|c|}{ Silver. } & \multicolumn{2}{|c|}{ Copper. } & \multicolumn{2}{|c|}{ Lead. } & \multicolumn{2}{|c|}{ Recoverable zinc. } & \multirow{2}{*}{$\begin{array}{c}\text { Total } \\
\text { value. }\end{array}$} \\
\hline & & Fine ounces. & Value. & Fine ounces. & Value. & Pounds. & Value. & Pounds. & Value. & Pounds. & Value. & \\
\hline $\begin{array}{l}1870-1880 . \\
1881-1890 . \\
1891-1900 . \\
1901-1910 . \\
1911-1917 .\end{array}$ & $1,889,050$ & $\begin{array}{r}17,860.00 \\
53,591.00 \\
107,244.19 \\
32,568.62\end{array}$ & $\begin{array}{r}\$ 369,199 \\
1,107,815 \\
2,216,910 \\
673,254\end{array}$ & $\begin{array}{r}6,217,716 \\
27,531,180 \\
31,830,831 \\
46,383,365 \\
23,336,718\end{array}$ & $\begin{array}{l}\$ 7,278,513 \\
28,363,774 \\
22,812,902 \\
26,577,997 \\
14,169,700\end{array}$ & $\begin{array}{r}1,563,325 \\
17,776,611 \\
11,688,620\end{array}$ & $\begin{array}{r}\$ 261,245 \\
2,562,996 \\
2,093,719\end{array}$ & $\begin{array}{r}11,954,000 \\
145,412,800 \\
295,716,775 \\
519,180,571 \\
280,180,718\end{array}$ & $\begin{array}{r}\$ 609,840 \\
6,275,539 \\
11,484,686 \\
23,353,792 \\
14,651,036\end{array}$ & $\begin{array}{l}23,330,131 \\
42,861,054\end{array}$ & $\begin{array}{r}\dddot{1}, 285,770 \\
3,665,337\end{array}$ & $\begin{array}{l}\$ 7,888,353 \\
35,008,512 \\
35,666,648 \\
55,997,465 \\
35,253,046\end{array}$ \\
\hline & & $211,263.81$ & $4,367,178$ & $135,299,810$ & $99,202,886$ & $31,028,556$ & $4,917,960$ & $1,252,444,864$ & $56,374,893$ & $66,191,185$ & $4,951,107$ & $169,814,024$ \\
\hline
\end{tabular}


GEOLOGY. ${ }^{1}$

PRINCIPAL FEATURES.

The oldest rocks of the Park City quadrangle are sedimentary strata which range in age from lower Carboniferous to Triassic. They have been arched up to form a part of the eastwardpitching Park City anticline-a prolongation of the Uinta anticline-whose axis traverses the quadrangle from east-northeast to westsouthwest, and they have been dislocated by many faults. They have been invaded, altered, and locally domed by diorite and diorite porphyry, which form the easternmost of the large intrusive masses that are exposed along the general course of the Park City anticline. The sedimentary and the intrusive rocks are overlapped on the east by the andesitic lavas of the intermontane trough.

The higher slopes, including the chief peaks and the valleys which radiate from them, bear evidence of local glaciation. The steep-walled amphitheaters or cirques which form the heads of these valleys contain much bouldery glacial drift. Below these cirques the valleys exhibit characteristic U-shaped profiles, ground and lateral moraines, boulder trains, perched erratics, striation, and scouring. The largest glacier of the district flowed southeastward from Bonanza Flat.

Each of the three main topographic divisions outlined on page 285 the north, east, and south slopes-differs from the others in geologic character. The north slope is chiefly formed of Pennsylvanian and Triassic strata, which dip northwestward at low angles and are intricately faulted. On the east slope the same strata occur with a general eastward dip; they are much intruded by diorite porphyry on the southern half of this slope and partly buried by andesite at the east. The south slope is occupied by diorite of the Clayton Peak mass, with its border of contact-metamorphosed sediments. These metamorphosed and hardened rocks stand up as the rugged backbone along whose northern side are found all the great bonanzas of the camp.

\section{SEDIMENTARY ROCKS.}

GENERAL FEATURES.

The sedimentary rocks of the Park City district include some of the upper part of the

1 Abstracted from Boutwell, J. M., op. cit., pp. 43-102. great limestone series of the region but belong mainly to five later formations, which range from Pennsylvanian to late Triassic or early Jurassic in age and have a total thickness of nearly 6,000 feet. The earliest of these formations is quartzitic; in the others the most abundant rock is shale, though a good deal of sandstone and limestone are present. The shale in the Mesozoic formations is mostly reddish where it is unaltered.

The best exposures of most of these rocks are found on the north side of Big Cottonwood Canyon, in the Cottonwood quadrangle, and the diagrammatic columnar section forming Plate XXIX is compiled from observations made at that locality.

CARBONIFEROUS SYSTEM.

Undifferentiated limestones. - Some limestone masses of obscure stratigraphic relations and structure are mapped as "undifferentiated limestone." They occur chiefly in the southern and southeastern parts of the district. They consist partly of blue limestone containing little impurity, and partly of carbonaceous or sandy limestone. Much of the limestone is metamorphosed to coarse white marble. Some beds are known to be of Pennsylvanian age, because they are interstratified with Weber quartzite; others are shown by their fossils to be of earlier Carboniferous age, and belong to the post-Cambrian limestone series described on pages $238-239$.

Weber quartzite.-According to Hintze ${ }^{2}$ the Weber quartzite is unconformable on the underlying limestones, its base being marked by a conglomerate made up of rounded chert pebbles and silicified corals together with much fine material, but there is little or no angular discordance at the contact.

The Weber quartzite, whose thickness is given by Boutwell as 1,350 feet, consists mainly of quartzite but contains beds of limestone which are especially abundant near the base. The quartzite is generally thick bedded. On fresh fracture it is light brownish gray, and it weathers to a glittering surface of lighter shade. It is finer and more even grained than the Cambrian quartzite.

${ }^{2}$ Hintze, F. F., jr., A contribution to the geology of the Wasatch
Mountains, Utah: New York Acad. Sci. Annals, vol. 23, pp. 115-120, 1913. 


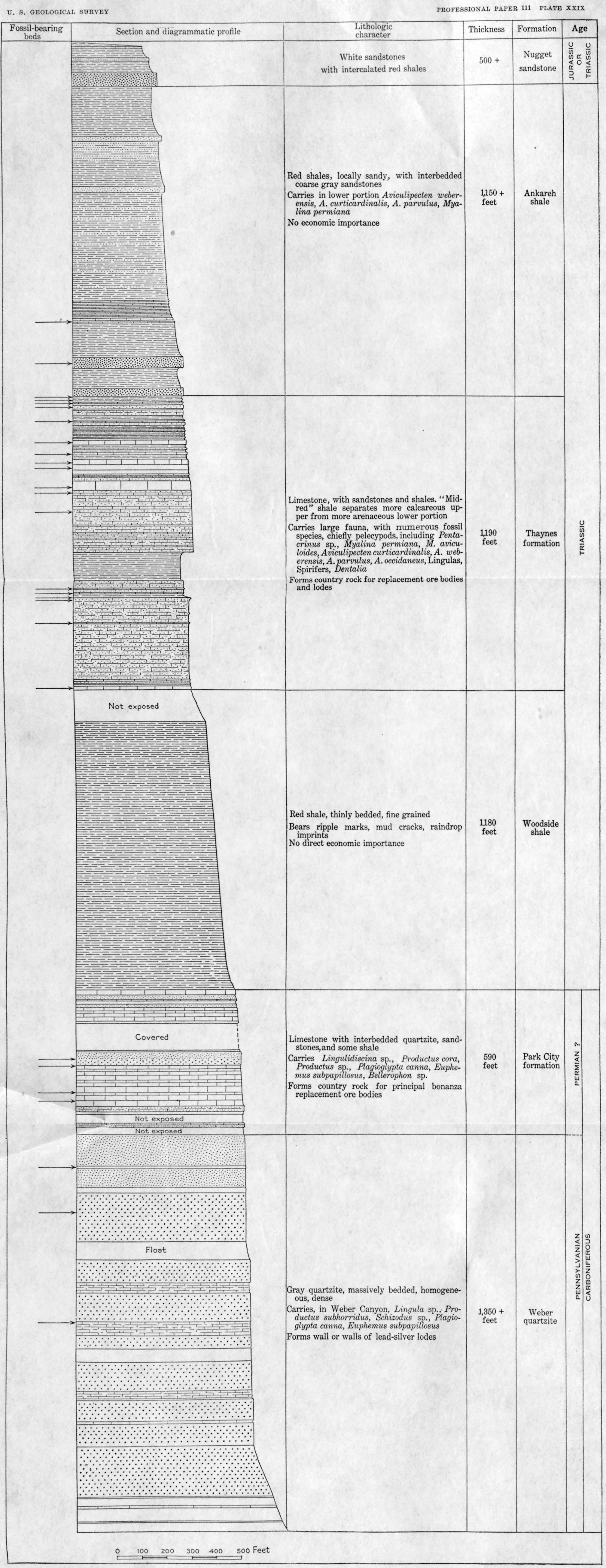

COLUMNAR SECTION SHOWING FORMATIONS PRESENT IN BIG COTTONWOOD CANYON After J. M. Boutwell. 
The Pennsylvanian age of the Weber quartzite has been proved by the finding of Pennsylvanian fossils in the limestone beds, including some of the lowest, of the formation and in the overlying Park City formation.

The Weber quartzite is extensively exposed in the middle and eastern parts of the Park City district and in the northern part of the Cottonwood quadrangle.

Park City formation.-Although Boutwell recognized no unconformity between the Weber quartzite and the Park City formation, evidence of such an unconformity near Ogden is given by Blackwelder. ${ }^{1}$

The Park City formation, so named in recognition of its preeminent economic importance, occurs in the northeastern and eastern parts of the district. Its type section is on the north side of Big Cottonwood Canyon, where it has a thickness of 590 feet. The formation also occurs in two zones lying east and west of Park City respectively. It consists of limestone, sandstone, shale, chert, and phosphate rock. The limestone is mostly gray or blue. The sandstones and shales are prevailingly grayish and are in part calcareous. A bed of phosphate rock, which is dark and exceptionally heary and has an oolitic structure, was noted by Boutwell ${ }^{2}$ about 300 feet above the base, and probably other beds occur in the middle and lower parts of the formation. This bed has not been developed as an economic resource in the Park City district, but the Park City formation oontains the great bulk of the phosphate that occurs in the western phosphate fields. ${ }^{3}$

The formation has yielded abundant fossils, which indicate that its lower part is of Pennsylvanian and its upper part of Permian age.

TRIASSIC SYSTEM.

Woodside shale.-The Woodside shale, about 1,100 feet thick, overlies the Park City formation unconformably, according to one of Bout-

\footnotetext{
1 Blackwelder, Eliot, New light on the geology of the Wasatch Mountains: Geol. Soc. America Bull., vol. 21, p. 532, 1910.

${ }^{2}$ Idem, pp. 113-114.

${ }^{3}$ See Gale, H.' S., and Richards, R. W., Preliminary report on the phosphate deposits in southeastern Idaho and adjacent parts of Wyoming and Utah: U. S. Geol. Survey Bull. 430, pp. 457-535, 1910; Blackwelder, Eliot, Phosphate deposits east of Ogden, Utah: Idem, pp. 536-551; and Schultz, A. R., A geologic reconnaissance of the Uinta Mountains, northern Utah: U. S. Geol. Survey Bull. 690, pp. 31-94, 1918 (Bull. 690-C).
}

well's structure sections (DD', Pl. XXVII), though no evidence of this relation is given in his text. It is the most homogeneous formation in the district and consists almost entirely of dark-red shale, which bears abundant ripple marks, mud cracks, and raindrop impressions. It apparently contains no fossils, but it is regarded as Triassic because of its resemblance to certain members in the overlying fossiliferous Thaynes formation.

The Woodside shale forms two north-south bands, one in the northeastern and one in the north-central part of the district, and a long strip along the north side of Big Cottonwood Canyon. It has some indirect economic importance because of the vast amount of water that it carries.

Thaynes formation. - The Thaynes formation, about 1,200 feet thick, grades into the formations above and below, from both of which it is distinguished by its limy composition. It consists of limestone and of shale and sandstone which are in part calcareous. It is divisible into three members: the upper, which is 630 feet thick, contains the largest proportion of limestone; the middle, 120 feet thick, consists mainly of maroon shale; and the lower, 450 feet thick, contains abundant sandstone. A characteristic rock occurring at many horizons is a fine-grained calcareous sandstone, blue-gray and compact when fresh but porous and brown when weathered. Much of this rock is richly fossiliferous. The fossils in the formation prove its Triassic age.

The formation occupies a large part of the northern half of the Park City quadrangle.

Ankareh shale.-The Ankareh shale is 1,150 feet thick in Cottonwood Canyon. It resembles the Woodside in being dominantly red, but it is more sandy, and includes a number of wellmarked beds of coarse gray sandstone, which range from 20 to 55 feet in thickness. It also comprises a few thin beds of limestone, which carry Triassic fossils. The formation occurs only in the northwestern part of the district.

Nugget sandstone.-The highest strata that occur in the Park City district consist of about 500 feet of white sandstone, interbedded with a little red shale, which represent the lower part of the Nugget sandstone. The age of the formation is not certain, but it is either Triassic or Jurassic, for fossils prove that the formation 
below is Triassic and the one above Jurassic. The Nugget sandstone is exposed in the extreme northwest corner of the Park City quadrangle.

\section{IGNEOUS ROCKS.}

TOPOGRAPHIC OCCURRENCE.

Igneous rocks occupy nearly one-third of the area of the Park City district. In distribution they coincide in general with the productive area and in occurrence they are intimately associated with ore bodies. The three petrographic types (diorite, diorite porphyry, and andesite) occur in distinct areas.

The diorite forms the most rugged and precipitous ridges and the loftiest summit in the region-Clayton Peak. (See Pl. XXX, B.) The generally homogeneous character of the rock, the absence of dominating structure planes, and the presence of readily removed mineral constituents have combined to permit deep and characteristic dissection. The eastern margin of this mass, with the single exception of an arm in the gap above the head of the Daly-Judge shaft, is covered by the extensive glacial deposits of Bonanza Flat.

Rising from beneath this covering on the east and northeast are extensive irregular masses of coarse diorite porphyry, which stretch eastward and northeastward for nearly 4 miles, surrounding Bald Mountain in the form of dikes and small stocks. This rock weathers somewhat easily and forms broad flaring saddles or gaps on divides, as at the head of Empire Canyon near the Lucky Bill shaft and east of the Little Bell shaft on the northern slope descending from Flagstaff Mountain. On the southwest slope of Bald Mountain it yields a coarse, loose sandy soil.

On the adjacent northeast and the extreme southeast and lying about the eastern foothills of the range are parts of the great extrusive mass of andesite, which floors the valley between the Wasatch and Uinta ranges. The surface of that portion of the extrusive mass which appears within the Park City area slopes gently eastward away from the Wasatch and is cut by numerous shallow gullies into parallel strips.

\section{QUARTZ DIORITE.}

Quartz diorite occurs in a general oval area, which extends from the head of Big Cottonwood Canyon eastward in the upper basin of
Snake Creek for over 3 miles and from the head of Snake Creek northward for 2 miles, forming the main divide of the Wasatch. It thus forms the easternmost of the three great igneous masses in the main zone of intrusive rocks of the middle Wasatch and occupies the southwestern portion of the Park City district. It cuts across sediments at the heads of the northwest tributaries of Snake Creek and of Big Cottonwood and is buried on the east by the glacial deposits of Bonanza Flat. Farther east it forms the broad tongue in the gap above the Daly-Judge tunnel, and small portions of its contact appear along the main road in Bonanza Flat immediately east. The best exposures were found along its northern and southern contacts.

Analyses of quartz diorite.

\begin{tabular}{|c|c|c|}
\hline & 1 & 2 \\
\hline 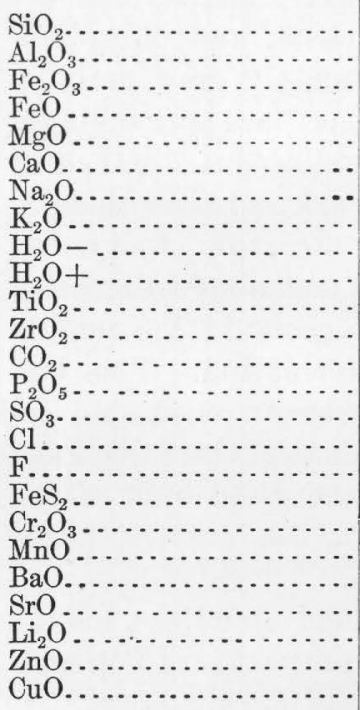 & $\begin{array}{r}59.35 \\
16.36 \\
2.90 \\
3.36 \\
3.08 \\
5.03 \\
3.73 \\
3.85 \\
.28 \\
.64 \\
.87 \\
.03 \\
\text { Trace? } \\
.44 \\
\text { None. } \\
.05 \\
\text { (?) } \\
.02 \\
\text { None. } \\
.07 \\
.16 \\
.05 \\
\text { Faint trace. } \\
.01 \\
.01\end{array}$ & $\begin{array}{r}63.46 \\
15.93 \\
2.61 \\
2.31 \\
2.27 \\
4.33 \\
3.66 \\
3.49 \\
.27 \\
.74 \\
.62 \\
.03 \\
\text { Trace. } \\
.16 \\
\text { None. } \\
.05 \\
\text { Trace? } \\
\text { a (0.01 S) } \\
\text { None. } \\
.09 \\
.15 \\
\text { (b) } \\
\text { Faint trace. } \\
\ldots . . . . . . . \\
\ldots . . . . . . .\end{array}$ \\
\hline & 100.29 & 100.17 \\
\hline
\end{tabular}

$a$ Trace from pyrrhotite.

$b$ Included in $\mathrm{CaO}$ above.

1. Quartz diorite, three-fourths of a mile northeast of Clayton Peak. W. F. Hillebrand, analyst.

2. Quartz diorite, east side of Brighton Gap. W. F. Hillebrand, analyst.

Hand specimens show a fine even-grained rock composed of a uniform mixture of light and dark minerals. New fractures generally present a bright, fresh appearance. The light minerals are chiefly white feldspar. Some pinkish feldspar is mingled with the white, and rarely quartz may be recognized. Of the dark minerals, glistening flakes of black biotite are 


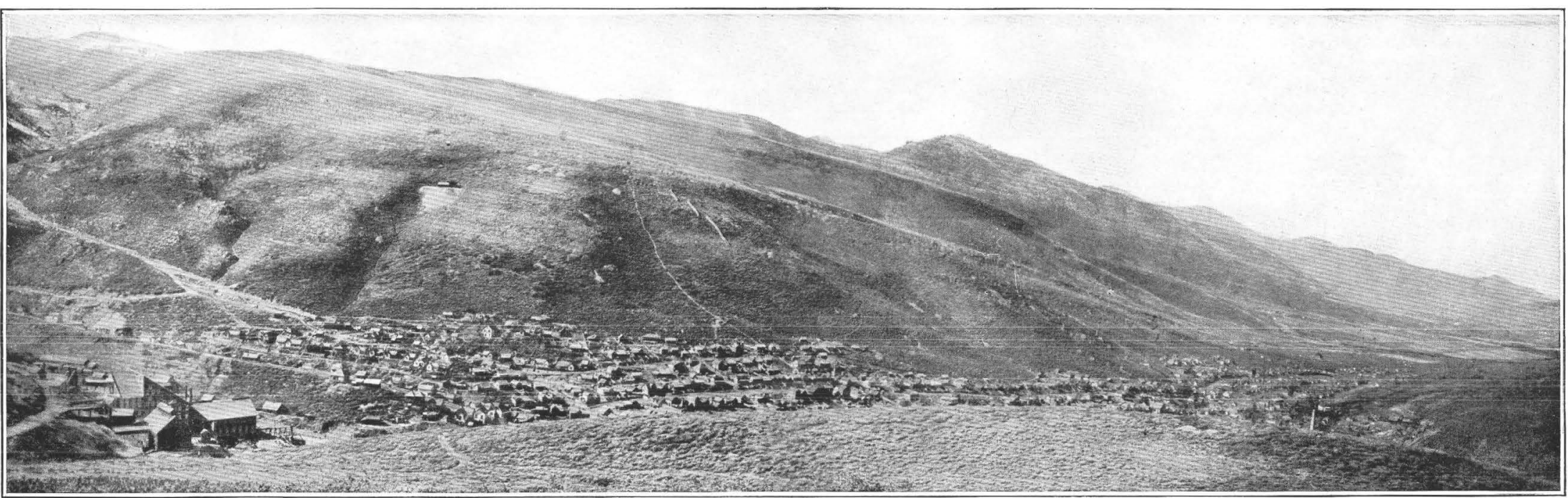

A. PARK CITY MONOGLINE.

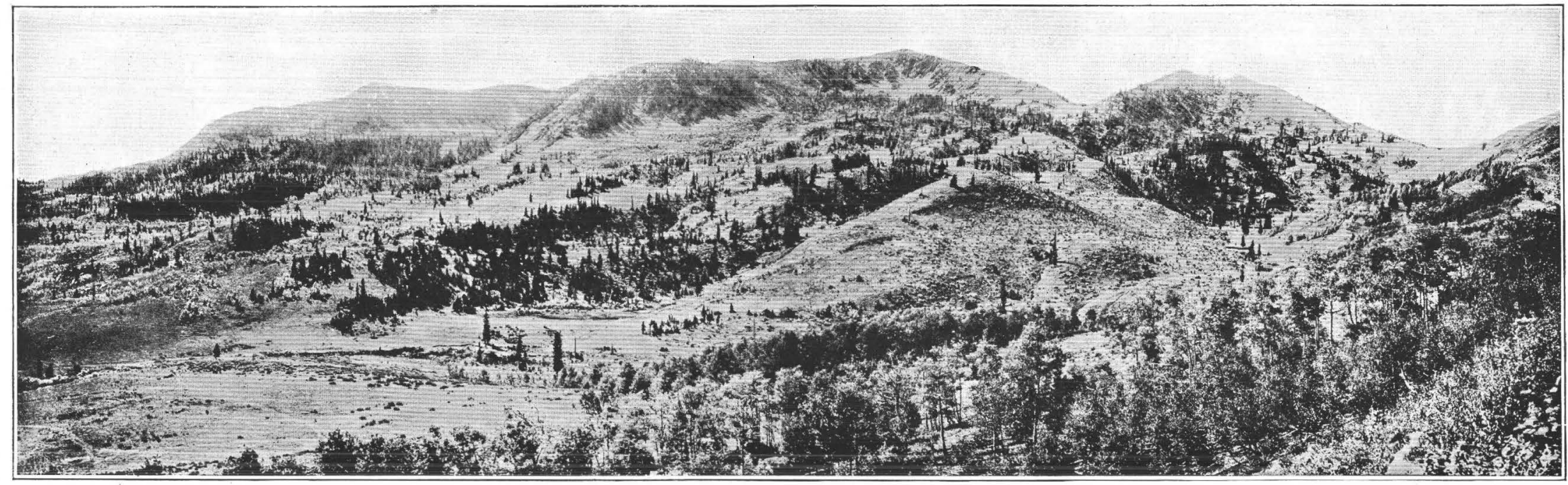

B. CLAYTON PEAK DIORITE STOCK. 
most noticeable, and the dull greenish-black color and lath shape of hornblende is less so. All are about equal in size, few exceeding one-eighth of an inch.

QUARTZ DIORITE PORPHYRY.

Diorite porphyry is the largest and most widely extended of the igneous formations. Most of it lies in the eastern and southern parts of the district, but a few small isolated bodies occur at the west and northeast. All the large areas and nearly all the exposures appear to be united on the surface into a single extremely irregular body which, except for a narrow junction on the east, is roughly separated by the quartzite on Bald Mountain into two parallel masses. The southern and major member extends from the extreme head of Empire Canyon in the region of the Daly-Judge, Daly West, Quincy, and Little Bell mines eastward and southeastward to its junction with the northern mass east of the Valeo mine, in Cottonwood Canyon. It is well exposed by the broad, shallow amphitheater and saddle at the south head of Empire Canyon and is characteristically developed in the main bodies which extend eastward and southward, in the irregular connecting dikes around the eastern wall of Bonanza Flat and about the heads of Durey and Pine canyons. From the connecting neck in Cottonwood Canyon the northern mass extends northward and northeastward around Bald Mountain, crossing Glencoe, Wasatch, and McHenry gulches, and an arm reaching northward enters McCune Hollow. Owing to the exceeding difficulty of tracing outlines on precipitous slopes amid dense scrubby growth the boundaries that are shown on the map necessarily fall far short of expressing the extremely irregular outlines of these masses.

The major part of this porphyry takes the form of irregular stocks and dikes issuing from the stocks. A few sills are present. The principal stocks are the elongated, roughly rectangular masses just south and east and northeast of Bald Mountain. Smaller masses lie at the head of Empire Canyon and between Bald and Bald Eagle mountains.

The usual appearance of the diorite porphyries of the Park City district in the outcrop is that of light-gray, faintly spotted rocks, but on fresh fracture the phenocrysts stand out more distinctly in a dark groundmass. Close examination shows that the color of the rock lies in the groundmass, which runs through shades of drab or deep bluish or greenish gray. It is also seen that the phenocrysts are not confined to the light feldspars but include indistinct crystals of the dark ferromagnesian minerals-hornblende, biotite, and, rarely, augite. In some fresh specimens the shining facets of the feldspars are striped with the multiple twinning of the plagioclases, and in others, especially in altered samples, may be discerned fragments of rough greasy quartz. The groundmass even under a hand glass appears to be no more than a fine crystalline mass of ill-formed minerals. Among these may be recognized with difficulty particles of biotite, feldspar, and pyrite.

The phenocrysts vary widely in size. Few are over half an inch in greatest length. Relatively the plagioclases develop the largest phenocrysts; next rank the hornblendes, which rarely attain a length greater than a quarter of an inch; finally the dark-brown micas, which here and there outmeasure the hornblendes but very generally are smaller in diameter though equivalent in area. Quartz, where it occurs as phenocrysts, very rarely measures more than an eighth of an inch in diameter, and augite is scarcely ever noticeable.

Two analyses of the diorite porphyries have been made and are given below, one from the ordinary variety typical of this district and another from a more quartzose phase.

Analyses of quartz diorite porphyry.

\begin{tabular}{|c|c|c|}
\hline & 1 & 2 \\
\hline 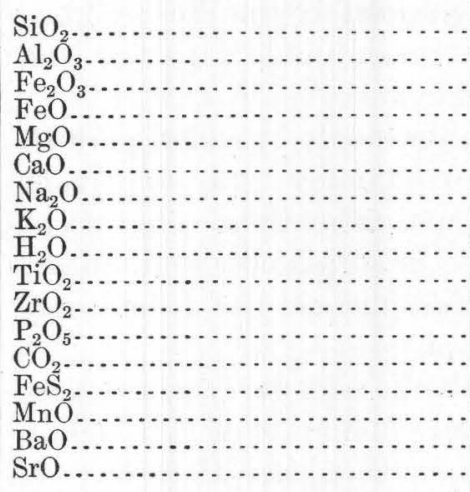 & $\begin{array}{r}59.68 \\
15.61 \\
2.49 \\
2.38 \\
2.52 \\
4.63 \\
3.96 \\
2.92 \\
2.51 \\
.62 \\
.01 \\
.29 \\
2.29 \\
.02 \\
.08 \\
.15 \\
.07\end{array}$ & $\begin{array}{r}61.64 \\
14.66 \\
1.95 \\
1.68 \\
2.55 \\
4.65 \\
2.71 \\
3.07 \\
3.60 \\
.48 \\
.01 \\
.24 \\
2.15 \\
.32 \\
.06 \\
.18 \\
.06\end{array}$ \\
\hline & 100. 23 & 100.00 \\
\hline
\end{tabular}

1. Quartz diorite porphyry from dike northwest of Daly West shaft. W. F. Hillebrand, analyst.

2. Quartz diorite porphyry from Valeo mine. Cottonwood Canyon. W. F. Hillebrand, analyst. 
These analyses rank well toward the acidic end of the diorite group, being high in silica. Probably one-third of the specimens contain enough quartz to be ranked with No. 2 of the table.

\section{ANDESITE.}

The two small portions of the great extrusive mass of andesite on the east afford good evidence as to its general characteristics. They lie in the extreme northeast and southeast corners of the region mapped, at the eastern base of the range, and embrace an area barely a mile square. The great expanse of these rocks which stretches eastward for about 8 miles to Kamas Prairie and northwest and southeast for about 30 miles shows high rugged hills rising 1,000 to 2,000 feet above its western margin in the Park City district. If the upper surface of these extrusive masses were originally level, the present lower elevations of its western portions which now wrap about the eastern flanks of the Wasatch Range must be due to denudation.

Low gullies cut deeply into the extrusive mass and show it to be made up of layers of varying destiny, coarseness, and massiveness. Some were clearly formed as flows, others as beds of bomblike bodies, possibly ejectamenta. All incline to the east.

In several of the transverse valleys in the West Hills sandstone and quartzite crop out from beneath the andesitic blanket and afford some clue to the ancient topography. The eastern dip from the flanks of the Wasatch Range and the western dip of certain beds in the eastern part of the area suggest the early valley form, although possibly the Wasatch has risen since the extrusion and imparted the easterly inclination.

The andesite is a decidedly speckled pinkish or greenish rock, commonly gray on fresh fracture. In hand specimens these colors seem confined to a dense fine-grained groundmass, in which are sprinkled phenocrysts of feldspar, hornblende, and mica.

Of the phenocrysts the feldspars seem to predominate, with smaller amounts of hornblende and still less biotite. In places they are arranged in parallel lines significant of rock flowage. Both phenocrysts and groundmass usually lack the lustrous appearance which characterizes a fresh rock. Some of the feldspars, however, have still retained fresh glassy faces on which may be distinguished the multiple twinning lines of plagioclase. The feldspars are the largest of the phenocrysts, ranging in size from one-fourth of an inch to small grains. Hornblende crystals are more uniform and are as a rule not longer than one-eighth of an inch. Biotite ranges between these two minerals. Rarely a few quartz grains may be recognized.

All phenocrysts grade into the groundmass, which is macroscopically very dense and indeterminate.

The general color of much of the rock is mottled, owing to change in texture, which indicates that the rock is composed of fragments in an andesitic matrix. All fragments, however, contain the same essential minerals as the matrix in like proportions, and the whole may be called andesite breccia.

A chemical analysis of the andesite is given on page 90.

The percentage of silica is somewhat low for rocks in this class, but the proportions of other elements are medial. From its mode of occurrence, mineralogic character, and chemical composition the rock seems to belong with the andesites.

$$
\text { ANDESITE TUFF. }
$$

The tuffs from the Park City district are gray to yellowish-gray rocks composed of white, yellow, and black particles, in places resembling a poorly compacted fine sandstone, from which they grade into a very soft, flaky, somewhat argillaceous rock containing larger grains. Specimens from the lower parts of the mass are somewhat laminated; but the laminations seem due rather to flowage, as in mud flows, than to water sorting, for the bedding lines are not distinct and the particles vary greatly in size. The rocks have, however, the appearance of rather even fineness, the grains averaging one-fifth of an inch in size and being loosely cemented together. The bright, fresh appearance of a crystallized rock is lacking. The constituent grains are too small to allow definite determination, though from the abundance of whitish and yellowish particles it may be surmised that considerable feldspar and probably quartz are present.

In addition to the main types described, there are numerous granitic and a few peridotite dikes in the district. 
GEOLOGIC RELATIONS.

Relations of igneous masses to one another.The relative age and other geologic relations of the three principal igneous masses have not been proved. The diorite has not been observed to cut or be cut by the diorite porphyry; and no conclusive field evidence as to the geologic relation of the diorite porphyry and the andesite has been found. No actual passage of porphyry as an intrusive upward and out into andesite as an extrusive, thus indicating contemporaneity, was observed. On the western margin of the extrusive area, however, fragments and a considerable oval area of porphyry are included in the andesite and would thus appear to be earlier. Further, this porphyry proves to be petrographically the same as the perfectly characteristic facies that outcrops near the Valeo mine. If this porphyry is earlier and is contemporaneous with the Valeo rock and the other porphyries of the district, then the porphyry as a whole is older than the andesite. Furthermore, the andesite fills, wraps around, and blankets an old topography which to every appearance was developed on the porphyry after its intrusion. It is therefore probable that the andesite not only is later than the diorite porphyry but was extruded after the porphyry had been extensively eroded

Relation of igneous rocks to sediments. -The intrusive rocks, quartz diorite and quartz diorite porphyry, cut all the consolidated sedimentary rocks with which they are in contact. The andesites rest upon Eocene ("Vermilion Creek") sedimentary rocks and the lower tuffs grade into the sedimentary series. These relations indicate that the diorite is not earlier than Triassic, that the porphyry is at least as late as early Triassic, and that the andesite is later than the "Vermilion Creek" (Eocene).

\section{STRUCTURE.}

The formations in this area constitute an anticline that trends somewhat east of north and west of south and that pitches northeast. This broad arch is modified by strong faulting and minor local folding, some of which was very likely caused by intrusions. (See Pl. XXVII.)

\section{FOLDING.}

The Park City arch, comprising all the sedimentary formations, embraces the entire area. It is broad and low, the formations on its flanks dipping gently northwest, east, and southeast, and its axis gently northeast. The western limb includes the formations from the Weber quartzite to the Nugget sandstone, inclusive, and forms a structural unit as a monocline. The dip averages $35^{\circ} \mathrm{NW}$. Just north of Park City the strike of the beds gradually swings eastward, and northeast of the city the upper formations disappear beneath extensive flows of andesite. All reappear, however, striking southward and passing down the east side of the area to form the eastern flank of the Park City anticline.

A few minor folds on this major fold are, as a rule, directly traceable to local deformation, which has caused many fractures. Thus, west of Jupiter Hill, along the south side of the divide, the metamorphosed beds appear to form a shallow trough broken along a fracture zone opened through the Jupiter mine and marked by the first strong gap in the divide west of Jupiter Peak. Crumpling was noted at the head of Thaynes Canyon, on the west side.

On the eastern limb the local deformation was apparently greater. At the north, along the east side of Deer Valley Meadow and Frog Valley, two areas show disturbance in strike and dip. North of upper Drain Tunnel Creek, in an angle between faults, the beds are somewhat disturbed; east and southeast of the head of Frog Valley they are much disturbed, contorted, and broken; in the extreme southeast corner of the area mapped, the formations show some crumpling and folding and some local breaks; and elsewhere local crumpling, steep tilting, and irregular contorting has been found.

\section{FAULTING.}

Six important zones of faulting have considerably modified the continuity of the Park City anticline. These include on the west side the Ontario and Daly West, the Crescent, and Massachusetts fault zones, and on the east the Frog, McHenry, and Cottonwood zones. No adequate and satisfactory correlation of these is apparent.

The Ontario and Daly West fault zone is known along its strike for 2 miles from a point on the surface immediately west of the Parleys Park shaft to an underground point considerably west of the Daly-Judge shaft and in depth for 2,000 feet in the Ontario and 2,100 feet in the Daly West. It is a strong zone of fractures ranging from single definite fissures 
to broad zones of brecciation, and the main Ontario fissure ranges in width from a few inches to a hundred feet. Its prevailing strike is N. $60^{\circ}$ E. and its average dip is $70^{\circ} \mathrm{NW}$. Structurally it is a great fault whose hanging wall has relatively dropped. The amount of displacement could not be precisely determined but was probably 230 feet just west of the Ontario No. 3 shaft and approximately 350 feet on the Daly West branch. It is later in date than the intrusion of the diorite porphyry and earlier than certain northwest faults. The economic effects of this dislocation has apparently been a relative elevation of the ore-bearing limestone members. Westward it is highly probable that the gap and decided offset in the main divide above the Daly-Judge shaft are due largely to this great fault zone.

The Crescent fault zone is known in the Daly-Judge drain tunnel on the east and considerably beyond the crest of Crescent Ridge on the west, thus extending for at least 9,000 feet. Its most prominent outcrop is at the junction of Crescent Ridge and Pioneer Ridge, where the Nugget sandstone and Ankareh shale are dropped into juxtaposition with the Thaynes formation. At this point the trend is slightly north of east and the dip apparently very steeply north. To the east the bedrock in the course of this fault is heavily blanketed with glacial material. Beyond, along the west wall of Empire Canyon, the Thaynes formation, equivalent to that on the north side of the fault zone in Crescent Ridge, reappears in prominent bluffs which continue southward. Clearly this is a great fault, and the apparent lateral offset to the west on the north side measures about 3,000 feet. The same displacement has undoubtedly separated the ore-bearing limestone of the Daly West from that in the distant Silver King mine, the two limestones belonging to one and the same formation.

Just north of this zone, at the collar of the old Massachusetts shaft, the Massachusetts fault is well defined between Weber quartzite on the north side and limestone and sandstone of the Park City formation on the south. It strikes $\mathrm{N} .70^{\circ} \mathrm{W}$. and stands about vertical. Although much obscured by glacial drift, it may be traced on the surface by isolated outcrops of limestone of the Park City formation on the south and of Weber quartzite on the north for about 3,000 feet. Underground it is well shown in the Daly-Judge tunnel, and especially in the Alliance tunnel, where it strikes N. $70^{\circ}-75^{\circ} \mathrm{W}$. and dips $68^{\circ}-70^{\circ} \mathrm{S}$. Although not positively identified in the Silver King mine proper, it is believed to have been cut by the King-Alliance connection. It has offset boundaries about 2,500 feet to the west on the north side. With the Crescent fault, it outlines an east-west wedge of sediments which has apparently been offset to the west.

In the northeastern part of the district the topography and the distribution and structure of formations give evidence of the great Frog Valley fault. Along the east side of Deer Valley meadow the Park City formation rises abruptly from the flat meadow bottom, the contact between limestone and the quartzite being concealed by alluvium. On the north, in the vicinity of the Cincinnati group and northward, a north-south fault has relatively raised the Weber quartzite on the west or moved the Park City formation southward on the east. Farther south, along the eastern upper slopes of Frog Valley, a strong north-south fracture is exposed in a gully with Woodside shale on the east and Weber quartzite on the west. On the south, about 100 feet above the valley, the fault divides and includes a narrow lens of Park City formation. Still farther south the fault continues around the eastern slope of Bald Eagle Mountain, with Thaynes formation on the east and Weber quartzite on the west. The course of the main fault around Bald Eagle Mountain, curving eastward, indicates that the plane of dislocation dips about $45^{\circ} \mathrm{W}$., and this is corroborated by conditions in the Ontario drain tunnel. The fault could not be found south of the bottom of McHenry Canyon, nor could its actual relation with the McHenry fault be observed.

These facts indicate a great compound overthrust fault. The west side has ridden up over the east side for many hundred and probably for more than 2,000 feet. On the east side of Bald Eagle Mountain the Weber quartzite laps up into contact with the Thaynes formation, concealing the entire Park City and Woodside formations. Economically, the recognition of this overthrust fault extends exploration beyond previously known limits of the ore-bearing Park City formation into regions 
of favorably fractured intrusion and metamorphism.

Another great fault, the McHenry, of different type but quite as extensive, lies immediately south of the Frog Valley fault. This fault is traceable eastward along McHenry Canyon from a point about half a mile below its head to a point about 2,000 feet east of the Liberty tunnel, a total distance of a mile. The actual fault plane appears at the surface where opened just east of the Hawkeye shaft as a zone of intense brecciation striking east-northeast and dipping $45^{\circ} \mathrm{N}$. between metamorphic limestone on the north and massive quartzite on the south. On the east it is marked by scattered quartzite ledges and a contact between metamorphic limestone of the Thaynes formation and Weber quartzite. Underground it has been opened for many hundred feet in the Lowell, McHenry, and Hawkeye mines. Much of these mines is inaccessible, but in portions of the Hawkeye the McHenry fault appears as a zone of intense fracturing and brecciation striking east, with a width ranging from a few inches to 170 feet but averaging a few feet. The hanging wall is commonly metamorphic limestone, though for many hundred feet on one level it is quartzite; and the footwall is quartzite, some metamorphic limestone, and porphyry. At one point well-defined slickensides pitch $45^{\circ} \mathrm{SW}$. The general effect of this great fault has been to offset the formation boundaries on the south side eastward for at least 2 miles.

The Cottonwood fault lies in the extreme southeastern part of the district, in Cottonwood Canyon, from which it is named. About 4,000 feet southeast of the Valeo mine the eastern wall of Cottonwood Canyon is interrupted by a low saddle, which marks a fault contact between Weber quartzite on the north and Woodside shale on the south. The fault has been followed along a sinuous east-west course for about 4,500 feet. Its effect has been to shift the formation on its north side toward the east for about 4,000 feet. It may thus be regarded as a smaller companion fault to the McHenry, the two inclosing between them a wedge which has moved relatively eastward or upward.

DEFORMATION BY INTRUSION.

The injection of great bodies of diorite and diorite porphyry into the sedimentary rocks obviously caused intense deformation. Whether the engulfing and absorption.of portions of the invaded sediments by the intrusive magmas was large or small, the compressive force exerted on the, sediments was, even if rated at its minimum, very great.

The introduction of the Clayton Peak mass, which probably entered the lower portion of these sediments only, without reaching the surface, doubtless domed the overlying Triassic and Jurassic sediments.

The invasion of the Carboniferous formations by diorite porphyry magma, apparently forcing its way irregularly northeastward, would seem to have been accomplished under very high pressure. Deformation directly traceable to it is seen in several places. Two miniature examples will suffice to prove its existence and to show its nature, and thus point the way for detecting similar effects on a larger scale.

In the Silver King mine, on the 1,100-foot level, the main crosscut south has exposed tongues of diorite porphyry extending upward into calcareous sandstone. Aside from the metamorphic influence of this intrusion, its structural effect consisted in crushing the rock ahead, in fracturing it, and in opening fissures. Similarly, a knob or miniature laccolith exposed on the north side of the main road just west of the West Quincy mine reveals flexing of beds, crushing, shattering, and fissuring.

The great intrusive bodies may reasonably be supposed to have acted in precisely the same manner on a proportionately larger scale. Thus, in the area of the Frog Valley overthrust fault and the McHenry and Cottonwood faults, a wedge a mile long north and south and 2,000 feet thick, comprising the lower formations on the west, is thrust up over the Park City and Woodside formations on the east until the Weber quartzite laps against the Thaynes formation; and on the south a block averaging 2 miles in width north and south and made up of sedimentary formations from the Weber to the Thaynes and intruded porphyries has moved bodily eastward at least 2 miles.

The evidence indicates that a series of intrusive bodies extends in a narrow east-west belt across the Wasatch Range; that they invaded the Park City area from the west, breaking upward and eastward; that those in this area are thus the highest and easternmost members; that at the east end and ahead of this chain of intrusives the formations are 
thrust eastward, one formation completely over the next two normally overlying ones; and that directly in the path of the intrusives the formations have given way, chiefly on two great faults, and have moved relatively eastward at least 2 miles.

The occurrence of horses of limestone of Pennsylvanian and of lower Mississippian (Madison) age in diorite porphyry in the southeastern portion of this area also indicates extreme deformation by intrusives, blocks of limestone from a few feet up to 1,000 and even 2,000 feet in length being entirely inclosed in porphyry. Some of these blocks may be safely correlated, by their relative position, with certain near-by limestone members intercalated in the Weber quartzite. Fossil evidence, in the opinion of Dr. Girty, shows some to be lower Weber (Pennsylvanian) and others to be Madison (lower Mississippian). In other words, the horses pretty clearly belong lower by several thousand feet than the lowest sediments outcropping in their normal sequence in this region, showing that the intrusive magma tore away portions of lower-lying formations and floated them up for thousands of feet.

\section{HYDROTHERMAL METAMORPHISM.}

Alteration by hot waters takes place chiefly along fissures and is characterized by the formation of quartz, sericite, and pyrite, and locally by other minerals. It occurs in the Park City district along certain major zones of fracture, especially adjoining extensive bodies of intrusive rock.

\section{CONTACT METAMORPHISM.}

EXTENT AND GENERAL CHARACTER.

The intrusion of diorite and of diorite porphyry has altered the sedimentary rocks for a variable distance-averaging, probably, a good deal less than a mile-from the contact on every side. The contact-metamorphic effects are most conspicuous, and have been most thoroughly studied, along that rugged western segment of the Weber-Provo watershed that is sometimes called the "contact divide." This crest lies near, and in general parallel to, the north side of the Alta-Clayton Peak stock. Its location and its rugged character depend upon the exceptional toughness of the metamorphic rocks that were formed near the diorite from strata whose resistance to erosion is normally weak. In a considerable area extending along the contact divide, the formations are so disguised by induration, change of color, recrystallization, and the development of new minerals that their boundaries can not be traced and they are mapped together. In many places, however, formations or even individual beds may be traced from outcrops where they are unaltered to the very contact, and the effect of metamorphism traced through all its gradations.

$$
\text { ALTERATION OF LIMESTONE. }
$$

The limestones have been greatly altered. Limestone has been replaced by sulphides in some places at the immediate contact, and it has been extensively altered to marble and to rocks containing metamorphic silicates.

Perhaps the most perfect example of sulphide along a contact was observed in the Silver King mine, 1,100-foot level, on the south crosscut at the fork of the drift west, where a band of pyrite about half an inch thick lay between diorite porphyry and a calcareous bed in a gangue of calcite. In the Daly West mine also a body of rich sulphide ore in metamorphic limestone immediately overlay diorite porphyry.

Coarse white marble may be seen at many places along the "contact divide" and in the horses of limestone inclosed by the diorite porphyry east of Bonanza Flat. There is little doubt that at all these places, which are near the contact, the recrystallization of the limestone was caused by the intrusive rocks. On the other hand, the marble that occurs on a knob southeast of Frog Valley, about a mile away from any exposed intrusive rock and close to the great Frog Valley overthrust, may have been formed by dynamic metamorphism due to the overthrusting.

The metamorphosed limestone containing silicates is generally greenish gray to olivegreen in color. It is most abundant in the Thaynes limestone, which forms a large part of the contact divide, and is well exposed on the crest south of the Daly-Judge mine, on Jupiter Hill, and near Scott Peak.

The minerals developed by this metamorphism comprise most of the regular contactmetamorphic series, the most common probably being epidote. Brown and green garnet are also found, generally in massive form but 
here and there partly crystallized. At one point large masses of vesuvianite are intergrown with spinel and minute crystals of chabazite are scattered thickly over the surface of the metamorphosed rock. Augite is abundant in many places. Mica is present, both biotite and muscovite, but chiefly the latter. Plagioclase feldspar, probably albite, was also detected.

In some places these minerals are massive, composing the entire rock, and in others they lie in a matrix of calcite. Associated with them are the metallic minerals specularite, sphalerite, pyrite, chalcopyrite, and magnetite, intergrown with the metamorphic silicates in such a way as to demonstrate their contemporaneous origin.

ALTERATION OF SHALE AND SANDSTONE.

The contact metamorphism of shale is as pronounced as that undergone by limestone, though less varied and perhaps less extensive. Metamorphosed Woodside and Ankareh shales occur south and east of the Daly-Judge shaft, and also in Jupiter Hill. The most conspicuous effect of metamorphism in the shales is the alteration of their prevailing color from red to green. Complete gradations may be traced from unaltered red shale to tough green hornstone, intermediate stages being represented by rocks that are mottled in green and red. Microscopic examination shows that this characteristic alteration is due chiefly to the development of epidote. There also appears to be an increase in quartz.

In the metamorphism of the coarser siliceous rocks, as sandstone, the apparent change is still more simple and less extensive. The impurities of the matrix are driven off and the silica, doubtless with additional magmatic silica, is united with the quartz grains in a solid mass of quartzite.

ORE DEPOSITS. ${ }^{1}$

MINERALOGY OF THE ORES.

NATIVE ELEMENTS.

Gold.-The "gold ledge" in the Silver King mine, 700-foot level, is reported to have yielded considerable gold, but microscopic examination of the rusty material failed to reveal gold. Men who sluiced and washed

\footnotetext{
1 Abstracted from Boutwell, J. M., op. cit., pp. 105-130. Descriptions of a few minerals found since Boutwell's study of the district are inserted.
}

tailings in Woodside Gulch below the Silver King and old Mayflower mills and also in Silver Creek in Park City proper are reported to have saved gold enough to make good pay.

\section{SULPHIDES.}

Galena.-The isometric lead sulphide (PbS) is the principal ore mineral in this district. It commonly occurs in massive form, both cleavable and granular, rarely crystalline, in fissures and beds in limestone and locally in quartzite.

Pyrite.-The only iron sulphide observed in the district, pyrite, is a relatively unimportant constituent of the ores. It is probably most common in ores which occur in or adjacent to fissures. Its usual occurrence is in granular, massive, and semicrystalline form intergrown with other sulphides in lode ores or interbanded with them in lode and replacement ores.

Chalcopyrite.-The sulphide of copper and iron, chalcopyrite, is rarely seen in the Park City district. In the few occurrences observed it is in massive form intimately intergrown with pyrite, galena, or sphalerite.

Chalcocite.-The black sulphide of copper, chalcocite, is rare in the district. It occurs sparingly as a coating on chalcopyrite and on cupriferous pyrite, more commonly in fracture zones at moderate depth. Nowhere is it known to form a vein or solid minable mass.

Sphaterite.-The sulphide of zinc, sphalerite, occurs abundantly in various forms throughout the district, usually in a rather deep brown to resin-colored massive specular form intergrown with ore minerals and in semicrystalline form. It is more common in lodes, particularly at considerable depth, and in beds in the Thaynes formation adjacent to fissures. It appears to increase with nearness to extensive intrusive bodies, as in the great fracture zone in the Ontario, Daly West, and Daly-Judge and their bed ores adjoining fissures in the Kearns-Keith and California.

SULPHARSENITES AND SULPHANTIMONITES.

Tetrahedrite.-Gray copper, tetrahedrite, is a complex sulphantimonite of copper $\left(4 \mathrm{Cu}_{2} \mathrm{~S}\right.$. $\mathrm{Sb}_{2} \mathrm{~S}_{3}$ ), which may contain arsenic and zinc. It occurs widely in this district in lodes and somewhat less commonly in bed ores, in both massive and crystalline form. 
Jamesonite.-Jamesonite was determined in three specimens from the California mine dump. Van Horn ${ }^{1}$ states that he has found jamesonite in notable amounts in the district.

Bournonite.-Van Horn reports finding bournonite $\left(\mathrm{PbCu}_{2}\right) \mathrm{Sb}_{2} \mathrm{~S}_{6}$ at the Silver King and Daly West mines.

CHLORIDES AND FLUORIDES.

Cerargyrite.-A specimen of rich copper ore from the ore bed in the Scottish Chief mine at the third level was reported to carry high values in silver. On chemical examination Dr. Hillebrand detected a chloride which he is inclined to regard as that of silver-cerargyrite. It was not found, however, in sufficient quantity to recognize with the naked eye.

Fluorite.-Fluorite was found in intimate association with lead-silver ore in two mines and was suspected at a few other points.

oXIDES.

Massicot.-One of the principal features of the mineralogy of the ores in this district is the earthy yellowish material resulting from the alteration of lead minerals. It varies from a dusty, bright-yellow coating through dull waxy, rusty and brownish-yellow or fleshcolored solid masses inclosing cores made up of concentric layers of cerusite, anglesite, and galena. In the mixed galena-tetrahedrite ore the products of oxidation of copper are also present. Qualitative analysis of the material shows that it is a mixture of several secondary lead minerals. Most careful attempts to isolate any particular class of this material for analysis were only partly successful, as the analysis indicates the presence of several minerals, probably including the lead monoxide, massicot $(\mathrm{PbO})$; the complex hydrous antimonate of lead, bindheimite; a little of the arsenate of lead, mimetite; probably other lead compounds; limonite; and calcite.

Magnetite.-Magnetite has been found in a number of places in the district but is not common. It occurs with garnet as a contact mineral in limestone adjacent to intrusive rocks.

Specularite.-The micaceous or specular variety of hematite, specularite, occurs at several points as a contact-metamorphic mineral in limestone adjacent to intrusive rocks. It is

1 Van Horn, F. R., Geol. Soc. America Bull., vol. 25, p. 47, 1914. most abundant in the contact zone at the southern head of Thaynes Canyon and along the overlooking divide to the southwest. The Thaynes formation was here invaded by diorite magma, which apparently extended northward underneath the sediments. Along the zone immediately overlying this intrusive and adjoining the dikes that break upward across the bedding the limestone is highly metamorphosed. The specularite occurs in sheaves, in curved folia, in large irregular masses, and in bands closely associated and intergrown with the products of contact metamorphism of the limestone. Green garnet is most abundant, with much calcite, some greenish quartz, and probably some epidote.

Limonite.-Hydrous oxide of iron, limonite, is found most abundantly in the oxidized superficial parts of ore bodies which have an iron base. Workings in ore zones near the surface have revealed extensive masses of limonite.

Pyrolusite. - A black mineral occurs commonly in the form of a dense black coating and also as a sooty powder on croppings of ore shoots and underground ore zones. An excellent sample taken from the cropping of the Ontario lode was determined by Dr. Hillebrand to be an "oxide of manganese."

Quartz.-Quartz is found in very many forms, both massive and crystalline, throughout the district but is not particularly abundant. In both lodes and beds the massive variety is a common gangue of the ore. In beds it is locally porous and honeycombed, as on some of the upper levels of the Silver King mine and on the Hanauer tunnel level. In lodes a massive gray silica commonly forms the body of the vein, with sugary quartz occupying areas among the metallic constituents. In the ore-bearing fracture zones in Daly-Judge ground on the west geodes formed, in which some excellent quartz crystals were found. One such specimen, which is the property of the Park City Bank, showed single crystals 3 inches across and 5 to 6 inches long. Another from the same locality shows sphalerite crystals embedded in and partly coated by aggregates of small quartz crystals. One of the most perfect crystals seen was found in the dump of the Jupiter lower tunnel. It is 1 by $2 \frac{1}{2}$ inches and shows at least four rhombohedra. On the Hanauer tunnel level of the Kearns-Keith mine the ore is locally replaced by layers of quartz a quar- 
ter of an inch thick, whose upper and lower surfaces are formed of crystals; these layers, like the walls of the ore body, are parallel to the bedding. The more common associates of the quartz are sphalerite and galena.

Spinel.-In the southwest corner of the area, 2,550 feet S. $35^{\circ}$ E. from Clayton Peak, a boulder about 2 feet in diameter was found in talus about at the contact of the main diorite mass with limestone. The limestone along the contact is highly metamorphosed, showing contact minerals, and the boulder is a solid mass entirely made up of two contact mineralsspinel and vesuvianite.

CARBONATES

Cerusite.-The carbonate of lead occurs commonly throughout the district as a normal product. Its more usual occurrence is in crevices or pits in galena which are lined with a thin zone of anglesite that bears inside a velvet-like layer of minute tabular pinkish to pearly-white crystals of cerusite.

Azurite and malachite.-The comparatively rare occurrence of the primary copper sulphides results naturally in a corresponding dearth of copper carbonates. They are, however, encountered here and there in the zone of superficial alteration and along fractures affording waterways.

Rhodochrosite.-Two possible occurrences of rhodochrosite are known. Part of a gangue mineral determined chemically to be rhodonite gave a slight intumescence, which was probably due to the presence of some of the carbonaterhodochrosite. Again, a specimen of pink semicrystalline material showing aggregates of minute curved rhombohedra is either rhodochrosite or colored dolomite.

Calcite.-A relatively unimportant part is played by calcite among the minerals of the district. It occurs locally as gangue in zinciferous lead ores, usually in bed deposits but here and there in lodes.

Dolomite.-Dolomite has not been recognized as of common occurrence, though in several places it is believed to be present, associated with calcite.

$$
\text { SILICATES. }
$$

Chrysocolla.-The hydrous silicate of copper, chrysocolla, is occasionally found. The best example seen occurred with tetrahedrite in the main ore bed of the Scottish Chief mine, on the third level east.

Garnet.-In certain localities garnet is somewhat abundant, notably in the southern part of the district in limestone adjacent to the great diorite intrusion of Clayton Peak. It is most common in dark-green massive replacements of limestone, though some brown and partly crystalline garnets are found.

Vesuvianite.-Vesuvianite was found in the southwestern part of the district, along the southern contact of the intrusive rock of Clayton Peak with limestone; -it is here intergrown with spinel.

Epidote.-Epidote in massive form is associated with garnet and specularite in metamorphic limestone adjacent to the Clayton Peak mass of diorite.

Chlorite.-Chlorite occurs in altered limestone adjacent to intrusives at several points on the surface and underground.

Serpentine.-Seams and beds of serpentine occur in decomposed fractured metamorphic limestone on the 1,500-foot level near No. 2 shaft of the Ontario mine.

Rhodonite.-The silicate of manganese, rhodonite, is rare in this district. On the Ontario 1,500-foot level near No. 2 shaft it is associated with quartz in the gangue of a lode carrying galena, pyrite, and sphalerite.

Mica.-Pale bluish-green imperfect crystals of mica, found in association with silicates which formed in contact zones adjacent to intrusive rocks, probably belong to the chlorite group, though some may be muscovite. One or two blackish hexagonal crystals of mica were seen. All the micas appear to lie at or near an igneous contact. The sericitic variety of muscovite is rather abundant as a gangue mineral. It was noted especially in the DalyJudge and Silver King mines, where it occurs as a white talcy gangue in fissure ore and as a replacement of limestone.

Chabazite.-In the contact zone along the southern margin of the Clayton Peak stock small pearly white crystals of chabazite fleck the metamorphic material.

Calamine.-Calamine is reported by Van Horn ${ }^{1}$ from the Quincy mine.

PHOSPHATES.

Pyromorphite.-In certain croppings and upper portions of shoots of the lead ore pyro- 
morphite is probably present in small quantities, but it has not been definitely determined.

Phosphate rock.-Phosphate rock occurs in the Park City formation.

\section{ARSENÁTES.}

Mimetite.-Mimetite is a combination of lead arsenate (90.7 per cent) and lead chloride (9.3 per cent) in hexagonal crystals. It is believed to be present in the yellow oxidation. products from the galena-tetrahedrite oress.

Bindheimite.-A yellow mineral believed to be in part bindheimite occurs as an alteration product of galena-tetrahedrite ore.

SULPHATES.

Anglesite.-The sulphate of lead, anglesite, occurs widely in moderate quantities in the lower part of the zone of oxidation, in both lode and replacement bodies, as the first product of the alteration of galena.

Chalcanthite.-The common hydrous sulphate of copper, chalcanthite, is rarely met in the mines of the district.

Barite.-Barite was found at a prospect on top of Flagstaff Mountain, where it had apparently incrusted the walls of fissures in quartzite.

Gypsum.-Gypsum was found in massive form on the dump of an old working of the Summit Co. at the head of Thaynes Canyon, where it apparently has been formed by mine waters. In a specimen of ore from the Wabash mine, 600-foot level south, Lindgren noted semicrystalline to fibrous gypsum forming the gangue of a granular zinciferous galenatetrahedrite ore.

Gostarite.-The hydrous sulphate of zinc, goslarite, was seen in small fibrous tufts in old workings on walls.

\section{OCCURRENCE OF THE ORES.}

TYPES OF ORE.

The ores of the Park City district occur as lode deposits and as bed deposits in sedimentary and intrusive country rocks. The two types of deposits are commonly associated throughout the region, though some lodes and veins occur alone. The principal lodes extend northeast. through the heart of the district across Ontario, Empire, and Woodside canyons. The chief bed deposits have been found in Empire and Woodside canyons. Deposits of both types also occur on the east and west.
Fissures trending northeastward carry lode ores in the intrusives as well as in quartzite and limestone. Bed ores are most extensive and of highest grade in the Park City formation and are less abundant and leaner in the Thaynes formation. Valuable bed ores have been mined to a depth of somewhat more than 900 feet; rich lode ore has been found to depths of 1,500 feet, and good milling ore to 2,000 feet. In general, the deposits appear to be closely associated with fissures or intrusive rocks.

LODE DEPOSITS.

Croppings.-Several lodes outcrop in this district, the best example probably being the Ontario, in Ontario Canyon. One of the locators of this great mineralized fracture zone has stated that the cropping consisted of "a little knob sticking out of the ground about 2 inches high," and that this was "the only cropping of the lode which was ever found." At the time of Boutwell's examination that part of the vein had been opened and showed on the surface as a zone of crushed quartzite 2 feet wide between definite parallel fissure walls. This zone had been traced along the surface for about 1,100 feet, and downward for 2,000 feet. At the point of discovery and along the strike the filling had undergone secondary and possibly tertiary silicification. The quartz formed is dull, honeycombed, chalcedonic, milky, and massive. The mineralization is indicated by black, brown, green, and yellow stains. The black and brown are manganese oxide, the green is crystalline and amorphous malachite, and the yellowish stains, which are termed by the prospector "chlorides," are not so readily determined but are probably due to alteration products of galena, such as pyromorphite, the oxide, massicot, and the arsenical antimonate, bindheimite. This discoloration or deposit is a common feature on siliceous croppings. On the strike toward the west at a point just west of the Daly boarding house is a rusty quartzite ledge, which is usually regarded as the cropping of the extension of this lode, and south of that, in the fork of the road, is another ledge of quartzite showing sheeting, which is held to be the apex of the vein at that point. Neither of these outcrops shows any mineralization beyond silicification and some staining with iron. 
Several other veins and lodes-for example, the New York lode-show rusting along a fracture zone. Some of the fissures on Crescent Ridge are similarly mineralized and show also copper carbonates.

Character.-The lode deposits of the district are extensive, strong, and valuable. They lie in a few continuous master zones, rather than in a large number of small fissures. They may be characterized as argentiferous lead ores with some zinc and, in certain places, copper. The lead is afforded in the upper portions by the carbonates and oxides and below by the sulphide and some sulphate. The silver appears to lie in the pyrite and galena. Zine is present as the sulphide. Copper appears as carbonates in the upper levels and to some extent at the intermediate levels, but occurs mainly in the deeper levels in tetrahedrite.

In general the upper parts of these deposits have proved richest, the middle section has been of high grade, and the deeper portions larger but leaner. Exceptions are known, however; thus, in the Silver King mine in several places the grade of the ore in the "gash" veins increased with the depth.

Some continuous seams or solid bands of ore occur between frozen contacts. The greater part of the lodes being worked at the present day, however, consist of disconnected seams and bunches of rich sulphide ore scattered through much waste in the fracture zones. Thus, in some of the small properties and on the 300 and 600 foot levels of the Ontario mine, especially in the footwall of the master lode, the ore lies in thin seams frozen to the walls. In the Silver King mine at the lower levels broad bands or tabular masses of solid sulphide ore were found entirely filling fissures. The other, more common, form of deposit is admirably exhibited in the Ontario mine on the 1,500-foot level, and in the Daly West mine on the 1,400 and 1,500 foot levels, where a strong fracture and breccia zone 100 feet in width is occupied by crushed quartzite which includes seams, streaks, and bunches of sulphide ore.

Intermediate types of occurrence in the Daly West stopes between the 1,400 and 1,500 foot levels consist of single streaks in a wide zone of breccia at or near either wall and a number of roughly parallel pay streaks dis- tributed through the zone. Perhaps the best example of this type of lode deposit was seen at the extreme west end of the Daly West 1,500 -foot level, where a lode 35 feet wide is made up of two strong ore streaks on the foot and hanging walls and many narrow seams and lenses of ore in fractures within the lode.

Areal distribution.-The lode deposits lie in a general east-west zone about 3 miles wide, which extends across the central part of the area from the west nearly to its eastern boundary. Some fracturing is found on the north and south, but no noteworthy mineralization except in this particular zone. Within the main Park City zone the master lodes, comprising the great Ontario and Daly West system and the Silver King group, traverse the ground exposed by Ontario, Empire, and Woodside gulches for about 3 miles along their strike and through a width of 2 miles. To the east, in the course of the zone, ore-bearing fissures and lodes have been found in McHenry, Wasatch, Glencoe, and Cottonwood canyons, and to the west of the master lodes, in the same course, other lodes extend across upper Thaynes Canyon. Those on either end, however, are relatively small.

Within this main area of master lodes two subzones are seen. The Ontario and Daly West system lies at the southeast side and includes most of the important lodes. The Silver King subzone lies about a mile to the northwest. Between these two subzones some fissures are found and a few lodes-for example, the American Flag. In general, however, the great lodes lie in two northeast-southwest zones about a mile apart.

Fissure systems.-The grouping of fissures into systems according to their trends, which has proved most significant in certain districts, does not appear to be practicable in the present area. Most of the fractures trend east, and a few transverse fissures trend north. Intersections are extremely rare. Characteristic members of the prevailing system are seen in the Ontario and Daly West fissure zones and the Silver King and Kearns-Keith fissure zones. The principal members of the other system recognized on the surface are the Frog Valley fault and the Massachusetts fault.

Intersections along these strongest members of the lesser system could not be made out. The fairly accordant alignment of the known 
portions of the Frog Valley fault and of topographic features athwart the course of the eastwest faults marked by Drain Tunnel Gulch and McHenry Canyon suggests that the northsouth system is the younger. The Massachusetts fault was not observed, on the surface or underground, in juxtaposition with any other fault.

Underground, in the Silver King, KearnsKeith, and Daly West mines, members of the main east-west system are in a few places cut by small fissures of the north-south system. This evidence accords with that noted on the surface in tending to show that the latter system is the younger.

Highly characteristic of the greater fissure system in this district is a branching or forking habit. Thus in both the southern series opened through the Ontario, Daly, Daly West, and Daly-Judge mines and the northern series opened through the Woodside, Mayflower, and Silver King mines the fissures of the east-west system appear to divide and subdivide. The feature is best shown in the Ontario mine, where a number of these branches or "spurs" have been extensively developed. Critical examination of their junctions indicates that these spurs are true branches contemporaneous with the parent fissures. They usually diverge slightly and then continue roughly parallel to the original fissure. It is hazardous, however, to conclude unqualifiedly that these "spurs" are not portions of oblique fissures cut by the master fissure, as the physical appearance of the junctions might be similar with either manner of origin. But so far as known no continuations (truncated extensions) have been found in the hanging wall and it is most probable that the "spurs" are true branch fissures.

Lode systems. - The system which trends east-northeast appears to include most of the great lodes The Ontario lode trends N. $60^{\circ} \mathrm{E}$. (average); the Daly West lode N. $60^{\circ}$ E.; and the Silver King lodes N. $60^{\circ}-80^{\circ}$ E. Most lodes trending differently are branches from lodes of this prevailing trend or closely approach this trend.

Localization in shoots.-Unfortunately large portions of the extensive workings on the veins are inaccessible. Nevertheless, certain fairly well-defined localizations of ore into shoots were recognizable. Thus, stope maps and sections published by the Ontario Co. indicate an extensive strong shoot pitching steeply westward from the surface on either side of Ontario Canyon to the lowest levels. Another of less extent, on the west, was opened through raise 3 , and a third in the vicinity of raises 4 and 5 . It appeared underground that enlargement of the lode occurred at the junction of the master lode with a few "spur" or branch veins, but intersections or forkings could not be established as the determining cause of the greater shoots. It seems not improbable that their location and form may be governed by that of passageways and inequalities in the original fissure.

In the Daly West similar localizations of ore or enlargements of the lode comprise two major and several minor shoots. One at the west end of the property is about 600 feet in length and is 35 feet in width just above the 1,400-foot level. The second shoot, lying north of the shaft, had been opened on the 1,500-foot level for 300 feet to a width of 30 feet. This shoot is unlike the former, which has bands or pay streaks of good width and tolerable persistence, in that the ores are distributed rather evenly in seams and bunches through a mass of crushed gangue.

The ore of the lodes in Silver King ground was not, so far as could be observed, localized into definite shoots. The nearest approach to one occurred in the "gash" lode near the Donkey winze. This was a lens or wedgeshaped mass of high-grade galena ore 20 feet through at its thickest part and followed 200 feet on its dip. It feathered out upward and laterally and terminated abruptly downward. No good reason for its location was apparent. In several of the smaller mines-for example, the Scottish Chief and Valeo-small shoots have been opened. When any reason for their formation could be found, it seemed to be either the form of the original fissure, or intersection with a feeding fissure, or shattering and consequent greater permeability of the country rock.

Relation to wall rock.-The influence of wall rock on lode ore, whether as regards position, amount, or character, was not very marked.

Long observation in the Ontario mine has given rise to the saying that the highest-grade silver-lead ore lies between quartzite walls, 
whereas ferruginous and zincky material occurs in the porphyry on the lower levels. Limestone walls naturally lend themselves to replacement and are apt to inclose the widest and most irregular lodes of the replacement type. For this reason, probably, veins were observed to expand between calcareous walls and to contract on reaching more siliceous or quartzitic walls.

The physical character of the wall rock seems to have influenced the character of fissures in a number of places. Thus, in the Ontario the massive quartzite seems to favor strong, even, well-defined fractures; limestone apparently breaks under stresses less readily and evenly; and porphyry contains the most irregular and ill-defined fractures.

Persistency.-In general, the fractures are strong, well defined, and notably persistent. The best example is found in the OntarioDaly West system. The main Ontario fissure has been explored continuously along its strike for approximately 5,000 feet, and the Daly-Daly West fissure, in the footwall of the Ontario and beyond to the west, for approximately 5,000 feet. Within these fissure zones the Ontario lode has been mined for about 4,000 feet, and thence along spur 2, a great lode, comprising the Daly and Daly West veins, has been mined for 5,000 feet more. The Ontario fissure is said to end on the east abruptly against a transverse fault. Its western end (in 1912) was a strong zone of sharp, well-defined fissures and brecciation that gave every indication of continuance. The ore within this fracture zone, however, pinched out nearly a thousand feet back to the east by normal feathering out, and the long stretch of comparatively barren fracture zone discouraged further work. However, another shoot may be found farther to the west. Similarly, the great Daly West lode, where opened in Daly-Judge ground west of that shaft, showed a strong fracture zone, and reports of latest developments indicate good ore contents.

The fracture zones containing the strongest lodes in Silver King ground, the "gash" and the "gold ledge," appear to continue with good strength beyond the extreme points opened. But the ore in them pinched out, and, owing to the barren unmineralized aspect of the fracture zones beyond, exploration was not carried fur- ther, though the continuations of the zones may contain ore. Smaller lodes show similar features.

The persistence of fissures in depth has been well said to be approximately proportional to their extent along their strike - that is, the longer and stronger the fissure the greater the depth to which it may be expected to extend. The fissures and fracture zones of this district are no exceptions to this broad generalization. Thus, the long Ontario zone has been opened continuously from the surface to the 2,000foot level and is wider, stronger, and more sharply defined on the 1,700-foot level than at the surface. On the bottom, or 2,000-foot. level, it lies largely in porphyry, where it is: naturally less distinct, but even at this depth it shows great strength, excellent walls, and widths of 1 to 2 feet. The mineral contents. vary considerably, being greatest and richest. between the 500 and 800 foot levels, especially between the 600 and 750 foot levels, and good down to the 1,500-foot level, where the width rose to 100 feet and the ore became a low-grade milling ore. Below this level between limestone walls, and particularly on the lowest level in porphyry, the ore was of low grade and carried much iron and zinc. This zincky ore on the bottom level occurred in two shootsone east of the shaft and the other west.

To the west the Daly West lode at a depth of 1,500 feet appeared like the Ontario lode at the 1,500-foot level-a notably wide zone of low-grade or milling ore carrying considerable iron and zinc in a gangue of silica. Development at lower levels is said to reveal the continuation downward of similar features.

The fractures of the "gash" lode in Silver King ground seemed to extend downward in the form of a broad zone of sheeting. The main shoot in this zone was reported by the operators to have terminated below sharply at a depth of 1,100 feet along a regular plane.

In some of the lesser mines shoots have been bottomed and in others found to persist to the deepest point worked.

In brief, it appears that although certain shoots of high-grade ore have given out at depths of approximately 1,000 to 1,500 feet, the fracture zones persist with great strength beyond the greatest depths explored, some carrying bunches of high-grade ore and others only large masses of milling ore. 
BED DEPOSITS.

Croppings.-Two great series of bed deposits have been opened - that in Silver King ground and that in Daly West ground - and a number of minor deposits, including those in the DalyJudge, Kearns-Keith, and Comstock mines. Certain outcrops have been held to be apexes of known ore bodies below, and underground work in connection with ownership litigation was asserted to have established continuous connection between ore bodies and croppings. It is unfortunate that the areas in which the beds that include the large, rich ore bodies would normally outcrop are deeply buried beneath glacial deposits. The known distinct cropping of the great Mayflower ore body led to an ore shoot which descended gradually into Silver King ground and might naturally be taken for a bed deposit. Although its inclination was doubtless influenced by the limestone beds, the parts of the shoot observed by the writer tend to show that its position and course are closely connected with fissures and that it can not be regarded as a normal bed deposit. Its cropping is said to have been a mass of solid galena. North of the mouth of Walker and Webster Gulch, about 400 feet directly above the Daly-Judge mill, a fracture zone contours the slope and at certain points marks the surface contact between the Weber quartzite and the Park City formation. Parts of this zone, which has been mined out, are said to have been mineralized. In the noted Fairview suit this was claimed as the apex of certain Silver King ore bodies, and an attempt was made to demonstrate this by making a connection.

The outcrop of the great ore-bearing bed in the Daly West ground and the croppings of shoots in this bed were not detected. The connection of the Daly West ore bed upward in the Quincy and Little Bell has been a mooted point, and its positive demonstration is rendered most difficult by complications due to intrusion and faulting. The cropping of the Quincy ore-bearing bed, the equivalent of the Daly West bed, is said to have been found at the east end of the present mine and just below the present wagon road. A connection between this cropping and the 100-foot level is stated to have followed the main shoot from the surface to the great ore bodies underground, but examination failed to reveal ore either in the raise or in the croppings.
About the headward slopes of the canyon the extensive intrusive mass of porphyry occupies the area in which the contact between Weber quartzite and Park City formation and the contact with the overlying ore-bearing member would normally outcrop. Again, a fault which traverses the bottom of the canyon just east of the Little Bell shaft may have dropped the ore-bearing member, so preventing its outcrop. The cropping of that member was not observed in mapping this region. Thus, in neither the Silver King nor the Daly West area were actual croppings of known bed-ore bodies observed.

On the southern slope of Scott Hill, however, on the Scottish Chief property, there are apparently croppings of a true bed ore body. Galena, anglesite, and cerusite occur here, with a gangue of calcite, garnet, and limonite, in a bed of coarse marble which belongs to the Thaynes formation. This ore-bearing bed has been followed underground and a shoot developed which appears to be the downward extension from these croppings.

Character.-The bed deposits form the bonanzas of this district. Many of them are large, continuous, of high grade, and comparatively shallow. The profits from these deposits have placed the younger large properties, such as the Daly West and Quincy and Silver King, among the great producing and dividendpaying mines.

In general the bed ores are sulphides, with some oxides of smelting grade. Those from the deeper or isolated parts of the beds are mainly galena, some gray copper, and pyrite. In certain places considerable sphalerite is present. The galena is both coarse and fine cleavable. In the oxidized portions anglesite, cerusite, an antimonate (probably bindheimite), and malachite are found. Calcite and quartz form the prevailing gangue. The ores are commonly dense and heavy, only the highly oxidized portions being lighter in weight, semiporous, and powdery.

Areal distribution.-The valuable bed deposits have been found on the upper north side of the main eastern spur from the Wasatch Range, which forms the main divide of the district. They thus lie about the headward portions of Empire, Woodside, and Thaynes canyons in the Daly West, Quincy, DalyJudge, Silver King, Comstock, and Scottish 
Chief mines. Excellent bed ore is also found in Walker and Webster Gulch and is developed in the Kearns-Keith mine. Aside from these, only minor bed deposits were observed.

Geologic distribution.-The bed ores occur in sedimentary formations that adjoin the northern flank of the great Clayton Peak laccolith of diorite and dip north and west over Weber quartzite. The ore bodies are found in the calcareous sediments. The Park City and Thaynes formations contain the bonanza ore. The Weber quartzite is known to carry a few small and isolated beds of no commercial importance. The two red-shale formations, the Woodside and Ankareh, are not known to be ore bearing. In the two calcareous formations the siliceous members are commonly barren. Much the larger number of bodies and much the higher grade of ore has been found in the Park City formation, which contained the extensive bodies of rich bed ore mined from Silver King and Daly West ground and some from the Daly-Judge. In the Thaynes formation, however, were found some of the bed bodies in the Daly-Judge, Kearns-Keith, Comstock, California, and Scottish Chief mines.

The character of the ores from the two formations is most distinct. Those from the Thaynes formation are commonly high in sphalerite, iron, and silica and are not only much lower in grade but much less desirable for either smelting or milling than those from the Park City formation. As compensation, however, they afford the zinc product which in recent years has been turned to excellent commercial advantage.

It appears fur ther that bed ore is practically restricted not only to these two formations but to certain members of them. This restriction is more notably true of the Park City formation. In the Daly West mine, on the 900-foot level, in the south crosscut at the west end of the property the bed deposits occur mostly in a certain limestone member 4 to 6 feet thick that lies approximately 60 feet above the Weber quartzite, between a hanging wall of fine siliceous gray impure limestone and a footwall of brown sandy quartzite. This favorable stratum is underlain successively by the following beds:
Section of beds below ore-bearing member in Daly West mine, 900-foot level. Feet. Cherty massive brown sandstone. . . . . . . . . . 12-15 Light-gray limestone, black cherts at top...... 4- 5 Black limestone, carbonaceous at base........ 20 White sandstone........................ 7 Gray siliceous limestone with sandy beds...... 15 Thin-banded gray shaly limestone........... $1 \frac{1}{2}$ Weber quartzite.

Similarly in the Silver King mine the principal bed deposits occur in a limestone member in the lower part of the Park City formation. Along the crosscut running northeast from the station on the 900-foot level the drift passes up through the Weber quartzite and the bassal.part of the Park City formation to the ore-bearing member. The beds traversed clearly embrace the equivalents of those noted in the Daly West, and other beds that were not observed in that mine. The existence of many strong strike faults renders any close measurement of thickness impossible. In general it appears here and elsewhere through this property that the principal ore-bearing member is somewhat higher than to the southeast in Daly West ground, being approximately 100 feet above the Weber quartzite, as shown in the structure section through the Silver King shaft and orebearing member. The ore-bearing series here comprises a bed of fine even-grained gray siliceous limestone overlying a fine-grained grayish brown quartzite. The ore appears to have formed in the base of the limestone over the quartzite. Above, on the 800-foot level, where the ore bed and walls show more clearly, a 3-foot bed of shaly limestone that gives way to ore lies between walls of fine-grained gray siliceous limestone.

Variations from these normal conditions'were also noted. In the Silver King mine certain beds at horizons above the main deposit carry ore in places. In the Daly West mine above drift C a large stope shows double ore beds, where a layer of brown sandstone or quartzite known as the "parting quartzite" separates a 15 -foot bed of ore from an underlying 6-foot bed of ore. Again, on the '01 level west, ore occurred in limestone immediately overlying Weber quartzite.

In order to ascertain the determining factors in the selective action through which ore forms 
in certain beds to the exclusion of others, sam- King and Daly West mines are from the Park ples were taken from the beds in which the ore City formation and those from the Scottish is best and from the hanging wall and footwall Chief are from the Thaynes formation. Partial of those beds. The samples from the Silver analyses follows:

Analyses of rock from ore beds and walls.

[Analyst, George Steiger, United States Geological Survey.]

\begin{tabular}{|c|c|c|c|c|c|c|c|c|c|}
\hline & 1 & 2 & 3 & 4 & 5 & 6 & 7 & 8 & 9. \\
\hline 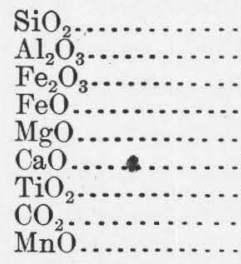 & $\begin{array}{r}1.50 \\
.31 \\
.11 \\
.16 \\
20.41 \\
30.54 \\
\text { None. } \\
46.03 \\
.28\end{array}$ & $\begin{array}{r}4.54 \\
.64 \\
\text { None. } \\
.30 \\
\text { 19. } 07 \\
29.69 \\
.04 \\
44.27 \\
.25\end{array}$ & $\begin{array}{r}86.77 \\
2.81 \\
.40 \\
.16 \\
.92 \\
3.99 \\
.12 \\
3.44 \\
.02\end{array}$ & $\begin{array}{r}2.97 \\
.68 \\
\text { None. } \\
.32 \\
19.11 \\
28.04 \\
\text { None. } \\
44.00 \\
.57\end{array}$ & $\begin{array}{r}3.81 \\
.19 \\
.38 \\
.16 \\
19.54 \\
30.11 \\
44.78\end{array}$ & $\begin{array}{r}64.86 \\
1.36 \\
.46 \\
.13 \\
6.30 \\
10.60 \\
.08 \\
13.78 \\
.19\end{array}$ & $\begin{array}{r}1.90 \\
1.70 \\
1.62 \\
1.40 \\
1.04 \\
50.51 \\
.08 \\
39.66 \\
.70\end{array}$ & $\begin{array}{r}63.81 \\
9.67 \\
\text { None. } \\
2.17 \\
4.30 \\
11.98 \\
.67 \\
1.11 \\
.44\end{array}$ & $\begin{array}{r}70.05 \\
7.47 \\
.19 \\
1.17 \\
2.81 \\
11.84 \\
.52 \\
1.03 \\
.31\end{array}$ \\
\hline
\end{tabular}

1. Bed replaced by main bedded ore deposits, Silver King mine, stope on 700 -foot level west (specimen 1126).

2. Hanging wall immediately over main ore bed, Silver King mine, stope on 700-foot level west (specimen 1128).

3. Second true hanging-wall bed, Silver King mine, stope on 700 -foot level west (specimen 1130).

4. Footwall immediately under main ore bed, Silver King mine, stope on 700-foot level west (specimen 1131).

5. Bed replaced by main ore bed, Daly West mine, stope A (specimen 953).

6. "Parting quartzite," barren bed between two ore beds, Daly West mine, roll incline between B and C levels (specimen 957).

7. Bed replaced by main ore bed, Scottish Chief mine (specimen 974).

8. Hanging wall of main ore bed, Scottish Chief mine (specimen 975).

9. Footwall of main ore bed, Scottish Chief mine (specimen 973).

The figures showing the composition of these beds bring out certain broad facts clearly. The ore beds are low in silica and high in lime, and those from the Park City formation are highly magnesian. The hanging walls, on the other hand, are high in silica and relatively low in lime, except No. 2, which was probably part of the ore bed and barren at the point of collection, the true hanging wall being No. 3 . The footwalls are also high in silica and low in lime, except No. 4 , which is likewise doubtless a barren portion of the ore bed instead of the true footwall. The specimens from the Scottish Chief show most clearly the high lime and low silica content of the ore bed and high silica and low lime of the walls. In brief, it appears that the ore forms best in pure or magnesian limestone and that the walls are siliceous.

Form and structure.-In general, the bed deposits are roughly lenticular. Some are very long along the strike, but most are longest along the dip. The margins are as a rule irregularly lobed, some of the lobes or arms being of considerable length. The periphery is commonly attenuated until it disappears. Normally these deposits occur in single or simple lenses, but some of them become compounded through the duplication of the original by others above and below.
The dimensions of the lenses differ greatly. The thickness ranges from a few inches to 6 or even 10 feet. The maximum dimension is usually the length along the strike, which in some lenses is approximately 500 feet and in one or two is indicated by mine maps as 600 to 800 feet. The width in the direction of dip averages possibly 50 feet, reaching 100 feet in several lenses, 150 feet in the great stope at the west end of the Daly West property on the 900-foot level, and about 200 feet through a length of 600 feet in the great stope in the Silver King mine.

As the lenses of ore coincide with or occupy parts of beds of limestone the dip and strike of these bedded deposits agree roughly with those of the inclosing limestone members. In some places entire members or beds of the limestone give way to ore. Many such beds of ore end evenly above and below on bedding planes of the overlying and underlying beds of limestone. Probably more of them, however, extend irregularly upward across the bedding, some ending in tongues or bulging surfaces and others expanding at a higher horizon to form a second ore bed.

Each bed of ore is made up of layers or laminae that correspond to the laminae of limestone which make up the member or bed of limestone. These layers range from a small fraction of an 
inch up to 1 or 2 inches in thickness, according to the thickness of the bands forming the original limestone bed. Finally, these laminae are seen, some by the naked eye and others by the microscope, to be themselves built up of minute layers of ore, which under the microscope are seen to be composed of interlocking grains of the several ore and gangue minerals, on a pattern similar to that of the original limestone. In the great stope A of the Daly West mine the upper face showed, between evenly preserved bedding planes, a 6 -foot bed of banded ore that was made up as follows:

Section of ore bed in stope A, Daly West mine.

Inches.

Coarse galena, with sphalerite................ 8-10

Fine-grained siliceous limestone..................

Pyrite, galena, and gray copper in siliceous limestone.

Coarse galena with white quartz.

Massive fine-grained galena and gray copper.......

Slightly oxidized ore with quartz bands...........

Footwall sandstone.

Similarly, on the 900-foot level at the west end the upper face shows a 4 -foot bed of banded argentiferous lead ore between a calcareous sandstone or siliceous limestone hanging wall and a sandstone footwall. The banding is brought out by partings of siliceous gangue. In the Silver King mine the walls of the stope adjacent to the incline at the north end leading from the 750 -foot to the 800 -foot level show a 4 -foot bed of well-banded rich, partly oxidized lead-silver ore between members of the Park City formation. Inspection shows that the bands of ore are structurally continuous with the bands of limestone of the inclosing beds.

In brief, the bed deposits occur in bodies of roughly lenticular form having a banded structure which is conformable with the bedding of the inclosing limestone even down to the minute laminations.

Relation to fissures.-The relation between bed deposits and fissures is intimate and complex. Fissures act both as conduits and as faults. Some of the most important bed deposits have strong, somewhat mineralized fissures rising through their footwalls or descending rootlike from them. Many such mineralized fissures pass upward through siliceous rock to bed deposits in limestone members. Their part as "feeders" is most admirably illustrated on a small scale in the Daly West mine, where an east-west fissure dipping $75^{\circ} \mathrm{S}$. and carrying granular carbonate ore crosses limestone beds into certain of which ore extends outward and upward.

In a precisely similar manner, on a larger scale, the mineral-stained though lean fractures in the 900-foot level followed by the back or work drift connecting the ore chutes on the south side ascend to the great bed deposits of the 900-foot level. Similarly, also, east-west, N. $70^{\circ} \mathrm{W}$. and N. $80^{\circ} \mathrm{E}$. fissures on the $900-$ foot level have been worked upward for 300 feet into extensive bedded deposits. In the Silver King mine fractures very clearly served as conduits for the solutions which supplied the great flat bed deposit adjacent to the Gillis raise. The same fractures that served for the passage upward of ore-bearing solutions akso served (if they extended to the surface) as conduits for the downward movement of surface waters, thus facilitating the superficial alteration and enrichment of the bedded ore bodies.

Relation to intrusive rocks. - That intrusions played a controlling part in the formation of the ore deposits is evident, but the physical relations between intrusive rocks and bed deposits are not so apparent in this district as elsewhere. Intrusive rocks, although abundant, are not common in close proximity to the great bed deposits. The principal occurrences may be briefly examined.

A great stock of diorite extends into the district from the southwest to the gap above the Daly-Judge and disappears beneath the glacial blanket covering the bottom of Bonanza Flat, and an extensive series of diorite porphyries rising from beneath the glacial blanket continues northeastward across the area, giving way at the extreme northeast to great flows of andesite. Abutting against these intrusive rocks and traversed by minor offshoots from them are the metamorphosed limestone formations in which the bed deposits occur. In the immediate vicinity of these deposits several intrusive masses outcrop. About the head of Empire Canyon, forming the upper part of the Quincy and Little Bell spur, is an extensive mass of diorite porphyry. Dikes of the same rock. appear about 125 feet south of the Quincy shaft, about the same distance west of the Daly West shaft, and farther west, extending from the pond southward nearly to the Daly-Judge shaft. Diorite extends through the gap above the Daly-Judge and along the west side of the canyon. At the collar of the old Massachu- 
setts shaft a small body of diorite porphyry crops out.

Within the Silver King area, singularly enough, not an outcrop of igneous rock was observed, although the dump at the mouth of a long tunnel up Woodside Gulch above the Silver King office shows much coarse diorite porphyry. Underground also, the immediate vicinity of the great bed deposits of the Silver King mine is singularly free from igneous rocks. A small body of peridotite on the 300-foot level northeast of the shaft, a small sill of the basic porphyry on the 750-foot level, and a block of diorite porphyry on the 800 -foot level are all the intrusive rocks known in the heart of the productive portion of the Silver King ground. In outlying portions, however, extensive dikes of coarse diorite porphyry appear.

In the adjacent Kearns-Keith ground bed deposits are in immediate contact with extensive dikes of diorite porphyry.

In the Daly-Judge mine porphyry traverses ground in the vicinity of bed deposits. The most notable example is the well-defined dike of diorite porphyry exposed on the 1,200-foot level for approximately 500 feet.

In the Daly West and Quincy mines bodies of coarse diorite porphyry, cut at several levels, appear to belong to a dike 10 to 40 feet wide, which trends east and apparently stands nearly vertical. West of the Quincy shaft bed ore in limestone abuts against the dike at several points, and on the west, in Daly West ground, extensive bodies of rich ore occur either in contact with or adjacent to it. Perhaps the clearest instance of ore in limestone beds adjacent to porphyry was found at a point where the Daly West dike, expanding to a width of at least 50 feet, cuts limestone in which a large body of rich ore formed immediately over the porphyry. The ore, composed of massive galena, gray copper, and the alteration products anglesite, cerusite, malachite, and azurite, occurred in bands continuous with the banding of the inclosing limestone. The limestone is somewhat altered and oxidized, the porphyry is likewise pyritized and oxidized, and both rocks at the contact show crushing, brecciation, silicification, and oxidation. The occurrence appears to be a normal intrusive contact between a diorite porphyry dike and limestone of the Park City formation, sulphide ore being found in the limestone along bedding adjacent to the porphyry and the whole mass being subsequently somewhat crushed and altered.

The facts show a close relation between bedded deposits and intrusive rocks.

Effect of faulting.-The effect of faults on bed deposits depends primarily on their relative position and age. Obviously a fault that does not intersect an ore body can not directly affect it, and a fracture that crosses an ore body but is of earlier date can have no effect as a fault, although the fissure formed by it may have served, as explained in a previous section, as a conduit for ore-bearing solutions. Faults intersect bed ore bodies and those of later date displace them.

In the Park City district faulting occurred previous to intrusion, and subsequent to intrusion and mineralization it was repeated along the same lines and also occurred along transverse courses. No extensive displacement of ore beds has occurred, indicating that the greater part of the movement on the faults took place before the deposition of the bed ores.

At the Daly West fracture zone the main orebearing bed was apparently truncated and displaced along the "roll" fault. The bed ore is clearly bent or dragged up on the north, and fragments of ore that show crushing, rounding, and slickensiding lie in the fissure. Clearly, faulting took place after ore deposition and displaced the bed. The fault strikes east and, where this displacement was noted, it dips $54^{\circ}-70^{\circ} \mathrm{S}$. It is offset to the north at least 40 feet and probably nearer 50 feet. In the stopes on this bed above to the south numerous small postmineral faults may be seen. The footwall shows many small displacements ranging from a few inches up to several feet, with corresponding offsets in the hanging wall. On the upper levels considerable faults of postmineral date have been revealed. In the same manner the ore bed in the Quincy ground is displaced for a few feet at several points.

In the Silver King mine the locus of the great bed deposits is similarly faulted on east-west zones. None of the faults here is more important than the "gash" fracture, whose relation to the bed ore is shown by the development. The "gash" strikes N. $60^{\circ}-70^{\circ} \mathrm{E}$. and dips $60^{\circ}$ NW. across the bedded ore body in limestone, which dips at an average $21^{\circ} \mathrm{N} .55^{\circ} \mathrm{W}$. The bed ore and the overlying and underlying beds of limestone end against the "gash" fault, 
whose hanging wall here is calcareous sandstone and gray carbonaceous limestone, although at lower levels both its walls are quartzite. The bedded ore is clearly faulted. On the 900foot level the drag in both footwall and hanging wall indicates a relative displacement downward on the hanging-wall side. Below, just above the 1,000-foot level, a drag on some ore in the footwall suggested movement in the opposite direction. On the whole the probabilities incline toward a drop on the hangingwall side.

The north-south and related northwestsoutheast faults are of still later date and should displace bed ore along intersections. Several such displacements along north-south faults occur in the Silver King and Daly West and in lesser mines, but the offsets appear too small to interfere with mining.

SUPERFICIAL ALTERATION OF ORES.

Alteration of the primary ores by surface waters in the Park City district reaches to a maximum depth of 1,700 feet, and to an average depth of 600 to 700 feet. The principal feature of interest is the complete oxidation of galena-tetrahedrite ores to hydrous antimonate of lead (bindheimite) at a depth of 1,200 feet.

GROUND-WATER LEVEL.

Ground water was encountered near the surface in the early days, but through mining operations it has been lowered to about 1,500 feet in the deepest workings.

EXTENT AND CHARACTER OF ALTERATION.

The bed ores, best exemplified in the Silver King and Daly West mines, are normally oxidized to depths of 500 to 800 feet. Thus the Quincy bed ore was thoroughly oxidized to just above the 300-foot level, where sulphides began, partly oxidized to the 400 -foot level, and oxidized in some degree to a depth of 570 feet. In the Daly West, stopes at 630 feet showed cores of sulphide inclosed in carbonate and oxide ore. Lower beds were entirely sulphide. In the Silver King mine the bed ore at the 750 and 800 foot levels was essentially carbonate, though some sulphide was admixed. On the 1,000 -foot level, where the "gash" and bed ore bodies come together, the bed ore was entirely sulphide. On the 1,200-foot level west, along a fissure, a bed of ore was completely oxidized.
Alteration varies most along fissures. The Ontario lode, being opened from the suriace to a depth of 2,000 feet, affords an excellent scale, though unfortunately much of the upper older portion of the mine is inaccessible. Some of the croppings of the lode showed galena, and on the Union 100-foot level west considerable seams of galena were observed. The outer parts of "spur" veins on the 1,000-foot level were composed of carbonate ore, and some carbonate ore was seen on the 1,700-foot level. In general, however, the oxidized ores were richest between the 600 and 750 foot levels and the carbonate ore below was leaner and less abundant. On the 1,500-foot level the ore was essentially sulphide.

The rich bedded ore in the Silver King and great blocks of slightly altered galena ore from the "gash" at a depth of about 1,100 feet afford complete epitomes of the succession of changes. The primary lead ore (lead sulphide, galena) alters to anglesite and this to cerusite. Further alteration results in a brownish-yellow, waxy amorphous mineral, which eventually passes into a dusty bright-yellow mixture of lead oxide, probably massicot, and several complex inseparable alteration products. Chief among these is a compound of lead and antimony, probably bindheimite, which is apparently derived from both galena and gray copper. Copper first becomes significant with the appearance of tetrahedrite, though some of it is contained in the pyrite. Critical search failed to reveal evidence of secondary origin for this rich copper mineral and thus tended to show that the tetrahedrite is primary and contemporaneous with the intergrown galena. Partly altered specimens of this ore from the Silver King and Daly West mines show pits and cavities crusted with the alteration products of these sulphides. Coating cores of the sulphide are the blue and green carbonates, azurite and malachite.

Silver was not found in sulphide form nor was it recognized in oxidized products. It is known to occur in the galena and in pyrite and sphalerite. Gold was not observed, though proved present by assays. The ore was richest where manganese was abundant, and apparently the gold ran highest where the ore was most altered and decomposed. 
GENESIS OF THE ORES.

The rich lode and bed ore bodies that have been successfully exploited are characteristic of their respective types. Broadly, they lie in sedimentary rocks within a few hundred feet of dioritic intrusives and give out within a comparatively short distance from them on either side. At greater distances all the geologic conditions continue the same, except that intrusive rocks are absent. The limit of influence of the intrusive rocks is the limit of workable ore; clearly it is a justifiable general conclusion that the intrusives were requisite for the formation of the ores.

This conclusion is fully supported by closer study of details. Along the zone of intrusives the sediments have suffered contact metamorphism, by which certain minerals-garnet, epidote, vesuvianite, augite, and mica, in a gangue of calcite-were formed that are universally recognized as due to the influence of intrusives. Along the contact, and intergrown with the contact minerals in a manner which clearly proves that they were formed at the same time, are the ore minerals pyrite, chalcopyrite, galena, specularite, sphalerite, and magnetite, demonstrating that the bonanza bed ores in limestone were formed by the intrusives.

The formations adjoining the intrusive rocks are much crushed, fractured, and fissured. In certain of these fissure systems, between walls of each type of rock-quartzite, porphyry, and limestone-valuable ores were formed of about the same metallic minerals that compose the bed ores-pyrite, chalcopyrite, galena, and tetrahedrite, with a gangue of quartz, calcite, and sphalerite. Their likeness in mineralogic composition to the bed deposits and their close association with intrusives, whose direct connection with bed deposits has been observed, strongly suggest that intrusives were also the causal factors in their formation. The excess of quartz and pyrite in the gangue and the silicification and sericitization of the walls point to the action of hot, probably alkaline aqueous solutions, such as would be expected to arise from an igneous magma. Finally, the presence of the additional gangue minerals rhodonite and fluorite indicates deposition from hot solutions or vapors expelled by underlying magmas.
Two other facts corroborate the conclusions above stated. The extension of ore in fissures through a composite footwall up to a bed deposit without continuing beyond through the hanging wall, and the definite upward termination of at least one lode, show that the ore-transporting agents moved upward. The inclusion of certain isolated portions of one vein within another, as, for example, the fragments of rhodochrosite and rhodonite as a core in quartz in a vein in Ontario ground, strongly suggests that at least some of the transporting agents were liquid; and consideration of chemical composition, solubility, and temperature leads to the conclusion that they were aqueous.

The process of deposition was one of replacement of limestone beds and, in many places, of the walls of fissures and to a minor extent of fissure fillings. Thus it has been shown that the bed deposits occupy portions of beds of limestone, that the layers or laminae which make up a bed of ore correspond in every way to laminae of limestone which compose the limestone bed, and finally that these laminae are made up of grains of ore and gangue minerals arranged in a pattern resembling that of the original limestone. Lode ores show similar evidence of replacement of walls, and here and there comb structure indicates some filling.

It is clear that ore deposition occurred at two or more periods, which may be dated with reference to other geologic events. Some of the bed ore was deposited contemporaneously with intrusion, but the lode deposits and apparently some of the bed deposits were probably formed later, after at least the surface of the intrusives had cooled to partial rigidity. It has been shown that the diorite is not earlier than Triassic and that the porphyry is at least as late as Lower Triassic and, together with the ore-bearing fissures, is earlier than the "Vermilion Creek" (Eocene). Hence some of the ore deposits were probably formed after Lower Triassic and before "Vermilion Creek" time.

Thus, between early Triassic and early Tertiary time, dioritic intrusives invaded this area, metamorphosed the sediments, and induced the deposition of rich lead-silver ores in certain members of the calcareous formations. After these intrusives had cooled to at least partial rigidity the composite country rock was broken 
by persistent northeast fractures. From the deep-lying, still molten remnant of the magma hot gases and aqueous alkaline solutions were expelled, by way of the fissures, upward and outward, transporting ore-making elements to zones where temperature and pressure were low enough to permit the deposition of ores. The hot solutions corroded and replaced with ore some of the purer beds of limestone through which they passed and thus formed the bed deposits. They formed the lode deposits partly by filling the fissures and partly by replacing the walls of fissures. Movement along the northeast fissures brecciated and faulted the ore and was followed by northwest fracturing, along which waters descending from the surface altered the superficial portions of the primary sulphide ores to rich oxide and carbonate ores-a process still in progress.

\section{BIBLIOGRAPHY.}

The following list comprises the more important publications bearing on the Park City mining district:

Almy, T. J., History of the Ontario mine, Park City, Utah: Am. Inst. Min. Eng. Trans., vol. 16, p. 35, 1888.

Ashburner, William, and Jenney, W. P., The Ontario mine, Utah: Eng. and Min. Jour., vol. 31, pp. 365$366,1881$.

Abstract of a report on the Ontario mine; embodies descriptions of the Ontario vein, the mine, the mill, and the ore in sight and gives general conclusions.

Boutweld, J. M., Progress report on the Park City mining district, Utah: U. S. Geol. Survey Bull. 213, p. 31, 1903; idem for 1903, U. S. Geol. Survey Bull. 225, p. 141, 1904; idem for 1904, U. S. Geol. Survey Bull. 260, p. 150, 1905.

The first report gives a general statement of the geography, general geology, and mining geology of the district; the second is chiefly devoted to newly discovered stratigraphic and structural features; and the third presents recent mining developments.

- Stratigraphy and structure of the Park City mining district, Utah: Jour. Geology, vol. 15, No. 5, pp. 434-458, 1907.

Gives descriptions of the formations with new names for four of them.

- Geology and ore deposits of the Park City district,

Utah: U. S. Geol. Survey Prof. Paper 77, 1912.

Describes in detail the geology and mines of the district.

Clayton, J. E., The drainage of the surface waters of the Ontario mine, Utah: Eng. and Min. Jour., vol. 37, p. 257, 1884 .

Discusses the inflow of surface waters and recommends footwall drainage.
Daly-Judge Mining Co., Report, Nov. 1, 1901, to Jan. 1, 1903.

Comprises the president's report on the organization of the company and condition of the property, a preliminary scientific report on the Daly-Judge mine by W. P. Jenny, and financial statements of the Daly-Judge and Anchor companies.

Daly Mining Co., Annual reports, 1886 and 1896.

Comprise the president's and superintendent's reports on the condition of mine, mill, etc., including tabular detailed financial statements of operation.

Daly West Mining Co., Annual reports, 1899 and 1902. Comprise the president's report on the progress of the company and detailed reports by other officers. Director of the Mint, Reports upon the production of precious metals in the United States, 1880-1903.

Contain detailed data on the geology, condition, and production of Park City mines.

Emmons, S. F., Descriptive geology: U. S. Geol. Expl. 40th Par. Final Rept., vol. 2, 1877.

The contributions of this author on the Wasatch Range and the western Uintas, with geologic map of these areas, are the only published geologic descriptions of the entire region. They present the best broad statement of the general geology of the Park City region and vicinity in print and should be consulted for the large geologic problems whose solution lies beyond the limits of this special area.

Structural relations of ore deposits: Am. Inst. Min. Eng. Trans., vol. 16, pp. 835 et seq., 1888.

Includes a concise description of the mode of occurrence of the Ontario ore deposits, with special emphasis on the characteristic structural features.

The Wasatch Mountains and the geologic panorama of the Wasatch Range: Cong. géol. internat., $5^{\ominus}$ sess., Compt. rend., pp. 381-385, 390, 1891.

General view of the geologic history of the Wasatch Range. Mentions Clayton Peak mass of granite, eastern eruptions, and the Ontario mine.

- Little Cottonwood granite body of Wasatch Mountains: Am. Jour. Sci., 4th ser., vol. 16, pp. 139-147, 1903.

Discusses the geologic relations and age of this igneous mass.

Getkie, Archibald, Archean rocks of the Wasatch Mountains: Am. Jour. Sci., 3d ser., vol. 19, pp. 363-367, 1880.

Presents general structural evidence to show that the age of the Little Cottonwood body of granite is not Archean but probably post-Carboniferous.

Hills, R. C., Orographic and structural features of Rocky Mountain geology: Colorado Sci. Soc. Proc., vol. 3, pp. 362-388, 400, 1891.

Reviews Dana and Emmons on movements in Rocky Mountains up to Cenozoic time and refers to Uinta and Wasatch in movements up to Mesozoic. Notes movement of several thousand feet in Uinta and Wasatch ranges since close of Eocene.

Hollister, O. J., Gold and silver mining in Utah: Am. Inst. Min. Eng. Trans., vol. 16, p. 13, 1888.

Includes a concise account of Park City mines with special attention to development costs and record of Ontario, and brief sketch of mining in properties on the west. 
Hollister, O. J., The resources and attractions of Utah, pp. 22-25, 1882.

Gives general sketch of the geology, geography, and climatology of Utah, and brief notes on the status of Park City mines in 1882.

Huntley, D. B., Precious metals: Tenth Census U. S., vol, 13, pp. 276, 438-442, 443, 1885.

Includes a detailed description of Ontario mine and mill and briefer notes on other mines near Park City.

Jenney, W. P., Structural features of the Ontario mineral belt, Park City, Utah: Min. and Sci. Press, vol. 92, pp. 6-7, 1906.

Describes the stratigraphy and the relations of the ore-bearing veins.

- The fissure system of the Ontario mineral belt: Min. and Sci. Press, vol. 92, pp. 24-25, 1906.

Block faulting and its relation to ore deposits: Min. and Sci. Press, vol. 92, pp. 54-55, 1906.

The ore deposits of the Ontario mineral belt: Min. and Sci. Press, vol. 92, pp. 108-109, 1906.

King, Clarence, Systematic geology: U. S. Geol. Expl. 40th Par. Final Rept., vol. 1, 1878.

Embodies the only systematic consideration of the entire geologic history of the Park City region from earliest to latest time. The conclusions regarding the great geologic events are based on the joint observations of the geologists in volume 2, "Deseriptive geology.",

Mineral Industry, 1892-1917. Gold and silver mining in the United States.

Includes brief notes on the conditions and workings of the mines and mills of Park City district.

Mrneral Resources of States and Territories west of Rocky Mountains, Reports, 1866-1868, by J. R. Browne and R. W. Raymond.

Notes on Utah mining in general, including special notice of Cottonwood mines.

Mineral Resources of the United States, United States Geological Survey, 1874 to 1893,1900 to date.

Contains statements on production of Park City mines.

Murphy, J. R., The mineral resources of the Territory of Utah, pp. 37, 73, 1872.

A good general sketch, including early conditions in Summit County, especially the first mines and locations in the Uinta mining district.

Ontario Silver Mining Co., Reports, 1885-1887, 1895, 1898-1901.

Comprises the superintendent's report on the condition of mine and mill, and secretary's report on receipts and disbursements, including tabular detailed financial statements of operation.

Peale, A. C., Colorado and Utah: U. S. Geol. Survey Terr. Sixth Ann. Rept., for 1872, pp. 105-108, 1873.

Describes detailed features of geology about head of Little Cottonwood Canyon.

RAYMOND, R. W., Statistics of mines and mining in States and Territories west of Rocky Mountains, 1869-1875.

Gives general notes on the early mining camps of the Wasatch, including the first mining activity in Parleys Park and special descriptions of Park City mines.
Rothwell, R. P., Mineral Industry, 1893, 1895-1900. Gives brief statements on current mining developments and production.

Silliman, Benjamin, Geological and mineralogical notes on some of the mining districts of Utah Territory, and especially those of the Wahsatch and Oquirrh range of mountains: Am. Jour. Sci., 3d ser., vol. 3, pp. 195-201, 1872.

Describes geology, mineralogy, and ore deposition of Cottonwood region.

Struthers, Joseph, Mineral Industry, vol. 10, p. 302, 1901; vol. 11, p. 265, 1902.

Gives notes on consolidation of large mining properties in Park City district and output and ore values for large mines.

Utah Board of Trade, Resources and attractions of Territory of Utah, 1879.

Includes brief sketch of Park City mining.

Warren, H. L. J., The Daly West mine, Park City, Utah: Eng. and Min. Jour., Oct. 14, 1889, p. 455.

Includes sketch of important events in history of Park City, description on Ontario mine, and account of Daly West ore bodies.

- Silver King mine and mill, Utah: Eng. and Min. Jour., p. 545, 1899.

Describes in some detail the mill, machinery, and process.

\section{BLUE LEDGE DISTRICT.}

By V. C. Heikes.

The Blue Ledge district, in Wasatch County, 5 miles west of Heber on the Denver \& Rio Grande Railroad, was organized May 10, 1870.

To the end of 1912 approximately 167 patents for mineral ground had been issued. Lead, silver, and gold are the recoverable metals, the output of which has been included in the total output of the Park City district. Huntley ${ }^{1}$ gives the early history as follows:

The Blue Ledge district [had] at the time of the writer's visit (October, 1880), 694 locations on record, of which probably not over 300 are still held. * * * Little ore was being extracted. * * * The McHenry mine was one of the first claims located in the district. The old McHenry Mining Co. was organized in 1873, and built a 20-stamp mill at Park City. The mill ran on company's ore for two months, but the ore was not free milling. The mill was then leased to the Ontario company for about a year. In 1876 the entire property was sold to the Winnamuck company, which expended considerable money in prospecting. The mine was bonded to Chambers, Hanauer \& McIntosh for $\$ 140,000$, who, in $1878-79$, spent $\$ 20,000$ in prospecting it. About December 1, 1880, the Winnamuck company again took possession.

Although ore is said to have been opened on several claims in the district, only the Valeo and Glencoe have had important productions. The Valeo was discovered about 1891. Its history is reviewed by Boutwell, ${ }^{2}$ as follows:

1 Precious metals: Tenth Census U. S., vol. 13, p. 443, 1885.

2 Geology and ore deposits of the Park City district, Utah: U. S. Geol. Survey Prof. Paper 77, pp. 196-197, 1912. 
The Valeo mine is situated on the southeastern slope of Bald Mountain near the head of Cottonwood Canyon, about 4 miles southeast of the Ontario mine and 3 miles south of the Hawkeye-McHenry. This is the principal property on the eastern slope. * * * In 1896 excellent ore was found on this property, and in August of that year some of the ore was shipped and surface improvements were made. * * * The year closed with new ore developments of much value. * * * In the fall of 1898 the property, comprising some 16 claims, was taken over by prominent mine owners to be opened systematically and operated on a large scale. After working out the main ore body they did some development work, but the results were deemed insufficient to warrant much outlay at that time. Since then only desultory work has been carried on, and at the time of visit, late in 1904, the property was inactive.

The metallic contents of the ore reported during the period of active mining were high. Thus, from a new vein cut in 1896, 29 per cent of copper, 10 to 14 ounces of silver, and $\$ 6$ to $\$ 8$ in gold to the ton were obtained, and a little later practically these same figures were given as the average tenor of the ore.

The production of copper ore from the Valeo continued intermittently till 1909.

Boutwell ${ }^{1}$ has also described the Glencoe property, in part, as follows:

The Glencoe mine is situated on the east slope of Bald Mountain, in Glencoe Canyon, about midway in its length, and near the center of the large intrusive of diorite porphyry that crosses the canyon at this place.

This property was located in the early seventies by Messrs. Cook, McCune, Cupit, and Braun. * * * The property then passed into the hands of the Glencoe Mining Co. * * * Near the close of 1882 the main tunnel had been cut 450 feet on the vein, from which ore had been taken to the amount of 200 or 300 tons. This ore is said to have assayed 40 to 50 per cent of lead and 40 ounces to the ton in silver. During the succeeding year several hundred tons of ore, said to be of low grade and refractory, were stored on the dump. For the following five years, ending with 1888, there is a blank in the record, but during the period from 1889 to 1892 the mine reached its highest prominence. In the first year of this period it was taken over by a new company, having a capital of $\$ 2,500,000$. Ore continued to be plenty, some new strikes were reported, and the new management decided to erect a concentrator of 100 tons capacity. This was completed in 1891 , and was the third concentrator in the camp. The reduction was 4 tons to 1 , and the concentrates are reported to have assayed 25 ounces to the ton in silver, 50 per cent of lead, and $\$ 3$ to the ton in gold. * * * Some carloads of the concentrates were shipped, but the ore grew zincky, and in 1892 the concentrator was hindered somewhat for lack of water. This was the close of the period of prosperity. In 1892 the minestood idle, and the machinery was attached and sold by the marshal to pay indebtedness thereon of over $\$ 11,050$. In 1895 the machinery was removed to Bingham, Utah, and meanwhile the completion of the Ontario drain tunnel had largely depleted this prop-

${ }^{1}$ Idem, p. 199. erty of the water used for milling. In the later nineties and early part of the decade following the mine stood practically idle. * * * In 1904, however, it was leased under bond, and work was resumed, the mill being renovated to treat the ore on the spot. These operations were interrupted by the death of the principal party, and for the next few years the mine is understood to have remained closed. This property was taken over by the Adirondack Mining Co., in 1908, a 150-ton mlll was erected at the mine, and other preparations were made for active operation.

The mill erected for the reduction of Glencoe ores operated for only a short season in 1909, producing lead concentrates containing gold and silver. Nothing has been reported since.

UINTA DISTRICT.

The Uinta district is situated on the eastern slope of the Wasatch Range in Summit County. It was originally a part of the Mountain Lake district, organized in 1867 , and was made a separate district on November 18, 1869, being the first of the five districts set off from the Mountain Lake district. ${ }^{2}$ It was reorganized July 8, 1871.

The adjoining Snake Creek and Blue Ledge districts were organized in 1870, in April and May, respectively. Parts of these three districts form what is now commonly known as the Park City district.

\section{SNAKE CREEK DISTRICT.}

The Snake Creek district, formerly part of the White Pine and Howland district, is in Wasatch County, 10 miles southwest of Heber on the Denver \& Rio Grande Railroad. It was organized in 1871. The first locations were the Pioneer and the Idaho, made in the fall of 1871 . During $1880^{3}$ the active properties were the Pioneer, Utah, and Jones Bonanza, now owned by the Daly-Judge Mining Co., and the New Bedford.

\section{ELKHORN DISTRICT.}

The Elkhorn district is in Wasatch County, east of the Blue Ledge district, or about 4 miles east of the Ontario mine in the Uinta district. Elkhorn district was organized May 21,1875 , and has four patented mining claims and many that are unpatented. The first patented were the Crawford (lot 37) and the

2 Boutwell, J. M., op. cit., p. 19, 1912.

${ }^{3}$ Huntley, D. 13., Precious metals: Tenth Census U. S., vol. 13, p $443,1885$. 
Victory (lot 38). In the discovery shaft of the Nelson and Queen properties samples of ore are said to have assayed 40 per cent lead, 15 ounces of silver, and $\$ 5$ in gold per ton. Development on this property has reached a depth of about 150 feet.

\section{PROVO DISTRICT.}

By G. F. Loughtin.

GENERAL FEATURES.

The Provo district, in the front hills of the Wasatch Range, east of Provo and south of Provo River (Pl. XXXI), was organized March 11, 1871. Considerable prospecting has been carried on, but only the Monarch mine, located in Rock Creek canyon about 1902, has shipped ore. Shipments of only 8 tons of lead-silver ore have been reported to the Survey from the Provo district, but according to a personal letter from Jonathan Buckley, about 50 tons had been shipped from the Monarch mine up to 1913. The property is owned by the Garden City Mining Co.

The Wasatch Range in this region includes the main ridge, known as Provo Peaks, whose summits attain elevations of 10,500 feet and more, and the front hills whose summits reach elevations of 8,500 to 9,000 feet. The front hills are separated from the main ridge by slightly to well developed longitudinal or strike valleys (Pl. XXXII), which are connected by transverse canyons with Utah Valley. The position of the longitudinal valleys, parallel to the Wasatch front, suggests that they are due to faults; ${ }^{1}$ but the only structural evidence noted was their coincidence with the outcrops of rapidly weathered strata. The principal transverse canyons, from north to south, are Rock, Dry, and Slate creeks.

The steep west front of the Wasatch Range in this district is fringed by a well-developed portion of the Bonneville shore terrace, and is marked at the mouth of Rock Creek by an exposure of the great Wasatch fault, along which recent movement has taken place. (See Pl. XII, p. 101.)

\section{GEOLOGY.}

The sedimentary rocks recognized in the front hills are of pre-Cambrian (?), Cambrian, and Mississippian age. The main ridge consists of

\footnotetext{
1 Emmons, S. F., Descriptive geology: U. S. Geol. Expl. 40th Par. Final Rept., vol. 2, pp. 345-348, 1877.
}

upper Mississippian and Pennsylvanian strata, but these lie without the limits of the mining district proper. No igneous rocks have been found in the Wasatch Range east of Provo; the nearest are the granodiorite and quartz diorite stocks in the Cottonwood and American Fork region, 20 miles to the north.

The pre-Cambrian (?) rocks are represented only by a small amount of peculiar conglomerate, similar to that in the Cottonwood and American Fork region to the north. (See p. 234.) It is rather well exposed at the mouth of Rock Creek canyon just above the creek bed, and poorly exposed in the lower part of Slate Creek canyon. It consists of angular to rounded and small to large pebbles of quartzite, schist, vein quartz, and calcareous slate or argillite in dark gray to brown shaly matrix. The Rock Creek exposure is bounded on the west by a fault dipping $60^{\circ} \mathrm{W}$., which separates it from mottled shaly limestone, a common variety in the Middle Cambrian of the region. The conglomerate marks approximately the axis of an anticline. At the fault it dips westward at a low angle, but eastward the dip flattens and then changes within a very short distance to vertical.

The Cambrian strata comprise a typical succession of quartzite, shale, and limestone. Two areas of the quartzite are exposed along the steep front slope - one in a gently arching band that pitches northward and southward from Rock Creek, and one in an irregular area that includes another arching band just south of Slate Creek canyon and an eastward-tapering portion along the lower walls of the canyon. West of the quartzite is a light greenish gray rock of medium grain composed of subangular quartz grains enlarged by secondary growth with microscopic interstitial aggregates of chlorite, a few small cubes of pyrite, and some microscopic zircons. In Slate Creek canyon some reddish quartzite beds are present, and in the upper part of the formation several beds of green and purple slate alternate with quartzite. Small amounts of the slate have been quarried in Slate Creek canyon. The quartzite is about 1,500 feet thick and is overlain by about 300 feet of shale (Ophir formation; see p. 79), which is followed by limestone.

The relations of the quartzite and shale to the limestone are conformable. At first sight the vertical beds of quartzite and shale just 


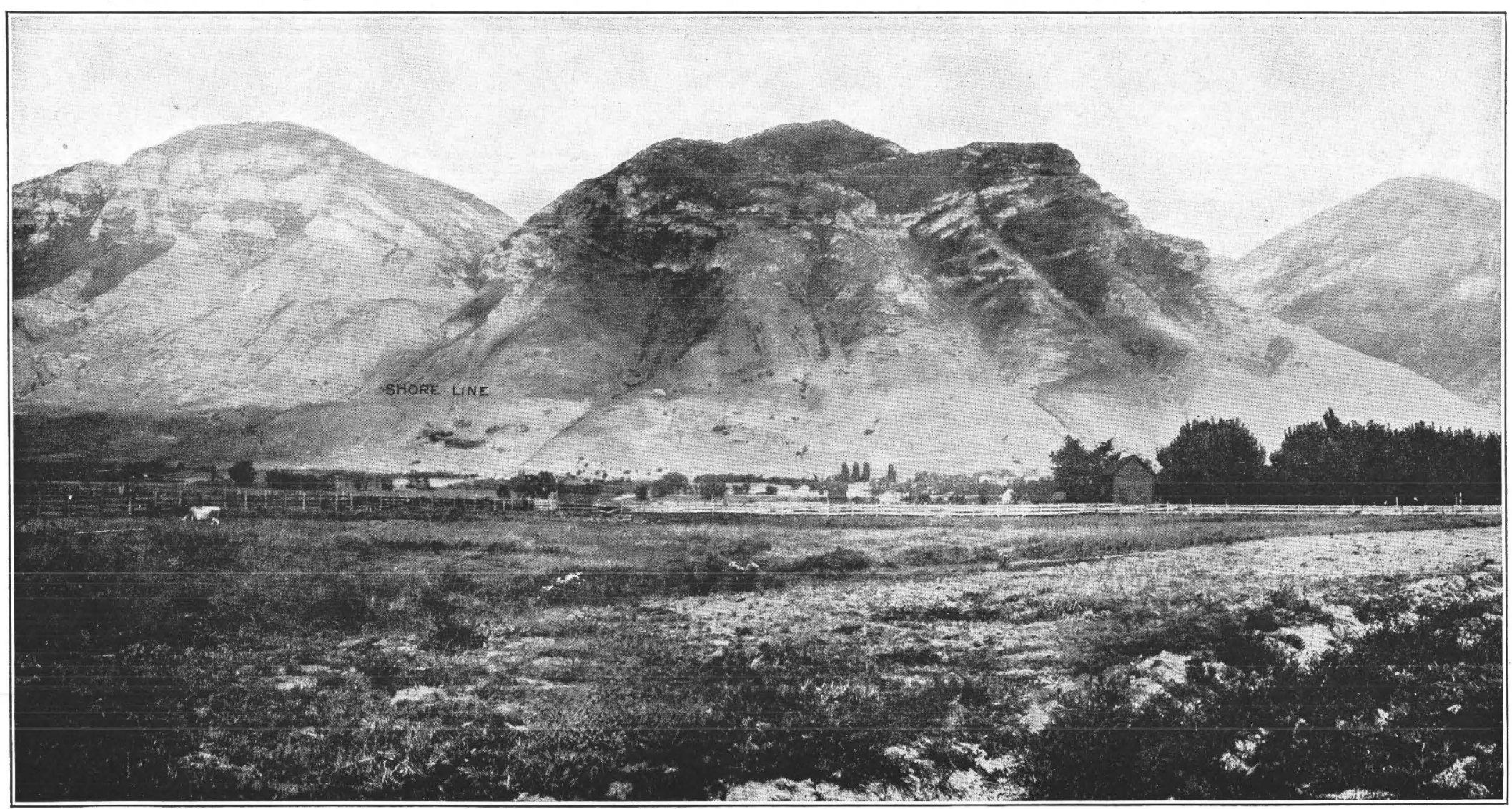

WASATCH FRONT AT PROVO, SHOWING SHORE LINE OF LAKE BONNEVILLE. 


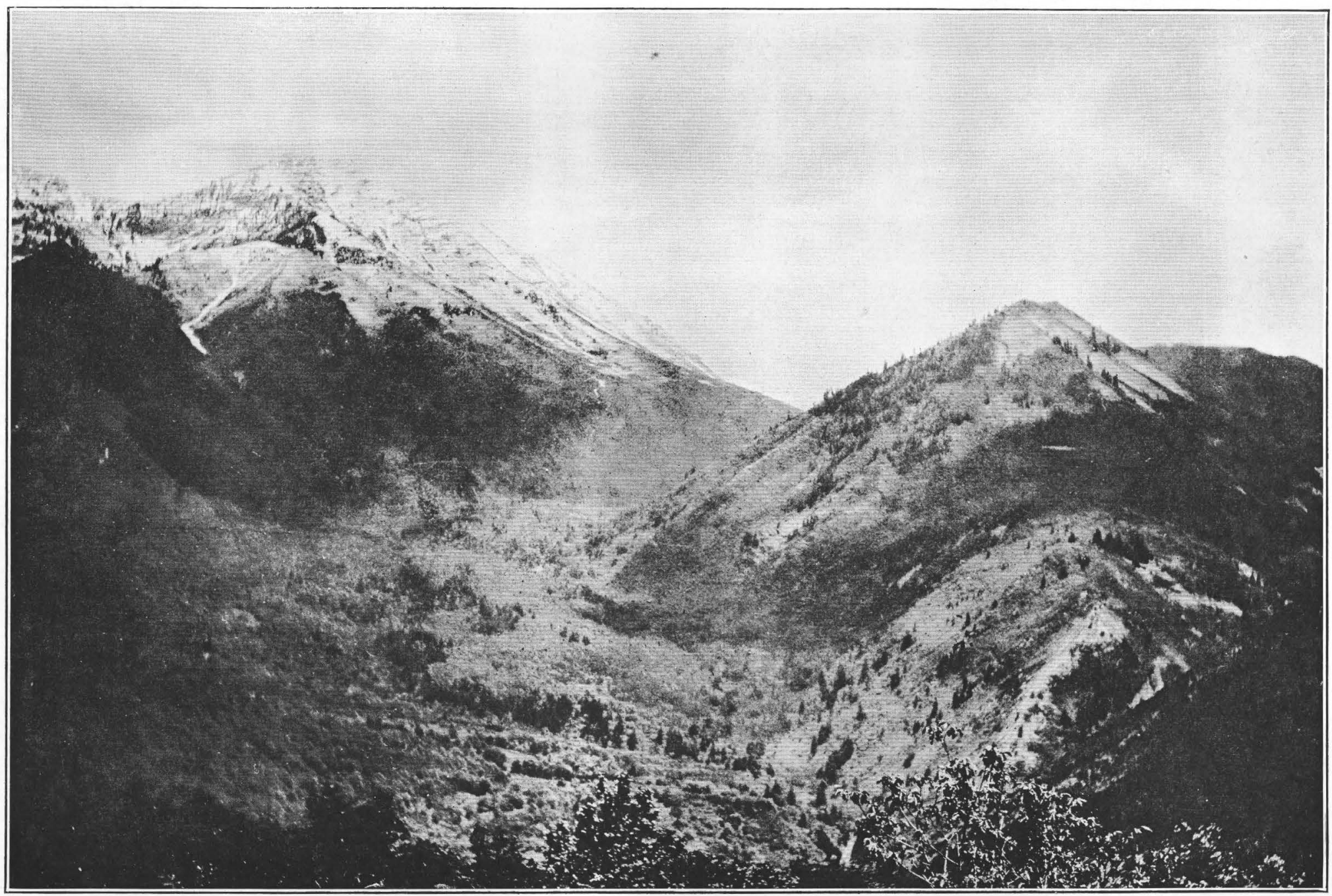

LONGITUDINAL OR STRIKE VALLEY SEPARATING MAIN WASATCH RIDGE AT PROVO PEAKS FROM THE FRONT HILLS. 
east of the anticlinal axis in the lower canyon walls appear to be separated by a strong unconformity from the nearly horizontal limestone beds that form the upper walls, but examination of the whole length of the canyon proves ${ }^{1}$ that the limestone beds also bend downward to the east and that the structure is an Sshaped fold with only its upper half exposed. In the Slate Creek area the conformable relation is at once evident. The structure here, too, is an anticline, a small band of limestone with west dip overlying the quartzite and shale on the west limb at the base of the slope.

The great limestone series that overlies the Ophir formation includes strata of Cambrian and Mississippian age, but no boundary between the two has been determined. No Cambrian fossils were found, but the prevailing shaly and mottled character of the lower beds and their stratigraphic succession are the same as in the Cottonwood and American Fork region to the north, where Middle Cambrian fossils have been found. The lowest fossils (Zaphrentis) suggesting Mississippian age were found about 1,600 feet above the top of the quartzite, but beds below this horizon have the lithologic character of lower Mississippian limestones. About 2,000 feet stratigraphically above the quartzite coarse-grained bluish-gray limestone of probable upper Mississippian age is present. This limestone forms the wall rock of the ore bodies in the Monarch mine. A short distance above this limestone the upper Mississippian consists of a thick series of intercalated limestone, shale, and quartzite, which caps the front hills and forms the lower west slope of the main ridge. The apparent enormous thickness of this intercalated series may be due in part to faulting, though no proof of faulting was found. The longitudinal, or strike, valleys separating the front hills from the main ridge owe their outline principally to the rapid erosion of soft strata, especially shaly carbonaceous limestones, in this series.

\section{ORE DEPOSITS.}

Although much prospecting has been done on a. small scale and many finds of mineral reported at different times, ore has been shipped from only one property, the Monarch mine, owned by the Garden City Mining Co. of Provo.

1 Emmons, S. F., U. S. Geol. Expl. 40th Par. Final Rept., vol. 2, pp. 345-346, 1877.

$$
35416^{\circ}-19-21
$$

The ore of this mine and of a few small prospects is lead carbonate and galena with low silver and high iron content replacing limestone along fissures. Small amounts of gold in limonite are said to have been found in shallow surface diggings on the front hill south of Slate Creek, but none of these surface doposits have continued downward in paying quantities. The Bonneville tunnel, about a mile long, has prospected this ground at depth with negative results. It crosses the anticlinal axis south of Slate Creek, passing through quartzite and shale into limestone 4,000 feet from the portal.

The Monarch mine is on the upper north slope of Rock Creek. Canyon near its mouth and is reached from the canyon bottom by a long winding trail. It is opened by an upper and a lower tunnel, about 130 feet apart in elevation, with drifts, crosscuts, and inclines in Mississippian limestone. The ore was conveyed to the canyon bottom by a long, narrow chute and thence hauled by wagon to the railroad at Provo. Outcrops of ore have been found on the steep canyon wall, and there is said to be a well-mineralized outcrop on the summit of the hill.

The upper workings are along two fissures, one trending N. $25^{\circ}$ E. and the other S. $70^{\circ}$ E. The workings on the latter extend 400 feet from an intersection with the former and have furnished most of the ore shipped. Ore has been found in bunches ranging from a few pounds to several tons in weight along the intersection of these fissures with certain beds, especially those of coarse grain, and in places of pronounced shattering. The lower workings have been opened to prospect these fissures at greater depth.

A prominent but undeveloped north-south fissure, stained with limonite and said to contain small amounts of ore minerals, outcrops west of the workings. It can easily be traced from the south side of the canyon across the bottom and up the north slope. In the lower part of the canyon, where the strata are vertical, the fissure coincides in position with the bedding, but along the upper north wall, where the beds have a low eastward dip, the fissure cuts obliquely across them, dipping about $60^{\circ} \mathrm{E}$. Its intersection with the coarsegrained Mississippian beds is a favorable place for prospecting. 
Primary mineralization consists of a replacement of limestone by a mixture of white dolomite, scalenohedral calcite, galena, and presumably pyrite and zinc blende. Oxidation has been so thorough, however, that nearly all the primary ore minerals have been removed, and the ore mined is principally cerusite and reddish-brown iron oxide. Up to 1913 about 50 tons of ore had been shipped, averaging about 9 ounces of silver to the ton, 35 per cent lead, and 36 per cent iron. Samples of especially high-grade ore have yielded 16 ounces of silver to the ton, 76 per cent lead, and a little gold. Examination of the lower walls and floors of the stopes may prove the presence of oxidized zinc ore. This type of mineralization, characterized by a general absence of quartz and by a low silver content, is typical of lead-zinc deposits formed at considerable distances from intrusive igneous bodies. Distinction should be made between quartz deposited with the ore and chert nodules and lenses, which are a part of the limestone and are no indication of ore. It has formed workable bodies in the purer limestone beds and at places where favorable openings have been made by excessive shattering, but as a rule it has no noteworthy influence on dense hard or shaly limestone or on shale or quartzite. The most promising ground for prospecting, therefore, is along fissures filled with dolomite spar at their intersection with the coarse-grained beds of Mississippian limestone.

\section{PAYSON DISTRICT.}

By V. C. Heikes.

The Payson district, in Utah County, organized in 1871-72, is in the western foothills of the Wasatch Range and is 12 miles square, the town of Payson being near its center. Seventy locations had been made up to September, 1880, at which time only five, having 120 to 300 feet of cuttings, were in force. The country rock is limestone. The ore is low grade, carrying 12 to 15 ounces of silver. None was shipped previous to $1880,{ }^{1}$ and no production has been reported to the United States Geological Survey.
SPANISH FORK DISTRICT.

By V. C. Heikes.

The Spanish Fork district is in Utah County, south of the Provo district. With the Cook district, it was organized during the mining excitement of 1871 and 1872. All the claims had been abandoned in $1880 . .^{1}$ No metals are known to have been produced in the Spanish Fork district.

\section{SANTAQUIN AND MOUNT NEBO REGION.}

By G. F. Loughuin.

GEOGRAPHY.

The Santaquin district in Utah County and the Mount Nebo district in Juab County are contiguous and form a unit so far as geologic and economic conditions are concernęd. (See fig. 40.) The mines and prospects lie in the southern part of the Wasatch Range, between latitudes $40^{\circ}$ and $39^{\circ} 15^{\prime}$ and along longitude $111^{\circ} 45^{\prime}$. This part of the range includes a northern portion, locally called Santaquin Mountain, which has a maximum elevation of 10,000 feet and a length of 8 miles, and a southern portion, which culminates in Mount Nebo at an elevation of 11,871 feet and has a length of 15 miles. Mount Nebo is the second highest and the southernmost summit of the Wasatch Range. Occasionally it has been referred to as the highest peak of the range, but according to the Salt Lake topographic sheet of the United States Geological Survey Timpanogos Peak, between American Fork and Provo canyons, is higher, having an elevation of 11,957 feet. The Santaquin and Mount Nebo ridges are separated by Santaquin Canyon, which in its upper course cuts the range in an east-west direction but which in its middle and lower courses swings northwestward and northward, emerging at Santaquin in a nearly due north course. The south end of the Mount Nebo ridge is marked by Salt Creek, which separates the Wasatch from the San Pitch Mountains. Salt Creek crosses the line of the mountain axis in a due westward course and emerges in Juab Valley at Nephi, where it turns northward in a meandering course for 12 miles, cuts through the low northeast end 
of Long Ridge in a bold canyon, emerging southward from Salt Lake City to Nephi and again south of Goshen, and continues through towns still farther south. Santaquin is also Goshen Valley, finally entering Utah Lake. reached by the Denver \& Rio Grande Rail-

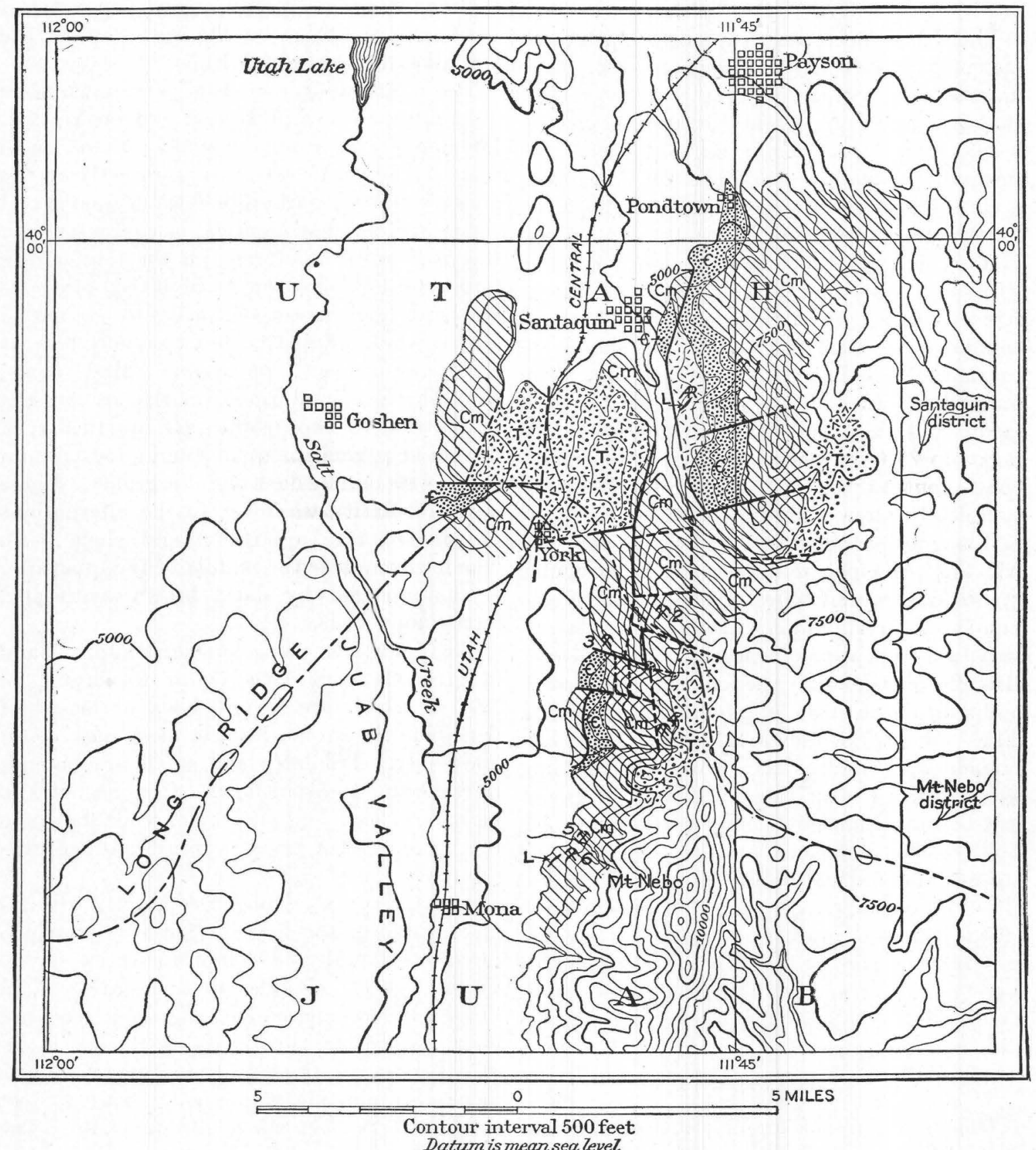

FIgURE 40.-Geologic sketch map of Santaquin and Mount Nebo region. $\mathbb{R}$, Pre-Cambrian granite; $\boldsymbol{\epsilon}$, Cambrian quartzite; Cm, Mississippian and earlier limestones; T, Tertiary conglomerate and volcanic rocks L, Lamprophyre dikes. Mines: 1, Union Chief; 2, Santaquin Chief and Santaquin King; 3, Big Nebo; 4, Eva and Nebo Highland; 5, Spider; 6, Freddie Lode (Eureka Leasing Co.).

Santaquin, Starr, and Mona, all farming towns, | road. Nephi, the county seat of Juab County, are the nearest to the different mines and are lies at the south base of Mount Nebo, 8 miles all reached by the "Salt Lake Route," or by south of Mona, 18 miles south of Santaquin, the main wagon road which follows the valley and 70 miles due south of Salt Lake City. 
GEOLOGY.

\section{SEDIMENTARY ROCKS}

PRE-CAMBRIAN ROCKS.

The oldest formation in the region is a complex of pre-Cambrian granite-gneiss with schist inclusions (schistosity dipping east-northeast), that is exposed for 2 miles or more along the lower range front east of Santaquin. Its prevailing color is pink to reddish, varying according to its content of red alkalic feldspar. Its texture varies from coarse to rather fine grained and from strongly gneissic, with or without augen, to granitoid, with no megascopic indication of foliation. Its mineral composition varies from that of granodiorite to that of alkaline granite or alaskite. The minerals in order of abundance are plagioclase (sodic andesine) and quartz, which together make up 75 to 80 per cert of the rock, microcline about 15 per cent, chlorite (representing completely altered biotite) 5 to 10 per cent, and magnetite and apatite less than 1 per cent. All the principal minerals are in irregular grains and exhibit more or less strain effects but show no apparent crushing, or "flaser" structure indicative of shearing. The plagioclase is considerably sericitized. Pegmatite and aplite form sills along foliation planes and dikes across the foliation. Dikes and sills branch from each other, proving that they were intruded after the main body of gneiss had become sufficiently rigid to be fractured. The schist inclusions comprise micaceous, hornblendic, and feldspathic (plagioclase) types, all of which vary with the grain and amount of the injected granitic material. They lie, as a rule, parallel to the foliation of the intrusive gneiss but are cut both along and across their foliation planes by aplitic and pegmatitic material.

CAMBRIAN ROCKS.

The Cambrian rocks include a basal quartzite 800 to 1,000 feet thick, according to aneroid measurements, and perhaps 1,500 feet or more of shale, limestone, and dolomite. The principal exposure of the quartzite is a band that extends along the front of the Santaquin Ridge for 6 miles and rests unconformably upon the pre-Cambrian granite. Another prominent exposure extends along the base of the Mount Nebo Ridge for 2 miles northward from North Canyon, which lies due east of Starr. Two small exposures of the topmost quartzite beds was noted, one at the base of the main ridge in Wash Canyon, southeast of York, and the other on the west slope of the low hills northwest of York.

The quartzite varies from nearly white to different shades of pink, red, and brown, and from moderately coarse conglomerate to typical shale. The basal beds, resting directly on the gneiss complex, contain pebbles of quartz and coarse red feldspar identical in character with the pegmatitic material in the underlying formation. Above the basal beds both conglomerate and arenaceous beds are composed almost wholly of quartz, but the shaly beds as a rule are distinctly micaceous. Mud cracks, worm borings, and ripple marks are present in the shale. The pebbles are practically all of vein or pegmatitic quartz and a few contain seams with minute dark metallic grains. There is no regularity whatever to the alternations of conglomerate, quartzite, and shale beds. One horizon, near the middle of the quartzite, is characterized by dark, brown-weathering, ferruginous beds.

The quartzite passes upward into a band of greenish shale (see Ophir formation, p. 79 ), in which are several beds or lenses of dark-blue limestone, for the most part dense and shaly. Trilobites and small brachiopods resembling Cambrian forms of Obotus, said to have been found in the shale, were shown to the writer, but a hasty search for others was unsuccessful.

Above the shaly Ophir formation is a series of limestones, the lower 1,500 feet of which resembles the Middle Cambrian section of the Tintic district, 20 miles to the southwest, in lithologic character and stratigraphic sequence but is less than two-thirds as thick. It includes mostly dark shaly beds, some dolomitic members, and one white bed, about 40 feet thick and 650 feet above the quartzite. The next 800 feet also has characteristics suggesting Cambrian age; and the top 500 feet, a series of alternating light-gray and dark bluish gray dolomitic beds, has lithologic characters similar to the Cole Canyon (Middle Cambrian) and Bluebell (Ordovician) dolomites in the Tintic district (p. 398) but is thinner than either. These limestones are found above the main quartzite exposures 
throughout the region, and the upper members are also exposed along the low ridge which separates the Santaquin and Goshen valleys.

MISSISSIPPIAN (AND EARLIER?) ROCKS.

The Cambrian limestones are overlain by 500 to 600 feet of mostly dark-gray dolomitic limestone, in which no fossils were found but which are probably to be correlated with the lower Mississippian, though they may be older. Directly above them, on the Santaquin Ridge, in similar rock, characteristic Madison (lower Mississippian) fossils were found, which G. H. Girty, of the Survey, has identified as Menophyllum sp., Syringopora surcularia?, Chonetes illinoisensis, Dielasma? sp., Spirifer centronatus, Euomphalus luxus, and Phillipsia sp.

At a horizon nearly 400 feet higher, black chert nodules in dark thin-bedded limestone become characteristic, cherty and noncherty beds alternating. Fossils in this cherty horizon were found in abundance on the west slope of the high south peak of the Santaquin Ridge, where the following forms were collected by the writer and determined by Mr. Girty:

Cyathaxonia arcuata?

Bellerophon sp.

Rhombopora sp.

Fenestella sp.

Productella concentrica?

Rhipidomella dalyana?

Camarotoechia metallica.

Cliothyridina sp.

Michelina placenta?

Syringopora surcularia.

Menophyllum sp.

Productus gallatinensis.

Spirifer grimesi.

Spirifer centronatus.

Spirifer suborbicularis.

Amplexus.

Zaphrentis? sp.

Leptaena rhomboidalis.

Composita sp.

Phillipsia peroccidens.

Aulopora.

Chonetes illinoisensis.

Schhizophoria swallowi.

The lower Mississippian forms most of the main upper parts of the Santaquin and Mount Nebo ridges. A small body of limestone with characteristic Madison fossils was found northeast of Santaquin, on the lower slope of the ridge, where it is apparently overridden by Cambrian quartzite. The fossils from this limestone were identfied by $\mathrm{Mr}$. Girty as follows:

\author{
Menophyllum sp. \\ Syringopora sur ularia? \\ Schuchertella chemungensis. \\ Chonetes illinoisensis. \\ Productella concentrica? \\ Productus sp. \\ Dielasma sp. \\ Spirifer centronatus. \\ Composita humilis? \\ Euomphalus ophirensis. \\ Euomphalus utahensis.
}

This limestone passes downward into limestone with Cambrian characteristics, and the latter in turn into shale and quartzite. The Cambrian limestone, however, appears remarkably thin, and it seems probable that a part of the section has been concealed by settling along a strike fault.

About 400 feet above the lowest black cherty beds near the crests of the main ridges are a few medium-gray coarse-grained limestone beds similar to that replaced by the great "Colorado Channel" ore body in the Tintic district. (See p.399.) Fossil staken from these beds were identified as Batostomella sp., Cystodictya sp., Fenestella several sp., Chonetes illinoisensis, and Rhipidomella dalyana? by Mr. Girty, and referred tentatively to the upper Mississippian.

These beds alternate with black cherty beds, and no definite boundary therefore can be drawn between lower and upper Mississippian. Two hundred feet above these coarse-grained beds shaly and sandy strata are interbedded with dark dense limestone, which is still in part cherty, and form a series similar in lithologic character and stratigraphic position to the upper Mississippian strata which separate the lower Mississippian limestone from the Weber (Pennsylvanian) quartzite. No attempt has been made to measure the thickness of this series in the Santaquin and Mount Nebo region. The thickness varies greatly, ranging from a few hundred feet on the east slope of the Santaquin Ridge to probably a few thousand feet on Mount Nebo, the greater part of which appears to consist of this intercalated series. Portions of the upper Mississippian beds are exposed also below the southern end of the Cambrian quartzite of the Santaquin Ridge on the northeast side of Santaquin Canyon, on the low hills on the west side of the canyon, 
and on the low western flanking ridge southeast of York and north of Wash Canyon. Fossil fragments, including a Productus of the cora group (probably a variety of $P$.giganteus), a Fenestella, a Martinia (?), and a Loxonema (?) were found in the exposures on either side of the lower Santaquin Canyon. These, according to Mr. Girty, are not sufficiently characteristic to serve as a basis for correlation, but so far as they go they accord with the lithologic character and stratigraphic sequence of the rocks, which are upper Mississippian. No Paleozoic strata of later age than Mississippian were seen in the district. The Weber quartzite and the Park City formation were evidently removed during an erosion interval which is expressed by a marked unconformity between pre-Pennsylvanian and Tertiary formations.

MESOZOIC ROCKs.

Mesozoic rocks, chiefly gray and red sandstones and shales with a few deposits of gypsum and rock salt, lie south and southeast of Mount Nebo but have not been studied by the writer. They have been tentatively correlated with the Jurassic formations because of their gypsum and salt deposits. ${ }^{1}$

TERTIARY ROCKS.

The best sections of Tertiary strata seen by the writer lie east of Santaquin Ridge and along the east slopes of the more northern summits of Mount Nebo Ridge, but time was too short to allow even a rough estimate of their thickness and sequence. Veneers of Tertiary rock are also present on the low red foothills (down-faulted blocks) east and west of the railroad between Santaquin and York. Both sedimentary and effusive volcanic rocks are present. The principal sedimentary types are a coarse conglomerate and a peculiar concretionary limestone, similar to that quarried for marble near Clinton, on the Denver \& Rio Grande Railroad.

The conglomerate consists of pebbles, and in places even small boulders, mainly of quartzite, limestone, and black chert in a soft red sandy matrix. The quartzite pebbles include both Cambrian and upper Mississippian types, the Cambrian greatly predominating. The limestone pebbles include the shaly

1 Boutwell, J. M., U. S. Geol. Survey Bull. 223, pp. 102-103, 1904 and Bull. 225, pp. 483-487, 1904.
Cambrian types, dolomitic types of lower Mississippian and probably earlier age, and the coarse-grained gray limestone of upper Mississippian age. This variety of pebbles proves that almost the entire Paleozoic section was exposed to erosion while the conglomerate was forming. There is no evidence, however, that the pre-Cambrian rocks were exposed to erosion at this time. Owing to the tendency of the red matrix to rapid weathering, many outcrops of the conglomerate are reduced to an aggregate of loose pebbles and boulders in a soft red soil.

The limestone is bleached to white on the surface but is pink on fresh fractures, weathering to a bright-red residual soil. It consists for the most part of a dense matrix full of large and small gray to brown concretions, of such shapes as to suggest that they were mostly formed by accretion of calcium carbonate around nuclei of shells. Several forms suggesting the outlines of pelecypods and gastropods were found, and one undoubted gastropod was collected which T. W. Stanton, of the United States Geological Survey, thinks may be a fresh-water Eocene type. The limestone is chemically very impure, containing a large amount of red clay sand and even pebbles, and it is probable that it will be found on more thorough study to grade into the conglomerate. The concretionary limestone lies near and perhaps at the base of the Tertiary section, but its thickness and horizontal extent are not known. It was found east of the Santaquin Ridge, on the upper eastern slopes of the Mount Nebo Ridge and in the low hills between Santaquin and York.

\section{IGNEOUS ROCKS.}

VOLCANIC ROCKS.

The volcanic rocks are limited to a coarse agglomerate of andesite or latite cobbles in a soft matrix of tuff whose outcrops, owing to the rapid weathering of the tuff, are, like the Tertiary conglomerate, mostly reduced to aggregates of loose cobbles. They overlie the Tertiary sediments and are limited in the Santaquin and Mount Nebo region to the areas covered by these rocks; but to the west on Long Ridge and the East Tintic Mountains they lie beneath andesite or latite flows on rhyolite or on Paleozoic sediments. This difference in distribution suggests that the Eocene 
sedimentary rocks of the Santaquin district|plementary to the aplitic phases; but their did not extend west of the longitude of Long freedom from the mechanical and chemical Ridge, and that Eocene sedimentation was alterations which characterized the prestopped or interrupted, locally at least, by vol- Cambrian rocks renders such a correlation canic eruptions which are tentatively assigned to late Eocene or to Miocene age.

The andesite or latite cobbles vary from gray to dull black in color and from dense to glassy porphyritic in texture. Two varieties, augite andesite and hornblende-augite andesite, have been noted in thin section, but others may also be represented. These two varieties are generally similar in character to members of the volcanic series of the Tintic district, which are in large part, if not wholly, of latitic or monzonitic composition.

DIKES.

The only exposures of intrusive rocks studied by the writer are two small dikes of lamprophyre, one on the Black Balsam claim close by the granite-quartzite contact on the first spur south of the Union Chief mine east of Santaquin, the other on the south side of Bear Canyon, northeast of Mona. Besides these, prospectors have reported other "porphyry" dikes; but nothing is known of any large dikes or other forms of intrusive rock in the district.

The two dikes studied are very similar megascopically. Their color is dark gray to black, and their surfaces sparkle with shiny black phenocrysts of biotite, which range from mere specks up to tablets 3 to 4 millimeters in diameter in a dense groundmass. In thin section, the Black Balsam dike consists of a groundmass composed of glass and albite crowded with small phenocrysts of augite biotite, olivine, magnetite, and apatite.

In the dike on the south side of Bear Canyon the groundmass consists almost entirely of albite, and phenocrysts of olivine are absent. Chalcite, chalcedony, and pyrite are secondary minerals in both dikes. The character of both dikes is best designated by the name "albite minette."

The lamprophyric character of these dikes suggests that they may be differentiates from the pre-Cambrian granite magma com-

1 For detailed descriptions see Loughlin, G. F., Two lamprophyric dikes near Santaquin and Mount Nebo, Utah: U. S. Geol. Survey Prof. Paper 120, pp. 101-109, 1918 (Prof. Paper 120-E).

quite unlikely.

So far as the character of their augite and biotite phenocrysts are concerned, the dikes have characteristics in common with the local effusive volcanic rocks and with the great volcanic series of the Tintic district, which is free from pronounced diastrophic alteration effects; but in the absence of calcic plagioclase phenocrysts they are strikingly different. While, therefore, there is little doubt that they belong to the great series of post-Eocene volcanic rocks they must be regarded as rather unusual members of the series.

STRUCTURE.

The rocks of the region have for the most part a homoclinal structure, with an easterly to northeasterly dip of near $30^{\circ}$. The strata northeast of Santaquin, however, dip northeast to north as if approaching an anticlinal axis; and those on the west slope and summit of Mount Nebo are sharply folded, with dips ranging from almost horizontal to vertical. The monoclinal structure is further complicated by overthrusts and block faulting.

FOLDS.

As the strata are for the most part homoclinal, it is in general fairly easy to estimate the depth to any special bed at any point. At Bear Canyon, however, northeast of Mona, and perhaps over a considerable part of Mount Nebo, the folding is more complicated. The mouth of Bear Canyon crosses the axis of an anticline which pitches south-southwest and whose west limb dips $45^{\circ}$ or more westward, but whose east limb is vertical. Besides this asymmetric character, several thin-bedded or shaly strata are crumpled and locally pinched and swelled, causing the thickness of the section to vary from place to place. Three or four limestone beds in this vicinity have perhaps been replaced by ore, but their stratigraphic positions and probable underground extents can be properly determined only after very detailed geologic mapping. 
FAULTS.

Types.-The principal structural features in the Santaquin-Mount Nebo district are faults, including doubtful overthrusts of general north-south trend, and a series of north-south and east-west block faults of the "Basin Range" type. (See fig. 40, p. 323.) In addition, systems of mineralized fissures, some of which are accompanied by distinct faulting, trend mostly northeast and north-northwest, though some trend approximately north and some east. Mineralization of these fissures probably took place long after the overthrusts but before the period of Basin Range blockfaulting.

Overthrusts.-The faults which are here described as overthrusts are in part so poorly exposed, their courses so nearly parallel to the north-south system of block faults, and the rocks aloug them so free from severe crumpling or crushing, that the writer is not fully convinced of their overthrust character. East of Santaquin the northern part of the pre-Cambrian granite appears to overlie quartzite, but the contact is concealed by débris. A little farther northward, however, the granite pinches out and the main body of Cambrian quartzite overlies a dark brecciated limestone, which passes downward into shale and quartzite. This lower quartzite exposure, in turn, overlies the fossiliferous Mississippian limestone (p. 325), which is very free from any of the crumpling or brecciation that is likely to accompany overthrusting. The Mississippian limestone is underlain conformably by Cambrian limestone and a third quartzite exposure.

The pre-Cambrian granite southward disappears beneath a high alluvial slope, now trenched by Santaquin Creek; but the main Cambrian quartzite body continues and at its southernmost exposure rests again upon fossiliferous upper Mississippian limestone, which, as northeast of Santaquin, is surprisingly free from contortions and ciushing. Reverse or overthrust faulting alone seems to explain the positions of the rocks, but the absence of disturbance in the overridden limestone is not easily explained. It is, however, a striking feature throughout the Wasatch couritry that though shales and even the thinner-bedded quartzites are much contorted along fault zones the adjacent heavily bedded limestones are practically free from such deformations. At the mouth of North Canyon, 8 miles south of Santaquin, an extremely brecciated and apparently nonfossiliferous limestone, which dips east beneath Cambrian quartzite, affords the most convincing evidence of an overthrust. A turinel of the Excelsior Mining Co., driven through the limestone into the quartzite, was inaccessible at the time of the writer's visit. No fossils were found in the underlying limestone, but the presence on the dump of fragments of a highly carbonaceous and finely pyritic bed similar to two found elsewhere in the Mississippian of the southern Wasatch Mountains and the Tintic district, gives a clue to the age of the limestone and accords with the structural relations in showing the fault to be an overthrust.

Block faults.-The undoubted normal or block faults of the district are marked by longitudinal and to a less degree by transverse valleys, whereas those interpreted as overthrusts appear unrelated to topography. (See fig. 40, p. 323.) From Santaquin southward for about 8 miles, nearly to North Canyon, the western side of the range is composed of parallel ridges separated by remarkably straight north-south canyons. The strata on opposite sides of these canyons are quite discordant. For example, just north of Wash Canyon (2 miles south of York) the upper Mississippian strata with gentle easterly dip form the low western ridge, whereas pre-Mississippian limestones lie directly opposite on the west face of the main ridge and upper Mississippian strata form the crest, about 2,000 feet higher. Wash Canyon follows a nearly east-west fault, the upper Mississippian limestone north of it having the same altitude as Cambrian quartzite and limestones south of it. Farther south a second east-west fault cuts off the North Canyon overthrust. East of York, the upper Mississippian of the western ridge is separated at another east-west fault from the Eocene sediments and volcanic breccia, which cover the low hills west of Santaquin Canyon, whereas the face of the main ridge east of the canyon is made up of the pre-Cambrian complex and lower Paleozoic strata, and the Tertiary beds are found only along its eastern base. The most obvious east-west (N. $70^{\circ}$ E.) fault in 
the district. $s$ that on the west side of the main ridge in a ravine $3 \frac{1}{2}$ miles south of Santaquin Canyon, where the entire Cambrian quartzite and the overridden Mississippian limestone end abruptly against the lower (probably Cambrian) limestone beds. The presence of Eocene conglomerate and late or post-Eocene volcanic agglomerate on these faulted blocks places the time of the faulting and Basin Range uplifts not earlier than Miocene. Block faulting on a smaller scale but in the same directions and probably of the same age is believed to be the cause of apparent discrepancies in thickness and stratigraphic sequence of the limestone series.

Mineralized fissures.-The mineralized fissures have not been traced on the surface, and underground developments as a whole are too few to afford an adequate idea of their persistence, origin, or arrangement in definite systems. The principal fissures east of Santaquin trend N. $40^{\circ}-60^{\circ} \mathrm{E}$., and those worked or prospected in the Mount Nebo ridge trend N. 25 W., N. $25^{\circ}$ E., north, east-northeast, and east, and parallel minor fissures east of Santaquin. It can not be said whether the more persistent fissures have fairly uniform trends throughout the district, or whether there is more than one system of relatively persistent fissures. It is certain, however, that mineralization in several places has occurred along minor or branch fissures, a fact which prospectors should bear in mind.

In the Union Chief lower workings, one narrow, approximately east-west fissure containing calcite, barite, and a little galena, is offset a few feet at one place by a barren strike fault which probably belongs to the block fault series. This is the only place in the district known to the writer where a contact between a mineralized fissure and a postmineral fault has been definitely exposed, though evidence in the Eva mine also suggests a postmineral fault. These occurrences, however, show that ore bodies are likely to be offset by faults and so add to the difficulties of mining, but it is possible, by careful study of the thickness and sequence of limestone beds and their displacements on the surface, to determine the amount and direction of such faults.
ORE DEPOSITS.

The ore deposits comprise vins and bedded replacement deposits of lead, zinc, and copper, only the first two of which have yet been found in commercial quantity. The copper deposits are believed to be genetically connected with those of lead and zinc, but their distribution and mode of occurrence are sufficiently distinctive to warrant separate description.

COPPER DEPOSITS.

The copper deposits thus far prospected are thin veins and stringers of chalcopyrite accompanied by specularite, chlorite, and quartz that follow fissure zones in the pre-Cambrian granite (gneiss) and in the Cambrian quartzite and shale.

The Sally Ann prospect, situated beside the Union Chief road in Green Canyon, has opened a mineralized fissure zone in the granite that strikes about $\mathrm{N} .15^{\circ} \mathrm{E}$., and is bounded by two well-defined slickensided walls about 15 feet apart. It is crossed by an east-west joint, also with slickensided walls. Both walls and the cross joint carry stringers of chalcopyrite partly altered to the green carbonate, malachite, and the red oxide, cuprite. The moderately shattered rock between the walls contains a small sprinkling of copper minerals. The gangue minerals are vein quartz, which in places lines small vugs, and the minerals of the altered granite. The chalcopyrite tends to occur separately from the vein quartz, though both may be present in different parts of the same short stringer, and partly replaces the minerals, especially the plagioclase feldspar, of the granite. The malachite also, in thin section, shows a tendency to replace plagioclase.

The Copper Bullion prospect in the second or third draw north of the Sally Ann follows a shear zone in the granite parallel to the northeast dip of the foliation. The shear surface is undulating, and is bordered for a few inches on either side by almost microscopic fractures filled with finely micaceous chlorite and specularite in microscopic grains which give the rock a dark-greenish color. Microscopic quartz and sericite are also present in the fractures, and with the other vein minerals impregnate the granite. Minute pyrite crys- 
tals are associated with these minerals in little dolomite was also noted in thin section. the veinlets, especially in the impregnated The vein minerals impregnate and replace the rock. A little green copper stain appears here and there and suggests the presence of a small amount of chalcopyrite.

The Santaquin Central (Brownstone) tunnel, in the upper north slope of Magee Canyon east-northeast from Santaquin, has exposed similar mineralization in a shale member of the Cambrian quartzite. A small quartz vein, which in some places pinches out and in others swells to 4 inches, follows a slickensided strike fissure in the shale. The quartz shows the effects of slickensiding, and the immediately adjacent wall rock is altered to a felty or finely micaceous mass of chlorite, in which are disseminated minute crystals of pyrite. Some small lumps of chalcopyrite lie along the contact between the vein quartz and the chlorite, and in thin section specularite and sericite are seen. The minerals are all more or less intergrown, though pyrite and quartz appear for the most part to have formed before the other minerals.

The mineralization in these prospects may have been little more than hydration of the granite, accompanied by more or less transfer and concentration of the constituents to favorable places along fissures. The water presumably contained sulphur in some form capable of forming pyrite and may have also introduced the copper, but the total amount of copper in any of the veins studied is so small that it may be ascribed to leaching from the pre-Cambrian rocks along the mineralized fissures. The next vein described, however, which is intermediate in character between the copper and the lead-zinc deposits, can not be attributed to strictly local origin and suggests that all the deposits are genetically connected.

The Black Balsam vein outcrops near the crest of a spur a little east of the Sally Ann, and has been prospected by a short tunnel, inaccessible when visited. The wall rock is more or less shattered pre-Cambrian granite cut by a black lamprophyre dike 3 feet thick. The vein which lies close by the dike, though not found in contact with it, trends northeast and dips about $70^{\circ} \mathrm{SE}$. The vein minerals are coarse-grained white calcite with a considerable though subordinate amount of fluorite, a few small oxidized grains of chalcopyrite (and pyrite?), and some green copper staining. A more crushed portions of the granite, giving the vein a gradational rather than a sharp contact. The vein minerals have intergrown contacts with one another, though the dolomite and calcite appear as a rule to have finished crystallizing before the fluorite. No lead minerals were noted by the writer, but an assay of a picked sample from the vein in the tunnel is said to have yielded 18.2 per cent copper, 8 per cent lead, 0.4 ounce of silver, and a trace of gold per ton. The metallic contents are thus intermediate between those of the copper and the lead-zinc veins. The gangue minerals may also signify an intermediate character, for fluorite in other Utah districts is commonly associated with quartz and copper ore, and calcite and dolomite are characteristic of lead or lead-zinc deposits. The local evidence in itself is far from convincing, but if compared with evidence in other districts strongly suggests this intermediate character.

LEAD-ZINC DEPOSITS.

OCCURRENCE.

The lead-zinc deposits, both in veinlike and in bed replacement forms, are confined to the limestones. Certain limestone beds, those most free from clay impurities and of granular rather than dense texture, are the most favorable and contain small bunches to rather large bodies of ore. Such beds are found throughout the limestone section. The coarse-grained beds (p. 325) are by far the most favorable, the dense argillaceous limestone commonly carrying ore only in narrow fissure fillings.

SANTAQUIN RIDGE.

Union Chief mine.-The workings of the Union Chief mine east of Santaquin are in Cambrian limestone, and the productive ground to date is limited to the upper workings, in strata which lie 400 to 550 feet above the top of the quartzite. The lowest stopes or better pockets are about 150 feet below the upper tunnel at the base of the main inclined winze, and have yielded mixed galena and lead carbonate ore which is said to run 20 to 50 and rarely over 100 ounces per ton in silver. In a raise just above the base of the winze the ore forms small bunches along a N. $50^{\circ} \mathrm{E}$. fissure with $50^{\circ}-70^{\circ} \mathrm{SE}$. dip, having for the most part 
filled openings in shattered impure limestone and been concentrated to some extent by oxidation and by the dissolving away of some of the limestone fragments by downward circulating waters. Bunches or lenses of coarsegrained massive calcite are also present, a little of which carries galena but most of which is barren. At the base of the raise and close by the winze the N. $50^{\circ} \mathrm{E}$. fissure is intersected by a N. $30^{\circ} \mathrm{W}$. fissure, dip $60^{\circ}-80^{\circ} \mathrm{W}$., along which a thin bed of dark-blue dolomitic limestone very free from clay impurities has been replaced for a short distance. Eighty feet below the upper tunnel, in a small winze near the main incline, a fissure which strikes $\mathrm{N} .10^{\circ}$ W. and dips $63^{\circ} \mathrm{W}$. is bordered by soft yellow clay, residual after impure limestone, in which are embedded lumps of galena and lead carbonate which run 3 to 5 ounces in silver. The ore is accompanied by some silicification of the limestone. Eighty feet west of the incline on the same level a fault that trends N. $60^{\circ} \mathrm{E}$. and dips about $60^{\circ} \mathrm{NW}$. carries a decomposed body of vein quartz and earthy iron oxide, which assays 16 per cent lead and 2 ounces silver. At the intersection of this fault with a west-northwest fissure, where the dip of the rock is locally reversed and forms a trough, a favorable bed has been replaced by a small body of galena (with lead carbonate) and calcite. The replacement body extends eastsoutheast along the fissure for 20 feet and stops against a north-northeast fault with steep west dip, probably a branch from the fault that trends N. $60^{\circ}$ E., which carries a little ore. On the 40-foot level at the intersection of two fissures that strike N. $70^{\circ} \mathrm{W}$. and N. $25^{\circ} \mathrm{E}$., respectively, a bedded replacement has been stoped over an area 20 feet square - the largest stope seen in the mine. The ore is said to have assayed 12 per cent lead and 2 ounces or less silver. The high silver content on the 150foot level strikingly contrasts with the lower tenor on the 80 and 40 foot levels and is evidently in large part the result of enrichment. No comparative assays of pure galena ores have been made and nothing definite is known as to the changes in silver content with depth. The generally decomposed conditions of the wall rocks prevents a proper estimate of the amount of silicification which accompanied ore deposition. So far as could be seen the ore is as a whole intermediate between the siliceous and nonsiliceous types.

In the lower tunnel workings no workable ore has been discovered, though several approximately east-west stringers of calcite with a little galena and one with a little barite and copper minerals also have been found cutting dense impervious limestone.

Blue Eagle and White Dragon prospects.On the south slope of the south peak of the Santaquin Ridge, a few small outcrops of oxidized ore have been prospected on the Blue Eagle and White Dragon claims. The ore lies in local enlargements of small northeastsouthwest fissures which cut dense, black, cherty limestone of lower Mississippian (Madison) age. The Blue Eagle ore is a porous mass of lead carbonate intergrown with microscopic quartz and in places stained by a greenishyellow earthy material that has the qualitative composition of vanadinite. The intergrown character of the lead carbonate and quartz suggests that they are both of secondary origin. The White Dragon ore consists of coarsegrained calcite inclosing grains of lead carbonate. The calcite around small vugs terminates in flat rhombs, or platy crystals, which are a typical associate of secondary ore. The absence in these prospects of undoubted primary ore suggests that the lead carbonate together with the quartz and calcite may be the product of local downward leaching from an ore body now completely removed by erosion. The presence of several veins and pockets of columnar and scalenohedral calcite, which are characteristic accompaniments of primary ore but which trend north or northnortheast and are cut by the lead carbonate fissures, lends weight to this suggestion. The original ore body may have been a bed replacement at the intersection of the primary calcite fissures with a favorable coarse-grained limestone bed that formerly lay about 200 feet above the present outcrops. The existence of such ores due to downward leaching, which are likely to form small local bunches along watercourses, should lead to caution in prospecting. No prospecting has been done in the coarsegrained beds.

Several other prospects along Santaquin Ridge have rather encouraging and others discouraging surface showings. Only one or two 
have been very extensively developed, and none has yet found ore in commercial quantity.

MOUNT NEBO RIDGE.

Big Nebo mine.-The Big Nebo mine is about a quarter of a mile south of Wash Canyon, near the base of the range. The ore body has been stoped along a N. $25^{\circ} \mathrm{W}$. vein that dips $60^{\circ}-$ $80^{\circ} \mathrm{E}$. in Cambrian limestone. The stoped portion is pod-shaped, with an average width of 4 feet, and pitches steeply southward parallel to the slickensides on the walls. The ore, lead carbonate carrying silver and having an average value of $\$ 36$ a ton, was followed down an incline for a short distance, but operations along the vein were suspended with a view to reaching it through a lower tunnel. The mine was idle when visited.

Santaquin Chief mine.-The Santaquin Chief mine is on the upper slope of the main ridge east of lower Wash Canyon and is reached by trails either from Wash Canyon or from Pole Canyon, which lies due south of Santaquin. The ore body forms a pipe in lower Mississippian limestone at the junction of a north-south with an east-west fissure, and had, when visited, been followed to a depth of 210 feet below its outcrop. The ore is coarse to finegrained galena, more or less altered to lead carbonate in a quartz-calcite gangue. The quartz forms dense masses replacing limestone, and small crystal druses, which appear to be secondary, around pockets. The calcite in part occurs with the quartz, massive calcite serving as a groundmass for quartz crystals, and also in veins which cut the quartz and presumably fill fractures opened during a late stage of primary mineralization after quartz deposition had been completed. The calcite in both occurrences tends. to form characteristic longpointed crystals, scalenohedrons, along openings. In thin section the quartz is seen to be accompanied by some sericite and chlorite, a few small granules resembling anatase or titanite, a few resembling fluorite, and fine grains of iron oxide probably after pyrite. The replacement quartz contains isolated grains and small patches of galena with pronounced cubic cleavage. The fine-grained galena tends to form streaks or narrow lenses which lie both within the quartz and along the edges of the quartz and tend to work into the calcite and limestone. The lead carbonate occurs in all stages from alteration rims around galena to complete replacements of it. No zinc minerals had been reported in 1912, but were later said to occur along the walls of the vein.

Santaquin King mine.-The Santaquin King workings are on the slope above those of Santaquin Chief. The surface showing is a zone of calcite veinlets trending east to east-southeast in broken limestone along the footwall side of a fault. Small amounts of lead minerals have been found associated with the calcite. The country rock in a tunnel, which was 80 feet long at time of visit, is the dense black cherty Mississippian limestone, which includes a dark carbonaceous bed of almost coal-like appearance. The favorable coarse-grained limestone beds outcrop about 200 feet above the tunnel mouth and have not been systematically prospected.

Eva mine.-The Eva mine is on the north slope of North Canyon near the crest of the main ridge. The ore is a replacement of the coarse-grained limestone of probable upper Mississippian age. Three such beds dip about $20^{\circ} \mathrm{S} .75^{\circ} \mathrm{E}$., and are said to be mineralized; but only the uppermost of the three has been stoped. This bed, which is somewhat dolomitized, lies about 150 feet below the lowest quartzite bed of the upper Mississippian and is overlain by a fine-grained highly carbonaceous and argillaceous bed locally called the "velvet lime." This impervious bed marks the upper limit of mineralization but is more than 10 feet above the ore shoot.

The ore lies along the bedding in parallel layers more or less separated by unreplaced rock which is ribboned with short veinlets of coarse white dolomite and calcite spar. The spar veinlets are also present between the ore and the hanging wall. Fissures in the ore body trend nearly north and also N. $70^{\circ} \mathrm{E}$. They are more or less filled with white spar, which varies from coarse massiv э to columnar or "onyx-like" in texture and forms longpointed crystals (scalenohedrons) around pockets. The spar itself contains little if any metal, but the thicker parts of the ore body lie along the spar-filled fissures. The ore body stops against a fault fissure which trends $\mathrm{N}$. $25^{\circ} \mathrm{E}$. and dips steeply west. The direction and amount of displacement along the fault had not been determined. The greater part of the stoping has been along the west or 
hanging side of the fault. The ground east of the fault is practically unprospected. It seems probable that the fault fissure was the main channel through which the ores were introduced and that the other fissures served to spread the solutions through the replaceable bed. The ore, however, along the fault is so oxidized that it may have been leached downward into the fault, and, if so, there is nothing to prove the relative age of the fault. According to either view, however, conditions for underground prospecting are the same, as they involve the location of the replaceable beds on both sides of the fault. The possible occurrence of good ore bodies on the east side of the fault is likely to depend upon the amount of minor fissuring through which the solutions could have spread along replaceable beds. The ore is composed of residuary lumps of coarse to fine grained galena in lead carbonate and of secondary zinc minerals. The most abundant zine mineral is the carbonate, smithsonite, but the dense white basic carbonatehydrozincite, and the hydrous silicate, calamine, are also conspicuous. No zinc blende was found, but its former presence may be marked by rusty cavities associated with practically unaltered galena. The zinc minerals are in part segregated from the lead ore and mined separately, and in part mingled with the lead minerals.

The ore is divided into three classes, according to the relative proportion of silver, lead, and zinc, but the average tenor of the ore of each class could not be learned. The better grades are said to contain as high as 20 ounces of silver per ton.

Eureka Leasing \& Mining Co.'s claims.On the south side of the mouth of Bear Canyon, northeast of Mona, is the group of claims operated by the Eureka Leasing \& Mining Co. (in 1912). Three or more ore bodies have been worked. The ore and gangue are of the same type as that of the Eva mine, except that some primary zinc blende still remains. The ores are classified according to lead and zinc contents and as a rule run low in silver, assays showing 2 to 14 ounces per ton. The ore bodies, except the Freddie lode, are replacements of the coarse-grained upper Mississippian limestone along fissures. In the only stope being worked during the writer's visit the bed dips about $45^{\circ}$ and the fissure some- what more steeply, and the oxidized zinc ore tends to concentrate in the bottom part. In other stopes, including the old Burriston workings and the Spider property on the north side of the canyon, both bed and fissure are practically vertical. The Freddie lode, which has been stoped through a low spur at the canyon edge, follows an east-west fissure, the ore occurring in bunches in the vein and in small replacement bodies in a rather fine grained limestone. This limestone is immediately underlain by a coal-black carbonaceous and phosphatic bed, on which the largest bunches of ore stoped rested. Another good-sized pocket of ore lay at the intersection of the eastwest vein with a north-south calcite vein. The phosphatic bed contains 10 to 15 per cent of phosphorus pentoxide $\left(\mathrm{P}_{2} \mathrm{O}_{5}\right)$.

\section{CONCLUSIONS.}

Although the copper deposits as a rule occur in siliceous rocks and the lead-zinc deposits in limestone the two types are transitional in character and were doubtless formed at the same period. The small size and scarcity of the known copper shoots and the very small amount of alteration or replacement of the walls offer little encouragement to copper mining.

The lead-zinc deposits as a whole are transitional from siliceous to nonsiliceous, though shoots of nonsiliceous ore are the more numerous. These deposits as a rule are characterized by low silver content. The relatively high silver content, in some shoots 20 ounces to the ton, is attributed to secondary concentration during oxidation. The nonsiliceous variety of ore has formed relatively extensive shoots only where pronounced shattering or particularly favorable limestone beds have afforded opportunity. The most extensive ore bodies are where mineralized fissures have intersected the coarse-grained upper (?) Mississippian limestone beds; but even these are small in comparison with the average mines of the more important districts of the State.

\section{PRODUCTION.}

\section{By V.C. Heikes.}

The region includes the Santaquin, the Mount Nebo, and the Mona mining districts. The Mona, however, has no metalliferous deposits of importance. 
SANTAQUIN DISTRICT.

The Santaquin district, in Utah County, organized in 1871 , occupies a nearly square area measuring about 6 miles on a side, east of Santaquin, a station on the Los Angeles \& Salt Lake Railroad. The United States Geological Survey has no records of any production previous to 1901. From 1910 to the end of 1917 470 tons of lead sulphide ore was produced, yielding 3,449 ounces of silver, 208 pounds of copper, and 206,522 pounds of lead, valued in all at $\$ 11,639$.

MOUNT NEBO DISTRICT.

The Mount Nebo or Timmons district in Juab County, on the western slope of Mount Nebo,
In September, 1880, Huntley ${ }^{2}$ reported:

The Mount Nebo district *** is situated on the western slope of Mount Nebo and the adjacent portions of the Wasatch Range, extending 15 miles north of Salt Creek. About 130 locations have been made; 10 of which * * * are still held * * *. The country rock is limestone. The ore is an ochery carbonate and galena, assaying from $\$ 10$ to $\$ 30$ silver and 55 per cent lead, and occurs in narrow-bedded veins.

The principal claims are the Olive Branch, Mount Queen, Germania, and Centennial, each having a few hundred feet of cuttings. Only 30 tons of ore have ever been shipped.

Since 1903 the United States Geological Survey has recorded the production reported from the district.

Production of Mount Nebo district, 1870-191\%.

\begin{tabular}{|c|c|c|c|c|c|c|c|c|c|c|c|c|}
\hline \multirow{2}{*}{ Year. } & \multirow{2}{*}{$\begin{array}{l}\text { Ore } \\
\text { (short } \\
\text { tons). }\end{array}$} & \multicolumn{2}{|c|}{ Gold. } & \multicolumn{2}{|c|}{ Silver. } & \multicolumn{2}{|c|}{ Copper. } & \multicolumn{2}{|c|}{ Ical. } & \multicolumn{2}{|c|}{$\begin{array}{c}\text { Recoverable } \\
\text { zinc. }\end{array}$} & \multirow{2}{*}{$\begin{array}{c}\text { Total } \\
\text { value. }\end{array}$} \\
\hline & & $\begin{array}{c}\text { Fine } \\
\text { ounces. }\end{array}$ & Value. & $\begin{array}{c}\text { Fine } \\
\text { ounces. }\end{array}$ & Value. & Pounds. & Value. & Pounds. & Value. & Pounds. & Value. & \\
\hline $\begin{array}{l}1870-1880{ }^{a} \\
1881-190{ }^{a} \\
1903 \ldots \ldots \\
1907 \ldots \ldots \\
1908 \ldots \ldots \\
1909 \ldots \ldots \\
1910 \ldots \ldots \\
1911 \ldots \ldots \\
1912 \ldots \ldots \\
1913 \ldots \ldots \ldots \\
1914 \ldots \ldots \ldots \\
1915 \ldots \ldots \\
1916 \ldots \ldots \\
1917 \ldots \ldots\end{array}$ & $\begin{array}{r}30 \\
400 \\
15 \\
102 \\
70 \\
27 \\
30 \\
262 \\
1,429 \\
616 \\
127 \\
397 \\
427 \\
133\end{array}$ & 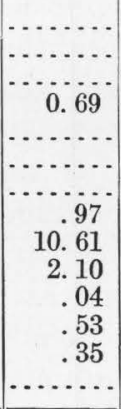 & 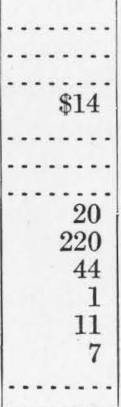 & $\begin{array}{r}900 \\
6,000 \\
370 \\
741 \\
2,450 \\
82 \\
585 \\
3,607 \\
16,152 \\
2,920 \\
624 \\
547 \\
1,903 \\
345\end{array}$ & $\begin{array}{r}\$ 1,111 \\
5,070 \\
200 \\
489 \\
1,299 \\
43 \\
316 \\
1,912 \\
9,933 \\
1,764 \\
345 \\
277 \\
1,252 \\
284\end{array}$ & 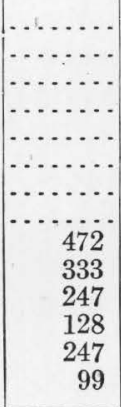 & $\begin{array}{r}\$ 78 \\
52 \\
33 \\
23 \\
61 \\
27\end{array}$ & $\begin{array}{r}33,000 \\
160,000 \\
3,523 \\
73,825 \\
49,000 \\
12,469 \\
23,674 \\
204,523 \\
832,246 \\
256,188 \\
75,180 \\
60,736 \\
100,822 \\
47,497\end{array}$ & $\begin{array}{r}\$ 1,815 \\
6,512 \\
148 \\
3,913 \\
2,058 \\
536 \\
1,042 \\
9,204 \\
37,451 \\
11,272 \\
2,932 \\
2,855 \\
6,957 \\
4,085\end{array}$ & \begin{tabular}{r}
$\ldots \ldots$ \\
$\ldots \ldots$ \\
\hdashline$\ldots .$. \\
\hdashline 11,359 \\
233,668 \\
131,749 \\
16,283 \\
206,229 \\
163,350 \\
26,041
\end{tabular} & \begin{tabular}{r}
$\ldots \ldots$ \\
$\cdots \ldots \ldots$ \\
$\cdots \ldots \ldots$ \\
$\cdots \ldots$. \\
$\cdots \ldots \ldots$ \\
\hdashline$\$ 647$ \\
16,123 \\
7,378 \\
830 \\
25,573 \\
21,889 \\
2,656
\end{tabular} & $\begin{array}{r}\$ 2,926 \\
11,582 \\
348 \\
4,416 \\
3,357 \\
579 \\
1,358 \\
11,783 \\
63,805 \\
20,510 \\
4,141 \\
28,739 \\
30,166 \\
7,052\end{array}$ \\
\hline & 4,065 & 15. 29 & 317 & 37,226 & 24,295 & 1,526 & 274 & $1,932,683$ & 90,780 & 788,679 & 75,096 & 190,762 \\
\hline
\end{tabular}

$a$ Estimated.

along the foothills and across Bear Canyon, was organized October 25, 1870. At that time the nearest railroad communication was American Fork, 62 miles distant. Wheeler ${ }^{1}$ says:

The principal mines are the Mountain Queen, shaft 30 feet; Olive Branch, tunnel 120 feet; Hague lode, Revolution, Atlantic, Aspenwall, Great Western, Monitor, Sultana, Olive Branch No. 2, Chicago lode, Little Agnes, St. Patrick, and Lily. * * * There is very little water in the immediate vicinity of the mines. *** On the southern slope of Mount Nebo and apparently within this district are two large gypsum and one large salt (rock) deposits.

1 Wheeler, G. M., U. S. Geog. Surveys W. 100th Mer. Prog. Rept. for 1872, pp. 25-26, 1874
MONA DISTRICT.

The Mona mining district is in the northeastern part of Juab County, near the town of Mona, on the Los Angeles \& Salt Lake Railroad, about 83 miles south of Salt Lake City. Most of the mining is for gypsum.

\section{LAKE MOUNTAINS.}

By G. F. Loughuin.

The Lake Mountains have a north-south length of about 17 miles and a maximum width of 6 miles. They lie between Utah Lake on the east and Cedar Valley on the west.

2 Precious metals: Tenth Census U. S., vol. 13, p. 460, 1885. 
There is no known record of ore produced from these mountains, though some prospecting has been carried on. Only the north and south ends of the ranges were visited.

\section{GEOLOGY}

At the north end, which includes the Lehi mining district, the rocks of the eastern slope consist of bluish-black dense and mostly thinbedded fossiliferous limestones of upper Mississippian age, which dip about $20^{\circ} \mathrm{SW}$. Fossils collected by the writer were determined as follows by G. H. Girty, of the United States Geological Survey, who states that the strata containing them can safely be placed in the upper Mississippian:

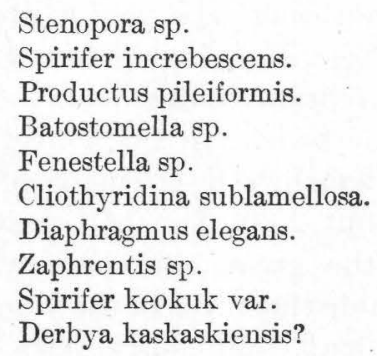

These strata belong to the series which lies beneath the Pennsylvanian quartzite and which, in the Wasatch and Oquirrh mountains and in the Tintic district, is characterized by alternating beds of limestone, shale, and limy quartzite. The shale and quartzitic beds are very scarce or absent in the northern Lake Mountains, as well as in the northern part of the East Tintic Mountains, 15 miles to the southwest. Although no quartzite was found in place the great number of quartzite cobbles and boulders in the canyons and eastern alluvial slopes indicates that the Pennsylvanian quartzite is probably present along the backbone and western. slope of the northern part of the range.

\section{LEHI DISTRICT.}

The Lehi district, organized January 11, 1894, is in Utah County, southwest of Lehi, a station on the Denver \& Rio Grande Railroad and the Los Angeles \& Salt Lake Railroad. The district borders the west shores of Utah Lake. Marble, "onyx marble," and clay are the predominating useful mineral products found.

The only evidences of mineralization seen by the writer are a few veinlets of columnar (scalenohedral) calcite. These veins, although accompanying or lying near ore bodies in some places, are by no means sure indications of ore, and the type of ore which they accompany is very unlikely to form deposits of industrial importance in so dense and impervious a rock as the local limestone. Some fabulously high assays of samples from this district at one time caused considerable excitement but proved to be fraudulent. Nothing of value was ever found.

\section{NORTH TINTIC DISTRICT. ${ }^{1}$}

The southern end of the Lake Mountains is included in the eastern part of the North Tintic district. The rocks here have an irregular anticlinal structure, lying nearly horizontal with slight undulations for nearly the entire width of the range (about 2 miles) but curving sharply to a nearly vertical dip in the easternmost exposures. The strata seen correspond in character to the Pine Canyon limestone of the Tintic district, which is mostly of lower Mississippian (Madison) age, but whose upper beds are tentatively correlated as upper Mississippian. At the Wanless, the only active prospect visited, a shaft had been sunk 75 feet in coarse-grained limestone similar to that containing the "Colorado Channel" ore body in the Tintic district. Some veins of white columnar calcite, or travertine, accompanied by some soft red iron oxide, were exposed in the bottom of the shaft.

\section{OQUIRRH RANGE.}

By B. S. Butler.

\section{GEOGRAPHY.}

The Oquirrh Range extends southward from Great Salt Lake for about 30 miles in Salt Lake, Utah, and Tooele counties. In its southern portion it is about 10 to 12 miles wide but in its northern portion it is scarcely half as much.

In common with most of the basin ranges the Oquirrh Range rises steeply from the flat valley bottoms to the crest of the range. Its highest portions are more than 10,000 feet and most of its crest is more than 8,000 feet above sea level, or from 3,000 to 5,000 feet above the bottoms of the intermontane valleys. Near the central portion of the range low extensions run both

${ }^{1}$ See also p.415. 
eastward and westward. The range has been carved by erosion into long spurs that extend from the crest to the desert and are separated by deep canyon-like valleys.

Only the larger valleys contain perennial streams, and none of these furnishes a large $P$ supply of water. Bingham, Butterfield, and Fairfield canyons on the east side of the range and Ophir, Soldiers, and Tooele canyons on the west side contain streams. The surface water is not sufficient for large agricultural operations, or even for mining, but it has been supplemented in recent years by flow from the deeper drain tunnels.

Timber was present in many of the canyons in the early days but is at present almost entirely lacking, and mining needs are supplied from other sources.

\section{PHYSIOGRAPHY.}

The Oquirrh Mountains are in a more advanced stage of erosional development than many of those in the Great Basin region, and the cause for their elevation is correspondingly obscured. Folding is now the most conspicuous structural feature, but the fact that the general trend of the range is north and the fold structure northwest suggests that the present mountains have been carved from a fault block uplifted along its western edge and that the folds are part of an older structure that has been truncated by the fault. Gilbert ${ }^{1}$ has described a fault later than the Lake Bonneville deposits along the west side of the range, and an earlier movement or movements along this same line would account for the present outline of the range.

Striking minor physiographic features of the range, especially around the northern end, are the beaches and terraces of the ancient lakes and the conspicuous bar at Stockton. ${ }^{2}$

\section{GEOLOGY.}

\section{SEDIMENTARY ROCKS.}

The sedimentary rocks of the range vary in age from Cambrian to Carboniferous. Quartzites and limestones are the most abundant, though some shales are also present.

The oldest rocks known in the range are the quartzite beds in Ophir Canyon, whose ex-

1 Gilbert, G. K., Lake Bonneville: U. S. Geol. Survey Mon. 1, p. 352, 1890.

${ }^{2}$ Idem, pl. 20. posed thickness is about 500 feet. Overlying these is a series of shales and limestones about 100 feet thick. Fossils collected from these beds were determined by L. D. Burling as Obolus (Westonia) ella (Hall and Whitfield) and Ptychoparia, and the series is probably to be correlated with the Lower Cambrian Pioche shale. Olenellus gitberti has been found in collections brought in by the Wheeler Survey. ${ }^{3}$ Overlying this limestone-shale formation is about 1,200 feet of strata composed largely of rather heavy-bedded limestone with some shaly and siliceous beds. A fossil, found by the writer a few hundred feet from the base, was determined by Mr. Burling as probably Cambrian. Gansl and Keefe ${ }^{4}$ state that the entire 1,200 feet is of Cambrian age, and Gilbert ${ }^{5}$ states that Carboniferous fossils were found separated from the Cambrian shales by less than 400 feet of limestone beds. In the Tintio district, which is in a southward extension of the Oquirrh Range, about 2,000 feet of Cambrian sediments overlie the great quartzite, which suggests a considerable thickness in the Oquirrh Range. It is evident that more data are needed to determine finally the age of these beds.

Above these unfossiliferous or sparsely fossiliferous strata are beds containing abundant Carboniferous fossils. At the base these are mainly limestones, but they pass into a series of interbedded limestones and quartzites. Spurr ${ }^{6}$ has estimated the thickness of Carboniferous sediments in the Mercur basin as 12,000 feet, and the total thickness from the base of the known Carboniferous to the Bingham quartzite is doubtless several thousand feet greater than it is in the Mercur basin.

The lower horizons from which fossils were collected (near the Cliff mine in Ophir Canyon and north of the Ophir-Dry Canyon divide) yielded a fauna determined by G. H. Girty as Madison. It included the following forms:

Schuchertella chemungensis.

Chonetes illinoisensis.

Spirifer centronatus.

Spiriferina solidirostris.

Loxonema sp.

${ }^{3}$ Walcott, C. D., Correlation papers-Cambrian: U. S. Geol. Survey Bull. 81, p. 319, 1891.

4 Gansl, G. C., and Keefe, G. A., The Ophir mining district: Salt Lake Min. Rev., vol. 12, p. 17, July 30, 1910.

5 Gilbert, G. K., U. S. Geol: Surveys W. 100th Mer. Rept., vol. 3, p. $26,1875$.

6 Spurr, J. E., Economic geology of the Mercur mining district, Utah: U. S. Geol. Survey Sixteenth Ann. Rept., pt. 2, p. 377, 1896. 
Euomphalus utahensis.

Syringopora? sp.

Zaphrentis sp.

Cystodictya sp.

Chonetes sp.

Productella concentrica.

Dielasma sp.

Eumetria marcyi.

Cliothyridina crassicardinalis.

Paraparchites sp.

From collections made between Dry Canyon and Soldiers Canyon on the west side of the range, the following fossils were determined by Mr. Girty and provisionally referred to the upper Mississippian:
Fenestella several sp.
Cystodictya sp.
Rhombopora sp.
Productus aff. $\mathbf{P}$. parvus.
Productus laevicosta.
Spirifer keokuk var.
Spiriferina sp.
Cliothyridina hirsuta.
Cliothyridina incrassata?
Monophyllum sp.
Cystodictya sp.
Hemitrypa sp.
Rhipidomella? sp.
Rhipidomella aff. R. dubia.
Batostomella sp.

Fossils collected from just north of Soldiers Canyon were determined by Mr. Girty as Productus semireticulatus, Marginifera splendens, and Spirifer cameratus, all of Pennsylvanian age.

Although more detailed work is necessary to determine the thickness of the divisions represented in the great limestone and the series of interbedded limestone, shale, and sandstone, it seems probable that fully one-half of the total thickness belongs to the lower Carboniferous or Mississippian.

Overlying the great limestone and series of interbedded limestone, shale, and sandstone is the Bingham quartzite, composed mainly of quartzite and sandstone with interbedded lenses of limestone. Keith ${ }^{1}$ estimates the thickness of this formation as probably 10,000 feet in the Bingham district. The Bingham quartzite is the highest formation known to be exposed in the Oquirrh Range, though phosphatic beds in the northern part of the range are supposed to lie at the same horizon as those above the Weber quartzite in northern Utah and Idaho.

${ }^{1}$ Keith, Arthur, Areal geology of the Bingham mining district, Utah: U. S. Geol. Survey Prof. Paper 38, p. 35, 1905.

$$
35416^{\circ}-19-22
$$

The apparent thickness of the Carboniferous rocks in the Oquirrh Range is much greater than in the neighboring ranges, and it is possible that this is due to faulting that has not been detected.

\section{IGNEOUS ROCKS.}

The igneous rocks of the Oquirrh Range are both intrusive and extrusive. The extrusive rocks, which are confined to the eastern foothills and the spur extending eastward near the central portion of the range, consist of flows and breccias of andesitic and latitic composition. The in trusive rocks include stocks, dikes, and sheets and are present in greater or less amounts from the Bingham district to the south end of the range.

The only large bodies of intrusive rock are the stocks of the Bingham district, with which are associated many smaller bodies and dikes and sills. These rocks are all of monzonitic composition, though differing somewhat from point to point. Numerous similar dikes lie farther south in the Stockton district, in Dry Canyon and in the "Birdseye" porphyry of Lion Hill and the Mercur district.

Dikes and sills in the southern part of the range in the Mercur and Ophir districts are fine grained and rather highly altered. Their composition is not definitely determined, but apparently they are considerably more siliceous than the other rocks. The dome structure centering at Ophir strongly suggests an underlying body of intrusive rock.

The similarity in composition of the rocks in the northern part of the area leaves little doubt that they are from a common source and were intruded at essentially the same time. The siliceous rocks at the southern end of the range are not so certainly of the same age and origin, but no known evidence shows that they are of different age, and their composition may well have resulted from differentiation of a single magma.

The relation of the intrusive to the extrusive rocks is nowhere clear, though the intrusives have been generally considered to be the older. In the Tintic district, to the south, the two are of essentially the same age, and it seems quite probable that the same may be true of the Oquirrh Range. 
There is no evidence of the geologic age of the intrusive rocks further than that they are younger than the Carboniferous rocks, which they cut, and older than the lake sediments. Comparison with other districts of the State suggests that they are of Tertiary age.

\section{STRUCTURE.}

Both folding and faulting are important in the Oquirrh Range. All the faulting seems later than the folding, and the latest faulting is believed to have been an important factor in outlining the range.

FOLDING.

The range is composed of a series of broad open folds trending and pitching generally northwest. In the southern part these folds are very regular, and where cut by deep canyons expose almost diagrammatic sections. The southern part of the range consists of an anticline on the west and a syncline on the east, both cut off by the western front of the range south of Tooele Canyon. The northern part of the range apparently has a similar general structure but is much more complicated by faulting.

At Ophir the western anticline has been raised into a dome or quaquaversal, giving the anticline a gentle southerly pitch and a rather pronounced northerly pitch, which to the north exposes successively younger beds, ranging from Lower Cambrian to upper Carboniferous or Pennsylvanian.

\section{FAULTING.}

The general north-south trend of the range is most readily explained as being due to a strong fault which truncated the folds along the western front. Recent movement is known to have taken place on a fault line extending along this front with relative uplift to the east. ${ }^{1}$

East-west faulting has also exerted an important influence on the large structural features of the district. In Ophir Canyon an east-west fault is associated with the dome structure, with whose formation it was probably associated.

Emmons ${ }^{2}$ has called attention to an east-

1 Gilbert, G. K., Lake Bonneville: U. S. Geol. Survey Mon. 1, p. 352, 1890.

2 Emmons, S. F., General geology of the Bingham mining district, Utah: U. S. Geol. Survey Prof. Paper 38, p. 22, 1905. west zone of faulting just south of Butterfield Canyon and to a second east-west fault north of Bingham Canyon that follows the general direction of Dry Canyon and that has thrown the Bingham quartzite down against the underlying limestones. Concerning the influence of the faults Emmons says that

It appears that the sedimentary rocks of the Bingham area at present occupy an abnormally depressed position relative to the portions of the range lying to the north and to the south of it, and that with respect to the northern portion, at least, this relation has evidently been brought about by faulting. * * *

In the northern third of the range, between Connor Peak and Salt Lake, as contrasted with the south half, eastwest to north trends characterize the master structure lines, and faulting is more prominent than folding. Evidence of this is seen on the steep northern face of the range that fronts toward Salt Lake, which apparently represents a fault scarp with a trend a little north of east. The sedimentary beds on this face, largely limestones, dip from $60^{\circ} \mathrm{N}$. to vertical, while small outliers in the lake beyond-Sheep and Black rocks-have southerly dips.

Detailed mapping of the range will doubtless reveal other large faults. Minor faults are numerous and many of them are important on account of their association with the ore deposits.

A fissuring of the rocks, possibly accompanied by slight movement, has had no important influence on the large structural features of the range but has been of large importance in connection with the deposition of ores. These ore-bearing fissures vary in direction from place to place, but throughout the range most of the important ones trend generally north. Barren fissures extend in every direction, especially in the Bingham district.

\section{ORE DEPOSITS.}

\section{CHARACTER AND DISTRIBUTION.}

The ore deposits of the several districts in the Oquirrh Range show rather marked differences when considered individually, but when viewed as a whole are sufficiently similar to indicate that they are closely related-that they probably derived their metal content from the same source and are of essentially the same age.

In character the ores of the Bingham district are the most varied in the range. They occur as disseminated deposits in altered monzonite and quartzite adjacent to the monzonite; as vein deposits in the monzonite and in the 
sedimentary rocks; and as replacement, fissure, and bed deposits in the limestone.

The disseminated deposits are typically copper; the replacement veins are lead-silver deposits, but many of them carry important amounts of copper and zinc. The replacement deposits in the limestone are both copper and lead-silver or lead-silver-zinc. Some deposits contain relatively small amounts of the baser metals and are essentially siliceous silver ores. All the ores carry some precious metal. The ores of the Stockton district are essentially lead-silver but contain some zinc and copper. The ores of Dry Canyon are mainly lead-silver and zine but contain some copper. Some of them were chiefly valuable for silver. The Ophir district, like Dry Canyon, is mainly lead-silver but also yields zine and copper. The Lion Hill area is typically a silver-producing district, but it also yields lead and small amounts of zinc and copper. The Mercur, West Dip, and Sunshine camps are chiefly gold producers, though the Mercur district has yielded some silver.

Thus, the Bingham district at the north is the only one containing valuable bodies of copper ore, and the districts in the extreme south of the range are noted principally for their precious metals. The intervening districts produce chiefly lead and silver but yield also a considerable amount of copper and zinc.

\section{GEOLOGIC RELATIONS.}

The character of the ore deposits bears a general relation to the igneous rocks of the range. In the Bingham district the important copper deposits lie either in or close to the large intrusive bodies and the lead-silver and zine deposits in the limestones some distance away. There are gradations between the copper and lead-silver deposits. Lead-silverzinc deposits occur in the intrusive rocks but are believed to be slightly younger than the copper deposits, which in places are cut by veins carrying lead, silver, and zinc.

In the Stockton, Dry Canyon, and Ophir districts only small dikes of intrusive rock are present, and the ore deposits associated with them are characterized by lead, silver, and zine and by minor amounts of copper.

In the districts in the south end of the range only relatively small bodies of siliceous igneous rock are present, and the associated deposits are characterized by precious metals and by a scarcity of base metals.

A further relation between the igneous rocks and the characters of the different deposits is indicated by certain of the ore and gangue minerals, which form within certain temperature ranges. The gangue minerals characteristically associated with the copper deposits, including biotite in the altered porphyry and garnet and other contact silicates in the limestones, are those that form at relatively high temperatures. The minerals associated with the lead-zinc ores are those that form at lower temperatures, being mainly quartz, some sericite, and a little garnet and tremolite. No minerals typical of high-temperature conditions were found in the precious-metal deposits toward the southern end of the range, but cinnabar, realgar, and minerals common to moderate temperatures are present.

From the above relations it may be considered that the ores are derived from a common source and that their distribution is due to varying conditions of temperature and pressure. Copper has been deposited under conditions of greatest heat and pressure, lead and zinc as these decreased, and precious metals and mercury and arsenic at the lower limits of deposition and at the greatest distance from the source. The presence of lead-zinc deposits in the monzonite body can be explained by assuming that the deposition continued over a considerable period and that they were deposited later than the copper and after the temperature had been reduced. Other conditions were probably factors in the deposition of the gold and silver deposits. (See p. 394.)

Ore has been deposited at many horizons, from Lower Cambrian to upper Carboniferous. The Ophir Hill deposits are in the Cambrian; the Lion Hill, Mercur, and Dry Canyon deposits in the lower Carboniferous, and the Stockton and Bingham deposits in the upper Carboniferous. The age of the sediments, therefore, does not appear to determine their importance as ore carriers.

The composition of the sedimentary rocks, on the other hand, does appear to be an important and perhaps a controlling factor. The lead-zinc ores most readily replace the purer limestones or dolomites, and only in small degree the siliceous sediments, and the gold deposits are closely associated with shaly beds, 
commonly containing carbonaceous matter, whose composition has probably helped to precipitate the gold.

Structurally, the deposits of the range have a general similarity, though individual deposits differ greatly in detail. Most of the deposits in the sedimentary rocks are associated with north-south fissures and have formed as replacements of certain beds in chimneys or shoots following the intersection of the ore fissure and the replaced bedding.

\section{MINERALOGY.}

The mineralogy of the several deposits and the alteration by surface agencies can best be discussed in connection with the description of the individual districts.

\section{BINGHAM OR WEST MOUNTAIN DISTRICT.}

\section{INTRODUCTION.}

The following description of the Bingham district is based very largely on the work of Boutwell, Keith, and Emmons, ${ }^{1}$ published in 1905. The writer, however, with G. F. Loughlin, spent several days in the district in August, 1912, collecting data on the disseminated deposits (which had been only slightly developed at the time of Boutwell, Keith, and Emmons's study of the district) and visiting most of the larger mines though attempting no detailed study of them. Free use has also been made of a paper by Beeson, ${ }^{2}$ dealing particularly with the disseminated deposits of the district. Atwood ${ }^{3}$ has also contributed to the study of the physiography of the range.

\section{LOCATION.}

The Bingham (West Mountain) mining district is on the eastern slope of the Oquirrh Range, about 20 miles southwest of Salt Lake City. The greater part of the mineralized area lies in Bingham Canyon and in canyons tributary, though some ore bodies are in canyons to the east, south, and west.

1 Economic geology of the Bingham mining district, Utah: U. S. Geol. Survey Prof. Paper 38, 1905.

2 Beeson, J. J., The disseminated copper ores of Bingham, Utah: Am. Inst. Min. Eng. Bull. 107, pp. 2191-2236, Nov., 1915.

${ }^{3}$ Atwood, W. W., The physiographic conditions at Butte, Mont., and Bingham Canyon, Utah, when the copper ores in these districts were enriched: Econ. Geology, vol, 11, pp. 697-740, 1916
HISTORY AND PRODUCTION.

By V. C. Heikes.

HISTORY.

The first discovery of mineral in the camp is said to have been made by G. B. Ogilvie in the fall of 1863 ; and the first claim, the WestJordan, was formally located by the discoverer and others. The district was organized as the West Mountain district, December 17, 1863. The first location was followed by others and by some development. Conditions, however, were unfavorable, owing to the lack of transportation facilities and of suitable reduction plants, and active production from the lodes did not begin till some years later.

In 1864 placer gold was found in the gravels of Bingham Canyon. Production began in the spring of 1865 and during the next six years totaled about $\$ 1,000,000$. After 1871 the importance of the placers declined, but they have produced intermittently till recent years and have yielded a total of nearly $\$ 1,500,000$.

The Union and Central Pacific railroads, which were completed in 1869 and were soon connected with Salt Lake City by the Utah Central, greatly improved transportation facilities, and in 1873 a railroad was opened from Salt Lake City to Bingham Canyon. These improved conditions stimulated lode mining. The first shipment of ore is said to have been a carload of copper ore shipped by Walker Bros. to Baltimore in 1868. Lead-silver ores, however, furnished the main production for some years.

In the early days only oxidized ores could be successfully treated and when the sulphide zone was reached the output of lead and silver declined. In the late seventies several mills were constructed to recover the gold from the gossan or oxidized portion of the ore bodies in limestone, but the output from this type of ore has not been large as compared with other types.

In 1881 new deposits of lead were discovered in Butterfield Canyon and these, with the output from the older portion of the district, produced considerable lead and silver till the fall in price of silver in 1893 dealt a severe blow to the business.

The production of copper from Bingham on an important scale began in 1896, the first 
large output being from the Highland Boy mine. The success of this mine stimulated prospecting, and soon an important output was being made from the low-grade sulphide deposits in the limestones.

Prospecting of the disseminated ores of the district was carried on from the time that copper became an important factor in the output of the camp, but it was several years before important production was made from this type of ore. About 1904 systematic development by churn drill and underground methods was begun by several companies, large bodies of ore were rapidly proved, and a small output from experimental mills was soon made. Extensive production, however, did not begin until the completion of the large concentrating plants of the Utah Copper Co. and the Boston Consolidated Copper Co. at Garfield, and of the Ohio Copper Co. at Lark. The mill of the Utah Copper Co. began operation in 1907, that of the Boston Consolidated in 1908, and that of the Ohio Copper Co. in 1909. The Utah Copper Co. had previously operated a 500-ton experimental mill in Bingham Canyon.

At the present time, through consolidation, a large part of the ground known to contain important bodies of disseminated copper ore is held by the Utah Copper Co., the Ohio Copper Co. being the only other important operator.

\section{MINING METHODS.}

The strong relief in the district is favorable to the opening of ore bodies by tunnels, and these have been very generally used since the early days of mining. In the lower areas, notably in the eastern part of the district, where depth could not be readily attained by tunnels, shafts were sunk, and in recent years these have been used in other parts of the district to develop the ore bodies to greater depth than has been found feasible by tunneling. For the most part, however, as greater depth has been desired, long drain tunnels have been driven, as the 14,000-foot Mascotte tunnel from the east side of the range to intersect the ore body in the Ohio Copper Co.'s ground, and the 11,000foot Utah Metal Mining Co.'s tunnel from the west or Tooele side of the range to upper Carr Fork.

The early development of the disseminated deposits was mainly by tunnel and, to a slight extent, by shafts. Later churn drills were brought into use, and a large percentage of the ore has been systematically developed by this method at a relatively low cost.

Methods of extraction of the ores have differed with the character of the deposit and huve changed as more economical methods have been developed. In the replacement veins the prevailing method in the early days was the square set and fill, and in many deposits this relatively costly method of extraction is still found necessary. In the smaller veins only stulls are required to hold the walls. More recently various modifications of the top slicing and caving systems have been successfully employed in extracting the larger sulphide ore bodies. In the disseminated ore bodies the underground extraction has been principally by the systems of caving and shrinkage stopes. For a large part of this type of deposits it has been found more economical to strip the overburden and remove the ore by open-cut methods. In this method the rock is shattered by heavy blasts and then handled by steam shovels. Since 1914 the Utah Copper Co. has mined practically all its disseminated ore by this method.

\section{REDUCTION.}

In the early days of mining in the district, when the oxidized lead-silver ores constituted the main output, treatment of the ores was relatively simple. Several blast furnaces, constructed in and near the district, made good saving of metals, though the high cost of operation made it possible to treat only the relatively high-grade ores.

Numerous attempts to treat the gold ores in the upper portion of many of the ore bodies were only indifferently successful. Several stamp mills were built and operated for short periods, the gold being recovered by amalgamation. Later at the Highland Boy mire cyanidation was tried but without satisfactory results. Considerable gold was recovered in the several mills, but it is doubtful if the metal recovered paid the costs of operation. Leaching of the siliceous ores of the Telegraph mine was early attempted, and in 1910 a 50-ton cyanide plant was built by the Utah Leasing Co. for this mine. The discovery of extensive bodies of copper sulphide ores led to the construction in the valley south of Salt Lake of smelters, which were operated successfully until 1907, when they were closed by order of the courts because of damage to vegetation. A copper-smelting 
plant that had been operated in Bingham Canyon by the Yampa Copper Co. for several years was closed in 1910.

At present the copper ores of the district are treated mainly at the plant of the Garfield Smelting Co. at Garfield, and that of the International smelter at International, on the west side of the Oquirrh Range. The Garfield smelter, completed in 1906, is especially adapted to the treatment of the concentrates of the district but is also equipped with blast furnaces for the treatment of direct-smelting ores. The International plant, when blown in in 1910, was equipped for the treatment of copper ore and concentrates, and later equipment for the treatment of lead ores was added. The lead ores and concentrates of the district are treated at the International smelter, at the plant of the United States Mining, Smelting \& Refining Co. at Midvale, and at that of the American Smelting \& Refining Co, at Murray.

Numerous mills have been and still are operated for the concentration of the lowgrade lead-silver ores. The zinc content of most ores has been low enough to be kept, by judicious mixing, below the percentage allowed by the smelters without penalty.

The United States Mining, Smelting \& Refining Co. has installed Huff electrostatic machines for treating zinc middlings from the ores from its Bingham mines and has made a considerable production of zinc. The zinc concentrates are shipped to eastern plants for further treatment. In 1915 the American Smelting \& Refining Co. built an experimental plant at Murray for the production of electrolytic zinc.

Since 1907 the low-grade disseminated copper ores of the district have been treated in three large mills - the Magna mill of the Utah Copper Co. near Garfield, with a daily capacity of about 18,000 tons of ore; the Arthur mill (originally Boston Consolidated) of the same company, with a capacity of about 15,000 tons, and the mill of the Ohio Copper Co. at Lark, with a capacity, when completed, of about 5,000 tons. With these mills operating at capacity, about 38,000 tons of ore can be treated daily, but this can be greatly exceeded at the sacrifice of metal recovered. In 1917 the Magna and Arthur mills treated an average of more than 34,000 tons of ore daily.
METAL CONTENT OF THE ORES.

DRY OR SILICEOUS ORE.

The dry or siliceous ores shipped to smelters from the Bingham (West Mountain) district comprise gold and silver ores carrying small quantities of the sulphide minerals of copper and lead. Such ores have been used at the smelters principally for converter lining. Silver bullion containing a little gold was treated at a cyanide mill in the district, but the tonnage does not enter into the averages given below and can not be given separately without disclosing individual production. The shipping grade of dry or siliceous ore was produced from the Old Jordan, Mystic Shrine, Story, Utah Apex, Parnall, Sampson, Buffalo, Niagara, Gold \& Silver, Utah Bingham, and Queen.

The average grade of the ores from the aggregate yield of these mines is as follows:

Siliceous ore, with average metallic content, produced in the Bingham (West Mountain) district and shipped to smelters, 1903-1917.

\begin{tabular}{|c|c|c|c|c|c|c|}
\hline Year. & $\begin{array}{l}\text { Quan- } \\
\text { tity } \\
\text { (short } \\
\text { tons). }\end{array}$ & $\begin{array}{l}\text { Gold } \\
\text { (value } \\
\text { per } \\
\text { ton). }\end{array}$ & $\begin{array}{c}\text { Silver } \\
\text { (ounces } \\
\text { per } \\
\text { ton). }\end{array}$ & $\begin{array}{c}\text { Copper } \\
\text { (per } \\
\text { cent). }\end{array}$ & $\begin{array}{l}\text { Lead } \\
\text { (per } \\
\text { cent). }\end{array}$ & $\begin{array}{l}\text { Aver- } \\
\text { age } \\
\text { gross } \\
\text { value } \\
\text { per } \\
\text { ton. }\end{array}$ \\
\hline 1903. & 1,848 & $\$ 0.93$ & 2. 23 & 0.24 & & $\$ 2.81$ \\
\hline 1904. & 1, 918 & 6.44 & 10.35 & 1. 40 & 0.34 & 16. 32 \\
\hline 1905. & 2,643 & 3.54 & 5. 30 & 1. 39 & $\ldots \ldots$ & 11. 10 \\
\hline 1908. & 2,412 & 5.27 & 18. 43 & $\ldots$. & .03 & 15. 06 \\
\hline 1909 . & 8,102 & 3. 40 & 11. 69 & .20 & .37 & 10.31 \\
\hline 1910. & 7,808 & 3.01 & 11. 49 & .85 & 1. 55 & 12.75 \\
\hline 191 & 1,071 & 8. 14 & 7.00 & 1. 39 & 2. 10 & 17.22 \\
\hline $191 \%$ & 1,432 & 7.03 & 5. 03 & .98 & .04 & 13.40 \\
\hline 191 & 718 & 7.70 & 6.73 & 1. 03 & 1. 22 & 16. 04 \\
\hline 191 & 820 & 5. 82 & 4. 33 & .79 & .10 & 10.39 \\
\hline 19$]$ & 498 & 4. 79 & 6.94 & .79 & .08 & 11. 06 \\
\hline 191 & 110 & 2. 58 & 4.65 & 1. 21 & & 11. 60 \\
\hline $191^{\prime}$ & 425 & 1. 07 & 4. 35 & .76 & .05 & 8. 94 \\
\hline
\end{tabular}

COPPER ORE AND CONCENTRATES.

Copper ores of two grades were shipped from the district, the bulk going to the concentration mills at Garfield and a fluxing grade directly to the smelters. They include ores carrying over $2 \frac{1}{2}$ per cent of copper, or even less in the case of the great disseminated copper deposit at Bingham. The copper ore shipped directly to the smelters came from the following properties, named in the order of their frequency as regular shippers: Highland Boy (Utah Consolidated), Yampa, Old Jordan, Commercial, Bingham, New Haven, Boston Consolidated, Columbia (Ohio Copper), Utah Apex, Utah Copper, Fortuna, Dalton \& Lark, 
Mystic Shrine, Bingham Consolidated, Butler Liberal, Copper Glance, New Red Wing, Story, Brooklyn, New England, Niagara, Valentine Script, Bingham Mary, Lone Pine, Pine Tree, Bingham Mines, Ute Copper, Yosemite, Winnamuck, Colorado \& Maple, and Gold \& Silver. The copper concentrates, as sulphides, were produced during the last decade from the Utah Copper, Columbia (Ohio Copper), Boston Consolidated, and Eddie.

The average grade of the ore and concentrates representing the aggregate yield of the district is shown in the following table:

Copper ore and concentrates, with average metallic content produced in the Bingham (West Mountain) district and shipped to smelters, 1903-1917.

Crude ore.

\begin{tabular}{|c|c|c|c|c|c|c|}
\hline Year. & $\begin{array}{l}\text { Quan- } \\
\text { tity } \\
\text { (short } \\
\text { tons). }\end{array}$ & $\begin{array}{l}\text { Gold } \\
\text { (value } \\
\text { per } \\
\text { ton). }\end{array}$ & $\begin{array}{c}\text { Silver } \\
\text { (ounces } \\
\text { per } \\
\text { ton). }\end{array}$ & $\begin{array}{l}\text { Cop- } \\
\text { per } \\
\text { (per } \\
\text { cent). }\end{array}$ & $\begin{array}{l}\text { Lead } \\
\text { (per } \\
\text { cent). }\end{array}$ & $\begin{array}{l}\text { Aver- } \\
\text { age } \\
\text { gross } \\
\text { value } \\
\text { per } \\
\text { ton. }\end{array}$ \\
\hline $\begin{array}{l}1903 \ldots \\
1904 \ldots \\
1905 \ldots \\
1906 \ldots \\
1907 \ldots \\
1908 \ldots \\
1909 \ldots \\
1910 \ldots \\
1911 \ldots \\
1912 \ldots \\
1913 \ldots \\
1914 \ldots \\
1915 \ldots \\
1916 \ldots \\
1917 \ldots\end{array}$ & $\begin{array}{l}427,844 \\
552,761 \\
648,896 \\
639,355 \\
717,704 \\
512,755 \\
593,523 \\
472,511 \\
567,941 \\
424,471 \\
493,833 \\
407,587 \\
393,374 \\
576,010 \\
442,720\end{array}$ & $\begin{array}{r}\$ 2.06 \\
2.01 \\
1.86 \\
2.34 \\
1.78 \\
1.57 \\
1.49 \\
1.64 \\
1.96 \\
1.93 \\
1.65 \\
2.40 \\
1.96 \\
1.63 \\
1.46\end{array}$ & $\begin{array}{l}1.96 \\
2.28 \\
2.12 \\
1.98 \\
1.58 \\
1.06 \\
1.14 \\
1.55 \\
1.78 \\
1.77 \\
1.47 \\
1.79 \\
2.06 \\
1.62 \\
1.50\end{array}$ & $\begin{array}{l}2.15 \\
2.30 \\
2.30 \\
2.46 \\
2.00 \\
2.07 \\
1.99 \\
2.25 \\
2.15 \\
1.64 \\
1.71 \\
1.74 \\
2.09 \\
1.87 \\
1.86\end{array}$ & 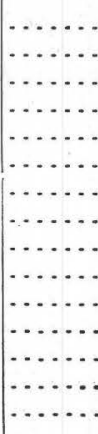 & $\begin{array}{r}\$ 9.03 \\
9.23 \\
10.34 \\
13.19 \\
10.81 \\
7.61 \\
7.25 \\
8.26 \\
8.29 \\
8.43 \\
7.85 \\
8.03 \\
10.35 \\
11.88 \\
12.91\end{array}$ \\
\hline \multicolumn{7}{|c|}{ Concentrates. } \\
\hline $\begin{array}{l}1904 \ldots \\
1905 \ldots \\
1906 \ldots \\
1907 \ldots \\
1908 \ldots \\
1909 \ldots \\
1910 \ldots \\
1911 \ldots \\
1912 \ldots \\
1913 \ldots \\
1914 \ldots \\
1915 \ldots \\
1916 \ldots \\
1917 \ldots\end{array}$ & $\begin{array}{r}9,215 \\
15,364 \\
14,963 \\
29,799 \\
99,164 \\
143,517 \\
176,279 \\
207,472 \\
250,420 \\
373,691 \\
355,152 \\
427,241 \\
555,557 \\
649,609\end{array}$ & $\begin{array}{r}\$ 2.85 \\
2.94 \\
2.61 \\
3.87 \\
3.18 \\
3.38 \\
4.75 \\
4.08 \\
2.99 \\
1.62 \\
2.07 \\
1.83 \\
1.74 \\
1.59\end{array}$ & $\begin{array}{r}1.28 \\
1.16 \\
.98 \\
1.73 \\
1.38 \\
1.55 \\
2.18 \\
1.93 \\
1.33 \\
.83 \\
.99 \\
.96 \\
.86 \\
.79\end{array}$ & $\begin{array}{l}25.90 \\
27.22 \\
22.86 \\
26.56 \\
22.12 \\
23.45 \\
25.84 \\
24.70 \\
20.08 \\
16.65 \\
17.56 \\
18.29 \\
17.87 \\
15.83\end{array}$ & & $\begin{array}{r}\$ 69.89 \\
88.57 \\
91.52 \\
111.24 \\
62.32 \\
65.17 \\
71.56 \\
66.88 \\
70.07 \\
53.75 \\
49.33 \\
66.35 \\
90.23 \\
88.70\end{array}$ \\
\hline
\end{tabular}

LEAD ORE AND CONCENTRATES.

In general the crude lead ore and concentrates are those containing over $4 \frac{1}{2}$ per cent of lead. The bulk of the lead ore, carrying low contents of lead and zinc, is shipped to Midvale, Utah, for concentration and separation.
A good average grade of lead ore is shipped directly to the smelters from the following properties, named in the order of their frequency as shippers during the last decade: Bingham New Haven, New England, Dalton \& Lark, Utah Apex, Silver Shield, Niagara, Sampson, Highland Boy (Utah Consolidated), Old Jordan, Queen, Montezuma, Utah Bingham, Story, Commercial, Butler Liberal, Fortuna, Yosemite, Utah Copper, New Red Wing, Phoenix, Massasoit, Winnamuck, Last Chance, Central Standard, North Utah, Yampa, Bingham Consolidated, Cluster, Mystic Shrine, United Bingham, Bingham-Butte, Conglomerate, Ute Copper, Petro, Green Grove, Ivanhoe, Bingham Group, Boston Consolidated, Greely, Utah Metal, Bingham Mines, Montana Bingham, Brooklyn, Julia Dean, and St. James.

The average grade of the ore and concentrates representing the aggregate yield of the district is shown in the following table:

Lead ore and concentrates, with average metallic content, produced in the Bingham (West Mountain) district and shipped to smelters, 1903-191\%.

Crude ore.

\begin{tabular}{|c|c|c|c|c|c|c|}
\hline Year. & $\begin{array}{l}\text { Quan- } \\
\text { tity } \\
\text { (short } \\
\text { tons). }\end{array}$ & $\begin{array}{l}\text { Gold } \\
\text { (value } \\
\text { per } \\
\text { ton). }\end{array}$ & $\begin{array}{c}\text { Silver } \\
\text { (ounces } \\
\text { per } \\
\text { ton). }\end{array}$ & $\begin{array}{c}\text { Copper } \\
\text { (per } \\
\text { cent). }\end{array}$ & $\begin{array}{c}\text { Lead } \\
\text { (per } \\
\text { cent). }\end{array}$ & $\begin{array}{l}\text { Aver- } \\
\text { age } \\
\text { gross } \\
\text { value } \\
\text { per } \\
\text { ton. }\end{array}$ \\
\hline $\begin{array}{l}19 \\
19 \\
19 \\
10\end{array}$ & $\begin{array}{r}6,047 \\
13,134 \\
53,340 \\
74,041 \\
47,355 \\
25,035 \\
24,443 \\
16,353 \\
91,818 \\
76,764 \\
161,067 \\
123,723 \\
146,067 \\
158,518 \\
142,564\end{array}$ & $\begin{array}{r}\$ 2.25 \\
.87 \\
.92 \\
1.23 \\
2.37 \\
2.83 \\
1.27 \\
1.41 \\
1.60 \\
1.16 \\
1.16 \\
1.20 \\
3.80 \\
1.06 \\
.94\end{array}$ & $\begin{array}{r}8.91 \\
11.77 \\
9.98 \\
8.36 \\
8.27 \\
8.57 \\
10.78 \\
11.80 \\
9.46 \\
6.23 \\
5.11 \\
5.47 \\
5.78 \\
5.66 \\
5.66\end{array}$ & $\begin{array}{r}0.38 \\
1.35 \\
.85 \\
.73 \\
.72 \\
1.49 \\
1.35 \\
.57 \\
.80 \\
.76 \\
.74 \\
.68 \\
.70 \\
.70 \\
.66\end{array}$ & $\begin{array}{r}8.78 \\
19.32 \\
19.23 \\
14.35 \\
16.18 \\
19.90 \\
22.76 \\
22.85 \\
16.12 \\
16.86 \\
14.39 \\
17.34 \\
15.94 \\
14.65 \\
13.65\end{array}$ & $\begin{array}{r}\$ 15.48 \\
27.79 \\
27.73 \\
26.10 \\
27.88 \\
28.03 \\
29.97 \\
29.34 \\
23.12 \\
22.67 \\
19.20 \\
19.56 \\
24.19 \\
28.49 \\
32.70\end{array}$ \\
\hline \multicolumn{7}{|c|}{ Concentrates. } \\
\hline 1917. & $\begin{array}{r}853 \\
3,143 \\
20,316 \\
13,859 \\
51,968 \\
56,714 \\
58,791 \\
54,152 \\
65,128 \\
75,321 \\
89,962 \\
110,409 \\
87,600\end{array}$ & $\begin{array}{l}.75 \\
1.72 \\
2.91 \\
1.82 \\
1.78 \\
1.72 \\
1.80 \\
1.89 \\
2.10 \\
3.70 \\
4.44 \\
3.74 \\
4.86\end{array}$ & $\begin{array}{r}14.63 \\
9.20 \\
9.98 \\
7.09 \\
6.82 \\
6.86 \\
6.09 \\
7.18 \\
7.45 \\
8.26 \\
7.05 \\
7.10 \\
8.95\end{array}$ & $\begin{array}{r}0.11 \\
.50 \\
.76 \\
.91 \\
.52 \\
.56 \\
.83 \\
.85 \\
.85 \\
.93 \\
.58 \\
.65\end{array}$ & $\begin{array}{l}19.27 \\
19.38 \\
26.77 \\
16.00 \\
18.48 \\
18.45 \\
19.84 \\
14.17 \\
16.44 \\
18.77 \\
22.26 \\
18.57 \\
17.37 \\
19.20\end{array}$ & $\begin{array}{r}\$ 27.13 \\
27.90 \\
38.90 \\
28.46 \\
23.11 \\
23.56 \\
24.21 \\
19.18 \\
23.84 \\
25.74 \\
27.90 \\
28.75 \\
35.23 \\
48.81\end{array}$ \\
\hline
\end{tabular}


The properties producing lead ores of milling grade concentrated at Bingham and Midvale were the New England, Utah Apex, Old Jordan, Telegraph and Galena (United States), Bingham New Haven, Butler Liberal, Phoenix, Silver Shield, New Red Wing, Last Chance, North Utah, Commercial, Massasoit, Yampa, Utah Copper, Winnamuck, Eagle Bird, Mystic Shrine, Central Standard, Shawmut, Montezuma, Bingham Mines, Highland Boy, Ute Copper, Brooklyn, Cluster, Dalton \& Lark, Queen, Ivanhoe, Niagara, and Utah Metal.

\section{COPPER-LEAD ORE.}

The copper-lead ores are classified according to the same method as the copper and lead ores. The producers of this kind of ore were the Sampson, Fortuna, Last Chance, and Summit. The average grade of the ore shipped is shown in the following table:

Copper-lead ore, with average metallic content, produced in the Bingham (West Mountain) district and shipped to smelters, 190\%-1913, 1916 .

\begin{tabular}{|c|c|c|c|c|c|c|}
\hline Year. & $\begin{array}{l}\text { Quan- } \\
\text { tity } \\
\text { (short } \\
\text { tons). }\end{array}$ & $\begin{array}{c}\text { Gold } \\
\text { (value } \\
\text { per } \\
\text { ton). }\end{array}$ & $\begin{array}{c}\text { Silver } \\
\text { (ounces } \\
\text { per } \\
\text { ton). }\end{array}$ & $\begin{array}{l}\text { Copper } \\
\text { (per } \\
\text { cent). }\end{array}$ & $\begin{array}{l}\text { Lead } \\
\text { (per } \\
\text { cent). }\end{array}$ & $\begin{array}{l}\text { Aver- } \\
\text { age } \\
\text { gross } \\
\text { value } \\
\text { per } \\
\text { ton. }\end{array}$ \\
\hline 1907. & 564 & $\$ 0.79$ & 12. 80 & 3.39 & 12.72 & $\$ 36.27$ \\
\hline 1908. & 189 & .36 & 13. 25 & 3. 64 & 20.00 & 33.81 \\
\hline $1911 \ldots$ & 187 & 6. 42 & 9.83 & 18.85 & 18. 44 & 75.36 \\
\hline $1912 \ldots$ & 15 & 24.67 & 22.67 & 3. 32 & 12.25 & 60.53 \\
\hline 1913 & 16 & 2. 25 & 46.81 & 5. 78 & 9.52 & 56.87 \\
\hline $1916 \ldots$ & 272 & 15. 29 & 9.96 & 3. 89 & 4. 90 & 47.77 \\
\hline
\end{tabular}

LEAD-ZINC ORE.

Crude lead-zinc ore was shipped from the Ute Copper (Winnamuck), Bingham, Orleans, and Jumbo properties. The average of the ores shipped follows:

Lead-zinc ore, with metallic content, produced in the Bingham (West Mountain) district and shipped to smelters, 1910-11, 1916-17.

\begin{tabular}{|c|c|c|c|c|}
\hline Year. & $\begin{array}{l}\text { Quantity } \\
\text { (short } \\
\text { tons). }\end{array}$ & $\begin{array}{c}\text { Gold } \\
\text { (value } \\
\text { per ton). }\end{array}$ & $\begin{array}{c}\text { Silver } \\
\text { (ounces } \\
\text { per ton). }\end{array}$ & $\begin{array}{c}\text { Copper } \\
\text { (per } \\
\text { cent). }\end{array}$ \\
\hline $\begin{array}{l}1910 \ldots \ldots \\
1911 \ldots \ldots\end{array}$ & $\begin{array}{l}101 \\
835\end{array}$ & $\begin{array}{r}\$ 1.24 \\
1.55\end{array}$ & $\begin{array}{l}8.36 \\
6.79\end{array}$ & $\begin{array}{r}0.30 \\
.24\end{array}$ \\
\hline $1916 \ldots \ldots$ & 6,930 & & ...... & \\
\hline $1917 \ldots \ldots$ & 3,006 & ... & & ... \\
\hline
\end{tabular}

Lead-zinc ore, with metallic content, produced in the Bingham (West Mountain) district and shipped to smelters, 1910-11, 1916-17-Continued.

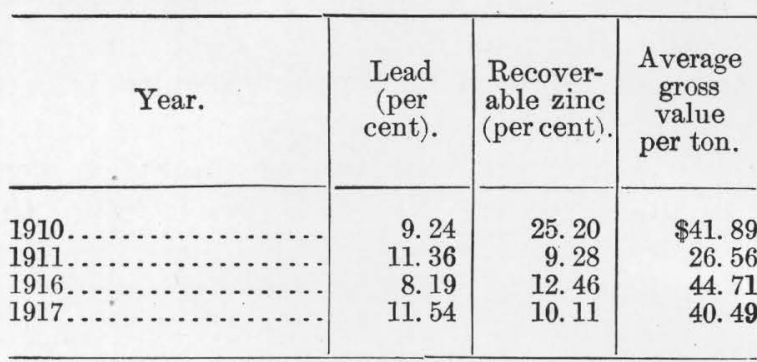

ZINC CONCENTRATES.

Zinc concentrates, recovered from ores treated largely at Midvale in the concentrating plant of the United States Mining Co., came from the Old Jordan (United States), Dalton \& Lark, Utah Copper, Commercial, Last Chance, Silver Shield, Cluster, New England, Ivanhoe, Massasoit, Butler Liberal, Niagara, Utah Apex, Utah Metal, and Winnamuck. The average grade of the concentrates is shown in the following table:

Zinc concentrates, with metallic content, produced in the Bingham (West Mountain) district and shipped to smelters, 1909-1913, 1915-191\%.

\begin{tabular}{|c|c|c|c|c|}
\hline Year. & $\begin{array}{l}\text { Quantity } \\
\text { (short } \\
\text { tons). }\end{array}$ & $\begin{array}{c}\text { Gold } \\
\text { (value } \\
\text { per ton). }\end{array}$ & $\begin{array}{l}\text { Silver } \\
\text { (ounces } \\
\text { per ton). }\end{array}$ & $\begin{array}{l}\text { Copper } \\
\text { (per } \\
\text { cent). }\end{array}$ \\
\hline $\begin{array}{l}1909 \ldots \ldots \ldots \\
1910 \ldots \ldots \\
1911 \ldots \ldots \\
1912 \ldots \ldots \\
1913 \ldots \ldots \\
1915 \ldots \ldots \\
1916 \ldots \ldots \\
1917 \ldots \ldots\end{array}$ & $\begin{array}{r}1,000 \\
4,548 \\
5,669 \\
3,041 \\
4,821 \\
6,550 \\
10,590 \\
5,874\end{array}$ & 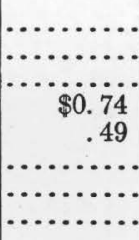 & 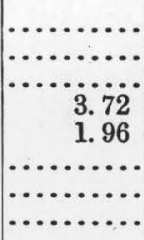 & 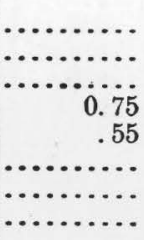 \\
\hline Yea & & $\begin{array}{l}\text { Lead } \\
\text { (per } \\
\text { cent). }\end{array}$ & $\begin{array}{l}\text { Recover- } \\
\text { able zinc } \\
\text { (per cent). }\end{array}$ & $\begin{array}{l}\text { Average } \\
\text { gross } \\
\text { value } \\
\text { per ton. }\end{array}$ \\
\hline $\begin{array}{l}1909 \ldots \ldots \\
1910 \ldots \ldots \\
1911 \ldots \ldots \\
1912 \ldots \ldots \\
1913 \ldots \ldots \\
1915 \ldots \ldots \\
1916 \ldots . . . \\
1917 \ldots \ldots\end{array}$ & $\begin{array}{l}\ldots \\
\ldots \\
\cdots \\
\cdots \\
\cdots\end{array}$ & 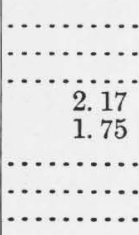 & $\begin{array}{l}32.48 \\
38.71 \\
40.22 \\
44.59 \\
35.49 \\
41.92 \\
40.82 \\
34.01\end{array}$ & $\begin{array}{r}\$ 35.07 \\
41.81 \\
45.85 \\
69.01 \\
44.71 \\
103.95 \\
109.40 \\
80.38\end{array}$ \\
\hline
\end{tabular}

The following table gives the yearly output of metals from the beginning of operations to the close of 1917: 
Quantity of ore sold or treated in Bingham (West Mountain) district, 1865-1917, and total metals recovered.

\begin{tabular}{|c|c|c|c|c|c|c|c|c|c|c|c|c|}
\hline \multirow{2}{*}{ Year. } & \multirow{2}{*}{$\begin{array}{l}\text { Ore, short } \\
\text { tons. }\end{array}$} & \multicolumn{2}{|c|}{ Gold. } & \multicolumn{2}{|c|}{ Silver. } & \multicolumn{2}{|c|}{ Copper. } & \multicolumn{2}{|c|}{ Lead. } & \multicolumn{2}{|c|}{ Recoverable zinc. } & \multirow{2}{*}{$\begin{array}{c}\text { Total } \\
\text { value. } a\end{array}$} \\
\hline & & Fine ounces. & Value. & $\begin{array}{l}\text { Fine } \\
\text { ounces. }\end{array}$ & Value. & Pounds. & Value. & Pounds. & Value. & Pounds. & Value. & \\
\hline $\begin{array}{l}1865 \ldots \\
1873 b_{\ldots} .\end{array}$ & & $43,506.00$ & $\$ 899,340$ & $1,207,212$ & $\$ 1,583,910$ & 90,500 & $\$ 25,311$ & $13,958,000$ & $\$ 862,192$ & & & $\$ 3,370,753$ \\
\hline $\begin{array}{l}1874 \ldots \\
1875 \ldots\end{array}$ & & $\begin{array}{l}\text { c4, } 111.00 \\
\text { c } 1,451.00\end{array}$ & $\begin{array}{l}84,982 \\
29,995\end{array}$ & $\begin{array}{l}d 416,920 \\
d 300,000\end{array}$ & $\begin{array}{l}533,658 \\
372,000\end{array}$ & $\begin{array}{l}d 120,000 \\
d 400,000\end{array}$ & $\begin{array}{l}26,400 \\
90,800\end{array}$ & $\begin{array}{r}e 4,000,000 \\
c 27,000,000\end{array}$ & $\begin{array}{r}240,000 \\
1,566,000\end{array}$ & & & $\begin{array}{r}885,040 \\
2058,795\end{array}$ \\
\hline 1876. & & $d 1,800.00$ & 37,209 & $d 435,000$ & 504,600 & d 536,000 & 112,560 & $f 26,000,000$ & $1,586,000$ & & & $2,240,369$ \\
\hline 1877. & & $g 3,750.00$ & 77,519 & d 550,000 & 660,000 & d 228,000 & 43,320 & $f 21,000,000$ & $1,155,000$ & & & 1, 935,839 \\
\hline 1878. & & g $3,000.00$ & 62,016 & d 650,000 & 747,500 & d 534,400 & 88,710 & $d 15,070,000$ & 542,520 & & & $1,440,746$ \\
\hline 1879. & & $g 4,000.00$ & 82,687 & ^ 950,000 & $1,064,000$ & d 100,000 & 18,600 & $d 8,460,000$ & 346,860 & & & $1,512,147$ \\
\hline 1880. & & $87,410.00$ & 153,178 & $d 430,965$ & 495,610 & d 50,000 & 10,700 & $\boldsymbol{d} 8,942,704$ & 447,135 & & & $1,106,623$ \\
\hline 1881. & & $g 4,317.00$ & 89,240 & d 805,193 & 909,868 & $d 45,000$ & 8,190 & $d 12,345,700$ & 592,594 & & & $1,599,892$ \\
\hline 1882. & & c $3,386.00$ & 69,995 & $c 433,134$ & 493,773 & d 50,080 & 9,565 & d $8,500,000$ & 416,500 & & & 989,833 \\
\hline 1883. & & c $3,173.00$ & 65,592 & c 439,981 & 488,379 & d 50,000 & 8,250 & $d_{16}, 250,000$ & 698,750 & & & $1,260,971$ \\
\hline 1884. & d 24,787 & $c 5,000.00$ & 103,359 & d 440, 590 & 489,059 & d 95,000 & 12,350 & $i 15,350,000$ & 567,950 & & & $1,172,718$ \\
\hline 1885. & & c $5,000.00$ & 103,359 & $c 1,350,000$ & $1,444,500$ & $d 100,000$ & 10,800 & $d 14,250,000$ & 555,750 & & & $2,114,409$ \\
\hline 1886. & & $c 5,000.00$ & 103,359 & $c 800,000$ & 792,000 & d 240,000 & 26,640 & $d 20,000,000$ & 920,000 & & & $1,841,999$ \\
\hline 1887. & & $c 4,400.00$ & 90,956 & $c 600,000$ & 588,000 & $d 500,000$ & 69,000 & $d 18,000,000$ & 810,000 & & & $1,557,956$ \\
\hline & & c $3,500.00$ & 72,351 & $c 483,000$ & 454,020 & $d 650,000$ & 109,200 & d $18,000,000$ & 792,000 & & & $1,427,571$ \\
\hline 1889. & & $c 4,705.00$ & 97,261 & c 561, 280 & 527,603 & d 250,700 & 33,845 & d $17,588,000$ & 685,932 & & & $1,344,641$ \\
\hline 1890. & & c4, 037.00 & 83,452 & c 450,990 & 473,540 & $d 175,000$ & 27,300 & $d 17,202,000$ & 774,090 & & & $1,358,382$ \\
\hline 18 & & c6, 664.00 & 135,690 & $\cdot c 750,500$ & 742,995 & d 594,618 & 76,111 & $d 26,563,000$ & $1,142,209$ & & & $2,097,005$ \\
\hline 1892. & & $c 4,644.00$ & 96,000 & c 605, 896 & 527,130 & d 497, 000 & 57,652 & $d 24,505,500$ & 980,220 & & & $1,661,002$ \\
\hline 1893. & & $c 8,000.00$ & 165,375 & c 650,000 & 507,000 & d 205,000 & 22,140 & $d 20,042,100$ & 741,558 & & & $1,436,073$ \\
\hline 1894 & & c $11,000.00$ & 227,390 & $c 650,000$ & 409,500 & $d 274,756$ & 26,102 & $d 14,250,000$ & 470,250 & & & $1,133,242$ \\
\hline 1895. & & $c 10,000.00$ & 206,718 & c 700,000 & 455,000 & d 610,708 & 65,346 & d $15,842,300$ & 506,954 & & & $1,234,018$ \\
\hline 1896 . & & $c 8,000.00$ & 165,375 & c 610,000 & 414,800 & d 500,000 & 54,000 & $d 15,542,312$ & 466,269 & & & $1,100,444$ \\
\hline & & c $7,200.00$ & 148,837 & $c 500,000$ & 300,000 & $d 1,419,010$ & 170,281 & d $11,456,782$ & 412,444 & & & $1,031,562$ \\
\hline 1898 & & с $9,000.00$ & 186,047 & $c 350,000$ & 206,500 & $\boldsymbol{d} 2,283,791$ & 283,190 & $d 5,720,000$ & 217,360 & & & 893,097 \\
\hline 1899 & & $c 8,611.00$ & 178,005 & c 201, 801 & 121, 081 & cj $4,145,028$ & 708,800 & $c 2,320,000$ & 104,400 & & & $1,112,286$ \\
\hline & $d 101,132$ & c $12,226.00$ & 252,734 & c 238,267 & 147,726 & c $6,196,660$ & $1,028,646$ & $c 4,260,000$ & 187,440 & & & $1,616,546$ \\
\hline & & $d 17,262.00$ & 356,837 & d 691,923 & 415,154 & $d 14,422,361$ & $2,408,534$ & d $2,754,779$ & 118,455 & & & $3,298,980$ \\
\hline
\end{tabular}
$a$ Average commercial prices used for each metal to make total for each calendar year.
$b$ In 1864 placers discovered and in 1865 gravel washing actively taken up. Estimated up to 1871 about $\$ 1,000,000$ in gold produced, but only known production included in table. First shipment of ore in
Utah was a carload of copper ore from Bingham in June, 1868. See U. S. Geol. Survey Prof. Paper 38, p. 83,1905 .

a Eslimated by V. C. Heikes from a separation of the total output reported by the Director of the Mint or given in the annual reviews of the Salt Lake Tribune and U. S. Geol. Survey Mineral Resources, 1882 1897. Part of the records of some early producers were used in the estimates.
$e$ Winnemuck mine largest producer of lead ores starts heavy output in 1872 .

$e$ Winnemuck mine largest producer of lead
$f$ Old Telegraph mine principal producer.

$o$ Salt Lake Tribune, Jan, 1, 1878.
$h$ U. S. Geol. Survey Sixteenth Ann. Rept., pt. 2, pp. 354-357, 1894-95.

$j$ Highland Boy mine starts with heavy output. 
Quantity of ore sold or treated in Bingham (West Mountain) district, 1865-1917, and total metals recovered-Continued.

\begin{tabular}{|c|c|c|c|c|c|c|c|c|c|c|c|c|}
\hline \multirow{2}{*}{ Year. } & \multirow{2}{*}{$\begin{array}{l}\text { Ore, short } \\
\text { tons. }\end{array}$} & \multicolumn{2}{|c|}{ Gold. } & \multicolumn{2}{|c|}{ Silver. } & \multicolumn{2}{|c|}{ Copper. } & \multicolumn{2}{|c|}{ Lead. } & \multicolumn{2}{|c|}{ Recoverable zinc. } & \multirow{2}{*}{$\begin{array}{c}\text { Total } \\
\text { value. } a \\
\end{array}$} \\
\hline & & Fine ounces. & Value. & $\begin{array}{c}\text { Fine } \\
\text { ounces. }\end{array}$ & Value. & Pounds. & Value. & Pounds. & Value. & Pounds. & Value. & \\
\hline 190 & 260,790 & $a_{26}, 580.00$ & 549,457 & $a 477,883$ & 253,278 & $a 14,759,621$ & $1,815,433$ & $a 3,896,436$ & 159,754 & & & $2,777,922$ \\
\hline & 759 & $3,192.00$ & 2,858 & a 880,129 & 475,270 & $a 17,279,804$ & & $a_{2}, 241,283$ & & & & $3,829,595$ \\
\hline 190 & 705,792 & $6,391.00$ & $1,165,685$ & $a 1,448,360$ & 829,476 & $a b 30,628,834$ & 3 , & $a 5,204,383$ & 227 , & & & $6,051,467$ \\
\hline 190 & $a 1,012,009$ & $a 63,701.00$ & $1,316,817$ & $a 1,980,583$ & $1,196,272$ & $a 39,219,734$ & $6,118,279$ & $a 23,494,879$ & $1,104,259$ & & & $9,735,627$ \\
\hline 190 & a. 996,121 & a $78,986.03$ & $1,632,786$ & $a 1,927,350$ & $1,291,325$ & $a 39,424,2$ & $7,608,885$ & $a 22,927,661$ & 1,306 , & & & $11,839,873$ \\
\hline 190 & $a 1,503,082$ & $5,730.24$ & 5,483 & $a 1,786,580$ & $1,179,143$ & $a 45,431,964$ & $9,086,393$ & $a_{21} 21,971,064$ & $1,164,466$ & & & $12,995,485$ \\
\hline & $a 2,691,640$ & a $60,382.69$ &, 221 & $a 1,053,146$ & 558,168 & $a 71,155,740$ & $9,392,558$ & $a 15,169,518$ & 637,120 & & & 11,836 , \\
\hline & $a 4,166,992$ & $3,599.47$ & 436 & $a 1,615,394$ & 840,005 & a 92,560 & $12,032,844$ & $a 30,365,819$ & & 649 & $\$ 3$ & 15,73 \\
\hline 19 & a $5,427,953$ & $a 85,526.61$ & 7, 992 & $a 1,800,410$ & 972,222 & $a 113,725,2$ & $14,443,110$ & $a 30,271,016$ & 1,331 & $3,572,347$ & 192,907 & $18,708,156$ \\
\hline 19 & $a 6,044,893$ & $a 110,38$ & 2 & $a 2,786,810$ & $1,477,009$ & a 129,995 , & 16,249 & a $46,576,337$ & 2 , & $4,715,121$ & 26 & $22,373,132$ \\
\hline & $a 6,567,948$ & $a 86,375.11$ & 1,7 & $a 2,028,496$ & $1,247,525$ & a $116,621,7$ & $19,242,596$ & $a 43,822,495$ & 1, & $2,711,982$ & 187,127 & $24,434,792$ \\
\hline 19 & $a 9,190,374$ & $a 85,856.66$ & $1,774,815$ & $a 2,408,692$ & $1,454,850$ & $a 144,920,494$ & $22,462,676$ & $a 71,001,138$ & $3,124,050$ & $3,421,724$ & 191,616 & $29,008,007$ \\
\hline & $7,800,661$ & $a_{104,07}$ & 2,1 & $2,383,0$ & $1,317,827$ & $141,924,811$ & 18,876, & $76,453,128$ & 2,981 , & $4,121,977$ & 210,221 & $25,537,240$ \\
\hline & 693, 184 & a $121,299.19$ & & $2,704,8$ & $1,371,351$ & $176,593,414$ & 30,903 & $80,004,006$ & $3,760,188$ & $5,491,359$ & 680,929 & $39,223,793$ \\
\hline 19 & $12,777,683$ & a $120,461.39$ & 2 & $3,095,335$ & $2,036,730$ & $223,619,6$ & 55,010, & $85,996,490$ & $5,933,758$ & $10,765,192$ & $1,442,536$ & $66,913,606$ \\
\hline & $14,150,394$ & $a^{a} 108,415$. & & $2,786,1$ & $2,295,7$ & $225,411,6$ & $61,537,387$ & $73,523,70$ & $6,323,039$ & $4,603,474$ & 469,554 & $72,866,895$ \\
\hline Total ${ }^{c}$. & & $1,515,018.90$ & $31,318,190$ & $48,415,824$ & $35,665,120$ & $1,658,636,866$ & $296,608,196$ & $1,058,092,538$ & $52,429,453$ & $40,052,718$ & $3,678,727$ & $419,699,686$ \\
\hline
\end{tabular}

$a$ U. S. Geol. Survey Mineral Resources, 1902-1917.
$b$ Utah Copper Co. begins production in 1904.

$\boldsymbol{c}$ These totals are for mine output and aggregate more than if smelters' and refiners' figures were used.

Metals produced in Bingham (West Mountain) district, 1865-1917, by periods.

\begin{tabular}{|c|c|c|c|c|c|c|c|c|c|c|c|c|}
\hline \multirow{2}{*}{ Period. } & \multirow{2}{*}{$\begin{array}{l}\text { Ore, short } \\
\text { tons. }\end{array}$} & \multicolumn{2}{|c|}{ Gold. } & \multicolumn{2}{|c|}{ Silver. } & \multicolumn{2}{|c|}{ Copper. } & \multicolumn{2}{|c|}{ Lead. } & \multicolumn{2}{|c|}{ Recoverable zinc. } & \multirow{2}{*}{$\begin{array}{l}\text { Total } \\
\text { value. }\end{array}$} \\
\hline & & Fine ounces. & Value. & $\begin{array}{c}\text { Fine } \\
\text { ounces. }\end{array}$ & Value. & Pounds. & Value. & Pounds. & Value. & Pounds. & Value. & \\
\hline \multirow[t]{2}{*}{$\begin{array}{l}1865-1880 . \\
1881-1890 \text {. } \\
1891-1900 \\
1901-1910 \\
1911-1917 .\end{array}$} & $66,225,137$ & $\begin{array}{r}69,028.00 \\
42,518.00 \\
85,245.00 \\
581,351.04 \\
736,876.86\end{array}$ & $\begin{array}{r}\$ 1,426,926 \\
878,924 \\
1,762,171 \\
12,017,572 \\
15,232,597\end{array}$ & $\begin{array}{r}4,940,097 \\
6,364,168 \\
5,256,464 \\
13,661,758 \\
18,193,337\end{array}$ & $\begin{array}{r}\$ 5,961,278 \\
6,660,742 \\
3,831,732 \\
8,010,313 \\
11,201,055\end{array}$ & $\begin{array}{r}2,058,900 \\
2,155,780 \\
16,726,571 \\
478,607,954 \\
1,159,087,661\end{array}$ & $\begin{array}{r}\$ 416,401 \\
315,140 \\
2,492,268 \\
69,101,973 \\
224,282,414\end{array}$ & $\begin{array}{l}124,430,704 \\
157,485,700 \\
140,501,994 \\
158,296,838 \\
477,377,302\end{array}$ & $\begin{array}{r}\$ 6,745,707 \\
6,813,566 \\
5,229,104 \\
7,450,422 \\
26,190,654\end{array}$ & $\begin{array}{r}4,221,889 \\
35,830,829\end{array}$ & $\begin{array}{r}227,982 \\
3,450,745\end{array}$ & $\begin{array}{r}\$ 14,550,312 \\
14,668,372 \\
13,315,275 \\
96,808,262 \\
280,357,465\end{array}$ \\
\hline & & $1,515,018.90$ & $31,318,190$ & $48,415,824$ & $35,665,120$ & $1,658,636,866$ & $296,608,196$ & $1,058,092,538$ & $52,429,453$ & $40,052,718$ & $3,678,727$ & $419,699,686$ \\
\hline
\end{tabular}


Platinum, palladium, bismuth, and other rare metals have been collected in the blister copper. Eilers ${ }^{1}$ gives their content in the blister copper from the Garfield smelter, which derives most of its ore and concentrates from the Bingham district, as follows:

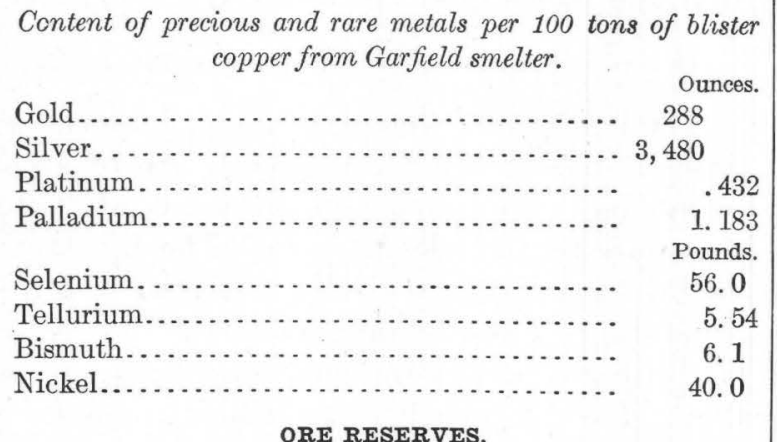

No close estimate of the total ore reserves of the district can be made. It is not the policy of the companies to block out large reserves of ore in limestone in advance of requirements, and the actual ore in sight by no means indicates the possibilities or probabilities in this class of ore.

It has not yet been demonstrated to what depth mining can be profitably carried on in this class of deposits, but it has been shown that the ores generally decrease in value with increase in depth, and in some of the deeper mines the indications are that the profitable limit under present conditions is not far distant. The size as well as the grade of the ore bodies also rather generally decreases with depth, and the probability of finding rich ore bodies at great depth is probably not great. However, considerable areas of promising ground have not yet been thoroughly prospected, and there are good reasons for expecting that important bodies of ore may be found in them. The extent of the limestones in the neighborhood of Carr Fork, including the Highland Boy, Yampa, and smaller beds or lentils, is relatively small, and the possibilities are less than in the much more extensive Jordan and Commercial limestones. Recent developments have revealed small beds of limestone, not known from surface exposures, some of which contain important ore bodies, and it is entirely possible that other beds will be found in future development. The largest and richest bodies of ores of the replacement vein type have probably been discovered, but

${ }^{1}$ Eilers, A., Am. Inst. Min. Eng. Bull. 78, p. 999, 1913. there is little doubt that this type of deposit will continue to furnish a large amount of ore for years to come.

The nature of the disseminated ores favors prospecting by churn drills and permits the development of large bodies at relatively low cost, and the extent of the operations makes this desirable and necessary. Very large bodies of this type of ore have therefore been demonstrated, and will doubtless be supplemented from territory not yet prospected. Further, the depth to which the deposits extend in workable amounts has not yet been fully demonstrated. The Utah Copper Co. at the close of 1916 reported that there had been 424,524,000 tons of ore developed and partly developed, with an average copper content of 1.415 per cent, of which $369,845,000$ remained to be mined. On March 15, 1909, the Ohio Copper Co. reported 13,484,865 tons of positive and probable ore with an average copper content of 1.606 per cent. It is evident that without further prospecting the district has sufficient ore of this type to supply the present milling capacity for years to come.

\section{PHYSIOGRAPHY.}

Topographically the district has rather strong relief, the elevations ranging from about 5,500 feet in the valley near the mouth of Bingham Canyon to about 9,200 feet at the summit of Clipper Peak. In general, the area presents the characteristics of a region in a mature stage of erosional development - that is, it has been dissected into a series of ridges and spurs with rather uniform slopes. A few areas of more resistant rocks have formed cliffs or steep slopes, and most of the minor irregularities, due to differences in the resistance of the different rock, are masked by the abundant float from the breaking down of the muchjointed quartzite that forms a large part of the rock of the district.

The slopes of the main valleys for several hundred feet above the present stream beds are much steeper than the general slopes, so that this portion of the valleys has the character of canyons and exhibits a young stage in stream development. At many points terrace deposits of stream gravels mark the line where this change of slope takes place.

At present the streams are cutting in gravels that have partly filled the lower parts of the 
canyons. Boutwell and Keith have shown that the "terrace gravels" slope more steeply to the east than do the present streams and have attributed the cutting in the lower portion of the valleys to differential uplift that tilted the range to the east. From observations over a wide area in western Utah the writer is led to believe that the cause for this renewal of down cutting was widespread rather than local and is inclined to attribute it to a general change, perhaps climatic, rather than to local changes in elevation. Certain features, however, seem to be most readily explained by differential movement, and it is recognized that this may have played a part.

\section{GEOLOGY.}

The rocks of the district include consolidated sedimentary rocks, unconsolidated sediments, intrusive rocks, and extrusive rocks. (See Pl. XXXIII, in pocket.)

\section{SEDIMENTARY ROCKS.}

The sedimentary rocks of the district are the Bingham quartzite, predominantly quartzite, with subordinate members or lentils of limestone and shaly and limy sandstones.

BINGHAM QUARTZITE.

The Bingham quartzite, which is by far the most widespread rock of the district, is a rather fine grained, usually nearly white quartzite, which shows a remarkable uniformity of character throughout its great thickness. It contains a few beds of pebbly conglomerate and locally it becomes shaly or limy, but for the most part it is composed of quartz grains cemented with silica and is everywhere almost identical in appearance. Except in the vicinity of limestone the bedding is usually obscure, owing in part to the massive character of the quartzite and in part to the presence of joints which have broken the quartzite into small blocks rarely more than a few inches in dimension. These abundant joints tend to obscure the indistinct bedding planes where the quartzite outcrops and cause it to break down readily, so that its surface is very largely mantled with a variable thickness of these angular fragments.

The thickness of the Bingham quartzite is somewhat uncertain, owing to the difficulty of recognizing duplications by faulting in a forma- tion of such uniform character. Keith has estimated the thickness in the Bingham district at 8,000 to 10,000 feet. Its age as determined by fossils in the limestones interbedded with the quartzite is upper Carboniferous (Pennsylvanian), and it has been correlated with the Weber quartzite of the Wasatch range.

LIMESTONES INTERBEDDED IN BINGHAM QUARTZITE.

The limestones, though of minor importance from a stratigraphic standpoint, are of great economic importance on account of their relations to the ore deposits. The limestone bodies are characteristically lenticular in form, thinning and thickening along both the strike and dip and even completely pinching out, so that it is frequently impossible to follow a given bed for long distances on the surface. This difficulty is increased by the abundance of float. There are many of these lenses in the quartzite. Keith says: "Almost any section where the rocks are continuously exposed for a hundred yards will show one or more layers of limestone or calcareous sandstone." Most of the contacts of limestone and quartzite are sharp, but some of them are gradual, the rocks merging through sandy layers or alternating. layers of limestone and sandstone. Along the strike the beds either gradually pinch out or pass into sandy layers and finally into normal quartzite.

Though calcareous layers are not infrequent through the formation the important Jordan and Commercial limestones occur in the lower part, and the Highland Boy, Yampa, and other limestones possibly considerably higher. It has been suggested, though not positively demonstrated, that the apparently higher beds are the same as the lower and have been forced to their present position by the intrusion of the Last Chance monzonite mass. It seems not improbable that the Highland Boy and the overlying limestones are lenses deposited at a considerably higher horizon than the Jordan and Commercial beds.

The unaltered limestones are usually composed of gray, blue, or even nearly black strata. These different colored beds are lenticular in places at least, as is especially well shown in the Yampa limestone. In following this limestone down the dip in mining operations the gray limestone has in part given place on the hanging wall to black limestone. As greater dip is 


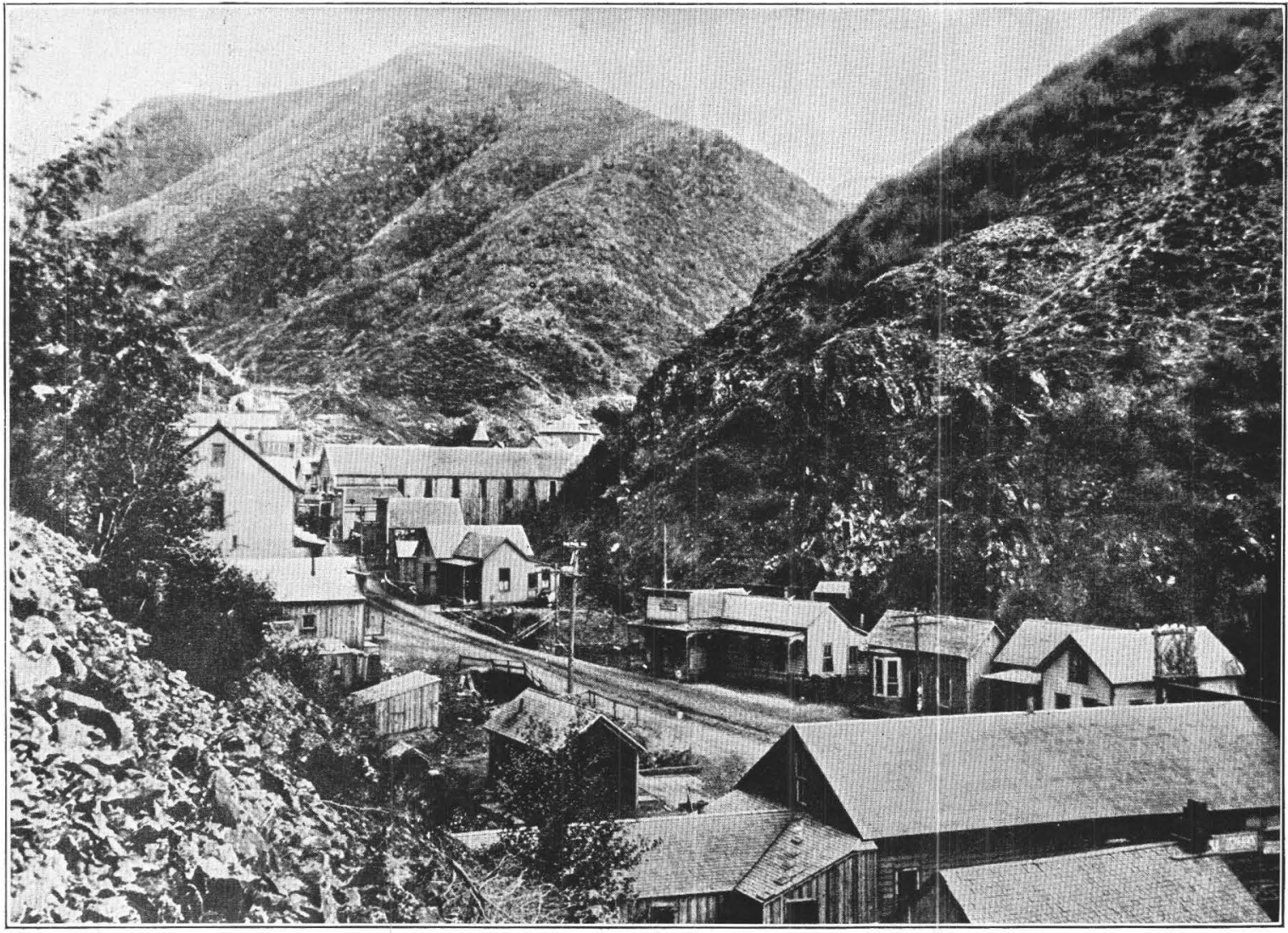

A. VIEW OF BINGHAM CANYON IN 1900, SHOWING LOCATION OF DISSEMINATED DEPOSITS.

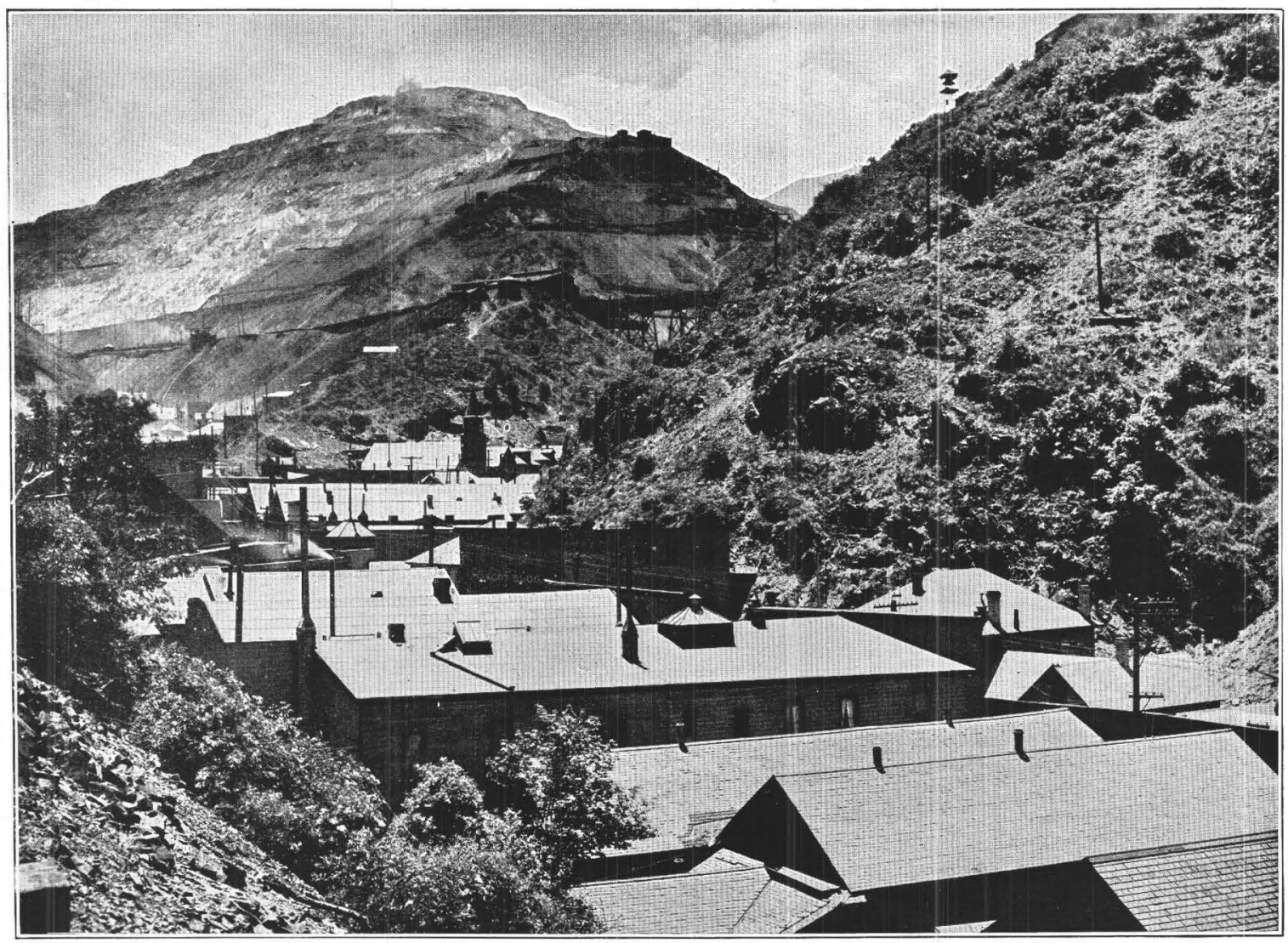

B. VIEW OF BINGHAM CANYON IN 1914 FROM SAME POINT AS SHOWN IN $A$.

Changes were produced by operations of Utah Copper Co. Photographs furnished by Utah Copper Co. 

gained the black limestone thickens and the gray limestone correspondingly thins till in places it has been almost wholly displaced.

Many of the limestone beds are siliceous, the silica being present either as sand grains or as chert. In some beds the chert appears as small nodular masses; in other beds it forms the greater part.

In the vicinity of some of the intrusive masses and in some places where the intrusives are not known to be in close proximity the limestones have been recrystallized to white marble and contain lime-iron silicates in small amounts. The "contact silicates," however, are much less abundant in this district than in several others.

The following tables ${ }^{1}$ show the composition of some of the limestones and the chemical changes resulting from their alteration:

Analyses showing changes undergone by limestone during metamorphism.

[Analyst, W. F. Hillebrand.]

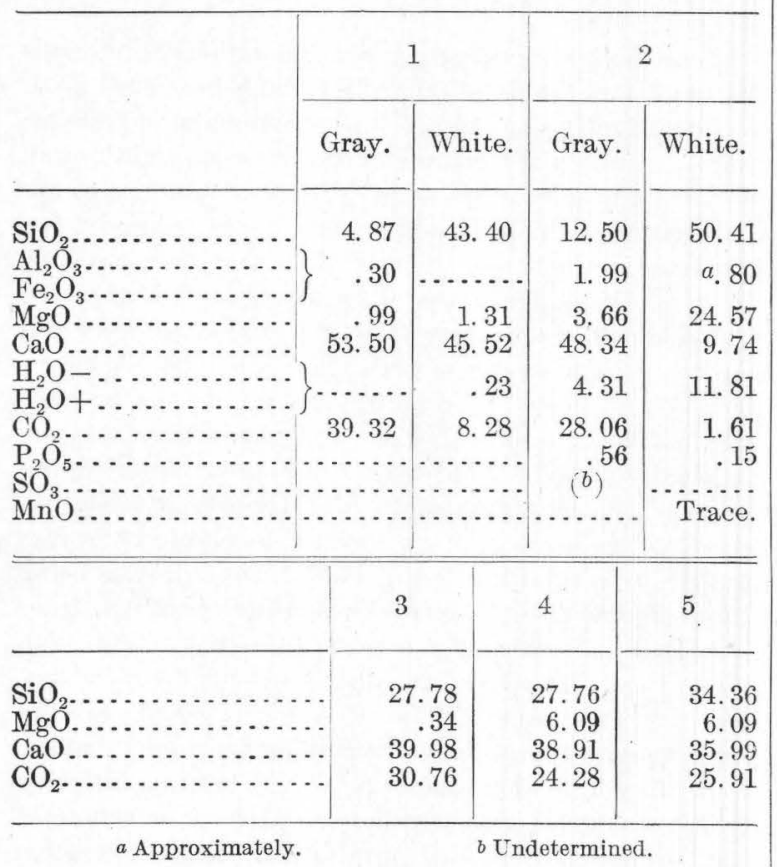

1. No. 7 tunnel, Highland Boy mine.

2. Emma West drift, Old Jordan mine.

3 . Blue limestone from south slope of West Mountain, on road to Tooele.

4. Slightly marmarized limestone from same locality.

5. Marble from same locality.

The last three analyses in the table are of specimens from the same bed showing changes that take place during alteration, No. 3 being least altered and No. 5 most altered. The first

1 U. S. Geol. Survey Prof. Paper 28, pp. 189, 191, 1905. two analyses are of material taken from opposite ends of a single specimen, the "gray" being the least altered. In all the analyses the notable change is the increase in silica and magnesia and the decrease in calcium and carbon dioxide.

Although the Bingham quartzite contains many limestone and calcareous beds, the important ones are relatively few. Keith and Boutwell have mapped and described eight limestone members and lentils-the Butterfield limestone, maximum thickness in the district about 300 feet; the Lenox limestone, maximum thickness 200 feet; the Jordan limestone and the Commercial limestone, each with an average thickness of about 200 feet; the Highland Boy limestone, maximum thickness about 400 feet; the Yampa limestone, maximum thickness about 400 feet, though in most places much less; the Tilden limestone, maximum thickness about 300 feet; and the Phoenix limestone, maximum thickness 300 feet. Numerous other limestone lentils, some of which are economically important, are present. Most of the members vary markedly in thickness along both the strike and the dip.

RECENT DEPOSITS.

The recent unconsolidated deposits consist of terrace gravels and present stream deposits. The terrace gravels are present about the base of the range and extend into the canyons as terraces on the canyon walls above the present stream. The latest deposits are those that are still being lajd down by the streams. Both the early and the present stream deposits have been worked for placer gold.

\section{INTRUSIVE ROCKS.}

DISTRIBUTION AND CHARACTER.

The intrusive rocks of the Bingham district are intimately associated with the ore deposits and are therefore of especial importance. They are of considerable areal extent and occur as irregular stocklike bodies, as dikes and sills, and possibly as laccolithic bodies. The two largest bodies in the district are the Bingham stock, which is near the head of Bingham Canyon and which contains the main body of the disseminated ore (see Pl. XXXIV), and the Last Chance stock, which is at the head of Carr Fork and which contains 
the Last Chance and other lead-silver deposits. There seems to be no good reason for considering either of these bodies as a true laccolith. The Bingham stock has been exposed by erosion to a depth of about 1,500 feet and has been drilled to a greater depth without showing any evidence that it does not extend indefinitely without marked decrease in size. The same is possibly true of the Last Chance body. Within an area of several square miles east of these main bodies are numerous smaller bodies of intrusiverock, some of which may be laccolithic in character. North, northwest, south, and southeast of the main bodies sills, intruded along the stratification planes of the sedimentary rocks, can be traced more or less continuously for long distances. In the vicinity of the main intrusive masses numerous dikes cut the sedimentary rocks.

\section{COMPOSITION.}

The intrusive rock in different localities differs considerably both in texture and in mineral and chemical composition. Moreover, in certain areas, especially in the Bingham body, it has been so altered that its original character is largely obscured. The rock is of medium composition and may be classed as monzonite, though in many places it contains sufficient quartz to warrant calling it quartz monzonite, and in others it is distinctly dioritic. In many places the gradation from one type to another can be directly traced, and there can be little doubt that all the intrusives were derived from a common magma.

The general composition of the intrusives of the district has been described by Keith ${ }^{1}$ as follows:

Two general lithologic varieties of "monzonite" are seen. The principal one is typified by the great masses between Carr Fork and Bingham Canyon and consists of a massive holocrystalline rock of medium grain and dark color. The other appears in many of the smaller dikes and sills, as at the Fortune and Zelnora mines, and consists of a coarsely porphyritic rock of gray color. The latter are directly connected with the former at the surface and in the same rock mass. Between these two extremes there are sundry facies of texture.

The monzonite is usually a dark gray, brown, or black rock, whope surfaces weather gray or rusty brown. The gray aspect is due to the feldspar, especially in the porphyritic varieties, and increases with the amount of that mineral, while the darker colors are caused by the biotite,

${ }^{1}$ Keith, Arthur, Descriptive geology of the Bingham mining district, Utah: U. S. Geol. Survey Prof. Paper 38, p. 51, 1905. hornblende, and augite. A rusty and brown appearance is often caused by the oxidation of the iron-bearing minerals, while decomposition of the feldspars in other places gives a whitish surface to the rock. The monzonite is composed principally of feldspar, with biotite, hornblende, augite, and quartz. All of these may appear in one rock, or the feldspars may occur with any combination of the others. As a rule, the orthoclase feldspars are numerous; in places, however, plagioclase feldspar prevails and the rock has a dioritic facies. Quartz is rarely seen in the hand specimen, but appears frequently in the thin section. It varies considerably in amount, and in places its quantity is sufficient to give the rock a decided resemblance to granite. In the porphyritic varieties small, corroded phenocrysts of quartz are sometimes to be seen. Usually, however, quartz is not a prominent constituent of the rock. Besides the principal constituents, feldspar, biotite, hornblende, and augite, and the minerals of the metalliferous deposits, there are few coarse minerals to be seen in the monzonite. Magnetite, pyrite, and chalcopyrite are found in small grains and are widely distributed through the rock. One or more of them is found in every thin section. Epidote appears here and there, but very sparingly. A little secondary calcite, chlorite, and muscovite are also found. The composition of the rock is simple, and practically all of the minerals are visible to the eye in one place or another.

In the monzonite porphyry two generations of minerals are found-(1) the porphyritic, in crystals from one-eighth to one-half inch long, and (2) the groundmass, of granular nature, in which the crystals range from one-eighth of an inch down to microscopic size. Feldspar and biotite are the minerals which usually compose the phenocrysts. Pyroxene is much less common than the other minerals either in the phenocrysts or in the groundmass. One section shows phenocrysts of quartz, which are very uncommon. Phenocrysts of orthoclase are conspicuous in the porphyry north of the Fortune mine. In the groundmass, however, both orthoclase and plagioclase feldspars are usually present. Porphyritic biotite characterizes the bodies of the formation south of Telegraph and Niagara mines. This variety of the monzonite porphyry is also marked by a very fine grain, most of the minerals being of microscopic size. This rock when fresh is of light-gray color, and underground it is very difficult to distinguish it from the quartzite and the cherty marble. On the surface, also, the same difficulty is encountered, for the porphyry weathers in fine, structureless fragments that are remarkably like the limestone and quartzite. It very closely resembles the weathered siliceous marble and quartzite, and only by the more or less bleached crystals of biotite can the porphyry be distinguished from the other rocks.

The fine-grained monzonite is not confined to the two localities above mentioned but is often to be seen near the contact of the monzonite with the other formations, in the smaller intrusive bodies, and even in the large masses. The smaller portions are not always characterized by this fine grain, however, but frequently are composed of monzonite porphyry of coarser grain than that seen in some of the largest masses. The great body of monzonite surrounding the Last Chance mine, for instance, contains no rock so coarse as that which is found in the nar- 
row sill that passes through the Fortune mine or as that which appears in one or two of the narrow dikes at the head of Carr Fork and Tooele Canyon. In a general way, however, it seems clear that the formation is coarser in the eastern bodies.

METAMORPHISM.

Character.-That the rock of the Bingham stock has been highly altered has not been universally recognized. Some men, who are thoroughly familiar with the rock, which constitutes the disseminated ore, maintain that it shows no important alteration except that due to surface waters or to weathering and that the primary ore and gangue minerals are original crystallizations from the magma. This belief has also found expression in the literature of the district, ${ }^{1}$ although it was advanced before the extent of the disseminated ores had been fully recognized.

This hypothesis is by no means without foundation and may appear very natural on superficial examination. Microscopic and chemical study and field evidence seem to the writer, however, fully to justify Boutwell's conclusion $^{2}$ that the rock has suffered extensive hydrothermal alteration, and that to this the primary mineralization is due.

The entire Bingham stock seems to have been affected by the alteration, and it is therefore impossible positively to determine its original character. Study of the less altered portions and of the field relations indicates that the original rock did not differ materially from that of the Last Chance and other bodies in the area. The main differences are probably due to secondary alteration.

The freshest rock of the Last Chance body is composed of orthoclase, plagioclase, augite, and biotite, rather abundant magnetite, or some magnetic iron mineral, small amounts of apatite and rutile, and a few crystals of zircon. The plagioclase feldspars vary in composition, but are all acidic, none being observed more basic than andesine. Many crystals of twinned plagioclase are surrounded by a graphic intergrowth of two untwinned feldspars with different indexes, both lower than that of the central crystal. Such intergrowths are also present without the central core of plagioclase. Other crystals of untwinned feldspar are composed

1 Keith, Arthur, op. cit., p. 64.

2 Boutwell, J. M., Economic geology of the Bingham mining district, Utah: U. S. Geol. Survey Prof. Paper 38, p. 172, 1905. entirely of orthoclase. Many augite crystals have been partly altered to a light-green, slightly pleochroic amphibole and, where alteration has progressed slightly farther, partly to chlorite.

The orthoclase is slightly clouded with an undetermined mineral, which possibly marks the beginning of sericitization. Where alteration is more intense the plagioclase contains a little epidote and in some specimens a little biotite. Biotite usually shows little alteration, but in some specimens a little epidote has developed along cleavages and in many others a little carbonate.

In the Bingham stock two distinct types of rock or ore are probably due to differences in the intensity rather than in the character of the alteration. These are recognized in the ore as the dark "porphyry" and the light "porphyry" and may well be described under these heads, though every gradation between these types may be found.

Dark "porphyry."-The typical dark "porphyry" is a dark brownish gray mottled rock. The dark minerals are grouped in irregular areas that give much of the rock a porphyritic appearance. Biotite, feldspar, and sulphides are the only minerals that can be readily recognized in the hand specimen. In the extreme type this rock has a rather uniform dark-brown color, which is due to the abundance of biotite and especially to its presence on fractures along which the rock breaks. The microscope shows that the biotite is the only original mineral that has not undergone marked alteration and that in some specimens even the biotite has been altered. The pyroxene and hornblende of the original rock have with few exceptions been entirely altered, the areas occupied by these minerals being occupied by irregular masses of small biotite foils. (See Pl. XVI, A, p. 165.) Some of the phenocrysts of original biotite have been attacked and the biotite redeposited as small foils. The plagioclase crystals are represented by areas of sericite and quartz and in some specimens by biotite. The orthoclase crystals show relatively slight alteration, but nearly all of them contain some sericite and some of them biotite, and in more advanced stages of alteration they are partly replaced by secondary orthoclase in small crystals. Magnetite, which is rather abundant in the fresh rock, is absent in 
extensively altered rock. In much of the altered rock small irregular crystals of rutile are rather abundant. The secondary biotite, which is the characteristic mineral of the dark "porphyry," differs from the original biotite in being in small foils and in being distinctly lighter in color, ranging from an olive-green with pleochroism in varying intensity to light brown with pleochroism much less pronounced than that of the original mica.

Where alteration has been relatively intense the original biotite phenocrysts have been entirely altered, and the secondary mica, instead of occupying approximately the area of the mineral from which it was formed, is disseminated rather uniformly through the mass. Granular quartz and clear unaltered orthoclase, evidently both secondary, occur in places. Sulphides are disseminated irregularly through the rock.

Light "porphyry."-The light "porphyry" is a light-gray rock in which phenocrysts of feldspar and grains of sulphide can be recognized in the hand specimen. Under the microscope it is seen to be composed of phenocrysts of feldspar and some crystals of altered biotite in a fine granular groundmass. (See Pl. XVI, $B$, p. 165.) The original phenocrysts of feldspar are orthoclase, and all of them contain numerous ioils of sericite, which in many is very abundant. Other areas are composed of a felted mass of sericite that may represent altered plagioclase crystals. The few mica phenocrysts are largely bleached to a colorless mica but contain small lenses of brown mica showing their derivation from biotite. The groundmass which forms a large percentage of the rock is composed of a fine granular intergrowth of clear orthoclase and quartz with some foils of sericite. In many specimens this granular groundmass embays the orthoclase crystals and extends along fractures and cleavages; there can be no doubt that the orthoclase phenocrysts are being altered to material of the character of the groundmass, and it is but natural to conclude that the feldspar of the groundmass represents in part an alteration of the earlier feldspar of the rock.

The rock is cut by small veinlets composed of quartz or quartz and orthoclase and grains of sulphide. The larger veinlets, which are very abundant in many places, are composed of quartz, so far as observed, but many of the small veinlets contain much orthoclase. There is no known difference in the age or occurrence of these veins, and there is doubtless every gradation from one to the other.

The original sulphides-pyrite and chalcopyrite with some bornite-are disseminated through the rock and are present in the veins where they have usually been the latest minerals to form, filling the spaces between quartz crystals.

Molybdenite in small flakes is disseminated through the rock in many places, and in a few it is rather abundant in veinlets, where it crystallized in part earlier than the quartz. A light-colored type of "porphyry" containing numerous crystals of a yellow micaceous mineral is seen under the microscope to be highly sericitized. The yellow crystals are biotite that has been bleached to a nearly colorless mica, probably muscovite filled with yellow grains of rutile. Though some of the fresh mica contains inclusions of rutile, none of them were observed to contain them so abundantly as the altered grains, and it is probable that the rutile has resulted in part at least from the alteration of the mica or of included ilmenite. These micaceous flakes were noted especially in the so-called "Pay Roll" porphyry and are said to be rather typical of this part of the altered area. They are less abundant, however, in specimens from other locations. The typical changes that have taken place in the mineral composition of the monzonite during alteration are the almost or complete alteration of augite, hornblende, plagioclase, and magnetite, and the partial alteration of the orthoclase and biotite to sericite, secondary biotite, quartz, and secondary orthoclase. In the dark porphyry the secondary biotite is abundant and the secondary orthoclase has been little developed. In the light porphyry biotite is of slight importance and secondary orthoclase and quartz make up a large part of the rock.

Alteration near lead-silver veins.-The alteration of the rock adjacent to the lead-silver fissures is in a general way similar to that of the Bingham stock, though it extends but a short distance from the fissure. In the incipient stages of alteration epidote and calcite are relatively abundant and the more intensely altered rock immediately adjacent to the 
fissures is composed of felted areas of sericite, probably representing feldspar phenocrysts, partly sericitized untwinned feldspar of the original groundmass and a secondary groundmass composed of a granular intergrowth of orthoclase and quartz.

Much of the sericitic mineral is light brown and has a rather faint pleochroism, indicating that it is not pure muscovite. Rutile is rather abundant. The rock is cut by small veinlets composed of quartz and orthoclase, many of which seem to merge into the secondary groundmass. In the veinlets the orthoclase completed its crystallization later than the quartz and is commonly interstitial. The opposite, however, is true in much of the groundmass, the quartz crystals including well-formed crystals of orthoclase. The older generation of feldspars are being attacked and worked over into a granular mass similar to that of the groundmass. This rock in advanced stages of alteration is similar in silicate mineral composition to the light "porphyry" copper ore.

The chemical and mineralogic changes due to alteration are further discussed on page 164.

\section{EXTRUSIVE ROCKS.}

The extrusive rocks of the Bingham district occur only along the desert valley bordering the Oquirrh Range and are not known to be of economic importance. Keith ${ }^{1}$ has described the formation as follows:

Most of the formation consists of massive or porphyritic andesites. Large masses of the breccia are seen, however, in the exposures near the Oquirrh Mountains. The rock of the andesite group seems to have been deposited as an overflow upon an existing surface. Its contact with the Carboniferous rocks is almost invariably covered with loose quartzite wash, so that its exact nature has not been determined. At certain points, for instance, near Dalton and Lark mine, it appears to cut across the edges of the quartzite like a dike. Half a mile farther north a similar but less definite arrangement is seen. Usually, however, the andesitic rocks occupy l'ow ground around and between the quartzites, as if deposited in previously formed hollows. Possibly the mass at the Dalton and Lark mine occupies one of the vents through which came the bulk of the formation. It is equally possible that the visible arrangement is due to subsequent faulting.

The andesites are usually fine or medium grained rocks of dark color. Exposure and disintegration produce a light or dark gray color through the alteration of the feldspars. In most places the rock has a porphyritic habit. While this is seldom conspicuous, occasionally

1 Keith, Arthur, op. cit., p. 55. $35416^{\circ}-19-23$ the phenocrysts are coarse and large, as, for instance; one-half mile northeast and east of Fortune mine.

The principal minerals of the andesite are plagioclase feldspar, green hornblende, augite, and biotite. Besides these there are small amounts of quartz, orthoclase, magnetite, pyrite, and chlorite. Of these minerals the plagioclase, hornblende, and augite appear as phenocrysts. The feldspar usually forms stubby crystals. In one instance the crystals are slim, with a somewhat ophitic structure. The hornblende and augite form irregular and patchy crystals. The same minerals appear in the groundmass in very fine grains and crystals. Chemical examination indicates an approach to latite in composition.

Portions of the formation consist of andesite fragments, less than a foot in diameter, embedded in a matrix of andesite. The fragments are of about the same composition as the matrix and probably result from the partial solidification and breaking up of the lava as it flowed. In this respect they differ little from some of the monzonite contact breccias, but are quite unlike other breccias shown in the mountains, where the monzonite was crushed by faulting movements that took place long after its intrusion.

In the vicinity of Lead mine one of these breccias rests upon a surface of decayed andesite and soil. From this it is evident that one brecciated flow followed an interval of exposure to erosion. The lapse of time shown thereby was probably not great. * * * Apparently they conform nearly to the present surface and have not been greatly eroded since their formation. Thus is furnished a probability of their recent origin.

\section{RELATIONS AND AGE OF THE IGNEOUS ROCKS.}

The intrusive and extrusive rocks have nowhere been found in contact in a manner that furnishes conclusive evidence as to their relative ages. The extrusive rocks lie against the range in a manner which suggests that they flowed against it after it had been eroded to approximately its present form. If this be true they are distinctly later than the intrusive rocks. In the Tintic district in the southern extension of the Oquirrh Range it has been shown that intrusive and extrusive rocks of essentially the same character as those at Bingham are contemporaneous in age and the same may hold true at Bingham. The writer knows of no positive evidence to show that the intrusive are older than the extrusive rocks.

Owing to the absence of sedimentary rocks later than the Carboniferous (except the recent sediments) it is not possible to determine directly the age of the igneous rocks except that they are post-Carboniferous. The marked similarity of the lavas to those in other sections. of the State, however, leads to the belief that they are of essentially the same age. If this 
correlation is correct they are of Tertiary age. (See p. 99.)

\section{STRUCTURE.}

Both folds and faults are important structural features of the Bingham district. Joints and fissures are economically important, and joints are important in determining the rapidity with which the formations were eroded.

\section{FOLDS.}

The folding in the district has been described by Keith ${ }^{1}$ as follows:

The folds exhibited are of two kinds, broad open flexures whose dips persist for miles, and small rolls, whose dimensions are measured by a few hundred feet. Of the former class only one appears within the Bingham district-a synclinal fold whose axis passes in a northwest direction just below the mouth of Carr Fork. On the southwest side of the axis the rocks dip toward the north and on the northeast side they dip toward the west. Thus, they constitute a fold which pitches toward the northwest and brings to the surface successively younger beds in that direction. On account of this pitch the oldest Carboniferous strata of the district, which appear in Butterfield Canyon, are not exhibited in any other part of the district but are overlain elsewhere by the younger quartzites and limestones in the order of their deposition. Thus, the youngest rocks shown within the area of the map are those appearing north and northeast of Markham Peak. The syncline which passes near Carr Fork might well be called the Bingham syncline. The anticline corresponding to it is seen in the upper part of Butterfield Canyon. * * * This has the same northwestward pitch, so that the formations on its west side dip approximately westward and parallel the line of the Oquirrh Mountains from Butterfield Canyon southward. Similar large folds characterize the Oquirrh Mountains throughout their extent, and their axes have approximately the same northwestern trend and pitch. These folds were produced during the first known deformation of the region, by compression in a northeastsouthwest direction. By them the uplift of the region was initiated and to them is due the greater part of the actual uplift.

The folds of the second order, which are recognized in the different mines under the term "rolls," are not so clearly of this origin. They seldom affect the outcrop of the formations but have been observed in several mines in working out the ore bodies and the contacts of limestone and quartzite. They are local warpings in a general plane of dip rather than well-defined folds with dips in opposite directions. The dips, which are reversed or contrary to the prevailing dip in the locality, are usually very slight and hardly more than flat. In the Niagara mine a roll has been worked out along an ore body. The average dip in the locality is $30^{\circ} \mathrm{N}$., but for a width of a few feet north and south of the roll this is replaced by a slight, nearly flat dip to the south.

These minor folds appear to be somewhat complicated by faults and are associated with them. It is possible

1 Keith, Arthur, op. cit., p. 56. that they are in part due to dislocation along fault planes. As the different blocks of the earth's crust moved past one another they were undoubtedly more or less dragged, one upon the other. Unless the faults were absolutely parallel in plane, when motion took place there would be a certain amount of wedging together and compression of some of the fault blocks. This might readily have caused local folds of this order. That such is the case, however, can not be definitely stated.

A minor fold or "roll" in the workings of the Old Jordan mine is ascribed by Boutwell ${ }^{2}$ to strike faulting. In places "rolls" are undoubtedly accompanied by strike faulting, but in other places they seem to be simply a local "buckling" of the beds, which in one direction may pass into strike faulting and in the others into the normal dip of the beds. Many of these minor folds are of prime economic importance.

\section{FAULTS AND FISSURES.}

Surficial evidences.-Fissures and faults are abundant in all parts of the Bingham district. Many of the fissures show no mineralization and are therefore not conspicuous, and many of those along which there has been movement are hardly more evident, owing to the uniformity of formations over considerable areas. These facts, together with the abundance of float in the district, make it exceedingly difficult, and in many places impossible, to locate and trace on the surface even the stronger fissures. In the underground workings, however, they are apparent.

Character.-The character of the fractures in the Bingham district differs considerably. Boutwell ${ }^{3}$ says:

The fractures of Bingham vary widely in general character. They range from a network of irregular cracks and zones of intense crushing to simple individual fissures and zones of fissures. The type which most commonly bears ore is a simple fissure characterized by a zone of finely comminuted gouge, averaging 1 to 4 feet in width and inclosed between slickensided walls. When such fissures carry ore, as along portions of the Galena, Silver Shield, Winamuck, Last Chance, and Montezuma fissures, they constitute normal veins. Groups or zones of fissures of this type are occasionally encountered. When they are ore-bearing, as in an instance on the Last Chance mine, British tunnel level, they constitute lodes. This characteristic lode consists of a zone of crushed, altered, slightly mineralized monzonite, 8 to 10 feet wide, lying between slickensided walls of the same rock and traversed by two strong veins and a number of minor seams. There are many gradations from these two most important types. One of these which directly influenced the forma- 
tion of some of the principal ore bodies in Bingham consists of an indefinite series of parallel fracture planes or fissures, each of which, unlike those which grouped in a crushed zone form a lode, preserve its individual character, and cuts the country in a direction roughly parallel to the strike and dip at an angle steeper than that of the bedding. A typical example of this class of fissures is in the Highland Boy mine.

Another type of fracturing is exhibited by a complex network of fracture planes, which occurs throughout the monzonite mass in Copper Center Gulch. So completely has this rock been thus broken up that one is practically unable to obtain a hand specimen a few inches in width which does not show these planes. This character of regional crushing is seen in quartzite along the roadside in Markham Gulch below the Ben Butler and in black shale in the Red Wing mine. Again, single fissures formed by movement along contacts or between sedimentary beds are common and frequently carry ore. In the Fortune ore was deposited along a plane of movement between a massive quartzite and an overlying porphyry sill. In the Montezuma the ore bodies formed for a portion of their extent along a plane of movement between two beds of black shale.

Distribution.-The general distribution of the fissures is given by Boutwell ${ }^{1}$ as follows:

Fissuring took place in all parts of this district and appears to have reached a maximum in the region about the head of Bingham Canyon, Muddy Fork, and upper Carr Fork. The intense fissuring and faulting which characterize this region extend north through ground opened by the Last Chance, Nast, Boston Consolidated, Highland Boy, York, and Petro mines; south through Ashland, Albion, and Neptune ground; and east through Old Jordan, Commercial, Niagara, and Telegraph ground. The crushing, fracturing, and fissuring which have occurred in this general region are beyond detailed description. Only a comparatively small portion of the several hundred fissures observed underground are recognizable at the surface. * * *

Strong fissures are not limited in their occurrence, however, to this particular area. Among the large number which have been found north of this locality are the Midland, Winamuck, and Dixon fissures in Main Bingham Gulch; the Julia Dean, Amazon, Liberal, Montezuma, Hoogley, and Rosa fissures in Markham Gulch; the U-and-I fissure in Dixon Gulch, and the Phoenix, Caromandel, and Cuba in lower Carr Fork. Types of strong fissures to the south of the central locality may be seen in the St. James, Eagle Bird, and Queen fissures. In brief, strong fissuring has taken place throughout the Bingham district.

Trend and dip.—* * * In general it appears that the fissures noted in which no metallic contents were observed trend toward all points of the compass in about equal num bers. If any distinct group of fissures is indicated by these trends it would appear that the greater number trend north-northwest, north, or north-northeast-that is, between N. $25^{\circ}$ E. and N. $20^{\circ}$ W. The observed fissures which inclose some metal, but insufficient to pay for mining, trend with a few known exceptions northeast-

1 Idem, p. 136. southwest. And far the greater portion of these lie between N. $5^{\circ}$ and $43^{\circ}$ E. Finally, over 84 per cent of the observed fissures known to carry pay ore trend northeastsouthwest, ranging between N. $5^{\circ}$ and $43^{\circ}$ E. Among them are included the Montezuma, Erie, Dixon, St. James, Colorado, Neptune, Spiritualist, Last Chance, Silver Shield, U-and-I, Tiewaukee, Ferguson, and Nast lodes. Those mentioned from the Colorado to the Nast, inclusive, trend between N. $39^{\circ}$ and $46^{\circ} \mathrm{E}$. Among the very small number of exceptions to the prevailing northeast trend of pay lodes are the Phoenix, Dayiight-Extension, Winamuck, Hoogley, and Midland. In brief, of the cases observed, the barren fissures display no distinct trend, the poorly mineralized fissures and the pay lodes with very few exceptions trend northeast-southwest.

The measurements of dips indicate that of those observed far the greater portion of the barren fissures dip toward the northwest, that a little more than 80 per cent of the poorly mineralized fissures dip toward the northwest, and that over 85 per cent of the pay lodes dip toward the northwest. Very few gently dipping slips or fissures were found. Over 90 per cent of the pay lodes observed dip between $45^{\circ}$ and $90^{\circ}$. In brief, the prevailing dip of both barren and mineralized fissures observed is toward the northwest, and the prevailing degrees of dip noted are from $45^{\circ}$ to $90^{\circ}$.

Age.-The relative dates of fissuring are discussed by Boutwell ${ }^{2}$ as follows:

* * * Although the evidence is not complete nor without apparent slight contradictions, it clearly indicates that fissuring occurred at distinct periods before and after the deposition of ore. ***

The facts indicate that the principal fissuring occurred after intrusion; that extensive fissuring in northeastsouthwest (and north-south) directions preceded the deposition of the principal lead and silver ores; that some fissuring probably occurred on east-west (northwest-southeast) planes before the deposition of the copper ores; that faulting along northwest-southeast and east-west planes followed the deposition of the main copper ores, and that pronounced movement on northeast-southwest (and northsouth) planes followed both the northwest southeast faulting and the deposition of lead and silver and copper ores. In brief, fissuring occurred successively in northeastsouthwest (east-west), northwest-southeast, and northeastsouthwest directions in at least three distinct periods.

Most of the fissuring evidently occurred after the intrusion of the monzonite, and the mineral-bearing fissures were probably formed very shortly after the instrusion. How much later the subsequent fissures were formed is uncertain.

Displacement.-The displacements have been discussed by Boutwell, ${ }^{3}$ as follows:

* * * They include faults trending with the strike of the sediments and trending with and oblique to the dip; faults trending transverse to the strike and dipping in either direction; faults whose probable inclination departs 
only slightly from the horizontal; faults trending with the strike and others trending with the dip in which differential movement of a torsional character occurred. There appears to have been no single direction of movement. Neither does any regular relation seem to exist between trend of fault and direction of displacement, nor between dip of fault and direction of displacement. It appears that displacement may be expected in any direction; that there is no constant relation between the direction of displacement and the dip or strike of a fault plane and that the amount of displacement proved underground rarely exceeds 150 feet and, except on innumerable minor faults, averages between 50 and 100 feet.

It is probable that important faults within this area have not yet been encountered underground. It is believed that in one or two instances these may include types not yet proved in Bingham, but evidence concerning them is difficult to obtain. Outside of this district, both to the north and south, considerable faulting probably occurred, and future stratigraphic study in connection with the general structure of the Oquirrh Range will probably reveal important and perhaps great faults.

Extensive developments made since the district was studied by Boutwell have revealed numerous faults and fissures that were then unknown and have led to some modifications of views concerning certain structures that were then only partly revealed; nevertheless, Boutwell's conclusions hold generally true for the more recently developed areas as well as for those that were accessible at the time of study.

\section{ORE DEPOSITS}

The ore deposits of Bingham, as of most districts of the State, are of several types, classified by Boutwell as veins (including lodes), bed deposits, and disseminated deposits. Many deposits can be readily assigned to one type; others present characteristics of two types and their proper assignment may be difficult.

\section{VEINS AND LODES.}

Fissuring occurred at several periods; and the strong northeast-southwest fissures were the more important ore bearers, though some few fissures with other strikes were also ore bearing. (See p. 355.) These fissures cut all formations, and many of them show different characteristics in different types of rock. ${ }^{1}$ Some fractures have produced zones of intensely crushed material in quartzite, irregular, anastomosing fissures in limestone, cleanly cut master fissures in igneous rocks, and may die out entirely in shaly material. The chemical com-

1 Boutwell, J. M., Economic geology of the Bingham mining district: U. S. Geol. Survey Prof. Paper 38, p. 126, 1905. position of the different types of rock has also variably affected deposition by the ore-bearing solutions, and the character and size of the ore deposits have been governed accordingly.

The fissures in the intrusive rocks being relatively strong and clear cut and the wall rock relatively inert to the action of the solutions, the deposits are largely confined to the fissure filling. The more readily shattered quartzite has produced less definite fissures and consequently less well-defined ore bodies. The combined effect of a series of fissures rather than a clean break and a readily replaced rock have resulted in the strongest areas of mineralization in the limestone. Boutwell ${ }^{2}$ says:

Ore makes lean in siliceous rocks, more plentifully in porphyry, and largest and richest in limestone. In that portion of the galena fissure which lies in quartzite under the Jordan limestone lead and silver ore occur in relatively thin, small, tabular bodies, but in those portions of the same fissure which lie in calcareous rocks, ore occurs in relatively wider and thicker bodies, as in the Highland Boy limestone in a small way and in the Jordan limestone on a grand scale.

Veins in monzonite were found in the Last Chance, Nest, and in part of the Silver Shield where the wall rocks have been altered for a comparatively short distance and the ore is largety confined to the fissure. The alteration of the wall rock consists of a replacement of the original minerals by sericite, quartz, and secondary orthoclase. The ores are typically lead-silver but contain also gold, copper, and zinc.

Most of the silver-lead veins in the quartzite have proved less productive than those in the monzonite. Examples of such veins are to be found in the mines in Markham Gulch, the Silver Shield, and others. The copper veins in quartzite (like those of the Ohio Copper mine) might be placed with the fissure deposits, but as they are closely related to the disseminated deposits they may well be treated with these deposits.

Veins in limestone commonly enlarge along certain beddings and show a close relation to the bed deposits in limestones and may well be discussed with them.

Much of the ore in the fissures occurs in more or less clearly defined pod-shaped shoots which change in thickness from point to point both on the dip and strike. 
BED DEPOSITS.

The bed deposits are confined to the limestone, the ore bodies forming as a replacement of the limestone and at many places preserving the structure to a marked degree. The orebearing fissures cut the limestone members, and at the intersection of beds especially susceptible to replacement the ore makes out laterally for considerable distances, forming bed deposits. The fissures themselves may or may not contain valuable ore deposits. In the more massive limestones some of the large ore bodies are associated with faults that have broken the limestone and have thus rendered it especially susceptible to replacement.

Generally, the large bodies of copper ore have formed along the bedding, as in the Highland Boy and Old Jordan mines, and the largest bodies of lead-silver ore occur both as replacement along the fissures and as bed deposits along certain beds in the limestone. Such bed deposits are present in the Yampa, Jordan, Commercial, and other limestones of the district.

Some of the important copper deposits of this character contain little lead, but the lead deposits contain copper, and some of them grade from ore in which lead and silver are the important metals to ore in which copper predominates.

The primary ore minerals in the copper deposits are pyrite, chalcopyrite, pyrrhotite, and minor amounts of arsenopyrite, bornite, and tetrahedrite. Specularite is locally abundant, as in portions of the Highland Boy mine. This specularite is in part rather strongly magnetic and doubtless contains some magnetite. The gangue minerals are quartz, residual carbonates, small amounts of garnet, and possibly other silicates.

The primary ore minerals of the lead-silver deposits are galena, pyrite, and minor sphalerite, chalcopyrite, and tetrahedrite in a gangue of residual carbonate and quartz.

Locally sericite is an important gangue mineral, especially in the deposits in the Bingham-New Haven mine, where it occurs as a soft talclike mineral with a greasy feel and silky luster.

DISSEMINATED DEPOSITS.

The disseminated deposits of the district are confined to the Bingham Canyon stock and to the immediately adjacent quartzite. The in- trusive body is mineralized throughout its extent-much of it sufficiently so to be ore. In places the quartzite is similarly mineralized for a short distance, and along fissured zones for a considerable distance, from the contact. This intrusive body and the quartzite have been cut by innumerable fissures that vary greatly in strike and dip and that cut the entire mass into small irregular blocks. So great has been this shattering that in many places it is difficult to break out a hand specimen that is not bounded by these fractures. The ore solutions passing along these fractures have altered the rock so that its original character can not usually be recognized. (See p. 351.) In the less-altered portions the mineralized rock consists largely of biotite resulting from the alteration of the dark minerals; sericite and quartz replacing the altered feldspars; and a granular groundmass of secondary quartz and orthoclase cut by veins of quartz and orthoclase. Scattered through both the veins and altered rock are grains of pyrite, chalcopyrite, and small amounts of molybdenite. A very little magnetic material, obtained from concentrates from the dark ore, appeared to be magnetite rather than pyrrhotite and possibly represents unaltered portions of the original magnetite.

The more highly altered rock is light colored and consists mainly of sericitized feldspar in a granular groundmass of secondary quartz and orthoclase, which in many places forms 50 to 75 per cent of the rock. Veins of quartz and orthoclase are also abundant, most of the larger ones being wholly of quartz, but many of the small ones containing considerable orthoclase. Grains of sulphide are disseminated through this as through the dark ore.

Under the microscope it is seen that there is every gradation between these types of ore, the lighter-colored material having been more highly altered. In the open pit both these types of ore are well exposed and are roughly separated by a prominent fault that cuts the ore body. The light-colored ore lies northwest of the fault on the hanging-wall side, and the dark ore southeast of it on the footwall side, though it is also present above the fault. At this locality the light-colored ore contains the most metal. In other parts of the ore body, however, both in the East Side workings and in the Boston Consolidated workings the 
dark ore is said to be of equally good grade. In addition to the small quartz veins the ore body contains large bodies of rather fine grained vein quartz. As seen in the mine, this material rather closely resembles the mineralized quartzite, but under the microscope it appears as typical vein quartz and shows no evidence of clastic origin. The quartz grains contain many cavities filled with gas and liquid and commonly contain a small cube resembling salt and frequently a reddish mineral that is probably hematite. The size of these bodies strongly suggests that they are in part a complete replacement of monzonite rather than a filling of open spaces. Sulphides are disseminated through this vein quartz. Locally the monzonite contains light-green chloritic material containing abundant iron sulphide. Under the microscope this is seen to be composed of a green, slightly pleochroic hornblende and of chlorite, which in part at least results from the alteration of the hornblende. This appears to be an altered and mineralized basic rock, possibly a dike rock. If so, it must originally have been composed largely of hornblende, for no feldspar or secondary mineral from feldspar was noted in the specimen examined.

In addition to the fissuring which has affected the rocks containing the ore body over a large area more pronounced movements have occurred along definite lines and are shown in faults that are well exposed in the pit and on the stripped levels above the pit. Fissures showing more pronounced movement are also present in other parts of the mineralized area. In many places where these movements occurred in the monzonite they caused the formation of rather heavy gouge. In the quartzite the result was an area of crushed rock. As some of the gouge contained only sparse amounts of sulphide, and some of the original dark silicates are still preserved, it is evident that at least some of the movement occurred previous to the main period of mineralization and that the gouge prevented the free circulation of the ore-bearing solutions. In other places, however, gouges contain sulphides and were probably formed after the main mineralization. In the quartzite and in the monzonite, where the movement did not produce strong gouges, the zones of movement were favorable to the movement of ore solutions, and in many places the mineralization is greatest adjacent to them.

A few "veins" in the disseminated ores contain galena and sphalerite and some copper and iron sulphides. The fissures containing these have cut the ore and this mineralization is evidently later than the main copper mineralization.

The entire monzonite mass of Bingham Canyon and some of the adjacent quartzite has been mineralized. To what extent ore has been formed has not yet been fully demonstrated. The map (Pl. XXXV) shows the mineralized area as determined by development of the Utah Copper Co. to the close of 1916. At that time ore had been fully or partly developed over 226.3 acres. (See also Pl. XXXVI, p. 360.)

The depth to which ore extends is also as yet undetermined, though it has been shown that the tenor decreases with depth. At the close of 1916 the average thickness of the developed ore body was 524 feet. In the quartzite the Ohio Copper Co. has developed its ore body to the 500 -foot level.

ALTERATION OF THE ORES.

Alteration of the deposits by surface solutions has been an important factor in producing the present condition of the ores, affecting both their character and their grade. It caused a material change in the metal content of the copper and gold ores, and it rendered large bodies of the lead-silver ores near the surface susceptible to the only metallurgic treatment practicable in early days.

COPPER ORES.

The copper ores of the district fall into two general types-replacement deposits in limestone and disseminated deposits in monzonite and quartzite-in both of which secondary alteration has been important.

\section{Replacement deposits.-Boutwell ${ }^{1}$ says:}

The facts observed at Bingham show in general that carbonates, oxides, and native copper occur at the surface; that these pass into secondary sulphides, which in turn give way to primary sulphides in depth. Thus in the Commercial, Telegraph, Jordan, Highland Boy, Neptune, Fortune, Columbia, and other properties the surface portion of the shoots of copper-iron ore were made up of malachite and azurite, and, in the Commercial, of cuprite also. These gradually pass into sulphides in depth. In the 1 Op. cit., p. 218. 


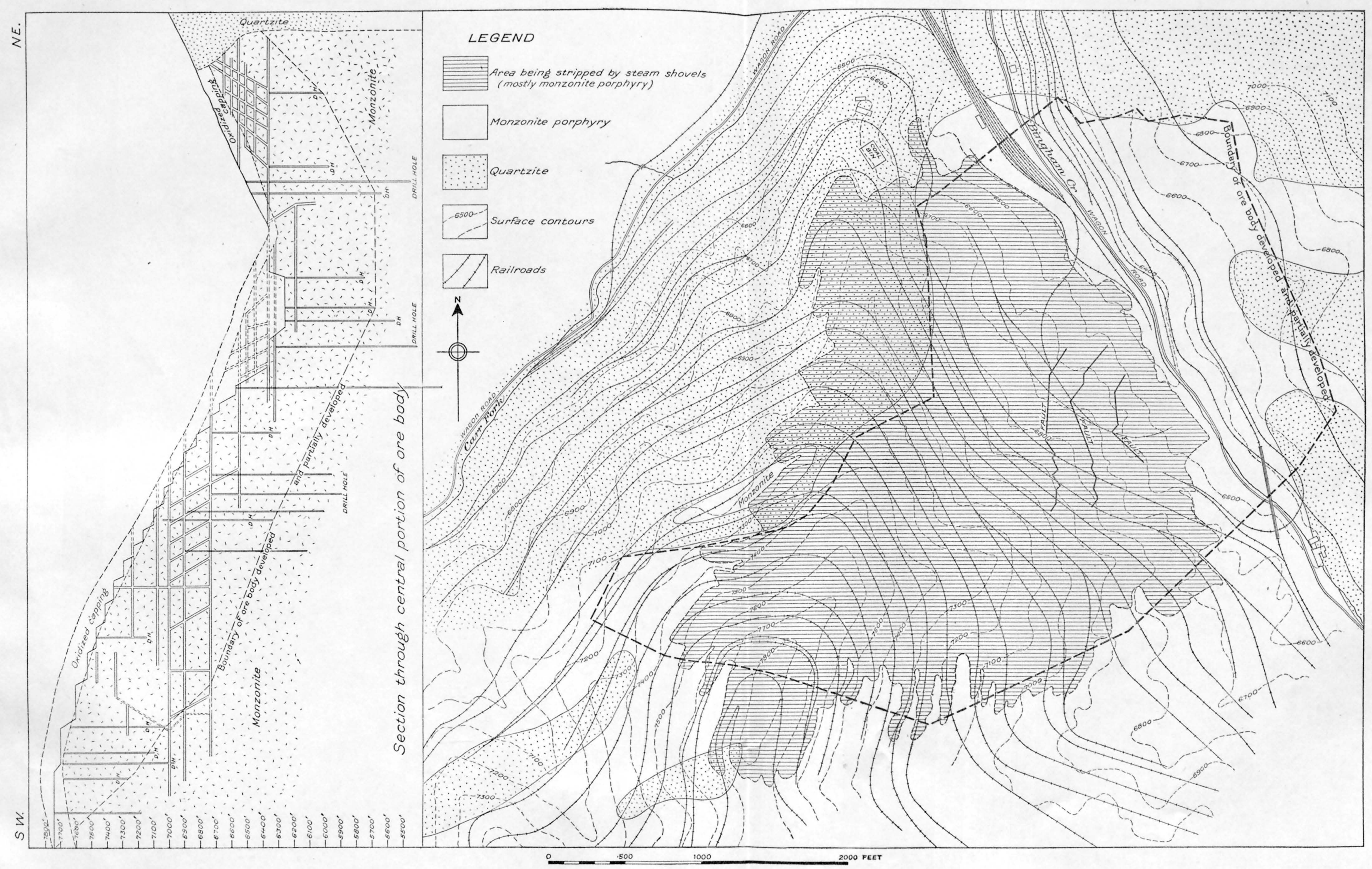


Columbia cores of black sulphide occur within the green carbonate. In the Carpenter Shop tunnel, Telegraph mine, and Crown Point incline the carbonate ore gives way to sulphides, bands of the former forking down into the latter, becoming narrower in depth, and finally thinning out entirely to give way to sulphide.

Black sulphide marking the zone of sulphide enrichment, then, constitutes the body of the copper ore for a considerable distance in depth. *** The thickness of the zone of oxides and carbonates is not so great as the thickness of the zone of black sulphides. The transition from the zone of oxidation to the zone of sulphide enrichment is gradual. It is to be seen in its earliest stage in the slight enrichment along fractures in primary sulphides, in hand specimens, and in thin sections showing various stages in its progress. * * * This enrichment may be observed to proceed gradually until, through the continued relative increase of the secondary sulphide and decrease of the primary, the entire mass of an ore body is made up of enriched high-grade black sulphide ore. This constitutes the so-called "black sulphide" ore, which is the richest copper ore in this camp. In its typical occurrence it is a loose, dry, dull granular black, earthy ore, intermingled with gray and grayish-black metallic scales and larger portions. This may frequently be seen inclosing cores of yellow sulphide and intimately associated with chalcopyrite and pyrite. Although this black ore varies in character somewhat, it is found on chemical examination of selected samples from several mines to consist chiefly of chalcocite (black sulphide of copper), tenorite (black oxide of copper), melaconite (massive earthy variety of the oxide of copper, tenorite), some tetrahedrite, and probably some enargite.

The stages of alteration and the general character above described are characteristic. Other types were noted, however. Thus in the Highland Boy alteration seems to have taken a somewhat different form; carbonates and oxides pass into a zone characterized by chalcopyrite, tarnished and coated with bornite and seamed with limonite. Specimens of Highland Boy ore from this zone show in thin sections under the microscope a granular, fractured mass of chalcopyrite traversed and rimmed about by seams of limonite. In the Northern Light, upper tunnel, in a corresponding zone, covellite coats chalcopyrite. And a specimen from the Kempton made up of pyrite crystals (possibly two generations) is coated with masses of chalcopyrite which in turn bear upon their surface crystals and coatings of tetrahedrite.

Below this zone of sulphide enrichment, low-grade cupriferous pyrite occurs. The passage out of this zone in depth is, like the entrance into it, gradual. Within the body of rich black ore nodules and grains of cupriferous pyrite occur, and in depth these become more numerous and pass into continuous bands which lead to the primary sulphides. The transition from secondary to primary sulphides, begun in this way, progresses by continued decrease of secondary and reciprocal increase of primary sulphides. Thus the lowest workings in the Commercial and Telegraph are still in a zone of sulphide enrichment, in the Jordan below the water level, and in the Highland Boy a zone of pyrite has been encountered, which shows a decrease in the copper content.
Since the above was written more depth has been attained in some of the deposits, notably in the Highland, Boy mine, where ore bodies have been developed to the thirteenth level. On the lower levels the mineralized bodies, though large, are, in large part, of too low grade to be mined at a profit under average conditions. The content shows a decrease in gold and silver as well as in copper.

Disseminated ores.-The alteration of the disseminated ores is in general similar to that of the replacement deposits, the important difference being that less of the copper has been left in the oxidized zone as carbonates and oxides, and more of it has been carried to lower levels and precipitated in the zone of sulphide enrichment.

The sulphides have been largely oxidized for a varying distance below the surface. At the surface some of the iron is usually present in limonite or some closely allied mineral, but some of it has been removed, the iron in limonite apparently not equaling that in the the primary ore. At the surface almost all of the copper has been removed, especially from the higher elevations. Below the surface and in the lower areas bordering Bingham Canyon more iron and considerable copper still remain, the iron in part as hydrous oxide and possibly in part as ferric sulphate, and the copper as carbonate and in places as sulphides. In part of the area the oxidized capping contains sufficient copper to be classed as ore, and a plant for the treatment of this class of ore by a leaching process began operations in 1917.

The silicate minerals of the ore have undergone remarkably little alteration. No analyses of the capping have been made, but microscopic study indicates that the orthoclase and sericite have been but slightly altered, though most of the biotite is distinctly bleached. Weathering would naturally break down the silicates, removing the potassium and magnesium and producing kaolin and allied minerals, but the microscopic study reveals no important alteration of this character except in the biotite.

In general it may be said that the alteration of the sulphides first resulted in the formation of iron and copper sulphates. Then the iron sulphate in part oxidized to ferric sulphate, in part possibly combined with other elements to 
form relatively stable sulphate minerals, such as jarosite, and in part broke down into ferric oxide and sulphuric acid.

In part both the copper and iron were removed as sulphates in solution. Part of the copper was temporarily fixed as the relatively stable carbonates.

The ferric sulphates if formed are only relatively stable and eventually break down, possibly into ferric oxide and sulphuric acid, which would act on the copper carbonates present and permit these to be removed in solution. Thus in the early stages of oxidation the "capping". would contain considerable copper, while in the final stages this would be largely removed. This process is of course constantly working downward, so that in reality the secondary sulphides are also involved in the oxidation process.

Along certain channels especially favorable to the circulation of solutions, notably in the fissures in the quartzite, oxidation has resulted in the formation of considerable amounts of oxide of copper and some of native metal.

The thickness of the oxidized zone is variable, but in general is greatest at the greatest elevation and least at the lower levels, though of course deeper along channels favorable to circulation. Thus in 1912 the average thickness of capping over the original Utah copper group, which lies at relatively low levels adjacent to Bingham Canyon, was estimated at 84 feet, and the average thickness in the Boston Consolidated and Pay Roll groups, at higher elevations, at 134 and 206 feet, respectively. The average thickness for the entire ore body as developed to the close of 1914 was 115 feet.

Underlying the zone of oxidation is the zone of secondary sulphides. In this zone the primary sulphides, pyrite, and chalcopyrite, and possibly some bornite, have been partly or wholly replaced by the copper sulphides covellite and chalcocite. A little bornite is present in the ore. In some places this appears to be a replacement of other sulphides, and in other places its relations strongly point to its primary origin.

It has been generally considered that the principal secondary sulphide of the deposit is chalcocite, but an examination of specimens from different parts of the ore body revealed a surprisingly large amount of covellite. Many of the fine grains in which much of the mineral occurs can be determined as covellite or chalcocite with difficulty without a polished ssction, but covellite appears to be the more abundant. Much sooty material and the surfaces of many grains are dark and look like chalcocite, but a large proportion of the secondary sulphide shows the deep indigo blue of covellite, and this can usually be seen with a lens in the hand specimen by scraping the surface of the grains. On the other hand, specimens that appear to contain abundant covellite when examined in polished sections are seen to contain abundant chalcocite covered by a very thin coating of covellite. Beeson states that covellite is the more abundant secondary sulphide in the higher portions of the ore body, but that chalcocite becomes increasingly abundant near the bottom of the canyon.

The change from the zone of the yellow oxidized ore to that of sulphide enrichment is usually very sharp, the "capping" resting on the ore with not more than a few inches or at most a few feet of transition. The change in metal content, however, is not usually so sudden. The metal in the "capping" not being susceptible to satisfactory recovery until recently, however, has made the line between ore and waste much more definite than is indicated by the metal content.

Underlying the zone of secondary sulphides is that of primary sulphides. Much of the material that contains little covellite or chalcocite is ore, but it decreases in tenor with increase in depth. This naturally suggests enrichment by the addition of copper in the form of chalcopyrite, and this seems to be the theory held by those most familiar with the ore deposit. Beeson has shown that some of the material that appears to be chalcopyrite is only a thin film of that mineral covering covellite or chalcocite, all three of the copper sulphides being of secondary origin.

The cross section of the ore body (see Pl. XXXV) shows that the ore goes deepest in high ground, where oxidation is greatest. Development also goes deepest in this part of the ore body, however, and until greater depth has been attained near the canyon bottom it can not be stated that the ore is not equally thick there. At the close of 1916 the average thickness of the commercial ore as developed in the property of the Utah Copper Co. was 524 feet. 

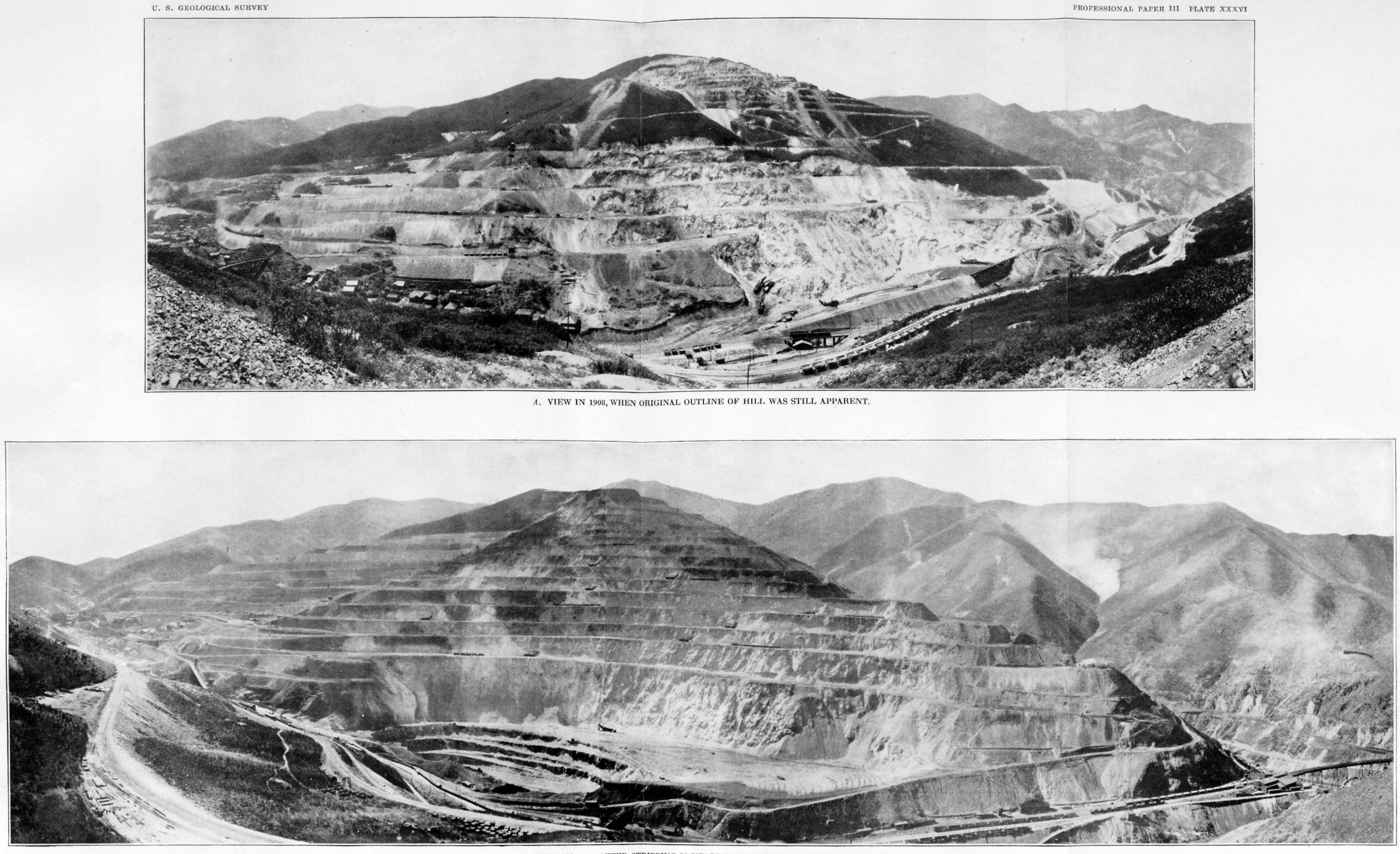
LEAD-SILVER ORES.

Galena, which forms the most important primary mineral of the lead-silver ores, is relatively resistant to weathering agencies. Consequently, the alteration of these ores has proceeded slowly, and many residual fragments of galena remain in the ore even near the outcrop. Tetrahedrite, which is an important silver-bearing mineral, is more readily attacked. The final product of alteration of the galena is ordinarily the carbonate, cerusite, though the sulphate, anglesite, commonly forms as an intermediate product and more complex sulphates are probably also formed. The oxidized lead-silver ore bodies show no marked migration of the lead or silver, though they have been somewhat enriched and were rendered much more favorable to the early treatment by the removal of other elements.

GOLD ORES.

The gold ores of the district have resulted from the alteration of auriferous pyrite bodies in the limestone. They were worked at numerous localities in the early days, but, although gold was obtained from some of them, none have proved very productive.

Oxidation of the pyrite freed the gold and concentrated it to some extent. Boutwell ${ }^{1}$ described the process as follows:

These changes probably comprise (a) the attack on gold-bearing pyrite, iron sulphide, by oxygen of surface waters, resulting in the formation of ferrous sulphate and consequent freedom of gold content; $(b)$ the breaking up of iron sulphate into sulphuric acid, limonite, and water; (c) the passage of the acid, water, and limonite downward, leaving the gold content in the resulting cavity, and thus the accomplishment of the relative concentration of free gold.

GENESIS OF THE ORES.

The ores of the district have probably been formed during one general period of mineralization and have had a common origin. The differences in the character of the ores are probably due to differences in the physical conditions under which they formed and possibly to slightly different times of formation during the general period of ore deposition.

The intimate association of the ore deposits with the intrusive rocks leaves little doubt of their close genetic relations. That the main ore deposition took place after the intrusion is evinced by the fact that deposits occur in the intrusive rocks as well as in the adjacent rocks. In the limestones the ore deposits are associated with fissures more closely than with dikes, but dikes of monzonite porphyry are rarely if ever far distant from a well-mineralized area in the limestone.

The general order of mineralization was probably about as follows: The intrusion of the monzonite bodies and the accompanying fissuring and alteration of the adjacent sediments; the cooling and crystallization of the monzonite and its fissuring from shrinkage and adjustment of stresses; the passage along the fissures both in the monzonite and in the adjacent sediments of solutions of deep-seated origin that altered the rocks and deposited the metals.

Highly heated solutions deposited goldcopper ores and less highly heated ones lead, silver, and zinc. Lead-zinc veins occur in fissures in the disseminated ore, and were evidently deposited later than copper. This, however, is not believed to indicate that the lead ores as a whole were later than the copper ores, but rather that at the time the copper ores were deposited physical conditions in those places were not favorable to the deposit of leadzinc ores. When the temperature and possibly the pressure in this zone had been reduced lead-zinc ores could and did deposit. Fissuring and faulting continued after the deposition of the ores, and finally the ores were altered by surface solutions.

\section{PLACER DEPOSITS.}

Auriferous gravels were the earliest deposits worked in the district, and in early days were the source of considerable gold. The placers occur as bench and stream gravels in Bingham Canyon and its tributaries. Boutwell ${ }^{2}$ summarizes their history as follows:

In post-Carboniferous time the Oquirrh Range gradually emerged above water level and grew northward. Streams flowed northward down its slopes and began the work which Bingham Creek and its tributaries are to-day carrying on. That work consisted of wearing down the surface, cutting valleys, and transporting downstream the product of that erosion. * * *

This generally continuous dissection has been made possible by a broad uplift with slight eastward tilting of the entire region accomplished during definite stages which were characterized by elevation followed by quiescence 
and degradation, and by subsequent aggradation which may be due to slight depression. ***

During these land movements the activity of the erosive agents has varied accordantly. At an early date auriferous gravel was formed by the erosion of gold-bearing ore shoots in limestones and of igneous and probably sedimentary auriferous rocks. Portions deposited in stream beds were subsequently left as benches by further stream incision. Repeated deposition and subsequent dissection have produced a series of high bench and rim deposits of auriferous gravel. The principal deposits of auriferous gravel were laid down (1) at the close of the erosion stage, marked by the mature slopes, and (2) after the close of the cutting of the recent canyon and the succeeding depression. The former is recorded by the Argonaut and Dixon bench gravels, and the latter by the wedge of creek gravels. Each removal of gravel and its included pay from higher to lower levels, as well as each transportation downstream, has acted further to sort and to concentrate the gold. Thus the present creek gravels, including their eastern continuation, include all the gold released from bedrock from earliest to latest time, except the relatively small per cent left on the benches and that removed by man. The present recent dissection of the creek gravels and any normal succession of activities which may follow will continue this process of natural concentration of the placer gold.

\section{BIBLIOGRAPHY.}

Atwood, W. W., The physiographic conditions at Butte, Mont., and Bingham, Utah, when the copper ores in these districts were enriched: Econ. Geology, vol.11, pp. 697-740, 1916.

Beeson, J. J., The disseminated copper ores of Bingham Canyon, Utah: Am. Inst. Min. Eng. Trans., vol. 54, pp. 356-401, 1917.

Bingham Bulletin, Bingham, Utah, May 5, 1899.

Boutweld, J. M., Economic geology of the Bingham mining district, Utah, with a section on areal geology by Arthur Keith and an introduction on general geology by S. F. Emmons: U. S. Geol. Survey Prof. Paper 38, 1905.

Braden, E. B., Special report on Utah in reports of the Director of the Mint for 1897, 1898, 1899.

Burchard, H. C., Reports of the Director of the Mint for 1881, 1882, 1883, 1884.

Еmmons, S. F., Descriptive geology: U. S. Geol. Expl. 40th Par. Final Rept., vol. 2, pp. 443-454, 1877. - Introduction, on the Oquirrh Mountains, to report by J. E. Spurr, on the Mercur mining district, Utah U. S. Geol. Survey Sixteenth Ann. Rept., pt. 2, pp. 349-369, 1895.

- The secondary enrichment of ore deposits: Am. Inst. Min. Eng. Trans., vol. 30, pp. 194-195, 1901. See also Boutwell.

Fenner, C., The Old Telegraph mine: School of Mines Quart., pp. 355-359, 1893.

Gilbert, G. K., Report on the geology of portions of Nevada, Utah, California, and Arizona: U. S. Geog. and Geol. Surveys W. 100th Mer. Final Rept., vol. 3, p. $25,1875$.

HanaUer, A., Special report on Utah in reports of the Director of the Mint for 1886-1896.
Hollister, O. J., Gold and silver mining in Utah: Am. Inst. Min. Eng. Trans., vol. 16, pp. 3-18, 1888.

Keith, Arthur. See Boutwell.

KInG, C., Systematic geology: U. S. Geol. Expl. 40th Par. Final Rept., vol. 1, pp. 184, 185, 213-214, 221, 293, 590,1878 .

Lavagnino, G., The Old Telegraph mine, Utah: Am. Inst. Min. Eng. Trans., vol. 16, pp. 25-33, 1888; Min. and Sci. Press, vol، 78, p. 584, 1899.

Mineral Resources of the United States, annual volumes, 1882-1917.

MuRPhy, J. R., The mineral resources of the Territory of Utah, with mining statistics, maps, etc., pp. 1-3, 6, $14-19,1872$.

RAYmond, R. W., Statistics of mines and mining in the States and Territories west of the Rocky Mountains, vols. 1-7, 1869-1877.

- Production of gold and silver in the United States: Am. Inst. Min. Eng. Trans., vol. 3, pp. 202-207, 1876.

RUSH VALLEY AND OPHIR DISTRICTS.

MINING HISTORY AND PRODUCTION.

By V. C. Heikes.

LOCATION OF THE DISTRICTS.

The Rush Valley and Ophir districts, in Tooele County, were formed June 12, 1864, and August 6, 1870, respectively. These districts were originally part of the West Mountain (Bingham) district. In 1863 they comprised the mining sections now known as Camp Floyd (Mercur), East and Dry Canyon, Tintic, and Tooele districts. A narrow-gage railroad, the Utah \& Nevada Railway, was constructed in the seventies from Salt Lake City to Stockton, and in 1905 this was made broad gage and became a part of the Los Angeles \& Salt Lake Railroad. In 1912 a branch of this railroad was completed from St. Johns to Ophir, doing awáy with a wagon haul of about 16 miles.

HISTORY.

RUSH VALLEY DISTRICT.

Rush Lake, from which Rush Valley takes its name, is a remnant of Lake Bonreville. ${ }^{1}$ In 1855 it was included in a military reservation laid out by Lieut. E. J. Steptoe for the purpose of securing to the military post at Camp Floyd the meadow and pasturage about the lake shore. Gilbert says: ${ }^{1}$

The land surveys in the valley in $1856 \mathrm{did}$ not include the military reservation but showed the existence upon it of a lake. According to Gen. P. E. Connor, who succeeded Col. Steptoe in 1862, there was then only a small

1 Gilbert, G. K., Lake Bonneville: U. S. Geol. Survey Mon. 1, p. 228, 1890. 
pond, the remainder of the lake bed being occupied by meadow land. In 1865 the water began to increase, the greatest height being attained in 1876 or 1877 , since which time it has subsided. The rise of the water submerged the meadow land and rendered the reservation useless for its original purpose. It was therefore officially relinquished by the War Department in 1869. In 1872, the water being near its highest stage, the lake was surveyed in connection with the surrounding country by one of the parties of the Wheeler survey and the length was determined to be $4 \frac{1}{4}$ miles. In 1880 , when the lake was visited by the writer, it was said by residents to have shrunken to half its maximum size.

The reservation ${ }^{1}$ for the military post was sold by the Government in 1861 and was repurchased in 1864 by Gen. Conner, who occupied it with a portion of the California and Nevada volunteers then stationed at Camp Douglas, near Salt Lake. The town of Stockton was surveyed and organized in March, 1864, and made a military post known as "Camp Relief."

The Rush Valley deposits were discovered ${ }^{2}$ in April, 1864, by some members of Company L, Second Cavalry, California Volunteers, who were guarding stock on thereservation. Assays from the first ledges discovered proved to be rich in silver, and a mining district was organized. The first house was built in Stockton during July, 1864, and in 1866 the town had 40 families and 400 inhabitants.

Soon after the organization of the district, Lieut. James Finnerty erected a small trial furnace to test ore, and about the same time a large one was built by the Rush Valley Furnace \& Smelting Co. Both were only partly successful, owing to the imperfect quality of the fire brick used. Subsequently Lieut. Finnerty built a second furnace and ran it with good results for a number of weeks, turning out a quantity of metal from surface ore. Attempts to separate the gold and silver from lead by means of the "Lyon process," which was used to smelt the ores of the Perigo mine ${ }^{3}$ in Gilpin County, Colo., were made by the Knickerbocker \& Argenta Mining \& Smelting Co. but were not successful, and the mines were abandoned in the later part of 1865. The Monheim \& Johnson Co. ${ }^{4}$ completed a blast furnace in 1866 to treat ores

1 Union Vedette, published at Camp Douglas, Salt Lake City, Apr. 22, 1864.

2 Idem, Apr. 2, 1866

${ }^{3}$ Lyon process and Perigo mines, Colo.: Union Vedette, Jan. 27 and July 18, 1866.

1 Union Vedette, Apr. 2, 1866 from the Delmonte and Great Basin ledges; J. W. Gibson in the same year erected and put in operation a smelter with a capacity of 600 pounds a day. The Union Vedette says:

Nine runs have been made of a hundred pounds each and 300 pounds of metal was obtained, some of which has been brought to this city and assayed by Bohm \& Molitor and gives $\$ 228$ in silver per ton. The remainder is nearly pure lead. * * *

Soon after the close of the Civil War the volunteers at Camp Douglas were disbanded, being relieved by regular troops from the east. Most of those who had mining prospects, after meeting and amending the by-laws so as to make claims perpetually valid which had but little work done on them, left the Territory to seek employment elsewhere. This action, which prevented all subsequent relocation of the same ground, greatly retarded and in fact prevented for some years the development of the Rush Valley district. ${ }^{5}$

The mining claims of the district center in the foothills 1 to 2 miles due east of Stockton, and extend about 2 miles north and a like distance south.

The early conditions of mining, reviewed in brief detail by Sloan ${ }^{6}$ in 1873 , are of interest. Sloan says in part:

About midway the district and 1 mile from Stockton is a heavy outcrop of a belt of blue limestone running east and west. Dipping under this is a well-defined vein, 3 feet in width, carrying argentiferous galena, mixed with iron ocher. The following mines are on this belt, which extends about a mile in length. On the east end is the first discovery in the district, called the Lincoln, now known as the Argent; developed by shaft 100 feet in depth and one 50 feet; ore 50 per cent lead and 40 ounces silver to the ton, though one lot yielded 60 per cent lead and 20 ounces silver. * * *

Adjoining west is the Tucson * * *. One lot of ore yielded 60 per cent lead and 87 ounces silver to the ton.

The formation is somewhat broken west of the Tucson, but it is evident the Bolivia is on the same vein; it is opened by a shaft over 100 feet in depth, and there is much ore on the dump * * *.

West from the Bolivia is the Silver King, from which was shipped the first carload of galena ore sent from Utah; * * * Average of ore in value about 50 per cent lead and 40 ounces silver to the ton.

Toward the north part of the district is the Southport; quartzite vein carrying galena and carbonates in large quantities; course of vein, north and south; * * * vein about 3 feet in width * * *. The St. Patrick, opened by an incline of 100 feet. This mine at one time yielded a large amount of ore.

5 Whitney's History of Utah, Salt Lake City, Utah, vol. 2, pp. 271$275,1893$.

6 Sloan, E. L., Salt Lake City Directory, 1874, pp. 148-151. 
Up Quandary gulch, one-fourth of a mile from Silver Spring, is the Quandary lode, developed by a shaft over 100 feet in depth, with levels run therefrom.

Opposite the gulch from the Quandary, is the Great Basin lode, opened by tunnel 100 feet, and shaft 150 feet; has produced high-grade ore.

A short distance above the Quandary up the gulch is the first extension north of the Great Central lode, a welldefined, true fissure vein, in quartzite, running north and south; ore about 50 per cent lead and $\$ 150$ per ton of silver.

North from the Quandary, on the top of the hill, is the mine Our Fritz, with shaft 100 feet in ore all the way, which assays about 60 per cent lead and $\$ 94$ in silver to the ton; ***.

The First National (formerly Flora Temple) is a welldeveloped mine with a shaft over 100 feet; strong vein and good body of ore.

Many of the claims, which were worked in the early days as individual properties, now form part of groups owned by the Bullion Coalition (formerly Honerine), Galena King, New Stockton, Black Diamond, Cyclone, Silver Coin, and Southport.

The Great Basin claim, which later became the property of the Honerine, also known as the National, was included in the group of 77 patented mining claims and fractions transferred to the Bullion Coalition Mines Co. in 1910. The property is opened by an adit 13,000 feet long. The total output of the Honerine and its predecessors is reported ${ }^{1}$ to have been 80,000 tons of ore valued at $\$ 1,250$,000 to the end of 1889. At that time there were 11,500 feet of openings and the greatest depth was 660 feet. A large concentrator was in operation and has been worked intermittently up to the end of 1913. Between 1890 and 1901 there appears to have been very little ore produced from the Honerine mines; at least, the United States Geological Survey is not in possession of the records.

The Jacobs smelter, built at Stockton in 1872, consisted of three vertical blast furnaces and used ores from the Fourth of July and Kearsarge mines near Ophir. The Fourth of July was owned by Lilly, Leisenring \& Co., of Philadelphia, who were owners of the Jacobs works. In 1879 the Great Basin concentrator, consisting of jigs, was installed in an extension building covering the Jacobs furnaces, and in

\footnotetext{
1 Jones, M. E., Internal commerce of the United States, p. 892, 1890.
}

$1880^{2}$ was milling 100 tons of ore a day, producing 20 tons of concentrate. One stack of the Jacobs smelter was in operation at the same time, reducing about 25 tons of ore a day and turning out about $5 \frac{1}{2}$ tons of bullion assaying 100 ounces of silver per ton.

The Chicago smelter, ${ }^{3}$ long ago dismantled, was built on the east shore of Rush Lake near Stockton, in August, 1873. Its last operation was recorded in 1880 . Huntley ${ }^{4}$ says:

The Chicago smelter is at Slagtown, on the eastern shore of Rush Lake, about 2 miles south of Stockton. It was built in 1873 by the Chicago Silver Mining Co., an English company, which once owned the Chicago and the Queen of the Hills mines in Dry Canyon. It ran quite steadily until 1877 . It was then idle until leased in 1879 to Mr. Brooks, who ran it until the autumn of 1880 , when it was shut down.

The Carson \& Buzzo smelting works, about half a mile south of the Chicago, erected two vertical blast furnaces in March, 1873, and commenced operations shortly afterward. The ores used were obtained chiefly from the Utah-Queen mine, owned by the same interests. Later Carson \& Buzzo erected extensive reduction works at West Jordan.

The Waterman smelting works were the most important and were operated at a later date (1886) than any in the vicinity. Huntley ${ }^{4}$ says:

The first furnace in the territory, an unsuccessful reverberatory, was erected here in 1864 by Ten. Connor and his officers. It was bought in 1871 or 1872 by Mr. I. S. Waterman. * * * This smelter ran quite steadily for several years on Hidden Treasure ore and some custom rock, but not profitably. * * * During the four years ending April 1, 1878, 26,270 tons of ore were smelted, and yielded 8,312 tons of base bullion, which sold for $\$ 109.64$ per ton, or $\$ 911,350$. During this time 3,300 tons of flue dust were caught, which assayed from 36 to 57 per cent lead and from 13 to 35 ounces silver.

The production of the Rush Valley district during its early activity is hard to ascertain. No complete records are available, and estimates from the district have been combined with those collected for the Ophir district. Since 1901 the figures have been collected by the United States Geological Survey.

\footnotetext{
2 Rept. Director of Mint upon production of precious metals, 1880, p. 130.

3 Cameron, J. E., jr., M. E., Mines and furnaces of Ophir, Dry Canyon, and Rush Valley districts, Utah Mining Gazette, June 6, 1874. 4 Precious metals: Tenth Census U. S., vol. 13, p. 450, 1885.
} 
Metals produced in the Rush Valley mining district, 1901-1917.

\begin{tabular}{|c|c|c|c|c|c|c|c|c|c|c|c|c|}
\hline \multirow{2}{*}{ Year. } & \multirow{2}{*}{$\begin{array}{l}\text { Ore } \\
\text { (short } \\
\text { tons). }\end{array}$} & \multicolumn{2}{|c|}{ Gold. } & \multicolumn{2}{|c|}{ Silver. } & \multicolumn{2}{|c|}{ Copper. } & \multicolumn{2}{|c|}{ Lead. } & \multicolumn{2}{|c|}{ Recoverable zinc. } & \multirow{2}{*}{$\begin{array}{l}\text { Total } \\
\text { value. }\end{array}$} \\
\hline & & $\begin{array}{c}\text { Fine } \\
\text { ounces. }\end{array}$ & Value. & $\begin{array}{c}\text { Fine } \\
\text { ounces. }\end{array}$ & Value. & Pounds. & Value. & Pounds. & Value. & Pounds. & Value. & \\
\hline 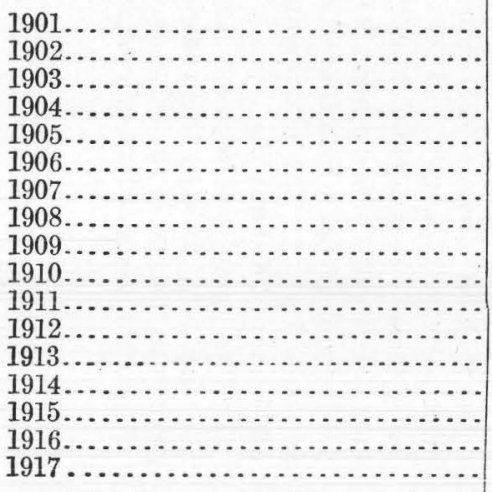 & $\begin{array}{r}a, 400 \\
496 \\
142 \\
b 44,145 \\
b 40,431 \\
b c 37,409 \\
b 48,318 \\
b 2,602 \\
b 5,627 \\
b 1,981 \\
10,107 \\
d 45,453 \\
b e 14,897 \\
19,332 \\
19,780 \\
24,710 \\
10,713\end{array}$ & $\begin{array}{r}34.54 \\
64.00 \\
4.69 \\
292.99 \\
322.00 \\
398.88 \\
324.43 \\
14.70 \\
21.48 \\
27.32 \\
477.38 \\
1,141.31 \\
585.09 \\
420.18 \\
398.15 \\
439.31 \\
708.53\end{array}$ & $\begin{array}{r}\$ 714 \\
1,323 \\
97 \\
6,056 \\
6,656 \\
8,246 \\
6,707 \\
304 \\
444 \\
565 \\
9,868 \\
23,593 \\
12,094 \\
8,686 \\
8,230 \\
9,081 \\
14,647\end{array}$ & $\begin{array}{r}6,618 \\
7,479 \\
1,211 \\
176,510 \\
56,025 \\
95,861 \\
130,487 \\
31,386 \\
24,096 \\
15,888 \\
102,863 \\
261,588 \\
128,675 \\
108,979 \\
90,666 \\
108,841 \\
79,797\end{array}$ & $\begin{array}{r}\$ 3,971 \\
3,964 \\
654 \\
101,052 \\
33,839 \\
64,227 \\
86,121 \\
16,635 \\
12,530 \\
8,580 \\
54,517 \\
160,877 \\
77,720 \\
60,265 \\
45,968 \\
71,617 \\
65,753\end{array}$ & $\begin{array}{r}5,248 \\
413 \\
3,858 \\
318 \\
5,779 \\
1,781 \\
10,354 \\
12,689 \\
319,859 \\
29,521 \\
21,680 \\
37,899 \\
118,943 \\
43,335\end{array}$ & $\begin{array}{r}\$ 656 \\
65 \\
745 \\
63 \\
763 \\
232 \\
1,315 \\
1,586 \\
52,777 \\
4,576 \\
2,883 \\
6,633 \\
29,260 \\
11,830\end{array}$ & $\begin{array}{r}a 200,000 \\
250,651 \\
27,009 \\
11,978,448 \\
3,499,020 \\
4,982,872 \\
6,622,042 \\
1,676,217 \\
1,213,266 \\
965,146 \\
4,969,476 \\
10,971,278 \\
4,619,259 \\
3,791,497 \\
4,151,151 \\
5,413,042 \\
3,315,077\end{array}$ & $\begin{array}{r}\$ 8,600 \\
10,271 \\
1,134 \\
524,057 \\
155,419 \\
284,024 \\
350,968 \\
70,401 \\
52,170 \\
42,466 \\
223,626 \\
493,708 \\
203,247 \\
147,868 \\
195,104 \\
373,500 \\
285,097\end{array}$ & $\begin{array}{r}9,019 \\
69,582 \\
99,034 \\
136,615 \\
56,490\end{array}$ & $\begin{array}{r}\$ 505 \\
3,549 \\
12,280 \\
18,306 \\
5,762\end{array}$ & $\begin{array}{r}\$ 13,285 \\
15,558 \\
1,885 \\
631,821 \\
195,979 \\
357,242 \\
443,859 \\
88,103 \\
65,376 \\
52,926 \\
289,597 \\
730,955 \\
298,142 \\
223,251 \\
268,215 \\
501,764 \\
383,089\end{array}$ \\
\hline
\end{tabular}

$a$ Estimated. $\quad \checkmark$ Partly milling ore, concentrates produced. $\quad c$ Mostly old tailings. $\quad d$ Includes 27,647 tons of old slag from early smelting operations. $e$ Includes 2,049 tons of old tailings and slag. 
OPHIR DISTRICT.

The ores in the Ophir district were discovered in 1865. ${ }^{1}$ Treasure Hill, in East Canyon, had long been a sacred spot whither the Indians repaired each year to hold councils and to obtain metal for bullets. Soldiers of Gen. Connor's command, attracted by these legends, located a cropping of lead ore at the St. Louis lode, now known as the Hidden Treasure mine. Other locations soon followed, among which were the Pocatello, made near where the Velocipede was afterward located on Silver Shield Hill, and the famous Wild Delirium at the foot of Ophir Hill.

Very little work was done on the locations until 1870, when the excitement caused by the rich developments in the Little Cottonwood district stimulated prospecting. In the summer of 1870, A. W. Moore laid out the town of Ophir, and a new mining district was organized. In August, 1870, horn silver was found on Silverado Hill, perhaps by W. T. Barbee, ${ }^{2}$ and the Silveropolis, Chloride Point, Shamrock, and other claims were located. A few days after the discovery of the Silveropolis lode, the Mountain Lion, Silver Chief, Mountain Tiger, Rockwell, and other locations were made on Lion Hill.

The nearest railroad point to Ophir in 1872 was the Utah Southern Railroad, which terminated at Lehi and was reached via Lewiston and Fairfield. In 1872 the Pioneer mill, belonging to Walker Bros., was treating 25 to 30 tons of ore a day, using a Blake crusher, fifteen 750-pound stamps, an Aikin furnace, six Wheeler pans, and three settlers. There were three smelting plants in the vicinity. ${ }^{3}$ Huntley ${ }^{4}$ says:

The Ophir district * * * includes several canyons and ridges on the western slope of the Oquirrh Range, the principal of which are Ophir or East Canyon and Dry Canyon, containing the mining camps of Ophir City and Jacob City, respectively. There was much excitement in 1872,1873 , and 1874, since which time the camp has gradually declined. At the period under review there were not 50 persons where formerly there were 1,000 . The records showed about 2,500 locations, on not over 150 of which was assessment work kept up. * * *

1 Wells, Spicer, Utah Mining Gazette, Jan. 7, 1874.

2 Huntley, D. B., Precious metals: Tenth. Census U. S., vol. 13, p. 477, 1885.

${ }^{3}$ Wheeler, G. M., U. S. Geog. Surveys W. 100th Mer. Prog. Rept., pp, 14-26, 1872.

4 Op. cit., pp. 450-454.
Much of the ore of the district has been very rich, the assays sometimes averaging among the hundreds, and even thousands. In East Canyon the ore was usually a very siliceous or milling ore; but that from Dry Canyon contained much lead and was smelted. This district has produced many million dollars; how many can never be known, as the mine owners of the early days are scattered over the Pacific coast. Many local attempts to treat the ores were made in East Canyon, but were for the most part failures. The works remaining at the period under review were the buildings of the Pioneer and the Baltic mills, and the Cleveland and the New Jersey arrastres.

The Pioneer mill was built in 1871 by Walker Bros., of Salt Lake City, to work ore from the Zella group and other mines on Lion Hill. It was a 20 stamp dry-crushing silver mill with an Aiken furnace, and cost about $\$ 75,000$. Many hundred thousand dollars in bullion were extracted. The machinery was moved to Butte, Mont., several years ago. The Baltic mill was a small 5-stamp mill, with two pans anda settler, and was run by a turbine water wheel. It was not worked regularly. The arrastres * * * were fairly successful, owing to the high-grade and free nature of the ore. Latterly, ore has been shipped to Salt Lake City or to the Stockton smelters. * * *

The following works were built in early times but had been moved away or were in ruins: Pioneer smelter, built in 1871; probably produced 125 tons of bullion. Ophir smelter, built in 1872; produced but little. Faucett smelter, built in 1872; small product. Brevoort mill, built in 1872; two stamps. Enterprise mill, built in 1873; five stamps. One mill (name unknown), built in 1874; five stamps. Also several small arrastres run by water wheels. The Zella group [East Canyon and vicinity] comprises the Zella, Mountain Tiger, Silver Chief, and Rockwell, patented, and several others unpatented. It is situated on the western side and near the summit of Lion Hill. The mines were discovered in the autumn of 1870 and sold to Walker Bros. in 1871, who worked them until 1876, since which time they have been leased. The ore outcropped in two places, the croppings assaying $\$ 200$ per ton. Three large bodies and several smaller ones were found about 20 feet below the surface. *** The total product of this group was estimated at $\$ 750,000$.

The principal work [on the Monarch group] was done in 1875 and 1876. Since then the property has been leased. * * * It is said that the ore averages 130 ounces silver per ton with from nothing to $\$ 8$ in gold, and from nothing to 12 per cent of lead. Much of it, however, would assay upward of $\$ 500$. * * * The total product to the close of the census year was $\$ 117,500$.

The Douglas mine was located in 1871, and was worked principally in 1875, 1876, and 1877 . It has been idle or leased since. It is situated near the western summit of Lion Hill, about a mile southeast of Ophir City. It is near the Monarch group, which it greatly resembles in gangue and ore. * * * The total product is said to be at least 1,000 tons of 100 -ounce ore.

The Trace group was located in August, 1878, and worked in a small way since by the owners. *** The total product to the end of the census year was $\$ 11,565$.

The other mines of East Canyon and vicinity are: 
Mines of East Canyon and vicinity.

\begin{tabular}{|c|c|c|c|}
\hline Mines. & $\begin{array}{l}\text { Total } \\
\text { length } \\
\text { of open- } \\
\text { ings. }\end{array}$ & $\begin{array}{l}\text { Total } \\
\text { prod- } \\
\text { uct. }\end{array}$ & Remarks. \\
\hline $\begin{array}{c}\text { Exchange and } \\
\text { Sunnyside. }\end{array}$ & $\begin{array}{l}\text { Feet. } \\
1,000\end{array}$ & $\$ 80,000$ & \\
\hline Lion.................... & 1,000 & 120,000 & 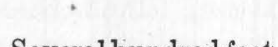 \\
\hline $\begin{array}{l}\text { Chloride Point } \\
\text { and others on } \\
\text { Silveropolis } \\
\text { Hill. }\end{array}$ & & & $\begin{array}{l}\text { Several hundred feet } \\
\text { of cuttings; pro- } \\
\text { duced many thou- } \\
\text { sands in early } \\
\text { days. }\end{array}$ \\
\hline $\begin{array}{l}\text { Miner's Delight } \\
\text { group. }\end{array}$ & $a 300$ & & $\begin{array}{l}\text { Ore assays } 19 \text { ounces } \\
\text { silver and } 11 \text { to } 14 \\
\text { per cent lead; sells } \\
\text { or } \$ 7 \text { per ton; } \\
\text { total prod u ct } \\
\text { many thousand } \\
\text { tons; } 1,200 \text { tons } \\
\text { extracted in cen- } \\
\text { sus year. } \\
\text { Has produced con- }\end{array}$ \\
\hline $\begin{array}{l}\text { Cleveland Min- } \\
\text { ing Co. } \\
\text { San Joaquin..... }\end{array}$ & $\begin{array}{r}1,430 \\
750\end{array}$ & $\begin{array}{r}100,000 \\
35,000\end{array}$ & $\begin{array}{l}\text { siderable ore. } \\
\text { Ore assays } \$ 150 \text { to } \\
\$ 1,000 \text { per ton. } \\
\text { Ore assays } \$ 100 \text { to }\end{array}$ \\
\hline Poorman. . & $b 500$ & Small. & $\begin{array}{l}\$ 400 \text { per ton. } \\
\text { Little ore ever } \\
\text { shipped. }\end{array}$ \\
\hline Buckhorn. & $a 300$ & & $\begin{array}{l}\text { Ore assays } 20 \text { ounces } \\
\text { silver, } 35 \text { per cent } \\
\text { lead; much ore } \\
\text { form erly pro- } \\
\text { duced. }\end{array}$ \\
\hline $\begin{array}{l}\text { Mountain Gem } \\
\text { and Antelope. }\end{array}$ & 1,000 & & $\begin{array}{l}\text { Surface ore assays } 20 \\
\text { ounces silver, } 30 \\
\text { per cent lead; sev- } \\
\text { eral thousand tons } \\
\text { shipped in } 1877 \\
\text { and 1878. }\end{array}$ \\
\hline California ... & & & $\begin{array}{l}\text { Ore assays } 25 \text { ounces } \\
\text { silver, } 55 \text { per cent } \\
\text { lead. }\end{array}$ \\
\hline
\end{tabular}
$a$ Incline; also other cuttings.
$b$ Drifts; also shaft of several hundred feet.

The Hidden Treasure mine [Dry Canyon] is situated on a steep hillside above and three-quarters of a mile northeast of Jacob City. It was located in 1865 as the St. Louis lode by Gen. Connor's soldiers, who had been told by Indians of the outcropping boulders of galena. Little work was done until April, 1870, when it was relocated as the Hidden Treasure. The mine has been extensively but irregularly worked since 1872. *** The ore assays from 15 to 40 ounces silver and 20 to 50 per cent lead. * * * During the four years ending April 1, $1878,28,400$ tons were mined. Most of this was smelted at the Waterman smelter at Stockton. The cash received for this amount of ore, whether sold as ore or as bullion, was $\$ 988,700$. Several thousand tons of ore were produced prior to 1874 .

The Chicago mine was located in 1871, and sold to an English company soon afterward. The mine was worked vigorously for several years but has been idle since 1876. * * * The mine produced considerably over 12,000 tons of ore. This company owns the Chicago smelter, and when the mine failed bought the Queen of the Hill, Falvilla, and Mahogany locations. They were located in 1870-71, and were worked extensively between 1873 and 1877 but very little since. Shortly after the purchase the Chicago company came to the fault and failed. * * * The product of these mines * * * was probably over $\$ 1,000,000$.

The Mono mine is situated half a mile south of Jacob City. It was discovered in the autumn of 1871 , and was owned in the early days by Gisborn, Embody, Heaton \& Miller. It was worked vigorously by them until 1875, when Gisborn bought the remaining two-thirds interest for $\$ 400,000$, mortgaging the whole to eastern capitalists for the money. About th ree months after the sale a fault was found, or the ore chute "pinched," and only a small prospecting force was employed until June, 1879, since which time it has been idle. * * * The total product was not known, even by the original owners, as they divided the proceeds after the sale of each lot By one it was placed somewhat over and by another somewhat under $\$ 1,000,000$.

The Mono tunnel site is in the ravine 800 feet below the Mono mine. Work was begun in 1872 or 1873 . The tunnel is about 1,100 feet in length. * * *

The Kearsarge mine, located half a mile west of Jacob City, was discovered in 1871. * * * The total product was unknown, perhaps $\$ 1,000,000$. * * * A few hundred tons of 40 -ounce ore were produced.

The Deseret group * * * were located in 1870-71. Work on them was begun in 1874 and discontinued January $1,1879 . * * *$ The total production of the group was estimated at $\$ 30,000$.

The other mines of Dry Canyon are:

Mines of Dry Canyon.

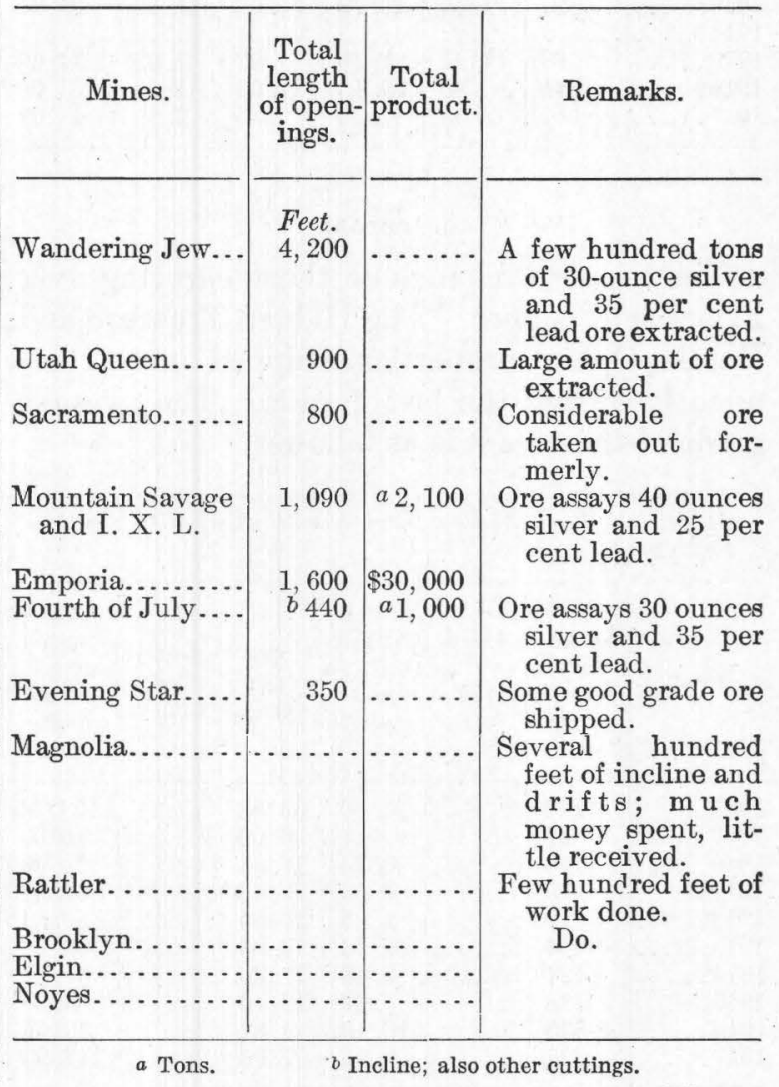


METAL CONTENT OF THE ORFS.

DRY OR SILICEOUS ORES.

The dry or siliceous ores shipped to smelters from the Ophir and Rush Valley districts comprise gold and silver ores carrying copper and lead in amounts too small to be of value. The mines, named in order, according to the frequency of their shipments in the last decade, were the Chloride Point, Lion Hill, Buffalo, Queen of the Hills, Hidden Treasure, and Sunrise Tunnel. The average grade of the ore shipped is shown in the following table:

Dry or siliceous ore, with average metallic content, produced in Ophir and Rush Valley districts and shipped to smelters, 1903-191\%.

\begin{tabular}{|c|c|c|c|c|c|c|}
\hline Year. & $\begin{array}{l}\text { Quan- } \\
\text { tity } \\
\text { (short } \\
\text { tons). }\end{array}$ & $\begin{array}{c}\text { Gold } \\
\text { (value } \\
\text { per } \\
\text { ton). }\end{array}$ & $\begin{array}{c}\text { Silver } \\
\text { (ounces } \\
\text { per } \\
\text { ton). }\end{array}$ & $\begin{array}{l}\text { Copper } \\
\text { (per } \\
\text { cent). }\end{array}$ & $\begin{array}{l}\text { Lead } \\
\text { (per } \\
\text { cent). }\end{array}$ & $\begin{array}{l}\text { Aver- } \\
\text { age } \\
\text { gross } \\
\text { value } \\
\text { per } \\
\text { ton. }\end{array}$ \\
\hline 1903. & 200 & $\$ 1.55$ & 145.00 & & & $\$ 79.85$ \\
\hline 190 & 141 & 2. & 79. & & & 48. 02 \\
\hline & 17 & 3. 65 & 41.53 & 0.69 & & 31.12 \\
\hline 190 & 40 & 1. & 65.00 & & & 45. 65 \\
\hline 1. & 180 & 2.55 & 87.40 & & 0.98 & 61.28 \\
\hline & 20 & $\overrightarrow{1}$. & 104. & & .38 & 57.37 \\
\hline & 19 & 1. & 74. & & 1. 20 & 41. 5 \\
\hline & 7 & 2.02 & 48. & & .94 & 29. 22 \\
\hline & 4 & 2. & 69. & & & 38.94 \\
\hline & 386 & 2. & 53. & & 1. 16 & 36.08 \\
\hline & 250 & 1. & 43. & .03 & 1. 26 & 29. 01 \\
\hline & 15 & 1.47 & 61.80 & .02 & 1.08 & 34.60 \\
\hline & 284 & & & .03 & & 23. 06 \\
\hline & 11 & 3.5 & 47. 26 & .35 & 2. 10 & 48. 09 \\
\hline
\end{tabular}

COPPER ORE.

The copper ores include those carrying over $2 \frac{1}{2}$ per cent copper. The Hidden Treasure and Eureka-Ophir properties shipped most frequently during the last decade. The average grade of the ores was as follows:

Copper ore, with average metallic content, produced in the Ophir and Rush Valley districts and shipped to smelters, 1903-1917.

\begin{tabular}{|c|c|c|c|c|c|c|}
\hline Year. & $\begin{array}{l}\text { Quan- } \\
\text { tity } \\
\text { (short } \\
\text { tons). }\end{array}$ & $\begin{array}{c}\text { Gold } \\
\text { (value } \\
\text { per } \\
\text { ton). }\end{array}$ & $\begin{array}{c}\text { Silver } \\
\text { (ounces } \\
\text { per } \\
\text { ton). }\end{array}$ & $\begin{array}{c}\text { Copper } \\
\text { (per } \\
\text { cent). }\end{array}$ & $\begin{array}{c}\text { Lead } \\
\text { (per } \\
\text { cent). }\end{array}$ & \begin{tabular}{|c} 
Aver- \\
age \\
gross \\
value \\
per \\
ton.
\end{tabular} \\
\hline $\begin{array}{l}1903 \ldots \\
1907 \ldots \\
1910 \ldots \\
1911 \ldots \\
1912 \ldots \\
1913 \ldots \\
1914 \ldots \\
1915 \ldots \\
1916 \ldots \\
1917 \ldots\end{array}$ & $\begin{array}{r}100 \\
52 \\
106 \\
70 \\
19 \\
104 \\
127 \\
138 \\
4,835 \\
227\end{array}$ & .. & \begin{tabular}{r}
21.00 \\
\hdashline 3.15 \\
4.50 \\
1.95 \\
1.78 \\
7.46 \\
.62 \\
10.10 \\
5.95
\end{tabular} & \begin{tabular}{|r|}
33.58 \\
4.00 \\
16.84 \\
22.46 \\
26.85 \\
16.85 \\
17.20 \\
18.10 \\
4.87 \\
7.70
\end{tabular} & & $\begin{array}{r}\$ 103.34 \\
16.00 \\
44.48 \\
58.54 \\
89.84 \\
53.38 \\
49.86 \\
63.68 \\
30.69 \\
47.99\end{array}$ \\
\hline
\end{tabular}

LEAD ORE AND CONCENTRATES.

In general, the crude lead ore is that containing over $4 \frac{1}{2}$ per cent of lead. The producers during the last decade, named according to the frequency of their shipments, were the Ophir Hill, Honerine, New Stockton, Galena King, Cliff, Jay Bird, Bullion Coalition, Buckhorn, Black Diamond, Silver Eagle, Queen of the Hills, Southport, Muerbrook, Hidden Treasure, Cyclone, Honerine West, Honerine Extension, Monadnock, Utah Queen, Commodore, Eureka Ophir, Grand Cross, Northern Light, Miner's Delight, Argenta, Lion Hill, Quandary, Emilie, Lost Boy, Buffalo, Brooklyn, Mono, and Ben Harrison. The average grade of the products shipped is shown in the following table:

Lead ore and concentrates, with average metallic content, produced in the Ophir and Rush Valley districts and shipped to smelters, 1903-191\%.

Crude ore.

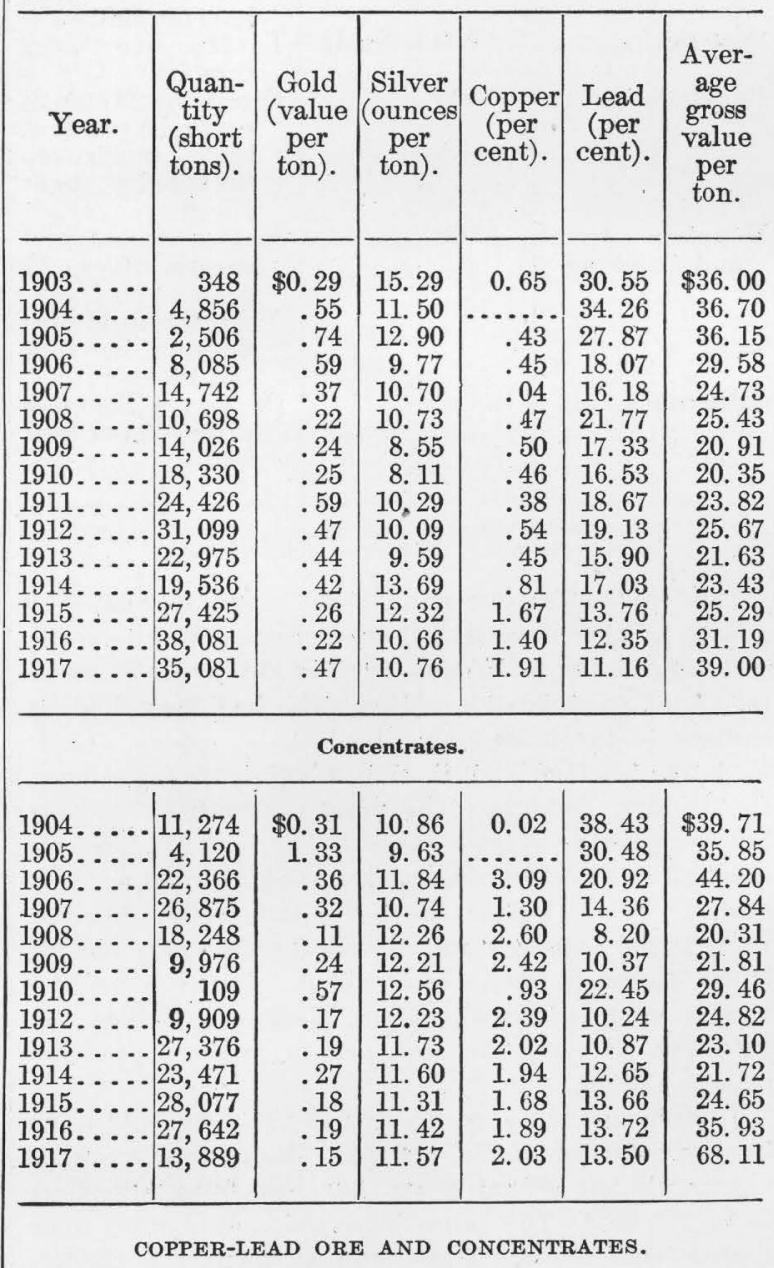

Copper-lead ore and concentrates are classified like the copper and lead ores. The pro- 
ducers for the past decade, named according to the frequency of their shipments, are the Eureka-Ophir, Hidden Treasure, Mono, Ophir Hill, Utah Queen, Kearsarge, Queen of the Hills, Montana, Surprise Tunnel, and Selah. The average grade of the product shipped is shown in the following table:

Copper-lead ore and concentrates, with average metallic content, produced in the Rush Valley and Ophir districts and shipped to smelters, 1903-191\%.

Crude ore.

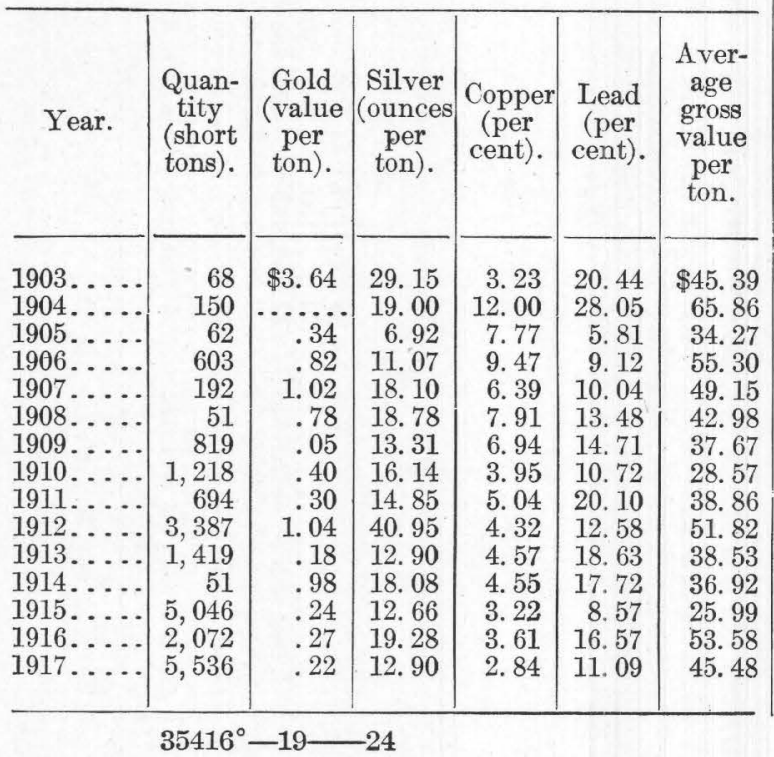

Copper-lead ore and concentrates, with average metallic content, produced in the Rush Valley and Ophir districts and shipped to smelters, 1903-1917-Continued.

Concentrates.

\begin{tabular}{|c|c|c|c|c|c|c|}
\hline Year. & $\begin{array}{l}\text { Quan- } \\
\text { tity } \\
\text { (short } \\
\text { tons). }\end{array}$ & $\begin{array}{c}\text { Gold } \\
\text { (value } \\
\text { per } \\
\text { ton). }\end{array}$ & $\begin{array}{c}\text { Silver } \\
\text { (ounces } \\
\text { per } \\
\text { ton). }\end{array}$ & $\begin{array}{c}\text { Copper } \\
\text { (per } \\
\text { cent). }\end{array}$ & $\begin{array}{l}\text { Lead } \\
\text { (per } \\
\text { cent). }\end{array}$ & $\begin{array}{l}\text { Aver- } \\
\text { age } \\
\text { gross } \\
\text { value } \\
\text { per } \\
\text { ton. }\end{array}$ \\
\hline $\begin{array}{l}1903 \ldots . \\
1904 \ldots . \\
1905 \ldots \\
1907 \ldots \ldots\end{array}$ & $\begin{array}{r}14,210 \\
16,707 \\
19,062 \\
8\end{array}$ & $\begin{array}{r}\$ 0.24 \\
.20 \\
.18 \\
1.00\end{array}$ & $\begin{array}{l}15.85 \\
13.47 \\
13.03 \\
30.00\end{array}$ & $\begin{array}{l}3.20 \\
2.94 \\
3.46 \\
4.70\end{array}$ & $\begin{array}{r}9.12 \\
7.07 \\
9.19 \\
21.00\end{array}$ & $\begin{array}{r}\$ 25.18 \\
21.63 \\
27.58 \\
61.87\end{array}$ \\
\hline
\end{tabular}

The zinc ores are those containing 25 per cent or more of zinc, irrespective of precious metals. Carbonates prevailed and some sulphides were included in the shipments. The shippers were the Hidden Treasure, Cliff, and Bullion Coalition.

The average grade of the ores is omitted, as there was only one shipper of concentrate in 1913 and only two in 1912 and 1913.

PRODUCTION.

The metal production of Ophir and Rush Valley districts from the beginning of operations to 1917 is shown in the following tables: 
Metals produced in Ophir and Rush Valley mining districts, 1901-1917.

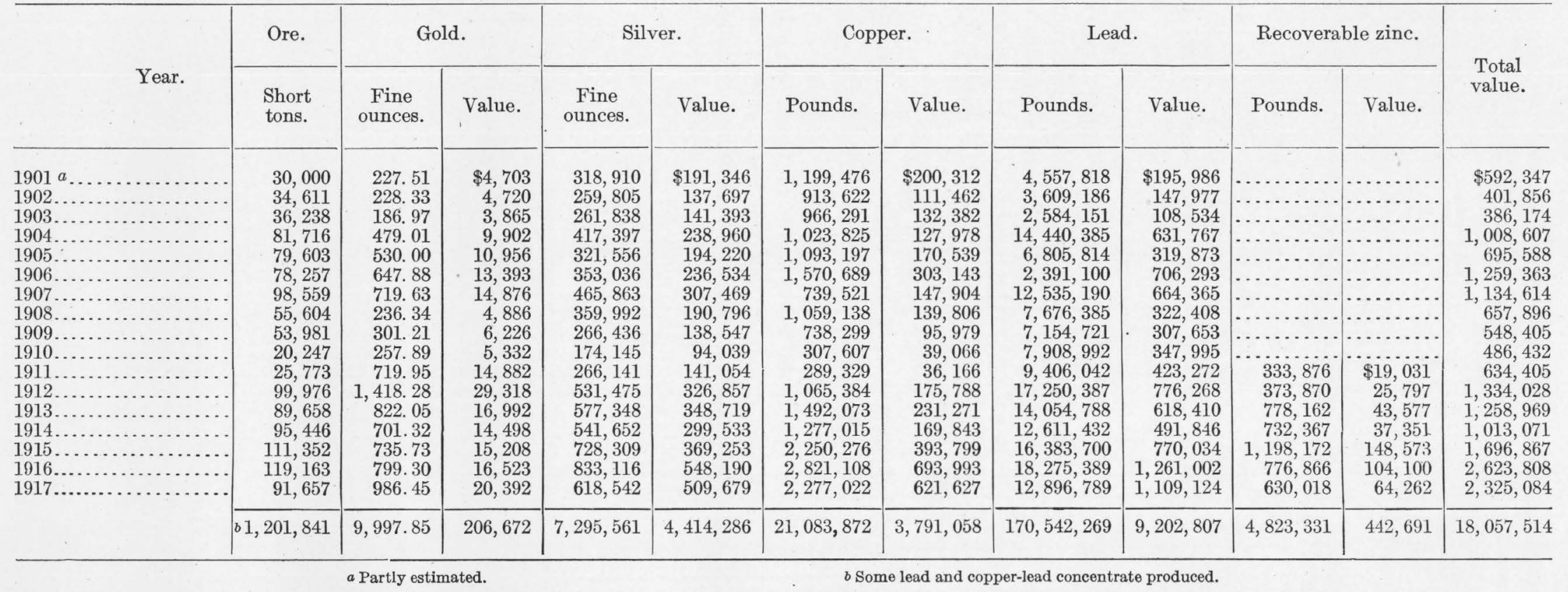

Metals produced in Ophir and Rush Valley mining districts, 18\%0-1917, by periods.

\begin{tabular}{|c|c|c|c|c|c|c|c|c|c|c|c|}
\hline \multirow{2}{*}{ Period. } & \multicolumn{2}{|c|}{ Gold. } & \multicolumn{2}{|c|}{ Silver. } & \multicolumn{2}{|c|}{ Copper. } & \multicolumn{2}{|c|}{ Lead. } & \multicolumn{2}{|c|}{ Recoverable zinc. } & \multirow{2}{*}{$\begin{array}{l}\text { Total } \\
\text { value. }\end{array}$} \\
\hline & Fine ounces. & Value. & Fine ounces. & Value. & Pounds. & Value. & Pounds. & Value. & Pounds. & Value. & \\
\hline \multirow[t]{2}{*}{$\begin{array}{l}1870-1880 \ldots \ldots \ldots \\
1881-1890 \ldots \ldots \\
1891-1900 \ldots \ldots \\
1901-1910 \ldots \ldots \\
1911-1917 \ldots \ldots \ldots\end{array}$} & $\begin{array}{r}12,436.25 \\
2,548.99 \\
3,411.06 \\
3,814.77 \\
6,183.08\end{array}$ & $\begin{array}{r}\$ 257,080 \\
52,713 \\
70,513 \\
78,859 \\
127,813\end{array}$ & $\begin{array}{l}3,885,938 \\
1,502,643 \\
1,575,538 \\
3,198,978 \\
4,096,583\end{array}$ & $\begin{array}{r}\$ 4,789,719 \\
1,499,742 \\
1,114,951 \\
1,871,001 \\
2,543,285\end{array}$ & $\begin{array}{r}1,942,682 \\
9,611,665 \\
11,472,207\end{array}$ & $\begin{array}{r}\$ 253,315 \\
1,468,571 \\
2,322,487\end{array}$ & $\begin{array}{r}77,582,430 \\
10,377,100 \\
17,358,239 \\
69,663,742 \\
100,878,527\end{array}$ & $\begin{array}{r}\$ 4,335,597 \\
447,930 \\
657,364 \\
3,752,851 \\
5,449,956\end{array}$ & $4,823,331$ & 442,691 & $\begin{array}{r}\$ 9,382,396 \\
2,000,385 \\
2,096,143 \\
7,171,282 \\
10,886,232\end{array}$ \\
\hline & $28,394.15$ & 586,978 & $14,259,680$ & $11,818,698$ & $23,026,554$ & $4,044,373$ & $275,860,038$ & $14,643,698$ & $4,823,331$ & 442,691 & $31,536,438$ \\
\hline
\end{tabular}


RUSH VALLEY (STOCKTON) DISTRICT.

GEOGRAPHY.

The Rush Valley district is on the west side of the Oquirrh Range, about 40 miles southwest of Salt Lake City. The shipping points for the district are Stockton, on the Los Angeles \& Salt Lake Railroad, and Bauer, a siding near the portal of the drain tunnel of the Bullion Coalition Co. All ore, excepting that taken through the Bullion Coalition tunnel, is hauled by teams 1 to 3 miles from the mines to the railroad.

The main mineralized area of the Rush Valley (Stockton) district is rather low down on the western slope of the Oquirrh Range, the outcrops of the main ore bodies being between 5,000 and 7,000 feet above sea level. In the higher parts of the range the topogiaphy is rugged, but in the lower slopes it is rather subdued. The earlier developments were mainly by winzes following the ore bodies, as the relief is not sufficient to make it possible to gain depth rapidly by tunnels. Several ore bodies have been developed by tunnels, however, above the water level and the large flows of water encountered as the workings were deepened made drain tunnels necessary. A large flow from the drain tunnel of the Bullion Coalition Co., the only deep tunnel of the district, is utilized for irrigation.

GEOLOGY.

SEDIMENTARY ROCKS.

The sedimentary rocks are interbedded limestones and quartzites. On the south, toward Soldiers Canyon, limestones predominate, but toward the north quartzites become increasingly abundant and appear to greatly predominate in the central and northern parts of the district. This appearance is due in part to the fact that the area is largely covered by débris and that the quartzite, being the more resistant, accumulates more rapidly than the limestone. Underground the quartzite is not conspicuous, but this is in part because prospecting has been largely confined to the limestone areas.

The quartzite is commonly fine grained and rather close jointed and readily breaks down into angular fragments. The limestone is blue or black and white. The blue beds are said to be nearly pure calcium carbonate and the white beds to be dolomitic and siliceous. The limestone of the Honerine mine is blue and lies between beds of white siliceous magnesian limestone, locally called "dolomite." With hydrochloric acid the blue limestone effervesces far more freely than the white. It has a specific gravity of 2.62 and the white of 2.88 .

Partial chemical analyses by R. C. Wells of the blue limestone and the white limestone overlying it (see p. 174) show that the blue is nearly pure carbonate, whereas the white is very siliceous. The close similarity of the white bed underlying the blue limestone to that overlying it warrants the conclusion that the two are of essentially the same composition, and it is probable that a similar chemical difference exists between the blue and white limestones in other parts of the district.

IGNEOUS ROCKS.

There are numerous dikes in the district, but they are not conspicuous on the surface, as they weather more readily than the inclosing rocks and are obscured by débris. Many are encountered in the mine workings. In general they strike north, like the main fissures of the district. They range in thickness from a few inches to 60 feet or more.

The dikes vary considerably in general appearance, owing largely to their texture. Many are characterized by phenocrysts of orthoclase feldspar, some of which are an inch in greatest dimension.

In the coarser rocks there are many crystals of altered plagioclase and an abundance of biotite crystals. In some of the dikes augite can be seen in the hand specimen, though this mineral is commonly altered to other minerals.

The dikes are commonly too highly altered to make accurate determination of their original composition possible, but they all appear to have essentially the composition of a quartz monzonite.

STRUCTURE.

The largest structural feature of the district is a broad anticline that strikes west of north and pitches rather steeply north. The main mineralized area of the district is near the crest of this anticline, and consequently the beds strike generally east and $\operatorname{dip} 60^{\circ}$ to $70^{\circ}$ $\mathrm{N}$., varying somewhat with their position relative to the axis of the anticline and to local structural features. 
The sedimentary rocks in the district have been cut by a series of fissures that are about parallel with the anticline and are most strongly developed near its crest. They dip west usually at a rather steep angle, some reaching $70^{\circ}$. The different fissures vary somewhat in dip, as do also individual fissures at different points. Some movement has occurred along nearly all the fissures. In most of them it is not more than a few feet; in one, however, it is as much as 120 feet.

\section{ORE DEPOSITS.}

GEOLOGIC RELATIONS.

Practically all the larger ore bodies are found in beds, locally designated east-west "veins," of blue limestone, near the intersection of northsouth fissures known as the north-south "veins." The ore occurs as shoots, pitching northwest, with the intersection of the ore bedding and fissures. Some replacements extend along the ore bedding for 100 feet, or even more, and some for only a few feet from the fissure. Individual shoots vary markedly from point to point. Some of them have been followed for 1,200 to 1,300 feet on the dip.

Experience has shown that mineralization is very likely to occur at the intersection of one of the ore beds with the fissures, and at present this is the guide to prospecting. Drifts are carried along the ore beds to the fissures or crosscuts are extended along the fissures to the ore beds, as is found most advantageous in individual cases. Many of these intersections show but little mineralization, but a large percentage of them show some.

Although for the most part the ore has formed in certain beds, some mineralization is present along the north-south fissures, both between the dolomitic or siliceous walls and between walls of the purer limestone. These deposits are commonly smaller than the limestone replacements, but some of them contain ore of relatively high grade.

No recogniżed close relation exists between the dike rocks and the ore deposits. Many dikes occupy the north-south fissures, and ore has formed adjacent to some of them.

Some of the more valuable ore bodies have formed on the footwall side of dikes, either immediately or several feet below. Mineralization has also occurred on the hanging-wall side, and it is not certain that the footwall is distinctly favorable. A similar condition has been noted in other districts, however, notably in the Fish Springs district, and may be of considerable importance. Although there does not appear to be any intimate relation between intrusive rocks and ore deposits, nevertheless the important ore deposits are not far from intrusive bodies and are absent from parts of the range where intrusive rocks are absent.

Faulting along fissures has displaced some beds from a few inches to as much as 120 feet. The main movement appears to have taken place before the ore deposition, though some of it was afterward. The fact that the faulting preceded the mineralization makes it no less important to find the separated portions of the ore bed, as both are likely to have been mineralized.

METAMORPHISM.

The typical change in the mineralized limestone is silicification and addition of sulphides. In many deposits the carbonates have been largely replaced by quartz and sulphides. Locally, fine-grained muscovite (sericite) is present, and specimens of limestone partly altered to epidote were collected from the dump of the drain tunnel of the Bullion Coalition mine. Contact silicates, however, are not abundant. The principal metallic sulphides in the ore shoots are galena, sphalerite, and pyrite, a little chalcopyrite and tetrahedrite, and in some specimens arsenopyrite, though this last does not appear to be an important constituent. The distribution of the sulphides in the unoxidized ore is irregular, some portions of a shoot being rich in galena, others in sphalerite or pyrite, and still others contain all three in considerable amounts. As yet comparatively little zinc ore of sufficient richness to make its marketing profitable has been developed, though some has been shipped and some mixed sulphide ore, both in the mines and on the dumps, may at some time be profitably treated.

The upper portion of the ore shoots has undergone oxidation, and the metals are commonly present as the carbonates, oxides, sulphates, and residual sulphides. The carbonate cerusite is the most abundant lead mineral in the oxidized zone. It is usually mixed with hydrated iron oxides but is occasionally found as small bodies of white, earthy car- 
bonate resembling chalk. The sulphate anglesite is doubtless present to some extent, though not important. Plumbojarosite, the basic lead-iron sulphate, formed by the oxidation of lead and iron sulphides, was noted from the 600-foot tunnel level of the Bullion Coalition workings and from the Ben Harrison mine. It is not possible to state how abundant it is as an ore mineral, as it has not generally been recognized. Zinc is present in the oxidized ore as the carbonate smithsonite, but no bodies of oxidized zinc comparable with those in the sulphide zone have been developed. In Dry Canyon, to the south, zine occurs in considerable amount in the oxidized zone. In numerous lead mines in the West oxidized zinc has been overlooked or neglected and has later been revealed in payable bodies upon the examination of old workings, and it is possible that such would be found in this district, though the writer knows of no reason except the presence of considerable zinc in the sulphide zone for so believing. The iron sulphide has commonly altered to hydrous iron oxide and to the basic sulphate.

TENOR OF THE ORES.

The ores of the district as a whole are of relatively low grade, and concentration has been necessary to raise much of the ore to a shipping grade.

According to the census report for 1880 the first-class ores from the Great Basin mine, the most important producer at that time, averaged 40 per cent lead, from 18 to 21 ounces silver, and $\$ 2$ gold per ton. ${ }^{1}$ Concentrating ores are estimated to have averaged 8 ounces silver per ton and 13 per cent lead.

The ore in the sulphide zone, like that in most of the lead-silver deposits of the State, is of lower grade than the oxidized ore and seems likely to prove less profitable.

MINES.

The principal mines operating in the district in 1912 were the Bullion Coalition, including what was formerly known as the Honerine and at an earlier period as the Great Basin; the New Stockton, formerly known as the Ben Harrison, and the Galena King. Other prospects shipped some ore in the same year.

1 Tenth Census U. S., vol, 13, p. 447, 1885.
The Honerine mine was located in 1865 by Gen. Conner and in early days made a large production, estimated at about $\$ 1,250,000$. The largest ore shoot, which occurred at the intersection of the "Honerine vein" or bed of blue limestone and a prominent north-south fissure, has been followed practically continuously, though pinching and swelling, for 1,200 to 1,300 feet down the dip. Valuable ore shoots have been developed in other beds of limestone at the intersection of north-south fissures, including those locally known as the St. Patrick, Hercules, and Ada.

The mine was first developed by a winze. Later a tunnel was driven that cut the main ore shoot about 600 feet below the outcrop. When the cost of pumping became excessive, a drain tunnel was driven from a point just above the level of Rush Valley. In 1912 this had been extended about 1,200 feet and intersected the ore bodies about 600 feet below the upper or 600-foot tunnel. Later, pumps were installed and a winze sunk below the tunnel level. Near the portal a concentrating mill, which utilizes the large flow of water from the tunnel, has been operated intermittently in recent years. The mine has been operated in part by the company and in part by lessees. Some of the ore was hand sorted by lessees, and second-class ore was concentrated in jigs to a profitable grade.

The Galena King mine is in the gulch above the Honerine mine. The geologic relations are in general similar, though the sedimentary beds stand at a somewhat steeper angle. The ore forms shoots near the intersection of certain limestone beds with north-south fissures. Oxidation has been rather complete to a depth of about 800 feet. Between 800 and 1,000 feet sulphides predominate, though there has been considerable oxidation. Some of the shoots carry considerable zinc in the lower levels, though it is not reported that zine was abundant in the upper levels. The original water level was at about the 800 -foot depth, but the mine is now drained by the Honerine tunnel to the lowest workings. The mine is developed to the 1,000-foot level by an inclined shaft. The Ben Harrison mine, of the New Stockton Co., is in the northeastern part of the district. Thesedimentary rocks are at a higher horizon than those farther south, and quartzitic sand- 
stones predominate with interbedded limestone. The dip of the beds is also steeper, being nearly perpendicular or locally dipping to the south. Dikes of porphyritic rock, similar in character to the other dikes of the district, are present. The sedimentary series here, as farther south, is cut by north south fissures that dip rather steeply west.

Ore occurs as a replacement of the limestone near the intersections of thenorth-south fissures. The mineralization is similar in character to that farther to the south, but the deposits contain more manganese. Oxidation has been rather complete to a depth of about 800 feet below which the ore is mainly sulphide, though some oxidation extends to the 1,000-foot level.

The mine is opened by a 1,000 -foot vertical shaft. It is equipped with a mill of a capacity of about 50 tons a day. In 1912 the mine was being worked by lessees. The second-class ore was jigged to bring it to shipping grade.

In a property northeast of the Ben Harrison mine the ore, unlike most of that from the district, is confined largely to the north-south fissures in quartzite. The ore is in part galena and in part oxidized and runs unusually high in silver for this district. Some of it is siliceous and owes its value mainly to silver. The ore bodies are small as compared with those forming as a replacement of the limestone beds.

Other properties in the district have made production in the past and some of them doubtless will contribute to the future output of the district.

\section{BIBLIOGRAPHY.}

Brisbane, R. B., Mining and milling at Stockton, Utah: Eng. and Min. Jour., vol. 85, p. 611, 1908.

Internal Commerce of the United States, p. 892, 1890.

Murphy, J. R., The mineral resources of the Territory of Utah, with mining statistics map, etc., p. 20, Salt Lake City, 1872.

Tenth Census of the United States, vol. 13, p. 447, 1885.

Wirson, G. B., Geology of the Honorine mine, Stockton,

Utah: Eng. and Min. Jour., vol. 85, p. 869, 1908.

\section{OPHIR DISTRICT.}

GENERAL FEATURES.

The Ophir district is on the west side of the Oquirrh Range, about 8 miles south of the Rush Valley district. It extends from Soldiers Canyon on the north to the Camp Floyd or Mercur district on the south. It has three divisionsDry Canyon, in the north, Ophir Canyon in the center, and Lion Hill in the south. Previous to 1912 the ores from the Ophir and Lion Hill districts were freighted to St. Johns and those from Dry Canyon to Stockton. In 1912 a standard-gage railroad was completed from St. Johns to Ophir.

The district is one of strong relief. The crest of the range is about 10,500 feet and the plain at its western base about 4,500 feet above sea level. The western slope is cut into a series of ridges separated by deep canyons, of which Soldiers, Dry, and Ophir canyons are the most important.

GEOLOGY.

The rocks of the district are largely sedimentary, though there are dikes and sills of intrusive rocks.

\section{SEDIMENTARY ROCKS.}

The sedimentary rocks consist of quartzites, shales, and limestones ranging in age from Cambrian to Carboniferous. The lowest formation exposed is a medium-grained reddish Cambrian quartzite on the north side of Ophir Canyon. Its thickness is not known, though several hundred feet of its upper portion is exposed.

Overlying the quartzite is a series of shales with interbedded limestone, to which the name Ophir formation is herein given. (See p. 79.) These rocks show some metamorphism, the shales especially having developed a schistose character. Certain beds of the limestone are commonly composed of light-gray and darkgray bands, most of them only a fraction of an inch thick. Both the light and dark effervesce with diluted hydrochloric acid, but the light are apparently the purer. In many places, where partly replaced by ore or other minerals, the banding is preserved. This series has a thickness of upward of 100 feet. Fossils collected from it were reported by L. D. Burling to be of Lower Cambrian age and the rocks to be probably correlated with the Pioche shale. Overlying the shales, apparently conformably, a great thickness of rather heavy bedded limestones, mostly bluish, with some lighter colored and a few shaly beds, extends into Dry Canyon. North of Dry Canyon considerable quartzite is interbedded with the limestone. A poorly preserved trilobite collected several hundred feet above the shale series was reported by Mr. Burling as probably 
Cambrian. Gansl and Keep ${ }^{1}$ report 1,200 feet of Cambrian limestone.

The lowest horizon from which Carboniferous fossils (determined by G. H. Girty to be lower Mississippian) were collected is 200 to 300 feet below the ore bed of the Cliff mine; and several collections made between this level and the summit of the divide between Ophir and Dry canyons proved to be of the same age. Collections from the north side of Dry Canyon and from midway between Dry and Soldiers canyons proved to be upper Mississippian, and fossils from just north of Soldiers Canyon were determined as Pennsylvanian.

Specimens of dark shaly rock collected from the dump of the Hidden Treasure mine in 1912 proved on examination in the Survey laboratory to be phosphatic. Since that time considerable phosphatic rock has been reported from this horizon.

In Lion Hill, south of Ophir Canyon the same series of rocks is exposed as to the north, though the section is not so complete. Neither the Cambrian quartzite nor shale series is exposed south of the canyon, and the rocks have been eroded from the surface down to the lower Carboniferous.

Sufficient fossils have not been collected to show how much of the great series of limestones belongs to the periods between Cambrian and Carboniferous. No fossils of Devonian, Silurian, or Ordovician age were collected, and no sediments may have been deposited during those periods, though this does not seem probable, as both Ordovician and Devonian are present in the neighboring Tintic district. Unconformities are present in the Tintic district below the Carboniferous and Ordovician, and it is possible that the Devonian and Ordovician and the upper part of the Cambrian were removed by erosion. It seems probable that the lower 1,200 feet of the formation is pre-Carboniferous and may include some post-Cambrian strata.

IGNEOUS ROCKS.

Igneous rocks have relatively slight areal distribution in the district. The largest bodies are around Lion Hill, where they have been mapped by Emmons and Spurr. In his report on the Mercur district to the south

1 Gansl, J. C., and Keep, G. A., The Ophir mining district of Utah: Salt Lake Min. Rev., vol. 12, p. 17, 1910.
Spurr ${ }^{2}$ has described two types of porphyry which he has called the Eagle Hill and Birdseye porphyries. The "Birdseye" is composed of abundant phenocrysts of feldspar with rather plentiful biotite and a few phenocrysts of quartz in a fine-grained groundmass. The rock is commonly highly altered and its original composition can not be positively determined, though it is probably that of a quartz monzonite. The Eagle Hill porphyry is a finegrained rock containing few inconspicuous phenocrysts of feldspar, biotite, and quartz. The freshest rock is light gray to nearly white but in places alters to yellow or pinkish. It also is too highly altered to permit determination of its original composition, though it appears to have been more acidic than the "Birdseye" porphyry.

The "Birdseye" porphyry outcrops at numerous points around Lion Hill and has been encountered in the underground workings. Apparently it forms a sheet between the limestone strata. It is also present on Porphyry Hill and Porphyry Knob southwest of Lion Hill.

The Eagle Hill porphyry is shown on a reconnaissance map by Emmons and Spurr ${ }^{3}$ as a sheet near the summit of Lion Hill, but the rock is difficult to recognize in its highly altered condition, and a detailed study of the area is necessary to determine its extent and position.

North of Ophir Canyon dikes cut the limestones. One striking generally north outcrops east of the Cliff mine and can be followed with some interruptions for more than a mile. Near the divide between Ophir and Dry canyons its outcrop forms a conspicuous white cliff. The rock is fine grained and resembles the Eagle Hill porphyry.

Several dikes are present in Dry Canyon, all of those noted striking generally north. Some of them contain abundant porphyritic crystals and resemble the "Birdseye" porphyry more strongly than the Eagle Hill porphyry.

Spurr considers that the two types of porphyry of the Mercur district were derived from a common magma, and it seems probable that the same holds true for the porphyries in the Ophir district.

2 Spurr, J. E., Economic geology of the Mercur mining district: U.S. Geol. Survey Sixteenth Ann. Rept., pp. 377-381, 1895. 3 Op. cit., pl. 25 , p. 360 . 
STRUCTURE.

Folds.-Folding is the most prominent structural feature in the Ophir district and is beautifully shown on the steep slopes of Ophir Canyon. Emmons and Spurr ${ }^{1}$ have shown that the southern end of the Oquirrh Range consists of a broad anticline on the west and a corresponding stncline on the east, both striking generally northwest. The crest of the anticline passes about through the summit of Lion Hill, through the main workings of the Ophir Hill mine, -a little west of the principal mines in Dry Canyon, and through the workings of the Queen of the Hill mine on the north side of Dry Canyon.

From Ophir the rocks of the western anticline dip away in all directions in a pronounced dome or quaquaversal structure. The dips to the north are rather pronounced, being as much as $25^{\circ}$ to $30^{\circ}$ just north of Ophir and becoming steeper farther north. South of Ophir Canyov the dips are much less.

Faults.-In determining the principal large features of this part of the range faulting has been much less important than folding. Some faults, however, are important structurally and some of less magnitude are important economically.

The important Ophir Canyon fault strikes north of east, nearly parallel with OphirCanyon, and dips steeply south. The vertical force that domed the strata apparently caused them to break along the line of this fault and raised the portion to the north more than that to the south, bringing the Cambrian quartzites against the lower part of the great limestone series. The displacement was greatest at the center of the dome and decreased both to the east and west. To determine the throw of the fault will require detailed geologic work to correlate the corresponding horizons in the limestones on opposite sides of Ophir Canyon. It is evident, however, that the throw is at least equivalent to the thickness of the Cambrian quartzites and shales exposed to the north of the fault, which amounts to several hundred feet.

Faults parallel to the main Ophir Canyon fault with throws of 40 feet or less have been encountered in the workings of the Ophir Hill mine, and other minor faults are present toward the Dry Canyon divide. In the Dry Canyon

\footnotetext{
${ }^{1}$ Spurr, J. E., op. cit., pl. 25, p. 360.
}

area detailed mapping will be required to determine the position and throw of the rather complex faults. Some of the important ore bodies of this district are reported to have been cut off by faults.

Fissures.-The limestone has been broken by fissures that trend generally north. They show little displacement and are important chiefly as channels for the ore-bearing solutions. They can not be recognized or traced on the surface, and their distribution is known only so far as they have been encountered in mine workings. From this, however, they appear to be most abundant near the crest of the anticline and to decrease in importance as the distance from the crest increases. This is of course the condition that would be normal if they have resulted from the bending of the limestone beds, for the crest of the anticline would be subjected to the greatest strain.

\section{ORE DEPOSITS.}

The ore deposits of the district show a general similarity in mode of occurrence but differ greatly in metal contents. The Dry Canyon and Ophir Canyon ores carry lead-silver and some zinc and copper; and the ores from Lion Hill carry typically silver, commonly some gold and lead, but very little copper and zinc.

REPLACEMENT DEPOSITS.

Practically all the deposits of the district have formed as replacements of certain beds of limestone in typical shoots or pipes following the intersections of the replaced beds and the ore-bearing fissures. In detail, however, they differ considerably. In some replacement has extended for a considerable distance from the fissures and has formed tabular bodies of ore; in others it has formed relatively small pipes. The position of the ore shoot is largely controlled by the position of the replaced limestone bed and the ore fissure. Most of the fissures are very steep, and many of them are nearly vertical, but the dip of the limestone beds varies greatly, and this dip governs the pitch of the ore shoots.

\section{ALTERATION OF THE LIMESTONE.}

In some places the alteration of the limestone by the ore-bearing solutions consists mainly of a replacement of the rock by the sulphide minerals forming the primary ore. In 


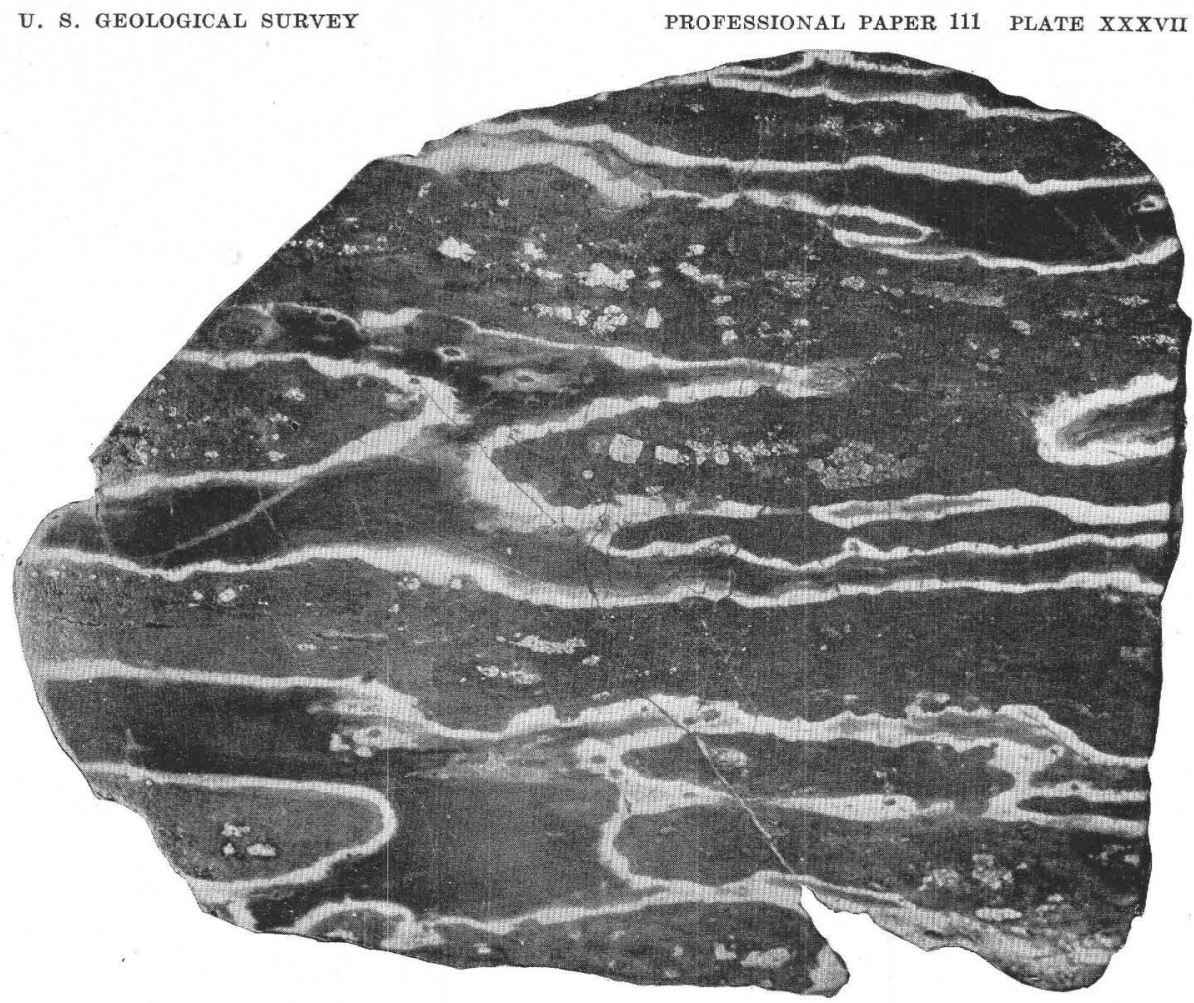

A. SPECIMEN OF ROGK FROM THE OPHIR HILL MINE, SHOWING ALTERATION OF LIMESTONF THAT CONTAINS ORE DEPOSITS. Layers containing crystals of pyrite are composed largely of epidote with orthoclase and quartz; intervening bands
composed largely of quartz and orthoclase. Two-thirds natural size

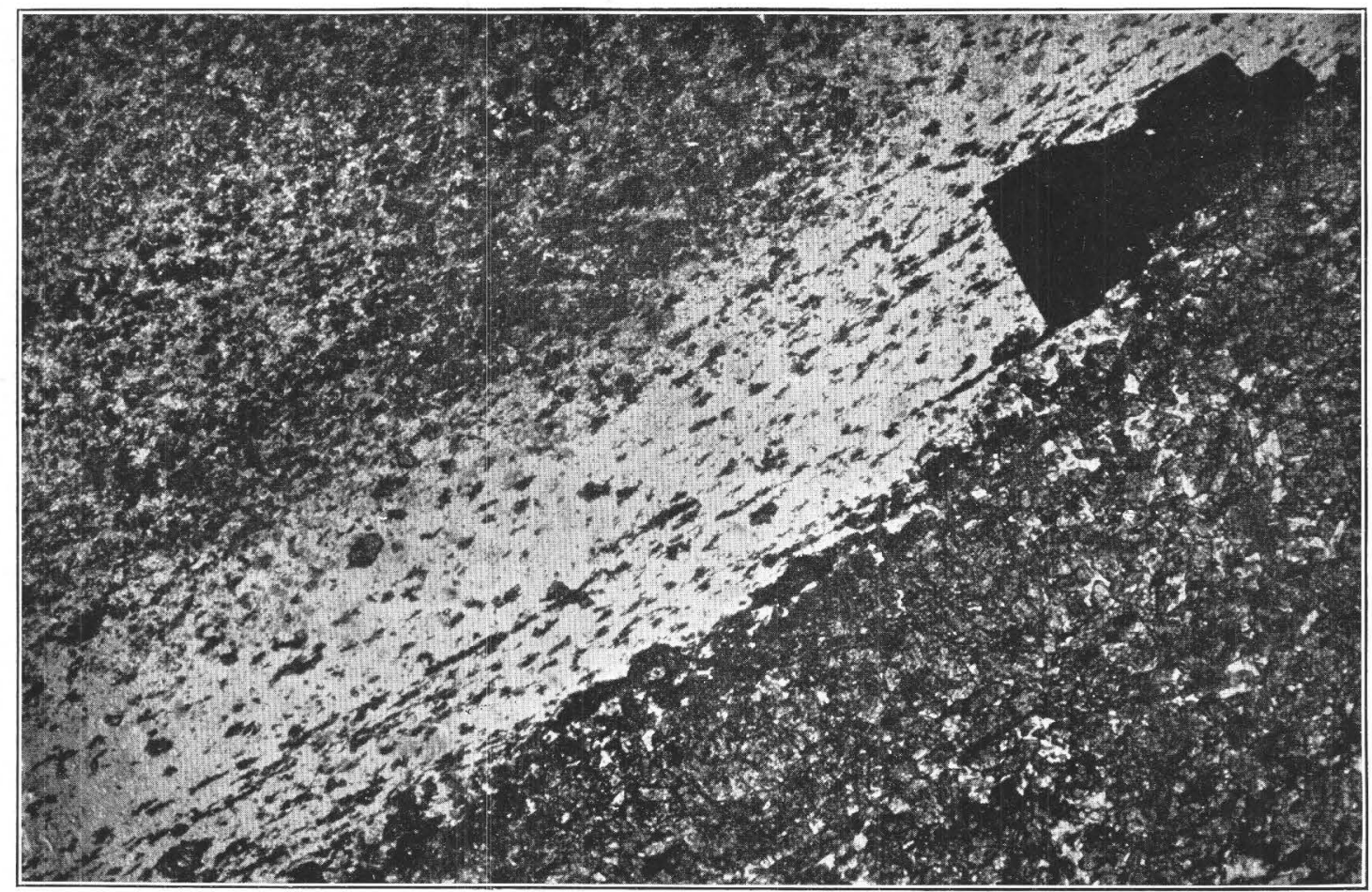

B. PHOTOMICROGRAPH SHOWING GRADATION FROM EPIDOTE LAYER TO QUARTZ-ORTHOCLASE LAYER,

Lower right area, mainly epidote; central band, mainly quartz and grains of pyrite; upper left area, quartz and orthoclase with some epidote. Enlarged 30 diameters. 


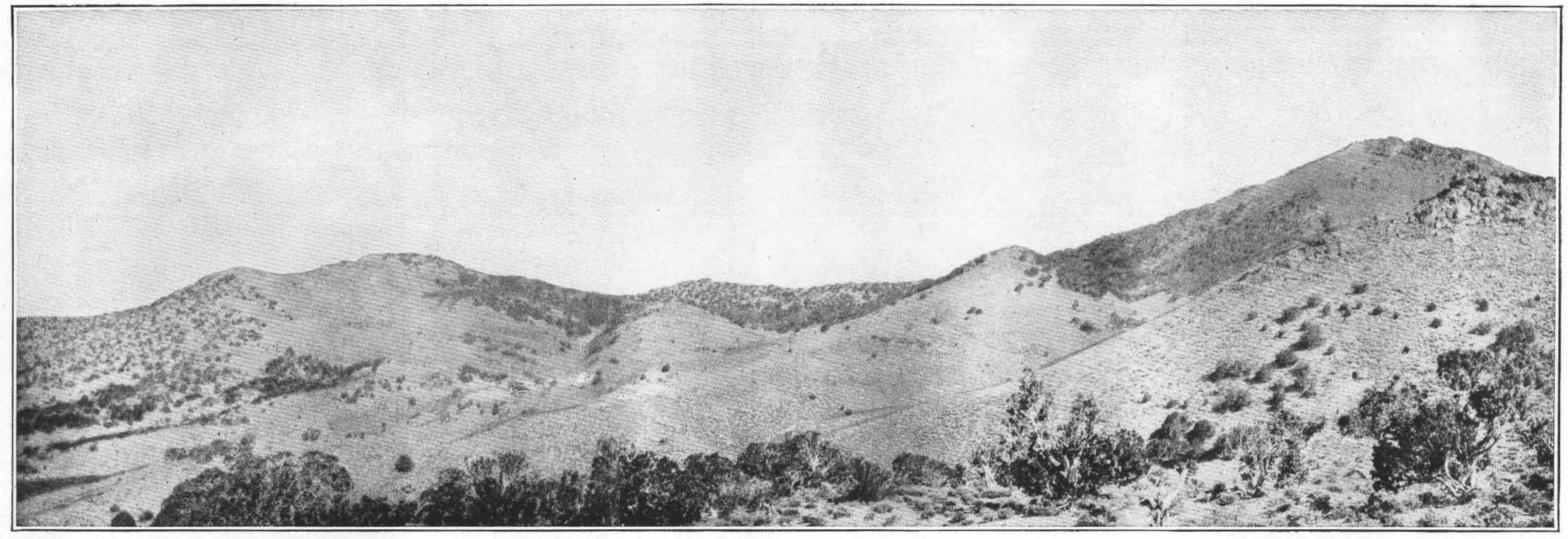

A. VIEW OF WEST TINTIC DISTRICT IN THE VICINITY OF SCOTIA MINE, SHOWING CHARACTERISTIC EXPOSURE OF GEOLOGIC FORMATIONS.

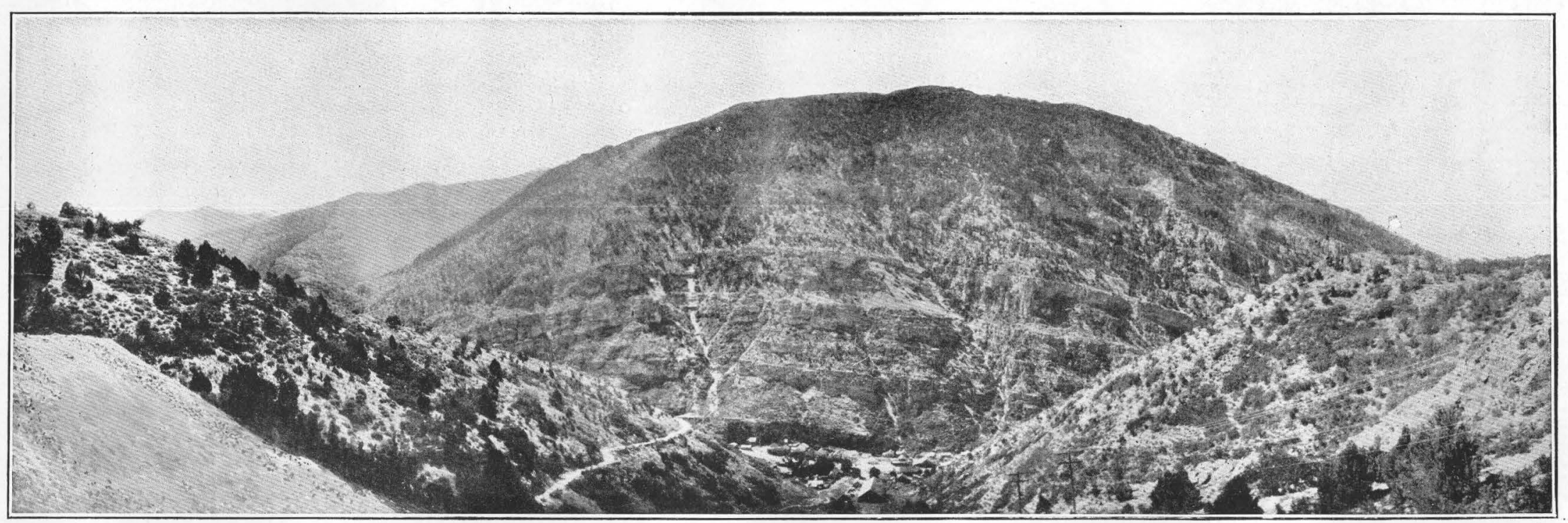

B. LION HILL, SHOWING OPHIR ANTICLINE ON SOUTH SIDE OF OPHIR CANYON, OPHIR.

Photograph by George St. Clair. 
other places the character of the limestone adjacent to the ore has been entirely changed.

In the Dry Canyon area the limestone shows relatively slight alteration. It has undergone some though usually not pronounced silicification and contains some silicate minerals. Veinlike masses of tremolite and wollastonite in limestone found on the dump of the Hidden Treasure mine have apparently resulted from replacement along fissures. In the silicified rock nearly perfect quartz crystals in carbonate grains and rather abundant negative rhombohedral crystals filled with liquid and gas are present, indicating that the carbonate has also been recrystallized. The gas bubbles in these cavities do not ordinarily occupy more than 20 per cent of the space. Near the Cliff mine garnet intergrown with sulphides was collected at several points. Epidote was noted in a similar relation, and it is evident that these silicates have resulted from the action o the ore solutions on the limestone.

The limestone beds adjacent to the ore bodies of the Ophir Hill mine have suffered very great changes. Least altered is a light-gray limestone having a rather striking and characteristic banding of light and dark gray layers, both of which effervesce freely with dilute hydrochloric acid. No chemical analysis of the rocks has been made, but the lighter-colored bands from qualitative tests appear to consist of nearly pure calcium carbonate and the darker beds to contain more impurity, mainly in the fo $m$ of silica. In the ore deposits this limestone has been largely replaced by ore sulphides and by gangue minerals and this grades along the bedding into rock that has been converted very largely into silicates and quartz and some sulphides. Th banding has commonly been preserved in this alteration (see Pl.XXXVII), except that instead of forming continuously in the bands the secondary minerals have in many places formed in lens-shaped bodies along a particular band.

In this altered rock epidote is abundant in green bands or lenses, surrounded by a light band about an eighth of an inch thick and the remainder consists of a gray mass, resembling unaltered limestone but harder. In thin section the green areas are seen to consist largely of epidote with minor amounts of orthoclase and a few crystals of wollastonite. The light area surrounding the epidote is composed largely of orthoclase and some epidote; and the gray mass consists of orthoclase, minute crystals of epidote, quartz, and sericite, which in places is rather plentiful. The minerals in these gray areas are very fine grained and difficult of determination, and it is possible that still others are present. It is evident, however, that the more important minerals resulting from the alteration are epidote, orthoclase, sericite, and quartz.

A partial analysis of the material of the gray areas and the light bands by W. C. Wheeler, of the United States Geological Survey, gave $\mathrm{K}_{2} \mathrm{O} 9.50$ per cent, $\mathrm{Na}_{2} \mathrm{O} 0.83$ per cent. If the alkalies are all calculated as feldspars it gives 63 per cent as the feldspar content of the rock.

It may be mentioned that locally, especially along the contact of quartzite and limestone, sericite (muscovite) is present in relative purity as a white micaceous substance commonly called "talc."

The typical alteration of the limestone at Lion Hill is silicification, the altered limestone or "zone rock" being very largely replaced by quartz. Considerable sericite is, however, scat- . tered through the rock and in places is rather abundant; barite is also rather plentiful but typically is a vein rather than a replacement mineral.

The alteration in the area is confined to a rather definite stratum ranging from a few feet to several scores of feet in thickness that normally and possibly invariably lies directly or closely beneath a sheet of porphyry. It is in this area of altered rock that most of the ore bodies have been found and for this reason it is commonly designated in the district as the "zone rock."

DRY CANYON.

In the early days of mining Dry Canyon yielded large amounts of ore, some of it of high grade. At the time of visit, in 1912, there was comparatively little activity. Lessees were taking ore from the Hidden Treasure property both from underground and from the old dumps, and some ore was being taken from other properties. Since 1912 considerable zinc from oxidized ores and other metals has been produced.

As in many of the older districts, the inaccessibility of many of the workings makes study of the ore deposits rather unsatisfactory. 
Moreover, there has been considerable faulting that can be worked out satisfactorily only by detailed mapping. The following notes on the mines are derived in part from early descriptions and in part from the writer's observations. For several mines no data are available. The oxidized zinc and copper ores have been described by Loughlin. ${ }^{1}$

Hidden Treasure mine.-The Hidden Treasure mine was the first to be located in the Dry Canyon and has been one of the largest producers. The limestone beds strike about N. $70^{\circ} \mathrm{E}$. and dip about $30^{\circ} \mathrm{NW}$. These beds are cut by fissures striking N. $35^{\circ}$ to $40^{\circ} \mathrm{W}$. and by several porphyry dikes, which, however, appear not to be intimately associated with the ore.

The ore deposits have formed as a replacement of the limestone adjacent to the fissures. The workings have been described as follows: ${ }^{2}$

The ore is found in one or two chimneys in a bedded vein in a compact bluish limestone, which dips about $30^{\circ}$ N. $32^{\circ} \mathrm{W}$. About 3 feet above the ore there is a contact vein an inch or so in width between an overlying stratum of siliceous slate (locally called "block slate") and the limestone beneath. Very rarely, however, does the ore body make to the contact (in some of the upper works the ore was on the contact). One chimney began at the surface, or at least within 60 feet of it, and continued for 600 feet. It then split into two chimneys, which continued 800 feet or more. The upper chimney was from 20 to 100 feet wide and from 3 to 20 feet thick. The branches were from 10 to 25 feet wide and from 1 inch to 20 feet thick. The ore found in the Chicago mine was in two bedded pipes, which were in a limestone stratum about 100 feet beneath these ore bodies. The pipes turned upward and finally connected with the Hidden Treasure vein. The ore of the Hidden Treasure is a soft reddish-brown ocher containing cerusite, galena, and traces of copper carbonates. It assays from 15 to 40 ounces silver and 20 to 50 per cent lead. A few hundred feet to the north of this mine, in the direction in which the ore bodies dip, a great dike of granitic porphyry cuts through the country. The mine was formerly opened by five inclines, three of which were in ore, and several tunnels. It was worked at the period under review through a 500-foot tunnel, from which an 800-foot incline was sunk between the two chutes of ore. The extent of the workings on this stratum was 1,600 feet on the dip and 450 feet horizontally.

Since the above description was written, a lower tunnel has been driven and connected with the old workings.

The production in the early days was from the lead-silver "carbonate" ores. Zine blende

${ }^{1}$ Loughlin, G. F., Zinc carbonate and related copper carbonate ores at Ophir, Utah: U. S. Geol. Survey Bull.690, pp. 1-14,1918 (Bull. 690-A).

2 Tenth Census U. S., vol. 13, p. 452, 1885. is mentioned as occurring in the mine, but at that time zine ores were of no value. In 1912 the principal production was in the zinc carbonate ore that was being taken from old stopes from which lead ore had been extracted. Apparently the zinc ore was nearly free from lead, and according to descriptions much of the lead ore mined was comparatively free from zine, suggesting a separation of the two metals during oxidation. In places, however, the oxidized zinc ore could be traced into sulphide ore, which was quite as free from lead as the zinc ore, a fact which strongly suggests separation of the sulphides. Both the sulphide and carbonate zinc ores were relatively low in silver. That zinc ore was rather abundant in the mine is shown by the amount thrown on the dump as waste in the extraction of the lead ores. In 1912 the dumps were being sorted principally for their zinc.

Copper is present but not in large quantity. It is generally in the form of the carbonates, malachite and azurite, though the copperiron-lead sulphate beaverite and the double copper-zinc carbonate aurichalcite were collected from the mine dump. Some specimens of the zinc ore that were not stained with iron are slate-blue in color and on testing show the presence of considerable copper. It is probable that this bluish zinc carbonate contains variable amounts of copper and that it is not of definite composition. Specimens collected from the dump show the replacement of sphalerite, chalcopyrite, and galena by covellite, but no opportunity was afforded for determining the amount of this secondary sulphide ore.

Chicago mine.-The Chicago mine is described as follows: ${ }^{3}$

The Chicago mine was located in 1871, and sold to an English company soon afterwards. The mine was worked vigorously for several years but has been idle since 1876 . Ore was found in two pipes 60 feet apart in the "reef" of limestone under the Hidden Treasure. These pipes came to within a few feet of the surface, covered only by the iron cap, and diverged somewhat as they went down. They were in general about $2 \frac{1}{2}$ feet in diameter but varied in shape considerably, especially beyond 400 feet. One pipe was followed 1,300 feet, and decreased in size until it was only 6 inches in diameter, when work was abandoned. This had five smaller pipes branching from it. The second pipe went down quite regularly for 800 feet, then suddenly rosé 60 feet and continued on its 
course. A second rise brought it to the Hidden Treasure vein. The ore is ocherous, assaying from 25 to 35 ounces silver and from 40 to 45 per cent lead. On the sides of the pipe there is usually from 6 inches to a foot of a valueless oxide of iron, frequently stained by copper carbonates. The total cuttings amount to about 5,000 feet. The mine produced considerably over 12,000 tons of ore.

Mono mine.-The Mono mine has been one of the large producers of the district. The exact metal output is not known but has been estimated at about $\$ 1,000,000$. The main production was made in early days, when a shoot of very rich ore was followed till (as reported) it was cut off by a fault. For part of its extent at least the ore shoot underlies a rather thick bed of black shale which in many places has been crushed to an impervious gouge that appears to have stopped the ore solutions and caused them to replace the limestone underneath. The early workings were described as follows: ${ }^{1}$

Ore began at the surface and was found in a chute from 10 to 50 feet long, from 3 to 5 feet wide, and 300 feet deep. Below that depth it was in a series of small deposits. It was an oxidized ore, from silver, lead, copper, and iron sulphides. Slabs of horn silver were frequently found so soft that they would retain the impression of a coin, like wax. Its value, by the ton, was from $\$ 150$ to $\$ 5,000$ in silver. This ore occurs in a stratum of clay shale. The ore chute seems to cross this stratum and enter a black shale at a depth of 400 feet. In the lower workings the ore was limited in quantity and only assayed about $\$ 100$ per ton.

The Mono tunnel is in the gulch about 800 feet below the upper workings and is designed to develop the area at greater depth. Some ore has been found in this tunnel, but as yet no bodies comparable in amount and value to those in the upper workings have been found.

Queen of the Hills mine.-The Queen of the Hills mine, including the Queen of the Hills, Flavilla, and Mahogany locations, was not in operation at the time of visit. These claims have been described as follows: ${ }^{1}$

These claims are on three chimneys in a bedded vein from 1 to 6 feet wide, dipping $17^{\circ}$ to $25^{\circ} \mathrm{W}$. between a siliceous limestone above and a blue limestone stratum below. *** The dip of the chimneys is N. $30^{\circ} \mathrm{W}$., being oblique to the dip of the strata. * * * The first chimney was 350 feet long (before being cut by the fault) and was from 25 to 40 feet wide, having a thickness of from 18 inches to 2 feet of ocherous ore containing but little copper and said to assay from 20 to 25 ounces silver and 50 per cent lead. The second chimney was 1,000 feet long, from 60 to 70 feet wide, and also had from 18 inches to 2

Tenth Census U. S., vol. 13, p. 453, 1885. feet of ore, generally upon the hanging wall, assaying about 40 ounces silver and 30 per cent lead. The third chimney was about the same size as the second, but the ore contained some tetrahedrite, much malachite, and little lead, and assayed about 60 ounces silver. Recently zine ore has been shipped from this mine.

Kearsarge mine.-The Kearsarge mine has been described as follows: ${ }^{1}$

The ore-bearing formation is a stratum of limestone, in which the ore occurs in chimneys and exceedingly irregular masses. The overlying stratum or hanging wall is a very compact siliceous limestone. One chimney began at the surface and went down 500 feet. * * * The ore is a soft ocher, similar to that of the Hidden Treasure but much richer. The mine was opened by a 945 -foot incline, having a dip of $30^{\circ}$ to $35^{\circ}$. The ore continued in the bottom of the incline 20 inches in width, but water had stopped the work.

Other mines.-Other mines that made considerable production in early days were the Deseret group, Utah Queen, Sacramento, Mountain Savage, Emporia, Fourth of July, and Wandering Jew.

OPHIR CANYON.

Cliff mine.-The Cliff mine is on the north slope of Ophir Canyon, a few hundred feet below the Dry Canyon divide. The mine was worked in the early days and since 1905 has been one of the important producers of the district.

The sedimentary rocks are limestones of lower Carboniferous age, probably near the base of the Carboniferous, for fossils of this age were found only a few hundred feet below the ore horizon. The main development is a little to the east of the crest of the anticline, where the sedimentary beds dip about $30^{\circ}$ a little east of north. A prominent porphyry dike striking about north and dipping steeply east cuts the sedimentary series a short distance west of the main workings. The sedimentary rocks are also cut by fissures striking a little east of north and dipping steeply east.

Ore bodies have been developed as very irregular replacements of the limestone along four fissures at two main horizons 40 to 50 feet apart. They pitch northeast in common with the intersection of the bedding and fissures. The limestone associated with the ore has been silicified and garnetized to some extent. The contact of the limestone and porphyry dike has been prospected for a short distance. 
Some mineralized rock is present but no ore has been found.

The principal primary sulphide minerals are galena, pyrite, sphalerite, and chalcopyrite. Adjacent to the fissures these have been largely altered to secondary minerals, principally carbonates and oxides and minor amounts of other minerals, including the lead-iron sulphate plumbojarosite. Near the fissures oxidation has usually been rather complete, but farther from the fissures, away from the main channels of circulation, sulphides are more plentiful and some nearly pure sulphide ore has been mined.

The most important output has been lead and silver, but the mine has also produced considerable copper and some zinc. The ores have been only moderately rich, but those thus far extracted have been of a shipping grade. The mine has been opened by three tunnels at successively lower depths, and in 1912 an incline had been sunk to a depth of 550 feet on the dip below the lower tunnel. The ore is transported to the railroad in Ophir Canyon by an aerial tram. Previous to 1912 it was freighted by traction engine from the base of the tram to St. Johns.

Ophir Hill mine.-The Ophir Hill mine of the Ophir Hill Consolidated Mining Co. is on the north side of Ophir Canyon, about half a mile northwest of Ophir. The ore bodies occur in the Cambrian shale-limestone series (Ophir formation) overlying the Cambrian quartzite. In the mining developments five strata of limestone have been recognized, though they are not entirely distinct at all points. The shale, especially in the lower part of the series, has been metamorphosed to a distinctly schistose rock. The limestone beds have suffered comparatively little alteration except that caused by the ore solutions. Several of the beds are composed of light and dark gray layers which give the rock a characteristic banded structure. Overlying the limestoneshale series are heavy-bedded blue limestones, in which little ore has been developed.

The developed area is just north of the Ophir Canyon fault and near the crest of the dome. The beds strike generally east and dip about $25^{\circ}$ a little east of north. Several minor faults that appear in the mine strike generally east. In most of them the downthrow is to the north, but in the most northerly it is to the south. Most of the throws are only a few feet, though that of the "Big" fault is about 40 feet.

A series of fissures striking a little east of north cut the sedimentary rocks nearly at right angles to the bedding and about parallel to the anticline and dip steeply west. They show no extensive movement, and as they cross the east-west faults with little or no displacement, they appear to be the youngest structural features. Four systems of replacement deposits - the Wild Delirium, Miners Delight, West stope, and Clark stope - have been developed adjacent to these fissures in each of five limestone beds or "veins."

The thickness of the ore beds changes somewhat from place to place but is approximately as follows: Top vein, 5 feet; Big vein, 20 feet; Middle vein, 10 feet; Copper vein, 8 feet; Blue vein, 6 feet. These "veins" are not everywhere entirely distinct, and at some points the Top and Big veins and the Blue and Copper veins are mined together. The maximum distance from the fissures to which the limestone has been replaced by ore minerals is 40 feet, and possibly more. The most extensive deposits are associated with the east-west faults, the limestone adjacent to which appears to have been crushed and thus rendered more permeable and susceptible to replacement. The primary ore minerals are pyrite and galena, some sphalerite and chalcopyrite, a little tetrahedrite and bornite, and probably other metallic minerals in small amounts. The more important gangue minerals are epidote, quartz, orthoclase, sericite, and residual calcite.

The north-south fissures carry no deposits of value. At the ore horizons they commonly contain ore from the thickness of a knife blade to 2 or 3 inches, but except for this they are said to be nearly or quite barren. Even this ore appears to be distinct from the bed ore, for it is separated from the beds by distinct walls, and it carries a much higher percentage of copper and zinc. This condition suggests that the fissures were reopened and filled after the deposition of the bedded ore.

Oxidation in this deposit has been relatively slight. The ore mined in recent years is a concentrating ore of rather low grade, averaging around 8 per cent lead and about an ounce of silver per unit of lead. The ore yields considerable copper and some gold and zinc. 
The mine was first worked through inclines on the dip. The main incline follows the ore to a depth of about 1,800 feet. A drain and working tunnel, through which the ore is transported by electric trains, has been driven to the ore body from a point just above the mill. A large tonnage of concentrating ore is developed in the mine and can be cheaply extracted, owing to the large size of the ore bodies and the small amount of timber required. In 1912 the capacity of the 150-ton mill was about doubled.

LION HILL.

The Lion Hill area is south of Ophir Canyon, the principal producing area being near the summit of the hill. (See Pl. XXXVIII, A.) Owing to the high grade of the ores, the relatively simple recovery of the metals, and the ease of development, the deposits being near the surface and in a position favorable to development by tunnels, this section of the district was early developed and for several years in the seventies was an important producer. With the exhaustion of the richer and more accessible deposits activity greatly declined and for many years operations were conducted principally by lessees. Recently several of the old properties have been combined as the Lion Hill Consolidated Co., and more systematic development of its territory has been undertaken.

The sedimentary rocks of Lion Hill are mainly limestones with interbedded calcareous shales. The lower part of the series, like that north of the canyon, is probably of Cambrian age, and for several hundred feet below the crest the rocks are of lower Carboniferous age.

The igneous rocks consist of porphyry dikes and sheets. The most important body outcrops at numerous points around the hill near the summit and appears to be a sheet, though it has not been shown to be continuous. It has been correlated by Emmons and Spurr ${ }^{1}$ with the Eagle Hill porphyry of the Mercur district, but in several places it is coarser grained, more porphyritic, and more basic in appearance, and resembles more closely the "Birdseye" porphyry. The other porphyry is on Porphyry Hill and Porphyry Knob and is the "Birdseye" porphyry of Emmons and Spurr in the Mercur district.

1 Op. cit., pp. 377-379.
The northwest-southeast anticline is beautifully exposed in Ophir Canyon. The dome structure in this anticline centering at Ophir Canyon has given the rocks a slight southward dip. The rocks here, as well as north of the canyon, have been broken by two series of fissures and faults, an east-west series generally parallel to Ophir Canyon and a north-south series about parallel with the trend of the anticline. The ore deposits are closely associated with the north-south fissures and are commonly found a short distance below the porphyry sheet. Over a considerable part of the mineralized area this porphyry is not present, but in many places the relations strongly suggest that it was once present and was removed by erosion.

Underlying the porphyry sheet and adjacent to the north-south fissures the limestone has been characteristically altered to a cherty, porous mass composed principally of silica with considerable sericite and small grains of residual calcite. This material is locally known as the "zone" rock and is associated with much of the ore.

The ores thus far developed are within a vertical distance of a few hundred feet. Welldefined fissures extend below the ore zone but are commonly open or are filled with calcite and contain no ore. The ores are almost entirely oxidized, the rich deposits containing horn silver and lead carbonate. Some ore collected by the writer contained in considerable abundance a yellow lead mineral, consisting of sulphur, lead, arsenic, iron, and in some specimens copper. Material of sufficient purity for careful quantitative study was not obtained. In some of the rich silver ore a possibly similar light-yellow sulphate fills small cavities. Plumbojarosite is rather abundant, and some of this ore is said to be rich in silver. In parts of the area, apparently especially in the northeastern, manganese oxides mixed with the iron oxides are rather abundant. The ore is characteristically a silver ore, though it contains considerable lead and gold and in places a little copper, zinc, antimony, and arsenic. The typical gangue mineral is the silicified limestone, but barite also occurs, and calcite is common. Locally, sericite, commonly called "talc," is present in considerable amounts. In some places the ore is surrounded by a gray, friable 
mass composed largely of small quartz crystals, s many of which are nearly euhedral in form and contain many small dark inclusions.

The ores of the area range in metal content from milling ores carrying a few dollars a ton to high-grade ores carrying hundreds of ounces. Considerable low-grade ore lies on the dumps and is contained in the mines, and some favorable ground in the district has never been systematically prospected. Many of the old workings are not now accessible. Some of them have been described as follows: ${ }^{1}$

The Zella group *** is on the western side and near the summit of Lion Hill. *** Three large bodies [of ore] and several smaller ones were found about 20 feet below the surface. The ore is a soft, yellow, siliceous chloride assaying several hundred dollars per ton. * * * It was impossible to ascertain, except approximately, the total product of this group, but it was estimated at $\$ 750,000$. * * *

The ore [of the Monarch group] is found in a stratum of quartzite, dipping slightly northeast. There is limestone below and porphyry, in some places at least, above this stratum. * * There are two or three large bodies * * * and several smaller ones. The ore is a porous quartz containing cavities filled with the "chloride" of the miners and some carbonate of lead. In the center of the body it is quite soft and fine but upon the edges very hard and coarse. * * * The total product to the close of the census year was $\$ 117,500$.

The Douglas mine *** is near the Monarch group, which it greatly resembles in gangue and ore. * * * Two bodies [of ore] have been found of about the same size 50 feet apart.

\section{BIBLIOGRAPHY.}

Tenth Census U. S., vol. 13, p. 450, 1885.

GANSL, G. C., and KeEP, C. A., Ophir mining district of Utah: Min. World, vol. 12, p. 17, 1910.

Murphy, J. R., The mineral resources of the Territory of Utah, with mining statistics and maps, p. 29, Salt Lake City, 1872.

Spurr, J. E., and Emmons, S. F., Mercur mining district, Utah: U. S. Geol. Survey Sixteenth Ann. Rept., pt. 2, pp. 343-455, 1895.

Internal commerce of the United States, 1890, p. 892, Washington, 1891.

CAMP FLOYD OR MERCUR DISTRICT.

HISTORY AND PRODUCTION.

\section{By V. C. HeIKes.}

The Camp Floyd district is about 55 miles south of Salt Lake City, in Tooele County, adjoining the Ophir mining district. It contains three distinct camps-Mercur, the most important, in Lewiston Canyon (see Pl. XXXIX); Sunshine, about 4 miles south of Mercur in Sun-

1 Tenth Census U. S., vol. 13, p. 451, 1885. shine Canyon; and West Dip (on the west dip of the anticline), about 2 miles west of Mercur near the western part of the range. The Salt Lake \& Mercur Railroad, which was dismantled in 1914, connected with the Los Angeles \& Salt Lake Railroad at Fairfield Junction and furnished transportation for the district. The district was first organized at the beginning of a silver excitement on April 16, 1870, and later was practically abandoned until the discovery of gold ore, which was successfully treated by cyanidation in 1891. On June 24, 1894 , it was reorganized.

The early history of the district is reviewed by Huntley, ${ }^{2}$ who says:

The Camp Floyd district is south of the Ophir district and is on the same range. It is an irregular rectangle, from 7 to 9 miles on a side, the mines themselves, however, being included within an area of a square mile. * * * The Carrie Steele mine * * * was discovered in 1873 by Leandro Steele; was worked from 1876 to July, 1879, when it was sold to the Carrie Steele Mining Co., of New York. * * * One large body of antimonial ore 20 feet thick and 60 by 70 feet in extreme width and length was found at the surface. The richest ore averaged $\$ 700$ and occurred in a seam from 8 to 10 inches wide next to the roof. * * * The mill *** was built by an English company in 1872-73 to work the ores of the Sparrowhawk mine. * * * It was purchased by the Carrie Steele Mining Co. in 1879, and ran from May 10 to August 15, 1880. * * *

The other mines of the Camp Floyd district are:

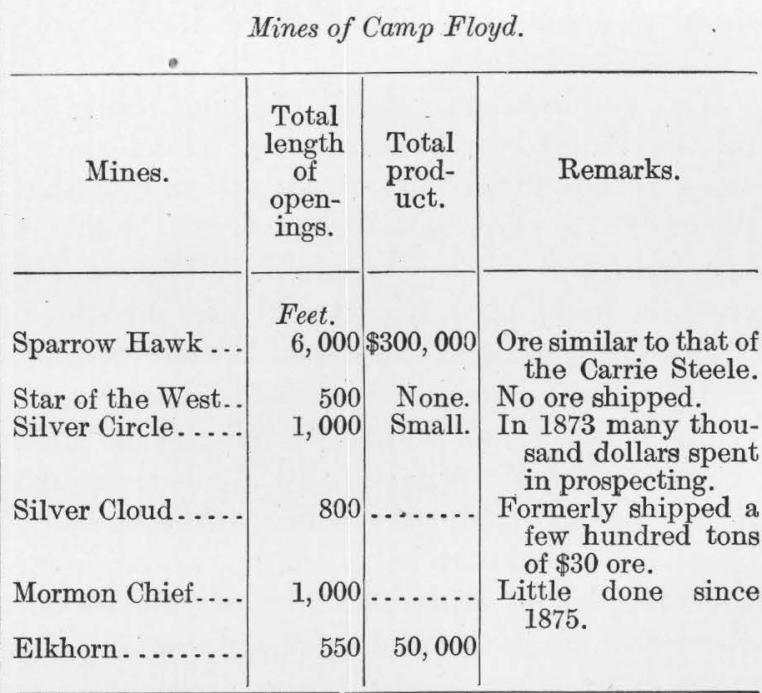

The production of the district from 1871 to 1881 is estimated by Spurr ${ }^{3}$ at 46,000 ounces of silver; the ores then worked contained no lead,

${ }^{8}$ Spurr, J. E., Economic geology of the Mercur mining district: U. S. Geol. Survey Sixteenth Ann. Rept. 1894-95, pt. 2, p. 355, 1895. 


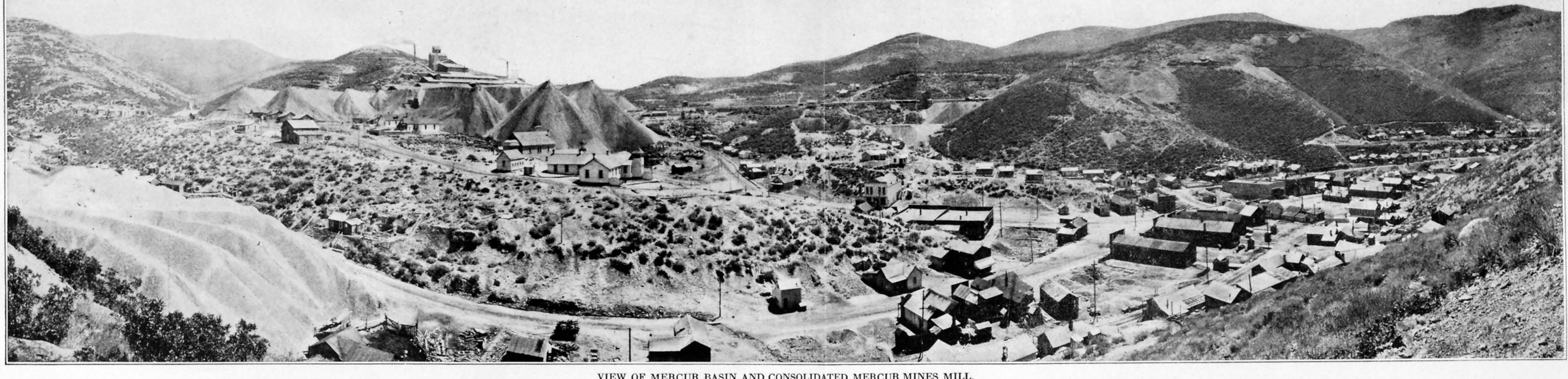


copper, nor gold. The gold production of Camp Floyd district, which became important in 1892, amounted in that and the succeeding year to about 19,000 ounces.

Gemmell ${ }^{1}$ gives the following history of the district up to 1897 :

When the district was organized on April 16, 1870, it naturally was called the Camp Floyd mining district. The first location in the district was a placer claim, located by L. Greeley on April 20, 1870. Other and similar locations followed, but placer d:ggings could not possibly be made to pay, for two very good reasons-lack of gold that could be panned and lack of water. The Sparrow Hawk, Last Chance, and Marion claims were among the first lode claims located. Some very rich silver ore was discovered on them (some of it going $\$ 4,000$ or $\$ 5,000$ to the ton) and they were soon sold to an English syndicate. The ore proved to be very "pockety," and after building a mill, spending about $\$ 700,000$ and clearing only about $\$ 100,000$, the company suspended operations.

Soon after the Sparrow Hawk discovery a rich strike was made in the Carrie Steele. It is said that from this pocket a few men took out about $\$ 83,000$ in three months. Other strikes followed, and in 1872 and 1873 the hills were swarming with prospectors. The town of Lewiston was built on the present site of Mercur and was soon a full-fledged mining camp. * * * But no steady producing mines were found; the excitement began to die away, and Lewiston, which had grown to a town of some 1,500 people by 1880 , had dwindled down to one house and to one inhabitant, Moses Manning, who remained to work out his own and others' assessments. It is estimated that during this excitement only about $\$ 350,000$ were taken out and that many times that amount was expended. Machinery, supplies, and. labor were all so high that it required $\$ 60$ ore to pay.

On April 30, 1879, a German named Arie Pinedo located the Mercur lode, believing he had discovered a valuable vein of cinnabar and naming the claim after the German word for Mercury-Mercur. Some cinnabar was found, but not in paying quantities, and Pinedo soon abandoned the claim and left the country. Other prospectors drifted in, and about 1883 the gold ledge was discovered. The assay returns showed the yellow metal to be present in paying quantities, but after numerous attempts at panning with never a color, the prospectors gave it up.

In March, 1889, Capt. Joseph Smith * * * put up a mill on the Marion ground for the purpose of working the silver ore and tailing dump. *** After spending $\$ 9,000$ or $\$ 10,000$ with no substantial result, Capt. Smith was forced to abandon the idea of making the silver ores pay. He remembered the stories of cinnabar and gold being found in the Mercur ore, sampled the vein in the summer of 1889, and got good returns in gold. All thought of mining for silver or cinnabar vanished, and during the

1 Gemmell, R. C., Eng. and Min. Jour., Apr. 24, 1897. winter of 1889-90 some work was done on the Mercur lode. A 5-ton lot of the ore was brought across the canyon to the Marion mill and treated with apparent success.

Messrs. G. S. Peyton and H. W. Brown associated themselves with Capt. Smith in March, 1890, and incorporated the Mercur Gold Mining \& Milling Co. * * * Twentyfive thousand dollars were spent under the direction of Capt. Smith in building a mill near a spring at what is now called Manning, about halfway between Mercur and Fairfield station. This was an amalgamating mill, like the one previously built on the Marion ground. * * * Five thousand dollars were spent in developing the mine and fixing up the wagon road from the mine to the mill. The attempt to treat the ore by amalgamation proved a failure, however, and once again the hopes of getting any money out of the ores of Camp Floyd district were blasted. About 1,500 tons were put through the mill that by careful sampling had averaged about $\$ 18$ per ton. Assays of the tailings showed an extraction of about 80 per cent, but the clean-up, instead of amounting to about $\$ 21,000$, proved to be less than $\$ 5,000$. Cyanide of potassium had been used for cleaning the quicksilver, and subsequent experiments proved that the gold had been dissolved and carried off by the cyanide.

About this time the successful treatment of gold ores by the cyanide process became generally known, and * * * a carload of ore was shipped to Denver for a practical test. An extraction of about 80 per cent was obtained by this test, and in the summer of 1890 the mill at Manning was remodeled and turned into a cyanide plant, by which the ore was successfully treated. Capt. Smith, having severed his connection with the Mercur mine, turned his attention to the development of the gold ledge in the Marion group of claims. He remodeled and added to the amalgamating mill previously built, and by June, 1893, started up the second cyanide plant in Mercur.

The successful treatment of the gold ores being assured, prospectors again swarmed in. Arthur Murphy and C. L. Preble located two claims on the old site of Lewiston, staked them out into town lots, and saw a new town (Mercur) grow to be about the same size as Lewistown in its palmy days-about 1,500 inhabitants. By 1897 Mercur had become a regularly organized municipality, with a water system and fire department. In 1900 the population reached 2,351 , but dwindled in the next decade to 1,047 inhabitants, and in 1913 was almost entirely abandoned on the closing of operations by the Consolidated Mercur Mines Co.

The following table shows the metal output from the Camp Floyd district from the beginning of operations to the close of 1913: 
Metals produced in Camp Floyd district, by periods.a

\begin{tabular}{|c|c|c|c|c|c|c|}
\hline \multirow{2}{*}{ Period. } & \multirow{2}{*}{$\begin{array}{l}\text { Ore } \\
\text { (short } \\
\text { tons). }\end{array}$} & \multicolumn{2}{|c|}{ Gold. } & \multicolumn{2}{|c|}{ Silver. } & \multirow{2}{*}{$\begin{array}{l}\text { Total } \\
\text { gross value } \\
\text { recovered. }\end{array}$} \\
\hline & & $\begin{array}{c}\text { Fine } \\
\text { ounces. }\end{array}$ & Value. & $\begin{array}{l}\text { Fine } \\
\text { ounces. }\end{array}$ & Value. & \\
\hline \multirow[t]{2}{*}{$\begin{array}{l}1871-1881{ }^{b} . . \\
1890-1900 \ldots \\
1901-1917 \ldots .\end{array}$} & $\begin{array}{l}1,929,993 \\
3,653,990\end{array}$ & $\begin{array}{l}382,790.00 \\
538,052.87\end{array}$ & $\begin{array}{l}\$ 7,912,973 \\
11,122,539\end{array}$ & $\begin{array}{c}46,000 \\
\cdots \ldots \ldots \\
2,760\end{array}$ & $\begin{array}{r}\$ 55,936 \\
\cdots \ldots \ldots . \\
1,576\end{array}$ & $\begin{array}{r}\$ 55,936 \\
c 7,912,973 \\
d 11,124,115\end{array}$ \\
\hline & $5,583,983$ & $920,842.87$ & $19,035,512$ & 48,760 & 57,512 & $19,093,024$ \\
\hline
\end{tabular}

$a$ From 1903 to $1907,3.338$ flasks of quicksilver were produced from the Sacramento mine.

$b$ Spurr, J. E., Economic geology. of the Mercur mining district, Utah: U. S. Geol. Survey Sixteenth Ann. Rept., pt. 2, p. $354,1895$. c A verage recovery, $\$ 4.10$ per $t$ on.
$d$ A verage recovery, $\$ 3.04$ per ton.

From 1890 to the close of 1917 there were produced in the Camp Floyd district by the Mercur, Delamar, Geyser-Marion, Sacramento, Sunshine, Overland, Daisy, and La Cigale properties 5,583,513 tons of ore valued at $\$ 19,034,984$. All had mills, and all except the La Cigale were successful in extracting fair values from the ores. The first five properties paid $\$ 3,881,323$ in dividends to stockholdersthe total amount paid during the greatest activity in the district. The old Mercur Gold Mining \& Milling Co. paid dividends of $\$ 1,481,000$ and the Delamar Mercur Mines Co. dividends of $\$ 689,812.99$ to August 1, $1900 .^{1}$ These two companies $^{2}$ had mined up to that time 1,045,136 tons of ore at a profit of $\$ 2,181,401$, or about $\$ 2.09$ per ton. From August 1, 1900, to 1913, inclusive, the Consolidated Mercur Mines Co. produced gold in precipitates and bullion valued at $\$ 10,549,377$, recovered from 3,291 ,485 tons of ore (including some tailings), or an average recovery value of $\$ 3.20$ per ton of material treated at a total cost ${ }^{3}$ of $\$ 2.82$ per ton. Dividends paid aggregated $\$ 1,374,500$ to July 31, 1913. The Mercur \& Brickyard-Golden Gate (Delamar) property yielded 4,336,621 tons of ore, from which $\$ 16,419,541$ was recovered, an average of $\$ 3.78$ per ton. Dividends paid during the life of the combined properties amounted to $\$ 3,445,312$.

After the first test was made on Marion and Mercur gold ore by amalgamation at the Marion mill in Lewiston Canyon, the mill erected at Manning in Fairfield Canyon for the treatment of the ore in 1890 was similarly equipped, using pan amalgamation.

\footnotetext{
1 Consolidated Mercur Gold Mines Co.'s annual report for the year ending June 30, 1901.

2 Idem, p. 13.

3 Howard, L. O., and Maguire, D., Cyanidation in the Mercur district of Utah: Pamphlet published by Salt Lake Min. Rev., p. 20, 1913

4 Letter from G. S. Peyton to V. C. Heikes, dated November 23, 1914. Mr. Peyton was then living at Rackerby, Cal.
}

In a personal communication ${ }^{4}$ G. S. Peyton, discoverer of the process that made Mercur famous, gives the early history of the Mercur mill as follows:

The Mercur mill was built under the advice and supervision of Joseph Smith, superintendent, at Manning in the years 1890-91 by the Mercur Gold Mining Co., organized in May, 1890. * * * The amount of gold first saved by this process of amalgamation was $\$ 3,000$, representing about 15 per cent of the value of the ore. In July, 1891, a car of the $\$ 17$ ore was shipped to Denver for trial by the cyanide process, which successfully extracted 92 per cent of the values. The amalgamation equipment and concentrators were then discarded, and the cyanide plant completed and started in February, 1892, on ore averaging $\$ 12$ per ton in gold, of which 86 per cent was saved.

As experience was gained in the handling of the ores by the new cyanide process the mill was enlarged. * * * In 1896 the mill was treating 225 tons of ore daily, or altogether 63,480 tons for the year, averaging in value about $\$ 12$ per ton in gold, of which about 80 per cent was saved. The average cost of mining and milling was about $\$ 2.80$ per ton. The total amount paid in dividends up to January 1,1897 , was $\$ 600,000$.

During 1897 and 1898 the Golden Gate mill was built at Mercur, and in 1900 the DelamarMercur Mines Co. and the Mercur Gold Mining $\&$ Milling Co. were combined and thereafter called the Consolidated Mercur Mines Co. All of the ore from the Mercur and Delamar mines was afterward treated in the Golden Gate mill, the Manning mill being used intermittently by the company and lessees for the re-treatment of tailings. The original capacity of the Golden Gate mill was 500 tons but by 1900 it was increased to 1,000 tons of ore daily: ${ }^{5}$

A summary of the production and costs of operations is given in the following table:

${ }^{5}$ For a full description of the original plant on the Delamar property see Director of Mint Rept. upon production of precious metals for 1899, pp. 181-187, 1900 . 
Summary a of classified ores and tailings treated at the Consolidated Mercur Mines Co.'s mill, 1901 to 1912 (from company reports).

Production.

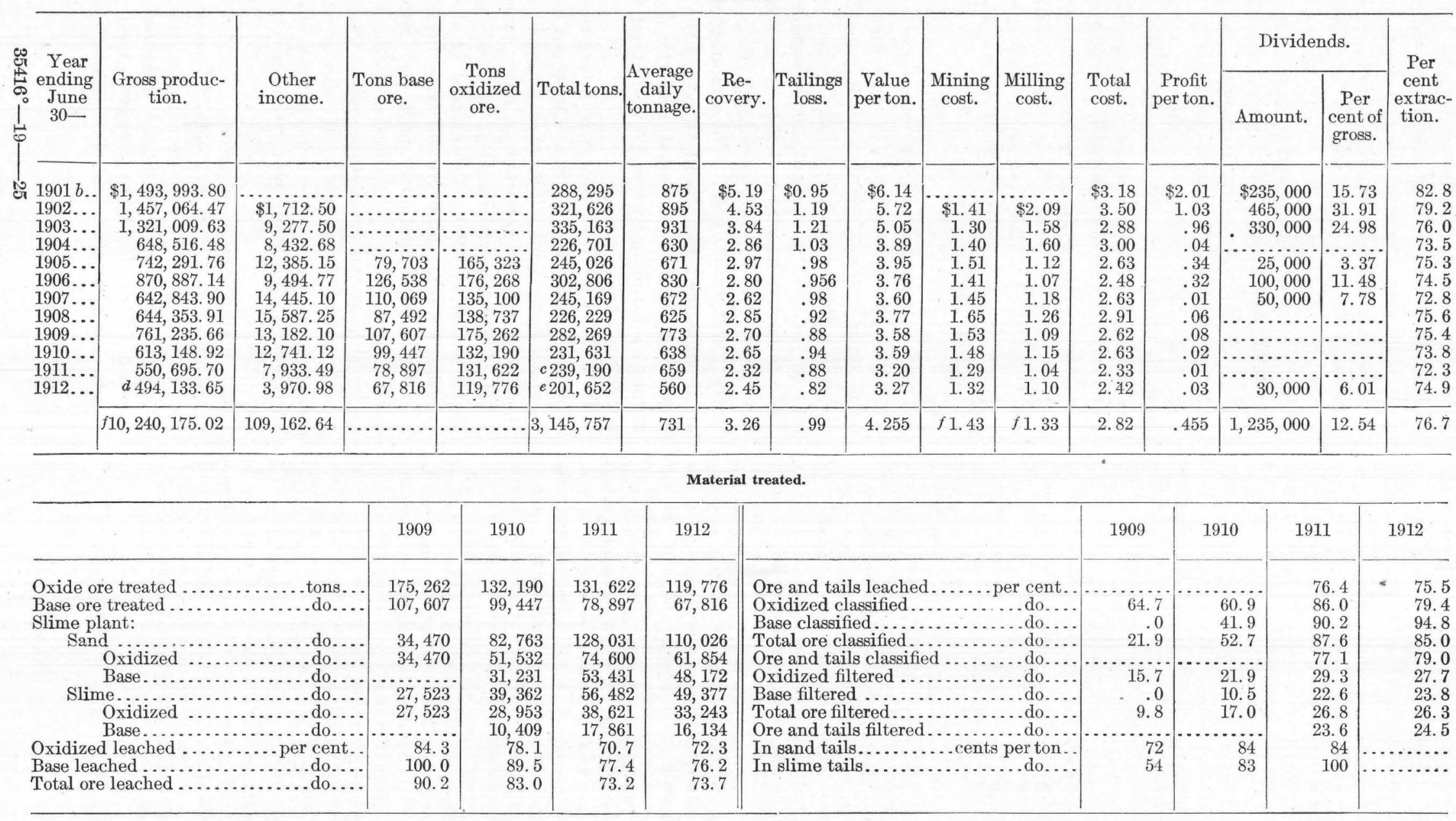

$a$ Cyanidation in the Mercur district, Utah, pamphlet published by Salt Lake Min. Rev., 1913.
$b$ For 11 months.

d Corrected figures from company report.
$e$ Includes 14,060 tons of tailings.

$b$ For 11 months.
$c$ Includes 28,671 tons of tailings. 
The character of the oxidized and base ores of the Golden Gate claims in Camp Floyd district are discussed by D. C. Jackling, ${ }^{1}$ who says:

Locally, the ores are classified into three varieties, according to their mode of treatment:

First, "oxidized ores," consisting of a mixture in which the calcareous and siliceous varieties predominate and in which the proportion of clay and talc is insufficient to interfere with percolation.

This class of ore contains only an insignificant quantity of compounds of base elements, showing only very small fractional percentages of mercury, as cinnabar and arsenic oxidized compounds.

Second, "talcy ores," which are almost entirely clay and talc, and soft, decomposed porphyry. These ores, like the class above, are almost free from base element compounds but impossible of percolation, for the reason that on contact with water they disintegrate and settle to an almost impervious mass.

Third, "base ores," consisting of a mixture of the above classes, with the calcareous and talcose varieties predominating, and containing large quantities of base-metal sulphides. Arsenic is the chief of these, occurring as realgar, orpiment, and mispickel, in quantities sometimes as high as 50 per cent, but averaging not to exceed 2 per cent. Realgar is by far the most plentiful of the arsenicbearing minerals, fully three-fourths of the arsenic appearing in this way. Antimony is present as stibnite. Occasional small quantities of galena occur.

Considerable quantities of iron pyrites are frequently encountered in minute crystals. Mercury is invariably present but in less quantities than in the oxidized ores. Various hydrous sulphates of iron are present, as well as oxidization products of arsenic, both simple and in combination with lime and magnesia. Some of the rarer elements, most notably tellurium, are also present, in traces only. The clays of this class of ore are invariably dark gray or black in color, due to a considerable quantity of carbon, frequently as much as 4 per cent, and in these are sometimes found organic compounds which decompose potassium cyanide very rapidly. Silver is very sparingly distributed in all classes of ore, rarely exceeding 1 ounce of silver to 10 ounces of gold. No metallic gold is visible in any of the ores until after they have been roasted, when occasional minute, irregular particles may be discovered under the microscope. All the clean, base minerals are invariably poorer in gold than the gangue with which they are associated. The clear crystals of realgar and orpiment carry none at all, or only traces, showing that the increased values of the base ore are not directly due to these basemetal minerals. The gold in whatever ore found dissolves very rapidly and completely in solutions of potassium cyanide, indicating that it is very finely divided in whatever condition it occurs, and these various facts have led me to the conclusion that the gold in these ores is present in a finely divided amorphous metallic state, having the black or brown color characteristic of the metal when in this condition, and consequently being unrecognizable under the microscope in its naturally occurring state.

1 Director of Mint Rept. on production of precious metals for 1899, $\mathrm{pp}$. 181-182, 1900
The Marion was the first mill to be built in the Mercur area. It was part of the old Sparrow Hawk works erected for the treatment of silver ores in 1872-73, operated again on silver ores in 1880, and again, for the last time, in March, 1889, when it treated 12 tons of ore daily by pan amalgamation with poor success. In 1893 it was changed to a cyanide plant, the second in the district, and was equipped for a capacity of about 50 tons of ore daily.

In 1893 the Camp Floyd district produced between 14,000 and 15,000 ounces of gold from the Mercur and Marion mines. The scarcity of water was a decided obstacle to milling in Lewiston Canyon until a pipe line was run from Ophir district in 1893. Ore from the Marion was crushed to a size that would pass through a $\frac{7}{8}$-inch mesh screen. The average cost of mining and milling was said to be about $\$ 2$ per ton.

The next summer (1894) the Geyser Co., whose claim adjoins the Marion, commenced work on a cyanide plant with a capacity of about 100 tons of ore daily, but finished it too late in the year to permit much production. The ore took 90 hours to leach, as it was not put through screens but was simply crushed in a Gates gyratory crusher. The amount of cyanide consumed was about three-eighths of a pound per ton of ore treated, and the cost of mining and milling was said to be about $\$ 1.60$ per ton.

In 1897 the Geyser-Marion interests were combined, and the Marion equipment added to the Geyser mill. The yield in gold from this property was reported to be $\$ 120,000$ in 1899. The property was last operated under its old name in 1900. It was sold at sheriff's sale shortly after and worked with little success by a new company until put into the hands of a lessee, who barely succeeded in making the property pay expenses. The dividend record shows nearly $\$ 100,000$ was paid to stockholders, and it is estimated that close to $\$ 500,000$ in gold was recovered between 1893 and 1913.

A fourth cyanide plant was built on the Sacramento property in 1895 . Success was poor at first, owing to the baseness of the ores, and thereafter only oxidized material was handled. Roasting furnaces were added to an enlarged mill in 1901 and slime tanks the fol- 
lowing year. The ore treated at the mill about $\$ 2.30$ a ton at the last, yielding all but averaged $\$ 4.60$ in gold per ton in the begin- 40 cents of its gold, which remained in the ning and as low as $\$ 3$ per ton at the end of tailings. The mill was closed for alterations operations in 1907. The costs of mining and in 1899 and was started again in 1901, having milling are said to have been about $\$ 1.50$ per ton, and the loss in the tailings averaged about $\$ 1$ per ton. The total value of the gold recovered during the life of the mine is estimated at $\$ 1,500,000$ and $\$ 308,000$ was paid in dividends. In addition, the Sacramento mine was for several years the most important producer of mercury in Utah.

\section{SUNSHINE.}

A few years after the first gold discoveries were made in the Camp Floyd district the Sunshine and Overland mills were built at Sunshine, 4 miles south of Mercur, to treat gold ores similar to those of Mercur. The Sunshine property was the first to be equipped with a cyanide mill, which operated from December, 1895, until October, 1896, milling about 9,000 tons of $\$ 3$ to $\$ 4$ gold ore and obtaining about $\$ 7,000$ in gold at the expenditure of several times as much. In 1898-99, according to Charles Butters, ${ }^{1}$ another unsuccessful effort was made to treat the ore. In 1902 the mill was again started but was closed at the end of the year after producing about $\$ 70,000$ in gold bullion. In 1908 the mill was overhauled by the Boston Sunshine Gold Mining Co., which treated 125 to 150 tons of ore daily, beginning in May, 1909. By July, 1910, the ore supply of the Sunshine mine was exhausted after slightly over 50,000 tons had been treated with an average recovery of $\$ 2.81$, or a total of $\$ 141,532$, extracted at a milling cost, it is reported, ${ }^{2}$ of 88 cents per ton, with only 20 to 40 cents left in the tailings. Dividends from these last operations aggregated $\$ 27,261$. In all the Sunshine mine is believed to have yielded about $\$ 221,000$ in gold.

The Overland Co. erected the second mill in the camp, starting operations in November, 1898 , on ore from its property. It was the first mill in the district to use electrical power. Development in the upper levels of the mine was by an incline shaft and in the lower by a vertical shaft that cut the ore bed at 1,600 feet on the dip. The first ores treated ranged from $\$ 6$ to $\$ 8$ per ton in gold, but decreased to

1 Personal communication.

2 Cyanidation in the Mercur district of Utah, pamphlet published by the Salt Lake Min. Rev., 1913.

been enlarged to treat 500 tons of ore daily.

It is reported that the cost of mining was 85 cents and milling 25 cents per ton. The last work on the property was done under a receiver in 1904-5. No dividends were ever reported, although the property had a record of producing $\$ 219,646$ in gold from about 156,000 tons of ore.

WEST DIP.

West Dip is $4 \frac{1}{2}$ miles northwest of Mercur and was so named from the fact that the rocks at that point dip about $45^{\circ} \mathrm{W}$., in contrast with the east dip in the Mercur camp, on the opposite side of the anticline.

Mining began in 1897, and in July, 1898, the Daisy mill, with a capacity of 112 tons a day, was erected. It is said to have produced $\$ 75,000$ in gold precipitates up to the end of 1899. In July, 1900, the Daisy mine and mill went into the hands of a receiver. The Daisy property ${ }^{2}$ is opened by an incline shaft to the 700 -foot level and had ore assaying from $\$ 4$ to $\$ 8$ per ton. The total costs of mining and milling amounted to $\$ 3$ per ton. Equipped about 1910 with modern machinery consisting of classifiers, mixers, and filter presses, the mill was the first to make a success of the West Dip ores. It was completely destroyed by fire in 1917.

In December, 1898, a mill was started on the La Cigale property, which is developed by several shafts, the deepest in 1897 being 410 feet sunk on an incline of $45^{\circ}$. The ore is difficult to treat, and at the end of 1899 work was abandoned. No other attempts have been reported.

\section{TOPOGRAPHY.}

By B. S. Butler.

The topography of the district is less rugged than that of the Ophir district to the north but is otherwise similar. The main canyons from Lewiston Peak cross the district toward the southwest, the direction becoming more southerly toward the southern extremity of the range. The area is thus composed of a series of southwest-trending ridges separated by canyons. 
GEOLOGY.

The geology of the Mercur district has been described by J. E. Spurr, ${ }^{1}$ from whose report the present account is largely taken, though the writer spent several days in the district in the summer of 1912.

\section{SEDIMENTARY ROCKS.}

The sedimentary rocks are mainly limestone with some sandy and shaly beds, all being of Carboniferous age. Spurr has separated them into the "Lower Blue limestone," "Lower Intercalated series," "Great Blue limestone," containing two shale members, and "Upper Intercalated series," which he describes as follows: ${ }^{2}$

Lower Blue limestone.-The lowest horizon * * * is a dark blue, at times semicrystalline limestone, carrying lower Carboniferous fossils. It forms a type which is ordinarily distinct from the other limestones of the district by reason of its somewhat darker color, as well as of the granular appearance which it derives from the ooarser grain and the typically semicrystalline condition. It is only in Lewiston Canyon that this lowest horizon is exposed within the district. * * * Going down the canyon from Mercur, it is met at about three-quarters of a mile from the town, rising up in the bed of the canyon with gentle northeasterly dip. It continues to form the bed of the canyon till very near the point where the canyon opens out upon the plain. At this point the slight southwestern dip has brought it down again, and it disappears below the overlying beds. In the middle of the exposure, directly in the anticlinal arch, a thickness of about 200 feet of this limestone is shown in the walls of the canyon. The bottom, however, is not seen, and so no statement in regard to the total thickness of the horizon can be made. A typical locality of this rock is at the mouth of Quartzite Gulch; this is also one of the best localities for fossils. Specimens collected at this point have been found by Mr. C. H. Schuchert to be of lower Carboniferous age.

Lower Intercalated series.-Directly above the lower limestone comes a series of alternating thin beds of limestone and calcareous sandstone, with rocks representing various stages between the mainly siliceous and the purely calcareous sediments. This series is about 600 feet thick. The thickest bed of sandstone, which has a thickness of about 100 feet, is at the bottom of the series. From this bed to the top of the series there are frequent alternations of siliceous and calcareous sediments, so closely following one another and presenting such numerous transitions from the one to the other as to show that the entire series was deposited at a comparatively uniform depth, just on the border between detrital deposits and those of organic origin. Nearly all the sandstones are more or less calcareous, and the limestones are usually siliceous.

1 Spurr, J. E., Economic geology of the Mercur mining district, Utah, with introduction by S. F. Emmons: U. S. Geol. Survey Sixteenth Ann. Rept., pt. 2, pp. 343-455, 1896.

2 Idem, pp. 371-377.
Great Blue limestone.-Next above the Lower Intercalated series comes the formation which occupies the most of the Mercur Basin. This is a comparatively uniform, massive limestone, of a dark gray-blue color, nearly like that of the Lower limestone. It breaks with a rough, conchoidal fracture; on weathering it becomes pulverulent, greenish or pinkish, or nearly white. From its color one might suppose that it is impure, but an analysis of a typical specimen shows that in reality it is very pure, containing only a small amount of insoluble matter. It is an entirely calcareous limestone, being quite free from magnesia; the color is due to the presence of a small amount of organic material. Usually the outcrop is very fresh, the changed material being carried away as fast as produced, but in many places the alteration products have accumulated, so that the rock is more or less altered to a depth of many feet. A notable instance is seen in the cut for the railroad, just southeast of the Sunrise shaft, where the rock has been altered to a light-gray powder for a depth of 20 feet or more, apparently by surface agencies alone.

The upper limit of this rock, which may be called the Great Blue limestone, is not distinct, for it passes gradually into the series next higher up. Its thickness, therefore, may be variously estimated, according as the upper boundary is defined; the maximum, however, is about 5,000 feet.

Shale beds.-There are certain variations in the nature of the generally uniform sediments which have enough character and persistence to be noticed. Most marked among these geologically, and most important economically, are the belts of black carbonaceous and calcareous shale. These are two in number, one situated near the bottom and the other near the top of the Great Blue limestone. The upper one is the larger and the more persistent in regard to its characters. It lies about 1,000 feet from the top of the Great Blue limestone, if the latter is considered in its maximum thickness, as estimated above; but if it is considered in its minimum thickness, then the shale itself may be held to indicate its upward termination. The shale lies in a strike valley which evidently owes its existence to the more ready erosion of the shale beds, as compared with those of the harder limestones. The thickness of the belt is somewhat more than 100 feet. These shales can not be considered as typical detrital sediments; they are simply phases of the limestone. In places, especially where they have been acted on by running water, they are soft and have no great cohesion; in other places on the same horizon the rock is so hard and contains so much lime that it deserves rather the name of a shaly limestone, if considered without reference to the other localities. Specimens from this shale belt nearly always effervesce with acid. The carbonaceous matter is varying in amount but never very great. * * *

The lower shale belt lies about 2,500 feet below the upper one, and about 1,000 feet above the bottom of the Great Blue limestone. Its characters are essentially the same as the upper but are less emphasized; for, as it is not so thick, its relation to the pure limestone on both sides is closer. This shale belt averages about 25 feet in thickness, but it is variable and often becomes shaly limestone, so that it is not always possible to identify it exactly. These two shale belts carry springs which furnish the entire water supply of the Mercur district. 
Just above the larger shale belt are usually thin-bedded, somewhat shaly limestones, which are transitional between the shale and the massive blue limestone. These rocks are distinguished by the thin plates into which they split on weathering, and the by brighter reddish and greenish color of the slightly weathered specimens. There is no sharp boundary between the shaly limestones and the rocks above and below.

Upper Intercalated series.-Above the upper shale belt the rocks begin to contain arenaceous layers, separated by very thick beds of pure limestone. At a distance of about 1,000 feet above the top of the shale these sandstone beds become so common as to mark the lower limit of a new lithological series, the Upper Intercalated series. This reproduces on a larger scale the characters of the Lower Intercalated series. The rock types are nearly the same, but the individual beds are thicker and farther apart. From the bottom of the series to the top of the ridge there are probably about a dozen beds of sandstone, each of which has a thickness of 100 feet or more: yet in places the sediments seem to alternate even more closely than in the lower series. Many of the beds present for considerable distances a complete intermediate stage between sandstone and limestone, and in places layers of mainly calcareous sediments alternate very uniformly with layers which are mainly arenaceous, each layer being only a few inches thick, and the alternation being many times repeated. The thickness of this Upper Intercalated series, as estimated from its base to the summit of the ridge which divides Mercur Basin from Pole Canyon, is 5,000 or 6,000 feet. This, however, is not the top of the series, for the rocks preserve their northeasterly dip for a considerable distance down the other side of the mountain into Pole Canyon before beginning to rise again on the other side of the syncline. The total thickness, therefore, must be upward of 6,000 feet, and may be as much as 10,000 feet.

Age of the strata.-Fossils were collected from the beds in the Mercur Basin at various points, so as to represent as well as possible the entire series from the Lower Blue limestone to the Upper Intercalated series. These were submitted to Mr. Charles Shuchert, of the United States Geological Survey, who found them all to be of Carboniferous age. According to his report, the Lower Blue limestone and the Lower Intercalated series are in the lower Carboniferous, while the Upper Intercalated series is probably in the Coal Measures. The boundary between these two divisions can not be closely defined. It may be in the middle or the upper part of the Great Blue limestone, or, more probably, at the top of it. The fossils form a gradually changing series, which begins somewhere above the base of the lower Carboniferous and seems to terminate in the upper Carboniferous. ${ }^{1}$

\section{ERUPTIVE ROCKS.}

Spurr ${ }^{2}$ describes the igneous rocks as follows:

In the Mercur district there are two distinct varieties of closely related eruptive rocks, which form sheets or small dikes in the Great Blue limestone. Both of these rocks

1 Of a series of fossil bryozoans and brachiopods from the lower shale belt, recently received, Mr. Schuchert says: "They are of the age (Burlington-Keokuk) of the Mississippian series."-S. F. Emmons,

2 Op. cit., pp. 374-376. belong to the class of quartz-porphyries, although they are very dissimilar in appearance.

Eagle Hill porphyry.-One of these varieties is found in greatest thickness and feshest condition in the vicinity of Eagle Hill, on the divide which separates the Mercur Basin from Sunshine and the southern end of the range. This rock in its freshest condition is nearly pure white, with a grayish, brownish, or sometimes pinkish tinge; it is compact and fine grained, and breaks with a conchoidal fracture and a rough texture. Small phenocrysts of quartz, feldspar, and biotite may often be observed, though they are never conspicuous; rarely the thin plates of biotite become nearly a quarter of an inch across.

A specimen of fresh rock shows under the microscope a finely microcrystalline groundmass, in places made up of very small spherulites, which occasionally grade into a micropegmatitic intergrowth of quartz and feldspar. Lath-shaped microlites of feldspar are very common, but the main part of the groundmass is not course enough to render the component minerals distinguishable. Phenocrysts are rare but are fresh when found. They consist, so far as observed, of quartz, biotite, and orthoclase feldspar. The quartz is in crystals or irregular grains, which show corrosion by the magma previous to the consolidation of the rock. The feldspar has crystal outlines, often rounded by corrosion, and shows no decomposition. The biotite is dark colored and strongly pleochroic; along its cleavage cracks some of the iron has separated out as oxide.

Except where the beds are thickest, the porphyry is usually considerably decomposed, and the thinner the sheet the more, as a rule, has it suffered from contact with atmospheric or other disintegrating agencies. On weathering, the rock loses cohesion and becomes a compact, very fine grained, chalky mass, so soft as to be easily impressed with the finger nail, or finally a loose powder. The weathered rocks are usually of a cream-yellow color, but they are often stained in a variety of shades-red', yellow, greenish gray, or nearly black.

The Eagle Hill porphyry seems to be split up chiefly into two principal sheets, which are well exposed on the sides of Eagle Hill. Both are in a general way parallel to the bedding of the limestone, so that they are true sheets; in places, however, the boundary cuts across the bedding at a considerable angle, which sometimes is as much as $90^{\circ}$. * * * When a continuous contact is mapped and plotted over a considerable distance the true relation of the limestone to the porphyry is very clearly seen.

Since the hills around Mercur are not covered by drift or alluvium, it is comparatively easy to trace continuously the line of contact of the eruptive with the sedimentary rocks. $* * *$

The uppermost of the two principal sheets is *** east of Eagle Hill on the ridge south of Mercur. The top of the knob next east from Eagle Hill is of limestone, and the porphyry forms a broad belt on its sides. This sheet is probably between 250 and 300 feet thick, but it dies out rapidly, and to the northwest the outcrop does not descend from the hill, but is replaced by limestone.

The second sheet, which is estimated to be stratigraphically about 700 feet below the first, is found in its greatest thickness and with its rocks in the freshest condition on the spur between Eagle Hill and Sunrise Hill. The greatest thickness exposed here is probably upward of 300 feet, but it seems to thin with great rapidity to the north 
and east, and to split into several small sheets. Owing to the northeast dip, these thin sheets are well exposed only in the places of deepest erosion, in this case in the lowest part of the Mercur Basin, at the head of Lewiston Canyon. Here, owing to their small thickness, they are much decomposed; they are also intimately connected with the ore deposition. There are here three small sheets, averaging about 10 or 15 feet in thickness. On the other side of the basin they seem to unite again, and the porphyry becomes temporarily thicker than in the basin. Yet it is probably now here more than 100 feet thick, and usually it is much less. The same general sheet of porphyry has been traced to the northern side of Lion Hill, at a point overlooking Ophir Canyon.

On the southern side of Eagle Hill the upper sheet occupies a considerable area; the lower sheet seems to be split up into two thin sheets, one of which runs around and joins the upper body while the other persists in the bottom of Sunshine Gulch, past the Glencoe and the Sunshine mines, till it disappears in the foothills south of Sunshine. Nearly all these outcrops are on the northeast limb of the anticline, where the rocks dip to the northeast.

The arching of the fold causes the outcrop to describe a curve on the southeast side of Lewiston Canyon. Here the porphyry can be traced rising up above the top of the canyon wall, till with the new dip to the southwest it comes down to the bottom of the canyon again at its very mouth. On the other side of the canyon there is a part of the corresponding curve, but it does not appear to be completed, so as to join itself with the first. This may be due to a local disappearance of the sheet.

The porphyry has its greatest development around Eagle Hill, and it seems probable that somewhere in this vicinity exists the channel through which it came up from below. The lower sheet is thickest on a line running directly from Eagle Hill to Lion Hill and appears to thin gradually from the former toward the latter, though the erosion of the deeper valleys has removed it from much of the intermediate region. Northeastward from this line it thins rapidly, and to the northwestward it thickens.

There has been much mining development in the district since the time of Spurr's investigation. and exposures in the ore zone are far more extensive, giving a correspondingly favorable opportunity for observation. The writer was informed by the management of the Consolidated Mercur Mines Co. that developments had failed to show the presence of thin porphyry sheets in connection with the ore zones and an examination of some of the best exposures in the mine failed to disclose them. Most of the rocks are much altered, and a sheet of altered porphyry might well be mistaken for an altered sediment, but it was possible to trace several supposed porphyry beds along the strike into unmistakable sedimentary rock. Moreover, several shale beds, commonly called "porphyry," carry abundant fossils that leave no doubt of their sedimentary origin.

The writer did not spend sufficient time in the district to follow out the supposed porphyry horizons in detail. At several points he was unable to recognize any porphyry and believes that porphyry at these horizons does not form continuous sheets extending out from the main masses.

Birdseye porphyry.-The other variety of porphyry, called by miners and explorers "birdseye" porphyry, is exposed on the area of the Mercur Basin map only in the northwest corner. It forms part of two conspicuous eminences, which have been called Porphyry Hill and Porphyry Knob. This rock does not in any way resemble the porphyry just described. In its freshest condition its general color is gray. The porphyritic crystals are well developed and make up a large part of the bulk of the rock. They consist of light-gray feldspars of rather uniform size, the larger varying from an eighth to a quarter of an inch in diameter; also regularly disseminated biotite in black hexagonal prisms about an eighth of an inch in diameter, and occasional quartz cry'stals. These, with many smaller phenocrysts, are set in a greenish-gray groundmass. On decomposition the groundmass assumes a deep olive-green color, which becomes brownish in places the feldspars become whiter, so that they stand out more sharply from the rest of the rock and the mica assumes a greenish-bronze color. The process of alteration of this rock is as different from that of the Eagle Hill porphyry as are the two rocks in appearance. In the beginning of the process the Eagle Hill variety breaks up into small, sharp fragments, which become dislodged and lie in great numbers on the surface above the solid rock. As disintegration proceeds the rock is finally reduced to the pulverulent state. In the birdseye porphyry, however, this is not the case. The alteration proceeds gradually throughout the rock, as it does in the disintegration of granites. The rock does not split or shell but remains firm till the process is far advanced; hence, by the time it loses its cohesiveness it is so much decomposed as to be ready to form soil. When the rock crumbles the minerals which make up the porphyritic crystals can still ordinarily be distinguished.

On the edge of the Mercur Basin the birdseye porphyry consists of a single sheet, conformable with the stratification and with the sheets of Eagle Hill porphyry. The horizon of the two porphyries is in a general way about the same, although near Porphyry Hill the sheet of the Eagle Hill variety is several hundred feet lower down than the birdseye porphyry. The latter occupies the summit of Porphyry Knob, where it has a columnar structure, which is developed by weathering. Between Porphyry Knob and Porphyry Hill erosion has worn down through the sheet and revealed the limestone beneath. The southwest slope of Porphyry Hill stands at right angles to the dip of the strata and the full thickness of the porphyry sheet is shown in section, the summit of the hill being formed of limestone strata. The porphyry outcrop followed southeast diminishes very gradually in 
thickness for some distance and then terminates so abruptly as to suggest a fault. No other evidence of a fault, however, can be found, and it is certain that no movement of great importance has occurred; moreover, no outcrop of porphyry representing the other side of a fault can be found. Northwestward the porphyry can be easily traced. It runs to the east of Lion Hill and is exposed high up on the northern wall of Ophir Canyon.

The birdseye porphyry in the Mercur district, therefore, is only the edge of the main mass. It seems to have its greatest development considerably northwest of that of the Eagle Hill porphyry, although it appears at about the same horizon and on the same general topographical and stratigraphical line. It is probable, therefore, that they are genetically connected-that they represent the same general magma which ascended along the line of weakness induced by the mountain building and crystallized at different times and under varying conditions.

No evidence of value with regard to the relative age of the two varieties of porphyry has been found. In a single place-on Lion Hill-a contact between the two was found, by the side of the road which leads to the mines, but it was of such a character and the rocks were so thoroughly decomposed that no evidence could be derived from it.

\section{STRUCTURE.}

The main structural features of the Camp Floyd district are relatively simple. The west side of the range is a simple anticline striking northwest about with the trend of the range. This anticline is well exposed in Lewiston Canyon, and in Ophir Canyon to the north. Its crest in Lewiston Canyon is about $1 \frac{1}{2}$ miles southwest of Mercur. The Mercur Basin is therefore on the east limb of the anticline, and the camp of West Dip, as indicated by the name, is on the west limb. The same structure extends south to the limit of the range.

Faulting is of minor structural though of some economic importance. The northeast fissures are of much importance in connection with the ore deposits but have exerted little influence in the general structure of the district.

\section{ORE DEPOSIT́S.}

\section{MERCUR.}

The ore deposits of the Mercur area comprise silver deposits and gold deposits, both locally called "ledges." Small amounts of silver ores have been mined from the gold "ledges," and small amounts of gold from the silver "ledges," but in general the silver "ledge" carries little gold and the gold ledge ores are remarkably free from silver. The silver ores are of little commercial importance, but the gold ores have yielded largely.
SILVER DEPOSITS.

The silver "ledge" occurs at a rather definite horizon in the limestone and can be traced, with interruptions, from Lion Hill on the north to Eagle Hill on the south. At both Lion Hill and Eagle Hill the ledge appears to be associated with porphyry bodies, but between these two points its close association with porphyry is not so apparent. The ledge does, however, appear to occupy about the same horizon throughout its extent.

The typical silver ledge is a cherty material resulting from the silicification of limestone. It is resistant to erosion and usually outcrops rather prominently. In addition to cherty quartz it commonly includes considerable calcite and barite, the barite being especially abundant in the ores. Sericite is present in considerable amount in many parts of Lion Hill and in less amount in the Mercur camp.

Locally, the ledge is an ore containing, in the Mercur district, stibnite and possibly other antimony minerals; copper carbonates; scorodite, and possibly other arsenic minerals; silver in small amount, mainly as the chloride, though in the primary ore doubtless as the sulphide or some silver-antimony mineral; and a little gold.

The following is an analysis of oxidized silver ore from the Sparrowhawk mine:

\section{Analysis of the Sparrowhawk ore. ${ }^{1}$}

[W. F. Hillebrand, analyst.]

Per cent.

Silicon dioxide $\left(\mathrm{SiO}_{2}\right) \ldots \ldots \ldots \ldots \ldots \ldots \ldots \ldots .61 .70$

Titanium dioxide $\left(\mathrm{TiO}_{2}\right) \ldots \ldots \ldots \ldots \ldots \ldots \ldots \ldots . \quad .20$

Aluminum sesquioxide $\left(\mathrm{Al}_{2} \mathrm{O}_{3}\right) \ldots \ldots \ldots \ldots \ldots \ldots \ldots .24$

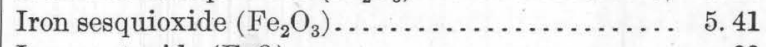

Iron protoxide $(\mathrm{FeO}) \ldots \ldots \ldots \ldots \ldots \ldots \ldots \ldots \ldots . .28$

Calcium oxide $(\mathrm{CaO}) \ldots \ldots \ldots \ldots \ldots \ldots \ldots \ldots \ldots . .44$

Barium oxide $(\mathrm{BaO}) \ldots \ldots \ldots \ldots \ldots \ldots \ldots \ldots \ldots . . .4 . \ldots \ldots$

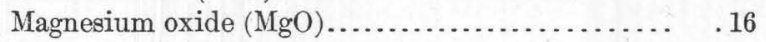

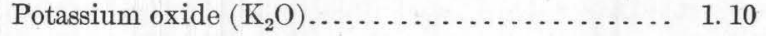

Sodium oxide $\left(\mathrm{Na}_{2} \mathrm{O}\right) \ldots \ldots \ldots \ldots \ldots \ldots \ldots \ldots \ldots \ldots \ldots \ldots \ldots \ldots . .12$

Lithium oxide $\left(\mathrm{Li}_{2} \mathrm{O}\right) \ldots \ldots \ldots \ldots \ldots \ldots \ldots$. Strong trace.

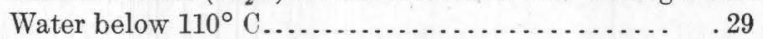

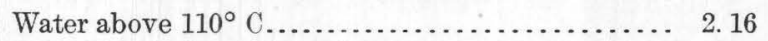

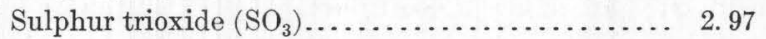

Phosphorus pentoxide $\left(\mathrm{P}_{2} \mathrm{O}_{5}\right) \ldots \ldots \ldots \ldots \ldots \ldots \ldots . .05$

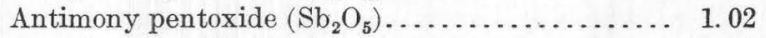

Arsenic pentoxide $\left(\mathrm{As}_{2} \mathrm{O}_{5}\right) \ldots \ldots \ldots \ldots \ldots \ldots \ldots \ldots . .40$

Molybdenum (Mo).................... Strong trace.

Tellurium $(\mathrm{Te}) \ldots \ldots \ldots \ldots \ldots \ldots . . . \ldots$ Strong trace.

99. 97 
The potassium and aluminum are present in very nearly the proportions for muscovite and are probably present as sericite, though some of the potassium may be present as jarosite and some of both the potassium and a?uminum as alunite.

The gangue minerals of the Mercur Basin and those of Lion Hill are very similar, but the metallic constituents differ considerably, those of Lion Hill containing considerable lead, more copper, and some zinc. Neither lead or zinc are reported from the Mercur deposits. The field relations and the character of the gangue minerals leave little doubt that the silver ores of the two areas are of common origin though they differ somewhat in metal content.

The average grade of the silver ores is not known. Some rich pockets were mined, but operations were never very extensive and soon ceased indicating that the average grade was not high,

$$
\text { GOLD DEPOSITS. }
$$

The accompanying generalized section (fig. 41) through the ore-bearing formation of the Mercur district was furnished by the Consolidated Mercur Co. It does not represent the thickness of the different formations at any given point but is an approximate average of their thickness as they have been encountered in the mine workings.

General section.-The names given for the strata in the general section (fig. 41) of the orebearing formation of the Mercur area are those in common use and do not necessarily represent the character of the material; in fact, some of the beds called "porphyry" contain fossils and are generally recognized to be sedimentary.

At the base of the ore series is a massive blue limestone with beds of shaly material. These are unmineralized and practically unaltered. Overlying this is the silver ledge, which is a cherty, rather porous mass, resulting from the silicification of limestone. It carries silver, and in places is a commercial ore. Locally, notably in the anticlinal body in the Brickyard and in the Geyser mines, gold ore has been mined from the silver vein.

Overlying the silver ledge is the Magazine vein. The lower part, known as the Hard Magazine, is a cherty material, resulting from the silicification of limestone and in many places closely resembles the silver vein; com- monly, however, it is more massive and does not possess the same porous character. The upper part, known as the Soft Magazine vein,

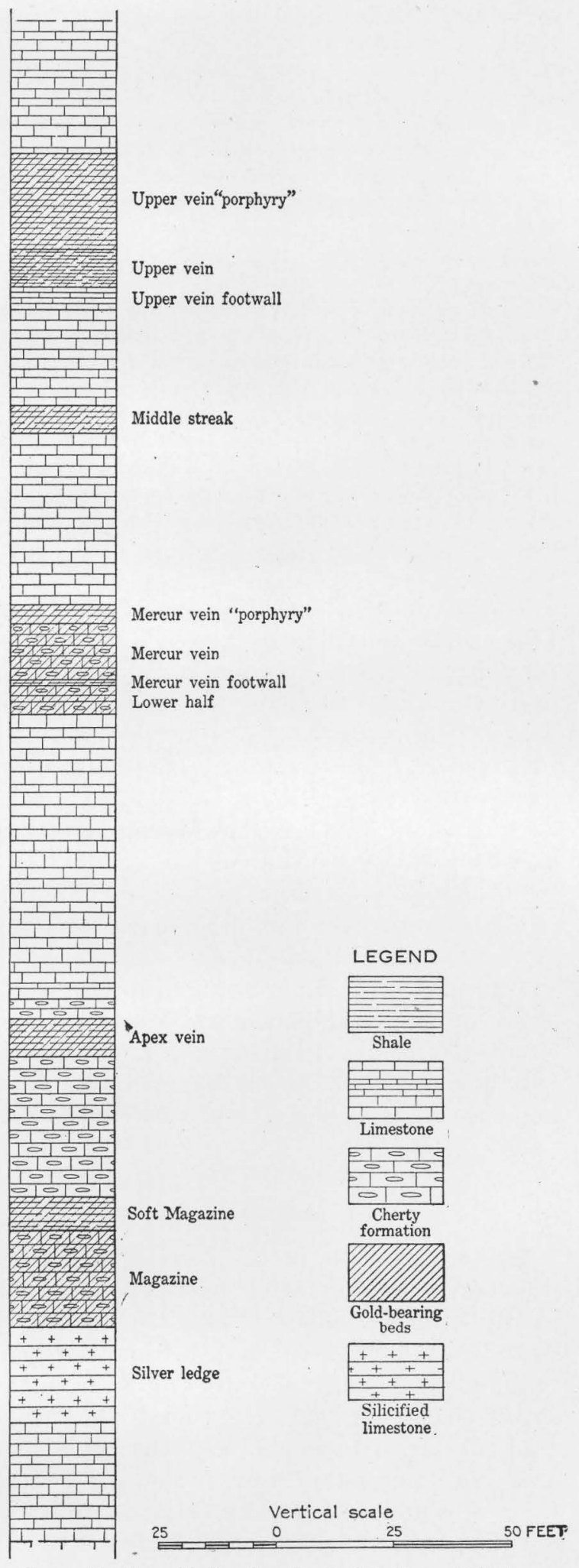

FIGURE 41.-Generalized section of are beds in Mercur district. 
is a shaly material, light colored and banded where oxidized and black where unoxidized. The hard magazine is about 20 feet thick and the soft about 7 feet. Both carry gold and have been mined.

Overlying the Magazine vein and about 30 feet of cherty material (altered limestone) that carries little gold is the shaly Apex vein which is about 8 feet thick and carries gold. It is overlain by about 4 feet of cherty material that is not ore and by 60 feet of relatively unaltered limestone.

'The Mercur vein, which lies next above, is 20 to 25 feet thick. Its upper 4 feet is known as the Mercur vein "porphyry." Its lower 20 feet is separated into two parts by the Mercur vein footwall, a thin persistent layer of shaly material. The upper 12 feet is known as the Mercur vein and the lower 6 feet as the Lower Half. The Mercur vein is characterized by nodular cherty masses, which are present where the limestone is little altered and appear to be original in the limestone rather than a result of mineralization. In many places the Mercur vein has been altered to a cherty mass very similar to the silver "ledge" and the Magazine vein. The Mercur vein "porphyry," where seen in the mine, is commonly a rather massive gray rock that is soft and easily penetrated by the pick. It is of rather shaly texture and appears to be an altered sedimentary rock.

Above the Mercur vein "porphyry" is about 36 feet of limestone followed by about 6 feet of shaly fossiliferous material, gray where oxidized and black where base. This is known as the middle streak and is gold bearing. Next above is 20 feet of limestone, above which lies the highest mineralized zone-about 40 feet of shaly and siliceous material as follows: Upper vein footwall, 5 feet; Upper vein, 8 feet; Upper vein porphyry, 20 feet; shale, 8 feet. Overlying this is the massive blue limestone.

The beds are cut by a series of fissures striking east of north and dipping very steeply west. The ore shoots follow approximately the intersection of the fissures with the ore beds. The relation between ore bodies and fissures is, however, less striking in this district than in the Ophir and Stockton districts.

Alteration.-The alteration of the rocks is largely dependent on their original character. Many of the limestone beds are silicified to a cherty quartz with small amounts of a mineral resembling sericite. The shaly beds appear to have suffered less alteration though they have probably gained silica and possibly some potassium, which have formed sericite. The potassium, however, may have been originally present in the shale. Most of the ore contains also considerable barite and secondary calcite. The principal metallic minerals are pyrite, realgar with some orpiment, and cinnabar. The following analysis is of sulphide ore from the Grasshopper shaft of the Golden Gate mine:

Analysis of Golden Gate ore. ${ }^{1}$

[W. F. Hillebrand, analyst.]

Per cent.

Silicon dioxide $\left(\mathrm{SiO}_{2}\right) \ldots \ldots \ldots \ldots \ldots \ldots \ldots \ldots \ldots, 66.42$

Titanium dioxide $\left(\mathrm{TiO}_{2}\right) \ldots \ldots \ldots \ldots \ldots \ldots \ldots \ldots \ldots . .85$

Aluminum sesquioxide $\left(\mathrm{Al}_{2} \mathrm{O}_{3}\right) \ldots \ldots \ldots \ldots \ldots \ldots \ldots .6 .85$

Iron sesquioxide $\left(\mathrm{Fe}_{2} \mathrm{O}_{3}\right) \ldots \ldots \ldots \ldots \ldots \ldots \ldots \ldots \ldots \ldots \ldots \ldots \ldots \ldots \ldots \ldots$

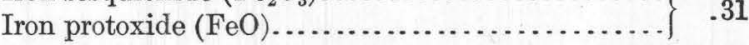

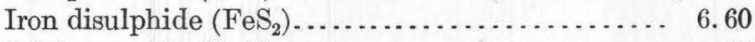

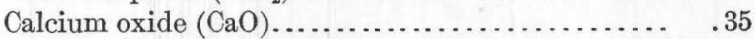

Barium oxide $(\mathrm{BaO}) \ldots \ldots \ldots \ldots \ldots \ldots \ldots \ldots \ldots \ldots . . . . \ldots \ldots$

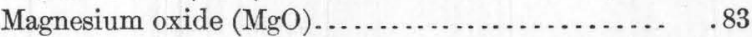

Potassium oxide $\left(\mathrm{K}_{2} \mathrm{O}\right) \ldots \ldots \ldots \ldots \ldots \ldots \ldots \ldots . .7 .73$

Sodium oxide $\left(\mathrm{Na}_{2} \mathrm{O}\right) \ldots \ldots \ldots \ldots \ldots \ldots \ldots \ldots \ldots . . .13$

Lithium oxide $\left(\mathrm{Li}_{2} \mathrm{O}\right) \ldots \ldots \ldots \ldots . . .$. Very strong trace.

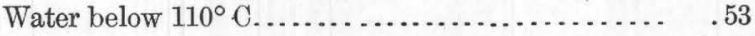

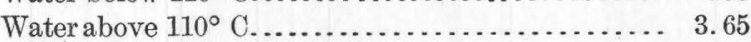

Sulphur trioxide $\left(\mathrm{SO}_{3}\right) \ldots \ldots \ldots \ldots \ldots \ldots \ldots \ldots \ldots . .31$

Phosphorus pentoxide $\left(\mathrm{P}_{2} \mathrm{O}_{5}\right) \ldots \ldots \ldots \ldots \ldots \ldots \ldots . .04$

Arsenic pentoxide $\left(\mathrm{As}_{2} \mathrm{O}_{5}\right) \ldots \ldots \ldots \ldots \ldots \ldots \ldots \ldots \ldots \ldots \ldots \ldots \ldots \ldots \ldots \ldots$

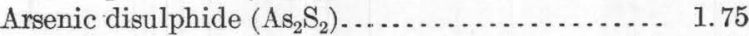

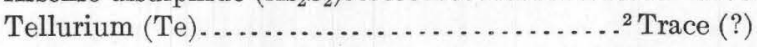

99.95

The alteration of the rock and the addition of gangue minerals in the ore shoots have not been sufficient to permit a reliable estimate of the value of the ore from its appearance. Much good ore does not perceptibly differ from waste, and it is necessary to sample and assay to determine its value. Realgar or cinnabar usually indicates good ore, but their absence is no proof of barrenness.

There is commonly a considerable difference in appearance between the oxidized and unoxidized (base) ore. The oxidized ore is generally light colored and more friable than the unoxidized; it lacks sulphides and contains sulphates, including scorodite, malanterite, jarosite, and gypsum.

1 Spurr, J. E., op. cit., p. 424.

2 In the opinion of Dr. Hillebrand there was tellurium in the sample analyzed, although on account of the small quantity obtained he was unable to submit it to a special test, and therefore thought best to indicate this lack of certainty by the interrogation mark. 
The following is an analysis of oxidized gold ore from the stope of the Apex tunnel in the Mercur mine. ${ }^{1}$

\section{Analysis of Mercur ore.}

[W. F. Hillebrand, analyst.]

Silicon dioxide $\left(\mathrm{SiO}_{2}\right)$

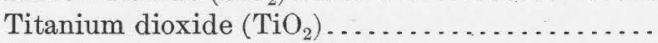

Aluminum sesquioxide $\left(\mathrm{Al}_{2} \mathrm{O}_{3}\right) \ldots \ldots \ldots \ldots \ldots \ldots$

Iron sesquioxide $\left(\mathrm{Fe}_{2} \mathrm{O}_{3}\right) \ldots \ldots \ldots \ldots \ldots \ldots \ldots$

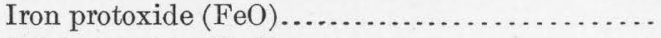

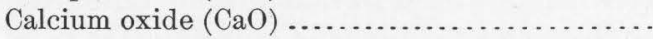

Barium oxide $(\mathrm{BaO}) \ldots . . . . . . . . . . . . . . . .$.

Magnesium oxide $(\mathrm{MgO}) \ldots \ldots \ldots \ldots \ldots \ldots . . . . . . . .$.

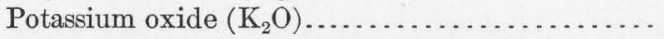

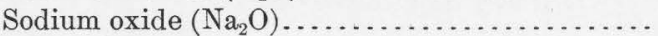

Lithium oxide $(\mathrm{LiO}) \ldots \ldots \ldots \ldots \ldots \ldots . . . \ldots$. Strong trace

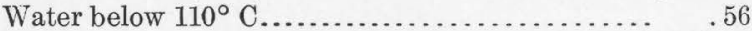

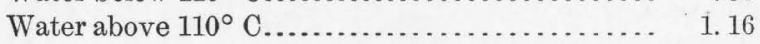

Sulphur trioxide $\left(\mathrm{SO}_{3}\right) \ldots \ldots \ldots \ldots \ldots \ldots \ldots \ldots \ldots . \quad .44$

Phosphorus pentoxide $\left(\mathrm{P}_{2} \mathrm{O}_{1}\right) \ldots \ldots \ldots \ldots \ldots \ldots \ldots . \quad .08$

Arsenic pentoxide $\left(\mathrm{As}_{2} \mathrm{O}_{5}\right) \ldots \ldots \ldots \ldots \ldots \ldots \ldots \ldots . \quad 1.60$

Molybdenum (Mo)........................ (?)

Tellurium $(\mathrm{Te}) \ldots \ldots \ldots \ldots \ldots \ldots \ldots \ldots \ldots \ldots \ldots \ldots, \quad(?)$

100.00

Occurrence of the gold.-Gold is never visible in either the oxidized or unoxidized ores of the district, and the form in which it is present has never been positively determined, though Spurr thinks it is present as the telluride in the base ore and as free gold, though probably in some special condition, in the oxidized ore. It has been suggested by Spurr and others that the gold of the Mercur district occurs in an allotropic form that will not readily amalgamate with mercury but is attacked by chlorine and potassium cyanide. Unfortunately gold has never been found in the oxidized ores of the Mercur district in sufficient concentration to make a careful chemical examination of its condition possible.

Experiments carried on for the Consolidated Mercur Mines Co. indicate an association of the carbon of the ore with the gold. The following are the carbon content and the insoluble gold in different types of ore examined:

Association of carbon and insoluble gold in Mercur ores.

\begin{tabular}{|c|c|c|}
\hline & Carbon. & $\begin{array}{l}\text { Insoluble } \\
\text { gold. }\end{array}$ \\
\hline 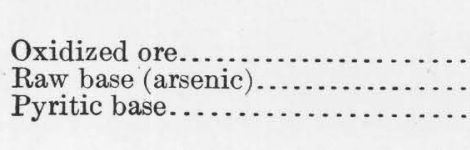 & $\begin{array}{r}\text { Per cent. } \\
0.105 \\
.358 \\
.450\end{array}$ & $\begin{array}{l}\$ 0.40 \\
.90 \\
\text { All but } \\
\text { trace. }\end{array}$ \\
\hline
\end{tabular}

${ }^{1}$ Spurr, J. E., op. cit., p. 426.
The insoluble gold given is an average of a number of tests made on raw ore after lime oxidation by agitation of 5 pounds of ore, ground to pass 200-mesh, by air in a 2-pound cyanide solution with 25 pounds of lime. The different ores were boiled for a week, the carbon scum being skimmed repeatedly. The oxidized ore gave almost no carbon, but the pyritic base gave a large amount. An analysis of the scum gave 10.3 per cent free carbon and $\$ 9.10$ gold; after agitation in potassium aurocyanide $\left(\mathrm{KAuCy}_{2}\right)$ solution and washing it assayed $\$ 90.60$ per ton.

There is considerable concentration of gold in the carbon content of the ore, as shown by head assay after boiling: Raw pyrite base, $\$ 3.31$; after boiling, $\$ 2.27$.

It is of course well known that carbon will precipitate gold from solution, though no general agreement has been reached as to the cause of such precipitation; and it has also been shown ${ }^{2}$ that in gold-silver cyanide solutions carbon precipitates gold more readily than silver, and that little silver precipitates while gold remains in solution. Spurr has shown that the gold is not particularly associated with the sulphides, and the data at hand point to its association with the carbon of the rocks.

Down the dip the character of the ore does not change notably after the sulphide ore has been reached, but the gold content decreases in a short distance from good ore to material too low in gold for commercial treatment.

The maximum distance from the outcrop to which ore has been developed is about 1,500 feet. The great bulk of the ore, however, has come from within a few hundred feet of the outcrop.

The decrease in the gold content of the ore with increasing distance from the surface suggests enrichment by surface solutions. On the other hand, the ores at or very near the surface are as rich as at any greater depth, and in the absence of an overlying leached zone it is not easy to find a source for such enrichment.

The grade of the ore is low. In 1902 it averaged $\$ 5.72$ per ton, of which $\$ 1.19$ was lost in the tailings. From that time the average of the ore treated has decreased till in recent years it has been as low as $\$ 3.50$ per ton with 80 to 90 cents lost in tailings.

2 Cowles, R. K., Precipitation of gold and silver by carbon: Min. and Sci. Press, vol. 105, p. 730, 1912. 
The average grade of the ore mined is of course dependent on the cost of extraction and treatment, for as low-grade rock is taken as can be profitably handled.

$$
\text { QUICKSILVER DEPOSITS. }
$$

The Sacramento is the only mine in the district from which quicksilver has been produced in commercial quantities, and it was inaccessible when the writer visited the district. Boutwell ${ }^{1}$ has described the deposit as follows:

The ore is earthy cinnabar with a siliceous gangue and yields 6 per cent on an average and 80 per cent in picked samples. It occurs in bands in an altered cherty limestone adjacent to a dike and to a fracture zone. In general the portion of this limestone which bears quicksilver constitutes a lenticular shoot measuring about 10 feet in thickness, 50 feet along the strike, and 140 feet on the dip. This lens is coincident with the bedding of the limestone along the middle and major portion of its dip, but at its upper edge it bends and cuts abruptly across the bedding; while at its lower edge, on approaching the dike and fracture on its dip, it drops sharply down across the bedding, pinching out at both its upper and lower terminations to thin edges.

\section{WEST DIP.}

The deposits at West Dip are about $4 \frac{1}{2}$ miles west of Mercur in strata. that dip rather gently west. The deposits were not being operated at the time of visit and consequently were not examined, but so far as learned from descriptions, the occurrence of the ores is similar to that at Mercur.

\section{SUNSHINE.}

The Sunshine district, about 4 miles south of Mercur, was also idle in 1912, but the occurrence of its ores is apparently similar to that at Mercur and West Dip.

\section{GENESIS OF THE ORES.}

The origin of the ores of the Camp Floyd district is not as apparent as in many districts of the State. So far as the character of the rock is concerned the location of the deposits appears to be due to the shaly strata, for the ores are associated with this zone and have not been found in the limestone or quartzite either above or below.

This association of ore with shale is susceptible of at least two interpretations: First, that the shale layers were relatively impervious to solutions and by interfering with the free circulation caused the deposition of the

\footnotetext{
1 Boutwell, J. M., Quicksilver: U. S. Geol. Survey Mineral Resources, 1906, p. 494, 1907.
}

ores; and second, that sor.ue constituent of the shale acted as a reducing agent and precipitated the gold from the solutions. It is well known that interference by shale layers tends to cause precipitation, but in the Camp Floyd district the solutions must have passed through several shaly beds, for several ore zones lie one above another. The ability of carbon or some substance associated with it to precipitate gold from solution is also known, and the apparent association of gold with the carbonaceous matter suggests that this has been an active factor in the formation of the deposits. Moreover, as gold is ordinarily more readily precipitated than silver, a solution that contained both gold and silver might have had much of its gold and little of its silver precipitated by the carbon of the rocks.

Spurr considers that the silver deposits are distinctly older than the gold deposits and that there is no intimate relation between the two. The writer failed to find convincing evidence of this and is inclined to consider all the deposits of essentially the same age, though he is not prepared to offer a definite explanation for the difference in the metal content of the ores. In other parts of the State, where a similar difference exists, there is practically no doubt that the ore deposits are of the same age and of common origin. (See p. 180.) The ore solutions are believed to have been deep seated and associated with the general mineralization of the range. (See p. 339.)

\section{BIBLIOGRAPHY.}

Allen, R. H., Mines and mills of the Consolidated Mercur Mines Co.: Eng. and Min. Jour., vol. 89, pp. 1273$1277,1910$.

Dern, G. H., The geology of Mercur mines and minerals, vol. 24 , pp. 543-545, 1904.

Gemmell, R. C., Eng. and Min. Jour., Apr. 24, 1897.

Hilus, R. C., Ore deposits of the Camp Floyd mining district, Tooele County, Utah: Colorado Sci. Soc. Proc., Aug. 6, 1894.

Huntley, D. B., Tenth Census U. S., vol. 13, pp. 454-455, 1885.

Maguire, D., and Howard, L. O., The romance of a famous gold mine: Salt Lake Min. Rev., pp. 13-15, June 15, 1913; pp. 13-17, June 30, 1913; pp. 10-15, July 15, 1913.

Palmer, L. A., Milling practices at the Consolidated Mercur: Salt Lake Min. Rev., vol. 10, p. 16, 1909.

Spurr, J. E., Economic geology of the Mercur mining district, Utah, with introduction by S. F. Emmons: U. S. Geol. Survey Sixteenth Ann. Rept., vol. 2, pp. 395$455,1896$. 
EAST TINTIC MOUNTAINS.

By Waldemar Lindgren and G. F. Loughlin.

GENERAL FEATURES.

The East Tintic Mountains in central Utah form one of the easternmost ranges of the Great Basin. They are crossed by latitude $40^{\circ} \mathrm{N}$. and longitude $112^{\circ} \mathrm{W}$. They include two organized mining districts, the Tintic in the central and the North Tintic (including the Boulter district) in the northern part of the range. The boundary between these two districts is approximately marked by the Denver \& Rio Grande Railroad, which extends eastward from Eureka, the largest settlement in the range. The area extending a few miles south of the railroad and east of longitude $112^{\circ}$ $5^{\prime} \mathrm{W}$. is locally known as the East Tintic district but is here included in the Tintic district.

The Tintic district proper has long been one of the most productive in Utah and has been studied in detail. The North and East Tintic districts have only a few productive mines and have been studied only in reconnaissance. These three districts are described in a recent Survey report, ${ }^{1}$ an abstract of which is given on pages $396-418$ of this paper.

\section{TOPOGRAPHY.}

The East Tintic Mountains are maturely dissected and show evidence of typical block faulting at only a few places. The highest peaks attain elevations of over 8,000 feet. The elevation of Tintic Valley on the west is about 5,500 feet and that of Goshen Valley on the east is 4,500 feet. The range is penetrated by a few prominent transverse gulches, in the most important of which are Eureka and Mammoth, the principal settlements of the Tintic district. (See fig. 42.) Silver City, the only other active settlement, is 3 miles south of Mammoth, at the mouth of a smaller gulch. These are all reached by the Denver \& Rio Grande and the Los Angeles \& Salt Lake railroads. Abandoned camps and old mill and smelter sites are Diamond, south of Silver City; Homansville, northeast of Eureka; and Tintic, to the southwest in Tintic Valley.

There are no permanent streams in the East Tintic Mountains, but several springs rise in the area of igneous rocks and a group of them

1 Lindgren, Waldemar, and Loughlin, G. F., Geology and ore deposits of the Tintic mining district: U. S. Geol. Survey Prof. Paper 107, 1919. supplies Silver City. The water supplies of Eureka, the Denver \& Rio Grande Railroad, and several mines are obtained from wells and infiltration galleries driven in surface débris over rhyolite and in the rhyolite itself. The water supply of Mammoth (including Robinson) is piped 18 miles from Cherry Creek in the West Tintic Mountains.

\section{TINTIC DISTRICT.}

GEOLOGY.

GENERAL FEATURES.

The East Tintic Range is composed of Paleozoic sedimentary and Tertiary igneous rocks. (See fig. 42.) The sedimentary rocks are chiefly a quartzite over 6,000 feet thick, overlain by 6,500 to 7,000 feet of limestone, including a small amount of shale. The igneous rocks are in part intrusive rhyolite porphyry and monzonite and in part extrusive rhyolites, latites, and perhaps andesites. The sedimentary rocks for the most part form a great north-trending anticline in the western part of the North Tintic district and an accompanying syncline which appears in the Tintic district proper and the eastern part of the North Tintic district. The limb common to both these folds has steep to vertical dips and locally even overturned dips. The western limb of the anticline and the eastern limb of the syncline have prevailing dips of $30^{\circ}$ or less. The folding east and south of the Tintic district proper is largely concealed beneath volcanic rocks, but a small part of an anticline is exposed at the head of Goshen Valley. The stratigraphy and structure are complicated by a large number of faults, the largest of which, in the Tintic district, are prevolcanic and have had little influence on the distribution and size of ore bodies.

SEDIMENTARY ROCKS.

The sedimentary rocks included Cambrian, Ordovician, Devonian, and Mississippian strata, interrupted by unconformities at or near the top of the Cambrian and at the base of the Mississippian.

CAMBRIAN SYSTEM.

The Cambrian strata include the great Tintic quartzite, over 6,000 feet thick, the shaly Ophir formation (see p. 398), and several limestones and dolomites. They range from Lower to Upper Cambrian. 


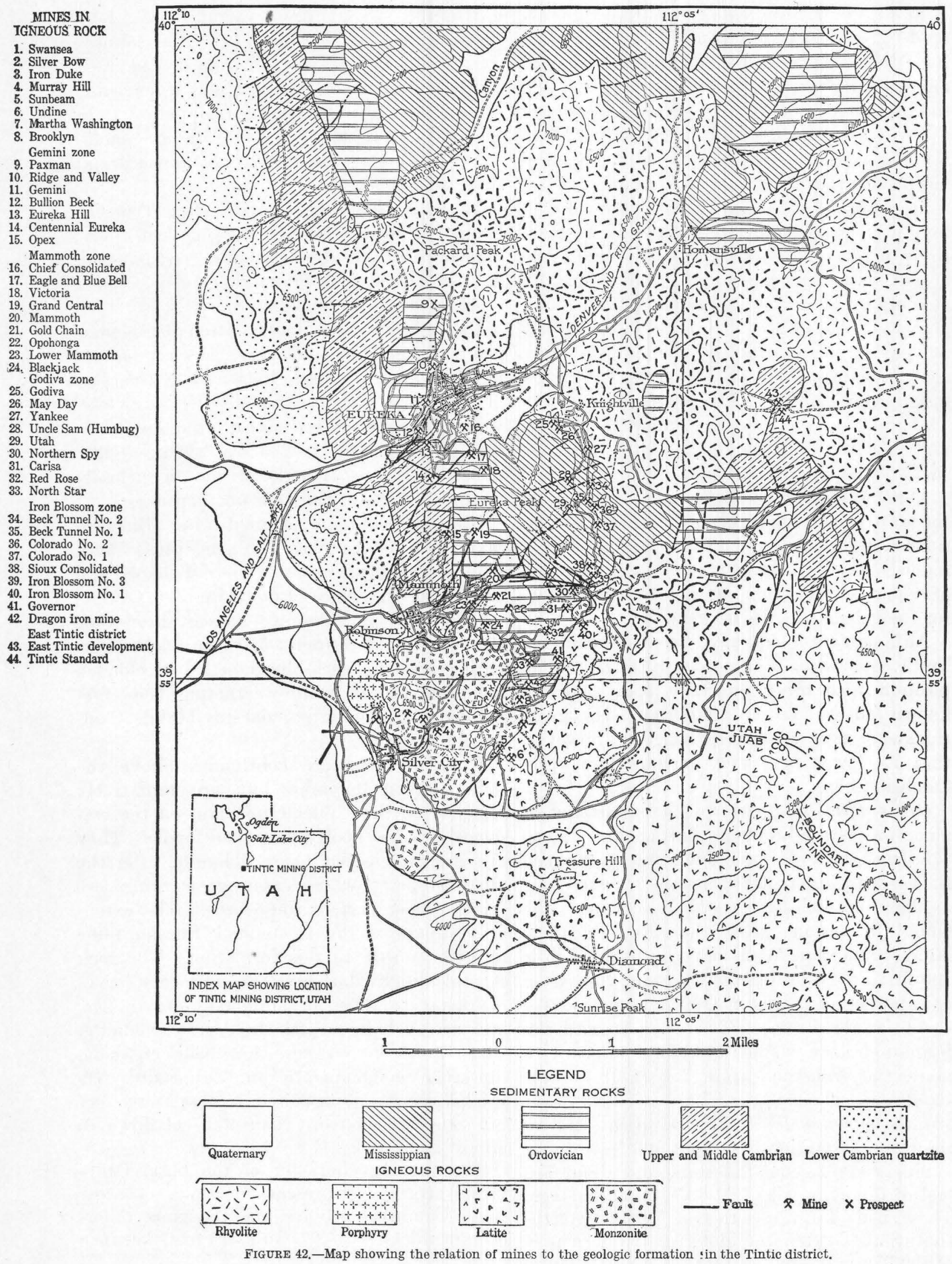


Tintic quartzite.-The Tintic quartzite extends along the west front of the range from the Mammoth northward for more than 6 miles, finally pitching below the surface along the axis of the anticline. It is also exposed at a few places south of Goshen Valley and in isolated patches in the igneous area from Mammoth southward. The typical rock is grayish white to pale pink, yellow, or brown in color, of fine, even grain, and is composed almost entirely of quartz. Indications of bedding are absent in many places, owing to uniformity of composition and to excessive jointing. Conglomerate beds, however, containing mostly pebbles of vein quartz and a few of quartzite are found throughout the formation, and a few insignificant slate bands have been noted. The upper beds are less pure than the average and pass conformably but abruptly into the shale of the Ophir formation.

Three or four miles northwest of Eureka, on the west slope of the ridge, the quartzite contains a 10-foot bed, green where fresh and dark reddish-brown where weathered, that contains 18.4 per cent of iron. It has been mistaken for the gossan of a fissure vein.

Although no fossils have been found in the Tintic quartzite, it accords in stratigraphic position with other quartzite beds that are known to be Lower Cambrian. Its great thickness, over 6,000 feet, suggests, however, that its lower part may include some preCambrian beds.

Ophir formation.-Above the quartzite, or along its eastern boundary, lies a band 150 to 475 feet thick of predominating gray-green shales with intercalated lenses of dark-blue argillaceous limestone, which is called the Ophir formation, after the Ophir district. Mìddle Cambrian fossils have been found in it 100 feet above its base. The same formation at a few other places in Utah contains Lower Cambrian fossils in its lowest beds, and the formation as a whole, therefore, appears to mark the transition from Lower to Middle Cambrian.

Beds overlying the Ophir formation.-Above the Ophir formation lies about 900 feet of prevailingly argillaceous limestone and about 710 feet of dolomite, all of Middle Cambrian age. These beds form a series of parallel northsouth bands extending along the western part of the Tintic district and into the North Tintic district. They are also present in the East Tintic district, where they form the country rock around the Tintic Standard and East Tintic Development mines, and in a few small areas about 12 miles south of Mammoth. In the detailed report ${ }^{1}$ these strata are subdivided, as follows, the lowest beds appearing at the top of the list:

Teutonic limestone, named after Teutonic Ridge, northwest of Eureka; 565 feet thick; dark bluish gray; argillaceous; in part mottled, in part striped with brown, and in part finely banded; weathers to light gray.

Dagmar limestone, named after the Dagmar property; 100 feet thick; argillaceous; dark to medium gray on fresh fracture but weathering white; very finely banded.

Herkimer limestone, named after the Herkimer property; 225 to 235 feet thick; argillaceous; dark bluish, mottled with brown; closely resembles parts of the Teutonic limestone.

Bluebird dolomite, named after Bluebird Spur west of Eureka; 200 feet thick; dark blue; spangled with short white rod-shaped and branching aggregates of dolomite.

Cole Canyon dolomite, named after Cole Canyon west of Eureka; 510 feet thick; alternating beds of dark-blue mottled or clouded dolomite and of white-weathering beds prevailingly of dolomite; contains Middle Cambrian fossils.

Dolomite beds are continuous above the Cole Canyon dolomite but are tentatively assigned to the Upper Cambrian, on the evidence of a few poorly preserved fossils. They are designated the Opex dolomite, after the Opex property, whose extensive workings are for the most part in these beds. The extensive stopes of the Centennial Eureka mine also are mostly in this formation. The rock is prevailingly dark-gray dolomite similar in character to those of Middle Cambrian age, and also includes a little light-gray dolomite, shaly limestone, a few thin beds of shale, limestone conglomerate, and quartzite. Its thickness where measured is about 400 feet but ranges from more than 400 feet down to almost nothing.

The varying character of the basal Ordovician strata, the presence in them of occasional Cambrian pebbles, and the great difference in thickness (1,227 to 3,315 feet) between

1 Lindgren, Waldemar, and Loughlin, G. F., op. cit., pp. 27-31. 
the Upper Cambrian sections, in the Tintic and in other regions in Utah, all indicate an unconformity between Upper Cảmbrian and Ordovician.

ORDOVICIAN SYSTEM.

The Ordovician strata include three divisions, with a total thickness of 2,300 to 2,400 feet, that extend in parallel north-south bands through the middle part of the Tintic district and into the North Tintic district. They are also prominent around Homansville and Pinyon Peak, 3 to 4 miles northeast of Eureka, and occupy an area of less than a square mile along Burriston Canyon in the East Tintic district.

Ajax limestone. - The lowest formation, named the Ajax limestone, after the old Ajax mine, is for the most part a magnesian limestone characterized by small nodules and lenses of light-gray chert. The uppermost part is very low in magnesia and grades into the middle formation. Lower Ordovician fossils are present but very scarce.

Opohonga limestone.-The Opohonga limestone, so called after the Opohonga mine, is a shaly limestone of rather light bluish-gray color, with lenticular bands and patches of yellowish or reddish brown. Its thickness, where measured between Mammoth and Eureka, is 825 feet, but it is considerably thicker in the North Tintic district. Lower Ordovician (Beekmantown) fossils are present.

Bluebell dolomite.-The upper formation is called the Bluebell dolomite after the Eagle and Bluebell mine, whose ore bodies it contains, as well as those of the Gemini, Chief Consolidated, Victoria, Grand Central, and Mammoth mines. It consists of alternating light and dark gray dolomite beds, which resemble those of the Cole Canyon (Middle Cambrian) dolomite so closely that the two formations have been confused in places, especially just north and south of Eureka, where faulting of great horizontal displacement has brought the two in line with each other. The Bluebell dolomite, however, is decidedly the thicker, ranging from about 700 to 1,100 feet, the variation being due, in part, to strike faulting and in part to an unconformity at its top. Fossils found at different places in this dolomite indicate a range in age from Lower to Upper Ordovician (Beekmantown to Richmond). The upper 400 feet, in which no fossils have been found, may be of Silurian or Lower Devonian age.

SILURIAN AND LOWER DEVONIAN SYSTEMS.

No Silurian or Lower Devonian strata have been recognized. If present, their lithologic characters are similar to those of the Ordovician dolomite, and their aggregate thickness can not be over 400 or 500 feet.

UPPER DEVONIAN SYSTEM.

Pinyon Peak limestone.-Upper Devonian fossils were found only along the upper eastern slope of Pinyon Peak, over a mile northeast of Homansville. They are contained in the Pinyon Peak limestone, a shaly limestone about 150 feet thick, similar in color and structure to the Opohonga (Ordovician) limestone.

CARBONIFEROUS (MISSISSIPPIAN) SYSTEM.

Victoria quartzite.-The lowest Mississippian strata, called the Victoria quartzite, rest unconformably upon the Devonian and Ordovician. The unconformity is marked by little or no discordance in dip, but by the variation in the age of the immediately underlying rocks and by the presence of pebbles of Ordovician dolomite in the basal beds of the Mississippian. The beds consist of more or less calcareous quartzite and conglomeratic limestone and reach a maximum of 85 feet in thickness.

Gardner dolomite. - Above the Victoria quartzite lies the Gardner dolomite (named after Gardner Canyon), which comprises 400 to 700 feet of prevailingly dolomitic dark bluishgray beds, characterized by fossils of Lower Mississippian (Madison) age. The Gardner contains intercalated beds of black limestone and two highly carbonaceous beds, the larger of which is 100 feet thick and marks the top of the formation.

Pine Canyon limestone.-The Gardner. dolomite is overlain by the Pine Canyon limestone, 1,000 feet thick, which consists for the most part of dark-blue to black and fine-grained strata, characterized by large nodules and lenses of black chert but containing in its upper part prominent beds of gray coarse-grained pure limestone, in one of which the famous ore body of the "Colorado Channel" was formed. Most of the Pine Canyon limestone, according to its fossils, is of Lower Mississippian age, but the upper 300 feet, approximately, is tentatively assigned to the Upper Mississippian. 
Humbugformation.-The Pine Canyon limestone is overlain by the Humbug formation, a series of limestone, shale, and sandstone beds of Upper Mississippian age. In the Tintic district it is only 250 feet thick, but in the North Tintic district, along the western front of the range, it is very much thicker.

\section{NOMENCLATURE.}

As the sedimentary rocks are classified in more detail in Lindgren and Loughlin's report ${ }^{1}$ than in the earlier report ${ }^{2}$ on the district, which has been referred to in many publications since 1899, the following table may be convenient in correlating the names in both.

\begin{tabular}{|c|c|}
\hline TOWER AND SMITH, 1899 AND 1900. & INDGREN AND LOUGHLIN, 1919. \\
\hline cumbug formation.... & .Humbug formation. \\
\hline & Pine Canyon limestone. \\
\hline & Gardner dolomite. \\
\hline odiva limestone. & Victoria quartzite. \\
\hline & $\begin{array}{l}\text { Pinyon Peak limestone. } \\
\text { Bluebell dolomite. }\end{array}$ \\
\hline & Opohonga limestone. \\
\hline & Ajax limestone. \\
\hline & Opex dolomite. \\
\hline ammoth (or Eureka limestone) ${ }^{3}$ & $\begin{array}{l}\text { Cole Canyon dolomite. } \\
\text { Bluebird dolomite. }\end{array}$ \\
\hline & Herkimer limestone. \\
\hline & Dagmar limestone. \\
\hline & $\begin{array}{l}\text { Teutonic limestone. } \\
\text { Ophir formation. }\end{array}$ \\
\hline
\end{tabular}

Tintic (or Robinson ${ }^{3}$ ) quartzite... Tintic quartzite.

\section{IGNEOUS ROCKS.}

CHARACTER AND AgE.

The greater part of the East Tintic Mountains south and east of Eureka is covered by Tertiary volcanic rocks, with which are included a few necks or stocks and dikes. They consist for the most part of rhyolite, monzonite, latite, perhaps andesite, and minor basalt. The sequence of eruptions is, so far as known, early latite or andesite, rhyolites, main latiteandesite group and monzonite, basalt. The eruptions took place long after the sedimentary rocks had been folded and faulted and eroded into topographic forms much like those of to-day.

1 Geology and ore deposits of the Tintic mining district: U. S. Geol Survey Prof. Paper 107, 1919.

2 Tower, G. W., jr., and Smith, G. O., Geology and mining industry of the Tintic district, Utah: U. S. Geol. Survey Nineteenth Ann. Rept., pt. 3, pp. 601-767, 1899.

${ }^{3}$ Used in Tower, G. W., jr., and Smith, G. O., U. S. Geol. Survey Geol. Atlas, Tintic special folio (No. 65), 1900.
EARLY LATITE OR ANDESITE.

The existence of biotite-augite latite or andesite earlier than the rhyolites is proved by specimens collected on the dump of a shaft whose upper part is in fluidal rhyolite. These may correspond to the lavas exposed beneath rhyolite near the Iron Blossom No. 3 mine but are too thoroughly altered to be satisfactorily identified. They cover an insignificant part of the igneous area.

\section{RHYOLITE.}

Three important areas of rhyolite and one of rhyolite porphyry were mapped during the first survey of the district. The southern rhyolite, called the Fernow rhyolite, and the northern rhyolite, unnamed, are not near the principal mining centers and are not described here. The middle rhyolite is called the Packard rhyolite, and the rhyolite porphyry the Swansea rhyolite. Besides these, there are two minor bodies of rhyolite and at least one horizon of rhyolite tuff. One of the minor rhyolite bodies, characterized by a marked fluidal structure, covers a small area east of the Iron Blossom No. 3 mine. It underlies the rhyolite tuff, which is overlain by the Packard rhyolite, and by its relations has been the means of detecting postvolcanic or "Basin Range" faulting in the northern part of the prominent ridge 3 miles east of Mammoth.

The Packard rhyolite covers an irregular area of 18 to 20 square miles north and east of Eureka. North of Eureka, at Packard Peak, which is believed to mark the center from which it erupted, the rhyolite is 800 to 1,000 feet thick and may once have been twice as thick. Several rhyolite dikes have been noted both at the surface near Packard Peak and in some of the mines near Eureka. Other dikes have been found in the East Tintic district and near Pinyon Peak. Contacts with the main latite-andesite series along its eastern and southern boundaries show the Packard rhyolite to be the older rock. The typical rock is pink to gray, in places brown or dark purple, and distinctly porphyritic. Where altered it is light greenish gray to white. The groundmass is for the most part stony (wholly or partly microcrystalline) but near the upper contact is locally a black to gray glass. The visible minerals, phenocrysts, are feldspars, quartz, and 
biotite. Plagioclase, as shown by the microscope, predominates over orthoclase (sanidine), although potash exceeds soda in the chemical analysis, which implies that a considerable amount of potash exists in the groundmass. Quartz occurs in glassy grains, many of them irregular and some with rather well-defined crystal outlines. Though less abundant than the feldspars it is widespread and is a distinguishing characteristic of the Packard and Swansea rhyolites as compared with the other igneous rocks of the district. Biotite forms typical six-sided crystals. Magnetite, apatite, zircon, and locally brown hornblende are minor constituents. Where the rock is altered the plagioclase is changed to sericite, calcite, and chalcedonic quartz, and the biotite to chlorite (delessite?), but the other minerals are not conspicuously changed. Chalcedony or opal, and locally tridymite, calcite, and heulandite, fill flow partings and fractures.

The Swansea rhyolite is an intrusive body nearly three-fifths of a mile long and averaging one-fourth of a mile wide, between Robinson and Silver City. A few dikes of it have been found to the north, principally in deep mine workings, and one rather large inclusion of it was found in the adjacent monzonite, which is a later intrusion. The Swansea rhyolite is similar to the Packard rhyolite in color and mineral composition but lacks the structures characteristic of extrusive rocks. It is on the whole more highly porphyritic, and its groundmass in most places is more thoroughly crystallized. Alteration to chlorite, sericite, quartz, and pyrite is prevalent. At one place, in the Swansea mine, tourmaline is present.

\section{LATITE-ANDESITE SERIES.}

So far as chemical determinations have been made the members of the latite-andesite series are all latites, but it is very possible that they include andesites also. The series covers by far the greater part of the range from the latitude of Mammoth southward. The sequence of eruptions, which has been studied in detail at only a few places, is, so far as known, (1) latite tuff and breccia erupted from an explosive vent at the west end of Volcano Ridge, just south of the area shown in figure 42 ; (2) augite latite erupted from the same vent; (3) monzonite porphyry and related biotiteaugite latite flows erupted through the Sunrise
Peak neck, 2 miles northeast of Volcano Ridge; (4) augite-hypersthene latites that may be related to the principal monzonite stock at Silver City. Besides these there are in the eastern part of the region latites characterized by brown hornblende that were probably erupted from an unknown vent.

The latite erupted from the Sunrise Peak neck is the most widespread rock in the area studied. It extends northward as far as the Iron Blossom mines, east of Mammoth, and northeastward probably as far as the edge of Goshen Valley. Near Sunrise Peak it is massive and is not readily distinguished from the rock in the neck. At greater distances its extrusive character is more marked. The fresh rock is dark-greenish or brownish gray, weathering to rusty or to chalky white. It is dense and porphyritic, containing phenocrysts of plagioclase, biotite, and a minor amount of augite. The groundmass in specimens taken from the lower part of Sunrise Peak is microscopically but completely crystalline, and consists of plagioclase, biotite, minor augite, orthoclase, quartz, and the usual minor accessory minerals. At the summit of Sunrise Peak and in the neighboring area the groundmass, as seen under the microscope, is glassy and no orthoclase or quartz is recognized. Alteration minerals are quartz, sericite, epidote, chlorite, and calcite.

Of the latites with prominent hypersthene, one well exposed on Tintic Mountain, the highest peak in the region and about 8 miles south of Mammoth, is of special interest as it covers an extensive area and represents the latest eruption in the main part of the range. It is similar in mineralogic and chemical composition to the monzonite stock at Silver City, which is younger than the stocks from other known volcanic vents. It consists of plagioclase, augite, hypersthene, and a little biotite, with microscopic magnetite and apatite in a minutely crystalline to glassy groundmass.

\section{MONZONITE.}

The monzonite forms a main stock occupying a considerable area between Mammoth and Silver City and a small area across the gulch to the south; also a minor stock a short distance to the northeast near the Carisa mine. Several associated dikes are found in the neighboring mines and in the limestone area east of $35416^{\circ}-19-26$ 
them. The monzonite is intrusive into all other rocks with which it is in contact and is economically the most important igneous rock in the district, for it is believed to mark the source of the ore deposits. Areal study shows that at the time of the monzonite intrusion the present surface around Mammoth was covered by 2,000 or 2,500 feet of volcanic rocks, which account for the relatively deepseated character of the monzonite.

The rock where fresh is dark smoky gray to purple, but where weathered is for the most part light gray or greenish gray, with brown and pink variations. It is medium even grained to rather porphyritic. Plagioclase and augite or hornblende are the most conspicuous minerals. Orthoclase is abundant but is not readily identified without a microscope. Quartz and biotite are also conspicuous under the microscope but are only minor constituents. Most if not all the hornblende is secondary after augite and perhaps hypersthene. Alteration is of the same type as in the latites but is more intense near the more important veins.

Minor variations of the monzonite include a highly quartzose phase developed around a large quartzite inclusion, a small segregation of alkalic granite, and a syenitic phase containing aegirite-augite found at a dolomite contact near the Carisa mine.

\section{BASALT.}

Three small bodies, probably intrusive sheets, of olivine basalt were found during the earlier survey at House Butte, 8 miles south of Mammoth and $1 \frac{1}{2}$ miles west of Tintic Mountain. Their geologic relations are obscured by talus accumulations, but they are believed to be later than the latite-andesite series which surrounds them, and they may be the youngest of all the igneous rocks.

\section{FAULTS.}

Five periods of faulting can be distinguished in the Tintic district: (1) During the folding of the strata; (2) after folding but before volcanic activity; (3) during volcanic activity; (4) closely following volcanic activity but before mineralization; and (5) distinctly later than mineralization. These periods were not all sharply separated from one another, and along some faults movements are known to have taken place during more than one of them.
In figure 42 only the largest faults are shown. Most of them trend northeast, northwest, or east. Smaller east-west faults are very abundant. Several north-south faults are known to exist but are not readily found on the surface because they coincide with the strike of the strata.

The earliest faults recognized are mostly compression faults formed by the folding forces after the shapes of the folds had been determined. They include local overthrusts and accessory east-west faults along the east boundary of the Tintic quartzite and most of the prominent faults of northeastward and northwestward trends in the limestone area. Owing to the flexible character of the shale in the Ophir formation few if any of these faults cross it. The movements of blocks along all of these faults appear to have been generally eastward, involving a considerable horizontal and some upward displacement. The largest horizontal displacement (nearly 2,000 feet) is in the fault zone that obliquely crosses Eureka Gulch. North-south faults also were probably formed at this time but are not readily distinguished on the surface. A number of east-west faults were also formed, some accessory to the strong northeast and southwest faults, others more closely related to eastward bulges along the quartzite contact. After the folding period the tendency of the rocks, now relieved from compression, to expand, gradual loss of frictional heat, and gradual isostatic readjustment all contributed to the development of tensional or normal faulting. This faulting was chiefly northsouth and east-west, and was marked by the settling of certain blocks and the tilting and convergence, or divergence, of adjacent blocks. Such faulting can be proved only where exposures are abundant and otherwise favorable for the detection of faults, but there is no reasonable doubt that they are prevalent throughout the district.

The network of faults already formed, and the general settling along them, gave conditions farorable to volcanic eruption. The pressure forcing up the lava columns, besides prying apart the strata to some extent just north of Mammoth Gulch, was sufficient to cause further movement along existing faults, as well as to produce new faults. The principal faulting at this time took place around the monzonite stock, though faulting may also have 
occurred in the vicinity of Packard Peak. The principal direction of displacement along some of these faults was upward, as along the Sioux Ajax fault, whose total vertical displacement is as much as 1,500 feet, although part of this may be due to movement at some earlier period. Along other faults the horizontal component of displacement was more pronounced. To this group belong the fault trending north-northeast through the Emerald and Grand Central mines and the fault trending northward through the Opex mine, where it is known as the "Parting," and the Centennial Eureka mine, where it is called the "East Limit." Along both of these faults the eastern wall moved northward, or away from the monzonite.

There is evidence that other faults, of greater displacement than those just mentioned, were formed by the upward pressure of the rising monzonite magma and were largely obliterated by the "stoping" action of the magma, which reduced the fault blocks near the fault lines to groups of large inclusions in monzonite. Available evidence at the present surface indicates that the monzonite stock made room for itself principally by thrusting apart and faulting away the adjacent rock masses and to a less though considerable extent by "stoping."

More fissuring or faulting took place after the cessation of volcanic eruptions, and is present both in igneous and sedimentary rocks. It is attributed in part to contraction of the igneous rocks, especially the monzonite, and to the general cooling of all the rocks in the district, also to further settling movements to compensate for the great amount of lava poured out upon the surface, as well as to the isostatic readjustment that may have been going on ever since the cessation of folding. No faults of great displacement are known to have been formed at this time. The development of new, open fissures, however, as well as the reopening of certain older faults, was a large factor in determining the courses of the mineralizing solutions, whose period of activity is believed to have followed shortly after that of the monzonite intrusion.

The final period of fissuring or faulting was that during which the Basin Ranges were dereloped. This period can not be sharply separated from that next preceding and is known to be still in progress in some parts of Utah. Some of the Tintic ore bodies are cut by postmineral fissures or brecciated by postmineral movements along older faults, and at a few places ore bodies have been clearly displaced; but at none of these places has the amount of faulting been great enough to interfere seriously with the following ore bodies.

At least one fault zone of the Basin Range type is known to exist in the region. This is at the north end of the latite-andesite ridge, 3 to 4 miles east of Mammoth. The physiography at a few places suggests the presence of other faults of this type, especially along the range front about 5 miles northwest of Eureka, but all direct structural evidence at these places is concealed.

\section{HISTORY AND PRODUCTION. \\ By V. C. HeIKes. \\ METALLURGIC DEVELOPMENTS. \\ GENERAL FEATURES,}

Owing to the poor transportation facilities the development of the mines in the Tintic district was not rapid until 1878, when the railroad from Salt Lake City reached Ironton, 5 miles from Eureka. However, there was considerable activity in mining the richest of the ores near the surface and shipping them to San Francisco, Cal., to Reno, Nev., to Baltimore, Md., and even to Swansea, Wales. Later, most of the ores were shipped to Argo and Pueblo, Colo., and to the Salt Lake valley smelters. The lower-grade ores were treated at mills and smelters in the district at first with indifferent success, as the reduction processes were not fully adapted to them. Ores taken from the immediate surface were handled in amalgamation plants, though entire success was prevented by the abundance of antimony in the ores, which caused the mercury to flour. This was overcome to a large extent by roasting or chloridizing.

SMELTING.

A small mill and a smelter were erected simultaneously in 1871 at Homansville, about $2 \frac{1}{2}$ miles east of Eureka. Owing to the refractory nature of much of the ore, milling was not a success and smelting was tried frequently. The first smelter, the Clarkson, which was begun by the Utah Smelting \& Milling Co. on June 17, 1871, turned out 172 tons of silver- 
lead bullion in 60 days. The ores smelted were from the Scotia, Swansea, and Eureka mines. After producing several hundred tons of lead bullion, the plant was closed and moved away in 1872. Other smelting furnaces were erected at Diamond City and ran on ores from the Showers mine and other ores obtained by purchase. Material treated contained 50 per cent of lead and $\$ 80$ in silver per ton. ${ }^{1}$ Two furnaces were erected at Goshen in the fall of 1874 and ran at intervals for six months, producing $7 \frac{1}{2}$ carloads of bullion and one of copper matte, but did not prove successful and were dismantled. In 1873 the Mammoth-Copperopolis built ${ }^{2}$ a smeltery of two furnaces, each of 12 tons capacity per 24 hours, at Roseville, 6 miles from the mine, and operated it for several months, producing 126 tons of black copper, containing 90 per cent of copper and some gold and silver, worth in all $\$ 252$ per ton. Early in 1882 the Mammoth (Crismon) Co., ${ }^{3}$ after some experimenting, erected two matting furnaces and after testing them closed down its 27-stamp mill and built additional furnaces. Eight, with a daily capacity of 8 tons of ore each, were in operation in 1882 , converting 5 tons of ore into 1 ton of matte at a cost of $\$ 12$ per ton of ore. The number of furnaces was increased to $14{ }^{4}$ early in 1884 and a refinery had nearly been completed when operations came to a standstill. The company was reported to have been heavily in debt. In the early part of 1886 some calcining furnaces, newly erected, were reported working well on Mammoth ore and were shipping matte to Argo, Colo., but in September of the same year, they were pronounced a failure. No further smelting is recorded in the district until 1908, when the Tintic Smelting Co. erected furnaces at Silver City for treating lead and copper ores from a number of the Knight mines. Before the close of the year, two lead furnaces, of a capacity of 250 tons each, were operating, and a copper furnace was about ready to be placed in operation. Two additional lead furnaces, making four in all, were added in 1909 and operated until October of that year. Although the Tintic Smelting Co. achieved technologic suc-

\footnotetext{
1 Raymond, R. W., Statistics of mines and mining in the States and Territories west of the Rocky Mountains for 1871, p. 317, 1872.

2 Raymond, R. W., idem for 1873, p. 274, 1874.

3 Director of Mint Rept. upon production of precious metals, 1882, p. $257,1883$.

4 Director of Mint Rept. upon production of precious metals, 1883, p. $628,1884$.
}

cess, the greater economy in shipping ores to the smelters near Salt Lake led to the abandonment of local smelting.

MILLING.

The first mill was started at Homansville for the treatment of Eureka mine ores in 1872, using the amalgamation process. It had a capacity of about 25 tons of ore per day but did very little work. A second mill, erected at Homansville by an Ohio corporation called the Wyoming Mining \& Milling Co., started ${ }^{5}$ January, 1873 , on ore from the old Wyoming mine, ${ }^{6}$ afterward the Eagle (part of the Eagle and Blue Bell). This mine proved a disappointment and the company bought other mines, among them probably the Sunbeam, ${ }^{7}$ and milled much ore. The Wyoming mill was equipped with 10 stamps, 4 amalgamating pans, and the first Stetefeldt chloridizing roaster furnace of 30 -ton capacity erected in Utah. The mill is said to have been the only one at that time successful, as all the other mills used freemilling methods and failed on all ores except those from the immediate surface. Antimony, which was the chief trouble, was overcome, according to Col. Locke, by thorough chloridizing and driving off the chloride by steam. Ore of the class that the mill could treat was mined, usually in small lots, by lessees and hauled to the plant, and was milled only when sufficient ore had accumulated for a run. The mill ran in this intermittent way until 1878, when it closed because its largest shipper, the Crismon-Mammoth mine, attempted to mill its own ore. Between April 29 and June, 1877, the Wyoming mill treated ore from the Crismon-Mammoth mine aggregating 1,907 tons containing gold and silver. Of this, 547 tons assayed $\$ 11.74$ in goid and 52.56 ounces of silver per ton. Most milling companies did not pay for gold previous to 1876 , and as no assays were made by the miners, except for silver, the mill man had the advantage. It was this that caused the mine owners to attempt to mill their own ores. In the spring of $1874 \mathrm{Col}$. Locke took charge of the Wyoming mill, and in February, 1877, he purchased it. Afterward it was bought by the Tintic Mining \& Milling Co., who reopened it on July 14, 1880. After this the charges for working the ore were $\$ 25$ per ton, guaranteeing 80 per cent in bullion of the assay value of the

5 Precious metals: Tenth Census U. S., vol, 13, p. 446, 1885 . 6 Tower, G. W., jr., and Smith, G. O., U. S. Geol. Survey Nineteenth Ann. Rept., pt. 3, p. 739, 1899.

${ }^{3}$ Statement by Col. Locke to G. F. Loughlin, May 26, 1914. 
silver and also of the gold if it exceeded $\$ 10$ per ton. The product ${ }^{1}$ of this mill while under Col. Locke's management, from the spring of 1874 to the spring of 1878 , was $\$ 39,059$ gold and $\$ 241,112$ silver, recovered from 3,261 tons of ore. In 1881 this mill again began operations and worked on custom ores, mostly from the Northern Spy ore, almost continuously up to 1886 .

In 1873 before purchasing the Wyoming mill the Tintic Co. built the Miller mill with 10 stamps, wet crushing, for custom work, near Diamond. Leaching ${ }^{2}$ was unsuccessfully attempted here in the spring of 1879 . The Shoebridge or Ely mill, built 6 miles south of Diamond in 1873 for custom work, had 15 stamps and 1 Aiken roasting furnace, and ran irregularly until February, 1877, when the company failed. ${ }^{3}$ The Hunt and Douglas process was introduced in 1876 . The property was bought by S. P. Ely in 1878, who ran it as a custom mill between October, 1878, and September, 1879. The process used at the mill has been described by Raymond. ${ }^{4}$

In 1873 the Mammoth-Copperopolis Co., at about the same time or shortly before it constructed its smelter, erected a mill at Roseville, 6 miles from the mine, ${ }^{5}$ but soon found that the large quantity of copper in the ore impeded operations very much. The mill had a capacity of $22 \frac{1}{2}$ tons of ore per 24 hours.

The Crismon-Mammoth 27-stamp mill was built 8 miles south of the mine between December, 1876, and February, 1879, and was closed in 1882. In 1891 a 15-stamp mill, equipped by John Shettle to treat Mammoth ores by the lixiviation process, was treating daily 40 tons assaying 18 ounces of silver per ton, and 15 more stamps were being added. ${ }^{6}$ This mill was sold to the Tintic Milling $\mathrm{Co}$. in May, 1892, and worked Northern Spy ore averaging $\$ 20$ in gold and silver.

Between 1886 and 1893 nearly all of the mines were shipping ores to the smelters, and all material not high enough in grade to warrant transportation was accumulating on the waste dumps, no water being available for milling them. In 1893, however, the Mammoth Min-

1 Precious metals: Tenth Census U. S., 'vol. 13, p. 446, 1885.

2 Idem, p. 456.

${ }^{3}$ Idem, p. 458 .

4 Raymond, R. W., Statistics of mines and mining in the States and Territories west of the Rocky Mountains for 1875, p. 395, 1877.

5 Raymond, R. W., idem for 1873 , p. 274,1874

${ }^{6}$ Eng. and Min. Jour., vol. 52, Oet. 3, 1891. ing Co. constructed a 20-mile pipo line from Cherry Creek and a pumping plant with a capacity of 600 gallons per minute, the whole at a reported cost of $\$ 130,000$. During the same year, the construction of quartz mills was resumed, and in 1895 four pan amalgamation plants were operating in the district-Eureka Hill, 100 stamps, daily capacity 250 tons; Bullion Beck, roller mills and concentrating: plant, daily capacity 200 tons; Mammoth, 60 stamps, daily capacity 180 tons; Farrell or Sioux mill, 20 stamps, daily capacity 60 tons. The Mammoth and the Farrell mills, at Robinson, operated very successfully on lowergrade ores, shipping both bullion and concentrates. The richer ores were shipped to the smelters near Salt Lake City and elsewhere. Later the smelters and ore buyers offered better prices and the railroads lower rates on some of the ores milled, making it an object to ship instead of mill, and all the milling plants were soon closed. In 1899 the shipping mines were the Mammoth, Bullion Beck, Centennial Eureka, Grand Central, Gemini, Eureka Hill, Swansea, South Swansea, Godiva, Humbug, Uncle Sam, Sioux, Sunbeam, Ajax, Star Consolidated, Four Aces, Carisa, Joe Bowers, May Day, Northern Spy, Eagle, Treasure Hill, Lower Mammoth, Tesora, Alaska, Showers Consolidated, Boss Tweed, Utah, Rabbits Foot, and Silver Park. The Tintic Iron mine shipped in 1899 nearly 600 cars of iron ore to be used as flux.

In 1905 concentration mills were built on the Godiva and Uncle Sam properties, using water piped 2 miles from Homansville. The Uncle Sam mill was also operated by the May Day Co. some time later. Attempts made by lessees of the May Day property to dry concentrate the carbonate ore by a process patented by Dietz \& Keedy resulted in a very good grade of cerusite concentrates. In 1913 the old ore and tailing dump of the May Day was treated in a cyanide plant operated by lessees. In the later part of 1913 a mill was completed to treat the low-grade ores of the Knight mines (the Iron Blossom, Colorado, Beck Tunnel, Black Jack, Dragon, and Swansea) by the Knight-Christensen process of chloridizing, roasting, and leaching, which was said to be excellently adapted to a mixture of oxidized, sulphide, and siliceous material that could be formed from the ores of these mines. Before certain mechanical difficulties could be overcome the plant was destroyed by fire on April 6, 1915. 
Reconstruction was begun on the site of the abandoned Tintic smelter in July, 1915, by the Tintic Milling Co., newly organized and representing a consolidation of the Knight-Christensen Metallurgical Co. and the Mines Operating Co., which operated successfully for two years at Park City, using the Holt-Dern process of roasting. The new mill is equipped with one Christensen and three Holt-Dern roasters and was in experimental operation in the spring of 1916. The ores to be treated contain from 4 to 30 ounces of silver and 0.03 to 0.20 ounce of gold per ton, 1 to 8 per cent of lead, and a trace to 1.75 per cent of copper. The sulphides from the Swansea mine will provide, with the addition of powdered coal, the fuel necessary to the ore mixture in the chloridizing roast. Briefly, the process consists in roasting a mixture of ores, salt, and powdered coal; condensing the acid roaster gases in salt solution; leaching the roasted ore with this solution and precipitating the metals successively-gold and silver on copper and copper on lead; it is hoped to treat the final lead solution electrolytically. ${ }^{1}$ Tests were made at the Eureka plant of the Utah Mineral Concentrating Co., which built a concentration plant of 100 tons daily capacity in the later part of 1914, equipped with rolls, tube mill, and Isbell concentrators. Low-grade ores from various parts of the Tintic district, and from the Chief mine especially, were intended for treatment in the plant. The plant was closed in October, 1916, and was used in 1917 as an experimental plant on ores from the Chief mines.

PRODUCTION.

TOTAL PRODUCTION.

The first of the tables on pages 408-409 shows the quantity and value, by metals, of the ore sold or treated in the Tintic district from 1869 to 1913 , inclusive. The annual production is shown beginning with 1877 . The second table summarizes the production by decades.

The tonnage and average metallic content of each kind of shipping product in the Tintic districtfrom 1903 to 1917 is given in the tables on pages 406-410. The ore classification is necessarily arbitrary in part.

1 Personal interview with Mr. George Dern, Dec. 22, 1915. For detailed article showing flow sheet of Knight-Christensen mill, with illustrations and full description of process, see Met. and Chem. Eng., p. 757 , December, 1914 .
DRY OR SILICEOUS ORES.

The dry or siliceous ores comprise gold and silver ores proper, fluxing ores carrying considerable quantities of iron and manganese oxides and very small quantities of gold and silver, and gold and silver bearing ores carrying lead or zinc in quantities too low to permit them to be classified as copper, lead, zinc, or mixed ores. The contributors of the dry or siliceous ores for the period were the Grand Central, Victoria, Dragon, Mammoth, Swansea, Lower Mammoth, Eagle and Blue Bell, Eureka City, Eureka Hill, South Swansea, Star Consolidated, Black Jack, Chief Consolidated, Hope, Garnet, Cornucopia, Windridge, Wyoming, Beatrice D., Mount Vernon, Iron Blossom, Brooklyn, Monterey, Gray Rocks, CentennialEureka, Ajax, Iron King, Shoebridge, Showers, Sunbeam, Victor, Rabbit Foot, Golden Treasure, and Tesora mines.

The Mammoth mine yielded the richest gold ores. The Dragon iron mine shipped ironmanganese ore for flux to the end of 1917. Its output ranged from 15,000 to 46,000 tons. The low average grade of this ore, estimated at about 40 cents in gold and not quite an ounce of silver per ton, largely affects the average of the crude ore in the following table:

Dry or siliceous ore and concentrates, with average metallic content, produced in Tintic district and shipped to smelters, 1903-191\%.

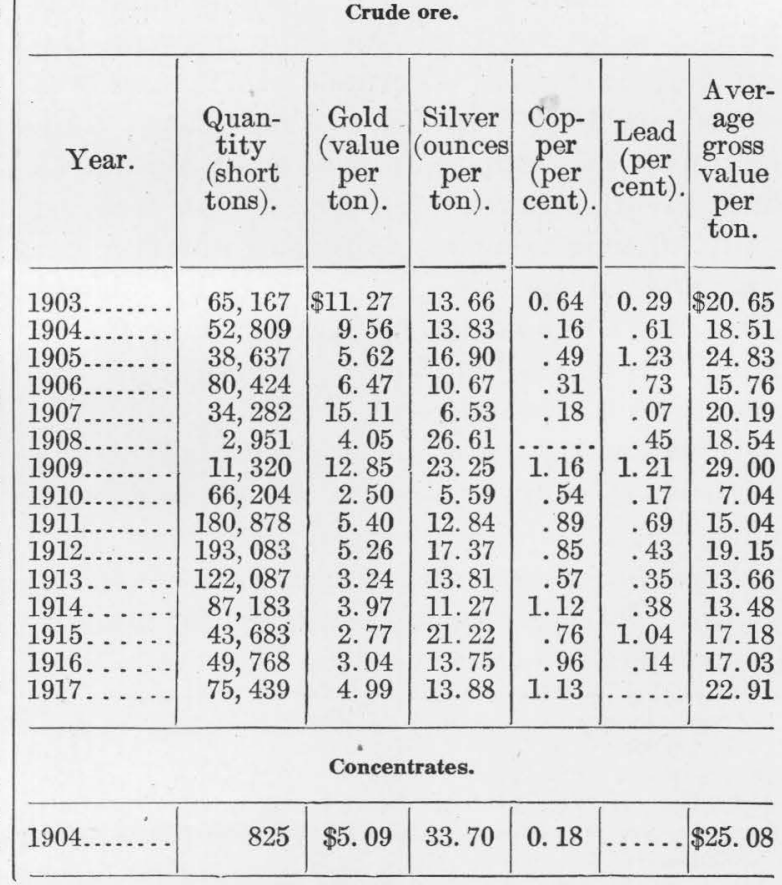


COPPER ORES.

The copper ores include those carrying over $2 \frac{1}{2}$ per cent of copper. A large contributor of these ores was the Centennial-Eureka mine. Other shippers of this kind of ore, named in the order of their importance, are the Carisa, Mammoth, Victor, Ajax, Laclede, Eagle \& Blue Bell, Opohonga, Bullock, Lower Mammoth, Gold Chain, Iron Blossom, Dragon, Eureka Hill, Brooklyn, Star Consolidated, Minnie Moore, Tesora, Grand Central, Homestake, Snowflake, Black Jack, Bullion Beck, Showers, Monterey, Argenta, Primrose, West Morning Glory, Shoebridge, United Sunbeam, Governor, Rabbits Foot, Neibaur, and United Tintic.

Copper ore, with average metallic content, produced in Tintic district and shipped to smelters, 1903-1917.

\begin{tabular}{|c|c|c|c|c|c|c|}
\hline Year. & $\begin{array}{l}\text { Quan- } \\
\text { tity } \\
\text { (short } \\
\text { tons). }\end{array}$ & $\begin{array}{c}\text { Gold } \\
\text { (value } \\
\text { per } \\
\text { ton). }\end{array}$ & $\begin{array}{c}\text { Silver } \\
\text { (ounces } \\
\text { per } \\
\text { ton). }\end{array}$ & $\begin{array}{c}\text { Cop- } \\
\text { per } \\
\text { (per } \\
\text { cent). }\end{array}$ & $\begin{array}{c}\text { Lead } \\
\text { (per } \\
\text { cent). }\end{array}$ & $\begin{array}{l}\text { Aver- } \\
\text { age } \\
\text { gross } \\
\text { value } \\
\text { per } \\
\text { ton. }\end{array}$ \\
\hline 1903 & 83,062 & $\$ 6.79$ & 17. 30 & 4.00 & & $\$ 27.0$ \\
\hline 904 & 116,8 & & 13. & 3.55 & 0.003 & 24.5 \\
\hline & 166,4 & 10. & 11. & 3.05 & .001 & 27.4 \\
\hline & 121,5 & 10. & 10. & 2.51 & .028 & 27.2 \\
\hline & 141,3 & 10. & 13. & 2. 47 & & 29.6 \\
\hline & 111,1 & 9. & 15. & 2.3 & .530 & 24. \\
\hline & 119 & & 12. & 2. & .640 & 21.5 \\
\hline & 87,3 & & 9. & 4. & .110 & 23.9 \\
\hline & 69 & 5. & 12. & 5. & .240 & 26.20 \\
\hline & 126, & & 10. & 3. & .870 & 24.3 \\
\hline & 146,9 & 4. & 8. & 2. 44 & . 050 & 16.9 \\
\hline & & & 10. & 1.94 & & 15.6 \\
\hline & 110 & 4. & 7. & 1.93 & .009 & 15.5 \\
\hline & & 3. & & 2. & & 21.31 \\
\hline & 96,8 & 2. & 8.74 & 3. 20 & & 27.3 \\
\hline
\end{tabular}

LEAD ORES.

In general the crude lead ores and lead concentrates are those containing over $4 \frac{1}{2}$ per cent of lead. The most persistent producers of lead product of shipping grade during the last 15 years were the Bullion Beck, Eureka Hill, Gemini, Lower Mammoth, May Day, Uncle Sam, Yankee, Eagle and Blue Bell, Ridge and Valley, Beck Tunnel, Black Jack, Mammoth, East Tintic Development, Iron Blossom, Centennial-Eureka, Chief Consolidated, Colorado, Godiva, Grand Central, Sioux, Eureka City, Clift, Ajax, Tetro, Joe Bowers, Martha Washington, Showers, Victoria, Frankie, Laclede, of ore.
Star Consolidated, Victor, Silver Park, South Swansea, Shoebridge, North Clift, Windridge, Utah Consolidated, Plutus Consolidated, Salvator, Carisa, Susan, Swansea, Crown Point, Diamond Queen, Neibauer, Dragon, Tintic Standard, Gold Chain, and Rabbits Foot.

Lead ore and concentrates, with average metallic content, produced in Tintic district and shipped to smelters, $1908-191 \%$.

Crude ore.

\begin{tabular}{|c|c|c|c|c|c|c|}
\hline Year. & $\begin{array}{l}\text { Quantity } \\
\text { (short } \\
\text { tons). }\end{array}$ & $\begin{array}{l}\text { Gold } \\
\text { (value } \\
\text { per } \\
\text { ton). }\end{array}$ & $\begin{array}{c}\text { Silver } \\
\text { (ounces } \\
\text { per } \\
\text { ton). }\end{array}$ & $\begin{array}{c}\text { Cop- } \\
\text { per } \\
\text { (per } \\
\text { cent). }\end{array}$ & $\begin{array}{l}\text { Lead } \\
\text { (per } \\
\text { cent). }\end{array}$ & $\begin{array}{l}\text { Aver- } \\
\text { age } \\
\text { gross } \\
\text { value } \\
\text { per } \\
\text { ton. }\end{array}$ \\
\hline 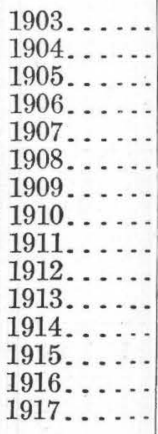 & $\begin{array}{r}36,206 \\
62,289 \\
53,307 \\
102,383 \\
90,267 \\
52,083 \\
125,923 \\
143,971 \\
92,067 \\
92,450 \\
117,562 \\
132,768 \\
116,647 \\
159,742 \\
151,878\end{array}$ & $\begin{array}{r}\$ 1.45 \\
.88 \\
1.82 \\
1.69 \\
3.08 \\
3.43 \\
4.22 \\
3.34 \\
2.80 \\
2.99 \\
3.16 \\
2.23 \\
2.04 \\
1.67 \\
1.38\end{array}$ & $\begin{array}{l}33.28 \\
25.41 \\
24.03 \\
23.38 \\
30.64 \\
43.80 \\
37.15 \\
27.73 \\
25.11 \\
24.22 \\
24.73 \\
22.95 \\
22.08 \\
19.53 \\
20.63\end{array}$ & $\begin{array}{r}0.60 \\
.46 \\
.43 \\
.33 \\
.34 \\
.38 \\
.07 \\
.41 \\
.13 \\
.25 \\
.30 \\
.36 \\
.11 \\
.11 \\
.12\end{array}$ & $\begin{array}{l}15.26 \\
16.24 \\
25.50 \\
14.19 \\
17.30 \\
21.92 \\
21.60 \\
12.74 \\
11.11 \\
10.81 \\
10.72 \\
13.45 \\
13.55 \\
12.14 \\
11.52\end{array}$ & $\begin{array}{r}\$ 33.89 \\
30.76 \\
41.78 \\
35.03 \\
43.01 \\
46.06 \\
42.31 \\
30.55 \\
26.42 \\
28.44 \\
28.45 \\
26.37 \\
26.38 \\
31.84 \\
38.87\end{array}$ \\
\hline \multicolumn{7}{|c|}{ Concentrates. } \\
\hline $\begin{array}{l}1903 \ldots \ldots \\
1904 \ldots \ldots \\
1905 \ldots \ldots \\
1906 \ldots \ldots \\
1907 \ldots \ldots \\
1908 \ldots \ldots \\
1909 \ldots \ldots \\
1910 \ldots \ldots \\
1911 \ldots \ldots \\
1911 a \ldots \ldots \\
1913 \ldots \ldots \\
1914 \ldots \ldots \\
1915 \ldots \ldots \\
1916 \ldots \ldots \\
1917 a \ldots \ldots\end{array}$ & $\begin{array}{r}416 \\
3,595 \\
1,400 \\
2,328 \\
2,593 \\
1,565 \\
881 \\
770 \\
574 \\
\ldots 58 \\
22 \\
155 \\
304 \\
\ldots \ldots\end{array}$ & $\begin{array}{c}\$ 2.28 \\
1.24 \\
5.95 \\
1.10 \\
1.11 \\
3.72 \\
3.28 \\
3.55 \\
2.45 \\
\cdots . . . \\
.48 \\
3.68 \\
\cdots \cdots \\
2.50 \\
\cdots \cdots\end{array}$ & $\begin{array}{r}38.69 \\
11.00 \\
20.03 \\
11.24 \\
13.87 \\
21.88 \\
21.90 \\
17.87 \\
15.93 \\
\ldots . . . \\
8.40 \\
53.45 \\
27.42 \\
24.59 \\
\ldots \ldots . .\end{array}$ & 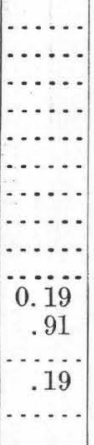 & $\begin{array}{c}19.86 \\
17.00 \\
20.10 \\
33.94 \\
37.75 \\
31.63 \\
30.45 \\
29.26 \\
25.20 \\
\ldots . . . \\
24.03 \\
39.25 \\
17.80 \\
35.52 \\
\ldots . . .\end{array}$ & $\begin{array}{r}\$ 39.86 \\
22.23 \\
37.06 \\
47.43 \\
44.97 \\
41.89 \\
40.86 \\
38.95 \\
33.57 \\
\cdots \ldots . . \\
27.29 \\
66.36 \\
30.64 \\
68.02 \\
\ldots \ldots .\end{array}$ \\
\hline
\end{tabular}

Copper-lead ores are classified after the same method as copper and lead ores. Contributors for the last 14 years were the United Sunbeam, Undine, Shoebridge, Laclede, Carisa, Windridge, Mammoth, Opohonga, Silver Queen, and Bullock. The table on page 410 gives the production and assay of this class 
Quantity and value of ore sold or treated in the Tintic district, Juab and Utah counties, 1869-1917, and total metals recovered.

\begin{tabular}{|c|c|c|c|c|c|c|c|c|c|c|c|c|}
\hline \multirow{2}{*}{ Year. } & \multirow{2}{*}{$\begin{array}{c}\text { Ore } \\
\text { (short } \\
\text { tons). }\end{array}$} & \multicolumn{2}{|c|}{ Gold. } & \multicolumn{2}{|c|}{ Silver. } & \multicolumn{2}{|c|}{ Copper. } & \multicolumn{2}{|c|}{ Lead. } & \multicolumn{2}{|c|}{ Recoverable zinc. } & \multirow{2}{*}{$\begin{array}{c}\text { Total } \\
\text { value. } a\end{array}$} \\
\hline & & Fine ounces. & Value. & Fine ounces. & Value. & Pounds. & Value. & Pounds. & Value. & Pounds. & Value. & \\
\hline $\begin{array}{l}1869-1876^{b} \\
1877 \ldots \ldots \\
1878 \ldots \ldots \\
1879 \ldots \\
1880 \ldots \\
1881 \ldots \\
1882 \ldots \\
1883 \ldots \\
1884 \ldots \\
1885 \ldots \\
1886 \ldots \\
1887 \ldots \\
1888 \ldots \\
1889 \ldots \\
1890 \ldots \\
1891 \ldots \\
1892 \ldots \\
1893 \ldots \\
1894 \ldots \\
1895 \ldots \\
1896 \ldots \\
1897 \ldots \\
1898 \ldots \\
1899 \ldots \\
18 .\end{array}$ & $\begin{array}{l}c 131,574 \\
c 186,223 \\
h 262,680 \\
h 266,761 \\
h 317,576 \\
h 278,504 \\
h 260,104 \\
h 256,578 \\
h 300,631 \\
h 360,391 \\
h 423,830 \\
h 400,430 \\
h 298,486 \\
h 293,474 \\
h 365,949 \\
h 392,386\end{array}$ & 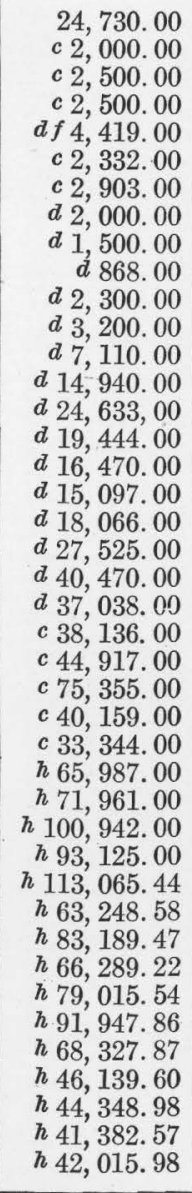 & $\begin{array}{r}\$ 511,215 \\
41,344 \\
51,680 \\
51,680 \\
91,349 \\
48,207 \\
60,010 \\
41,344 \\
31,008 \\
17,943 \\
47,545 \\
66,150 \\
146,977 \\
308,837 \\
509,209 \\
401,943 \\
340,465 \\
312,083 \\
373,457 \\
568,992 \\
836,589 \\
765,643 \\
788,341 \\
928,517 \\
1,557,726 \\
830,160 \\
689,282 \\
1,364,072 \\
1,487,558 \\
2,086,656 \\
1,925,066 \\
2,337,270 \\
1,307,464 \\
1,719,679 \\
1,370,320 \\
1,633,396 \\
1,900,731 \\
1,412,462 \\
953,790 \\
916,775 \\
855,454 \\
868,547 \\
\end{array}$ & $\begin{array}{r}894,000 \\
c 150,000 \\
c 130,000 \\
c 250,000 \\
d f \quad 181,545 \\
c g 151,073 \\
d 232,558 \\
c g 523,798 \\
c g 619,194 \\
d 868,925 \\
d e \quad 825,000 \\
d 1,412,463 \\
d 1,201,620 \\
d 2,055,700 \\
d 3,801,700 \\
d 2,901,730 \\
d 2,011,642 \\
d 1,990,860 \\
d 2,582,033 \\
d 3,517,166 \\
d 3,955,843 \\
d 2,877,600 \\
c 3,389,507 \\
c 3,329,833 \\
c 4,809,971 \\
c 2,685,735 \\
c 2,978,394 \\
h 3,620,362 \\
h 3,938,630 \\
h 2,951,348 \\
h 4,610,794 \\
h 4,949,082 \\
h 4,118,440 \\
h 6,404,847 \\
h 5,222,742 \\
h 5,514,702 \\
h 7,073,104 \\
h 5,829,484 \\
4,666,944 \\
4,370,984 \\
5,113,566 \\
5,558,763\end{array}$ & \begin{tabular}{|r}
$\$ 1,139,580$ \\
180,000 \\
149,500 \\
280,000 \\
208,777 \\
170,712 \\
265,116 \\
581,416 \\
687,305 \\
929,750 \\
816,750 \\
$1,384,214$ \\
$1,129,523$ \\
$1,932,358$ \\
$3,991,785$ \\
$2,872,713$ \\
$1,750,129$ \\
$1,552,871$ \\
$1,626,681$ \\
$2,286,158$ \\
$2,689,973$ \\
$1,726,560$ \\
$1,999,809$ \\
$1,997,890$ \\
$2,982,182$ \\
$1,611,441$ \\
$1,578,549$ \\
$1,954,995$ \\
$2,254,866$ \\
$2,386,614$ \\
$3,089,232$ \\
$3,266,393$ \\
$2,182,773$ \\
$3,330,520$ \\
$2,820,281$ \\
$2,922,792$ \\
$4,349,959$ \\
$3,521,008$ \\
$2,580,820$ \\
$2,216,089$ \\
$3,364,727$ \\
$4,580,421$ \\
\end{tabular} & 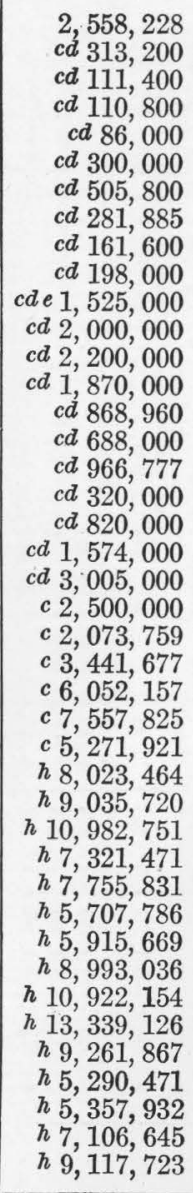 & $\begin{array}{r}\$ 699,903 \\
59,508 \\
18,492 \\
20,609 \\
18,404 \\
54,600 \\
96,608 \\
46,511 \\
21,008 \\
21,384 \\
169,275 \\
256,000 \\
369,600 \\
252,450 \\
135,558 \\
88,064 \\
112,146 \\
34,560 \\
77,900 \\
168,418 \\
324,540 \\
300,000 \\
257,146 \\
588,527 \\
1,004,658 \\
1,262,157 \\
643,174 \\
1,099,215 \\
1,129,465 \\
1,713,309 \\
1,413,044 \\
1,551,166 \\
753,427 \\
769,037 \\
1,142,115 \\
1,365,269 \\
2,200,956 \\
1,435,590 \\
703,632 \\
937,638 \\
1,748,234 \\
2,489,138\end{array}$ & 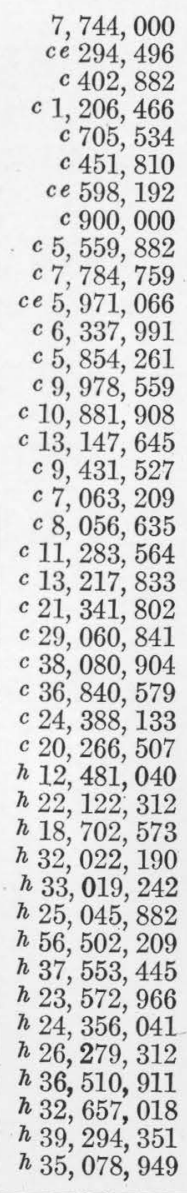 & $\begin{array}{r}\$ 549,540 \\
16,167 \\
18,104 \\
49,465 \\
35,277 \\
21,687 \\
29,311 \\
38,700 \\
205,716 \\
303,606 \\
274,669 \\
285,210 \\
257,587 \\
389,164 \\
489,686 \\
565,349 \\
377,261 \\
261,339 \\
265,869 \\
361,074 \\
396,535 \\
768,305 \\
1,104,312 \\
1,713,641 \\
1,620,985 \\
1,048,690 \\
830,927 \\
524,204 \\
967,851 \\
879,021 \\
1,825,265 \\
1,750,019 \\
1,051,927 \\
2,429,595 \\
1,652,352 \\
1,060,784 \\
1,096,022 \\
1,156,289 \\
1,423,926 \\
1,534,880 \\
2,711,311 \\
3,016,789\end{array}$ & $\begin{array}{r}3,709,737 \\
3,596,544 \\
758,217 \\
3,845,058 \\
3,711,156 \\
1,182,941\end{array}$ & $\begin{array}{r}\$ 255,972 \\
201,406 \\
38,669 \\
476,787 \\
497,295 \\
120,661\end{array}$ & $\begin{array}{r}\$ 2,900,238 \\
297,019 \\
237,776 \\
401,754 \\
353,807 \\
295,206 \\
451,045 \\
707,971 \\
945,037 \\
1,272,683 \\
1,308,239 \\
1,991,574 \\
1,903,687 \\
2,882,809 \\
5,126,238 \\
3,928,069 \\
2,580,001 \\
2,160,853 \\
2,343,907 \\
3,384,642 \\
4,247,637 \\
3,560,508 \\
4,149,608 \\
5,222,575 \\
7,165,551 \\
4,752,448 \\
3,741,932 \\
4,942,486 \\
5,839,740 \\
7,065,600 \\
8,252,607 \\
8,904,848 \\
5,295,591 \\
8,248,831 \\
6,985,068 \\
6,982,241 \\
9,803,640 \\
7,726,755 \\
5,700,837 \\
6,082,169 \\
9,177,021 \\
11,075,556\end{array}$ \\
\hline & & $1,574,942.11$ & $32,556,936$ & $125,271,682$ & $83,343,232$ & $171,493,635$ & $27,552,435$ & $752,049,426$ & $35,358,411$ & $16,803,653$ & $1,590,790$ & ent \\
\hline
\end{tabular}


$a$ Average commercial prices used for each metal to make total for each calendar year.
$b$ In December, 1869 , West Tintic first attracted attention, and the Sunbeam mine wa

Martha Washington, Black Dragon, Black Eagle, and Swansea, all operated between 1870 and 1876 , In 1873 the the first important producer, along with the Seotia; then the Eureka Hill, Mammoth, Shoebridge copper in Utah. 1882 to 1897 . Parts of the records of some early producers were used in the estimates. $d$ Estimated by G. W. Tower and G. O. Smith, who gave table and remarks on production for 1880 to 1896 (U. S. Geol. Survey Nineteenth Ann. Rept.,pt. 3, pp. $615-616,1899)$ : "It is thought the production
of silver and gold previous to 1880 did not exceed $\$ 2,000,000$ From 1880 to 1896 , inclusive, the production in gold has been 201,967 ounces and in silver $28,308,092$ ounces. In addition to the silver and gold, Tinti of silver and gold previous to of lead and copper. The only method of calculation of the lead and copper is by finding the ratio of copper to either gold or silver. As silver is more uniformly distributed in the ore than gold, this metal has been chosen as the basis of calculation. The average content of copper and lead in 240,000 tons of ores was 0.6 per cent and 13.5 per cent respeetively. The ores which have furnished the to every 87.5 ounces of silver and 20 pounds of lead to every 3.8 ounces of silver. Applying these ratios to the total production of the camp it is shown that there should have been produced $6,470,000$ pounds of per and 74, 3 .

producer of lead, yielded largely gold, silver, and copper.
$f$ Figures originally 3,012 ounces of gold and 8,682 ounces of silver, corrected from Tenth Census U. S., vol. 13, p. 314, 1885.
$g$ Tower and Smith (U. S. Geol. Survey Nineteenth Ann. Rept., pt. 3, p. 615, 1899) give, 1880 to 1888, 682 ounces; 1881, 105,354 ounces; 1883, 224,800 ounces; $1884,612,194$ ounces. These figures have been corrected from producers' reports, the Eureka Hill being the largest producer for the years given.

$h$ U. S. Geol. Survey Mineral Resources, 1903 to 1917.
$i$ These totals are for mine output and aggregate more than if smelters' and refiners' figures were used.

Metals produced in Tintic district, Juab and Utah counties, 1869-1917, by periods.

\begin{tabular}{|c|c|c|c|c|c|c|c|c|c|c|c|}
\hline \multirow{2}{*}{ Period. } & \multicolumn{2}{|c|}{ Gold. } & \multicolumn{2}{|c|}{ Silver. } & \multicolumn{2}{|c|}{ Copper. } & \multicolumn{2}{|c|}{ Lead. } & \multicolumn{2}{|c|}{ Recoverable zinc. } & \multirow{2}{*}{ Total value. } \\
\hline & Fine ounces. & Value. & Fine ounces. & Value. & Pounds. & Value. & Pounds. & Value. & Pounds. & Value. & \\
\hline $\begin{array}{l}1869-1880 \ldots \ldots \ldots \ldots \\
1881-1890 \ldots \ldots \ldots \ldots \\
1891-1900 \ldots \ldots \ldots \ldots \\
1901-1910 \ldots \ldots \ldots \ldots \\
1911-1917 \ldots \ldots \ldots \ldots\end{array}$ & $\begin{array}{r}36,149.00 \\
61,786.00 \\
332,518.00 \\
731,310.71 \\
413,178.40\end{array}$ & $\begin{array}{r}\$ 747,268 \\
1,277,230 \\
6,873,756 \\
15,117,527 \\
8,541,155\end{array}$ & $\begin{array}{r}1,605,545 \\
11,692,031 \\
31,366,185 \\
41,480,374 \\
38,127,547\end{array}$ & $\begin{array}{l}\$ 1,957,857 \\
11,888,929 \\
21,484,966 \\
24,475,664 \\
23,535,816\end{array}$ & $\begin{array}{r}3,179,628 \\
9,911,245 \\
21,441,370 \\
76,565,474 \\
60,395,918\end{array}$ & $\begin{array}{r}\$ 816,916 \\
1,422,994 \\
2,955,959 \\
11,476,109 \\
10,880,457\end{array}$ & $\begin{array}{r}10,353,378 \\
54,318,428 \\
187,524,539 \\
282,103,533 \\
217,749,548\end{array}$ & $\begin{array}{r}\$ 668,553 \\
2,295,336 \\
7,434,670 \\
12,959,851 \\
12,000,001\end{array}$ & $16,803,653$ & $1,590,790$ & $\begin{array}{l}\$ 4,190,594 \\
16,884,489 \\
38,749,351 \\
64,029,151 \\
56,548,219\end{array}$ \\
\hline
\end{tabular}


Copper-lead ore, with average metallic content, produced in Tintic district and shipped to smelters, 1903-191\%.

\begin{tabular}{|c|c|c|c|c|c|c|}
\hline Year. & $\begin{array}{l}\text { Quan- } \\
\text { tity } \\
\text { (short } \\
\text { tons). }\end{array}$ & $\begin{array}{c}\text { Gold } \\
\text { (value } \\
\text { per } \\
\text { ton). }\end{array}$ & \begin{tabular}{|c} 
Silver \\
(ounces \\
per \\
ton).
\end{tabular} & $=\begin{array}{c}\text { Copper } \\
\text { (per } \\
\text { cent). }\end{array}$ & $\begin{array}{l}\text { Lead } \\
\text { (per } \\
\text { cent). }\end{array}$ & $\begin{array}{l}\text { Aver- } \\
\text { age } \\
\text { gross } \\
\text { value } \\
\text { per } \\
\text { ton. }\end{array}$ \\
\hline 1903. & 388 & $\$ 1.84$ & 48.31 & 14.53 & 16.03 & $\$ 81.21$ \\
\hline 1904. & 128 & 1. 13 & 14. 53 & 2.87 & 2. 59 & 19.14 \\
\hline 1906. & 485 & 1. 49 & 27.11 & 3.82 & 16.00 & 52.90 \\
\hline 1907 & 330 & 1. 09 & 33.18 & 3.84 & 6.91 & 45.67 \\
\hline 1908 & 24 & .92 & 37.79 & 3.84 & 24.66 & 51.79 \\
\hline 1909 . & 46 & .59 & 27.26 & 3.75 & 5. 39 & 29.15 \\
\hline 1910 & 42 & 1. 26 & 16.24 & 7.61 & 16.14 & 43.54 \\
\hline 1911. & 56 & 5.70 & 15.87 & 5.11 & 13.58 & 39.12 \\
\hline 1912 & 472 & 2.53 & 128.14 & 3.49 & 8.13 & 100.18 \\
\hline 1913 & 43 & 1. 67 & 32.56 & 3.26 & 18. 22 & 47.46 \\
\hline 1914 & 180 & .73 & 15.97 & 2.96 & 9.88 & 25.14 \\
\hline & 72 & .53 & 27.21 & 3.86 & 8.98 & 36.29 \\
\hline 1916 & 78 & 3.44 & 52.53 & 3.44 & 11.39 & 70.63 \\
\hline 1917 & 3 & 2. 67 & 38.33 & 2.85 & 13.63 & 73.33 \\
\hline
\end{tabular}

ZINC ORES.

The zinc ores are those containing 25 per cent or more of zinc, irrespective of precious-metal content. All the ore mined is a mixture of carbonate and silicate of zine ore. Shippers of this class of ore from 1912 to 1917 were the Lower Mammoth, Uncle Sam, East Tintic Development, May Day, Gemini, Godiva, Ridge and Valley, Yankee, Chief Consolidated, Bullion Beck, Iron Blossom, Colorado, Sioux, and Empire.

$Z$ inc ore, with average metallic content, produced in Tintic district and shipped to smelters, 1912-191\%.

\begin{tabular}{|c|c|c|c|c|c|c|}
\hline Year. & $\begin{array}{c}\text { Quan- } \\
\text { tity } \\
\text { (short } \\
\text { tons). }\end{array}$ & $\begin{array}{c}\text { Gold } \\
\text { (value } \\
\text { per } \\
\text { ton). }\end{array}$ & $\begin{array}{c}\text { Silver } \\
\text { (ounces } \\
\text { per } \\
\text { ton). }\end{array}$ & $\begin{array}{c}\text { Lead } \\
\text { (per } \\
\text { cent). }\end{array}$ & $\begin{array}{c}\text { Re- } \\
\text { cover- } \\
\text { able } \\
\text { zinc } \\
\text { (per } \\
\text { cent). }\end{array}$ & $\begin{array}{l}\text { Aver- } \\
\text { age } \\
\text { gross } \\
\text { value } \\
\text { per } \\
\text { ton. }\end{array}$ \\
\hline $\begin{array}{l}1912 . . \\
1913 . . \\
1914 \ldots \\
1915 \ldots \\
1916 \ldots \\
1917 \ldots\end{array}$ & $\begin{array}{l}6,306 \\
6,265 \\
1,064 \\
7,029 \\
7,318 \\
1,883\end{array}$ & $\begin{array}{l}\$ 0.33 \\
\cdots\end{array}$ & $\begin{array}{r}1.36 \\
\cdots . . \\
\cdots .68 \\
.68\end{array}$ & $\begin{array}{r}1.91 \\
\ldots . \\
\cdots \\
.34 \\
.21\end{array}$ & $\begin{array}{l}29.41 \\
27.91 \\
27.57 \\
27.35 \\
25.02 \\
29.12\end{array}$ & $\begin{array}{r}\$ 43.47 \\
31.26 \\
28.11 \\
68.53 \\
67.37 \\
59.41\end{array}$ \\
\hline
\end{tabular}

LEAD-ZINC ORES.

Most lead-zinc ores are purchased by manufacturers of pigment. In 1913, however, it was purchased by producers of spelter, some of whom save the residues for their gold, silver, and lead content. In 1913 the May Day, East Tintic Development, Tintic Standard, and Uncle Sam mines shipped an aggregate of 192 tons of ore, yielding 9.45 per cent lead and 23.29 per cent recoverable zinc, the whole valued at $\$ 34.40$ per ton. The Chief, Ridge and Valley, and Showers mines were producers in 1914, 1916, and 1917.

\section{ORE DEPOSITŚ. \\ DISTRIBUTION.}

The ore deposits of the Tintic district are found in only a small part of the Tintic Range, the extensive areas of rhyolite and latite or andesite being for the most part barren. The district proper lies mainly on the western slope, measuring about 4 miles from north to southfrom Silver City to a point north of Eurekaand 2 miles from east to west. (See fig. 42, p. 397.) Some outlying areas, however, contain deposits of greater or less value. On the south, prospects are found from Silver City to Diamond; on the east, about 2 miles from the divide, are the deposits of the East Tintic district; on the north about 9 miles from Eureka are the Scranton mines of the North Tintic district.

The general mineralization reaches its maximum east of Silver City, in an area of monzonite $1 \frac{1}{2}$ miles long and 1 mile wide; but few mines in this vicinity have yielded a great production. The monzonite and adjacent parts of the other volcanic rocks are extensively altered and impregnated with pyrite and are traversed by many fissure veins, with a general northeast trend and steep dip, some of which have yielded considerable oxidized ore. Among the mines on these veins are the Undine, Sunbeam, Martha Washington, Murray Hill, Silver Bow, Swansea, and others, the Swansea vein cutting the intrusive Swansea rhyolite near the monzonite contact. No distinct boundary separates the monzonite from the altered latite porphyry (in part at least extrusive) on the east, and the veins cut both formations. Very little work has been done on these deposits for 20 years, most of it having been stopped when large quantities of water were encountered 100 to 400 feet below the surface. The Swansea is the only mine that has been worked below water level.

The sedimentary rocks north of the monzonite are not broadly mineralized, but they contain a number of vein zones along which the limestone and dolomite are silicified over widths ranging from a few to 300 feet. Ore 
outcrops in places but is neither continuous nor common and is chiefly confined to the southern part of the limestone area.

Four vein zones of northward trend have yielded the bulk of the district's production. All but one are in line with the main zone of the monzonite, but it is impossible to trace any of them across the contact at the surface. The Gemini zone, the westernmost, comprises, from north to south, the Ridge and Valley, Gemini, Bullion-Beck, Eureka Hill, and Centennial mines. The Mammoth zone, adjoining the Gemini on the east, comprises the Chief, Eagle and Blue Bell, Grand Central, Mammoth, Golden Chain, Opohonga, Lower Mammoth, and Black Jack mines. The Godiva zone, next in order, comprises the Godiva, Uncle Sam, May Day, Humbug, Utah, Northern Spy, Carisa, Red Rose, and North Star mines. Finally, the Iron Blossom zone, the easternmost, comprises the Beck tunnel, Colorado, Sioux, Iron Blossom, Governor, and Dragon mines.

The Gemini zone does not cross the limestone monzonite contact but is closely connected with the second zone in the lower workings of the Centennial Eureka and Grand Central mines. In the upper levels of Centennial Eureka and in the mines to the north the ore follows north-south fissures. In the lower levels of the Centennial Eureka it extends along the strong southward-dipping cross breaks to a depth of about 2,000 feet. South of these cross breaks extensive prospecting has failed to find ore in line with the Gemini zone.

The second or Mammoth zone has been proved to cross the monzonite contact without interruption in the Lower Mammoth mine at depths of 1,700 and 1,800 feet. A little farther north it follows a series of northerly and north-northeast fissures through the Golden Chain, Ajax, and Mammoth properties. A lateral fissure zone a little to the west carries the ore on northerly fractures through the Grand Central, Victoria, Eagle and Bluebell, and Chief mines. A west-dipping fissure in the Grand Central carries the ore down to a depth of 2,000 feet, whence it connects through the lower workings of the Centennial Eureka with the ore of the first zone..

The third and fourth zones, which are roughly parallel, lie east of the divide, about a mile east of the second zone. The third zone crosses the monzonite contact, without conspicuous outcrops, 1,500 feet southwest of the North Star mine, and extends northeastward to the Northern Spy mine, where it turns northward and has been followed to a point in the Godiva mine where the barren rhyolite overlies the limestone. The fourth zone crosses the monzonite contact at the Dragon mine, also without conspicuous outcrops, and extends northeastward to the Iron Blossom No. 3 mine, where it turns northward, losing its veinlike character, and continues along the Colorado channel, a flat replacement body evidently formed at the intersection of northsouth fractures with a limestone bed particularly susceptible to replacement. In the Beck tunnel No. 2 workings, the northward course of the fourth zone ends abruptly and the ore is deflected westward along cross breaks into the Uncle Sam (Humbug) mine, where it joins the third or Godiva zone.

\section{RELATION TO FISSURES.}

The fissures in the igneous rocks in general trend N. $15^{\circ}-35^{\circ}$ E. Less commonly they trend N. $70^{\circ}$ E., or, as the Swansea vein, a little west of north. The dip is commonly $75^{\circ}-80^{\circ} \mathrm{W}$. Few veins are traceable for more than half a mile.

The fractures in tne sedimentary rocks (see p. 402) are many and complex and are present in all parts of the area irrespective of mineralization. They were, however, formed mostly before mineralization, and many of them antedate the volcanic period. Some of the largest faults-for instance, the great faults in Eureka Gulch and some of those in the east-west ridge to the south-had so healed at the time of mineralization that they had little or no influence on the course of the ore solutions. On the other hand, the Sioux-Ajax fault, east of Mammoth, had a marked influence on the deposits in the Iron Blossom zone.

As regards ore deposition, the most important though not the most conspicuous fractures are those that trend approximately northsouth and that generally have a vertical or steep easterly dip. In the western zones they nearly or quite coincide with the upturned bedding planes. They are also abundant along the eastern zones, where the strata dip at lower angles. Both north and north-northeast 
trending fractures are important in the southern part of the Mammoth zone, the ore alternating from one system to the other. East to northeast fractures that dip $50^{\circ}-70^{\circ} \mathrm{S}$. (known as cross breaks) are locally important and at several places form mineralized connections between parallel north-south ore bodies. The most conspicuous are the two heavily mineralized fissures in the Centennial Eureka mine, which mark the south end of the Gemini ore zone.

\section{MINERALIZATION.}

GENERAL CHARACTER.

The deposits of the district may be conveniently divided into those in igneous rocks, those in sedimentary rocks, and a small group of oxidized iron-ore deposits at or near the contact of sedimentary and igneous rocks. Contact metamorphism, indicated by alteration of the limestones to enstatite, spinel, and minor amounts of garnet, diopside, and wollastonite, is pronounced along the monzonite-limestone contact. Comparative study of the original and metamorphosed limestones proves that silica and probably alumina were the principal constituents introduced by the intruding magma, the metalliferous emanations contemporaneous with contact metamorphism having probably largely escaped into the porous volcanic rocks that then overlay much of the monzonite area. Deposits in both igneous and sedimentary rocks are characterized by the same essential mineral composition. The principal gangue minerals are quartz, usually as fine-grained jasperoid, and barite. The ore minerals are principally galena and enargite, small quantities of zinc blende, and pyrite, oxide, carbonate, or arsenate of bismuth, and subordinate tetrahedrite, famatinite, and chalcopyrite. The metals, arranged in their order of importance, are silver, lead, copper, gold, zinc, bismuth, arsenic, and antimony, but the last three are of small importance from an economic standpoint.

DEPOSITS IN IGNEOUS ROCKS.

Veins.-The deposits in the igneous rocks have been worked to shallow depths only, and operations have generally ceased at water level. Only the Swansea mine has attained a notable depth, its shaft going down 940 feet, 290 feet below water level.

The veins, which are rarely more than a few feet wide, have been formed both by filling and replacement, and the ore in some places grades into the altered country rock. The primary ore minerals, in order of abundance, are pyrite, galena, and enargite, in a gangue of quartz, much of which is well crystallized, barite, and a little microscopic alunite. Little is known of the details of the oxidation of these ores, for few of them have been worked in the last 20 years. Limonite and lead carbonate are the principal minerals, and much of the oxidized ore extracted was rich in silver. The metals of importance are silver, lead, copper, and locally gold. Silver is most abundant, as a rule, in the galena and enargite, but in the Swansea mine enough of it is said to be contained in the pyrite to make ore.

The important constituents of the ores from the mines in the igneous rocks range as follows:

Average content of cres in icneous rocks, Tintic district.

Ounces per ton. Gold .......................... $0.02-0.18$

Silver......................... $12.0-39.9$ Per cent.

Copper.......................... 0. 26-11.15

Lead ............................ .5 $5-24.9$

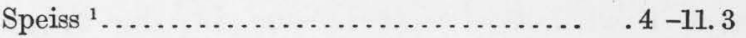

Silica................................. $16.0-40.4$

Iron ............................ 9.1 -31.0

Sulphur............................ $12.0-32.0$

Zinc................................ .4 1.1

Lime............................. . 0

Altered wall rock.-The wall rock of the veins is characterized by propylitic alteration. In and close to the ore-bearing veins it is completely replaced by quartz and pyrite, and locally by barite. Sericite is present, if at all, only in very minute quantity. This most intensely altered rock passes gradually into quartz-sericite-pyrite rock, in which the original porphyritic texture is preserved. This rock, bleached white on the weathered surface, is especially conspicuous along the vein zone that extends northeastward by the Sunbeam and Martha Washington mines to the Iron Blossom No. 3 mine, and is also conspicuous on some of the low hills east of the Iron Blossom No. 3 mine. At greater distances from the principal vein zones this rock passes into green or greenish-gray rock, in which the original minerals are largely replaced by sericite, chlorite, epidote, calcite, chalcedonic quartz or

' Speiss, in smelting, contains the arsenic and part of the sulphur, iron, and copper of the original ore. 
opal, and a little pyrite. This type of alteration is very widespread.

The rather conspicuous pyrite in the quartzsericite-pyrite rock, which amounts to 4 or 5 per cent and is accompanied by a little chalcopyrite, has given rise to the suggestion that this rock may be worked as a low-grade copper ore. Tests of the pyrite concentrates, however, show that the amount of copper is probably too small in view of the low topographic relief and the rather shallow ground-water level.

DEPOSITS IN SEDIMENTARY ROCKS.

General features.-In the sedimentary rocks, which are mainly dolomite, limestone, or shaly limestone, the character of mineralization is different. Extensive impregnation of pyrite and sericite is absent and the ore zones are marked by strong silicification, jasperoid and some barite replacing limestone or dolomite. The jasperoid in some places resembles a finegrained quartzite, and in others, in the northern and eastern part of the district, assumes a cherty or flinty appearance. Its width ranges from a few feet to 100 and rarely to 200 feet. In the ore shoots it contains finely disseminated galena, some zinc blende and pyrite, and in places a lighter and more distinctly crystalline quartz and some barite. Other ore shoots contain much enargite and some pyrite and chalcopyrite or some famatinite or tetrahedrite. Such copper shoots usually contain a little lead, especially along the margins, abundant barite, less conspicuous jasperoid, and, when oxidized, much limonite. The lead shoots and copper shoots usually occur separately, but mixed shoots are found, for instance, in the Eureka Hill mine.

Oxidation.-The water level in the sedimentary rocks stands from 1,650 to 2,400 feet below the surface, according to the elevation of the shaft, and broadly speaking is found about 300 feet above the level of Utah Lake, at an elevation of 4,860 feet. Explorations in ore below the water level have been undertaken only in the Gemini mine.

Oxidation has thus penetrated to unusual depths, but in none of the stopes seen in 1911 to 1914 is it complete, although both galena and enargite are more abundant in the lower levels than near the surface. The principal oxidation minerals formed in the lead and zinc mines are anglesite, cerusite, plumbojarosite, smithsonite, calamine, and hydrozincite; those formed in the copper mines include a long series of copper arsenates, malachite and azurite, more rarely cuprite, and native copper. Silver in the oxidized ores takes the form of cerargyrite (horn silver) and of native metal. Some rich oxidized ores show native gold.

Most Tintic ores are soft crumbling masses of cellular and honeycombed appearance, more or less stained by limonite and oxidized copper minerals, and containing in places residual galena and enargite. Too little work has been done in depth to throw much light on oxidation processes below water level. It is certain that a rich sulphide ore 250 feet below water level in the Gemini mine shows some oxidation, having developed small cerusite crystals pierced by wires of native silver. Proustite and argentite, found sparsely in some mines, were probably deposited during the general process of oxidation in places where the supply of oxygen was scant.

In a large part of the upper zone not enough oxygen was available for complete oxidation. In those places much galena remains and much of the enargite has undergone partial oxidation, and high above water level secondary chalcocite and covellite have contemporaneously developed.

No positive conclusions have been reached as to the existence of sulphide enrichment below or at water level, but such enrichment may account for a very peculiar rich ore from the Gemini mine, which contains galena, pearceite, zinc blende, and marcasite. It occurs from 250 feet above to 250 feet below water level and is certainly later than the first mineralization.

Relation of ore bodies to country rock.-The character of the ore bodies bears a marked relation to that of the country rock. None of the main zones enter the Tintic quartzite, the Ophir shale, or the Middle Cambrian limestones below the Cole Canyon dolomite. Deposits in these formations consist of short quartz veins or lenses in quartzite and shale and veins or bunches of dolomite and calcite in the limestones, none of which are of economic importance.

The main zones pass through the metamorphic zone and through a variety of limestones 
and dolomites. In the region of most intense mineralization ore has been stoped to a minor extent where the zones cut metamorphic limestone composed largely of silicates and also where they cut argillaceous or shaly limestone. The larger ore bodies, however, have replaced limestone and dolomite that contain 10 per cent or less of insoluble impurities where such beds are cut by mineralized fissures. At several places these ore bodies end abruptly against impure, dense-textured beds. The most remarkable example of this selective replacement is the "Colorado Channel" or Iron Blossom ore zone, which has replaced a single bed of coarsegrained limestone containing about 98 per cent calcium carbonate and 1 per cent magnesium carbonate for nearly a mile long along a northsouth fissure zone that coincides in strike with the main synclinal axis, and has ignored finegrained, less pure beds above and below. The coarse-grained limestone was particularly susceptible to replacement even where the oreforming solutions had migrated long distances from their source and had been weakened by decrease of temperature, reaction with country rock, and probably dilution with meteoric water. This same type of limestone contains, besides the "Colorado Channel," the largest ore bodies in the North Tintic district and in the southern Wasatch Mountains.

Horizontal variation.-The deposits of the Tintic district show marked mineral variation with distance from the intrusive monzonite. Four zones of distinct character may be recognized:

In the monzonite, quartz in well-developed crystals is accompanied by much pyrite and some barite, galena, enargite, zinc blende, and chalcopyrite.

In the sedimentary rocks for a mile to $1 \frac{1}{3}$ miles north of the monzonite contact the gangue consists of fine-grained replacement quartz containing some small druses of wellcrystallized quartz and much barite. The ores contain much enargite, a little pyrite, and in places tetrahedrite and famatinite. There are a few lead shoots, and the copper shoots contain a little lead. The ores also carry gold, averaging in the better grades of ore $\$ 10$ to $\$ 20$ a ton, and some silver, probably averaging 20 ounces to the ton.

Farther north in the same vein zones the sedimenary rocks contain principally galena and a little zinc blende and pyrite. The silver content is higher than farther south, averaging perhaps 30 to 40 ounces to the ton. There is practically no gold. The gangue minerals consist of predominant quartz in the form of an extremely fine grained cherty replacement of limestone or dolomite and of a moderate amount of barite. Few of the quartz crystals in the sparse drusy cavities are more than 1 millimeter in length. This zone continues, as far as known, for $1 \frac{1}{2}$ miles north of the end of the copper zone.

Farther north and east, beyond the leadsilver shoots, the mineralization becomes more feeble. The gangue minerals consist of calcite, dolomite, and a little quartz; the ore minerals comprise galena, zinc blende, and a few ounces of silver to the ton.

Gold and copper seem thus to occur on the whole near the monzonite, and lead, silver, and zinc mainly farther away. This arrangement may correspond to deposition in successively cooler zones and to a gradual spreading of the ore-forming solutions northward until they became so mingled with surface waters that their solvent power declined.

Vertical variation.-Far less marked is the variation in the composition of the ore with depth. The separation of the ore into lead and zinc shoots depends on the oxidation, the zinc migrating downward and replacing the limestone or dolomite wall rock and the oxidized lead ore forming without migration. ${ }^{1}$ Lead and copper shoots may be found in close proximity in a single mine in the copper zone but show no definite change with depth. In some mines which in the upper levels carry only lead copper begins to appear with depth.

\section{GENESIS.}

There can be no reasonable doubt that the ores both in the igneous and in the sedimentary rocks were derived from the same source. The similarity of the mineralization; the general continuity in strike, and finally the actual tracing of one of the normal veins across the monzonite-limestone contact are sufficient proof. The deposits were probably formed by hot waters, charged with igneous emanations, which rose through fissures formed in the monzonite after its consolidation. These

1 The genesis of the oxidized zinc ores has been described in detail by Loughlin, G. F., The oxidized zinc ores of the Tintic district, Utah: Econ. Geology, vol. 9, pp. 1-19, 1914. 
waters penetrated the sedimentary rocks north of the monzonite and spread, gradually cooling and losing their power of mineralization.

The ore deposits were formed immediately after the close of volcanic activity at a depth of only a few thousand feet.

\section{IRON-ORE DEPOSITS.}

Along the contact of limestone and igneous rocks south and southeast of Mammoth there is a great deal of surface oxidation and the limestone contains irregular bodies of limonite, kaolin, and jasperoid. Small deposits of this type are found near the Black Jack shaft and in the hills a mile east of the Iron Blossom zone, but the largest is that of the Dragon iron mine.

At the surface this mine is in an open cut, about 200 by 75 feet in area and over 200 feet deep. The ore body of the pit is said to end just below the 300-foot level. Small deposits of the limonite-kaolin mixture are found in the same mine as far down as the 800-foot level. The limestone porphyry contact slopes southward and eastward beneath the porphyry, and the limonite-kaolin masses thus far found are all in the limestone, at or very near the contact.

The great body of iron ore occurs in irregular nearly vertical shoots, whose largest dimension trends approximately east or north. They are completely surrounded by masses of hard kaolin, which are penetrated along the margins by small offshoots of iron ore. The ore is a compact limonite, with perhaps some hematite, containing 55 to. 57 per cent iron and 4.5 per cent silica. Much of it contains a trace of gold and as much as 2 ounces a ton of silver. Few copper stains have been observed. The arsenate of iron, pharmacosiderite, may be seen in places, but the quantity is insignificant. Isolated masses of copper-lead-silver ore in a quartz-barite gangue, found in the pit in line with the Dragon vein, are probably parts of this vein that have been later surrounded by limonite. Parts of the kaolin masses close by the iron ore are stained black by hydrous manganese oxide.

The genesis of these deposits is attributed to the downward migration of aluminum, iron, and manganese sulphates leached from a great thickness of pyritic porphyry that formerly overlay the present surface. These salts on reaching the limestone replaced it, forming kaolin, limonite, and wad. The kaolin itself was in part replaced by limonite and carried farther, thus forming the lower and lateral parts of the deposit. Rough calculation shows that the amount of pyritic porphyry was ample to supply the iron ore of even the large Dragon deposit.

\section{NORTH TINTIC DISTRICT.}

GEOGRAPHY.

The North Tintic district includes all the country in the East Tintic Range north of the Tintic and East Tintic districts. The area includes three nearly parallel ranges, the first two forming forks of the main range and the third a branch connecting with the Lake Mountains to the east.

There are no towns or villages in the district, and the only camp that has been continuously occupied is that of the Scranton mines in Barlow Canyon, one of the long transverse canyons that cut the west slope of the western range. Water is obtained in the western part of the district by wells driven in the alluvium of Rush Valley west of the mountains, and in the central and eastern parts from springs along the edge of Cedar Valley, which lies between the middle range and the Lake Mountains.

The Bolter (Boulder) district is 8 miles east of Lofgreen station on the Los Angeles \& Salt Lake Railroad, in Tooele County. It is here, however, regarded as part of the North Tintic district.

\section{GEOLOGY.}

The rocks of the district are Paleozoic quartzite, shale, and limestone, overlain at a few places by small masses of extrusive andesite and cut by a few dikes of rhyolite and monzonite porphyry. Their stratigraphic succession and structural relations are generally the same as in the Tintic district proper, except that a rather prominent quartzite, absent in the Tintic district, has been found in the Middle Cambrian limestone near the Hot Stuff prospect. The western and middle ranges are parts of a great anticline with gently dipping western and steeply dipping eastern limbs. The northward-pitching axis of the anticline extends along Broad Canyon, which separates the two ranges. The axis 
of the syncline, which is the dominant structural feature of the Tintic district proper, extends along Cedar Valley, its east limb forming the eastern part of the three ranges of the North Tintic district. Owing to these folds upper and lower Mississippian limestones form the western, Ordovician the central, and Cambrian the eastern part of the western range; the same formations in reverse order form the middle range; and the Mississippian, underlain by 150 feet of Devonian shaly limestone, forms the summit and central part of Pinyon Peak (the only part of the eastern range to be considered), and the Ordovician the remainder, except for a small amount of Cambrian at the east base.

The fissuring and faulting which characterize the Tintic district persist in the North Tintic district. Faults of considerable offset have been noted but have not been studied systematically. Premineral faults of large displacement are not, so far as noted, closely associated with ore bodies. One postmineral fault trends northward through the Scranton mine but has not been found to displace ore bodies of any importance. The most prominent mineralized fissures trend north to N. $15^{\circ}$ E., rarely east, and are associated with oblique branches or cross fissures, also mineralized.

\section{HISTORY AND PRODUCTION.}

By V. C. Heires,

The Norih Tintic district is in Tooele and partly in Juab County, in the Tintic Mountains, 6 to 10 miles northwest of Eureka. The producing mines are in Tooele County. Ore shipments are made from Delmonte, a station on the Los Angeles \& Salt Lake Railroad, about 3 miles west of the mines. The name of the district was formerly Oasis but was changed to Caledonia in 1875 and to North Tintic in 1879. The production previous to 1902 is not accurately known. However, the New Bullion ${ }^{1}$ property, worked by lessees about 1897 , produced from surface ores $\$ 35,000$ net in lead and silver. The largest producer of the district is the Scranton mine, which yielded oxidized lead ores between 1902 and 1905 and began the shipment of oxidized zinc and lead-zinc ores in 1906. The following table gives statistics collected by the U. S. Geo'ogical Survey to the end of 1917 :

1 Report of New Bullion Mining Co. by E. W. Clark and others, Ophir, Utah, 1906.

Metals produced in the North Tintic district, 1902-191\%.

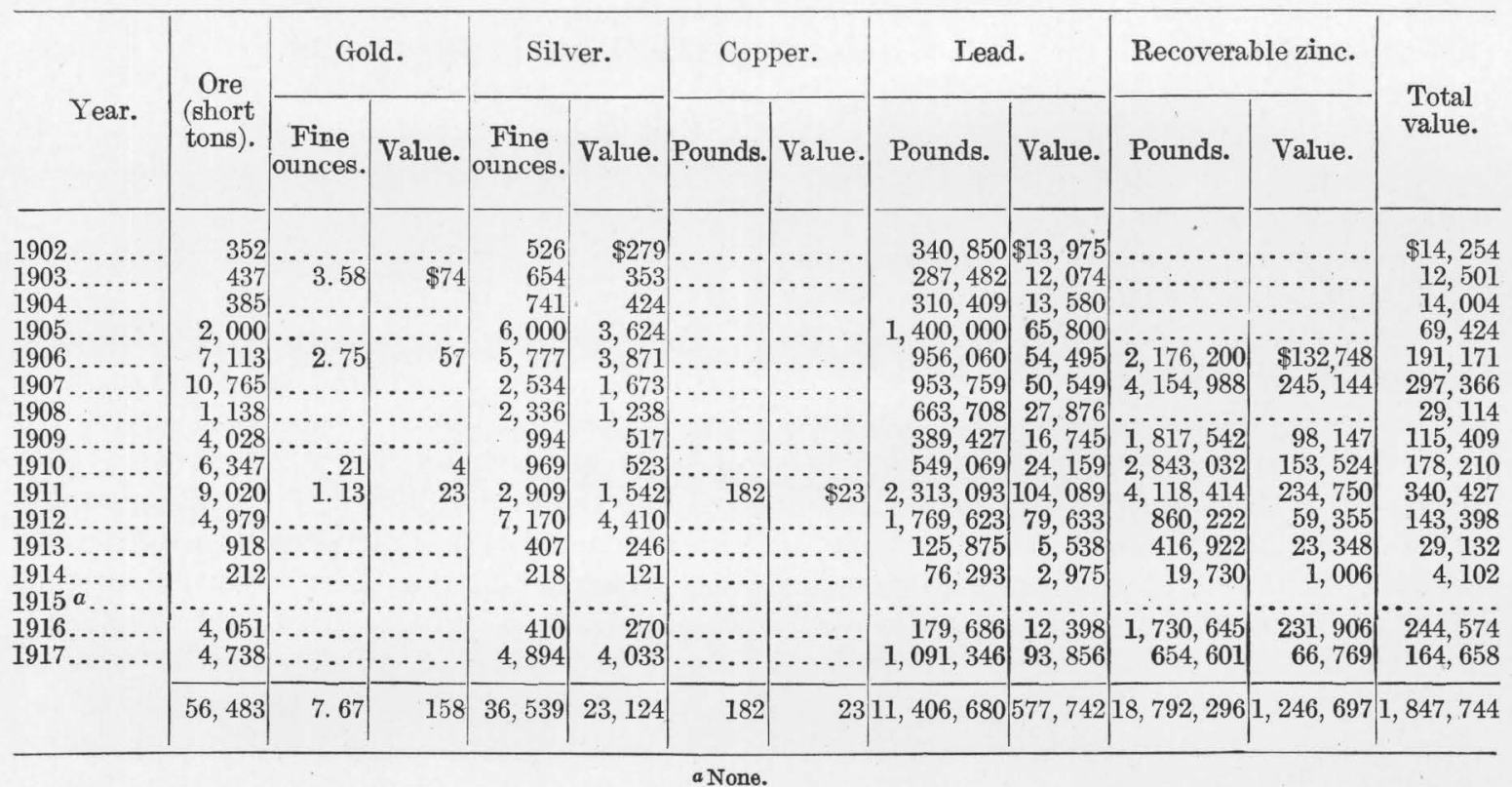


ORE DEPOSITS.

WESTERN RANGE.

Ore deposits in the western range have been successfully worked at two places, the Scranton mines in Barlow Canyon, about 9 miles northwest of Eureka, and the New Bullion (Bal Hinch) mine in Miners Canyon, about 3 miles farther south. The ore bodies of the Scranton are in coarse-grained limestone of probable upper Mississippian age, identical in character with that of the Colorado Channel or north half of the Iron Blossom zone in the Tintic district. Those of the New Bullion are at a somewhat lower horizon, probably near the boundary between the Pine Canyon limestone and the underlying Gardner dolomite, but the stratigraphy in this vicinity has not been determined with certainty.

These ore bodies, which have yielded oxidized lead, lead-zinc, and zinc ores, are all formed along the intersection of single fissures or branching and crossing fissures with specially replaceable limestone beds. Most of them vary from small bunches to bedded replacement or blanket bodies of considerable extent. Those of the Scranton mines lie in a nearly northsouth zone, strongly indicating that the mineralizing solutions migrated along a pronounced fissure zone and spread more or less where intersecting fissures or permeable beds gave opportunity. Fractures in that zone show premineral displacements of a few feet.

The ore and gangue are generally similar in character to those formed in the Tintic district by the cooler parts of the mineralizing solu-. tions. The principal gangue along the trunk fissures is mostly dark cherty quartz, and away from the trunk fissures dolomite and calcite. Only small remnants of sulphide ore remain in the oxidized ore, which consists chiefly of cerusite, smithsonite, and calamine, and which contains galena and zinc blende but very little pyrite. The abundance of iron oxide in the ore, however, shows either that considerable pyrite was present or that the blende contained considerable iron.

The metal content of the oxidized ore depends largely on the thoroughness of replacement of the limestone by primary sulphides and on the amount of zinc that migrated during oxidation. Where replacement was complete the zinc was mostly removed from the $35416^{\circ}-19-27$ lead ore during oxidation and was more or less concentrated into separate bodies or bunches. This process was especially pronounced in the southern part of the Scranton property, especially in the Magazine tunnel, where a large body of oxidized zinc ore was mined at the down dip end of a large lead stope. Where the primary ore only impregnated the limestone and did. not wholly replace it the unreplaced part precipitated the oxidized zinc as carbonate and produced the lead-zinc or "combination" ore prominent in the northern part of the Scranton property and in part at least of the New Bullion mine.

The lead ores shipped have assayed 0.5 to 3 ounces of silver to the ton, 21 to 33 per cent lead, 2 to 3 per cent zinc, 22 to 32 per cent iron, and 8 to 24 per cent insoluble; the zinc ores 0.5 ounce of silver to the ton, 0 to 2.5 per cent lead, 32 to 52 per cent zinc, 6 per cent or less iron, and 14 per cent or less insoluble; the combination ores 0.5 to 7 ounces of silver, 8 to 40 per cent lead, 14 to 33 per cent zinc, 5 to 14 per cent iron, and 7 to 15 per cent insoluble. The low silver content, averaging about 1 ounce to the ton in the Scranton mines and about 5 ounces in the New Bullion mine, is characteristic.

Other properties, prospecting in mineralized ground of the same type as that described, are the North Scranton and the Tintic Zinc Co., which is located between the Scranton and New Bullion mines.

Little or no ore has been produced from the middle range, but several promising outcrops both of siliceous and nonsiliceous ore have been prospected to some extent. The siliceous outcrops are prominent at the south end of the range, north of Packard Peak, and are approximately in line with the Gemini ore zone of the Tintic district. They consist of gray cherty quartz replacing coarse-grained Mississippian limestone of the "Colorado Channel" type. The principal prospects from which any data have been obtained are the Farragut and De Prezin. Assays of material in the quartz replacement have shown low values in gold, silver, and copper, and up to 11 per cent lead. One small shoot said to assay 7 per cent bismuth was found in the De Prezin property.

Nonsiliceous ores are on the east slope of the range, about 7 miles north of Packard Peak, 
on the Tintic-Humboldt property. The char- Other mineralized outcrops of more or less acter of the ore and gangue minerals, so far as promise have been prospected, but so far as exposed, and the country rock, are the same as known no ore of shipping grade has been found at the Scranton mines in the western range. $l$ in quantity.
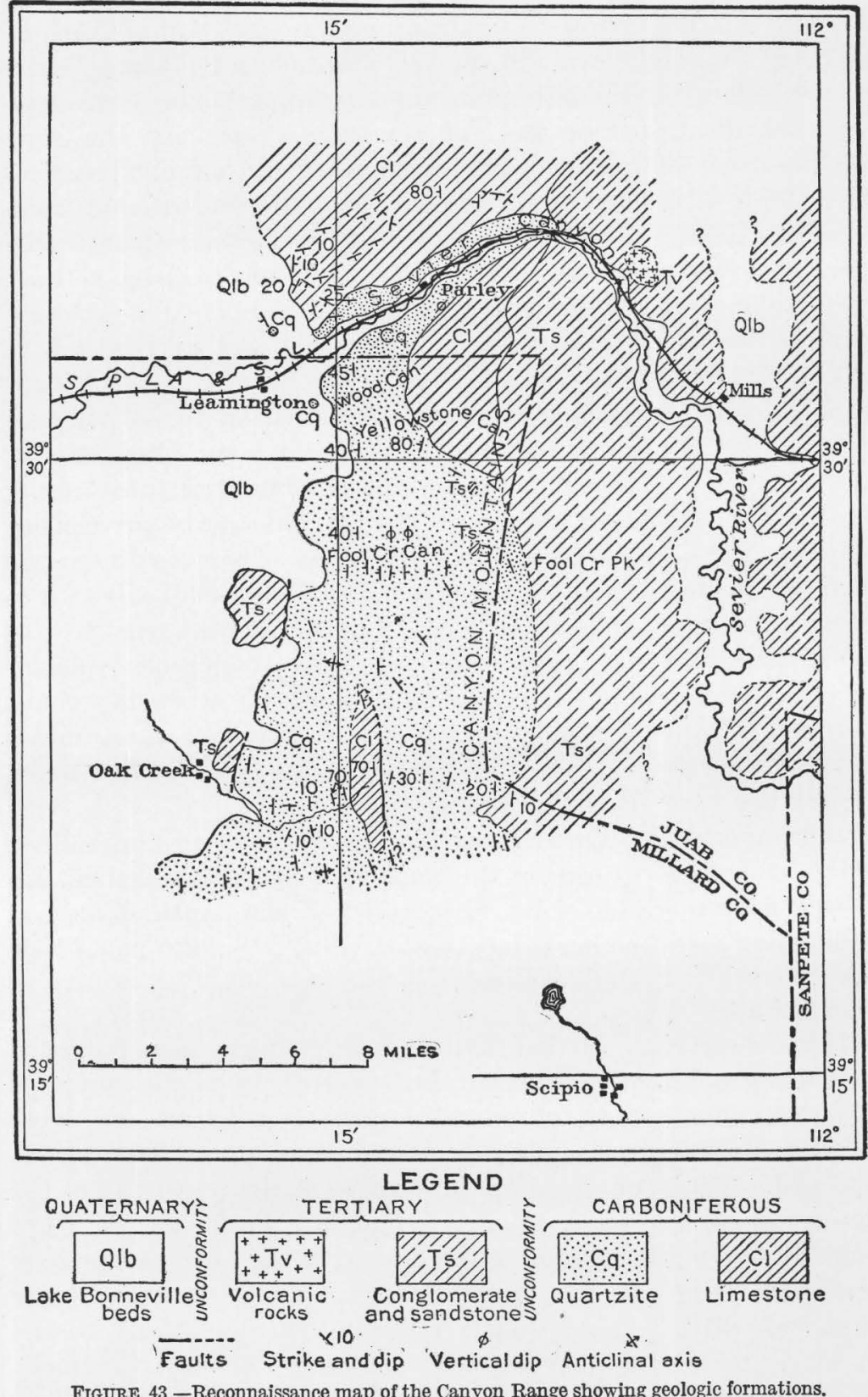

\section{CANYON RANGE. ${ }^{1}$}

By G. F. Loughuin.

GENERAL FEATURES.

The Canyon Range is in west-central Utah, in line with the East Tintic and Oquirrh ranges to the north. The few small mines and prospects in the range are scattered along the west slope from Leamington north for 12 to 13 miles to the hills south of Oak Creek (fig. 43), in the Leamington or Oak Creek mining district. Leamington, on the Los Angeles \& Salt Lake Railroad, and Oak Creek, reached by a 10-mile stage route from Leamington, are small agricultural towns.

\section{GEOLOGY.}

The Canyon Range is composed almost entirely of sedimentary rocks - Carboniferous limestone and quartzite overlain unconformably by Eocene conglomerate, but volcanic rocks have been reported from the extreme northern and southwestern parts. The valleys on either side of the range are floored with the Pleistocene Lake Bonneville beds and locally with later alluvial deposits.

\section{SEDIMENTARY ROCKS.}

CARBONIFEROUS LIMESTONE.
EASTERN RANGE.

The only ore body in the eastern range from which ore has apparently been shipped is one formerly worked in the Lehi-Tintic mine. The ore, an oxidized silver-lead of good grade, is said to have followed a N. $50^{\circ} \mathrm{E}$. fissure, probably in Mississippian limestone, but to have pinched out downward. Later work has consisted of prospect tunneling beneath this body.
The Carboniferous limestone is the prevailing rock northwest of Sevier Canyon and along the middle western slope of the range south of Sevier Canyon as far as the south boundary of

1 For a less condensed description of the geology of this range see Loughin, G. F., A reconnaissance in the Canyon Range, west-central Utah: U. S. Geol. Survey Prof. Paper 90, pp. 51-60, 1914. The origin of the range from the physiographer's standpoint is discussed by W. M. Davis (The Wasatch, Canyon, and House ranges: Harvard Coll. Mus. Comp. Zool. Bull., vol. 49 pp. 28-34, 1905). 
Yellowstone Canyon. North of Sevier Canyon it has generally low dips, associated with gentle anticlinal and synclinal flexures, but locally its beds stand nearly vertical. South of Sevier Canyon its dip ranges from steep westerly to vertical. The limestone on both sides of Sevier Canyon dips beneath quartzite. A smaller limestone area lies across Oak Creek in a monocline, which dips $70^{\circ}$ beneath the quartzite on the west and is separated from the quartzite on the east by a strike fault. Limestone is also said to be exposed in the narrow southern part of the range, near Scipio. A lens of limestone in quartzite was noted on the north side of Fool Creek, well above the main limestone formation.

The lithologic character of the limestone varies somewhat in different places. The lowest strata seen, about 3 miles northwest of Sevier Canyon, are thick to rather thin bedded, of medium to dark gray color, and fine to rather coarse grained texture. Fossils are fairly abundant in certain beds. At a higher horizon, due north of Parley station, which is 5 miles northeast of Leamington, intercalated beds of shale are conspicuous. About a mile north of Parley station, on the east wall of a southwardsloping canyon, a prominent bluff of vertical limestone and chert pebble conglomerate lies in the zone of these intercalated shale beds. The stratigraphic significance of this conglomerate can not be determined without detailed study, but from the paleontologic evidence it appears to be a local variation within a single limestone formation.

The uppermost limestone beds differ in character. On the west slope of the range, northwest of Sevier Canyon, they are very cherty, nodules and continuous bands of chert comprising as much as 50 per cent of them. Perfect pseudomorphs of brachiopod shells are conspicuous in much of the chert. Shale beds at this place are not conspicuous.

In Wood Canyon the uppermost beds are of light to medium gray color and are dolomitic. Many of them are characterized by a concretionary or pisolitic structure, the concretions ranging up to an inch or more in diameter and offering greater resistance to weathering than the matrix. Above and intercalated with these strata are beds of striped shaly limestone, alternating with shale, and these in turn are overlain by a bed of brown ferruginous quartzite, which is overlain by typical quartzite.

At no place is the entire thickness of the limestone exposed. A rough estimate of the exposed thickness northwest of Sevier Canyon gives 1,700 to 2,000 feet, but the many local variations in strike and dip give many chances for error. The thickness of the limestone in Yellowstone Canyon is certainly much greater, but the entire exposed width was not studied, and the lower part of the limestone is concealed beneath thick bodies of Eocene conglomerate. In Oak Creek canyon the exposed thickness is at least 3,500 and may be over 4,000 feet.

Fossils collected from the upper cherty limestone beds on the west slope of the range, $2 \frac{1}{2}$ to 3 miles northeast of Leamington station, were determined by G. H. Girty, of the United States Geological Survey, as follows:

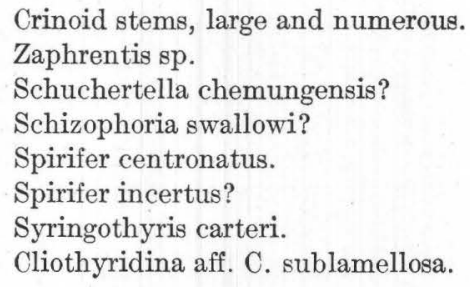

Another lot, collected at a horizon much lower stratigraphically, in the saddle between the two main ridges of the range, about $2 \frac{1}{2}$ miles north of Parley station, contains Spirifer centronatus and Composita humilis. Mr. Girty states that the first lot "is clearly of lower Mississippian or Madison facies," and that the second lot "is less diagnostic, since there are two Pennsylvanian species very similar to the only two comprised in the collection; but since the latter occurs below the first it must needs be Madison also." Fragments of fossils similar to those listed above were noted in Yellowstone Canyon in the upper part of the limestone.

The fossils prove that the upper 1,700 to 2,000 feet of the limestone is of lower Mississippian or Madison age. Cambrian fossils were found by Burling in the limestone area near Scipio, ${ }^{1}$ and it may be that some of the limestone represents ages between Cambrian and Carboniferous, as in the Tintic district to the north.

${ }^{1}$ Burling, L. D., written communication. 
QUARTZITE.

The quartzite of the Canyon Range is exposed along the western half of Sevier Canyon and extends continuously southward well beyond Oak Creek. South of the divide between the Yellowstone and Fool Creek canyons the quartzite constitutes the summit and entire western slope of the range, with the exception of the faulted band of limestone across Oak Creek.

The quartzite as a rule is of fine even grain and is nearly white to light and dark brown or south side of Sevier Canyon, near its mouth, where it stands vertical in a pinched synclinal trough of southwesterly pitch. It was not traced southward across Wood and Yellowstone canyons but is undoubtedly present in that part of the range. South of Yellowstone Canyon the red member follows the west edge of the range almost as far south as Fool Creek. It then swings southeast, crossing the lower part of Fool Creek canyon and following an undulating course, probably passing north and east of Fool Creek Peak, the highest peak of the range.
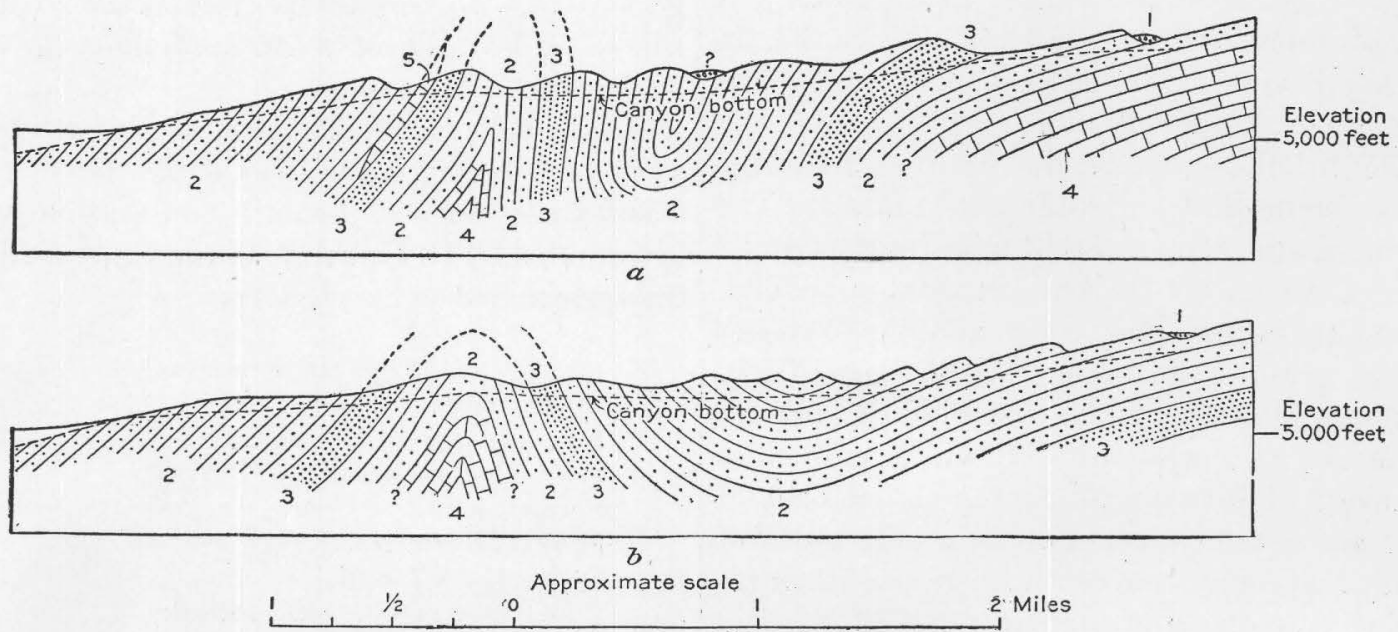

Figune 44.-Generalized section along north $(a)$ and south $(b)$ sides of Fool Creek canyon. 1, Tertiary conglomerate and sandstone; 2, Carboniferous quartzite; 3 , red member of the quartzite; 4 , Carboniferous limestone; 5 , limestone lentil in quartzite.

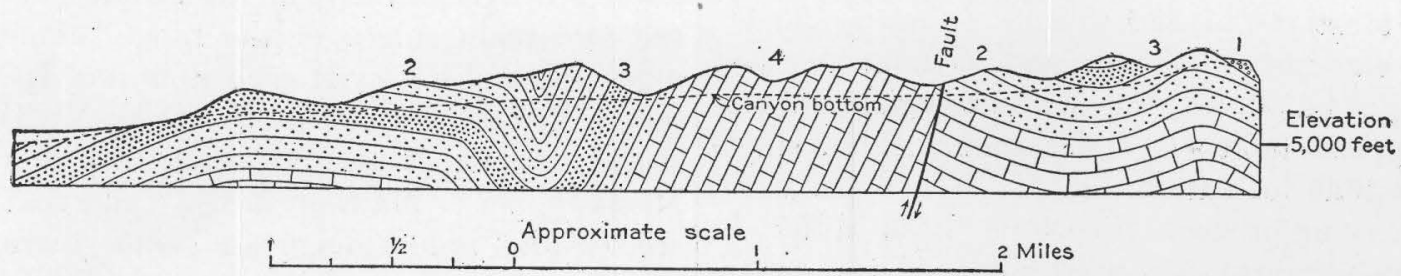

FIGURE 45.-Generalized section along north side of Oak Creek canyon. 1, Tertiary conglomerate and sandstone; 2, Carboniferous quartzite; 3 , red member of the quartzite; 4 , Carboniferous limestone.

reddish brown. Some of its beds are greenish. (See fig. 44.) South of Fool Creek canyon the Its general appearance is very similar to that of the thick Cambrian quartzite exposed in the Tintic district and at several places along the Wasatch Range, thus accounting for the fact that the quartzite has heretofore been regarded as Cambrian.

The quartzite contains a conspicuous and persistent dark-reddish finely banded member, 400 or 500 feet thick, which is a convenient horizon marker and indicator of the geologic structure. (See figs. 44 and 45.) The northernmost exposure of this member is on the red member is probably present in the western part of the range but was seen only in the vicinity of Oak Creek. North of Oak Creek canyon (see fig. 45) it is again prominent along the west edge of the range and is exposed in a very gentle anticline for a considerable distance along both walls of the canyon from near its mouth to the first north branch. Here a sudden steepening of the easterly dip carries it below the surface, but it reappears about a mile farther up the canyon a short distance west of the limestone band. It again appears 
in the trough of a gentle syncline on the north slope of the canyon near its head. It was not followed south of Oak Creek canyon.

A lens of gray limestone was noted on the north side of Fool Creek canyon, and detailed study may prove the presence of others.

The entire thickness of the quartzite was at no place exposed, owing to erosion of its upper portion. On the north side of Fool Creek canyon the thickness of the exposed vertical strata of the east limb of the close anticline appears to be at least 5,000 feet. Elsewhere the variations in dip prevented a closer estimate.

No fossils were found in the quartzite, but its apparent conformable position above limestone of Madison age suggests that its lower part at least is Mississippian, though its upper part may be Pennsylvanian. A similar quartzite of great thickness, containing some limestone beds, forms the greater part of the West Tintic Mountains, the southern end of which is almost connected with the northwest end of the canyon Range; and the writer has found upper Mississippian fossils in the limestone beds. Correlation, therefore, with this quartzite fixes the age of the quartzite of the Canyon Range as upper Mississippian.

\section{EOCENE CONGLOMERATE.}

The Eocene conglomerate is almost wholly confined to the east half of the range A few small outliers were noted on the higher spurs north of Fool Creek, and their approximate positions are shown in figures 44 and 45. A considerable area, in which the rocks are very poorly exposed, was traversed along the low foothills north of the town of Oak Creek.

In the principal area the Eocene consists of light-gray and red beds of conglomerate and sandstone, the conglomerate pebbles including limestone, quartzite, and chert. The western boundary of the principal area is exposed in Sevier Canyon near its northernmost point, where a coarse conglomerate rests unconformably on quartzite. On both sides of the canyon the boundary can easily be seen from a distance, owing to the marked contrast in color between the younger and older formations. South of the canyon the Eocene beds rest on the upturned lower Mississippian limestone and form the crest and upper west slope of the range along the heads of Wood and Yellowstone canyons. North of Fool Creek
Peak the west boundary crosses the summit and extends southward along the eastern slope as far as the saddle at the head of Oak Creek canyon, where the contact is well exposed, the Eocene beds, with a dip of about $10^{\circ} \mathrm{E}$., abutting against a steep erosion surface of quartzite.

The rocks which form the low foothills north of Oak Creek are almost completely reduced to a loose mass of limestone, quartzite, and chert cobbles, with a few remnants of consolidated conglomerate. The presence of the Eocene material in these deposits is presumably due to the sinking of a block during the faulting period when the Basin Ranges were developed. ${ }^{1}$

As only the eroded western edge of the Eocene beds was studied, no idea of its thickness was gained. The beds are assigned to the Eocene by correlation with similar strata in the southern. Wasatch Mountains ${ }^{2}$ and in the ranges immediately east of the Canyon Range. ${ }^{3}$

\section{QUATERNARY DEPOSITS.}

The Quaternary deposits include the Lake Bonneville beds of clay and marl deposited in Pleistocene time and the overlying alluvial deposits at the mouths of the canyons. The Lake Bonneville beds are terraced by Sevier River and are well exposed at Leamington and along the sides of Sevier Canyon. ${ }^{4}$

\section{VOLCANIC ROCKS.}

No volcanic rocks were seen at close range. From a distance a bed of dark columnar volcanic rock was seen overlying Eocene beds northeast of the canyon. (See fig. 44.) Volcanic rocks are said to be abundant in the extreme northern part of the range, and porphyry dikes are reported along Dry Canyon south of Oak Creek. ${ }^{5}$

\section{STRUCTURE.}

The Carboniferous rocks are characterized by a few major folds with steep dips, by several intervening minor folds with gentle dips, and by a prominent strike fault, which appears to be coincident with a broken anticline. The

1 These foothills were tentatively regarded by Davis as abnormal landslides: Harvard Coll. Mus. Comp. Zool. Bull., vol. 49, geol. ser., vol. 8, No. 2, pp. 28-34, 1905.

2 Loughlin, G. F., Jour. Geology, vol. 21, p. 448, 1913.

3 U. S. Geog. Surveys W. 100th Mer., atlas sheet 50.

1 Gilbert, G. K., Lake Bonneville: U. S. Geol. Survey Mon. 1, pp. 104, 166,192 , and $193,1890$.

5 Oral information by James Overson, cf Leamington, Utah. 
northernmost major fold is the asymmetric syncline of southwesterly pitch, whose axial plane is nearly parallel with the western half of Sevier Canyon. Its northwest limb dips $25^{\circ}-40^{\circ} \mathrm{SE}$. and becomes lower away from the axis, passing into an area of prevailingly monoclinal structure, though the general low and regular inclination of the beds is interrupted by several inconspicuous anticlines and synclines. The southeast limb is nearly or quite vertical along Sevier Canyon, but along Wood and Yellowstone canyons it dips about $45^{\circ} \mathrm{W}$.

In Fool Creek canyon an anticline and syncline with north-south axes are exposed. (See fig. 44.) On the north side the details of the structure are not very clear. The moderate westerly dip of the quartzite changes eastward to vertical, which persists for about $1 \frac{1}{2}$ miles and then gradually changes to a moderate westerly dip, which continues eastward probably to the crest of the range. The only clue to the structure is given by the red quartzite member, aided by comparison with the simpler structure on the south side of the canyon, which shows the strata to be folded into a close anticline of vertical dip and an unsymmetrical syncline with vertical west limb and moderately dipping east limb. (See fig. 44.) Detailed study, however, may show the vertical strata to be more complexly folded. The structure on the south side of the canyon needs no special comment. The lengths of these folds are not definitely known, but the anticline may extend as far north as the rim of the south fork of Yellowstone Canyon, where the uppermost limestone beds stand nearly vertical. That the limestone is probably not far below the surface where the anticline crosses Fool Creek may be inferred by the proximity of the red member of the quartzite to the top of the limestone in Sevier and Oak Creek canyons.

Between Fool Creek and Oak Creek canyons several minor folds can be seen from the western foothills. In the lower part of Oak Creek canyon a gentle anticline with limbs dipping about $10^{\circ}$ is well exposed. About 2 miles above the mouth this passes into a syncline, both of whose limbs dip $60^{\circ}$ to $70^{\circ}$. (See fig. 45.) The west limb is relatively small, but the east limb is at least $1 \frac{1}{2}$ miles in horizontal width and brings the limestone to the surface. The limestone is bounded on the east by a strike fault, probably a compression fault, which separates it from quartzite of gentle easterly dip. East of the fault the quartzite is folded into a rather gentle syncline and anticline, the anticlinal axis lying just east of the crest of the range.

The character of the folds shows that the dominant compressive force was eastward in the central and southern parts of the range and northwestward in the northern part.

\section{LEAMINGTON (OAK CREEK) DISTRICT.}

ORE DEPOSITS.

CHARACTER AND DISTRIBUTION.

The Leamington or Oak Creek district, which extends along the west slope of the range, was organized March 11, 1886 . During 1895, when the second smelter was operated for the treatment of ores of the Ibex and Charmed mines produced in the Detroit district, some of the lead ores from the Leamington district are said to have been utilized, but no record of the amount is available. The White Horse claim in 1901 yielded 7 tons of silver ore, presumably containing lead, but no record of the lead was kept. The Yellowstone claim from 1903 to 1906, inclusive, shipped to the Salt Lake smelters 350 tons of lead ore carrying silver.

LEAD AND ZINC.

Yellowstone mine.-The Yellowstone mine is in the south fork of Yellowstone Canyon, about 4 miles southeast of Leamington. The workings include an inclined shaft 200 feet deep, following the dip of the limestone (about $60^{\circ}$ W.), and drifts at the 50, 100, and 170 foot levels. The ore forms small replacement bodies in one of the limestone beds adjacent to fissures. On the 50-foot level small bodies were stoped along a north-south strike fissure and one body where the bed was somewhat shattered at the intersection of the strike fissure and an east-west cross fissure. The 170foot level follows the contact between a shale and limestone bed, along which a zone of veinlets, consisting chiefly of spar (dolomite and calcite), is said to assay 3 to 4 per cent lead.

The ore stoped consisted principally of galena and cerusite (lead carbonate) in a gangue of ferruginous dolomite and calcite spar. A little secondary aragonite was noted on a crust of fibrous calcite that lined a pocket along the strike fissure on the 50-foot level. Assays of the ore have run from 30 to 65 per 
cent lead, the higher grade carrying 5 to 6 ounces of silver. A little gold has also been reported. The mine has been worked intermittently and has shipped only about 15 carloads of ore in more than 20 years. No zinc has been found.

Arbroath mine.-The Arbroath shaft is about an eighth of a mile north of the Yellowstone, in a low spur which separates the south fork from the north fork of Yellowstone Canyon. The material on the dump shows the mineralization to be of the same type as that of the Yellowstone mine. The ore found during assessment work is reported to be of two grades, the higher carrying 76 per cent lead and 9 ounces of silver and the lower 10 to 11 per cent lead and 1 ounce of silver. Only a small quantity of ore has been found thus far.

Wood Canyon group. - The Wood Canyon group of claims is on the north side of Wood Canyon and includes the uppermost beds of the limestone formation. The mineralized outcrop is a brown, rust-stained dolomitic bed, containing a large amount of ferruginous dolomite spar, white where fresh and brown where weathered, through which are scattered grains of galena and yellowish-brown zinc blende. The stained rock is closely associated with two fissures, one trending north and the other S. $55^{\circ} \mathrm{E}$., both of whose outcrops are marked by shallow gulches.

COPPER PROSPECTS.

A small copper prospect in quartzite on the low ridge just north of the mouth of Fool Creek canyon consists of mineralized white vein quartz with numerous fractures stained by films of green and blue copper carbonates, and containing small spots and patches of darkbrown iron oxide evidently derived through oxidation of pyrite and chalcopyrite. Other copper and lead prospects have been reported along Dry Canyon, south of Oak Creek.

COMPARISON WITH ORES OF OTHER DISTRICTS.

The lead and lead-zinc ores of the Canyon Range are similar in mineralogy and mode of occurrence to certain ores in the North Tintic, East Tintic, Santaquin, and Mount Nebo districts. The ores of these districts are, as a rule, rather remote from important bodies of intrusive igneous rock and consist essentially of galena, zinc blende, and more or less pyrite, or oxidation products of thesesulphides, ingangues of dolomite, calcite, and minor quartz. Their usual silver content averages 3 to 5 ounces, but in some deposits rises to 10 ounces per ton. The sizes and shapes of the ore bodies vary according to conditions; some strong fissures contain continuous veins, and some permeable beds of pure limestone are rather extensively replaced; but argillaceous and dolomitic beds have yielded only small bodies of high-grade ore and a few more extensive bodies of milling ore.

The ore bodies of the Canyon Range are no exception to this rule. Those mined have replaced dolomitic limestone beds along their intersections with narrow fissures and are small or of low grade. The higher-grade ore bodies may be mined at no great expense, but the cost of prospecting for new bodies after old ones have become exhausted is likely to equal or exceed the net receipts from ore sales.

Small copper prospects found near the lead and zinc mines in some of the districts named are quartz veins containing chalcopyrite and pyrite or their oxidation products and are confined to the siliceous rocks-quartzite, schist, or granite. The copper prospects of the Canyon Range may, from the meager knowledge available, be classed with this type. A few veins intermediate in composition between these and the lead and zinc deposits have been found, suggesting that the two types were derived from a common source. None of these copper-bearing veins appear to have yielded steady shipments of ore.

\section{SHEEPROCK MOUNTAINS.}

By G. F. Loughuin.

GENERAL FEATURES.

The Sheeprock Mountains (fig. 46) form a narrow range about 20 miles long that trends northwest across longitude $112^{\circ} 30^{\prime}$ W. and latitude $40^{\circ} \mathrm{N}$. They lie between the Simpson Mountains on the west and the West Tintic Mountains on the east, and form a southward continuation of the Onaqui Range, separated from it by a low pass west of Fausts. Mining districts in the range are the Columbia, the eastern part of the Erickson, the Blue Bells, and the West Tintic.

The highest summits of the range rise 7,000 feet and more above sea level. Both the east 
and west slopes are pronounced, but the western are the steeper. Canyons cut both the west and east bases of the range well back toward the middle, leaving rather a narrow sinuous crest line. Those in and near the granite stock on the west slope (Pl. XII, $B, \mathrm{p} .101$ ) are distinctly "hanging" in character. They maintain broad V-shaped cross sections and uniform gently graded bottoms throughout most of their courses, but near their mouths grades, merging without breaks into the alluvial slopes which fringe the range.

Many of the canyons contain running water, and the bottoms of those in the northern half of the range are covered with a rather thick tree growth, in marked contrast to the semiarid alluvial slopes and valleys into which they empty. Although the mountains are well watered, even the larger streams disappear very near their canyon mouths. These streams

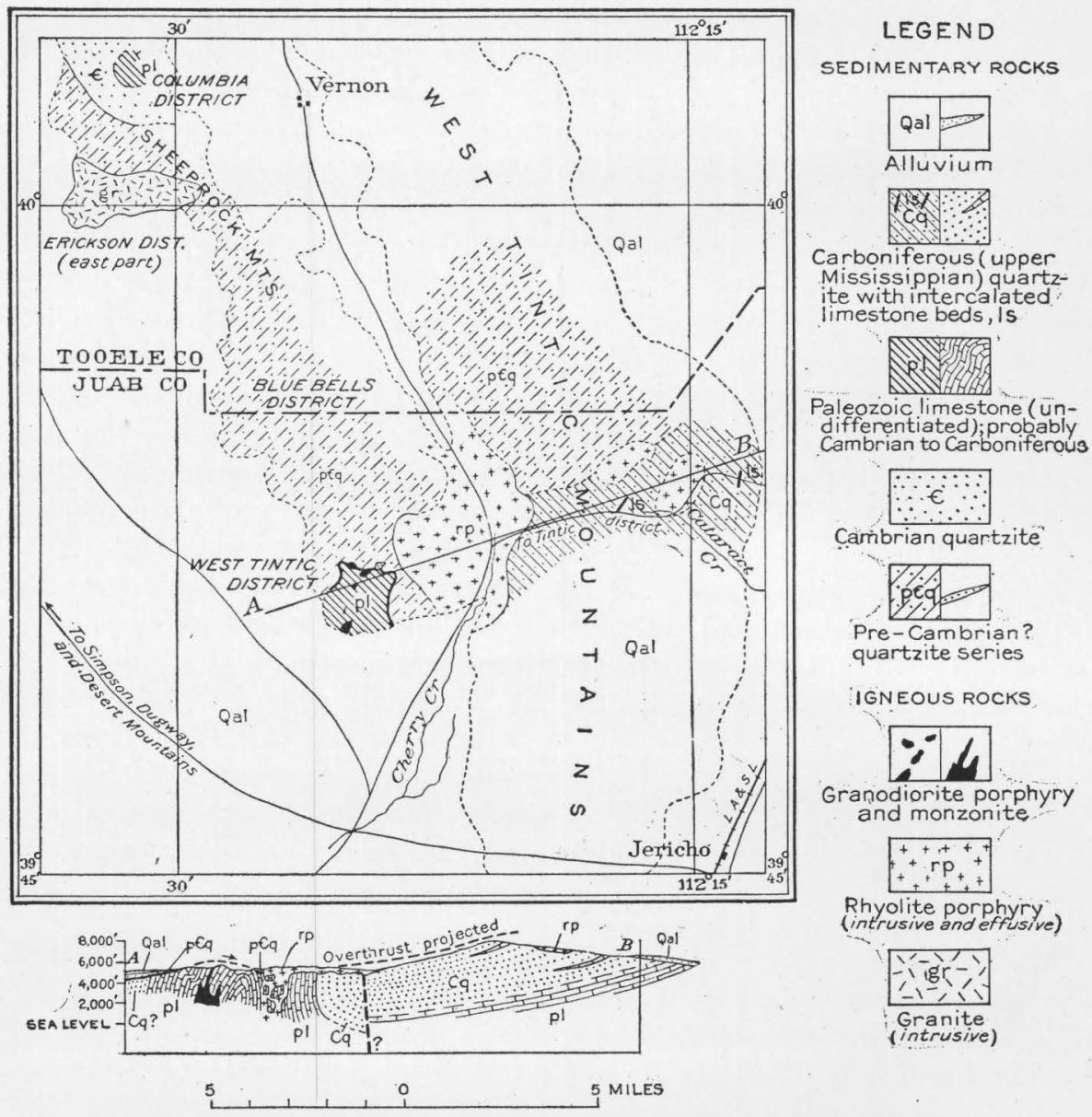

FIGURE 46.-Reconnaissance geologic map of the Sheeprock Mountains and part of the West Tintic Mountains.

the bottoms steepen abruptly and their creek beds follow a sharply zigzag course between low vertical walls. There are no indications of glaciation, and, as the base of the range is well above the highest level of Lake Booneville, a lowering of water level can not account for the hanging character. Quite possibly it is due to a renewal of faulting and uplift in rather recent times, since which the small creeks have been able to make only a beginning of down cutting to the new base-level. The canyons in the east slope have normal irrigate a few ranches near the base of the range.

The Sheeprock Mountains (see fig. 46) consist mostly of sedimentary rocks. The most extensive formation is a series of dark to light brownish quartzite, shale, and conglomerate, of probable pre-Cambrian age, that stretches from the south end of the range for threefourths of its length. Overlying this in the northern part of the range is a succession of Cambrian quartzite, shale, and limestone. At 
the southern end of the range, in the West Tintic district, an area of limestone of undetermined age probably includes Cambrian, Mississippian, and perhaps intermediate strata. This limestone is separated from the pre-Cambrian (?) quartzitic formation by an overthrust fault. All the formations dip prevailingly northeastward, and all dip at low angles, except those of the southern limestone area, most of which dip steeply.

Igneous rocks are represented by a prominent stock of granite or granodiorite in the northcentral part of the range and by several small stocks of granitic, monzonitic, and rhyolitic rocks at the southern end. Dikes and sills of granite, granite or rhyolite porphyry, and monzonite or diorite porphyry are abundant in places and have been noted in the vicinity of all mineralized areas.

\section{COLUMBIA AND ERICKSON DISTRICTS.}

The Columbia district and the eastern part of the Erickson district (the western part is in the Simpson Mountains) lie in the same mineralized area in the north-central part of the range. The Columbia district lies east and the Erickson district west of the divide. The geologic formations include pre-Cambrian (?) and Cambrian sedimentary rocks, the largest granite stock of the range, and dikes of rhyolite and monzonite porphyry.

GEOLOGY.

SEDIMENTARY ROCKS.

The sedimentary rocks overlie the intrusive granite, striking from northwest to west and dipping northeast of north. Near the intrusive contact this dip is rather steep, averaging about $45^{\circ} \mathrm{N}$. or NE., but it appears to flatten as distance from the contact increases.

The pre-Cambrian (?) includes beds of pure and of dark chloritic quartzite, chloritic shale, and poorly assorted conglomerate. A section through the upper parts of Hard-to-Beat Canyon on the southwest and of Harker Canyon on the northeast of the divide shows in ascending order, first, a zone of prevailingly lightcolored quartzite just above the intrusive granite contact; second, a series of chloritic conglomerate, quartz, and shale; third, a zone of prevailingly light-colored quartzite; and fourth, a zone of green, purple, and black shale. Each zone, however, contains beds characteristic of the other three. The fourth zone is overlain by light to dark gray limestone of Cambrian age.

The light quartzite is typical and requires no special description. Contact metamorphism has made no conspicuous change in its character.

The chloritic series, where unaltered, is green on fresh and dark brown on weathered surfaces. The pebbles of the conglomerate consist of vein quartz, granite, gneiss, and quartzite, in a sandy matrix of chlorite, sericite, and fine quartz and feldspar grains. The quartzitic and arkose layers are of the same composition as the conglomerate matrix. The shale differs from the quartzitic beds in a predominance of chlorite and sericite over quartz and feldspar. The appearance, however, of the chloritic rocks along the upper slopes and summits visited is much changed by contact metamorphism. They appear crystalline, and at a glance may readily be mistaken for greenstones-chloritized dolerite or diabase. This is especially true of the more arkose beds, but the conglomerate is readily identified by its pebbles, which are embedded in a crystalline matrix but have undergone no conspicuous change themselves.

The shale beds have lost much of their shaly character, and the terms hornfels and slate are appropriate to some of them. Much of the shale along its bedding planes has developed small "knots" or lumps common to many contact-metamorphosed slates. No careful study of this metamorphism was made, but there seems to have been little or no change other than the recrystallization of the minerals in the rock with consequent obliteration of clastic structure. The "knots" in the only specimen collected proved in thin section to be wholly changed to limonite.

The limestone was not studied, as no ore deposits in it have yet been reported. Fossils said to have been found in its basal beds east of James's ranch near the north end of the west face of the range indicate Middle Cambrian age. L. D. Burling, who identified the fossils, reports as follows:

This locality, for which little stratigraphic information was obtained in the field, can be definitely correlated with a section which I measured in 1905 in the Simpson Mountains, where it forms the third limestone bed above the quartzite series. It is Middle Cambrian in age and is probably to be correlated with the Wheeler formation in the House Range. It contains Ptychoparia kingi? and Agnostus interstrictus? 
IGNEOUS ROCKS.

The granite forms the south and southwest precipitous fronts of the range and extends well up the canyons to within a mile of the divide. Its upper contact slopes eastward and probably northward, eventually disappearing beneath the surface. The low flat ridges at the south base of the range are also of disintegrated granite which passes insensibly into the alluvial slopes of the valley. The granite is of the same general character as that of Desert Mountain. Its outcrops are in general badly crumbled to a depth of a foot or more, and it is thoroughly cut up by vertical and inclined sheet jointing, which has permitted successive thin sheets to be removed by erosion, thus maintaining nearly vertical cliff faces of considerable height. The main type is light gray in color and medium to coarse grained porphyritic in texture. Most of the phenocrysts are white to pale-pink alkalic feldspar 1 inch or less in length or are slightly weathered smoky quartz in round to irregular grains one-third of an inch or less in diameter. A few are flakes of biotite one-eighth of an inch and more in diameter. The groundmass doubtless contains both plagioclase and alkalic feldspar with quartz, biotite, and minor accessories, but all that was seen was too badly weathered to permit megascopic distinction between the groundmass feldspars and too crumbly to be studied in thin section. The main type is cut by many local dikes ranging from aplite to pegmatite in texture, many of them having margins of aplite and middle portions of pegmatite or even pure quartz. Most of the dikes seen trend about N. $25^{\circ} \mathrm{W}$. Near the contact with the overlying quartzite the granite is finer grained but maintains the porphyritic character. This contact phase, exposed along the upper walls of canyons, is cut by parallel joints dipping about $40^{\circ} \mathrm{W}$. and so closely and evenly spaced that the rock resembles a sedimentary formation when viewed from the canyon bottoms.

Two dikes of rhyolite, or quartz porphyry, were found on J. H. Ekker's Godiva claim in the reentrant at the south base of the main granite body. They trend a little north of west and dip $60^{\circ} \mathrm{S}$. or more, cutting through a complex of granite and metamorphosed arkose (which resembles fine dark granite). They are light gray to pale pink, with dense groundmass and small typical phenocrysts of feldspar and quartz. One weathered dike of rather acidic monzonite porphyry cuts the metamorphic chloritic sediments in a saddle on the crest of the ridge above the Sharp mine.

FISSURES.

The principal joint systems, including much vertical sheet jointing, strike N. $25^{\circ}-45^{\circ} \mathrm{W}$. and approximately northeast around the Copper Jack mines at the south base of the mountains. A mile or more to the west, at the mouth of Hard-to-Beat Canyon, they strike north and east, northwest, and northeast, and minor joints lie in various intermediate directions. Farther north, around the Old Sharp mine, they strike prevailingly north and east. In all these places the northwest and north joints dip southwest or west, the northwest generally between $65^{\circ}$ and $45^{\circ}$ and the north about $80^{\circ}$. The northeast and east joints, so far as seen, are mostly vertical, but some northeast ones dip steeply southeast. The joint systems show no direct relation to the dikes, but some of them evidently served as channels for ore-forming solutions.

\section{HISTORY AND PRODUCTION.}

By V. C. HeIKes.

The Erickson (Black Crook) district was organized January 30, 1894. No production from it has been recorded by the United States Geological Survey.

The Columbia district, in Tooele County, 9 miles southwest of Vernon, was organized the later part of 1871. According to Huntley ${ }^{1}$ there was some excitement there in 1871 and 1872 and again in 1875 and 1876. In 1875 the Ohio Co. spent a large amount of money recklessly and failed. The veins worked averaged 3 to 4 feet in width, but the ore, which is said to have averaged 10 to 25 ounces of silver and 30 to 40 per cent lead was of too low grade to pay at that distance from a market. Several hundred tons were shipped, but developments were, as a rule, very slight. In 1880 only about 10 claims had kept up assessment work.

Since 1880 the Sharp mine, a lead-silverzinc property, has been the only notable producer. In the later part of 1908 a 50-ton

1 Precious metals: Tenth Census U. S., vol. 13, p. 455, 1885. 
concentrator, equipped with rolls, Huntington screen jigs, and Wilfley tables, was built. Some lead concentrate was shipped in 1908 and 1909, and shipments of lead-zinc sulphides have been reported. ${ }^{1}$ In 1914 the lessees were shipping a fair grade of crude ore.

\section{ORE DEPOSITS.}

\section{OCCURRENCE AND CHARACTER.}

The ore deposits are veins in granite or in quartzite, none in limestone having been reported. They may be classified as quartzfeldspar veins carrying specularite and galena, quariz-fluorite veins carrying pyrite and chalcopyrite (copper veins), and quartz veins carrying pyrite, zinc blende, and galena (lead-zinc veins). Only the last two are of economic interest. The copper deposits lie along the south base of the granite stock and the leadzinc deposits to the north in the quartzite and shale on the upper slopes; but it is quite possible that some copper ore also occurs farther north.

\section{QUARTZ-FELDSPAR VEINS.}

The one quartz-feldspar vein found is on J. H. Ekker's Godiva claim. A shattered zone trending east to east-southeast through metamorphic arkose and granite is filled by a network of small irregular veins which are accompanied by some impregnation and replacement of the walls. Talus greatly obscures the outcrops, and good exposures are seen only in a few shallow prospect pits and two short tunnels. The vein matter varies from fine pegmatite to nearly pure quartz, quartz forming the margins and feldspar as a rule filling the central portions. From its optical properties the feldspar appears to be mostly orthoclase, but it includes a few grains of plagioclase. The kaolinized state of the feldspar renders the determinations rather unsatisfactory. A little microscopic muscovite is present in the veins. Both the pegmatitic and the quartzose portions contain specularite and more or less galena. The specularite is very similar to the galena in color and luster and may easily be mistaken for it at a hasty glance but can be readily identified on close inspection by its flaky or scaly form and its red streak. A few microseopic pyrite grains are associated with the specularite.

1 Communication from L. D. Gordon to G. F. Loughlin.
The wall rock, whether arkose or granite, is altered to an aggregate of quartz and sericite which in places is impregnated with considerable specularite. Galena seems on the whole to be limited to the veins. The total width of the veined and impregnated zone in some exposures is 10 to 15 feet. A small and exceptionally rich sample from a shallow pit in veined and completely silicified granite is said to have assayed 6 per cent lead and 15 ounces of silver per ton.

This vein zone is closely related to the local aplite and pegmatite dikes in character. Some phases of the granite contain large blebs of quartz identical in character with those in small pegmatite segregations which contain a little specularite and possibly once contained a little pyrite or galena now represented by small rusted pits. The pegmatite phase in turn appears to grade into the quartz-feldspar veinlets, which contain well-crystallized quartz of earlier growth than the feldspar, and which are accompanied by alteration and impregnation of the wall rock. Further data as to the relative age of the veins could not be obtained A rhyolite ("quartz porphyry") dike, distinctly later than the aplite and normal pegmatite, forms the approximate hanging wall of the vein zone for a short distance, but the exposures are so poor that it could not be determined whether the vein is later than the dike or whether the dike is later than the vein and coinciding with its course merely by chance. If the dike is later than the vein there may be two periods of mineralization; for although the quartz-fluorite veins (next described) do not come in contact with rhyolite dikes in this vicinity they do elsewhere and are everywhere later than the dikes.

COPPER VEINS.

The quartz-fluorite veins with pyrite and chalcopyrite lie west of the Godiva claim, near the base of the granite cliffs. Four properties on these veins have been worked, but all were idle and their workings were inaccessible when visited. Apparently the veins follow the $\mathrm{N}$. $25^{\circ}-45^{\circ} \mathrm{W}$. fissures. Two of them evidently form sheeted zones in porphyritic granite, and the filling of closely parallel fissures was accompanied by alteration and replacement of the intervening granite. The veins are said to range from a mere streak to 6 and to even 15 
feet. Nothing definite can be said regarding the horizontal extent of the veins or of the proportion of rich ground in the whole vein. The vein minerals vary in quantity, and all of them are not present in all specimens. The general arrangement, judging from specimens on the dumps, is for fluorite and the sulphides to segregate near the margins of fissures and for quartz to fill the central portions, but this arrangement evidently depends on the degree to which the different minerals have been able to segregate. In specimens showing the margins of veins the granite retains its appearance, but the original biotite is replaced by small pyrite grains, and the plagioclase by a soft yellowish-green material (presumably a microscopic aggregate of sericite and silica possibly stained in places by green copper minerals); the alkalic feldspar and quartz have undergone no appreciable change. The vein contact is sharp but not straight, suggesting that a portion of the wall has been replaced. The fluorite forms single crystals and coarsegrained aggregates of colorless to purple (green where stained with malachite), either pure or mixed with the other minerals. The pyrite and chalcopyrite also tend to form separate aggregates, and some specimens are composed almost wholly of chalcopyrite and fluorite in irregular masses, but others are composed chiefly of fluorite and pyrite. Quartz forms a matrix for the other primary vein minerals and also forms small prisms of late primary or secondary origin along minor fractures. Study of polished surfaces and thin sections shows that the pyrite and fluorite finished crystallizing about the same time and earlier than the other minerals. Some of the pyrite crystals were distinctly earlier than the fluorite. The chalcopyrite and quartz crystallized together, but the quartz continued to crystallize after the chalcopyrite had all deposited. This order, pyrite, fluorite, chalcopyrite, quartz shows the order in which the minerals finished crystallizing, but the periods of crystalization clearly overlapped, and some quartz was crystallizing before all the pyrite. A few microscopic scales of specularite were found inclosed in quartz, but its relations to the other minerals could not be determined.

Superficial alteration in the veins is marked by partial alteration of pyrite and chalcopyrite to limonite, and by the filling of fluorite cleavage cracks and small fractures in both veins and walls with malachite and iron oxide. Small vugs may be partly filled with white to pale-brown kaolin, evidently introduced mechanically by infiltrating waters. The incompleteness of oxidation and the shallow depth to ground water are not favorable to the occurrence of any strong zones of enriched sulphides, and it is probable that the value of the ore as a whole will not improve with depth. The copper content of the ore on the dumps does not average much if any over 5 per cent and nothing indicates a high tenor in silver.

The principal workings in this type of vein are those of the Copper Jack Mining Co., which has operated the Copper Jack and Flying Dutchman shafts. According to C. C. Griggs, president of the company, the Copper Jack shaft is 140 feet deep and follows a 3-foot vein which averages 6 per cent copper. The Flying Dutchman claims have two inclined shafts, one of which is about 240 feet long with a slope of about $40^{\circ}$ and follows a vein considerably richer in copper than the Copper Jack. Its width is 3 to 15 feet. The Copper Jack shaft struck a strong flow of water at about 80 feet, and water was standing within 20 feet of the surface when seen by the writer. The water surface in the Flying Dutchman shaft is said to stand about 100 feet down the incline. Four veins are said to run lengthwise (average trend, N. $30^{\circ} \mathrm{W}$.) through the property. Their average copper content is 3 to 5 per cent, but one 100-foot portion of the Copper Jack vein carries 7 or 8 per cent and includes considerable high-grade material running 20 to 30 per cent. The silver ranges from 1 to 7 ounces per ton.

The other properties in the vicinity are those of the White Rat (formerly the New Utah) Mining Co. and the Right Bower Mining Co. Their ore and gangue are of the same type as that of the Copper Jack. Both have struck water at shallow depths, the water in the Right. Bower shaft standing close to the surface.

The great obstacles which prevent the successful mining of these veins is the shallow depth to water, which involves the necessity of pumping almost from the start of operations, and the 30-mile haul to the railroad at Tintic Junction or Center. 
LEAD-ZINC VEINS.

OCCURRENCE AND CHARACTER.

The quartz veins with zinc and lead minerals are found on the upper slopes of the range on both sides of the divide and have been worked in Harkers, Albert Ekkers, Pine, and neighboring canyons. The mines and prospects here too were all idle when visited, and none of the workings was accessible, so that study was necessarily confined to the dumps. The ore fragments vary from pyrite with no other visible sulphides to irregular mixtures of pyrite, zinc blende, and galena. Quartz is the only gangue mineral seen in many specimens, but others, which represent replacement or impregnation of chloritic wall rock, contain considerable chlorite. A thin section of the chloritic rock suggests that impregnation of the ore minerals has been accomplished by recrystallization (and partial removal) of the wall rock, the quartz re-forming into relatively few and large crystals interspersed with felty masses of practically pure chlorite. The ore minerals as a whole have intergrown contacts with the gangue, but many of the pyrite crystals are nearly perfect, whereas the galena and blende as a rule have irrogular outlines.

Oxidation is well advanced in the uppermost parts of the veins nearest the divide, and the removal of sulphides has left a limonite ore more or less filled with white cerusite (lead carbonate) crystals and presumably carrying considerable silver.

The only mines which have shipped ore from this type of vein in recent years are the Sharp and the New Sultana.

\section{SHARP MINE.}

The Sharp mine, at the head of Harker Canyon in the Columbia mining district, has, as already noted, produced lead concentrates, a small amount of lead carbonate ore, and some lead-zinc sulphide ore. According to L. D. Gordon, a former operator of the mine, the lead carbonate ore contained about 40 per cent lead and 20 ounces of silver to the ton, and the mixed sulphide ore about 30 per cent lead and 25 per cent zinc. The mine has been worked through tunnels aggregating 1,250 feet in length. The main tunnel when visited was caved in, and a small stream of water issued from it. The ore on the dump included both primary sulphide, lead carbonate, and limonite, but nothing is known of their relative amounts. The wall rock includes a large amount of the chloritic beds that have been replaced and impregnated to some extent by ore. The ore recently mined by lessees has been hauled by wagon to Dunbar, a station on the Los Angeles \& Salt Lake Railroad, about 12 miles to the east.

NEW SULTANA MINE.

The New Sultana ore body had not been opened at the time of the writer's visit in 1912. It is reported ${ }^{1}$ to be a vein 4 feet thick in quartzite, and the ore is said to contain 60 cents in gold and 5 ounces in silver to the ton, 48 per cent lead, and 28 per cent iron. The zinc content is not known. One hundred tons of ore are said to have been mined in 1914.

OTHER PROPERTIES.

Deposits on the Erickson side of the divide include the Indianapolis in Pine Canyon, the Free Coinage in Albert Ekkers Canyon, and others whose names have not been learned. No information regarding the extent of the veins or values of the ores on these properties has been obtained. Ore from these mines must be hauled 20 miles down canyon roads of generally gentle grade to the valley west of the mountains and northward and eastward along the valley road through the pass to Faust and Center. The mines on both sides of the divide are thus handicapped by distance from a railroad but are fortunate in their location on steep slopes where tunnels from the canyon bottoms can be driven and made to drain the portions of the ore bodies which lie above the canyon levels.

\section{BLUE BELLS DISTRICT.}

LOCATION.

The Blue Bells district lies on the east side of the Sheeprock Mountains, about 6 miles southeast of the Erickson district and close to the south boundary of Tooele County. It is reached by a 10-mile wagon road from Lofgreen, on the Los Angeles \& Salt Lake Railroad. The road extends westward from Lofgreen, across a low pass in the West Tintic Range, and turns southward along

1 Oral statements by Lew Merriman and James Morgan, of Eureka, Utah. 
Vernon or Faust Creek to Green's ranch, | phosed shaly rock, granite, and gneiss in a where it turns westward again along a shallow canyon through the east foothills of the Sheeprock Mountains.

\section{PRODUCTION.}

By V. C. Heikes.

The Blue Bells district was organized on February 12, 1896. Its known production has been small. matrix of shaly character. The pebbles, or cobbles, are prevailingly large, being 4 to 12 inches or more in diameter. The largest noted was an elliptical quartzite boulder $4 \frac{1}{2}$ feet long. The irregular size and distribution of the pebbles and the shaly character of the matrix suggest a glacial origin for the conglomerate.

The only igneous rock noted was a highly weathered northwestward-trending dike of

Metals produced in Blue Bells district, 1891-191\%.

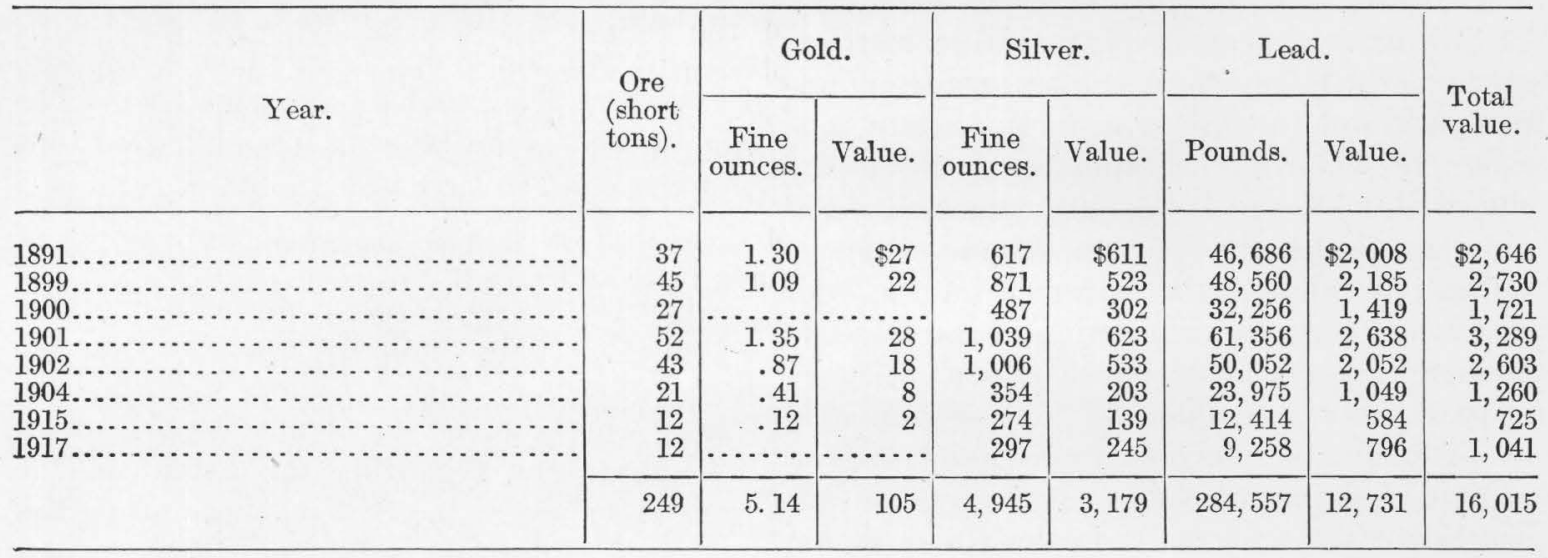

GEOLOGY.

The only sedimentary formation noted was the great series of early Cambrian or pre-Cambrian quartzite, shale, and conglomerate, which is so prominently exposed in the Erickson and Columbia districts to the northwest. The strata at and near the crest of the range, around the Morgan workings, strike northwest and dip $40^{\circ} \mathrm{NE}$. A mile or more to the east, around the Black Hawk workings, they strike nearly east and dip north at a low angle. Not enough work has been done to determine the structure accurately, but the strata appear to form a monocline, broken by major and minor faults.

The quartzite members of the series are light to medium brown, medium grained, and in places cross-bedded. The shale is greenish gray where fresh and brown where weathered and has a more or less metamorphosed appearance, locally with the characters of slate or even phyllite. The conglomerate is typically unassorted and is composed of subangular pebbles of quartzite, metamor- monzonite porphyry, about 200 feet wide, exposed on a high short spur just northeast of the Morgan shaft. It lies between a southwest wall of quartzite and a northeast wall of shale, relations which suggest that it was intruded along a fault.

The principal structural feature, other than the moderate degree of folding already mentioned, is faulting. Faults of rather small displacement and fissures are numerous in the limited area examined, but not enough observations were made to determine the directions of the principal systems. The strongest faults and fissures noted trend N. $40^{\circ}$ W. with dip $55^{\circ} \mathrm{SW}$., N. $30^{\circ}$ E. with dip $70^{\circ}-80^{\circ}$ SE., and N. $85^{\circ}$ E. with dip about $50^{\circ} \mathrm{S}$. One of the N. $40^{\circ} \mathrm{W}$. faults is accompanied by accessory fissures, characterized by brecciation but little or no apparent displacement. These accessory fissures trend N. $60^{\circ}-70^{\circ}$ E., north, N. $20^{\circ}$ E., and east. They were noted only at one place, the Black Hawk workings, where they appeared to radiate from a N. $40^{\circ} \mathrm{W}$. fault. 
ORE DEPOSITS.

MINES.

The only ore deposits reported in the Blue Bells district are those on the R. E. P. property, which includes two groups of workings, the Morgan and the Black Hawk.

Morgan mine.-The Morgan workings lie close to the crest of the range and include one inclined shaft and two tunnels.' One vein has been worked through the shaft and upper tunnel, and another mineralized fissure has been prospected through the lower tunnel. The productive vein, where stoped, strikes N. $85^{\circ}$ W. and dips $50^{\circ}-55^{\circ} \mathrm{S}$. West of the stoped ground the strike is said to curve southwestward. Below the stope the dip is said to flatten to $42^{\circ}$. Ore of shipping grade was found close to the surface and extended down the dip for 80 feet, to a short distance below the tunnel level, and then pinched out. The inclined shaft followed the ore; and the upper tunnel, 45 feet vertically below the shaft collar, was driven along the strike of the vein for 185 feet. The stoped ground had caved and could be studied only at its eastern end.

The ore seen consisted of brecciated quartz cemented by a mixture of galena and cerusite, accompanied by a little quartz and barite. Quartz in fine druses and a few barite crystals are the only conspicuous gangue minerals. A little microscopic calcite is also present.

The galena forms rather fine grains and aggregates, both impregnating the rock and partly lining cavities. The cerusite varies from dark gray to white. The dark variety, when treated with hydrochloric acid, yields free chlorine, which suggests that the dark color is due to a manganese oxide. Under the microscope remnants of galena are bordered by a dull black material, which may be a manganese oxide, and this in turn is surrounded by cerusite. In some places the galena has disappeared and only an irregular mixture of the cerusite and the black mineral remains. The white variety occurs in aggregates from which the dark color has been removed, and also in scattered rectangular platy crystals in the cavities. Cerusite also occurs as little veinlets and interstitial grains in the wall rock.

Small specks of oxidized pyrite are scattered among the lead minerals. The quartz is pres- ent as a matrix for the ore minerals and as small well-formed crystals lining cavities. As a matrix in leached places it is a white or lightbrownish honey-combed material. The barite occurs in typical platy crystals, some half an inch in length, thinly scattered, and mostly but not wholly in the cavities.

The lower Morgan tunnel is a short distance south of the upper tunnel, and extends for 265 feet along a crushed zone in quartzite. The strike of this zone is $\mathrm{N} .30^{\circ} \mathrm{E}$., and its average dip is about vertical. It has been traced on the surface from the tunnel mouth to the crest of the range, where a small amount of displacement along it is shown by an offset shale bed. The outcrop of the crushed zone has typical gossan stains, but prospecting thus far has shown only a small scattered distribution of lead minerals. Other gossan-stained fissures near and parallel to this one were noted near the crest of the ridge.

Black Hawk mine.-The Black Hawk workings are in the foothills about a mile east of the Morgan workings. The ore thus far found has occurred along faults and adjacent bedding planes. The principal fault trends N. $40^{\circ} \mathrm{W}$., between a southwest wall of conglomerate and a northeast wall of quartzite. Branch fissures in the quartzite extend from the fault in various directions, suggesting roughly a radial arrangement. They are all marked by brecciated quartzite. The largest ore shoot found was a layer of partly oxidized galena about 10 inches thick along a bedding plane in the quartzite closely associated with the principal fault and an oblique branch fissure. It was followed in a narrow flat stope for a distance of 30 feet before it pinched to a thin streak. Small bunches of ore and one shoot of workable size have been found in the minor fissures.

The ore seen in the Black Hawk workings was all galena-cerusite in a gangue of brecciated quartzite. No barite was noted.

GENESIS.

Although there is no strong evidence as to the ultimate source of the ores, the relation of ore shoots to fissuring indicates that orebearing solutions ascended along faults or crushed zones and deposited ore at points where excessive shattering along a fault or at the intersections of faults with other fissures or 
bedding planes allowed the solutions to permeate and replace the rock more thoroughly than elsewhere. All deposits so far discovered are small, and further prospecting is likely to result in the discovery of additional small shoots rather than of persistent ore bodies.

\section{WEST TINTIC DISTRICT.}

By G. F. Loughuin.

\section{GEOGRAPHY.}

Although the West Tintic district probably includes part of the West Tintic Range the few mines in the district that have produced ore lie to the west, in the low, southern part of the Sheeprock Mountains. The two ranges are separated by the two narrow valleys of Vernon and Cherry creeks. (See fig. 46, p. 424, and Pl. XXXVIII, $B$, p. 377.) Cherry Creek, which flows southward for 6 to 7 miles before disappearing at the northern end of Sevier Desert, is the principal stream and furnishes water for the towns of Mammoth and Robinson in the Tintic district 18 miles to the east, as well as for a few ranches in its valley. The mines of the West Tintic district, however, which are about 3 miles west of Cherry Creek, obtain their water from a well on Hassell's ranch about $1 \frac{1}{2}$ miles to the northeast.

The nearest towns to the West Tintic district are Eureka and Mammoth, in the Tintic district. From these towns the district is reached by a wagon road, for the most part of only moderate grade, that extends for 25 miles over a broad pass in the south-central part of the West Tintic Range. Ore may be hauled over this road to Tintic Junction or by a road to the south that extends from Cherry Creek valley to Jericho station on the Los Angeles \& Salt Lake Railroad. The distance from the Scotia mine to Jericho is 16 to 17 miles.

\section{GEOLOGY.}

The formations in the West Tintic district include Paleozoic and probable pre-Paleozoic sedimentary rocks, and intrusive and effusive igneous rocks of probable Tertiary age. As a rule the sedimentary rocks form the more prominent summits and the igneous rocks the lower foothills, valleys, and some of the broader saddles. (See figs. 46, p. 424, and 47.)

\section{SEDIMENTARY ROCKS.}

PRE-CAMBRIAN (?) QUARTZITE.

The thick formation of quartzites, shales, and shaly conglomerates, which forms the bulk of the Sheeprock Range from the Columbia district southward, extends to the southern foothills of the range. In the West Tintic district its southern boundary is an irregular crescent, concave southward, and partly surrounding an area of limestone and dolomite that contains the productive mines and more promising prospects. The quartzite overlies the limestone but (see p. 438) is an overthrust.

The lithologic character of this formation in the West Tintic district is generally the same as in the districts to the northwest. The quartzite members, though much fractured, are the more resistant to erosion and form caps to many of the lower and higher summits, and the conglomerate and shale occupy the slopes and are in large part concealed beneath débris. The quartzite varies in composition from light colored and relatively pure to the dark-brown ferruginous variety so characteristic of the formation. The conglomerate members consist of angular to subangular cobbles or small boulders of older quartzite, schist, and slaty rocks, in a shaly to schistose matrix, and here as elsewhere bears a rather strong resemblance to glacial till. The shale mostly is gray to green, weathering to brown, and of typical structure.

The strike and dip of the formation vary and can be accurately determined at only a few places. The dips as a whole, however, are low to moderate to the north or northeast.

The formation is cut by many veins of white massive quartz, whose outcrops appear barren. They strike in many directions and none of them are traceable over considerable distances.

There is no local evidence to indicate the age of this formation, but as it is continuous northward to the Columbia district, where it underlies quartzite of Lower and Middle Cambrian age, there can be no reasonable doubt that it is either very early Lower Cambrian or pre-Cambrian.

PALEOZOIC LIMESTONE.

Dolomitic limestone, of uncertain age, occupies an area of a few square miles at the southern end of the range, and is surrounded by 
the quartzite series except on the south, where it / district to the east. A few bands are cherty. is bordered by alluvium. Its northern bound- Optical and chemical study shows that much ary is about $1 \frac{1}{2}$ miles long and passes just north of the Walker shaft of the Scotia mine. From this northernmost and narrowest part it diverges southward. Its central part forms of the unmetamorphosed rock in the West Tintic district is very close to a pure dolomite in composition. The only impurities noted under the microscope are finely divided carbon,

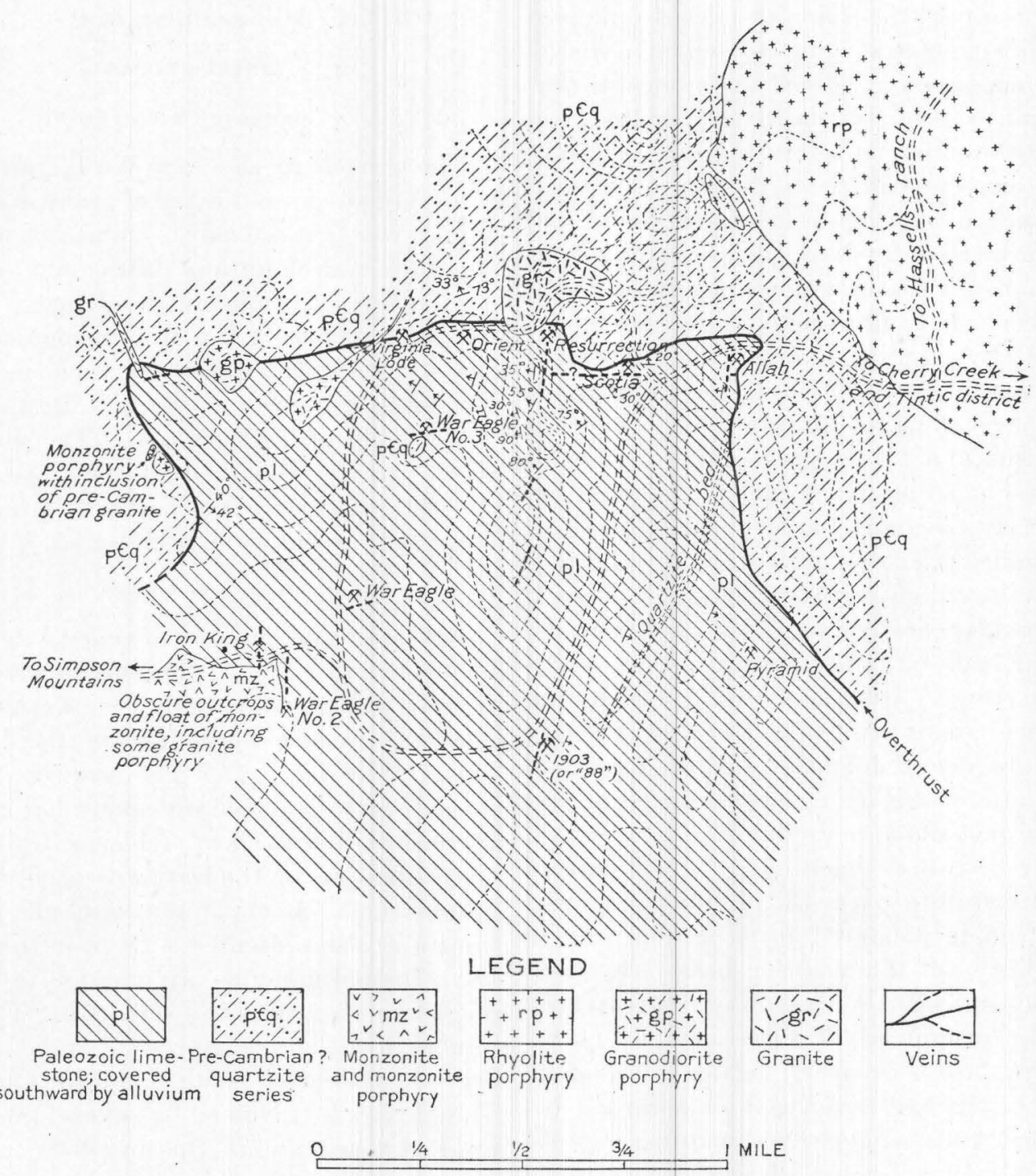

FIGURE 47.-Sketch map showing main geologic features and the locations of mines and prospects in the West Tintic district.

the high north-south ridge southwest of the Scotia mine and also comprises the lower ridges to the east and west.

- Where not affected by contact metamorphism it is prevailingly of dark bluish gray and fine grained. Some beds are of very even texture, others are finely banded with lighter gray streaks, and others are spangled with short white markings characteristic of certain Middle and Upper Cambrian dolomites in the Tintic which colors the rock, and a few minute but well-formed quartz crystals.

Where affected by incipient metamorphism the rock is partly or completely bleached to very light gray or white by the elimination of carbon, but the composition is not appreciably affected. Tremolite is the only silicate mineral noted in this phase of the rock. Although it is more abundant in bleached rock it has been noted forming radiating aggregates in $35416^{\circ}-19-28$ 
unbleached dolomite. More intense metamorphism nearer the intrusive igneous contacts has developed a number of typical silicate minerals, the most conspicuous of which are garnet and epidote; diopside, tremolite, hornblende, actinolite, phlogopite, titanite, and chlorite are present in fine to microscopic gray to green aggregates, some of which resemble chert in appearance. These metamorphic minerals tend to form abundantly in certain layers and to be bounded by layers of granular calcite. The presence of calcite as the prevailing carbonate in the thoroughly metamorphosed rock is in marked contrast to the prevailing dolomitic character of the unmetamorphosed rock.

A bed of shaly limestone, which marks approximately the upper limit of the ore horizon in the Scotia mine, deserves special mention. At one place along its outcrop, southeast of the Walker shaft, it forms the hanging wall of an old open-cut stope which yielded bonanza ore in the early days and for this reason has been locally called the "bonanza shale." The rock is bluish gray, lighter than the dolomitic rock, microgranular, and very thin bedded to shaly. The thin beds of limestone are separated by shaly partings. Immersion in dilute hydrochloric acid yields brisk effervescence, proving a general absence of dolomite, and the abundant residue after solution consists chiefly of fine quartz grains and sericite flakes.

Cherty beds have been noted in the eastern and northwestern parts of the limestone area. A few thin intercalated beds of quartzite in the vicinity of the eastern beds are much fractured and filled with comby quartz veins. The most prominent of these extends northward with approximately vertical dip, along the top of the low ridge east of the road between the "1903" and the Scotia mines (fig. 47) to the saddle southeast of the Scotia mine, where it passes beneath the contact of the limestone and pre-Cambrian (?) quartzite series. A few sandy beds were noted between the south end of the high limestone ridge and the road junction to the west.

No determinable fossils have been found in the limestone area. The only characteristic markings in the central and eastern parts of the area are the short white spangles, similar to those in the Middle and Upper Cambrian limestone of the Tintic district, which appears in a few beds. These with the prevailing dolomitic character suggest correlation with Cambrian; but as later Paleozoic limestones, including those of Mississippian age, are also conspicuously dolomitic, no definite age is assigned to the rock. The black chert nodules near the northwest corner of the limestone area strongly suggest lower Mississippian age.

IGNEOUS ROCKS.

GENERAL CHARACTER.

The igneous rocks of the West Tintic district consist of stocks and dikes of granitic and monzonitic rocks, extensive bodies of extrusive rhyolite, and doubtless latite, the extrusive equivalent of monzonite, though no welldefined outcrops of this were recognized. The granitic rocks comprise one inclusion of preCambrian granite and stocks, dikes, and sills presumably of Tertiary age. The monzonitic rocks are also assigned to the Tertiary. No contacts between the Tertiary granitic and monzonitic rocks have been found.

PRE-CAMBRIAN GRANITE.

Pre-Cambrian granite is represented by an inclusion 3 or 4 feet in diameter in a monzonite porphyry dike, which cuts the quartzite series near the western boundary of the limestone area. (See fig. 47.) The granite is pink, rather coarse grained, and somewhat gneissoid. It consists of pink alkalic feldspar, white plagioclase, and quartz, the last two obscured by fine granulation. A small quantity of chlorite after biotite is also present. As seen in thin section the principal minerals are microperthite, calcic oligoclase, quartz, and chlorite. The usual minor constituents are present, and one allanite crystal associated with epidote was noted. The section is traversed by several microscopic crushed zones, and in this respect is markedly different from the intrusive granite of the district. The presence of this inclusion suggests that a portion of the granite which is known to underlie the quartzite series in some parts of the State is present in the segment overthrust upon the limestone, though not exposed at the surface.

\section{TERTIARY INTRUSIVE ROCKS.}

Character and distribution.-The intrusive rocks of the district vary in appearance but are for the most part very similar in chemical composition and fall in the granodiorite or 
quartz monzonite groups. The most alkalic (salic) variety noted is a muscovite granite, and the most ferromagnesian (mafic) variety is a dioritic phase of monzonite.

The intrusive bodies are for the most part small, and most of them are grouped in an eastnortheast zone near the northern boundary of the limestone area. A small complicated stock, much obscured by débris covering, is present in the southwest part of the area, and dikes of granite porphyry and monzonite porphyry are very abundant, most of those noted trending a little east of north or a little north of east. No distinct age relations have been found.

Granodiorite group.-A stock of roughly triangular outline is exposed along the curving ridge northwest of the Scotia mine. It consists mostly of light-gray coarse-grained, considerably disintegrated rock, with minor varieties of aplite and granite porphyry along the border. Contact metamorphism along its border is expressed by induration of shale beds in the quartzite and by slight alteration in the adjacent part of the limestone. The mineral composition and texture of the coarse-grained rock is essentially similar to that of the larger granodiorite in the Columbia-Erickson district to the northwest and on Desert Mountain to the southwest.

The border porphyry phase is of interest for comparison with the variations in the other stocks. It consists of a very fine grained groundmass with prominent rounded grains of quartz, the largest of which are 3 millimeters in diameter, white crystals of altered feldspar, and a few weathered scales of biotite. It differs from the main body of the stock merely in the smaller size of most of its components. In thin section the quartz phenocrysts show some resorption, and their corroded edges are fringed with secondary quartz, which is accompanied by a little calcite and sericite. The plagioclase crystals $\left(\mathrm{An}_{35-45}\right)$ are considerably altered. Biotite phenocrysts are altered to a mixture of chlorite and calcite, with or without sericite. The groundmass consists of fine graphic intergrowths of quartz and alkalic feldspar inclosing some short laths of plagioclase (oligoclaseandesine) _ A few spherulites consisting largely of quartz are associated with the graphic intergrowths.

The narrow wedge-shaped stock to the west crosses the overthrust without displacement and ends northwestward as a sill in the quartzite series. Another small stock just west of this one also cuts the overthrust. These two stocks consist of granodiorite porphyry, with prominent phenocrysts of feldspar but none of quartz in an aplitic groundmass. A small amount of altered biotite and 3 or 4 per cent of oxidized pyrite grains are also present. In thin section most of the plagioclase is too much sericitized to be identified, but a few grains indicate calcic andesine. Biotite is altered to chlorite. The groundmass consists of quartz and feldspar, mostly in graphic intergrowth. The feldspar is much kaolinized but appears to include both alkalic and plagioclase varieties, the latter less calcic than the plagioclase phenocrysts. The pyrite is associated with sericite, secondary quartz, and chlorite, and is clearly an alteration product. This rock differs from that first described mainly in the absence of quartz phenocrysts, though it contains a large amount of quartz in the groundmass.

Another small stock (not accurately outlined in fig. 47) outcrops to the southeast just west of the overthrust contact. This rock is light pink and composed of plagioclase, biotite, and a few hornblende crystals with scattered fine grains of magnetite and titanite in an extremely fine grained groundmass. In thin section the feldspar phenocrysts prove to be mostly plagioclase with a few of microperthite $\left(\mathrm{Or}_{80} \mathrm{Ab}_{20}\right)$. The plagioclase includes two varieties; large crystals of labradorite $\left(\mathrm{An}_{60}\right)$ partly resorbed, and oligoclase $\left(\mathrm{An}_{25}\right)$ in relatively small grains and in one place forming a rim around an older labradorite. Biotite and common hornblende are typical and considerably chloritized. The groundmass consists of abundant quartz and alkalic feldspar (microcline microperthite), with a less amount of sodic plagioclase. Minor constituents include magnetite, titanite, apatite, and zircon.

A dike of muscovite granite, which trends N. $25^{\circ}$ W. across the overthrust contact in the extreme northwest corner of the limestone area, is nearly white, fine, even grained, and composed of white feldspar, colorless quartz, thinly scattered muscovite, and some flakes of biotite. As estimated in thin section, the feldspars comprise about 55 per cent, quartz 40 per cent, and muscovite and minor accessories 5 per cent. Four-fifths of the feldspar is perthitic microcline with small unoriented 
inclusions of plagioclase. The remainder is surface by the pink color of the alkalic feldplagioclase-oligoclase-andesine $\left(\mathrm{An}_{30}\right)$ with spar. This color disappears a fraction of an more sodic outer zones. The muscovite tends to form poikilitic crystals inclosing small wellcrystallized grains of quartz, and appears to have been on the whole the latest important mineral to crystallize. The minor constituents noted are biotite, separate or intergrown with muscovite, magnetite, and zircon.

The composition of this rock is very similar to that of the groundmass of the rocks previously described (p. 435). Those rocks contained no primary muscovite, but the presence of muscovite in this rock may well be attributed to a greater concentration of water and fluorine in a salic portion of magma and does not necessarily indicate the intrusion of a distinct magma. In other words, the muscovite granite is regarded as a salic differentiate from the granodioritic magma.

The large area of granite porphyry and rhyolite porphyry northeast of the limestone area has the same general composition as the granodioritic rocks, but part of it differs in possessing textures characteristic of effusive rocks. In spite of these textures all the contacts with the quartzite series on the west are nearly vertical and intrusive. To the east, however, the rocks are in part clearly extrusive, and it is concluded that the main vent through which the lavas of the region were erupted is in the western part of this area.

The greater part of the rock in this vent varies in texture from very fine grained porphyry to rhyolite porphyry, although several eruptions are represented. Much of it is light gray, dense porphyritic, and contains abundant phenocrysts of quartz and feldspar, with a little biotite and magnetite. In thin section the quartz phenocrysts show resorption and many of them are cracked or even "faulted," the groundmass filling the fractures. The feldspar forms roughly rectangular grains, some of them with resorbed rims. Plagioclase (andesine) is somewhat more abundant than alkalic feldspar, a few grains of which have a poorly defined structure suggesting microcline. Biotite and minor accessories are typical.

Another rock in the vent, intrusive into the one just described, is of dark-purplish color and somewhat denser texture but is essentially identical in mineral composition. The appearance of this rock is also characterized on the inch away from the surface or from fracture lines, and is clearly the result of weathering. Several dikelike intrusions of rhyolitic rock in this area were noted along the road that extends northward and eastward by Hassell's ranch to the divide between Vernon and Cherry creeks, but none were studied in detail. A special variation, however, is represented by the narrow body of rhyolite breccia that cuts the quartzite series vertically just west of the main area. (See fig. 47.) This rock is purple to gray, finely fragmental, and consists of banded to massive fragments of rhyolite in a fine matrix ot the same material. Its chemical and mineral composition is shown by the microscope to be similar to the rocks of the main area, from which it differs only in texture. Monzonite.-The only stocklike body of monzonite in the immediate vicinity of the mines is in the southwest part of the limestone area and is so obscured by débris of rhyolitic or granodiolitic porphyry that its exact outline and structural relations are not easily determined. Dikes and sills of monzonite porphyry have been noted at several places throughout the limestone area. The typical monzonite is gray, medium, and even grained, and consists chiefly of gray translucent feldspars, biotite and augite, the augite being more or less altered to hornblende. Both feldspars are recognizable megascopically, plagioclase as a rule forming gray or white lath-shaped twinned crystals which are surrounded by alkalic feldspar of slightly different color and with no definite crystallographic outline. Pyrite is present as small grains scattered through the rock and also as thin films or sheets along fracture planes. In thin section the plagioclase presents a marked zonal growth, the zones ranging in composition from $A_{50}$ to $A n_{25}$ or being even somewhat more sodic. They average about $A_{35}$. The alkalic feldspar, which has a very fine perthitic structure, forms irregular grains of various sizes. Some of the smaller form partial rims around plagioclase, and the larger ones have a poikilitic character, inclosing crystals of all the other primary minerals except quartz. Quartz forms irregular grains, some of which are a millimeter in diameter, mostly interstitial to the other minerals but in part forming micrographic intergrowths with alkalic feld- 
spar. The microscopic quartz amounts to and alkalic feldspars are especially concentrated. nearly 10 per cent of the rock. Biotite forms The plagioclase is contained mainly in the phetypical grains, some with resorbed margins. nocrysts or earlier-formed minerals and the Augite forms prismatic grains averaging about alkalic feldspars mainly in the groundmass or a millimeter in length and showing all stages later-formed minerals of the intermediate of the transition from fresh augite into compact (granodioritic) rocks of the district. Sufficient green hornblende with typical cleavage and time to allow certain degrees of concentration pleochroism. Some of the augite (or horn- of the earlier groups of minerals before the blende) grains are intergrown with biotite. later groups began to crystallize accounts for Minor accessories include rather abundant the variations in composition and for the titanite and magnetite in irregular to hypautomorphic grains, apatite in typical well-formed prisms, and rarely zircon.

Besides the typical rock variations of dioritic character are present in the monzonite stock. Some are feldspathic; others have a preponderance of black minerals. In the feldspathic variety the plagioclase has about the same composition as in the typical monzonite, but alkalic feldspar and quartz are very scarce. Biotite is the principal accessory and is accompanied by a little uralitic hornblende (after augite?). The darker variety consists of zonal plagioclase, averaging near $\mathrm{An}_{50}$ in composition, and primary hornblende accompanied by a little biotite. No augite is present. Alkalic feldspar and quartz form fine interstitial aggregates among the predominant minerals. Magnetite, titanite, and apatite, the first two frequently of megascopic size, are conspicuous minor constituents in both varieties.

Alteration.-Alteration has affected all the igneous rocks of the district to a greater or less extent, but the kind of alteration is the same in all of them and is of the propylitic type. The common alteration minerals are sericite, chlorite, epidote, calcite, quartz, and pyrite, and these are accompanied in some of the rocks by uralitic hornblende, secondary titanite, and magnetite. The relations of these minerals to one another show that they were formed at the same time, and they are attributed to the action of heated waters that permeated the rocks during ore deposition. Kaolin and limonite are the principal minerals formed since that time by surface weathering.

Paragenesis.-The different intrusive rocks of the district are closely related. In some the more calcic plagioclase and the black silicates are concentrated in relatively large proportions; and in one, the muscovite granite, the quartz

different textural characteristics of the rocks.

TERTIARY EXTRUSIVE ROCKS.

The principal area of extrusive volcanic rocks extends eastward from the vent already described across Cherry Creek valley, 3 miles distant, and partly up the west slope of the West Tintic Range. Small isolated areas lie on the east slope of the range. The rocks, so far as noted, are prevailingly rhyolitic and include flows and breccias, but as they are some distance from the mining district proper they have not been studied in detail.

\section{STRUCTURE.}

FOLDING.

The exact structure of the limestone has not been determined. The strata at the Scotia mine dip $20^{\circ}-25^{\circ} \mathrm{N}$. and appear to lie conformably beneath the quartzite series. South of the Scotia mine, along the high limestone ridge, they strike north-northeast and dip very steeply west. On the low ridge to the east they strike similarly but dip from vertical to steeply east. These relations, together with the distribution of the cherty zone, suggest a sharp anticline with a north-pitching axis approximately along the road between the "1903" and the Scotia mines and through the Scotia property. In the limestone area west of the high ridge débris coverings and metamorphism greatly conceal the structure. Near the west contact, across the ridge southwest of the Orient shaft, there is some indication of a local pinched syncline, but the attitude of the beds as a whole is the same as those on the high ridge. The available data suggest a major anticline with nearly vertical limbs, whose axis is about halfway between the middle of the limestone area and its eastern contact with the quartzite series. 
OVERTHRUST

The structure of the limestone is thus unsymmetrical with respect to the quartzite series, and other discordances in position exist between the two rocks along the contact. The disappearance of the thin quartzite bed in the eastern limestone area beneath the great quartzite series has already been mentioned. This structure either implies the very rapid pinching out of some hundreds of feet of limestone and their equally sudden reappearance just to the north, or is due to an overthrust. The attitude of the beds is apparently conformable at the Scotia mine, but a shale member, which immediately overlies the limestone, is beveled off both to the east and west. At the saddle between the Scotia and Orient mines a small mass of quartzite rests on limestone, the contact dipping northeast at a low angle. Just south of this point, on the high limestone ridge, the limestone strata strike a little east of north, but the limestone-quartzite contact continues westward across the Orient and Virginia Lode claims without regard to the strike and dip of the limestone. At the Virginia Lode prospect the limestone is separated from a shale member of the quartzite by a nearly vertical east-west fault. From this point westward the contact is complicated by two small stocks and a few dikes of granitic and monzonitic rock.

At the northwest corner of the limestone area the limestone strikes N. $25^{\circ} \mathrm{W}$. and dips nearly vertically, but the quartzite contact curves from east to west through an angle of about $115^{\circ}$ to a trend paralleling the limestone bedding. Southward along the west contact the attitude of the limestone beds varies. At one place, at the head o $f$ a small branch gulch in a southwest direction from the Virginia Lode prospect, the limestone close to the contact strikes N. $40^{\circ} \mathrm{E}$. and dips $42^{\circ} \mathrm{SE}$., whereas the contact strikes about north. The limestone is much contorted and somewhat metamorphosed. From this point southward the contact extends along the crest of a low south-sloping ridge, until the ridge surface sinks below it, leaving only limestone, and thus proving that the plane of contact along this ridge dips west at a low angle, away from the dip of the limestone. The limestone at some places along the contact is overlain by quartzite and at others by shale. Both the limestone and quartzite are scattered at several places along the contact.
Within the limestone area a low ridge. south of the War Eagle No. 3 open cut is capped by quartzite but consists otherwise of steeply dipping limestone whose exposures surround the quartzite. The quartzite is not intercalated in the limestone and is regarded as a remnant of the great quartzite series which once overlay the limestone.

The evidence, although obscured along much of the contact by débris, all points to discordant relations between the limestone and quartzite, which, coupled with the stratigraphic evidence already given, indicates an overthrust fault of undulating character. The limestone area was completely covered by the quartzite at one time, the fault contact arching over it. To regard the contact as an unconformity would necessarily imply an immense thickness of preCambrian limestone in the West Tintic district and nowhere else in the Great Basin region. Furthermore, no fragments of the limestone and only pebbles and cobbles of siliceous sediments have been found in the overlying quartzite, whereas the structural details of the contact are indicative of disturbance.

Results of a brief reconnaissance in the West Tintic Range along the Tintic Road lend support to the foregoing interpretation. Along the road the sedimentary rocks consist of quartzite with intercalated beds of shale and limestone dipping westward at a low angle. Fossils collected from two limestone beds were determined by G. H. Girty, as follows:

Bed southwest of Summer ranch: Sponge?, Zaphrentis? sp., Bellerophon sp.

Bed 100 yards north of the Mammoth reservoir: $Z a p h$ rentis sp. and Lithostrotion whitneyi.

Mr. Girty states that these faunas are too scant and too poorly preserved to be assigned to any definite horizon, but he regards them as probably upper Mississippian.

Along the crest of the range north of the road and on its west slope down to the divide between Cherry and Vernon creeks lie coarse conglomerate and quartzite of pre-Cambrian (?) age, whose western dip suggest that they formerly extended over the upper Mississippian quartzite and that the overthrust extends as far eastward as the crest of the West Tintic Range. Their exact trend in the West Tintic Range, however, can be determined by detailed work alone, much of their surface being covered by disintegrated volcanic 
rocks and care being necessary to distinguish the light-colored quartzite members in the pre-Cambrian (?) from beds of similar appearance in the upper Mississippian (?) formation. The stratigraphic and structural relations of the rocks in the West Tintic Range and the West Tintic mining district are shown in figures 46 (p. 424) and 47 (p. 433).

The age of the overthrust is clearly greater than that of the Tertiary igneous rocks but can not be definitely determined on local evidence. It may be contemporaneous with the overthrusts in the Wasatch Range, which are of Cretaceous age.

\section{FAULTING AND FISSURING.}

With the exception of the overthrust already described, faults of considerable displacement are not conspicuous. Those actually exposed and also those strongly suggested in the field lie in two systems that trend nearly north and nearly east. A porphyry sill at the small ironore prospect on the Virginia Lode claim is displaced 3 feet by a north-south fault with a $60^{\circ}$ dip, and a well-defined east-west fault with nearly vertical dip is exposed just to the west. Its strike coincides with the limestone-quartzite contact, but its vertical dip suggests that it may cut the plane of the overthrust at this place. Another fault, which trends nearly north, is suggested by a deflection of the overthrust contact east of the Resurrection (Prairie Bell) prospect but has not been traced northward or southward. Other faults of similar trends are suggested at a few places by apparently discordant relations of the strata. None of them are closely connected with ore deposits.

Mineralized fissures also follow two prevailing directions: N. $15^{\circ}-20^{\circ}$ E. with vertical dip and $\mathrm{N}$. $70^{\circ} \mathrm{E}$. with steep southerly dip.

\section{HISTORY AND PRODUCTION.}

No satisfactory account of the production of the West Tintic district can Be given, for in the earlier years its output was included by the Director of the Mint with the Tintic district. The Scotia mine has been undoubtedly the largest producer, but accurate data of its output are not available. According to W. W. Riter, of Salt Lake City, who was one of its original owners, the first pocket of ore, found about 1870, amounted to about 250 tons of 65 per cent lead ore containing a moderate proportion of silver. This ore vas shipped to Swansea, Wales, and to smelters south of Salt Lake City. In 1871 the property was sold to Joab Lawrence and associates, who joined in building the Homansville smelter in the Tintic district. This enterprise failed, and the smelter was moved away in 1872. The mine later passed into the hands of the Boston-Tintic Mining Co., by whom it has been worked or leased intermittently. The production of the Scotia mine since 1880 has probably amounted to somewhat more than 3,000 tons, valued at about $\$ 150,000$.

From 1902 to 1913 only two mines shipped ore, both in small amounts.

\section{ORE DEPOSITS.}

\section{GENERAL CHARACTER.}

The ore deposits of the district comprise several types, transitional into one another, which indicate deposition at temperatures ranging from those existing along the margins of crystallizing intrusive rocks down to moderate and even low. All the types are in limestone, in or closely associated with fissures, some of which coincide with the bedding of the rock.

The deposits formed at highest temperatures are of the contact-metamorphic type. More or less contact metamorphism has been produced around all the larger ore bodies of granodioritic and monzonitic rocks and also along some of the dikes and sills. The most intense metamorphic effect is just north of the monzonite stock in the southwest part of the limestone area, and the only contact-metamorphic ore body of much promise - that of the Iron King mine-is in this place.

\section{MINES.}

IRON KING MINE.

The workings of the Iron King mine are in both metamorphic limestone and monzonite and cut dikes of granite porphyry. The mine in 1913 was opened by a shaft 200 feet deep and by 200 feet of drifts, but the underground workings were not accessible when visited. A part of the ore body, however, was exposed 
along a narrow deep open cut. The ore body forms a vertical band a few feet thick, parallel to the vertical north-south bedding.

The most conspicuous ore minerals are magnetite and specularite, which form an apparently solid mass, colored in places by green copper stains. Some specimens are of magnetite, others of hematite, and both varieties contain disseminated grains and well-defined veinlets of pyrite. No chalcopyrite was recognized, and the green copper stains may have been derived from copper in the pyrite. A small shipment in 1913 contained two classes of ore, one carrying 0.282 ounce of gold and 2.6 ounces of silver to the ton, 6.2 per cent copper and 40.9 per cent iron; and the other carrying 0.15 ounce of gold and 1.55 ounces of silver to the ton, 3.15 per cent copper and 48.8 per cent iron.

The margins of the ore show replacement of an epidotic phase of the metamorphic limestone, a relation which indicates that the ore was formed at a later stage of contact metamorphism than were the silicate gangue minerals. The silicate rock, as shown by specimens on the dump, is also cut and replaced to some extent by vein quartz and calcite, which imply that mineralization continued after the temperature had fallen below the range at which the silicates had formed.

VIRGINIA LODE.

Another type of contact-metamorphic ore that has been prospected on the Virginia Lode claim is pyritized shale along the hanging wall of a porphyry dike. Oxidation has decomposed the pyrite and concentrated the iron along the margin of the dike in the form of limonite in a layer ranging from a thin film to 6 feet thick. A similar deposit of limonite has been opened in a prospect tunnel on the Allah property east of the shaft. No assays of either ore were obtained. Deposits of this type may be mistaken for the weathered outcrops of a silver-lead deposit, but it is improbable that valuable silver-lead deposits will be found in either shale or quartzite.

WAR EAGLE CLAIMS.

Closely related to the magnetic ore of the Iron King mine is that of the War Eagle No. 2, which forms a north-south vein a short distance to the east. The vein is opened by a shaft 70 feet deep, with short drifts on the 25 and 70 foot levels. The vein sends short tongues into the wall rock, which includes both metamorphic limestone and silicified granodiorite porphyry. Monzonite is exposed in surface workings near the vein. The ore thus far found occurs in small bodies, from one to a few tons in weight, of barren or lowgrade massive quartz associated with branch fissures at their junction with the main vein, between stretches. The primary ore mineral is chalcopyrite in irregular patches, usually in a matrix of fine-grained specularite. The gangue mineral is quartz, with local developments of bairite and calcite. Chalcopyrite also forms scattered grains or bunches in milky quartz and occurs as narrow bands alternating with cherty replacement quartz. Some bunches of lead ore are present, but no primary lead minerals have been found. The chalcopyrite is largely oxidized to a dark resinous or pitchy form of limonite and to malachite and chrysocolla. The oxidized lead ore, with which some copper minerals are mixed, consists of cerusite and bindheimite (hydrous antimonate of lead) and probably. a little anglesite, accompanied by small amounts of the zinc minerals, most conspicuous of which is aurichalcite. This ore, which is characterized by the yellow color of the earthy bindheimite and is locally called "chlorides," is rich in silver, and one small sample is said to have assayed 821 ounces to the ton. Both lead and copper ores contain more or less black manganese oxide. Secondary gangue minerals are finely crystalline to chalcedonic quartz and calcite.

The War Eagle claim, a short distance northeast of the War Eagle No. 2, contains copper ore similar to that just described except that it lacks specularite. The workings are opened by an inclined shaft 200 feet deep sunk along the hanging wall of a granite porphyry dike, along which bunehes of ore were found. A drift on the 200-foot level follows a vein trending S. $70^{\circ} \mathrm{W}$., which also follows a dike hanging wall. A winze from this level follows the dip of the vein, which is said to expand downward to a width of 4 feet and to contain rich ore some of which assays 13 per cent copper and 200 ounces of silver to the ton. The average content is said to be about 4 per cent copper and 16 ounces of silver to the ton. 
On the War Eagle No. 3 prospect, considerably farther north, a vein trending N. $75^{\circ} \mathrm{E}$. and dipping from vertical to steeply north has been mined from the surface for lead ore, but the workings were not accessible when visited. Ore seen on the surface consists of galena partly oxidized to cerusite, accompanied by white patches of calamine, a little microscopic smithsonite, and brown and black stains of limonite and wad. The principal gangue at the surface is calcite in banded columnar masses (travertine), which extend in places 2 feet into the footwall of the open cut. The general run of ore is said to have been accompanied by soft red iron oxide. Its silver content is not stated, but gold to the value of $\$ 5$ a ton has been reported.

The relations of the three War Eagle prospects indicate that the temperature of ore deposition decreased northward. Though not along a single vein, it seems probable that the three prospects are connected by a system of intersecting approximately north-south and east-west fissures. The mineral composition of the War Eagle No. 2 ore indicates a high temperature, though not so high as that required for contact-metamorphic ore; the nonsiliceous type of lead-zinc ore at, the War Eagle No. 3 is characteristic of deposition at relatively low temperatures.

\section{ORIENT WORKINGS.}

The Orient workings, north of the War Eagle No. 3, were inaccessible. On the dump was a small pile of oxidized copper-iron ore and some metamorphic limestone with a few green copper stains. No primary ore was found.

$$
\text { "1903" OR "1888" MINE. }
$$

The "1903," formerly the " 1888 ," mine, near the southeast base of the high limestone ridge, is of particular interest because of its varied character. It is opened by an inclined shaft 140 feet deep and by 150 feet or more of drifting on the 45-foot level, mostly east of the shaft. The country rock is dolomitic limestone, partly metamorphosed, with steep eastward dip. Quartzite, which outcrops west of the shaft, is said to be cut by a short winze from the west end of the 45-foot level.

The deposit consists of a N. $15^{\circ} \mathrm{E}$. quartz vein, parallel to the bedding, intersected at the shaft by an east-west mineralized fissure with southerly dip. The quartz in the main vein is mostly dense and cherty but is well crystallized around cavities. In a shallow pit 200 feet north of the shaft the vein consists of quartz, barite, and galena. The barite forms a network of platy crystals, and the quartz and galena fill the interstices, impregnate the barite crystals, and fill cracks in them. Pyrite and a few specks of zinc blende are minor constituents. A little cerusite and secondary quartz are also present.

The material in and coose by the cross fissure, which is followed by the shaft, is mainly quartz-fluorite-galena ore, accompanied in places by quartz-chalcopyrite-galena ore. The variety containing chalcopyrite resembles that from the War Eagle vein, but its galena is more conspicuous. The chalcopyrite forms relatively pure large grains or masses some of which are 2 inches in diameter; and the galena forms fine-grained aggregates inclosing a few small grains of chalcopyrite. The quartz is fine grained and resembles quartzite and chert. The fluorite variety consists of rather coarsegrained fluorite and galena in a matrix of cherty quartz, which in places is apparently absent. The ore cut in the shaft and along the drift to the east was 1 to 4 feet thick and contained an average of 22 per cent lead. The principal shoot is a heavy galena ore of this general type on the east or hanging side of the main vein, about 30 feet north of the drift along the cross break. It lies between two bands of chert-tremolite rock and extends upward from the level at $45^{\circ} \mathrm{N}$. $5^{\circ} \mathrm{E}$. The walls of the stope are of low-grade fluorite-galena ore with varying amounts of quartz.

The composition of the ore mined is as follows: Gold (trace), silver 1.3 ounces to the ton, lead 46.8 per cent, copper 0.2 per cent, insoluble 17.1 per cent, sulphur 5.1 per cent, iron 1.2 per cent, lime 26.1 per cent. The ratio of lead to sulphur indicates that four-fifths of the lead was present as galena. The low silver content of this slightly oxidized ore is in striking contrast to the high content in the thoroughly oxidized antimonial lead ores of the War Eagle No. 2 and Scotia mines.

A variety of ore containing barite, carbonate, and galena, noted only on the dump of the "1903" mine, forms bands in and contains inclusions of the quartz-galena ore. The barite forms a typical network of plates, and the other minerals fill the interstices. The 
carbonate is mostly calcite, which incloses small rhombs of ferruginous dolomite.

Secondary ore minerals are limonite, malachite, chrysocolla, cerusite, and calamine, the calamine indicating the former presence of a considerable though minor amount of zinc blende. The secondary gangue minerals are drusy quartz, calcite, and aragonite in the form of tufts of needles on the secondary calcite.

The different types of primary ore in the "1903" mine include most of those found in the entire district. The chalcopyrite-galena type represents a transition from deposition at rather high to moderate temperatures; the fluorite and the barite-quartz types are believed to represent deposition at moderate temperatures, and the barite-carbonate type represents a still lower temperature, and, from its structural relations, appears to mark the last stage of deposition. Failure to find the fluorite and barite-quartz types in contact prevents a statement as to their relative ages. The fluorite type has not been found in any other mine in the district.

\section{ALLAH PROSPECT,}

The quartz-barite-galena type of ore is also represented a mile north of the " 1903 " mine by the veins on the Allah property. One vein, 4 or 5 feet wide, strikes N. $10^{\circ} \mathrm{E}$. and dips $80^{\circ}$ $\mathrm{W}$. and is associated with two east-west veins traceable for considerable distance by float. Very little prospecting has been done on these veins. Besides the well-defined veins several small bunches of similar composition are exposed on the surface and in the 198-foot shaft and appear to be local enlargements of tight fissures or at the intersections of fissures. No ore has been mined on this property, but the well-defined veins merit more attention than they have received. The presence of limonite similar to that in the Virginia lode was mentioned on page 440 .

SCOTIA MINE.

The deposits in the Scotia mine, at the northeast base of the high limestone ridge, are associated with a strong quartz vein that trends S. $65^{\circ} \mathrm{W}$. to the south of the Walker shaft and with north-south fissures that have been followed from the shaft northward. The vein has been dereloped by a few shallow inclined shafts and by about 450 feet of drifts, inac- cessible when visited; and the north-south fissures have been opened by a 150-foot vertical shaft and by drifts and inclines on the 50,86 , and 150 foot levels.

The quartz vein, called the "Blue Jay" vein, trends S. $65^{\circ} \mathrm{W}$. closely parallel to a monzonite porphyry sill, and probably connects with a N. $15^{\circ} \mathrm{E}$. vein which extends along the east slope of the high limestone ridge and on which the Resurrection (Prairie Bell) prospect is located. The Blue Jay vein dips $70^{\circ}-80^{\circ} \mathrm{N}$., but its vertical extent is not known. Workings beneath it on the 50-foot level were inaccessible, and those on the 150-foot level have not exposed any prominent quartz veins. The quartz of the vein varies from the fine-grained replacement type to milky and well-crystallized varieties. It contains fine grains of pyrite, and much of it is stained with malachite, azurite, light-green copper arsenates, and an unnamed hydrous lead arsenate, perhaps the equivalent of the antimonate, bindheimite. It is, so far as seen, of low grade but has yielded some very rich ore from its hanging-wall side. The principal ore shoot is now represented by the "Bonanza" open cut, which extends downward across the bedding of a shaly limestone, known as the "bonanza shale," into the underlying limestone. This rock, at the open cut, dips $40^{\circ}-45^{\circ} \mathrm{N}$., steeper than elsewhere on the property and, together with the shattered character of the rock, indicates considerable disturbance along the vein fissure. The ore impregnated the laminae of the shaly rock and evidently replaced the limestone below. The shaly character of the rock may have had some influence on the gold content. (See p. 394.) Oxidation, however, further concentrated the metal contents, which ran well in gold, silver, and lead. A short distance west of the "Bonanza" open cut the shaly horizon has been explored by inclined shafts and drifts, and considerable silver-lead ore containing some copper and up to $\$ 33$ to the ton in gold is said to have been mined from them. These old workings were inaccessible in 1913.

The ore associated with the fissures trending N. $15^{\circ} \mathrm{E}$. has been followed from the 86 -foot level, west of the Walker shaft, northward and downward below the 150 -foot level. The ore horizon, 70 to 80 feet thick, is in the limestone below the "bonanza shale" and above a finegrained granite porphyry sill. The primary 
ore minerals are galena, jamesonite, pyrite, arsenopyrite, and a little chalcopyrite and zinc blende; the secondary minerals are cerusite, anglesite, bindheimite, a hydrous lead arsenate, limonite, and hematite, pharmacosiderite and scorodite. The primary gangue minerals are replacement quartz, which has replaced limestone, and scalenohedral calcite; the principal secondary mineral is calcite in crusts and flat rhombohedrons.

The main ore body begins opposite the shaft on the 86-foot level, where it consists of a little galena and black replacement quartz in a mass of soft hematite. Mineralized ground was worked from this point northward for 170 feet to a cave which contained several loose boulders of high-grade ore. A small stope extends from the west end of the cave, following a northerly fissure down to the 150-foot level, below which small amounts of ore have been found close to the fissure. A short distance north of the cave, at the top of No. 6 raise, a remnant of ore consists of lenses of galena and jamesonite, partly oxidized, along a silicified bed. Considerable arsenopyrite and pyrite ("sulphides"), said to have formed a casing around the galena-jamesonite ore, have been mined in this vicinity, but little of them was in sight in 1913. The arsenopyrite is partly oxidized to the hydrous arsenates, pharmacosiderite and scorodite, and to earthy hematite and limonite.

On the 150-foot level two northerly fissures, one on either side of the shoot just described, have been followed along inclined winzes. Both are accompanied by small bunches of rather fine grained galena with a little pyrite and zinc blende and some copper stains. Quartz is inconspicuous, and calcite is the principal visible gangue mineral. These bunches are formed mostly along bedding planes close to the fissure and just above the porphyry sill. The eastern fissure lies about 80 feet from the main stope, and the bedding planes of the intervening ground contain small amounts of sulphides, especially pyrite. The western fissure, 90 feet from the main stope, is not so clearly related to it.

The ore content north of the shaft has in general ranged as follows according to smelter returns: Gold 0.19 to 0.35 ounce and silver 16.85 to 34.65 ounces to the ton, lead 26.7 to 54.75 per cent, iron 5.45 to 15.55 per cent, in- soluble 2.45 to 9 per cent, zinc 1.4 to 3.3 per cent, sulphur 0.7 to 3.8 per cent, and speiss ${ }^{1} 26$ to 41 per cent. The percentages of sulphur show that most of the ore was oxidized. Some "boulder" ore from the cave is said to have contained 60 per cent lead and 200 ounces of silver to the ton, and the oxidized arsenopyrite ore from $\$ 10$ to $\$ 15$ of gold to the ton.

The changes in mineral composition of the ore imply that the northern part is farthest from the source and that the metal contents of the ore decrease in value northward, especially as very little oxidation has taken place below the 150-foot level. From this it may be inferred that the ore solutions came from the south, possibly from the "Blue Jay" vein; but no connection with this vein has been established, and the fact that other low-grade quartz bodies have been found but not explored suggests that the ore was introduced through some nearer channel.

\section{CONCLUSIONS.}

The ores of the West Tintic district include several varieties which grade into one another. They were introduced through two intersecting systems of fissures, one trending N. $65^{\circ}-75^{\circ} \mathrm{E}$. and the other N. $15^{\circ}-20^{\circ} \mathrm{E}$. They doubtless followed the more open courses along these fissures, and formed deposits only in those that varied in dimensions. The deposits as a rule are small bodies formed where conditions were especially favorable to replacement of limestone. It is a striking fact that the largest deposits studied are not in the vein proper but are adjacent to it in easily replaceable rock, shattered zones, or along branch fissures. This relation is illustrated in the War Eagle No. 2 by the small shoots of high-grade ore, in the "1903" mine by the galena shoot, and in the Scotia mine by the "bonanza" open cut and perhaps by the ore body north of the Walker shaft. The fact that the Scotia ore body is larger than the others is attributed to the unmetamorphosed state of the limestone and to the introduction of the ore between an impervious roof and floor. The size of this ore body, however, is small when compared to those in the average mines of the leading districts, and it must be concluded that ore deposition in the West Tintic district has taken place

1 See footnote, p. 412. 
on a correspondingly small scale, and under conditions that did not favor the concentration of deposition in a few main channels.

The work done justifies the conclusion that with more favorable transportation facilities the district could maintain a small steady output, but that under present conditions there is little hope of steady production.

\section{DESERT MOUNTAIN.}

By G. F. Loughlin.

Desert Mountain, or, more appropriately, the Desert Hills, include a cluster of low bare peaks which lie about 12 miles southwest of the West Tintic mining district. The nearest railroad station is Jericho, about 20 miles to the east. (See fig. 46.) There is nowater at Desert Mountain; the nearest supplies are at Judd Creek, 8 miles north-northwest, on the road to Simpson Mountains, and at Cherry Creek in the West Tintic district, 12 miles east.

\section{GEOLOGY.}

Only the western face of the mountain was visited. The rock here is mostly a light-gray granite cut by a few diabase dikes. Apophyses from the granite are intrusive into a dark quartzite which has not been studied closely, but which presents the same dark colors on weathered surfaces as does the pre-Cambrian(?) quartzite series of the Sheeprock Mountains and the southern Simpson Mountains. The quartzite is exposed at the southern and northern end of the mountain and in low knolls which extend to the northeast. Detritus from the principal valley which drains the southern part of the mountain area contains a large number of pebbles of volcanic rocks (mostly rhyolitic), but no extrusive rocks were seen in place.

The granite is light gray and ranges in texture from even grained to porphyritic. The main body is much crumbled on the surface, is medium grained, and in places contains phenocrysts of alkalic feldspar (microcline) and of quartz half an inch in diameter. Its principal minerals are white feldspar (both plagioclase and microcline), gray glassy quartz, and black to brownish flakes of biotite. Another type is an aplite which forms dikelike and irregular masses in the main body, to which it is similar in color but is much finer grained. It is fresh even close to the surface and in addition to the above minerals contains a small percentage of muscovite. It also contains phenocrysts of feldspar and quartz, few of which are conspicuous. Many of the aplitic dikes have coarse-grained pegmatitic variations which grade into massive quartz veins. Several such quartz occurrences outcrop along the road among the low hills just north and northeast of the Rockwell shaft, but none are large enough to be of any economic interest or to show any promising indications of metal contents.

The diabase is dark greenish gray and has a fine-grained ophitic texture, except along the dike margins and narrow offshoots, where it is black and dense. The visible minerals are white feldspar in short rodlike grains, in a soft dark-green chloritic material. There is a suggestion of porphyritic texture in places, a chloritized dark material (presumably augite) forming small phenocrysts. Microscopic study shows the feldspar to be principally plagioclase $\left(\mathrm{An}_{35}\right)$ accompanied by a little orthoclase. The composition of the former, more sodic than in the average diabase, and the presence of the latter are characters tending toward those of monzonite.

Both the topography and distribution of the quartzite and granite suggest faulting, especially around the valley just mentioned, but no faults were proved. The granite is thoroughly fissured in several directions, the principal systems trending north-south (dipping $45^{\circ}-60^{\circ}$ W.) and east-west (dipping $60^{\circ}-65^{\circ} \mathrm{N}$.). In both of these systems sheet jointing is very conspicuous. Another strong system has gentle dip and near the quartzite approximately parallels the intrusive contact.

\section{ORE DEPOSITS.}

The only known important ore deposit in Desert Mountain is the vein followed by the Rockwell inclined shaft, near the northwest end of the mountain, south of a group of low foothills. There are a few other prospects in the vicinity, but only a little work has been done on them. The vein follows a north-south sheeted fissure zone, which dips $60^{\circ} \mathrm{W}$. The outcrop of copper-stained rock is 6 to 8 feet wide. It is partly covered by dump débris but is exposed for at least 50 feet south of the shaft, which begins in ore. The cliffs, however, on the spur just north of the shaft, although they 
are cuit by a strong north-south fissure zone in line with the vein, show no vein material. Any southern continuation of the vein is concealed beneath alluvium. The inclined shaft is said to be 235 feet deep and to follow the vein along its dip for almost the entire distance, but it was accessible to a depth of only about 100 feet. The width of the vein through this distance varies considerably. At one place the sheets of granite between close parallel fissures are impregnated and strongly stained with the blue silicate or green carbonate to a thickness of 3 to 4 feet; at another, mineralization is limited to a few streaks of the silicate or carbonate along the hanging wall of the fissure zone. At no place is replacement of the granite very pronounced, and the average copper content can not be much, if any, over 5 per cent. The bottom of the shaft cuts a diabase dike which is said to lie along the footwall of the vein. Fragments of this diabase on the dump are mineralized, proving the dike to be older than the vein.

The primary ore is chalcopyrite in large and small irregular grains partly altered to brownish-black iron oxide, accompanied by a little pyrite in small irregular grains. It occurs both in fissure fillings and in grains impregnating the granite and diabase. The gangue minerals are quartz and barite, which fill cavities and impregnate the wall rock for an inch or two, so that no sharp line can be drawn between vein and wall. The texture of the impregnated granite is preserved, but its feldspars and biotite are completely replaced by aggregates of microscopic sericite, quartz, and sulphides. Secondary minerals are brownishblack iron oxide, which marks the former presence of chalcopyrite in partly or wholly leached rock, and chrysocolla, which with malachite and secondary quartz fills veinlets cutting all the minerals of vein and wall alike, including the brownish-black iron oxide. The secondary quartz, either as minute glassy crystals or as chalcedony, continued to be deposited even after the copper silicate and carbonate.

The whole shaft is above water level, but the downward leaching of the ore is far from complete. Chalcopyrite can be found close to the surface, and considerable leaching, to judge from mineralized diabase fragments on the dump, has taken place at the bottom of the shaft. Chrysocolla and malachite aro distributed all along the shaft and drift walls and show no special tendency to concentrate into bunches of high-grade ore.

Although the mineralized material is of high enough grade, especially if concentrated, to pay under more favorable circumstances, the long wagon haul, the railroad and smelter charges, and the lack of water prevent profitable working under present conditions.

\section{SIMPSON MOUNTAINS (ERICKSON DISTRICT).}

By G. F. Loughurn.

\section{GENERAL FEATURES}

The Simpson Mountains, also known locally as the Judd Creek Mountains, are about 18 miles long from north to south and 2 to 6 miles wide and are bisected by latitude $40^{\circ} \mathrm{N}$. and inclosed between longitude $112^{\circ} 39^{\prime}$ and $112^{\circ}$ $43^{\prime} \mathrm{W}$. They are separated by an alluvial valley on the east from the Sheeprock Mountains and by the old river bed on the west from the McDowell Mountains. (See fig. 48.) Their northern part is crossed through a pass by a stage road from Fausts to the Dugway Mountains; their middle part, including Indian Springs post office, is reached by a road, through the Sheeprock Mountains, from Vernon, or by a valley road from Fausts; and their southern part is most easily reached by road through the West Tintic Mountains from Eureka and other towns in the Tintic mining district. Each of these routes requires at least a day's travel on horseback or with a light rig.

A few springs in canyons along the lower slopes afford sites for camps. Simpson Spring, the northernmost, is on the west slope about 3 miles south of the north pass. A few prospects are located here, but none were reported ఓctive in 1912. Indian Springs, also on the west slope, in the long west-draining canyon of Indian Creek, which cuts the range nearly in the middle and is separated from the northeastward drainage by a low flat divide, furnish water for the O. K. Silver Mining Co., whose mine is the only one active at present, and for the irrigation of land. Sixmile Spring, about 4 miles south of Indian Springs, is the site of temporary prospectors' camps. Death and Blaine canyons on the south slope contain springs which supply water to a few prospectors and to ranging herds. Judd Creek, east of 
these, supplies water for a ranch and, except in the driest seasons, flows far enough southward to afford a watering place on the road from Tintic. Desert Spring on the southeast slope is a similar watering place on the road to the Sheeprock Mountains and to Vernon. Limited growth of cottonwoods and other trees tary but are cut by a few porphyry dikes and are covered in places by remnants of volcanic flows.

The sedimentary rocks may be divided into a lower series composed mostly of darkweathering chloritic quartzite and shale and

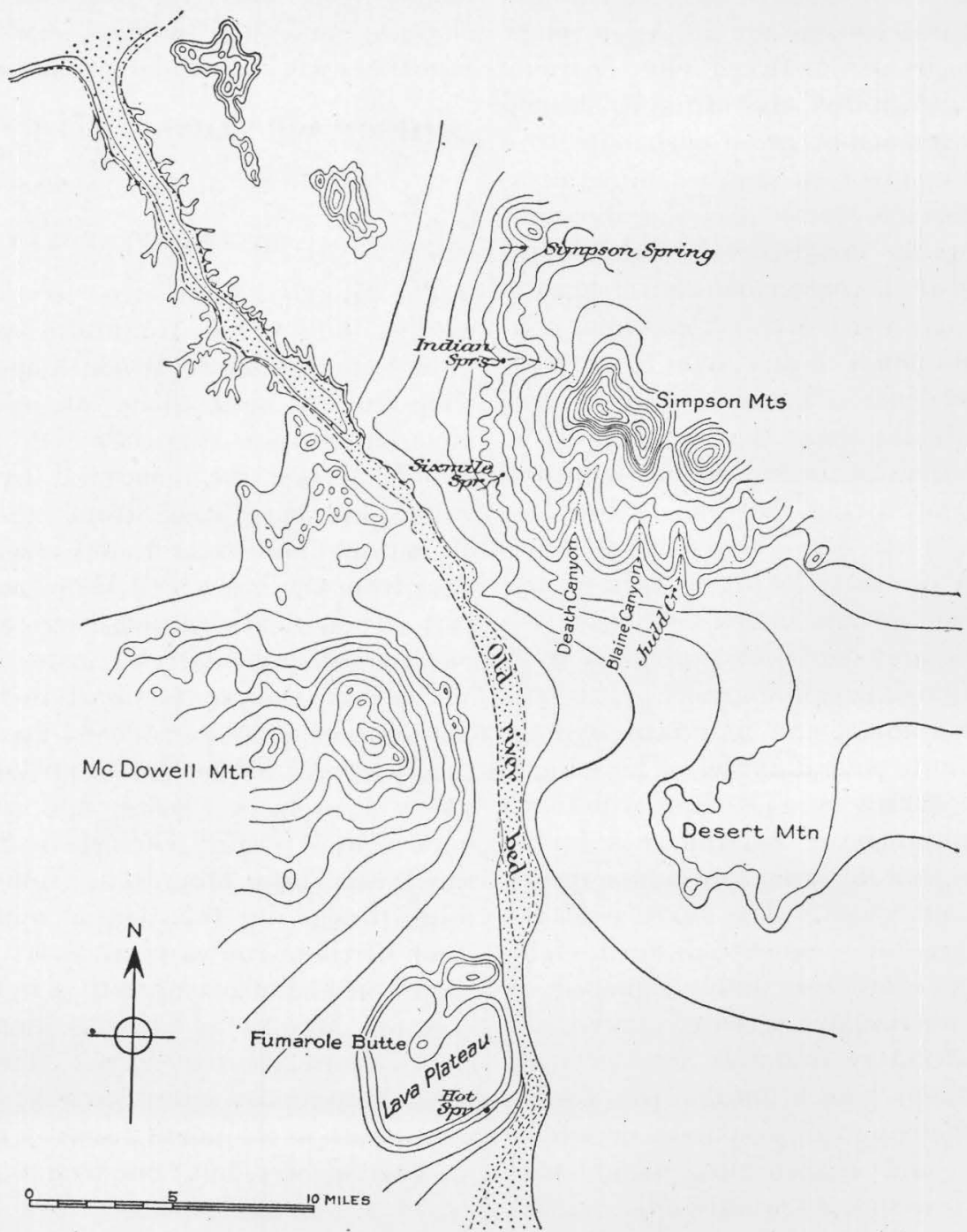

FIGURE 48.-Contour map showing positions of Simpson and McDowell mountains, Fumarole Butte, and Desert Mountain,

are grouped around several of the springs, but only stunted junipers ("cedars") and some mountain pine grow elsewhere. The junipers, however, are large enough to furnish mine timber for present developments.

\section{GEOLOGY.}

The Simpson Mountains were studied only around Blaine and Death canyons and Indian Springs. The rocks here are mostly sedimen- an upper series composed mostly of a lighterweathering, nearly pure quartzite with a few intercalated beds of limestone, shale, and chloritic quartzite.

CHARACTER AND DISTRIBUTION.

The lower series makes up all the ridges from the southern base of the range as far as the divide that separates the southward drainages of Death and Blaine canyons from the north- 
ward and westward drainage of Lee, Indian Creek, and other canyons. Its thickness is very great, amounting to some thousands of feet, but can not be accurately estimated until the faults are carefully mapped, as they obviously cause some repetition. The series is composed throughout of irregularly a!ternating beds of greenish shale, dark and light quartzite, and conglomerate; but green shale is most conspicuous on the lower southern spurs, especially at altitudes below Camp Blaine; green chloritic quartzite is most prominent for the next 800 to 1,000 feet above; a band containing considerable pure quartzite follows; and a considerable thickness of coarse conglomerate with thin alternating beds of shale and quartzite covers all. The shales throughout contain abundant mud cracks, and the quartzites are commonly ripple-marked and cross-bedded. These characters, together with the abrupt alterations between conglomerate and shale and an absence of fossils, indicate, although they do not prove, continental deposition.

The chloritic quartzite is greenish gray to dark purple, weathering to a brown. It is very fine grained and faintly banded. No minerals can be identified megascopically save minute sparkling specks of quartz. The rock consists of subangular grains of quartz and a few of plagioclase and mica in a feltlike matrix of sericite, chlorite, calcite, and secondary quartz. With increase of matrix and corresponding diminution in size of quartz grains the rock passes into shale. The conglomerate beds are composed almost wholly of quartz pebbles, including milky and smoky vein quartz, chalcedonic quartz, and occasionally quartzite, in a more or less argillaceous sandy matrix. Pebbles of granite, granite porphyry, and locally of gneiss are also common, though quite subordinate to the quartz. One conglomerate bed, containing, besides quartz, pebbles of fine-grained ferruginous sandstone cemented principally by more or less oxidized pyrite. is said to assay $\$ 2.60$ in gold, which is probably contained in the pyrite cement of the ferruginous sandstone pebbles.

Near the summit of the southernmost peak east of Blaine Canyon and not far from the conglomerate horizon a dark calcareous shale bed is exposed; but no limestone, except a small isolated exposure of tremolite rock in the bed of a shallow south-sloping gulch west of the Happy Jack mine, is known to exist in the lower series. This rock is gray to greenish gray on fresh fracture but badly rust stained on weathered surfaces. Among the interlocking tremolite blades are the weathered remnants of pyrite cubes, mostly interstitial but a few included in tremolite. This rock is evidently the metamorphic equivalent of a limestone bed well down in the horizon of prevailing shale.

North of Death Canyon and along the divide into Lee Canyon the rocks differ markedly from those farther south. The peaks along the divide consist of a uniformly colored quartzite which appears to rest conformably upon the dark beds of the lower series. A short distance down Lee Canyon, along a local anticlinal flexure, a bed of dark-blue cherty dolomitic limestone is exposed within the quartzite. According to the strike and dip of the whole formation, this dolomitic bed should be expected to outcrop in the head of Death Canyon, but no such bed was found there, and it is tentatively concluded that the dolomitic bed is a lens or changes southward to a shaly member near the top of the lower series. West of Lee Canyon down Indian Springs Canyon, two or three other stratigraphically lower limestone beds that alternate with light and dark quartzite vary from light to dark and from finely granular to dense and shaly. They appear to change southward into shaly or quartzitic beds, but none of them was followed for any considerable distance along its strike. The lowest crosses the canyon just below the Indian Springs posi office, where it overlies dark beds like those of the lower series. Detailed areal work may require a different interpretation. The light-colored quartzite which overlies the dolomitic bed in Lee Canyon appears to form all the peaks east of Lee Canyon and north of Indian Springs, but none of these peaks was ascended.

$$
\text { AGE AND CORRELATION. }
$$

Fossils collected by L. D. Burling in 1905 prove the limestone beds to be of Middle Cambrian age. According to the tentative interpretation that the limestones change southward into shaly members of the lower series, the upper part of that series is also Middle Cambrian and the lower part Lower Cambrian or earlier. The general similarity of the lower 
series to the oldest rocks in the Sheeprock Range on the east also suggests very early Cambrian or pre-Cambrian age.

\section{IGNEOUS ROCKS.}

The igneous rocks include a few dikes or sills of granodiorite porphyry and monzonite porphyry and remnants of equivalent extrusive rocks. One diabase dike also was found.

GRANODIORITE PORPHYRY.

Five dikes (or sills), ranging in texture from granodiorite porphyry to dacite porphyry and locally called "quartz porphyry," were found. One of these, 65 feet in width, trends nearly south in a shallow southwest-sloping gulch just west of the low knoll by the Happy Jack mine. The dike was not traced for any considerable distance but is said to continue northward just west of the divide between Death and Blaine canyons for nearly a mile. The rock is light gray and very fine grained to dense porphyritic. The uniform white color of the altered feldspar phenocrysts and groundmass gives it a more granitic appearance than is really the case. The phenocrysts include altered plagioclase crystals up to 5 millimeters in length, quartz single grains and aggregates up to 4 millimeters in diameter, biotite, mostly faded, in 6-sided and irregular plates, and dark-greenish (altered?) hornblende in prisms 2 to 3 millimeters in length. The groundmass consists of irregular grains, 1 millimeter or less in diameter, chiefly of quartz and feldspars, but is much obscured by alteration to sericite, epidote, and chlorite. Owing to the alteration and to uncertainty as to ratio between plagioclase and alkalic feldspar it is impossible to classify the rock exactly. It is either a granodiorite or a quartz monzonite intrusive, but is distinctly more acidic than the monzonite described below.

A short distance northwest of the above occurrence, in a shallow south-sloping gully, a dike or sill of similar composition but finer texture outcrops. Of the other dikes of this group one 60 feet wide trends N. $20^{\circ} \mathrm{E}$. across the east spur of the southernmost peak east of Blaine Canyon. A large dike outcrops with a N. $70^{\circ}$ W. course on the east side of the Blaine Canyon road, about 1,500 feet southeast of the Happy Jack tunnel. A small dike was found farther south in the wash of the gulch just west of the knob at the mouth of Blaine Canyon, but its trend could not be determined. A small dike was also found at a small prospect on the west side of the Death Canyon road near the Utonia lower tunnel.

\section{MONZONITE PORPHYRY.}

The monzonite porphyry is medium to dark gray and very fine grained porphyritic. The phenocrysts include plagioclase $\left(\mathrm{An}_{40-45}\right)$, biotite, hornblende, and a few quartz grains. Small pyrite grains are also present. Some small dark patches or segregations evidently owe their darker color to a general lack of phenocrysts. The groundmass consists of small but fairly well formed laths of plagioclase and hornblende, virtually the smallest of the phenocrysts, embedded in a matrix of alkalic feldspar and quartz with little or no biotite. Microscopic quartz amounts to about 10 per cent of the rock.

In mineral composition the monzonite closely resembles the granodiorite, differing from it pronouncedly only by its greater abundance of black minerals and its corresponding lack of quartz. The plagioclase feldspars in the monzonite are somewhat less sodic than those in the granodiorite. The two rocks evidently had a common source, but it is not known which type was erupted first.

DIABASE.

The one diabase dike found outcrops on the west slope of the ridge west of Death Canyon, at its south end, and at about the same elevation as the Good Hope and the Last Hope No. 3 tunnels. The dike trends about north and south through dark quartzite and shale but is not well exposed for any considerable distance. It is dark gray on fresh fractures but weathers dark brown-about the same color as the weathered quartzite around it. It has the typical fine-grained ophitic texture, interrupted by a few small round feldspathic spots less than half an inch in diameter. The visible minerals are plagioclase $\left(A n_{65}\right)$, biotite, and a dull indeterminable material which the microscope proves to be altered augite. A little microscopic alkalic feldspar may be present in the interstices between plagioclase crystals, and small aggregates of serpentine represent the former presence of olivine. A little hornblende is also present. Calcite, the most conspicuous alteration product other than serpen- 
tine, is accompanied by sericite and, in a veinlet, is intergrown with alunite. A little chlorite and epidote are also present. The abundance of biotite,' the optical character of the augite, and the presence of brown hornblende give the rock a distinct resemblance in character to the latites and andesites in the Tintic and other districts of Utah, and it therefore seems probable that the diabase as well as the granodiorite and monzonite porphyries belongs to the great series of Tertiary igneous rocks.

\section{EXTRUSIVE ROCKS.}

Remnants of lava flows were noted at the low divide between Indian Springs and Lee canyons, and on the low hills on the north side of Indian Creek just west of the Indian Chief shafts. The one on the divide includes tuffs and flows of andesitic or latitic composition. The other is a dense rhyolite with phenocrysts of quartz and sanidine (glassy orthoclase) and weathered remnants of plagioclase and a very small amount of black minerals. Small fragments of obsidian (black volcanic glass) have been picked up at several places on the slopes.

These surface flows are found only in valleys and on lower hills, proving that the eruptions took place when the topography was much as it is to-day. How far they extend is not known, but probably similar remnants occur in some of the broader valleys and on the lower ridges flanking the range.

\section{STRUCTURE.}

The structure in the part of the range near Blaine and Death canyons and Indian Springs is for the most part homoclinal, the strata striking northwest and dipping $30^{\circ}-35^{\circ} \mathrm{NE}$. At the south end of the ridge west of Death Canyon is a gentle anticlinal flexure with northerly pitch, which dies out northward, and just north of the divide between Death and Lee canyons is a similar flexure. These are the only exceptions noted to the general northeastward dip.

The principal structural features of the area are fissuring and faulting. The most prominent fissures trend parallel to the bedding, north to N. $15^{\circ} \mathrm{W}$. and N. $65^{\circ}-85^{\circ} \mathrm{W}$. Other faults and fissures trend N. $70^{\circ}-80^{\circ}$ E., N. $40^{\circ}-50^{\circ}$ E., N. $20^{\circ}$ E., and N. $45^{\circ}$ W.

Most of the fissures parallel to the bedding are strongly slickensided and may mark faults of considerable displacement, though the extent of displacement along any particular bed has not been found. Several bedded fissures are mineralized.

Fissures striking north to N. $15^{\circ} \mathrm{W}$. (nearly parallel to the strike of the rocks) include both barren and mineralized fissures. The barren fissures are strongly slickensided and accompanied by faulting. At a small prospect on the

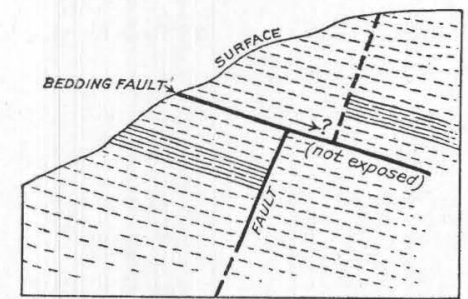

FIGURE 49.-Fault of steep westward dip cut off by a bedding fault at a small prospect on the southern peak east of Camp Blaine, Simpson Mountains.

southern peak east of Camp Blaine (fig. 49) a fault of steep westward dip that cuts off a dark calcareous shale bed is itself cut off by a fault along the bedding. Another fault, a reverse one with strike N. $5^{\circ}-10^{\circ} \mathrm{W}$. and dip $42^{\circ} \mathrm{W}$., is exposed for a considerable distance along the Blaine lower tunnel. It finally flattens rather abruptly and its upper end merges with a bedding plane that dips gently

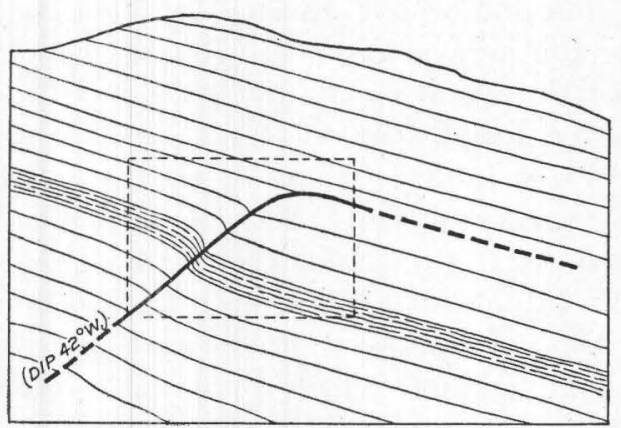

Figure 50.-Reverse fault exposed in Blaine lower tunnel, Camp Blaine, Simpson Mountains. Part exposed at different places along tunnel inclosed in dotted square.

eastward (fig. 50). The mineralized fissures of the system that trends north to N. $15^{\circ}$ W. can not be followed on the surface for any considerable distance.

Fissures that strike N. $65^{\circ}-85^{\circ}$ W. and dip steeply north are the most persistent of any found but are relatively short compared to the strong fissures of the larger mining districts. Most but not all of them are mineralized. The $35416^{\circ}-19-29$ 
most persistent of this system are the main fissures in the upper Blaine tunnel and in the Silver Reef tunnels, the Blaine fissure having been followed for at least 400 and the Silver Reef fissure (in the lower tunnel) for over 500 feet. Other fissures of the same system-for example, the West End fissure of the Blaine and the principal fissure of the Happy Jack workings-have not proved continuous either horizontally or vertically, but after a short distance branch into a number of fractures and disappear within a few feet. It is probable that where such a fissure ends a second parallel fissure begins near by and virtually continues the first; but the finding of the continuation is a matter of chance. Mineralized branch fissures trending in different directions are connected with these main fissures. The strikes of those noted are N. $80^{\circ}$ E., N. $70^{\circ}$ E., N. $50^{\circ} \mathrm{E}$., and N. $45^{\circ} \mathrm{W}$. The dips where measured are southerly.

The only other fissure worthy of mention is a N. $40^{\circ} \mathrm{E}$. fault fissure, with small displacement, seen on the ridge east of Blaine Canyon. Besides these fissures, others in various directions are associated with rock shattering and accessory to the stronger fissures, as in the Happy Jack tunnel.

The dikes lie mostly parallel to the north to N. $15^{\circ} \mathrm{W}$. and the N. $65^{\circ}-85^{\circ} \mathrm{W}$. fissure systems; but one, which outcrops on the east spur of the southern peak east of Blaine Canyon, is 60 feet thick and trends N. $20^{\circ}$ E.

The critical feature of the fissures is their lack of continuity. Some of them, including those parallel to the bedding and the barren faults noted in the system that strikes north to N. $15^{\circ} \mathrm{W}$., appear to have been formed during the period of compression which produced the anticlinal flexures. This force was evidently insufficient to produce intense folding in the district, though capable of shearing the rocks and producing local compression faults. Owing to the unequal resistance of the different strata, clean-cut fissures were developed in the more quartzitic beds but failed to persist in the more shaly beds; the broken quartzitic masses, or blocks, could thus yield by fault movement and be squeezed against or even into the yielding shale beds, producing the complications of bedding shown in the Happy Jack tunnel. The sliding of block upon block would take place not only across but along the bedding, with the result that although the total displacement is considerable, the movement along any one fissure, or fault plane, is small. The fissures would form a network, but no single fissure would necessarily persist for any considerable distance.

After the close of this period of compression more fissuring took place, the more persistent fissures evidently affording channels for the dikes. Further fissuring probably took place after the dike intrusions, but no definite data on this point are at hand, except that the dikes have undergone the same kind of alteration as that shown by the sedimentary rocks along the mineralized fissures.

The presence of older fissures as well as the uneven rigidity of the sedimentary rocks would both tend to interrupt the continuity of later fissures. Where the disrupting force was strongest, it may have been sufficient to produce a fissure that persisted through the thinner shale beds and was only slightly interrupted where crossing older fissures, but that broke up on entering weaker or thicker flexible shaly beds and formed two or more fissures approximately but not quite in line. A new fissure, especially where the disrupting force is relatively weak, on approaching an older fissure is likely to be deflected toward the older fissure. The rock beyond the older fissure may or may not be cut by another new fissure, and the new fissures on opposite sides of the old are not likely to be in line. The rock at the junction of fissures may be considerably shattered. The disrupting force, furthermore, may not, for one reason or another, be of uniform intensity and fissures may branch and die out even where the rock is reasonably uniform. Too little work has been done to compare the relative influence of these different conditions in the Simpson Mountains, but all have evidently been operative in producing the complex network of fissures. (See fig. 51.)

\section{ORE DEPOSITS.}

GENERAL FEATURES.

\section{OCCURRENCE AND CHARACTER.}

The ore deposits of the Simpson Mountains lie within the Erickson mining district, which includes all the Simpson Mountains and also the western slopes of the Sheeprock Mountains as far north as Government Creek. Nearly all 
the deposits are in vein form, but some replacement bodies occur at Indian Springs. Many small outcrops, or "blowouts," of mineral veins are scattered over the surface of the Simpson Mountains, but few of them are traceable for considerable distances, partly because they are hidden by float and talus and partly because they are not persistent. A few veins are distinct for horizontal distances of 300 to 500 feet and have local bunches or shoots of pay ore, and some ore bodies occur as small isolated bunches with

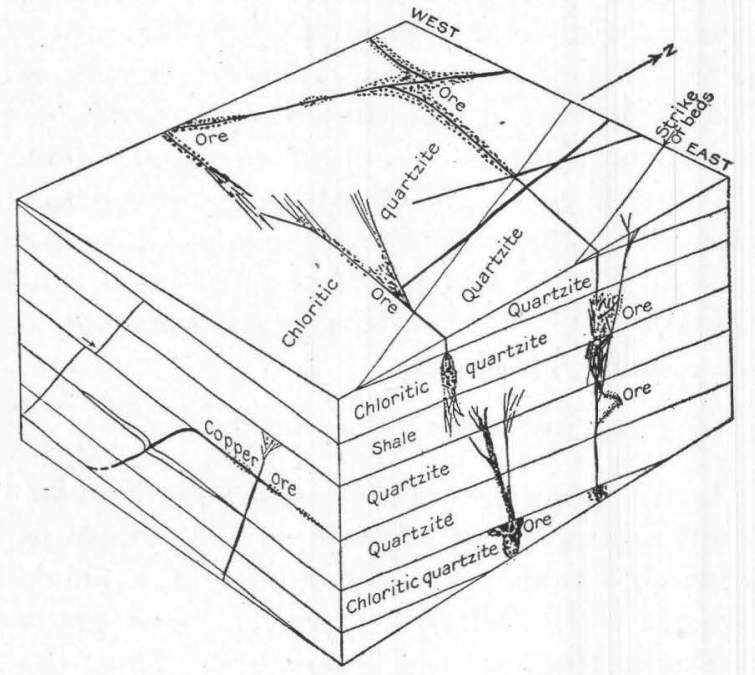

Figure 51.-Diagram showing relations of different fissures to one another, also relation of ore shoots to fissuring and composition of wall rock in southern part of Simpson Mountains.

no apparent connection other thaninconspicuous barren fissures.

The veins may be divided into two groupsthose parallel to the bedding and those filling nearly vertical fissures.

BED DEPOSITS.

Deposits parallel to the bedding are composed chiefly of white milky quartz with some small bunches of chlorite, scattered lumps of chalcopyrite, some of which are 2 inches in diameter, and a few small aggregates of specular hematite. These deposits are mostly lenticular but range from a succession of short detached lenses along the same bedding plane to a relatively continuous deposit with local lenticular bulges. The average thickness of the bulges is about 5 or 6 inches, and the maximum thickness seen was about 1 foot. One or both of the walls as a rule is light colored relatively pure quartzite. Where chloritic quartzite or shale forms one wall, chlorite is likely to be conspicuous. The chalcopyrite lumps are more or less altered to bornite, chalcocite, malachite, azurite, and chrysocolla. Under the microscope the chalcopyrite is full of irregular granules of pyrite. A few grains of galena have been found.

The amount of ore in these quartz-chalcopyrite deposits is insignificant, except in the Highland Lassie No. 1 prospect at Sixmile Spring (p. 456), which isalso exceptional in the position of the vein. The workings were not accessible when visited, but the ore body is said to be small, though rich, and to cut across the bedding, pinching out a short distance below the surface. A very little barite was found with this ore.

\section{FISSURE DEPOSITS.}

The veins filling nearly vertical fissures vary considerably in composition. Those seen at Indian Springs are composed of quartz with a minor amount of calcite and a varying amount of very fine pyrite grains. A few grains of chalcopyrite were also noted. The quartz fills cavities developing typical comb structure and also replaces the calcareous wall rock. The calcite is mostly a later growth filling fractures in the quartz and also in places filling the central portions of cavities or pockets. The pyrite is found along the edges of cavities and scattered among the microscopic quartz grains. This pyritic quartz-calcite ore is said to contain gold to the amount of $\$ 7$ to $\$ 12$ per ton, but where pyrite is locally concentrated into visible streaks or patches of fine grains, the amount is considerably larger. The small amount of chalcopyrite holds the same relations to the gangue as does the pyrite but occurs in larger grains.

The veins at one horizon on the O. K.-Silver Reef property merge with a strong deposit of vein and replacement quartz which follows the bedding for a considerable distance. The original bed was probably a limestone, but replacement has been so complete that no remnants of the former rock could be found. The nearest exposed beds above and below it look like shaly limestone but are siliceous and yield no effervescence when touched with hydrochloric acid. The oxidized ore in this replacement body contains sulphantimonites of silver and horn silver, and shipments made early in 1916 are reported to have yielded 400 to 500 ounces 
of silver and 0.02 to 0.235 ounce of gold to the ton. ${ }^{1}$ Silver in valuable amounts has been found at only two places- the O. K. incline and the Silver Reef open cut.

The veins of lead-zine ore around Blaine and Death canyons also contain quartz, but it is less conspicuous and in many places is subordinate to calcite and chlorite. The metallic minerals are galena, zinc blende, pyrite, and locally chalcopyrite. Both the gangue and ore minerals vary in quantity, and each predominates locally, but as a whole calcite is perhaps the most abundant gangue and galena and zinc blende the most abundant ore minerals. The width of these veins is very irregular, and ore shoots occur at intervals, evidently where chlorite beds and excessive shattering have produced favorable conditions. (See fig. 51.) Some veins, which are marked for considerable distances by a little impregnation of the walls by pyrite and by a few scattering crystals of galena and zinc blende, abruptly expand, on meeting a favorable chloritic bed, to 1 to 6 feet of ore. The chloritic beds were evidently readily subject to attack by the vein-forming solutions; and it is noteworthy that the gangue minerals here, quartz, calcite, and chlorite, are the same as those which constitute the rock. Sericite, which is prominent in the rock, is also a minor gangue mineral. The ratio of gangue minerals, however, is very variable and in most or all places is markedly different from that in the wall rock. Considerable transfer of material in solution must have taken place, the rock constituents being removed and the ore minerals depositing in their stead. Where conditions of deposition were most favorable, galena and blende in good-sized crystals or aggregates tended to concentrate in the central part of the shoot and pyrite to impregnate the surrounding walls; but in most shoots considerable pyrite in crystals, some of which are a quarter of an inch or more in diameter, are scattered through the ore. The pyrite in the rock around the margins of a shoot is commonly fine grained.

Fluorite was seen in one place, associated especially with leached quartz and lead carbonate, but the caving in of the workings prevented an adequate study of its occurrence. It is, however, of interest as a connecting link between the composition of the veins of the

${ }^{1}$ Mining Press, Feb. 5, p. 216, and Mar. 4, p. 355, 1916.
Simpson Mountains and those of the Sheeprock Mountains to the east.

Alunite, in microscopic flakes intergrown with calcite, was found in a veinlet cutting a diabase dike. This intergrowth is of particular interest as an indication that the alunite was deposited by an alkaline or neutral solution, for acidic solutions would have dissolved rather than deposited calcite. It supplements evidence in the Marysvale district (pp. 546-550) that alunite may be a primary constituent of veins deposited by ascending solutions as well as a secondary mineral deposited by acidic waters in the zone of oxidation. This occurrence is also of interest in showing the similarity between the Simpson Mountain veins and those of other ranges. The alunite, a hydrous potassium-aluminum sulphate, is confined to the veinlet, and the feldspar of the diabase is considerably altered to sericite, a hydrous potassium-aluminum silicate.

RELATIONS BETWEEN THE DIFFERENT VEINS.

Surface exposures and underground developments are too slight to show any definite transition or change in the contents of a single vein, but the different types of veins grade into one another in composition. Thus the quartz-pyrite veins and replacement bodies contain a little chalcopyrite and more or less calcite and may grade into the quartz-chalcopyrite veins and also into the veins rich in calcite. The quartz-chalcopyrite veins contain a small amount of galena, and as one of them at the Last Hope No. 3 prospect (p. 456) passes into a small body of rich galena ore, the connection between them and the calcitelead-zinc veins is reasonably well established. At one prospect on the ridge west of the Blaine tunnels a vein composed of calcite, considerable quartz, galena, and oxidized copper minerals is clearly intermediate between the last two types mentioned. No definite relation. as to relative depth of crystallization or distance from their source can be established until the area has been mapped and studied in detail.

\section{OXIDATION.}

The oxidation products or secondary minerals of the veins present no unusual features. Pyrite has oxidized to limonite, giving a typical limonite-stained quartz, which retains 
the gold originally in the pyrite. Chalcopyrite, as proved by microscopic study of polished surfaces, has altered to pitchy black to brown. limonite, and all these minerals are cut by veinlets of the copper carbonates, malachite and azurite, and the silicate, chrysocolla. Galena has changed to the lead carbonate, cerusite (also called "crystallized lead" and "sand carbonates"), and remains in the veins above water level, but no conspicuous alteration product of zinc blende has yet been found, although zinc blende and galena occur together. The decomposition of zinc blende was accompanied by transfer of the zine as sulphate away from its original position, and it is to be expected that, in the absence of limestone beds which oxidized zinc ore could replace, no concentration of oxidized zinc ore has taken place. Small amounts of calamine, the hydrous silicate, may be found, however, replacing chloritic quartzite or lining cavities.

A few bodies of the black manganese ore, chiefly pyrolusite and wad, are also found. One, on the south slope of the peak east of Blaine Canyon, has been prospected and found to replace a shaly bed between quartzite strata, but no definite connection between it and unoxidized material has been exposed. It consists of a few high-grade lumps or segregations in a soft brownish-black earthy material. Another outcrop of manganese ore is exposed near the south end of a low spur just southeast of Camp Blaine. The workings were not accessible, but it was said that the manganese ore was followed down an incline for 120 feet and that within. 20 feet of the surface some lead-silver ore was found. There thus seems to be a close relation. in origin between the lead and manganese ore. It is interesting in this connection to cite the work of Nishihara, who has shown that galena from several different places contains small amounts of manganese, probably as sulphide; ${ }^{1}$ but in the Utonia workings, inaccessible in 1912 , the black manganese ore changes abruptly to rhodonite, the manganese silicate, at water level, 100 feet below the surface. This deposit and others in the Tintic and Erickson districts were studied by J. T. Pardee in 1918, when manganese ore was being shipped from

1 Nishihara, G. S., The rate of reduction of acidity of descending waters by certain ore and gangue minerals and its bearing upon secondary sulphide enrichment; Econ. Geology, vol. 9, pp. 743-757, 1914. the Black Jack group and development work was being conducted on several other claims in the vicinity. ${ }^{2}$

\section{MINES. BLAINE MINE:}

The Blaine mine, owned by the Blaine Gold \& Silver Mining Co., in Blaine Canyon, on the southern slope of the Simpson Mountains, was worked in the eighties, when 100 tons of sandy lead carbonate ore, mined from the shaft, was shipped to the old smelter at the Hot Springs north of Abraham. The workings in a spur on the west side of the canyon include the old shaft, a short tunnel called the West End, and an upper and lower tunnel. The country rock, a dark-weathering impure quartzite, includes several intercalated green massive to shaly beds containing abundant chlorite, sericite, and calcite.

The upper Blaine tunnel, which lies at the approximate boundary between oxidized and unoxidized ore, follows a fissure with $\mathrm{N}$. $65^{\circ}-70^{\circ} \mathrm{W}$. strike and $75^{\circ} \mathrm{N}$. dip, whose walls are sprinkled with fine pyrite and some galena and blende. At 255 feet from the entrance the ore forms a vein 12 to 22 inches thick (average 14 inches). It has been followed. down the fissure in a winze for 30 feet or more and upward in a 40-foot raise, in which its width is 10 to 12 inches, with some pinches. The ore in the winze comprises blende, galena, and pyrite, with some lead carbonate and oxides of iron and manganese. A 12-ton sample taken 30 feet below the tunnel level ran 51 per cent zinc, 13 per cent lead, and 4 ounces of silver and 0.021 ounce of gold per ton. The ore in the raise is chiefly lead carbonate, with some galena, and averages $25 \mathrm{per} \cdot \mathrm{cent}$ lead (no zinc reported). Farther west, at the second crosscut, the rein swells to a width of 5 to 6 feet. The fissure beyond this place leaves the south wall of the drift but is cut by a south crosscut toward the shaft, where both of its walls are impregnated with fine galena. Eight feet south of this fissure another, striking N. $70^{\circ}$ E. and converging eastward with it, is accompanied by the usual ore in a greenish gangue and locally by blende and galena in a white gangue composed chiefly of calcite. Two

2 Manganese ore in Tintic district, Utah: U. S. Geol. Survey Press Bull. 379, pp. 3-4, September, 1918. 
other parallel or slightly converging veins with chloritic ore have been cut by the second crosscut to the north. The northern of these two, which lies in an east-west fissure zone accompanied by some faulting, has been flolowed for a short distance and is said to have contained some fluorite in the gangue, but none was seen during the writer's visit. A barren white quartz vein along the bedding is cut off by a fault just south of this northern vein.

The lower Blaine tunnel extends 740 feet nearly due north. About 400 feet from its mouth it crosses a few white quartz veinlets 1 to 3 inches thick which carry a little pyrite, chalcopyrite, and a few grains of galena. From this point northward it follows for a considerable distance a reverse fault of small displacement, which trends N. $10^{\circ} \mathrm{W}$. and dips $42^{\circ} \mathrm{W}$., along which are many east-west fractures. The north-south fissure finally flattens and merges with a bedding plane beneath a massive quartzitestratum. Seven hundred feet from the tunnel mouth, short east and west crosscuts have been run along a fault fissure that strikes N. $70^{\circ}$ W. and dips about $70^{\circ}$ N., and that may be the same as that followed by the upper tunnel. The hanging wall is shattered chloritic quartzite thoroughly impregnated with fine grains of pyrite and coarse grains and aggregates of blende and galena and crisscrossed by veinlets of white calcite. The ore body just east of the tunnel is about 8 feet wide, and lies in the wedge between the main fissure and a branch northwest-southeast fissure with southwest dip, which crosses the tunnel 12 feet north of the main fissure. West of the tunnel the main fissure branches and the ore disappears from the crosscut along a north-northwest branch fissure. Assays of samples from the lower tunnel have shown 24 per cent lead and $3 \frac{1}{2}$ ounces of silver per ton. No assay for zinc was made.

The West End tunnel and winze west of the shaft follow a nearly vertical north-dipping east-west fissure, which yielded oxidized leadsilver ore. The ore gave out where the fissure appears to feather out downward, and no prospecting has been yet attempted to hunt for any continuation of it. The shaft also follows a steep north-dipping fissure which may be in the same zone as the main fissures exposed in the upper and lower Blaine tunnels.
The ore bodies thus far exposed in the Blaine workings lie where fissures that strike N. $65^{\circ}-80^{\circ} \mathrm{W}$. and $\operatorname{dip} 70^{\circ}-80^{\circ} \mathrm{N}$. cut the more chloritic beds, and the largest exposures appear to be where these beds are shattered and the fissures branch. The ore in places extends a short distance from the fissure along bedding planes, replacing or impregnating the chloritic rock. The ore is not continuous along the fissures but lies in small shoots between lean or barren stretches, in which the fissure crosses beds of purer quartzite or crosses more favorable chloritic beds but is not markedly shattered.

\section{HAPPY JACK PROSPECT.}

The Happy Jack prospect, under the same control as the Blaine mine, is on the west side of Blaine Canyon, about half a mile south of the Blaine lower tunnel. The workings, which are all above water level, include a shallow inclined shaft and short drift, both of which follow the mineralized fissure zone, and a sinuous northwest tunnel about 250 feet long, which connects with the bottom of the shaft 10 feet below the short drift.

The country rock is impure quartzite and shale in irregularly alternating beds, which dip easterly. The dip varies greatly within short distances from horizontal to vertical. The beds are much fractured in various directions and greatly disturbed by local faulting and crushing. In one place a hard quartzitic block has been squeezed against soft chloritic rock, crushing it to a soft gouge which tends to surround the slickensided quartzite block. The crushed material that is exposed is barren, and the only ore of any consequence lies along an east-west fissure zone with an average dip of $80^{\circ} \mathrm{S}$. that persists from the surface down to the tunnel level, where it shows some signs of pinching out downward. The ore exposed in 1912 was all sandy lead carbonate. It forms bunches where the fissure zone crosses the more chloritic beds The ore in the shaft thinned out downward, but the short level west of the shaft has opened another body which extends about 15 feet across the strike of the fissure zone but has not yet been followed along the fissure. The fissure where cut on the tunnel level is not mineralized and attempts to find a downward continuation of the ore have not succeeded. The only ore found on the tunnel level is close to the face and comprises three or: 
four small bunches of sandy lead carbonate with kaolin and iron and manganese oxides. This material forms thin connected lenses with central bunches of $\mathrm{PbCO}_{3}$ that follow a flatdipping bedding plane for about 20 feet and cross through a short cross fracture to a bedding plane 2 feet higher. These lenses are possibly offshoots from the main fissure, which should lie a little north of the tunnel face. No ore has been shipped.

\section{O. K. MINE.}

The O. K. mine, owned by the O. K. Silver Mining \& Milling Co., lies well up the south slope of Indian Springs Canyon above the camp and post office. The country rock includes a bed of dark calcareous rock that dips $32^{\circ} \mathrm{E}$. between belts of light quartzite. The ore body lies parallel to the bedding and is a replacement of the basal member of the calcareous belt. The principal mining has been along an incline from the outcrop down the dip, and the ore extracted is said to have been largely silver sulphantimonides and horn silver in a quartzose gangue, the best values lying along the bottom of the incline. At the base of the incline a short drift leads to a series of caves lined with stalactites and stalagmites. The bottom of one of these cares is also said to have contained ore of unspecified character.

SILVER REEF MINE.

The Silver Reef mine, owned by the O. K. Silver Mining \& Milling Co., is on the north side of the canyon, opposite Indian Springs post office. In 1912 it was opened by two tunnels, a shaft, and a small open cut. The country rock is mostly light to dark brown weathering quartzite, with a few bands of shale and three or four of limestone or dolomite. The beds dip $30^{\circ}$ to $35^{\circ} \mathrm{NE}$. The mineralized fissures strike west-northwestward. The workings include two tunnels, a shaft, and a small open cut.

The lower tunnel follows a narrow fissure vein in dark impure limestone. Between 500 and 600 feet from the tunnel mouth the vein material is a crushed black silicified limestone 5 to 6 feet wide, filled with quartz, calcite, and fine-grained pyrite, lying between two parallel slickensided fissures. On the south side of the crushed zone are 6 feet of barren wall rock, then a second quartzose crushed zone vein with a dip of $50^{\circ} \mathrm{N}$., which may join with the first crushed zone below the tunnel level. The ore in the crushed zones is said to average $\$ 7$ to $\$ 12$ a ton.

The upper tunnel also follows a crushed zone vein, either the same as that in the lower tunnel or one closely parallel. The ore is of the same type as that in the lower tunnel but is said to have yielded higher returns. Specimens said to represent the richer gold ore are evidently local concentrations of fine pyrite with an inconspicuous quartz gangue.

The shaft goes down about 40 feet in rusted quartz, in line with the upper tunnel vein, and connects with two short drifts, one east-southeast along the rein and one southwest along a branch vein. Ore from these workings consists of quartz and limonite containing silver and a little gold.

The ground around the shaft shows only quartz in short reticulate veinlets with marked comb structure and innumerable small pockets surrounding fragments of silicified rock. The quartz outerop is 30 to 40 feet wide and can be traced for a short distance south of the shaft and northward beyond the limits of the property. The small open cut, just opened at the time of the writer's visit, has exposed some oxidized material said to yield very high values in silver. The exact source of the silver could not be found at the time, as the only recognizable primary mineral found was a little chalcopyrite. Specimens sent to the writer in 1916, probably from a newly opened ore body 60 feet below the surface, contain sulphantimonides and chloride of silver in a gangue of rusted pyritic quartz. Both silver minerals are secondary. A shipment from this body yielded 488 ounces of silver and 0.235 ounce of gold to the ton, and 0.15 per cent copper, and another yielded 405 ounces of silver and 0.02 ounce of gold to the ton. ${ }^{1}$ The ore is hauled to a loading point near Tintic Junction on the Los Angeles \& Salt Lake Railroad.

\section{INDIAN CHIEF PROSPECT.}

The Indian Chief, formerly called the Yellow Jacket, property adjoins the Silver Reef on the west. The workings include three inclined shafts. Only one of these shafts was accessible at the time of the writer's visit, and the

\footnotetext{
1 Min. and Sci. Press, vol. 112, pp. 216, 355, 1916.
} 
bottom of this was filled with water which $\mid$ drift follows a N. $3^{\circ} \mathrm{W}$. fissure, dipping $68^{\circ} \mathrm{W}$., stood 95 feet below the shaft collar. The for about 20 feet along its intersection with a three shafts lie on or close to a fault fissure chloritic stratum which lies between two hard which strikes N. $70^{\circ} \mathrm{W}$. and dips $65^{\circ} \mathrm{N}$. The quartzite beds. The ore, galena and cerusite, amount or direction of displacement is not now largely leached, is represented by a known. The immediate country rock is a spongy gossan held together by a fine network gray dolomitic limestone which overlies or lies within black dense argillaceous limestone. The footwall of the fault consists of gray dolomitic rock for a few feet from the surface and of black limestone for the rest of the way to the bottom of the workings. The hanging wall consists entirely of black dense limestone criss-crossed by barren calcite veinlets. Small bunches of lead carbonate and galena ore were found at the surface in two of the shafts but did not persist downward and were evidently confined to the gray dolomitic rock. Some of the ore fragments on the dump had quartz gangue; others had no conspicuous amount of quartz. The sorted ore is said to have run 60 to 70 per cent lead and 8 to 14 ounces of silver to the ton. The third shaft was sunk in a copper-stained limonite body, but no relation of this material to the country rock or to the lead ore could be determined, owing to the surface coverings of débris. The quartz body, which passes north-northwestward from the Silver Reef shaft, traverses the Indian Chief property, but there it shows no promising samples.

UTONIA TUNNELS.

The Utonia tunnels are in the middle part of the west slope of Death Canyon. They are four in all, but none was being worked when visited. All are in the lower impure quartzite, and all are said to have struck water. Only the lowest was entered. This tunnel penetrates to a fissure vein that strikes east and dips steeply north and carries galena, blende, and cerusite (lead carbonate). A watercourse follows the vein. It is reported that two carloads of lead-zinc ore were shipped in the nineties, but their value is not known. Similar ore is said to occur in the other tunnels. Black manganese ore derived from rhodonite has already been mentioned (p. 453).

GOOD HOPE PROSPECT.

The Good Hope lead-silver prospect, worked by B. F. Fleiner and others, is located on the southeast slope at the end of the ridge and is reached by trail from Death Canyon. A short of quartz, chiefly as a replacement of the chloritic bed. Some fragments of fluorite lining vugs in quartzite were found on the dump.

\section{LAST HOPE PROSPECT No. 3}

The Last Hope No. 3 tunnel, worked by Swen Nelson, is on the west slope of the ridge, above and directly eas' of Sixmile Spring. The tunnel follows a thin seam of vein quartz eastward a!ong a nearly horizontal bedding plane in impure quartzite. The quartz contains a few small pockets lined with crystals, more or less: oxidized chalcopyrite in irregular lumps, some of which are 2 inches in diameter, and small scattered crystals of galena. About 50 feet from the tunnel mouth the bedded quartz vein connected with a vertical east-west lens-shaped body of coarse-grained galena 2 to 3 feet thick, 5 to 6 feet high, and 10 feet or more long, with warped cleavage surfaces almost totally free from gangue. Some ore still remains in its eastern face. The walls around the galena body were so docomposed that no relations with fissuring or wall rock could be determined. The tunnel continues for some distance beyond the galena body, but no more ore has been uncovered. A few other bedded quartz veins 6 inches or less thick outcrop a short distance above the tunnel mouth but have not yet been prospected.

\section{HIGHLAND LASSIE PROSPECT No. 1.}

The Highland Lassie No. 1 is on the slope just north of Sixmile Spring. The workings are now caved, but a small pile of copper ore remains on the dump. The ore is chalcopyrite, mostly altered to pitchy black and brown limonite, malachite, and chrysocolla, accompanied by only a little fine-grained vein quartz. It replaces rather pure quartzite. The malachite and chrysocolla fill cracks traversing the other minerals. The vein quartz is not easily distinguished from the quartzite wall rock. In fact it may be simply recrystallized quartzite mixed with the replacing copper minerals. The ore is said to have followed a short fissure which for a short distance dipped steeply west, 
normal to the dip of the quartzite, then changed to a steep easterly dip and pinched out. Assays of the copper ore are said to have yielded very good returns of silver.

FUTURE OF THE DISTRICT.

Without doubt mineralization around Indian and Sixmile springs and Blaine and Death canyons extends over a wide area, but ore as a rule appears to be confined to small disconnected bodies. This condition is due to the variation in character of the country rock, the scarcity of persistent fissures, and the character of the solutions that deposited the ore. The solutions were evidently not able to effect any conspicuous replacement of the pure quartzite, and fissures in that rock were not continuous or open enough to permit the deposition of ore minerals in commercial quantity. Where the solutions, percolating through the network of fissures, came in contact with the green chloritic beds, they produced some replacement, the extent of which varied with the amount of chlorite and calcite in the rock and the presence of branch fissures or local shattering which would allow a more thorough permeation. The size of an ore shoot is thus limited to the thickness of certain replaceable beds, and may further be limited in any direction by the local pinching out of a fissure. Large ore bodies therefore are not to be expected, but small bodies of good ore are known to be present.

The high-water level is unfavorable. Soft oxidized ore, chiefly lead carbonate in which the silver content may be relatively high, is limited by it to the uppermost part of a de posit and passes downward to a mixed sulphide ore composed chiefly of galena, zinc blende, and pyrite, the mining of which involves the removal of water. This water may, of course, under some circumstances, be used for irrigation.

The most serious obstacle is the lack of rail transportation. Ore must be hauled by wagon about 40 miles to the Los Angeles \& Salt Lake Railroad.

Even under these adverse conditions, the assay results from several prospects would be promising if they represent average samples and not picked specimens, as many of them do. Present conditions seem to warrant mining with small forces of men and without expensive equipment, so that the abrupt pinching out of a body shall cause the least possible loss of capital; they also warrant systematic prospecting in connection with present work. Success in such prospecting will depend largely on a knowledge of the positions of replaceable chloritic quartzite and limestone beds and of the direction and distribution of mineralized fissures.

A great many small ore bodies doubtless exist, and the problem is to find them with as little dead work as possible. The limestone beds around Indian Springs might be expected to contain the largest bed replacements, but no promising evidence of mineralization has been found in any except those in the O. K. and Silver Reef workings.

\section{FUMAROLE BUTTE AND LAVA PLATEAU.}

By G. F. Loughuin.

Fumarole Butte, locally known as "The Crater," and the surrounding lava plateau lie just within the southern boundary of Juab County, about 12 miles north of Abraham and 19 miles west of Lynn Junction on the Los Angeles \& Salt Lake Railroad. The Lava Plateau is bounded on the east by the old river bed. (See fig. 48, p. 446.) The butte and plateau form a denuded volcano composed of basaltic lava, which was erupted in Tertiary time after the upheaval of the surrounding Basin Ranges and was subjected to considerable erosion before the Lake Bonneville epoch of Quaternary time. ${ }^{1}$ The butte, which is about 160 feet high, is a denuded volcanic neck of dense basalt, and is surrounded by a depression attributed to the relatively rapid erosion of the cinder cone. Moist air at a temperature of $62^{\circ}-73^{\circ} \mathrm{F}$. issues from thirty or forty erevices in it. The plateau is made up of successive flows of vesicular basalt and is about 5 miles in diameter. It is bounded by low cliffs, attributed to the collapse of the hard basalt when undermined by the erosion of underlying cinder or tuff beds. The edges of the plateau are cut by several short valleys; also by one principal valley which heads at the volcanic neck and extends northeastward for some distance along a possible fault, and then turns sharply along an undoubted fault to the old river bed. The por-

1 Gilbert, G. K., Lake Bonneville: U. S. Geol. Survey Mon. 1, pp. 332335,1890 . 
tion of the plateau north of the valley is marked by two minor wave-cut terraces which converge northward, one sloping $3^{\circ} \mathrm{N}$. and the other $1 \frac{1}{2}^{\circ} \mathrm{S}$., which indicate that faulting, with northward tilting of the northern block, continued during the existence of Lake Bonneville. The valley contains deposits laid down during both the older and later stages of the lake. The age of the fault and of the erosion along it can thus be fixed within reasonably close limits-distinctly later than the upheaval of the Basin Ranges and earlier than the existence of Lake Bonneville; with some faulting continuous during the earlier stages of the lake. The faults, though part of the great system of Great Basin faults, are distinctly younger than the mineralized faults and fissures in the neighboring mountain ranges, as evidence shows that mineralization in them took place before the upheaval of the ranges.

A marshy area on the flat between the southeast edge of the plateau and the old river bed contains a number of low mounds from which hot springs issue, probably from a buried fault extending along the southeast or east side of the plateau.

Temperatures of the springs ranging from $110^{\circ}$ to $178^{\circ} \mathrm{F}$. were recorded by Gilbert. It is said that up to 1901 or 1902 one of the springs used to spout in geyser fashion and that the water rose 10 feet in the air. Red, yellow, green, and white slimy algous deposits containing carbonates of calcium, iron, and a little magnesia, and a little silica and gypsum are accumulating in streams that flow from the springs. A partial analysis of a considerable deposit of hardened red material that forms a low mound around an extinct spring vent shows that it consists chiefly of calcium carbonate, with 4.47 per cent total iron as $\mathrm{Fe}_{2} \mathrm{O}_{3}$, a very little silica, and traces of alumina and magnesia. The thickness of this mass or of the marshy growth around the springs is not known, but it is doubtless very slight, the material resting upon the old lake beds. The water from the springs is strongly saline; a field test made by O. E. Meinzer, of the United States Geological Survey, showed it to contain about 1,600 parts per million of chlorine. ${ }^{1}$

In the eighties a small smelter was erected at the Hot Springs with the intention of treat-

${ }_{1}^{1}$ Meinzer, O. E., U. S. Geol. Survey Water-Supply Paper 277, p. 103, 1911. ing ores from surrounding districts, and an attempt made to use the "iron ore" around the extinctspring vent for a flux. Only a very small amount of the spring deposit was mined, and the venture was not successful. The exact causes of the failure are not known, but the low percentage of iron quoted above may be one cause.

\section{DUGWAY-GRANITE RANGE.}

By B. S. Butler.

\section{GEOGRAPHY.}

The Dugway-Granite Range is somewhat irregular and has been given different names in different portions of its length. ${ }^{2}$ Its north part is known as the Granite Range; that farther south, beyond a low pass, as the Dugway Range; that south of the Dugway road as the Thomas Range; that still farther south, in the latitude of the Detroit mining district, as the Drum Mountains; and that at the extreme south as the Little Drum Mountains. Mining operations have been carried on in the Detroit district, in the Dugway district, and in the Granite Range.

The Dugway Range is more irregular than the House and Fish Springs ranges to the west, being composed of several rather indefinite ridges trending slightly west of north, although the range as a whole trendsnearly north. In butfew places does it attain an elevation of 7,000 feet, and it contains numerous broad open valleys.

Water is scarce and usually is not of the best quality. Only a very little irrigation is possible, and all farm produce must be brought from other districts. In the Detroit district at Joy a tunnel in the volcanic rocks furnishes a small flow of water, and a well supplies water to ore freighters. Wildhorse Spring in the Thomas Range furnishes a small supply of water. The Dugway district contains no permanent water supply, but several cisterns have been constructed in which small supplies can be stored. The Granite Range, on the other hand, contains several springs, and supplies could doubtless be developed in many of its canyons.

Wood is scarce, and there is none suitable for mine timber or for building purposes.

The nearest railroad point for the Granite and Dugway districts previous to 1917 was St. Johns, about 50 miles distant. In 1917 a

2 U. S. Geol, Survey topographic map of Fish Springs quadrangle, 
railroad was completed from Wendover to Gold Hill, 30 to 40 miles from the different sections in the northern part of the range. The Detroit district is about 30 miles from Oasis. Transportation costs are therefore high for all the districts of the range.

\section{PHYSIOGRAPHY.}

The general physiography of the GraniteDugway Range, though apparently somewhat more complex, does not differ materially from that of the other Basin ranges. The structure is a monocline with westerly dip, the outline of the range being due to faulting with relative uplift on the east. The faulting was apparently later than the outflow of the lavas which form the western foothills. In the Thomas Range ridges of the sedimentary rocks were apparently brought up in the lava areas by faulting parallel to that forming the main range. Gilbert ${ }^{1}$ gives the following description of its general structure:

The Thomas [Granite-Dugway] Range, like the Onaqui, is a simple uplift, presenting throughout its extent a bold escarpment to the east, while at the west its slope is that of its strata, which dip beneath the desert. At Dugway Pass, where we crossed it, its rocks are calcareous but were not found to contain fossils. There is reason, however, to surmise, from stratigraphical data, that they belong to the Silurian series. A short distance north of the pass is an outflow of gray trachyte, and south of it the range is entirely buried beneath a similar lava. Between this and the House Range, but nearer the former, are two low ridges parallel to the first, of like condition and dip, and similarly accompanied by volcanic eruptions.

The old beach lines of Lake Bonneville are especially well marked around the north end of the Dugway Range. Two terraces are conspicuous, the lower and stronger of which has a width varying from a few score to several hundred feet in places especially favorable to wave cutting. Erosion since the recession of the waters of the lake has been so slight that this terrace has not been dissected except along its front, and for long distances it shows only minor irregularities.

\section{GEOLOGY .}

The range is composed of sedimentary rocks from Cambrian to Carboniferous in age and of igneous rocks. Granite Mountain is the only large body of intrusive rock. The main area

1 U. S. Geog. and Geol. Surveys W. 100th Mer. Rept., vol. 3, p. 27, 1875 . of extrusive rocks is on the western side of the mountain and extends from the Dugway road as far south as Joy.

\section{SEDIMENTARY ROCKS.}

The sedimentary beds were examined by the writer in only two districts, the Detroit and the Dugway.

The lowest stratum exposed in the Detroit district is 2,000 feet of rather uniformly medium-grained quartzite with some beds containing pebbles. On unweathered surfaces the rock is gray but it weathers to reddish brown. Overlying the quartzite is 200 to 300 feet of shale with interstratified sandy beds, which have been considerably metamorphosed and have developed a schistose structure with rather abundant muscovite. Indistinct fossil remains are present. Overlying this is a series of blue limestone and shale at the base that grades up into heavy-bedded blue and gray limestone. Its total exposed thickness is probably fully 4,000 feet.

Fossils were collected (localities 220 and 221) from the shaly limestone series overlying the schistose shales and from several higher horizons, locality 235 boing at the highest. These collections were reported on by L. D. Burling as follows:

Locality 220. The collection contains Agraulos, Ptychoparia, and Obolus sp., an association of species usually found several hundred feet below the horizon of 221 .

Locality 221. Ptychoparia cf. P. cordillerae Rominger, Protospongia (spicules), Agnostus of. A. interstrictus were obtained from a stratum that is definitely to be correlated with the horizon of the Middle Cambrian Wheeler formation in the House Range, Utah.

Locality 223. The collection appears to contain fossils from two horizons, part of it coming from a shaly limestone which contains Agnostus and Protospongia (spicules) and is very much the same as locality 221 , and part from an oolitic limestone that contains $P$ tychoparia like $P$. subcoronata, Zacanthoides, and Olenoides sp., and that is definitely to be correlated with the Ute limestone of the Blacksmith Fork section, which is also Middle Cambrian in age.

Locality 227. Acrotreta ophirensis was collected from a stratum that is to be correlated with the Middle Cambrian Marjum limestone of the House Range, Utah.

Locality 233. Ptychoparia was collected from a horizon that is very close to that of localities 220 and 221.

Locality 235. The collection contains Crepicephalus texanus Shumard, Lingulella desiderata Walcott, and Acrotreta idahoensis? and is from a stratum that is to be correlated with the Upper Cambrian Orr formation of the House Range, Utah. 
It is apparent from the stratigraphic and fossil evidence that the rocks in this district range from Lower to Upper Cambrian.

In the Dugway district the rocks, in part at least, lie considerably higher stratigraphically. The general succession in this part of the range is as follows: At the base 4,000 to 5,000 feet of limestone, with interstratified shaly and sandy beds; in places distinctly shaly. This is overlain by at least 2,000 feet of quartzite, with interstratified beds of limestone, which at one place comprise probably more than 200 feet of limestone and shaly beds. Fossils were collected from loose pieces believed to have been derived from the limestone interbedded with the quartzite series at the north end of the range. The fossiliferous fragments were found below the level of the old bench, and it is possible that they may have been transported farther than is apparent.

On these collections Mr. Girty made the following report:

No. 563:

Fenestella sp.

Ambocoelia parva?

Bellerophon sp.

Proetus sp.

No. 574:

Campophyllum nevadense?

Zaphrentis multilamella?

Productus gallatinensis?

Productus pileiformis?

Girtyella? sp.

Spirifer keokuk var.

Composita sp.

Cliothyridina hirsuta?

Eumetria marcyi.

Lot 574 I may assign to the upper Mississippian, but 563 can not be certainly placed. It is very improbable that it is Pennsylvanian, and its more likely reference is to the upper Mississippian.

Though fossils were not collected from them, it seems probable that the sedimentary rocks exposed in the northern portion of the range are not younger than lower Mississippian and are possibly older than Carboniferous. The rocks between the Dugway and Detroit districts have not been examined by the writer, but it seems probable that most of them are older than Carboniferous.

Sedimentary rocks at the southern end of the Granite Range consist of quartzites and mica schists that have apparently resulted from the alteration of a shale-sandstone series. Though no fossils were found in the sediments, their general character indicates that they are probably not younger than Cambrian.

\section{IGNEOUS ROCKS.}

INTRUSIVE ROCKS.

The Granite Range is made up almost entirely of intrusive rock, sedimentary rocks being observed only at its southern end. The intrusive body is complex, being composed of granitic rocks that differ considerably in physical and chemical character, and is most interesting petrologically. The main body of intrusive rock has been cut by many pegmatitic dikes striking with the general trend of the range, which gives it, when viewed from a distance, the aspect of a sedimentary formation.

The northern part of the Granite Range, where examined, is composed of a mediumgrained light-colored granite composed essentially of quartz, orthoclase, plagioclase near albite in composition, muscovite, and biotite. The mica is variable in amount, in places being rather abundant and in other places nearly absent. Locally there are segregations of mica, lenses of rock being made up in large part of muscovite. Débris in the valleys extending into the range in the northern part contains abundant boulders of a coarse porphyritic granite carrying orthoclase crystals an inch or less in greatest dimension and a considerable proportion of plagioclase. This granite was not seen in place but must be present in large bodies in the northern part of the range. In the southern part of the range the main body of the rock, so far as observed, is coarsely porphyritic with feldspar crystals an inch or less in length. It contains more biotite and apparently a higher percentage of plagioclase than the granite of the northern part of the range. Although here called granite this rock on more thorough examination may prove to be quartz monzonite.

The entire range is cut by numberless pegmatitic dikes that range in thickness from an inch or less to several feet and in lateral extent from lenses that outcrop for a few feet to those that can be traced for hundreds of feet. Normally they are composed of quartz, orthoclase, some plagioclase, and abundant muscovite, but the proportion of these constituents differs in different dikes and in different parts of the same dikes. Feldspar and muscovite are 
abundant in some and of slight importance in others. Numerous veins or "dikes" of coarse white quartz also range in size from mere veinlets to large bodies that can be traced for hundreds of feet. The siliceous dikes make up fully 20 per cent of the rock over large areas. Still other dikes are more basic than the main body of the range. A conspicuous dike of this character in the northern part of the range can be traced for at least several hundred yards and perhaps for 2 to 3 miles. It is a mediumgrained green dioritic rock, probably a quartz diorite, though under the microscope the specimens collected proved to be too highly altered to permit determination of the original mineral constituents. Theabundantdark silicates have altered to serpentine and chlorite; the feldspars contain much sericitic muscovite; considerable pyrite is present; and quartz forms several per cent of the rock.

The coarse porphyritic granite was probably the earliest rock, though conclusive evidence as to the relative age of this and thefiner-grained muscovite granite in the northern part of the district was not obtained. The pegmatitic dikes are later than either, and the veins of coarse white quartz are later than the pegmatites, wherever their relative age was determined. The basic dikes are later than the pegmatite dikes and earlier than the metal-bearing veins of the area. The relation of the basic dikes to the quartz "dikes" was not seen.

In the Dugway district no large bodies of intrusive rock were seen, though there are numerous dikes, several being noted cutting the quartzite in the northwest part of the district. All are highly altered, probably from quartz diorite or quartz monzonite. Farther south at the Buckhorn mine the limestone is cut by a dike probably of similar composition though more highly altered than those to the north.

In the Detroit district the sedimentary rocks are cut by numerous dikes and irregular bodies of intrusive rock, ranging from moderately coarse grained to fine-grained porphyries. All the specimens examined microscopically are of monzonitic composition, being composed of plagioclase and orthoclase with different proportions of the dark minerals, biotite hornblende, augite, and hypersthene, in different dikes. In most specimens examined the biotite is partly and in some specimens very largely altered to augite and iron ore. Accessory minerals are magnetite and apatite, the former being rather abundant. In the finegrained rock it is difficult to estimate the relative abundance of orthoclase and plagioclase, and a chemical examination might show that some of the dikes would be more accurately classed as diorites.

\section{EXTRUSIVE ROCKS.}

Extrusive rocks cover a large area on the western side of the range, between Joy and the Dugway district, but the main body was not examined by the writer. Gilbert has classed them as trachyte, though doubtless a detailed study would show numerous flows of differing compositions.

The extrusive rocks at the north end of the range consist of rhyolitic and latitic flows and tuffs. In the Detroit district they are of essentially the composition of latite, though there are flows of andesite and others that have rather abundant quartz and may prove to be rhyolites, though typical rhyolite was not observed.

In general the flows in this range are similar to those that farther east show a marked similarity over large areas.

\section{AGE AND RELATIONS OF THE IGNEOUS ROCKS.}

The age of the igneous rocks can not be closely fixed from local evidence. They are younger than the Carboniferous beds and older than the unconsolidated Quaternary sediments. The relative ages of the intrusive and extrusive rocks have not been ascertained. It is possible that some of the dikes represent the channels through which the extrusive rocks reached the surface. Both in the Detroit district and in the Dugway district the lavas have apparently filled mature valleys, and unless the northern part of the range has had a very different physiographic development from the southern it would seem that the granite body forming the Granite Range must have been uncovered and deeply eroded before the eruption of the lavas.

The similarity of the lavas to those farther east suggests that they are of the same general age, namely Tertiary. The granite is similar to that of the Ibapah stock in the Deep Creek Range and to the granite of the Raft River Range, but whether these are to be correlated with the intrusive Jurassic rocks to the 
west or with the intrusive Tertiary rocks to the east is undetermined.

\section{GRANITE RANGE.}

There has been very little metal production from the Granite Range. According to unpublished notes by Ellsworth Daggett, who visited the district in 1898 , three claims had yielded up to that time about 22 tons of ore, consisting principally of galena containing gold and silver. No other production had been recorded up to 1913. At the time of the writer's visit there was no mining activity in the district, and thorough study of the mines was impossible. There has, however, been some prospecting. The most extensive development has been near the northern end of the range on the property of the Desert Mining Co., on a vein in general paralleling the basic dike already mentioned. (See p. 461.)

The dike, which outcrops prominently, strikes nearly north and dips steeply east. The vein so far as developed is closely associated with the dike. At some points it shows its best development on the footwall, but at other points it is strongest on the hanging wall or even within the dike. The close association of the dike and vein does not seem to indicate a close genetic relation, but rather that the fissure was a line of weakness along which the dike was intruded and later the vein-forming solutions passed.

The vein ranges from a mere stringer to several feet in width, though it is by no means universally present along the dike. It is commonly rather prominently banded. The principal mineral constituents are quartz, fluorite, and hematite and locally a little galena and chalcopyrite. The vein is reported to contain gold and silver. The dike rock within and adjacent to the vein has been altered to a chloritic material, but the granite shows but slight change even at the contact with the vein.

The vein has been prospected at different levels by several hundred feet of drifting, but at the time of visit no large bodies of ore had been found.

Near the contact of the granite and schist at the southern end of the range there are many bodies of coarse white quartz and numerous banded veins composed of quartz and fluorite with some hematite and a little copper carbonate. Veins of this character have been prospected to a slight extent, but no ore bodies have been found. The veins occur both in the granite and in the schist and the vein minerals are similar to those in the northern part of the range.

The granite at the southern end of the range is broken by many joints, most of which contain a film of limonite that indicates that they have been mineralized. There has been no prospecting of this character of material and so far as observed no metals are present other than the iron of the limonite.

\section{DUGWAY DISTRICT.}

HISTORY AND PRODUCTION.

$$
\text { By V. C. Heikes. }
$$

Dugway district was discovered in 1869 and organized in 1872. It is situated in Tooele County and is reached by wagon road from St. John, the shipping station on the Los Angeles \& Salt Lake Railroad, 55 miles to the southwest. A stack furnace ${ }^{1}$ was completed in the later part of 1876. The largest production was made from the Buckhorn claim, about a mile from Gilson's old town of Buckhorn and about 650 feet above it. Ellsworth Daggett ${ }^{2}$ visited the property in 1898 . He reports that a pocket or series of pockets of high-grade ore was found in 1891 in this property and that about 60 tons were shipped, bringing about $\$ 68,000$ at the smelter. Some of the shipments are said to have contained as high as 1,800 ounces of silver per ton. From another source ${ }^{3}$ it is reported that a carload of ore shipped assayed 9.5 per cent lead and 604 ounces of silver and 3.8 ounces of gold per ton, and that in less than four months to the end of June, 1891, the Buckhorn had yielded $\$ 22,000$. According to Hanauer, ${ }^{4}$ there was shipped in 1891 and 1892 from the Buckhorn and other claims in Dugway district 196 tons of ore, containing 232 ounces of gold and 23,800 ounces of silver. Daggett more conservatively estimates the ore shipped at 162 tons and reports that the works visible in 1898 consisted of an open cut about 40 feet square and of several short tunnels and holes running off from it, including a shaft reported

1 Salt Lake Tribune, Jan. 1, 1877, and Jan. 6, 1878.

2 Mining notes unpublished.

${ }^{3}$ Mine notes: Eng. and Min. Joúr., vol. 51, Apr. 25, 1891, and vol. 52, July 18, 1891.

- Hanauer, A., Director of Mint Rept. upon production of precious metals, 1891, p. 224; idem, 1892, p. 172. 
to be about 100 feet deep but inaccessible. Most of the ore shipped from the Buckhorn property was reported to Daggett as having come from this open cut and connecting works. About 1,000 tons of ore, mostly lead ore, is estimated to have been shipped from the district previous to 1903, but none is recorded since that time.

In recent years development has been confined largely to that necessary to hold the more promising land in the hope that the building of a railroad through the section will permit profitable sale or exploitation.

\section{ORE DEPOSITS.}

The ore deposits are in the quartzite and limestones.

In the northern part of the area the sedimentary rocks have been considerably fissured, and the limestones in these fissured areas have in places been highly silicified, as in the vicinity of the Four Metals mine. At other points the limestone has been bleached and softened, and the rock in many places has been reddened from the oxidation of iron minerals.

The deposits may be roughly classified as replacement fissure veins in the limestone and as fissure veins in the quartzite.

Some prospecting in persistent fissures in the quartzite in the northwestern part of the district has revealed small shoots of galena ore which have a high lead content but are said to contain relatively little silver.

The replacement veins in limestone are also numerous but have been little prospected. The Four Metals mine, the most extensively developed, was idle at the time of visit but is reported to have a depth of nearly 400 feet on the dip. It is said that considerable lead carbonate ore was extracted from the upper levels and shipped. At the time of visit the ore on the dump was mainly mixed lead and zinc sulphides.

Some of the replacement veins in limestone carry copper, but no large deposits of copper ore have been developed. At several places in the district deposits of lead ore have been found at or near the contact of the quartzite and limestone. Their restricted distribution is apparently due to the relative ease with which solutions could circulate along the contact.
The Buckhorn mine is in the southern part of the mineralized area. The deposit is said to have been a small irregular body of very rich ore occurring at the surface, but it was so completely worked out that the writer was unable to get specimens for mineralogic examination. The limestone is cut by a "porphyry" dike too highly altered for its original composition to be determined. The ore deposit, so far as its position could be judged from the workings, was in the limestone adjacent to the porphyry dike. Considerable prospecting has been done both laterally and vertically, but it is reported that no extension of the main ore body or additional ore bodies were discovered.

The opportunities for examining the different deposits were so slight that the writer does not feel justified in expressing a definite opinion on the future of the district. Past experience, however, would seem to indicate that much of the mineralized material is not of sufficiently high grade to make its extraction and shipment profitable under present transportation conditions. There has been mineralization over a large area, and with cheaper transportation facilities some of the deposits could doubtless be worked at a profit. The developments, so far as the writer was able to see them, however, seem to give no strong promise of very large or very rich deposits.

\section{DETROIT DISTRICT.}

\section{HISTORY AND PRODUCTION.}

By V. C. Heikes.

The Detroit mining district was organized in the fall of 1872 as the Drum district but was abandoned until reorganized under the name of Detroit in 1879. It lies 30 to 35 miles north-northwest of Oasis, in Millard County, extends into Juab County, and includes the camp of Joy. In 1882 the Desert Mining Co. did some mining on the E. P. H. claim, which, at a depth of 100 feet, is said to have produced from an 18-inch vein ore assaying $\$ 36$ to $\$ 43$ in gold and silver and 14 per cent of bismuth. Ore containing 26.4 per cent of copper was shipped to a plant near Chicago in 1883, and as an experiment some copper ore was shipped to Swansea, Wales, in 1884. During the spring of 1888 a small hot-air blast furnace was erected at the Hot Springs, 11 miles north of 
Abraham. After many difficulties it was put of gold. The Detroit district produced from in operation by the Alto Mining \& Smelting 1904 to 1917, inclusive, 1,511 tons of ore, conCo., whose headquarters were at the Hot taining $\$ 11,142$ in gold, 5,127 ounces of silver, Springs, known then as Wyano post office. All the fluxing ores were supplied from properties in the district within 10 miles of the smelter. Shipments to eastern points aggregated 130,000 pounds of copper bullion, said to have been the largest quantity of copper bars at that time produced in Utah. Subsequently the smelter was destroyed by fire. In 1894 the Ibex property, whose deepest workings were then down to 200 feet, was put in operation by the Utah Gold Mining \& Smelting Co., all the properties of the district were idle, and

Metals produced in the Detroit district, 1904-191\%.

\begin{tabular}{|c|c|c|c|c|c|c|c|c|}
\hline \multirow{2}{*}{ Year. } & \multirow{2}{*}{$\begin{array}{l}\text { Ore } \\
\text { (short } \\
\text { tons). }\end{array}$} & \multicolumn{2}{|c|}{ Gold. } & \multicolumn{2}{|c|}{ Silver. } & \multicolumn{2}{|c|}{ Copper. } & \multirow{2}{*}{$\begin{array}{c}\text { Total } \\
\text { value. }\end{array}$} \\
\hline & & $\begin{array}{c}\text { Fine } \\
\text { ounces. }\end{array}$ & Value. & $\begin{array}{c}\text { Fine } \\
\text { ounces. }\end{array}$ & Value. & Pounds. & Value. & \\
\hline 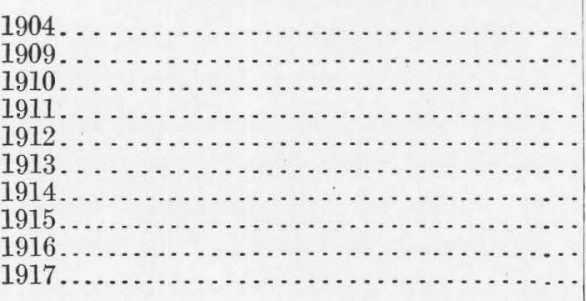 & $\begin{array}{r}180 \\
181 \\
89 \\
66 \\
21 \\
337 \\
39 \\
184 \\
191 \\
223\end{array}$ & $\begin{array}{r}155.00 \\
33.87 \\
6.16 \\
53.19 \\
8.99 \\
101.38 \\
7.95 \\
76.19 \\
52.24 \\
44.01\end{array}$ & $\begin{array}{r}\$ 3,204 \\
700 \\
127 \\
1,100 \\
186 \\
2,096 \\
164 \\
1,575 \\
1,080 \\
910\end{array}$ & $\begin{array}{l}768 \\
757 \\
288 \\
619 \\
283 \\
866 \\
162 \\
624 \\
343 \\
417\end{array}$ & $\begin{array}{r}\$ 440 \\
394 \\
156 \\
328 \\
174 \\
523 \\
89 \\
317 \\
226 \\
344\end{array}$ & $\begin{array}{r}8,000 \\
\ldots \ldots \ldots \\
26,062 \\
9,797 \\
2,966 \\
29,853 \\
7,518 \\
23,363 \\
33,543 \\
28,148\end{array}$ & $\begin{array}{r}\$ 1,000 \\
\cdots \ldots .310 \\
3,225 \\
489 \\
4,627 \\
1,000 \\
4,088 \\
8,252 \\
7,685\end{array}$ & $\begin{array}{r}\$ 4,644 \\
1,094 \\
3,593 \\
2,653 \\
849 \\
7,246 \\
1,253 \\
5,980 \\
9,558 \\
8,939\end{array}$ \\
\hline & 1,511 & 538.98 & 11,142 & 5,127 & 2,991 & 169,250 & 31,676 & 45,809 \\
\hline
\end{tabular}

and some ore was shipped to the Hanauer smelter, near Salt Lake.

On January 11, 1895, a smelter for the treatment of ores from the Ibex and Charmed claims was blown in near Leamington. The siliceous character of the ores made the addition of lead ore necessary, and lead concentrates were bought from the Horn Silver mine at premium prices. Some low-grade lead ore was also hauled by wagon from the Utah mine at Fish Springs. During April and May it produced about $\$ 35,000$ from Ibex ores. The smelter, however, did not prove profitable and went into the hands of a receiver, by whom it was operated until August, 1895, when the Ibex property reverted to the original owners. The total output ${ }^{1}$ of the Ibex smelter in 1895, including ores purchased, was' $1,531,910$ pounds of unrefined lead (including copper) containing 66,577 ounces of silver and 1,328 ounces

\footnotetext{
1 Director of Mint Rept. upon production of precious metals, 1895, p.178,
1896 .
}

and 169,250 pounds of copper, valued in all at $\$ 45,809$. The ore came from the E. P. H., Charm, Ibex, and Copperhead claims. The Ibex group was the largest producer.

\section{ORE DEPOSITS.}

All the ore deposits occur in the sedimentary rocks. There has been alteration along fissures in the lava flows, but these are reported to be barren of valuable metals. In June, 1912, 
contain much pyrite, or limonite that has resulted from the oxidation of pyrite, together with chalcopyrite and its oxidation products and small amounts of other sulphides. The sulphides are said to contain considerable gold and silver, several mines averaging from $\$ 10$ to $\$ 15$ in precious metals. Much of the material, however, is not of sufficiently high grade for profitable shipment under ordinary conditions, and attempts at treatment in the district have thus far not been very successful.

In addition to the metalliferous deposits of the range there is an occurrence of topaz near Topaz Mountain. The writer did not visit this locality but according to descriptions the topaz occurs as disseminated crystals in altered volcanic rocks over a considerable area. It is not suitable for cutting.

Bixbyite, an oxide of iron and manganese (essentially $\mathrm{FeO} \cdot \mathrm{MnO}_{2}$ ), has been described by Penfield and Foote ${ }^{1}$ from the west side of the range south of the Dugway road, where it is said to be associated with topaz and decomposed garnet in an altered rhyolite.

Some mineralizing action in the volcanic rocks is evident, but so far as the writer is aware no ore deposits have been discovered.

\section{FISH SPRINGS DISTRICT.}

By B. S. Butler.

\section{GENERAL FEATURES.}

The Fish Springs district is in Juab County, at the north end of the Fish Springs Range, which is the northern extension of the House Range, from which it is separated by a low pass. The nearest railroad point prior to 1917 was Oasis, on the Los Angeles \& Salt Lake Railroad, about 60 miles in a direct line from Fish Springs and about 70 miles by the freighters' road. Gold Hill is now the nearest railroad point.

The range contains little timber suitable for either fuel or building. Lumber for buildings and the little required for the mines must be hauled from the railroad or from adjacent ranges, and the cost is high. Gasoline is generally used for power.

The water supply of the camp is obtained from the lowest level of the Utah mine, at a depth slightly below 800 feet.

1 Penfield, S. L., and Foote, H. W., Am. Jour. Sci., 4th ser., vol. 4, p. $105,1897$.
Analysis of water from Utah mine. ${ }^{2}$

[Recalculated from hypothetical combinations in grains per gallon. Analyst, C. C. Crismon; date, September, 1901.]

Parts per million.

Total solids........................... 2,255

Volatile and organic matter................ 239

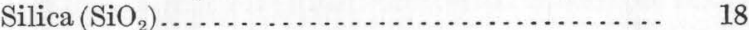

Oxides of iron and aluminum $\left(\mathrm{Fe}_{2} \mathrm{O}_{3}+\mathrm{Al}_{2} \mathrm{O}_{3}\right) \ldots \ldots .13$

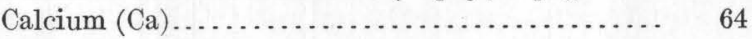

Magnesium (Mg)....................... 67

Sodium and potassium $(\mathrm{Na}+\mathrm{K}) \ldots \ldots \ldots \ldots \ldots \ldots . . \ldots 1$

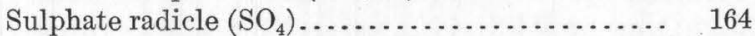

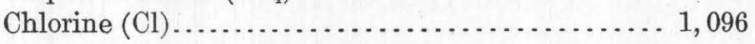

On the flat at the north end of the range several hot springs, some of which have a temperature above $100^{\circ} \mathrm{F} .,^{3}$ furnish a considerable flow of rather highly mineralized water. Fish Springs, near the Thomas ranch, at the eastern base of the range, has a considerable flow of water of fair quality. Good drinking water is obtainable from the artesian wells at Callao.

Farm supplies are obtained from the ranches in Snake and Fish Springs valleys and from Deseret.

The cost of freighting ore from the camp to Oasis is about $\$ 12$ per ton. Eight-horse teams are able to haul about 15,000 pounds when the roads are in good condition. Twelve to fourteen days are commonly required for the round trip. The total cost of freight from the mines to the smelters is about $\$ 15$ per ton for ore valued at less than $\$ 100$ per ton.

\section{HISTORY AND PRODUCTION.}

By V. C. Heikes.

The Fish Springs district was organized March 20, 1891. C. C. Van Alstine is reported to have discovered the first.mineralized float, which led to the discovery of the Utah and Galena mines in 1890, which later became the principal producers of the district. From its discovery to 1914 the Utah mine has made regular shipments, which, for the full productive period, have averaged 48 cents per ton in gold, 128.35 ounces per ton of silver, and 44.04 per cent lead, a gross average value of $\$ 121.58$ per ton. The mine has produced 12,997 dry tons of ore containing $\$ 6,227$ in gold, 1,668,205 ounces of silver, 11,447,930 pounds of lead, valued, at each year's commer-

2 Meinzer, O. E., Ground water in Juab, Millard, and Iron counties, Utah: U. S. Geol. Survey Water-Supply Paper 277, p. 126, 1911.

${ }^{3}$ Idem, p.125. 
cial prices, at $\$ 1,580,186$. The dividends paid | common with other ranges of the region are are reported to total $\$ 283,726$. From 1891 to December, 1897, the dividends of the company amounted to $\$ 152,000$, indicating a profit on the ore shipped of $\$ 45$ per ton and a total cost per ton, including freight and sampling charges, of $\$ 76$ per ton.

The Galena property adjoins the Utah on the west and is second in importance of production. It is reported to have yielded about 3,000 tons of ore, beginning in 1891, and shipping irregularly for the past ten years. The gross value of the ore produced was about $\$ 330,000$, the wave-cut terraces about its northern end that mark the higher stages of the predecessor of the Great Salt Lake. A road for light traffic crosses the range in the latitude of Fish Spring. Physiographically, the range is similar to other Basin Ranges. Its block-fault character was recognized by Gilbert, ${ }^{1}$ who says:

The House Range was long ago recognized as a faulted monocline in which the direction of displacement is reversed midway. The northern third of the range [the Fish Springs Range] exhibits a westerly dip, and is Metals produced in Fish Springs district, 1891-191\%.

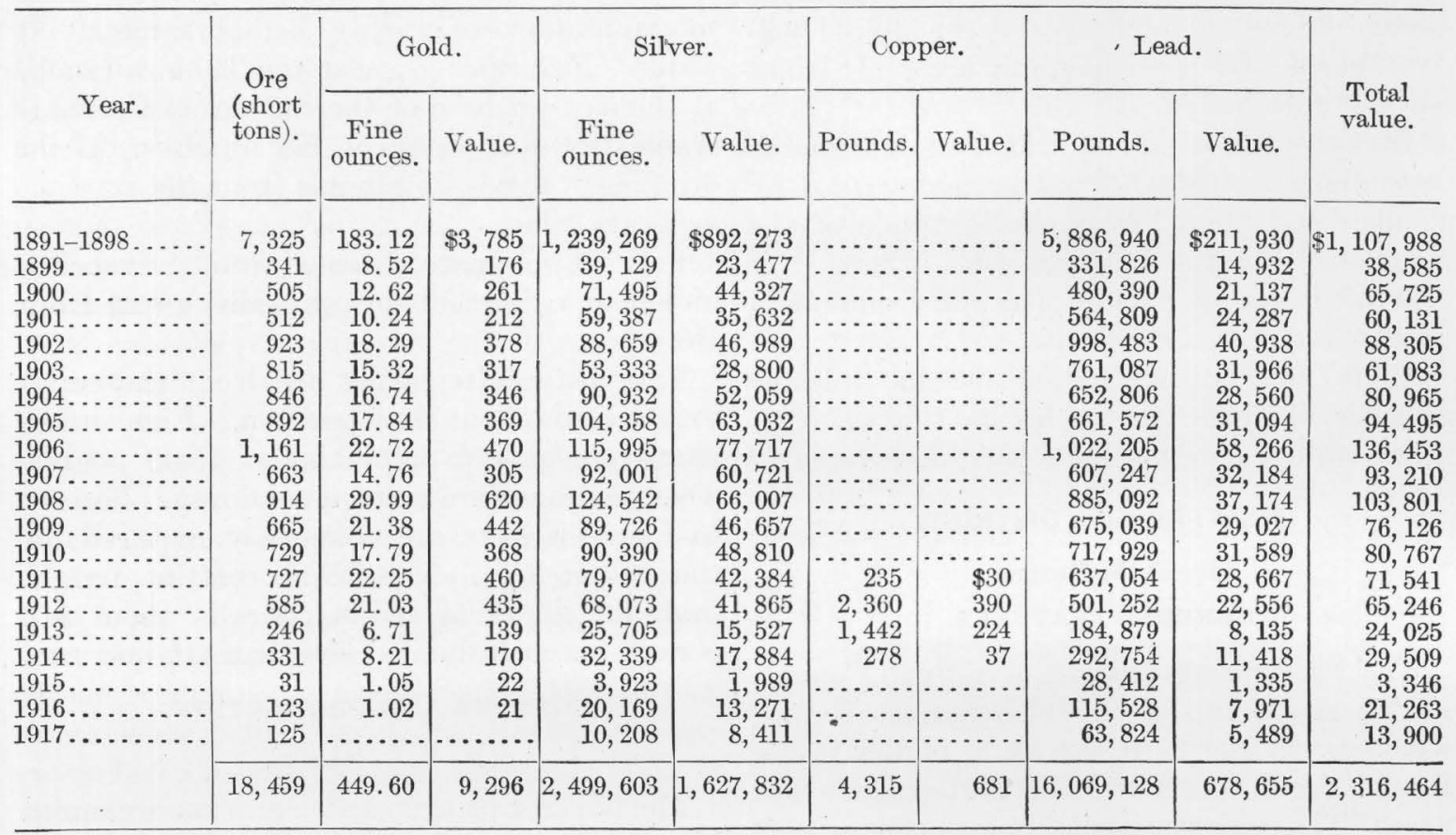

out of which $\$ 80,000$ is said to have been returned in dividends.

The Emma claim was the next largest producer, Other producers are the Vulcan, Utah No. 2, Cactus, Spanish, Ada, Wild Cat, Early Harvest, and Last Chance claims.

\section{PHYSIOGRAPHY,}

The elevation of the range in the north is about 7,000 feet and farther south is about 8,500 . The elevation of the lower parts of the desert valleys is about 4,350 feet, giving a relief of over 4,000 feet. The range, especially on the east, rises abruptly from the desert plain in slopes that are mostly rugged and cut by narrow canyons. Striking features of this in easterly dip and is faulted on the western base. ${ }^{2}$ This determination was subsequently confirmed by the discovery of a well-defined fault scarp in the vicinity of Fish Spring, and an obscure and probably very ancient scarp at the western base of the southern division.

That the range is in an immature stage of physiographic development is shown by its rugged character and its narrow canyons.

If the line of thermal springs represents the position of a strong fault along the front of the range $^{3}$ the retreat of the front of the range since it was uplifted has not been great.

1 Gilbert, G. K., Lake Bonneville: U. S. Geol. Survey Mon. 1, p. 353, 1890 .

2 Gilbert, G. K, Report on the geology of portions of Nevada, Utah, California, and Arizona: U. S. Geog. and Geol. Surveys W. 100th Mer. Rept., vol. 3, pp. 27-28, 1875

3 Meinzer, O. E., op. cit., p. 126. 
The position of Fish Springs Pass has apparently been determined by an east-west fault zone. At the north end of the range the old wave-cut terraces may be followed for long distances. They mark the water level at different stages of Lake Bonneville, the predecessor of the present Great Salt Lake.

\section{GEOLOGY.}

SEDIMENTARY ROCKS.

Sedimentary rocks make up a large part of the House Range. Those in the northern part (the only part examined by the writer) are predominantly limestone, interspersed with shaly and siliceous beds and at one horizon by several hundred feet of rather massive quartzite. South of Fish Springs Pass the quartzite outcrops near the divide, and north of the pass near the eastern base of the range.

Fossils were collected from the following localities: 141, float on the east side of Fish Springs Range, the material apparently coming from a horizon considerably below the quartzite; 142, divide just south of the trail from Fish Springs to the Thomas ranch just beneath the quartzite; 143, limestone overlying quartzite east of the Carnation mine. On these collections Edwin Kirk made the following report:

Locality 141. Fish Springs Range:

Dinorthis fontinalis White.

Dalmanella pogonipensis Hall and Whitfield.

Orthis cf. O. tricenaria Conrad.

Cystid plate genus?

Locality 142. Fish Springs Range:

Orthis near $\mathrm{O}$. hamburgensis Walcott.

Dalmanella cf. D. electra Billings.

Syntrophia calcifera Billings.

Eccyliopterus michleranus? Hall.

Bathyurus sp.

Pliomera sp.

Sponge n. gen. near Climacospongia.

Locality 143:

Dalmanella near D. pogonipensis Hall and Whitfield Raphistoma? sp.

Maclurea annulata? Walcott. Asaphus sp.

These three lots contain fossils identical with those obtained by Mr. Walcott in the upper part of the Pogonip limestone of the Eureka district, Nevada. In correlation with formations in the East these beds might broadly be classed as Beekmantown.

From the fossil evidence it seems probable that all the sedimentary rocks in the northern part of the range are of Ordovician or Silurian age, though it is possible that the lowest beds, from which fossils were not collected, are of Cambrian age. Farther south, in the House Range, a considerable thickness of Cambrian sediments is exposed.

\section{IGNEOUS ROCKS.}

A large area of flow rocks west of the Fish Springs Range, mapped as basalts in early days, were not examined in the course of the present work, but will not improbably eventually be found to be of a type much more siliceous than basalt.

In the vicinity of the mining district the igneous rocks are confined to a few dikes in the sedimentary rocks. The largest of these up to 50 feet in thickness is near the Utah mine. It strikes generally east. This dike outcrops prominently near the western front of the range A smaller dike near the Emma mine on the south is of the same general character.

Much of the surface rock is stained reddish brown from iron. The freshest specimens collected consist of a light-gray groundmass containing rather abundant phenocrysts of quartz, orthoclase, and biotite. Under the microscope the rock is seen to consist essentially of phenocrysts of orthoclase, quartz, and biotite in a groundmass composed largely of quartz and orthoclase. In some specimens the groundmass is very finely crystalline and the minerals can not be positively determined. Apatite is a rather abundant accessory mineral, and most of the specimens contain secondary minerals, notably calcite, which is locally rather abundant. All the specimens examined are of essentially the same composition, and the rock may be classed as a granite porphyry.

\section{STRUCTURE.}

The general structure of the range is relatively simple, but the detailed structure is locally rather complex and will require careful mapping before it can be properly interpreted. The range has been outlined by north-south faults and has been relatively uplifted on the east. The beds have a westerly dip that is locally $35^{\circ}$ but that averages considerably less. Lesser north-south faults range in extent from "slips" whose displacement can scarcely be detected to those whose displacement is measured in scores of feet; there is also eastwest faulting that is especially marked near Fish Springs Pass, north of which the rocks have 
been relatively lowered or thrown to the east several thousand feet. Numerous east-west fissures and faults of small throw have been occupied by dikes or havefurnished the channels for the circulation of ore solutions. So far as observed, the east-west faults are the older and are cut off by the north-south faults, which (at least the "slips" seen in the mines) are apparently later than the granite porphyry dikes and the deposition of the ores.

\section{ORE DEPOSITS.}

All the ore deposits of the district are replacements of limestone, and all thus far developed are associated with the east-west fissuring. All of them are lead-silver ores, in which the silver content is uniformly high and the gold content low.

\section{UTAH-GALENA FISSURE,}

The most productive area thus far developed is associated with the Utah-Galena fissure zone, which trends east, south of and parallel to the largest granite porphyry dike of the district. The fissure dips more steeply than the dike; on the surface the two are about 50 feet apart and on the lowest or 800foot level of the Utah mine they are nearly 100 feet apart. The ore bodies occur very irregularly. Many of them seem to follow the intersection of the fissures with certain of the limestone beds, but irregularity is too great to warrant any general statement. In prospecting it has been the custom to follow the fissures, even though they become very "tight" and show little indication of mineralization and even though they are interrupted by north-south faults or "slips." Many of these faint leads have been followed to valuable deposits.

Practically all the ore thus far extracted has come from a fissured area south of and underlying the granite porphyry dike. Small bodies of ore have been found at the contact, and the limestone in places has been replaced by sericitic muscovite, but more commonly the shoots lie at some distance though usually not more than 100 feet from the contact.

Some prospecting has been done on the north or hanging-wall side of the porphyry dike on the 800 -foot level, and a little ore has been found. In several similar occurrences in the State the larger ore bodies lie on the footwall sides of dikes.

The limestone usually shows little alteration, even within a few feet of an important ore body, and much credit is due to the management of the Utah mine for the skill it has shown in the search for ore.

The primary mineralization in the Utah mine consists of galena and pyrite and a little sphalerite replacing the limestone. Secondary copper minerals in small amount have probably resulted from the alteration of chalcopyrite. Some oxidation of the ore continues to the deepest levels of the mine, and some shoots of ore have been largely altered to secondary minerals, though some bodies of galena ore show only slight alteration. The final products of alteration are commonly cerusite and limonite. Before the oxidation is complete sulphates are locally present in considerable abundance.

The galena alters along the cleavage plane, first to anglesite and then to cerusite. In the shoots where pyrite is present in considerable abundance the basic ferric-lead sulphate plumbojarosite is commonly formed. Shoots of ore in which this mineral is abundant were seen in the mine, and the writer was told that in some places it forms a casing around the high-grade ores. In the more highly oxidized shoots the plumbojarosite has been altered to limonite and cerusite. The writer did not get material in which silver minerals could be definitely determined. Some specimens of galena rich in silver do not contain a recognizable silver mineral. In the oxidized ore horn silver is said to occur.

Migration of the valuable metals appears to have been very slight. The galena was first altered to the sulphate, anglesite, or to plumbojarosite, both of which are relatively insoluble, and later to the carbonate, which is only slightly soluble, so that the lead moved very little. The same seems to have been true in large part for the iron. The pyrite was first altered to sulphate, which in part combined with lead compounds to form plumbojarosite and in part oxidized to limonite, and as already noted the plumbojarosite eventually altered to two relatively insoluble lead and iron minerals, cerusite and limonite. Copper shows more tendency to migrate; the replacement of galena by covel- 
lite was noted, and though the ore as a whole contains little copper, the presence of considerable amounts of the secondary copper minerals in small areas suggests considerable migration and concentration of that metal. Silver, like lead, seems to have moved but little during oxidation, probably owing to the presence of abundant chlorine in the ground water (see analyses, p.465), which caused the formation of the slightly soluble silver chloride as soon as the original silver mineral was altered.

Both the sulphide and oxidized ores are of high grade, and it is doubtful if they have been materially changed in metal content by oxidation, so that it may be expected that ores found at deeper levels will show no marked decrease in tenor.

Only high-grade ore and some associated second-grade ore have been extracted. Most of the second-grade ore can not be profitably shipped under present conditions and is left in the mine, from which it can be extracted cheaply.

The occurrence of the ore in the Galena mine, which is on the same fissure system, is similar to that in the Utah mine. The mine has been developed to a depth of 700 feet and considerable ore extracted. It has not been operated for several years and was not examined by the writer.

In 1918 a mill was built for the treatment of the low-grade ores of the district.

\section{OTHER FISSURES.}

The Emma mine has been developed on a fissure a few hundred feet south of the UtahGalena fissure. The occurrence of the ores is very similar to that in the Utah mine, though the ore shoots are smaller and the ore zone not so extensive. As in the Utah mine, a small dike of the granite porphyry is closely associated with the ores.

The Meteor and other prospects have been operated on this fissure zone but were not active at the time of visit.

Stillfarther south the Carnation mine has been developed on another essentially parallel fissure. It was opened in the spring of 1912 by an inclined shaft 230 feet deep, which follows the dip of a north-south fault or "slip" that cuts the east-west ore fissure. All development at the time of visit had been east of the fault.
The ore, as in other sections of the camp, occurs in irregular shoots, between which the fissure shows little mineralization. The ore mined has been of high grade.

\section{DEEP CREEK RANGE.}

By B. S. Butler.

GEOGRAPHY.

The Deep Creek range extends for nearly 50 miles along the western border of Utah in Tooele and Juab counties. The fortieth parallel of latitude crosses the range near its central part. To the west is the Deep Creek valley, a fertile agricultural section watered by streams from the high mountains of the southern part of the range. On the east the range is bordered to the north by the southward extension of the Great Salt Lake Desert and to the south by Snake Valley. Streams from the mountains supply several ranches in Snake Valley.

Prospecting and mining have been most extensive in the northern part of the range in the vicinity of Clifton and Gold Hill but have also been carried on at the Queen of Sheba mine on the west side of the range and on Trout Creek and Granite Creek on the east side of the range.

The nearest railroad point prior to 1917 was Wendover, on the Western Pacific Railroad, 40 to 50 miles from the more active part of the mineral region. In 1917 a railroad was completed from Wendover to Gold Hill. The old overland stage route from Salt Lake to the west passes through a low gap in the northern part of the range and furnished a route to St. Johns, on the Los Angeles \& Salt Lake Railroad, which was the most convenient shipping point for the district.

The lack of cheap transportation has been a serious handicap in the development of the district. Only part of the ores are susceptible to milling, and the region has been too remote for cheap smelting, even if a suitable mixture of ores could be had. The advent of the railroad should greatly stimulate development and production.

In the southern and higher part of the range, including the Spring Creek, Willow Springs, Trout Creek, and Granite Creek areas excellent water is abundant, the melting snow from the higher parts of the range sup- 
plying the streams until well into the summer. In the northern part of the range, where the elevations are relatively low, the water is scarce and of poor quality. Kane Spring, at Gold Hill, furnishes a small supply that was used for the mill and for stock, and in periods of greatest flow for drinking and cooking. It is far from satisfactory for drinking, however, at least until one becomes accustomed to it. Ocher Springs, which are said to flow approximately 2 gallons per minute, supply the Gold Hill mine. There are other springs from which a small flow of water could undoubtedly be developed. Springs at Clifton furnish water that is used for all purposes but is not of very good quality. Other springs in the eastern part of the district furnish small flows of water. Redding Spring, on the desert east of the range, is said to have an abundant supply of water of good quality. Artesian water of good quality for drinking can be obtained from Ibapah in the Deep Creek valley or from Callao east of the range.

Timber suitable for building, mining, and fuel is present in considerable quantity in the southern part of the range. North of the Overland Canyon, except in the higher parts of Dutch Mountain, cedar and a few other low scrubby trees are the only timber, and over much of the district even these are almost absent. Near the summit of Dutch Mountain there is some timber of fair quality.

The roads are in general good, considering the attention given them, the relatively gentle grades and gravelly soil in the northern part of the range being favorable to the preservation of roads.

The mineralized districts are near the fertile Deep Creek valley, from which they obtain farm products at reasonable prices.

\section{PHYSIOGRAPHY.}

The Deep Creek Range in common with other of the Basin Ranges rises abruptly from the desert plateau. The lower parts of the desert have an elevation of about 4,500 feet and the mountains a maximum elevation of 12,100 feet. The southern and central parts of the range are composed largely of quartzite and granite and are steep and rugged, the streams being in deep canyons. The northern part of the range has much less relief and the weaker rocks have resulted in broader valleys and more gentle slopes. Overland Canyon is a low pass across the range which has been a main route of travel through the region since early days.

In the northern part of the range there are no perennial streams and few springs. In the southern part, on the other hand, the larger canyons contain streams that persist throughout the year and furnish water for the irrigation of numerous ranches. The largest stream of the region is Deep Creek, which in the wet season flows to the desert north of the range.

The physiographic features of the Deep Creek Range and vicinity do not differ materially from those of many parts of the Great Basin. To the north is the level barren expanse of the Great Salt Lake Desert with a southward extension into Snake Valley that represents the bottom of an old lake from which the waters have receded. Around the northern end of the mountains the old shore lines are prominent. Flanking the range on either side are the great alluvial deposits characteristic of "desert mountains.

The range itself is probably a relatively uplifted block outlined on both the east and the west by north-south faults. Gilbert ${ }^{1}$ says:

The Deep Creek Range, which forms part of the western boundary of the Bonneville Basin, is faulted on both sides. In the vicinity of the old overland road crossing the ridge from Willow Spring to Deep Creek settlement, to which vicinity observation was restricted, the range is flanked on the east by a broad and high alluvial slope. No fault scarp was seen, but near the lower margin of the slope a partial section of the lake sediments shows that they were disturbed during the period of their deposition. The Yellow Clay at one place suffered uplift and erosion before the deposition of the White Marl, so that there is unconformity of dips, and at another point the Yellow Clay and White Marl together are so greatly disturbed that their inclination is toward the mountain. The superficial topography that must have been created by these disturbances was obliterated by wave work, and at the locality of the section the upper edge of the inclined block was planed away in the formation of a terrace of the Provo shore.

On the west side of the range an ancient and nearly obliterated scarp crosses the alluvial slope near its upper edge. On the opposite side of the Deep Creek valley a better preserved fault scarp follows the eastern base of the Gosiute Range. It lies far above the Bonneville shore line and was not critically examined.

1 Gilbert, G. K., Lake Bonneville: U. S. Geol. Survey Mon. 1, p. 353, 1890. 
An east-west structural break across the range in the region of the Overland Pass has thrown the rocks north of the pass relatively down. Erosion has carved narrow canyons in the resistant quartzites and granites, and has produced a very rugged topography. In the softer rocks to the north the canyons have been broadened into a comparatively mild relief.

\section{GEOLOGY.}

SEDIMENTARY ROCKS.

The lowest formation exposed (the one that forms the main part of the range toward the south) consists chiefly of quartzite with intercalated schist layers. The schist is composed largely of quartz and mica, muscovite and biotite mica being present in about equal amounts. The quartzite also contains some mica. Near the base of the formation as exposed at Trout Creek in the east side of the range there are some metamorphosed calcareous beds. The thickness of the quartzite was not measured but is certainly several thousand feet, as it makes up almost the entire range at the latitude of Trout Creek, the overlying limestone being present only in the foothills on the west side. No fossils were found, but the general character of the rock has led to its being provisionally referred to the Cambrian, though the base may be pre-Cambrian.

Overlying the quartzite-schist formation are heavy-bedded limestones. In the southern part of the range they are present only on the western side in the foothills. North of the Ibapah mass of granite they form the western part of the range, and in the vicinity of Overland Pass they form a large part of it. North of the pass the Cambrian quartzite is entirely lacking, younger formations making up the entire range. Fossils were not collected from this limestone south of Overland Pass by the writer, but Mr. James Lauton furnished him with a collection said to have come from a horizon 1,000 to 2,000 feet above the quartzite collected just south of Johnsons Canyon.

This collection was examined by Edwin Kirk, who reports the following species: Orthis n. sp. near O. tricenaria Conrad, Clitambonites? ionensis Walcott, Aparchites? sp. Mr. Kirk states that the fossils represent the horizon of the upper part of the Pogonip limestone, which may be correlated with the lower part of the Simpson formation of Oklahoma, which is held to be basal Ordovician by Ulrich.

North of the Overland Pass the structure of the range is complex, and a clear understanding of the sedimentary series can be obtained only by a detailed mapping of the geology of the area.

The south end of Clifton Mountain is composed on the western side principally of limestone, and on the eastern side is made up of a great shale series, much of which is very siliceous, and of some beds of quartzite and shaly limestone. Fossils collected from the limestone talus in the canyon above the spring at Clifton were determined by G. H. Girty as Zaphrentis sp., Menophyllum sp., Schuchertella chemungensis (?), and Euomphatus utahensis. Mr. Girty says: "I think that the Madison (lower Mississippian) is present in it, but there are also suggestions of upper Mississippian."

In a collection from the shale series on the east side of the range Mr. Girty determined Fusulina sp., Batostomella sp., Rhombopora lepidodendroides, and Bellerophon sp. Mr. Girty states that this collection is of Pennsylvanian age.

No fossils were collected from the limestones between Clifton and Gold Hill. A few hundred yards southwest of Gold Hill a collection (No. 578) was made, from which Mr. Girty determined Productus pileiformis, Martinia sp., Spiriferina transversa?, Nucula? sp., Myalina aff. M. sanctiludovici, Aviculipecten sp., and Edmondia sp. Mr. Girty states that these are probably upper Mississippian.

The structure in the region between Gold Hill and Clifton is too complex to make it possible without detailed study to give even an approximate correlation of the different areas of limestone that have been included in the monzonitic intrusive. It is probably safe to say that they are all of Carboniferous age.

In the vicinity of Gold Hill south and southeast of the post office and north and northwest of the Gold Hill mine considerable areas of shaly and siliceous sediments show much alteration and induration.

Dutch Mountain, which forms the northern end of the Deep Creek Range, is composed of limestone and quartzite, which strike northeast and dip northwest at a low angle. At the base of the range to the east, on the road to the Spotted Fawn mine, are several hundred feet 
of limestone with interbedded strata of shale and shaly limestone. Overlying the limestone is about 1,000 feet of white and reddish quartzite. Above the quartzite is 100 to 200 feet of micaceous shale that has been considerably metamorphosed with the development of rather abundant mica, giving it a distinctly schistose appearance. Overlying the shale and extending to the summit of the mountain is a series of limestone and interbedded shaly limestone whose exposed thickness is about 2,000 feet.

Fossils were collected in débris just above the shale beds, and it is believed that they were derived from the limestone not more than a few hundred feet higher. From this collection Mr. Girty determined Zaphrentis sp., Batostomella sp., Fenestella sp., Chonetes sp., Productus punctatus, and Straparollus sp.

Fossils were also collected near the summit of the range above the Spotted Fawn mine, among which Fenestella sp., Cystodictya sp., and Productus cora? were determined.

Mr. Girty considers that both collections are probably upper Mississippian.

The ages of the quartzite and of the limestone underlying the quartzite have not been determined by fossil evidence. At no other locality within the State has the writer noted sediments as highly metamorphosed as the micaceous shales in rocks known to be younger than Cambrian.

\section{IGNEOUS ROCKS.}

The area contains large bodies of igneous rocks, by far the more important being intrusive rocks, though there are lesser bodies of extrusive rock.

\section{EXTRUSIVE ROCKS.}

Lava flows so far as observed are confined to the northern end of the range. They are present northwest of Dutch Mountain, where Deep Creek has cut a canyon in them, and east and southwest of Clifton Mountain on the flanks of the main range. Several small areas of lava near the bottom of the valley north of Clifton lie entirely within the range, surrounded by limestone and quartz monzonite, and appear to have flowed over the area after the valley had been eroded to essentially its present form.

The flow rocks vary considerably in appearance, but those observed were of medium com- position-latites and quartz latites, with some that might be classed as andesites. Their relation to the sedimentary rocks and to the intrusive rock was seen only in the valley north of Clifton, where they appear to occupy valleys eroded in both the sedimentary and the intrusive rocks and are consequently distinctly later. They may be provisionally regarded as of Tertiary age in common with most of the effusive rocks of adjacent portions of Utah and Nevada.

\section{INTRUSIVE ROCKS.}

The intrusive rocks consist of stocks of granitic rocks and of dikes cutting both the sedimentary rocks and the larger intrusive bodies.

sтоскs.

Ipabah stock. - The largest body of intrusive rock exposed in the area centers in Mount Ibapah, in the central part of the.range. It extends along the range for about 6 miles with a width of approximately 8 miles, and is thus one of the largest intrusive bodies in the State.

The rock as seen on both sides of the range appears to be uniform. It has a very coarsegrained granitic texture containing feldspar crystals as much as an inch in greatest dimension. Under the microscope and in the hand specimen the rock is seen to be composed of orthoclase, quartz, and biotite, but with considerable plagioclase near oligoclase in composition. The chief variation is in the amount of quartz. Some of the plagioclase crystals are inclosed in the larger orthoclase crystals. Not infrequently the plagioclase crystals are surrounded by a fringe composed of a fine micropegmatitic intergrowth of feldspars. Albite is rather abundant intergrown with orthoclase. Muscovite occurs as an alteration product of biotite and to a slight extent as an alteration of feldspar. Accessory minerals are rare. There is a little magnetite and occasional crystals of zircon and apatite. The rock is classed as granodiorite, though it closely approaches a soda-rich granite. The composition of the rock is shown in an analysis by R. C. Wells, from a specimen from Granite Canyon. (See p. 96.)

Gold Hill and Clifton stock.-In the Gold Hill and Clifton district, in the northern part of the range, the sedimentary rocks have been intruded by a body of quartz monzonite which 
has been exposed by erosion and occupies numerous areas amid the sedimentary rocks. Many of the smaller limestone bodies appear to be underlain at no great depth by monzonite, and in fact appear to be sedimentary blocks resting upon monzonite. The general arrangement of the sedimentary and the intrusive rocks suggests that the present surface is near the more or less irregular top of an extensive intrusive body that occupies a large area in the district. The larger bodies of quartz monzonite (that forming the northern part of Clifton Mountain, for example) probably once extended to considerably greater heights. Were the present surface reduced a thousand feet the area now occupied by sedimentary rocks would probably be much smaller and that occupied by the intrusive rocks correspondingly larger. In fact, some rather large areas of sedimentary rocks would probably give place entirely to intrusive rock at even less depth.

The main intrusive rock throughout the Gold Hill and Clifton district is generally uniform in appearance and not markedly varied in composition. On fresh breaks it is a rather dark greenish rock of medium texture, in which orthoclase, plagioclase, biotite, and hornblende are readily recognized. Quartz is present, but in most hand specimens is not conspicuous. Under the microscope the rock is seen to have a typical granitic texture and to be composed of orthoclase, plagioclase, quartz, biotite, and hornblende, with magnetite, apatite, sphene, and zircon as accessory minerals. The orthoclase appears to be nearly as abundant as the plagioclase, which has a composition close to andesine. Mineralogically the rock is a typical quartz monzonite. An analysis by $R$. C. Wells shows the chemical composition of a representative specimen collected near Gold Hill. (See p. 96.)

Locally the rock differs considerably from the general type. Adjacent to the ore bodies at Gold Hill, for example, it is distinctly porphyritic, being composed of phenocrysts of feldspar, mostly plagioclase, biotite, and hornblende in an aplitic groundmass composed largely of quartz and orthoclase with magnetite and apatite as accessory minerals, the apatite commonly showing a very striking pleochroism from dark brown to deep purple. In mineral composition it differs chiefly in having more quartz and a little more orthoclase.
DIKES,

Occurrence and character.-Dikes and small bodies of the quartz monzonite in the sedimentary rocks commonly have a porphyritic texture but usually do not differ materially in composition from the main body of the rock.

Dike rocks later than the main intrusive bodies cut both sedimentary and intrusive rocks in the vicinity of the intrusive centers. These dike rocks vary greatly in character but may be separated into those more basic and those more siliceous than the main intrusive bodies.

Basic dikes.-All the basic dikes noted in the vicinity of Clifton and on the east side of Clifton Mountain that cut quartz monzonite, are dark gray in color, and are rather sparingly sprinkled with phenocrysts of quartz and feldspar.

A specimen taken from a dike about half a mile west of Clifton is seen under the microscope to be composed of quartz, plagioclase, and augite phenocrysts in a groundmass of plagioclase laths and augite. The feldspar, both of the phenocrysts and groundmass, is near andesine in composition. The feldspar and augite of the groundmass have the typical intersertal structure characteristic of diabase dikes. A somewhat similar specimen from the east side of Clifton Mountain contains some orthoclase, both as phenocrysts and in the groundmass. Dikes at other points are apparently somewhat more basic than those described but are too highly altered for their original composition to be determined.

In and adjacent to the granite mass in the southern part of the range basic dikes were observed only in the schist south of Granite Canyon, where several diorite dikes are present. Specimens that were examined microscopically are composed essentially of plagioclase and hornblende with a little quartz and iron ore. Only small areas of the main granite mass were examined and it is entirely probable that basic dikes are present in it as well as in the quartz monzonite in the northern part of the range.

Siliceous dikes.-Siliceous dikes, both aplitic and pegmatitic, are rather numerous in the intrusive rocks.

Numerous coarse pegmatitic dikes, composed essentially of quartz, orthoclase, and muscovite, with a little local tourmaline, and numer- 
ous "dikes" or veins of coarse pegmatitic quartz, are associated with the large Ibapah stock of granite, especially in the vicinity of the Queen of Sheba mine. The true pegmatite appears to grade into the pegmatitic quartz. Similar dikes are reported well within the main granite mass. Mr. James Lauton gave the writer specimens of beryl said to have come from a quartz "dike" or vein in the main granite mass. In the quartz monzonite in the Gold Hill and Clifton area typical pegmatites are less abundant, though some are present in the area north of Clifton.

A pinkish rock outcropping in the rather flat bottomed valley 1 to $1 \frac{1}{2}$ miles northwest of Clifton appears in the hand specimen to consist largely of feldspar and under the microscope to be composed of rather abundant phenocrysts of plagioclase near oligoclase and of a few of hornblende in an aplitic groundmass of quartz and orthoclase. Accessory sphene is especially abundant. The relations of this more siliceous rock to the main body of quartz monzonite were not clear on account of poor exposure, but it appears to be intrusive into the main body. A very similar rock at the Gold Hill mine was probably intruded into the main body before the quartz monzonite was thoroughly solidified and in consequence more or less blending occurred. In the region northwest of Clifton small dikes of an aplitic rock are composed of quartz, orthoclase, some plagioclase, hornblende, and tourmaline, with abundant accessory titanite and apatite.

In this same region a coarse pegmatitic dike, composed largely of crystals of pink feldspar several inches in greatest dimension with a lesser amount of lenticular quartz, contains scattered sheathlike bodies of fibrous amphibole that have been partly altered to biotite, muscovite, and orthoclase. The larger of these bodies are 6 inches in diameter and a foot or more in length. They readily fall to pieces when taken from the rock. What appear to be remnants of the original mineral are occasionally seen as dark-green fibers of amphibole.

Only a few hundred feet away other pegmatitic dikes contain metallic minerals in considerable amount. (See p. 476.)

\section{RELATION AND AGE.}

The different intrusive rocks cut all of the consolidated sedimentary rocks in the range.
Their relation to the flow rocks was not positively determined, but they appear to be earlier. (See p. 472.)

No known evidence indicates more than one period of important intrusions in the district, though some later dike rocks may be associated with the lava flows. It has not been shown that the granite of the Ibapah Mountain mass is of the same age as the quartz monzonite of the Gold Hill and Clifton area, but it seems most natural to consider it so in the absence of positive evidence. The Ibapah mass is the deeper-seated rock, being intrusive into Cambrian and Ordovician sediments, whereas the quartz monzonite is intrusive into Carboniferous sediments. Here, as in the Little Cottonwood and Park City districts, the deeperseated rock is the more siliceous.

Both the aplitic and pegmatitic dikes intrude the main intrusive masses and are, with little doubt, differentiation products of its crystallization. Some aplitic dikes appear to have been intruded so soon after the solidification of the stock that their margins blended with the main intrusive mass and definite walls are lacking. Both aplitic and pegmatitic rocks include gradations from siliceous rocks having essentially the mineral constituents of the main intrusive, but with more orthoclase and quartz and less of the dark silicate and plagioclase, through rocks composed essentially of quartz and orthoclase with minor amounts of other constituents, to rocks in which tourmaline is important, to those containing metallic oxides and sulphides, and to the tourmaline quartz veins that are so abundant in the district.

The relation of the basic dikes to the other rocks is not so clear. Many intrusions of medium composition were followed by intrusions of both more basic and more siliceous rocks that have resulted from the differentiation of the magma. The evidence is conclusive that the more siliceous rocks in this region have resulted from such a differentiation, and the same is probably true of the basic rocks, though the evidence in regard to these is by no means so conclusive.

\section{STRUCTURE.}

The detailed structure of the district is altogether too complicated to be determined in a brief reconnaissance. The major structural features, however, are useful in aiding mining 
development, though of course study of the details is essential in individual developments.

The general outline of the Deep Creek Range is probably due to faulting along both its east and west sides. ${ }^{1}$ The deep Overland Gap across the range is cut by erosion along a structural break, whose position is determined by the doming of the sediments apparently resulting from the intrusion of the quartz monzonite. The intrusion of a large body of material into the sedimentary series greatly disturbed the earlier rocks and caused divergent dips and strikes within very small areas.

That there has been some faulting since the intrusion of the igneous rock and since the deposition of the ores is shown by gouges and slickensides in both intrusive rocks and ore deposits, and this later faulting may be of large importance in mine development. That there has also been some movement along the contacts of the intrusive rock with the sediments is probable, as these would naturally be planes of weakness. It should be kept in mind, however, that the general relations of the igneous to the sedimentary rocks result from the intrusion of the igneous material and not from the complex faulting of sedimentary rocks deposited on an earlier granitic basement.

\section{HISTORY AND PRODUCTION.}

By V. C. Herkes.

CLIFTON DISTRICT.

The Clifton district is in Tooele County, 43 miles south-southeast of Wendover, on the Western Pacific Railroad. Gold Hill and Clifton are the principal camps of the district. The first discovery of mineral is said to have been made in 1858 , but the hostility of the Indians retarded development until 1869, when the first mining operations were begun and the district was organized (on Oct. 18). Huntley ${ }^{2}$ reviews the conditions in November, 1880, as follows:

A smelter was built in 1871 and was moved in 1876 to a spot 6 miles distant by the St. Louis Consolidated Co. Probably 150 tons of bullion were produced. * * * About 50 claims, of over 500 located, are still worked occasionally. Little has been done since 1877 .

1 Gilbert, G. K., Lake Bonneville: U. S. Geol. Survey Mon. 1, p. 353, 1890.

2 Precious metals: Tenth Census U. S., vol. 13, p. 456, 1885
The smelter built in 1871 is reported by an old resident ${ }^{3}$ and mine owner of the district to have been a stack furnace operated with three blacksmith bellows. Three tons of lead bullion represented the results of the first operations. In 1872 Gilbertson \& Berry's furnace was built at Clifton to treat the ores from the Gilbertson mine at Gold Hill. About 30 tons of lead bullion ${ }^{4}$ shipped to Salt Lake averaged $\$ 93$ in silver per ton. A few years later this furnace was moved to Gold Hill by J. W. Harker. The crude ore smelted carried about $\$ 4$ in gold, 30 ounces of silver per ton, and 25 to 30 per cent of lead.

Activity in mining did not again assume importance until 1892, when a mill was put in operation at Gold Hill. The ores treated were from the Cane Springs, Alvarado, and Gold Hill claims, which were credited with a total gold production of $\$ 207,986$ from September, 1892, to November, 1895. Of this total probably half the ore and more than three-fifths of the gold came from the Alvarado mine. No complete record of the amount of ore handled exists, but a partial record shows 9,475 tons of ore milled from August, 1892, to May, 1894, assaying $\$ 14$ per ton and yielding $\$ 97,393$, or $\$ 10.28$ per ton. At the same rate, the total ore worked was about 19,000 tons. ${ }^{5}$ The gold produced was very pure, some of it 0.946 fine.

The Midas property is about 3 miles southeast of Clifton. In 1896 and prior to that year 95 tons of ore averaging $\$ 56$ in gold and a trace in silver per ton were treated at the Cane Springs mill and shipped to the smelter. In 1902 a 40-ton cyanide mill was constructed and treated 622 tons with a reported saving of $\$ 15$ per ton in gold. In 1904 the mill was operated again, but the results were unfavorable, and the property was practically abandoned.

The Clifton district again revived in 1909, when the Alvarado claim produced some gold ore of shipping grade, and the Western Utah Copper Co. developed the Gold Hill and Cane Springs groups and opened considerable lead and low-grade copper ore. However, none. of the ore was shipped, as the plan was to smelt it at some future time in the district.

3 Dunyon, Isaac, Salt Lake City, personal interview.

4 Fabian, Bentham, Resources of Utah, 1872, p. 16, Salt Lake City, Utah, 1873 .

${ }^{5}$ Daggett, Ellsworth, unpublished mining notes. 
SPRING CREEK DISTRICT.

The Spring Creek district, in Juab County, about 16 miles south of Ibapah, a settlement in the Deep Creek region, and 105 miles northwest of Oasis on the Los Angeles \& Salt Lake Railroad, was organized June 4, 1891. The only producing property in the district was the Queen of Sheba, which has been worked intermittently and whose total gold output probably does not exceed $\$ 40,000$.

JOHNSON PEAK OR TROUT CREEK DISTRICT.

The Johnson Peak or Trout Creek district is in the western part of Juab County, 20 miles south of Callao, Utah. In 1912 some copper ore containing gold and silver was shipped from it to the smelter near Salt Lake.

\section{GOLD HILL AND CLIFTON DISTRICT. ${ }^{1}$}

\section{ORE DEPOSITS.}

The ore deposits differ greatly both in occurrence and in the metal constituents for which they are valuable. Prior to 1917 the gold deposits had been the most productive, but since then lead, silver, copper, tungsten, and bismuth have been mined. Probably all the ores were not formed at exactly the same time, but there is no known evidence to show more than one general period of mineralization.

The deposits may be separated into replacement veins in the intrusive rock and replacement deposits in the sedimentary rocks. Some deposits may extend from one type of rock into the other, but in general they are distinct.

REPLACEMENT VEINS IN QUARTZ MONZONITE.

Replacement veins in quartz monzonite range from those that contain much feldspar and are closely allied to pegmatite, if indeed they may not be more properly called pegmatite, to quartz-tourmaline veins, to quartzcarbonate veins in which carbonates are abundant and tourmaline of minor importance, and to quartz and quartz-carbonate-sulphide veins. The chief value of the deposits are in tungsten, copper, lead, or gold.

1 Since this report went to press a description of the region by J. F. Kemp and Paul Billingsley has been published in Econ. Geology, vol. 13, pp. 247-274, June, 1918.

\section{PEGMATITIC VEINS.}

The largest pegmatitic veins noted in 1912 outcrop in a flat-bottomed valley about a mile northwest of Clifton on the Reaper group of claims. The natural exposures are rather poor. The three prospects opened at the times of the writer's visit are probably on separate veins, though it is possible that two of them are on the same vein. The material of one vein on which a shaft has been sunk 30 to 35 feet is orthoclase quartz, a green fibrous amphibole, tourmaline, a little epidote, and a carbonate containing iron, calcium, and probably other constituents. Apatite is rather plentiful. Danburite, which is rather abundant in the quartztourmaline veins, was not noted but may be present. Magnetite is rather abundant. Other metallic minerals are powellite and scheelite. Gold is said to occur in the deposits and it was in search of this metal that the shaft was sunk. Stains of copper carbonate are present but are not abundant. The powellite in the vein plainly resulted from the alteration of molybdenite. Considerable molybdenite appears in picked specimens but forms only a small percentage of the whole ore. Tungsten is present in scheelite and perhaps in other minerals, though none was recognized in the specimens collected.

At the time of visit the width of the dike or vein had not been disclosed, but it is at least several feet. Adjacent to the shaft a body composed largely of scheelite 18 to 24 inches in thickness had been exposed for 4 or 5 feet along the strike and 3 or 4 feet below the outcrop. Deeper in the shaft other apparently smaller bodies of scheelite were exposed. The scheelite occurs in large crystals, some of which are 4 inches long. One block of nearly pure scheelite ore on the dump was estimated to weigh fully 200 pounds.

The bodies of high-grade ore appear to occur as lenticular masses in the vein and suggest segregations of the scheelite through the pegmatite material of which the scheelite is an essential part. The scheelite was one of the earliest minerals to form. Much of it is in well-formed crystals and little of it includes the other minerals.

Considerable development work on this vein has been done since the writer examined it. and some scheelite has been shipped. 
A few hundred feet from the opening just described a shallow shaft on a similar or possibly on the same vein showed no scheelite. A short distance farther north a shaft about 10 feet deep has been sunk on a pegmatite dike composed essentially of feldspar quartz and fibrous amphibole, which occurs in sheaf-like aggregates 6 inches in maximum diameter and a foot or more in length. The original amphibole has been partly altered to a light-green amphibole, chlorite, and biotite, and some muscovite. No sulphides or oxides of iron were noted.

The quartz monzonite adjacent to these veins has been altered for a short distance to quartz muscovite and chlorite with some oxide of iron. The chlorite may have resulted from the surface alteration of some magnesian mineral formed by the hydrothermal action of the vein-forming solutions, but no remnants of such a mineral remained in the sections examined.

QUARTZ-TOURMALINE VEINS.

Closely allied to the pegmatitic veins are the quartz-tourmaline veins that are abundant in the quartz monzonite between Clifton and Gold Hill. These veins vary considerably in composition, but all contain abundant quartz, tourmaline, some pyrite and chalcopyrite, carbonate, amphibole, and diopside, and considerable apatite and sphene. Vesurianite, garnet, epidote, and galena occur in some of the veins. Danburite, a borocalcium silicate $\left(\mathrm{CaB}_{2}\left(\mathrm{SiO}_{4}\right)_{2}\right)$, was noted in numerous specimens and may prove to be locally abundant. Zircon, rutile (some of which results from the alteration of titanite), and orthoclase are present in many specimens. Fluorite was noted, but is not an important constituent.

In several of the veins radiating laths several inches in length appear to be the alteration products of some mineral, possibly tourmaline. Under the microscope they are seen to be composed of orthoclase, microperthite, quartz, muscovite, considerable carbonate, and tourmaline in small amount. The tourmaline occurs as rather large crystals with pleochroism from dark green to nearly black and as very fine radiating needles with a pleochroism from nearly colorless to slate-blue. The blue tourmaline is doubtless later than the brown and may have formed from its alteration. The form and habit of the altered crystals are similar to those of the tourmaline of the veins, and the brown crystals of tourmaline suggest remnants of the original mineral.

The principal primary metallic minerals of the veins are magnetite, hematite, pyrite, chalcopyrite, and in some veins galena. Scheelite in small amount was noted in the veins in several parts of the area and is apparently a common constituent. Its most abundant occurrence in veins is in the Lucy L. group of claims, where the vein is in the quartz monzonite, but close to the limestone contact the deposit has some of the characteristics of the contact deposits. The associated minerals are carbonates, quartz, diopside, a green amphibole, brown and green mica, vesuvianite, a mineral resembling garnet but showing usually strong birefringence and in many specimens twinning, orthoclase, danburite, epidote, and small amounts of allanite, sphene, and apatite. The metallic minerals in addition to the scheelite are magnetite, hematite, sulphides of iron and copper and their oxidation products, and molybdenite and its oxidation products. Tin has been reported from the veins but was not noted by the writer. The character of the veins is similar, however, to those in which tin occurs, and it would not be surprising to find that metal in small amount.

The typical alteraiion of the quartz monzonite adjacent to the veins is to a rock composed essentially of quariz, biotite, and muscovite. A green pleochroic mica and chlorite are commonly abundant but are probably alteration products of the brown mica. Tourmaline, carbonates, sphene, and apatite are common constituents of the altered wall rock. A fragment of wall rock from the Lucy $L$. scheelite vein is composed of diopside and a green pleochroic hornblende, carbonate, epidote, and several crystals of allanite.

The abundance of magnesian minerals both in the veins and in the altered wall rock is characteristic. Another characteristic is the presence of an unusual amount of titanium, usually as titanite. Boron minerals are also abundant. Tourmaline is an important constituent of most of the veins, and danburite is common. So far as the writer is aware this is the only district in the State from which danburite has been reported. 
The solutions forming these veins must have been rich in silica, boron, magnesia, potassium, iron, and titanium, and must have carried sulphur, copper, lead, tungsten, and molybdenum. Sodium was largely removed and calcium to some extent, though the carbonate and other calcium minerals present in some of the veins may account for a part of the lime contained in the original quartz monzonite of the wall rock.

Ores of this type are valuable chiefly for their copper and possibly for their tungsten content. As a rule they are too low grade to be shipped at a profit under conditions existing before the advent of the railroad and consequently have had comparatively little development. Some copper ore of fair grade has been found, but as a whole the development to date is not very encouraging. Scheelite was noted in several veins, but not much ore of good grade in commercial quantity has yet been proved; however, the possibility of finding this mineral should be kept in mind. Considerable development has been done on the Pole Star, Clifton Copper Belt, Frankie, Lucy L., Gold Bond, and other groups.

Some veins in the district contain no tourmaline and little, if any, magnesian silicates, but are otherwise similar to those described. The most valuable constituent of these is copper.

QUARTZ-CARBONATE LEAD VEINS.

In the quartz monzonite forming the northern part of Clifton Mountain east and northeast of Clifton many veins, composed essentially of quartz and carbonate, carry small amounts of galena and other sulphides. Their chief value has been in lead and silver.

Most of the veins outcrop prominently and can be traced for hundreds of feet. The general strike is about N. $60^{\circ} \mathrm{E}$. and the dip is steeply east; both, however, vary considerably. Most veins show a banded structure, in some indistinct and in some well developed. The relative amounts of quartz and carbonates differ greatly in different veins and in different parts of a single vein. Some veins are composed very largely of carbonatesprobably iron-magnesium-calcium carbonates of variable composition.

The wall rock has undergone pronounced sericitization. Chlorite and a green pleochroic mica are present, but magnesian minerals ap- pear to be less abundant than in the wall rock of the tourmaline quartz veins.

Comparatively little prospecting has been done on this type of vein, though small bodies of ore of good grade have been developed north of Clifton.

QUARTZ AND QUARTZ-CARBONATE GOLD VEINS.

Numerous veins that carry gold in amounts that have encouraged prospecting occur from $1 \frac{1}{2}$ to 3 miles north and north-northeast of Clifton and have yielded a small production.

Through this section a body of quartz, in many places several hundred feet wide, can be traced on the surface northward for a mile or more. The thickness of the "vein" is probably not so great as the width of the outcrop, for it may dip west at a low angle, though the exposures do not indicate this conclusively. The quartz body is composed largely of fine crystalline quartz, cut by veins of coarser quartz, some of which are of amethystine color. In some areas the rock carries considerable carbonate and, it is said, a little lead and some gold.

The veins that have been prospected for gold are small, not more than a few feet in thickness, but many of them can be traced for considerable distances along the strike. Those examined trend predominantly northwest.

Quartz is the prevailing gangue with a subordinate amount of carbonate. Pyrite and chalcopyrite are usually present in small amount, and galena and sphalerite were noted. Specular hematite is abundant in small flakes in much of the gangue, giving it a dark color. The gold is said to occur free. The alteration of the wall rock does not differ materially from that of the quartz-carbonate lead veins. A specimen of wall rock from the Troy vein showed typical sericitization of the feldspars and alteration of the magnesian minerals to chlorite. The chlorite has possibly formed by the surface weathering of magnesian mica.

Some very rich ore is said to have been produced from a pocket in the Troy vein. This pocket, however, was very limited in extent, and prospecting on the veins has not revealed additional pockets. Other veins are said to contain ore of milling grade, but these have not been extensively opened, nor have milling tests been made. 
DEPOSITS IN SEDIMENTARY ROCKS.

Deposits in sedimentary rocks may be divided into contact deposits, or those forming in the immediate vicinity of the intrusive contact, and replacement fissure deposits, or those in which ore minerals have replaced sedimentary rock along fissures some distance from the contact.

CONTACT DEPOSITS.

Contact deposits occur in the sedimentary rocks at or near the quartz monzonite contact and contain, as gangue minerals, silicates and other minerals generally recognized as forming only at relatively high temperatures. In this district they may be divided into two principal classes-namely, those that have their chief metal values in copper and those in which gold is most important.

COPPER DEPOSITS.

At numerous points between Gold Hill and Clifton, along the contact of the limestone and quartz monzonite, the limestone has been replaced by garnet, diopside, amphibole, epidote, tourmaline, axinite (noted in several places), magnetite, specularite, sulphides of iron and copper, and here and there a little galena and sphalerite. Carbonate, which is commonly present in considerable quantity, is probably in part at least a recrystallization of the original limestone, to which iron has been added. The iron oxides are commonly abundant, as is also tourmaline. Apatite and titanite are present in small amount. The sulphides of iron and copper have been largely altered to oxides and carbonates to the depth to which prospecting has extended-which is rarely more than 100 feet below the outcrop.

Many of these deposits are mineralogically very similar to some of the veins in the quartz monzonite and not improbably contain tungsten minerals. Prospecting has developed in them some copper ore of fair grade, though not sufficiently rich for shipment before the advent of the railroad.

The deposits occur at intervals along the contact, and the reason for their distribution is not everywhere clear. Some appear to be associa ted with fissuring of both the quartz monzonite and limestone. Others have no apparent relation to structure.
Another type of contact deposit is exemplified by large bodies of fine-grained cherty quartz that have replaced the limestone. This quartz commonly contains some limonite, probably resulting from the oxidation of sulphides, and has a jasperoidal character. Large "reefs" of this character may be seen south of the road between Gold Hill and Clifton, about $1 \frac{1}{2}$ miles from Clifton. A little prospecting has been done about the margins of these reefs and some stains of copper carbonates were seen, but no ore bodies have been found.

GOLD DEPOSITS.

General features. - Contact deposits valuable chiefly for their gold content are present at several localities and have furnished the chief output of the district. Some of these deposits occur some distance from large bodies of the intrusive rock but contain as gangue minerals the silicates that characterize contact deposits.

This type of deposit, which has been worked in at least four mines, is strikingly uniform in mineral composition and mode of occurrence wherever it has been developed. It is a replacement of certain beds of limestone by "contact" silicates and sulphides. Much of the limestone bed shows continuous alteration for a considerable distance along its strike and dip, but the ore is confined to "shoots" within this mineralized bed.

The most characteristic mineral of the altered limestone is wollastonite, which forms a large percentage of all the ore. A green, slightly pleochroic pyroxene with optical properties near diopside is universally present in small amount and is locally abundant. Garnet and vesuvianite were noted in ore from the Midas mine. The principal sulphides are chalcopyrite and bornite and some molybdenite. Specimens from the Midas dump contained arsenopyrite, but this mineral does not appear to be an important ore constituent. The sulphide minerals differ in amount in the different ore bodies and in different parts of the individual ore bodies. In the Alvarado and Midas mines sulphides were not abundant, but in the Cane Springs mine chalcopyrite and bornite are rather plentiful. The sulphides formed in part contemporaneously with the gangue minerals and in part later in interstitial spaces and in fissures in the silicates. 
The alteration of chalcopyrite, the earliest sulphide, begins around the margin of the grains and along fissures and proceeds inward till all the chalcopyrite has changed to bornite. A gray mineral, probably chalcocite, has partly replaced the bornite and in some instances the chalcopyrite. The alteration to chalcocite is, however, usually confined to thin envelopes surrounding the other sulphides.

The gold occurs in large part as free gold and probably to some extent also in the sulphide. The free gold, like some of the sulphides, occurs in part between the silicate crystals, suggesting that it was deposited slightly later. The gold shows a distinct tendency to crystal form.

The richest gold ore seen by the writer is somewhat oxidized, and shows a distinct tendency to concentrate along small fissures, not uncommonly in association with copper sulphides. Some specimens, however, contain no sulphides, and the native gold appears to have been deposited as an original constituent. A large part of the gold, indeed, has probably been obtained from ore that contained very little sulphide. The bullion from the Alvarado and Midas mines particularly is exceptionally fine.

Alvarado mine.-The Alvarado mine, about a mile east of the Gold Hill post office and about one-fourth of a mile west of the Gold Hill mine, is in limestone at the contact with quartz monzonite. The contact is irregular, dikes of the quartz monzonite extending into the limestone, and fragments of the limestone being partly inclosed in the quartz monzonite. The ore, which is typical of the contact gold deposits, replaces the limestone irregularly and extends along the contact for several hundred feet. In places it is stoped to a width of 40 feet, and at other places it nearly pinches out. The mine has been opened to a depth of about 200 feet. The grade of the ore varies greatly from place to place, and there is usually no sharp distinction between ore and waste, the material mined as ore being dependent on the possibility of profitable treatment. The ore treated at the mill is reported to have yielded gold to the value of about $\$ 15$ per ton, with $\$ 4$ to $\$ 5$ lost in tailings.

Cane Springs mine.-The Cane Springs mine is about one-fourth of a mile west of the Gold Hill post office. The sedimentary series con- sists of rather massive beds of limestone interstratified with coarse siliceous shale, approaching quartzite. The principal ore body has formed as a replacement of a coarsely crystalline limestone. The principal minerals, wollastonite and garnet, and the minor minerals are all typical of the contact gold deposits, although no quartz monzonite or intrusive rock of any kind was observed near the mine.

The ore is similar to that of the Alvarado mine except that it has a considerably higher sulphide content. The ore body has been faulted in several places, but the movement was slight and no serious trouble was experienced in following the ore shoot. The shoot, where best developed, is about 150 feet along the strike and from a few feet to 20 feet in width. So far as developed, the shoot decreased both in length and in thickness with increasing depth.

The mine has been developed by an incline shaft to a depth of about 160 feet.

Midas mine.-The Midas mine is near the south end of Clifton Mountain about 3 miles south of the Clifton camp. The sedimentary rocks in the vicinity are limestones with intercalated siliceous beds. These have been invaded by the quartz monzonite which outcrops near the mine and has been encountered in the mine workings.

At the time of the writer's visit the mine was closed. The main ore body seems to be a replacement of a 4 -foot bed of limestone lying between siliceous strata. This bed is not in immediate contact with the intrusive rock at the outcrop but is reported to be cut by it in the mine workings. As in the Alvarado and Cane Springs mines the limestone has been largely replaced by wollastonite, diopside, and garnet, and by some sulphides and sulpharsenides. The gold occurs free and apparently in large part at least as an original constituent of the ore.

The ore apparently formed in shoots in the limestone for several hundred feet along its strike. At depth it is reported to have been faulted off, the ore abutting against "granite." Such a relation suggests that the contact is an intrusive rather than a true fault contact and that the ore has made out from this contact along the bed.

The ore milled from the deposit is said to have averaged about $\$ 20$ per ton, principally 
in gold with very little silver. A 50-ton mill $\mid$ carbonates and arsenates of iron and copper. on the property was operated for several Most of the copper ore also carries some lead. years but was closed in 1904 and is in poor The primary ores evidently were composed of repair.

Gold Hill mine.-The Gold Hill mine is a contact deposit that differs considerably from those previously described. The rocks in the vicinity of the mine consist of limestone, shale, and quartz monzonite. The limestone is an irregular block, partly surrounded by quartz monzonite and cut by dikes of the same rock. The limestone has been greatly altered in part to a rather coarsely crystalline marble and in part (locally) to wollastonite, diopside, and other silicates. Along the eastern side, adjacent to the shale, it has been highly silicified and consists mainly of fine cherty quartz containing veinlets of coarser quartz and numerous vugs lined with quartz crystals. At the surface much of this material contains considerable iron and is jasperoidal. East of this silicified zone there is a body of altered black shale. The quartz monzonite outcrops to the west of the limestone and is present as irregular bodies in the limestone. This is the normal quartz monzonite of the region but is rather more porphyritic than that of much of the area.

The structure is typical of an intrusive contact, the sedimentary rocks now present apparently representing remnants of the sedimentary formation that covered the entire intrusive body at higher level. The silicified zone between the shale and limestone suggests alteration along a strong fissure or fault that can be followed for a considerable distance to the south.

The mine contains gold, copper, and leadsilver ores. The gold ores are similar to those of the Alvarado mine to the west, consisting of limestone that has been altered to wollastonite and diopside and that carries free gold as its valuable metal constituent. Some ore of this character was mined and milled at the Cane Springs mill, but its amount was apparently rather small. The copper ore occurs as a replacement of limestone along fissures - that thus far developed being to the west of the zone of cherty quartz.

Oxidation of the ore has been very complete, and it is impossible to identify the original metallic minerals. The oxidation products sulphides and sulpharsenides of iron, copper, and lead. The copper ores commonly are rather rich in precious metals.

The report of the superintendent of the Western Utah Copper Co., dated September 30, 1909, places the actual copper ore in sight in the mine at 102,957 tons and the probable additional supply at 25,500 tons, a total of 128,457 tons. The report does not give the average metal content of this ore.

In 1917 the shipments of ore were 32,023 tons, of which 28,718 tons was copper ore, averaging 2.98 per cent copper and 4.33 ounces silver per ton, and 3,305 tons was lead-silver ore, averaging 5.62 per cent lead and 7.98 ounces silver per ton. As the work progressed there were indications that less ore of commercial grade would be available in the developed area than was estimated in earlier reports.

Lead ore is present in different parts of the mine. That treated at the Gold Hill smelter in the early days is reported to have been taken out near the outcrop of the ore body. The largest body developed is on the 300-foot level and below and has been prospected by a winze 45 feet below the 300-foot level. This ore is east of the quartz body.

The lead ore is of rather low grade but has an excess of iron, which ranges from 25 to nearly 40 per cent. Silica is usually not more than 15 per cent. The lead ore is of particular interest in that much of the lead is present as the hydrous ferric lead sulphate plumbojarosite. Probably a careful examination of the ore would show the presence of ferric lead sulpharsenates also.

Another feature of interest in this deposit is the abundance of the pale-green ferrous arsenate, scorodite, massive bodies of which outcrop in the gossan of the Gold Fill deposit.

REPLACEMENT VEINS IN SEDIMENTARY ROCKS.

Deposits have formed as replacements of sedimentary rocks along fissures at a considerable distance from an intrusive contact in many parts of the district.

The chief production from this type of deposits has been of lead-silver ores, though consist of abundant hydrous iron oxide and there has been some prospecting of gold$35416^{\circ}-19-31$ 
bismuth ores. The main production is reported to have come from the limestone area forming the southern end of Clifton Mountain, in which numerous veins have been opened to a slight extent. The ore is all oxidized, is usually high in iron, and is reported to carry considerable silver. In several prospects in this area the rather unusual minerals plumbojarosite and beudantite were noted in considerable amount, but whether or not they constituted any large part of the ore mined was not learned.

To the west of Gold Hill post office is an extensive area of limestone in which are small bodies of intrusive rocks. Numerous veins in this area have been prospected, and a little ore has been shipped. Lead-silver is the main ore thus far developed.

In the limestone of Dutch Mountain are veins of lead-silver ore. The Spotted Fawn is said to be the most promising of those on the east side of the mountain, and is the only one that was examined by the writer. The ore occurs as a replacement of the limestone along a fissure. The surface ore is oxidized but apparently only to a depth of 30 feet. The primary ore is galena in a gangue of coarse quartz. Some ore is reported to have been shipped from this deposit.

In the area of limestone northeast of Clifton there has been some prospecting on veins in the limestone. The Success mine is said to have developed some zinc ore. This section of the camp was not visited by the writer.

A rather unusual type of replacement deposit in limestone in which the more important metals are bismuth and gold is being prospected by the Wilson Consolidated Co. about $1 \frac{1}{2}$ miles northwest of Clifton. The most prospecting has been on a vein that strikes east of north and dips westward. Some dikes of a highly altered intrusive rock near the deposit have no apparent close connection with the ore deposits.

The limestone adjacent to the fissure has been recrystallized to a rather coarsely crystalline carbonate. Considerable quartz is present, and locally a white micaceous chlorite is rather abundant. The primary metallic minerals are the sulphides of bismuth and copper, a tungsten mineral containing lead, probably stolzite, and possibly scheelite. Gold is probably also to be included among the primary minerals. The quartz and the metallic minerals replace the coarsely crystalline carbonate of the vein and were evidently deposited after the recrystallization of the limestone. The copper and bismuth sulphides have altered in part to carbonates and oxides, and some native bismuth is reported. The gold observed occurs as free gold closely associated with the bismuth sulphide. Tungsten was determined in but one specimen. A small fragment of a mineral that gave a reaction for tungsten also showed a reaction for lead, and it seems probable that the mineral is stolzite, though sufficient material for a more careful determination was not secured. A thin section from this specimen contained small grains of a mineral resembling scheelite. It seems probable that both stolzite and scheelite occur in small amounts in the ore. Selected specimens of the vein material contain a rather high percentage of bismuth. The vein as a whole, however, appears to have only a low content of this metal.

An occurrence somewhat similar to the deposit just described has been prospected on the lands of the Lucy L. Mining Co. between Clifton and Gold Hill. Bismuth (sulphide and carbonate) and native bismuth are present in coarse vein quartz. It is reported that "bunches" or "pockets" of ore contain considerable gold.

\section{RELATIONS OF THE SEVERAL TYPES OF DEPOSITS.}

The ore deposits of the district are believed to have been formed during one general period of mineralization. There is no evidence of mineralization previous to the intrusion of the quartz monzonite, and it probably took place at the time of and following the intrusion of that rock.

The aplitic and pegmatitic dikes in tne quartz monzonite were, with little doubt, intruded shortly after the crystallization of the main body of intrusive rock. The close similarity of some of the metal-bearing pegmatitic veins to the barren pegmatitic dikes gives ample grounds for the belief that they are of common origin and that the productive veins represent a more advanced stage of differentiation. A similar gradation from the metal-bearing pegmatite veins to the quartz-tourmaline-carbonate copper veins, and from these to the quartz- 
carbonate lead-silver veins, leads naturally to the belief that all are the results of the same general process.

The contact copper deposits, characterized by boron minerals, iron oxides, and magnesian silicates, are so similar in character to the tourmaline quartz veins that there can be no reasonable doubt that the solutions that formed the two had a common origin, and there can likewise be no doubt that the contact copper deposits at the south end of Clifton Mountain, where boron minerals were "not noted but where other typical contact minerals such as garnet, diopside, and vesuvianite are present, are genetically connected with the intrusive rock in the same general manner as the tourmalinebearing contact deposits. At the south end of Clifton Mountain the contact copper deposits show mineralogic gradations to the lead-silver replacement veins in many of which arsenic is an important constituent. In other parts of the district the relation between the contact deposits and the replacement veins can not be so definitely traced but may be logically inferred. The presence of tungsten in at least one of these veins indicates a relation between it and the other tungsten-bearing veins of the district.

The contact gold deposits are mineralogically typical of deposits formed in limestone adjacent to an intrusive body, but they differ rather materially from the other contact deposits in the district. Many of them contain considerable copper but no magnetite and specularite, almost no lead and zinc, and probably no boron. Molybdenum and arsenic, on the other hand, are present. In the Gold Hill mine the wollastonite gold ores are closely associated with copper and lead ores carrying a rather high percentage of arsenic, but the relation of the gold to the copper and lead was not clear.

The relation of the bismuth gold veins to the other deposits of the district was not ascertained.

Within a large area it is not to be expected that the ore-forming solutions will emanate from a common center, and it may be expected that the solutions in different areas will differ considerably in their initial composition, and as they progress from the point of origin, depositing some constituents and taking up others, will undergo a progressive and continuous change. Ordinarily it is not easy to distin- guish effects due to original differences in solution from effects due to acquired differences or from effects due to the physical conditions under which the solutions acted; indeed, it is to be expected that all these factors were active and must be considered. Study of the mineralogic relations, however, may indicate which has been the most important.

All deposits, whether in quartz monzonite or in sedimentary rocks, that contain abundant boron minerals, iron oxides, copper and iron sulphides, and scheelite are confined to a rather definite zone and are either in or are closely associated with the intrusive rock. Some of the minerals are those that are generally recognized as characteristic of high temperature and pressure. Quartz-carbonate veins are present within this area, but they are not abundant.

In the monzonite outside of this area quartzcarbonate-lead veins are abundant and in the limestone are replacement lead veins. These do not contain minerals especially characteristic of high temperatures and pressures.

The contact gold veins, from their relation to the main body of intrusive rock and their mineral composition, are believed to have been formed under conditions of less temperature and pressure than the contact deposits containing boron minerals, iron oxides, and copper, but probably at higher temperature and pressure than the lead-silver veins. In metal content they are related to the copper deposits in carrying considerable of that metal but differ in the absence of tungsten; wollastonite and diopside are the principal gangue minerals. Their chief resemblance to the lead-silver veins is that both contain arsenic minerals, and their close association in the Gold Hill mine suggests that they were formed under nearly similar conditions.

The above relations may be explained as follows: After the intrusion and partial crystallization of the quartz monzonite the rocks of the area were fissured so as to permit the passage of solutions from deep-seated sources. When these solutions were at high temperature they deposited feldspar, tourmaline, magnetite, specularite, and kindred minerals and naturally became depleted in the elements forming those minerals. At the same time the solutions dissolved calcium and sodium from the wall rock and naturally became richer in these elements. At greater distances the temperature and pres- 
sure were reduced and carbonates, galena, and other minerals were deposited and of course the nature of the solutions was still further changed. As the whole system cooled heat and pressure became less in the zone where previously minerals characteristic of high temperature and pressure had been deposited, and the carbonate quartz veins could be deposited in association with tourmaline quartz veins. That there are so few of these carbonate quartz veins in the central area seems to indicate that the principal mineralization occurred before the system had cooled to any great extent, and that those that do exist record the dying phases of mineralization.

If these conclusions are correct the action in this district differed considerably from that at Dolores, Mexico, where Spurr, Garry, and Fenner have shown that there was a progressive change in the original character of the mineralizing solutions, and also differed somewhat from that in the Ely, Nev., district where Spencer finds a sudden and marked change in the mineral solution near the close of the period of primary mineralization.

The writer does not maintain that no changes in the initial character of the ore solutions resulted from differentiation, but only that the major changes in the deposits were due to the physical conditions at different points and that the marked changes in the composition of the solutions were in part at least due to the precipitation of certain elements and the solution of others in their place.

WILLOW SPRINGS DISTRICT.

The Willow Springs district is in the higher parts of the Deep Creek Range, a few miles south of Overland Canyon. The higher portions of the range were covered with snow at the time of the writer's visit, and this district was not examined. The rock formations are said to consist of limestones and quartzites with some slaty shales and a few "porphyry" dikes. The ores occur as replacement veins in the sedimentary rocks. Both lead and copper ores are present, but there has been little production and comparatively little development in this district.

\section{DRY CANYON.}

Dry Canyon is on the east side of the Deep Creek Range south of the Overland Pass. ising.
This district was not visited by the writer. The mineralization is said to consist of replacement veins in limestone in part at least associated with "porphyry" dikes. The principal metals are lead and silver. A few small shipments of ore have been reported.

\section{GRANITE CREEK DISTRICT.}

The Granite Creek district is on the east side * of the Deep Creek Range, about 12 miles southwest of Callao. Granite Creek, flowing from the higher parts of the range, supplies excellent water, and the higher parts of the range contain considerable timber.

The mineralized area is in the schist quartzite rocks which form the base of the sedimentary series exposed in the range. The schists, for the most part, at least, have resulted from the alteration of sandstones and shales. In some of the beds pebbles of quartz and a granitic rock can be detected, though they have been drawn out into lenticular form and metamorphosed to a considerable extent. Some "beds" of a green hornblende rock that seem to conform to the bedding of the sedimentary rocks may be of intrusive origin.

North and west of the schist area the large Ibapah stock of coarse-grained biotite granite has been intruded into the sedimentary series. (See p. 472.) Dikes of the granite can be traced directly from the main mass into the sedimentary series and dikes of finer-grained rock having a composition similar to that of the main mass are present in the schist series at some distance from the contact. Pegmatite dikes are present in the granite and also in the schist, and several dikes of rather coarse-grained rock of dioritic composition were noted in the schist.

Veins of coarsely crystalline quartz are common in the schist. Some veins of a fine cherty quartz that appear to have formed in part at least by the replacement of the rock adjacent to the fissures carry small amounts of pyrite, pyrrhotite, magnetite, galena, sphalerite, and chalcopyrite and are said to contain gold and silver. There has been some prospecting of the veins and a small production, but, except for a few small rich pockets, the ore has been of low grade, and the indications for large bodies even of such ore can not be said to be prom- 
JOHNSON PEAK OR TROUT CREEK DISTRICT.

The Trout Creek district is located on the east side of the Deep Creek Range, about 3 miles south of Granite Creek. Trout Creek, which comes from the higher parts of the range, furnishes a supply of excellent water, and the higher parts of the range contain considerable timber.

The sedimentary rock is the same schist quartzite formation as that at Granite Creek, except that beds several hundred feet lower are exposed at Trout Creek. These include several strata of impure limestone. No intrusive rocks were observed in or near the deposits.

The schist series has been cut by several fissures along which there has been alteration of the rocks, especially the limestones. Tremolite and other silicate minerals were noted in these alteration zones. Lead and zinc minerals are both present in small amounts at several prospects.

The principal development has been on the north side of Trout Creek near the base of the range. At one point (in 1912) an incline has been sunk on a fissure developing a deposit of zinc. This was not examined in the underground workings, but the vein is said to be 2 to 4 feet wide and has been drifted on for some distance. The ore on the dump consisted of a dark sphalerite with a gangue of fluorite. Some of the zinc ore on the dump is of good grade but probably could not be shipped at a profit under ordinary conditions. Scheelite is reported to have been found in the district in 1916.

\section{SPRING CREEK DISTRICT.}

The Spring Creek district is on the west side of the Deep Creek Range, about 15 miles south of the settlement of Ibapah. The streams from the high range furnish a supply of excellent water and there is also good timber on this part of the range.

\section{GEOLOGY.}

The sedimentary rocks in the main mineralized area near the Queen of Sheba mine are quartzites, though limestones are present along the western foothills of the range south of Fifteenmile Creek. The quartzite is commonly a rather fine-grained reddish-brown rock. Occasionally there are beds that contain small pebbles. The general strike of the beds is about with the range, a little east of north, with a dip to the west at an angle around $30^{\circ}$. Near the granite the strike and dip of the quartzite are variable. To the north of the quartzite is the Ibapah mass of granite. This is the coarse granite already described. There are many dikes of granite in the quartzite near the main granite mass. Near the quartzite the granite appears to be rather fine grained and slightly more basic.

There are numerous dikes of coarse pegmatite composed essentially of quartz, feldspar, and muscovite with occasionally a little tourmaline. In addition to the true pegmatite dikes there are numerous dikes or veins of coarse pegmatitic quartz.

ORE DEPOSITS.

The principal ore deposit thus far developed is that of the Queen of Sheba mine. The ore body occurs in quartzite near the granite contact. The quartzite for some distance from the contact is apparently underlain at no great distance by the granite. The main fissure strikes about N. $60^{\circ}$ E. and dips rather steeply to the southeast. The vein ranges in thickness from a few feet to 15 feet or even a greater thickness. The fissure filling is mostly quartz though very often the quartz gives place to a pegmatite composed essentially of quartz, orthoclase, albite, and muscovite. At other points the vein filling is of a much finer grained rock resembling an aplite in appearance and composed of essentially the same minerals as the pegmatite with pink garnet as a rather abundant accessory mineral. Locally the vein material contains some biotite. The different types of vein material grade into each other and are evidently of a common origin. The ore consists of a porous vuggy quartz usually containing considerable hydrous oxide of iron with some manganese. A little galena is occasionally present and pyromorphite was also noted in the ore. Stains of copper carbonate are also occasionally seen. The gold is free in the oxidized portion of the vein, though it may originally have been contained in sulphides. Where the porous quartz changes in character to a more massive type or when the feldspathic constituents come in, the metal content quickly decreases. In the lower workings (in 1912) the vein passes from the quartzite into granite 
and essentially at the contact of these rocks the character of the vein filling in the ore shoot that was being followed changes from quartz to a feldspathic rock and ceases to be ore. Whether this is a local change such as occurs at higher levels or whether the vein filling in the granite will be uniformly feldspathic can be determined only by additional development.

It may be noted in this connection that in the very similar deposits in the Park Valley district (see p. 498) the ore occurs in veins inclosed in the granitic rock.

The outcrop of the vein is rather prominent and it is reported that good ore was present practically at the outcrop. The main vein is cut by cross breaks that have brecciated the rock but usually have resulted in but slight displacement. Commonly there is some gouge matter on these breaks.

The largest ore shoots in the mine are associated with the cross breaks, suggesting that these have influenced the formation of the shoots. The loose brecciated rock along these breaks furnishes the easiest course for the passage of solutions, and as the brecciation occurred after the formation of the veins, the rich shoots may most naturally be attributed to enrichment by descending solutions. There was, however, no opportunity to ascertain by a study of primary ore the changes due to oxidation. Moreover, the reported presence of good ore at the outcrop indicates that there has been no extensive downward leaching.

The deposit had been followed down the dip from the outcrop for about 500 feet in 1912 . It is reported $^{1}$ that considerable additional development has been done since then, and some metal produced. The total bullion produced is said to have averaged about 0.650 fine.

The apparent gradation from pegmatitic rock into quartz veins containing metallic constituents naturally suggests that the primary deposits were formed by differentiation of the granitic magma. Very similar deposits that are believed to have a similar origin occur in the Park Valley district (see p. 498), and Spurr $^{2}$ has described similar deposits in the Silver Peak district, Nev., which he ascribes to similar differentiation.

1 Reagan, A., The Deep Creek gold mining district: Min. and Eng. World, vol. 41, Dec. 12, 1914

2 Spurr, J. E., Ore deposits of the Silver Peak quadrangle, Nev.: U. S. Geol. Survey Prof. Paper 55, p. 122, 1906.
The ore from the mine has been treated at a mill on Fifteenmile Creek, to which it was transported over a gravity tram about a mile long.

\section{SILVER ISLET RANGE.}

By B. S. ButLer.

GENERAL FEATURES.

The Silver Islet district is in the range of the same name, near the western border of the Great Salt Lake desert. The nearest railroad point is Wendover on the Western Pacific, about 15 miles to the southwest. Timber is almost totally lacking on the range, and water for drinking and cooking was in 1912 hauled from Wendover. Brackish water is obtained by sinking wells into the alluvium at the base of the mountain.

The district was organized in 1872. Nothing is known of its early production. The deposit in the Carrie Mack property, said to have been discovered by a sheep herder named McKeller about 1902, shipped some lead ore by wagon 35 miles to Lucin on the Southern Pacific Railroad. Production was first reported from Silver Islet Range to the Geological Survey in 1908. Shipments increased after the building of the Western Pacific Railroad. The total output of the district from 1908 to 1913, inclusive, aggregates 760 tons of ore containing $\$ 809$ in gold, 110,614 ounces of silver, 57,535 pounds of copper, and 414,339 pounds of lead, valued in all at $\$ 90,219$.

The relatively low range rises abruptly from the flat alkali desert which nearly surrounds it. Its general trend is northeast. About 10 miles northwest of Wendover it is separated into two parts by a low pass whose summit is only a few hundred feet above the level of the desert.

\section{GEOLOGY.}

\section{SEDIMENTARY ROCKS.}

The rocks of the range, so far as observed, are sedimentary with the exception of a few small dikes. Limestones make up by far the greater part, though a considerable thickness of conglomerate and quartzite is exposed at the north end of the portion of the range south of the low pass.

The rocks of the southern portion of the range were not examined except as they could 
be seen from the road leading to the mines, and no fossils to indicate their age were obtained.

Fossils collected at different horizons in the northern part of the range were submitted for paleontologic examination to Edwin Kirk, who reports as follows:

No. 173. East side of Silver Islet. Second canyon north of Morrison camp:

Dalmanella pogonipensis Hall and Whitfield.

Clitambonites? near C. ionensis Walcott.

Straparollus? sp.

Maclurea? annulata Walcott.

Eccyliopterus michleranus? Hall.

Bathyurus sp.

Leperditia bivia White.

No. 174. East side of Silver Islet. Third canyon north of Morrison camp:

Dalmanella cf. D, perveta Hall.

Bucanella n. sp. similar to B. nana Meek.

Eccyliopterus sp.

Lophospira n. sp.

Homotoma sp.

Coleoprion sp.

Cyrtodonta n. sp.

Several undescribed species of Ostracoda, of the genera Leperditia, Leperditella, and Aparchites.

The lots listed above fall within the upper part of the Pogonip limestone. They may be correlated with the lower part of the Simpson formation of Oklahoma, which is held to be basal Ordovician by Ulrich. This general faunal aggregate is widely distributed throughout the West and maintains a fairly uniform character.

It is evident that the rocks of the northern part of the range are of Ordovician age with possibly older rocks to the north of the point where they were examined.

In the atlas accompanying the report of the Fortieth Parallel Survey the range is given as Carboniferous. No statement was found in the text of that report to indicate on what evidence this determination was based, but it appears probable that the rocks of the southern and more accessible portion of the range were determined by the geologists of that survey to be Carboniferous and that the more remote portion, not visited by them, was inferred to be Carboniferous also.

\section{IGNEOUS ROCKS.}

The observed igneous rocks are confined to a few dikes. One near the Morrison group is a dark medium-grained rock in which biotite crystals are conspicuous. In the hand specimen the rock is suggestive of the lamprophyric type. Under the microscope it is seen to be composed essentially of plagioclase, orthoclase, biotite, hornblende, and some quartz, with magnetite and apatite as accessory minerals. The rock has undergone considerable alteration, calcite, chlorite, and epidote being rather abundant secondary minerals. Plagioclase is considerably more abundant than orthoclase, and hornblende and biotite are approximately equal. In mineral composition, therefore, the rock is intermediate between kersantite and camptonite. Another dike, exposed near a prospect on the west side of the range, is apparently similar in mineral components but contains a much larger percentage of the feldspar and a correspondingly smaller percentage of the ferromagnesian minerals. These last are too highly altered for their original form to be definitely determined, but both biotite and hornblende were present in the original rock. The rock is dioritic in composition and may be classed as diorite porphyry.

\section{STRUCTURE.}

The sedimentary beds of the range strike about northeast and dip northwest and are cut by numerous faults. At the south end of the portion of the range north of the pass a strong northeast-trending fault that cuts the limestone is marked by a zone of highly brecciated rock 20 feet or more in width. In places the slickensided and polished walls of the fault stand up as a prominent cliff. The displacement was not determined but is apparently considerable; for east of the fault the sedimentary beds are much flatter than to the west and in some places a gentle easterly dip replaces the prevailingly westerly one.

The limestone is also cut by a series of fissures striking nearly north and dipping steeply west. The fissures are east of the fault and appear to be cut off by it; at least they have not been noted west of the fault. The fissures are also cut by faults with small displacement, one of which, revealed in the development of an ore body on the Morrison group, has a throw of approximately 20 feet.

\section{ORE DEPOSITS.}

In the deposits in the Morrison group the ore bodies occur as lenticular bodies in the fissures, "pinching" and "swelling" along both the strike and the dip. Bodies of ore extending out from the fissure along certain 
beds of limestone that are so characteristic in most of the deposits in limestone are not present in this deposit. The width of the vein differs greatly from place to place, widening from a mere stringer to several feet and again "pinching" to a stringer.

The original filling of the fissures apparently consisted mainly of quartz with sulphides of lead, copper, and iron, and some antimony mineral, possibly jamesonite. Silver is an important constituent. The sulphides to the present depth of development have been largely oxidized to carbonates of lead and copper hydrous oxide of iron together with rather abundant bindheimite.

The principal value of the ore is in its lead and silver, though some of it carrics several per cent of copper. The ore thus far extracted is of high grade, carload lots averaging as high as $\$ 120$ per ton.

Other developments on the east side of the range have yielded comparatively little ore. They were not active at the time of visit and could not be examined.

On the west side of the range a deposit that has been considerably developed occupies a fissure striking almost north and standing nearly vertical. Not far from the prospect a nearly vertical dike of diorite porphyry several feet thick, that apparently cuts the ore vein, can be traced northwest for several hundred feet. The limestone is recrystallized in the vicinity of the dike, and for 10 to 12 feet from it has been rather highly silicified and colored red by iron. Under the microscope the silicified rock is seen to be composed of quartz, calcite, and abundant foils of muscovite. The original vein filling in this fissure, as in those on the east side of the range, is quartz and the metallic sulphides. The property was idle at the time of visit and the workings were not examined, but so far as could be judged from an examination of the dump oxidation has been rather complete to the depth of present development.

The genesis of the deposits of the district is not strongly indicated from the evidence collected. Many of them are associated with dikes, but the dikes are apparently of later age and indicate no close genetic relation.

There appears to be no reason, however, for considering the origin of these deposits to be different from that of similar deposits that are definitely related to bodies of intrusive rock.

\section{LAKESIDE DISTRICT.}

By V. C. Heikes.

The Lakeside district is in Tooele County, in a low range skirting the Great Salt Lake. Dell is the railroad point on the Western Pacific Railroad. The district was organized March 25, 1871, and was the scene of some mining excitement ${ }^{1}$ from 1871 to 1874 , since which time little has been done. A number of claims, about 2 miles from the lake and 500 feet above it, are said to have shippedbut not profitably - a large quantity of lesd ore containing silver in early days.

\section{NEWFOUNDLAND DISTRICT.}

By V. C. Heikes.

The Newfoundland district, in Box Elder County, is in a small mountain range in a marshy desert 6 miles south of Newfoundland station on the Southern Pacific Railroad. It was organized in 1872. Huntley says ${ }^{2}$ that many locations had been made but few claims patented prior to 1880 ; that the formations comprise both sedimentary rocks and some porphyry, and that the veins are narrow (18 inches) and contain milling ore. No production has been reported

\section{PILOT RANGE.}

By B. S. Butler.

TOPOGRAPHY.

The Pilot Range (Ombe Range) trends a few degrees east of north and is about 30 miles in length and 4 to 5 miles in width. Its highest point is Pilot Peak, which reaches an elevation of approximately 10,000 feet. Its northern portion, which is 2,000 to 3,000 feet lower, slopes steeply eastward to the Great Salt Lake Desert and with relative gentleness westward to the Tecoma Valley.

\section{IUCIN DISTRICT.}

\section{LOCATION.}

The Lucin district is in the Pilot Range, on the boundary of Utah and Nevada, a few miles south of the Union Pacific Railroad. The nearest station on the main line is Tecoma, $\mathrm{Nev}$., which is 7 to 10 miles from the mines by wagon road; but shipments are made from 1 Huntley, D. B., Precious metals: Tenth Census U. S., vol. 13, p. 456,
1885

2 Idem, p. 484. 
the base of the range, to which a spur from the main line has been constructed. The ores of the Copper Mountain mine are transported from the mine to the terminal of this spur by an aerial tram.

\section{HISTORY AND PRODUCTION.}

By V. C. Heikes,

The deposits of the Lucin district were discovered in the summer of 1868, and the district was organized September 2, 1872. The mines are in the Lucin Range of mountains, on the dividing line between Utah and Nevada, but are all on the Utah side, in Box Elder County.

A smelting furnace was erected in 1871 at Buel City, at the edge of the foothills among which are the mines. Copper ${ }^{1}$ was first discovered in native form, the red and black oxides and green and blue carbonates. Subsequently, galena was found in considerable quantity. According to Huntley ${ }^{2}$ all the early production was prior to 1876 . He says:

The English Tecoma company, or the Tecoma Mining Co. of Utah (Ltd.), owns several claims, two of which, the Gladstone and the Shanly, were patented. * * * This was the same company that bought the Flagstaff and the Last Chance (in Salt Lake County). About 1,000 tons of low-grade ore ( 30 per cent lead and from 10 to 25 ounces silver) was extracted, which was shipped to the company's furnace at Truckee, Cal., about 500 miles distant. The total cuttings aggregated possibly 1,500 feet.
The American Tecoma company, or the Tecoma Mining Co., owned eight patented claims. A furnace was erected in 1871; and while the mines were looking well the property was sold to Howland \& Aspinwall, of New York, in 1872. The latter owners extracted several thousand tons of ore (averaging about 35 ounces silver and 45 per cent lead) from two well-defined surface bodies and shut down in 1875 or 1876 . The claims have been idle since. In the lower parts of the ore bodies much wulfenite was found.

In 1874 about forty tons of horn-silver ore were collected on the Black Warrior claim from surface deposits by gopher-hole work, which were said to have yielded $\$ 16,000$.

Between 1886 and 1894 the copper properties were vigorously worked and subsequently sold to the Salt Lake Copper Co., which ereeted, in 1893 and 1894, very extensive electrolytic works in the northern part of Salt Lake City. This plant shipped in October, 1894, two carloads (61,832 pounds) of ingot copper, said to have been the first fine copper shipped out of Utah. Some of the ores treated were from the old Copperopolis mine (in the Tintic district), which was purchased by the company in 1894 and thereafter known as the Ajax Mining Co. By the end of 1894 the electrolytic plant and property were in the hands of a receiver and considered a complete failure.

Statistics prior to 1876 are not available, but estimates based on the reports of Huntley ${ }^{2}$ and Murphy ${ }^{3}$ and information from former owners of the property in the district are tabulated as follows:

Mctals produced in Lucin district, 1870-191\%.

\begin{tabular}{|c|c|c|c|c|c|c|c|c|c|c|c|c|}
\hline \multirow{2}{*}{ Period. } & \multirow{2}{*}{$\begin{array}{l}\text { Ore } \\
\text { (short } \\
\text { tons). }\end{array}$} & \multicolumn{2}{|c|}{ Gold. } & \multicolumn{2}{|c|}{ Silver. } & \multicolumn{2}{|c|}{ Copper. } & \multicolumn{2}{|c|}{ Lead. } & \multicolumn{2}{|c|}{ Zinc. } & \multirow{2}{*}{$\begin{array}{l}\text { Total } \\
\text { value. }\end{array}$} \\
\hline & & $\begin{array}{c}\text { Fine } \\
\text { ounces. }\end{array}$ & Value. & $\begin{array}{c}\text { Fine } \\
\text { ounces. }\end{array}$ & Value. & Pounds. & Value. & Pounds. & Value. & Pounds. & Value. & \\
\hline \multirow[t]{2}{*}{$\begin{array}{l}1870-1905 . . \\
1906-1913 . . \\
1914-1917 . .\end{array}$} & $\begin{array}{l}29,864 \\
99,748 \\
22,883\end{array}$ & $\begin{array}{r}\cdots \\
27.29 \\
77.14\end{array}$ & $\begin{array}{r}\$ 563 \\
1,595\end{array}$ & $\begin{array}{r}176,000 \\
21,886 \\
27,250\end{array}$ & $\begin{array}{r}\$ 220,282 \\
12,387 \\
20,815\end{array}$ & $\begin{array}{r}1,675,200 \\
12,027,418 \\
2,874,703\end{array}$ & $\begin{array}{r}\$ 237,835 \\
1,767,346 \\
697,077\end{array}$ & $\begin{array}{r}3,720,000 \\
177,481 \\
851,641\end{array}$ & $\begin{array}{r}\$ 219,720 \\
7,973 \\
67,063\end{array}$ & & & $\begin{array}{r}\$ 677,837 \\
1,788,269 \\
790,087\end{array}$ \\
\hline & 152,495 & 104.43 & 2,158 & 225,136 & 253,484 & $16,577,321$ & $2,702,258$ & $4,749,122$ & 294,756 & 34,680 & 3,537 & $3,256,193$ \\
\hline
\end{tabular}

GEOLOGY.

The rocks of the Pilot Range consist of sedimentary and igneous formations, the latter consisting of both intrusive and extrusive rocks.

\footnotetext{
1 Murphy, J. R., Mineral resources of the Territory of Utah, Salt Lake City, 1872.

2 Huntley, D. B., op. cit., p. 484
}

SEDIMENTARY ROCKS.

In the southern part of the Pilot Range, according to Hague, ${ }^{4}$ quartzite is the prevailing rock, Pilot Peak being composed entirely of this rock and a total of 6,000 to 7,000

3 Op. cit., pp. $41-42$

${ }^{4}$ Hague, Arnold, and Emmons, S. F., Descriptive geology: U. S. Geol. Expl. 40th Par. Final Rent., vol. 2, p. 496, 1877. 
feet being exposed. The extreme south end of the range is composed of limestone. North of Patterson Pass limestone occupies the eastern portion of the range for several miles, and still farther north in the principal mineralized area it is the predominant sedimentary rock. Quartzite interbedded with shale and limy shale is present on the east side of the range for several miles north of Patterson Pass.

In the vicinity of the mines several thousand feet of heavy-bedded limestone is apparently overlain by fully as great a thickness of a siliceous series of quartzite, conglomerates, and shale with interbedded limy shale. This siliceous series is also present south of the main mineralized area.

Hague ${ }^{1}$ states that near the northern end of the range and at the eastern base Tertiary beds outcrop that "consist mainly of white, thinly bedded calcareous and siliceous shales, remarkably fissile and frequently bituminous." From their character they are thought to be equivalent to the Green River Eocene, though fossils were not found in them. They have been deformed, but what are believed to be late Tertiary beds at the north end of the range lie nearly horizontal. These beds, according to Hague, consist of "fine siliceous rhyolitic material interstratified with occasional fine sands."

Hague has provisionally correlated the quartzite with the Weber quartzite of the Wasatch Range. He states, however, that some of the quartzite has undergone considerable metamorphism and may be older than the Weber quartzite.

The limestones at the south end of the range are referred by Hague to the "Upper Coal Measures." They yielded Productus punctatus and Spirifer cameratus.

The entire sedimentary series at the north end of the range is of Carboniferous age, consisting of Pennsylvanian and probably upper Mississippian.

Fossils were collected from several horizons south of the main east-west fault. From about the central portion of the limestone as exposed G. H. Girty determined Zaphrentis multilamella?, Spirifer agalainis?, Eumetria? sp., and Bellerophon aff. B. percarinatus. Mr. Girty says that he is uncertain of the position of this fauna in the section. A somewhat similar fauna in the Oquirrh Range appears to be at the base of the Pennsylvanian or at the top of the Mississippian.

Several hundred feet above the base of the shale-quartzite series, a collection which Mr. Girty regards as upper Mississippian yielded Lingulidiscina newberryi var. marshallensis? and Martinia sp. A fossil from still higher in the series was determined by Mr. Girty to be Fusulina aff. F. cylindrica and of Pennsylvanian age.

Near the eastern base of the range, fossils were collected that were identified by $\mathrm{Mr}$. Girty as crinoidal fragments, Martinia sp., and Spirifer aff. S. cameratus and are regarded by him as upper Mississippian. It seems probable that there is a strong fault in this part of the range, though none was recognized in the hasty traverse made.

The only collection from north of the main east-west fault was made near the base of the limestone cliff about due east of the terminal of the ore tram. Fusulina cylindrica, Rhombopora lepidodendroides?, and Bellerophon sp. were determined and are considered by Mr. Girty to be of Pennsylvanian age. In the field this horizon was thought to be approximately equivalent to that from which fossils were collected in the limestone south of the fault, but the fossil evidence indicates that it is considerably higher.

\section{IGNEOUS ROCKS.}

INTRUSIVE ROCKS.

According to Hague, the largest body of intrusive rock in the range is exposed in Patterson Pass. It has a width from north to south of about 2 miles and extends entirely across the range. North of Patterson Pass less extensive bodies of the granite outcrop on both the east and west sides of the range-for instance, on the east side, on the Copper Mountain property, southeast of the lower tunnel, which is driven in granite for a part of its length; and on the west side in numerous places along the foothills.

Hague $^{2}$ gives the following description of the granite at Patterson Pass:

This granite is a medium-grained rock, somewhat friable in texture and of a reddish-gray color, derived from 
an admixture of both red and white feldspars. The mineral constituents are chiefly quartz in small translucent grains, associated with both microcline and triclinic feldspars. Mica in thin brown flakes, frequently adhering to the broader faces of the feldspar, is present but in subordinate amounts. The white feldspars are frequently an inch in length, forming a strong contrast to the smaller: but more abundant red crystals.

Similar granitic rock is exposed in the north end of the range. The orthoclase is approximately equal in amount to the plagioclase, which has a composition varying little from andesine. The dark silicates are commonly largely altered to a chloritic material that has apparently been derived principally from biotite, though perhaps to some extent from hornblende. Quartz is rather abundant, in places probably amounting to 20 per cent. The rock is locally called granite, but quartz monzonite is a more exact name.

On the east side of the range the intrusive rock is cut by dikes that differ from the main body of the quartz monzonite in containing a much larger amount of dark mineral (hornblende, in the sections examined) and more plagioclase, which is also of more basic composition. Quartz is present but not in large amount. The more basic of these dikes have essentially the composition of quartz diorite, and several of them have distinctly lenticular forms that strongly suggest basic segregations.

The sedimentary rocks are cut by more siliceous and more basic dikes. Typical diabase dikes, composed essentially of plagioclase and pyroxene with minor amounts of magnetite and apatite, are present in the workings of the Copper Mountain mine and in the granite north of Tecoma Hill and probably at other points. Siliceous dikes were noted in the limestone of Tecoma Hill and are doubtless present at other localities. The rock is light gray to nearly white and usually is porphyritic. The phenocrysts are orthoclase and quartz inclosed in a fine groundmass of orthoclase and quartz, of which the orthoclase is considerably the more abundant in the specimens examined. Dark silicates are almost entirely absent, though small areas of quartz carbonate and a little chlorite and muscovite possibly represent altered biotite. On weathering, the phenocrysts of orthoclase are readily removed, giving the exposed surface of the rock a characteristic pitted appearance. On the north side of Tecoma Hill numerous aplitic dikes in the limestone near the granite contact are composed of an intergrowth of quartz and orthoclase and are usually of medium grain. Many of the fissures containing aplitic dikes also contain a vein of coarse quartz with sulphides.

EXTRUSIVE ROCKS.

The extrusive rocks are confined mainly to the north end of the range. According to Hague both rhyolite and basalt flows occur, the rhyolite being the earlier. The rhyolites are glassy rocks containing phenocrysts of quartz and sanidine, and the basalts are holocrystalline porphyritic rocks with rather abundant feldspar phenocrysts.

Hague ${ }^{1}$ gives the following analyses of the basalts:

Analyses of basalt from Pilot Range.

[R. W. Woodward, analyst.]

\begin{tabular}{|c|c|c|}
\hline & 1 & 2 \\
\hline 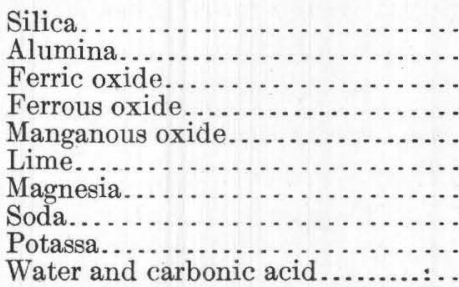 & $\begin{array}{r}54.80 \\
17.58 \\
.97 \\
8.84 \\
\text { Trace. } \\
8.22 \\
4.47 \\
3.14 \\
1.16 \\
.94\end{array}$ & $\begin{array}{r}54.79 \\
17.59 \\
.94 \\
8.85 \\
\text { Trace. } \\
8.13 \\
4.54 \\
2.97 \\
1.16 \\
.98\end{array}$ \\
\hline
\end{tabular}

Hague states that there is a small outflow of gray rhyolite along the east base of Pilot Peak.

RELATIONS OF IGNEOUS AND SEDIMENTARY ROCKS.

That the quartz monzonite of the Lucin district is clearly intrusive in the Carboniferous rocks is shown by dikes of a rock closely resembling the quartz monzonite that cut the sedimentary rocks, by the presence near the quartz monzonite contact of rather abundant aplitic dikes that are evidently offshoots of the main mass, and locally by the presence of contact silicates in the limestones adjacent to the contact. The igneous rock is in contact with different horizons in the sedimentary series over a thickness of at least several thousand feet, a relation readily and naturally accounted for if the quartz monzonite is intrusive in the sedimentary rocks. It seems likely that the bodies of quartz monzonite outcropping on the east and west side of the range are connected

1 Op. cit., p. 500. 
and that igneous rocks may be relatively more abundant at no great depth.

Some basic dikes cut the quartz monzonite, and it seems probable that the basic dikes in the sedimentary rocks are also later than the quartz monzonite, though positive evidence on this point is lacking. The siliceous porphyry dikes were not observed in the quartz monzonite and their relation to that rock is not known.

The flow rocks at the northern end of the range are later than the Carboniferous and earlier than the late Tertiary sedimentary rocks. They were not observed in contact with the intrusive rocks, and the relative ages of the two are not known.

STRUCTURE.

The structure of the district is too complicated to be thoroughly understood without detailed geologic work. Faulting has evidently been important; from the paleontologic evidence it has apparently been more important than general inspection would indicate. Folding has apparently played a minor part. Possibly, however, the rocks underwent broad open folding before they were faulted.

In the vicinity of Copper Mountain the rocks strike a little west of north and dip approximately $30^{\circ} \mathrm{E}$. Whether their altitude is due to faulting and tilting or to broad open folding of which only one limb is exposed has not been positively determined. Indeed, the intrusion of the quartz monzonite may have exerted no small influence on the present position of the sedimentary beds.

A strong east-west fault that crosses the range south of Copper Mountain has caused the formation of a pass. Its throw has not been determined but was large. The siliceous rocks south of this fault do not extend north of it; those to the north seem to have been thrown down relatively to those to the south. A strong north-south fault extending north from the east-west fault along the crest of Copper Mountain is marked by a strong zone of brecciated and highly silicified rock. About 1,000 yards to the west another strong fault of similar trend extends south from the east-west fault and is possibly a continuation of the Copper Mountain fault, the two portions having been separated by the east-west movement. There are many minor faults in the district and probably some others of large displacement. Fissures trending both east and north have been channels for ore solutions and for the intrusion of dikes

ORE DEPOSITS.

CONTACT DEPOSITS.

Contact deposits in the limestone adjacent to the quartz monzonite are accompanied by contact silicates, garnet, diopside, tremolite, and the like. These deposits have been prospected to some extent north of Tecoma Hill but have not yet been shown to be of commercial importance.

\section{FISSURE DEPOSITS.}

The replacement-vein type, which has furnished practically the entire output of the district, may be subdivided according to metallic content.

COPPER DEPOSITS.

The most important copper deposit-that of the Copper Mountain mine of the Salt Lake Copper Co._-is a replacement of limestone apparently chiefly along certain beds adjacent to a north-south fault zone. The sedimentary rock in the vicinity is limestone, and the only intrusive rock seen in the mine is a diabase dike 20 to 50 feet thick. The strike of the dike corresponds in a general way with that of the fault zone, and the intrusion apparently followed this plane of weakness. The accessible workings at the time of visit did not furnish conclusive evidence of the relation of the dike to the ore but indicated that it was intruded after the deposition of the ore. There has been movement along the fault zone, however, since the dike was intruded.

The ore thus far developed is entirely oxidized, consisting of hydrous oxides of iron, oxide of copper, "copper pitch" (a black substance containing copper and manganese), carbonates of copper, silicate of copper, and a large amount of a clayey mineral that is white to dark blue, according to the quantity of copper it contains. This material was reported by W. T. Schaller to be a hydrous aluminum silicate. Some specimens of the blue mineral approach the composition of chrysocolla. According to Ryan ${ }^{1}$ some of the

1 Ryan, G. H., Salt Lake Min. Rev., vol. 16, p. 20, 1914. 
"talcy" material contains as high as 27 per cent of alumina. Irregular masses of cuprite are in places inclosed in this material, making a high-grade ore.

The character of the ore differs greatly at different points; for example, the southern part of the east ore body is mainly hydrous iron oxide which contains little copper but which is so high in iron that a large quantity has been shipped as fluxing ore. The northern part of the deposit contains much more copper and some of it is high-grade ore. For a considerable distance south of the known ore the outcrop of the fault zone is a highly silicified limestone stained with oxides of iron, in which no ore has been found.

The ore was doubtless formed by the oxidation of bodies of iron and copper sulphides, though neither was seen in the mine, the oxidation being unusually complete.

The ore body outcrops prominently, and much ore has been extracted by open-cut methods. The ore thus far mined has been in two bodies, separated by a relatively barren zone. The eastern wall of the eastern deposit is formed in part by the diabase dike. Prospecting east of the dike has failed to find ore in important amounts. Ore has been developed for 150 to 200 feet below the outcrop, but rather extensive prospecting at greater depth has failed to discover important bodies. In 1912 a tunnel which was being driven from the east side of the mountain 900 to 1,000 feet below the outcrop of the ore body, to prospect the supposed downward extension of the ore zone, had not encountered ore but had found a considerable body of quartz monzonite nearer to the ore zone than is apparent on the surface.

LEAD-SILVER DEPOSITS.

Several deposits in the district were worked mainly for their lead-silver content in the early days but are at the present in large part inaccessible. (See p. 489.) The Tecoma mine has been the most important producer of this type.

The sedimentary rock of Tecoma Hill is limestone, which, along the north side of the hill, has undergone some contact alteration and mineralization from the quartz monzonite there exposed. Dikes of siliceous granite porphyry cut the limestones. A strong one strikes generally east and apparently dips steeply south. The limestones are also cut by northeast-southwest fissures, some of which contain dikes.

The ore bodies could not be studied, but they apparently occurred as replacements of the limestone along the fissures, the main ore shoots being formed where certain beds of limestone had been replaced for some distance from the fissures.

The ore thus far extracted has been oxidized. It contained much iron and in places much wulfenite, the molybdate of lead. Hague ${ }^{1}$ says:

The molybdate of lead frequently forms so high a percentage of the ore as to interfere seriously with its treatment in the ordinary lead furnaces, rendering a modification of the methods employed very desirable. The crystallized wulfenite from the Tecoma mine occurs in large masses, the faces of individual crystals having been observed from an inch to $1 \frac{1}{2}$ inches in length. They possess a resinous luster, a lemon-yellow color, and are frequently transparent and exceedingly brittle. In size and brilliancy the finest specimens far surpass the famous wulfenite crystals from the limestones of Bleiberg in Carinthia. Associated with the wulfenite, adhering to the broad tabular faces, may occasionally be seen well-developed crystals of cerusite and anglesite (carbonate and sulphate of lead).

Plumbojarosite, a basic lead-iron sulphate, was collected from the dump of the Tecoma mine, but it is not known to what extent it was present in the ores.

In 1912 the Copper Mountain Mining Co. was extracting some oxidized lead ore north of the Copper Mountain copper mine from similar sedimentary rocks. The main development was in a fissure striking N. $60^{\circ} \mathrm{W}$. and dipping northeast along which the mineralized band is practically continuous though not of uniform width, extending farther into some limestone beds than into others and being in places nearly cut out by coarse calcite which fills the fissures except for an inch or two in the hanging wall. The thickness of the ore varies from a few inches to 2 feet or more. Some copper ore has also been exposed. The output of lead ore from this part of the district has not been large.

In 1912 the Mineral Mountain Mining Co. was prospecting its property in the southern part of the district. Asmall amount of development was being done on other properties and some ore was shipped. 
GENESIS.

The present development of the district gives little clue to the origin of the ores. The Copper Mountain deposit is associated with a basic dike but affords no evidence of intimate genetic relation between it and the ore deposits. The same is possibly true of the siliceous dikes and the ore deposits in Tecoma Hill, their close association appearing to be due to the fact that both the ore solutions and the dikes entered the rocks along the same fracture zones.

The contact deposits that occur to a small extent in the limestone near the quartz monzonite are apparently genetically associated with its intrusion. This fact and the study of similar deposits whose relations are more apparent leads to the belief that all the ore deposits of the district are genetically associated with the intrusion of quartz monzonite. Heated solutions carrying the constituents of the ores rose along the fissures and deposited sulphides and other minerals in limestone beds favorable to replacement. These deposits were subsequently oxidized by descending solutions.

VARISCITE DEPOSITS.

Variscite, a hydrous aluminum phosphate $\left(\mathrm{AlPO}_{4} \cdot 2 \mathrm{H}_{2} \mathrm{O}\right)$, occurs 5 miles northwest of Lucin and has been mined to some extent as a gem material.

According to Sterrett ${ }^{1}$ the variscite occurs as balls, nodules, and irregular masses in a cherty breccia containing fragments of limestone.

\section{BIBLIOGRAPHY.}

Hague, Arnold, and Emmons, S. F., Descriptive geology: U. S. Geol. Expl. 40th Par. Final Rept., vol. 2, p. 496, 1877.

Huntley, D. B., Precious metals: Tenth Census U. S., vol. 13, p. 484, 1885.

RYAN, G. H., Geology and ore deposits in Lucin mining district: Salt Lake Min. Rev., vol. 16, pp. 20-22, 1914.

Sterrett, D. B., Variscite near Lucin, Utah: U. S. Geoi. Survey Mineral Resources, 1910, pt. 2, p. 894, 1911.

GROUSE 、 CREEK RANGE.

BY B. S. ButLeR.

LOCATION.

The Grouse Creek Range, in the northwestern part of the State, in Box Elder County, extends from a few miles north of the Southern Pacific Railroad (Lucin cut-off) to the northern

1 Sterrett, D. B., U. S. Geol. Survey Mineral Resources, 1910, pt. 2, p. 894, 1911 boundary of the State, a distance of nearly 40 miles. Its southern and central portion lies between the Grouse Creek valley on the west and the Muddy Creek valley on the east. Farther north it merges with the Raft River Range.

\section{GEOLOGY.}

\section{SEDIMENTARY ROCKS.}

The lowest formation in the range observed by the writer is a thick series of hornblende and mica schist, which is overlain, in places at least, by a gneissic conglomerate, and this in turn by a series of impure limestones whose maximum observed thickness is about 100 feet. The limestone is followed by a series of sandy and shaly sedimentary deposits. Along the west side of the range a series of conglomeratic and sandy beds is overlain by light-gray tuffs. East of Grouse Creek the lowest beds exposed are a rather coarse conglomerate composed of pebbles of schist and quartzite. The pebbles are similar to the rocks exposed in the Grouse Creek Range. Overlying the conglomerate are thick beds of white tuff.

No fossils were found in the sedimentary series, but the highly metamorphosed character of the lower formations strongly suggests pre-Cambrian age and the less metamorphosed formations have been assigned to the same age (see Pl. IV), though they may prove to be younger. Hague ${ }^{2}$ mentions finding an Aviculipecten in beds in the south end of the range; indicating the presence of Paleozoic rocks.

If the rocks of the main range are preCambrian they contain more limestone than the corresponding rocks farther to the east. However, they seem lithologically to resemble the pre-Cambrian more closely than any younger rocks.

The conglomerates and tuffs along the western base of the range are regarded as of Tertiary age. Hague ${ }^{2}$ refers them to the horizon of the Humboldt formation (Pliocene) from their general resemblance to the beds developed in the upper Humboldt Valley.

\section{INTRUSIVE ROCKS.}

The largest body of intrusive rock exposed in the range is near its southern end and is said to extend 6 to 7 miles from east to west

2 Hague, Arnold, U. S. Geol. Expl. 40th Par. Rept., vol. 2, p. 429, 1877. 
and about half that distance from north to south. Farther north a canyon southeast of Grouse Creek settlement has cut through thesedimentary rocks and exposed a body of intrusive rock, and other canyons are said to have done the same. The range may be underlain by a large body of intrusive rock, only comparatively small areas of which have been exposed.

The rock of the large mass in the southern end of the mountains varies considerably in composition. A large part of it is granodiorite or quartz diorite, but small bodies are probably true diorite, and others might be classed as quartz monzonite. The rock exposed at Red Buttes, southeast of Grouse Creek, is similar in composition to the larger body in the south end of the range.

Numerous pegmatite dikes composed of quartz and feldspar appear to grade into veins or dikes of pegmatitic quartz, many of which are large and can be traced for several thousand feet.

\section{HISTORY.}

By V. C. Heikes.

The Ashbrôok district is in the northwest corner of Utah, where the Grouse Creek and Goose Creek ranges unite. It can be reached from Kelton, on the old line of the Southern Pacific Railroad, 55 miles to the east over a good wagon road, and from Burley, Idaho, on the Oregon Short Line, 83 miles to the north. The district is in an open rolling hill country, culminating here and there in high ridges and low mountain ranges. The mines are grouped within a circle a mile in diameter 7,000 feet above sea level. The first claim, the Homestake, was located August 19, 1873 , and the district was organized July 1, 1874. The deposits have been worked at various times in a small way and are opened by a tunnel 1,400 feet long.

In 1891 the Lexington and Argenta claims of the Vipont group were worked under bond and lease. The Argenta claim, which was found to yield the richest silver ore, shipped nearly 26 tons, containing an average of 116.9 ounces of silver and 0.13 ounce of gold per ton, to the old Telegraph smelter in 1892 and a similar lot in 1893. The option was allowed to expire for want of sufficient funds for development. ${ }^{1}$

1 Statement of G. Lavignino, Salt Lake City, March, 1915
A milling plant, erected on the Vipont group in August, 1897, contained a Lewis roller mill, two amalgamating pans, and one settler, and treated, in 14 days, an average of 8 tons of ore per day, resulting in a bar of bullion weighing 99.5 pounds, of which one-twentieth was reported $^{2}$ to be gold and the remainder silver. In 1899 the mill equipment was enlarged by the addition of a double-deck Wilfley table.

\section{PRODUCTION.}

The only mining operations have been on the Vipont group, which, as already noted, yielded previous to 1899 some silver ore of shipping grade and milled some ore. From 1899 to 1904 685 tons of ore were mined. The production of the district during the seventies and eighties would aggregate as much as shown in the following table. The mines had been idle since 1904 but became active in 1917 .

Production of metals in Ashbrook district.

\begin{tabular}{|c|c|c|c|c|c|c|}
\hline \multirow{2}{*}{ Year. } & \multirow{2}{*}{$\begin{array}{c}\text { Ore } \\
\text { mined. } \\
\text { (short } \\
\text { tons). }\end{array}$} & \multicolumn{2}{|c|}{ Gold. } & \multicolumn{2}{|c|}{ Silver. } & \multirow{2}{*}{$\begin{array}{l}\text { Total } \\
\text { value. }\end{array}$} \\
\hline & & $\begin{array}{c}\text { Fine } \\
\text { ounces. }\end{array}$ & Value. & $\begin{array}{c}\text { Fine } \\
\text { ounces. }\end{array}$ & Value. & \\
\hline 1899. & 225 & 37.17 & $\$ 768$ & 18,245 & $\$ 10,947$ & $\$ 11,715$ \\
\hline 1 & 22 & 9.04 & 187 & 3,374 & 2,092 & 2,279 \\
\hline 1901. & 200 & 3. 30 & 68 & 1, 639 & 983 & 1,051 \\
\hline 19 & 28 & 5. 58 & 115 & 1,640 & 869 & 984 \\
\hline 19 & 91 & 7.75 & 160 & 3,189 & 1,722 & 1,882 \\
\hline & 119 & 4. 30 & 89 & 1,612 & 923 & 1,012 \\
\hline \multirow[t]{2}{*}{$1917 \ldots$} & 27 & 3.74 & 77 & 1,400 & 1,153 & 1,230 \\
\hline & $a 7.12$ & 70.88 & 1,464 & 31,099 & 18,689 & 20,153 \\
\hline
\end{tabular}

ORE DEPOSITS.

\section{DEVELOPMENT.}

Prospecting in the range began many years ago and has been intermittent to the present time, but no important production has resulted except in the northern extension of the range, near the Idaho line, where the Vipont mine, in the Ashbrook district, produced for a short time. At the time of visit (1915) prospecting was being carried on in the south end of the range, where scheelite deposits had been discovered by Frank Edison and were being prospected under the direction of George W. Riter, of Salt Lake City.

${ }^{2}$ Mining notes: Eng. and Min. Jour., Oct. 16, 1897. 
TUNGSTEN DEPOSITS.

ROSEBUD CREEK DISTRICT.

OCCURRENCE.

The deposits of scheelite (calcium tungstate; $\mathrm{CaO}, 19.4$ per cent; $\mathrm{WO}_{3}, 80.6$ per cent) occur principally as a replacement of limestone. Associated with the scheelite is abundant quartz, epidote, chlorite, and muscovite, and lesser amounts of garnet and probably other silicates. Neither magnetite nor hematite was noted, and both are certainly notably scarce. Likewise, little sulphide is present though some galena has been found, and some of the limonite may have been derived from sulphide of iron. Barite was noted in several of the prospects and is apparently rather plentiful but was nowhere seen to be inclosed in scheelite nor scheelite in it.

The minerals replacing the limestone appear to have formed at essentially the same time. No other mineral has been observed inclosed in the scheelite, and it was possibly among the earliest to form, though the general relations indicate that the primary minerals were essentially contemporaneous.

At a few places the effects of mineralization extend along fissures a short distance into the intrusive body, but nowhere were they observed more than a few feet from the contact and nowhere did they change in character, indicating that the areas were within the influence of the limestone.

The deposits have undergone considerable oxidation. Among the secondary metallic minerals were noted cerusite, resulting from the alteration of galena, and vanadinite, possibly also a product of the oxidation of galena. Some of the scheelite is coated with a yellow material that is probably tungstate, though it was not obtained in sufficient amount for an accurate determination.

\section{ORIGIN.}

The minerals associated with the scheelite are the same as those present in other districts in the State where metal deposits occur as a replacement of limestone associated with intrusive bodies and where the evidence is pretty conclusive that the metais have been deposited from solutions coming from the intrusive rocks. The deposits differ in some of the associated gangue minerals from the scheelite replacement deposits of the Clifton district, but their general relations are similar and they are believed to have had a similar origin.

COMMERCIAL IMPORTANCE.

At the time of visit it had been shown that scheelite is present at numerous places along the contact. At no locality, however, had extensive development been made, and the exposures were not sufficient to warrant a prediction concerning the future possibilities of the deposits. At no place had material carrying more than a few per cent of scheelite been developed and most of the rock was very low in grade.

OTHER DEPOSITS.

North of the intrusive body at the south end of the range the quartz veins have been prospected at numerous localities but most extensively at the Mogul mine and at Red Buttes. At neither locality, however, were operations in progress at the time of visit, and few data concerning the deposits were obtainable. Specimens containing galena in a gangue of quartz and calcite were obtained on the dump of the Mogul mine and specimens composed of quartz and sulphides of iron and copper on the dump of the Red Buttes tunnels. Some of the black shale on the dumps of the Red Buttes tunnels was impregnated with iron sulphide. Both deposits are said to contain gold and silver.

The prospects north of Red Buttes were not visited. Considerable prospecting is said to have been done in the area between Red Buttes and the Vipont mine.

The deposits of the Vipont mine, in the Ashbrook district, are said to occur as a replacement of limestone associated with dikes of "quartz porphyry." The metallic minerals are sulphide of iron and lead, with arsenic and antimony minerals, in which the silver is said to be the most abundant. The oxidized ores are said to contain pockets of "chloride" and native silver.

\section{RAFT RIVER MOUNTAINS. TOPOGRAPHY.}

The Raft River Mountains extend east and west for about 20 miles. South of the range is the broad Park Valley, from which the mountains rise to an elevation of about 2,000 feet. The streams south of the crest have carved the range into a series of ridges and 
valleys, producing a topography which, as a whole, is not rugged when compared with that of other mountains of the State.

The range is sufficiently high to receive a rather heavy precipitation and the snow lingers till late in the spring, furnishing water to numerous streams.

\section{PARK VALLEY DISTRICT.}

By B. S. Butler.

The writer spent but one day in the Park Valley district, and the following notes are based on observations made during that time and information furnished by Messrs. T. W. Ireland and Harry Martin, in charge of the principal mines of the district.

\section{GENERAL FEATURES.}

The Park Valley district is in the northwestern part of Box Elder County, at the southern base of the Raft River Mountains. The district is about 25 miles northwest of Kelton, the nearest railroad station on the old line of the Union Pacific Railroad.

Though there are no large streams, sufficient water for milling is furnished by the streams from the mountains. Coal has been generally used as a fuel for power purposes, but the long haul has made it expensive. The Susannah mine has employed gasoline power.

\section{HISTORY AND PRODUCTION.}

By V. C. Heikes.

Golden, the principal camp of the district, is on the southern slope of the Raft River Range. A company was formed in 1896 to operate the Century property and was the beginning of activity in the district. Shortly after a Crawford amalgamation mill of 10 tons daily capacity was erected and considerable gold bullion 0.954 fine was recovered. This mill was eventually discarded and a new one, with sixteen 1,000-pound stamps and five Wilfley concentrators, was erected. About 75 per cent of the assay value of the ore was recovered by amalgamation and 15 per cent by the recovery of lead concentrates. This mine ceased producing about 1905 on account of the exhaustion of the better grade of ore that had been developed and the necessity of more development, which has been performed from time to time up to 1913 . About $\$ 400,000$ has been produced in gold, silver, and lead and $\$ 35,000$ paid to the mine stockholders.

To the west the extension of the Century vein was opened in the Susannah property. The high-grade gold ore was shipped and the second-class ore was treated in a 10-foot Lane slow-speed roller mill, which was constructed in July, 1909. Since then a small amount of gold bullion has been produced every year.

GEOLOGY.

SEDIMENTARY ROCKS

The sedimentary rocks in the vicinity of Golden, near the west end of the range, where they were examined by the writer, consist of a series of quartzites and schists, both highly metamorphosed. The quartzite shows the development of muscovite and a schistose cleavage and the schist is typically a dark biotite schist, but there are all gradations between the two. The formation, several thousand feet of which is exposed, is evidently a metamorphosed series of interbedded shales and quartzites. No other formation is exposed south of the divide in the vicinity of Golden, and as the range was not examined to the east, where later rocks are apparently present, it is not possible to give its exposed thickness. No fossils were collected from the sedimentary series and its age is therefore not known, but as its general character and appearance are similar to those of the pre-Cambrian of the Wasatch Range, it is provisionally considered of that age.

IGNEOUS ROCKS.

Igneous rocks were observed only in the immediate vicinity of Golden, but granite is reported to outcrop in Pine Canyon, several miles to the east.

The main intrusive body consists of coarsegrained porphyritic granite composed mainly of quartz and feldspar and some biotite. The porphyritic crystals are microcline and inclose small crystals of acidic plagioclase. Crystals containing many foils of sericitic mica appear to be plagioclase. The groundmass of the rock is an intergrowth of quartz and orthoclase, with foils of biotite and muscovite.

Near the contact with the sedimentary rocks the granite has a schistose or gneissic structure.

Both the granite and the sedimentary rocks adjacent to the granite are cut by numerous 
pegmatite dikes, which vary greatly in size and composition. They are composed essentially of quartz and orthoclase, but they grade from rock in which feldspar is abundant to pegmatitic quartz veins from which it is entirely absent.

In many dikes the feldspar is concentrated near one or both walls and the quartz in the center or adjacent to one wall. In such dikes there is no definite boundary between the feldspathic portion and the quartz portion. Many such dikes contain small amounts of sulphide, which was one of the latest minerals to crystallize. The order of crystallization of the minerals was first quartz and feldspar, later quartz alone, and finally sulphides.

\section{RELATIONS OF SEDIMENTARY AND IGNEOUS ROCKS.}

The general relations of the rocks exposed in the vicinity of Golden suggests that the sedimentary rocks are younger than the intrusive and were deposited upon them. More detailed examination, however, suggests that the granite is intrusive. No dikes clearly connected with the main granite mass were seen in the sedimentary rocks, but many masses of the sedimentary rocks within the granite can be most readily accounted for by supposing that they were included at the time of intrusion. Pegmatite dikes are present both in the granite and in the sedimentary rocks. In the sedimentary rocks they are most abundant near the granite contact and decrease in abundance as the distance from the granite increases. These dikes are believed to be closely related to the granite and to represent a late phase of the igneous activity. If so, the granite is younger than the sedimentary rocks.

\section{STRUCTURE.}

The general structure of the range is that of an anticline or dome. The sedimentary rocks of the south side strike east and dip south, away from the mountains; and observations from the summit of the range indicate that on the north they dip north, also away from the mountains. This gives an anticlinal or dome structure to the range. In the vicinity of Golden streams have removed the sedimentary rocks and have exposed an intrusive granite mass. This relation strongly suggests that the main structural feature of the range is due to a doming of the sedimentary rocks by the intru- sion of a granitic mass. This explanation is strengthened by the fact that the main structures due to folding and faulting in the general region trend north and south.

Many of the pegmatitic dikes in the sedimentary rocks are parallel to the bedding or schistosity, but some of them cut across the bedding.

\section{ORE DEPOSITS.}

The ore deposits occur in a series of veins that strike about N. $20^{\circ}$ E. and $\operatorname{dip} 40^{\circ}-50^{\circ}$ $\mathrm{SE}$., or even more steeply.

The Century vein, which is the most important yet developed, can be traced along the strike for several thousand feet. Whether it is continuous or is composed of a series of lenses along the same general strike has not been positively demonstrated. Several veins essentially parallel with the Century vein have been but slightly developed.

The mineral fissures cut the granite and what appear to be fragments of schist inclosed in the granite. At some points the fissure cuts through the schist with little change in size, but at other points it feathers out on entering the schist. The vein pinches and swells along both the strike and dip from a few inches to several feet in thickness.

The veins contain several distinct kinds of filling. At many points along the hanging wall the filling consists of a pegmatitic intergrowth of orthoclase and quartz, commonly designated "hanging-wall quartz." At other points it consists of coarse white quartz and at still other points of finer-grained quartz with sulphides and sulpharsenides or their oxidation products. The portions of the vein containing orthoclase and coarse white quartz carry little if any metal. The ore shoots are confined to the finer quartz.

The unoxidized ore contains galena, sphalerite, pyrite, chalcopyrite, and arsenopyrite, and the oxidized ore probably contains their common oxidation products. Rich oxidized ore carries visible free gold. Lead is commonly regarded as an indication of relatively rich ore, and at some points at least copper is considered to be less favorable.

The ore mined from the district has been largely oxidized, and reliable data as to the grade and character of the unoxidized material are not available. Small developments in the 
Century mine are said to have encountered a good grade of unoxidized ore, and prospecting northeast of the Century has developed base ores that are said to be of good grade but not suited to treatment in the mills of the district.

Gold is the most valuable constituent of the ore, but silver and some lead have also been obtained.

The occurrence of the ore is similar to that of the Queen of Sheba mine in the Deep Creek Range (p. 485). The genesis of this type of deposit is discussed on page 486.

The mines that have made the principal production to the present time are the Century and the Susannah. These are on the same vein, the Century to the east and the Susannah to the west. Both are developed by tunnels. The outcrop of the vein is too low to permit deep development by tunnel, and if the vein is to be prospected at depth it must be by shaft or winze. This will necessitate the pumping of water. How much water would be developed by such work is of course unknown, but it is reasonable to suppose that it will be considerable.

There has been considerable prospecting by other companies in the vicinity of Golden and some prospecting in Pine Canyon, several miles to the east, on what is reported to be a large body of quartz in granite.

\section{BIBLIOGRAPHY}

MacFarren, H. W., The Park Valley mining district of Utah: Salt Lake Min. Rev., vol. 11, pp. 17-18, 1909.

Briefly describes the geology, developments, and metallurgic plants of the district.

Higarns, W. C., The Century and Susannah mines, Utah: Salt Lake Min. Rev., vol. 11, pp. 19-22, 1909.

\section{PROMONTORY DISTRICT.}

By B. S. Butler and V. C. Heikes.

\section{INTRODUCTION.}

The Promontory district was visited by the writers in August, 1915. Through the courtesy of Mr. S. S. Arentz, manager of the Lake View Mining Co., a much better idea of the geology was obtained than would have been otherwise possible in the time available. Free use has also been made of a published description ${ }^{1}$ of the Lake View Mining Co.'s property by Mr. Arentz and of other data furnished by him.

1 Salt Lake Min. Rev., vol. 17, pp. 12-15, 1915
GENERAL FEATURES.

The Promontory district is in Box Elder County, near the south end of the Promontory Mountains, a north-south range extending southward from the north shore into the Great Salt Lake. The southern end of the promontory is crossed by the Southern Pacific Railroad (Lucin cut-off), which (through Saline station, on the western side of the promontory) serves the portion of the range in which ore deposits have been developed. The station, Promontory, is about 25 miles to the north, on the old line of the Southern Pacific.

The area in which ore has been produced is 3 to 4 miles north of the Lucin cut-off and about 1,000 to 1,500 feet above it. It is reached by a wagon road whose grade is moderate for most of the distance but becomes rather steep near the camp. Wagons and a motor truck haul ore to the railroad and supplies to the camp.

The range supports a rather scanty growth of cedar and other scrubby trees which are available as fuel. Some springs rise on the south end of the promontory but none near the camp. At the time of the writer's visit, water was brought in on the railroad for the section crew at Saline and for the Lake View Mining Co.'s camp, but the attempt to develop a supply in the vicinity was being considered.

The camp of the Lake View Mining Co., owners of the only producing claims of the district, is on an old beach of Lake Bonneville, predecessor of the present Great Salt Lake, which forms a bench on the mountain side and affords a level and very beautiful camp site.

The range lies within the area covered by the Fortieth Parallel Survey and was examined by Hague, ${ }^{2}$ who says:

This range extends from the northern limit of the map about 45 miles to the southward, forming a rocky promontory, which divides the two northern arms of Salt Lake, with a varying width from 4 to 7 miles, and reaching in its highest point 3,000 feet above the level of the lake. North of the railroad the range [North Promontory Range] is comparatively low, with rounded outlines, the greater part of its surface being covered with loose soil and grass, and showing but few outcrops. The underlying formation, however, belongs to the Wasatch limestone, and is evidently a continuation to the northward of the same beds which characterize the more important portions of the

2 Hague, Arnold, and Emmons, S. F., Descriptive geology: U. S. Ge ol. Expl. 40th Par. Rept., vol. 2, p. 420, 1877. 
range projecting into the lake. The railroad passes through a low depression in the range, which, on the summit, attains an altitude 4,943 feet above sea level, or over 700 feet above the level of Salt Lake. The old Pliocene Lake, at its highest elevation, unquestionably occupied this pass, isolating the main portion of the Promontory Mountains. * * * All along the east and west sides of the Promontory Mountains old terraces and beach lines may be traced with more or less distinctness, indicated by loose deposits of sand and gravel, or by benches cut in the hard mass of limestone. The elevation of the highest of these terraces is approximately 940 feet above the present level of the lake.

\section{GEOLOGY.}

\section{SEDIMENTARY ROCKS.}

No detailed description of the geology of the range has been published. Hague ${ }^{1}$ says:

To the south and west of the railroad, at Promontory station, the range, which is quite narrow, consists of a series of limestones, of a prevailing gray color, in the lower part of which are dark heavy beds of nearly black limestone, all dipping to the westward at an angle of $38^{\circ}$. About 4 miles south of Promontory station the range widens rapidly to the westward, attaining a width of 6 to 7 miles, of which the western third is occupied by the same series of limestones, which here rise with an easterly dip and overlie a limited outcrop of Archean schists.

These Archean rocks are exposed on the southwest corner of this projection of the range and consist of quartzites and mica-bearing schists, closely resembling those described in the Archean bodies of the Wahsatch. The main crest to the east of this western projection is occupied by conformable strata, dipping, as already mentioned, about $38^{\circ} \mathrm{W}$. They are much contorted, and show more or less faulting, so that their thickness can not be accurately determined. It is, however, not less than 3,800 feet. About the middle of the series there is an included zone of yellowish-brown sandstone, more or less calcareous, within which are several beds of gray limestone. Its lower portion is sharply defined from the underlying limestones, but 300 feet above, where it passes again into the limestones, it shades off gradually through shaly beds. The general strike of this portion of the range is N. $28^{\circ} \mathrm{E}$.

Along the extreme eastern foothills, on the edge of the lower Quaternary plain, which borders the lake shore, are outcrops of easterly dipping beds, which evidently show a portion of the eastern half of an anticlinal fold, of which the main mass just spoken of is the western member. This anticlinal fold appears very distinctly in the group of hills about 8 miles south of Promontory station, of which Benada Peak is the culminating point. Here a distinct northern axis cuts the range, and south of that point the rocks dip to the eastward. Through the pass, about $1 \frac{1}{2}$ miles north of Benada Peak, passes a synclinal axis quite parallel to the anticlinal, which lies 1 or $1 \frac{1}{2}$ miles to the west of it. Here the easterly dipping members of the western anticlinal and the westerly dipping parts of the eastern or second anticlinal meet. The second anticlinal passes through Benada Peak itself and, as has been said,

\footnotetext{
1 Op. eit., p. 428.
}

to the south of that point, for about 12 miles down the range, the greater part of the limestones dip uniformly to the east at angles varying from $20^{\circ}$ to $40^{\circ}$. At Flat Rock Point, on the west side of the range, are found portions of the western members of this anticlinal fold, dipping at a gentle angle into the lake, and consisting, for the most part, of gray and drab limestones, among which are intercalated bands of yellowish-brown sandstone, similar to that described in the westerly dipping mass south of Promontory station.

From the westerly dipping limestones, about 5 miles south of Promontory station, near Antelope Springs, were obtained the following fossils: Productus prattenianus, Spirifer opimus, Athyris subtilita, [and] Streptorhynchus (fragments); while the limestones farther south afforded Zaphrentis stansburyi [and] Productus semireticulatus. These fossils are all clearly of Carboniferous age, though of themselves not distinctly characteristic, either of the Upper or Lower Coal Measures limestones. The thickness of the series and its relation to the underlying Archeans, however, as well as its general lithological character, all serve to ally it rather to the latter division.

About 14 miles south of Benada Peak the Carboniferous limestones are found to abut unconformably upon a series of Archean schists, which occupy the whole lower 7 or 8 miles of the range, with a strike $\mathrm{N} .30^{\circ}$ to $35^{\circ} \mathrm{W}$, and a dip to the northeast. The Archean strata consist largely of siliceous schists and imperfectly bedded hornblendic and micaceous gneisses, together with thick beds of quartzite and more or less interspersed argillaceous schists. Just west of the southernmost extremity of the range, the Archean rocks come hearly down to the water's edge, presenting a cliff, some 50 feet in height, of dark argillaceous schist, which has apparently a dip of $25^{\circ} \mathrm{W}$.

Hague's statement that Archean rocks form the southern end of the promontory was apparently based on an examination along the western base, for limestone makes up an important part of the central and eastern part of the range.

Only the rocks forming the central portion of the series exposed were examined by the writers. The basal formation of the range is Archean schists. This is overlain by a great series of quartzite whose thickness has not been determined but is several thousand feet at least. This series is believed to be equivalent to the Cambrian and Algonkian quartzites and shales, which in the Wasatch Range are variable in thickness but in Big Cottonwood Canyon exceed 10,000 feet. Overlying the quartzite is 700 to 800 feet of shales, impure limestones, and sandstones, with some beds of rather pure limestone toward the top. Overlying this series are several thousand feet of heavy bedded limestones which were not examined. 
Fossils collected from the shale series overlying the quartzite and from the shale above the "middle bed" were examined by Edwin Kirk, of the United States Geological Survey, who reports:

The fossils are not in a very satisfactory state of preservation but approximate determinations are possible. All the evidence points to their lower Middle Cambrian age.

Lot 1. - Shale above lower "big" quartzite 100 to 400 feet above quartzite, about one-fourth of a mile north of Lake View camp: Ptychoparia sp., Bathyuriscus sp.

Lot 2.- South of Lake View camp in shale above ore limestone: Micromitra (Iphidella) pannula (White).

Lot 3.-In shale above (?) ore bedding; collected by S. S. Arentz: Zacanthoides sp.

Lot 4.- Float from shale above quartzite: Neolenus of. superbus Walcott, Bathyuriscus cf. B. productus Hall and Whitfield.

Lot 5.-Shale above "ore limestone" south of Lake View camp: Ptychoparia sp., algae.

Lithologically and paleontologically theshales and limestones between the quartzite and the upper limestone series rather closely resemble the shales and limestones at a similar horizon in the Wasatch, Oquirrh, Tintic, and other ranges, though both the shales and limestones in the Promontory Range show a greater development than those in the ranges named. The limestone is, however, even more strongly developed at this horizon in northeastern Utah. The upper part of the quartzite series is doubtless of Cambrian age, and the lower part may be Algonkian, though this has not been determined. The limestone-shale series overlying the quartzite is determined by the paleontologic evidence to be Cambrian, and that of the upper limestone probably ranges from Cambrian to Carboniferous.

\section{IGNEOUS ROCKS,}

No igneous rocks were observed in the vicinity of the mineralized area. Mr. Arentz states that a dike 4 feet in width and traceable for about 150 feet cuts the heavy-bedded limestones east of the Lake View property. In the hand specimen this is a dark-green rock apparently having the composition of a rather basic diorite, or possibly diabase. Similar rocks are said to cut the quartzite west of the Lake View property.

\section{STRUCTURE.}

The general structure of the range at the southern end is monoclinal. The beds strike about N. $40^{\circ} \mathrm{W}$. and $\operatorname{dip} 30^{\circ}-40^{\circ} \mathrm{NE}$. This apparent monocline may be the eastern limb of an anticline whose western portion has been removed by erosion, as indicated by Hague's description of the range farther to the north and by a small outcrop of west-dipping sediments near the south end of the promontory. Minor faulting trending north and also east has an observed displacement of only a few feet. A strong east-west break, 6 to 7 miles north of the south end of the range, along which the rocks to the south have been relatively depressed, was observed at a distance, and no details concerning it are known. Fissures striking about north and dipping steeply west are rather abundant throughout the area that has been prospected.

\section{ORE DEPOSITS.}

Before 1916 prospecting had been largely confined to two localities, both of which are near the southern and western side of the promontory. The activity is largely confined to the zinc-lead deposits.

\section{ZINC-LEAD DEPOSITS.}

Mr. Arentz, ${ }^{1}$ manager, reports to the Lake View Mining Co. on the zinc-lead deposits as follows:

For several years previous to 1915 a coterie of Ogden men, headed byMr.James Wortherspoon, Lorenzo Farr,John Farr, and Mr. Carlson, held two groups of placer claims covering a bed of marbleized limestone, and also a large portion of what is now the Lakeview Mining Co.'s property. This placer property was held by location over a period of some five years; the amount of work done was almost negligible. December, 1914, several men, headed by I. F. Farr, were employed to work on this placer property on the marble outcrop, about 1 mile north of the Judge Henderson wheat field. During noons and Sundays the workmen walked up the wash to the limestone beds outcropping above. Boulders of lead-zinc carbonate were discovered in the talus and traced to the outcrop of ore in place found at the top of the 100-foot bed of limestone forming the so-called middle bed in contact with shale. Four locations were then made. * * After an examination made in February of this year [1915] by Samuel S. Arentz, of Salt Lake, a fifth interest was negotiated for and obtained on March 9. Mr. Arentz began operations as one-fifth owner, and under contract to manage the mine for one year.

The Lakeview Mining Co. was then incorporated for 500,000 shares, par value 5 cents. * * *

Your company has sold no stock; began operations without money in the treasury, all expenditures made by the original owners has been returned to them, and from the lst of May, less than 60 days after beginning of operations, it has been self-supporting. 
The net weight of ore shipped to August 1, 1915, was | $1,961,900$ pounds averaging-

Lead ............................

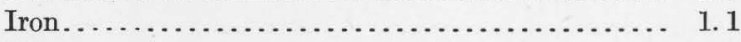

Silver..................................... .02

Gold................................. Trace.

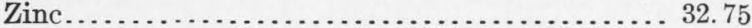

Sulphur................................... .2

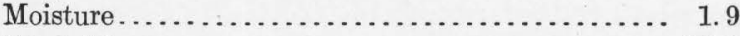

Insoluble.............................. 16.0

Gross returns for 21 cars, $\$ 35,636.75$. The company reports the paying of dividends to August 1 of $\$ 8,119.75$ and net balance of $\$ 7,180.14$.

Prospecting of zinc and lead deposits at the time of visit had been confined almost entirely to the "middle" limestone bed, which is 50 to 75 feet in thickness and lies between members composed prevailingly of shale. The ores replace this limestone where it is in close association with north-south fissures. The largest deposits thus far developed are just beneath the overlying shale, but important mineralization occurs at lower horizons in the orebearing limestone. The ores are entirely oxidized, consisting of zinc and lead carbonate, a little hydrous iron oxide, and manganese oxide. The gangue consists mainly of unreplaced limestone with some quartz.

Observations were confined to very shallow developments and it is not possible to generalize as to the relations of the ores. The carbonate ores, however, were undoubtedly derived from the alteration of sulphides, though no sulphide was observed.

In the oxidation of mixed lead-zinc sulphides in limestone the lead ores generally remain essentially in the position of the original sulphides, and the zinc ores form at lower levels, 1 the zinc sulphate produced by the oxidation of the sulphides having passed into the underlying limestone and reacted with it to form zinc carbonate. In the Promontory district, however, zinc seems to be far more abundant than lead, and it is possible that this was the case in the sulphide bodies. In some places the zine ores lie beneath the lead ores, as they do in other districts, but in other places this relation does not appear to obtain. Mr. Arentz ${ }^{2}$ has pointed out, for instance, that in passing from

1 Butler, G. M., Some recent developments at Leadville; the oxidized zine crest: Econ. Geology, vol. 8, p. 1, 1913. Knopf, Adolph, Mineral resources of the Inyo and White mountains, Cal.: U. S. Geol. Survey Bull. 540, p. 81, 1914. Loughlin, G. F., The oxidized zinc ores of the Tintic district, Utah: Econ. Geology, vol. 9, pp. 1-19, 1914.

2 Salt Lake Min. Rev., vol. 17, p. 13, 1915. the crest of the spurs toward the canyon bottoms the zinc shows progressive decrease and the lead corresponding increase. Determination of the general relations must therefore await further developments.

Prospecting has been carried on along the outcrop of the "middle bed" for about 4,500 feet. Numerous openings show bodies of ore, from which considerable ore has been extracted.

\section{COPPER DEPOSITS. ${ }^{3}$}

Copper deposits in the quartzite series on the western side of the promontory about $1 \frac{1}{2}$ miles northwest of Saline have been prospected for several years. In 190714 tons of hand-sorted ore averaging 3.85 per cent copper and 1 ounce of silver per ton were shipped.

The deposits outcrop on the crest of a ridge near the shore of the lake. The beds strike N. $45^{\circ}-50^{\circ}$ E. and $\operatorname{dip} 16^{\circ}-20^{\circ} \mathrm{SE}$. The primary deposits consisted of disseminated chalcopyrite and possibly bornite, which, at the surface, have been altered to carbonates.

The development consists of two shafts about 200 yards apart, sunk from the crest of the ridge to depths of about 50 and 120 feet. At a lower horizon an incline shaft has been sunk on a westerly pitch nearly at right angles to the dip of the beds to a depth of 80 feet, and from the vicinity of the same point a tunnel has been driven eastward for about 100 feet. From a point about 200 feet lower, near the shore of Great Salt Lake, another tunnel has been driven eastward for 452 feet to intersect the downward extension of the ledge outcropping on the ridge.

Some mineralized rock was observed in the prospect openings, and it is said that richer deposits were found at points not accessible at the time of visit. The ore shipped was obtained from surface blocks of mineralized quartzite 15 feet to 50 feet in thickness.

\section{FREMONT ISLAND DISTRICT.}

By V. C. Heikes.

The Fremont Island district, organized August 3,1871 , is in Weber County and includes the whole of Fremont Island in Great Salt Lake. Small veins carrying gold, silver, copper, and lead occur and were first developed by the Utah

${ }^{3}$ Based on observations by Mr. V. C. Heikes and information furnished by Mr. C. A. Redfield, of Ogden, Utah. 


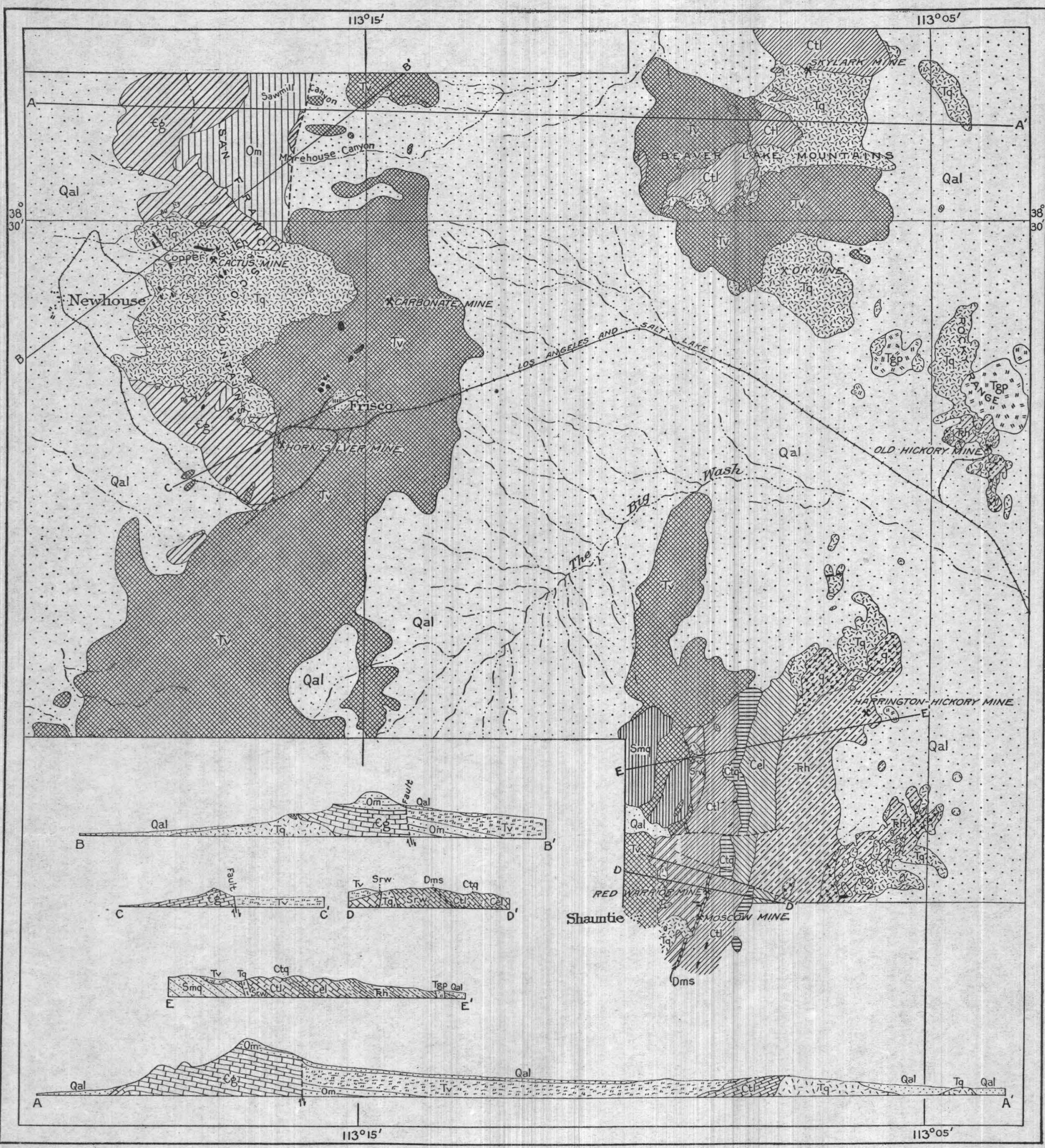

LEGEND

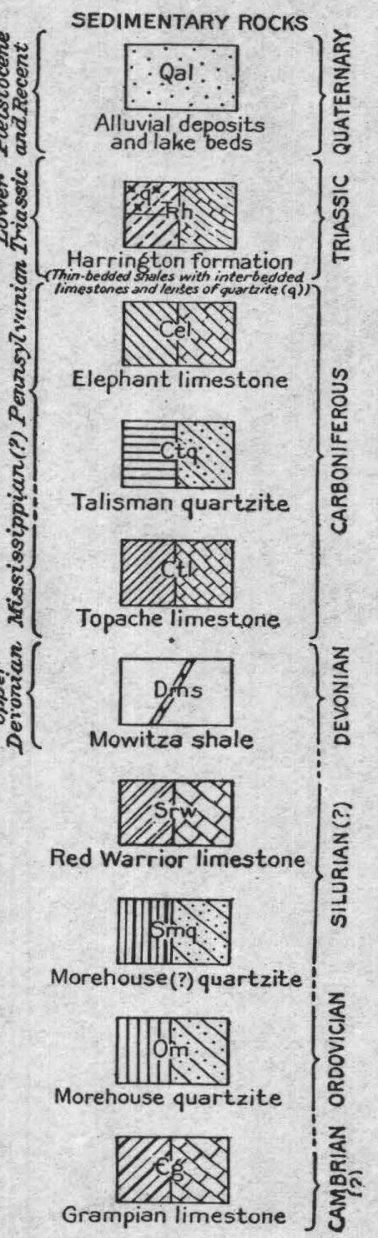

Grampian limestone

IGNEOUS ROCKS

ZTd:

Dikes and small
intrusive bodies

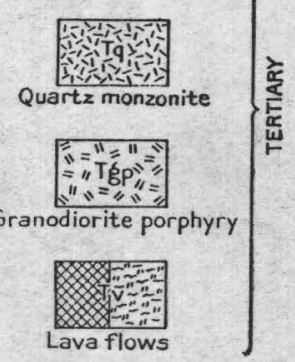

- thanant $\quad 1 \quad 2 \quad 3 \quad 4$ MILES

Faults

GEOLOGIC MAP AND SECTIONS OF THE MINING DISTRICTS OF THE SAN FRANCISCO REGION. 
$\&$ Nebraska Mining Co., 38 claims having been | erected in the summer of 1873 (closed 1877). located by 1873 , but none was ever patented. In 1875 the Troy furnace (which ran for only a There is said to be on the island a great abun- few months) was erected 5 miles south of Mildance of slate, some of which is suitable for ford to treat Mammoth ores. The oldest proroofing.

\section{SAN FRANCISCO AND ADJACENT DISTRICTS.}

By B. S. ButLer.

LOCATION.

The San Francisco, Preuss, Star, North Star, Beaver Lake, and Rocky districts, here discussed together because of their geologic relations, lie adjacent to each other in the northcentral part of Beaver County, Utah, about 180 miles a little west of south of Salt Lake City. (See Pl. XL.) Milford, a few miles east of the district, on the Los Angeles \& Salt Lake Railroad, is the railroad center of the region. A branch of the same railroad extends to Frisco and Newhouse and serves the Horn Silver, Cactus, and other mines.

The San Francisco and Preuss districts are in the San Francisco Range, the Beaver Lake and Rocky districts in the Beaver Lake and Rocky ranges, and the Star districts in the Star Range.

\section{HISTORY AND PRODUCTION.}

\section{By V. C. HeIKes.}

The prosperous years of Beaver County began in 1872, when Shauntie, Shenandoah City, Elephant City, and South Camp were thriving. Most of the ore produced was treated at the Shauntie smelter, consisting of two small stacks

1 Summarized from Butler, B. S., Geology and ore deposits of the San Francisco and adjacent districts, Utah: U. S. Geol. Survey Prof. Paper 80,1913 , from which descriptions of the mines or fuller details of the geology may be obtained. ducing mine, said by the Mormons to be the oldest mine in Utah, is the Rollins property in the Lincoln district; it was worked between 1860 and 1863 and made a few tons of lead in a primitive way. A 15-ton furnace was built in the fall of 1875 and was operated for two years. ${ }^{2}$ Another authority ${ }^{3}$ states that in the fifties (1854) a Mormon named Isaac Grundy erected the first furnace on the Pacific coast near the Rollins mine and melted the lead ore from this property, producing bullion which was hauled to Salt Lake and made into bullets. The Horn Silver mine, on a deposit which was discovered September 24,1875 , made steady shipments of ore until furnaces were erected in 1876, and from 1880 to 1884 was one of the largest producers of lead-silver ore in the State.

\section{SAN FRANCISCO DISTRICT.}

The San Francisco district is about 7 miles square and lies upon both flanks of the San Francisco Mountains. It was organized August 12,1871 , and was of little importance until 1876, a year after the discovery of the Horn Silver mine. Frisco is the town and post office. (See Pl. XLI, A.)

The early history of the mines has been reviewed by Butler, who prepared the output figures in the subjoined table from the records of the United States Geological Survey.

2 Tenth Census U. S., vol. $13, \mathrm{pp}, 472-475,1885$

3 Eissler, M., The metallurgy of argentiferous lead, preface, 1891.

Meta s produced in the San Francisco and Preuss districts, Utah, to the close of $191 \%$.

\begin{tabular}{|c|c|c|c|c|c|c|c|}
\hline Year. & Ore (tons). & $\begin{array}{l}\text { Gold (fine } \\
\text { ounces). }\end{array}$ & $\begin{array}{l}\text { Silver(fine } \\
\text { ounces). }\end{array}$ & $\begin{array}{c}\text { Copper } \\
\text { (pounds). }\end{array}$ & $\begin{array}{c}\text { Lead } \\
\text { (pounds). }\end{array}$ & $\begin{array}{l}\text { Recover- } \\
\text { able zine } \\
\text { (pounds). }\end{array}$ & Total value. \\
\hline 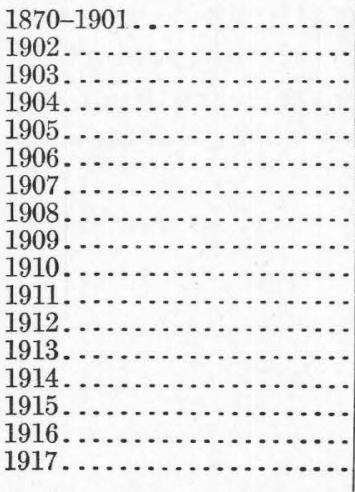 & $\begin{array}{r}18,250 \\
17,347 \\
15,912 \\
141,519 \\
236,229 \\
215,204 \\
220,005 \\
53,385 \\
77,781 \\
254,625 \\
189,446 \\
140,458 \\
86,810 \\
46,076 \\
241,090 \\
266,349\end{array}$ & $\begin{array}{r}3,545.00 \\
202.73 \\
807.86 \\
545.04 \\
1,616.00 \\
2,667.67 \\
2,354,75 \\
2,032.19 \\
647.26 \\
596.75 \\
1,853.66 \\
1,450.89 \\
926.85 \\
579.23 \\
453.96 \\
1,264.72 \\
277.52\end{array}$ & $\begin{array}{r}13,718,280 \\
112,813 \\
96,027 \\
110,541 \\
137,412 \\
289,165 \\
279,379 \\
106,877 \\
205,974 \\
249,156 \\
136,585 \\
183,780 \\
167,227 \\
153,812 \\
171,049 \\
303,867 \\
217,110\end{array}$ & $\begin{array}{r}4,327,047 \\
717,353 \\
432,409 \\
1,588,287 \\
3,427,918 \\
5,108,127 \\
4,626,736 \\
5,609,611 \\
1,114,085 \\
984,310 \\
3,646,016 \\
2,216,191 \\
2,044,156 \\
1,435,845 \\
221,798 \\
1,726,515 \\
2,141,315\end{array}$ & $\begin{array}{r}290,040,964 \\
3,657,063 \\
5,505,694 \\
7,432,855 \\
3,464,007 \\
4,762,488 \\
3,811,321 \\
1,900,371 \\
3,528,134 \\
3,908,122 \\
2,472,647 \\
4,735,712 \\
6,561,691 \\
5,494,252 \\
6,134,931 \\
4,104,648 \\
3,564,395\end{array}$ & $\begin{array}{r}391,676 \\
1,358,000 \\
780,276 \\
933,136 \\
\ldots \ldots . \cdots \\
656,457 \\
451,879 \\
64,927 \\
1,173,366 \\
5,497,062 \\
7,143,746 \\
2,824,183 \\
3,450,671 \\
3,538,898\end{array}$ & $\begin{array}{r}\$ 20,142,479 \\
293,690 \\
347,988 \\
417,902 \\
894,088 \\
1,553,814 \\
1,415,469 \\
918,939 \\
452,476 \\
468,245 \\
681,430 \\
802,758 \\
1,033,559 \\
866,607 \\
773,462 \\
1,396,422 \\
1,458,486\end{array}$ \\
\hline & $2,220,486$ & $21,822.08$ & $16,639,054$ & $41,367,719$ & $361,079,295$ & $28,264,277$ & $33,917,814$ \\
\hline
\end{tabular}


The Horn Silver mine (see Pl. XLI) was discovered in 1875 and for about 10 years was one of the most productive mines of the State. After 1885 its production greatly decreased, but it has been in almost continuous operation to the present time. To the close of 1913 it had yielded metals of a total value of $\$ 20$,768,471 and had paid in dividends $\$ 6,892,000$.

The Beaver Carbonate mine was discovered in the fall of 1878 and the following year was purchased by the Frisco Mining \& Smelting Co. for $\$ 150,000$. It was an active producer for nearly seven years but was closed about

- 1885 and remained idle till 1908, when considerable development work was done but little metal produced. Its total metal output is estimated at 2,593 tons of lead and 533,910 ounces of silver, with a total value of about $\$ 808,000$.

Other mines in the district have made small production.

\section{PJEUSS DISTRICT.}

The Preuss mining district, in Beaver County, is an old district that was reorganized September 4,1880 . In that year it contained 25 recorded claims. The Cactus mine ${ }^{1}$ has been the principal producer, yielding low-grade copper ore for concentration. A 50-ton concentrator using jigs was erected in the bed of Copper Gulch in the spring of 1883. In 1889 the Comet copper smelter was operated for about 30 days. In October, 1896, the Cactus Co. started the construction of a 200-ton concentrator. In 1900 the property was acquired by the Newhouse Mines \& Smelters Co., later reorganized as the South Utah Mines \& Smelters, which constructed a concentration mill and later on enlarged its capacity to 800 tons daily capacity. Production began in March, 1905, and to the close of 1913 themine had yielded $24,155,073$ pounds of copper, $9,535.37$ ounces of gold, and 216,943 ounces of silver. The production by years of this prop-

1 Described in U. S. Geol. Survey Bull. 260, pp. 243-248, 1905; also Prof. Paper 80, pp. 174-178, 1913. erty has been included in the output of the San Francisco district.

\section{STAR DISTRICT.}

The Star district is 5 to 10 miles southwest of Milford, a station on the Los Angeles \& Salt Lake Railroad. Its organization and early history are fully reviewed by Huntley ${ }^{2}$ as follows:

The original Star district, 12 miles square, situated on the Picacho Range, a few miles southwest of Milford, was organized July 8, 1870. On November 11, 1871, the northern portion was reorganized as North Star district, and the two districts, called respectively North Star and South Star. * * * In the South Star the books showed 1,046 and in the North Star 581 locations, but probably not over 350 were owned in 1880 . * * * The prosperous days of the district were in $1872,1873,1874$, and 1875. Then there were the thriving mining camps of Shauntie, Shenandoah City, Elephant City, and South Camp. * *.* Most of the ore produced was treated at the Shauntie smelter. Two small stacks were built at the, town of Shauntie in the summer of 1873 . In the following spring these were torn down, and one stack of 20 tons' capacity was built. This was burned in June, 1875, was rebuilt in the following autumn, and was shut down in the summer of 1877. * * * About 12,000 tons of ore were worked, which produced about 3,000 tons of bullion, containing $\$ 325,000$ in silver and $\$ 10,000$ in gold.

The Troy furnace, erected in 1875 on the Beaver River bottoms, 5 miles south of Milford, to smelt Mammoth mine ore, ran but a few months.

The Latey \& Williams smelter is a single-stack custom smelter, and was erected at Milford, east of the districts, in the autumn of 1876 .

The Milford 10-stamp mill, built in the town of Milford, was erected in the fall of 1873 , at a cost of $\$ 45,000$, by * * * the Harrington \& Hickory Consolidated Mining Co., to work the ores of the old Hickory mine, which had been sold to it for about $\$ 100,000$. The mill ran a few months on about 35-ounce ore in the winter of 1873-74, and produced from $\$ 9,000$ to $\$ 12,000$ in base bullion.

An estimate of the early production, made by Butler, ${ }^{3}$ covers the period 1870-1912. Since 1880 there has been very little activity in the Star district and the metal output was not important. The statistics of the production for 1904 to 1913 , inclusive, are taken from the records of the United States Geological Survey.

2 Op. cit., p. 118.

8 Precious metals: Tenth Census U. S., vol. 13, pp. 471-474, 1885 . 


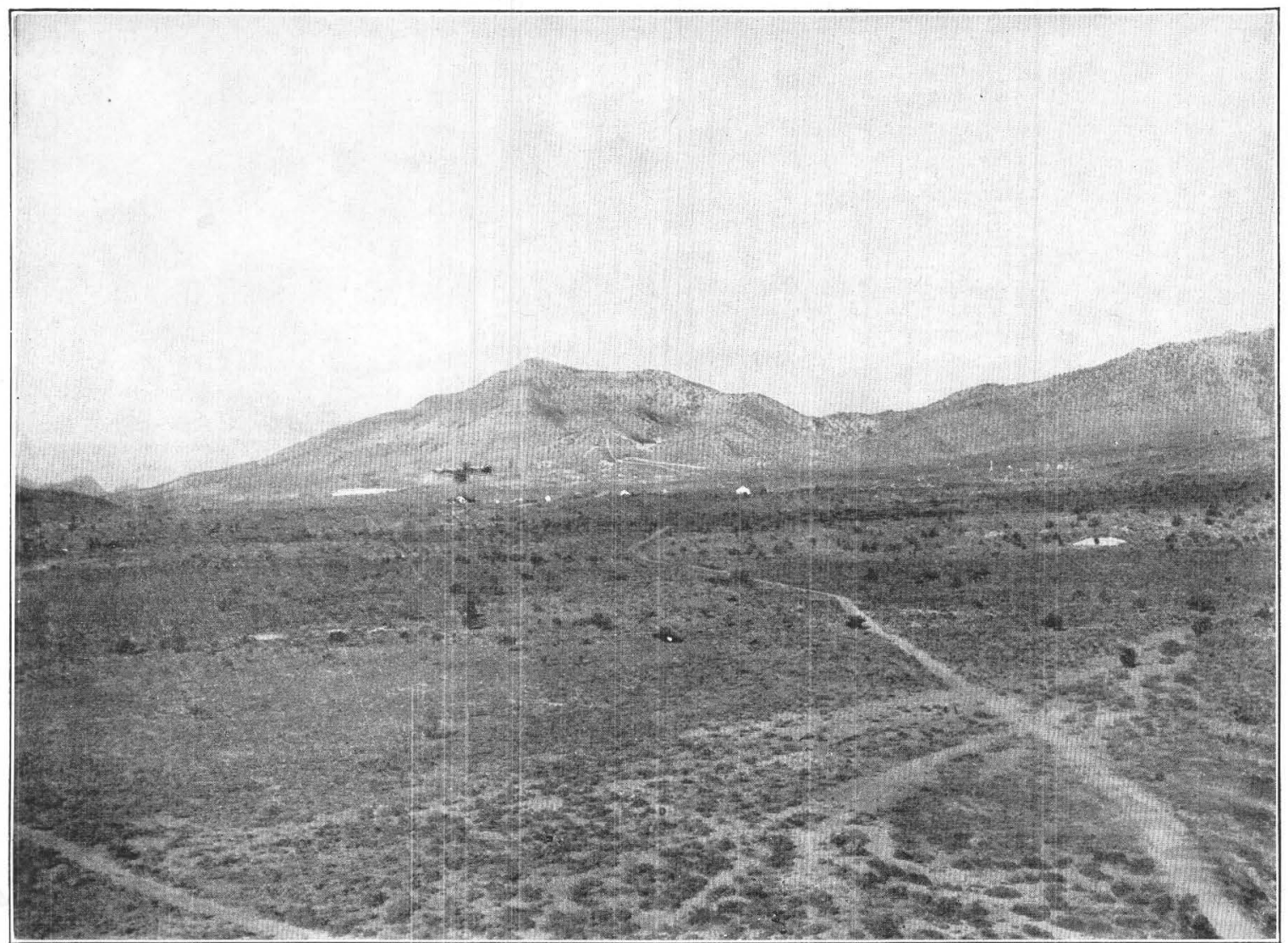

A. HORN SILVER MINE AND VILLAGE OF FRISGO; CONTACT OF QUARTZ MONZONITE AND LIMESTONE IN LOW SADDLE; SQUAW SPRINGS PASS AT LEFT.

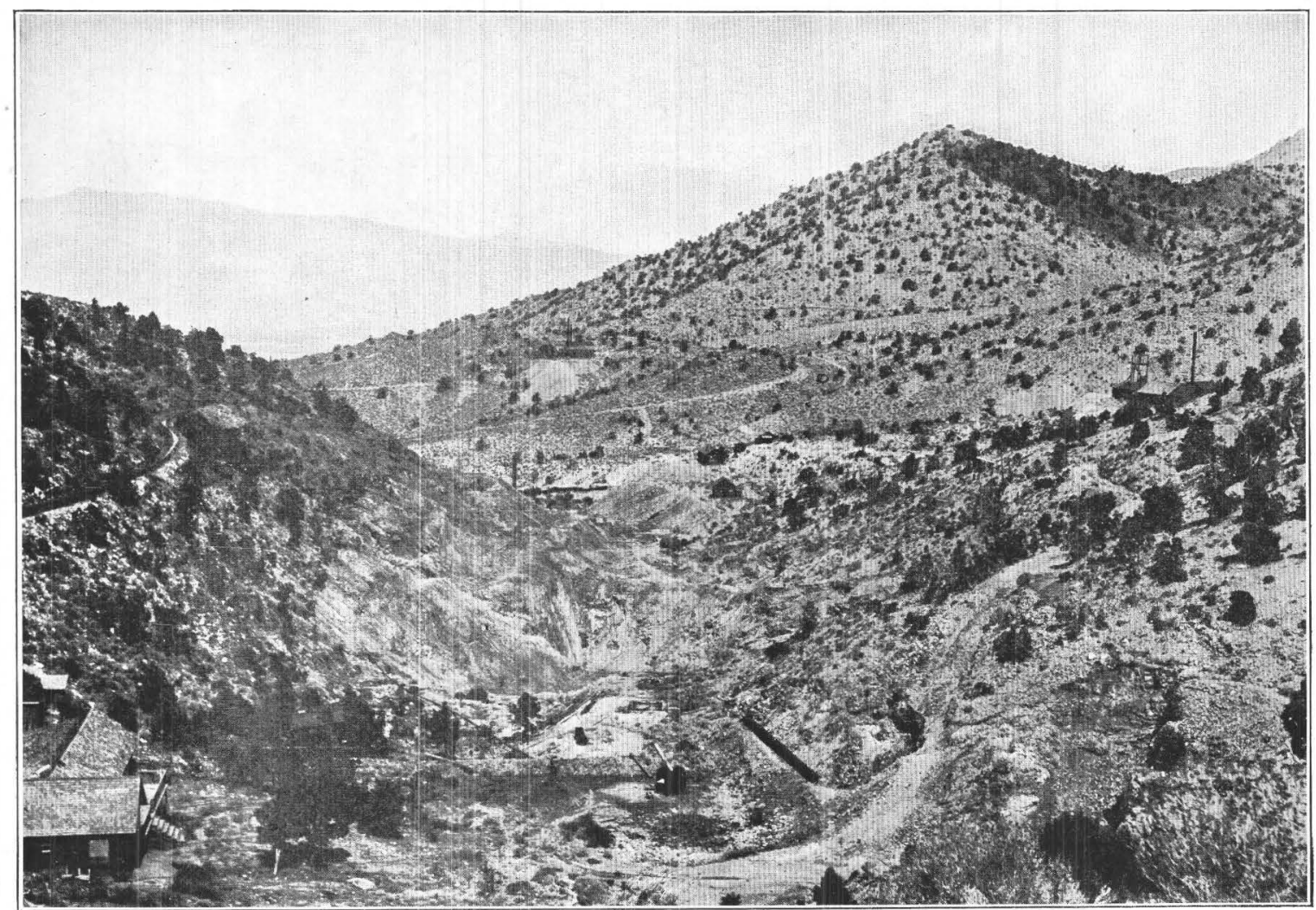

B. VIEW LOOKING WEST FROM A POINT NEAR COMET MINE, SHOWING OUTCROP OF CACTUS ORE BODY. 

Metals produced in the Star district (Star and North Star), 1870-191\%.

\begin{tabular}{|c|c|c|c|c|c|c|c|}
\hline Year. & $\begin{array}{l}\text { Ore (short } \\
\text { tons). }\end{array}$ & $\begin{array}{c}\text { Gold (fine } \\
\text { ounces). }\end{array}$ & $\begin{array}{c}\text { Silver } \\
\text { (fine } \\
\text { ounces). }\end{array}$ & $\begin{array}{c}\text { Copper } \\
\text { (pounds). }\end{array}$ & $\begin{array}{c}\text { Lead } \\
\text { (pounds). }\end{array}$ & $\begin{array}{l}\text { Recovera- } \\
\text { ble zinc } \\
\text { (pounds). }\end{array}$ & $\begin{array}{l}\text { Total } \\
\text { value. }\end{array}$ \\
\hline $\begin{array}{l}1909 \ldots \ldots \ldots \\
1909 \ldots \ldots \ldots \\
1910 \ldots \ldots \ldots \\
1911 \ldots \ldots \\
1912 \ldots \ldots \\
1913 \ldots \ldots \\
1914 \ldots \ldots \\
1915 \ldots \ldots \\
1916 \ldots \ldots \\
1917 \ldots \ldots \\
\ldots \ldots\end{array}$ & $\begin{array}{r}1,100 \\
1,714 \\
1,985 \\
4,265 \\
2,835 \\
4,343 \\
4,660 \\
4,734 \\
5,144 \\
8,728 \\
7,096 \\
4,693 \\
7,823 \\
10,689\end{array}$ & $\begin{array}{r}750.00 \\
36.28 \\
247.00 \\
60.50 \\
73.05 \\
71.40 \\
39.23 \\
53.84 \\
68.79 \\
63.60 \\
34.81 \\
284.79 \\
33.73 \\
123.84 \\
710.51\end{array}$ & $\begin{array}{r}500,000 \\
10,310 \\
43,500 \\
34,603 \\
49,179 \\
41,550 \\
67,098 \\
88,628 \\
51,809 \\
51,355 \\
153,774 \\
131,426 \\
103,542 \\
49,188 \\
14,688\end{array}$ & $\begin{array}{r}62,500 \\
128,000 \\
67,994 \\
176,896 \\
94,276 \\
129,449 \\
141,533 \\
86,299 \\
67,875 \\
124,457 \\
58,286 \\
21,374 \\
153,696 \\
175,170\end{array}$ & $\begin{array}{r}11,000,000 \\
93,000 \\
738,149 \\
556,300 \\
597,282 \\
1,144,329 \\
2,198,484 \\
2,300,102 \\
2,051,357 \\
2,916,957 \\
3,875,524 \\
3,840,954 \\
2,452,716 \\
1,717,284 \\
1,703,957\end{array}$ & 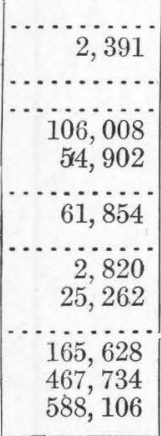 & $\begin{array}{r}\$ 1,100,000 \\
17,580 \\
86,088 \\
69,267 \\
107,258 \\
86,583 \\
147,065 \\
171,491 \\
131,979 \\
175,554 \\
284,828 \\
236,115 \\
192,749 \\
253,903 \\
323,380\end{array}$ \\
\hline & 69,809 & $2,651.37$ & $1,390,650$ & $1,487,805$ & $37,186,395$ & $1,474,705$ & $3,383,840$ \\
\hline
\end{tabular}

NORTH STAR DISTRICT.

The North Star district, in Beaver County, organized November 11, 1871, is reviewed with the Star district and its production is included in the table of Beaver County.

BEAVER LAKE DISTRICT.

The Beaver Lake district is 12 miles west of Smyths siding on the Los Angeles \& Salt Lake Railroad. The early operations in the district are recorded by Huntley, ${ }^{1}$ as follows:

The Beaver Lake district is situated north of the Star and Rocky districts and was organized in August, 1871, upon the discovery of a belt of copper veins from an inch to 2 feet in width. Some work was done in 1872 and 1873, and a few tons of ore were shipped, assaying 30 per cent copper, 16 ounces silver, and $\$ 12$ gold. * * * In September, 1872, lead and silver ores were discovered. The leading mine is the San Francisco, which was sold for $\$ 10,000$. About $\$ 8,000$ worth of high-grade silver-lead ore has been extracted from a 110 -foot shaft. It has been idle since 1873. The Dexter and Mountain King are iron mines and shipped 400 tons of flux each between 1873 and
1877. A small vein containing graphite (or molybdenite) was also discovered. * * * The Riverside smelter was erected in 1873 at a point 7 miles north of Milford to work the copper ores of this district.

The largest production from this district came from the O. K. mine about 1900-1901; and the mine was again operated in 1906, 1907, and 1913 to 1917 , inclusive. The production is included in that of the Rocky district.

\section{ROCKY MINING DISTRICT.}

The Rocky mining district, in Beaver County, was organized March 27, 1872, and is 10 miles northwest of Milford, on the Los Angeles \& Salt Lake Railroad. It is about $1 \frac{1}{2}$ by 3 miles in extent and includes within its boundaries a small isolated range north of the Star district and east of the San Francisco district. The principal output has been from the Old Hickory mine. The production of the district is combined with that of the Beaver Lake district in the following table:

Metals produced in the Beaver Lake and Rocky districts, 18\%0-1917.

\begin{tabular}{|c|c|c|c|c|c|c|}
\hline Period. & $\begin{array}{l}\text { Ore (short } \\
\text { tons). }\end{array}$ & $\begin{array}{l}\text { Gold (fine } \\
\text { ounces). }\end{array}$ & $\begin{array}{l}\text { Silver (fine } \\
\text { ounces). }\end{array}$ & $\begin{array}{c}\text { Copper } \\
\text { (pounds). }\end{array}$ & $\begin{array}{c}\text { Lead } \\
\text { (pounds). }\end{array}$ & $\begin{array}{c}\text { Total } \\
\text { value. }\end{array}$ \\
\hline \multirow[t]{2}{*}{$\begin{array}{l}1870-1902 \ldots \ldots \ldots \ldots \\
1902-1917 \ldots \ldots \ldots\end{array}$} & $\dddot{108,766}$ & $\begin{array}{l}225.00 \\
415.69\end{array}$ & $\begin{array}{l}13,250 \\
86,831\end{array}$ & $\begin{array}{r}931,000 \\
4,160,281\end{array}$ & $\begin{array}{l}80,000 \\
35,671\end{array}$ & $\begin{array}{r}\$ 105,000 \\
1,205,784\end{array}$ \\
\hline & & 640.69 & 100,081 & $5,091,281$ & 115,671 & $1,310,784$ \\
\hline
\end{tabular}

TOTAL METAL PRODUCTION OF BEAVER COUNTY.

The total metal production of the mines in Beaver County, which includes not only the 1 Tenth Census U. S., vol. 13, p. 474, 1885. districts in the San Francisco, Beaver Lake, Rocky, and Star ranges, but also those in the Wah Wah range (p. 527) and the Mineral Range (p. 529), is shown in the following table: 
Quantity of ore sold or treated in Beaver County, Utah, 1860-1917, and total output of metals recovered.

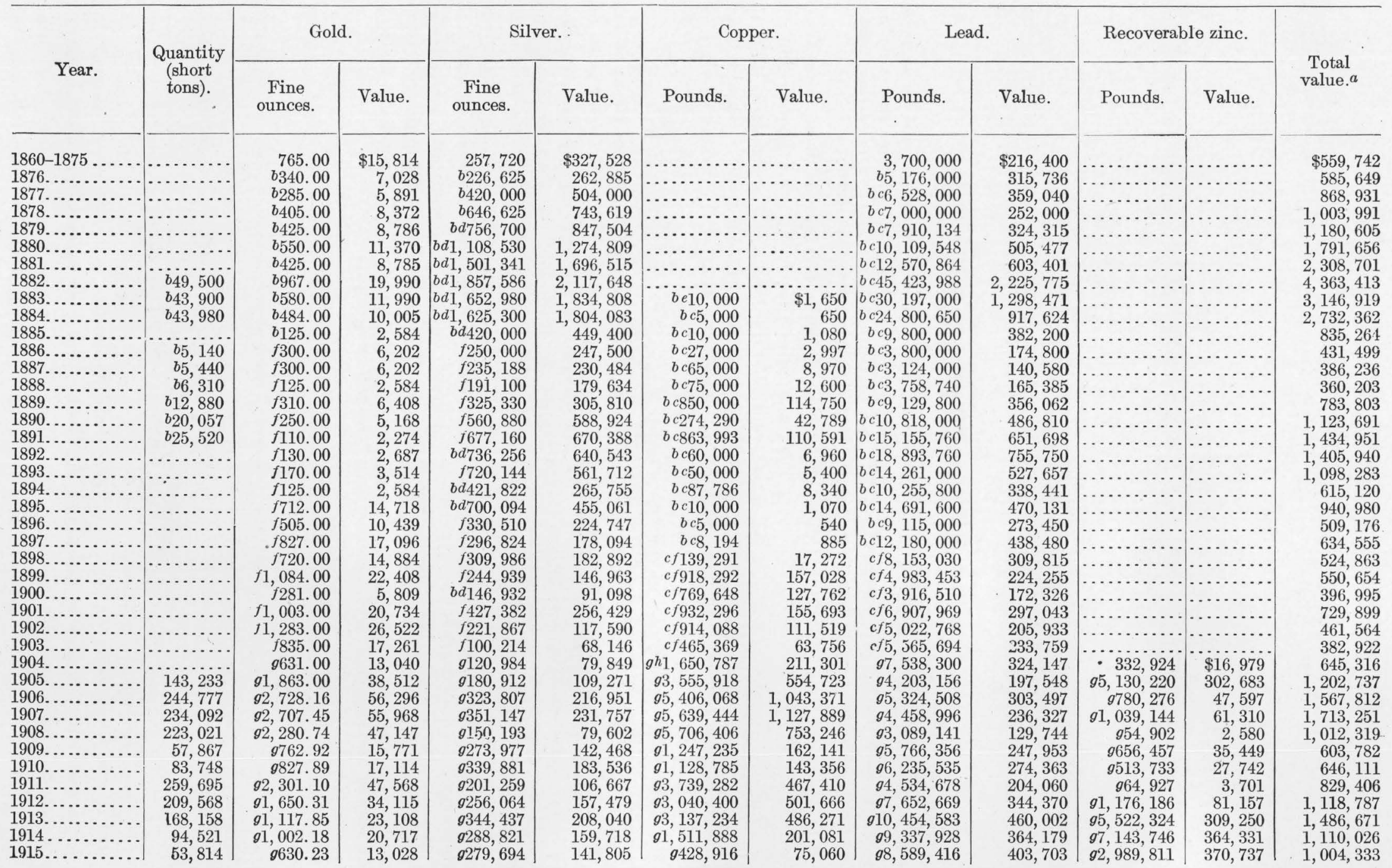




\begin{tabular}{|c|c|c|c|c|c|c|c|c|c|c|c|c|}
\hline $\begin{array}{l}1916 \ldots \\
1917 . .\end{array}$ & $\begin{array}{l}276,141 \\
308,038\end{array}$ & $\begin{array}{l}g 2,023.62 \\
g 2,192.06\end{array}$ & $\begin{array}{l}41,832 \\
45,314\end{array}$ & $\begin{array}{l}\text { g } 381,862 \\
\text { g297, } 833\end{array}$ & $\begin{array}{l}251,265 \\
245,415\end{array}$ & $\begin{array}{l}g 3,203,688 \\
g 3,702,085\end{array}$ & $\begin{array}{r}788,107 \\
1,010,669\end{array}$ & $\begin{array}{l}95,948,220 \\
95,321,400\end{array}$ & $\begin{array}{l}410,427 \\
457,640\end{array}$ & $\begin{array}{l}g 3,969,405 \\
g 4,133,464\end{array}$ & $\begin{array}{l}531,900 \\
421,613\end{array}$ & $\begin{array}{l}2,023,531 \\
2,180,651\end{array}$ \\
\hline Total $i$ & & $37,139.51$ & 767,739 & $21,160,906$ & $19,588,392$ & $49,638,383$ & $8,478,593$ & $411,403,954$ & $17,980,774$ & $33,507,519$ & $2,577,029$ & $49,392,527$ \\
\hline
\end{tabular}

a Average commercial prices used for each metal to make total for each calendar year.
$b$ Estimates by V. C. Heikes from a separation of the total output reported by the Director of the Mint are given in the annual reviews of the Salt Lake Tribune and of the U. S. Geol. Survey Mineral Resources, 1882-1897. Part of the records of some early producers were used in the estimates.

$c$ Bulk of copper and lead produced from Horn Silver ores.
$d$ Horm Silver mine yielded 1,865,230 ounces for the years 1879-1881; 1,552,981 ounces in 1882; 1,116,898 ounces in 1883; 1,560,000 ounces in 1884; 315,900 ounces in 1885; 636,256 ounces in 1892; 321,823 ounces in 1894; and 143,932 ounces in 1900.

$f$ Director of Mint reports.

Mineral Resources U. S. Geological Survey, 1904-1913.

i These totals are for mine output and aggregate more than if smelters' and refiners' figures were used.

Metals produced in Beaver County, 1860-1917, by periods.

\begin{tabular}{|c|c|c|c|c|c|c|c|c|c|c|c|}
\hline \multirow{2}{*}{ Period. } & \multicolumn{2}{|c|}{ Gold. } & \multicolumn{2}{|c|}{ Silver. } & \multicolumn{2}{|c|}{ Copper. } & \multicolumn{2}{|c|}{ Lead. } & \multicolumn{2}{|c|}{ Recoverable zinc. } & \multirow{2}{*}{$\begin{array}{l}\text { Total } \\
\text { value. }\end{array}$} \\
\hline & $\begin{array}{c}\text { Fine } \\
\text { ounces. }\end{array}$ & Value. & $\begin{array}{c}\text { Fine } \\
\text { ounces. }\end{array}$ & Value. & Pounds. & Value: & Pounds. & Value. & Pounds. & Value. & \\
\hline \multirow[t]{2}{*}{$\begin{array}{l}1860-1880 \ldots \ldots \ldots \\
1881-1890 \ldots \ldots \\
1891-1900 \ldots \ldots \\
1901-1910 \ldots \ldots \ldots \\
1911-1917 \ldots \ldots \ldots \\
\end{array}$} & $\begin{array}{r}2,770.00 \\
3,866.00 \\
4,664.00 \\
14,922.16 \\
10,917.35\end{array}$ & $\begin{array}{r}\$ 57,261 \\
79,918 \\
96,413 \\
308,465 \\
225,682\end{array}$ & $\begin{array}{l}3,416,200 \\
8,619,705 \\
4,584,667 \\
2,490,364 \\
2,049,970\end{array}$ & $\begin{array}{r}\$ 3,960,345 \\
9,454,806 \\
3,417,253 \\
1,485,599 \\
1,270,389\end{array}$ & $\begin{array}{r}1,316,290 \\
2,912,204 \\
26,646,396 \\
18,763,493\end{array}$ & $\begin{array}{r}\$ 185,486 \\
435,848 \\
4,326,995 \\
3,530,264\end{array}$ & $\begin{array}{r}40,423,682 \\
153,423,042 \\
111,605,913 \\
54,112,423 \\
51,838,894\end{array}$ & $\begin{array}{r}\$ 1,972,968 \\
6,751,108 \\
4,162,003 \\
2,450,314 \\
2,644,381\end{array}$ & $\begin{array}{r}8,507,656 \\
24,999,863\end{array}$ & $\begin{array}{r}\$ 494,340 \\
2,082,689\end{array}$ & $\begin{array}{r}\$ 5,990,574 \\
16,471,318 \\
8,111,517 \\
9,065,713 \\
9,753,405\end{array}$ \\
\hline & $37,139.51$ & 767,739 & $21,160,906$ & $19,588,392$ & $49,638,383$ & $8,478,593$ & $411,403,954$ & $17,980,774$ & $33,507,519$ & $2,577,029$ & $49,392,527$ \\
\hline
\end{tabular}


CHARACTER AND METAL CONTENT OF ORES. DRY OR SILICEOUS ORES.

The dry or siliceous ores shipped to smelters from Beaver County comprise very siliceous gold and silver ores and oxidized iron-manganese ores of little or no value except for fluxing. Some small lots of very rich gold ores were shipped from the Newton district at intervals and the bulk of the oxidized iron ore was shipped from the Bradshaw and Lincoln districts. The producers contributing to the output of dry or siliceous ore during the decade were the Rob Roy, Nip and Tuck, Sheep Rock, Hub and Lady Bryan, Old Hickory, Kitty Clough, Cave, Black Warrior, and Park mines.

The average grade of the ores shipped was as follows:

Dry or siliceous ore, with average metallic content, produced in Beaver County and shipped to smelters, 1906-1917.

\begin{tabular}{|c|c|c|c|c|c|c|}
\hline Year. & $\begin{array}{c}\text { Quan- } \\
\text { tity } \\
\text { (short } \\
\text { tons). }\end{array}$ & $\begin{array}{c}\text { Gold } \\
\text { (value } \\
\text { per } \\
\text { ton). }\end{array}$ & $\begin{array}{c}\text { Silver } \\
\text { (ounces } \\
\text { per } \\
\text { ton). }\end{array}$ & $\begin{array}{c}\text { Copper } \\
\text { (per } \\
\text { cent). }\end{array}$ & $\begin{array}{l}\text { Lead } \\
\text { (per } \\
\text { cent). }\end{array}$ & $\begin{array}{c}\text { Aver- } \\
\text { age } \\
\text { gross } \\
\text { value } \\
\text { per } \\
\text { ton. }\end{array}$ \\
\hline 1906. & $a 6,391$ & & & 1. 67 & & $\$ 6.45$ \\
\hline 907 & & $\$ 12.13$ & 20.87 & .87 & & 29. 33 \\
\hline 1908 & 18 & 79.89 & 2.11 & & & 81.00 \\
\hline 190 & 17 & 53.88 & 4.88 & & 1.03 & 57.29 \\
\hline 199 & 2,107 & 1.74 & 3. 64 & .45 & .52 & 5. 32 \\
\hline & 1,806 & 3.95 & 13.51 & .44 & .53 & 12.69 \\
\hline 19 & 28 & 56.86 & 56.50 & & & 91.61 \\
\hline & 403 & .91 & 8. 20 & .53 & .60 & 8.03 \\
\hline & 1,026 & .29 & 12.83 & .40 & 0.76 & 9. 04 \\
\hline & 110 & 21.15 & 8. 39 & .015 & .96 & 26. 77 \\
\hline & 1 & 83.00 & 41. 00 & & & 110. 00 \\
\hline 1917. & 91 & .27 & 12.14 & 1. 16 & .67 & 17. 78 \\
\hline
\end{tabular}

COPPER ORES AND CONCENTRATES.

The copper ores include those usually carrying over $2 \frac{1}{2}$ per cent of copper. Sulphide ores were shipped most frequently by the Cactus, $\mathrm{O}$. K., and Imperial mines and oxidized ores by the St. Mary, Kathleen, Cave, Commonwealth, Old Harrington, Harrington Hickory, King of the Hill, Buckeye, Creole, Horn Silver, Blue John, Copper Mountain, Baby Jack, Copper Ranch, Old Hickory, Montreal, and Copper King.

The copper concentrates were largely from ores treated at the Cactus mill.

The average grade of the ores and concentrates shipped from 1905 to 1913 was as follows:
Copper ore and concentrates, with average metallic content, produced in Beaver County and shipped to smelters, 1905$191 \%$.

\begin{tabular}{|c|c|c|c|c|c|c|}
\hline Year. & $\begin{array}{l}\text { Quan- } \\
\text { tity } \\
\text { (short } \\
\text { tons). }\end{array}$ & $\begin{array}{c}\text { Gold } \\
\text { (value } \\
\text { per } \\
\text { ton). }\end{array}$ & $\begin{array}{c}\text { Silver } \\
\text { (ounces } \\
\text { per } \\
\text { ton). }\end{array}$ & $\begin{array}{c}\text { Copper } \\
\text { (per } \\
\text { cent). }\end{array}$ & $\begin{array}{r}\text { Lead } \\
\text { (per } \\
\text { cent). }\end{array}$ & $\begin{array}{c}\text { Aver- } \\
\text { age. } \\
\text { gross } \\
\text { value } \\
\text { per } \\
\text { ton. }\end{array}$ \\
\hline 1905. & 200 & & 2.70 & 2.00 & & $\$ 7.88$ \\
\hline 1906 & 457 & $\$ 2.89$ & 5. 69 & 8.01 & & 37.66 \\
\hline 1907 & 27,231 & .66 & 1.97 & 5.35 & 0.08 & 23.45 \\
\hline & 4,126 & 1.35 & 1.64 & 13. 19 & ......... & 37.04 \\
\hline 190 & 205 & .71 & 1. 38 & 9.00 & & 24.82 \\
\hline & 54 & 1.85 & 10.05 & 12.72 & & 39.57 \\
\hline 10 & 692 & .96 & 3. 39 & 11.14 & .05 & 30.67 \\
\hline & 15,232 & .09 & 1.30 & 2.74 & ........ & 9.93 \\
\hline & 18,184 & .02 & 1.1 & 2.68 & & 9.06 \\
\hline & 1,223 & 1.01 & 3.70 & 13.51 & & 39.00 \\
\hline & 3,078 & .08 & 1.58 & 3. 49 & . & 13. 12 \\
\hline & 27,901 & .35 & 1.13 & 2.64 & $\ldots .$. & 14. 11 \\
\hline & 32,368 & .11 & 61 & 2.34 & .015 & 13.43 \\
\hline
\end{tabular}

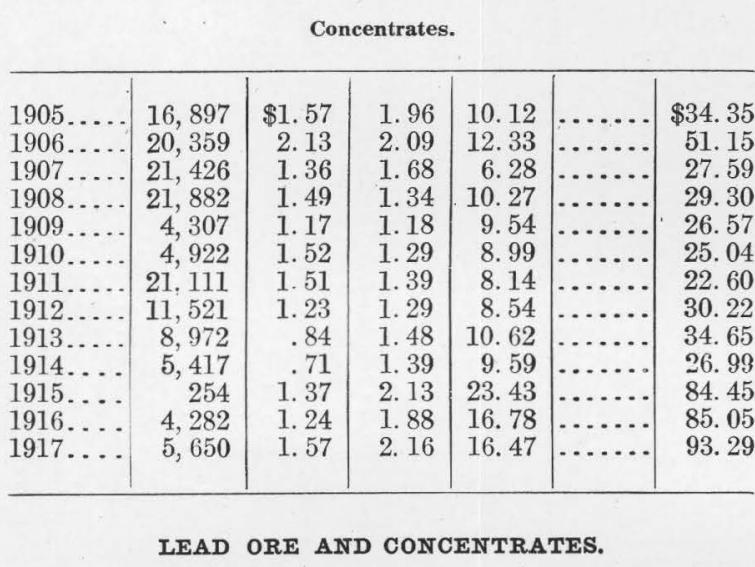

In general, the crude lead ores and concentrates are those containing over $4 \frac{1}{2}$ per cent of lead. The most important shipper of crude ore in the county was the Horn Silver mine, which yielded an important output each year during the last decade. The Moscow and Cedar Talisman shipped regularly, but in smaller quantities and for seven years the Red Warrior was a good shipper. Other shipping properties were the Harrington-Hickory, Summit, Big Gentile, Beaver Carbonate, Rebel and Wild Bill, Cave Consolidated, Atlas, Hecla, Hoosier Boy, Lydia, Flora, Jennie Fraction, St. Mary, Big Four, White Rock, Hobson, O. K., Oak Leaf, Lincoln, Silver King, Washington, Harriet, Majestic, Admiral Dewey, Hub, Monitor, Gold Reef, King David, Moscow Bonanza, Mammoth, Silver Glance, Utah Gold \& Copper, 
Oneida, Lower Cave, Indian Queen, and Volunteer.

The lead concentrates were chiefly from the Horn Silver and Beaver Carbonate dumps at Frisco but included a test lot of Moscow ore from the Star district.

The average grade of the ores and concentrates was as follows:

Lead ore and concentrates, with average metallic contents, produced in Beaver County and shipped to smelters, 1903-1917.

Crude ore.

\begin{tabular}{|c|c|c|c|c|c|c|}
\hline Year. & $\begin{array}{l}\text { Quan- } \\
\text { tity } \\
\text { (short } \\
\text { tons). }\end{array}$ & $\begin{array}{l}\text { Gold } \\
\text { (value } \\
\text { per } \\
\text { ton). }\end{array}$ & $\begin{array}{l}\text { Silver } \\
\text { (ounces } \\
\text { per } \\
\text { ton). }\end{array}$ & $\begin{array}{l}\text { Copper } \\
\text { (per } \\
\text { cent). }\end{array}$ & $\begin{array}{l}\text { Lead } \\
\text { (per } \\
\text { cent.) }\end{array}$ & $\begin{array}{l}\text { Aver- } \\
\text { age } \\
\text { gross } \\
\text { value } \\
\text { per } \\
\text { ton. }\end{array}$ \\
\hline $1903 \ldots$ & 5,409 & $\$ 2.01$ & 11. 27 & 0.71 & 34.63 & $\$ 39.15$ \\
\hline $1904 \ldots$ & 9,938 & .90 & 10.46 & 1.90 & 29.30 & 37.05 \\
\hline $1905 \ldots$ & 6,647 & .74 & 13.10 & .05 & 26.20 & 33.52 \\
\hline $1906 \ldots$ & 14,551 & .75 & 17. 27 & $\cdots$ & 17.76 & 32.74 \\
\hline $1907 \ldots$ & 13,321 & .62 & 17. 12 & .14 & 16.56 & 30.01 \\
\hline $1908 \ldots$ & 5,730 & 1. 10 & 15.57 & .35 & 22.43 & 29.13 \\
\hline $1909 \ldots$ & 11,905 & .71 & 17.08 & .41 & 18.71 & 26.76 \\
\hline 1910. & 12,684 & .40 & 19. 21 & .45 & 17.11 & 26.97 \\
\hline 1911. & 9,458 & .65 & 14. 05 & .63 & 22.48 & 29.92 \\
\hline 1912. & 13,488 & .75 & 11. 11 & .49 & 21. 48 & 28.53 \\
\hline 1913. & 16,050 & .38 & 12.73 & .42 & 18.45 & 25.61 \\
\hline $1914 \ldots$ & 10,525 & .81 & 17. 98 & .49 & 27.42 & 33.45 \\
\hline 1915. & 6,646 & .29 & 21. 37 & .34 & 31.08 & 41. 54 \\
\hline 1916. & 15,598 & .87 & 12. 16 & .52 & 11. 78 & 27. 73 \\
\hline $1917 \ldots$ & 18,716 & 1. 44 & 9.35 & .66 & 10.82 & 31.41 \\
\hline
\end{tabular}

Lead ore and concentrates, with average metallic contents, produced in Beaver County and shipped to smelters, 1903-1917-Continued.

Concentrates.

\begin{tabular}{|c|c|c|c|c|c|c|}
\hline Year. & $\begin{array}{c}\text { Quan- } \\
\text { tity } \\
\text { (short } \\
\text { tons). }\end{array}$ & $\begin{array}{c}\text { Gold } \\
\text { (Value } \\
\text { per } \\
\text { ton). }\end{array}$ & $\begin{array}{c}\text { Silver } \\
\text { (ounces } \\
\text { per } \\
\text { ton). }\end{array}$ & $\begin{array}{c}\text { Copper } \\
\text { (per } \\
\text { cent). }\end{array}$ & $\begin{array}{l}\text { Lead } \\
\text { (per } \\
\text { cent). }\end{array}$ & $\begin{array}{l}\text { Aver- } \\
\text { age } \\
\text { gross } \\
\text { value } \\
\text { per } \\
\text { ton. }\end{array}$ \\
\hline & $\begin{array}{r}2,122 \\
484 \\
168 \\
37 \\
305 \\
13 \\
2,341 \\
3,943 \\
3,800 \\
2,946 \\
.1,285\end{array}$ & $\begin{array}{r}\$ 2.68 \\
2.04 \\
.14 \\
.24 \\
1.12 \\
.15 \\
.71 \\
.86 \\
1.50 \\
1.19 \\
1.29\end{array}$ & $\begin{array}{r}8.15 \\
11.73 \\
21.08 \\
15.28 \\
9.34\end{array}$ & $\begin{array}{r}2.40 \\
.12 \\
.28 \\
.25 \\
.45 \\
.34\end{array}$ & $\begin{array}{r}26.89 \\
6.14 \\
24.27 \\
27.46 \\
36.62 \\
18.05 \\
19.91\end{array}$ & $\begin{array}{l}27.3 \\
29.5 \\
47.5 \\
38.3 \\
45.1\end{array}$ \\
\hline
\end{tabular}

ZINC ORES AND CONCENTRATES.

The zine ores and concentrates are those containing 25 per cent or more of zinc, irrespective of their precious metals. The bulk of the crude ore shipped was sulphides from the Horn Silver mine, but a trial shipment was from the Moscow. Siliceous and carbonate zinc ore was produced during several years from the Cedar Talisman properiy.

Concentrates of zinc were produced principally from the Horn Silver ores but include a test lot from the Moscow ores.

The average grade of the ores and concentrates was as follows:

Zinc ore and concentrates, with average metallic content, produced in Beaver County and shipped to smelters, 1904-191\%.

Crude ore.

\begin{tabular}{|c|c|c|c|c|c|c|c|}
\hline Year. & $\begin{array}{l}\text { Quantity } \\
\text { (short } \\
\text { tons). }\end{array}$ & $\begin{array}{c}\text { Gold } \\
\text { (value } \\
\text { per ton). }\end{array}$ & $\begin{array}{c}\text { Silver } \\
\text { (ounces } \\
\text { per ton). }\end{array}$ & $\begin{array}{c}\text { Copper } \\
\text { (per } \\
\text { cent). }\end{array}$ & $\begin{array}{c}\text { Lead } \\
\text { (per } \\
\text { cent). }\end{array}$ & $\begin{array}{c}\text { Recover- } \\
\text { able zine } \\
\text { (per cent) }\end{array}$ & $\begin{array}{c}\text { Average } \\
\text { gross value } \\
\text { per ton. }\end{array}$ \\
\hline 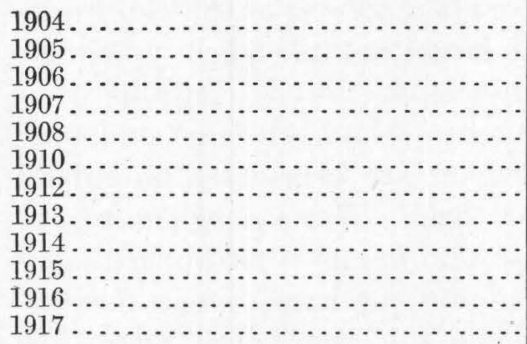 & $\begin{array}{r}522 \\
8,445 \\
1,615 \\
4,252 \\
99 \\
859 \\
2,031 \\
7,317 \\
2,402 \\
2,452 \\
497 \\
1,311\end{array}$ & $\begin{array}{r} \\
\$ 0.23 \\
\hdashline \\
\hdashline \\
.12 \\
.31 \\
\hdashline\end{array}$ & $\begin{array}{r}3.16 \\
2.14 \\
10.00 \\
7.77 \\
10.54 \\
6.91 \\
1.15 \\
1.85 \\
2.46 \\
3.00 \\
\ldots \ldots .\end{array}$ & $\begin{array}{l}\cdots \\
\cdots \\
\cdots\end{array}$ & $\begin{array}{r}5.83 \\
12.00 \\
5.22 \\
5.95 \\
.7 .29 \\
4.29 \\
.43\end{array}$ & $\begin{array}{l}31.89 \\
30.37 \\
24.15 \\
12.22 \\
27.73 \\
29.90 \\
28.89 \\
32.93 \\
33.77 \\
28.89 \\
21.08 \\
25.58\end{array}$ & $\begin{array}{r}\$ 34.36 \\
37.38 \\
36.27 \\
19.55 \\
36.74 \\
47.05 \\
45.27 \\
43.24 \\
34.44 \\
76.89 \\
63.35 \\
52.93\end{array}$ \\
\hline
\end{tabular}

Concentrates.

\begin{tabular}{|c|c|c|c|c|c|c|c|}
\hline 1912. & 3 & $\$ 0.33$ & 5.00 & 0.60 & 2. 03 & 47.00 & $\$ 72.00$ \\
\hline $1913 \ldots \ldots$ & 1,334 & .03 & .59 & .03 & .66 & 26.38 & 30.60 \\
\hline $1914 \ldots \ldots \ldots \ldots \ldots \ldots \ldots \ldots \ldots \ldots$ & 2, 069 & & $\ldots \ldots \ldots$ & & & 38.25 & 39.01 \\
\hline . & 1,875 & & 3.25 & & 1. 62 & 41.93 & 107.17 \\
\hline 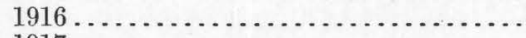 & 535 & ... & $\ldots \ldots \ldots$ & $\ldots$ & $\ldots \ldots \ldots$ & 38.91 & 104.29 \\
\hline 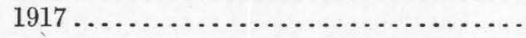 & 128 & ... & .......... & .. & $\cdots$ & 33.97 & 69.30 \\
\hline
\end{tabular}


COPPER-LEAD ORES.

The copper-lead ores are classified like the copper and the lead ores. The producers of this kind of ore were the Moscow, Horn. Silver, O. K., Lincoln, Progressive, Empire, Commonwealth, Wild Bill, and Kathleen.

The average grade of the ore shipped was as follows:

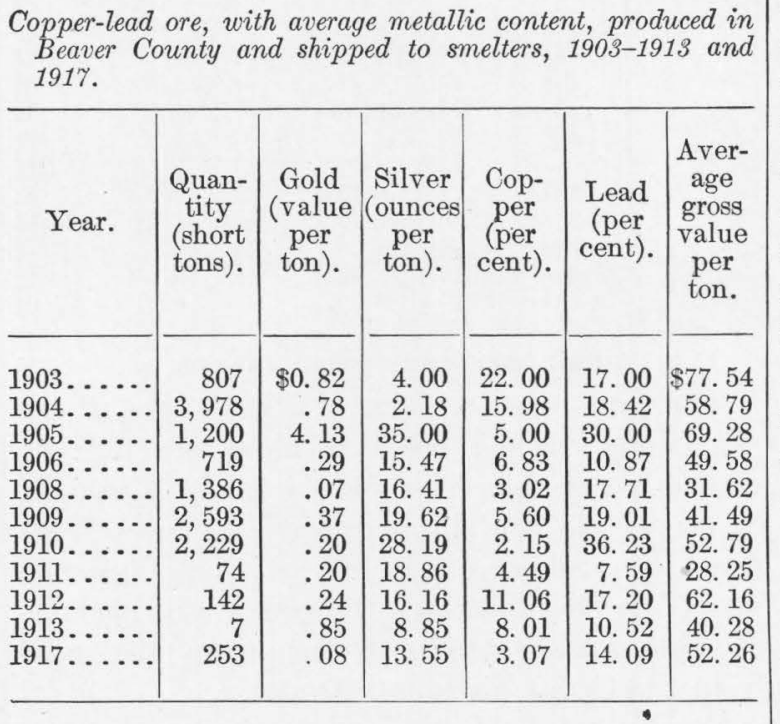

LEAD-ZINC ORE.

The lead-zinc ore has come entirely from the Horn Silver mine. The average grade of the ores shipped was as follows:

Lead-zinc ore, with average metallic content, produced in Beaver County and shipped to smelters, 1909, 1911, 1914, and 1916.

\begin{tabular}{|c|c|c|c|c|c|c|}
\hline Year. & $\begin{array}{l}\text { Quan- } \\
\text { tity } \\
\text { (short } \\
\text { tons). }\end{array}$ & $\begin{array}{c}\text { Gold } \\
\text { (value } \\
\text { per } \\
\text { ton). }\end{array}$ & $\begin{array}{c}\text { Silver } \\
\text { (ounces } \\
\text { per } \\
\text { ton). }\end{array}$ & $\begin{array}{c}\text { Lead } \\
\text { (per } \\
\text { cent). }\end{array}$ & $\begin{array}{c}\text { Recov- } \\
\text { erable } \\
\text { zinc } \\
\text { (per } \\
\text { cent). }\end{array}$ & $\begin{array}{l}\text { Aver- } \\
\text { age } \\
\text { gross } \\
\text { value } \\
\text { per } \\
\text { ton. }\end{array}$ \\
\hline $\begin{array}{l}1909 \ldots . \\
1911 \ldots . \\
1914 \ldots \\
1916 \ldots\end{array}$ & $\begin{array}{r}897 \\
261 \\
6,083 \\
628\end{array}$ & $\begin{array}{r}\$ 0.18 \\
.27 \\
\ldots \ldots\end{array}$ & $\begin{array}{r}9.05 \\
10.01 \\
2.52\end{array}$ & $\begin{array}{r}12.92 \\
11.62 \\
8.04 \\
8.68\end{array}$ & $\begin{array}{l}36.59 \\
12.44 \\
32.37 \\
27.13\end{array}$ & $\begin{array}{r}\$ 55.52 \\
30.21 \\
34.44 \\
84.70\end{array}$ \\
\hline
\end{tabular}

PHYSIOGRAPHY.

BY B. S. Butler.

Topographically and physiographically the San Francisco region is similar to other ranges of the Great Basin region. Characteristic features are north-south ranges rising abruptly from flat desert valleys. The ranges have several features in common. For example, in the
Mineral Range on the east, the San Francisco Range within the area, and the Wah Wah Range next to the west, the following common characteristics are found. A gentle easterly slope and an abrupt westerly slope; a gentle easterly dip of the strata; a lava covering extending up the eastern slopes but absent from the western; and a rather straight western front that disregards the differing resistance of the component formations - features that are best explained by the supposition that the ranges were formed at a comparatively recent date by a breaking up of the area into blocks along north-south faults and the tilting of the resultant blocks, and that the areas between the ranges were subsequently partly filled by débris from the erosion of the higher portions.

The Beaver Lake, Rocky, and Star ranges do not show characteristics in common with the other ranges and may have resulted from other causes.

\section{GEOLOGY.}

The rocks of the area include sedimentary, intrusive, and extrusive formations, all of which are intimately connected with the ore deposits. (See Pl. XL, p. 502.)

\section{SEDIMENTARY ROCKS.}

The sedimentary rocks range in age from Ordovician and possibly from Cambrian to Triassic. (See fig. 52.) Although no marked structural unconformities have been recognized, there were probably periods of nondeposition and possibly of erosion while the sedimentary rocks were being formed.

The Grampian limestone, the lowest formation in the area, is exposed in the San Francisco Range. In large part it is a heavy-bedded blue dolomitic limestone, but it contains beds of light-gray limestone and siliceous and arenaceous beds, which are especially abundant in the upper 300 feet. Those near the top of the formation contain fossils of Ordovician age.

Overlying the Grampian limestone in the San Francisco Range is the Morehouse quartzite, which consists, at the base, of 400 to 500 feet of nearly white rather fine grained quartzite overlain by a pink quartzite nearly 1,500 feet thick, near whose base are some shaly members. A quartzite member about 2,500 feet thick that forms the base of the section exposed in the 
Star district is believed to be the upper portion of the Morehouse quartzite the top of which is not present in the San Francisco Range. To what extent, if any, the two members are duplications has not been determined. No fossils were found in the quartzite, but as it lies between known Ordovician and Devonian rocks it has been provisionally assigned to the Ordovician and Silurian.

Next above the Morehouse quartzite is the Red Warrior limestone, which for the most part is a heavy-bedded blue dolomitic and in
Overlying the Mowitza shale is the Topache limestone of 1,500 feet of heavy-bedded blue limestone with beds of shale and chert.

Fossils collected near the center of the formation indicate that it is probably lower Carboniferous (Mississippian).

A persistent quartzite (Talisman quartzite) about 400 feet thick, though rather variable, separates the Topache limestone from the overlying Elephant limestone of Pennsylvanian age, a heavy-bedded dolomitic and siliceous limestone about 1,000 feet thick.

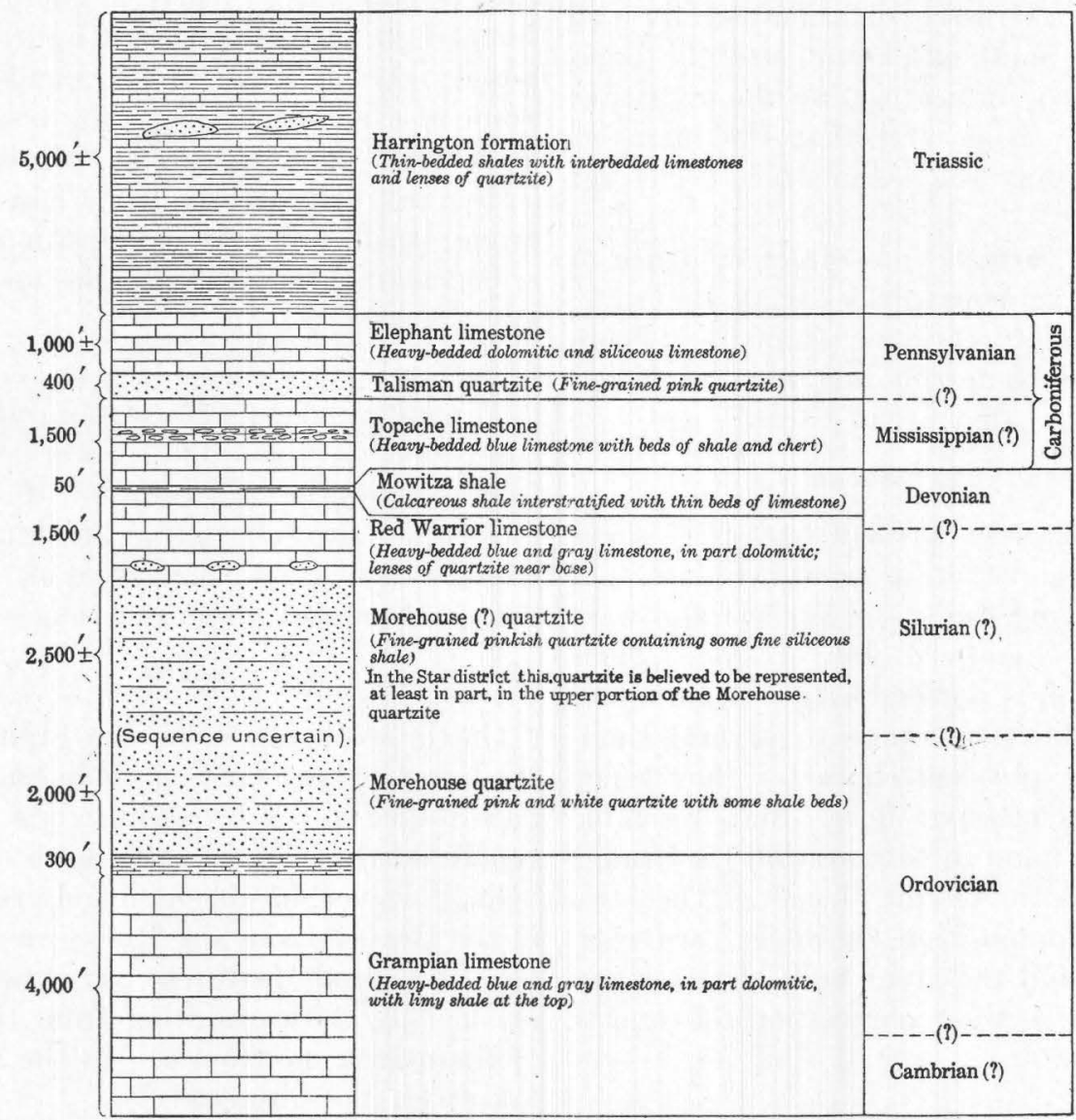

FIGURE 52.-Generafized section of the sedimentary series in the San Francisco and adjacent districts.

part rather siliceous limestone about 1,500 feet thick. In its lower part are lenses of quartzite and in its upper part beds of gray limestone. No fossils were collected from this formation, but as it is overlain by Upper Devonian rocks it is regarded as in part at least Devonian and possibly in part Silurian.

Thenext higher formation is the Mowitza shale, which consists of about 50 feet of calcareous shale interstratified with thin beds of limestone. Its age has been determined as Upper Devonian.
Overlying the Elephant limestone and representing the youngest consolidated bed in the area is the Harrington formation, which consists of shales with beds of limestone and lenses of quartzite. Approximately 5,000 feet of these beds are exposed. Fossils collected from the lower and central portions of the formation have been determined as of Triassic age.

Unconsolidated deposits in the district consist of lake beds and alluvial depcsits of Pleistocene and Recent age. 
IGNEOUS ROCKS.

INTERRELATIONS AND AGE.

The relation of the intrusive and extrusive rocks is far from clear at many points in the area. In the Rocky Range, however, dikes from the quartz monzonite stock intrude the lava flows, and in the San Francisco district, just northwest of Frisco, dikes of quartz monzonite porphyry similar in composition to the stocks cut the flow rocks. These facts, together with the porphyritic character of the quartz monzonite of the stocks near the contact with the extrusive rocks, especially well shown in the point extending into the lavas north of Frisco, indicate that the extrusive rocks are the earlier and that the intrusive rocks cut not only the sedimentary rocks but also the lavas.

The district furnishes no direct evidence of the age of the igneous rocks except that they are younger than the Triassic sediments. From a comparison with neighboring areas, however, it is believed that they are of Tertiary age.

\section{EXTRUSIVE ROCKS.}

Extrusive rocks are present over large areas in the region, and there is good evidence that they once covered the entire surface and were later in part removed by erosion. Their complete section is nowhere exposed, but their aggregate thickness amounts to several thousand feet. In physical character they range from tuffs to massive flows that resemble intrusive rocks; and in composition they range from rhyolite to olivine basalt. The two extremes in composition, however, are relatively scarce, and the great bulk of the extrusive rocks have the composition of quartz latite. (See p. 90.)

\section{INTRUSIVE ROCKS.}

Stocks are present in all the ranges in the area (see Pl. XL), and dikes and irregular bodies cut all the formations. The large bodies are of granitic texture and intermediate composition ranging from quartz monzonite to granodiorite. They are believed to have a common origin and to be simply variants resulting from the differentiation of a common magma. The chemical and mineral composition are given in another part of this paper. (See p. 96.)

The dike rocks are of at least two ages. Dikes of the quartz monzonite extend from the stocks into the adjacent rocks and more basic dikes cut the quartz monzonite stocks and other formations. Siliceous dikes are also present in the quartz monzonite and in the sedimentary rocks.

The more basic dikes vary in composition from those differing but little from the quartz monzonite to those in which the dark silicates compose a large part of the rock. The most basic rocks are of lamprophyric type.

The siliceous dikes range from irregular bodies of granitic rock (shown in Copper Gulch) that do not differ greatly in composition from some of the stocks to typical aplitic dikes composed essentially of quartz and orthoclase. Some of the aplitic dikes contain sulphide that is believed to be original. All the intrusive series are believed to have had a common origin, their different compositions being ascribed to differentiation of the magma.

\section{STRUCTURE.}

The main recognizable structural features of the region have resulted from a gentle folding followed by the intrusion of the monzonite stocks and the subsequent breaking of the region into blocks and the tilting of the blocks to form the present mountain ranges.

FOLDS.

On the west side of the San Francisco Range the lower beds of the Grampian limestone have been folded into a broad anticline that pitches gently north. The western limb of the upper beds, however, has been entirely removed, and in the Beaver Lake and Rocky ranges the earlier structural features have been entirely masked by those resulting from the intrusion of the quartz monzonite. In the Star district folds were not observed.

STRUCTURAL FEATURES RESULTING FROM INTRUSION OF IGNEOUS ROCKS.

The intrusive rocks for the most part broke through the earlier formations instead of spreading out in laccolithic form. They did, however, dome the overlying rocks to some extent, for these commonly dip away from the center of intrusion.

In the Star district, especially, an intrusive mass seems to have forced a block of sedimentary rocks bodily before it to make room for the entering material. To what extent "stop- 
ing" (the engulfment, sinking, and dissolving of the invaded rock) provided space for the entering material is not definitely known, but the writer is inclined to the view that its effect was of minor importance, as Boutwell ${ }^{1}$ believes it to have been in the Park City district.

FAULTS.

The most important structural features of the region are the result of faulting. Normal faulting is usually associated with the Basin

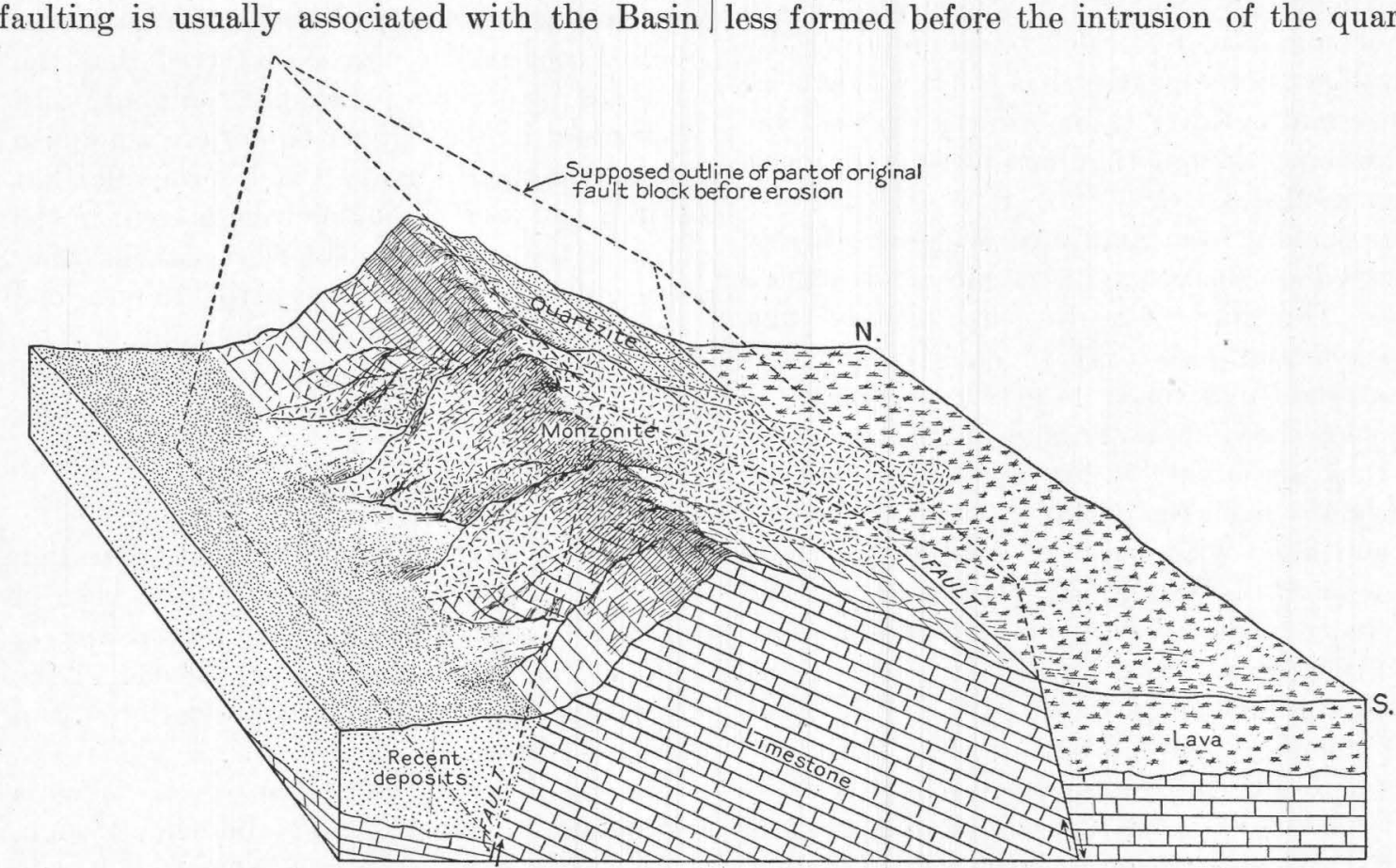

FIGURE 53.-Generalized stereogram representing the relations of the formations in part of the San Francisco Range north of Squaw Springs Pass.

Range structure and is believed to outline the San Francisco Range both on the east and west. A fault on the east, exposed in the workings of the Horn Silver mine, has a known displacement of 1,600 feet and doubtless much more. (See fig. 53.) Another notable normal fault passes northeast through Squaw Springs Gap in the San Francisco Range and throws the lavas on the south of the range down against the limestone on the north.

The intrusion of the quartz monzonite bodies is believed to have laterally displaced the surrounding rocks. Such a displacement is shown in the central portion of the Star district, and similar displacements are possibly present, though less clearly shown in

\footnotetext{
1 Boutwell, J. M., Stratigraphy and structure of the Park City mining. district, Utah: Jour. Geology, vol. 15, p. 458, 1907
} $35416^{\circ}-19-33$ association with other stocks. In the Star district there has been movement along planes that are essentially horizontal but that have irregularities resembling a warped surface. The rocks along the fault planes are highly polished and grooved, but it is not demonstrated that there has been extensive movement.

Faulting has probably been in progress over a long period. Some important faults doubtless formed before the intrusion of the quartz monzonite, and others have certainly occurred since. The faulting doubtless extended into late Tertiary time and may be still in progress.

FISSURES.

Fissures are important in the area, as they have furnished channels for the passage of the ore-bearing solutions. In the Star district most of the important fissures strike nearly east and dip vertically or very steeply. In the other districts the fissures show less uniformity of direction. Fissures in the sedimentary rocks were probably formed for the most part at the time of the quartz monzonite intrusion by stresses in the limestone resulting from the injection of the igneous material. Some little fissuring, especially near the contact, may be attributed to the stresses caused by the shrink- 
age of the cooling mass. Probably similar causes led to fissuring in quartz monzonite.

\section{METASOMATISM.}

\section{ALTERATION OF QUARTZ MONZONITE.}

In general the quartz monzonite has been little altered except along fissures and zones of fracture, where, in its most highly altered condition, it has been changed to essentially a quartz sericite rock with variable amounts of minor constituents. Such zones are especially well shown in Copper Gulch in the San Francisco Range and in the O. K. zone in the Beaver Lake Mountains, though they are present at many other localities.

In passing from unaltered rock to a highly altered zone the stages of the alteration can be seen. The dark silicates are usually first attacked and pass over to chlorite and carbonate and eventually largely to sericite; the feldspars become more and more sericitized till they are composed largely of that mineral; and finally even the quartz crystals are broken up and filled with sericite. In the two zones most carefully examined the most marked difference in the alteration is that rather abundant carbonate was formed in the Copper Gulch zone and none at all in the O. K. zone. The chemical composition of the fresh and altered rock in the two zones (pp. 164-165) shows that silica $\left(\mathrm{SiO}_{2}\right)$ has decreased somewhat in both. Alumina $\left(\mathrm{Al}_{2} \mathrm{O}_{3}\right)$ shows little change; in the Cactus deposit it has slightly increased, in the $\mathrm{O}$. K. deposit slightly decreased, the resulting differences, however, being no greater than might be found in two samples from the same rock mass. In the Cactus deposit the oxides of iron have remained nearly constant, but in the $\mathrm{O}$. K. deposit iron has been removed. Magnesia $(\mathrm{MgO})$ has been reduced in both zones, undoubtedly by the alteration. Both lime $(\mathrm{CaO})$ and soda $\left(\mathrm{Na}_{2} \mathrm{O}\right)$ have been almost completely removed, but potash $\left(\mathrm{K}_{2} \mathrm{O}\right)$, especially in the Cactus zone, and combined water show marked increase. Titanium oxide $\left(\mathrm{TiO}_{2}\right)$ remains nearly constant. Carbon dioxide $\left(\mathrm{CO}_{2}\right)$ has been markedly added in the Cactus zone but not in the O. K. zone. Sulphur and copper have been added in both zones. The samples selected for analysis contained little sulphide and in this respect do not represent the average of the altered rock.

The chemical and mineralogic changes that have taken place in the rock give some indication of the composition of the solutions that produced them. Elements that have been added to the rock by these solutions were necessarily carried by them. Elements thatwere removed may have been already contained to some extent in the solutions, though probably not in large degree. From this it may be inferred that the solutions contained potassium, sulphur, and copper and in the Copper Gulch ore zone also iron and carbon dioxide. It is probable that the iron and carbon dioxide were present in the solutions that produced the alteration in other zones but not in sufficient quantity to be added to the rock. The fact that the solutions removed neither silica nor alumina might well indicate that they were not deficient in these substances.

\section{ALTERATION OF LAVAS.}

The lavas have suffered extensive alteration in several areas, especially along the base of the San Francisco Range near Frisco and in the central portions of the Beaver Lake Mountains and of the southwestern San Francisco Range.

The characteristic alteration of the lavas is a pronounced sericitization and silicification. In the early stages the dark silicates alter to chlorite and carbonate and in advanced stages magnesium, calcium, and sodium are largely removed. In extreme phases of alteration the resultant rock is composed essentially of quartz, andalusite, and sericite. Andalusite does not appear in the. rock so long as feldspar is present. Apparently mica formed so long as the rock contained sufficient sodium or potassium to combine with the alumina set free by the breaking down of the feldspars, and only when the feldspar had entirely altered did further removal of the bases result in the formation of andalusite.

The following tables give a partial analyses of the lavas in differen' stages of alteration and the mineral composition calculated from the analyses: 
Partial analyses and mineral composition of fresh and altered lava from San Francisco region, Utah.

Partial analyses.

\begin{tabular}{|c|c|c|c|c|}
\hline & 1 & 2 & 3 & 4 \\
\hline 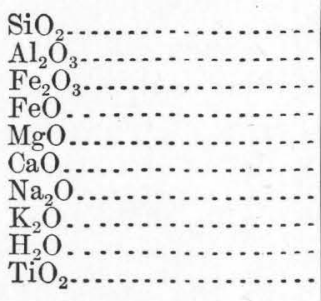 & $\begin{array}{r}64.48 \\
\ldots \ldots . . . \\
\ldots \ldots . \\
\text { None. } \\
1.95 \\
4.81 \\
3.39 \\
\ldots \ldots \ldots\end{array}$ & $\begin{array}{r}76.74 \\
16.10 \\
.10 \\
.34 \\
.58 \\
3.99 \\
2.34 \\
.\end{array}$ & $\left\{\begin{array}{r}72.32 \\
20.96 \\
.50 \\
\ldots \ldots . . \\
\text { None. } \\
.15 \\
.55 \\
.93 \\
3.91 \\
1.10\end{array}\right.$ & $\left\{\begin{array}{r}67.93 \\
19.46 \\
.28 \\
1.42 \\
3.54 \\
3.91 \\
\cdots \ldots\end{array}\right.$ \\
\hline
\end{tabular}

Mineral composition.

\begin{tabular}{|c|c|c|c|c|}
\hline Quartz. & 20 & 58.0 & 56.34 & 31 \\
\hline Orthoclase molecule.... & 20 & & 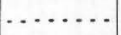 & 22 \\
\hline olecule & 40 & & & 30 \\
\hline Anorthite molecule....... & & & & 7 \\
\hline Hornblende an & & & & \\
\hline $\mathrm{Mu}$ & - & 34.2 & 7. 96 & \\
\hline $\mathrm{Pa}$ & & 6.7 & 7.64 & \\
\hline Anc & & & 26.35 & \\
\hline $\mathrm{Ilm}$ & & & 1. 05 & \\
\hline $\mathrm{Ru}$ & & & .55 & \\
\hline Calc & & .6 & & \\
\hline Lime $(C$ & & & .15 & \\
\hline
\end{tabular}

1. Quartz latite near summit of Beaver Lake Mountain north of O.K. mine (specimen 187). R. C. Wells, analyst.

2. Altered volcanic rock from ridge north of O.K. mine (specimen 189). George Steiger, analyst.

3. Highly altered volcanic rock from ridge west of $\mathrm{O} . \mathrm{K}$. mine (specimen 193). R. C. Wells, analyst.

4. Latite northeast of Frisco (specimen 20). George Steiger, analyst.

Mineralogically, alteration of the lava, especially in its earlier stages, shows many similarities to that of the quartz monzonite. Chemically, it far more closely resembles the results of weathering, where the change is the result of a progressive leaching of the different elements with no notable additions. The chief mineralogic difference is that the minerals are hydrated in the weathered rock but are anhydrous in the altered lavas.

\section{ALTERATION OF SEDIMENTARY ROCKS.}

Alteration of the sedimentary rocks adjacent to the quartz monzonite bodies, commonly designated contact alteration, differs greatly in different rocks and from point to point in the same rock. Commonly quartzite and shales show comparatively slight change and limestone more extensive alteration.

At many localities the limestone has been merely marmarized, but at others both its character and composition have been greatly changed. These differences are especially well shown around the stock in the San Francisco Range. Marmarization is the characteristic alteration on the north side of the stock and is important at some points along the south side, but at others on the south side contact silicates make up the bulk of the rock. The marmarization seems to have been the earliest effect of the intrusion, the recrystallization of the limestone being due largely to the heat of the intrusive material, and the silicate zones seem to have been produced slightly later, when the outer portion at least of the stock had solidified and the solutions from deep-seated sources were directed into certain parts of the limestone through fissures.

The character of the silicate zones was influenced to an important extent by the original composition of the limestone. Diopside and tremolite are abundant where the rock was notably magnesian, and garnet is more characteristic where it was more purely calcium carbonate. At some points, however-notably in the Rocky district, where iron ore has replaced limestone - the original material has been very largely removed.

In large part the minerals of the contact zone are contemporaneous, though in places the contact silicates are cut by veins composed of quartz, sulphides, magnetite, and even of feldspar. Distinctly later than the contact silicates are veins composed largely of magnesite $\left(\mathrm{MgCO}_{3}\right)$ and, near the iron deposits in the Rocky Range, veins of the rare mineral thaumasite $\left(3 \mathrm{CaO} \cdot \mathrm{SiO}_{2} \cdot \mathrm{SO}_{3} \cdot \mathrm{CO}_{2} \cdot 15 \mathrm{H}_{2} \mathrm{O}\right)$.

Away from the igneous contact silicates decrease and carbonates increase, though along fractures the silicates are present for a considerable distance and grade into veins where the alteration of the wall rock is chiefly silicification. The width of the silicate zone is very variable. South of the stock in the San Francisco Range it has a maximum width of fully one-fourth mile from an exposed contact, but at other points it is only a few yards.

The minerals forming the zone as already noted vary greatly from place to place. They include garnet (grossularite and andradite molecules are present in varying amounts), diopside, tremolite, vesuvianite, muscovite, epidote, chlorite, fluorite, quartz, calcite, specularite, magnetite, pyrite, and chalcopyrite. 
Molybdenite, sphalerite, and galena are rather rare.

Analyses of specimens that represent changes that have taken place in the alteration are given on pages 170 .

In comparing the analyses of the limestones to determine the changes that have taken place in alteration it is necessary to consider changes in the volume and the density of the rock. It has not been shown positively whether the volume has increased or decreased as a result of alteration, but it is believed that the change, if any, has been slight. The change in density, as shown by the specific gravity of the rocks, has been considerable. If the volume is assumed to have been constant, the amount of addition or subtraction of the several oxides can be determined by calculating the amount of each present in a given volume of rock. (See p.170.) The changes, of course, differ at practically every point. Some of the more important, however, doubtless apply with varying intensity in all parts of the zone and represent the general change that has taken place. Generally speaking, silica shows a marked increase, the addition to each of the two highly altered rocks being almost identical. Alumina and ferric oxide also show a marked increase; the amount of each added to the different rocks differs, but the sum of the two is more nearly equal. Ferrous oxide is not important in either the unaltered or altered rock. Magnesia shows a decrease, but this can not be certainly ascribed to alterations, for the original magnesia content varies sharply within very short distances. Calcium shows a slight decrease in both of the altered rocks, and carbon dioxide is practically absent from both. Copper, zinc, and lead, and probably small amounts of other metallic elements have been added. Sulphur has been added, and in some parts of the zone potassium has been notably added, as indicated by the presence of muscovite. To sum up, it seems very certain that there have been important additions of silica, alumina, ferrous oxide, sulphur, copper, and zinc, and lesser additions of potassium, manganese, and other metals. It is logical to assume that these substances were contained in the solutionsns entering the limestone supposedly from a crystallizing magma.
COMPARISON OF ALTERATION OF DIFFERENT KINDS OF ROCK.

The solutions that effected the alteration in the quartz monzonite probably contained silica, potassium, iron, sulphur, copper, and carbon dioxide, and possibly alumina. The solutions that effected the alteration in the limestone contained silica, alumina, ferrous oxide, sulphur, copper, zinc, potassium, and other substances in minor amount. The similarity of the solutions seems in accord with the belief that they had a common origin and that they were given off by a crystallizing magma.

The altered volcanic rock in the areas of extensive metamorphism shows no important additions of substances but rather a progressive leaching. This would seem to indicate that the solutions differed from those affecting the quartz monzonite and adjacent sedimentary rocks and may have been ordinary atmospheric waters. Such waters, heated by the intrusion of the quartz monzonite magma, might be expected to produce an alteration chemically similar to but mineralogically different from weathering.

\section{ORE DEPOSITS.}

MINERALIZATION.

The ore deposits of the San Francisco region are believed to be of essentially the same age, the deposition of all the ores closely following the intrusion of the quartz monzonite. The marked differences in the deposits are probably due chiefly to the character of the rock in which the deposits were formed; to distance from the intrusive body, which affected the temperature and pressure; and to the time of formation, the solutions in the later part of the general period of mineralization probably being of somewhat different composition from those that were active at its beginning.

\section{INFLUENCE OF ROCK TYPES,}

The character of the rock in which the deposits were formed was doubtless one of the more important factors in determining the general type of the deposit.

DEPOSITS IN QUARTZ MONZONITE.

The quartz monzonite has been mineralized at numerous localities in the region, but so far mineralization has been shown to be extensive 
at only two places - in the Cactus ore zone in Copper Gulch (see Pl. XLI, B) and in the $\mathrm{O} . \mathrm{K}$. ore zone in the Beaver Lake district. Characteristically the deposits carry copper and some gold and silver, though some veins carrying galena have been opened.

In both zones the deposits are associated with fractures along which there has been a

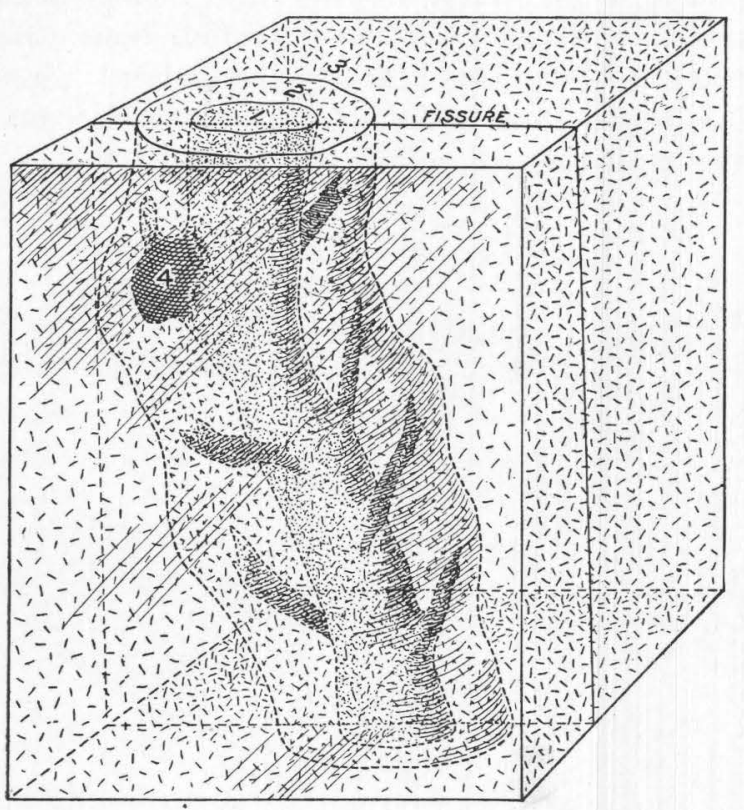

FIGURE 54.-Generalized stereogram showing the relation of pegmatitic quartz and altered and mineralized quartz monzonite in the $\mathrm{O} . \mathrm{K}$. mine. 1, Pipe of pegmatitic quartz; 2, altered quartz monzonite; 3 , quartz monzonite; 4 , high-grade ore.

brecciation of the rock but probably not extensive displacement. The deposits are more or less chimney shaped, especially the O.K. deposit, which consists of a central "chimney" of pegmatitic quartz surrounded by altered and mineralized quartz monzonite. (See fig. 54.) In the Cactus ore zone the ore and gangue minerals are deposited in spaces between corroded fragments of the quartz monzonite. In both zones the structural relations indicate that the spaces occupied by the ore and gangue minerals were formed largely by the solution of the rock in the early stages of mineralization and not by dynamic movement.

In the O. K. deposit the solutions were apparently relatively confined, and the dissolving action was strong, resulting in the formation of a more or less cylindrical channel with a maximum dimension of fully 100 feet, now filled with quartz, some of whose individual crystals have a diameter of 10 inches and a length of 2 feet. The body as a whole strikingly resembles a coarse pegmatite, though no feldspar or mica are present. Sulphides are abundant in the main chimney only locally, as in the ore body on the second level, where by enrichment they form high-grade ore. They are much more abundant in the small veins of quartz extending from the main mass into the adjacent rock. The characteristic primary minerals in the O. K. deposit are quartz, chalcopyrite, and pyrite with molybdenite in relatively small amount. An aplitic rock, probably a dike, exposed in the bottom of the shaft, contains chalcopyrite and molybdenite, apparently as original constituents.

The Cactus ore zone contains the minerals found in the O.K., and also hematite, magnetite (?), tourmaline, siderite, anhydrite, and barite in important amounts. The sequence of deposition is rather definite. The earliest effect of the ore solutions was the sericitization of the quartz monzonite and the deposition of quartz, chalcopyrite, and pyrite and small amounts of hematite and tourmaline in the wall rock. This was followed by the deposition of hematite and tourmaline and the continued deposition of quartz and the sulphides, mainly in open spaces. Still later deposition in the open spaces consisted mainly

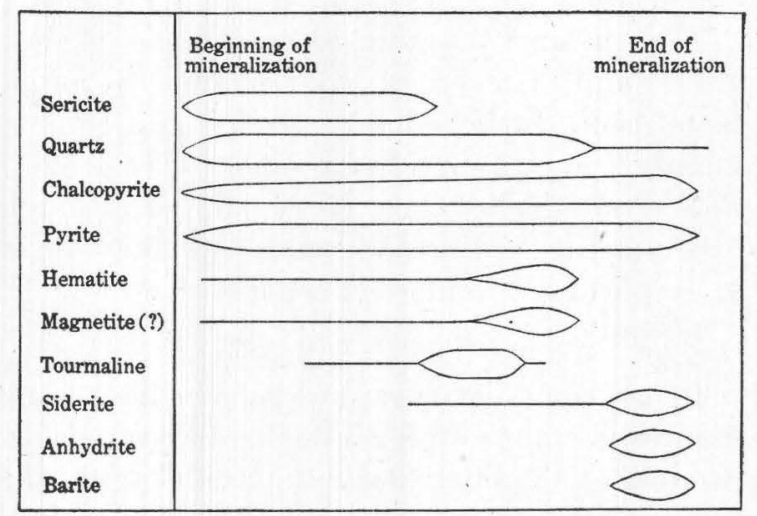

Figure 55.-Diagram showing the relative period of formation of the principal ore and gangue minerals of the Cactus ore zone.

of siderite, anhydrite, and barite, together with the sulphides. (See fig. 55.)

The earlier mineralization of the Cactus ore zone was similar to that of the O.K. ore zone, and the final differences may be due to the longer and more varied mineralization of the Cactus zone. The later minerals are in general those that form under conditions of less heat 
and pressure, and the succession might naturally be attributed to a gradual reduction of the heat and pressure in the zone. Opposed to this hypothesis, however, is the presence of anhydrite, which, differently from most salts, decreases in solubility with increase in temperature and naturally would not precipitate from a cooling solution. Lindgren ${ }^{1}$ says: "It is suggested as a possibility that during the later part of mineralization the anhydrite was precipitated by a reaction between ascending solutions of sodium sulphate and descending solutions containing calcium carbonate."

The formation of barite, anhydrite, and other sulphates as primary minerals in ore deposits is discussed on page 184 . It is concluded that at comparatively low temperature they may form from igneous emanations.

DEPOSITS IN SEDIMENTARY ROCKS.

CONTACT DEPOSITS.

The typical contact deposits occur as very variable replacements of the limestone near the quartz monzonite in a zone differing greatly in thickness. In most places the replacement consists largely of lime and magnesian silicates with variable amounts of sulphides, but locally, as at the Old Hickory mine, it consists largely of magnetite.

The primary contact deposits are of low grade and, except in the magnetite zones, have been little mined, production coming mainly from the oxidized zone. (See p.523.) Characteristically they carry copper, though other metals are present and iron may form an important commercial constituent.

\section{REPLACEMENT-FISSURE DEPOSITS.}

In mostmassive limestones replacement along fissures is rather uniform in the different beds, producing a tabular deposit parallel with the fissure. Where the sediments differ in physical character and in chemical composition, however, the ore deposition extends out from the fissure in particular beds for considerable distances but leaves adjacent beds largely unaffected. This selective replacement is probably due in part to physical and in part to chemical differences in the beds.

The tabular development is perhaps best shown in the Mammoth mine deposit in the

${ }^{1}$ Lindgren, Waldemar, Anhydrite as a gangue mineral: Econ. Geology, vol. 5, p. $522,1910$. massive Topache limestone, which, though it shows a pronounced swelling or extension in some beds, also replaces the intervening beds to a considerable extent.

Replacement along particular beds is well shown in the Harrington-Hickory mine and in the mines in the limestone underlying the Mowitza shale, especially the Red Warrior and Moscow mines, in which the replacement is almost exclusively along certain beds, the resultant deposits forming chimneys that follow the intersection of the ore fissure and the replaced bed. (See fig. 56.). In the de-

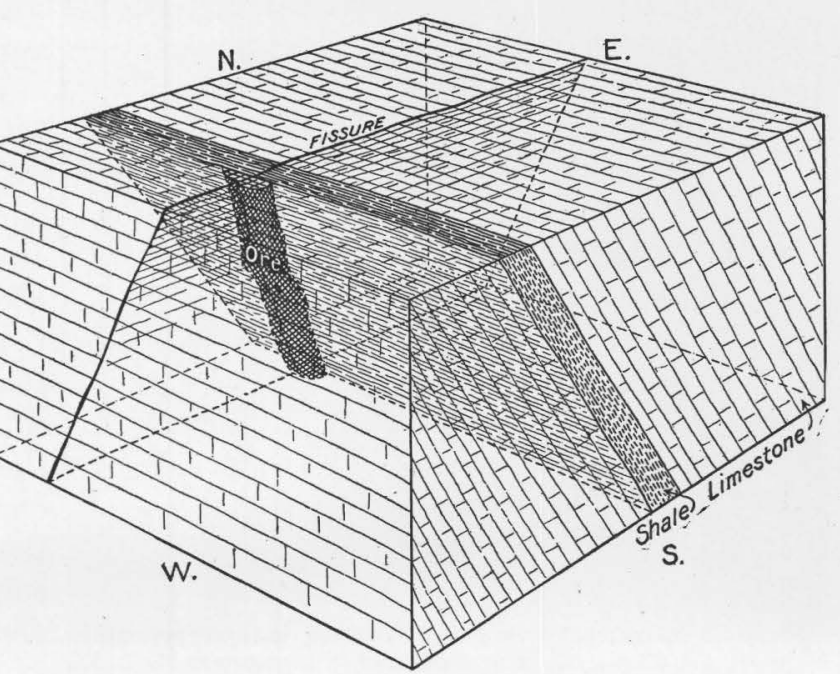

Figure 56.-Stereogram showing ore shoot beneath shale. The shoot follows the intersection of the ore fissure and the limestone bed beneath the shale. The ore makes out from the fissure along the limestone bed

posits underlying the Mowitza shale the reason for this selective deposition seems to be largely" physical. In the shale the fissures are "tight" and relatively impervious; and the ore-bearing solutions, rising till they came to the stricture, were forced to spread out and replace the more permeable underlying beds. A similar formation of ore bodies beneath shale beds has been noted in several localities in the West. In the Harrington-Hickory mine the chemical composition of the beds has undoubtedly influenced the form of the deposit. The series is made up of interbedded limestone, quartzite, and siliceous shales and limestones. The main ore deposition has been in the limestone, the siliceous beds being very slightly replaced. The characteristic alteration of the limestone adjacent to the fissures is silicification. The most important metals of this class of deposits are lead and silver, though some zinc and copper are present. The de- 
LONGITUDINAL SECTION

SHOWING GENERALIZED OUTLINE OF ORE BODIES AND AREAS OF MINERALIZED GROUND

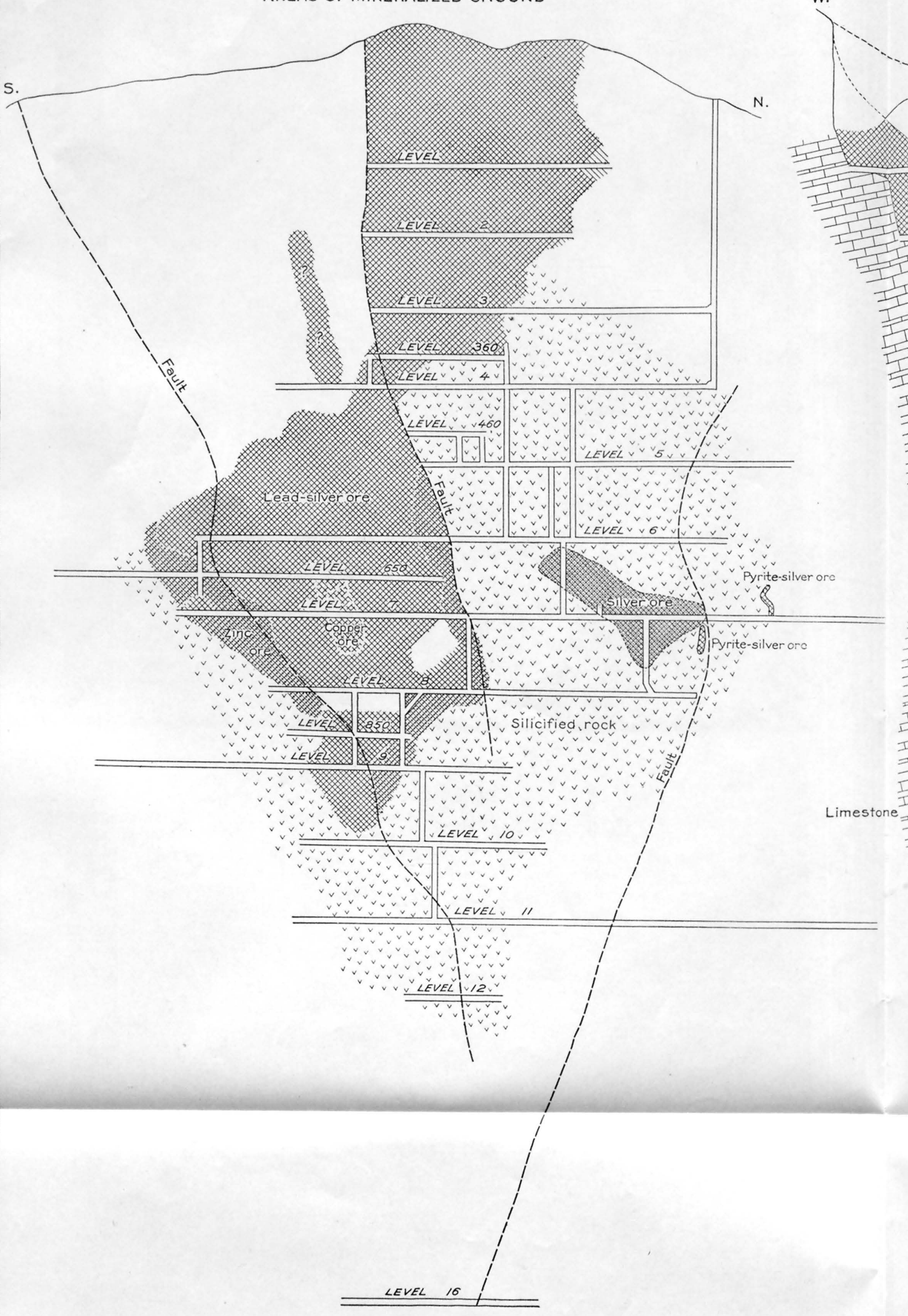

TRANSVERSE SECTION

w.

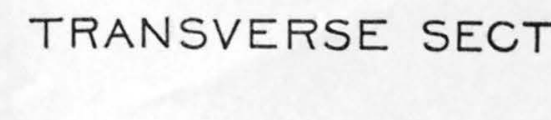

Surface before cavin

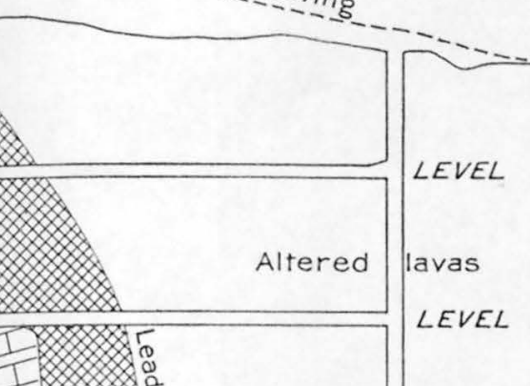

II I cman.

LEVEL 7

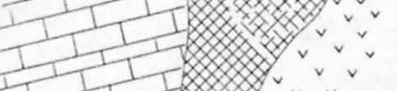

7 1 T 1 .

LEVEL 8

II I I

1

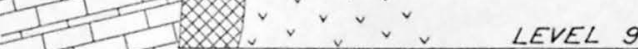

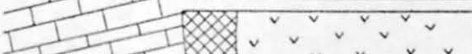

I šilicifièd rock

II I I

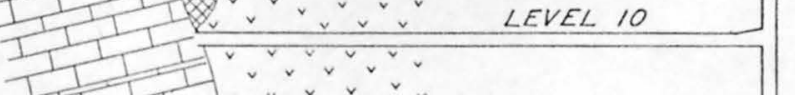

III I

I I I $\cdots$

11 I

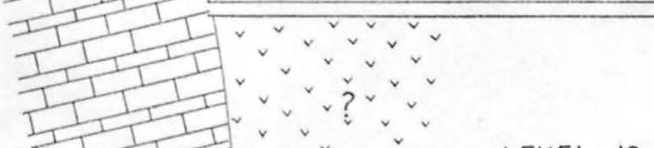
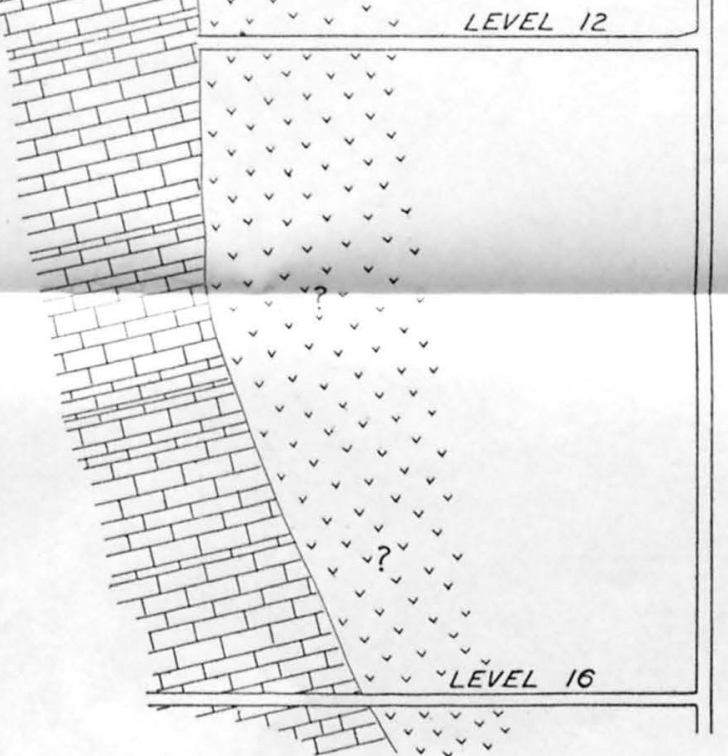

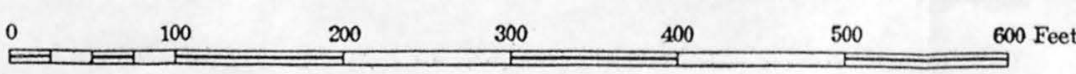


posits have undergone extensive secondary alteration.

TRANSITION DEPOSITS.

Deposits that may be considered transitional are formed like the replacement-fissure deposits, as a replacement of limestone along fissures, but involve the formation of contact minerals such as garnet, magnetite, fluorite, and muscovite. These deposits occur at no great distance from the igneous rock. Such deposits are present in the Wild Bill and Hub mines, where, in fact, they merge into true contact deposits. The Harrington-Hickory and Moscow mines may also be considered of this type, for they contain contact minerals in considerable amount, though as contrasted with the Wild Bill and Hub mines they resemble the replacement-fissure type rather than the contact type. Though the replacement deposits in sedimentary rocks are confined mainly to the limestones or highly calcareous sediments, some ore occurs as a replacement of quartzite and the general relations are similar to those of the deposits in limestone.

\section{MINERALIZATION IN LAVA FLOWS.}

GENERAL CHARACTER.

Mineralization of commercial importance in the volcanic rocks is, so far as known, confined to two deposits on the eastern flank of the San Francisco Range-the Horn Silver and the Beaver Carbonate.

The deposits are replacement-fissure veins in which the ore and gangue minerals in part filled open fissures and in part replaced the brecciated rock adjacent to the fissures. In the Horn Silver deposit the ores occur in and adjacent to a strong north-south fault whose displacement exceeds 1,600 feet. In the Beaver Carbonate deposit they lie along an east-west fault of undetermined displacement.

The alteration of the wall rock adjacent to the deposits varies considerably. In the Horn Silver deposit the less intense alteration causes a sericitization of the lavas, and the most intense results in replacements by a finely crystalline quartz containing rather abundant pyrite and some barite. The almost complete silicification of the rock extends 100 to 125 feet from the fissure and in depth persists beyond the lower limit of the ore bodies. (See Pl. XLII.) The limestone which forms the footwall of the deposit has been but slightly silicified. The alteration seems to have affected mainly the permeable brecciated lavas and to have changed the massive limestone but little.

In the Beaver Carbonate mine, on the other hand, the wall rock shows much less intense alteration. The hornblende has been chloritized and the plagioclase partly sericitized, but the orthoclase and biotite show little alteration.

ORE MINERALS.

In the Horn Silver deposit the principal primary ore minerals are galena, pyrite, and sphalerite, and the less important are sulphantimonides and sulpharsenides. The ore minerals occur almost entirely as a replacement of the volcanic rocks and are believed to be essentially contemporaneous in origin. The important primary gangue materials are quartz, barite, and the altered country rock.

In the Beaver Carbonate mine the primary ore minerals are galena, pyrite, and sphalerite, and the principal gangue materials are carbonate, quartz, and the altered country rock. Cherty quartz, sulphides, and calcite, deposited in general in the order named, fill the open spaces between the breccia fragments. The periods of deposition are not sharply defined, however, as some sulphide was deposited with the quartz, some calcite with the sulphides, and a little quartz with the caleite.

ORIGIN OF THE ORES.

All the ore deposits of the region are believed to have been formed during the same general period by solutions having a common origin. This community in origin is indicated by the similarity of the solutions that effected the alteration in the quartz monzonite and in the contact zones in the limestone, and by the fact that the contact deposits grade into the replacement-fissure deposits in the sedimentary rock. The community of these solutions and those that formed the deposits in the extrusive rocks is less clearly śhown but is strongly suggested by the general relations of the deposits. A long finger extends from the main body of the quartz monzonite toward the Horn Silver deposit, and is said to reach the Horn Silver fault on the eleventh level. The Beaver Carbonate mine is also in line with the eastward extension of the quartz monzonite body and 
the fissures may logically be supposed to reach that rock at depth; in fact it seems highly probable that the fissuring was the result of the intrusion. These relations, though by no means conclusive, certainly suggest a genetic connection. Such a connection for similar deposits is also shown in the Marysvale district to the east. ${ }^{1}$

That the solutions affecting the rocks at different points were exactly the same does not, however, seem probable. As the solutions traverse the rock they are constantly taking up and depositing material; and a solution deficient in a particular element at one point may be rich in that element at some other point. Differences in the character of the rock and in the temperature and pressure may also affect the solutions by checking or hastening deposition. For example, in the contact zones the solutions deposited copper and iron sulphides and only small amounts of lead and zine sulphides; but in the replacement-fissure deposits, farther from the intrusive mass and under conditions of less heat and pressure, they deposited lead and zinc.

The origin of the ore-bearing solutions is not susceptible of positive proof, but certain facts indicate that the quartz monzonite magma was their original source. The solutions consisted either of meteoric waters that collected their metal content from the rocks through which they circulated, or of magmatic waters that already contain the metallic elements in solution, or of both. Either of them may have been heated-as the depositing solutions unquestionably were; the magmatic solutions would naturally be heated, and the meteoric waters might be heated by contact with the intrusive rocks. Which of them furnished the deposits or was dominant in furnishing them can be inferred from the character of the deposits.

The quartz monzonite (see p. 512) contains aplitic dikes whose composition and relations indicate that they are the siliceous differentiation products of the quartz monzonite. In the bottom of the O.K. shaft what appears to be an aplitic dike contains chalcopyrite and molybdenite as original constituents of the rock, thus seeming to indicate that the sulphides were relatively abundant in the siliceous differentiation product of the magma.

1 Butler, B. S., and Gale, H. S., Alunite, a newly discovered deposit near Marysvale, Utah: U. S. Geol. Survey Bull. 511, 1911.
In the same mine the "chimney" of quartz with sulphides of copper and molybdenum, which forms the "ore channel," has every appearance of a coarse pegmatite, and it seems reasonable and logical to consider this a further stage in the differentiation of the magma. As the same solutions that carried and deposited the pegmatitic quartz undoubtedly deposited the ore minerals in this quartz and altered the surrounding rock and deposited the sulphides in it they were probably a differentiation of the quartz monzonite magma.

The similarity of the Cactus deposit to that of the O.K. mine leaves no room for doubt that the solutions had a similar origin, though they passed through a more varied cycle of physical conditions, the later minerals of the Cactus deposit not having been formed in the $\mathrm{O} . \mathrm{K}$. deposit. Moreover, the presence of tourmaline and copper minerals intimately associated with an aplitic dike on Black Mountain, south of the Cactus deposit, point to the same conclusions concerning the origin of the solutions for this and for the O. K. deposit.

That the ores were deposited during the general period of igneous activity of which the intrusion of quartz monzonite is one phase is indicated by the presence of dikes of kersantite cutting the ore body of the Cactus mine. These dikes are believed to represent a late stage in the differentiation, probably closely following the deposition of the ores.

In the sedimentary rocks the evidence as to the origin of the solutions is most conclusive for the contact deposits. The very close association of the contact ores with the quartz monzonite is in itself suggestive of genetic relation. At the immediate contact at some points a blending of the quartz monzonite and the altered limestone connotes a transition from minerals characteristic of the one to minerals characteristic of the other. This condition is most readily explained by assuming that the altering solutions were given off by the igneous body. It is most natural to extend this explanation to similar deposits where the relation is less close and the solutions may have been of a deeper-seated origin. Further, small fissures that were opened in the altered limestone, probably soon after the intrusion, in the readjustment of stresses, contain veinlets or dikelets of quartz, feldspar, magnetite, and sulphides. These do not differ 
greatly in composition from the aplitic dikes in the quartz monzonite, and it is most natural to suppose that they had a similar originthat is, that they were a differentiation from the quartz monzonite magma and indicate the giving off of solutions competent to effect the existing alteration of the limestones. The similarity in the composition of the solutions that effected the alteration in the quartz monzonite and in the limestone also points to a common origin.

The close relation between the different types of deposit in the sedimentary rocks indicates a similar origin for each type, and it is believed that the metal content of all the deposits was derived from the quartz monzonite magma, though it is entirely possible that meteoric waters may have played some part in the formation of deposits at a distance from the intrusive body.

In metal constituents the deposits in the lava flows are similar to the replacement-fissure deposits in limestone, both types being characteristically lead-silver-zinc-copper ores with very little gold. The general relations of the ores in the lava to those in the intrusive rock suggest derivation from the quartz monzonite magma and agrees with observations in other districts. Such an origin for the deposits in this region has, however, not been positively demonstrated.

\section{SECONDARY ALTERATION OF ORES.}

GENERAL FACTORS.

The change produced in the mineral deposits of this region by the action of surface solutions has been an important though variable element in the production of the ore deposits as they now exist. It is a striking fact that some of the deposits have been but little affected by such alteration, though the character of neighboring deposits has been completely changed.

The secondary alteration has been dependent on several factors, among the more important of which are the position of the ground-water table, the rapidity of erosion, the physical character of the deposit, and the mineral composition of the deposit. All these factors have doubtless had some effect on each of the deposits, but in several of the deposits some one factor seems to have been dominant.
WATER LEVEL.

The position of the ground-water level has largely determined the limit of secondary alteration in the ore bodies, for alteration has probably not extended very far below this level, though if given sufficient time it would reach this level regardless of other conditions. Other
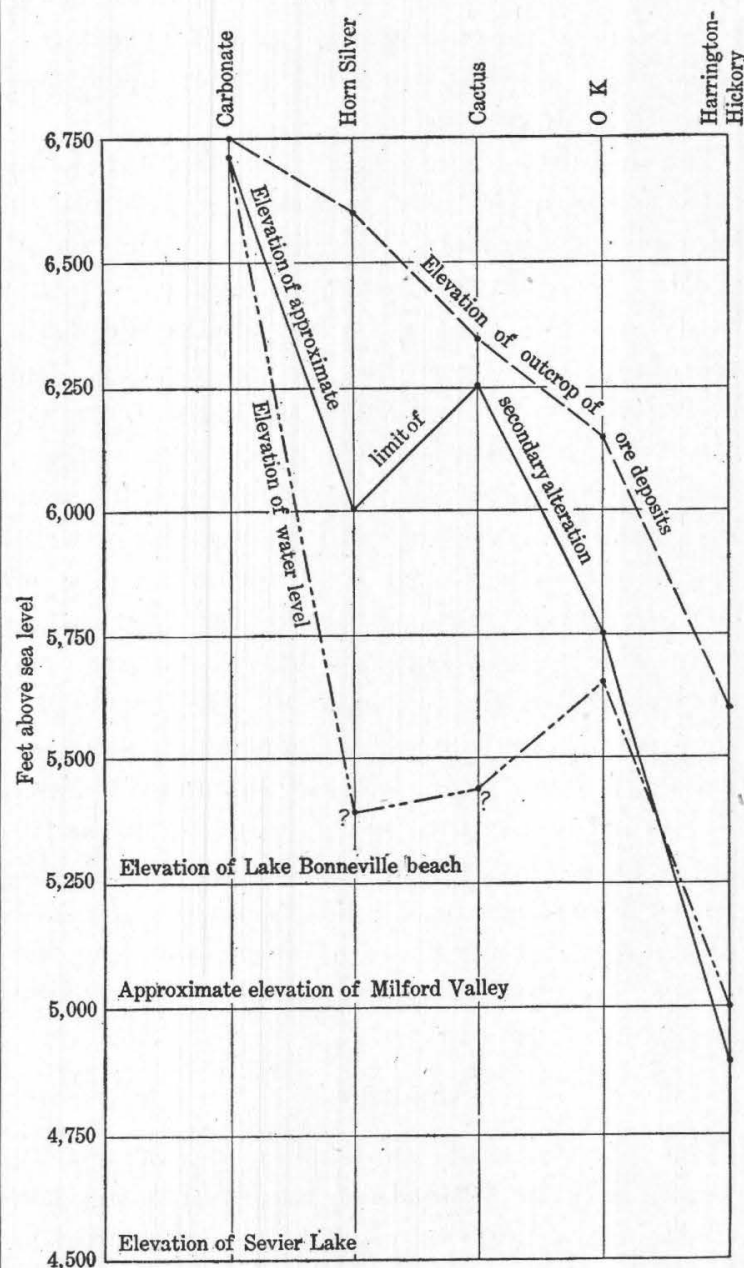

FIGURE 57.-Diagram showing the relation of secondary alteration to outcrop of ore body and to water level in San Francisco and adjacent districts.

factors have been of great importance, however, in determining the rate of alteration.

The water level has been determined in but few mines of the district. Figure 57 shows the elevation above sea level of the outcrop of several of the deposits, the lower limit of important secondary alteration, and the upper limit of the ground-water level (the actual position may be considerably lower).

It is not likely that the water level has remained constant for long periods in the past. 
In fact, there are good reasons for believing that it has been both higher and lower than it is now. The beaches of the old Lake Bonneville are about 750 feet above the present surface of Sevier Lake. On the other hand, the great alluvial cones at the mouths of the valleys upon which the Bonneville beaches were deposited testify to a long period of aridity preceding the Lake Bonneville epoch, and it is not unlikely that at that time the water level was lower than at present.

The inability to determine the position of the water level in the past makes it impossible to determine accurately the relation of the water level to secondary alteration, but it is practically certain that in some of the deposits secondary alteration has never reached the ground-water level even in its highest stages. This is especially true of the Cactus mine, where the water level in Lake Bonneville time must have been considerably below the present zone of alteration, and it is doubtless true of the Horn Silver mine also. On the other hand, at the Harrington-Hickory mine oxidized ores are present on the sixth level, 100 feet below the present position of the ground water, indicating a lower water level at an earlier period.

The Carbonate mine is the only one in the region where the present water level and the zone of oxidation show a close relation. In that mine the water level is but slightly below the surface, and this has prevented any extensive alteration of the ore body.

EROSION.

The rate at which the surface is lowered by erosion may be important in determining the extent of the zone of alteration, for if erosion is sufficiently active the altered rock may be removed almost as rapidly as it is formed. There is little doubt that erosion is lowering the surface in the San Francisco Range more rapidly than in some other parts of the area. From this it is to be expected that the zone of alteration will be thinner in the San Francisco Range than, for instance, in the Beaver Lake Range; and comparison of the very similar Cactus and O.K. deposits proves this to be the case. As will be shown later, however, it is thought that the shallowness of the zone of alteration in the Cactus mine is due in partpossibly in large part-to causes other than rapid erosion, although its situation in the bottom of Copper Gulch is favorable to rapid erosion.

PHYSICAL CHARACTER OF DEPOSITS.

It is readily apparent that the physical character of a deposit will have an important influence on the rate at which it will yield to secondary alteration. A massive, dense deposit or one for some other reason relatively impervious to solutions must necessarily alter more slowly than an open, porous one, other conditions being equal. As examples of this difference may be cited massive garnetiferous deposits like that of the Imperial mine, which have suffered relatively superficial alteration, and more open fissure deposits like some of those in the Star district, which have been altered for at least several hundred feet below the outcrop. The influence of the physical condition, however, may be offset by other factors, as in the Cactus deposit, which although open and readily permeable has been only superficially altered.

\section{MINERALOGIC CHARACTER OF DEPOSITS.}

The mineralogic character of a deposit may be important in determining both the rate and the character of secondary alteration.

ALTERATION IN QUARTZ MONZONITE.

In the O.K. deposit, to a depth of fully 200 feet, the sulphides, pyrite and chalcopyrite, are altered mainly to hydrous iron oxide and in relatively slight degree to copper carbonates, except in the lower part of the zone, where the carbonates become abundant. Underlying this zone of hydrous iron oxide is a zone of enriched sulphides (covellite and chalcocite) replacing chalcopyrite and pyrite. Beneath the enriched sulphides are primary sulphides.

In the Cactus mine there is a shallow zone in which the sulphides have been altered to hydrous oxides of iron and carbonates of copper, the copper minerals being relatively abundant and the ore showing little loss in copper content. Directly beneath the zone of oxide and carbonate are primary sulphides. No enriched sulphides are present.

There seems to be nothing in the physical character of the deposit or in the position of the water table to account for this difference. The relative shallowness of the zone of oxides and carbonates in the Cactus deposit might be explained by the more rapid erosion of the 
outcrop; but this in no wise explains the absence of enriched sulphides. The cause for the differences must be sought in the mineral composition of the ores.

The minerals of the O. K. deposit are mainly chalcopyrite and pyrite in gangue of quartz and muscovite (sericite). The Cactus deposit contains, in addition, important amounts of carbonates (calcium, magnesium, iron, and manganese) hematite, tourmaline, and lesser amounts of anhydrite and barite. There is no reason for believing that the hematite, tourmaline, anhydrite, or barite have affected notably the alteration products resulting from oxidation of the sulphides. The carbonate, however, seems to have been an important factor.

In the O.K. deposit the alteration may be assumed to have taken place in the generally accepted manner, namely, pyrite was oxidized to sulphuric acid and ferrous sulphate, and chalcopyrite to cuprous and ferrous sulphate. The ferrous sulphate upon further oxidation yielded ferric sulphate, which in turn formed hydrous oxide and sulphuric acid, and the acids thus formed assisted in the further oxidation of the sulphide. The copper and iron sulphates were carried to lower portions of the ore body, where the reducing effect of the sulphides on the solutions caused the precipitation of the copper and formed the zone of enriched sulphides.

In the Cactus deposit the sulphuric acid resulting from oxidation of pyrite reacted with the carbonate gangue to form sulphates of lime, magnesia, and iron. The relatively stable lime and magnesia sulphates were deposited or carried out of the ore zone, and the iron sulphate in turn broke down. This process removed the acidic radical in the oxidation process either by depositing it as sulphate or by removing it in solution. The copper sulphate reacted with the carbonate, yielding copper carbonate and sulphates. The relatively stable copper carbonate remained in the oxidation zone. So long as it was abundant it prevented the migration of the copper sulphate solutions to the zone where the copper content would be deposited as sulphide. It seems, therefore, that the abundant carbonate gangue has been the controlling factor in preventing the formation of a zone of enriched sulphide in the Cactus deposit.
SEDIMENTARY ROCKS.

Contact deposits.-Oxidation in the contact deposits has generally been relatively shallow and consists commonly in the formation of carbonates and hydrous oxides and secondary sulphides apparently in a manner similar to that in the Cactus deposit. Where calcite was an important gangue mineral carbonates resulted; where the contact silicates were the main gangue copper migrated downward and formed enriched sulphides. In the subsequent oxidation of the enriched sulphides the oxide of copper is a common product. Much of the ore thus far extracted from the contact zones has been considerably enriched by these secondary processes.

Replacement-fissure deposits.-The replacement-fissure deposits have been extensively altered and primary ores are exposed in relatively few places in the area. Probably, however, they consisted of sulphides of lead, zinc, iron, and copper in a gangue of calcite and quartz and in some places of contact silicates.

The oxidized-ore minerals are mainly limonite, cerusite, small amounts of copper and zinc, usually as carbonates, and still smaller amounts of sulphates, including anglesite and the more complex jarosite and plumbojarosite.

The change that has taken place has been essentially from galena to anglesite and later to cerusite, which is the common lead mineral of oxidized ore, or to some extent has combined with iron in the complex sulphate plumbojarosite. Pyrite has altered to limonite, and chalcopyrite to limonite and copper carbonate. In some places jarosite has apparently been an intermediate product between iron sulphide and limonite. Zinc is present to some extent in the oxidized ores as smithsonite and calamine but has been largely removed from the upper portion of the ore body.

In general it may be said that lead, iron, and copper have migrated only slightly and that sulphur and zine have been largely removed. Zinc has possibly been deposited at greater depth as carbonate and silicate.

ALTERATION IN LAVA FLOWS.

Zones of alteration.-The Horn Silver and Beaver Carbonate mines are the two important deposits thus far developed within the lava flows. In the Beaver Carbonate mine the 
water table is near the surface and ore shows comparatively slight alteration. In the Horn Silver deposit the water table is deep, and alteration has been an important factor in the formation of the ore body.

In the Horn Silver mine the important primary minerals of the main ore body are galena, sphalerite, and pyrite, small amounts of jamesonite or some closely allied mineral, chalcopyrite and possibly other copper minerals, argentite, and pyrargyrite or some mineral closely allied to it. Some relatively small bodies (notably to the north of the main shoot on the seventh level) consist mainly of pyrite with small amounts of the other minerals.

The enriched sulphide zone consists of the secondary copper minerals, covellite and chalcocite, and the zinc sulphide, wurtzite, and of the primary minerals in variable amounts.

In the oxidized zone the recognized lead minerals are anglesite, cerusite, plumbojarosite, beaverite, linarite, and bindheimite. Zinc occurs as smithsonite, calamine, and goslarite; copper as brochantite, malachite, azurite, chrysocolla, and chalcanthite, and in leadcopper minerals; silver as cerargyrite; and iron and manganese as hydrous oxides. The characteristic features of the oxidized zone are the great predominance of sulphates, the small amount of oxidized zinc ore, and the small amount of oxidized copper ore, except immediately above the secondary sulphide ore.

Oxidized zone.-Galena, when acted on by surface waters, was altered to anglesite, and as this mineral is relatively insoluble there was little migration of the lead. Some of the anglesite was subsequently altered to cerusite but not in important amounts, as indicated by the following analysis ${ }^{1}$ of a representative sample of the ores from the upper levels:

\section{Analysis of Horn Silver ore.} [S. B. Newberry, analyst.]

Per cent.

Silica..................................... 15.17

Sulphate of barium...................... .49

Sulphate of lead........................... 74.51

Sesquioxide of iron ....................... 4. 4.80

Sesquioxide of alumina......................... 1.71

Sulphide of antimony......................... . .37

Sulphide of arsenic .......................... 1.12

Lime and magnesia.......................... .50

Carbonic acid............................. .62

Silver (by fire assay, 78.33 [ounces] per ton).

99.62

1 Hooker, W. A., Report to the Horn Silver Mining Co., 1879.
No zinc was found; the quantity is certainly very small and did not show itself, although a special determination was made to ascertain it. The metallic lead, arsenic, and antimony in the ore are as follows: Lead, 50.90 per cent; arsenic, 0.93 per cent; antimony, 0.26 per cent. The amount of moisture in the ore is very small, the average of the run of mine being less than 3.5 per cent, and the sample analyzed above had been thoroughly dried.

To a relatively slight extent lead entered the complex sulphates beaverite and plumbojarosite.

Sphalerite was likewise oxidized to the sulphate, and this highly soluble material was largely removed from the oxidized zone. The movement of the zinc is amply exemplified at the present time in the lower levels of the mine where the surfaces of zinc ore are frequently covered with festoons of goslarite. To a slight extent smithsonite and calamine were formed and remained in the oxidized zone.

The copper minerals in the zone of oxidation were formed from the alteration of the rich sulphide ores. Chalcocite and covellite alter to brochantite, which is the important copper mineral of the zone; and the brochantite apparently commonly alters in turn to the soluble sulphate, which is carried out of the zone; and thus the oxidized copper ores are kept close to the sulphides. To a slight extent the brochantite alters to carbonate and silicate, but these are apparently eventually acted on by acidic solutions and the copper removed, as indicated by their scarcity in the upper parts of the ore body.

The silver in the argentiferous galena and in other minerals commonly combines with chlorine (probably derived from the salts of the desert) and forms cerargyrite. As silver chloride is only slightly soluble, there has been little migration of silver.

Pyrite has probably altered to ferrous sulphate and sulphuric acid. The ferrous sulphate in part may have altered to ferric sulphate and eventually to limonite and sulphuric acid. In part ferric sulphate evidently combined with other metals to form the relatively insoluble basic ferric sulphates. These, however, eventually broke down, and limonite may have been a resulting product. Much of the iron has been removed, probably as the sulphate. This removal is especially evident where argentiferous pyrite has been altered, the resultant rock being a cellular mass in which the cavities retain the form of the altered pyrite crystals. 


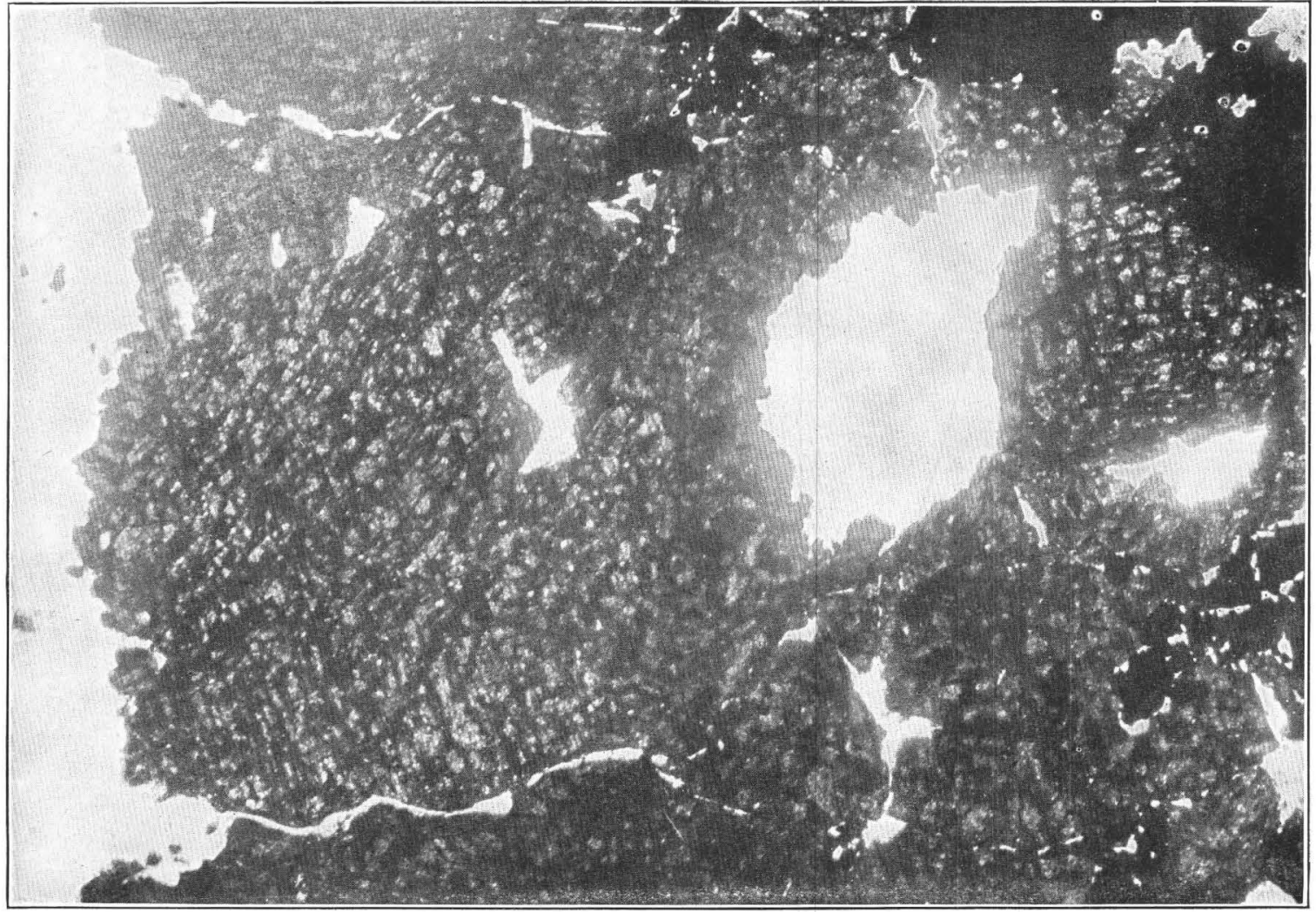

A. PHOTOMICROGRAPH OF SPECIMEN OF ZINC SULPHIDES FROM THE HORN SILVER MINE. Light areas, holes in section; dark areas, galena; gray areas, zinc sulphides. Enlarged 43 diameters.

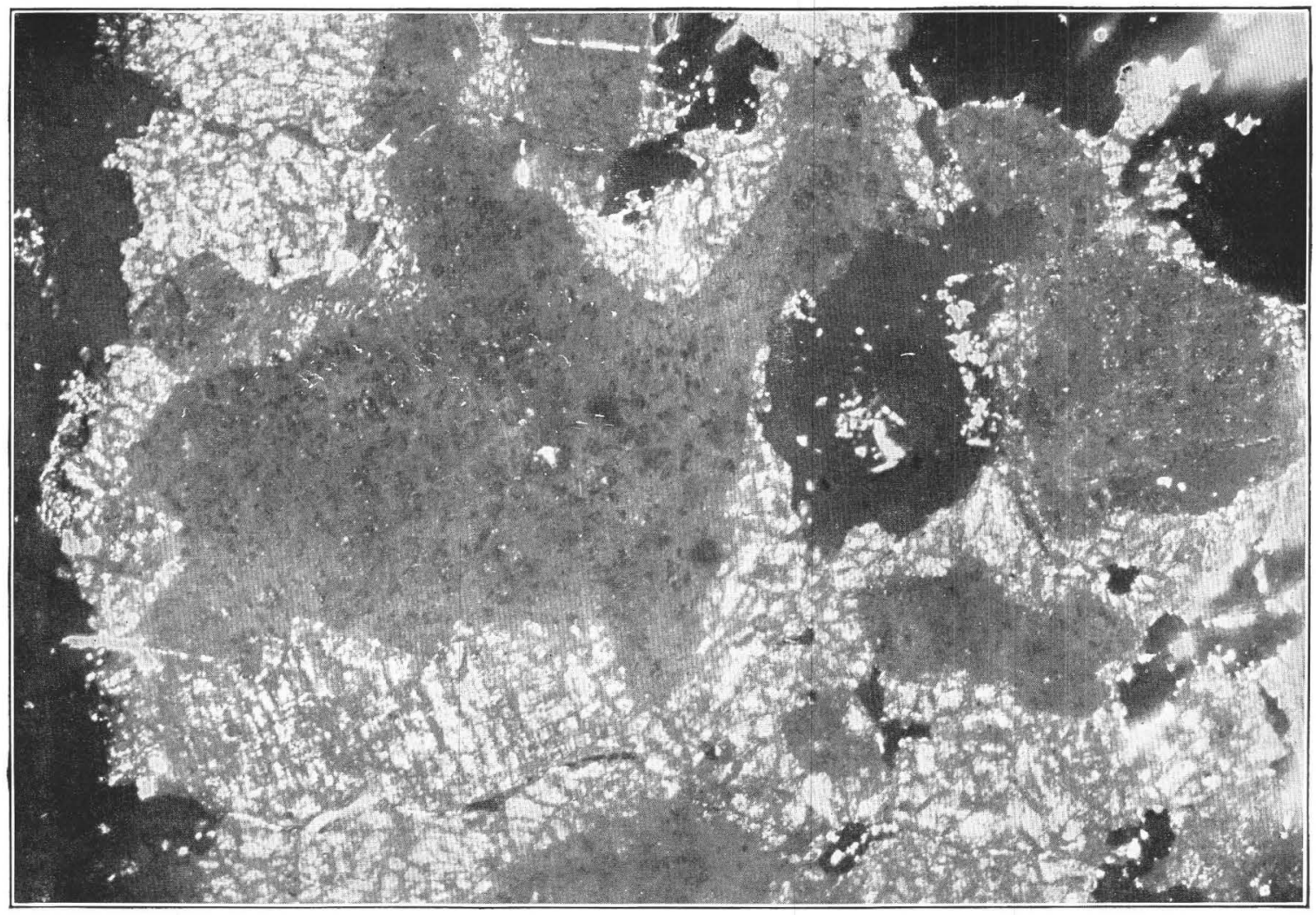

B. PHOTOMICROGRAPH OF SAME SPECIMEN AS THAT SHOWN IN A TAKEN WITH CROSSED NICOLS.

Light areas, wurtzite; gray areas, sphalerite. 
Partial record by levels of lead, copper, silver, and gold taken from the Horn Silver mine.

\begin{tabular}{|c|c|c|c|c|}
\hline & Lead. & Silver. & Gold. & Copper. \\
\hline 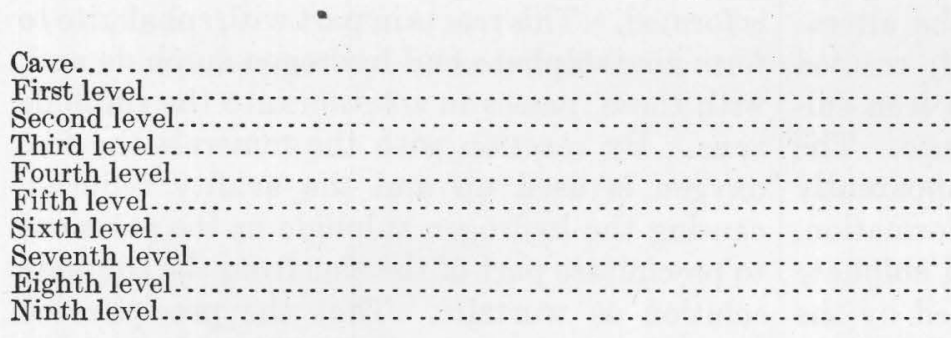 & $\begin{array}{r}\text { Per cent. } \\
\text { 46. } 37 \\
36.97 \\
38.12 \\
40.32 \\
43.45 \\
32.94 \\
37.63 \\
31.91 \\
34.18 \\
28.24\end{array}$ & \begin{tabular}{r|} 
Oz. perton. \\
23.94 \\
64.39 \\
36.29 \\
33.49 \\
20.20 \\
43.88 \\
26.16 \\
31.02 \\
28.63 \\
22.88
\end{tabular} & $\begin{array}{l}\text { Oz.perton. } \\
0.00515 \\
\cdots \cdots \\
\cdots \cdots \\
\cdots \cdots \\
\cdots \cdots \\
\cdots \cdots \cdots \\
.002565 \\
.01144 \\
.00973 \\
.03223\end{array}$ & 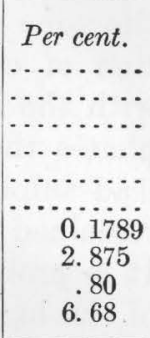 \\
\hline & 36.61 & 31.98 & .005131 & .7669 \\
\hline
\end{tabular}

Unfortunately some of the figures in these from the ninth level is stated in another part tables seem to represent the level from which of the company's report to have come from the the ore was hoisted rather than that from seventh and eighth levels.

which it was extracted. For example, the The following table shows the metal content copper ore that is shown in the tables as coming of several lots of ore taken from the mine:

Metal content of some ores from the Horn Silver mine.

\begin{tabular}{|c|c|c|c|c|c|c|c|}
\hline & 1 & 2 & 3 & 4 & 5 & 6 & 7 \\
\hline 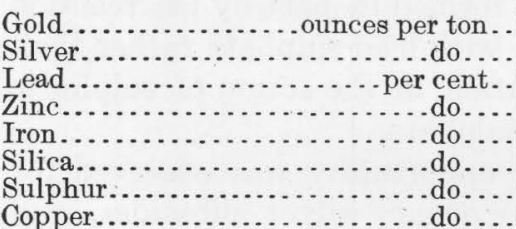 & $\begin{array}{r}78.33 \\
50.90 \\
0.00 \\
3.36 \\
15.7 \\
. . .\end{array}$ & $\begin{array}{l}51.00 \\
43.50 \\
0.00 \\
(b) \\
(b) \\
(b)\end{array}$ & $\begin{array}{l}(a) \\
(a) \\
\\
8 \\
40 \\
4 \\
40 \\
20 \\
28\end{array}$ & $\begin{array}{l}0.013 \\
6.50 \\
10 \\
35 \\
2 \\
35 \\
15\end{array}$ & $\begin{array}{c}0.000 \\
5.59 \\
9.41 \\
35.40 \\
(a) \\
(a) \\
(a)\end{array}$ & $\begin{array}{l}0.000 \\
2.83 \\
17.41 \\
(a) \\
(a) \\
(a) \\
(a) \\
23.7\end{array}$ & $\begin{array}{l}0.013 \\
10 \\
11.6 \\
20.7 \\
5.3 \\
35.4 \\
18.0\end{array}$ \\
\hline
\end{tabular}

$a$ Not reported.

$b$ Not estimated.

1. Oxidized ores. Analyses from report by W. A. Hooker.

2. Average of all ores to 300 -foot level as determined by Hooker.

3. Average yield of 500 tons of zinc ore from seventh level. Emmons, S. F., Am. Inst. Min. Eng. Trans., vol. 31, p. 658,1902 .

4. Approximate average of zinc ore from 700 -foot level, by M. C. Morris, general manager. The sulphur is evidently too low, as it is not sufficient to combine with the metals to form sulphides, though the analysis sums practically to 100 and other general analyses and the study of the ores show that the metals are present as the sulphides.

5. Average of zinc ore shipped in 1905, from company's report.

6. Average of copper ore shipped in 1904, from company's report.

7. Average of shipment of zinc-lead ore from 900 -foot level; figures furnished by M. C. Morris, general manager.

So far as the statistics included in these tables are concerned the oxidized zone may be considered as including the first five levels. The average metal content recorded from these levels is lead 38.99 per cent and silver 38.63 ounces per ton. The average in lead and silver of ores hoisted from the ninth level (largely primary) was silver 22.88 ounces per ton and lead 28.24 per cent; and the average of certain shipments of primary zinc-lead ore from the 900-foot level shows silver 10 ounces per ton, lead 11.6 per cent, and zinc 20 per cent. The average of all ores mined has been lead 33.61 per cent and silver 32.04 ounces per ton. It is evident from these figures that the ores in all parts of the main ore body show a definite relation between lead and silver content of approximately an ounce of silver to each per cent of lead.

If an ore similar in composition to those of the lower levels, which are regarded as essentially primary, should have all the zinc sulphide and a part of the iron removed and the silica content reduced to 15 per cent (as low as that in the analysis on p. 524) the resulting product would be comparable to the average of the oxidized ore. It is evident, therefore, 
that the lead and silver content of ore in the oxidized zone has been materially increased by the process of alteration and that the zinc and copper have been largely removed.

In the relatively small silver-ore bodies there has been a marked increase in silver content, due to the removal of iron sulphide.

In the zone of sulphide enrichment the zinc content of much of the ore has been raised from probably 20 to 25 per cent to 35 per cent or more. This increase has been due to an addition of zinc sulphide and possibly, to a lesser extent, to the removal of other constituents.

As the primary ore carries only a small percentage of copper, there has evidently been a marked addition of this metal in the enriched sulphide zone.

In the rich zinc ores there has been a relative decrease in lead due to the addition of zinc, so that these ores contain a lower percentage of lead than either those of the primary zone or the oxidized zone.

The process of alteration has resulted in the enrichment of the oxidized zone in silver and lead. Primary ores only moderately rich in these metals have been changed to high grade. In the zone of sulphide enrichment material that was too low in zinc to be profitably mined under ordinary conditions and material that contained very little copper have been converted into ores.

\section{WAH WAH RANGE.}

By B. S. Butler.

The following notes are the result of a twoday reconnaissance by the author across" the Wah Wah Range at Pine Grove Canyon and at Wah Wah Pass. The portion of the range north of the Wah Wah Pass was not examined.

\section{GENERAL FEATURES}

The Wah Wah Range is a prominent nortinsouth range of southwestern Utah extending from $38^{\circ}$ to $39^{\circ}$ north latitude. It is the range next west from the San Francisco Range, lying between Preuss or Wah Wah Valley on the east and Sage Brush Valley on the west. It attains elevations of 9,000 feet (estimated) but for the most of its extent is 1,000 to 2,000 feet lower. In general its eastern slope is relatively gentle and its western slope abrupt. The range is divided into two nearly equal parts by the low Wah Wah Pass, which is trav- ersed by the road from Newhouse to Osceola and Ely, Nev.

Water is scarce, the supply being derived from springs and small streams that sink into the gravels as soon as they leave the mountains. Both springs and timber are, however, more abundant than in many of the desert ranges. The water supply for Newhouse is derived from springs in the range.

\section{GEOLOGY}

SEDIMENTARY ROCKS.

The range is made up largely of sedimentary rocks, though both intrusive and extrusive rocks are present. The lowest formation exposed is a massive red quartzite which forms a large part of the range south of Pine Grove Canyon but which gradually dips below the surface to the northward and is not present north of Wah Wah Pass. The Red Buttes, just south of Wah Wah Pass, at the west base of the range, are the most northerly portion of the quartzite observed. Overlying the quartzite in the vicinity of Pine Grove Canyon are shales and shaly limestones with an estimated thickness of 800 to 1,000 feet. The shale series is overlain by massive limestone and dolomitic limestone having a thickness of several thousand feet. In the latitude of Wah Wah Pass and northward this limestone series makes up the bulk of the range.

Fossils collected from the upper portions of the limestone series on the Pine Grove road and to the east of Wah Wah Pass and from the shale series overlying the quartzite in Pine Grove Canyon were reported on by L. D. Burling as follows:

Lot 2.-Shale series, Pine Grove Canyon, Middle Cambrian, containing Ptychoparia sp. and Bathyuriscus sp. This fauna is characteristically found in limestone bands in shale in the lower part of the Middle Cambrian only a few hundred feet above the top of the quartzite series, in several of the ranges of western Utah.

The collections from the limestone contained Crepicephalus texanus, Agraulos sp., and Ptychoparia sp. Of these Mr. Burling says:

The specimens of Crepicephalus texanus are hardly to be distinguished from specimens of the same species occurring in Middle Cambrian limestone in Tennessee and Alabama. The same species occur in both the Orr formation (Upper Cambrian) and the Weeks limestone (Middle Cambrian) of the House Range, Millard County, Utah. It is associated in the Orr formation with Illaenurus and Ptychaspis, species which are absent in the Weeks formation. 
The fossil evidence in limestone and shales, together with comparison with sections elsewhere, indicates that the limestones are probably of Middle to Upper Cambrian age.

IGNEOUS ROCKS.

EXTRUSIVE ROCKS.

Along the eastern base of the range and extending partly up the eastern slope are heavybedded volcanic flows. South of Pine Grove Pass they reach the summit of the range and apparently form a much larger proportion of it than they do farther north. As exposed in Black Canyon on the Pine Grove Road the lowest beds are gray trachytic-looking rocks containing rather abundant phenocrysts of plagioclase, hornblende, biotite, and a few of quartz. The groundmass, forming a large percentage of the rock, is glassy. The composition is probably that of latite or possibly andesite. Overlying the gray lavas are flows that weather to a dark reddish brown. These contain a much larger proportion of glass than the underlying lavas but probably do not differ from it greatly in composition. The uppermost flows observed are rather fine grained andesite containing abundant phenocrysts of plagioclase and augite in a groundmass of glass and microscopic crystals of plagioclase and augite. Magnetite is rather abundant. The rock is a typical augite andesite.

\section{INTRUSIVE ROCKS.}

No large bodies of intrusive rock were observed or are reported from the range. Small intrusive masses were seen near the summit at Wah Wah Pass and in Pine Grove Canyon on the west side of the range and are possibly present at other places. The intrusive rock at Wah Wah Pass outcrops as irregular masses, but the dome structure of the range at this point and the alteration of the limestone suggests that much larger bodies are present at no. great distance below the present surface. The rock is a dark fine-grained porphyry probably of monzonitic or dioritic composition.

In Pine Grove Canyon a dikelike body of granite porphyry probably 1,000 feet wide is exposed along the strike for several thousand feet. It is a fine-grained rock containing rather abundant phenocrysts of quartz and orthoclase and fewer of plagioclase in a groundmass too finely crystalline for its mineral composition to be definitely determined. Several small dikes noted in the Pine Grove district are so highly altered that their original composition can not be determined, but in general they are similar to the larger intrusive body, though some of them at least contain considerable biotite and much less quartz.

\section{STRUCTURE.}

The range is typical of the Basin Range type of mountains, being composed of a block that has been faulted along its western front and uplifted so that the beds dip east.

The strike of the beds is in general parallel with the range but inclined sufficiently to the southeast to lift the quartzite from Wah Wah Pass to Pine Grove Canyon several hundred feet above the base line of the mountains. The dip of the beds varies considerably; at Pine Grove it is about $45^{\circ}$, but north of Wah Wah Pass the strata seem from a distance to be nearly horizontal.

At Wah Wah Pass the rocks have a gentle dome structure which has possibly resulted from the intrusion of an igneous mass that is just being uncovered. The doming of the rocks has rendered them particularly susceptible to erosion at this point and resulted in the formation of the low pass.

East-west faulting was noted especially in Pine Grove Canyon, whose lower course it apparently determines. The movement has apparently been at least 1,000 feet, with downthrow to the north. Careful study would doubtless show many small faults and probably other large displacements.

The only production from the range has been lead ore from the Pine Grove district and some iron from near English Springs. A little prospecting has been done on the east side of the range a few miles south of Pine Grove Pass and in the latitude of Wah Wah Pass.

\section{PINE GROVE DISTRICT.}

\section{ACKNOWLEDGMENTS.}

The writer wishes to acknowledge courtesies by the Revenue Mining Co. A geologic map of the company's property prepared by Mr. C. C. Jones was furnished by the company and was of great aid.

GENERAL FEATURES.

The Pine Grove district is on the west side of the Wah Wah Range about 18 miles southwest of Newhouse, the nearest railroad point. The 
shortest route from Newhouse leads nearly southwest across Wah Wah Valley and thence westward over a rather high pass. A road with better grades crosses the range at Wah Wah Pass and thence follows the western front south to Pine Grove Canyon. Heavy grades are encountered on each route, both going and coming.

The district was organized in 1873 , but no work was done until it was reorganized in 1879 . There were in 1880 about 20 locations. Little has been done except by the Pine Grove Consolidated Mining Co. and the Revenue Mining Co. A mill was constructed in the district but has not been operated. It is reported that a little ore was shipped from the district in the early days.

Pine Grove Creek furnishes a small flow of water throughout the year. Timber is present in sufficient quantity to supply any likely demands for some time to come.

\section{ORE DEPOSITS.}

The rocks of the district have been cut by a series of fissures striking about northwest. Slight displacements along the fissures have crushed the quartzite adjacent to the fissures and have formed breccia zones. The fissures in the limestone are less conspicuous, as the character of the rock was not favorable to the formation of breccia.

The most extensive prospecting has been done on the fissures or breccia zones in the quartzite. The primary ore, mainly galena with some pyrite, occurs as a filling between the breccia fragments and possibly to some extent as a replacement of the quartzite. The deposits occur as small lenses, many of which are near one wall of the breccia zone. Near the surface the galena has been altered to sulphate and carbonate of lead and the pyrite to limonite.

The rock adjacent to the fissures in the limestone has in places been partly replaced by galena and pyrite. These minerals have been oxidized near the surface but not to the same extent as the deposits in quartzite.

The developments in the district and the time given to the study do notwarrant any very positive statements concerning the origin of the ores. No very intimate relation between the ore deposits and either the granite porphyry body or the small dikes has been observed, but comparison with other districts suggests that the deposition of the ores was due to the igneous activities.

At the time of visit little material that under present conditions could be regarded as ore was exposed in the prospect openings.

\section{WAH WAH PASS REGION.}

Prospecting in the vicinity of Wah Wah Pass has been confined to a few shallow pits and trenches. Fair assays are reported but have apparently not been sufficiently encouraging to lead to extensive prospecting.

\section{ENGLISH SPRINGS.}

The iron deposits in the eastern foothills of the Wah Wah Range near English Springs, about 20 miles west of south from Newhouse, were not examined, and no description of them has been found in the literature. Some ores from them were shipped to the Frisco smelters about 1880 .

\section{INDIAN PEAK DISTRICT.}

The Indian Peak district is in the Needle Range, in the western part of Beaver County, about 35 miles north of Modena and about the same distance from Lund, on the Los Angeles \& Salt Lake Railroad. There has been some prospecting in the district for many years and there has been a small production of lead and silver.

The district was not visited by the writer and no description of the geology has been found in the literature. The ore deposits are said to be replacements of limestone adjacent to fissures.

\section{MINERAL RANGE. ${ }^{1}$}

By B. S. Butler.

\section{GENERAL FEATURES}

The Mineral Range extends a little east of north across Beaver County between Milford Valley on the west and Beaver Valley on the east. The principal railroad point is Milford, on the Los Angeles \& Salt Lake Railroad, about 7 or 8 miles west of the central part of the range and 10 to 25 miles by road from the principal mineralized areas. (See fig. 58, p. 532.)

The central part of the range is rugged, rising to an elevation of 11,000 feet and being cut by narrow canyons that render travel 1 Report based mainly on a reconnaissance of the range in the summer of 1910 . 
difficult. Beaver Canyon is a low pass, which is utilized as a transportation outlet for Beaver Valley and the east side of the range. South of Beaver Canyon the range is much lower, the slopes usually gentle, and travel much easier.

Water is scarce, but enough for the needs of prospectors can usually be developed without going a great distance from the prospect. In many parts of the range juniper (cedar), piñon, oak, and other scrubby trees furnish a rather abundant fuel supply and are used to some extent for timbering. There is good timber in the range east of Beaver. The irrigated lands along Beaver Creek furnish abundant farm products. Electric power for mining can be had from the plant on Beaver Creek.

\section{HISTORY AND PRODUCTION.}

By V. C. Herkes.

The range contains the Lincoln, Bradshaw, Granite, North Granite, McGarry, Antelope, and Jarloose districts.

\section{LINCOLN DISTRICT.}

- The Lincoln district, organized January 16, 1871 , is in Beaver County on the eastern slope of the Mineral (Granite) Range, 20 miles southeast of Milford, on the Los Angeles \& Salt Lake Railroad, and 4 miles north of Minersville, the supply point and settlement. It adjoins the Bradshaw district on the southeast corner. The district was first called Pioneer district and was organized in 1864. According to Fabian, ${ }^{1}$ "the Mormons commenced working the old Spanish mine as far back as 1854, which has since been named the Rollins lode. The other principal claims in the district are [1872] the Quincy, Alameda, Wasatch, Lewis Grundy, Creole, Galena, and St. Cloud."

Eissler ${ }^{2}$ says:

The first "parcel" of silver-lead ore on the Pacific coast was smelted by a Mormon named Isaac Grundy, back in the fifties.

When Brigham Young learned that Johnston's army was coming to Utah he sent Grundy down to Beaver County to obtain material for leaden bullets to be used against the coming army. Grundy went to what was afterwards known as the Rollins or Lincoln mine, and getting out ore he smelted in a small furnace several tons of bullion, which was sent to Salt Lake City and there molded into bullets. Grundy may be considered, therefore, as the pioneer of the metallurgy of lead on the Pacific coast; and

1 Fabian, Bentham, The resources of Utah, p. 14, Salt Lake City, 1872. 'Eissler, M., The metallurgy of argentiferous lead, preface, 1891.
I have just learnt (August, 1891) that he died only a few weeks ago at Minersville, Utah, at the age of 80 .

The Rollins lode was operated again between 1860 and 1863. Ore was smelted in this district, and it is said that some lead ore was shipped to Omaha for reduction. Huntley ${ }^{3}$ says:

The principal claim in the district is the old Rawlings or Rollins mine. It is claimed by the Mormons that it is the oldest mine in the territory. They worked it in 1860 , 1861,1862 , and 1863, and made a few tons of lead in a primitive way. The mine was sold in 1875 to the Lincoln Silver Mining Co. A 15-ton furnace was built in the fall of the same year. The company worked both the mine and the smelter for two years. * * * The incline was sunk 220 feet, and showed a 6 -foot vein at the bottom. One-fourth of this was pyrites and the remainder galena. In the upper works the ore body was from 8 to 12 feet wide. The average assay of the ore was $\$ 40$ silver and $\$ 15$ gold About 100 tons of bullion, worth $\$ 165$ per ton, were produced.

The December group of mines had been recently sold to the December Mining Co. of Chicago. The principal vein is from 1 foot to 4 feet wide, carrying a smelting ore which assays $\$ 100$ per ton when selected. A few tons have been shipped. There are 200 feet of cuttings.

The Coral Reef, Yula, and Richmond are a group on one vein, said to be from 3 to 5 feet wide, containing a low-grade smelting ore, 20 ounces silver, 30 per cent lead, and some zinc blende and pyrite. *** About 80 tons had been sold formerly.

No statistics are available of any of the properties producing in the Lincoln district between 1880 and 1901. In 1907 the Lincoln or Rollins mine was reopened, but it is not known what was found in the lower levels. The Survey has no record of shipments from the property.

About 200 tons of low-grade fluxing iron ore, carrying values in gold, silver, and copper, was taken from the Creole property in 1907, and several shipments of lead ore have been made from the Harriet claim. All production has been included with that of Beaver County: (See pp. 506-507.)

\section{BRADSHAW DISTRICT.}

The Bradshaw district, in Beaver County, organized May 1, 1875, ${ }^{4}$ adjoins ihe Lincoln district on the north, and is about 10 miles southeast of Milford, on the Los Angeles \& Salt Lake Railroad. Huntley says: ${ }^{5}$

The Cave mine, the principal mine of the district, is about 8 miles southeast of Milford and northwest of Minersville on a steep mountain side, about 4,300 feet above the

\footnotetext{
3 Precious metals: Tenth Census U. S., vol. 13, p. 475, 1885.

4 Record in office of U. S. surveyor general, Salt Lake City, Utah.

5 Op. cit., pp. $474-475$.
} 
Beaver River, and over 6,000 feet above sea level. The cave in which the mineral was first found was discovered in 1859. * * * It was not located, however, until 1871. Little was done until 1875 and 1876, when some ore was worked at the Milford mill. The mine became financially involved * * * and in September, 1879, the mine became the property of the Frisco Mining \& Smelting Co.

In places the ore has been very rich, assaying as high as $\$ 500$ to $\$ 800$ per ton. Ore of the lowest grade assays $\$ 5$ in gold and silver. All the limonite and ocher, without regard to its grade, was shipped to the smelter at Frisco, it being worth from $\$ 8$ to $\$ 10$ for flux alone. The average grade of all the ore shipped could not be ascertained, but for several hundred tons recently shipped it was given at from 5 to 7 per cent lead, $\$ 22.50$ silver, and $\$ 7.50$ gold per ton. * * * The total assay value of the ore produced prior to June 1,1880 , was estimated at $\$ 270,000$, onequarter of which was gold.

The Jolly Boy is in the northern part of the district, and was discovered in the fall of 1879. * * * Four tons - of selected ore, a soft ocher, averaged $\$ 12$ silver and $\$ 333$ gold.

The Cave mine is reported by its owners to have been an occasional producer between 1880 and 1900. Since 1900 it has yielded about 1,400 tons of low-grade oxidized iron ore. In 1908 the Hecla produced ore containing gold, silver, lead, and a little copper.

GRANITE AND NORTH GRANITE DISTRICTS.

The Granite and North Granite mining districts, organized in 1863 and 1865, are in Beaver County, northeast of the Lincoln district and northwest of Beaver. According to Huntley, ${ }^{1}$ the bismuth property on the east side of the range attracted the most attention:

It was diseovered about $1865 * * *$ and known (August, 1880) as the Major lode. The vein is 5 to 7 feet wide and contains a tough quartz or gangue. In this, some pyrite, galena, and, it is said, 3 per cent of bismuth are found. A few tons were shipped years ago, and were said to have averaged from 7 to 10 per cent bismuth.

In several parts of the district there are signs that some oxidized iron ore was produced and hauled, probably to the Frisco smelter, in the eighties. In the last decade small quantities of low-grade copper and lead ores have been shipped, but the returns barely paid expenses of shipment and treatment.

\section{M'GARRY AND ANTELOPE DISTRICTS.}

The McGarry and Antelope districts, at the north end of the range on the western slope were organized in 1876 and 1877 but have produced little metal.
JARLOOSE DISTRICT.

The Jarloose district is in the volcanic area, a few miles southeast of Minersville. Numerous "strikes" have been reported, but thus far there has been no important metal production and but little prospecting.

\section{PHYSIOGRAPHY}

By B. S. Butler.

The Mineral Range is to be classed with the Basin Range type of mountain, though in its present stage of physiographic development it is not as typical as some of the ranges of the State. In general, however, it shows a nearly straight western front determined by faulting, a relatively steep western slope, and a gentler eastern slope. The portion of the range south of Beaver Canyon is composed of relatively weak lavas and is more mature topographically; and the fault-block structure is much less apparent. Morever, the uplift of this portion of the range is much less, as it is separated from the northern part by an east-west fault in the latitude of Beaver Canyon.

\section{GEOLOGY.}

\section{SEDIMENTARY ROCKS.}

Sedimentary rocks are largely confined to the area north of Beaver Canyon where, except for a space on the west side, they surround the central mass of intrusive rocks. (See fig. 58.) Lee ${ }^{2}$ gives the following section of the rocks as exposed in Beaver Canyon:

Section of rocks exposed in Beaver Canyon, 4 miles east of Minersville.

1. Basalt, several hundred feet.

2. Rhyolitic flows, tuffs and breccia, many hundred feet.

3. Andesitic flows, tuffs and breccia, several hundred feet.

4. Uncemented gravel and boulders of limestone, Feet. quartzite, and andesite................ 250

5. Coarse consolidated conglomerate consisting of limestone, quartzite, and various crystalline rocks, the boulders having a maximum diameter of 5 feet . . . . . . . . . . . . . . . . . . . Unconformity.

6. Red shale ............................ 60

7. Earthy-gray limestone.................. $\quad 15$

8. Red shale............................ 10

9. Gray limestone ........................ 10

10. Red shale and ripple-marked sandstones..... 40

2 Lee, W. T., Water resources of Beaver Valley, Utah: U. S. Geol. Survey Water-Supply Paper 217, p. 10, 1908. 


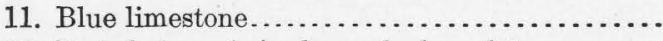

12. Red shale and ripple-marked sandstones......

13. Limestone containing Aviculipecten weberensis, Aviculipecten aff. A. occidentalis, Myalina aff. M. perattenuata, Bakewellia n. sp., Pleurophorus sp.. Schizodus sp .

14. Shale

15. Limestone containing same fosilsas

16. Buff shale with a subordinate amount of limestone.

17. Shale and limestone containing Aviculipecten n. sp., Pleurotomaria? sp., Bakewellia n. sp., Naticopsis sp., Xenodiscus? sp., undetermined ammonoids............................

18. Red shale.

19. Yellowish-brown shales alternating with ripplemarked sandstones.

20. Quartzitic basal conglomerate................. Unconformity.

21. Cherty limestone containing Zaphrentis? sp., Fistulipora sp., Septopora sp., Productus aff. P. subhorridus, Meękella? sp., Spirifer aff S. cameratus, Squamularia aff. S. perplexa, Spiriferina aff. S. kentuckyensis, Spiriferina sp., Composita aff. C. subtilita, Hustedia aff. H. meekana, Pugnax aff. $P$. osagensis.

22. Yellowish quartzite

. Cherty limestone containing Squamularia? sp. and Hustedia aff. $H$. meekana..............

Base not exposed where section was measured.

Concerning the sedimentary rocks, Lee says:

A thick series of massive limestones overlies the granite and is well exposed in the Mineral Mountains north of Minersville. These limestones are overlain in turn by red sandstones, shale, and volcanic products, as shown in the section.

The massive cherty limestone at the base of the section is referred with little doubt to the Aubrey. The fossils were examined by George H. Girty, of the United States Geological Survey, who states that they probably belong in the Aubrey fauna, although many of the most characteristic forms of the fauna are wanting. The stratigraphic position and general field relations of the limestone show that it is probably the same as the typical Aubrey limestone of the Grand Canyon region farther to the south.

The red sediments overlying the cherty limestone yielded a number of well-preserved fossils which also have been examined by Dr. Girty, who states that the fauna is the same as that of the Permian beds of Walcott's ${ }^{1}$ Grand Canyon section and of the "Permo-Carboniferous" of the Wasatch Mountains.

In Colob Plateau, about 50 miles south of Beaver, a thickness of more than 8,000 feet of strata was measured between the base of the Permian and the top of the Benton. Of this great thickness only 565 feet of the base of the Permian remain in Beaver Canyon, the upper beds having been eroded away. The red beds are overlain by a coarse conglomerate, presumably equivalent in age to the Eocene conglomerates of the plateaus, and these are covered in turn by extensive masses of volcanic rock.

1 Walcott, C. D., The Permian and other Paleozoic groups of the Kanab Valley, Ariz.: Am. Jour. Sci., 3d ser., vol. 20, pp. 221, 225, 1880. part of the Triassic, as exposed in the Star district to the west.

20

$\left\{\begin{array}{l}x \\ x \\ x \\ x \\ x \\ x+x \\ x+x \\ x+4\end{array}\right.$

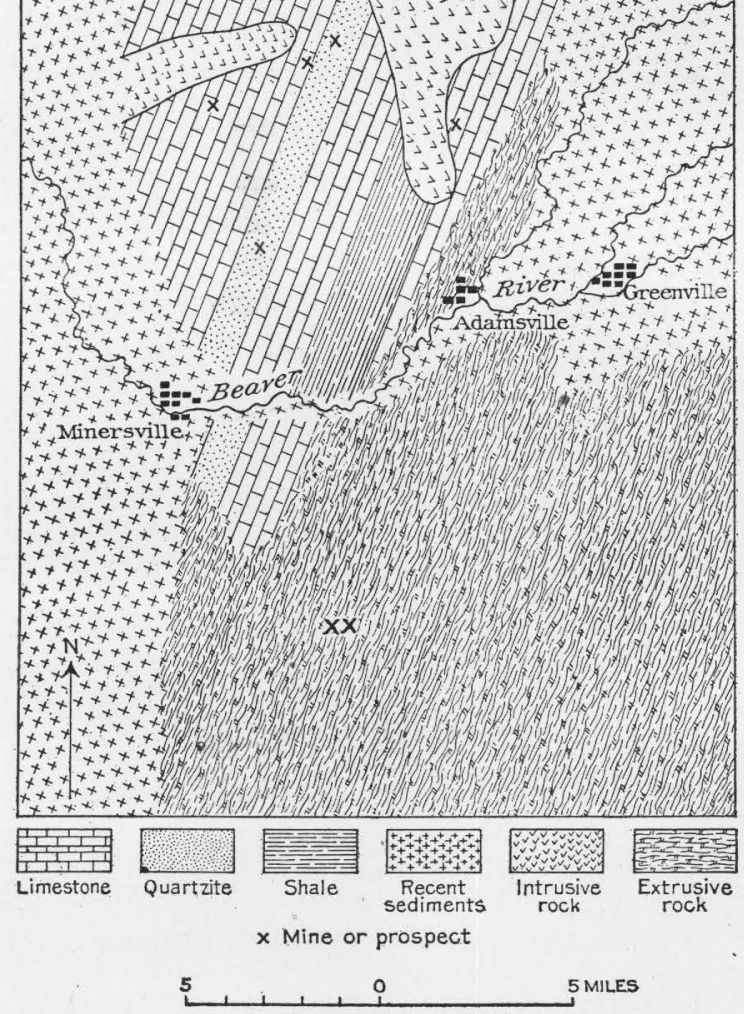

Figure 58,-Reconnaissance geologic map of Mineral Range.

The sedimentary rocks at the northern end of the range apparently correspond to the lower portion of the section given above. 
IGNEOUS ROCKS.

INTRUSIVE ROCKS.

The main body of the intrusive rock forms the central portion of the range. It has a north-south extension of about 15 miles and a width of 4 to 8 miles. This main mass was examined in but few places and only general statements as to its character are warranted from the facts gathered. It is a light-colored granitic rock varying considerably in texture and probably in composition. Specimens believed to be representative are rather coarse grained and are composed largely of quartz, orthoclase, microcline, plagioclase, and biotite. Orthoclase and microcline are greatly in excess of plagioclase, and the rock is a true granite. Both north and south of the main mass, and possibly within it, are small bodies of more basic rocks of monzonitic and dioritic composition.

Bodies of fine-grained granite porphyry, similar in composition to the main body of the granite, occur also in the sedimentary rocks. At the east base of the north end of the range there are outcrops of a coarse granitic rock overlain by recent basaltic flows. The relation of this to the main intrusive body of the range was not determined.

In addition to the larger intrusive bodies mentioned, numerous dikes cut both the sedimentary and intrusive rocks. They are fine grained, usually not distinctly porphyritic, and when freshest are dark green. Most of them have the composition of diorite, though some are more basic. These dikes weather readily to a brown earthy mass, and as they are usually less resistant than the surrounding rocks, they are not conspicuous at the surface.

EXTRUSIVE ROCKS.

Extrusive rocks are most important south of Beaver Canyon, where they form a large part of the range, and in Beaver Valley east of the range. The volcanic rocks range from rhyolites to basalts, but a large proportion are of intermediate composition near latites. The latest flows are cellular basalt, which cover large areas east and northeast of the range.

RELATION OF THE INTRUSIVE AND EXTRUSTVE ROCKS.

The intrusive rocks were nowhere seen in contact with the main body of extrusive rocks and their relative age has not been determined. In the Tushar Range to the east the intrusive rocks are later than the main extrusive body, and the same relation may exist in the Mineral Range. The basaltic flows are very recent and represent the latest igneous activity of the region.

\section{STRUCTURE.}

The present attitude of the sedimentary rocks is due in part to the effects of the granitic intrusion and in part to later movements. South of the granitic mass they strike north to northeast and dip east. To the north of the granitic mass the strike and dip are irregular but are probably prevailingly to the west.

Faulting is believed to have been important in producing the Mineral Range. It is believed that the front of the range is determined by a strong north-south fault with downthrow to the west.

A short distance south of Beaver Canyon the sedimentary rocks are buried beneath lavas and are at much lower levels than to the north. There is apparently a strong east-west fault near the site of Beaver Canyon, though its exact location was not determined.

Fissures are numerous and have been of importance in furnishing passages for the metal-bearing solutions that have produced the ore deposits. They show great divergence in strike and dip, and no general rule governing their positions was determined.

ORE DEPOSITS.

The mineral deposits comprise replacement deposits in sedimentary rocks and veins in volcanic rocks. The replacement deposits are found principally in the limestone surrounding the central granitic mass, and the veins are confined to the volcanic rocks south of Beaver Canyon.

\section{REPLACEMENT DEPOSITS IN SEDIMENTARY ROCKS.}

The replacement deposits in sedimentary rocks may, in turn, be separated into those formed near the granite contact, containing calcium, iron, and magnesium silicates as gangue minerals and commonly designated contact deposits, and those formed as a replacement of limestone adjacent to fissures at some distance from the contact. 
CONTACT DEPOSITS.

OCCURRENCE AND CHARACTER.

Contact deposits are probably the most numerous of any type in the range. Although they have yielded only small amounts of metal, the surface showings have been sufficient to encourage considerable prospecting. The limestone at and near the large intrusive bodies is commonly recrystallized to a white crystalline limestone and contains small amounts of the contact silicates. Garnet, vesuvianite, and tremolite are most abundant, but epidote, chlorite, and muscovite are present. At places along the contact the silicate minerals become abundant, and magnetite, hematite, and the sulphides of copper, lead, and zinc are present. Most of these deposits are irregular or "bunchy," and though bodies of good ore have been found, most of them are too small to be profitably worked. Small shipments have been made from the Oak Leaf property on the east side of the range, where the deposits grade from typical contact deposits to deposits resembling those of the replacement fissure type. Contact deposits have been prospected at numerous points along the east side of the granite body, and a little ore is reported to have been shipped from several claims.

$$
\text { MINES. }
$$

Bismuth mine.-Deposits that mineralogically are to be classed with the contact deposits occur at some distance from large bodies of intrusive rock. An example of this type is the "Bismuth" mine on the east side of the range, where a stratum of limestone about 6 feet thick has been almost completely replaced by contact minerals, mainly vesuvianite and green amphibole with some fluorite, calcite, and sulphides. The sulphides-pyrite, bismuthinite, molybdenite, and possibly others-are intergrown with the silicate minerals. The stratum is overlain and underlain by white siliceous limestones that have been recrystallized but have not developed abundant contact silicates. Granite is exposed a few hundred feet both northeast and southwest of the prospected area on the strike of the sedimentary beds. The replaced bed has been exposed along the strike by open cuts and shafts for several hundred feet and can be traced on the surface for a greater distance.
The writer has no reliable data as to the metal content of the ore. A hasty inspection of the dumps and shallow workings revealed no material that appeared to carry more than a small percentage of either bismuth or molybdenum.

Lincoln mine.-The Lincoln mine, about 5 miles northeast of Minersville, may also be classed with the contact deposits, though it has some characteristics of the replacementfissure deposits. The sedimentary rocks in the vicinity are limestones, siliceous limestones, and quartzites of upper Carboniferous age, cut by granitic amd monzonitic rocks and some more basic dikes. East and south of the mine the granitic stocks are of considerable size. The limestone has been crystallized, and near the contact of the intrusive rocks and to some extent along fissures silicate minerals, garnet, tremolite, etc., have been developed.

The deposit was not examined underground, but from surface relations it appears to be in limestone near the contact of a monzonite porphyry dike. In the limestone on the dump contact silicates are plentiful and are intimately associated with ore minerals-galena, pyrite, chalcopyrite, and sphalerite. Zinc is said to have been unimportant in the upper portion of the ore body, but sphalerite is reported to be plentiful in the lowest workings, a report which seems to be confirmed by the presence of rather abundant sphalerite in the material last thrown on the dump. The shaft is said to have reached a depth of about 300 feet when work was stopped by the inflow of water.

Observations were not sufficient to determine whether the ore minerals were deposited at the time of the intrusion of the dike or were the result of later solutions passing along a fissure previously occupied by the dike.

The conditions in the Lincoln (formerly Rollins) mine at the time of the earlier operations are reported by P. T. Farnsworth ${ }^{1}$. as follows:

The shaft of the Rollins mine was sunk at an incline of about $80^{\circ}$ for 230 feet in limestone, following a chimney of lead ore, which formed quite a large deposit on the surface. The lead ore of shipping grade was followed within the dimensions of the shaft and at 200 feet entirely gave out, being replaced by zinc sulphide near the water level. No ore was found by drifting, which was done at a depth of 100 feet. The total output of lead did not aggregate a thousand tons.

1 Personal communication, Mar. 2, 1915. 
Nip and Tuck mine.-The Nip and Tuck mine is about 4 miles northeast of the Cave mine near the summit. of the range. The rocks in the vicinity are mainly limestone and quartzite, which have been intruded by finegrained granite porphyry. In general the porphyry has been intruded along the bedding planes but in numerous places has broken across the beds. There has been some movement later than the intrusion, and the planes of least resistance appear to have been very commonly along the contact between the intrusive and the sedimentary rocks, producing in many places a gouge with prominent slickensiding.

Mineralization is said to have been most extensive in blue limestone underlying granite porphyry. The ore is largely oxidized, consisting of hydrous iron oxide, carbonate, and probably also sulphate of lead, with associated gold and silver. The precious metals are rather high and are commonly the most valuable constituents of the ore. The presence of tremolite in some of the ore and the presence of that and other contact minerals in limestone associated with the porphyry at other points suggest that the deposits are to be classed with the contact type.

Hecla mine.-The Hecla mine is southwest of the Nip and Tuck and several hundred feet lower. It was not in operation at the time of visit and was examined only superficially. The ore deposits, like those of the Nip and Tuck mine, are closely associated with granite porphyry.

\section{REPLACEMENT-FISSURE DEPOSITS.}

BRADSHAW DISTRICT.

Cave mine.-The most important and largest replacement-fissure deposit yet developed in the range is the Cave mine on the eastern slope of the range, about 6 to 7 miles north of Minersville and about 10 miles southeast of Milford, at an elevation of about 7,000 feet.

The sedimentary rocks in the vicinity are the Carboniferous limestones. Some highly altered basic dikes outcrop near the mouth of the lower tunnel, and bodies of fine-grained granite porphyry and more basic rocks lie to the north and west.

The sedimentary rocks have been considerably faulted and fissured. There are numerous east-west and north-south fissures, both dipping steeply. Some nearly horizontal movement is shown in the lower tunnel and in a small cave north of the discovery cave. The main ore shoot appears to be associated with a north-south fissure, though observations were not sufficient to show that other fissures had not influenced the deposition of the ores. Where the limestone was particularly favorable to replacement, mineralization extended considerable distances from the fissure. The original ore minerals were doubtless sulphides, but oxidation has been rather complete to the depth of present developments. The ores extracted have consisted principally of limonite and cerusite with associated gold and silver. The high percentage of iron has made it possible to market much ore that could not have been profitably extracted for its gold, silver, and lead contents alone.

The main ore shoot has been developed by an irregular incline about 300 feet deep (estimated), whose bottom is connected with the surface by a tunnel about 2,000 feet long. A higher tunnel connects with the workings about 140 feet below the outcrop. Prospect and development openings have been made in several directions from the main shoot, but few of them could be examined. The cares associated with the ore deposits appear to have resulted from a shrinkage of the deposit in oxidation and probably also from solution of the limestone along this relatively open channel.

Huntley ${ }^{1}$ describes the conditions as follows:

The ore occurs entirely on the bottoms of caves in limestone or dolomite. Five large caves and 15 smaller ones had been found. They are all connected by seams of ocher, or by holes which serve as runways for mountain rats. Beyond the caves already known there are doubtless others, as holes and other seams lead outward. The largest cave is 120 feet long, 30 feet wide, and 20 feet high, extreme dimensions. One of average size is not over 12 feet in extent. All have an extremely irregular outline. The roofs of some are covered with a thin coating of copper carbonate and silicate. There is usually a vacant space from 1 foot to 10 feet between the roof and the ore. On the ore is usually a mass from 1 foot to 3 feet thick of blocks of limestone which have fallen from the roof. The upper portions of the deposits are generally softer, more earthy, and less valuable than the lower, where the carbonate of lead occurs. In some places the fine ocher changes into a hard massive limonite, with cavities having botryoidal and stalactitic surfaces. In spots, pure granular or crystallized sulphur is found, though not frequently.

1 Huntley, D. B., Precious metals: Tenth Census U. S., vol. 13, p. 474, 1885. 
Minor deposits.-Several other deposits in the Bradshaw district have produced ores, but none were active at the time of visit.

ANTELOPE DISTRICT.

In the Antelope district, at the north end of the range on the west side, are deposits which are probably to be classed with the replacement-fissure type. The ores are in certain beds of the limestone, but at the surface fissures crossing the bedding were not observed associated with the deposits.

The ore consists for the most part of galena in a gangue of barite and calcite. Oxidized ores are present to a minor extent at the surface and some float containing copper carbonates in a barite gangue was seen. There has been some prospecting of the deposits by shallow inclines and by tunnel, but at the time of visit no operations were being carried on.

\section{VEINS IN VOLCANIC ROCKS.}

So far as known, the veins in the volcanic rocks are present only in the portion of the range south of Beaver Canyon commonly known as the "Jarloose" district.

The volcanic rocks have been cut by fissures that trend north to northeast, adjacent to which they have been silicified and pyritized. On weathering, these metamorphosed rocks alter to yellow to reddish brown, and, being more resistant, usually stand slightly above the general level. This rock when examined in the hand specimen is seen to contain small veinlets of quartz and crystals of pyrite, or, in the weathered rocks, cavities containing the alteration products of pyrite.

The portions containing the most iron are said to give the best pannings of gold. The silicified "ledges" are numerous, and some of them can be traced for several hundred feet. Material that was said to "pan well" was in small ledges and was apparently confined to small streaks in the ledges. One poorly defined vein, containing abundant calcite with some quartz and copper carbonate, was stated to have assayed high in gold and silver. Considerable prospecting has recently been reported.

\section{ORIGIN OF THE ORES.}

The origin of the contact deposits and of the closely allied replacement veins in the sedimentary rocks can be referred, with much assurance, to the intrusion of the granitic rocks. Evidence as to the origin of the veins in the volcanic rocks is meager, but comparison with those in the Tushar Range to which they are most closely allied suggests that they also are after-effects of igneous activity.

\section{BIBLIOGRAPHY.}

Gimbert, G. K., U. S. Geog. Surveys W. 100th Mer. Prog. Rept. for 1872, p. 21, 1874.

- Geology of portions of Nevada, Utah, California, and Arizona, 1871-72: U. S. Geog. and Geol. Surveys W. 100th Mer. Rept., vol. 3, pt. 1, p. 29, 1875.

LEE, W. T., Water resources of Beaver Valley, Utah; U. S. Geol. Survey Water-Supply Paper 217, 1908.

\section{TUSHAR RANGE.}

By B. S. Butler. ${ }^{1}$

GEOGRAPHY.

The Tushar Mountains are in southern Utah in Beaver and Piute counties. Their northern extension is the Pavant Range, from which they are separated by a low divide. They are the highest mountains in southern Utah and their peaks, except for some in the Uinta Mountains, are the highest in the State. Mount Belknap, Mount Baldy, and Delano Peak all rise above 12,000 feet. The range trends generally north between Sevier Valley on the east and Beaver Valley and its northward extension on the west. The width of the range in the latitude of Marysvale is about 15 miles.

From the summits of Delano, Baldy, and Belknap peaks the mountain slopes away in all directions. The slope northward along the crest of the range to the Clear Creek Pass is relatively rapid, the crest line descending 5,000 feet in about 10 miles. Southward from the main summits the descent of the crest is less abrupt, maintaining a height of nearly 10,000 feet for about 20 miles and then descending to slightly over 7,000 feet in Fremont Pass. From the main crest long spurs separated by deep canyons descend laterally to the valleys on the east and west. The bottoms of both Sevier and Beaver valleys in the latitude of the highest peaks are about 6,000 feet above sea level, giving the higher peaks a maximum relief of about 6,000 feet and the crest of the range for many miles a relief of fully a mile. In Sevier Valley south of Marysvale the base of the range is bordered

1 Based on a reconnaissance made by the writer in the fall of 1911. 
by a gently sloping gravel terrace, in which Sevier River and the mountain streams have cut relatively narrow canyon-like valleys.

The high range receives a relatively heavy precipitation, which, falling as snow in winter, melts slowly and maintains the stream flow far into the summer. In some seasons snow remains in the range in protected places throughout the year.

The drainage is into Sevier River. That from the east side of the range flows directly to the river, and that from the west flows to Beaver Creek, which flows westward through the Mineral Range and joins the Sevier north of Milford. The streams coming into the Sevier Valley furnish water for the irrigation of numerous ranches, and Beaver River supplies several prosperous communities. The waters of the Beaver River are also utilized for the development of electric power, and other streams could be so utilized if necessary. The higher portions of the range (except the highest peaks which are above timber line and nearly devoid of vegetation) bear a rather abundant growth of timber suitable for building and mining. Generally, the camps of the Tushar Range are better supplied with water, timber, and farm products than most districts of the State.

\section{PHYSIOGRAPHY.}

Physiographically the Tushar Range, as noted by Dutton, ${ }^{1}$ is a transitional between the basin ranges on the west and the high plateaus on the east, being broader and less tilted than the one and narrower and more tilted than the other. It consists of a long narrow block bounded on the east and west by great faults. Sevier.Valley, to the east of the range, is a remarkable structural trough formed by the relative sinking of a narrow block between two great parallel faults.

However, though the main outline of the range is due to great structural breaks and dislocations, most of the details are the result of erosion, which has dissected the great tabular mass forming the range into spurs and canyons. Some of the east-west canyons, however, apparently owe their position to fault zones, though they do not follow them throughout their extent. The greater part of the erosion is due

1 Dutton, C. E. Geology of the high plateaus of Utah, p. 173, U. S Geog. and Geol. Survey Rocky Mountain Region, 1880. to ordinary agencies, but that in the higher parts of the range is partly due to glaciers, às is plainly shown by cirquelike valleys and morainal deposits.

In the vicinity of Marysvale gravel terraces that occupy the margins of, the valleys high above the present levels of the streams were evidently formed before the main river canyon was cut to its present depth.

This canyon cuts through a mass of igneous rocks that Dutton ${ }^{2}$ attributes to outbursts of volcanic material in the bottom of the valley:

Twenty miles north of Circle Valley and just below the hamlet of Marysvale another considerable barrier lies across the valley of the Sevier. It consists of a mass of rhyolitic lavas, which broke out in the valley bottom in many eruptions and now remain as a chaos of tangled sheets stretching from wall to wall. The river has maintained a canyon through the mass right at the base of the spurs of the Tushar, whose front here is not mural but mountainous.

Dutton evidently did not examine this barrier closely and was not aware that it was made up in considerable part of granitic rock intrusive into the flows and tuffs. It is hardly conceivable that a large mass of fluid rock material could have been intruded into a small mass of lavas and tuffs after the valley had been formed in essentially its present form and solidified as a granitio rock. To the writer it seems more natural to assume that in the sinking of the block that forms the bottom of Sevier Valley some portions were depressed less than others and thus there were structural elevations and depressions-the valley south of Marysvale being such a depression and the barrier north of Marysvale being such an elevation-or that irregularities in the surface previous to faulting were retained in the sunken block. Dutton ${ }^{3}$ notes that local uplifts transverse to the valley are associated with the obstruction south of Circle Valley. Such uplifts may well have occurred in connection with the obstruction near Marysvale, though no evidence of them was noted. Whatever the cause of the barrier the area behind it would naturally be a collecting ground for the sediments from the adjacent mountains till the river had cut through the barrier and furnished an outlet. The stream then began clearing the valley of the material. The terraces represent the portion still remaining. 
GEOLOGY.

SEDIMENTARY ROCKS.

The exposed rocks of the range are largely igneous, the basement on which the extrusive rocks rest being exposed in relatively few places and over relatively small areas. Wherever exposed it is seen to be composed of sedimentary rocks-mainly limestones and quartzitic sandstones with some shaly sediments. Its largest exposure is along the east front of the range between Bullion and Tenmile canyons. Within the main canyons (Bullion, Little Cottonwood, and Tenmile) the sedimentary rocks outcrop for several miles.

The rocks are too poorly exposed and have been too greatly disturbed to make an accurate understanding of their stratigraphy possible without detailed mapping. In Little Cottonwood Canyon, where the exposures are best, a rough estimate of the thickness shows interbedded quartzite and limestone 500 to 600 feet thick, overlain by 300 to 400 feet of massive quartzite overlain in turn by a series of limestone and shaly beds whose thickness probably exceeds 1,000 feet, the whole overlain by quartzite, a few hundred feet of which is still preserved. In Tenmile Canyon there is a considerable thickness of sandstones and shales. The relations of the two were not determined.

The age of the sedimentary rocks of the Tushar Range is given as Jurassic by Dutton ${ }^{1}$ on the basis of the presence of the fossil form Pentacrinus asteriscus. Fossils obtained by the writer from the upper limestone of Little Cottonwood Canyon were determined and ascribed to the Jurassic by J. B. Reeside, jr., as follows:

7890. No. 45. Loose fragments from upper limestone, Cottonwood Canyon: Ostrea cf. O. strigilecula White, Pholadomya cf. P. kingii Meek, and Camptonectes stygius White.

7891. No. 27. Cottonwood Canyon: Camptonectes stygius White, Camptonectes? sp., and Pentacrinus sp.

\section{IGNEOUS ROCKS.}

\section{EXTRUSIVE ROCKS.}

Areally the volcanic rocks are by far the most widespread. They vary in character from massive flows of porphyritic rock to extensive beds of fine stratified tuffs, locally known as shale, interstratified with beds of volcanic débris accumulated from the earlier

1 Op. cit., p. 184. flows by erosion between eruptions. According to Dutton ${ }^{2}$ such volcanic sediments are present in large amounts in the southern part of the range and indicate that at the time of their accumulation the northern part of the range was the higher and furnished the material for the sediments deposited to the south.

In the northern part of the range the volcanic rocks may be roughly separated into a basal portion composed mainly of massive flows and breccias and an upper portion composed predominantly of tuffs and thin flows. The basal portion is well exposed in Bullion, Little Cottonwood, and Tenmile canyons and is present to a less extent farther north on the west side of the range.

In mineral composition the successive flows show slight differences in composition, but all belong to intermediate groups. Quartz phenocrysts are present in most of the rock, though in some places they are relatively scarce. Plagioclase (andesine) predominates over orthoclase in the phenocrysts. In the groundmass the relative abundance of the feldspars can not be determined. Both hornblende and biotite were abundant but have usually been partly or entirely altered to secondary minerals. From microscopic study the rocks are classed as dacite, though chemical investigation would doubtless show that some of them are quartz latite and some possibly might be classed as andesite.

Overlying the heavy flows and forming the higher parts of the range, especially to the north, where they extend well down toward the base, is a series of light-colored rhyolitic flows and tuffs, locally known as "shale." Similar rocks were seen in considerable abundance in the volcanic mass in Sevier Valley north of Marysvale. The composition of these rocks is not known, as they have not been analyzed chemically and are too fine grained to be determined microscopically. In large part they are distinctly rhyolitic and are doubtless either true rhyolites or quartz latites. Whether these rhyolitic rocks ever covered the entire range can not be stated positively. Their greater abundance toward the north, however, suggests that they were erupted from vents in the northern part of the range and that if they ever extended over the southern and southeastern portions, it was as a relatively thin 
covering. The latest eruptive rocks in the range are basaltic flows, which cover an extensive area southeast of Beaver.

\section{INTRUSIVE ROCKS.}

Intrusive rocks as observed in the range are of relatively slight areal extent. Two considerable bodies were noted and numerous dikes are present in various parts of the district. It is possible and even probable that sills of porphyry are also present, but if so, they resemble the flow rocks so closely that detailed study will be necessary to prove their presence. The larger intrusive bodies are in the Antelope Range north of Marysvale and on the western flanks of Baldy and Belknap peaks, several miles north of Beaver. Neither body has been carefully outlined, but each is several square miles in extent. The one north of Beaver, shown on earlier maps as pre-Cambrian, occupies 30 to 40 square miles, and the one in the Antelope Range must occupy 8 to 10 square miles.

The main body of both intrusive masses is composed of rather abundant quartz with orthoclase and plagioclase in about equal amounts. The rock contains also considerable augite, biotite, and magnetite and in composition corresponds to quartz monzonite. Locally, the rocks are more acidic and pass into true granite. Some phases of the rocks that showed no free quartz may be classed as monzonite.

Dikes cut both the volcanic and the sedimentary rocks of the range. Most of them are rather fine grained, porphyritic, and range in composition from quartz monzonite porphyry to basic types containing abundant augite and biotite, with the general composition of camptonite. They closely resemble the porphyritic lavas, from which they are not readily distinguished, and without detailed work it is impossible to state how abundant they are. Prominent dikes of the monzonitic and dioritic composition are present near the Sevier Consolidated and Annie Laurie mines, and more basic dikes were noted in upper Tenmile Canyon and in the Deertrail mine.

RELATION OF THE INTRUSIVE TO THE FLOW ROCKS.

The relation of the large intrusive masses to the flow rocks is not everywhere obvious, but dike rocks extending from the main mass into the overlying volcanic rocks were noted, and these, together with the change in texture of the intrusive rock from granitic to distinctly porphyritic near the contact with the flow rocks, indicates that the intrusive rocks are later than the flows. Their present relations are believed to be due to the intrusion of the granitic rocks into the flows rather than to the burial of an old erosion surface beneath the lavas.

The flow rocks have been considerably altered near the intrusive contact, and the general outline of the granitic areas in the Antelope Range can be readily traced from a distance by the highly colored rocks at the contact. A similar alteration in the Indian Creek area is shown at the Red Buttes, north of the Rob Roy mine.

\section{AGE OF THE IGNEOUS ROCKS.}

Within the Tushar Range only Jurassic sediments and those of recent formation have been recognized, so that it is impossible to determine closely the age of the igneous rocks. The extrusive rocks flowed out on the eroded surface of the Jurassic sediments and are therefore post-Jurassic. From evidence in adjoining areas, however, Dutton has concluded that volcanism began in early Tertiary time and continued through a long period. The latest volcanic activity, the outpouring of basaltic lavas, was of very recent date and may have occurred only a few thousand years ago. It seems probable that the volcanic eruptions which built up the main range were active at intervals through the middle and possibly into late Tertiary time. The granitic rocks are later than the main body of the flows and their intrusion may have taken place as recently as late Tertiary.

\section{STRUCTURE.}

Faulting has been important in the creation of the present Tushar Range. According to Dutton a fault extends for miles along the eastern front of this range and its extensions and is paralleled by another fault (the Sevier fault) a few miles to the east. Serier Valley is considered to have been formed by the subsidence of the block between these great faults.

The western face of the Tushar Range is in line with the extension of the Hurricane fault, which is prominent farther south and is considered by Lee ${ }^{1}$ to form the western boundary of the range. Within the Tushar Range there

1 Lee, W. T., Water resources of Beaver Valley, Utah: U. S. Geol. Survey Water-Supply Paper 217, p. 13, 1908. 
has been considerable north-south faulting parallel to the great faults that outline the range. These minor faults are, as a rule, not readily recognized, on account of the similarity of the successive flows and the small amount of sedimentary rocks, but in places they are easily determined. Such a fault is well exposed near the Crystal mine, south of Cottonwood Canyon, where the volcanic rocks are thrown down against the quartzites, the fault being marked by a zone of fault breccia. The northward extension of this fault marks the boundary between the quartzite to the east and the volcanic rocks to the west. A similar relation is seen in the workings of the Bully. Boy mine, in Bullion Canyon, where in places quartzite forms one wall of the ore vein and volcanic rocks the other, and strong slickensiding testifies to the movement that has taken place. Similar displacements doubtless occur within the volcanic rocks, but, as already stated, the similarity of the rocks renders recognition difficult without detailed geologic work.

East-west faulting seems to have been less important, both in determining the structure of the range and in connection with the ore deposits. Some fissuring, which was unaccompanied by important movement but which permitted the circulation of mineral-bearing solutions, may also have taken place.

The main faulting occurred later than the extrusion of the bulk of the flow rocks. Its exact geologic time is not readily fixed, and, in fact, the movement doubtless continued at intervals over a considerable period. Dutton, ${ }^{1}$ from a study of the faults over a wide area, concluded that the main fault movement began in late Tertiary time and continued perhaps even to the present day. That movement along some of these faults is still in progress has been indicated by severe earthquakes in recent years.

\section{HISTORY AND PRODUCTION.}

By V. C. Heikes.

The area of the Tushar Range ancludes tne Gold Mountain, Ohio, Mount Baldy, Newton, and Henry districts.

\section{GOLD MOUNTAIN DISTRICT.}

The Gold Mountain district, in Piute and Sevier counties, was organized April 24, 1889. Kimberly, which was the principal camp, is 15

1 Dutton, C. E., Geology of the high plateaus of Utah, U. S. Geog. and Geol. Survey Rocky Mtn. Region, 1880. miles southwest of Sevier on the Denver \& Rio Grande Railroad. According to Lindgren, ${ }^{2}$ the region was known to be mineral bearing from the earlier days, for it lies only a few miles northwest of Marysvale and Bullion Creek. The ores, however, did not prove amenable to the ordinary amalgamation procese, and the primitive reduction works were complete failures. With the advent of the cyanide process, however, a method which permitted the successful working of the ores was devised.

In 1892 the Sevier Consolidated Gold Mining Co. completed a 10-stamp pan-amalgamation mill and produced 100 ounces of gold and 398 ounces of silver from 210 tons of ore.

In 1894 the gold shipments are said to have averaged $\$ 5,000$ monthly. During 1895 two mills, the Butler and Sevier, were in operation. In 1899 the Annie Laurie Mining Co. built its present mill and worked continuously from January, 1901, till the end of 1908. In 1905 the Sevier Co. replaced its 10-stamp mill with a new mill using a different treatment that involved concentration as well as plate amalgamation and cyanidation. The district produced a rather steady but small quantity of gold between 1892 and 1897 and again between 1903 and 1907. Between 1910 and 1913 the Sevier and Annie Laurie produced several thousand dollars' worth of gold and silver bullion.

Statistics of production for the district prior to 1901 are not available, but estimates, based on considerable information, are submitted in the tabulation below. Since 1902 the statistics of production have been compiled from the records of the United States Geological Survey.

\section{OHIO DISTRICT.}

The Ohio mining district is 6 miles southwest of Marysvale on Sevier River in Piute County. The district was organized in February, 1868, and again in August, 1872. In the seventies Bullion and Webster cities were important camps. Bullion was once the county seat of Piute County and contained about 200 inhabitants and 40 to 50 dwellings. Wheeler, ${ }^{3}$ in 1872 , states that the principal claims were the Daniel Webster, with a shaft

2 Lindgren, Waldemar, The Annie Laurie mine, Piute County, Utah: U. S. Geol. Survey Bull. 285, p. 87, 1906.

${ }^{8}$ U. S. Geog. Surveys W. 100th Mer. Prog. Rept. 1872, pp. 14-26, 1874 . 
TUSHAR RANGE.

Metals produced in Gold Mountain district, 1892-191\%.

\begin{tabular}{|c|c|c|c|c|c|c|}
\hline \multirow{2}{*}{ Year. } & \multirow{2}{*}{$\begin{array}{l}\text { Ore } \\
\text { (short } \\
\text { tons). }\end{array}$} & \multicolumn{2}{|c|}{ Gold. } & \multicolumn{2}{|c|}{ Silver. } & \multirow{2}{*}{$\begin{array}{l}\text { Total } \\
\text { value. }\end{array}$} \\
\hline & & $\begin{array}{l}\text { Fine } \\
\text { ounces. }\end{array}$ & Value. & $\begin{array}{c}\text { Fine } \\
\text { ounces. }\end{array}$ & Value. & \\
\hline 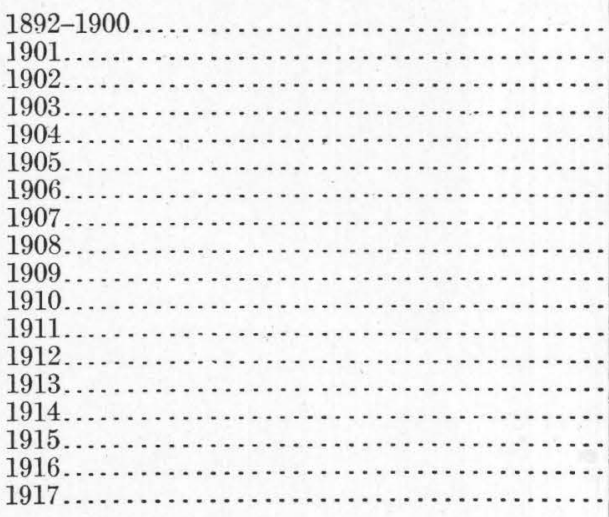 & $\begin{array}{r}a \\
21,500 \\
50,000 \\
78,946 \\
63,246 \\
59,586 \\
65,800 \\
73,909 \\
53,850 \\
13,341 \\
49 \\
6,090 \\
3,004 \\
310 \\
10,874 \\
131 \\
115 \\
87 \\
74\end{array}$ & $\begin{array}{r}7,740.00 \\
18,007.72 \\
23,306.80 \\
20,335.60 \\
18,427.80 \\
19,283.00 \\
15,854.75 \\
12,289.90 \\
3,075.00 \\
21.89 \\
563.51 \\
1,051.56 \\
144.43 \\
2,383.47 \\
279.54 \\
448.82 \\
213.58 \\
133.90\end{array}$ & $\begin{array}{r}\$ 160,000 \\
372,253 \\
481,794 \\
420,374 \\
380,936 \\
398,615 \\
327,747 \\
254,055 \\
63,566 \\
452 \\
11,649 \\
21,738 \\
2,985 \\
49,271 \\
5,778 \\
9,278 \\
4,415 \\
2,768\end{array}$ & $\begin{array}{r}51,000 \\
48,213 \\
69,223 \\
67,109 \\
56,647 \\
55,536 \\
52,126 \\
37,138 \\
9,425 \\
28 \\
1,358 \\
1,256 \\
455 \\
5,371 \\
1,510 \\
2,003 \\
923 \\
908\end{array}$ & $\begin{array}{r}\$ 33,507 \\
28,928 \\
36,688 \\
36,239 \\
32,430 \\
33,544 \\
34,924 \\
24,511 \\
4,995 \\
15 \\
733 \\
666 \\
279 \\
3,244 \\
835 \\
1,016 \\
607 \\
748\end{array}$ & $\begin{array}{r}\$ 193,507 \\
401,181 \\
518,482 \\
456,613 \\
413,366 \\
432,159 \\
362,671 \\
278,566 \\
68,561 \\
467 \\
12,382 \\
22,404 \\
3,264 \\
52,515 \\
6,613 \\
10,294 \\
5,022 \\
3,516\end{array}$ \\
\hline & 500,912 & $143,561.27$ & $2,967,674$ & 460,228 & 273,909 & $3,241,583$ \\
\hline
\end{tabular}

$a$ Partly estimated.

65 feet deep and a tunnel 50 feet long. Other Canyon, some distance from the mine, but the claims were the Homestead, Blue Cloud, yield did not equal expectations. ${ }^{2}$ In 1884 Spring Town, Niagara, Morning Star, St. Lawrence, and Great Western. Gold-bearing sand was discovered in Pine Gulch Creek in the early part of 1868 , and about $\$ 100$ worth of gold was washed out at an expense of several thousand dollars. This led to the discovery of a gold quartz vein by Capt. Hess. Considerable quicksilver, caught in the sluice boxes, was at one time thought to be a survival of earlier operations but is now known to have been derived from local rocks. In 1872 a mill with two 400-pound stamps, run by a 12-horsepower engine, was built by the Piute Silver Mining Co. but proved a failure and was not worked.

Huntley ${ }^{1}$ says:

The Ohio mining district is a few miles square and includes several precipitous ridges and deep gorges on the eastern face of the Mount Baldy Range, 90 miles south of Juab. It was organized in 1868 or 1869 and reorganized in August, 1872. There were 130 locations on the records, but not a quarter of that number are still owned. Marysvale, 6 miles from the mines, in the valley of the Sevier River, is the district post office and the settlement from which supplies are obtained.

The Copper Belt property was developed in 1882 through a shaft 300 feet deep. Ore was milled at a 10-stamp mill in Bullion

1 Precious metals: Tenth Census U. S., vol. 13, p. 462, 1885. the principal properties were the Copper Belt, Mohawk, Belle of the Vale, Manhattan, Webster, Bully Boy, Giles, Filmore, Elsie, Sierra Nevada, Bucher, and Chattanooga. In 1898 the Wedge property was discovered and has been a considerable producer of high-grade gold ore.

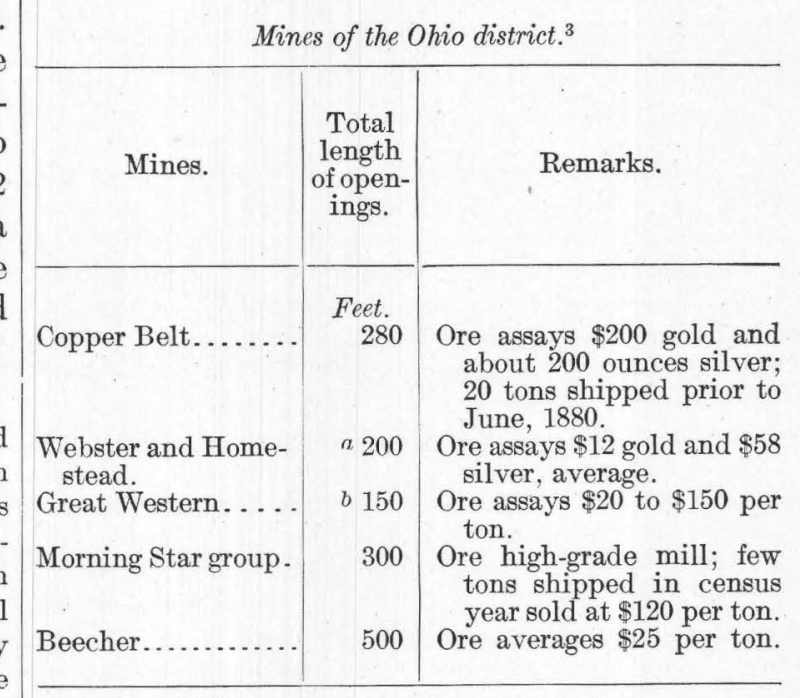
$a$ Shafts; also crosscuts, etc. $\quad b$ Shaft.

The Denver \& Rio Grande Railroad was completed to Marysvale in 1900, and although it stimulated production to some extent the \begin{tabular}{l}
\hline 2 Director of Mint Rept. upon production of precious metals, 1882, p. \\
$259,1883$. \\
3 Op. cit., p. 462.
\end{tabular} 
ores shipped from the Ohio district did not in limestone. The ore contains horn silver in which come up to expectations. The production of the Ohio and Mount Baldy districts between 1868 and 1903 can not be exactly stated but is said to have been, with milling ores included, between 8,000 and 10,000 tons. Only since 1904 have the reports of producers been available to complete the following table: particles of gold are visible. Seven tons of the sorted ore had been shipped and averaged about $\$ 100$ gold and $\$ 200$ silver per ton.

The Lucky Boy claim on the side of this mountain contains small bunches of selenide of mercury in limestone. Other promising prospects in the district are the Alma, Plata de Mina, Uncle Sam, Rothschild, Clyde, Crystal, and Monte del Rey.

Metals produced in Ohio and Mount Baldy mining districts, 1904-1917.

\begin{tabular}{|c|c|c|c|c|c|c|c|c|c|c|}
\hline \multirow{2}{*}{ Year. } & \multirow{2}{*}{$\begin{array}{l}\text { Ore } \\
\text { (short } \\
\text { tons). }\end{array}$} & \multicolumn{2}{|c|}{ Gold. } & \multicolumn{2}{|c|}{ Silver. } & \multicolumn{2}{|c|}{ Copper. } & \multicolumn{2}{|c|}{ Lead. } & \multirow{2}{*}{$\begin{array}{l}\text { Total } \\
\text { value. }\end{array}$} \\
\hline & & $\begin{array}{l}\text { Fine } \\
\text { ounces. }\end{array}$ & Value. & $\begin{array}{c}\text { Fine } \\
\text { ounces. }\end{array}$ & Value. & Pounds. & Value. & Pounds. & Value. & \\
\hline 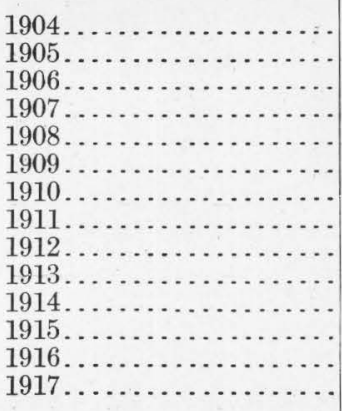 & $\begin{array}{r}73 \\
49 \\
30 \\
136 \\
20 \\
53 \\
157 \\
154 \\
a 1,025 \\
a \quad 935 \\
1,326 \\
69 \\
239 \\
2,054\end{array}$ & $\begin{array}{r}26.31 \\
15.00 \\
5.00 \\
34.00 \\
5.79 \\
16.87 \\
531.36 \\
204.66 \\
22.87 \\
121.42 \\
101.96 \\
1,168.69 \\
221.41 \\
905.83\end{array}$ & $\begin{array}{r}\$ 544 \\
310 \\
103 \\
703 \\
120 \\
349 \\
10,984 \\
4,230 \\
473 \\
2,510 \\
2,108 \\
24,159 \\
4,577 \\
19,725\end{array}$ & $\begin{array}{r}2,140 \\
1,400 \\
380 \\
4,407 \\
414 \\
1,050 \\
7,432 \\
4,137 \\
2,368 \\
4,368 \\
10,166 \\
772 \\
6,265 \\
45,832\end{array}$ & $\begin{array}{r}\$ 1,225 \\
845 \\
255 \\
2,909 \\
220 \\
545 \\
4,013 \\
2,192 \\
1,457 \\
2,638 \\
5,622 \\
391 \\
4,123 \\
37,766\end{array}$ & \begin{tabular}{r}
$\ldots \ldots$ \\
$\ldots \ldots \ldots$ \\
\hdashline 13,454 \\
205 \\
3,632 \\
12,127 \\
7,816 \\
3,106 \\
3,904 \\
3,635 \\
463 \\
5,622 \\
18,770
\end{tabular} & $\begin{array}{r}\ldots . \\
\$ 2,691 \\
27 \\
472 \\
1,540 \\
977 \\
512 \\
605 \\
483 \\
81 \\
1,383 \\
5,124\end{array}$ & \begin{tabular}{r}
17,350 \\
12,560 \\
\hdashline 32,296 \\
2,927 \\
881 \\
$\ldots \ldots \ldots$ \\
\hdashline$\ldots \ldots$. \\
21,889 \\
46,458 \\
119,832 \\
3,231 \\
49,983 \\
540,476
\end{tabular} & $\begin{array}{r}\$ 759 \\
590 \\
\ldots \ldots . . . \\
1,712 \\
123 \\
38 \\
\ldots \ldots . . . \\
985 \\
2,044 \\
4,673 \\
152 \\
3,449 \\
46,481\end{array}$ & $\begin{array}{r}\$ 2,528 \\
1,745 \\
358 \\
8,015 \\
490 \\
1,404 \\
16,537 \\
7,399 \\
3,427 \\
7,797 \\
12,886 \\
24,783 \\
13,532 \\
108,096\end{array}$ \\
\hline & 6,320 & 3, 381. 17 & 69,895 & 91,131 & 64,201 & 72,734 & 13,895 & 847,883 & 61,006 & 208,997 \\
\hline
\end{tabular}

$a$ Ore yielded some concentrates at Bully Boy mill.

\section{MOUNT BALDY DISTRICT.}

The Mount Baldy district, in Piute County, adjoins the Ohio district on the north and extends along the precipitous eastern face of the same mountain range for 8 miles. Huntley ${ }^{1}$ describes it as follows:

It was organized September 18, 1878, and the records show 190 locations. *** The Deer Trail mine is situated on a very steep mountain side, 1,500 feet above the Sevier River valley, 5 miles southwest of Marysvale. It was discovered in September, 1878, and was the first location in the district. It was worked steadily until July, 1880. * * * The property consists of the Deer Trail, Green-eyed Monster, and Cliff claims on the same vein; the $\mathrm{Pi}$ Ute and Red Pine claims on a parallel vein on the bluff 1,000 feet above; two 5-acre mill sites and a sawmill site. *** It (the ore) assays about $\$ 8$ gold, $\$ 150$ silver, and 35 per cent lead. The second-class ore is a hard quartz, assaying about $\$ 2$ gold and $\$ 48$ silver, and is still on the dump. * * * The exact product can not be stated but was a few hundred tons. * * *

The Green-eyed Monster is the northern extension of the Deer Trail. In this claim the vein suddenly enlarges and the ore is of lower grade. * * * It is estimated that the entire mass would average from $\$ 20$ to $\$ 25$ per ton, one-third of the value being gold. ***

The Pluto mine is on the mountain side above the Deer Trail. It was located in June, 1879. It is a 20 -inch vein

1 Precious metals: Tenth Census U. S , vol. 13, p. 463, 1885.
It is reported ${ }^{2}$ that a carload of ore was shipped from the Crystal mine in 1880.

Several hundred tons of smelting ore is mentioned in the census report as having been shipped from the district prior to 1880 . All the ore shipped was hauled many miles until the railroad was completed to Manti in 1890 and to Marysvale in 1900. Records on file with the United States Geological Survey show shipments made in 1878 and for some of the following years:

Metals produced in Mount Baldy district, 1878-1882.

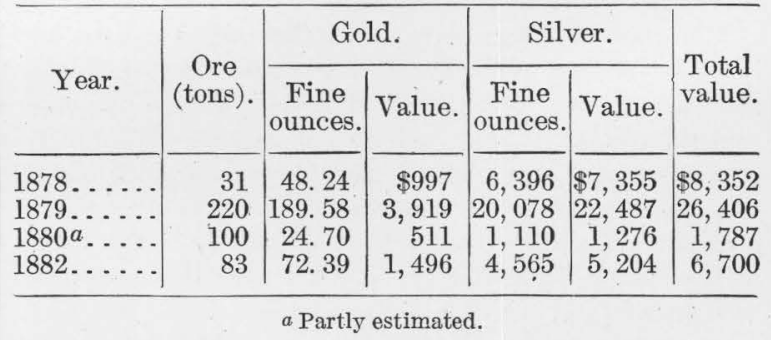

The production of gold, silver, and copper since 1903 is included in the table for the Ohio and Mount Baldy districts. (See p. 544.) 
In addition to shipping ore the Green-eyed Monster of the Deertrail group produced about 6,000 tons of milling ore containing about $\$ 15$ in gold and 10 ounces of silver per ton. This ore was treated at a mill in Bullion Canyon, but owing to the large quantity of "talc" it contained and the unsuitable milling facilities the extraction did not average much over 60 per cent. The tailings, some of which were subsequently treated, were to a large extent carried away by flood waters. This body of milling ore is reported to have contained appreciable quantities of mercury in some of the workings. Development has continued and a large body of ore is said to have been proved, for the treatment of which a milling plant was completed in 1918.

Adjoining the Deertrail on the west, and owned by the same interests, is an interesting property known as the Lucky Boy. Selenide of mercury is found here and was worked for quicksilver, at one time yielding as high as 60 per cent. The total production is estimated as 213 flasks, valued at $\$ 8,308$. $^{1}$

\section{NEWTON DISTRICT.}

The Newton mining district, in Beaver County, 55 miles east of Milford, on the Los Angeles \& Salt Lake Railroad, was organized November 26, 1892. By July, 1893, a 10-stamp amalgamation mill was operating on ore taken from the Rob Roy claim. The first gold bullion, valued at $\$ 800$, was shipped in August, 1893. During September of the same year the Cremona group of claims was operated by the Sheep Rock Co. It is reported ${ }^{2}$ that between November, 1892, and September, 1893, the Rob Roy property produced from $\$ 7,000$ to $\$ 9,000$ worth of gold from ore treated in its amalgamation mill. The ore mined did not appear to be in place and was soon exhausted. Considerable development has since been done on the property in trying to find the ledge from which the rich ore came. No records of the production of the district until 1908 are available, since which time the statistics have been compiled by the United States Geological Survey. They are included in the table giving the output of Beaver County.

1 McCaskey, H. D., Quicksilver: U. S. Geol. Survey Mineral Resources, 1911, p. $914,1912$.

2 Personal interview with P. T. Farnsworth, Salt Lake City, March, 1915.
HENRY DISTRICT.

The Henry district, organized July 6, 1883, is in the southern part of Sevier County. Between 1902 and 1911 there were shipped from the district 1,598 tons of ore containing $\$ 8,583$ in gold and 28,316 ounces of silver, valued in all at $\$ 24,289$. Some iron flux was shipped to Salt Lake smelters from the Krotki iron claims, southeast of Sevier, in the Durkee (unorganized) district, which is considered to be part of the Henry district.

ORE DEPOSITS.

GENERAL FEATURES.

The ores of the Tushar Range show great diversity in metal content. Some are essentially gold-silver ores, and others contain copper, lead, and zinc in considerable amounts. In the Antelope district some ores are valuable chiefly for their iron. The Tushar Range also has the only important deposits of alunite yet discovered in the State, and it contains one of the two mines of the State that have produced quicksilver in commercial amounts. The deposits show too many gradations to be readily divided into classes, but for convenience in description they may be grouped as veins and replacement deposits. Placer deposits are of small importance.

\section{VEINS.}

The principal metals produced by the vein deposits are gold and silver, thuugh they also produce some lead and copper and contain considerable quantities of zinc. The alunite veins, which are included in this class, may prove a source of aluminum as well as of potash.

Most of the veins strike generally north to northwest, but a few strike nearly west. Most of them dip steeply.

\section{GOLD-SILVER VEINS.}

The veins in which gold and silver are the chief valuable metals are confined almost exclusively to the volcanic rocks. Such veins are found at several localities in the range. The most important is that about Kimberly, though there has been production from veins of this class from the Newton district, from the recently discovered Fortuna district on the western side of the range, and from the "Horse Heaven" area between Bullion and Little Cottonwood canyons. Similarveins have been prospected to a slight extent in Tenmile Canyon. 
The veins have apparently formed as fillings of open fissures and in many places have a rather indefinite banded structure. In some of them the contact with the wall rock is sharp and there is strong slickensiding, but in others the vein is "frozen" to the walls and the contact is much less definite.

Alteration of the wall rocks is irregular, though rather pronounced. Nowhere, so far as observed, has there been sufficient addition of metals to the wall rock to make ore. The common alteration is sericitization of the feldspars and change of the dark silicates to chlorite and some epidote. Silicification is pronounced in many places.

The typical gangue minerals of the veins are quartz and carbonate and at several places adularia in considerable abundance. Barite is also a constituent of the gold-silver veins-in some places being rather plentiful though nowhere as abundant as the carbonate. Fluorite was noted in the Wedge vein and is probably present in others.

The carbonate is apparently variable in composition. In the oxidized ores hydrous oxides of both iron and manganese have apparently resulted from the alteration of the carbonate. Specimens were collected from the dump of the Dalton mine in which the carbonate is rhodochrosite, but this is apparently exceptional. Much of the carbonate is apparently nearly pure calcite. The carbonate and barite are among the earliest minerals to form, though some barite has formed in vugs lined with quartz. In many places both carbonate and barite have been partly or wholly replaced by quartz and adularia, giving the quartz the peculiar lamellar structure characteristic of this type of vein, both here and in other districts.

In many of the veins sulphides are rather sparse, though present in much of the adjacent altered rock. According to Lindgren ${ }^{\mathbf{1}}$ the Annie Laurie vein contains pyrite and small amounts of argentite and native gold. Copper stains are present, but the original copper mineral was not noted. Quicksilver is also reported as occurring in the mine. In the veins between Bullion and Little Cottonwood canyons pyrite is usually plentiful and tetrahedrite occurs in many places in considerable amount.

\footnotetext{
1 Lindgren, Waldemar, The Annie Laurie mine, Piute County, Utah: U. S. Geol. Survey Bull. 285, p, 89, 1906.
}

The only apparently primary silver mineral recognized has silvery-white metallic luster. It could not be separated in sufficient quantity for analysis, but tellurium and selenium are both shown by qualitative tests of rich ore. Much of it is coated by a dark-gray material of dull luster, apparently an alteration product. The mineral contains free gold in minute fissures, and possibly gold is one of its essential constituents. Material free from native gold was not obtained to test for other gold. In specimens of rich ore from the upper levels of the Bully Boy mine all the free gold is closely associated with this mineral and is possibly an alteration product of it. In specimens of rich ore from the same mine cerargyrite (horn silver) forms thin films along fissures.

So far as observed the tetrahedrite carries but little silver. Material containing several per cent of this mineral is said to contain only small quantities of precious metals and is ore only when it contains sufficient copper to be valuable for that metal.

The effect of secondary concentration on the ore could not be determined satisfactorily during the writer's visit. There seems to be no doubt that some of the richest ore occurred very near the outcrop of the ore bodies, so that, so far as indicated by past experience, richer zones are not to be expected at greater depths. Some placer deposits have been worked near the mouth of Bullion Canyon, and others are reported along the west base of the range, indicating that some metal-bearing portions of the veins have been eroded. The fact that more extensive placers are not associated with the larger veins (namely those near Kimberly) is probably due to the fact that only a small portion of the veins has been eroded and to the fact that part of the erosion was accomplished by glaciers which did not concentrate the gold in workable placers. Experience has shown that with increasing depth the ores decrease in value. None of the deeper workings on the gold-silver veins could be examined, but it is currently reported that the ore of the lower levels of the Annie Laurie mine is of much poorer grade. In the Sevier mine sufficient depth has not been attained to indicato positively the effect of depth. The same appears to be true in other mines between Bullion and Little Cottonwood canyons, as richer 
ore was found near the surface in the Bully Boy and Webster, the Dalton, and other mines than has been found as greater depth has been attained.

LEAD-COPPER-ZINC VEINS.

The veins that contain lead, copper, and zinc minerals in considerable abundance contain also gold and silver and are very closely related to the gold-silver veins, into which they doubtless grade. The veins carrying base metals thus far developed are mainly confined to Bullion and Little Cottonwood canyons and like the gold-silver veins are for the most part associated with north-south fissures.

Most of the base-metal deposits are within or closely associated with sedimentary rocks, limestones, or quartzites and all are at relatively low levels, whereas many of the important goldsilver deposits are found at the higher elevations. As the sedimentary rocks are also confined to the basal portion of the range, it is not readily apparent whether the distinction is due to the sedimentary rocks or the difference in vertical position. Not improbably it is due to both.

The lead-copper-zinc veins, like the goldsilver veins, were in part formed in open fissures, and some of them have beautifully polished walls, as in parts of the Bully Boy mine; others, however, have also replaced the wall rocks for short distances from the fissures. The adjacent volcanic rocks have undergone alteration similar to that of the rock adjacent to the gold-silver veins. The feldspars have been replaced by sericite and carbonate, and the dark silicates have commonly altered to chloride. Pyrite is rather sparingly present.

The abundant gangue minerals are quartz and carbonate, and the less abundant are barite and fluorite. The carbonate is an iron-manganese-calcium carbonate which on alteration commonly yie!ds abundant hydrous oxides of iron and manganese. Both the carbonate and the barite were among the earliest vein minerals and have been partly replaced by quartz.

The primary metallic minerals are pyrite, chalcopyrite, tetrahedrite, galena, and sphalerite. Of these the pyrite is the earliest. It occurs mostly in irregular grains but in places shows definite crystal outline. Under the microscope pyrite crystals from the Clyde mine show films of chalcopyrite filling microscopic fissures. In other grains the films have been $35416^{\circ}-19-35$ considerably broadened by replacement of the pyrite, and the grains appear to have been shattered and cemented by the chalcopyrite. In many grains replacement has proceeded till only small cores of pyrite remain and in some even the core has disappeared. Not all the chalcopyrite has formed at the expense of pyrite, but some appears to have crystallized independently of other minerals. Chalcopyrite and tetrahedrite are apparently of the same age, in many places being intimately intergrown. The tetrahedrite, so far as observed, however, does not form at the expense of pyrite, as does a part of the chalcopyrite. Galena is also of the same age as the chalcopyrite and tetrahedrite. Intricate intergrowths of galena and tetrahedrite are present in some of the ore, and sphalerite is also apparently of the same age. The only secondary sulphides positively recognized as the result of descending solutions are those of copper (chalcocite and covellite), which have formed commonly from chalcopyrite and to a slight extent from tetrahedrite. There has been very little direct replacement of pyrite by either chalcocite or covellite, though portions of pyrite grains first replaced by chalcopyrite have later been altered to covellite. It is probable that zino sulphide has also been replaced by copper sulphides, though no material showing this was present in the sections examined.

In material from the Clyde mine, grains of sphalerite contain lathlike bodies of doublerefracting material, evidently wurtzite. Some grains are largely composed of such laths. The relations of the minerals in this material does not suggest secondary alteration, though wurtzite is believed to be most commonly formed as a secondary mineral.

In the upper levels of all the base-metal deposits the ores have been oxidized, but material suitable for a careful study of the oxidation products was not available. Probably the galena was largely altered to lead carbonate and perhaps to lead-antimony compounds, and the copper minerals to carbonates and possibly to more complex copper compounds.

In the quartz monzonite of the Antelope Range numerous veins are composed of finegrained cherty quartz containing some sulphide and said to contain small amounts of gold and silver. In the Bradburn tunnel a vein of this character contains epidote, garnet, 
and magnetite, in addition to sulphides, and on the dump of this tunnel were collected specimens of an aplitic rock, apparently a dike containing tourmaline, pyrite, and chalcopyrite. Though there has been considerable prospecting of the veins in the quartz monzonite of the Antelope area there has been no important production of ore.

VEINS OF IRON ORE.

Some shipments have been made from deposits of iron ore in the quartz litite body in the central part of the Antelope Range. The ore bodies occur in irregular fissures. The quartz litite in the vicinity has been highly altered, being converted to a cherty mass. This body of silicified rock has been more resistant to erosion than the surrounding rock and stands up as a hill several hundred feet high. The iron deposits are near the summit of the
The ore consists of yellow and reddish earthy hydrous oxide of iron, with some brown and black hydrous oxides of manganese and iron, and some beautifully formed stalactitic masses of limonite. The ores, as they now exist, appear to have been formed by the alteration of other minerals. In general the deposit does not differ markedly in appearance from the gossans formed by the oxidation of sulphide bodies. No remnants of sulphide were observed in the ore body, nor was sulphide noted in the adjacent wall rock. Considerable iron oxides together with other oxides were evidently removed from the monzonite during the alteration and this may have collected in the fissures and formed the bodies of iron ore.

ALUNITE VEINS.

In the area between Bullion and Little Cottonwood canyons, and south of Little Cotton-

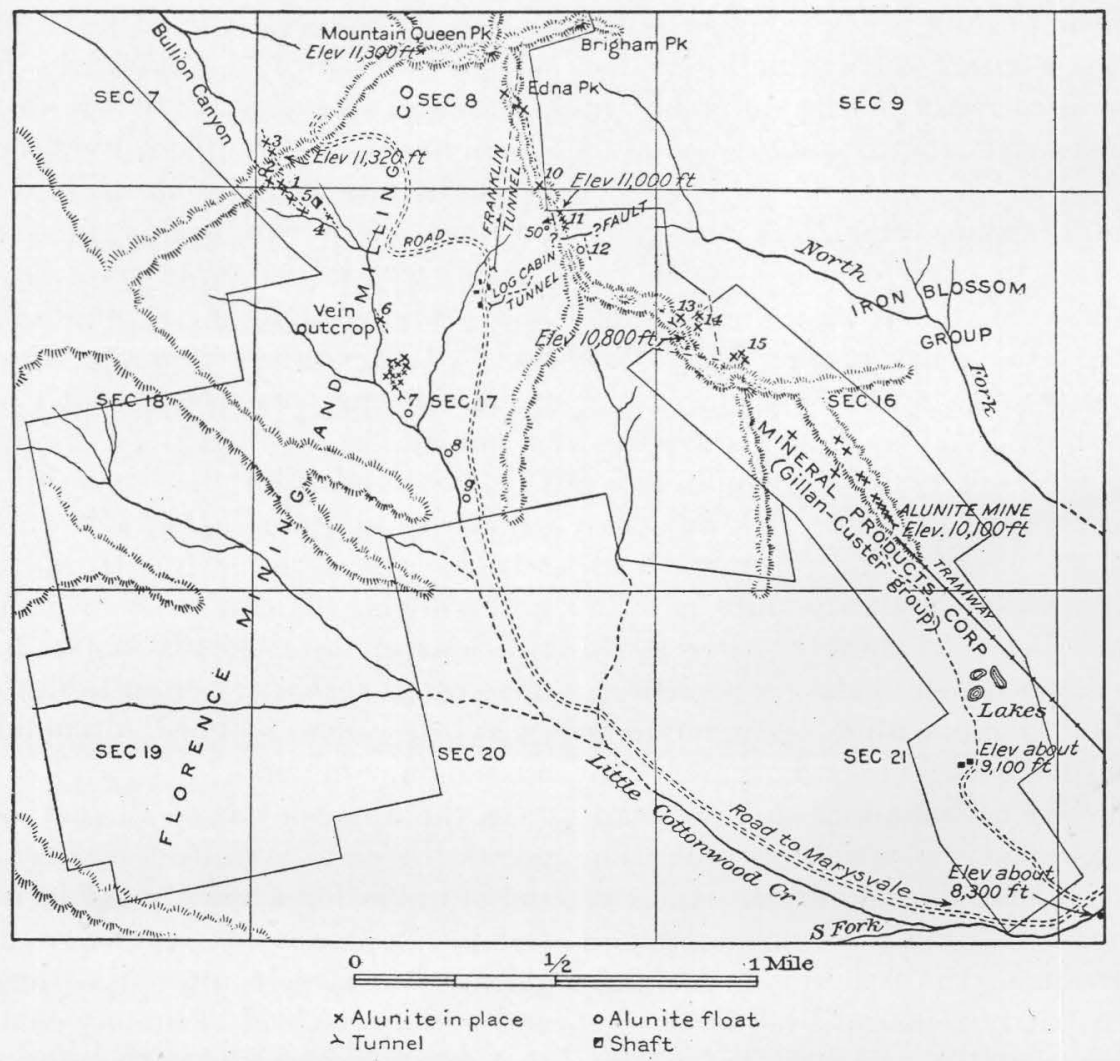

FIGURE 59.-Map showing location of prospects in the principal group of alunite deposits near Marysvale.

elevation and near the center of the area of wood Canyon, north as far as Belnap, and in the altered quartz monzonite. The silicified area area northeast and east of Marysvale there is irregular but probably exceeds a mile in has been considerable development of alunite length from north to south and is fully half a deposits during the last few years. (See fig. mile in width. The altered rock is composed 59.) The nature of these deposits was firstrecessentially of quartz with small amounts of ognized in the fall of 1910, though the veins of oxides of iron and possibly of manganese. pink spar had long been known to prospectors. 
ALTERATION OF THE COUNTRY ROCK.

The deposits occur in large veins of almost pure alunite and as partial replacements of country rock.

The wall rock has been intensely altered for many feet from the veins, giving rise to the extensive masses of the silicified rock exemplified in the Edna "geyser." In the alteration of the rock the feldspar crystals have changed to a felted mass of needle-like crystals of alunite with some kaolinite. (See Pl. XXI, B, p. 182.) The dark silicates and the magnetite have also been entirely altered, only the phenocrysts of quartz remaining practically unattacked. The altered rock is made up essentially of quartz, alunite, pyrite, and of some kaolinite, all the constituents of the original lava except silica, alumina, potassium, and iron having been removed and sulphur having been added to the alumina and potassium and iron to form alunite and pyrite. At some places the potassium has been removed from the altered rock, which consists largely of cherty quartz; at other places there has been a notable addition of potash. Large bodies of such rock contain as high as 8 . per cent of potash, while the silica content may be reduced to less than 20 per cent. The large bodies of alunitized rock near Deer Creek and those east of Sevier River are prevailingly of this replacement type, as contrasted with the veins of nearly pure alunite that occur in the higher parts of the Tushar Range southwest of Marysvale.

OCCURRENCE AND CHARACTER.

The alunite deposits that have been extensively mined occur as banded veins (see $\mathrm{Pl}$. $\mathrm{XX}, B$, p. 181) between rather definite walls, though, as already noted, alunite is an important constituent of the wall rock. It is apparent that the main veins are not replacements of the country rock, for where replacement has occurred in the wall rock of these veins the quartz phenocrysts are practically unaltered and the silica set free by the alteration of other minerals is not removed. The vein, on the other hand, is almost free from silica. In some portions of the vein the material is coarsely crystalline, the crystals having a tabular form and in places extending across a

\footnotetext{
${ }^{1}$ Butler, B. S., and Gale, H. S., Alunite-a newly discovered deposit
} near Marysvale, Utah: U. S. Geol. Survey Bull. 511, p. 20, 1912. layer of the banding. Commonly the crystals tend to diverge from a center of tufts, this being more noticeable under the microscope than in the hand specimen. The rhombohedral faces of the crystals are not usually well developed, but in many places an open cavity between two bands shows well-developed rhombohedral faces, which, however, have commonly been somewhat etched by later solution. What in the hand specimen appear to be crystals are seen under the microscope to be composed of numerous smaller crystals diverging from a central axis, forming a very striking plumose structure. The difference in orientation of these component parts of the "crystal" group gives it a wavy extinction between crossed nicols.

The lines marking the separation of the bands forming the vein are seen under the microscope to consist of narrow bands of finely crystalline material of various orientations. The larger "crystals," however, cross these lines without change in orientation, suggesting that the fine material has been deposited in a fissure breaking across the crystals. Probably there was a slight change in conditions of depesition, after which some of the crystals continued their growth and others began to form from new centers.

In other parts of the vein the alunite is finer grained and locally lighter in color. In some places it is very dense and breaks with a conchoidal fracture; in others, where there has been some movement, it is schistose and shows numerous slickensided faces. Under the microscope the finely grained material is seen to be a granular mass of irregular crystals of alunite. Associated with these in the section examined is a mineral with lower index and having the general characters of kaolinite. Chemical analysis indicates that both kaolinite and some quartz are present as impurities in the alunite. Through this fine-grained material are scattered veinlets half an inch or more in thickness of more coarsely crystalline alunite. Loughlin ${ }^{2}$ considers that the alunite in these veinlets has resulted from the recrystallization of the fine material which incloses them.

The deposits near Deer Creek and east of Sevier River are largely the result of replacement of the volcanic rocks, as contrasted with distinct veins. The more completely replaced rock is a dense fine-grained brittle material

${ }^{2}$ Loughlin, G. F., Recent alunite developments near Marysvale and Beaver, Utah: U. S. Geol. Survey Bull. 620, p. 244, 1915. 
breaking with shelly fracture and having somewhat the appearance of porcelain. Locally it is rather soft and chalky and grades from slightly altered lavas to rock composed largely of alunite. Large bodies of the alunite rock are found in the district, but up to the present time little potash has been produced from them.

The following description of the character of the deposit is taken from Loughlin's report. ${ }^{1}$ Those desiring a more detailed description are recommended to that report and an earlier one by the writer and H.S. Gale. ${ }^{2}$

All the deposits thus far found are doubtless veins cutting porphyry (altered dacite), though in only a few exposures have their true thicknesses and exact trends been determined. The alignment of prospect pits and trenches and the distribution of float, however, indicate for the most part trends of N. $20^{\circ}-40^{\circ} \mathrm{W}$., though at a few openings the trend is nearly due north. The dips of the different veins are for the most part $50^{\circ}-70^{\circ} \mathrm{W}$., but vertical dips have been noted at a few places and a steep easterly dip was recorded at one obscure exposure. None of the veins have been opened continuously along their strike, but the alignment of openings indicates probable lengths of 500 to 800 feet for continuous veins and of 1,500 to 5,000 feet for vein zones. The widths of the veins or vein zones are considerable, but the prospect trenches on all but the Custer vein did not, as a rule, afford a satisfactory estimate of the width or thickness. The Custer vein contains an average thickness of about 10 feet of high-grade alunite, on each side of which smaller veins or bands of alunite alternate with similar thicknesses of quartz or highly silicified porphyry.

The best exposure in the western zone is on the L. \& N. No. 4 claim and shows an exposed thickness of 26 feet, of which $20 \frac{1}{2}$ feet is high-grade alunite and $5 \frac{1}{2}$ feet quartz. Other openings show thicknesses of 8 to 20 feet. The veins are distinctly banded, bands of nearly pure alunite alternating with bands of quartz. The alunite portions themselves are for the most part banded by parallel to concentric markings similar to those in travertine, or "onyx marble," and characteristic of open fissure fillings, but have also been found in some degree by replacement. The general distribution of the veins is indicated on the surface by elongate to irregular areas of silicification, many of which appear to have determined the positions of ridges and prominent peaks through their superior resistance to erosion.

Three varieties of alunite have been noted in the veinscoarsely crystalline, fine grained to dense, and laminated. The coarsely crystalline variety is by far the most common. It is pink to reddish and forms large masses of columnar to platy crystals as well as small veinlets that cut the other two varieties. It is practically pure but contains minute quantities of pyrite or limonite and silica (chalcedony and opal). It is most readily recognized in the field by these properties, together with its high specific gravity (about 2.82 ), which is distinctly higher than that of calcite (2.71);

1 Loughlin, G. F., op. cit., p. 241.

2 Butler, B. S., and Gale, H. S., Alunite, a newly discovered deposit near Marysvale, Utah: U. S. Geol. Survey Bull. 511, p. 7, 1912. the only mineral in the region that is likely to resemble it in crystalline form.

The fine-grained variety is pink to white and resembles porcelain where hard and chalk where softened by weathering. Under the microscope some specimens are seen to consist almost entirely of minute crystals of alunite with only an apparently negligible amount of pyrite, silica, and kaolin; but in other specimens these impurities are more conspicuous. The fine-grained variety may resemble kaolin, or miner's "talc," especially if enough kaolin is present to yield its characteristic odor; but the finegrained alunite, like the coarse-grained variety, may be recognized by its high specific gravity.

The laminated or shaly variety differs from the finegrained variety only in its structure, which is evidently due to shearing along the plane of the vein. Such a structure could have been developed in either of the other varieties.

CHEMICAL COMPOSITION.

The following analyses of Marysvale alunite, which are all at present available, show the character of the coarsely crystalline and dense white varieties:

Analyses of alunite from Marysvale region, Utah.

Crude alunite from Custer group. $a$

\begin{tabular}{|c|c|c|c|}
\hline & 1 & 2 & 3 \\
\hline 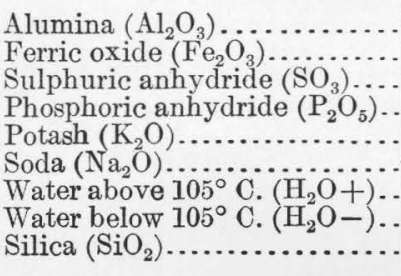 & $\begin{array}{r}37.18 \\
\text { Trace. } \\
38.34 \\
.58 \\
10.46 \\
.33 \\
12.90 \\
.09 \\
.22\end{array}$ & $\begin{array}{r}34.0 \\
\text { Trace. } \\
36.54 \\
.50 \\
9.71 \\
.56 \\
13.08 \\
.11 \\
5.28 \\
\end{array}$ & $\begin{array}{r}37.0 \\
38.6 \\
\cdots \cdots . . \\
11.4 \\
\cdots \cdots \\
\cdots \cdots\end{array}$ \\
\hline & 100.10 & 100. 18 & 100.0 \\
\hline
\end{tabular}

$a$ Copied from U. S. Geol. Survey Bull. 511, p. 8, 1912.

1. Selected specimen of a clear pink, subtransparent, coarsely granular crystalline alunite. Supposedly best material. W. T. Schaller, analyst.

2. Selected specimen of a light-pink, very finely granular rock, of almost porcelain-like conchoidal fracture and no distinct structure. W. T. Schaller, analyst.

3. Theoretical composition according to Dana, Textbook of mineralogy, 1900 edition, p. 537 .

Coarsely crystalline alunite from Florence Mining \& Milling Co.'s claims.

\begin{tabular}{|c|c|c|}
\hline & 4 & 5 \\
\hline Loss on ignition.... & 42.8 & 42.1 \\
\hline Insoluble residue (alumina with per- & 39.3 & 37.6 \\
\hline Potassium sulphate $\left(\mathrm{K}_{2} \mathrm{SO}_{4}\right) \ldots \ldots \ldots \ldots$ & 16. 8 & 18.5 \\
\hline Equivalent potash $\left(\mathrm{K}_{2} \mathrm{O}\right) \ldots \ldots \ldots \ldots$ & & \\
\hline
\end{tabular}

4. 1,000-pound sample from Sunshine Fraction claim. 5. 1,000-pound sample from North Fork claim. 
Calcined alunite.

[Said to represent the average of the coarsely crystalline alunite used in analyses 4 and 5 . Determined by fusion with sodium carbonate.]

\begin{tabular}{|c|c|c|}
\hline & $4 a$ & $5 \mathrm{a}$ \\
\hline \multirow[t]{2}{*}{$\begin{array}{l}\text { Silica }\left(\mathrm{SiO}_{2}\right) \\
\text { Alumina }\left(\mathrm{Al}_{2} \mathrm{O}_{3}\right) \\
\text { Ferric oxide }\left(\mathrm{Fe}_{2} \mathrm{O}_{3}\right) \\
\text { Sulphuric anhydride }\left(\mathrm{SO}_{3}\right) \cdots \cdots \\
\text { Potassa }\left(\mathrm{K}_{2} \mathrm{O}\right) \ldots \ldots \ldots \ldots \\
\text { Lime }(\mathrm{CaO}) \\
\text { Magnesia }(\mathrm{MgO})\end{array}$} & $\begin{array}{l}0.03 \\
61.1 \\
1.6 \\
19.0 \\
17.2 \\
\text { None. } \\
.29\end{array}$ & $\begin{array}{r}0.72 \\
61.1 \\
1.1 \\
18.1 \\
18.6 \\
\text { None. } \\
\quad .31\end{array}$ \\
\hline & 99.22 & 99.93 \\
\hline
\end{tabular}

[The same material determined by leaching.]

\begin{tabular}{|c|c|c|}
\hline . & $4 b$ & $5 b$ \\
\hline $\begin{array}{l}\text { Insoluble residue. } \ldots \ldots \ldots \ldots \\
\text { Potassium sulphate }\left(\mathrm{K}_{2} \mathrm{SO}_{4}\right) \ldots \ldots \ldots \ldots \\
\text { Aluminum sulphate }\left(\mathrm{Al}_{2}\left(\mathrm{SO}_{4}\right)_{3}\right) \ldots \ldots \ldots\end{array}$ & $\begin{array}{r}61.8 \\
32.6 \\
\text { 4. } 4\end{array}$ & $\begin{array}{r}62.2 \\
32.0 \\
5.0\end{array}$ \\
\hline & 98.8 & 99.2 \\
\hline
\end{tabular}

4 and $5,4 \mathrm{a}$ and $5 \mathrm{a}, 4 \mathrm{~b}$ and $5 \mathrm{~b}$. Made by Solvay Process Co. for Florence Mining \& Milling Co.

The following description of the occurrence of alunite at Sheep Rock is abstracted from the paper by Mr. Loughlin: ${ }^{1}$

$$
\text { SHEEP ROCK DEPOSIT. }
$$

The Sheep Rock deposit is a quartz-alunite rock of too low grade to be of immediate commercial importance as a source of alunite but of considerable scientific interest.

Sheep Rock is in the Newton mining district, at the west base of the Tushar Mountains, about 10 miles northeast of Beaver. (See fig. 60.) It is a bare-topped nearly circular ledge about 900 feet in diameter, with a gently rounded summit of nearly white quartzalunite rock, in part weathered into clusters of rounded residual boulders, which when seen from a distance bear a striking resemblance to a flock of sheep.

The relations of the deposit to the andesitic country rock are very obscure. Its west, south, and north sides are covered with talus and brush and pass beneath the alluvium of the valley; and the saddle connecting it with the andesite foothills is covered with float.

\footnotetext{
1 Loughlin, G. F., op. cit., pp. 258-264.
}

The float, however, shows that the two rocks merge within a short space, and that the Sheep Rock deposit was formed by the replacement of andesite. No definite connection with neighboring metalliferous quartz veins is apparent on the surface, and none has been made in the underground.workings of the mine.

The material of the deposit as a whole is of uniform character, light-gray to pinkish color, and very fine grained, banded texture, which, however, includes brecciated and concretionary phases and rock in which the porphyritic texture of the andesite is preserved. The alunite content also shows variations ranging from 10 per cent or less up to 60 per cent, but as a whole appears to be rather uniform and to average about 30 per cent, equivalent to 3.5 per cent of potash $\left(\mathrm{K}_{2} \mathrm{O}\right)$.

The three following partial analyses of the quartz-alunite rock, two of average samples and one the high-grade variety, were made by R. K. Bailey, of the United States Geological Survey:

Analyses of quartz-alunite rock from Sheep Rock deposit.

\begin{tabular}{|c|c|c|c|}
\hline & 1 & 2 & 3 \\
\hline $\begin{array}{l}\text { Silica }\left(\mathrm{SiO}_{2}\right) \\
\text { Sulphate radicle }\left(\mathrm{SO}_{3}\right) \ldots \ldots \ldots \ldots \\
\text { Potash }\left(\mathrm{K}_{2} \mathrm{O}\right) \ldots \ldots \ldots \ldots \ldots \ldots \ldots\end{array}$ & $\begin{array}{r}60.83 \\
13.83 \\
3.89\end{array}$ & $\begin{array}{r}70.78 \\
10.56 \\
2.90\end{array}$ & $\begin{array}{r}30.12 \\
26.53 \\
6.87\end{array}$ \\
\hline
\end{tabular}

1. Average sample at summit of Sheep Rock.

2. Average sample around stake No. 2 (fig. 60).

3. High-grade sample, north slope of Sheep Rock.

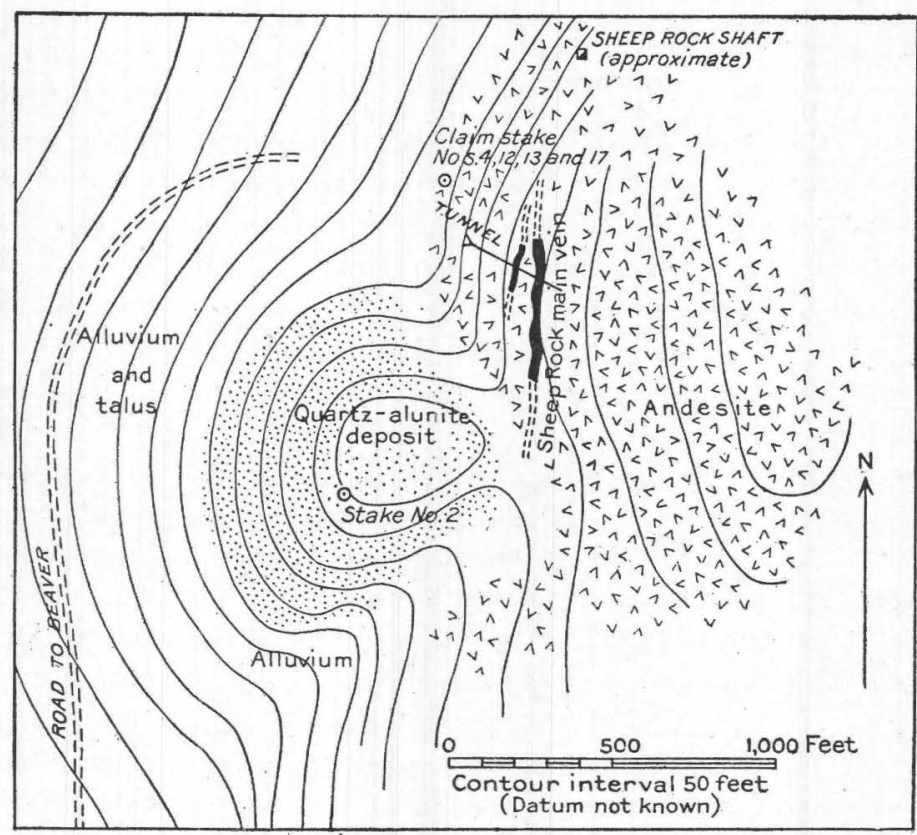

FIGURE 60.-Geologic sketch map showing relation of Sheep Rock quartz-alunite deposit to country rock and metalliferous veins. 
In analysis 1 the ratio of the sulphate radicle to potash is almost exactly that of pure potash alunite. Calculation from these data gives over 13 per cent of alumina and 35.6 per cent of alunite. In analysis 2 the excess of 0.6 per cent of the sulphate radicle over the ratio between the sulphate radicle and potash for alunite is 0.6 per cent, a small excess which may have been present in the soda alunite molecule. The calculated percentage of alumina is only 9.5 per cent and of alunite 25.7 per cent. In analysis 3 the excess of the sulphate radicle is 3.2 per cent, which also may have been present in soda alunite. The calculated percentage of alumina in No. 3 is 22.3 per cent and that of alunite 60.3 per cent.

Since the examination by $\mathrm{Mr}$. Loughlin alunite deposits have been reported from east of the Deertrail mine, north of Marysvale, and in the Antelope Range.

\section{REPLACEMENT DEPOSITS.}

Replacement deposits comprise those formed chiefly by replacement of rock adjacent to fissures as contrasted with the vein deposits, which were formed chiefly as a filling of open fissures. There are gradations between these classes, as exemplified in the Bully Boy and Webster mines, but most deposits distinctly belong to one or the other.

The only distinctive replacement deposits of known importance are the Deertrail lead-silvergold deposit and the Lucky Boy quicksilver deposit.

\section{DEERTRAIL MINE.}

In the vicinity of the Deertrail mine the rocks are mainly the Jurassic quartzites overlain by 500 to 600 feet of limestone containing beds of shaly and quartzitic material. Within the workings of the Deertrail mine several small dikes of a highly altered lamprophyric rock carry abundant remnants of diopside and biotite.

Considerable faulting has occurred in the vicinity of the mine. The exact position of the great north-south fault that determined the front of the range is not known, but it can not be far to the east. In the gulch north of the mine the limestone and quartzites on the south abut against red shales and sandstones to the north along a fault striking west of north. East-west faulting has apparently shattered the rocks in the gulch. In the lower tunnel of the mine a north-south fault of unknown throw is exposed. There has also been some movement along some east-west fissures.

The general dip of the formations is $10^{\circ}-15^{\circ}$ W. In the Deertrail workings the attitude of the beds varies considerably from place to place on account of local disturbances. The ore is a blanket deposit that has replaced the limestone immediately above the quartzite and probably to some extent the quartzite itself. The replacement appears to be associated with east-west fissures. At several points the principal replacement has taken place at two horizons separated by 20 to 25 feet of relatively unaltered rock.

The character of the ore varies considerably. The most abundant gangue is a white micaceous aggregate composed largely of sericitic muscovite, in most places friable and capable of being readily crushed in the hand. Where the limestone has not been so fully replaced, however, the aggregate is rather compact. A partial analysis by W. T. Schaller gives the following result:

Analysis of sericitic muscovite gangue.

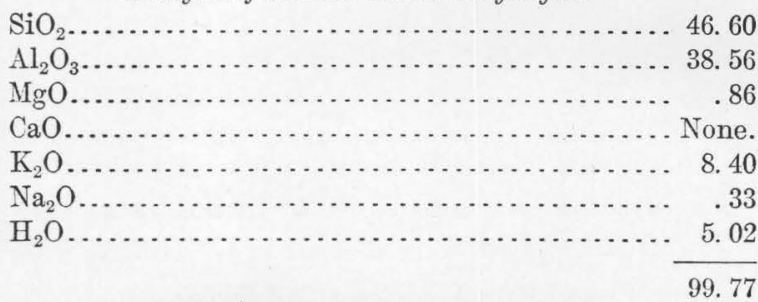

This analysis corresponds to about 75 per cent of muscovite containing a small amount of the paragonite molecule and about 25 per cent of a mineral approaching kaolinite in composition. In the southern portion of the property especially there is considerable coarse crystalline vein quartz. In panning the sericitic material it is seen to contain considerabje zircon in rounded crystals and numerous black crystals of titanium oxide, probably octahedrite. Galena and pyrite and a small amount of copper sulphide were apparently the principal primary sulphides. The suiphides are largely oxidized and but little primary sulphide wasseen (1912). That observed was in the margin of the deposit where, with a relatively small amount of sericitic muscovite, it replaced recrystallized limestone. The sulphides were altered to oxides, carbonates, and sulphates. D. B. Huntley ${ }^{1}$ says: "The ore is a soft, friable,

1 Tenth Censu s U. S., vol. 13, p. 463, 188.5. 
greenish-yellow ocher, containing the products from the oxidation of lead, iron, and copper sulphides. It assays about $\$ 8$ gold, $\$ 150$ silver, and 35 per cent lead."

According to a statement by G. T. Henry, the ores shipped from the mine amounted to about 350 tons, averaging about 1 ounce gold and nearly 100 ounces silver per ton and about 50 per cent lead. The lead was probably largely in the form of the carbonate and sulphate, though on the old dump specimens of plumbojarosite were collected, and Huntley's description suggests that it may have been an important ore mineral. Jarosite in considerable amount is also associated with the "talcose" ores. Hydrous oxide of iron and some manganese are present in all parts of the mine. Mr. Henry states that the sericitic ore contained small amounts of quicksilver.

Sufficiently rich material to determine in what form the gold and silver occur was not obtained. Panning of the sericitic ore did not yield colors of free gold. Mr. Henry states that in the early eighties between 6,000 and 7,000 tons of ore from the Green-eyed Monster (one of the claims of the group) was milled. The general average assay value was about $\$ 15$ gold and 10 to 12 ounces silver per ton, but the sericitic character of the ore prevented the recovery of much more than 60 per cent of the assay content. It seems probable that the gold, in part at least, is finely divided free gold. LUCKY BOY PROSPECT.

The quicksilver deposit of the Lucky Boy mine has been described by H. D. McCaskey ${ }^{1}$ as follows:

The Lucky Boy quicksilver prospect was briefly described as follows by J. E. Clayton, president of the Salt Lake Mining Institute, in a letter to G. J. Brush, of the Sheffield Scientific School, dated October 6, 1884: ${ }^{2}$

The mine is situated about 5 miles southwest of Marysvale, 200 miles south of Salt Lake City. It is on the east face of a mountain slope and near a profound fault extending north and south. To the east are eruptive rocks, including porphyry and trachyte. Underlying the ore beds to the west is quartzite of unknown thickness, over this about 400 feet of gray limestone, and in contact between these the Deertrail vein is situated, carrying gold, silver, lead, and a little copper. In the upper portions of the limestone the selenide of mercury is found in a bed of

1 MeCaskey, H. D., U. S. Geol. Survey Mineral Resources, 1911, pt. 1, p. $914,1912$.

2 Penfield, S. L., Crystallized tiemannite and metacinnabarite: Am. Jour. Sci., 3d ser., vol. 29, p. 454, 1885. shaly limestone 15 to 20 feet thick. The vein has been traced north and south about 100 feet along the outcrop and dips into the mountain at an angle of about $15^{\circ}$ below the horizon. The ore occurs in masses intermixed with the shaly limestone, crystals being very rare. The accompanying minerals are barite, oxide of manganese, quartz, and calcite. The ore bed is overlain by a yellowish sandy lime shale carrying sub-Carboniferous fossils.

The locality was visited by the writer in 1910. *** The workings of the Lucky Boy mine just north of Cottonwood Canyon form a bowl-shaped open cut about 100 feet in diameter and 60 feet deep, a drift to the west about 80 feet into the mountain following the gently dipping bediding planes, a tortuous winze from the face of the drift turning back and coming out on the mountain side about 50 feet below the open cut, and a shaft at the bottom of the open cut, now filled with broken rock, reported to have been sunk about 40 feet on a north-south narrow nearly vertical vein carrying barite and some cinnabar. The cinnabar ore, it seems, was of low grade, and the commercial ore was mainly of onofrite and to a smaller degree of tiemannite, the sulphoselenide and the selenide of mercury, which were found in a deposit from 2 to 8 inches thick, following the bedding planes and impregnating the impure dark-gray limestone. Tiemannite was reported also from the barite vein, and the fissure here may have been the channel for the ore solutions. The intersection of this fissure with the bedding vein would be about where the open cut now is, and indeed much of the original deposit has probably been eroded away. The deposit was evidently superficial, for the life of the operations was short, the total output small, and it is now difficult to find even samples of ore in the workings. The occurrence is of especial interest as being the only deposit of the selenides of mercury in the country ever worked on a commercial scale, however small. The reduction was by two retorts operated in Cottonwood Canyon to the south of the mine. In the Deertrail gold mine, several hundred feet vertically below the Lucky Boy, and along the gently westward-dipping bedding planes at the quartzite and limestone boundary, cinnabar with pyrite was reported in a small lens. The deposition of quicksilver minerals in both properties may have been due to solutions arising through the same vertical north-south fissures thought to extend parallel to the great Sevier 
fault, and may have been localized by transverse fissures similar to those known elsewhere in the district.

McCaskey ${ }^{1}$ estimates the production of mercury from the mine as 213 flasks, valued at $\$ 8,308$.

RELATIONS OF THE DIFFERENT DEPOSITS.

No facts have been observed that indicate more than one period of mineralization in the region, and certain resemblances between the several types of deposit suggest that they had a common origin. The gradation from veins in which lead, copper, and zinc are important constituents to those in which gold and silver are of chief importance leaves no doubt of the close relation and common origin of these two types of deposit.

The relations of the replacement deposits, as the Deertrail and Lucky Boy, are not so clearly indicated. These two deposits apparently are related in origin, for mercury, which is the principal metal of the Lucky Boy, is also present in the Deertrail. The Deertrail ore, like that of most of the veins, runs high in silver and gold as compared with base metals; much of it, indeed, is valuable solely for its precious metals. In the Lucky Boy mine the mercury is present as the selenide and sulphoselenide, and the gold ores contain both selenium and tellurium. The presence of the relatively rare element selenium in both types of deposit suggests a close relationship, as does also the presence of mercury in both.

The alunite veins differ markedly from the others but are still believed to be genetically related. The striking difference is in the absence of metallic sulphides in the alunite veins. Pyrite is present in the altered wall rock, but this has evidently been formed from iron already present, and no other metal except aluminum has been added. The resemblances are the presence of sulphates in both the alunite veins and in the metal deposits (in the latter in the form of barite). Perhaps the most striking resemblance is in the presence of potassium-aluminum minerals in all the deposits - in the Deertrail ore in large amount as muscovite, in the gold-silver veins as adularia (locally rather abundant), and in the alunite veins as hydrous potassium-aluminum sulphate.

1 Op. cit., p. 914.

\section{CONDITIONS OF DEPOSITION.}

The composition of the veins and the general relations indicate that they are related in origin, but the wide difference in their minerals suggests that they must have formed under different conditions. That different minerals were deposited at slightly different times during the period of mineralization is indicated by the replacement of carbonates and barite by quartz and adularia. That they were deposited under different conditions is amply shown by the presence of magnetite and garnet, minerals generally recognized as forming under conditions of considerable heat and pressure, in some veins in the intrusive rock of the Antelope Range, while in other deposits are mercury and selenium minerals, adularia and alunite, which are regarded as forming under conditions of relatively low temperature and pressure.

These facts might be explained by the following order of events: (1) Successive beds of lava and tuff were ejected, with intervening periods of quiescence, during which the lavas lost most of their heat; (2) monzonitic masses were intruded with dikes extending into the lavas and more or less fissuring of the intruded rock; (3) the outer portions of these intrusive masses crystallized and in the readjustment due to cooling and possibly to other forces both the recently intruded rock and the overlying flows were further fissured; (4) along these fissures rose heated solutions, which within the intrusive mass were highly heated, and deposited minerals characteristic of this condition, but which as they passed into the cooler overlying rocks were subjected to reduced temperature and pressure, and this condition was recorded in the character of the deposits. The solutions seemingly underwent a progressive change in composition, depositing first abundant carbonates, later quartz and adularia, and finally sulphates.

The fact that the base metals occur most abundantly in close association with sedimentary rocks suggests that the sedimentary rocks may have precipitated the metals from the solutions. It is also noteworthy that the largest deposits, both of the quartz-adularia gold-silver and of the alunite, are at considerably higher elevations than the main deposits of base metals and are therefore considerably nearer the original surface, which may have been an important factor in determining the difference in character. 
SOURCE OF MINERALIZING SOLUTIONS.

The origin of the solutions that formed the deposits can not be positively determined, but the most likely source seems to be the water given off by the crystallization of the magma that formed the intrusive body which underlies the lavas.

In this district, as in others where similar deposits have been studied, it is apparent that potassium and aluminum minerals were more abundantly deposited in the later stages of mineralization-either the solutions became richer in potassium and aluminum or the conditions for deposition of these elements became more favorable. The relative physical conditions under which the quartz-adularia veins and the alunite were deposited are not perfectly clear, but it seems highly probable that the alunite veins were deposited at lower temperature and pressure than the quartz-adularia veins, and that they represent a later stage, when the composition of the solutions had undergone a change. The relative rarity of alunite deposits may be due to the fact that they form near the surface and consequently have only in a few places been preserved. It is evident that when the alunite was formed the solutions were rich in sulphate, and if it was deposited later than the carbonate and quartzadularia veins, as seems probable, it is to be expected that in places it will be found superimposed on the quartz-adularia, as the quartzadularia is superimposed on the earlier carbonate veins.

The source of the potassium and aluminum has not been positively determined. In general, however, the potash contained in alunite is thought to have been derived from the alteration of the feldspar of the rock in which the deposits occur. In part, such an origin can be confidently stated for the alunite of the Marysvale deposit, but that it holds true for the main vein is not evident.

The characteristic alteration of the wall rock of veins of this type consists in a progressive leaching of the elements, potassium and aluminum being the latest, except silica, to be removed, but in some places these also have been leached out. In the wall rock of the alunite vein near Marysvale, however, the alunite appears to be sufficiently abundant to account for a large part of the potassium of the original rock, and therefore the rock immediately adjacent to the vein can not be considered as furnishing all the potassium for the vein by lateral secretion. In some of the other veins, however, practically all constituents except silica and iron have been removed and have not been deposited near by. This permits the interpretation that a part at least of the potassium and aluminum content of the vein may have been derived from the wall rock at greater depth where conditions were favorable for solution, the enriched solutions, rising into cooler zones, having redeposited these elements. If this is true one might expect that if the vein could be traced to the original surface the alunite deposits would gradually merge into those carrying other salts that were precipitated at still lower temperaturesif, indeed, alunite did not extend to the surface while more soluble salts were carried out on the surface in solution-and that on the other hand with increasing depth a zone would be reached that was not favorable to the deposition of alunite.

That the potassium and aluminum in the veins of this district were introduced by the solutions and were not derived directly from the wall rock is further indicated by the high potassium and aluminum content (as muscovite) of the Deertrail ores; these occur in quartzite and limestone, which do not contain notable amounts of potassium or aluminum, and consequently both of these elements must have been introduced. There seems no reasonable doubt that the mineral content of the veins, for the most part at least, was introduced by deep-seated solutions.

In this respect the evidence in the Marysvale region agrees with that in other districts of the West where similar Tertiary veins occur. Lindgren ${ }^{1}$ has called attention to the similarity of the deposits in the northern part of the range to those of De Lamar, Idaho, and further similarities are shown by the sericitic ores of the Deertrail mine, which seem to resemble closely some of the "talcose" ores of the Idaho deposits that carry as high as 12.91 per cent ${ }^{2}$ of potassa $\left(\mathrm{K}_{2} \mathrm{O}\right)$. Lindgren concludes ${ }^{3}$ that the main content of the Idaho

1 Lindgren, Waldemar, The Annie Laurie mine, Piute County, Utah: U. S. Geol. Survey Bull. 285, p. 90, 1906.

2 Lindgren, Waldemar, The gold and silver veins of Silver City, De Lamar, and other mining distriets in Idaho: U. S. Geol. Survey Twentieth Ann. Rept., pt. 3, p. 171, 1900.

3 Idem, p. 166. 
veins was brought up from depth by thermal waters, and that the removal of alumina from the wall rock indicates the presence of sulphuric acid in the waters, though sulphates do not seem to have been deposited, or if deposited have not been preserved. Spurr ${ }^{1}$ has concluded that the veins in the Tonopah district, Nev., which contain notable amounts of potassa in the form of adularia and in many respects resemble the adularia veins in the Marysvale district, derived their mineral content from heated waters given off by crystallizing magmas.

Schrader ${ }^{2}$ has described similar deposits in the Black Mountains, Mohave County, Ariz., containing notable amounts of potassa in the form of adularia, and attributes their origin to hot waters ascending through the lavas at the close of igneous activity.

Schrader ${ }^{3}$ has also described very similar deposits in the Jarbidge district, Elko County, Nev., which contain as high as 11.84 per cent of potassa $\left(\mathrm{K}_{2} \mathrm{O}\right)$ in the form of adularia. $\mathrm{He}$ concludes that the veins were formed by ascending thermal solutions rich in silica, aluminum, and potassium.

Similar veins in New Mexico have been attributed by Lindgren, Graton, and Gordon ${ }^{4}$ to ascending thermal waters, and a similar origin has been stated by Umpleby ${ }^{5}$ for veins carrying some adularia in the Republic district, Wash. The writer believes that the deposits in the Gold Springs and State Line districts, Utah, and in the adjacent Fay district, $\mathrm{Nev}$., are to be attributed to a similar origin.

Opinion appears to be uniform, therefore, that the veins carrying adularia were deposited by ascending thermal waters rich in silica, alumina, and potassa. Nowhere, however, outsite of the Marysvale district have important alunite deposits associated with the adularia veins been recognized.

Of the alunite deposits of which detailed descriptions are available the one that shows

\footnotetext{
1 Spurr, J. E., Geology of the Tonopah mining district, Nev.: U. S. Geol. Survey Prof. Paper 42, p. 262, 1905.

2 Schrader, F. C., Mineral deposits in the Cerbat Range, Black Mountains, and Grand Wash Cliffs, Mohave County, Ariz.: U. S. Geol. Survey Bull. 397, p. 48, 1909.

${ }^{3}$ Schrader, F. C., A reconnaissance of the Jarbidge, Contact, and Elk Mountain mining districts, Elko County, Nev.: U. S. Geol. Survey Bull. 497, p. 53, 1912.

'Lindgren, Waldemar, Graton, L. C., and Gordon, C. H., The ore deposits of New Mexico: U. S. Geol. Survey Prof. Paper 68, p. 71, 1910. 5 Umpleby, J. B., Geology and ore deposits of the Republic mining district: Washington Geol. Survey Bull. 1, p. 42, 1910.
}

the closest relation to the type under discussion is that at Goldfield, Nev., where alunite occurs as an important primary gangue mineral of gold deposits.

Ransome ${ }^{6}$ considers the alunite at Goldfield to have been formed by solutions of deepseated origin charged with hydrogen sulphide that rose to the surface of the earth, where the hydrogen sulphide was oxidized to sulphuric acid. The acidic solution percolated downward and in a heated zone reacted with potassium-aluminum silicates to form alunite.

Larsen ${ }^{7}$ has described the occurrence of alunite in the San Cristobal quadrangle, Colo., and also of the allied mineral hinsdalite $(2 \mathrm{PbO}$. $3 \mathrm{Al}_{2} \mathrm{O}_{3} \cdot 2 \mathrm{SO}_{3} \cdot \mathrm{P}_{2} \mathrm{O}_{3} \cdot 6 \mathrm{H}_{2} \mathrm{O}$ ), which is associated with metal sulphides. Larsen says: "The field relations point strongly to deep-seated hot sulphuric-acid solutions without the aid of surface agents." Larsen, however, suggests the possibility of the mineral having formed in a manner similar to that described by Ransome for Goldfield.

The alunite deposits in the Marysvale district are believed to have formed near the surface, and it is possible that the sulphate may have been formed by the oxidation of hydrogen sulphide, but this must have occurred by the mingling of solutions at considerable depth.

For further discussion see page 184.

\section{GOLD MOUNTAIN DISTRICT.}

By B. S. Butler.

The Gold Mountain district has been by far the most productive in the range. The output, which has been entirely of precious metals, has been principally from the Annie Laurie and Sevier mines.

Annie Laurie mine.-The Annie Laurie mine has been operated very little for several years, and most of its workings were in-. accessible at the time of visit. Lindgren, ${ }^{8}$. who visited the mine in 1904, when it was in operation, describes it as follows:

The deposits occur in well-defined quartz veins cutting through the core of this old volcanic district. As far as known, no deposits occur in the rhyolite or in the great masses of rhyolite tuffs to the north of the Annie Laurie. They are confined to the dacite already mentioned as occurring near the mines. The Annie Laurie vein

6 Ransome, F. L., Geology and ore deposits of Goldfield, Nev.: U. S. Geol. Survey Prof. Paper 66, pp. 189-195, 1909

7 Larsen, E. S., Alunite in the San Cristobal quadrangle, Colo.: U. S. Geol. Survey Bull. 530, p. 179, 1911.

8 Lindgren, Waldemar, The Annie Laurie mine, Piute County, Utah: U. S. Geol. Survey Bull. 285, pp. 87-90, 1906. 
courses nearly north and south and dips from $45^{\circ}$ to $60^{\circ}$ $\mathrm{W}$. About a mile to the west is a parallel vein called the Sevier, on which the Sevier Mining Co. is now erecting a mill. The extension of the Sevier toward the north is being sought for in the Holland tunnel.

The Annie Laurie vein is very poorly exposed on the surface, being largely covered by morainal material. There is, however, a large outcrop rising boldly above the Blue Bird tunnel, and this formed the point of discovery. The vein has not been found on the surface at any point north of this. Within a moderate distance north from the northernmost workings the Annie Laurie vein should enter the rhyolite. How this will affect the deposit is as yet problematical. On the surface none of the productive veins appear to occur in this rock.

The quartz forms an almost continuous sheet along the vein, rarely less than 3 feet in thickness and often expanding to a width of 20 feet or more. As a rule the walls are poorly defined and slickensides indicating motion are rare. In places it contains, parallel to the walls, streaks of iron oxides and black, sooty, manganese ores. Near the walls the vein very commonly shows brecciation, and the quartz here often contains abundant and sharply defined inclusions of country rock. While it is almost impossible to obtain fresh rock at any place in the mine, and chloritization as well as carbonatization have frequently occurred, the rock is not changed very much in appearance, and the included greenish fragments are sharply outlined against the white quartz.

The mine workings have not penetrated below the zone of oxidation, and neither the quartz nor the country rock seem to contain any unoxidized sulphides. In only one place, in the crosscut of the lowest tunnel, was some fresher dacite found which contained specks of pyrite.

In addition to the regular vein, which is often referred to as the East vein, there is also in certain parts of the workings a smaller fissure which lies a short distance to the west and which differs in some respects from the former. Its quartz contains more gold, its vein is narrower, and slickensides appear sometimes on the walls. It is principally known from No. 3 tunnel, in the richest part of the vein.

Two faults with a throw of 20 and 40 feet are known on the Blue Bird and No. 4 levels, but on the whole the vein is little disturbed.

The ore consists of a white, normal vein quartz, often very friable, breaking easily into small fragments. It is sometimes drusy but more commonly massive. Calcite is abundant in certain parts of the deposit but has often been dissolved by surface waters, leaving a hackly or lamellar quartz of striking appearance. As a rule no ore minerals are visible, although on panning the quartz may yield a little visible gold.

The pyrite which the ore contained is doubtless converted to limonite, while the decomposition of the carbonates has resulted in the formation of oxides of manganese as well as more limonite. A slight copper stain appears in places, especially where the ore is rich. Finely divided argentite is no doubt present, but only in small quantities. On concentration the ore yields a very small quantity of sulphides, which are extremely rich in silver.

The value of the gold in the ore exceeds that of the silver. Samples of ore of the East vein yield, for instance, gold, $\$ 12$; silver, $\$ 2.30$; or gold, $\$ 5.60$; silver, $\$ 2.05$. Samples from the West vein contain, for instance, gold, $\$ 11$; silver, 32 cents; or gold, $\$ 4.80$; silver, 68 cents. The richest ore is stated to assay from $\$ 15$ to $\$ 18$ per ton, odd samples frequently rising to $\$ 100$ per ton. The average value of the ore is said to be between $\$ 7$ and $\$ 8$ per ton. The bullion obtained from the zinc boxes is stated to be 0.925 fine. One analysis shows 230 parts of gold, 695 parts of silver, 65 parts of zinc, and 10 parts of copper, the zinc being derived from the shavings in the boxes. The average bullion would contain about 750 parts silver and 250 parts gold. * * *

The ore shoots of the Annie Laurie vein have an illdefined lenticular form when projected on the plane of the vein, and appear to pitch $45^{\circ}$ or less to the north. Some of them at least have cores consisting of bunches of rich ore, gradually decreasing in tenor toward the outside. On No. 3 level in the shoot the vein is in places 23 feet wide.

Sevier mine.-The Sevier vein strikes nearly north and dips rather steeply east. The ledge can be followed by interrupted outcrops for fully 3,000 feet and in its greatest development exceeds 30 feet in width. The ore occurs in shoots that are irregular in form and very variable in size. The vein matter of the ledge is quartz with considerable carbonate and some adularia, together with iron oxide that has resulted from the oxidation of sulphides. The vein quartz has the lamellar form and hackly fracture cbaracteristic of this type of vein. Lindgren ${ }^{1}$ says:

The ore of the Sevier mine is in general similar to that of the Annie Laurie, although a drusy structure is more common; in places well-crystallized masses of amethystcolored quartz appear. * * * A considerable amount of argentite is present in finely divided form, and panning also yields a little fine gold.

At the time of the writer's visit the ore was being extracted from an open cut. At depth, in some places at least, the vein quartz has apparently given place to silicified country rock with small stringers of quartz, but whether this condition is local or general can not be stated.

The ore is treated at a mill on the property by amalgamation and cyanidation.

\section{OHIO DISTRICT.}

By B. S. Butler.

The Ohio mining district has never made a large production, though it has been the scene of considerable development. The Bully Boy and Webster mine has been the largest producer, and the Cascade, Shamrock, Dalton, 1 Op. cit., p. 90. 
Wedge, and others have made small productions.

Bully Boy and Webster mine.-The principal workings of the Bully Boy and Webster mine have been on two veins, striking generally north and dipping steeply west. The country rock is quartzite and porphyritic lava. The veins evidently occupy fault fissures, for in the west vein the quartzite has been faulted against the lava in a part of the developed area. The vein is in part inclosed in the volcanic rocks, in part lies between quartzite and lava, and at the south end of the tunnel is wholly in quartzite.

The vein filling is mainly quartz, with subordinate amounts of carbonate, fluorite, and barite. The carbonate in places becomes abundant. The vein is in many places indistinctly banded, indicating that it was formed in an open space. The pay ore is in irregular shoots that occur in any part of the vein.

The ore varies considerably in mineralogy and metal content. The west vein contains lead and some copper, gold, and silver. The east vein is richer in gold and in the upper levels, at least, contains less lead. The upper levels have yielded some very rich gold-silver ore.

In the upper levels the ores have been oxidized, the lead and copper being present largely as carbonates. In the lower levels the lead is galena and the copper minerals are chalcopyrite and tetrahedrite. Manganese is abundant in all parts of the mine but especially in the quartzite on the lowest level of the west vein. In most parts of the mine it is present as hydrous oxide, but in the south end of the lower tunnel the vein is made up largely of a brown carbonate that yields oxides of iron and manganese on weathering. In the rich gold ore the gold is in part native and in part probably combined with silver as telluride and selenide. Both tellurium and selenium are present in the ore.

The ore at present developed in the mine is of milling grade. A mill was built on the property in 1913 and some ore concentrated. It was later destroyed by fire.

Shamrock mine.-The Shamrock mine is in a vein of quartzite that strikes northwest and dips steeply southwest. The vein filling is quartz and some carbonate with chalcopyrite, tetrahedrite, and galena. The sulphides have been partly oxidized. The ore occurs as irregular shoots in the vein. Development has been by two tunnels, about 70 feet apart vertically, with raises and winzes in the ore shoots. It is reported that a few carloads of ore have been shipped from the mine.

Cascade mine.-The Cascade mine is developed in a vein in quartzite that strikes west of north and dips steeply west. The vein filling is quartz, with some carbonate, as in the other veins of the district. The sulphide minerals are chalcopyrite, tetrahedrite, galena, and sphalerite, all of which are partly oxidized. The ore, as in the other mines, contains gold and silver. It is reported that some has been shipped. The deposit is developed by several hundred feet of tunnel, with raises and winzes. Deseret mine.- The Deseret mine, east of the Bully Boy, is in a parallel vein and the ore is apparently of the same general character, though the works were not accessible at the time of visit.

Dalton mine.-The Dalton mine has long been idle and the workings were not examined. It is in a north-south vein, apparently of quartz carbonate, similar to other veins of the district, except that it contains rhodochrosite. Tetrahedrite and pyrite are plentiful in some specimens of ore. The mine produced a few thousand dollars' worth of rich gold-silver ore and a mill was erected in Bullion Canyon for the treatment of the lower-grade material, but little ore was treated in this mill.

Wedge mine.-The Wedge vein is a quartzcarbonate-adularia vein in the volcanic rocks. It is reported that a small amount of rich gold-silver ore was mined near the surface. Since the writer's visit additional ore has been developed and shipped. There are other prospects in the district and probably small production has been made from other properties.

\section{MOUNT BALDY DISTRICT.}

By B. S. Butler.

Deertrail mine.-The Deertrail mine has made the largest production of any mine in the district. It is a replacement deposit forming an irregular flat-lying body in limestone just above heavy bedded quartzite. The high-grade ore consisted principally of the oxidation products of galena and pyrite with a high gold and silver content. The milling ore is a friable material composed of sericitic 
muscovite, quartz, and hydrous iron oxide and owes its value to gold and silver. The amount of this class of ore is large, but its character renders the saving of the gold and silver difficult. In the early eighties a mill in Bullion Canyon treated 6,000 to 7,000 tons of ore, but the loss in tailings was high. At a rough estimate the value of the metal produced from all ore mined is about $\$ 150,000$.

The fine sericitic mica of this deposit could probably be washed and sold if it were not for the cost of transportation. A mill was built and put in operation on the property in 1918.

Lucky Boy mine.-The Lucky Boy quicksilver deposit which has replaced limestone consists of tiemannite and onofrite. Its general character is described on page 551 .

Clyde mine.-The Clyde mine is developed on a fissure vein striking west of north. The mine was idle at the time of visit and the workings were not examined. The ore on the dump consists of pyrite, chalcopyrite, tetrahedrite, sphalerite, and wurtzite in a gangue of quartz with some carbonate. The vein is developed by a winze from a tunnel several hundred feet above the bottom of Cottonwood Canyon. A second tunnel was driven near the bottom of the canyon, but no ore is reported. The mine is reported to have shipped a few carloads of copper-silver-gold ore.

Crystal mine.-The Crystal mine on the south side of Little Cottonwood Canyon is developed in veins in quartzite. The ore is reported to have carried lead with gold and silver. A mill was constructed on the property, but little ore was treated.

There has been considerable prospecting in the district by other companies but no large production of ore. The alunite veins of the district (see p. 546) have yielded considerable potash and are a possible source of aluminum.

Krotki iron mine.-The Krotki iron mine in the Antelope Range (see p. 546) has produced some iron and manganese ore, which has been shipped to the valley smelters for flux.

\section{NEWTON DISTRICT.}

By B. S. Butler.

There has been prospecting at numerous points in the Newton district, but only the Rob Roy and Sheep Rock mines have been productive.
Rob Roy mine.-The Rob Roy mine is near the contact of the intrusive quartz monzonite porphyry and the overlying volcanic rocks, both of which have been fissured and the fissures filled with vein quartz. Adjacent to the veins the rocks have been extensively altered and in many places silicified and pyritized. The Rob Roy vein strikes about north and dips west at a rather low angle. The mine has produced a little rich gold ore.

Sheep Rock mine.-The Sheep Rock mine is about 3 miles south of the Rob Roy. According to Loughlin the geologic conditions are as follows:

The country rock is andesitic porphyry, which is all more or less sericitized and pyritized and in places is highly silicified. At the bottom of the Sheep Rock shaft (300 feet deep) the sericite rock contains patches of calcite and fluorite. The rock on the surface is largely reduced to "float." This float contains much vein quartz, and it is surprising that it has led to so little prospecting.

The Sheep Rock vein, which alone has been prospected and developed, strikes north to $\mathrm{N}$. $20 \mathrm{E}$. and dips $65^{\circ}$ to $70^{\circ} \mathrm{E}$. The vein matter is quartz, in part slightly amethystine and containing remnants of unreplaced calcite, and preserves in part the shattered structure of the country rock. The quartz is full of cavities lined with crystals and is characterized by the hackly structure where partly replaced calcite has been removed.

The only ore minerals recognized are pyrite (or limonite pseudomorphs), native gold, and a fine dark material said to be argentite or cerargyrite (horn silver). The pyrite forms small cubes and grains both in the white comby quartz and in the silicified porphyry. The gold and silver minerals were seen only in pannings from the high-grade ore, although specimens with visible gold were seen in $\mathrm{Mr}$. W. A. Wilson's office in Salt Lake City. Some ruby silver is said to occur in thin seams. Tellurium also has been reported.

The vein is all oxidized, so far as it has been worked, to the 300 -foot level. Ore has been mined from the surface, where it was 5 feet thick, down to the 300 -foot level, where its maximum width is 25 feet. The ore of shipping grade occurs in shoots, and is usually found associated with prominent black stains of 
hydrous manganese oxide. Picked samples of this ore have assayed more than a thousand dollars a ton, but the average shipping ore probably ranges from $\$ 50$ to $\$ 100$.

The parts of the vein inclosing the high-grade shoots and also the adjacent pyritized rock carry some gold and silver in pyrite and at the time of visit were being treated in an experimental 5 -stamp mill with encouraging results.

Placer ground in the vicinity of the Sheep Rock mine has been prospected recently, but no definite results have been reported.

Veins containing tungsten in the form of wolframite are reported as occurring near the head of North Creek.

\section{FORTUNA DISTRICT.}

By G. F. Loughuin.

Considerable excitement prevailed in the summer of 1914 over the discovery of gold ore at the camp of Fortuna in the foothills about 10 miles north of Beaver City at the mouth of Rocky Hollow. When the writer visited the camp for a few hours on September 9, 1914, it consisted of 11 or 12 tents and 1 or 2 tent wagons.

The developments on different properties included two tunnels each less than 100 feet long and several smaller prospects. Prospecting has continued during the fall and winter, and encouraging results have been reported in press notices, but little or no ore has been shipped.

The country rock, so far as seen, is andesitic porphyry, mostly extrusive. Several dikes clearly cut the extrusive rock.

The deposits are replacement veins similar to those at the Sheep Rock mine and in the Marysvale district. The principal gangue minerals are quartz (with adularia?) and calcite, the quartz replacing the calcite, where both are found together. Quartz is in places the only megascopic gangue mineral, occurring both as distinct crystals around cavities and as dense forms replacing the wall rock. The dense variety has the same appearance as the quartzadularia aggregates in the Marysvale veins, but no adularia was detected in the powdered Fortuna material.

The ore minerals recognized are limonite (the oxidation product of pyrite) and native gold, which may be recovered by panning oxidized ore. The limonite occurs in thickly scattered minute cubic grains (pyrite pseudomorphs) which are mostly in replaced porphyry within or adjacent to the veins. Little or none was noted in the well-crystallized quartz.

All the ore thus far found has been oxidized, and the most promising material seen consisted largely of soft vein material heavily stained with manganese and iron oxides. No assays of the ore were obtained.

The deposits plainly belong to the quartzadularia type, which, as a whole, varies greatly in value, some veins being productive and others practically barren. Development can alone determine their economic probabilities in a new district.

\section{BIBLIOGRAPHY.}

Butler, B. S., and Gale, H. S., Alunite, a newly discovered deposit near Marysvale, Utah: U. S. Geol. Survey Bull. 511, 1912.

Dutron, C. E., Geology of the high plateaus of Utah, with atlas: U. S. Geog. and Geol. Survey Rocky Mtn. Region, pp. 169-188, 1880.

Describes the general geology of the Tushar Range.

Gib Bs, J. F., Brief study of the geology of the Mount Baldy belt, Piute County, Utah: Reaper Job Print, Richfield, Utah.

Describes the general geology and mineralization of the Tushar Range, with a map of the mineralized area.

Marysvale Red Book. Privately published in 1916. Briefly discusses history and geology of the mining districts of the Tushar Range, with maps.

Huntley, D. B., Precious metals: Tenth Census U. S., vol. 13, p. 462,1885 .

Describes mining developments and production of Piute County previous to 1880 .

Lindgren, Waldemar, The Annie Laurie mine, Piute County, Utah: U. S. Geol. Survey Bull. 285, pp. 87-90, 1906.

Describes the Annie Laurie and other mines of the Gold Mountain district.

Loughuin, G. F., Recent alunite deposits near Marysvale and Beaver, Utah: U. S. Geol. Survey Bull. 620, pp. 237-270, 1915.

McCaskey, H. D., U. S. Geol. Survey Mineral Resources, 1911, pt. 1, p. $914,1912$.

Describes the occurrence of mercury ore in the Lucky Boy mine.

\section{SALINA CREEK DISTRICT.}

By G. F. Loughuin.

The Salina Creek district is in the western foothills of the Wasatch Plateau east of Salina, a town on the San Pete Valley branch of the Denver \& Rio Grande Railroad. The Lead Hill, the only mine for which production has been recorded, is on the north side of the canyon of Salina Creek, about 4 miles east of Salina. This mine produced lead ore and concentrates from 1908 to 1912. 
GEOLOGY.

SEDIMENTARY ROCKS.

The district lies in a very interesting part, geologically, of the Plateau province. The sedimentary rocks represented are of Jurassic, Cretaceous, and early Tertiary (Eocene) age and are capped in places by andesitic lavas. (See fig. 61.)

The Jurassic rocks, according to Richardson, ${ }^{1}$ form a band about 2 miles wide, extending northeastward in a range of low barren hills from Salina Creek, just east of the town, for 11 miles to Mayfield. They consist of a considerable but undetermined thickness of fissile shales, generally drab in color but locally red, and of a few intercalated layers of drab sandstone a few inches to several feet in thickness. Lenses of gypsum and rock salt are irregularly interbedded throughout the formation. Both sides of the Jurassic in this district are bounded by faults and abut against Eocene strata.

The Cretaceous in the region is represented by beds of Colorado and Montana age. Only the Colorado is exposed within the district proper, but the Montana occupies a large area drained by the upper part of Salina Creek. The Colorado deposits outcrop in the bottom of the canyon of Salina Creek, from beneath a considerable thickness of Eocene beds, about 4 miles east of Salina. They consist of thin-bedded buff sandstone ranging in color from gray through yellow, purple, and red; some from subordinate drab, purple, and green shale carrying Inoceramus labiatus; ${ }^{2}$ a few thin beds or lenses of fine conglomerate, containing pebbles of quartzite and chert; and some calcareous beds. The strata range in hardness from loosely coherent sands to semiquartzites. At their western limit they stand almost vertical and are directly overlain by nearly horizontal Eocene beds. The dip flattens eastward, and at Rattlesnake Hill, $1 \frac{1}{2}$ miles east of the mine, it is $30^{\circ}-40^{\circ} \mathrm{E}$.

Eocene strata form a line of low ridges along the west side of the Jurassic area, and cover a large area extending eastward from the Juras-

\footnotetext{
${ }^{1}$ Richardson, G. B., Underground water in the San Pete and central Savier valleys, Utah: U. S. Geol. Survey Water-Supply Paper 199, p. 8, 1997.

2 Idem, p. 9.
}

sic area for 6 miles and more. They consist of at least 2,000 feet of drab, green, and red shales, reddish-buff and gray sandstones, and whitish fresh-water limestones. The stratigraphy is varied, and even adjacent sections are rarely alike. Numerous fresh-water fossils, including Sphaerium, Planorbis, Physa, Goniobasis, and Vivipara, ${ }^{3}$ occur in these rocks, which are referred to the Wasatch formation of the Eocene. Near the Lead Hill mine red and white cliff-forming sandstones are overlain by gray to greenish shales and sandstones, and by cherty limestone, which caps the hills. The red and white sandstones carry the ores of the mine. They thicken somewhat to the east, and expose lower and lower beds, suggesting a westward overlap on the Colorado beds. The dip along Salina Creek is prevailingly $2^{\circ}-3^{\circ} \mathrm{W}$.

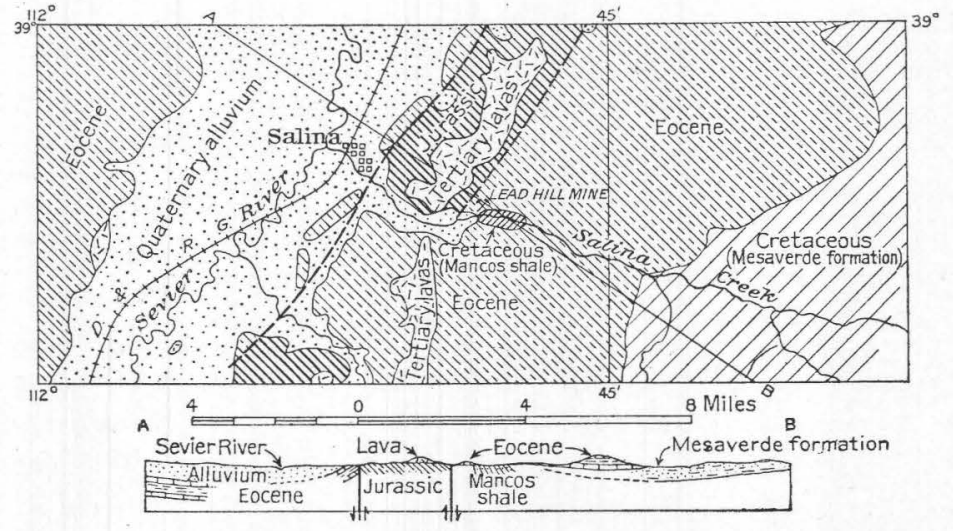
eastward.

The lavas in the district are exposed in two masses, each 4 or 5 miles long and 1 to 2 miles wide. One trending northeastward caps the upturned Jurassic beds just north of Salina Creek; the other, trending southward, caps the nearly horizontal Eocene beds directly to the south. Both masses are correlated with the extensive lavas to the south and are assigned to the Tertiary. The fact that they rest directly upon Jurassic strata implies that the Eocene had been removed from this part of the district before they were erupted. They include rhyolite and andesite and are somewhat weathered but are free from the propylitic alteration that characterizes many such rocks when permeated by ore-forming solutions.

Idem, p. 10 


\section{STRUCTURE.}

The faults of the Sevier fault zone which bound the block of Jurassic beds thrust up against the Eocene are marked by narrow tributary canyons trending about N. $30^{\circ} \mathrm{E}$. Other faults of northeasterly, northerly, and easterly trends have been noted north and east of the Lead Hill mine. Their relations to the Sevier fault zone have not been determined.

Little is known of the relation of these faults to mineralization. A vein 3 to 4 feet thick of chertlike replacement quartz was found approximately in line with the eastern member of the Sevier fault zone, in Twist Canyon, half a mile or more north of Salina Creek. The vein strikes N. $35^{\circ}$ E., dips southeastward, and cuts a dense impure limestone bed of the upper member of the Eocene. The rock along a north-south fault east of the Lead Hill mine is said to be mineralized, but no fissures of importance have been found associated with the ore of the mine, which impregnates a calcareous sandstone bed. Small amounts of ore have been found in the vertical Colorado (Cretaceous) beds close by the mine workings, and suggests that fissures at this place coincide with the vertical bedding.

\section{ORE DEPOSITS.}

LEAD HILL MINE.

The workings of the Lead Hill mine, totaling about 800 feet of drifts and inclines, are in a basal bed of Eocene sandstone, locally white, which, as a rule, is separated from the underlying Colorado beds by a red material that has no definite structure and suggests an old residual soil. This material, however, is absent through much of the mine, which is in an old erosion channel on the Jurassic surface. The ore is lead-zinc sulphide with little or no silver and with local streaks and bunches of oxidized copper ore. It is all of milling grade. Small shipments of lead concentrates and copper concentrates have been made.

The mineralized sandstone is mostly medium grained but is conglomeratic in places. Its principal constituents are grains of quartz, microcline, plagioclase, and muscovite and fragments of calcareous sandstone, shale, and quartzite, with small amounts of garnet, zircon, biotite, titanite, and chlorite. The matrix is calcite. The ore and gangue minerals, which replace the calcite matrix in lenses and streaks through a vertical thickness of 6 feet, are galena (accompanied by a little cerusite), zinc blende, a little pyrite, chalcocite, malachite, azurite, and celestite (strontium sulphate). No chalcopyrite was found. Little or no replacement of the sand grains has taken place.

Concentration is effected in a 5 -stamp mill but is considerably hampered by the presence in large amount of gangue minerals of rather high specific gravity. The middlings from the mill consist of much zinc blende (specific gravity 3.5 to 4 ), a rather small amount of galena (7.5), a little cerusite (6.5), pyrite (5), chalcocite (5.7), and malachite (4); considerable celestite (4), garnet (4), calcite (2.7), quartz (2.65), feldspar (2.6 to 2.7), a little zircon (4.7), and biotite (2.8). The middlings thus make a zinc ore, which can not be cleanly freed from gangue, although it may be better separated than it is from minerals with a specific gravity of less than 3.

The heads consist of galena and cerusite, considerable zine blende, and minor amounts of pyrite and the other minerals named above. They are said to contain 38 per cent lead. The differences in specific gravity suggest that a better separation of the lead minerals from zinc blende and gangue is possible.

The celestite, whose presence as a gangue mineral in Utah ore deposits is unique, is colorless to white and ranges in size from fine irregular grains up to poikilitic crystals 2 or 3 millimeters long that inclose unaltered sand grains. It occurs with galena and blende, and in the average middlings it and the zinc blende are the most prominent minerals. The two are so nearly equal in specific gravity that mechanical separation of them is difficult. The celestite, however, is also found nearly free from metallic minerals, as shown in the analysis below.

Chemical analysis of celestite concentrates, Lead Hill mine, Salina Creek, Utah.

[R. C. Wells, analyst.]

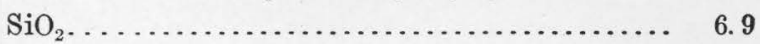

$\mathrm{TiO}_{2}$, etc................................ 1.0

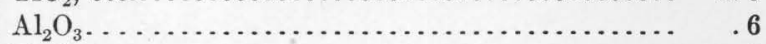

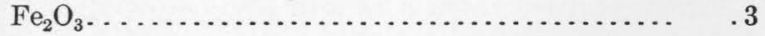

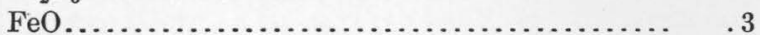

SrO................................ 45.8

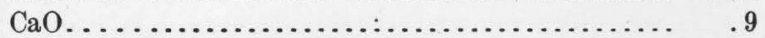

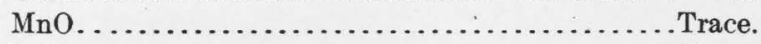

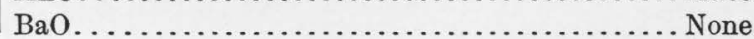




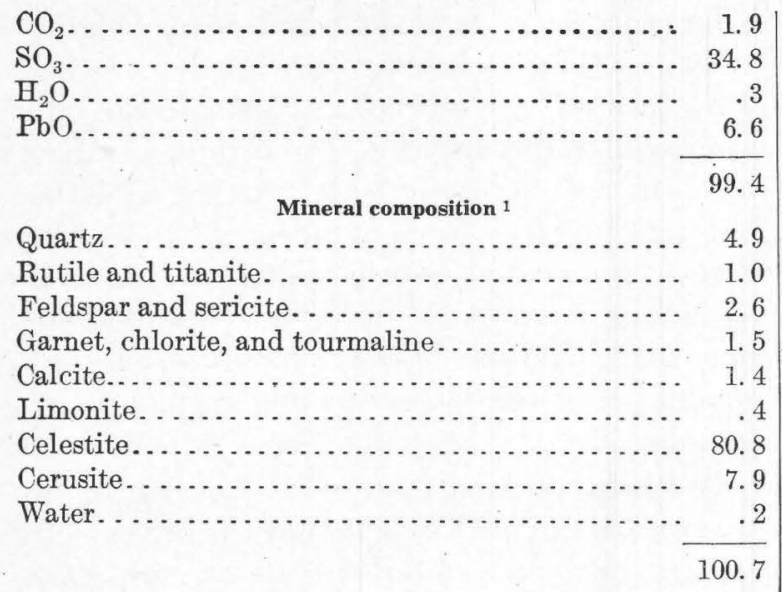

If considerable celestite can be found free from metallic minerals it may serve as a source of strontium, which is employed in one process of sugar manufacturing, in the making of fireworks and signal lights, and in several other chemical industries.

\section{GENESIS OF THE ORES.}

The genesis of the ore is uncertain. The mineral composition of the ore is, with the exception of celestite, similar to that of other lead-zine deposits low in silver, some of which are directly though not closely associated with intrusive igneous rocks. The failure of the ore to replace any other minerals than calcite is also characteristic. The mineralized fissures suggest that some mineralization may have been effected by ascending solutions from a possible igneous source, and the slightness of the mineralization along vertical bedding planes in the Colorado formation further suggests that locally solutions rose along these bedding planes to the Eocene contact and then spread along the basal calcareous sandstone bed. On the other hand, there is nothing at present known to prevent acceptance of the view that the ore was concentrated from the overlying strata by a process similar to that which formed the copper deposits in the "Red Beds" of the Plateau region. It must be admitted, however, that though copper deposits in the "Red Beds" are abundant, no galena-blende deposits in these beds have previously been described.

According to either view the Lead Hill deposit is exceptional. It differs, however, from other lead-zine deposits of Utah only in being in calcareous sandstones instead of in limestones.

1 Based on the analysis and on microscopic study. $35416^{\circ}-19-36$
Its similarity to these deposits and the absence in the Plateau region of lead-zine deposits that can be attributed with a fair degree of certainty to descending waters favor the conclusion that it was formed by ascending solutions that had become so cooled and perhaps so diluted by descending waters that they had already lost practically all their silica and precious metals.

\section{COYOTE DISTRICT. ${ }^{2}$}

By G. B. Richardson.

\section{LOCATION.}

Coyote Creek, a branch of the East Fork of Sevier River, occupies a short, narrow valley in the northwestern part of Garfield County, in the midst of the High Plateaus of Utah. The mining camp is about 40 miles by road southeast of Marysvale, the terminus of the San Pete \& Sevier branch of the Rio Grande Western Railway. The elevation of the mines is about 7,000 feet and that of the Awapa Plateau to the north and the Aquarius Plateau to the south and east is 2,000 to 3,000 feet higher.

\section{GEOLOGY.}

The general geology of the region has been described by Dutton. ${ }^{3}$ The igneous rocks consist of lava sheets, beds of tuff and volcanic conglomerate, and intrusive masses. They cap the highest plateaus and overlie an eroded surface of Eocene strata which outcrop at lower elevations around the igneous uplands. Beneath the Tertiary rocks lie several thousand feet of Mesozoic and Paleozoic sediments, which are exposed in a series of descending benches southward from the High Plateaus to the platform in which Colorado River has cut the Grand Canyon. The igneous plateaus are traversed by a number of normal faults of large displacement which trend in general north. One of these faults, aided by erosion, has exposed in the Coyote Creek valley a small area of Eocene sediments in which the antimony occurs.

The valley of Coyote Creek is occupied by a variable succession of strata. At the base of the section is 150 feet of a gray conglomerate composed of a sandy matrix containing rounded

2 Reprinted with slight emendations from U. S. Geol. Survey Bull. 340, pp. $253-256,1908$. There has been no extensive production or development since the description was written.

${ }^{3}$ Geology of the High Plateaus of Utah, U.S. Geog. and Geol. Survey Rocky Mtn. Region, 1880. 
quartz and quartzite pebbles whose maximum diameter is 6 inches. This conglomerate is overlain by a great mass of fine-textured buff and reddish sandstone and subordinate drab and red sandy and clayey shale and thin-bedded limestone, amounting in all to several hundred feet. No fossils have been found in these rocks, but they are provisionally referred to the Eocene because of their lithologic resemblance to other Eocene strata in the Plateau region. They are overlain by about 1,000 feet of andesitic tuff and lava, which caps the surrounding plateaus. The rocks are approximately flat, having only a general low northeastward dip. At the mouth of Coyote Canyon a fault causes the strata to dip steeply westward.

\section{ORE DEPOSITS.}

The occurrence of antimony in southern Utah has long been known-Huntley says that the deposits were located in May, 1879. They have been worked at irregular intervals since 1880 and it is reported that more than $\$ 100,000$ worth of ore has been shipped from the property on Coyote Creek, in Garfield County, which has been described by Blake. ${ }^{1}$

The ore consists of stibnite and its oxidation products, which occur generally in flat-lying deposits in the sandstone and conglomerate. The chief zone of mineralization is adjacent to the contact oi the conglomerate and overlying sandstone, the ore occurring most commonly in fine-textured argillaceous sandstone a few feet above the conglomerate. In many places a bed of clay shale about 5 feet thick immediately underlies the ore-bearing sandstone, and locally the upper part of the conglomerate is mineralized. The ore does not occur persistently and uniformly, though it is present most commonly at this general horizon on both sides of Coyote Creek.

In the early days of development attention was given chiefly to the lenses of ore, the "kidney" deposits. The known lenses have all been worked out but are said to have ranged from several inches to 20 feet in thickness. One of them is said to have yielded 55 tons of ore. No large bodies of stibnite are in sight now, but there is much low-grade ore.

The occurrence and character of the deposits differ in the different prospects. A common

\footnotetext{
IBlake, W. P, U. S. Geol. Survey Mineral Resources, 1883 and 1884, pp. $643-644,1885$.
}

occurrence is in layer-like bodies of irregular thickness but averaging only a few inches. The "layers" are not continuous and are only approximately parallel to the bedding. -Many of them are undulatory and thicken and thin out irregularly. In a number of places thin bodies of ore cut across the bedding of the sandstone and connect the more nearly horizontal deposits. The ore also commonly occurs disseminated in the sandstone in irregular segregations.

A characteristic feature of the antimony deposits of Coyote Creek is that the ore consists only of stibnite and its oxidation products, gangue minerals being almost completely absent. Only one exception was observed, at the Emily claim, on the south side of the creek, where in a small gash vein only a few inches wide stibnite and pyrite are associated with calcite. A thin section cut along the contact of the stibnite with the country rock shows an uneven junction, the stibnite extending very irregularly into the sandstone. Locally stibnite, with well-defined crystal faces, penetrates and is partly embedded in adjacent quartz grains of the sandstone.

The stibnite occurs in several forms. In the larger ore bodies it commonly forms aggregates of prismatic crystals arranged radially or in columnar masses. In one group crystals 6 inches long were observed. It also forms indiscriminately mixed groups of acicular crystals. Adjacent to the outcrop it is almost universally oxidized, the steel-gray sulphide giving place to the lighter brown, yellow, and white oxidation products. W. T. Schaller, of the United States Geological Survey, who examined a number of oxidized-ore specimens, reports that they are anhydrous and easily fusible and that they are either valentinite or senarmontiteprobably the former, as reported by Blake. ${ }^{1}$ In many places the valentinite occurs in acicular crystals as a pseudomorph after stibnite. Locally associated with the ore and forming efflorescences on the walls of the country rock are epsomite; a hydrous aluminum sulphate, probably alunogen; a hydrous ferrous sulphate; and gypsum.

Small quantities of arsenic minerals have been found in the valley of Coyote Creek contiguous to the antimony deposits, but so far as known not immediately associated with 
them. On the north side of the creek, about 100 feet southeast of the stibnite prospect known as "Black Jack No. 2," there is a small deposit of the sulphides of arsenic in shales of Eocene age. Realgar and orpiment in irregular seams ranging in thickness from a fraction of an inch to about 6 inches and only a few inches in length occur in a blue-drab clay shale. No other vein minerals are present, and the realgar and orpiment, in small crystals, are intimately associated. Other similar small deposits of arsenic are reported from the valley of Coyote Creek.

The antimony ore is epigenetic-that is, it was formed subsequently to the deposition of the rocks in which it is found, and its origin is probably connected with the adjacent igneous rocks, as suggested by Blake. The antimony may have been derived from these rocks either during their intrusion through the sediments or less probably after their eruption on the surface, the stibnite being deposited from percolating solutions in part filling existing spaces and in part by metasomatic replacement. The bed of shale which in many places immediately underlies the ore apparently arrested the solutions and determined the local concentration of the stibnite. In such places the solutions were evidently not directly ascending but were moving either laterally or downward.

The deposits of antimony adjacent to Coyote Creek have been worked sporadically for the last 27 years. For the most part this work has been limited to the exploitation of the large lenses and little or no systematic mining has been done. There has been considerable prospecting, however, and a score or more of tunnels have been driven into the deposits at various places on both sides of the creek.

In the past work has been chiefly directed toward getting high-grade ore running between 50 and 60 per cent of antimony. The "Kidney" deposits were exploited, and hand-sorted ore was shipped. One attempt was made to smelt the ore on the property but proved unable to meet competition.

It is difficult to estimate the amount of available antimony. The dumps and tunnels of the old prospects show a great amount of low-grade ore, and the problem is how to handle it economically.
GOLD SPRINGS AND STATE LINE DISTRICTS.

By B. S. ButLer.

GEOGRAPHY.

The Gold Springs and State Line districts are on the Utah-Nevada State line at about latitude $38^{\circ}$. The nearest railroad point for both districts is Modena, on the Los Angeles \& Salt Lake Railroad, about 10 miles in a direct line and about 16 by road from Gold Springs and about 17 miles from the State line. The districts are in an irregular group of volcanic hills - a southern extension of the Snake and Cedar ranges-whose elevation varies from about 6,000 to 7,000 feet, with a few points rising above 7,000 feet.

There are no large streams in the range, but small streams and springs furnish water throughout the year suitable for domestic purposes and have been utilized in the metallurgic plants in the treatment of the ores.

The mountains support a rather plentiful growth of cedar and other scrubby trees, which furnish an abundant fuel supply and are utilized to some extent for timber in the mines.

GEOLOGY.

\section{IGNEOUS ROCKS.}

All the rocks of the districts are igneous and all, so far as determined, are extrusive. They may be readily separated into three general groups-latite, rhyolite, and rhyolite tuffeach of which would doubtless be subdivided on detailed study.

The latite is exposed in the lower areas in the vicinity of Gold Springs and westward to Fay and Deer Lodge, Nev. The rock is commonly porphyritic, containing rather abundant phenocrysts of plagioclase (oligoclase) and fewer of orthoclase. Quartz phenocrysts are commonly absent. Some dark mineral, which was rather abundant in the specimens examined, has been altered to chlorite, which gives the rock a distinct greenish color. Probably both biotite and pyroxene were present. The groundmass is too fine for determination of the constituent minerals, though it is for the most part crystalline.

The rhyolite forms the higher elevations in the Gold Springs district and is the prevailing rock to the north in the State Line dis- 
trict. In the Gold Springs district it is especially well exposed on the higher parts of Buck Mountain and Bull Hill. The rhyolite is commonly much less massive than the latite and a thin platy structure is common. All the beds contain fragments of tuff and many, especially in the eastern part of the State Line district, are distinctly tuffaceous. The rhyolites are too fine grained for their composition to be determined except by chemical analyses and they may prove to be in part quartz latites. The more massive beds contain rather abundant phenocrysts of quartz and fewer of orthoclase and plagioclase. The less massive and tuffaceous beds are composed largely of glass. The rhyolites were not traced from the Gold Springs district to the State Line district, but the similarity of the rock at the two localities is strong indication that they are to be correlated.

The rhyolitic tuff lies south of Deer Lodge, both north and south of the old Pioche road, in extensive fine-grained white to yellowish beds containing a few thin obsidian flows. Its relation to the other rocks of the district was not determined, but it seems to correspond to the rhyolite tuff described by Spurr ${ }^{\mathbf{1}}$ from Meadow Valley to the southwest. If this suggested correlation be correct the tuff is probably the oldest rock exposed in the region.

\section{STRUCTURE.}

The area does not appear to have been affected by extensive folding or faulting. The formations appear to be essentially horizontal, though careful mapping would doubtless show considerable irregularity.

Fissuring has been extensive and has involved some movement, though the similarity of the wall rocks over considerable thicknesses makes it difficult to determine its amount. In the southern part of the area, about Gold Springs, Fay, and Deer Lodge, nearly all the fissures trend north. Farther north, in the State Line district, they trend much more irregularly, some of the most conspicuous trending east. Most of the north-south fissures dip $50^{\circ}$ to $70^{\circ} \mathrm{E}$. in the Gold Springs district, but farther west many of them dip west. The fissures are strong and the silicification of the rocks adjacent to them has caused their posi-

1 Spurr, J. E., Descriptive geology of Nevada south of the fortieth parallel and adjacent parts of California: U. S. Geol. Survey Bull. 208, p. 148, 1903. tion to be marked by prominent outcrops, many of which can be followed for several hundred feet; the great fissure about $1 \frac{1}{2}$ miles west of Deer Lodge can readily be traced for 2 to 3 miles and with less certainty for a considerably greater distance.

\section{HISTORY AND PRODUCTION.}

- By V. C. Heikes.

EARLY WORK.

The old stage road from Frisco to Pioche passes through the area, and the prominent ledges that mark the fissures must have been seen by many prospectors and mining men during the early days at Pioche. These early visitors, however, do not seem to have been attracted by the ledges, probably because most of them were in search of lead-silver ores, for which limestone was considered the most favorable formation, and also because placers are not associated with the gold deposits of this region and no gold was revealed by the panning of the gravels. It was not till 1896, therefore, that prospecting began in the State Line district and was quickly extended over the area, for most of the fissures outcrop prominently and preliminary prospecting proved relatively easy.

For several years subsequent to the discovery there was considerable activity. Mills were built for treating the ore and there was a considerable production of gold and silver. Many of the ore shoots, however, decreased in size and metal content with increased depth, and this, together with the necessity of pumping, resulted in the closing of most of the mines.

\section{STATE LINE DISTRICT.}

The State Line district, in Iron County, 17 miles northwest of Modena, on the Los Angeles \& Salt Lake Railroad, was organized in the summer of 1896. An amalgamation mill built by A. Popkiss soon after the opening of the district was sold in November, 1898, to the company operating the Johnny property for the treatment of its low-grade ore. Better ore was shipped direct to smelters. This mill was moved in 1912 to the Big Fourteen claims, where some ore was tested.

The Ophir mill, which was started in November, 1901, treated 150 tons of ore per day by the Russell lixiviation process and later by the 
cyanide process. Neither process was successful and the mill was closed in 1902.

GOLD SPRINGS DISTRICT.

The Gold Springs district lies along the UtahNevada State line in Iron County, 17 miles northwest of Modena, a station on the Los Angeles \& Salt Lake Railroad. The Jennie property, the only producer whose records are available, was the mainstay of the district from 1907 to 1909 , producing several thousand dollars' worth of gold and silver from the ore in a mill first designed for amalgamation and later widened to include the cyanidation process for the treatment of tailings. In fineness the bullion produced ranged from 0.687 to 0.526 in silver and from 0.274 to 0.385 . in gold. Between 1907 and 1911 the district is credited with the production of 12,189 tons of ore, yielding $\$ 48,118$ in gold and 8,441 ounces of silver, valued in all at $\$ 52,903$.

\section{ORE DEPOSITS}

By B. S. Butler.

OCCURRENCE AND CHARACTER.

The ores occur in well-defined veins. In the Gold Springs district they strike in general north and dip east. From east to west the principal veins are the Jumbo, about a mile east of Gold Springs; the Independence, about one-fourth of a mile west of the Jumbo; the Jennie, about half a mile west of Gold Springs; the Talisman, about 600 feet west of the Jennie; and the Snowflake, 1,000 to 1,200 feet west of the Talisman. Several other veins do not outcrop prominently and have been only slightly prospected. Farther north and west, near Fay and Deer Lodge, Nev., are other fissures of the same general trend and character. The most extensively developed are those on which the Horseshoe and Homestake mines are located. Some prospecting has been done on the Iris, on the Deer Lodge, on a prominent fissure west of Deer Lodge, on Bull Hill, and elsewhere.

In the Gold Springs district the most productive fissures have been found in the latite and the opinion seems to prevail that they do not extend into the rhyolite. This is not correct, however, as prominent fissures near the summit of Bull Hill are certainly in the rhyolite and contain gold, though they have been little prospected and, so far as known, have yielded no production. The latite seems to be the more favorable rock for the deposition of ores, but this is by no means demonstrated, for in the southern part of the Gold Springs district and farther to the north in the State Line district some of the best deposits have been found in the rhyolite.

The veins for the most part have formed as a filling of open fissures and are distinctly "branded" or crustified. The composition of the vein filling differs greatly in different veins and from place to place in individual veins. Quartz, usually fine grained and in many places chalcedonic, is probably the most abundant mineral. Many small cavities in the veins are lined with well-crystallized quartz, and much of it has replaced carbonate and has a characteristio lamellar or hackly structure. Next in abundance to quartz is a carbonate that is probably largely calcium carbonate, though stains on its weathered surfaces show that it contains some iron and manganese. This carbonate differs considerably in appearance and probably also in composition at different localities. Some veins are composed very largely of this mineral, others contain. it abundantly in some areas; and still others have a structure that shows that it has been replaced by later minerals.

Next to the carbonate in abundance is the vein-forming feldspar adularia, which, like the quartz, has commonly formed as a replacement of the carbonate. Where abundant it gives a yellowish color to the ore and is sometimes known as "yellow quartz." It occurs in well-formed crystals and also as irregular masses that do not show definite crystal outline. Locally it forms 50 per cent of the vein filling, but in most places is much less and in many is not present at all.

Fluorite is more variable in occurrence. It was noted in many of the veins but usually in small amount. It was observed most abundantly in a prospect near the summit of Bull Hill, where it was the prevailing mineral in parts of the vein. Most of it is a deep lilac color, though some of it is pale green.

At the time of visit the best opportunity for observing the relation of the different minerals was where ore was being extracted.

With regard to economic value, the vein material in the Jennie mine can be roughly separated into white finely crystalline quartz containing little metal; into a yellowish mix- 
ture of quartz, carbonate, and adularia, commonly designated as "yellow quartz" and containing the most metal; and into the coarsely crystalline almost barren carbonate. In mining, the carbonate and the white quartz are commonly rejected. The relative abundance of the different minerals varies greatly from place to place.

A partial analysis by Chase Palmer of a specimen of "good ore" from the Jennie mine gave the following composition:

Analysis of ore from the Jennie mine.

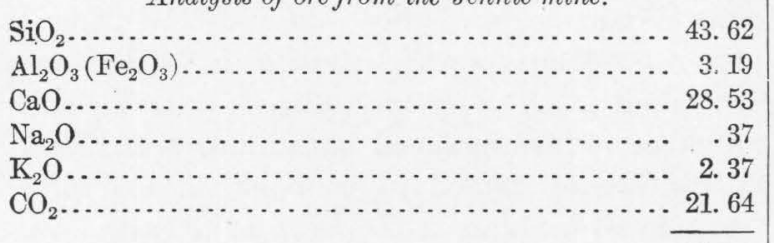

Mineral composition as calculated from analysis.

Calcite................................. 49. 20

Quartz................................. 32.46

Adularia (orthoclase molecule, 13.90; albite mole-

cule, 3.14)................................ 17.04

Excess $\mathrm{CO}_{2} \ldots \ldots \ldots \ldots \ldots \ldots \ldots \ldots \ldots \ldots \ldots \ldots \ldots \ldots \ldots \ldots \ldots . .95$

Carbonate was evidently the earliest mineral to form and was later partly replaced by quartz and adularia. On the lowest level of the Jennie mine veins composed largely of carbonate appear to cross the main vein at a low angle and to be later than the quartz-adularia veins, thus indicating two periods of carbonate formation. The exposure, however, did not permit the relative age to be positively determined, and no similar relation was observed elsewhere.

\section{METALLIC MINERALS.}

Near Gold Springs and Fay the vein matter contains very little of the metallic minerals. A little pyrite is usually closely associated with wall rock or included fragments of the wall rock, a few copper stains were noted, and gold is frequently visible. In some microscopic sections a light-colored gold, which probably contains considerable silver, is associated with a dark-gray metallic mineral from whose alteration it appears to have been derived. The alteration also yields a cloudy white material, which is usually associated with a little hydrous iron oxide. Sufficient material was not obtained to determine either the original mineral or the cloudy alteration product. It is reported that rich ore from the State Line district shows rather abundant tellurium, and it seems probable that the gray mineral may be a telluride of gold and silver.

In the White Horse claim west of Deer Lodge silver ore contains the chloride of silver, cerargyrite, and that mineral is probably in the other veins of the district. Manganese oxide is present in small amount in most and probably all of the veins of the district. A yellow fibrous mineral collected from the south end of the Jumbo ledge was determined by W. T. Schaller as molybdite. Native mercury is reported from several localities and was panned from material from the Homestake mines. Other metals are reported from the similar veins in the State Line district and from east of Modena and are possibly present in the veins of the Gold Springs district.

In gold and silver content the ores range from those in which the value of the two metals is approximately equal to those in which the value of the silver is much the greater.

\section{ALTERATION.}

Most of the wall rock adjacent to the veins has been rather highly altered. This has commonly resulted in a distinct hardening that has rendered it more resistant to weathering and erosion than the surrounding rock and has caused the veins to outcrop as distinct ridges or ledges, many of which stand several feet above the general level.

Mineralogically, the change in the rock shows considerable differences. The most characteristic change is to quartz and orthoclase containing variable amounts of pyrite. Where alteration has been less intense the dark silicates have been chloritized, rather abundant carbonate has developed through the feldspars and the groundmass, and some pyrite has formed. In still other places, probably where the altering conditions have been unusually intense (especially at the south end of the Jumbo vein) the rock has been rather highly sericitized. Kaolinite is present in many places, having apparently resulted from the action of surface waters on the rather highly pyritized wall rock.

The altered wall rock commonly contains but little gold and silver, and such as is present is probably contained in small veinlets rather than disseminated through the rock.

In many places the vein material is tightly "frozen" to the walls of the fissures, but in 
some a gouge, due to movement since the formation of the veins, lies along one or both walls and separates the vein material from the wall rock.

\section{ORE SHOOTS.}

The veins are not uniformly metalliferous, the ore occurring in distinct shoots. In the Jennie mine these shoots pitch distinctly north, but this does not seem to be uniform throughout the district. Several shoots decrease in size and in metal content with increase of depth, but this also may not be general. In persistency the veins vary greatly, some showing little change and others (including some that are 4 feet wide and are traceable for several hundred feet along the strike), breaking up at a depth of not more than 100 feet into small stringers of quartz in a zone of highly altered rock. The stringers may reunite at greater depth into a definite vein and they may not. In prospecting it is far safer to follow down the ore shoots than to drive long and expensive tunnels to intersect them at depths to which they may not extend as workable deposits. Much money and effort have been fruitlessly expended in the region in this manner, and future prospectors should profit by the experience.

\section{STATE LINE DISTRICT.}

No active operations were in progress in the State Line district at the time of the writer's visit, and no opportunity was afforded for examination of the underground workings on the most extensively developed veins.

The veins are in general similar to those in the Gold Springs, Utah, and Fay, Nev., districts to the south but are much less regular. North-trending veins predominate, but some of the most productive trend east. The northsouth veins dip prevailingly west at rather steep angles, and the east-west veins dip north. Carbonate is apparently much less plentiful and pyrite much more plentiful than in the veins farther south. Where the fissures have traversed tuffaceous and brecciated areas the alteration of the wall rock has extended for a long distance, producing, especially in the eastern and northern parts of the district, large bodies of resistant rock that form very irregular and rugged outcrops.

As in the districts to the south, the relative amount of gold and silver differs greatly in different deposits. In the Ophir mine, for instance, the value of the ore is almost entirely in silver, and in the Johnny mine the value of the gold is considerably greater than that of silver, though in weight silver considerably predominates.

Exploration in the Ophir mine is said to have been carried to a depth of about 500 feet and in the Johnny mine to about 300 feet, at which level water in considerable amount was encountered. Numerous other deposits in the districts have been prospected and some have produced gold and silver.

The genesis of this type of ores and their distribution in the State are discussed on page 179 and need not be considered here.

The ores occur along a north-south fracture zone several miles in length, which may have been a zone of weakness along which the lavas rose and poured out over the surface. Later recurrent movements along the zone produced fissures through which solutions resulting from the differentiation of deep-seated magmas rose and deposited the vein material and altered the rocks adjacent to the veins.

\section{MODENA AREA.}

Some little prospecting has been done near Modena on veins in rhyolite that are in general character similar to those farther north. They contain abundant carbonate which apparently is higher in iron and manganese than that to the north, as the oxidized ores contain these metals in relative abundance and they are said to carry some gold and silver. There has been little if any production from them.

\section{ESCALENTE DISTRICT.}

The Escalente district is among the low rolling hills about 12 miles east of Modena. The rocks of the district, which consist of latites and rhyolites with tuffs and breccias, belong to the same series as those of the Gold Springs-State Line districts to the northwest. They are cut by numerous fissures, whose prevailing strike is north to northeast, though one very prominent fissure zone strikes east. The rocks adjacent to the fissures have been hardened and they commonly outcrop prominently, the great eastwest fissure forming a conspicuous ridge.

The only fissure that has been extensively prospected (the one worked by the Escalente Mining Co.) is 4 to 10 feet wide, strikes north- 
east, and dips steeply southeast. Outcrops can be traced for $1 \frac{1}{2}$ to 2 miles but may represent several fissures with the same general strike. Where exposed in the Escalente mines, the walls of the fissure are smooth and well defined.

The veins are of the same general type as those to the northwest but show certain differences, the most pronounced being a smaller amount of carbonate and a greater abundance of base metals. In the specimens examined microscopically fluorite is abundant. Carbonate was deposited in two distinct periods; that formed earlier has been partly replaced by quartz and adularia and that formed later was the last mineral deposited, occurring as a partial filling of cavities along the center of crustified veins. The calcite of the later period may have been deposited by descending solutions and not have been directly connected with the primary deposition of the ore.

The Escalente vein is rather open and porous and had been oxidized to the depth of the development at the time of visit (about 150 feet). The metals so far as observed are all secondary, most of them occurring as incrustations on the cavities in the veins. Oxides of iron and manganese are most abundant. Yellow and green incrustations, which are also abundant, were submitted for determination to W. T. Schaller, who reported as follows:

The abundant yellow coating or stain is descloizite, a lead-zinc vanadate.

The greenish hexagonal crystals are pyromorphite, the chlorophosphate of lead.

The green coating is nickel arsenate, probably annabergite.

The green crystals are arsenate of copper and manganese with a little calcium and uranium (?) and a trace of vanadium.

The form of the silver in the vein was not determined, but in the oxidized zone it is probably the chloride. Assays showing a rather high silver content have been obtained from the prospect, but the average of the vein is rather low, though no definite figures are available.

A little prospecting at one point on the vein, or on a parallel vein, disclosed rather abundant manganese, which is said to contain some silver.

\section{BIBLIOGRAPHY.}

The geology of State Line district, Utah: Salt Lake Min. Rev., vol. 9, No. 23, pp. 15-17, 1911.

Sмгтн, G. H., State Line mining district, Iron County, Utah: Min. and Sci. Press, vol. 84, p. 101, 1902.

\section{IRON SPRINGS DISTRICT。}

\section{INTRODUCTION.}

The greater part of the following description of the Iron Springs district is abstracted from a report by C. K. Leith and E. C. Harder. ${ }^{1}$ The writer (B. S. Butler), however, visited the northern end of the district and has made observations in adjacent sections of the State which lead him to suggest certain interpretations that differ from those set forth by Leith and Haraer.

\section{GEOGRAPHY.}

The Iron Springs district lies between longitudes $113^{\circ} 10^{\prime}$ and $113^{\circ} 26^{\prime} 30^{\prime \prime}$ and latitudes $37^{\circ} 35^{\prime}$ and $37^{\circ} 47^{\prime} 30^{\prime \prime}$ in Iron County, southern Utah, about 250 miles south of Salt Lake City. Lund, on the Los Angeles \& Salt Lake Railroad, is 22 miles northwest of the district. The district lies near the eastern margin of the Basin Range province and includes several basin ranges and hills, principal among which are the Harmony Mountains, Iron Mountain, Antelope Range, Granite Mountain, The Three Peaks, and the Swett Hills. To the south are the Pine Valley Mountains. Immediately west, north, and east of the district lies the desert, beyond which on the west and north are other basin ranges, and on the east, 12 miles away, is the Hurricane fault scarp of the High Plateaus. On the southwest the district is continuous, with a series of ranges and hills extending west of the Pine Valley Mountains well into Nevada. The elevation ranges from 5,300 to 8,000 feet.

The drainage is through small creeks that lose themselves in the desert a short distance from the mountains.

The tops of the Harmony Mountains retain snow until the middle of summer, and consequently have an abundance of vegetation, such as yellow pine, fir, cottonwood, quaking aspen, and mountain mahogany. The tops and slopes of the other mountains are dry and are corered with a growth of scrub cedar and piñon.

\section{GEOLOGY.}

GENERAL FEATURES.

The dominating geologic features of the district are three large laccoliths, constituting the Three Peaks, Granite Mountain, and Iron Mountain, which lie northeast and south-

1 The iron ores of the Iron Springs district, southern Utah: U. S. Geol. Survey Bull. 338, 1908. 


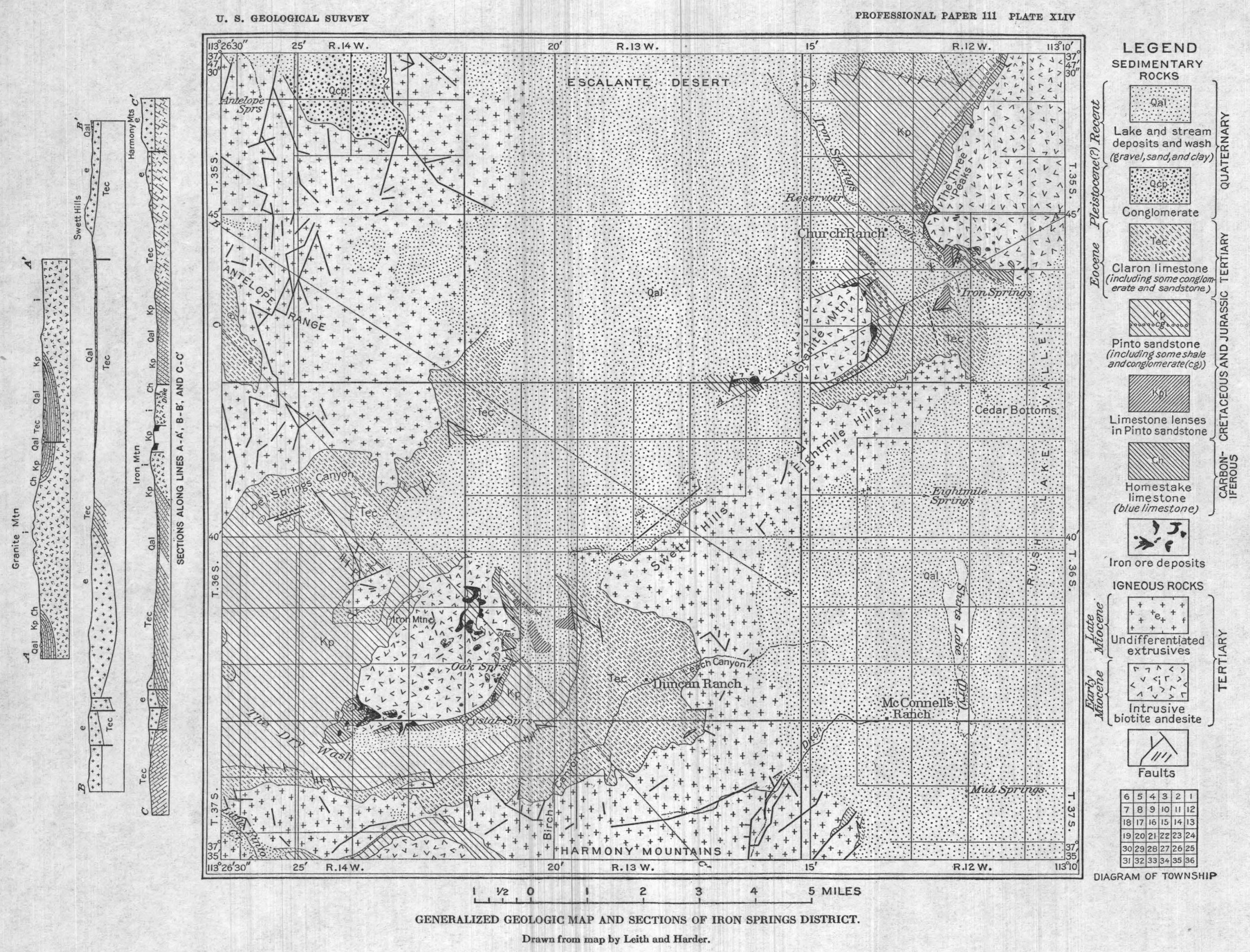



west across the district. (See Pl. XLIV.) down to the Carboniferous limestone, as on the Three unconformable sedimentary series, west side of Iron Mountain. The Cretaceous aggregating 4,000 feet in thickness, outerop in rocks are principally sandstone, with layers or successive rings around these laccoliths and lenses of shale, conglomerate, and limestone dip outward asymmetrically, very steeply at breccia. At the contact with the laccoliths the the contact, less steeply farther away. Still farther from the laccoliths nearly horizontal lava flows 2,000 feet thick lie on the tilted sedimentary rocks. These general relations are modified by faulting.

\section{STRATIGRAPHY.}

All the rock formations of the district are more or less covered on the middle and lower slopes by unconsolidated and partly consolidated erosion débris, both aqueous and subaerial, which spreads out on the lower ground to make the deserts. The detailed succession is shown in figure 62 .

The laccoliths, ${ }^{1}$ whose upper parts only are exposed, consist of andesite of remarkably uniform texture and composition. Within their area are a few veins of iron ore, fault blocks of ore, and Carboniferous and Cretaceous sediments.

In contact with the laccoliths for the most part is Carboniferous limestone, a pure, dense, blue limestone, with a few feet of sandy material appearing locally at the base. The contacts are at most localities nearly vertical, this being due partly to faulting and partly to the fact that erosion has cut down far enough to expose the vertical sides of the laccoliths. Locally,

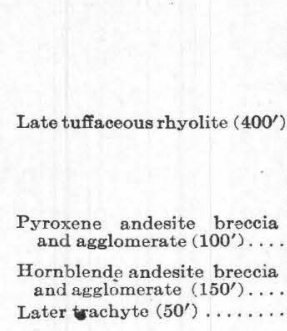

where erosion has not cut so far, the limestone dips distinctly away from the andesite at an angle as low as $10^{\circ}$. The limestone is altered at the contact to a maximum distance of 1,000 feet, as measured on the erosion slopes, by loss of carbonates, development of anhydrous silicates, and replacement by ore.

Cretaceous sediments outcrop in a zone outside of the Carboniferous limestone, except where locally they are faulted down against the laccolith, or where the laccolith has penetrated the Cretaceous and erosion has not yet cut

1 That these are laccolithic bodies has not been demonstrated and the writer is inclined to regard them as stocks.

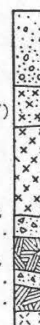

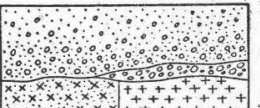

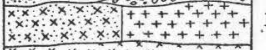
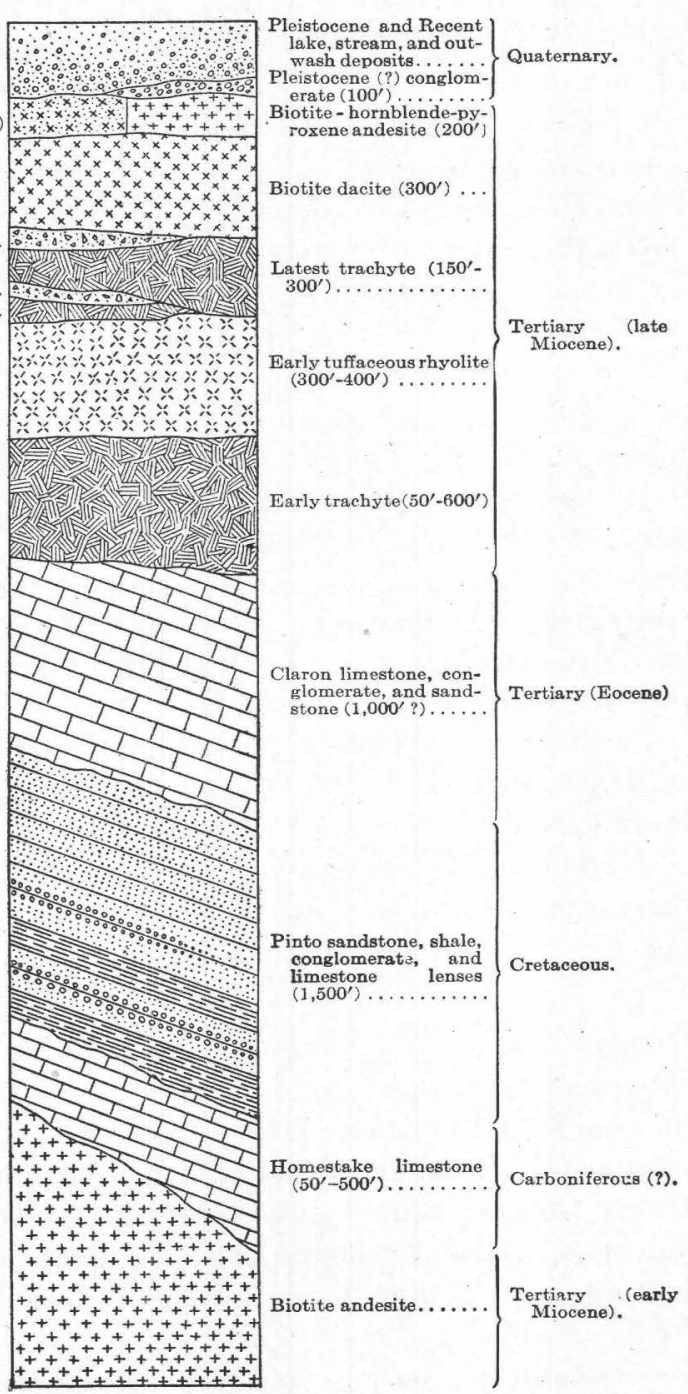

FIGURE 62.-Geologic column of the Iron Springs district.

sandstone has been indurated and amphibole has developed.

The relations of the Cretaceous sandstone to the underlying Carboniferous limestone are those of apparent conformity, but the contact is rendered somewhat obscure by the presence of shale at the base of the Cretaceous sandstone. The lower portion may be in part Jurassic, but separation could not be made. The greatly varying thickness of the Carboniferous limestone may be due partly to erosion and partly to intrusion of andesite at different horizons. If it represents erosion, it shows unconformity. Notwithstanding the conformity 
of structure, it is not unlikely that there may be a hiatus between the two systems, for the correlation of the two is fairly well based, and the Permian, Triassic, and some Jurassic sediments are lacking between them.

The Eocene series outcrops in a zone still farther away from the laccoliths. It consists of limestone and conglomerate, characterized principally by pink and bright-red colors and separated by a basal conglomerate from the Cretaceous sediments below. Its dip averages about the same as that of the Cretaceous, from which it is separated by a marked erosion unconformity.

Miocene lavas and tuffs rest nearly horizontally upon the eroded edges of the Eocene sediments and to a less extent upon the Cretaceous.

In the northwestern part of the area, near Antelope Springs, a Pliocene or Pleistocene fluviatile deposit, principally a conglomerate containing fragments of lavas of the earlier andesite laccolith, and of the sediments, occupies an embayment in the lavas.

Pleistocene and Recent lake, stream, and outwash deposits, consisting of gravels, sands, and clays derived by erosion from all of the rocks of the district, occupy rearly half of the area and mask the rock formations of the lower ground.

\section{STRUCTURE.}

Fault scarps are common, and streams or canyons prevailingly follow faults and joints, especially the former. The larger and more conspicuous faults trend prevailingly north, but others follow other directions. At several localities, especially near the ore deposits, the faults tend to follow the periphery of the andesite laccoliths.

The fault planes are vertical, or nearly so. The displacements range from vertical to horizontal but are chiefly vertical in the faults mapped. The maximum vertical displacement known is 2,000 feet; the maximum horizontal displacement is unknown. Hinge faults, the displacement at one end of which is opposite to that at the other, were found locally in the lava area. Probably many faults with a displacement parallel to the dip of the beds have not been detected. Allowing for a considerable unknown horizontal component of displacement, there remains a probable dominance of vertical movement sufficient to indicate that the net result of the faulting has been the ex- tension of the area; in other words, the faults are primarily tension phenomena.

Conspicuous in the andesite are fissures, some of them filled with ore, which curve, taper, branch, and parallel themselves in such a manner as to suggest that they are stretch fractures. In the andesite area on Three Peaks a conspicuous parallel fracturing is spaced at intervals of a fraction of an inch for several feet. In the neighborhood of ore veins the fissures trend parallel to the veins.

The faults and other fractures are believed to be due principally to the successive extension, shortening, and settling that accompanied the intrusion and the cooling of the laccoliths, as cited by Spurr for some of the faults of the Tonopah district. The faults are tension phenomena and are so numerous and so intricate in their intersections that it is easier to explain them by somewhat local strains accompanying cooling than by strain on the rocks of the district as a whole. The faults outlining the periphery of the andesite and the stretch fractures within the andesite may be ascribed definitely to this cause. A rough calculation of the cubic shrinkage of a mass of andesite the size of the Iron Mountain laccolith in crystallizing from a glass to andesite indicates a horizontal radial shortening of 200 to 500 feet (according to the depth assumed for the mass), a large enough factor to be important in the development of fractures.

So far as the faulting was due to the intrusion and cooling of the andesite, it followed the intrusion closely and is of Tertiary age. Other faults cut the lava flows and are therefore considerably later than the laccolith intrusions. These faults are, from their nature, probably in part due to the cooling of the lavas.

Certain of the larger faults, especially those trending north and showing great extent and continuity across both igneous and sedimentary formations, may be due to other causes than cooling. They seem to belong more to the order of deformation producing the Hurricane fault to the east than to the deformation associated with local igneous action. The whole Iron Springs district represents a downthrow on the west side of the Hurricane fault. The stresses have affected large areas. There can be little doubt that these great faults are essentially tensional in nature, but the cause of the tension is not clear. 
GEOLOGIC HISTORY.

The principal events in the geologic and physiographic development of the district have been in order as follows:

(1) Deposition of Carboniferous limestone, with thin fragmental base, on unknown basement.

(2) Nondeposition, perhaps erosion, followed by deposition of Cretaceous and perhaps of some Jurassic sandstone with layers of shale, conglomerate, and limestone.

(3) Erosion, followed by deposition of Eocene limestone and conglomerate in an inclosed basin. Shallow water, strong currents, and rapid changes obtained through both Cretaceous and Tertiary time.

(4) Intrusion, in early Miocene time, of andesite laccoliths, principally into the Carboniferous limestone but also into the overlying Cretaceous, accompanied by tilting of all the formations away from the laccoliths, steeply near the laccoliths, less steeply farther away. Metamorphism of limestone and sandstone near the contact.

(5) Fissuring and faulting caused by cooling of laccoliths.

(6) Advent of ore-depositing solutions through fissures in the andesite, depositing iron ore in the andesite fissures and in the adjacent limestone and altering the wall rock.

(7) Erosion, exposing the laccoliths and rings of sediments and ores around them.

(8) Extrusion of late Miocene lavas over the entire area, except possibly some of the higher peaks of the exposed laccoliths, effecting a secondary concentration of the ores and further altering the underlying rocks.

(9) Further faulting.

(10) Vigorous erosion, reexhuming the andesite cores and developing the Pleistocene conglomerate and the Pleistocene and Recent mantle of stream, lake, and other alluvial deposits.

Several of the intrusive bodies in central and southern Utah, and particularly in the Tintic, Frisco, and Marysvale regions, where both the extrusive and intrusive rocks are very similar to those at Iron Springs, are known to be later than the associated extrusive rocks; and from observations in the northern part of the district and from a study of the map accompanying Leith and Harder's report, the writer suggests that in the Iron Springs district also the extrusive rocks are perhaps earlier than the intrusive. His reasons are as follows:

The extrusive rocks through nearly their entire extent rest upon the Tertiary sediments. At a few localities they are represented on the map as in contact with Cretaceous rocks, but nowhere are they in contact with the Carboniferous sediments or with the intrusive rocks. If they had flowed over a mature erosion surface in which all these rocks were exposed, one would expect that somewhere they would be in contact with the earlier rocks, especially because the lavas are nearly as resistant to weathering and erosion as the intrusive rocks and are far more resistant than the sedimentary rocks. In general also they dip away from the intrusive bodies as much as would be expected considering their distance from them.

The lavas may have been poured out on a surface of Tertiary rocks (with possibly some exposures of Cretaceous rocks) which was subsequently lifted by the igneous intrusive into a broad anticline with subsidiary domes at points where the intrusive was greatest. This anticline, rising above the general elevation, was vigorously attacked by erosion, which eventually removed all the rocks above the intrusive body and left the several formations outcropping about it in concentric bands regardless of their degree of resistance to erosion.

Leith and Harder designate three principal periods in the development of the topography: (1) Intrusion of laccoliths in early Miocene time, followed by faulting and erosion exposing the laccoliths and surrounding belts of sediments and developing in the laccolith cores a mature type of topography; (2) extrusion of late Miocene lavas, followed by faulting and by erosional exhumation of the laccolith cores and surrounding sediments, so far as they had been covered by the lavas; and development of a mature type of topography in the lavas themselves; (3) development of the hurricane fault to the east, causing a slight renewal of activity, exhibited in the sharp canyons and steep sides of some of the lava hills. They note that, according to Huntington and Goldthwait, their earliest period is not recognized in the Toquerville district to the southeast. If it should prove that the intrusions in the Iron Springs district were later than the extrusions, this earlier erosion period would be eliminated and the sequence of events in the two districts would be in essential harmony. 
SEDIMENTARY FORMATIONS.

CARBONIFEROUS SYSTEM. HOMESTAKE LIMESTONE.

Distribution and character.-The Homestake limestone outcrops in or around the andesite laccolith areas in contact with the andesite.

West of the Three Peaks laccolith it is exposed in a band extending from the northern boundary of the district southwestward for about 3 miles and then southeastward to a point northeast of Iron Springs, except for about a mile, where the Cretaceous formations are faulted into contact with the andesite.

Northeast of the Granite Mountain laccolith a band of Homestake limestone is exposed for about 2 miles. Both ends of this band are overlapped by the Pinto sandstone, which here again comes in contact with the andesite. At the Desert Mound, southwest of Granite Mountain, the Homestake limestone again appears. It is cut off by a fault on the west and disappears under the lake and stream deposits on the east.

The Iron Mountain laccolith is bordered by the Homestake limestone on its northeast, east, south, and southwest sides, with a few interruptions due to faulting or covering by surface deposits. Southwest of the laccolith the outcrop of the limestone is rather wide, owing to the fact that the surface of the supporting laccolith is nearly horizontal here, as shown by the tongue of andesite extending westward from the main mass and by the few andesite outliers in the Homestake limestone. On the west and north sides of the Iron Mountain laccolith, as in Granite Mountain, the Homestake limestone is not exposed, the Cretaceous sandstones lapping against the laccolith.

A patch of Homestake limestone is present in the Comstock iron deposit in the Cretaceous area southwest of the Homestake mine; others are scattered irregularly within the area of the Iron Mountain laccolith.

The Homestake limestone is a dark bluishgray limestone of dense texture, with uniform characteristics throughout its entire extent, except near the laccolith contact. Under the microscope it appears to be made up of exceedingly minute grains of calcite with scattered grains of pyrite, magnetite, and chert.

The bedding of the Homestake limestone is very indefinite, and is easily confused with sec. ondary fracturing. Where well defined the limestone is generally thin bedded.
Many of the altered contact phases of limestone are hard to distinguish from a muchfractured quartzite or clayey sandstone which is locally exposed below the limestone and constitutes a part of the same formation. The sandstone lies between the ore deposits and the andesite, or between the ore and the limestone. It is conspicuous also in the limestone patches faulted into the andesite.

The thickness of the Homestake limestone, as shown by exposures, ranges from 50 to 500 feet. The average thickness has been taken to be about 200 feet. The variation is probably due to intrusion of laccoliths at different horizons. If the intrusion has followed the base, the variation in thickness may indicate unconformity with the overlying Pinto sandstone.

Contact metamorphism.- The limestone adjacent to the andesite has been locally replaced by iron ore and has been generally vitrified, silicated, and kaolinized in a band usually not more than 60 feet wide along the erosion surface but locally a few hundred yards wide where the erosion surface is nearly parallel to the limestone-andesite contact. Locally either or both contact phases are absent.

The altered limestone is a grayish, yellow, or greenish, fine-grained, argillaceous-looking rock. Near the contact it is soft, and farther away it is hard and fractured into small irregular blocks. The principal minerals are albite, kaolin, actinolite, diopside, quartz, orthoclase, serpentine, phlogopite, andradite, iron ores, osteolite, andalusite, wollastonite, and calcite, varying greatly in proportion in different places but usually occurring in quantity in the order named. They are found in veins, in breccias, and disseminated through the rock. In addition, there are local residues of a glassy base.

Another phase is coarsely crystallized limonite-stained marble, in some places found in a narrow belt between the andesite and the normal silicated contact phase and elsewhere outside of the normal phase or associated with the ore. It is thought possible that this limonitic marble is a later material, filling openings along the contact left by the cooling and crystallization of the intrusive and intruded masses.

Analyses of various phases of the Homestake limestone are given on page 171. 
As a result of consideration and calculation of the analyses, Leith and Harder arrive at the following general conclusions concerning the changes that have taken place:

It is concluded that in general there has been large loss of material from the limestones at the contact without conspicuous introduction of new material except soda, but that exceptional phases show clearly the introduction of silica and iron. Both normal and exceptional phases of the contact rocks are cut by later veins of calcite and iron ore, with associated minerals similar to those of the limestone contact.

A consideration of the density and volume changes leads the authors to the conclusion that there has been a pronounced shrinkage of the limestone during metamorphism. They sum it up as follows:

If the principal chemical change in the development of the contact phase has consisted in the elimination of calcite and to a less extent of magnesia, iron, and potassa, leaving alumina and silica substantially unchanged in their ratios, this has involved a very considerable loss of weight, and, as the densities of the fresh and altered rocks differ so little, the loss in volume also has been large. Kemp, ${ }^{1}$ Lindgren, ${ }^{2}$ and others have cited lack of structural evidence of diminution in volume at limestone contacts as favoring the view that materials musthave been introduced from without to take the place of the calcium carbonate. Kemp ${ }^{3}$ in a review of Bulletin 338, dissents from the conclusions concerning the additions during metamorphism; Lindgren ${ }^{4}$ expresses a similar opinion. In the Iron Springs district the field evidence does not positively prove or disprove important volume change, but there is no apparent field evidence to contradict the evidence for diminution of volume here calculated. The limestone, though tilted away from the andesite laccoliths, nowhere shows evidence of crumpling or crowding where the bedding can be observed. In the altered phase the bedding has been destroyed, and it is easy to conceive that this structurally amorphous zone may represent only a part of the volume of the original rock, the calcium carbonate having been driven off and the other constituents concentrated. The change in volume of the limestone would scarcely be expected to stand out conspicuously in the field relations, for it has occurred, if at all, in the band which now does not show original textures or structures, by which change of volume can be measured in crumpling or folding. In general it appears that there may have been important diminution of volume, accomplished essentially by loss of materials and not by change of density of minerals.

Observations in the northern part of the field failed to reveal to the writer evidence that the contact metamorphism in this district is essentially aifferent from that in other districts of the State, where, it is believed, additions of magmatic material have been extensive.

1 Kemp, J. F., Ore deposits at the contacts of intrusive rocks and limestone and their significance as regards the general formation of veins: Econ. Geology, vol. 2, pp. 1-13, 1907.

2 Lindgren, Waldemar, The copper deposits of the Clifton-Morenci

district, Ariz.: U. S. Geol. Survey Prof. Paper 43, 375 pp., 1905.

${ }^{3}$ Kemp, J. F., Econ. Geology, vol. 4, pp. 782, 791.

- Mineral deposits, p. 670, New Xork, McGraw-Hill Book Co., 1913.
Introduction of ore.-The introduction of ore took place after the development of the silicated contact phase, as is demonstrated by its occurrence in fissures that intersect this phase. The silicated contact phase is found also along parts of the contact where ore is absent. The introduction of ore-bearing solutions effected further metamorphism of the limestone of approximately the same sort, nearly all of the minerals found at the barren contacts being duplicated within and adjacent to the ore itself. Apatite, amphibole, biotite, pyrite, and garnet are more abundant in association with the ores than elsewhere in the contact phase, and albite and orthoclase appear in the contact phase and not in the ores. Beyond this it has not been found possible to separate the metamorphic effect of the ore-bearing solutions, aside from its deposition of ore, from the earlier contact effect of the andesite, although it is thought likely that additional careful field work might discover further criteria for their separation.

CRETACEOUS SYSTEM (PERHAPS IN PART JURASSIC). PINTO SANDSTONE.

The composition of the Pinto sandstone, which conformably overlies the Homestake limestone, varies somewhat in different parts of the district. A generalized section in the northeastern part of the district follows.

Generalized section of Pinto sandstone in Granite Mountain and Three Peaks areas.

Sandstone, yellowish brown and gray.......... $1,000+$ Conglomerate, with interbedded sandstone .... 20-40

Sandstone and shale, variegated.............. 40-75

Conglomerate............................. 8

Cherty limestone breccia ................. 10-20

Sandstone, maroon and spotted................ 40-60

Shale, purple and green.................. 30-50

TERTIARY SYSTEM (EOCENE SERIES).

CLARON LIMESTONE.

The Claron limestone unconformably overlies the Pinto sandstone. It consists mainly of limestone, with a few thin layers of conglomerate and a few heavy beds of sandstone, and of a basal conglomerate 2 to 25 feet thick.

Adjacent to the lavas the limestone has been metamorphosed to white, gray, or red chert, chalcedony, and moss agate or jasper throughout a maximum thickness of 15 feet. The red moss agates and jaspers are colored with iron. A white powdery calcium carbonate, apparently deposited by hot springs, and especially abundant north of Eightmile Hills, is asso- 
ciated with many of these cryptocrystalline varieties of quartz and with many ore deposits.

At Chloride Canyon and elsewhere, near the contact with the lavas, the limestone contains veins carrying calcite, barite, and quartz, and subordinate amounts of galena, pyrite, chalcopyrite, siderite, limonite, magnetite, and copper carbonates. Gold and silver are reported, the silver probably being contained in the galena. Similar mineral veins are found in the Homestake limestone, both associated with and remote from iron-ore deposits.

\section{QUATERNARY SYSTEM.}

Pleistocene and Recent conglomerates, sandstones, and clays are present over much of the lower areas of the district.

\section{IGNEOUS ROCKS.}

The igneous rocks of the district are both intrusive and extrusive. Biotite andesite laccoliths were intruded into the Paleozoic and to a less extent into the Mesozoic rocks after the deposition of the Tertiary sediments. Later a bedded series 1,000 to 2,000 feet in thickness, consisting of rhyolitic, trachytic, and andesitic flows, tuffs, and breccias, was extruded.

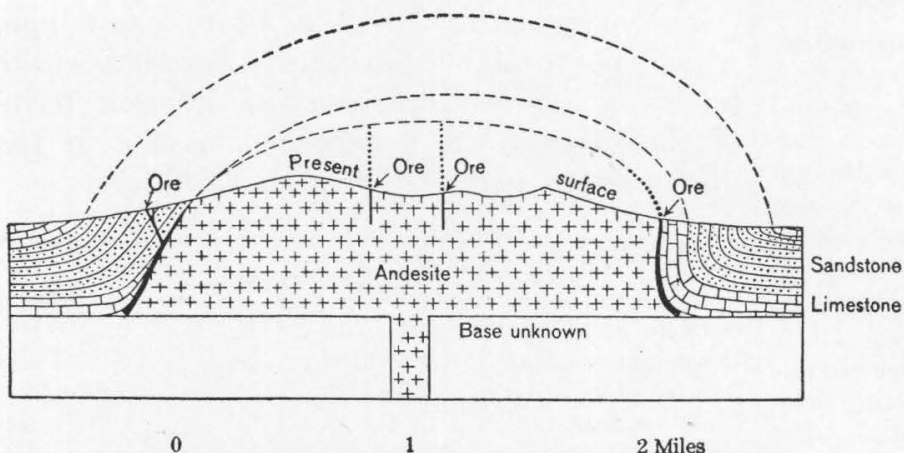

FIGURE 63,-Ideal cross section through the Iron Mountain laccolith, showing structural relations of ore.

The lavas rest on the eroded and upturned edges of the Eocene and Cretaceous sediments, indicating that a considerable period of erosion intervened between the intrusion of the biotite andesite and the outpouring of the extrusive rocks. They have been correlated with the Miocene lavas of the Wasatch Mountains, and hence the andesite intrusion is post-Eocene and probably early Miocene.

Quaternary basalts surround the Iron Springs district but do not occur within it.

\section{LACCOLITHS (EARLY MIOCENE).}

DISTRIBUTION AND STRUCTURE.

The laccoliths form the cores of the three principal mountain groups of the district - the
Three Peaks, the Granite Mountain, and the Iron Mountain - and also the core of a fourth, Stoddard Mountain, which lies mainly southwest of the area mapped. The size and form of the laccolithic bodies can be best understood by reference to figure 63 .

It is estimated that at the time of intrusion the laccoliths were covered by approximately 4,500 feet of sedimentary rocks. According to calculations made by Gilbert for the Henry Mountains, laccoliths of the size of the Iron Springs bodies would require a minimum covering of 7,000 feet. Leith and Harder attribute the greater efficiency of the Iron Springs covering to greater strength and resistance in the overlying sediments, notably the Homestake limestone. It may be noted, however, that if the 1,000 to 2,000 feet of extrusive rocks now exposed, and probably a considerable thickness that has been removed, are older instead of younger than the intrusive rocks, their thickness added to that of sedimentary rocks would satisfy Gilbert's calculations. However, it seems likely that these bodies are stocks rather than laccoliths.

PETROGRAPHY.

The intrusive andesite ${ }^{1}$ is the rock with which the iron-ore deposits are associated. Deposits are found on the borders of all the andesite areas except Stoddard Mountain (outside the Iron Springs district), where its absence is probably due to the absence of limestone.

The rock is a light-gray biotite andesite with porphyritic texture. The phenocrysts, consisting of feldspar, biotite, hornblende, and diopside are numerous, occupying more than half of the rock mass and reaching a maximum diameter of an eighth of an inch. The most abundant phenocrysts are plagioclase (labradorite), but some of orthoclase are present. A large number of feldspars show zonal growth. They are comparatively fresh, showing alteration only along cracks, along lines of zonal growth, and on the surface. The alteration products are calcite, kaolin, quartz, and sericite, typical katamorphic products. The next most abundant phenocryst is biotite, in shiny black hexagonal plates, in many places altered to phlogopite with a golden luster and with reaction rims of magnet-

${ }_{1}$ To rocks of this general character in other districts the name of monzonite porphyry has commonly been applied. 
ite. In the Stoddard Mountain area and parts of the other areas the biotite is almost entirely decomposed to ferrite. In a few places it has altered to green chlorite. The biotite has abundant inclusions, mainly apatite, but in places quartz, magnetite, and zircon. The hornblende is generally in dark-green prismatic crystals, with inclusions of magnetite, biotite, and quartz. Like the biotite the hornblende in the andesite of the Stoddard Mountain area is almost entirely decomposed to ferrite. The diopside is light green and is noticeably associated with magnetite, which formsinclusions and surrounds borders. It is generally more or less altered to uralite along cracks and around the border. Fragments of magnetite are abundant. Ferrite is present as an alteration product of the ferrous silicates.

The groundmass is cloudy from alteration but seems to be composed mainly of fine crystalline quartz and feldspar, both orthoclase and plagioclase. Biotite, hornblende, pyroxene, and magnetite are also represented, but less abundantly.

The biotite andesite has the same texture and mineral composition throughout the different areas. The absence of marginal facies (as a basic edge), dikes, and pegmatitic veins is especially noticeable.

\section{METAMORPHISM.}

For a few feet near its contact with the ores the andesite has a greenish-yellow color and dense texture, very similar to that of the silicated limestone at the andesite contact. The two are with great difficulty discriminated. The grain of the contact phase is much finer than that of the main mass of the andesite. The groundmass consists of finely crystalline feldspar and quartz (principally feldspar) and is cloudy with dark clayey-looking material, much of which is not recognizable, but some of which is clearly muscovite and rarely chlorite. The contact between the altered phase and the fresh andesite is sharp.

A comparison of the analyses of the fresh and contact phases brings out clearly the conspicuous introduction of soda. All other constituents show a possible loss, though ferric iron has developed at the expense of ferrous iron. At present specimens from horizons surely below the influence of weathering can not be obtained, and the oxidation of the ferrous iron may really be a superposed weathering effect.
Analyses of fresh and altered andesites. [Analyst, R. D. Hall, University of Wisconsin.

\begin{tabular}{|c|c|c|c|c|c|}
\hline & A & B & $\mathrm{C}$ & $\mathrm{D}$ & $\mathrm{E}$ \\
\hline $\begin{array}{l}\mathrm{Na}_{2} \mathrm{O} \\
\mathrm{K}_{2} \mathrm{O} \\
\mathrm{H}_{2} \mathrm{O}- \\
\mathrm{H}_{2} \mathrm{O} \\
\mathrm{P}_{2} \mathrm{O}_{5} \\
\mathrm{BaO}_{5}\end{array}$ & $\begin{array}{r}65.29 \\
11.57 \\
2.10 \\
2.67 \\
2.87 \\
4.85 \\
2.10 \\
5.18 \\
.50 \\
1.82 \\
.22 \\
.17\end{array}$ & $\begin{array}{r}63.63 \\
15.64 \\
3.59 \\
.93 \\
2.32 \\
4.46 \\
1.70 \\
5.22 \\
.40 \\
1.70 \\
.15 \\
.05\end{array}$ & $\begin{array}{r}65.80 \\
14.48 \\
3.96 \\
.70 \\
2.35 \\
3.19 \\
3.78 \\
3.32 \\
.12 \\
2.71 \\
.12 \\
.06\end{array}$ & $\begin{array}{r}63.82 \\
14.28 \\
2.72 \\
.81 \\
5.98 \\
.70 \\
3.62 \\
4.24 \\
2.30 \\
1.68 \\
.04 \\
.04\end{array}$ & $\begin{array}{r}63.76 \\
16.05 \\
1.91 \\
.58 \\
2.46 \\
4.25 \\
6.26 \\
2.84 \\
1.22 \\
.93 \\
.28 \\
\text { None. }\end{array}$ \\
\hline & 99.34 & 99.79 & 100.59 & 100.23 & 100.54 \\
\hline
\end{tabular}

A. Specimen 46612. Fresh andesite east of Granite Mountains.

B. Specimen 46377. Weathered andesite from Desert Mound.

C. Specimen 46433. Altered andesite near iron-ore contact from Blowout, south of Iron Mountain.

D. Same nearer iron-ore contact.

E. Specimen 46481. Altered andesite near iron-ore contact from Emma claim on east slope of Iron Mountain.

When the normal weathered andesite from the surface is compared with the fresh andesite the change is found to be very different from that along the ore contacts. All constituents, including soda, show a loss relative to the alumina.

EXTRUSIVE ROCKS (LATE MIOCENE).

The extrusive rocks occupy two main areas in the district - the Antelope Range area and the Swett Hills, Eightmile Hills, and Harmony Mountains area. There are small exposures at Upper Point, in the northeastern quarter, and northwest of Iron Mountain.

There is a succession of 9 flows in the following order:

Succession of lava flows in Iron Springs district.

9. Biotite-hornblende-pyroxene andesite.......... 200

8. Late tuffaceous rhyolite (Antelope Range)....... 400

7. Biotite dacite.............................. 300

6. Pyroxene andesite agglomerate and breccia...... 100

5. Latest trachyte........................ 150-300

4. Hornblende andesite breccia and agglomerate.... 150

3. Later trachyte............................ 50

2. Early tuffaceous rhyolite................ 300-400

1. Early trachyte......................... 50-600

Of these Nos. 1, 2, 5, and 7 extend throughout the area and for a number of miles to the south and west, but the rest are present only in parts of the district. There is little evidence of erosion between the successive flows, unless the absence of certain beds in different places may be taken as such. The border of the lava series is the oldest formation, and inside of this 
successively younger flows outcrop, the latest in the center. Local faulting and sheets of outwash deposits have somewhat obscured these relations in places.

The Antelope Range lavas occupy a broad syncline pitching to the northeast, while those of the Swett Hills and Harmony Mountains have a general eastward dip and are not folded.

CHEMICAL AND MINERAL COMPOSITION.

Analyses have been made of the intrusive andesite and of the four principal flows, namely, the early trachyte (1), early rhyolite (2), latest trachyte (5), and dacite (7). Of the rest of the flows, some, though they have considerable horizontal distribution, are very thin, and the others are local in their distribution.

The following table shows an approximation of the average chemical composition of the lavas and andesite, obtained by averaging the analyses. The general similarity of composition indicates that both may have come from the same reservoir.

Average chemical composition of laccoliths and extrusive rocks.

\begin{tabular}{|c|c|c|}
\hline & Laccoliths. & $\begin{array}{c}\text { Extrusive } \\
\text { rocks. }\end{array}$ \\
\hline 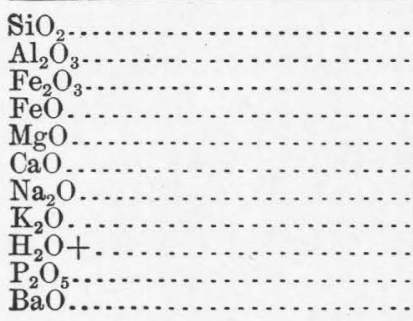 & $\begin{array}{r}64.46 \\
13.60 \\
2.85 \\
1.80 \\
2.59 \\
4.65 \\
1.90 \\
5.20 \\
2.21 \\
.18 \\
.11\end{array}$ & $\begin{array}{r}66.42 \\
15.41 \\
3.48 \\
.96 \\
1.34 \\
3.40 \\
1.86 \\
5.99 \\
.95 \\
.19 \\
.09\end{array}$ \\
\hline & 99.55 & 100.09 \\
\hline
\end{tabular}

SOURCE.

The question naturally arises whether the intrusive and the extrusive rocks came from the same reservoir. The chemical composition of the laccolithic rocks and of the different flows show small range. With very little differentiation all the different phases may have originated from the same parent magma. It is certain, however, that the laccoliths did not act as vents through which the lavas were outpoured. The andesite had been intruded, solidified, and eroded when the lavas were poured out over the eroded edges of the uplifted sediments. That the lavas came to the surface through the laccoliths after their solidification and erosion does not seem likely, for the andesite areas show no dikes or stocks, unless the ore veins be so called. Neither are there stocks or dikes elsewhere in the district through which the eruptions might have occurred; hence we are driven outside of the area for the source of the extrusive rocks.

\section{HISTORY AND PRODUCTION.}

By V. C. Heikes.

The Iron Springs district includes two mining districts - the Iron Springs, in the northern part of the area, and the Pinto Iron, in the southern part.

Iron Springs district.-The Iron Springs district, in Iron County, 22 miles south-southeast of Lund, on the Los Angeles \& Salt Lake Railroad, was first organized in 1871, and was reorganized on March 27, 1879. About 1856, at Cedar City, 8 miles east of Lund, considerable iron ore was reduced with fair success in an imperfect furnace.

Pinto district.-The Pinto iron district, organized May 26, 1868, is in Iron County, a few miles southwest of the Iron Springs district, 20 miles west of Cedar City, and 32 miles southeast of Modena, the nearest station, on the Los Angeles \& Salt Lake Railroad. Huntley ${ }^{1}$ gives the following description of the district:

There were [July, 1880] 23 iron claims, 1,500 by 600 feet each, in an area 1 mile wide and 4 miles long, beginning 3 miles northeast of the town. * * *

In 1868 the Great Western Milling \& Mining Co. was organized by five Mormons. A rude furnace, a foundry, * * * were erected. * * * In 1875 or 1876 the works were shut down. ** * The company made only four runs, in all about nine months, and produced 400 tons of pig iron. This was made into castings, principally shoes and dies for the mills at Pioche, and was considered of excellent quality. The company expended about $\$ 100,000$. * * *

The old Silver Belt district was included in the Pinto district. The former was cut off in 1873, and joined again in 1875. It is located north of Pinto district, and contained at the time of the writer's visit 60 locations. The ore is quartzite, with some copper stain and lead, and assays from $\$ 40$ to $\$ 60$ silver per ton. The veins are from 2 to 4 feet wide.

In 1912 a trial shipment of lead ore containing a little silver was made from the Homestake claim.

\section{IRON-ORE DEPOSITS. ${ }^{2}$ ICCURRENCE.}

The iron ore occurs in disconnected masses within ageneral northeast-southwest area about $1 \frac{1}{2}$ miles wide by 20 miles long (see Pl. XLIV) lying for the most part on the eastern and southern slopes or foothills of the Three Peaks, Granite Mountain, and Iron Mountain. Most

1 Precious metals: Tenth Census U. S., vol. 13 , pp. 476-477, 1885

${ }^{2}$ Abstracted from Leith, C. K., and Harder, E. C., op. cit., pp. 66-86. 


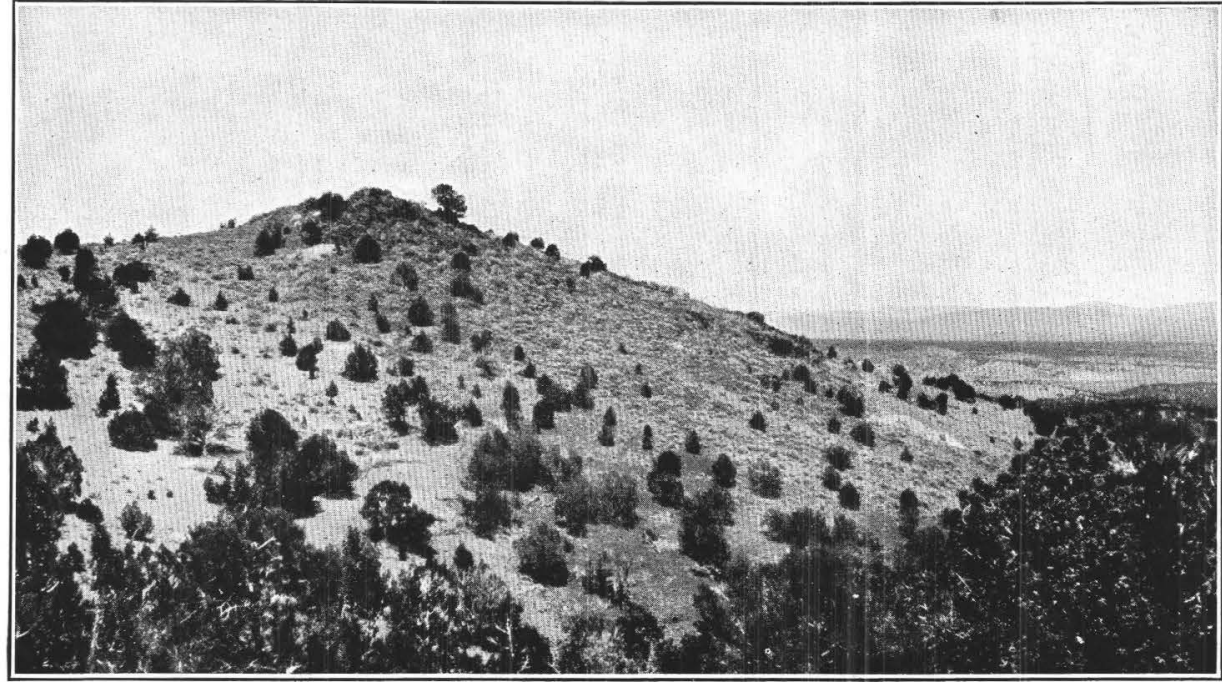

A. VIEW SHOWING SOUTHERN CROSS IRON-ORE DEPOSIT, EAST OF GRANITE MOUNTAIN, LOOKING NORTH.

The ore forms the summit and the dark area on the slope to the right and foreground; the light area to the west is footwall andesite; hanging-wall sediments occupy the lower half of the slope to the right.

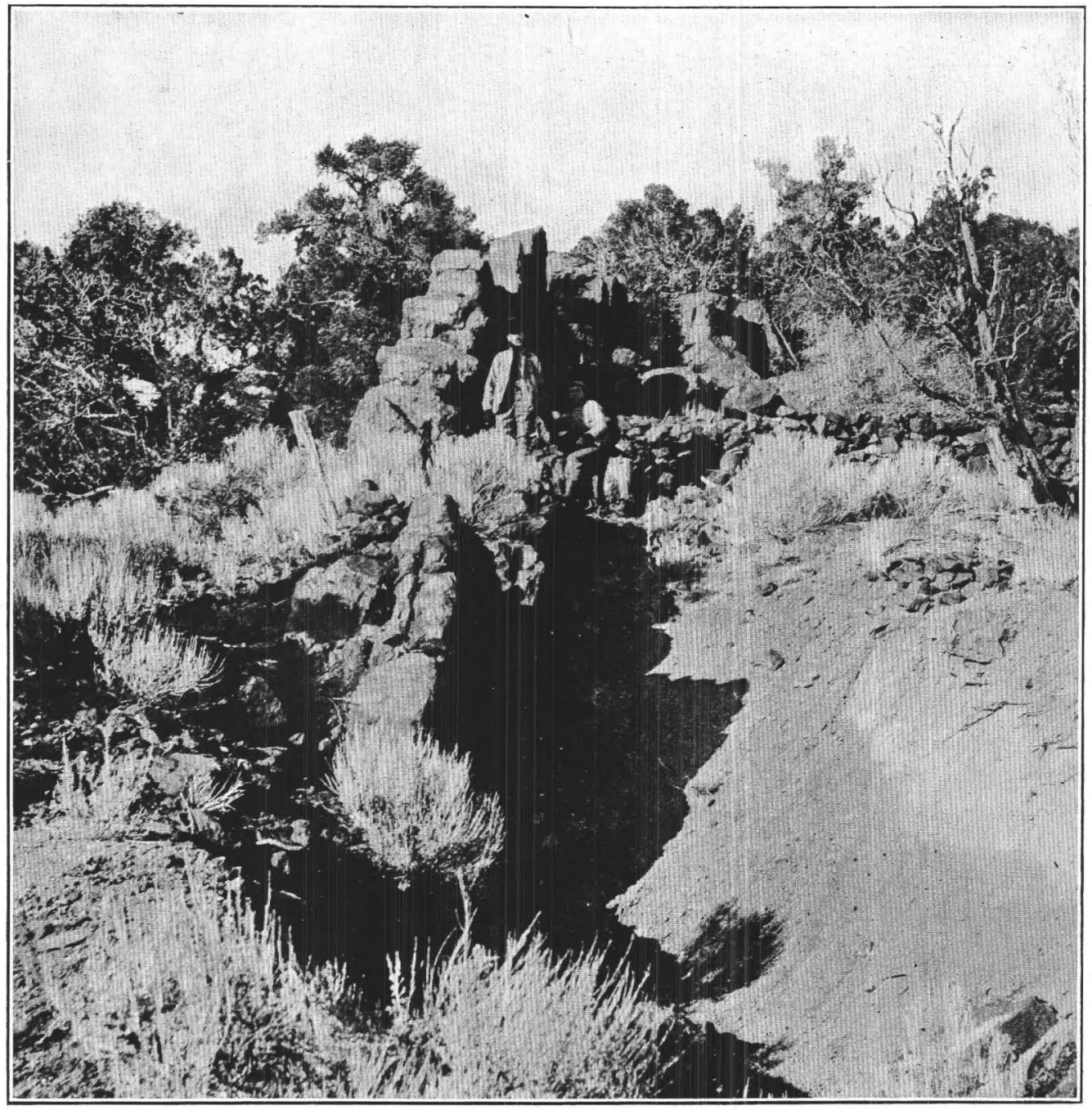

B. CHESAPEAKE IRON-ORE FISSURE VEIN, IRON MOUNTAIN (BOUNDED BY ANDESITE), Photograph by Leith and Harder. 
of them are at elevations of 5,600 to 6,700 feet, but some, as on Iron Mountain, are at or near the tops of the mountains at elevations between 7,000 and 8,000 feet.

Some of the iron-ore exposures rise 200 feet above the surrounding country as black, jagged ridges. (See Pl. XLIV, B.) Others, including several of the larger deposits on the lower slopes, are recognized only by isolated exposures and by black iron-formation fragments disseminated in loose detrital material. Some of the ore does not outcrop at all, being covered by andesite detritus washed from the upper slopes, though even here fragments of ore are likely to appear farther down the slopes. In such places the exact shape and distribution of the deposits can not be determined without trenching or pitting. Fortunately such work will suffice fairly well throughout the possible ore-bearing areas, though there are places where areal extensions of iron-ore belts may be found by underground exploration, or where belts, mapped as continuous on the basis of surface fragments, may really be discontinuous. The deepest pits in the district, 130 feet, have not yet reached water level.

GEOLOGIC AND STRUCTURAL RELATIONS.

The ore deposits for the most part lie at or near the contact of the andesite laccoliths and the Homestake limestone. Some of them are entirely within the andesite well up the slopes, and others are entirely within the limestone, though few of these are far from the contact. (See fig. 63.)

\section{EPOSITS IN ANDESITE.}

The deposits within the andesite appear at the surface in long, narrow bands from 20 feet to less than 1 foot in width, standing from a few feet to 30 feet above the adjacent andesite. These are true veins or fissure deposits. Most of the fissures which they fill are somewhat curved, taper at one or both ends, almost invariably branch, and are accompanied by subsidiary parallel fissures. Their orientation is diverse; in general they follow the directions of the adjacent jointing and faulting.

DEPOSITS AT ANDESITE-LIMESTONE CONTACT.

The larger and more numerous deposits are along the andesite-limestone contact. (See Pl. XLV, A.) The outcrops are commonly lens-shaped, with their longer diameters parallel to the contours of the hills, but some have $35416^{\circ}-19-37$ irregular polygonal shapes, due partly to faulting and partly to the angle between the erosion surface and the plane of the andesite-limestone contact (which the ores follow). The deposits at the contact have as a hanging wall either the fresh limestones or the silicated phase characteristic of the contact with the andesite. The ore protrudes irregularly into the limestone in large and small masses and veins. Small masses of the ore, measuring from a few inches to a few feet, lie entirely within the limestone, and fragments of limestone lie in the ore. Along fault planes the limestone is locally brecciated and cemented by ore for a few inches or a few feet, notwithstanding which the contacts on a large scale are usually even and continuous. The dip of the contact of the ore and the hanging wall is almost invariably steeper than the dip of the bedding of limestone-that is, almost vertical but with a slight dip away from the andesite.

The footwall is principally andesite, but at many localities the ore is separated from the andesite by a thin layer of the silicated contact phase or the sandy basal phase of the limestone. The contact with the footwall andesite as a whole is considerably more regular than that with the hanging-wall limestone. There is less interpenetration of the two masses, though some fragments of andesite do protrude into the ore or are entirely surrounded by it, and andesite breccias with ore cement are not uncommon along faults. Andesite dikes or offshoots are rare in the ores and limestone near the contacts but are known in one locality east of Iron Mountain. The andesite near the contact is altered to a soft clay retaining andesite texture. The contacts may be vertical or inclined but are commonly somewhat steeply inclined away from the andesite.

These simple relations of ore to wall rock are complicated by faulting to a considerable extent-probably to a larger extent than has been proved. Because of the faulting the ore may be nearly or quite surrounded by andesite or by limestone or by any combination of these rocks.

Much of the faulting is earlier than the ore deposition, as is shown by the fact that the fault breccias are cemented by ore, as in the Desert Mound and the Marshall claim in the Three Peaks area. Other faults are distinctly later than the ore, as on the Chesapeake and other claims on Iron Mountain. 
The earlier and the later faulting are not certainly to be distinguished in all places in the present state of development of the deposits, for the structural relations are in part similar. The age of the late faulting of the ore deposits is provisionally assigned to the postlava period, because this has been a period of considerabie faulting throughout the district.

The shape of the deposits in vertical cross section is incompletely known because exploration has been shallow. The general relation of the ore bodies to the inclosing rocks is shown in figure 63 (p. 574).

\section{DEPOSITS IN BRECCIAS.}

The ore constitutes cement or minute veins in fault breccias of Homestake limestone and Pinto quartzite at the Milner, Dear, Excelsior, Duluth No. 2, and Desert Mound claims, and of andesite at the Marshall, Blowout, Dexter, and Pot Metal claims. At the Desert Mound claim a fault breccia crosses andesite. Ore, limestone, and magnetite constitute breccia fragments.

\section{ORES.}

The ores as they appear above water level (beneath which pits have not yet been sunk) are mainly magnetite and hematite, usually intimately intermixed but locally segregated. The magnetite apparently constitutes about 70 per cent and the hematite 30 per cent of the whole. Deeper exploration may develop a higher percentage of hematite. At the surface the ore is ordinarily hard crystalline magnetite and hematite in porous, gnarled, and contorted masses, with coarsely crystallized quartz and fibrous chalcedony as the principal gangue mineral, wholly or partly filling cavities in the ore. Other gangue minerals occurring in small and practically negligible amounts are apatite, mica, siderite, diopside, garnet, pyrite, chlorite, calcite, barite, galena, amphibole, copper carbonates, limonite, and amethyst. Of these minerals barite and galena are more closely associated with the limestone than with the ore. Melanterite, associated with pyrite, was found in process of formation in the long tunnel on the Duncan claim. Beneath the surface the ore is usually softer and contains a larger proportion of soft bluish, reddish, brownish, grayish, and greenish banded hematite, limonite, and magnetite in greatly varying proportions and relations. The gangue materials are more abundant than near the surface, and calcite is in relatively increased proportion as compared with the quartz. The banding in the contact ores partly represents the bedding of the limestone, which the ore replaces. Banding in the dike or vein ores in the andesite is possibly the result of original deposition. Some of the softer ore at lower levels entirely lacks this banding. Locally, as on the west side of Lindsay Hill, the contact ore contains parallel streaks of a yellow clayey-looking mixture of iron carbonate, iron sulphate, glass, and probably some residual clay. Some of the narrow ore veins in the andesite possess a comb structure formed by the meeting and interlocking of apatite crystals which project from the walls, but in places do not entirely close the vein.

In the ore breccias the cements are magnetite, limonite, calcite, and quartz. At the Milner mine and elsewhere the magnetite has been deposited first about the fragments, here consisting of quartz, then hematite, then limonite, but exceptionally in the same locality the reverse order appears.

For the following information concerning the composition of the ores the writers are indebted to Mr. Fred Lerch, of Biwabik, Minn., and to Mr. R. N. Dickman, of Chicago, Ill., both of whom have exhaustively sampled the ores of the district for commercial purposes. Corroborative figures were obtained from other commercial sources, and a few analyses were made for the writers. In all, about 200 analyses from 400 samples of ores have been available, about two-thirds of them containing determinations only of iron, silica, and phosphorus, and one-third showing the percentages of all the common elements.

The average composition of the ores of the Iron Springs district, determined by combining all available analyses of the ores of the district from surface and pits, is as follows:

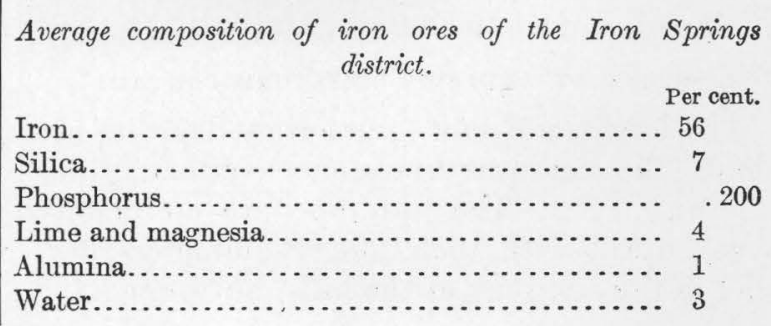




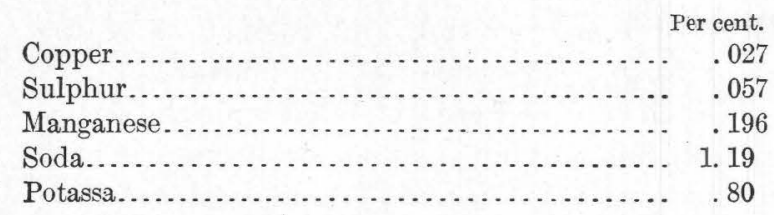

The samples run as low as 45 per cent in iron and as high as 69 per cent. The hard ore in the andesite averages higher than the ore in the limestone. The ore at the surface, with few exceptions, has 3 to 12 per cent more iron than that below.

Phosphorus may diminish slightly in the deepest explorations (below about 100 feet), but its distribution is so irregular and capricious that this generalization is doubtful. Variations of 0.050 to 3.18 per cent occur within short distances, both vertical and horizontal. A few 10-foot samples of ore run below the Bessemer limit, but practically all the ore mined will be non-Bessemer ore.

Silica, averaging about 7 per cent, ranges from 2 to 28 per cent, the lower figures being more common in the ore in the andesite. Silica at the surface is about 4 per cent less than it is just below the surface.

Lime and magnesia range from 1.5 to 11 per cent. The hard ores in the andesite carry slightly less than the soft ores in the limestone. In both types the deeper ores carry the higher percentage. Both lime and magnesia increase relatively faster than silica with depth, the common ratio of silica to calcium and magnesium oxides at thesurface being 2 to 1 by weight; and more nearly 1 to 1 below the surface.

Combined water ranges from less than 1 per cent in the magnetite to 4 per cent in the soft ores, averaging about 3 per cent. One determination of moisture in crystallized magnetite gives 0.45 per cent after heating to $110^{\circ} \mathrm{C}$.

Sulphur averages 0.057 per cent. In the deep workings of the Duncan deposits it exceeds this figure and calls for serious consideration. No general evidence of increase with depth is apparent, but water level has not yet been reached.

Copper, titanium, and manganese are present but not in injurious amounts.

Soda and potassa are determined in a single specimen.

A comparison of average analyses of Iron Springs iron ores with Lake Superior hematites and with the Silurian hematites of Alabama is made in the following table. The Iron
Springs ores are intermediate between the other two classes.

Average analyses of Iron Springs iron ores, Lake Superior ores, and Alabama ores.

\begin{tabular}{|c|c|c|c|}
\hline & $\begin{array}{l}\text { Iron } \\
\text { Springs } \\
\text { ores. }\end{array}$ & $\begin{array}{l}\text { Lake } \\
\text { Supe- } \\
\text { rior } \\
\text { ores. }{ }^{a}\end{array}$ & $\begin{array}{l}\text { Ala- } \\
\text { bama } \\
\text { hema- } \\
\text { tites. } b\end{array}$ \\
\hline 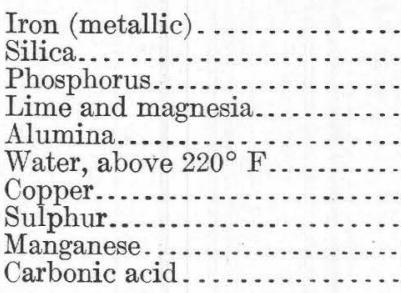 & $\begin{array}{l}56 \\
7 \\
.200 \\
4 \\
1 \\
3 \\
.027 \\
.057 \\
.196\end{array}$ & $\begin{array}{l}59.6 \\
7.5 \\
.067 \\
1.3 \\
1.5 \\
4.0 \\
\ldots . \ldots . \\
.019 \\
\ldots . . .\end{array}$ & $\begin{array}{r}37 \\
13.44 \\
.37 \\
16.2 \\
3.18 \\
.50 \\
.07 \\
.07 \\
12.24\end{array}$ \\
\hline
\end{tabular}

a Average cargo analyses for 1905 .

$b$ Birkinbine, John, The iron ores of Alabama (average analysis by B. Phillips): U.S. Geol. Survey Nineteenth Ann. Rept., pt. 6, p. 62, 1898.

TONNAGE.

The iron-ore deposits vary from mere stringers to those having an area of $1,670,000$ square feet. The aggregate surface of all the ore deposits of the district is $5,430,000$ square feet or 0.2 square mile.

The aggregate tonnage of all grades of ore in the district, determined by multiplying the known area by the best available information as to depth in pits, drill holes, and erosion sections, is 40,000,000 tons. The largest single deposit, figured on the same basis, has $15,600,000$ tons. It is altogether likely that the figures are much too small rather than too large, because the depths used in the calculation have been those actually observed, and observation has not yet gone to the bottom.

\section{GENESIS.}

The principal ore deposits-those near the contact of the andesite and limestone-are partly replacements of limestone. The original bedding of the limestone has been preserved in the ore in places, and there is gradation between the ore and the limestone. These deposits also in part fill fissures in limestone or between limestone and andesite, or in andesite. The source of the iron-bearing solutions is the same for the limestone replacements and for the rein fillings in the limestone and in the andesite, for the mineralogic and textural characters are the same and in a few places they are actually connected. Ser- 
eral hypotheses as to this source suggest themselves: (1) That the ore-bearing solutions were associated with the intrusion of the andesite as "igneous after-effects"; (2) that they were meteoric waters, cold, or heated by contact with the laccolith, acting after the laccolithic intrusions and before the eruption of the surface flows; (3) that they were hot solutions, magmatic or meteoric or both, connected with the late eruptives of the district, deriving the ores from the extrusive or from the underlying rocks; (4) that they were cold meteoric waters later than the extrusive rocks; (5) that they were due to some combination of these sources. The deposition of the ore is best explained by the first hypothesis, but later concentrations of the ore have occurred in the order given.

For a detailed discussion of the several hypotheses the reader is referred to Bulletin 338. The processes that are believed by Leith and Harder to have produced the deposits as they are now are briefly summarized by them essentially as follows:

Andesite laccoliths were intruded in Paleozoic and Mesozoic sediments, with consequent tilting of the strata in quaquaversal manner about the laccolith and contact metamorphism of the zone adjacent to it, accompanied and followed by fissuring, jointing, and faulting. Hot ore-bearing solutions entered through fissures in the andesite into the adjacent sediments, depositing ore as dikelike masses in fissures in the andesite, as fissure fillings and replacements in the limestone, and as cements in breccias of andesite, limestone, and quartzite. The solutions introduced also garnet, diopside, amphibole, phlogopite, apatite, calcite, quartz, and pyrite, most of which had also been developed in the limestone by the preceding contact metamorphism. Soda was conspicuously increased in the wall rocks. It is thought that the solutions were pneumatolytic aftereffects of the andesite intrusion.

Erosion developed mountains with andesite cores, encircled by belts of sediments at uniform elevations on the slopes, except where displaced by faults or where cut back by differential erosion. The areas between the mountains were left with low relief. The ores were exposed and partly eroded calcite, apatite, and perhaps other gangue materials were leached and redeposited below. There was more or less oxidation and hydration of the ores along fissures beneath the surface.

Tertiary lavas were extended over the entire area, furnishing hot magmatic waters and heat to meteoric waters and thereby developing coarsely crystalline magnetite and hematite in the ore deposits and especially at the surface, leaching the gangue materials so far as they were left by weathering near the surface, and depositing in the cavities chalcedony and to a slight extent magnetite, hematite, limonite, siderite, chlorite, barite, calcite, galena, and the copper carbonates.

Erosion reexhumed the andesite mountains from under the lavas and brought to light the sediments and ores on the slopes, a process accompanied by local surface oxidation and hydration of the ores and leaching of the gangue materials, chiefly calcite but also apatite. Differential erosion caused some of the ore outcrops to stand above the adjacent rocks, but others, whose hard cap had been eroded away, were cut well down to the level of adjacent rocks. Faulting of the ore deposits preceded and accompanied the erosion, developing structural relations all of which can not be distinguished from those determined by faulting before deposition of the ores.

Should the lavas prove to be older than the intrusive rocks, several of the above steps would be eliminated.

\section{BULL VALLEY DISTRICT. ${ }^{1}$}

\section{GENERAL FEATURES.}

The Bull Valley district lies about 25 miles southwest of the Iron Springs district, extending from Garden Springs on the northeast southwestward to Bull Mountain and 40 to 50 miles beyond. (See fig. 64.) The district, which has only recently been explored and staked, is much more difficult of access than the Iron Springs district and is consequently less well known. The nearest railway station is Modena, 28 miles distant by way of Enterprise.

The principal ore deposits lie several miles below the headwaters of Moody Run, which empties into Magotsu Creek 10 miles below the Mountain Meadows. From this point they extend eastward about 3 miles to Garden

1 Abstracted from Leith, C. K., and Harder, E. C., The iron ores of the Iron Springs district: U. S. Geol. Survey Bull. 338, pp. 90-92, 1908. 
Springs, a short distance west of the Mountain Meadows monument, the site of the famous Mountain Meadows massacre. To the southwest, deposits occur on Bull Mountain 2 or 3 miles distant and on Cove Mountain an equal distance beyond.

\section{GEOLOGY.}

The essential geologic features of the district are the same as those in the Iron Springs district-a series of laccoliths, surrounded by sediments dipping quaquaversally away, again surrounded and overlain by flat-lying lavas, the whole being bounded on north and west by later flows of basalt. The topography is

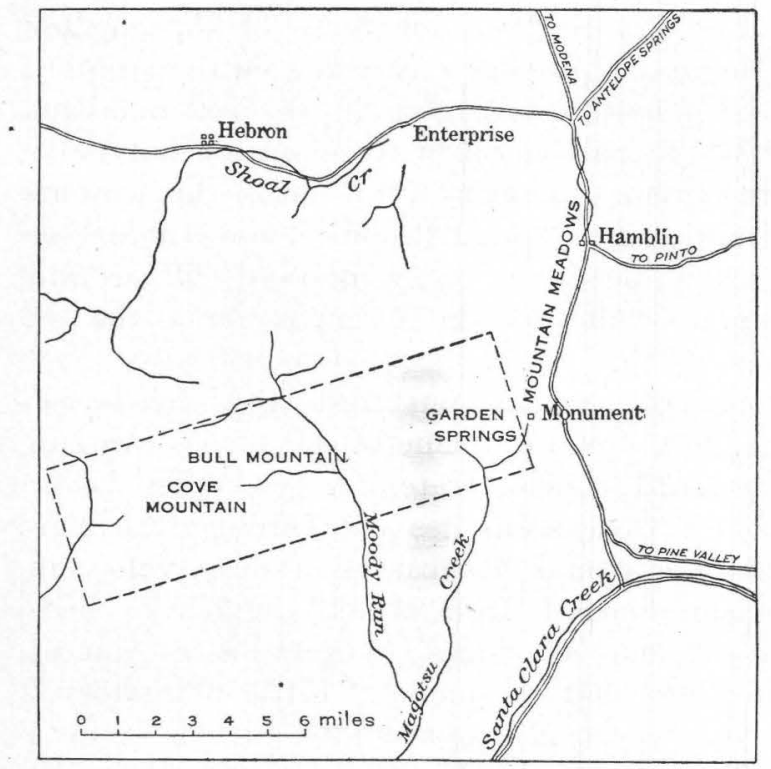

FIGURE 64.-Sketch map of Bull Valley iron district.

rougher than that of the Iron Springs district, and evidences of volcanism (basalt flows and cinder cones) are more conspicuous. The general aspect is barren and forbidding. The same topographic and geologic conditions are said to extend for about 40 miles to the southwest into Nevada, throughout an area from which ores are reported.

\section{ORE DEPOSITS.}

The ore deposits were examined in their discontinuous occurrence between the headwaters of Moody Run on the west and Garden Springs on the east and were found to be similar in almost every feature to those of the Iron Springs district. The principal deposits are associated with limestone fault blocks that lie within the andesite, and subordinate deposits follow the main contact of andesite and limestone, which strikes southwest across Moody Run and dips southeast. Flat-lying flows fringe the ore-bearing areas. On the south are acidic flows and tuffs, on the north acidic flows and tuffs and basalts. A white band near the base of the acidic lavas is very conspicuous and in most of the district is sufficiently near the limestone-andesite contacts to make it a useful marker for the ores.

The greatest width of ore observed at the surface was 115 feet but was not sufficiently well exposed to make it certain that this 115 feet was continuous ore. This particular deposit has a length of approximately 700 feet.

The iron is both magnetite and hematite, as in the Iron Springs district, but the hematite on the lower slopes has a fine granular texture and a steel-blue color which is not seen in the Iron Springs district.

The composition of the ore at the surface, as sampled by Lerch Bros., is as follows:

Composition of the Bull Valley district ores.

[Analyst, Fred Lerch, Biwabik, Minn.]

\begin{tabular}{|c|c|c|}
\hline . & Iron. & $\begin{array}{l}\text { Phos- } \\
\text { phorus. }\end{array}$ \\
\hline Across 150 feet, Pilot No. 9. . & 58.98 & 0.195 \\
\hline Across 250 feet, Pilot No. 8 .. & 62.38 & .217 \\
\hline Across 60 feet, Pilot No. 7 ... & 62.06 & .163 \\
\hline Pilot No. $12 \ldots$. & 66.40 & .072 \\
\hline Across 40 feet, Pil & 64.13 & .434 \\
\hline
\end{tabular}

A little pitting, trenching, and tunneling has scratched the upper parts of the deposits.

\section{BIBLIOGRAPHY.}

Dutton, C. E., Report on the geology of the High Plateaus of Utah; U. S. Geog. and Geol. Survey Rocky Mtn. Region, 1880; Tertiary history of the Grand Canyon district: U. S. Geol. Survey Mon. 2, 1882.

Girbert, G. K., Report on the geology of portions of Nevada, Utah, California, and Arizona in 1871 and 1872: U. S. Geog. Surveys W. 100th Mer. Rept., vol. 3 , pt. 1, pp. 17-187, 1875 .

Howeld, E. E., Report on the geology of portions of Utah, Nevada, Arizona, and New Mexico in 1872 and 1873: U. S. Geog. Surveys W. 100th Mer. Rept., vol. 3, pt. 3, pp. 227-301, 1875.

Jennings, E. P., Origin of the magnetic iron ores of Iron County, Utah: Am. Inst. Min. Eng. Trans., vol. 35, pp. 338-342, 1905.

Kemp, J. F., Review of U. S. Geol. Survey Bull. 338: Econ. Geology, vol. 4, pp. 782-791, 1909. 
Lerth, C. K., Reply to review of Bull. 338 by J. F. Kemp: Econ. Geology, vol. 5, pp. 188-192, 1910.

Leith, C. K., and Harder, E. C., The iron ores of the Iron Springs district, southern Utah: U. S. Geol. Survey Bull. 338, 1908.

Marvine, A. R., Report on the geology of route from St. George, Utah, to Gila River, Arizona, in 1871: U. S. Geog. Survey W. 100th Mer. Final Rept., vol. 3 , pt. 2, pp. 189-225, 1875.

Newberry, J. S., The genesis of the ores of iron: School of Mines Quart., pp. 9-12, November, 1880.

Poweld, J. W., Exploration of the Colorado River of the West and its tributaries: U. S. Geog. and Geol. Survey Rocky Mtn. Region, 1875. Report on the lands of the arid region of the United States, with a more detailed account of the lands of Utah: U. S. Geog. and Geol. Survey Rocky Mtn. Region Final Rept., (2d ed.), 1879.

SILVER REEF (HARRISBURG, LEEDS) DISTRICT.

By B. S. Butler.

\section{GENERAL FEATURES.}

The Silver Reef district is in the east-central part of Washington County in southwestern Utah. Leeds is in its central part, Toquerville is about 6 miles to the northeast, and St. George about 20 miles to the southwest. The district can be reached from Modena on the Los Angeles \& Salt Lake Railroad by way of St. George, a distance of about 90 miles, or from Lund by way of Cedar City, a distance of about 70 miles.

The region is arid. In the lowlands, in the vicinity of the mines, there is no timber and for the most part only a scanty growth of desert plants. In the Pine Valley Mountains there are cedar and other trees suitable for wood and timber. Water is scarce. A stream from the Pine Valley Mountains supplies water for the settlements at Leeds and Harrisburg, for the irrigation of small areas, and for milling at Silver Reef. Virgin River is only a few miles from Silver Reef and touches the northwest end of East Reef. Some milling was done on the river.

Virgin River is a good-sized stream and furnishes ample water for all purposes. The soil is apparently fertile and where properly irrigated yields abundant crops. Both the soil and climate appear especially well adapted to the cultivation of grapes, peaches, and similar fruits. Farming is confined to small areas that can be irrigated, but the agricultural possibilities seem sufficient to supply any probable local demands; and most agricultural products can be obtained at reasonable rates. The absence of a railroad is a serious drawback to farming, and a local demand would greatly stimulate that industry.

The climate is mild and delightful in winter but is hot in summer. Rainfall is light, the average yearly precipitation at St. George for 19 years ranging from 3.55 to 18.71 inches (average 8.66 inches).

\section{TOPOGRAPHY.}

In the immediate vicinity of Silver Reef the region is rough, but the relief is not great. The elevation here is about 4,000 feet. Northwest of Silver Reef the strong cliff-making members of the Triassic and Jurassic formations and the volcanic rocks of Pine Valley Mountains produce a very rugged topography, the mountains rising to 10,000 feet, or about 6,000 feet above Silver Reef. A few miles east the great Hurricane Cliff forms the western front of the Plateau Province, and still farther east a succession of benches and cliffs extend up the valley of the Virgin as far as the eye can reach.

Northeast and southwest from Leeds extends a broad anticline of soft shales overlain by hard conglomerate. A few miles below Leeds weathering has cut through the conglomerate and has carved a deep valley in shales beneath from which the harder beds stand out as ridges. Vegetation is almost lacking; and its name, "Little Purgatory," seems especially appropriate. Leeds is in a strike valley eroded in the soft shales between the hard Shinarump conglomerate and the sandstones forming the silver reefs.

GEOLOGY.

SEDIMENTARY ROCKS.

The sedimentary rocks of the Silver Reef district range in age from upper Carboniferous to Tertiary. The region has been studied in some detail by Huntington and Goldthwait, ${ }^{1}$ and the following general descriptions and geologic map (Pl. XLVI, in pocket) and section (fig. 65) are taken from their paper.

The Aubrey formation, in the Toquerville district, consists of a rather massive gray limestone, capped by a series

1 Huntington, Ellsworth, and Goldthwait, J. W., The Hurricane fault in the Toquerville district, Utah: Harvard Coll. Mus. Comp. Zool. Bull., vol. 42 , pp. 201-259, 1904. 
of colored shales. The limestone resists erosion with much strength. Where it has been cut by the recent Hurricane fault, it stands up as a steep ragged wall. * * * East of the fault scarp the Aubrey stretches away as a broad platform, which for miles has been swept clean of the overlying Moencopie shales. It extends from Toquerville clear to the Grand Canyon, a vast yellow dust-covered plain, thinly drained by dry washes, with here and there a low limestone ridge, a black basaltic cone, or a highly colored Moencopie mesa.

The Moencopie shales, when protected by the strong Shinarump cap, stand up in broad ragged mesas that are

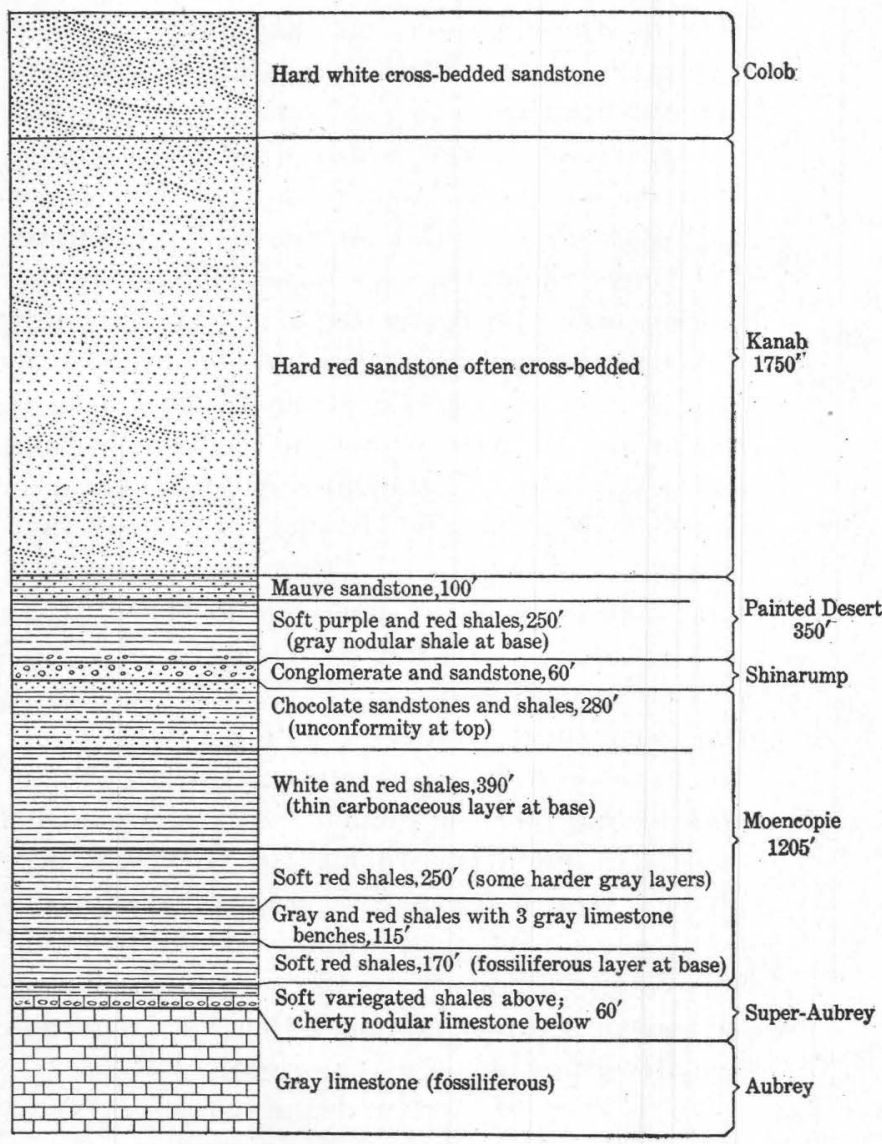

FiguRE 65.-Section of rocks exposed along Le Verkin Canyon between Toquerville and Colob. After Huntington and Goldthwait.

remarkable for both color and sculpture. From the top of one of these tables to the plain at its base, the bare slopes descend very steeply, with an occasional narrow bench, limited by a cliff, where a harder member asserts its strength. Seen from a distance, the alternating horizontal bands of chocolate, gray, lavender, and red stand out with ribbon-like uniformity and distinctness. In contour these tables are very irregular, with long headlands and reentrants, down the slopes of which are cut innumerable gullies and ravines, systematically placed, so as to form a minute pattern of tapering, branching, and sprawling spurs that give the impression of a conventional design. Where the shales have lost their conglomerate cap, however, they have either been dissected into a choppy badland topography of gullies and ridges, or, as is more often the case, they have melted away into broad, gently sloping grade plains, which stretch out from the escarpment for miles, until at last they merge into the Aubrey platform.

In sharp contrast to the weak Moencopie shales below and the soft Painted Desert shales above, the Shinarump stands out firmly as a bench and cliff maker. In the eastern part of our area, among the plateaus, it forms the flat top of . the "Permian" terrace, and its outlying tables. Not uncommonly its edge projects out over the soft shales beneath, like an ornamental molding. Often, where it is the uppermost member remaining, its top is flat and clean, but where it merely flanks the bold Kanab escarpment its platform is banked by landslides from above. This is well shown at Rockville, near the Virgin River, where the waste of the shales is particularly rapid.

Where the strata have been folded the Shinarump again is conspicuous. Between Toquerville and St. George, where a great plunging anticline has been unroofed by erosion, the conglomerate forms a cigar-shaped hill, splitting at its southern end so as to surround a long amphitheater. ***

The Painted Desert formation is a series of shales, elsewhere chiefly clay shales, but in the Toquerville district more sandy. Although varied in color, they are uniformly weak.

At the top of the Painted Desert series, as we have limited it, and at the base of the Kanab, there is a thick sandstone member, of a lavender or mauve color, and of such hardness that it often forms a bench above the shales, after the manner of the Shinarump, though hardly so conspicuously. * * *

Above the mauve sandstone, at the base of the Kanab, is a thin series of weak beds whose nonresistance permits the development of the platform beneath; then comes about 1,700 feet of uniformly hard, brick-red sandstone, occasionally cross-bedded. It is the unusual thickness and massiveness of this hard sandstone formation that makes it the greatest cliff builder in the region. ** * Although at Rockville its imposing front trends toward Toquerville, it turns rather sharply, a few miles east of Le Verkin Creek, and runs northwest to Colob. The architecture of the Kanab is massive and grand. Lofty though the red cliffs really are, their height is even exaggerated, as a result of prominent vertical jointing, by deep rifts which cut the cliffs from top to bottom. Below, the rifts show as sharp upright slits through the rock, but at the top they widen out into ragged gashes, chopping up the rock into pinnacles and spires.

Within the limits of our map the Kanab does not attain this grandeur of form. Only along the eastern base of the Pine Valley Mountains is the entire formation exposed, and there it has an ancient subdued topography. * * *

The Colob formation also, in the vicinity of Toquerville, is not displayed to best advantage. Along the Pine Valley Range it forms rounded foothills and long sloping 
ridges, which have little individuality asiảe from their pure white or occasional buff color. Far to the eastward, at the Temples of the Virgin, and along the marvelous White cliffs, the more magnificent features of sculpture are brought out by active erosion. Even in our region, however, where recent erosion has been actively at work, the structural detail of the Colob is well shown in long sweeping curves of cross-bedding. The slow crumbling away of the fine white sand grains brings out the frostwork pattern in a way that is at once pleasing and grotesque. The mysterious name "Colob" is well suited to it.

The Cretaceous and Tertiary formations are not well exposed in the immediate vicinity of Silver Reef and were not examined. In the Iron Springs district to the northwest, Leith and Harder (see p. 569) have described a section consisting of 1,500 feet of Cretaceous sandstone, shale, conglomerate, and limestone resting unconformably on Carboniferous limestone and overlain unconformably by 1,000 feet of Eocene limestone, conglomerate, and sandstone.

The correlation of the section of Huntington and Goldthwait with the Colob section of Dutton is shown in the following table:

Correlation of rocks of Silver Reef district with Colob Plateau.

\begin{tabular}{|c|c|}
\hline $\begin{array}{l}\text { Silver Reef (Huntington and } \\
\text { Goldthwait). }\end{array}$ & Colob Plateau (Dutton). \\
\hline $\begin{array}{l}\text { Tertiarylimestone, shale, and con- } \\
\text { glomerate. }\end{array}$ & $\begin{array}{l}\text { Tertiary limestone, shale, and con- } \\
\text { glomerate. }\end{array}$ \\
\hline $\begin{array}{l}\text { Cretaceous sandstone, shale, and } \\
\text { limestone. }\end{array}$ & $\begin{array}{l}\text { Cretaceous sandstone, shale, and } \\
\text { limestone. }\end{array}$ \\
\hline Colob sandstone. & $\begin{array}{l}\text { Jurassic shale. } \\
\text { Jurassic sandstone. }\end{array}$ \\
\hline $\begin{array}{l}\text { Kanab sandstone. } \\
\text { Painted Desert sandstone and } \\
\text { shale. } \\
\text { Shinarump conglomerate. }\end{array}$ & $\begin{array}{l}\text { Triassic sandstone, shale, and con- } \\
\text { glomerate. }\end{array}$ \\
\hline $\begin{array}{l}\text { Moencopie shale and sandstone. } \\
\text { Super-Aubrey shale and lime- } \\
\text { stone. } \\
\text { Aubrey limestone. }\end{array}$ & $\begin{array}{l}\text { Permian shale and sandstone. } \\
\text { Carboniferous limestone. }\end{array}$ \\
\hline
\end{tabular}

IGNEOUS, ROCKS.

Igneous rocks were not observed in place in the immediate vicinity of Silver Reef. The abundance and large size of the igneous fragments that litter the surface to the north and west suggest that they originated close at hand. Closer examination, however, indicates that they were derived from the igneous rocks in the Pine Valley Mountains or from a southward extension of that body that has since been removed by erosion and were transported to their present position by some means whose nature is not clear.

The igneous rocks in place in the region consist of the extensive lava flows in the Pine Valley Mountains, of a small body of similar rock about 2 miles south of Bellevue, and of extensive flows of basaltic rocks that extend for many miles along the front of the plateau.

The rocks of the Pine Valley Mountains are evidently similar to the extrusive rock of the Iron Springs district. No intrusive bodies have been reported in the Pine Valley Mountains, but they have never been carefully sought for and may be present. The flows in the Iron Springs district ${ }^{1}$ range from andesites to rhyolites, and the rocks farther south are probably of the same general character.

The character of the body south of Bellevue has not been definitely determined. Huntington and Goldthwait state that "the smaller andesite hills near Toquerville are either intrusive portions which never reached the surface or stocks of extrusions of which all other traces have been removed." All the flow rocks in the general region are believed to be of Tertiary age, and rest upon Eocene sediments, as has been shown in the Iron Springs district. Rocks of the same general character between Bellevue and Toquerville are in contact with Jurassic and Cretaceous sediments, and if they are of the same age as those to the northwest their position is most naturally interpreted as being due to intrusion. Neither in the very short time available for field study nor in later study of specimens was the writer able to find positive evidence of their relations to the sedimentary rocks, for they are porphyritic and have a fine crystalline groundmass whose texture is duplicated by both intrusive and extrusive rocks. From their position in the sedimentary series they are regarded tentatively as of intrusive origin.

To the west of the Hurricane scarp for several miles north and south of Toquerville are large bodies of basaltic lava, and similar rocks are found to a lesser extent east of the scarp.

The earlier rhyolitic, latitic, and andesitic lavas rest upon Eocene sediments and are probably of Miocene age. The basaltic flows are much later and may all be classed as Recent, though their accumulation has been in progress over a long period. Some of the earlier flows have been extensively eroded, but others show so little change that they may be only a few hundred years old.

1 Leith, C. K., and Harder, E. C., The iron ores of the Iron Spring district, southern Utah: U. S. Geol. Survey Bull. 338, p. 17, 1908 


\section{STRUCTURE.}

Folding was the principal factor in producing the structure in the immediate vicinity of Silver Reef, though both folding and faulting have been important in the general region.

Following the deposition of the Eocene sediments and probably the extrusion of the earlier lavas, the region was thrown into a series of broad open folds having a general northeast trend. This series of folds has been described by Huntington and Goldthwait as foliows:

East of a line drawn along the southern portion of the Hurricane fault and extended northward up the valley of Le Verkin Creek the strata are nearly horizontal. Between that line and the old shore line of the Mesozoic Sea west of the Pine Valley Mountains the strata are compressed into two synclines and two anticlines which culminate in a great overturned fold at Kanarra. North of Kanarra the continuation of these plications was not studied; toward the south they gradually die out until, 15 or 20 miles beyond Toquerville, they have greatly broadened and persist only as gentle monoclines dipping toward the east. The most western of these folds is the broad gentle syncline in which lies the lava of the Pine Valley Mountains. In the neighborhood of the mountains the dip is everywhere gentle, and the flat bottom of the trough is several miles wide. Toward the southwest this syncline almost vanishes, but the western limb seems to persist as an eastward-dipping monocline whose lower limit is now the Grand Wash fault.

The next fold to the east is a remarkable anticline which runs northeast 18 miles from Price City south of St. George to Leeds, where it bends more to the north for 10 miles, until it is lost under alluvium and lava a short distance north of Bellevue. When what seems to be the same fold reappears at Kanarra it has again bent somewhat to the northeast. Although near St. George this fold is finely exposed as a typical breached anticline, that portion fades into insignificance when compared with the extraordinarily diagrammatic portion near Harrisburg and Leeds. Here erosion had removed all the strata as far as the Shinarump, which at Leeds forms a great rounded nose pitching toward the north and shaped like the decked front of a round-topped canoe. As the anticline rises toward the south the deck of the nose gains a greater elevation, until, halfway from Leeds to Harrisburg, the center is broken open where it has been undermined by the wearing away of the soft Moencopie shales. A few miles farther south, a five minutes' walk from the road southwest of Harrisburg, brings one to the top of the Shinarump Cliffs on the northwest side of the anticline. Under the observer's feet is the hard Shinarump formation dipping $40^{\circ} \mathrm{NW}$. On its resistant surface erosion proceeds very slowly, and for many miles this edge of the anticline forms a ridge. In front of the observer a precipitous cliff 50 or 60 feet high bounds abruptly a perfect anticlinal trough, a mile or more wide, a sort of hand specimen or model showing at a glance a diagrammatic type not only of an anticlinal trough but also of an anticlinal ridge. Under the Shinarump Cliffs lie the bright-colored Moencopie shales, red, gray, and brown, the edges of which are truncated like those of the overlying sandstone and conglomerate, although at a lesser angle. At the very center lies a little rounded ridge where erosion has laid bare the harder underlying Aubrey limestone, which rises as an anticlinal core in the midst of an anticlinal trough. Beyond the ridge the naked particolored shales again rise gradually in brilliant bands to a Shinarump Cliff exactly like that on which we are standing, except that it faces in the opposite direction and dips to the southeast.

North of Bellevue where the fold disappears under a covering of lava it is still a normal anticline, but where what seems to be the same fold reappears at Kanarra it has been compressed to such an extent that it has been completely overturned and the strata lie in inverted order with a rather steep dip to the northwest. As this fold has been cut at this point by both the old and the new Hurricane faults, only a small portion is now exposed.

The trough lying east of this anticline is unimportant. It dies out completely south of Toquerville, while at Kanarra it is so far compressed that the two limbs touch each other. The most eastern anticline lies close to the line of the Hurricane fault. On the south it flattens out, although the eastern limb persists as an eastward-dipping monocline, at the base of which is the Hurricane fault. In the northern half of the region it is a strong arch with a dip of from $20^{\circ}$ to $40^{\circ}$. The ridge east of Bellevue is formed where it brings up a hard core of Aubrey limestone which has since been bisected longitudinally by the Hurricane fault. On the eastern side of this core all the overlying strata have been stripped off; on the western side where the country has been dropped far down by the fault, the overlying strata are to a great extent preserved.

Faulting in the immediate vicinity of Silver Reef has not been important. A few miles to the east, however, is the great Hurricane fault marked by the Hurricane cliff, where faulting on a grand scale has taken place. This fault can be traced with a general strike east of north for scores of miles north and south from this region, and its displacement is measured by hundreds of feet. Movement along this line began much later than the folding of the region (possibly in late Tertiary time) and has continued intermittently till very recently if not to the present time.

\section{HISTORY AND PRODUCTION.}

By V, C. Herkes.

Huntley, ${ }^{1}$ who visited the district in July, 1880, says:

Harrisburg district, better known as Silver Reef, is in the eastern part of the county, and covers an area of about 5 miles square. The old Mormon town of Leeds was the settlement nearest the mines in early times, and also gave a name to the region. As the mines were developed, the town of Silver Reef was built. * * * Silver was dis.

1 Precious metals: Tenth Census U. S., vol. 13, pp. 477-482, 1885. 
covered in 1869 by John Kemple, who found, near Harrisburg, a piece of float which assayed $\$ 17,000$. He filled up his small shaft and left the country, but returned with others and organized the district June 22, 1874. He worked his claims for a few months, when becoming discouraged, he returned to Star district. * * * The district owes its development entirely to Mr. W. T. Barbee, who went there in the summer of 1875 . He discovered very rich ore on the Tecumseh claim, and shipped 10 tons of $\$ 500$ ore to Salt Lake City in the following November. He continued the shipments of ore to Salt Lake City and to Pioche during the following year. This caused the rush to the district, principally from Pioche, in the summer and fall of 1876. The recorder's books showed 640 locations, but probably not over 150 claims were owned at the period under review. ***

Mills have been erected in the district in the following order: Leeds, February, 1877; Pioneer, three-stamp, demolished fall of 1877; Christy, January 8, 1878; Barbee \& Walker, March, 1878; Stormont, July 4, 1878. In 1877 and 1878 many rude leaching works were erected. * * *

The total production of the district has been * * * $\$ 3,243,738.92$.

Beginning at the northern extremity of each reef the important mines are located in the following order:

White reef.-Barbee \& Walker, Pinkham \& Dodge, Leeds, Thompson \& McNally, and Gisborn.

Buckeye reef.-Silver Flat, Manhattan, Tecumseh, all three belonging to the Christy Co.; Kinner, Buckeye, Last Chance, owned by the Stormont Co.; Maggie, California, both belonging to the Christy Co.; and Emily Jane.

East reef.-Vanderbilt, Duffin, Dykes \& Stapeley, Toquerville, Maud, and Dixie.

The other mines of the Silver Reef or Harrisburg district are:

Mines of the Silver Reef district.

\begin{tabular}{|c|c|c|c|}
\hline Mines. & $\begin{array}{l}\text { Total } \\
\text { length } \\
\text { of } \\
\text { open- } \\
\text { ings. }\end{array}$ & $\begin{array}{c}\text { Total } \\
\text { product. }\end{array}$ & Remarks. \\
\hline Pinkham \& Dodge & $\begin{array}{l}\text { Feet. } \\
727\end{array}$ & No ore & Large bodies of $\$ 16$ \\
\hline Emily Jane... & & $\begin{array}{l}\text { shipped. } \\
280 \text { tons. }\end{array}$ & $\begin{array}{l}\text { ore. } \\
\text { Ore, } \$ 20 \text { and } \$ 30 \text {; de- } \\
\text { velopments lim- } \\
\text { ited. }\end{array}$ \\
\hline Vanderbilt... & 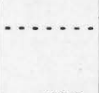 & 240 tons. & $\begin{array}{l}\text { Average of ore pro- } \\
\text { duced } \$ 100 ; \text { in- } \\
\text { cline of } 60 \text { feet. }\end{array}$ \\
\hline Duffin. . & 900 & & $\begin{array}{l}\text { Total product, many } \\
\text { hundred or thou- } \\
\text { sand tons of } \$ 80 \text { to } \\
\$ 100 \text { ore. }\end{array}$ \\
\hline Toquerville. . & 1,000 & & $\begin{array}{l}\text { Several hundred } \\
\text { tons of } \$ 50 \text { ore } \\
\text { shipped. }\end{array}$ \\
\hline Maud. & 440 & $\$ 33,986$. & $\begin{array}{c}\text { Ore assays from } \$ 30 \\
\text { to } \$ 100\end{array}$ \\
\hline Dixie. & 100 & 400 tons & $\begin{array}{l}\text { to } \$ 100 . \\
\text { Ore produced valued }\end{array}$ \\
\hline Gisborn. & & 500 tons. & $\begin{array}{l}\text { Value of ore pro- } \$ 30 \text { per ton. } \\
\text { duced } \$ 20 \text { to } \$ 25 \\
\text { per ton. }\end{array}$ \\
\hline
\end{tabular}

Several of the leaching works erected in the district were operated on tailings till the Stormont closed in 1887, when they too were suspended. In March, 1889, the Christy Co. stopped work, practically closing the camp. From 1890 to 1909 occasional lots of silver were recovered from ores worked under a lease in the Brundage mill from the Leeds, Thompson, Red Star, Free Coinage, and Wonder claims.

The Silver Reef district yielded silver annually from 1875 to 1897 , when production ceased. It began again in 1902 and, except for 1906, continued until 1909. The production of the district between 1875 and 1902 has been compiled from the records of the Director of the Mint and from 1903 to 1909 from the records of the United States Geological Survey. The output arranged by periods is as follows:

Production of Silver Reef district, 1875-1909, by periods.

\begin{tabular}{|c|c|c|}
\hline Period. & $\begin{array}{l}\text { Silver } \\
\text { recovered. }\end{array}$ & $\begin{array}{c}\text { Total } \\
\text { value. }\end{array}$ \\
\hline \multirow[t]{2}{*}{$\begin{array}{l}1875-1880 \ldots \ldots \\
1881-1890 \ldots \ldots \\
1891-1900 \ldots \ldots \\
1901-1909 \ldots \ldots\end{array}$} & $\begin{array}{l}\text { Ounces. } \\
3,319,054 \\
3,590,598 \\
206,069 \\
95,742\end{array}$ & $\begin{array}{r}\$ 3,808,890 \\
3,966,118 \\
158,140 \\
53,994\end{array}$ \\
\hline & $7,211,463$ & $7,987,142$ \\
\hline
\end{tabular}

a Average commercial price used for silver to make total for each calendar year.

Some of the operating companies in the Silver Reef district were close corporations, and it is difficult to ascertain what was paid in dividends. The amount has been variously estimated from $\$ 900,000$ to $\$ 1,300,000$.

\section{ORE DEPOSITS}

\section{OCCURRENCE AND CHARACTER.}

The workable ore deposits occur in the "Painted Desert formation" between the Shinarump conglomerate and the massive red Kanab sandstone of Huntington and Goldthwait. In the vicinity of Silver Reef the lower 200 to 300 feet of the "Painted Desert formation" consists of weak shale and sandstone, which have been deeply eroded and underlie Leeds Valley. Overlying this shale series is a massive sandstone varying from reddish to gray, which outcrops as a rather prominent ridge (Butte Reef). Between this sandstone 


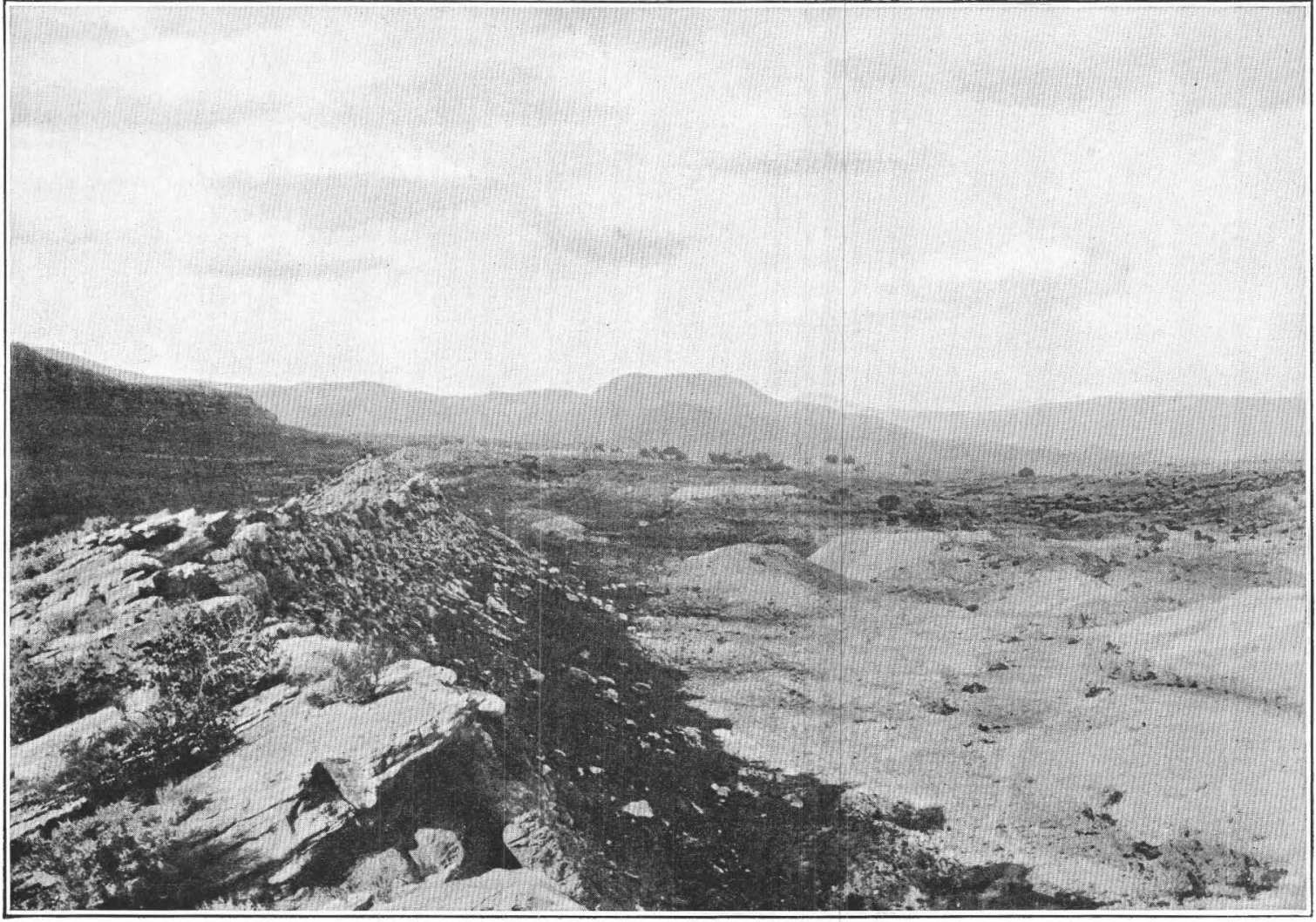

A. VIEW LOOKING NORTH ALONG WHITE AND BUCKEYE REEFS IN THE SILVER REEF DISTRICT. White Reef at left; Buckeye Reef at right.

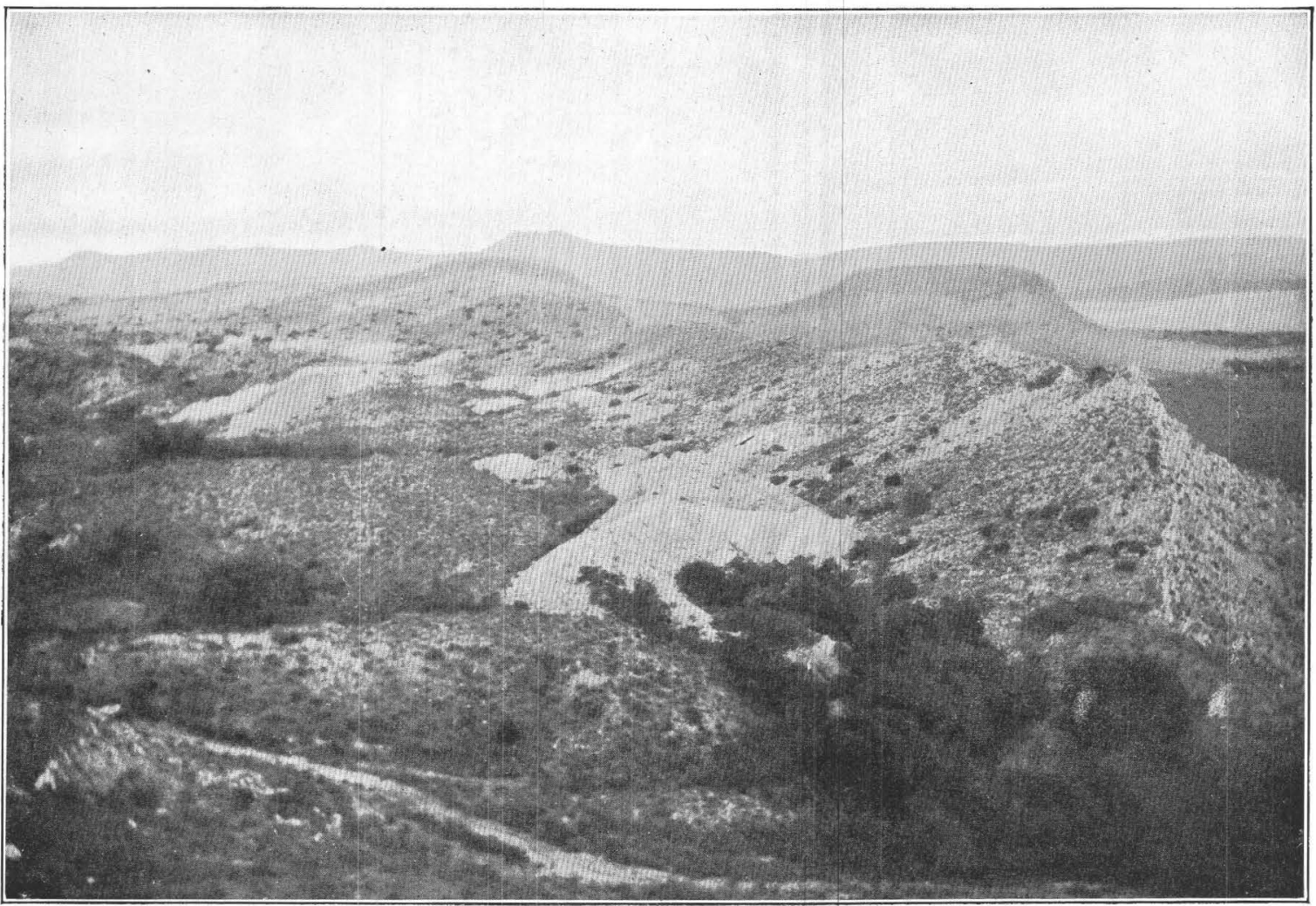

B. VIEW LOOKING SOUTH ALONG BACK SLOPE OF WHITE REEF, SILVER REEF DISTRICT. 


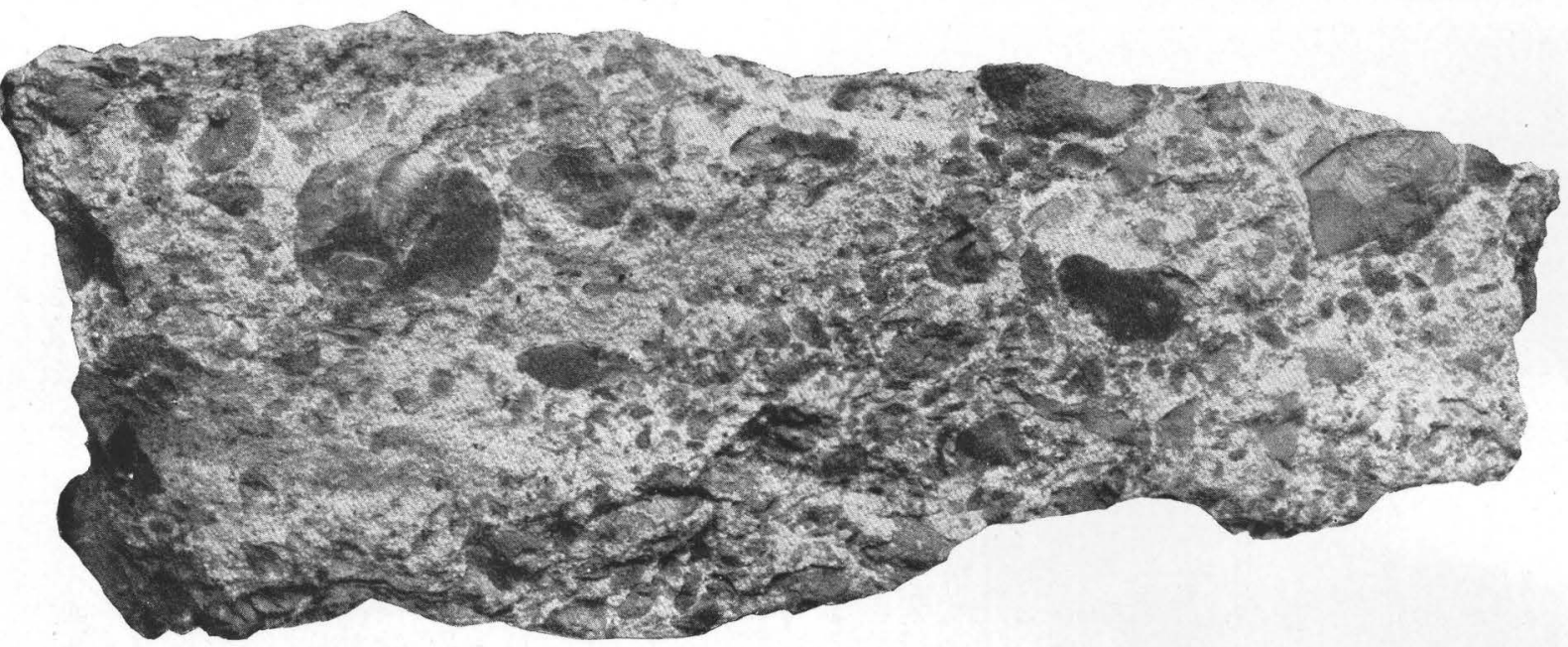

A. SPECIMEN OF GLAY CONGLOMERATE ORE, SILVER REEF DISTRICT.

View parallel to bedding.

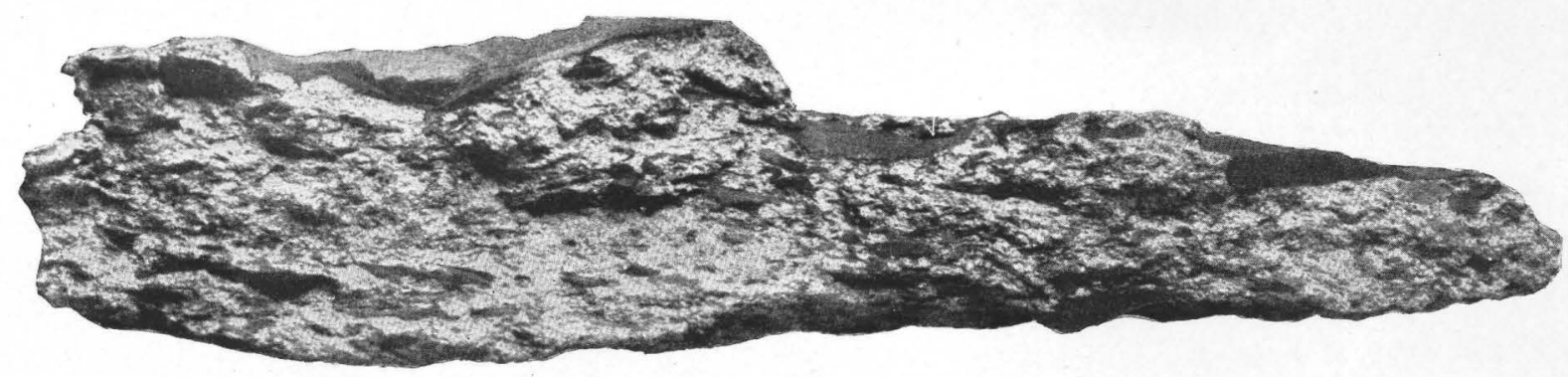

B. SPECIMEN SHOWN IN A VIEWEd ACROSS BEDDING, SHOWING LENTICULAR FORM OF CLAY "PEBBLES."

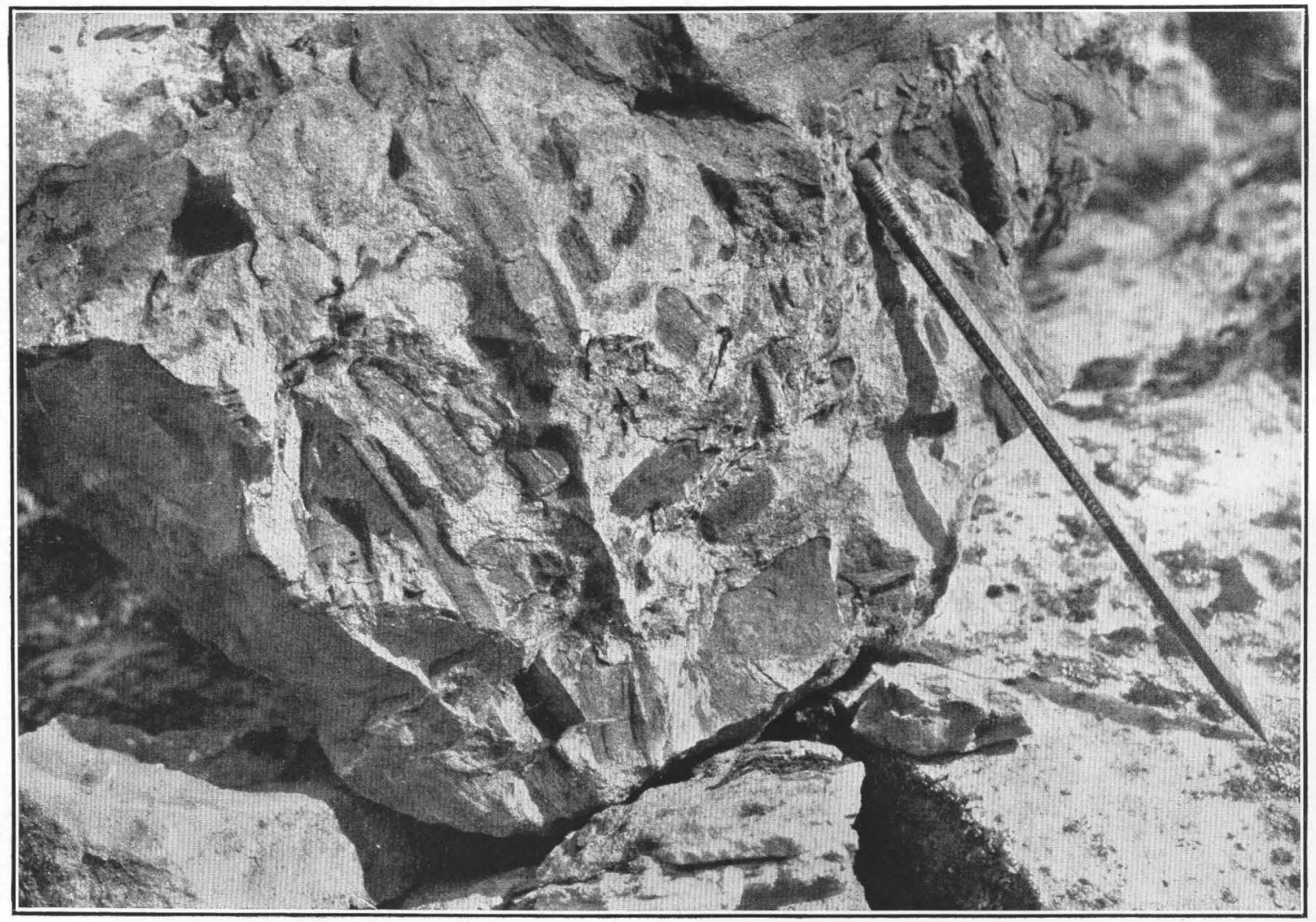

C. SPECIMEN OF SILVER ORE FROM WHITE REEF, SILVER REEF DISTRICT, SHOWING FOSSIL PLANT REMAINS. 
and the Buckeye Reef is about 100 feet of shaly beds. Overlying the Buckeye Reef is about 50 feet of shale, overlain by the relatively massive gray sandstone of the White Reef, which outcrops prominently for several miles. $\mathrm{Be}$ tween White Reef and the Kanab sandstone of Huntington and Goldthwait are several hundred feet of weak shales whose position is marked by the lowland between the reef and the sandstone cliff. (See Pl. XLVII.)
The dip of the beds necessarily varies from point to point. West of Leeds, where the reefs are nearly parallel, the dip is $20^{\circ}-40^{\circ} \mathrm{W}$., but to the north, where the beds swing around the nose of the anticline, the dip changes from west to north and becomes much less. It is also stated that the dip varies somewhat with depth. On the East Reef the conditions are essentially similar to those to the west, except that the direction of the dip is reversed.

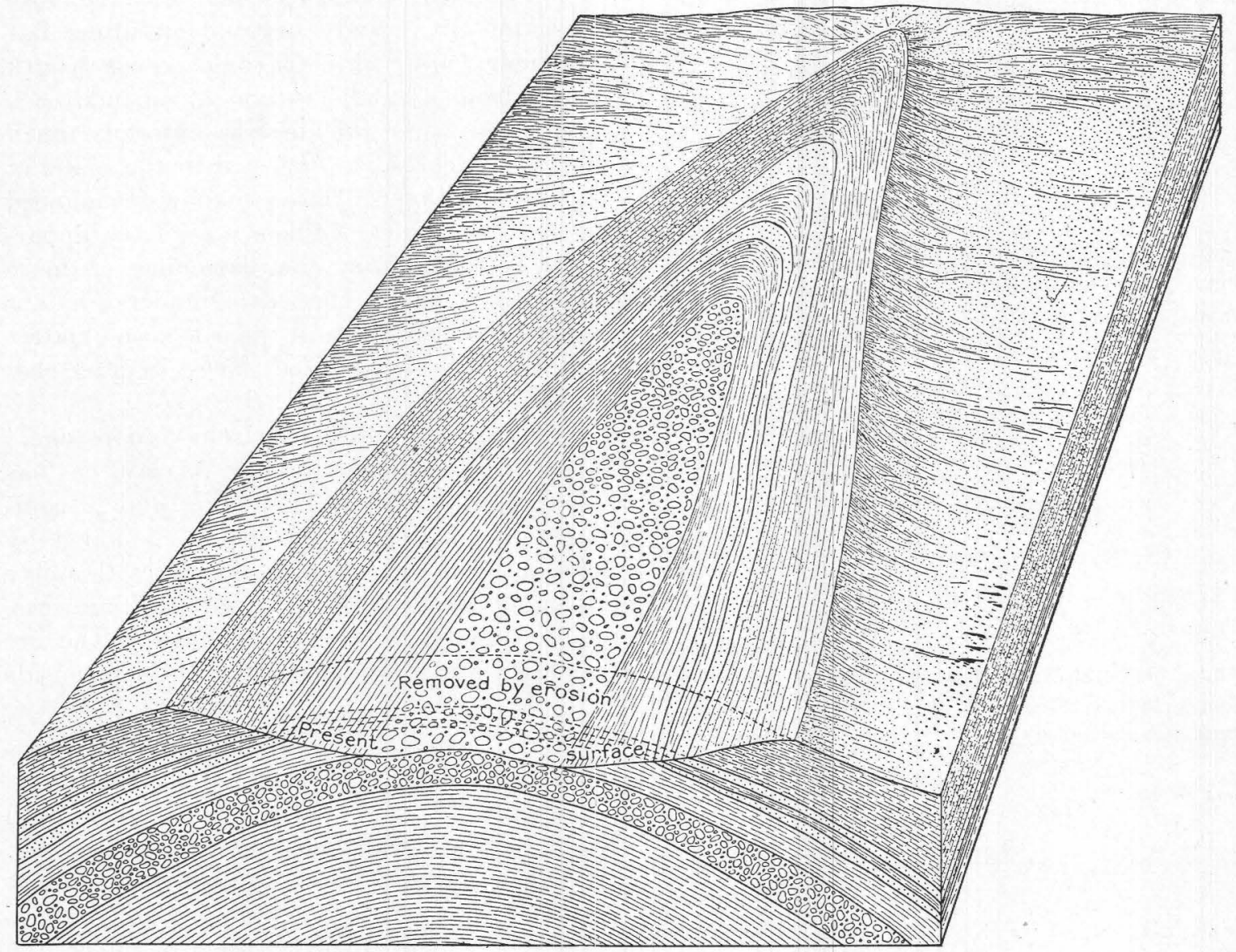

FIGURE 66.-Generalized diagram showing relations of the formations near Silver Reef.

West of Leeds and thence southward the "reefs" are nearly parallel, but to the north, as they turn eastward in passing around the nose of the anticline, they gradually separate and, where they pass beneath the surface, are several hundred feet apart. Where they reappear on the east side of the anticline they are less distinct and are generally spoken of in combination as the East Reef, though they have been worked and can doubtless be traced as separate strata or reefs. The relations of the formations are generalized in figure 66 .
As seen on the surface and in the accessible mine workings one is rather impressed by the lack of extensive faulting and fissuring. The reports of those in charge of operations, however, indicate that fissuring and minor faulting are of common occurrence. Rolker ${ }^{1}$ states:

Slips are frequently met in the producing sandstone beds. Some of these slips are caused by very fine fissures or cracks, as fine as a sharp blade of a knife. They sometimes throw the ore into the over or underlying [beds] producing side branch. In some cases they also cause the

1 Rolker, C. M., The silver sandstone district of Utah: Am. Inst. Min. Eng. Trans., vol. 9, p. 29, 1881. 
silver to pinch out entirely. Often they are also the leaders to a new deposit. Faults are met with, which throw the silver-bearing stratum from a few inches to several feet within the same line of bedding. The faulting lines are usually filled out with clay, and they generally contain silver. The faults and slips occur in all the mines. I append a sketch of two types, figure 67 being

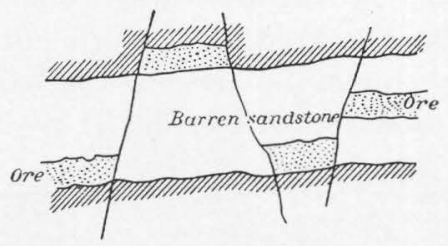

Figure 67.-Faulting, Buckeye mine. After C. M. Rolker.

from the Buckeye mine and figure 68 from the Last Chance mine.

The silver solution seems to have left its traces in some of these faulting lines, being prevented, of course, from impregnating the immediate sides by the clay lining, until it found an easily permeable stratum above or below. The faulting lines were formed during and after the tilting took place and previous to the silver deposition.

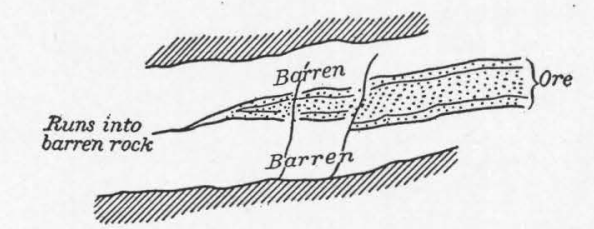

Figure 68.-Faulting, Last Chance mine. After C. M. Rolker.

The central portion of the Buckeye Reef, on its west branch, shows for about 400 feet in length a reverse dip (to the east), forming a complete curve, following the bed down on its dip, and showing the upper portion of this curve faulted 40 feet off to the west. In the Kinner mine, in one place it shows, besides, a doubling up before

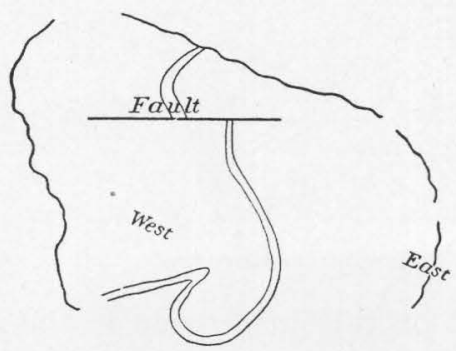

Figure 69.-Structure of Buckeye Reef, Kinner mine. After C. M. Rolker.

it assumes the regular west dip, as is indicated in the accompanying sketch.

The ore occurs in irregular shoots at different positions within the "reefs," and it pinches and swells along the dip and strike. (See fig. 70.) Much of the rich ore is associated with carbonized vegetable remains, either stems 6 to 8 inches in diameter and several feet long or small rushlike bodies. (See Pl. XLVIII, C.) The plants have ordinarily been partly silicified and partly carbonized. Some of the larger fragments have been largely replaced by silica, and in these the silver content is said to be small. On the other hand, the highly carbonized plants are favorable localities for the precipitation of minerals.

Not all the ore, however, is closely associated with plant remains. Considerable silver has been obtained from a peculiar conglomerate consisting of a sandy matrix containing flat lenticular lenses of clay shale whose length ranges from a small fraction of an inch to 3 inches and whose thickness is uniformly much less. The lenses are flattened in the plane of the stratification. The lenses show pronounced slickensiding where broken, and have apparently resulted from the flattening of more spherical bodies. The silver mineral is apparently present both in the sandstone matrix and on the slickensided faces in the clay lenses. (See Pl. XLVIII, A.)

Silver is also obtained from "soapstone," a rather thin stratum of shale or clay that has been slightly sheared in folding and is composed of small lenticular bodies bounded by slickenside faces. In some localities this clay material can be broken to minute fragments, each bounded by slickenside faces. The ore minerals apparently. lie along the slickenside planes.

Much of the ore is said to have been sandstone, not differing greatly from the normal sandstone of the "reefs." The mineralized sand rock is usually composed of rather thin lamellae, is iron stained, and contains nodular masses of clay and iron that are said to contain a relatively large amount of silver and other nodules that are composed largely of iron oxide cementing quartz and strongly suggesting altered pyrite. Massive beds of sandstone inclosed in these "shoots" are said to be commonly too low in silver content to be of commercial value.

Rolker ${ }^{1}$ gives the following description of the reefs:

The reefs themselves are made up of whitish-gray and red to reddish-brown sandstones, and between the reefs lie beds of clay shale, varying in color from blue to green to cinnamon brown. The ore occurs in similar strata of 1 Op. cit., pp. 24-26. 
sandstone and clay shale. The roof is generally marked/less frequently vegetable remains than the remaining by a reddish micaceous sandstone, while the floor is made up of an arenaceous sandstone of a whitish color, with argillaceous sands underlying. The outcrop of the ore portion and the White Reef, and in parts these remains are absent. In other parts, and this holds true for the whole district, we find the producing sandstone beds

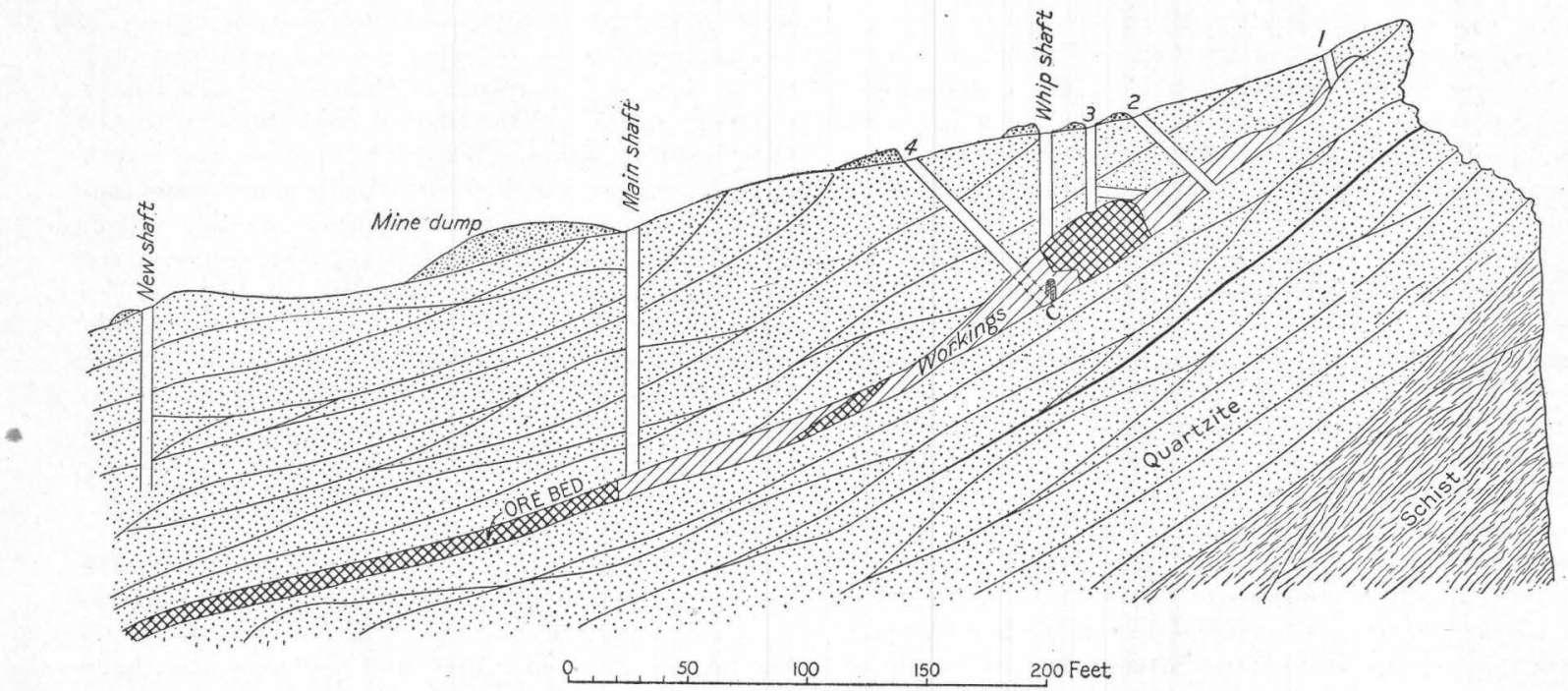

FIGURE 70.-Vertical cross section of Last Chance mine.

is marked on the east face of the reef, with the exception of those places where the former apex of the reef has been washed off, as in portions of the Buckeye Reef on its northwest side of the horseshoe. The ore is by no means confined always to one bed, but it is limited to a silver zone of from 30 to 90 feet wide, horizontally measured, and anywhere within this belt the horn silver is liable to be found. As a rule it is more concentrated in certain layers (beds) of this belt, but in places it is so scattered as to bring the grade down to a uniform $\$ 10$, which at present does not pay to work. Frequently, also, the ore is thrown in consequence of very fine slips from one bed into another. Hence the giving out of the ore in one bed is not exactly a discouraging fact, for a crosscut may, and very often does, prove it to have jumped into a lower or higher bed, respectively. In other words, the argentiferous sandstone belt is compound in structure. The producing branches, two or three in number, run together in places, at least two of them do, and then again continue for long distances with barren strata between, which vary in thickness from 3 to 15 and even 30 feet or more. In the depth, or following the dip, they have kept pretty well their own ground, but I have no doubt that what is now considered two and three separate beds will at a greater depth form but one bed throughout. The producing branches in all the mines change occasionally from a sandstone to a clay shale, even in the same bed, but certain portions of the reef, especially the northwestern portion of the Buckeye Reef, and the southern and a part of the central portion of the White Reef, show a preponderance of clay shale and argillaceous sandstone. The latter strata are also found in some of the northern parts of the White Reef.

Of course the less clayish or argillaceous the sandstones the less slimes are produced in the mill. The southern and part of the middle portion of the Buckeye Reef show underlaid by a stratum of highly argillaceous sandstones of variable thickness of from 10 inches to 2 feet, which carry much silver, and frequently show solid sheets of

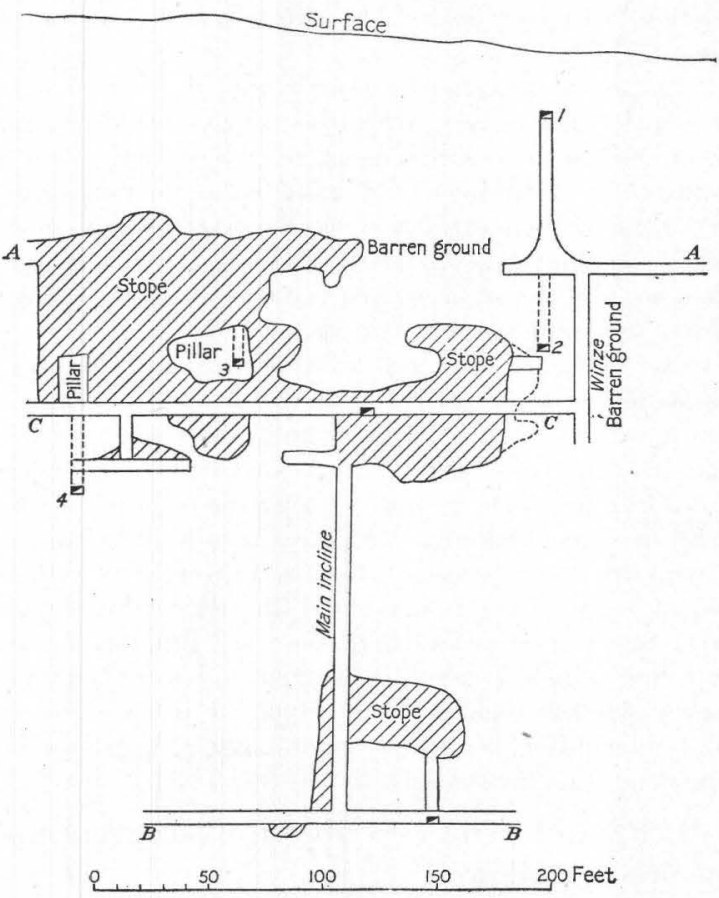

FIGURE 71.-Longitudinal section of workings of Last Chance mine, projected at plane of ore bed. After R. P. Rothwell.

horn silver along the seams of the thickness of a knife blade. I have known such seams to mill right along from $\$ 60$ to $\$ 130$; unfortunately their occurrence is not as frequent as might be wished. 
The ore itself is what is known as cerargyrite or chloride of silver, which, however, below true water level will change to the sulphuret of silver, with native silver in places. Of the latter ehange two indications have been met with. A tested sample yielded in a certain mine only 65 per cent of chloride of silver. This proportion will decrease in the ratio as water level is passed and the ore gets more outside of the reach of waters charged with oxygen and chloride of sodium. The grade of the camp is probably $\$ 20$ to $\$ 25$, though I have mined portions of beds which averaged right along $\$ 35$ to $\$ 55$, and others run as low as $\$ 14$ to $\$ 17$; and at times even $\$ 8$ and $\$ 10$.

We find in the same line of bedding strata holding petrifactions from 6 inches to 3 feet thick, which contain no silver ore, while above and below it silver is found in good permanent grades in strata showing a scarcity of vegetable remains. Again, I have seen a stratum where the upper 2 feet assayed about $\$ 30$, then 6 inches assaying $\$ 100$ or more, then 15 inches barren, and below it a layer of $\$ 20$ rock, all of the strata being full of petrifactions.

Another frequent occurrence is a foot or 2 -foot seam of sandstone, full of petrifactions, charged with red oxide of copper, azurite, and malachite to some extent, and carrying no silver, while below it good paying ores were found free from copper, or in places barren rock. Such a copper cap has always been found a good indication for an ore body near by, and drifts which I started on this indication have since opened finely. As another matter of interest I found the seams, in which the vegetable remains are covered with autunite, ${ }^{1}$ which is quite frequent around the Gad shaft, and the two carbonates of copper, unproductive, with pay seams, frequently above and below them.

As to the occurrence of copper in the silver bed I have observed a curious fact. If the copper present be azurite, or a grassy green looking malachite, the amount of silver in the bed will diminish, and it is a bad indication for the life of this particular shoot. If the copper presents, however, a pale but lively green, with a bluish shade in it, as we often find the stain on quartzy ores, it invariably improves the grade of the silver ore.

Other objects of interest in the beds are occasional pieces of vegetable matter changed into lignite, some of which will assay high in silver and others again be free from it. They are, in instances, coated with native silver and also intergrown in cases with pyrites, holding a very small amount of copper. In places trunks and branches of trees are found, some of which assay well, while others do not. The silver is not alone limited to the outside bark, but I tried pieces from the very interior of such branches, which I carefully washed and scrubbed, and they yielded as high as $\$ 40$ in silver. I also noticed, in the Buckeye Reéf, a 6-inch seam of jasper, resting between sandstone and clay shale.

R. P. Rothwell ${ }^{2}$ describes the occurrence of the ores as follows:

The silver occurs as chloride and sulphide and occasionally as native silver, disseminated through the more porous and fissured beds, and especially in the bedding

1 This mineral is possibly carnotite.

2 The Silver Reef district, southern Utah: Eng. and Min. Jour., vol. 29, p. $25,26,1880$. and fracture planes of the sandstone, and coating the bright "slipped" surfaces of the hard shale beds-locally known as soapstone-where these beds have been disturbed and crushed. Wherever the shale is compact and has not been crushed-that is, wherever it remains in a condition in which water could not pass through it-it contains no silver. And wherever the sandstone beds become very hard, compact, and unfissured they appear to become poorer, and the silver is confined more largely to the bedding planes. The silver, that at some depth below the surface was distributed with more or less uniformity throughout the ore-bearing bed, appears to collect in the planes between the beds as these approach the outcrop, giving the appearance of the silver "vein," so called, having split up and come to the surface as thin leaders or stringers of very rich ore. This is not only the well-recognized condition of the silver-bearing beds everywhere near their outcrop, but it is the condition we should naturally expect from the mineral-bearing solution collecting in the bedding planes, as these offered more available channels near the surface.

It is quite evident that the silver we now find coating the polished surfaces of the crushed shales and filling the cracks and coating the surfaces of the fossilized (petrified) wood frequently found in the sandstone beds must have come there after these substances had assumed their present conditions. We may therefore expect to find in future, as has been found thus far, that the conditions which facilitate the percolation of the silver-bearing solution, where the rocks contained suitable precipitants, will favor the occurrence of ore, and the rocks becoming compact, hard, and unbroken-conditions which would naturally impede the percolation of water-will be found unfavorable to the occurrence of rich ore bodies.

The occurrence of ore in these sandstone beds is extremely capricious, as might be expected from the method of deposition suggested. It occurs in numerous chimneys or chutes, and has collected in portions of the beds where ferruginous or carbonaceous matter appears to have attracted it; yet copper, which in many places stains the rocks green, seems, on the contrary, to be an unfavorable indication for silver.

These ore chimneys are sometimes small and at other times they are several hundred feet in horizontal length in the bed. The ore at their limits-sometimes suddenly, sometimes gradually - disappears, while the sandstone bed frequently continues apparently undisturbed; in the former case it is generally noticed that the bed is crossed by a fissure, and it has sometimes been found that the ore, which up to the fissure impregnated one division of the bed, will pass up or down and continue beyond it in another part of the bed, or will pass completely into another bed. Consequently it is necessary to "cross-cut" quite frequently in prospecting in order to ascertain whether the ore which has disappeared from one bed may not be found in a neighboring one which at another point may have been quite barren.

The silver, though occurring chiefly in a few easily recognized beds in each reef, is by no means confined to these; in some of the mines it is found in paying quantities in only one, in other places in two, three, or four beds, while several of the other seams of sandstone contain small quantities or traces of the metal; and in those 
which, in certain divisions, carry paying quantities of silver, the balance of the bed too poor to be milled contains rich nodules and pockets of ore, and is broken up and sorted in the mines, producing an important part of the ore milled. It therefore happens that, while the dimensions of the rich portions of the bed may be small, perhaps 1, 2, or 3 feet, yet as much as 5 or 6 feet of intermediate or overlying poorer rock will contain sufficient rich ore in these nodules to make it profitable to break it down and sort it. This feature is observed in all the mines of the camp, and necessitates the exercise of judgment, guided by frequent assays, to estimate fairly the yield of ore in the reserves. It is evident that a sample taken over the entire thickness of rock which it pays to take down would give an assay so low as to make it appear worthless; yet perhaps one-third of the bed would give a high-grade ore, and the remaining two-thirds, yielding extremely rich ore in small iron-stained nodules and in plant impressions (which would be avoided in taking a sample), though apparently of little value, will, in reality, yield nearly as much silver as the one-third from which we obtained a good assay.

In the Last Chance mine, and also in the Buckeye mine, are places where it pays to mine out the bed to the height of 10 to 14 feet; yet a sample of this entire thickness would give so low a return that the whole bed would be rejected. Nevertheless, by the exercise of skill in sorting the ore, a large amount of good ore is obtained from portions of the bed which, according to the sample, would be worthless. Indeed, for this reason it is found that the sample assays in all of these mines run much below the actual mill returns from the same ore.

For the reasons already stated, the ore chimneys seem almost as capricious in their vertical as in their horizontal dimensions. Nevertheless, where exploration has been continued, either in depth or horizontally, other chutes or chimneys have generally been found within a short distance. Asnone of the mines have exceeded a few hundred feet in vertical depth (the deepest mine in the district extends 600 or 800 feet on the bed from the outcrop to the deepest point opened-a vertical depth below the surface of perhaps 200 feet), the question of the continuation or recurrence of ore bodies at a great depth is an open one. no data sufflcient to base an authoritative opinion on having yet been afforded, though the past experience seems to prove that no depth yet attained has exercised any injurious influence upon the richness of the ore.

The work already done on the silver-bearing reefs has fully demonstrated that the ore is more abundant and richer at certain points than at others, and a most careful examination of each particular property is necessary to determine its value; for while the rocks which contain the ore are as continuous as other sedimentary beds, the occurrence of pay in them appears to be subject to the same laws, conditions, and accidents which have governed the deposition of similar ores in fissure veins.

The following description of the occurrence of ores in the Barbee and Walker mines by W. M. Nesbit is given by Jenney: ${ }^{1}$

\footnotetext{
1 Jenney, W. P., The chemistry of ore deposits: Am. Inst. Min. Eng.
} Trans., vol. 33, p. 464, 1902.
Watson M. Nesbit, who was connected with mining operations at Silver Reef from 1878 to 1888 , gives the author the following statement of the manner of occurrence of the ore: In the Barbee and Walker mine, water was struck at a depth of about 500 feet vertically. Near that point the ore changed in appearance and character, and gave great trouble in amalgamation, the extraction being very low. The ore was treated hot, in pans; a thick scum rose on the pans, like heavy petroleum oil, and had to be removed from time to time during the amalgamation. From a charge of $1 \frac{1}{2}$ tons of ore, as much as a gallon of this oily material would be obtained. The ore at water level, if carefully stoped, averaged 12 to 16 ounces of silver per ton; but only a part of the silver could be saved in pans. A very little pyrite appeared at water level - the first seen in the mines. About 100 to 200 feet above water level, on the slope of the beds, the ore was in places very rich; and small bunches of lignite coal, 4 to 10 inches across, were found embedded in the soft sandstone, with native silver deposited in thin scales on the joints of the coal. Most of the ore at this depth was silver sulphide. At one place a tree trunk, 18 inches in diameter, was found; the heartwood was silicified and very hard, and carried 8 to 10 ounces of silver per ton. The sapwood and bark, 3 to 6 inches in thickness, were altered to soft, crumbling lignite, full of silver sulphide; it assayed 5,000 ounces of silver per ton. The ores from the Silver Reef mines never showed any gold by assay; but in leaching the ore by the Russell process, the silver sulphides produced contained a trace of gold.

\section{MINERALOGY.}

The mineralogy of the ores is relatively simple. In the upper parts of the ore bodies practically all the silver is in the chloride, cerargyrite (horn silver). Some parts of the reefs, especially of the East Reef, contain copper carbonates in small amounts; Mr. Rolker reports autunite in the Gad shaft; and the writer found a small amount of a yellow uranium-vanadium mineral that resembles carnotite. Mr. Don Maguire has kindly furnished the writer with a specimen from the Buckeye Reef, containing a yellow uranium mineral together with blue and green carbonates of copper. D. B. Huntley also reports the presence of a uranium mineral from the Tecumseh mine, as follows: ${ }^{2}$

The following peculiar action of the bullion was noticed in this district, and especially at the Christy mill, when working on some Tecumseh ore, which contained a number of minute yellow specks. After the bullion was poured from the pot into the mold and had apparently solidified, it would begin to swell (not sprout) and rise slowly in the mold until the spongy surface was from 3 to 4 inches above the first surface. The melter noticed that this action was

${ }^{2}$ Huntley, D. B., Tenth Census U. S., vol. 13, p. 481, 1885. 
prevented, or at least diminished, by keeping the molten silver in the pot a considerable time before pouring. A person said to be connected with the laboratory of Hamilton College, New York, while visiting at Silver Reef, took some samples of these yellow ores, and, on returning to the East, reported that they contained phosphate of uranium. This statement has not been authenticated, but is given for what it may be worth.

Hydrous iron oxide is rather uniformly present with the silver ores and is abundant in many of the richer ones.

It is commonly reported that below water level both the silver and copper are present mainly as sulphides, with a little native silver. Newberry, ${ }^{1}$ however, states that the average of four analyses of silver ores showed 0.23 per cent of selenium and 0.26 per cent of silver, which would suggest that part of the silver at least may be combined in some form with selenium. The abundance of hydrous iron oxides in the oxidized ores indicates some iron in the unoxidized ores.

It seems to be the general experience of all who worked in the district that abundant copper indicates relatively low silver content. Rolker's statement, however, seems to indicate some exceptions to this rule.

\section{EXTENT AND DEPTH.}

The important mineralization thus far discovered is within about 2 miles of the northern end of the reefs. The same formations can be followed for many miles southward, and it is reported that at numerous localities a low content of silver has been found, though nowhere sufficient to be of economic importance. Newberry states that sandstones at essentially the same horizon in the vicinity of Cedar City contain silver. The most promising locality next to the Leeds district seems to be in the vicinity of Virgin City on North Creek. This locality was not visited and no description has been found in the literature, but from common report the occurrence is apparently similar to that at Silver Reef.

The maximum distance on the incline to which the ore beds have been followed is about 1,000 feet, in the Maggie, California, and Tecumseh, on the Buckeye Reef. At that distance from the outcrop the beds are little more than 150 feet vertically below the surface. ${ }^{2}$

1 Eng. and Min. Jour., vol. 31, p. 5, 1881.

2 Director of the Mint Ann. Rept. for 1882, p. 269, 1883.
On the Thompson and McNally claims, on the White Reef, vertical depths of 245 feet were attained at a distance of 560 feet on the incline outcrop. ${ }^{3}$

No detailed information as to the relative output from different depths on the reefs is available, but it is probably safe to say that by far the greater part of the silver came from within 500 feet of the outcrop and within 150 feet of the surface.

On the Buckeye Reef water was reached in some of the mines a few feet below the surface, and it is reported that in wet seasons the shafts are filled with water to the surface. The flow of water, however, does not seem to have been great.

The failure to follow the ores to greater depths is not readily explainable at this late date. It is variously ascribed to the refractory character of the ores; to the added costs of work and of pumping at increased depth; and to a decrease in silver content. Though each of these factors doubtless increased the cost of production it seems reasonably certain that a material decrease in the silver content at depth was the main cause for the abandonment of the deeper workings.

The principal mines on the different reefs in 1880 were given by Huntley ${ }^{4}$ as follows from north to south:

White Reef: Barbee \& Walker, Pinkham and Dodge, Leeds, Thompson and McNally, and Gisborn.

Buckeye Reef: Silver Flat, Manhattan, Tecumseh, Kinner, Buckeye, Last Chance, Maggie, California, and Emily Jane.

East Reef: Vanderbilt, Duffin, Dykes \& Stopeley, Toquerville, Maud, and Dixie.

TENOR OF ORES.

The grade of the ore extracted has depended on the possibility of profitable treatment. In the early days, when the ores were shipped to Salt Lake or Pioche, only very high grade material could be profitably mined. Later a much lower grade was treated in the district. The Director of the Mint stated ${ }^{5}$ in 1882 that for the three and one-half preceding years the Stormont Silver Mining Co. milled about

3 Idem, p. 269.

4Huntley, D. B., Tenth Census U. S., vol. 13, p. 479, 1884

6 Director of the Mint Ann. Rept. for 1882, p. 269, 1883 
50,000 tons of ore averaging 22 ounces of silver per ton, and that in five years the Christy Mining \& Milling Co. treated 55,000 to 60,000 tons, yielding an average of 27.75 ounces. Later, ore yielding as low as 10 ounces per ton was milled, but the average was probably considerably above that.

\section{GENESIS.}

The origin of the ores in the sandstones has long been discussed, but as yet no general agreement concerning them has been reached. The Silver Reef deposits are the most important of the type in this country, and about 1880 their origin was vigorously argued. Two ideas were advanced, one that they were deposited from gaseous or watery solutions given off by igneous rocks, and the other that they were precipitated, while the sandstones were being formed, by decaying vegetable matter, from the water of a shallow sea. More recently another idea has been advanced-that the metals were originally deposited with the sediments, probably largely as eroded mineral fragments from veins, and were later dissolved and reprecipitated in a more concentrated form by circulating waters. ${ }^{1}$ Lindgren also considers that the first deposits were argentiferous chalcocite and that the silver ores have resulted from a reworking of these deposits.

The relation of these deposits to the Leeds anticline leaves small room for doubt that they were deposited after the formation of this structure in Tertiary time. It is, of course, possible to suppose that the relation is accidental, but this does not seem likely. If this relation to the structure is granted, the ores were not formed till Tertiary time, and, of course, the idea that they were deposited with the sediments in Triassic time is untenable.

Whether the metals were deposited from solutions given off from an igneous magma or concentrated from material deposited with the sediments is not so easily determined. Very pronounced volcanic activity took place about the time of the folding of the strata in Tertiary time. Further, an igneous body has apparently been intruded on the line of the northward extension of the Leeds anticline, a few miles north of the point where the ore-bearing

1 Lindgren, Waldemar, Mineral deposits, p. 368, New York, 1913. $35416^{\circ}-19-38$ reefs pass below the present surface. ${ }^{2}$ (See Pl. XLVI.) Solutions given off by such bodies might readily work upward through the porous sandstone strata along the crest of the anticline and deposit their metal load as they reached areas of less heat and pressure or reacted with the carbonaceous or other material in the sandstone. The ores contain selenium, as do also the silver, gold, and mercury ores in the Marysvale district, where, with much greater certainty they may be attributed to an igneous origin. Selenium is, however, common in the sandstone ores of the Plateau region.

On the other hand, it is reported, apparently reliably, that the sandstones at this horizon contain small amounts of silver over large areas, and it is also known that they carry gold. (See p. 634.) If at the time of the uplift and folding of the region, or later, a circulation was set up that centered along the crest of the anticline, the metal might readily have been concentrated to the existing extent.

Possibly, as suggested by Lindgren, enrichment has been an important factor in forming the ores from argentiferous chalcocite, but the writer has failed to find much evidence of it. Rich ores were found at the surface, and migration of silver seems to be unimportant. If enrichment were due to the precipitation of silver or silver sulphide on copper sulphide ores carrying both copper and silver would probably be found; the presence of copper, however, is said to indicate low silver content.

If the ores are related to the structure they were deposited near the summit of the anticline and for only a few hundred feet down either limb; and if several hundred feet of the ore-bearing beds were removed from the summit of the anticline little if any ore would remain. This may explain the absence of ore in the sandstone south of Harrisburg and Virgin River, where several hundred feet of the "reefs" have been eroded from the summit of the anticline.

\section{FUTURE OF THE DISTRICT.}

Operations in the district are now (1917) practically abandoned and for many years only small operations have been carried on by lessees (chloriders). Most of the high-grade ore in the known ore-bearing territory above water level has certainly been extracted. It is com-

\footnotetext{
2 Huntington, Ellsworth, and Goldthwait, J. W., op. cit., p. 218.
} 
monly stated, however, by those familiar. with the mines that a rather large quantity of rock containing 5 to 12 ounces of silver per ton remains in the old workings and on the dumps. If such ore exists it will doubtless be treated at some time, and if sufficiently abundant it could be done at relatively low cost, for electric power could be generated on Virgin River, and farm produce is not excessively high.

The northward extension of the reefs, where they pass beneath the present surface and form the roof of the Leeds anticline, seems to be the most promising area for new prospecting.

Uranium minerals were seen in but small quantity in the district. This, however, may have been due to failure to examine proper places or to lack of familiarity with this class of ore when the district was visited. Future operators should keep in mind the possibility of finding uranium in commercial quantities.

\section{BIBLIOGRAPHY.}

Arentz, S. S., U. S. Bureau of Mines Tech. Paper 90, pp. 19-20, 1915.

Cazin, F. M. F., The origin of the copper and silver ores in Triassic sandrock: Eng. and Min. Jour., Dec. 11, 1880, p. 381; Apr. 30, 1881, p. 30.

Huntington, Ellsworth, and Goldthwait, J. W., The Hurricane fault in the Toquerville district, Utah: Harvard Coll. Mus. Comp. Zool. Bull., vol. 42, pp. 199, 259, 1904.

Huntley, D. B., The mining industry of Utah: Precious Metals, Tenth Census U. S., vol. 13, pp. 477-482, 1885.

Jenney, W. P., The chemistry of ore deposition: Am. Inst. Min. Eng. Trans., vol. 33, p. 462, 1903.

Maynard, G. W., Eng. and Min. Jour., vol. 29, June 12, 1880.

New berry, J. S., Report on the Stormont Silver Mining Co., Utah: Eng. and Min. Jour., vol. 30, p. 269, 1880; The Silver Reef sandstone: Eng. and Min. Jour., vol. 31, pp. 4-5, 1881.

Director of the Mint Ann. Repts., 1881, p. 237, and 1882, p. 268.

Rolker, C. M., The Silversandstone district of Utah: Am. Inst. Min. Eng. Trans., vol. 9, pp. 21-23, 1881.

Rothwell, R. P. (editor), The Silver sandstone formation of Silver Reef: Eng. and Min. Jour., May 22, p. 351, 1880; Jan. 10, 17, 24, pp. 25, 45, 59, 79, 1880.

- Discussing paper on Bassick mine: Am. Inst. Min. Eng. Trans., vol. 11, p. 117, 1883.

\section{SANTA CLARA DISTRICT.}

The Santa Clara district, in Washington County, is 10 miles west of St. George. The sandstone strata of the Silver Reef district are present in this district and were the basis of prospecting. It was organized in the spring of 1880. Around St. George and between it and Silver Reef there are several districts, Volcanic, Gunlock, and others, that cover miles of sandstone country and contain many locations. Little work, however, has been done in them and no ore has been shipped. ${ }^{1}$

\section{BEAVER DAM MOUNTAINS.}

By B. S. Butler.

\section{GENERAL FEATURES.}

The Beaver Dam Mountains, in the southwestern part of Washington County, trend in general northward from Colorado River as a well-defined range for about 20 miles to a low pass, beyond which a less well-defined portion extends several miles farther. The range is generally from 4,000 to 5,000 feet high but in places attains a maximum elevation of about 7,000 feet, Water is scarce, there being no perennial streams and but few springs. There is no timber on the range suitable for building, but a growth of "cedar" (juniper) and other scrubby trees serves for fuel and can be used for mine timbering to some extent.

\section{GEOLOGY.}

The rocks in the mountains range in age from pre-Cambrian to Triassic. Except for pegmatitic dikes in the schists on the west side of the range and extrusive flows and a few dikes in the Bull Valley region, they are of sedimentary origin.

\section{SEDIMENTARY ROCKS.}

The sedimentary series apparently corresponds closely with that studied by Gilbert at the mouth of the Grand Canyon. ${ }^{2}$ (See Pl. VI.)

The lowest rocks exposed where the old Overland trail crosses the Beaver Dam Mountains are mica and hornblende schists cut by pegmatitic dikes. The schist is overlain by several hundred feet of red quartzite containing beds of fine conglomerate, and this in turn is overlain by several hundred feet of sandy shale, sandstone, and arenaceous limestone. Next above lies heavy-bedded blue limestones and heavy-bedded gray limestones, each esti-

1 Precious metals: Tenth Census U. S., vol. 13, p. 483, 1885.

2 U. S. Geog. and Geol. Survey W. 100th Mer., Rept., vol. 3, pt.1, p. 196,1875 . 
mated to be 600 to 800 feet thick. Overlying the gray limestones are thinner-bedded limestones overlain by sandstones. The rocks seem to correspond with Gilbert's section essentially as follows: The quartzite and conglomerate overlying the schists and the shaly sandstone series belong to the Tonto group. The great series of limestones limited upward by the sandstone series are apparently to be correlated with the Redwall limestone; and the upper sandstone series belongs with the Aubrey group.

Fossils were collected from the limestones in which the Dixie and other mines of the Tutsagubet district have been developed, and from the limestone in the Bull Valley gold district in the northern extension of the range. G. H. Girty assigns both collections to the Pennsylvanian, though he states that they show some unusual features. In the collection from the Tutsagubet district he determines the following forms:

Derbya crassa.

Productus arkansanus?

Productus cora.

Spirifer rockymontanus.

Phillipsia sp.

In the collection from Bull Valley he determines the following:

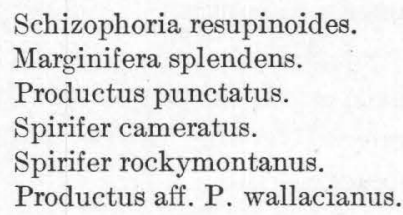

IGNEOUS ROCKS.

The only igneous rocks observed in the southern part of the range were pegmatite dikes, which are rather plentiful in the small area of schists that was examined. The dikes are rather coarse grained and are composed essentially of quartz, pink feldspar, and a relatively small amount of muscovite. They were not observed cutting the sedimentary series and are probably older than the basal quartzite.

In the northern extension of the range igneous rocks are abundant. In the Bull Valley iron district both intrusive and extrusive rocks are abundant. (See p. 581.) Near the Bull Valley gold district extrusive rocks prevail north and west of the district. They are porphyritic in character and many of them contain rather numerous phenocrysts of quartz, biotite, orthoclase, and plagioclase. Quartz and biotite are rather variable in amount; quartz is nearly wanting in some rocks and biotite is present in only small amount in others. A large part of these rocks are probably quartz latites, though some flows are probably true rhyolite and others may properly be classed as andesite. Dikes in the sedimentary series were noted especially in the canyon of the East Fork of Beaver Dam Wash; they are usually highly altered but are apparently of moderately basic composition.

\section{STRUCTURE.}

The sedimentary rocks of the district strike in general north and dip east at a rather low angle. The range, which is apparently to be classed with the basin range type, has evidently resulted from faulting along its western ${ }^{\circ}$ face and from relative uplift and easterly tilting. Minor faulting and fissuring has furnished channels for the solutions that formed the ore deposits.

\section{TUTSAGUBET DISTRICT.}

The Tutsagubet district is near the central portion of the Beaver Dam Range, about 14 miles nearly due west from St. George and about 60 miles southeast of Acoma, Nev., the nearest railroad point on the Los Angeles \& Salt Lake Railroad.

\section{HISTORY AND PRODUCTION.}

By V. C. Heikes.

Tutsagubet district, in Washington County, organized June 2, 1883, was first mentioned by Raymond, ${ }^{1}$ who refers to it in 1872 as the St. George district, in which no claims had been opened or worked up to April, 1871, though many locations had been made. Later Raymond $^{2}$ reports that in $\mathbf{1 8 7 5}$ a furnace was erected near St. George on Virgin River for the treatment of copper ore from the Grand Gulch mine, in the Bentley district, Mohave County, Ariz., 129 miles south of St. George. The furnace was abandoned shortly after its completion, and there is no record of its having reduced any ore from the district.

\footnotetext{
${ }^{1}$ Raymond, R. W., Statistics of mines and mining in the States and Territories west of the Rocky Mountains for 1871, p. 329, 1873.
}

Territories west of the Rocky
${ }^{2}$ Idem for 1875 , p. 281,1877 . 
In 1884 the Mountain Chief Mining Co. built a one-stack furnace on Virgin River to reduce lead carbonate ores said ${ }^{1}$ to assay 65 per cent of lead and 15 ounces of silver. Charcoal was used for fuel and smelting begun November 8, 1884. In September, 1885, the company was in litigation and the property closed. The amount of lead bullion produced is not known. Between 1884 and 1888 the Apex or DixieCopper mine, first known as the Pen mine, was worked, and is reported ${ }^{2}$ to have shipped 300 tons of copper ore, largely carbonate, out of the district. S. R. Callaway, ${ }^{3}$ superintendent of the Dixie $/$ stone adjacent to fissures.

Metals produced in Tutsagubet district, 1887-191\%.

\begin{tabular}{|c|c|c|c|c|c|c|c|c|c|}
\hline \multirow{2}{*}{ Period. } & \multicolumn{2}{|c|}{ Gold. } & \multicolumn{2}{|c|}{ Silver. } & \multicolumn{2}{|c|}{ Copper. } & \multicolumn{2}{|c|}{ Lead. } & \multirow{2}{*}{$\begin{array}{c}\text { Total } \\
\text { value. }^{a}\end{array}$} \\
\hline & $\begin{array}{c}\text { Fine } \\
\text { ounces. }\end{array}$ & Value. & $\begin{array}{c}\text { Fine } \\
\text { ounces. }\end{array}$ & Value. & Pounds. & Value. & Pounds. & Value. & \\
\hline $\begin{array}{l}\text { Prior to } 1887 . \ldots . \\
1890-1894{ }^{2} \ldots \ldots \\
1898-1909 \text { e....... } \\
1914-1917 \ldots \ldots .\end{array}$ & $\begin{array}{c}1.35 \\
\cdots \cdots \\
0.18\end{array}$ & $\begin{array}{c}\$ 28 \\
\cdots \cdots \\
4\end{array}$ & $\begin{array}{r}b 1,200 \\
18,562 \\
124,426 \\
667\end{array}$ & $\begin{array}{r}\$ 1,176 \\
15,786 \\
74,735 \\
388\end{array}$ & $\begin{array}{r}\text { b } 300,000 \\
1,784,065 \\
8,318,266 \\
192,735\end{array}$ & $\begin{array}{r}\$ 41,400 \\
209,606 \\
1,233,570 \\
48,540\end{array}$ & $\begin{array}{c}(c) \\
\ldots \ldots \ldots \\
43,669 \\
\cdots \ldots \ldots \ldots\end{array}$ & $\begin{array}{r}\$ 2,315 \\
\ldots \ldots \ldots \ldots\end{array}$ & $\begin{array}{r}\$ 42,576 \\
225,392 \\
1,310,648 \\
48,932\end{array}$ \\
\hline & 1. 53 & 32 & 144,855 & 92,085 & $10,595,066$ & 1, 533, 116 & 43,669 & 2,315 & $1,627,548$ \\
\hline
\end{tabular}

$a$ Includes gold worth $\$ 28$.

$b$ Estimated from 300 tons of copper ore said to have been produced.

c Lead unknown.

$d$ Figures of metal production largely taken from Director of Mint reports. No ore tonnage given.
$e$ From 1902 to 1909 the reports of producers were used; prior to 1902 the production is partly estimated through reliable sources.

mine between 1889 and 1893 , reports that the company received about $\$ 300,000$ for ore and bullion shipped to Swansea, Wales, and to Denver, Colo. In May, 1891, 13 tons shipped out of the district from a new find assayed copper, 54.2 per cent; sulphur, 4.1 per cent; iron, 5.7 per cent; silica, 2.6 per cent; and silver, 4 ounces. At the time it cost $\$ 30$ per ton to ship by wagon, 154 miles to Milford, the nearest railroad point. In 1899 a small furnace at St. George produced 8 to 20 tons of blister copper per month from ore containing 15 per cent of copper with charcoal and coke fuel. Coke cost $\$ 27$ per ton at the smelter. In November, 1900, another but larger furnace at Shem, 12 miles northwest of St. George, produced 3 to 4 tons of bullion th daily from ore containing 10 to 15 per cent of copper. This small smelter operated intermittently under several managements until 1907. The copper bullion produced in 1901

1 Eng. and Min. Jour., Oct. 18, p. 272, 1884.
2 Eng. and Min. Jour., Mar. 21, 1891.

${ }^{3}$ Personal interview, 1914.

averaged between 89 and 91 per cent of copper and 14 and 21 ounces of silver per ton; some of that produced several years later carried 93 per cent of copper and 5 to 6 ounces of silver per ton. Occasional lots of matte assayed about 74 per cent of copper and 7 ounces of silver. The last production of the district was a small lot of copper ore shipped to one of the Salt Lake smelters in 1909.

ORE DEPOSITS.

All the ores are replacement deposits in lime- 
ever, and more complex sulphates indicate that sulphides must have been present in the original ores, perhaps as both iron and copper sulphides or as an iron-copper sulphide. The copper minerals are said to be principally the carbonates, azurite and malachite, and also cuprite and to a less extent some complex sulphates and phosphates of copper, iron, and lead. Some lead occurred as the carbonate cerusite, the sulphate plumbojarosite, and other complex sulphates. Iron oxide is relatively abundant, as indicated by the dump. Unreplaced and silicified limestone are the principal nonmetallic materials. The ore extracted probably yielded approximately 12 per cent copper and 1.5 ounces silver per ton.

The developments of the Superior mine are in a northwest-southeast fault zone, in which the limestone has been highly brecciated. The ore occurs as irregular masses through the breccia. The copper minerals are principally carbonates and a little silicate, in a gangue of brecciated limestone with numerous veinlets of calcite.

LEAD-SILVER DEPOSITS.

The Paymaster mine, a short distance south of the Dixie mine, has been developed along a northwest fissure. The ore forms irregular bodies in the limestone adjacent to the fissure. There has been several hundred feet of development work, but no important bodies of ore have been found, though large bodies of oxidized iron ore are said to have been encountered. Ore on the dump contained the carbonate of lead, cerusite; the sulphate of lead and iron, plumbojarosite; and the basic iron sulphate, jarosite. A small smelter erected to treat the ores from. the mine was never successfully operated.

In the Black Warrior mine the ore deposits are associated with an extensive cave, which extends from the surface downward on a gentle dip for more than 200 feet along a fissure or fault where the limestone was considerably crushed. When discovered the cave was thickly studded with stalagmites, stalactites, and columns of calcite, and the floor was littered with fallen blocks of limestone. The ore was found in fissures in the sides and top of the cave and beneath the blocks of limestone. The ore is said to have been silver-bearing cerusite and was of high grade. Abundant limonite has apparently resulted in part at least from the oxidation of an iron-bearing carbonate and possibly in part from iron sulphide. Little devel- opment had been done at the time of the writer's visit aside from following the ore bodies that opened into the cave.

The original metallic sulphides, together with some iron-bearing carbonate, may have replaced limestone adjacent to a fissure. Later, surface solutions descended along the fissure, oxidized the ores, and dissolved and carried away a considerable amount of the limestone, forming the cave. Still later, solutions laden with lime carbonate entered the cave and deposited part of their load as stalagmites, stalactites, and columns.

A little prospecting has been done and some ore found in numerous other claims in the district, but in general it has not been sufficient to encourage extensive development under present conditions.

\section{BULL VALLEY (GOLDSTRIKE) DISTRICT.}

GENERAL FEATURES.

The Bull Valley or Goldstrike district is in the western part of Washington County, near the Nevada line. The nearest railroad point is Modena, on the Los Angeles \& Salt Lake Railroad. A small stream in Bull Valley is said to furnish a supply of water throughout the year. A rather scanty growth of cedar and other scrubby trees affords fuel and some mine timber.

The finding of specimens of rich gold rock has caused one or two gold excitements in Bull Valley, but to the close of 1913 the gold production had been limited to such specimens. In 1914 and 1915 developments were active, a mill was erected, and it is reported that some gold was produced.

\section{GEOLOGY.}

The sedimentary rocks of the district comprise a series of limestones with interbedded quartzite and some shale. The extrusive rocks in the southern part of the district are latite and rhyolitic flows and some more basic rocks. Dikes and small sills of intrùsive rock cut the sedimentary rocks and are especially well exposed in the canyon of the east fork of Beaver Dam Wash.

\section{ORE DEPOSITS.}

DEVELOPMENT.

All the mineral deposits noted in the district at the time of the writer's visit have been formed by replacement of the sedimentary 
rocks, and, so far as known, the gold deposits since explored have a similar origin. The deposits that have received attention in the southern part of the district are chiefly of gold, though antimony and arsenic deposits have been slightly prospected.

\section{GOLD DEPOSITS.}

The few gold deposits exposed in the district at the time of the writer's visit were in sedimentary rocks along fissures. The sediments adjacent to the fissures are highly silicified. Quartz and carbonate are the main nonmetallic minerals. The outcrops are stained yellow and brown with iron. A specimen of vein material examined under the microscope showed the presence of a yellow mineral resembling jarosite. This mineral could not be separated in the specimen collected, but a test showed the presence of sulphate, and the mineral is doubtless jarosite or some closely allied mineral. The gold occurs free so far as determined.

A specimen of high-grade ore (Pl. XLIX) from some distance below the surface, presented to the National Museum by M. R. Evans, contains native gold in a carbonate gangue. The carbonate is in part calcite and in part a light-brown mineral that contains iron and probably some manganese. The gold occurs as thin leaves in minute fissures in the carbonate along cleavages in and between mineral grains. In the specimen the gold is most abundantly associated with the brown carbonate, though occurring also in the calcite. Qualitative tests of the brown carbonate showed iron and a little manganese. The sheets of gold have a beautiful pitted surface corresponding to the etched surfaces of the carbonate crystals. This appears from descriptions to be its normal occurrence in rich pockets.

The sulphates in the ore deposits suggest that the original minerals were, in part at least, sulphides. The association of the gold with ferric sulphate suggests a similarity to the goldplatinum-palladium deposits of southern $\mathrm{Ne}$ vada, which Knopf ${ }^{1}$ thinks have resulted from enrichment of the leaner sulphides.

The occurrence of the gold replacing the carbonate associated with limonite and man-

1 Knopf, Adolph, A gold-platinum-palladium lode in southern Nevada: U. S. Geol. Survey Bull. 620, pp. 1-18, 1915. ganese is also sufficiently suggestive of enrichment, so that operators should keep the idea in mind in development.

\section{ARSENIC DEPOSITS.}

The arsenic deposit occurs in sandy sediments in a breccia zone that outcrops in the bed of Arsenic Canyon, where the stream has swept away the débris. The arsenic sulphide forms irregular areas surrounded by quartz, giving the rock an amygdaloidal appearance. Much of the quartz has a distinct crystal outline, and surrounds rosettes of fibrous material of distinctly lower index, from which it appears to have been derived. (See Pl. XLVIII.) As seen in thin section the fibrous mineral is light brown and contains few inclusions. The quartz, on the other hand, is colorless and contains abundant inclusions of a mineral of rather high index and birefringence and, apparently, extinction parallel to the elongation. It contains also abundant dark inclusions and some gas cavities, a small proportion of which inclose liquid. A small cube was noted in one such cavity. The relations suggest that in the fibrous chalcedonic mineral the materials that form the inclusions in the quartz are dissolved in the silica.

The principal metallic mineral of the deposit is the red sulphide of arsenic, realgar, which, on exposure to the weather, appears to alter to the yellow sulphide, orpiment.

Practically no development work has been done on the deposit at the time of visit.

\section{ANTIMONY DEPOSITS.}

Antimony is said to occur in at least two localities. A prospect a few hundred yards northeast of the gold prospect of R. G. McQuarrie consists of a body of stibnite 6 to 12 inches thick, which has been uncovered for a distance of about 6 feet. It appears to be a flat-lying deposit near the contact of limestone and quartzite, the sandy sediments underlying and the limestone overlying. Antimony is also reported from farther northeast.

IRON DEPOSITS.

The iron deposits in the northern part of the district are discussed on page 581 . 
U. S. GEOLOGICAL SURVEY

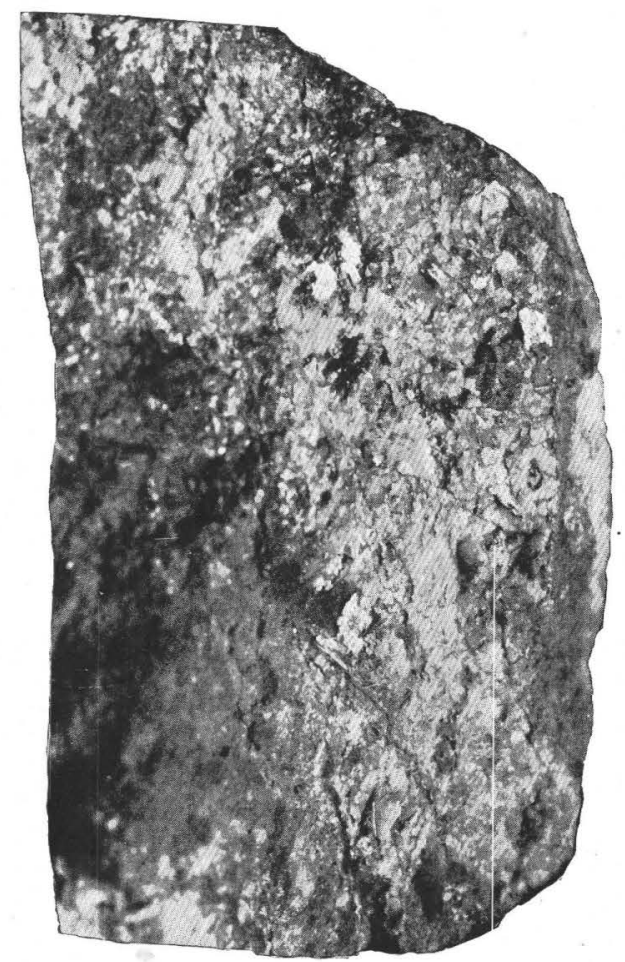

A. SPECIMEN OF NATIVE GOLD IN CARBONATE GANGUE FROM THE BULL VALLEY DISTRICT.

U. S. Nat. Mus. No. 88457. Enlarged one-half.

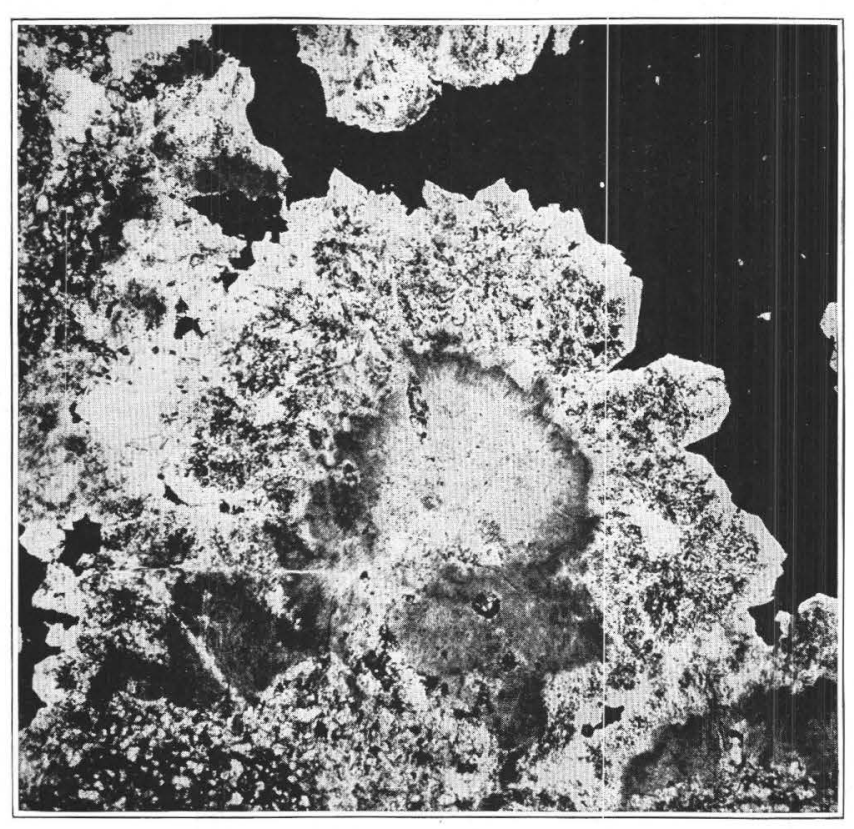

c. PHOTOMICROGRAPH SHOWING ROSETTE OF QUARTZ IN SPECIMEN OF ARSENIC ORES FROM BULL VALLEY DISTRICT.

Dark areas, realgar; light areas, quartz. Enlarged 30 diameters.
PROFESSIONAL PAYER 111 PLATE XLIX

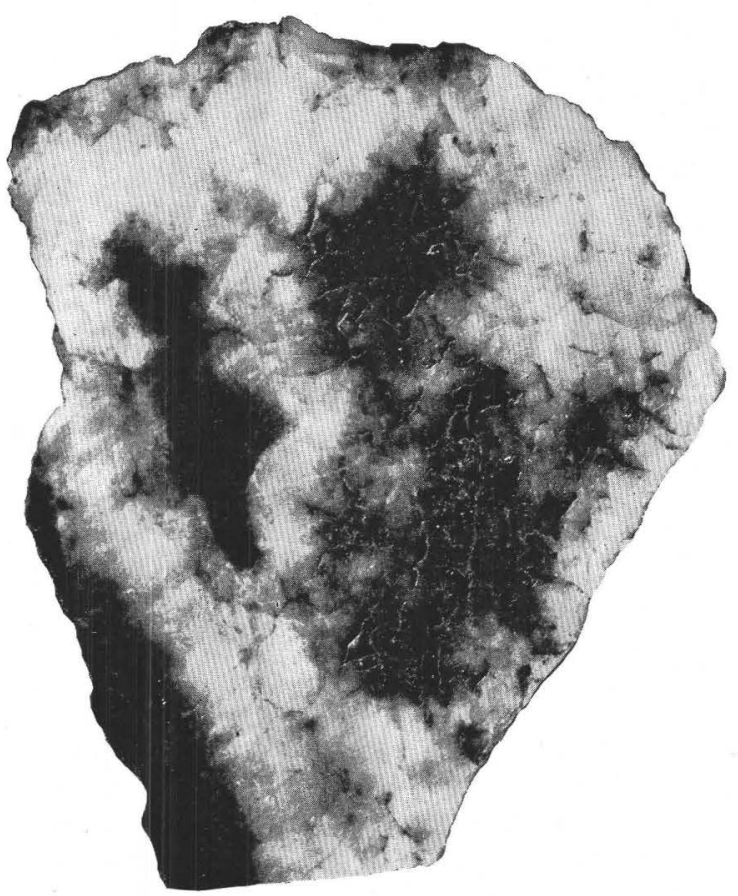

$B$. POLISHED SURFACE OF SPECIMEN SHOWN IN $A$. Veinlets of metallic gold; dark areas, brown carbonate containing
a little limonite. Enlarged 4 diameters.

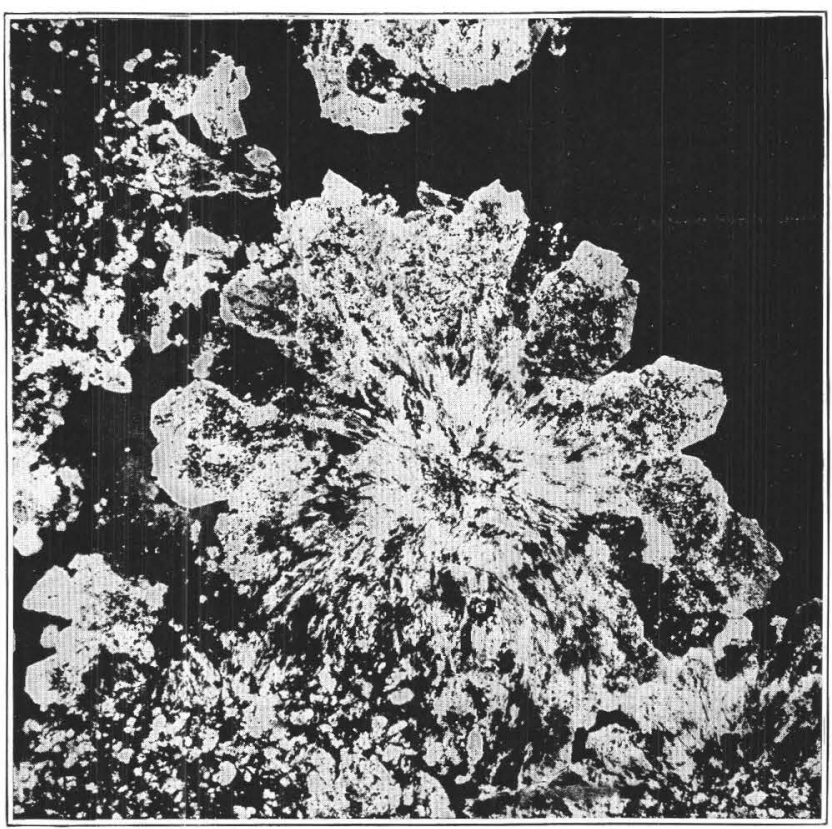

D. SPECIMEN SHOWN IN $C$, WITH CROSSED NICOLS.

Enlarged 30 diameters. 



\section{UINTA MOUNTAINS.}

By B. S. Butler.

INTRODUCTION.

The Uinta Mountains have yielded relatively small amounts of metals and have therefore been little studied by the writer in preparation for this paper. In September, 1913, he spent two days in a trip from Vernal to the Dyer mine, and the same month he and F. L. Hess visited prospects in the vicinity of Browns Park. The following statements concerning the geology of the range are largely a compilation.

\section{PHYSIOGRAPHY.}

The Uinta Range extends from the Wasatch Range in the northeastern part; of Utah eastward into Colorado, a distance of about 150 miles, with an average width of approximately 35 miles. Its glacial features have been described in detail by Atwood, ${ }^{1}$ and its topography and physiography have been summarized by Boutwell ${ }^{2}$ as follows:

The general form of the range is an elongated, broad, flat-topped arch. As the main east-west divide lies north of the center of the range, a north-south profile shows unsymmetrical slopes. The northern slopes fall off steeply to a great undulating basin, while the southern slopes descend very gently to an extensive plateau region. The elevation of the range varies from 6,500 feet in its western foothills, where it dips under Kamas Prairie, to 12,400 on Mount Agassiz, 12,500 on Hayden Peak, 13,200 on Mount Tokewana, 13,250 on Mount Lovenia, and 13,486 (corrected) on Emmons Peak.

An oval central area is encircled by a series of generally continuous, unsymmetrical ridges, with steep inwardfacing scarps and more gentle outfacing slopes. Dissection has reduced the inclosed interior plateau to a region of strong relief characterized by an exceedingly narrow steep-sided main east-west divide, which rises into isolated peaks and falls off steeply to the north and south to heads of great canyons. These canyons, especially those draining to the south, are characterized by broad, flaring, highlying upper levels, deeply trenched by very narrow steepsided gorges. In the western part of the range some of these headward portions, on emerging from the interior area, continue north or south along radial courses through the encircling ridges and down their gentle outfacing slopes. Others on reaching these ridges turn abruptly and escape by longitudinal valleys, whose alluvial bottoms are terraced and trenched. A third class of streams, which are characteristically short and not graded, head near the crests of these encircling ridges and flow down infacing scarps toward the interior of the area (opposite to the direction of prevailing dip), thence out by the longitudinal valleys. In the eastern part of the range the drainage departs from these simple types. Thus, in different parts of its course, Green River exhibits char-

1 Atwood, W. W., Glaciation in the Uinta and Wasatch mountains: U. S. Geol. Survey Prof. Paper 61, 1909.

2 Boutwell, J. M., Iron ores of the Uinta Mountains, Utah: U. S. Geol Survey Bull. 225, pp. 221-22s, 1904. acteristics of several different types of drainage. In the extreme western portion of the range Provo and Weber rivers, the master streams of the region, pursue longitudinal courses for a large portion of their extent. They are fed not only by headwaters of transverse radial streams but also by streams flowing toward the interior against the dip.

In brief, the range is an elongated dome composed of $\mathrm{a}$ deeply dissected central plateau and encircling cuestas. The dissection of the central area is characterized by a postmature master divide, surmounting broad glacial amphitheaters, which in turn are incised by deep, narrow canyons. Intermediate between the eastern and western portions of the range the drainage is largely consequent; at the eastern end it is complex, Green River probably being superimposed, locally at least, and in the western portion the master streams follow partially graded, subsequent courses, and obsequent drainage is well developed.

Since this description was prepared a paper by Schultz ${ }^{3}$ on the Uinta Mountains, with special reference to phosphate, has been published.

A feature of the physiography that is of interest, as it is of widespread occurrence in eastern Utah, is the high gravel-capped plateau or bench that is strongly developed on both the north and south sides of the range at its eastern end at least. Rich ${ }^{4}$ has described its occurrence on the north side, where its elevation is 7,600 to 8,500 feet. On the south side, in the longitude of Vernal, its elevation ranges from about 8,000 feet at its outer edge to about 9,000 feet where it merges with the old mountain topography of the central portion of the range. Farther east it may be somewhat lower. Split Mountain and the Yampa Plateau are concordant in elevation with this plateau surface and are evidently to be correlated with it.

The top of the plateau is an old erosion surface that slopes gently from the mountain and has beveled all the formations regardless of hardness or position. Near the central mountain mass the more resistant strata form low ridges that alternate with longitudinal valleys cut in the softer rock. This surface in the eastern part of the range has been covered by a mantle of coarse gravel composed largely of pebbles and boulders of red sandstone (probably the Bishop Mountain conglomerate of Powell) derived from the central portion of the range. Near its outer margin the plateau is cut by deep canyons, but few of them reach completely across the plateau, so that

3 Schultz A. A geologic reconnaissance of the Uinta Mountains, northern Utah, with special reference to phosphate: U. S. Geol, Survey Bull. 690, pp. 31-94, 1919.

4 Rich, J. L., The physiography of the Bishop conglomerate, southwestern Wyoming: Jour. Geology, vol. 18, p. 601, 1910. 
east-west travel along the base of the range is quartzite. This quartzite is exposed on the comparatively easy whereas along the front of north side of Browns Park for several miles east the plateau it is practically impossible. At and west of Red Creek Canyon, including Red several lower levels other gravel-covered Creek, Jessie Ewing, and Willow Creek canbenches or mesas strongly suggest periods of yons, where there has been considerable proserosion followed by uplifts that allowed further deepening of the stream beds. These benches, however, were not examined in sufficient detail to warrant an attempt to explain them, but they afford an interesting problem in the physiographic development of the region.

\section{pecting in it.}

The great quartzite series of the Wasatch Range has already been subdivided and detailed study will probably result in the subdivision of the stratigraphically corresponding great red quartzite series in the "Uinta forma-

Generalized Paleozoic section in the Uinta Range.

[By F. B. Weeks.]

\begin{tabular}{|c|c|c|c|}
\hline Formation. & Character. & Thickness. & Age. \\
\hline $\begin{array}{l}\text { Permo-Carboniferous.. } \\
\text { Weber formation ..... }\end{array}$ & 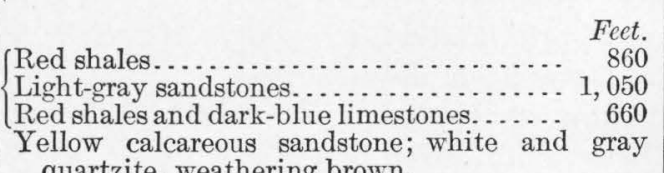 & $\left\{\begin{array}{r}\text { Feet. } \\
2,570 \\
2,200 \text { to } 2,700\end{array}\right.$ & $\begin{array}{l}\text { Permian. } \\
\text { Pennsylvanian. }\end{array}$ \\
\hline $\begin{array}{c}\text { Mississippian series (upper } \\
\text { part Pennsylvanian series). }\end{array}$ & $\begin{array}{l}\text { quartzite, weathering brown. } \\
\text { Alternating beds of white sandstone; thin-bedded } \\
\text { blue and gray cherty limestones and massive } \\
\text { dark-green and buff limestones at base. }\end{array}$ & 700 to 1,070 & Mississippian. \\
\hline Ogden quartzite. & White and greenish massive quartzite and green & 0 to 1,100 & Ordovician. \\
\hline Lodore shales. & $\begin{array}{l}\text { Argillaceous and sandy, green, red, purple, and } \\
\text { black shales; green shales, containing many } \\
\text { nodules. }\end{array}$ & 500 to 1,200 & Cambrian. \\
\hline "Uinta" formation.. & $\begin{array}{l}\text { Thin-bedded green sandstones with conglomerate } \\
\text { layers; striped quartzites; and red and brown } \\
\text { quartzites or sandstones. Base not exposed. }\end{array}$ & $12,000+$ & Pre-Cambrian. \\
\hline
\end{tabular}

A similar plateau in the western portion of the range has not been described, though inspection of the topographic maps suggest its presence.

GEOLOGY.

SEDIMENTARY ROCKS.

The sedimentary formations of the Uinta Mountains range in age from Archean to Recent, but their satisfactory classification must wait for detailed geologic work. Several reconnaissance studies have grouped the formations in a general way. The most recent classification is that by Weeks. ${ }^{1}$

Unconformably underlying the "Uinta formation," as described by Weeks, is Powell's Red Creek quartzite, ${ }^{2}$ presumably of Archean age, which consists of mica, hornblende, staurolite, and garnet schists with beds of white

1 Weeks, F. B., Stratigraphy and structure of the Uinta Range: Geol. Soc. America Bull., vol. 18, pp. 427-448, 1907.

2 Powell, J. W., Geology of the eastern portion of the Uinta Mountains and a region of country adjacent thereto, p. 137, U. S. Geol. and Geog. Survey Terr., 2d div., 1876. tion." It is also probable that the limestone members will be further subdivided.

Overlying the Paleozoic section as given by Weeks are the Jurassic and Triassic sandstones and shales with beds of limestone having a total thickness of over 5,000 feet, according to Powell. These are overlain by 36,000 feet of Cretaceous sandstones and shales, and these in turn by 20,000 feet of Tertiary sandstones and shales.

\section{IGNEOUS ROCKS.}

So far as the writer is aware, igneous rocks have not been previously reported in the main range, though they are present in Kamas Valley, which separates the western end of the mountains from the Wasatch Range. However, the writer and F. L. Hess found numerous dikes in the quartzite formation in Red Creek and Jessie Ewing Creek (Red Creek quartzite of Powell), and they are reported as present in this formation at other localities. Most of them are dark-green dioritic rocks that have been considerably altered, but a few small peg- 
matite dikes in Jessie Ewing Canyon are composed essentially of quartz, pink feldspar, and muscovite.

\section{STRUCTURE.}

The larger structural features of the Uinta Mountains are comparatively simple and are well understood. The detailed structure is in places more complex and for the most part remains to be worked out.

In general, the range is a great east-west anticlinal fold. On the east it gradually merges into the plateau structure of westem Colorado, and on the west it narrows and disappears beneath
The fold is unsymmetrical, the crest being considerably north of the center. The south limb is long and gentle, and the north limb is much shorter and steeper and is broken in many places by extensive east-west faulting.

\section{HISTORY AND PRODUCTION.}

EARLY RECORDS.

That there has been some mineralization in the Uinta Range has long been known. In 1876 Powell $^{2}$ published a map of the eastern portion on which he outlined on the north side of Browns Park a "copper and silver area"

Metals produced in the Carbonate district, 1891-191\%.

\begin{tabular}{|c|c|c|c|c|c|c|c|c|c|c|}
\hline \multirow{2}{*}{ Year. } & \multirow{2}{*}{$\begin{array}{l}\text { Quan- } \\
\text { tity of } \\
\text { ore } \\
\text { (short } \\
\text { tons). }\end{array}$} & \multicolumn{2}{|c|}{ Gold. } & \multicolumn{2}{|c|}{ Silver. } & \multicolumn{2}{|c|}{ Copper. } & \multicolumn{2}{|c|}{ Lead. } & \multirow{2}{*}{$\begin{array}{c}\text { Total } \\
\text { gross } \\
\text { value. }\end{array}$} \\
\hline & & $\begin{array}{c}\text { Fine } \\
\text { ounces. }\end{array}$ & Value. & $\begin{array}{c}\text { Fine } \\
\text { ounces. }\end{array}$ & Value. & Pounds. & Value. & Pounds. & Value. & \\
\hline 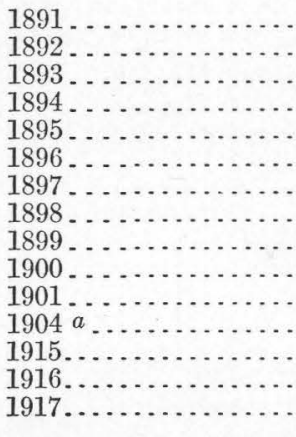 & $\begin{array}{r}18 \\
73 \\
93 \\
73 \\
36 \\
111 \\
30 \\
500 \\
906 \\
1,751 \\
270 \\
500 \\
6 \\
5 \\
5\end{array}$ & $\begin{array}{r}5.22 \\
21.19 \\
26.99 \\
21.19 \\
10.45 \\
32.22 \\
8.71 \\
96.75 \\
175.31 \\
350.00 \\
39.18 \\
125.00 \\
\ldots \ldots . .\end{array}$ & $\begin{array}{r}\$ 108 \\
438 \\
558 \\
438 \\
216 \\
666 \\
180 \\
2,000 \\
3,624 \\
7,235 \\
810 \\
2,584 \\
\ldots . . .\end{array}$ & $\begin{array}{r}468 \\
1,898 \\
2,418 \\
1,898 \\
936 \\
2,886 \\
780 \\
10,000 \\
18,120 \\
35,020 \\
20,250 \\
8,000 \\
27 \\
26 \\
20\end{array}$ & $\begin{array}{r}\$ 463 \\
1,651 \\
1,886 \\
1,196 \\
608 \\
1,962 \\
468 \\
5,900 \\
10,872 \\
21,712 \\
12,150 \\
4,580 \\
14 \\
17 \\
17\end{array}$ & $\begin{array}{r}17,784 \\
71,136 \\
90,896 \\
71,136 \\
35,568 \\
108,680 \\
30,900 \\
300,000 \\
558,800 \\
1,156,100 \\
108,000 \\
25,000 \\
5,724 \\
5,423 \\
4,098\end{array}$ & $\begin{array}{r}\$ 2,294 \\
8,252 \\
9,817 \\
6,758 \\
3,806 \\
11,737 \\
3,708 \\
37,200 \\
95,555 \\
191,912 \\
18,036 \\
3,125 \\
1,002 \\
1,334 \\
1,119\end{array}$ & 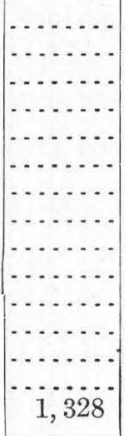 & 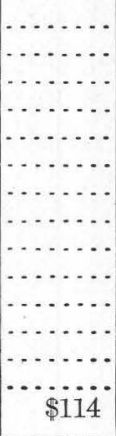 & $\begin{array}{r}\$ 2,865 \\
10,341 \\
12,261 \\
8,392 \\
4,630 \\
14,365 \\
4,356 \\
45,100 \\
110,051 \\
220,859 \\
30,996 \\
10,289 \\
1,016 \\
1,351 \\
1,250\end{array}$ \\
\hline & 4,377 & 912.21 & 18,857 & 102,747 & 63,496 & $2,589,245$ & 395,655 & 1,328 & 114 & 478,122 \\
\hline
\end{tabular}

$a$ The output reported by one company for: 1904 was received too late that year for tabulation and the total is not included elsewhere.

the lavas of Kamas Valley, which separates the Uinta and Wasatch ranges. Formations from pre-Cambrian to Cretaceous were involved in the uplift. Since the uplift erosion has removed many thousands of feet from the summit of the range. At present the central portion is composed principally of the "Uinta" quartzite, surrounded by outcrops of progressively younger formations, through the Cretaceous. Where Green River cuts through the eastern end of the range a small area of preCambrian schists is exposed. The uplift of the range, according to Powell, ${ }^{1}$ began at the close of Cretaceous time but continued through early Tertiary, the material removed from the higher portion being deposited around the base. coextensive with his Red Creek quartzite, and in $1877 \mathrm{~S}$. F. Emmons ${ }^{3}$ noted the occurrence of copper-silver ores on Willow Creek. In 1879 iron ores were shipped from the southwestern part of the range to Park City to be used as flux. ${ }^{4}$

\section{CARBONATE DISTRICT.}

The largest metal production has been from the Carbonate district, principally from the Dyer copper mine. The history of this district, prepared by V. C. Heikes, follows:

The Carbonate district is in Uinta County, 82 miles north-northwest of Dragon, on the

2 Powell, J. W., op. cit., atlas.

3 Hague, Arnold, and Emmons, S. F., Descriptive geology: U. S. Geol. Expl. 40th Par. Final Rept., pt. 2, p. 270, 1877.

4 Boutwell, J. M., Iron ores in the Uinta Mountains, Utah: U. S. Geol. Survey Bull. 225, p. 226, 1904. 
Uintah Railway, which operates from Mack, Colo., a station on the Denver \& Rio Grande Railroad. In 1887 L. P. Dyer and others located the Ace, Antietam, and other claims, some of which were patented and known as the Dyer group. Previous to 1897 old records ${ }^{1}$ show the shipment of about 400 tons of copper glance, which assayed an average of 49.47 per cent of copper and 26 ounces of silver and $\$ 6$ in gold per ton. During 1897 the only carload shipped contained 51.5 per cent of copper. In the next two years about 200 tons of similar ore was shipped. A 42-inch water-jacket blast furnace was installed in October, 1899, and ran during open seasons for nearly two years. The ore smelted averaged about 33.5 per cent of copper, and in one operation it was possible to produce copper from 95 to 98 per cent pure, as the ore contained no detrimental minerals. The ore and bullion shipped was loaded at Price, Utah, and Carter, Wyo. Since October, 1901, the plant has been idle. The metal production of the district is largely estimated from such records as were available.

\section{ORE DEPOSITS.}

IRON ORES.

RHODES PLATEAU.

Iron ores have been developed to some extent at several localities in the range. Among those earliest discovered were the deposits of Rhodes Plateau, which have been briefly described by Boutwell. ${ }^{2}$

\section{LOCATION.}

These iron deposits are situated in Wasatch County Utah, in the southwestern portion of the Uinta Range about 10 miles south of its main divide, on the main divide between Provo and Duchesne drainages at the head of Soapstone Basin, at an elevation of between 9,600 and 9,700 feet above sea level. The locality is easily accessible from the west by way of Provo River and Soapstone Creek. It is reported that the continuation of the same route leading by other deposits to the south may also be taken from the Duchesne on the east.

\section{HISTORY AND DEVELOPMENT.}

The iron was probably discovered and first used by the Indians, and a reliable authority informs the writer that the red ore of these iron deposits was used by them for paint.

\footnotetext{
1 Pope, R. M., letter to V. C. Heikes, dated Duchesne, Utah, June 5 , 1913.

2 Boutwell, J. M., Iron ores in the Uinta Mountains, Utah: U. S. Geol. Survey Bull. 225, pp. 226-228, 1904.
}

About 25 years ago the most promising deposits were located by a party from Heber led by a man named Cummings. It is believed that they did the first actual development work on the property and hauled a few loads of ore to the smelters in Salt Lake Valley. Two years later, when Mr. [T. W.] Potts first visited the locality, he noted "two small cuts about 200 feet apart" which "looked as though 10 or 12 tons of ore might have been taken out." 3 In 1879, upon the completion of a smelter at Park City, he mined 200 tons of this iron ore and delivered it at the smelter for flux. The following year he delivered 300 tons, and further shipments were then stopped by the closing of the smelter. It is thus known that shipments were made amounting to 500 tons. It is believed that the total is a little higher. In 1882 or 1883 the ground was surveyed for patent, and seven claims, each 600 by 1,500 feet, were eventually patented to E. P. Ferry.

\section{CHARACTER OF ORE.}

The ore is a red hematite of two varieties, the red ocherous and the gray massive semispecular. It varies in purity from samples of higher grade, which are solid pure iron, to samples which are breccias made up of angular fragments of ore, to others which include barren siliceous gangue, and finally to those in which the barren country rock predominating incloses patches of lean ore. The following analysis is of a selected sample of the high-grade, massive, semispecular variety:

Analysis of red iron ore (hematite).

$$
\text { [Analyst, E. T. Allen.] }
$$

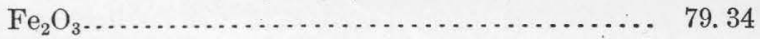

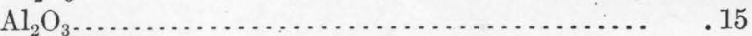

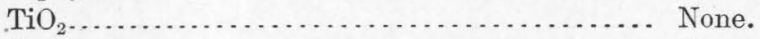

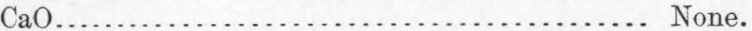

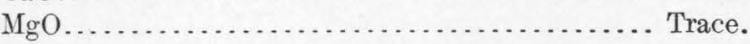

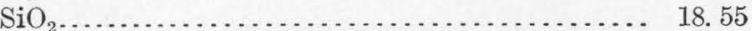

S....................................... None.

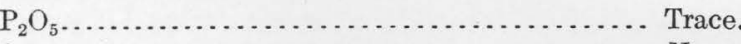
$\mathrm{Au}$..................................................

The above analysis reveals not only a high content of iron and a suitable amount of silica but also a most desirable absence of the deleterious elements, titanium and sulphur, and only a trace of phosphorus. In short, it indicates a high-grade workable iron ore.

$$
\text { OCCURRENCE OF ORE. }
$$

The features shown by the few comparatively restricted croppings, together with those revealed in the two small open cuts, did not afford complete evidence as to the true nature of the occurrence of the iron. The country rock is a gray limestone. In the saddle in which the ore has been worked the general southerly dip of the strata (S. $50^{\circ} \mathrm{W}$. $10^{\circ}$ ) passes into a gentle northerly dip, thus forming a shallow trough. Further, certain disagreements of dips and zones of breccia suggest that the deformation at this point includes not only local folding but also fracturing

3 The principal historical facts here given are based on information supplied by W. V. Rice, of Salt Lake City, who visited this locality in the early eighties, while associated with the owners of the property from which ore was shipped, and by T. W. Potts, of Woodland, who assisted in the survey of that ground for patent and took the contract to transport the ore to Park City. 
and perhaps faulting. The age of the limestone member in which the ore is found is proved by its fossil contents to be lower Carboniferous.

The croppings of the iron ore, and thus the pits which have been opened in them, appear to lie in certain fairly distinct easterly-westerly lines or zones. This fact, in connection with the presence of breccia in the upper pit and the exposure of a marked breccia zone in the lower pit, suggests that the ore occurs along lines and zones of fracture. Further, the fact that the limestones, both in the breccias and in the country traversed by the breccias, has given place to iron ore, and the apparent but indistinct retention of bedded structure by the ore, leads to the belief that the iron ore is a replacement of limestone in and adjacent to east-west fracture and breccia zones.

COMMERCIAL ASPECTS.

The above analysis indicates that this ore is of excellent quality. So little development work has been done that there is meager basis for estimating its quantity. * * * At present the nearest railroad point is Park City, about 35 miles west. Standing timber is plentiful, and a small creek flows across the property.

\section{NORTH OF VERNAI}

POPE DEPOSITS.

The Pope iron mine is near the summit of the Uinta Range in Uinta County, about 25 miles northwest of Vernal, near the Dyer copper mine. The deposits have been prospected to some extent, and a little ore was shipped to the Dyer copper smelter for flux.

The ore is said to be low in sulphur and phosphorus and to be of good quality for making iron, but the deposits have not been sufficiently prospected to demonstrate their size or the grade of the ore as it would average in mining. The abundant float below the outcrop suggests a rather large body. It is probable, however, that iron constitutes a much higher proportion of the float than it does of the rock from which the float was derived, for the ore is much heavier than the limestone and tends to concentrate as a placer deposit.

The ore replaces limestone, probably of Mississippian age. Even in high-grade ore the structure of the replaced beds can be detected, and there is every gradation from high-grade ore through partly replaced to little-altered limestone. Replacement has evidently occurred in certain beds, but whether or not the deposits are closely associated with fissures was not positively determined. The determination of the commercial importance of the deposits must await more extensive development, for which there will be little encouragement till the transportation facilities are improved.
WOODSIDE DEPOSITS.

Woodside iron prospect was opened in 1913 in a branch of Ashley Canyon about 20 miles northwest of Vernal, Uinta County, and about 2 miles west of the old "Red Pine Sit." The few feet of development work does not show the extent or the structural relations of the deposit, but the small amount of float below the outcrop does not indicate a large body of ore. The development exposes some rich hematite, which, according to Grant Carpenter, is low in phosphorus and sulphur, like other deposits of the range.

The country rock is probably of Pennsylvanian age. Float collected near the prospect contained fossils which were determined by G. H. Girty as Stenopora sp. and Composita subtilita, and were ascribed by him probably, though not certainly, to the Pennsylvanian. He says: "There is scarcely a doubt that it is not Madison, though it may be upper Mississippian." Other fossils were collected near the Lime Kilns, and about 1 mile west of the Lime Kilns and at a lower horizon. From these collections Mr. Girty made the following determinations:

The Lime Kilns:

Derbya crassa?

Spirifer rockymontanus.

Composita subtilita.

Pleurophorus sp.

Astartella concentrica.

Myalina sp.

One mile west of the Lime Kilns, at a lower horizon:

Derbya crassa.

Spirifer rockymontanus.

Composita subtilita.

The iron deposit, like others in the range, replaces limestone. There is evidence of fissuring or faulting of the rocks associated with the deposit, and the replacement probably took place adjacent to a fissure. Other deposits have been reported from the range, but no reliable descriptions of them are available. Careful prospecting may disclose additional deposits.

\section{COPPER DEPOSITS. .}

DISTRIBUTION.

The Dyer mine, north of Vernal, is the only deposit in the range from which copper has been produced, though there has been considerable prospecting for copper north of Browns Park. 
In the western part of the range copper has been reported, as noted by Boutwell: ${ }^{1}$

Copper is stated to have been found in a narrow seam near Rockport, in the river bed just east of the north line of the town. In 1874 small seams of argentiferous lead ore were discovered in the southwest portion of the range, on Beaver Creek, 2 to 3 miles southeast of Kamas; and. iron associated with some lead was reported in the fall of 1902 in Hoyles Canyon, in the extreme western end of the Uinta Range.

\section{DYER MINE.}

GENERAL FEATURES.

The Dyer mine is about 25 miles nearly north of Vernal, from which it is reached by wagon road. Some of the grades are heavy and in places the sand is deep. The mine is nearly 10,000 feet above sea level and about 4,500 feet above Vernal.

Timber for all purposes is abundant in the vicinity. Water is not plentiful at the mine, but it is reported that a good supply is available at the smelter site, about 3 miles away. The main workings of the mine consist of an open cut or pit from which it is said a large part of the ore produced has been taken. Shafts have been sunk in the bottom of the pit and considerable prospecting by tunnels has been done. The mine was not in operation at the time of visit and no underground examination was made.

GEOLOGY.

The country rock is a rather heavy-bedded limestone, in which the copper deposits occur about 200 to 300 feet stratigraphically above a massive quartzite, which is apparently the Ordovician quartzite, as determined by Weeks. No fossils were found, but it seems very probable that the limestone is of Mississippian age.

\section{ORES.}

The ore, so far as determined from the dump and from report, is in part carbonates (largely malachite) and in part chalcocite. The carbonates are apparently the principal ore minerals, sulphides being present only as small cores that have not been entirely oxidized but are commonly filled with minute veinlets of the carbonates. It is reported that much of the ore shipped averaged 50 per cent copper and carried a little gold and silver.

1 Op. cit., p. 225.
So far as learned the ore forms irregular bodies in the limestone. Two such bodies, one almost directly beneath the other but with very inconspicuous connection, have furnished most of the ore extracted, though other small bodies have been found. The ore was originally probably chalcocite replacing limestone and was subsequently largely altered to copper carbonates.

Apparently little gangue was deposited with the metallic minerals. The limestone in the vicinity of the mine is cut by a few small veins of fine-grained cherty quartz, and some cherty material is associated with the ores, but this may have been of earlier formation. It is stated that the rich ore extended practically to the surface and that considerable float ore lies below the outcrop.

A yellow earthy mineral disseminated in cellular limestone is exposed in the open cut, apparently in the footwall of the copper deposit. This material was examined by W. T. Schaller, who reported that it contained vanadium and copper but no uranium. Its position suggests that it was leached from the copper ore and precipitated on the footwall.

About 100 feet stratigraphically below the outcrop of the copper deposit and only a few hundred feet distant from it is the Pope iron deposit. The proximity of two deposits naturally suggests genetic relationship, but no evidence of such was seen. So far as known no copper minerals have been found in the iron deposit, and the copper ore is rather noteworthy for its small content of iron.

Lead minerals containing some silver have been reported from prospects on the slope north of the Dyer mine. None of these prospects were examined.

\section{BROWNS PARK AREA.}

In an area north of Browns Park, including Red Creek, Jessie Ewing, and Willow Creek canyons, considerable prospecting has been done and some copper ore has been extracted and is on the mine dumps, but so far as learned no shipments have been made.

$$
\text { GEOLOGY. }
$$

The rocks of the district consist of the series of pre-Cambrian schists and quartzites, called Red Creek quartzite by Powell. Unconformably overlying these in Jessie Ewing Canyon is the "Uinta" quartzite, which con- 
sists of 50 to 75 feet of coarse conglomerate overlain by red ferruginous shales and these again by red quartzite. The lower members vary considerably from place to place, the conglomerate member being,much thinner in Red Creek Canyon, as reported by F. L. Hess.

The older schists and quartzites are cut by dioritic dikes and in Jessie Ewing Canyon by small pegmatitic dikes. These were nowhere seen extending into the overlying red quartzite series, and as they are more metamorphosed than the red quartzite they are thought to be pre-Cambrian in age.

Faults and fissures connected with the ore deposits in Jessie Ewing Canyon strike in general northeast about parallel to the schistosity of the rocks. Part of the faulting is later than the deposition of the red quartzite, but it is probable that the fissuring connected with the ore deposits is earlier.

ORES.

Many of the fissures are occupied by the dioritic dikes. The ore deposits are very commonly irregular veins of quartz or quartz and carbonate carrying the metallic minerals. Quartz is apparently the prevailing gangue mineral, though a brown carbonate was noted at several places. The original sulphides were pyrite and some copper sulphide, presumably chalcopyrite, and were contained in the veins and disseminated for short distances in the quartzite, schist, and diorite forming the walls.

The copper sulphides at present developed are mainly bornite and chalcocite. The pyrite grains have been fissured and exhibit the structure that Graton has characterized as "exploded bomb structure." In some specimens bornite has replaced almost the whole of the grains, leaving only small cores of pyrite; but in others the bornite forms only as small veinlets in the grains. The bornite in turn has been partly replaced by chalcocite. Commonly the replacement by chalcocite began along the contact of the pyrite and bornite and progressed inward toward the center of the veinlets. In some veinlets the relations indicate that the chalcocite first replaced pyrite and was in turn replaced by bornite, but the relations as a whole strongly indicate the other order. In the field it was considered that the richer sulphide ores had resulted from enrichment by downward- moving solutions. Near the surface much of the copper sulphide has been oxidized to carbonate.

In Red Creek one vein in particular contains considerable hematite. Willow Creek was not visited, but the deposits are said to be similar to those in Jessie Ewing and Red Creek canyons.

URANIUM DEPOSITS.

In some of the deposits in Red Creek Canyon, in the Browns Park area, a small amount of carnotite is found. Its mode of occurrence, accordingto F. L. Hess, seems to be similar to that of the copper minerals. ${ }^{1}$

OURAY REGION.

DEVELOPMENT

In the vicinity of Ouray, Uinta County, near the junction of Green and Duchesne rivers, the numerous occurrences of copper ore have been somewhat prospected.

There has been no important production from the region. Early in 1910 a leaching plant was completed by the Uteland Mining Co. on Green River about 5 miles below Ouray but has not been operated.

GEOLOGY.

The consolidated rocks of the region are all Tertiary sediments, and are believed by E. G. Woodruff ${ }^{1}$ to belong to the Eocene Bridger formation. They consist of interbedded sandstones and shales-at some horizons of rather thick sandstone beds overlain by thick shale beds, and at other horizons of alternate rather thin beds of sandstone and shale.

The sandstone beds and to a lesser extent the shale beds thin and thicken rather abruptly along the strike; and some of the thinner beds pinch out entirely in a very short distance. Most of the sandstone beds are of medium grain, though some are of coarse sandstone or fine conglomerate. Pronounced cross-bedding is common in the sandstone. The shales are commonly fine clay shales that readily break down on exposure to the weather.

A rock that was noted at several localities in small lenses consists of a fine sandy matrix inclosing small lenticular masses of hardened clay and rather abundant fragmental plant remains.

1 Oral communication. 
At numerous localities the sandy beds contain plant remains, consisting of isolated stems of plants, some of which are several inches in diameter and several feet in length, of abundant leaves, reeds, and fragments collected in lenticular bodies, few of which are more than a few inches to a foot in thickness and more than a few yards in extent.

The sedimentary rocks are nearly horizontal and there is little faulting. Fissuring is most conspicuous where the fissures have been filled with gilsonite. A very few fissures were noted in connection with the copper deposits.

\section{ORES.}

The principal prospects thus far developed are 4 to 5 miles north and 3 to 4 miles northwest of the Uteland mill. Other prospects are close to the mill and still others are reported near Green River, a short distance above Ouray.

The typical occurrence of the copper ore is in the sandstone in close association with plant remains that have been in part silicified and in part carbonized. The carbonized portions have been partly replaced by some copper minerals. Chalcocite was the only copper sulphide recognized, but the rather abundant oxide of iron associated with some of the copper carbonate suggests that the original copper mineral may have been in part at least chalcopyrite or bornite.

The ores at the surface are practically all oxidized, prevailingly to malachite. Many fragments of tossil plants in the oxidized material are surrounded by a shell of sand grains cemented by hydrous oxide of iron, outside of which the grains are cemented by carbonate of copper. It seems probable that both the iron and copper have been derived from the minerals that originally replaced the fossil plants, and that during the process of oxidation the copper moved farther outward than the iron.

The replacement of large fragments of plants has produced small bodies of rather high grade ore, and the replacement of small fragments scattered through the sandstone has produced low-grade ore.

The ore bodies outcrop as narrow bands along a cliff or, where the surface chances to be eroded just down to the copper-bearing strata, strew the surface with copper ore over consid- erable areas. These copper-bearing beds correspond to the lenses containing abundant plant remains and are usually thin, so that in actual mining operations it would be necessary to break considerable waste rock and it would be difficult to prevent its admixture with the ore.

In 1917 it was reported that molybdenum ores had been discovered 2 miles west of Ouray, on the south side of Duchesne River. According to W. T. Schaller the molybdenum is in the mineral ilsemannite, a hydrous sulphate, $\mathrm{MoO}_{3} \mathrm{SO}_{3} .5 \mathrm{H}_{2} \mathrm{O} .^{1}$ So far as known there has been no production from this occurrence.

\section{LITTLE SPLIT MOUNTAIN. 2}

Little Split Mountain is in the eastern part of Uinta County, near the point where Green River crosses the Utah-Colorado line.

Copper was discovered in the region about 1896 , and it is reported that in 1899 about 5 tons of concentrate, produced by hand-cobbing ore, was shipped to Park City and yielded about 56 per cent copper and 69 ounces of silver per ton. No gold was reported. In recent years there has been no production.

The copper deposits are reached from Jensen, a distance of about 30 miles, by a wagon road that in 1913 was in poor repair.

The rocks of the mountain consist of interbedded sandstones, shales, and limestone with seams of coal of upper Carboniferous age. The rocks have been faulted and dip at angles of $45^{\circ}$ and upward.

Copper carbonate and chalcocite occur in a sandstone about 8 feet thick above two seams of coal 6 to 8 inches thick and 10 to 12 feet apart. Above the copper-bearing sandstone is a whiter bed 2 feet thick, which seems to contain no copper. The copper minerals replace plant remains and bones. A little copper occurs in carbonaceous shale below the sandstone.

Gold is reported from the base of the copperbearing sandstone.

\section{BIBLIOGRAPHY.}

Berkey, C. P., Stratigraphy of the Uinta Mountains: Geol. Soc. America Bull., vol. 16, pp. 517-530, 1905.

Boutwell, J. M., Iron ores in the Uinta Mountains, Utah: U. S. Geol. Survey Bull. 225, pp. 221-228, 1904.

1 Schaller, W. T., Ilsemannite, hydrous sulphate of molybdenum: Washington Acad. Sci. Jour., vol. 7, pp. 417-420, 1917.

2 Based on observations by F. L. Hess. 
Eldridge, G. H., The Uintaite (gilsonite) deposits of Utah: U. S. Geol. Survey Seventeenth Ann. Rept., 1895-96, pt. 1, pp. 909-949, 1896.

Emmons, S. F., Uinta Mountains: Geol. Soc. America Bull., vol. 18, pp. 287-302, 1907.

Hague, Arnold, and Emmons, S. F., Descriptive geology U. S. Geol. Expl, 40th Par. Final Rept., pt. 2, pp. 207-310, 1877.

Powell, J. W., Geology of the eastern portion of the Uinta Mountains and a region of country adjacent thereto, U. S. Geol. and Geog. Survey Terr., 2d div., 1876.

RICH, J. L., The physiography of the Bishop conglomerate, southwestern Wyoming: Jour. Geology, vol. 18, pp. 601-632, 1910.

Schultz, A. R., A geologic reconnaissance of the Uinta Mountains, northern Utah, with special reference to phosphate: U. S. Geol. Survey Bull. 690, pp. 31-94, 1919.

Weeks, F. B., Stratigraphy and structure of the Uinta Range: Geol. Soc. America Bull., vol. 18, pp. 427448, 1907.

White, C. A., On the geology and physiography of a portion of northwestern Colorado and adjacent parts of Utah and Wyoming: U. S. Geol. Survey Ninth Ann. Rept., 1887-88, pp. 677-712, 1889.

Winchester, D. E., Oil shale in northwestern Colorado and adjacent areas: U. S. Geol. Survey Bull. 641, pp. 139-198, 1917; Oil shale of the Uinta Basin, northeastern Utah, and Results of dry distillation of miscellaneous samples: U. S. Geol. Survey Bull. 691 , pp. 27-55, 1918.

\section{SAN RAFAEL SWELL.}

By B. S. Butler.

The following summary of the topography and gaology of the San Rafael Swell is quoted from Lupton: ${ }^{1}$

\section{TOPOGRAPHY}

The most prominent feature of the topography of this region is a series of buttes, mesas, and "castles," which encircle an area, locally known as "Sinbad," which is 40 to 50 miles long and 10 to 20 miles in width. These fantastically eroded forms represent the outcrop of a gray massive cross-bedded Jurassic sandstone 800 feet thick. It is practicable to cross the Swell at only a few places on account of the almost impassable barrier formed by the sandstone rim. Nearly vertical scarps and canyon walls 300 to 500 feet in height are not unusual. The buttes and "castles" above referred to are conspicuously shown on the San Rafael topographic sheet. Low "hogbacks," formed by resistant beds in the overlying strata, the tops of which produce dip slopes of varying extent depending on the inclination of the beds, encircle this belt of rugged topography. A view to the west from the interior of the Swell gives one the impression of looking up a very gently inclined varicolored stairway, the steps of which increase in height as the top, represented by the Wasatch Plateau, is approached. Badland topography is common, especially near stream courses.

1 Lupton, C. T., Notes on the geology of the San Rafael Swell, Utah: Washington Acad. Sci. Jour., vol. 2, pp.1 85-188, 1912. See also Emery, W. B., The Green River Des ert section, Utah: Am. Jour. Sci., 4th ser., vol. 46, pp. 551-577, 1918 .

\section{GEOLOGY.}

Structurally the Swell is an elongated almost flat-topped dome extending northeast and southwest. The dip of the strata along the west flank is generally less than $10^{\circ}$, whereas that along the east flank is as much as $70^{\circ}$. The strata in the interior of the dome are comparatively flat lying, the principal line of flexure being near the east flank. Local minor domes were noted along the west side. Faults with displacements ranging up to more than 100 feet were observed in and near Cedar Mountain or Red Plateau at the north end of the region. Considerable faulting probably has occurred along the east flank.

Carboniferous (?), Triassic, Jurassic, and Cretaceous formations are well exposed. The lower part of the section described below was correlated with the section noted by Gilbert in the Henry Mountains region, whereas the upper part is almost equivalent to the Book Cliffs section to the north. The lowest rocks exposed in this region are represented by a limestone probably of Carboniferous age noted by F. L. Hess near the San Rafael River on the east side of the Swell. Above the limestone there is a series of several hundred feet of sandstone and shale interbedded which probably are representatives of the Shinarump group (of Permian and Triassic age) and the Vermilion Cliff sandstone (of Triassic age). Unconformably (?) overlying these beds is a massive much cross-bedded gray sandstone 800 or more feet thick. This is the Gray Cliff sandstone (of Jurassic age) of Gilbert's Henry Mountains section, which forms the striking topography referred to above and is in all probability the same as the White Cliff sandstone of the eastern Uinta and southern Utah sections of Powell. Conformably overlying this sandstone is a sequence of 1,350 feet of reddish and gray sandstone, sandy shale, and thick beds of gypsum, which is approximately equivalent to the Flaming Gorge formation of Powell and corresponds closely with the Flaming Gorge formation as described by Gilbert in the Henry Mountains. Five hundred feet of conglomerate, sandstone, and sandy shale of greenish drab color overlying these strata correspond to the larger part of the Henry Fork formation as identified by Gilbert in the Henry Mountains, but probably should be classified with the Flaming Gorge formation of Powell. Sixty to one hundred feet of grayish sandstone (which, near Cedar Mountain, is replaced by conglomerate) and sandy shale with thin streaks of coal at the top and base unconformably (?) overlie the conglomeratic strata just described and probably represent the Dakota sandstone. This sandstone corresponds to the uppermost part of Gilbert's Henrys Fork formation. The Mancos shale, about 4,000 feet thick and consisting of three members, rests upon the Dakota (?) in apparent conformity. In places, however, a thin bed of conglomerate separates the Dakota(?) sandstone from the overlying shale. The Mancos outcrops in a monoclinal valley, the west part of which is known as Castle Valley. The lowest member consists of about 600 feet of bluish-drab shale which is sandy in its lower and upper portions. Overlying this is a sandstone member approximately 500 feet thick containing coal beds near the top. This sandstone probably is equivalent to the Bluegate sandstone of Gilbert's Henry Mountains section and is represented at the north end of the Swell in the vicinity of Sunnyside Junction by a thin concretionary sandy formation. Overlying the sandstone is about 3,000 feet of grayish-drab shale, which is sandy in its lower and upper parts. Conformably overlying the Mancos shale is the Mesaverde formation, 1,100 feet thick (in the vicinity of Emery), which caps the east scarp of 
the Wasatch Plateau. This formation consists mainly of sandstone with beds of sandy shale and coal intercalated.

Sills and dikes of basalt, which were noted at several localities near the south end of the Swell, extend as far north as Muddy or Curtis Creek.

ORE DEPOSITS.

No mining was carried on in the vicinity of the San Rafael Swell until the discovery of the rare metals a few years ago led to prospecting and to the shipment of considerable ore.

URANIUM-VANADIUM-RADIUM DEPOSITS. ${ }^{1}$

Uranium and vanadium deposits have been found at numerous points along the San Rafael Swell; and ores have been mined and shipped principally from the claims of the Radium Co. of America, about 12 miles west of Green River and a little north of the point where San Rafael River passes through the reef and from the deposits at Temple Rock, toward the southern end of the reef, about 45 miles from Green River.

The uranium-vanadium deposits along the San Rafael Reef occur at two horizons, though at neither are they confined to a single definite bed ${ }^{2}$ but occur in sandstone strata separated in places by beds of shale.

The lower horizon is in the Triassic shales below the reef sandstone at or near the horizon of the Shinarump conglomerate. The principal mining at this horizon has been at Temple Rock, though prospects have been located to both the north and the south and deposits are reported from the west side of the Swell. At Temple Rock the uranium and vanadium minerals occur in strata of sandstone and are usually associated with fossil plant remains.

The upper horizon is in the McElmo formation. As at other localities in the State the minerals impregnate the sandstone and replace the plant remains in certain strata of sandstone. The deposits usually form lenses of no great extent and in places replace only a single tree trunk. ${ }^{3}$

Mining on the claims of the Radium Co. of America began in 1912 and has been conducted intermittently since that time. Deposits in the sandstone of the McElmo are reported farther north on the Swell.

${ }^{1}$ See also Hess, F. L., Carnotite near Green River, Utah: U. S. Geol. Survey Bull. 530, pp. 161-164, 1913.

2 Boutwell, J. M., Vanadium and uranium in southeastern Utah: U. S. Geol. Survey Bull. 260, p. 200, 1905.

${ }^{3}$ Howard, L. O., The development of our radium-bearing ores: Salt Lake Min. Rev., Feb. 28, 1914.
COPPER DEPOSITS.

Copper deposits in the sandstone have been reported at several places along the east side of the Swell but have not been visited by the writer. They are reported to be similar in character to the "red bed" deposits in other parts of the State.

\section{LA SAL MOUNTAINS.}

BY B. S. BUTler.

GENERAL FEATURES.

The La Sal Mountains are in eastern Utah, a few miles from the Utah-Colorado State line in Grand and San Juan counties - about half in each. The region is reached from the Denver \& Rio Grande Railroad from either Thompson or Cisco. From Thompson a daily stage runs south for about 35 miles to Moab, which is the distributing center for the western and southern side of the range. From Cisco a stage line runs 38 miles to Richardson and Castleton, at the base of the north end of the range.

The La Sal Mountains are an irregular group about 15 miles long from north to south and 4 to 6 miles wide. The highest peak, Mount Peale, is slightly over 13,000 feet high, and several peaks reach 12,000 feet. The higher peaks rise 5,000 to 6,000 feet above the surrounding plateau.

Surrounding the central mountain mass is a plateau or mesa that in many places has not been maturely dissected by the streams and that forms benches sloping gently from the mountains. The drainage is radial from the central mass and is typical of the laccolithic mountains of the plateau country. The drainage from the west side is to Grand River and from the east side to the Dolores and thence to the Grand. A short distance from the mountains the streams are in canyons, but near the mountains an old mature erosion surface is still preserved, and it is possible to irrigate the mesas surrounding the mountains from the streams before they enter the canyons.

Water is scarce throughout the area. Small streams, some of which persist throughout the summer, flow from the mountains, where snow lies till late in the spring. The stream in Spanish Valley is the largest and irrigates several hundred acres about Moab. Other streams serve to irrigate a few ranches. On the high mesas small areas are irrigated and dry farming is conducted with considerable 
success. The agricultural possibilities of the region seem sufficient to supply any mining community that is likely to develop. On the higher slopes of the mountains is considerable timber that is suitable for building and for mine timbering.

\section{GEOLOGY.}

The prevailing rocks are sedimentary, the igneous rocks being confined to the core of the mountains.

\section{SEDIMENTARY ROCKS.}

SEQUENCE AND CORRELATION.

The following generalized section shows the sequence of the rocks and their correlation with those to the west:

\begin{tabular}{|c|c|c|c|}
\hline $\begin{array}{l}\text { San Juan } \\
\text { Mountains, } \\
\text { Colo. }\end{array}$ & \multicolumn{2}{|c|}{ La Sal region, Utah. } & $\begin{array}{l}\text { Uinta Moun- } \\
\text { tains, Utah }\end{array}$ \\
\hline Mancos. & Mancos s'ale. & $\begin{array}{l}\text { Feet. } \\
3,000\end{array}$ & \multirow{2}{*}{ Henrys Fork } \\
\hline Dakota. & $\begin{array}{l}\text { Dakota sandstone. } \\
\text { - Unconformity }\end{array}$ & $40+$ & \\
\hline McElmo. & $\begin{array}{l}\text { McElmo formation } \\
\text { (sandstone and } \\
\text { shale). }\end{array}$ & 1,200 & $\begin{array}{l}\text { Flaming } \\
\text { Gorge. }\end{array}$ \\
\hline La Plata. & \multirow{2}{*}{$\begin{array}{l}\text { La Plata sandstone } \\
\text { (gray sandstone). } \\
\text { Unconformity- } \\
\text { Triassi c (sand- } \\
\text { stone with shale } \\
\text { at base). } \\
\text { Unconformity }\end{array}$} & $650-800$ & White Cliff. \\
\hline Dolores. & & $300-350$ & $\begin{array}{l}\text { Vermilion } \\
\text { Cliff. }\end{array}$ \\
\hline $\begin{array}{l}\text { Cutler. } \\
\text { Rico. }\end{array}$ & $\begin{array}{l}\text { Permian (sand- } \\
\text { stone and shale, } \\
\text { gypsiferous). }\end{array}$ & $50-800 ?$ & Shinarump. \\
\hline Hermosa. & $\begin{array}{l}\text { Pennsylvanian } \\
\text { (limestone and } \\
\text { sandstone). }\end{array}$ & $1,000 ?$ & Aubrey. \\
\hline
\end{tabular}

The oldest sedimentary rocks recognized in the region are interbedded limestone, sandstone, and shale of Pennsylvanian (upper Carboniferous) age. ${ }^{1}$ Newberry describes over 1,200 feet of Carboniferous sediments from Canyon Colorado, a few miles above the junction of Grand River. Powell collected

${ }^{1}$ Cross, Whitman, Stratigraphic results of a reconnaissance in western Colorado and eastern Utah: Jour. Geology, vol. 15, pp. 634-679, 1907. $35416^{\circ}-19-39$
Carboniferous fossils from the rocks at the junction of Grand and Green rivers. Cross describes a section about three-fourths of a mile northwest of Grand River, on the stage road between Moab and Thompson, which consists of 539 feet of interbedded limestone, sandstone, and shale underlying a cliff of red, pink, and gray sandstone, apparently embracing the Vermilion Cliff sandstone and possibly a part of the White Cliff sandstone. "The upper $104 \frac{1}{2}$ feet of the section represents the fossiliferous Triassic beds immediately below the Vermilion Cliff sandstone. $* * *$ The next 44 feet of beds is provisionally referred to the Permian." The remainder of the section is believed to be Pennsylvanian. Pennsylvanian strata were observed by the Cross party in Sinbad Valley, Colo., and had been previously reported from that locality.

Southeast of the La Sal Mountains, in Big Indian Valley, an anticline striking northwest has brought up the Carboniferous rocks. About 10 miles southeast of La Sal the northeast wall of the valley for several miles is formed of interbedded sandstones and limestones. Fossils collected from these were determined by G. H. Girty as follows:

Fistulipora sp.

Lot A.

Batostomella sp.

Streblotrypa? sp.

Chonetes aff. C. granulifer.

Productus pertenuis.

Marginifera wabashensis.

Rhynchopora aff. R. nikitini.

Rhynchopora aff. R. illinoisensis.

Squamularia perplexa.

Spiriferina kentuckyensis.

Bellerophon sp.

\section{Lot B.}

Echinocrinus sp.

Batostomella sp.

Productus semireticulatus.

Productus cora.

Productus nebraskensis?

Productus pertenuis?

Marginifera wabashensis.

Rhynchopora aff. R. nikitini.

Rhynchopora aff. R. illinoisensis.

Squamularia perplexa.

Of these Mr. Girty says: "Lots A and B are closely related and are clearly of Pennsylvanian age. I would hardly regard them as late Pennsylvanian, and certainly they are not Permian." Stratigraphically the limestone 
series appears to be the equivalent of that described by Cross near Moab.

The members immediately above the Pennsylvanian limestone underlie Big Indian Valley at the point where they were crossed and therefore could not be examined; but, as Big Indian Valley is a strike valley, it may be inferred that they are weak rocks, probably comprising much shale. The southeast wall of the valley consists of a thick series of red sandstones which are apparently equivalent to the Dolores formation to the east and the Vermilion Cliff to the west.

Several hundred feet of sandstone and shales and gypsiferous beds, reported to lie between the Pennsylvanian limestone series and the Triassic at several localities in the vicinity of the La Sal Mountains, is regarded as of Permian age. Cross has described such beds from near Moab, and gypsiferous beds believed to overlie the Pennsylvanian limestone in the lower part of Spanish Valley probably belong to the same series. Gypsiferous beds were observed by the Cross party in Fisher Valley, north of the La Sal Mountains.

Cross also describes a sub-Triassic formation on West Creek near the Utah-Colorado line as having a thickness of 879 feet of conglomerate arkose and shale. What seems to be the same formation is reported by Peale from southeast of the mountains, and there seems little doubt that it occurs throughout the region. There is believed to be a pronounced erosional unconformity at the base of the Triassic, and it is possible that at some places the underlying beds were completely eroded. This formation is believed to be the equivalent of the Cutler and Rice formations of the San Juan region and a part of the Shinarump group of Powell.

TRIASSIC SYSTEM.

The strata between the unconformity at the top of the Permian and the base of the massive gray sandstone above are considered to be Triassic. As measured by the Cross party near Moab they form a massive cliff of red sandstone about 200 feet thick overlying 100 feet of more shaly beds. The total thickness of the strata is probably 300 to 350 feet. They entirely surround the range and are usually conspicuous. They are equivalent to the Dolores of the San Juan region and to the Vermilion Cliff and the upper part of the Shinarump group of Powell.
JURASSIC SYSTEM.

The Jurassic is represented by the La Plata and McElmo formations. The La Plata, in the vicinity of Green River, is described by Lupton ${ }^{1}$ as a cross-bedded coarse-grained very massive gray sandstone about 700 to 800 feet thick.

South of the La Sal Mountains, as described by Cross, it consists of three members-a lower gray massive cross-bedded sandstone 250 feet thick; a middle member of about 100 feet of thin-bedded strata, sandstone for the most part, with shaly and impure calcareous members between, and an upper member of fine and even-grained, strongly cross-bedded, yellowish or pinkish, massive sandstone about 300 feet thick. The total thickness of the La Plata south of the La Sal Mountains is therefore about 650 feet. The formation thins eastward till in its type locality in the Telluride quadrangle it is only about 100 feet thick. The La Plata is considered by Cross to rest unconformably on the Triassic, but in the La Sal region the unconformity is not conspicuous.

The McElmo formation, in the vicinity of Green River, is divided by Lupton ${ }^{2}$ into three members. A lower red sandstone, thin bedded above and massive below, 700 feet thick; a middle member, the Salt Wash sandstone ("gray conglomeratic sandstone which outcrops in cliffs. The sandstone in places is lenticular, soft, and friable"), thickness 150 to 175 feet; and an upper member of "gray conglomerate, variegated sandy shale and clay, and a few feet of limestone about 175 feet from the top," thickness, 325 to 350 feet, making a total thickness for the McElmo formation of about 1,225 feet. This formation, which has been generally regarded as the equivalent of the Flaming Gorge of Powell, outcrops at many points around the La Sal Mountains and undoubtedly once covered the region.

\section{Cretaceous system.}

The Cretaceous in the vicinity consists of the Dakota sandstone, which lies unconformably on the Jurassic rocks, and of the Mancos shale. The thickness of the Dakota sandstone is variable. In the vicinity of Green River Lupton gives it as about 40 feet, but south of the range it is said to be considerably greater.

I Lupton, C. T., Oil and gas near Green River, Grand County, Utah: U. S. Geol. Survey Bull. 541, p. 125, 1914.

2 Op. cit., p. 11. 
Overlying the Dakota sandstone is the Mancos shale, which, according to Lupton, consists of about 3,000 feet of shale with interbedded sandstone. Only the basal portion is exposed near the La Sal Mountains.

\section{TERTIARY AND QUATERNARY SYSTEMS.}

Tertiary rocks are not known near the mountains. Quaternary deposits comprise the glacial deposits in the higher parts of the range, usually not extending below 10,000 feet, and the gravel deposits in Wilson Mesa.

IGNEOUS ROCKS.

The following description of the igneous rocks is abstracted from Hill's report: ${ }^{1}$

The core of the La Sal Mountains is composed of a series of rocks probably all of which are derive from the same magma. The earliest and by far the most widely distributed rock is a light-gray, fine to medium grained porphyry, with distinct phenocrysts of plagioclase and hornblende and smaller ones of pale-green augite. Normally this rock shows no quartz, but here and there blebs are noted up to oneeighth inch in diameter. Orthoclase phenocrysts are seen in some specimens, but this mineral is usually more abundant in the groundmass, a large proportion of which is made up of finely granular plagioclase. The normal rock is a monzonite porphyry, but with more abundant quartz it approaches quartz monzonite porphyry. The monzonite porphyry forms the main intrusive mass and also the knob northwest of Castleton.

At least two and possibly three sets of dikes cut the monzonite porphyry in a general northnortheast direction. They range from a few feet to 100 feet in width but are relatively short. The most common type has a fine-grained gray feldspathic groundmass containing conspicuous tabular phenocrysts of plagioclase and orthoclase up to half an inch or more in diameter and a small proportion of ferromagnesian minerals. This rock has been classed by Prindle ${ }^{2}$ as syenite porphyry. It weathers gray to yellow and is, as a rule, not iron stained except near veins.

A second type of porphyry dike rock, called by Prindle noselite syenite porphyry, occurs in

1 Hill, J. M., Notes on the northern La Sal Mountains, Grand County, Utah: U. S. Geol. Survey Bull. 530, pp. 106-108, 1913.

2 Prindle, L. M., Analyses of rocks and minerals: U. S. Geol. Survey Bull. 419, pp. 120-121, 1910. a few dikes 20 feet or less in thickness in the monzonite porphyry and the syenite porphyry. It is composed of very large zonally banded orthoclase crystals up to $1 \frac{1}{2}$ inches across set in a medium-grained porphyritic groundmass. The groundmass, which constitutes less than one-third of the rock, contains megascopic crystals of orthoclase, pyroxene, and noselite in a feltlike mass of orthoclase (without crystal outlines) and aegirite needles. The orthoclase crystals are rounded and in places weather out of the groundmass as nearly perfect crystals. The groundmass becomes pitted and brownishyellow on weathering.

A third type of dike rock, quartz monzonite porphyry, was found only about half a mile west of Basin post office, and there the croppings were largely covered by slide rock. The material is all intensely altered, leaving a yellowish-white pitted groundmass showing scattered plagioclase feldspars with abundant quartz blebs and prismatic crystals of altered white orthoclase from one-eighth to threefourths of an inch in longest dimension. It may be that this is simply a very siliceous phase of the monzonite porphyry, though its high orthoclase content makes it appear to be a distinct type.

The sedimentary beds adjacent to the intrusive rocks seem to contain no contactmetamorphic minerals, and the descriptions of these mountains make no mention of contact metamorphism. Cross says:

One interesting difference between these magmas [the laccolithic] and the closely allied ones of the Elk Mountain diorites has already been alluded to. Not only are the sediments adjoining the laccolithic masses unattacked by heat, but they seldom exhibit any development of secondary minerals as contact phenomena.

The age of the laccolith can not be fixed definitely. The Mancos shale is involved in the doming, so the intrusion is later than Early Cretaceous. Cross places it as Tertiary, on an estimate of the time required for the erosion of several thousand feet of sediments that hypothetically must have overlain those now exposed at the time of the intrusion to account for the uniform conditions of cooling shown by the porphyries of the several laccolithic groups through a great vertical range.

Analyses and descriptions of the principal rocks, types of the La Sal Mountains, are given on page 93. 


\section{STRUCTURE.}

DOMES.

The La Sal is a typical laccolithic mountain group (p. 93), being formed by igneous rocks that have risen through relatively narrow fissures and spread out between certain strata doming the overlying rocks. From every direction the higher surrounding strata tend to curve upward. The rocks at the base of the mountains, however, in many places show little disturbance till very close to the igneous core and in some localities they do not curve up at all but are crosscut by the igneous intrusion. For the most part the intrusion appears to dome the Cretaceous shales and to crosscut the Jurassic and Triassic sandstones.

FOLDS.

Folding is conspicuous and important. A series of broad open major folds extends for 40 miles northwest and southeast, with the La Sal Mountains near the center. At some points these folds resemble domes ${ }^{1}$ rather than true folds and some of them may owe their origin to underlying intrusive bodies. A mass of "porphyry" near the axis of the anticline several miles from the central core of the mountains suggests such an origin for Castle Valley. Anticlinal valleys have commonly developed along the crests of the anticlines. Conspicuous among them are Castle Valley and its extension, Salt Wash, northwest of the mountains, and Sinbad, Paradox, Gypsum, and Big Indian valleys southeast of the mountains.

\section{FAULTS AND FISSURES.}

Faulting has been far less important in the region than folding, though numerous faults are present and some are of large extent. The faults are less conspicuous than the folds and are not clearly understood. Cross ${ }^{2}$ has noted a zone of faulting traversing Spanish Valley, and Peale has described an important fault parallel to Sinbad, ${ }^{3}$ Gypsum, and Paradox valleys. ${ }^{4}$

1 Peale, A. C., U. S. Geol. and Geog. Survey Terr. Ninth Ann Rept., for 1875 , pt. 1 , p. 63,1877 .

${ }^{2}$ Cross, Whitman, Stratigraphic result of a reconnaissance in western Colorado and eastern Utah: Jour. Geology, vol. 15, pp. 634-679, 1907.

3 Peale, A. C., op. cit., p. 62.

1 U. S. Geol, and Geog. Survey Terr. Tenth Ann. Rept., 1876, pt. 1 , pl. 9,1878 .
Boutwell ${ }^{5}$ has described a zone of deformation trending northeast across Richardson Amphitheater. Minor faults have been noted in the region of Castle Valley by Hill, ${ }^{6}$ and detailed work will doubtless disclose many more faults in the region.

Fissures, or breaks in the rocks along which there has been but little movement, are numerous and are associated with the ore deposits in the intrusive rocks and with some of those in the sedimentary rocks.

\section{MINING HISTORY.}

The early history of the district is given by Hill ${ }^{7}$ as follows:

The earliest discoveries of minerals in this area were made about 1886, the first location being made in 1888 on the ridge between Bachelor and Miners basins, on what is now the High Ore claim. Practically no mining was done in these mountains until 1896, when a party of prospectors did some work that resulted in the discovery of the Tornado deposit in $1897 . * * *$ Shortly after the discovery of the Tornado, a small stamp mill was installed in Miners Basin. *** After about 100 tons of ore had been run through the mill it was closed and has not been operated since.

In 1907 it was first noted that the gravels on Wilson Mesa carried gold. For two years these gravels were washed by crude methods, and in 1910 a little excitement was created in Salt Lake and Grand Junction over the richness of the deposits.

There has been practically no production from the quartz mines, and it is probable that $\$ 5,000$ would cover the entire output from both quartz and placer mining in the region.

The prevailing high price of copper previous to the marked decline in 1907 greatly stimulated prospecting and development in the sedimentary formations around the $\mathrm{La}$ Sal Mountains, notably in the Big Indian Valley south of the range and to a less extent in Lisbon Valley southeast of the range, in Salt Wash northwest of the range, and elsewhere. The decline in 1907 retarded development, however, and though a few tons of ore were shipped from the different copper prospects there was no important production, and little development work was done at most of the properties for several years. In 1917 a mill was completed for treating the ores of the Big Indian mine.

\footnotetext{
5 U. S. Geol. Survey Bull. 260, p. 205, 1905.

6 Hill, J. M., Notes on the northern La Sal Mountains, Grand County, Utah: U. S. Geol. Survey Bull. 530, p. 108, 1913.

7 Idem., p. 109.
} 
Vanadium and uranium minerals were discovered about 1898 near Richardson ${ }^{1}$ by a man named Walsh and were developed to some extent soon after. The first shipment was made in 1904, when more than half a carload was sent to Buffalo, N. Y., for experimental purposes. . Since 1898 numerous deposits have been discovered around the La Sal Mountains in Utah and considerable ore has been shipped.

\section{ORE DEPOSITS.}

\section{PLACER DEPOSITS.}

The placer deposits of Wilson Mesa have been described by Hill ${ }^{2}$ as follows:

The flat mesas south of Castle Valley are covered by a coating of gold-bearing gravel. This deposit is usually very thin, being indicated by scattered boulders and pebbles or by small flattened mounds of like material here and there on the sandstone bedrock. In a few places it attains greater thicknesses. Some of the larger deposits stand as low rounded knobs, but most of them seem to occupy reentrants in cliffs. The latter was apparently the position at the Point Lookout placer. A combination of the two forms is seen at the Black Cap workings. A third and much rarer occurrence is along what appears to be an old channel which runs northwestward from the Black Cap.

The gravels are the same throughout, consisting of subangular cobbles of igneous material similar to that seen in the La Sal Mountains to the east, with a relatively small proportion of sandstone fragments. They range in size from one-fourth of an inch to $2 \frac{1}{2}$ feet, with an average size of about 10 to 12 inches. Fragments of monzonite porphyry cut by quartz stringers are fairly abundant and magnetite cobbles up to 4 or 5 inches in diameter are not at all rare. There seems to be a slight decrease in size of the boulders at the western edge of the deposits, but it is not everywhere the same and is rather doubtful. There is practically no stratification of these gravels except along the present drainage lines in reworked material.

The gold, said to be worth from $\$ 19$ to $\$ 20$ an ounce, occurs in small wires or flakes, and none of that seen appeared to be much water worn. It is distributed throughout the thickness of the deposits, which are said to be of about the same grade from the surface to bedrock. Besides the gold that can be recovered by washing, it has been found that the "ribbon rock" (the monzonite porphyry cut by quartz stringers) contains a fairly large portion of the gold value of the gravels. Some of the miners assert that for every ounce saved by sluicing 10 ounces is lost in the ribbon rock which goes over the dump.

There is no natural water supply on Wilson Mesa. A ditch originally built for irrigation is said to supply about 12 cubic feet a second from the beginning of the thaw in A pril to the last of July, when the greater part of the snow

${ }^{1}$ Boutwell, J. M., U. S. Geol. Survey Bull. 260, p. 207, 1905. 2 Hill, J. M., op. cit., p. 114. has disappeared from the mountains. From then until October the supply is about 8 cubic feet a second, and it is furth $r$ diminished during the winter. The water is all taken from Mill Creek, and considerable trouble has been experienced in obtaining enough for sluicing, as the town of Moab also takes its supply from this source and has a prior right to the water.

The origin of the gravels has not been definitely proved. They are similar in character to gravels around the Uinta Mountains that Powell and later writers have attributed to stream action when the mountains were higher and the precipitation greater. On the other hand, Atwood has described somewhat similar gravels in the San Juan Mountains, Colo, which he attributes to an early period of giaciation. Hill states that the gravel is composed largely of igneous rocks similar to that in the range and there seems no doubt that it was derived from the higher parts of the range.

Gold-bearing gravels in Miners Basin are described by Hill ${ }^{3}$ as follows:

The town of Basin is located on a flat just above a very small, indistinct terminal moraine of the last glacial epoch. This moraine is composed entirely of angular igneous material, none of which has traveled over a mile and much of it a very inconsiderable distance. The moraine lies on the top of a débris-filled $V$-shaped valley. Both the glacial material and the débris contain a little fine free gold. The amount of material is, however, very small and hard to handle on account of the large angular talus blocks included in it.

\section{GOLD-COPPER VEINS IN INTRUSIVE ROCKS.}

The following description of the veins in the monzonite porphyry is also from Hill: ${ }^{4}$

There has been very little work done on the mineral deposits of the La Sal Mountains. The greatest depth reached is perhaps 150 feet below the surface, and 95 per cent of the shafts and tunnels are not more than 50 feet below the grass roots. The general procedure seems to have been to locate a mineralized zone on the hill slope and then go into the valley bottom and start a long crosscut to reach it in depth. As yet few of these crosscuts have reached the desired goal.

The general direction of the lodes seems to be northwest and southeast to east and west, with one or two eastnortheast fractures. The northwest-southeast trend corresponds in a general way to the longer axis of the intrusive mass.

There are two rather distinct types of deposits-one characterized by glassy quartz with copper, silver, and gold, and the other with apparently the same kind of quartz, but containing largely gold in a pyritic carrier. The deposits of the former type are usually simple, rela-

${ }^{3}$ Idem, p. 117

${ }^{4}$ Idem, p. 110 
tively narrow quartz veins that have affected the walls to a much less degree than the second type. The goldpyrite deposits appear to be stockworks or zones of minute branching, interlacing quartz-filled fissures. In the deposits of this type the wall rock is altered and impregnated with pyrite, forming masses of low-grade ore as much as 20 feet across. These two types, though more or less distinct, merge into each other and in places the goldpyrite deposits show copper minerals. Veins characterized by carbonate gangue were seen in two places and carry both pyrite and chalcopyrite.

The ores so far developed are largely oxidized, but remnants of chalcopyrite and pyrite are found surrounded and cut by masses of limonite, malachite, and chrysocolla. These three oxides are more or less mixed, the iron being much more abundant than the copper minerals, forming a low-grade copper-pitch ore. Very minor amounts of bornite and chalcocite occur in Beaver Basin, but were not noted elsewhere. Azurite is rather uncommon. Glassy, coarsely crystalline quartz is by far the most abundant gangue mineral. It is usually rather smoky but may be clear. Calcite and siderite are seen in some veins, and associated with them in one place is a very minor amount of fluorite. Barite with limonite was noted in one deposit in sandstone near the monzonite porphyry. The association of glassy quartz with much copper-bearing limonite in small stringers is commonly seen in the brownish float of the mountains.

The lodes are later than all the porphyries except possibly the very siliceous quartz monzonite mass half a mile west of Basin. It seems possible that they may be the final product of the intrusion.

COPPER DEPOSITS IN SEDIMENTARY ROCKS. DISTRIBUTION.

At several localities around the La Sal Mountains copper and copper-silver ore has been found in sufficient abundance to encourage prospecting; and the Cashon mine, Montrose County, Colo., has produced important amounts of copper and silver. Prospecting has been carried on in Big Indian Valley south of the range, Lisbon Valley southeast of the range, Salt Wash Valley northwest of the range, about 9 miles east of Dewey, and to a slight extent at numerous other localities. At the time of the writer's visit, in 1913, all the copper properties were idle and the following notes are the result of such examination as could be made under the existing conditions.

\section{BIG INDIAN VALLEY.}

The deposits in Big Indian Valley are 4 to 5 miles south of La Sal post office and are reached from Thompsons, the nearest railroad point, by way of Moab, a distance of 75 miles by road. The ores occur in gray medium-grained sandstones with lenses of rather fine conglomerate. The beds are believed to be at about the middle of the Triassic (at or near the horizon of the Shinarump conglomerate), beneath the prominent cliff-making (Vermilion Cliff) sandstone. The thickness of the beds in which mineralization has been shown is probably 200 to 300 feet, though it is only at certain horizons through this thickness that the rocks have been mineralized to an important extent.

In the mineralized zone there has been considerable fissuring of the sandstone. The most prominent fissures strike about N. $50^{\circ}$ $70^{\circ} \mathrm{W}$. magnetic; others strike in other directions, notably nearly north. Some movement along the fissures is indicated by slickensiding, but no important displacement was noted. Along most of the fissures there has been mineralization, which on the surface appears as carbonate of copper and hydrous oxides of iron with some manganese oxide.

In the vicinity of the fissured area the more permeable sandstones, particularly the conglomerate lenses, have been impregnated by copper minerals, which were deposited between the pebbles. In many places a very close connection between the impregnated sandstone and the fissures is not apparent; but as the mineralized rock is confined to the fissured zone it seems reasonable to suppose that the solutions migrated from the fissures.

Mineralization has taken place along the general strike of the fissuring for $1 \frac{1}{2}$ to 2 miles. Approximately a mile northwest of the Big Indian mine a shaft has been sunk to a depth of perhaps 100 feet; some good ore was on the dump, and shallow openings along the ledge show copper carbonates. Mineralized rock can be found for at least half a mile southeast of the Big Indian mine, but not in sufficient quantity to have encouraged extensive prospecting.

At the surface and in the shallow workings the copper minerals are those that have resulted from oxidation processes, mainly azurite and malachite and some cuprite. They are disseminated through the sandstone or occur (the carbonates particularly) as botryoidal masses lining fissures or cavities. On the dump specimens containing sulphides were found, indicating that the oxidized ores were probably derived from sulphides.

Specimens of the impregnated sandstone sulphide ore are seen under themicroscope to consist of sand grains cemented by sulphide. Many sand 
U. S. GEOLOGICAI SURVEY

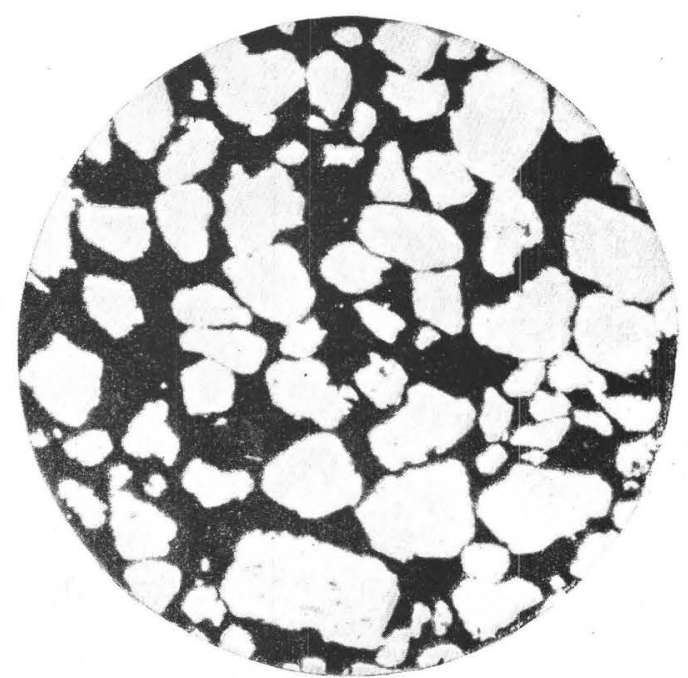

A. PHOTOMICROGRAPH OF SANDSTONE COPPER ORE.

Light areas, quartz grains; dark matrix, copper sulphides (chalcocite and chalcopyrite).

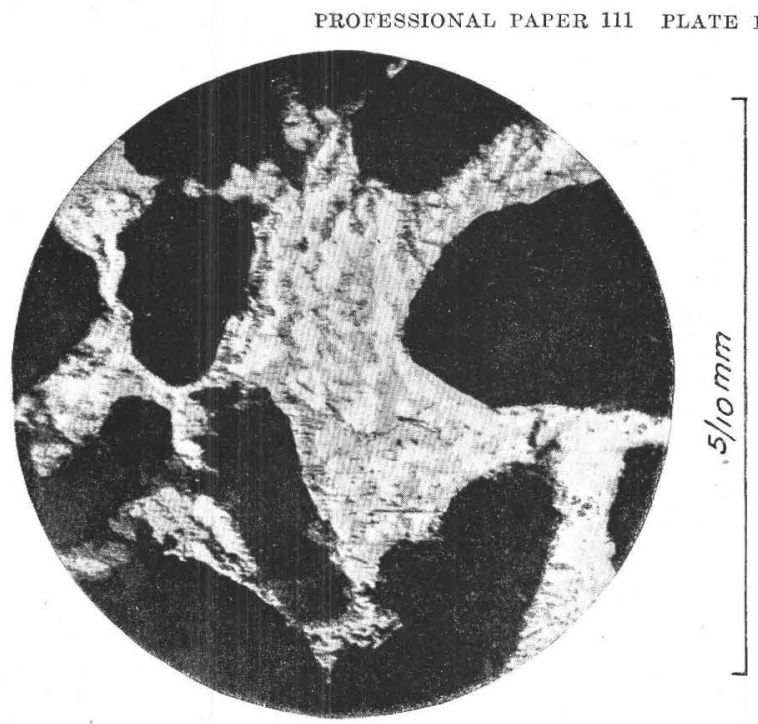

$B$. PHOTOMICROGRAPH OF SANDSTONE COPPER ORE, SHOWING COPPER SULPHIDE MATRIX.

Black areas, quartz grains. Gray mottled areas, copper sulphide; light areas, chalcopyrite; dark areas, chalcocite.

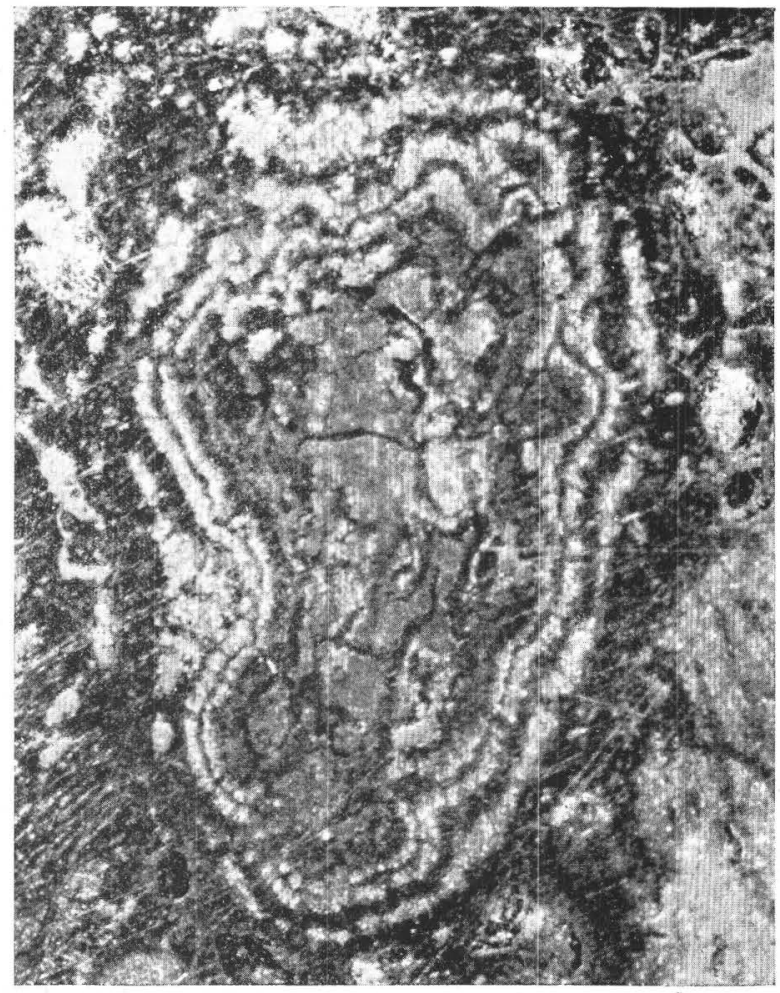

C. CONCENTRIC BANDS OF PYRITE AND COVELLITE, Central area, largely pyrite, with veins of covellite. Enlarged
25 diameters.

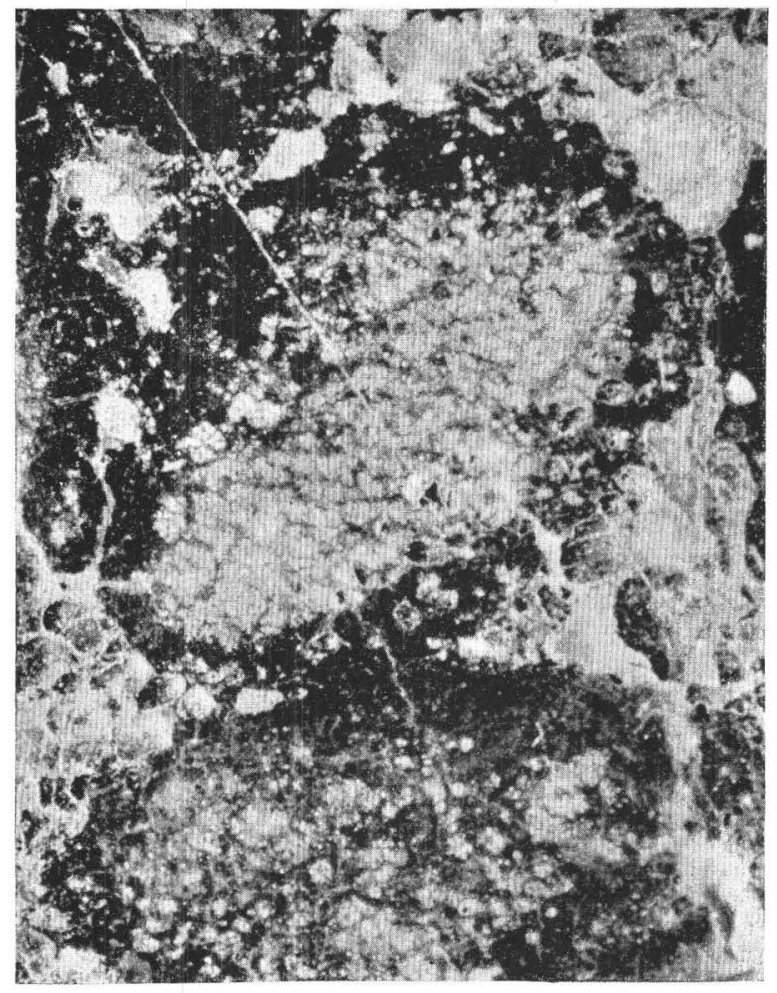

D. NODULES OF PYRITE SURROUNDED BY COVELLITE.

Light areas, nodules of pyrite; dark borders, covellite; pyrite of central area partly replaced by covellite. Enlarged 25 diameters.

PHOTOMICROGRAPHS OF ORE FROM THE BIG INDIAN MINE, LA SAL MOUNTAINS. 


- n


grains are completely surrounded by the sulphide (see Pl.L, $A$ ) and are separated from other grains by one-fourth to one-third of their diameter. Occasionally the sulphide is in a fissure in the grain. As the grains in the normal sandstone are commonly in contact, it seems that some of those in the ore must have been partly replaced by the sulphide. The sulphide is in large part chalcocite, in which are remnants of a yellow sulphide (see Pl. L, $B$ ), apparently chalcopyrite. The chalcocite has formed largely, if not entirely, as a replacement of this sulphide.

Nodular masses of sulphide resembling concretions, found on the dump, consist of quartz grains with much more sulphide cementing material than the ordinary sandstone ore. The cement is a yellow sulphide, probably pyrite, and a mottled blue and blue-gray material, which may be a mixture of covellite and chalcocite. From a sixteenth to an eighth of an inch from the surface of the nodules the yellow sulphide is absent, while within this outer zone it may form a large percentage of the material (see Pl. L, D). One small nodule was examined which showed concentric zones of the yellow and blue sulphides (see Pl. L, $C$ ). The natural explanation of the occurrence of the sulphides seems to be that first the yellow iron sulphide was deposited and that later it was in part replaced by the copper sulphides which in turn were for the most part altered to carbonates.

The most extensive development is at the Big Indian mine, which has been prospected by several tunnels and an inclined shaft. Only part of the underground works could be examined. Some good ore has been found, but the richer grade is in small bodies and would be difficult to mine without mixing with poor ore or waste. The great bulk of the mineralized rock carries a rather low percentage of copper, and much of the low-grade ore occurs in thin lenses and is difficult to extract without breaking barren rock.

IISBON VALLEY.

The deposits in Lisbon Valley are near the Colorado-Utah line, 12 to 14 miles southeast of La Sal post office. The ores occur in sandstones with interbedded shales and at least one bed of carbonaceous shale containing much coaly material. The exact stratigraphic hori- zon was not determined, but it is believed to be near the base of the Triassic.

In the vicinity of the Lisbon mine the beds strike about $\mathrm{N} .70^{\circ} \mathrm{W}$. (magnetic) and dip about $40^{\circ} \mathrm{SW}$. The ore is disseminated in sandstone. Surface trenching has revealed several mineralized horizons, but the main development consists of an inclined shaft which follows a sandstone stratum containing plant remains, which is underlain by carbonaceous shale containing seams of coaly material.

The ore, so far as observed, is all oxidized and occurs as a cement of the sandstone and, to some extent, in the carbonaceous material in the sandstone. It also occurs as botryoidal masses lining openings in the rocks. The coaly material underlying the sandstone is said to carry a low percentage of copper. Material of this character was collected and when examined several weeks later was seen to contain a light-green material that had formed as an efflorescence on the surfaces and along fractures. When treated with water a solution containing copper and iron sulphate is obtained. Probably most of the copper is present as sulphate and has possibly leached downward from the sandstones above.

The coarse strata have apparently been most favorable to the deposition of the metallic minerals. No important fissures connected with the deposits were noted, but careful study would possibly reveal such.

In the inclined shaft, which has been sunk to a depth of perhaps 100 feet, some ore of good grade has been taken out; and in trenching across the formation and by other shallow workings several other mineralized strata have been found. At the time of visit only a small tonnage of ore had been extracted or developed.

\section{SALT WASH.}

Salt Wash Valley is cut in the crest of a broad anticline extending from near Thompsons southeast to Grand River and the La Sal Mountains. Its floor slopes northwest and southeast from a divide about halfway between Thompsons and Grand River. The formations along it were not carefully traced into areas where they are known, but it is thought that the copper-bearing beds are in the McElmo formation. The sediments near the copper deposits at the north end of the belt are mainly gray sandstone with some shale and calcareous 
beds. The southern end of the belt was not visited but is reported to be at essentially the same stratigraphic horizon. Toward the north, where the prospects were visited, there has been considerable fissuring parallel with the anticline and in some places there has been movement along the fissures, though the displacement has probably not been great.

The copper deposits occur on both sides of the valley, from about 10 miles southeast of Thompsons nearly to Grand River, in the portions of the anticline nearest the crest. No deposits have been reported from the flanks of the anticline. The ore deposits are in the vicinity of fissure zones, but the ores do not generally occur in the fissures, usually impregnating the sandstone. Near the old Indian trail a small stringer of ore apparently occurs in a fissure. A common occurrence of the copper minerals is as small spherical concretions in the sandstone, usually not more than one-half inch in diameter, but in places thickly scattered through certain beds. At the surface these spheres weather out and collect in depressions, where a small amount of rather high grade ore can be scooped up. The prevailing minerals are the carbonates, azurite, and malachite, the blue carbonate usually predominating. Microscopic examination of the spherules revealed the presence of a little gray and yellow sulphide-probably chalcocite and pyrite. Iron and manganese oxides are rather abundantly associated with the copper minerals, and some spheres of iron and manganese oxides similar to those of copper carbonate and some concretions of calcite were noted.

Some of the copper ores, notably those from the fissure near the old Indian trail, are said to contain considerable silver. This ore contains barite as a gangue mineral, and the presence of rather abundant remnants of chalcopyrite indicates that that mineral was the most important original copper sulphide. A greenishyellow earthy mineral, observed at several localities near the north end of the belt, and associated in small amounts with the copper and iron minerals, was found not to contain vanadium nor uranium, though in general appearance it resembles low-grade carnotite sandstone ore.

Remnants of sulphides in the carbonate ore indicate that the copper and iron were proba- bly originally deposited as sulphides and were later oxidized.

Little ore has been shipped. When copper is high, it would probably be profitable to gather the surface ores, but it is doubtful if systematic exploitation of the deposits would meet with much success.

Hill ${ }^{1}$ describes a deposit east of Dewey as follows:

About 9 miles east of Dewey, the halfway station on the Cisco-Castleton road at Grand River, a copper-silver mine entirely in sandstone, with no igneous rock in the vicinity, is said to be producing some ore. The property was not visited, but the writer had an opportunity to see some of the ore. It consisted of chalcocite deposited in small seams cutting white sandstone and also disseminated in the adjacent walls. Along the borders of these seams a thin zone of malachite is usually present, and this mineral, together with azurite, stains the sandstone near the fissure. The mine is now being worked for its silver, which occurs in native form and as silver chloride. The development is rather shallow. The vein is said to strike a few degrees north of west and to be traceable for more than a mile.

Emmons ${ }^{2}$ has described an apparently similar deposit on the east side of the La Sal Mountains in Montrose County, Colo.

URANIUM-VANADIUM DEPOSITS.

Deposits of uranium and vanadium occur near Richardson, north of the La Sal Mountains, and 27 miles from Cisco, the nearest railroad point on the Denver \& Rio Grande Railroad. Some ore has been shipped, but the deposits have not been actively worked for several years.

The ores occur in a breccia zone associated with a strong northeast fracture in sandstones of probable Triassio age. ${ }^{3}$ The ore minerals are of various compounds of vanadium, uranium, copper, and arsenic.

Uranium-vanadium deposits have been discovered in the McElmo sandstones at numerous localities around the La Sal Mountains both in Utah and in Colorado. The most extensively developed deposits in Utah are on Pack Creek southeast of Moab, in Dry Canyon and Big Indian Canyon south of the La Sal Mountains, and at several localities between these areas. Deposits are reported from Lisbon Valley,

1 Hill, J. M., Notes on the northern La Sal Mountains, Grand County, Utah: U. S. Geol. Survey Bull. 530, p. 118, 1911.

2 Emmons, W. H., The Cashin mine, Montrose County, Colo.: U. S. Geol. Survey Bull. 285, pp. 125-128, 1906.

${ }^{3}$ Boutwell, J. M., Vanadium and uranium in southeastern Utah: U. S. Geol. Survey Bull. 260, p. 203, 1905. 
southeast of the mountains. There has been considerable development at Gateway east of the mountains, 15 miles southeast of Thompson, northwest of Dome Plateau, and near Courthouse northwest of Moab.

All deposits in the McElmo formation around the La Sal Mountains show a striking resemblance, though there is some variation in mineral composition. Characteristically they occur as small bodies in sandstones closely associated with fossil plant remains. The metals in these deposits include vanadium, uranium, chromium, copper, and selenium in various mineral combinations. For a discussion of the genesis of the uranium-vanadium deposits see page 155 .

\section{MANGANESE DEPOSITS.}

Deposits of manganese, in the form of pyrolusite, occur in the sandstone at severai localities. From 1901 to 1906 the Colorado Fuel \& Iron Co. mined and shipped this material, but under ordinary conditions it was not profitable. During 1916, 1917, and 1918 the high prices caused by the war made mining of these deposits profitable. J. T. Pardee ${ }^{1}$ describes the deposits of the Little Grande district as follows:

The manganese ore occurs as irregular lenses or "blankets" that lie a few feet below the surface along the bedding planes of a gypsiferous, calcareous red sandstone near the middle of the McElmo formation (Jurassic?); as veins and nodular concretions along joints below the blankets; and as fragments in the soil, residual from the weathering of ore of the two forms first mentioned. In the area examined the rocks dip but a few degrees from the horizontal and the surface trace of the manganiferous stratum is therefore a very sinuous line, winding around mesas, cliffs, and canyons. From a point near Green River the outcrop of the manganiferous beds runs in general southeastward about 25 miles and thence apparently swings northeastward around the La Sal Mountains. A manganiferous bed is reported to crop out at many places from Green River westward to and beyond the San Rafael swell.

Manganese occurs rather persistently along the part of the bed that was examined, but only in places is it pure enough or in bodies large enough to be considered ore. Few of the blanket deposits are more than 50 feet long and most of them measure 20 feet or less. Generally they are closely spaced for a mile or two, forming rich or workable areas that are separated by long, barren stretches. Ordinarily the workable blankets range in thickness from 2 to 6 inches, but a few reach a thickness of 3 feet.

${ }^{1}$ Manganese in the Green River district, Utah: U. S. Geol. Survey Press Bull. 384, pp. 2-3, October, 1918.
Loose fragments of ore are scattered over thousands of acres, but owing to variations in their distribution and in the proportion of fragments of rock mixed with them only comparatively small areas are workable under present conditions. In places the fragments of ore, most of them about as big as a walnut, completely cover the ground and can be easily raked up and loaded in wagons. Ordinarily, however, in the workable areas, the fragments are distributed through a foot or less of sandy soil, the completely disintegrated matrix of the original ore bodies. This dry screening ground will yield 10 to 100 pounds or more of ore a square yard but generally not more than 25 pounds.

The bulk of the ore has the properties of pyrolusite, which, as suggested by commonly occurring crystal forms, is probably secondary or pseudomorphic after manganite. Wad is widespread but not abundant, and rhodochrosite occurs sparingly in two mines.

Many of the blanket deposits appear to be almost pure manganese dioxide. Several carloads have been shipped that carried 70 to 85 per cent of manganese dioxide, the principal impurities being lime and silica. The ore generally contains less than $1 \frac{1}{2}$ per cent of iron, very little phosphorus, and, rather curiously, from a trace to one-half of 1 per cent or more of copper. In places the blankets grade into material consisting largely of lime and gypsum. The nodular concretions and irregular replacements along joints contain more silica than the ore of the blankets. The residual ore in the soil generally contains 40 per cent or more of manganese, from 8 to 15 per cent of silica, and less than 2 per cent of iron. An average of 35 car samples of mixed ore shipped from the C. F. \& I. mine contained 41.3 per cent of manganese, 10.6 per cent of silica, and 1.5 per cent of iron.

It is interesting to record the fact that celestite (strontium sulphate) occurs in nonpersistent beds, from 1 to 6 inches thick, associated with gypsum in the manganiferous stratum at several places in the C. F. \& I. mine.

The manganese, lime, and gypsum were originally deposited in a body of water during the Jurassic period, and after the region had been uplifted, and the manganiferous stratum uncovered by erosion in late Tertiary time the ore bodies that are now exploited were formed by the action of surface waters. It is not clear whether concen. tration of the manganese is still in progress.

Most of the mines in this district were operated part of the time during 1916 and 1917. At present (October, 1918) three operators are producing 400 to 600 tons of highgrade manganese ore a month. Most of this ore comes from the C. F. \& I. and Salt Wash mines, operated by the Green River Mining Co. The other active operators are The Needles Mining Co. and J. B. Fonder.

The deposits are worked solely by open pits. The bedded deposits (blankets) bear an overburden ranging in thickness from a few inches to 6 feet, which is stripped off by hand or with plow and scraper. It is rarely profitable to mine them by drifting under cover or to remove more than 6 feet of overburden. Residual fragments of manganese ore are separated from the soil by dry screening and hand picking.

At the C. F. \& I. mine a revolving screen driven by a gasoline engine has been discarded for one-man handshaking screens and stationary sloping screens such as are 
commonly used by mortar mixers to clean sand. In this way one man can produce from 1,000 to 2,000 pounds of ore a day. The quantity of ore produced from the blankets by one man is variable but averages nearly the same as that obtained from the residual deposits.

It is estimated that 7,300 tons of high-grade ore (containing more than 40 per cent of manganese) is available for mining under present conditions and without modification of existing methods. Most of this may be classified as "furnace" ore, though a considerable part of it could be hand sorted to "dioxide" ore. About two-thirds of the quantity estimated is contained in the blankets and the remainder in the residual deposits. The above estimates include 20 mines, 2 of which supply more than half the total.

In addition, 22,500 tons, chiefly in the residual surface deposits, are possibly available to mining under improved conditions or methods. Some way other than handpicking should be devised to separate the rock fragments from the ore.

Under present conditions the ore in the Green River district that contains much less than 40 per cent of manganese can not perhaps be mined profitably, but such ore happens to be not very abundant. About 5,000 tons of ore containing from 15 to 40 per cent of manganese and considerable lime is available for mining. In addition, there is a considerable amount of ore containing smaller percentages of manganese and much silica, most of it in some abandoned claims at the locality known as Court House.

Manganiferous iron ore was observed at only one place, where an outcrop promises to yield several hundred tons of apparently low-grade material. The iron oxides are generally distinct from the manganese and occur chiefly in the layer next below it, but no material rich enough to be classified as iron ore was seen.

The total production of manganese ore prior to 1910 is given by Harder ${ }^{1}$ as 3,815 tons, the largest production being made in 1901 and smaller outputs in 1903, 1904, and 1906.

\section{BIBLIOGRAPHY.}

Boutweli, J. M., Vanadium and uranium in southeastern Utah: U. S. Geol. Survey Bull. 260, pp. 201-210, 1905. Cross, Whitman, Stratigraphic results of a reconnaissance in western Colorado and eastern Utah: Jour. Geology, vol. 15, pp. 634-679, 1907.

Emmons, W. H., The Cashin mine, Montrose County, Colo.: U. S. Geol. Survey Bull. 285, pp. 125-128, 1905.

Harder, E. C., Manganese deposits of the United States: U. S. Geol. Survey Bull. 427, p. 275, 1910.

Hrul, J. M., Notes on the northern La Sal Mountains, Grand County, Utah: U. S. Geol. Survey Bull. 530, pp. 99-118, 1911.

Lupton, C. T., Oil and gas near Green River, Grand County, Utah: U. S. Geol. Survey Bull. 541, 1914.

Moore, R. B., and Kiтhil, K. L., A preliminary report on uranium, radium, and vanadium: U. S. Bur. Mines Bull. 70, 1913.

1 Harder, E. C., Manganese deposits of the United States: U. S. Geol. Survey Bull. 427, p. 275, 1910 .
Newberry, J. S., Report of expedition from Santa Fe, N. Mex., to the junction of the Grand and Green rivers of the Great Colorado of the West in 1855, Washington, 1876.

Peale, A. C., Report as geologist of the Grand River division: U. S. Geol. and Geog. Survey Terr. Ninth Ann. Rept., for 1875, pp. 31-101, 1877.

- Report as geologist of the Grand River division: U. S. Geol. and Geog. Survey Terr. Tenth Ann. Rept., for 1876, pp. 161-185, 1878.

\section{ABAJO (BLUE) MOUNTAINS.}

By B. S. Butler.

M. R. Thorpe spent part of the summer and fall of 1915 in studying the Abajo Mountains and presented the results of his work to the faculty of Yale University in partial fulfillment of the requirements for the degree of bachelor of philosophy. Mr. Thorpo has kindly allowed the writer to make the following notes from this material. Those especially interested in the region are recommended to consult the complete report:

\section{GEOGRAPHY.}

The Abajo Mountains are in eastern San Juan County. Monticello, the nearest settlement, is about 6 miles northeast of the mountains; Grayson is about 20 miles south; Moab is about 70 miles north; and Thompsons, on the Denver \& Rio Grande Railroad, is about 40 miles farther north. Dolores, Colo., on the Denver \& Rio Grande narrow-gage railroad, is 60 miles east of Monticello. From Thompsons to Moab the wagon road is good, and from Moab to Monticello it is fair and is being improved. This route is used by the mail stage and for freighting most of the supplies for the region.

The Abajo Mountains are relatively high, and in consequence the winters are cold and the summers only moderately warm. Precipitation is above the average for the Plateau region and a rather abundant forest growth clothes the mountains. Several streams, which head in the mountains and flow across the surrounding plateau till the water disappears, are utilized for irrigation, which, with dry farming, has been practiced with success. The mountains and surrounding plateaus furnish range for cattle, sheep, and horses, and stock raising is the most important industry of the region.

The Abajo Mountains form a typical roughly circular laccolithic mountain group which rises 
abruptly from the surrounding plateau to elevations of 10,000 to 11,000 feet or 3,000 to 4,000 ieet above the plateau. The streams, which radiate from the mountains, drain to Colorado River through San Juan and Grand rivers.

\section{GEOLOGY .}

The sedimentary rocks, which cover most of the area, range in age from Triassic to Cretaceous. The lowest formation extensively exposed around the mountains is the Vermilion Cliff sandstone, which is cut by canyons to the north and west; it has a thickness of 250 to 300 feet. Overlying it is 75 to 100 feet of shales and sandstones, which is overlain by the White Wall sandstone with a thickness of 300 to 400 feet. Above the White Wall sandstone is the McElmo formation of 500 to 600 feet of red and green shales and rather massive beds of light-colored sandstone. This is exposed on all sides of the mountains except the northwest. Overlying the McElmo are Cretaceous rocks (about 200 feet of Dakota sandstone and an equal thickness of Mancos shale), which nearly surround the mountains and extend well up toward the summits.

In the central portion of the Abajo group are exposed several laccoliths, which were intruded at different horizons in the Triassic and the Cretaceous rocks. The rocks are rather fine grained porphyries of monzonitic composition that closely resemble those of the other laccolithic mountains of the Plateau region. A few dikes cut the laccoliths and the adjacent sedimentary rocks.

The sedimentary rocks near the contact with the laccolithic bodies have undergone some metamorphism, the sandstone being changed to quartzites and the shales to hornfels. Locally considerable pyrite- has been introduced into the sedimentary rocks near the contact.

The structure is laccolithic, the sedimentary rocks having been raised and arched over the intrusive rocks. The numerous laccoliths intruded at different horizons, together with the influence of earlier structural features, has, however, caused tho structure to vary somewhat from the typical.

\section{ORE DEPOSITS.}

The first metal discovered in the Abajo Mountains was placer gold. In 1893, follow- ing the San Juan "boom" of the previous year, placer gold was found on Johnson Creek. This discovery produced considerable excitement, but very little gold was extracted and the placers were soon abandoned. Shortly afterward prospecting for lode deposits was undertaken and is still continued. Much money and labor have been expended in development and in mill building; but little metal has been recovered, and no deposit has paid the expenses of operation.

Most of the work has been done on mineralized areas near the contact of the intrusive and sedimentary rocks, near which considerable pyrite and some gold have been added in places to the sedimentary rocks.

\section{WHITE CANYON REGION.}

By B. S. Butler.

\section{GENERAL FEATURES.}

In the White Canyon region are included White Canyon and areas to the north and south that are said to contain some mineral deposits. White Canyon joins the Colorado from the southeast, at Hite, Utah. The region is reached from the north from the town of Green River on the Denver \& Rio Grande Railroad by way of Hanksville and Hite and from the southwest from Bluff, on San Juan River. A wagon road from Green River has been built as far as Hite. At Dandy Crossing, just above Hite, animals can easily swim the river, and supplies can be taken across in boats. From Hite the trail, which was once used as a wagon road and which is still an excellent pack trail, passes through White Canyon to the Natural Bridges, ${ }^{1} 40$ to 45 miles distent, and thence to Bluff.

Topographically the region is typical of the plateau country. White Canyon is a deep cut in the gently inclined rocks, whose harder strata form nearly perpendicular cliffs, topped by benches worn back in the weaker rocks. Such a bench, a few rods to half a mile in width, formed on the surface of the massive white Carboniferous sandstone, borders the inner canyon for nearly its entire length and furnishes an easy road. This bench is bordered by nearly unscalable cliffs.

1 Cummings, Byron, The great natural bridges of Utah: Nat. Creog. Mag., vol. 18, pp. 199-204, 1907; vol. 21, pp. 156-167, 1910; Colossal natural bridges of Utah, idem, vol. 15, pp. 367-369, 1904; Century Mag., August, 1904. 
The inner canyon in the white sandstone is in most places very steep and narrow and can be crossed in few places. In the vicinity of the Natural Bridges it is particularly rugged and picturesque and is especially interesting, both because of the scenery and of the ruins left by the prehistoric inhabitants.

Perennial water supplies are scarce and of rather poor quality. The largest supply, so far as the writer is aware, is at Fry's cabin, when a small stream is said to persist through the year. Early in the spring and late in the fall good water can usually be found in the shallow "tanks" that have been eroded in the massive sandstone. Many of these are inaccessible to the cattle ranging in the canyon, and the water is unpolluted. Water holes are also present in the canyon, but the water is of poorer quality. Good timber is lacking, but cedar and other scrubby trees and sagebrush afford fuel for travelers.

The canyon furnishes range for cattle, but no other use is made of the land, and cultivation on an important scale is not possible. The nearest source of farm supplies is the Henry Mountains region and small areas of irrigable land near Colorado River. From the east supplies can be obtained from Bluff on San Juan River, or Grayson and Monticello, at the base of the Abajo Mountains.

\section{GEOLOGY}

STRATIGRAPHY.

The lowest rock exposed in White Canyon is a massive cross-bedded gray sandstone, several hundred feet of which has been cut through in the upper part of the inner canyon without exposing the base. Above this gray sandstone is 300 to 400 feet of red sandy shale with intercalated beds of sandstone. About 100 feet below its top is a lenticular bed of fossiliferous gray sandstone, in which most of the ore deposits are supposed to occur. Overlying the red shale is a white sandstone that in places attains a thickness of 50 feet but that is distinctly lenticular, nearly pinching out for considerable distances. This sandstone contains small lenses of rather fine conglomerate. Where examined, south of Fry's cabin, it consisted of about 6 feet of conglomerate at the base, overlaid by 15 to 20 feet of sandstone.

Above the white sandstone is a red shaly formation at least 200 feet thick. This in turn is followed by massive red sandstone regarded as Vermilion Cliff sandstone.

The formations exposed in White Canyon seem to correspond to the Aubrey sandstone, Shinarump group, and Vermilion Cliff group of Gilbert's Henry Mountains section.

The following table shows the probable correlation with the Henry Mountains section:

Correlation of Henry Mountains and White Canyon sections.

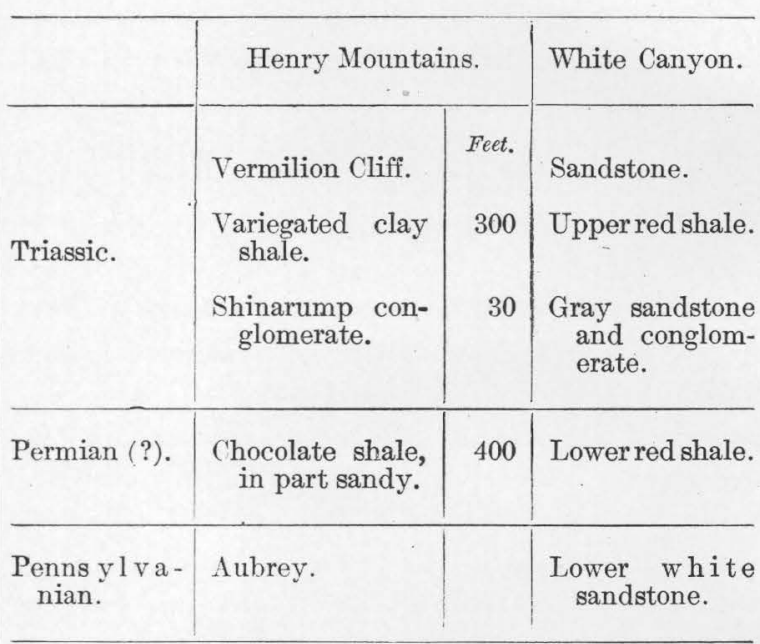

\section{STRUCTURE.}

The structure of the region is simple. In passing southeast up the canyon from Colorado River to the vicinity of the Natural Bridges, a distance of about 30 miles in a direct line, the lower white sandstone rises from an elevation of about 3,500 feet (below the surface of Colorado River) to fully 6,000 feet, an average of about 100 feet to the mile. The impression gained in going up the valley is that of a great dome structure or very broad anticline. Southeastward from the Natural Bridges the strata are nearly horizontal for several miles and then dip eastward, at first gently and then pronouncedly near Comb Wash. The region constitutes a broad uplift with relatively steep dips along the easterly margin and gentle, rather uniform dips along the west margin to Colorado River. (See Pl. IV.) This uplift extends from the vicinity of the Abajo Mountains through the Orejas del Oso (Bear's Ears) to Monument Valley and thence into Arizona. Holmes ${ }^{1}$ describes the region south of the Abajo Mountains as follows:

1 Holmes, W. H., Geology of the Sierra Abajo and west San Miguel Mountains: U. S. Geol. and Geog. Survey Terr. Tenth Ann. Rept., 1876, pt. 1, pp. 190-191, 1878. 
On the east the Bear's Ears Plateau ends in a great monoclinal fold, with the downthrow on the east. The Cretaceous floor of the Sage Plain extends westward to the line of this fold and occupies about the same absolute horizon as the middle portion of the Triassic formations to the west. The throw of the fold would therefore be approximately 1,000 feet. Although the amount of displacement is so slight the fold is easily traced by a number of monoclinal valleys that follow its axis from the base of the Abajo group to the San Juan. The ridges that separate these valleys have smooth, sloping faces to the east, and one of them, which presents a continuous line of white or pinkish faces, can be traced south to the San Juan, and far beyond into Arizona. Macomb and Epsom creeks on the north, and the Rio de Chelly on the south, occupy the more prominent of these valleys.

Woodruff ${ }^{1}$ has described a sharp fold along the eastern border of the San Juan oil field. The outcrop of the La Platz and Vermilion Cliff sandstones along this fold forms the Comb Wash Reef.

A gentle anticlinal fold, or "warp," which trends approximately along the axis of White Canyon nearly at right angles to the larger uplift, dips very slightly to the north and several degrees to the south.

There is little faulting in the canyon, though there are some fissures, along some of which there has doubtless been slight movement.

\section{ORE DEPOSITS.}

\section{DEVELOPMENT.}

Copper deposits have been known in White Canyon for several years, but owing to the remoteness of the region prospecting has been slight. The unusually high price of copper in 1906 and 1907 stimulated prospecting, and in 1907 a reduction plant was in transit from Green River to Fry's cabin in the upper part of the canyon when the financial troubles of that year put a stop to the undertaking. From 1907 to 1913 but little work was done beyond that necessary to hold the unpatented claims. Some ore was shipped in 1916.

The deposits are typical of those in sandstone throughout the Plateau region. They occur principally in the lenticular white sandstone about 100 feet below the top of the lower shale series.

\section{MINES.}

The Dolly Varden claim, about 9 miles from Hite, contains the most extensive deposit so far developed. The copper minerals impregnate

1 Woodruff, E. G., Geology of the San Juan oil field, Utah: U. S. Geol Survey Bull. 471, pp. 76-104, 1912. the lower part of the white sandstone on the south side of the canyon for a maximum thickness of 15 to 20 feet. The main mineralized zone is on a ridge and is exposed on two sides. About 200 to 250 feet from the point of ridge in a southerly direction the mineralized rock diminishes in thickness to $1 \frac{1}{2}$ to 2 feet, and within about 400 feet it disappears entirely. Westward it can be followed for a greater distance, but 300 to 400 feet away it becomes very thin. A tunnel driven in the copper-bearing formation in the most promising part of the outcrop for about 200 feet shows considerable copper in the first 125 feet but little in the last 50 feet. The area of greatest mineralization is cut by fissures that trend N. $70^{\circ}-90^{\circ} \mathrm{W}$. They show little displacement. Along them and extending from them into the bedding is a deposit of black mineral cementing the grains of sand, and with this is some copper carbonate. The black mineral was tested in the Survey laboratory and found to contain considerable cobalt and is probably some form of cobalt oxide. Its composition was not recognized in the field and no accurate data on the amount present were obtained.

The beds are irregularly mineralized, some small lenses containing a rather high percentage of copper, but taken as a whole the ore is of rather low grade. The richest ore observed is in a lens of rather fine conglomerate with a maximum thickness of about 6 inches.

Much of the ore is associated with plant remains, the original copper minerals evidently having partially replaced or having been precipitated by the vegetable matter.

The metalliferous minerals at the surface are mainly carbonates of copper, hydrated oxide of iron, and a black cobalt mineral. Sulphides, which were observed in a few pieces of ore from the dump, consist of cores surrounded by oxidized minerals. In polished sections they are seen to consist of bornite that has been partly, and in some specimens almost entirely, replaced by chalcocite. No chalcopyrite was observed. This fragmentary evidence indicates that the original form of the copper was bornite.

Blue Dike prospect.-The Blue Dike prospect is a mile west of Fifteenmile Crossing, 15 miles from Hite, on the south side of White Canyon. The copper occurs in a lens of white crossbedded sandstone interbedded with the red 
shale and sandstone series at or near the horizon of the Dolly Varden prospect.

The lens of sandstone is 12 to 15 feet thick, but the copper-bearing rock in the thickest portion is about 10 feet and thins to zero. The mineralized portion is exposed for 150 to 200 feet along the strike. There is a slight seepage of water from the rock, and everywhere the mineralized outcrop is covered by an abundance of efflorescent salts ranging in color from white to varying shades of blue, green, pink, and yellow. The salts are hydrous sulphates, probably of varying composition. The green and blue minerals contain copper; the yellow salts were tested in the Survey laboratory and found to be sulphates of uranium; and the pink salts give tests for cobalt. As yet no thorough chemical or mineralogic study of these salts has been made.

A little water collected in the bottom of a short tunnel was strongly acidic and contains sufficient copper to plate a knife blade in a few minutes. The walls of a tunnel that extends about 40 feet into the ledge are everywhere coated with the efflorescent salts.

A short tunnel driven in the ledge for assessment work in the fall of 1914 revealed sulphides, in large part as a replacement of plant remains and in lesser amount as a cementing material between sand grains. The sulphides noted are chalcopyrite, coveilite, chalcocite, and a little pyrite. The chalcopyrite and pyrite appear to have been the earliest of the sulphides and to have been partly replaced by covellite, which in turn was partly altered to chalcocite, the latter mineral being present in relatively small amount in the specimens examined.

In the replacement of the vegetable matter the cellular structure is preserved and is brought out rather prominently when the chalcopyrite alters to covellite. (See Pl. XIV.)

Oxidized copper minerals and a yellow uranium sulphate are associated with all the sulphide exposed. The examination of polished sections failed to reveal any uranium mineral associated with the sulphides from which the sulphate of uranium could have been derived, though the relation is strongly suggestive of the derivation from the sulphides. None of the sulphide was sufficiently free from oxidation products to permit conclusive chemical proof of the presence of other uranium than that contained in the sulphate. There seems little doubt, however, that the iron, copper, cobalt, and uranium were all present in the sulphide ore and that the recognized uranium and cobalt have been derived from the alteration of that ore.

\section{HENRY MOUNTAIN REGION.}

By B. S. Butler.

GEOGRAPHY.

The Henry Mountains are an isolated group in Garfield County, southwestern Utah, lying between $37^{\circ} 40^{\prime}$ and $38^{\circ} 15^{\prime}$ north latitude and $110^{\circ} 30^{\prime}$ and $111^{\circ}$ west longitude. The group has a northwest-southeast length of about 35 miles and a general width of 8 to 10 miles. Mount Ellsworth, its southernmost peak, is only a few miles from Colorado River. Hanksville, the nearest settlement, is on Fremont or Dirty Devil River, about 15 miles north of Mount Ellen, the most northerly peak, and is about 60 miles by road from Green River on the Denver \& Rio Grande Railroad, the nearest railroad point; and is about 150 miles from Richfield, on the Marysvale branch of the Denver \& Rio Grande Railroad.

In winter, except on the higher parts of the mountains, the temperature is mild and pleasant, but in summer it is hot. Except on the mountains, the rainfall is light and uncertain. The average rainfall at Hite is given in the table (p. 63).

The plateau around the mountain bears but a scanty vegetation, and in many places overstocking has greatly reduced the normal amount. The result of overstocking is strikingly shown in places where ledges of rock have prevented access of stock to small areas. Such protected areas bear a rather plentiful growth of bunch grass, whereas the accessible areas are nearly stripped of vegetation. The same difference is noted between areas near water and those so remote that stock can rarely feed upon them. The region, if not ruined by overstocking, will furnish grazing for a large number of animals. The higher portions of the mountains bear a rather abundant growth of timber, ample for any uses that seem likely to develop. Gilbert has estimated the forested area as approximately 25 square miles, mostly fir, but including considerable spruce and some yellow pine. Water is not 
abundant, but several perennial streams from the mountains suffice to irrigate several hundred acres of land each. At Hanksville several hundred acres are already under irrigation from Fremont River and more can be placed under cultivation. The agricultural output of the region can be considerably increased and seems sufficient to supply any mining communities that are likely to develop. Coal, said to be of fair quality, occurs west of the range but has been very slightly developed.

\section{TOPOGRAPHY。}

The Henry Mountains rise 5,000 to 6,000 feet above the general plateau surface, which in the vicinity is approximately 5,000 feet above sea level. The bottoms of the principal canyons are 1,000 to 1,500 feet below the surface of the plateau. The individual mountain peaks are roughly dome-shaped and coalesce at their bases.

Mount Ellen, the northernmost peak, is a somewhat elongated dome with a maximum diameter of about 12 miles, a minimum diameter of 8 to 9 miles, and a maximum elevation of 11,300 feet. Mounts Pennell and Hillers, next to the south, are nearly circular and coalesce at their base. The basal outline of Mount Hillers is about 8 miles in diameter and that of Mount Pennell is considerably less. Mount Pennell reaches an elevation of about 11,000 feet and Mount Hillers slightly less. They are separated from Mount Ellen by a rather high divide (elevation, about 7,000 feet) and from Mounts Holmes and Ellsworth (on the south) by a low divide, which scarcely reaches 5,000 feet.

Mounts Holmes and Ellsworth, the southernmost peaks, are united at their base, and together are scarcely larger than the more northerly peaks. They are each 4 to 5 miles in diameter at the base and slightly above 8,000 feet in elevation.

The range is surrounded by a deeply dissected plateau, which, except along certain lines, is exceedingly difficult to traverse. Close to the bases of the mountains, however, the physiographic development is much more mature, the streams are in shallow canyons, and movement is relatively easy. Gently sloping spurs, some of which are covered with gravel, extend from the base of the range and are evidently remnants of a once continuous surface that has been dissected by streams along its outer margin, and in some places has been largely removed. The surface of these spurs are at an elevation of $7,000^{\circ}$ to 8,000 feet. This old dissected erosion bench strongly suggests those surrounding the Abajo, La Sal, and Uinta Mountains, and is probably to be correlated with them, though it is less well preserved.

Other benches at lower elevations evidently represent periods of stability when the streams greatly broadened their valleys. One such bench, 150 to 200 feet above Colorado River, is very conspicuous. It is gravel covered and extends into the side canyons, and evidently marks a level at which the river stood for a long period. Other gravel-covered benches are lower down; and gravel deposits 1,000 feet above the river evidently represent other stages in the development of the canyon. A correlation of these stages with the physiography of the mountains presents an interesting problem, but one that will require detailed work.

The drainage of the mountains is radial from each peak, but at the base it is collected into master streams (Cresent and Trachyte creeks to the northeast and Pine Alcove (Bullfrog) Creek to the southwest), which flow for the most part southeast to Colorado River. The drainage from the north and west side of Mount Ellen is to Fremont River through Lewis and Bowl creeks and thence to Colorado River.

\section{GEOLOGY.}

\section{SEDIMENTARY ROCKS.}

The sedimentary rocks range in age, according to Gilbert, from Carboniferous to Cretaceous. The following sedimentary section is given by Gilbert: ${ }^{1}$

$$
\text { Section in the Henry Mountains. }
$$

Cretaceous: Feet.

Masuk sandstone, yellow, heavy bedded..... 500

Masuk shale, gray, argillaceous, and toward the top slightly arenaceous................... 500

Blue Gate sandstone, yellow and heavy bedded. $\quad 500$

Blue Gate shale, blue-black and argillaceous, weathering to a fine gray clay (Inoceramus deformis and $I$. problematicus)............. 1,000 Tununk sandstone, yellow and heavy bedded.. 100

1 Gilbert, G. K., Geology of the Henry Mountains, p. 4, U. S. Geol. and Geog. Survey Rocky Mtn. Region, 1877. 
Cretaceous-Continued.

Tununk shale, blue-black and argillaceous, weathering to a fine gray clay (Inoceramus problematicus and Baculites anceps)..........

Henrys Fork group:

a. Friable yellow sandstones with numerous fossils * * *................

b. Arenaceous shales, purple, green, and white, with local beds of conglomerate..........................

c. Coarse sandstone and conglomerate, with many white grains and pebbles, interleaved with local beds of purple and red shale, and containing immense silicified tree trunks...........

Jura-Trias:

Flaming Gorge group; arenaceous shales or badland sandstones, purple and white at top and red below.........................

Gray Cliff group; massive cross-laminated sandstone, buff to red in color..................

Vermilion Cliff group; massive cross-laminated sandstone, red, with a purple band at the

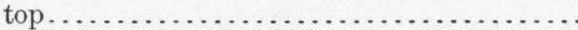
Shinarump group; consisting of-

a. Variegated clay shale; purple and white above and chocolate below, with silicified wood ......................

b. Gray conglomerate, with silicified wood; the "Shinarump conglomerate"......

c. Chocolate-colored shale, in part sandy..

Carboniferous:

Aubrey sandstone, massive, cross-bedded; base not exposed.

Gilbert ${ }^{2}$ gives the following description of the sedimentary formations:

Cretaceous.-The three upper sandstones, the Masuk, the Blue Gate, and the Tununk, are so nearly identical in their lithologic characters that I was unable to discriminate them in localities where their sequence was unknown. This was especially the case upon the summits of Mounts Ellen and Pennell, where they occur in a somewhat metamorphosed condition. All of them contain thin beds of coal, none of which are continuous over large areas, and only one of which was observed of workable thickness. $A t$ the western foot of Mount Ellen a bed 4 feet thick lies at the base of the Blue Gate sandstone.

There is almost equal difficulty in discriminating the Masuk, the Blue Gate, and the Tununk shales. The first is usually of a paler color and is more apt to include arenaceous bands. It has not been found to contain fossils, while the lower shales rarely fail to afford them when search is made. The Blue Gate and Tununk shales are typical examples of fine argillaceous sediments. They are beautifully laminated and are remarkably homogeneous. It is only in fresh escarpments that the lamination is seen, the weathered surface presenting a structureless clay. The fossils of these shales are so numerous, when they have been sought out and studied, that they will probably serve not merely to discriminate the two eet. but also to correlate them with some of the beds which have been examined elsewhere in the Colorado basin. For the present I am unable to refer any of the Cretaceous rocks above the Henrys Fork group to the divisions which have been recognized elsewhere, and it is for this reason that I have given local, and perhaps temporary, names to

10 such beds as I have need to mention in the discussion of the structure of the mountains.

The fossils of the Henrys Fork group have been more fully collected, and they have been referred without question by Dr. White to the group of that name, as recognized in the Green River basin. The white grit which lies at the base of the group is a conspicuous bed of unusual persistence, and is recognized wherever Cretaceous rocks are found in the upper basin of the Colorado.

Jura-Trias.-The rock of the Flaming Gorge group is of a peculiar character. It is ordinarily so soft that in its manner of weathering it appears to be a shale. It is eroded so much more rapidly than the Henrys Fork conglomerate above it that the latter is undermined, and always appears in the topography as the cap of a cliff. Nevertheless, it is not, strictly speaking, a shale. The chief product of its weathering is sand, and wherever it can be examined in an unweathered condition it is found to be a fine-grained sandstone, massive and cross-laminated like those of the Gray and Vermilion cliffs, but devoid of a firm cement. In a number of localities it has acquired, locally and accidentally, a cement, and it is there hardly distinguishable from the firmer sandstones which underlie it. In the immediate vicinity of the Henry Mountains it varies little except in color from summit to base, but in other localities not far distant it is interrupted near the base by thick beds of gypsum and gypsiferous clays, and by a sectile, fossiliferous limestone.

The Gray Cliff and Vermilion Cliff sandstones are often difficult to distinguish, but the latter is usually the firmer, standing in bold relief in the topography, with level top, and at its edge a precipitous face. The former is apt to weather into a wilderness of domelike pinnacles, so steep sided that they can not often be scaled by the experienced mountaineer, and separated by narrow clefts which are equally impassable.

The colors of the two sandstones are not invariable. The lower, which although not reddened throughout its mass is usually stained upon its surface with a uniform deep color, appears in Mount Ellsworth and at other points of elevation with as pale a tint as that of the Gray Cliff. The latter sandstone, on the other hand, where it lies low, is often as deep in color as the Vermilion. Standing upon one of the summits of the Henry Mountains and looking eastward, I found myself unable to distinguish the Gray Cliff sandstone by color either from the lower part of the Flaming Gorge group or from the Vermilion sandstone. The bleaching of the redder sandstone in Mount Ellsworth is probably a result of metamorphism; the reddening of the gray sandstone may depend on the hydration of the iron which it contains.

The thickness of individual strata in these great sandstones is remarkable, and is one of the elements which must be taken into account in the discussion of the problem-which, to my mind, is yet unsolved - of the manner in which such immense quantities of homogeneous sand were accumulated. Ordinarily the depth of strata is indefinable, on account of the impossibility of distin- 
guishing stratification from lamination; but where, as in this case, the lamination is oblique to the stratification, the upper and lower limits of each stratum are definitely marked. I have at several points measured single strata with thicknesses of about 50 feet, and near Waterpocket Canyon a stratum of Vermilion Cliff sandstone was found to be 105 feet thick.

One other measurement is worthy of record; the inclination which oblique lamination bears to the plane of the stratum in which it occurs appears to have a definite limit. The maximum of a series of measurements made at points where to the eye the dip seemed to be unusually great is $24^{\circ}$.

Carboniferous.-Beneath the Jura-Trias is the Carboniferous. A few hundred feet of its upper member, the Aubrey sandstone, are exposed near the summit of Mount Ellsworth. At that point the sandstone is altered to the condition of a quartzite, but where it is cut by the upper and lower canyons of the Dirty Devil River it is massive and cross-laminated, differing from the Gray Cliff sandstone chiefly in the abundance of its calcareous cement.

The following table shows the probable correlation of the formations of the Henry Mountains with those of southwestern Colorado:

Correlation of formations in Henry Mountains with those of southwestern Colorado.

\begin{tabular}{|c|c|c|c|}
\hline Age. & \multicolumn{2}{|c|}{ Southwestern Colorado. } & $\begin{array}{l}\text { Henry Moun- } \\
\text { tains (Gilbert). }\end{array}$ \\
\hline \multirow[t]{2}{*}{ Cretaceous. } & \multicolumn{2}{|c|}{ Mancos shale. } & $\begin{array}{l}\text { Masuk sand- } \\
\text { stone. } \\
\text { Masuk shale. } \\
\text { Blue Gate sand- } \\
\text { stone. } \\
\text { Blue Gate shale. } \\
\text { Tununk sand- } \\
\text { stone. } \\
\text { Tununk shale. }\end{array}$ \\
\hline & \multicolumn{2}{|c|}{ Dakota sandstone. } & $\begin{array}{c}\text { Henrys Fork } \\
\text { group. }\end{array}$ \\
\hline \multirow{2}{*}{ Jurassic. } & \multicolumn{2}{|c|}{ McElmo formation. } & $\begin{array}{l}\text { Flaming Gorge } \\
\text { group. }\end{array}$ \\
\hline & \multicolumn{2}{|c|}{ La Plata sandstone. } & Gray Cliff group. \\
\hline Triassic. & \multicolumn{2}{|c|}{ Dolores formation. } & $\begin{array}{l}\text { Vermilion Cliff } \\
\text { group. }\end{array}$ \\
\hline \multirow{2}{*}{ Carboniferous. } & Permian(?). & $\begin{array}{l}\text { Cutler for- } \\
\text { mation. } \\
\text { Rico for- } \\
\text { mation. }\end{array}$ & $\begin{array}{l}\text { S h in a r u m p } \\
\text { group. }\end{array}$ \\
\hline & $\begin{array}{c}\text { Pennsyl- } \\
\text { vanian. }\end{array}$ & $\begin{array}{l}\text { Hermosa } \\
\text { formation. }\end{array}$ & $\begin{array}{l}\text { Aubrey sand- } \\
\text { stone. }\end{array}$ \\
\hline
\end{tabular}

According to Gilbert the sedimentary series shows no unconformity of dip, but erosional unconformities are determined at the top of the Aubrey group, beneath the Shinarump conglomerate, and at the base of the Vermilion Cliff. No unconformity is recognized at the close of the Jurassic, but the presence of such a break at other localities in the Plateau region and the presence of a conglomerate member at the base of the Cretaceous suggest such an unconformity.

\section{IGNEOUS ROCKS.}

\section{PETROGRAPHY.}

A collection of the typical igneous rocks was made by Gilbert, and a microscopic description by C. E. Dutton was published in his report. ${ }^{1}$ Later descriptions of the rocks were published by Cross. ${ }^{2}$ The writer was unable to make a systematic study of the rocks, and the following statements concerning their petrographic character are taken principally from the publications named.

Intrusive rocks occupy the central portion of the mountain masses in all the peaks of the group. In Mount Hillers the higher portion of the peak is composed almost entirely of igneous rock, and in most of the other peaks, though sedimentary rocks are more abundant even in the higher portions, they are cut by numerous intrusive bodies. Afewintrusive bodies outcrop on the flanks of the group. One, which caps a butte south of Trachyte Creek and northeast of Mount Hillers, might readily be mistaken for a lava flow but has been shown by Gilbert to be intrusive and has been described by him as the Howell laccolith.

The typical rock of the larger masses, so far as observed by the writer, is a gray rather fine grained granitic rock that shows distinct phenocrysts that are rather prominent on the weathered surfaces. The prevailing phenocrysts are plagioclase, those of hornblende are much less numerous; and some of magnetite and titanite can be readily detected with the hand lens. Float was observed at several localities where the porphyritic character was much more pronounced. The porphyritic crystals being large and the groundmass rather fine, the relation of

1 Gilbert, G. K., op. cit., p. 16.

2 Cross, Whitman, Geology of Leadville: U. S. Geol. Survey Mon. 12, pp.359-362, 1886; The laccolithic mountain groups of Colorado, Utah, and Arizona: U. S. Geol. Survey Fourteenth Ann. Rept., pt. 2, p. 175, 1893. 
this "bird's-eye porphyry" to the normal porphyry was not observed. In some of the smaller dikes and sills the groundmass is very fine grained and the porphyritic character of the rock is more pronounced, the color is much darker, and the rocks resemble a dense lava and are sometimes mistaken for eruptive rock, as in the case of the Howell laccolith.

Mineralogically the rocks show a marked resemblance throughout and are doubtless to be considered as of a common type. Dutton designated the rocks as trachytes, but their mineral composition is typical of the type now called quartz monzonite or granodiorite, and they may be properly called quartz monzonite porphyry, though some of the rock corresponds more nearly to granodiorite porphyry.

The following petrographic description of the rocks was written by Cross $^{1}$ from a study of the specimens collected by Gilbert:

The rock collection made by Gilbert is now represented in the United States National Museum by specimens from about 30 different masses. They represent large and smaIl laccoliths, sheets, and dikes, and come from all parts of the group. As a rule but one specimen was collected from each mass, but the uniformity of these rocks is so great that in most cases the average of the mass is no doubt fairly represented by the single specimen.

As was indicated by Dutton's examination, there is practically but a single rock type. It is a holocrystalline porphyry, characterized by phenocrysts of plagioclase, with hornblende or augite, and by a granular groundmass consisting chiefly of orthoclase and quartz. Its granular equivalent would be a quartz-bearing diorite, and its lava form would be andesite, approaching dacite in some cases. The rock is what has hitherto been called porphyrite by American petrographers and by some Europeans.

The group is especially characterized by its uniform porphyritic structure. Among the phenocrysts plagioclase is always the dominant mineral. It occurs in stout crystals usually between 1 and 4 millimeters in length with a few somewhat larger ones. Occasionally the average size is nearly 5 millimeters, but more frequently it is less than 3 millimeters. Hornblende and augite are smaller than the plagioclase in general, with a tendency of the former to develop here and there in prisms 1 centimeter or more in length.

Nearly all of the rocks are hornblendic without either augite or biotite. In four of them augite replaces most of hornblende and in two others is present in subordinate amount. Biotite is a minor constituent of a single rock.

Quartz phenocrysts, always more or less rounded by resorption, were observed in eight rocks, and are no doubt sporadically present in nearly all of them. Orthoclase phenocrysts are developed sparingly in two rocks, but these are not to be compared with the large crystals occurring in some types to be described from other groups.

1 Cross, Whitman, Laccolithic mountains of Colorado, Utah, and Arizona: U. S. Geol. Survey Fourteenth Ann. Rept., pt. 2, p. 175, 1893.
Garnet appears scattered irregularly through two of the specimens.

The groundmass is typically granular in the great majority of cases, and consists most naturally of quartz and orthoclase. As quartz decreases the evenness of grain diminishes, and in the feldspathic rocks the grains are elongated instead of exhibiting even dimensions. If plagioclase enters into the groundmass it is in microlitic form. The quartz is clear and distinct from the more or less clouded orthoclase, except in the finer-grained rocks. A tendency of the quartz to form rude dihexahedral crystals is often seen. Micropegmatitic structures are entirely absent. In two cases a patch or micropoikilitic structure is imperfectly developed.

The average size of the groundmass grains is between 0.02 and 0.04 millimeter for more than half the rocks. In another large division the groundmass is cryptocrystalline, though never far below the limits of probable identification. The average grain rises above 0.04 millimeter in but three rocks, and never reaches 0.1 millimeter.

The microscopic accessory constituents are apatite, magnetite, and zircon, in the usual development; titanite, very characteristic of a large number; and allanite, seen sparingly in five rocks. Magnetite often occurs in two generations - in large phenocrystic grains and in minute ones belonging to the groundmass.

Distribution of types.-The different mountains and different kinds of occurrences are quite evenly represented in the collection. Eight are from large laccolites, three from small ones; eight from sheets, and nine from dikes.

The augite-porphyrites are all from Mount Pennell or Mount Hillers, but hornblendic rocks apparently predominate in both mountains. The augitic types are mainly from sheets, but it is possible that the main Hillers laccolite is of this rock.

As to the grain of the rocks - the cryptocrystalline forms are all from dikes, mainly in Mounts Ellsworth and Holmes. The average-grained rock occurs in laccolites, sheets, and dikes. The three coarser-grained ones come from dikes or sheets in different mountains.

The observations then confirm the conclusions of Dutton that these specimens indicate no differences of composition or structure corresponding either to geographical or geological distribution or to the size or form of the intruded masses. The collection is of course not large enough to permit of a positive statement that no correspondence between occurrence and characteristics of any kind exists in the Henry Mountains, but it does clearly prove that certain generalizations can not be made.

Three analyses of the intrusive rock of the Henry Mountains are given on page 94 .

AGE.

The age of the intrusive rocks from direct evidence can only be determined as later than the Cretaceous sediments which they intrude. No Tertiary sediments are present in the vicinity of the Henry Mountains. From a consideration of the depth at which the laccoliths are supposed to have formed, Gilbert says that "what evidence we have, then, indicates that 
the epoch of laccolitic intrusion was after the accumulation of deep Tertiary deposits and before the subsequent degradation had made great progress; that it was at or near the close of the epoch of local Tertiary sedimentation."

\section{METAMORPHISM.}

The effect of the intrusive bodies on the adjacent sediments is described by Gilbert as follows:

Wherever the trachytes came in contact with the sedimentaries the latter were more or less altered. Large bodies of trachyte produced greater changes than small. The laccoliths both metamorphosed their walls more completely and carried their influence to a greater distance than the sheets and dikes. The summits of the laccoliths had a greater influence than the edges, a phenomenon to which I shall have occasion to revert. The sandstones were less affected than the shales, at least in such characters as readily catch the eye. Clay shales were indurated s. as to clink under the hammer, and Capt. Dutton discovered with the microscope that minute crystals of feldspar had been developed. Sandstones were usually modified in color, and their iron was segregated so as to give a mottled or speckled appearance to the fracture. They were indurated, but the granular texture was always retained.

The trachyte carries numerous small fragments of sedimentary rock broken apparently from its walls, and these are as thoroughly crystalline as their matrix.

The altered rocks are usually jointed, but nothing approaching to slaty cleavage was seen, nor has there been any crumpling.

The reciprocal influence of the sandstone and shale upon the trachyte was small. Specimens broken from the contact surface of a laccolith and from its interior can not be distinguished. In the Marvine laccolith, however, there is a difference between the exterior and interior portions in their ability to withstand erosion.

On the ridge extending from Mount Pennell toward Mount Hillers rather notable contact alteration was noted. Blocks of shales, shaly sandstones, and apparently some sediments rather rich in lime carbonate are partly inclosed in the monzonite porphyry. The shales have been rather highly indurated, and the calcareous sediments contain abundant contact minerals. Epidote is the most abundant of these; garnet and a green amphibole and probably other silicates are present; and magnetite and specularite occur in small amount. Some pyrite is present, and the rather abundant limonite indicates that it may have been rather plentiful. Small fissures in the monzonite porphyry near the altered sedimentary rocks also contain contact minerals, notably epidote, and the porphyry rock adjacent to the contact contains epidote as an alteration product of other minerals. At several points around the mountains pieces of float containing contact minerals were observed, and it is evident that considerable contact alteration accompanied the intrusion.

\section{STRUCTURE.}

The general structural relations of the Henry Mountains are relatively simple. They are laccolithic mountains and are usually referred to as the type of this structure on account of Gilbert's classic description of them, in which the term was first applied, though the general structural relations of such mountains had been ascertained some years earlier from studies of similar mountains in Utah and Colorado.

The simplest form of laccolithic mountain is produced by the intrusion of igneous ma-

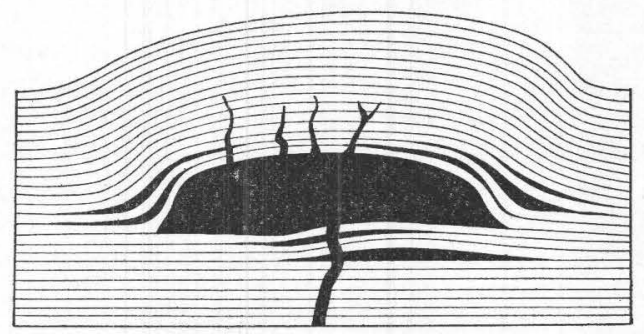

FIGUP.E 72.-Ideal cross section of a laccolith, with accompanying sheets and dikes. After Gilbert.

terial through a fissure till it reaches a horizon favorable for its extension laterally. Such conditions may result from the presence of a body of shale through which the fissure does not pass. A stratigraphic break may also favor lateral movement. The material moving outward tends to form a body with a circular outline. As more material is added, the pressure from below, transmitted through the fluid mass, lifts the overlying strata to make room for additional material and eventually forms a distinct dome. (See fig. 72.) The arching of the strata would naturally fissure the upper portion of the dome, and the igneous material would occupy such fissures and form dikes such as are common in the mountains of this group, notably in Mount Ellsworth. It is readily seen that though the typical laccolith is of simple structure, the igneous material is likely to spread out at different horizons and to produce a great complexity of laccoliths, sills, and dikes, and such is the case in many places in the Henry Mountains. (See fig. 73.) 
The accompanying diagram shows the horizon of the laccolithic bodies of the different peaks and the number that Gilbert determined for each peak.

The peaks, as they exist to-day, are the result of erosion. The igneous rocks forming the laccolithic bodies are more resistant to weathering and erosion than the surrounding

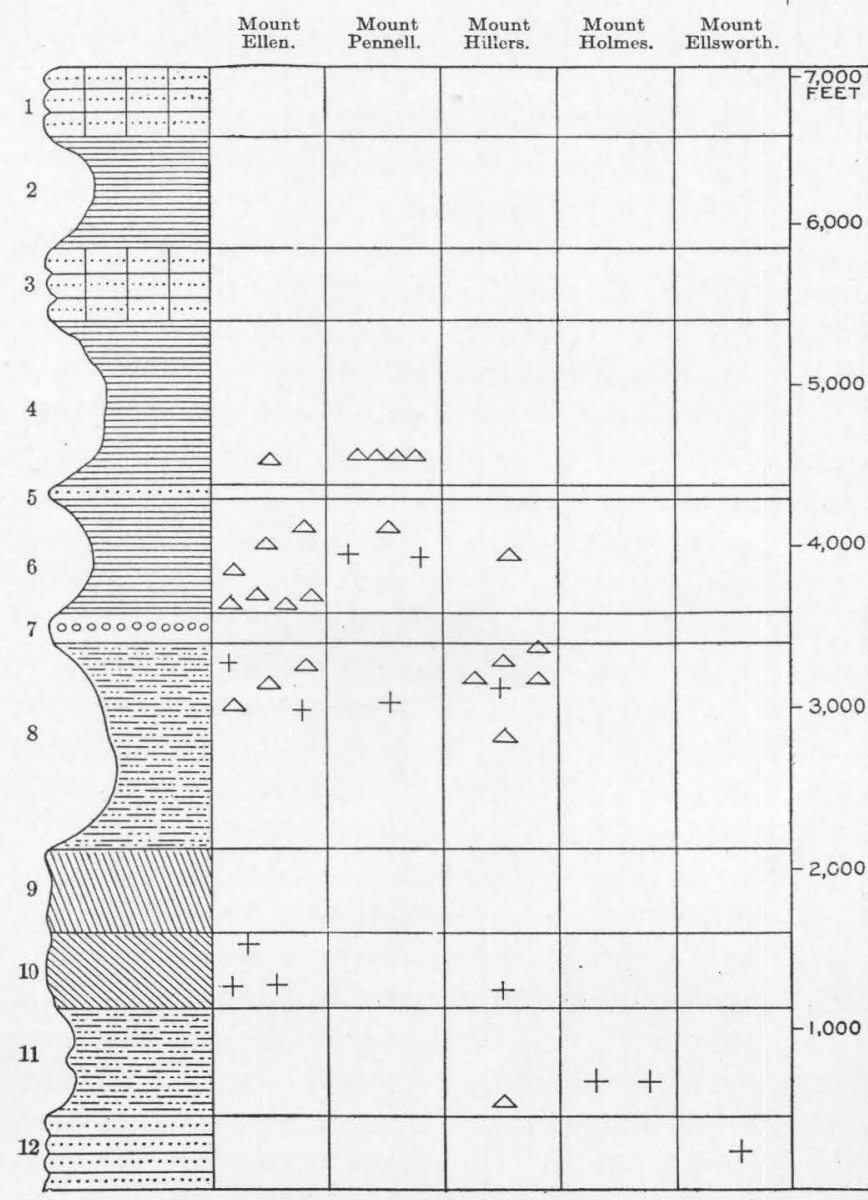

FigURE 73.-Diagram showing the vertical distribution of the laccoliths of the Henry Mountains. Triangles mark the horizons of determined laccoliths and crosses mark the horizons above which the invisible laccoliths can not rise. After Gilbert. 1, Masuk sandstone; 2, Masuk shale; 3, Blue Gate sandstone; 4, Blue Gate shale; 5, Tununk sandstane; 6, Tununk shale; 7, Henry's Fork conglomerate; 8, Flaming Gorge shale; 9, Gray Cliff sandstone; 10, Vermilion Cliff sandstone; 11, Shinarump shale; 12 , Aubrey sandstone.

sedimentary rocks and have consequently worn. away less rapidly.

\section{HISTORY AND PRODUCTION.}

The first lode deposit to be discovered in the Henry Mountains that proved of any consequence was the Bromide vein, which is said to have been discovered in 1889 or 1890 by the partners, J. C. Sumner and Jack Butler. Active development of the mine was carried on in 1891, and a stamp mill was built and operated intermittently till the following summer. The mine was closed in 1893 and remained idle till 1902, when it was reopened and made a small production. In 1913 it was idle and had been for some time. The finding of the Bromide vein stimulated prospecting in the region, and severalsmall veins were discovered and prospected to some extent. Next to the Bromide the most extensive development has been on the Oro prospect. A one-stamp mill was erected and some ore treated.

Interest in the carnotite deposits of Colorado and eastern Utah resulted in prospecting for similar ores in the Henry Mountains region in 1912, since when numerous deposits of uranium and vanadium ore have been located.

For several years there has been a small gold production from the channel of Crescent Creek and from the benches near its head. Placer gravels along Colorado River near the base of the mountains are described on page 637.

The metal production of the region is not known but has not been large. It is reported that the Bromide mine produced about $\$ 15,000$ in 1892 and a little more since. The uranium and vanadium ores were shipped from the district in 1913 and 1914, but there has been little shipped since the opening of the war.

\section{ORE DEPOSITS.}

DEPOSITS IN OR CLOSELY ASSOCIATED WITH INTRUSIVE ROCKS.

\section{VEINS.}

The fissure deposits in the igneous rock are prevailingly gold-copper deposits. The area most extensively prospected and apparently most promising is near the head of Crescent Creek, in the general vicinity of the Bromide and Oro, the only mines that have been productive.

Bromide mine.-The Bromide vein is typical of the group. It outcrops about 9,000 feet above sea level, strikes a little east of north, and dips very steeply west. It has rather well-defined walls, the distance between which varies greatly along both the strike and the dip, in places coming nearly together and in other places separating to a width of 4 feet or more. 
Numerous fractures that cross the main vein nearly at right angles appear as a rule to have had little effect on it. There has been slight movement in some of them, and it is said that one small cross vein containing amethystine quartz was rich in gold where it crossed the main vein.

The vein filling is very largely brecciated wall rock that has been slightly altered by the ore solutions, some vein quartz, and a fibrous white mineral, mainly laumontite though possibly containing other zeolites. The principal primary metallic minerals are pyrite, chalcopyrite, specularite, magnetite, and ilmenite. The magnetite and ilmenite may not be true vein minerals but may have been contained in the original quartz monzonite. A sample of mill concentrates contained a large percentage of magnetite, a lesser amount of rather feebly magnetic material, and a residue largely composed of sulphide and copper carbonates. Native gold contributes most to the value of the ore.

The wall rock in and adjacent to the vein has been somewhat altered. The freshest quartz monzonite in the vicinity of the vein shows a slight secondary development of epidote and carbonate and a little pyrite. In the vein the feldspars have been partly sericitized, the hornblende partly altered to chlorite, which has also been deposited in open spaces in small spheroidal masses. The alteration of the wall rock has been in most places comparatively slight. To the depth of the tunnel level the ores have been partly oxidized, the sulphides altering to oxides of iron and carbonate of copper.

The mine has been opened by a tunnel about 380 feet long connecting with a shaft at a depth of about 125 feet. A winze has been sunk 60 feet below the tunnel level. The vein has been developed on the tunnel level for perhaps 200 feet and has been stoped on different levels from the tunnel level to the surface. It is reported that ore is present in the bottom of the winze, but at the time of visit this was filled with water and could not be examined. A crosscut tunnel, started from Crescent Creek near the mill, will, if extended, intersect the downward extension of the plane of the vein about 400 feet below the present tunnel level. The face of the crosscut tunnel was about 900 feet from this objective point in 1913.
Exact figures of the average grade of the ore are not available, but Frank Bennett estimates that the ore milled yielded $\$ 10$ to $\$ 11$ per ton on the plates and that an additional amount was obtained from the concentrates. The mine is equipped with a five-stamp mill with amalgamation plates and a Wilfley table.

Cuprum claim.-On the Cuprum claim, a short distance east of the Bromide vein, a magnetite vein strikes about north and stands nearly vertical. Where examined in an open cut it had a maximum width of about 18 inches with small stringers extending through the adjacent quartz monzonite.

The vein mineral is principally magnetite (lodestone) with a small amount of quartz and copper carbonate. A large part of the copper minerals are associated with the quartz and have probably been derived from sulphides that may have been deposited most abundantly with the quartz.

The wall rock has been altered in a manner similar to that of the Bromide vein, though in the specimens examined alteration appeared more intense in the magnetite vein.

The ore is said to carry $\$ 4$ to $\$ 5$ per ton in gold, and some of it contains notable amounts of copper carbonate. The ore containing most copper is said to be richest in gold.

Oro mine.-The Oro mine is on the opposite side of Crescent Creek from the Bromide and at a slightly lower elevation. The vein, which strikes nearly north and dips steeply west, is similar to that of the Bromide. It has been developed by several hundred feet of tunnel and a shaft about 70 feet deep. Some ore has been milled at a one-stamp mill on Crescent Creek.

Other claims.-Other veins in the same region are said to be similar in character but have been but slightly prospected. There has been a little prospecting on the east side of Mount Pennell near the head of Straight Creek. The mineralization has been along fracture zones in the porphyry. At the surface it consists principally of oxides of iron and carbonate of copper.

On the Baby Ruth claim small irregular fissures in the porphyry have been prospected. The porphyry is rather fine grained and in the vicinity of the fissures has been slightly silicified. The gold is apparently in small veinlets of limonite that ramify the brecciated por- 
phyry. Some of the ore is said to be high |Crescent Creek deposits are reported to have grade, but the average is low. An arrastre on been located, and on Crescent Creek W. Hicks Straight Creek about 2 miles below the mine is said to have treated a few tons of ore.

A little prospecting has been done on Mount Hillers. The prospects were not visited by the writer, but from descriptions they appear to be similar to the copper prospects of Straight Creek.

CONTACT DEPOSITS.

A little prospecting has been done in the contact deposits, especially in those on the ridge extending from Mount Pennell toward Mount Hillers. Irregular blocks of the sedimentary rock, mainly shales but in part evidently calcareous, rest on the quartz monzonite. In the calcareous members abundant contact silicates, mainly of a yellow-green epidote but also containing amphibole and garnet, have developed. Pyrite was seen in some specimens, and the amount of limonite in places suggests that sulphides were originally present in considerable abundance. Some of the limonite is said to contain as much as $\$ 20$ in gold per ton. The contact material at other points is said to contain small amounts of gold.

At the time of the writer's visit several claims had been located for thorium, which was said to occur in the epidote. A sample of this material, however, which was submitted to the chemical laboratory of the Geological Survey, was reported by W. T. Schaller to contain no thorium and no rare earths.

\section{DEPOSITS IN SEDIMENTARY ROCKS.}

The most important deposits in the sedimentary rocks are of uranium and vanadium. Minerals containing these elements have been found in sandstones of Gilbert's Flaming Gorge group that are believed to be equivalent to the McElmo formation of western Colorado. The formation outcrops along the eastern side of the mountains from Bowl Creek on the north to a point south of Mount Hillers, passes between Mount Hillers on the north and Mount Holmes and Mount Ellsworth on the south, and extends southwest to Hoxie (Hall) Creek. (See fig. 74.) At numerous localities uraniumvanadium deposits have been found. The northernmost deposit known is about 2 miles south of Gibbon's ranch. Between this and bearing gravels in this locality has been known

has located several claims. Near Trachyte Creek the Standard Chemical Co. has done a large amount of development work, and in 1914 shipped considerable ore. Four to five miles northwest of Mount Ellsworth the Standard Chemical Co. has also done considerable development and has shipped ore from the Delmont and Lida groups of claims.

The occurrence of these ores is similar to that of radium-bearing ores in sandstone elsewhere in Utah. Most of the minerals are closely associated with carbonized plant remains. Where the plant remains are entirely silicified no deposits were seen. Thus in the rather extensive exposure of the sandstone between Hoxie (Hall) and Pine Alcove (Bullfrog) creeks, and east of the latter, silicified trees are rather plentiful in places, but no uranium or vanadium was noted with them.

Some deposits are confined to a single tree trunk and some form lenses in the sandstone. Such lenses had been followed in on the bedding for 60 to 75 feet (1914), rarely more, but most of them pinch or decrease in value within a much shorter distance.

The mineralogy of the ores is similar to that in other sections. The principal uranium mineral is carnotite. Vanadium is present in the carnotite and as hewettite or metahewettite. An undetermined chromium compound is associated with many of the deposits, and they contain small amounts of selenium.

The origin of the deposits is doubtless the same as that of the similar deposit in Utah and Colorado. (See p. 155.)

Along Colorado River there has been some prospecting of the Triassic sandstone. Small deposits of copper have been found and uranium minerals are re ported, but there has been no production of either. These deposits occur at essentially the same horizon as those in White Canyon.

\section{PLACER DEPOSITS.}

Placer gravels occur in the bed of Crescent Creek and on benches at higher levels. In 1914 the gravels in the bed of the creek were being sluiced and some dry washing was being done on the higher benches. The presence of geld- 
for several years but they have yielded in all When the streams renewed their downcutting only a few hundred dollars in gold. the bench gravels were in part reworked and

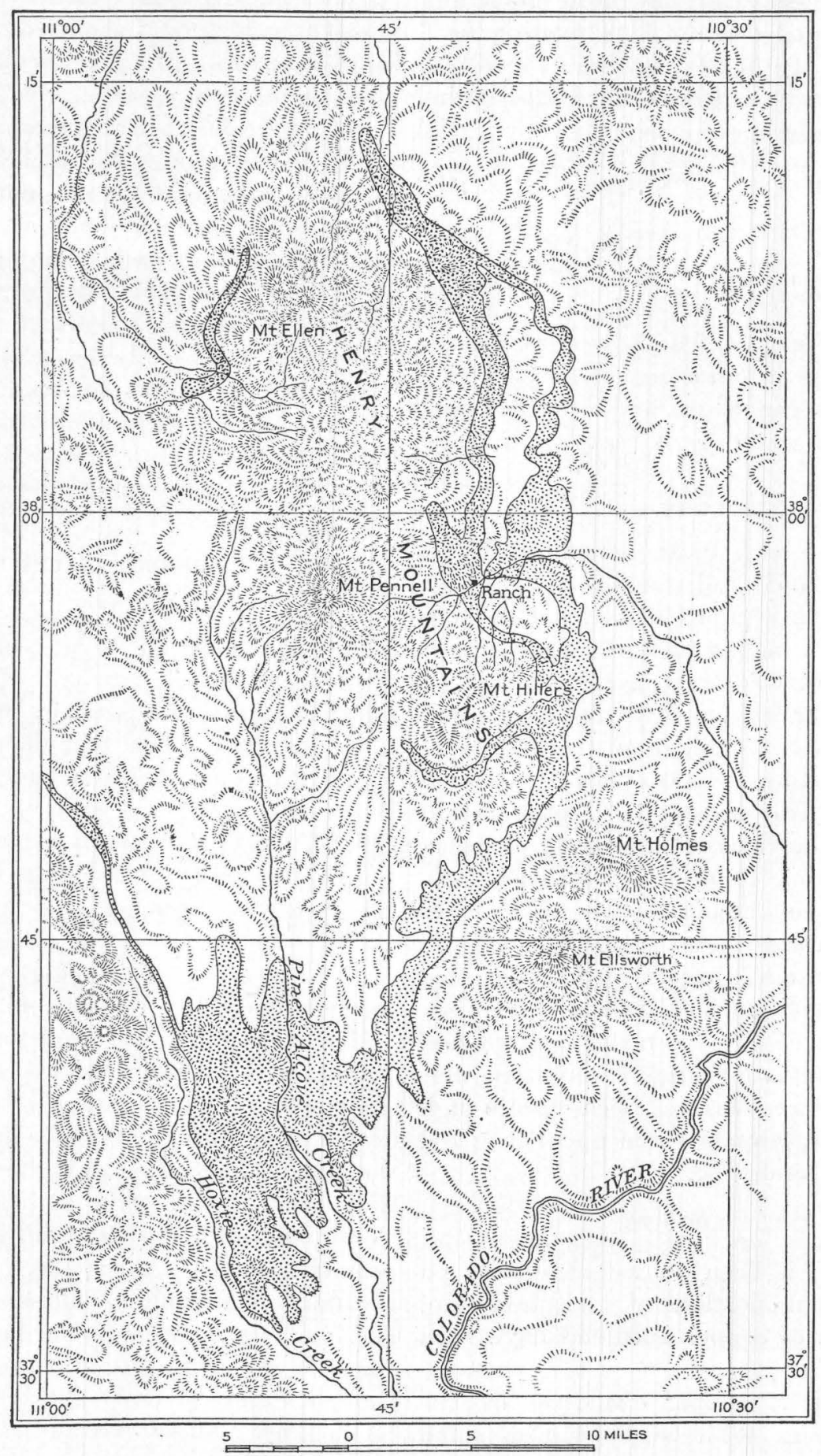

FIgURe 74.-Sketch map showing distribution of the uranium-vanadium bearing sandstone in the vicinity of the Henry Mountains. Prepared by B. S. Butler and W. L. Whitehead.

The gravel on the benches apparently accu- formed the channel gravels. Barite sand is mulated from the material coming from the abundant in the placer gravels and is believed mountains before the present canyons were cut. to be derived from veins in the mountains at 
the head of Crescent Creek. The placer gravels, so far as known, are confined to Crescent Creek, near whose head the most important gold-bearing veins occur. This relation naturally leads to the belief that the gold of the placers was derived from the gold-bearing veins in the mountains.

\section{MINERS MOUNTAIN.}

By B. S. Butler.

Miners Mountain is in the western part of Wayne County, a few miles southeast of the settlement of Torrey and southwest of Fruita. For many years intermittent prospecting for copper has been carried on, and a few hundred pounds of high-grade ore is reported to have been shipped.

\section{GEOLOGY.}

The youngest rock in the mountain is an impure, shaly, and sandy limestone about 75 feet thick. This is underlain by 100 to 150 feet of red shaly beds, which in turn is underlain by a massive sandstone having an observed thickness of over 200 feet with the base unexposed. Fossils collected from the limestone were determined by G. H. Girty to be of Lower Triassic age. The underlying shales should probably also be regarded as Lower Triassic, and the sandstone is probably Carboniferous. Surrounding the mountain are the higher Triassic and Jurassic formations.

Miners Mountain consists of an elongated dome-shaped uplift which trends northwest. The surface of the dome is mainly determined by the rather resistant Triassic limestone, but in numerous places this has been cut through by the streams, revealing the underlying red shales and the sandstone.

\section{ORE DEPOSITS.}

Prospecting has been carried on mainly on the southeastern portion of the mountain, where deposits of copper and lead have been explored.

The deposits of copper examined by the writer and W. L. Whitehead occur as small lenses in sandstone and shale strata in the red shale series just beneath the fossiliferous limestone. The ores are practically all oxidized, consisting of azurite and malachite associated with considerable limonite. In the development of the deposits several shafts have been sunk to depths of 30 to 50 feet and short tunnels have been driven.

The lead deposits examined occur in the massive sandstone formation, probably 200 feet below the top. A lenticular zone of less massive material between two massive beds of sandstone has been mineralized for several hundred feet along the strike. Limonite is the most abundant of the metallic minerals. With it are stringers and small kidneys of cerusite, and disseminated through it is plumbojarosice in small amount and possibly other sulphates. So far as learned there has been no production from the lead deposits.

The deposits of Miners Mountain are similar to the "red bed" deposits at other localities in the State and doubtless have a similar origin. The genesis of this type of deposit is discussed on page 155 .

\section{RABBIT VALLEY.}

GEOLOGY.

The domal structure of Miners Mountain extends northwest nearly to Thurber, where the sedimentary rocks are buried beneath volcanic material. The boundary between the sedimentary and volcanic rocks is said by Dutton to mark the site of a great fault. From Thurber to a point a few miles east of Torrey the valley of Fremont River has been cut near the crest of this dome. East of Torrey the stream flows along the northern side of the dome to the point where it breaks through the Water Pocket fold.

The Carboniferous sandstone of Miners Mountain is overlain by red shaly beds and shaly and sandy limestone of Lower Triassic age. Along either side of the mountain and to the north of the valley lie higher Triassic shales with beds of sandstone, and above these the Vermilion Cliff and White Cliff sandstones form prominent cliffs. About 150 to 200 feet below the massive Vermilion Cliff sandstone are two, and in places three, lenticular beds of sandstone that are rather persistent through the region, though at any given locality one or more may be lacking. These contain rather abundant plant remains.

\section{URANIUM DEPOSITS.}

Deposits of uranium associated with the plant remains in the sandstone beds were observed near the mill east of Thurber and are 
reported from several localities between there and Grand Wash, and thence southward along the west side of the Water Pockets beyond Temple Creek. A little prospecting has been done near the Thurber mill and at other points, but the only place from which there has been production is at the head of Grand Wash, near Fruita (Junction). The sedimentary series at this point follows:

\section{Section near Fruita (Junction).}

Massive cross-bedded Vermilion Cliff sandstone.

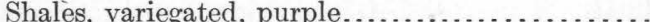

Sandstone, brown........................ 15-20

Peculiar conglomeratic rock composed of concretionary bodies, mainly calcium carbonate in clay matrix, with interbedded limestone........... Shale, chocolate.

Sandstone, loosely cemented, gray, with streaks of red and green; contains abundant plant remains. 10-20

Shale, chocolate........................ 30

Sandstone with fossil trees.

Shale, chocolate......................... \pm 10

Sandstone, gray .......................... \pm 10

Shale, green and chocolate.

The Triassic rocks at the head of Grand Wash comprise three sandstones that contain fossil plant remains. The lower has a maximum thickness of 10 feet at Grand Wash but is distinctly lenticular and toward Capital Wash reaches a thickness of 30 to 40 feet. On the Old Dixon prospect, the only prospect from which shipment has been made, uranium minerals occur in a lens containing carbonized plant material. On the opposite side of the wash the fossil material observed was mainly logs and contained little uranium but considerable iron. The second sandstone is rather strongly cemented, contains but few logs, and these are but little mineralized. The upper sandstone is loosely cemented and contains abundant logs, some of which are 3 feet in diameter. The logs are mainly silicified but are commonly surrounded by a thin layer of carbonized material. Outside the carbonized material surrounding the $\operatorname{logs}$ and associated with that within the logs are red and yellow minerals, mainly hydrous ferric oxides and sulphates, probably mainly limonite and jarosite. Some of these iron minerals rather strongly resemble uranium and vanadium minerals and are frequently mistaken for them.

The uranium occurs as it does in the Triassic rocks at other localities and is doubtless of similar origin.

\section{NAVAJO MOUNTAIN.}

By B. S. Butler.

Navajo Mountain is on the Utah-Arizona boundary, a few miles south of the junction of San Juan and Colorado rivers, in the midst of a rough desert region, remote from railroads and difficult of access. The discovery of a great natural bridge ${ }^{1}$ a few miles north of the mountain has attracted a few travelers in recent years; otherwise the district has few attractions.

Topographically, the mountain is a great dome that reaches an elevation of 10,400 feet and is deeply dissected by streams radiating from the summit.

The sedimentary rocks of the mountain are sandstone and shales of Jurassic and Triassic age with a small area of Cretaceous rocks at the summit. ${ }^{2}$ Igneous rocks have been generally reported, but Gregory states that none are exposed. The dome structure, however, is interpreted as being due to an underlying igneous mass that has lifted the overlying sedimentary rocks.

As is common with remote and difficultly accessible regions, rich silver and gold deposits in the vicinity of Navajo Mountain have been vaguely rumored. Gregory, however, says that there is little basis for the reports. It should be borne in mind, however, that uranium and vanadium deposits may be found around this mountain, and that some copper deposits of the character common to the Plateau region are known to be present there.

\section{PARIA REGION.}

By B. S. Butler.

Paria, in Kane County, has been the scene of some mining activity, mainly for gold, and uranium deposits in Triassic sandstones have been reported from a few miles farther south. No description of the uranium deposits has been published, but they are probably similar to those in the Triassic at other localities in the State.

1 Cummings, Byron, The great natural bridges of Utah: Nat. Geog. Mag., vol.21,pp.156-167, 1910. Pogue, J.E., The great Rainbow Natural Bridge of southern Utah: Nat. Geog. Mag., vol. 22, pp. 1048-1056, 1911. Roosevelt, Theodore, Across the Navajo Desert: The Outlook, Oct. 11, 1913, pp. 309-317.

2 Gregory, H. E., Geology of the Navajo country: U. S. Geol, Survey Prof. Paper 93, map, 1917. 


\section{GEOGRAPHY.}

The writer has not visited Paria, but an account of the region, quoted in large part below, has been published by A. C. Lawson. ${ }^{1}$

Paria is a settlement on a flood plain of the Paria River now consisting of one family, which maintains a post office for the convenience of the sheepherders of the region. It is situated about midway between Lees Ferry at the head of the Marble Canyon and Canyonville in southern Utah. To the north and south of Paria the river flows through a narrow canyon with precipitous walls, but at Paria the course of the stream is in the Shinarump clay for about 3 miles; and in this stretch it has, by horizontal corrosion, evolved a conspicuous flood plain having a maximum width of about half a mile. On the northeast side of the flood plain the Shinarump clay forms a buttressed pedestal about 400 feet high, upon which rests the massive brightred sandstone of the Vermilion Cliff. The total height of the scarp is probably about 800 feet and its upper half is vertical. The lower half of the scarp, forming the pedestal, is a curiously sculptured slope having a width at the southeast near Paria of from 400 to 500 feet, but widening toward the northwest to about 3,000 feet. The slope is dissected by numerous steep gulches which head up to the base of the vertical cliff; and these have tributary gulches. The areas bounded by the drainage lines of these gulches are shaped in smooth, steep-sided, bare domes. The surface of the slope is thus remarkably mammillary, and presents a type of erosional form which is quite characteristic of the Shinarump, although it has been scarcely alluded to in numerous descriptions of the physiography of the Plateau province. * * *

On the southwest of the Paria flood plain the Vermilion Cliff sandstone has been removed, except for one isolated butte about 40 acres in extent; and the relief is determined by the peculiar mammillary or domed forms of the Shinarump clay. The breadth of the clay on this side of the river is about 4,000 feet. At its southwestern margin the clay is seen in fine exposures to rest upon a light-gray sandstone, with a gentle northeast dip. This sandstone, being more resistant than the clay, projects generally beyond the limit of the latter as a well-defined backwardsloping bench.

To the southwest of the Shinarump extends the Permian, the upper surface of which forms a gently sloping plateau on the flank of the East Kaibab monocline. The plateau is intricately dissected by innumerable narrow vertically walled canyons, so that it is practically impossible to traverse it. Still farther to the southwest, this sloping plateau of Permian strata ends at an escarpment overlooking the top of the Aubrey limestone as it bends up in the great monocline.

\section{GEOLOGY.}

In the Plateau province he who runs may read the sequence of formations. In my own case the pleasure of the reading was drawn out in a leisurely walk of 80 miles from Lees Ferry to Paria by way of House Rock Valley. Along this route the great roll of the East Kaibab monocline is splendidly revealed in the surface of the Aubrey

1 Lawson, A. C., The gold of the Shinarump at Paria: Econ. Geology, vol. 8, pp. 434-446, 1913. limestone, where it has been stripped of its covering of Permian and later strata. In the descent from the head of House Rock Valley to Paria the Permian is exposed from top to bottom in the winding canyon followed by the wagon road. It consists of several hundred feet of thinly bedded red-mud shales and sandy shales. In its lower and middle part the strata are traversed by innumerable narrow gash veins of gypsum. These range usually from an inch to an eighth of an inch in thickness, and lie nearly flat, but generally at a small angle with the bedding. * * *

In the upper 200 to 300 feet of the Permian section the gypsum veins are not notable features of the canyon walls. The latter are variegated in color, however, by the intercalation of thin beds of green shale with the prevailing red beds. The green beds make up about 10 per cent of this portion of the Permian section. The uppermost bed of the Permian is distinct from all below it in that it is a persistent stratum of hard, massive red-brown sandstone from 10 to 20 feet thick.

Resting on the Permian is the basal formation of the Shinarump group. The superposition is well exposed along a northwest-southeast line of contact less than a mile southwest of the Paria River at Paria. The basal formation is from 30 to 50 feet thick and is a rather coarsetextured light-gray sandstone, which is in some parts pebbly, and which contains numerous fragments of silicified wood. The stratigraphic relation of sandstone to the underlying Permian is described by Walcott ${ }^{2}$ as unconformable. The erosional break figured by him is very plain at one locality, but as he points out it involves no essential discordance in the dip of the two formations; so that it is not easily detected elsewhere.

The clays of the Shinarump which rest on this basal sandstone are the most interesting feature of the section. They have a maximum thickness of about 400 feet on the northeast side of the Paria but appear to be considerably less than this in the section through the butte on the southwest side, where the complete section of the beds between the Permian and the Vermilion Cliff sandstone is revealed.

The stratification of the Shinarump clays is not less remarkable than their erosional forms. Viewed at a distance the formation is seen to consist of thick layers of different colors sharply marked off one from another. One or two beds of sandstone occur in the sections, but with this exception the diversely colored layers are homogeneous as to texture and resistance to erosion; so that the bedding planes do not mark any break or interruption of the profiles of the domes into which the whole formation has been carved. The colors of the beds have been subdued by weathering, so that the strong deep tones seen in fresh cuts appear as faded and harmonious tints on the natural slopes. The general effect is that of a pleasing gray relieved by thick horizontal bands of pink, chocolate, maroon, green, purple, black and white; but the gray tints prevail in the lower part of the section and the reddish tints in the upper part. ***

Three sections of the Shinarump clays were examined in great detail by cutting trenches in the face of the slopes. One of these was chosen on the northeast side of the Paria flood plain, one on the southwest side, and the third on the southwest margin of the formation where it overlooks the 
Permian plateau. The sections were thus about half a mile apart. and on a line transverse to the strike of the formation.

The first-mentioned trench was a continuous cut from the level of the river up to a point 210 feet above it across the edges of the strata in the middle part of the formation. The second was similarly cut from the level of the river across 174 feet of the lower part of the formation. The third was cut from the top of the basal sandstone across 240 feet of the clays, or about two-thirds of the total thickness in this section. The measurements of the beds in these trenches afforded an exact section of the Shinarump as far as they extended, but as the measurements had to do merely with color distinctions, the character of the beds being for the most part otherwise identical, I shall here refer only to certain special features. In the most southwesterly section a 2-foot bed of light-gray medium-textured sandstone was encountered interrupting the continuity of the clays at 110 feet above their base. Above this the clays are sandy for several feet. Half a mile to the northeast, in the middle section, a bed of similar sandstone 15 feet thick occurs, the base of which is 125 feet above the Paria flood plain. Half a mile to the northeast, in the remaining section, this same bed of sandstone has expanded to a thickness of 50 feet of soft sandstone with a layer of 2 feet of hard sandstone at its base. Above the 50-foot bed of sandstone, after an interval of 9 feet of red and purple clays, is another bed of sandstone, 4 feet thick, which is much harder than the thick bed below. Along the northeast side of the Paria these sandstones are prominent features of the Shinarump section and form a notable interruption in. the otherwise smooth profiles of the clays. In the most southwesterly section a 4 -foot bed of black clay occurs 23 feet above the sandstone last described and is succeeded by green clay. In the middle section this black clay is 10 feet thick and contains lenses of chert. It is here succeeded by a bed of hard sandstone 2 feet thick, which causes a notable interruption in the otherwise smoothly domed profiles of the formation. This black clay is missing in the section on the northeast side of the Paria.

Besides these variations in the stratigraphy of the Shinarump clays it is also apparent that the colored bands, which appear so uniform in particular sections, are not persistent; but that in the same stratigraphic horizon the colors are to a considerable extent interchangeable.

Throughout the clays of the Shinarump there are numerous irregularly nodular concretions consisting almost wholly of carbonate of lime and magnesia. These have diameters ranging up to about 2 inches, but most of them measure less than an inch across.

On top of the Shinarump clays lies the massive, red Vermilion Cliff sandstone splendidly displayed in a vertical cliff on the northeast side of the Paria to a thickness of about 400 feet. The change from the clays to the sandstone is abrupt, and there is little or no evidence of the transitional gradation which Dutton has observed at this contact in other parts of the Plateau province. * * *

One of the most striking properties of the Shinarump clay is its behavior in water. Samples of the clay taken in the field are usually moist and the amount of water which may be driven off at $105^{\circ} \mathrm{C}$. is very considerable. But when a fragment of the clay is immersed in water it immediately swells enormously and breaks down rapidly into an incoherent flat cone. When this material is examined microscopically it appears to be composed almost wholly of a colloidal substance with a very small admixture of fine silt and some concretions of carbonate of lime and iron oxide. The swelling and slacking of the clay in water is probably due to the colloidal absorption of water. The mixture is in such a fine state of division that it passes freely through filter paper. This peculiar behavior of the Shinarump clay is in marked contrast to other sedimentary clays, such, for example, as the clay of the delta of the Colorado. * * * The clays of the Shinarump require only to be sprinkled with water to cause them to promptly disintegrate and flow freely with the water. It is this behavior with water that has led to schemes of extracting their gold content by hydraulic methods. With rocks of this kind the rate of erosion, other things being equal, must increase as some large function of the increase of rainfall. If we assume that in Quaternary or Pleistocene time the rainfall of the region was $\mathrm{x}$ times greater than at present the rate of denudation was doubtless $x^{n}$ times greater where " $n$ " is no small figure. At present the rainfall is slight and the result is that the clays have been superficially disintegrated to a depth of from 1 to 2 feet. The swollen clay of this surface layer dries out and becomes a loose fluffy pulp of extreme lightness, softness, and incoherence. At times of heavy rains, such as occur occasionally on the desert, this material is washed down to the river in enormous quantities. It was found by experiment that swiftly running water carries in suspension about 30 per cent of its weight of dry pulp.

A sample of the gray Shinarump clay from Lees Ferry was submitted to chemical analysis by Prof. W. C. Blasdale with the following result:

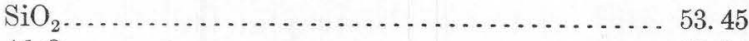

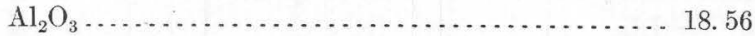

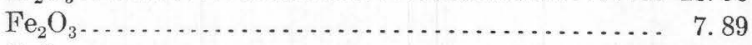

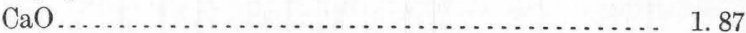

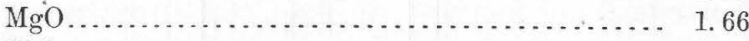

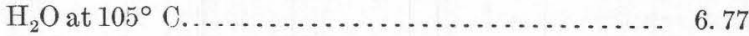
Ignition loss above $105^{\circ} \mathrm{C} \ldots \ldots \ldots \ldots \ldots \ldots \ldots . . .26$

There are also small amounts of carbonates and sulphates soluble in water in the clay. In it most of the iron is present in the form of minute concretions of limonite, and the lime and magnesia are in the form of carbonates. If we deduct these together with the corresponding amounts of $\mathrm{H}_{2} \mathrm{O}$ and $\mathrm{CO}_{2}$ and reduce the balance to percentages we get the following results: $\mathrm{SiO}_{2}=71.6 ; \mathrm{Al}_{2} \mathrm{O}_{3}=$ $24.9 ; \mathrm{H}_{2} \mathrm{O}=3.5$.

From this it appears that the ratio of silica to alumina is nearly $3: 1$, which is far greater than should be the case if the clay, deducting the concretions above referred to, were composed wholly of kaolin. There is not sufficient quartz present to account for the excess of silica. The proportion of water present is also much too small for kaolin. It seems probable, therefore, that a considerable proportion of the flocculent colloidal substance seen under the microscope is in reality silicic acid, and that the presence of silica in this form may account for the peculiar behavior of the clay with water. 


\section{GOLD DEPOSITS.}

DISSEMINATED DEPOSITS IN CONSOLIDATED SEDIMENTARY ROCKS.

CHARACTER OF THE SEDIMENTS.

Finely distributed gold is reported to occur in the sedimentary rocks over wide areas in the Plateau region in formations ranging from Permian to Jurassic and possibly in still younger rocks. Considerable money and time have been expended on this class of deposits, but there had been no known production. Nevertheless the occurrence is of much geologic interest.

The gold occurs in sediments ranging from moderately coarse sandstone to extremely fine clay. It is all very finely divided and, it is said, can not be collected by panning, a fire or amalgamation assay being necessary to determine the tenor of the rock.

An attempt to extract the gold on an industrial scale has been made at Paria, on Paria River, in Kane County, about 15 miles north of the Utah-Arizona boundary, and at Spencer Camp, on lower San Juan River. ${ }^{1}$

\section{PARIA AREA.}

At Paria the gold is contained in part in an extremely fine clay of rather unusual character, which it was once thought might be treated by hydraulic methods. In the fall of 1911 considerable machinery for this purpose was freighted to the camp from Marysvale. So far, however, no method of profitable treatment has been devised.

Lawson ${ }^{2}$ discusses the gold deposits of the clay as follows:

The purpose of my examination of the sections at Paria was in part to determine the quantity of gold present. * * * The nearly horizontal attitude of the beds made it possible to sample the clays by vertical cuts on the face of the bare hill slopes. The cuts were made deep enough to get beneath the veneer of slacked pulp which covers the unweathered clay. A sample from of 25 to 30 pounds was taken every 10 feet measured vertically by leveling. The sampling was done on the assumption that whatever gold the clay might contain was all very fine, and practically uniformly disseminated in any given stratum. The lower part only of the formation was sampled, comprising from one-half to two-thirds its entire thickness. The samples, after careful crushing and quartering, were submitted to Mr. E. H. Simonds, of San Francisco, for assay. This he did with the utmost care, in quadruplicate for each sample.

IGregory, H. E., Geology of the Navajo country: U. S. Geol. Survey Prof. Paper 93, p. 40, 1917.

${ }^{2}$ Lawson, A. C., op. cit.
The first series of 18 samples was taken from a trench 174 feet high on the southwest side of the Paria River. Of these one was found to contain 10 cents per ton, nine 5 cents per ton, two $2 \frac{1}{2}$ cents per ton, four contained a trace, and one contained none. These results were checked by taking an aggregate made up of equal weights of every one of the 18 samples. The assay of this aggregate sample was 5 cents per ton. It is worth noting that the sample which yielded 10 cents per ton was taken from the 15 -foot bed of sandstone described as occurring in this section.

The second series of 22 samples was taken from a trench 210 feet high on the northeast side of Paria. Of these, one yielded $12 \frac{1}{2}$ cents per ton, two $7 \frac{1}{2}$ cents, eight 5 cents, five $2 \frac{1}{2}$ cents, five a trace, and one none. The average of the entire cut is about 4 cents per ton.

The third series of samples was taken from a trench 240 feet high, beginning at the top of the Shinarump sandstone on the southwest margin of the formation. Of these one yielded $7 \frac{1}{2}$ cents per ton, five yielded 5 cents, one $2 \frac{1}{2}$ cents, sixteen a trace, and one none. Confirming these results, an aggregate of equal amounts of 13 samples from the first series of 18 yielded to assay by Mr. W. S. Morley 4 cents in gold per ton. A similar aggregate of 16 samples from the second series yielded Mr. Morley 2 cents per ton, and an aggregate of 20 samples from the third series yielded also 2 cents per ton. Comparable results are obtained by amalgamation assays on large samples, using chemically pure mercury.

To those unfamiliar with the hydraulic method of mining, the gold content of the Shinarump clays may appear tc be so small as to be insignificant and unworthy of attention from a practical point of view. But under the most favorable conditions gravel containing 5 cents per yard, or $2 \frac{1}{2}$ cents per ton, may be worked at a profit. The peculiar way in which the Shinarump clay slacks and runs with water suggests that it may be no less susceptible of hydraulicking than banks of gravel. This suggestion, coupled with an exaggerated notion of the amount of gold contained in the clays, has led to various attempts to exploit them for gold. The ground has been staked out in hundreds of placer claims and these have been offered for sale at large figures. The value of the ground is, however, very problematical. If a method of successful hydraulicking and recovery of the gold be developed, it will only be after a long period of experimentation, at large expense, at a few favored localities where a vast yardage of the clays is free from overburden and where abundant water may be had cheaply. No large expenditure for the acquisition of territory would be justified until the method of winning the gold has been demonstrated.

At present, the occurrence is interesting from a geological rather than a practical point of view. We may safely assume, on the basis of the sampling at Paria, that the Shinarump clay there contains on the average 5 cents per cubic yard. The same formation appears to be similarly auriferous at Lees Ferry and at San Juan, and it is probable from the extreme uniformity in the physical characteristics of the formation wherever it has been observed, that it is similarly auriferous throughout its extent. * * *

The gold is not confined to the Shinarump clays in the Plateau province. A cut 140 feet high was made in the underlying Permian shales and 14 samples secured for 
assay. Of these, two yielded 10 cents in gold to the ton, five yielded 5 cents, six a trace, and one none. An aggregate of equal parts of these 14 samples yielded to an amalgamation assay 4 cents per ton. This result is probably representative of the gold content of the entire thickness of the Permian, since the conditions of sedimentation appear to have been very uniform throughout. The Permian beds do not, however, slack in water, and there is no prospect of their being susceptible of hydraulic mining. They are, however, quite as interesting as the Shinarump as an instance of the occurrence of gold in fine-grained sedimentary rocks.

\section{SAN JUAN RIVER REGION.}

Gold was first reported from San Juan River by an Indian trader named Williams in the fall of 1892. Tales of fabulously rich deposits, both in river placers and in sandstones adjacent to the river, spread through the West, and several hundred men "stampeded" to the region in midwinter (1892-93) and suffered great hardships. The river and its tributaries were staked for many miles. After fighting and bloodshed it was found that the gold was too fine to be worked on a small scale, and in a few months the region was practically abandoned.

The possibility of working the sandstone deposits has been investigated several times since. As late as 1910 machinery was taken into the region to crush and treat the rock but was never operated. The sandstone is said to contain 20 to 40 cents, or even more, per ton, in gold. The writer has not visited the district and has no reliable data pertaining to the gold content of the sandstones. It may be recalled, however, that apparently reliable reports stated that the deposits at Paria contained from 30 to 65 cents per yard in gold, and considerable money was spent on this assumption, whereas Lawson found that the average for those deposits is about 5 to 10 cents per cubic yard. It is possible that a more careful sampling will show a much lower content for the sandstones of San Juan River region than is commonly reported.

\section{OTHER DEPOSITS.}

The Triassic sandstones in the vicinity of the Henry Mountains are said to carry gold, assay values exceeding $\$ 1$ per ton being reported. However, anyone considering working these sandstones should remember the Paria experience, and make careful investigation before attempting to treat them. Assays of sand- stone from the La Sal Mountain region show gold and silver present. Ash from the Pleasant Valley coal is said to have yielded 60 to 80 cents per ton in gold."

It is evident, as pointed out by Lawson, that the gold is widely distributed, but thus far it has not been found possible to extract it profitably. The widespread occurrence of the gold is of interest, however, as indicating that the sediments were derived from a rather highly mineralized area, and further, as furnishing a possible source for the placer gold of Colorado, San Juan, Green, and Grand rivers.

PLACER DEPOSITS.

GENERAL FEATURES.

Placer gold has been known for a number of years in the rivers of eastern Utah, including the Colorado and its main tributaries, Grand, Green, and San Juan rivers. The deposits have been worked sporadically and numerous devices have been tried for saving the very fine gold.

The richer gravels have been worked in a small way, some probably at a profit, but attempts to operate on a large scale have not met with success. The total production has been only a few thousand dollars, of which Colorado and Green River deposits have furnished the greater part.

The gold-bearing gravels are found at intervals from Wyoming to Arizona. They are most extensive, however, on Colorado River, between the mouth of Fremont (Dirty Devil) River and the southern boundary of the State, on Green River, above the mouth of the Duchesne, and on San Juan River near Bluff. Few of the river placers were visited by the writer, and little concerning them is to be found in the literature.

COLORADO RIVER.

DEVELOPMENT.

The most active operations on Colorado River have been carried on from about the mouth of Crescent Creek southward to a few miles below the mouth of San Juan River. Attempts at dredging and other placer operations were carried on farther south. The region has little rainfall and the tributary 1 Jenney, W. P., The chemistry of ore deposits: Am. Inst. Min. Eng. Trans., vol. 33, p. 461, 1902. 
streams normally carry little water, and many of them are dry for a large part of the year, preventing large hydraulic or sluicing operations with water from a source above the river. Pumping from Colorado River for sluicing is expensive. A water wheel was tried at the Good Hope Bar and was later set up at the Gold Coin placer, but was not notably successful. Dredges were used a short distance above the mouth of Pine Alcove Creek and farther south toward Lees Ferry, but neither was successful. Moreover, the very fine division and flaky character of the gold make it hard to save, and the percentage recovered by the methods so far employed is said to be very low. In view of these difficulties and the remoteness of the region, and the consequent high cost of supplies, it is not surprising that the efforts to work the placers have not met with marked success.

\section{OCCURRENCE.}

Gold is present in the river bed, in bars a few feet above the river, and in benches many feet higher. At the Gold Coin placer, according to Frank Bennett, the upper bench is 197 feet and the lower bench 65 feet above low-water mark. Other benches, said to be gold bearing, are estimated to be 1,000 feet above the river. These benches are remnants of old canyon bottoms in which lower channels have been progressively cut. The bench gravels examined are rather fine, few of the pebbles measuring more than 6 inches, and probably 50 per cent being less than 1 inch.

On some of the river bars coarser material was present and the relative proportion of coarse material was somewhat greater than on the benches. The fine material consists mainly of quartz sand but contains a large amount of heary sands. The heary sand consists mostly of magnetite, which can be readily removed by an ordinary hand magnet. A considerable portion of the remainder, consisting largely of hematite and ilmenite, can be removed with an electromagnet. The remainder is principally garnet, a black mineral that is probably chromite, zircon, and small amounts of rutile. Pebbles of hematite, the largest an inch in diameter, were noted, especially on the Gold Coin claim.

Many of the mineral grains composing the heavy sands are well rounded. Others, notably those of zircon and chromite, show nearly perfect crystal outlines. The heavy minerals are abundant in the gravels. Mr. Bennett states that the gravels of the Gold Coin placer contain as high as 6 per cent of "black sand," and other deposits probably contain about the same proportion.

The gold is in small flakes; the largest seen (in a sample panned from the Gold Coin placer) was 0.36 millimeter long and 0.26 millimeter broad. The average dimensions, however, are much less, the greatest diameter not greatly exceeding 0.10 millimeter. Flakes with a diameter of 0.05 millimeter are not uncommon. (See Pl. LI.)

Most of the gold from the Gold Coin placer is very clean and has the color of very pure gold. Some flakes, however, are yellowish green and are evidently not so pure. The gold is about 0.960 fine, but it is said to vary somewhat on different bars. The records of output from several bars show about 12 parts of gold to 1 part of silver. Three small colors of a gray metallic material, found in a pan from the Gold Coin placer, show the same rounding and pitting as the gold colors, and are believed to be platinum, which is known to be present in the deposits.

The gold content of the gravels is said to be rather uniformly distributed vertically instead of being concentrated on bedrock. The richest ground is said to contain considerable clayey material. The gold gravels are commonly covered by sand, in places several feet thick, that has been derived from the adjacent cliffs. Gravels at the upstream end of bars are said to contain more gold than those lower down; and the high benches are said to be commonly richer than the lower ones; but there are exceptions to both these rules.

The gold content of the gravels, of course, varies from place to place and to obtain an average would require very extensive sampling. Some of the results of operations are available, but it is reasonable to suppose that only the richer gravels were treated. Mr. Bennett states that about 1,000 yards of gravel from the upper bar of the Gold Coin claim yielded gold to the value of $\$ 730$, or about 73 cents per yard. Gravels from a bar near the mouth of Red Creek are said to have yielded from 70 cents to more than $\$ 1$ per yard. The "black sands" are said to contain considerable gold that is not recovered. 


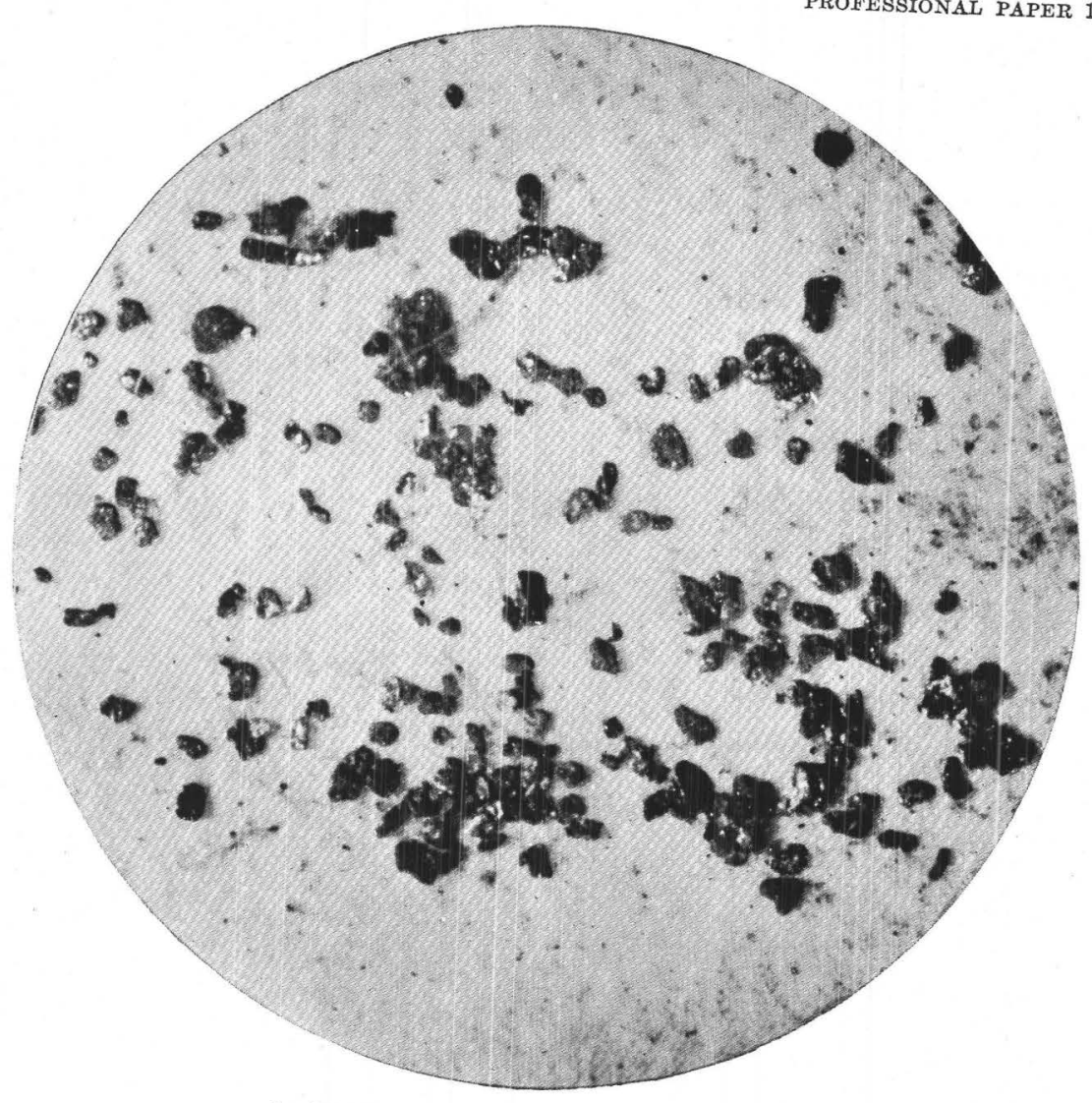

A. Placer Gold of COlorado River

Enlarged 25 diameters.

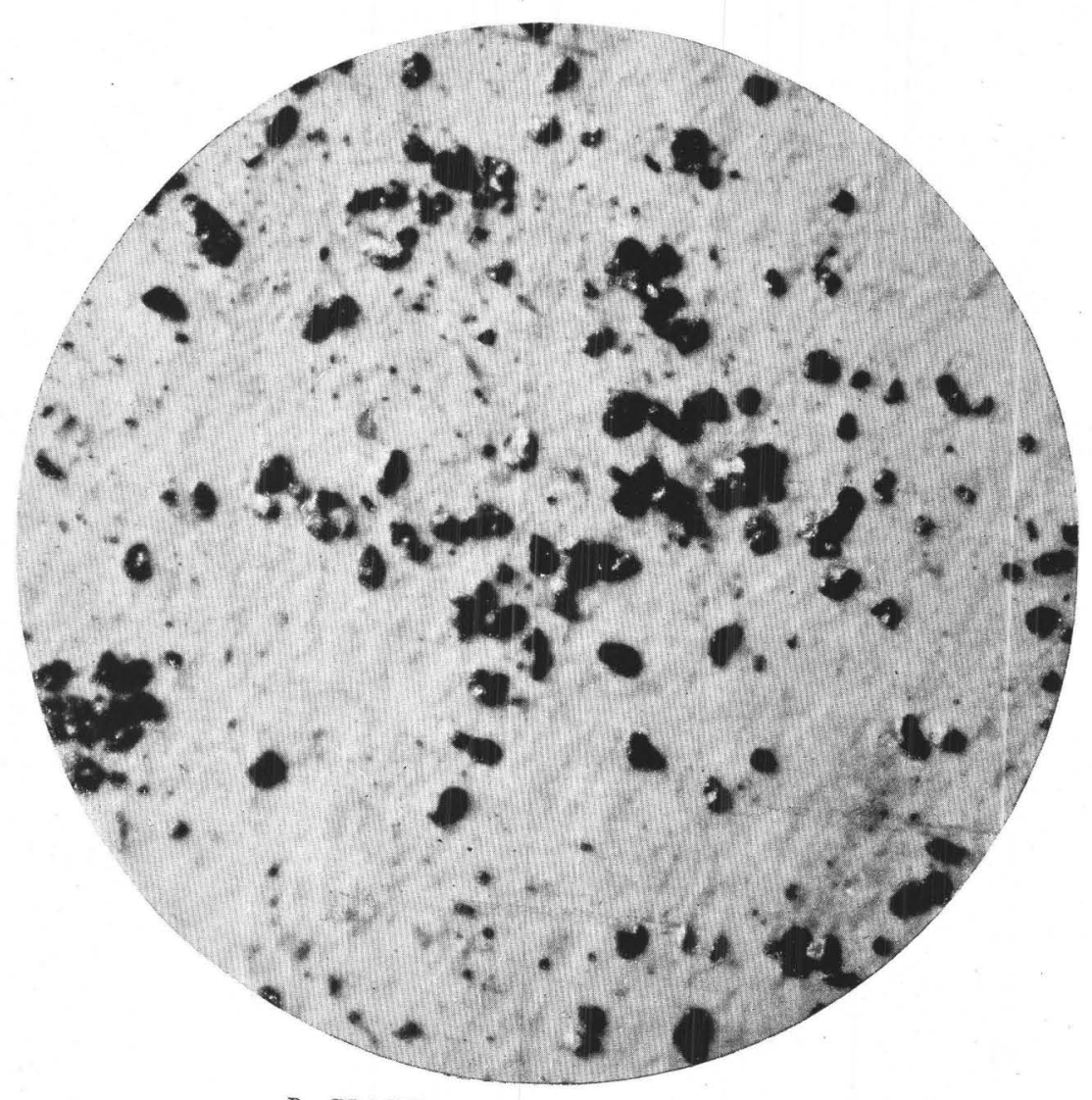

B. PLACER GOLD OF GREEN RIVER.

Enlarged 25 diameters.

PHOTOMICROGRAPHS OF PLACER GOLD. 

Very few data are available as to the platinum content of the gravels. A sample of "black sand" examined by D. T. Day and R. H. Richards ${ }^{1}$ yielded 6.36 ounces gold and 0.15 ounce platinum per ton, and some highgrade gold concentrates are said to have assayed 1 part of platinum to 9 parts of gold.

Bert Seaboldt has kindly furnished estimates made by several men who have examined the gravel bars along the river. These estimates are based mainly on the results of panning and show a variation from 25 cents per cubic yard to double or triple that amount. The writer has heard other estimates as low as 5 cents per yard for the general run of the river sands. It is probably needless to say that great caution and skill are required in estimating the gold content of the gravels, and one accustomed to coarse gold is likely to be misled by the very fine and "flaky" gold of Colorado River.

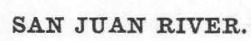

The placer deposits of San Juan River were not examined by the writer but have been described by Gregory, ${ }^{2}$ who states that reports of rich deposits of gold in gravel bars and terraces of the San Juan, below the mouth of Montezuma Creek, caused the "Bluff excitement" of 1892, when 1,200 people rushed to the river and went away empty handed.

Several plants have been installed along the river, notably that of the Oregon Gold Mining Co., near the mouth of Montezuma Creek; at Zana Camp, 3 miles below the mouth of Nakai Canyon and about 20 miles above the junction of the San Juan and the Colorado; at Spencer Camp, in the Great Bend in the San Juan 6 miles below Zana Camp; and 4 miles below Nakai Canyon. Minor operations have been carried on at other localities.

The output from these operations has been small, and the larger undertakings, at least, have been failures. Gregory says: "That gold is widely distributed in the San Juan Valley is indicated by the fact that nearly every pan from the bars shows a color." The metal, however, is in excessively fine flakes. The cost of transportation is too great to justify operations without a yield larger than has been reported.

1 U. S. Geol, Survey Bull. 285, p. 159, 1905.

${ }^{2}$ Gregory, H. E., Geology of the Navajo country: U. S. Geol. Survey Prof. Paper 93, p. 139, 1917.
GREEN RIVER.

Gold has been found and some prospecting done on Green River at numerous points from the Wyoming line southward. Gravels in Browns Park are said to contain gold, and some prospecting has been done, though there has been little production. Near Jensen attempts have been made to recover the gold by both dredging and sluicing, but neither method has been very successful in recovering the fine gold. Considerable prospecting has been done in the vicinity of Jensen, where large bodies of gravel are reported to contain gold in small amount. According to Newton Stewart, of Jensen, the gravels capping the mesas bordering Green River in that vicinity also contain gold in small amount.

At the Horseshoe Bend of Green River, about 15 miles a little west of south from Vernal, considerable placer mining has been done. This was the only locality where operations were being carried on at the time of the writer's visit, and circumstances permitted only a very hasty examination.

The gravels are on the inner side of the great oxbow curve made by the river. Where they occur, near the "top" of the bow, the river is cutting against its outer bank and has gradually receded from its inner bank. The goldbearing gravels, which rise several feet above high-water mark, have been prospected along the river front for upward of a mile and are said to extend a quarter of a mile back from the river, though sufficient prospecting has not been done to outline their areas.

The pay gravel is said to rest upon clay, which is underlain by the decomposed sandstone of the region. The deposits are covered by sand that has drifted over them, in places to a thickness of 5 feet or more. The gravel contains many pebbles 2 to 4 inches in diameter or even larger but few boulders that exceed a foot in diameter. The gold is reported to be rather uniformly distributed vertically; at least it shows no marked tendency to concentrate at the base. There are evidently rich streaks horizontally and the same is probably true vertically.

The mineralogy of the fine material is similar to that of Colorado River. Magnetite is abundant, as are also garnet, hematite, ilmenite, chromite, and zircon. The gold is almost 
identical in appearance with that of Colorado River in color, size, and shape, except that the sample examined contained fewer of the greenish-yellow "colors." Two flakes of a gray metallic mineral collected in a pan are believed to be platinum.

The gravels vary in gold content from place to place, and it is difficult to determine their average tenor. Some of the gravel worked is said to have yielded $\$ 1$ per yard. In these operations, however, the better ground was selected, and it is safe to say that in any large operations the average would be very much lower.

The only water supply is Green River and in working the ground it is necessary to elevate both the gravel and the water.

As in other places in eastern Utah difficulty has been experienced in recovering the fine gold. In the fall of 1913 the Fine Gold Placer Mining Co. had nearly completed a plant designed especially for recovering the fine gold, but to the present time (1917) it has made no important production.

\section{GRAND RIVER.}

A small amount of placer gold has been recovered from the bars of Grand River. The writer did not see these deposits, but they are said to be similar to those of Green and Colorado rivers.
SOURCE OF THE GOLD.

The source of the gold in the placers has never been definitely ascertained, and has been much disputed.

It is, of course, recognized that the goldbearing veins of the La Sal, Abajo, Henry, and possibly Uinta mountains may have and probably did furnish a portion of the gold, though the gold of the Henry Mountains at least is said to differ considerably from the river gold. Moreover, so far as known at present, the veins in these mountains do not seem adequate to account for the gold along the rivers.

It seems to be the prevailing opinion among men who have worked the river deposits that the gold in the sedimentary rocks has been concentrated to form the auriferous gravels of the rivers.

Schrader ${ }^{1}$ has described, very similar deposits from Wind and Big Horn rivers, Wyo., and considers their most probable source to be the lodes in the pre-Cambrian rocks. Green River heads in essentially the same region, and it is entirely probable that at least part of its gold has been derived from a similar source and has been concentrated by repeated reworkings. In like manner it is possible that the gold of the San Juan placers was derived from the lode deposits near the headwaters of that stream.

1 Schrader, F. C., Gold placers of Wind and Big Horn rivers, Wyo.: U. S. Geol. Survey Bull. 580, pp. 127-145, 1914. 


\section{APPENDIX.}

CARBONIFEROUS AND TRIASSIC FAUNAS.

By George H. Girty.

DISCRIMINATION OF FAUNAS.

The plates of Carboniferous and Triassic fossils that accompany this report were made up at the request of Mr. Butler with the purpose of aiding the geologist to discriminate and identify the rock groups that he was called on to investigate. The performance of this task in a way that would accomplish the desired object was less simple than it may appear. The first requirement of any form selected for illustration as characterizing a given geologic age was that it must be closely restricted to the rocks of that age. Any species that ranges beyond the limits of a formation was ineligible in proportion to this transgression. It was also necessary that the species selected should be of common occurrence, for obviously any type that was rarely found, though ever so sharply restricted in geologic range, would be of little use for the purpose required. Again, it was necessary that the species selected should be easily recognized, for though many types that are more or less restricted to and characteristic of definite horizons are readily differentiated by the trained eye, it is for the layman and not the professional paleontologist that these plates are primarily intended, and if the layman can not readily detect the difference between the forms they might as well, for him, be the same form. Lastly, it was necessary that the species selected should be species that occur in Utah. This requirement was in one way helpful, because species that in one region are restricted in range and are characteristic of a definite horizon may in another pass through several horizons and not be characteristic of any. In another way, however, this requirement introduced an element of hazard, for if the species ranges through several faunas in another area its apparent restriction to one horizon in Utah was probably apparent only and the appearance was due to insufficient evidence.

$35416^{\circ}-19-41$
Now there are really very few species that fulfill all these requirements, and the user of these plates will probably find them serviceable in proportion to the accuracy of his observation and the soundness of his judgment. $\mathrm{He}$ is likely to find similar forms, though rarely the same forms, at more than one of the horizons here differentiated. He must not expect to find in one spot all the forms figured as characterizing a horizon, though he may find them, and, on the other hand, he must rest his judgment less on the presence of any one of the forms and more on the association of a number of them.

Proceeding along broad lines, I have distinguished four Carboniferous and one Triassic fauna in Utah, and these are represented, though of course in a very partial way, on the six accompanying plates. Each of the faunas will doubtless be subdivided into several stages when it has been studied carefully in connection with more detailed stratigraphic information than is now available.

\section{LOWER MISSISSIPPIAN FAUNA.}

The lower Mississippian fauna corresponds to the Madison limestone fauna of Montana, Wyoming, and other States. The term Waverly has been applied to it in many of the reports on the geology of Utah because of its resemblance to the fauna of the Waverly group of Ohio. The Madison horizon is commonly very fossiliferous and can often be identified by that fact alone. Spirifer centronatus is abundant at this horizon, also the very finely striated Chonetes loganensis. Species of Chonetes and Spirifer similar to these occur in the Pennsylvanian. Leptaena analoga appears to be absolutely diagnostic of the Madison fauna in Utah wherever it is found, but it is rather rare. Large, loosely coiled gastropods of the Euomphalus and Straparollus group are an important feature of the Madison fauna. Species resembling the Madison species do indeed occur at other horizons, but at these they are far less abundant. 
UPPER MISSISSIPPIAN FAUNA.

The two plates of upper Mississippian fossils constitute a somewhat new and not unimportant contribution to the paleontology of Utah. The upper Mississippian is lacking over vast areas in the West, owing apparently to pre-Pennsylvanian erosion, so that Pennsylvanian rocks rest directly on limestones of Madison age, and it was not until rather recently that I had the necessary faunal and stratigraphic information to establish the presence of rocks of upper Mississippian age in Utah. Most of the species shown on the plates have already been recognized in Utah, but their horizon as upper Mississippian has not been recognized, or at least has not been plainly indicated. The assemblage of species as shown here is more or less provisional; some of the types may not belong in the upper Mississippian at all and others may belong in different subfaunas. Upper Mississippian rocks occur also in Idaho, where, in fact, my best collections have been obtained. The fauna deserves full and careful treatment. This horizon is especially characterized by its corals. Large zaphrentoid corals like those figured, possessing numerous rays or septa, are in many places very abundant and are more or less characteristic, though smaller species similar to them are found at almost all horizons in the Paleozoic. Large colonial types are also abundant, especially in Idaho. They belong chiefly to the genus Lithostrotion. A large Productus of the type of $P$. giganteus and a large Spirifer of the type of $S$. striatus are likewise significant. In general, the upper Mississippian fauna of this region resembles the fauna of the Mountain limestone of Great Britain, the Ural Mountains, and eastern Asia more than it does the higher Mississippian of the upper Mississippi Valley region, but in a measure it combines the two facies.

\section{PENNSYLVANIAN FAUNA.}

The Pennsylvanian faunas of Utah are perhaps less known than those of any other horizon, for the rocks of Pennsylvanian age do not contain many fossils and are not adapted lithologically to preserve them well. The fauna, so far as it is known, seems to come mostly from the lower part of the Pennsylvanian of Utah, and it resembles the lower faunas (post-Pottsville, however) of the Pennsylvanian of the Mississippi and Ohio valleys.

\section{PERMIAN FAUNA.}

The Permian fauna of Utah is a very distinct and easily recognized unit. It is the Spiriferina pulchra fauna that at one time spread over Idaho, Wyoming, Utah, and Nevada. Because it is pronouncedly unlike the Carboniferous faunas that preceded it and because it includes a few types like Aulosteges (which, so far as known, is restricted to rocks of Permian age) the Spiriferina pulchra fauna is classed as Permian. It does not, however, agree closely with the typical Permian fauna of Russia, and it is strikingly different from the other Permian faunas of North America such as the Guadalupian fauna or the Kansas and Texas Permian. Indeed, it is doubtful whether as much as 10 per cent of its species can be found in the central and eastern parts of the continent, and even that small proportion belongs to such baffling types as Composita, in which few sharp specific lines can be drawn. As presented on Plate LVI, the Spiriferina pulchra fauna has little that is new and valuable to the professional paleontologist, except perhaps that it brings together somewhat more definitely than before certain species, already known, into a single well-defined fauna.

\section{IOWER TRIASSIC FAUNA.}

The Lower Triassic of Utah as now known comprises the beds called Permo-Carboniferous by the geologists of the King Survey and by others. In the Park City district "the PermoCarboniferous" was discriminated into three formations, the Woodside, Thaynes, and Ankareh, but these formations have not as yet been traced across the State. They have, however, been traced into southeastern Idaho, where they were found to embrace the Meekoceras beds, the typical Lower Triassic of North America. The Meekoceras beds are regarded as occurring in the Thaynes limestone. In addition to Meekoceras and other types of Ammonites the Lower Triassic has a large and varied fauna comprising pelecypods and gastropods, besides some brachiopods and Bryozoa, unfortunately as yet almost completely undescribed. The typical ammonite fauna is not known in the lower part of the "PermoCarboniferous" (Woodside), but the molluscan 
species found there ally this part of the section with that above. Because of this alliance, because the formation next below appears to be Permian (the final epoch of the Paleozoic), and because a most profound and abrupt faunal change occurs between the Permian fauna and the Woodside (all the abundant and characteristic Paleozoic types of brachiopods, such as Productus, Chonetes, Derbya, Composita, Spirifer, and the rest, becoming extinct at that fatal line), the Woodside is confidently grouped with the overlying beds, with which, indeed, it lithologically belongs. If the Meekoceras fauna of the Thaynes is Triassic, the Woodside also is Triassic.

The Lower Triassic fauna originally extended the entire length of the State from Idaho to Arizona and probably westward into California. In Walcott's Kanab Canyon section it forms the beds which he calls Permian, his Permian fauna containing one or two species of Meekoceras as well as many pelecypods that occur also in the "Permo-Carboniferous" of the Wasatch Range. The exact equivalence with the Lower Triassic of northern Utah can not be predicated, but from such facts as are now available it seems probable that all of the Kanab Canyon "Permian" is Triassic and that the underlying Carboniferous limestone (Kaibab) is Permian.

\section{DESCRIPTION OF SPECIES.}

Productus brazerianus Girty, n. sp.

Pl. LIII, figs. 1, 1a, 2, 2a.

Shell large, subquadrate. Probably the width always exceeds the length, but in some specimens it exceeds it much more than in others. The hinge line is as wide as or slightly wider than the shell in front and the cardinal angles are nearly right angles. The anterior outline is broadly curved and the lateral outlines nearly straight above. The convexity of the ventral valve is low, greatest toward the margins. The beak is small and not very prominent. The ears are rather large, undefined, and arched, and are separated from the vault of the shell by a broad depression. The dorsal valve is shaped much like the ventral (as viewed from the inside) save that the convexity is lower and more regular and the beak smaller and less prominent.

The surface is marked by fine, subequal, radiating costae which increase by bifurcation and are somewhat wider than the striae between them. They are more or less wary and irregular. There are also fine, concentric, crenulating striae and concentric wrinkles, which as a rule are fine, irregular, and faint. I have not been able to determine definitely whether spines are present in this form; presumably some were developed but probably they were neither large nor numerous.

This type is very abundant in the upper Mississippian (Brazer limestone) at certain localities, but at others it can not be found at all. The shells are apt to be so packed one upon the other that it is difficult to obtain perfect specimens. In general Productus brazerianus suggests $P$. cora and other species related to it, but from these forms it is clearly distinguished by its broad shape, its low convexity, its small beak, and by its lack of large spines on the body of the shell, and of strong wrinkles on the ears. More immediately, it is of the family of $P$. giganteus and may be identical with some of the varieties of that species. $P$. giganteus, however, is in an unsatisfactory state, because of the large number of forms that have been referred to it. For this reason and because I have no specimens whatever for comparison, I have deemed it better to describe as new the American form and leave for future determination its relation to the European one. What may probably be regarded as typical $P$. giganteus is, I judge, distinct from my shell by reason of its greater size, high convexity, much extended auricles, longitudinal folds, cardinal spines, and other characters. Young specimens perhaps show some of these differences less clearly.

Productus hemisphericus, which Davidson considers only a more or less doubtful variety of $P$. giganteus, resembles $P$. brazerianus more than $P$. giganteus itself. It shows, however, some of the same differences, such as the row of spines along the cardinal line and the extended ears (not, however, in all specimens ${ }^{1}$ ). One of Davidson's specimens of P. striatus also suggests $P$. brazerianus, but of course the shorthinged spatulate typical variety resembles it only remotely. Even $P$. cora, as identified by Davidson, is not without suggestions of $P$. brazerianus; not only is his form a different species from true P. cora, however, but as com-

1 Davidson, Thomas, British fossil Brachiopoda, vol. 2, pl. 40, fig. 9, Paleont. Soc., 1858-1863. 
pared with $P$. brazerianus it is more highly vaulted, has a larger and more prominent umbo, and has much stronger concentric wrinkles.

Although $P$. brazerianus is apparently distinct from typical $P$. giganteus, most citations of $P$. giganteus in American literature probably belong to it. It is also probable that the form identified by Meek in Montana as P. Tatissimus belongs to $P$. brazerianus, but this suggestion is made only on the hypothesis that Meek's specimen was imperfect.

In configuration $P$. brazerianus closely resembles $P$. magnus of the Mississippi Valley region. $P$. magnus, however, has its surface sprinkled with numerous small spines and has costae that are not only coarser but that tend to become obsolete toward the front. $P$. siebenthali, a manuscript species from the Hindsville member of the Batesville sandstone of Arkansas, is also an allied form. The dorsal valve of $P$. siebenthali has numerous, more or less strong, fine, concentric wrinkles, and the ventral valve has a row of spines along the hinge line and does not show the broadly flattened shape over the visceral region which is rather characteristic of $P$. brazerianus. The costae are likewise much finer. The differences in the number and distribution of the spines can not be pressed, though I have been quite unsuccessful in finding definite evidence of spines in $P$. brazerianus, especially along the hinge line and on the ears, where they would be apt to be larger and more numerous than on the rest of the surface.

\section{Aulosteges hispidus Girty, n. sp. \\ Pl. LVI, figs. 8, 8a, 8b.}

Shell rather large, ovate, expanding from an almost pointed posterior to a broadly rounded anterior end, the outline but little interrupted by the projection of the small depressed ears. The largest specimens observed are about 40 millimeters long. The width is variable but always distinctly less than the length. The convexity of the ventral valve is moderate, rather high transversely, and more shallow lengthwise. The sides and front are apt to descend strongly, but the slope backward to the umbo is apt to be gradual. The auricles are small and indistinct. The cardinal area is low; it lies about in the plane of the shell edges.

The dorsal valve is nearly flat, of an ovate shape with a small terminal beak.
The surface of the ventral valve is marked by very fine, wavy, radial lirae, as in some varieties of Productus cora. There are also numerous rather stout spines. which appear to be differently arranged in different specimens. Commonly there appears to be a rather broad spinose belt passing around the shell well toward the front, in which the spines are large and closely set. In several specimens the shell in front of this band is almost without spines and is marked only by the fine, sharp, wavy lirae. In some specimens again the surface back of the spinose band appears to be almost without spines, or to have the spines smaller and less numerous than on the band itself. Such appears to be the character of this part of the surface in the type specimen. The spines are really rather numerous, but they are smaller than those on the spinose band and are broken off so close to the surface that they are represented only by small perforations in the shell and are therefore less conspicuous than those of the band, which stand out prominently.

Aulosteges hispidus unquestionably belongs to the group of Autosteges. This relationship is indeed strongly suggested by the shape and surface characters alone and is proved by the area of one specimen, which I uncovered with some difficulty. The area is small, being only about 3 millimeters high in a specimen at least 25 millimeters long. It is marked by transverse grooves and has a narrow pseudodeltidium. The pseudodeltidium itself, however, appears in the specimen to be broken or cut away, leaving a small open slit.

Of the American species referred to this genus $A$. hispidus resembles $A$. guadaloupensis in shape but differs from it widely in surface character. It agrees more nearly with $A$. medlicottianus var. americanus in sculpture but differs from it in configuration. Even the sculpture, though similar in general plan, differs notably in detail.

$A$. hispidus is one of the rarer species of the Spiriferina pulchra fauna, but it is important in determining the geoologic age of that formation, all the species of Aulosteges being, I believe, of Permian age.

Spirifer pseudocameratus Girty, n. sp.

Pl. LVI, figs. 10-15.

Shell rather large, distinctly wider than high but less transverse than many species of the 
genus. The greatest width is found at the hinge line, the cardinal angles being acute in shells that are proportionally wide but more nearly rectangular in shells that are proportionally high.

The ventral valve is rather convex, especially in the umbonal region, and the rather small beak is strongly incurved. The area appears to be high in some specimens but only moderate in others; it is somewhat oblique to the plane of the valves but is more or less strongly recurved toward the perpendicular. The sinus is not deep but is fairly well defined. It is occupied by two small costae that unite toward the beak and gradually enlarge toward the front where they are of about the same size as the other plications. The costae that border the sinus, one on each side, also give off by division one and sometimes two costae on the sides or in the bottom of the sinus. The costae on the sides of the shell are strongly fasciculate in groups of three, and these may be subequal, or one may be large and two small. Of these fascicles there are three or four on each side of the beak; four or five other costae, either in pairs or singly, are developed beyond, toward the cardinal angles.

The dorsal valve is moderately convex. The fold is low but well defined. It is divided into two lobes by a more or less deep median groove. Each lobe bears two or three costae, and the lobes so closely resemble the fascicles on the sides that in some specimens it is not at first apparent that there is any fold at all. The lateral costae, like those of the ventral valve, are strongly fasciculate near the fold and grade laterally into a nonfasciculate arrangement.

The finer surface markings are not well shown. Probably like other species of the same kin, this one was covered with fine radial and concentric tracings, but at present only the striae of growth can be seen.

This species will immediately suggest the common Pennsylvanian type, usually known as Spirifer cameratus. More careful comparison, however, will show numerous differences. Though both species vary more or less, $S$. pseudocameratus is higher in proportion to its width, whereas $S$. cameratus, or, as I shall call it, $S$. triplicatus, is proportionally wider and more extended at the hinge line. S. triplicatus has rather finer costae and a more rapidly widening fold and sinus. Its fold and sinus are also more angular, the fold especially being high and pointed, whereas that of $S$. pseudocameratus is low and rounded. The fold of typical pseudocameratus is, moreover, rendered biplicate by a median groove; and though a median groove occurs on the fold of $S$. triplicatus also, it is shallow and merely blunts the crest of the ridge. S. triplicatus also has more numerous costae in the fold and sinus.

This is probably the same species that Meek identified as Spirifer cameratus, though Meek's specimens were obtained in Nevada instead of Utah. Meek noted several differences from typical S.triplicatus, in part the same differences because of which I consider $S$. pseudocameratus distinct from $S$. triplicatus. He apparently placed so much importance on the fact that his form, like $S$. triplicatus, had fasciculate costae that he did not give adequate weight to other differences of which he himself noted some, others perhaps not being shown by his specimens, which were evidently not very good. My own, too, are rather poor, but I have many of them.

\section{Spirifer triplicatus Hall.}

$$
\text { Pl. LIV, fig. } 22 .
$$

By this name, used by Hall in 1852, I intend to designate the species currently known as Spirifer cameratus Morton. Morton's type specimens were obtained at Putnam Hill near Zanesville, Ohio; Hall's from a locality in northeastern Kansas. S. triplicatus is a common and well-known form that occurs in the coal measures of Missouri, Illinois, Kansas, and other States in the same region. Typical $S$. cameratus is from the Pottsville (Mercer limestone). It is common at Putnam Hill, and my collection contains a number of specimens. Broadly speaking all these early spirifers of the triplicatus group have the ribs less strongly fasciculate than typical $S$. triplicatus. This is true at least of my specimens of $S$. cameratus from Putnam Hill and they also differ more or less in having the fold and sinus rather low and rounded instead of high and angular. They seem to have a more quadrate or pentagonal outline than $S$. triplicatus, one which is higher in proportion to the width, less extended at the hinge, and fuller below it. These differences appear to be maintained perhaps only in a general way and to be not very great in degree, but in my judgment they warrant holding 
S. cameratus as distinct from S. triplicatus, both on their own account and on account of the difference of geologic age with which they are correlated.

I propose therefore to recognize two species among this group of spirifers, for one of which $S$. cameratus is clearly the oldest name and for the other probably S. triplicatus. The only term that seems at present likely to conflict with $S$. triplicatus is $S$. meusebachanus Roemer, which has priority over $S$. triplicatus but not over $S$. cameratus. It is impossible at this writing to determine with certainty the relationship of the Texas form. It may prove to be distinct from both $S$. triplicatus and $S$. cameratus; if it belongs to either it belongs probably to $S$. cameratus. To distribute correctly the long synonymy of $S$. cameratus would be difficult. Most of the citations would doubtless fall to $S$. triplicatus. Another species that must be considered in this connection is $S$. gorei Mather, which is said to differ from $S$. cameratus (S. triplicatus) by lacking fasciculate ribs. Mather's statement is that the ribs of $S$. gore $i$ are not fasciculate at all, whereas those of $S$. cameratus are only faintly fasciculate. The two forms may be distinct species, but their geologic age is about the same.

\section{Composita mira Girty.}

Pl. LVI, figs. 16, 16a.

1877. Athyris roissyi Meek, U. S. Geol. Expl. 40th Par. Final Rept., vol. 4, pt. 1, p. 82 , pl. 9, figs. 3-3b. Carboniferous limestone: Ruby group; Wachoe Mountains; Mahogany Peak; Egan Range, Nev.

1899. Athyris mira Girty, Geology of the Yellowstone National Park: U. S. Geol. Survey Mon. 32, pt. 2, p. 570 .

A large Composita occurs rather persistently in the Spiriferina pulchra fauna of Utah. It is characterized by its large size, its rotund shape, its narrow fold and sinus which though rather strong are developed chiefly toward the front, and by its surface markings, which consist of numerous rather strong, irregularly disposed, imbricating lamellae of growth. There is also a narrow variety of this form in the Spiriferina pulchra fauna. It is commonly much longer than wide, even the most rotund specimens being only slightly wider than long.

These specimens appear to agree remarkably well with the form to which, in 1899, I gave the name Athyris mira. The original speci- mens of Athyris mira were the original specimens of Athyris roissyi as identified by Meek. Meek's specimens came from Nevada, and they are distinguished by almost the same characters that I have mentioned for those from Utah. I called attention to the fact that Athyris mira possessed an open, triangular delthyrium, instead of the round pedicle opening depicted by Meek's figure, whose appearance I was inclined to ascribe to breakage. The conformation of Meek's specimen, however, may be no different from that which can often be observed in Composita. In ventral valves of that genus the triangular delthyrium was mostly closed by a deltidium, and the small round pedicle opening above the deltidium encroached on the umbo through resorption or wear by the pedicle. The deltidium is in fact rarely preserved, but owing to the curvature of the ventral beak that part of the shell is concealed by the other valve. When the dorsal valve is lost, however, or has the umbonal part broken, the ventral valve is apt to show a triangular aperture below, open because of the loss of the deltidium, and a circular aperture above occupying the apex of the umbo. Thus the condition observed in Athyris mira may not be as anomalous as I conreived it to be at the time.

As to the generic position of Athyris mira, the configuration appears to be that of $\mathrm{Com}$ posita rather than of Athyris or Cliothyridina. In fact, Meek states that his specimens of Athyris roissyi pass by easy gradations into forms that are difficult to separate from $\mathrm{Com}$ posita subtilita Hall. The really critical character in these shells, however, is the surface ornamentation. Meek's specimens have the surface marked by stronger and more numerous imbrications than is common in Composita but certainly not stronger and more numerous than is compatible with that genus. On the other hand, there is not the slightest evidence for believing that the imbrications of $A$. mira were ever prolonged into the spinose fimbriae of Cliothyridina or the lamellose frills of Athyris. Indeed, I strongly believe that they were not prolonged. I am satisfied that they were not prolonged in the Utah specimens, which I refer without hesitation to Composita. The main difference shown by the Utah specimens, when compared with Meek's description and figures, is that Meek represents the imbri- 
cations as more regular though apparently not stronger than they are in my specimens.

Meek's figures of Athyris roissyi strikingly resemble his figures of Athyris? persinuata on the same plate, and apparently the two forms occur in association. Athyris persinuata seems to be rather smaller, rather more elongated, to have a stronger fold and sinus, and to lack the regular imbrications; those which it has occurring only toward the margin. It is probable that both forms actually belong to the genus Composita, and if the differences mentioned do not hold good Composita mira will become a synonym of $C$. persinuata. The shells from Utah agree better with $C$. mira than with $C$. persinuata for, though they vary considerably in other characters, none of them has the fold and sinus so remarkably developed as they appear to be in Meek's species.

Compositas of uncommonily large size seem to be somewhat characteristic of the late Carboniferous faunas of North America, a very robust type that much resembles this one occurring in the Permian of Kansas. The Kansas form is probably distinct from $C$. mira, however, by reason of its nearly smooth surface and its more ovate shape, which tends to be relatively longer and to have its greatest width farther toward the front of the shell. In the Utah specimens the greatest width is about midway, though the difference is not entirely constant.

Aviculipecten? deseret Girty, n. sp. Pl. LVII, figs. 7-9a.

Shell small. Length slightly greater than width. Hinge line short, about one-half the width lower down or a little more. Beak nearly central on the cardinal line to which the axis of the shell is nearly perpendicular. Shape more or less symmetrical though one side is usually a little better developed than the other. The ventral and lateral outlines are regularly rounded. Above the middle the outlines contract somewhat, then become subparallel and nearly straight, so that the two ears are similar in size and shape, and the cardinal angles are angles of $90^{\circ}$ or somewhat less. The convexity is moderate with a gradual descent to the ears, which are depressed but not defined either by a sulcus in the surface or a sinus in the outline.
The sculpture consists of numerous fine, regular, unequal radiating costae. The costae of the largest size number about 20. Between these occur three or more much smaller ribs, of which the median one or two are as a rule distinctly more prominent than the others. Even the primary costae are more or less perceptibly alternating, so that the ribs really belong to three and possibly four or more series. They are relatively high and thin, and the striae between them are broad and flat. Toward the sides the costae rapidly become finer and more equal, so that the ears are almost, if not quite, smooth in some specimens and in others covered with very fine, equal lirae. There are also very fine, regular, concentric lirae of about the same size as the finest radiating ones but more closely arranged, and with the costae they produce a finely cancellated surface. They do not seem to cross the larger ribs, or at least to make crenulations upon them.

This species seems normally to have a length of 16 millimeters, but many specimens are smaller.

The generic position of Aviculipecten? deseret is a matter of doubt. I have some reason to believe that the shell is equivalve, and in that case the generic position would not be with Aviculipecten nor even with the Pectinidae. None of the specimens observed has any trace of a byssal sinus, from which fact, from their sculpture, and from their convexity all must, on the assumption that they belong to the Pectinidæ, represent one valve only of the complete shell and that the left valve. Now, it would seem somewhat paradoxical to find in the same collection over 30 specimens of the left valve and no corresponding right valves nor even any shells of different character that could with any probability represent the right valve. Furthermore, as has already been mentioned, though most of the specimens are almost symmetrical bilaterally, some seem to be better developed on one side and others on the other. Finally, though the axis is in a general way about perpendicular to the cardinal line, it appears to be slightly curved in the umbonal region, pointing in some specimens toward one side and in other specimens toward the other. With this difference may be correlated a slight inequality in the proportional length of the parts of the hinge 
line on either side of the umbo (the beak pointing to the longer side?) and also a slight inequality in the descent of the shell to the two ears. To determine this correlation of parts would require a larger series of complete specimens than is contained in my collection.

Aviculipecten? deseret is closely related to Aviculipecten? superstrictus White. It differs, however, in being only half as large, in being relatively shorter on the hinge line, and in being much less gibbous, with a correspondingly more gradual descent to the ears. A. superstrictus is more copiously supplied with the small intermediate lirae, which are, moreover, less strongly differentiated in size. The regular concentric lamellae are also lacking on $A$. superstrictus so far as observed, but the typical specimens are not so preserved that this character would be well shown, if originally present.

Myalina? platynotus (White).

P1. LVII, figs. 16, 17.

1880. Volsella (Modiolina) platynota White, U. S. Geol. and Geog. Survey Terr., Contributions to invertebrate paleontology Nos. 2-8, p. 146, pl. 37, figs. 3a, 3b. Jurassic (?); Head of Lincoln Valley, southeastern Idaho.

1883. Volsella (Modiolina) platynotus White, U. S. Geol. and Geog. Survey Terr. Twelfth Ann. Rept., for 1878, pt. 1, p. 146, pl. 37, figs. 3a, 3b. Jurassic (?); Head of Lincoln Valley, southeastern Idaho.
This form is well distributed and abundant in the Lower Triassic of Utah and Idaho and appears to be characteristic of the horizon. It is largely confined to the Thaynes limestone and the specimens illustrated are from that formation. It is not certain that my specimens belong to the species described by White as Volsella (Modiolina) platynota, and my figures do not look at all like his because they are differently oriented, what he regards as the anterior side being in my figures represented as the hinge. As to the orientation of my specimens there can be little doubt, because the side which I regard as the hinge is straight and has a very distinct cardinal area or hinge plate, whereas the side that corresponds to the hinge of White's figure is curved and has a thin edge without any suggestion of cardinal structures. Of course, if the orientation of White's figure is correct, the two forms are widely different, not only in specific but in generic character.

I have referred my form to the genus Myalina because in shape and in what little is known of the structure it is more or less comparable with the Carboniferous Myalinas. I much doubt whether it is a true Myalina, however, and even if it is it represents a type distinctly different from the Myalinas of the Pennsylvanian and Permian of this country. 
PLATES LII-LVII. 


\section{PLATE LII.}

\section{Zaphrentis stansburyi Hall.}

Figure 1. Side view of an imperfect specimen, which has the edge of the calice and the lower extremity broken away.

After Meek, Paleontology, U. S. Geol. Expl. 40th Par. Final Rept., vol. 4, pt. 1, pl. 6, fig. 3, 1877. Hall's specimens came from Stansburys Island, Cloth Cap, and Flat Rock Point, in Great Salt Lake, and the original of Meek's figure, copied here, came from the same horizon in the Wasatch Range, Utah.

\section{Zaphrentis? multilamella Hall?}

Figure 2. A specimen broken longitudinally, showing imperfectly the internal structure. The fossula is on the right.

2a. A view of the calice of the same, with its margins broken away and its bottom filled with rock. After Meek, Paleontology, U. S. Geol. Expl. 40th Par. Final Rept., vol. 4, pt. 1, pl. 6, figs. $4 \mathrm{a}$ and $4 \mathrm{~b}, 1877$. Hall's specimens came from Cloth Cap and Flat Rock, in Great Salt Lake, and the original of Meek's figures, copied here, came from Strongs Knob, in Great Salt Lake.
Cyathophyllum nevadense Meek.

Figure 3. Side view of a much-weathered specimen showing the edges of the septa and the dissepiments, and the calice, seen obliquely, partly filled by hard calcareous matter.

After Meek, Paleontology, U. S. Geol. Expl. 40th Par. Final Rept., vol. 4, pt. 1, pl. 6, fig. 3, 1877. The original specimen is from Boxelder Peak, Wasatch Range, Utah.

\section{Zaphrentis excentrica Meek.}

Figure 4. Side view of the type specimen. After Meek, Paleontology, U. S. Geol. Expl. 40th Par. Final Rept., vol. 4, pt. 1, pl. 4, fig. 1c, 1877. The original specimen is from Boxelder Peak, Wasatch Range, Utah.

\section{Lithostrotion whitneyi Meek.}

Figure 5. A mass of limestone including several of the corallites.

After Meek, Paleontology, U. S. Geol. Expl. 40th Par. Final Rept., vol. 4, pt. 1, pl. 6, fig. 1, 1877. The original specimen is from Boxelder Peak, Wasatch Range, Utah. 
U. S. GEOLOGICAL SURVEY

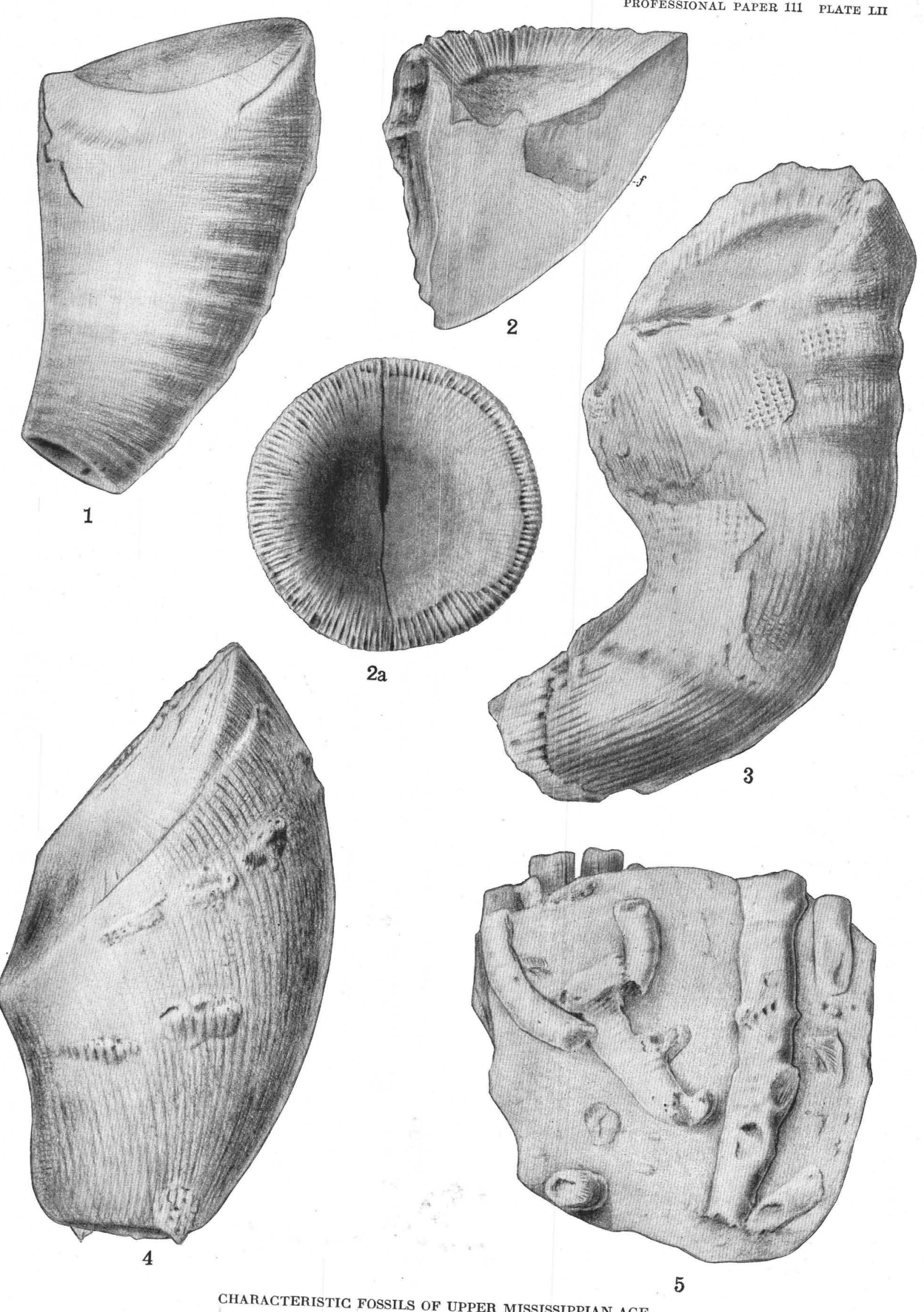


U. S. GEOLOGICAL SURVEY

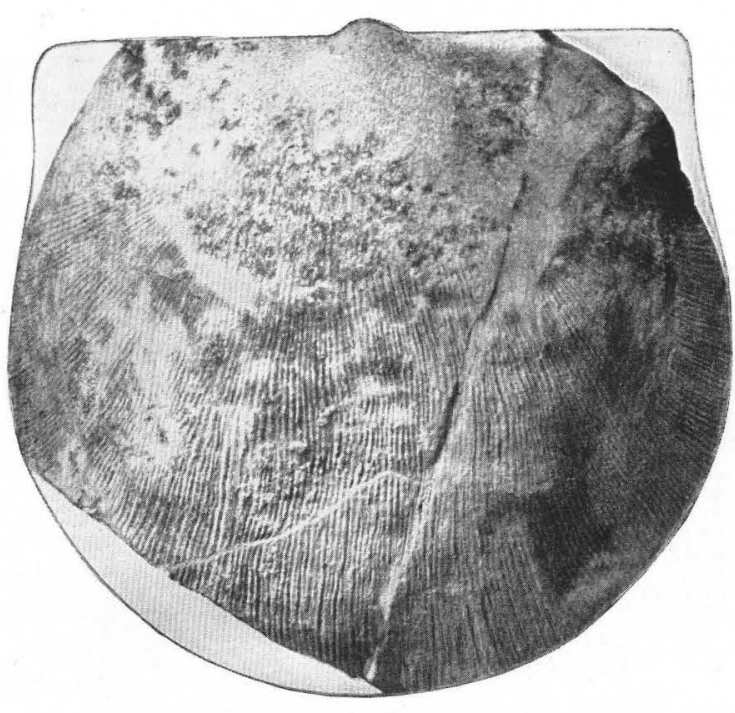

1

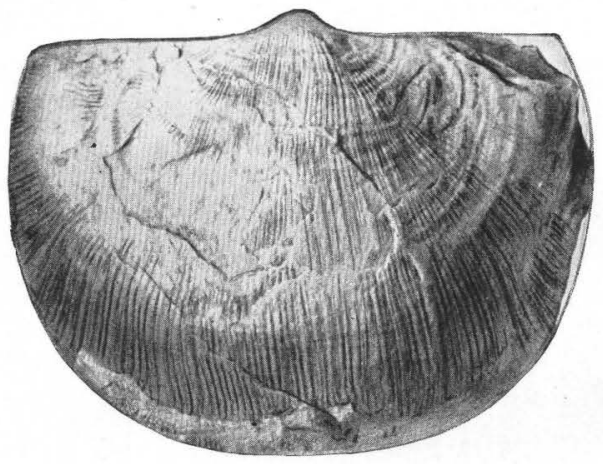

2

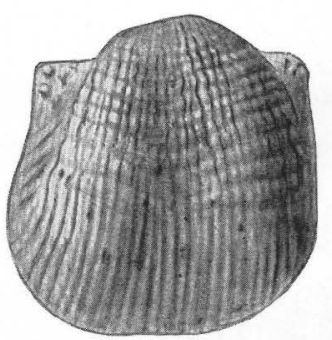

6

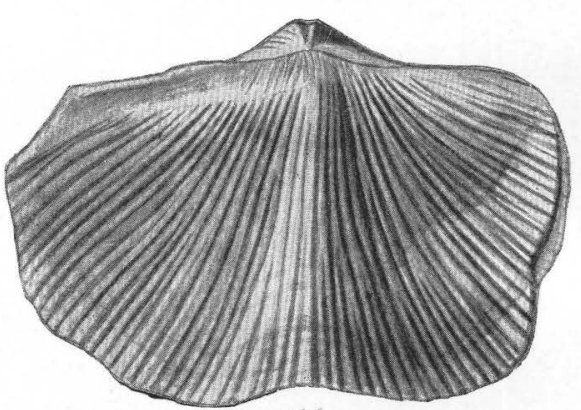

10

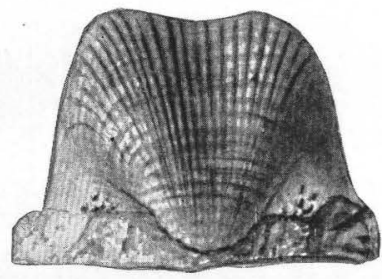

$6 a$

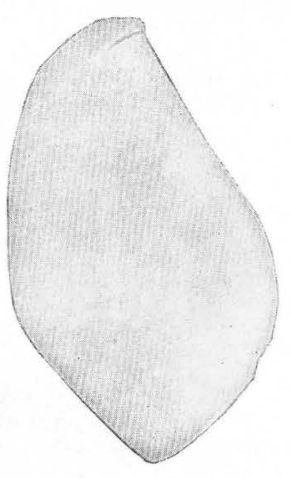

$2 a$

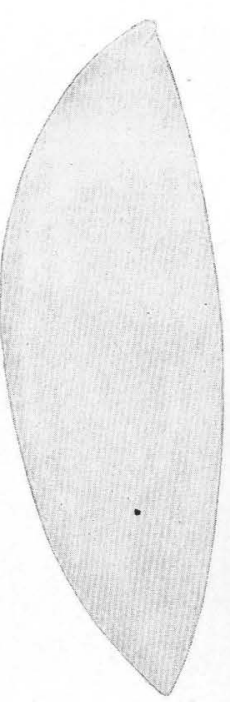

$1 \mathrm{a}$
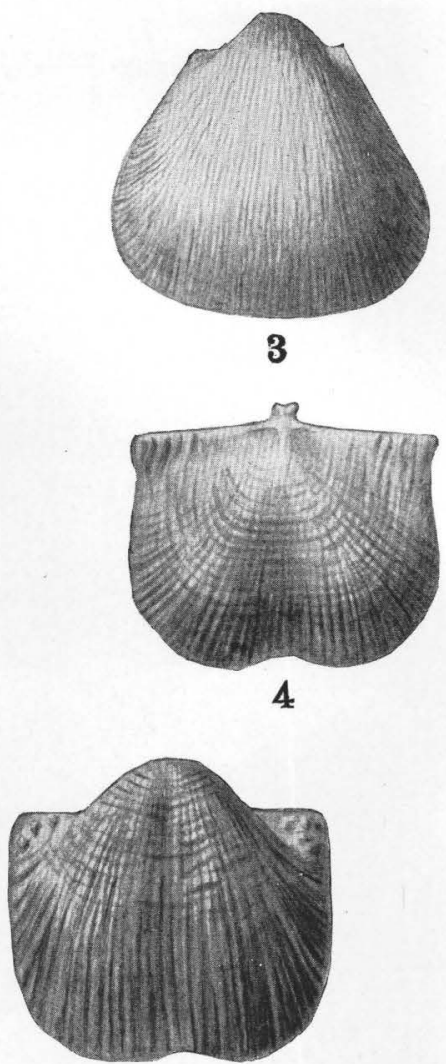

5

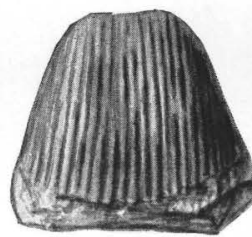

8

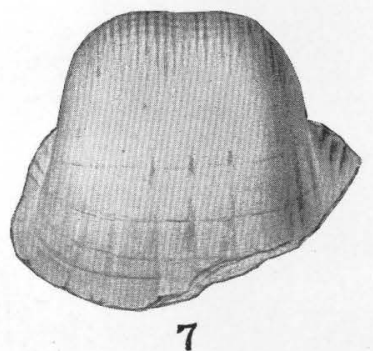

7

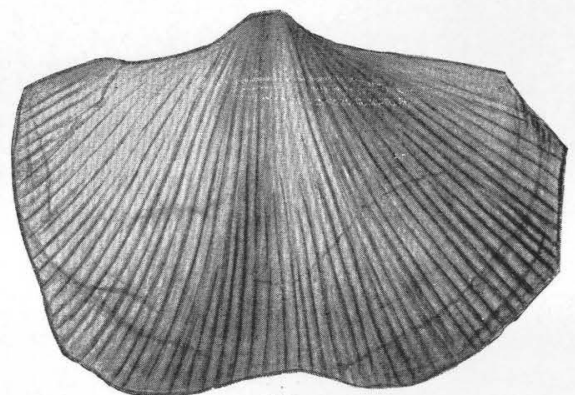

$10 \mathrm{a}$

CHARACTERISTIC FOSSILS OF UPPER MISSISSIPPIAN AGE.
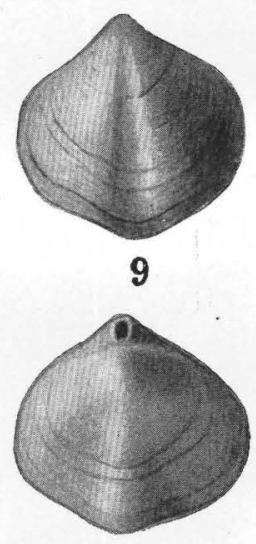

$9 \mathrm{a}$

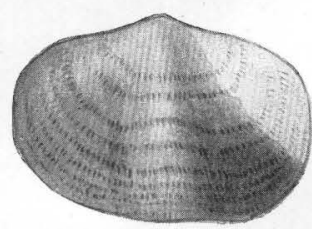

11

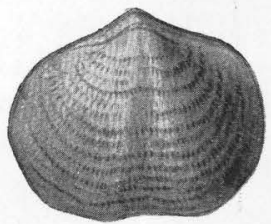

12 


\section{PLATE LIII.}

Productus brazerianus Girty, n. sp. (pp. 643-644).

Figure 1. A large dorsal valve seen from above.

1a. Side view in outline.

2. A small ventral valve seen from above.

2a. Side view in outline.

The figured specimens are from the Wayan quadrangle in Idaho, but the same species occurs in the Wasatch Range in Utah.

\section{Productus ovatus Hall.}

Figure 3. A ventral valve seen from above.

After Hall and Whitfield, U. S. Geol. Expl. 40th Par. Final Rept., vol. 4, pt. 2, pl. 5, fig. 7, 1877. The figured specimen is from Dry Canyon, Oquirrh Mountains, Utah.

Productus burlingtonensis Hall.

Figure 4. Interior of a dorsal valve seen from above.

5. A ventral valve seen from above.

After Hall and Whitfield, U. S. Geol. Expl. 40th Par. Final Rept., vol. 4, pt. 2, pl. 5, figs. 9 and 10, 1877. The figured specimens are from Dry Canyon, Oquirrh Mountains, Utah. The identification given by Hall and Whitfield is no doubt incorrect, but the exact affinities have not been determined.

Productus semireticulatus Martin.

Figure 6. A ventral valve seen from above.

6a. Posterior view of same.

After Hall and Whitfield, U. S. Geol. Expl. 40th Par. Final Rept., vol. 4, pt. 2, pl. 5, figs. 5 and 6,1877 . The figured specimen is from Dry Canyon, Oquirrh Mountains, Utah. This may be only a coarse-ribbed variety of the species cited as $P$. burlingtonensis.

\section{Productus semistriatus Meek.}

Figure 7. Anterior-ventral view of the type specimen. After Meek, Paleontology, U. S. Geol. Expl. 40th Par. Final Rept., vol. 4, pt. 1, pl. 7, fig. 8,1877 . The original specimen is from a locality southeast of Great Salt Lake, Utah.

Diaphragmus elegans Norwood and Pratten.

Figure 8. Anterior view of a ventral valve.

After Hall and Whitfield, U. S. Geol. Expl. 40th Par. Final Rept., vol. 4, pt. 2, pl. 5, fig. 4, 1877. The figured specimen is from Dry Canyon, Oquirrh Mountains, Utah.

Composita subquadrata Hall?

Figure 9. Ventral view.

9a. Dorsal view of the same.

After Hall and Whitfield, U. S. Geol. Expl. 40th Par. Final Rept., vol. 4, pt. 2, pl. 5, figs. 19 and 20, 1877. The figured specimen is from Dry Canyon, Oquirrh Mountains, Utah.

Spirifer striatus Martin.

Figure 10. Dorsal view.

10a. Ventral view of same.

After Hall and Whitfield, U. S. Geol. Expl. 40th Par. Final Rept., vol. 4, pt. 2, pl. 5, figs. 13 and 14, 1877. The figured specimen is from Dry Canyon, Oquirrh Mountains, Utah.

\section{Reticularia setigera Hall.}

Figure 11. A dorsal valve.

12. Ventral view of a smaller specimen that preserves the surface ornamentation.

After Hall and Whitfield, U. S. Geol. Expl. 40th Par. Final Rept., vol. 4, pt. 2, pl. 5, figs. 17 and 18, 1877. The figured specimens are from Dry Canyon, Oquirrh Mountains, Utah. 


\section{PLATE LIV.}

MADISON.

Schuchertella aff. S. chemungensis Conrad.

Figure 1. A ventral valve having fine and even ribs. After Hall and Whitfield, U. S. Geol. Expl. 40th Par. Final Rept., vol. 4, pt. 2, pl. 4, fig. 2, 1877. The figured specimen is from Logan Canyon, Wasatch Range, Utah.

2. A dorsal valve of unusual breadth, having ribs that alternate in size.

After Hall and Whitfield, U. S. Geol. Expl. 40th Par. Final Rept., vol. 4, pt. 2, pl. 4, fig. 1, 1877. The figured specimen is from Ogden Canyon, Wasatch Range, Utah.

\section{Leptaena analoga Phillips.}

Figure 3. A characteristic specimen showing the fine radial markings and the fine even concentric wrinkles.

After Hall and Whitfield, U. S. Geol. Expl. 40th Par. Final Rept., vol. 4, pt. 2, pl. 4, fig. 4, 1877. The figured specimen is from Dry Canyon, Oquirrh Mountains, Utah.

Chonetes loganensis Hall and Whitfield.

FIgUre 4. The type specimen, which is a ventral valve. After Hall and Whitfield, U. S. Geol. Expl. 40th Par. Final Rept., vol. 4, pt. 2, pl. 4, fig. 9, 1877. The figured specimen is from Logan Canyon, Wasatch Mountains, Utah.

Spirifer centronatus Winchell.

Figure 5. A large dorsal valve.

6. A smaller ventral valve.

After Hall and Whitfield, U. S. Geol. Expl. 40th Par. Final Rept., vol. 4, pt. 2, pl. 4, fig. 5, 1877. The figured specimens are from Dry Canyon, Oquirrh Mountains, Utah.

\section{Straparollus ophirensis Hall and Whitfield.}

Figure 7. Side view of the typical specimen.

7a. The lower, or umbilical, side.

After Hall and Whitfield, U. S. Geol. Expl. 40th Par. Final Rept., vol. 4, pt. 2, pl. 4, figs. 26 and 27, 1877. The figured specimen is from Dry Canyon, Oquirrh Mountains, Utah.

\section{Euomphalus laxus White.}

Figure 8. Upper side.

8a. Profile of same.

After Hall and Whitfield, U. S. Geol. Expl. 40th Par. Final Rept., vol. 4, pt. 2, pl. 4, figs. 24 and 25, 1877. The figured specimen is from Dry Canyon, Oquirrh Mountains, Utah.

Euomphalus utahensis Hall and Whitfield.

Figure 9. Upper side of a rather small specimen represented by a gutta-percha impression.

After Hall and Whitfield, U. S. Geol. Expl. 40th Par. Final Rept., vol. 4, pt. 2, pl. 4, fig. 21, 1877. The figured specimen is from Dry Canyon, Oquirrh Mountains, Utah.

Proetus peroccidens Hall and Whitfield.

Figure 10. A rather small pygidium, $\times 2$.

After Hall and Whitfield, U. S. Geol. Expl. 40th Par. Final Rept., vol. 4, pt. 2, pl. 4, fig. 32,1877 . The figured specimen is from Ogden Canyon, Wasatch Range Utah.

Proetus loganensis Hall and Whitfield.

Figure 11. The type specimen, a pygidium, $\times 2$. After Hall and Whitfield, U. S. Geol. Expl. 40th Par. Final Rept., vol. 4, pt. 2, pl. 4, fig. 33, 1877. The figured specimen is from Logan Canyon, Wasatch Range, Utah.

PENNSYLVANIAN.

Myalina subquadrata Shumard.

Figure 12. A left valve.

The figured specimen is from the Drum limestone at Drum, Kans.

Chaetetes milleporaceus Troost.

Frgure 13. Side view of a broken specimen, showing the innumerable small tubes of which the coral is composed.

After White, U. S. Geog. and Geol. Surveys W. 100th Mer. Final Rept., vol. 4, pt. 1, pl. 6, fig. 2a, 1877. The figured specimen is from the Virgin Range, near St. George, Utah. 
U. S. GEOLOGICAL SURVEY

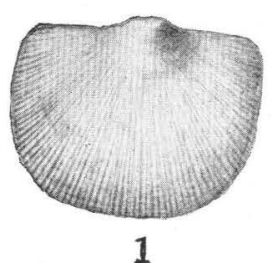

1

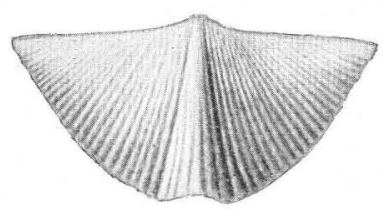

5
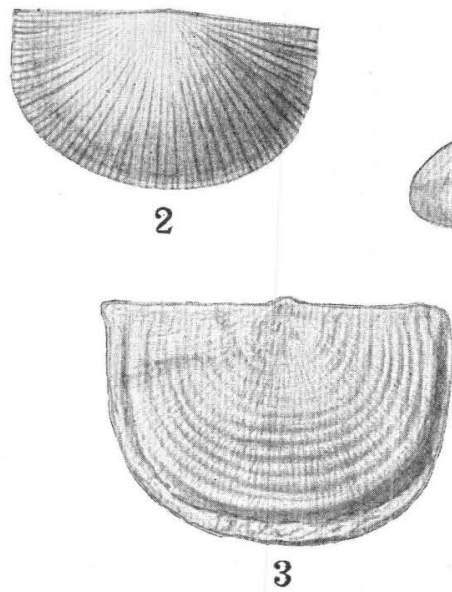

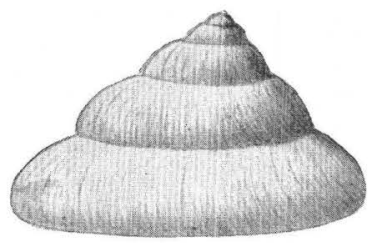

7

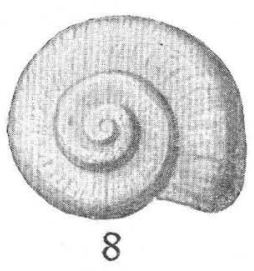

$7 a$
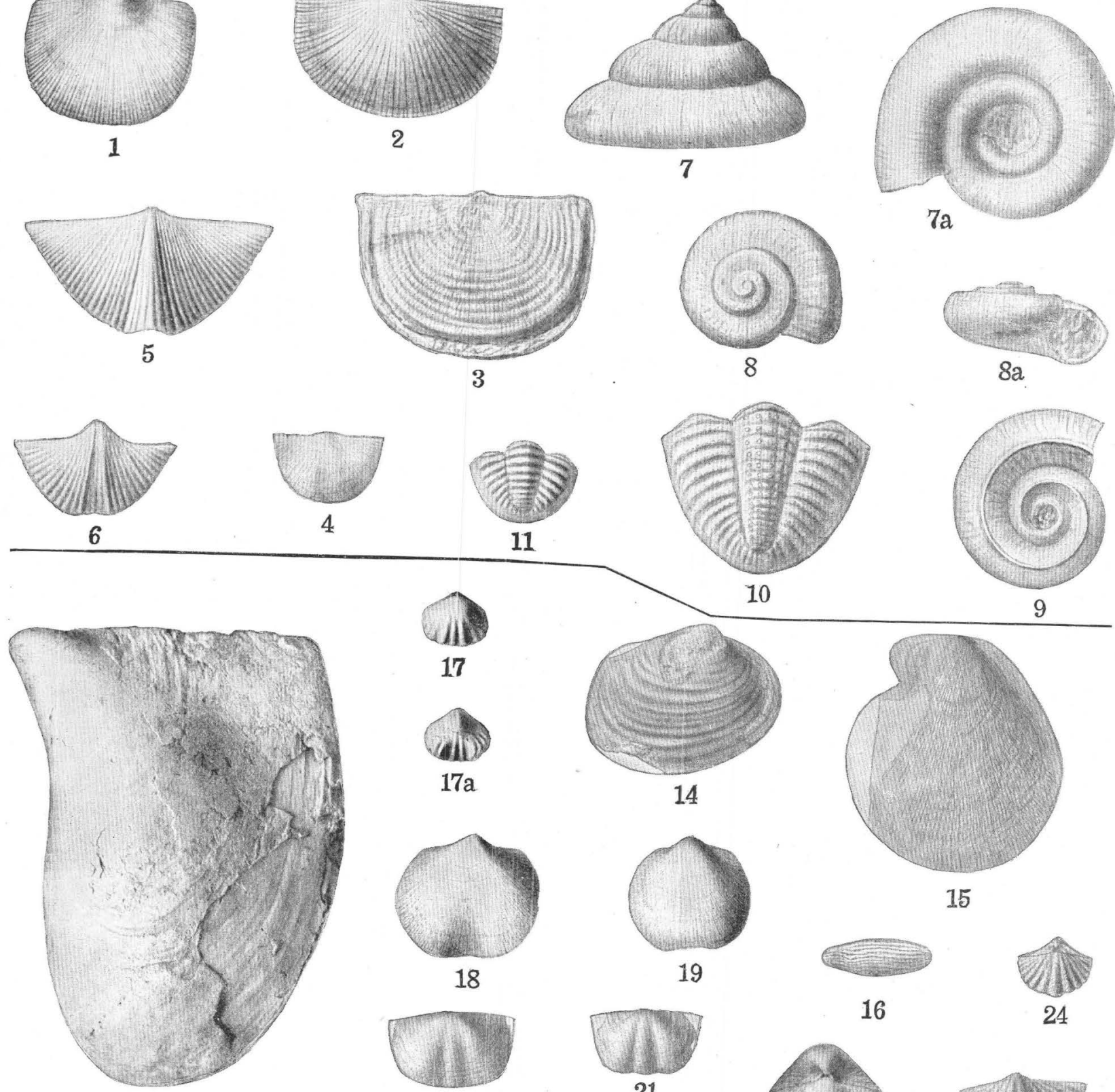

12

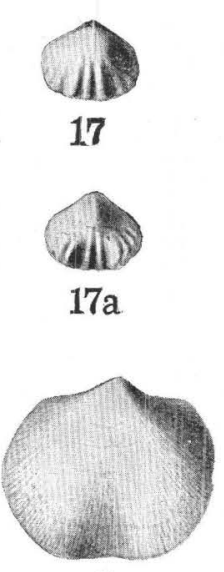

18
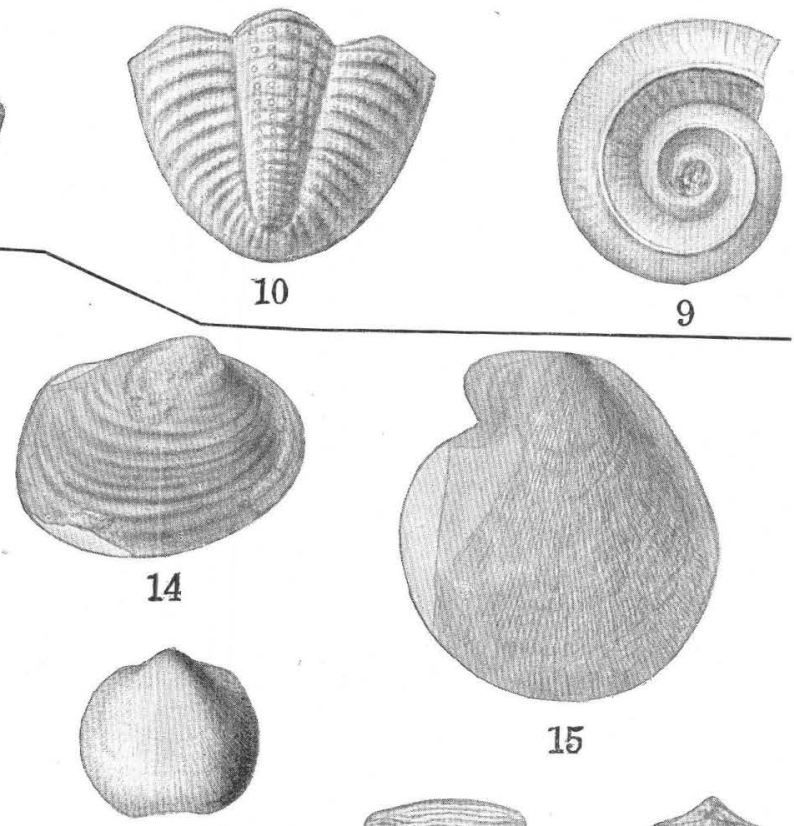

19

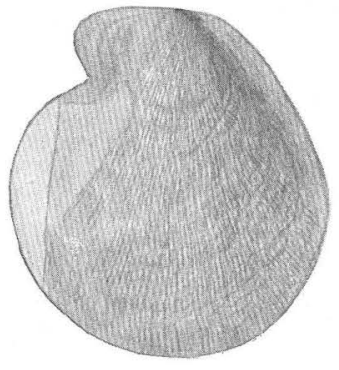

15
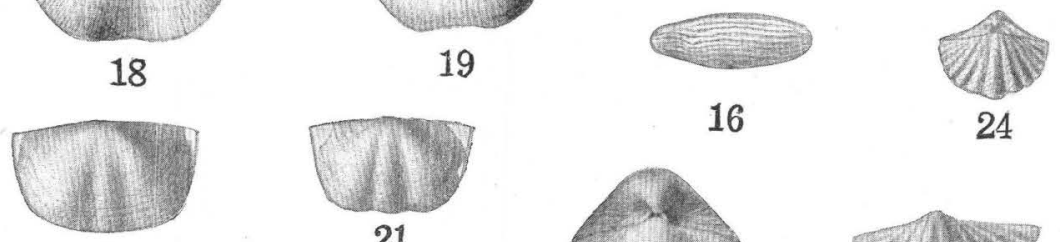

20

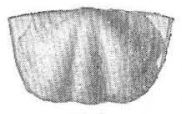

21

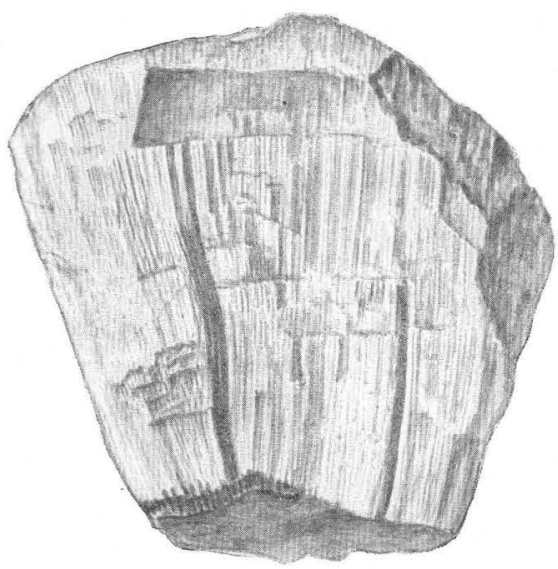

13

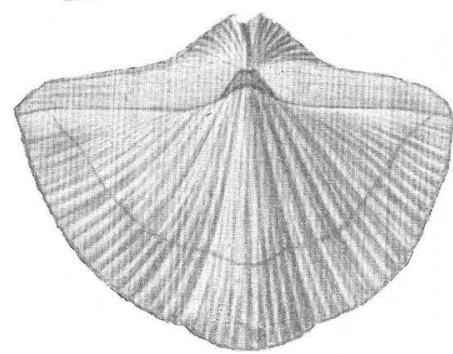

22

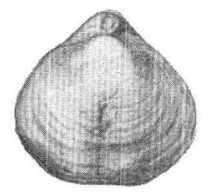

27

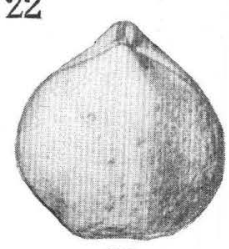

28
24
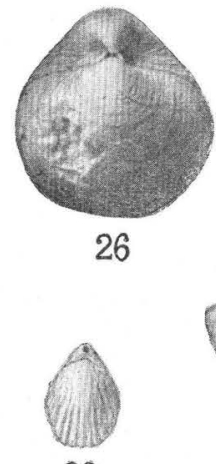

29

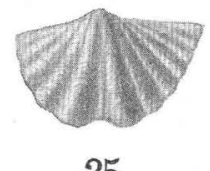

25

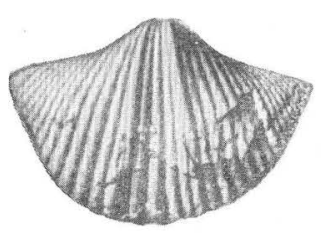

23

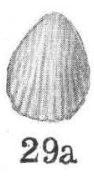

$29 \mathrm{a}$

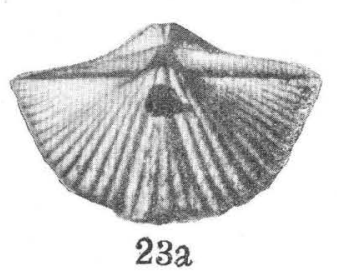

CHARACTERISTIC FOSSILS OF LOWER MISSISSIPPIAN AND PENNSYIVANIAN AGE. 

Edmondia gibbosa MeCoy.

Figure 14. A right valve.

After Girty, U. S. Geol. Survey Prof. Paper 16, pl. 9, fig. 8, 1903. The figured specimen from the Rico quadrangle, Colo.

Pseudomonotis kansasensis Beede.

Figure 15. A left valve.

After Girty, U. S. Geol. Survey Prof. Paper 16, pl. 8, fig. 4, 1903. The figured specimen is from the Rico quadrangle, Colo.

\section{Fusulina cylindrica Fischer de Waldheim.}

Figure 16. Side view, $\times 2$.

After White, U. S. Geog. and Geol. Surveys W. 100th Mer. Final Rept., vol. 4, pt. 1, pl. 6, fig. 6a, 1877. The figured specimen is from an undesignated locality in Utah. The species is probably not true Fusulina cylindrica, though it is commonly cited under that name.

Pugnoides osagensis Swallow.

Figure 17. Dorsal view.

17a. Ventral view of the same.

After Girty, U. S. Geol. Survey Bull. 544, pl. 10, figs. 11 and 11c, 1915. The figured specimen is from the Coalgate quadrangle, Okla. The form may be, as it is commonly considered to be, the same as Rhynchonella utah of Marcou, but, if so, Marcou's figures must be very poor.

\section{Schizophoria resupinoides Cox?}

Figure 18. A ventral valve.

19. A smaller dorsal valve.

After White, U. S. Geog. and Geol. Surveys W. 100th Mer. Final Rept., vol. 3, Suppl., Appendix, pl. 3, figs. $2 \mathrm{a}$ and $2 \mathrm{~b}, 1881$. The figured specimens are from Manuelitos Creek, N. Mex. This species is not Schizophoria resupinoides of Cox and may prove to belong to Mather's Schizophoria altirostris.

Chonetes mesolobus var. decipiens Girty.

Figure 20. View of a ventral valve.

21. View of another ventral valve.

After Girty, U. S. Geol. Survey Prof. Paper 16, pl. 1, figs. 20 and 22, 1903. The figured specimens are from the Durango quadrangle, Colo.
Spirifer triplicatus Hall (p. 645).

Figure 22. Dorsal view.

After White, U. S. Geog. and Geol. Surveys W. 100th Mer. Final Rept., vol. 4, pt. 1, pl. 10, fig. 1a, 1877. The figured specimen is from near Santa Fe, N. Mex.

Spirifer rockymontanus Marcou.

Figure 23. Ventral view of a specimen of medium size.

23a. Dorsal view.

After Girty, U. S. Geol. Survey Prof. Paper 16, pl.6, figs. 1 and 1a,1903. The figured specimen is from the Durango quadrangle, Colo. The identification adopted is the current one. Marcou may have included two distinct species in his Spirifer rockymontanus, and the form figured here may not be identical with either of them.

Spiriferina kentuckyensis Shumard.

Figure 24. Dorsal view of a specimen.

25 . Ventral view of an unsymmetrical specimen enlarged to 2 diameters.

After White, U. S. Geog. and Geol. Surveys W. 100th Mer. Final Rept., vol. 4, pl. 10, figs. 4a and 4c, 1877. The figured specimens are from an undesignated locality in the Great Basin region.

Squamularia perplexả McChesney.

Figure 26. Dorsal view.

. After Girty, U. S. Geol. Survey Bull. 544, pl. 11, fig. 2, 1915. The figured specimen is from the Coalgate quadrangle, Okla. Most specimens of this species are smaller than the one figured, and rather broader.

\section{Composita subtilita Hall.}

Figure 27. Dorsal view.

28. Dorsal view of a larger and longer specimen. After Girty, U. S. Geol. Survey Prof. Paper 16, pl. 7, figs. 4 and 6,1903 . The figured specimens are from the Durango quadrangle, Colo.

\section{Hustedia mormoni Marcou.}

Figure 29. Dorsal view.

29a. Ventral view of same.

After White, U. S. Geog. and Geol. Surveys W. 100th Mer. Final Rept., vol. 4, pl. 10, figs. $7 \mathrm{a}$ and $7 \mathrm{~b}, 1877$. The figured specimen appears to be from an undesignated locality in New Mexico or Nevada. Marcou's original specimens are said to have come from Utah. 


\section{PLATE LV.}

\section{Productus cora D'Orbigny.}

Figure 1. The type specimen, a ventral valve, seen from above, $\times 1 \frac{1}{2}$.

1a. Side view of same, $\times 1 \frac{1}{2}$.

After Tschernyschew, in Com. geol. [Petrograd] Mém., vol. 16, No. 2, p. 289, figs. A and $\mathrm{B}, 1902$. The specimen is from Yarbichambi (?), Bolivia.

2. Side view of a typical specimen.

2a. Dorsal view.

2b. Posterior view.

2c. Ventral view.

After Kozlowski, in Annales de paléontologie, vol. 9, pl. 6, figs. 1a, 1b, 1c, 1d, 1914. The figured specimen is from Yarbichambi, Bolivia.

Productus inflatus var. coloradoensis Girty.

Figure 3. Ventral view.

4. Dorsal view of another specimen.

After Girty, U. S. Geol. Survey Prof. Paper 16, pl. 3, figs. 1 and 3, 1903. The figured specimens are from the Leadville district, Colo.

Marginifera splendens Norwood and Pratten.

Figure 5. Dorsal view.

5a. Ventral view.

After Girty, U. S. Geol. Survey Bull. 544, pl. 10, figs. 2 and $2 b, 1915$. The figured specimen is from the Wewoka quadrangle, Okla.
Marginifera muricata Norwood and Pratten.

Figure 6. Dorsal view.

7. Ventral view of another, more coarsely ribbed specimen.

After Girty, U. S. Geol. Survey Bull. 544, pl. 10, figs. 3 and 4,1915 . The figured specimens are from the Wewoka quadrangle, Okla.

\section{Pustula nebraskensis Owen.}

Figure 8. Ventral view of an exfoliated specimen.

9. Dorsal view of a smaller, more perfectly preserved specimen.

After Girty, U. S. Geol. Survey Prof. Paper 16, pl. 5, figs. 1 and 2, 1903. The figured specimens are from the Durango quadrangle, Colo.

\section{Pustula semipunctata Shepard.}

Figure 10. A ventral valve with well-preserved surface, seen from above, $\times 1 \frac{1}{2}$.

11. Dorsal view of a characteristic specimen.

11a. Ventral view of same.

The figured specimens are from the Iola limestone, at Iola, Kans. 


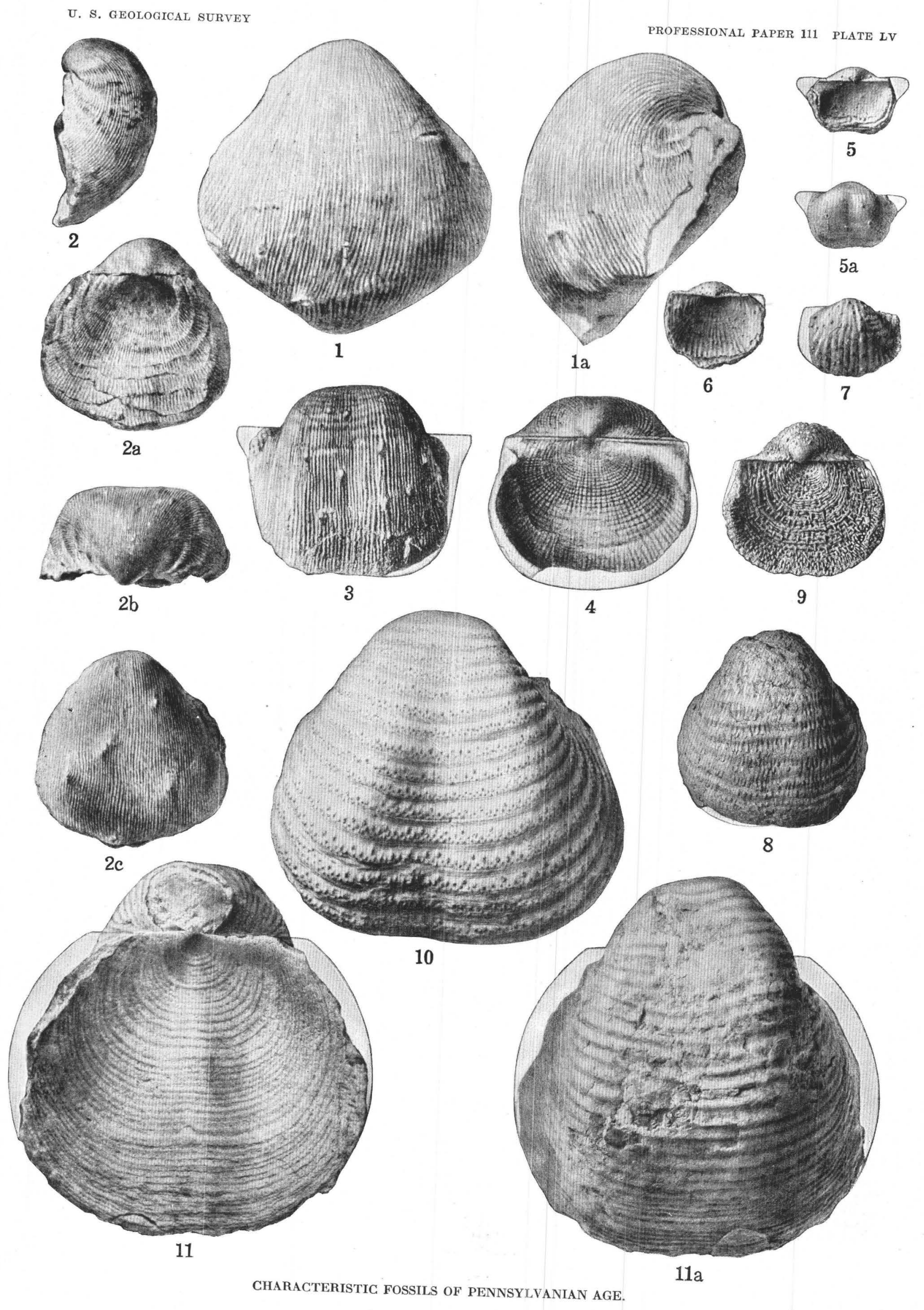



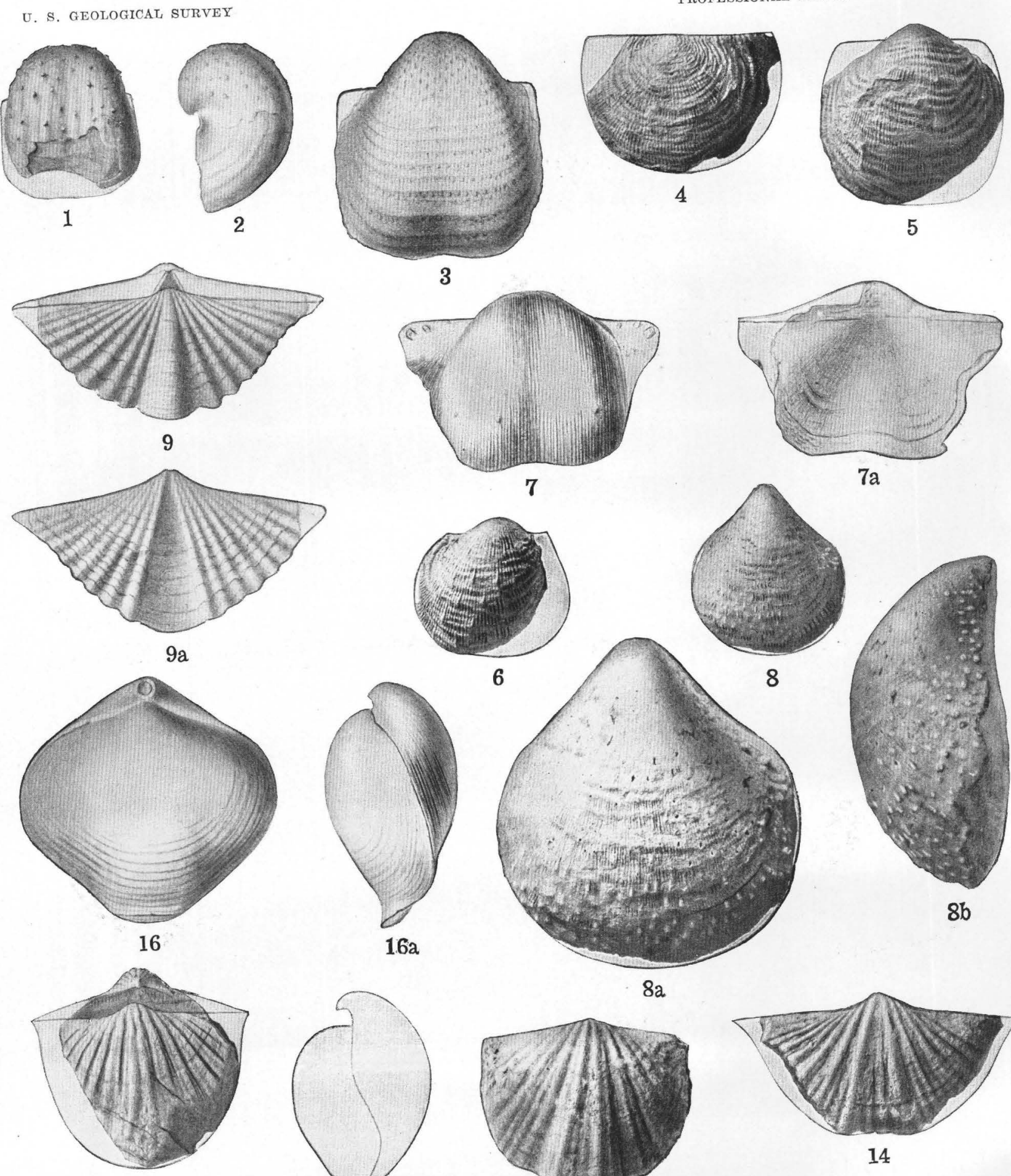

10

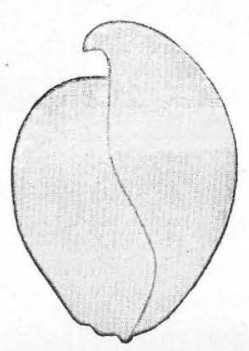

10a

6

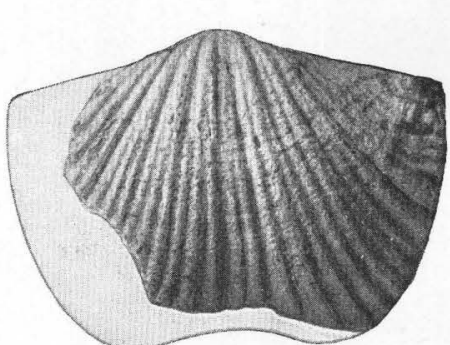

13

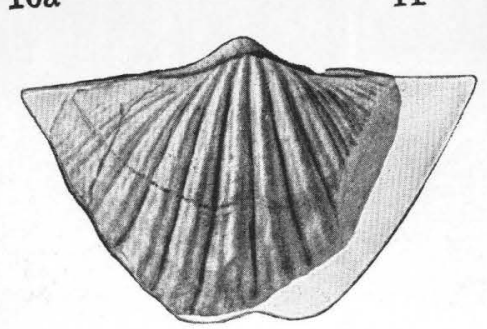

12

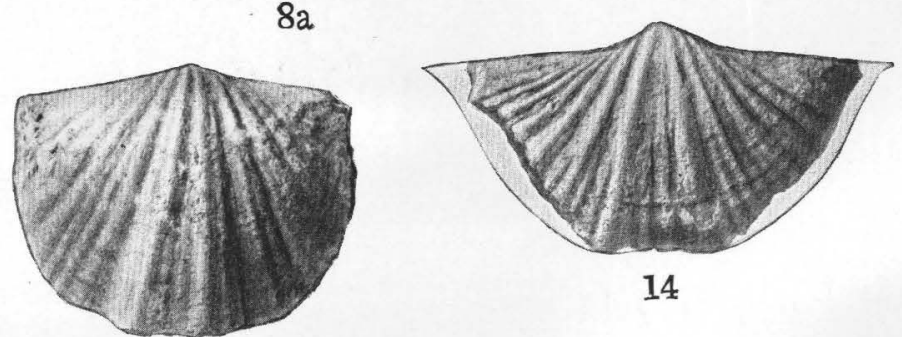

11

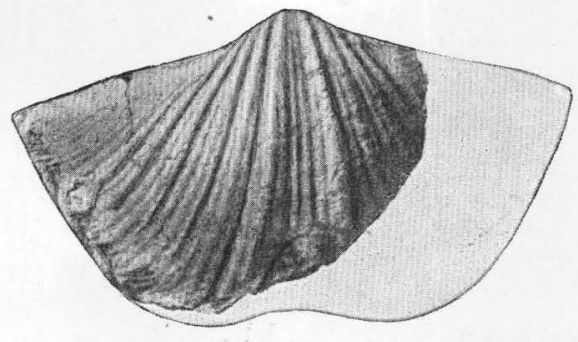

15

CHARACTERISTIC FOSSILS OF PERMIAN AGE. 


\section{PLATE LVI.}

Pustula subhorrida Meek.

Figure 1. Front view of a ventral valve.

2. Side view of another ventral valve.

After Meek, U. S. Geol. Expl. 40th Par. Final

Rept., vol. 4, pt. 1, pl. 7, figs. 3 and 3a, 1877.

The figured specimens are from an undesignated locality in the Great Basin region.

\section{Pustula nevadensis Meek.}

Figure 3. Ventral valve seen from above. After Meek, U. S. Geol. Expl. 40th Par. Final Rept., vol. 4, pt. 1, pl. 8, fig. 2b, 1877. The figured specimen is from an undesignated locality in Nevada.

Productus phosphaticus Girty.

Figure 4. External mold of a dorsal valve.

5. A characteristic ventral valve.

6. A ventral valve showing numerous spines that spring from raised costae.

After Girty, U. S. Geol. Survey Bull. 436, pl. 2, figs. 7-9, 1910. The figured specimens are from Montpelier, Idaho.

\section{Productus multistriatus Meek.}

Figure 7. Ventral view of a characteristic specimen.

7a. Dorsal view of the same.

After Meek, U. S. Geol. Expl, 40th Par. Final Rept., vol. 4, pt. 1, pl. 8, figs. $3 \mathrm{~b}$ and $3 \mathrm{c}$, 1877. The figured specimens are from an undesignated locality in Nevada.
Aulosteges hispidus Girty, n. sp. (p. 644).

Figure 8. The typical specimen, a ventral valve, seen from above.

8a. Same, $\times 2$.

8 b. Side view, $\times 2$.

The figured specimen is from Weber Canyon, Wasatch Range, Utah.

Spiriferina pulchra Meek.

FIgURE 9. Dorsal view of the original tryical specimen.

9a. Ventral view.

After Meek, U. S. Geol. Expl. 40th Par. Fina Rept., vol. 4, pt. 1, pl. 8, figs. 1 and 1a, 1877. The figured specimen is from Nevada.

Spirifer pseudocameratus Girty, n. sp. (p. 644).

Figure 10. Dorsal view of a narrow specimen.

10a. Side view in outline.

11. Dorsal view of a characteristic specimen.

12. Dorsal view of a specimen that has the fold deeply divided.

13. A ventral valve of somewhat different type.

14. A ventral valve that is uncommonly wide at the hinge.

15. An imperfect ventral valve.

The figured specimens are from Weber Canyon, Wasatch Range, Utah.

Composita mira Girty (p. 646).

Figure 16. Dorsal view of a large specimen accidentally compressed.

16a. Side view of same.

After Meek, U. S. Geol. Expl. 40th Par. Final Rept., vol. 4, pt. 1, pl. 9, figs. 3 and $3 b$, 1877. The figured specimen is from an undesignated locality in Nevada. 


\section{PLATE LVII.}

Aviculipecten utahensis Meek.

Figure 1. A left (?) valve, natural size.

1a. A portion of the surface of the same, magnified to show the minute, crowded, concentric striae.

After Meek, U. S. Geol. Expl. 40th Par. Final Rept., vol. 4, pt. 1, pl. 9, figs. 7, 7a, 1877. The figured specimen is from eastern Nevada.

\section{Aviculipecten weberensis Hall and Whitfield.}

Figure 2. View of a left valve, showing the strongly alternating coarser and finer sculpture.

After Hall and Whitfield, U. S. Geol. Expl. 40th Par. Final Rept., vol. 4, pt. 2, pl. 6, fig. 5, 1877. The figured specimen is from the foothills of the Wasatch Range, southeast of Salt Lake City, Utah.

Aviculipecten parvulus Hall and Whitfield.

Figure 3. Figure of a left valve, $\times 3$, showing the strong, elevated, primary rays, with finer ones between.

After Hall and Whitfield, U. S. Geol. Expl. 40th Par. Final Rept., vol. 4, pt. 2, pl. 6, fig. 6, 1877. The figured specimen is from the foothills of the Wasatch Range, southeast of Salt Lake City, Utah.

Aviculipecten curticardinalis Hall and Whitfield.

Figure 4 . The type specimen, $\times 2$.

After Hall and Whitfield, U. S. Geol. Expl. 40th Par. Final Rept., vol. 4, pt. 2, pl. 6, fig. 4, 1877. The figured specimen is from the foothills of the Wasatch Range, southeast of Salt Lake City, Utah.

\section{Aviculipecten occidaneus Meek.}

Frgure 5. A small left valve, $\times 2$.

6. A left valve which has the anterior ear broken away.

After Meek, U. S. Geol. Expl. 40th Par. Final Rept., vol. 4, pt. 1, pl. 12, figs. 13, 13a, 1877. The figured specimens are from Weber Canyon in the Wasatch Range, Utah.
Aviculipecten? deseret Girty, n. sp. (p. 647).

Figure 7. A small left (?) valve, seen from above.

7a. Same, $\times 2$.

8. An imperfect specimen that has well-preserved sculpture. Seen from above, $\times 4$.

9. A characteristic left (?) valve, seen from above.

9a. Same, $\times 2$.

The figured specimens are from Dry Canyon in the Wasatch Range, east of Salt Lake City, Utah.

Sedgwickia? concava Meek and Hayden.

Figure 10. A right valve, as obtained by a gutta-percha impression in the natural mold.

After Hall and Whitfield, U. S. Geol. Expl. 40th Par. Final Rept., vol. 4, pt. 2, pl. 6, flg. 3,1877 . The figured specimen is from the foothills of the Wasatch Range, southeast of Salt Lake City, Utah.

Myacites inconspicuus Meek.

Figure 11. A left valve, $\times 2$.

After Meek, U. S. Geo.. Expl. 40th Par. Final Rept., vol. 4, pt. 1, pl. 12, fig. 10, 1877. The figured specimen is from Weber Canyon in the Wasatch Range, Utah. This figure so much resembles Hall and Whitfield's figure of Sedgwickia? concava as to suggest strongly that they are the same species. Hall and Whitfield's fossil is without much doubt wrongly identified; if it is the same as Myacites inconspicuus, it will go into the synonymy of that species; if it is not the same it is probably a new species.

\section{Astartella? forresteri Girty.}

Figure 12. Right valve of a typical specimen, $\times 2$.

12a. Same in outline, natural size.

12b. Anterior view, $\times 2$.

12c. Cardinal view, $\times 2$.

13. Right valve of a differently shaped specimen, $\times 2$.

13a. Same in outline, natural size.

14. Left valve of a large specimen with an extended anterior end.

The figured specimens are from near Torrey, Wayne County, Utah. 
U. S. GEOLOGICAL SURVEY
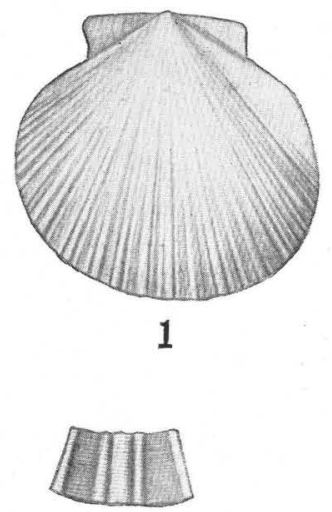

1a

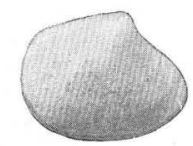

12

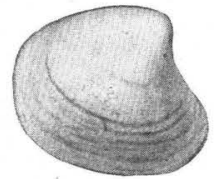

13

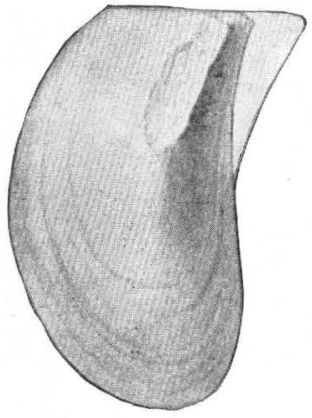

15

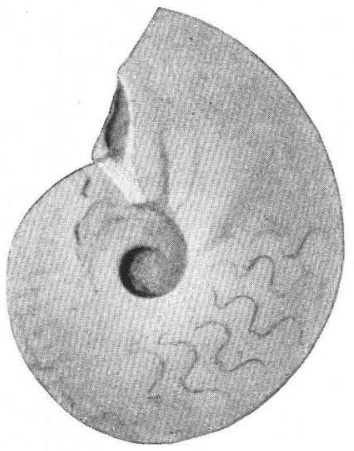

19

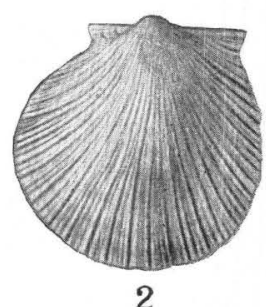

2

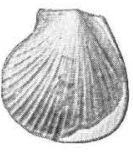

7

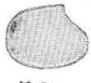

$12 a$
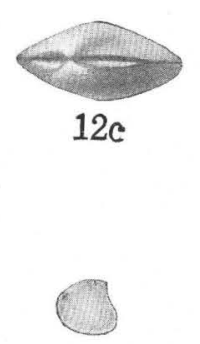

$13 a$

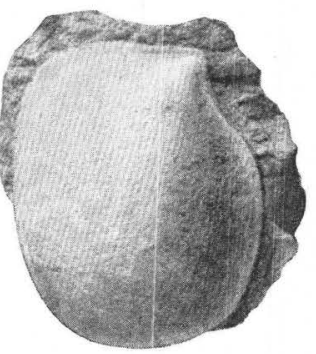

16
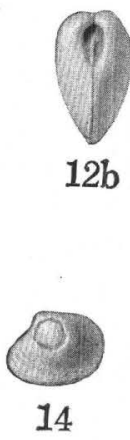

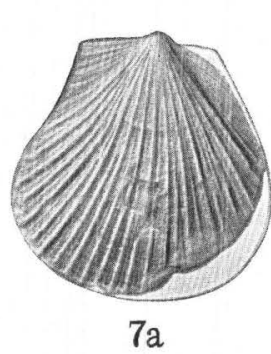

PROFESSIONAL PAPER 111 PLATE LVII
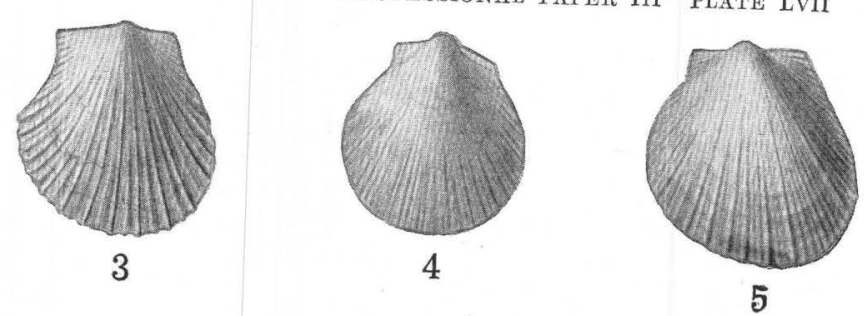

5
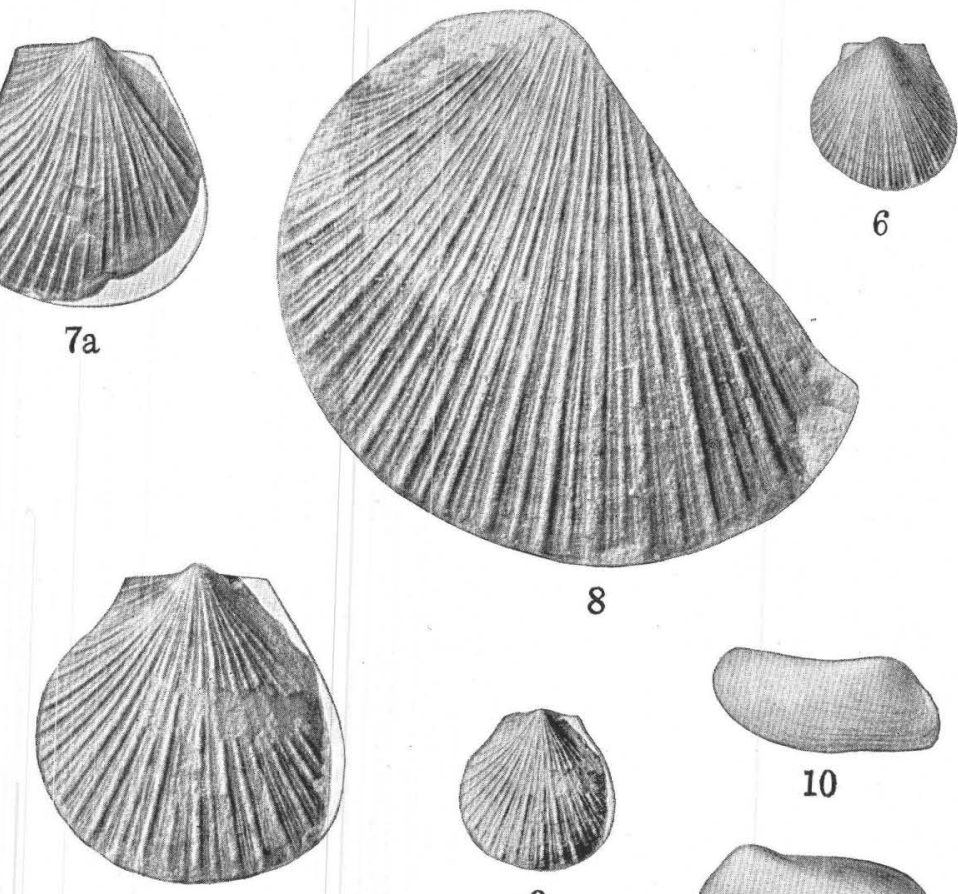

$9 \mathrm{a}$
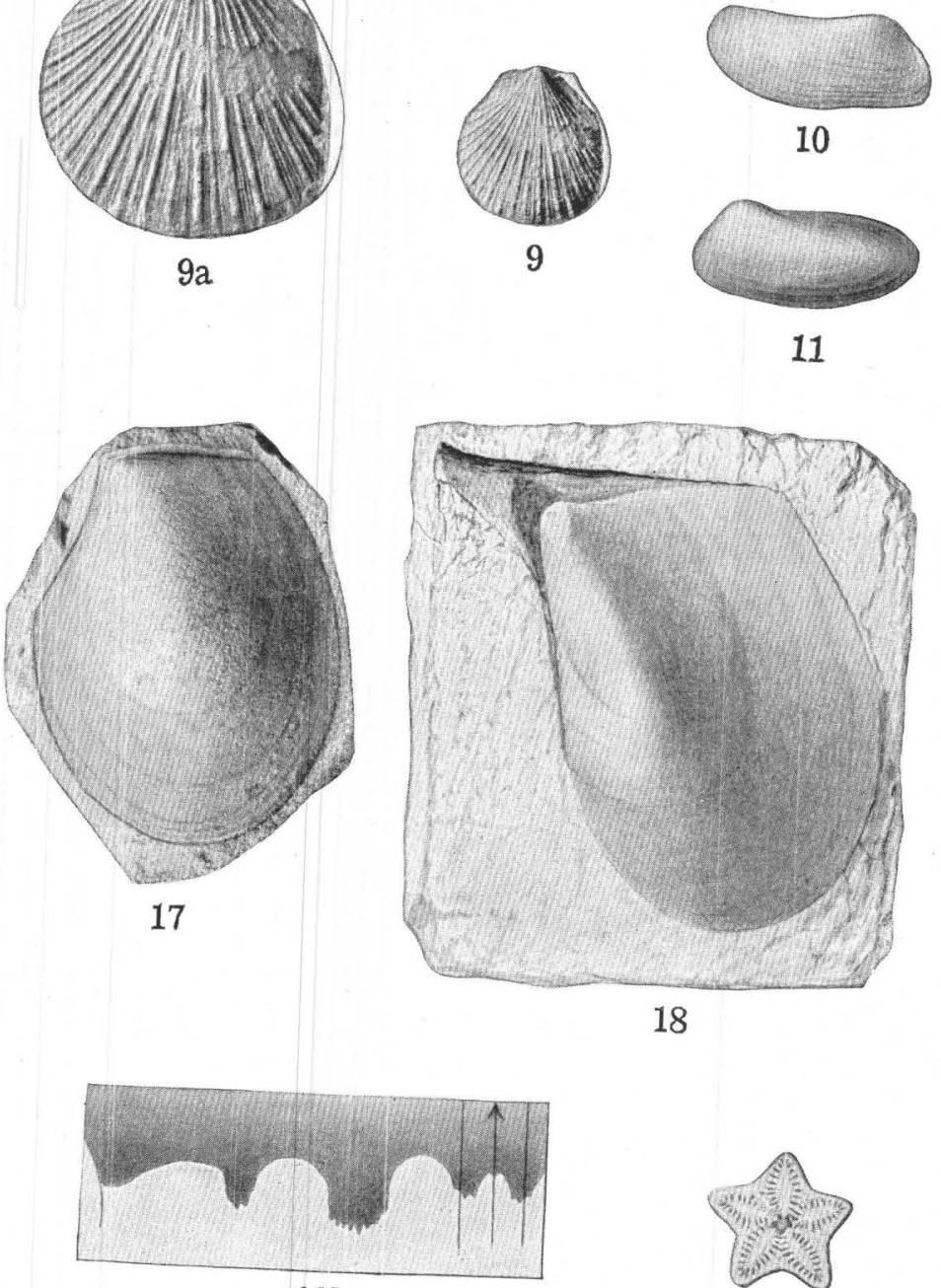

$19 b$

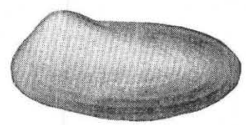

11

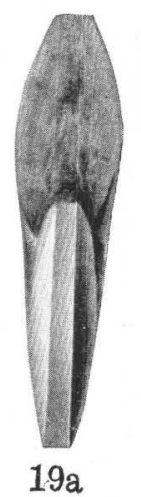

CHARACTERISTIC FOSSILS OF LOWER TRIASSIC AGE.

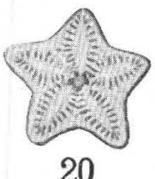





\section{Myalina permiana Swallow.}

FIgURE 15. View of a mold of a right valve, showing the usual form. The outline at the beak shows the extreme of other specimens.

After Hall and Whitfield, U. S. Geol. Expl. 40th Par. Final Rept., vol 4, pt. 2, pl. 6, fig. 7, 1877. The figured specimen is from the foothills of the Wasatch Range, southeast of Salt Lake City, Utah. The identification quoted above is almost certainly erroneous, and the species is probably a new one.

Myalina? platynotus White (p. 648).

FIGURE 16. A rather short and broad right valve.

17. A characteristic left valve.

The figured specimens are from the base of the Thaynes limestone, Park City district, Utah.

Myalina aviculoides Meek and Hayden.

Figure 18. View of an internal mold of a left valve with the impression of the extended beak showing in the matrix.

After Hall and Whitfield, U. S. Geol. Expl. 40th Par. Final Rept., vol. 4, pt. 2, pl. 6, fig. 8, 1877. The figured specimen is from the foothills of the Wasatch Range, south$35416^{\circ}-19-42$ east of Salt Lake City, Utah. The identification quoted above is almost certainly erroneous, and the species is probably a new one.

Meekoceras gracilitatis White.

Figure 19. Side view of a rather small specimen.

19a. Front view of same.

$19 \mathrm{~b}$. Suture of same, $\times 2$.

After Hyatt and Smith, U. S. Geol. Survey Prof. Paper 40, pl. 12, figs. 7, 8, and 10 The figured specimen is from Aspen Ridge, near Soda Springs, Idaho, but very similar specimens occur in limestones supposed to represent the Thaynes limestone, in the Wasatch Range, Utah.

Pentacrinus asteriscus Meek and Hayden?

Figure 20. View of a disk referred with doubt to this species, $\times 2$.

After Hall and Whitfield, U. S. Geol. Expl. 40th Par. Final Rept., vol. 4, pt. 2, pl. 6, fig. 16, 1877. The figured specimen is from the Pah-Ute Range, Nev. Star-shaped crinoid stems similar to this, though probably not the same species, are rather characteristic of the lower Triassic rocks of Idaho and Utah. They occur, for instance, in the Thaynes limestone of the Park City district. 


\section{-}




\section{INDEX.}

A.

Page.

Abajo Mountains, geography of. geology of. gold deposits in

Abbey prospect, description of.

Acknowledgments for aid

Adamite, occurrence of.

Adularia, deposition of.

Agriculture. .

See also general features under names of localitits.

Ajax limestone, nature of.....

Albion mine, ore bodies in....

- Allah prospect, ore bodies on.

Allen, E. T., analyses by.

.....................

................

Alpine district, ore deposits in...

Alta overthrust fault, description of...

Alta-Clayton Peak stock, description of . .

Alta-Gladstone vein, description of

Alteration, action of mineralizing solutions in .

contact, chemical and mineralogic changes due to

surface, importance of.

in the Park City district.

influence of erosion on..

influence of ground water level on. See also Metasomatism.

Aluminum, possible commercial source of. solution and deposition of, by vein-forming solutions....... 182-183

lunite, absence of, from sedimentary rocks. analyses of...

banded veins of, plate showing

banded, with quartz, photomicrograph showing..

deposition of....

116,181-182,546-550

origin of . . ................................. 186-187, 193-194

plumose crystals of, photomicrograph showing. .

wall rock of alunite vein altered to, photomicrograph of.....

Alvarado mine, ore body in.

American Consolidated Copper Co.'s property, fissure veins on, deseription of.

American Fork, faults at head of, description of.

28sits in, descriptions of........ 279-280

geclogy of ...

history of mining in.

location and topography of.

$228-229$

production in.

See also Cottonwood-American Fork area.

Amphibole group, occurrence of

Andalusite, occurrence of.

Andesite, analyses of.

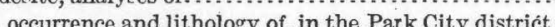

Anglesite, genesis of ..................................... 206, 210

occurrence of. ...................................... 115, 306

Anhydrite, cceurrence and origin of ................. 115, 185-186

Ankareh shale, occurrence and lithology of .................. 295

Ankerite, occurrence of...

Annabergite, occurrence of

Annie Laurie mine, ore bodies in.

Antelope district, location of. ore deposits in.

Antelope group, production from.

Antimony, production of.

Antimeny minerals, occurrence of surface alteration of..

Aragonite, cccurrence of..

Arbroath mine, description of.

Arentz, S. S., acknowledgment to.
Argenta district, general features of...................... geology of ......................................... 218-219 ore deposits of..................................... 219 Argentite, action of surface waters on...................... 207 occurrence of ................................... 107 primary or secondary rank of, doubtful................. 207 Arizona, geologic columnar section of part of:............. In pocket. Arsenic, copper minerals containing, surface alteration of........ 210 occurrence of ................................. 562-563 ore of, containing rosette of quartz, photomicrographs of..... 598 recovery of ..................................... 143 Arsenic minerals, occurrence of................ 106-108, 114-115,306 surface alteration of . .............................206-207 Arsenobismite, occurrence of........................... 109 Arsenopyrite, occurrence of . .......................... 108 Ashbrook district, history of mining in ..................... 495

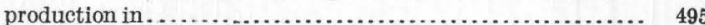
Assimilation by ragmas, definition of . . . . . . . . . . . . Astartella forresteri Girty ................................... 656 Atwood, W. W., cited .............................. $70-71$

Aulosteges hispidus Girty, n. sp..........................644, 655 Aurichalcite, occurrence of............................ 111 Austin mine, production from............................ 284

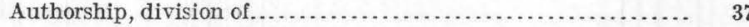

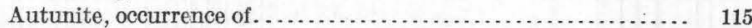

A viculipecten curticardinalis Hall and Whitfield.............. 656 occidaneus Meek.................................... 656 parvulus Hall and Whitfield . ........................ 656 utahensis Meek ........................................ 656 weberensis Hall and Whitfield .......................... 656 Aviculipecten? deseret Girty, n. sp.................... 647-648, 656 Axinite, occurrence of ................................. 113

Azurite, occurrence of .............................. 111, 305

Baby Ruth claim, ore on.............................. $629-630$

Bailey, R. K., analyses by ............................ 549

Barite, occurrence of . ................................ 115, 185, 306 replacement of, by quartz and adularia, photomicrograph showing.. 175

Barry Coxe mine, description of...................... 268-269

Basalt from Pilot Range, analyses of .......................... 491

Basin province, character of............................ $\quad 71$ correlation of ............................................ 74

Basin Ranges, development of......................... $73-7$ erosion and sedimentation in ........................ $72-73$ origin of.................................................... $71-72$ Bay State mine, description of......................... 270 Bear River, course of .................................... $\quad 59$

Bear River Range, geology of ........................ 216-217 location of....................................... 216 ore deposits of.................................. 217-218

Beaver Canyon, section of rocks in.................... 531-532

Beaver Carbonate mine, alteration of.................... 523-527 ore bodies in .................................... 519 production from................................... 504

Beaver County, production in........................ 505-507

Beaver Dam Mountains, general features of.................. 594

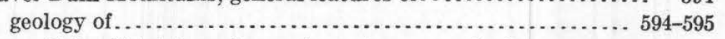

Beaver Lake district, analyses of quartz monzonite from........ 96 history of mining in ............................... 505

Beaver Lake Mountains, plate showing...................... $\quad 69$

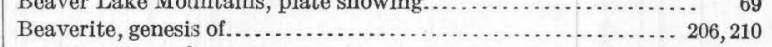
occurrence of........................................ 116 Beeson, J. J., acknowledgment to......................... 230

Ben Harrison mine, description of..................... 373-374

Beryl, occurrence of................................... 112

Beudantite, occurrence of .................................. 115 
Page.

Bibliography.

See also under names of ranges and districts.

Big City tunnel, location of, plate showing.

Big Cottonwood Canyon, columnar section in.

Mill D Fork of, view in...

Big Cottonwood district, bed deposits in, description of.

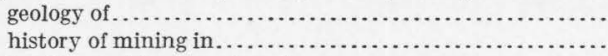

location and topography of ........................ 227-228

production in.

See also Cottonwood-American Fork area.

Big Cottonwood fault, description of.

Big Indian mine, copper ore in.

Big Indian Valley, copper deposits in

Big Nebo mine, description of.

Bindheimite, occurrence of.

Bingham, Utah Copper Co.'s property at, geologic map and section of.

Bingham Canyon, gold placers in.....

in 1900 , plate showing

in 1914, plate showing..

Bingham district, bed deposits in, nature and occurrence of

bibliography of...

copper deposits in, alteration of . . . . .

surface alteration of..

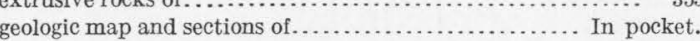

reology of . .

gold ores in, alteration of

history of mining in..

igneous rocks in.

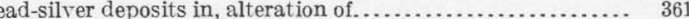

limestone in ...................................... 348-349

location of.

ore deposits in ....................................... $356-36$

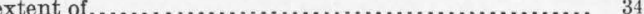

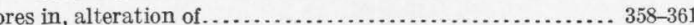

genesis of ..................................... 361

physiography of.

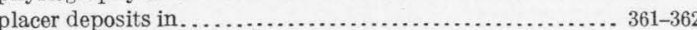

production in . .................................. 342-347

sedimentary rocks in, nature and age of . . . . . . . . . . . . . . 348-349

structure of . ....................................... 354-356

veins and lodes in, form and origin of ...................... 356

Bingham quartzite, nature of ......................... 337,348

Bingham stock, alteratio $\mathrm{n}$ of . . ......................... 351-352

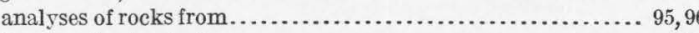

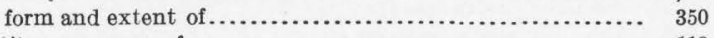

Biotite, occurrence of ................................... $\quad 113$

"Birdseye" porphyry, nature and occurrence of........... 375, 390-391

Bismite, occurrence of................................. 109

Bismuth, content in blister copper from the Bingham district...... 347

mining of.....

occurrence of.

recovery of.

Bismuth mine, ore body of

Bismuthinite, occurrence of

Bismuthite, occurrence of.

Bixbyite, occurrence of.

Black Balsam rein, description of .

Black Bess prospect, description of

Black Crook district. See Erickson district.

Black Hawk mine, ore bodies in.

Black Warrior mine, ore bodies in.

Blackjack, occurrence of

(n............................

from $. . . \ldots \ldots \ldots \ldots \ldots \ldots \ldots \ldots \ldots . .217$

Blackwelder, Eliot, cited.............................. 70,234

Blaine mine, ore bodies in............................. 453-454

Blende, occurrence of .................................. 107

Blue Bells district, geology of . . .

location of............................................. $429-430$

ore deposits in, genesis of............................ 431-432

production in.

Blue Dike prospect, ore body in

430
-622

Blue Dike prospect, ore

$21-622$

Blue Lodge district, history of mining in
Blue Mountains, Oreg., quartz-tourmaline-copper deposits in..... 161

Blue Mountains, Utah. See Abajo Mountains.

Bluebell dolomite, nature of.............................. 399

Bonneville, Capt. B. L. E., exploration by...................... 117

Book Cliffs, section of Cretaceous rocks near.................. 85

Borickite, occurrence of . ...................... 114

Bornite, occurrence of................................... 107

Boron minerals, occurrence of............................. 115

Boulder Bonanza-Humming Bird claims, production from...... 217

Bournonite, occurrence of . ........................... 108, 303

Boutwell, J. M., cited.................................. 318-319, $354,355,356,358-359,361-362,395,599,602-603,604$

Boutwell, J. M., and Woolsey, L. H., cited.................. 99

Box Elder district, geology of........................... 221 ore deposits of................................... 221, 222

Bradshaw district, history of mining in................... $530-531$ ore deposits in...................... 535-536

Branborg property. See American Consolidated Copper Co.'s property.

Breccia ores, plate showing............................. 174

Brecciation, influence of, on mineralization.................. 175

Brochantite, occurrence of ............................. 115

Bromide mine, ore bodies in.......................... $628-629$

Browns Park area, copper ores in........................ 605 geology of .......................................... 604-605

Brownstone tunnel. See Santaquin Central tunnel.

Brucite, occurrence of ................................. $\quad 110$

Buckeye Reef, plate showing............................. 586

Buckhorn claim, production from ...................... 462-463

Buckland Mining \& Development Co.'s property, description of. 226-227

Buffalo tunnel, description of............................. 256

Bull Valley district, bibliography of...................... 581-582 general features of . ................................... $580-581$

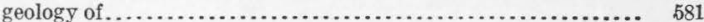

ore deposits of.......................................... 581

southern part of, antimony deposits in................... 598

arsenic deposits in ................................ 598

general features of................................. 597

geology of .......................................... 597

gold deposits in ................................. 598

ore deposits in, development of................... 597-598

Bullion Coalition Mines Co., properties consolidated by......... 364 See also Honerine mine.

Bullion Divide, location of ........................... 231

Bully Boy and Webster mine, ore bodies in ................... 556

Burling, L. D., fossils determined by.......... 336, 374-375, 425, 459, 527

Butte mine, description of ........................... 267

mine, description of ................................... 276

ctus mine, alteration in ............................. 522-523

ore body in, origin of ................................ 520

plate showing ...................................... 504

Cactus ore zone, mineralization of...................... $516-518$

Calamine, occurrence of . .............................. 113,305

Calcite, occurrence of. ................................... 111, 305

replacement of, by quartz and adularia, photomicrograph of.. $\quad 175$ smithsonite pseudomorphs after, plate showing............ 206

Cambrian period, characteristic fossils of, plates showing ....... 76, 77

formations of. . .

rocks of, in the Santaquin and Mount Nebo region, nature and occurrence of.................................. 324-325

Cambrian quartzite, early, nature and distribution of........... $78-79$

Camp Floyd district, bibliography of.................... 395

geology of ........................................... 388-391

gold in, method of occurrence of...................... 394-395

history of mining in............................... 382-387

ore deposits in . . . . . . . . . . . . . . . . . . . . .

genesis of.......................................... 395

production in .................................. 382-383, 384

sedimentary rocks in............................... 388-389

structure of ........................................ $\quad 391$

topography of .................................... 387

Cane Springs mine, ore body in . ........................ 480

Canyon Range, Carboniferous limestone in . . . . . . . . . . . .

Eocene conglomerate in................................. 421

geology of .............................................. $418-422$

quartzite in ........................................ $420-421$

structure of................................... $421-422$ 
Carbonate district, production in

Carbonate fault, description of..

Carbonate Hill mine, content of ore from

Carbonate mine, description of.

Carbonate minerals, occurrence of .

Carboniferous sediments, nature and distribution of .

See also under names of ranges and districts.

Cardiff mine, dividends paid by...

location of, plate showing..

mineralized thrust faults in

Cardiff vein, description of

Carnation mine, ore bodies in............................ 469

Carnotite. See Uranium.

Cascade mine, ore bodies in

Cave mine, description of.

$601-602$ 249

219

$277-278$

111,305

. 80-81

ore bodies in.

Celestite, occurrence of.

occurrence of, in gangue.

uses of.

Celestite concentrates, analysis of.

Century mine, development of . ore bodies in.

Cerargyrite, occurrence of.

Cerusite, genesis of. occurrence of.

Chabazite, occurrence of..

Chaetetes milleporaceus Troost.

Chalcanthite, occurrence of

Chalcedony, occurrence of.

Chalcocite, occurrence of..

(107,303

Chalcophyllite, occurrence of............................. 114

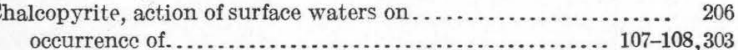

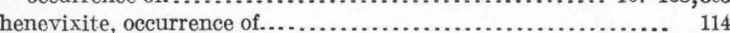

Chesapeake iron-ore fissure vein, plate showing............... 576

Chicago mine, ore bodies in .......................... 378-379

Chlorides and fluorides, occurrence of...................... 304

Chlorite, occurrence of.

occurrence of, in fissures in pre-Cambrian granite, plate showing. .

Chonetes loganensis Hall and Whitfield.

mesolobus var. decipiens Girty.

Chromium, occurrence of

Chrysocolla, occurrence of ................................. 114, 305

Cinnabar, occurrence of.

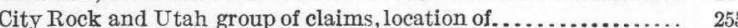

City Rock Gulch, minor faults near, descript

City Rocks fissure, deposits associated with, description of...... 266-267

Clarke, F. W., cited.

Claron limestone, nature and mineralization of ............. 573-574

Clay "conglomerate" ore, plates showing..................... 587

Clayton, J. E., cited.................................... 551

Clayton Peak stock, deformation caused by................... 301 plate showing ...................................... 296

Cliff mine, ore bodies in .............................. 379-380 Clifton district, history of mining in $\ldots \ldots \ldots \ldots \ldots \ldots \ldots \ldots \ldots$
quartz monzonite from, analysis of $\ldots \ldots \ldots \ldots \ldots \ldots \ldots \ldots$ veins in.

$160-161$ See also Gold Hill and Clifton district.

Climate of Utah...

Clyde mine, description of................ 144

Cobalt, occurrence of .................................. 144, 152

Colob plateau, rocks of .................................. $583-584$

Colorado, geologic columnar section of part of ............... In pocket.

Colorado Plateau, relief map showing part of.

Colorado River, canyon of. placer gold on, mining of occurrence of. .

copper veins in........................ 427-428

geology of ................................. $425-426$

history of mining in.............................. $426-427$

ore deposits in.................................... 427-429

Columbus overthrust fault, description of................. 245-246

Columbus prospect, description of

Columbus Consolidated mine, dividends paid by.

Columbus-Rexall mine, location of, plate showin

ore deposits in
Page.

Comet mine, view west near, plate showing ................ 504 Composita mira Girty. . . .......................... 646-647,655 subquadrata Hall. subtilita Hall ....................................... 653 Composition, chemical, influence of, on replacement of rocks...... 174 Concentrates, quantities of, shipped to smelters, 1903-1917..... 124-125 Concentration by the action of foreign substances, deposits due to. 158 chemical, deposits due to, age of...................... 158 deposits due to, distribution of ................... 152-153 genesis of................................. 155-158 nature of $\ldots \ldots \ldots \ldots \ldots \ldots .153-154$ relation of geologic structure to ...................... 154-155

relation of igneous rocks to ........................ 156

Conditions, physical, of ore deposition..................... 167-168

Conichalcite, occurrence of.

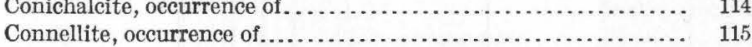

Conner, Gen. E. P., prospecting by soldiers under............. 118

Consolidated Mercur Mines Co's mill, output and cost of operation of ......................................... 384-385 plate showing ....................................... 382 Contact deposits, alteration in, by surface solutions............ 209 See also under names of ranges and districts.

Copper, association and distribution of.................. 152-153 contact deposits of, nature and occurrence of................ 168-169 deposition of, from ore-bearing solutions................. 193 fissure deposits of, nature and origin of .................. 176 in fissure replacement deposits, surface alteration of .......... 210 occurrence of .................................... 106 production of. $126-131,135-138$

See also Production of metals and production under names of ranges and districts.

Copper Belt mine, operation of .......................... 541

Copper Bullion prospect, copper indications on................ $329-330$ Copper Jack mine, ore bodies in......................... 428 Copper-lead ores of Beaver County, metal content of............ 510 of the Bingham district, metal content of................. 344 of the Ophir and Rush Valley districts, metal content of . . . 368-369 of the Tintic district, metal content of................ 407,410 Copper minerals, alteration of by surface solutions......... 206, 207,

Copper Mountain mine, ore body in..................... $492-493$ Copper ore, metal content of. See under names of ranges and districts.

oxidized, plate showing .............................. 206

sandstone, photomicrographs of........................... 614

"Copper pitch ore," occurrence of.............................110-111

Corkite, occurrence of .................................. 115

Cosalite, occurrence of...................................... 108

Cottonwood-American Fork area, Cambrian rocks in ..............235-238

elimate of ............................................. 232

contact metamorphism in .............................242-243

Devonian (?) and Carbonierous limestone in. ..............237-239

drainage of..........................................231-232

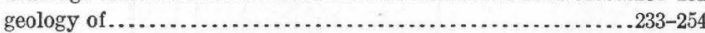

glacial features of................................232, 234-235

igneous rocks in......................................239-243

location of......................................................

ore deposits in......................................265-283

pre-Cambrian rocks in............................. 234-235

sedimentary rocks of . ..................................233-239

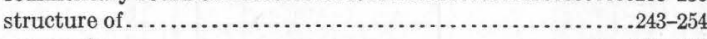

surveys in..............................................229-230

timber in.......................................... 232

topography of.................................................

transportation in ............................................

water supply of ...................................... $\quad 232$

Cottonwood-Atlantis mine, ore bodies in .................... 282

Cottonwood Creek, course of...............................231-232

Cottonwood Divide, location of............................... 231

minor faults crossing, descriptions of . . . . . . . . . . . . . . $249-250$

Cottonwood fault, description of............................ 301

deformation near..................................... 301

Cottonwood-Park City area, geologic reconnaisance map of.In pocket.

Cottonwood region. See Big Cottonwood and Little Cottonwood districts.

294 Cotunnite, occurrence of................................... 109

294 Cotunnite, occurrence of................................... 109 
Page.

Covellite, occurrence of. pyrite surrounded by, plate showing

replacing zine sulphide, plate showing.

Covellite and pyrite, concentric bands of, plate showing. . Cote district, geology of

location of......

ore deposits in .....................................562-563

Crandallite, occurrence of................................ 114

Creedite, occurrence of .................................. 187-188

Crescent fault zone, description of .......................... 300

Cretaceous sediments, nature and distribution of............... 84-85 See also under names of ranges and districts.

Crismon, C. C., analysis by.

Croppings. See Outcrops.

Cross, Whitman, cited..

Cross, Whitman, and Spencer, A. C., eited.

Crystal mine, ore bodies in

Cuprite, occurrence of.

Cuproscheelite, occurrence of.

Caprum claim, ore bodies in.

Cyanide process, development

Cyanotrichite, occurrence of...

Cyathophyllum nevadense Meek.

Dalton mine, ore bodies in.

Danburite, occurrence of

Daubreite, occurrence of

Day, A. L., and Shepherd, E. S., cited.........................188, 189

De Launay, L., cited....................................186-187

Deep Creek Range, dikes in..............................4 73-474

geography of...................................... $469-470$

geology and physiography of ...................................

intrusive rocks from, analyses of ...................... 96

sedimentary rocks in................................471-472

Deer Creek, alunite near................................. 547, 548

Deertrail mine, history of . . ............................ 542, 556-557

ore bodies in.

deposition of .

Deformation, relation of, to intrusion.................252-254,301-302

Denver \& Rio Grande Railroad, construction of.................119-120

Deposits, contact, chemical and physical changes involved in...169-173

contact, genesis of ................................. 174 relation of, to deposits in intrusive rocks................ $173-174$

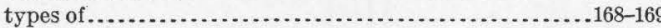

fissure, nature of . origin of.......................................... 177-179

in extrusive rocks, nature and distribution of...............179-181 relations of........................................

in the Tushar Range, origin and relations of...............552-554

placer, origin and occurrence of.........................150-151

replacement, origin of.

sandstone, nature and distribution of.

origin of. .

types of, compared

vein, nature and origin of

Descloizite, occurrence of. .

Deseret mine, ore of

Desert Mountain, geology of ore deposit in.

Detroit district, history of mining in . ................ ore deposits in.

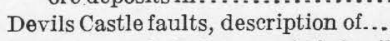

tic fos ils of plate show.............

sediments of nature and distribution of

Dewey, copper deposit east of ................................

Diaphragmus elegans Norwood and Pratten....................

Diaspore, occurrence of.

Differentiation of magmas, definition of . ......................

Dike, definition of.

Dikes in the Cottonwood-A merican Fork area, descriptions of ..... 24 in the San Francisco and adjacent districts, descriptions of. .

in the Santaquin and Mount Nebo region, nature and occurrence of.

pre-Cambrian, cut off by Cambrian conglomerate, plate showing............................................. istricts, mining, list of.............................. 146-150 mining, organization of ............................. 145 production of metals by............ 129-131, 132, 133,137, 140,142 Dividends paid by mining companies....................... 263 Dixie mine, ore bodies in............................. 596-597 Dolly Varden claim, ore bodies in ......................... 621 Dolomite, occurrence of ................................... 111, 305 Doming, age of........................................... 103 cause of .......................................... 105

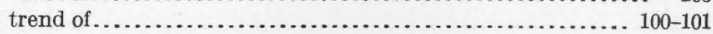

Dominguez, Father, exploration by ...................... 117 Drainage of Utah. ....................................... $59-60$

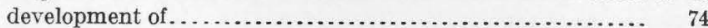

Dry Canyon, Deep Creek Range, ores in....................... 484

Dry Canyon, Oquirrh Range, ore deposits in............... $377-379$ Oquirrh Range, mines of, production from ................. 367 Dry ores. See Siliceous ores.

Dufrenoysite, occurrence of............................... 108

Dugway district, history of mining in..................... 462-463 ore deposits in ................................... 463

Dugway-Granite Range, geography of................... $458-459$ geology of ....................................... $459-462$ sedimentary rocks of .................................. $459-460$ Dutchman mine, description of ........................ 270 Dutton, C. E., cited............................. 82, 83, 86-87, 99,537 generalized section of volcanic rocks by.................. 89 Dyer mine, copper ores in............................. $603-604$

E.

Eakins, L. G., analysis by ............................ 91

Eagle Hill porphyry, nature and oceurrence of . . ........... 375, 389-390

East Canyon, mines of, production from................... 367

East Tintic district, location of............................. $\quad 396$

East Tintic Mountains, geography of..................... 396

Edmondia gibbosa McCoy ................................. 653

1888 mine. See 1903 mine.

Eissler, M., cited.

Eldorado mine, ore body of .................................

Eldridge, G. H., cited................................. 86

Elkhorn district, organization and development of . . . . . . . $319-320$

Embolite, occurrence of ............................. 109

Emily mine, working of................................. 255

Emma mine, description of . . . . . . . . . . . . . . . . . . . .

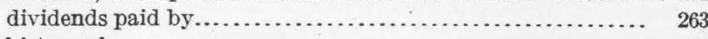

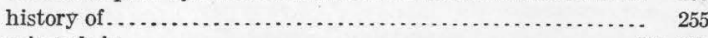

minerals in..................................... 274-275

ore bodies in ................................ 469

stratigraphic place of..................................... 272

production from................................. 259,261

Enargite, action of surface waters on.................... 206

occurrence of....................................... 108

English Springs, iron deposits near...........................

Epidote, occurrence of ................................. 112, 305

Erickson district, future of mining in.......................... 457

general features of............................... 445-446

geology of................................. $425-426,446-450$

igneous rocks in ................................. 448-449

ore deposits in ............................. 427-429, 450-457

sedimentary rocks in.............................. 446-448

structure of......................................... 449-450

Erinite, occurrence of ................................ 114

Erosion in the Basin Ranges................................... $72-73$

influence of, on surface alteration...................... 204

removal of altered rock by ........................... 522

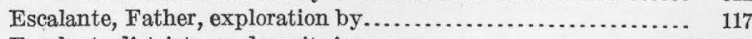

Escalente district, ore deposits in........................... 567-568

Euomphalus laxus White............................... 652

utahensis Hall and Whitfield...............................

Eureka, location of.................................... 396

Eureka Leasing \& Mining Co.'s claims, description of..............

Eva mine, description of ............................. 332-333

Evarena fault, description of ................................. 249

Extrusive rocks, age of, with relation to the intrusive rocks....... 99 compòsition of ....................................... 90-91 nature and origin of ................................. $88-89$ ore deposits in ................................ 179-183 
F.

Famatinite, occurrence of. Farmington district, geology and ore deposits of.

Farnsworth, P. T., cited .

Faulting, hanging valley probably formed by, plate showing..... recent, along Wasatch Range, plate showing

Faults, effect of, on bed deposits.

character and distribution of ........................ $354-355$

displacement by . . .................................... 355-356

in the Ophir district, features of

in the Oquirrh Range, features of.

in the Park City dlstrict, descriptions of.................. 299-301

in the Santaquin and Mount Nebo region, types and features

$$
\text { of ........................................ } 328-329
$$

in the Tintic district, periods and effects of.................. 402-403

in the West Tintic district, features of..

influence of, on structure of the Cottonwood-American Fork area..

normal, age of

cause of. .

definition of.

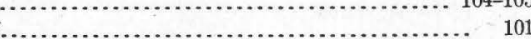

distribution of .................................. 101

overthrust, deposits associated with ....................... 280-282

reverse or overthrust, age of ........................... 103-104

definition of..................................... 101

distribution of..................................... 101

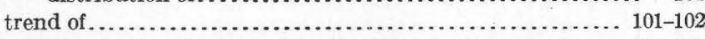

Faunas, summaries of.................................... tions.

192-193

Field work, record of.

Fish Springs district, general features of.

geology and physiography of

mining and production in

ore deposits of..

Fissure, Santa Maria, plate showing

Fissure deposits in the American Fork district, descriptions of.................................. 251, 269-270

in the Big and Little Cottonwood districts, descriptions of ................................... 251, 266-269

surface alteration in ............................. 210-213

in pre-Cambrian granite, plate showing................... 223

in the Ophir district, features of.

in the Santaquin and Mount Nebo region, features of....... 329

Flagstaff mine, description of.

dividends paid by...

history of...

production from......................................... 259, 261

proup, nature and age of .

Fluorite, occurrence of ............................. 109, 304

Folds in the Bingham district, nature and origin of.............. 354

in the Cottonwood-American Fork area, influence of, on struc-

in the Ophir district, fea.............................. 244-245

in the Oquirrh Range, features of

in the Park City district, features of.

the Santequin and Mount Nebo region, fea

in the West Tintic district, effects of

nature and distribution of.

origin of..

Fool Creek canyon, copper prospect near.

Fortuna district,

Fossils, characteristic, of Cambrian age, plates showing........... 76,77

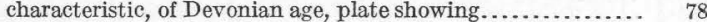

of Jurassic age, plate showing.

of Lower Mississippian and Pennsylvanian age, plate showing..

of Lower Triassic age, plate showing . . . . . . . . . . ......

of Ordovieian age, plate showing

of Permian age, plate showing..

of Silurian age, plate showing.

of Upper Mississippian age, plates showing
Fossils, occurrence of...

Page.

$237,239,294,295,325,335,336,374-375,419$

$425,438,459,460,467,471,472,487,494,500,501$,

$511,527,532,538,559,595,603,605-606,609$

plant, with silver ore, plate showing ................... 587

plates showing, use of .

selection of for description...

.

Franklin Furnace, N. J., ore deposits at .................... 193

Frederick tunnel, description of ........................ 256

Frémont, Capt. J. C., exploration by ..................... 117

Fremont Island district, minerals in..................... 502-503

Frisco, plate showing ................................ 504

Frog Valley fault, deseription of......................... $300-301$

deformation near .................................... 301

Fruita, section near ................................... 633

Fuller mine, working of . . . . . . . . . . . .

Fulton, C. H., cited .................................... 191

Fumarole Butte, geology and spring deposits of............. 457-458

Fusulina cylindrica Fischer de Waldheim.................... 653

Gale, H. S., Butler, B. S., and, cited ........................ 187

Galena, action of surface waters on ..................... 206, 210-211

occurrence of .

Grlena King mine, description of ....................... 373

Gangue, replacement of . ............................... 194

Gannett, Henry, eited .................................. 116

Garden City district. See Swan Creek district.

Gardner dolomite, nature of............................. 399

Garfield fissure, description of ...............................

Garnet, action of surface waters on ....................... 205

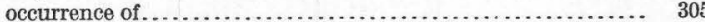

Garnet group, occurrence of ........................... $\quad 112$

Gemmell, R. C., cited.................................... 383

Geography of Utah................................. $57-67$

Geocronite, occurrence of................................ 108

Geologic map and sections of Iron Springs district............. 568

of the Bingham mining district...................... In pocket.

of the mining districts of the San Francisco region........... 502

of the Silver Reef district........................... In pocket.

of Utah Copper Co.'s property at Bingham.................. 358

Geologic reconnaissance map of Cottonwood Park City area... In pocket. Geology of the Park City district........................ 294-303

of Utah..................................... 34-105

correlated columnar sections showing .............. In pocket. reconnaissance map showing................... In pocket. Gilbert, G.K., cited ............... 82, $362-363,459,466,470,623-625,627$ on the origin of the Basin Ranges..................... 71-72 Girty, G. H , fossils determined by....................... 325 $326,335,336-337,375,419,438$ $460,471,472,532,595,603,609$

Glacial deposits, distribution of .

Godjva claim, mineral vein on........... 42 \%

Gold, concentration of, by surface agencies.................. 214 contact deposits containing, nature and occurrence of..... 169,209 fissure deposits containing, nature and alter ation of ......... 177 fissure replacement de posits of, surface alteration in ........ 212-213 in consolidated sediments, occurrence and source of......... 151-152 in volcanic rocks, surface alter ation of .................... 214 native, in carbonate gangue, plates showing............ 598 occurrence of . .................................. 106, 303 pegmatitic quartz veins containing, surface alteration in...... 208 placer, from Colorado River and from Green River, photomicrographs of.

precipitation of, in shale............................... 174

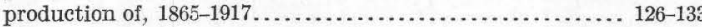

See also Production of metals and production under names of ranges and districts.

Gold Hill and Clifton district, contact deposits in ............ 479-481 deposits in sedimentary rocks in .................... 479-483

elations of the ore deposits in ......................... 482-482 replacement veins in quartz monzonite in .............. 476-478

Gold Hill and Clifton stock, lithology of ................... 472-474

Gold Hill mine, ore bodies in ............................. 48 
Gold Mountain district, mines in mining and milling in production in.

Gold quartz veins, nature and occurrence of................... 162 Gold-silver deposits in extrusive rocks, nature and occurrence of. 179-181 Gold Springs district, alteration of wall rock in .............. 566-567 geography of geology of. mining and milling in................................ 564, 565 ore deposits of.................................... 565-568 metals in ore shoots in.

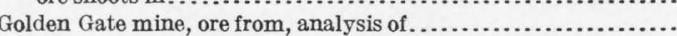
ore from, mineral content of.

Goldstrike district. See Bull Valley district.

Goldthwait, J. W., Huntington, Ellsworth, and, cited...... 582-584, 585 Good Hope prospect, ore body in............................ 456 Goslarite, occurrence of................................. 115, 306 Göthite, occurrence of ................................... 110 Grand River, placer gold on.:........................... 640 Granite Creek district, ores in ............................. 484 Granite district, ore bodies in .............................. 531

Granite Range, composition of stock in..................... 96-97 ore bodies in.

Great Basin, relief map showing part of. ...................... 68

Great Logan syncline, deformation of...................... 252

Great Salt Lake, level of, chart showing variation in............ 204

Great Salt Lake Basin, precipitation in, chart showing.......... 204

Great Salt Lake Desert, features of ......................... $57-58$

Green-eyed Monster mine, production from................ 542,543

Green River, area drained by .............................. placer gold on......................................... $639-640$

Greenockite, occurrence of.............................. 107

Grizzly fissure, deposits associated with, description of........ 266-267

Grizzly thrust zone, description of...................... 246-247

Ground water, discharge zone of............................. 203

gathering zone of................................... 203

level of, conditions governing ................ 203-204

Grouse Creek Range, geology of ........................ 494-495

location of.

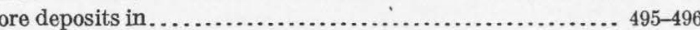

See also Ashbrook and Rosebud Creek districts.

Grundy, Isaac, development of lead deposits by............... 118

Gunnison, Lieut., survey for railroad by ...................... 118

Gustavus Adolphus fissure, description of.................. 268

Gypsum, occurrence of.

$115,186,306$

\section{H.}

Hague, Arnold, eited........................ 490-491, 493, 499, 500 Halemaumau, Hawaii, gases from, analyses of................. 189 Hall, R. D., analyses by ........................... 90,171; 575 Haloid minerals, occurrence of.......................... 108-109

Happy Jack prospect, ore bodies in . . . .................... 454-455

Harder, E. C., Leith, C. K., and, cited...................... 573

Hardscrabble dist rict, operations in .......................... 226

Harker, Alfred, cited..................................... 188

Harrington-Hickory mine, mineralization in............... 518-519

Harrisburg district. See Silver Reef district.

Haüynite, occurrence of.

184-185

Hecla mine, location of

production from.

Helena region, Mont , tourmaline

Hematite, action of surface waters on........................... occurrence of.

Henry district, production in..............................

Henry Mountain region, contact deposits in.................... geography of . ....................................... $622-62$ geology of ....................................... 623-628 igneous rocks in, age of............................. 626-627 petrography of.................................625-626 metamorphism in ore deposits in...

placer deposits in .

sedimentary rocks of ............................... $623-625$

topography of ....................................... 623

veins in igneous rocks in . . . . . . . .
Page. m..................... 9 correlation of strata in, with those in southwestern Colorado.. 625 with those in White Canyon ...................... 620 gold placers in ....................................... 151 origin of............................................. 104 section of strata in. .................................... $623-624$ structure of . . . . . . . . . . . Hess, F. L., cited ..................................... 155 Heulandite, occurrence of . .............................. 113 Hewett, D. F., cited .................................. 185-186 Hewettite. See Vanadium.

Hidden Treasure mine, ore bodies in ........................ 378 High Plateau, Tertiary beds of High Plateau, Tertiary beds of................................ $456-87$ Hill, J. M., cited.............................. $611,612,613,616$ Hillebrand, W. F., analyses by.......................... 91 $93,94,95,170,296,297,349,391,393,394$

Hinsdalite, occurrence and origin of ..................... 183, 187 possible genesis of ..................................... 194

History, eivil, of Utah mining, of Utah.............................. 118, 254-259 Holmes, W. H., eited.................................... $620-621$ Homestake limestone, nature and distribution of............ 572-573

Honerine mine, development of ............................ 364

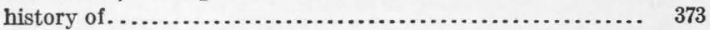
limestone of, analysis of ................................ 174 Honeycomb fault, minor faults near, descriptions of ............ 250 Honeycomb Fork, fissure deposits on, description of............ 267 Hooker, W. A., cited............. 524 Horn silver, occurrence of................................ 108 Horn silver mine, location of, plate showing................. 504 alteration of............................ 213-214,523-527 ore from, analysis of ................................ 524 metal content of................................ 525-526 production from. Horn silver ore body, sections of, plate showing.............. 518 Hot Springs district, development in...................... 227 Howell mine, deseription of.................................. 268 Humbug formation, nature of ............................ 400 Huntington, Ellsworth, and Goldthwait, J. W., cited...... 582-584, 585 Huntley, D. B., cited ........................ 255-257, 258, 266, $267,270,275,276,277,278,279,318,334,364,366-367,378,379$, $382,475,489,504,505,530,531,535,541,542,585-586,591-592$ $\begin{array}{ll}\text { Hustedia mormoni Marcou...................................... } & 653 \\ \text { Hydrozincite, occurrence of. ................................ } & 111\end{array}$ Hypogene, use of the term ............................... 205 Hyrum-Paradise region, early production from................ 218 ore deposits of.................................... 217-218

Ibapah stock, analysis of granodiorite from.................. 96

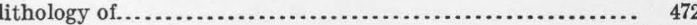

Igneous rocks, age of.................................... 99-100 damming of mineralizing solutions by ................... 175 distribution and kinds of............................. $88-100$ order of eruption of................................... 89 ore deposits in, alteration of, by surface solutions......... 213-214 relation of, to chemical concentration of ore deposits......... 156 vein types in, relations of ............................ 163-168 See also extrusive and intrusive rock, and geology under names of ranges and districts.

Ilmenite, occurrence of................................... 110 Indian Chief prospect, ore bodies in........................ $455-456$ Indian Peak district, ore deposits in........................... 529 Intrusion, relation of, to deformation............... 252-254,301-302 Intrusive rocks, age of, in relation to the extrusive rocks......... 99 composition of, causes of differences in.................. 97-99 distribution and nature of............................. 91 mode of intrusion of . ............................... 91-98 ore deposits in, alteration of .......................... 208-209 nature and origin of ................................. 159-168 veins in.

Iron, association of

basic sulphates of, genesis of.

contact deposits of, nature and occurrence of. ................

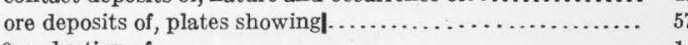

cproduction of ...................................... 143 
Page.

Iron King mine, description of.. minerals, alteration of, by surface solutions.

Caring district, analyses of andesite from .

Carboniferous roc

contact metamorphism in ............................. $572-573$

Cretaceous rocks in .................................. 573

extrusive rocks in .................. 575-576 composition of . ................................ 90

geography of.

geologic history of.

geologic map and section

geology of.

ron-ore deposits in, composition of.................. 578-579

genesis of............. 579-580

geology of ....................................... 577-578

occurrence of..................................... 576-577

tonnage of..................................... 579

iron production in ............................... 570

laccoliths in, distribution and structure of................ 574

metamorphism of .............................. 575

petrography of .................................... 574-575

sedimentary formations in . ........................ $572-574$

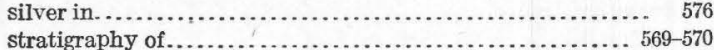

structure of. .......................................... 570

Tertiary rocks in . . . . . . . . . . . . . . . . . . . . . . . $573-574$

J.

Jackling, D. C., cited.

occurrence of

Jarosite, genesis of

Jarloose district, location of veins in voleanic rocks in.

Jenney, W. P., cited.

Jennie mine, ore from...

ore from, analysis of

mining in........................... 470

ores in

Jolly Boy mine, production from.

Junction, section near.

Jurassic period, characteristic fossils of, plate showing ............

Jurassic sediments, correlation of.

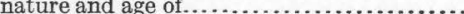

\section{K.}

Kaolin, occurrence of

Kearsarge mine, ore body in .............................. 379

Keith, Arthur, cited. $350-351,353,354$

Kennebec mines, descriptions of

Kermesite, occurrence of.

Kilauea, Hawaii, gases from, analyses of..........................

Kimball, J. P., acknowledgment to.

King, Clarence, cited.

King Solomon vein, features of.

Kirk, Edwin, fossils determined by

Knopf, Adolph, cited.

.... 71

Krotki iron mine, production from ....................... 543,557

L

La Plata claim, discovery of ore on.

La Sal Mountains, analyses of rocks from. bibliography of.

Carboniferous formations in copper deposits in sedimentary rocks in

Cretaceous formations in.

domes in.

faults and fissures in.

folds in..

general features of

geology of.

gold in bench gravels of

gold-copper veins in..

history of mining in.
La Sal Mountains, igneous rocks in Page.

Jurassic formations in .............................. 610

manganese deposits in............................ 617-618

placer deposits in . ................................ 613

sedimentary rocks of . ..............................69-611

structure of . ........................................ 612

Triassic formations in .............................. 618

uranium-vanadium deposits in ..................613,616-617

Laccoliths, distinguishing features of...................... 91 distribution of, in the Henry mountains.................. 620 formation of................................. 197-198,627

forms and composition of .................. 93-94 mineralization of................................. 196,197-198, 201

Lake Bonneville, location of............................... 87 shore line of, plate showing........................... $\quad 320$

Lake deposits, nature of..................................

Lake Mountains, geology and ore deposits of................. 334-335
Lake View Mining Co., operations of................. 499, 500-501

Lakeside district, mining in ............................ 488

Larsen, E. S., cited................................... 187

Last Hope No. 3 prospect, ore bodies on.................... 456

Laumontite, occurrence of.............................. 113

Lava flows, alteration of ore deposits in . . . . . . . . . . . . $523-527$

mineralization in. ................................. 519

Lava plateau, geology and spring deposits of.............. 457-458

Lawson, A. C., cited ......................... $634-635,636-637$

Le Verkin Canyon, rocks exposed along. ..................... 583

Lead, contact deposits containing......................... 169 early smelting of .................................... 118 occurrence of...

production of, $1870-1917$......................... nnder names of ranges and districts.

Lead Hill mine, ore bodies in......................... $560-561$

Lead minerals, surface alteration of............. 206,209-211, 213-215

Lead ores from Beaver County, metal content of . .............. 508-509

from the Bingham district, metal content of.............. 343-344 from the Ophir and Rush Valley districts, metal content of... 368 from the Park City region, metal content of............. 290,291

from the Tintic district, metal content of ................. 407

Lead oxychlorite, occurrence of ....................... 109

Lead-silver fissure deposits, nature and distribution of .......... 176-177

Lead-zinc deposits in the Santaquin and Mount Nebo region.... 330-333

Lead-zinc ores from Beaver County, metal content of........... 510

from the Bingham district, metal content of............... 344

from the Tintic district, metal content of ................... 410

Leadhillite, occurrence of .................................. 111

Leamington district, ore deposits in ................... 422-423

Lee, W. T., cited $\ldots \ldots \ldots \ldots \ldots \ldots . . . .531-532$

Leeds district. See Silver Reef district.

Lehi district, organization and mineral products of ,............ 335

Leith, C. K., and Harder, E. C., cited....................... 573

Leptaena analoga Phillips.................................. 652

Lerch, Fred, analyses by.................................. 581

Lettsomite, occurrence of................................ 116

Leverrierite, occurrence of................................. 113

Limestone, alteration of, chemical changes produced by........ 169-172 alteration of, in the Ophir district, results of..............376-377 volumetric changes produced by .................... 172-173 altered ore bearing, plates showing ...................... 376 analyses of, showing changes from metamorphism...... 170-172, 349 contact metamorphism of, in the Park City district........ 302-303 Limestone breccia, mineralized, plate showing................ 174

Limonite, genesis of................................... 205 occurrence of........................................ 110, 304

Linarite, occurrence of ................................ 115

Lincoln district, history of mining in ...................... 530

Lincoln mine, description of............................ 530, 534

Lindgren, Waldemar, acknowledgment to.................. 38 cited................................. 156,185,191,194, 518, 554-555 Lion Hill, ore bodies on .................................. 381-382 plate showing...................................... 377

Lisbon Valley, copper deposits in......................... 615

Lithostrotion whitneyi Meek................................ $\quad 650$

Little Cottonwood Canyon, view on north side of.............. 294

LittleCottonwood Creek, minor faults south of, descriptions of . . 250-251

Little Cottonwood district, bed deposits in, descriptions of..... 270-276 
Page.

Little Cottonwood district, history of mining in............ 254-257 location and topography of.......................... 227-228 production in ...................................... 259-263 tunnels in.

See also Cottonwood-American Fork area.

Little Cottonwood stock, analyses of rocks from ............... 95,96 description of

Live Yankee .aim

Los Angeles \& Salt Lake Railroad, construction of ............... 120

Loughlin, G. F., cited................................. 548

Lucin district, bibliography of.

geology of.

history of mining in

igneous rocks in.

relations of, to sedimentary rocks

location of..

ore deposits in.

genesis of.

sedimentary rocksin

structure of.

Lucky Boy mine, description of. mineralsin.

Lucky Chance mine, fissure deposit in.

Ludwigite, occurrence of. .

Lunge, George, cited

Lupton, C. T., cited.

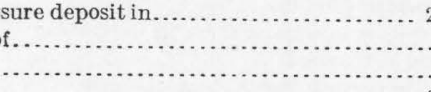

\section{M.}

McCaskey, H. D., cited.

McElmo formation, divisions of .

MeGarry district, location of.

$\mathrm{McHenry}$ fault, description of .

deformation near.

Magmas, assimi ation by

differentiation of

Magnesoludwigite, occurrence of.

Magnetite, action of surface waters on.

occurrence of.

Magnetite-hematite veins, nature and occurrence of. . . . . . . . . 162-163

Mahogany c'aim, ore body in ......................... $\quad 379$

Malachite, occurrence of.............................. 111, 305

Mammoth, locetio

Mammoth mine, mineralization in ....................... $518-519$

Manganese, association and distribution of . . ................. 152, 153

production of $-143,206$

Manganese minerals, surface a'teration of .................... 205-206

Manganite, occurrence of

Map, geo'ogic, of Utah.

. In pocket.

reief, showing parts of Rocky Mountain, Colorado Plateau, and Great Basin areas

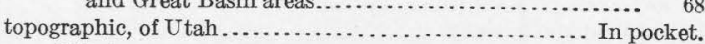

of Utah, compilation of........................... 74-76

Marble, production of, by contact metamorphism ............... $\quad 302$

Marcasite, occurrence of ................................ 108

Marginifera muricata Norwood and Pratten................. 654

splendens Norwood and Pratten........................ 654

Martite, occurrence of................................. 205

Marysvale, gold placers near............................. 151

Massachusetts fault, description of ...................... $\quad 300$

Massicot, occurrence of ............................. 110,304

Maxfield mine, description of . ........................ 278-279

dividends paid by ................................. 263

working of..

Meadow Lake, Calif., quartz-tourma'ine-copper deposits at.......

Meekoceras gracilitatis White................................

$\mathrm{Me}^{\top}$ aconite, occurrence of.

Melanterite, occurrence of ............ 109

Mercur, gold ledges at

settlement and dec.ine of ................................ 383

silver ledges at ........................................ $391-392$

Mercur Basin, plate showing............................. 382

Mereur district. See Camp Floyd district.

Mercury. See Quicksilver.

Merry, James P., ana'ysis by

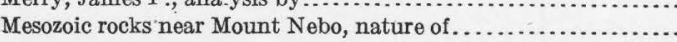

274
Metallurgy, progress of Page.

Metals, geographic and geologic distribution of ............... 120-125 native, occurrence of ............................... 106 production of, $1865-1917 \ldots \ldots \ldots \ldots \ldots \ldots \ldots \ldots \ldots \ldots . . . . .126-145$

chart showing

source of, in ore deposits . .......................... 156-157

Metamorphism, contact, in the Cottonwood-American Fork area, effects of ................................... 242-243

contact, in the Park City district, extent and nature of..... 302-303 physical and chemical changes produced by .......... 169-173 hydrothermal, in the Park City district, occurrence of....... 302 Metasomatism in the San Francisco and adjacent districts...... 514-516 Mica, occurrence of................................... 113, 305

Michigan-Utah mine, location of, plate showing.............. 294

Midas mine, ore bodies in ............................ 480-481 Milkmaid mine, production from........................... 284 Mill Creek district. See Hardscrabble district.

Mill D South Fork, minor faults near, descriptions of ......... 248-249 Miller, B. L., and Singewald, J. T., cited..................... 193 Miller mine, description of............................. 279-280 production from ................................... 263 working of ................................................ 258,259

Milling of ores, progress in.......................... 120-125, 126 Mimetite, occurrence of . .................................... 114, 306

Mineral products, nonmetallic, value of.................... 126

Mineral Range, bibliography of.......................... 536

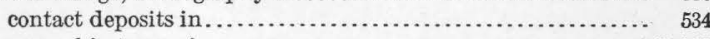
general features of ..................................... $529-530$ geo'ogy and physiography of ...................... 531-533

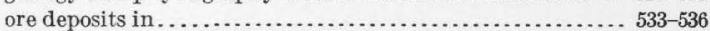

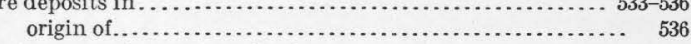
replacement-fissure deposits in ......................... $535-536$ stock in, composition of ............................. 97 structure of ........................................ 533 veins in volcanic rocks in .................................

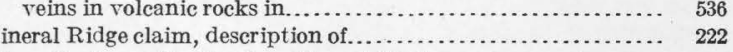
Mineral Ridge claim, description of..........

Minerals, composition and occurrence of. ............... 105-116 composition and occurrence of, in the Park City district.... 303-306

Miners Basin, placer deposits in......................... 613 Miners Mountain, geology of . . . . . . . . . . . . . . . . . . . .

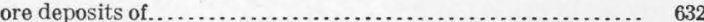

Mining in Utah, history of ............................. 118, 254-259

Minium, occurrence of .............................. 110

Mispickel, occurrence of ................................... 108

Mississippian, age, characteristic fossils of ................. 641-642 characteristic fossils of, plates showing ............. $650,651,652$ sediments of, in the Santaquin and Mount Nebo region. . . 325-326 nature of.......................................... 81

Mixite, occurrence of .................................. 115

Modena area, prospecting in................................... 567

Molybdenum, occurrence of........................ 106-107,566, 606 production of..................................... 144

Molybdenum minerals, occurrence of ...................... 116

Molybdite, occurrence of ................................ 109

Mona district, gypsum mining in............................. 333,334

Mono mine, ore bodies in.............................. 379

Montezuma claim, description of ...................... 267-268

Montezuma fault, description of......................... 249-250

Monticellite, occurrence of............................... 112

Moon claim, production from........................... 218

Morgan Consolidated claim, description of.................. 220

Morgan Crescent mine, description of...................... $\quad 220$

Morgan district, location and geology of .................... 219 ore deposits of.................................... 219-221

Morgan mine, ore bodies in ........................... 431

Morgan Mountain, description of....................... 218-221

Mormon Girl claim, ore body on........................... 222

Mormons, settlement by ................................. 117

Morning Star claims, ore bodies on . ..................... 227

Morrison Claims, ore bodies on ....................... 487-488

Mount Baldy district, gold placers in ....................... 151 mines in ............................................. 556-557 mining in . . . . . . . . . . . . . . . . . . . . . . . . . . . . $542-543$

Mount Ellen, description of ............................ $\quad 623$

Mount Ellsworth, description of.......................... 623

Mount Hillers, description of ............................. 623

Mount Holmes, description of . ........................... 623 
INDEX.

Page.

Mount Nebo district, geography of ...................... $322-323$ geology of.

ore deposits of.

production in.

structure of.

$324-329$

329-333

334

$327-329$

Mount Nebo ridge, mines on ............................. 332-333

Mount Pennell, description of

Mountain Lake, faults northwest of, descriptions of ............ 251

Mountain Lake fault, description of......................... 251

Muscovite, occurrence of.

Myacites inconspicuus Meek

Myalina aviculoides Meek and Hayden permiana Swallow......

subçuadrata Shumard...

Myalina ? platynotus (White)

\section{N.}

Nabob mine, ore bodies in...

Napoleon-Maghera claims, metal content of ores from

Navajo Mountain, geology of...

Nebraska mine, production from.

Nevada, geologic columnar section of part of................ In pocket.

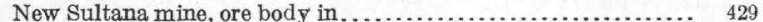

Newberry, S. B., analysis by............................. 524

Newfoundland district, ores in

Newton district, alunite deposit in ....................... 549-550

history of.

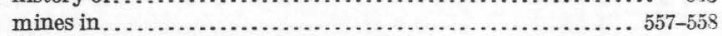

Nickel, content of, in blister copper from the Bingham district... 347 recovery of......................................... 144

1903 mine, ore bodies in.............................. 441-442

Nip and Tuck mine, ore bodies of ........................ $\quad 535$

North Granite district, mining in ........................ 531

North Star claim, description of.................... 255, 275-276

North Star district, history of mining in................. 504-505

North Tintic district, geography of........................ 415 geology of ........................................ $335,415-416$ ore deposits in..................................... 417-418

organization and production of.

Noselite, occurrence of................................. 184-185

Nugget sandstone, nature and occurrence of .................. 295-296

O.

O. K. mine, ore bodies in

ore bodies in, alteration of. origin of...

K ore zone mineralization

Oak Creek district. See Leamington district.

Octahedrite, occurrence of.

Ogden Boilermakers claim, ore body on...

Ogren Buckhorn Mining Co.'s property, ore bod

223

Ohio district, history of mining in ....................... 540-542 mines in ..................................................... 555-556

Olivenite, occurrence of ................................. 114

Onofrite, occurrence of.

Ontario mine, early history of.......................... 286

Ontario and Daly West fault zone, description of................ 299-300

Opal, occurrence of........................ 109

Ophir anticline, plate showing.

Ophir Canyon, mines in................................ 379-381

Ophir and Rush Valley districts, ores of, metal content of....... 368-369 production in............ $369-370$

Ophir district, bibliography of.

general features of.

geology of.

history of mining in.

ore deposits of..................................... 376-382 organization of

Ophir fault, description of..

Ophir formation, nature and occurrence of . ................... 79,398

Ophir Hill mine, ore bodies in . ........ 380-381

Ophir mine, desciption of

Opohonga limestone, nature of.

Oquirrh Range, geography of

geology of.....

ore deposits in.
Ordovician period, fossils of, plate showing......... Page. rocks of, nature and distribution of..................... $79-80$

Ore deposits, alteration of, by surface agencies........ 202-216 associated with fissures, nature and genesis of ............ 174-179 associated with igneous rocks, age of...................... 195-196 change in character of, with distance from source.......... 184 classification of contact, absence of, from zone of highest temperature and pressure in extrusive rocks.

183 in extrusive rocks, nature and distribution of............. 179-181 in intrusive rocks, nature and origin of . ................. 159-168 in sandstone, alteration of ........................... 207 influence of selective replacement in forming................. 174 introduction of foreign substances as a cause of ............ 158

origin of......................... 150-202 relation of different types of intrusive bodies to.......... 196-201 outline of ........................................ 34-35 replacement fissure, deposits in extrusive rocks similar to. . 183-184 sedimentary rocks containing ......................... 202 types of, in the Park City district...................... 306 See also Production of metals and names of ranges and districts. Oregon property, description of . ......................... 267 Ores, assays of ........................................ 280

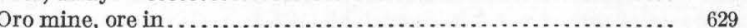

Orpiment, occurrence of.................................... 106

Orthoclase, occurrence of................................. 111-112

Ouray region, copper ores of............................... 606

geology of ..........................................605-606

Outcrops in the Park City district, features of ............... 306-307

Overland claim, ore body on ............................. 222

Oxides, occurrence of............................... 109-111,304-305

Oxidized zinc ores, formation of, conditions favorable for........ 212

P.

Pacific mine, description of................................ 269

Packard rhyolite, nature and occurrence of.................. 400-401

Palladium, occurrence of ................................ 145

Palmer, Chase, analysis by ............................... 566

Pardee, J. T., cited........................................ 617

Paria region, geography of.................................. 634

geology of .......................................... $634-635$

disseminated gold deposits in, occurrence of . . .............. 636, 637 sampling and assaying of.......................... 636-637 placer gold in, occurrence and development of............ $637-640$ source of ......................................... 640

Park City anticline, description of............................ 299

influence of, on structure of the Cottonwood-American Fork (243,244

Park City area, analyses of intrusive rocks from............. 95, 96 geologic map of ................................... In pocket.

Park City district, bibliography of....................... 317-318 composition of andesite from ......................... 90-91

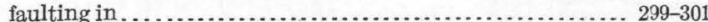

folding in .......................................... 299

geography of ...................................... 285

geology of ................................. 228-229, 294-303

history of mining in. .............................. 285-287

igneous rocks in .................................. 296-299

location and topography of ........................... 227-228

lode deposits in ...................................... 306-309

ore bodies in, genesis of............................ 316-317

minerals of ...................................... 303-306

ores of, reduction of . . . . . . . . . . . . . . . . . . . . . . . . $287-289$

production in ..................................... 289-293

sedimentary rocks of . ............................. 294-296

water supply and mine drainage in ..................... $\quad 287$

Park City formation, occurrence and lithology of............. 295

Park City monocline, plate showing......................... 296

Park Valley district, bibliography of ...................... 499

geology of .......................................... 497-498

history of mining in................................ 497

igneous rocks in.................................... 497-498

location of.......................................... 497

ore deposits of..................................... 498-499

structure of ...................................... 498

Paymaster mine, ore bodies in .......................... 597

Payson district, organization and development of............. 322

Pearceite, occurrence of ................................ 109 

gold quartz vein sin, concentration in

Pennsylvanian age, characteristic fossils of characteristic fossils of, plates showing. sediments of, nature of.

Pentacrinus asteriscus Meek and Hayden

Periclase, occurrence of.

Permian age, characteristic fossils of. characteristic fossils of, plate showing.

Peruvian Gulch, faults near, descriptions of

Peruvian mine, ore bodies of.

Peyton, G. S., cited.

Pharmacosiderite, occurrence of

Phlogopite, occurrence of..

Phosgenite, occurrence of

Phosphates, occurrence of.

Physiography of Utah, development of

Pilot Range, geography of.

Pine Canyon limestone, nature of.

Pine Grove district, general features of ore deposits in.

Pintadoite, occurrence of.

Pinto district, iron production in

Pinto sandstone, generalized section of

Pinyon Peak limestone, nature of.

Pittsburgh fault, description of. .

Placer deposits, distribution and origin of

in the Bingham district, occurrence and origin of.. production from.

in the Paria region, occurrence and development of

in the La Sal Mountains.

near Marysvale.

production from.

Plagioclase group, occurrence of

Plants, replacement of, by minerals.

Plateau province, correlation of, with central western Wyoming. . correlation of, with the San Juan Mountain region, Colo.... .

with the Uinta Range.

development of

features of.

topography of.

Platinum, occurrence of

Platinum metals, 106,145,151, district.

Plumbojarosite, occurrence of . . ...............................

Pluto mine, production from.

Pope mine, iron ore in.

"Porphyry," light, mineral composition of.

in 1908 and in 1915 , plates showing. See also Alunite.

Powell, J. W., cited.

Powellite, occurrence of

Pre-Cambrian rocks,

in Great Salt Lake Basin, chart showing ............... 204

Preuss district, history of mining in ....................... 503,50

Prince of Wales claims, production from..................... 261 working of......................................... 257

Prince of Wales mine, description of.........................276-277

Production of metals, $1865-1917 . . . \ldots \ldots \ldots \ldots \ldots \ldots \ldots \ldots \ldots \ldots \ldots \ldots \ldots . .126-145$ See also production under names of ranges and districts.

Productus brazerianus Girty, n. sp........................643-644,651 burlingtonensis Hall.

cora D'Orbigny...

inflatus var. coloradoensis Girty.

multistriatus Meek.

ovatus Hall.

phosphaticus Girty

semireticulatus Martin.

semistriatus Meek.

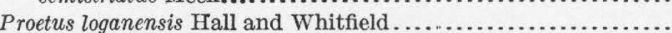
peroccidens Hall and Whitfield.

Promontory district, general features of ......................499-500 geology of ............................................. $500-501$ ore deposits of..

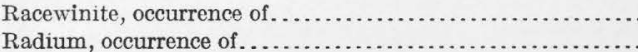

Raft River Mountains, composition of stock in............... 97

exceptional plan of.................................. $\quad 57$

topography of .................................... 496-497

Railroads. See Transportation.

Rainfall. See Precipitation.

Ransome, F. L., acknowledgment to..................... 38 cited................................................... preface by....................................... 31 Raymond, R. W., cited......................... 267-268, 273-274

Reade \& Benson mine, description of...................... 277

Reade \& Benson thrust zone, description of................. 246

Realgar, occurrence of................................... 106

651 Reaper claims, pegmatitic veins on........................ 476-477

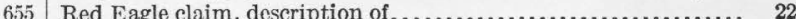

,

$\begin{array}{ll}651 & \text { Redfield, C. A., acknowledgment to............................. } 502 \\ 651 & \text { Reduction of ores, methods employed in ............. } 287-289,341-342\end{array}$

652 Reeside, J. B., ir., fossils determined by..................... 538

2 Relief of the surface, description of ...................... 57-59 map showing, in parts of Rocky Mountains, Colorado Plateau, and Great Basin areas........................... See also Physiography. ore deposits of...........................................321-322

(1) kansasensis Beede............................. 653

$\begin{array}{ll} & \\ \text { Pugnoides osagensis Swallow....................................... } & 110 \\ & 653\end{array}$

nebraskensis Owen................................. 654

semipunctata Shepard................................. $\quad 654$

$\begin{array}{cc} & 108 \\ & \end{array}$ nodules of, surrounded by covellite, plate showing........... 614 Pyrite and covellite, concentric bands of, plate showing......... 614 Promorphite, occurrence of....................................114, 305-306 Pyroxene group, occurrence of............................... 112 Qurtz Quartz copper veins, nature and origin of.....................161-162 surface alteration in .208-209

in the Park City district, occurrence and lithology of.........296-297 iartz diorite porphyry, analyses of ........................... 297 artz monzonite, analyses of.................................296, 165-166 photomicrographs of .............................. 164

urtz monzonite porphyry, photomicrographs of.............. 165 $\begin{array}{ll}\text { enriched with biotite, photomicrograph of.................. } & 165 \\ \text { enriched with orthoclase, photomicrograph of.............. } & 165\end{array}$ uartz silver-lead veins, nature and varieties of............... 162 surface alteration in Quartz-tourmaline-scheelite veins, nature and origin of..........160, 161 175

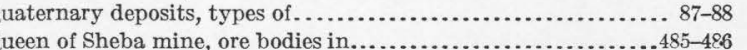
Queen of the Hills mine, ore bodies in........................ 379 fissure deposits of, occurrence of ....................... 177 occurrence and deposition of................106, 542, 543, 551-552, 566 production of............................. 144

\section{7} . ss 3

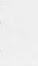
政

4

.


Replacement. See Ure deposits and Vegetable material. Reticularia setigera IIall.

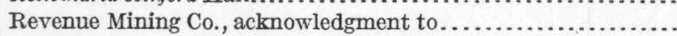

Rexall mine. See Columbus-Rexall mine.

Rhodes Plateau, iron-ore deposits in........

Rhodochrosite, occurrence of.

Rhodonite, occurrence of. ores derived from.

Rob Roy mine, ore bodies in. production from

Rock, replaced, physical condit

Rocky Mountains, plate showing. relief map showing part of...

Rolker, C. M. cited.

Rollins mine, early operation of.

Rothwell, R. P. cited

Rush Valley district, bibliography of.......................... 374 geography of .......................... geology of.

history of mining in.

ore deposits of................................... 372-374

organization of . ....................................... 362

production in.

See also Ophir and Rush Valley districts.

Rutile, occurrence of.

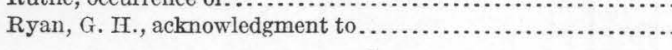

S.

Sacramento mine, quicksilver ore in, description of.

Salina Creek district, geology of ......................... $559-560$ ore deposits of

$$
\text { genesis of. }
$$

structure of.

Sally Ann prospect, copper deposit on.

Salt Wash, copper deposits on.

年

Wash anticline, relation of copper deposits to............. 154

Salt Wash sandstone, nature and position of.

Sampson fault, description of.

San Francisco district, analysis of quartz monzonite from......... composition of extrusive rocks from.

history of mining in. veins in..

contact deposits in, alteration of........................ 523

erosion in, removal of altered rock by ................... 522

faults in........................................... 513

fissures in...................................... 513-514

folds in.......................................... $\quad 512$

geologic map and sections of............................ 502

geology of..

$510-516$

lavas in, alteration of........................... $514-515,523-527$

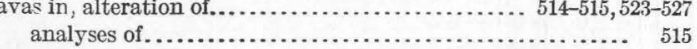

distribution of............................................ 512

mineralization in................................. 519

location of ......................................... 503

ore deposits in, conditions affecting.................... 516 origin of.......................................... 519-521 secondary alteration of ........................... 521-527

physiography of.................................... 510

quartz monzonite in, alteration of ..................... 514, $522-523$ occurrence of...................................... 512 ore deposits in................................ 516-518

replacement-fissure deposits in...................... 518-519 alteration of.................................... 523

sedimentary rocks in, age and distribution of ................ 510-511 alteration of.................................... 515-516 ore deposits in................................... 518-519

structure of .

water level in, position of............................ 521-522

San Juan Mountain region, Colo., correlation of the Plateau province with

San Juan River, placer gold on........................ 637,639

San Rafael Swell, copper deposits in........................ 608

Cretaceous beds near, section of . .......................... 85

geology of ........................................... $607-608$

topography of.

uranium-vanadium-radium deposits in.................. 608
Sands, black, value of.................................. Page.

Sandstone, contact metamorphism of....................... 303

ore deposits in, alteration of ........................... 207 origin of........................................... $152-158$ Santa Clara district, location of ............................ 594 Santaquin Central tunnel, copper in......................... 330 Santaquin Chief mine, description of ......................... 332 Santaquin district, geography of ............................ $322-323$ geology of ........ ore deposits of . $329-333$ production in ........................................ 334 sedimentary rocks of, nature and distribution of............. $324-326$ structure of ............................... 327-329 Santaquin King mine, description of . ....................... 332 Santaquin Ridge, mines on................................ $330-332$ Savage claim, description of.............................. 267-268 Scapolite, occurrence of................................... 188

Schaller, W. T., analyses by ............................. 548, 550

minerals determined by ................................ 568 Scheelite, occurrence of....................................... 116 Schizophoria resupinoides Cox?........................... 653

Schuchertella aff. S, chemungensis Conrad..................... 652 Scope of the report..................................... $37-38$ Scorodite, occurrence of .................................... 114 Scotia mine, ore bodies in ............................... 442-443 Sections, geologic columnar, of Utah and adjacent parts of Colorado, Arizona, and Nevada................... In pocket. Sedgwickia? concava Meek and Hayden........................ 656 Sedimentary rocks, ore deposits in................... 168-179, 202 succession of ........................................ 77-88 See also under names of ranges and districts.

Selenium, content of, in blister copper from the Bingham district. Selenium minerals, occurrence of ......................... 106-108 Sells mine, ore bodies of.................................. 276

Sericite, occurrence of .................................. 113

Serpentine, occurrence of................................. 113, 305

Sevier mine, ore bodies in ................................. 555

Sevier River, alunite near........................... 547, 548

Shale, closing of fissures in ............................. 175 contact metamorphism of .............................. 303 Shamrock mine, ore bodies in ........................... 556 Sharp mine, ore bodies in .............................. $\quad 429$

Sheep Rock, alunite deposit in ......................... $549-550$ Sheep Rock mine, description of ...................... 557-558 Sheeprock Mountains, general features of................... 423-424 geology of

Sheet, definition of.

Shepherd, E. S., Day, A. L., and, cited........................ 188, 189 Shinarump group, nature and distribution of........... 81-82, 634-635 Siderite, occurrence of..................................... 111

Sierra Madre district, geology of.......................... 223-224 ore deposits of .................................... 224-226 Silicates, occurrence of .............................. 111-114, 305

Siliceous ores from Beaver County, metal content of............ 508 in the Ophir and Rush Valley districts, metal content of ..... 368 of the Bingham district, metal content of................ 342 production from.................................. 289, 406 Sill, definition of ....................................... 91

Silliman, Benjamin, cited............................. 274-275 Silurian period, characteristic fossils of, plate showing.......... 78 rocks of, nature and distribution of....................... $79-80$

Silver, association and distribution of ...................... 152,153 contact deposits containing.............................. 169 fissure deposits containing, nature and distribution of...... 176-177 occurrence of ......................................... 10 s ore of, with fossil plant remains, plate showing............ 587 price of fluctuations in .................. 134-135

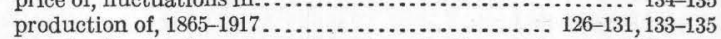
See also Production of metals and produetion under names of ranges and districts.

Silver Dipper vein, description of . ......................... 269 Silver Fork fault, description of.......................... 247-248 intrusive rocks affected by ............................. 253

Silver glance, occurrence of............................. 107

Silver Islet Range, general features of.......................... 486 geology of .................................................. $486-487$ ore deposits of................................... 487-488 
Silver King fissure, description of.

Silver King mine, deformation due to intrusion in.

Silver Lake district, fissure deposits in

Silver Lead Mines Co., production by.

Silver-lead-zinc- copper deposits in extrusive rocks, nature and occurrence of.

Silver minerals, alteration of, by surface solutions . . 207,209-211, 213-215

Silver Queen claim, ore body on.

Silver Reef deposits, genesis of.

position of, on an anticline.

Silver Reef district, bibliography of.

future of. .

general features of

geologic map and sections of

geology of

igneous rocks of

mining and production in

ore deposits in, extent of.

mineralogy of.

nature and occurrence of

ores of, genesis of.

tenor of.

sedimentary rocks of.

topography of

structure of

Silver Reef mine, ore bodies in.

Simpson Mountains, future of mining in general features of

geology of

igneous rocks in

ore deposits in.

ores in, oxidation of.

sedimentary rocks in

structure of....

Singewald, J. T., Miller, B. L., and, cited.

Sloan, E. L., cited.

Smelters, gases from, formation of sulphates in quantities of concentrates shipped to, 1903-1917........... 124-125 quantities of ores shipped to, $1903-1917 \ldots \ldots \ldots \ldots \ldots \ldots \ldots . . .122-123$

Smelting, history of, in the Little Cottonwood district. progress of.

Smithsonite, occurrence of

pseudomorphs of, after calcite, plate showing.

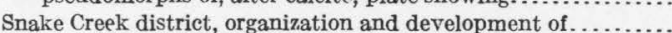

Snow fault, description of.

Solutions, ore-bearing, composition of

ore-bearing, modification of, during deposition............. 194-195.

Solvay Process Co., analyses by...........................

South Hecla mine, description of.................... 276, 282 dividends paid by ................................. 263

South Star and Titus mine, operation of . ...................

Southern Cross iron deposits, plate showing.

Spangolite, occurrence of.

Spanish Fork district, organization of.

Sparrowhawk mine, analysis of ore from

Specularite, occurrence of.

Spencer, A. C., Cross, Whitman, and, eited

Sphalerite, action of surface waters on... occurrence of. See also Zinc.

Spinel, occurrence of.

Spirifer centronatus Winchell pseudocameratus Girty, n. sp......................... $644-645,655$ rockymontanu.s Marcou.................................. 653 striatus Martin ....................................... 651

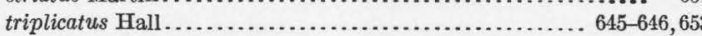

Spiriferina kentuckyensis Shumard. pulchra Meek.

Spring Creek district, geology of. ore deposits in. mining in...

Spurr, J. E., cited..

Squamularia perplexa McChesney

Squaw Springs Pass, plate showing

Stabler, Herman, on water power of Utah

Stansbury, Capt., exploration for railroad by

Star district, history of mining in quartz monzonite from, analysis of age.
Tage. $566-567$ bibliography of ................................. 568 geography of ................................... 563 geology of ....................................... 563-564 mining and milling in ............................... 564-565 ore deposits of ...................................... 565-568 Steamboat mine, minerals in.............................. 266 teen, Rector, cited .................................. 286 Steiger, George, analyses by..................... 165, 166, 170, 312 Stephanite, occurrence of.............................. 108 Stibnite, action of surface waters on ........................ 207 See also Antimony.

Stock raising in Utah................................. 65

Stocks, apically truncated, mineralization associated with........ 197 composition of ......................................... 95-99 distinguishing features of.............................. 91 distribution and texture of ................... 94-95 formation of..................................... 198-199 in the Cottonwood-American Fork area, descriptions of..... 239-240 medially truncated, little mineralization associated with.... 196-197 ore deposits associated with ........................ 199-201 truncation of................................... 196 Stockton district. See Rush Valley district.

Stokes, H. N., analyses by ............................... 91

Stolzite, occurrence of...................................... 116

Stoping, magmatic, process of................................ $91-92$

Straparollus ophirensis Hall and Whitfield................... 652

Stratigraphy of Utah............................... $74-100$

Stream deposits, gold from ................................ 88

Structural features, geologic ages of.................... 102-103 relative ages of .................................. 102 Structure, major features of, position and relation of, plate show-

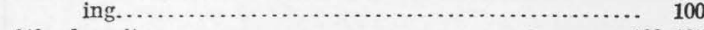
of the deposits................................. 100-105 relation of chemically concentrated deposits to .......... 154-155 See also under names of ranges and districts.

Sulpharsenites and sulphantimonites, occurrence of........... 303

Sulphates, deposition of, in veins....................... 182-183 formation of.................................. 184, 190-195 function of, in the genesis of ore deposits............... 195 occurrence of ............................ 115-116, 184-188, 306 Sulphides, occurrence of................................... 106-108, 303 Sulphosalt minerals, occurrence of........................ 108 Sulphur, occurrence of ................................ 106

Sulphur trioxide, formation of............................ 189

Sulphuric acid, formation of ........................... 189, 190 formation of, from sulphur and water.................... 193 Supergene, use of the term ............................. 205 Superior faults, description of ............................ 248 Superior mine, ore bodies in.......................... 597 Sunshine, history of mining at ........................... 387 ore deposits at ..................................... 395

usannah mine, operation of . ...................... 497, 499

vonbergite, occurrence of.................................. 188

Swan Creek district, ore deposits of........................ 217

Swansea rhyolite, nature and occurrence of............... 400, 401

ylvanite, occurrence of ............................... 108

T.

alc, occurrence of ................................... 113

ylor prospect, description of .......................... $\quad 267$

ecoma mine, ores from............................... 493 rium, content of, in blister copper from the Bingham district. $\quad 347$

occurrence of ............................ 145, 552,557, 566

ellurium minerals, occurrence of ...................... 106-108

Temperature, highest and lowest, by months and years at 72 stations...

mean, by months and years at 58 stations ................... $61-60-61$

range of, in which ore deposits form . . . . . . . . . . . . . 185

Tennantite, occurrence of ................................ 108

Tenorite, occurrence of .......................................... 109

Tertiary sediments, nature and distribution of .............. 85-87

See also under names of ranges and districts.

Tetrahedrite, action of surface waters on ...................... 206

lead and zincin ..................................... 271 occurrence of....................................... 108, 303

haumasite, occurrence of................................. 113, 188

Thaynes formation, occurrence and lithology of ............ 295 
INDEX.

Page.

Thomas Range, composition of rhyolitefrom.

Thorium, claims located for.

Thorpe, M. R., acknowledgment to....

Tiemannite, occurrence of

Tillite, occurrence of..

Timpanogos Peak, elevation of.

in sulphide, deposition of ...

Tintic district, geology of

iron ores in

monzonitefrom, analysis of

ore deposits in, distribution o

genesis of...

mineralization of

production in.

rhyolitefrom, composition of.

smelting and milling in...

Tintic quartzite, nature and distribution of. use of name.

Titanite, occurrence of

Titus mine, dividends paid by

Toledo mine, working of.

Toledo vein, descrir:tion of

Tom Moore tunnel, location of, plate showing .

Topaz, occurrence of

Topography of Utah. map showing

Tourmaline, occurrence of

Transportation, facilities for railroad construction for

$410-411$

414-415

411-414

riassic age, characteristic fossils of . sof, plateshowing .

sediments of, correlation of nature and distribution of See also under names of ranges and district

Trout Creek district, miningin ores in...

Tungsten, contact deposits containing..

deposits of, in the Grouse Creek Range

occurrence of.

production of.

Tungsten minerals, occurrence of.

Tungsten sulphide, deposition of.

398

........................... 193 use of in the Cottonwood-American Forkarea

Tushar Range, alunite veinsin ........................ 546-550 bibliography of ....................................... 558

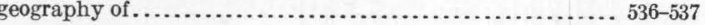
geology of ........................................ 538-540

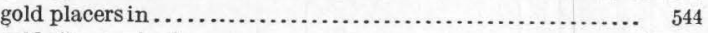
gold-silver veins in ................................. 543-545 history of miningin ............................ $540-543$

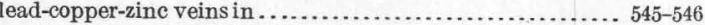
ore deposits in .................................... 543-554 deposition of ................................. 552-554 physiography of.................................... 557 replacement deposits in ......................550-552 structure of ..................................... 539-540 veins of iron ore in ................................ 546

Tutsagubet district, copper deposits in.................. 596-597

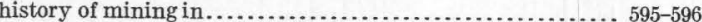
lead-silver deposits in .............................. 597

Twin Pine claim, ore body on.

Tyrolite, occurrence of.

Tyuyamunite, occurrence of.

\section{U.}

Uinta Basin, section of formationsin

Uinta district, organization of.

Uinta Mountains, bibliography of .

606-607 correlation of the Plateau province.....................603-606 correlation of the Plateau province with .................... 70

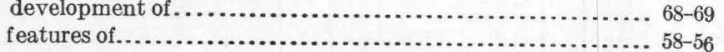

geology of.

iron-ore deposits in.

physiography of.

production in.

structural relations of, to the Wasatch Range
Uinta Mountains, structure of ........................... Page. 601

Union Chief mine, description of . ......................... 330-331

Union Pacific Railroad, construction of..................... 119

Union Vedette, cited.

Uranium, association and distribution of .................... 152, 155 deposition of. ........................................ 153 occurrence of ..................... 115, 605, 608, 622, 628, 630,632-633 recovery of ..................................... 145 ranium minerals, alteration of .................... 207, 207-208 occurrence of....................................... 154

Uranospinite, occurrence of .............................. 115

Utah, reconnaissance geologic map of .................... In pocket. topographic map of ...................................

Utah Centennial claims, description of . ................ 269-270

Utah Copper Co., ore body of, surface alteration in............. 209 ore body of, thickness of ........................... 360

Utah-Galena fissure, mineralization of ................... 468-469

Utah mine, analysis of water from........................ 465

Utahite, occurrence of.................................. 116

Utonia tunnels, ore bodies in.......................... 456

Uvanite, occurrence of . . . . .

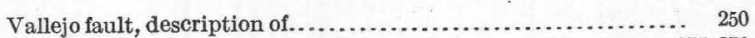

Vallejo mine, description of . . . . . . . . .

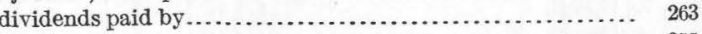
working of

Valley, hanging, in Sheep Rock Range, plate showirg.......... 101 strike, separating main ridge of Wasatch Range from front hills, plate showing............................. 321

Valley deposits, genesis and nature of ................... 87-88

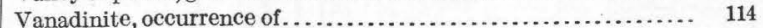

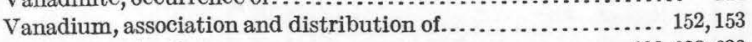
occurrence of..................................... 608, 628, 630 recovery of.

Vanadium minerals, alteration of.................... 207, 207-208 occurrence of.................................... 114-115, 154

Variscite, occurrence of................................ 114, 494

Vegetable material, carbonized, from the Dolly Varden mine, photomicrograph of.

replaced by ores, longitudinal and cross sections of cellular structure of, photomicrographs showing ............. 152

replaced by sulphide, photomicrograph of .................. 152

replaced by iron sulphide largely altered to limonite, plates showing..

replacement of, by minerals. . . . 153-154, 155-156

Vegetation, distribution of ............................... 65

Veins, alteration of rocks adjacent to....................... 194 alunite, nature and occurrence of. ...................... 181, 182, 183 gold, alteration of wall rock adjacent to, photomicrographs showing...................................... 180

gold-quartz, nature and occurrence of..................... 162 in intrusive rocks, features of............................ 265 in the Gold Hill and Clifton district..................... 476-478

lead-silver, alteration near.............................. 352 magnetite hemitite, nature and occurence of .............. 162-163 mineral composition of .............................. 163 pegmatitic gold quartz, nature and origin of............... 159 quartz-copper, nature and origin of................... 161-162 occurrence of, in other States........................ 162 quartz-silver-lead, nature and varieties of................. 162 quartz-tourmaline-copper, nature and origin of.......... 160,161 quartz-tourmaline-scheelite, nature and origin of........... 160,161 relations between various types of .................... 181-183 replacement of gangue stuff in.......................... 194

types of, in the igneous rocks, relations of................ 163 Vermilion Cliff sandstone, nature and age of. ................. $82-83$ Vesuvianite, occurrence of................................ 112, 305 Victoria No. 1 prospect, description of....................... 217

Victoria quartzite, nature of ............................. 399

Vipont property, ores in................................ 496 production from........................................ 495

Virginia Lode claim, deseription of .......................... 440

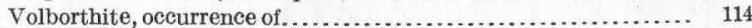

Volcanic rocks. See Igneous rocks.

Volcanoes, gases from, constituents of.................... 188-189

Volume, changes in, caused by contact metamorphism ........ 172-173 
w.

Wad, oceurrence of..

Wah Wah Pass, prospecting near.

Wah Wah Range, general features of geology of production from structure of

Walcott, C. D., cited. alteration of, photomicrographs showing.

War Eagle claims, description of.

Wasatch King mine, production from

Wasatch mines, ore bodies in.

Wasatch Mountains at Provo, plate showing description of

development of.

features of.

recent fault along, plate showing.

structural relations of, to the Uinta Mountain

west front of plate showing...

Water power, development and possibilities of ..................

Water-power plants, statistics of.

Waterfall vein, description of

Waters, atmospheric, action of, in chemical concentration of or

Weber district, geology of................................... 221 ore deposits of.

Weber quartzite in the Park City district. . . . . . . . . . . . 294-295

Webster mine, ore bodies in............................... 556

Wedge mine, ore bodies of............................... 556

Wells, R. C., analyses by...................... 95, 165, 174, 271, 560

West Dip, history of min ore deposits at.

West Mountain district. See Bingham district.

West Quincy mine, deformation due to intrusion near...

West Tintic district, geography of

geology of. 387

gold in

ger mining in .

near Scotia mine, plate showing..................... 337

ore deposits in . . . . . . . . . .

overthrust in ...................................... $438-439$

sedimentary rocks of $. \ldots \ldots \ldots \ldots \ldots \ldots \ldots \ldots \ldots \ldots \ldots \ldots \ldots \ldots, 432-434$

silver in............................... 439,440,441,442,443

structure of . ...................................... 437-439

Western Utah Copper Co., production by .................... 481

Wheeler, G. M., cited ................................... 334

White Canyon region, general features of . . . . . . . . . . . . $619-620$ geology of

$620-621$

ore deposits in.
110

White Dragon prospect, description of -2.33

White Pine Gulch, veins in.

veins in

White Reef, plates showing ............................. 586

Wild Dutchman mine, description of...................... 270

production from . . . . .............................. 263

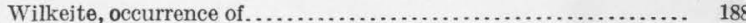

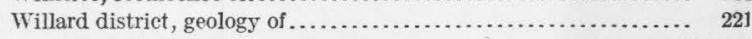
ore deposits of................................... 221,222

Willemite, occurrence of............................. 112

Willow Springs district, ores in .......................... 484

Wilson Mesa, placer deposits on ............................ 613

Wind, erosion and transportation by........................ 73

Wooci Canyon claims, description of ...................... 423

Woodside prospect, iron ore in ........................... 603

Woodside shale, occurrence and lithology of.................. 295

Woolsey, L. H., Boutw ell, J. M., and, cited................... 99

Wulfenite, occurrence of . ........................ 116

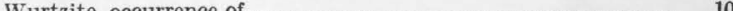

Wyoming, central western, correlation of the Plateau province with.

Yellow Jacket claim, production from ...................... 218

Yellowstone mine, description of .......................... 422-423

$\mathrm{Z}$.

Zaphrentis excentrica Meek. ................................ 650

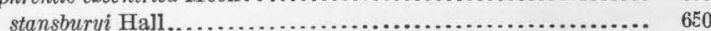

Zaphrentis : multil amella Hall?................................ 650

Zeunerite, occurrence of .............................. 115

Zinc, deposition of, at Franklin Furnace, N. J............... 193 occurrence of ................................... 107

ores of, from Beaver County, content of................ 509 in the Ophir and Rush Valley districts, shippers of...... 369 oxidjzed, conditions favorable for formation of........... 212 treatment of . . . . . production of, 1904-1917....................... 126-131,141-142 sulphide of, replaced by covellite, plate showing........... 206 sulphides of, photomierographs of .................... 207, 524 See also Production of metals and production under names of ranges and districts.

Zinc minerals, surface alteration of ................ 206, 209, 211-215 Zinc-silver-lead fissure deposits, nature and development of ...... 177 Zircon, occurrence of .................................. 112

Zoisite, occurrence of ................................. 112

\section{ADDITIONAL COPIES}

OF THIS PUBLICATION MAY BE PROCURED FROM

THE SUPERINTENDENT OF DOCUMENTS

GOVERNMENT PRINTING OFFICE

WASHINGTON, D. C.

AT

$\$ 1.50$ PER COPY 